UNIVERSIDAD

POLITECNICA

DE VALENCIA

\title{
LA CIUDAD DE LA EDIFICACIÓN ABIERTA VALENCIA, 1946-1988
}

Javier Pérez Igualada

TESIS DOCTORAL

Director: Luís Alonso de Armiño Pérez. 

Aunque mucha cosas son arrebatadas por el tiempo, otras muchas permanecen; $y$ aunque no tengamos ahora la fuerza que en los viejos días fue capaz de conmover la tierra y el cielo, seguimos siendo quienes somos...

Alfred Tennyson.

Para Carmen, Javier y Santiago, siempre. 



\section{N D I C E}

\section{INTRODUCCIÓN}

I. ENTRE EL PLAN GENERAL DE 1946 Y EL PLAN SUR DE 1958. PRIMEROS PLANES Y PROYECTOS URBANOS BASADOS EN LA EDIFICACIÓN ABIERTA EN VALENCIA

INTRODUCCION

1. LOS INICIOS DE LA EDIFICACIÓN ABIERTA EN VALENCIA, 1931-36.

2. DE LA MANZANA AL BLOQUE: GRUPOS DE VIVIENDAS DE PROMOCIÓN MUNICIPAL, 1940-49

Grupo Alboraya-Generalísimo Franco (1942-50). 43

Grupo Montdúver

Grupo Carretera de Barcelona (1944-52)

47

Grupo Federico Mayo (1947-53)

3. LA EDIFICACIÓN ABIERTA EN EL PLAN GENERAL DE ORDENACIÓN URBANA DE VALENCIA Y SU CINTURA DE 1946.

El ensanche sureste (1946)

El barrio residencial de Burjasot-Benimamet (1946)

4. LA EDIFICACIÓN ABIERTA EN LOS PROYECTOS PARCIALES DE DESARROLLO DEL PLAN GENERAL DE 1946

5. GRUPOS DE VIVIENDAS DE PROMOCIÓN PÚBLICA Y DE COOPERATIVAS, 1950-56 81 Grupo Ruiz Jarabo (1949-56)

Grupo Camino de Alba (1952-56)

Edificio Renfe-Aragón (1950-54) 
6. LOS PROYECTOS DE EJECUCIÓN DE POLÍGONOS PARA VIVIENDAS DE RENTA LIMITADA Y LOS BARRIOS RESIDENCIALES No 2 Y $3 \quad 107$

Polígono de Valencia al Mar(1956) 109

Polígono de Campanar (1956) 113

$\begin{array}{ll}\text { Polígono Avenida de Castilla (1955) } & 117\end{array}$

Polígono de Monteolivete (1955) 119

Barrios residenciales No 2 y 3 en la Avenida de Castilla (1956) 123

7. LA DEFINICIÓN DEL MARCO NORMATIVO GENERAL DE LA EDIFICACIÓN ABIERTA 125

Las Ordenanzas de la Comisión Central de Sanidad Local de 1955

La Ley del Suelo de 1956: Los Planes Parciales 128

II. ENTRE EL PLAN SUR DE 1958 Y EL PLAN GENERAL DE 1966.

LA FORMACIÓN DE LA PERIFERIA URBANA.

INTRODUCCIÓN

1. DESPUÉS DE LA RIADA: LA EDIFICACIÓN ABIERTA EN LAS PROPUESTAS DEL PLAN SUR, 1958

2. LOS GRUPOS DEL PLAN RIADA

Grupo Virgen de la Fuensanta (1958-60) 141

Grupo Virgen del Carmen (1958-62) 151

3. LA EDIFICACIÓN ABIERTA DE PROMOCIÓN PRIVADA: EL BARRIO VIRGEN DE LA LUZ Y LOS EPISODIOS AISLADOS EN ÁREAS URBANAS CONSOLIDADAS

Barrio Virgen de la Luz (1958)

Grupo Stella Maris (1958-60)

Grupo Bernardo Lassala (1958-62)

Grupo Santa María Micaela (1958-61). $\quad 173$

Grupo Pintor Maella (1961) 177

$\begin{array}{lr}\text { El conjunto de la Ciudadela } & 179\end{array}$

4. POLÍGONOS DE PROMOCIÓN PÚBLICA: LOS PROYECTOS NO REALIZADOS 181

Polígono de Valencia al Mar (1960) 183

Polígono de Campanar (1961) 191

$\begin{array}{ll}\text { Polígono Avenida de Castilla (1960) } & 201\end{array}$

Polígono de Monteolivete (1960) 207

Centro Comercial de Moneolivete (1960) 215

5. PLANES PARCIALES MUNICIPALES DE DESARROLLO DEL PLAN SUR, 1958-1965 217

La edificación abierta en las operaciones de renovación urbana

del centro histórico: el Plan Parcial 1-3-4 (1958-60) 219

Las zonas de las Facultades, Mestalla y el Llano del Real: Plan Parcial $11(1958 / 60) 227$

La zona del Paseo al Mar, de polígono a plano de alineaciones: Plan Parcial 12-B

(1958/1963)

Grao-Cabanyal-Malvarrosa: El Plan Parcial 13 (1962) 255

Benimaclet: Plan Parcial $22(1961 / 62) \quad 259$

Torrefiel y Orriols: El Plan Parcial $23(1962)$

Oeste de Campanar : Plan Parcial 8-B (1963) 265

Marxalenes: Plan Parcial 9 (1960) 267

Benicalap: Plan Parcial 24 (1966) 271

La zona de la Avenida de Castilla: Planes Parciales I-b y I-c (1962-63) 277

Los terrenos de la Estación del Norte: Plan Parcial 5-B (1963) 283

Malilla: Plan Parcial 5-C (1964) 289 
III. ENTRE EL PLAN GENERAL DE 1966 Y EL PGOU DE 1988.

LA CONSOLIDACIÓN DE LA PERIFERIA URBANA

INTRODUCCIÓN

1. LA EDIFICACIÓN ABIERTA EN EL PLAN GENERAL DE VALENCIA ADAPTADO A LA SOLUCIÓN SUR DE 1966

2. LA EDIFICACIÓN ABIERTA EN LOS PLANES PARCIALES DE DESARROLLO DEL PLAN GENERAL DE 1966

3. LA EDIFICACIÓN ABIERTA EN EL PLAN GENERAL DE ORDENACIÓN URBANA DE VALENCIA DE 1988. LOS RESTOS DEL NAUFRAGIO DEL ORDEN ABIERTO

4. LAS ÁREAS DE EDIFICACIÓN ABIERTA EN VALENCIA ENTRE 1968 Y 1988

4.1. EL SECTOR NORESTE

LA ZONA DE LAS FACULTADES, MESTALLA Y EL LLANO DEL REAL:

EL PLAN PARCIAL NO 11 (1967)

LA PROLONGACIÓN DEL PASEO AL MAR:EL PLAN PARCIAL No 12 (1968)

EPISODIOS AISLADOS DE EDIFICACIÓN ABIERTA EN EL LLANO DE

ZAIDÍA: EL PLAN PARCIAL No $10(1968 / 1974)$

TORREFIEL Y ORRIOLS: EL PLAN PARCIAL No 23 (1967)

BENIMACLET: EL PLAN PARCIAL NO 22 Y EL PERI DEL SECTOR 4

CAMINS AL GRAO: EL PLAN PARCIAL No 14 (1967/1975)

351

GRAO-CABANYAL-MALVARROSA: EL PLAN PARCIAL NO 13 (1968/1974)

4.2. EL SECTOR NOROESTE

EL POLÍGONO DE CAMPANAR Y EL PLAN PARCIAL No 8 (1968/1972)

453

EL OESTE DE CAMPANAR: PLAN PARCIAL No 8-b (1968)

457

MARXALENES: EL PLAN PARCIAL No 9 (1967/1973)

485

EL ÁREA DE LA SALIDA DE ADEMÚZ: PLAN PARCIAL No 24-A (1970/1975)

497

EL ESTE DE BENICALAP: PLAN PARCIAL 24-B (1970/1975)

517

535

4.3. EL SECTOR SUROESTE

553

EL PROYECTO PARCIAL NO 25 (1967)

557

EL GRUPO ANTONIO RUEDA Y EL POLÍGONO DE LA

AVENIDA DE CASTILLA (1965/68)

PATRAIX: EL PLAN PARCIAL No 26 (1967/1973)

563

579

ENTRE LA FUENSANTA Y LA LUZ: PLAN PARCIAL No 26-B (1967)

593

LA CRUZ CUBIERTA Y SAN MARCELINO: PLANO PARCIAL No 3 (1967) 605

4.4. EL SECTOR SURESTE

621

MALILLA: LOS PLANES PARCIALES 5-B Y 5-C(1967/1973)

625

EL PLAN PARCIAL REFORMADO DEL POLÍGONO FUENTE DE SAN LUÍS (1969)

643

EL PLAN PARCIAL No 4b-16I (1968/1973) 



\section{INTRODUCCIÓN.}

\section{El orden abierto y la edificación aislada}

En esta tesis nos proponemos estudiar las áreas residenciales de edificación abierta en la ciudad de Valencia, en el período comprendido entre 1946 y 1988.

Antes de pasar a concretar el alcance y objetivos de ese estudio, así como la sistemática y fuentes del mismo, hemos considerado oportuno realizar en esta introducción una presentación preliminar del tema de la edificación abierta, presentación cuya finalidad es, exclusivamente, la de mostrar el marco general en el que se encuadrará nuestro trabajo.

Llamaremos edificación abierta, en sentido general, a aquella cuya disposición de volúmenes permite el contacto directo con el medio exterior de amplios paramentos de la misma. Esta definición sirve tanto para describir una casa unifamiliar o en hilera de dos plantas, insertas en una parcela vallada con jardín privado, como para describir un bloque colectivo de varios pisos o una torre de gran altura situados entre amplios espacios libres de carácter público.

Para Stübben y Baumeister, la edificación abierta es la constituida por edificios unifamiliares aislados, normalmente de una o dos plantas, cuya volumetría es libre siempre que se respeten unas distancias mínimas fijadas a los lindes de parcela y al frente de caIle. ${ }^{1}$ El modelo urbano que resulta de la agregación de edificación abierta de este tipo es el de la ciudad jardín, basado en la dispersión de la ciudad por su territorio circundante mediante la implantación de áreas residenciales de baja densidad.

Las áreas residenciales que nos proponemos estudiar, sin embargo, no están formadas precisamente por casas unifamiliares con jardín, sino que responden al modelo calificado por Martí como ciudad concentrada. ${ }^{2}$

El modelo de ciudad concentrada asume como datos de partida la alta densidad y la construcción de grandes edificios colectivos con viviendas de alquiler. Estos edificios pueden asumir la forma de manzanas cerradas con edificación perimetral continua y espacios libres interiores, como en las experiencias de Amsterdam, Viena o Hamburgo, o la de edificación abierta a base de bloques aislados, resultado de la agregación de células elementales de vivienda.

Martí ha puesto de relieve el hecho de que las propuestas residenciales de la cultura moderna, se caracterizan, tanto en el frente de la ciudad jardín como en el de la ciudad concentrada, por el intento de restablecer una relación equilibrada entre edificación y espacio libre que se había perdido como consecuencia de los procesos especulativos ligados a la formación de la ciudad industrial, causantes de una degradación en las condiciones de vida urbanas.

La formulación de los principios del orden abierto realizada entre 1919 y 1939, principalmente en Alemania, parte del estudio autónomo de la célula de vivienda racional, de su disección interior
1. Ver Piccinato, Giorgio, La costruzione dell' urbanistica. Germania 1871-1914, Officina Edizioni, Roma, 1977 (La construcción de la urbanística. Alemania 18711914, Oikos-Tau, Barcelona, 1993).

2. Martí Arís, Carlos, Las formas de residencia en la ciudad moderna, Servicio de Publicaciones de la UPC, Barcelona, 1991. 

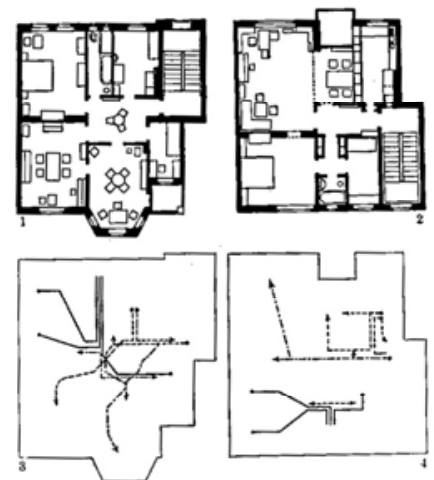

A. Klein, estudios de distribución, 1928.

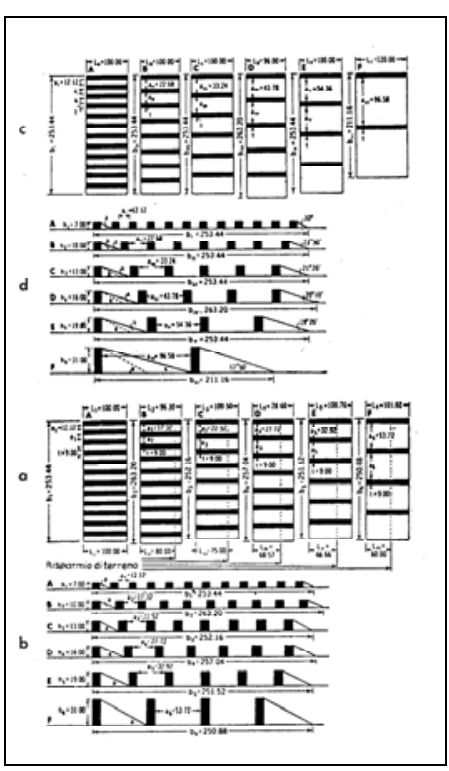

Walter Gropius. Diagramas presentados en el CIAM, Bruselas, 1930.

Ernst May Evolución de la manzana. Das Neue Frankfurt 2-3, 1930

1 Klein, Alexander, Vivienda mínima: 1906-1957, Gustavo Gili, Barcelona, 1980. Aymonino, Carlo, ed., Lábitazione razionale: atti del congressi CIAM 1929-1930. Marsilio, Padova, 1971 (La vivienda racional. Actas de los congresos CIAM, Gustavo Gili, Barcelona, 1973). para racionalizar los usos y la distribución. Trabajos como los de Alexander Klein o los presentados en el CIAM de Frankfurt de 1929, permiten establecer los requisitos funcionales para la vivienda racional de bajo coste. ${ }^{1}$

Las bases para la organización racional de la vivienda mínima racional (existenzminimum) son la definición de nuevas condiciones distributivas, agrupando y ordenando los usos internos, la fijación de estándares mínimos óptimos de superficie y cubicación, estableciendo dimensiones mínimas de las piezas y parámetros de iluminación, ventilación y soleamiento, así como la definición precisa del equipamiento de los núcleos fijos de cocina y baño.

El edificio-tipo se compone a partir de la agregación de viviendas-tipo. El bloque agrupa racionalmente las células de vivienda, permitiendo una óptima distribución interior de las mismas y una adecuada orientación, soleamiento y ventilación de las piezas habitables, todas ellas recayentes al exterior. La vivienda queda así liberada de la tiranía de las alineaciones de calle, de las medianerías y de los patios de luces, y puede proyectarse de dentro afuera, desde sus propias leyes internas. $Y$ puede, al mismo tiempo, asentarse entre amplias zonas verdes. Es el final de la distinción entre interior y exterior, entre público y privado, del decoro que imponía la fachada pública a la calle en la manzana perimetral, pero también es el principio de la vivienda digna para todos, que incorpora una serie de mejoras fundamentales en las condiciones de habitabilidad.

En un célebre artículo publicado en 1930 en la revista Das Neue Frankfurt, Ernst May sintetiza de forma magistral, con cuatro dibujos, la evolución de la manzana. El primer dibujo muestra la manzana densa y compacta del siglo XIX, con patios de luces y viviendas que o bien son muy profundas o bien, en los modelos más especulativos, se reparten en viviendas recayentes a calle y viviendas que sólo disponen de fachada a los patios interiores.

En el segundo dibujo, vemos algo similar a unas manzanas de Amsterdam, con espacios libres interiores y un perímetro edificado continuo formado por viviendas pasantes. En el mismo espacio que ocupaba la manzana densa aparecen ahora varias manzanas de menor tamaño. La disminución de tamaño es una consecuencia lógica de la disminución de la profundidad edificable de las viviendas, y implica que aparezcan más calles de las que eran necesarias en la manzana intensiva del XIX.
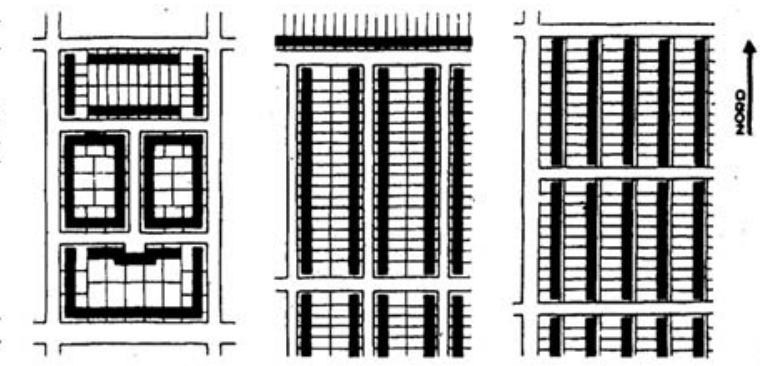
En el tercer dibujo, el tamaño de la manzana crece con respecto al anterior, pero es menor que el de la manzana del XIX, aproximadamente como si la partiéramos por la mitad longitudinalmente. La manzana, mucho menos densa, deja de estar edificada en todo su perímetro: desaparecen sus lados cortos y pasa a estar formada por dos hileras paralelas de casas orientadas en dirección Norte-Sur, con un espacio interior parcelado asociado las viviendas. Es el modelo presente en conjuntos como Kiefhoek, Praunheim o Römerstadt.

En el cuarto dibujo, por último, aparece representado con toda claridad el principio de la edificación en línea o zeilenbau: las hileras dejan de estar agrupadas de dos en dos a ambos lados de una calle y pasan a ser autónomas, dispuestas en dirección NorteSur y con acceso a cada bloque desde un paso peatonal paralelo al mismo. Las calles, perpendiculares a las hileras, quedan reducidas a mero canal de tráfico rodado. Es el caso de las siedlungen Westhausen o Bad-Dürrenberg.

La independencia entre los edificios y la alineación de la calle, tanto para las casas en hilera como para los edificios altos, adquiere la consideración de postulado urbanístico en 1930, en el $3^{\circ}$ CIAM de Bruselas, titulado Formas construidas y formas del suelo.

Herbert Boehm y Eugen Kaufmann, en su ponencia presentada a ese Congreso, plantean, como alternativa al modelo de urbanización en doble hilera propio de las siedlungen, un modelo de urbanización con hileras simples, equidistantes, transversales a las calles. Este modelo, que es el de la denominada edificación en línea o zeilenbau, es considerado el único capaz de garantizar una absoluta igualdad de todas las viviendas en cuanto a orientación y disfrute de espacio libre, además de permitir una construcción industrializada.

Por su parte, Walter Gropius, en la célebre conferencia titulada ¿Edificación alta, media o baja?, expone dos esquemas gráficos que relacionan, en un conjunto residencial formado por bloques paralelos, los parámetros de densidad de viviendas, altura de los edificios y distancia entre ellos. El segundo esquema muestra que, para una densidad de viviendas constante, cuanto mayor es la altura de los edificios, mejores condiciones tienen las viviendas en cuanto a soleamiento y más suelo queda disponible para espacios verdes. Con todo ello queda abierto el camino a lo que hoy llamamos bloque de edificación abierta con espacios verdes públicos a su alrededor, que será la célula base para, por agregación, construir la ciudad de la arquitectura moderna.

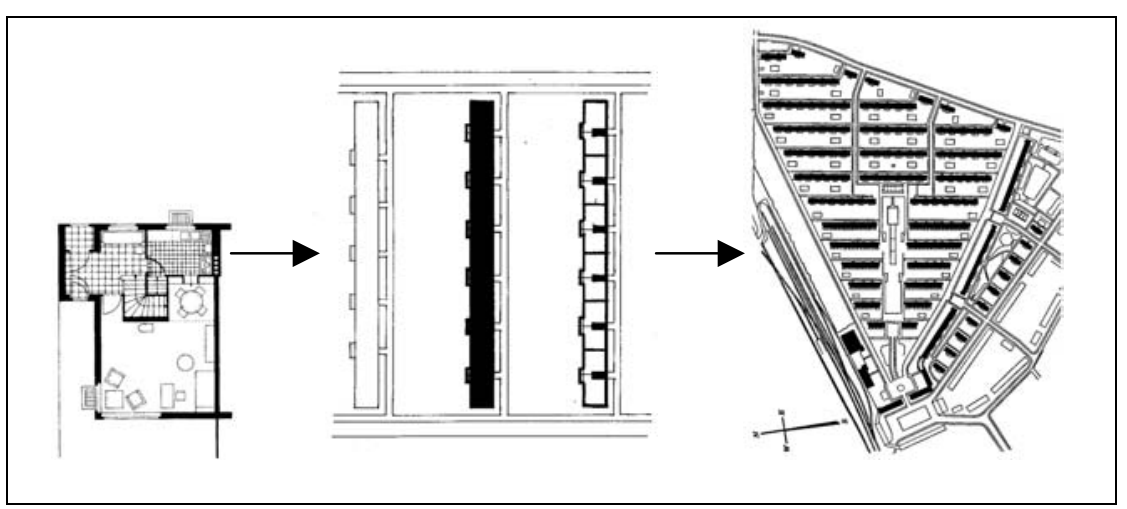

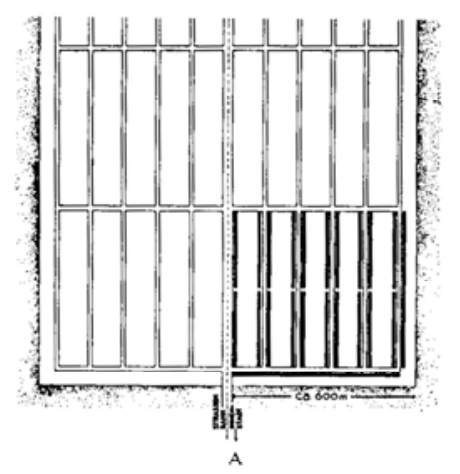

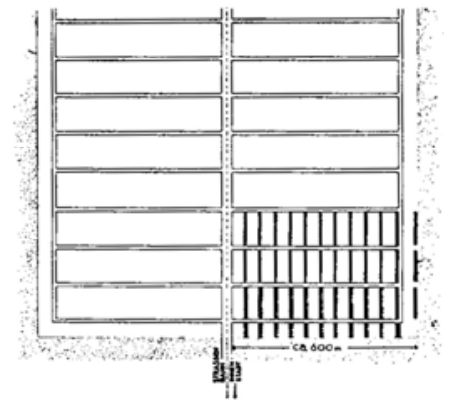

E. Boehm, E. Kaufmann. Diagramas presentados en el CIAM, Bruselas, 1930.

Composición por agregación: célula de vivienda-bloquebarrio. Siedlung Bad Dürrenberg, A. Klein, 1930. 


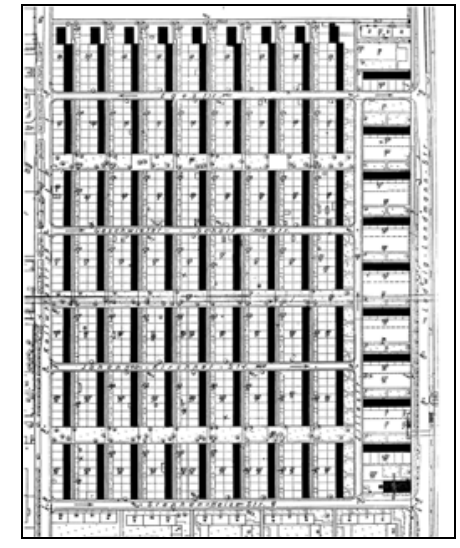

Westhausen (Frankfurt, 192931) E. May, E. Kaufmann, F. Kramer, O.Fuster, F. Schüster.

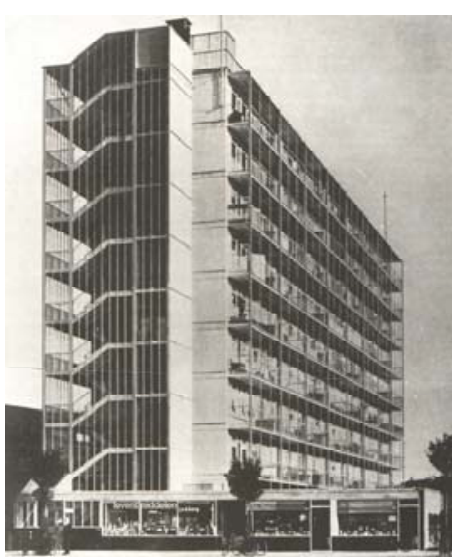

Edificio Bergpolder (Rotterdam, 1933-34), W. Van Tijen, J.A. Brinkmann y L.C. Van der Vlugt.
El modelo del zeilenbau o edificación en línea, en el que los bloques se disponen en posición transversal con respecto a las calles y equidistantes entre sí, aparece tanto en los conjuntos de casas en hilera como en los de casas de pisos o bloques de altura media. En el primer caso, la subdivisión del suelo en parcelas valladas permite reconstruir el plano del suelo, agrupando las hileras de dos en dos. En el segundo caso, la tendencia será a que el espacio entre los bloques se acabe convirtiendo en un espacio verde público, que ocupa todo el terreno sin edificar.

En un primer momento, las realizaciones urbanísticas del movimiento moderno consistían básicamente en conjuntos de viviendas unifamiliares (las colonias o siedlungen) cuyo modelo de ocupación de suelo era idéntico al de la ciudad-jardín, aunque con predominio de la hilera frente a las casas aisladas o pareadas, es decir, con los edificios en paralelo (aunque retrasados) a la alineación de calle, a modo de manzanas rectangulares edificadas únicamente en sus lados largos.

Por otra parte, la dificultad para introducir el ascensor en los edificios de vivienda de promoción pública llevó a que el tipo óptimo según Gropius, es decir, la slab house o bloque lineal alto dotado de servicios colectivos, no pasara en este periodo inicial de prototipo de laboratorio, con alguna notable excepción como los bloques Bergpolder y Plaslaan (Rotterdam, 1933-34) de W. Van Tijen, J.A. Brinkmann y L.C. Van der Vlugt o el Highpoint (Londres, 1934-35), de Berthold Lubetkin y Tecton.

En cambio, el tipo de bloque lineal de altura media, cuyo prototipo es la casa en línea de Mies Van der Rohe en la Weissenhof (1927), fue el habitual en numerosas realizaciones de conjuntos residenciales, entre las que podmeos destacar la siedlung FriedrichEbert-Ring (Rathenow, 1930) de Otto Haesler, la Siemensstadt (Berlín, 1930), de Scharoun, Gropius y Bartning, el barrio Dammerstock (Karsruhe, 1928), de Gropius, el Bad Dürrenberg (Dresde, 1930) de A. Klein y la siedlung Westhausen (Frankfurt, 1929-31) de E. May.

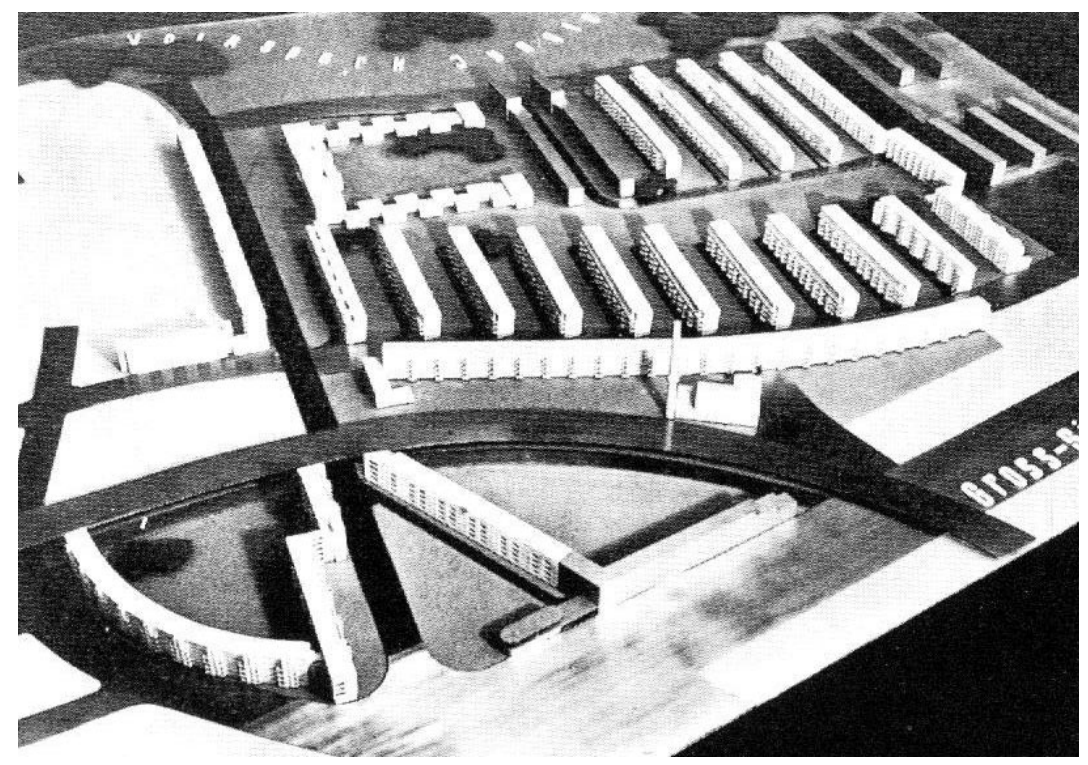


Sin embargo, el zeilenbau plantea algunos problemas de índole urbana. El primero de ellos es el de la desaparición de la calle entendida como recorrido lineal con calzada central para el tráfico rodado y dos aceras laterales para dar acceso a las viviendas que se sitúan a ambos lados de la misma. En lugar de ello, tenemos un simple camino peatonal que da acceso a viviendas sólo a un lado. Al mismo tiempo, se genera una multitud de espacios verdes igual de seriados y monótonos que los edificios, y todos ellos de carácter público: desaparece la diferenciación entre espacios libres interiores de manzana y espacios libres exteriores.

Por otro lado, dentro de un bloque lineal la esquina es una anomalía que es preciso extirpar, un tipo de vivienda que se sale de la norma establecida en las células tipo. En la edificación en línea desaparece, por ello, el lado corto de la manzana holandesa, que queda abierto, dejando a la vista dos testeros, ciegos por lo general. El edificio producido en serie es, por tanto, como un perfil de acero laminado, que se corta cuando llegamos al final del espacio disponible.

Existen, sin embargo, propuestas residenciales alternativas al zeilenbau, en las que, sin dejar de recurrir a bloques compuestos a partir de células tipo de vivienda racional, se aportan fórmulas para integrar la edificación abierta en una disciplina urbana, lo que supone, como en todo compromiso, renunciar a algunos principios.

Podemos señalar tres estrategias para recomponer o reinterpretar la manzana urbana partiendo de la utilización del bloque lineal como elemento básico de composición de la misma:

a) La reconstrucción del lado corto de la manzana, plegando el bloque lineal para formar una $L$ o una $U$, como en el caso de la siedlung Carl Legien (Berlín, 1925-30) de Taut, o bien uniendo los bloques lineales de dos en dos con una edificación del espacio intermedio entre ellos que puede adoptar formas diversas: un núcleo de escalera y ascensores en los Immmeubles-Villas (París, 1922-25) de Le Corbusier o una torre en la Cité de la Muette (Drancy, 191932-34) de Beaudoin y Lods.

b) El bloque a redent, extensión del sistema anterior para formar una edificación continua grecada, que queda en parte alineada y en parte retranqueada con respecto a las calles circundantes. La Casa-Bloc (Barcelona, 1934-36) de Sert y los apartamentos Nirwana (La Haya, 1927) de Duiker son dos ejemplos notables de esta solución.

c) La manzana híbrida, en la que se unen los bloques lineales de dos en dos al superponerlos a un zócalo de edificación cerrada. Es el modelo planteado por Hilberseimer en su propuesta para la Ciudad vertical de 1927.

La Ciudad Vertical se distingue de todas las demás propuestas urbanísticas de su época por ser el único modelo en el que la residencia y el trabajo no están separados, sino superpuestos en edificios de carácter mixto, en los la residencia se asocia al orden abierto de los bloques y el trabajo al orden cerrado de la manzana. ${ }^{1}$

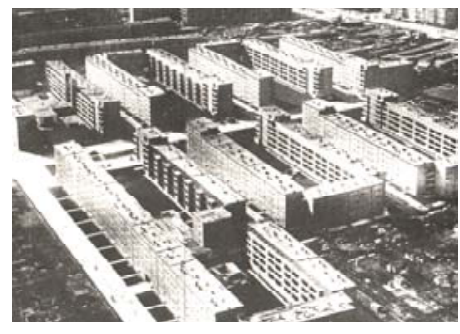

Reconstrucción del lado corto de la manzana: Carl Legien. Berlín, 1925-30. Bruno Taut, Max Hilligen.

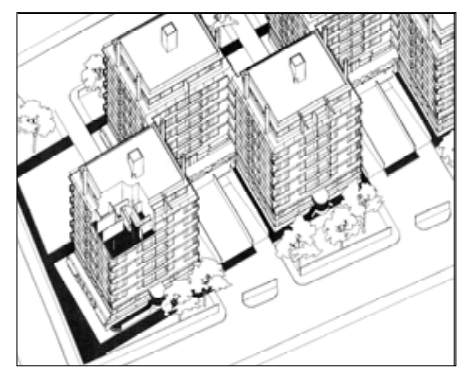

Edificación a redents: Apartamentos Nirwana (La Haya, 1927), Johannes Duiker..

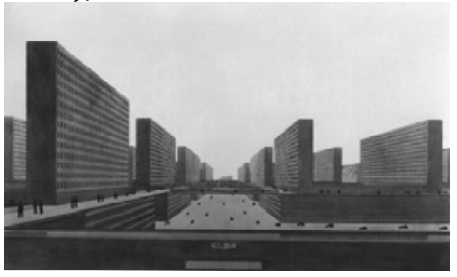

Manzana híbrida: Ciudad vertical. Ludwig Hilberseimer, 1927.

1. Para una exposición más detallada de los sistemas de reformulación de la manzana a partir del bloque, ver Pérez Igualada, Javier, Manzanas, bloques y casas. Formas construidas y formas del suelo en la ciudad contemporánea, Universidad Politécnica de Valencia, Valencia, 2003. 


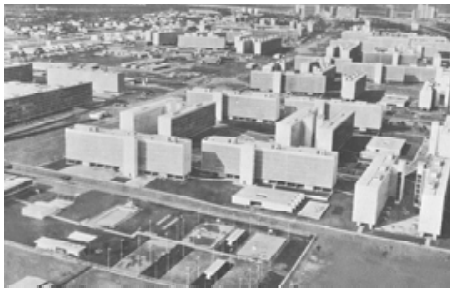

Manzana residencial, Brasilia, 1955-58. Oscar Niemeyer

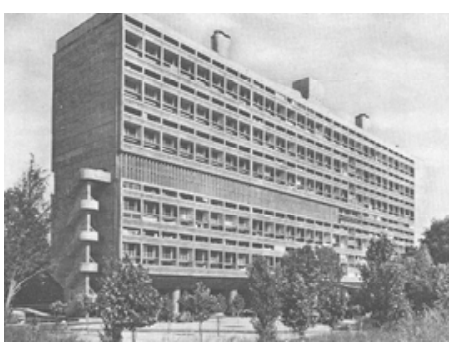

Unité d'habitation. Marsella, 1947-52. Le Corbusier.

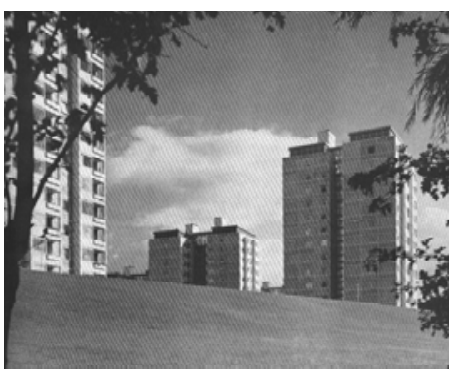

Bellahöj.Copenhague, 1950-56 Mogens Irming y Tage Nielsen.

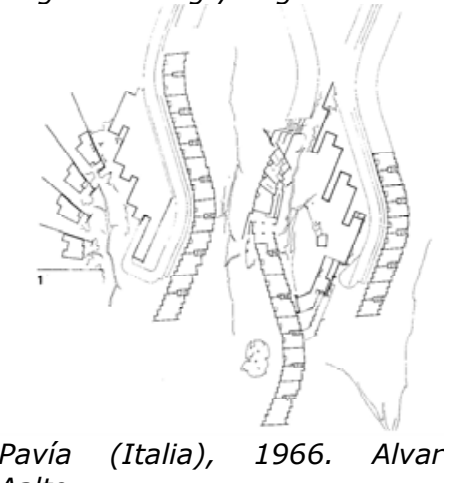

Aalto.

Hansaviertel. Interbau 1957. Berlín.
Durante el IV CIAM, celebrado a bordo del Patris II en 1943 y centrado en el tema de la ciudad funcional, se redactó la Carta de Atenas, que establece los principios del urbanismo funcionalista.

Tras el paréntesis de la II Guerra Mundial, la continuidad del orden abierto marca la etapa comprendida entre 1945 y 1965, en la que se realizan de forma masiva conjuntos residenciales que desarrollan los tipos ya prefigurados en el periodo de entreguerras.

Los principios del orden abierto, progresivamante incorporados a la práctica profesional y a la propia legislación, se aplicarán a todos los ámbitos del urbanismo: la reconstrucción de las áreas destruidas, la construcción de nuevos conjuntos residenciales alrededor de los grandes núcleos urbanos (como los barrios de Slotermeer o Slotervaart en Amsterdam), y la creación de nuevas ciudades (como las new towns inglesas de Harlow, Basildon, Runcorn, Cumbernauld o Milton Keynes, o las de Tapiola en Helsinki, Vallingby en Suecia, Farsta en Dinamarca, así como en las nuevas capitales Brasilia y Chandigarth).

En este periodo, los sistemas tradicionales de agrupación de baja densidad, como las casas en hilera o las casas-patio, siguen utilizándose con regularidad, en especial en las new towns y en las ciudades-jardín escandinavas.

Los bloques lineales de altura media perderán la rigidez y uniformidad de la edificación en línea de los años 30, pero también se abandonará, por lo general, cualquier intento de reformulación de la manzana a partir del bloque. La manzana perimetral, salvo excepciones como la del proyecto de Perret para Le Havre, sencillamente dejará de utilizarse en los proyectos de unidades residenciales.

Igualmente, y en coherencia con la doctrina de la zonificación de las funciones urbanas expresada en la Carta de Atenas, la vía abierta por Hilberseimer en su propuesta para la Ciudad Vertical no tendrá continuidad: la manzana mixta o híbrida no encaja en esa doctrina.

Los edificios altos aislados, en forma de bloques o de torres, insertos en amplios espacios verdes, que en los años 30 eran un ideal que se realizó sólo en contadas ocasiones, conocen una etapa de esplendor, y se emplearán como elemento base de numerosas realizaciones, que tendrán en la Unité $d$ 'Habitation de Le Corbusier su modelo de referencia más influyente.

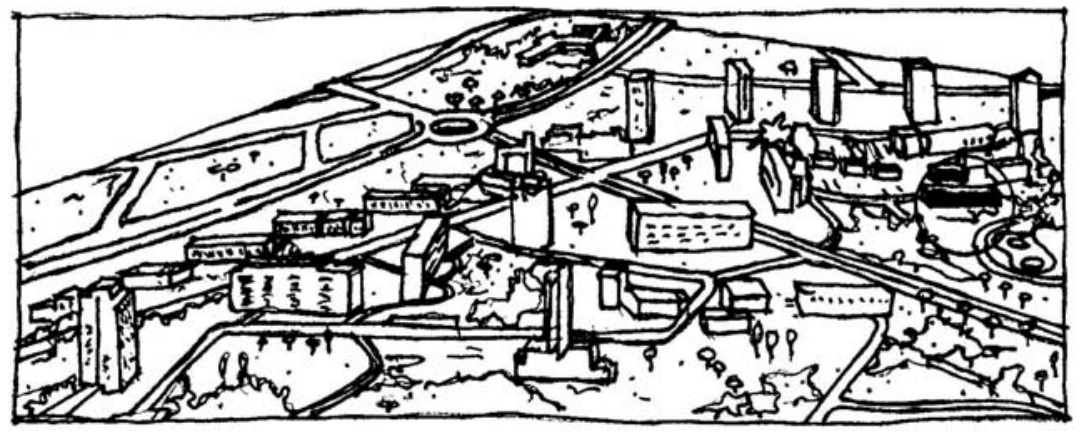


Al mismo tiempo, los desarrollos residenciales mixtos (mixed developement), teorizados por Bakema y van den Broek, aportarán una búsqueda de variedad dentro del orden abierto, variedad que se obtiene mediante la combinación de edificios de diferentes alturas y tipologías en un mismo conjunto urbano.

Las agrupaciones elementales de edificios en línea de los años 20 dejan paso, por tanto, a composiciones mucho más elaboradas. La investigación en torno a la vivienda y sus sistemas de agregación continúa la iniciada en el período de entreguerras, y la nueva ciudad de la arquitectura moderna empieza a contar con una serie cada vez más abundante de realizaciones.

El Hansaviertel, conjunto residencial construido para la exposición Interbau de Berlín de 1957 representa fielmente los principios del orden abierto, con sus edificios aislados de diversos tipos asentados en amplios espacios verdes.

A partir de los años sesenta, algunos postulados urbanísticos del Movimiento Moderno empiezan a ser revisados críticamente. El ala heterodoxa de la modernidad, representada por los arquitectos vinculados al Team $X$, sin embargo, plantea todavía una crítica desde dentro, que pretende introducir cambios y mejoras en la doctrina, pero que no la abandona radicalmente, como ocurrirá más adelante: el orden abierto sigue vigente. Esa revisión crítica llevará a una fragmentación del bloque hasta entonces sin fisuras de la doctrina funcionalista, y a la proliferación de posiciones diversas ante el proyecto urbano.

El colapso del orden abierto va asociado, finalmente, a un incremento de complejidad insostenible, a una ambición sin límites que lleva a concebir el proyecto urbano como un proyecto de arquitectura de escala gigante. Los dinosaurios del movimiento moderno son barrios como el de Toulouse le Mirail en Francia, el Biljmermeer en Amsterdam, o los de Markisches Viertel y Gropiusstadt en Berlín.

Tanto las megaestructuras como la vía hipertecnológica de Archigram resultarán finalmente callejones sin salida, que acabarán devolviendo las propuestas urbanas de la modernidad a su punto de partida de los años 20: a la esfera de la utopía inicial.

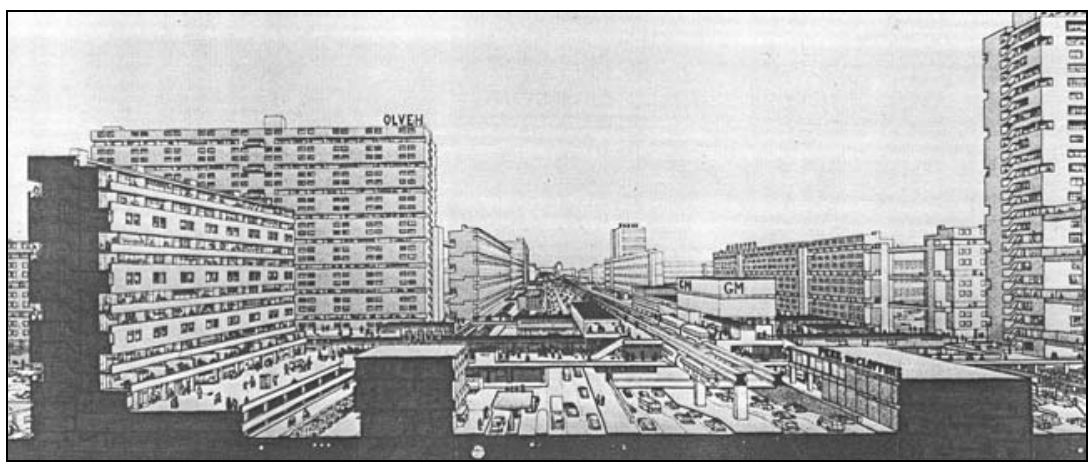

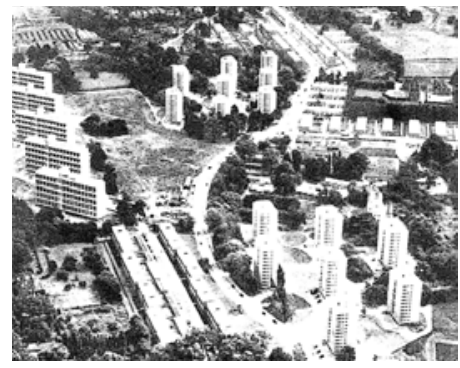

Roehampton, Sector Oeste. Londres, 1952-59. London County Council (LCC), Willian Howell, Stanley Amis y John Killick.

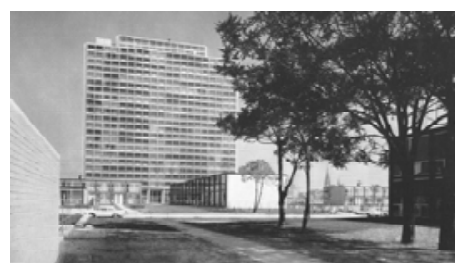

Lafayette Park. Detroit, 195563. L. Mies van der Rohe, $L$. Hilberseimer.

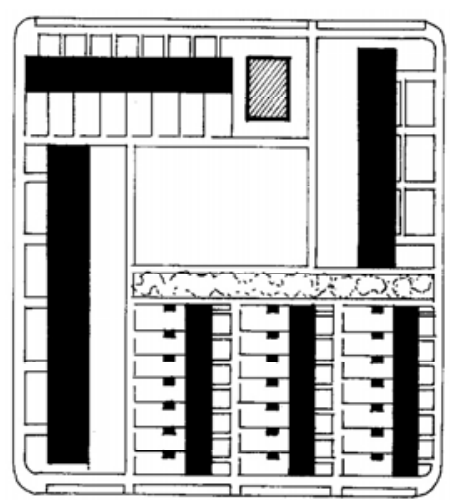

Klein Driene. Hengelo, 195658. Bakema-Van den Broek.

Plan Pampus. Amsterdam, 1965. Bakema-Van den Broek. 


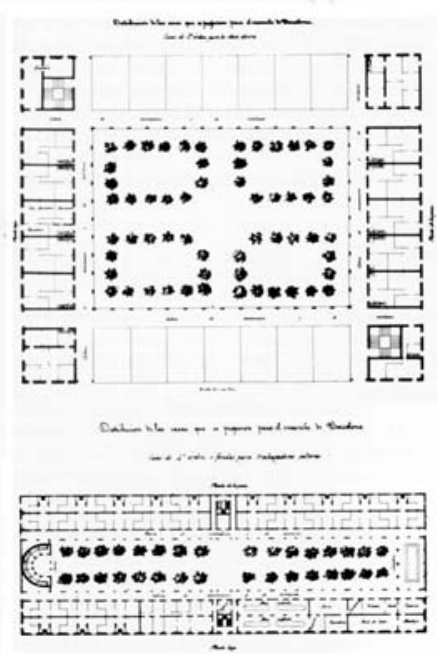

I. Cerdá. Casas para la clase obrera del Anteproyecto de Ensanche de Barcelona de 1855

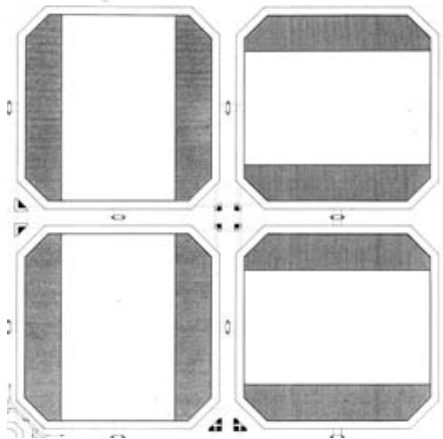

I. Cerdá. Manzanas tipo del Proyecto de Ensanche de Barcelona de 1859.

1. En relación con Cerdá, ver Sabaté Bel, Joaquín, "De la casa aislada a los bloques y la manzana cerrada en el proyecto Cerdá", Historia Urbana, 4, Valencia, 1992 y Serratosa i Palet, Albert, Com., Tarragó i Cid, Salvador, Dir., Cerdà. Urbs $i$ territori. Una visió de futur. Catálogo de la Muestra, Fundació Catalana per a la Recerca, Electa, Barcelona, 1994.

2. Zuazo, Secundino y Jansen, Hermann, Anteproyecto del trazado viario y urbanización de Madrid (Estudio preliminar de Lilia Moure Rubio), Colegio Oficial de Arquitectos de Madrid, 1986. Ver también Sambricio, Carlos, Moure, Lilia y Ezquiaga, José Ma, Madrid, urbanismo y gestión municipal 1920-1940, Ayuntamiento de Madrid, Área de Urbanismo e Infraestructuras, Gerencia Municipal de urbanismo, Madrid, 1984.

\section{La edificación abierta en España.}

Dentro del modelo de la ciudad concentrada, las propuestas para el Ensanche de la ciudad de Barcelona realizadas por Ildefonso Cerdá pueden adscribirse ya al orden abierto. En el Anteproyecto de Ensanche de 1855, Cerdá engloba la edificación en dos categorías: casas para la clase obrera, formadas por agrupaciones de bloques de dos o tres plantas alrededor de un gran patio central, y casas con jardines intercalados, aisladas, pareadas o agrupadas en hileras cortas, destinadas a la clase burguesa. Posteriormente, en el proyecto de 1859 para el Ensanche de Barcelona, la edificación se dispone en forma de bandas o bloques de unos 20 metros de profundidad que ocupan dos o tres lados de su característica manzana achaflanada, y que serían finalmente sustituidos por una edificación perimetral continua también profunda ${ }^{1}$.

La importación de las teorías urbanísticas formuladas en Europa en el periodo de entreguerras se produce en España a partir de 1929, principalmente a través sobre de los trabajos de Secundino Zuazo en Madrid y del GATEPAC en Barcelona.

En el Anteproyecto de trazado viario y urbanización de Madrid, memoria presentada por Zuazo, junto con el profesor Hermann Jansen de la Escuela de Charlotenburgo de Berlín, al Concurso Internacional celebrado en 1930 para la extensión de Madrid, se formalizan diversas propuestas residenciales enraizadas en el orden abierto. La gran aportación de este proyecto está, según Moure, en el planeamiento de la ciudad en función de la habitación como célula generadora ${ }^{2}$.

De estas propuestas, algunas, como la manzana abierta de la "Casa de las Flores", buscan una solución de la vivienda colectiva dentro de la trama del ensanche. Otras plantean una reforma interior de carácter radical en el centro histórico, sustituyendo las viviendas insalubres de las manzanas por agrupaciones de bloques lineales. En otras, como la de prolongación de la Castellana, la edificación abierta es el soporte de un eje de vertebración y extensión de la ciudad. Esta extensión se planteaba de acuerdo con una zonificación estricta, que diferenciaba zonas de viviendas de lujo, zonas de viviendas de clase media y zonas de vivienda popular.
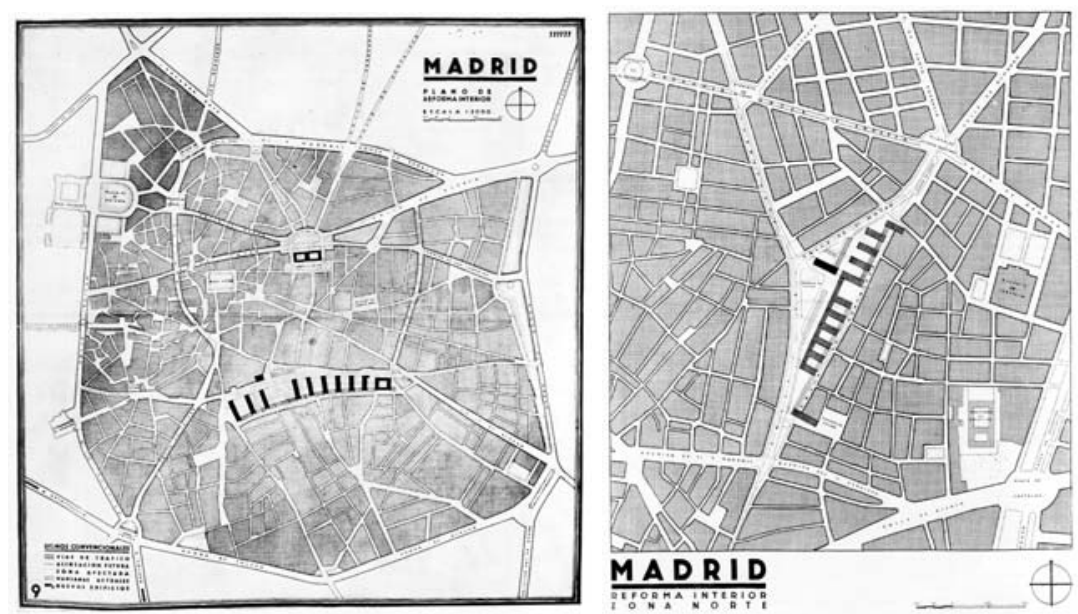

Zuazo- Jansen. Propuestas de reforma interior. Anteproyecto de trazado viario y urbanización de Madrid, 1930. 


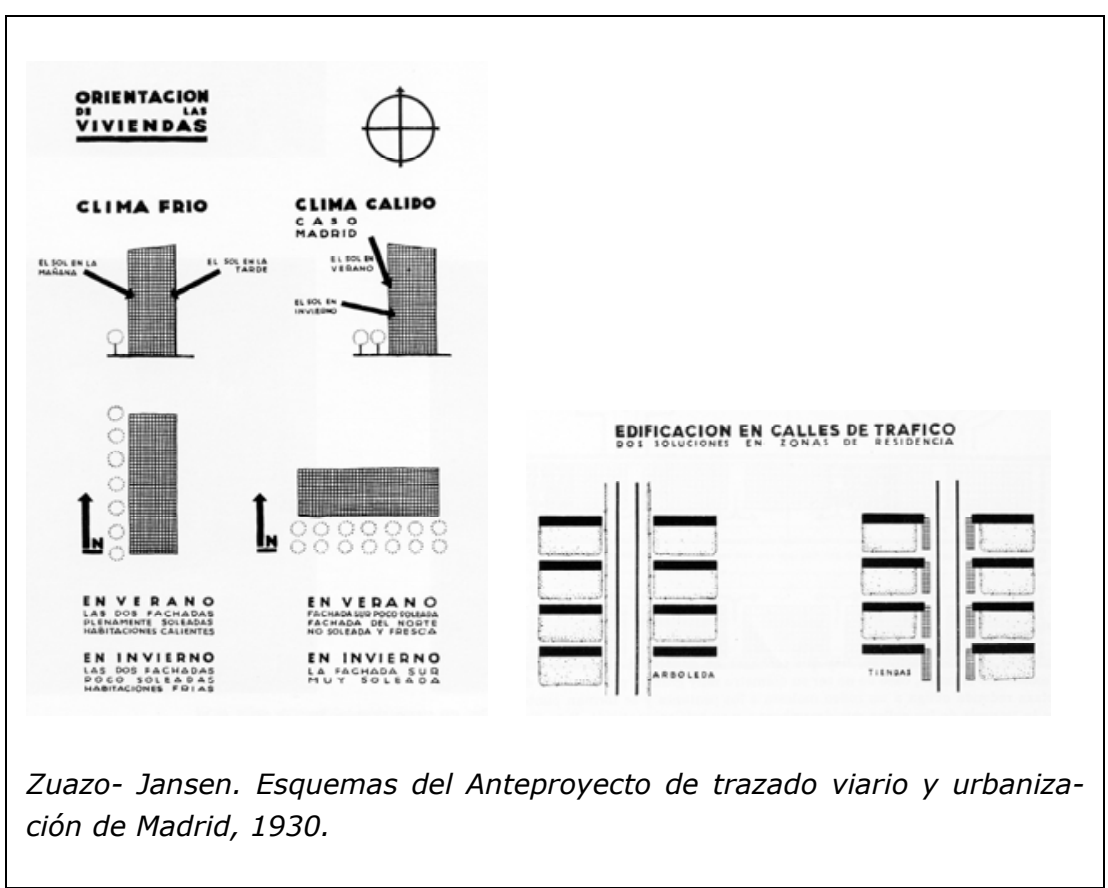

Zuazo no se limita a adoptar sin más el sistema de edificación en línea sino que plantea variantes interesantes al mismo. Así, en un esquema relativo a la orientación de las viviendas, contrapone la habitual disposición según la directriz norte-sur de los bloques lineales de los proyectos europeos, adecuada para los climas fríos, a la que considera adecuada para los climas cálidos como el español, que es la directriz este-oeste (con fachadas a norte y sur). En otro esquema, propone que los bloques lineales ortogonales a las calles de tráfico se combinen con cuerpos bajos de edificación comercial alineados con la calle.

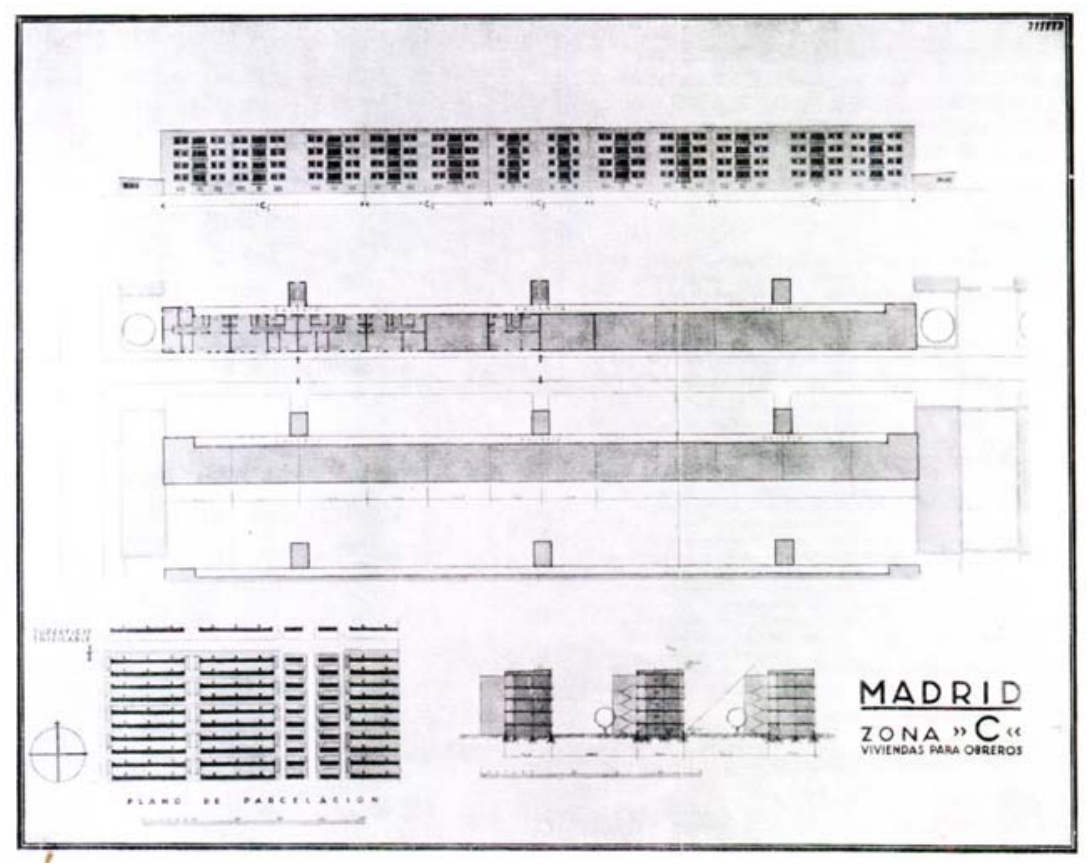

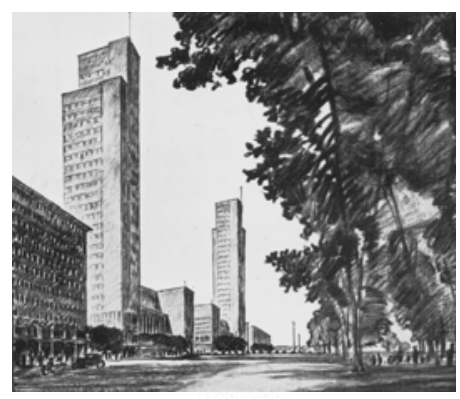
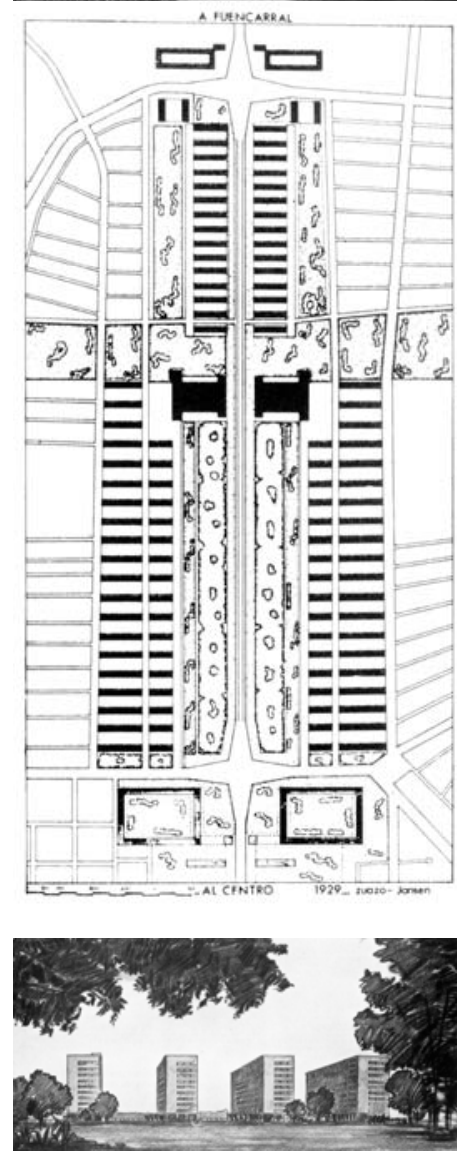

Zuazo-Jansen. Proyecto de prolongación de la Castellana, Planta y perspectivas, Madrid, 1930.

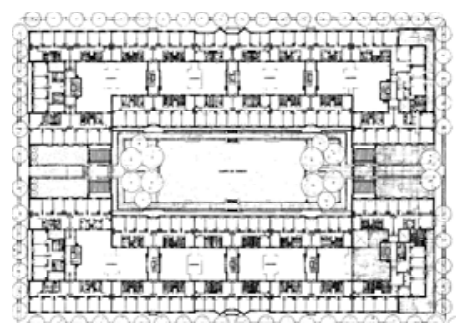

S. Zuazo. Casa de las Flores, Madrid, 1931.

Zuazo- Jansen. Viviendas para obreros. Anteproyecto de trazado viario y urbanización de Madrid, 1930 


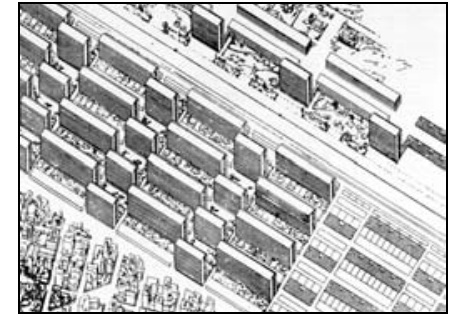

Proyecto para la urbanización de la diagonal. Barcelona, 1930-31. GATCPAC.
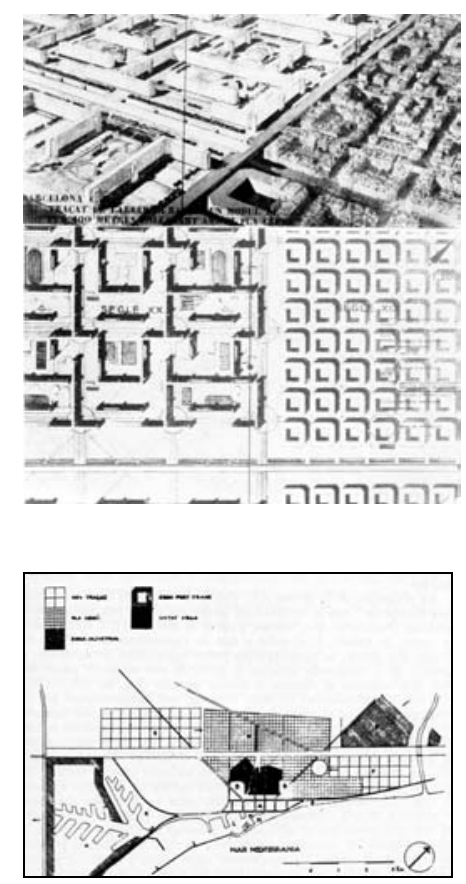

Plan Maciá, Barcelona, 193335, GATCPAC.

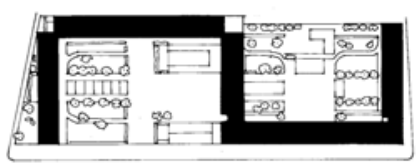

Casa-bloc. Barcelona, 1934-36. Josep Lluís Sert, Joan B. Subirana, Josep Torres Clavé.

1. A.C. Documents d'Activitat Contemporánea, revista del GATEPAC, Barcelona, 1931-37. Reedición facsímil, Gustavo Gili, Barcelona, 1975. Ver también Torres i Capell, Manuel de, La formació de la Urbanística Metropolitana de Barcelona. L'Urbanisme de la diversitat, Mancomunitat de Municipis de l'Àrea Metropolitana de Barcelona, Barcelona, 1999.

2. Ver Bidagor Lasarte, Pedro, "Situación general del Urbanismo en España. 1939-1964", Arquitectura, 62, Madrid, 1964.
El GATEPAC. (Grupo de Artistas y Técnicos para el progreso de la Arquitectura Contemporánea, asociación de arquitectos constituida en Zaragoza en 1930 y vertebrada en tres grupos regionales, tenía como objetivo principal el de difundir las teorías y realizaciones de la arquitectura moderna, en su condición de grupo español representante del CIRPAC (Comité International pour la Réalisation des Problemes Architecturaux Contemporains), fundado a su vez en la célebre reunión del castillo de La Sarraz de 1928. Para ello se publicó entre 1931 y 1937 la revista A.C. (Documentos de Actividad Contemporánea), cuyo formato estaba claramente inspirado en el de $L$ 'Esprit Nouveau de Ozenfant y Le Corbusier. ${ }^{1}$

El Grupo Este o grupo catalán del GATEPAC, integrado entre otros por Jose Luís Sert y Josep Torres Clavé, es responsable de la mayoría de las obras y proyectos de la asociación, como el de la Ciudad de Reposo y Vacaciones de 1929-34, el plan de urbanización de la diagonal de Barcelona de 1930-31 y otros realizados en colaboración con el propio Le Corbusier, como el Plan Maciá para Barcelona de 1932-34 o el proyecto de remodelación de una manzana del ensanche de 1933. La realización más importante del GATEPAC es la denominada casa-bloc de Sert, Torres Clavé y Subirana, construida entre 1934 y 1936, que es un ejemplo único de adaptación del sistema de edificación a redents preconizado por Le Corbusier a una manzana urbana.

En el periodo inmediatamente posterior a la guerra civil, entre 1938 y 1941, se crearon en España varios organismos centrales relacionados con la reconstrucción, la vivienda y el urbanismo: la Dirección General de Regiones Devastadas, el Instituto Nacional de la Vivienda (I.N.V.), la Dirección General de Arquitectura, la Junta de Reconstrucción de Madrid, el Instituto Nacional de Colonización y la Obra Sindical del Hogar y la Arquitectura. ${ }^{2}$

Los proyectos de Regiones Devastadas o del Instituto Nacional de Colonización suponen un repudio del urbanismo racionalista en favor de una vuelta a la tradición de la ciudad jardín, apoyada en una arquitectura por lo general de corte historicista.

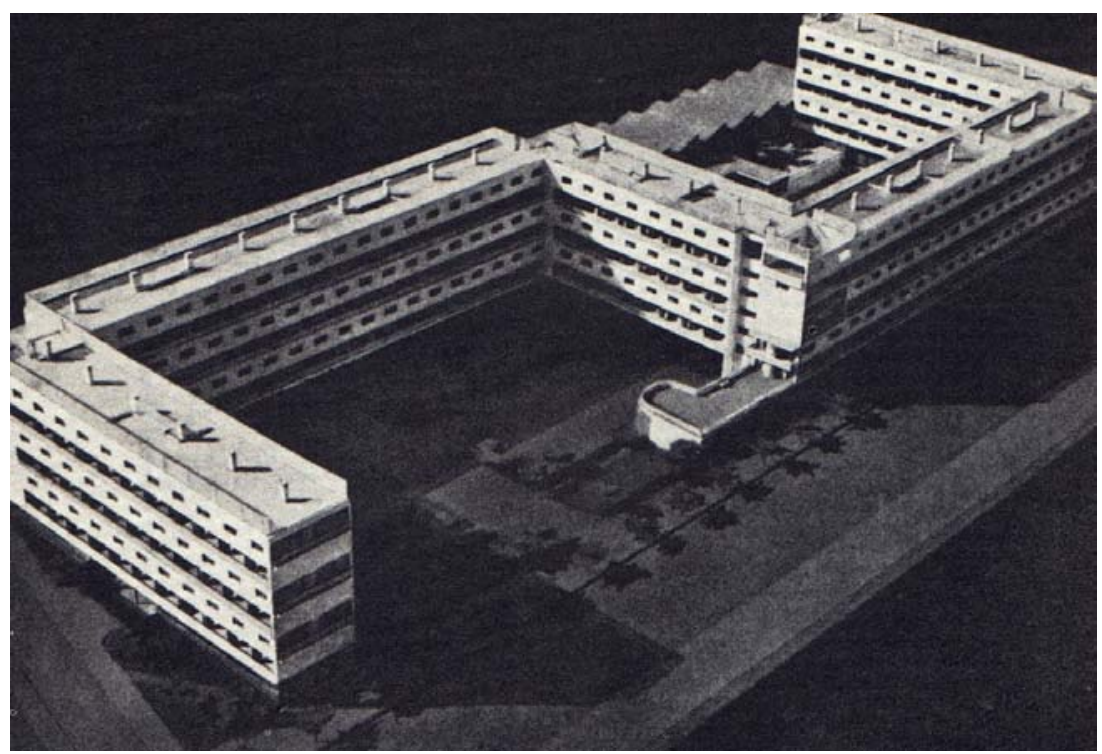


En este periodo, las ordenanzas arquitectónico-urbanísticas redactadas en 1942 por el I.N.V. para reglamentar la construcción de viviendas de protección oficial, con su defensa del bloque de dos crujías y de la disolución de la edificación abierta en la naturaleza, son, como señala Terán, un singular documento técnico alineado con las corrientes urbanísticas internacionales, que se afianzan progresivamente en España a partir de 1953, con el final del periodo autárquico y la apertura del país al exterior. El VIII congreso CIAM, celebrado en 1951 en Hoddeson, dedicado al tema del "Corazón de la Ciudad" y dirigido por Josep Lluís Sert, tuvo, según Terán, una gran infuencia en relación con la difusión en España de los principios urbanísticos asociados al orden abierto. ${ }^{1}$

Los episodios legislativos que señalan el cambio de orientación en materia de urbanismo son el Plan Nacional de la Vivienda de 1954, la Ley de Viviendas de Renta Limitada de 1954, la de Viviendas Subvencionadas de 1957, la Ley de Régimen del Suelo y Ordenación Urbana de 1956 , en la que se define el carácter y contenido documental del Plan Parcial como figura de planeamiento $y$, finalmente, la creación del Ministerio de la Vivienda en 1957 y de la Gerencia de Urbanización, dependiente del mismo, en 1959.

En Madrid, a principios de los años cincuenta, la edificación abierta está ya presente, de modo aún titubeante, en algunos planes parciales de desarrollo del Plan General de 1942 de Bidagor. Terán señala que la torpeza compositiva que muestran estos planes pone de manifiesto la novedad del orden abierto y el carácter de ejercicio de aprendizaje que tienen. ${ }^{2}$

Los dos episodios que marcan, según Terán, el cambio de orientación en la morfología volumétrica del planeamiento parcial dominante a lo largo de los años cincuenta son, en primer lugar, las propuestas presentadas al concurso para la ordenación del Centro Comercial de la Avenida del Generalísimo (1954) y, en segundo lugar, la experiencia de los "poblados dirigidos", programa de construcción de nuevos barrios periféricos destinados a eliminar el chabolismo.
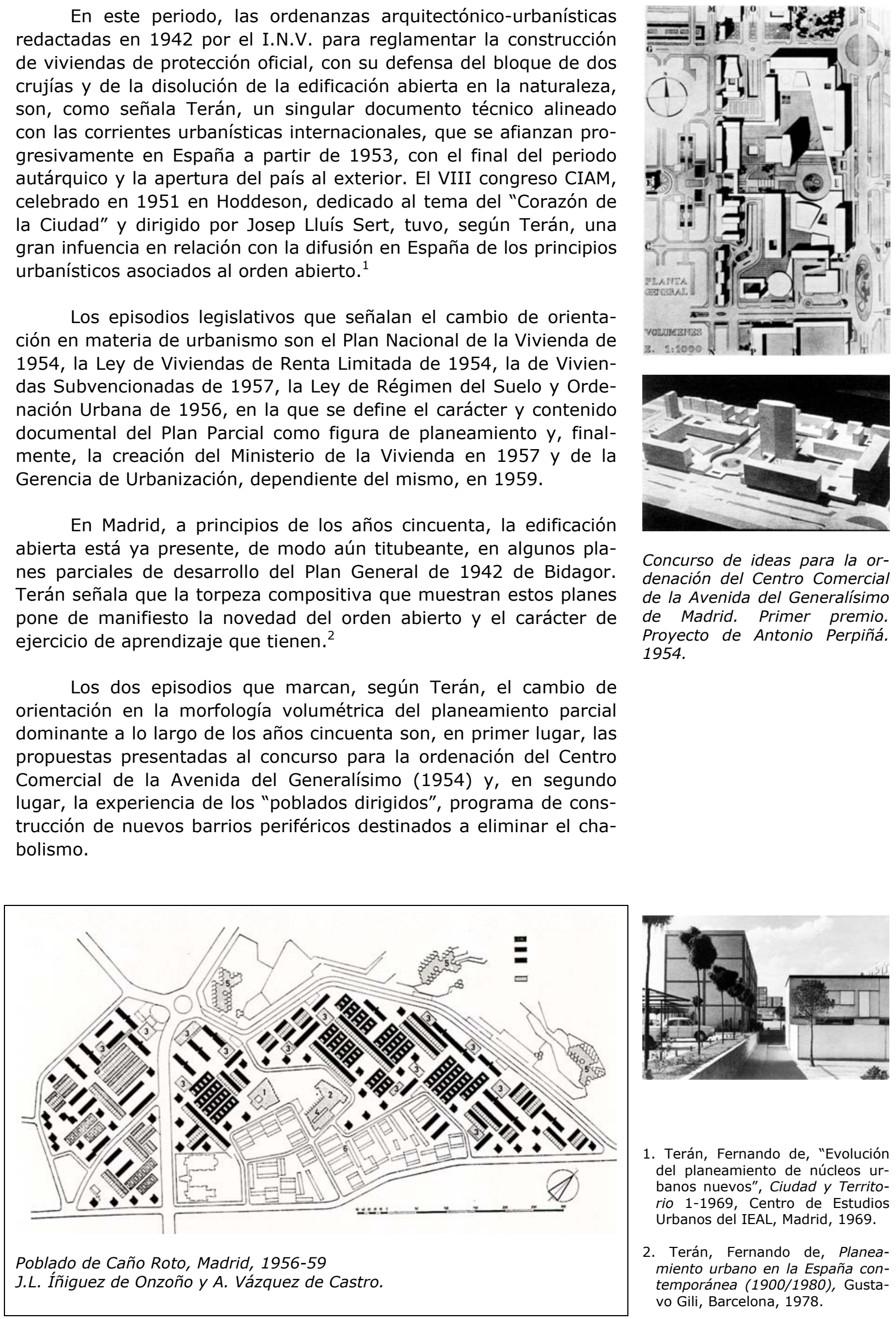

Concurso de ideas para la ordenación del Centro Comercial de la Avenida del Generalísimo de Madrid. Primer premio. Proyecto de Antonio Perpiñá. 1954.

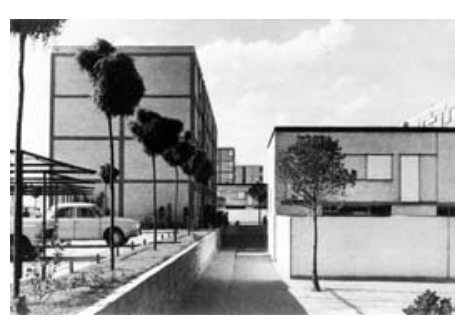

1. Terán, Fernando de, "Evolución del planeamiento de núcleos urbanos nuevos", Ciudad y Territorio 1-1969, Centro de Estudios Urbanos del IEAL, Madrid, 1969.

2. Terán, Fernando de, Planeamiento urbano en la España contemporánea (1900/1980), Gustavo Gili, Barcelona, 1978. 

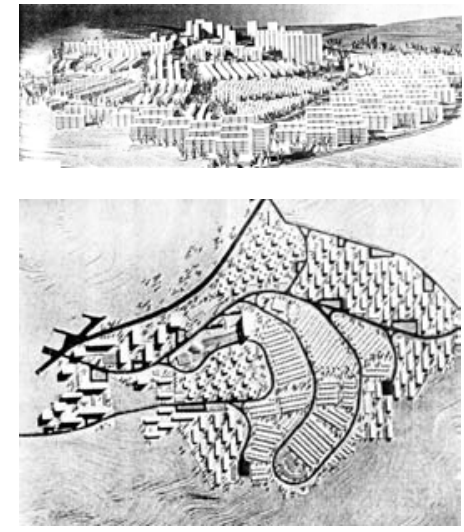

Polígono el Valle. Jaen, 1961. Maqueta.

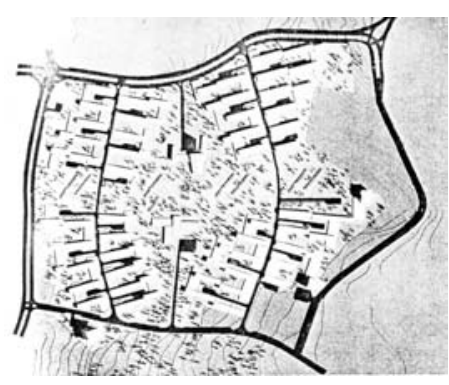

Polígono Magdalena. Avilés.

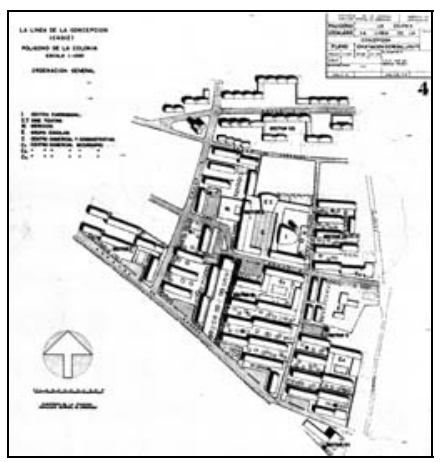

Plan Parcial del Polígono La Colonia. La Línea de la Concepción, 1959. Gerencia de Urbanización.

Plan Parcial del Polígono Pumarin, Gijón. Gerencia de Urbanización. Maqueta.

1. Fernández-Galiano, Luis, Isasi, Justo F., Lopera, Antonio, La quimera moderna. Los poblados dirigidos de Madrid en la arquitectura de los 50, Hermann Blume, Madrid, 1989.

2. Terán, Fernando de, Planeamiento urbano en la España contemporánea (1900/1980), Gustavo Gili, Barcelona, 1978.
Los poblados dirigidos fueron proyectados a partir de esquemas compositivos basados en el mixed developement teorizado por Bakema y van den Broek, combinando casas bajas unifamiliares y bloques de pisos. Este sistema no tendrá continuidad en las áreas residenciales de edificación abierta proyectadas a partir de finales de los años 50 por la Obra Sindical del Hogar y por la Gerencia de Urbanización, en las que el bloque de pisos de altura media y, más tarde, el bloque alto o la torre, serán los tipos más utilizados. ${ }^{1}$

Entre 1959 y1964, la Gerencia de Urbanización redacta más de doscientos planes parciales, acometiendo la expropiación y urbanización de más de 9.000 hectáreas de suelo.

En los años sesenta, a los planes parciales de iniciativa estatal se superponen los promovidos por particulares, que con excesiva frecuencia modifican previsiones de los planes generales. Las únicas disposiciones generales que existen en ese momento para orientar la redacción de estos planes son las contenidas en el capítulo tercero del Plan Nacional de la Vivienda, publicado en 1961, donde se establecía la cifra de 500 hab/Ha como densidad media aconsejable para España, se fijaba el valor del suelo urbanizado en el $15 \%$ del coste de la edificación y se señalaban las necesidades de edificaciones complementarias de todo tipo para los tres tipos de unidades urbanas en los que se escalonaban los conjuntos de viviendas: el núcleo residencial, de unos 5.000 habitantes y $10 \mathrm{Ha}$, la unidad de barrio, de 20.000 habitantes y $40 \mathrm{Ha}$ y la unidad de distrito, de unos 100.000 habitantes y 250 hectáreas. Como señala Terán, las prescripciones de 500 hab/ha y del valor del suelo urbanizado, que se tradujeron en la fisonomía apelmazada de los polígonos de este periodo, eran incompatibles con las reservas de suelo prescritas para dotaciones y con las necesidades de espacio para viario y aparcamientos, por lo que fueron finalmente abandonadas. ${ }^{2}$

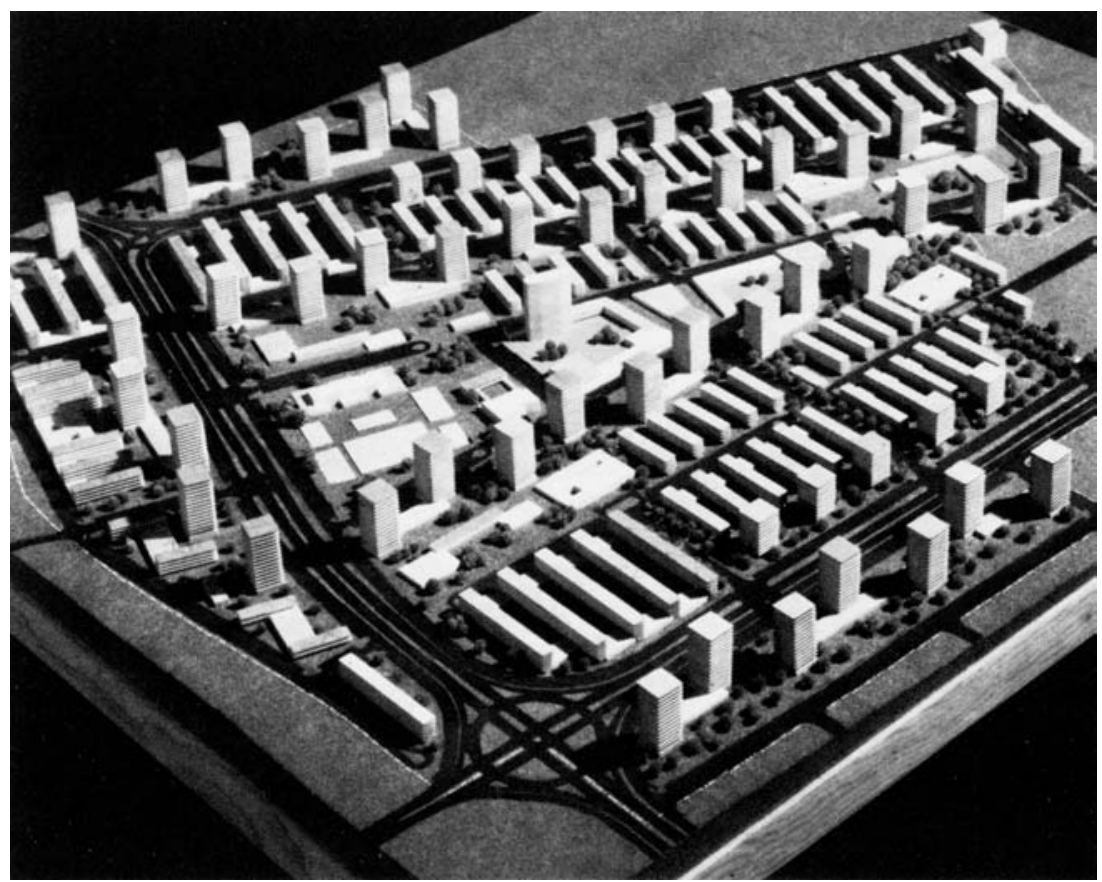


Los polígonos de edificación abierta de Barcelona y su comarca, construidos principalmente a partir de finales de los años cincuenta, han sido analizados en profundidad en su tesis doctoral por Ferrer. ${ }^{1}$

De ellos, los polígonos construidos entre 1955 y 1964 son operaciones de extensión urbana de tamaño medio y de menos de 1000 viviendas por lo general, contiguos a los tejidos residenciales existentes. Forman parte de este grupo los polígonos del Plan de Urgencia Social de 1958, como el de la Gineueta, San Martín, Badalona, San Ildefonso, Sudoeste del Besós y Montbau. A partir de 1965, en cambio, los polígonos promovidos por la OSHA y por la iniciativa privada, de tamaño superior a las 2000 viviendas, se emplazan en las proximidades de los cascos urbanos de los municipios de la comarca de Barcelona. Los grandes polígonos de promoción privada o institucional de finales de los sesenta, como el de La Paz o las Unidades Vecinales de Absorción de la OSHA, ocupan Iocalizaciones aisladas, ligadas únicamente a infraestructuras viarias principales, tendencia que se acentuará en los polígonos metropolitanos de los años setenta como los de Bellvitge, Gornal, Pedrosa, Sant Joan Despí, Badia, grandes operaciones de vivienda de promoción pública en las que se contempla ya una reserva de espacio importante para equipamientos. A lo largo de estas etapas, la torre y el bloque lineal alto irán ganando protagonismo como tipos edificatorios preferentes frente al bloque de altura media.

La valoración que diversos arquitectos realizaron de los polígonos de Barcelona y su comarca en los célebres números 60 y 61 de la revista Cuadernos de Arquitectura de 1965 es ya abiertamente crítica con los principios del orden abierto y la edificación aislada, frente a los que se afirman, como nuevos valores para la configuración de conjuntos residenciales, la superación de la zonificación y el proyecto del espacio público integrado por calles y plazas. ${ }^{2}$

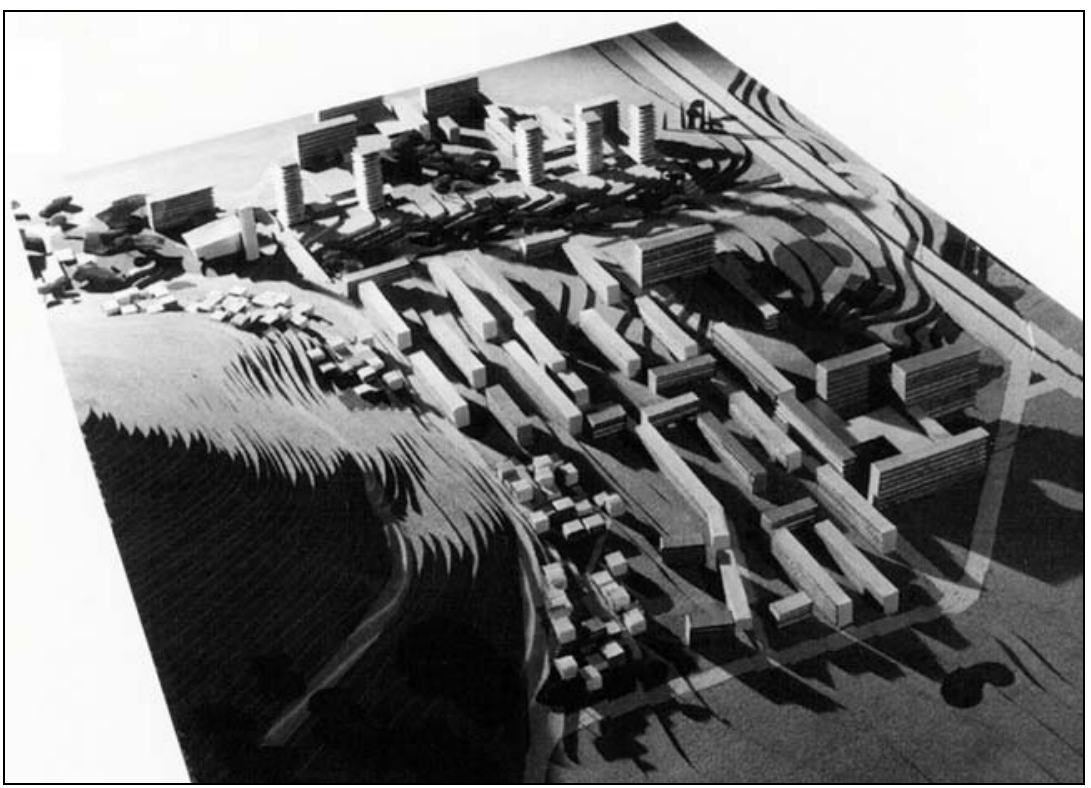

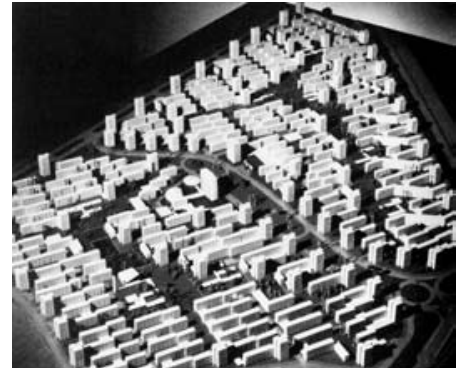

Polígono de Bellvitge. Barcelona. Maqueta de la versión de 1957. A. Perpiñá.

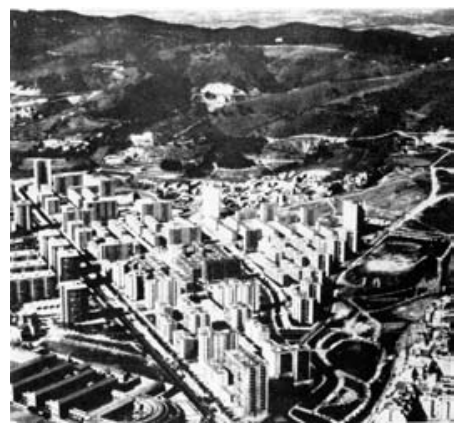

Polígono de la Gineueta, Barcelona, 1956-59. OSHA.

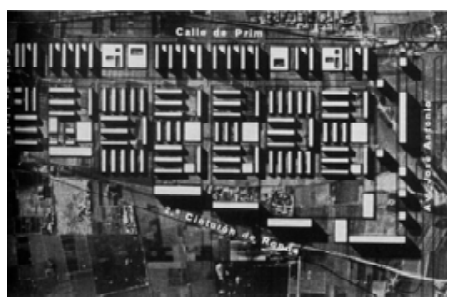

Polígono del Sudoeste del Besós, Barcelona, 1960-65. Patronato Municipal de la Vivienda. G. Giráldez, E. Giralt, P. López, J. Puig Torné, J. Subias.

Polígono de Montbau, Barcelona, 1960-65. Patronato Municipal de la Vivienda. Primera versión. P. López Iñigo, G. Giráldez Dávila, J. Subias Farga.

1. Ferrer i Aixalà, Amador, Els polígons de Barcelona, Edicions Universitat Politécnica de Catalunya, Barcelona, 1996.

2. AA. VV., "Los suburbios", Cuadernos de Arquitectura, 60 y 61, Barcelona, 1965. 
Esquema de una Comunidad urbana. Miguel Durán Loriga. Temas de Arquitectura, 59, 1964.

Concurso del Plan Parcial de ordenación de la Huerta del Rey, Valladolid, 1961. Primer premio. Corrales y Vázquez Molezun.Maqueta y planta parcial.
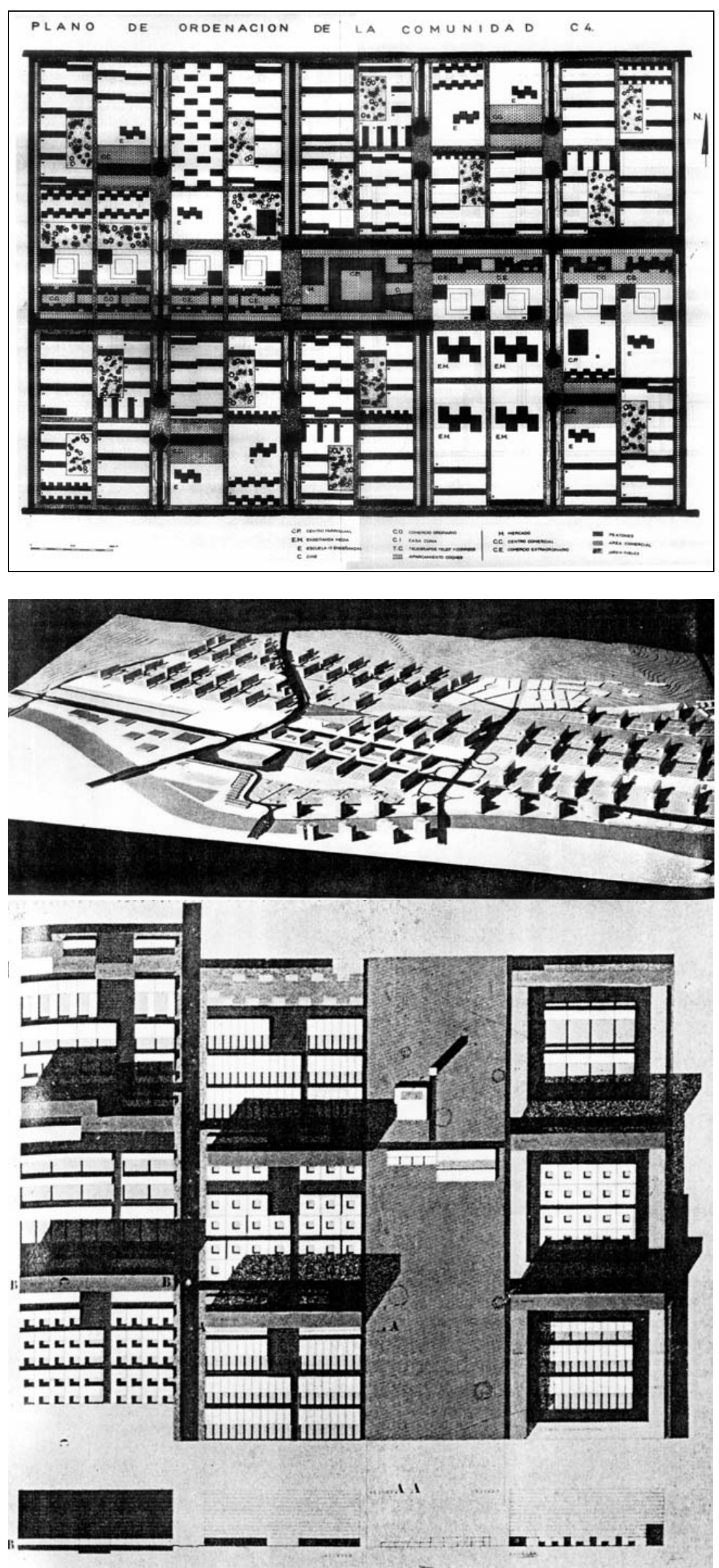
La síntesis más completa de los principios del planeamiento de núcleos urbanos nuevos sobre bases racionalistas fue la elaborada por Miguel Durán para la Gerencia de Urbanización, que aunque no alcanzó rango normativo tuvo una cierta difusión al publicarse por entregas en la revista "Temas de Arquitectura". ${ }^{1}$

El cuestionamiento de los planteamientos ortodoxos del urbanismo racionalista se refleja ya los concursos de proyectos de 1961 para los polígonos Huerta del Rey de Valladolid, Alces en Alcazar de San Juan, Alameda en Málaga y Aravaca en Madrid, así como en el de ordenación del valle de Asúa.

En el número 62 de la revista Arquitectura, Cano Lasso, arquitecto Jefe de la División de Planeamiento de la Gerencia de Urbanización, hace un balance de la actuación de dicho organismo entre 1959 y 1964 cuya transcripción es la mejor descripción de las dudas que, a mediados de los años sesenta, suscita el urbanismo del orden abierto en los profesionales más inquietos, y que abrirá paso a la revisión y al cuestionamiento generalizado de sus postulados que se producirá a partir de mediados de los setenta:

Cuando la Gerencia acometió su tarea, el urbanismo español parecía avanzar con pie seguro por un camino despejado. después de un largo aislamiento, la toma de contacto con el exterior nos había producido un deslumbramiento del que aún no nos habíamos repuesto. Roto el hilo de una auténtica tradición creadora, y faltos de experiencia, una vez más creímos que nuestra solución estaba en seguir con la mayor fidelidad posible a los países que marchaban por delante de nosotros.

Los principios de la carta de Atenas, después de largos años de desconocimiento, brillaban como dogmas. la victoria era reciente y había sido costosa, pero parecía ofrecernos un camino de éxitos espectaculares; la abundancia de revistas, haciendo llegar a todos los rincones las últimas realizaciones escandinavas, inglesas o alemanas, y los frecuentes contactos con el extranjero, ejercían, por otra parte, una influencia a la que era difícil sustraerse.

El urbanismo oficial quiso abrirse a la nueva corriente con cautela y prudencia. El temor a grandes errores cerró también el camino a la posibilidad de grandes aciertos, y el urbanismo se encauzó por una línea de compromiso que, como suele suceder en estos casos, participa de casi todos los defectos de las distintas soluciones.

La mayor dificultad del urbanismo estriba en ser, en mayor o menor grado, una técnica propia de cada país que debe desarrollarse siguiendo un proceso en el que no es posible suprimir etapas ni importar patentes. Las formas inglesas o nórdicas de urbanismo paisajista, derivadas de su propia tradición, y basadas en una baja densidad, magníficos paisajes naturales y clima adecuado, fueron transplantadas con densidades dos o tres veces mayores a los suburbios de nuestras ciudades, donde no existe el paisaje ni era posible crearlo por razones de economía y clima. Las exigencias de una economía pobre, imponiendo densidades no inferiores a $3 \mathrm{~m} 3 / \mathrm{m} 2$, edificación modesta y escasos márgenes para urbanización y conservación, redujo nuestros intentos de urbanismo paisajista a unos tímidos remedos difícilmente reconocibles. ${ }^{1}$

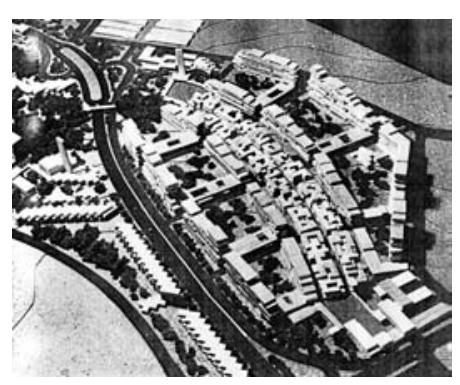

Concurso del Plan Parcial de Ordenación del Polígono "Alameda", Málaga, 1961. Capote, Chinarro, Esteve, Rokiski y Serrano Súñer.

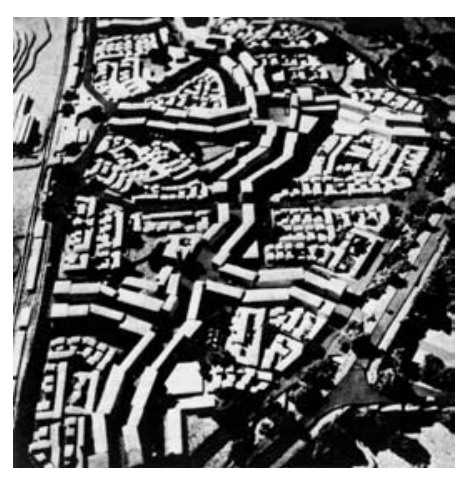

Plan Parcial del Polígono Aravaca, Madrid, 1961. Vázquez de Castro.

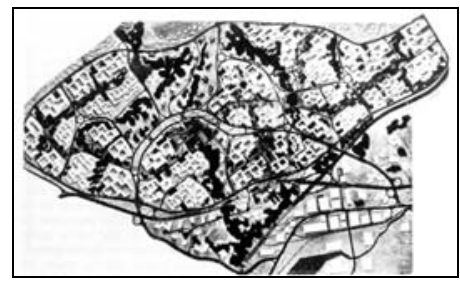

Concurso Internacional del Valle de Asua, 1961. Soldevilla, Rodríguez y García Lanza.

1. Durán Loriga, Manuel, "Urbanismo", Temas de Arquitectura, núms. 52-59, Madrid, 1963-64.

2. Cano Lasso, Julio, "La Gerencia de Urbanización del Ministerio de la Vivienda", Arquitectura, 62, Madrid, 1964. 


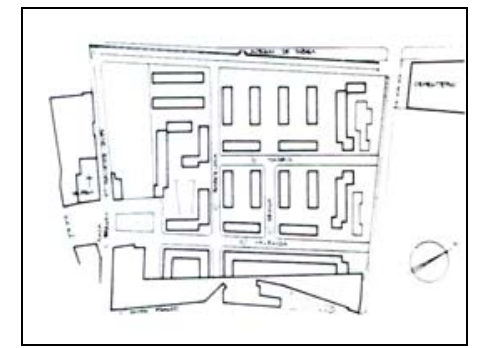

Grupo Nuestra Señora del Socorro, Benetuser, 1956. M. Muñoz Monasterio.

Grupo Churruca, Puerto de Sagunto, 1945. J. Cort Botí.

Grupo Las Torres, Castellón, 1955. V. Vives Llorca

Grupo Rafalafena, Castellón, 1957. V. Vives Llorca
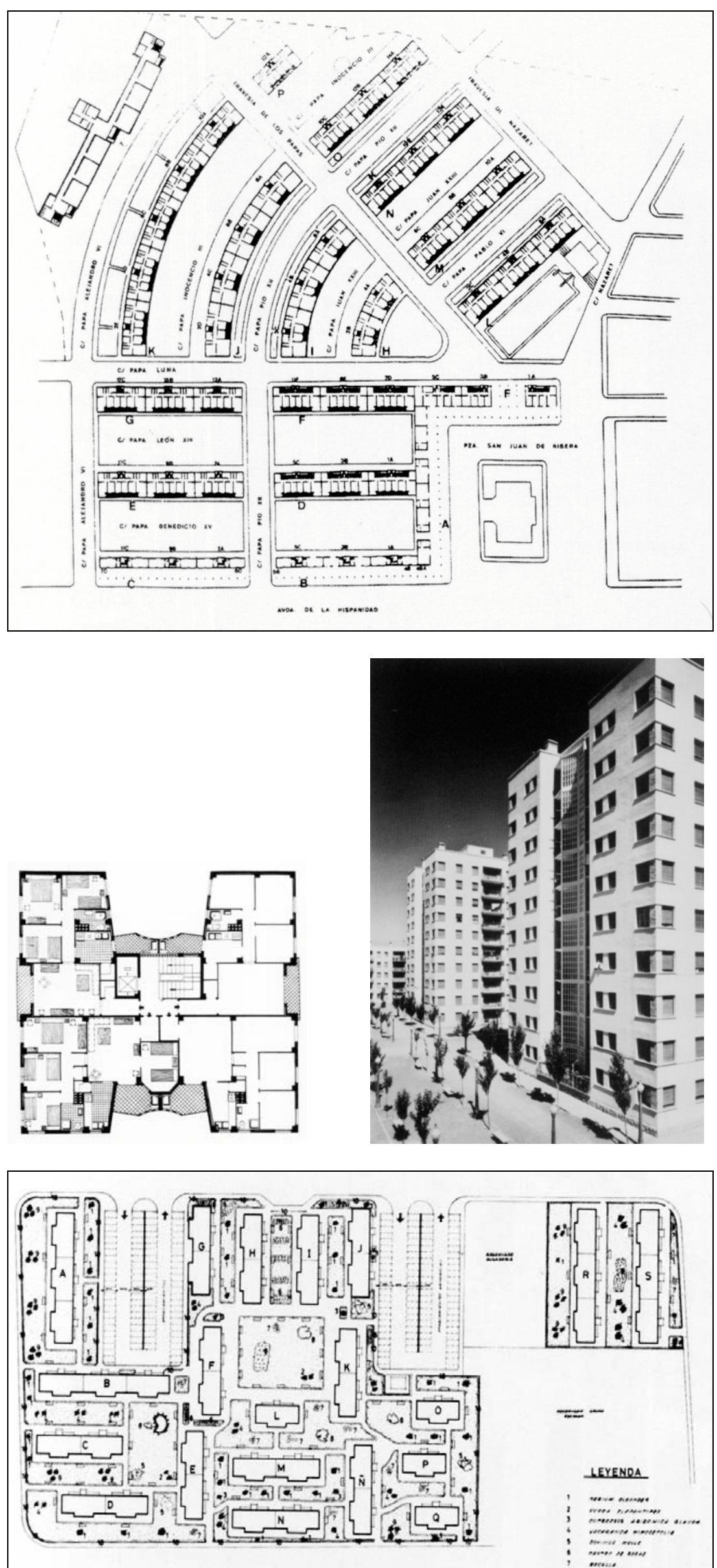


\section{La edificación abierta en la Comunidad Valenciana: de los grupos a las urbanizaciones.}

A partir de mediados de los años cincuenta, la edificación abierta se afianza como sistema de proyecto habitual en los conjuntos de viviendas de promoción pública que se construyen en la Comunidad Valenciana.

En la provincia de Valencia, podemos destacar el grupo Nuestra Señora del Socorro de Benetuser (1956) y el barrio del Carmen de Játiva (1955), así como los diversos conjuntos localizados en el Puerto de Sagunto: los grupos Churruca (1945), Ciudad Dormida (1947), Salas Pombo (1955) y Goyoaga (1961). ${ }^{1}$

En Alicante, la zona norte de la ciudad concentra un gran número de conjuntos de viviendas de promoción pública, tales como los grupos Francisco Franco, Virgen del Remedio, La Paz, Colonia Requena y Juan XXIII. Estos barrios no se proyectaron como una extensión del área urbana consolidada, sino que han sido durante mucho tiempo enclaves aislados, conectados con la ciudad únicamente por infraestructuras viarias, lo que ha contribuido a su carácter marginal.

En la provincia de Alicante, ejemplos significativos de grupos de edificación abierta son el grupo San Mauro de Alcoy (1956) y el barrio de San Francisco de Sales en Elda (1956-68), compuestos por bloques lineales de dos crujías dispuestos en línea, y los barrios de San Antón en Elche (1959) y de Caramanchel en Alcoy (1973), ambos basados en el tipo de bloque de cinco crujías con patios interiores. $^{2}$

En Castellón, los grupos Magdalena (1954) y Rafalena (1957) son interesantes ejemplos de barrios basados en agrupaciones de bloques lineales. Especial interés tiene el grupo Las Torres (1955), que es uno de los primeros ejemplos de utilización de la torre -de 10 plantas en este caso- como tipo edificatorio en la vivienda de promoción pública.

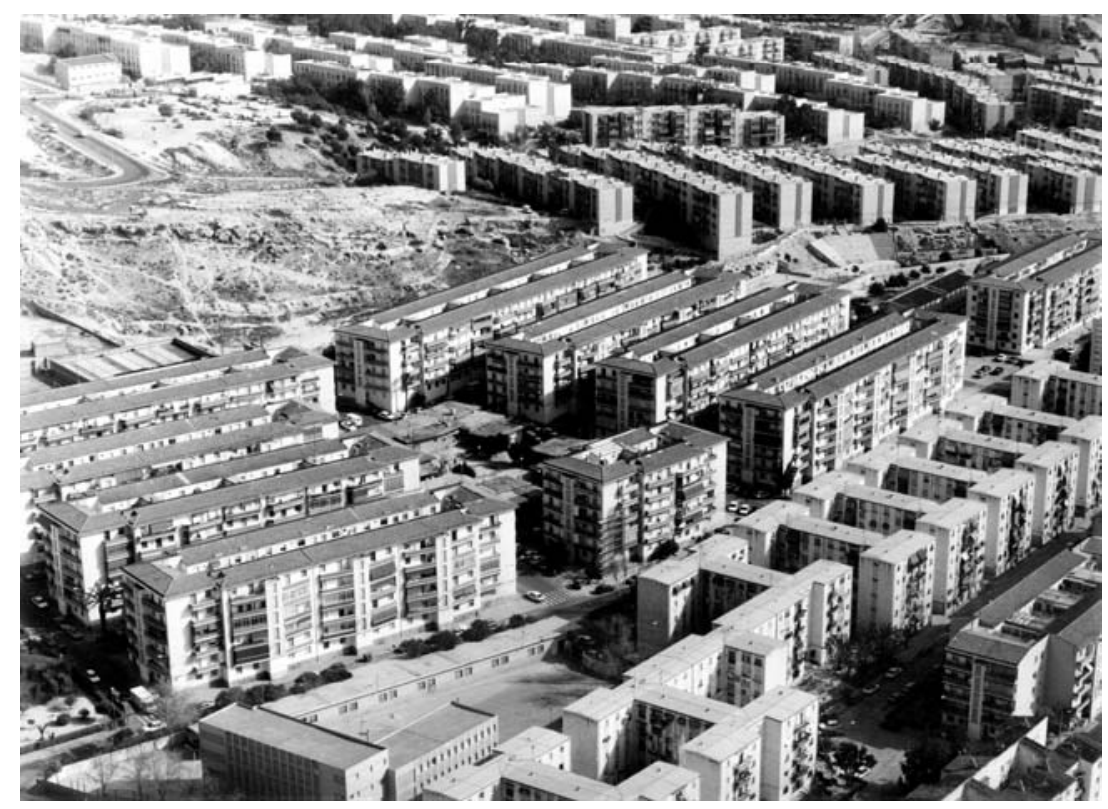

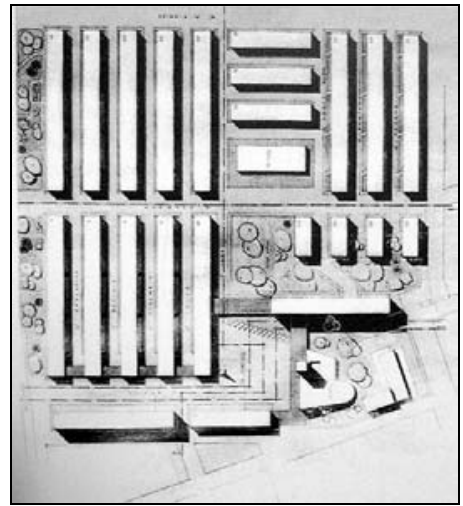

Barrio San Francisco de Sales, Elda, 1956-68. J.A. García Solera.

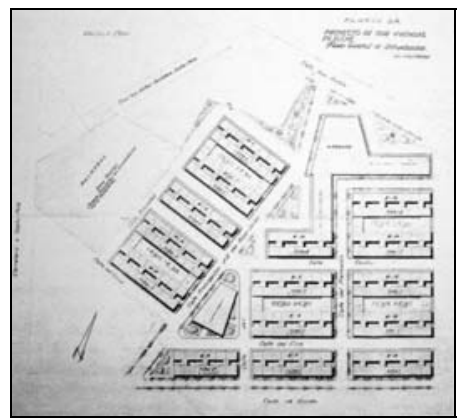

Barrio de San Antón, Elche, 1959. S. Pérez, A. Serrano, F. Muñoz, F. López.

Edificación abierta en la zona norte de Alicante: barrios Virgen del Remedio, La Paz, Colonia Requena y Juan XXIII.

1. Los grupos de Puerto de Sagunto has sido analizados con detalle en el marco de los Estudios para la Redacción del Plan Especial de Puerto de Sagunto, dirigidos por el profesor Luís Alonso de Armiño.

2. Ver Varela Botella, Santiago, Los barrios de viviendas en Alicante $y$ provincia 1940-1970, Colegio Oficial de Arquitectos de la Comunidad Valenciana, Valencia, Consellería d'Obres Públiques, Urbanisme i Transports, 1998. 


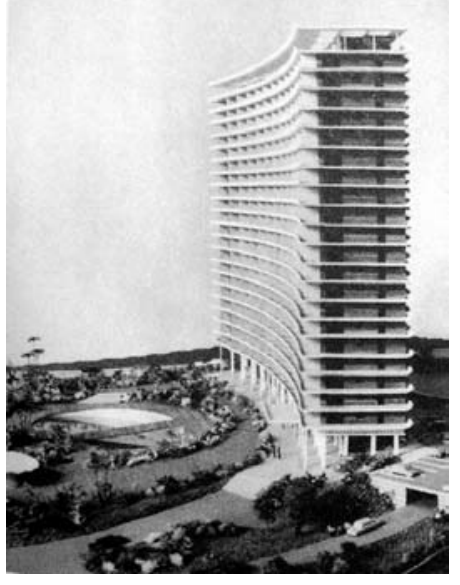

Residencial La Chicharra, La Albufereta, Alicante, 1966-73.

Plan del primer Polígono de la Playa de San Juan, Alicante, 1959. J.Guardiola.

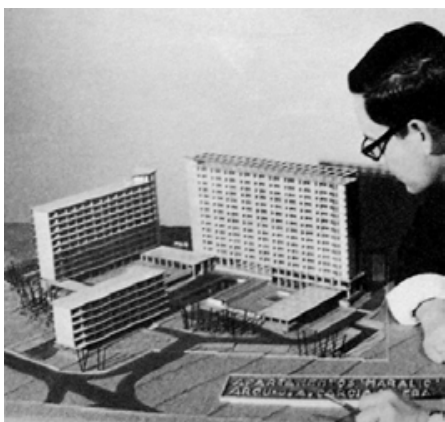

Urbanización Maralic, Alicante 1962. J.A. García Solera.

Plan de ordenación de La Albufereta- Serra Grossa, Alicante, 1961. J. Guardiola Gaya.

Complejo Vistahermosa, Alicante, 1962. J.A. García Solera.
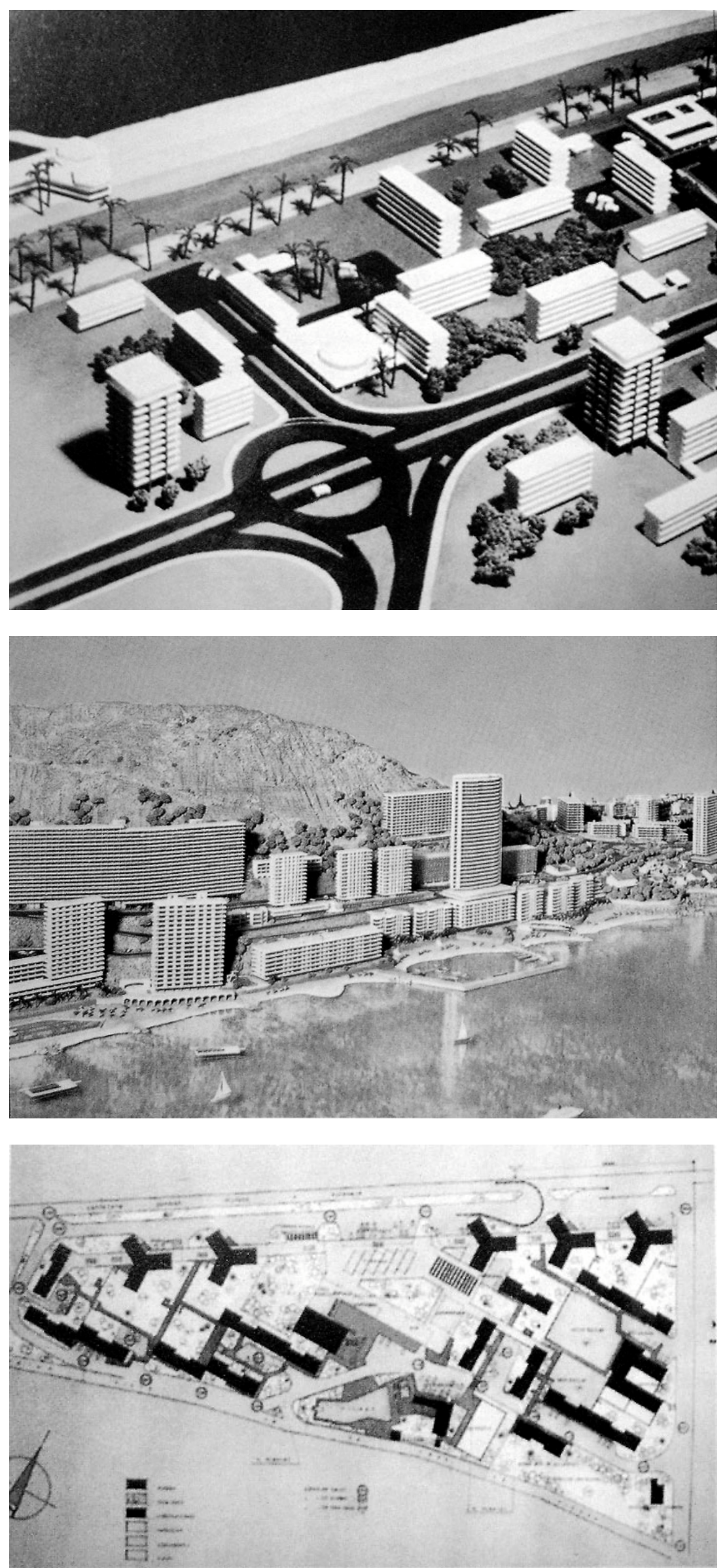
Sin embargo, los desarrollos urbanos más importantes basados en el orden abierto en la Comunidad Valenciana entre 1960 y 1975 no son los grupos de viviendas de promoción pública, sino las denominadas "urbanizaciones" o "complejos", conjuntos residenciales vinculados al ocio y al turismo de playa construidos a lo largo de todo el litoral. ${ }^{1}$

En estos conjuntos, la edificación abierta, en forma de bloques o de torres, se dispone en el interior de una parcela vallada, cuyos espacios libres se destinan a jardines, piscina o aparcamientos de carácter privado. En función del tamaño de la parcela, ésta alberga uno o más bloques y un programa más o menos amplio de instalaciones comunitarias.

El planeamiento urbanístico previo necesario para estas urbanizaciones podía ser muy somero, limitándose a fijar una cuadrícula de calles de tamaño suficiente y unas normas relativas a altura, edificabilidad y distancias a lindes, como lo demuestra el caso de Benidorm. Por ello, los proyectos urbanos globales con indicación de volúmenes, como el del Polígono Primero de la Playa de San Juan de 1958 y el de ordenación de La Albufereta de 1961, ambos en Alicante, o el Plan Parcial del Saler de 1962 en Valencia, serán poco habituales en este periodo. ${ }^{2}$

El modelo de las urbanizaciones del litoral valenciano puede considerarse como la transposición al terreno del ocio y la segunda residencia de un modelo concebido con anterioridad en la esfera de la vivienda social de promoción pública, que es el del bloque alto dotado de servicios colectivos. Los comienzos de este modelo, que quedó fijado como prototipo en la Unité d'habitation de Le Corbusier, están ligados, paradójicamente, al colectivismo soviético y a las experiencias de Ginzburg, y sus derivados son los bloques del welfare state británico de los años 50 como los de Alison y Peter Smithson.

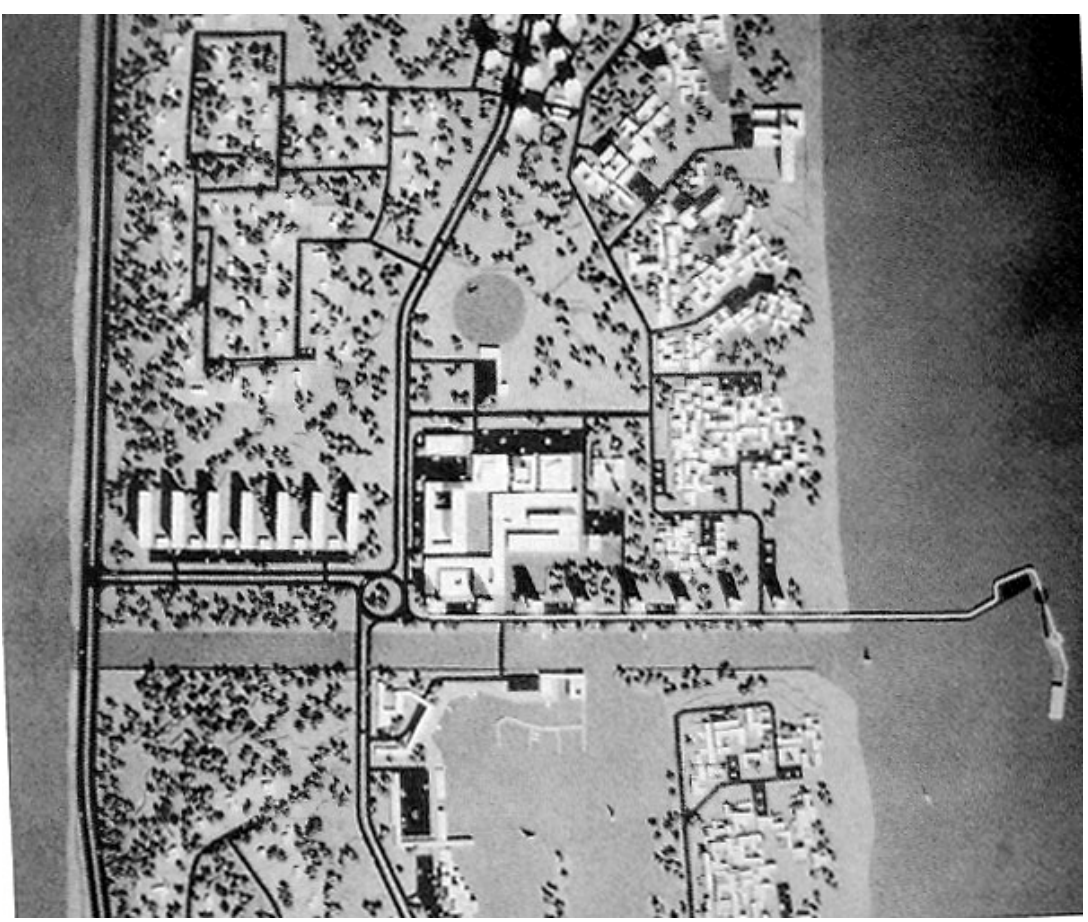

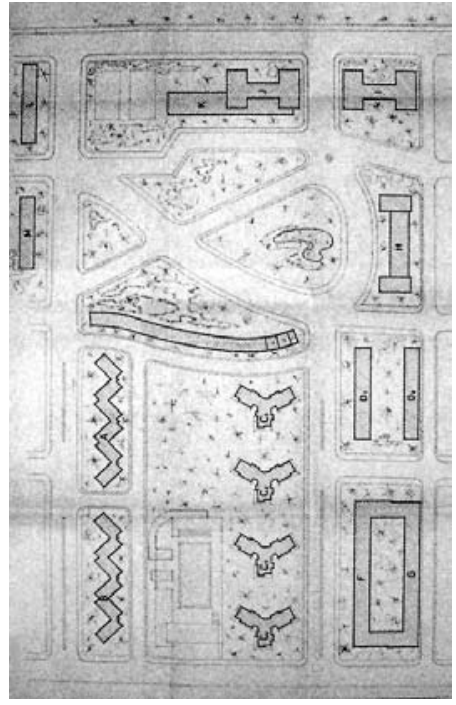

Urbanización Colonia Ducal, Gandía, 1961. P. Soler, F. García, J.J. Estellés.

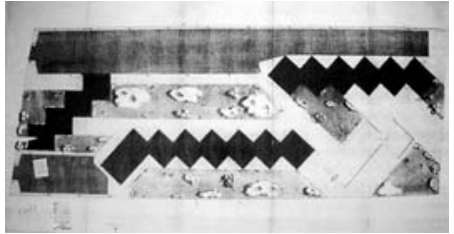

Urbanización Tres Carabelas, El Perelló, 1964. V. Valls, J. García Sanz.

Plan Parcial del Saler, Valencia, 1962. J. Cano Lasso, E. Temes y L.F. Vivanco.
1. Ver VV.AA., La arquitectura del sol, Colegios de Arquitectos de Cataluña, Comunidad Valenciana, Islas Baleares, Murcia, Almería, Granada, Málaga y canarias, Barcelona, 2002.

2. Temes Riancho, Vicente, Vivanco Bergamín, L. Felipe, Cano Lasso, Julio, "Proyecto de ordenación turística de la Albufera y playas de Saler", Arquitectura, 65, Madrid, 1964 


\section{La edificación abierta en la ciudad de Valencia.}

La elección de la ciudad de Valencia como ámbito espacial del presente trabajo se debe, además de a razones obvias de facilidad de acceso a las fuentes y de residencia, a la voluntad de aportar datos que contribuyan a un conocimiento más detallado de la ciudad de mayor tamaño y capital de la Comunidad Valenciana.

Los principios de la edificación abierta en Valencia, que están ligados al modelo de ciudad jardín como soporte de la vivienda obrera, y su papel en el crecimiento urbano de Valencia del periodo comprendido entre 1856 y 1936 han sido estudiados por Blat ${ }^{1}$. La sustitución de la casa unifamiliar por el bloque de viviendas colectivo como tipo idóneo para resolver el problema de la vivienda social, que señala el final del trabajo de Blat, marca el comienzo del nuestro, en el que nos centraremos en el estudio de la edificación abierta de alta densidad que, en nuestra ciudad, sucedió progresivamente a partir de 1930 a la de baja densidad como modelo para la construcción de la periferia.

El ámbito temporal que planteamos para nuestro trabajo es el comprendido entre el Plan General de Valencia y su Cintura de 1946, primera ordenación global de la ciudad basada en criterios urbanísticos que podemos considerar contemporáneos, y el Plan General de Ordenación Urbana de 1988, redactado tras las primeras elecciones municipales democráticas. Entre ambas fechas, con una curiosa cadencia decenal, se producen los hechos siguientes: en 1956 se aprueba la Ley del Suelo (con la figura del Plan Parcial como instrumento para la ordenación de conjuntos residenciales); en 1966 se aprueba el Plan General de Valencia y su Comarca adaptado a la Solución Sur, que sustituye al de 1946, y en 1976 se aprueba la reforma de la Ley del Suelo (a la que se añadirá en 1978 el Reglamento de Planeamiento). La redacción de un nuevo Plan General se aborda, por tanto, cada veinte años, y la Ley del Suelo cambia también cada veinte años, pero con un desfase temporal de diez años con respecto a dicho Plan.

En este periodo, una parte de la edificación abierta de Valencia, que es la integrada en conjuntos residenciales de promoción pública, ha sido estudiada por Gaja ${ }^{1}$. Nuestro trabajo puede entenderse, en cierta medida, como una extensión del suyo, a fin de abarcar también las áreas residenciales de edificación abierta de promoción privada, que en el caso de Valencia son, como veremos, las predominantes en la conformación de la periferia.

1. Blat Pizarro, Juan, Vivienda obrera y crecimiento urbano (Valencia 1856-1936), Generalitat Valenciana, Consellería d'Obres Públiques, Urbanisme i Transports, Colegio Oficial de Arquitectos de la Comunidad Valenciana, Valencia, 2000.

2. Gaja Díaz, Fernando, La promoción pública de la vivienda en Valencia (1939-1976), Generalitat Valenciana, Consellería d'Obres Públiques, Urbanisme Transports, 1989.
En la ciudad de Valencia, el primer conjunto significativo de edificación abierta es el Grupo Virgen de los Desamparados, construido entre 1952 y 1955 en la Avenida de Castilla. La utilización del bloque aislado como tipo básico para el proyecto de áreas residenciales periféricas se afianza a finales de los años 50 en conjuntos de promoción pública como los grupos Fuensanta (1957) o Virgen del Carmen (1958).

Pero la consagración definitiva de la edificación abierta, más allá de la excepcionalidad de la promoción pública, llega en Valencia de la mano de los Planes Parciales que desarrollaron el Plan General de 1966, en los que los bloques de edificación abierta pasan a ser el 
tipo preferente (a veces casi en exclusiva) a partir del cual se aborda la ordenación de áreas urbanas periféricas.

El recurso a la edificación abierta será en lo sucesivo, hasta principios de los 80 , el modo de operar habitual en todos los proyectos urbanísticos (sean planes parciales, estudios de detalle o planes generales) que abordan el tema del crecimiento de la ciudad, y más en concreto el de la creación de nuevas áreas residenciales que se añaden a las existentes, es decir, el de la construcción, en definitiva, de la periferia.

Un primer análisis y valoración de conjunto de los Planes Parciales de desarrollo del Plan General de 1966 ha sido ya realizado por Giménez, dentro de su extenso trabajo de investigación sobre la formación de la periferia metropolitana de Valencia, y constituye otra de las referencias de partida para el nuestro, en el que nos proponemos acercar más la mirada a cada uno de dichos planes, y a las diversas redacciones que de los mismos se producen en el periodo objeto de estudio. ${ }^{1}$

En el origen de este trabajo está la línea docente que inspira los programas de los cursos de urbanismo impartidos en los últimos años en la Escuela de Arquitectura de Valencia, y en especial en la asignatura Urbanística II, coordinada por el Profesor Luís Alonso de Armiño, Director de esta tesis. El análisis de las principales experiencias europeas en torno al tema de las unidades residenciales de la ciudad moderna, basadas en el orden abierto, es uno de los contenidos centrales de esa línea docente. ${ }^{2}$

Las unidades residenciales, que en nuestro país responden habitualmente a la denominación de polígonos, son conjuntos integrados por viviendas y equipamientos, desarrollados a partir de un proyecto unitario que engloba tanto la urbanización como la edificación. Los polígonos, de promoción pública por lo general, son la forma de crecimiento característica de la ciudad moderna: frente a la construcción casa por casa de la ciudad tradicional, implican un crecimiento de la ciudad por paquetes residenciales completos, por partes (unidades vecinales o barrios), de acuerdo con una hipótesis de integración escalonada de unidades urbanas (casa-barriociudad).

En otras ciudades españolas, los polígonos como forma de crecimiento urbano han sido estudiados en profundidad, en trabajos de investigación como los realizados por Moya sobre los barrios de protección oficial de Madrid y por Ferrer sobre los polígonos de Barcelona, que suponen importantes referencias de base para el nuestro. ${ }^{3}$

En este trabajo nos proponemos estudiar con cierto grado de detalle los conjuntos residenciales de edificación abierta que forman la periferia de la ciudad de Valencia, y comparar sus características con las que presentan los modelos canónicos del urbanismo funcionalista $y$, en particular, los conjuntos residenciales proyectados $y$ construidos en España.

Es necesario señalar que la aproximación a la periferia de Valencia que pretendemos realizar está centrada en la forma urbana, entendida como cristalización de todos los demás aspectos que con-
1. Giménez Baldrés, Enrique J. Parcelaciones Residenciales Suburbanas. La formación de la periferia metropolitana de Valencia, Universidad Politécnica de Valencia, Valencia, 1996.

2. Algunas publicaciones docentes que se inscriben en esta línea son las siguientes:Alonso de Armiño Pérez, Luís, Pérez Igualada, Javier, Análisis de unidades residenciales, Vol. I y II., , Universidad Politécnica de Valencia, Valencia, 1990. Pérez Igualada, Javier, Manzanas, bloques y casas. Formas construidas y formas del suelo en la ciudad contemporánea, Universidad Politécnica de Valencia, Valencia, 2003

3. Ver Moya González, Luís, Barrios de promoción oficial. Madrid, 1939-1976, Colegio Oficial de Arquitectos de Madrid, Madrid, 1983. Ferrer i Aixalà, Amador, Els polígons de Barcelona, Edicions Universitat Politécnica de Catalunya, Barcelona, 1996. Ver también Sambricio, Carlos, ed., Un siglo de vivienda social (19032003). Nerea, San Sebastián, 2003. 
curren en la ciudad (historia, sociología, economía). Ello supone primar la observación de la ciudad tal como es realmente, con el objetivo de conocer cómo son hoy las áreas residenciales de edificación abierta en las que se materializaron, al menos parcialmente, los principios de la ciudad moderna. En definitiva, ceñirse a los dibujos y al terreno, a los proyectos y a la realidad construida, significa optar por una aproximación estrictamente disciplinar al tema de estudio.

En nuestra aproximación a la forma urbana daremos prioridad a las formas del suelo, más que a las formas construidas. Como señala Panerai, la creación de tejido urbano se hace principalmente a partir de una diferenciación clara y estable entre el suelo público y el privado:

Replantear la cuestión de la parcelación significa hacerse con los medios para superar la estéril oposición entre el proyecto arquitectónico y el urbanismo a través de la actualización de los mecanismos y técnicas que permitieron durante siglos hacer ciudades. ${ }^{1}$

La aproximación a la periferia es, en un primer momento, sincrónica: todos los momentos del crecimiento urbano se nos presentan a la vez, superpuestos en una realidad única, que alberga algunos episodios completos y otros abortados, así como fragmentos y piezas contradictorias entre si. Profundizar en esa mirada inicial exige conocer de qué modo se ha llegado a configurar esa realidad. Deberemos, para ello, estudiar los planes y proyectos redactados para ordenar la periferia, incluyendo los planes originales y los modificados, los planes realizados y los no realizados, para poder confrontarlos cualitativa y cuantitativamente con lo que realmente se construyó.

El interés fundamental de este trabajo está por ello, a nuestro juicio, en aportar documentación para conocer con un grado de detalle suficiente las áreas periféricas de edificación abierta de Valencia, en las que vive una parte importante de la población de la ciudad pero que hasta ahora, a excepción de los polígonos de promoción pública, han sido poco valoradas como porción de ciudad digna de estudio o, por lo menos, mucho menos estudiadas que otras áreas urbanas tales como el centro histórico o el ensanche.

Esta labor documental debería permitirnos realizar una evaluación equilibrada de la ciudad real de la edificación abierta en relación con la doctrina urbanística que la inspiró, que es la del movimiento moderno, la del urbanismo funcionalista. En este sentido, la afirmación de que la periferia real de nuestras ciudades constituye una versión degradada de la ciudad de la arquitectura moderna, una vulgarización de las ideas que la inspiraron, es ya un lugar común, algo habitualmente aceptado. Convendría, sin embargo, aproximar más la mirada y ver sin tópicos ni intermediarios cómo se ha operado esa degradación, cuáles han sido sus mecanismos, y com-

1. Panerai, Philippe R., Castex Formes Urbaines: de l'ilot à la barre, Bordas, París, 1980 (Formas urbanas: de la manzana al bloque, G.Gili, Barcelona, 1986).

2. Solá-Morales, Manuel de, "La segunda historia del proyecto urbano", Urbanismo, 5, Barcelona, 1987. probar así algunas cosas: en qué medida los principios y los modelos teóricos son responsables de algunos problemas, cuales siguen siendo sus grandes virtudes y qué correcciones necesitan esos modelos a la luz de los resultados de su aplicación, todo ello desde una posición que, como dijo Solá-Morales, no es ya la de los urbanistas propagandistas de la modernidad ni la de los que en su contra quisieron parecer polémicos en los años $80 .^{2}$ 


\section{Agradecimientos}

Las principales fuentes de documentación utilizadas para la elaboración del presente trabajo han sido los expedientes originales de los planes parciales redactados por la Oficina Municipal de Urbanismo que se conservan en el Archivo de Planeamiento del Ayuntamiento de Valencia. Los principales documentos, tanto escritos como gráficos, que integran dichos expedientes, para el periodo y ámbito de nuestro estudio, están recogidos en el Anexo de Documentos que acompaña a este trabajo. Se ha recurrido además a la consulta de expedientes del Archivo Histórico Municipal de Valencia para completar los datos relativos a algunos proyectos concretos.

Deseo expresar aquí mi enorme gratitud hacia Ricardo Martínez Alzamora, arquitecto a cargo del Archivo de Planeamiento, ya que sin las facilidades de él obtenidas para el examen y reproducción de la documentación original obrante en dicho Archivo este trabajo habría resultado sin duda mucho más largo y dificultoso.

En cuanto a las fuentes bibliográficas utilizadas, podemos destacar, además de las referencias ya indicadas más arriba, el Boletín del Colegio Oficial de Arquitectos de la Zona de Valencia, las colecciones de las revistas Hogar y Arquitectura, Revista Nacional de Arquitectura y Cuadernos de Arquitectura y Urbanismo y el Informe Prevasa, consultados en el Centro de Información Arquitectónica (C.I.A.) de la Escuela de Arquitectura de Valencia y, sobre todo, en la Biblioteca del Colegio de Arquitectos de Valencia, a cuya responsable, Fina Alberola, quiero agradecer su amable atención.

El material cartográfico general de Valencia proviene principalmente del Archivo de la Escuela de Arquitectura, a cargo del profesor Luís Perdigón, a quien agradezco las facilidades proporcionadas para la obtención de la documentación necesaria.

En otro orden de cosas, debo necesariamente dar las gracias a los creadores de los diferentes programas informáticos utilizados para transcripción de textos, tratamiento de texto y de imágenes y dibujo, ya que sin ellos no habría podido en modo alguno afrontar en solitario este trabajo.

Pasando al terreno de las deudas que nunca podré pagar, deseo expresar aquí mi agradecimiento a Jaime Prat y Álvaro Page. Me siento afortunado por haber podido contar desde hace ya largos años con una amistad y apoyo que seguramente no merezco.

Dentro de la Escuela de Arquitectura de Valencia, deseo mostrar mi agradecimiento al profesor Vicente Vidal, así como a mis compañeros del Departamento de Urbanismo y, de modo particular, al profesor Juan Luís Piñón, referente siempre para mí de excelencia intelectual.

Este trabajo comenzó el año 2002, bajo la dirección del profesor Luís Alonso de Armiño Pérez, al que quiero agradecer no sólo su ayuda fundamental como director de esta tesis, sino también su magisterio continuado a lo largo del tiempo, que comenzó ya en mis años de formación y ha continuado posteriormente, siempre de forma grata, en la esfera profesional y docente. 
Por último, quiero también dar las gracias a Bob Dylan, Tom Waits y Leonard Cohen por su música, a J.D. Salinger, Daniel Pennac y Preston \& Child por sus novelas, a Kenneth Clark, Javier Marías y Rafael Argullol por sus libros y artículos, a Harold Foster, Jack Kirby y Serge Clerc por sus tebeos, a Jean Loup Sieff, Bob Carlos Clarke y Edward Weston por sus fotografías, a Edouard Manet, Jean-Auguste-Dominique Ingres, Amedeo Modigliani y Tiziano Vecellio por sus cuadros y a Francis Ford Coppola y Quentin Tarantino por sus películas. Todos ellos nos demuestran que existen muchos otros mundos además del de la arquitectura. 
I. ENTRE EL PLAN GENERAL DE 1946 Y EL PLAN SUR DE 1958 LOS INICIOS DE LA EDIFICACIÓN ABIERTA EN VALENCIA 



\section{INTRODUCCIÓN.}

En esta sección estudiaremos los inicios de la edificación abierta en Valencia. Estos inicios van ligados a la iniciativa pública, ya que será principalmente en los proyectos de grupos de viviendas de promoción municipal o estatal donde se introducirán progresivamente los tipos de vivienda y de edificio propios del orden abierto.

Como antecedentes, revisaremos, en primer lugar, los contados ejemplos de proyectos basados en la edificación abierta en Valencia entre 1930 y 1936, que en Europa es un periodo importante de formulación de principios del urbanismo moderno.

Las primeras realizaciones basadas en el orden abierto no son en Valencia el resultado de planes urbanísticos, sino de proyectos para la construcción de grupos o conjuntos de viviendas. Examinaremos por ello algunos de estos grupos de viviendas, promovidos por el Ayuntamiento de Valencia entre 1940 y 1949, en los que podemos ver como se opera gradualmente la transición de la manzana al bloque como tipo básico edificatorio.

Pasaremos después a estudiar las primeras tentativas de planeamiento de cierto alcance basadas en la edificación abierta en nuestra ciudad, que son, por una parte, los dos proyectos de barrios residenciales que formaban parte del Plan General de Valencia de 1946, y, por otra, algunos de los Proyectos Parciales de Desarrollo de dicho plan, en los que aparecen fragmentos de mayor o menor tamaño proyectados con bloques.

El grado de realización de estos primeros planes será casi nulo. Los primeros conjuntos de viviendas de cierta entidad construidos en Valencia serán algunos de los grupos promovidos entre 1950 y 1956 por el Instituto Nacional de la Vivienda y la Obra Sindical del Hogar, en el marco del "Plan 5000 viviendas para Valencia" y del Plan Sindical de la Vivienda, cuyo estudio ocupará el siguiente apartado de esta sección.

A continuación, estudiaremos un grupo de planes urbanísticos no realizados pero que presentan un gran interés en relación con el tema de este trabajo, ya que en ellos se opera la sustitución generalizada del planeamiento anterior, con tejidos de ensanche formados por manzanas cerradas, por nuevas ordenaciones basadas en los tipos de la edificación abierta, en áreas de la periferia de una extensión considerable y con mayores reservas de suelo para equipamientos y espacios libres, lo que supone una primera aproximación a la idea de crecimiento de la ciudad por partes o unidades vecinales característica del urbanismo funcionalista. Estos planes son los promovidos por el Ayuntamiento y desarrollados en los denominados "Proyectos de Ejecución de Polígonos para la construcción de Viviendas de Renta Limitada", redactados entre 1955 y 1956 para los sectores de Paseo al Mar, Campanar, Avenida de Castilla y Monteolivete.

A ello añadiremos los planes realizados por la Corporación administrativa Gran Valencia para los Barrios Residenciales no 2 y 3 en la Avenida de Castilla, similares a los anteriores pero localizados en áreas sin planeamiento parcial previo. 
La sección termina con la exposición del marco normativo en el que se inscribirá en adelante la edificación abierta: las Ordenanzas de la Comisión Central de Sanidad Local de 1955 y, sobre todo, la Ley del Suelo de 1956, que define por primera vez las determinaciones propias de un Plan Parcial como figura de planeamiento, dejando obsoletos los proyectos parciales redactados con anterioridad a ella.

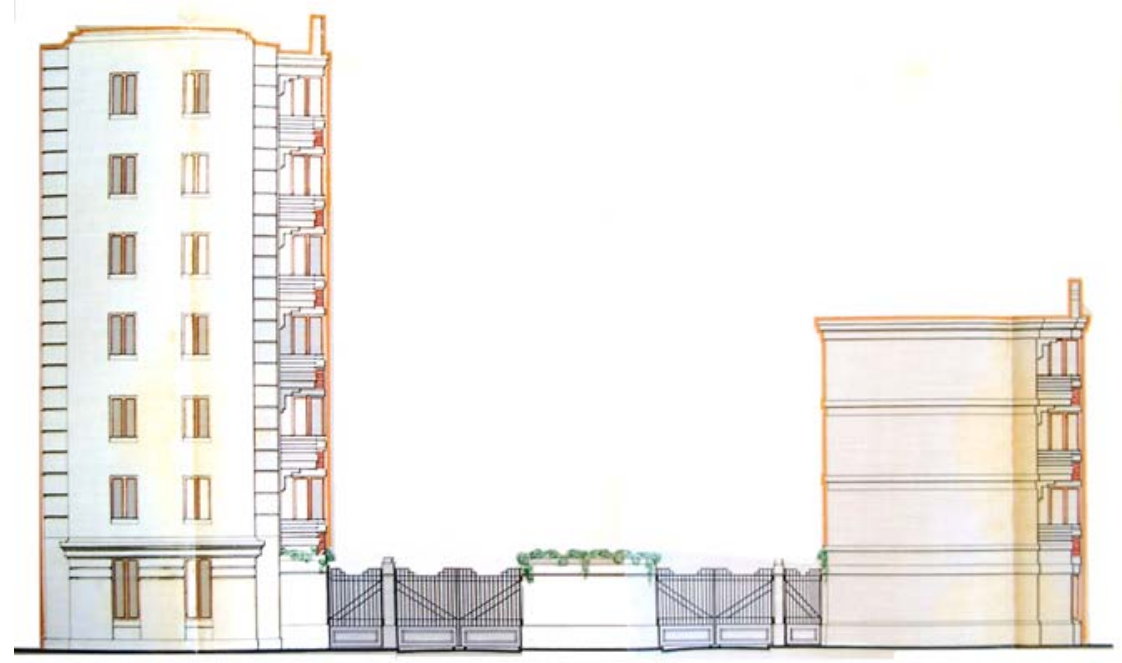

Planta y alzado del Bloque IV (Camino Hondo del Grao). Casas baratas para la ciudad de Valencia. Vicente Valls Gadea, Construcciones Inmobiliarias S.A, 1932 (Archivo Histórico Municipal de Valencia)

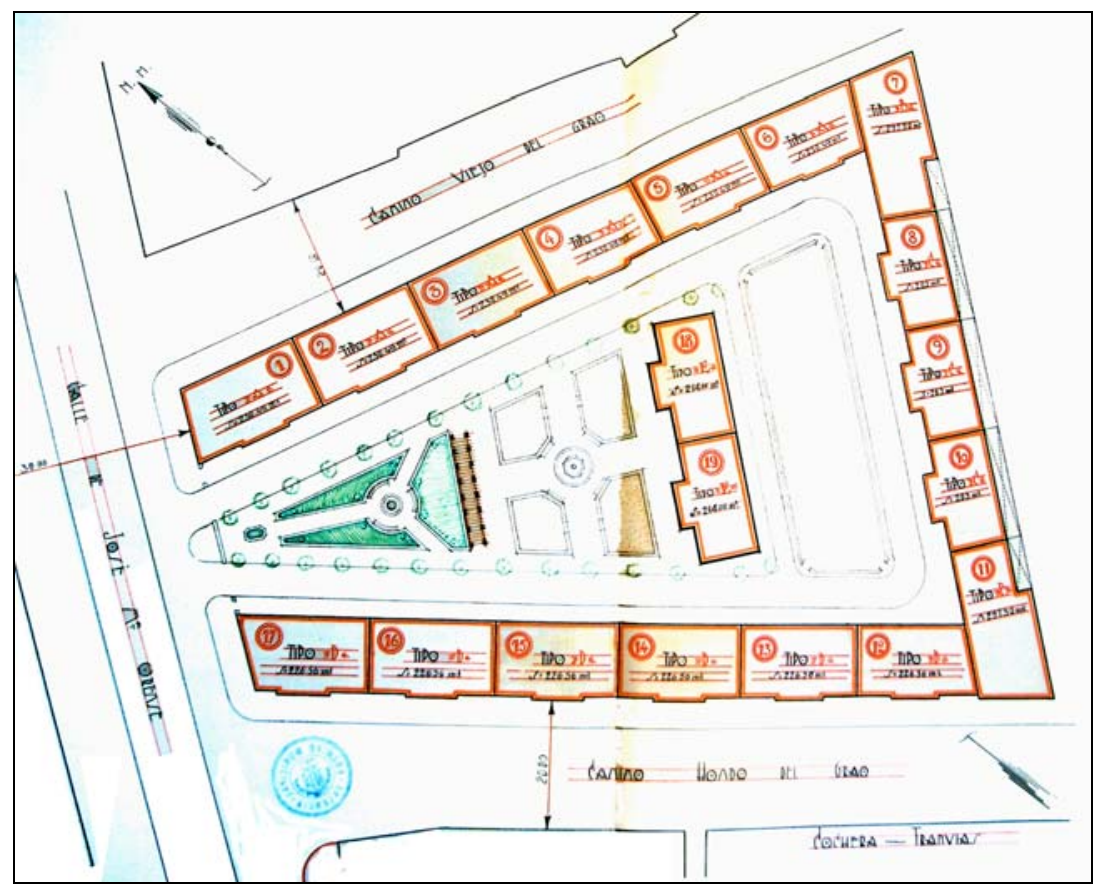




\section{LOS INICIOS DE LA EDIFICACIÓN ABIERTA EN VALENCIA.}

1931-36.

La arquitectura y el urbanismo en Valencia en el periodo comprendido entre 1931 y 1936 han sido estudiados por Tomás Llorens, que señala que en la época de la República no existe una vanguardia arquitectónica significativa en nuestra ciudad ni, por tanto, proyectos comparables a los de Zuazo y Jensen para Madrid o a los del GATEPAC para Barcelona ${ }^{1}$.

Los planes urbanísticos vigentes en Valencia durante el periodo 1930-36 eran el plan de remodelación de Aymamí de 1908, modificado por Goerlich en 1928, el Plan de Ensanche de Mora de 1907 , en su versión definitiva de 1927, y los denominados planes de influencia urbana, que prolongan por lo general la trama del ensanche más allá de los límites del mismo. Además, existen una serie de proyectos urbanos vinculados a la idea de ciudad-jardín, de los cuales el más importante es el redactado por el arquitecto municipal José Pedrós en 1931 para el Paseo de Valencia al Mar.

Los conjuntos de viviendas obreras realizados en Valencia en el periodo 1903-1936, impulsadas por la Ley de Casas Baratas de 1924, han sido estudiados por J. Blat, que señala que en los años treinta más de cuarenta grupos de viviendas de cooperativas, junto con muchos otros de iniciativa privada, se extendían a lo largo del extrarradio, conformando una periferia dispersa en abierto contraste con la ciudad compacta del ensanche ${ }^{2}$.

Sin embargo, los tipos residenciales asociados a la ciudadjardín presentes en esas realizaciones (la casa con jardín, en hilera, aislada, pareada, o de esquina, según el tipo Mulhouse) no tendrán continuidad en nuestra ciudad. La disolución en 1928 de la Federación Internacional de Ciudades Jardín marca, según Blat, el inicio del predominio del bloque colectivo frente a la casa unifamiliar como tipo más idóneo para resolver el problema de la vivienda social.

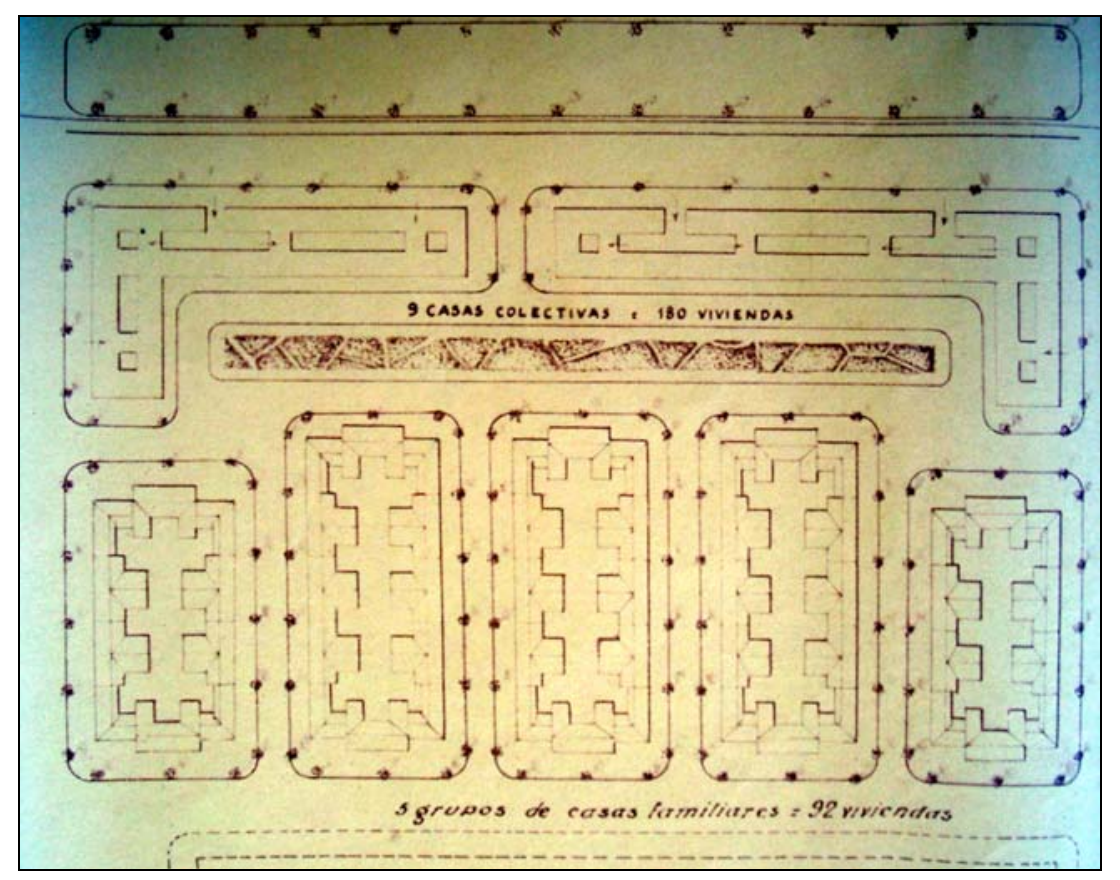

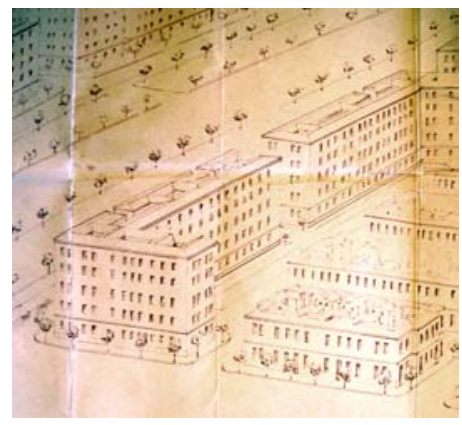

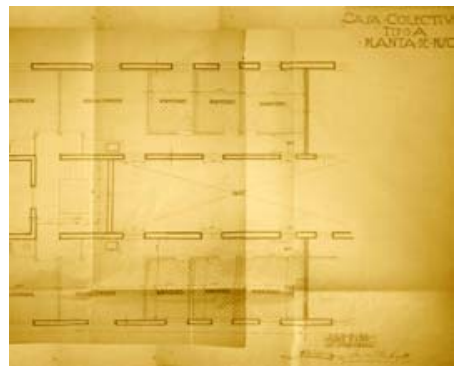

Concurso de iniciativas para la construcción de viviendas modestas en Valencia, 1930. Propuesta de Fomento de Construcciones y Contratas S.A. Perspectiva (fragmento), planta del módulo tipo de viviendas y planta de ordenación de la zona de Paseo al Mar (Archivo Histórico Municipal de Valencia).

1.Llorens, Tomás, "El moviment modern i el racionalisme a I'arquitectura i l'urbanisme valencians", en "El Pais Valenciá, 1931-1939", Arguments, 1, L'estel, Valencia, 1974.

2.Blat Pizarro, Juan, Vivienda obrera y crecimiento urbano (Valencia 1856-1936), Generalitat Valenciana, Consellería d'Obres Públiques, Urbanisme i Transports, Colegio Oficial de Arquitectos de la Comunidad Valenciana, Valencia, 2000. Blat señala que el importante papel de la International Housing Association en la definición de la vivienda moderna ha quedado eclipsado por la mayor difusión que tuvieron los congresos CIAM. 

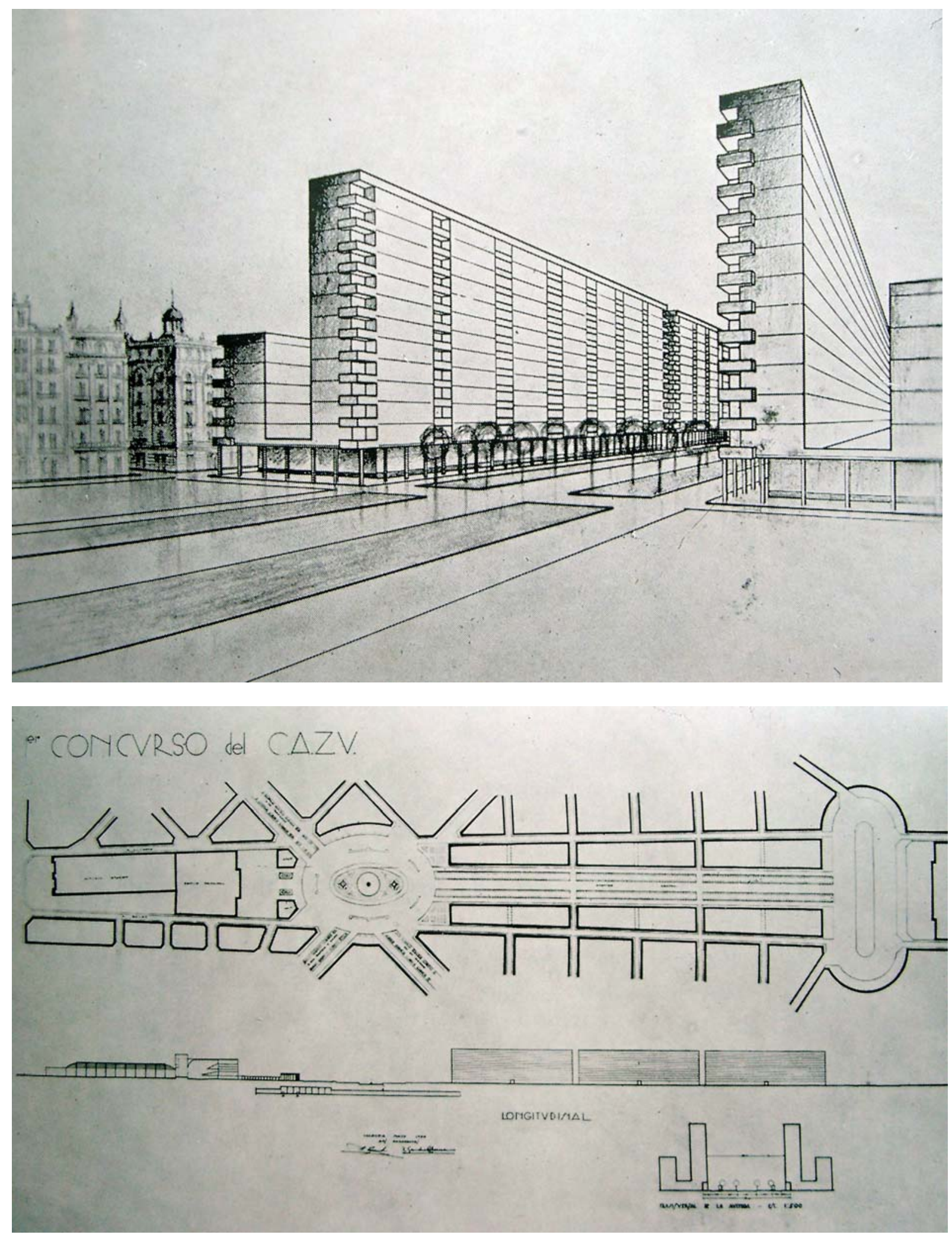

E. Pecourt, L. Sancho, Anteproyecto premiado en el primer concurso del C.A.Z.VA. (Boletín del Colegio oficial de Arquitectos. Zona de Valencia, no 9, 1935) 
En 1930 el Ayuntamiento de Valencia convocó un concurso de proyectos para la construcción de dos mil casas baratas, dirigido a empresas constructoras. Además de las casas unifamiliares, en algunas de las propuestas presentadas encontramos ya bloques colectivos asimilables a la edificación abierta.

Así, por ejemplo, en el proyecto de Fomento de Obras y Construcciones S.A. (FOCSA), aparece un modelo de bloque doble lineal con cuatro viviendas por planta para cada caja de escalera, semejante al de Zuazo en la casa de las Flores. Con agrupaciones lineales o en $\mathrm{L}$ del módulo tipo, se ordena la zona de Paseo al Mar.

La empresa Construcciones Inmobiliarias S.A. (CISA) resultó adjudicataria del concurso, y como consecuencia de ello el arquitecto Vicente Valls Gadea proyectó cuatro manzanas con equipamientos en su espacio libre interior. Tres de estas manzanas están formadas por edificación perimetral profunda, con patios de luces, con tipos similares a los empleados en la Finca Roja por E. Viedma. La cuarta manzana, en cambio, situada en el camino Hondo del Grao y de forma trapezoidal, está formada por bloques de dos crujías dispuestos en forma de $U$ en torno a un espacio ajardinado en el que se sitúa una escuela, según un modelo que reaparecerá en diversas promociones municipales posteriores. Este modelo, en el que las células de vivienda son pequeñas y poco profundas, sin patios de luces y con un espacio libre de acceso público, puede considerarse como un modelo de transición entre la manzana perimetral y el bloque aislado. De hecho, viene a ser un bloque desde el punto de vista de los tipos de vivienda, pero una manzana desde el punto de vista de su relación con el sistema de calles en el que se inserta.

Por otra parte, y en otro ámbito, hay que señalar que entre 1930 y 1936 se publicó el Boletín del Colegio de Arquitectos de la Zona de Valencia (BCAZV), en el que ya en 1932, el arquitecto J.B. Vila Pedroso publicó un breve escrito en defensa del movimiento moderno.

En 1935, el BCAZV publicó los dos anteproyectos premiados en el concurso convocado para ordenar los terrenos de la estación del Norte, realizados por Ramón Liern y por Enrique Pecourt y Luís Sancho. El proyecto de Pecourt y Sancho puede considerarse como la primera propuesta de cierto alcance urbano basada en la edificación abierta realizada en Valencia: dos bloques lineales de distinta altura, unidos en planta baja, flanquean un nuevo eje urbano. El cambio de escala con respecto a la cornisa de las edificaciones del ensanche se resuelve igualando a la misma uno de los dos bloques, mientras que el que flanquea la nueva avenida asume una altura mayor.

Pecourt ya había publicado con anterioridad en el BCAZV ${ }^{1}$ dos artículos relativos al soleamiento, en los que deduce, a partir de los cálculos correspondientes a nuestra área geográfica de la cantidad de calor recibida por una pared según su orientación y de la determinación de las sombras arrojadas, la distancia adecuada entre bloques lineales y la orientación idónea para los mismos, que es la misma que propone Zuazo: fachadas a norte y a sur y calles de directriz este-oeste.

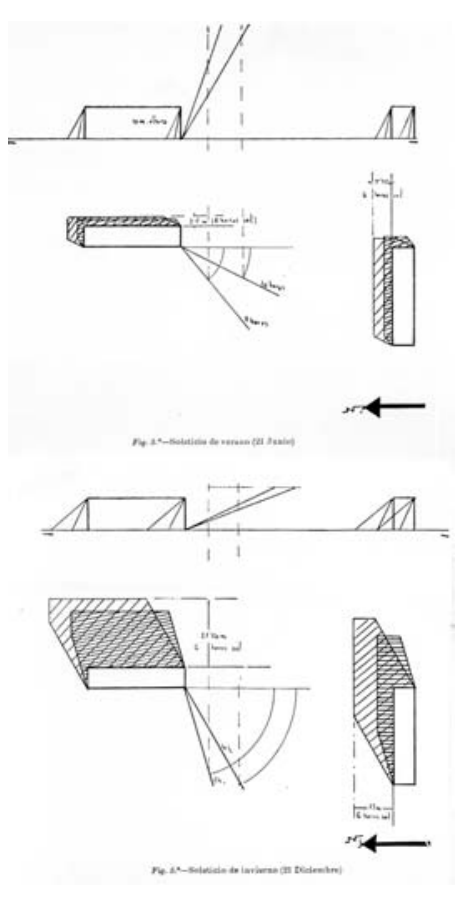

E. Pecourt, Ilustraciones del artículo "Notas sobre soleamiento", BCAZV,1933
1. El tipo de edificio propuesto es similar al del proyecto de Hilberseimer para la City de Berlín, que a su vez reproduce a escala menor el de su proyecto para la Ciudad Vertical.

2. E. Pecourt, "Notas sobre soleamiento", Boletín del Colegio Oficial de Arquitectos - Zona de Valencia, no 2, 3, 1933) 
Proyecto de bloques de viviendas económicas acogidas a los beneficios de la ley para la "clase media" a emplazar junto al Camino de Burjasot. Perspectiva del proyecto. Javier Goerlich, 1946.

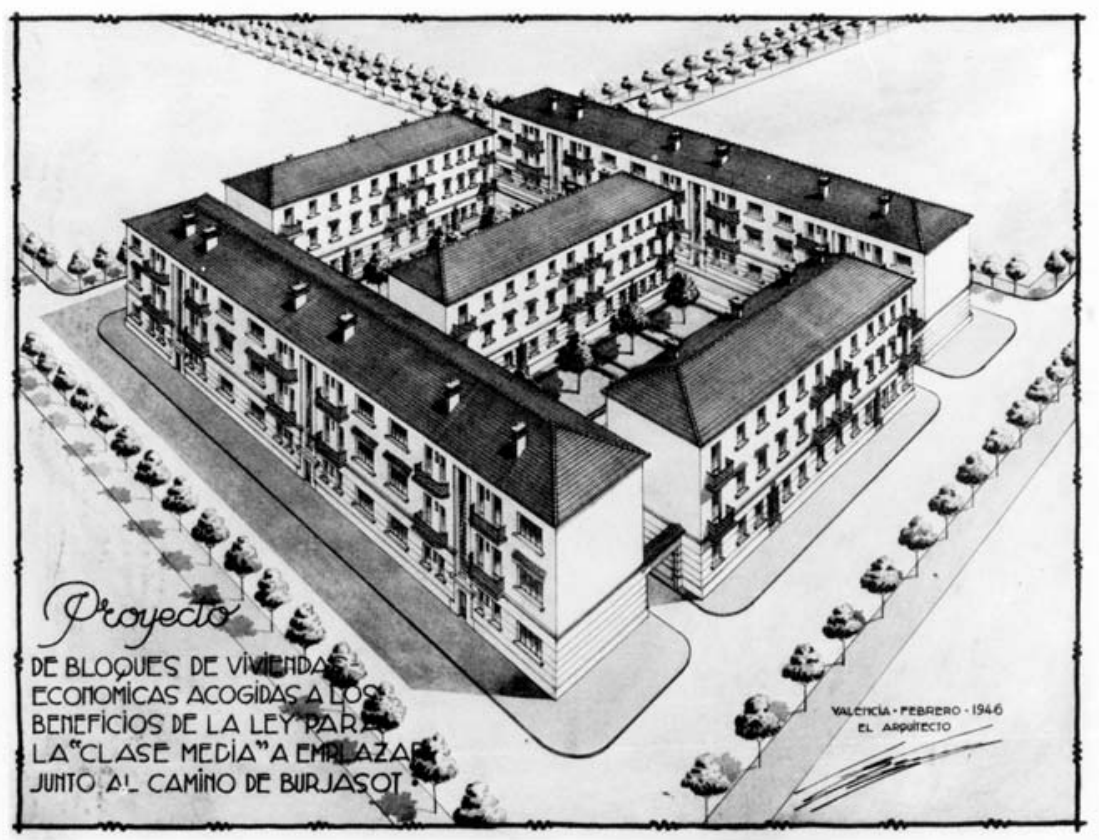

Tabla I.1

Valencia. Grupos de viviendas de promoción pública. 1940-49

\begin{tabular}{|c|c|c|c|}
\hline PROMOTOR & GRUPO & VIVIENDAS & AÑOS \\
\hline \multirow{13}{*}{$\begin{array}{l}\text { Ayuntamiento } \\
\text { de Valencia }\end{array}$} & Alameda & 256 & $1940(\mathrm{Pr})$ \\
\hline & Alboraya-General Franco & 258 & $1942-49$ \\
\hline & Industria & 100 & $1942-48$ \\
\hline & Matías Montero & 242 & $1943(\mathrm{Pr})$ \\
\hline & San Vicente Ferrer & 254 & $1943(\mathrm{Pr})$ \\
\hline & Carretera de Barcelona & 348 & $1944-52$ \\
\hline & Parque de Nazaret & 142 & $1946(\mathrm{Pr})$ \\
\hline & Artes Gráficas & 140 & $1945-62$ \\
\hline & Facultad Cc. Económicas & 148 & $1946(\mathrm{Pr})$ \\
\hline & Xúquer & 210 & $1946(\mathrm{Pr})$ \\
\hline & Federico Mayo & 140 & $1947-53$ \\
\hline & San Jerónimo & 108 & $1948-50$ \\
\hline & Camino de Alba & 296 & $1948(\mathrm{Pr})$ \\
\hline \multirow{4}{*}{ OSHA } & Pampló Gómez & 42 & $1940-53$ \\
\hline & Ramiro Ledesma & 88 & $1943-46$ \\
\hline & Ramón Laporta & 164 & 1944-54 \\
\hline & V. Desamparados Fase I & 704 & $1945-55$ \\
\hline DGRV & Virgen del Castillo & 256 & $1939-45$ \\
\hline
\end{tabular}

Notas:

(Pr) Año proyecto. Grupo no realizado.

Los grupos sombreados son los que incluyen, en mayor o menor medida, elementos asimilables a la edificación abierta.

Abreviaturas:

OSHA: Obra Sindical del Hogar y la Arquitectura.

DGRV: Dirección General de Regiones Devastadas. 


\section{DE LA MANZANA AL BLOQUE: GRUPOS DE VIVIENDAS DE PROMOCIÓN MUNICIPAL 1940-49}

Los conjuntos residenciales de promoción pública de Valencia han sido estudiados con detalle por F. Gaja ${ }^{1}$ en su tesis doctoral, en la que se presta especial atención al proceso de realización de los mismos: la adquisición de suelo, la tramitación administrativa y la financiación, la construcción y sus etapas, además de analizar los elementos del proyecto urbano y arquitectónico de los barrios.

En el período 1939-1949 la mayoría de los grupos o conjuntos residenciales construidos en Valencia son de iniciativa municipal, y se realizan sobre solares expropiados, adquiridos o cedidos por el Ayuntamiento, con proyectos redactados por los arquitectos municipales $^{2}$.

Además de las actuaciones municipales, en el periodo 19391949 dos organismos estatales promueven conjuntos de viviendas en Valencia: la Obra Sindical del Hogar y la Arquitectura (OSHA) y la Dirección General de Regiones Devastadas, aunque su papel es poco relevante, en comparación con el Ayuntamiento, en este periodo: la OSHA construye cuatro grupos, con 994 viviendas en total, y Regiones Devastadas uno, el Virgen del Castillo, de 250 viviendas.

Los conjuntos residenciales promovidos por el Ayuntamiento de Valencia entre 1940 y 1949 son los indicados en la Tabla I.1. En la mayor parte de ellos, lo más habitual es el recurso a modelos de manzana unitaria con patio interior más o menos abierto a las calles circundantes, según el modelo de la manzana perimetral de Amsterdam Sur o de las hoffe vienesas, aunque a una escala mucho menor.

En algunos de estos grupos de promoción municipal, al igual que ocurre en muchas hoffe, la mayor permeabilidad entre las calles y el espacio libre interior de la manzana, unido al hecho de que las tipologías de vivienda sean pasantes, originando bandas de edificación poco profundas, de dos crujías, hacen que podamos considerarlos como edificaciones que anticipan la relación entre edificación y espacio libre característica de la edificación abierta. Es el caso de conjuntos como el grupo Alboraya-Generalísimo Franco, el de la Carretera de Barcelona o el Federico Mayo ${ }^{3}$.

En todos estos ejemplos, el espacio interior de manzana adquiere un carácter de espacio público, accesible a peatones o vehículos y en el que se sitúan incluso equipamientos como escuelas. Ello es posible a causa de la disminución del espesor del perímetro que deriva del cambio del tipo de vivienda, que hace que, a igualdad de tamaño de la manzana con respecto a una de ensanche, queda más superficie libre interior. Destinar a escuelas los interiores de manzana no es, sin embargo, una solución generalizable, por lo que la vía alternativa -disminuir el tamaño de la manzana- será la más habitual.

Por otro lado, en algunos de los ejemplos mencionados vemos como la edificación de la manzana se plantea como una suma de bloques lineales más que como una franja perimetral continua.
1. Gaja, Fernando. La promoción pública de la vivienda en Valencia (1939-1976), Generalitat Valenciana, Consellería d'Obres Públiques, Urbanisme i Transports, 1989.

2. Gaja, F. Op. Cit., p. 56. La continuidad de Javier Goerlich como arquitecto mayor entre 1931 y 1956 se señala como un factor tal vez determinante en la historia de la política municipal de construcción de viviendas.

3. Para los grupos tratados en esta sección, la fuente principal es Gaja, F., Op.Cit. Además, aparecen reseñados en:

-Llopis, Amando y Dauksis, Sonia, eds., Arquitectura del siglo $X X$ en Valencia, Institució Alfons el Magnánim-Diputació de VaIencia, Valencia, 2000.

-Peñín Ibáñez, Alberto. Valencia 1874-1959. Ciudad, arquitectura y arquitectos, Escuela Técnica Superior de Arquitectura de Valencia, Valencia, 1978. -VV.AA., Registro de Arquitectura del siglo $X X$, Comunidad Valenciana, COACV, COPUT, IVE, Valencia, 2002. 


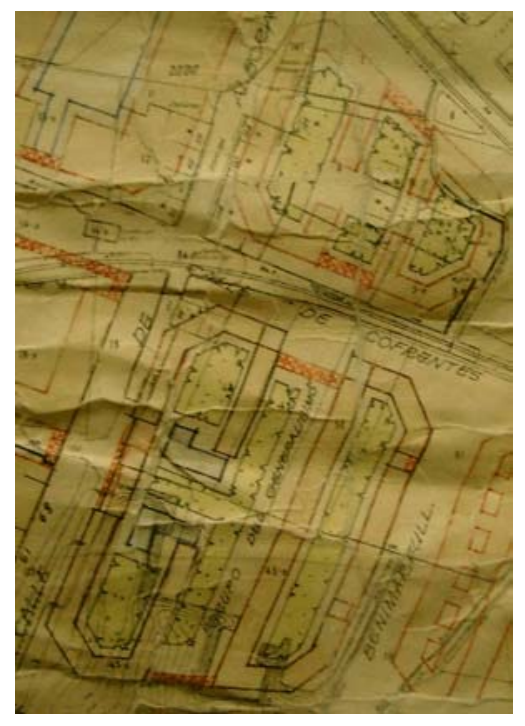

Grupo Alboraya. Planta del grupo en la Hoja 10 de desarrollo del Plan General de 1946 (Archivo de Planeamiento. Ayuntamiento de Valencia).

Grupo Alboraya Planta de conjunto. (Sombreado color sobre Cartografía Básica Municipal de Valencia, 1983).

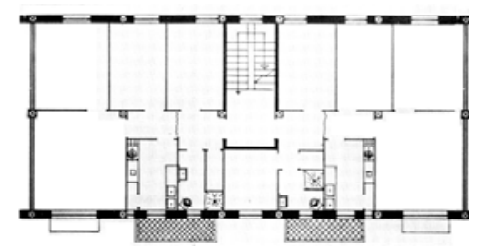

Grupo Alboraya. Planta tipo de viviendas.

Grupo Alboraya. Perspectiva del proyecto, 1943.
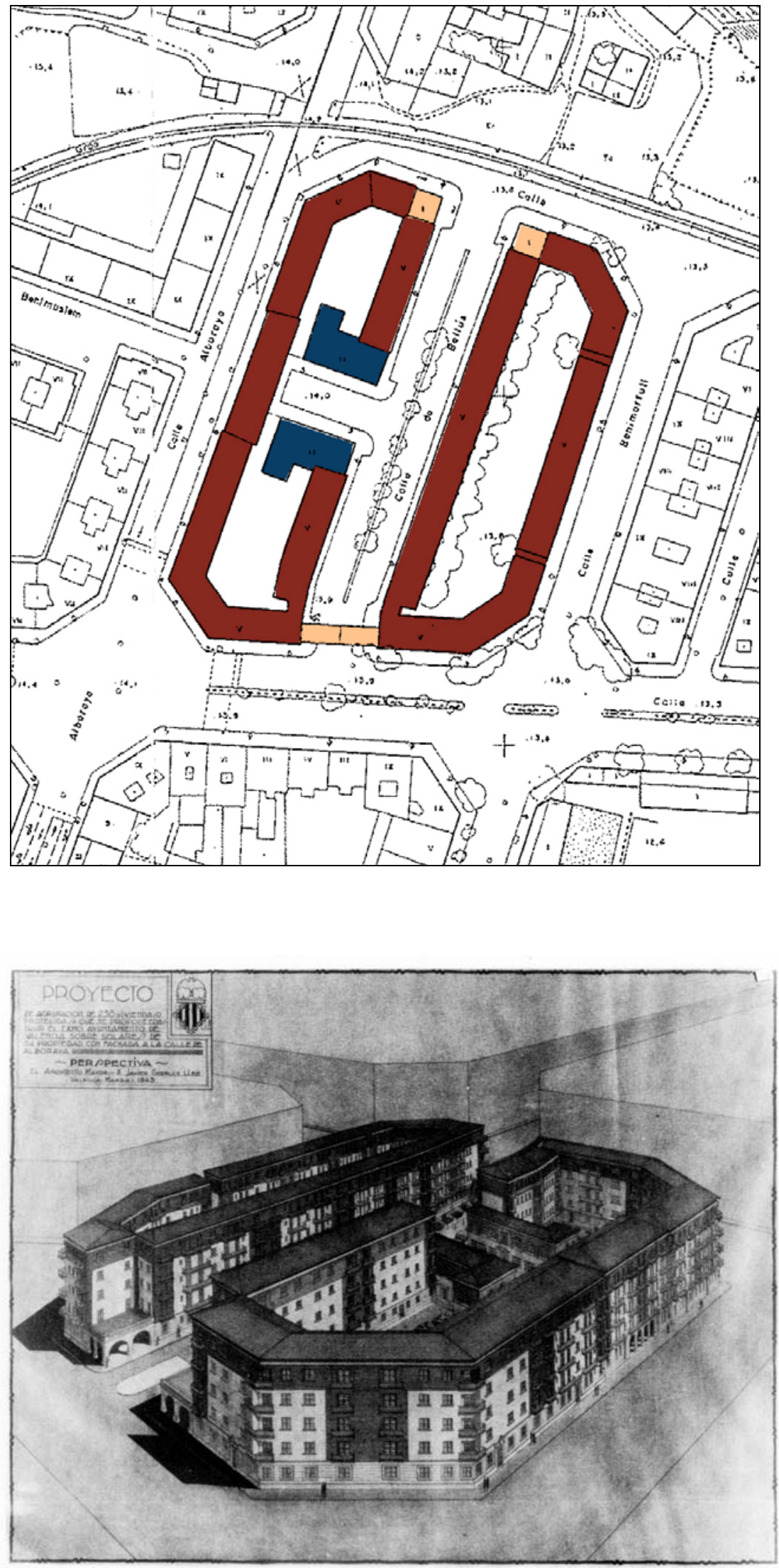
El Grupo Alboraya, que cambió su nombre por el de Generalísimo Franco poco antes de su finalización en 1950, fue proyectado por Javier Goerlich en 1943, en una manzana de ensanche de dimensiones aproximadas $100 \times 130$ m, limitada por las calles Alboraya, Cofrentes, Genaro Lahuerta y Molinell.

El grupo incluye 268 viviendas protegidas, destinadas a población desplazada por derribos del centro histórico, funcionarios municipales e inmigrantes.

La edificación está basada en células tipo de vivienda de dos crujías, con superficies que oscilan entre 76 y $126 \mathrm{~m} 2$, dispuestas en módulos yuxtapuestos de dos viviendas por caja de escalera. Parte de la planta baja está destinada a locales comerciales.

Esta edificación se agrupa en dos semimanzanas alargadas de $\checkmark$ plantas $(\mathrm{PB}+4)$ situadas a cada lado del espacio libre interior. La semimanzana este es cerrada, con edificación en todo su perímetro, mientras que la oeste tiene forma de C abierta al espacio interior, dejando espacio para una plaza en la que se disponen sendas escuelas para niños y niñas. Esta plaza está conectada por un pasaje con la calle Alboraya.

El espacio interior se completa con jardín lineal en dirección norte-sur, paralelo al cual discurre una calle (la calle Bellús) accesible al tráfico rodado y limitada en su extremo por una arcada con pérgola que la separa de la calle Molinell. No existe ningún vallado bajo esa arcadas, por lo que el espacio libre interior es de uso público, como ocurrirá con los espacios entre bloques de edificación abierta.

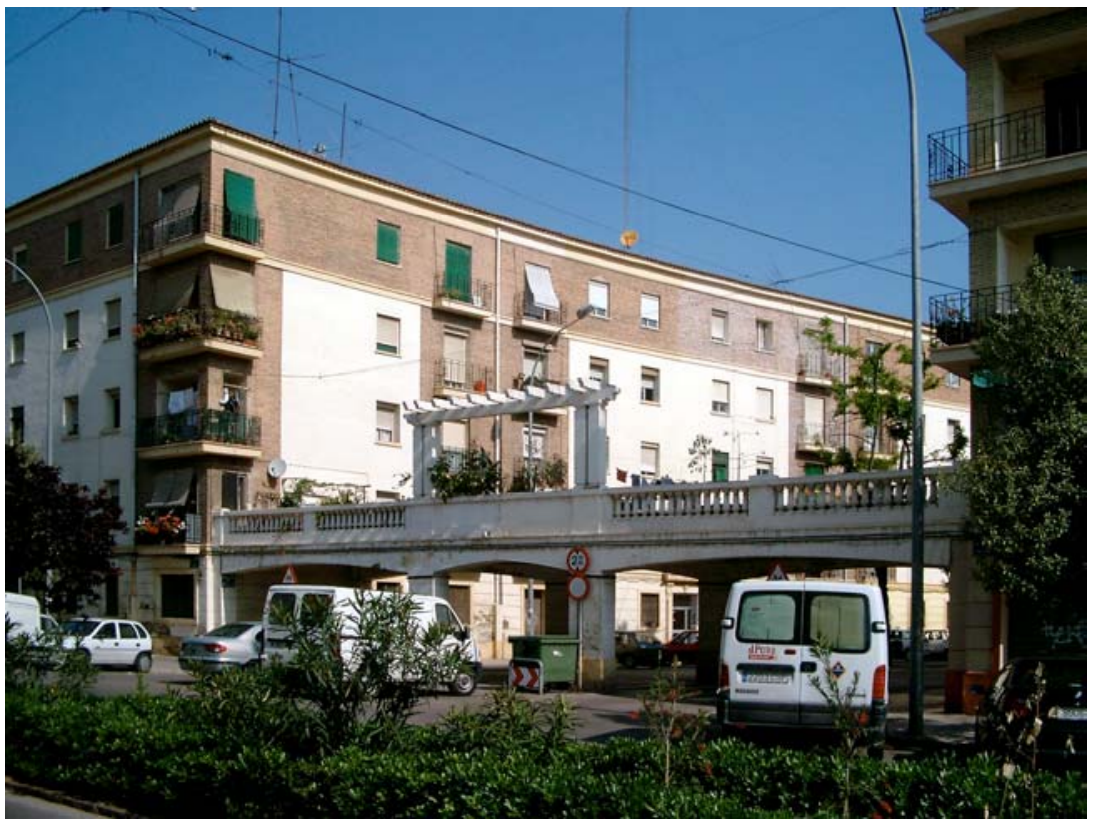

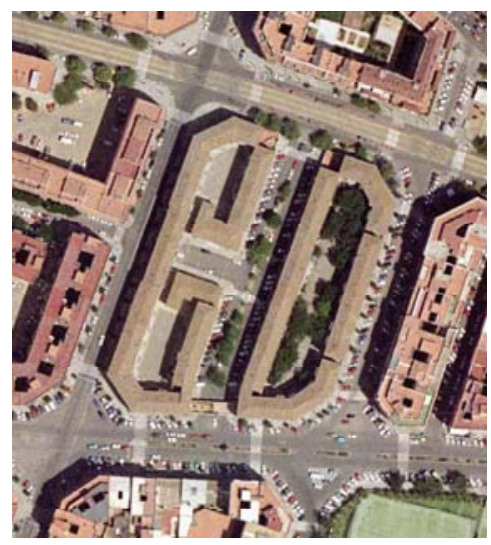

Grupo Alboraya. Ortofoto 2002 (AUMSA).
Grupo Alboraya. Vista actual desde la calle Molinell. 

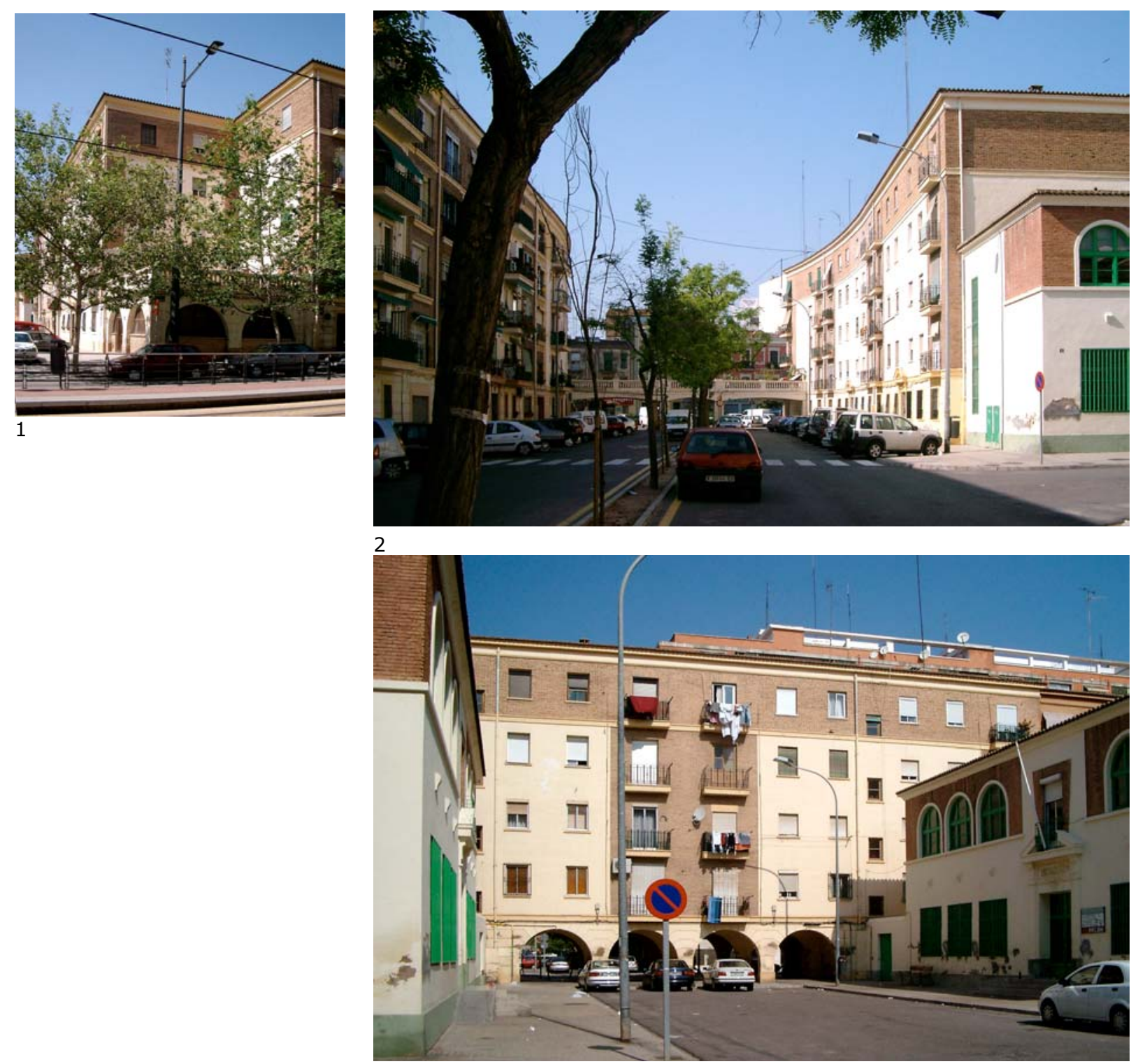

1. Esquina a calle Cofrentes

2. Vista de la calle interior hacia la calle Molinell.

3. Vista de la plaza central con las escuelas.

4. Pasaje desde la calle Alboraya a la plaza.

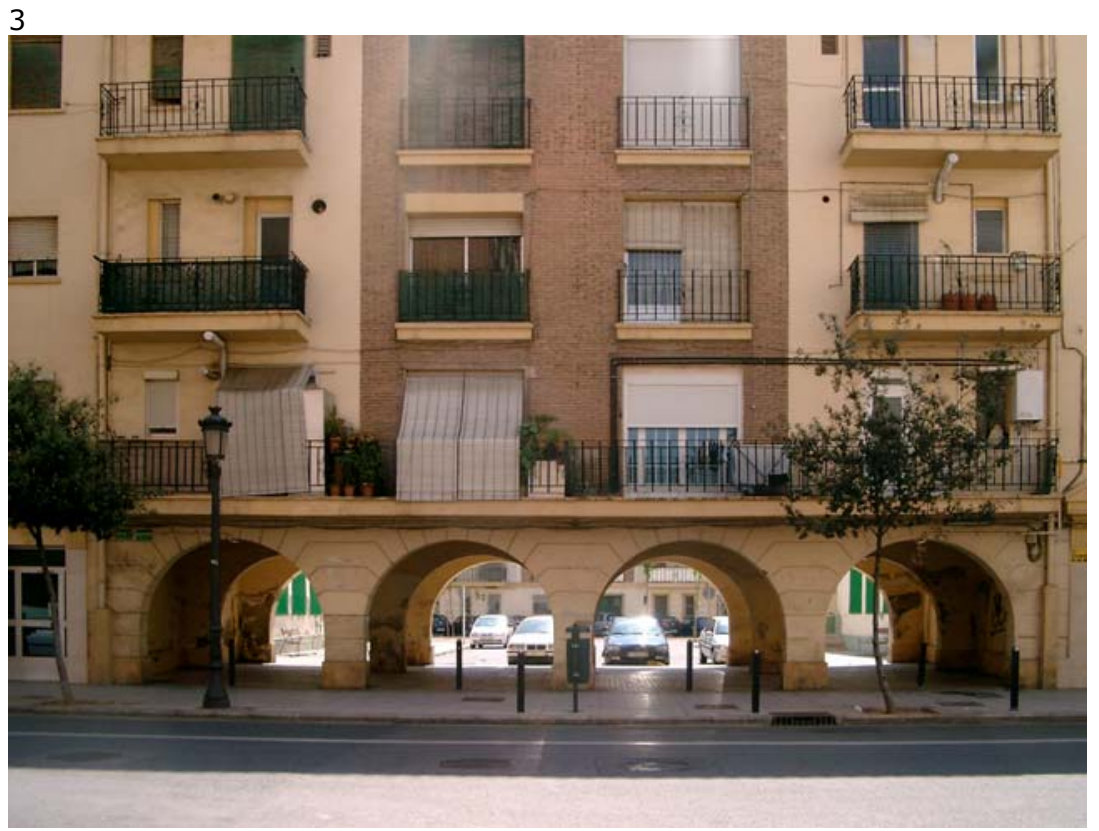


La concepción de la manzana como agrupación de bloques se hace perceptible en el lado norte, donde las esquinas que flanquean la calle central se vacían en todas las plantas excepto la baja, de modo que los bloques quedan unidos sólo por un vértice.

En el grupo Alboraya podemos ver como, al igual que ocurre en las manzanas de los años veinte de Amsterdam Sur o Hamburgo, la utilización de células de vivienda de dos crujías conlleva una disminución del tamaño de la manzana con respecto a la de ensanche, ya que es la única forma de mantener una proporción razonable, y económicamente viable, entre espacio edificado y espacio libre, cuando la edificación es una banda perimetral poco profunda.

Por ello, las proporciones entre el espacio libre y el espacio edificado del grupo Alboraya recuerdan a alguna de las parejas de manzanas proyectadas por K. Schneider para el barrio Jarrestadt de Hamburgo. Sin embargo, tal vez el sea la casa de las Flores el referente más apropiado, ya que, sin la racionalidad distributiva y la brillantez arquitectónica de la obra de Zuazo, el grupo Alboraya responde de alguna manera al mismo sistema de manzana formada por una pareja de bloques dobles que flanquean un espacio interior que debe convertirse necesariamente en un espacio público, de calle, si se quieren evitar las viviendas recayentes a patios interiores, prohibidas por las normas urbanísticas.

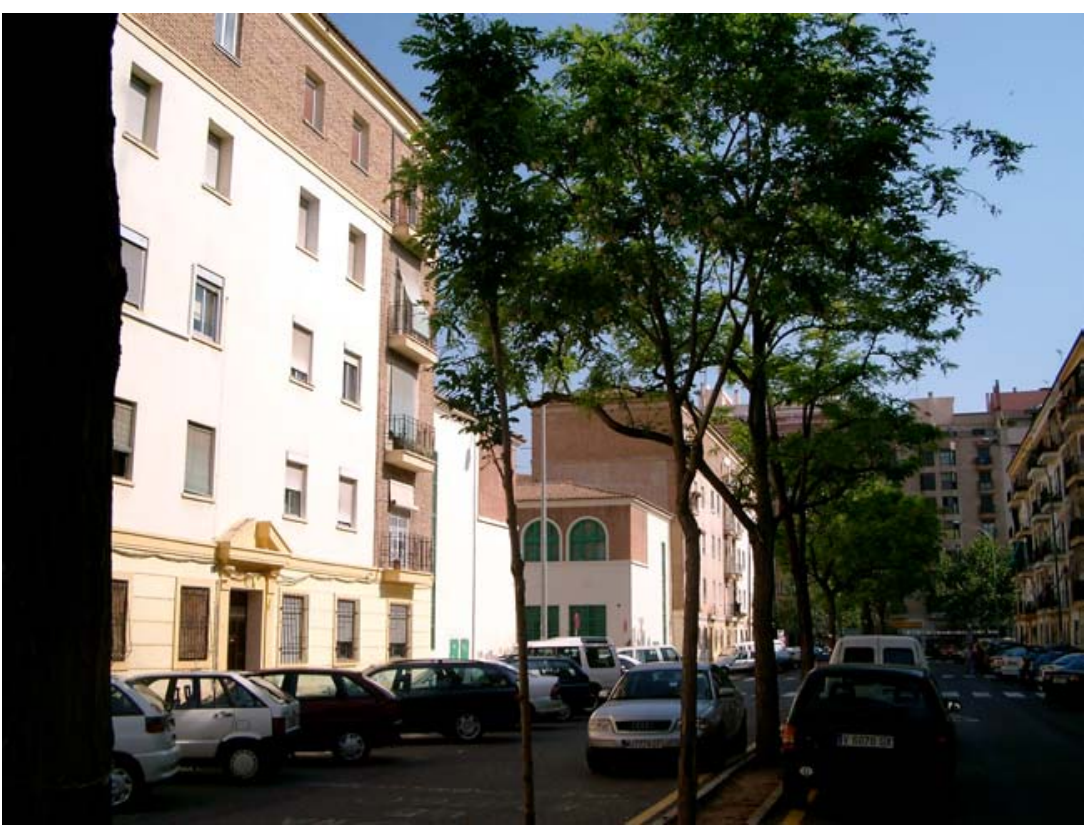

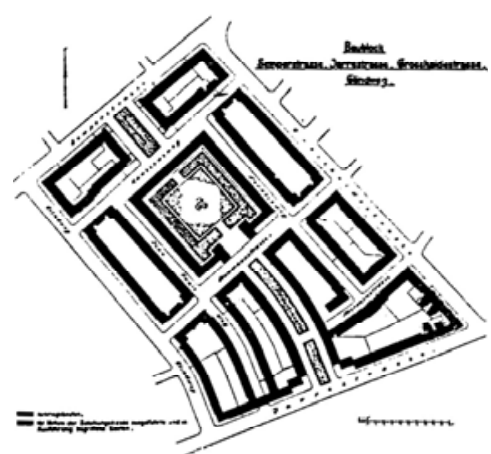

Hamburgo. Conjunto Jarrestadt, 1927-30. Karl Schneider

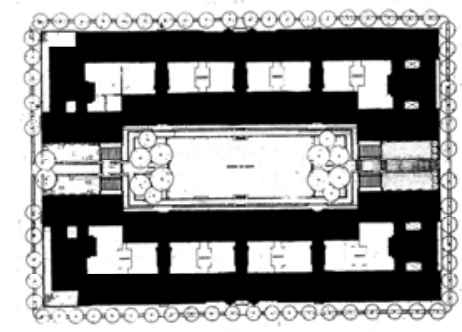

Casa de las Flores. Madrid, 193132. Secundino Zuazo.

Grupo Alboraya. Vista de la calle interior hacia el norte 


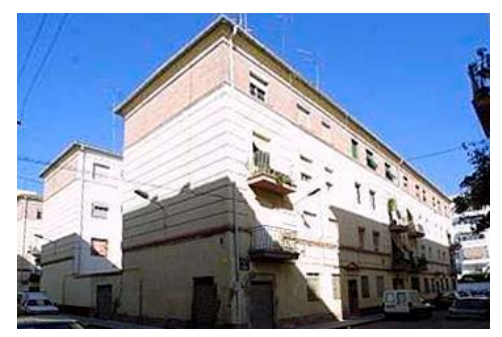

Grupo Montduver. Vista desde la calle Estubeny.

Grupo Montduver. Planta de conjunto (Sombreado color sobre Cartografía Municipal, 1983)
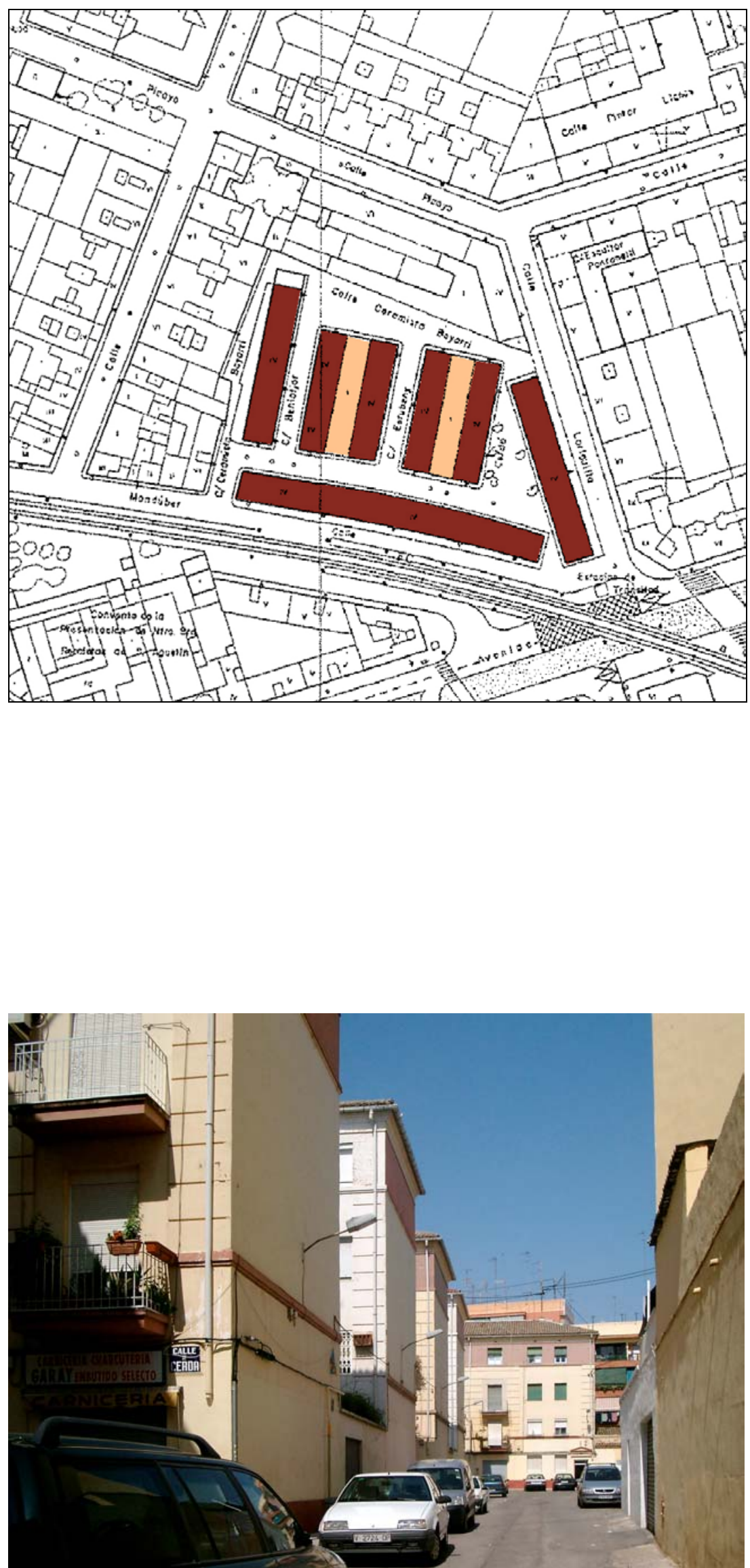

Grupo Montduver. Vista de la calle Ceramista Bayarri. 


\section{GRUPO MONTDUVER}

El grupo Montdúver es el primer conjunto de viviendas de Valencia que podemos considerar de edificación abierta, ya que está formado íntegramente por bloques lineales de dos crujías.

El conjunto, cuyo lenguaje arquitectónico es muy parecido al del grupo Alboraya, ocupa la mayor parte de una manzana próxima a la ronda de Tránsitos. Los bloques perimetrales, recayentes a las calles Montdúver y Loriguilla, están alineados con dichas calles, y el primero de ellos tiene una traza ligeramente curvada. La solución de la esquina es característica de la edificación abierta, sustituyendo el chaflán propio de la manzana cerrada por los dos testeros ciegos de los bloques unidos por una pérgola en planta baja.

Detrás de la delgada pantalla formada por estos bloques perimetrales, se disponen cinco bloques lineales interiores que rellenan el espacio interior de manzana. Estos bloques son equidistantes, y tienen una orientación aproximadamente norte-sur, con fachadas de las viviendas a este y oeste. Cuatro de ellos se unen dos a dos mediante edificación de una planta, formando dos micromanzanas.

El conjunto resulta muy denso, y es un ejemplo claro del uso de la edificación abierta seriada como relleno de un espacio interior de manzana que ha aumentado considerablemente su superficie frente con respecto a la manzana de ensanche como consecuencia del adelgazamiento de la edificación perimetral.

En este caso, los bloques que ocupan el corazón de la manzana están muy próximos entre sí, formando un conjunto muy denso, en el que el único espacio libre digno de mención es el pequeño jardín triangular que resulta de la diferente alineación de los bloques perimetrales y los interiores.

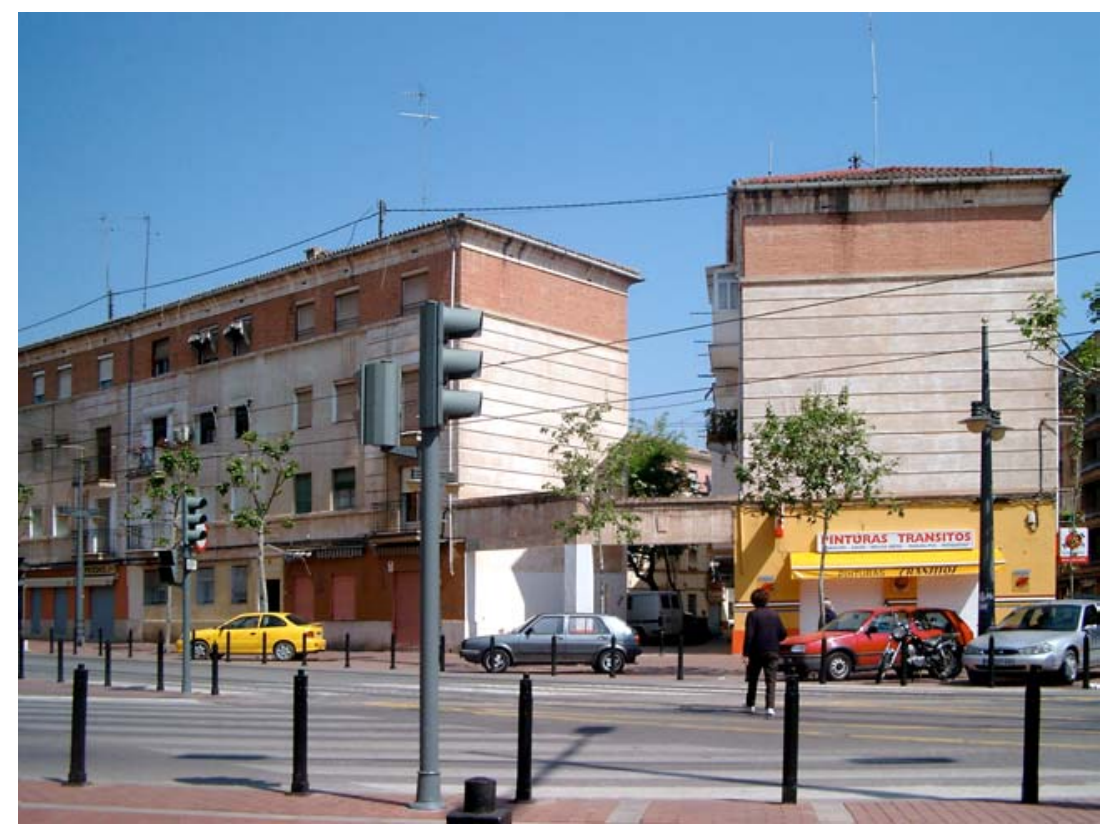

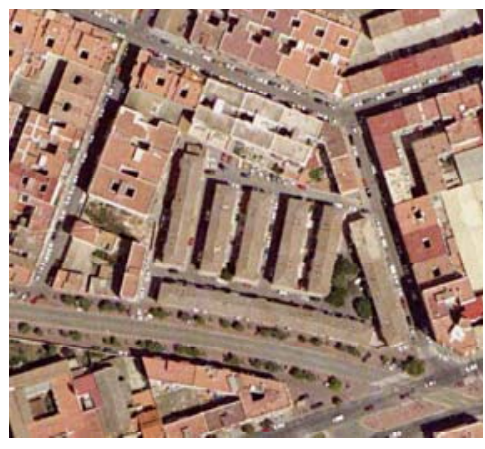

Grupo Montduver. Ortofoto 2002 (AUMSA)
Grupo Montduver. Vista de la esquina de las calles Montduver y Loriguilla. 
Grupo Carretera de Barcelona. Planta de conjunto. Cartografía Básica Municipal de Valencia, 1983.

Grupo Carretera de Barcelona. Perspectiva.del proyecto, 1944.
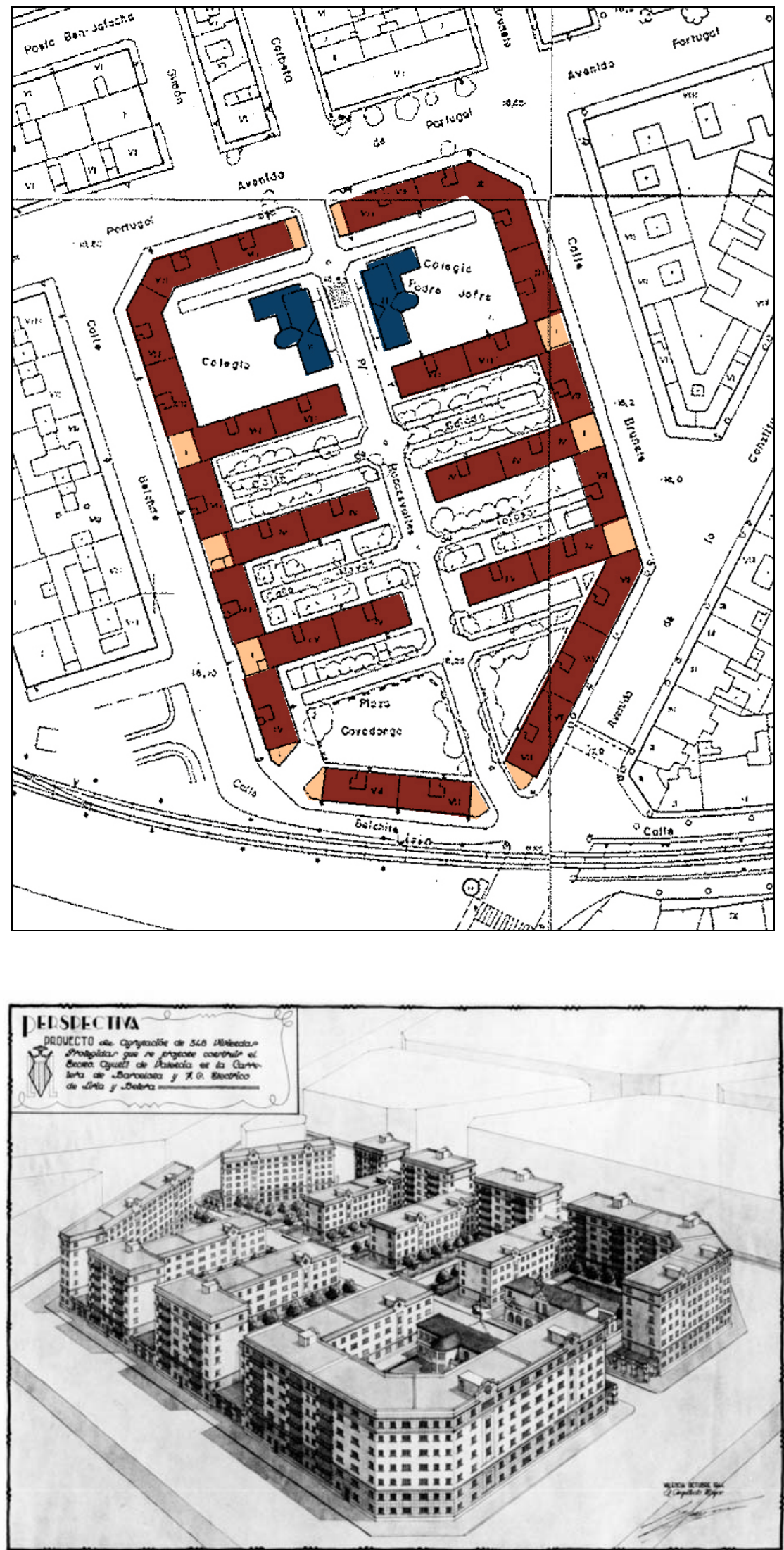
El Grupo Carretera de Barcelona fue proyectado por Javier Goerlich en 1944, en una manzana de forma pentagonal con dimensiones medias aproximadas de 100×150 m, calificada como de "Ensanches Futuros" y situada junto a la carretera de Barcelona (actual Avenida de la Constitución) y el ferrocarril eléctrico de Liria y Bétera. Con sus 348 viviendas protegidas, es el mayor grupo de viviendas promovido por el Ayuntamiento de Valencia. Los trámites para su construcción, que finalizó en 1952, comenzaron en 1942.

Las viviendas son de dos crujías, con superficies que oscilan entre los 83,60 y los 87,52 m2, excepto 6 viviendas de 136,08 m2. Estas viviendas se distribuyen entre nueve bloques de VII plantas $(P B+6)$ alineados con las calles perimetrales y seis bloques de IV plantas ortogonales a los anteriores.

Cada caja de escalera sirve a dos viviendas por planta, lo que supone que, a diferencia de las hoffe vienesas citadas como modelo que inspira este grupo, las viviendas son pasantes, con dos fachadas a orientaciones diferentes y ventilación cruzada. En las hoffe, en cambio, lo habitual es que cada caja de escalera sirva a cuatro viviendas por planta, que son viviendas a una cara: unas están volcadas sólo a las calles exteriores y otras sólo al patio interior.

La alineación exterior de la manzana queda interrumpida en las plantas de piso por el retranqueo de los brazos ortogonales que penetran hacia el interior, que generan una discontinuidad de los volúmenes desde la calle acentuada por su menor altura. Los locales comerciales se sitúan en el frente de calle correspondiente al retranqueo.

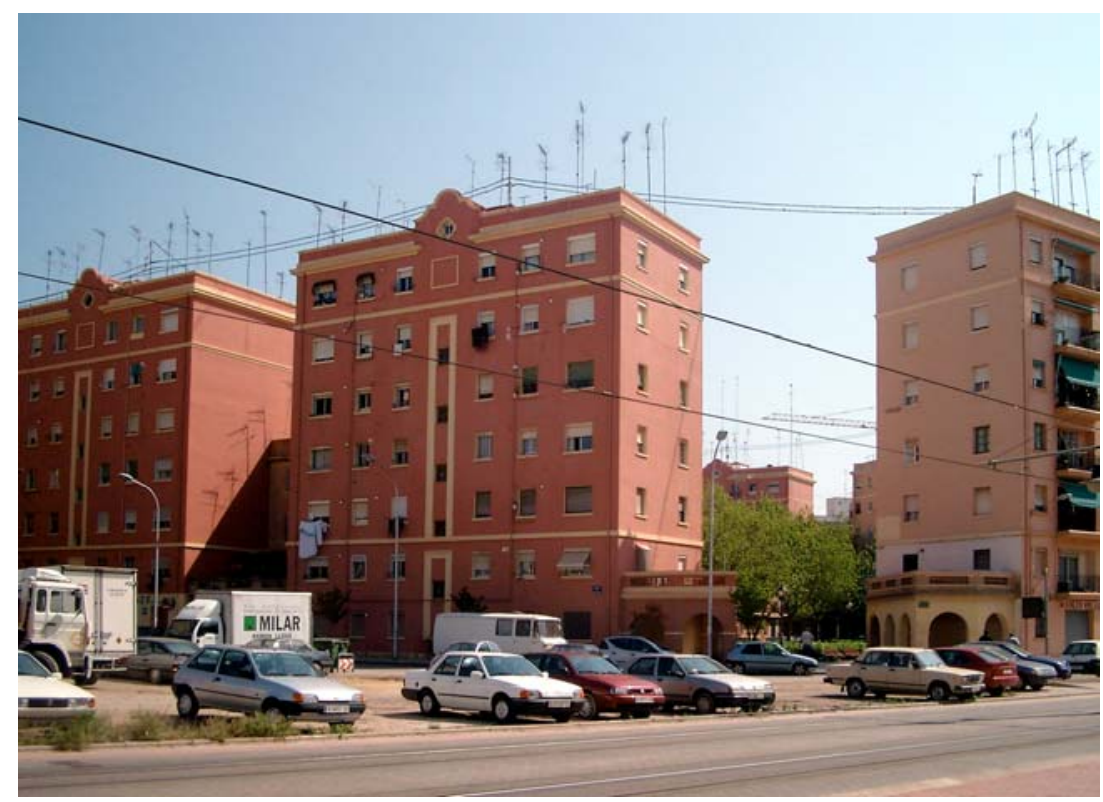

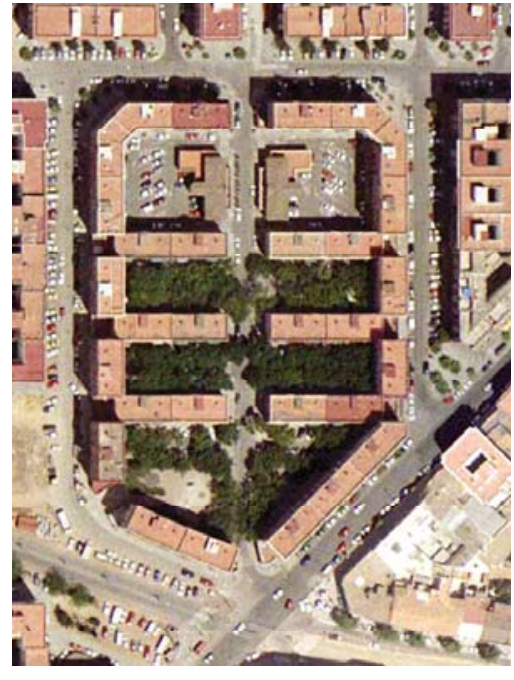

Grupo Carretera de Barcelona. Fotografía aérea, 2002 (AUMSA).
Grupo Carretera de Barcelona. Vista desde el suroeste. 

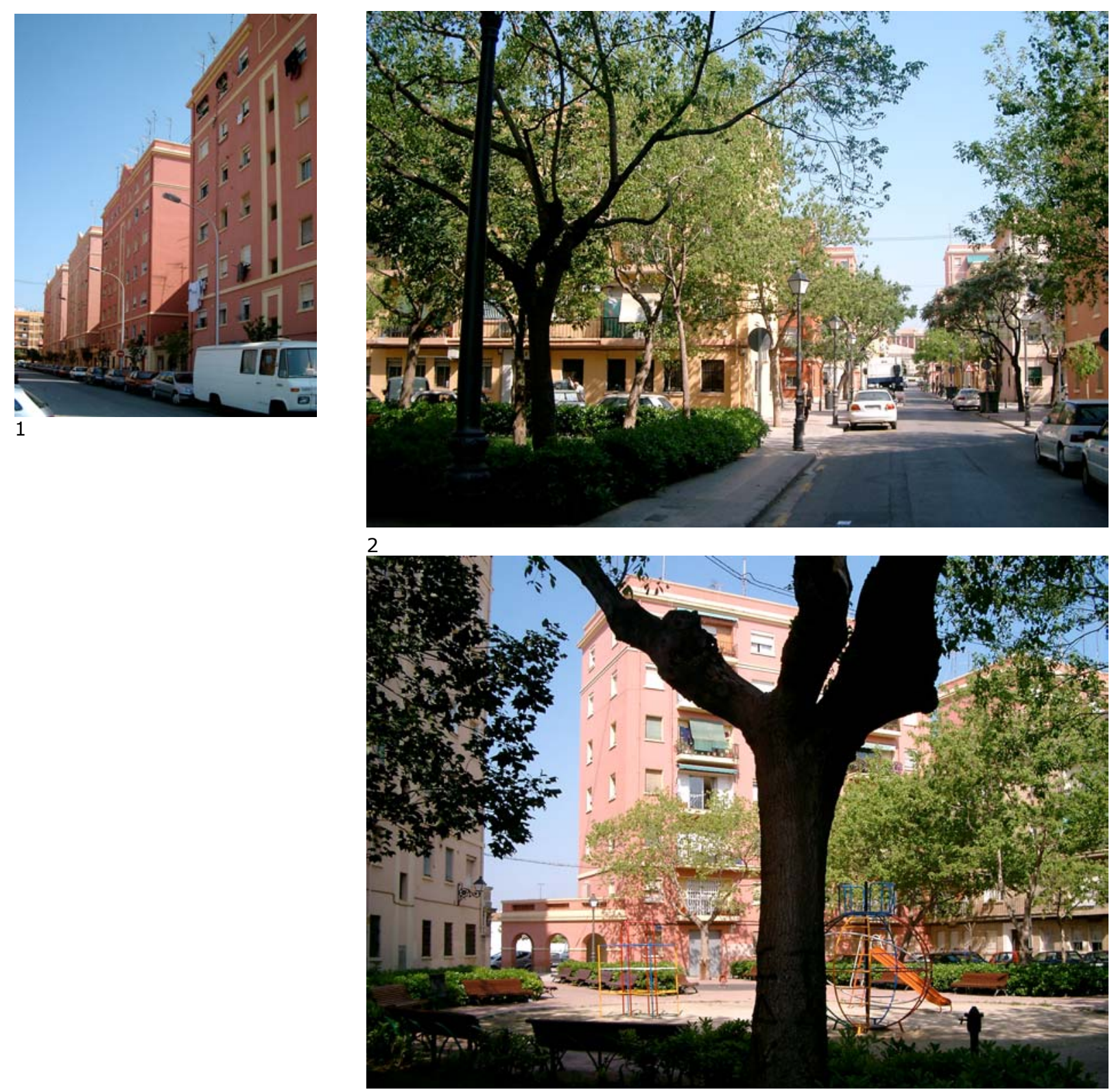

1. Alzado oeste (calle Belchite)

2. Vista de la calle interior hacia el norte.

3. Espacios libres laterales a la calle interior. (Plaza Covadonga)

4. Acceso desde la esquina suroeste.

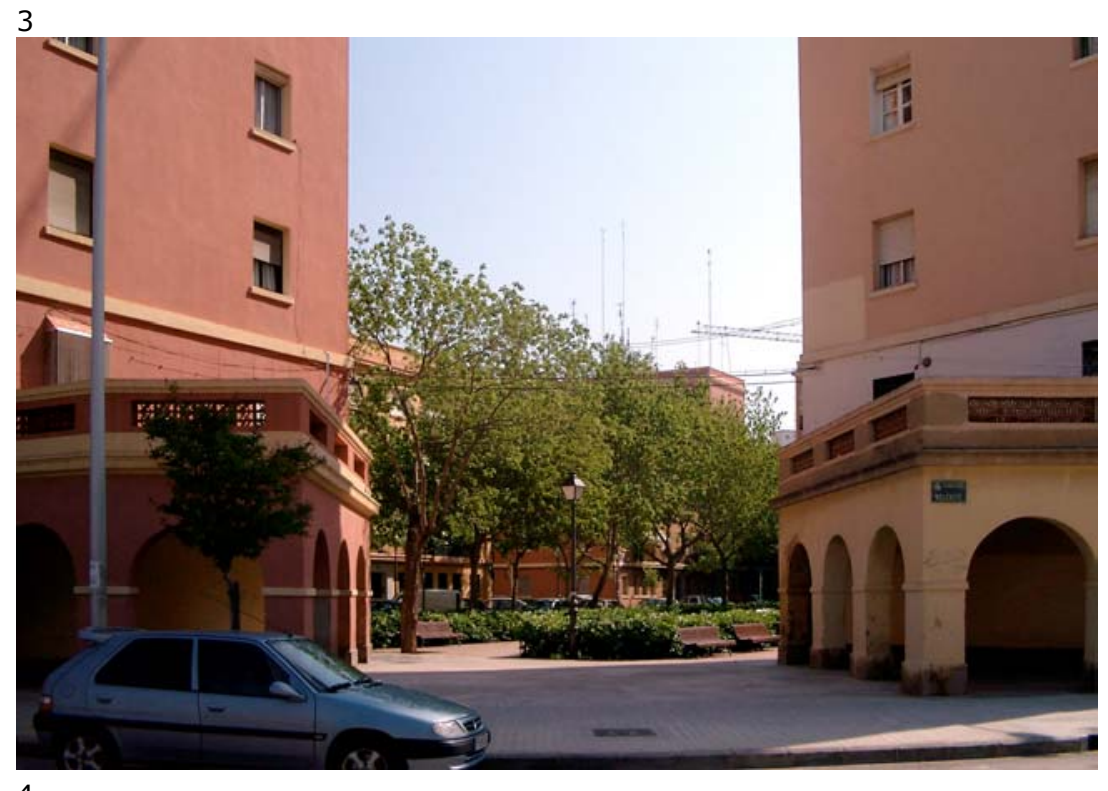


Además, en la parte sur, el tratamiento del perímetro es claramente discontinuo, ya que las esquinas se dejan vacías y permiten percibir los dos bloques lineales que forman ese lateral como volúmenes diferenciados, aunque enlazados en planta baja. No ocurre así en el lado norte, en el que las esquinas están construida del modo tradicional en los ensanches, con chaflán incluido.

El espacio interior resultante de la disposición de la edificación en forma de dos peines simétricos es una calle central a la que se abren espacios laterales ajardinados, dos de los cuales se destinan a escuelas. Esta calle central, igual que ocurre en el grupo Alboraya, tiene características de espacio público, ya que desde ella se accede a todos los zaguanes. El acceso a la calle desde el exterior, para peatones y vehículos, se realiza directamente desde el lado norte y a través del filtro de una arcada en el lado sur.

La contradicción entre la localización de los escasos locales comerciales abiertos al exterior, a unas calles laterales cuya fachada es una sucesión de ventanas de viviendas de planta baja, y la localización introvertida de los zaguanes, recayentes a la calle interior de manzana, es uno de los temas problemáticos que van asociados desde un primer momento a las manzanas con espacio libre interior, y que reaparecerán en numerosas propuestas posteriores de reinterpretación de la manzana a partir del bloque.

El grupo Carretera de Barcelona muestra una alternativa para mantener un tamaño de manzana grande, similar al de ensanche pero sin tener que recurrir a edificación perimetral profunda con patios de luces. Es el método, ya empleado por M. Brinkmann en la manzana de Spangen, en Rotterdam (1919-20), de proyectar, además de la edificación perimetral, brazos o cuerpos de edificación que penetren en el espacio interior de manzana, para contribuir a mantener una proporción razonable de espacios libres. ${ }^{1}$

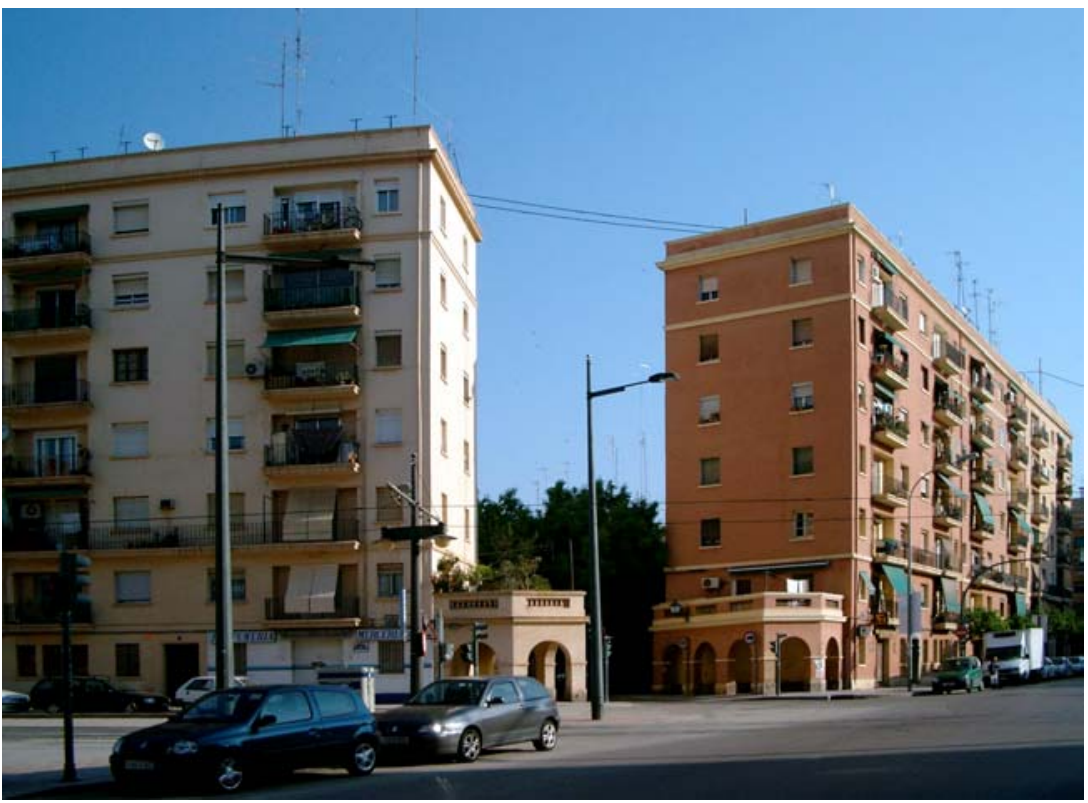

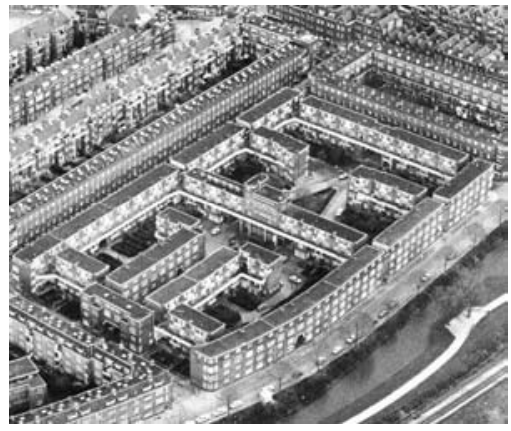

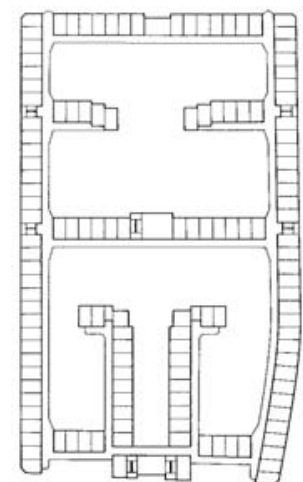

Manzana en Spangen. Rotterdam, 1919-20. Michiel Brinkmann.

Grupo Carretera de Barcelona. Vista desde la Av. Constitución.

1. El uso actual de los edificios escolares es de comisaría de policía, y los espacios interiores junto a las escuelas han sido ocupados por aparcamientos. 

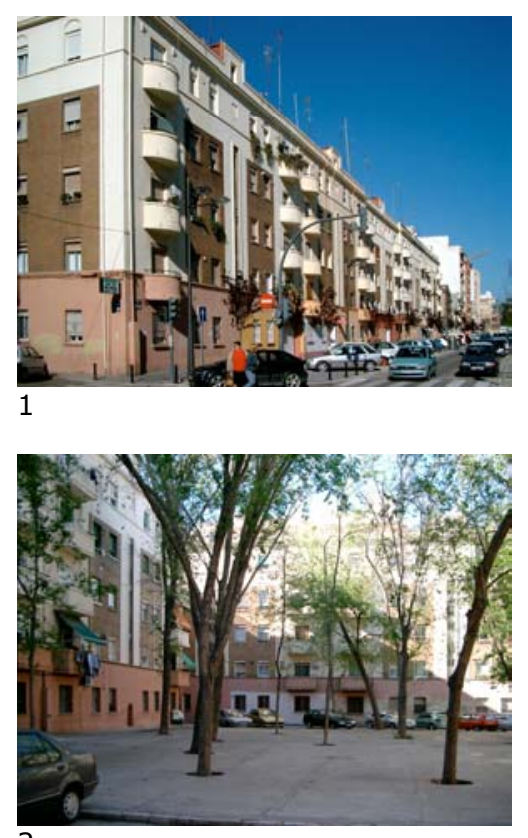

2

Grupo Federico Mayo. Planta de conjunto. Color sobre Cartografía Municipal, 2000 y planta original, 1947.

1. Vista desde la calle Jerónimo Monsoriú.

2. Patio interior.

3. Escuela en el patio interior.
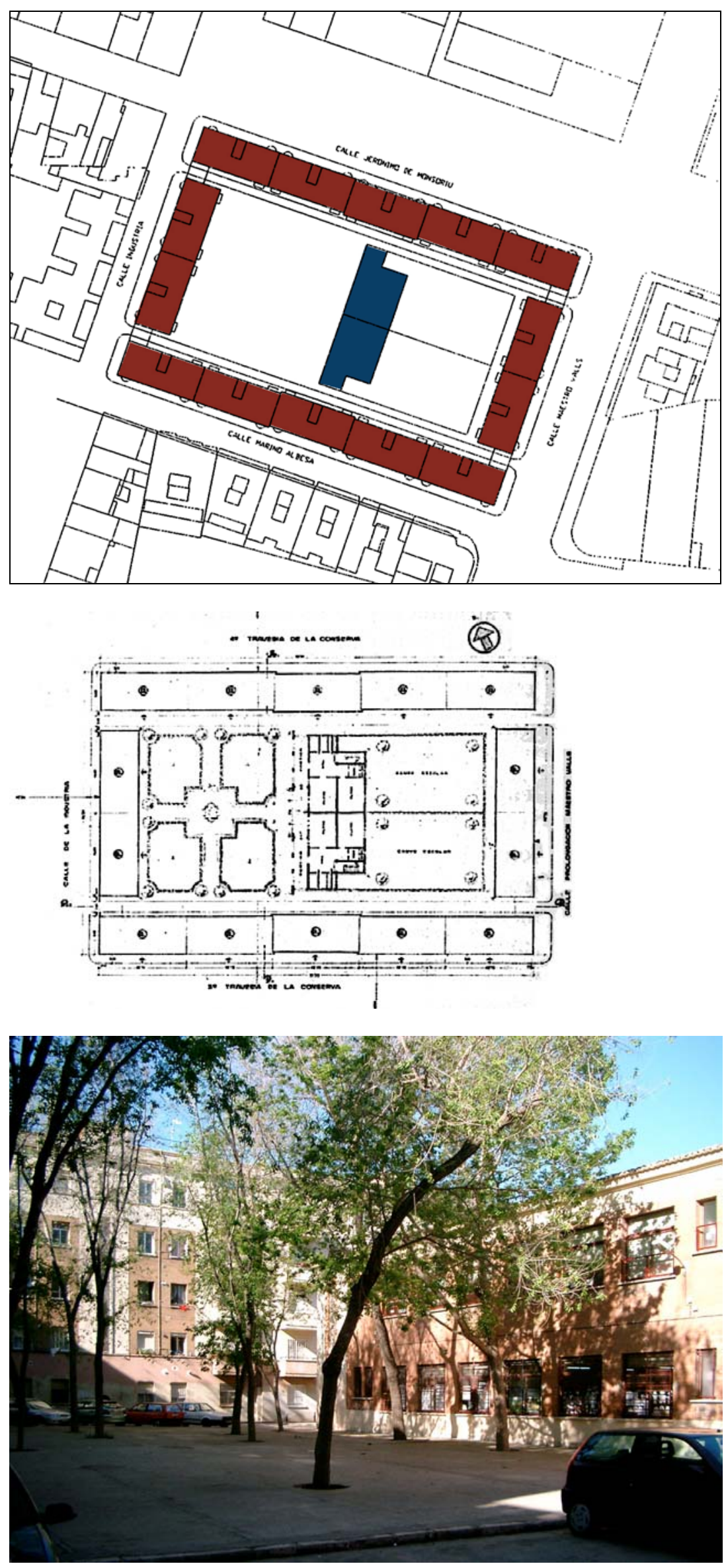


\section{GRUPO FEDERICO MAYO (1947-53)}

Inicialmente denominado grupo Industria II, el grupo Federico Mayo, proyectado en 1947 por Javier Goerlich y construido entre 1950 y 1953, está considerado como el mejor grupo de viviendas protegidas de este arquitecto. Ocupa una manzana rectangular de dimensiones aproximadas de 60×100 m. limitada por las calles Industria, Jerónimo Monsoriú, Maestro Valls y Marino Albasa.

El grupo incluye 140 viviendas, dispuestas en cuatro bloques lineales (dos largos a norte y sur y dos cortos a este y oeste) de $\mathrm{V}$ plantas $(\mathrm{PB}+4)$ alineados con las calles perimetrales. Los bloques dejan un espacio libre interior, accesible desde el paso que queda entre los mismos en planta baja, y en el que se sitúa una escuela y un jardín.

El arco de paso de planta baja está ocupado por unas terrazas que enlazan los bloques, ofreciendo una imagen continua de la edificación entre las plantas primera y tercera. En la planta cuarta, en cambio, al desaparecer la terraza intermedia entre los bloques, se evidencia el volumen prismático de cada uno de ellos por separado.

Las viviendas son de doble crujía, con fachadas a la calle y al espacio interior, dispuestas a razón de dos por planta y caja de escalera, y con superficies comprendidas entre 72 y $76 \mathrm{~m} 2$ útiles, Los bloques largos del lado norte y sur incluyen cinco núcleos de escalera cada uno, y los de los lados este y oeste dos.

Algunas de las viviendas de planta baja han sido transformadas en locales comerciales.

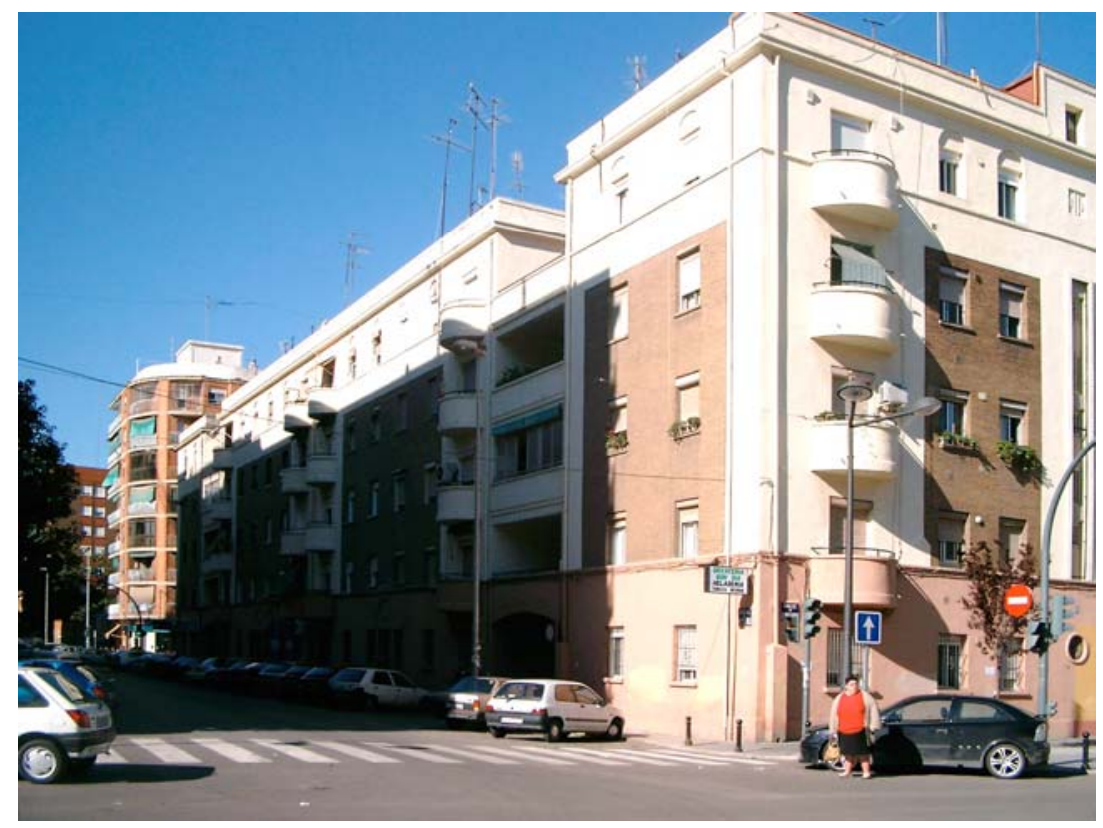

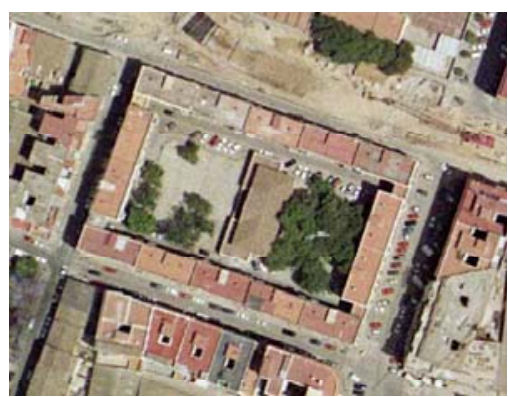

Grupo Federico Mayo. Ortofoto 2002 (AUMSA).
Grupo Federico Mayo. Vista actual desde la calle Maestro Valls. 


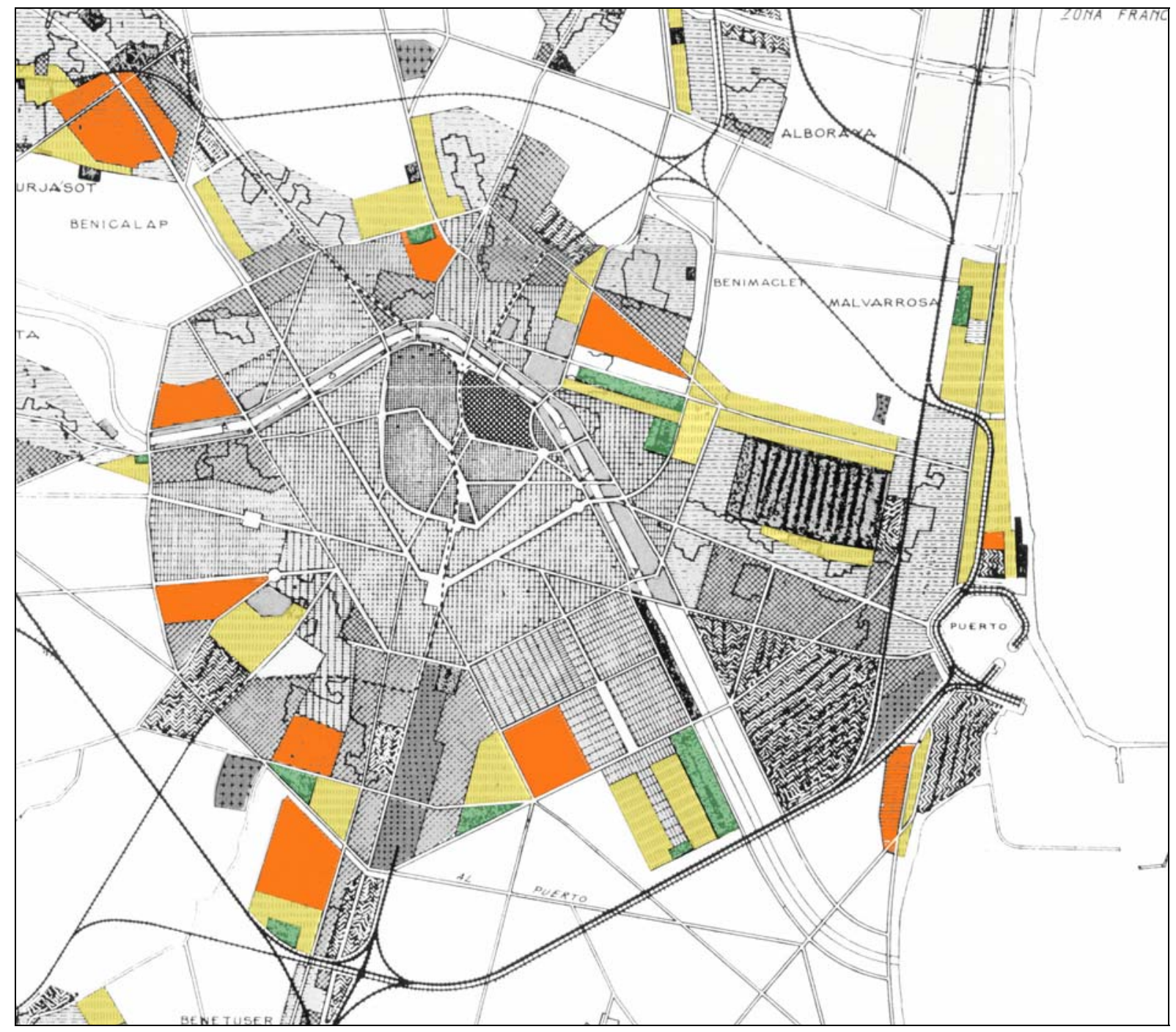

\section{EDIFICACIÓN ABIERTA \\ CIUDAD-JARDÍN \\ ZONAS VERDES}

Areas de edificación abierta previstas en el Plan General de Ordenación urbana de Valencia y su Cintura de 1946. (Elaboración propia a partir del plano del Plan incluido en "La Gran Valencia, trayectoria de un Plan General", Generalitat Valenciana, 1986). 


\section{LA EDIFICACIÓN ABIERTA EN EL PLAN GENERAL DE 1946.}

El Plan de Ordenación Urbana de Valencia y su Cintura, redactado por un equipo dirigido por Germán Valentín Gamazo, fue aprobado definitivamente el 18 de diciembre de $1946^{1}$.

Este Plan adopta un modelo radiocéntrico y descentralizador, con un núcleo central (la ciudad de Valencia) y una serie de núcleos satélites industriales y residenciales (los pueblos de la comarca). Entre el núcleo central y los satélites y separando a éstos entre sí aparece el espacio de la huerta, que juega un papel de cinturón verde. Este cinturón limita el crecimiento del núcleo central, que queda englobado por un anillo viario, del que parten vías radiales que enlazan al núcleo con las poblaciones satélites, que están unidos, a su vez, por un segundo anillo viario.

Las zonas calificadas como edificación abierta en el Plan de 1946, dentro del término municipal de Valencia, son las siguientes:

- En la zona del distrito marítimo, aparecen calificadas como edificación abierta dos zonas, una más pequeña correspondiente al barrio Virgen del Castillo y otra alargada junto a Nazaret.

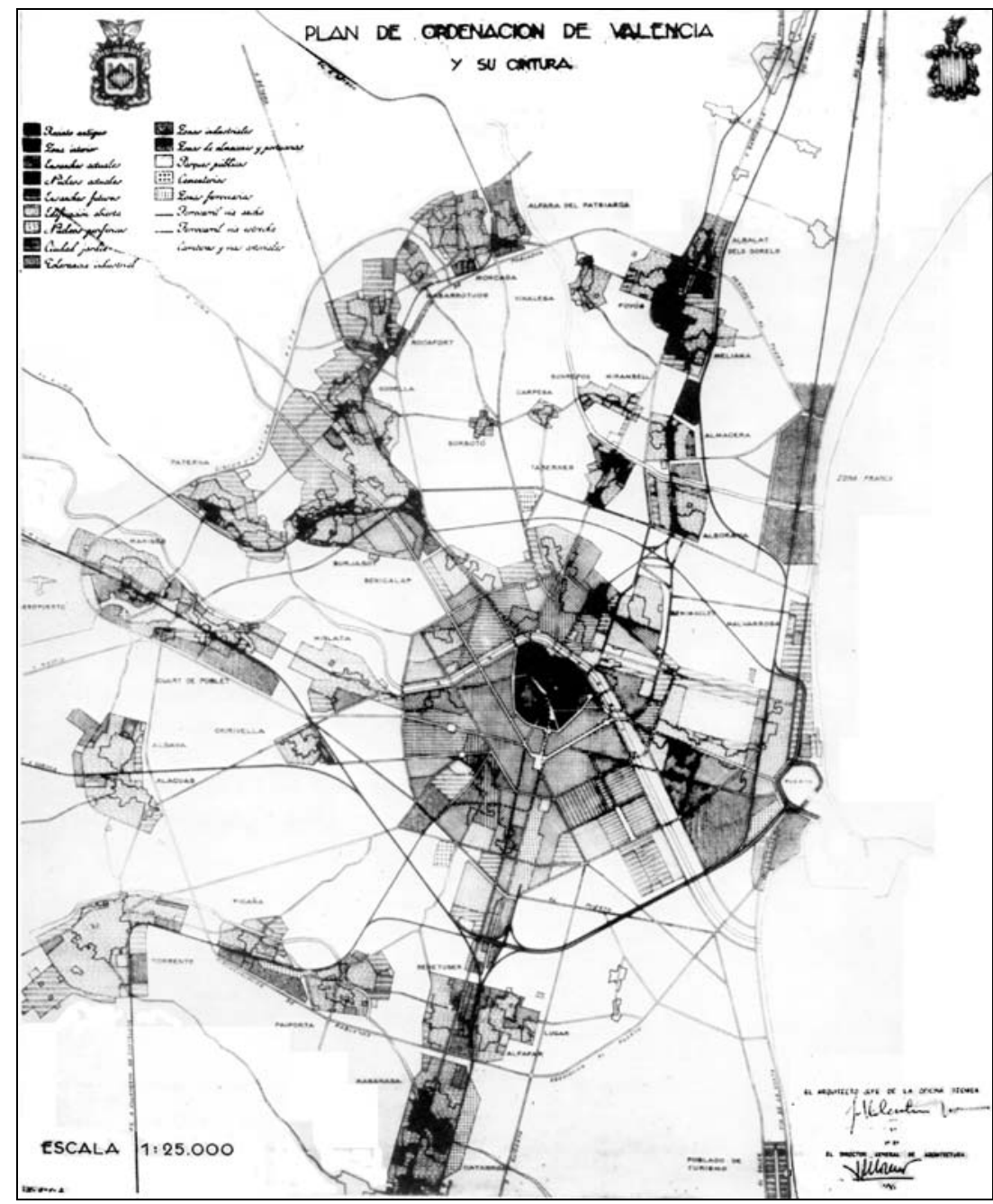

Plan de Ordenación Urbana de Valencia y su Cintura. Germán Valentín Gamazo, 1946.

1.En relación con el Plan de 1946 y el análisis general de sus Planes Parciales, ver Giménez Baldrés, Enrique J. Parcelaciones Residenciales Suburbanas. La formación de la periferia metropolitana de Valencia, Servicio de Publicaciones de la UPV, Valencia, 1996, pp. 455-477. 
Vista de un centro vecinal. Exposición del Plan de Ordenación Urbana de Valencia y su Cintura, 1946.

Ordenación del Turia a su paso por Valencia. Exposición del Plan de Ordenación Urbana de Valencia y su Cintura, 1946.

Perspectiva con las propuestas de ordenación del Turia y del enlace de las grandes vías en el espacio de la Estación del Norte.
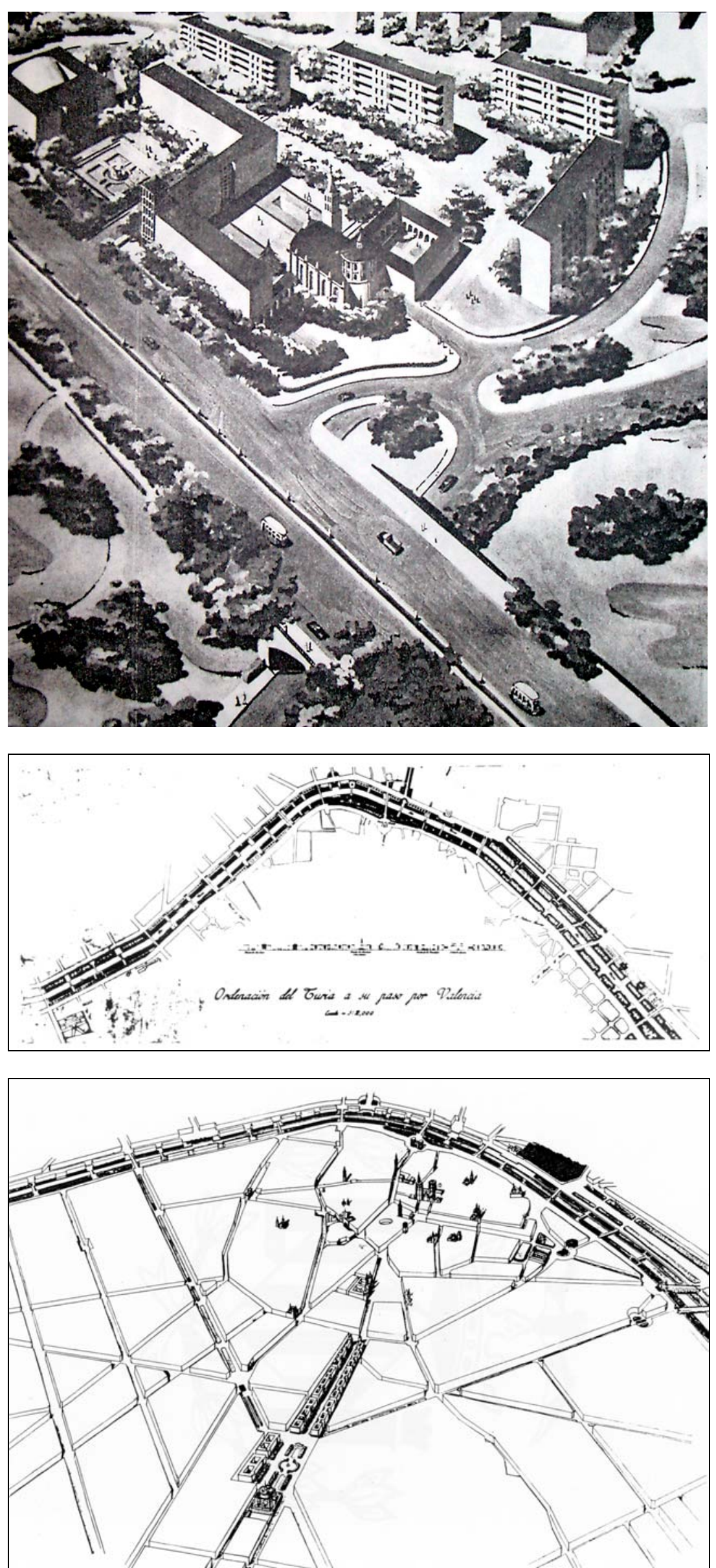
- En la zona noreste, está calificada como edificación abierta un área triangular que ocupa el espacio comprendido entre las calles de Botánico Cavanilles, la ronda de Tránsitos y el Paseo al Mar.

- En la zona noroeste, aparecen calificadas como edificación abierta dos zonas: una situada en Marxalenes, junto a la carretera de Barcelona y la ronda de Tránsitos, y otra situada al oeste del núcleo de Campanar, junto a la ronda de Tránsitos y el cauce del río Turia.

- En la zona suroeste, hay tres zonas calificadas como edificación abierta: una en Patraix, en el lado sur de la actual calle Tres Forques, y otras dos al oeste de la calle San Vicente.

- En la zona sureste, está calificada como edificación abierta una zona rectangular junto a Monteolivete que, con la denominación de Ensanche Sureste, es objeto de una ordenación pormenorizada a escala 1:2000 en el propio Plan.

Todas estas zonas están situadas junto a la ronda de Tránsitos, que forma el anillo viario delimitador del núcleo central. Junto a ellas aparecen en muchos casos zonas calificadas como ciudadjardín, que son asimilables conceptualmente a una edificación abierta de baja densidad.

Fuera del término municipal de Valencia, está calificada como edificación abierta la zona correspondiente al denominado "Barrio residencial en Burjasot-Benimamet", cuya ordenación está incluida, como la del Ensanche Sureste, en la documentación del propio Plan general. Estos dos conjuntos, no realizados, marcan el inicio del progresivo abandono de los modelos vinculados a la ciudad-jardín, y de la sustitución progresiva de la manzana por el bloque como módulo base para la ordenación urbana.

La edificación abierta está presenta también en otras propuestas de ordenación integradas en el Plan General, como las de algunos diseños para centros de barrio y, sobre todo, la ordenación del cauce del río Turia, donde encontramos una serie de bloques lineales destinados a formar una nueva fachada de la ciudad al cauce en todo su recorrido.

Como veremos al analizar el planeamiento parcial de desarroIlo, las propuestas del Plan General se mantuvieron en muy pocos casos, y las zonas finalmente proyectadas con edificación abierta no se corresponden con las previstas en el Plan. 

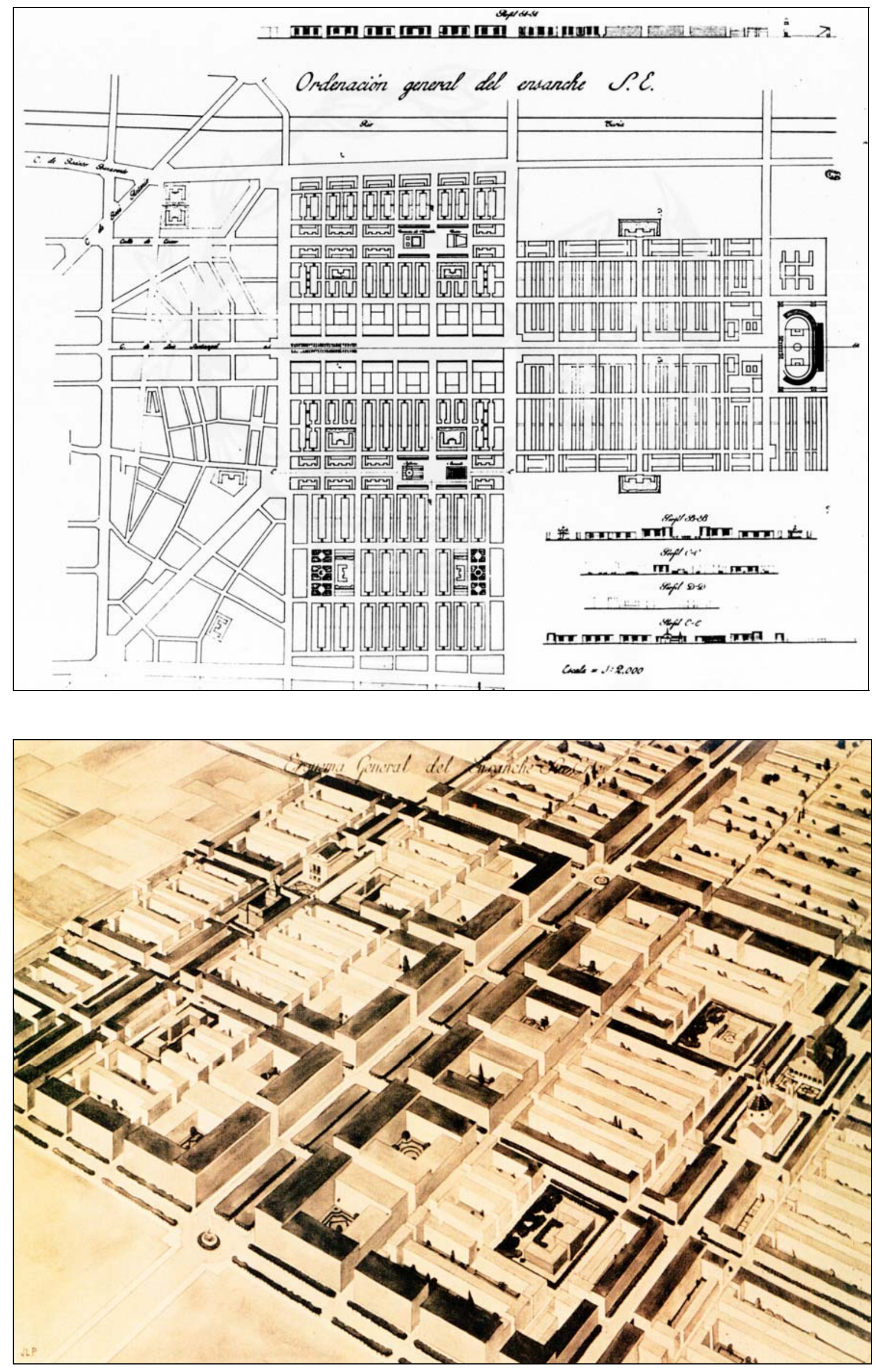


\section{EL ENSANCHE SURESTE (1946)}

La "Ordenación general del ensanche S.E." incluida en el Plan General de 1946 es una propuesta de transición, en la que encontramos un primer sector proyectado mediante manzanas similares a las del Plan de Berlage para Amsterdam Sur y un segundo en el que las manzanas pasan a estar compuestas por bloques lineales.

El primer sector es el situado junto al barrio de Monteolivete, entre la actual Avenida de la Plata y el cierre sur de la ronda de Tránsitos. Es un sector que forma la tercera corona de ensanche en esta parte de la ciudad ${ }^{1}$. La franja central de este sector está ocupada por manzanas cerradas con edificación profunda que flanquean el eje central que estructura el conjunto, que es la prolongación de actual calle General Urrutia.

Las manzanas rectangulares alargadas con edificación perimetral poco profunda ocupan el resto del sector al este y al oeste, y son el tipo básico constitutivo de su tejido. Estas manzanas están abiertas por los lados cortos, con pasos al espacio libre interior. Los dos bloques en $\mathrm{C}$ que resultan de ello, con fachadas a norte y sur, están ya muy próximos a la edificación abierta.

La disolución del lado corto de la manzana rectangular está ya planteada de manera decidida en el segundo sector, en el que el eje central está flanqueado por bloques lineales profundos. Completando cada manzana, se sitúan otros bloques lineales delgados en perpendicular, agrupados de dos en dos, de modo que cada manzana incluye cuatro de ellos. A continuación, las franjas siguientes son ya de manzanas compuestas únicamente por parejas de bloques lineales dispuestos según la directriz este-oeste ${ }^{2}$. Las manzanas de borde, por último, están formadas por bloques lineales agrupados en torno a un espacio libre central.

La disposición de los centros vecinales previstos tiene interés, ya que muestra una evidente intención de localizar los edificios públicos como cierre de perspectiva de los ejes viarios importantes.

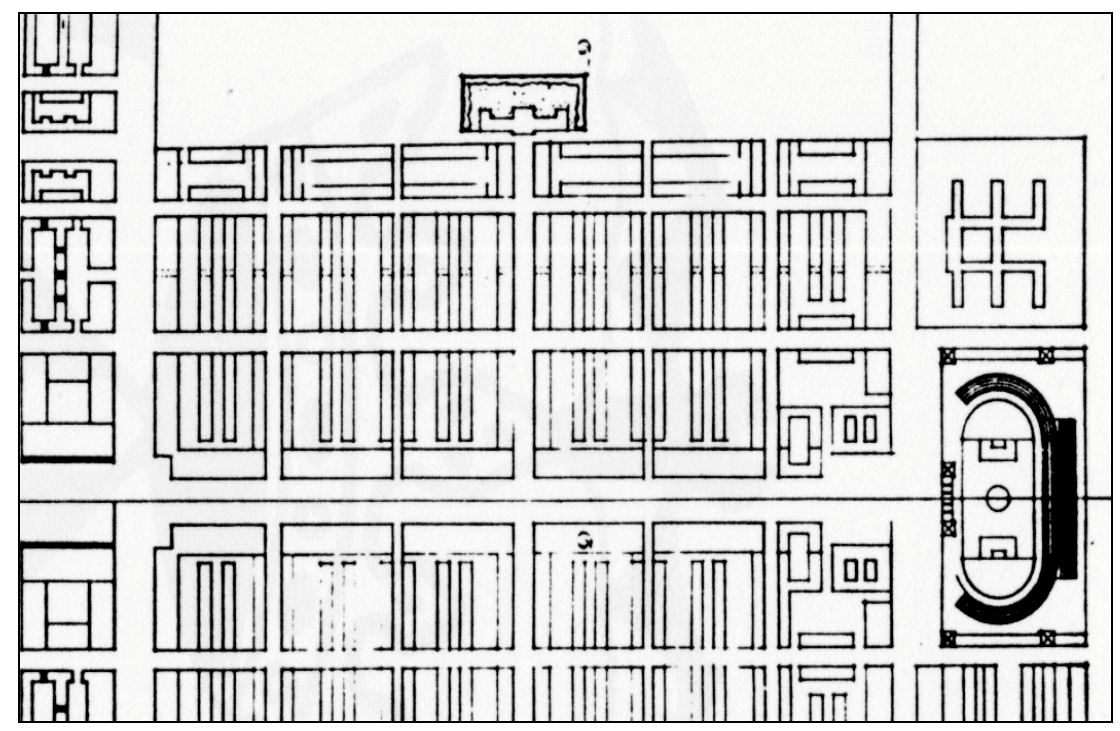

Página opuesta:

Planta de Ordenación general y perspectiva del Ensanche S.E. CMGV.

Ensanche sureste. Detalle de la zona sur.

\footnotetext{
1.Las vías que delimitan estas coronas son la calle Colón, la Gran Vía Marqués del Turia, la Avenida Peris y Valero y la Avenida de la Plata.
}

2.Esta orientación es la recomendada para nuestro país por Zuazo, frente a la habitual directriz norte-sur de los bloques lineales europeos. Ver Zuazo, Secundino y Jansen, Hermann, Anteproyecto del trazado viario y urbanización de Madrid (Estudio preliminar de Lilia Moure Rubio), Colegio Oficial de Arquitectos de Madrid, 1986. 


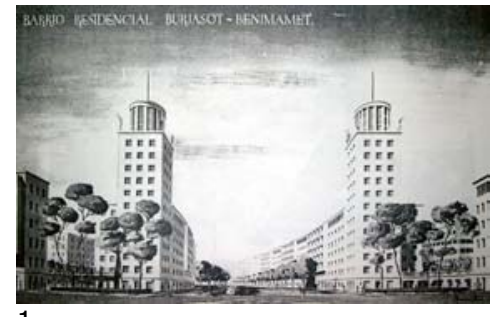

1

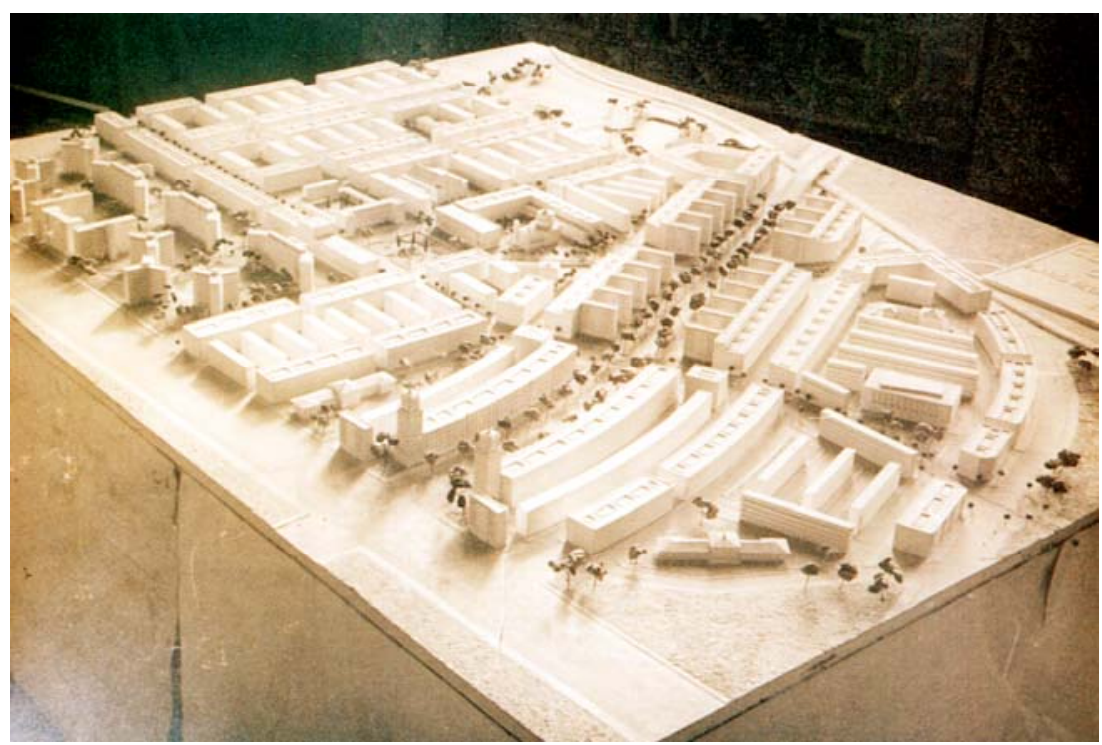

2

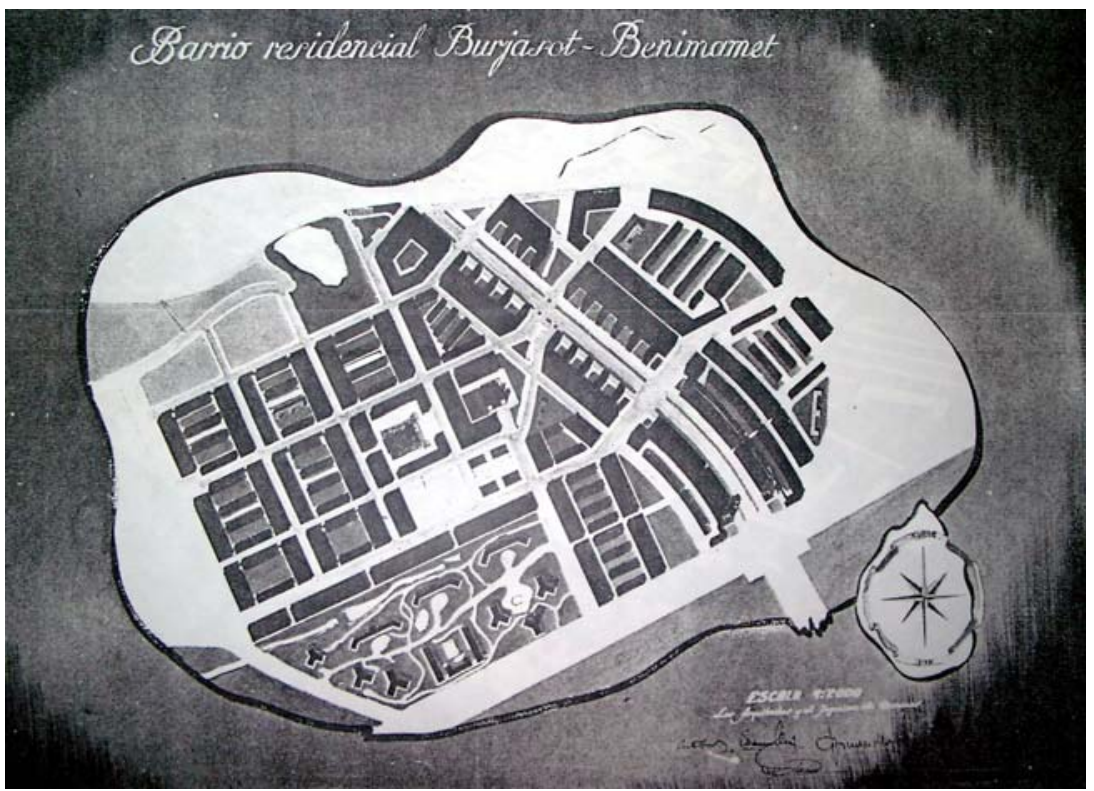

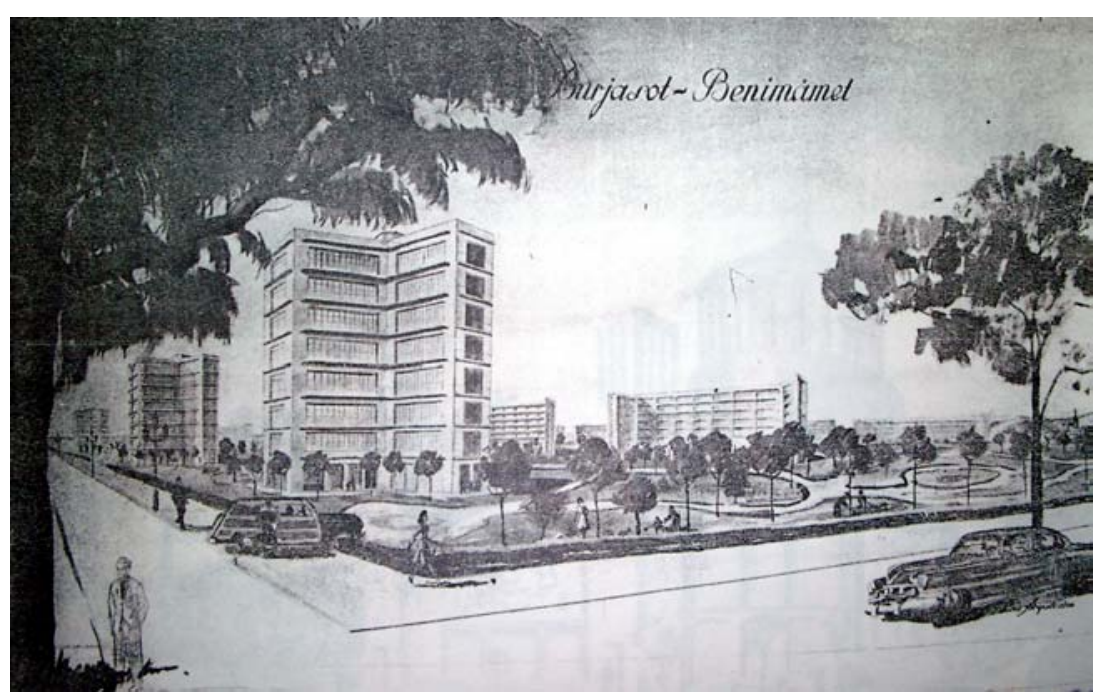

Barrio residencial en BurjasotBenimamet (Archivo de Planeamiento. Ayuntamiento de Valencia)

1. Vista de las torres gemelas en el inicio del eje principal.

2. Vista general de la maqueta.

3. Planta del barrio.

4. Vista de la zona del suroeste, con los bloques inspirados en Le Corbusier. 


\section{EL BARRIO RESIDENCIAL DE BURJASOT-BENIMAMET (1946)}

El Barrio Residencial en Burjasot-Benimamet, adscrito posteriormente al Proyecto Parcial de Desarrollo no 1 , relativo a la zona afectada por el nuevo trazado de la carretera de Ademúz que prolongaba hacia el noroeste la Gran Vía Fernando el Católico, puede considerarse como el primer plan urbanístico basado en la edificación abierta en Valencia, aunque queda fuera del término municipal de la ciudad.

La composición del barrio se apoya en el eje de directriz curva que lo atraviesa de sureste a noroeste. El inicio del eje está marcado por dos torres gemelas, y a lo largo de su recorrido está flanqueado en un primer tramo por bloques lineales profundos y en el segundo por bloques en peine.

Los bloques en peine o a redents se componen de un cuerpo de edificación longitudinal profundo y cuerpos transversales delgados dispuestos a intervalos regulares. ${ }^{1}$

A ambos lados del eje central se disponen una serie de manzanas mixtas, formadas por dos bloques laterales profundos y cuatro bloques transversales delgados. Las manzanas tipo, casi cuadradas, son las situadas al oeste del eje, aunque el sistema compositivo es el mismo en las manzanas más irregulares y de mayor tamaño que quedan en la parte este.

Podemos ver que a los bloques profundos situados en los frentes este y oeste de las manzanas se les asigna una cierta función envolvente, mientras que los bloques delgados son un relleno neutro del espacio intermedio, y sus testeros no son perceptibles desde las calles perimetrales.

En el sector suroeste del barrio aparece la zona con un diseño urbano más vanguardista: sobre un espacio ajardinado surcado por caminos peatonales sinuosos, se sitúan diversos bloques en patte de poule y torres que se inspiran directamente en Le Corbusier ${ }^{2}$.

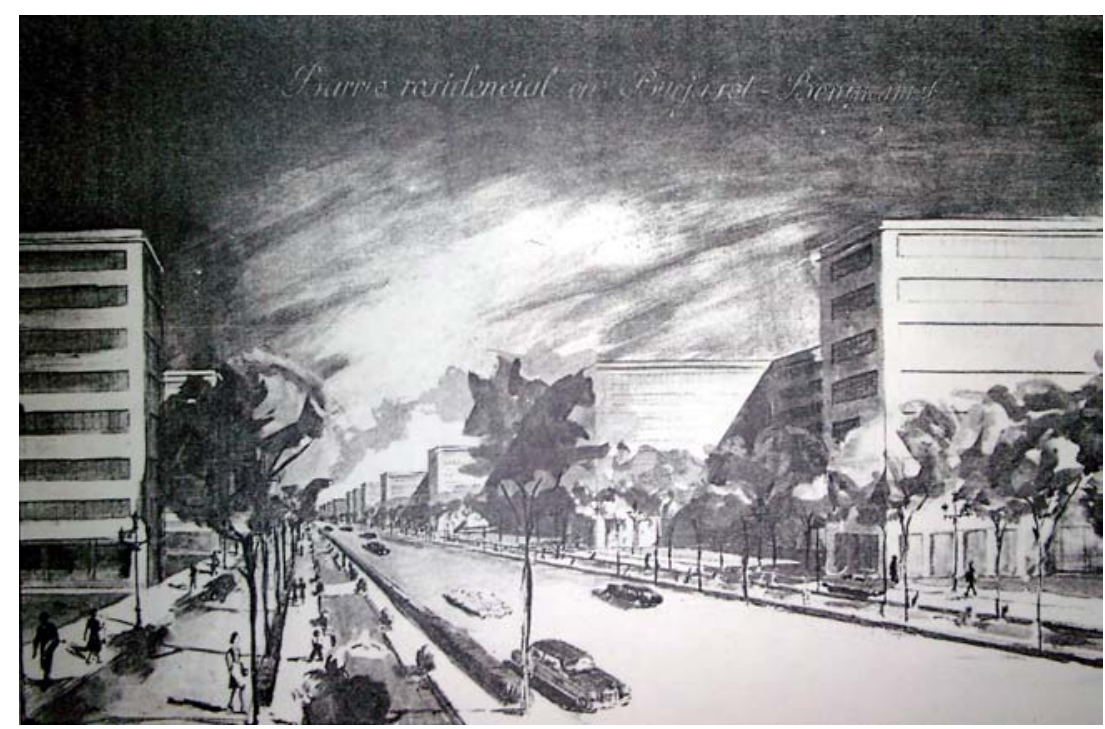

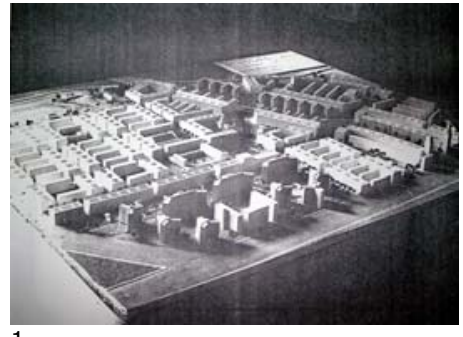

1
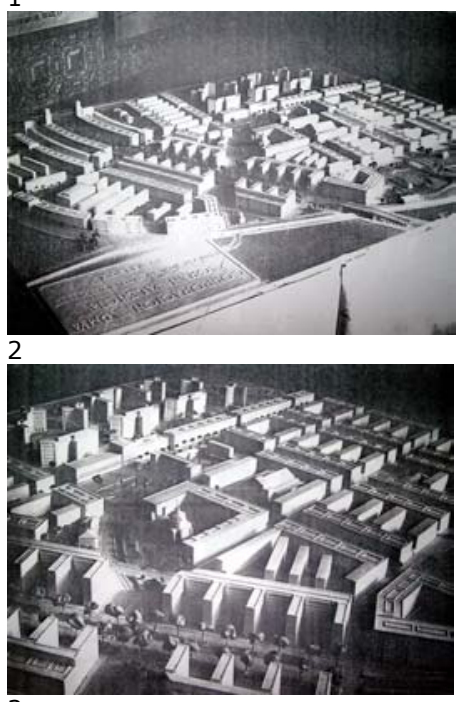

3

1--3. Barrio residencial en Burjasot-Benimamet. Vistas de la maqueta.

4. Perspectiva del eje central con bloques en peine.

1. Este tipo en peine reaparecerá posteriormente, como veremos, en varios Planes Parciales.

2.La referencia más directa son los bloques residenciales del proyecto para el bastión Kellermann, utilizados después en diversas propuestas urbanas como las de $\mathrm{He}$ llocourt (1936), Roma (1935) y el Plan director de Argel de 1942 entre otras. 


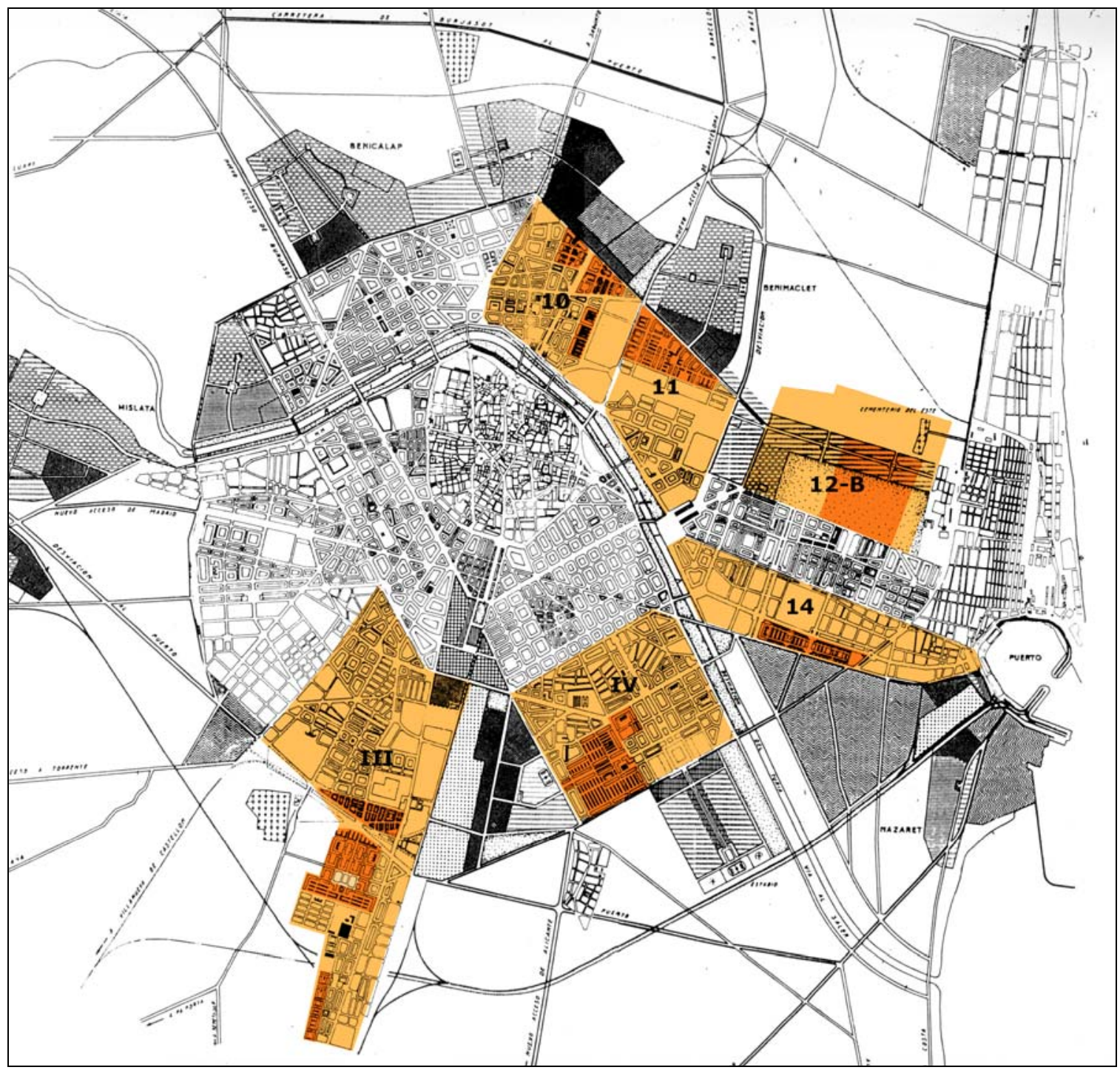

Hojas y Proyectos Parciales de Desarrollo del Plan General de 1946 que incluyen áreas de edificación abierta (Elaboración propia: Sombreado sobre transcripción de Planeamiento parcial realizada por E.Giménez a partir del plano de zonificación del Plan de 1946)

Tabla I.2. Áreas de edificación abierta incluidas en los Planes Parciales de desarrollo del Plan General de Valencia de 1946.

\begin{tabular}{|c|c|c|c|}
\hline ZONA & $\begin{array}{c}\text { PLAN } \\
\text { PARCIAL }\end{array}$ & $\begin{array}{c}\text { AÑ̃O } \\
\text { APROBACIÓN }\end{array}$ & $\begin{array}{c}\text { ÁREAS DE EDIFICACIÓN ABIERTA } \\
\text { INCLUIDAS EN EL PLAN }\end{array}$ \\
\hline \multirow[t]{6}{*}{ NORESTE } & \multirow[t]{3}{*}{ Hoja 10} & \multirow{3}{*}{1956} & Molinell-Tránsitos \\
\hline & & & Maximilano Thous - Tránsitos \\
\hline & & & Alboraya - Pintor Genaro Lahuerta \\
\hline & Nuevo Barrio (Hoja 11) & $1952(*)$ & Zona entre Paseo al Mar y C. Tránsitos \\
\hline & Hoja 12-B & $1952(*)$ & Prolongación Paseo al Mar-Algirós. \\
\hline & Hoja 14 & 1954 & Av Baleares - Av. Francia \\
\hline \multirow[t]{3}{*}{ SUROESTE } & \multirow[t]{3}{*}{ Proyecto Parcial no III } & \multirow[t]{3}{*}{1948} & Av. 10 Mayo - Tomás Villarroya \\
\hline & & & Ciudad del aprendiz \\
\hline & & & Camino Real de Madrid - La Torre \\
\hline SURESTE & Proyecto Parcial no IV & 1953 & Sur de Monteolivete \\
\hline
\end{tabular}

(*) Año de redacción. 


\section{LA EDIFICACIÓN ABIERTA EN LOS PLANES PARCIALES DE DESARROLLO DEL PLAN GENERAL DE 1946.}

El planeamiento parcial de desarrollo del Plan de 1946 se redacta con dos denominaciones: Proyectos Parciales de Desarrollo y Hojas.

Las Hojas abarcan los planes del centro histórico (Hoja 1-34), del ensanche sureste y suroeste (Hojas 2, 5, 6 y 7), de las áreas urbanas del norte interiores al Camino de Tránsitos (Hojas 8, 9, 10 y 11), de los poblados marítimos (Hoja 13) y de las zonas intermedias entre éstos y la ciudad central (Hojas 12, 14).

Los Proyectos Parciales de Desarrollo comprenden las zonas exteriores a Tránsitos del arco suroeste de Valencia (Proyectos Parciales I, II y III) y del sureste (Proyecto Parcial IV).

No existe planeamiento parcial para las áreas urbanas del norte de Valencia, en torno a los poblados de Benimaclet, Torrefiel y Benicalap, exteriores al Camino de Tránsitos. Fuera del término municipal, el Proyecto Parcial no 2 para Burjasot-Benimamet de 1952 recoge la ordenación adjunta al Plan General para un barrio residencial en esa zona, aunque amputada y desvirtuada.

En estos planes pueden distinguirse, según Giménez ${ }^{1}$ dos etapas significativas. La primera, de 1948 a 1950, se limita a traducir al nuevo plan las zonas con planeamiento anterior. La segunda etapa, de 1952 a 1955, además de completar algunas zonas urbanas, es significativa sobre todo por el abandono de las tipologías de ciudad-jardín como modelo básico para el crecimiento y la transformación de la periferia, y su sustitución por ordenaciones basadas en la edificación abierta de bloques lineales aislados.

La manzana cerrada sigue siendo, en cualquier caso, el módulo base para la ordenación urbana en la mayor parte de los planes, incluso en los realizados para áreas de la periferia con grandes porciones de suelo vacante en ese momento, como las de Campanar y Marxalenes (Hojas 8 y 9) o las de la Avenida de Castilla y Patraix (Proyecto Parcial I). En estas áreas es donde, en un periodo posterior, se modificará en mayor medida el planeamiento, sustituyendo las manzanas por bloques en todas las zonas sin edificar.

En la Tabla I.2 se recogen los planes en los que existen zonas de edificación abierta. Todos ellos fueron redactados entre 1952 y 1956 por arquitectos de la Oficina Técnica Municipal de Urbanismo, excepto el Proyecto Parcial de Desarrollo no IV, elaborado por la Oficina Técnica de la Corporación Administrativa Gran Valencia en 1953.

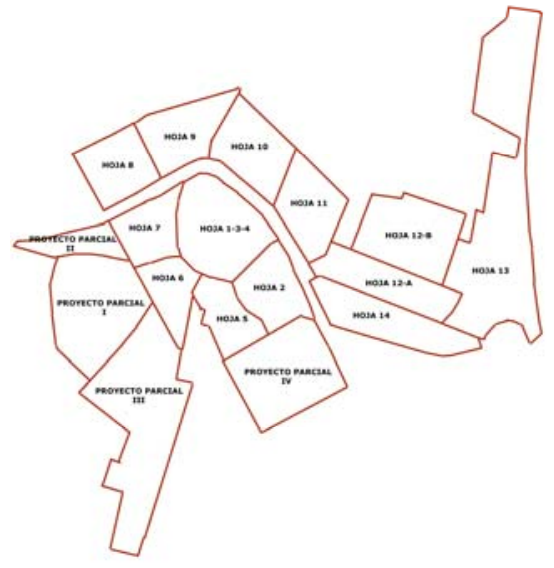

Ámbito de las Hojas y Proyectos Parciales de desarrollo del Plan General de Ordenación de Valencia de 1946.
1. Giménez Baldrés, Enrique J., Parcelaciones Residenciales Suburbanas. La formación de la periferia metropolitana de Valencia, Servicio de Publicaciones de la UPV, Valencia, 1996. 
Proyecto Parcial III, 1948

Detalle de la zona entre el Parque de Artillería y la Ronda de desvío al Puerto (Del "Proyecto de Rectificación de Alineaciones en la Zona entre la Av. de Gaspar Aguilar y el Camino Real de Madrid", 1962, Archivo de Planeamiento, Ayuntamiento de Valencia)
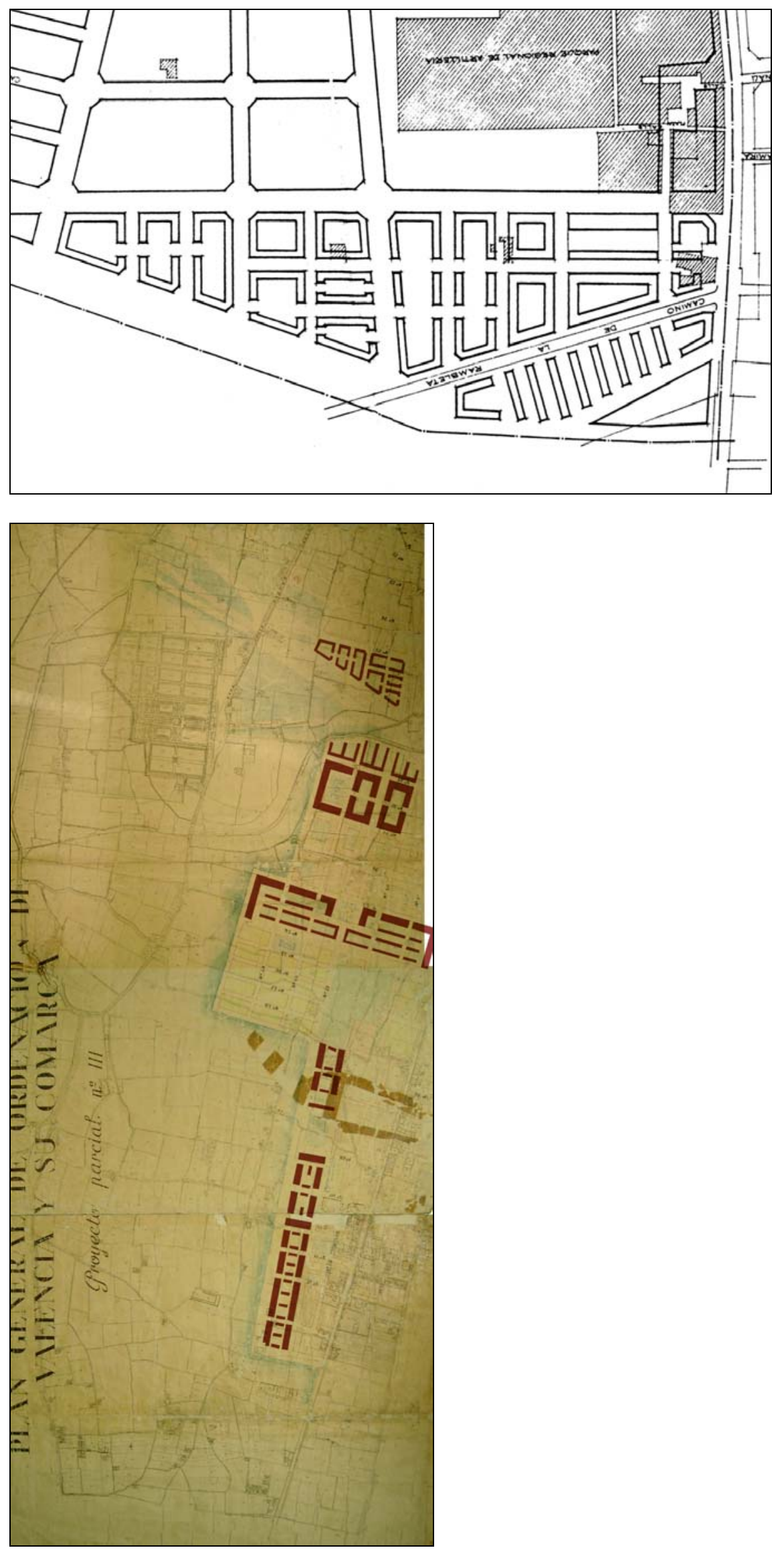

Proyecto Parcial no III, 1948, fragmento (Elaboración propia: sombreado de la edificación abierta sobre copia del plano entelado original. Archivo de Planeamiento, Ayuntamiento de Valencia). 


\section{LA EDIFICACIÓN ABIERTA EN EL ÁREA SUROESTE: EI PROYECTO PARCIAL DE DESARROLLO NO III (1948-1951)}

El Proyecto Parcial de Desarrollo no III, redactado por la Oficina Técnica de la Corporación Administrativa Gran Valencia en 1948, incluye varias zonas proyectadas con edificación abierta, aunque la mayor parte del mismo está resuelto con manzanas cerradas. Las zonas de edificación abierta, que presentan características muy variadas, están engarzadas por un eje central norte-sur paralelo al Camino Real de Madrid.

La primera de las zonas que puede asimilarse a la edificación abierta es el triángulo limitado al sur por la nueva Ronda de desvío al Puerto, al norte por la actual Avenida Primero de Mayo, y al este por el Camino Real de Madrid (calle San Vicente). El Camino de la Rambleta forma una diagonal simétrica a la de la ronda con respecto al eje norte-sur central de la calle Carteros.

Esta zona está ordenada mediante pequeñas manzanas abiertas con edificación perimetral de dos crujías y espacio libre interior, salvo en el espacio entre el Camino de la Rambleta y la ronda, donde se proyecta una serie de bloques lineales equidistantes rematada a ambos lados por unos bloques en $\mathrm{U}$.

El grado de permeabilidad entre el espacio libre interior y las calles circundantes es variable, ya que hay manzanas completamente cerradas y otras con uno, dos o cuatro pasos que rompen la continuidad del perímetro edificado, que queda descompuesto en fragmentos de edificación lineales, en $\mathrm{U}$ o en C.

La reducción del tamaño de la manzana con respecto a la del ensanche es una consecuencia lógica del paso a una célula de vivienda de superficie más reducida, aunque en este caso, junto con manzanas de un tamaño parecido a las proyectadas por Berlage para Amsterdam Sur, nos encontramos con micromanzanas cuya superficie es la cuarta parte de la de una manzana de ensanche.

De toda esta zona, se construyó únicamente la manzana situada más al este, recayente al Camino Real de Madrid a la altura de la Cruz Cubierta.

Al otro lado de la Ronda de desvío al Puerto, se proyecta otra zona de edificación abierta, formada por una edificación en peine de dos crujías, que constituye el borde norte del barrio de San Marcelino. Este barrio, promovido en 1949 por el Patronato Nuestra Señora de los Desamparados, está formado por un tejido de manzanas rectangulares con edificación perimetral profunda que adopta dos formas principales: una $U$ abierta a la calle o bien dos cuerpos en $U$ enfrentados que envuelven un espacio libre público. En algunos de los espacios libres que resultan de la edificación en $U$ abierta a la calle se sitúan grupos escolares, y en otros jardines.

Al sur de San Marcelino, encontramos otra zona con edificación abierta, resuelta de manera simétrica a ambos lados del eje vertebrador central, mediante unos bloques profundos en $L$ y $C$ que envuelven una zona rellena con bloques delgados de directriz esteoeste dispuestos en línea.

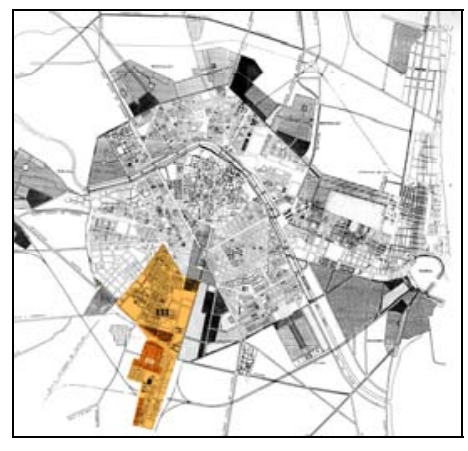

Proyecto Parcial III, 1948. Localización. 
Proyecto Parcial III, 1948

Detalle de la zona del Camino Real de Madrid (Del "Proyecto de Reforma de Alineaciones en el Barrio de Nuestra Señora de Gracia", 1951, Archivo de Planeamiento, Ayuntamiento de Valencia)

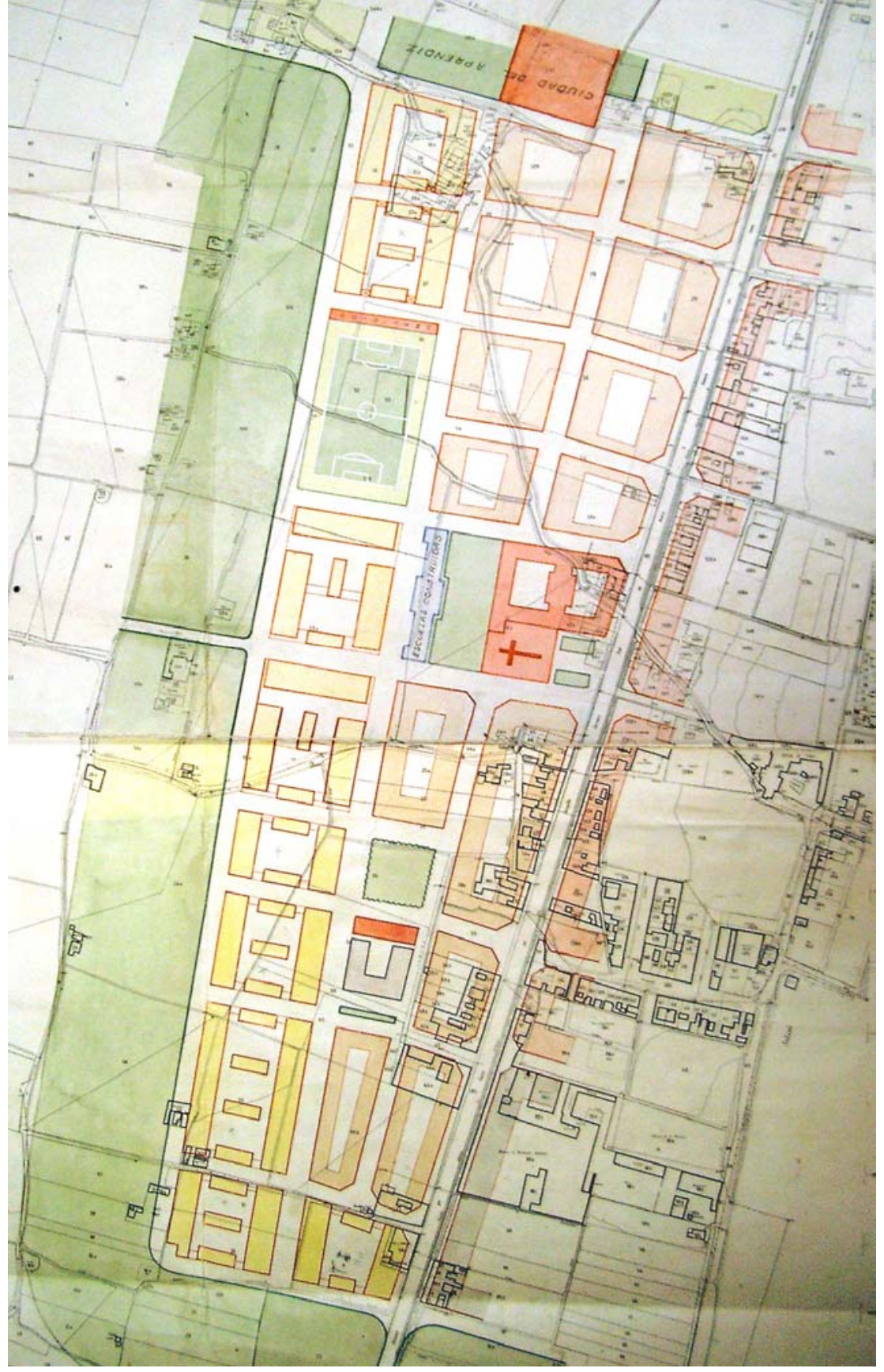

Siguiendo hacia el sur el trazado del eje central, en el siguiente tramo del mismo se prevé al oeste un área de manzanas rectangulares calificadas como ciudad jardín, y al este la parcela destinada a la denominada "Ciudad del Aprendiz", proyectada por la Central Nacional Sindicalista.

En el último tramo el eje deja de ser central y pasa a ser el límite con la huerta, cuyo borde está tratado como zona verde continua. En este tramo el eje se acerca al del Camino real de Madrid, del que queda separado por tres filas de manzanas. La tercera de estas filas de manzanas, que es la que define el borde urbano, es la ordenada con edificación abierta.

Esta tercera fila de manzanas se añadió para poder integrar en la zona un grupo de viviendas promovido por el INV, lo que se 
hizo en el "Proyecto de Reforma de Alineaciones en el Barrio de Nuestra Señora de Gracia" de 1951. Este grupo de viviendas se construyó entre 1952 y 1959 en las dos manzanas situadas a los lados del Camino de Alba, transversal a la Carretera Real de Madrid $^{1}$.

Además de la necesidad de integrar el grupo del INV, la Memoria del Proyecto de Reforma de Alineaciones de 1951 añade como justificación para añadir la tercera fila de manzanas lo siguiente:

Además el hecho de estar construidos los dos elementos fundamentales del Centro Cívico, la Iglesia Parroquial y las Escuelas, justifican sobradamente la ampliación en profundidad del barrio que nos ocupa. ${ }^{2}$

Los edificios públicos previstos en la zona, además de los existentes con anterioridad al plan (la Iglesia de Nuestra Señora de Gracia y el grupo escolar Manjón) son un Mercado y un edificio para Tenencia de Alcaldía y Casa de Socorro, que ocupan una manzana completa abierta a una plaza y a una plazoleta. La manzana situada al norte del grupo Camino de Alba se destina a campo de deportes o parque.

La edificación en las manzanas de edificación abierta se dispone del mismo modo que ya hemos visto en el proyecto para el barrio residencial de Burjasot-Benimamet, combinando bloques profundos en dirección norte-sur que ocupan los lados este y oeste de la manzana, y bloques delgados de directriz este-oeste que ocupan el espacio intermedio entre los bloques profundos. Sin embargo, en este proyecto el reducido tamaño de la manzana hace que los bloques delgados resulten excesivamente cortos y pierdan proporción.

Dentro del ámbito del Proyecto Parcial III existe también una propuesta de 1955, firmada por Camilo Grau Soler, en la que se utilizan bloques lineales equidistantes dispuestos en abanico para la ordenación de los terrenos resultantes del traslado de la Estación de Ferrocarriles Eléctricos de Jesús.

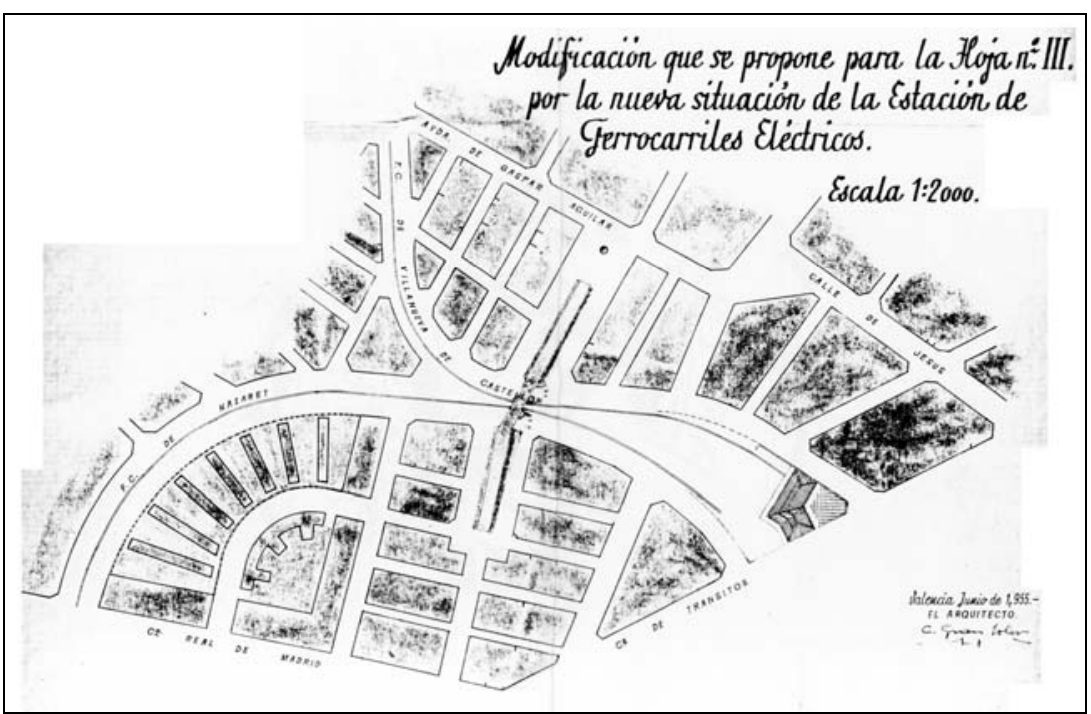

Propuesta de modificación de la Hoja III por la nueva situación de la Estación de Ferocarriles Eléctricos, Camilo Grau Soler, 1955 (Archivo de Planeamiento, Ayuntamiento de Valencia)

1. El Grupo Camino de Alba se analiza en el apartado siguiente de esta sección. Ver pp. 88-89.

2. Memoria del "Proyecto de $\mathrm{Re}$ forma de Alineaciones en el Barrio de Nuestra Señora de Gracia" de 1951. Esta justificación es la misma que se utilizó anteriormente para ampliar de una a dos las filas de manzanas junto al Camino Real de Madrid en la Memoria del Proyecto Parcial III de 1948. 


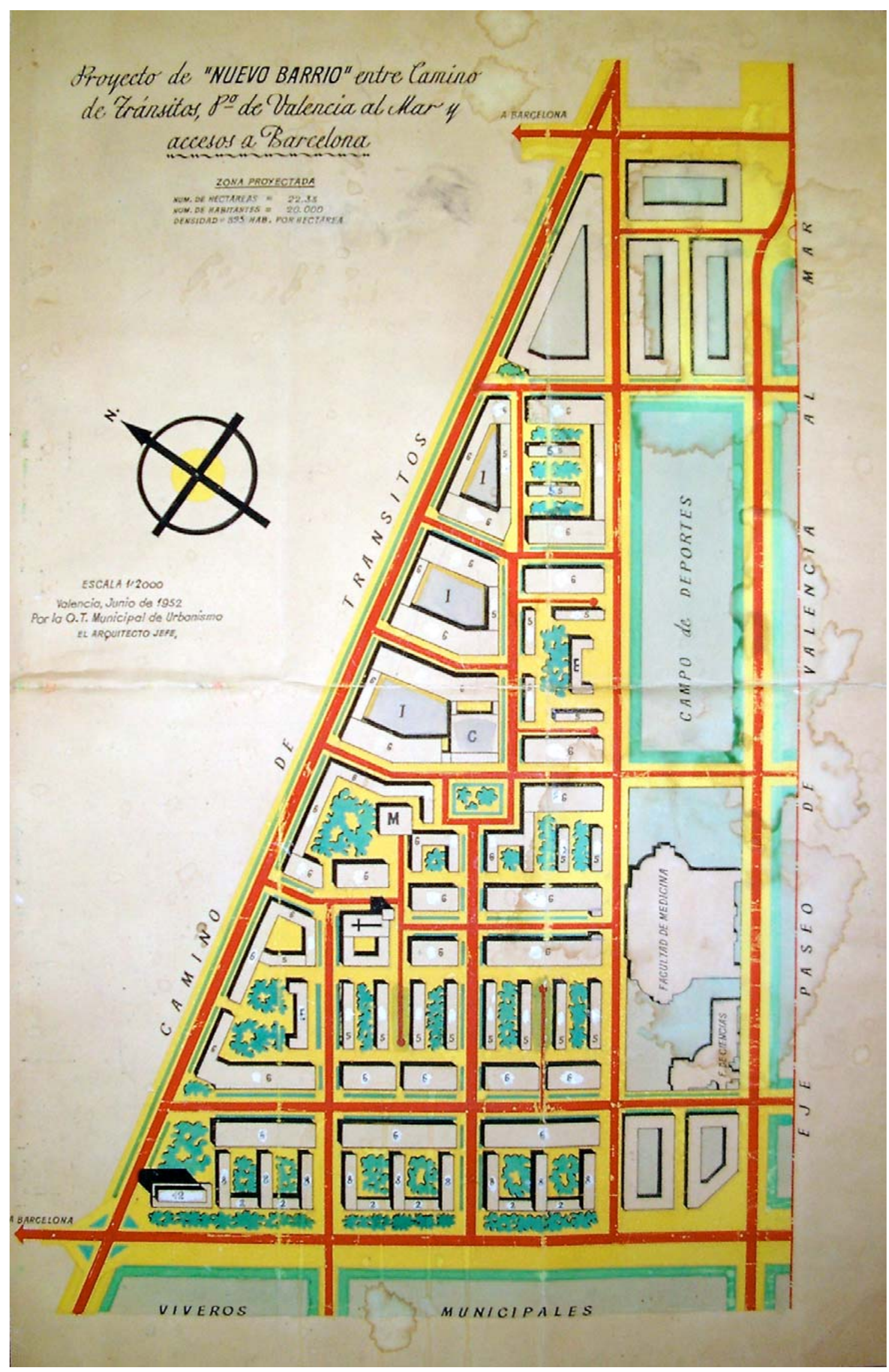

Proyecto de Nuevo Barrio entre Camino de Tránsitos, Paseo al Mar y accesos de Barcelona, 1952 (Archivo de Planeamiento. Ayuntamiento de Valencia). 


\section{NUEVO BARRIO ENTRE EL CAMINO DE TRÁNSITOS, PASEO DE VALENCIA AL MAR Y ACCESOS A BARCELONA. (1952)}

La zona en la que se proyecta el "Nuevo Barrio entre el Camino de Tránsitos, Paseo de Valencia al Mar y Acceso de Barcelona", formará parte posteriormente de la Hoja 11. En la Hoja 11 aprobada en 1956 por la Comisión Central de Sanidad Local, sin embargo, no se conservó ninguno de los elementos integrantes de la ordenación de este Nuevo Barrio.

En el proyecto para el Nuevo Bario, la franja recayente al Paseo al Mar aparece ocupada por las dos grandes manzanas de las Facultades -Ciencias y Medicina- y del campo de deportes de la Universidad, junto con dos grupos al este y al oeste de manzanas cerradas.

El resto de la zona está ocupado por edificación abierta, con la única excepción de cuatro manzanas trapezoidales recayentes al Camino de Tránsitos, entre el acceso de Barcelona y la actual calle Gómez Ferrer.

La composición de la edificación abierta sigue la pauta iniciada en el proyecto para el Barrio Residencial de Burjasot-Benimamet incluido en el Plan General de 1946, que ya hemos analizado anteriormente. Así, la edificación abierta se organiza mediante una combinación de bloques lineales profundos (de cinco crujías, con previsibles patios interiores) y bloques lineales delgados (de dos crujías), a los que se asignan funciones diferentes: los bloques profundos se alinean con los ejes viarios principales en dirección norte-sur, flanqueándolos y delimitándolos espacialmente. Los bloques delgados, dispuestos a intervalos regulares en dirección esteoeste, perpendiculares a los bloques profundos, rellenan el espacio intermedio entre éstos. Con este sistema, las calles mantienen su configuración espacial y los bloques lineales se emplean para recomponer la manzana de otro modo, a partir de elementos perimetrales independienes, no para eliminarla.

En cuanto al trazado viario, encontramos en este proyecto los sistemas de composición clásicos por ejes primarios y secundarios, y la voluntad de crear secuencias urbanas con cierres de perspectivas apoyados en edificios públicos.

La voluntad de hacer compatible la edificación abierta con una definición clara de los límites de los espacios públicos resulta tambén evidente en la plaza que se proyecta en un lateral de la calle Gómez Ferrer, donde vemos como se modifica la traza de los bloques para acotar adecuadamente el espacio de dicha plaza. Lo mismo ocurre con los bloques recayentes al Camino de Tránsitos, que se pliegan para adaptarse a las alineaciones del perímetro de la manzana en la que se sitúan.

Los testeros de bloques lineales ortogonales a la calle sólo son visibles desde ésta en un caso: cuando los bloques se abren al gran parque público de los Viveros. Esta serie de bloques viene rematada por una torre que ocupa el vértice noroeste del conjunto, y que dispone del adecuado espacio libre alrededor para acentuar su carácter de hito arquitectónico ${ }^{1}$.

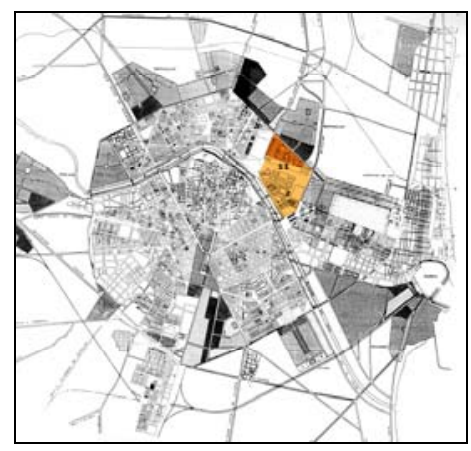

Hoja 11 y nuevo barrio entre el Camino de Tránsitos, Paseo de Valencia al Mar y accesos a Barcelona, 1952. Localización.

1. El grafismo utilizado en el plano deriva claramente del utilizado por Le Corbusier en sus proyectos urbanos: viario rodado en rojo, aceras y recorridos peatonales en amarillo y edificios con sombras arrojadas. Este mismo grafismo es el utilizado también en el conocido Proyecto de rectificación parcial del sector NE de la Avenida del Generalísimo, en Madrid, de 1954 

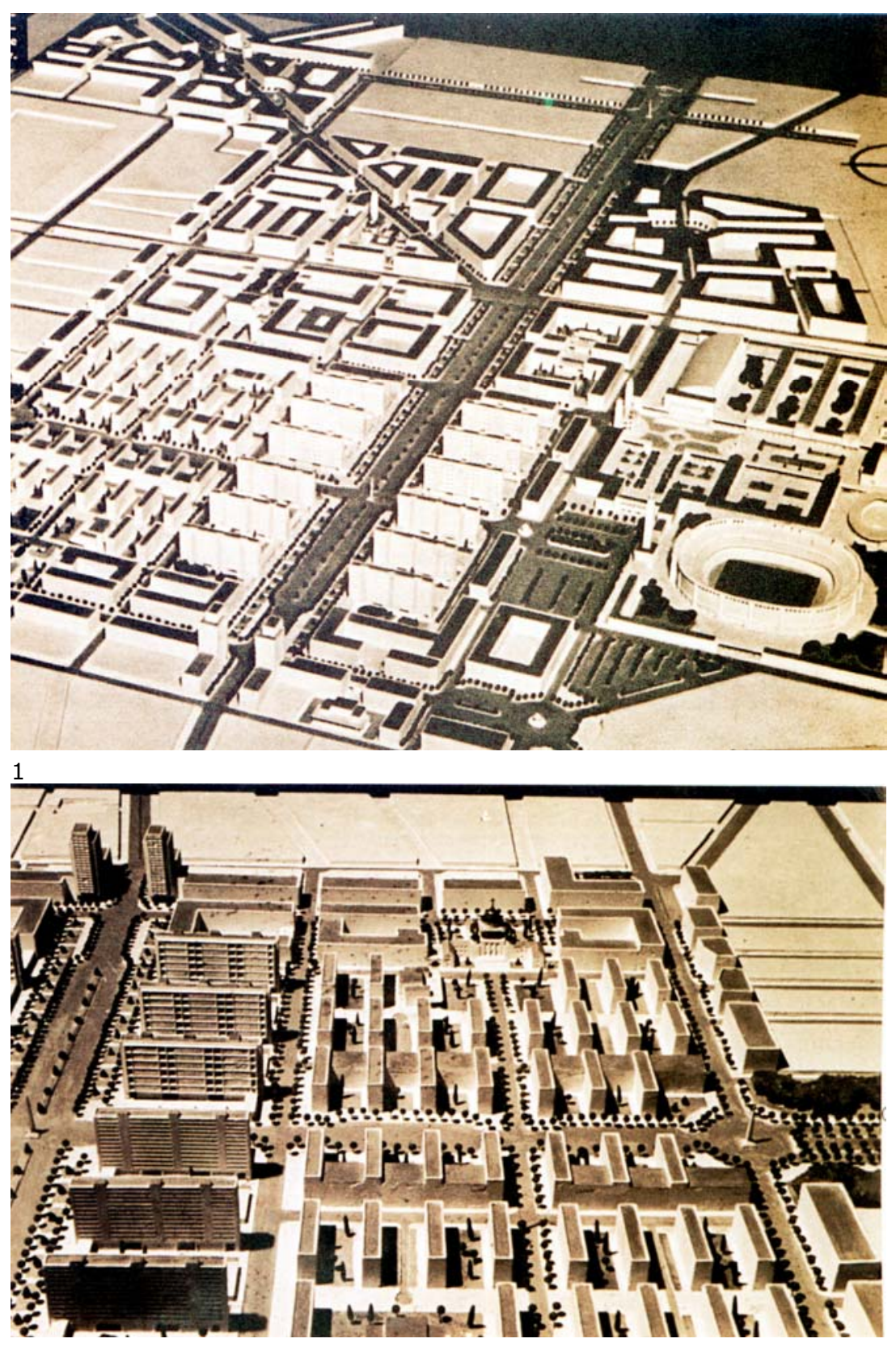

1,2,3. Vistas de la maqueta del plan parcial de la Hoja 12B de 1952 (Archivo de Planeamiento, Ayuntamiento de Valencia)

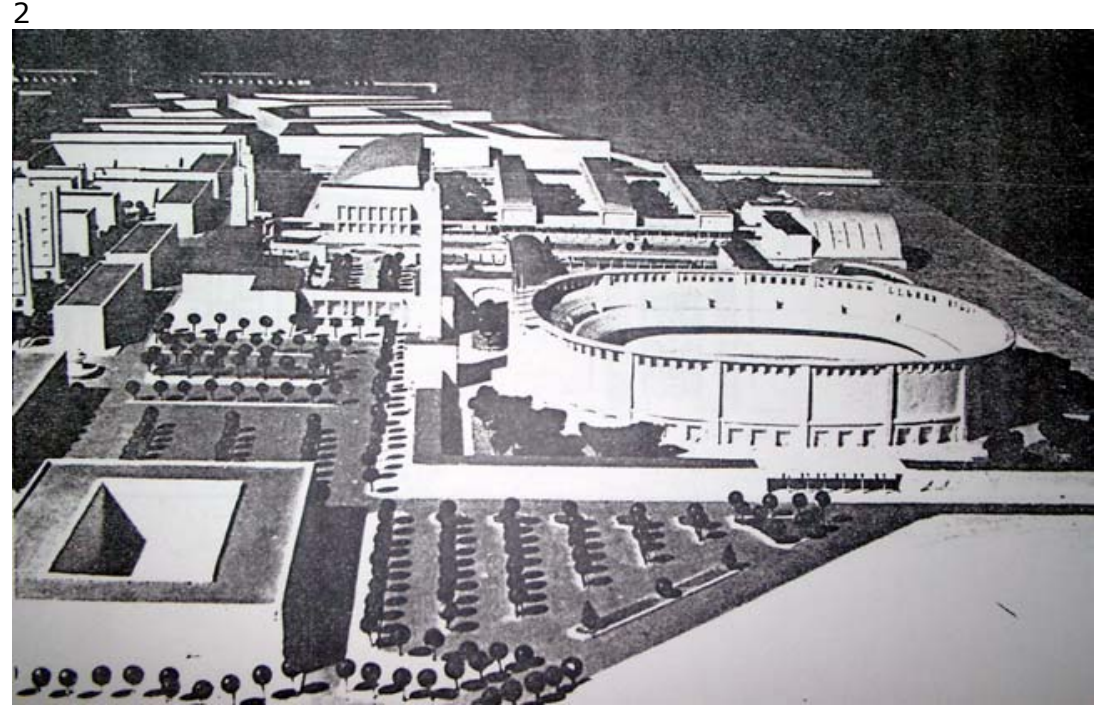




\section{LOS INICIOS DE LA EDIFICACIÓN ABIERTA EN EL PASEO AL MAR: LA HOJA 12-B DE 1952.}

En el Plan General de 1946, el área correspondiente a la Hoja 12-B está destinada a Zona de Reserva atravesada por una continuación del primer tramo del Paseo de Valencia al Mar, reduciendo la anchura de éste a la de una calle ordinaria y bordeándola de edificación de Ciudad-Jardín.

La ocupación de la zona para uso residencial se produce en el proyecto parcial correspondiente a la Hoja 12-B, redactado en 1952 por la Oficina Técnica Municipal de Urbanismo del Ayuntamiento de Valencia, con el titulo de "Plano de alineaciones y zonificación del sector comprendido entre el Nuevo Acceso de Barcelona, FF.CC. Económicos y de Aragon al Puerto, actual FF.CC. de Tarragona y continuación de c/ Amadeo de Saboya". La Memoria del plan justifica la ocupación de la zona de reserva del modo siguiente:

Se pensó, y así queda plasmado en el plano, la conveniencia de continuar el Paseo, que estaba ya, por así decirlo, grabado y aceptado en la mente de los valencianos como obra o empeño importante para el futuro embellecimiento y mejora de la Ciudad, y destinar ya la Zona de reserva a un barrio modelo de salubridad y belleza, con modos de edificación que desearíamos ver extendidos a otras partes de la Ciudad y que no son posibles más que en las Zonas vírgenes de construcción, por causa del gran realismo que la práctica del urbanismo impone.

Se ha dedicado pues, el centro de la zona, a Edificación Abierta o sea edificación, en general, sin patios de luces ni patio central de manzana, quedando los edificios rodeados de jardín, o simplemente zonas arboladas.

Al norte del Paseo de Valencia al Mar, después de una serie de bloques abiertos, parece que quedarían muy bien ubicados, un gran Estadio Municipal y la futura Feria Muestrario, que gozaría de amplitud para poder ser muy ajardinada y de magníficas comunicaciones por ferrocarril para mercancías. ${ }^{1}$

Así, la ordenación planteada en este proyecto para la zona comprendida entre la calle Santos Justo y Pastor y el Paseo al Mar resuelve el área entre Serrería y Músico Ginés con edificación abierta. Una serie de bloques altos, de 14 plantas, de los cuales sólo se construyeron siguiendo una pauta similar al plan, aunque con menor altura, los de la primera fase del Grupo Paseo de Valencia al Mar (1952-59) ${ }^{2}$, se disponen en ortogonal al Paseo al Mar, a uno y otro lado del mismo. Otros bloques de menos altura y más cortos, dispuestos en dirección este-oeste, ocupan el espacio restante hasta la calle Santos Justo y Pastor.

Para los bloques recayentes al Paseo de Valencia al Mar, de 14 plantas y $14 \mathrm{~m}$ de profundidad, sin patios interiores, se prevé una distribución de las viviendas con calle interior servida por una escalera, un grupo centralizado de ascensores y dos escaleras supletorias a los lados ${ }^{3}$.

La Memoria del plan señala, en cuanto a las características de la edificación abierta proyectada, que su densidad no es baja, ya que sigue las determinaciones en cuanto a distancia entre bloques de las Ordenanzas de Zonas de Edificación abierta, que fijan una

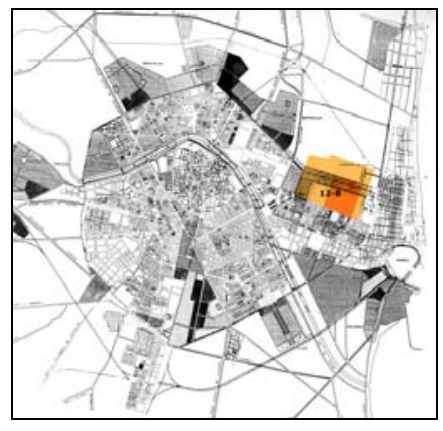

Hoja 12-B, 1952. Localización.

1. Hoja No 12-B. Plano de alineaciones y zonificación del sector comprendido entre el nuevo acceso de Barcelona, F.C. económicos y de Aragón al puerto, actual F.C. de Tarragona y continuación de Cl Amadeo de Saboya, 1952. Memoria (Ver Anexo de Documentos, pp. 27-33).

2.Este grupo se analiza en el apartado siguiente de esta sección. ver pp. 84-87.

3. La Memoria indica que se adjuntan unos esquemas en planta de estos edificios que no hemos podido localizar. Por la descripción que se realiza, esta distribución resutaría bastante parecida a la de los bloques lineales altos proyectados por Hilbersemer para su Ciudad Vertical. 
distancia igual a la altura de la Edificación para orientación Este y Oeste, y de vez y cuarto la altura de la edificación para orientación N.S. Al respecto, la Memoria comenta que

Valencia, donde los terrenos que han de ser edificables comienzan con las características de ser de huerta y precio superior a 25.000 ptas. la hanegada, para ir luego subiendo con la calificación de solares, no puede permitirse distancias entre los bloques de dos veces o dos veces y media la altura de la edificación, como es corriente en otras ciudades, y deberá buscar para sus barrios modelos, formas de gran salubridad pero de buena densidad. De otra forma se llegaría a cubrir excesiva huerta. ${ }^{1}$

Este texto es una de las pocas referencias que podemos encontrar en el planeamiento en apoyo de la alta densidad con la que desde un primer momento se proyectaron los conjuntos residenciales de edificación abierta en Valencia.

La Memoria señala que las directrices del proyecto son los tres principios fundamentales de la actuación urbanística: Utilidad, belleza y salubridad.

La utilidad se descompone a su vez en tráfico y sociología. En lo relativo al tráfico, el plan se apoya en el eje del Paseo al Mar, de $100 \mathrm{~m}$. de anchura, que lo atraviesa de oeste a este, y en una serie de ejes transversales, de dirección norte-sur, iniciados en la Hoja $12-A$ de $1950^{2}$. Estos ejes, que enlazan la Avenida del Puerto con el Paseo al Mar, son la Avenida de Cardenal Benlloch, la actual calle Manuel Candela (prevista en el plan para el trazado del nuevo ferrocarril en zanja o en alto), la actual calle Músico Ginés (denominada Avenida del Estadio en el plan) y la prolongación de la calle Maestro Valls. A ello se suma la diagonal de la actual calle Yecla.

Los equipamientos se tratan en el apartado de sociología. En la zona central de edificación abierta, además del Estadio y la Feria Muestrario situados al norte, que corresponden a toda la Ciudad, el plan prevé como elementos propios una Iglesia y Centro Parroquial, Mercado, Sala de Espectáculos y cinco grupos escolares.

1. Hoja No 12-B. Plano de alineaciones y zonificación del sector comprendido entre el nuevo acceso de Barcelona, F.C. económicos y de Aragón al puerto, actual F.C. de Tarragona y continuación de C/ Amadeo de Saboya, 1952. Memoria (Ver Anexo de Documentos, pp. 27-33).

2. La Memoria de la Hoja 12-B indica expresamente que su viario está íntimamente ligado al de la Hoja 12-A. Acerca del papel del plan correspondiente a la Hoja 12-A como catalizador de la ocupación del espacio anexo al Paseo al Mar, acabando con la idea de ciudad lineal inicial de esta vía, ver Giménez Baldrés, Enrique J., Parcelaciones Residenciales Suburbanas. La formación de la periferia metropolitana de Valencia, Servicio de Publicaciones de la UPV, Valencia, 1996, pp. 473-475.
La salubridad, por su parte, va asociada en el plan a la edificación abierta, sin patios interiores y con abundantes espacios libres entre los edificios.

La mención expresa a la belleza como directriz del proyecto urbano no puede dejar de conmovernos hoy. En el apartado dedicado a ella, la Memoria señala que la belleza

Se confía, en gran parte, a la sensación de libertad y amplitud que ha de producir, para todo aquel que circule por el Sector, el hecho de no quedar casi nunca enclaustrado por dos paramentos de edificaciones. En las vías principales, además de su gran anchura y zonas ajardinadas, los bloques de edificación son perpendiculares al eje de la vía, de tal manera que la perspectiva de jardines y arbolados dará la sensación de no tener fin. La sensación que producirá, será la de un gran parque con bloques de edificación aislados.

La situación de los edificios públicos como final de perspectiva de las calles interiores o de barrio, las torres final de perspectiva del Paseo de Valencia al Mar, la torre del Estadio como final de la Avd. que 
va al mismo y las edificaciones de entrada a la Feria Muestrario y sus torres serán también elementos de Belleza del conjunto.

Por último la acertada disposición del suelo de las calles, en las que se procurará que quede la mayor cantidad posible de tierra viva, que lleve o pueda llevar una planta, reservando el asfaltado para lo estrictamente necesario de circulación de vehículos y el enlosado, o pavimento idóneo, para la de peatones; la ordenación de las edificaciones, que en gran parte serán unificadas ya que tendrán, como luego se verá, que ser construidas por una sola Entidad y en otros casos se unificarán lo suficiente por efecto de los artículos de la Ordenanza de Edificación abierta, que a esto tiende, contribuirán también a la belleza del Sector. ${ }^{1}$

La belleza está asociada por tanto a los espacios libres propios de la edificación abierta, a la composición (cierres de perspectiva, puntos focales, etc.) y al carácter unitario de la arquitectura.

Este último aspecto, el carácter arquitectónico unitario de los edificios, va asociado necesariamente a la gestión pública de los conjuntos residenciales, tal como señala la Memoria del plan:

La urbanización de toda esta Zona pudiera ser realizada por el Excmo. Ayuntamiento con expropiación de terrenos y construcción posterior o bien mixta entre Ayuntamiento y Empresa particular. Esto es imprescindible en las edificaciones recayentes al Paseo de Valencia al Mar, en que por su naturaleza no puede permitirse la diversidad que la edificación por particulares implica. De todas maneras en toda la Zona, la intención de brillantez y de barrio modelo que la vista del plano indica llevará anejo, en la urbanización, una actuación total por parte del Excmo. Ayuntamiento sobre solares. ${ }^{2}$

Como veremos más adelante, esto no fue en absoluto lo que ocurrió en la zona de la prolongación del Paseo de Valencia al Mar. 
Proyecto Parcial de Desarrollo no IV Zona S.E., 1953. (De Giménez).

Proyecto Parcial de Desarrollo no IV Zona S.E., 1953. (Transcripción de 1956, E 1:2000, Archivo de Planeamiento, Ayuntamiento de Valencia)

Proyecto Parcial de Desarrollo no IV Zona S.E., 1953, fragmento (Elaboración propia: sombreado de la edificación sobre copia del plano entelado original).
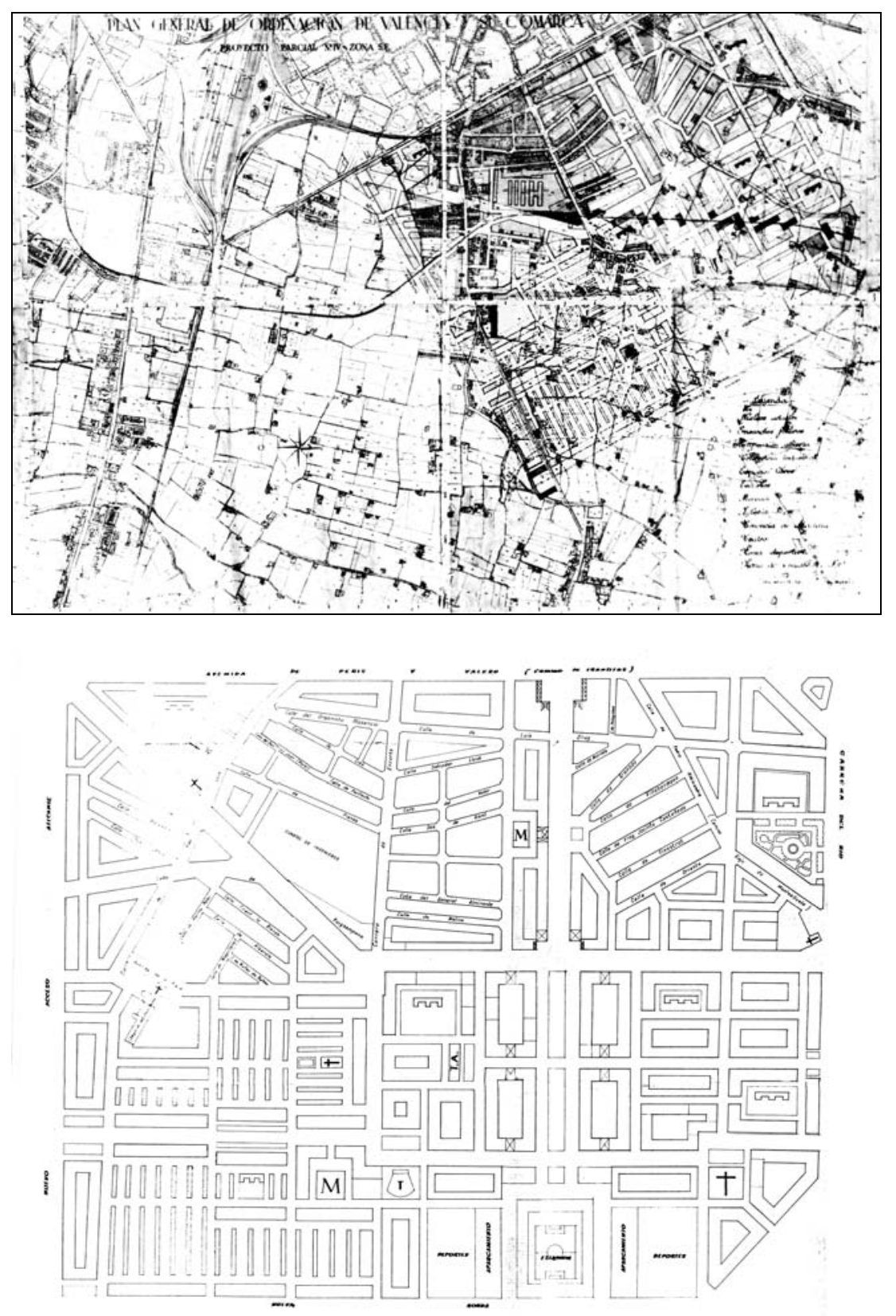

ESCALA 1:20OO

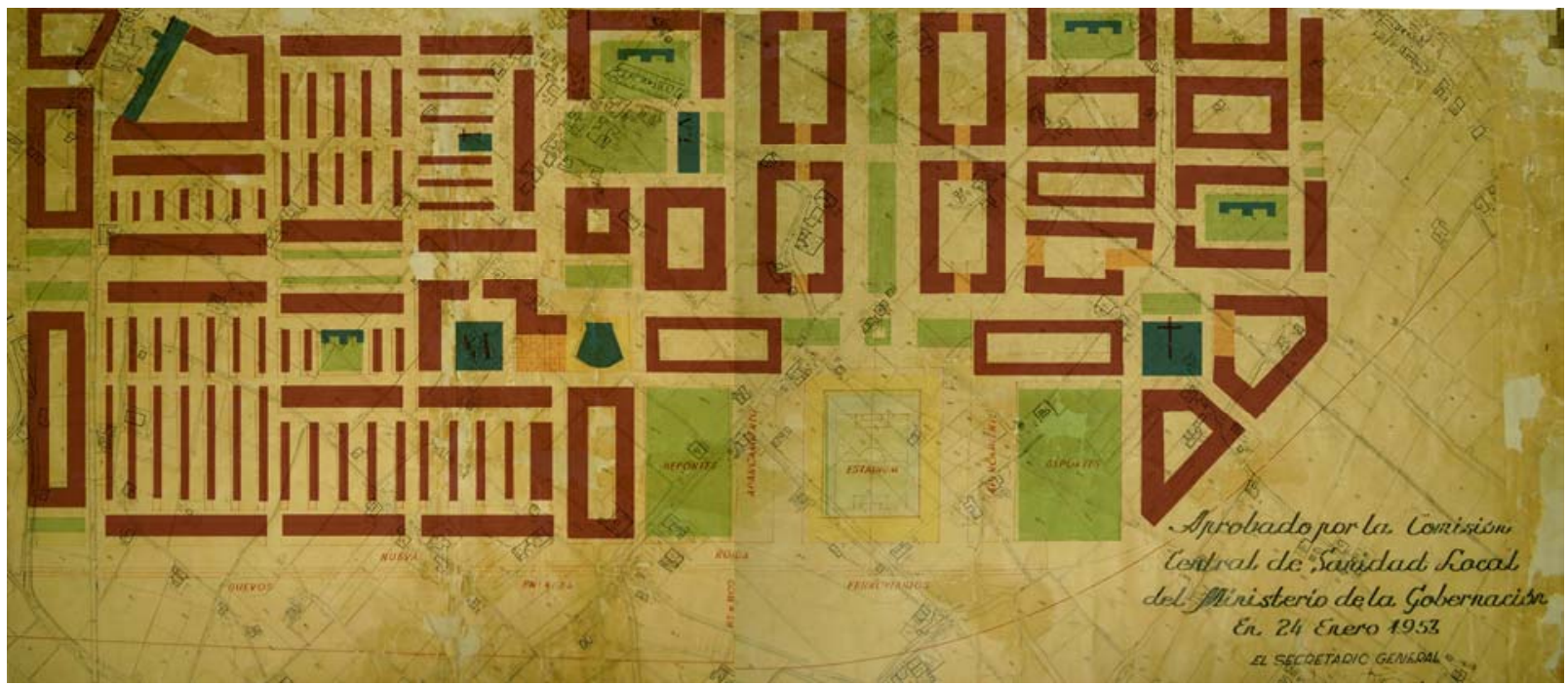




\section{LA EDIFICACIÓN ABIERTA EN EL ÁREA SURESTE: EL PROYECTO PARCIAL DE DESARROLLO NO IV (1953).}

El Proyecto Parcial de Desarrollo no IV aprobado por la Comisión central de Sanidad Local en 1953 modifica otro anterior de 1948 que ordenaba la totalidad de la zona mediante manzanas cerradas.

El proyecto parcial de 1953 incluye dos sectores: la mitad norte corresponde al barrio de Monteolivete, de ensanche con manzanas irregulares, y la mitad sur es una zona de expansión hasta la ronda exterior. Esta segunda zona es la destinada a edificación abierta en el Plan General de 1946, que ya incluía una ordenación para la misma que hemos analizado anteriormente: el denominado Ensanche Sureste. La zona de ciudad-jardín exterior a la ronda, que formaba parte del Ensanche Sureste, no se contempla ya en el Proyecto Parcial IV.

En el Proyecto Parcial IV, la edificación abierta ocupa el cuadrante suroeste, entre el acceso de Alicante y la actual calle General Urrutia. La Avenida de la Plata es su límite norte, y la Ronda exterior el límite sur. El trazado viario se apoya en un dos ejes principales que se cruzan: uno de dirección este-oeste, correspondiente a la actual Avenida Hermanos Maristas, y otro de dirección norte-sur, en prolongación de la calle Luís Santángel, que se remata con un importante núcleo de equipamientos deportivos situados junto a la Ronda exterior.

La edificación abierta sigue aquí la pauta compositiva habitual de este periodo, que ya hemos encontrado en otros proyectos, como el Barrio Residencial de Burjasot-Benimamet o el Nuevo Barrio entre Tránsitos y Paseo al Mar: combinación de bloques lineales profundos y bloques lineales delgados, los primeros con una función envolvente y de delimitación del espacio público (calles y plazas) y los segundos como tejido uniforme que rellena el espacio intermedio entre los bloques profundos.

Así, vemos como los bloques profundos flanquean los ejes viarios principales, y se pliegan para definir plazas y cierres de perspectiva, como en el nudo en turbina proyectado a mitad del eje central este-oeste, en torno al cual se sitúa un centro vecinal.

La diferencia principal con los demás proyectos del mismo periodo es que aquí el espacio intermedio relleno con edificación en línea de bloques delgados es de mayor tamaño en casi todas las manzanas, lo que permite situar en ese espacio unos bloques más alargados e, incluso, dos bloques separados por una calle.

Las únicas edificaciones realizadas de acuerdo con este plan son los tres bloques lineales y el fragmento de bloque profundo que forman el grupo Felipe Rinaldi, junto al colegio Salesiano. ${ }^{1}$

En el cuadrante sureste de este proyecto parcial, la edificación se resuelve con manzanas por lo general cerradas, aunque algunas de ellas forman una $U$ abierta a la calle que envuelve una parcela escolar.

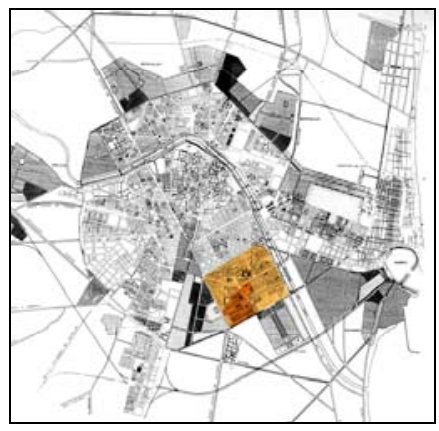

Proyecto parcial de Desarrollo no IV, 1953. Localización.
1. El grupo Felipe Rinaldi será analizado en el apartado siguiente de esta sección. Ver pp. 94-95. 


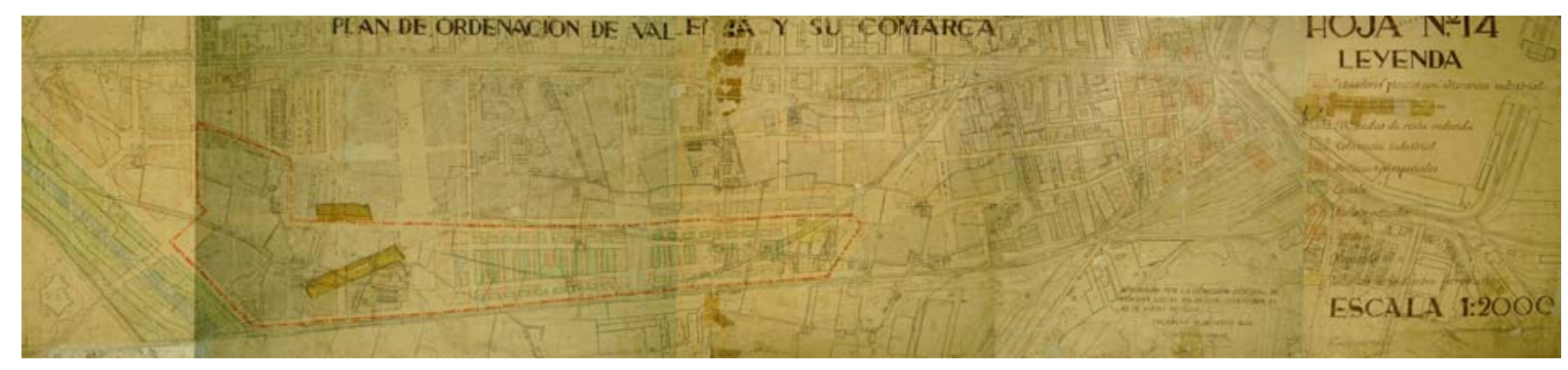

Plan de Ordenación de Valencia y su Comarca. Hoja 14, 1954 (Plano original entelado E:1:2000, Archivo de Planeamiento, Ayuntamiento de Valencia).

Detalles de zonas de edificación abierta (Sombreado de edificación sobre Hoja 14).
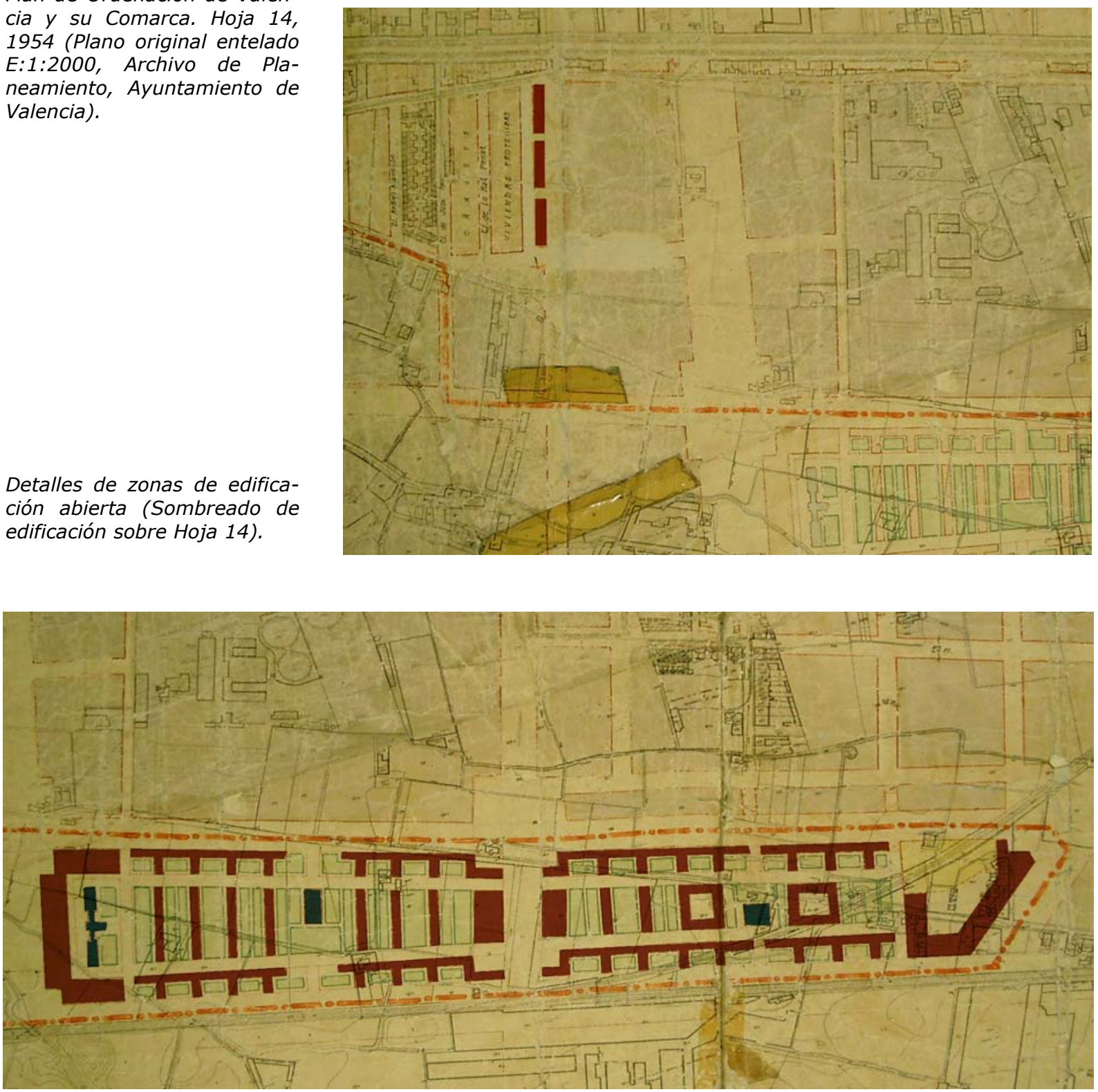


\section{LA ZONA DE CAMINS AL GRAO: HOJA 14 (1954)}

La Hoja 14 del Plan de Ordenación de Valencia y su Comarca, aprobada por la Comisión Central de Sanidad Local en 1954, ordenaba la zona limitada al norte por la actual Avenida del Puerto, al este por la dársena portuaria, al sur por la actual Avenida de Francia y al oeste por el cauce del río Turia.

En esta Hoja 14, ordenada en su mayor parte mediante manzanas cerradas convencionales de ensanche, se incluye un conjunto de edificación abierta de buen tamaño, que ocupa un espacio alargado limitado al norte por la Avenida de las Baleares, al este por la calle Menorca, al sur por la Avenida de Francia y al oeste por la calle Padre Tomás Montañana.

Los tipos de bloques utilizados en este conjunto son tres: el bloque lineal delgado, el bloque lineal profundo y el bloque a redents. Además, aparecen también ocasionalmente manzanas cerradas.

Los bloques profundos ocupan los extremos este y oeste, así como los flancos de la calle Pintor Maella. Los bloques a redents se sitúan en los laterales norte y sur, con los dentados abiertos siempre a esta última orientación. En la parte central se sitúan los bloques lineales poco profundos, con directriz norte-sur y a intervalos regulares coincidentes con los de los dientes de los redents.

La principal diferencia de este proyecto con respecto otros del mismo periodo es que los elementos envolventes de los bloques de dos crujías no son bloques profundos, con patios interiores, sino bloques a redents, en los que los patios se abren a la calle, según el modelo ideado por Henard.

Las zonas verdes son los espacios intermedios entre los bloques lineales, junto con los patios abiertos a calle que forman los redents. En el centro de cada una de las dos mitades del conjunto e crean dos núcleos de equipamientos en torno a sendas plazas o jardines, interrumpiendo la continuidad de la edificación de borde. Envuelta por el bloque profundo en $U$ del extremo oeste se dispone también una parcela escolar.

De toda esta ordenación de la zona sur no se llegó a realizar ningún edificio, pese a que permaneció en vigor como documento legal durante un largo periodo, entre 1954 y 1986, año de aprobación del Plan General.

La única edificación abierta construida de la Hoja 14 es el conjunto formado por tres bloques lineales de dos crujías recayentes a la calle Río Escalona.

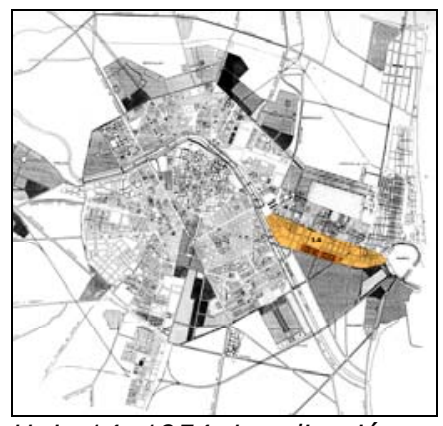

Hoja 14, 1954. Localización.

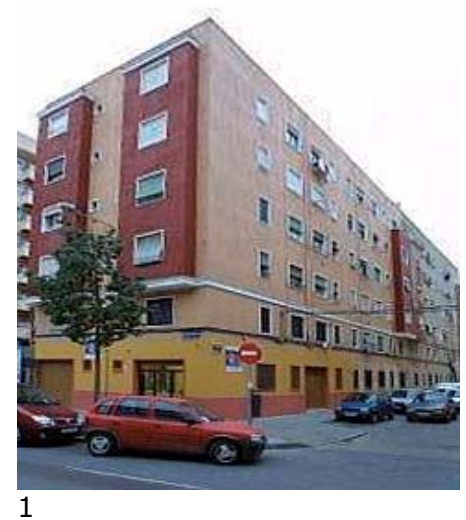

1
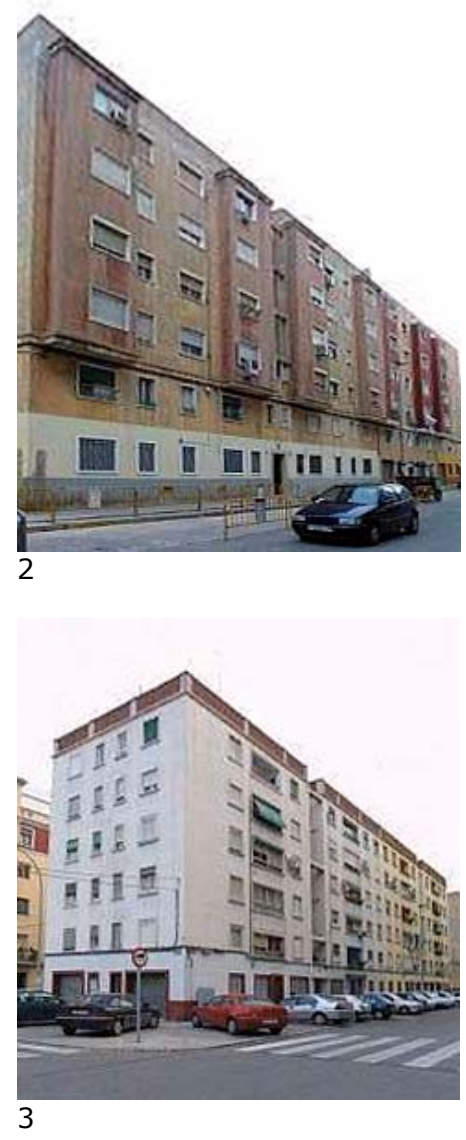

1-3. Bloques lineales de la calle Río Escalona. 

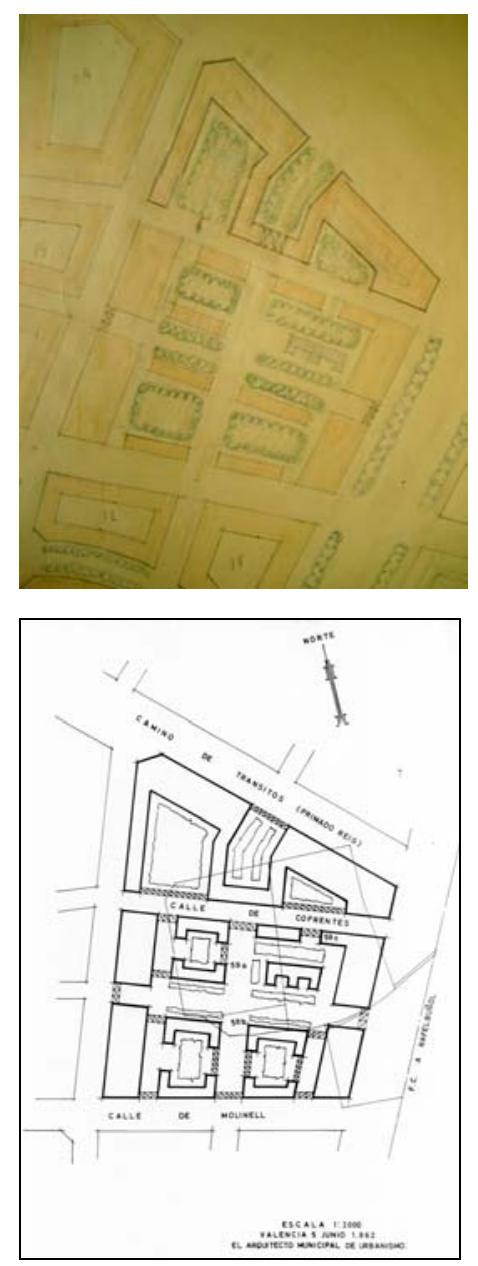

Zona de edificación abierta entre las calles de Bilbao y Alboraya. Boceto previo y solución aprobada. (Archivo de Planeamiento, Ayuntamiento de Valencia)
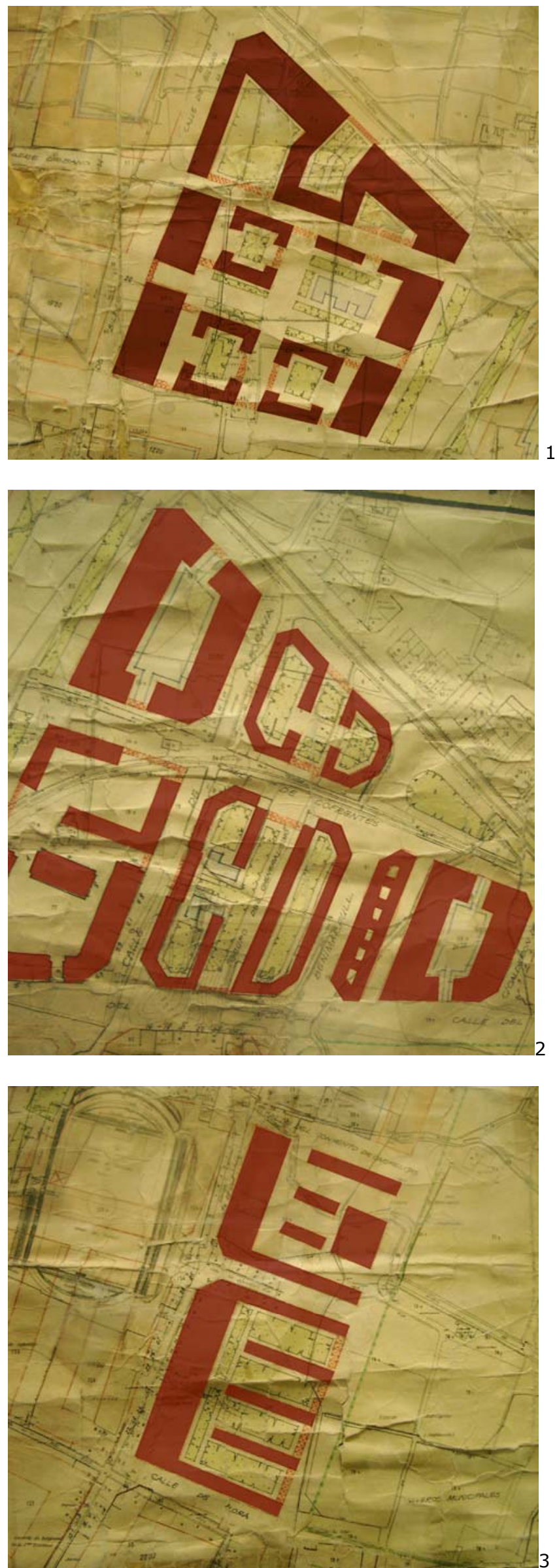

1-3. Plan de Ordenación de Valencia y su Comarca. Hoja 10, 1956. Detalles de zonas con edificación abierta (Sombreado de edificación sobre plano original entelado E 1:2000, Archivo de Planeamiento, Ayuntamiento de Valencia). 


\section{ZAIDÍA: HOJA 10 (1956)}

La zona del Llano de Zaidía, ordenada en la Hoja 10, aprobada por la Comisión Central de Sanidad Local en 1954 de 1956, es una zona interior al camino de Tránsitos que formaba parte del ensanche de Mora de 1917. Es, por tanto, una zona con planeamiento anterior, ocupada en su mayor parte por manzanas cerradas, con un grado de consolidación variable.

Las zonas de edificación abierta incluidas en la Hoja 10 de 1956 son tres. Las dos primeras son contiguas y están situadas al norte, en el espacio triangular comprendido entre el Camino de Transitos y la calle Molinell y limitada al oeste por la calle Bilbao. La tercera es una franja rectangular situada entre la calle Alboraya y los jardines de Viveros.

En la zona de edificación abierta situada entre la calle Alboraya y la calle Bilbao, aparecen una serie de bloques profundos envolventes alineados con las calles perimetrales de los lados norte, este y oeste. Los bloques delgados, de dos crujías, se sitúan dentro de esta envolvente, bien como brazos complementarios de los bloques profundos (como en el frente al Camino de Tránsitos) o bien como relleno del espacio intermedio, formando cuatro micromanzanas formadas por parejas de bloques en $\mathrm{C}$, una de las cuales se libera de edificación para albergar una escuela.

En la segunda zona de edificación abierta situada al norte, la ordenación viene condicionada por la presencia de las manzanas abiertas de los grupos Almazora y Alboraya/General Franco. Junto a ellos, la edificación adopta formas muy variadas: manzanas abiertas formadas por dos bloques profundos en $\mathrm{C}$, bloques profundos aislados, bloques en $L$ y en $U$ de dos crujías, e incluso una agrupación que reproduce a pequeña escala el grupo Alboraya, analizado en la sección anterior.

La tercera zona de edificación abierta sigue la pauta habitual del periodo, con un bloque profundo alineado con la calle principal, en dirección norte-sur, y varios bloques lineales perpendiculares, de directriz este-oeste, algunos de los cuales están unidos como brazos al bloque profundo. En esta caso, los bloques profundos envuelven únicamente el lado oeste, y los testeros de los bloques lineales se abren directamente al parque de Viveros. Los espacios intermedios entre los bloques están proyectados como zonas verdes.

La ordenación dibujada en esta Hoja 10 de 1956 para las zonas de edificación abierta mencionadas se mantuvo en parte en la siguiente ordenación de la misma zona, que es la denominada Plan Parcial 10, redactada en 1968 en desarrollo del Plan General de 1966.

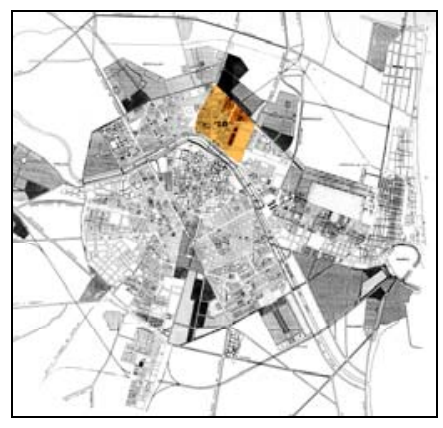

Hoja 10, 1956. Localización.
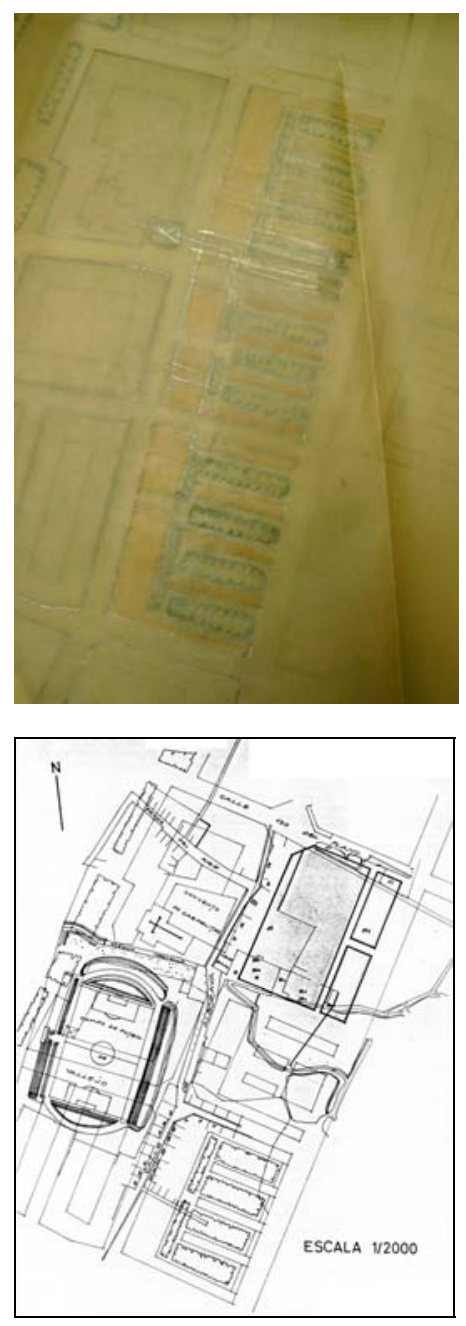

Zona de edificación abierta junto a los Jardines de Viveros. Boceto previo y remodelación (Archivo de Planeamiento, Ayuntamiento de Valencia). 
Tabla I.3

Valencia. Grupos de promoción pública 1950-56

\begin{tabular}{|l|l|r|c|}
\hline \multirow{2}{*}{ PROMOTOR } & GRUPO & VIVIENDAS & AÑOS \\
\hline \multirow{4}{*}{$\begin{array}{l}\text { INV /AV } \\
\text { (Plan 5000) }\end{array}$} & Malvarrosa & 456 & $1949-59$ \\
\cline { 2 - 4 } & Ruiz Jarabo (INV/JOP) & 168 & $1949-56$ \\
\cline { 2 - 4 } & Camino de Alba & 438 & $1952-56$ \\
\cline { 2 - 4 } & Cardenal Benlloch & 630 & $1952-60$ \\
\cline { 2 - 4 } & Paseo Valencia al Mar & 537 & $1952-60$ \\
\cline { 2 - 4 } & Covife (INV/CVF) & 75 & $1955-58$ \\
\hline RENFE & Edificio Renfe-Aragón & 78 & $1950-54$ \\
\hline \multirow{2}{*}{$\begin{array}{l}\text { INV/UNL } \\
\text { (Plan 5000) }\end{array}$} & Salas Pombo & 276 & \\
\cline { 2 - 4 } & Girón de Velasco & 2.910 & $1952-57$ \\
\hline INV (PSV) & V. de los Desamparados & & \\
\hline
\end{tabular}

Tabla I.4

Valencia. Principales grupos de viviendas promovidos por cooperativas y empresas, 1950-56.

\begin{tabular}{|l|l|c|l|}
\hline TIPO PROMOcIón & GRUPO & VIVIENDAS & AÑos \\
\hline \multirow{4}{*}{$\begin{array}{l}\text { Viviendas } \\
\text { Protegidas }\end{array}$} & Copuva (INV/COPUVA) & 203 & $1951-64$ \\
\cline { 2 - 4 } & Aragón (RENFE) & 78 & $1950-54$ \\
\cline { 2 - 4 } & San Marcelino (PNSD) & & 1949 \\
\cline { 2 - 4 } & Tendetes (PNSD) & & 1949 \\
\cline { 2 - 4 } & Patraix (PNSD) & 296 & 1949 \\
\cline { 2 - 4 } & Torrefiel (PFR) & 449 & $1954-$ \\
\hline $\begin{array}{l}\text { Viviendas de } \\
\text { Renta Limitada }\end{array}$ & Agrifersa & 136 & $1953-$ \\
\cline { 2 - 4 } & Fuente S. Luís (PFR) & & \\
\hline
\end{tabular}

Notas:

Los grupos sombreados son los proyectados total o parcialmente con edificación abierta.

Abreviaturas:

Agrifersa: Agrios y Fertilizantes, S.A.

AV: Ayuntamiento de Valencia.

COPUVA: Cooperativa Popular Valenciana.

INV: Instituto Nacional de la Vivienda.

JOP: Junta de Obras del Puerto.

OSHA: Obra Sindical del Hogar y la Arquitectura.

PFR: Patronato Felipe Rinaldi.

PNSD: Patronato Nuestra Señora de los Desamparados

PSV: Plan Sindical de la Vivienda.

UNL: Unión Naval de levante.

RENFE: Red Nacional de Ferrocarriles Españoles. 


\section{GRUPOS DE VIVIENDAS DE PROMOCIÓN PÚBLICA Y DE COOPERATIVAS, 1950-56.}

En el año 1949 se produjo una avenida del río Turia que arrasó más de dos mil chabolas de las zonas más bajas de Valencia, muchas de ellas situadas en el propio cauce del río. En 1950, respondiendo a un convenio firmado entre el Ayuntamiento de Valencia y el Instituto Nacional de la Vivienda (INV), se aprobó el "Plan 5.000 Viviendas para Valencia", cuyo objetivo era la construcción de viviendas protegidas para contribuir a erradicar del chabolismo ${ }^{1}$.

En el marco del Plan 5000 se promueven una serie de grupos, y se incorporan al mismo otros ya iniciados anteriormente. Estos grupos, enumerados en la Tabla I.3, suponen un aumento en la escala de la actuación pública, ya que la mayoría de ellos superan las 300 viviendas. De ellos, se proyectan mediante bloques de edificación abierta el grupo Ruiz Jarabo, la primera fase del grupo Paseo Valencia al Mar (popularmente denominado Isla Perdida), y el grupo Camino de Alba. En los restantes grupos del Plan, la edificación adopta por lo general la forma de manzanas cerradas compuestas con células de vivienda de dos crujías $^{2}$.

Por otra parte, en desarrollo del Plan Sindical de la Vivienda, se construye en fases sucesivas (entre 1954 y 1962) en la zona de la Avenida de Castilla el grupo Virgen de los Desamparados, que es el primer conjunto de edificación abierta de un tamaño importante realizado en Valencia.

Además de los conjuntos de promoción pública, en el periodo comprendido entre 1952 y 1962 se promovieron en Valencia por parte de cooperativas de funcionarios y empresas diversos una serie de grupos de viviendas que pueden considerarse representativos del proceso de progresiva sustitución de la manzana por el bloque como edificio urbano tipo. Se trata de promociones de tamaño moderado, compuestas por agrupaciones de uno a tres edificios como máximo.

De estas edificaciones, las realizadas hasta 1954 son grupos de Viviendas Protegidas o Bonificables, mientras que las construidas a partir de ese año son grupos de Viviendas de Renta Limitada. Estos grupos, como veremos, serán los predominantes en la etapa siguiente, a partir de 1957.

La edificación abierta es menos habitual que la manzana como modelo para los grupos de Viviendas Protegidas, aunque existe algún ejemplo aislado, como el edificio Renfe-Aragón.

En cuanto a los grupos de Viviendas de Renta Limitada, examinaremos en este apartado dos de los primeros construidos en Valencia: el grupo Agrifersa y el Rinaldi de Fuente de San Luís.
1. Gaja señala que a la riada, como justificación del Plan 5000, habría que añadir las operaciones de reforma interior en el centro y los desalojos consiguientes por derribos. Ver Gaja, F., Op. cit., pp. 122-150.

2. Una de las tres manzanas que integran el grupo Malvarrosa puede considerarse como edificación abierta, ya que está formada por dos bloques en $\mathrm{C}$ laterales $\mathrm{y}$ un bloque lineal central, actualmente demolido.

3.Examinaremos las determinaciones de La Ley de Viviendas Protegidas en el apartado 6 de esta sección, que trata de los Proyectos de Ejecución de Polígonos para la construcción de Viviendas de Renta Limitada. 


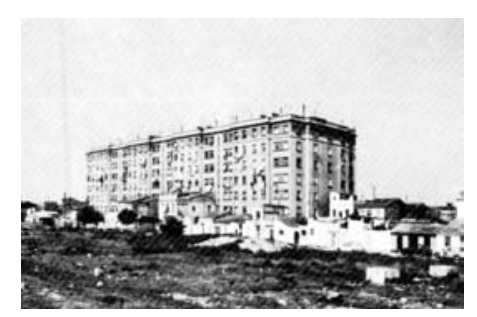

Grupo Ruiz Jarabo, h. 1970, rodeado de chabolas y viviendas autoconstruidas del Clot del Cabanyal.

Planta de situación (Sombreado sobre plano de estado actual del Polígono de Valencia al mar, 1960).
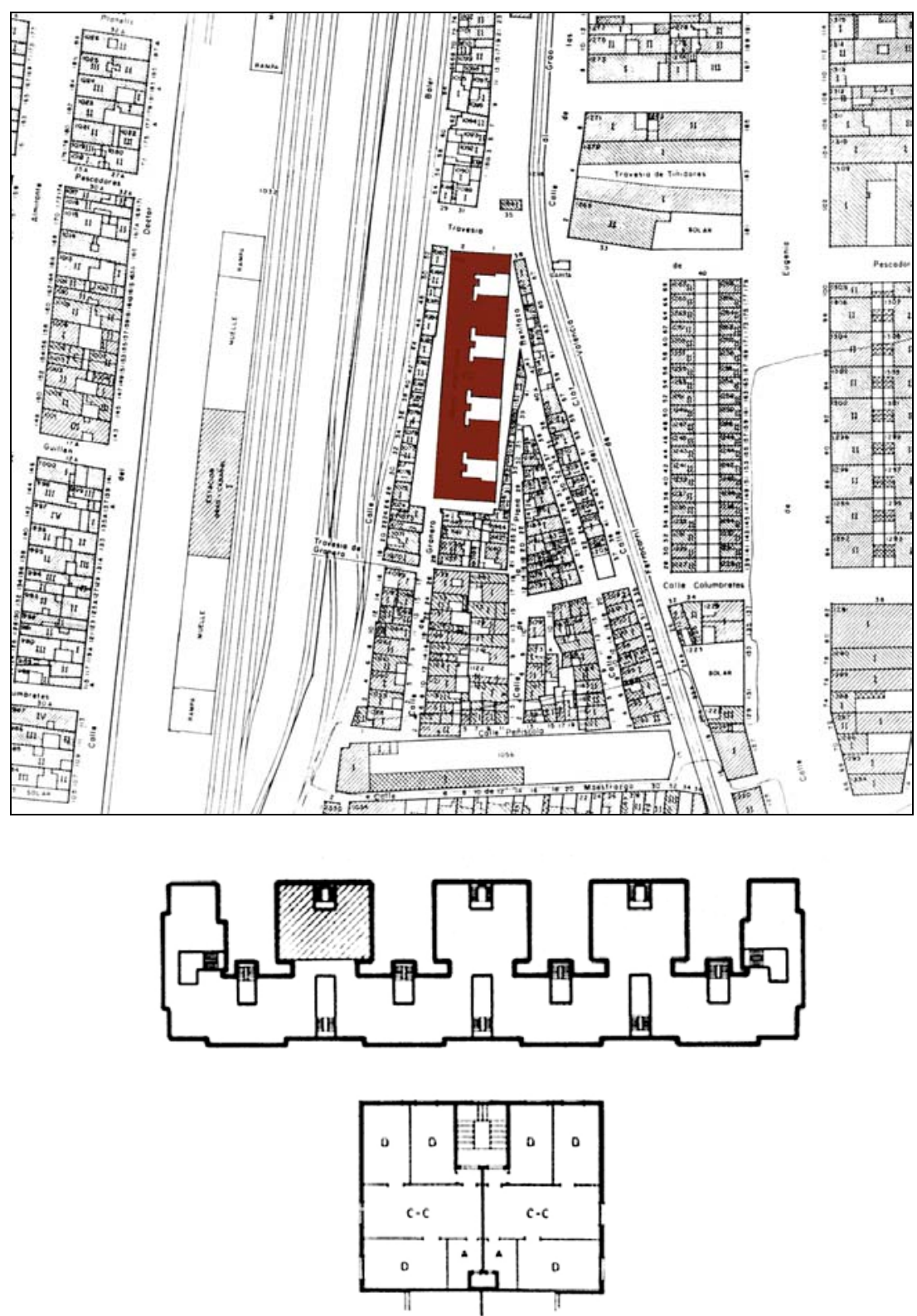

Planta del bloque y de una vivienda tipo (Peñín).

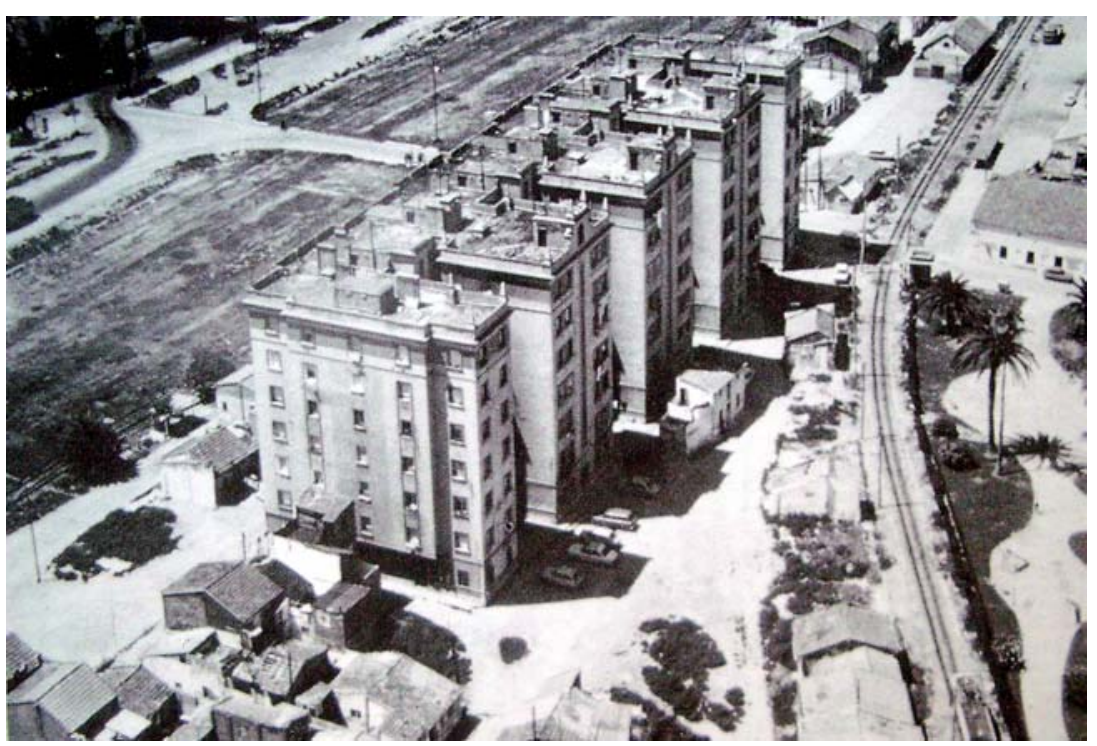




\section{EL GRUPO RUIZ JARABO (1949-56).}

El Grupo Ruiz Jarabo, de 230 Viviendas Protegidas, forma parte, como la Isla Perdida, del Plan 5000. Proyectado por A. Tatay en 1949 , es el primer grupo del INV en Valencia, ya que se terminó en 1956.

El grupo es un bloque aislado de VII plantas $(P B+6)$, todas destinadas a viviendas, situado en una zona de viviendas semichabolista conocida como "Clot del Cabanyal". La expropiación y demolición de estas viviendas, de las cuales aún subsiste una pequeña parte, no se puso en marcha hasta los años 90, a través del Programa de Actuaciones Urbanísticas del Marítimo (PAUM) promovido por el Instituto Valenciano de la Vivienda (IVVSA).

Pese a que la imagen arquitectónica del edificio muestra un exceso de residuos historicistas, la tipología del grupo Ruiz Jarabo es de edificación abierta, en concreto de bloque lineal profundo con patios abiertos a fachada, aunque ello no se aprovecha para obtener tres viviendas por planta en cada caja de escalera, como es habitual en este tipo.
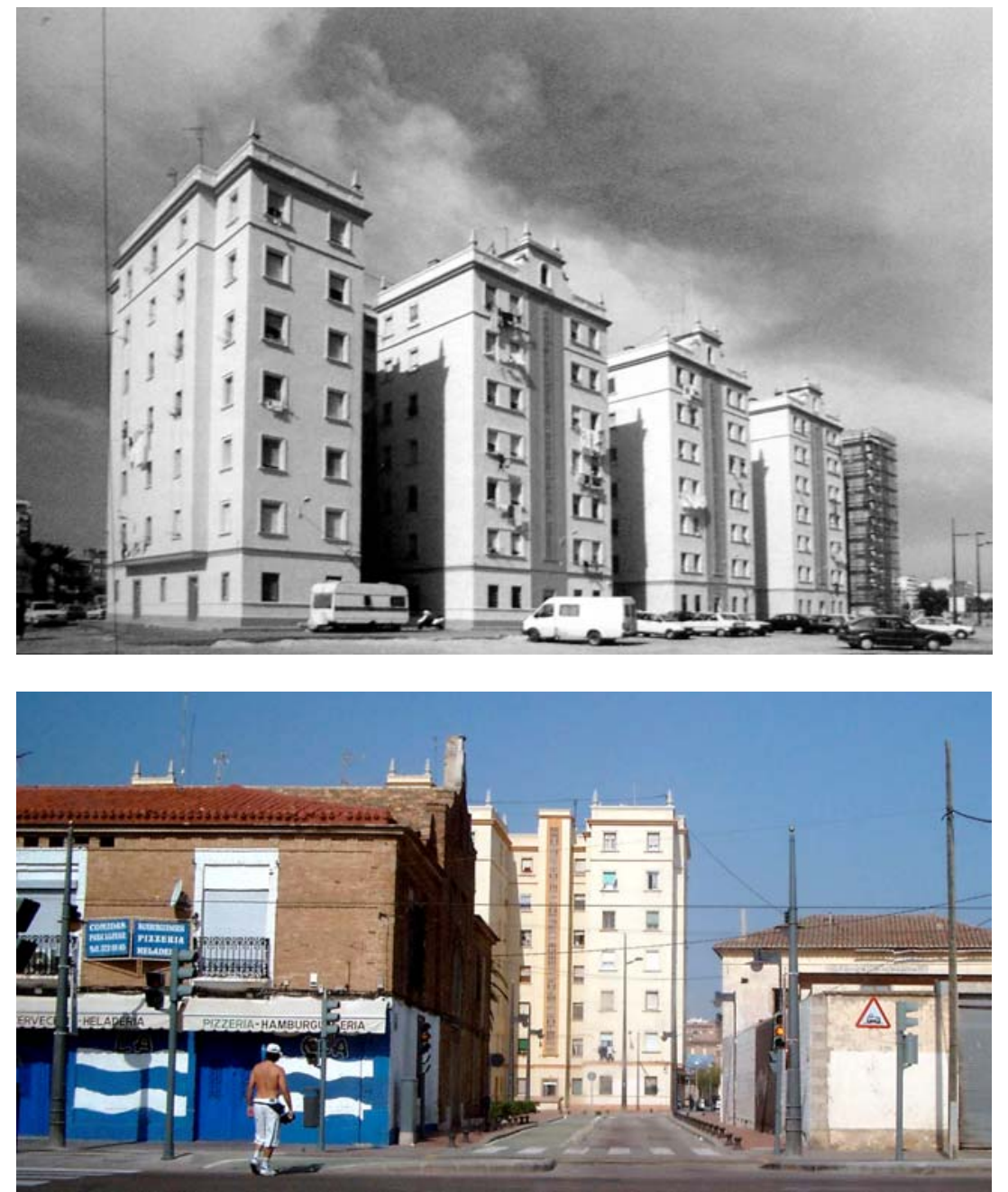
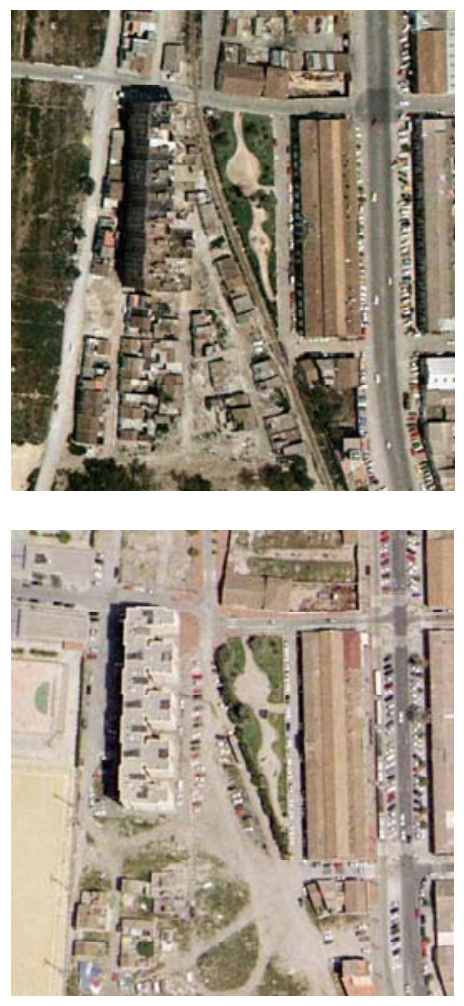

Grupo Ruiz Jarabo. Fotografías aéreas de 1980 y 2002 (AUMSA)

Grupo Ruiz Jarabo. Vista actual desde la Plaza Hombres del Mar.

Grupo Ruiz Jarabo. Vista actual desde la calle Eugenia Viñes. 


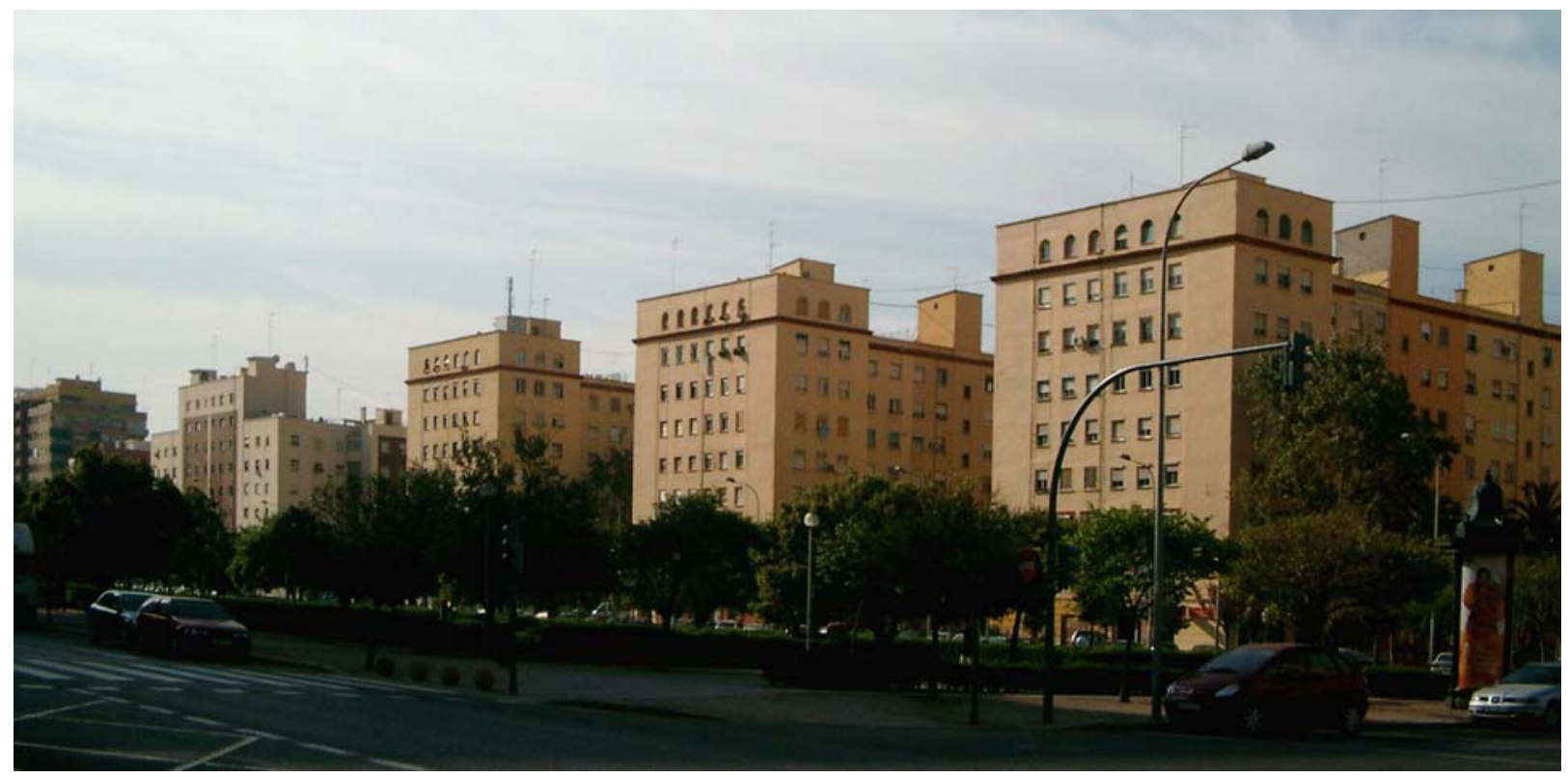

Grupo Isla Perdida. Vista actual desde el Paseo al Mar.

Grupo Isla Perdida. Planta de conjunto (Elaboración propia. Sombreado sobre Cartografía Municipal de 1983)

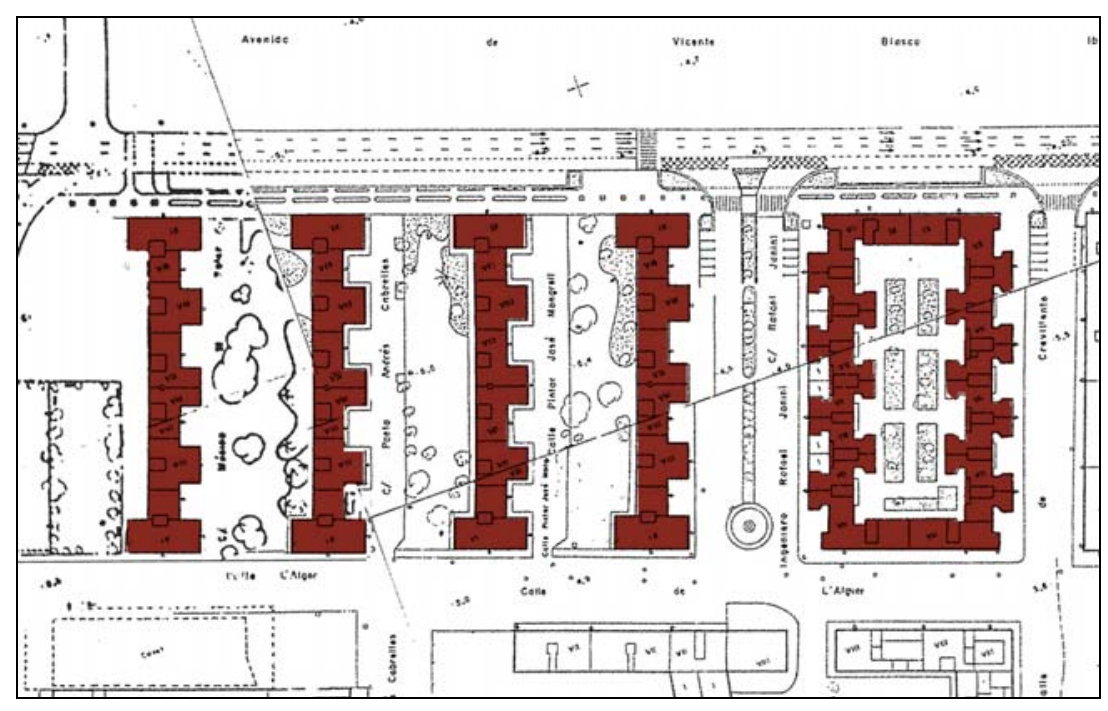

Grupo Isla Perdida. Planta de viviendas tipo de la primera fase.

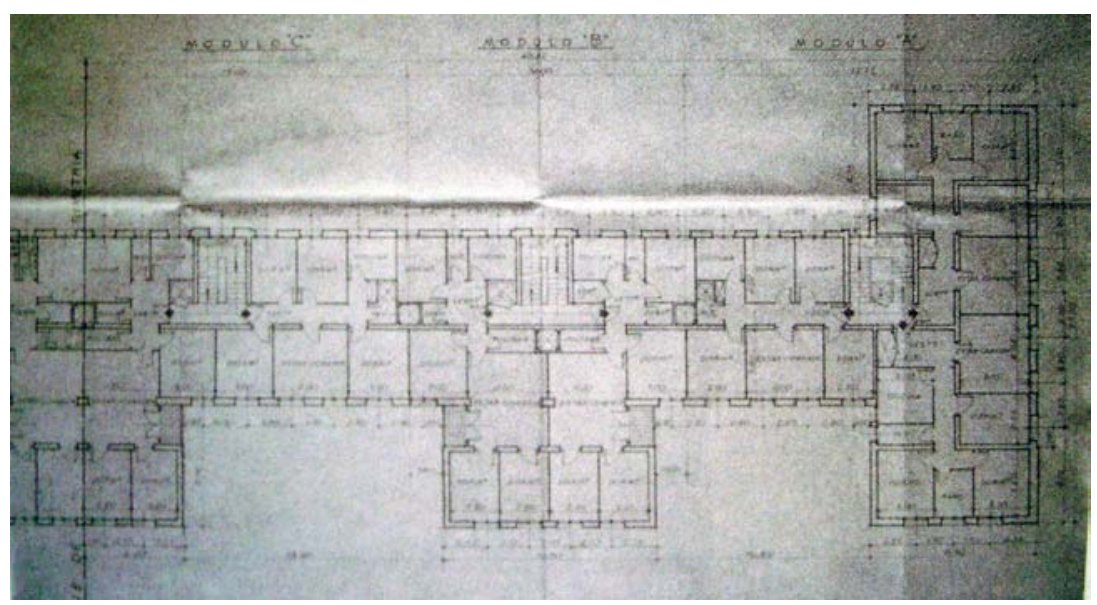




\section{LA ISLA PERDIDA (1954-59 y 1956-60).}

La Isla Perdida es el nombre con el que, a causa de su localización en mitad de la huerta, aislado con respecto al resto de la ciudad, se conocía popularmente al Grupo Paseo al Mar, proyectado por el equipo de Madrid del INV dirigido por José Fonseca ${ }^{1}$ y construido por el INV en el marco del llamado "Plan 5.000 Viviendas para Valencia".

El grupo, se realizó en dos fases muy diferentes. La primera (fase A), proyectada en 1952 y construida entre 1954 y 1959, de 456 viviendas, sigue el modelo del zeilenbau o edificación en línea, y se compone de cuatro bloques lineales equidistantes de IX plantas $(\mathrm{PB}+8)$, ortogonales a la futura prolongación del paseo al Mar y con espacios intermedios destinados a jardines. La localización de estos cuatro bloques responde en líneas generales a las previsiones de planeamiento de la Hoja 12-B de 1952, anteriormente analizada.

Estos bloques presentan en su fachada este un contorno dentado, propio de los bloques profundos con patios abiertos a fachada. Sin embargo, el frente ocupado por esos patios es mayor que el ocupado por la edificación, por lo que también pueden considerarse como bloques poco profundos con torreones. Por ello, existen viviendas tanto de dos como de tres crujías, según su situación en el bloque. La mayor parte de las viviendas de la fase A tienen una superficie mayor de $90 \mathrm{~m} 2$, que es superior a lo habitual en los grupos de promoción pública.

Por otra parte, en los testeros no se conserva la orientación de la planta, sino que se adopta un giro de la distribución, enlazando a cada lado la última de las viviendas de dos crujías con otras dos orientadas ortogonalmente al bloque. En el proyecto original, los locales comerciales se situaban en esos brazos cortos que configuran un frente seriado y uniforme en las calles perpendiculares a los bloques (Paseo al Mar por el norte y L'Alguer por el sur).

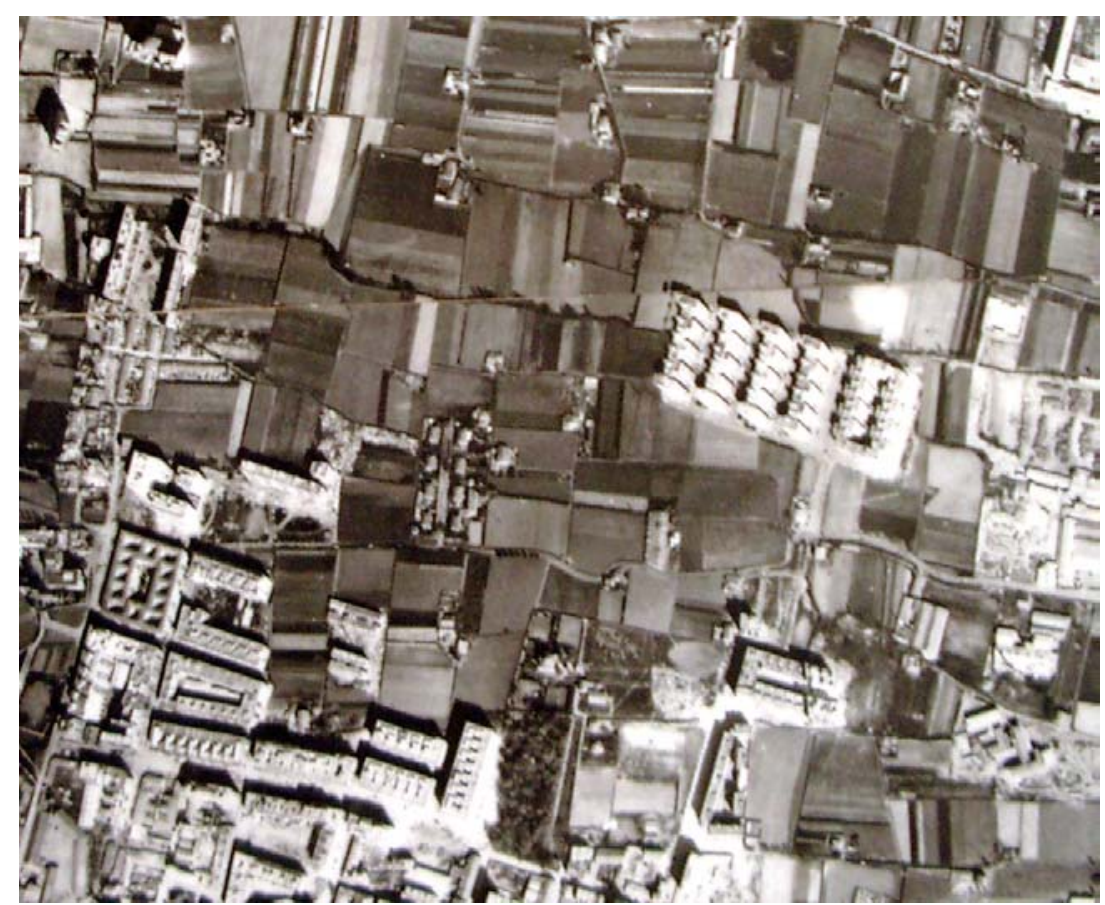

Grupo Isla Perdida. Fotografía aérea, h. 1965 (ETS de Arquitectura de Valencia).
1. José Fonseca, Manuel Ruiz de la Prada, Juan Piqueras, José Gómez Mesa, José Ma Rodriguez Cano y Manuel Basterreche. 


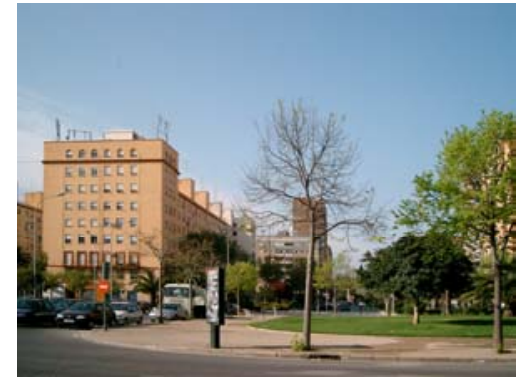

Grupo Isla Perdida. Bloque junto a la calle Músico Ginés.
Los bloques lineales muestran la ambigüedad típica del zeilenbau en su relación con la calle y los espacios libres, ya que el acceso a zaguanes se produce únicamente por el lado este, desde los laterales de los patios abiertos a fachada. En el lado opuesto, la planta baja es una sucesión de ventanas enrejadas, sin puertas de acceso a zaguanes. Lo superficie de los espacios intermedios entre los bloques se reparte a partes iguales entre jardines y bolsas de aparcamientos

La fase $B$, de 300 viviendas responde al siguiente plan para la zona, que es el del Polígono de Valencia al Mar que analizaremos más adelante. Proyectada en 1955 y construida entre 1956 y 1960, ya no responde al modelo de la edificación abierta, sino al de manzana cerrada con edificación perimetral poco profunda y espacio libre interior con pasajes de acceso desde la calle. Las viviendas, por otra parte, tienen superficies comprendidas entre 44 y $70 \mathrm{~m} 2$, menores que las de la fase $A$.

En la actualidad, la Isla Perdida está rodeada de edificación, como consecuencia del importante desarrollo urbano de la zona de la prolongación del Paseo al Mar.

Los bloques de la Isla Perdida han pasado a formar parte de la serie de bloques de edificación abierta que flanquean a ambos lados el paseo al mar (actual Av. Blasco Ibáñez) construidos a partir de las previsiones del Plan Parcial 12 de 1968. De todos los bloques, los que forman el frente del conjunto de la Isla Perdida son los menos altos y los que parecen más proporcionados con las dimensiones del Paseo, además de ser los únicos que muestran un carácter unitario.

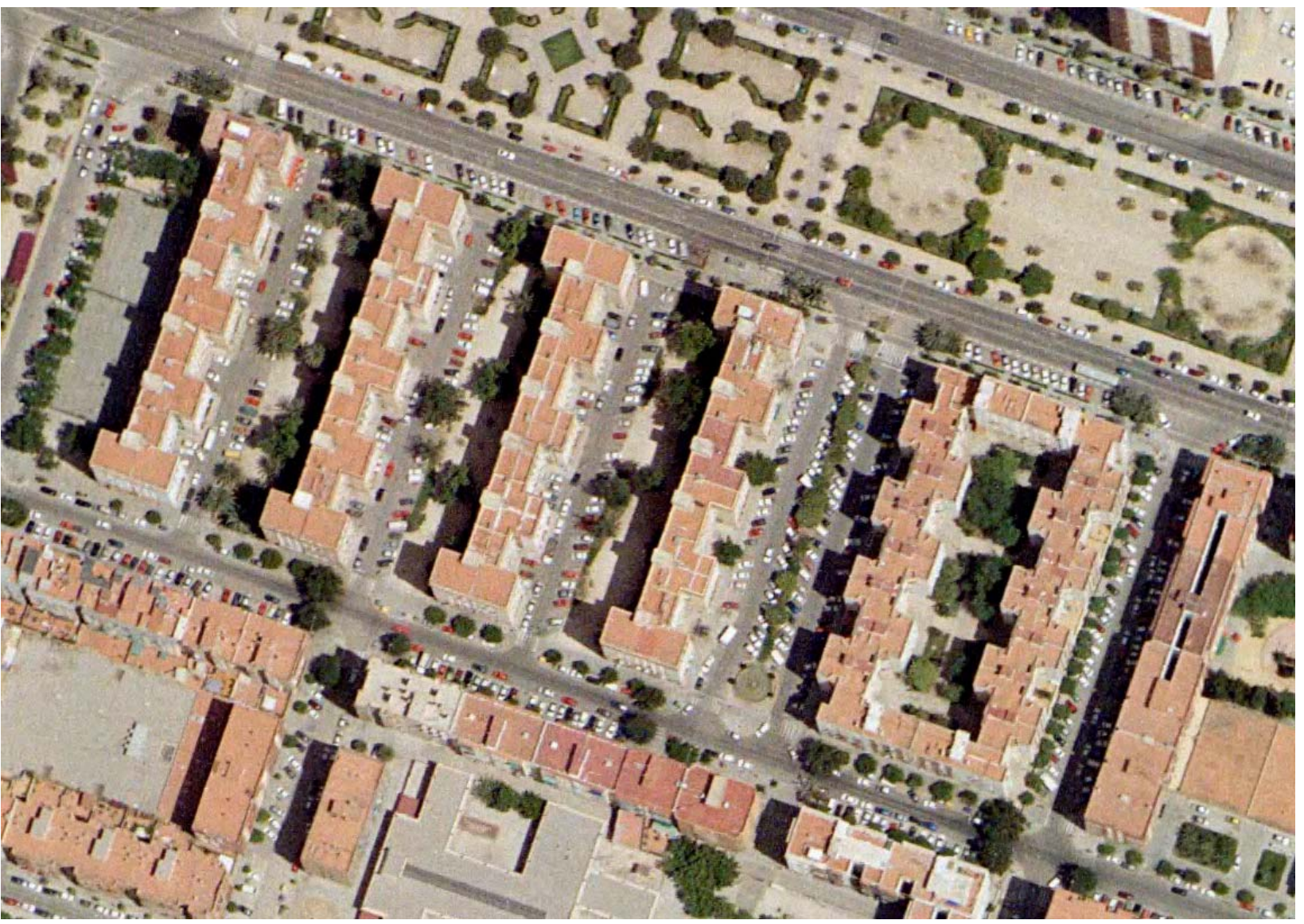




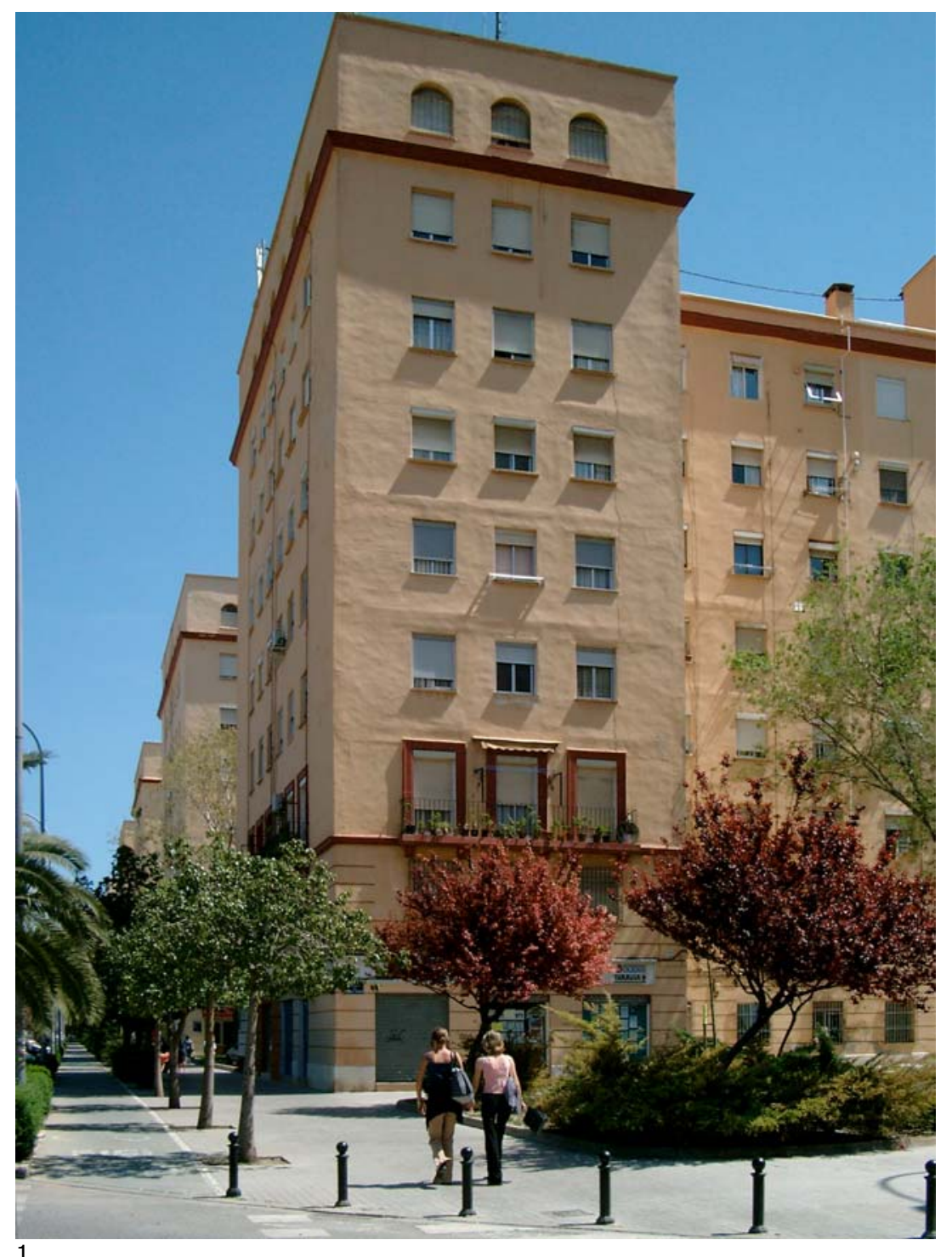

1

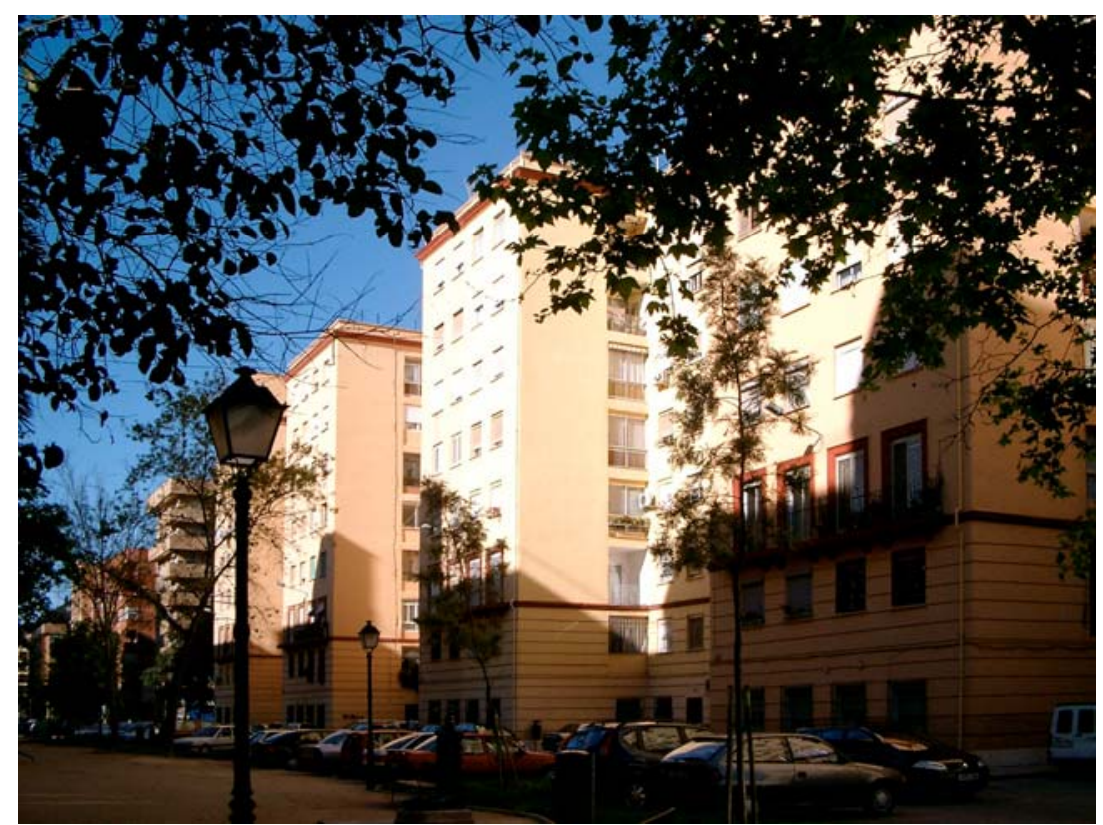

2

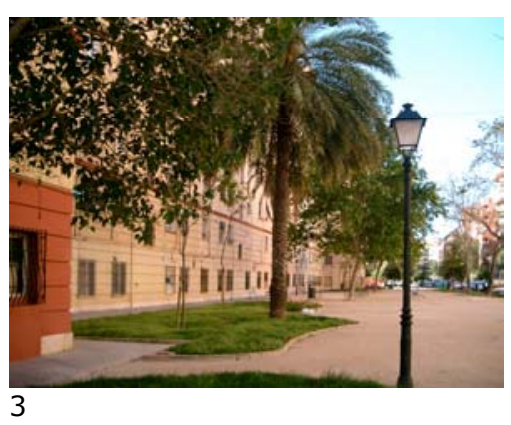

Grupo Isla Perdida. Vistas actuales.

1. Vista desde la esquina de Paseo al Mar con la calle Músico Ginés.

2. Vista de una bolsa de aparcamiento junto a la fachada este de un bloque

3. Vista de un jardín intermedio junto a la fachada oeste de un bloque. 
Grupo Camino de Alba. Perspectiva del proyecto inicial no realizado. Javier Goerlich, mayo 1943
Grupo Camino de Alba. Planta de conjunto (Color sobre Cartografía Municipal 2001)

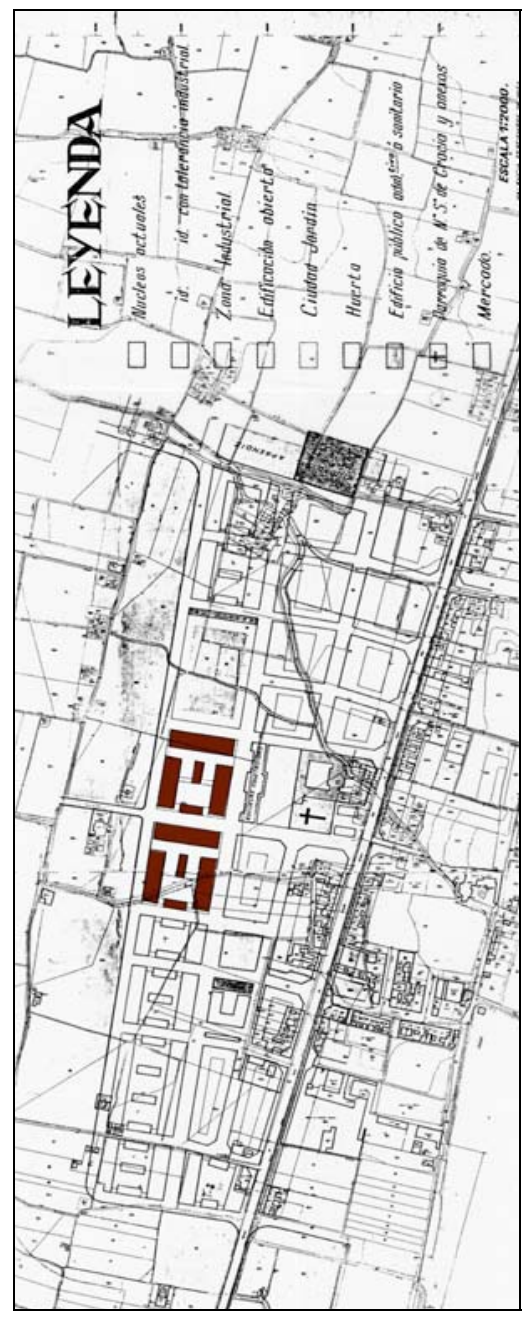

Grupo Camino de Alba. Localización del grupo en el Proyecto de Reforma de Alineaciones en el Barrio de Nuestra Señora de Gracia, 1951, en el ámbito del Proyecto Parcial de Desarrollo no III (Elaboración propia. Sombreado sobre copia del plano de Proyecto).

Grupo Camino de Alba. Vista actual del espacio libre interior.
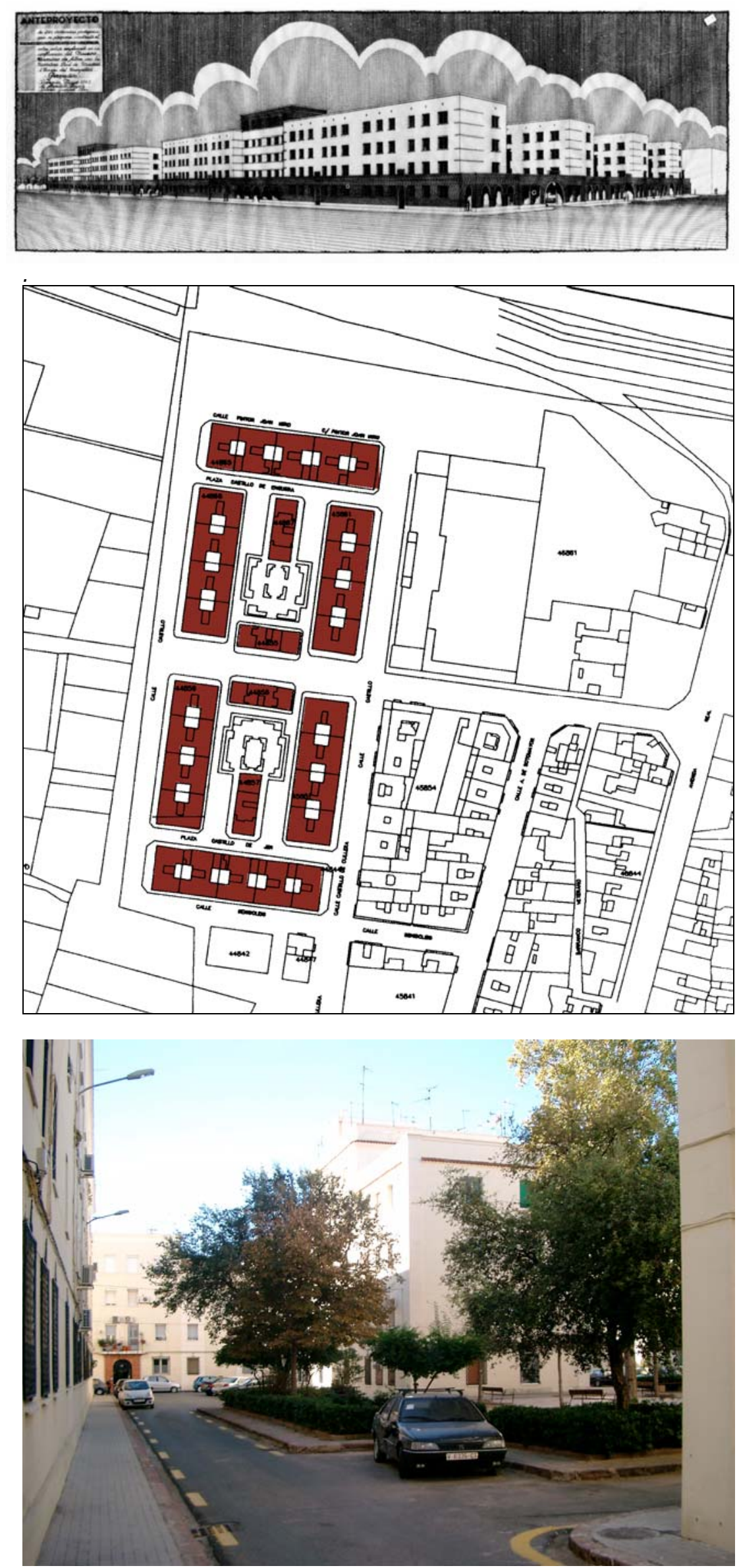


\section{GRUPO CAMINO DE ALBA (1952-56).}

El grupo ocupa dos manzanas situadas a los lados del Camino de Alba, transversal a la Carretera Real de Madrid. La realización del nuevo cauce del río Turia como consecuencia del Plan Sur de 1958 dejó a este conjunto aislado con respecto a la periferia sur de la ciudad.

El proyecto inicial de de Javier Goerlich para el grupo, de 1948, se componía de 296 viviendas integradas en dos manzanas compuestas por bloques en peine de dos crujías. Tras la adscripción del grupo al "Plan 5000 Viviendas para Valencia", el proyecto fue descartado, redactándose en 1952 por el INV un nuevo proyecto, con 442 viviendas, en el que los bloques de tres de los lados de cada manzana pasan a ser de cinco crujías con patios interiores. Un bloque corto de dos crujías ocupa el cuarto lado, a ambos lados del Camino de Alba, y otro se sitúa en el propio espacio interior delimitado por los bloques profundos.

En ese espacio interior, además, se construyeron en 1958 unas viviendas prefabricadas para damnificados de la riada de 1957, que subsistieron hasta mediados de los años ochenta.

El esquema de manzana abierta formado por bloques perimetrales de cinco crujías, con patios, y bloques interiores de dos crujías, es el previsto en la ordenación de 1951 para toda la zona de extensión oeste del barrio de Nuestra Señora de Gracia, dentro del Proyecto Parcial no III de desarrollo del Plan general de 1946, que hemos descrito en un apartado anterior. Las dos manzanas del Grupo Camino de Alba serán las únicas que se construirán con arreglo a dicho plan parcial.

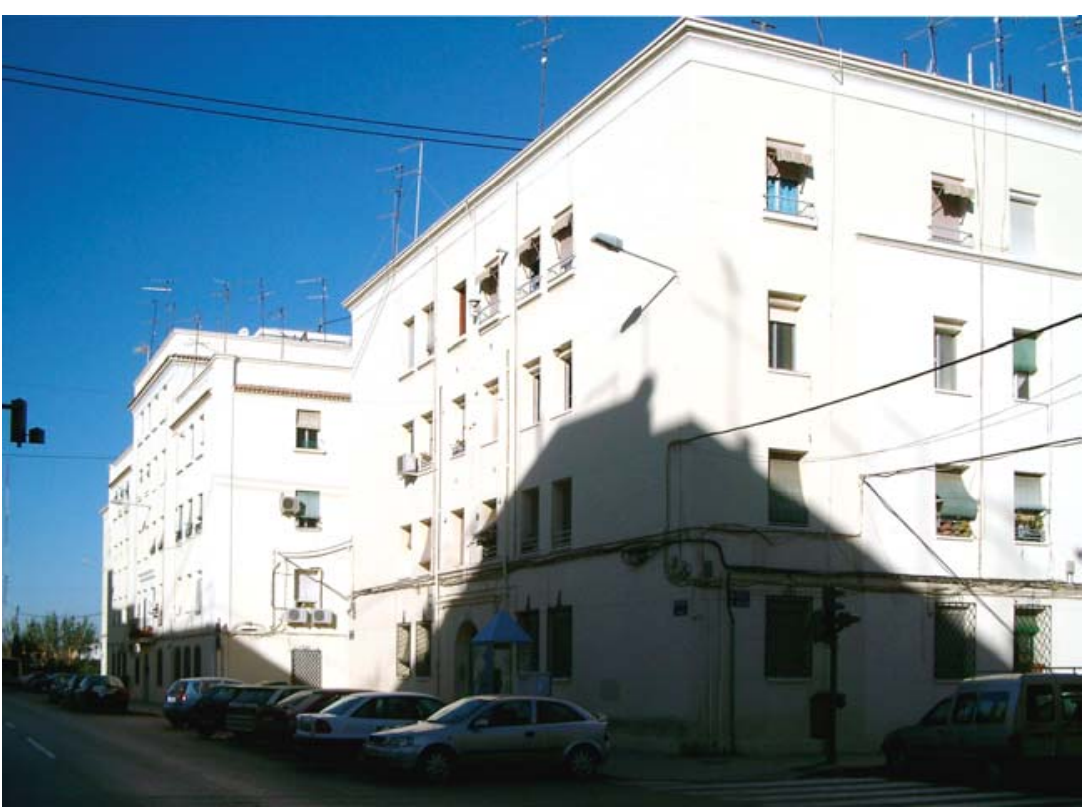

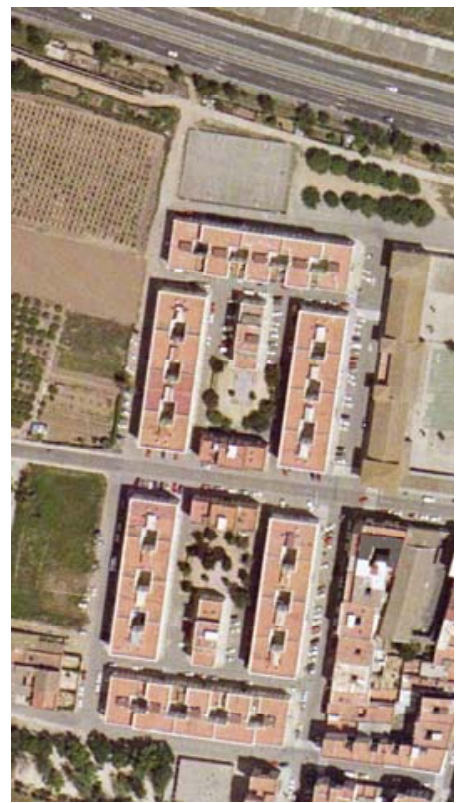

Grupo Camino de Alba. Ortofoto 2002 (AUMSA).

Grupo Camino de Alba. Vista desde la calle Camino de Alba. 
Edificio Renfe-Aragón. Situación (Color sobre Cartografía Básica Municipal, 1983)

Edificio Renfe-Aragón Alzado lateral (Archivo Histórico Municipal de Valencia)

Edificio Renfe-Aragón. Planta tipo.

Edificio Renfe-Aragón. Vista actual desde la Avenida de Aragón.
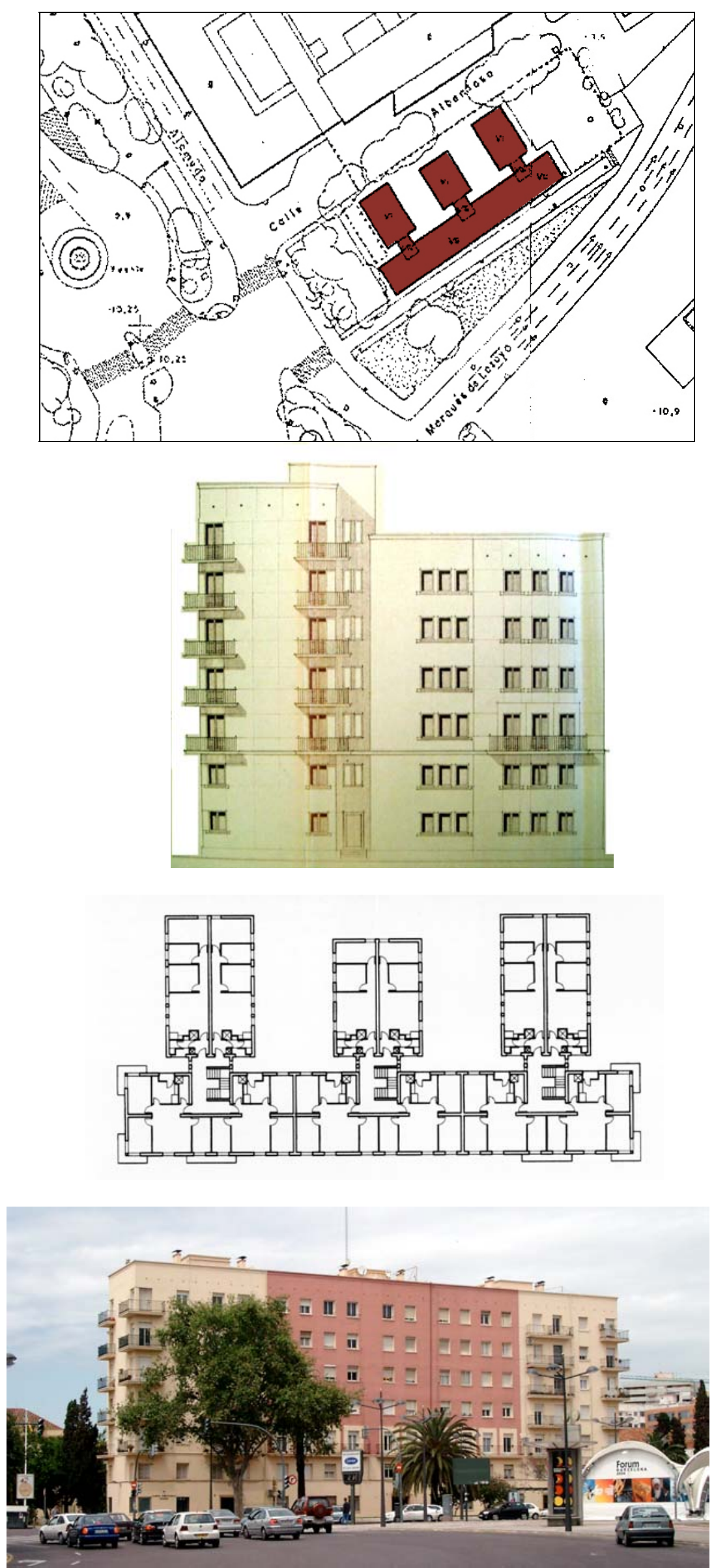


\section{EDIFICIO RENFE-ARAGÓN (1950-54).}

El edificio "Renfe-Aragón", obra del arquitecto Fernando Ruiz Jaime y construido entre 1953 y 1954, es la primera de las promociones vinculadas a cooperativas de funcionarios que podemos adscribir a la edificación abierta. Se trata de un bloque de 78 Viviendas Protegidas, promovido por RENFE para sus trabajadores y proyectado en terrenos de la antigua Estación Central de Aragón.

Llopis $^{3}$ ha puesto de relieve los elementos arquitectónicos que caracterizan a este edificio como muestra de arquitectura racionalista: la racionalidad distributiva de la planta en peine, con tres núcleos de escalera y ascensor cada uno de los cuales da acceso a cuatro viviendas ajustadas y con piezas perfectamente ventiladas, la estricta y aristada volumetría, la tersura de las fachadas lisas, con huecos seriados y una ausencia total de elementos decorativos.

Este edificio, tras la demolición de la antigua estación ferroviaria, ha quedado situado en la esquina entre el Paseo de la Alameda y la Avenida de Aragón, con su lado largo alineado con ésta última. En el lado opuesto, el edificio está envuelto por un vallado perimetral, por lo que los espacios libres intermedios entre los cuerpos de edificación salientes son de carácter privado.

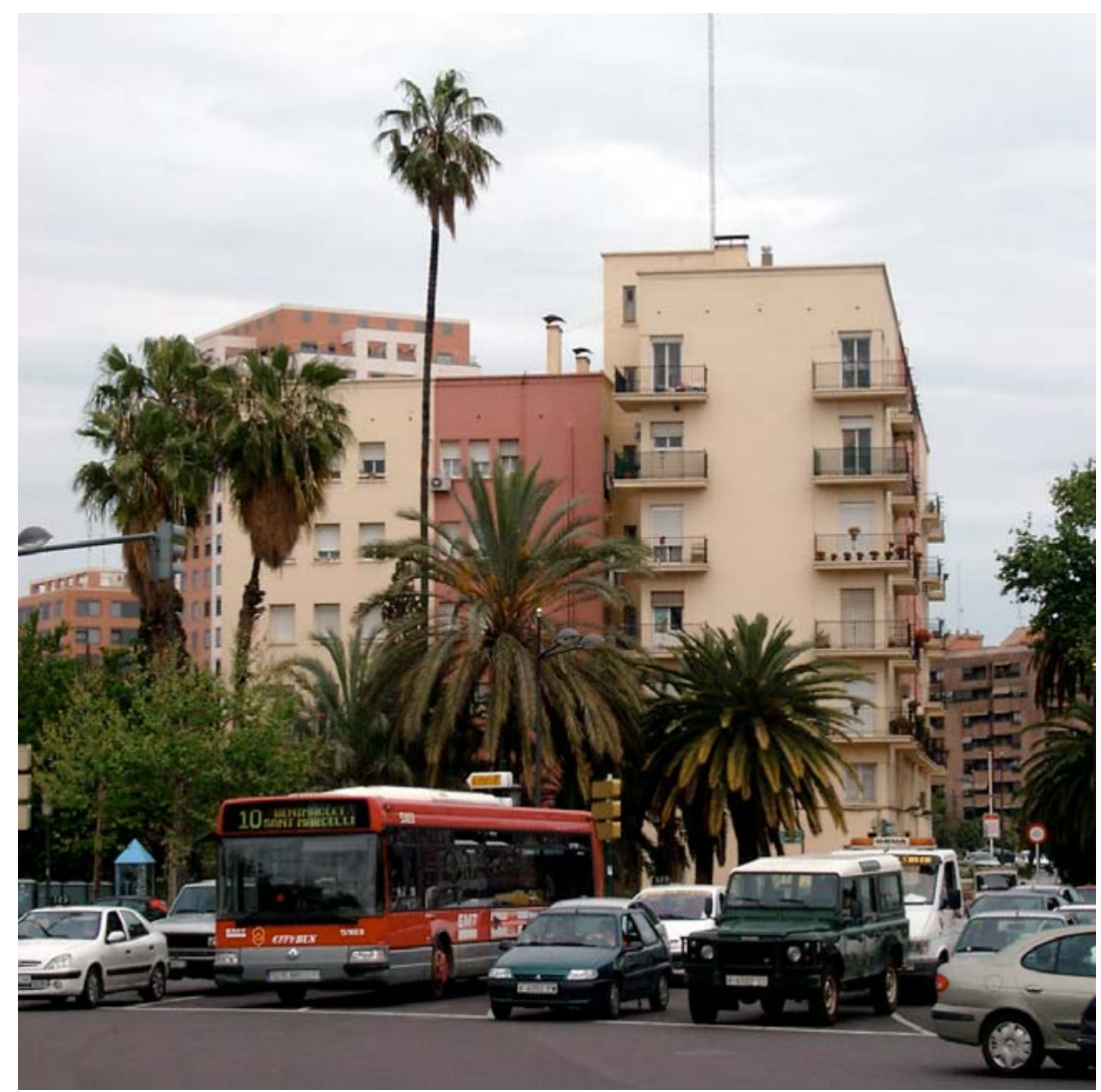

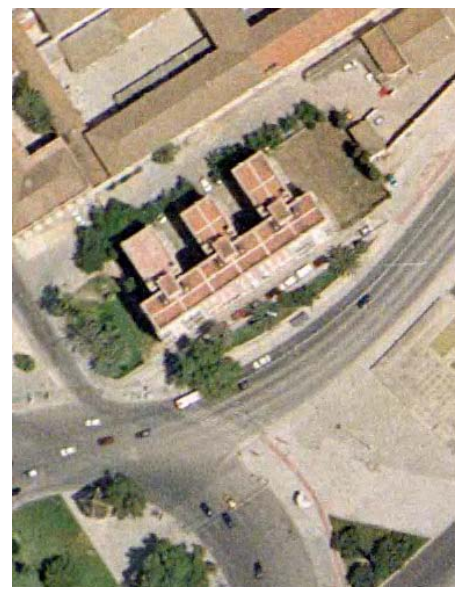

Edificio Renfe-Aragón. Ortofoto 2002. (Ayuntamiento de Valencia, AUMSA)

Edificio Renfe-Aragón. Vista actual desde el Paseo de la Alameda.
1. Ver Llopis, Amando y VTiM, "Arquitectura moderna en Valencia. Del rechazo de la vanguardia a la necesidad de encontrar ideas y proyectos acordes con el espíritu de una nueva época", en Llopis, Amando y Dauksis, Sonia, eds., Arquitectura del siglo XX en Valencia, Institució Alfons el Magnánim-Diputació de Valencia, Valencia, 2000. 

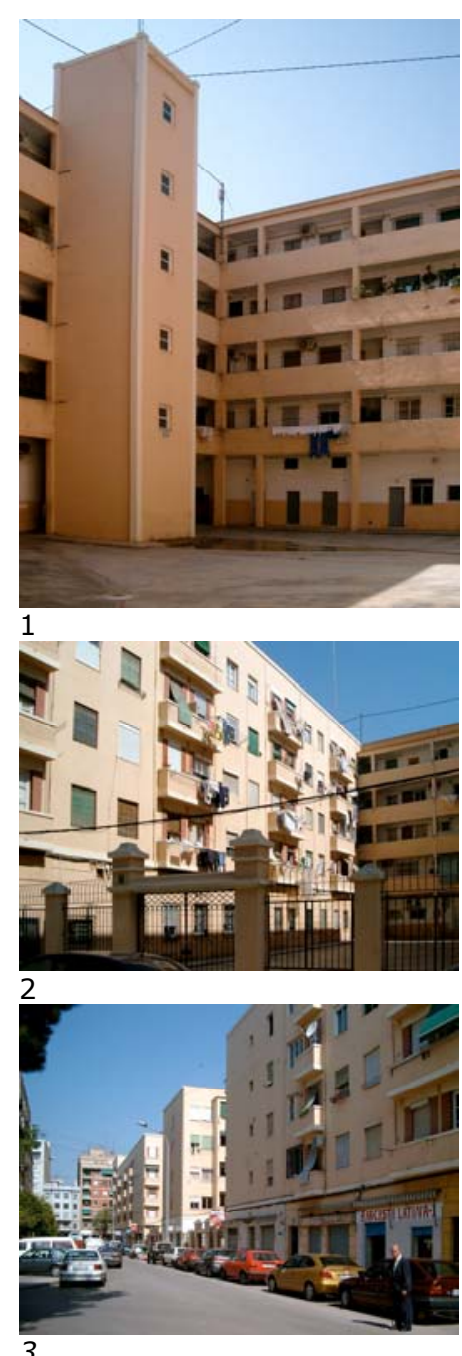

3

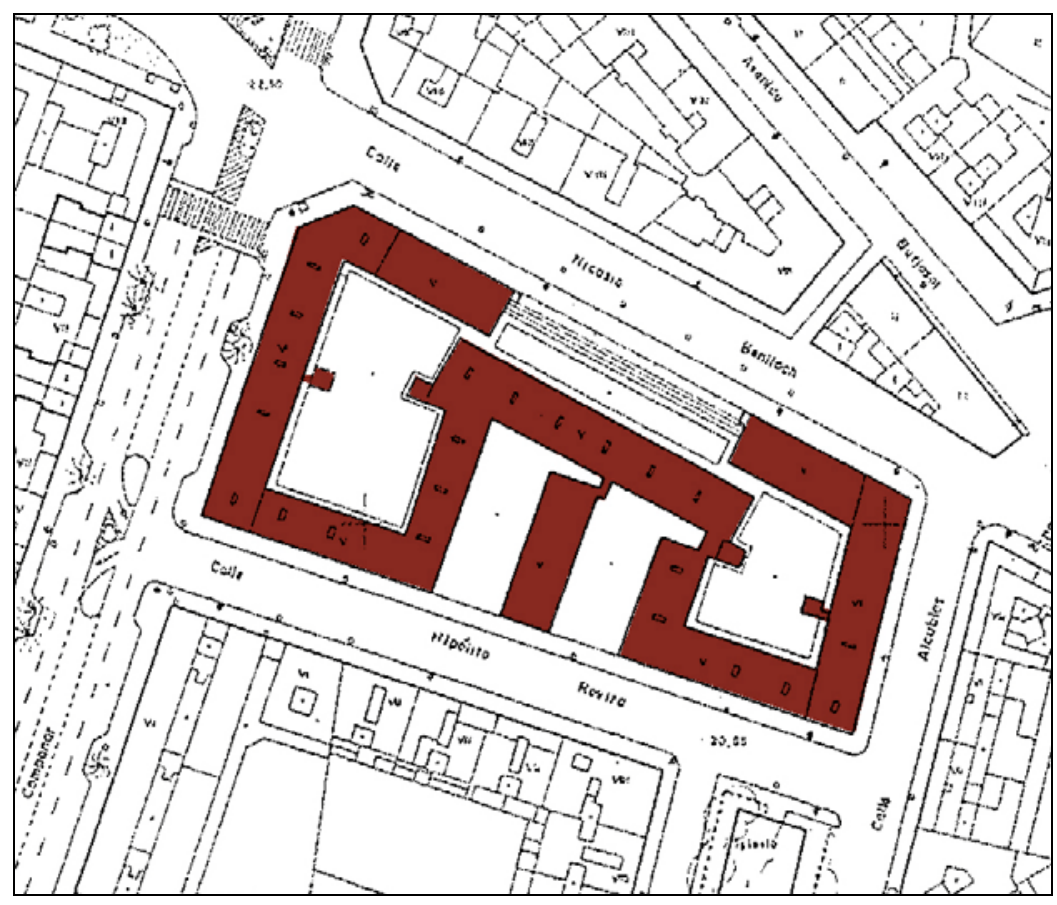

Grupo Agrifersa. Planta (Color sobre Cartografía Básica Municipal, 1983)

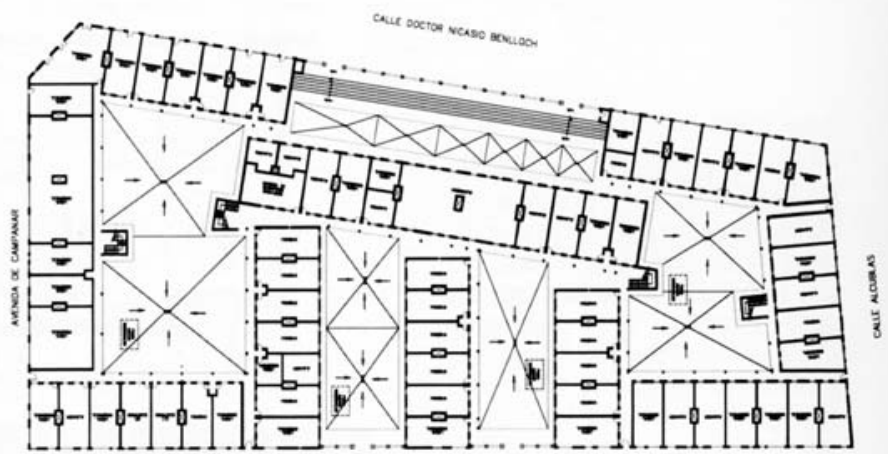

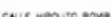

Planta tipo de distribución

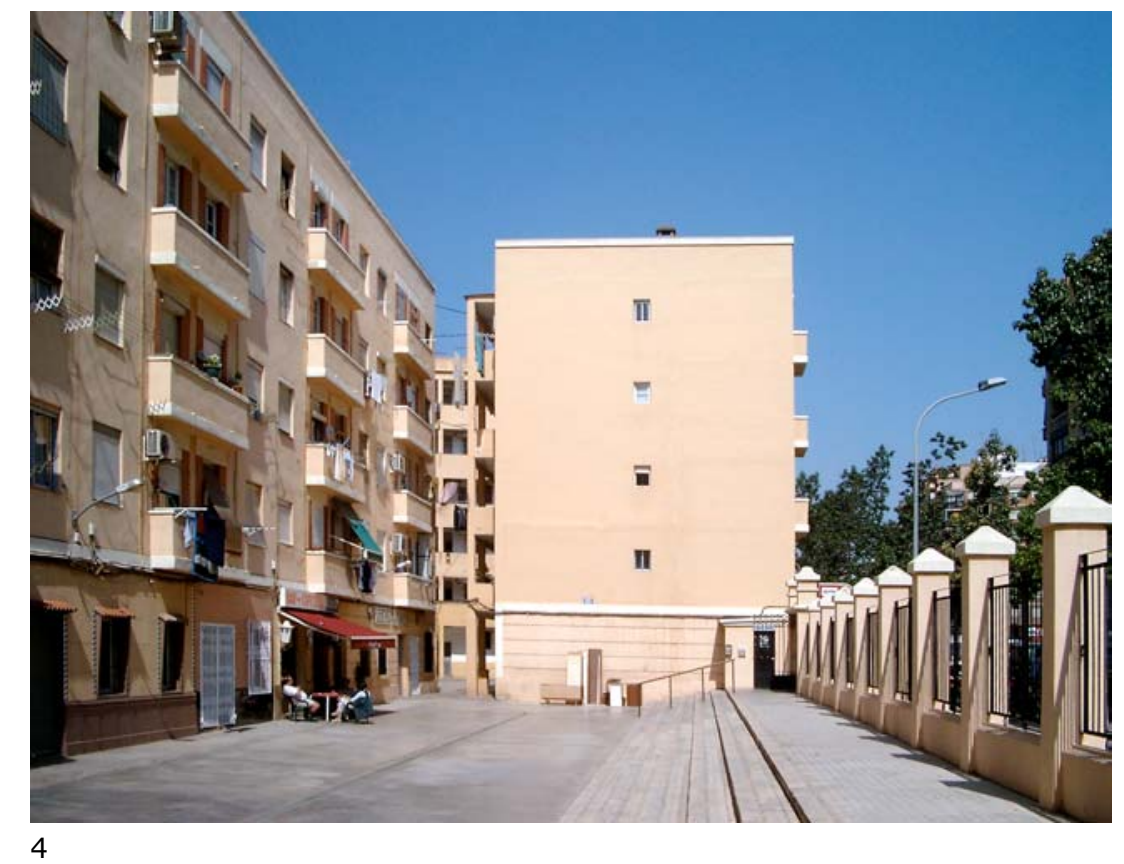

1. Vista de un patio interior, con el corredor de acceso y la caja de escalera.

2-3. Vistas desde la calle Hipólito Rovira-

4. Vista del patio abierto a la calle Nicasio Benlloch. 


\section{GRUPO AGRIFERSA (1954)}

El grupo Agrifersa, proyectado en 1954 por Pascual Genovés para la empresa Agrios y Fertilizantes, S.A., está situado en la calle Nicasio Benlloch (antigua carretera de Paterna).

Con 350 viviendas de Renta Limitada, ocupa una manzana completa, de dimensiones aproximadas de 50x130 m. La edificación, de $\mathrm{V}$ plantas $(\mathrm{PB}+4)$ es poco profunda, y se dispone de forma grecada, como un bloque lineal continuo de directriz quebrada que queda retranqueado con respecto a las calles perimetrales en su parte central. De este modo, se crean dos patios interiores envueltos por la edificación y dos espacios abiertos a la calle a norte y sur. En este último, de mayor tamaño, se sitúa un bloque lineal ortogonal a la calle Hipólito Rovira, que densifica tal vez en exceso ese frente.

Todos los espacios libres abiertos a calles perimetrales están separados de éstas por un vallado.

El acceso a las viviendas se realiza mediante corredores sin acristalamiento dispuestos siempre por la fachada opuesta a la caIle, con cajas de escalera exteriores a los mismos, que conforman volúmenes emergentes en los patios.

La fecha del proyecto del grupo Agrifersa (1954, año de transición entre el régimen de Viviendas Protegidas y el de Viviendas de Renta Limitada) explica tal vez que se parezca más a los grupos de promoción municipal de Goerlich de los años cuarenta que a los conjuntos de viviendas de R.L. de finales de los años 50, en los que el bloque lineal y el orden abierto serán la referencia básica de proyecto.

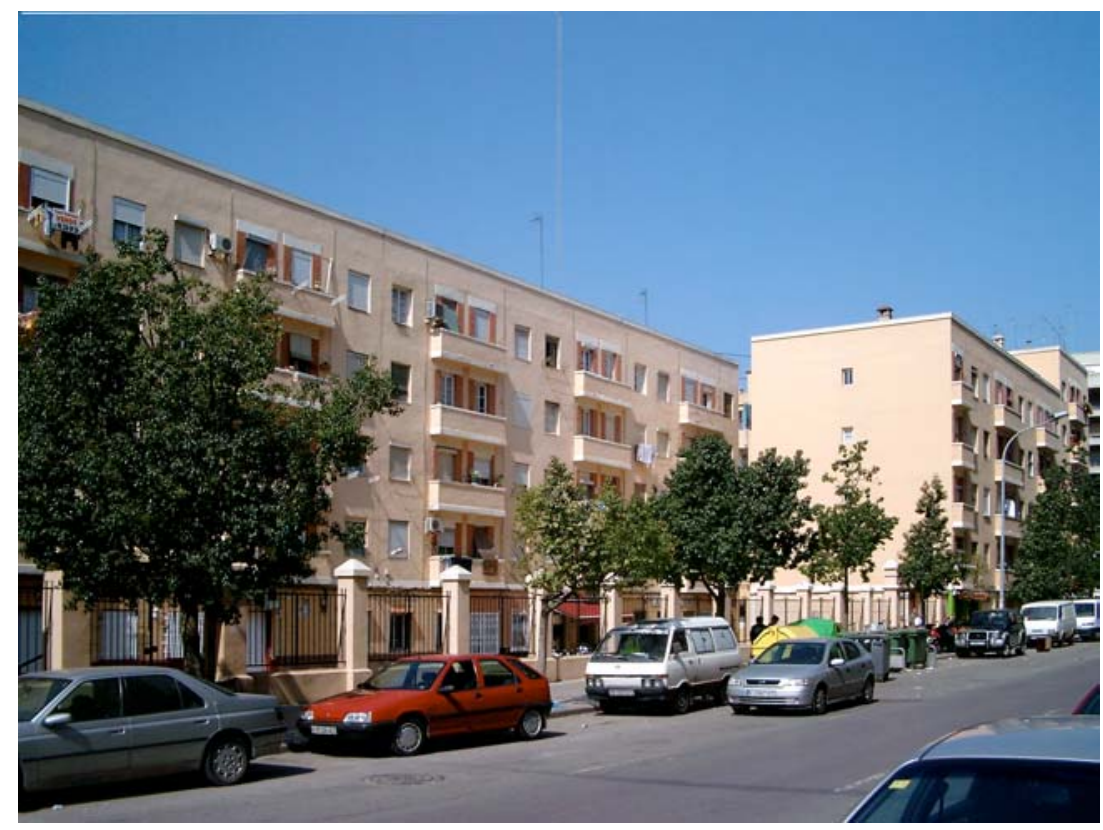

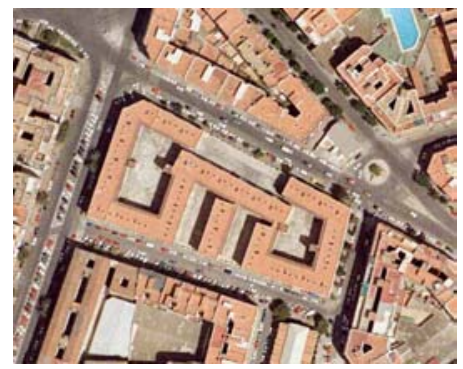

Grupo Agrifersa. Ortofoto 2002 (AUMSA).
Vista desde la calle Nicasio Benlloch. 


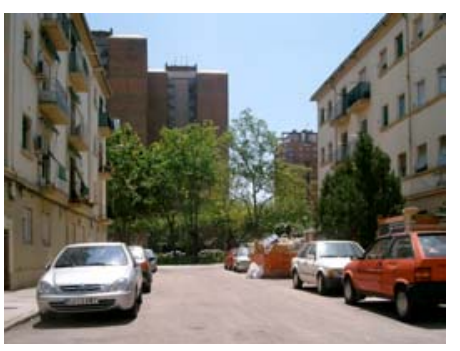

Grupo Rinaldi. Fuente S. Luís.

Grupo Rinaldi. Fuente S. Luís (Color sobre CartografíaMunicipal de valencia, 2001)

Grupo Rinaldi. Fuente S. Luís Localización en el proyecto parcial no IV (1953) de desarrollo del Plan General de 1946.

Grupo Rinaldi. Fuente S. Luís. Vista desde la calle Rafael Albiñana.
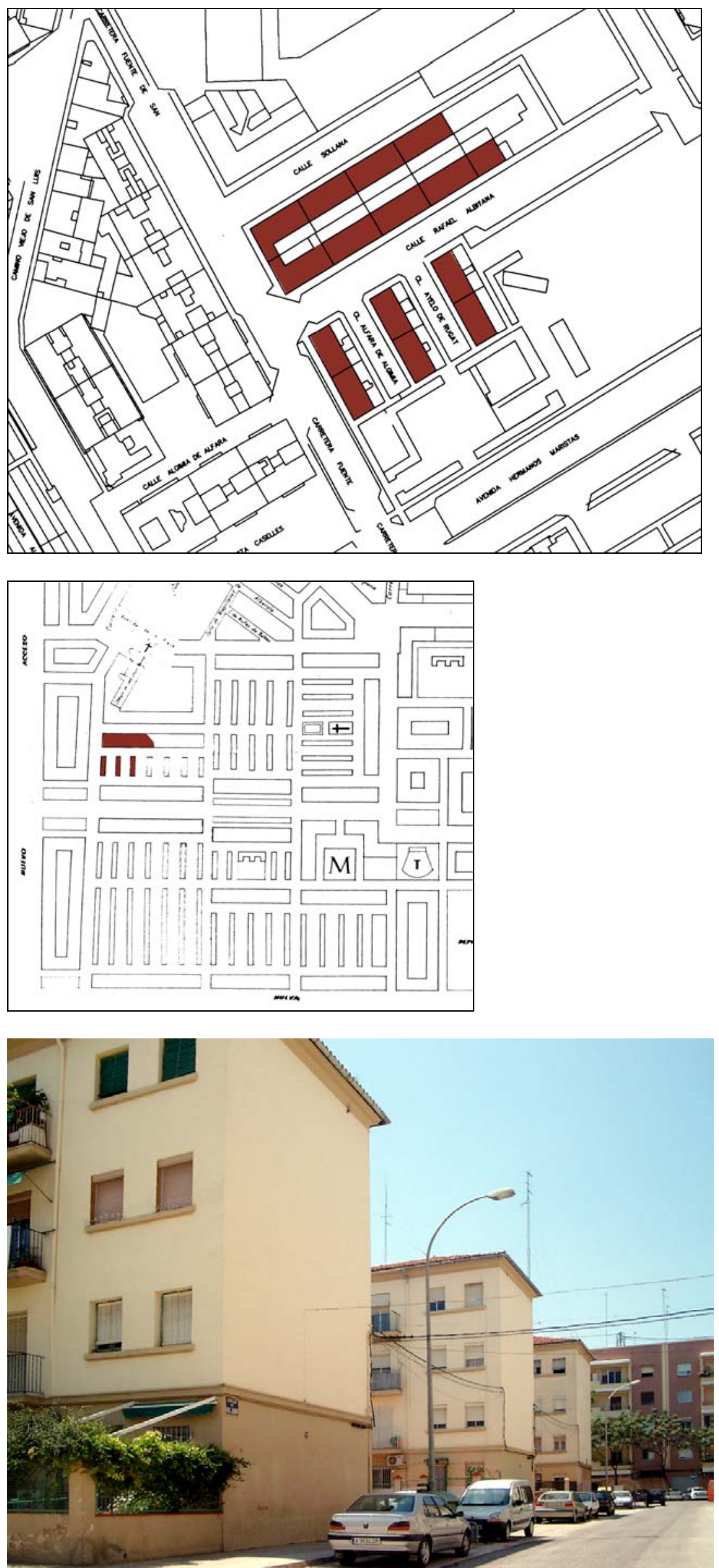


\section{GRUPO RINALDI-FUENTE DE SAN LUÍS (1953).}

El Patronato Felipe Rinaldi, institución sin ánimo de lucro vinculada a la Orden de los Salesianos, construyó en Valencia tres grupos de viviendas proyectados por $M$. Peris Vallbona: el de Torrefiel (pr.1949), el Santo Domingo Savio y el de la Fuente de San Luís.

El grupo Rinaldi de la Fuente de San Luís es la unica edificación realizada de las previstas en el sector de edificación abierta del Proyecto Parcial no IV (1953) de desarrollo del Plan General de 1946, que hemos analizado en un apartado anterior.

En concreto, el grupo Rinaldi es un fragmento de una manzana abierta de gran tamaño integrada por sendos bloques profundos en sus bordes norte y sur, alineados con las calles principales, y bloques cortos de dos crujías ortogonales a los anteriores que rellenan de manera seriada el espacio interior.

El fragmento construido, edificado en fases sucesivas a partir de 1954, está formado por tres bloques lineales equidistantes de dos crujías y un fragmento del bloque profundo del lado norte de de la manzana prevista en el Proyecto Parcial no IV. Este último bloque, dado el carácter continuo del patio interior, puede considerarse también como una manzana estrecha y alargada.

Los tres bloques dispuestos en línea disponen de un jardin adosado, situado en la fachada opuesta a la de acceso y vinculado a las viviendas de la planta baja. Los testeros ciegos de estos bloques ocupan la primera línea de la Avenida Hermanos Maristas, ya que el bloque profundo recayente a dicha avenida que debía envolverlos por el sur no llegó a construirse.

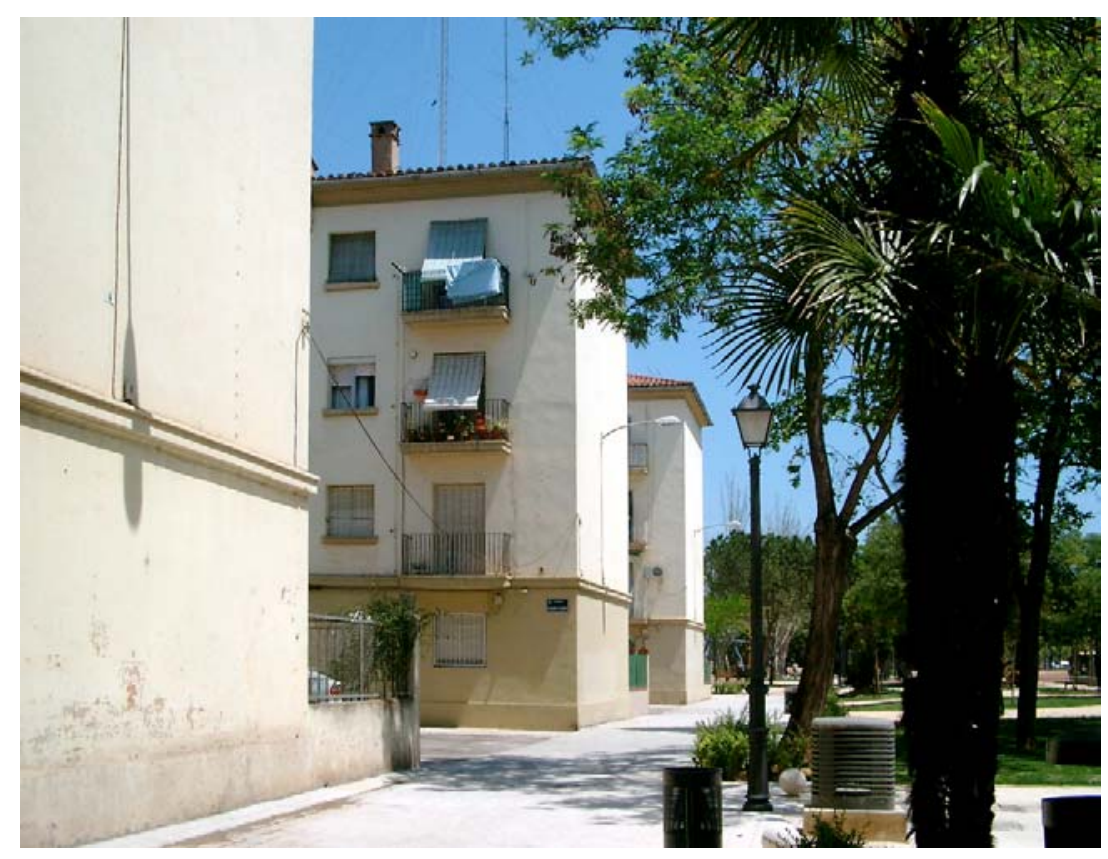

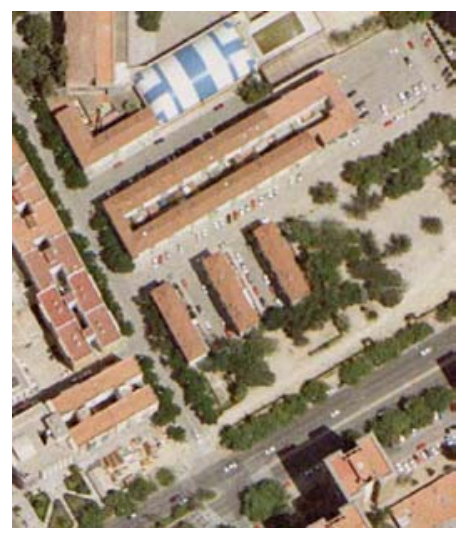

Grupo Rinaldi. Fuente S. Luís. Ortofoto 2002 (Ayuntamiento de valencia, AUMSA).

Grupo Rinaldi. Fuente S. Luís. Vista actual desde la Avenida Hermanos Maristas. 


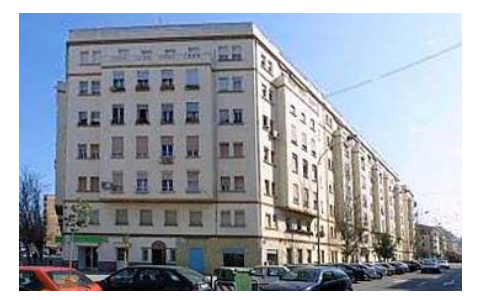

Grupo Almazora Planta de conjunto (Color sobre cartografía Básica Municipal de Valencia, 1983).
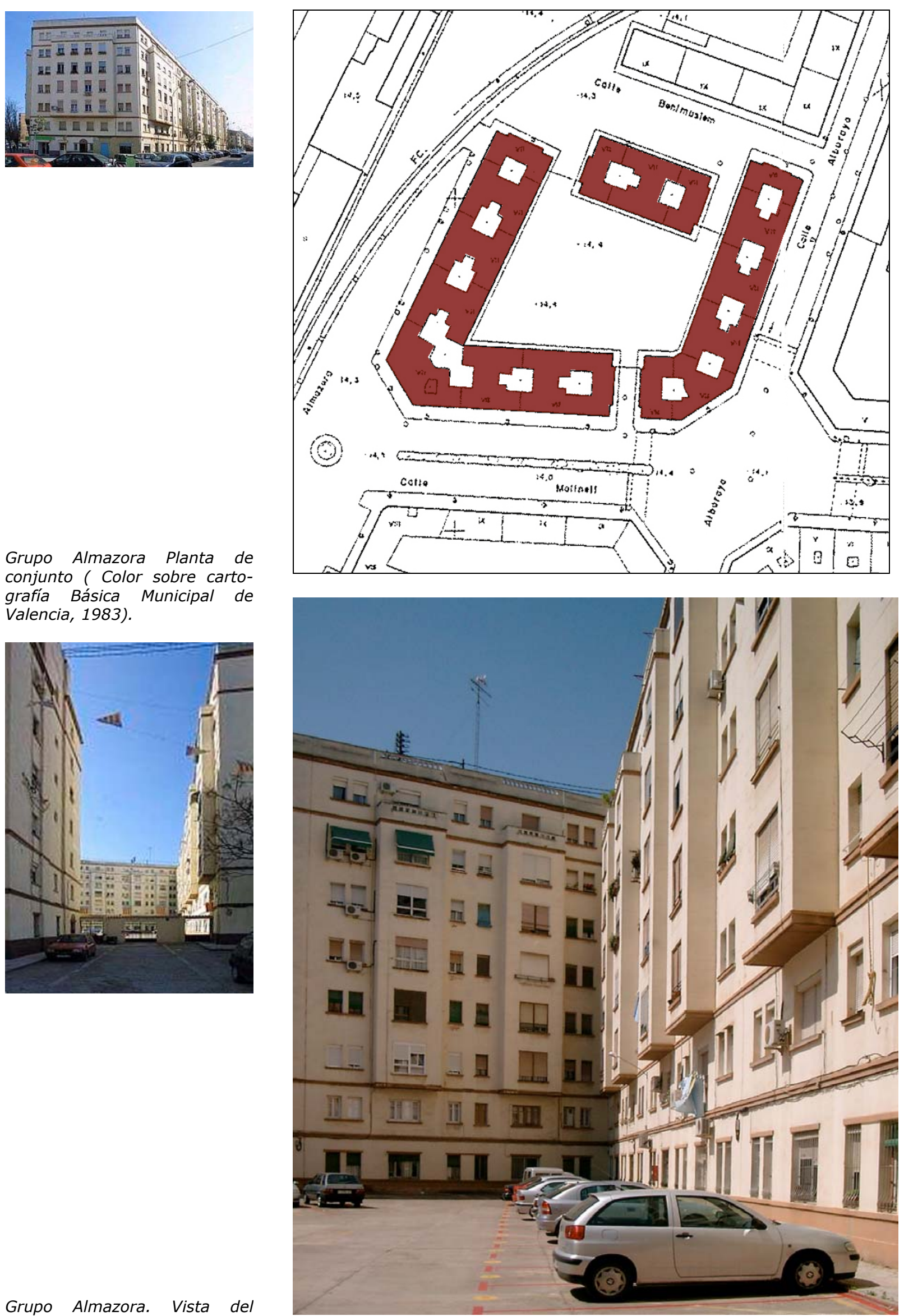

Grupo Almazora. Vista del patio interior. 


\section{GRUPO ALMAZORA}

El grupo Almazora ocupa una manzana completa de dimensiones aproximadas de $90 \times 90 \mathrm{~m}$. , limitada por las calles Alboraya, Benimuslem, Almazora y Molinell.

La manzana está formada por tres bloques profundos de cinco crujías con patios de luces. Dos de estos bloques están alineados con las calles Almazora, Molinell y Alboraya, y tienen una planta en L con chaflán. Sus testeros, junto con un tercer bloque corto, en cambio, forman un frente escalonado en la calle Benimuslem.

La ruptura de la continuidad de la edificación perimetral que se produce en este conjunto, así como la todavía tímida ruptura con el sistema de alineaciones, son pasos sucesivos de la evolución hacia hacia la manzana integrada por edificación abierta de bloques aislados, en un proceso que arranca de la manzana cerrada unitaria, cuyo ejemplo más notable en Valencia es la Finca Roja, y que continuará con la sustitución de la edificación perimetral profunda por una franja delgada de dos crujías, para completarse cuando la edificación adquiere completa independencia con respecto a las alineaciones viarias.

En este ejemplo podemos ver que la gran profundidad del perímetro edificado permite mantener unas dimensiones de manzana similares a las de la manzana de ensanche convencional con edificación entre medianeras.

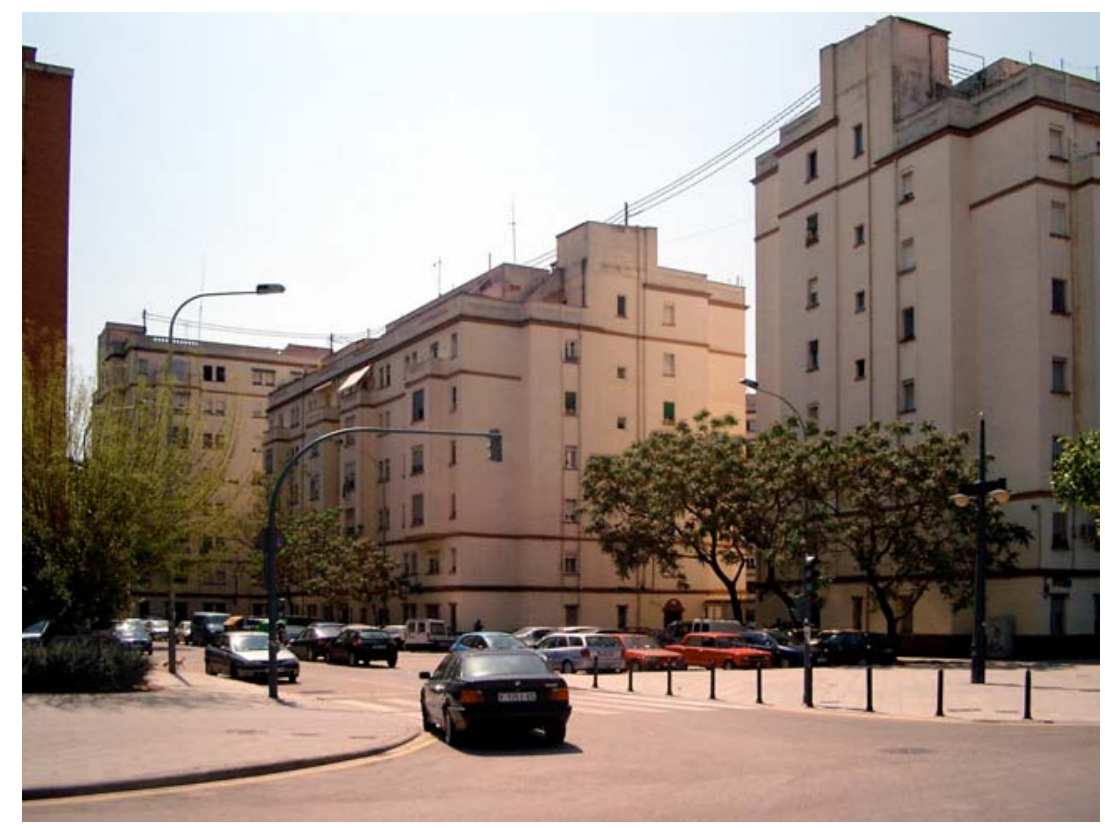

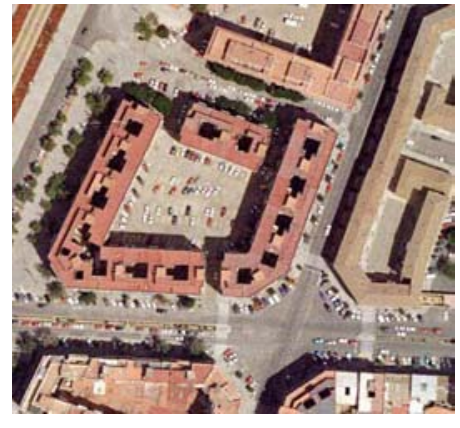

Grupo Almazora. Ortofoto 2002 (Ayuntamiento de Valencia, AUMSA).

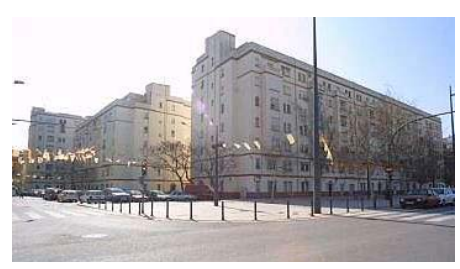

Vistas desde la calle Benimuslem. 
Grupo Virgen de los Desamparados. Proyecto inicial modificado, Francisco Cabrero, Luís Costa, Antonio Tatay, octubre de 1946 (Archivo Histórico Municipal de Valencia).

1. Emplazamiento.

2. Viviendas tipo C. Planta.

3. Viviendas tipo A. Alzado.

3. Perspectiva.

4. Planta de ordenación.

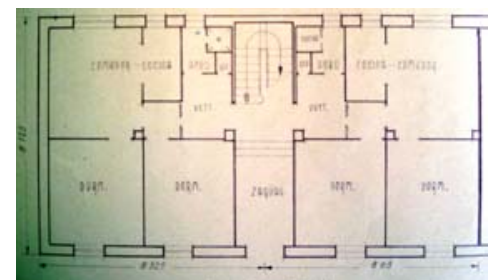

2

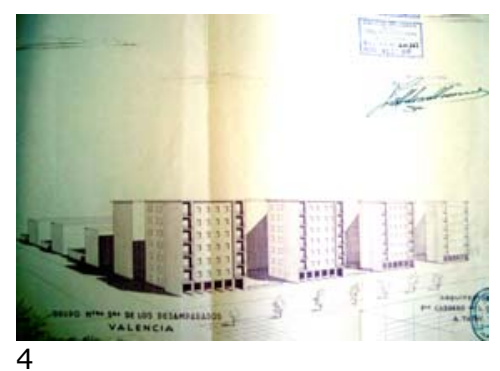

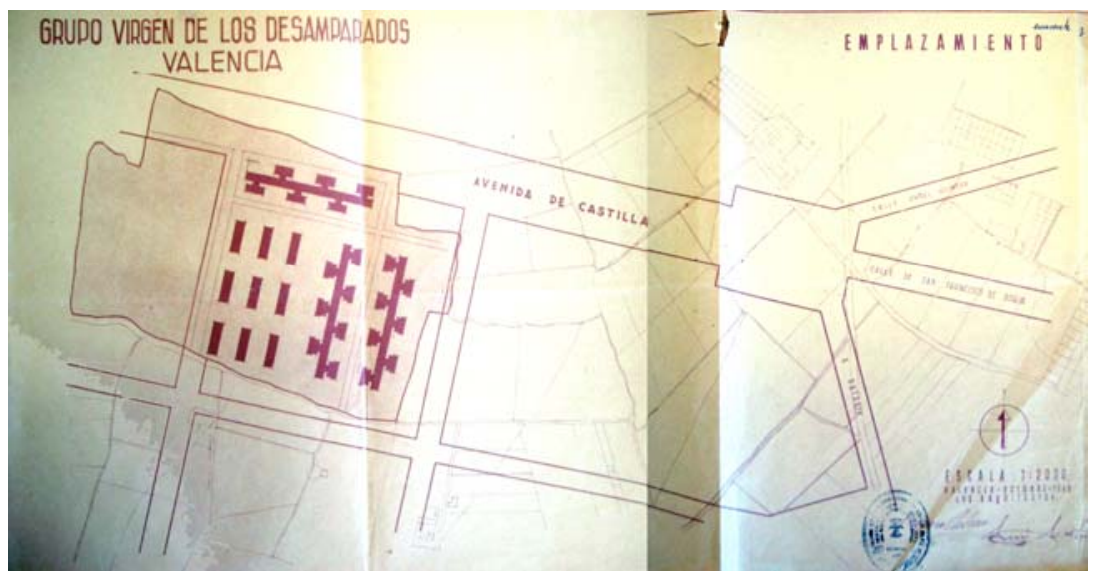

1

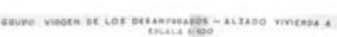

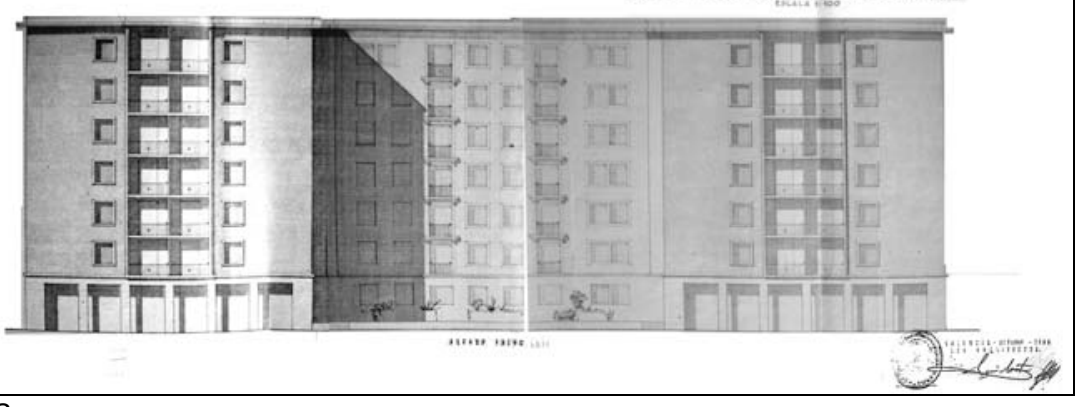

3

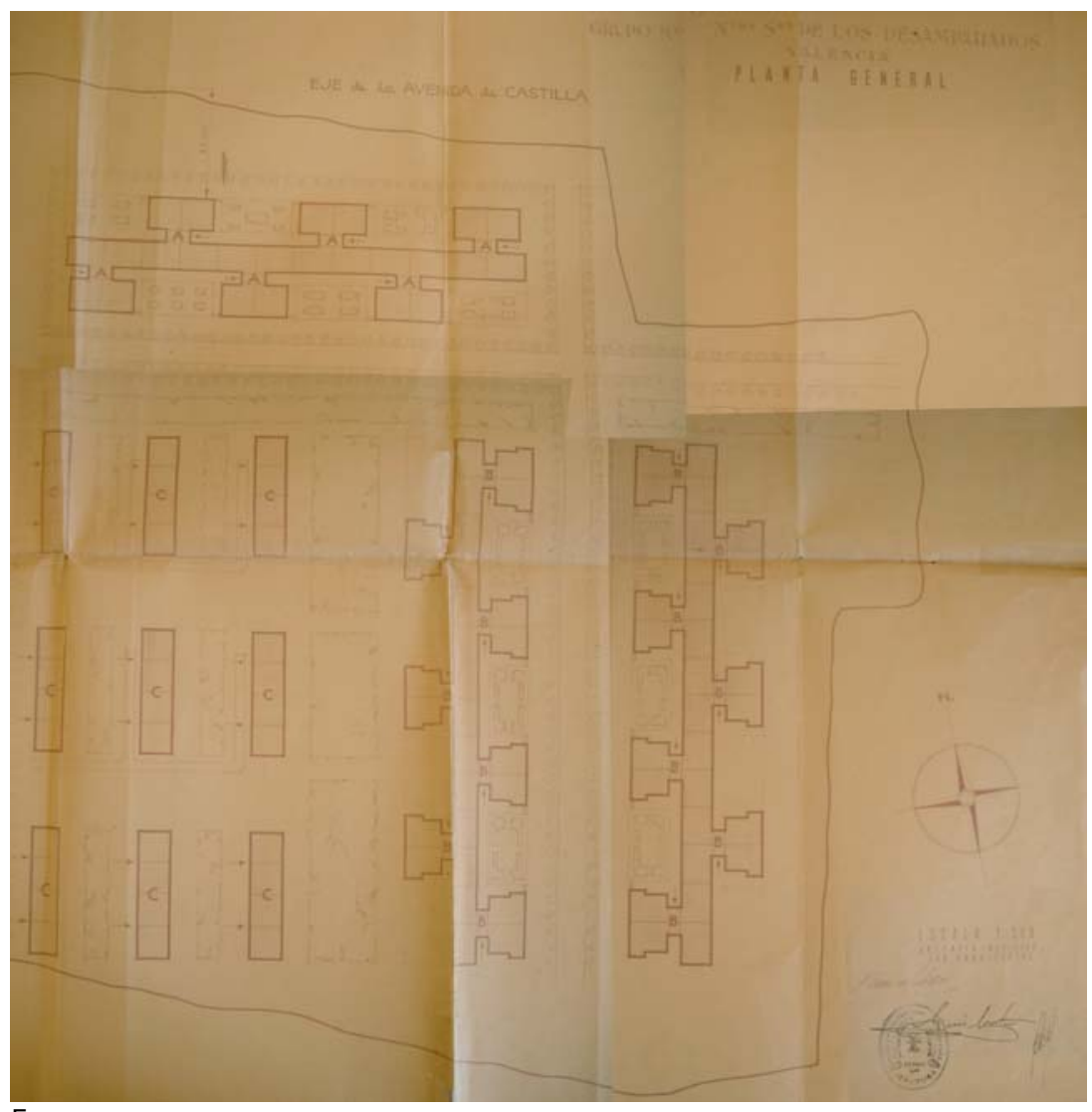

5 


\section{EL GRUPO VIRGEN DE LOS DESAMPARADOS (1952-62).}

El grupo Virgen de los Desamparados es un conjunto residencial promovido por la Obra Sindical del Hogar (OSHA) y situado en el lado Sur de la actual Avenida del Cid (antes Avenida de Castilla). El conjunto, que es el mayor de los promovidos por la OSHA en Valencia, comprende un total de 2.910 viviendas en una superficie de 8,76 Has.

Su construcción se desarrolló en cuatro fases, desde 1952 hasta 1962, aunque las primeras actuaciones de compra de terrenos datan de $1944^{1}$. El grupo, por ello, es una suma de actuaciones, algunas de ellas contradictorias entre sí, más que el resultado de un proyecto global, por lo que, pese a su tamaño, no podemos considerarlo todavía como un polígono o unidad residencial integrada.

El proyecto inicial para el grupo, o Fase I, redactado por los arquitectos Francisco Cabrero, Luís Costa, Antonio Tatay en 1945 y modificado para reducir el número de viviendas de 1.624 a 704 en octubre de 1946, es anterior a la aprobación en diciembre de ese año del Plan General de Ordenación de Valencia y su Cintura. En este proyecto, el trazado y la disposición de la edificación siguen ya los patrones de la edificación abierta, y los bloques se proyectan a partir la agregación de una célula o tipo básico: la vivienda de doble crujía. Los dos tipos de bloque previstos en esta Fase I, lineal y en peine, se utilizarán también en los proyectos redactados por Luís Costa en 1954 para la Fase IIA (112 viviendas) y en 1955 para la Fase III (474 viviendas). La Fase IV (300 viviendas), proyectada por Luís Costa y Vicente Valls en 1959, en el marco del Plan Sindical de la Vivienda, en cambio, utilizará como tipo básico el bloque con planta en I.

A los largo de las diversas fases de construcción del grupo, por tanto, los tipos de edificios que se proyectarán serán los siguientes:

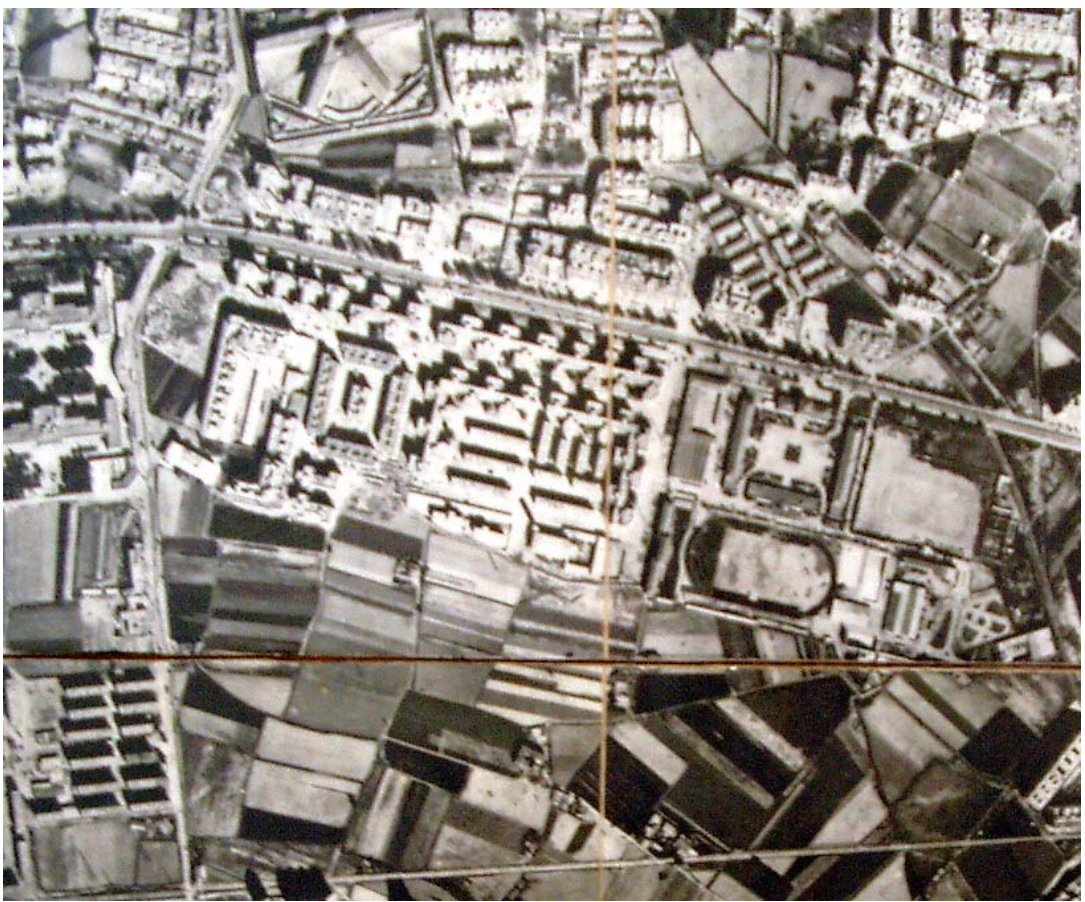

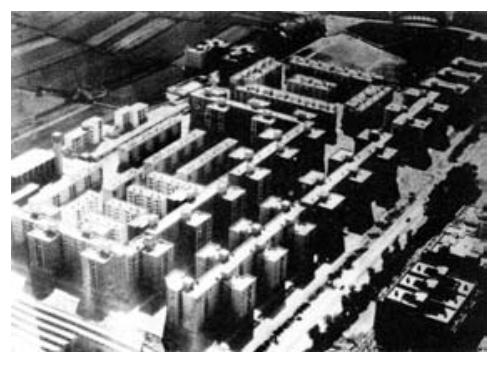

Grupo Virgen de los Desamparados. Fotografía aérea, h. 1965.

Zona del grupo Virgen de los desamparados. Fotoplano, $h$. 1965 (ETS de Arquitectura de Valencia).
1. Ver Gaja, F., Op. cit., pp. 87-91 y 163-168. 
Grupo Virgen de los Desamparados. Planta de viviendas tipo de bloque a redent y bloque doble (Peñín).

Grupo Virgen de los Desamparados Plano de conjunto (Elaboración propia sobre Cartografía Básica Municipal de 1983).

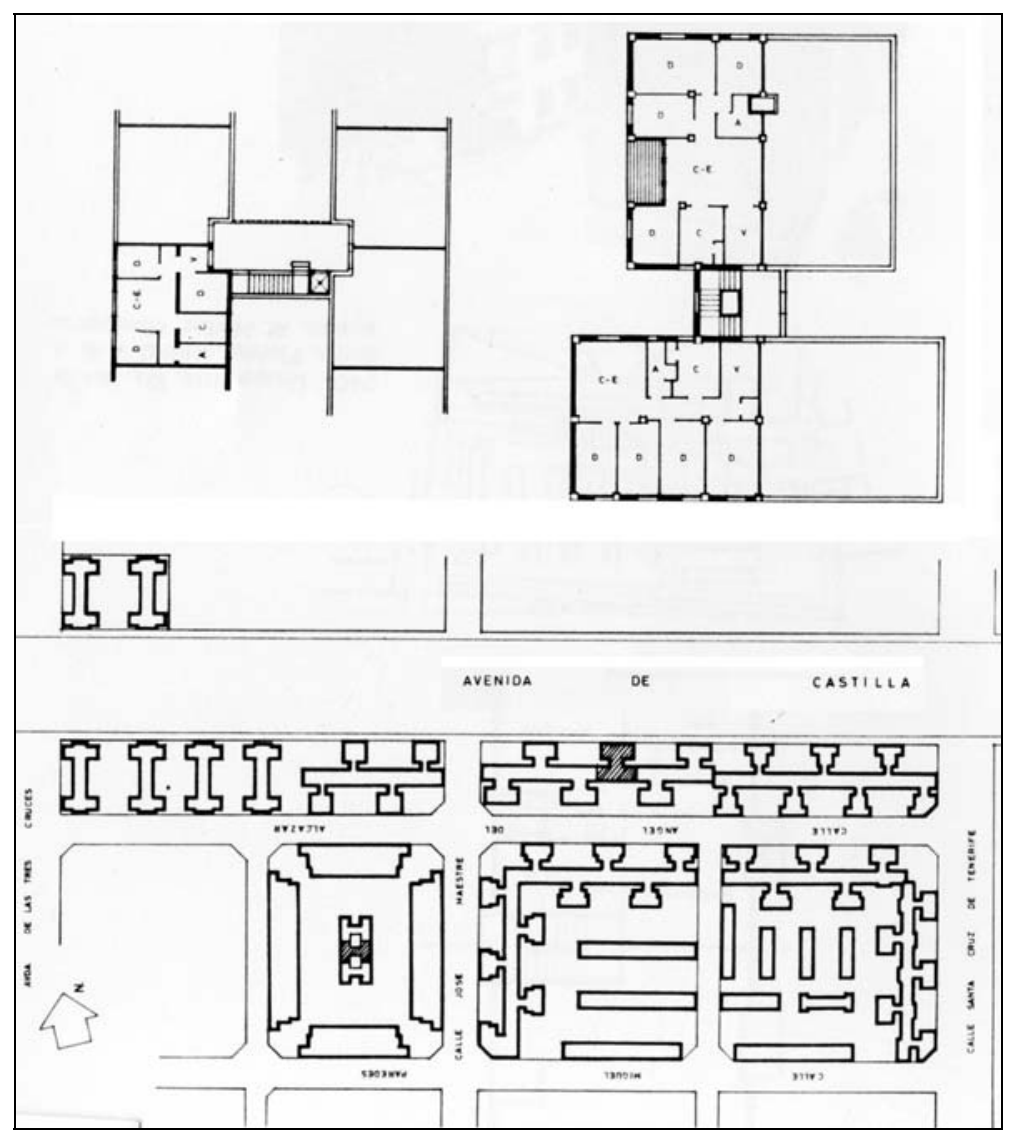

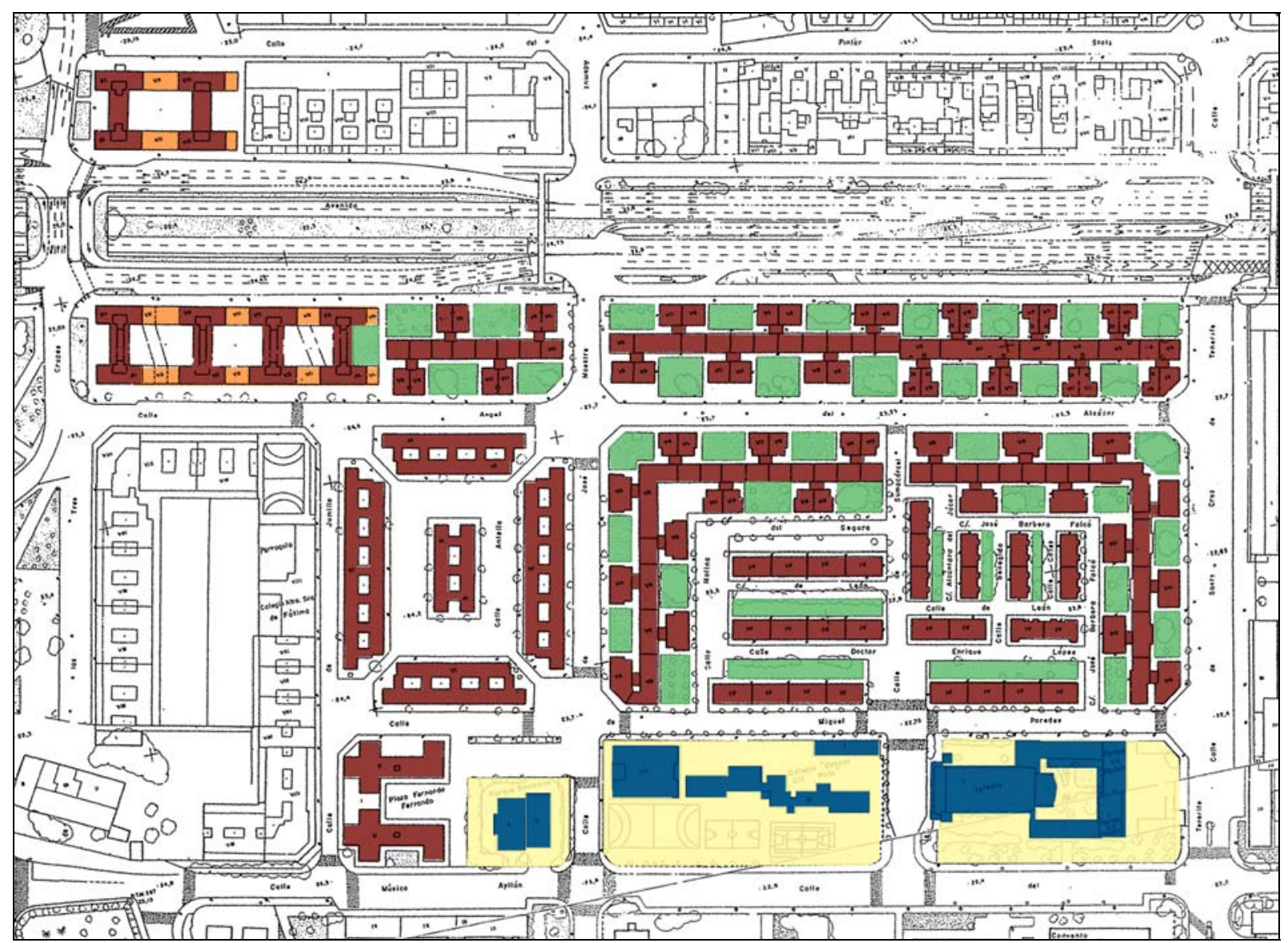


- el bloque lineal, con dos viviendas por caja de escalera. Es un tipo utilizado en la Fase I y en la Fase III, subetapa III, y vinculado a las viviendas de menor tamaño.

- el bloque a redents, en peines alternados, de VII alturas, con 4 viviendas por caja de escalera y espacios residuales o patios abiertos a la calle tratados como zonas verdes. Es un tipo utilizado en la Fase I, en la Fase II A. y en la fase III, subetapas I y II.

- el doble bloque con patios de luces, de VI alturas, con 4 viviendas por caja de escalera, formando una manzana abierta. Corresponde a la Fase II $B$.

- la manzana mixta, formada por bloques con planta en I de VII y XI alturas, enlazados por una edificación comercial perimetral de una planta, con patios interiores ajardinados. Corresponde a la IV fase, de superior calidad.

El bloque a redents es el tipo más utilizado en el frente recayente a la Avenida de Castilla, y constituye la imagen pública del barrio. Este frente, entre las actuales Avenida del Cid y C/ Angel del Alcázar, está ocupado por dos bloques a redent, uno de ellos largo y el otro corto, y, en su extremo oeste, por bloques perpendiculares a la Avenida y unidos por un zócalo comercial (cuatro en el lado sur y dos en el lado norte).
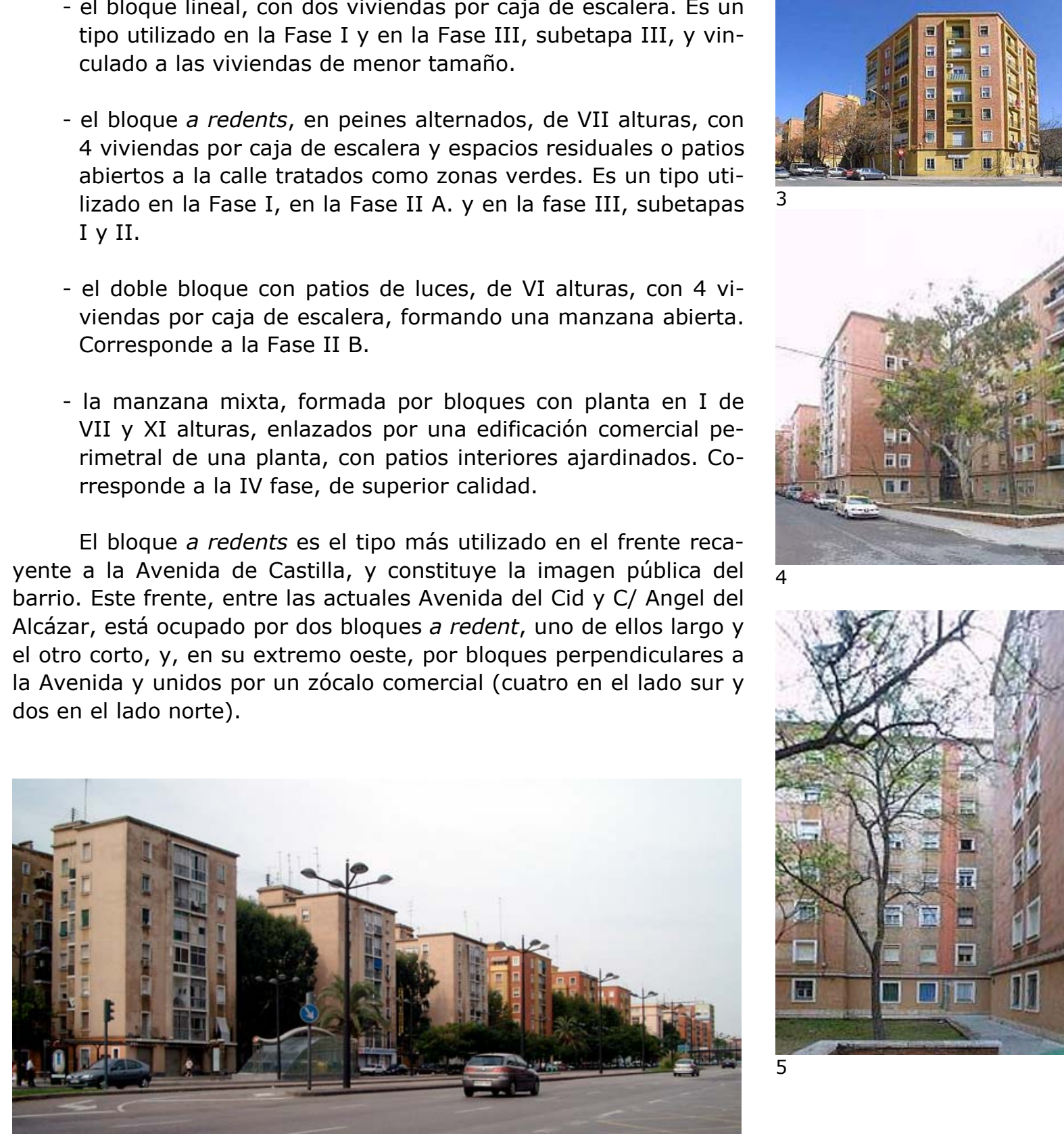

3

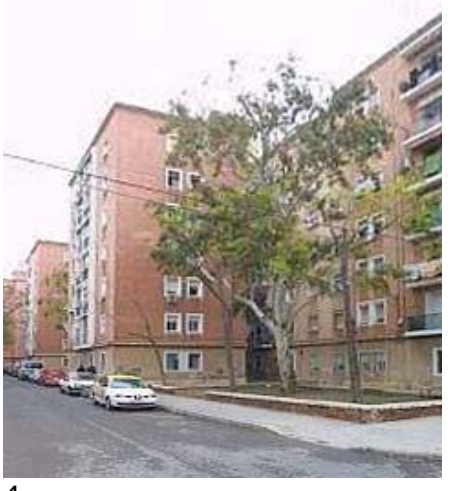

4

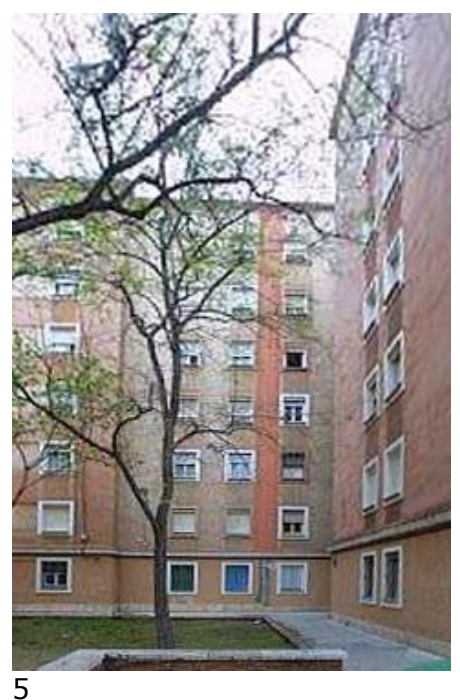

1

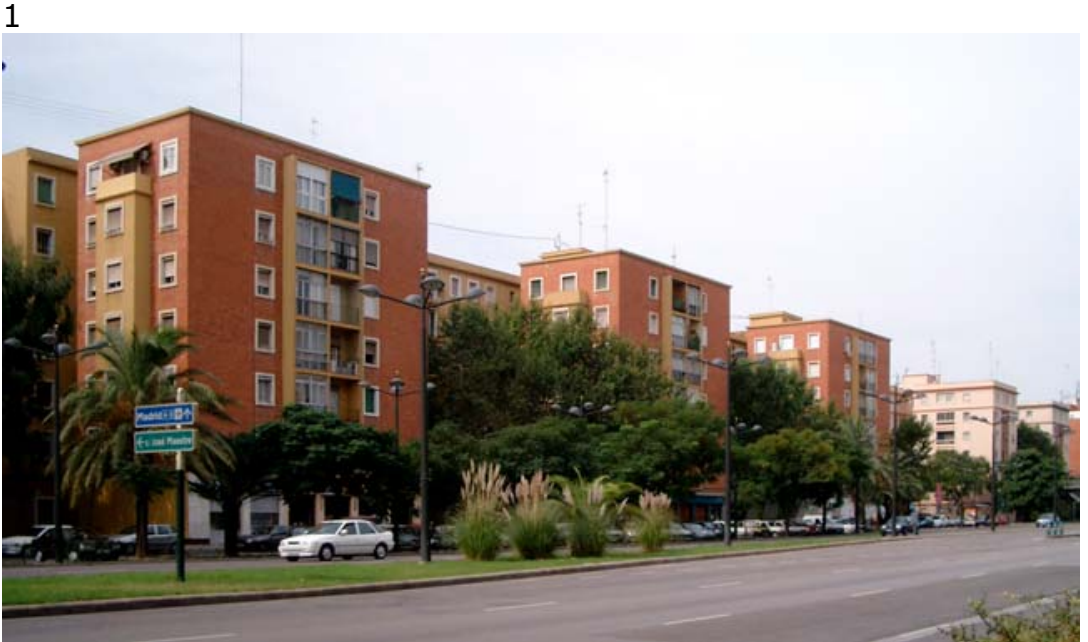

Bloques a redents.

1-2. Avenida del Cid.

3. Esquina José Maestre-

Miguel Paredes.

4-5. Calles Santa Cruz de Tenerife y José Barberá Falcó. 


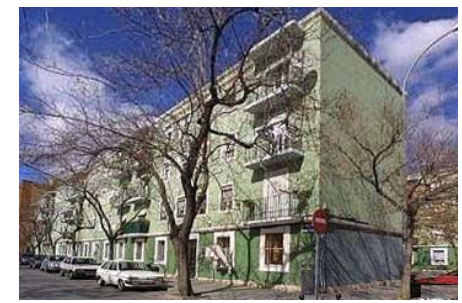

1

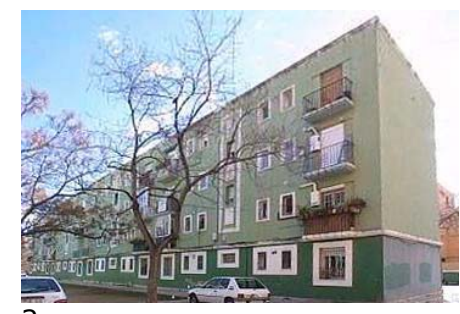

2

Detrás de esta primera línea de bloques de la Avenida de Castilla, entre las Calles Angel del Alcázar y Miguel Paredes, aparecen cuatro manzanas de características muy diferentes.

La manzana situada más al oeste (entre la Avenida Tres Cruces y la C/ Jumilla) es una manzana clásica de ensanche, con edificación entre medianeras de gran profundidad y patios de luces, según el modelo de ensanche.

La manzana contigua a la anterior (entre las calles Jumilla y José Maestre) es una manzana abierta en sus esquinas formada por bloques dobles (con patios de luces) de cinco crujías y un pequeño doble bloque en el patio central. Este tipo edificatorio supone un retroceso con respecto a los principios originales de la edificación abierta, que implican viviendas pasantes, piezas exteriores y abolición de los patios. El espacio libre interior de manzana, por otra parte, queda desvirtuado por la presencia en él de otro edificio, también en forma de bloque doble, que invade un lugar habitualmente destinado a jardín.

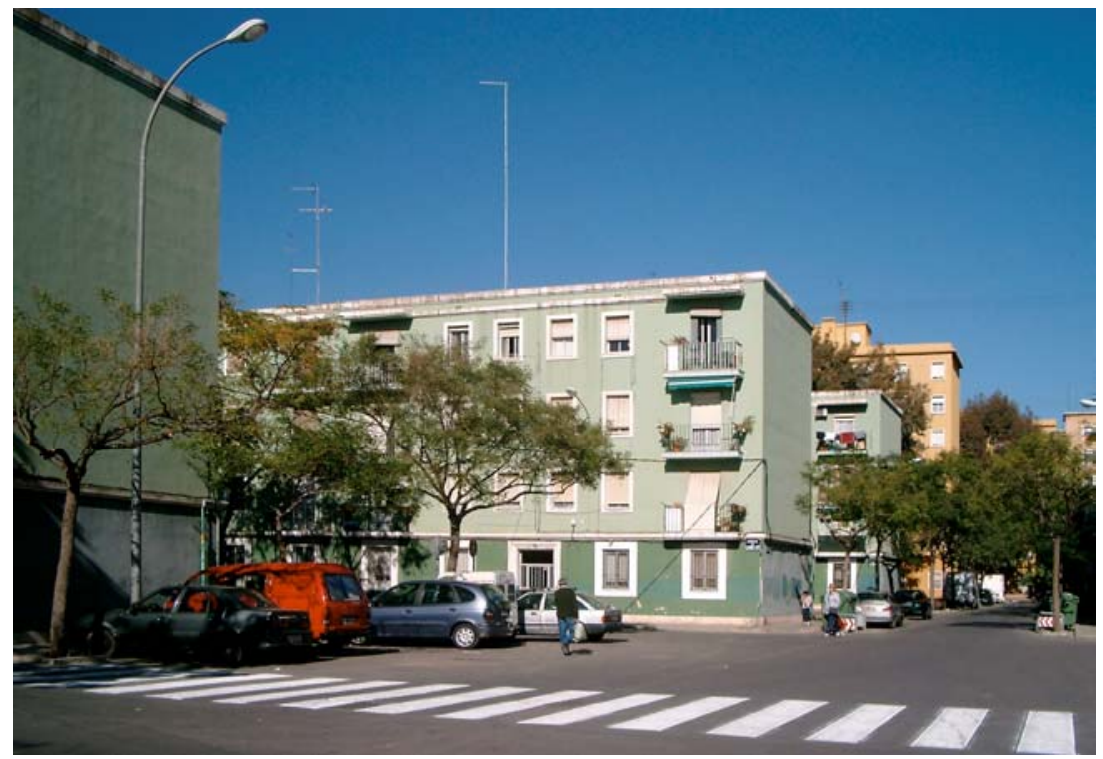

3

Grupo Virgen de los Desamparados. Vistas actuales.

1-2. Bloque lineal. Fachadas a calles Miguel Paredes y Doctor Enrique López.

3. Vista de la calle Sumacárcel desde el sur.

4. Bloque lineal en la calle Miguel Paredes.

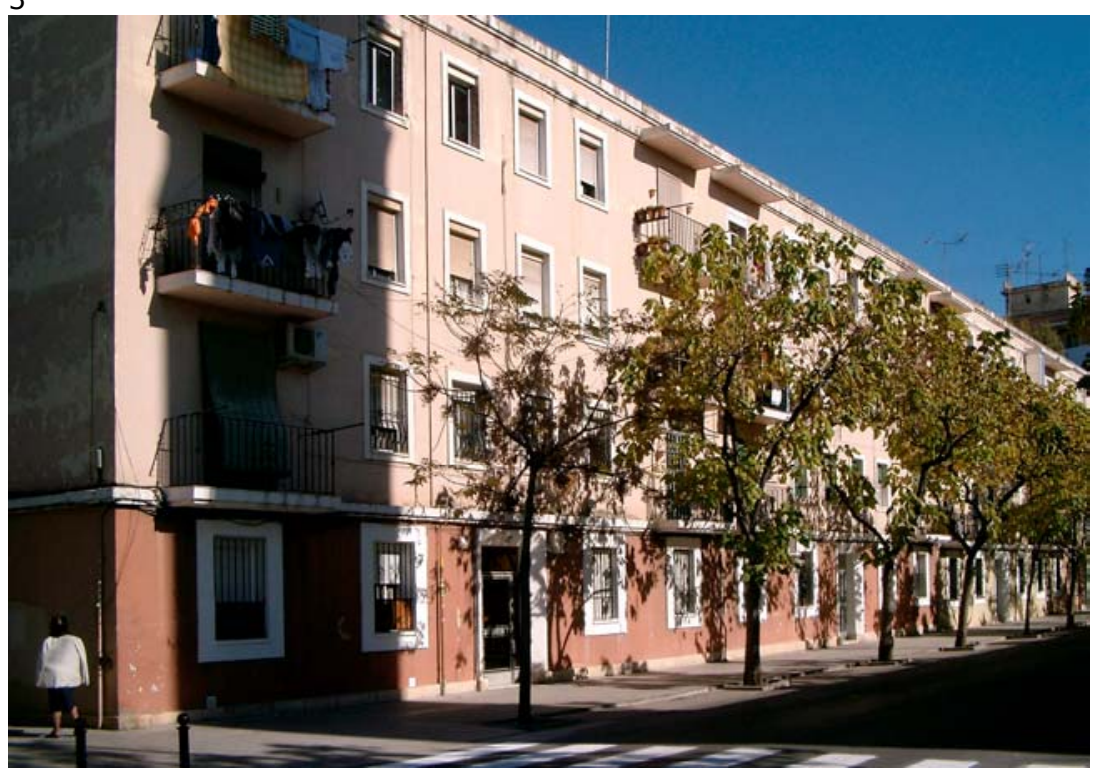


Las dos manzanas restantes (entre las calles José Maestre y Sumacárcel y entre esta y Santa Cruz de Tenerife) están formadas por bloques a redents con planta en $L$, simétricos, que definen dos lados de una especie de manzana abierta rellena de bloques lineales de 4 y 5 plantas y de longitud y orientación variables. El espacio libre entre estos bloques lineales y las calles está tratado como zona verde pública.

En las manzanas situadas más al sur, entre Miguel Paredes y Músico Ayllon, se disponen una serie de equipamientos, diseñados como edificios exentos en su parcela, con algunos fragmentos de edificación abierta al oeste, como los dos bloques de planta cruciforme recayentes a la calle Jumilla.

El resultado de todo ello es un conjunto residencial en el que, con la excepción de las manzana mixta de bloques en I con zócalo comercial recayentes a la Avenida del Cid, el resto de la edificación traslada la huella de su planta tipo al suelo sin variaciones. El plano privado-publico coincide con el de edificado-no edificado.

Todo el espacio no edificado es público, y cuando no es calle es considerado como zona verde. No hay, sin embargo, en todo el barrio ninguna zona verde con papel estructurante: todas son pequeñas áreas verdes dispersas.

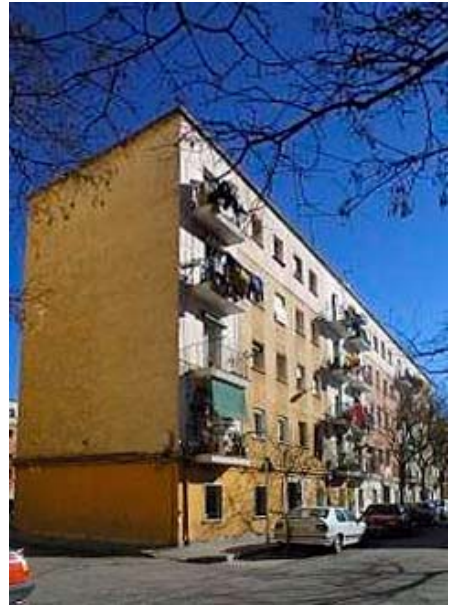

Bloque lineal. Calle Sumacárcel.
Grupo Virgen de los Desamparados. Ortofoto 2002 (AUMSA).

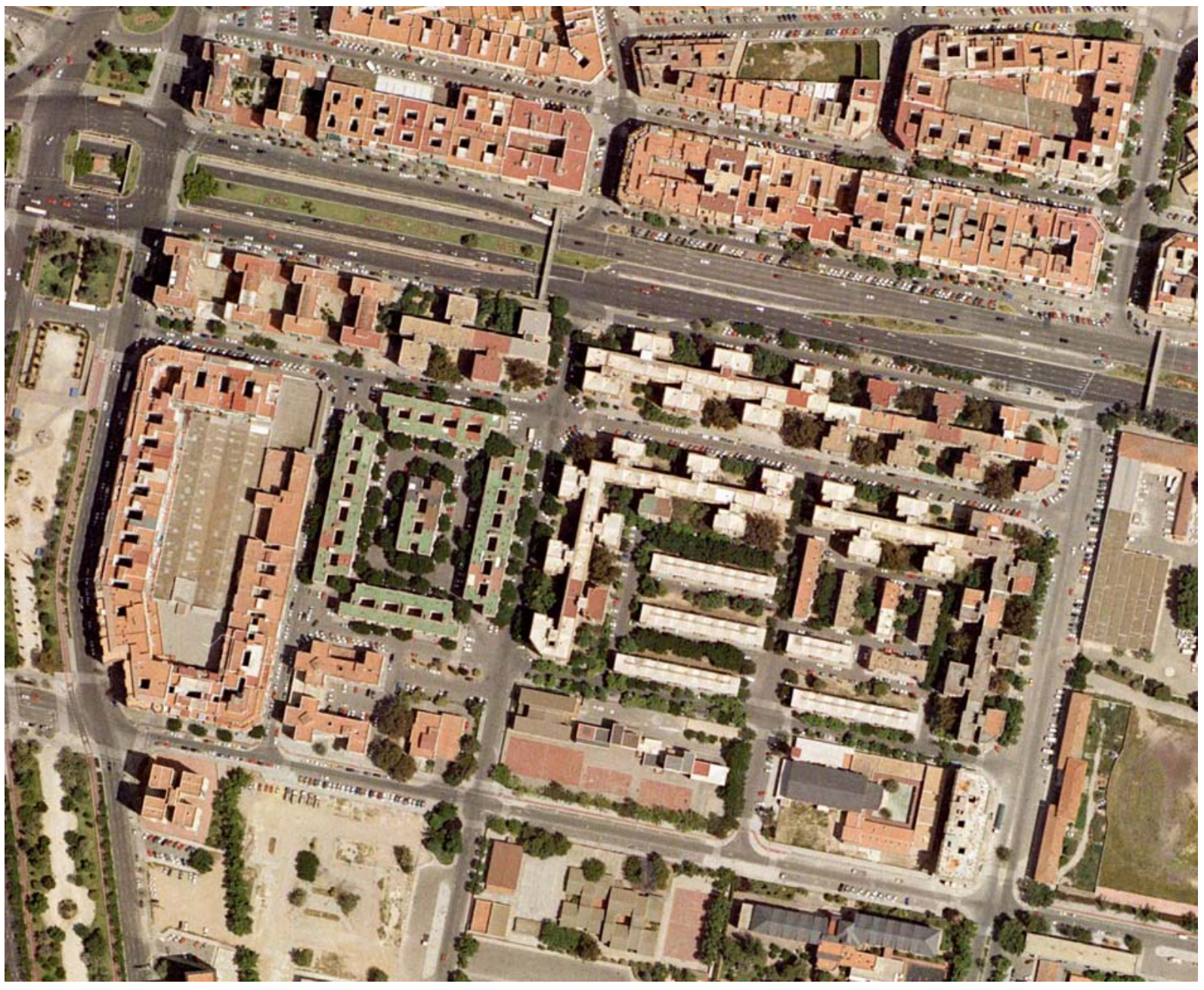



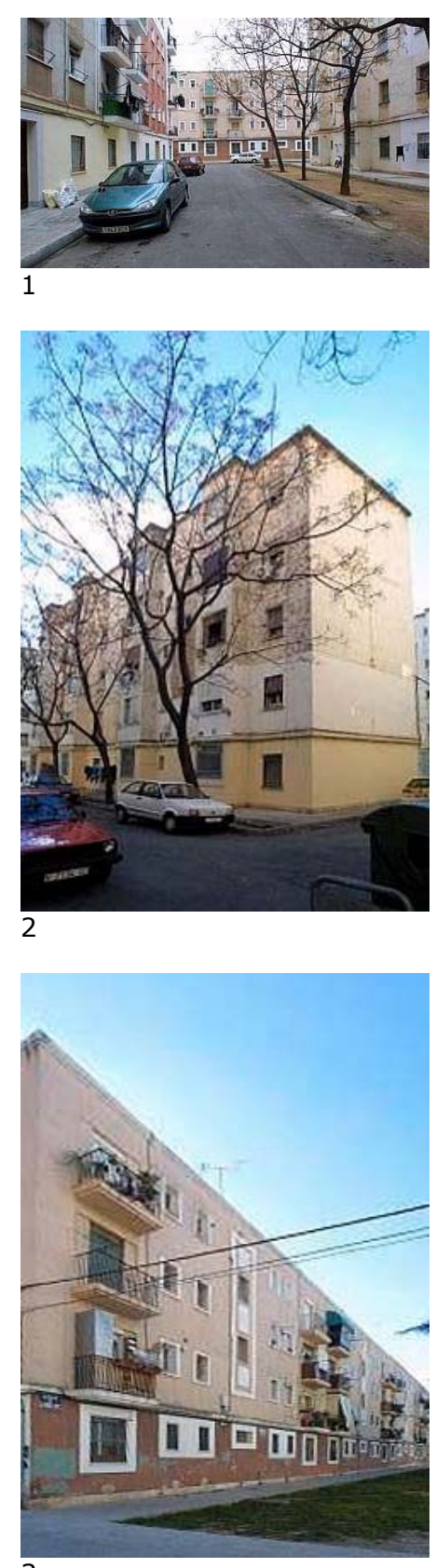

3

1. Calle Benegida, vista hacia el sur.

2. Bloque lineal corto en caIle Benegida.

3. Bloque lineal largo. Calle Enrique López.

4-5. Avenida del Cid, lado sur y norte. Bloques de VII y IX alturas de la Fase IV.
En cuanto a la edificación, sólo los bloques a redent, con su gran longitu proporcionan una cierta legibilidad al espacio público, igual que ocurre, por eje vienesas: su gran tamaño es determinante.

Sin embargo, en las dos manzanas que están rellenas literalmente de bloques lineales, algunos de ellos muy cortos, como los que flanquean las calles Jucar, Benegida y Cotes, la disposición aleatoria de dichos bloques, unida al exceso de calles convencionales alrededor de los mismos, que desvirtúa el modelo original de espacios verdes intermedios, se traduce en una falta de legibilidad del espacio público.

Dado que no existe un viario especializado, con unas calles destinadas al tráfico rodado, otras al aparcamiento y otras a jardines y recorridos peatonales, la malla final resultante, con un viario que acaba envolviendo uno a uno a cada bloque, resulta más pequeña incluso que la de la ciudad histórica.

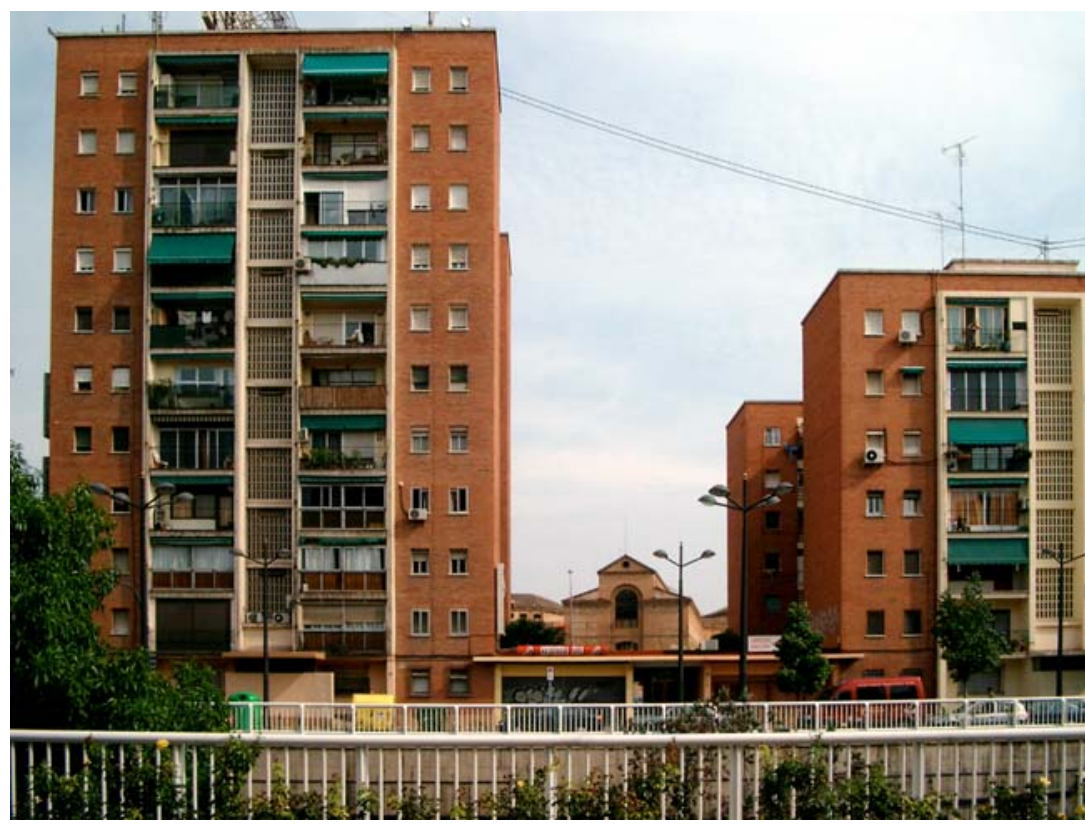

4

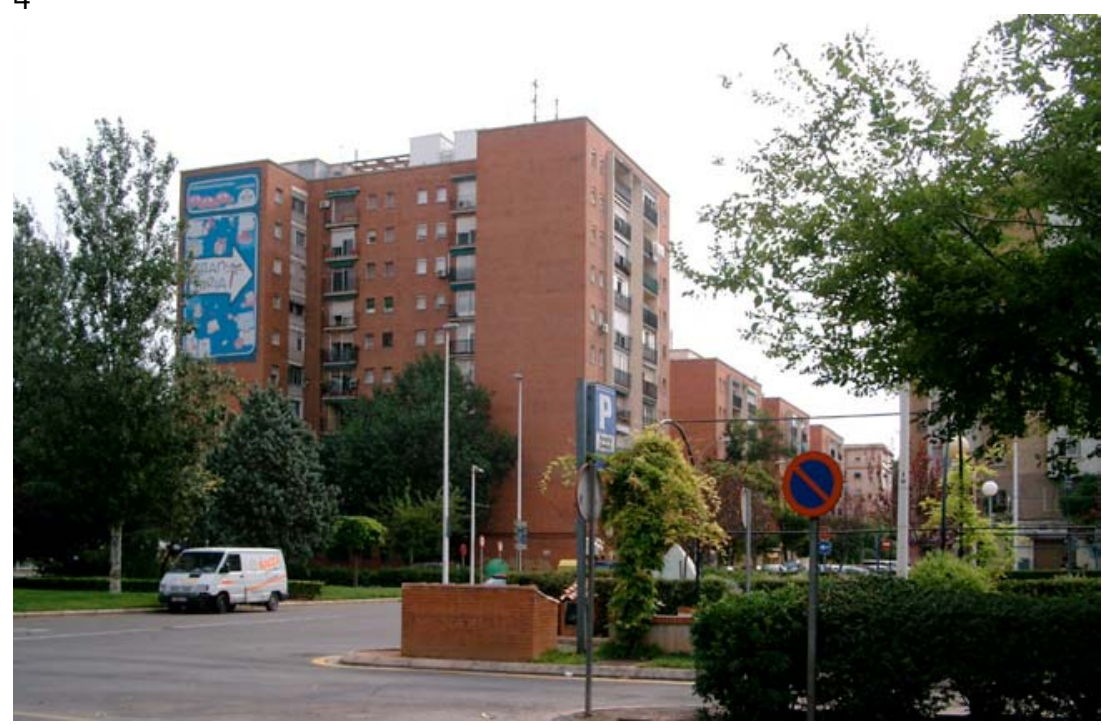


Por otra parte, la localización de viviendas en las plantas bajas de los bloques, tanto en los lineales como en los redents, habitual en conjuntos de promoción pública, especialmente en los construidos para segmentos de población de rentas bajas, hace que la calle quede desprovista de locales comerciales y que las aceras, y con ellas las calles, pierdan gran parte de su carácter urbano y pasen a adquirir un aspecto un tanto desolado.

La vitalidad del conjunto se resiente de la excesiva especialización funcional, y la sensación de hallarnos en un lugar aparte, separado de la dinámica urbana, se hace evidente cuando vemos, en una calle desierta, la ropa tendida en la parte exterior de una ventana enrejada de planta baja.

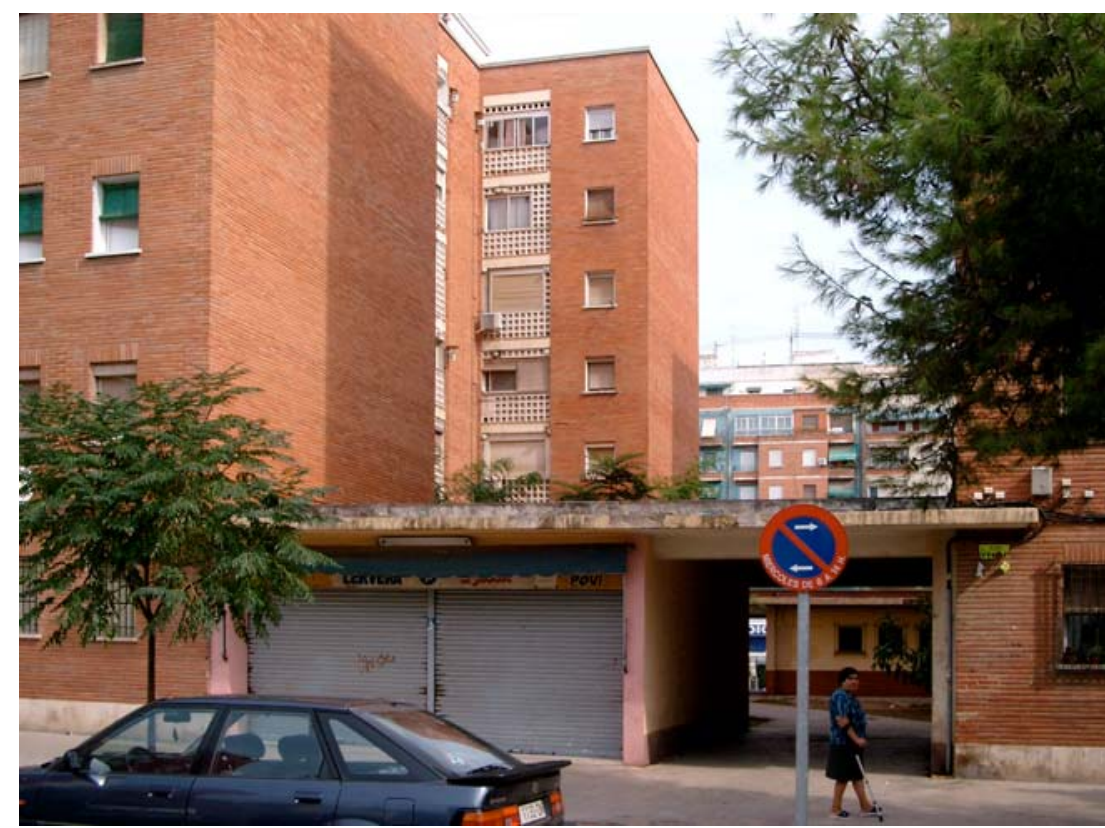

1

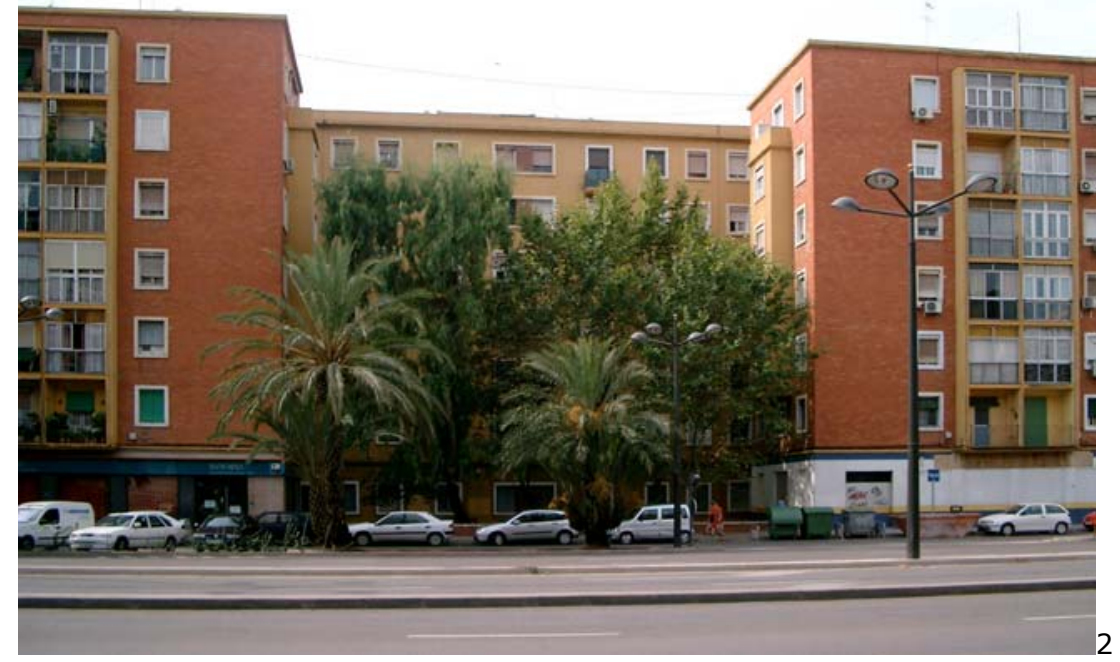

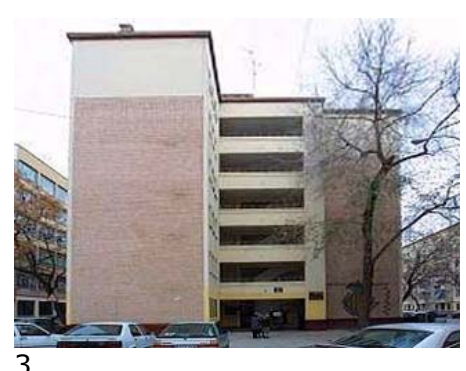

3
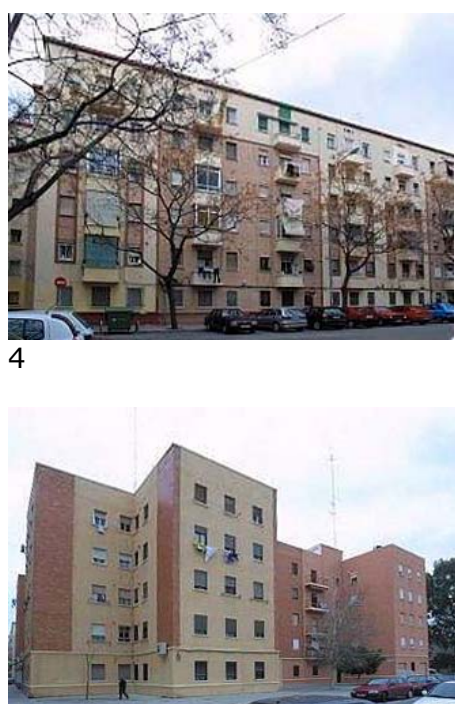

5

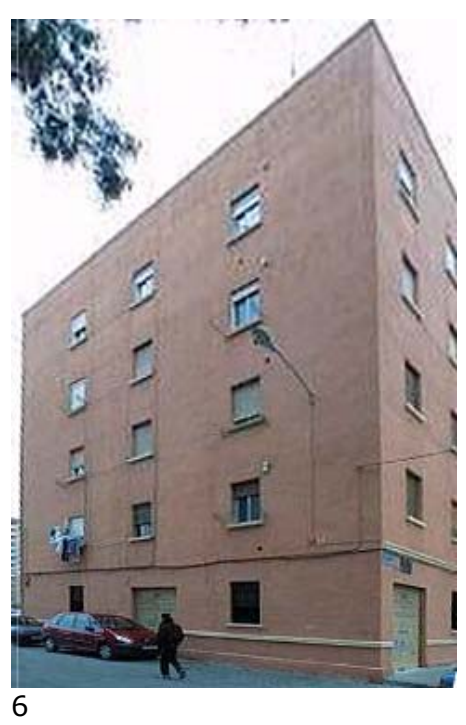

1. Calle Ángel del Alcázar. Planta baja de enlace entre bloques en I de la Fase IV.

2. Bloques a redents en la Avenida del Cid.

3-4. Bloques dobles de las calles Jumilla y Antella.

5-6. Bloques en cruz. Calle Músico Ayllón esquina con calle Jumilla. 


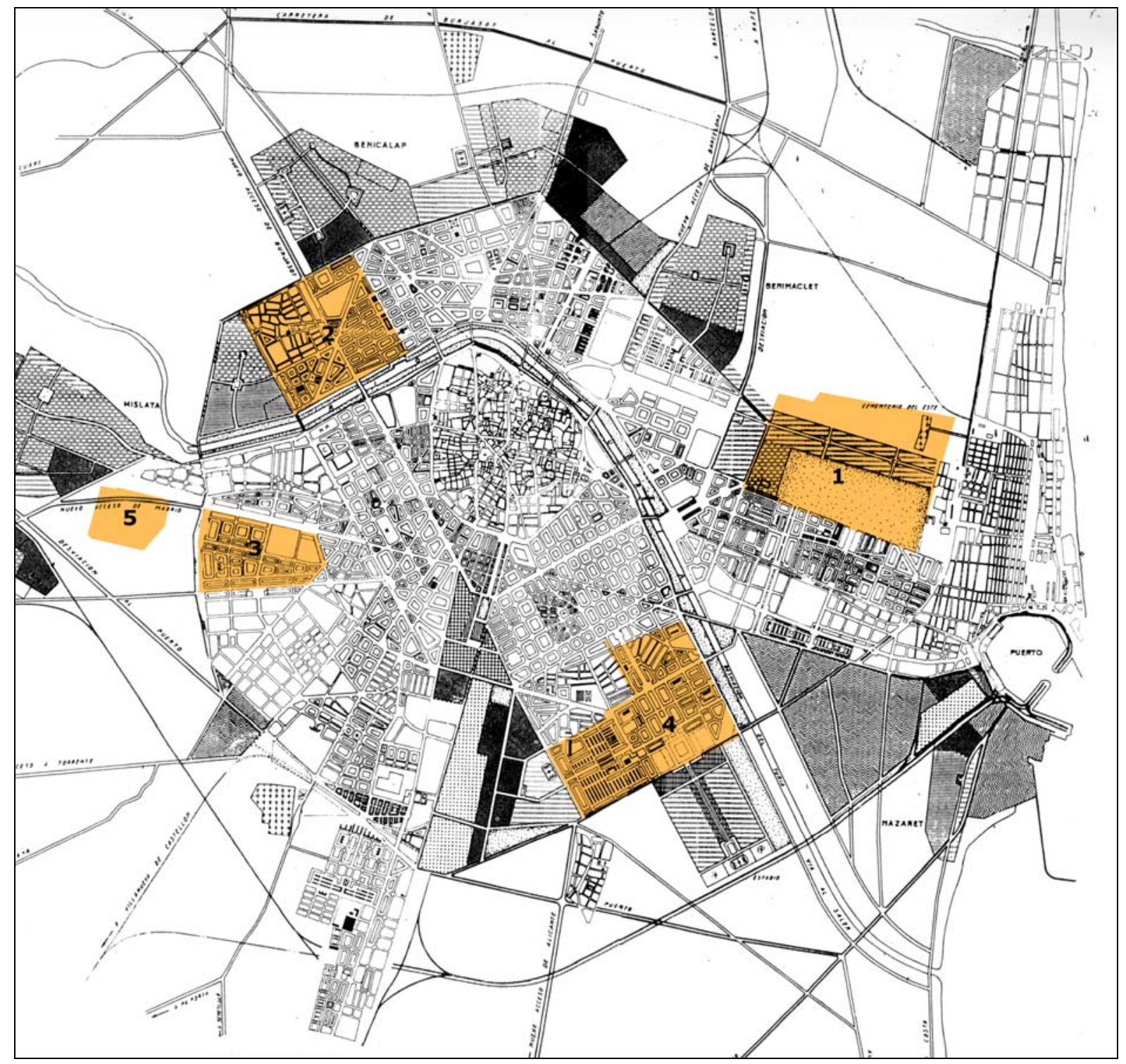

Polígonos preferentes para la urbanización y edificación. Ayuntamiento de Valencia, 1955. (Elaboración propia: sombreado sobre transcripción de Planeamiento parcial realizada por E. Giménez a partir del plano de zonificación del Plan de 1946)

1. Polígono Paseo Valencia al Mar.

2. Polígono Campanar.

3. Polígono Avenida de Castilla.

4. Polígono Monteolivete.

Barrios residenciales no 2 y 3.

Corporación Administrativa Gran Valencia.

5. Barrio Residencial no 2.

(El Barrio Residencial no 3 está situado en Quart de Poblet). 


\section{LOS PROYECTOS DE EJECUCIÓN DE POLÍGONOS PARA VIVIENDAS DE RENTA LIMITADA Y LOS BARRIOS RESIDENCIALES No 2 Y 3.}

Entre 1955 y 1956 se redactan para diferentes áreas de Valencia una serie de planes en los que la edificación abierta deja de ser la excepción para pasar a ser la regla. Por una parte, promovidos por el Ayuntamiento de Valencia, se redactaron los denominados "Proyectos de Ejecución de Polígonos con destino a la formación de solares para emplazamiento de Viviendas de Renta Limitada" para cuatro Sectores de la ciudad: Valencia al Mar, Campanar, Avenida de Castilla y Monteolivete ${ }^{1}$. Por otra parte, la Corporación Administrativa Gran Valencia redactó los proyectos para los Barrios Residenciales no 2 y 3 en la Avenida de Castilla.

El objeto de los Proyectos de Ejecución de Polígonos era el de definir las expropiaciones y consiguientes obras de urbanización necesarias para poder desarrollar el Proyecto de Alineaciones definido para cada Sector seleccionado, de modo que se obtuviesen los solares suficientes, dotados de todos los servicios, para la construcción sobre ellos de viviendas de Renta Limitada. Ninguno de estos proyectos fue realizado.

La Ley de Viviendas de Renta Limitada se promulgó el 15 de julio de 1954, y estuvo en vigor hasta 1963. Es una ley liberalizadora, de apoyo a la promoción privada, para lo que se establecen dos grupos de viviendas: grupo I y grupo II. Las promociones de viviendas de grupo II, destinadas a los segmentos de población de menor capacidad adquisitiva, disponen de créditos oficiales, institucionales y privados, exenciones fiscales y otras medidas de apoyo. El Reglamento de la Ley, de 1955, establece los criterios de clasificación de las viviendas de este grupo en tres categorías en función de su superficie. Para cada una de estas categorías se establece un coste por $\mathrm{m} 2$ construido que resulta de multiplicar un módulo fijado por la administración por un coeficiente.

Los Proyectos de Ejecución de Polígonos comienzan con la definición de nuevas alineaciones para los sectores en los que se pretende construir viviendas de Renta Limitada. En estos sectores, que disponían de un planeamiento anterior aprobado, se sustituyen las anteriores ordenaciones basadas en manzanas cerradas por otras en las que la edificación abierta es la base de la composición. Este cambio es congruente con las Ordenanzas Técnicas de 1955 de la Ley de Viviendas de Renta Limitada, que establecen que para los núcleos urbanos de nueva creación los bloques de edificación deberán ser necesariamente de dos crujías.

En cuanto a parámetros urbanísticos, las Ordenanzas Técnicas señalan que la separación entre bloques será como mínimo igual a su altura. Además, indican que el coeficiente de edificabilidad máximo será de 3 a $6 \mathrm{~m} 3 / \mathrm{m} 2$. Este coeficiente será el que se utilizará como referencia en los Proyectos de Ejecución de Polígonos.

Los Barrios Residenciales No 2 y 3, por su parte, son proyectos redactados en 1956 por Gran Valencia para unas zonas de la Avenida de Castilla que no disponían de planeamiento parcial previo.
1. La delimitación de los "Polígonos preferentes para la urbanización y edificación" en los sectores de Monteolivete, Avenida de Castilla, Paseo de Valencia al Mar y Campanar fué aprobada por acuerdo del Ayuntamiento pleno de fecha 22 de noviembre de 1955, con la finalidad de obtener para dichos polígonos los beneficios de la ley de 3 de diciembre de 1953, que por aplicación del decreto de 2 de abril de 1954 se concedían a Valencia, así como los de la Ley de 15 de julio de 1954 de Viviendas de Renta Limitada. 


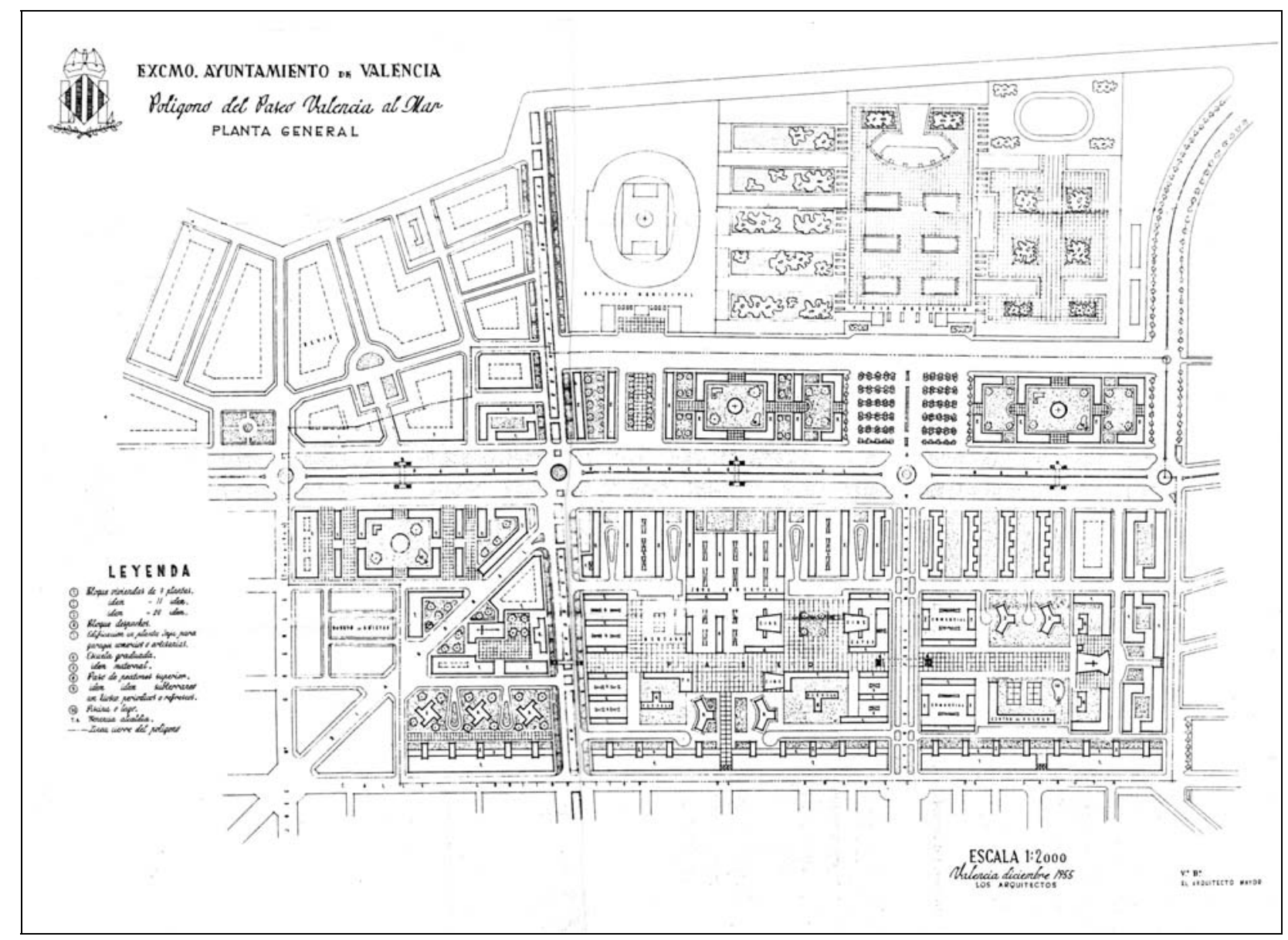

Proyecto de Ejecución de Polígono Sector Paseo Valencia al Mar para Viviendas de Renta Limitada, 1956. Planta y secciones viarias.

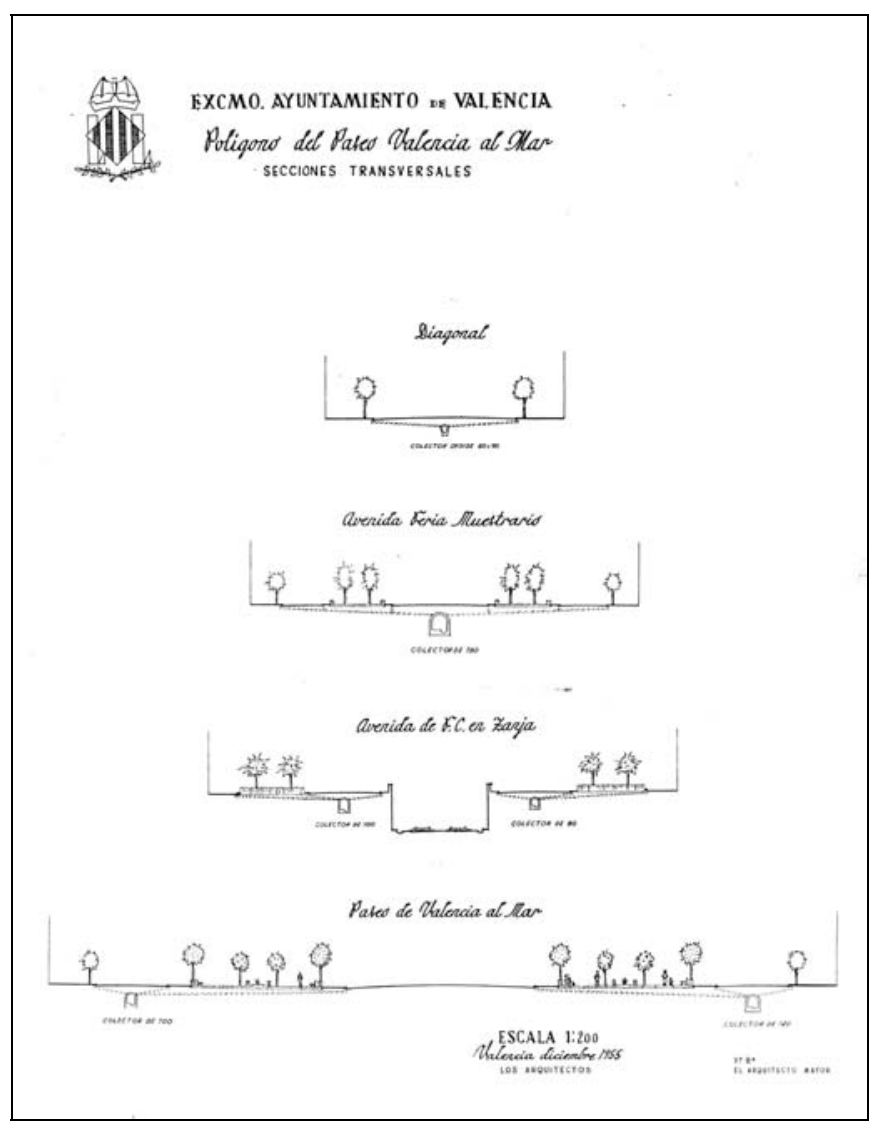


El "Proyecto de Ejecución del Polígono del Sector de Paseo de Valencia al Mar con destino a la formación de solares para emplazamiento de viviendas de Renta Limitada" fue redactado en 1956 por los arquitectos Vicente Valls Abad y Julio Bellot Senent. ${ }^{1}$

El proyecto supone una modificación sustancial del plan de 1952 para la misma zona, que hemos analizado anteriormente.

En primer lugar, el espacio ocupado por la edificación abierta se amplía hacia el este y el oeste, abarcando la práctica totalidad del suelo vacante. Además, esta edificación abierta se diversifica: además de los bloques lineales aislados, se proyectan torres con planta en $\mathrm{Y}$ o en esvástica, bloques profundos en peine, bloques unidos por bajos comerciales y bloques en $L$ envolviendo un espacio libre.

La serie de bloques lineales ortogonal al Paseo al Mar se conserva en el lado sur, aunque dos de ellos tienen su testero retrasado con respecto al Paseo. Los cuatro bloques que forman la primera fase del grupo "Isla Perdida" aparecen ya construidos.

En el lado norte del Paseo, en cambio, los bloques ortogonales se sustituyen por una mezcla de bloques lineales y bloques en $L$ que forman grandes manzanas rectangulares con espacios intermedios e interiores ajardinados. Esta disposición se adopta también en el frente sur del Paseo, en el tramo entre la Avenida Cardenal Benlloch y la calle Manuel Candela.

El resto de la zona norte sigue ocupado por las extensas parcelas destinadas a Feria Muestrario y Estadio Municipal, aunque estos elementos aparecen en posición invertida con respecto al plan anterior.

Por lo que se refiere al trazado, la sección viaria prevista para el Paseo al Mar no es de tipo bulevar, sino de tráfico jerarquizado en paralelo, compuesta por calzada central, bandas de jardines laterales y calles de servicio junto a los edificios. Se prevén pasos inferiores de peatones para cruzar la calzada central.

Por el centro de la actual calle Ramón Llull-Manuel Candela, discurre, en zanja, la línea de Ferrocarril, que sólo se cubre en las intersecciones.

La principal novedad que se introduce en este proyecto es la creación de un eje este-oeste intermedio entre el Paseo al Mar y la actual calle de Justo y Pastor, en forma de paseo peatonal continuo, interrumpido únicamente por los ejes norte-sur. Este eje peatonal, que aglutina en torno a él todos los equipamientos de la zona, reaparecerá con algunas variantes en el Plan Parcial 12 de 1968.

La existencia del paseo peatonal es posible gracias al trazado viario proyectado, que es de tipo ramificado, con viales sin salida que penetran en una manzanas de gran tamaño (supermanzanas en la terminología habitual de los planes parciales) sin atravesarlas.
3. Ayuntamiento de Valencia. Proyecto de Ejecución del Polígono del Sector de Paseo de Valencia al Mar con destino a la formación de solares para emplazamiento de viviendas de Renta Limitada, 1956. Ver Anexo de Documentos, pp. 43-45. 
Página opuesta:

Proyecto de Ejecución de Polígono Sector Paseo Valencia al Mar para Viviendas de Renta Limitada, 1956.

1. Edificación en planta tipo.

2. Edificación en planta baja.

3. Equipamientos.

(Elaboración propia sobre Planta General).
Así, en el extremo oeste del eje peatonal se sitúa un núcleo de equipamientos que incluye una Iglesia y una escuela. En la supermanzana central se proyecta un centro cívico, que incluye un mercado situado junto a un extensa planta baja comercial que engloba varios bloques lineales, una Tenencia de Alcaldía y una zona con cines, cafés y un hotel en torno a una plaza, así como dos parcelas escolares. Dos torres con planta en $\mathrm{Y}$ se abren al centro cívico, y entre ellas se sitúa un brazo transversal del paseo peatonal que llega hasta la calle que limita la zona por el sur.

El paseo peatonal continúa en la supermanzana del este, y queda rematado por un núcleo de equipamientos que incluye una Iglesia (que cierra la perspectiva del paseo), dos parcelas escolares y un espacio deportivo y de juegos. Este núcleo final queda envuelto por bloques lineales en $L$, excepto en el lado norte, en el que se sitúan otras dos torres en $\mathrm{Y}$.

Muchos de los elementos que flanquean el paseo peatonal en esta supermanzana se mantendrán en posteriores redacciones de este plan parcial, como los bloques en $L$, las manzanas con bloques sobre un zócalo comercial o el conjunto de Iglesia y escuelas.

Las manzanas formadas por bloques enlazados por bajos comerciales se concentran en los frentes de los ejes norte-sur (actuales calles de Manuel Candela y Músico Ginés) y en el frente al Paseo al mar de la supermanzana central, además de en el centro cívico descrito anteriormente.

La edificación abierta que forma el límite sur de la zona, que queda enfrentada con las manzanas de ensanche, se resuelve con bloques en peine, formados por un bloque profundo alineado a la calle y cuerpos de edificación transversales de dos crujías. Este tipo de edificio aparecía ya en el proyecto del Barrio Residencial de Burjasot-Benimanet de 1946 para configurar su eje central, y será utilizado con cierta frecuencia en otros planes parciales del periodo 1955-1965. propia sobre Planta General).

Trazado viario (Elaboració

Polígono Sector Paseo Valencia al Mar para Viviendas de Renta Limitada, 1956.

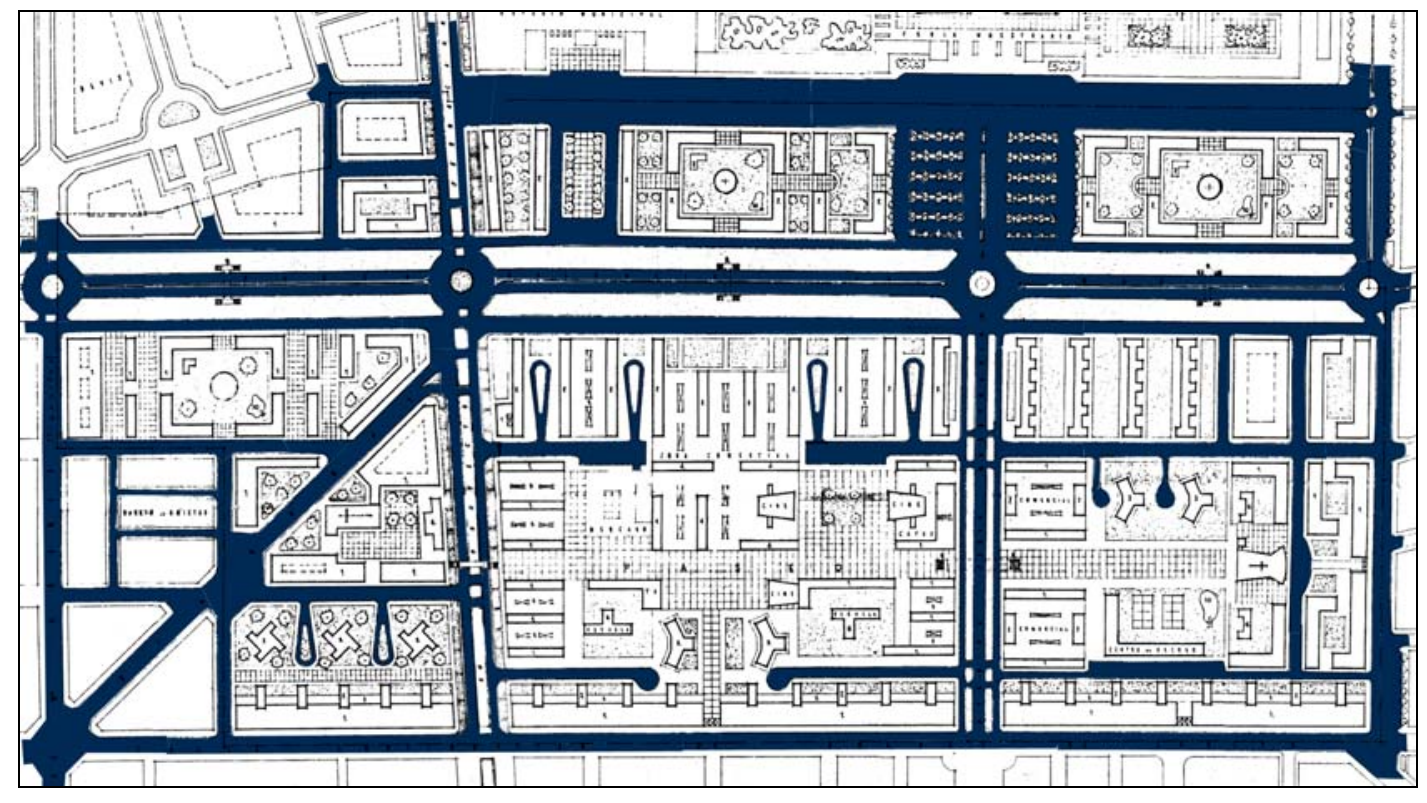



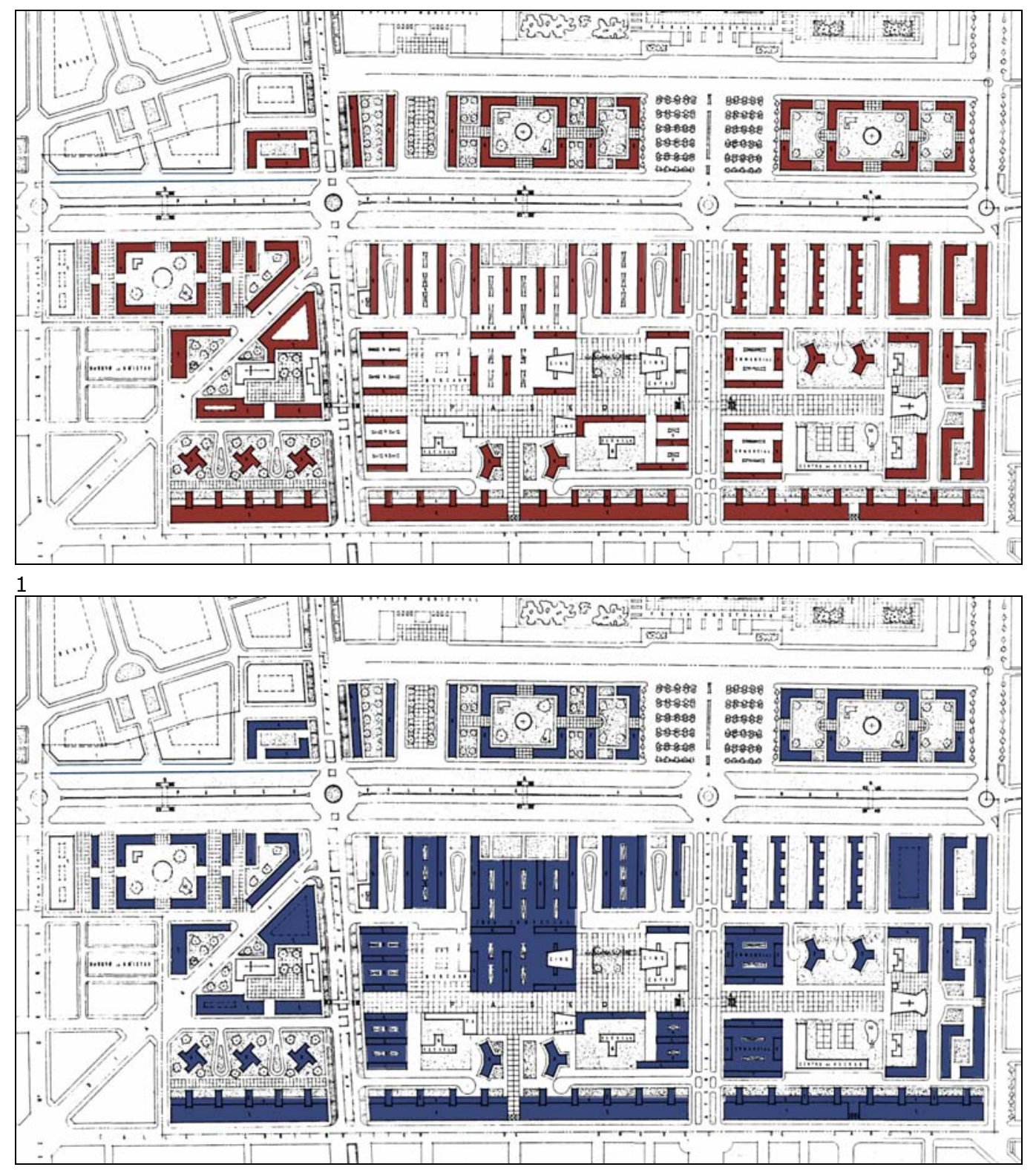

2

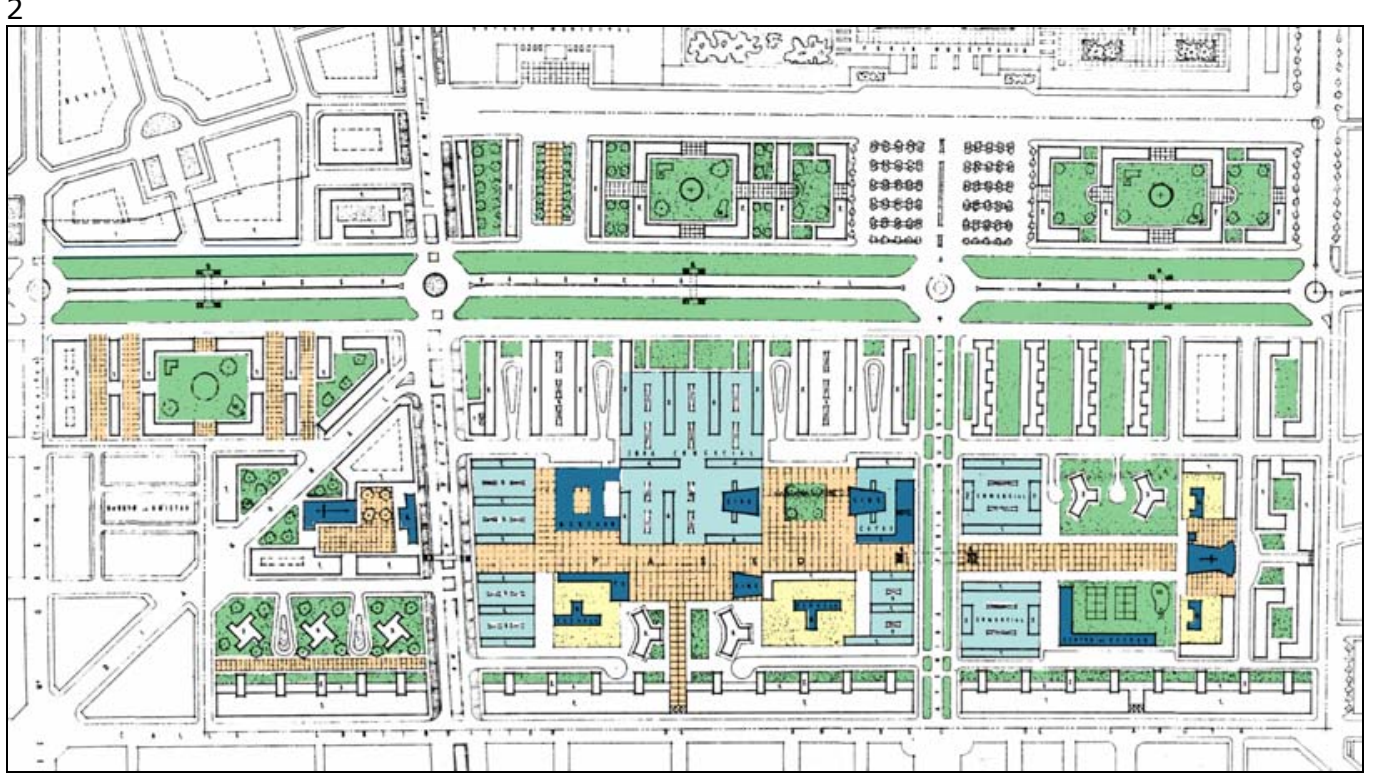




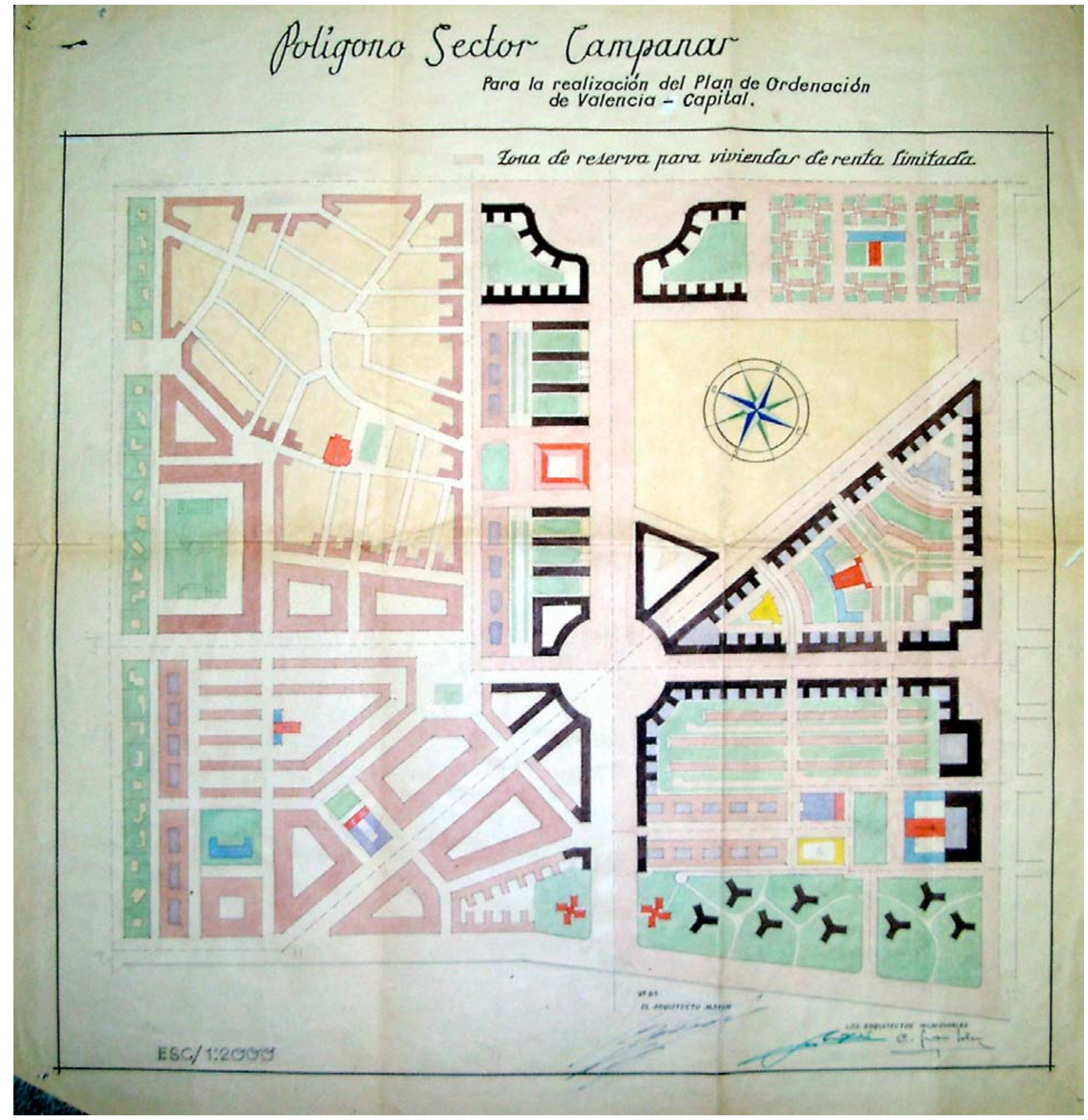

Proyecto de Ejecución del Polígono Sector Campanar para Viviendas de Renta Limitada, 1955. 
El "Proyecto de Ejecución del Polígono del Sector de Campanar con destino a la formación de solares para emplazamiento de viviendas de Renta Limitada" fue redactado en 1955 por los arquitectos José Pedrós Ortiz y Camilo Grau Soler ${ }^{1}$.

El sector de Campanar forma parte de las Hojas 8 y 9 de desarrollo del Plan General de 1946. Se trata de un área de forma casi cuadrada situada en el noroeste de Valencia, que engloba el poblado de Campanar y el Preventorio de San Francisco Javier. ${ }^{2}$

Este sector está limitado al sur por el río Turia, y atravesado de sur a norte por la prolongación de la Gran Vía de Fernando el Católico y en diagonal por el Camino de Tránsitos, a lo que se añade un eje este-oeste de directriz quebrada que coincide aproximadamente con la actual calle de Vall de la Ballestera.

La ordenación del sector que aparece en las Hojas 8 y 9 es de manzanas cerradas. En una primera propuesta de modificación de alineaciones, de mayo de 1955 , se introducen una serie de bloques en $U$ en la franja entre el poblado de Campanar y el eje central norte-sur, que se remata con una plaza circular delimitada por cuatro cuerpos de edificación simétricos.

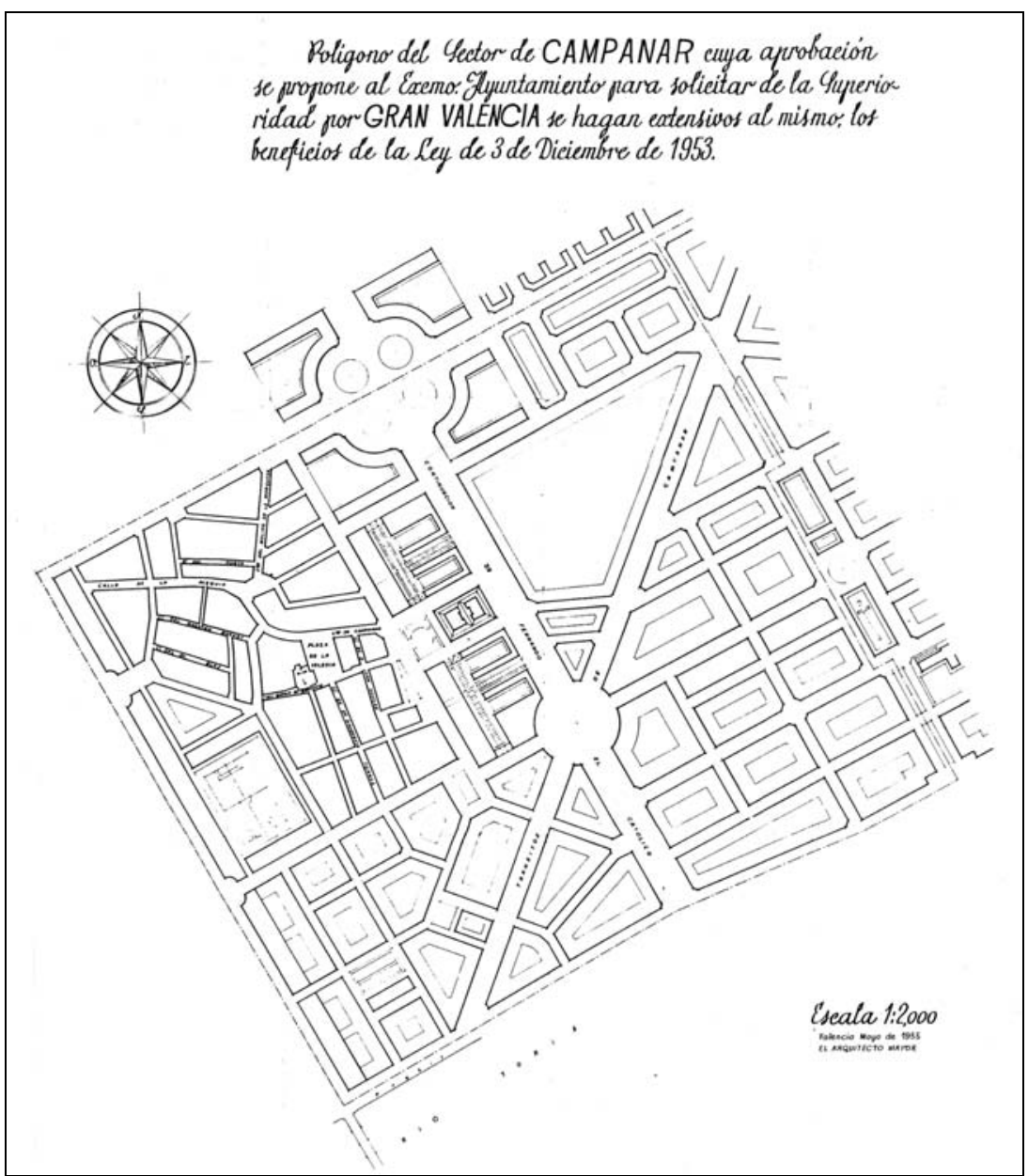

Polígono Sector Campanar, 1955. Propuesta de modificación de alineaciones, mayo 1955.

1. Ayuntamiento de Valencia. Proyecto de Ejecución del Polígono del Sector de Campanar con destino a la formación de solares para emplazamiento de viviendas de Renta Limitada, 1956. Ver Anexo de Documentos, pp. 47-51

2.El Plano Parcial no 8 fue redactado en octubre de 1951 y aprobado por la Comisión Central de Sanidad Local el 20 de diciembre de 1952. 


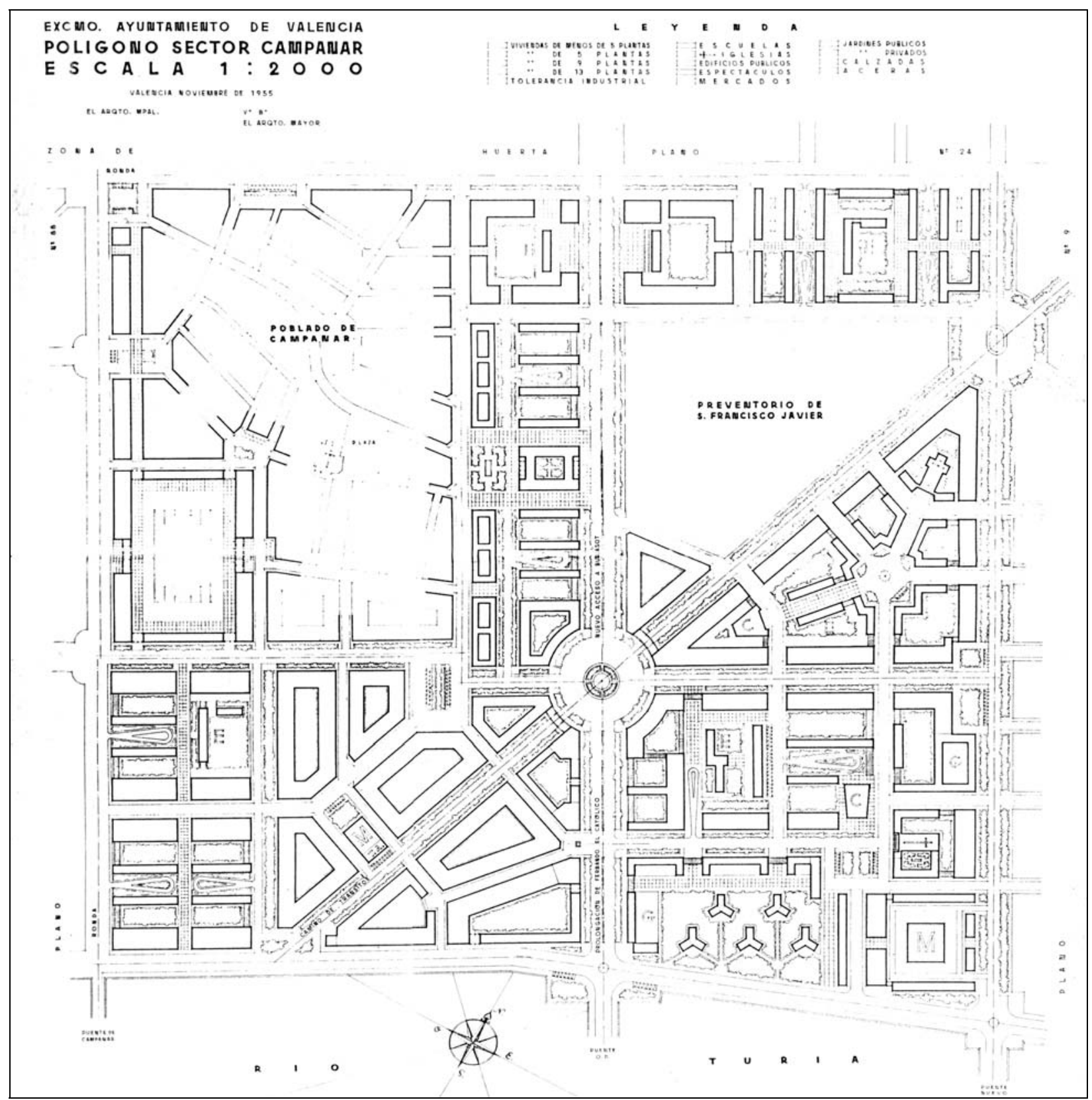

Polígono Sector Campanar,

noviembre 1955. 
La modificación sustancial de la ordenación de la zona se produce en el Proyecto de Ejecución del Polígono del Sector Campanar de 1955, en el que la mayor parte de las manzanas son sustituidas por edificación abierta. Esta sustitución, sin embargo, no comporta una modificación del trazado viario, que se mantiene prácticamente invariable.

No hay, por tanto, un nuevo proyecto global basado en el orden abierto, sino una mera sustitución de la edificación perimetral continua de las manzanas de ensanche por otra edificación más discontinua.

En el primero de los dos proyectos existentes para dicho Polígono, podemos ver que la edificación abierta está proyectada todavía con un pulso poco firme. Se introducen los nuevos tipos de edificios, pero la composición se apoya en la definición del espacio público de calles y plazas.

Así, la edificación abierta no asoma a las vías principales, excepto en dos puntos. El primero de ellos es la mitad este del frente al río Turia, donde se proyecta un grupo de torres con planta en $Y$ junto con dos torres en esvástica que flanquean el inicio de la proIongación de la Avenida Fernando el Católico. El segundo es el tramo de esta Avenida entre el eje este-oeste y la plaza circular, donde aparece una serie de bloques ortogonales.

El resto de las vías principales están flanquedas por bloques profundos en peine, por bloques profundos con patios interiores o por manzanas cerradas. Detrás de esta pantalla de edificación alineada, aparecen los bloques lineales de dos crujías.

La búsqueda de variedad en los tipos de edificios parece un objetivo del proyecto: además de las manzanas cerradas convencionales, y de edificación abierta en forma de bloques profundos, bloques delgados, torres en $Y$ o en esvástica, se prevé una banda de ciudad jardín con viviendas unifamiliares junto a la ronda oeste, así como un singular grupo de tres manzanas en la zona noreste formadas por la yuxtaposición de edificios con planta en esvástica.

En la versión del proyecto del Polígono de Campanar fechada en noviembre de 1955, podemos ver que el orden abierto resulta más evidente.

En esta versión del proyecto, los tipos de edificios que se combinan se reducen a tres: bloques lineales profundos, bloques de dos crujías y torres en $\mathrm{Y}$.

Los bloques profundos continúan asumiendo la función de delimitar calles y plazas, aunque las alineaciones son ahora más discontinuas, con más interrupciones, y con presencia a veces de los testeros de los bloques de dos crujías, que asoman al primer plano. Además, se suprimen los elementos urbanos más arcaizantes, como la plaza semicircular del borde norte.

El Polígono de Campanar, con su superficie considerablemente ampliada por el este, sería objeto de una nueva ordenación en 1960. En la nueva ordenación no se conservó ninguno de los elementos del Proyecto de Ejecución del Polígono de 1955. 


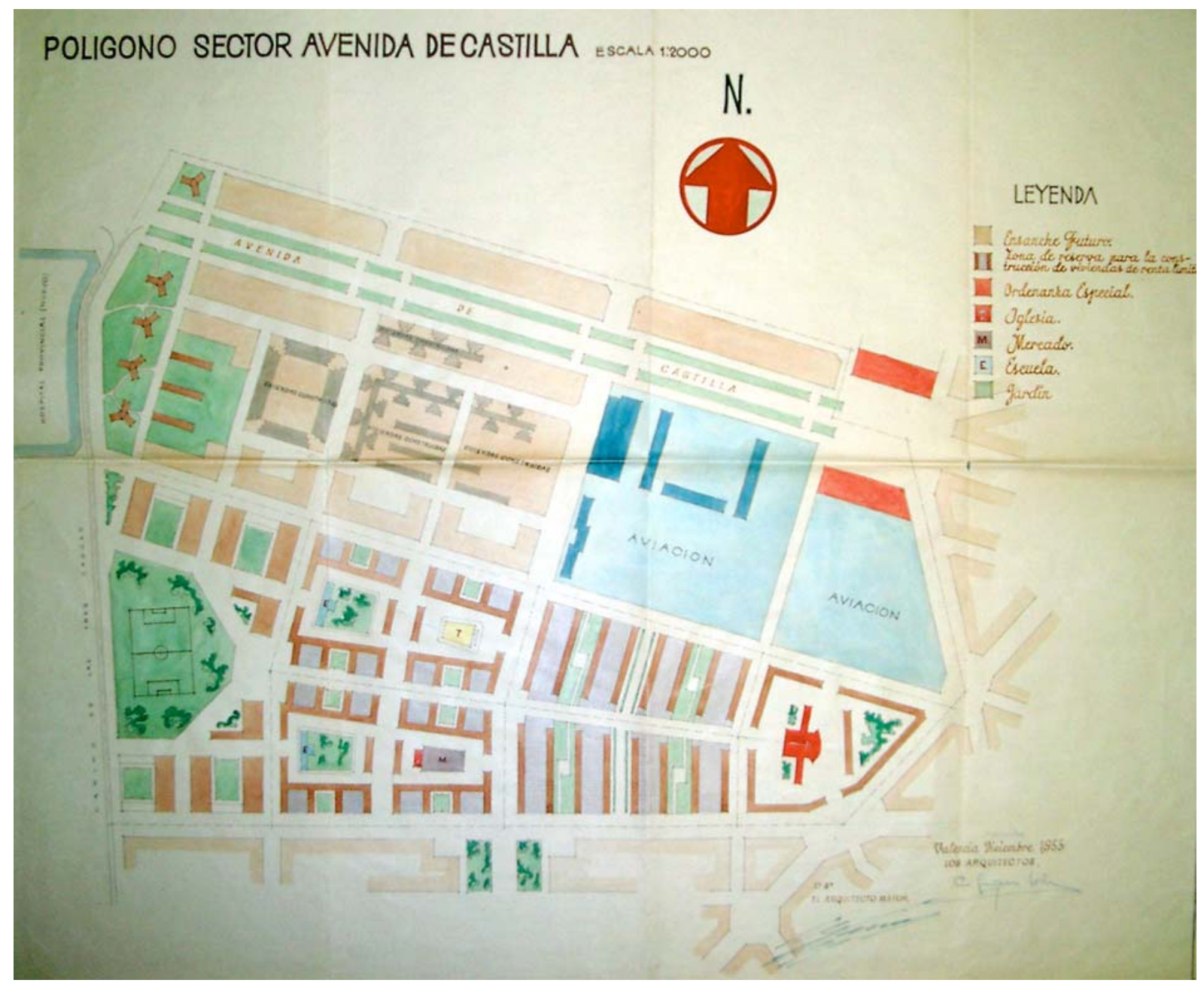

Polígono Sector Avenida de Castilla, 1955. Planta de nuevas alineaciones propuestas.

Líneas vigentes del Sector de la Avenida de Castilla destinado a la urbanización y formación de solares, 1955

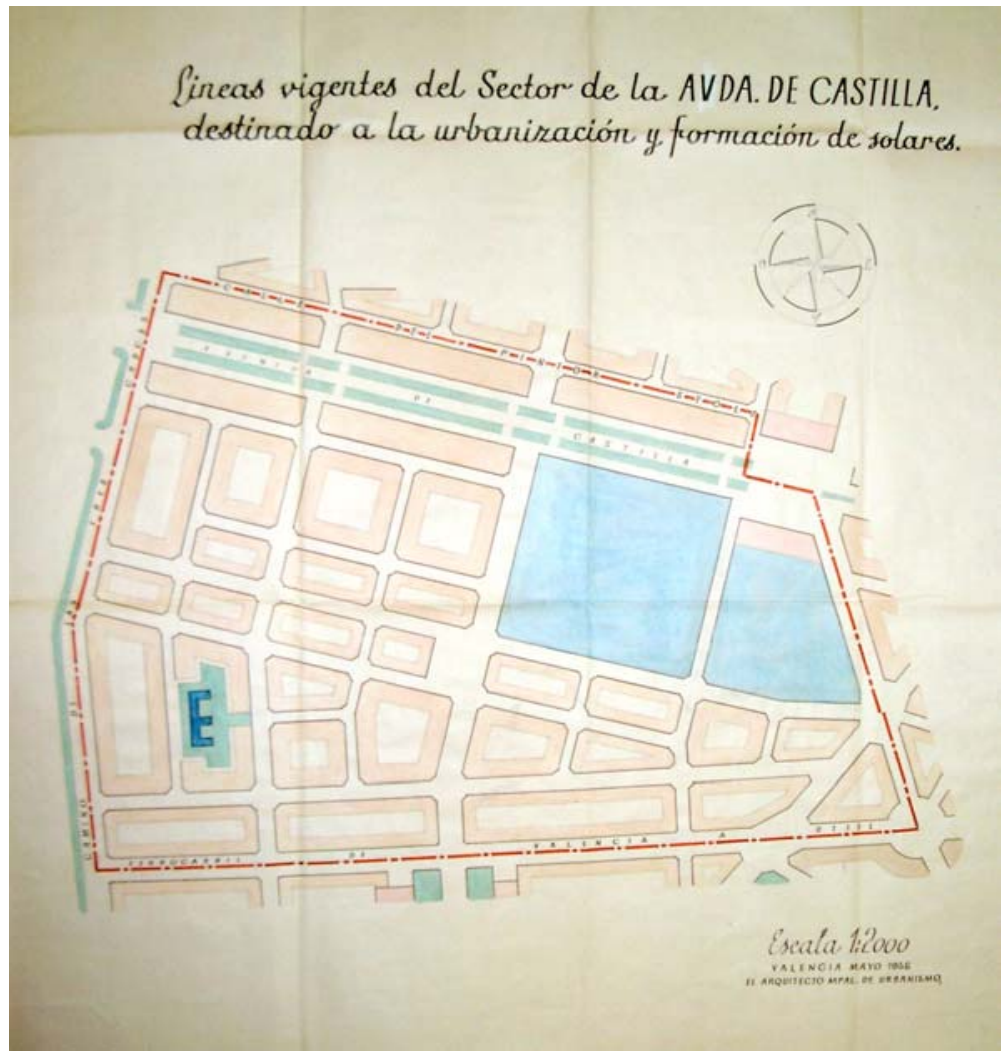




\section{POLÍGONO AVENIDA DE CASTILLA (1955)}

El "Proyecto de Ejecución del Polígono del Sector de la Avenida de Castilla con destino a la formación de solares para emplazamiento de viviendas de Renta Limitada" fue redactado en 1955 por los arquitectos Javier Goerlich Lleó y Camilo Grau Soler ${ }^{1}$.

El sector de la Avenida de Castilla forma parte del Proyecto Parcial I de desarrollo del Plan General de 1946. Se trata de un área de forma trapezoidal situada en el cuadrante suroeste de Valencia, cuyos límites son la Avenida de Castilla al norte, el Camino de Tres Cruces al oeste, la calle Tres Forques al Sur y las de Enguera y Archiduque Carlos al este.

La calle Músico Ayllon, que discurre de este a oeste, divide en dos el polígono, cuya mitad sur es la que es realmente objeto de una nueva ordenación, ya que la mayor parte de la mitad norte está ocupada por el grupo Virgen de los Desamparados y los cuarteles de Aviación.

La ordenación del sector realizada en el Proyecto Parcial I es de manzanas cerradas que rellenan la totalidad del espacio disponible, sin zonas verdes ni equipamientos de ningún tipo, excepto una pequeña parcela escolar.

En la nueva ordenación, se sustituyen las manzanas cerradas por edificación abierta: bloques lineales de cinco y tres crujías, bloques a redents y torres con planta en $\mathrm{Y}$. Se proyecta, además, un nuevo trazado viario para la mitad sur del polígono, y se destina una apreciable cantidad de suelo a zonas verdes y equipamientos diversos.

El nuevo viario se compone de un eje central trazado a lo largo de la bisectriz de las calles Músico Ayllón y Tres Forques y una serie de calles transversales ortogonales a dichas calles, que acometen por tanto de manera oblicua al eje central. En los dos extremos de dicho eje se sitúan equipamientos: una zona verde y deportiva al oeste y una Iglesia al este, cerrando la perspectiva.

Los distintos tipos de edificios proyectados no se mezclan, sino que se sitúan en franjas homogéneas separadas por las calles transversales. En la primera franja, en torno a la zona deportiva del extremo oeste, aparecen bloques profundos aislados, dispuestos en perpendicular a las calles de borde. La segunda franja está ocupada por cuatro bloques a redents, dos alineados con el perímetro y dos flanqueando el eje central; el espacio libre entre los bloques exteriores y los interiores se destina a jardines y equipamientos. La tercera franja está ocupada por bloques lineales ortogonales a las calles perimetrales, y la última está formada por varios bloques lineales que envuelven la Iglesia.

En el espacio situado frente al Hospital Provincial, único disponible de la mitad norte del Polígono, se proyecta un grupo de cuatro torres con planta en $Y$, de acompañadas por algunos bloques lineales en segundo plano. Una quinta torre al otro lado de la Avenida de Castilla completa el conjunto.
4.Ayuntamiento de Valencia. Proyecto de Ejecución del Polígono del Sector de la Avenida de Castilla con destino a la formación de solares para emplazamiento de viviendas de Renta Limitada, 1956. Ver Anexo de Documentos, pp. 53-57. 


\section{VALENCIA CAPITAL : ordenación del sector de Monteolivete}

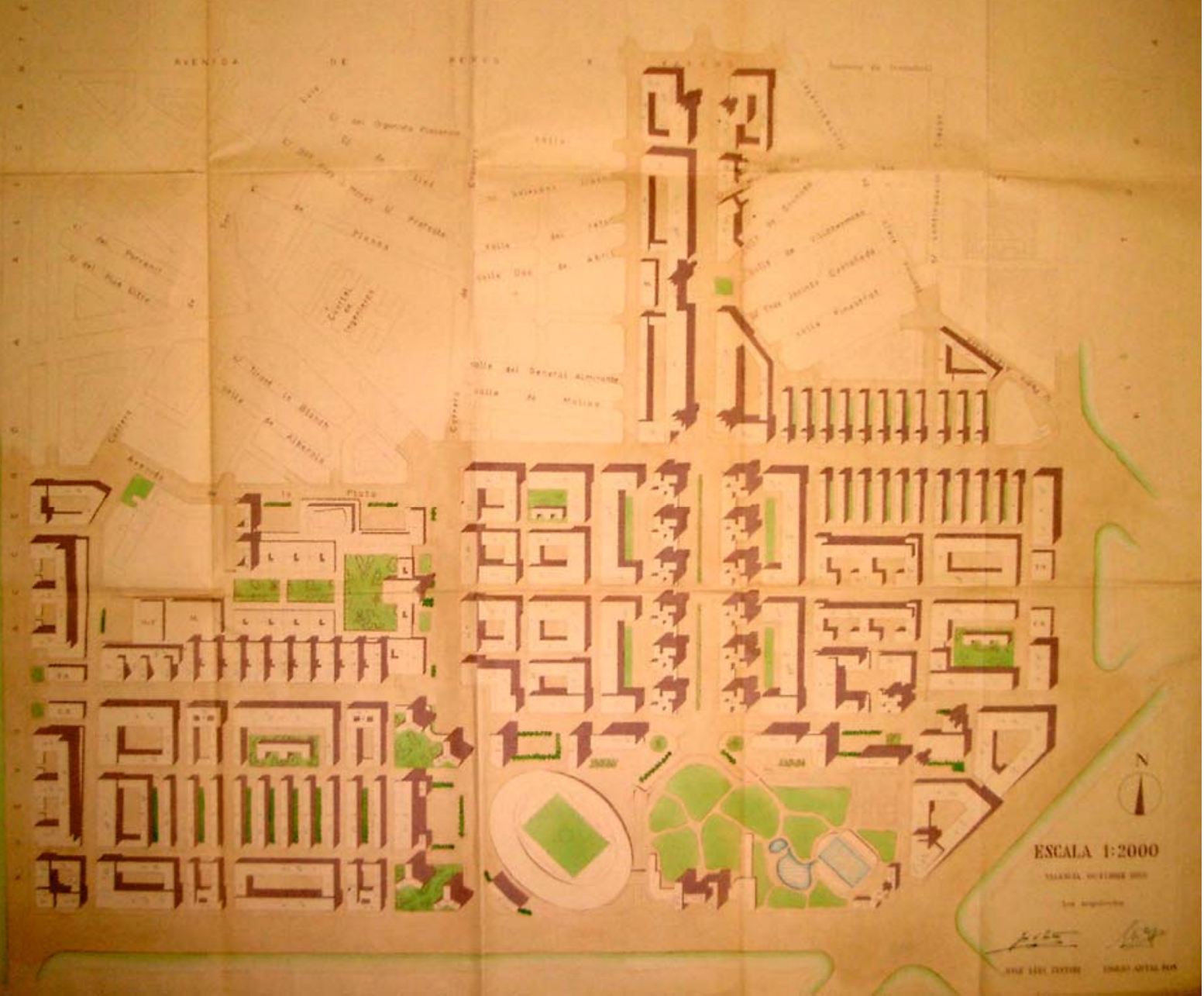

Polígono Sector Monteolivete, 1956. Plano de volúmenes.

Líneas vigentes del Sector de Monteolivete destinado a la urbanización y formación de solares para viviendas de Renta Limitada, 1956.

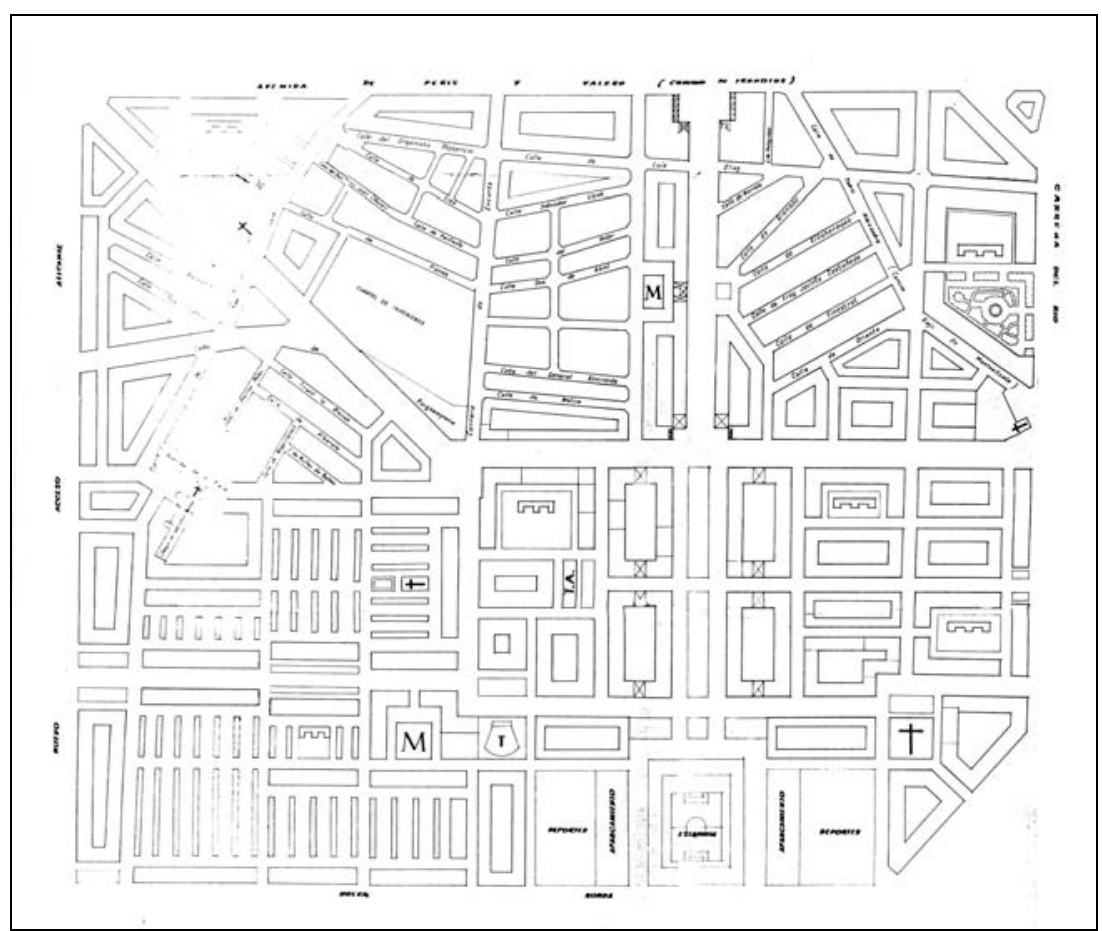


El "Proyecto de Ejecución del Polígono del Sector de Monteolivete con destino a la formación de solares para emplazamiento de viviendas de Renta Limitada" fue redactado en 1956 por los arquitectos José Luís Testor Gómez y Emilio Artal Fos ${ }^{1}$.

El sector de Monteolivete objeto de este proyecto ocupa la mayor parte del área ordenada en el Proyecto Parcial no IV de desarrollo del Plan General de 1946. Se trata de un área situada en el cuadrante sureste de Valencia, compuesta por dos rectángulos de superficie desigual -el superior de menor extensión que el inferiorunidos por la Avenida de la Plata y la continuación de la misma. Los límites del sector son la Avenida de Peris y Valero al norte, el Camino Nuevo de Monteolivete o del Saler al este, la ronda formada por el nuevo desvío del Ferrocarril de Valencia a Tarragona al sur y el nuevo acceso a Alicante al oeste.

El Proyecto Parcial no IV, aprobado en 1953, ya incluía una extensa zona de edificación abierta, que hemos analizado anteriormente. Tres años más tarde, el nuevo proyecto modifica completamente la ordenación anterior, aunque conservando los ejes viarios principales.

El principal eje interno, que ya estaba previsto en el Proyecto Parcial no IV, es la llamada Gran Avenida en el nuevo proyecto: un eje norte-sur de $40 \mathrm{~m}$ de ancho que prolonga la calle Luís Santángel. Esta Avenida, de $1 \mathrm{Km}$ de longitud, comienza en una plaza en la Avenida de Peris y Valero y termina en un parque tras el cual, como fondo de perspectiva, se emplaza un gran edificio de 25 plantas.

Se mantienen también los dos ejes principales en dirección este-oeste previstos en el Proyecto Parcial no IV. El primero de ellos es el que separa la zona de manzanas de ensanche del bario de Moneolivete de la nueva extensión urbana, y está constituido por la Avenida de la Plata y su prolongación hasta el Camino del Saler a partir de una plaza en la que se desplaza el eje y a la que acometen la Carrera de Encorts y la vía que cruza Moneolivete en diagonal (actual Avenida Doctor Waksmann).

El segundo eje este-oeste, que coincide aproximadamente con la actual Avenida Hermanos Maristas, atraviesa la zona de edificación abierta desde el acceso de Alicante hasta el Camino del Saler, y tiene también una cambio de eje a partir de una plaza situada a la misma altura que la plaza del eje de la Avenida de la Plata.

Estas dos plazas se enlazan mediante un eje norte-sur paralelo a la Gran Avenida, en prolongación de la Carrera de Encorts. Desde la segunda plaza, este eje continúa en el nuevo proyecto hasta la Ronda que limita la zona por el sur.

En cuanto a la edificación, lo primero que hay que destacar es el modo en que se representa, mediante un plano de volúmenes con las sombras arrojadas por los edificios, que es el plano característico del urbanismo moderno ${ }^{2}$.
1.Ayuntamiento de Valencia. Proyecto de Ejecución del Polígono del Sector de Monteolivete con destino a la formación de solares para emplazamiento de viviendas de Renta Limitada, 1956. Ver Anexo de Documentos, pp. 59-69.

2. La rotulación del plano de volúmenes es también moderna, con letras de plantilla similares a las usadas por Le Corbusier. 


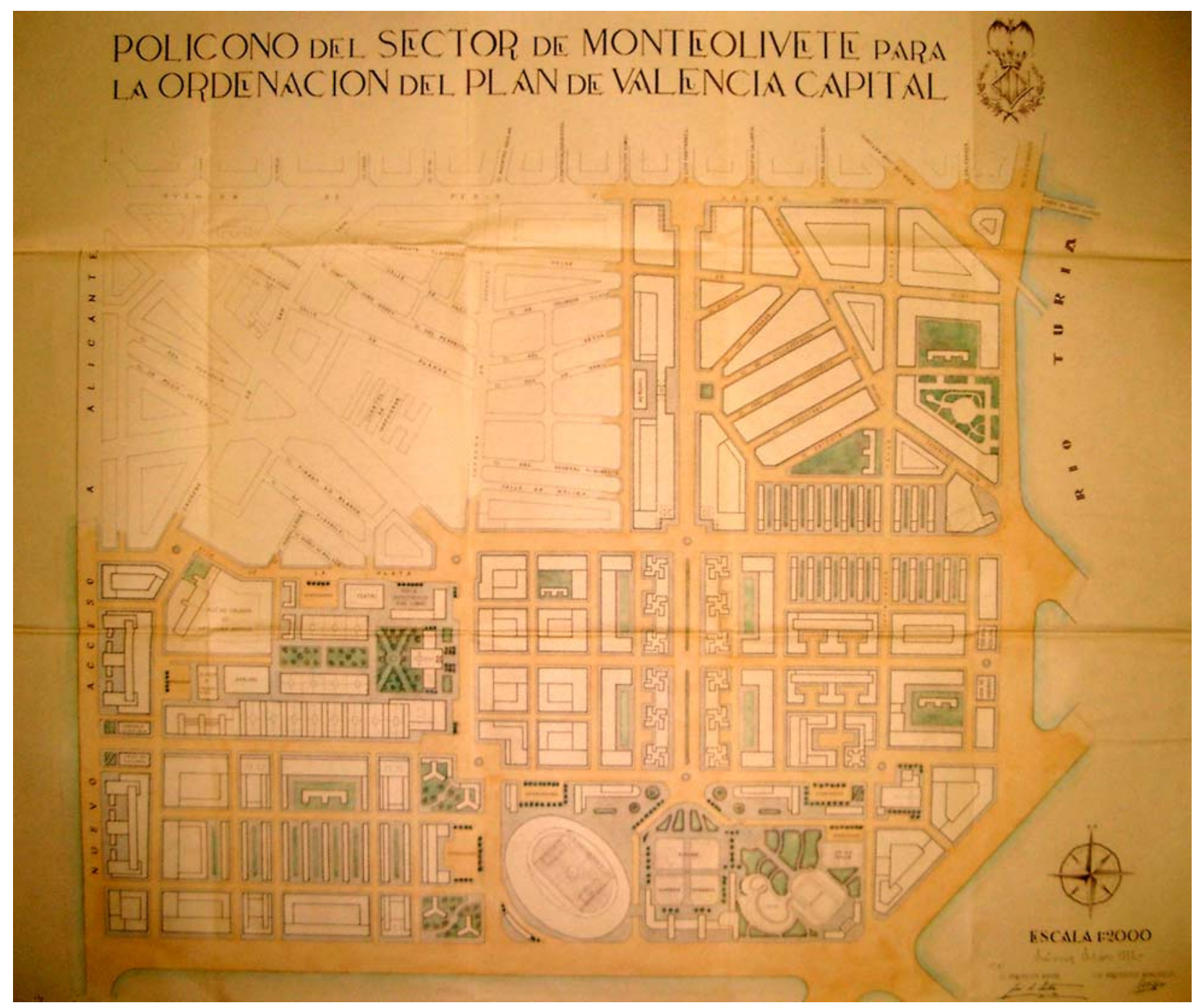

Polígono Sector Monteolivete, 1956. Plano de pavimentación de aceras y calzadas.

Polígono Sector Monteolivete, 1956. Hoja de alineaciones propuestas superpuesta a parcelario de estado actual.

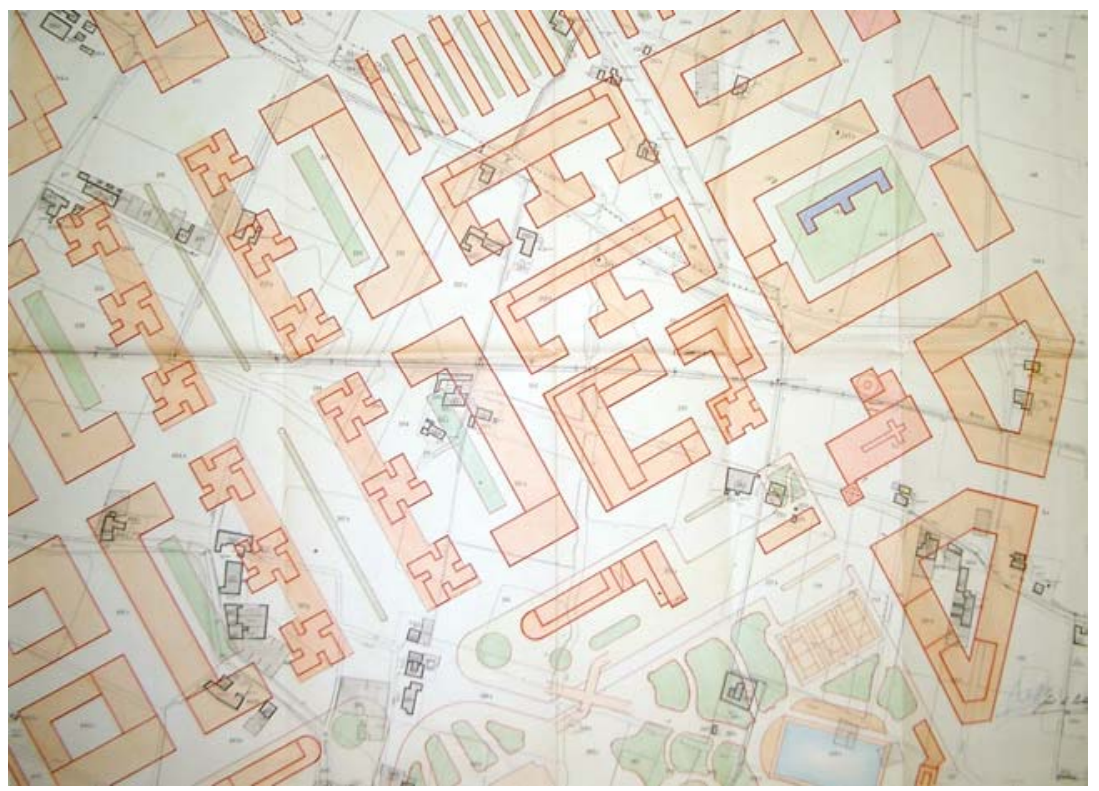


Igual que ocurre en los demás proyectos para polígonos de 1955-56, a los tipos iniciales de la edificación abierta en Valencia (bloques lineales de dos o cinco crujías y bloques en peine) se añaden las torres con planta en $\mathrm{Y}$ o en esvástica.

La principal diferencia con respecto al Proyecto Parcial IV, anterior plan para la zona, en cuanto a la edificación abierta es que ésta asume el protagonismo en la configuración de los ejes principales, en vez de ser un relleno de un espacio intermedio entre bloques profundos que flanquean dichos ejes.

Así, por ejemplo, series de torres con planta en esvástica unidas por bajos comerciales aparecen a ambos lados de la Gran Avenida, en el tramo central de la misma, comprendido entre los dos ejes principales este-oeste.

En el tramo entre la Gran Avenida y el Camino del Saler del eje este-oeste que prolonga la Avenida de la Plata, se proyectan bloques lineales ortogonales a ambos lados del eje.

En el eje este-oeste que coincide con la actual Avenida Hermanos Maristas, encontramos en un primer tramo un flanco sur ocupado por bloques profundos al que se opone un frente norte formado por bloques ortogonales al eje. Después, una pareja de torres en $\mathrm{Y}$ se sitúan junto a la plaza intermedia. En tramo siguiente, unas torres de planta rectangular se sitúan delante de las parcelas destinadas a equipamientos en el lado sur, mientras que en el lado norte los bloques profundos alineados se interrumpen en el encuentro con la Gran Avenida, donde emergen las dos primeras torres de la misma.

Los bloques profundos a redents, con patios abiertos a la caIle, se utilizan para ordenar el frente oeste abierto al acceso de Alicante, así como algunas manzanas de la mitad este del sector.

Los bloques lineales envueltos por un perímetro de bloques profundos se mantienen únicamente en la parte suroeste del sector.

La presencia en el sector de zonas ordenadas mediante manzanas cerradas o semiabiertas intercaladas entre bloques de edificación abierta es una prueba más de que uno de los objetivos básicos de estos proyectos era la diversificación de los tipos de edificios y, por tanto, de viviendas.

En cuanto a los equipamientos, además de las parcelas escolares diseminadas por el sector, se proyectan dos grandes áreas de concentración de equipamientos. La primera, ya prevista en el Proyecto Parcial IV, es la situada al final de la Gran Avenida, entre el eje este-oeste y el límite sur. En ella se sitúa un gran parque y un estadio, junto con otras instalaciones deportivas diversas.

El segundo núcleo de equipamientos es una gran zona comercial situada en el cuadrante noroeste, junto a la Avenida de la Plata y al eje norte-sur que prolonga la Carrera de Encorts.

Además, se localizan diversos equipamientos de menor escala, como Tenencias de Alcaldía, Casas de Socorro, Retén de Bomberos o Iglesias, junto a plazas o intersecciones viarias importantes. 


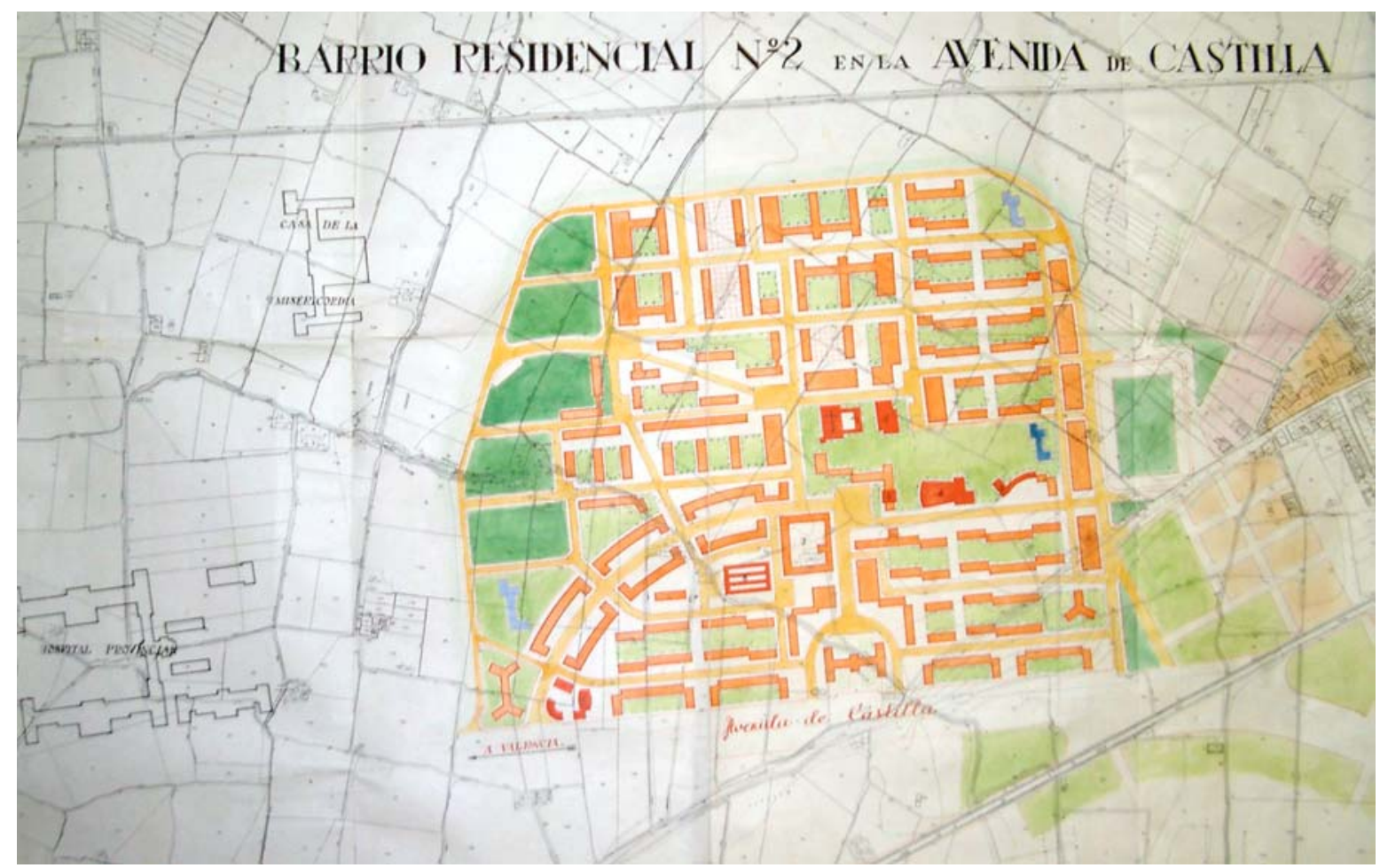

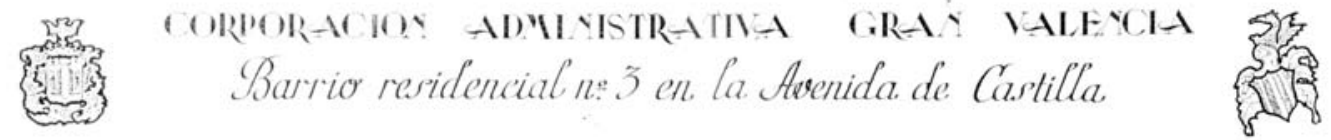

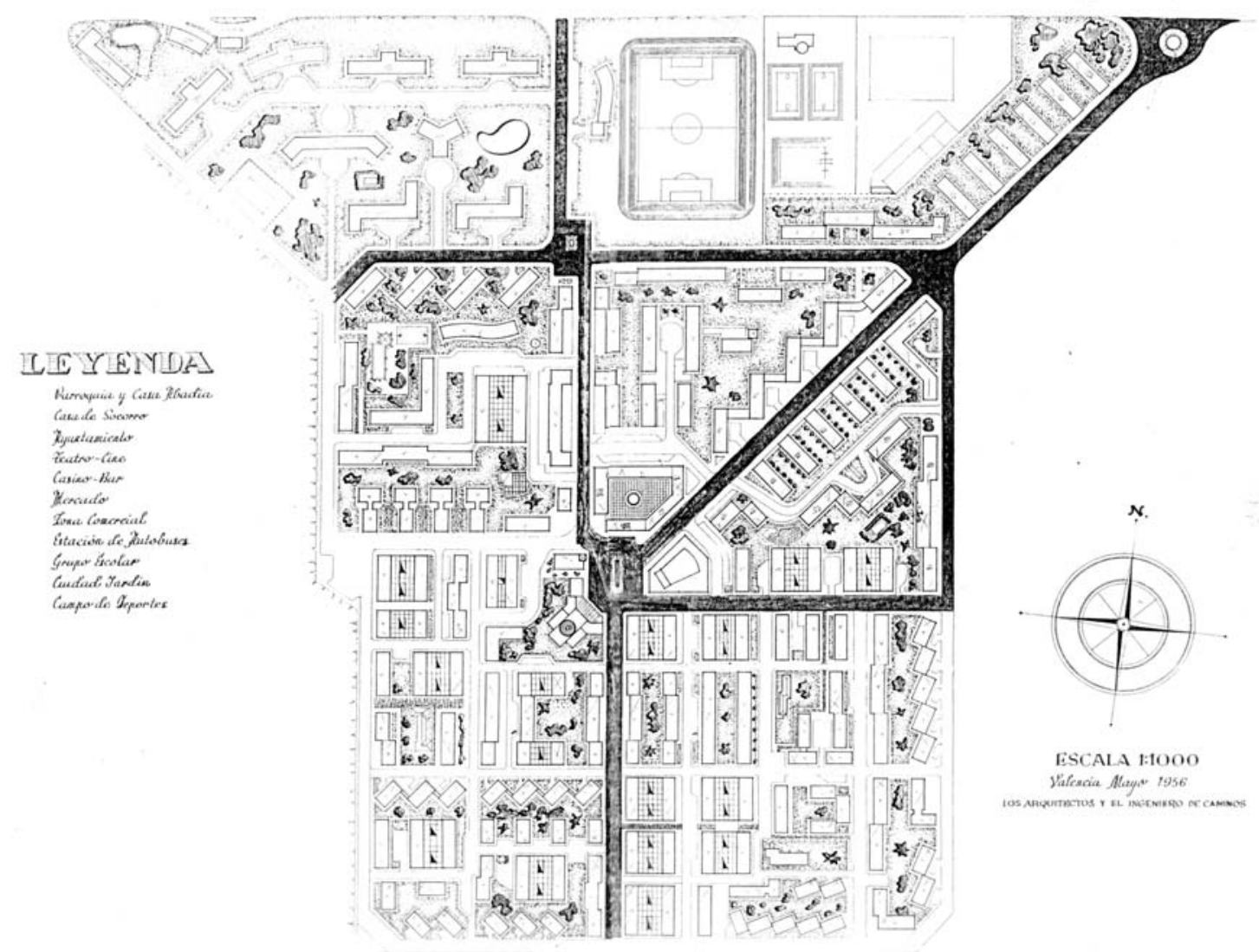




\section{LOS BARRIOS RESIDENCIALES No 2 Y 3 EN LA AVENIDA DE CASTILLA (1956).}

Las propuestas de la Corporación Administrativa Gran Valencia para os Barrios Residenciales no 2 y 3 en la Avenida de Castilla ${ }^{1}$ son, junto con los Proyectos para los Sectores de Paseo al Mar, Monteolivete, Campanar y Avenida de Castilla, las primeras que plantean un crecimiento de la ciudad por sectores completos, en lugar de una mera extensión urbana. Estos proyectos pueden por ello considerarse como antecedentes de los polígonos de promoción pública del periodo posterior.

El barrio residencial no 2 está localizado entre el Hospital Provincial y la población de Xirivella, y la Avenida de Castilla es su límite norte ${ }^{2}$. El barrio no 3, por su parte, está situado en el término municipal de Quart de Poblet.

El barrio no 2 está proyectado íntegramente con edificación abierta, la mayor parte de la cual adopta la forma de bloques lineales de dos crujías de directriz este-oeste o norte-sur, que a veces presentan retranqueos o cuerpos cortos de edificación en sus extremos. Hay también algunos bloques profundos, y bloques singulares con planta en $\mathrm{Y}$ o doble $\mathrm{Y}$. También existe una zona en el borde este de manzanas calificada como ciudad-jardín.

Los bloques lineales adoptan dos disposiciones: en parejas, alineados con los lados largos de la manzana en la que se sitúa, dejando un espacio verde intermedio, o en series de bloques ortogonales a las calles perimetrales, con espacios verdes intercalados.

El viario que se proyecta para el barrio no 2 se organiza a partir de dos ejes oeste-este que comienzan a uno y otro lado del estadio proyectado junto al ensanche de Xirivella. Uno de estos ejes se desvía hacia el sur en diagonal a mitad de su recorrido, y funciona como eje colector del viario secundario interno.

El segundo eje este-oeste, que es el principal, comienza en Xirivella y llega a la plaza central del barrio, donde se bifurca en un eje norte-sur que termina en la Avenida de Castilla, tras bordear el edificio destinado a estación de autobuses que cierra la perspectiva. A partir de la plaza, el eje se prolonga con un trazado curvo hasta desembocar en la Avenida de Castilla en el vértice noreste.

Los equipamientos se concentran en el espacio intermedio entre los dos ejes de dirección este-oeste. Alrededor de un parque, se sitúan una escuela, una iglesia, un casino-bar, un teatro-cine, y un Ayuntamiento, este último recayente a la plaza principal, a la que se abre igualmente el edificio de Mercado, junto al que se sitúa una zona comercial.

El Barrio Residencial no 3, por su parte, es un proyecto que muestra un uso más titubeante de la edificación abierta, con bloques excesivamente cortos y un exceso de variedad tanto en las formas como en la disposición de los diferentes tipos de bloques, que se yuxtaponen de un modo poco justificado.
Página opuesta: Barrios Residenciales $N^{\circ} 2$ y 3 en la Avenida de Castilla. Corporación Metropolitana Gran Valencia, 1956.

1.Corporación Administrativa Gran Valencia. Barrios Residenciales No 2 y 3 en la Avenida de CastiIla, 1956. Ver Anexo de Documentos, pp. 35-39.

2.A esta ordenación proyectada para el Barrio Residencial no 2 tuvo que ajustarse el Barrio de la Luz, construido a partir de 1958 y que analizaremos posteriormente. 


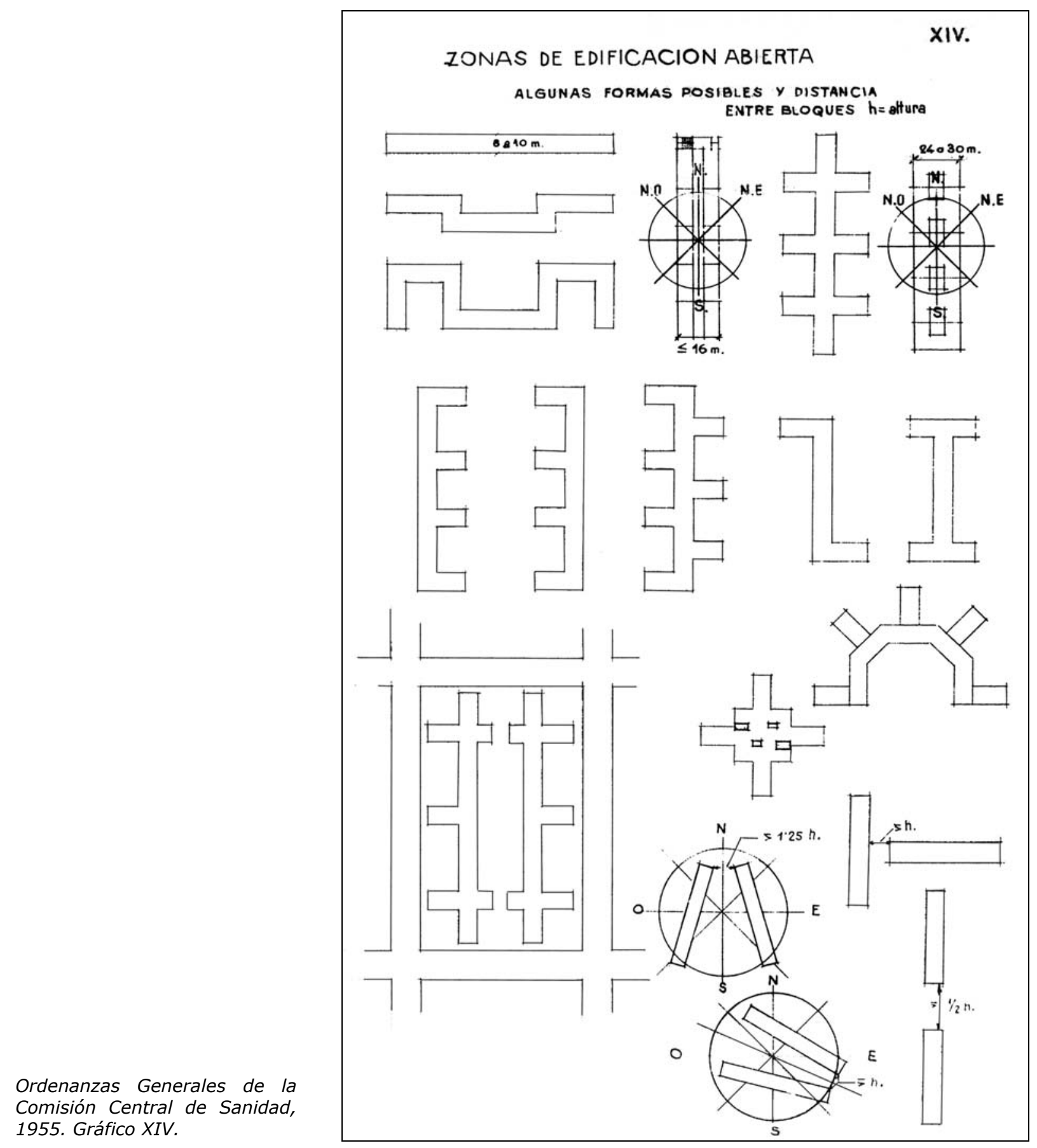




\section{LA DEFINICIÓN DEL MARCO NORMATIVO GENERAL DE LA EDIFICACIÓN ABIERTA}

\section{La regulación de la edificación abierta en las Ordenanzas de la Comisión Central de Sanidad Local de 1955}

El Plan de Ordenación de Valencia y su Cintura de 1946 incluía un proyecto de bases generales para las Ordenanzas reguladoras de la edificación. Posteriormente, la Comisión Central de Sanidad Local redactó las Ordenanzas Generales de la Edificación números 1 a 6, aprobadas en 1951, que se completaron con las ordenanzas números 7 a 12, aprobadas en 1955.

Estas Ordenanzas tendrán un largo periodo de vigencia, ya que las Normas Urbanísticas del Plan General de 1966 no añadieron gran cosa a las mismas. Una buena parte de los Planes Parciales de desarrollo de éste Plan remiten a esas Ordenanzas.

Las zonas de edificación abierta están reguladas en la Ordenanza Especial no 9. El Art. 173 define estas zonas del modo siguiente:

En las zonas a que se refiere la presente Ordenanza estará constituida, en general, la edificación por bloques sin patios interiores de ninguna clase, rodeados de espacio abierto, excepto en los casos en que los planos indiquen lo contrario, al establecerse, en partes de la zona, bloques de más de dos crujías o manzanas cerradas para situar comercios, garages, salas de espectáculos, etc., o bien para limitar vías de tráfico.

Las formas permitidas de edificación serán siempre las derivadas del edificio a doble crujía, sin patios interiores ni de manzana, constituyendo, por lo tanto, bloques alargados, de la profundidad que indiquen los planos. La forma principal de bloque lineal podrá doblarse y ramificarse. Cuando este previsto en los planos parciales de alineación y zonificación puede también realizarse bloques alargados de más de dos crujías ${ }^{1}$.

Estas formas posibles para la edificación abierta están dibujadas en el gráfico XIV.

En cuanto a las condiciones de las parcelas, el Art. 174 señala lo siguiente:

El terreno de estas zonas, destinado a la edificación por particulares, se divide en dos partes: la de construcción propiamente dicha y parte delantera o posterior arbolada o ajardinada. Este terreno ajardinado, mientras no sea propiedad municipal, deberá cercarse en las condiciones que se indicaran y junto con el edificable, constituyendo la parcela edificable cuyas condiciones ha de determinar este artículo. ${ }^{2}$

En el gráfico XV, que complementa el Art. 174, podemos ver que la parcela tipo de la edificación abierta se identifica como un fragmento de bloque lineal con un frente mínimo de $7 \mathrm{~m}$. de anchura. La parcela se concibe de modo similar a la propia de una vivienda en hilera con espacios libres delante y detrás de la edificación, siendo medianeras los lados que limitan con los fragmentos de bloque colindantes.

1.Ordenanzas Generales de la Comisión Central de Sanidad, 1955. Art. 173. Ver Anexo de Documentos, pp. 7-19. 
Por lo que se refiere a los usos permitidos en las zonas de edificación abierta, el Art. 175 de las Ordenanzas señala lo siguiente:

Estas zonas son de carácter residencial y, por lo tanto, solamente se permitirán comercios en las calles comerciales señaladas en los planos y pequeños comercios, garages con capacidad máxima de seis coches y actividades artesanas en las plantas bajas de las edificaciones de las restantes calles. ${ }^{1}$

El Art. 175 indica también los usos a los que deberán destinarse los espacios libres de parcela y los intermedios entre bloques:

Los espacios comprendidos entre edificación y calle, estarán ajardinados o arbolados y deberán cerrarse con muro de 0'80 m. de altura, con o sin verja, o bien con seto vivo recortado de 0'80 a $1 \mathrm{~m}$. de altura.

Los espacios comprendidos entre edificaciones no podrán cercarse más que para separarlos de la calle y serán destinados a jardín y juego de niños.

Podrán establecerse calles particulares, que podrán cerrarse con verja o seto, como se ha dicho, y de la misma forma las parcelas recayentes a ellas. ${ }^{2}$

Los espacios libres de parcela, por tanto, pueden ser públicos o privados, pero siempre deberán destinarse a jardines y zonas de recreo.

En cuanto al volumen de la edificación, el Art. 176 señala lo siguiente:

La altura de los edificios, mientras en los planos no se especifique otra cosa, queda regulada por la distancia entre ellos en la siguiente forma: la distancia mínima entre las fachadas de dos bloques alargados, cuyos ejes sean paralelos, será igual a la altura, cuando la orientación de los ejes esté en el cuadrante N.E.-S.E. y de una vez, más un cuarto de la altura, cuando esté en el cuadrante N.O. La distancia entre la fachada de un bloque y otro de dirección normal será igual a 2/3 de la altura. La distancia entre bloques alineados, es decir, cuyos ejes están en la misma dirección, será de $1 / 2$ de la altura. Se considerará a estos efectos paralelo, aunque no lo sea exactamente, cuando el ángulo de los ejes sea menor o igual o de $30^{\circ}$. La altura de que se habla es la altura a cornisa sobre la cual sólo podrá edificarse la baranda del terrado, de 1'20 m. Sobre esta altura el resto de protección que se desea será verja metálica. La escalera no podrá acusar torre en fachada, para evitar sea visible desde el exterior y se rompa la línea de coronación de los bloques.

Los espacios entre bloques situados en manzanas distintas se contarán por mitad a partir del eje de la calle. ${ }^{3}$

El Art. 176 indica también que la distancia entre bloques que ramifiquen otros, en forma de peines o redientes se fijarán aplicando las reglas anteriores a los elementos que se forman.

1.Ordenanzas Generales de la Comisión Central de Sanidad Local, 1955. Art. 174. Ver Anexo de Documentos, pp. 7-19.

2.Ibid., Art. 175.

3.Ibid., Art. 176.

Estas reglas están representadas gráficamente en el gráfico XIV. Es notable la introducción en la ordenanza de condiciones relacionadas con la orientación de los bloques, como el aumento de la distancia entre los mismos bloques cuando su directriz principal es norte-sur, para consegur una mayor penetración en el espacio entre los bloques de la luz solar más baja procedente del este o del oeste. 
El Art. 176 señala además las alturas mínimas de plantas, que se fijan en $3,60 \mathrm{~m}$. para la planta baja y en $3 \mathrm{~m}$. para la planta tipo, forjado incluido. Se señala, asimismo, que el número mínimo de plantas permitidas es de cuatro.

La regulación de áticos y voladizos se realiza en los Artículos 177 y 178 . Los voladizos sepermiten cuando la distancia entre bloques es mayor de $16 \mathrm{~m}$, y cuando el bloque no linda con la calle la mitad de la fachada puede estar ocupada por miradores cerrados de ancho $1 \mathrm{~m}$. Desde la segunda planta, pueden construirse balcones de ancho $1 \mathrm{~m}$, separados 0,60 $\mathrm{m}$. del predio vecino ${ }^{1}$.

Por último, el Art. 180 se refiere al Ornato, y señala que ambas fachadas de cada bloque ostentarán la misma categoría decorativa en cuanto a materiales, elementos y composición. El artículo indica asimismo que cuando no exista una terraza común accesible deberán preverse en cada vivienda tendederos, que tendrán una celosía que oculte vistas a fachada.

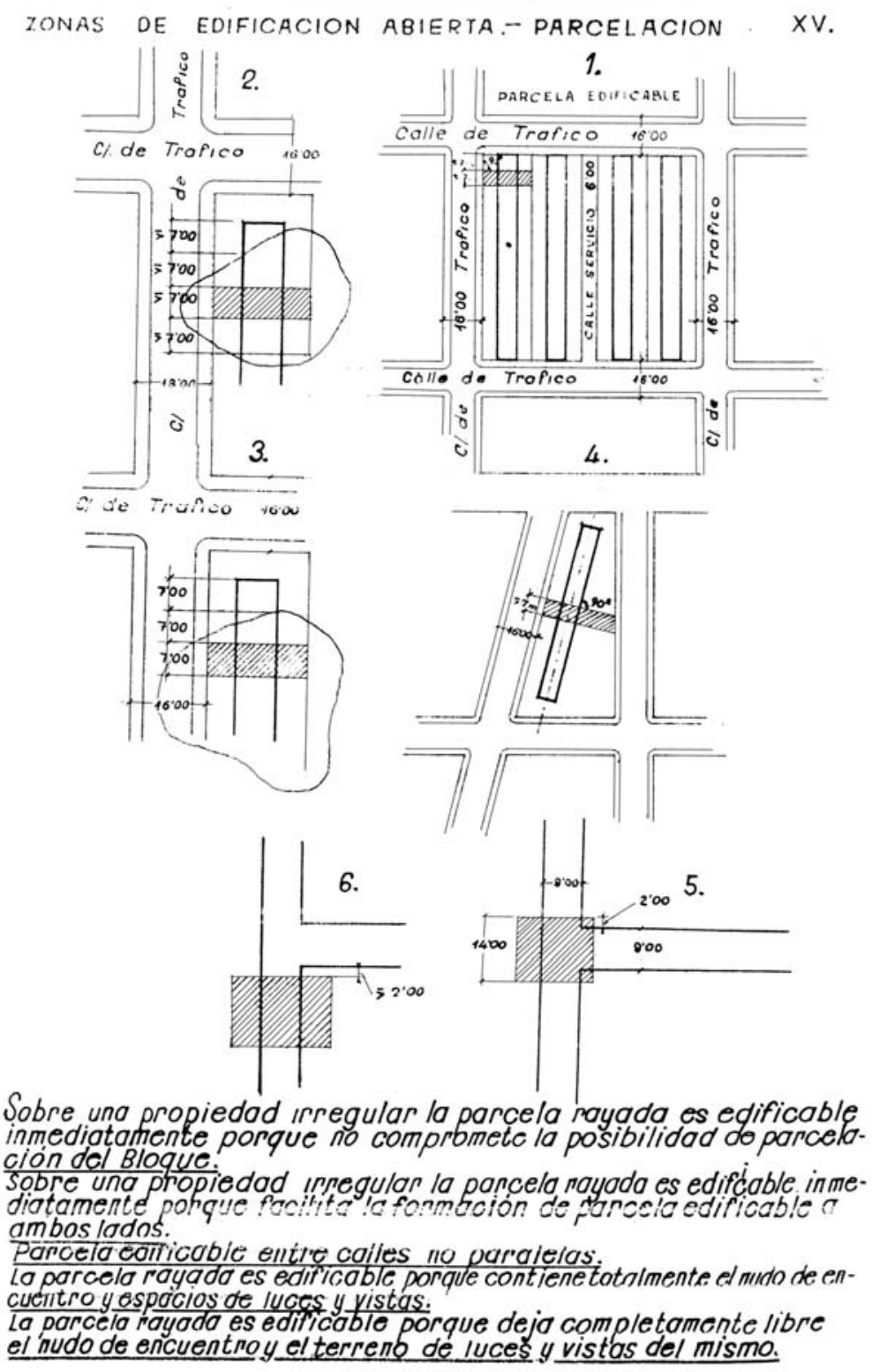

Ordenanzas Generales de la Comisión Central de Sanidad, 1955. Gráfico XV.
1. El Art. 178 de las Ordenanzas indica también que cada vivienda podrá tener una terraza con desarrollo lineal máximo de $6 \mathrm{~m}$. y saliente de 1'30 m. Este voladizo, para ser considerado terraza, tendrá que tomar hacia dentro por lo menos $0,70 \mathrm{~m}$. 


\section{Los Planes Parciales en la Ley del Suelo de 1956}

La Ley de Régimen del Suelo y Ordenación Urbana aprobada el 12 de mayo de 1956 es el marco normativo general de los Planes Parciales redactados en Valencia a largo de todo el periodo de vigencia doctrinal de los principios del orden abierto.

El artículo 10 de la Ley del Suelo señala las determinaciones y documentación que deben integrar los Planes Parciales:

"1. Los Planes parciales de ordenación municipal o comarcal, para el desarrollo del Plan general, contendrán estos extremos:

a) Delimitación de perímetros de las zonas en que, por su distinta utilización, se divide el territorio urbano.

b) Señalamiento de alineaciones, nivelaciones y características de las vías y plazas que se deben conservar, modificar o crear.

c) Superficies para espacios libres.

d) Emplazamientos reservados en cada zona a edificios y servicios públicos.

e) Reglamentación del uso de los terrenos, en cuanto a volumen, destino y condiciones sanitarias y estéticas de las construcciones y elementos naturales, en cada zona.

2. Los Planes Parciales estarán integrados por los documentos siguientes:

a) Memoria justificativa de la ordenación, de las etapas para realizarla y de los medios económico-financieros disponibles y que deberán quedar afectos a la ejecución del Plan.

b) Planos de información que muestren el estado de los terrenos objeto de ordenación en su topografía, construcciones y vegetación existentes y uso a que se destinan.

c) Planos de proyecto, normalmente a escala de 1:2.000, con curvas de nivel de metro en metro, referidos a los extremos que señalan los apartados a) a d) del párrafo anterior.

d) Esquemas de los servicios de agua, alcantarillado, alumbrado, transporte $y$, en general, de los servicios mínimos obligatorios asignados a los Municipios por la Ley.

e) Ordenanzas reguladoras de las materias enunciadas en el apartado e) del párrafo anterior. ${ }^{\prime 1}$

El procedimiento administrativo para la tramitación de los Planes Parciales está regulado en los artículos 32 a 35 de la ley del Suelo, y consta de las etapas siguientes:

- Redacción del Plan Parcial por el Ayuntamiento u organismo competente para ello.

- Aprobación inicial del Plan.

- El Plan se somete a información pública durante un periodo de un mes, plazo en el que se pueden presentar reclamaciones de organismos o particulares afectados.

- Aprobación provisional del Plan, con las modificaciones que puedan resultar del periodo de información pública.

- Remisión del Plan al Consejo Nacional de urbanismo del Ministerio de la Vivienda o Comisión de Urbanismo competente, para su evaluación.

- Subsanación de deficiencias señaladas por el Ministerio de la Vivienda.

- Aprobación definitiva del Plan, en un plazo inferior a seis meses. Puede estar condicionada a una serie de modifica-

1. Ley de Régimen del Suelo y ciones. 
Tal como señala Ferrer, la definición de Plan Parcial que realiza la ley del Suelo se inscribe plenamente en las tendencias urbanísticas derivadas del IV Congreso CIAM y la Carta de Atenas ${ }^{1}$.

El Plan Parcial se concibe como un instrumento de planeamiento que desarrolla el Plan General de un Municipio, ordenando una determinada zona del mismo. La extensión de dicha zona no está fijada por la Ley y resulta ser, de hecho, muy variable; en los Planes Parciales objeto de nuestro estudio oscila entre las $61,97 \mathrm{Ha}$ del PP 8-B y las 321,88 Ha del PP3.

La zonificación prevista en el Plan General, que señala a grandes rasgos los usos en todo el terreno municipal, es la base obligada sobre la cual el Plan Parcial asigna usos pormenorizados. La delimitación de perímetros de zonas a que hace referencia el apartado 1 a) sería, por tanto, una transcripción de la reflejada en el Plan general o bien un desarrollo más detallado de la misma.

Sin embargo, como indica Ferrer ${ }^{1}$, la asignación de usos detallados propia de los Planes Parciales tenía a veces como objetivo no tanto el desarrollo sino más bien la modificación de la zonificación o el uso previstos en el Plan General. En relación con los espacios libres, por ejemplo, y para evitar que estas modificaciones les afectasen, fue promulgada la ley de protección de espacios verdes (2-XII-63).

Las determinaciones relativas a las reservas para espacios libres y equipamientos en los Planes Parciales, señaladas en el apartado 1 , puntos $c$ ) d) son muy poco concretas. Se habla genéricamente de edificios y servicios públicos, sin mencionar expresamente ninguno de ellos, ni siquiera el escolar, tan íntimamente ligado desde sus inicios a la propia idea de unidad vecinal.

La Ley del Suelo de 1956 no fija unos estándares para equipamientos en función del número de viviendas o de habitantes, ni detalla las necesidades en cuanto a espacios para uso deportivo, asistencial, cultural o recreativo. Únicamente con respecto a las zonas verdes se señala que la reserva de suelo para parques y jardines no será inferior al $10 \%$ de la superficie del terreno que se ordena.

El resultado de todo ello será una permanente pugna entre la Administración y los particulares que buscan obtener la mayor edificabilidad posible en sus terrenos.

En cuanto a la edificación, el trazado viario (plano de alineaciones, apartado 1 b) y las normas reguladoras de la edificación (condiciones de forma y volumen, apartado 1e y ordenanzas, apartado 2 e) son los instrumentos previstos en el artículo 10 de la Ley del Suelo para la definición y ordenación de la misma en un Plan Parcial.

Con la introducción de la edificación abierta y los bloques aislados, el plano de alineaciones se convirtió, junto con el de zonificación, en el más importante de los documentos del Plan Parcial, al dejar de ser un plano relacionado con el sistema de calles y espacios públicos para convertirse en un planivolumétrico que fijaba la
1. Ferrer Aixalá, Amador. Presentación y estadística de los Planes Parciales en la provincia de Barcelona (1956-70), COACB, Barcelona,1974. 
planta y volumen exactos de los edificios, prefigurando en el Plan la forma final de todo el conjunto.

Terán, en un conocido artículo sobre la evolución del planeamiento de los núcleos urbanos nuevos, publicado en 1969 en la revista Ciudad y Territorio, señalaba que nada en el texto de la Ley del Suelo obliga a esta interpretación "arquitectónica" de los Planes Parciales, que lleva a confundirlos con un plano de volúmenes o, incluso, con una maqueta. En lugar de ello, el Plan Parcial podría limitarse a establecer una ordenación general de la red viaria principal, de los sectores en que por su distinta utilización se descomponga el territorio y de las alineaciones y rasantes de las vías y de los perímetros que delimitan estos sectores, asignando también unas características volumétricas a cada uno de ellos ${ }^{1}$.

En definitiva, Terán propone que el Plan Parcial, como documento que avanza una ordenación, tenga un carácter posibilista y parcialmente indeterminado, lo que no es contradictorio con un desarrollo unitario de ese plan en el momento en que sus diversas fases puedan ser acometidas.

1. Terán, Fernando de, "Evolución del planeamiento de núcleos urbanos nuevos", Ciudad y Territorio 1-1969, Centro de Estudios Urbanos del IEAL, Madrid, 1969. 
II. ENTRE EL PLAN SUR DE 1958 Y EL PLAN GENERAL DE 1966 LA FORMACIÓN DE LA PERIFERIA URBANA 



\section{INTRODUCCIÓN.}

Esta sección está dedicada al estudio de las áreas residenciales de edificación abierta proyectadas en Valencia en el periodo comprendido entre los años 1957 y 1966 . El inicio y final del periodo vienen fijados, respectivamente, por la gran riada del Turia que tuvo como consecuencia la aprobación del denominado Plan Sur, y por la aprobación del Plan General de Ordenación Urbana de Valencia y su Comarca adaptado a la Solución Sur.

Comenzaremos la sección examinando el Plan Sur de 1958, y en particular las propuestas de conjuntos de edificación abierta para los nuevos centros urbanos previstos en dicho Plan.

A partir de 1957, el modelo de la edificación abierta pasa a ser el único que se utilizará en los proyectos de conjuntos de viviendas, en los que además la administración central asume el protagonismo de la promoción y construcción. Es el caso de los dos grupos de viviendas de promoción pública construidos en Valencia en el marco del denominado "Plan Riada" de 1957: el Grupo Virgen de la Fuensanta y el Virgen del Carmen, con cuyo análisis continuaremos esta sección.

A continuación, estudiaremos los conjuntos de viviendas promovidos por cooperativas y empresas entre 1958 y 1966, en los que existen ejemplos notables, pese a su reducida escala, de uso de la edificación abierta. Estos grupos marcan el inicio del predomino de la promoción privada, que arranca con la legislación sobre Viviendas de Renta Limitada de 1954, predominio que será absoluto en los años sesenta y setenta.

En el siguiente apartado, volveremos al terreno de la promoción pública, analizando los Planes Parciales redactados entre 1960 y 1961 para los Polígonos de Valencia al Mar, Campanar, Avenida de Castilla y Monteolivete. Estos planes iniciales para los cuatro polígonos, gestionados por la Gerencia de Urbanización, serían descartados o modificados sustancialmente a partir de finales de los años sesenta, como veremos más adelante.

Finalizaremos la sección con un análisis de los Planes Parciales redactados por la Oficina Técnica Municipal de Urbanismo del Ayuntamiento de Valencia entre 1958 y 1966, después de la aprobación del Plan Sur pero antes de la aprobación del Plan General adaptado a la Solución Sur. En estos planes se aplican ya, de forma incipiente, los criterios establecidos por la Ley del Suelo de 1956, y en ellos, además de las previsiones de equipamientos señaladas por dicha Ley, aparece un diseño urbano basado en el uso generalizado de la edificación abierta. 
Utilización del antiguo cauce del Turia en la Solución Sur. (Delegación del Gobierno, Valencia. Ordenación técnica de la ciudad y su comarca, 1958).
Nuevo centro urbano en los terrenos de la estación del Norte (Delegación del Gobierno, Valencia. Ordenación técnica de la ciudad y su comarca, 1958).
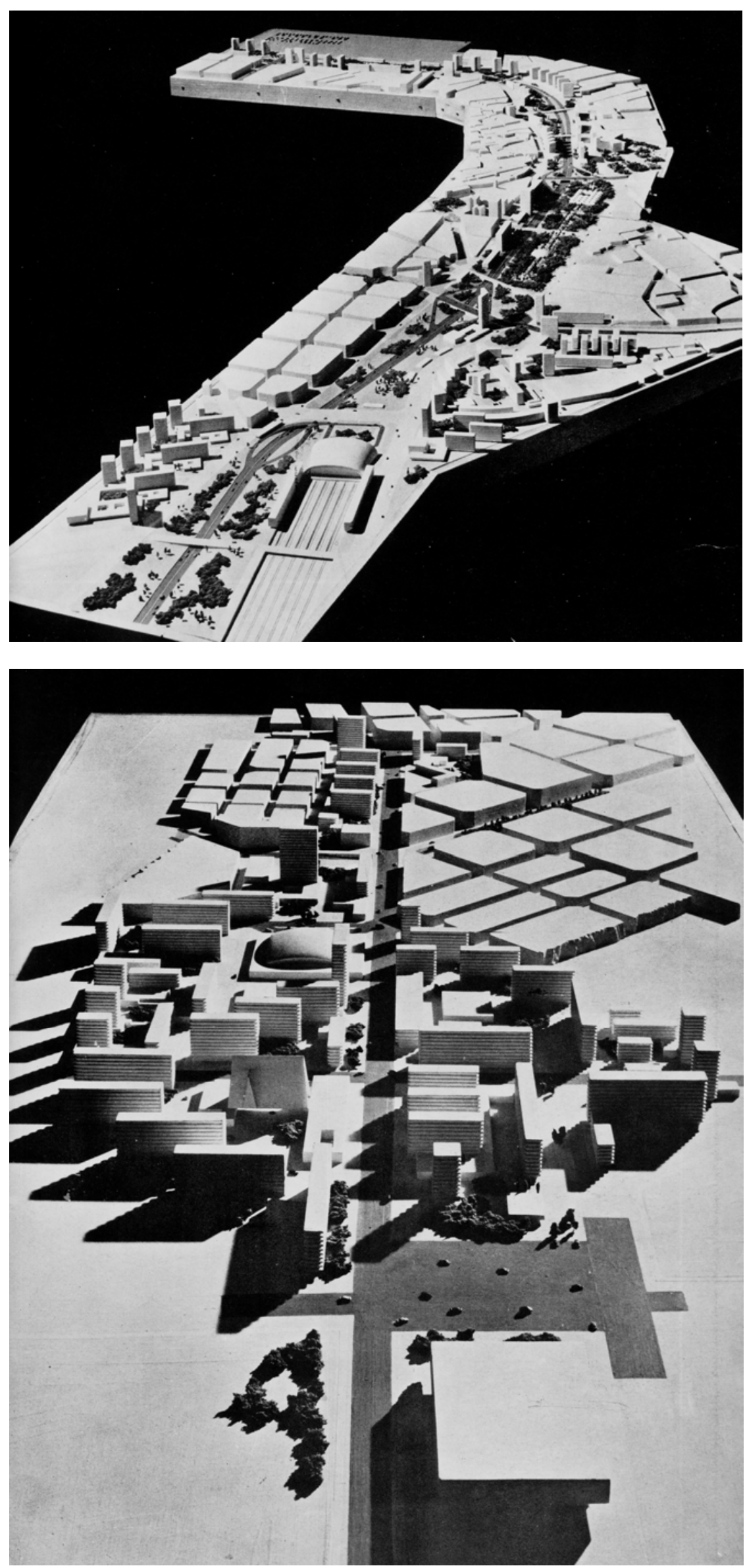


\section{LA EDIFICACIÓN ABIERTA EN LAS PROPUESTAS DEL PLAN SUR DE 1958.}

La Comisión Técnica Especial ${ }^{1}$ creada en enero de 1958 por el Ministerio de la Vivienda para resolver los problemas planteados por la inundación del río Turia de 1957, estudió tres alternativas para el encauzamiento del río, denominadas soluciones Centro, Norte y Sur. La primera planteaba el mantenimiento del cauce existente, mejorando su capacidad hidráulica frente a avenidas. Las otras dos planteaban su desvío, por el norte o por el sur. La solución norte, de enlace del Turia con el cauce del Carraixet ampliado, fue la primera en ser descartada. Las otras dos (Centro y Sur) fueron objeto de un análisis comparativo, plasmado en un documento editado por la Delegación del Gobierno². Finalmente, en julio de 1958 fue aprobada la solución Sur, que contemplaba un nuevo cauce entre Quart de Poblet y el mar de 200 metros de anchura.

Los componentes fundamentales del Plan Sur para Valencia, aprobado por Ley en diciembre de 1961, son la solución hidráulica del nuevo cauce y el trazado viario definido en el "Plan de Accesos de Carreteras y sus enlaces", aprobado por el Ministerio en 1959.

En el documento elaborado por la Comisión Técnica Especial se planteó la descongestión del centro urbano mediante la creación de tres nuevos centros estratégicamente situados. Las propuestas de ordenación que se muestran a través de maquetas para dos de estos centros están basadas en el uso generalizado de bloques de edificación abierta, tanto en forma de bloques como de torres.

El primero de estos centros se planteaba en los terrenos liberados al desplazar la Estación del Norte de su actual emplazamiento, como extensión hacia el sur (accesos desde Catarroja y Torrent) del centro urbano tradicional de Valencia, situado alrededor de la Plaza del Ayuntamiento.

El segundo de los centros, junto a la salida hacia Ademuz, en la margen izquierda del río, frente a la Gran Vía Fernando el Católico, del que no se muestra maqueta o plano alguno, ha sido el único de ellos realizado posteriormente (se trata de la actual zona de Nuevo Centro), reforzado por la instalación en sus proximidades de la estación de autobuses.

Estos dos centros se proponen tanto para la Solución Centro como para la Sur.

El tercer centro, exclusivo de la Solución Sur, está previsto en las proximidades de la nueva Estación Central prevista, y en terrenos liberados por la desaparición de la Estación de Aragón. Esta zona está muy bien comunicada con la salida hacia el norte (autopista a a Barcelona) y con la autopista de enlace sur. En la maqueta del estudio, pueden observarse en las inmediaciones de la nueva Estación tres enclaves diferentes de edificación abierta mixta. Dos de ellos, los situados en el lado norte del cauce, reaparecerán como centros comerciales en el planeamiento posterior al Plan de 1966.

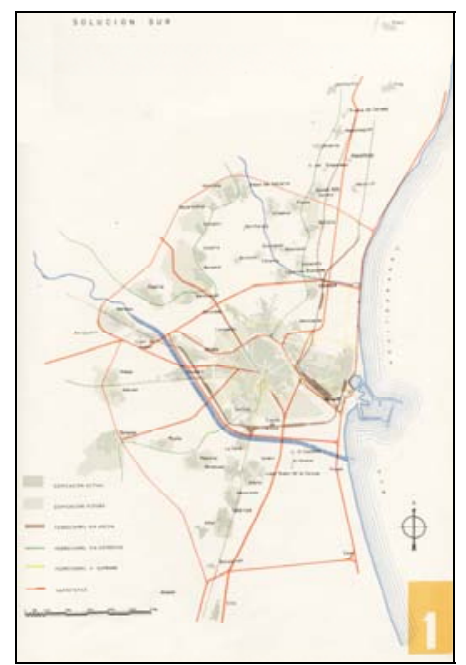

Solución Sur. Delegación del Gobierno, Valencia. Ordenación técnica de la ciudad y su comarca, 1958.

\begin{abstract}
1.La Comisión, creada el 24 de enero de 1958, estaba presidida por el Ministro de la Vivienda, Pedro Gual Villalbí, con Pedro Bidagor, Director General de Urbanismo, como vicepresidente $y$ Vicente Mortes, Director General de la Vivienda, como secretario. Los vocales eran los Directores Generales de Urbanismo, de Obras Hidráulicas, de Caminos, de Ferrocarriles, de Puertos, de Agricultura y de Arquitectura, el Gobernador Civil, el Alcalde de Valencia y el Presidente de la Diputación Provincial.
\end{abstract}

2.Delegación del Gobierno, Valencia. Ordenación técnica de la ciudad y su comarca, Imp. Tipografía Artística, Valencia, 1958. 


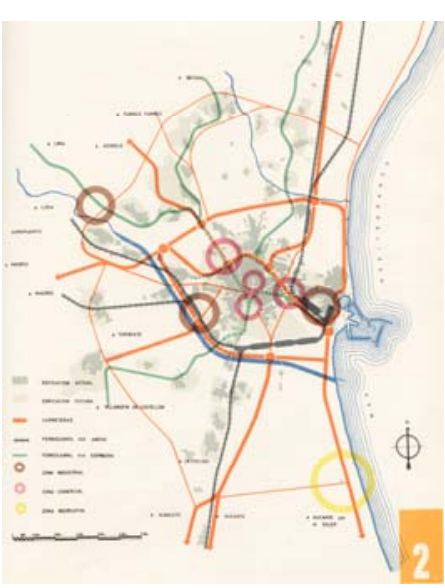

Valencia. Solución Sur. Ordenación viaria y centros de trabajo, ocio y recreo (Delegación del Gobierno, Valencia. Ordenación técnica de la ciudad y su comarca, 1958).

1,2. Propuesta para el uso urbano del cauce del Turia. Tramo central (Delegación del Gobierno, Valencia. Ordenación técnica de la ciudad y su comarca, 1958).
Además, el documento señala las posibilidades de desarrollo urbanístico que ofrece el cauce abandonado del río en la Solución Sur, dado que la expansión de la ciudad hacia el Norte hace del mismo la columna vertebral de la nueva ciudad.

El eje del cauce se estructura a partir de la autopista proyectada en el lecho del mismo, que al discurrir a cota inferior a la ciudad no tiene interferencias con la circulación de la misma. Esta autopista, conectada mediante unos pocos nudos con los accesos y la ciudad, enlaza elementos tan significativos como el aeropuerto, los centros comerciales, la estación, el puerto y las playas.
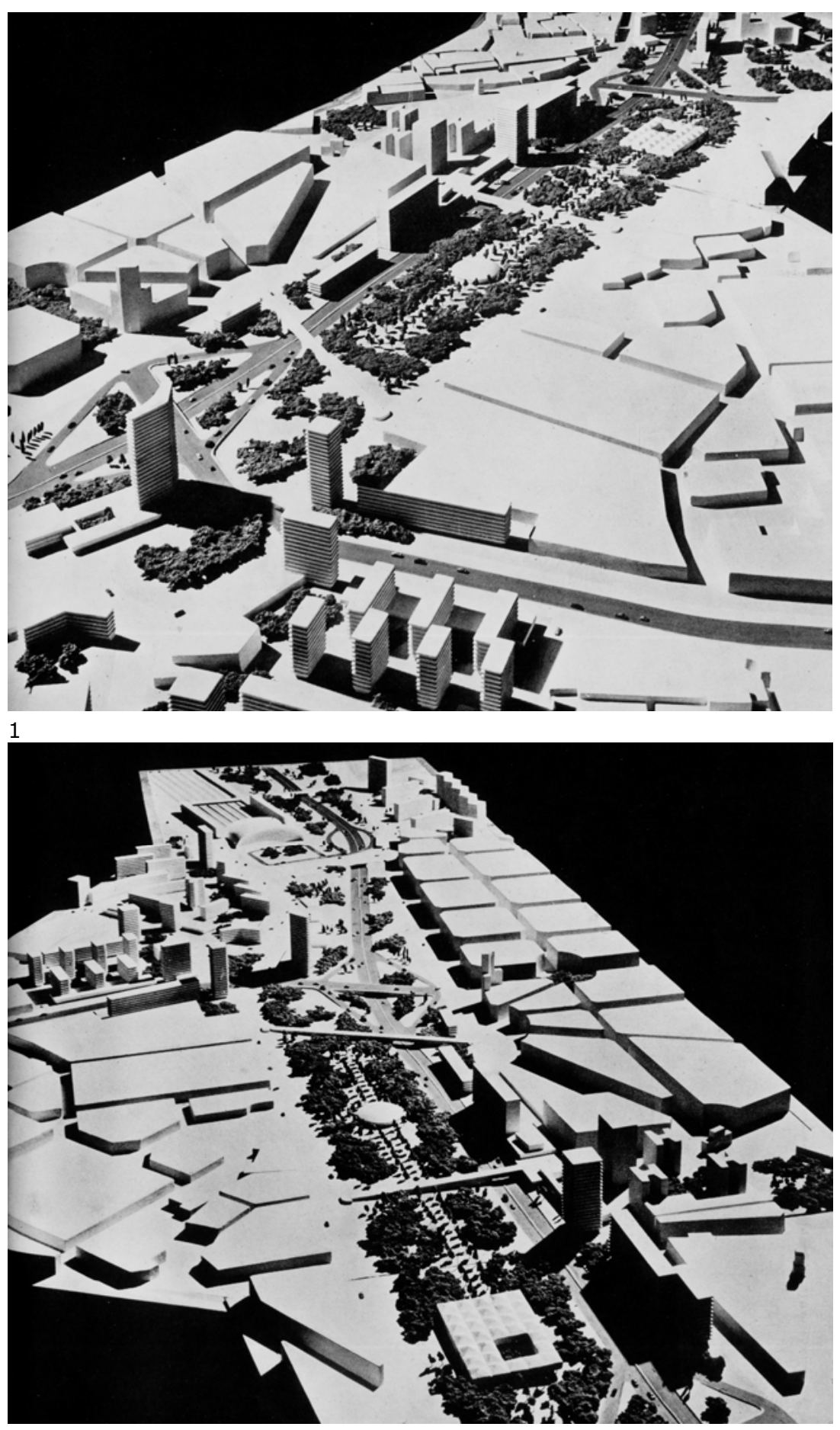


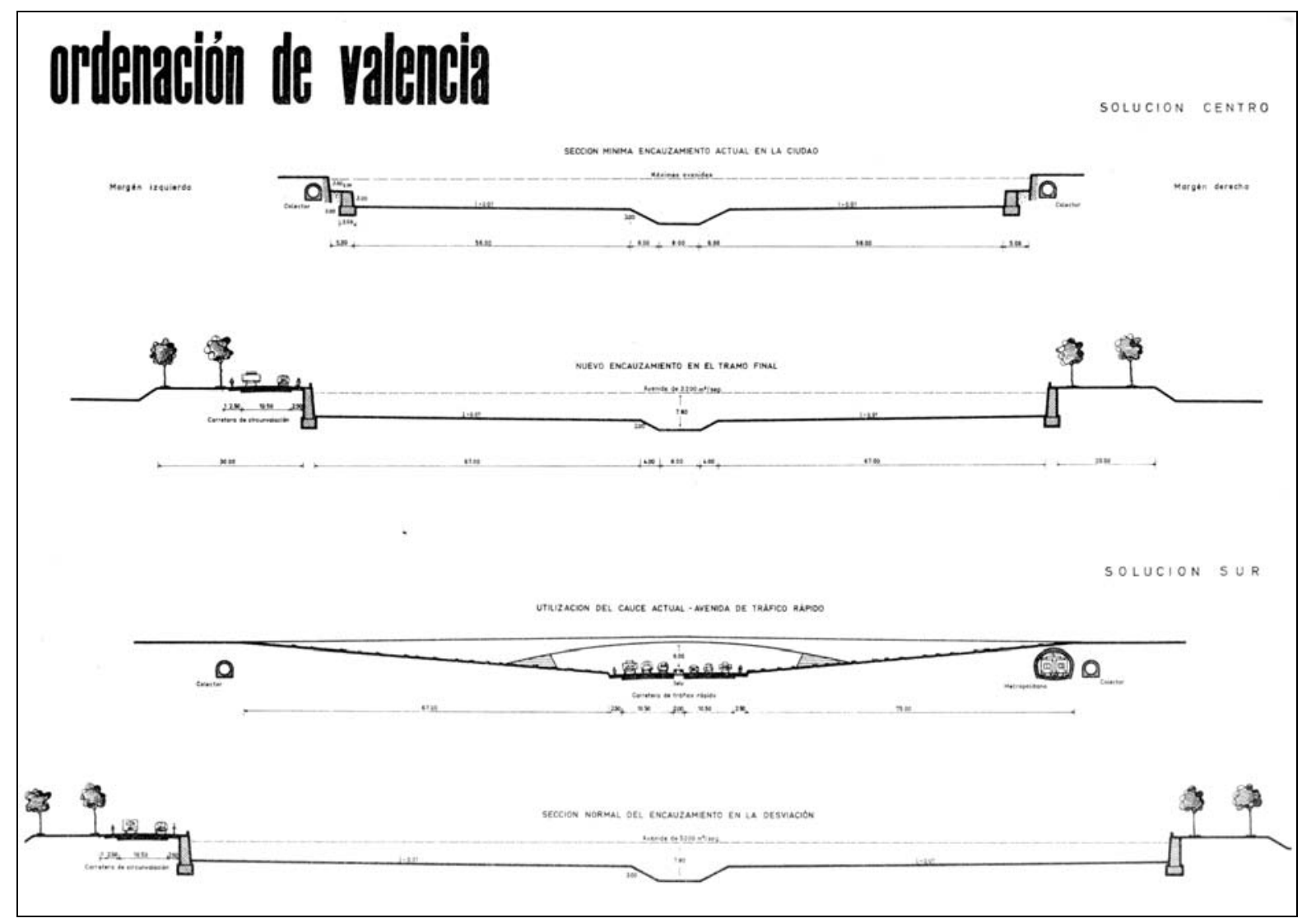

En cuanto al aprovechamiento del cauce para la construcción, el estudio señala, en primer lugar, que dada la estratégica situación de los solares su rendimiento económico será necesariamente elevado.

En lo referente al uso, se indica como más adecuado un uso comercial en el tramo entre Fernando el Católico y el Puente de Hierro, con oficinas, hoteles, establecimientos recreativos y algunas tiendas. Para el tramo exterior a Fernando el Católico se sugiere un uso exclusivamente residencial de categoría no elevada y para el tramo posterior al Puente de Hierro, un uso vinculado a las instalaciones ferroviarias de la nueva Estación y factorías industriales.

Por último, se señala también en el estudio que:

El cauce que abandona el Turia constituye, por otra parte, una magnífica ocasión para dotar a la ciudad de algunas expansiones verdes que actualmente se echan muy de menos. Especialmente entre Viveros y puente de Aragón, hay ocasión para crear con laz zonas actuales un amplio recinto verde para usos recreativos, bordeado en su margen derecha por instalaciones de hoteles y de espectáculos. ${ }^{1}$

Las edificaciones que se mencionan para el tramo central del cauce del Turia aparecen en la maqueta en forma de torres y bloques lineales de formas y volúmenes variados, que suponen una importante transformación de la mayor parte de la fachada al río del casco histórico.

1.Delegación del Gobierno, Valencia. Ordenación técnica de la ciudad y su comarca, Imp. Tipografía Artística, Valencia, 1958, p. 33.

Secciones del cauce del Turia. Soluciones Centro y Sur. Delegación del Gobierno, Valencia. Ordenación técnica de la ciudad y su comarca, 1958. 


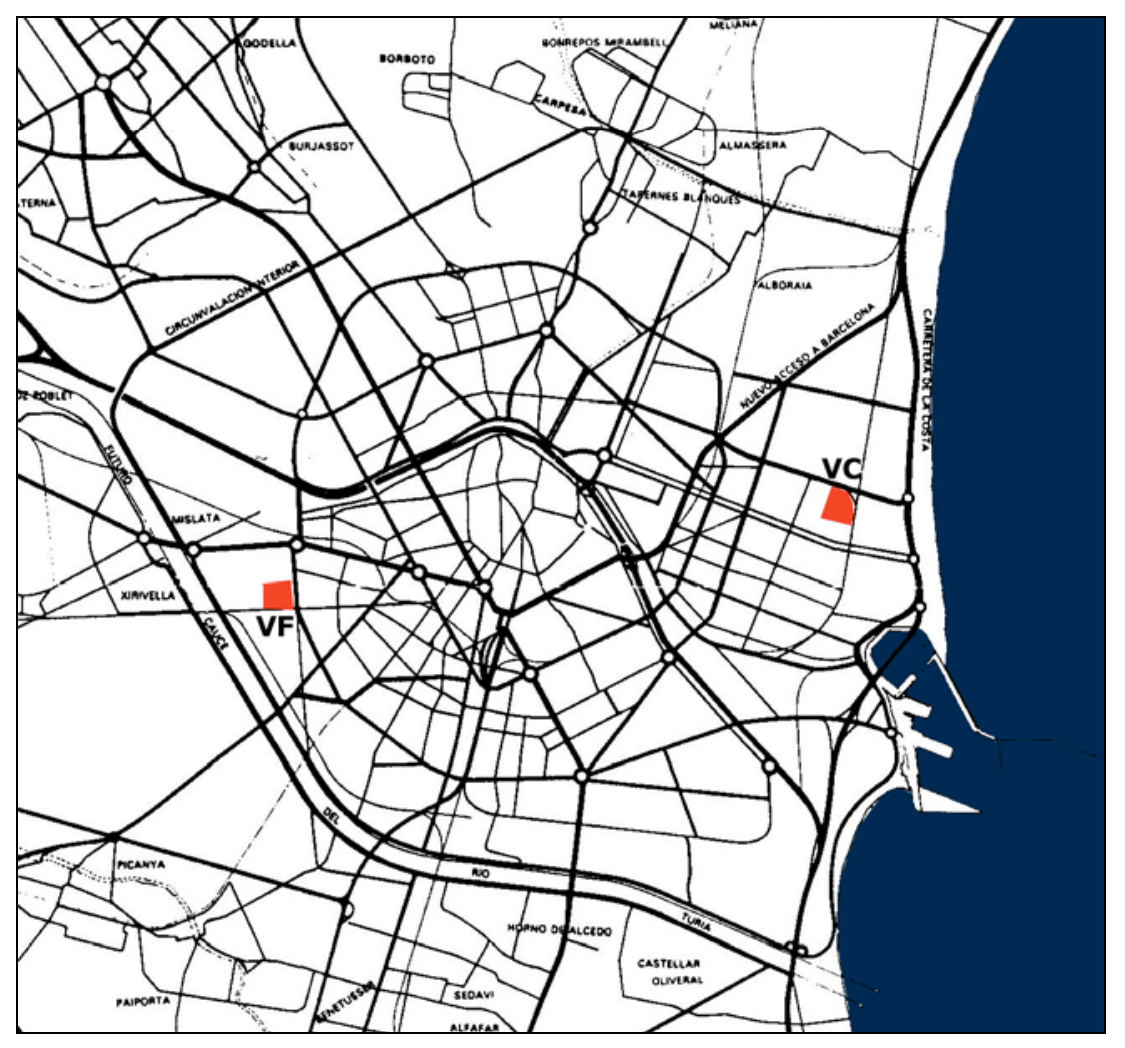

Localización de los grupos de viviendas del Plan Riada.

VC: Virgen del Carmen.

VF: Virgen de la Fuensanta.

Tabla II.1

Valencia. Conjuntos residenciales del Plan Riada.

\begin{tabular}{|l|l|r|c|}
\hline PROMOTOR & GRUPO & VIVIENDAS & AÑOS \\
\hline INV/AV. & Virgen de la Fuensanta & 880 & $1957-60$ \\
\hline OSHA & Virgen del Carmen & 600 & $1958-62$ \\
\hline
\end{tabular}

Abreviaturas:

AV: Ayuntamiento de Valencia.

INV: Instituto Nacional de la Vivienda.

OSHA: Obra Sindical del Hogar y la Arquitectura. 


\section{LOS GRUPOS DE VIVIENDAS DEL PLAN RIADA (1958-62)}

En 1957, año de la Gran Riada del Turia, se crea el Ministerio de la Vivienda. Estos dos hechos marcan el final del Plan 5000 y, además, el final de la época de predominio municipal en la promoción de viviendas.

Cuatro días después de la Gran Riada, el Ministerio de la Vivienda aprobó con carácter de urgencia el llamado "Plan Riada", cuya finalidad era la de proveer de viviendas a los damnificados por la misma. Como consecuencia de dicho plan, se proyectarán y construirán cuatro grupos de viviendas, con un total de 1812 viviendas. Los dos grupos de mayor tamaño, situados en Valencia, son el grupo Virgen de la Fuensanta, de 880 viviendas, situado en la zona oeste de la ciudad, cercano a la Avenida de Castilla, y el grupo Virgen del Carmen, de 600 viviendas, situado en la zona noreste, próximo a los poblados marítimos. Los otros dos grupos del Plan Riada son el Virgen de la Merced de Paterna y el Virgen de la Paloma de Torrente. ${ }^{1}$

Con los grupos Virgen del Carmen y Virgen de la Fuensanta da comienzo una etapa diferente de la promoción pública de viviendas en Valencia, que podemos caracterizar por tres rasgos principales:

- El aumento de tamaño de las actuaciones, que pasan de la escala de la manzana a la de los grandes conjuntos, precursores de los Polígonos de los años 60 y 70.

- El recurso en el proyecto al orden abierto propio del urbanismo funcionalista y al lenguaje arquitectónico asociado al mismo.

- El predominio de la iniciativa estatal, a través de la OSHA y el INV, frente a la iniciativa municipal.

Con estos grupos, en definitiva, se introduce en Valencia el modelo de crecimiento urbano propio de la ciudad funcional, por adición de "partes" completas, de unidades residenciales integradas por viviendas y equipamientos, proyectadas y construidas de modo unitario. Esta es la principal diferencia entre los dos grupos del Plan Riada y el grupo Virgen de los Desamparados, anteriormente analizado.

Sin embargo, estas nuevas piezas de la ciudad no se localizaron junto a los tejidos existentes, sino que se optó por lugares aislados en los que el coste de los terrenos era más bajo, lo que dificultó su integración en la ciudad como un fragmento más de la misma.

1. Para los grupos del Plan Riada, ver Gaja, F., Op.cit, pp. 178190 


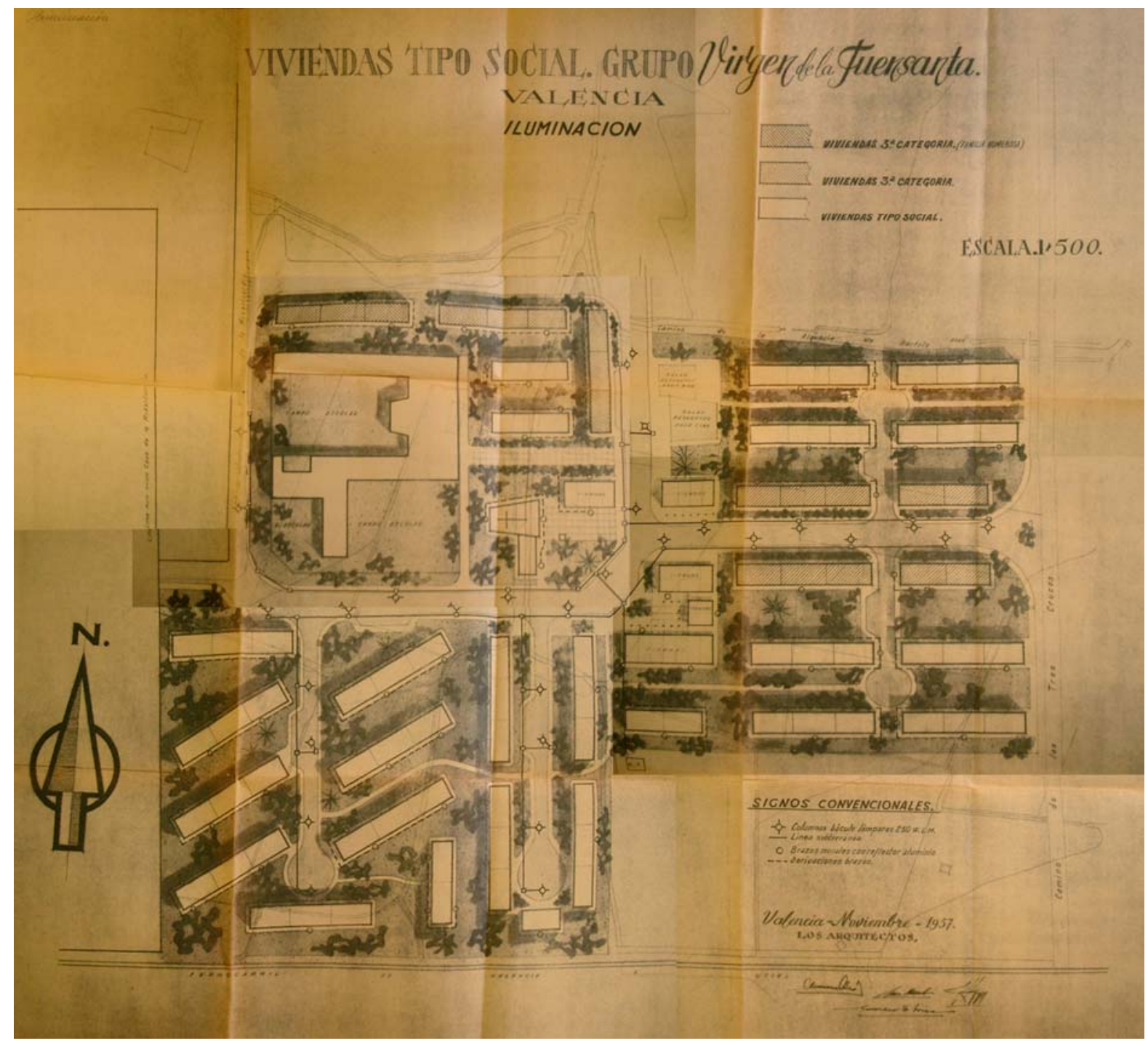

Grupo Virgen de la Fuensanta. Planta general (Del Proyecto de urbanización. Archivo Histórico municipal).
Tabla II. 2

Grupo Virgen de la Fuensanta. Resumen de características.

\begin{tabular}{|c|c|c|}
\hline \multicolumn{2}{|c|}{ SUPERFICIE TOTAL } & $65.334 \mathrm{~m} 2(6,53 \mathrm{Ha})$ \\
\hline \multicolumn{2}{|c|}{ NÚMERO DE VIVIENDAS } & 880 VIV. \\
\hline \multicolumn{2}{|c|}{ DENSIDAD } & $135 \mathrm{Viv} / \mathrm{Ha}$. \\
\hline \multirow{4}{*}{ USO DEL SUELO } & VIVIENDAS & $11.238 \mathrm{~m} 2(17,2 \%)$ \\
\hline & EQUIPAMIENTOS & $11.960 \mathrm{~m} 2(18,2 \%)$ \\
\hline & ZONAS VERDES & $29.930 \mathrm{~m} 2(45,8 \%)$ \\
\hline & VIARIO $(*)$ & $12.206 \mathrm{~m} 2(18,8 \%)$ \\
\hline
\end{tabular}

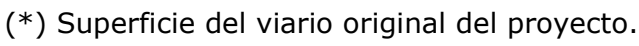




\section{GRUPO VIRGEN DE LA FUENSANTA (1957-60).}

El Grupo Virgen de la Fuensanta, proyectado por M. Lleó, J.R. Pons, J.A. Pastor, C. E. Soria y C. Grau en noviembre de 1957, un mes después de la Gran Riada del Turia, ocupa unos terrenos limitados al este por la Avenida de las Tres Cruces, al sur por la calle Tres Forques, al oeste por la Casa de la Misericordia y al norte por las calles Rey Saud y Escultor Salzillo. Construido entre 1958 y 1960, incluye 880 viviendas, por lo que es el mayor conjunto residencial del Plan Riada.

En las inmediaciones del grupo existen diversos equipamientos no vecinales que ocupan parcelas de gran tamaño, el más importante de los cuales es el Hospital Provincial (actual Hospital General). Como puede verse en la fotografía aérea de la ETS de Arquitectura, hacia 1965 el grupo estaba todavía rodeado por terrenos agrícolas por todos sus lados excepto por el oeste, en el que se encuentra la parcela de la Casa de la Misericordia. En las proximidades se encuentran, además, otros conjuntos de edificación abierta: el grupo Virgen de los Desamparados, al otro lado de la Avenida de las Tres Cruces, y el barrio Virgen de la Luz, más al oeste.

El barrio, al igual que el cercano barrio de La Luz, quedará posteriormente englobado en el Plan Parcial 26Bis. En este plan se ordenará con bloques de edificación abierta la franja intermedia entre el Hospital General y el grupo Fuensanta.

El grupo Virgen de la Fuensanta puede considerarse ya como un polígono, un conjunto residencial integrado por viviendas y equipamientos, proyectado y construido de modo unitario, que supone la adición a la ciudad de una "parte" completa. Esta nueva porción urbana se localiza en un lugar separado del resto del tejido consolidado de la periferia, como una isla rodeada de campos de cultivo.

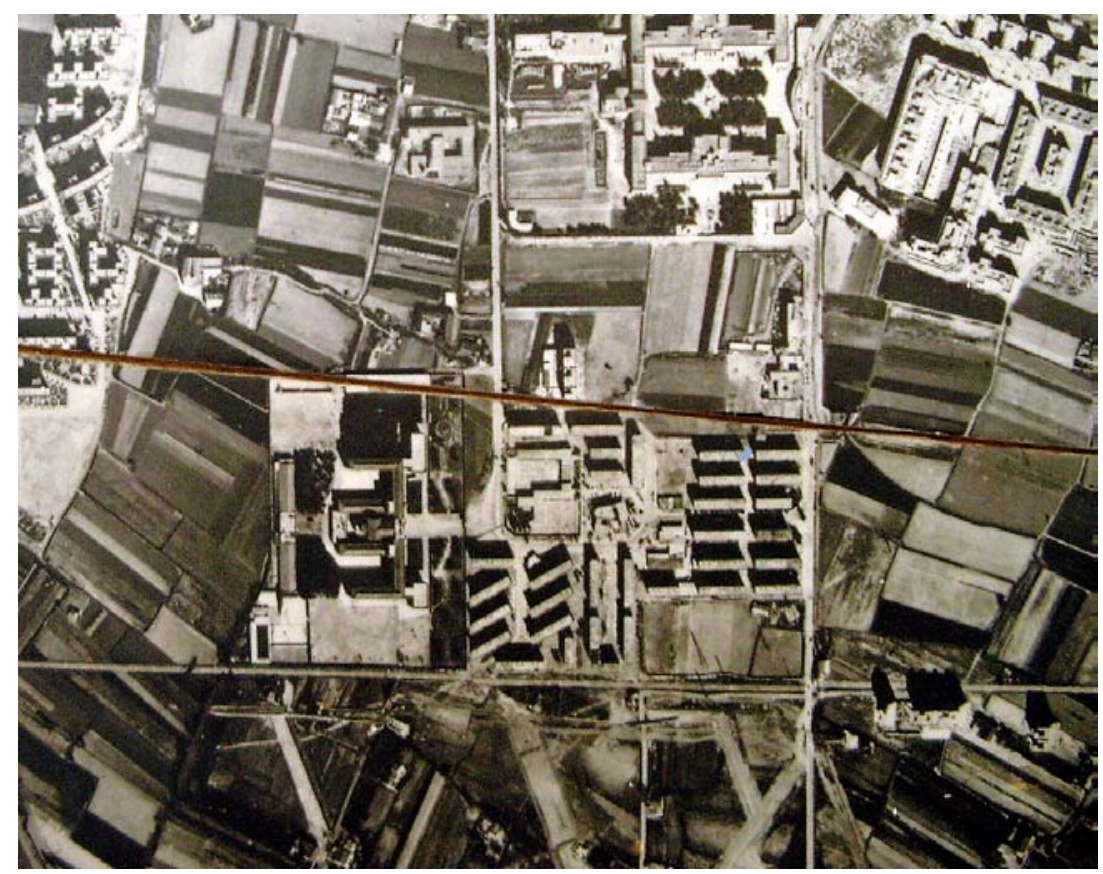

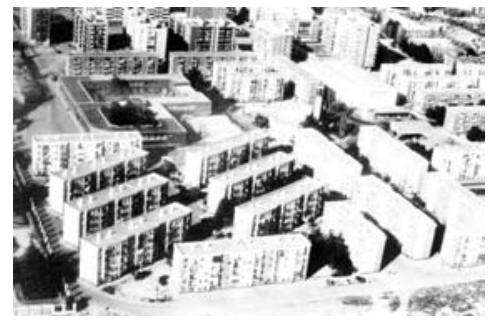

Grupo Virgen de la Fuensanta. Fotografía aérea (Gaja)
Zona del grupo Virgen de la Fuensanta. (Fotografía aérea, h. 1965, ETS de Arquitectura de Valencia). 

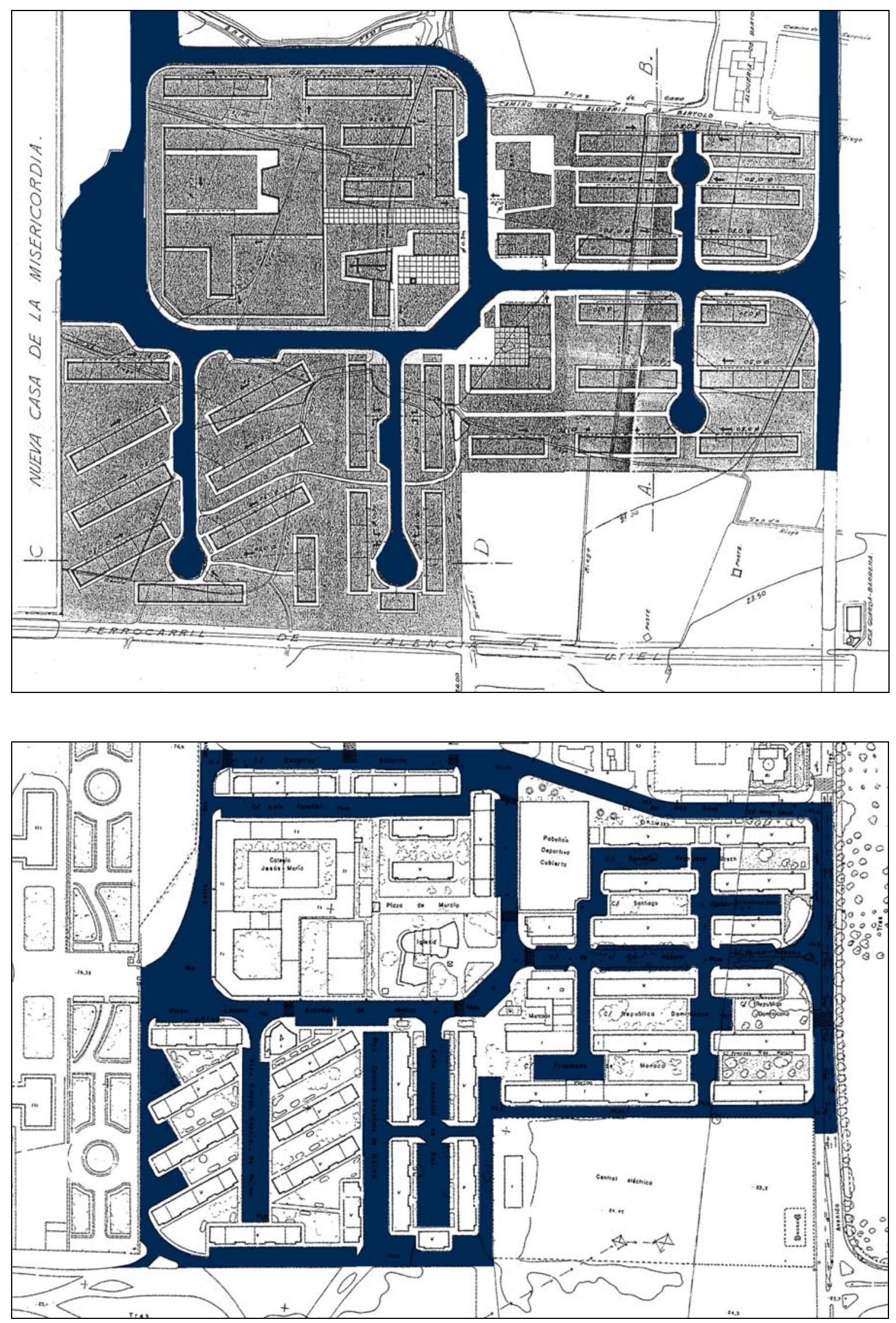


\section{Trazado viario.}

El viario original del Grupo Virgen de la Fuensanta sigue un esquema de trazado ramificado, con un eje central de directriz quebrada (la calle de La Habana) y calles en cul-de-sac que arrancan del mismo. Estas calles o ramales sin salida se disponen en perpendicular a los bloques en la mitad este del barrio, en paralelo a los mismos en el ramal que forma la calle Lucrecia Bori y en diagonal en los bloques en torno a la denominada plaza Colonia Española de Méjico.

La memoria del Proyecto de Urbanización señala lo siguiente:

Se ha previsto en esta urbanización el conseguir un mínimo coste proyectando las indispensables vías de circulación y de acceso a las diferentes viviendas.

Como se observará en los planos se proyecta una calle principal de acceso al centro cívico y que une a su vez el actual camino de Tres Cruces con el ya construido camino de entrada para la nueva Casa de la Misericordia y un reducido número de calles en fondo de saco para facilitar la entrada a los diferentes bloques de viviendas.

Estos bloques de viviendas se sitúan rodeados de parques, pero como se considera muy costoso el entretenimiento o cuidado de jardines formados por céspedes o plantaciones que requieren un constante cuidado y riego, lo cual puede considerarse como no conveniente para este tipo de viviendas, se prevé que en los espacios libres no pavimentados estarán recubiertos por una capa de gravilla que a su vez que es limpia, proporcionará un aspecto agradable.

Se proyectan masas de arbolado, principalmente pinos, eucaliptus, cedros, cipreses y arbustos de flor, como adelfas, rosales, celindas y espídeas.

De esta forma se conseguirán masas de verde que valorarán las construcciones, siendo económico el entretenimiento de las zonas libres $^{1}$.

El viario ramificado original no prevé ningún espacio para aparcamientos en superficie en los ramales sin salida, y los edificios tampoco disponen de ellos. Por ello, igual que ocurrió en el otro grupo del Plan Riada, se abrieron posteriormente nuevas calles al tráfico rodado, con la intención de obtener espacio para aparcamiento. La separación de tráficos, por tanto, fracasó por el error de cálculo relativo a las necesidades de plazas de aparcamiento que es común a tantos conjuntos de edificación abierta.
Página opuesta:

Plano de trazado viario. Proyecto inicial y final.

(Elaboración propia sobre Proyecto de Urbanización de 1957 y Cartografía Básica Municipal, 1983)

1.Excmo. Ayuntamiento de Valencia. Proyecto de urbanización del Grupo Virgen de la Fuensanta, Noviembre 1957. Memoria.

Sección transversal. Calle de La Habana y espacios verdes entre bloques (Proyecto de urbanización, 1957. AHM).

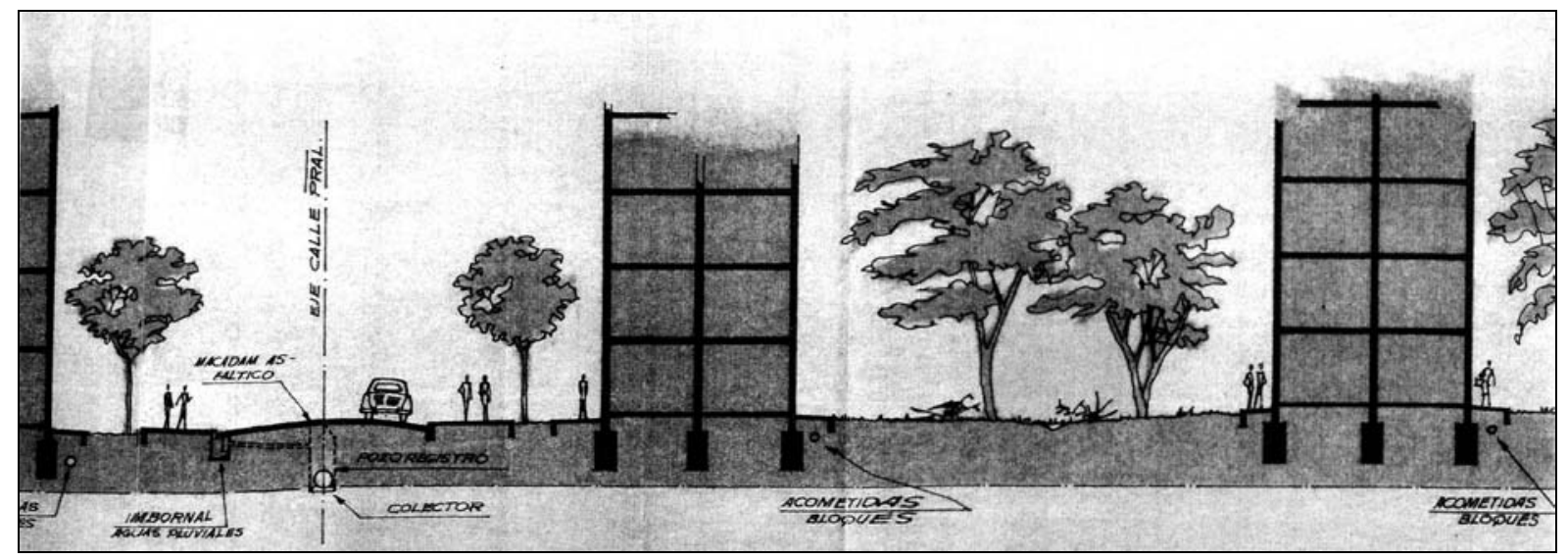




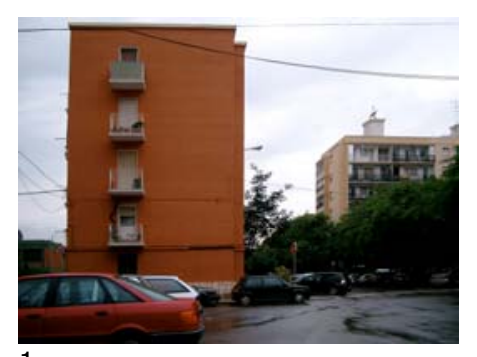

1

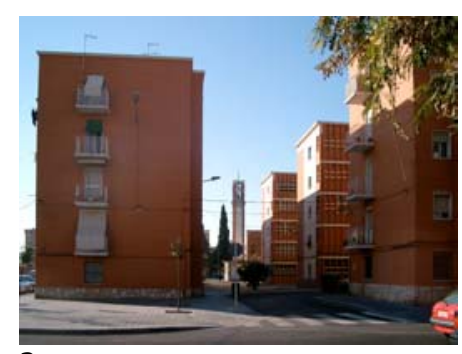

2

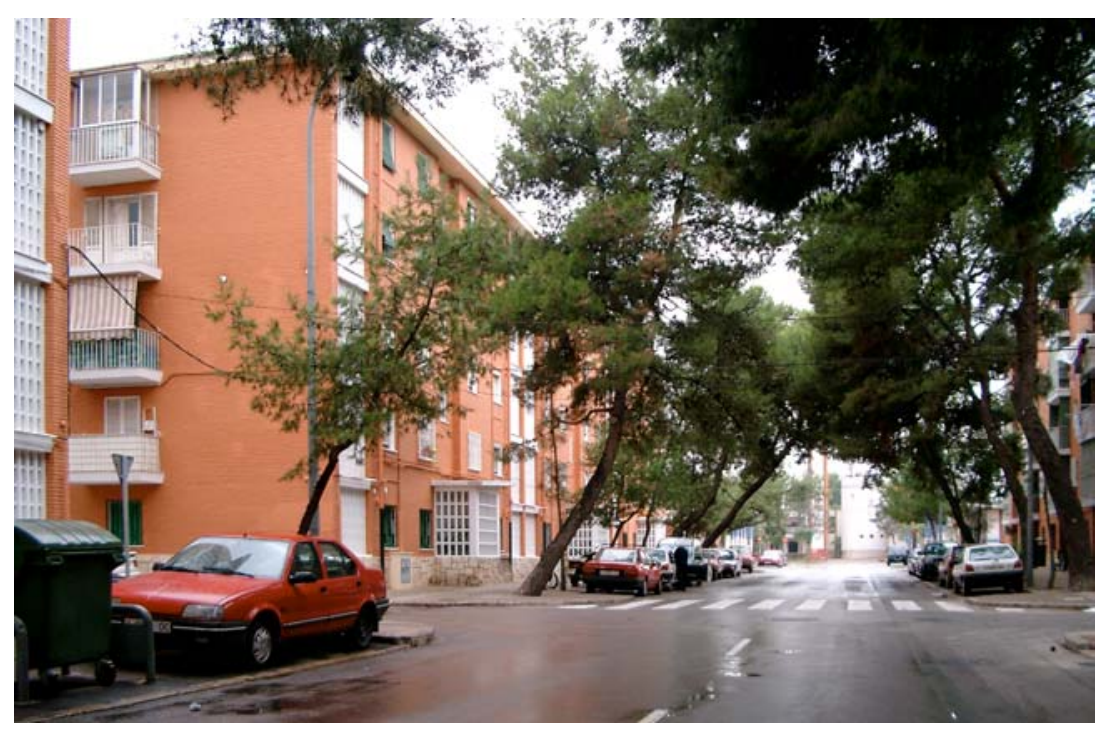

3

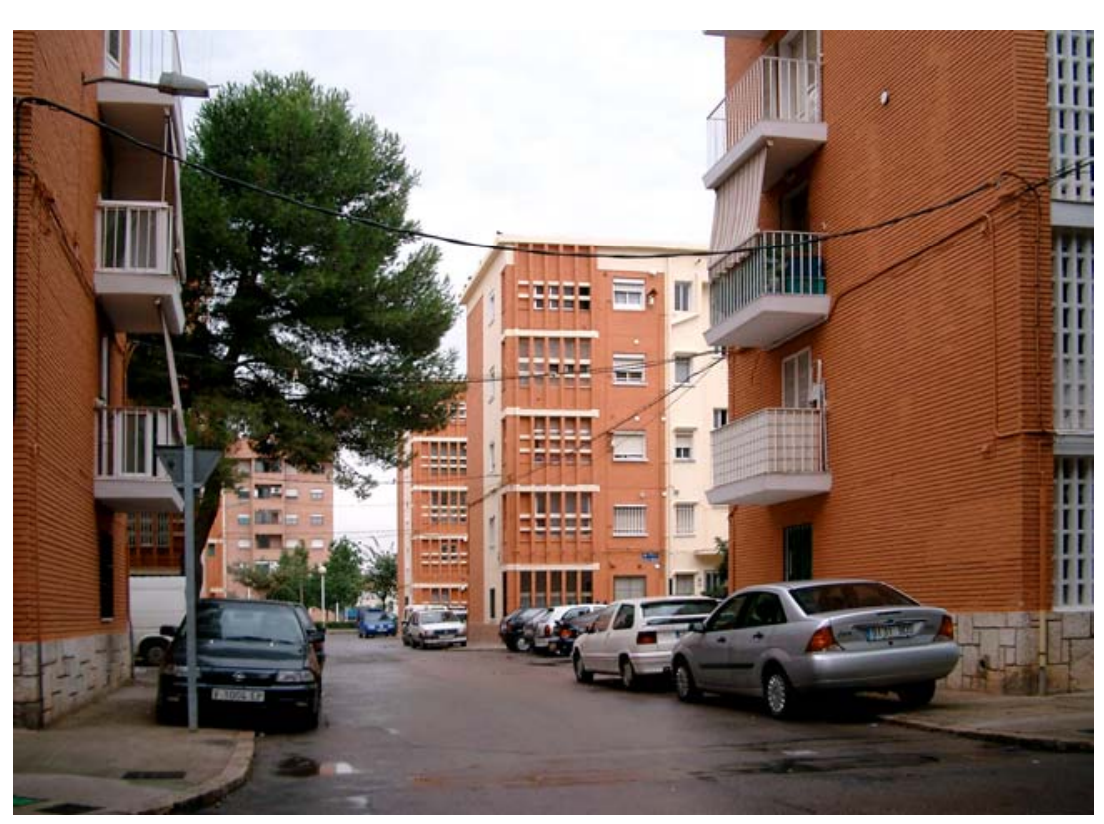

4

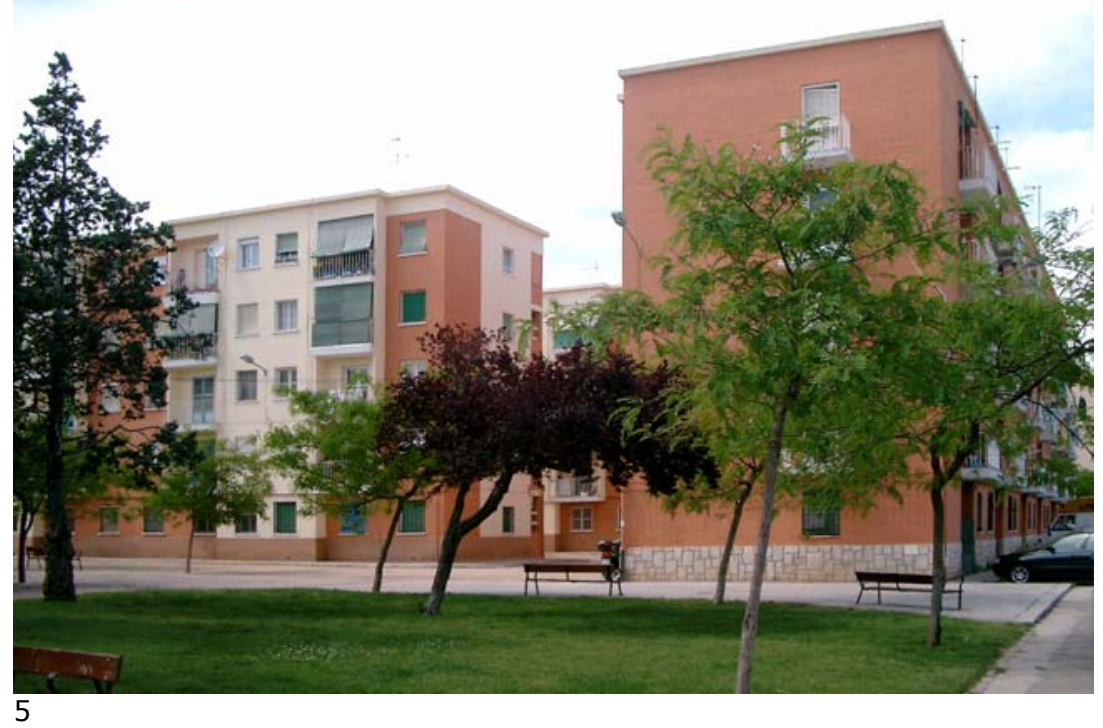

Grupo Virgen de la Fuensanta. Vistas actuales.

1. Calle Escultor Salzillo. Bloque situado al fondo de la calle Rey Saud

2. Travesía de la calle Escultor Salzillo, vista hacia la Iglesia.

3. Calle La Habana, vista hacia el oeste.

4. Calle transversal a la Habana por el sur.

5. Bloques en la Plaza de Murcia, en el lado norte de la Iglesia. 


\section{Edificación}

Las viviendas del Grupo Virgen de la Fuensanta, de superficies comprendidas entre $58,61 \mathrm{~m} 2$ y $65,37 \mathrm{~m} 2$, se disponen en bloques lineales aislados de $\mathrm{V}$ plantas $(\mathrm{PB}+4)$ y dos crujías, con dos viviendas por caja de escalera. Casi todos los bloques son de una longitud similar, correspondiente a tres cajas de escalera y seis viviendas por planta. La planta baja está también destinada a viviendas.

Se adopta en general la equidistancia entre bloques propia de la edificación en línea o zeilenbau, y los espacios intermedios entre los mismos están previstos en el proyecto original como zonas verdes.

La orientación de los bloques lineales no es uniforme, sino que prima en el proyecto la voluntad de obtener un efecto de variedad de ambientes y perspectivas. Así, como hemos señalado anteriormente, podemos ver que en las zonas este y norte del barrio los bloques están dispuestos en dirección este-oeste, es decir, con fachadas a norte y a sur, de manera que quedan situados en perpendicular a los ramales sin salida, a los que recaen sus testeros, y en paralelo al eje central de acceso de la calle de La Habana. En cambio, en el cuadrante suroeste hay una agrupación de bloques dispuestos en dirección norte-sur en paralelo a uno de los ramales sin salida, el de la calle Lucrecia Bori, y otra con bloques dispuestos según la diagonal NE-SO en torno al ramal de la Plaza Colonia Española de Méjico.

Las entradas a los zaguanes se produce siempre desde el lado norte o desde el oeste, por lo que no existe simetría de accesos o bilateralidad con respecto a las calles o a los espacios verdes intermedios entre bloques, con la única excepción del eje de la calle de La Habana.
Grupo Virgen de la Fuensanta. Plano de edificación (Color sobre Cartografía Básica Municipal de Valencia de 1983)

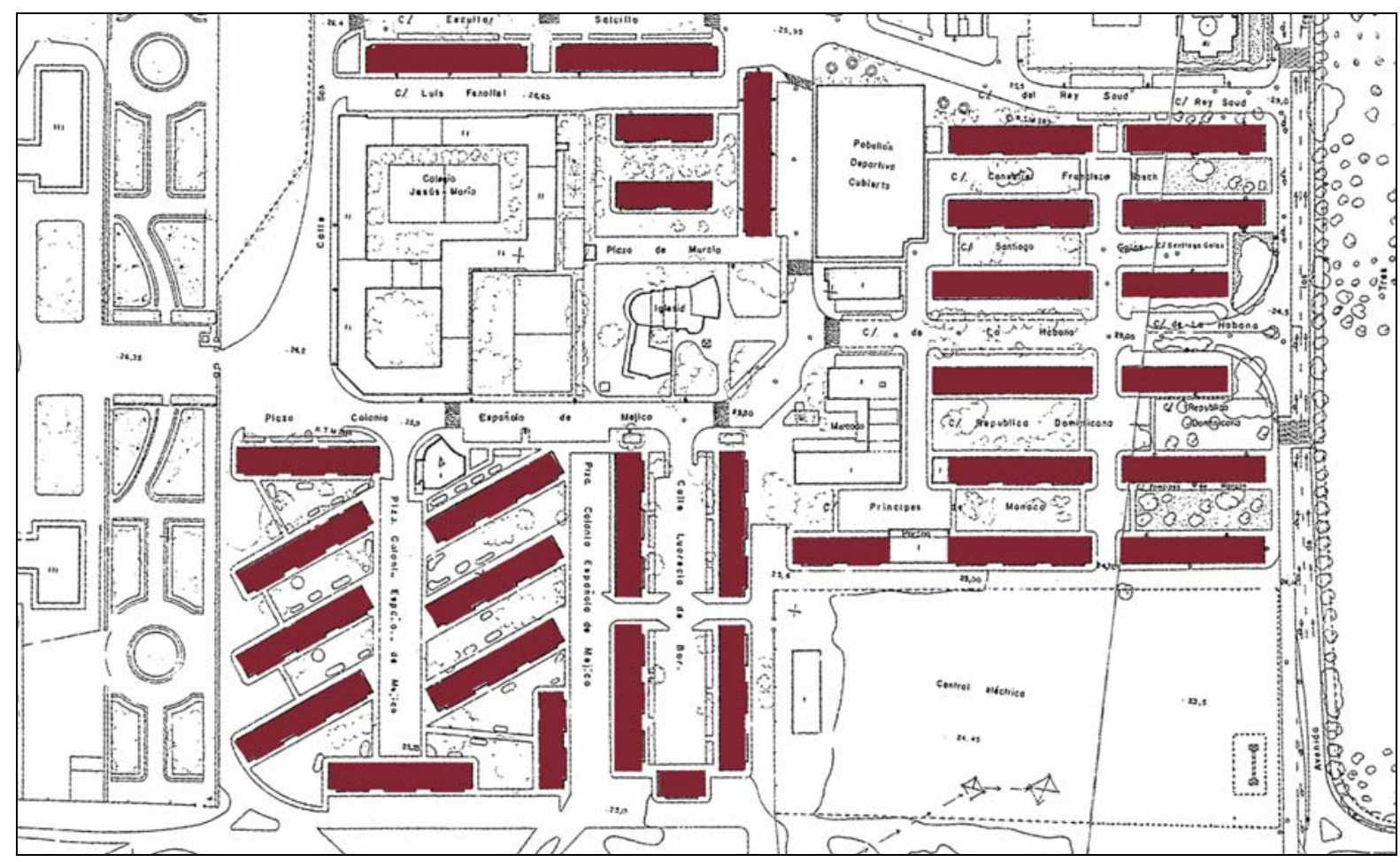




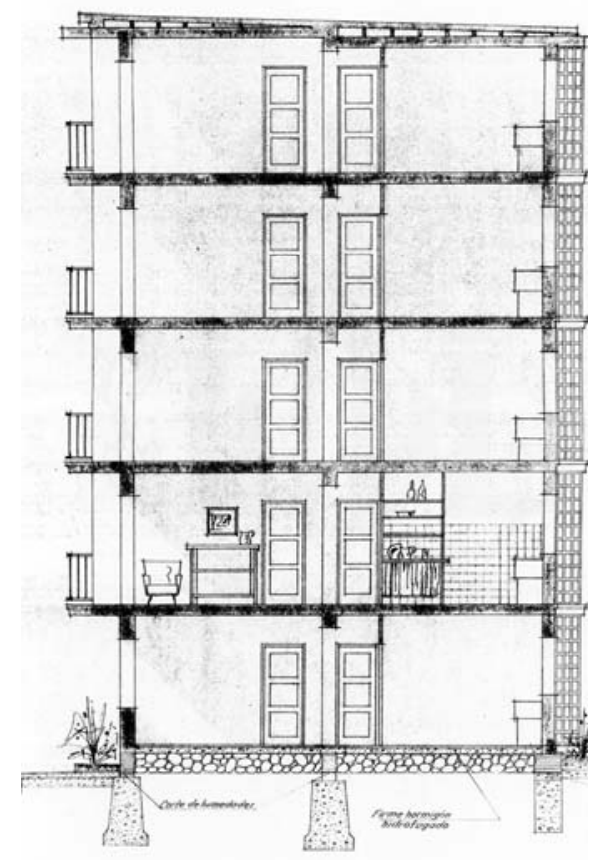

Grupo Virgen de la Fuensanta. Viviendas sociales. Planta baja, planta tipo, fachada de acceso y sección. (Archivo Histórico Municipal de valencia)
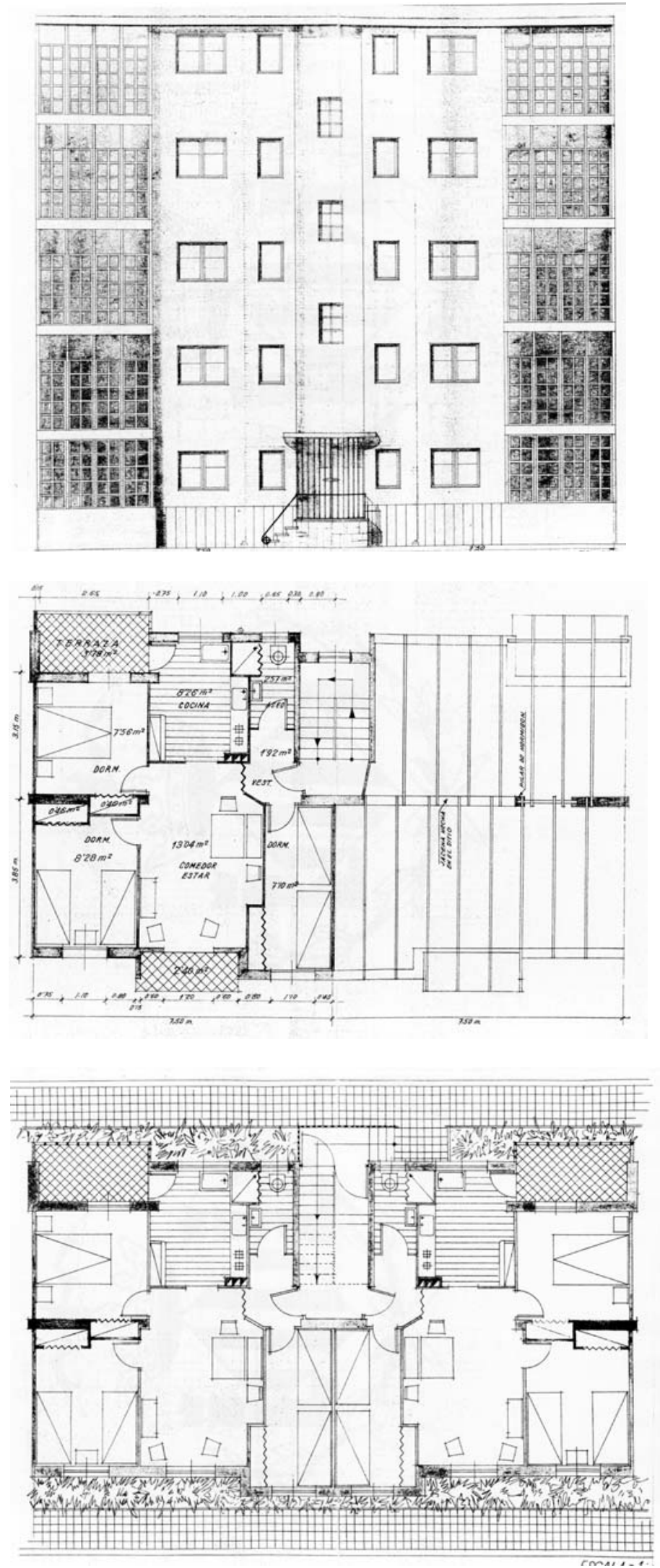


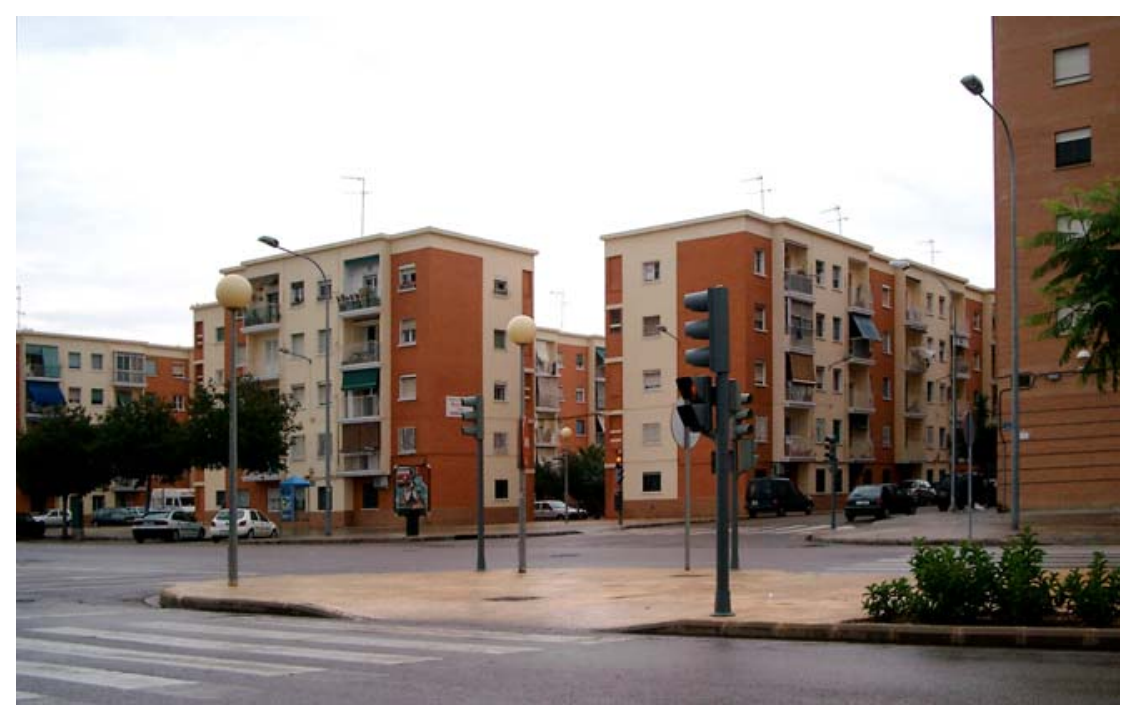

1

Los bloques lineales son la unidad edificatoria mínima, y como tales, no están construidos a trozos, como ocurre frecuentemente en la edificación abierta de promoción privada, sino de una sola vez.

Las fotografías aéreas permiten apreciar el carácter unitario del barrio, propio de los conjuntos de promoción pública. Este carácter unitario se refuerza en este caso con la seriación y repetición del bloque tipo y con el uso de un repertorio homogéneo y reducido de materiales.

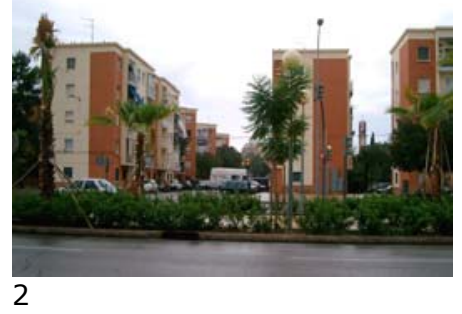

1. Vista desde la calle Tres Forques. Grupo de bloques en torno a la calle Lucrecia Bori.

2. Vista desde la calle Tres Forques.
Grupo Virgen de la Fuensanta. Ortofoto 2002 (AUMSA)

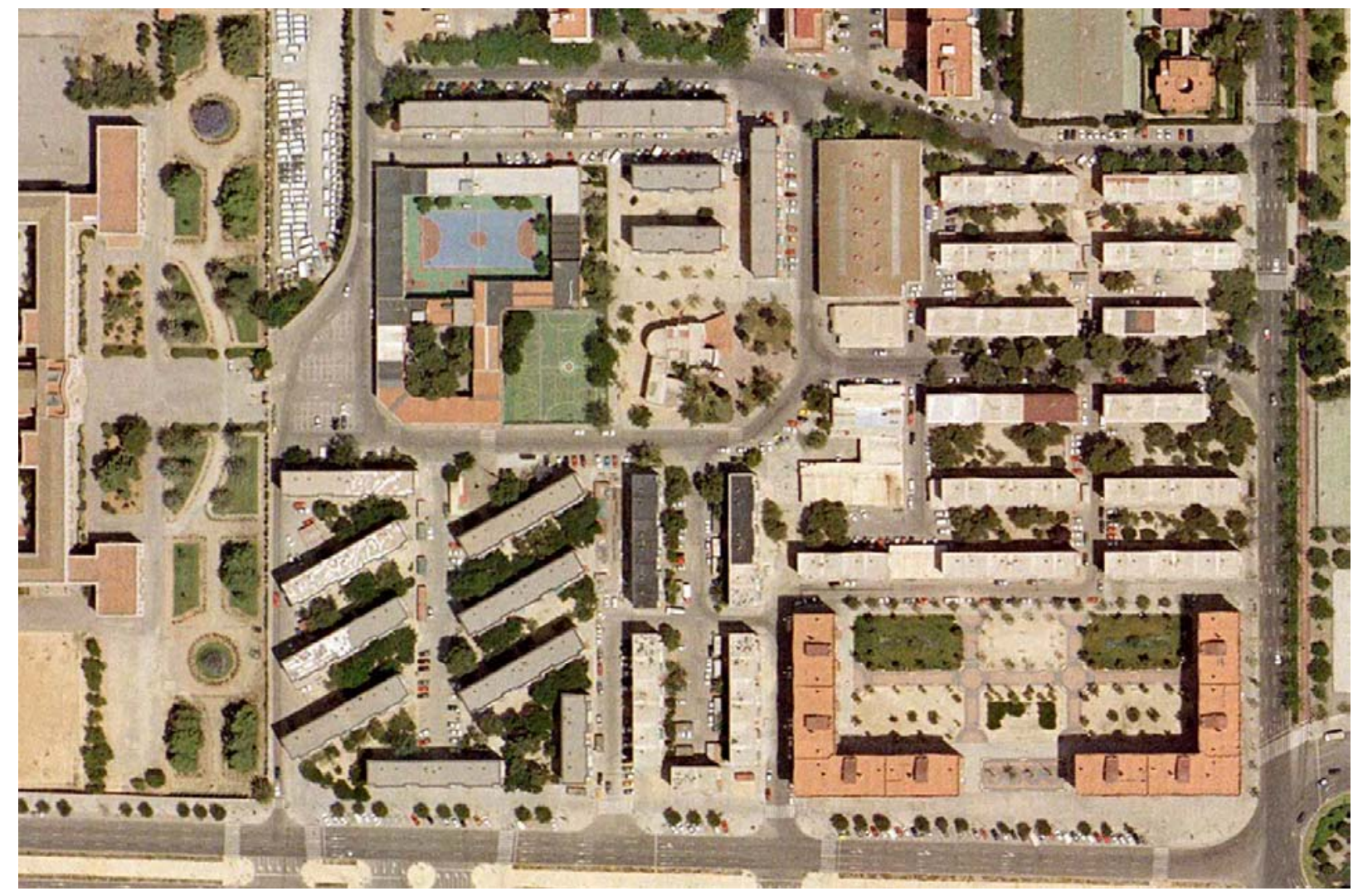


Plano de equipamientos. Proyecto inicial y final.

(Elaboración propia sobre Proyecto de urbanización de 1957 y Cartografía Básica Municipal, 1983)
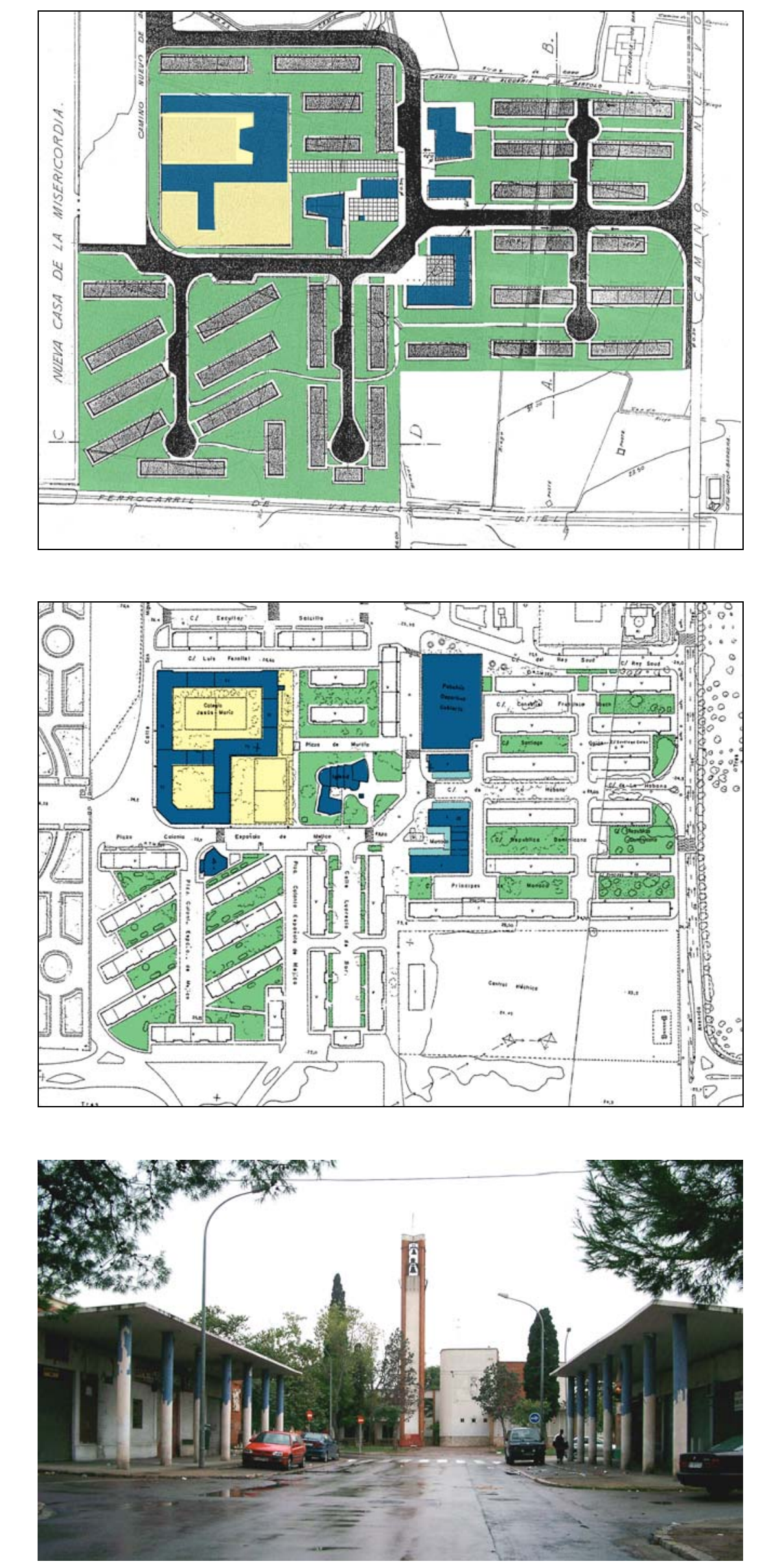

Calle de La Habana. Locales comerciales con pórticos, con la iglesia al fondo, cerrando la perspectiva. 


\section{Equipamientos}

A diferencia de lo que ocurre en el grupo Virgen de los Desamparados, analizado en la sección anterior, en el grupo Virgen de la Fuensanta los equipamientos ocupan un lugar central en la composición del conjunto.

El grupo Virgen de la Fuensanta está proyectado de acuerdo con una estricta zonificación racionalista. Los edificios de viviendas, supuestamente inmersos en zonas verdes, son exclusivos para este uso, sin locales comerciales en planta baja. Los equipamientos se disponen en torno a un centro vecinal, que incluye una iglesia, una casa-abadía, un grupo escolar y dos hileras de locales comerciales con pórticos delanteros.

La iglesia y su campanario cierran la perspectiva de la calle La Habana, que está flanqueada por los pórticos simétricos de los edificios destinados a locales comerciales. La escuela, por su parte, se sitúa en un segundo plano, aunque conectada peatonalmente con la plaza central del barrio (plaza de Murcia).

A los equipamientos originales del proyecto se añadió posteriormente un pabellón deportivo cubierto, así como una ampliación del edificio escolar.

Las zonas verdes previstas en el proyecto son únicamente los espacios intermedios entre bloques. La superficie de estas zonas verdes quedó reducida de manera considerable como consecuencia de las modificaciones introducidas en el viario original, que convirtió bastantes de ellas en calles con aceras, calzadas y bandas de aparcamiento.

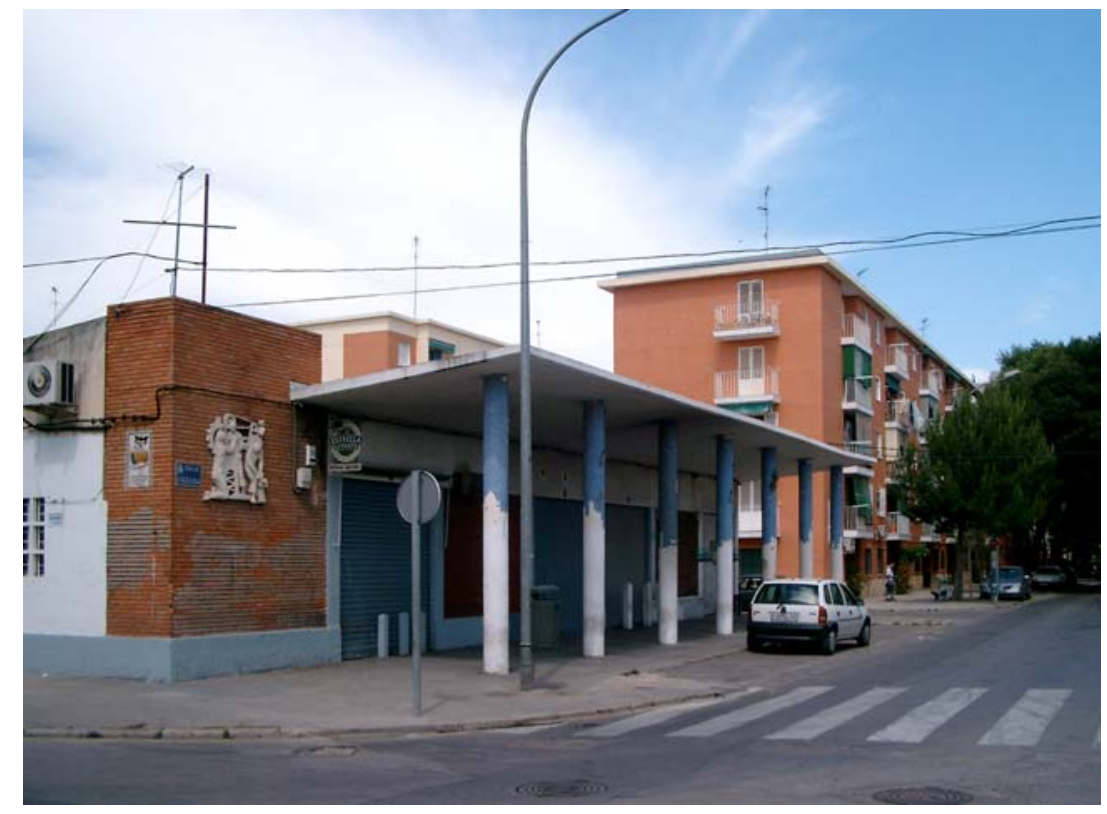

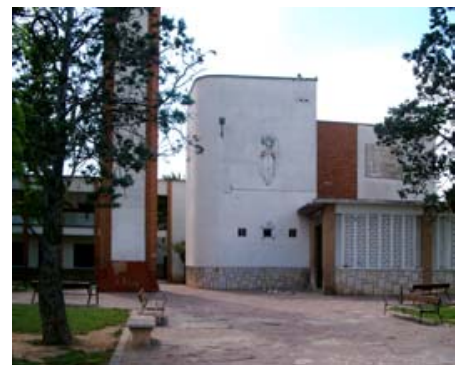

Grupo Virgen de la Fuensanta. Iglesia en la Plaza de Murcia.
Grupo Virgen de la Fuensanta. Calle de La Habana, vista hacia el este. 
Grupo Virgen del Carmen. Vista aérea (Informes de la Construcción, 149, 1963)

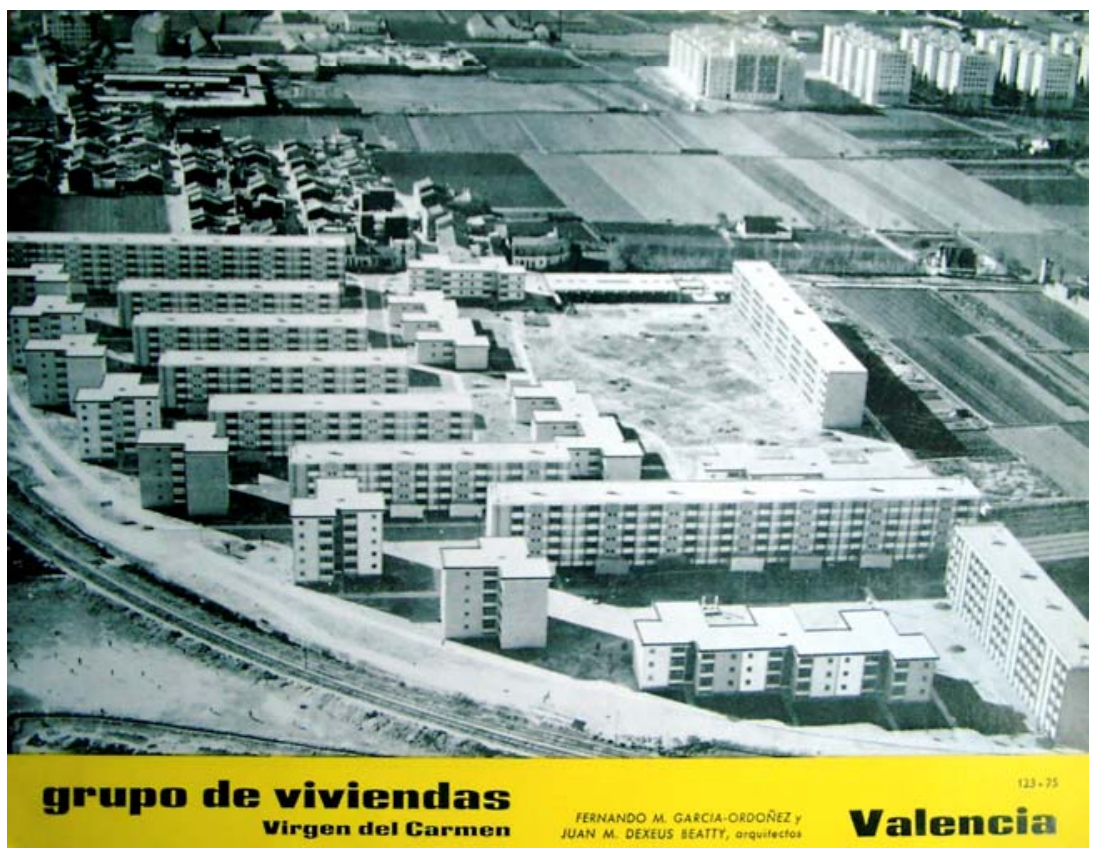

virgen del Garmen
Malentia

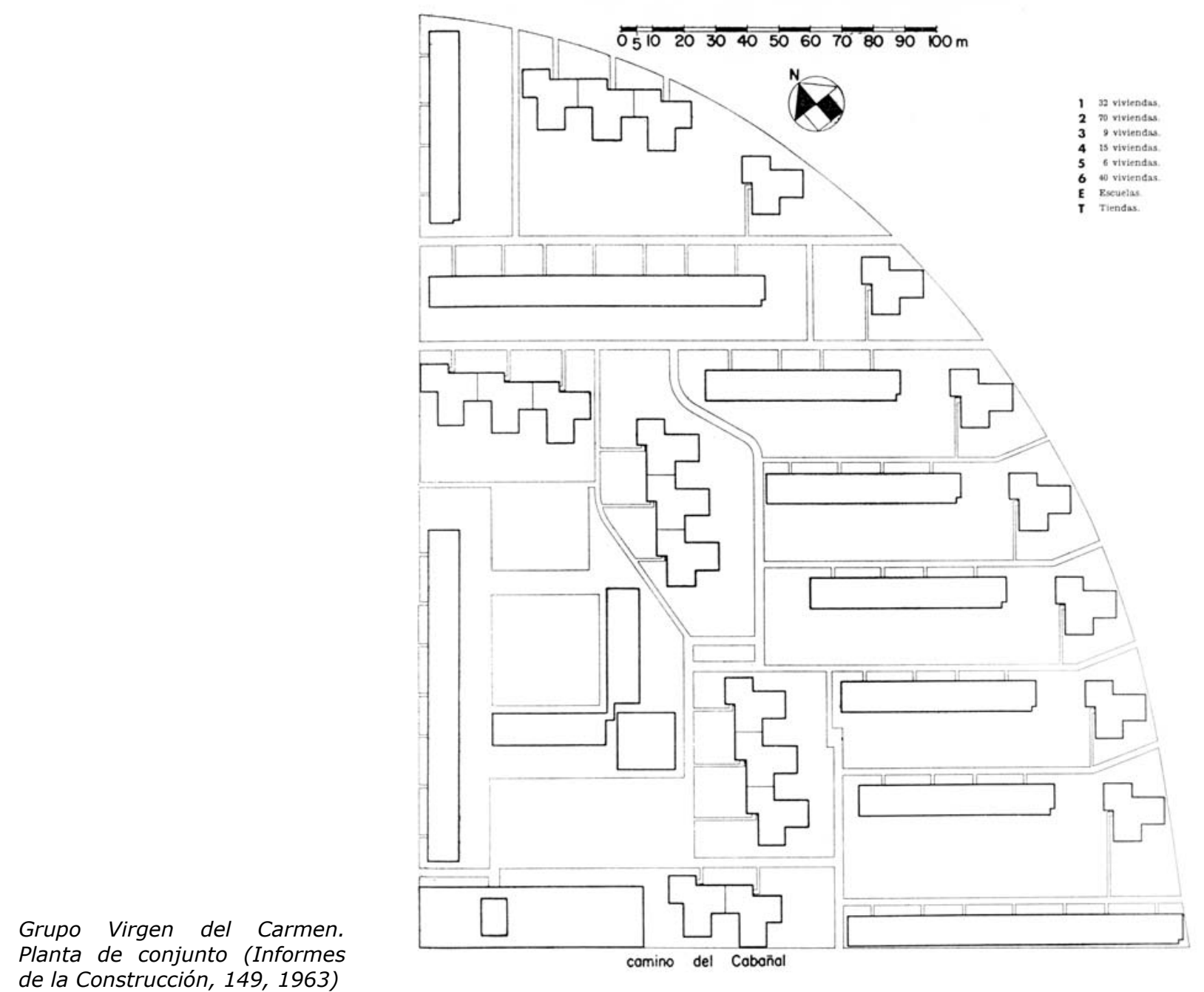

Grupo Virgen del Carmen. Planta de conjunto (Informes de la Construcción, 149, 1963) 


\section{GRUPO VIRGEN DEL CARMEN (1958-62).}

Dentro del Plan Riada, la OSHA realizó el grupo Virgen del Carmen, proyectado en 1958 por Fernando Martínez García-Ordóñez y Juan Ma Dexeus Beatty y construido entre 1958 y 1962. El grupo, de 614 viviendas de renta limitada, está situado junto al barrio del Cabañal, pero separado de éste por vías férreas que, además, trazan un arco que marca el límite noreste del conjunto.

El grupo fue edificado en una zona calificada de "reserva urbana", que fue recalificada como suelo "urbano edificable".

La tardía finalización del grupo hizo que fuese finalmente adjudicado parcialmente a funcionarios, dado que los damnificados por la riada ya habían sido atendidos.

El camino del Cabañal fue durante bastante tiempo la principal vía de acceso al grupo, aparte de los caminos entre campos de cultivo. Más tarde, tras la aprobación del Plan General adaptado a la Solución Sur de 1966, el grupo quedó integrado en el ámbito del Plan Parcial 12. Los autores del proyecto señalan, curiosamente, que el barrio está muy bien comunicado, argumentando que el $\mathrm{Ca}$ mino del Cabañal es una vía de bastante tráfico en la que existe además una línea regular de autobuses urbanos ${ }^{1}$.

El conjunto está proyectado en base a los principios del urbanismo funcionalista, tales como la separación de tráficos y la utilización de edificación abierta, con bloques insertos en espacios verdes de carácter público. Igualmente, el lenguaje arquitectónico utilizado es de adscripción racionalista, con piezas prefabricadas, estructura de hormigón vista y células de vivienda estandarizadas.

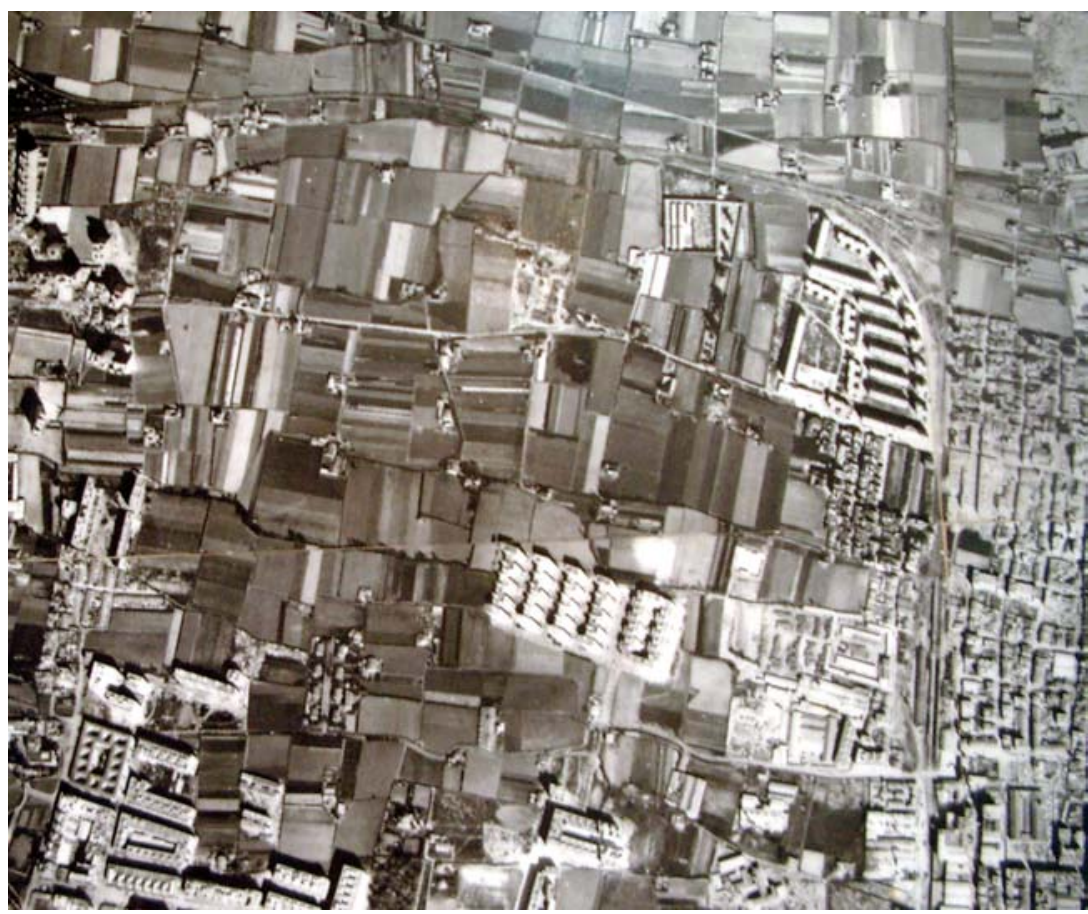

Grupo Virgen del Carmen. Fotografía aérea, h. 1965 (ETS de Arquitectura de Valencia)

1. García Ordóñez, Fernando M., Dexeus Beatty, Juan Ma, "Grupo de viviendas Virgen del Carmen. Valencia", Informes de la Construcción, '149, Instituto Eduardo Torroja de la Construcción y del Cemento, Madrid, 1963. 
Planta tipo de bloque lineal y de palazzina (Informes de la Construcción, 149, 1963)
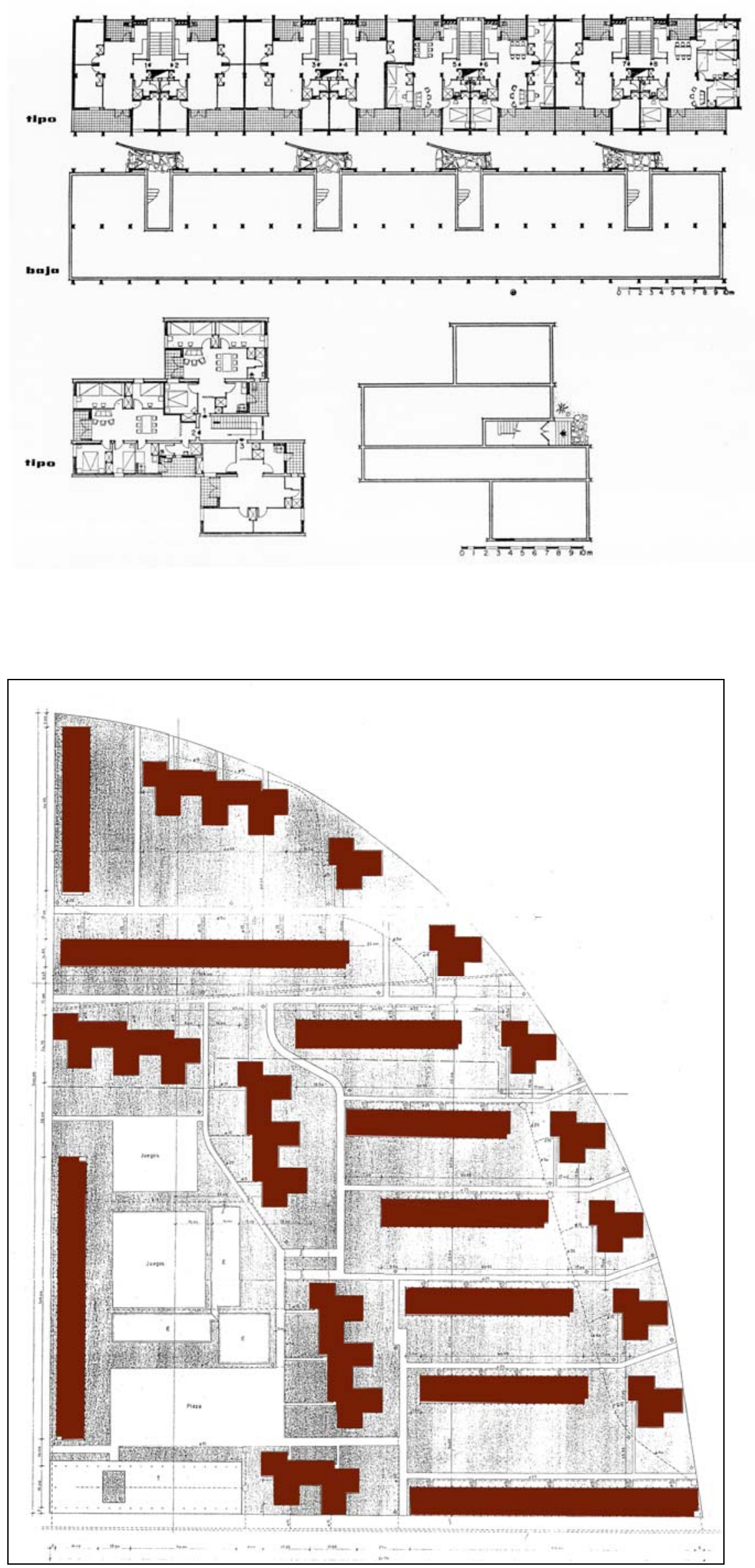

Planta de edificación en planta baja y en planta tipo (Elaboración propia a partir del Plano de urbanización, saneamiento y alumbrado general, 1958) 


\section{Edificación.}

En el grupo Virgen del Carmen, con el objeto de huir de un conjunto residencial monótono, se utilizan tres tipos de edificios de manera combinada:

- Bloque lineal de IV o V plantas, de longitudes variables (8 o 14 viviendas por planta, con 2 viviendas por caja de escalera).

- Palazzinas con planta en forma de $\mathrm{T}$ de $\mathrm{V}$ plantas, de $3 \mathrm{vi}$ viendas por planta.

- Bloque en cadena de III plantas, formado por la yuxtaposición de dos o tres palazzinas.

La mayor parte de los bloques lineales adoptan la forma de la edificación en línea o zeilenbau: bloques equidistantes, de igual orientación (en esta caso, con fachadas a norte y sur). Dos de ellos, sin embargo, se disponen ortogonalmente a los anteriores, según una directriz norte-sur alineada con la calle Campilllo de Altobuey, limite del barrio por el oeste.

Las palazzinas, situadas a continuación de los bloques lineales este-oeste, como cierre de perspectiva de los espacios verdes intermedios entre los mismos, conforman el alzado del bario en su borde este, que describe un arco paralelo al trazado de la línea de ferrocarriles eléctricos.

Los bloques en cadena, por su parte, juegan un cierto papel envolvente en torno a la zona destinada a centro vecinal, así como de cierre de los espacios interbloques.

En la parte norte, la edificación en línea se sustituye por una disposición perimetral de los edificios en torno a un espacio libre.

Las alturas de la edificación son variables, aumentando desde la zona de las escuelas (dos plantas) hacia los bordes (cinco plantas).

Las superficies de las viviendas oscilan entre 69,56 y 96,37 $\mathrm{m} 2$ construidos.
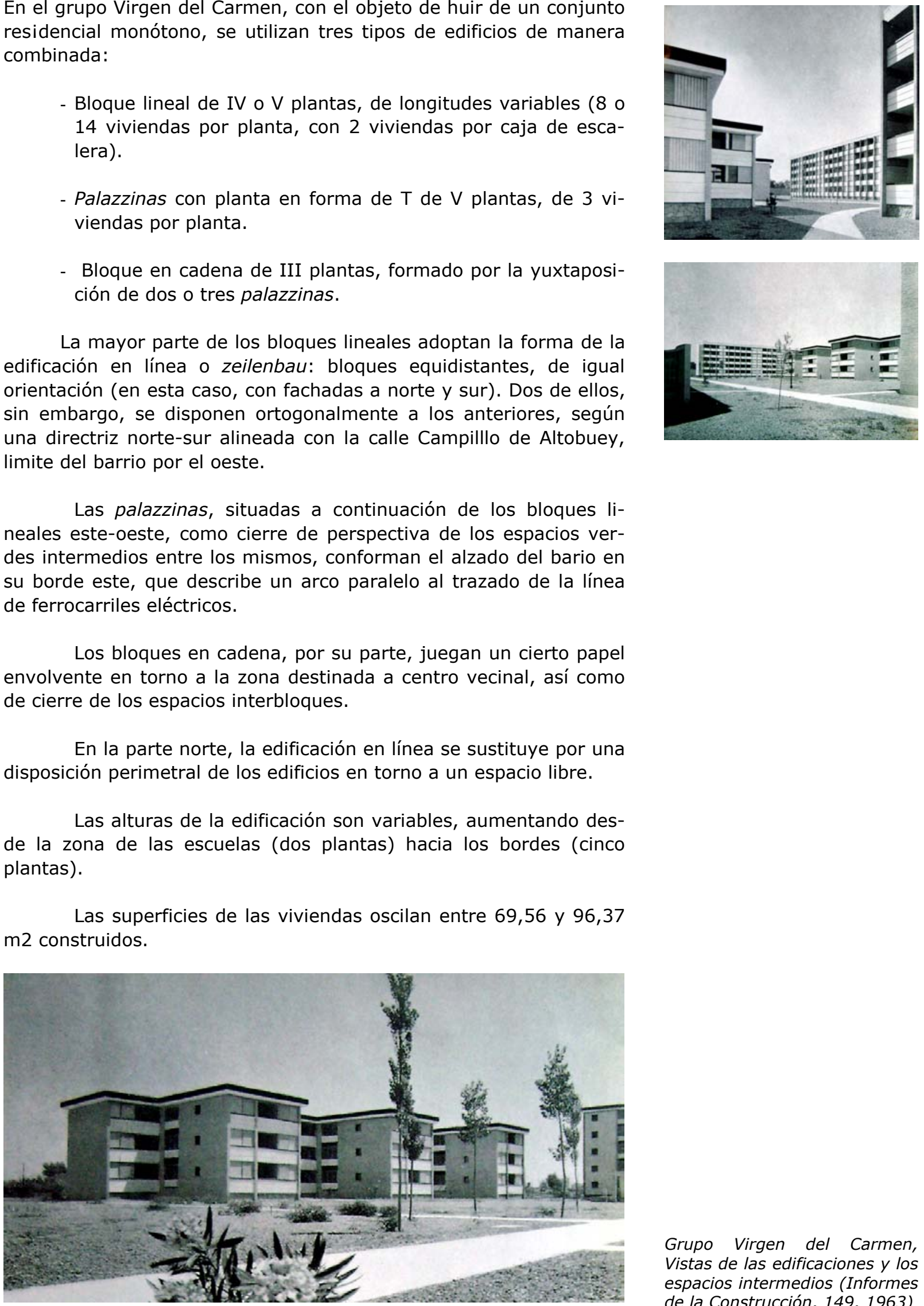

Grupo Virgen del Carmen, Vistas de las edificaciones y los espacios intermedios (Informes de la Construcción, 149, 1963) 

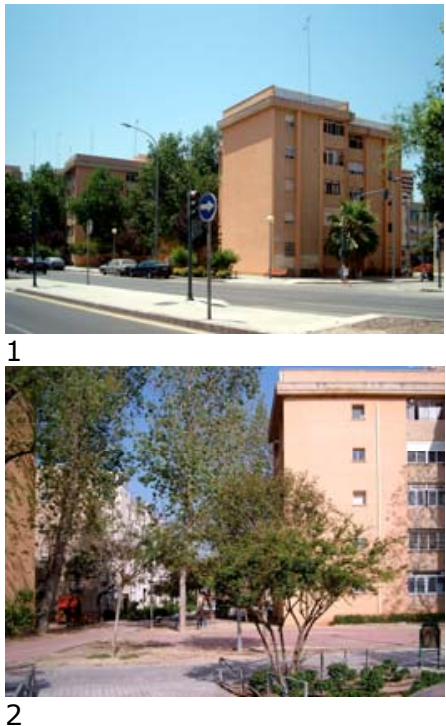

2

La poca altura de su edificación es precisamente uno de los elementos que diferencian más claramente a este conjunto con respecto a los que resultarán de los planes parciales municipales posteriores y de la promoción privada, en los que la edificación abierta asumirá, como veremos, alturas y densidades mucho mayores. La reducida altura de las edificaciones, unida a su poco desarrollo en planta, en especial en el tipo de las palazzinas, hace que por una parte las calles parezcan inusualmente amplias aunque no lo sean en realidad, y que, además, el arbolado pueda llegar a envolver a los edificios, al superar la altura de cornisa de los mismos.

El otro aspecto que diferencia claramente al barrio en cuanto a su edificación es consecuencia del carácter unitario del proyecto que deriva de la promoción pública del mismo: la homogeneidad de la edificación desde el punto de vista arquitectónico, que se consigue mediante el uso del mismo repertorio de materiales y de sistemas compositivos en todos los edificios, y mediante la repetición de los mismos.

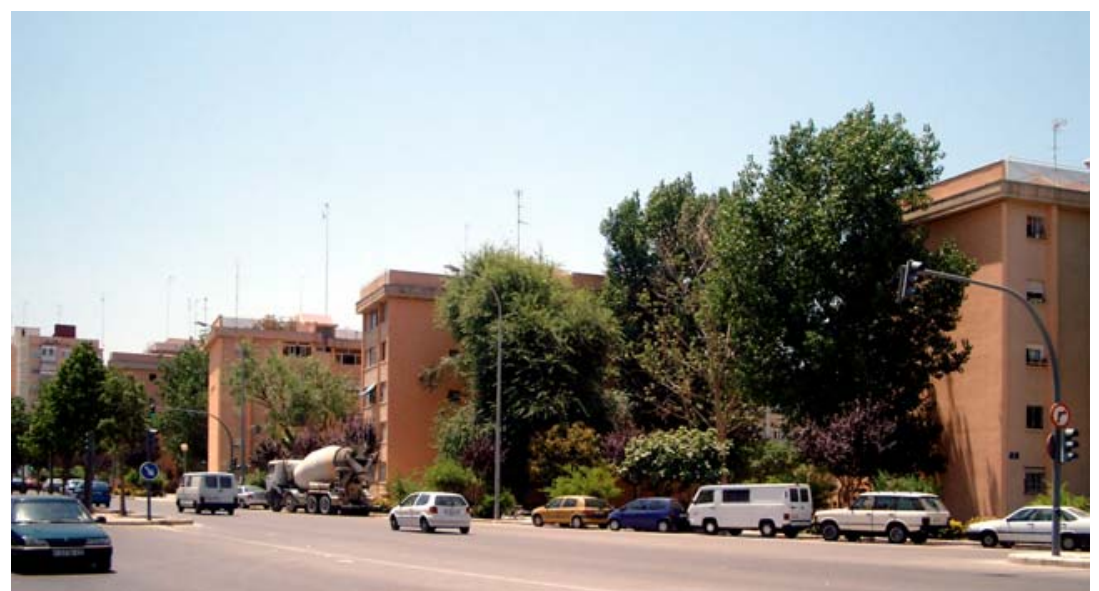

3

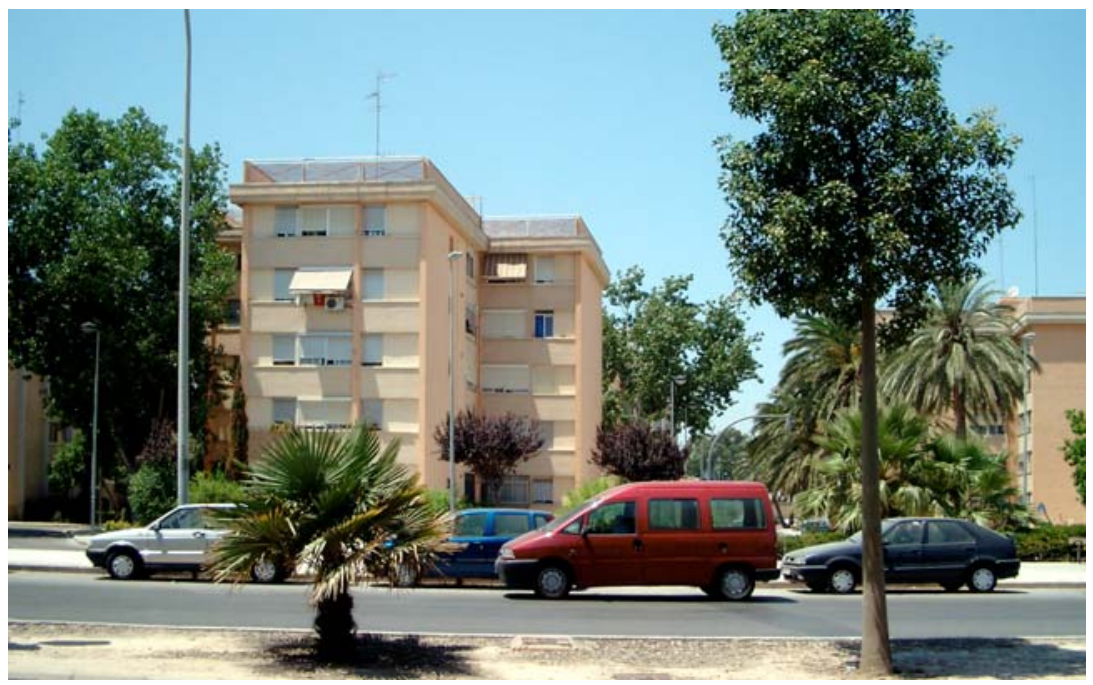

4 


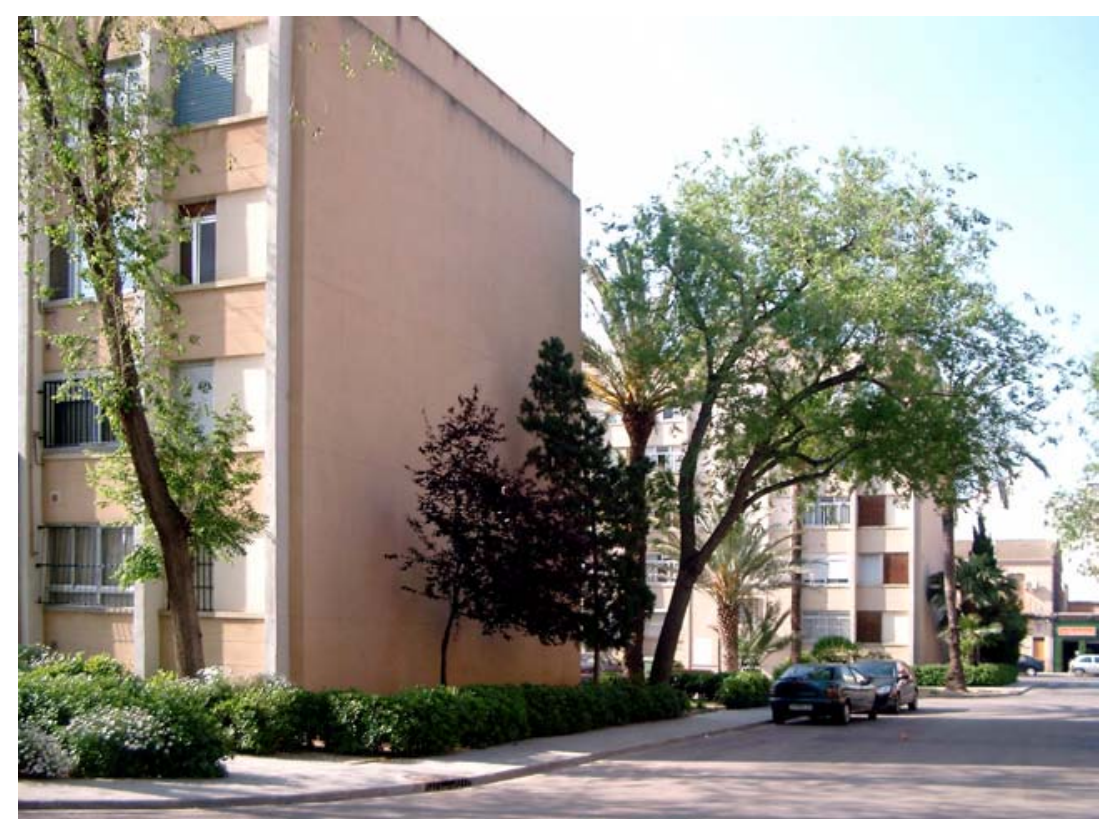

1

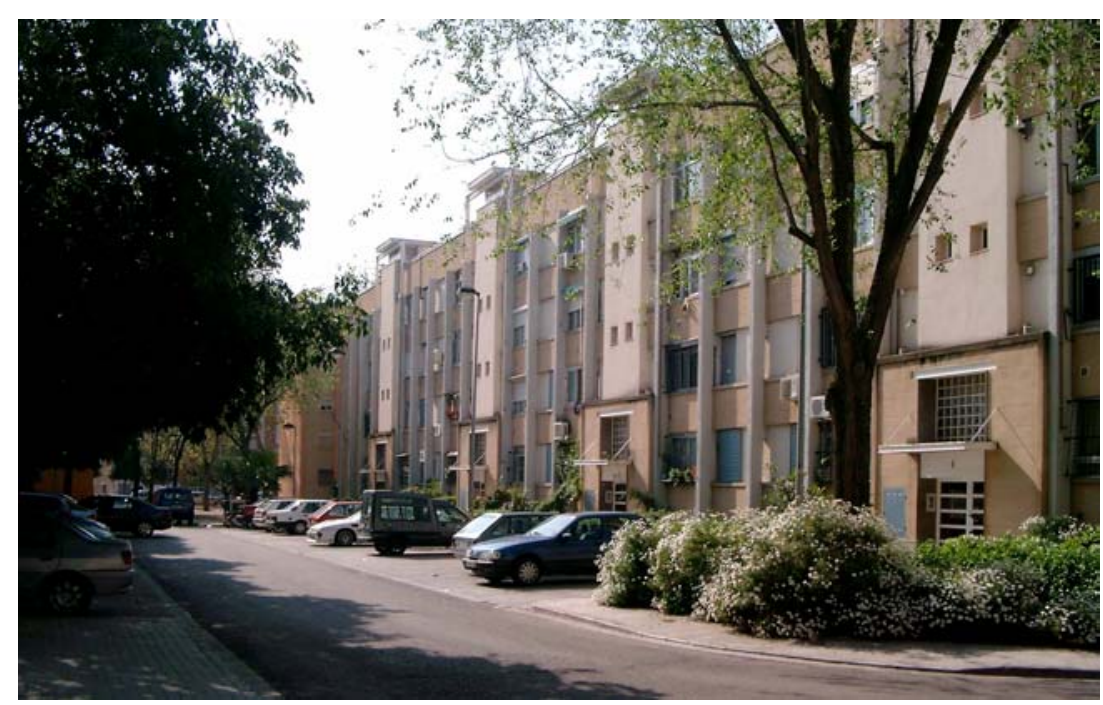

2

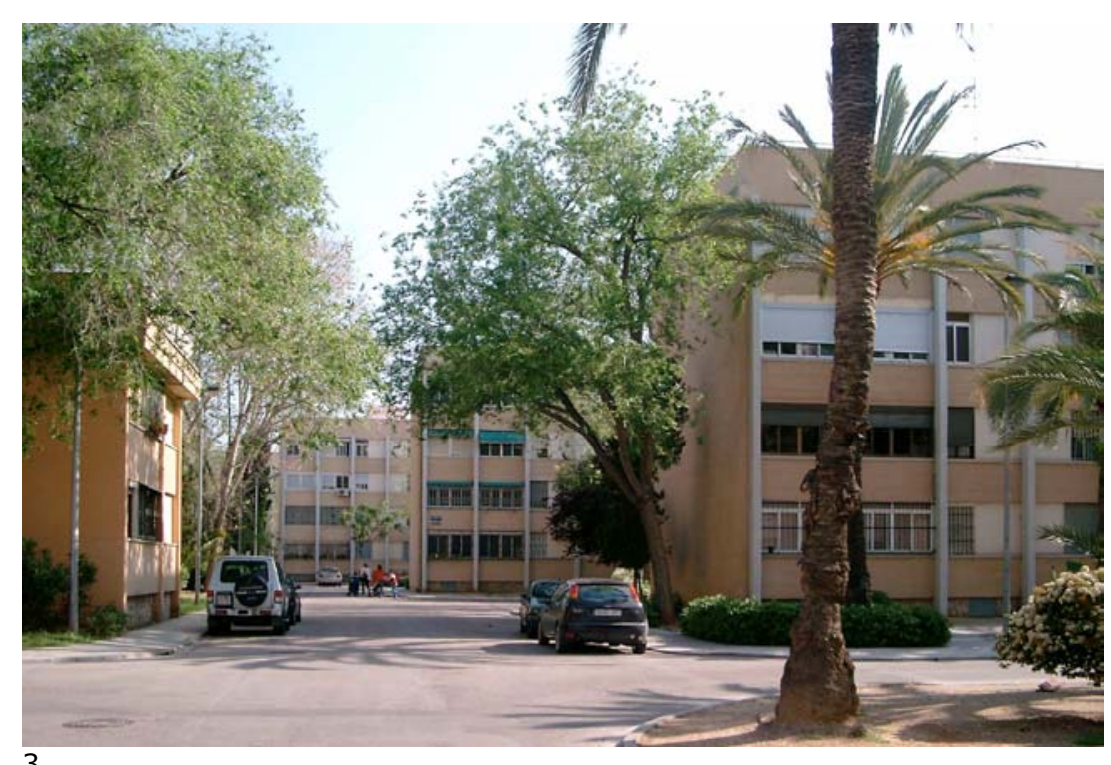

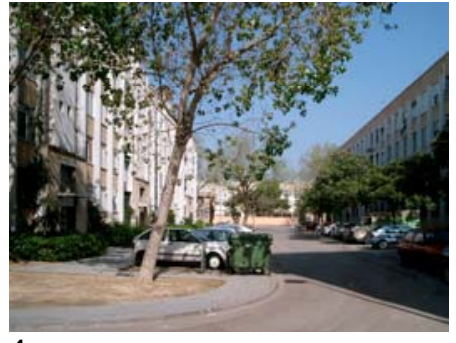

4

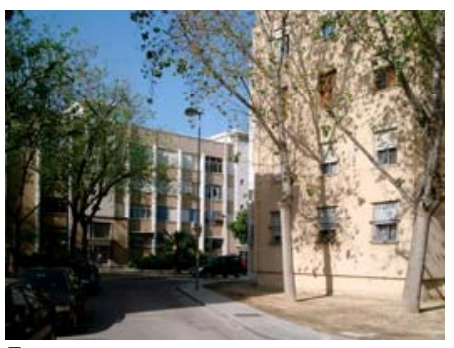

1. Calle sin nombre, vista hacia el sur. Testeros de los bloques lineales.

2. Calle Actor Mauri, vista hacia el este.

3. Calle sin nombre, vista hacia el norte.

4. Calle Pintor Dalmau, vista hacia el este.

5. Calle diagonal entre un bloque lineal y una palazzina. Al fondo, calle Jaime Villanueva 


\section{Equipamientos}

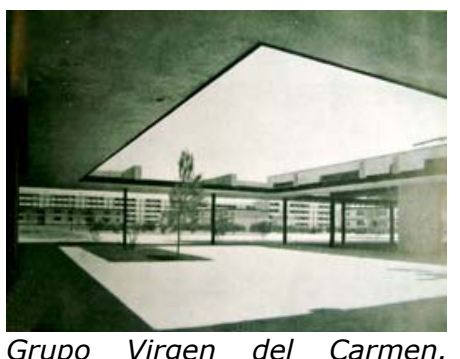

Vista de la plaza porticada (Informes de la Construcción, 149, 1963)
Grupo Virgen del Carmen. Planta de equipamientos (Elaboración propia a partir del Plano de urbanización, saneamiento y alumbrado general, 1958)
El proyecto original prevé una localización excéntrica, en el vértice suroeste, del centro vecinal del barrio. Los elementos que componen este centro son un grupo de tiendas y una escuela, dispuestos en torno a una plaza.

Las tiendas ocupan la franja recayente al Camino del Cabañal, que es la calle más importante de entre las que circundan el barrio. Un atrio porticado inserto en esta franja comercial enlaza el Camino del Cabañal con la plaza que constituye el centro del grupo. Las edificaciones que envuelven la escuela son de menor altura que las demás.

En la actualidad, el espacio destinado a locales comerciales está ocupado por una estación de servicio y un lavacoches, que actúa como barrera entre el barrio y el Camino del Cabañal. Por otra parte, el recinto de la escuela se ha ampliado con respecto al original, por lo que ha desaparecido la plaza prevista como centro del barrio.

El barrio es, pues, absolutamente monofuncional, y carece de locales comerciales propios, por lo que depende completamente de los de su entorno.

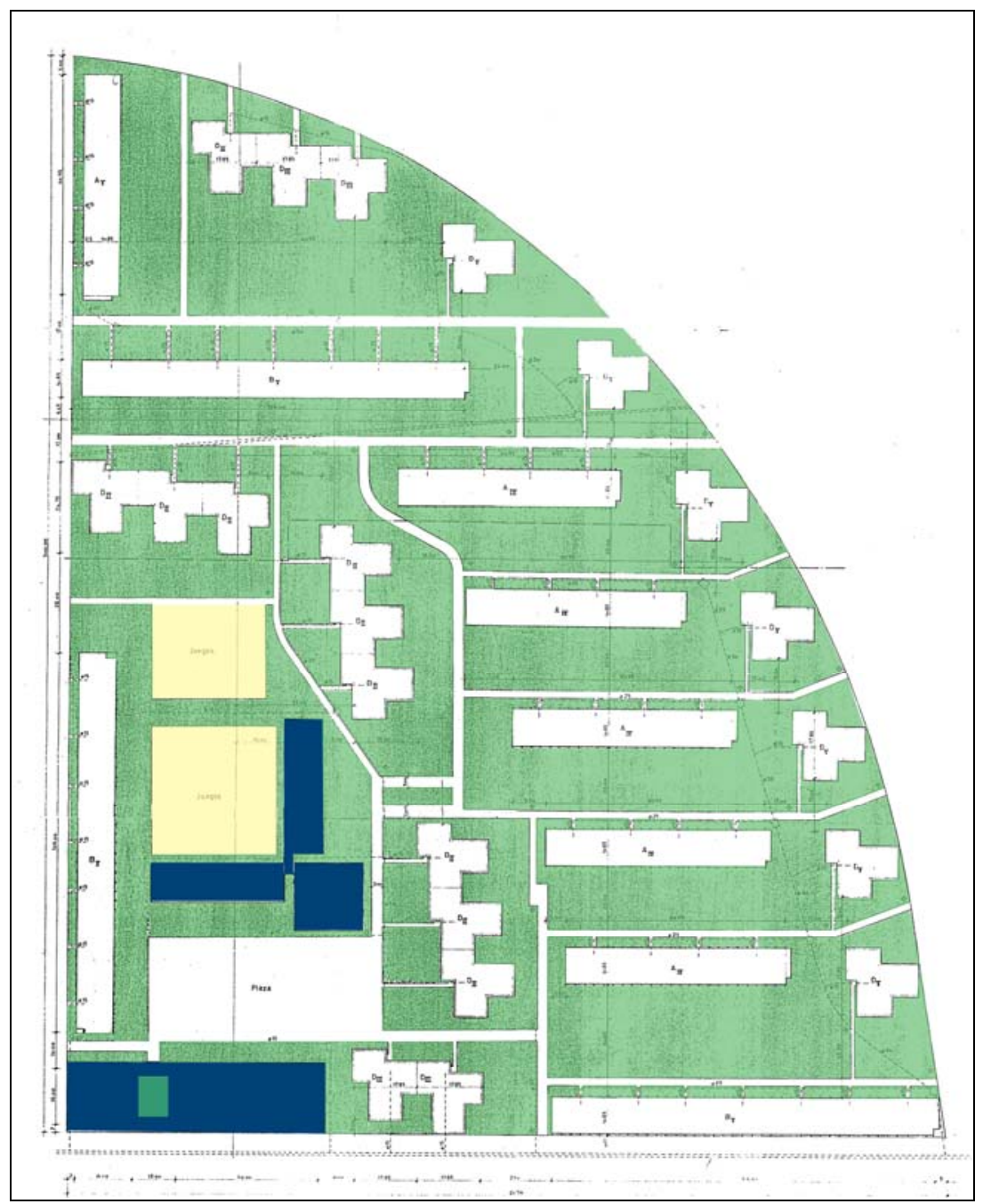




\section{Trazado viario}

En el trazado viario del proyecto original de 1958 del grupo Virgen del Carmen, se planteaba una estricta separación entre el tráfico rodado y el peatonal. Las únicas calles previstas para el tráfico rodado eran las perimetrales, y el viario interno para el acceso a las viviendas era exclusivamente peatonal.

Este trazado inicial fue modificado en dos etapas. Primero, en 1972 , se proyectó un nuevo viario en el que aparecen ya dos calles destinadas al tráfico rodado que penetran en el barrio. Una de estas calles, la de Isidro Ballester, atraviesa el barrio de este a oeste. La segunda es un ramal sin salida que arranca del camino del Cabanyal en perpendicular al mismo, en dirección norte.

Posteriormente, en 1977, se planteó una nueva modificación del viario con la que quedaron definitivamente desvirtuados los supuestos originales de separación de tráfico rodado y peatonal. Esta modificación introducía de manera generalizada el tráfico rodado en el interior del conjunto, convirtiendo los espacios verdes entre bloques en calles con aparcamientos. Ello suponía reconocer y asumir el hecho real de que los coches de los vecinos llevaban años invadiendo esos teóricos espacios verdes intersticiales.

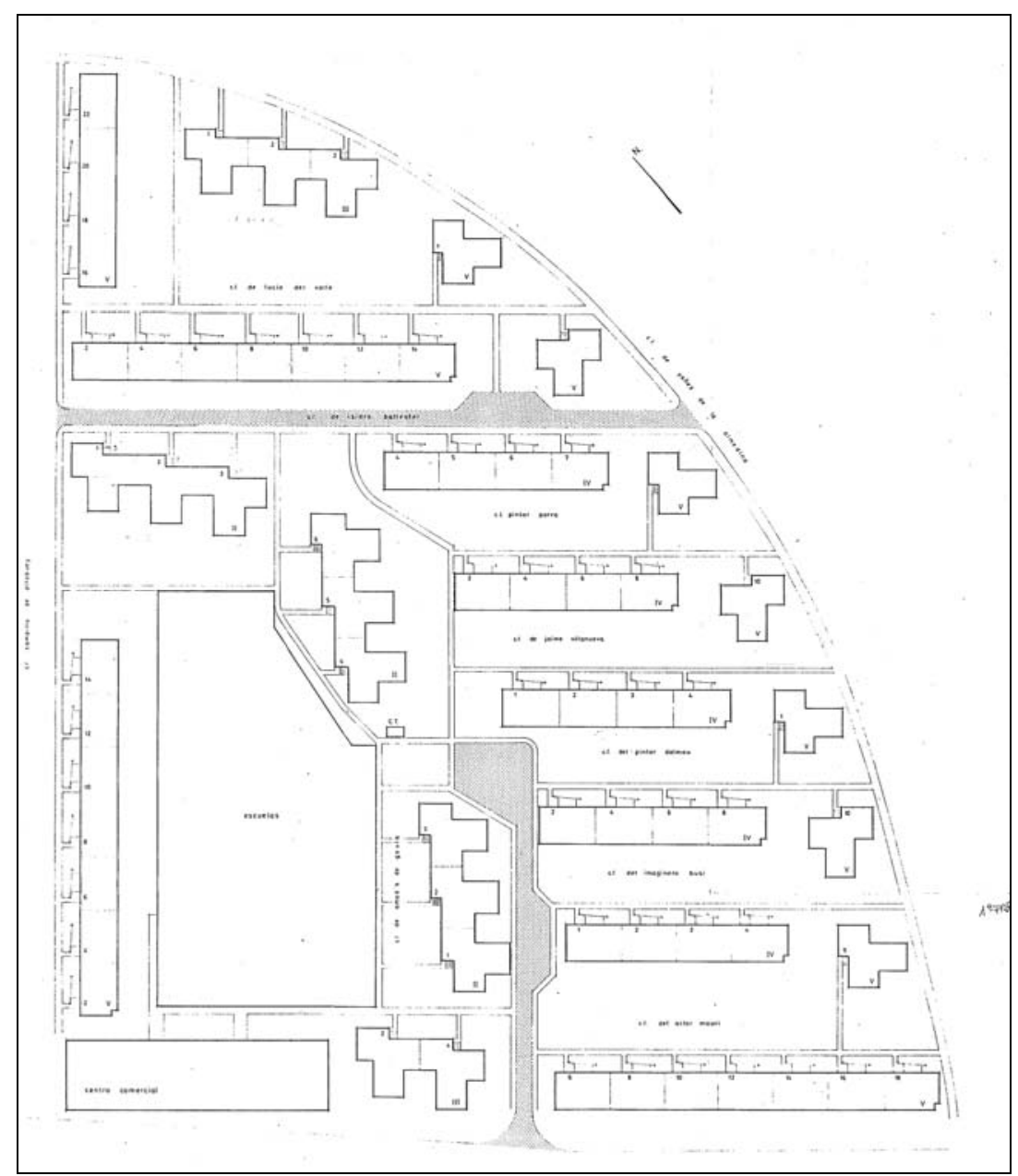

Grupo Virgen del Carmen. de la Planta viaria. Primera modificación (Archivo de Planeamiento. Ayuntamiento de Valencia) 
Con el nuevo trazado viario, los delgados bloques dispuestos en línea pasan a estar rodeados de calles. Estas calles, sin embargo, no tienen la bilateralidad propia de las calles urbanas: en los bloques dispuestos en según la directriz este-oeste, por ejemplo, la calle paralela a la fachada norte cumple una función de acceso a zaguanes, pero en la calle paralela a la fachada opuesta no hay acceso a zaguanes, sino una sucesión de ventanas de viviendas de planta baja.

Las fotografías del barrio Virgen del Carmen que se publicaron en 1963 en la revista Informes de la Construcción muestran una urbanización precaria y desangelada, con unos pocos árboles escuálidos sobre una alfombra supuestamente verde.

Desde entonces, esta situación ha mejorado ostensiblemente en lo referente a la calidad de la urbanización y de la jardinería ${ }^{1}$. Actualmente, el arbolado, ya crecido, tiene un protagonismo considerable en la imagen del barrio, y compite en altura con los edificios. El suelo, en cambio, sigue asfaltado en su mayor parte y ocupado por calzadas y bandas de aparcamiento.

Grupo Virgen del Carmen. Planta viaria. Segunda modificación (Elaboración propia. Color sobre Cartografía Básica Municipal de 1983)

1. El Instituto Valenciano de la Vivienda llevó a cabo una rehabilitación integral del barrio, incluyendo edificios y espacios libres, a finales de los años 90. La restauración de la edificación supuso la introducción de algunos añadidos dudosos y poco coherentes con el lenguaje arquitectónico original

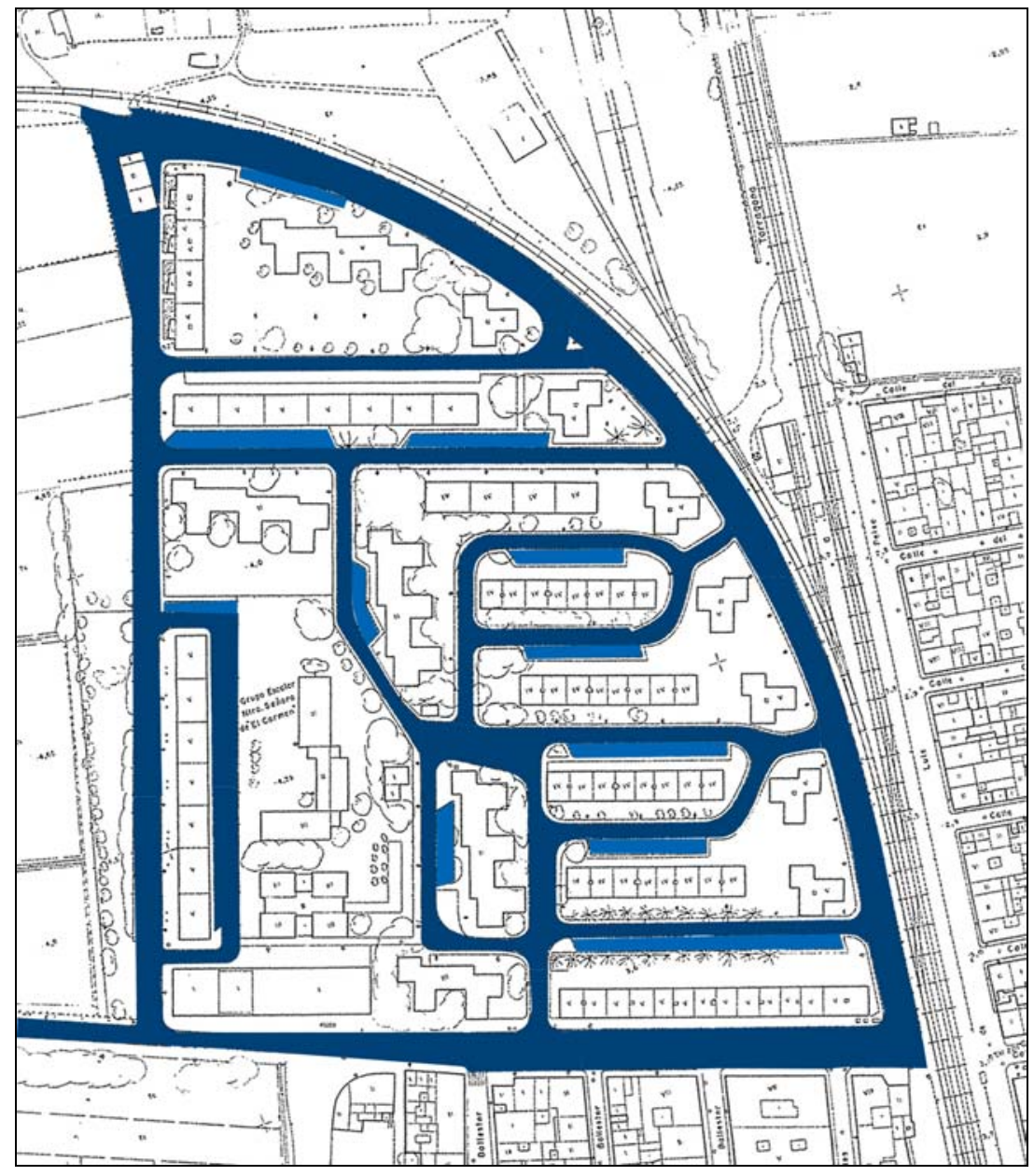



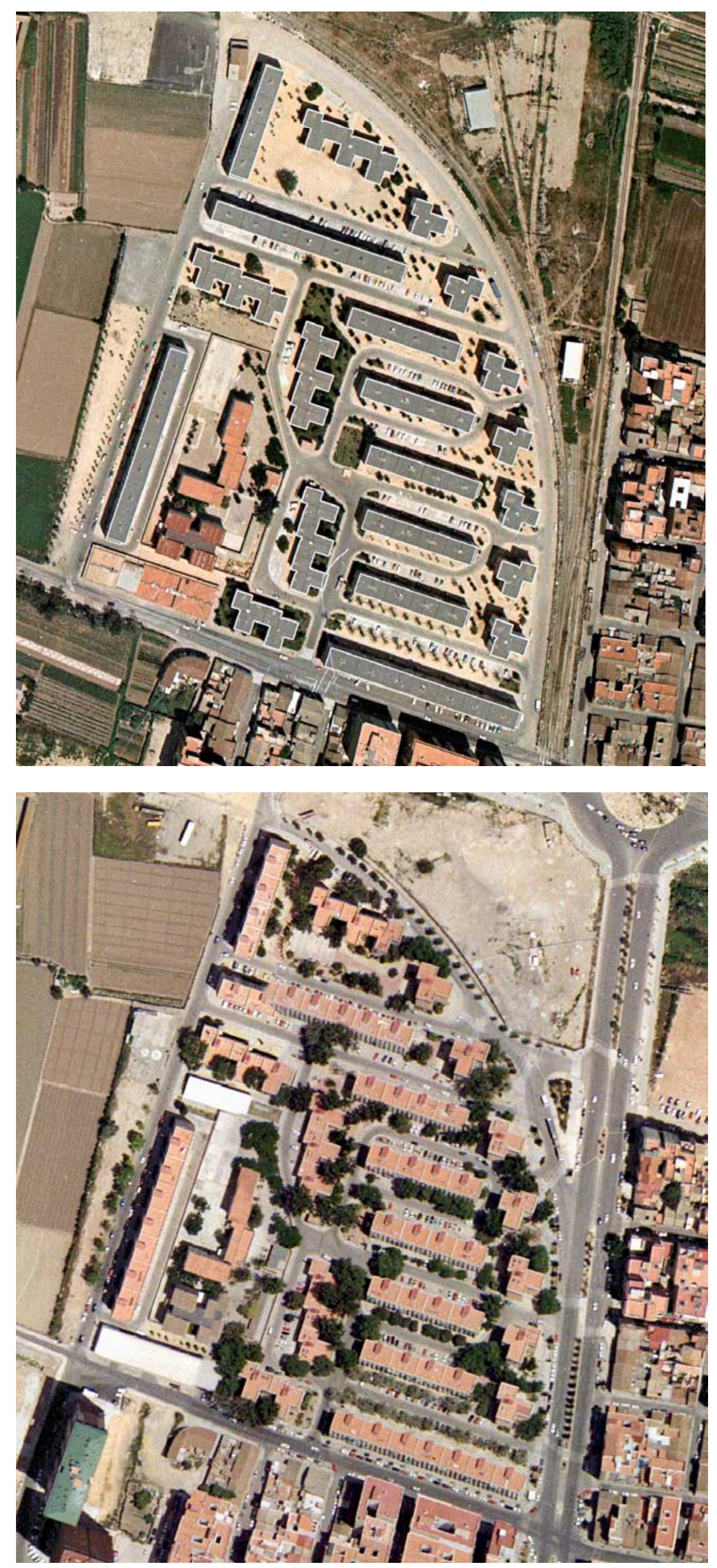

Grupo Virgen del Carmen. Fotoplano, 1980(AUMSA).
Grupo Virgen del Carmen. Ortofoto 2002 (AUMSA). 


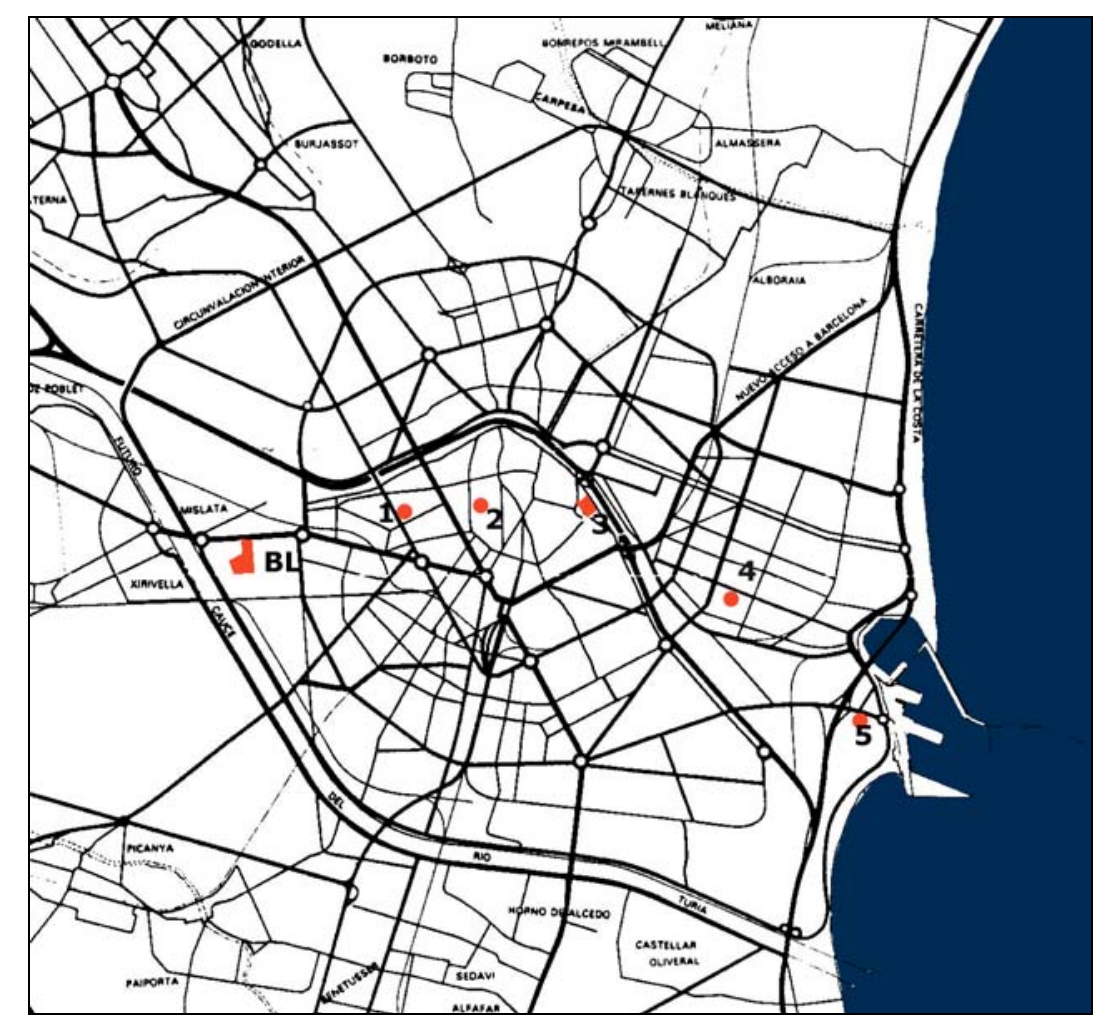

Grupos de viviendas de renta Limitada. Localización.

BL. Barrio de la Luz.

1. Grupo Santa Maria Micaela.

2. Grupo Bernardo Lassala.

3. Conjunto de la Ciudadela.

4. Grupo Pintor Maella.

5. Grupo Stella Maris.

Tabla II.3

Grupos de Viviendas de Renta Limitada de promoción privada proyectados mediante edificación abierta. Valencia, 1957-62.

\begin{tabular}{|l|r|l|}
\hline GRUPO & VIVIENDAS & AÑOS \\
\hline Barrio de la Luz & 1.157 & $1957-$ \\
\hline Stella Maris & 240 & $1958-60$ \\
\hline Lassala (CFDP) & 40 & $1956-62$ \\
\hline Sta. María Micaela (CAC) & 138 & $1958-61$ \\
\hline Pintor Maella & 610 & $1961-$ \\
\hline Elcano & 34 & $1958-62$ \\
\hline Químicos & 18 & $1957-58$ \\
\hline Proviman & 56 & $1957-58$ \\
\hline Cataluña (CFAV) & 136 & $1956-69$ \\
\hline Ciudadela & 136 & $1961-$ \\
\hline
\end{tabular}

Abreviaturas:

CAC: Cooperativa de Agentes Comerciales.

CFAV: Cooperativa de Funcionarios del Ayuntamiento de Valencia.

CFDP: Funcionarios de la Diputación Provincial. 


\section{LA EDIFICACIÓN ABIERTA DE PROMOCIÓN PRIVADA: EL BARRIO VIRGEN DE LA LUZ Y LOS EPISODIOS AISLADOS EN ÁREAS URBANAS CONSOLIDADAS.}

Como hemos señalado anteriormente, la Ley de Viviendas de Renta Limitada, promulgada en 1954, supuso un apoyo a la promoción privada de viviendas, a través de créditos, exenciones fiscales y otras medidas complementarias. Esta promoción privada empezará a asumir protagonismo en Valencia a partir de 1957, con posterioridad a la Gran Riada del Turia.

Entre 1958 y 1966, la edificación abierta y el lenguaje arquitectónico racionalista asociado a la misma se introducirán de manera decidida en diversos grupos de Viviendas de Renta Limitada promovidos en la ciudad por parte de cooperativas de funcionarios o particulares y empresas.

En algunos de estos grupos, como en los de Santa María Micaela, Pintor Maella o Bernardo Lassala, fragmentos de bloques de edificación abierta aparecen insertos en tejidos urbanos consolidados de ensanche $o$, incluso, de centro histórico, como partes de manzanas cerradas. Lo mismo ocurre, a mayor escala, en operaciones aisladas de renovación urbana como la del conjunto de la Ciudadela.

Es otros casos, como en el grupo Stella Maris, situado junto al poblado de Nazaret, la edificación abierta es la nueva forma que asume la extensión de los tejidos urbanos consolidados.

En todos estos episodios aislados, cuyo tamaño no supera el de la manzana, los bloques y las torres propios del orden abierto coexisten por lo general con edificación entre medianeras.

El único conjunto de viviendas de Renta Limitada de promoción privada realizado en Valencia en este periodo cuyo tamaño es superior al de una manzana y resulta asimilable al de un conjunto residencial es el Barrio de la Luz, construido a partir de 1958 junto al eje de la Avenida de Castilla.

La Tabla II.3 recoge los grupos más representativos de Viviendas de Renta Limitada construidos en el periodo 1958-62 por cooperativas y empresas. Analizaremos a continuación aquellos que constituyen episodios aislados, enmarcando el análisis de los restantes en el contexto de los planes parciales de los que forman parte. Así, por ejemplo, los grupos Elcano, Proviman y Cataluña se analizarán conjuntamente con el Plan Parcial 11, de cuyo ámbito forman parte.
1.Para los grupos promovidos por cooperativas y empresas, ver Peñín Ibáñez, Alberto, Valencia 1874-1959. Ciudad, arquitectura y arquitectos, Escuela Técnica Superior de Arquitectura de Valencia, Valencia, 1978., pp. 189206 y Llopis, Amando y VtiM, "Arquitectura moderna en Valencia. Del rechazo de la vanguardia a la necesidad de encontrar ideas y proyectos acordes con el espíritu de una nueva época", en Llopis, Amando y Dauksis, Sonia, Op. cit., pp. 65-87. 
Barrio Virgen de la Luz. Planta de conjunto (Sombreado sobre Cartografía Básica Municipal de Valencia de 1983).

Barrio Virgen de la Luz inserto en Barrio Residencial No 2 de la Avenida de Castilla, 1958 (Archivo de Planeamiento, Avuntamiento de Valencia).
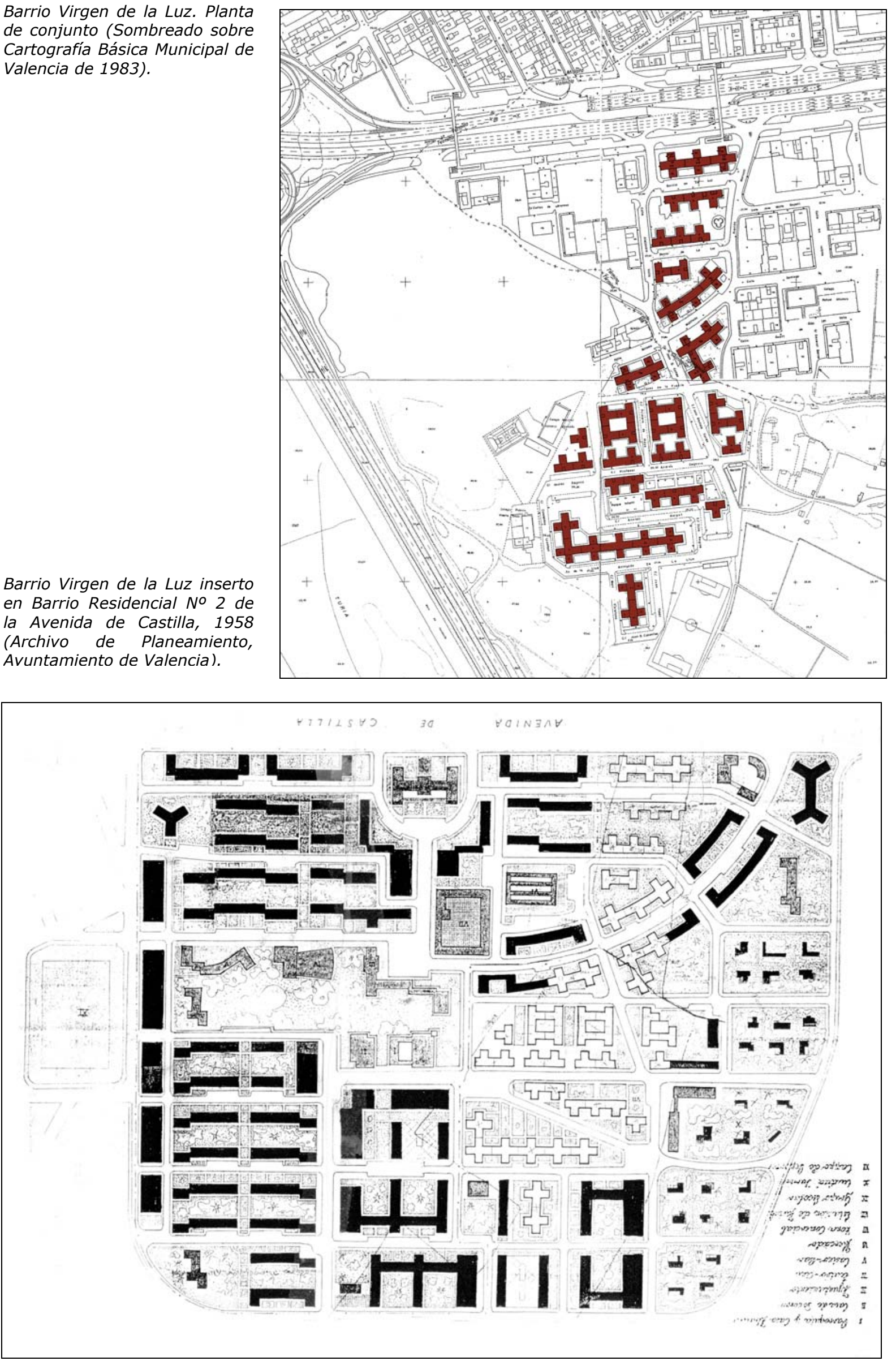


\section{BARRIO VIRGEN DE LA LUZ (1957)}

El conjunto del barrio de la Luz, con 1.157 viviendas de renta limitada y 70 locales comerciales, proyectado por V. Figuerola en 195758 para la Inmobiliaria "La Alquería", es la promoción privada de mayor tamaño de los años cincuenta. De los grupos de promoción pública, únicamente el Virgen de los Desamparados alberga un número de viviendas mayor, pero realizadas en fases sucesivas.

Peñín califica la ordenación del barrio como "anárquica. Sin estructuración urbana y con la sola intención del máximo aprovechamiento"1.

Sin embargo, la ordenación de los bloques del Barrio de la Luz no resulta tan anárquica si la observamos inserta en el Plan al que se ajusta, que es del denominado "Barrio Residencial no 2 en la Avenida de Castilla", analizado en la Sección anterior ${ }^{2}$.

Así, podemos ver que si algunos bloques no siguen la alineación de la Avenida de Castilla es porque formaban parte de un eje de directriz curva previsto en el proyecto para el Barrio Residencial no 2, eje que desapareció en el planeamiento posterior. Lo mismo ocurre con otros bloques más al sur dispuestos de forma escalonada $y$ en $L$, que flanqueaban un eje diagonal del proyecto mencionado.

Los bloques del Barrio de la Luz, que tienen entre V y VIII plantas, son el resultado de la agregación de dos módulos básicos de agrupación de viviendas. Los dos módulos utilizados son el módulo en $\mathrm{T}$ (tres viviendas por caja de escalera en cada planta) y el módulo en cruz (cuatro viviendas por caja de escalera).

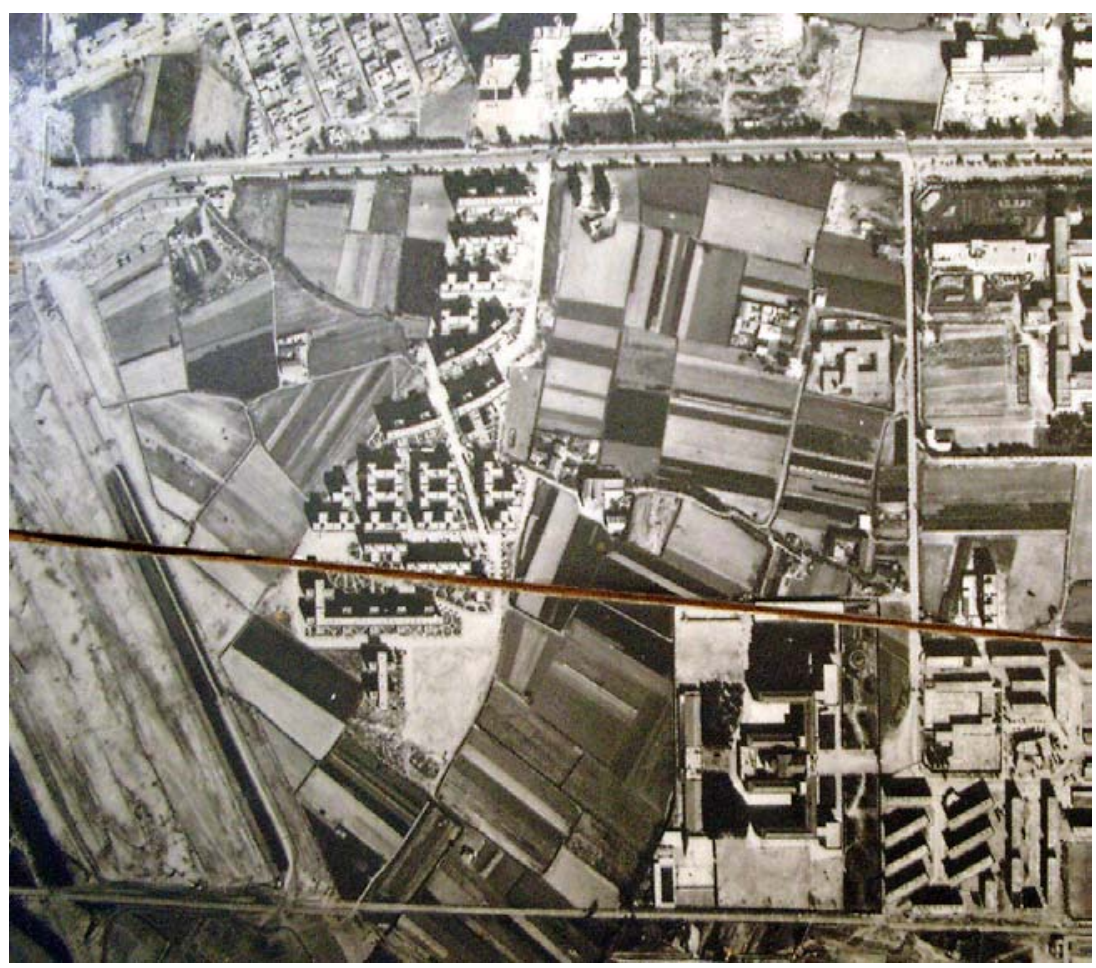

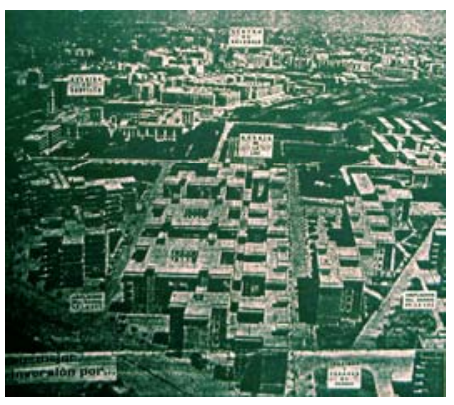

Barrio Virgen de la Luz. Vista aéra (Anuncio publicitario. Diario Las Provincias, 1 enero 1961)

Barrio Virgen de la Luz. Fotografía aérea, h. 1965 (ETS de Arquitectura de Valencia).

1.Peñín, A., op. cit., p. 198

2.Ver Sección I, Capítulo 4. 


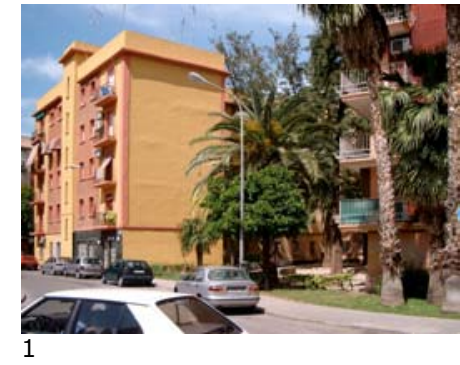

Barrio Virgen de la Luz. Vistas actuales.

1. Calle Alejandro Volta.

2. Bloque en la Avenida del Cid.

1.Ver al respecto Plunz, Richard, "Las formas del bloque en los orígenes de la vivienda pública", en UR Urbanismo Revista, 3, Laboratorio de Urbanismo, ETS de Arquitectura de Barcelona, Barcelona, 1985.
La agregación de los módulos se produce generalmente en línea, uno a continuación de otro, configurando bloques dentados a una o dos caras, según se utilice el módulo base en $\mathrm{T}$ o en cruz. Estos bloques incluyen dos, tres y hasta 6 módulos en un caso.

Además del encadenado en línea, existen agrupaciones de módulos cruciformes que forman un bloque dentado en $L$, y también micromanzanas obtenidas por una yuxtaposición de módulos en $T$ en las dos direcciones del plano.

La planta dentada basada en un módulo cruciforme o en T es poco habitual como tipo de la edificación abierta en Europa, donde, salvo casos aislados como el edificio Highpoint, el bloque lineal con dos viviendas por caja de escalera y planta será el elemento más utilizado.

Este tipo, en cambio, fue utilizado con frecuencia en los conjuntos de viviendas de promoción pública de EEUU de finales de los años treinta, en los que podemos encontrar abundantes ejemplos de bloques dentados, como los de las Williamsburg Houses, las Red Hook Houses, las Queensbridge Houses o las East River Houses. ${ }^{1}$

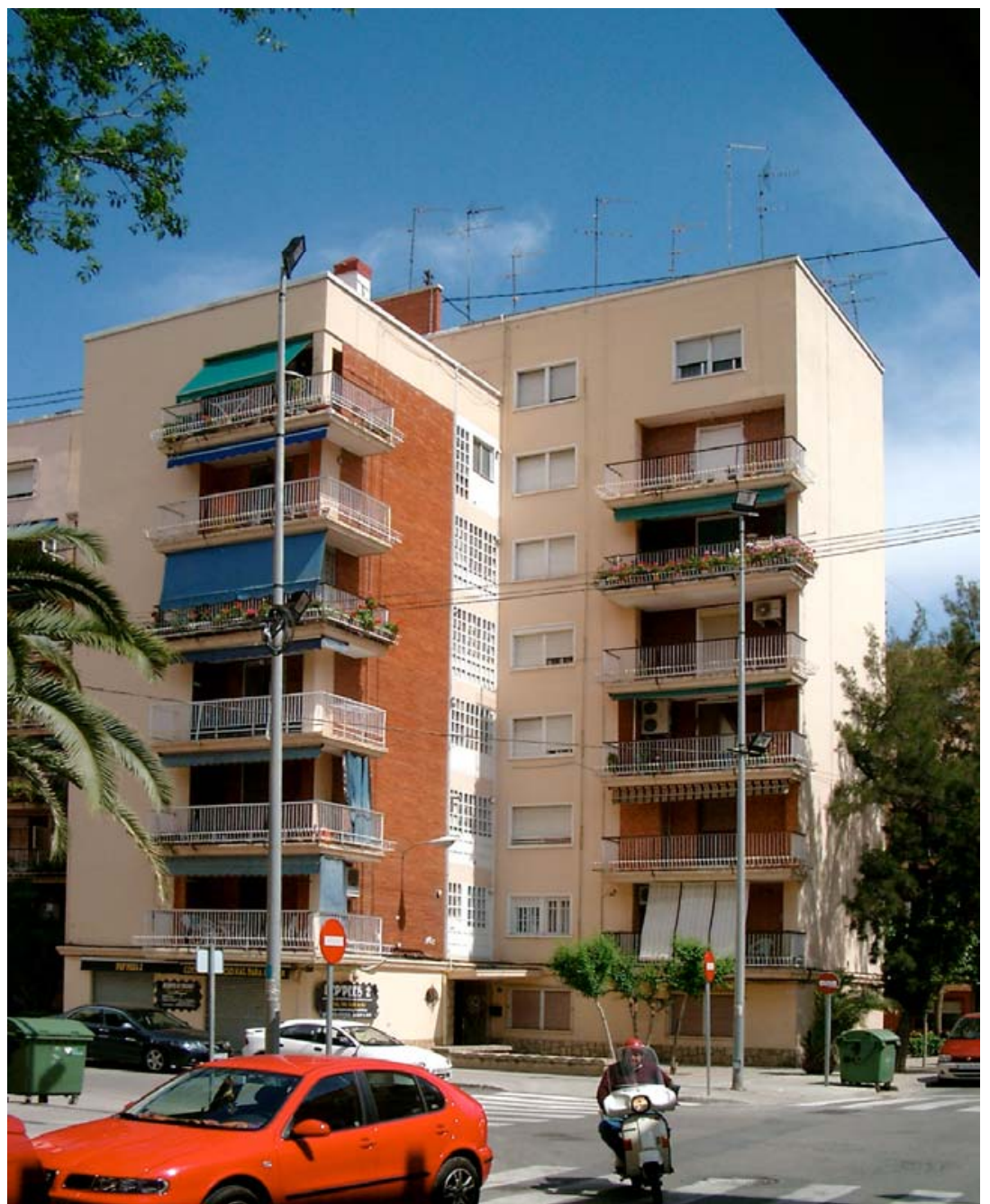




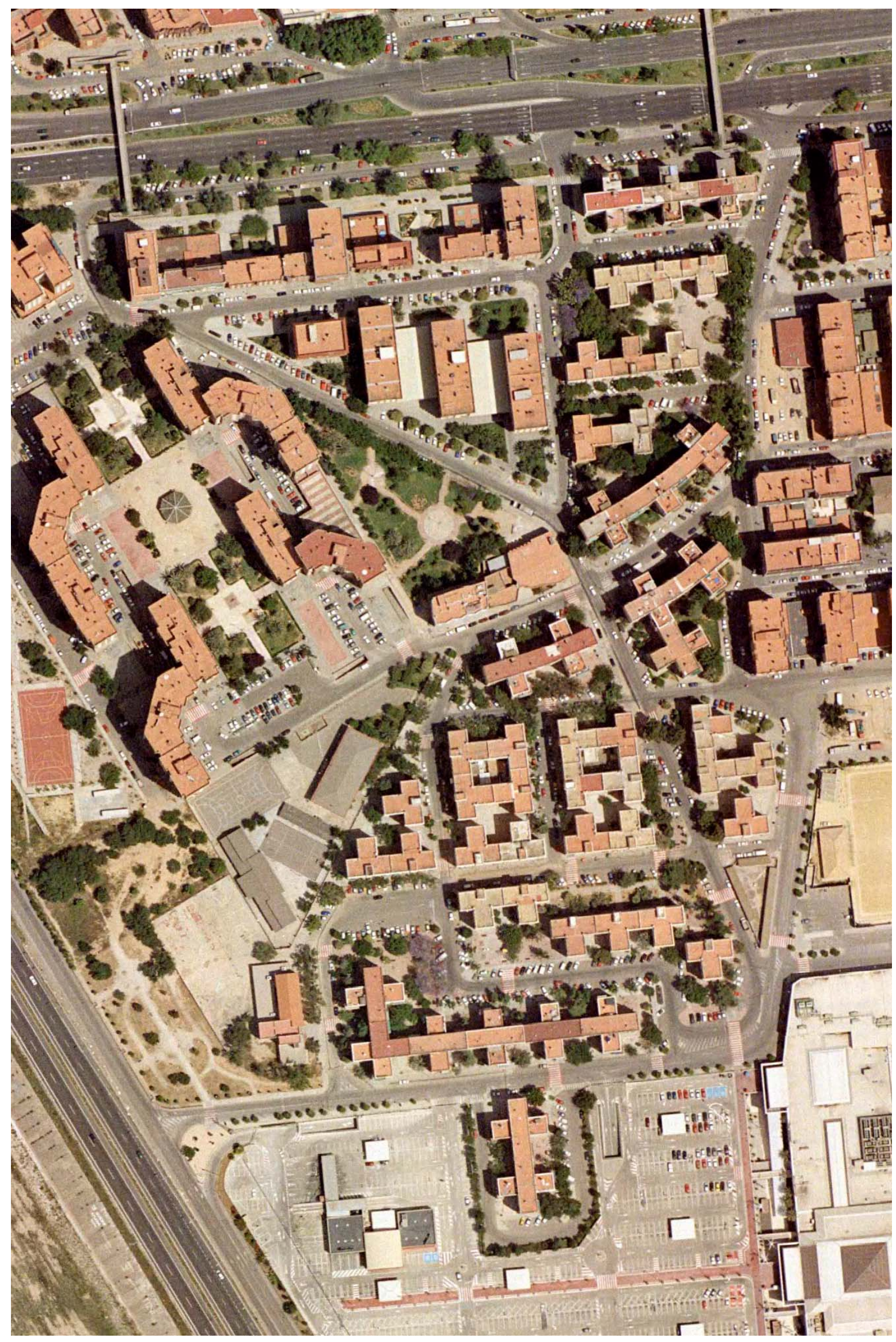

Zona del Barrio de la Luz. Ortofoto 2002 (AUMSA). 


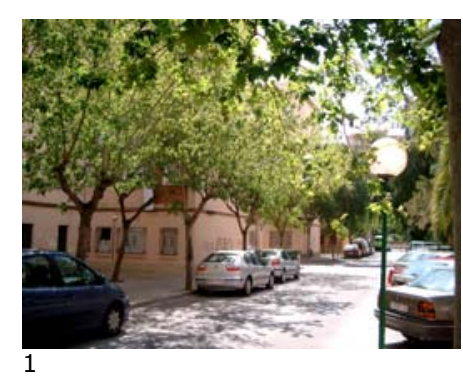

1

Como ocurrió en otros conjuntos de viviendas de la periferia de Valencia, la urbanización, los servicios y los equipamientos se realizaron bastante después que la edificación, y de hecho las viviendas se ocuparon cuando las calles estaban todavía sin alumbrado ni asfalto ${ }^{1}$.

Cuando se construyó, el Barrio de la Luz estaba rodeado de campos de cultivo por todos sus lados menos por el norte, correspondiente al eje de la Avenida de Castilla, a la que da frente uno de los bloques. La ordenación prevista en el proyecto para el Barrio Residencial $n^{\circ} 2$ se hizo inviable como consecuencia del trazado del nuevo cauce previsto en el Plan Sur, que afectaba a la mayor parte de su superficie. El barrio quedó finalmente englobado en el ámbito del Plan Parcial 26B (1967), que se limita a rellenar con bloques desarticulados los vacíos existentes en la zona.

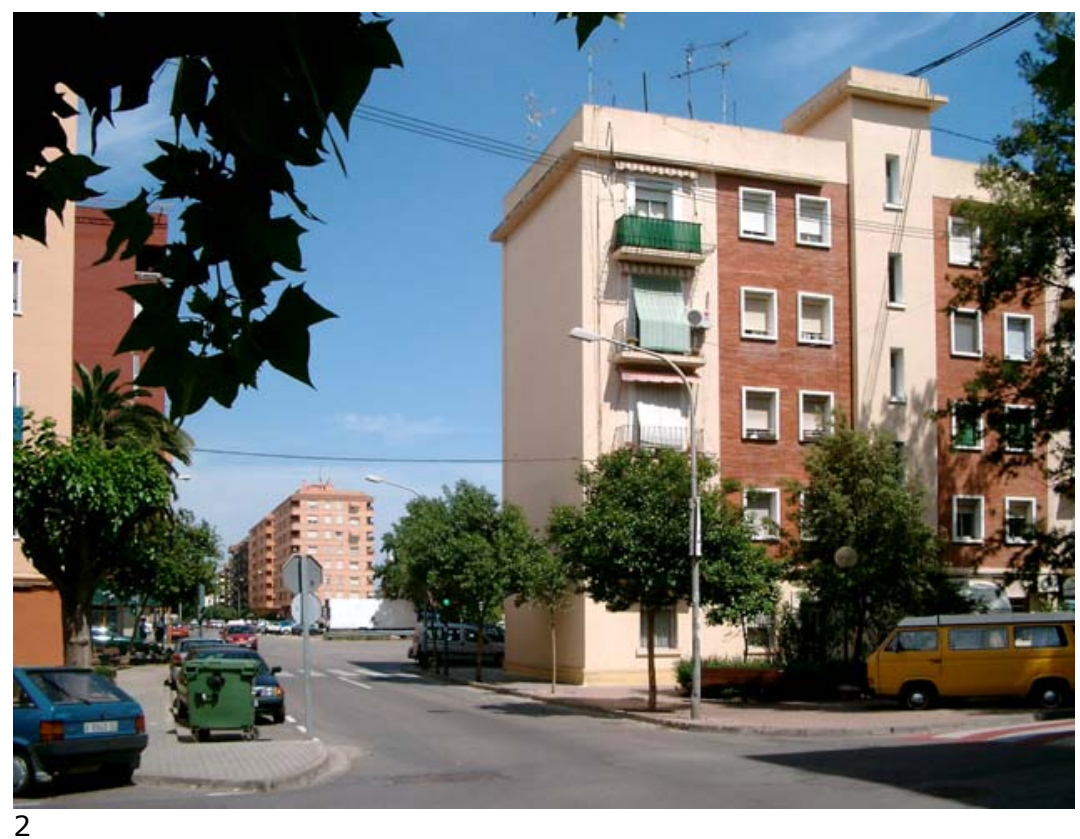

Barrio Virgen de la Luz. Vistas actuales.

1. Calle Antonio Machado.

2. Calle José María Bayarri.

3. Calle Alejandro Volta.

1. Banyuls Gacía, Jeroni, Valencia barrio a barrio. La Fontsanta y La Llum, Ayuntamiento de Valencia, 1986.

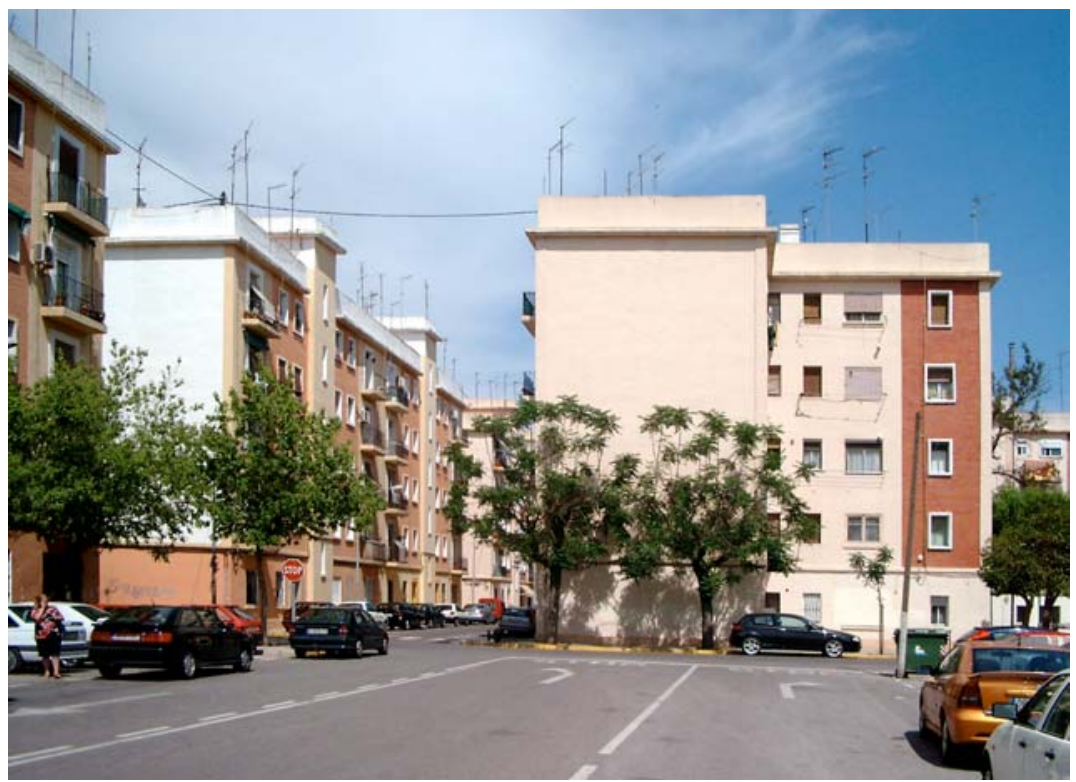


En la actualidad, el Barrio de la Luz está envuelto por las edificaciones previstas en el Plan Parcial 26B, así como por otras situadas ya en el término municipal de Xirivella, entre las que se encuentra un centro comercial al sur.

Sobre la zona, por tanto, se han ido depositando sucesivamente edificaciones no demasiado congruentes entre sí, y la legibilidad del espacio público queda por ello afectada en buena medida. A ello contribuye, sin duda, el exceso de uniformidad de los bloques del barrio de la Luz, que faltos del trazado viario que justificaba su localización, parecen dispuestos totalmente al azar.

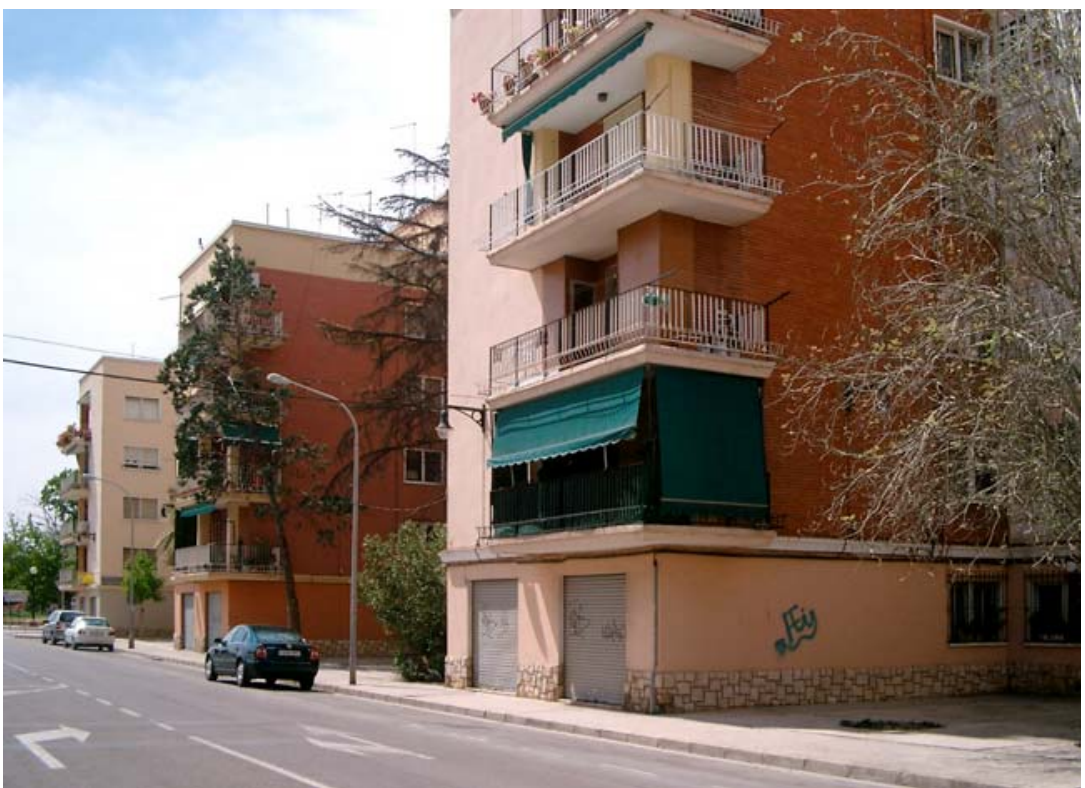

1

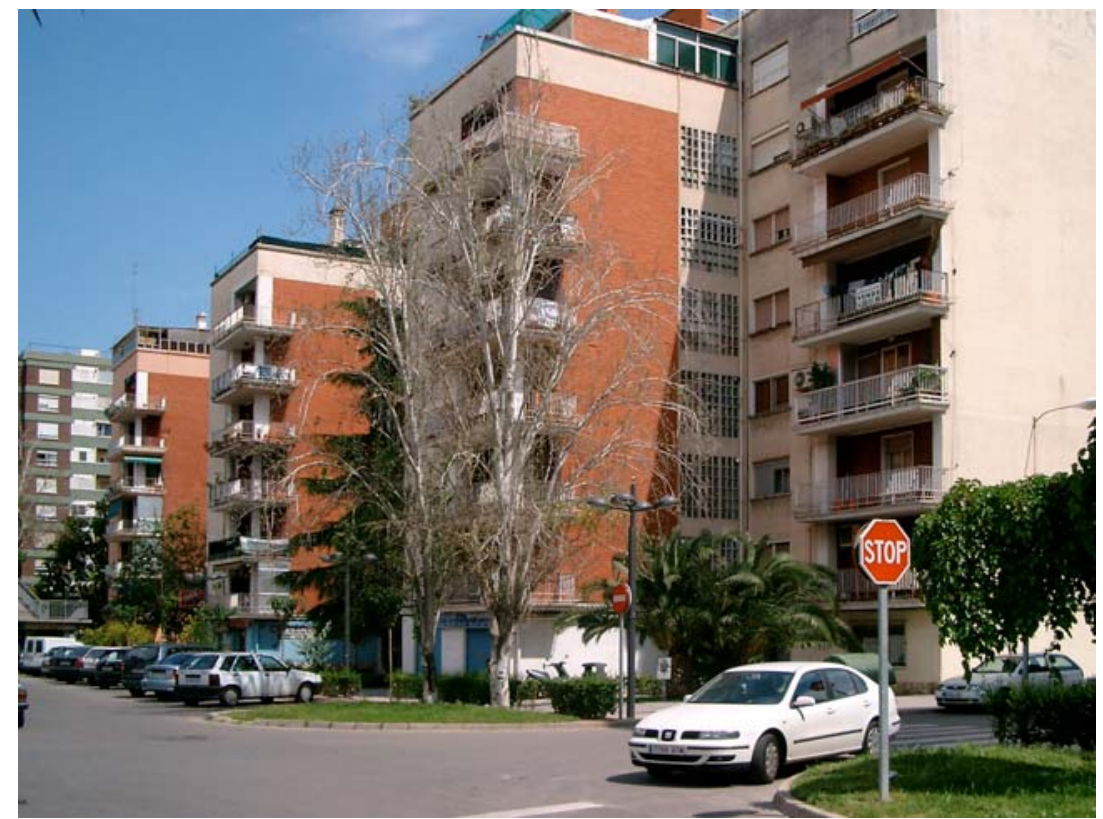

Barrio Virgen de la Luz. Vistas actuales.

1. Calle Molino Chirivella.

2. Avenida del Cid.

3. Calle Antonio Machado. 


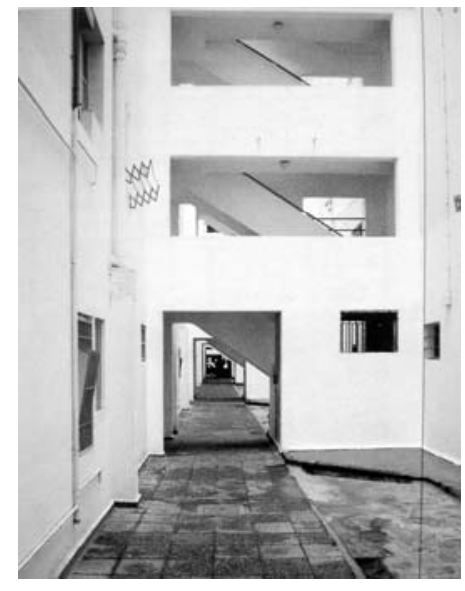

Grupo Stella Maris. Patio interior con cajas de escalera.

Grupo Stella Maris. Planta baja y tipo, Alzados lateral y frontal y sección transversal (Archivo Histórico Municipal)

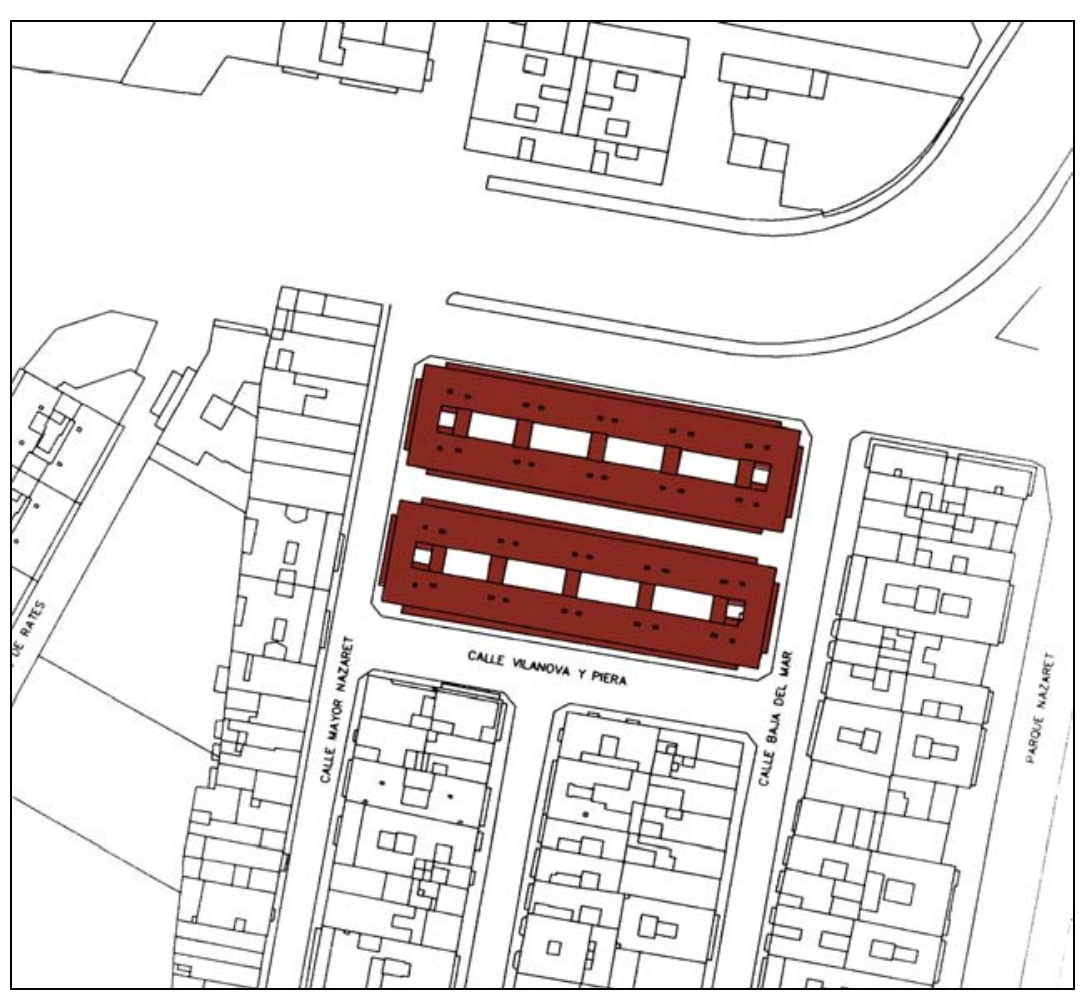

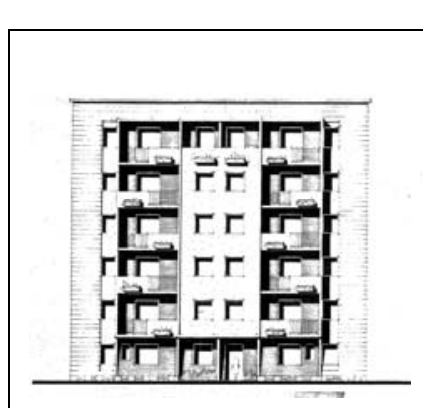
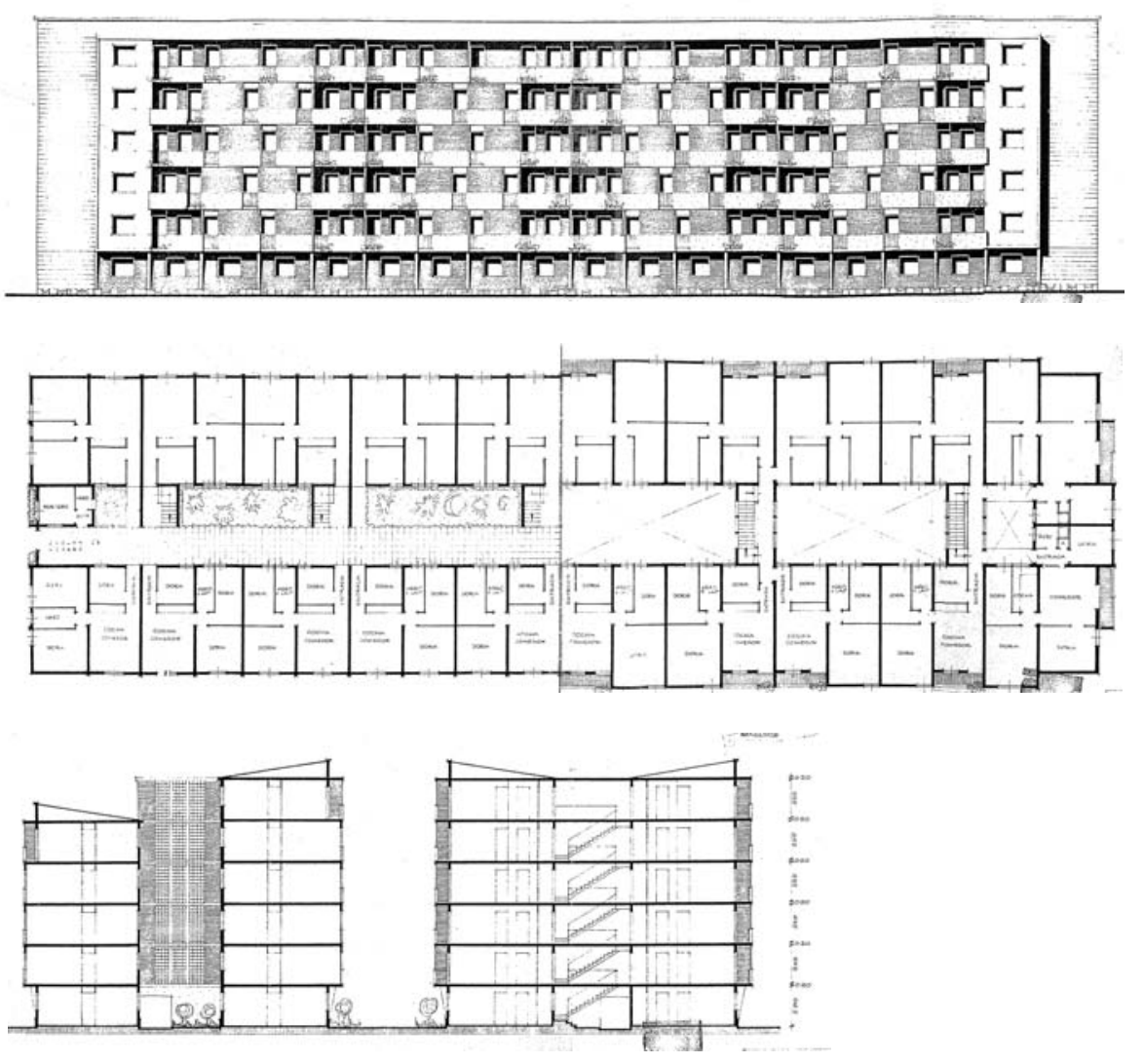


\section{GRUPO STELLA MARIS (1958-60)}

El grupo Stella Maris, de promoción privada, incluye 240 viviendas de Renta Limitada. Proyectado por Cayetano Borso y Rafael Contel en 1958, fue construido entre 1958 y 1960 . Está situado en el borde norte del poblado de Nazaret, cerca del puente de Astilleros. Este poblado, situado en terrenos bajos junto a la desembocadura del Turia, sufrió los efectos de la Gran Riada de 1957, que causó la destrucción de 247 casas.

El conjunto se compone de dos bloques profundos de cinco crujías con patios interiores y una calle intermedia de sólo $8 \mathrm{~m}$. de anchura proyectada originalmente como zona cerrada y ajardinada de uso comunitario.

Los bloques profundos del Stella Maris no son bloques con patios de luces, como fue habitual después en la promoción privada, sino más bien bloques dobles: dos bloques lineales de dos crujías cada uno unidos por las cajas de escalera, que son el único elemento intercalado en el espacio intermedio entre los bloques, y que están tratadas además como escaleras abiertas al exterior. Esta disposición permite acceder a cuatro viviendas por planta en cada caja de escalera y mantener al mismo tiempo células de viviendas pasantes, con habitaciones a calle o a patio y ventilación cruzada.

Los testeros, sin embargo, están macizados, ya que en ellos se renuncia al doble bloque y se recurre a las viviendas de esquina, que comportan un cambio de orientación de las piezas habitables.

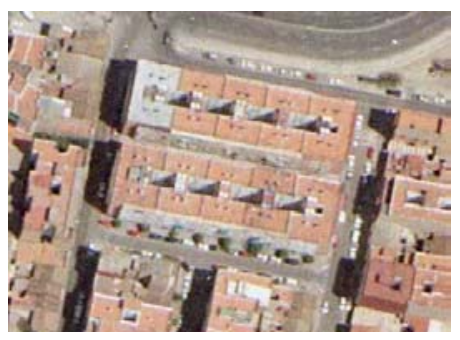

Grupo Stella Maris. Ortofoto 2002 (AUMSA).

Grupo Stella Maris. Perspectiva del proyecto (Llopis).

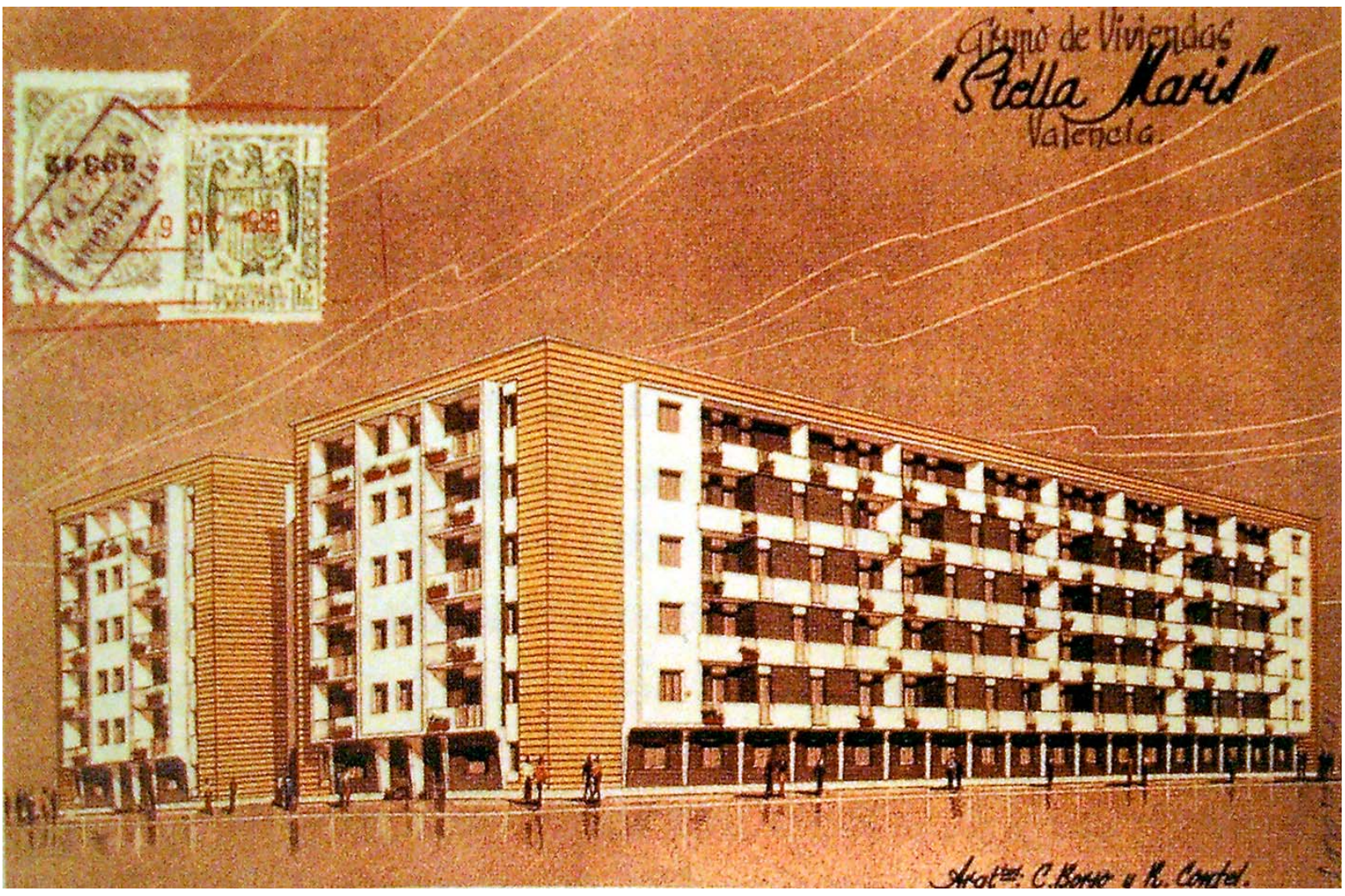




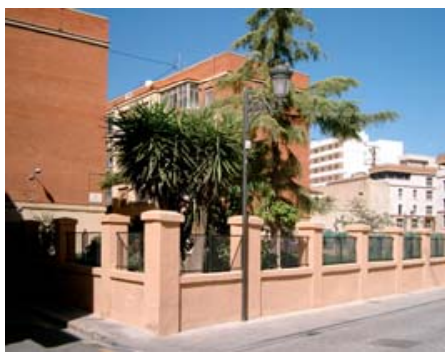

Grupo Bernardo Lassala. Vista del jardín privado y los testeros de los bloques.

Grupo Bernardo Lassala. Planta de situación (Color sobre Cartografía Municipal 2004)

Grupo Bernardo Lassala. Alzado de proyecto (Peñín).

Grupo Bernardo Lassala. Vista del patio interior.
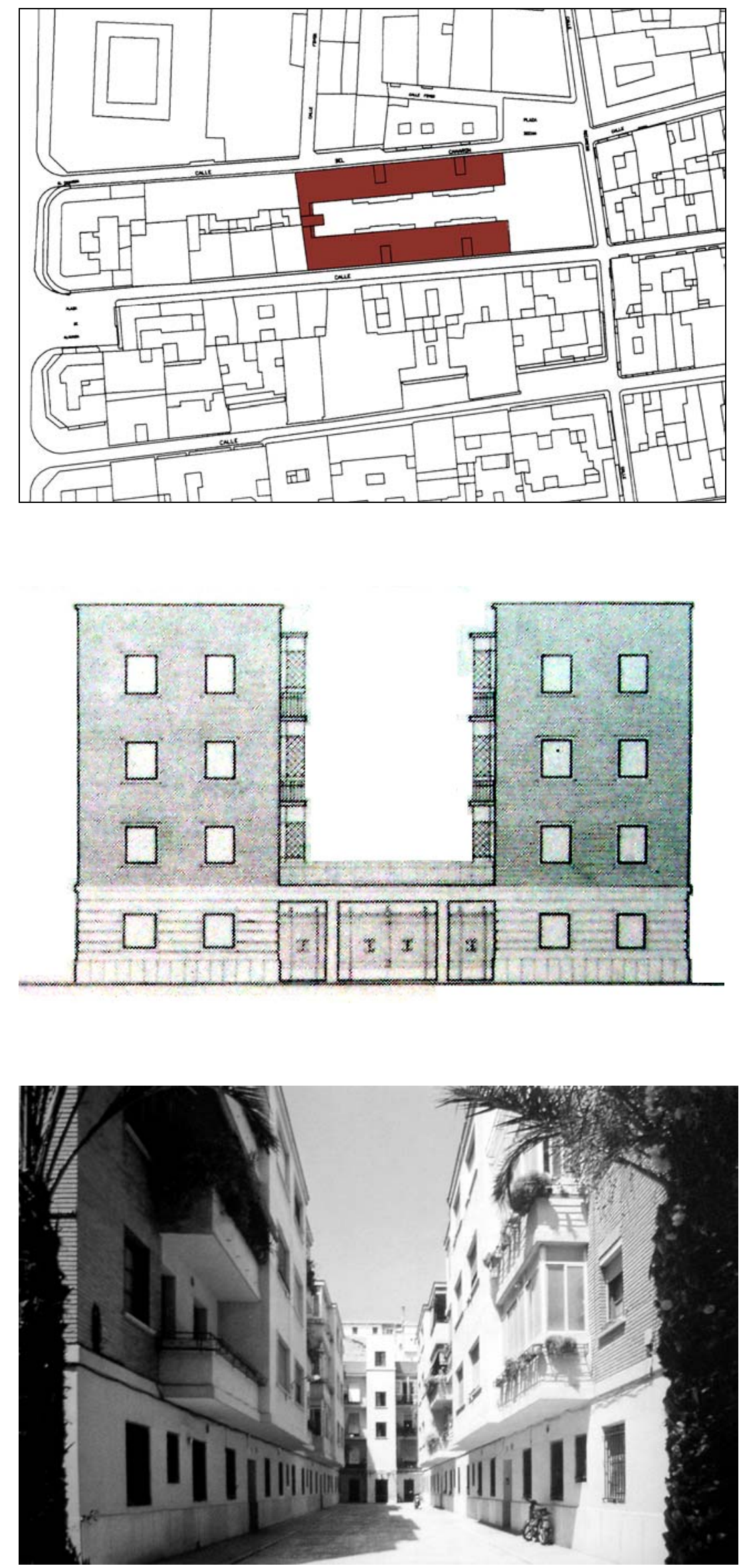


\section{GRUPO BERNARDO LASSALA (1958-62).}

El grupo Lassala, de 40 viviendas de Renta Limitada, es un fragmento de manzana resuelto con edificación abierta, situado en el centro histórico, junto a la plaza de la Bocha, en el barrio de Velluters. Promovido por la Cooperativa de Funcionarios de la Diputación Provincial, fue proyectado por Luís Albert en 1957 y construido entre 1958 y 1962. La discreción y buena factura de la sencilla y racional arquitectura de este grupo han sido puestas de relieve por diversos autores ${ }^{1}$.

Alineados con las calles Camarón, a norte, y Triador, a sur, se sitúan dos bloques lineales paralelos de IV plantas $(\mathrm{PB}+3)$, todas ellas destinadas a viviendas.

Los bloques, de viviendas pasantes de dos crujías, dejan un espacio intermedio entre ellos desde el que se accede a los zaguanes. Las calles mencionadas son muy estrechas, por lo que las viviendas se abren a ese espacio intermedio, al que se llega a través de un jardín privado vallado que ocupa el lateral este de la manzana, junto a la calle Recaredo, aprovechando que los testeros de los bloques están retranqueados con respecto a la alineación de esta calle.

La paradoja del bloque lineal como elemento fragmentario, y situado además en un entorno constreñido de centro histórico, se hace evidente cuando observamos los testeros ciegos recayentes al jardín, la alineación de los bloques con las calles norte y sur, y la consiguiente medianera del lado oeste, o la propia simetría que es consecuencia de una obligada introversión para obtener para las viviendas mejores condiciones que las que ofrecen las angostas calles perimetrales.

Los testeros recayentes al jardín no eran paramentos ciegos en el proyecto inicial, sino que tenían unas ventanas que desaparecieron en los bloques finalmente construidos. En proyecto estaba prevista también una pérgola en planta baja que separaba el jardín del patio interior.

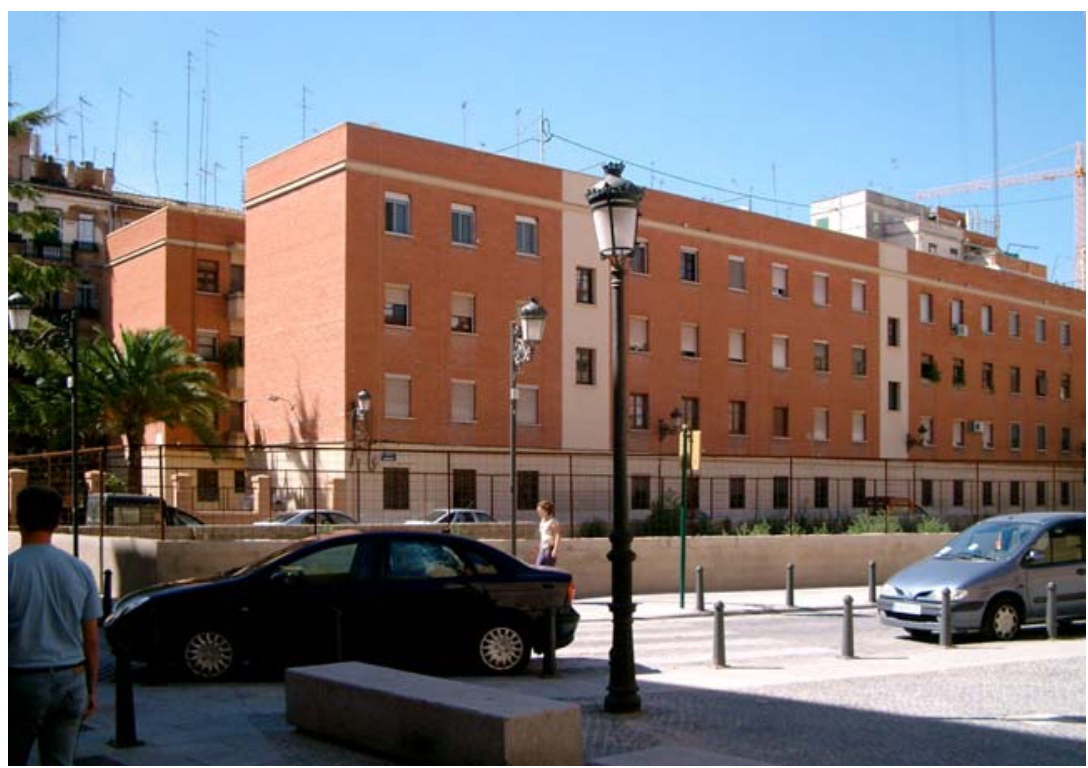

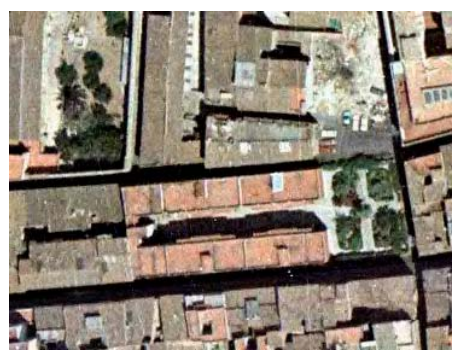

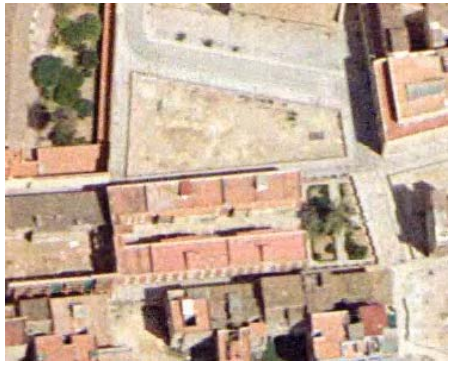

Grupo Bernardo Lassala. Fotografía aérea de 1980 y Ortofoto 2002 (AUMSA)

Grupo Bernardo Lassala. Vista desde la actual Plaza de la Bocha.

1.Peñín Ibáñez, Alberto, Luís Albert, Arquitecto, 1902-1968, Colegio Oficial de Arquitectos de la Comunidad Valenciana, Valencia, 1984. 


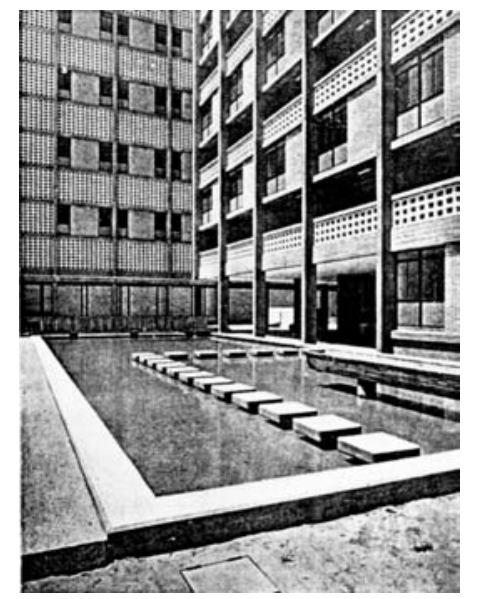

Grupo Santa María Micaela. (Fotografía de Finezas, Arquitectura, 34, 1961)

Grupo Santa María Micaela Planta de situación (Color sobre Cartografía Municipal de Valencia, 2002).
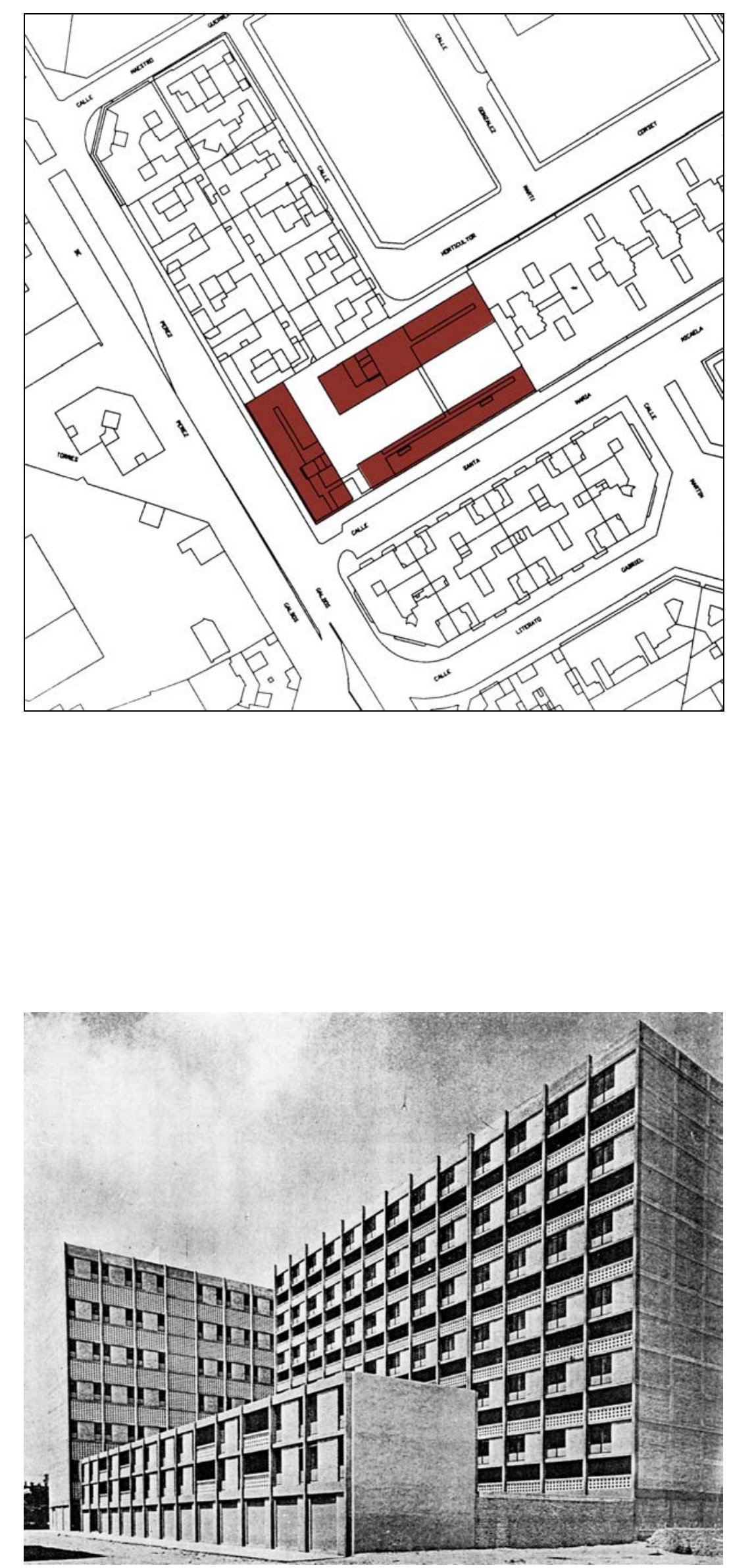

Grupo Santa María Micaela (Fotografía de Finezas, Arquitectura, 34, 1961).

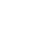




\section{GRUPO SANTA MARÍA MICAELA (1958-61).}

El grupo Santa María Micaela, de 138 viviendas de Renta Limitada y bajos comerciales, fue proyectado por Salvador Artal en 1958 para la Cooperativa de Agentes Comerciales, y construido entre 1958 y 1961. Ocupa un solar de esquina de una manzana de ensanche, con fachadas a la Avenida Pérez Galdós, a la calle Santa María Micaela y a la plaza Horticultor Corset, siendo medianeras en el resto de lindes. El carácter ejemplar de este grupo, excepcional a todos los niveles dentro de la arquitectura valenciana, ha sido puesto de relieve a lo largo de los años en diversas publicaciones ${ }^{1}$.

El arquitecto autor del proyecto lo describe así:

A pesar de que todo el solar fuese edificable, agrupé las viviendas en tres bloques, dos altos de doce plantas y uno bajo de dos plantas, recayente al lado Sur, dejando el resto del solar para jardines. Esta variación de volúmenes y alteración de las ordenanzas municipales fueron aprobadas por el Ayuntamiento de Valencia. Con la colocación de los bloques de esta forma conseguí:

a) Buen soleamiento de las viviendas y buenas vistas. Todos los ambientes habitables son exteriores.

b) Mayor número de viviendas.

c) Liberación de terreno para espacios abiertos, para recreación de los inquilinos.

d) Centralización de servicios, porterías, instalaciones...

La entrada al grupo se efectúa por un acceso único situado en el bloque bajo. A través del jardín, y bajo pasos cubiertos, se llega a los otros bloques ${ }^{2}$.

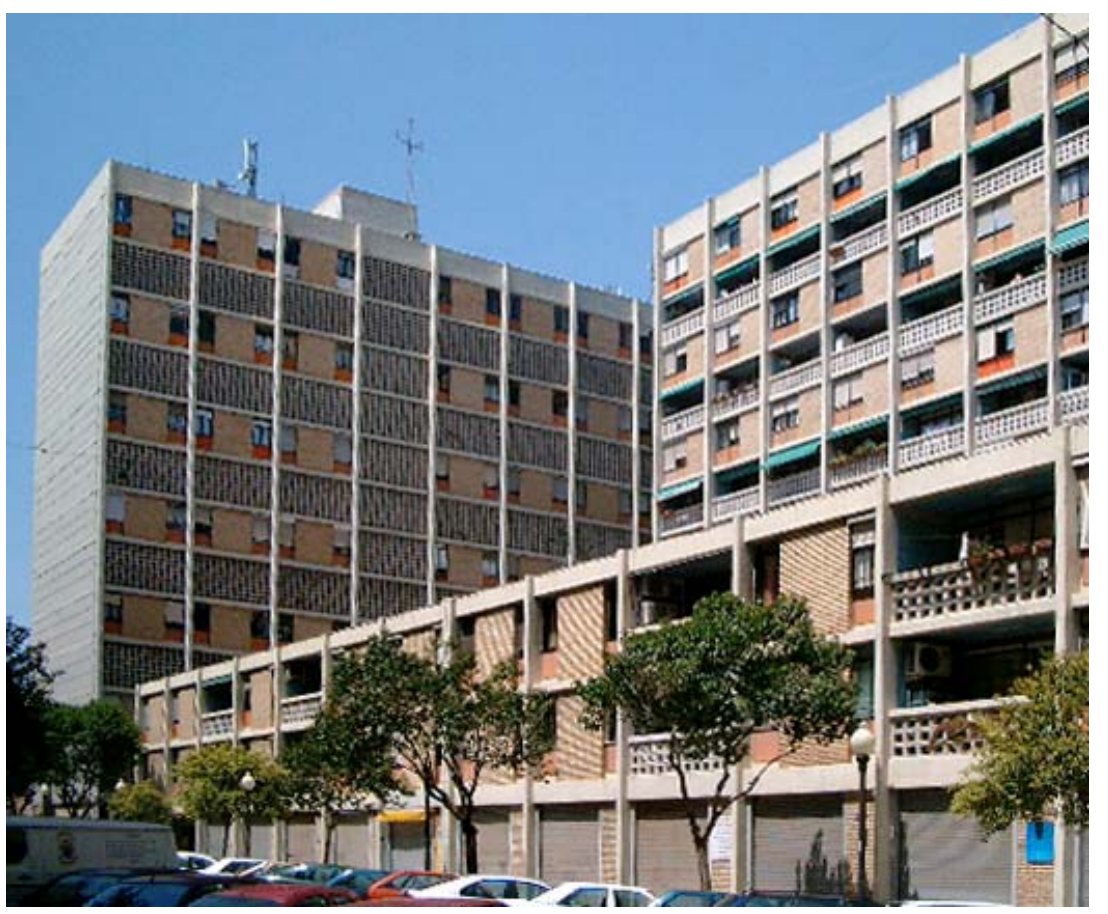

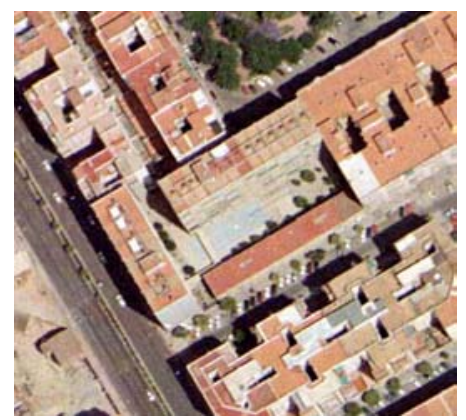

Grupo Santa María Micaela. Ortofoto 2002 (AUMSA).

Vista actual desde la calle Santa María Micaela.

1.Ver, por ejemplo, Giménez, Emilio y Llorens, Tomás, "La imagen de la ciudad. Valencia", Hogar y Arquitectura, 86, Madrid, 1970. Peñín Ibáñez, Alberto, Valencia 1874-1959. Ciudad, arquitectura y arquitectos, Escuela Técnica Superior de Arquitectura de Valencia, Valencia, 1978. Jordá Such, Carmen, ed., 20x20. Siglo XX. Veinte obras de arquitectura moderna, Catálogo de exposición, Generalitat Valenciana, Colegio Oficial de Arquitectos de la Comunidad Valenciana, Valencia, 1997.

2. Artal Ríos, S., "Grupo de viviendas en Valencia", Arquitectura, 34, Madrid, 1961. Las alturas a que se refiere Artal son las de plantas de piso, a las que hay aue añadir la nlanta haia 


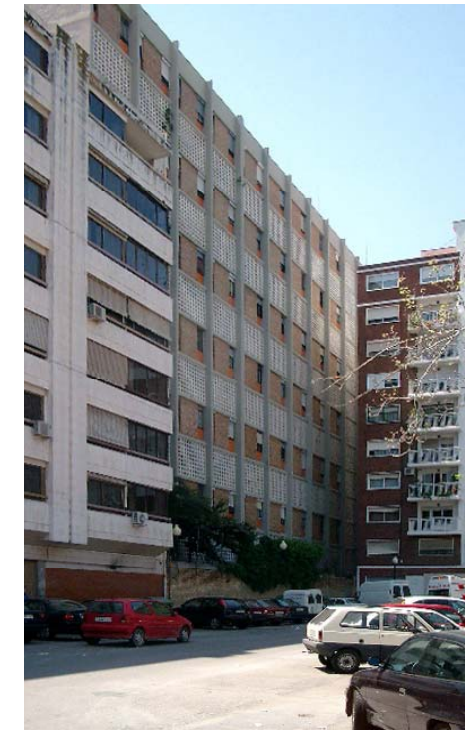

Grupo Santa María Micaela. Fachada a la Plaza Horticultor Corset
1.La fotografía de Finezas que abre el artículo de Arquitectura citado muestra tres bloques aparentemente aislados, pero el primer plano es en realidad una medianera en la que la edificación colindante no ha sido aún construida.
A las escaleras de acceso a las viviendas del bloque bajo se llega por una galería abierta al jardín interior. Las viviendas de los bloques altos son dúplex con acceso por corredor, tipología muy poco habitual en la edificación abierta en Valencia por su escasa aceptación social.

Aunque hay una voluntad evidente identificar tres volúmenes separados, la realidad es que los tres bloques están adosados siempre a una medianera por uno de sus dos testeros ${ }^{1}$. El bloque alto interior ocupa una posición singular para mantener su carácter de bloque lineal aislado: hasta la mitad de su longitud acompaña a una medianera, y la separación que guarda con respecto a la misma se mantiene en la otra mitad del bloque, pero ya como retranqueo con respecto a la línea de fachada de la Plaza Horticultor Corset.

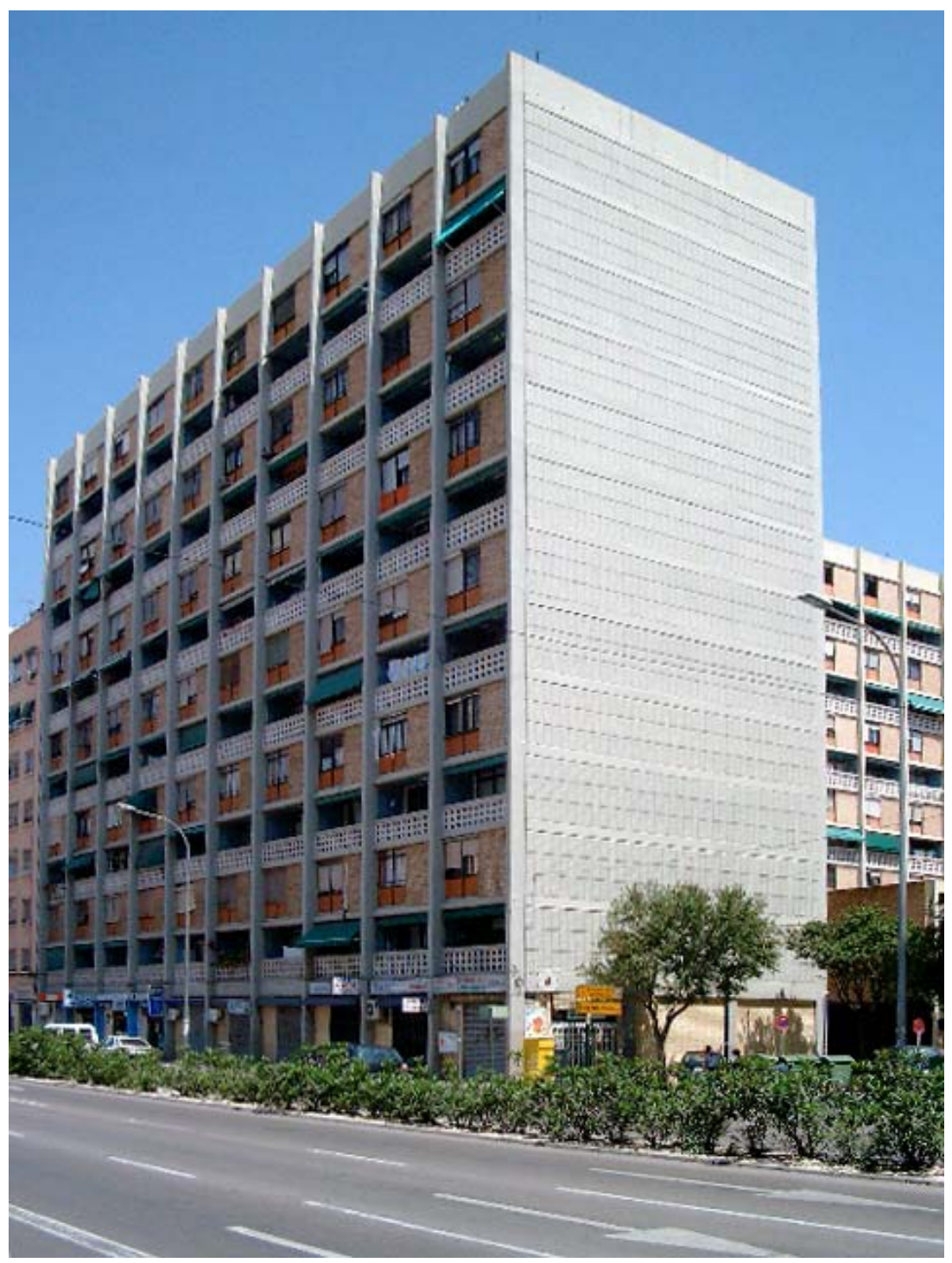



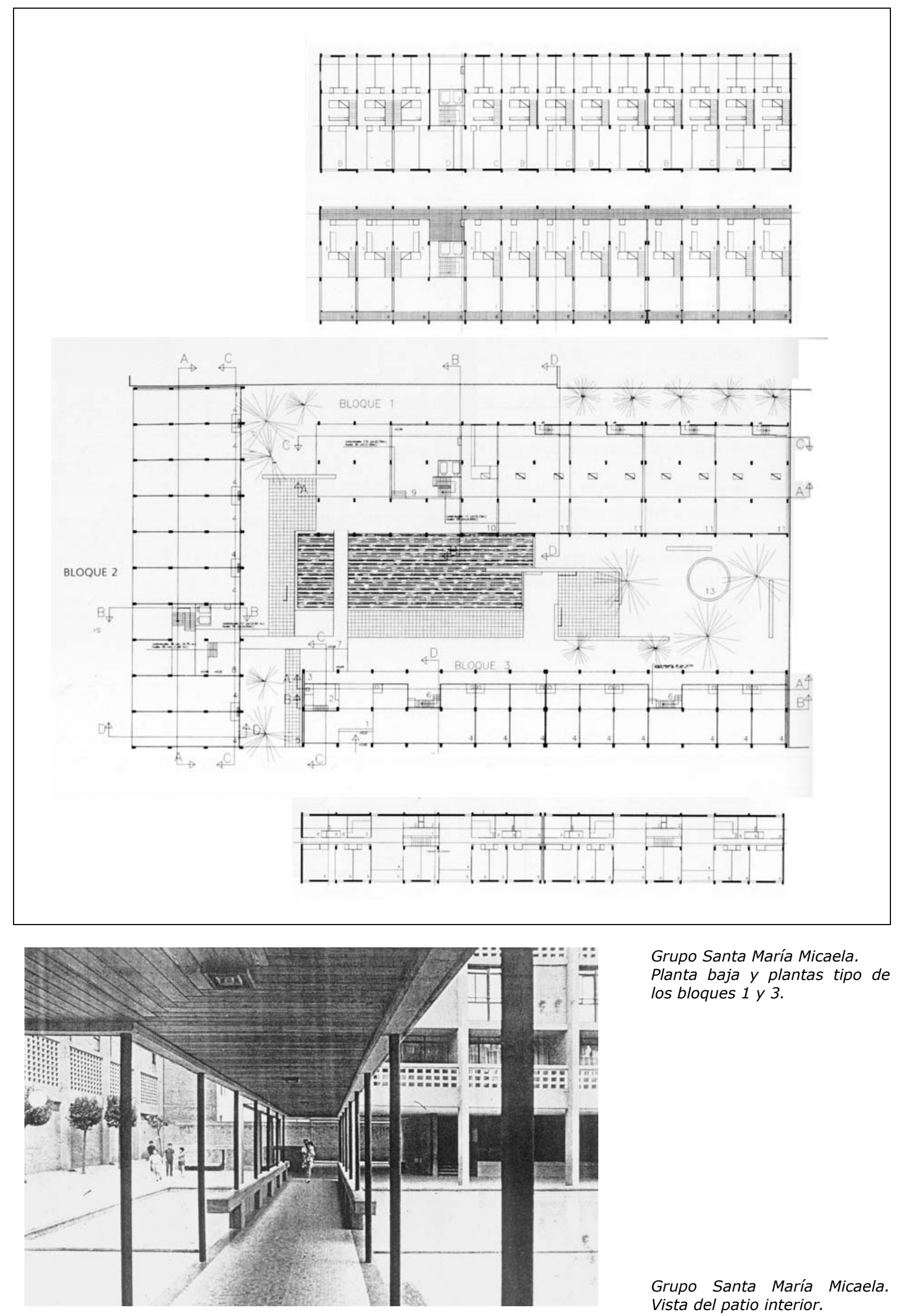

Grupo Santa María Micaela.

Planta baja y plantas tipo de los bloques 1 y 3.

Grupo Santa María Micaela. Vista del patio interior. 


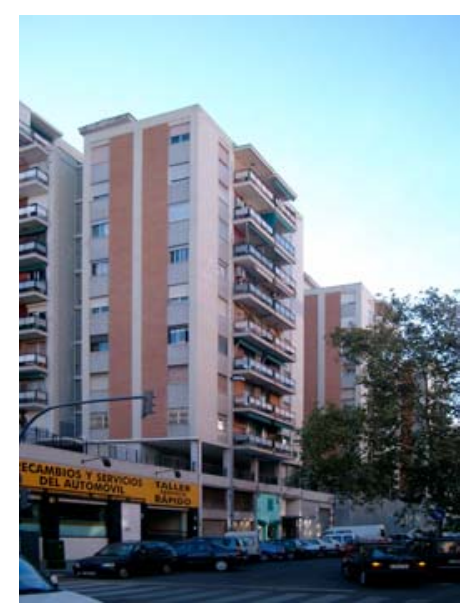

Vista actual desde la calle Pintor Maella.
Planta tipo y perspectiva de proyecto de las galerías comerciales (Archivo de Planeamiento. Ayuntamiento de Valencia ).

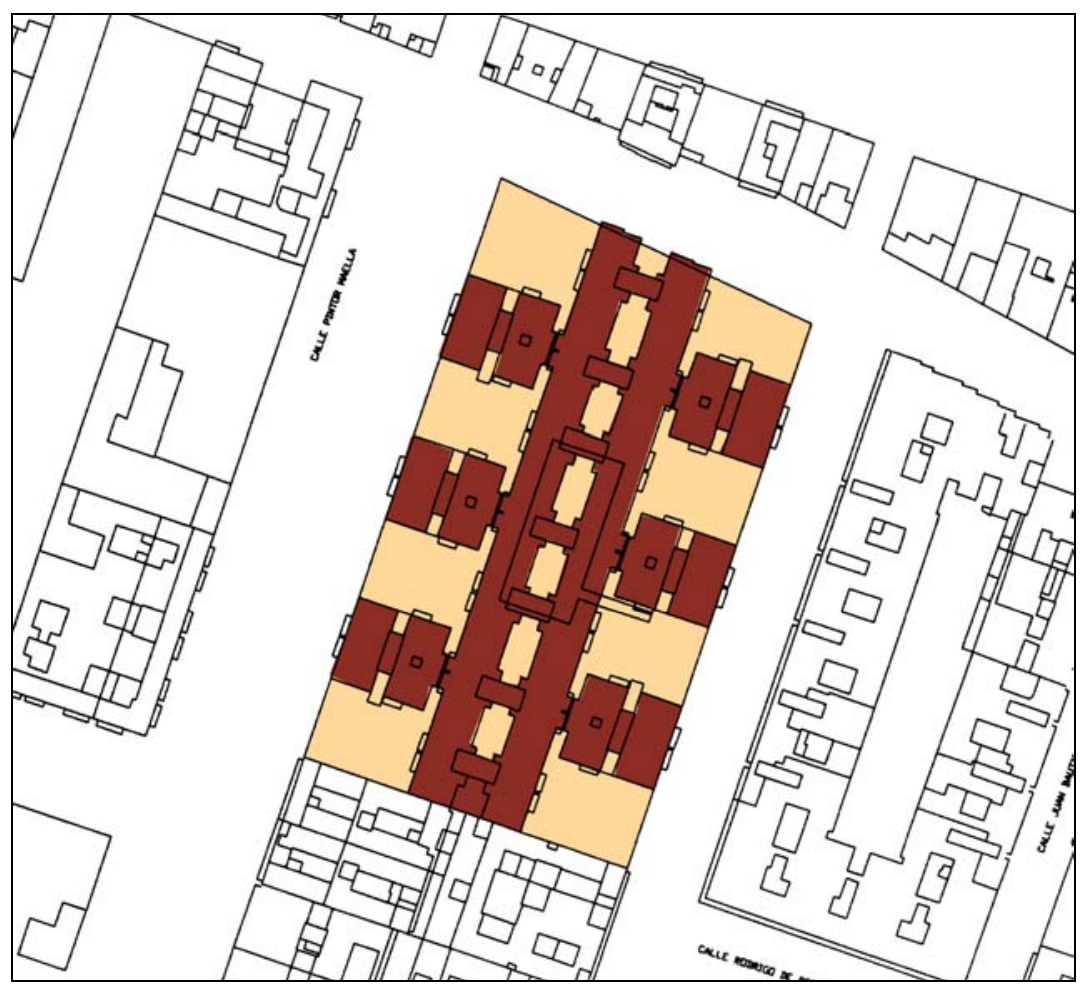

Planta de situación.(Color sobre Cartografía Municipal 2004)

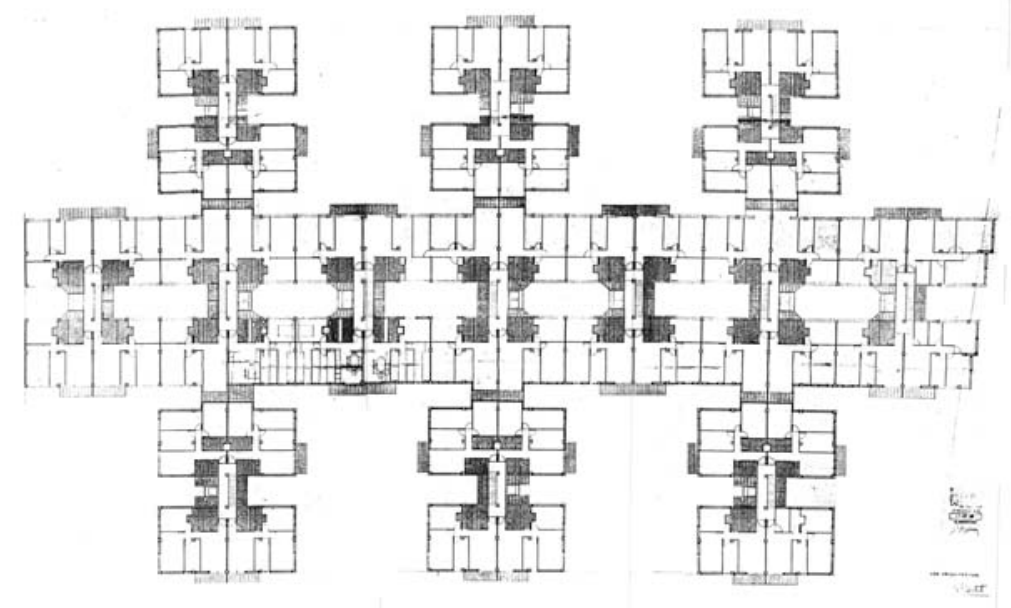

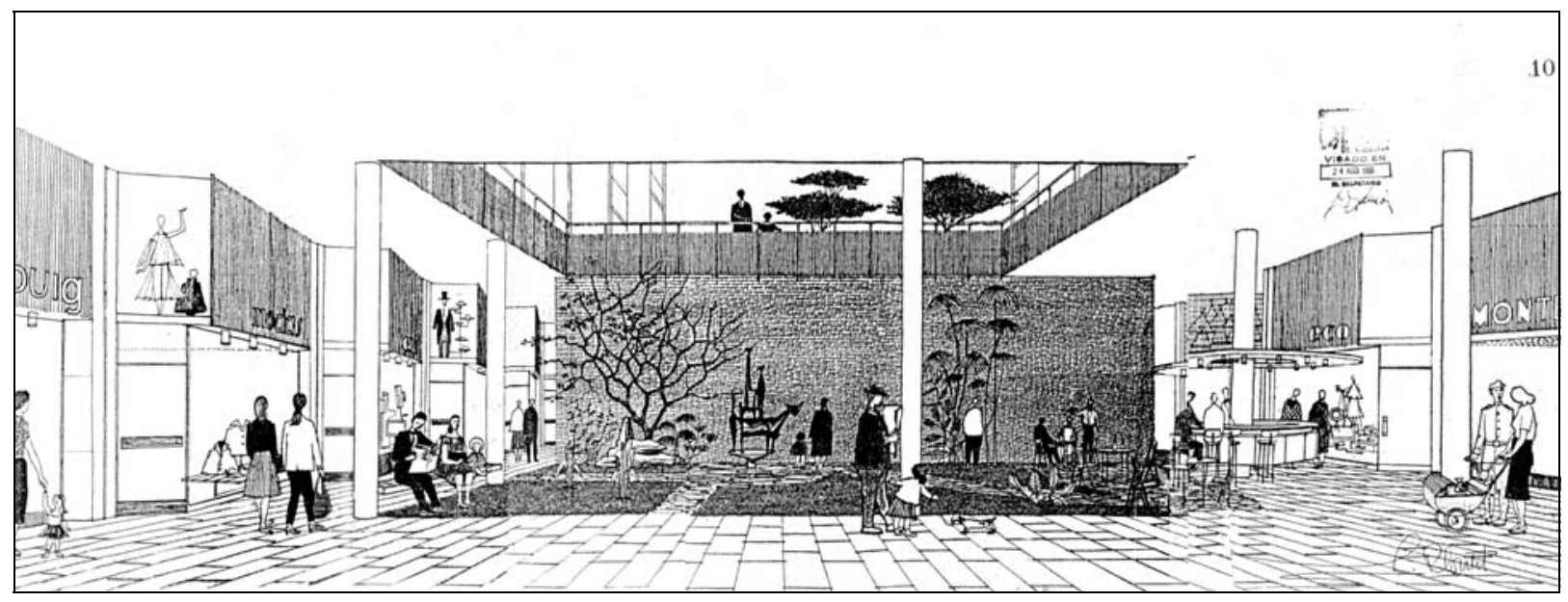


El grupo Pintor Maella, de 610 viviendas de Renta Limitada y galerías comerciales, en planta baja y entresuelo, fue proyectado por Cayetano Borso González y Rafael Contel Comenge en 1961. Ocupa un solar de esquina de una manzana alargada del distrito marítimo próxima a la Avenida del Puerto, con fachadas a las calles Pintor Maella al oeste, Islas Canarias al norte y Juan Bautista Marco al este, siendo medianera su lado sur.

La edificación se compone de un bloque lineal doble situado en el centro del solar, a lo largo de toda su longitud, y torreones de menor altura adosados a ambos lados. Los torreones, de dos viviendas por escalera, están dispuestos a intervalos regulares y alineados con las calles laterales, por lo que el conjunto tiene una imagen urbana de manzana mixta, con edificación a redents sobre un potente zócalo de dos plantas, destinado originalmente a galerías comerciales, que ocupa la totalidad del solar.

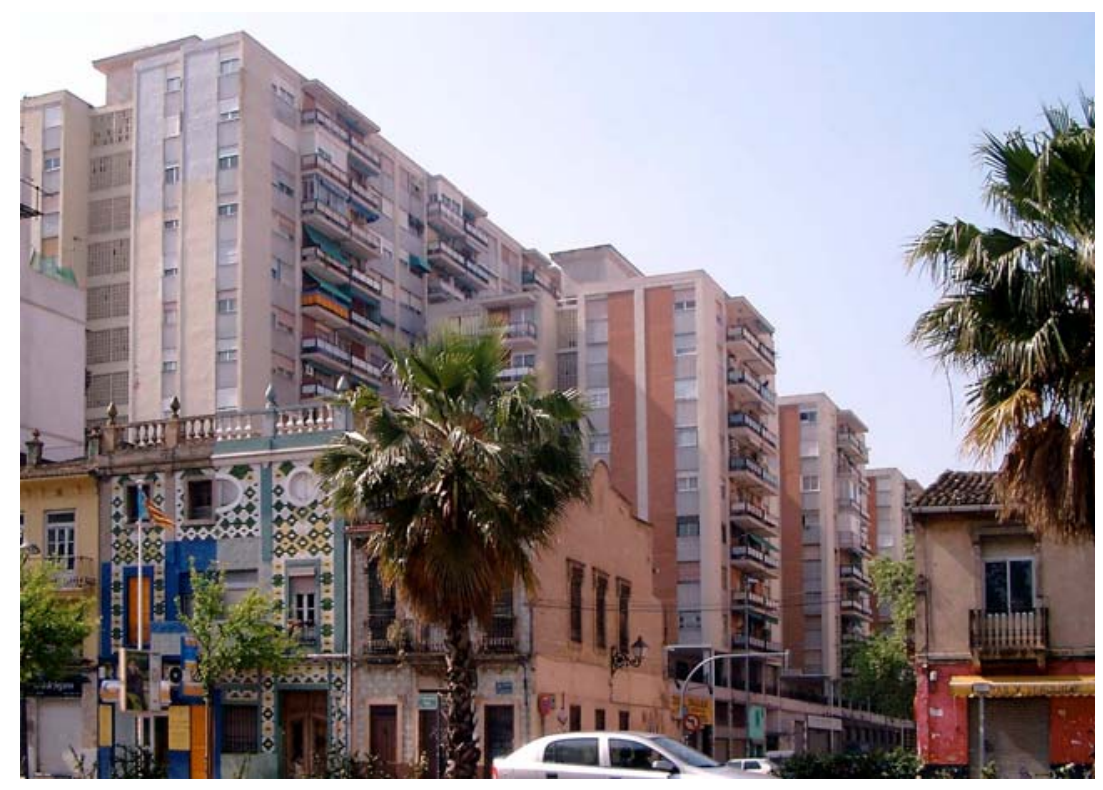

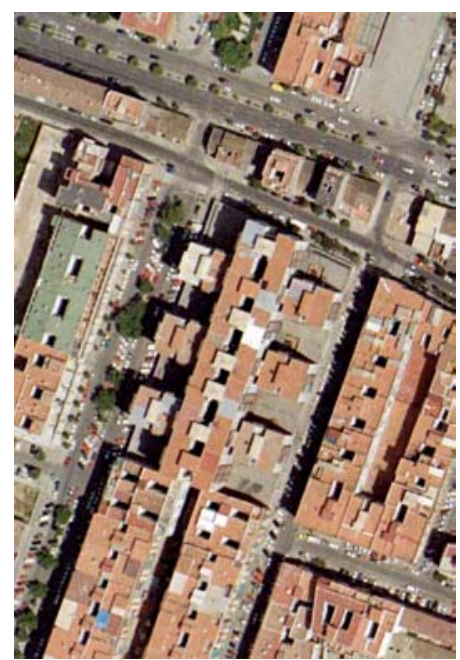

Grupo Pintor Maella. Ortofoto 2002 (AUMSA).

Vista actual desde la Avenida del Puerto.

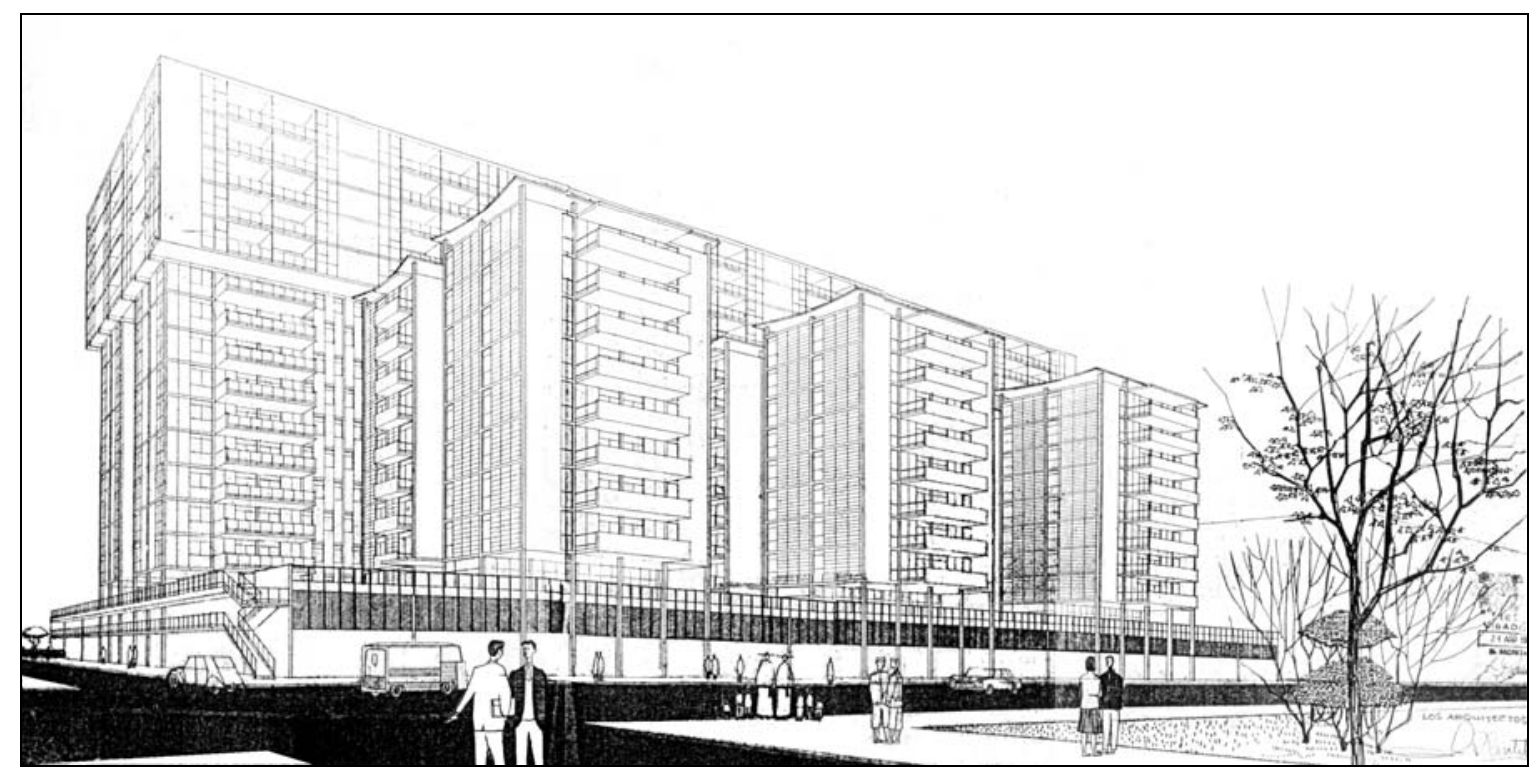

Perspectiva exterior del proyecto (Archivo de Planeamiento. Ayuntamiento de Valencia). 


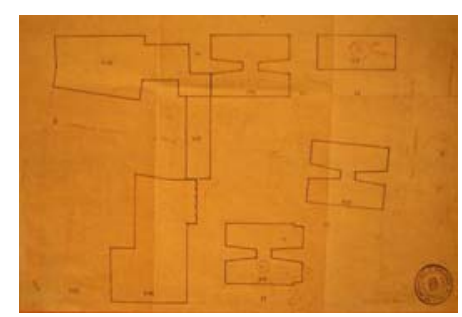

Ordenación de los terrenos de la antigua Ciudadela, 1961. Salvador Pascual (Herrero)

Conjunto de la Ciudadela Planta (Color sobre Cartografía Básica Municipal de 1983)

Conjunto de la Ciudadela. detalle de la maqueta de la Ordenación Técnica de la ciudad y su comarca de 1958.

Conjunto de la Ciudadela. Vista desde el cauce del Turia.
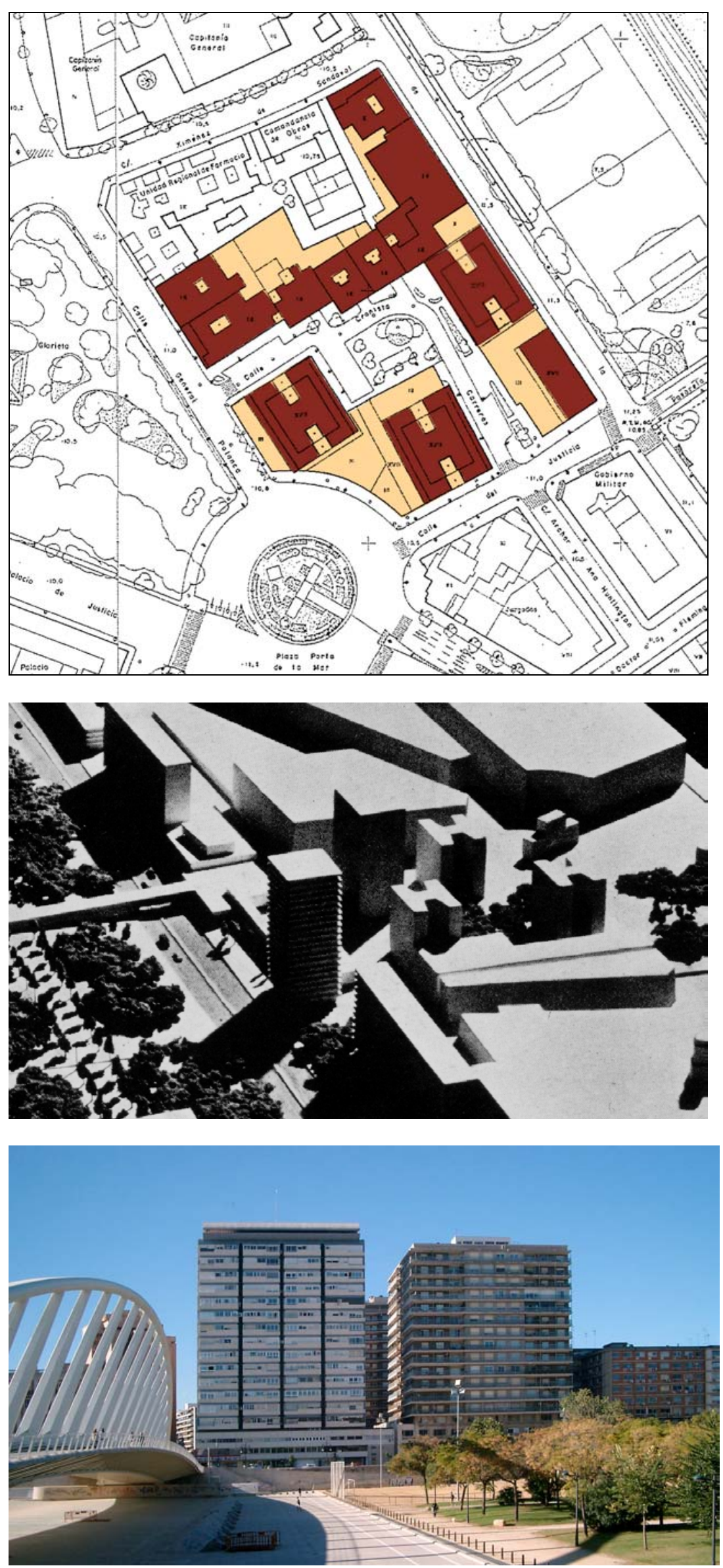


\section{EL CONJUNTO DE LA CIUDADELA (1961)}

La Ciudadela ocupaba la manzana limitada por el Paseo de la Ciudadela, la calle Justicia, la Glorieta (calle General Palanca) y la calle Ximénez Sandoval. En Plan Parcial 1-3-4 de 1956, este espacio estaba ordenado mediante dos manzanas cerradas de ensanche.

La sustitución de la manzana cerrada por la edificación abierta se refleja en la maqueta de la propuesta para el uso urbano del cauce del Turia de la Ordenación Técnica de la ciudad y su comarca de $1958^{1}$, que daría origen al Plan Sur. En ella podemos ver que en los terrenos de la antigua Ciudadela aparece un grupo de tres torres con planta en forma de $\mathrm{H}$ y otra, más alta, de planta rectangular. Estos edificios forman parte de un conjunto más amplio que incluye otros bloques altos y una torre más, enlazados entre sí mediante plataformas elevadas, que ocupan terrenos situados ya dentro del viejo cauce.

Esta disposición de volúmenes se mantiene en el plano de 1961 de Ordenación de los terrenos de la antigua Ciudadela, de Salvador Pascual. Las tres torres en $\mathrm{H}$ son de XII plantas y la de planta rectangular, situada en la esquina de la calle Justicia y del Paseo de la Ciudadela, de XX plantas. Dos de las torres están unidas por un zócalo edificado de tres plantas que sigue la alineación circular de la Plaza Porta de la Mar por un lado y la de las propias torres por el lado opuesto, dejando un pequeño espacio ajardinado anexo a la calle Cronista Carreres. La tercera torre en $\mathrm{H}$ no está alineada con las otras dos, sino con el frente del Paseo de la Ciudadela, y está además adosada a la edificación entre medianeras contigua que ocupa el resto de la manzana.

El modelo de edificación abierta utilizado, que es el de la manzana mixta, en la que se superponen en vertical el orden cerrado de la edificación perimetral y el orden abierto de las torres, queda lastrado por el exceso de proximidad entre éstas, que desvirtúa su carácter de edificios aislados, sobre todo en el frente recayente al río, que resulta excesivamente denso.

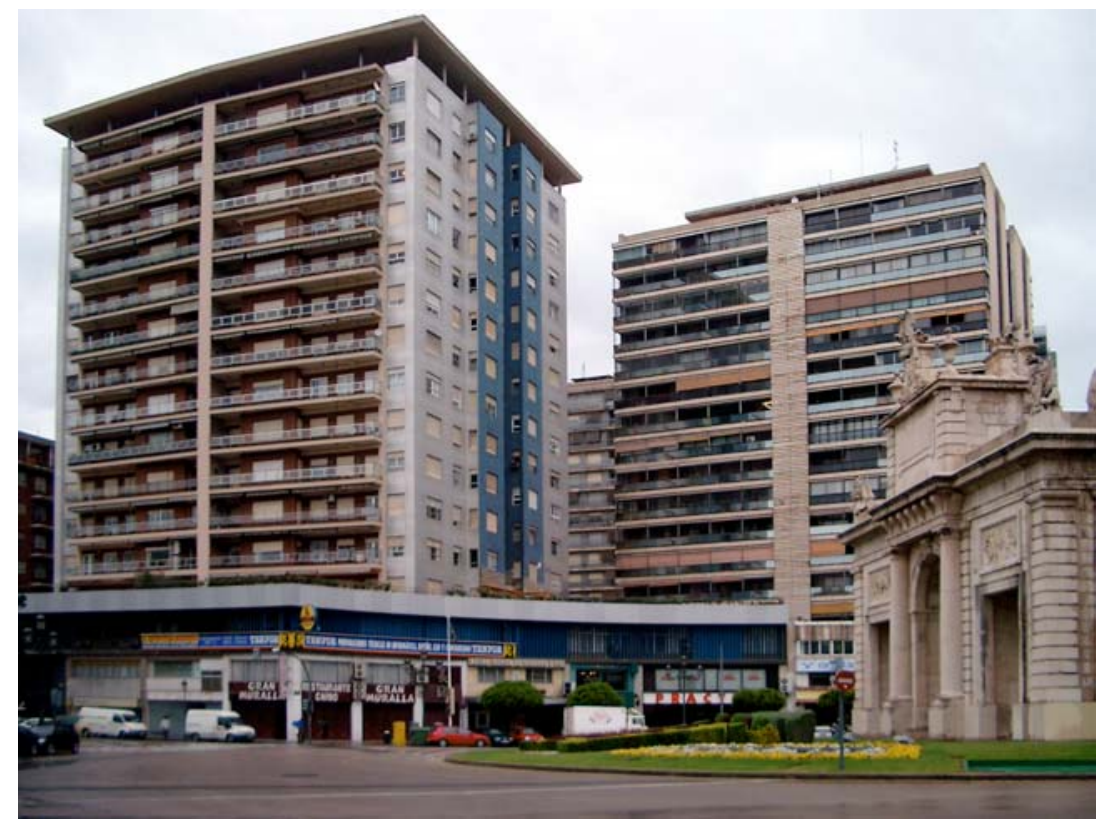

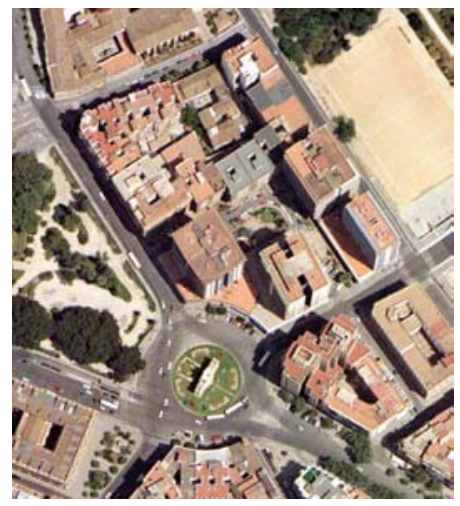

Conjunto de la Ciudadela Ortofoto 2002 (AUMSA).

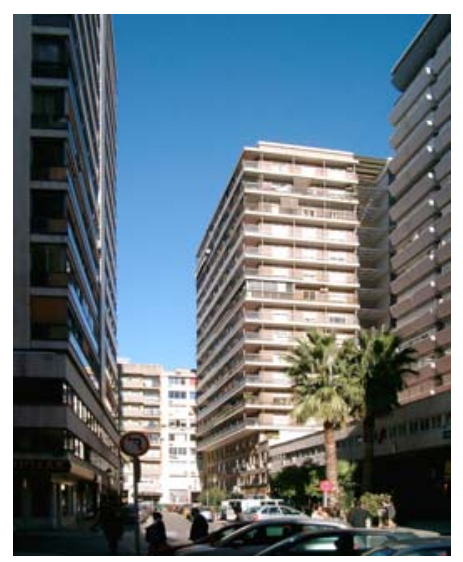

Conjunto de la Ciudadela. Vista hacia la calle Cronista Carreres

Vista actual desde la Plaza Porta de la Mar.

1. Delegación del Gobierno, Valencia. Ordenación técnica de la ciudad y su comarca, Imp. Tipografía Artística. Valencia. 1958. 


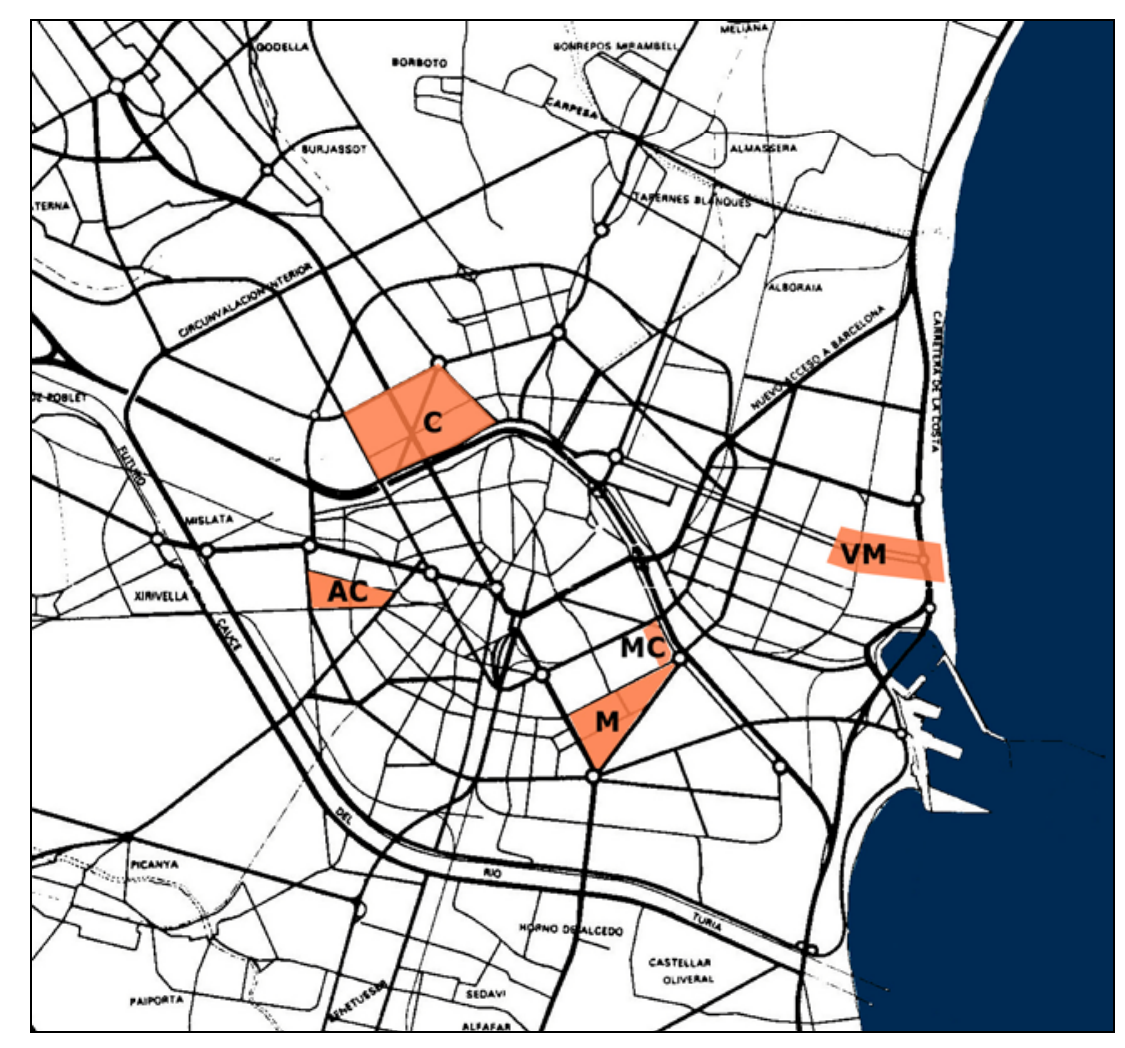

Localización de los Polígonos de promoción pública.

VM Polígono de Valencia al Mar.

C Polígono de Campanar.

AC Polígono de Avenida de Castilla.

M Polígono de Monteolivete / Fuente de S. Luís.

MC Centro Comercial de Monteolivete.

Tabla II.4

Valencia. Polígonos de la Gerencia de Urbanización, 1960-61

\begin{tabular}{|l|c|c|c|}
\hline POLÍGONO & $\begin{array}{c}\text { SUPERFICIE } \\
\text { (Ha) }\end{array}$ & VIVIENDAS & $\begin{array}{c}\text { AÑO } \\
\text { PROYECTO }\end{array}$ \\
\hline Valencia al Mar & 50,24 & 10.000 & 1960 \\
\hline Campanar & 102,00 & 10.000 & 1960 \\
\hline Av. Castilla & 28,73 & $3.908(*)$ & 1961 \\
\hline Monteolivete & 57,40 & 6.000 & 1960 \\
\hline Monteolivete/Centro Comercial & 9,62 & 740 & 1960 \\
\hline
\end{tabular}

(*) En el Plan Parcial reformado de 1968, el número de viviendas previsto se reduce a 2.050 . 


\section{POLÍGONOS: LOS PROYECTOS NO REALIZADOS}

En 1959, al Ayuntamiento de Valencia convocó un concurso para adjudicar los trabajos de redacción de los Planes Parciales de los polígonos residenciales de Valencia al Mar, Campanar, Avenida de Castilla y Monteolivete. Los polígonos se localizan pues al norte, sur, este y oeste de la ciudad.

Los Planes Parciales fueron adjudicados a diversos equipos de arquitectos, que los redactaron entre 1960 y 1961, siendo informados tanto por el Ayuntamiento como por la Dirección General de Urbanismo del recientemente creado Ministerio de la Vivienda.

Los planes para estos cuatro polígonos se redactan en el marco del Plan Sur de 1958, y no tienen en cuenta las ordenaciones propuestas anteriormente para las mismas zonas, que son las correspondientes a los Proyectos de Ejecución de Polígonos para Viviendas de Renta Limitada de 1955-56, analizados en la sección anterior.

La principal diferencia de los polígonos de Valencia con respecto a los realizados en otras ciudades españolas, y con respecto a los grupos del Plan Riada antes analizados, es que no son barrios aislados, sino que se sitúan junto al resto del tejido urbano, como ampliación de la ciudad considerada como un todo continuo.

La extensión de los polígonos es desigual, y oscila entre las 28,73 Ha del Polígono de la Avenida de Castilla y las $102 \mathrm{Ha}$ del Polígono de Campanar.

Pese a estar proyectados mediante bloques de edificación abierta, las densidades de edificación son también diferentes en los polígonos: los de Valencia al Mar y Campanar prevén el mismo número de viviendas, 10.000 , y el segundo tiene una superficie casi del doble que el primero.

Además de los cuatro polígonos residenciales mencionados, analizaremos en este apartado también el Plan Parcial redactado en 1960 para el Centro Comercial de Monteolivete, que puede entenderse como un complemento del polígono del mismo nombre.

La ejecución de los polígonos fue asumida por la Gerencia de Urbanización, organismo autónomo creado en 1959 y destinado a llevar a cabo las tareas técnicas y económicas necesarias para el desarrollo de la gestión urbanística asignada a la Dirección General de Urbanismo. Como hemos señalado anteriormente, entre 1960 y 1964, la Gerencia de Urbanización realizó más de doscientos Planes Parciales en toda España, acometiendo la expropiación y urbanización de más de 9.000 hectáreas ${ }^{1}$.

Por razones diversas, los planes para los cuatro polígonos de Valencia fueron posteriormente sustituidos por otros diferentes. Los nuevos planes, que estudiaremos en la sección siguiente de este trabajo, conservan algunos de los elementos previstos en los polígonos de la Avenida de Castilla y de Campanar. En cambio, los planes de 1960 y 1961 para los polígonos de Valencia al Mar y Monteolivete (tanto el del conjunto residencial como el del centro comercial) fueron descartados íntegramente.
1. Ver al respecto Cano Lasso, Julio, "La Gerencia de urbaniza- ción del Ministerio de la Vivien- da", Arquitectura, 62, Madrid, 1964.




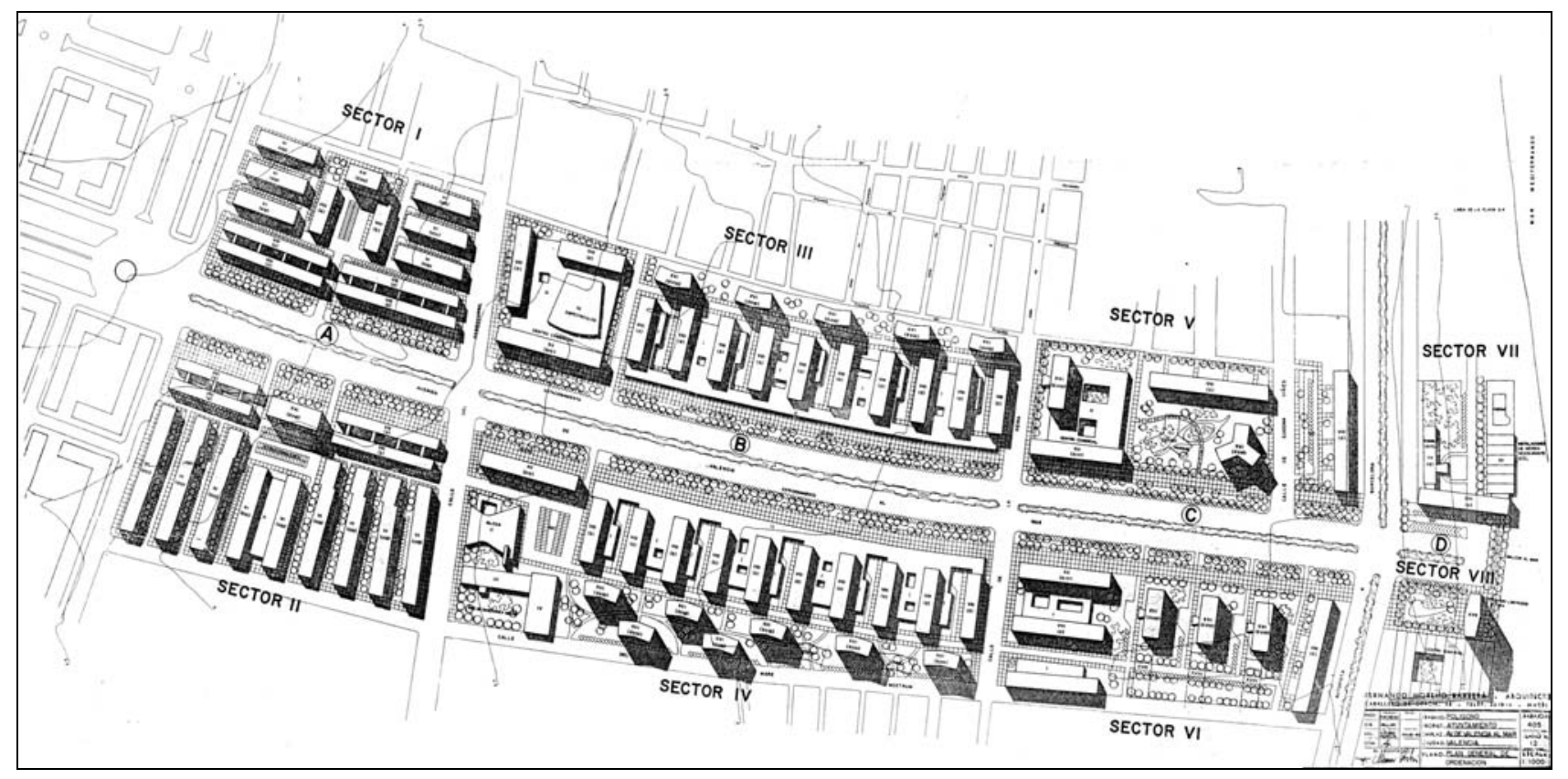

Polígono Valencia al Mar. Planta general de ordenación.

Polígono Valencia al Mar. Avance de Planeamiento. Alternativa 1.

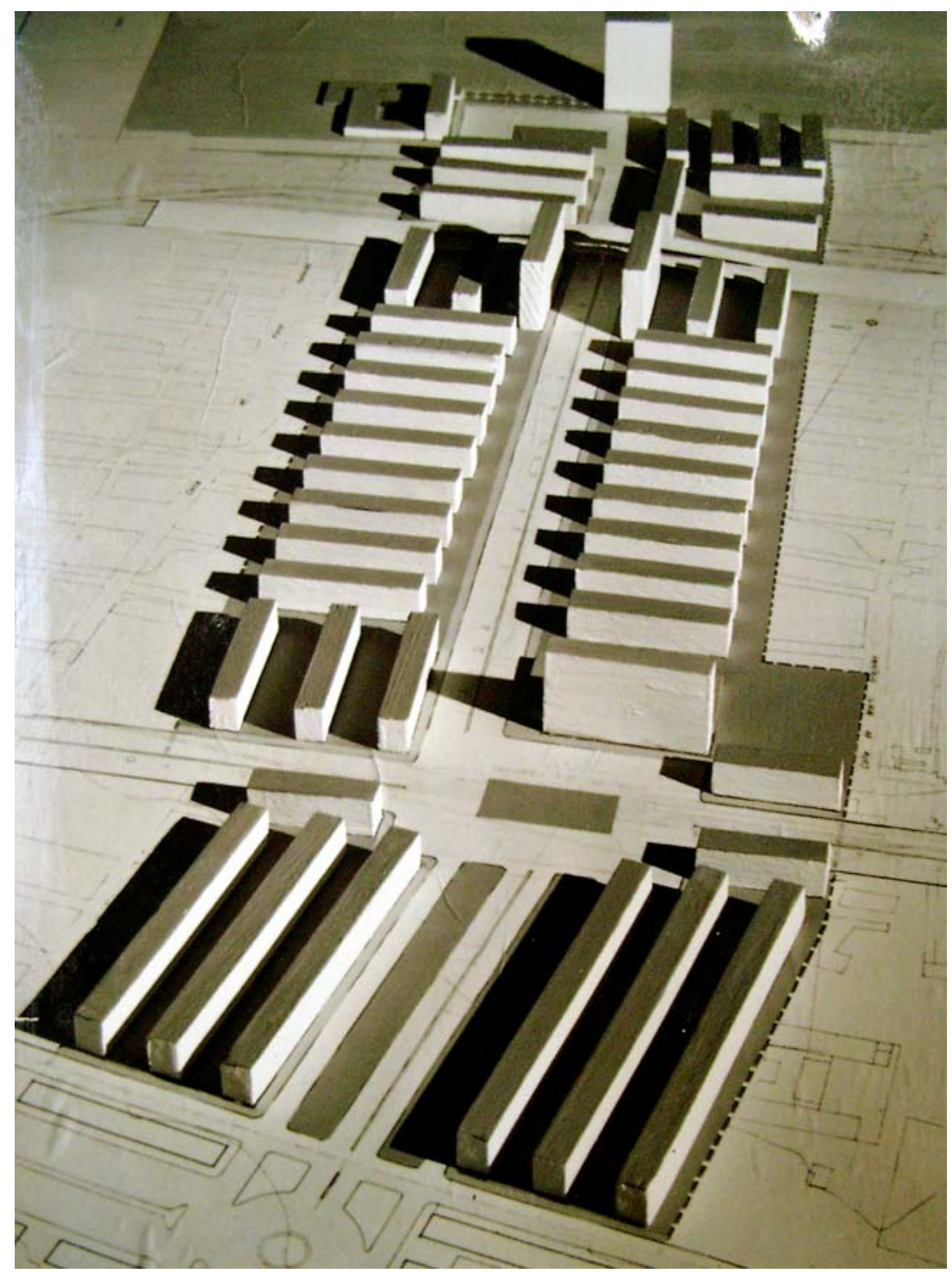




\section{POLÍgONO DE VALENCIA AL MAR (1960)}

El proyecto para el Polígono de la prolongación de la Avenida de Valencia al Mar fue redactado en 1960 por el arquitecto Fernando

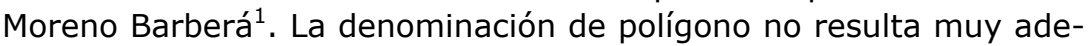
cuada para el proyecto, ya que realmente la zona ordenada es únicamente una banda de una anchura de $300 \mathrm{~m}$ a partir de la prolongación del eje de la Avenida.

Del estudio de alternativas presentado en el Avance del Plan Parcial, el Ayuntamiento eligió la no 2, que planteaba una trazado de directriz curva para la prolongación de la Avenida de Valencia al Mar, descartando otras, como la $n^{0} 1$, con un desarrollo rectilíneo a partir de una plaza que articula el cambio de dirección de la Avenida.

El proyecto implicaba la demolición completa de todas las edificaciones existentes en todo el ámbito ordenado, arrasando el barrio del Cabañal, lo que generó, lógicamente, un aluvión de alegaciones ${ }^{2}$.

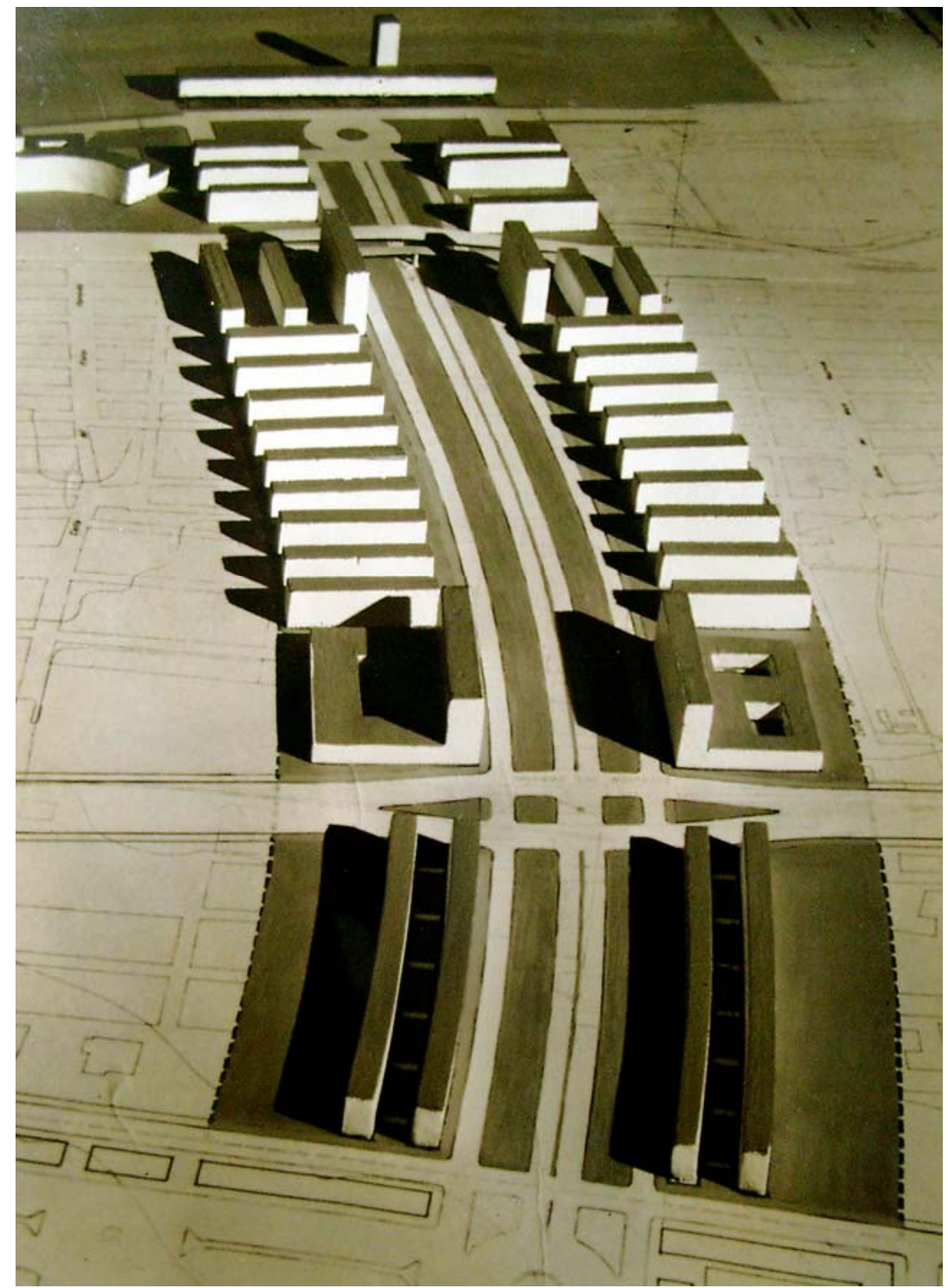

Polígono Valencia al Mar. Avance de Planeamiento. Alternativa 2.

1.Polígono No 6. Paseo Valencia al Mar, 1960. Ver Anexo de Documentos, pp. 73-93.

2.El bloque Ruiz Jarabo del INV, terminado en 1956, es mencionado en la Memoria del Plan, que señala que, al quedar justamente en el centro de la Avenida, su expropiación y demolición no serían necesarios hasta el último momento. 


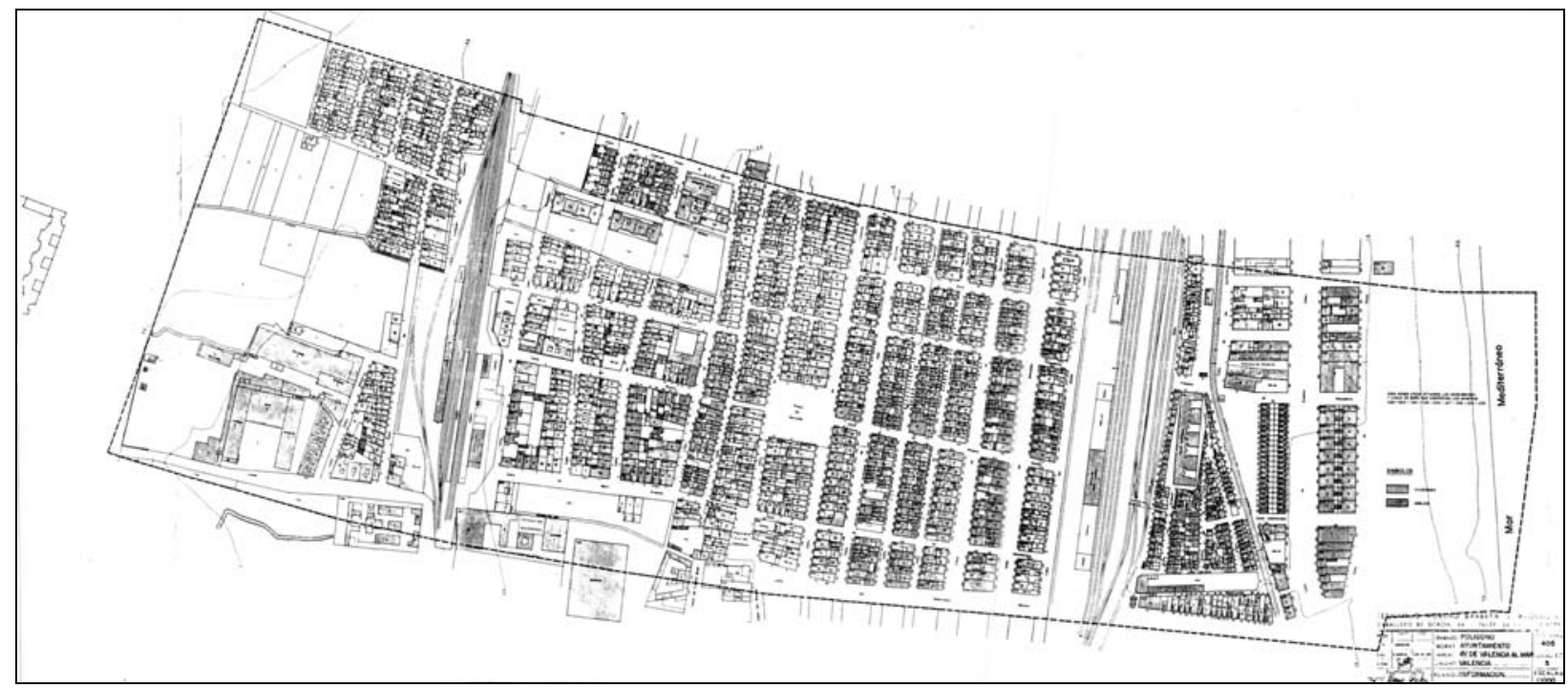

Polígono Valencia al Mar. Plano de información. Estado actual.
Polígono Valencia al Mar. Plano de circulaciones.
Para la sección transversal de la prolongación de la Avenida de Valencia al Mar se descarta la solución de bulevar ajardinado central y aceras estrechas junto a los edificios, que la Memoria del Plan califica como no agradable a la circulación y causa de la disminución del valor comercial de las edificaciones al alejar a los transeúntes de los edificios y de los locales de planta baja. Se opta por ello por una solución semejante, según la Memoria, a la existente en las avenidas principales de las grandes ciudades como París o Berlín: dos calzadas centrales separadas sólo por una mediana ajardinada, bandas de aparcamientos y enormes aceras laterales que se convierten en un lugar de estancia con abundante arbolado y espacio para terrazas con mesas de cafés, vitrinas, etc.

La Avenida está interrumpida únicamente por tres ejes transversales, que corresponden, de oeste a este, a la denominada Calle del Ferrocarril, que ocupa el espacio liberado al modificar la solución Sur el trazado ferroviario, la calle de la Reina, vía de acceso al Cabañal, y la carretera a Barcelona por la costa trazada en el estudio de la Red Arterial de Valencia.

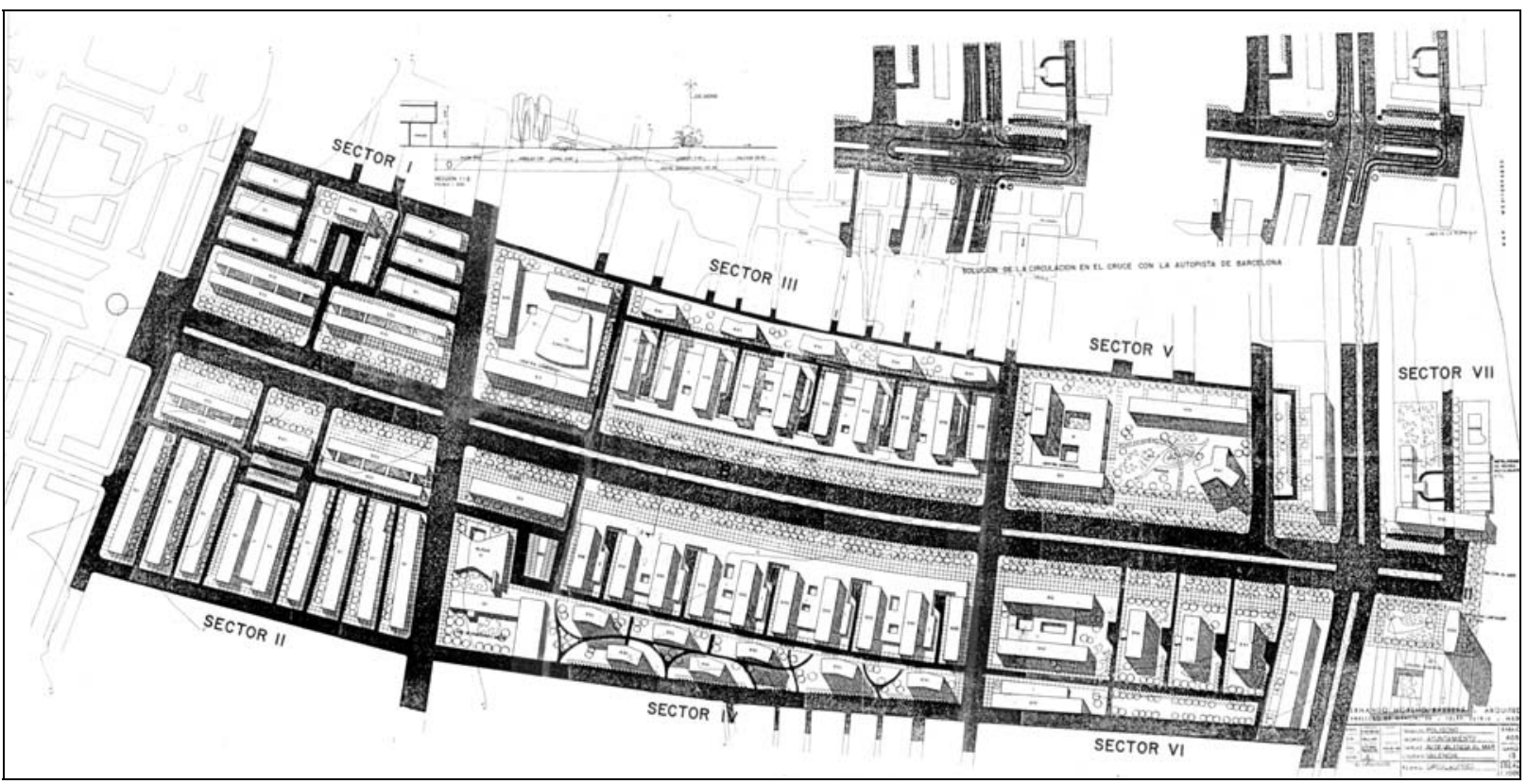


En relación con esta carretera de la costa, la Memoria del plan señala que su trazado causa un grave perjuicio a los intereses de la ciudad, ya que la obra civil necesaria para construirla (muros de contención, escolleras, etc.) supone la destrucción de la playa. Lo que se propone, sin embargo, no es suprimir dicha carretera, sino trazarla por la calle Eugenia Viñes, expropiando y demoliendo las casas de una y dos plantas que bordean dicha calle.

Para el cruce de la Avenida de Valencia al Mar con la carretera de la costa, se rechaza la solución de rotonda, que según la Memoria ocupa mucha superficie y carece de ambiente y de calidad urbanística. El cruce se resuelve de una manera urbana, mediante semáforos y ensanches laterales para cambio de sentido, aunque la solución que se considera ideal es un paso superior o inferior de la carretera. que:

En relación con los equipamientos, la Memoria del plan señala

El Polígono que se proyecta tendrá que completarse con el estudio de las zonas colindantes en las que se deberán emplazar las zonas deportivas, verdes, etc. a las que no se debe destinar el terreno de elevado coste de urbanización próximo a la Avenida de Valencia al Mar. ${ }^{1}$

El plan se limita, por tanto, a hacer un cálculo de los equipamientos necesarios, que deberán situarse fuera de la zona ordenada, cuyo terreno se considera "demasiado valioso para destinarlo a edificaciones no rentables"2. Los únicos equipamientos que se sitúan en la zona, por exigencia municipal, son una Iglesia y un Instituto de Enseñanza Media, en la manzana recayente a la calle del Ferrocarril y a la calle de Matí Grajales, límite sur del polígono.

Para la dotación de zonas verdes, el plan remite a los espacios de jardín entre los bloques, y menciona la extensa superficie de la Avenida como espacio libre a efectos de aireamiento.

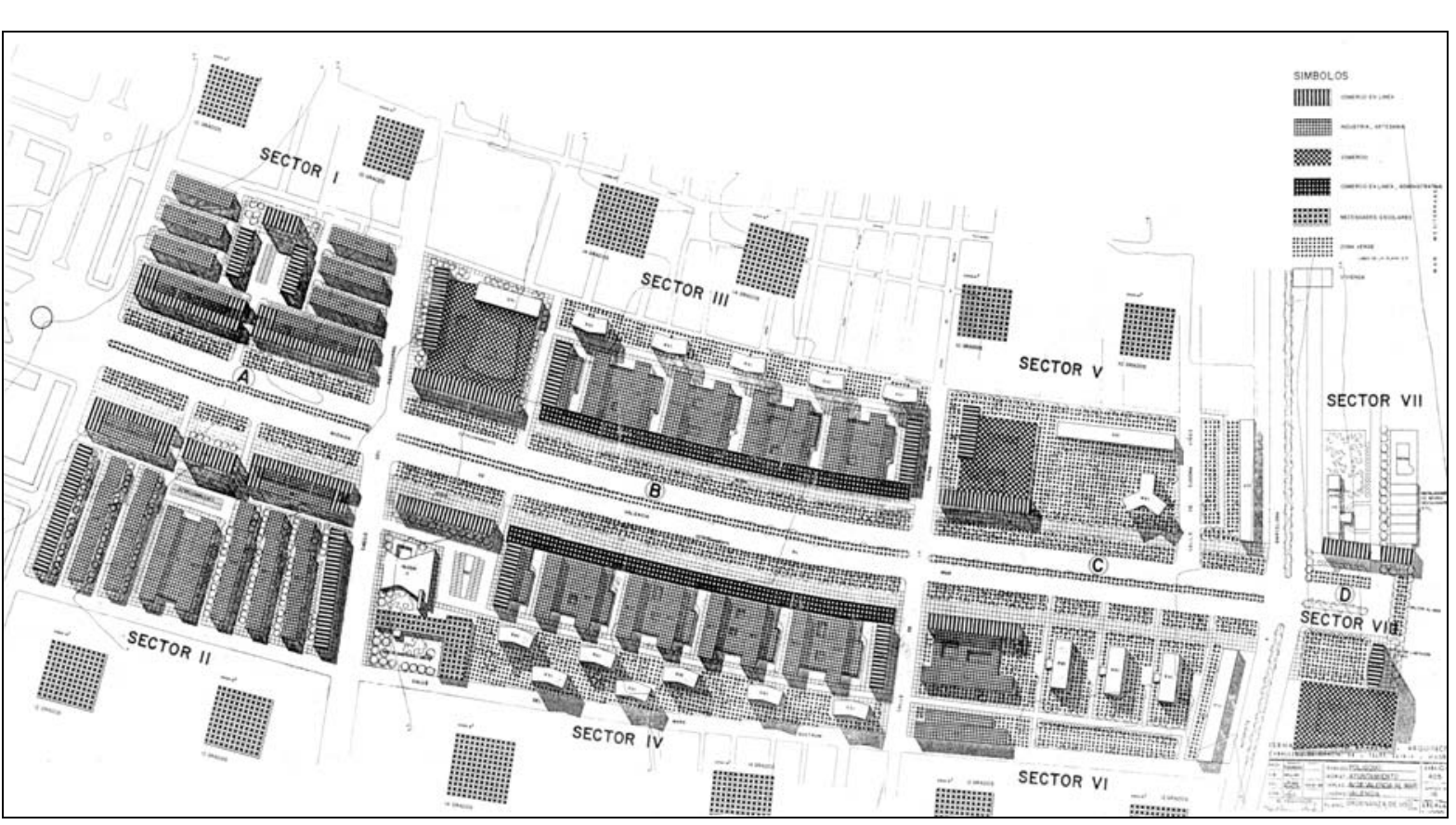

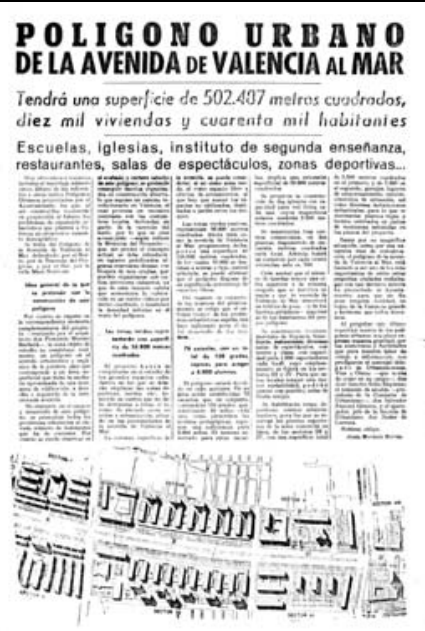

Jornada, Diario de la Tarde. 10 de febrero de 1961

1. Polígono No 6. Paseo Valencia al Mar. Memoria. Anexo de Documentos, p. 74

2. Ibid. p. 79.

Polígono Valencia al Mar. Plano de ordenanzas de usos. 

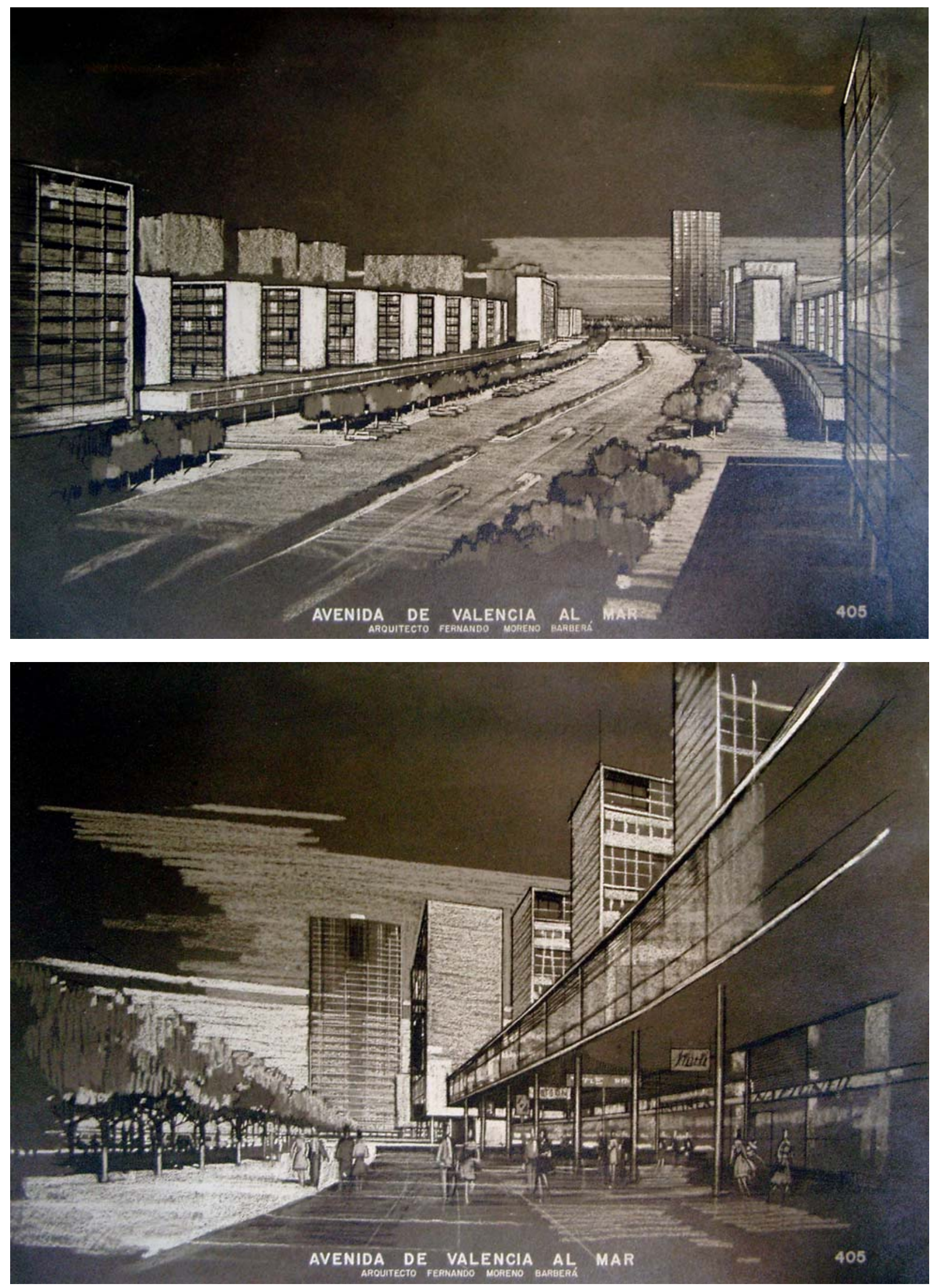

Polígono Valencia al Mar. Perspectivas de la Avenida de Valencia al Mar. 


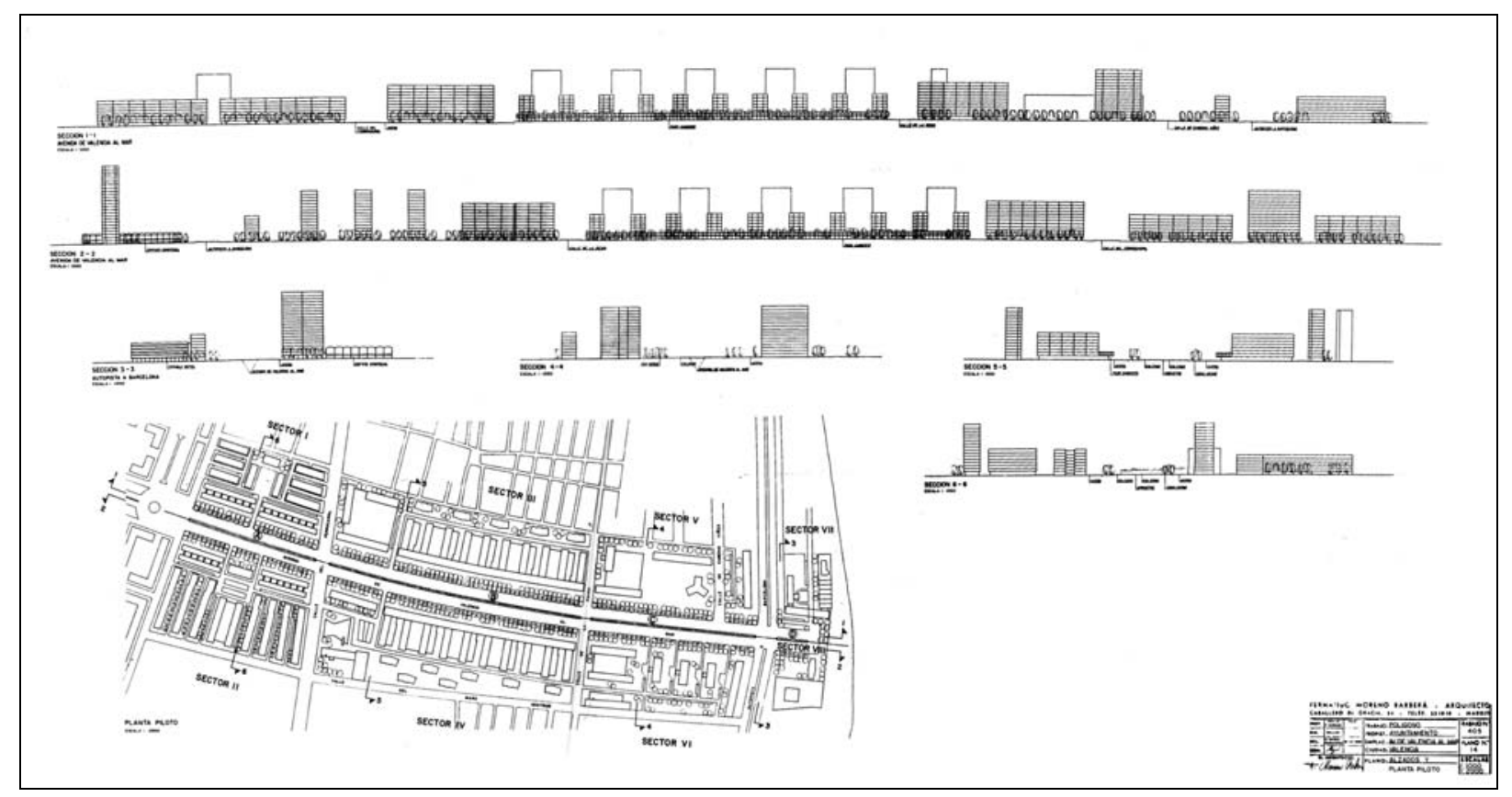

La edificación proyectada y su relación con el espacio libre se describen de forma detallada en al apartado de la Memoria titulado "Formación de ambientes urbanísticos y composición de masas", que comienza así:

La Avenida de Valencia al Mar se proyecta tratarla no como una arteria de circulación únicamente sino como un elemento de la ciudad definido estéticamente, que produzca impresiones sucesivas al recorrerlo tanto de estrechez como de amplitud, de cerrado y diáfano, cuyos edificios responderán a ritmos alternados, tanto en dirección como en altura, etc. ${ }^{1}$

El primer tramo de la Avenida (Sectores I y II) está flanqueado por manzanas muy compactas. Los bloques alineados con la Avenida son bloques dobles, y los situados detrás bloques lineales de 6 plantas que rellenan el espacio disponible. Los bloques del lado norte se ordenan en torno a una plaza central formada con un edificio elevado al fondo y dos edificios bajos laterales. En el lado sur, un edificio alto se sitúa frente a la embocadura de dicha plaza.

En el tramo central de la Avenida se proyectan cuatro edificios de 16 plantas paralelos a la misma que la limitan, y entre ellos, dos hileras de 10 edificios colocados en peine, retranqueados $10 \mathrm{~m}$. de la alineación anterior. Acerca de estos edificios, la Memoria del plan afirma que:

La pretendida rigidez de los bloques paralelos y repetidos no existe. Sólo la repetición de elementos da escala y grandeza a las composiciones, siempre que estén debidamente acentuadas como en el caso presente. ${ }^{2}$

Uniendo los edificios en peine, se proyecta una edificación de dos alturas con la parte baja en porche, para fines comerciales o de oficinas. El objetivo que se persigue es que la Avenida no sea una calle desierta, sino un lugar lleno de vida con tiendas, oficinas, espectáculos y viviendas. ${ }^{3}$

Polígono Valencia al Mar. Alzados y planta piloto.
1. Polígono No 6. Paseo Valencia al Mar. Memoria. Anexo de Documentos, p. 78.

2. Ibid. p. 78.

3. La Memoria alude a experiencias similares realizadas en Suecia y en la reconstrucción de Inglaterra. Se refiere, probablemente, al Torg de Estocolmo y al centro de Coventry. 


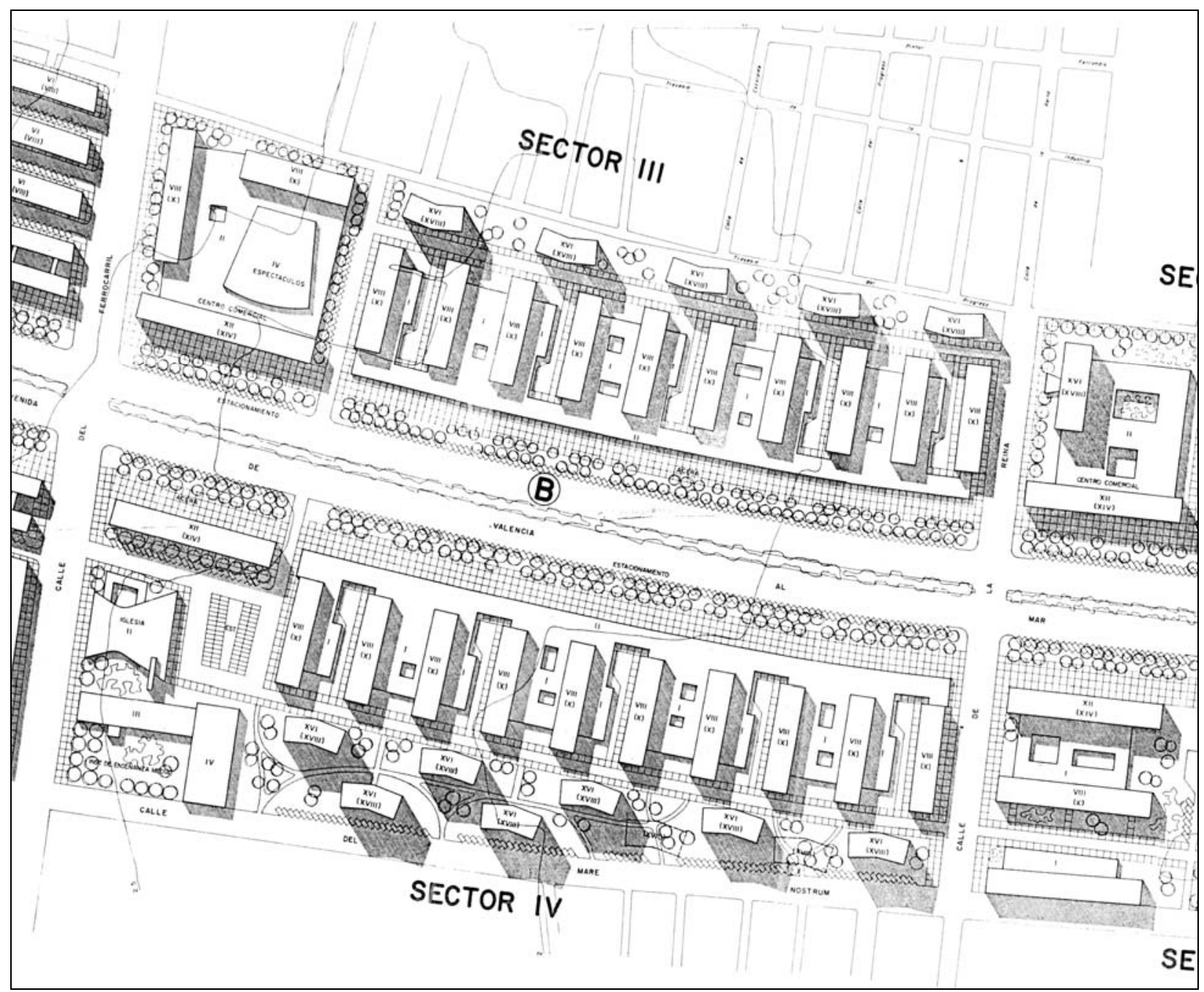

Polígono Valencia al Mar. Planta general de ordenación. Detalle de la zona central.
El acceso de peatones a los bloques se produce desde la Avenida de Valencia al Mar, donde quedan estacionados los vehículos. Una calle posterior paralela a la Avenida con ramales sin salida cada dos bloques resuelve los accesos de vehículos para suministros. Tras esta calle, se sitúan una serie de torres aisladas de 16 plantas, cuya función, según la Memoria del plan, es "velar la actual edificación existente de baja calidad".

Detrás de los tres de los cuatro bloques altos paralelos a la Avenida se sitúan edificios para locales comerciales y de espectáculos, que forman un zócalo sobre el que se levantan otros bloques. El espacio trasero del cuarto bloque es el destinado a Iglesia e Instituto de Enseñanza Media.

En el tramo siguiente de la Avenida, se crean dos zonas a derecha e izquierda con edificios altos que liberan suelo para zonas verdes, configurando un recinto que se cierra con dos bloques perpendiculares a la Avenida, alineados con la carretera de la costa. Respecto al final de la Avenida, la Memoria del plan señala lo siguiente:

Una Avenida de esta importancia y dimensiones debe terminar llegando a alguna parte, no disolverse en un simple nudo de circulación, ya que su objetivo no es el de proporcionar una llegada rápida a la carretera de Barcelona, sino que tiene valor en sí misma. ${ }^{1}$ 


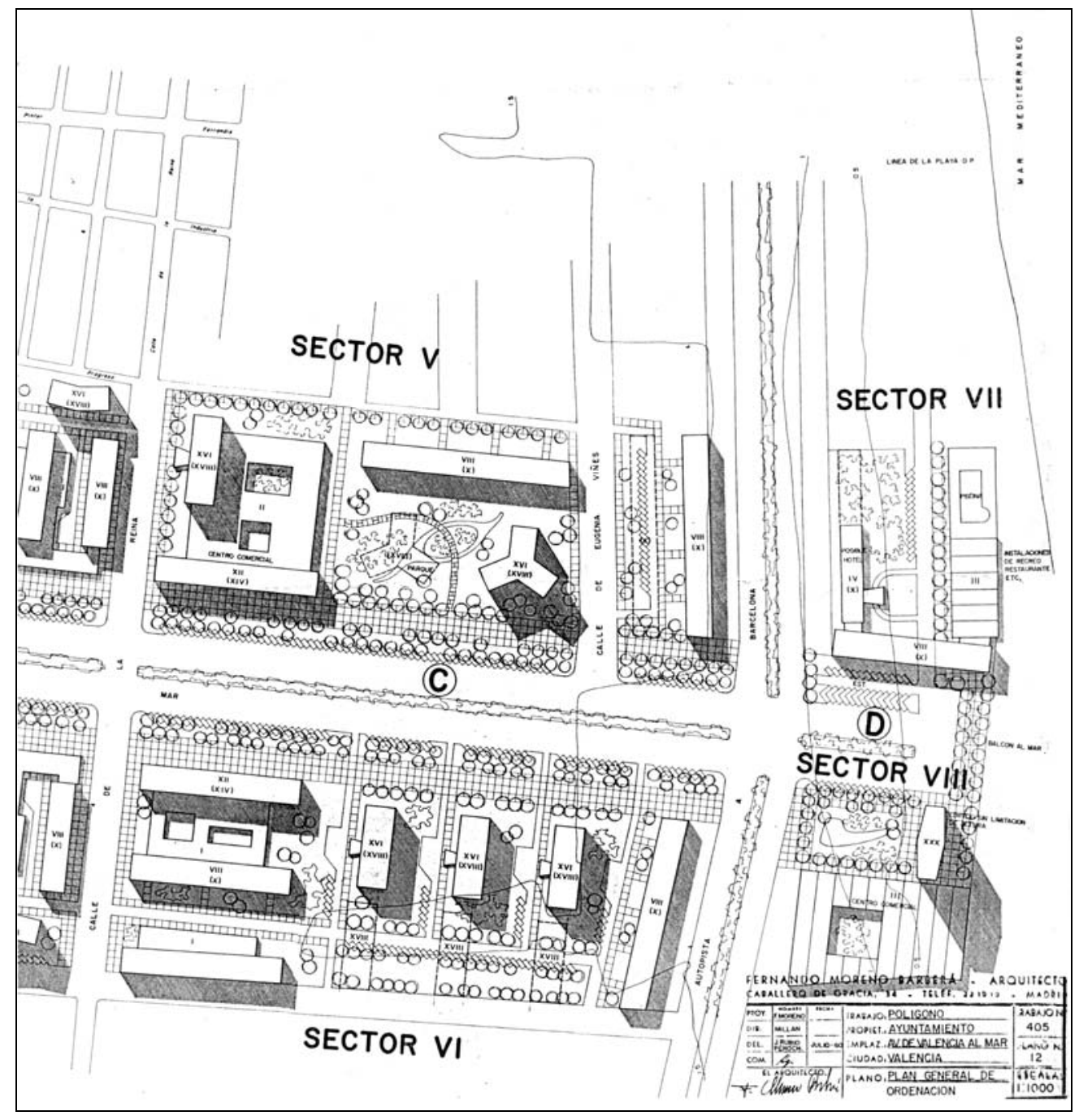

Por ello, una vez cruzada carretera de la costa, se crea la llamada "Plaza Terminal", presidida por una torre "de la máxima altura posible, sin limitación". ${ }^{1}$

Polígono Valencia al Mar. Planta general de ordenación. Detalle de la zona este.

Esta torre, dada la curvatura de la Avenida, se percibe desde una distancia superior a $2 \mathrm{Km}$., y es el elemento que cierra visualmente la Avenida.

Junto a la torre, un edificio comercial permite configurar una plaza lateral que recoge toda la acera sur. En la zona situada a eje de la Avenida se prevé "una plantación de palmeras formando un balcón sobre el Mediterráneo". 2

El principal interés de este plan es que muestra de manera muy clara, con su detallada explicación de los mecanismos compositivos del proyecto, los planteamientos del urbanismo racionalista ortodoxo, así como su actitud hacia la ciudad existente, de tabula rasa.

El proyecto de Moreno Barberá será pronto descartado, y ya en 1962, dos años después de su redacción, fue sustituido por una nueva ordenación - el Plan Parcial 13- que abarcaba toda la zona del Cabanyal y la Malvarrosa, manteniendo la destructiva prolongación del Paseo al Mar.

1.Polígono No 6. Paseo Valencia al Mar. Memoria. Anexo de Documentos, p. 79.

2.Polígono No 6. Paseo Valencia al Mar. Memoria. Anexo de Documentos, p. 80. Esta zona está identificada con el rótulo de "Balcón al mar" en la Planta General de Ordenación, lo que supone una curiosa coincidencia con la denominación inicial del proyecto municipal actualmente en curso para la reutilización de la dársena interior del Puerto. 

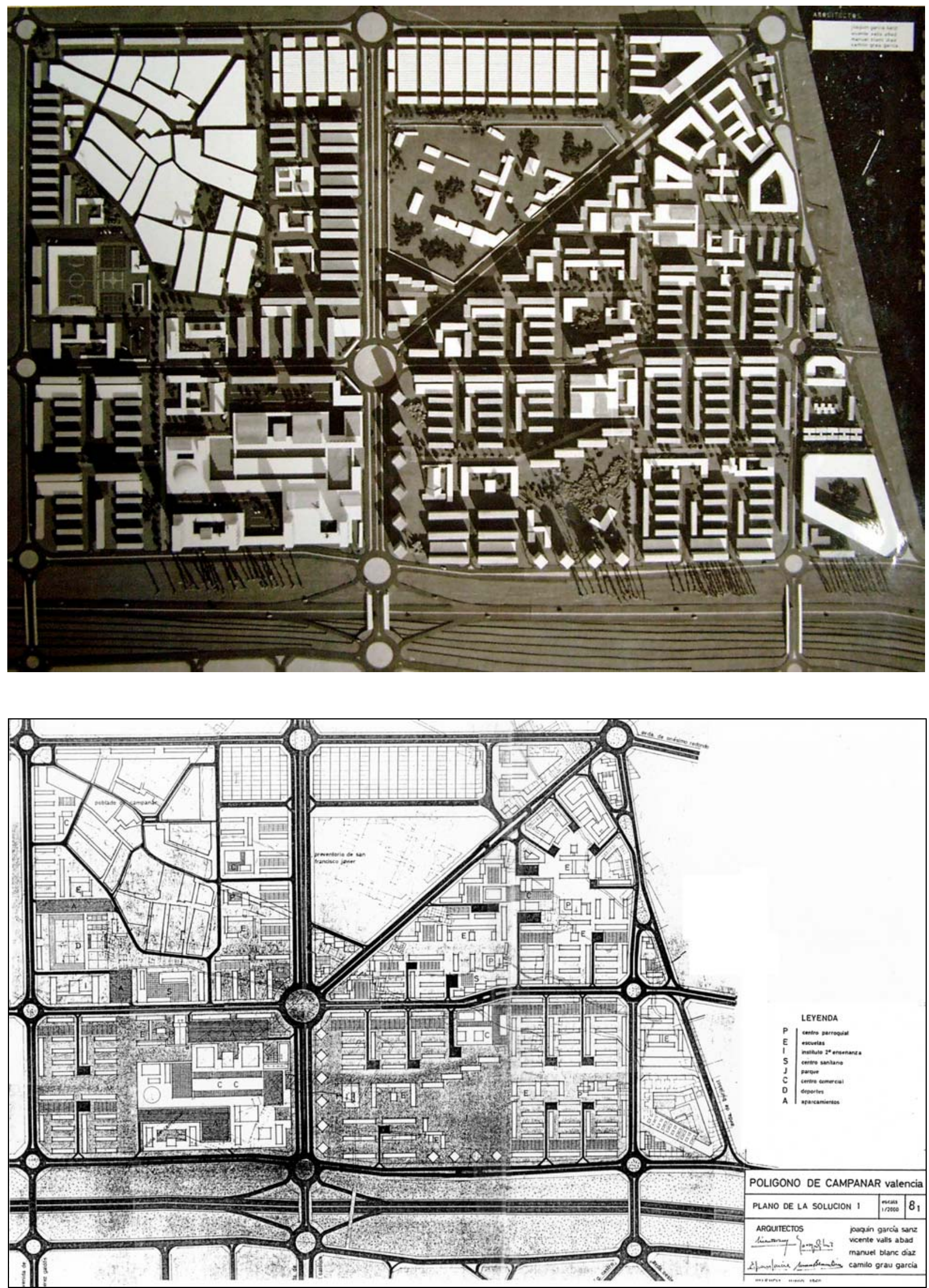


\section{POLÍgONO DE CAMPANAR (1961)}

El Plan Parcial del Polígono de Campanar fue redactado entre 1960 y 1961 por los arquitectos Joaquín García Sanz, Vicente Valls Abad, Manuel Blanc Díaz y Camilo Grau García, equipo adjudicatario del concurso convocado al efecto por el Ayuntamiento en 1959.

El plan ordena el área limitada al sur por el río Turia, al oeste por la actual Avenida de Maestro Rodrigo, al norte por la Avenida del General Avilés y al este por la Avenida de Burjasot.

Las edificaciones existentes en la zona ordenada, además del núcleo del poblado de Campanar y de la extensa parcela del Preventorio de San Francisco Javier, eran escasas, y se concentraban a lo largo de los ejes viarios principales, como la Avenida de Burjasot, junto a la que se encuentra el grupo Agrifersa y fragmentos de algunas manzanas ya iniciadas.

Por otra parte, el plan parcial del polígono no tiene en cuenta los planes anteriores para la zona. Así, el Proyecto de Ejecución del Polígono de Campanar para Viviendas de Renta Limitada de 1956, anteriormente analizado, que introducía ya la edificación abierta, es descartado y sustituido por un nuevo diseño urbano. Este nuevo diseño está basado también en el uso generalizado de la edificación abierta, pero muestra un mayor conocimiento de los elementos de la misma y una mayor destreza en el manejo de los recursos compositivos asociados a ella. Además, plantea un conjunto integrado de viviendas y equipamientos, es decir, una auténtica unidad vecinal, para lo que se introducen en el polígono unas reservas de suelo para equipamientos basadas en estándares de países europeos, que suplen la indefinición al respecto de la Ley del Suelo de 1956.

La documentación integrante del plan, tanto escrita como gráfica, muestra, como ocurre en los restantes polígonos, un grado de desarrollo muy superior al presente en los planes parciales redactados desde el Ayuntamiento.

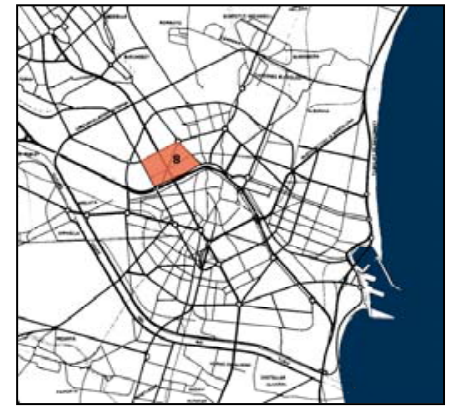

Polígono de Campanar. Localización.

Página opuesta:

Plan Parcial del Polígono de Campanar, 1961. Maqueta y Planta de la Solución 1.

Plan Parcial del Polígono de Campanar, 1961. Maqueta. Vista desde el sur.

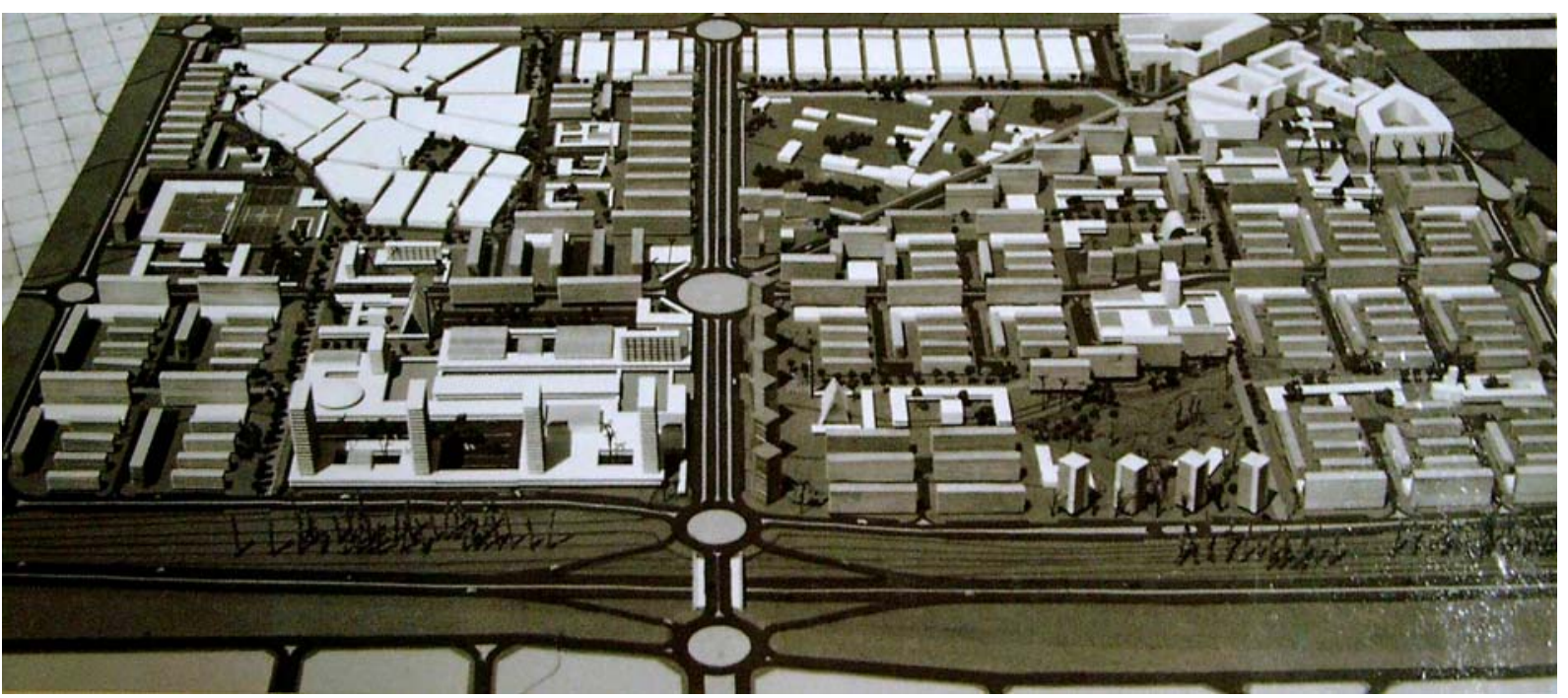


Plan Parcial del Polígono de Campanar, 1961. Planta de la Solución 2.

Plan Parcial del Polígono de Campanar, 1961. Planta de la Solución 3.
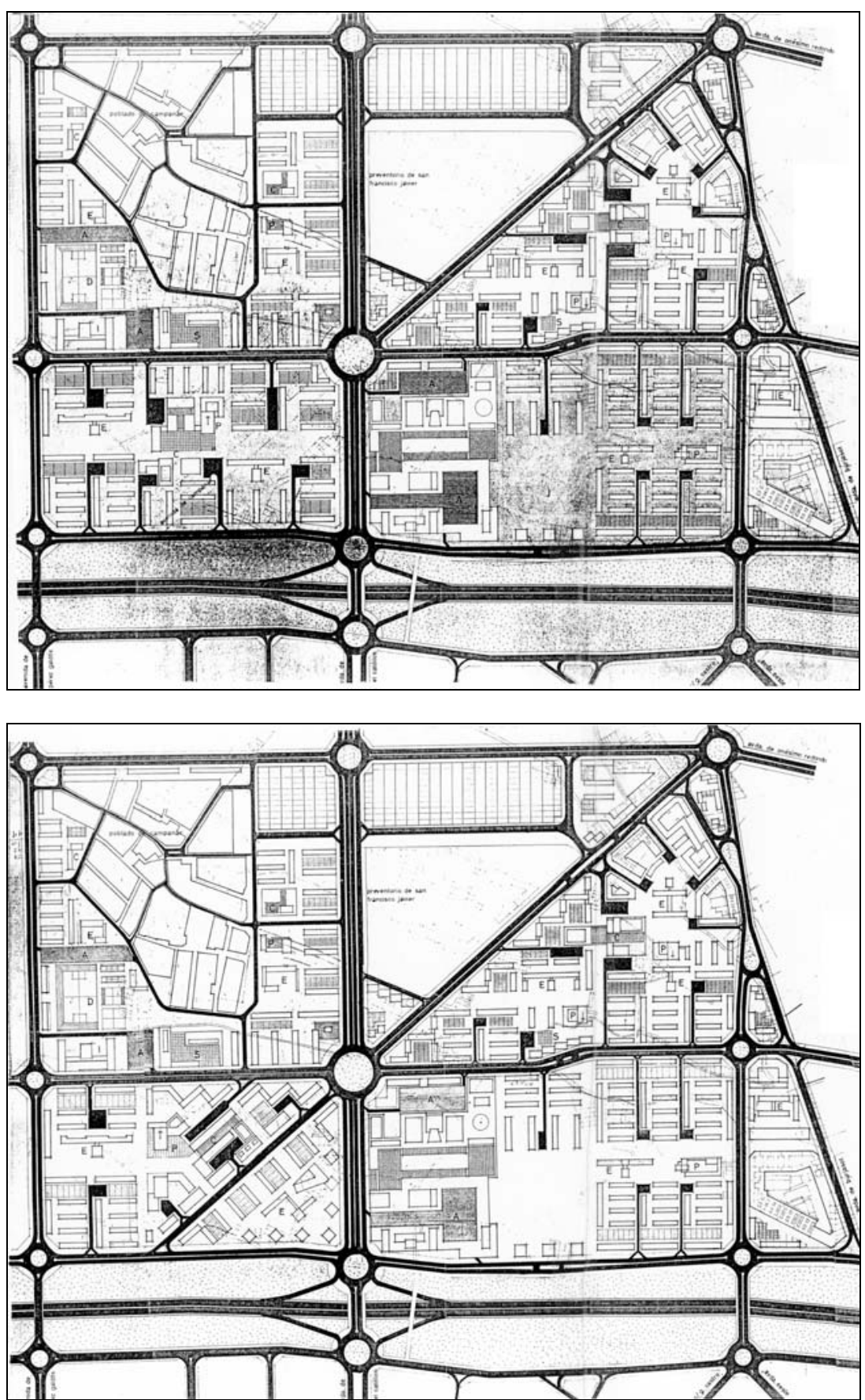

La Memoria del Plan Parcial señala que la estructura urbanística proyectada para el polígono se basa en la división del mismo en una serie de supermanzanas limitadas por la red viaria fundamental.

La red viaria fundamental del polígono es la prevista en el Plan Sur de 1958. Esta red está compuesta por los elementos siguientes:

- tres ejes de dirección este-oeste, que son el nuevo Camino de Tránsitos (actual Avenida General Avilés) al norte, la calle Joaquín Ballester y su prolongación (actual calle Vall de la Ballestera) en el centro y la avenida junto al cauce del río Turia al sur. 
- cuatro ejes de dirección norte-sur, que son la Avenida de Burjasot, la calle Padre Ferris, el nuevo acceso de Ademuz (actual Avenida Pío XII) y la nueva vía límite del polígono por el oeste (actual calle Maestro Rodrigo)

- El eje diagonal del Camino de Tránsitos, de dirección norestesuroeste.

La principal modificación que introduce el plan en el viario fundamental del Plan Sur es la supresión del tramo diagonal del Camino de Tránsitos comprendido entre el cruce con el acceso de Ademuz y el río Turia. La memoria del plan justifica este cambio en el hecho de que el nuevo acceso de Ademuz recoge todo el tráfico del Camino de Tránsitos, por lo que queda vacío de contenido su último tramo diagonal, que además partiría en dos una manzana en la que se sitúa el gran centro comercial de Valencia Norte previsto en el Plan Sur.

El plan prevé también el convertir la Avenida de Burjasot en vía de segundo orden, haciendo de la calle Padre Ferris la vía principal del lado este del polígono, que a través de un nuevo puente sobre el Turia lo conectará con la desembocadura de la Avenida del oeste y con la ronda de la calle Guillem de Castro.

En dos de las tres soluciones dibujadas como estudio de alternativas del plan se mantiene la supresión del último tramo diagonal del Camino de Tránsitos, con diferentes localizaciones del centro comercial (al oeste del acceso de Ademuz en la solución 1, que es la desarrollada en el plan parcial, y al este en la solución 2). Sólo en la solución 3 se mantiene el tramo diagonal mencionado, aunque los redactores del plan hacen constar que la consideran como una solución claramente insatisfactoria.
Plan Parcial del Polígono de Campanar, 1961. Maqueta. Vista desde el oeste.

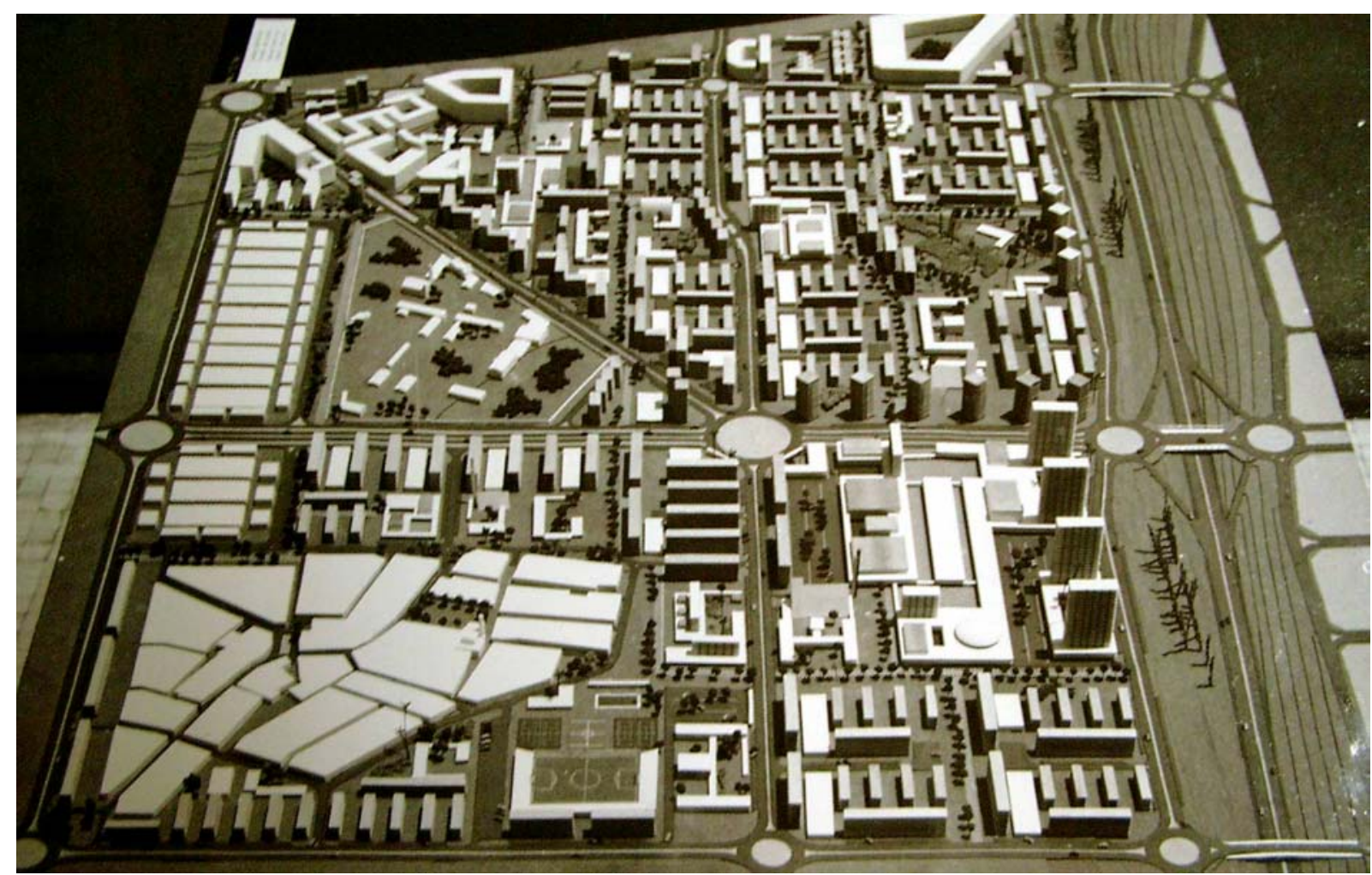




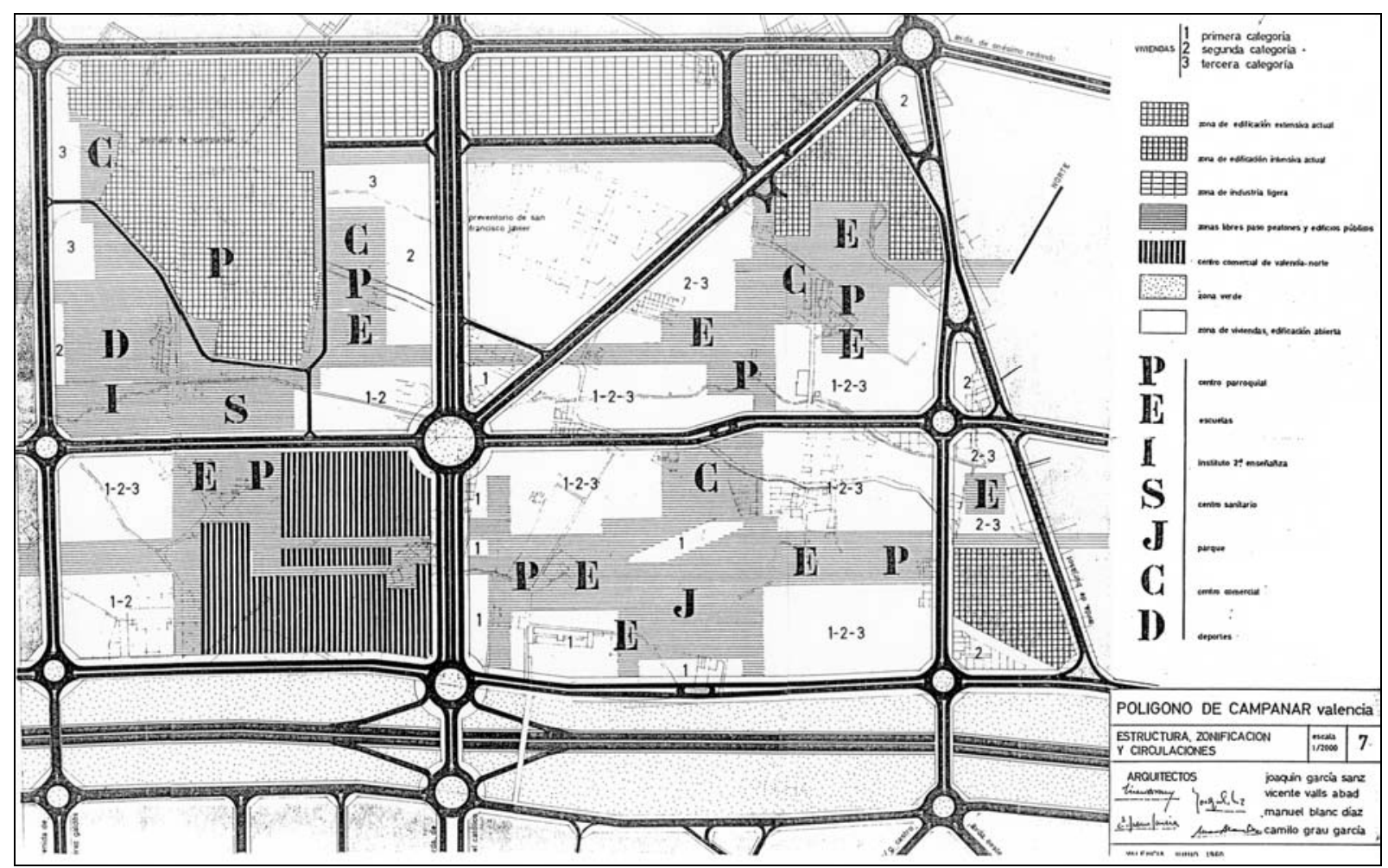

Plan Parcial del Polígono de Campanar, 1961. Plano de estructura, zonificación y circulaciones.
1. Plan Parcial de Ordenación de Polígono de Campanar, 1961. Memoria. Ver Anexo de Documentos, pp. 97-115.
La red viaria principal define unas supermanzanas en cuyo interior se plantea, en las zonas nuevas de edificación abierta, un viario de tipo ramificado, con ramales sin salida y un núcleo central de equipamientos y espacios verdes. Al respecto, la Memoria del plan señala lo siguiente:

Dentro de cada una de estas supermanzanas, se crean las unidades vecinales (dos por cada supermanzana, por regla general) cuyas viviendas se agrupan alrededor de los pequeños centros comerciales y del Centro cultural y religioso integrado por la escuelas y parroquia respectivamente.

Hemos procurado que la circulación de peatones y la comunicación entre los centros de unidades vecinales, se realice a través de amplios espacios verdes, que, dispuestos en sentido perpendicular, atraviesan las supermanzanas creando espacios de expansión sin más interferencias que los cruces del sistema principal de viales a que antes aludimos, proyectándose subterráneos los que atraviesa al nuevo acceso de Ademuz que por su naturaleza requiere esta solución. $^{1}$

La idea de unidad vecinal se refiere aquí, como vemos, a una unidad de escala inferior a la de la neigborhood unit europea. La idea de supermanzana, por su parte, sigue literalmente la del modelo de Radburn, aunque como soporte de una edificación de bloques, más densa que la del modelo original de casas unifamiliares.

En las zonas con edificación preexistente integrada en manzanas cerradas, el viario previsto es del tipo mallado tradicional. En estas zonas, el plan se limita a completar las manzanas ya iniciadas con edificios de gran profundidad edificable. Este mismo criterio es el que se utiliza para regularizar el perímetro del poblado de Campanar, al que se rodea de un anillo viario de acceso y de una cintu 
rón verde y de equipamientos que lo dotan de servicios y a la vez lo separan de las nuevas áreas proyectadas a su alrededor. ${ }^{1}$

Con esta estructura, el polígono se desglosa en cuatro subpolígonos, A, B C y D, correspondientes a los cuatro cuadrantes que definen los dos ejes centrales norte-sur y este-oeste del acceso de Ademuz y la calle Joaquín Ballester.

La ordenación de volúmenes en las zonas residenciales de edificación abierta está basada en la repetición de un módulo tipo de agrupación de bloques lineales, cuya superficie oscila entre 0,5 y $1 \mathrm{Ha}$.

Este módulo tipo sigue el modelo de la edificación mixta preconizado por Bakema y Van den Broek y desarrollado en conjuntos residenciales como los de Pendrecht o Klein Driene. En concreto, el módulo proyectado para el polígono de Campanar está formado por grupos de 3 a 5 bloques lineales de altura media dispuestos en dirección este-oeste, un bloque ortogonal a los anteriores, paralelo al ramal sin salida, y un bloque alto recayente a las vías principales a norte o sur, junto al cual se sitúan edificaciones de una planta destinadas a garajes, talleres o pequeñas industrias artesanas.

La Memoria del plan señala que en algunas zonas se prescinde del módulo tipo para resolver áreas de forma irregular, como el frente de la Avenida de Campanar, y en los puntos destacados del conjunto, en los que se introduce edificación singular, como las series de torres recayentes al lado este del primer tramo del acceso de Ademuz, o las del frente al río Turia, junto al parque del subpolígono A, a fin de evitar la monotonía en la composición, especialmente en calles de gran recorrido. En la edificación abierta que envuelve el poblado de Campanar tampoco se recurre al módulo tipo, sino a edificación en línea de bloques lineales o bien a agrupaciones de parejas de bloques con edificación intermedia en planta baja.

El plan prevé para las distintas unidades vecinales los servicios necesarios para dotarlas de completa autonomía de funcionamiento. Para ello, además de zonas verdes, escuela y centro parroquial, se proyectan unos centros cívicos secundarios, que alojarán usos administrativos, comerciales, de oficinas, sanitarios, culturales y de ocio.

Además de los núcleos de equipamientos propios de cada unidad vecinal, el plan prevé para todo el conjunto una zona deportiva, un Instituto de Enseñanza Media y un Hospital, así como un amplio parque que completa el sistema de espacios libres proyectado, organizado mediante ejes verdes peatonales que van enlazando las distintas supermanzanas. ${ }^{1}$

El plan prevé también el establecimiento de una zona destinada a industrias ligeras que permitan absorber parte de la mano de obra del polígono, evitando desplazamientos innecesarios. Esta zona se sitúa en la parte norte del polígono, junto a la prolongación del Camino de Tránsitos.

Para la cuantificación de las reservas de suelo para todas estas dotaciones, que se realiza de forma muy detallada, el plan recurre por regla general a normas francesas
1.La memoria del plan señala que con ello se resuelve el problema del "aspecto poco afortunado que, en general, ofrecen las fachadas de los edificios del poblado". Ver Plan Parcial de Ordenación del Polígono de Campanar, 1961. Memoria. Anexo de Documentos, pp. 97-115. 

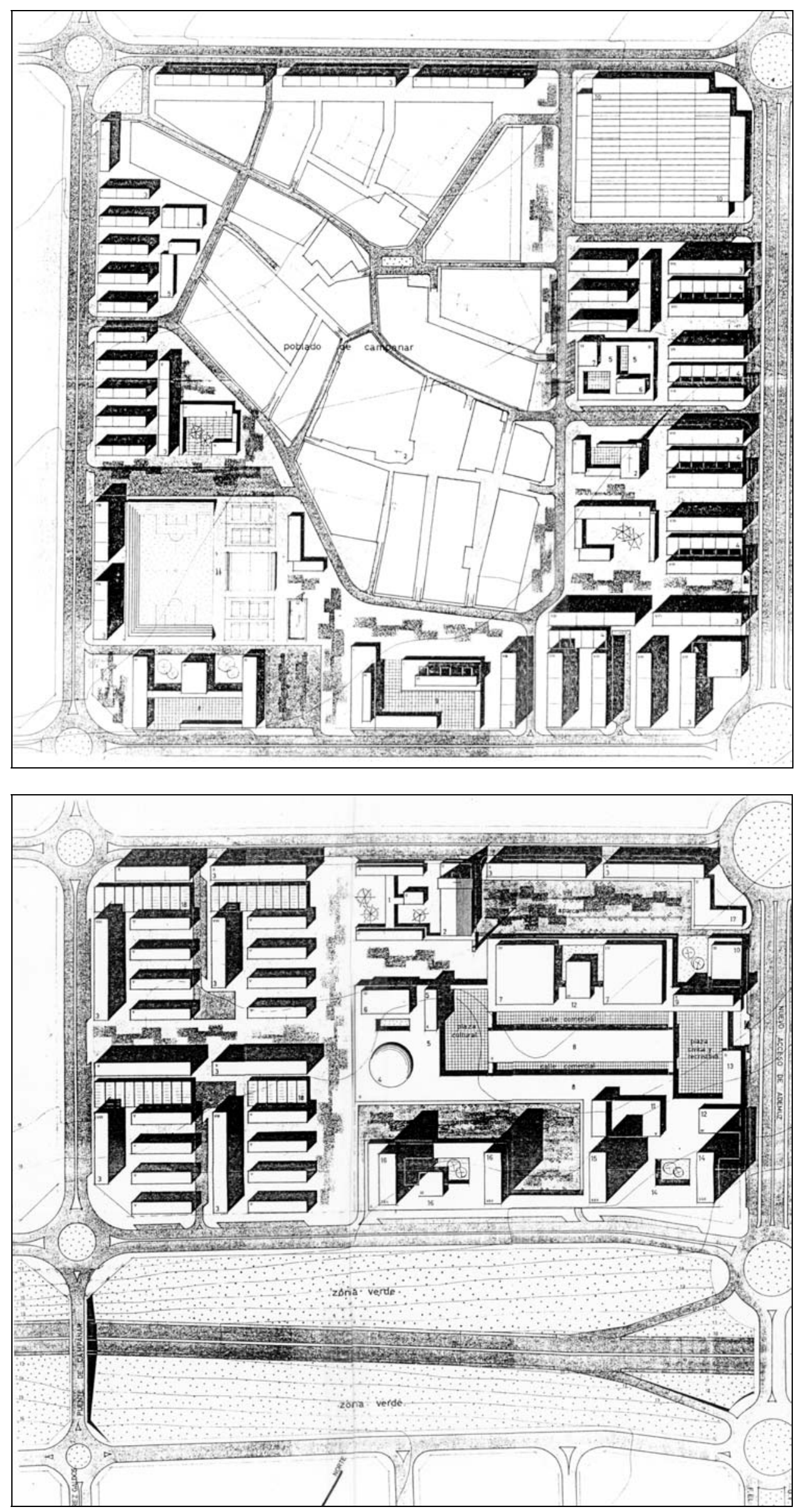
A todo ello se suma el Centro Comercial de Valencia-Norte, previsto por el Plan Sur para descongestionar la zona comercial del centro de Valencia, y para dar al mismo tiempo adecuado servicio a los habitantes de las poblaciones cercanas del arco noreste, que entran a la ciudad por el nuevo acceso de Ademuz.

El centro comercial, señala la Memoria del plan, está integrado por cuatro núcleos fundamentales: zona administrativa, zona comercial de tiendas, zona de esparcimiento y espectáculos y núcleo cultural.

Estos núcleos se articulan arquitectónicamente en un conjunto presidido por cuatro bloques altos de 20 plantas situados en perpendicular al cauce del río y dando frente al mismo. Estos bloques están enlazados por una edificación baja de profundidad variable, que deja espacios verdes intermedios y que forma un continuo con la del resto del centro comercial por la parte este, correspondiente a los dos bloques destinados a apartamentos y hotel. Los otros dos bloques, destinados a oficinas privadas y públicas, quedan envueltos por un espacio verde que los separa del área comercial.

El centro comercial en sí adopta un esquema de tipo polar, con dos extremos constituidos por sendas plazas que concentran usos diferentes. La zona administrativa y de esparcimiento se organiza en torno a la plaza situada al este, cerca del acceso de Ademuz. En ella se proyecta un edificio administrativo (tenencia de alcaldía, teléfonos, telégrafos, correos) y dos salas de espectáculos. A continuación siguen dos calles de comercios a ambos lados, edificados a dos alturas, con una banda de edificación más profunda al norte para grandes almacenes y supermercados, a cuyas espaldas se sitúa otro gran aparcamiento. Como polo final se forma otra plaza más tranquila en la que se disponen los edificios de carácter cultural (auditorium, museos, bibliotecas, salas de conferencias, etc.).

El informe del Ayuntamiento de Valencia sobre el Plan Parcial del Polígono de Campanar indica, además de otras sugerencias, que debería mantenerse el último tramo diagonal del Camino de Tránsitos suprimido en el plan.

Esta observación se repite en el informe de la Dirección General de Urbanismo, que califica el anteproyecto de Polígono de Campanar como revolucionario en Valencia, aconsejando la introducción de un mayor porcentaje de manzanas más densas con bloques de seis crujías, así como evitar la monotonía de los bloques lineales, procurando favorecer la variedad en el conjunto y en los detalles.

Los redactores del plan defienden en la memoria del mismo las soluciones adoptadas en relación con los informes oficiales, señalando que la ordenación propuesta está de acuerdo con las tendencias del urbanismo moderno, aceptadas en el extranjero y en otras ciudades españolas, siendo una ordenación que contribuye a mejorar el funcionamiento y la calidad ambiental del conjunto urbanístico proyectado.
Página opuesta:

Plan Parcial del Polígono de Campanar, 1961. Planos de ordenación general de los subpolígonos $C$ y $D$. 

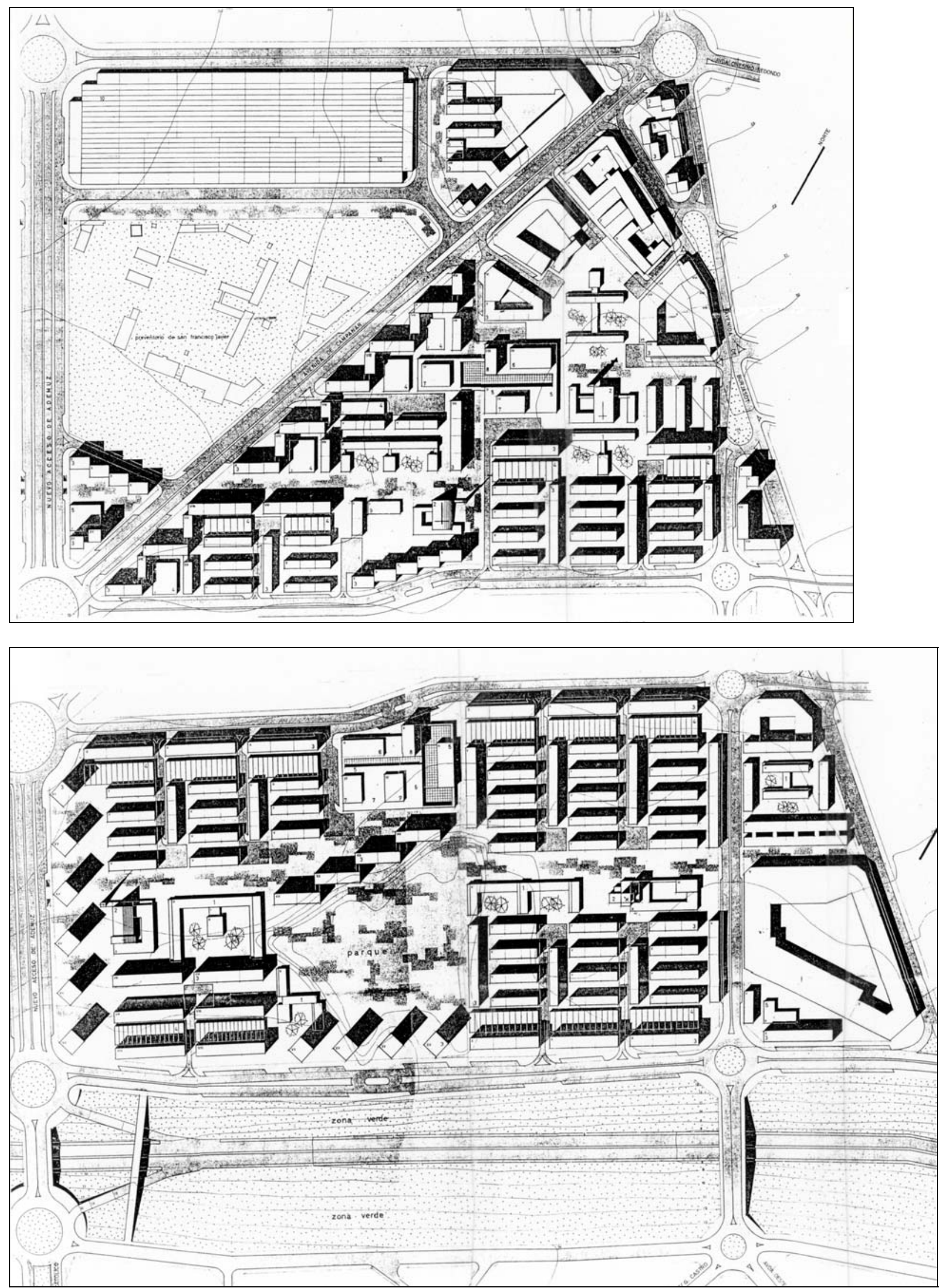
Finalmente, la ordenación será modificada y en un nuevo plano presentado en 1962 podemos ver que el proyecto definitivo es similar a la solución 3 del estudio de alternativas. Así, la Avenida de Campanar continúa en diagonal hasta el río, lo que permite respetar los edificios ya construidos como parte de manzanas cerradas de planes anteriores. A los lados de este eje diagonal se disponen áreas residenciales de edificación abierta en forma de bloques lineales escalonados.

El centro comercial, por su parte, se traslada en el plano modificado de 1962 al otro lado del acceso de Ademuz, contraviniendo la localización prevista en el Plan Sur, y el espacio disponible para el mismo se reduce de manera considerable con respecto a la solución 3 mencionada debido a la presencia de la parcela de la Escuela Patronato de la Juventud Obrera. Además, el gran parque previsto en esta zona se suprime y sus terrenos se destinan a futura estación de autobuses. Como consecuencia de todo ello, las supermanzanas quedan desvirtuadas, al introducirse nuevos viales que las atraviesan transversalmente, como la Avenida de Campanar o las calles que rodean el centro comercial y la estación de autobuses

Los bloques que integran el módulo tipo de manzana también sufren modificaciones, ya que los espacios libres intermedios entre ellos pasan a estar ocupados por bajos comerciales que unen los bloques de dos en dos.

Estas no serán, sin embargo, las últimas modificaciones que sufra la ordenación de la zona, que quedará definitivamente alterada con la decisión de implantar en la misma la Ciudad Sanitaria La Fé. El polígono de promoción pública de Campanar quedará, además, reducido a menos de la mitad del subpolígono $A$, y el resto de las áreas residenciales se ordenarán finalmente a través del Plan Parcial 8, redactado por el Ayuntamiento, cuyas sucesivas versiones, de 1968 y 1971, estudiaremos en la sección siguiente.
Página opuesta:

Plan Parcial del Polígono de Campanar, 1961. Planos de ordenación general de los subpolígonos $B$ y $A$.

Plan Parcial del Polígono de Campanar. Plano modificado, 1962.

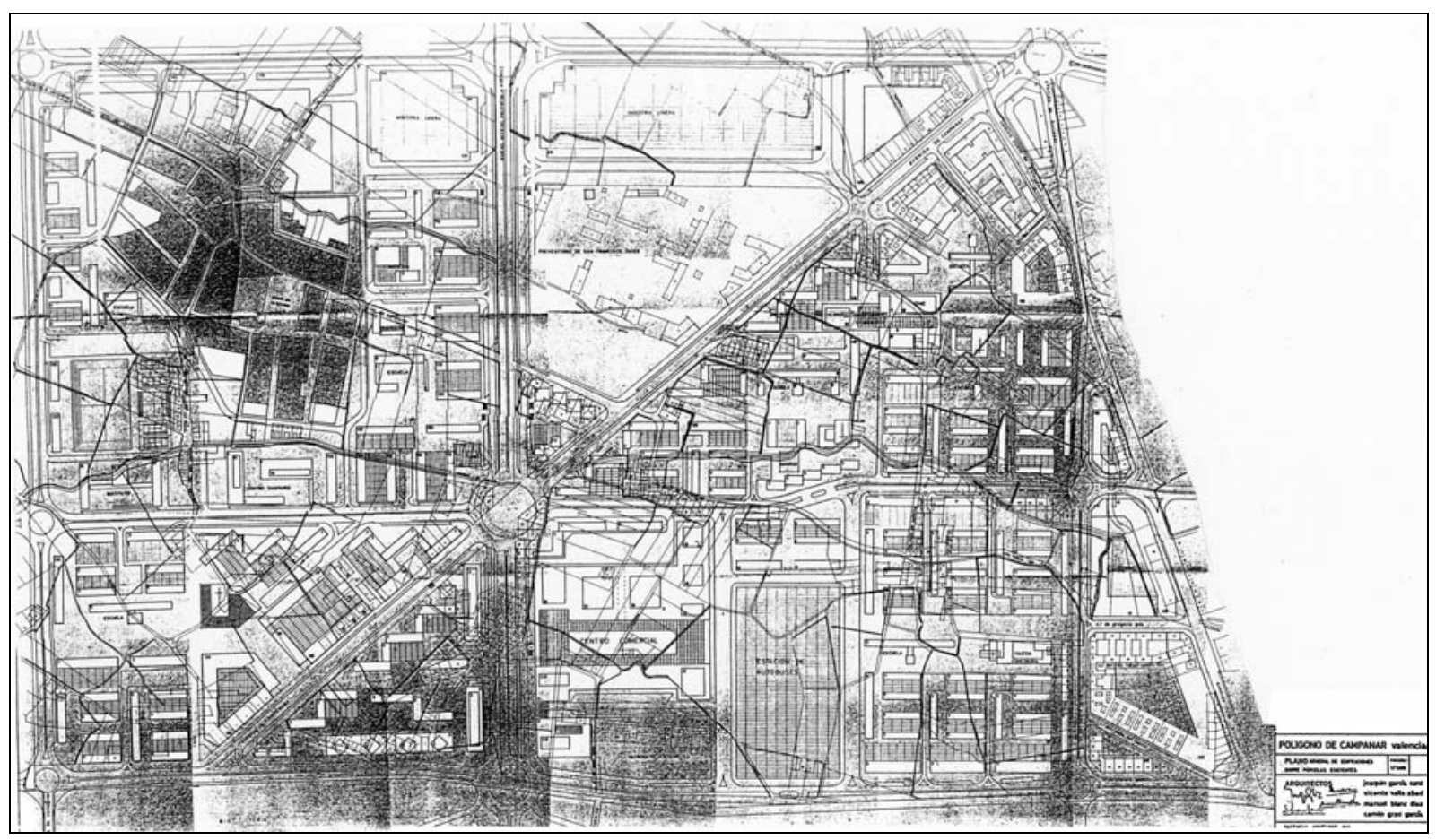




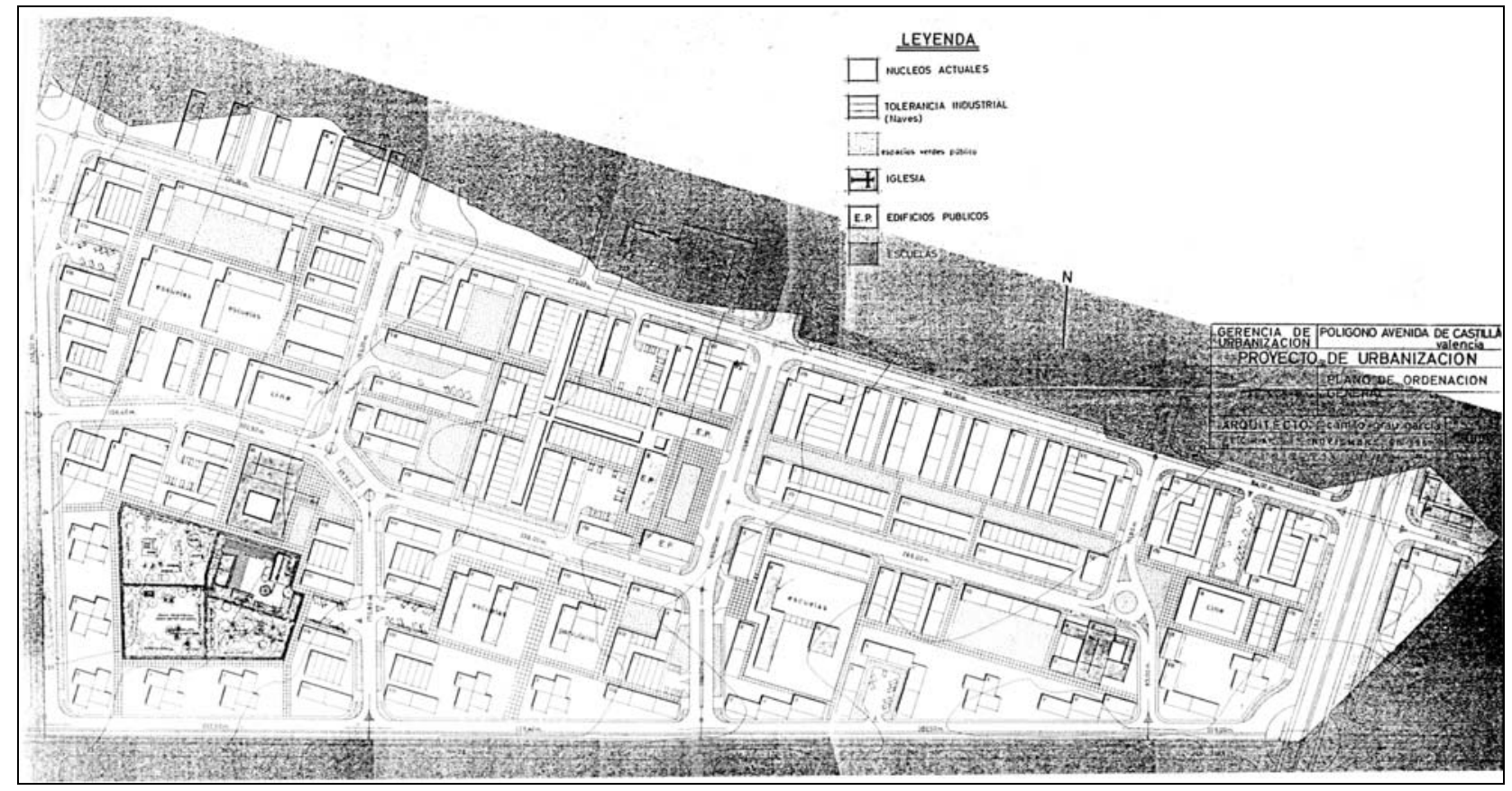

Polígono Avenida de Castilla. Proyecto de urbanización.

Plano de Ordenación, 1961.

Polígono Avenida de Castilla. Polígono Sector Avenida de Castilla, 1958.

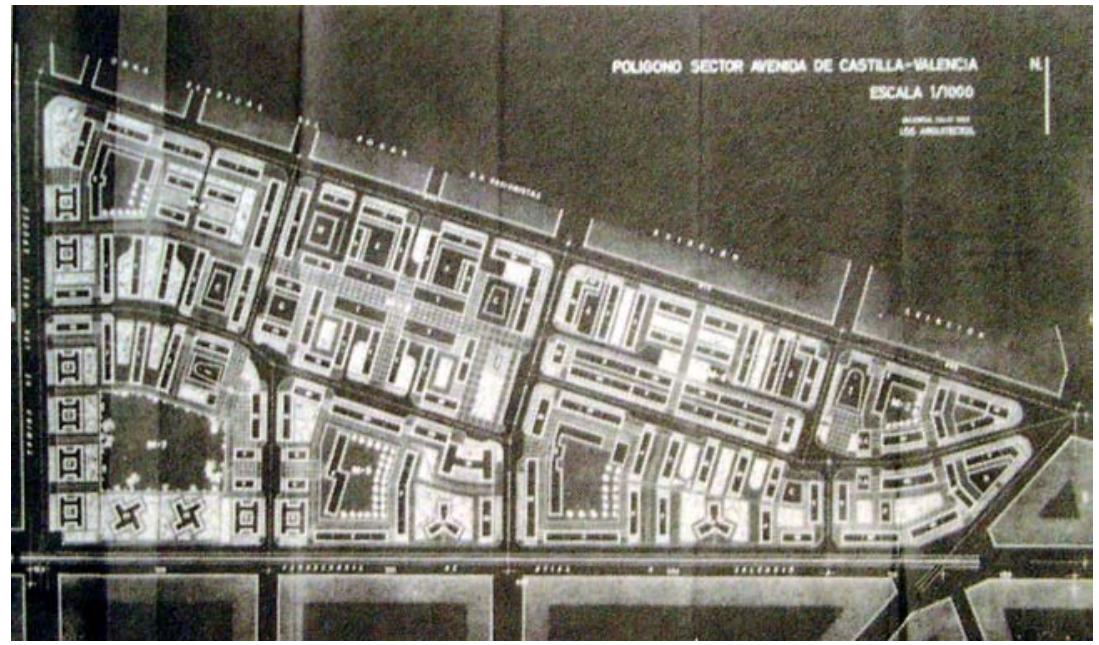




\section{POLÍGONO AVENIDA DE CASTILLA (1960)}

El Plan Parcial de Ordenación del Polígono de la Avenida de Castilla fue redactado en 1960 por el arquitecto Camilo Grau García, como consecuencia del concurso convocado al efecto por el Ayuntamiento de Valencia. El Proyecto de Urbanización correspondiente, promovido ya por la Gerencia de Urbanización del Ministerio de la Vivienda, es de 1961.

Los límites del polígono son la calle Músico Ayllón al norte, la calle Tres Forques al sur, la Avenida de las Tres Cruces al oeste y la calle Archiduque Carlos al este. El ámbito ordenado por el plan es, por tanto, el mismo que el del Proyecto de Ejecución del Polígono del Sector de la Avenida de Castilla de 1955, que hemos analizado en la sección anterior. La ordenación de 1960, sin embargo, es completamente diferente, aunque está basada también en la edificación abierta, y deriva de la planteada en un proyecto intermedio entre ambos, redactado por Javier Goerlich y Camilo Grau Soler en $1958^{1}$.

El trazado viario previsto en el plan de 1960 es similar al de 1958, y adopta la forma de malla de gran tamaño que genera unas supermanzanas dotadas de bolsas de aparcamientos en forma de ramales sin salida. Esta malla está compuesta por un eje longitudinal este-oeste de directriz quebrada, formado por las calles Llombay y Guilllem Despuig, y tres ejes transversales en dirección norte-sur, correspondientes a las calles José Maestre, Santa Cruz de Tenerife y Alfredo Cullá/ Francisco Dolz. Este trazado subdivide el polígono en las siete manzanas identificadas en el Plano de Parcelación (S1 a S7) ${ }^{2}$.

El plan prevé dos etapas para su realización. La primera, de menor tamaño, corresponde a la mitad este, entre las calles Archiduque Carlos y Santa Cruz de Tenerife, y la segunda, entre esta última calle y la Avenida de las Tres Cruces, a la mitad oeste.

En las intersecciones del eje central este-oeste de directriz quebrada con los ejes transversales se sitúan los principales núcleos de equipamientos del conjunto, dispuestos como elementos de cierre de la perspectiva de los diferentes tramos de dicho eje central.

Así, junto al cruce de la calle Llombay con José Maestre se localiza un Cine en el lado norte y un Centro Parroquial en el lado sur, con una plaza previa desde la que se accede al parque vecinal que ocupa, junto con una guardería, el centro de la manzana S7.

El siguiente cruce, con la calle transversal de Santa Cruz de Tenerife, está tratado en forma de dos cruces en $\mathrm{T}$, de modo que la perspectiva de las calles este-oeste de Llombay y Guillem Despuig queda cerrada respectivamente por un edificio escolar y por tres edificios públicos dispuestos en $U$ en torno a una plaza. De esta plaza, que por su situación y características es la principal del barrio, arranca un eje peatonal a cuyos lados se sitúan, detrás de unos pórticos, unas galerías comerciales. Este eje peatonal se bifurca hacia el norte y el sur, de modo que las galerías comerciales terminan en las calle Músico Ayllón y Llombay, formando una planta en $\mathrm{T}^{3}$.

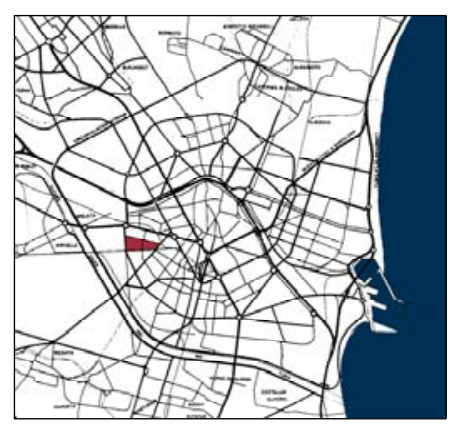

Polígono Avenida de Castilla. Localización.

1.Ver Gaja, op.cit., pp. 200-202.

2.En el plan de 1958 , el eje esteoeste continúa hasta la confluencia de las calles Músico Ayllón y Archiduque Carlos.

3.En el plan de 1958, la planta en T se convierte en planta en cruz al prolongarse el eje peatonal que arranca desde la plaza hasta la manzana siguiente. 


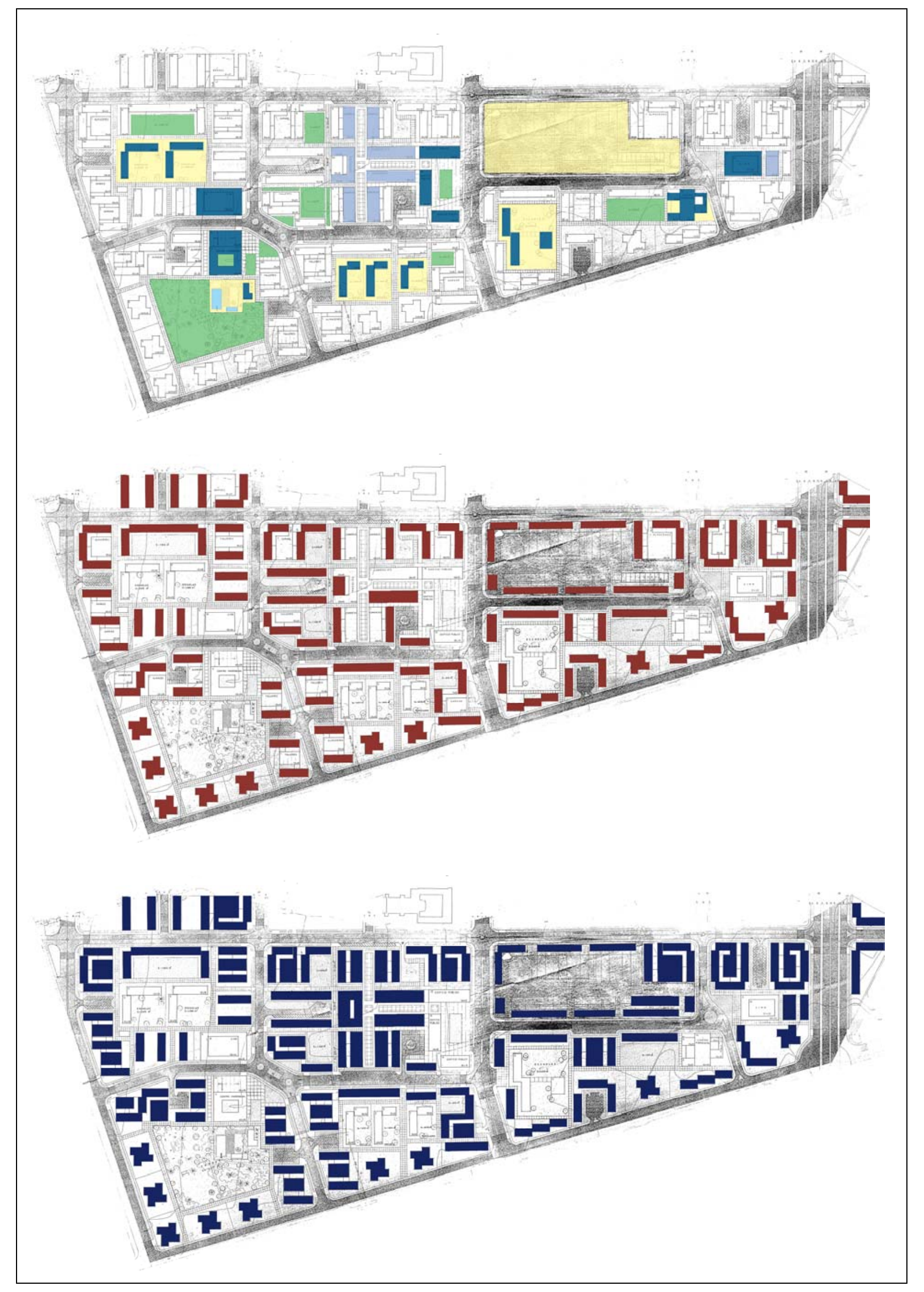




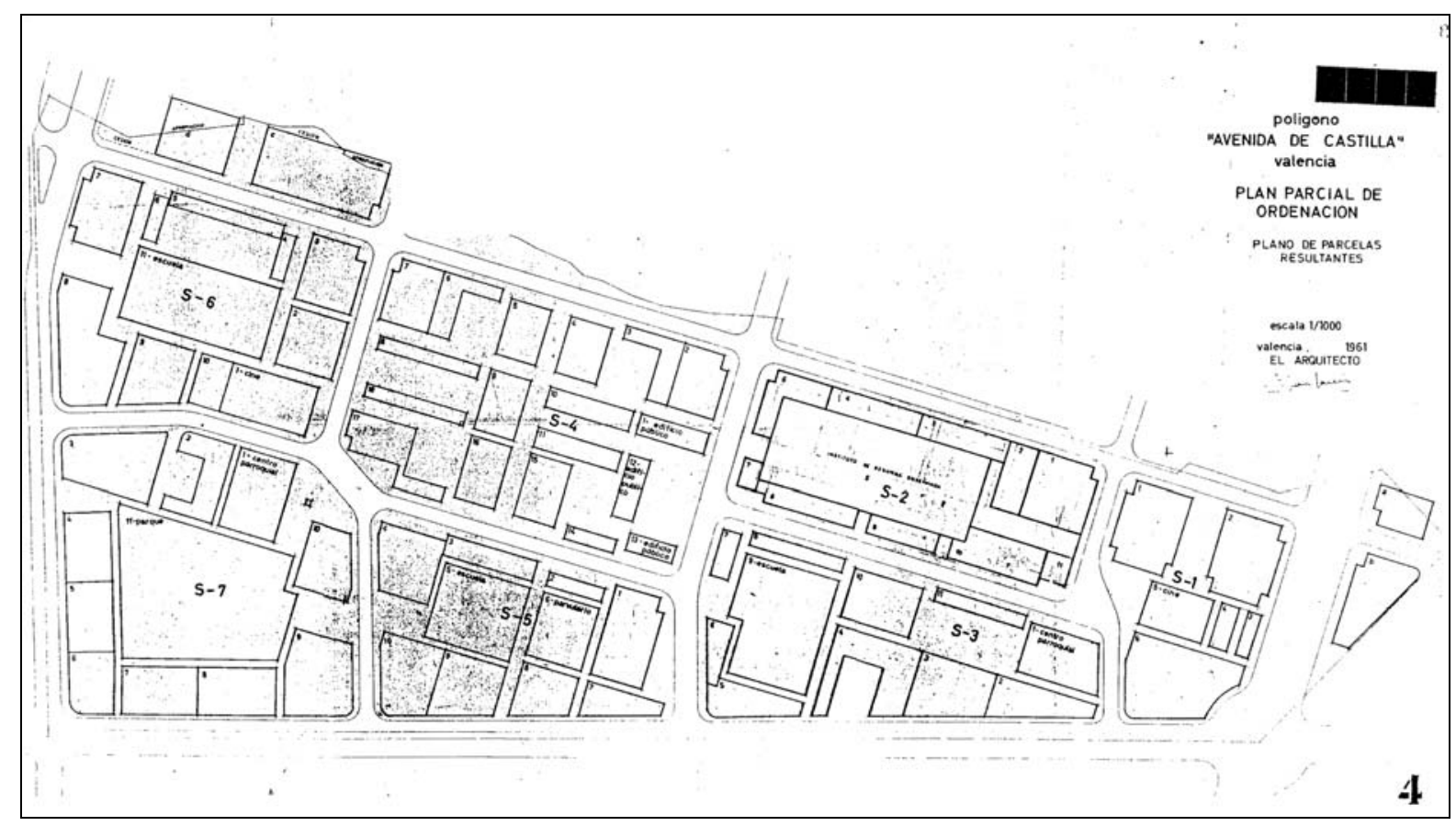

Finalmente, en el tercer cruce transversal, entre las calles Guilllem Despuig y Alfredo Cullá, y cerrando la perspectiva de la primera calle, se sitúa un tercer núcleo de equipamientos que incluye otro cine y otro Centro Parroquial.

La edificación está localizada en el perímetro de las manzanas, reservando el espacio central para los equipamientos, que quedan conectados con los bloques de viviendas situados a su alrededor por recorridos peatonales. Así, además del parque vecinal de la manzana S-7, podemos ver que en el centro de las manzanas S-5 y S-6 se proyectan sendas parcelas escolares, con la edificación separada por sexos habitual de la época.

Las zonas verdes restantes se disponen junto a los edificios de equipamientos, en forma de pequeños parques rectangulares dispersos por todo el barrio.

En cuanto a la edificación, los tipos utilizados en el plan son dos: el bloque de dos crujías y la torre ${ }^{1}$.

Los bloques de dos crujías adoptan formas diversas: bloques lineales, bloques lineales escalonados, bloques en $L$ o bloques en $U$, con unas alturas que oscilan entre las $\mathrm{V}$ y las $\mathrm{X}$ plantas. Todos estos bloques se proyectan siempre como elementos aislados, con todas sus plantas, incluida la baja, destinadas a viviendas. Cuando los bloques se agrupan de dos en dos con edificación comercial en planta baja, esta edificación se separa de los bloques, dejando unos patios intermedios, solución muy poco habitual en los planes parciales del periodo que estamos estudiando.

La geometría de los bloques y las torres se ajusta en todos los edificios a líneas paralelas y ortogonales al eje de la calle Músico Ayllón, paralelo a su vez a la Avenida de Castilla.

Polígono Avenida de CastiIla,1961. Plano de parcelación.
Página opuesta: Polígono Avenida de Castilla, 1961. Planos de equipamientos, de edificación en planta tipo y de edificación en planta baja (Elaboración propia. Color sobre plano de ordenación).

1. En el plan de 1958, a estos tipos hay que añadir los de los bloques con planta en forma de I enlazados dos a dos, similares a los del Grupo Virgen de los Desamparados, y los de los bloques con planta en forma de $Y$. 

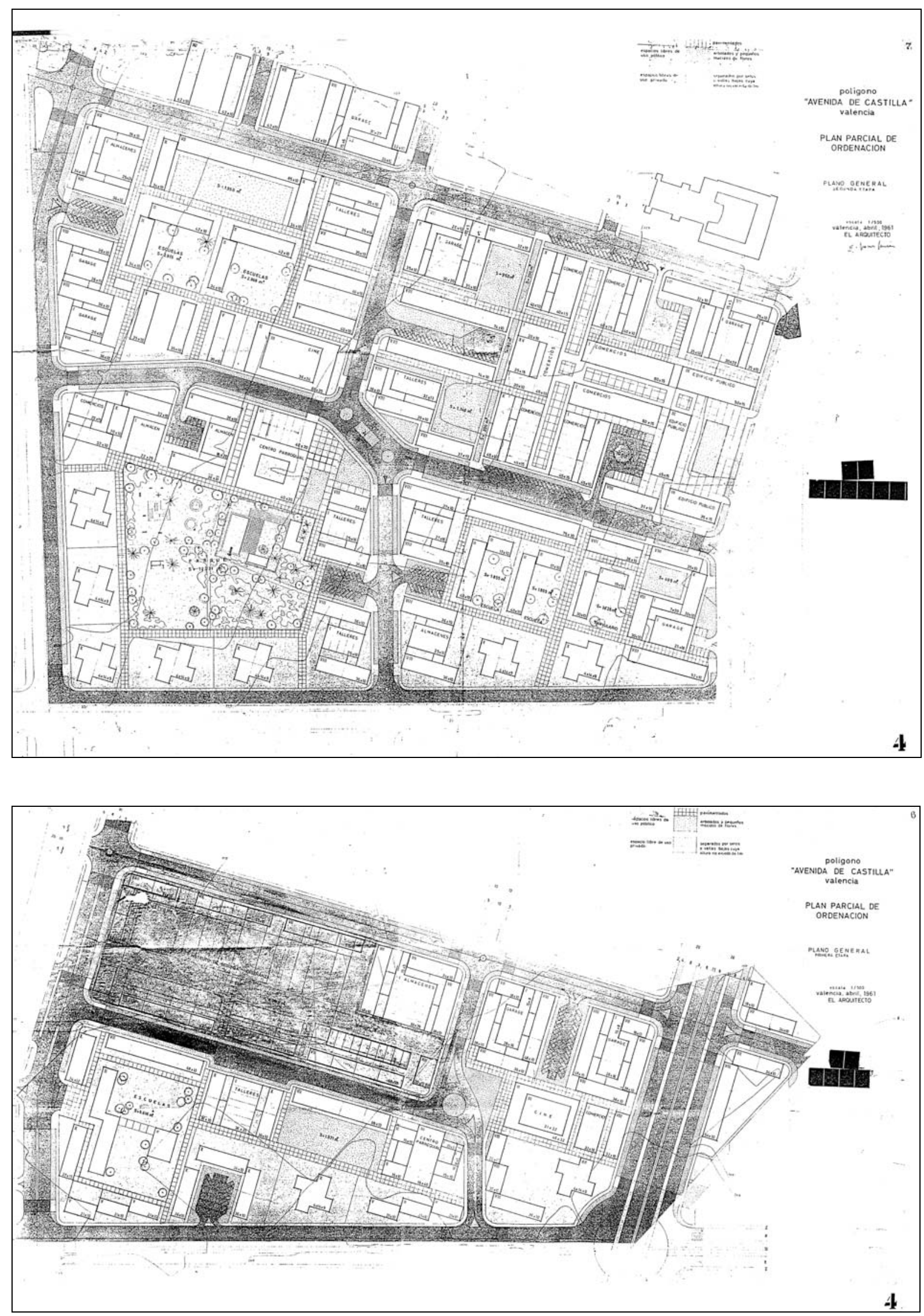

Polígono Avenida de Castilla. Plan Parcial de Ordenación,1961. Plano general. Etapas 1 (abajo) y 2 (arriba). 
Las torres, con planta en forma de aspa de molino y $\mathrm{X}$ plantas $(P B+9)$, se sitúan en los bordes sur y oeste del barrio, como edificios aislados en una parcela ajardinada. A estas torres no se les asigna un papel de definición completa de ninguno de los bordes del barrio, ya que su seriación queda interrumpida por los bloques lineales con bajos comerciales que se sitúan a ambos lados de todas las intersecciones de las calles interiores con el viario perimetral exterior.

Los bloques son por lo general muy cortos, de modo que cuando se asocian mediante edificación en planta baja dan como resultado unas micromanzanas que como unidades urbanas no tienen entidad suficiente como para delimitar espacios públicos o modificar la proporción de vacíos y llenos del plano del suelo. Únicamente algunos bloques más largos, alineados con el eje viario central, consiguen apoyar el trazado del mismo.

El plan para el polígono de la Avenida de Castilla sufrió una primera modificación de cierta importancia cuando se destinó la mayor parte del suelo de la manzana S-2 a Instituto de Enseñanza Media, lo que supuso la supresión de la serie de bloques ortogonales que formaban el frente a la calle Musico Ayllón.

Posteriormente, en 1965, se redactó el proyecto para el Grupo Antonio Rueda, que ocupa el área este, correspondiente a la primera fase de ejecución del polígono. En el proyecto para dicho grupo, la edificación no se ajustará a los parámetros de forma y volumen fijados en el plan parcial de 1960.

Finalmente, se redactó en 1968 un Plan Parcial Modificado del Polígono, en el que lo único que se conservó del plan de 1960 fue el trazado viario, ya en grado avanzado de realización. La edificación de la zona se realizó con arreglo a este Plan Parcial Modificado, que junto con el grupo Antonio Rueda será objeto de estudio en la sección siguiente del presente trabajo.
Polígono Avenida de Castilla, 1961. Plano de replanteo definitivo de la urbanización.

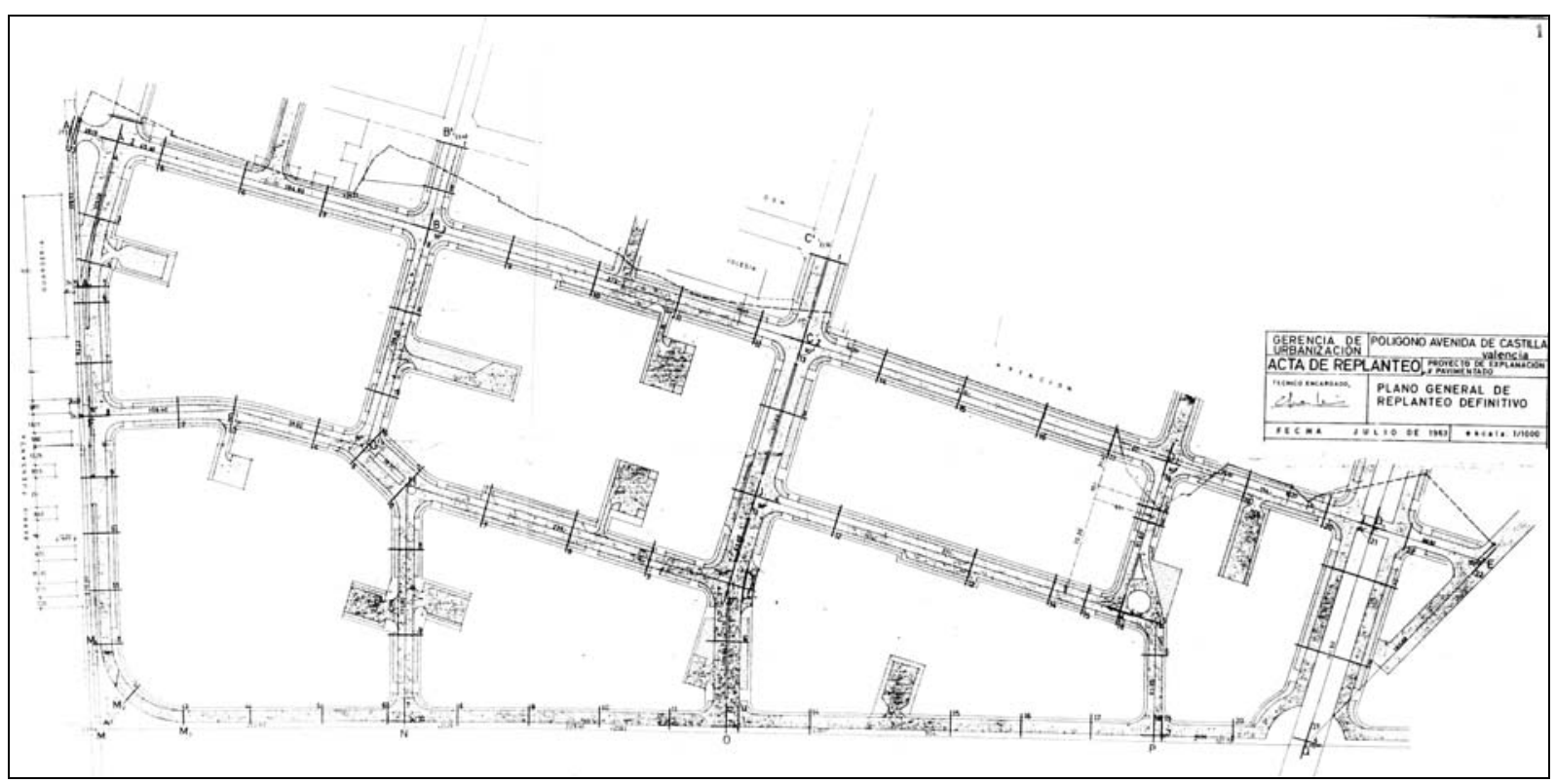




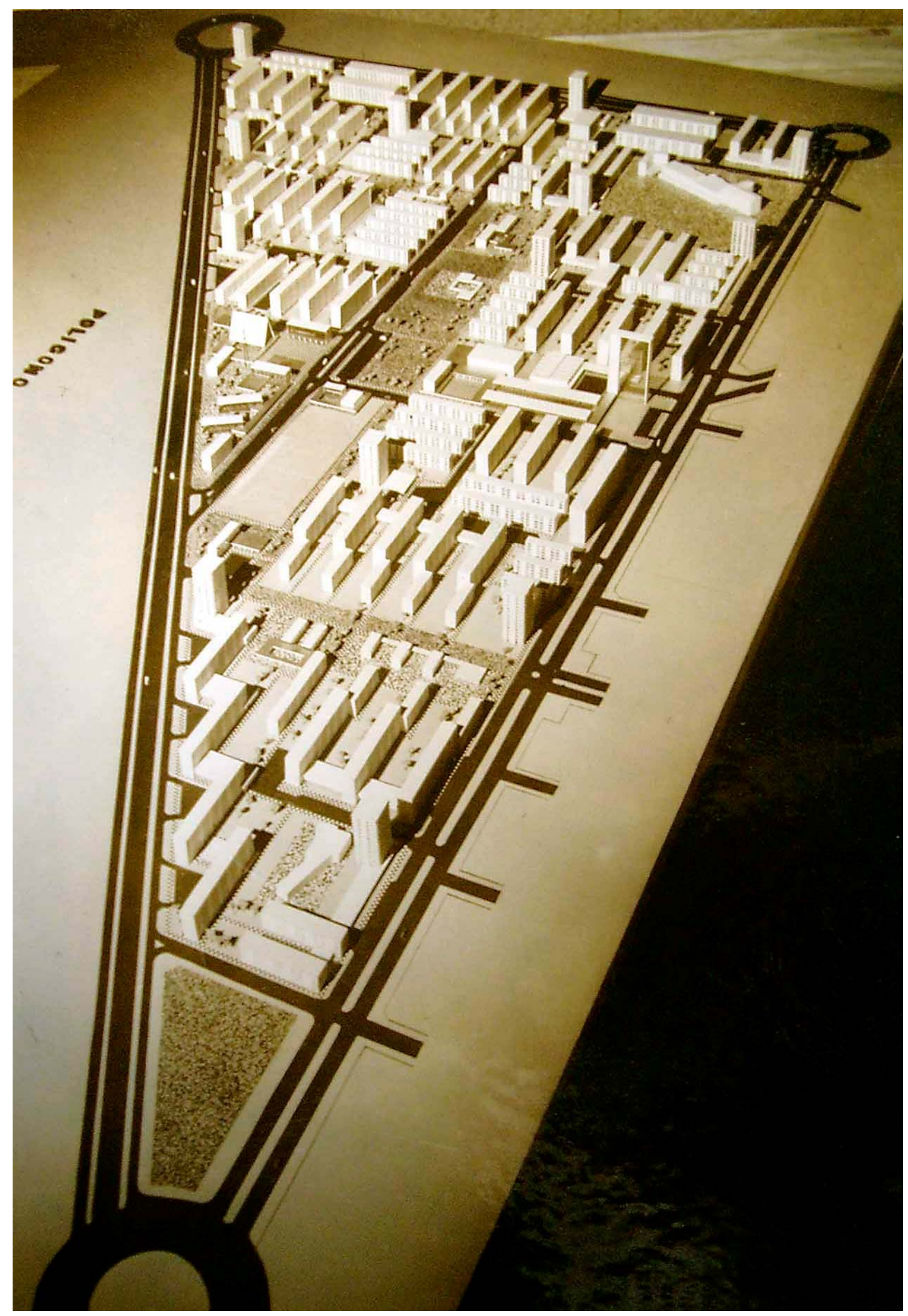

Plan Parcial del Polígono de Monteolivete, 1960. Maqueta. 


\section{POLÍGONO DE MONTEOLIVETE/FUENTE DE SAN LUÍS (1960)}

El Plan Parcial para el Polígono de Monteolivete (que pasará a denominarse en adelante Polígono Fuente de San Luís) fue redactado en 1960 por los arquitectos Luís García Camarero, Luís Martínez Lebrato y José Ma Pagola de la Puente, por encargo de la Gerencia de Urbanización del Ministerio de la Vivienda. Existen dos versiones del plan ligeramente diferentes, a causa de las modificaciones introducidas durante su tramitación.

El área ordenada por este plan, que tiene una superficie de $57,4 \mathrm{Ha}$, es una parte de la incluida en el Polígono del Sector de Monteolivete de 1956, que hemos analizado en la sección anterior. En concreto, se trata de uno de los dos triángulos en que queda dividida dicha zona por la nueva vía diagonal prevista en el Plan Sur como enlace entre los accesos a Barcelona y la carretera de Alicante; esta carretera constituye el límite este del polígono, que limita al norte con la Avenida de la Plata y el barrio de Monteolivete.

La zona estaba ocupada únicamente por cultivos de huerta y por edificación rural dispersa a lo largo de los caminos principales (Carrera de Encorts y Carrera de San Luís), salvo una zona con edificaciones recientes situada en el ángulo noroeste del polígono, entre el Colegio Salesiano y el acceso de Alicante. Estas edificaciones, entre las que se cuenta el grupo Rinaldi, son las únicas realizadas de acuerdo con el planeamiento anterior.

La Memoria del plan señala que la urbanización del polígono se plantea como una unidad residencial autónoma para 28.000 personas, repartidas en unas 6.000 viviendas. En el apartado relativo a zonificación, se señala que esta unidad residencial se divide funcionalmente del modo siguiente:

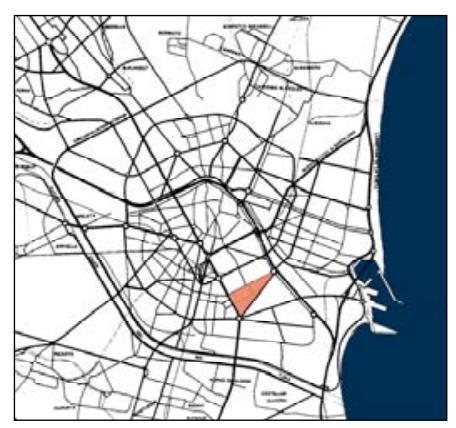

Polígono de Monteolivete. Localización.

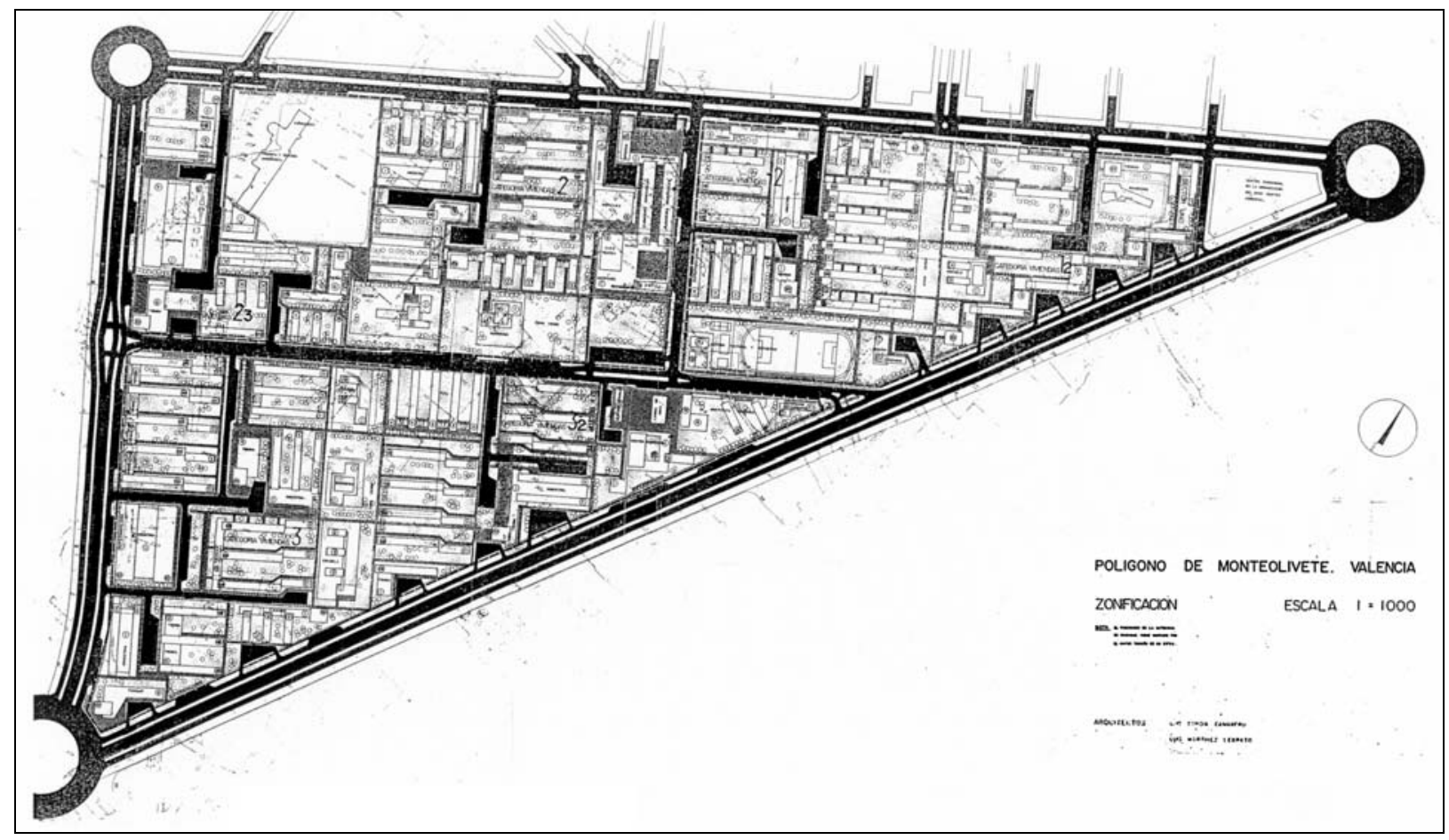

Plan Parcial del Polígono de Monteolivete, 1960. Plano de zonificación (Versión definitiva) 

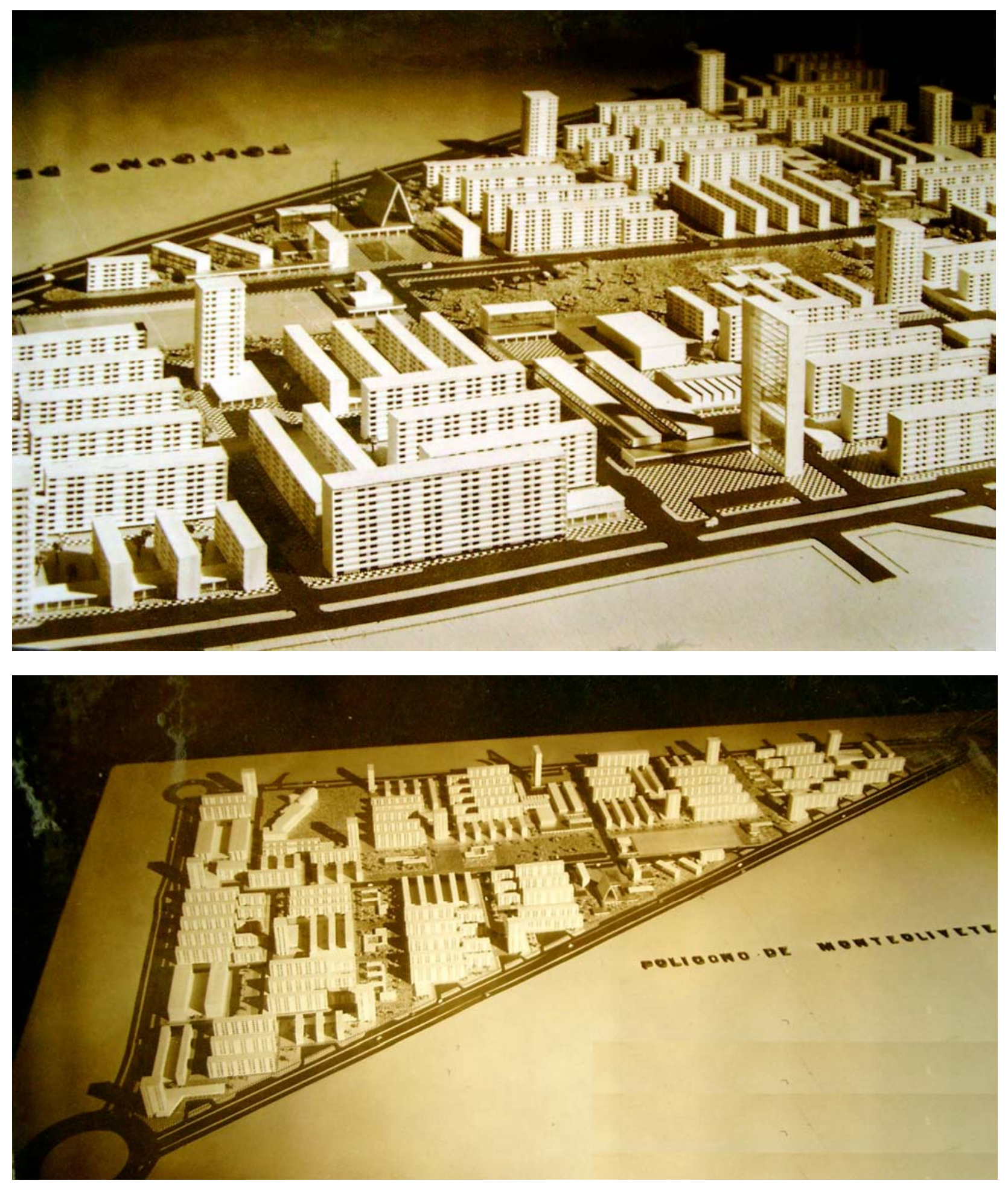

Plan Parcial del Polígono de Monteolivete, 1960. Maqueta. Vistas desde el norte y desde el sur. 
Se ha previsto la diferenciación del conjunto en tres supermanzanas, como unidades residenciales menores dotadas de vida propia, y cada una de éstas, a su vez, en dos vecinales (sectores) con los servicios propios para el abastecimiento cotidiano. En el centro de gravedad de cada supermanzana se establecerá, como elementos esenciales $y$ definitorios de uso común, las escuelas, una guardería y un pequeño dispensario, debidamente aislados en el seno de la zona verde correspondiente.

Las condiciones climáticas permiten y aconsejan un planteamiento urbanístico abierto (especialmente hacia el Este, de donde proviene el influjo moderador de la brisa) y la disposición de masas verdes que, penetrando entre las áreas edificables, han de condicionar, en gran manera, el clima interior del poblado. A este efecto, se ha decidido la implantación de una zona verde central con ramificaciones en ambos terminales, para la interpenetración con los bloques de viviendas; esta zona verde constituirá el pulmón del polígono, permitiendo la situación de todas las instalaciones de tipo escolar, cultural, cívico y deportivo, que han de resumir la vida íntima del polígono. ${ }^{1}$

La idea de composición escalonada por unidades urbanas completas, integradas por viviendas y servicios, propia del urbanismo funcionalista, queda reflejada con claridad. Junto a ella, aparece la atención a las condiciones climáticas (soleamiento, vientos, orientación), que es una de las bases originales de la arquitectura y el urbanismo racionalistas.

Las tres supermanzanas indicadas son el resultado del trazado del viario interno principal, que se compone de dos ejes: uno longitudinal, coincidente con la actual Avenida Hermanos Maristas, y otro transversal que conecta el eje anterior con la Avenida de la Plata. La $\mathrm{T}$ que dibujan estos dos ejes subdivide la zona en tres supermanzanas, una rectangular (Sector 1) y dos triangulares (Sectores 2 y 3), para cada una de las cuales se proyectan penetraciones en forma de ramales sin salida en cuyo fondo se sitúan bolsas de aparcamientos, desde las que senderos para peatones enlazan con las viviendas.

El viario, por tanto, se proyecta de acuerdo con el principio canónico del urbanismo funcionalista de separación de las circulaciones rodadas y de peatones.

En cuanto a la composición del conjunto, la Memoria del plan enumera como factores que se han tenido presentes la expresión de ritmos, estudio de rompimientos y contrastes, articulación de espacios libres, cerramiento de perspectivas, definición de siluetas e implantación de elementos focales, añadiendo que el enfoque del estudio plástico de los sectores se ha dirigido hacia el punto de vista del viandante, despreciando la espectacularidad de las panorámicas aéreas que no tienen interés para el habitante de la ciudad.

La edificación está formada en su mayor parte por bloques lineales de dos crujías de directriz quebrada, de ocho plantas en su cuerpo de edificación principal y cinco plantas en el tramo extremo con el eje desplazado. Los bloques están dispuestos por lo general según una directriz NE-SO, es decir, con fachadas a sureste y noroeste, óptimas desde el punto de vista del soleamiento y la aireación. Una franja de comerciales enlaza a veces los bloques en planta baja.

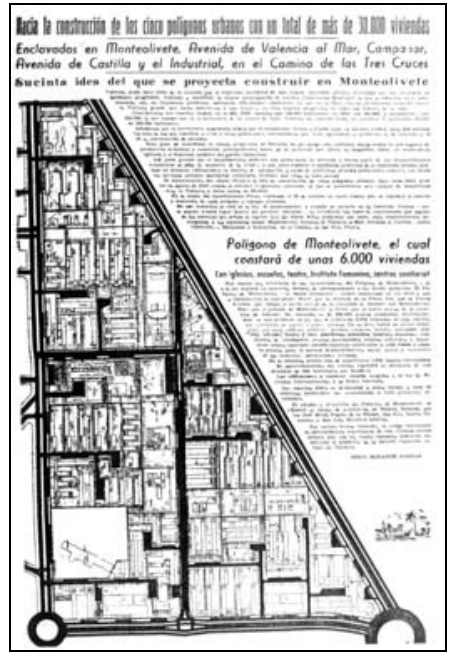

Jornada, Diario de la tarde, 13 enero 1961.

1.Plan Parcial de Ordenación del Polígono Fuente de San Luís, 1960. Memoria. Ver Anexo de Documentos, pp. 137-153. 


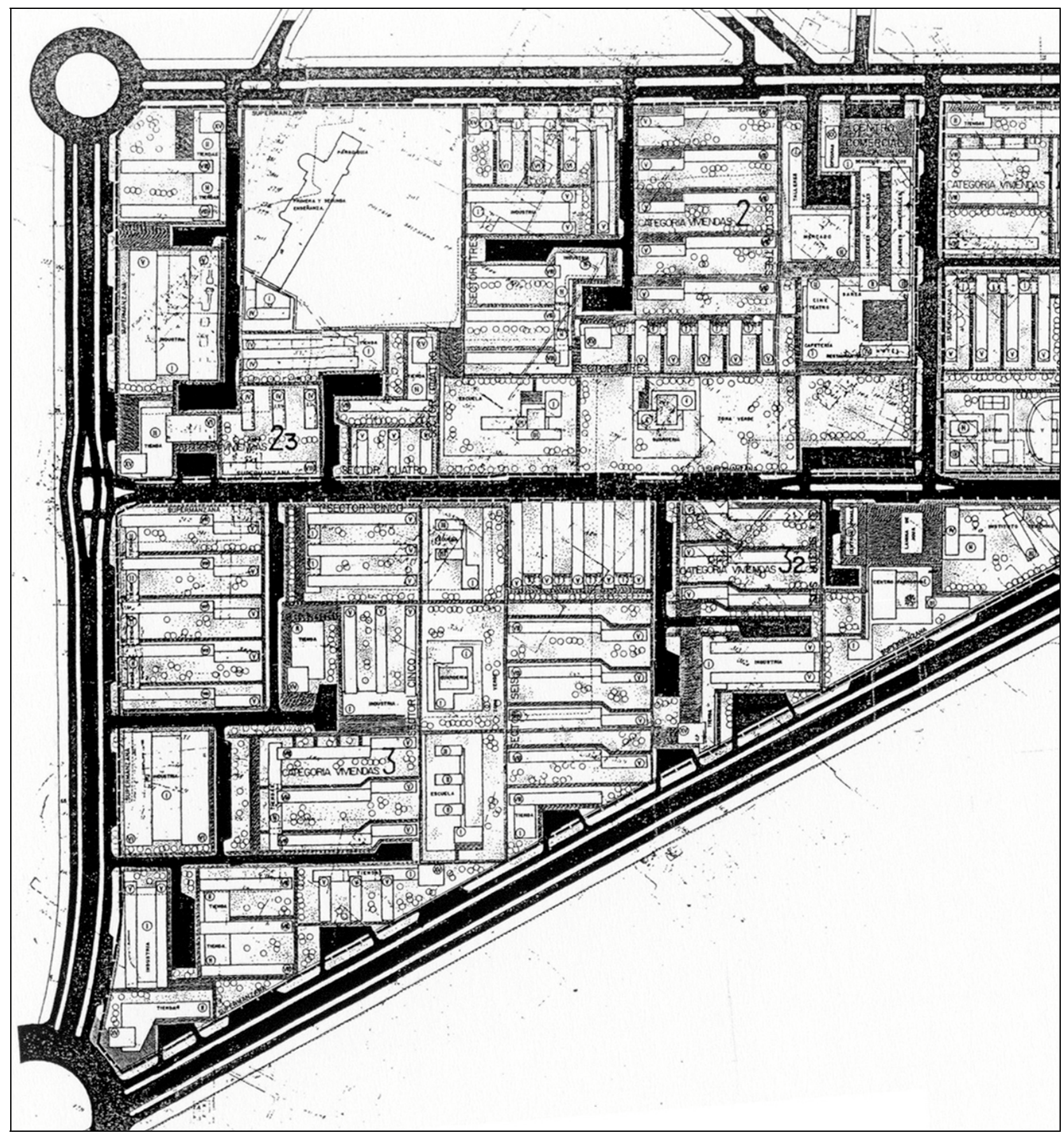

Plan Parcial del Polígono de Monteolivete, 1960. Plano de estructura urbanística. Detalle de la zona oeste (Versión final).

1. Plan Parcial de Ordenación del Polígono Fuente de San Luís, 1960. Memoria. Anexo de Documentos, p. 144
Un pequeño número de bloques se disponen con la orientación girada con respecto a la general, con el fin de definir espacios libres y de facilitar el trazado de la red de circulación peatonal.

Como contrapunto a los bloques, una serie de torres de 15 plantas emergen como hitos aislados en puntos estratégicos del conjunto. La mayoría de las torres están unidas por un cuerpo bajo comercial a un grupo de bloques cortos en peine.

La Memoria del plan introduce el concepto de potencia o profundidad del área edificable entre espacios libres, que se fija en 200 $m$, a fin de evitar distancias excesivas a las bandas de equipamientos, y de obtener "vistas agradables, abundante aireación y permeabilidad de tránsito". ${ }^{1}$ 


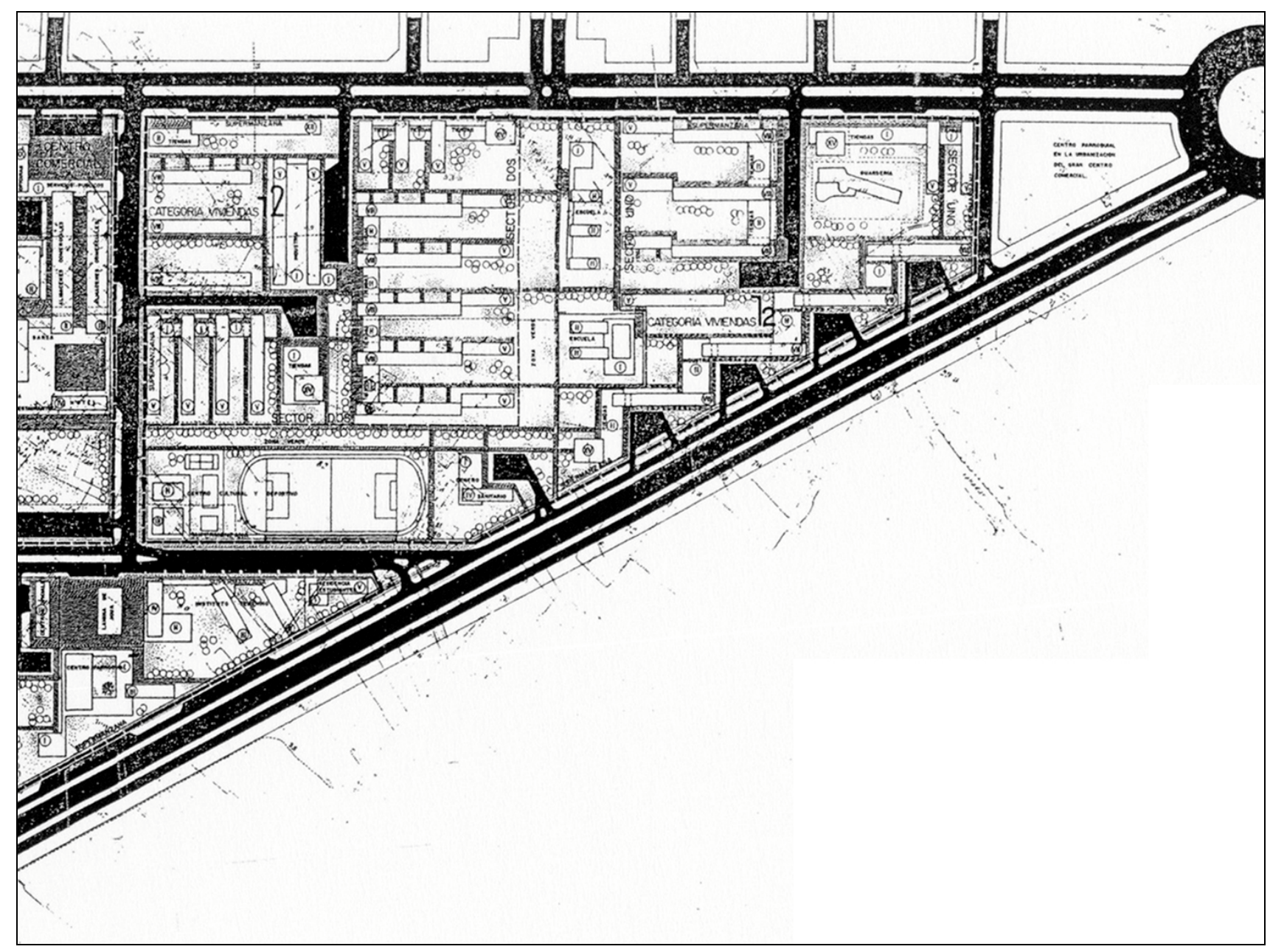

El sistema de zonas verdes y equipamientos está formado por unas bandas continuas en las que se integran los edificios públicos y los espacios libres. Dos de estas bandas, de dirección norte-sur, se sitúan en el centro de las supermanzanas triangulares (sectores 2 y 3 ), y se proyectan como zonas tranquilas y libres de tráfico en las que se localizan las escuelas, guarderías, paseos y zonas de recreo de dichos sectores.

La tercera banda de equipamientos, que enlaza las dos anteriores, forma una gran masa verde continua en el centro del polígono, acompañando a modo de alameda al eje viario longitudinal esteoeste. Intercalados en la masa verde, se disponen espacios para instalaciones deportivas y escuelas.

En el cruce con el eje viario norte-sur que conecta con la Avenida de la Plata, se crea una cuarta banda transversal de equipamientos, formada por un centro comercial que flanquea dicho eje viario y un centro cívico situado al otro lado del parque central.

El centro comercial está constituido por una galería comercial formada por bloques bajos que imitan una calle a la que se accede desde una plaza o lonja previa cerrada por una torre de 20 plantas destinada a oficinas, que cumple, señala la Memoria, un papel de volumen plástico de contraste y elemento focal interesante desde la Avenida de la Plata.
Plan Parcial del Polígono de Monteolivete, 1960. Plano de estructura urbanística. Detalle de la zona este (Versión final). 


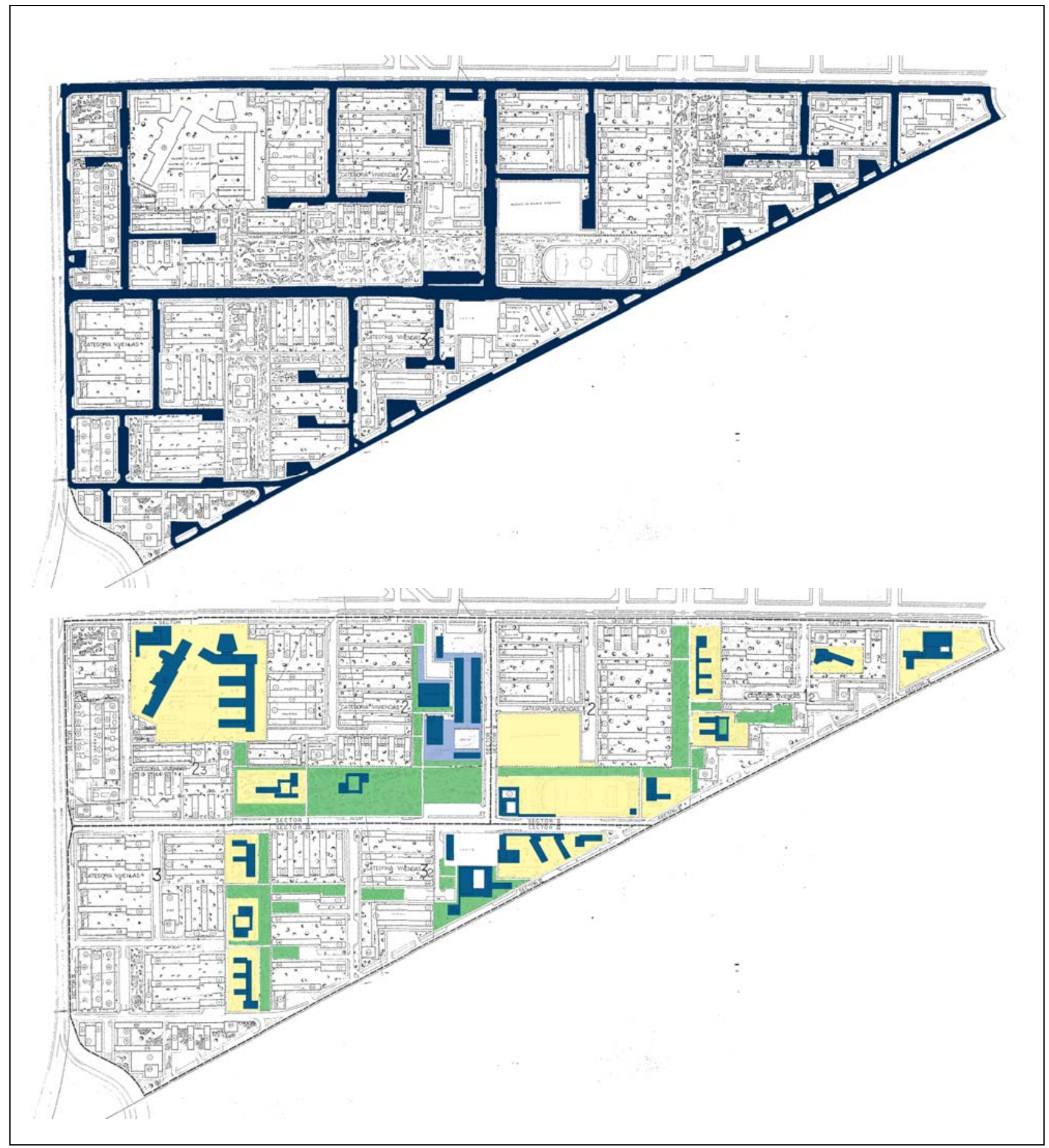

Plan Parcial del Polígono de Monteolivete, 1960. Planos de viario y equipamientos (Elaboración propia sobre Plano de estructura urbanística del Plan, versión inicial)
El mercado se sitúa junto a la galería comercial, con acceso de abastecimiento trasero oculto a la vista desde las zonas peatonales. Al fondo del centro comercial, y abriéndose a la zona verde, se disponen los volúmenes destinados a hotel y sala de espectáculos, ligados por un cuerpo bajo previsto para la instalación de bares y cafeterías.

En la descripción del centro comercial, así como en la del centro cívico, podemos ver una influencia directa de las ideas expresadas en el CIAM de Hoddeson dedicado al tema del Corazón de la Ciudad: 


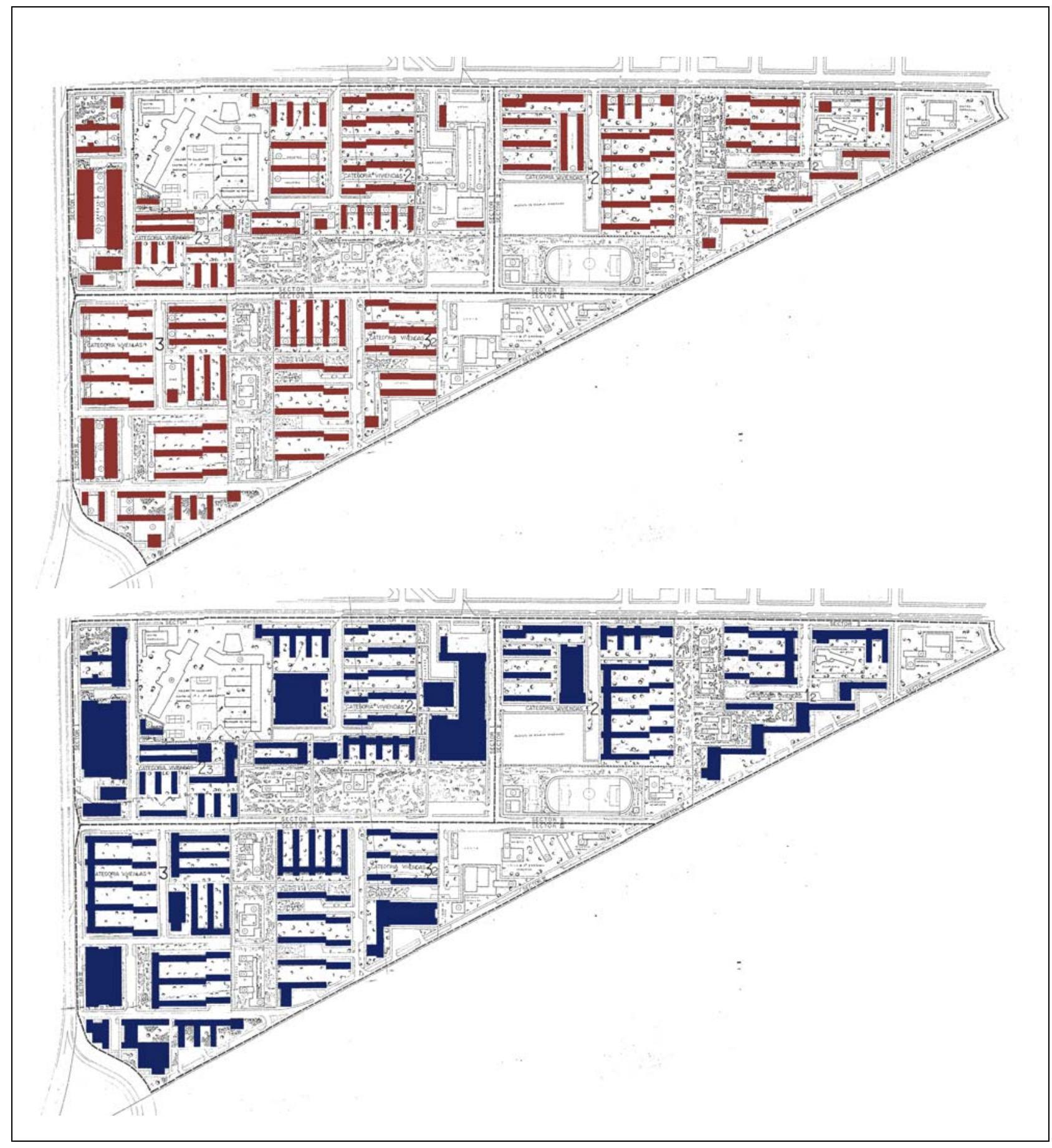

Se ha tratado de integrar con edificios de carácter oficial y de uso comunitario una plaza representativa que, a modo del foro romano compendiara un poco las actividades de tipo social y cívico para los habitantes del poblado. Componen el Centro los siguientes edificios: la iglesia parroquial, como elemento fundamental $y$ eje simbólico $y$ estético de la plaza; el instituto de secunda enseñanza y un bloque en el que irán instalados los servicios públicos. ${ }^{1}$
Plan Parcial del Polígono de Monteolivete, 1960. Planos de edificación en planta tipo y edificación en planta baja (Elaboración propia sobre Plano de estructura urbanística del plan, versión inicial)

1. Plan Parcial de Ordenación del Polígono Fuente de San Luís, 1960. Memoria. Anexo de Documentos, $\mathrm{p}$. 145. 


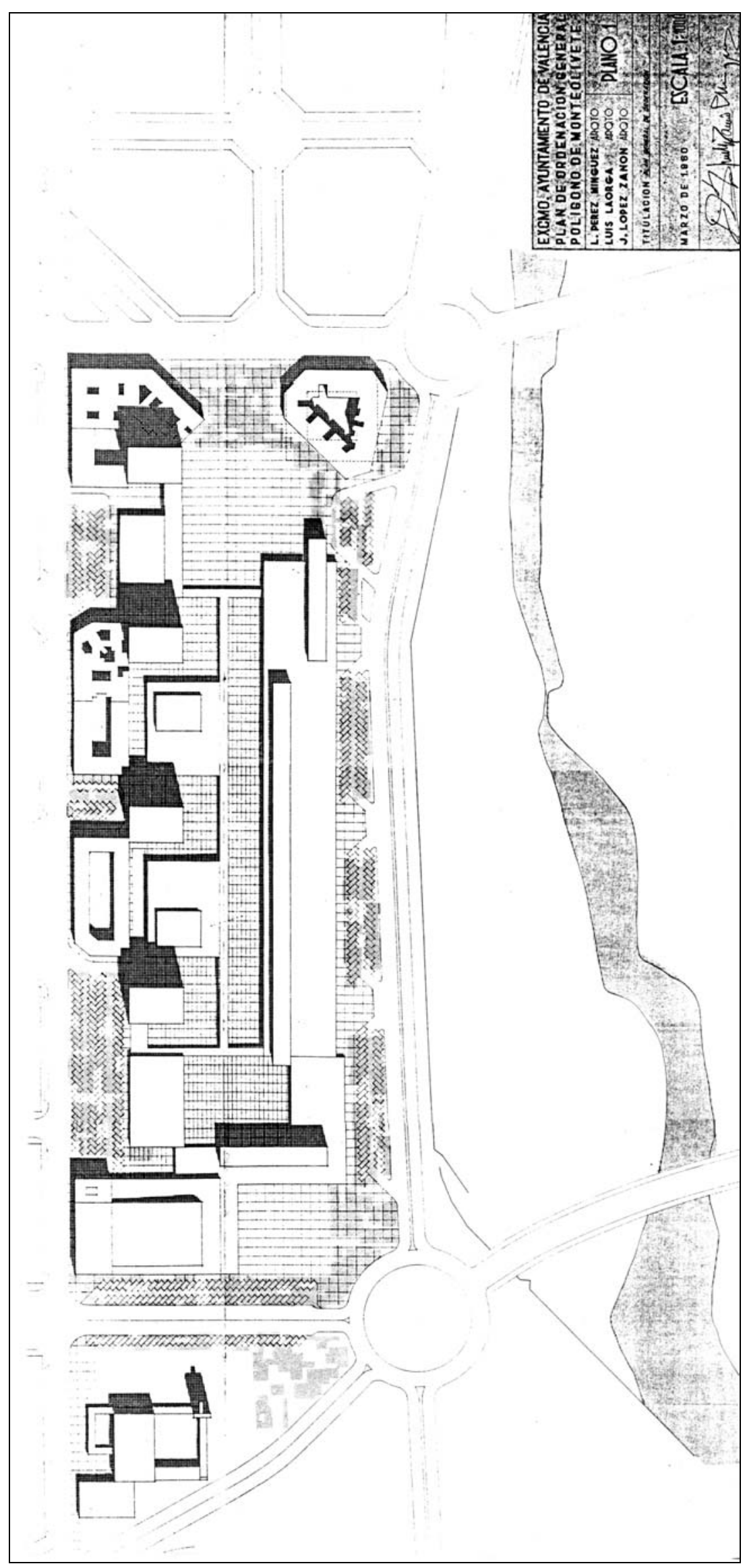




\section{CENTRO COMERCIAL DE MONTEOLIVETE (1960)}

El Plan Sur de 1958 contemplaba, como hemos visto en un apartado anterior, la implantación de un centro comercial en las proximidades de la nueva Estación Central de Ferrocarriles. El proyecto redactado en 1960 por Luís Pérez Mínguez, Luís Laorga y José López Zanón sitúa dicho centro comercial en la margen derecha del Turia, junto al barrio de Monteolivete ${ }^{1}$.

El centro comercial está proyectado como un conjunto de edificación mixta de carácter intensivo, englobando usos comerciales, representativos y residenciales en una composición en la que

Se ha huido de las normas en desuso de composición uniforme de volúmenes y trazado, manejando formas de características variadas, buscando armonías equilibradas por compensación. ${ }^{2}$

Así, las viviendas adoptan tres formas: edificios que completan las manzanas ya iniciadas en las calles de Escultor José Capuz y Avenida de Peris y Valero, bloques lineales aislados situados sobre la terraza que cubre los edificios comerciales, y cuatro torres de veintisiete plantas alineadas a lo largo de la composición.

La zona comercial se describe en la Memoria del plan del modo siguiente:

La zona comercial ocupa el centro del sector, organizado a base de edificios de dos plantas, que cierran espacios con diferentes ambientes, con una calle comercial exclusivamente de peatones y diversas placitas.

Entrando en el polígono por la Avenida de Peris Valero, se sitúa en una gran plaza el edificio representativo de la Administración Municipal y servicios ya reseñados. En el extremo opuesto, al final de la calle comercial, y cerrando el conjunto, se agrupan formando dos plazas, una abierta y otra cerrada, todos los edificios de tipo cultural y turístico, entre los que destaca en altura el Hotel de viajeros y en volumen la sala de espectáculos. ${ }^{3}$

La circulación rodada está separada de las superficies exclusivamente dedicadas a peatones, situando los estacionamientos en zonas marginales próximas a los lugares de máxima concentración pública.

La edificabilidad total es de $8 \mathrm{~m} 3 / \mathrm{m} 2$, correspondiendo un $65 \%$ a viviendas y el resto a comerciales y equipamientos.

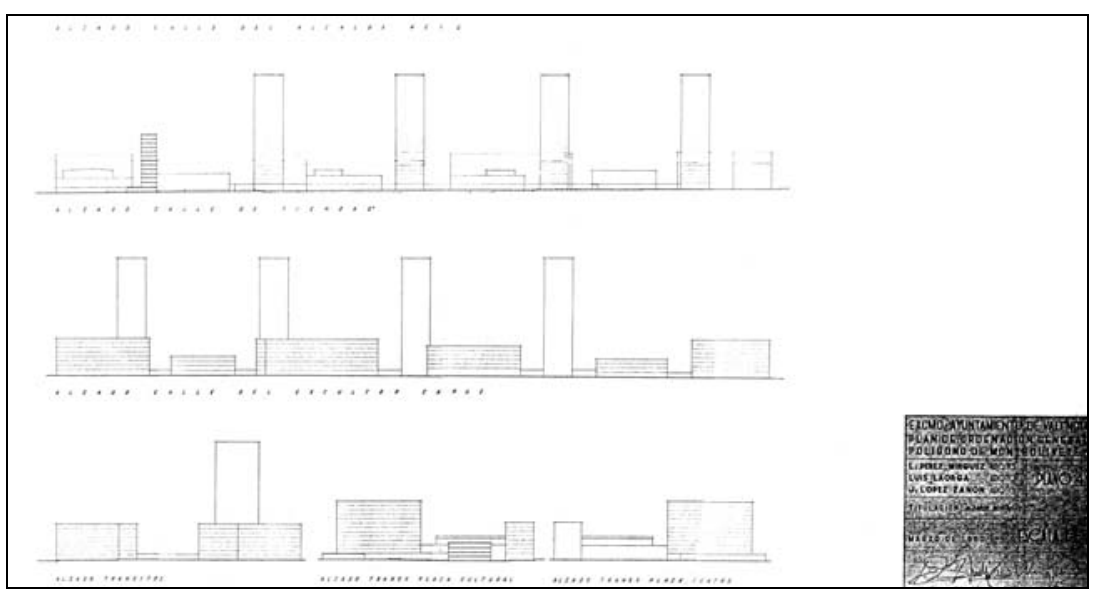

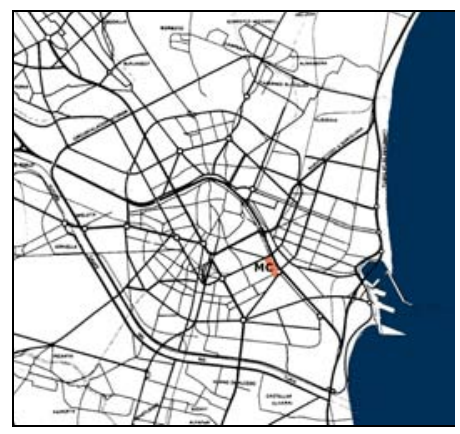

Centro Comercial de Monteolivete. Localización.
Centro Comercial de Monteolivete. Alzados de conjunto, 1960.

1. La maqueta de la Ordenación Técnica de la ciudad y su comarca de 1958 muestra ya en la misma zona un conjunto formado por bloques y torres enlazados por edificaciones de una planta que prefigura la ordenación de 1960.

2. Ordenación Parcial del Polígono de Monteolivete (Centro Comercial), 1960. Ver Anexo de Documentos, pp. 155-161.

3. Ibid. p. 156 


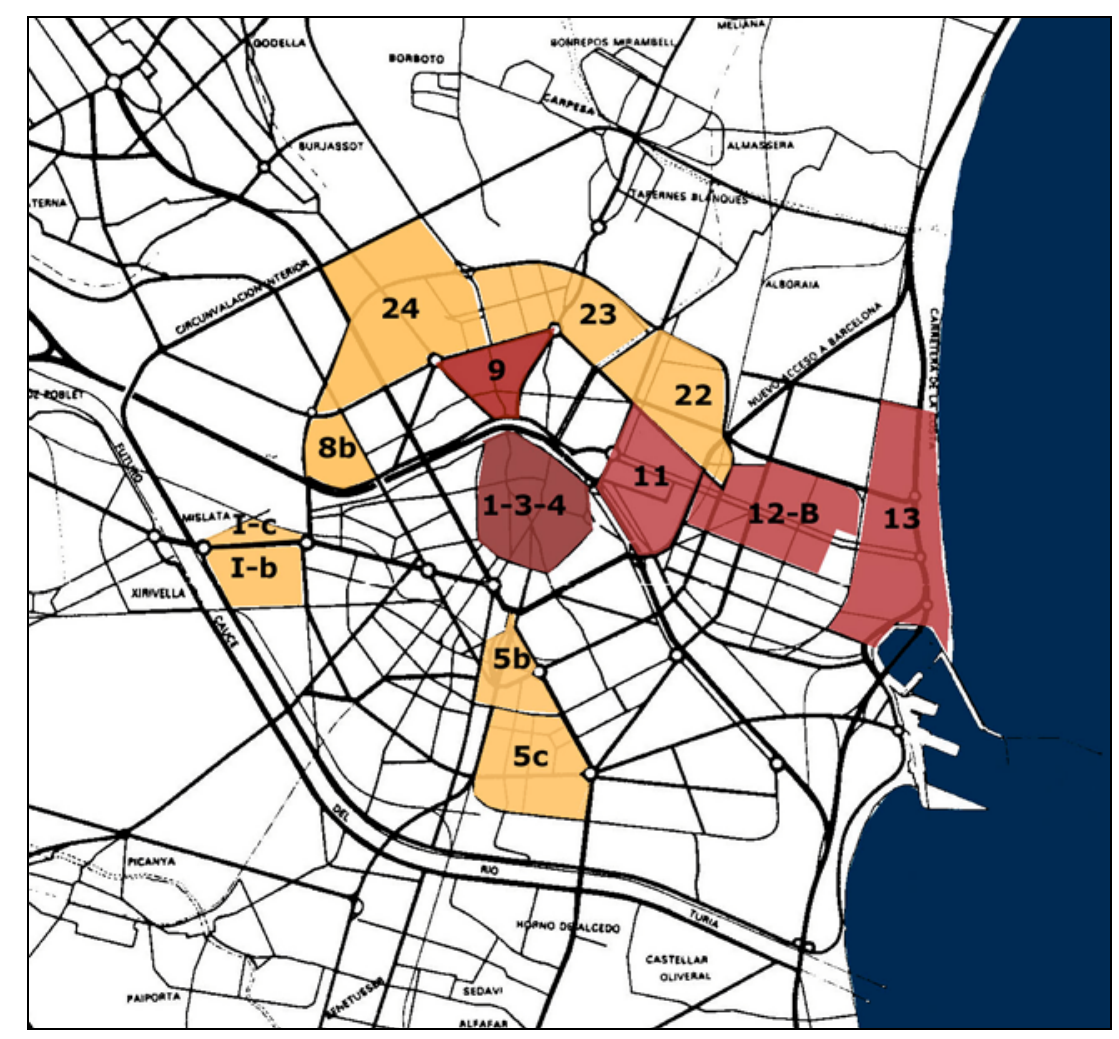

Planes Parciales con áreas de edificación abierta redactados por el Ayuntamiento de Valencia en desarrollo del Plan Sur, 1958-1965 (Elaboración propia sobre planimetría incluida en La Gran Valencia. Trayectoria de un Plan General).

REMODELACIÓN DE PLANES PARCIALES ANTERIORES (SUSTITUCIÓN DE MANZANAS POR EDIFICACIÓN ABIERTA).

PLANES NUEVOS PARA ZONAS SIN PLANEAMIENTO PARCIAL ANTERIOR.

Tabla II.5. Planes Parciales Municipales de desarrollo del Plan Sur, 1958-65.

\begin{tabular}{|l|l|c|}
\hline \multicolumn{1}{|c|}{ ZONA } & PLAN PARCIAL & $\begin{array}{c}\text { AÑO } \\
\text { REDACCIÓN }\end{array}$ \\
\hline CENTRO & $1-3-4$ & $1958 / 60$ \\
\hline \multirow{4}{*}{ NORESTE } & 11 & $1958 / 60$ \\
\cline { 2 - 3 } & $12-\mathrm{B}$ & $1958 / 60$ \\
\cline { 2 - 3 } & $22 \mathrm{~B}$ & 1961 \\
\cline { 2 - 3 } & 23 & 1962 \\
\hline \multirow{3}{*}{ NOROESTE } & 8 bis & 1963 \\
\cline { 2 - 3 } & 9 & 1960 \\
\cline { 2 - 3 } & 24 & 1966 \\
\hline \multirow{3}{*}{ SUROESTE } & $\mathrm{I}-\mathrm{C}$ & 1963 \\
\hline \multirow{3}{*}{ SURESTE } & $\mathrm{I}-\mathrm{b}$ & 1962 \\
\cline { 2 - 3 } & $5-\mathrm{B}$ & 1964 \\
\hline
\end{tabular}




\section{Planes PARCIALES DE DESARROLlo DEL PLAN SUR, 1958-1965}

Entre 1960 y 1965, la Oficina Técnica Municipal de Urbanismo del Ayuntamiento de Valencia, a cargo del arquitecto Julio Bellot Senent, redactó una nueva versión de la mayor parte de los Planes Parciales de la ciudad, con la finalidad de adaptarlos a las previsiones del Plan Sur aprobado en 1958, y del Plan de Accesos de Carreteras y sus Enlaces, de 1959.

Esta adaptación supone por lo general, en los planes correspondientes a zonas urbanas no consolidadas, una modificación completa de los mismos, introduciendo de manera decidida la edificación abierta en zonas ordenadas anteriormente mediante tejidos de ensanche formados por manzanas cerradas. Es el caso de los planes parciales 9 , I-b y I-c.

La edificación abierta se introduce también en algunas operaciones de renovación urbana que afectan al centro histórico, como la de la prolongación de la Avenida del Oeste a través del barrio del Carmen y la de los solares resultantes del derribo del antiguo Hospital Provincial, ambas incluidas en el ámbito del Plan Parcial 1-3-4.

La principal novedad de esta nueva oleada de planes estriba en el hecho de que, por primera vez, se redactan planes parciales para las áreas del norte exteriores a la ronda de Tránsitos, situadas en torno a los poblados anexionados a Valencia de Benimaclet (Plan Parcial 22), Orriols-Torrefiel (Plan Parcial 23) y Benicalap (Plan Parcial 24), áreas todas ellas para las que no se había llegado a redactar planeamiento parcial de desarrollo del Plan General de 1946.

En el sureste de la ciudad, se redactan también por vez primera los planes parciales correspondientes a las zonas de la Estación Central de RENFE y de Malilla (Planes Parciales $5 b$ y 5c).

Aunque pocos de estos planes llegaron a ser aprobados definitivamente, sirvieron de base para la concesión de licencias y generaron expectativas de aprovechamiento urbanístico en los ámbitos que ordenaban. De hecho, en algunos casos los planes posteriores para las mismas zonas, redactados después de la aprobación del Plan General de 1966, que estudiaremos en la sección siguiente, no son más que una modificación de mayor o menor entidad de estos primeros planes para adaptarlos a las determinaciones del nuevo Plan General y, en particular, a las del trazado viario previsto en el proyecto de Red Arterial de Valencia.

Los planes parciales redactados por el Ayuntamiento entre 1958 y 1965 se solapan con los de los cuatro polígonos de promoción pública gestionados por la Gerencia de Urbanización que hemos analizado en el apartado anterior, abarcando entre ambos la práctica totalidad del suelo vacante de la periferia de Valencia.

Como documento técnico, estos planes parciales municipales son muy pobres, ya que los más completos constan de Memoria y Ordenanzas muy breves y de seis o siete planos, de los cuales los únicos realmente significativos desde el punto de vista de la ordenación urbanística son los denominados "Estado actual y alineaciones" y "Planeamiento". ${ }^{1}$
1. Los planos restantes son por lo general el de emplazamiento, denominado "Ubicación y Transporte" y los tres planos de Esquemas de las redes de instalaciones urbanas (Alumbrado, Agua potable y Alcantarillado). 


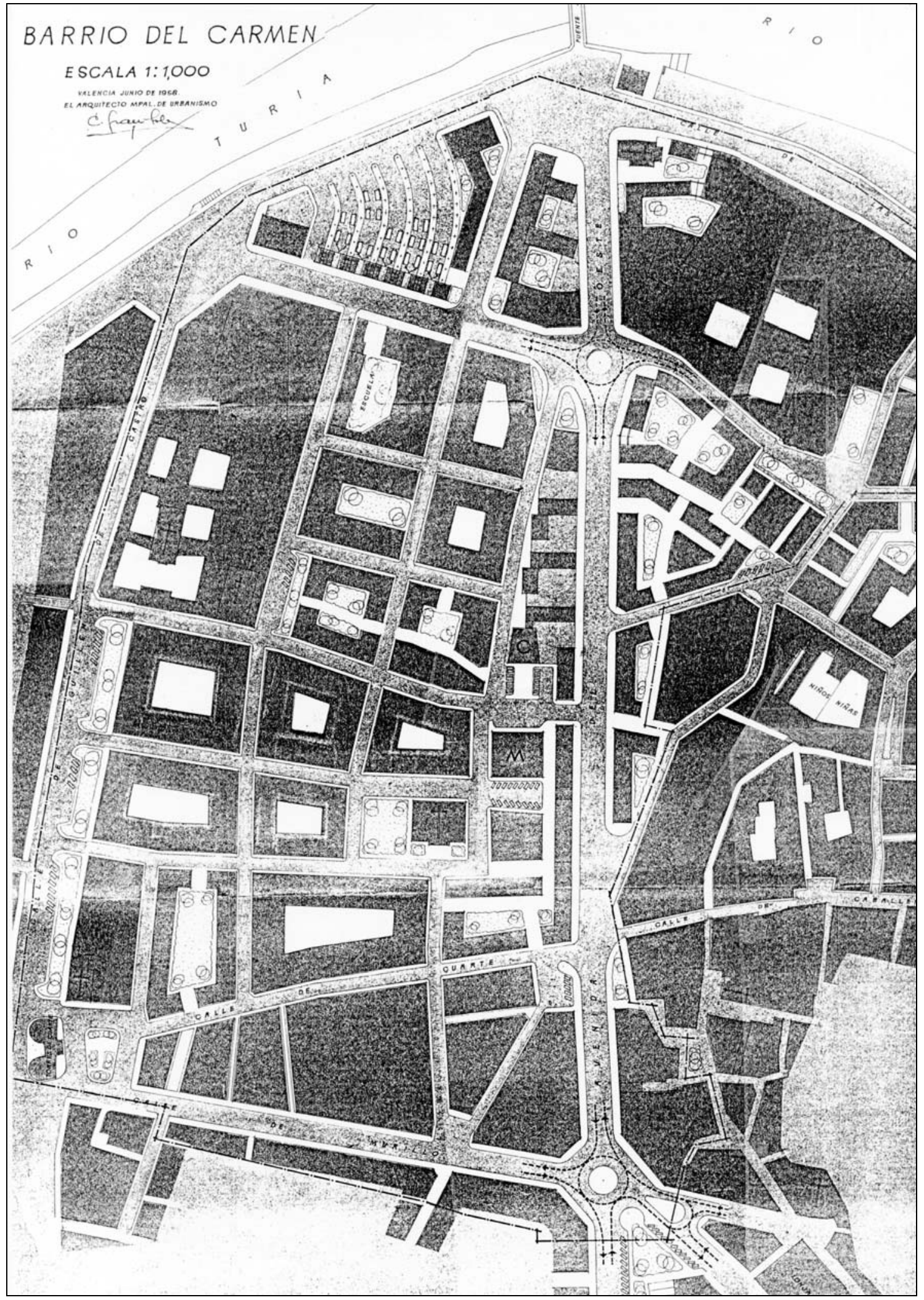

Plan Parcial 1-3-4. Barrio del Carmen. Camilo Grau Soler, 1958. 


\section{LA EDIFICACIÓN ABIERTA EN LAS OPERACIONES DE RENOVACIÓN URBANA DEL CENTRO HISTÓRICO: EL PLAN PARCIAL 1-3-4.}

Las operaciones de renovación urbana en el centro histórico de Valencia hasta 1949 giran en torno a las propuestas de Aymamí de 1908, reformuladas y ampliadas por Goerlich a partir de 1928.

El plan que define la ordenación del centro histórico en desarrollo del Plan General de 1946 es el Plano Parcial 1-3-4, que fue aprobado con algunas exclusiones en $1956^{1}$. Este plan contemplaba la prolongación de la Avenida del Oeste y de la calle de la Paz, la apertura de las calles María Cristina y Poeta Querol y la ampliación de las plazas de la Reina y de la Virgen.

\section{El barrio del Carmen.}

Después de la riada de 1957 se suspendió el planeamiento en el barrio del Carmen. Para esta zona, que ocupa el cuadrante noroeste del centro histórico, se redactó en 1958 un nuevo plan, en el que se introduce la edificación abierta en los solares resultantes de la prolongación de la Avenida del Oeste, mediante un trazado que sigue siendo rectilíneo como el proyectado por Aymamí, pero flanqueado por bloques en lugar de manzanas. ${ }^{2}$

La edificación abierta del proyecto de 1958 adopta diversas formas a lo largo de la Avenida del Oeste. Así, aparecen algunos bloques alineados con dicha Avenida, bien como edificios lineales aislados o bien formando parte de una edificación perimetral de manzanas con espacio libre interior, como los del lado este. Otros bloques son edificios en $L$ dispuestos ortogonalmente a la Avenida, $y$ otros son edificios en peine o torres combinadas con bloques, como en el tramo final junto río.

Al proyecto le falta, por todo ello, la claridad y contundencia en la forma de plantear el orden abierto que podemos encontrar en las propuestas de Zuazo y Jansen de 1929-30 para la Plaza del Progreso o la calle Fuencarral de Madrid, que, aunque lejanas en el tiempo, son la más clara muestra en nuestro país del uso de la edificación abierta como instrumento para la mejora de la ciudad histórica ${ }^{3}$.

El trazado rectilíneo de esta solución se sustituyó en la nueva versión del plan, de 1960, por otro de menor sección y apoyado en la directriz de las calles existentes (Bolsería, la calle Alta y Salvador Giner).

En este nuevo trazado, la prolongación de la Avenida del Oeste aparece flanqueada por unos bloques de VIII plantas de gran longitud, interrumpidos únicamente por una serie de pasajes. Detrás de estos bloques continuos, las calles Sogueros y Alta se convierten en calles traseras paralelas a la Avenida, que absorben las irregularidades del tejido histórico. Este tejido queda, así, en segundo plano, velado por los bloques que ocupan la primera línea del nuevo eje viario.

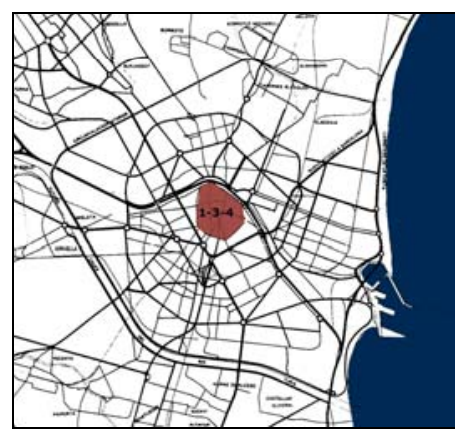

Plan Parcial 1-3-4. Localización.

1. "Proyecto Parcial de Alineaciones y zonificación del casco Antiguo", redactado por la Oficina Técnica Municipal de Urbanismo, siendo Arquitecto Mayor Javier Goerlich, y aprobado el 7-12-1956. Las propuestas municipales de reforma interior fueron duramente cuestionadas por el arquitecto Enrique Pecourt, desde el propio Ayuntamiento primero y desde el Colegio de Arquitectos más tarde. Ver Herrero Colás, Adolfo, "Valencia: un modelo no cuestionado. El fantasma de la reforma interior", Historia Urbana, 4, Valencia, 1992.

2. El plan de 1958 para el barrio del Carmen presenta ciertas similitudes con el Plan Vilaseca para Barcelona de 1959. Ver Pecourt, Juan, ed., Ciutat Vella: Materiales para el Urbanismo, Catálogo de exposición, Colegio Oficial de Arquitectos de la Comunidad Valenciana, Valencia, 1992.

3. Zuazo, Secundino y Jansen, Hermann, Anteproyecto del trazado viario y urbanización de Madrid (Estudio preliminar de Lilia Moure Rubio), Colegio Oficial de Arquitectos de Madrid, 1986. 


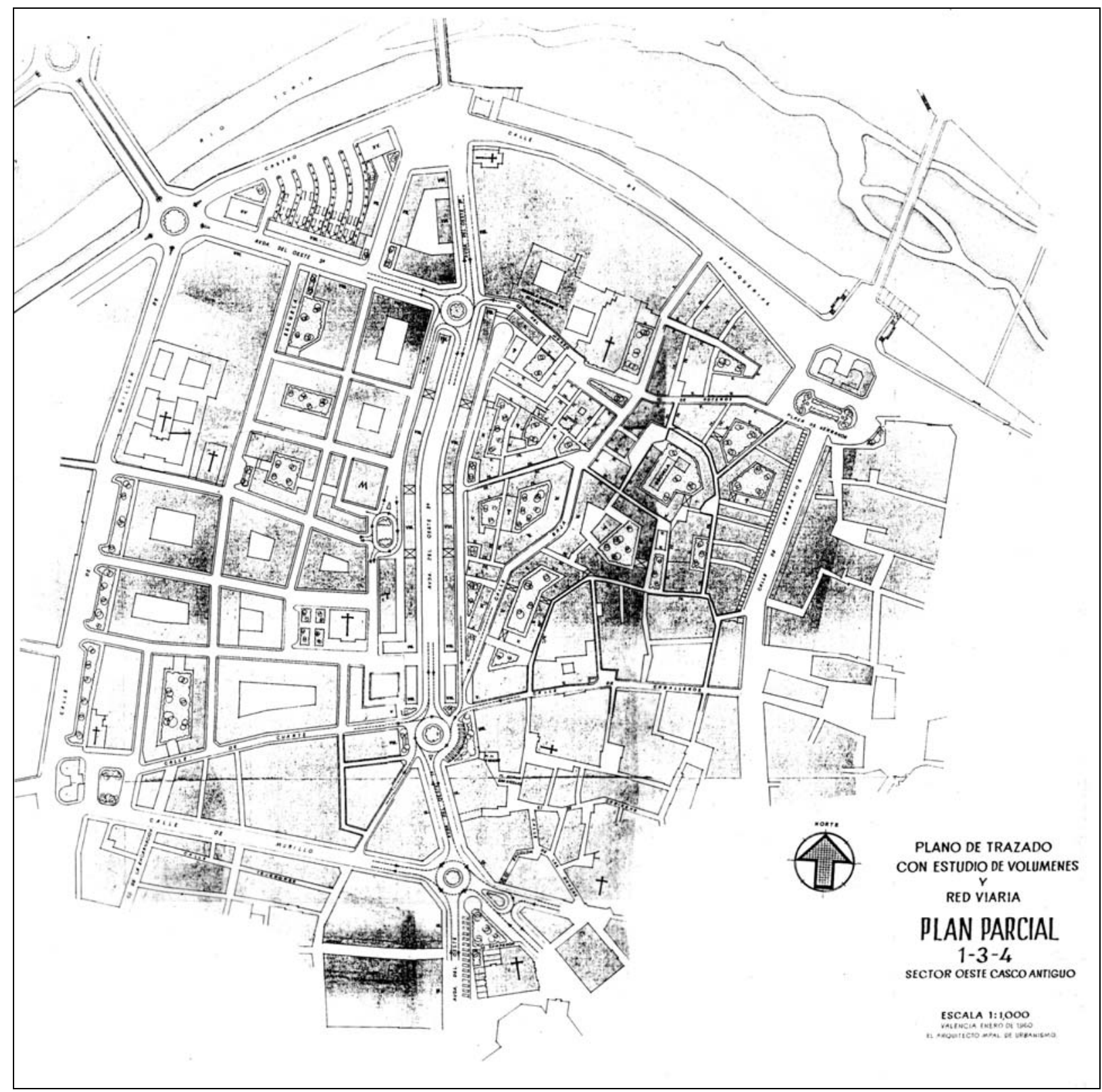

Plan Parcial 1-3-4. Sector oeste Centro Histórico, 1960.
El proyecto, por tanto, sigue la pauta de las operaciones clásicas de reforma interior, de acuerdo con el patrón instaurado por Haussmann en las aperturas de los bulevares de París, aunque la profundidad de las manzanas que acompañan al nuevo trazado se reduce hasta convertirse en bloques lineales de dos crujías.

En el plan para el barrio del Carmen, se prevé también la creación de un eje transversal a la Avenida del Oeste, que se obtiene ensanchando la calle Na Jordana. En la gran manzana triangular limitada por dicha calle y el paseo de la Pechina, marginal derecha del río Turia, el plan contempla la demolición de todas las edificaciones existentes y su sustitución por un amplio espacio de aparcamiento envuelto por bloques de edificación abierta rematados en sus extremos por torres de XV plantas.

Debemos resaltar que no existen bloques tan largos como los proyectados para la Avenida del Oeste en ningún otro plan parcial 
coetáneo. De hecho, la fragmentación de la promoción inmobiliaria de esa época conducía más bien a lo contrario, y es habitual encontrar en los proyectos para la periferia bloques muy cortos. No es de extrañar, por tanto, que los únicos edificios finalmente realizados del sector oeste del Plan Parcial 1-3-4 fueran dos pequeños fragmentos de bloque lineal, uno a cada lado de la futura Avenida, que, una vez descartada la prolongación, dejaron a la vista unas altísimas medianeras en el corazón del centro histórico.

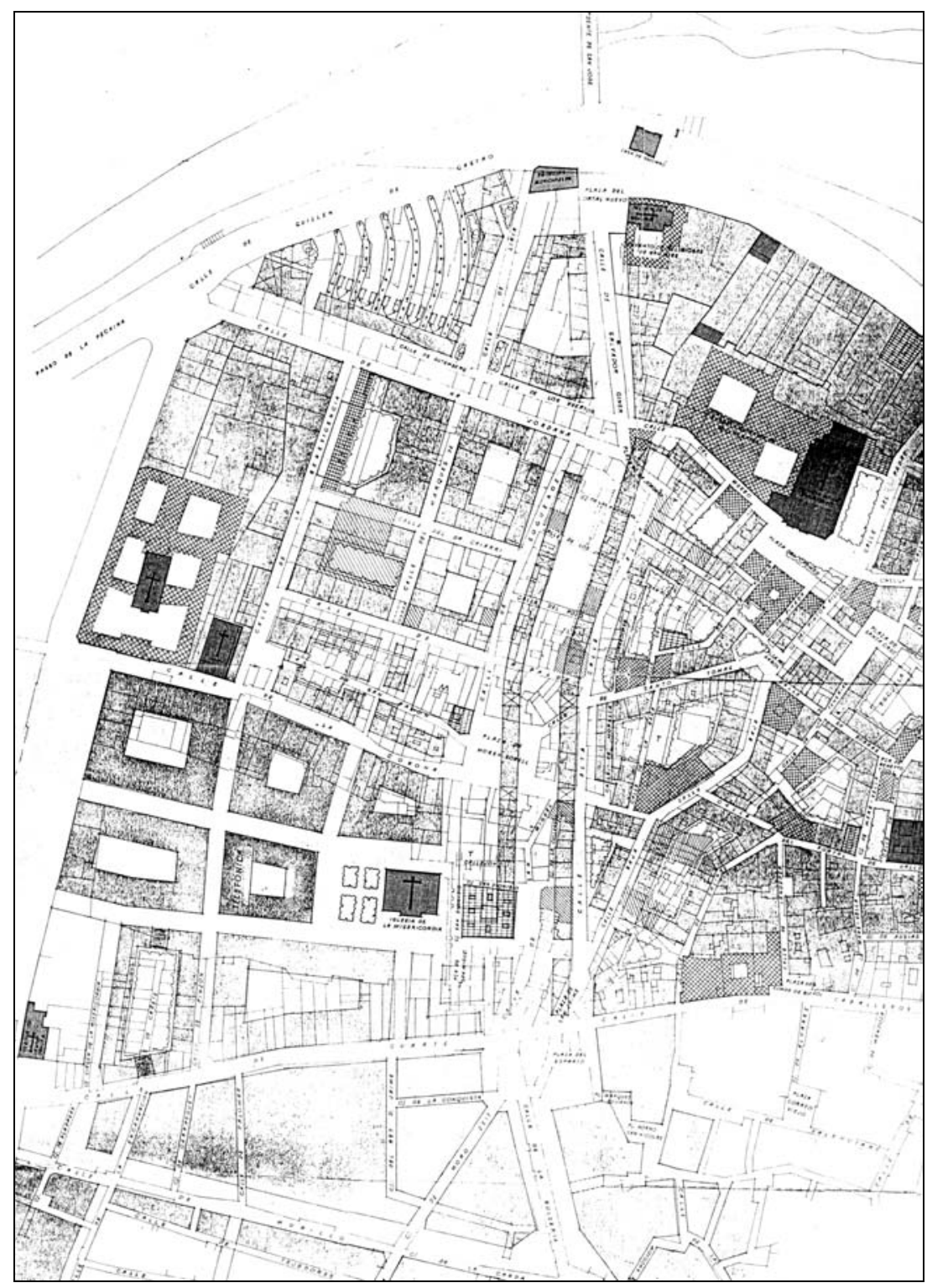

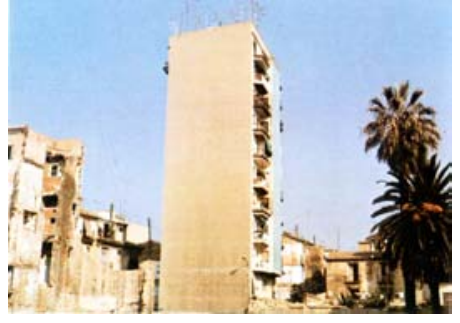

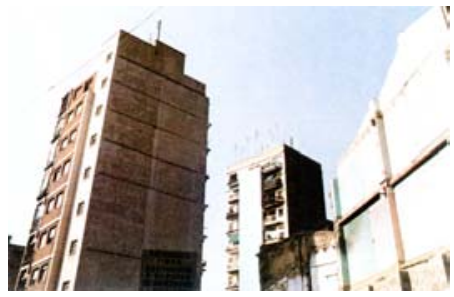

Fragmentos de bloques construidos de acuerdo con el Plan parcial 1-3-4 de 1960 en las calles Alta y Sogueros del barrio del Carmen (La ciudad que queremos. Avance del Plan General de Ordenación Urbana 1985).

Plan Parcial 1-3-4. Sector oeste Centro Histórico, 1960. Superposición de estado actual $y$ proyecto. 


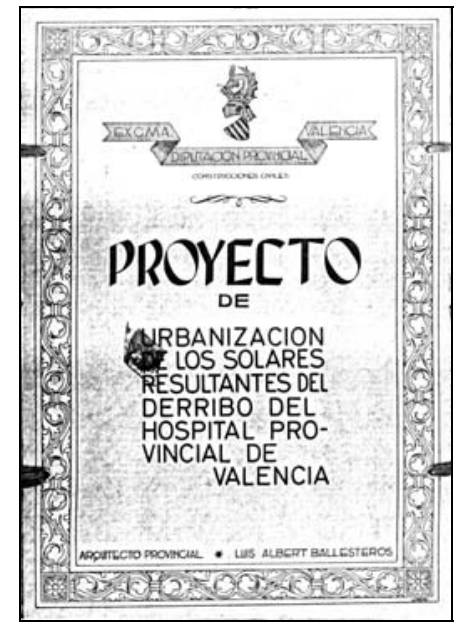

1

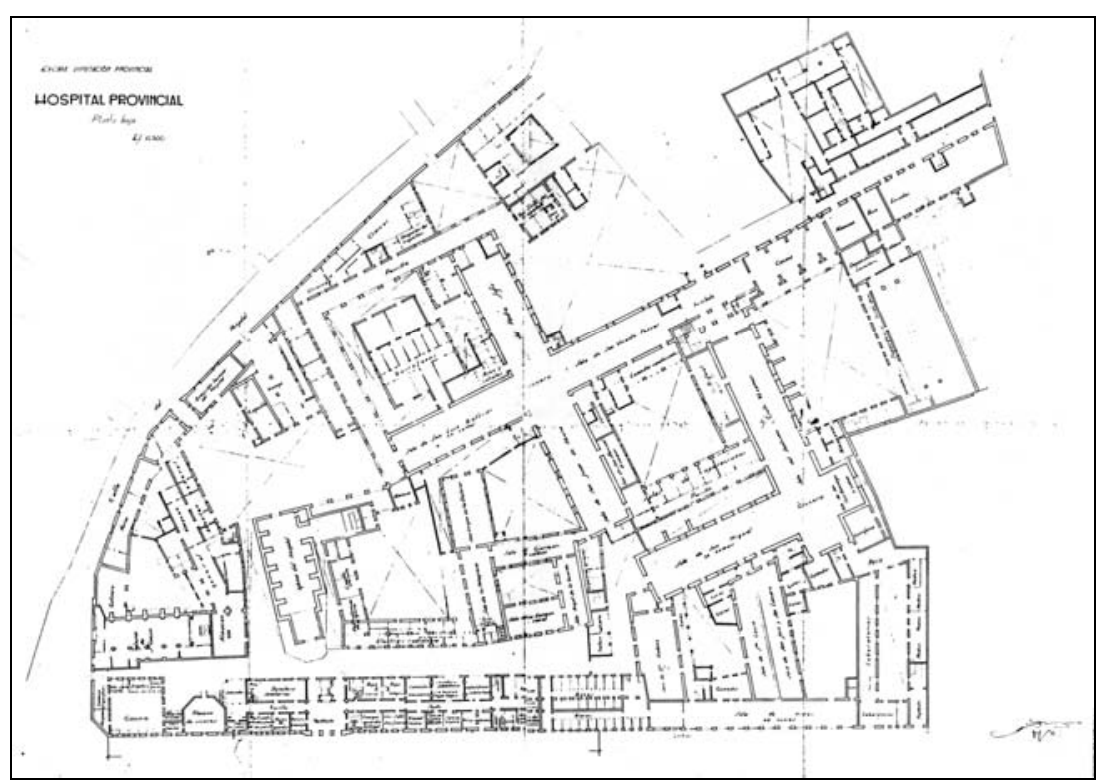

2

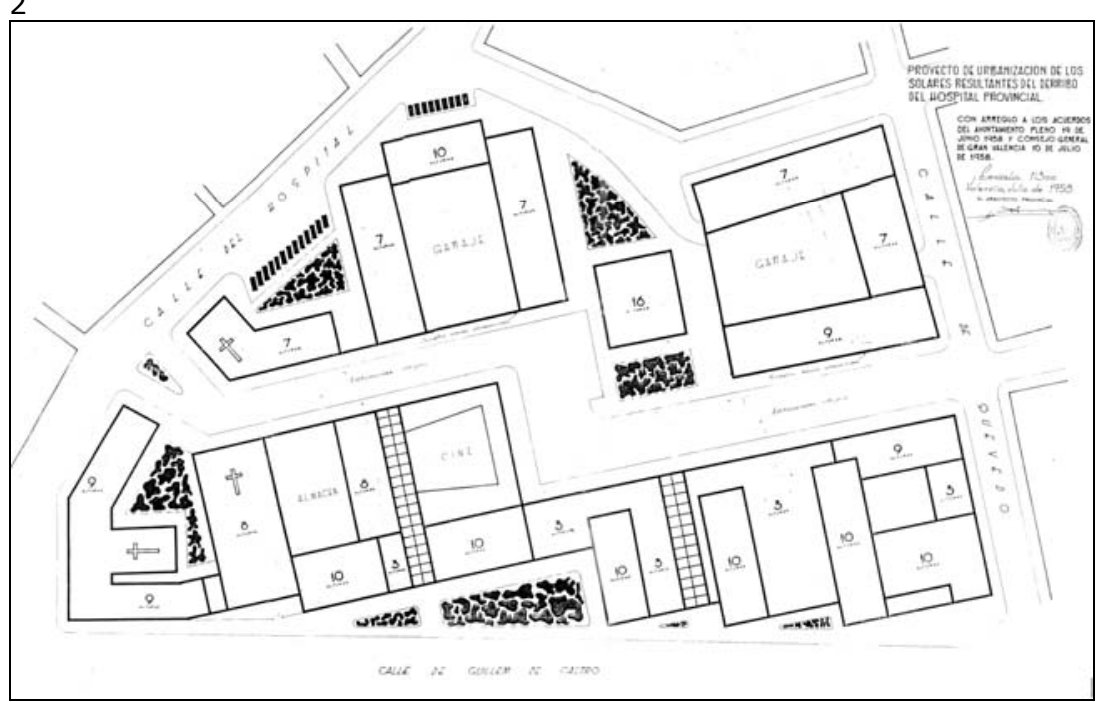

3

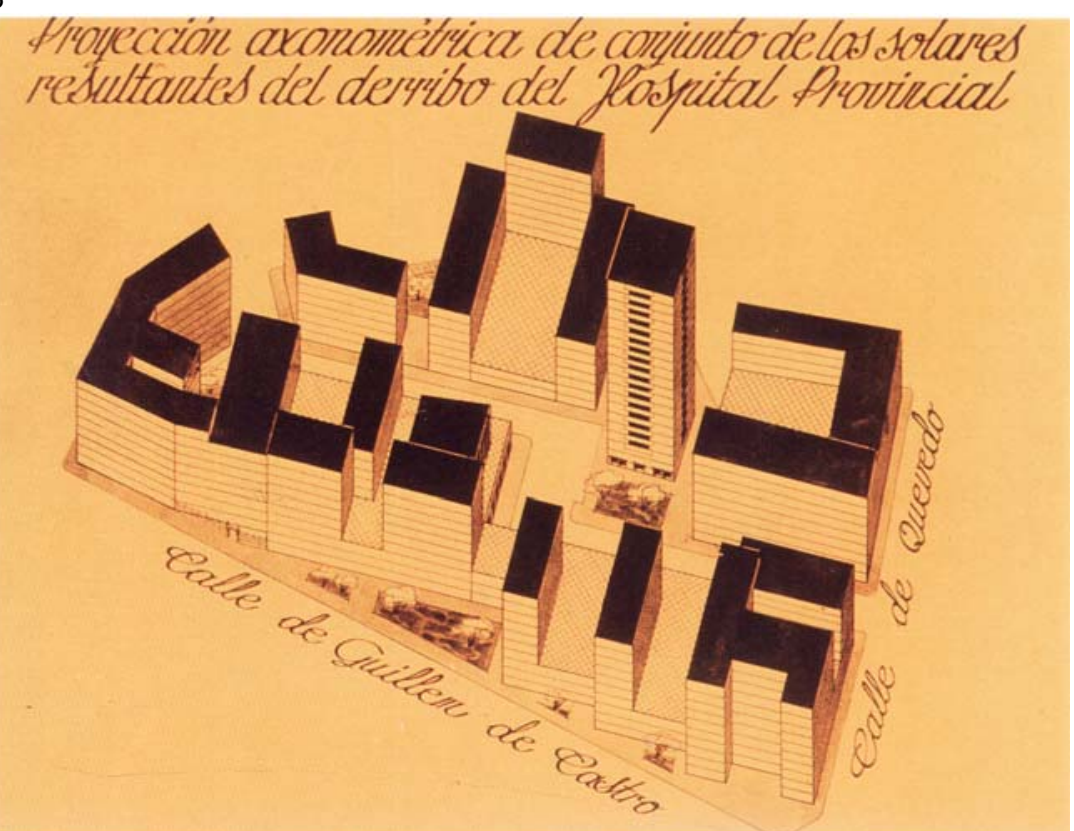

Proyecto de urbanización de los solares resultantes del derribo del Hospital Provincial de Valencia. Diputación Provincial de Valencia. Luís Albert Ballesteros, arquitecto provincial, 1958.

1. Portada del proyecto.

2. Planta de estado actual.

3. Planta de ordenación.

4. Proyección axonométrica.

5. Alzado parcial a la calle Guillem de Castro. 


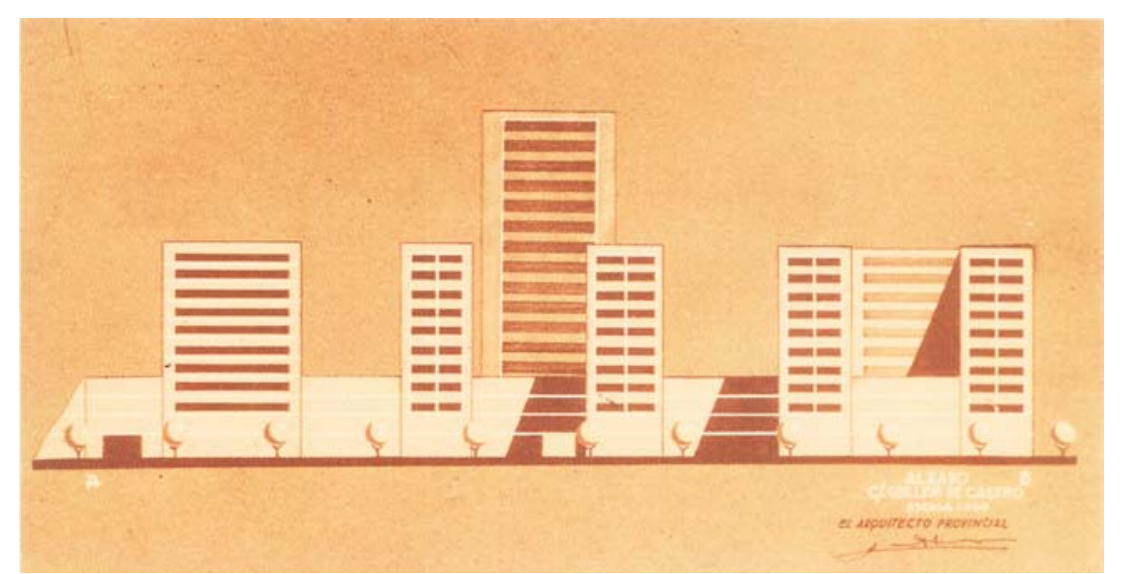

5

\section{Los solares resultantes del derribo del Hospital Privincial.}

El Hospital Provincial, dependiente de la Diputación de Valencia, estaba situado originalmente en una amplia manzana triangular del centro histórico de Valencia, limitada por la calle Guillem de Castro al sur, por la calle del Hospital al norte y por la calle de Quevedo al este. El traslado del Hospital a su nuevo emplazamiento, junto a la Avenida de Castilla, y la demolición prevista de las edificaciones existentes, liberaba unos terrenos muy apetecibles para usos residenciales por su localización central.

La primera ordenación de dichos terrenos, incluida en el Plano Parcial 1-3-4 de 1.956, consistía en una simple división de los mismos en manzanas y calles, y fue excluida de la aprobación de dicho plan por la Comisión Central de Sanidad Local, que la consideró inadecuada.

En 1958 la Diputación Provincial propuso una nueva ordenación, redactada por el arquitecto Luís Albert, para los terrenos resultantes de la demolición del Hospital, en la que se introducían las modificaciones propuestas por la Comisión Central de Sanidad.

El proyecto de la Diputación divide en dos la manzana mediante una calle central este-oeste que enlaza las calles de Quevedo y Hospital. Esta calle tiene un trazado quebrado, con una plaza intermedia junto a la que se sitúa un cine y una torre que preside la composición.

En la semimanzana norte se sitúan, a uno y otro lado de la torre, sendas manzanas formadas cada una de ellas por la agrupación de tres bloques dispuestos en $U$ sobre un zócalo comercial de dos plantas. A ello se añade un pequeño bloque en $L$ junto a la calle Hospital que engloba en su planta baja una de las capillas preexistentes.

En la semimanzana sur, la edificación no se alinea con la calle de Guillem de Castro, sino con la calle central interior central, por lo que aparecen unos retranqueos triangulares ajardinados en el frente a dicha Avenida. La edificación adopta la forma de manzana mixta, con un zócalo comercial de tres plantas sobre el que se sitúan bloques rectangulares de alturas y proporciones en planta diversas, buscando un efecto de variedad en la silueta del conjunto ${ }^{1}$.
1. Las otras dos capillas del antiguo Hospital que se conservan en esta semimanzana sur quedan también englobadas en los volúmenes de los bloques que se sitúan sobre ellas. 


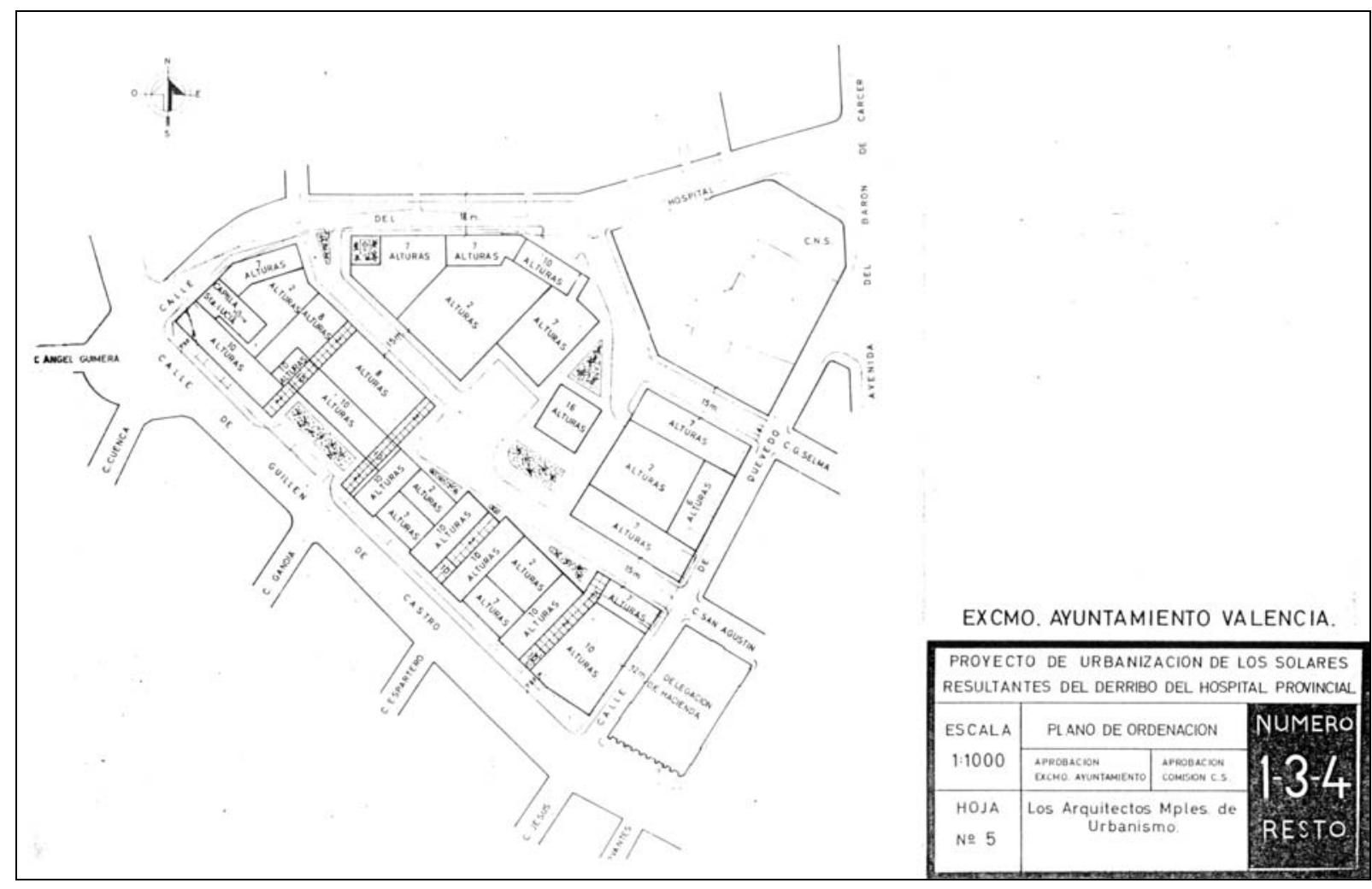

Plan Parcial 1-3-4 Resto. Proyecto de urbanización de los solares resultantes del derribo del Hospital Provincial. Ayuntamiento de Valencia, 1961.
1. Ver Memoria del plan, Anexo de Documentos, pp. $x x x$
El zócalo comercial de la semimanzana sur está atravesado por dos pasajes que comunican la calle Guillem de Castro con la calle central proyectada.

La búsqueda de variedad volumétrica en la composición es explícita en la Memoria del Plano de Ordenación de la zona redactado por la Oficina Técnica de Urbanismo del Ayuntamiento de Valencia en 1961, que forma parte de la nueva versión del Plan Parcial 13-4. Así, en dicha Memoria se señala que las alteraciones de la línea de fachada en la calle de Guillem de Castro buscan obtener un conjunto más movido y atractivo que el que resultaría de una ordenación convencional de manzanas ${ }^{1}$.

Este plan municipal de 1961 se basa en los elementos principales del plan de Albert de 1958, tales como la calle central esteoeste, la plaza central con una torre y el recurso a manzanas mixtas formadas por bloques enlazados por extensos zócalos no residenciales. Se mantienen también, aumentando su número, los pasajes de conexión entre la calle Guillem de Castro y la calle central.

La modificación principal que el nuevo plan introduce es la de alinear la semimanzana sur con la calle Guillem de Castro, además de variaciones en la forma de la planta de diversos bloques. Con ello se persigue, según la Memoria del plan, obtener un espacio libre interior amplio y una densidad que no sea excesiva. El resultado no es muy convincente, ya que el frente a la calle Guillem de Castro aumenta en compacidad, y la opción de alinear los bloques con las calles perimetrales resta claridad y rotundidad geométrica al espacio libre central, al tiempo que elimina los retranqueos triangulares ajardinados, que resultaban más coherentes con la lógica de la edificación abierta. 

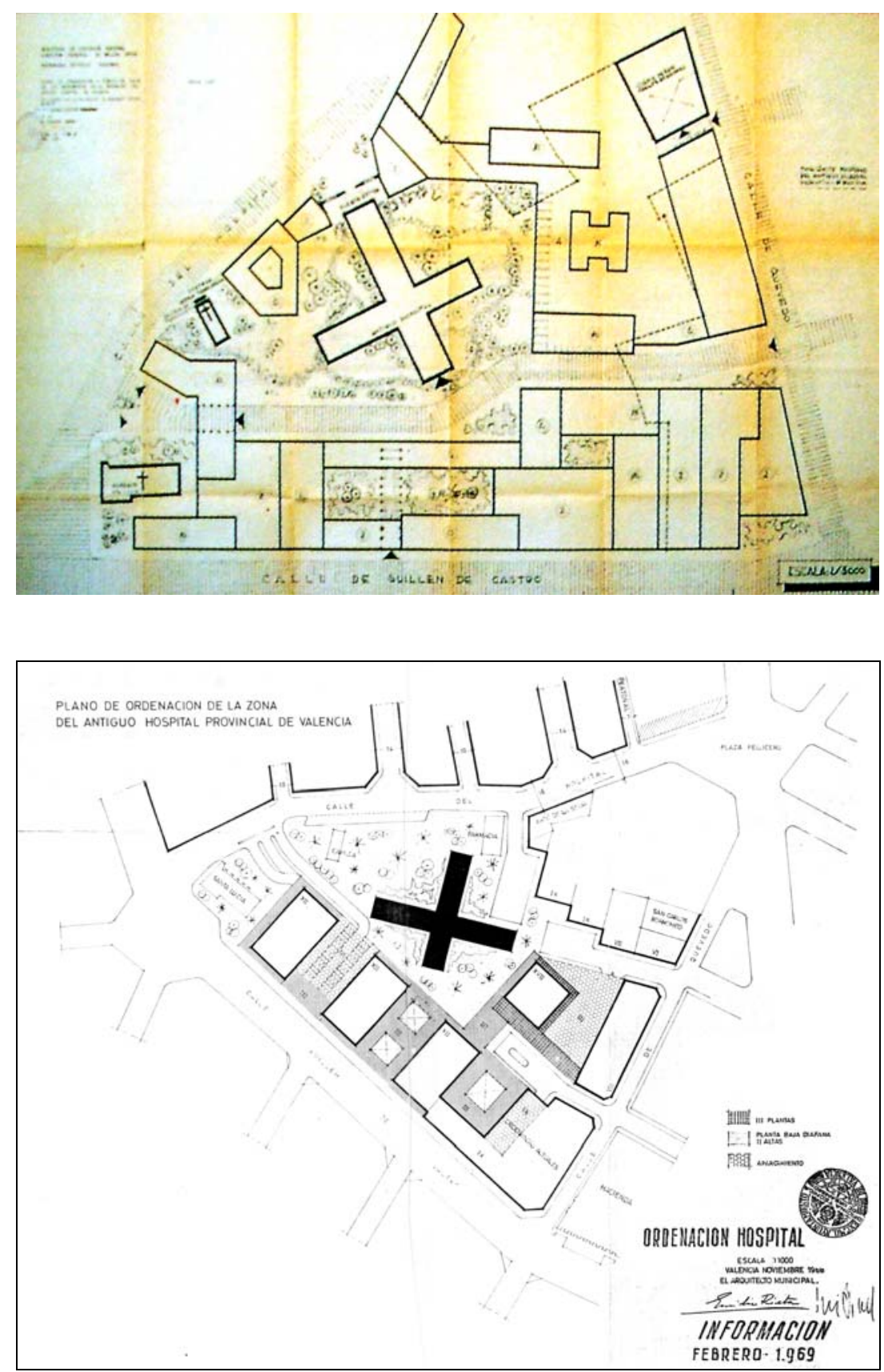

Tras la declaración de conjunto monumental para los pocos edificios que quedaron en pie del Hospital, entre ellos el edificio principal con planta en cruz y las capillas situadas al oeste, los estudios urbanísticos posteriores concentrarán la edificación en la franjas adyacentes a las calles de Guillem de Castro y Quevedo, como ocurre, con diferentes disposiciones de los bloques, en las dos ordenaciones fechadas en 1968.

De la ordenación municipal de 1968, se construyeron parte de los edificios situados junto a la calle Quevedo, que forman un frente de edificación denso de manzanas compactas. El frente a la calle Guillem de Castro quedó en su mayor parte sin edificar y forma los actualmente denominados jardines del Hospital.
Ordenación de la manzana del antiguo Hospital. Plano de conservación y puesta en valor de los monumentos en el perímetro del antiguo Hospital de Valencia, 1968. Ministerio de Educación Nacional, Dirección General de Bellas Artes.

Plano de ordenación de la zona del antiguo Hospital Provincial de Valencia, 1968-69. Ayuntamiento de Valencia. 


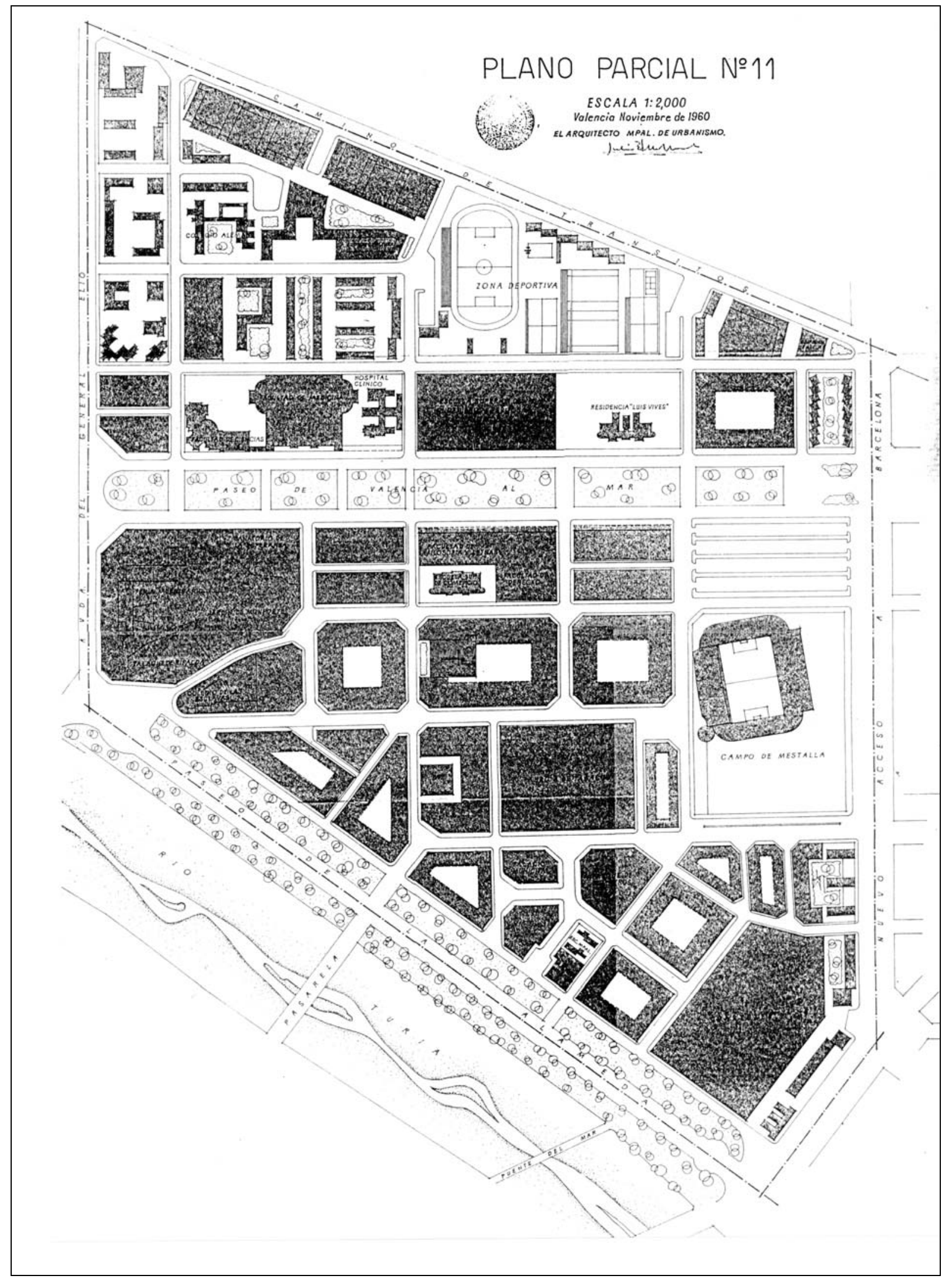

Plano Parcial no 11, 1960. 


\section{LAS ZONAS DE LAS FACULTADES, MESTALLA Y EL LLANO DEL REAL: EL PLAN PARCIAL No 11 (1958/1960)}

El Plano Parcial no 11 ordena el área limitada por el Camino de Tránsitos al norte, por el Paseo de la Alameda (margen izquierda del Rio Turia) al sur, por el nuevo acceso de Barcelona (actual Avenida de Aragón) al este y por la calle General Elío / Botánico Cavanilles (jardines de los Viveros Municipales) al oeste.

La mitad sur del plano, entre el Paseo al Mar y la Alameda, corresponde a un tejido de manzanas de ensanche con un grado de consolidación alto. Un buen número de las manzanas, además, están destinadas a equipamientos, como la de la Feria Muestrario y el Sanatorio de la Esperanza, la de la Fábrica de $\operatorname{Tabacos}^{1}$, bomberos, cuarteles y varios colegios privados, así como el campo de fútbol de Mestalla.

El suelo vacante que ordena el plan es el situado en la mitad norte del plano, entre el Camino de Tránsitos y las manzanas de las edificaciones universitarias -Facultades de Ciencias y de Medicina, campo de deportes y Colegio Mayor Luís Vives- que ocupan el frente del Paseo al Mar.

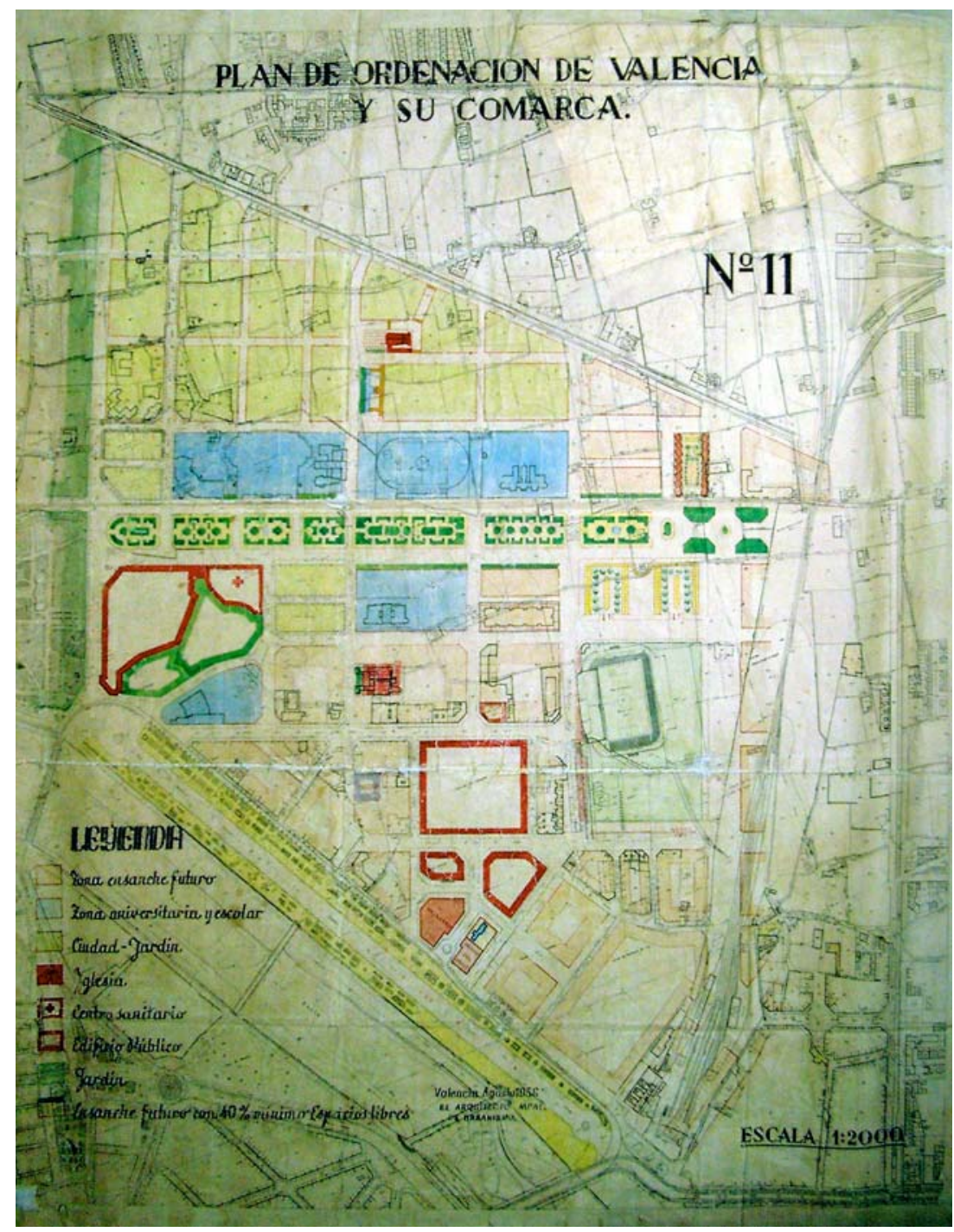

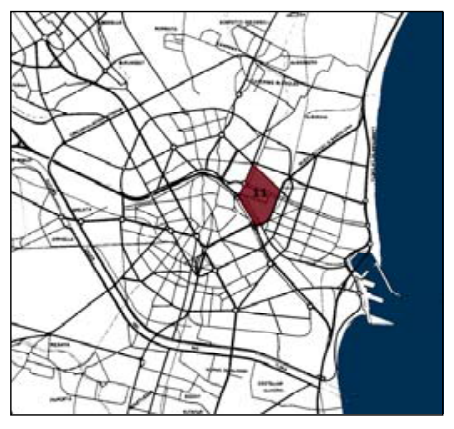

Plan Parcial 11. Localización

Plan de Ordenación de Valencia y su Comarca, Hoja no 11, 1956 (Archivo de Planeamiento. Ayuntamiento de Valencia).
1.Se trata de los edificios construidos para la Exposición Regional de Valencia de 1909. 

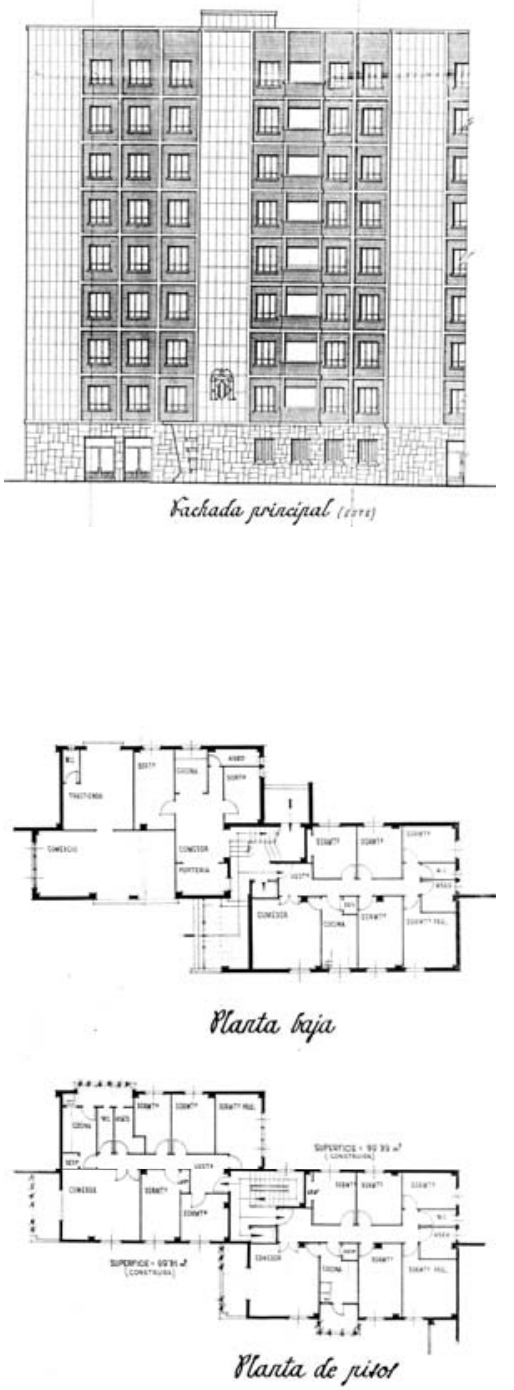

Proyecto de 136 viviendas subvencionadas en el Paseo Valencia al Mar, 1956. Promotor: Cooperativa de Viviendas para funcionarios municipales. Arquitectos: Camilo Grau Soler, Julio Bellot Senent, Carlos Soler López (Archivo de Planeamiento, Ayuntamiento de Valencia).
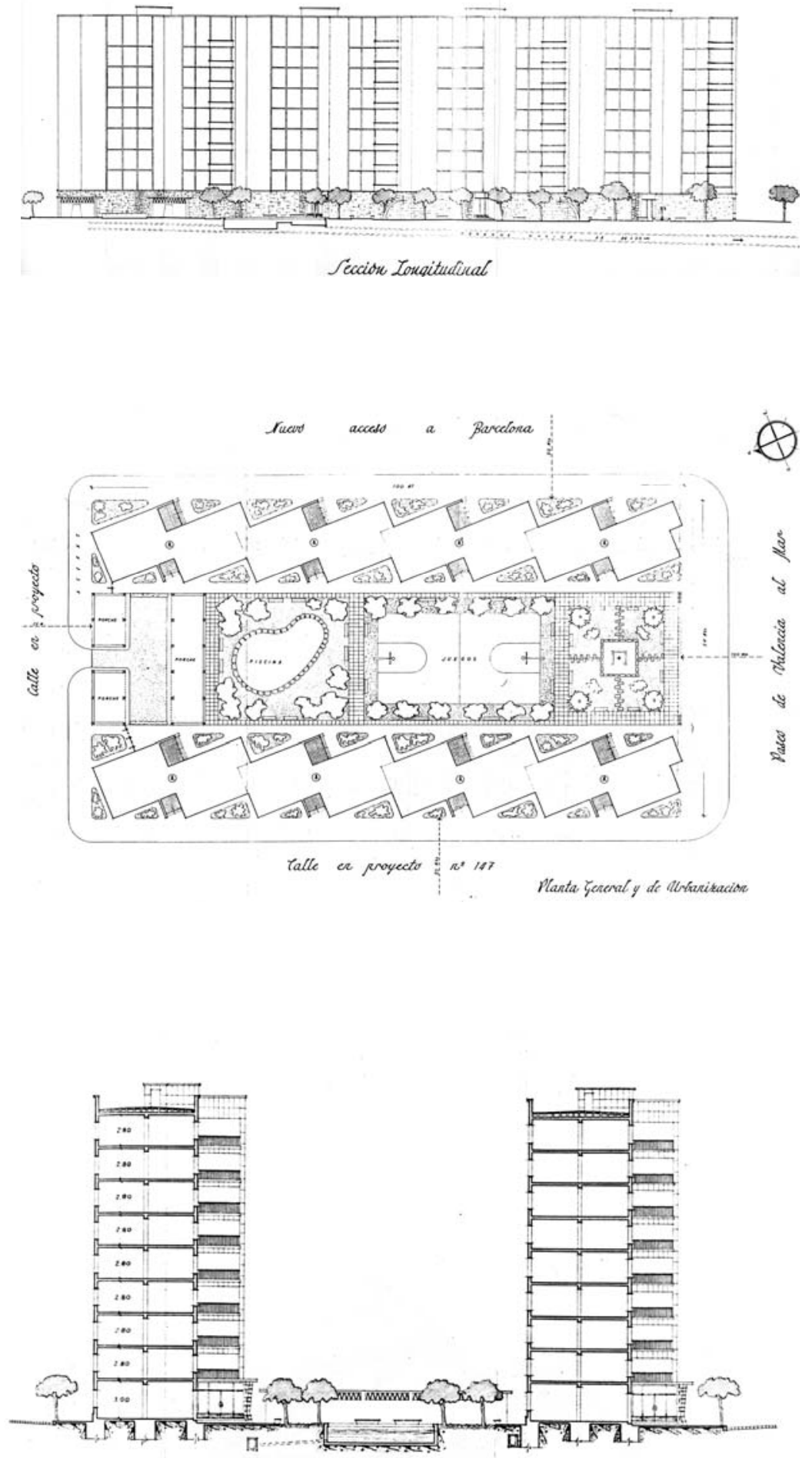

Seccion torausversal 
En la sección anterior hemos analizado el proyecto de 1952 para un nuevo barrio de edificación abierta entre el Paseo al Mar y el Camino de Tránsitos ${ }^{1}$. En la Hoja no 11 de desarrollo del Plan General de 1946, fechada en 1956, la mayor parte de esa misma zona norte aparece ordenada mediante manzanas con calificación de ciudad-jardín, excepto en la parte este, donde se prevé un pequeño grupo de manzanas cerradas junto a otra destinada a viviendas de promoción municipal.

La ordenación de esta última manzana responde a un proyecto de 136 viviendas subvencionadas promovido por la Cooperativa de Viviendas para Funcionarios Municipales y redactado en 1956 por los arquitectos Camilo Grau Soler, Julio Bellot Senent y Carlos Soler López.

Las 136 viviendas se reparten en dos bloques de IX plantas en diente de sierra, de dos crujías y orientados en dirección nortesur, es decir, paralelos al nuevo acceso a Barcelona (actual Avenida de Cataluña). En el espacio libre intermedio entre los bloques se sitúan una piscina, jardines y un pequeño aparcamiento.

El principal interés de esta propuesta es que muestra un modelo de manzana equipada, con espacios libes de parcela asociados a la edificación abierta, proyectada de manera unitaria como unidad urbana completa.

Sin embargo, la ampliación proyectada posteriormente de la anchura del nuevo acceso a Barcelona de 50 a 80 metros, hizo inviable este proyecto al quedar reducido a menos de la mitad el solar disponible para el mismo, por lo que se redactó un proyecto nuevo en 1963 de características muy diferentes, que analizaremos más adelante. $^{2}$

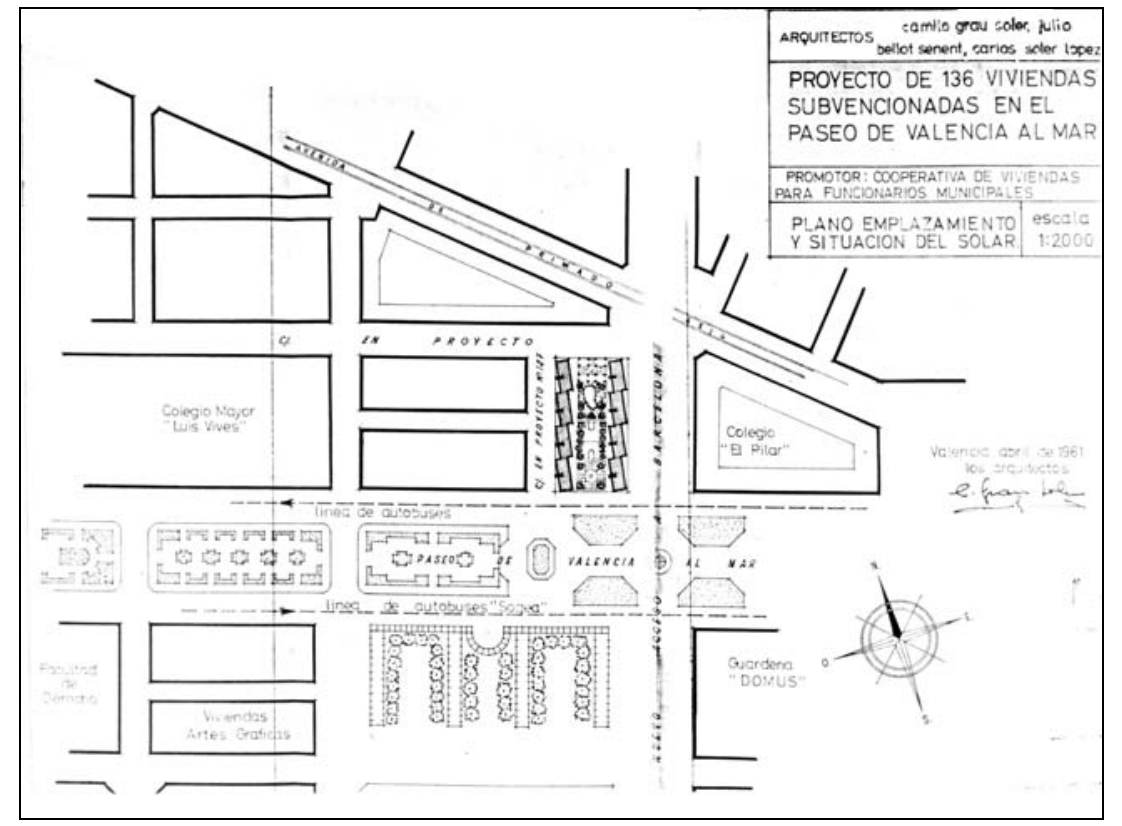

Proyecto de 136 viviendas subvencionadas en el Paseo Valencia al Mar, 1956. Planta de situación.

1. Ver sección I, p. 68.

2. Ver p. 243 de esta sección. 
Proyecto de Parcelación de la manzana situada entre las calles General Elio, Juan Martorell, Camino Nuevo de Alboraya y Calle en Proyecto $n^{\circ}$ 132, P. Navarro y J. Trullenque, 1957 (Archivo Histórico Municipal).

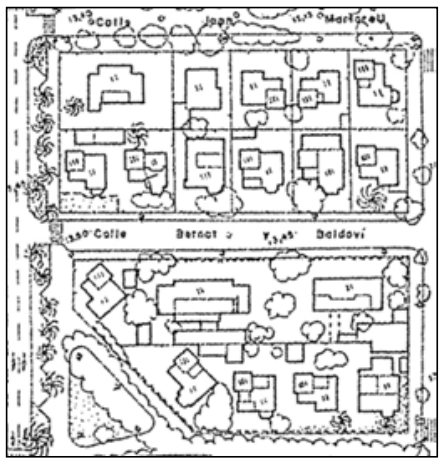

Casas de los periodistas. E. Viedma Vidal, 1934-36.
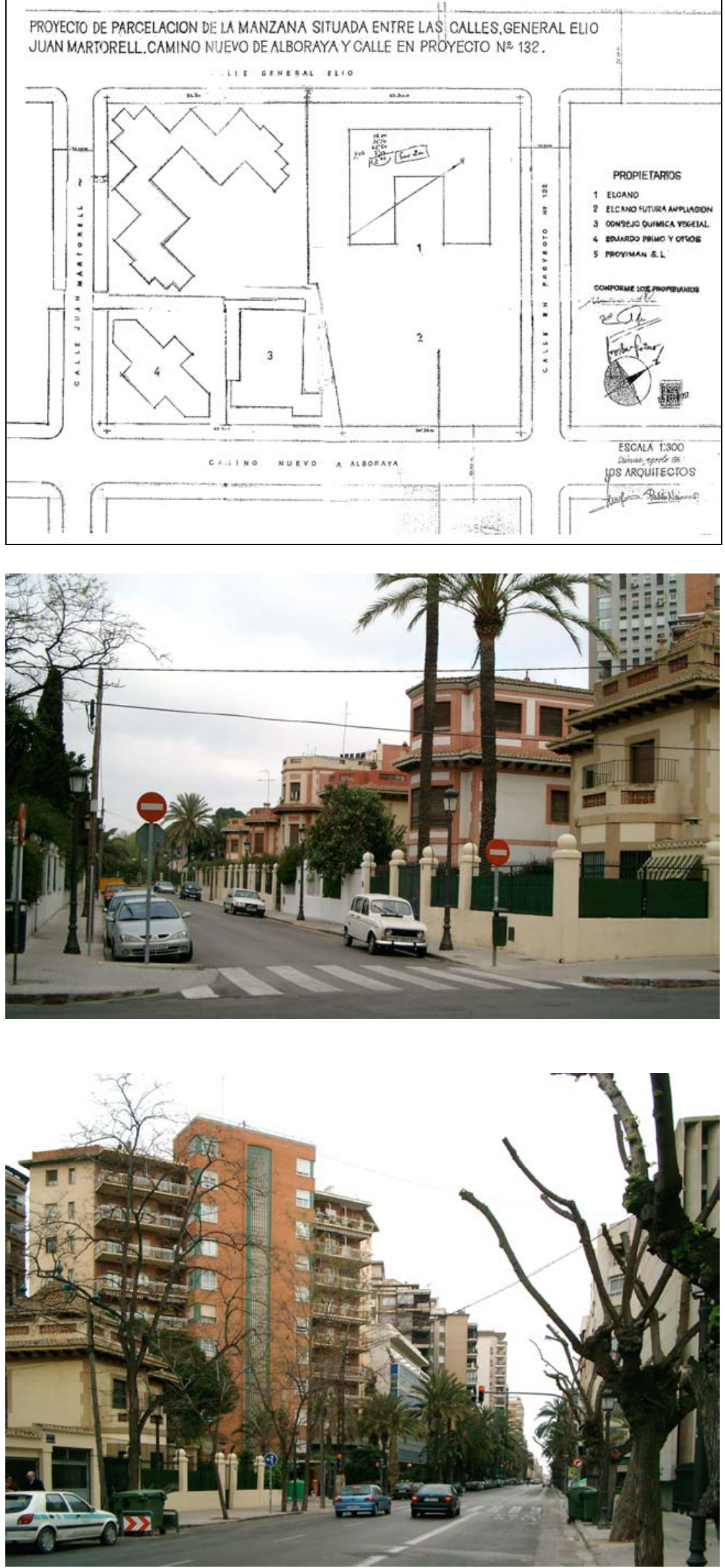


\section{La primera manzana de Jaime Roig: los edificios Proviman, Químicos y Elcano.}

En el lado norte del Paseo al Mar, las dos primeras manzanas situadas entre las calles Jaime Roig y Botánico Cavanilles son las de las Ilamadas Casas de los Periodistas de 1934-36, formadas por viviendas unifamiliares. La tercera manzana, limitada por las calles Jaime Roig, Álvaro de Bazán, Botánico Cavanilles y Juan Martorell, está calificada como ciudad jardín en la Hoja 11 de 1956, pero en ella aparecen dibujados una serie de edificios que no pueden ser considerados en modo alguno como ciudad-jardín.

Esta manzana será la primera de la nueva zona residencial que iba a desarrollarse en años sucesivos junto a los jardines de Viveros y las nuevas Facultades, y en ella tanto la forma de los edificios como su inserción en la manzana muestran un cambio importante con respecto a los primeros planteamientos de la edificación abierta en Valencia.

Así, en lugar de bloques lineales entre zonas verdes públicas, el modelo que se adoptará para esta zona será el de edificación abierta en forma de torres o bloques aislados dotados de zonas ajardinadas privadas y garajes subterráneos. Estas zonas ajardinadas son por lo general meros espacios intersticiales resultantes de la separación a lindes de los edificios. ${ }^{1}$

El proyecto de parcelación de la manzana que estamos analizando, redactado en 1957 por los arquitectos Pablo Navarro y Julio Trullenque, muestra en ella cuatro edificios, propiedad de Proviman S.L., de Eduardo Primo y otros (grupo Químicos), del Consejo de Química Vegetal y de Elcano, así como un solar también propiedad de esta última entidad. Las dimensiones de la manzana son de $90 \mathrm{x}$ 120 metros.

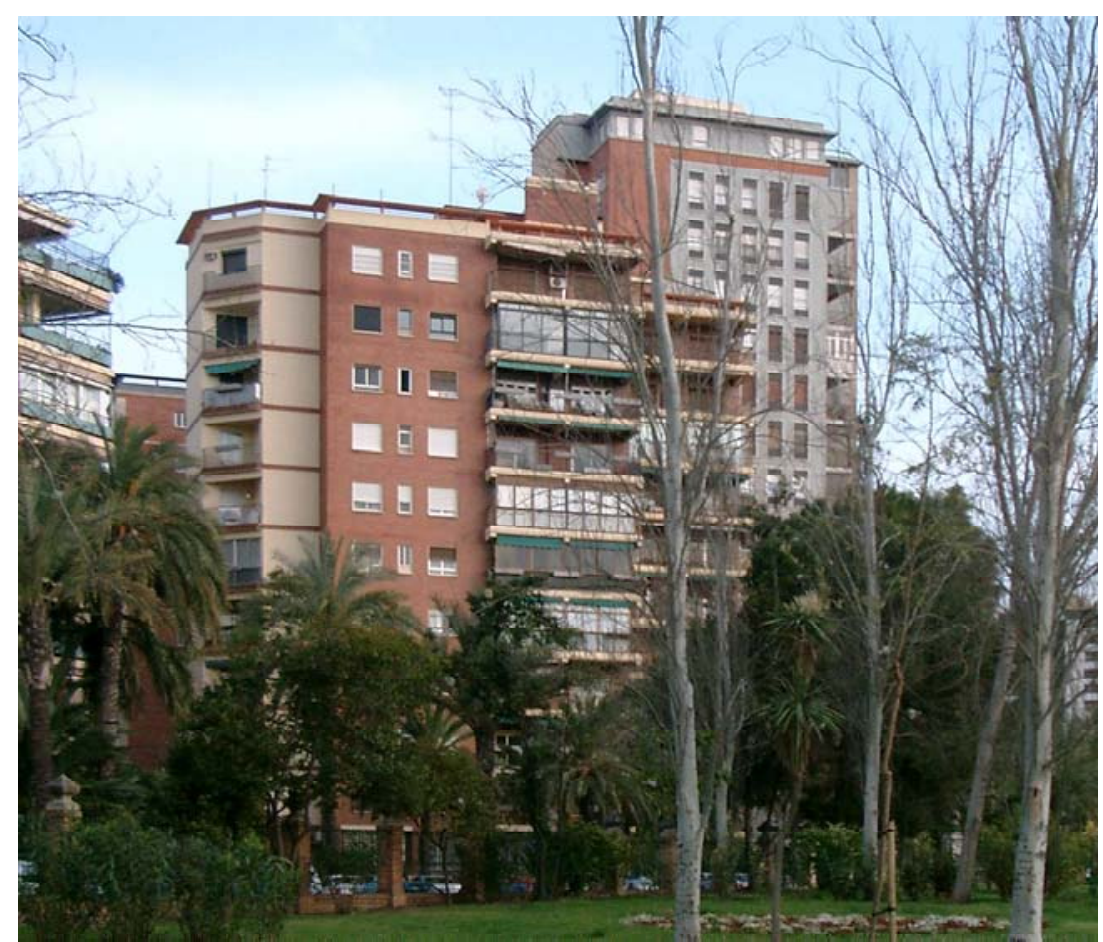

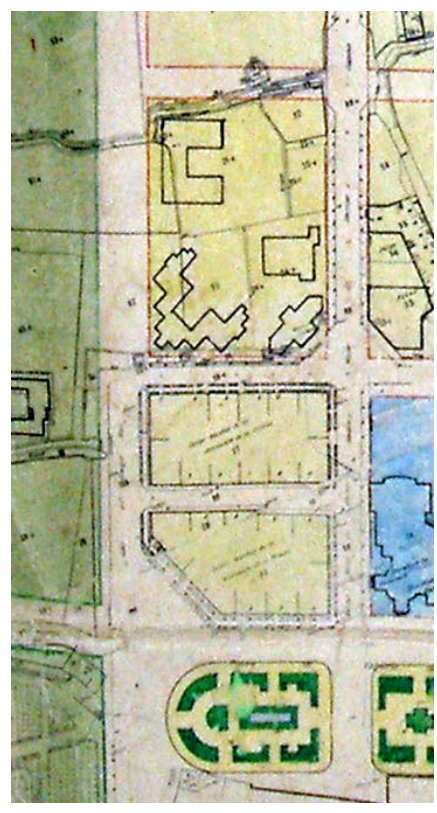

Las tres manzanas entre Jaime Roig y Botánico Cavanilles. Fragmento de la Hoja 11, 1956 (Archivo de Planeamiento, Ayuntamiento de Valencia).

Edificio Proviman S.L., 195658. P. Navarro y J. Trullenque. Vista actual desde los jardines de Viveros.
1. Este modelo es similar al de la zona residencial de la Bonanova de Barcelona, construida entre 1945 y 1975. Ver Aballanet, Albert, Castiñeira, Isabel, Monteys, Xavier, Paricio, Antoni, Residencia urbana en Barcelona 1945-1970. El área de La Bonanova (Sarrià-Sant Gervasi), Edicions UPC, 2000. 
Edificio Proviman S.L., $1956-$ 58. P. Navarro y J. Trullenque. Vista actual desde el oeste.

El denominado "grupo Químicos", de 18 viviendas de Renta Limitada, está situado en la esquina sureste de la manzana (calle Joan Martorell con Jaime Roig). Fue proyectado en 1957 por Pablo Navarro y Julio Trullenque, y terminado en 1958, por lo que es el primero construido en la manzana. Es un edificio de nueve plantas, con dos viviendas muy amplias en cada una de ellas.

La esquina suroeste (calle Joan Martorell con Botánico Cavanilles) está ocupada por un edificio de 56 viviendas, promovido por Proviman y proyectado también por P. Navarro y J. Trullenque. La planta está formada por una torre central de XV plantas situada en la esquina y dos cuerpos de edificación de forma escalonada adosados a ambos lados, de XI plantas.

La esquina noroeste de la manzana (calle Álvaro de Bazán con Botánico Cavanilles) está ocupada por la parcela del edificio Elcano, proyectado por Luís Gutierrez Soto en 1957 y construido entre 1958 y 1962 . El edificio, de ocho plantas y ático, está retranqueado tanto con respecto a las calles como a los lindes. Tiene una planta en $U$, abierta a un jardín comunitario posterior en el proyecto original y cerrada finalmente con un cuerpo bajo de edificación anexo a las viviendas de planta baja, de modo que los jardines son de uso privativo de dichas viviendas.

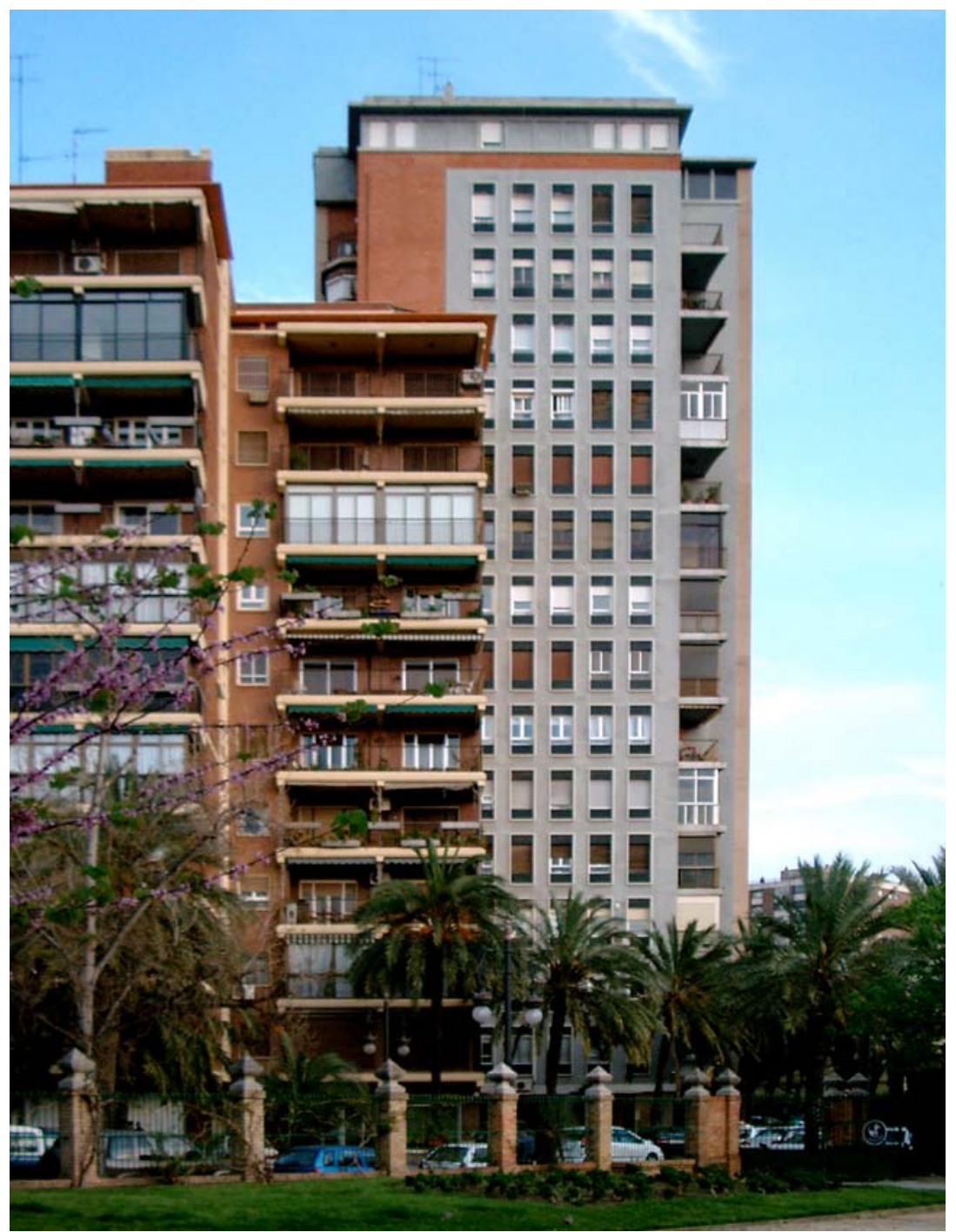



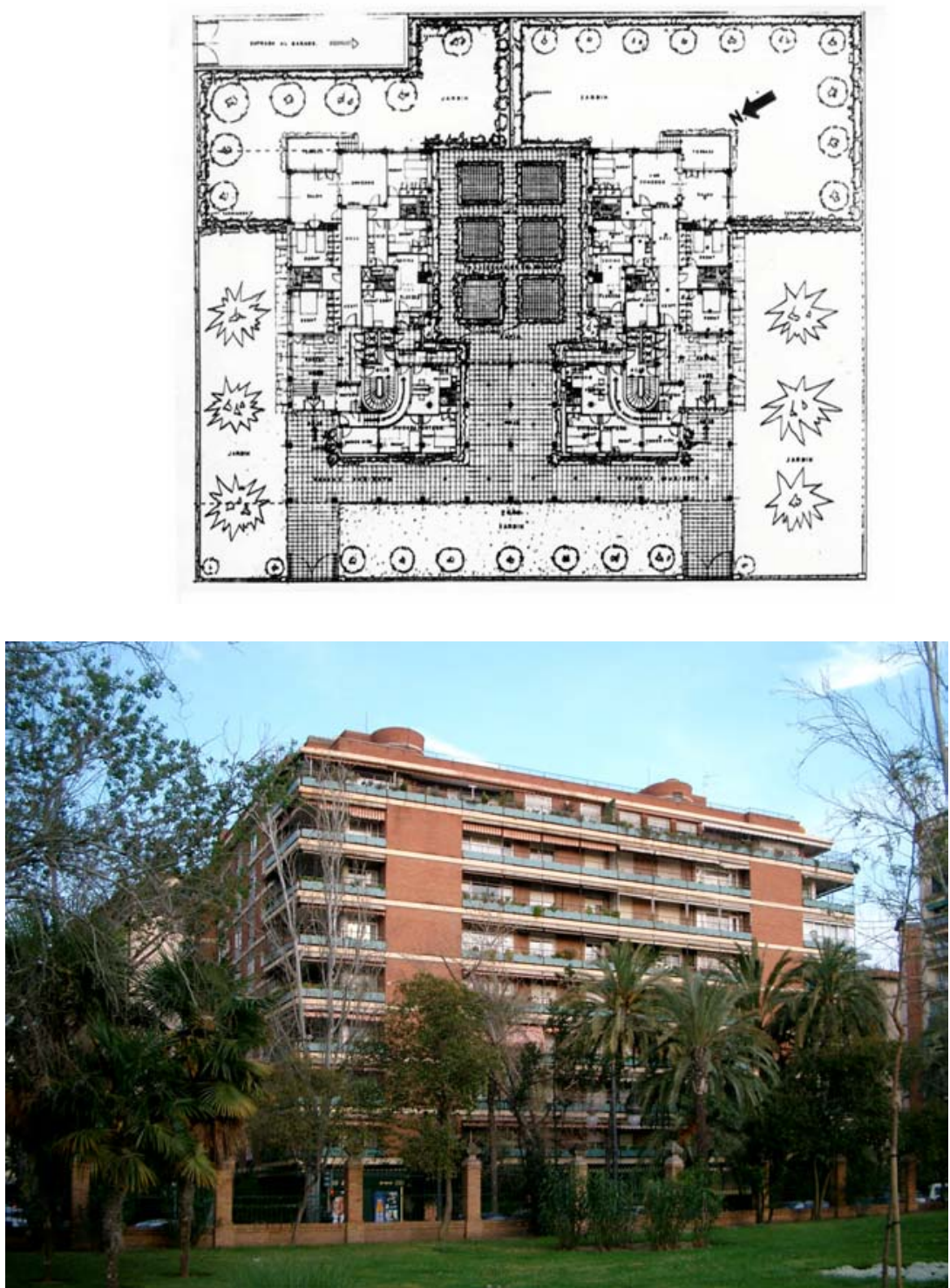

1

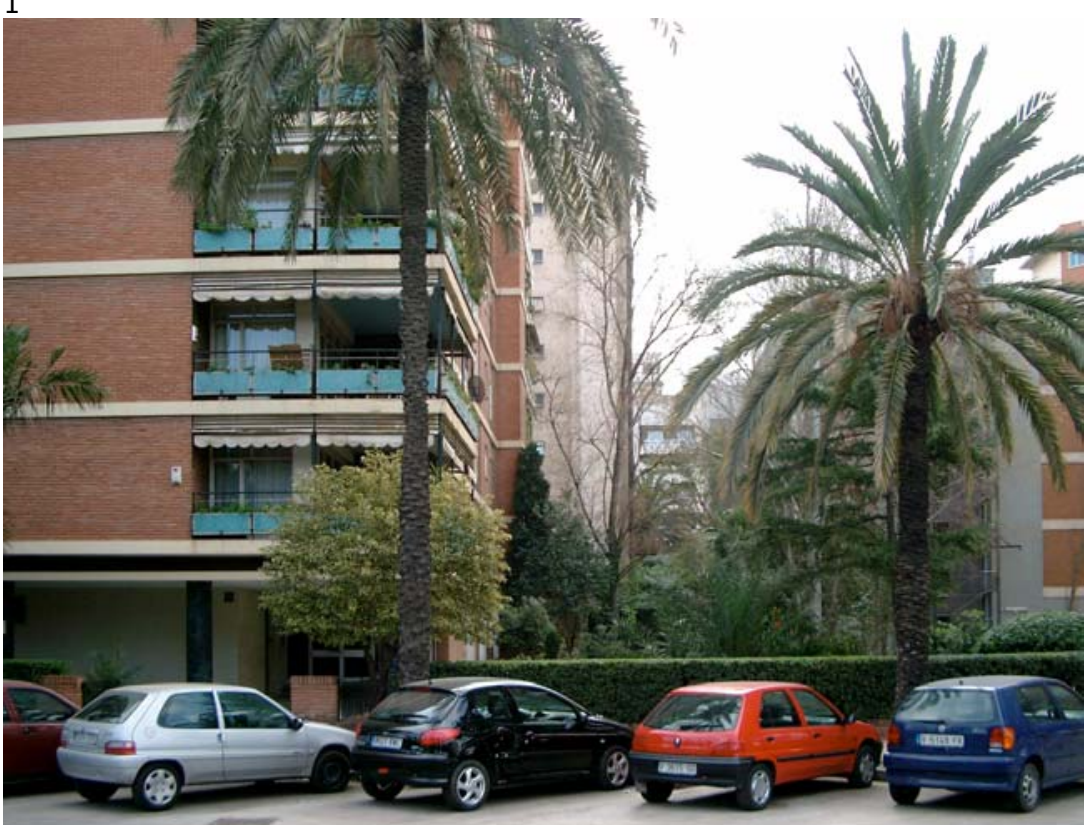

2
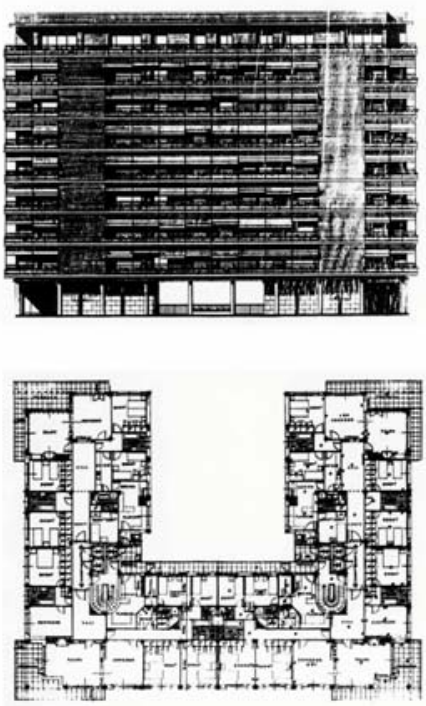

Edificio Elcano. Luís Gutierrez

Soto, 1957-62. Planta baja, planta tipo y alzado a calle Botánico Cavanilles.
1. Edificio Elcano. Vista desde los Jardines de Viveros.

2. Edificio Elcano. Vista desde la calle Botánico Cavanilles. 


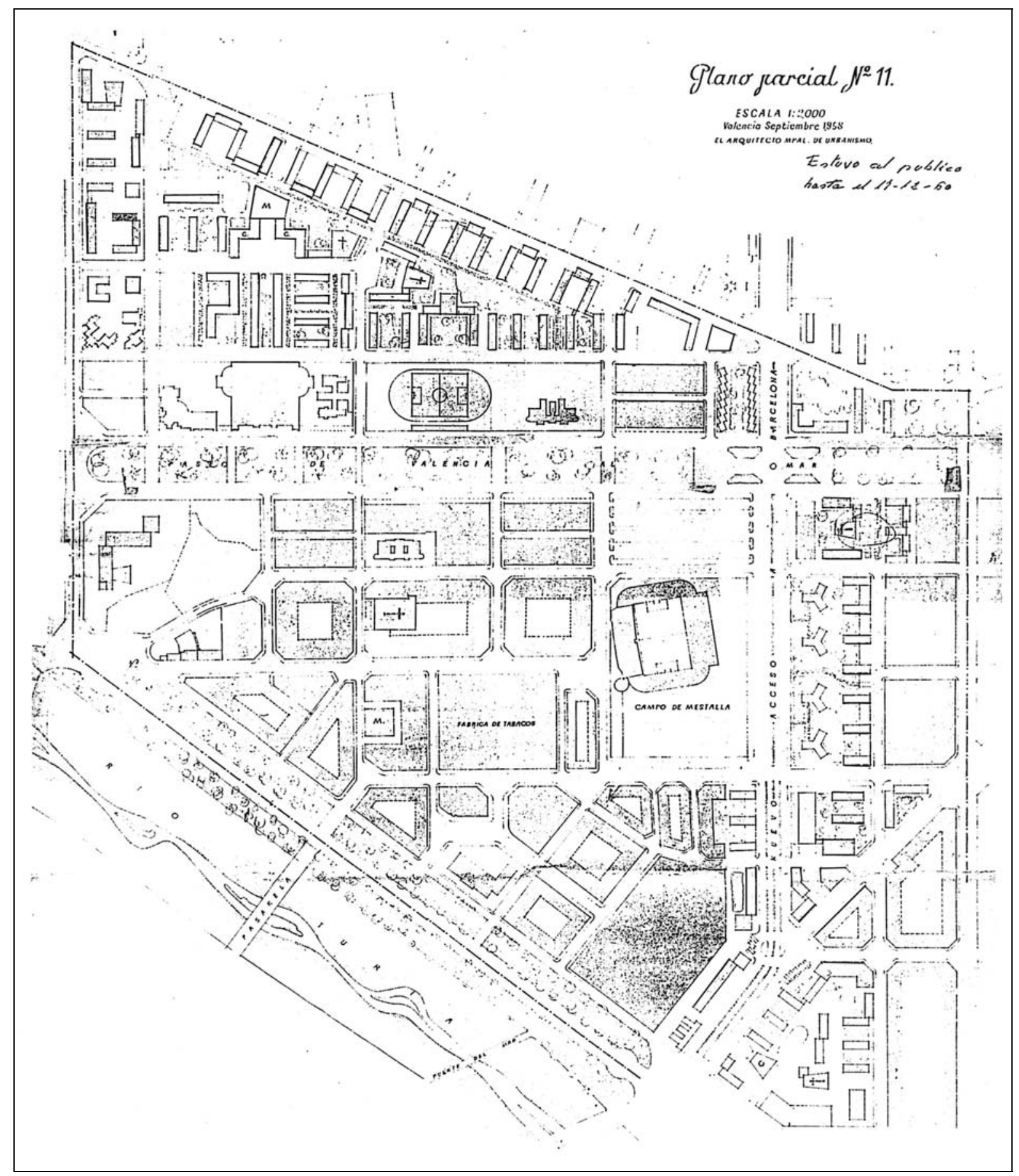

Plan Parcial no 11, 1958.

Ayuntamiento de Valencia. 


\section{El Plan Parcial 11 de 1958.}

El Plan Parcial no 11 de 1960 modifica una versión anterior del mismo fechada en 1958, que no fue aprobada. Esta versión de 1958 tiene un perímetro diferente, ya que el límite este no está en el nuevo acceso de Barcelona, sino que se extiende hasta la Avenida Cardenal Benlloch.

En esta zona, que pasaría finalmente a formar parte del Plan Parcial 12, encontramos ya en el plano de 1958 del PP 11 la serie de torres con planta en $Y$ que acabarán construyéndose en el lateral este del acceso de Barcelona (la actual Avenida de Aragón). Estas torres van acompañadas por bloques lineales equidistantes de directriz este-oeste, enlazados por un cuerpo de edificación norte-sur, solución que será objeto de una sobredensificación extrema en el planeamiento posterior, como veremos más adelante.

El tramo de la Avenida de Aragón comprendido entre la calle Amadeo de Saboya y el cauce del río Turia está flanqueado también a este y oeste por conjuntos de bloques de edificación abierta. La franja del lado oeste, mas estrecha, incluye el edificio Renfe-Aragón de 1950. En el lado este, los bloques rodean un espacio interior destinado a equipamientos.

Además del conjunto de la Avenida de Aragón, el Plano Parcial no 11 de 1958 muestra también una ordenación basada en bloques de edificación abierta en el sector norte, comprendido entre el Paseo al Mar y el Camino de Tránsitos.

Las principales diferencias con respecto al plan de 1952 para ese mismo sector, del que no se conserva ningún elemento en la nueva ordenación, son dos: por una parte, los bloques de edificación abierta adoptan una disposición menos dependiente del viario, y por otra, la definición de los espacios públicos de calles y plazas pierde peso como tema proyectual.

En el plano de 1958 se reflejan los edificios ya construidos o, al menos, proyectados de la manzana comprendida entre Botánico Cavanilles, Juan Martorell, Jaime Roig y Alvaro de Bazán, así como la manzana del grupo de promoción municipal junto al acceso de Barcelona.

Los bloques de edificación abierta, que son todos de dos crujías, adoptan dos disposiciones diferentes: bloques lineales dispuestos en dirección norte-sur o este-oeste, como los que ocupan los frentes de las calles Jaime Roig y Menéndez Pelayo, o bien composiciones de bloques en $\mathrm{U}$ o a redent, como los recayentes al $\mathrm{Ca}$ mino de Tránsitos.

Los edificios de las Facultades de Ciencias y de Medicina, así como el recinto del campo de deportes de la Universidad de Valencia, ocupan dos grandes manzanas del lado norte del Paseo al Mar. Un núcleo de equipamientos propiamente vecinales se sitúa en el centro del triángulo destinado a edificación abierta, con un mercado y comercios abiertos a la calle Álvaro de Bazán, y una iglesia al fondo de esta calle, tras el cruce con la calle Doctor Gómez Ferrer. 
Plan Parcial 11, 1960. Detalle de la zona noreste.

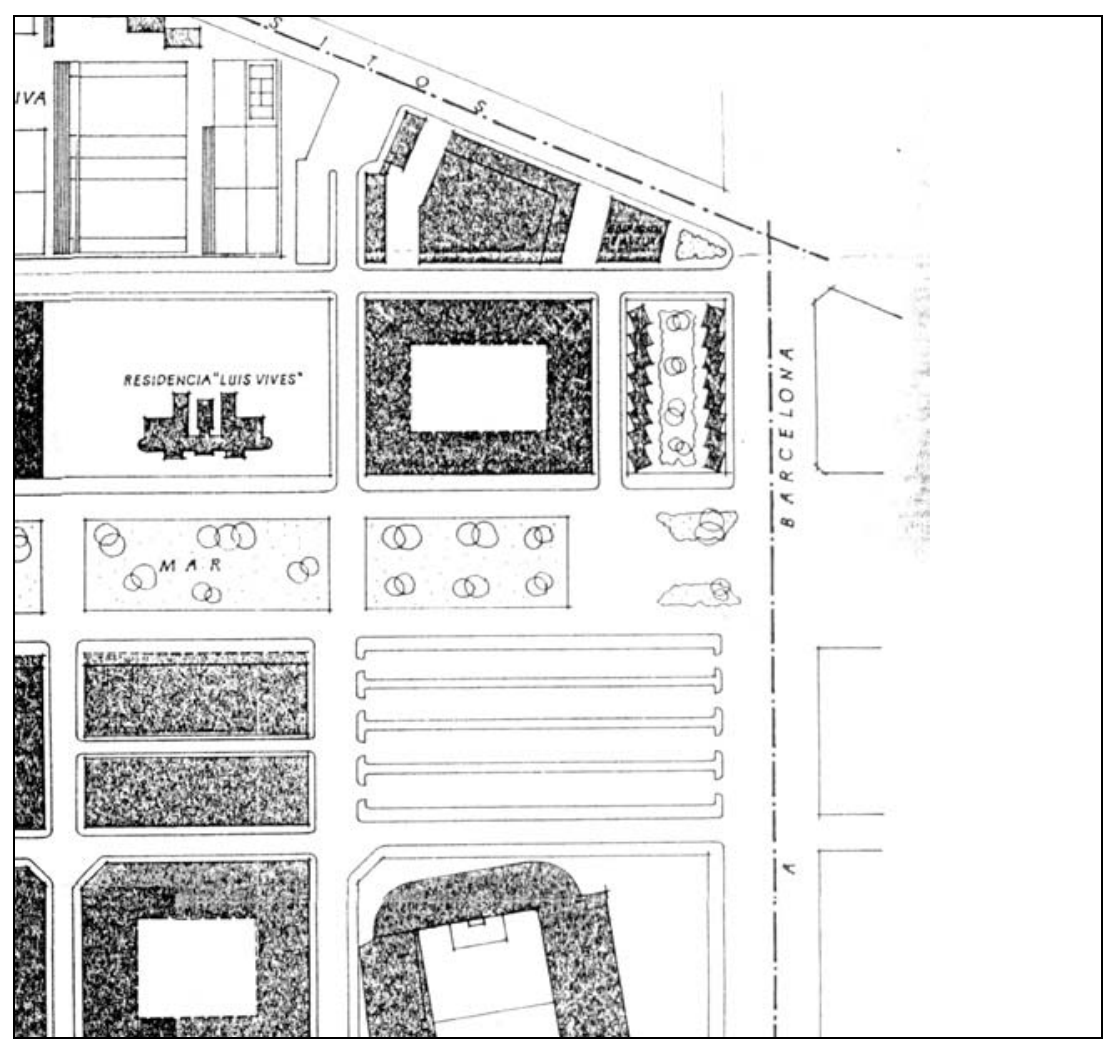

Modificación del Plan Parcial 11, para adaptarlo a la ampliación a $80 \mathrm{~m}$. de la sección del nuevo acceso de Barcelona, 1962. Detalle de la zona noreste.

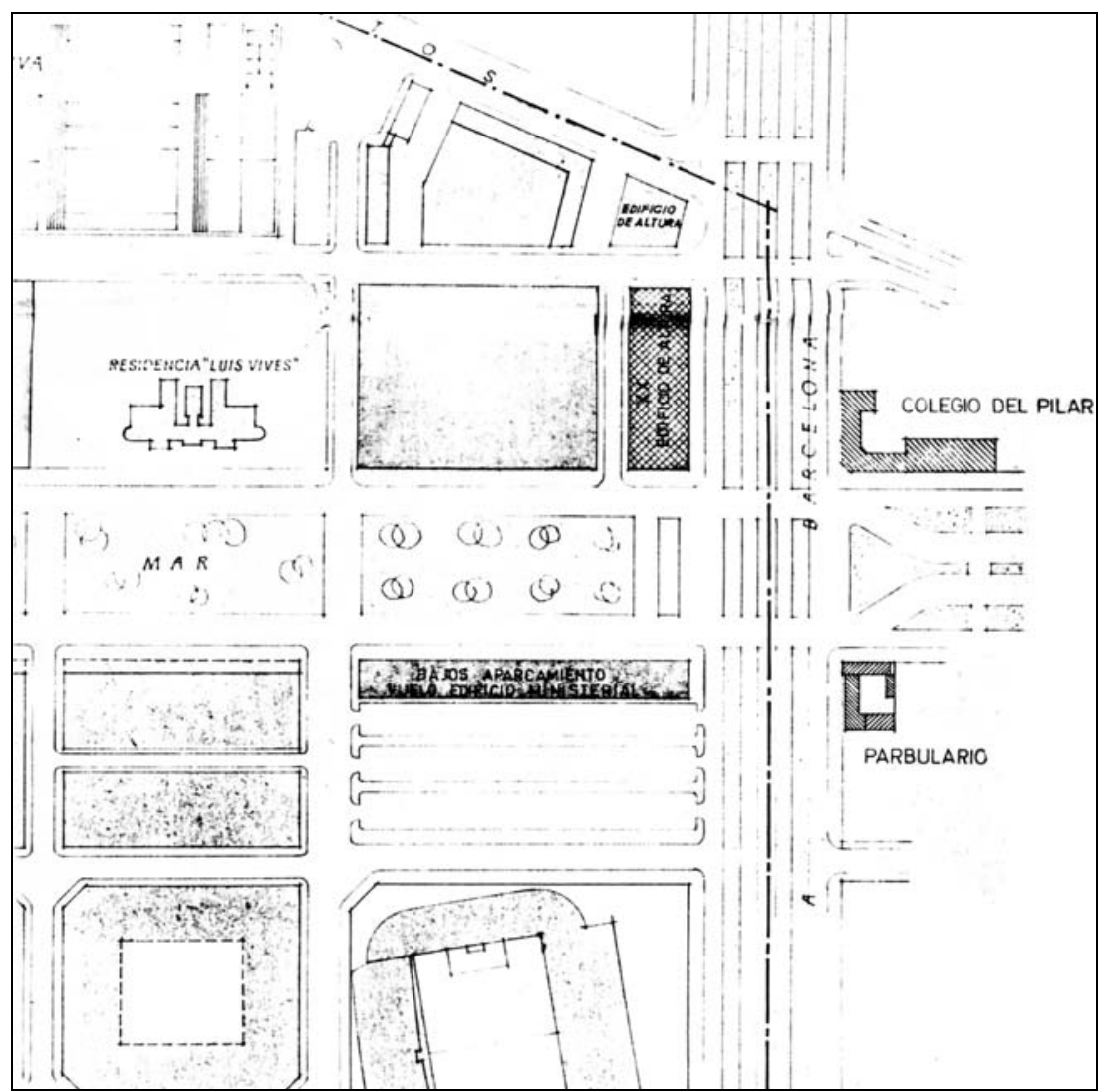




\section{El Plan Parcial 11 de 1960 y sus modificaciones.}

El Plano Parcial no 11, aprobado definitivamente por el Ministerio de la Vivienda el 29 de Diciembre de 1960, es el único planeamiento parcial formalmente en vigor para la zona en los catorce años que transcurren entre 1960 y 1974, ya que la tramitación para la aprobación de la nueva versión del Plan Parcial no 11 , redactada en 1968 , se alarga hasta esa última fecha.

Los objetivos del Plan Parcial de 1960 están claramente expresados en su Memoria:

Así pues, el objeto de este estudio es simplemente ordenar en lo posible todo lo existente y crear, hoy más bien completar por haberse ya iniciado, una zona de edificación abierta al norte del Paseo de Valencia al Mar de carácter residencial propio y muy apto para la clase intelectual, que la concentración de edificios de enseñanza superior señala como habitante probable de la zona. ${ }^{1}$

La versión del PP11 de 1960 introduce dos modificaciones principales con respecto a la de 1958. La primera de ellas es la nueva delimitación del plan, que deja fuera del ámbito ordenado la zona entre el nuevo acceso de Barcelona y la Avenida Cardenal Benlloch. La segunda es el traslado de la zona deportiva universitaria, desde la manzana que ocupaba recayente al Paseo al Mar, que se asigna a la Escuela de Ingenieros Agrónomos, hasta un nuevo recinto más amplio que ocupa todo el espacio trapezoidal limitado por el Camino de Tránsitos y las calles Gascó Oliag, Menéndez Pelayo y Gomez Ferrer, para lo que se suprime toda la edificación prevista en dicho espacio en la versión del plan de 1958.

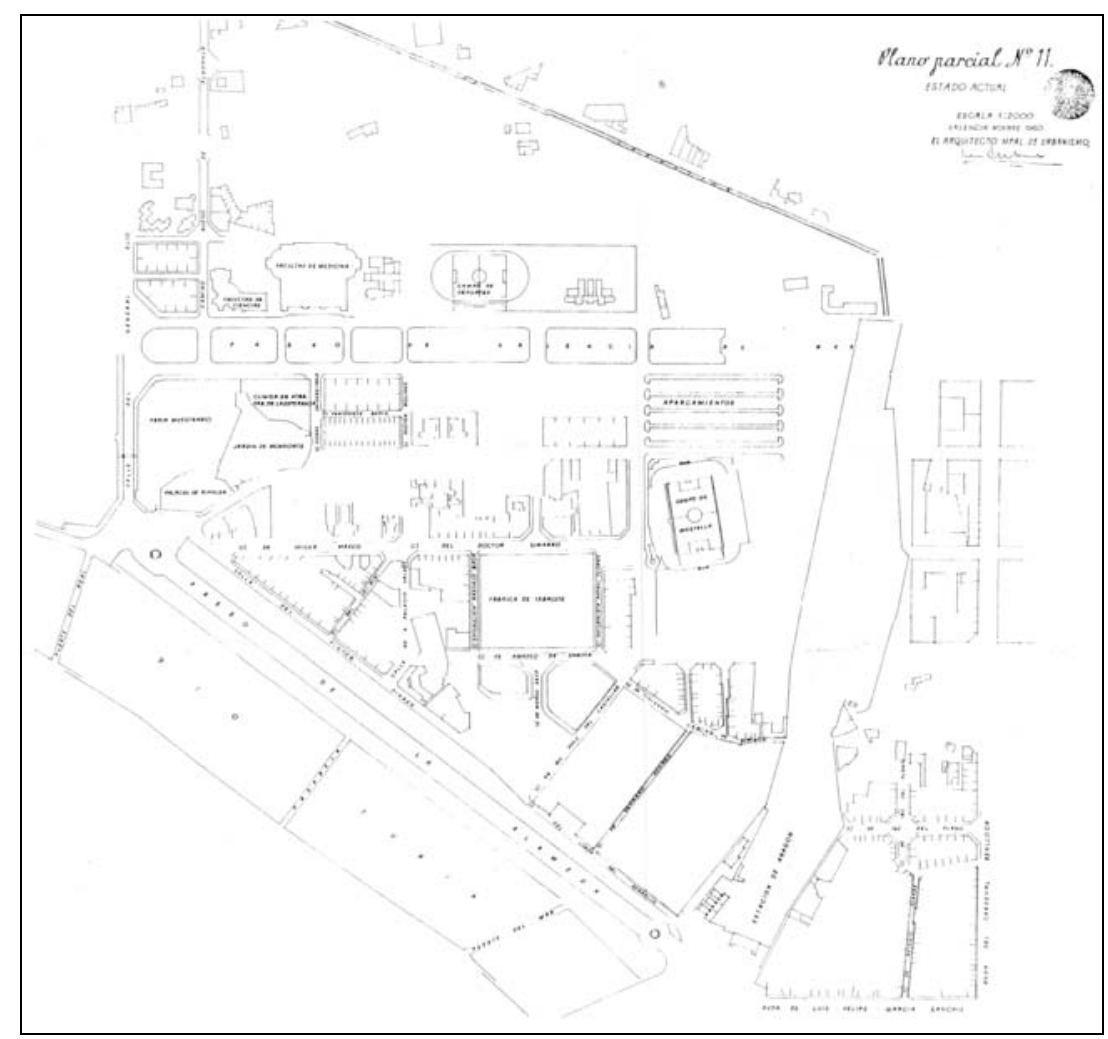

Plan Parcial 11, 1960. Plano de estado actual.

1. Plan Parcial 11, 1960. Memoria. Anexo de Documentos, p. 183. 


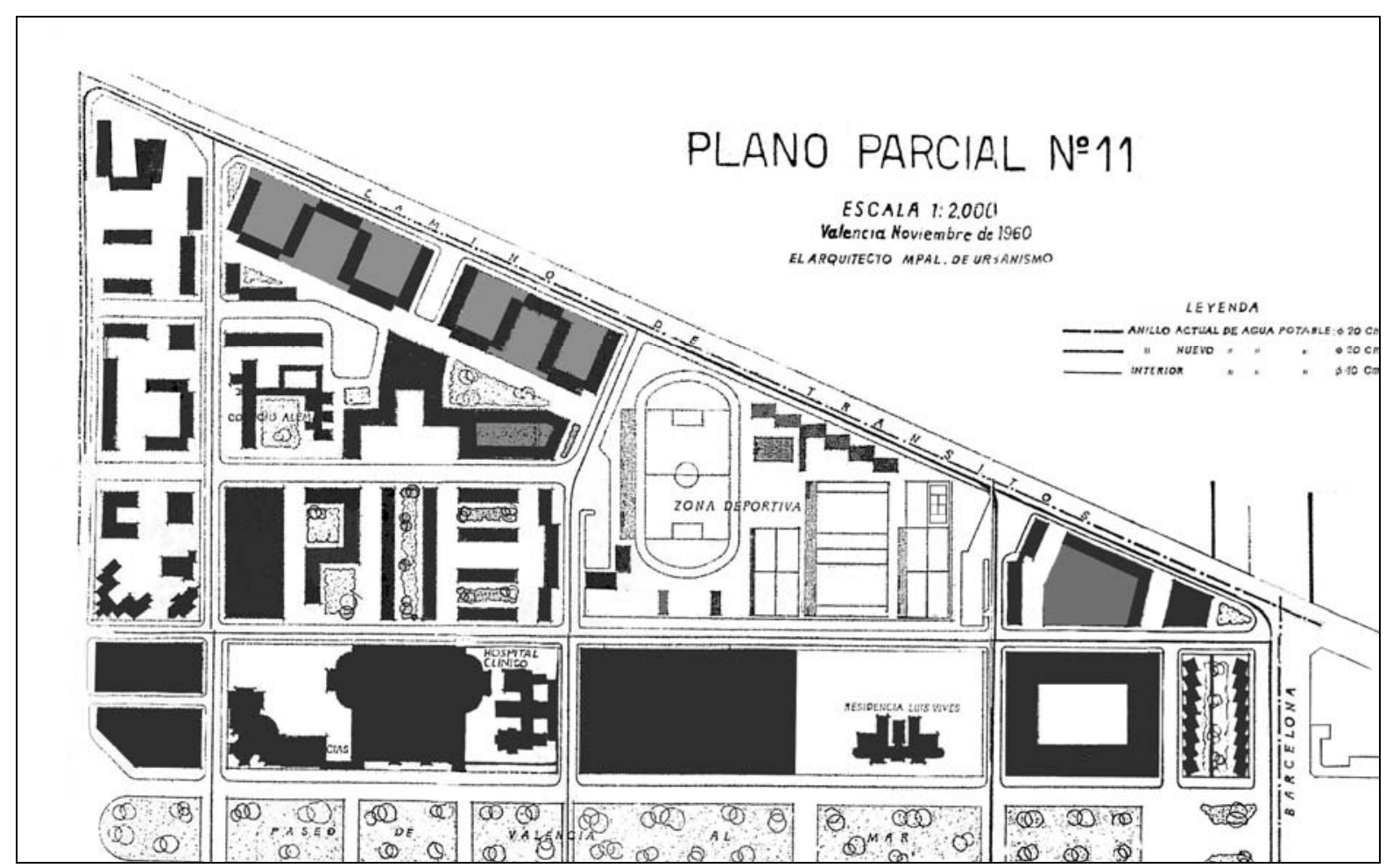

1

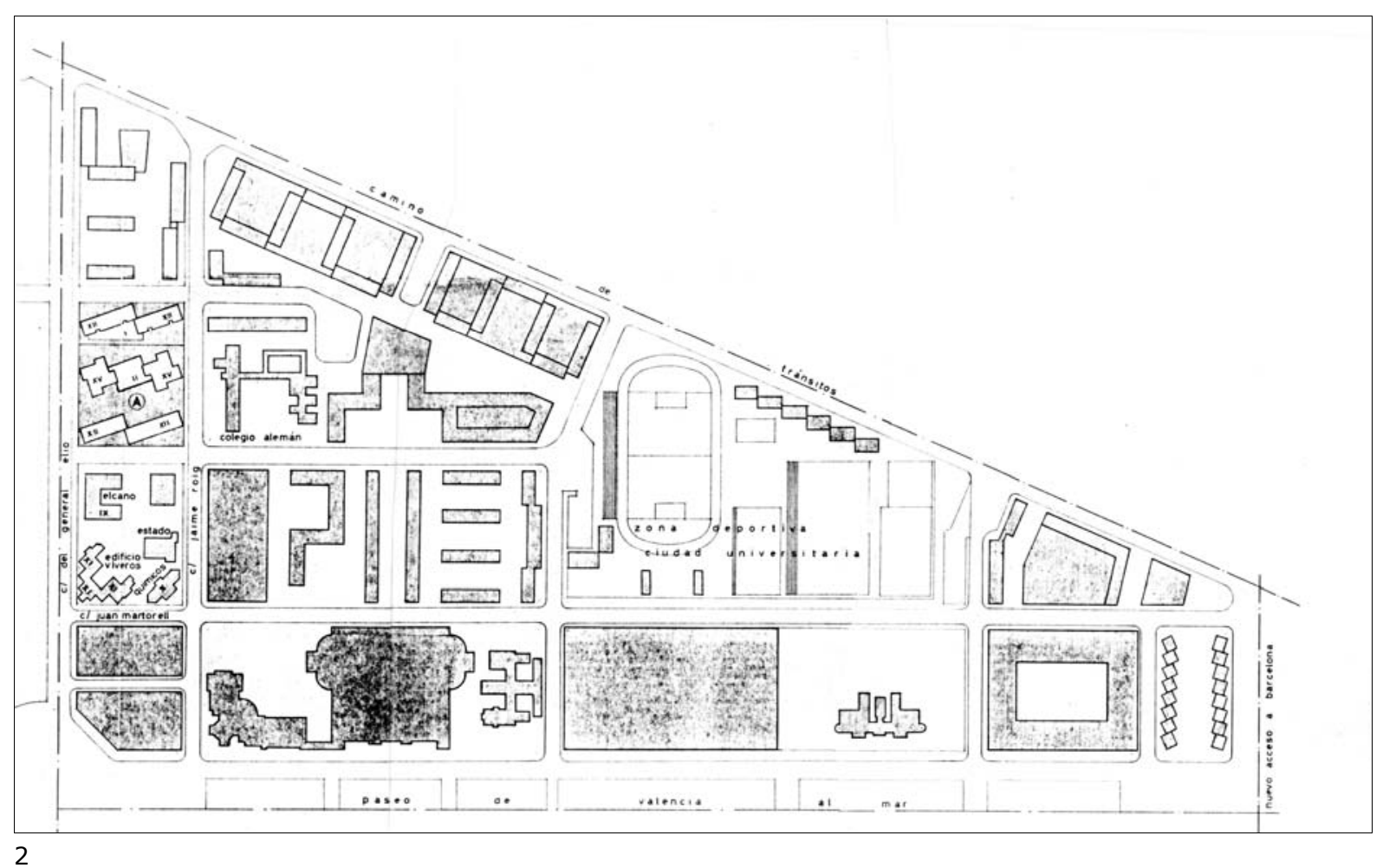

1. Plan Parcial 11, 1960. Plano aprobado por el Ministerio de la Vivienda. Detalle de la zona norte.

2. Plan Parcial 11. Propuesta de modificación de la zona norte, 1962.
La edificación abierta del sector norte queda así subdividida en dos áreas, una mayor al oeste y otra menor al este, separados por la extensa zona deportiva. En el centro del área mayor, comprendida entre las calles Botánico Cavanilles y Doctor Gómez Ferrer, se modifica la disposición de algunos bloques de la calle Jaime Roig para obtener el suelo necesario para el Colegio Alemán, manteniendo a espaldas del mismo el centro comercial. 
El Plan Parcial 11 fue modificado en $1962^{1}$ con objeto de adaptarlo a la ampliación de 50 a $80 \mathrm{~m}$. de la sección viaria del nuevo acceso de Barcelona proyectada por la Jefatura de Obras Públicas. La ampliación se realizó por el lado oeste, respetando las edificaciones existentes o proyectadas del lado este, como los Colegios del Pilar y Guadalaviar. Las edificaciones afectadas eran, en el tramo norte, la manzana de la Cooperativa de Funcionarios Municipales, y en la parte sur los bloques previstos junto a los cuarteles. La Memoria indica que el retiro de las manzanas se procura compensar con un aumento de altura.

Además, en el Plan Parcial modificado se introduce otra variación con respecto al de 1960, que es la de convertir en edificable parte de los aparcamientos situados al norte del Campo de Fútbol de Mestalla, siguiendo la parte baja con su mismo destino de aparcamientos y las plantas altas con destino a edificio ministerial. ${ }^{2}$

Desde el mismo momento de su aprobación definitiva, el 2912-1960, el Plan Parcial 11 estuvo sujeto a modificaciones parciales permanentes derivadas de solicitudes de particulares, hasta el punto de que, prácticamente, cada nueva petición de licencia de obras para un proyecto de edificación implicaba, por regla general, una sustitución de las alineaciones oficiales por otras diferentes.

La primera modificación, aprobada definitivamente por el Ministerio de la Vivienda en 1962, es la realizada en la manzana limitada por las calles Jaime Roig, Bachiller, Botánico Cavanilles y Álvaro de Bazán, contigua a la de los grupos Proviman y Elcano. La edificación prevista en el PP11 para dicha manzana se sustituye por otra diferente compuesta por dos bloques escalonados en los laterales norte y sur y dos torres en el centro de los lados este y oeste.

Esta modificación es la única de las realizadas entre 1960 y 1967 -fecha de la nueva redacción del PP11- que fue aprobada por el Ministerio de la Vivienda.

El siguiente grupo de modificaciones, aprobado por acuerdo del Ayuntamiento Pleno en 1963, está reflejado en el plano adjunto al Informe del Arquitecto Municipal sobre las mismas, que indica que dichas modificaciones "suponen aumento de espacios libres aunque de carácter privado-, y aumento de salubridad amén de estar dotadas de gran brillantez". ${ }^{3}$

Las modificaciones son tres:

1) Se reordena la edificación en la manzana limitada por las calles Jaime Roig, Avenida de Primado Reig, Botánico Cavanilles y Bachiller, en la que se ha edificado la Iglesia de la Orden Carmelita.

2) A petición del Colegio Alemán, se sitúa un campo de deportes anejo al mismo, suprimiendo la edificación comercial prevista en el plan.

3) En la esquina de las calles Jaime Roig y Álvaro de Bazán, parte de la manzana cerrada prevista en el plan se sustituye por bloques aislados que corresponden a los edificios del denominado grupo de Ingenieros.

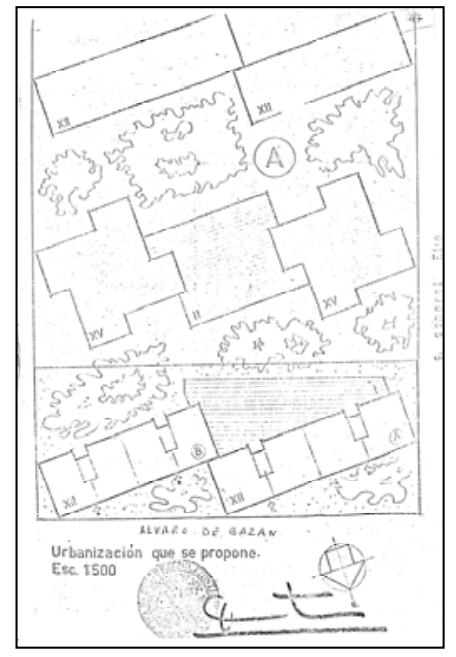

Modificación de alineaciones en la manzana limitada por las calles Jaime Roig, Bachiller, Botánico Cavanilles y Álvaro de Bazán, 1962.

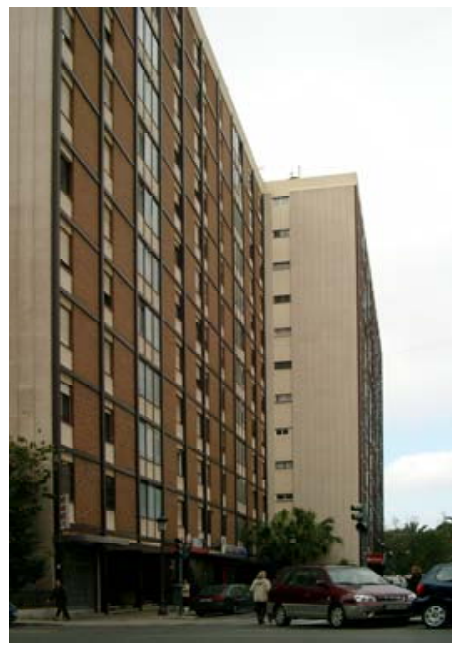

Edificio recayente a la calle Bachiller de la manzana anterior.

1.La modificación del PP11 fue aprobada por el Ministerio de la Vivienda en 1964. Ver Documento 11.1, Anexo de Documentos, p. 189.

2 Como consecuencia del concurso convocado en 1962, en esta parcela se construirán dos edificios gemelos de oficinas. El primero, realizado entre 1965 y 1968 , es el edificio de la Confederación Hidrográfica, del arquitecto Miguel Colomina.

3. Documento 11.2. Informe del Arquitecto Municipal de Urbanismo sobre modificaciones en la zona norte del Plan Parcial 11, 20-7-1963 (Anexo de Documentos, p. 191). 


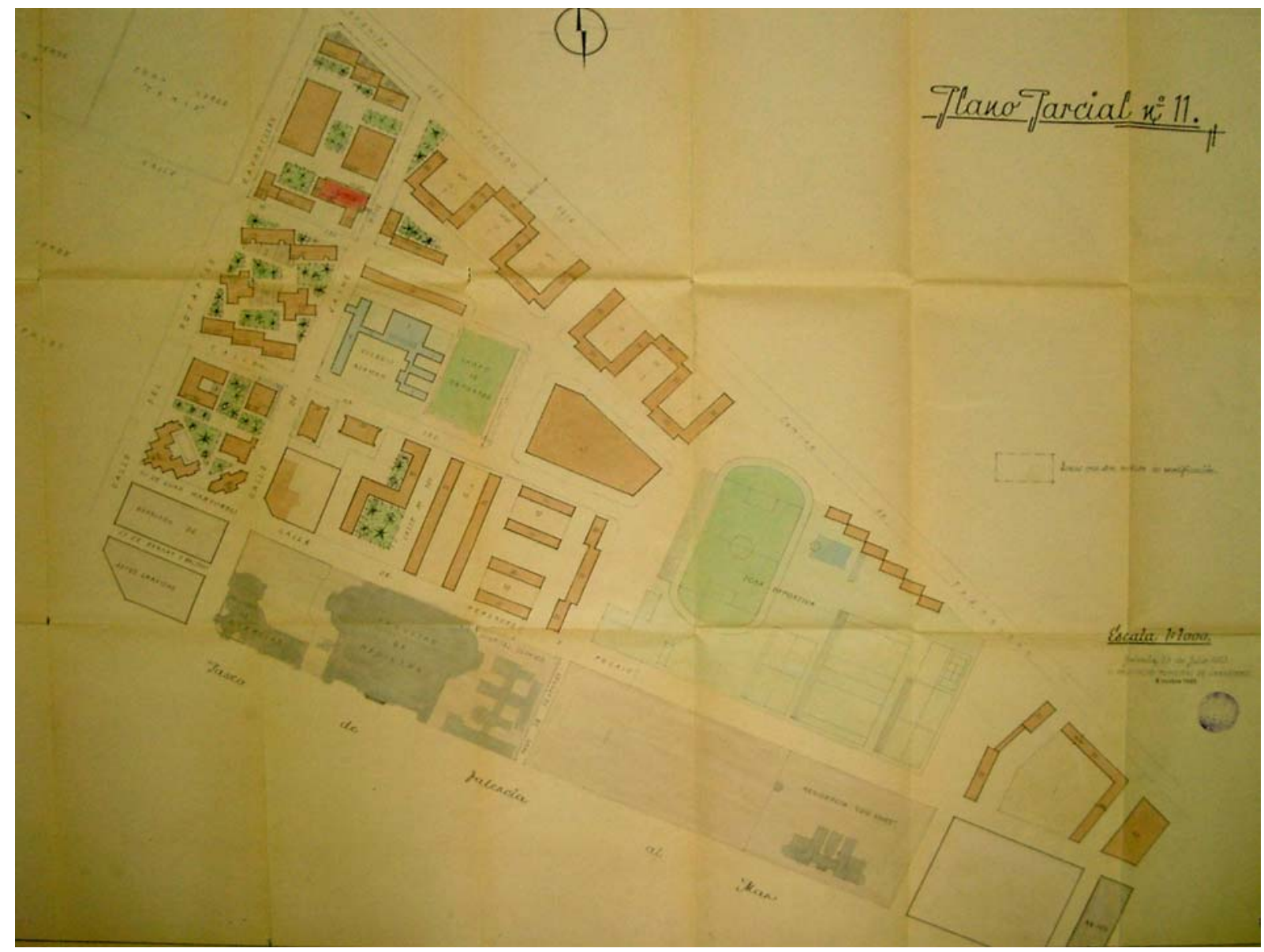

Plan Parcial 11. Modificación de alineaciones de la zona norte, 1963. Plano adjunto al Informe del Arquitecto Municipal.
La primera modificación supone una ocupación mucho mayor del suelo de la manzana. Los espacios intermedios entre los edificios, además, no se destinan a jardines, sino que están atravesados por un vial interior con aparcamientos que penetra en la manzana. En cuanto a la edificación, que en el plan era de bloques lineales de dos crujías, podemos ver que la modificación propuesta sitúa en los lados este y oeste de la manzana unos bloques compactos muy profundos, impropios de un conjunto de edificación abierta.

La modificación relativa al campo de deportes de Colegio Alemán se justifica porque supone un aumento de espacios libres. Aparte de que se trata de un espacio libre privado, este supuesto aumento no es tal, ya que si observamos el plan de 1963, podemos ver que la edificación contigua al colegio del plan original dejaba unos espacios libres abiertos a las calles Álvaro de Bazán y a Bachiller. Estos espacios desaparecen al transformarse esa edificación en una manzana trapezoidal compacta, también impropia en una zona de edificación abierta.

En el plano de 1963, junto a las tres modificaciones mencionadas, aparece otra más que afecta a los bloques lineales situados entre las calles Álvaro de Bazán y Menéndez Pelayo: la supresión de los jardines intermedios entre las parejas de bloques y su sustitución por bajos comerciales.

También podemos observar en el plano de 1963 que las alineaciones aprobadas por el Ministerio de la Vivienda en 1962 para 
la manzana limitada por las calles Jaime Roig, Bachiller, Botánico Cavanilles y Álvaro de Bazán se han modificado en el bloque escalonado del lado sur, donde en lugar de un dentado de dos tramos aparece otro de tres.
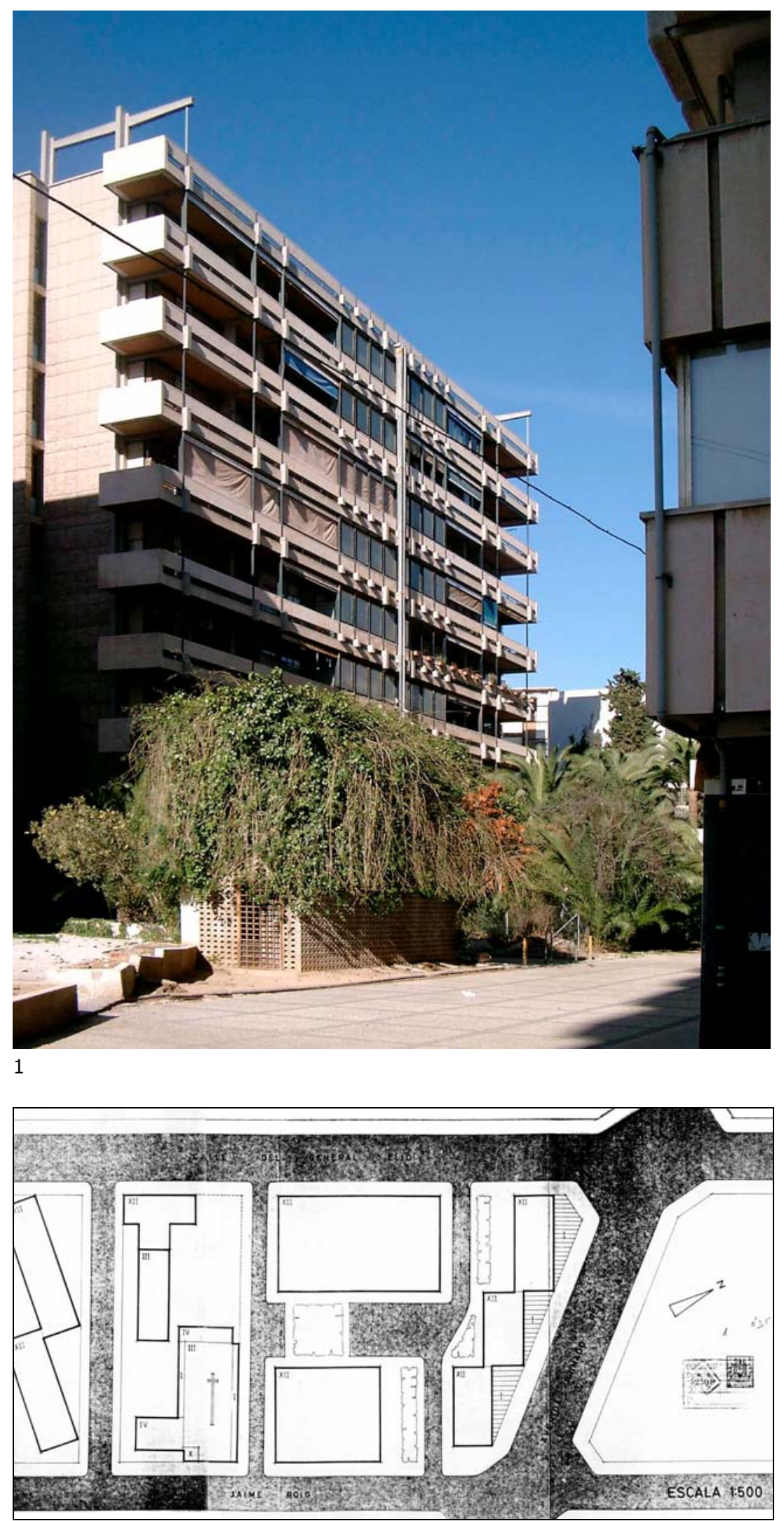

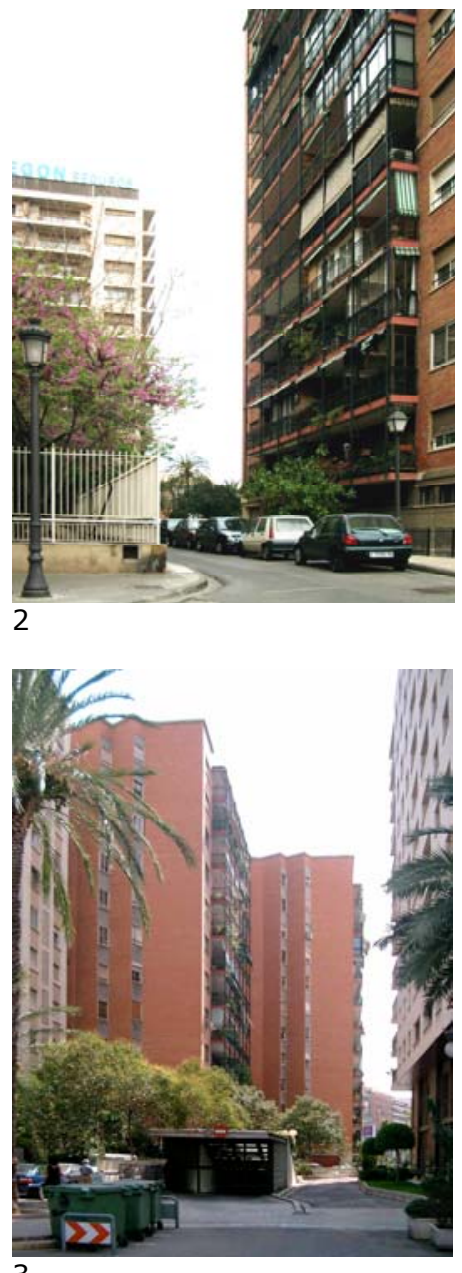

3

1. Grupo Ingenieros. Calle Jaime Roig esquina con calle Alemania.

2. Bloque escalonado en la Plaza Músico Albéniz. Vista hacia el oeste.

2. Bloque escalonado en la Plaza Músico Albéniz. Vista hacia el este

Modificación de alineaciones en la manzana limitada por las calles Jaime Roig, Bachiller, Botánico Cavanilles y Avenida Primado Reig, 1965 


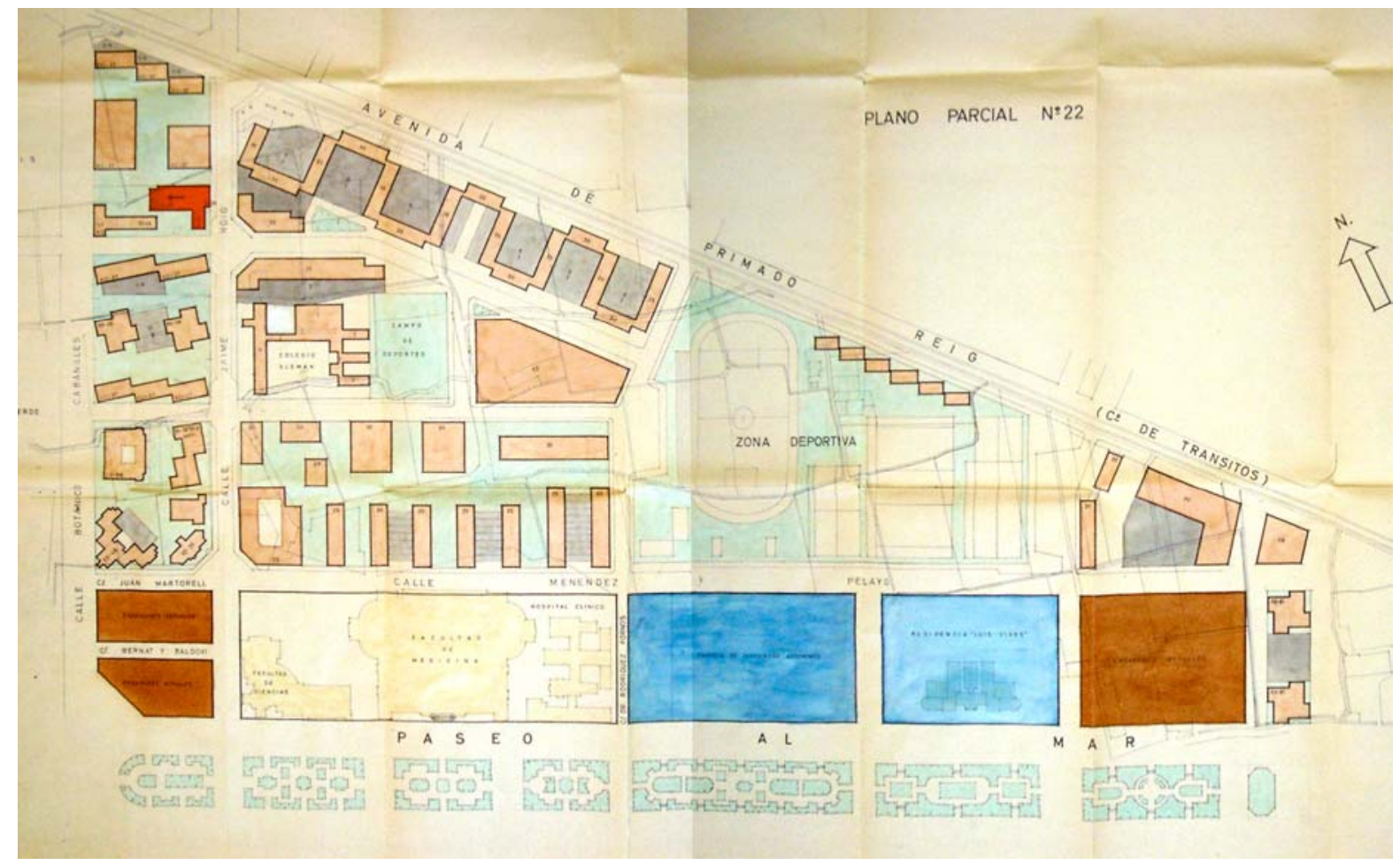

Plan Parcial 11. Propuesta de modificación de la zona norte, 1964.
La siguiente propuesta de modificación de la zona norte del PP11 está fechada en 1964, y en ella se introducen las siguientes modificaciones adicionales:

1) Se modifica completamente la disposición de los bloques prevista en la manzana limitada por las calles Jaime Roig, Álvaro de Bazán, Dr. Gómez Ferrer y Menéndez Pelayo. La nueva ordenación se compone de una serie de bloques ortogonales a esta última calle, un bloque profundo y dos micromanzanas en el lateral norte, así como un pequeño bloque junto a los dos del grupo de Ingenierios. Esta ordenación está planteada a partir del parcelario rústico original, asentando un edificio en cada parcela y evitando así las reparcelaciones.

2) Los dos bloques de dos crujías que flanquean la calle Bachiller, uno en $\mathrm{L}$ y otro lineal junto al Colegio Alemán, se convierten en bloques profundos con chaflanes en el extremo recayente a la calle Jaime Roig y con bajos comerciales que generan medianerías. La imagen resultante es de fragmento de manzana de ensanche más que de edificación abierta.

3) Se completa la manzana de los grupos Proviman, Químicos y Elcano con una torre situada en el solar vacante en la esquina de las calles Jaime Roig y Álvaro de Bazán. Una vez más, las alineaciones que se dibujan modifican las vigentes del plan, y son, claramente, una mera transcripción de un proyecto arquitectónico previo.

4) En la zona este, junto al nuevo acceso de Barcelona, el plano de 1964 aumenta la profundidad edificable del bloque en $\mathrm{L}$ recayente a la Avenida de Primado Reig. Además, el plano transcribe el proyecto definitivo para el grupo de 136 viviendas promovido por la Cooperativa de Funcionarios Municipales. 
Como hemos visto anteriormente, en 1956 se redactó un primer proyecto para un conjunto de 136 viviendas de Renta Limitada destinado a la Cooperativa de Funcionarios del Ayuntamiento en la manzana recayente al Paseo al Mar y al nuevo acceso de Barcelona. El aumento de anchura de este acceso hizo inviable el proyecto al reducir el tamaño del solar, por lo que se planteó un nuevo proyecto, redactado por Camilo Grau Soler en 1963 y terminado en 1969, que mantiene el número de viviendas, concentrándolas en dos torres de XVII plantas $(P B+16)$ unidas en planta baja por locales comerciales y un garaje. Este conjunto será la única actuación del Patronato Municipal de la Vivienda, organismo creado por el Ayuntamiento de Valencia en 1962.

La planta de distribución muestra cuatro cuadrados en turbina, cada uno de los cuales corresponde a una vivienda, enlazados interiormente por el núcleo central de accesos y exteriormente por unas galerías que separan de la calle los espacios vacíos intermedios entre las viviendas. Esta disposición dota a las torres de una esbeltez superior a la que se cabría esperar de la proporción entre su superficie y su altura.

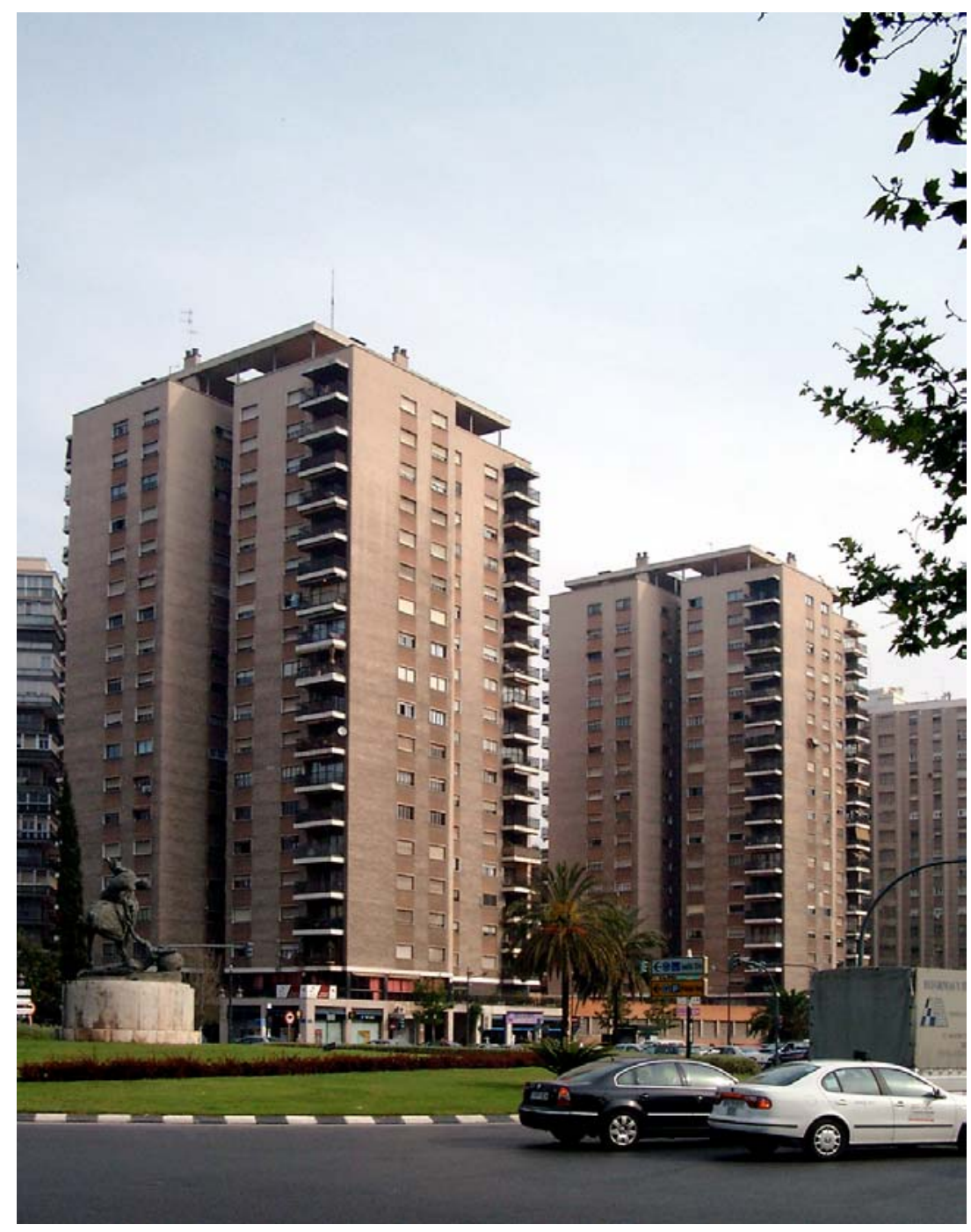

1

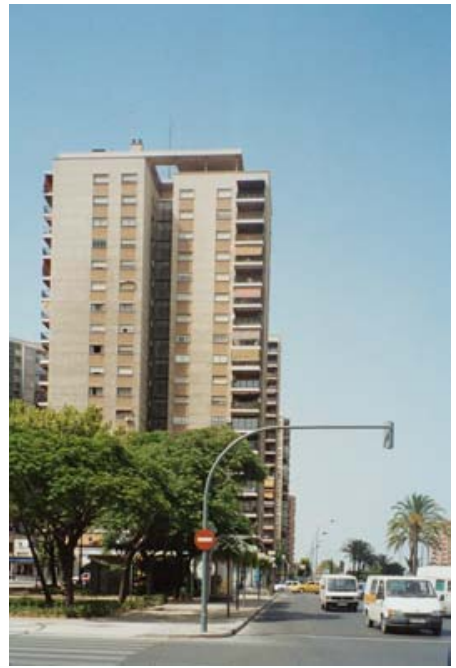

2

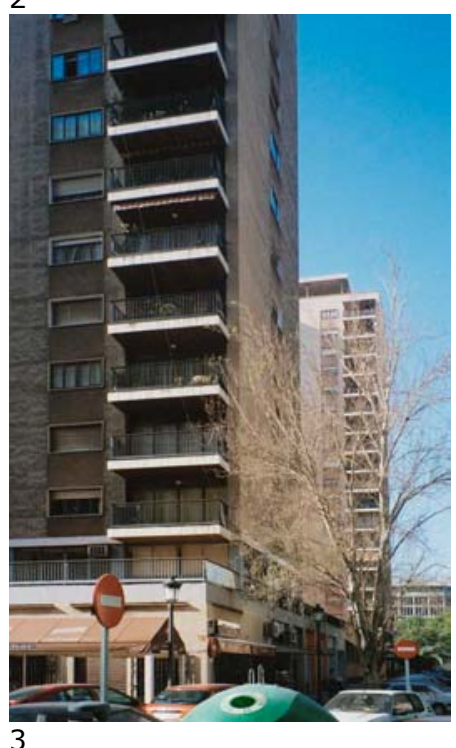

3

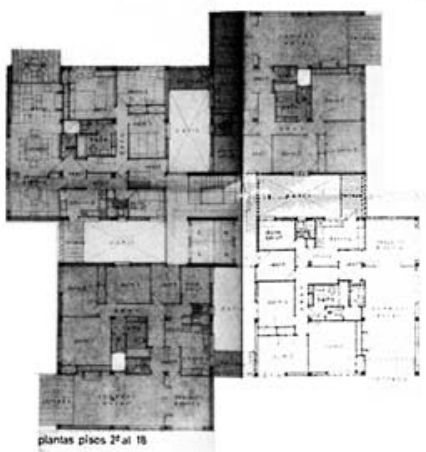

Conjunto de viviendas para funcionarios municipales en la Avenida de Cataluña. C. Grau Soler, 1963.

1, 2, 3: Vistas actuales.

4: Planta tipo 


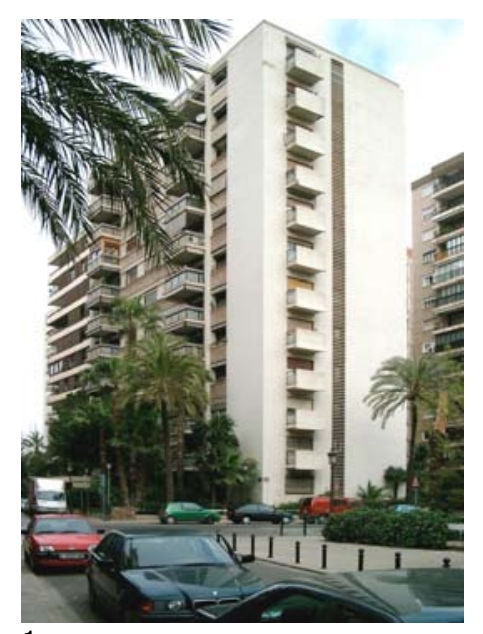

1

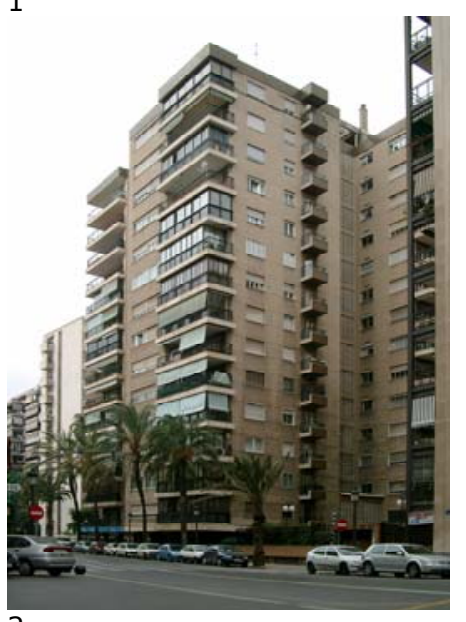

2

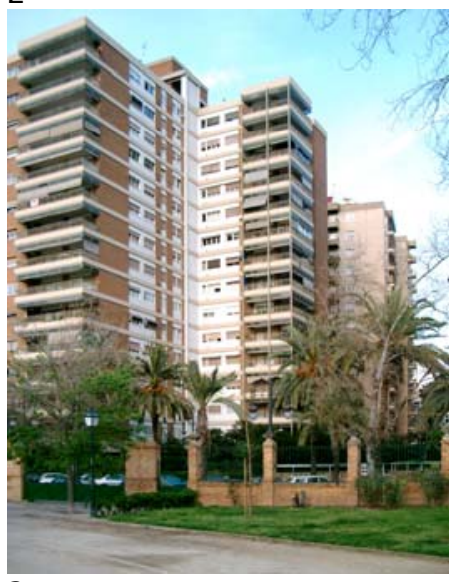

3

Edificios de la manzana limitada por c/ Jaime Roig, Bachiller, Botánico Cavanilles y Álvaro de Bazán

1. Bloque escalonado en c/ Álvaro de Bazán.

2. Torre con planta en $\mathrm{H}$ en c/ Jaime Roig.

3. Torre con planta en $T$ en c/ Botánico Cavanilles.

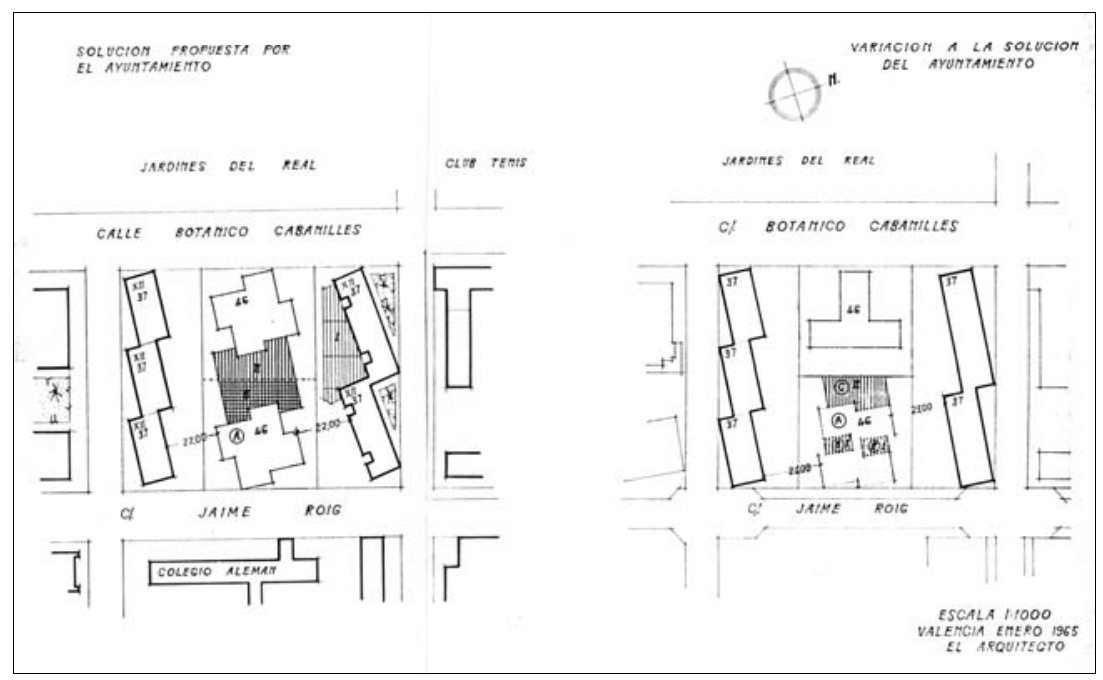

Modificación de líneas en manzana limitada por c/ Jaime Roig, Bachiller, Botánico Cavanilles y Álvaro de Bazán, enero 1965

Con posterioridad a la Propuesta de modificación de la zona norte del Plano Parcial 11 de 1964, las modificaciones parciales de alineaciones continúan sucediéndose sin interrupción en dicha zona, al ritmo de los proyectos arquitectónicos que se redactan para la construcción de edificios. Las más relevantes son las siguientes:

1) En 1965 se propone la modificación de la forma en planta de las dos torres de la manzana limitada por las calles Jaime Roig, Bachiller, Botánico Cavanilles y Álvaro de Bazán, sustituyéndose la planta en aspa de molino por otras en $\mathrm{T}$ y $\mathrm{H}$ que serán las que finalmente se construirán.

2) En el área destinada en el plan a zona deportiva universitaria, se construye el Colegio Mayor Universitario femenino de La Asunción, según alineaciones aprobadas definitivamente por el Ministerio de Vivienda en 30 de Mayo de 1966

3) En la manzana comprendida entre el Paseo al Mar y las calles Ramón Gordillo, Menéndez Pelayo y Gascó Oliag, que figura en el PP11 de 1960 como manzana cerrada calificada como Ensanches Actuales, se proyecta una nueva ordenación, que fue aprobada inicialmente el 3-12-1965 y provisionalmente el 4-03-1966 por el Ayuntamiento, previa exposición al público.

La ordenación de esta manzana deriva de un anteproyecto redactado por el arquitecto Miguel Fisac en abril de 1965 y promovido por Dacosa, Tramesa y otros. La manzana original de ensanche se subdivide en dos, en cada una de las cuales se sitúan 8 torres de planta cuadrada dispuestas en diagonal y unidas por los vértices opuestos, con lo que se origina un contorno escalonado continuo exterior y tres patios interiores. El conjunto no puede calificarse como edificación abierta, sino que es un intento de introducir los tipos del orden abierto en la edificación en manzana cerrada, disponiendo la edificación de modo que tenga una cierta independencia con respecto a las alineaciones perimetrales, lo que permite obtener un perímetro de fachada mayor. 


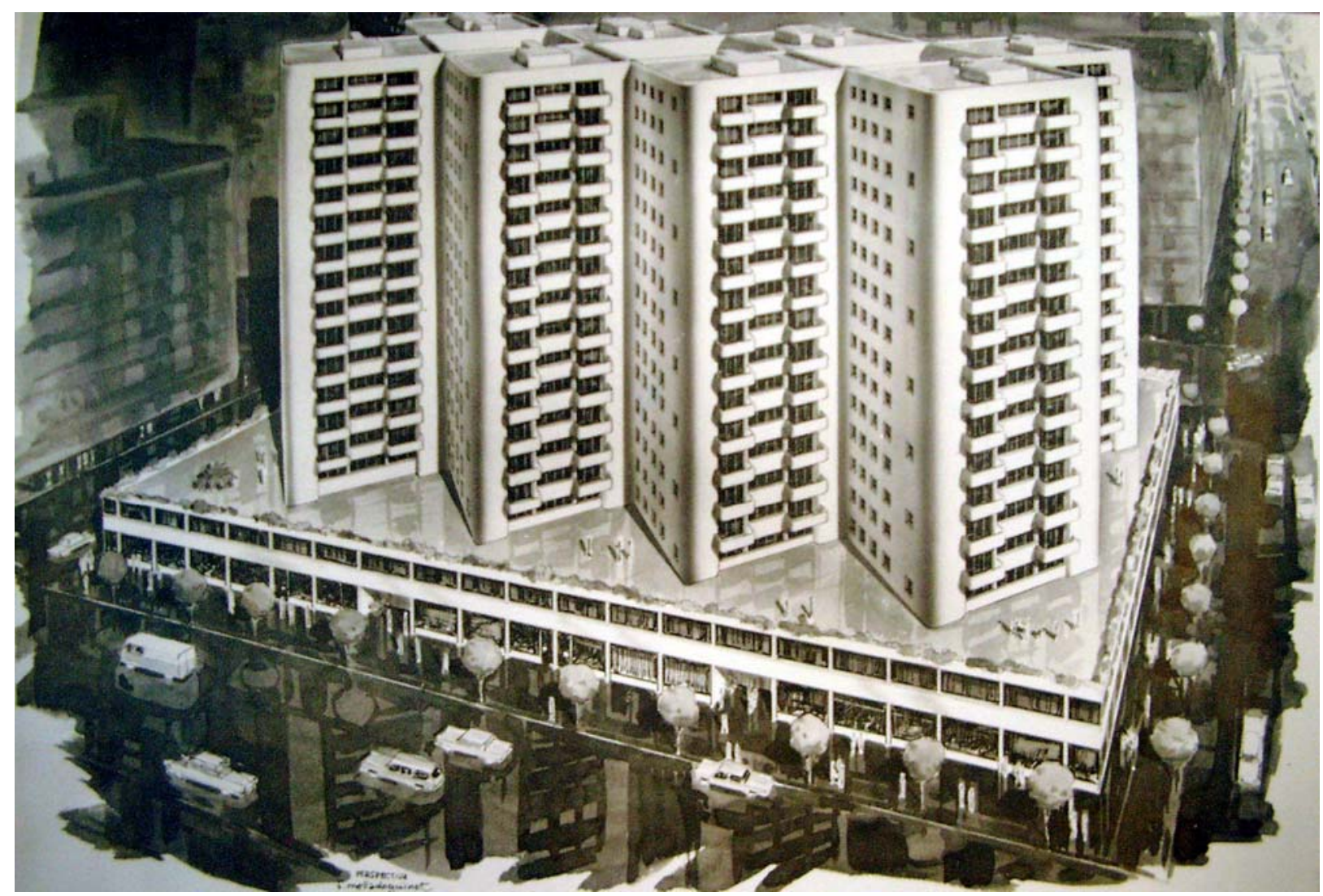

ANTEPROYECTO PARA LA CONSTRUCCION DE 240 VIVIENDAS SUBVENCIONADAS Y 8 LOCALES COMERCIALES PARA DACOSA TCO

VIVIENDA TIPO E PLANTA PRIMERA

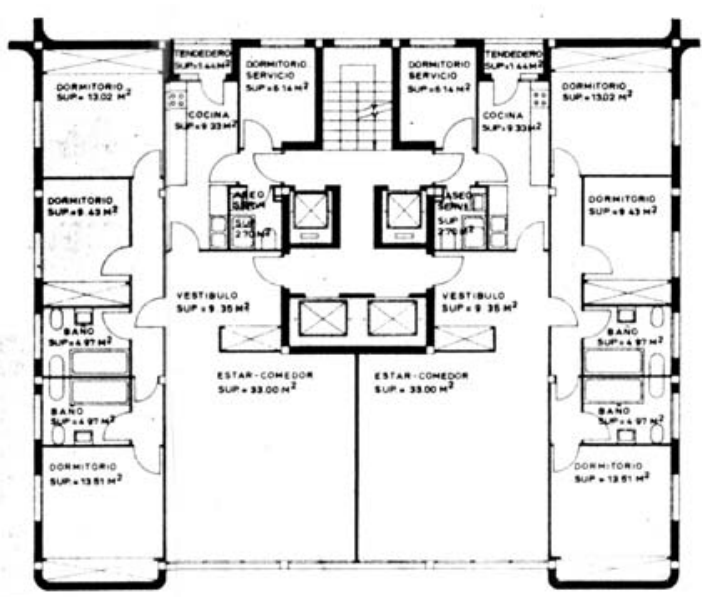

SUP EDFICADA DE URA VIVENOAA $14667 \mathrm{~m}$

ESCAL A 1100

$11575 \mathrm{~m}^{2}$

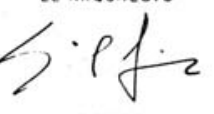

Anteproyecto para la construcción de 240 viviendas subvencionadas y 8 locales comerciales para Dacosa, Tramesa y otros titulares, situado en Paseo de Valencia al Mar y calles en proyecto. Miguel Fisac, Abril 1965. Perspectiva y planta de vivienda tipo B (Archivo de Planeamiento. Ayuntamiento de Valencia). 


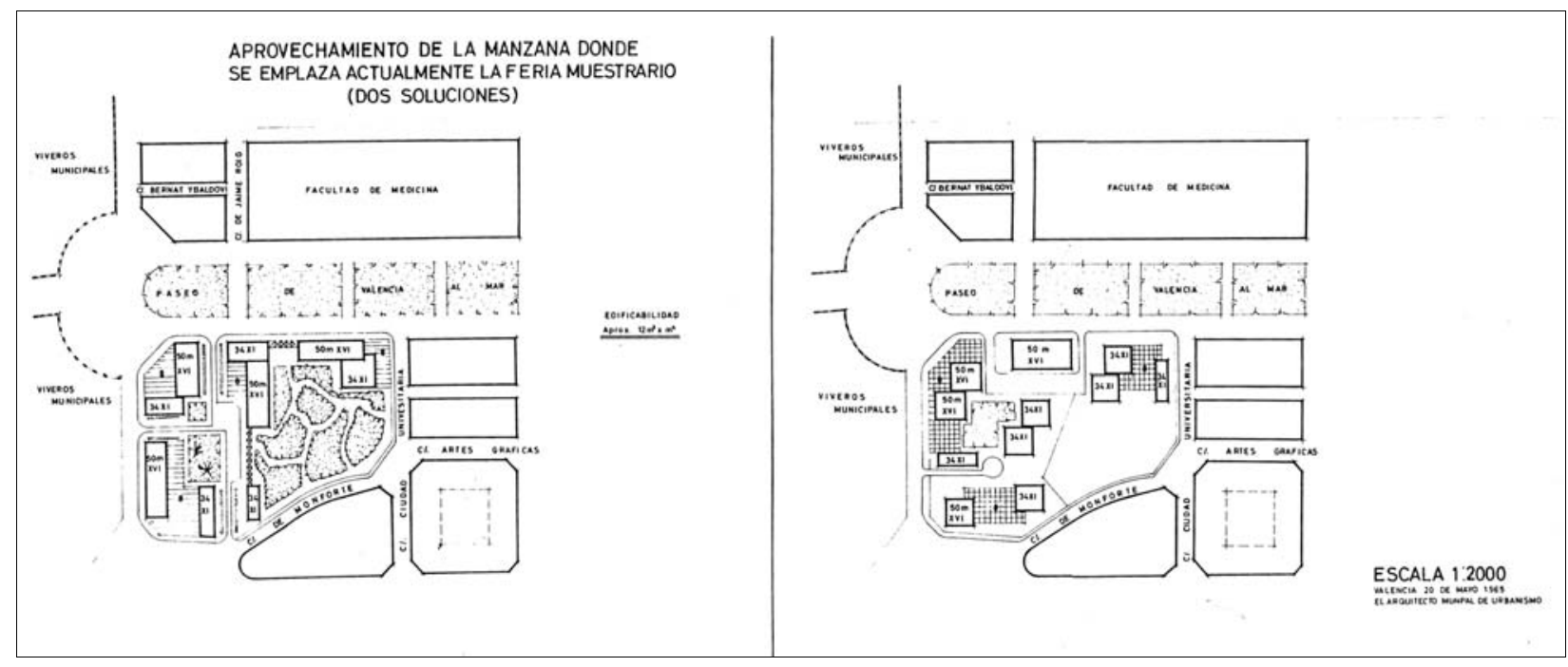

1

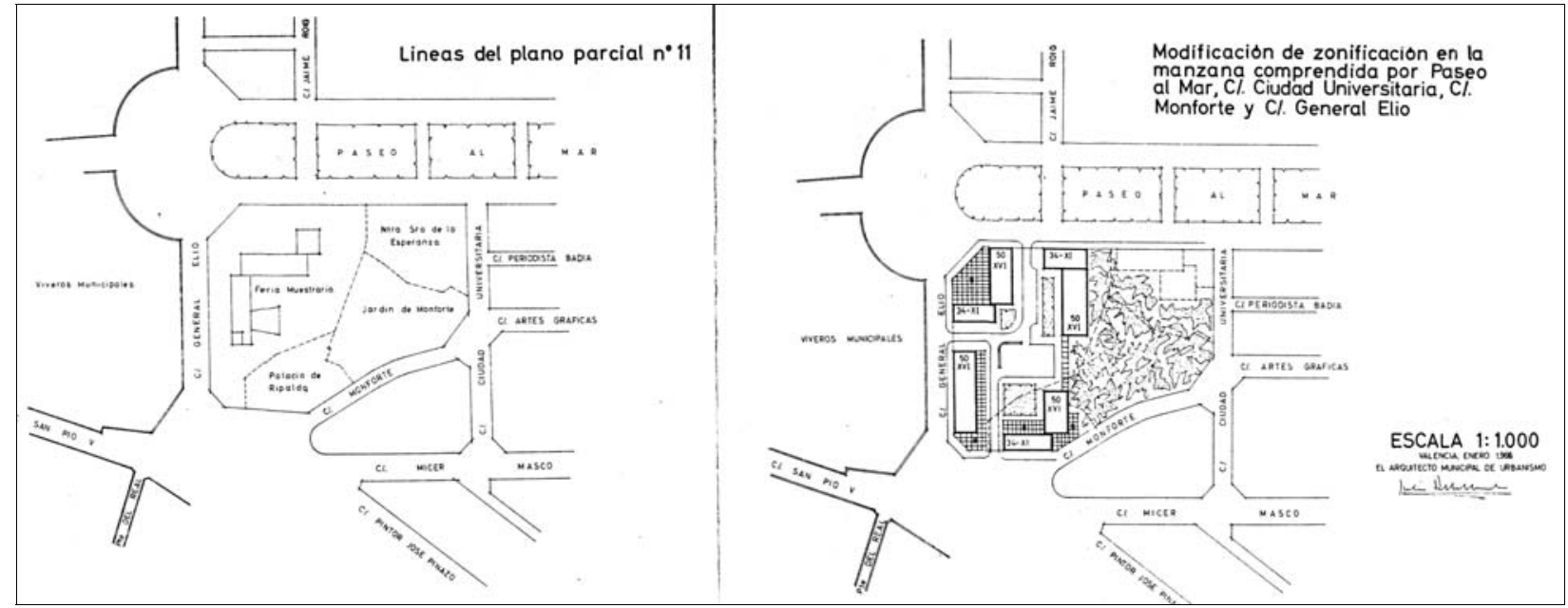

2

Propuestas sucesivas para la edificación del Llano del Real.

1. Modificación zona Llano del Real. Mayo 1965

2. Modificación zona Llano del Real. Enero 1966.

3. Parcelas de la manzana

A. Feria Muestrario

B. Palacio de Ripalda.

D. Jardin de Monforte.

F. Sanatorio de la

Esperanza.

C, E, a. Propiedades de la familia Monforte

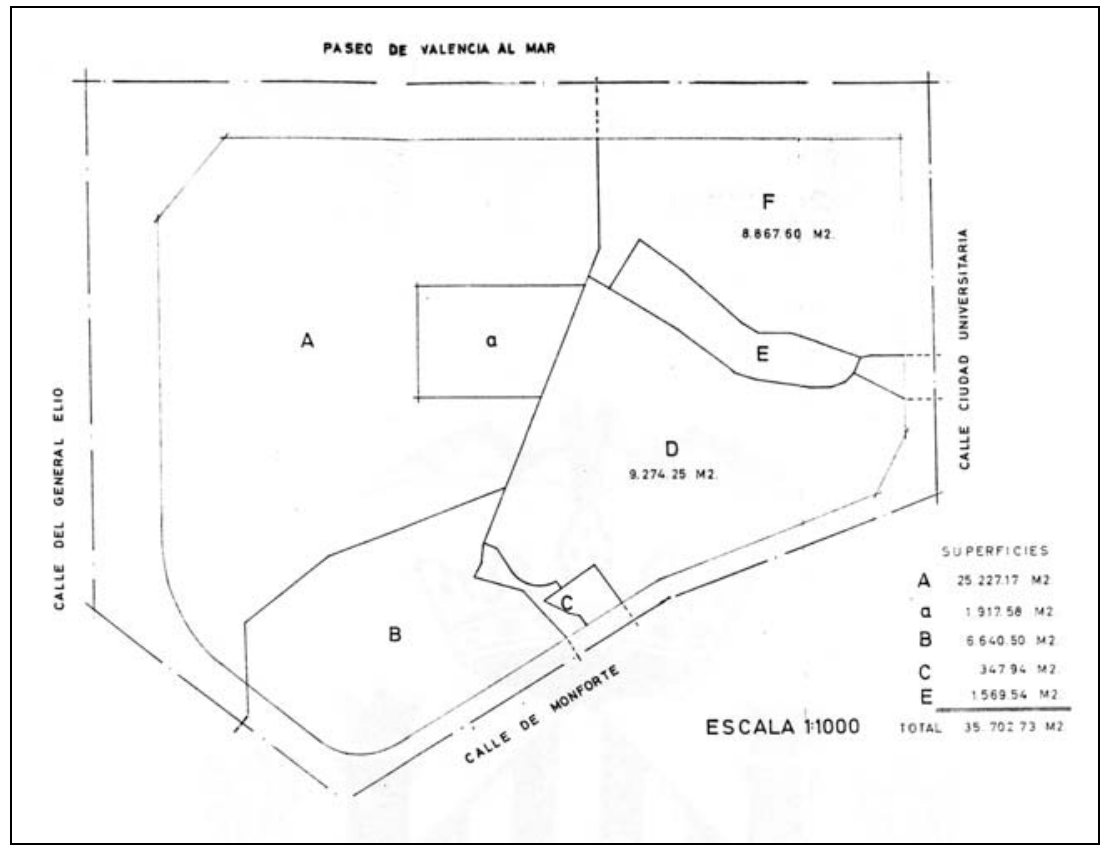




\section{El Llano del Real, 1965-66.}

A las modificaciones introducidas entre 1961 y 1965 en la zona norte del Plan Parcial 11 hay que sumar otra de gran importancia al suroeste, en la zona denominada Llano del Real.

La operación inmobiliaria del Llano del Real, en la zona comprendida entre el Paseo al Mar, General Elio, Monforte y Ciudad Universitaria, se desarrolla a partir de 1965 en los terrenos ocupados por el Palacio de Ripalda y la Feria Muestrario municipal, junto al Jardín de Monforte y el sanatorio de la Esperanza (actual Clínica Quirón).

Esta operación, que en su tiempo fue la promoción residencial de gran lujo más importante de la ciudad, ha sido estudiada con detalle por Sorribes, que la califica como uno de los ejemplos más claros de política urbana supeditada a los intereses inmobiliarios ${ }^{1}$.

Así, la iniciativa de la promoción es pública, y supone, además del derribo del Palacio de Ripalda, la enajenación de los terrenos de la Feria Muestrario, supuestamente por la necesidad de financiar la nueva Feria Muestrario Internacional, y la formulación de un Plan Especial que maximiza las ventajas para la iniciativa privada.

La propuesta municipal de ordenación definitiva, aprobada en 1968, contempla una manzana ordenada mediante cuatro bloques de edificación abierta en torno a una plaza central de jardines y aparcamientos, con una edificabilidad de $10,5 \mathrm{~m} 3 / \mathrm{m} 2$. La edificación abierta en una zona que era en teoría, según el PP 11, de "Ensanche hasta Tránsitos" es posible gracias a la creación de unas calles peatonales, con lo que se obvia el límite de altura de $27 \mathrm{~m}$ fijado para dicha zona en las normas Urbanísticas del Plan General de 1966.

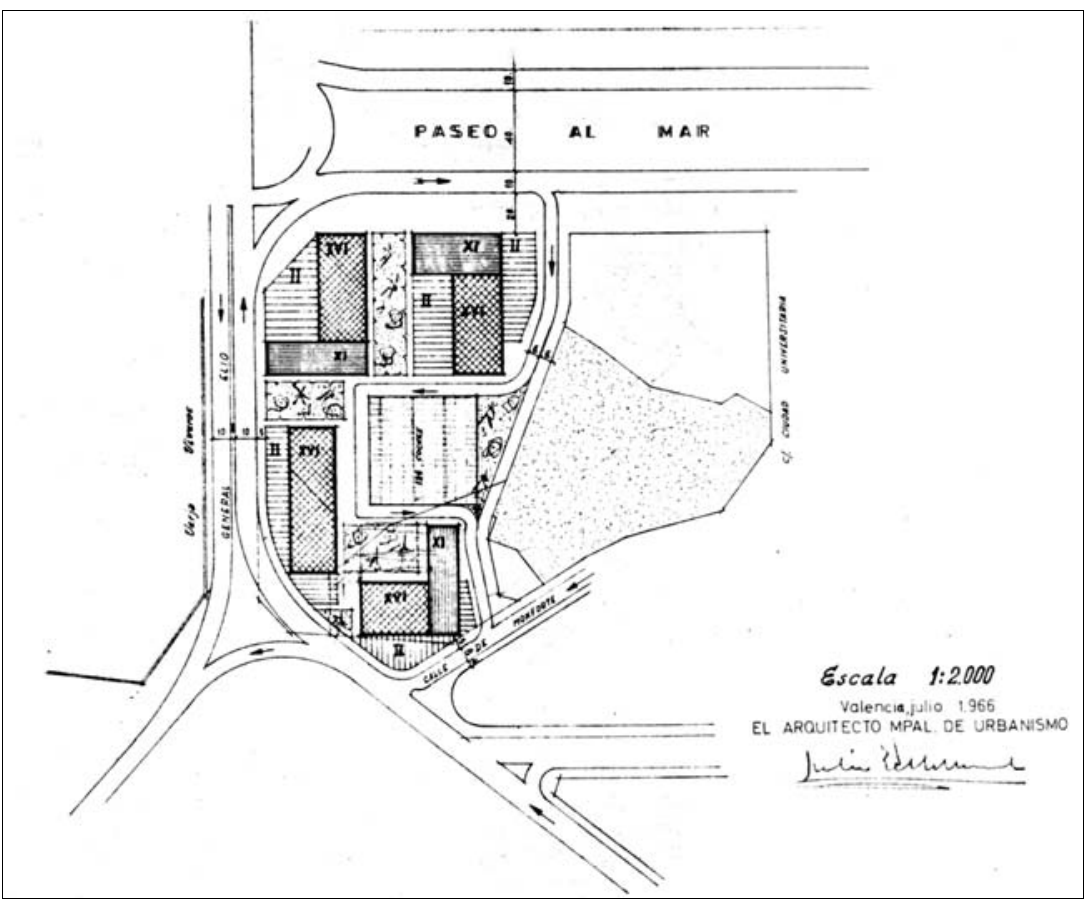

Modificación zona Llano del Real. Julio 1966

1. SORRIBES I MONRABAL, Josep. Desarrollo capitalista y proceso de urbanización en el País Valenciano (1960-75), Institución Alfonso el Magnánimo, Institució Valenciana d'Estudis i Investigació, Valencia, 1985. 


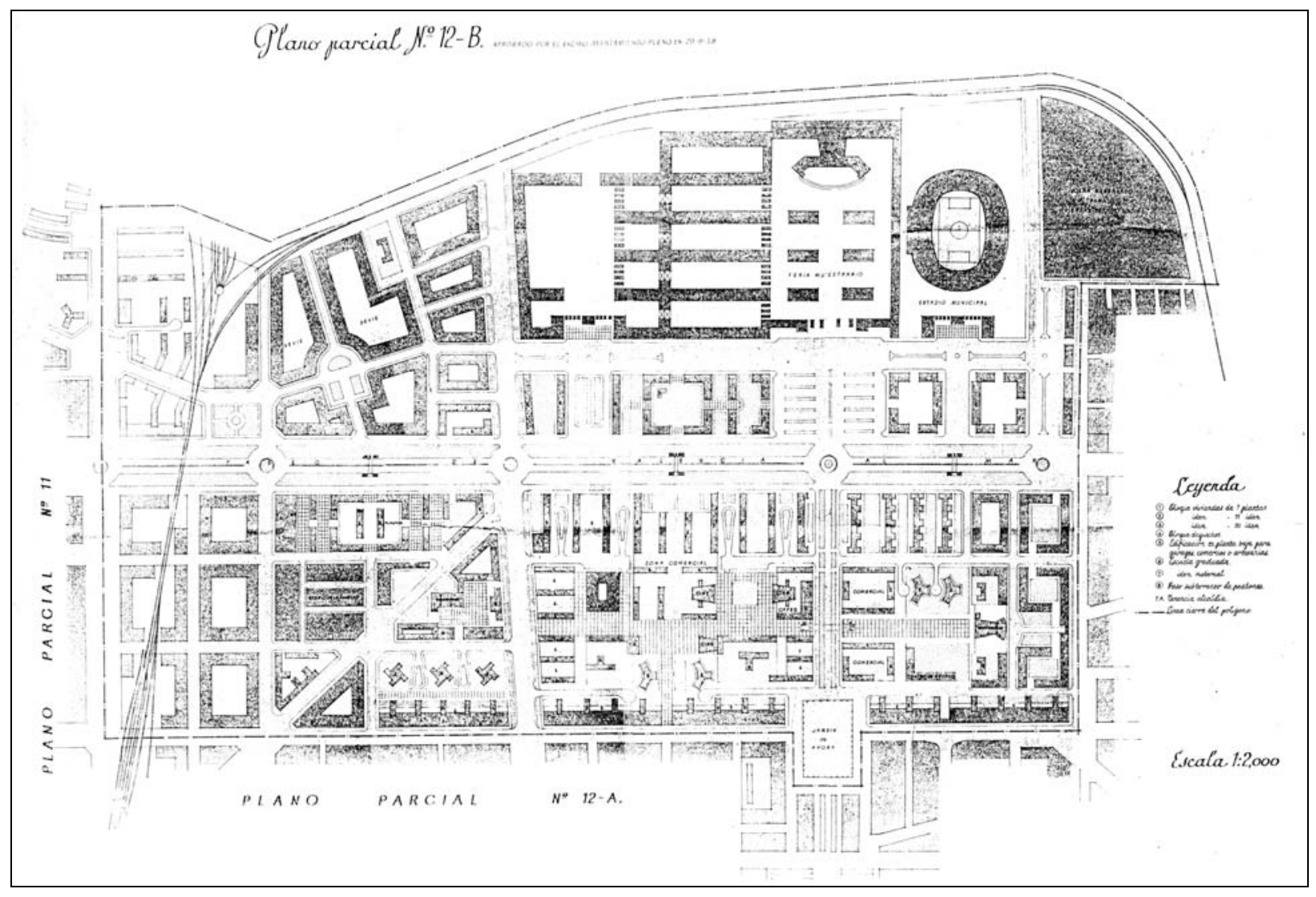

Plan Parcial 12-B, 1958.

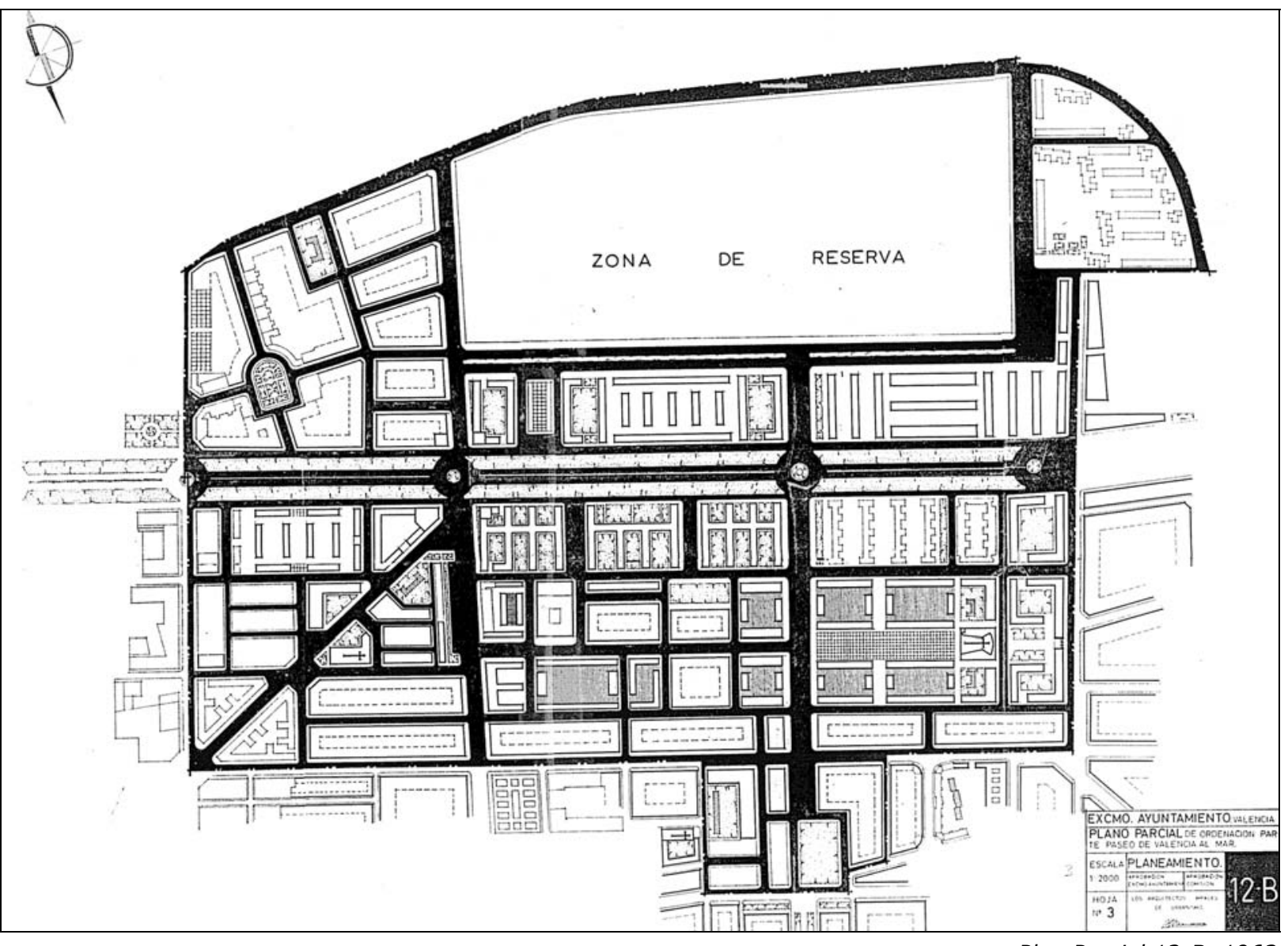

Plan Parcial 12-B, 1963. 


\section{la zona del paseo al mar: de polígono a plano de ALINEACIONES EL PLAN PARCIAL No 12-B (1958/63):}

La primera ordenación de la zona de la prolongación del Paseo de Valencia al Mar es la de 1952. La segunda es la de 1956, denominada "Proyecto de Ejecución del Polígono del Sector de Paseo de Valencia al Mar con destino a la formación de solares para emplazamiento de viviendas de Renta Limitada". En la sección anterior hemos analizado con detalle estas dos primeras ordenaciones. ${ }^{1}$

En 1958 se aprobó por el Excmo. Ayuntamiento el Plano Parcial 12-B, con una ordenación prácticamente igual a la del polígono de 1956. Las únicas diferencias que presenta el plan de 1958 con respecto al de 1956 son las siguientes:

1) La parcela del grupo Virgen del Carmen, del Plan Riada, aparece sombreada como zona de reserva para viviendas subvencionadas

2) El Estadio y la Feria Muestrario invierten su posición, volviendo a la inicial del plan de 1952.

3) La disposición de los bloques se modifica en las manzanas del lado norte del Paseo al Mar, junto al Estadio.

4) Se conserva el jardín y palacete de Ayora, modificando el diseño del cruce entre las actuales calles de Justo y Pastor y Músico Ginés.

El nuevo plan parcial para la zona, denominado Plano Parcial 12-B, se redacta en 1963. La Memoria del mismo señala que la nueva redacción del plan se debe al hecho de que no se espera una intervención pública para el desarrollo de la zona, lo que hace necesario modificar las previsiones del plan de 1958, que "dejaba un exceso de zonas de destino fijo en relación con el carácter actual que es el de plano de alineaciones, destinado a la ejecución por particulares." 2

A ello se añade, como justificación de la nueva ordenación, la necesidad de respetar edificaciones realizadas y la supresión del proyecto de ferrocarril subterráneo que había de atravesar la zona de norte a sur, a lo largo de las actuales calles de Manuel Candela y Ramón Llull.

En el plano de estado actual del Plano Parcial 12-B de 1963, podemos ver que se reflejan las edificaciones ya construidas del grupo Virgen del Carmen, así como la de la manzana de la segunda fase del conjunto de la Isla Perdida, además de algunos fragmentos de bloques lineales en la parte oeste.

El Plan Parcial 12-B de 1963 supone, como veremos, un retroceso evidente con respecto a las anteriores propuestas de ordenación para la misma zona, tanto en lo referente al viario como a la edificación y al adecuado equilibrio entre equipamientos, espacios libres y viviendas: descartada la iniciativa pública, el propio plan asumirá los objetivos de la promoción privada en cuanto a aprovechamiento máximo de los terrenos.

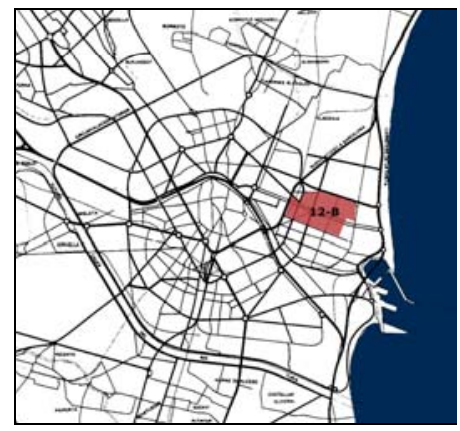

Plan Parcial 12-B. Localización
1. Ver Sección I, pp. 70-73 y 108111.

2. Plan Parcial No $12 \mathrm{~B}, 1963, \mathrm{Me}-$ moria. Anexo de Documentos, pp 203-204. El eufemismo "exceso de zonas con destino fijo" puede traducirse como "exceso de equipamientos". 
Plano Parcial 12-B (1963). Plano parcelario.

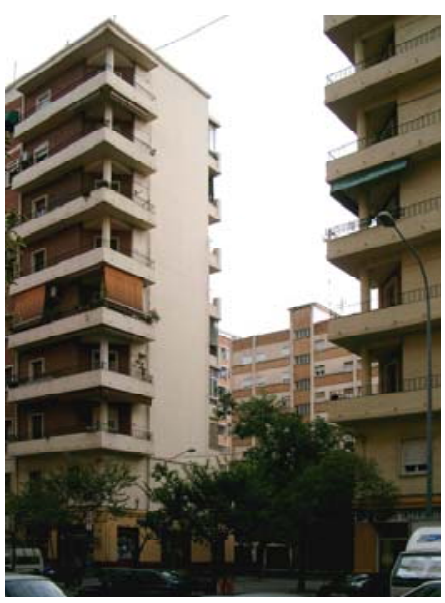

Bloques en la calle Amistat. Vista hacia el este.

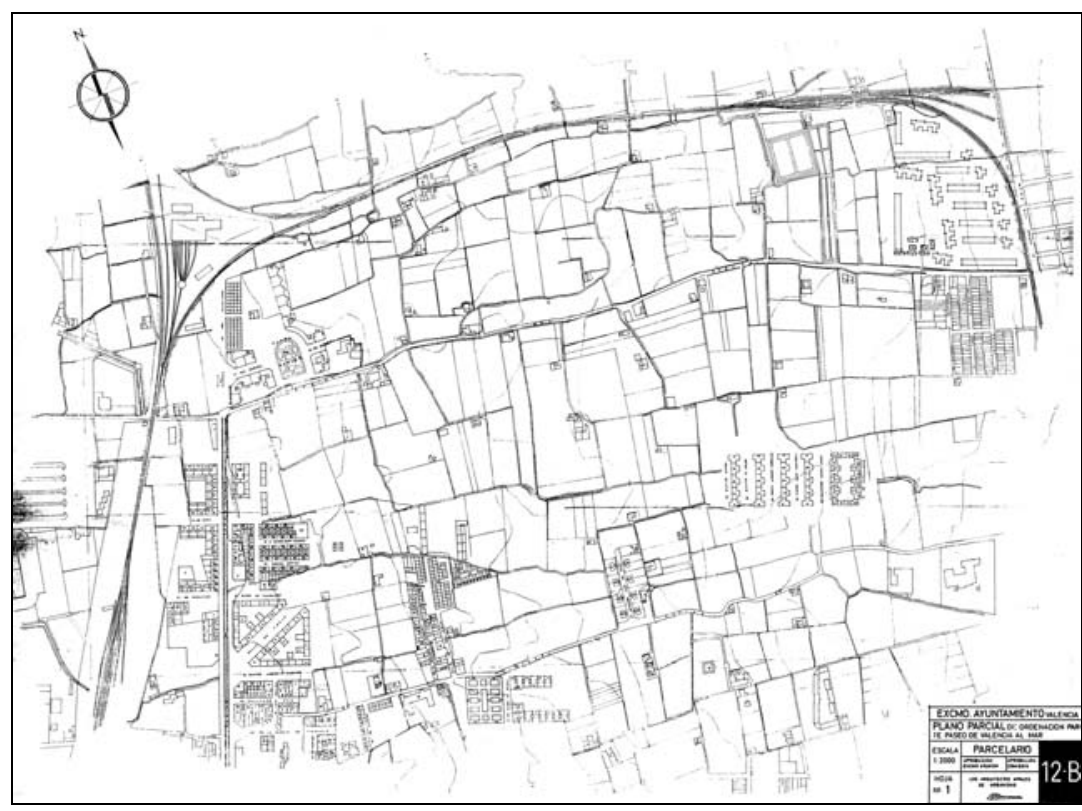

En cuanto al viario, el trazado ramificado y especializado del plan de 1958, compuesto por supermanzanas con viales de penetración en cul-de-sac, se sustituye en el nuevo plan de 1963 por un convencional y simplista viario mallado.

La vuelta a los tipos tradicionales afecta también a la edificación. Por una parte, se amplía la superficie ordenada mediante manzanas cerradas. Por otra, se simplifica el repertorio de tipos de la edificación abierta, eliminando los bloques o torres con planta en Y o en aspa de molino presentes en el plan anterior, y ampliando el número de manzanas resueltas mediante el tipo de cuatro bloques dos largos y dos cortos- situados sobre una planta baja comercial.

En el plano de Planeamiento del PP-12B de 1963, la modificación más aparente con respecto al plan de 1958 es la supresión de toda definición formal en la inmensa parcela destinada a Estadio y Feria Muestrario, que queda en blanco, con un rótulo que la califica como "Zona de Reserva".

La supresión de la planta del Estadio y de la Feria Muestrario no deja de ser lógica si observamos que en la franja edificable entre el Paseo al Mar y la zona de reserva han desaparecido la mayor parte de las plazas, espacios libres, aparcamientos e incluso calles, que en el plan de 1958 estaban situados frente a los accesos a los dos grandes equipamientos mencionados. En esa franja del lado norte del Paseo al Mar, la nueva ordenación es, simplemente, un relleno del espacio disponible con bloques lineales dispuestos sin ningún criterio compositivo claro, que duplican la ocupación del suelo de la ordenación anterior.

En el frente sur del Paseo al Mar, el PP-12B de 1963 conserva los bloques ortogonales previstos en el plan anterior, paralelos a los cuatro ya construidos de la Isla Perdida. Sin embargo, en lugar de las plantas bajas de enlace entre bloques del plan de 1958, se proyectan ahora unos cuerpos transversales de edificación que unen entre sí los bloques, formando unos dobles peines. Con este sistema, los bloques quedan desvirtuados al perderse la permeabilidad de la edificación en las plantas altas. 
Pero donde más evidente se hace el carácter regresivo de la versión de 1963 del PP-12B es en la franja comprendida entre los bloques ortogonales al Paseo al Mar y la actual calle Justo y Pastor. En esta zona, el eje peatonal este-oeste previsto en el plan de 1958 se elimina en el tramo comprendido entre las calles Manuel Candela y Músico Ginés, y con él se suprimen los equipamientos que formaban el centro cívico: la zona comercial, la Tenencia de Alcaldía, la zona con cines, cafés y hotel en torno a una plaza, así como las dos parcelas escolares. Únicamente se mantiene el mercado.

Los restantes tramos de este eje peatonal también sufren modificaciones. En el extremo oeste, junto a la calle Yecla, desaparece la plaza en torno a la cual se situaban diversos equipamientos. En el tramo este del eje, entre las calles Músico Ginés y Maestro Valls, se conserva el paseo peatonal y el núcleo final de equipamientos (una iglesia en el centro flanqueada por dos parcelas escolares), pero se suprime la manzana dotacional contigua destinada a deportes y juegos prevista en el plan de 1958.

La Memoria del plan de 1963 señala que la reserva de zonas verdes supera el $10 \%$ del suelo, tal como exige la Ley del Suelo de 1956. Esta Ley, como hemos visto, no fija superficies mínimas para otros equipamientos, y la cuestión de la reservas de suelo para escuelas se zanja en la Memoria del plan con un vergonzoso texto que, con diferentes palabras, volveremos a encontrar en diversos planes parciales:

Se establece en los planos el emplazamiento de cinco grupos escolares que, si con su superficie no cubren las necesidades para la población escolar, serán completados con facilidad, dado el carácter abierto de la edificación. ${ }^{1}$

Los bloques de $\mathrm{V}$ plantas perpendiculares a la calle Pedro J. Núñez son, junto con algunos fragmentos de bloques próximos a la calle Manuel Candela, los únicos realizados con arreglo al Plan Parcial 12-B de 1963. Estos bloques forman parte de los escasos ejemplos de edificación abierta de altura media en Valencia.

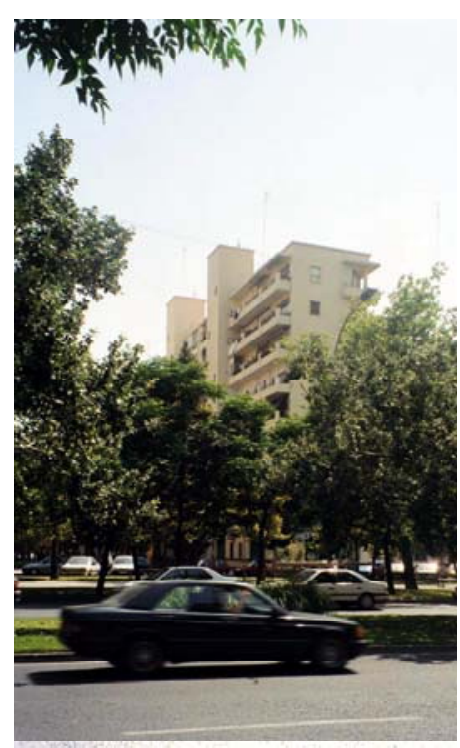

Bloque en la calle Amistat. Vista desde el Paseo al Mar.

1.Plan Parcial 12.B, 1963, Memoria. Anexo de Documentos, p. 203.

Plano Parcial 12-B (1963). Detalle de la zona de edificación abierta (Elaboración propia, sombreado en color sobre Plano de Planeamiento).

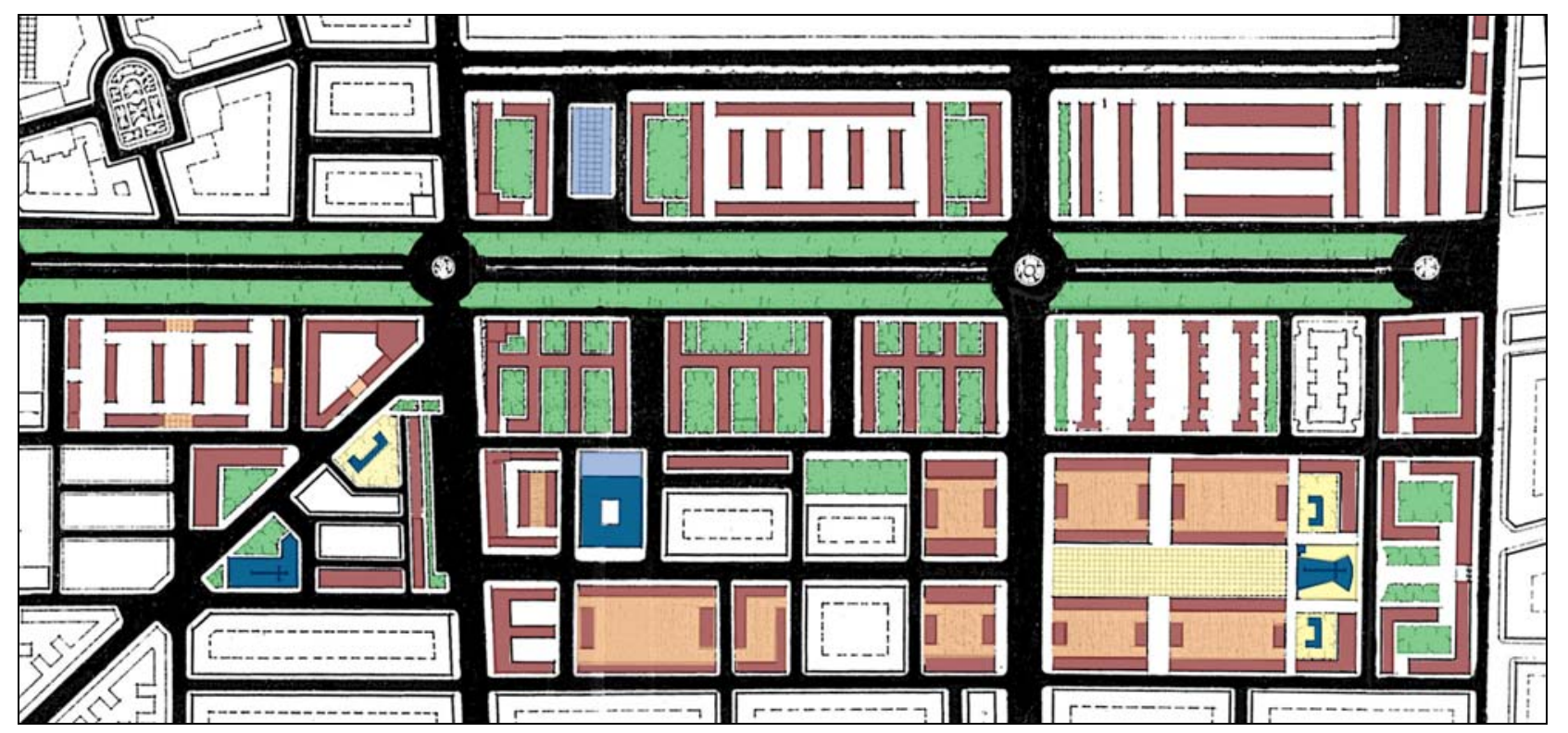




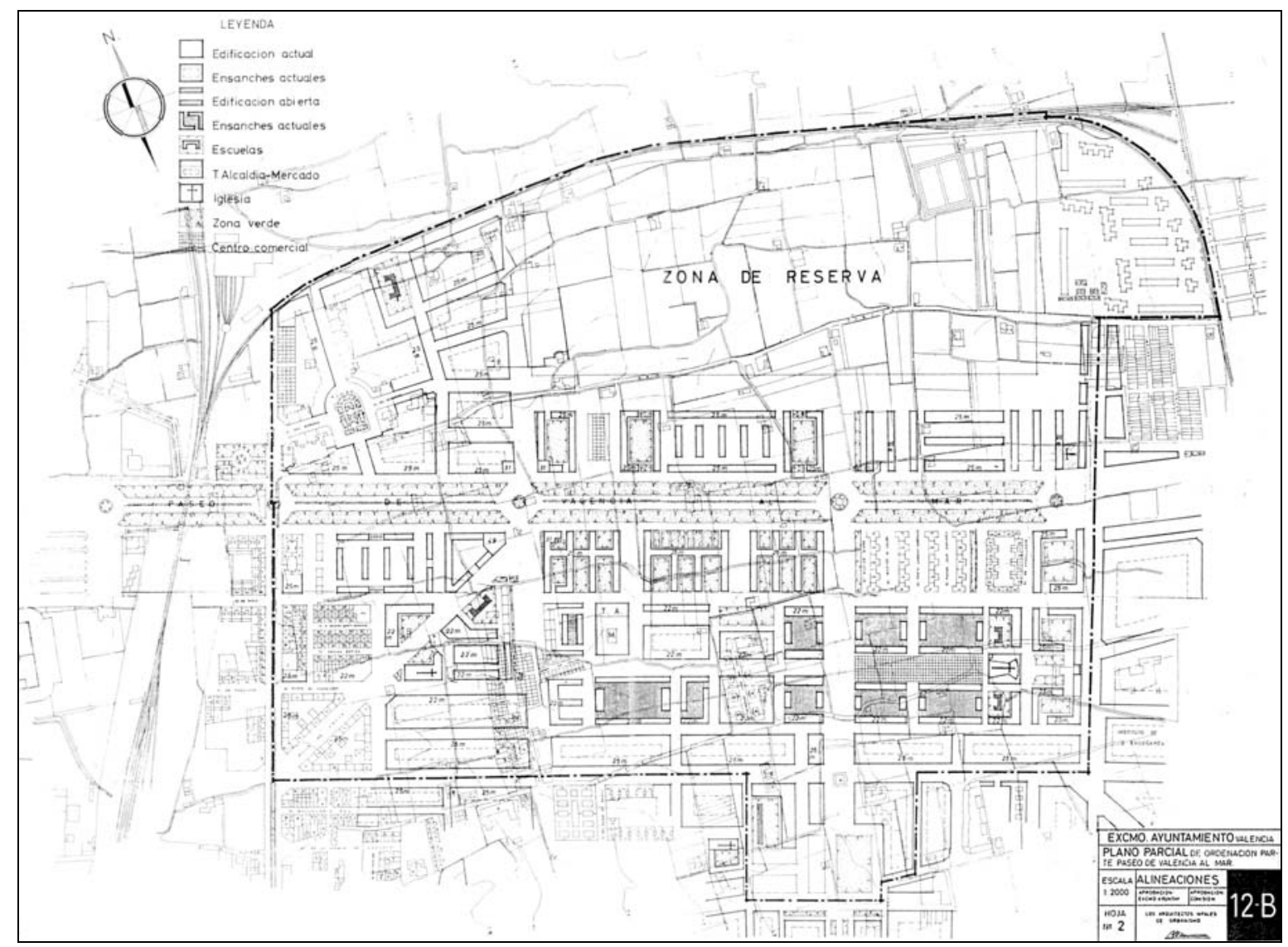

Plano Parcial 12-B (1963). Plano de alineaciones.

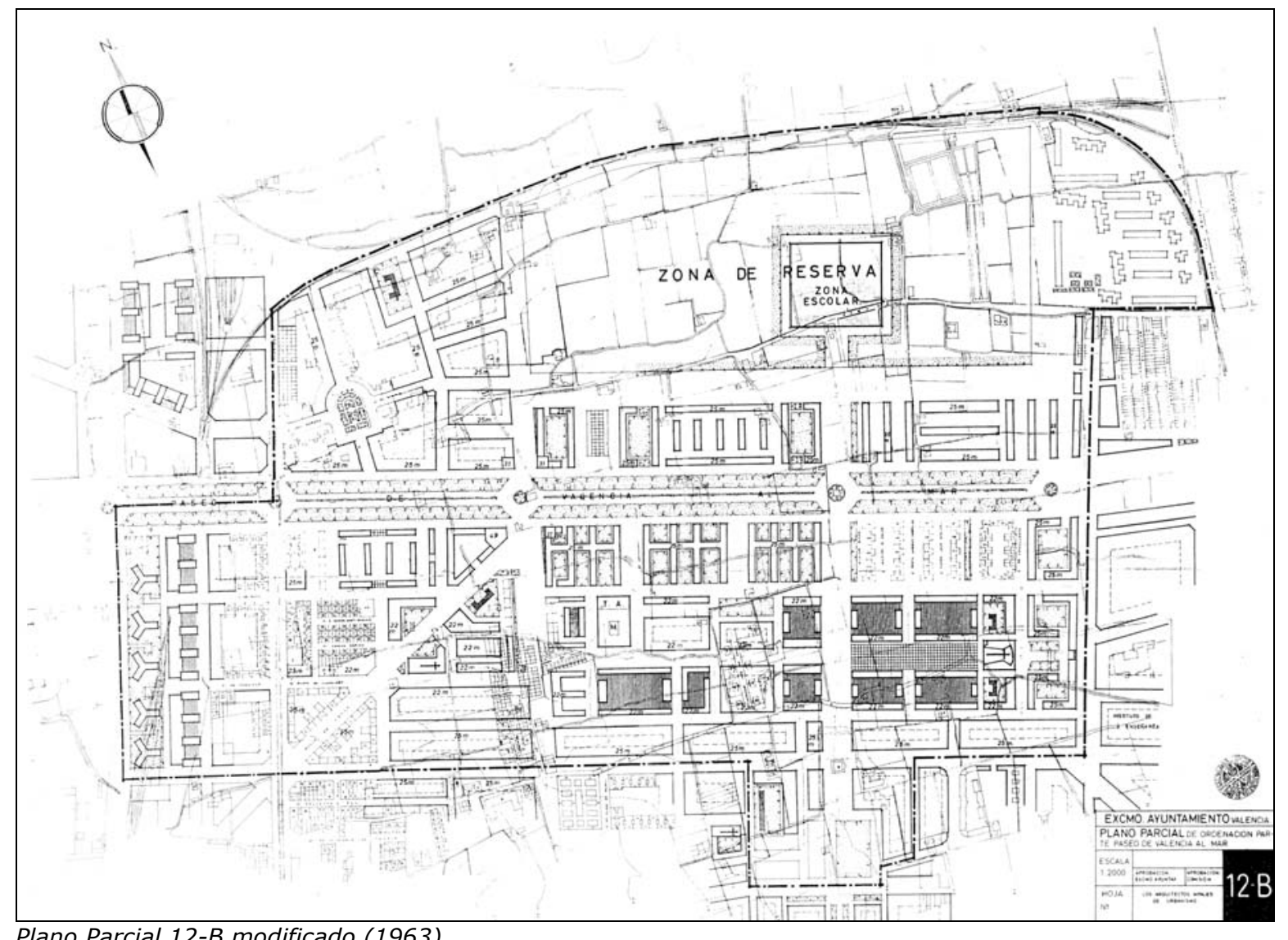


El Plano Parcial de 1963 sufrió dos modificaciones puntuales con anterioridad a la aprobación del Plan General de 1966. La primera, que se justifica como modificación motivada por la solución sur, consiste en ampliar los límites del Plan Parcial 12-B para incluir en mismo la edificación proyectada para los terrenos de la Estación de Ferrocarril de Aragón, que figuraba anteriormente en la versión de 1958 del Plan Parcial 11, aunque ahora se proyectan cinco torres con planta en $\mathrm{Y}$ en vez de cuatro, y unos bloques profundos en peine más densos, en lugar de los bloques cortos enlazados del PP11.

La segunda modificación es la previsión de una nueva parcela escolar en la zona de reserva situada al norte, cuya localización muestra claramente que los usos de Estadio o Feria Muestrario no se tiene ya en consideración para dicha zona.

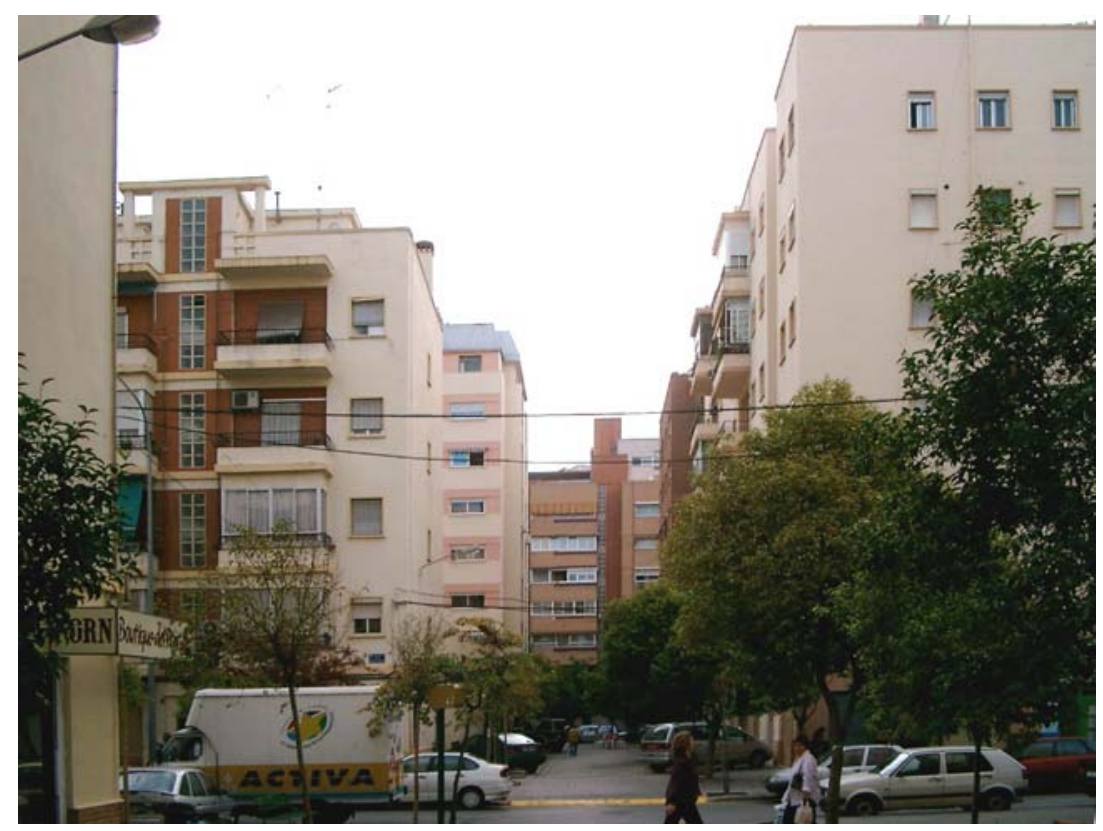

1

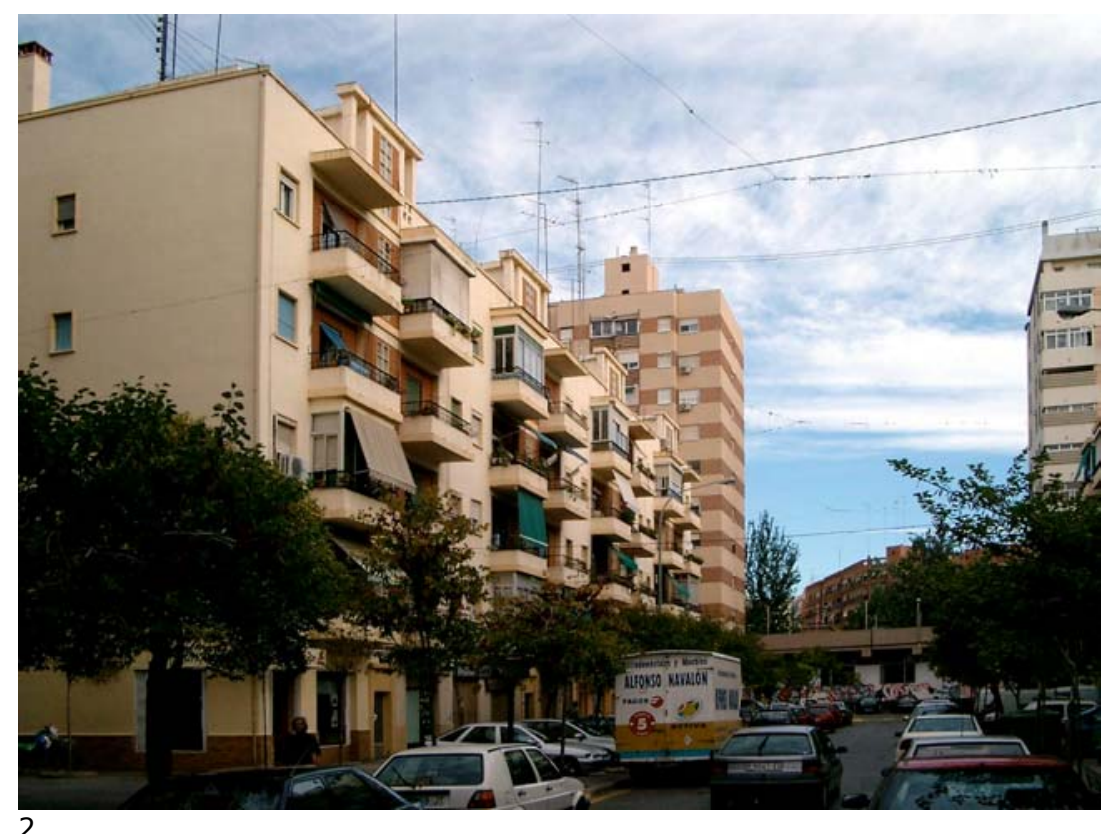

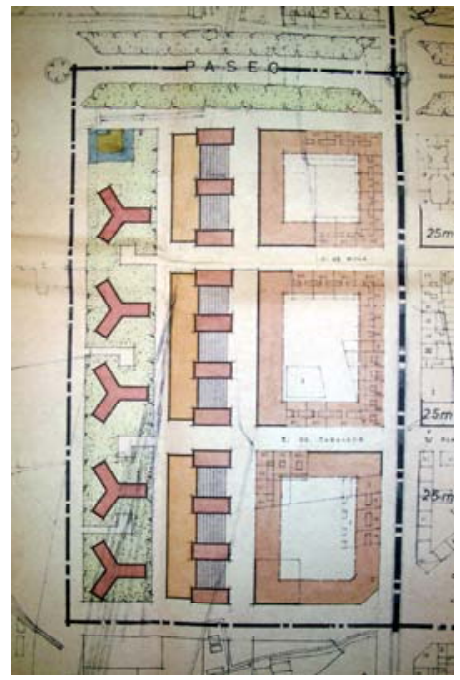

Plano Parcial 12-B modificado (1963). Detalle de la zona del nuevo acceso de Barcelona.
1. Bloques lineales en la calle Pedro J. Núñez, vista hacia el este.

2. Bloque en la calle República Argentina, vista hacia el norte. 


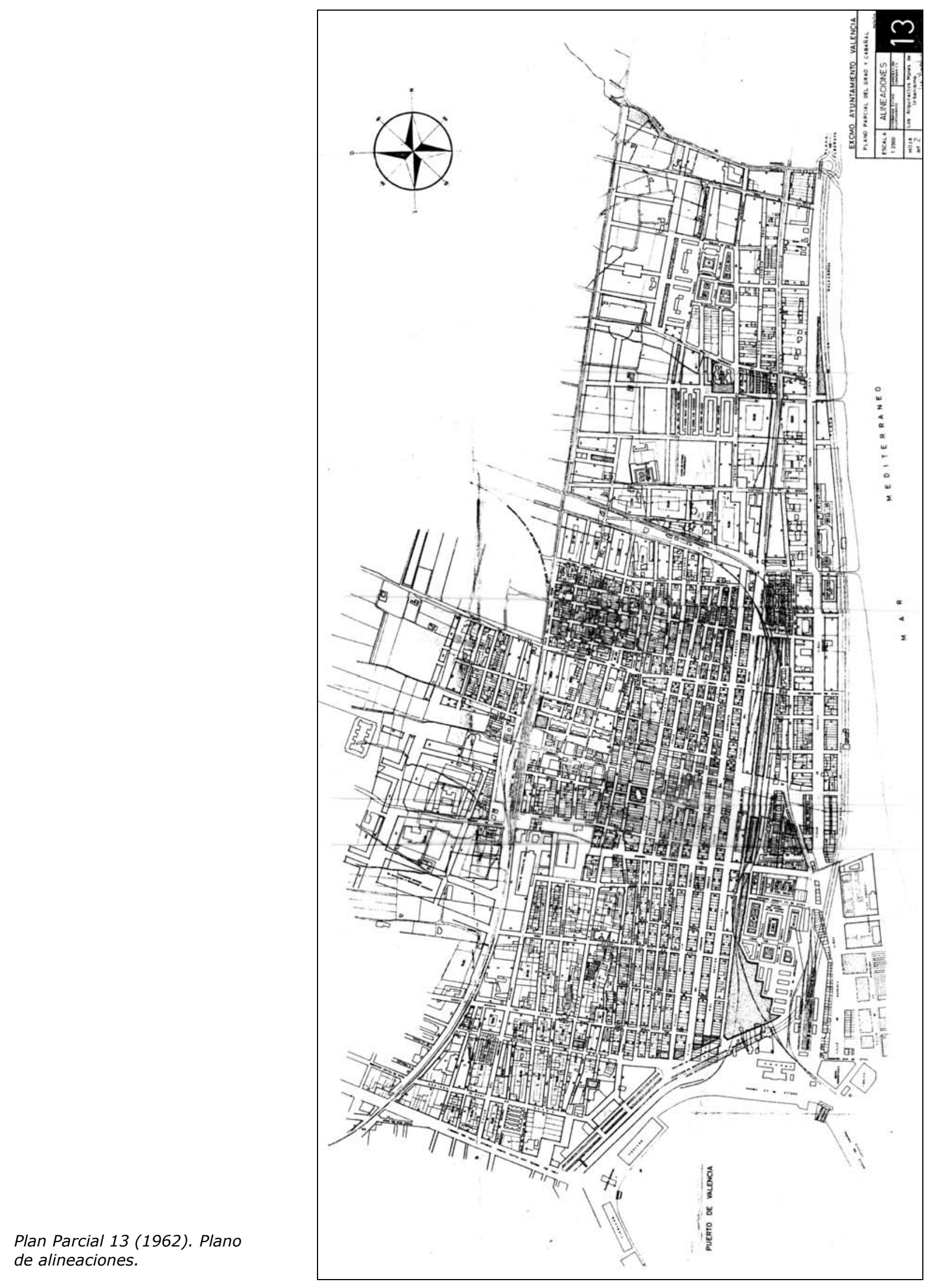




\section{GRAO, CABANYAL Y MALVARROSA: EL PLAN PARCIAL 13 (1962)}

A excepción de dos manzanas de la Malvarrosa y de los seis bloques lineales que amplían por el sur al grupo Ramón Laporta, no aparece en el Plan Parcial 13 ninguna otra zona ordenada mediante edificación abierta. Si recogemos aquí este plan, redactado por la Oficina Municipal de Urbanismo del Ayuntamiento de Valencia en 1962, es principalmente para poderlo comparar con el proyecto de Moreno Barberá para el Polígono de Valencia al Mar de 1960, que hemos estudiado anteriormente.

El Plan Parcial 13 de 1962 mantiene la prolongación del Paseo al Mar hasta la costa, pero reducida a una cuestión de alineaciones, como en los planos de reforma interior decimonónicos: sólo dos años después de su redacción, el proyecto de Moreno Barberá, que planteaba una nueva ordenación de la edificación adyacente a la prolongación del Paseo, es abandonado definitivamente.

Los bloques lineales aparecen a los lados de la prolongación del Paseo como subproducto de la apertura del mismo, a modo de manzanas estrechas y alargadas similares a las que flanqueaban los nuevos bulevares trazados por Haussmann en Paris cien años antes.

En el resto del ámbito ordenado, que incluye áreas urbanas casi completamente construidas como las del Grao y el Cabanyal, el plan se limita a ratificar las alineaciones existentes, manteniendo el tejido de manzanas alargadas tradicional de los poblados marítimos.

En posteriores redacciones de este plan, veremos que aparecerán áreas ordenadas mediante edificación abierta en la Malvarrosa, que es la zona situada al norte, menos edificada.

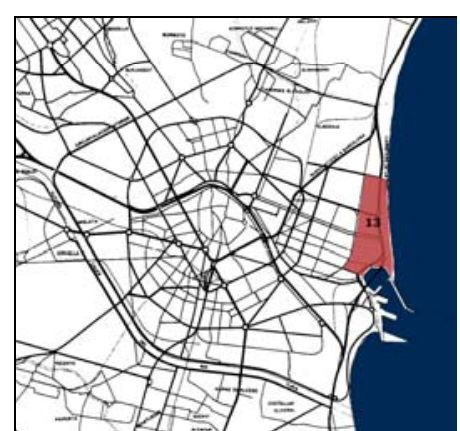

Plan Parcial 13. Localización

Plan Parcial 13 (1962). Plano de planeamiento.

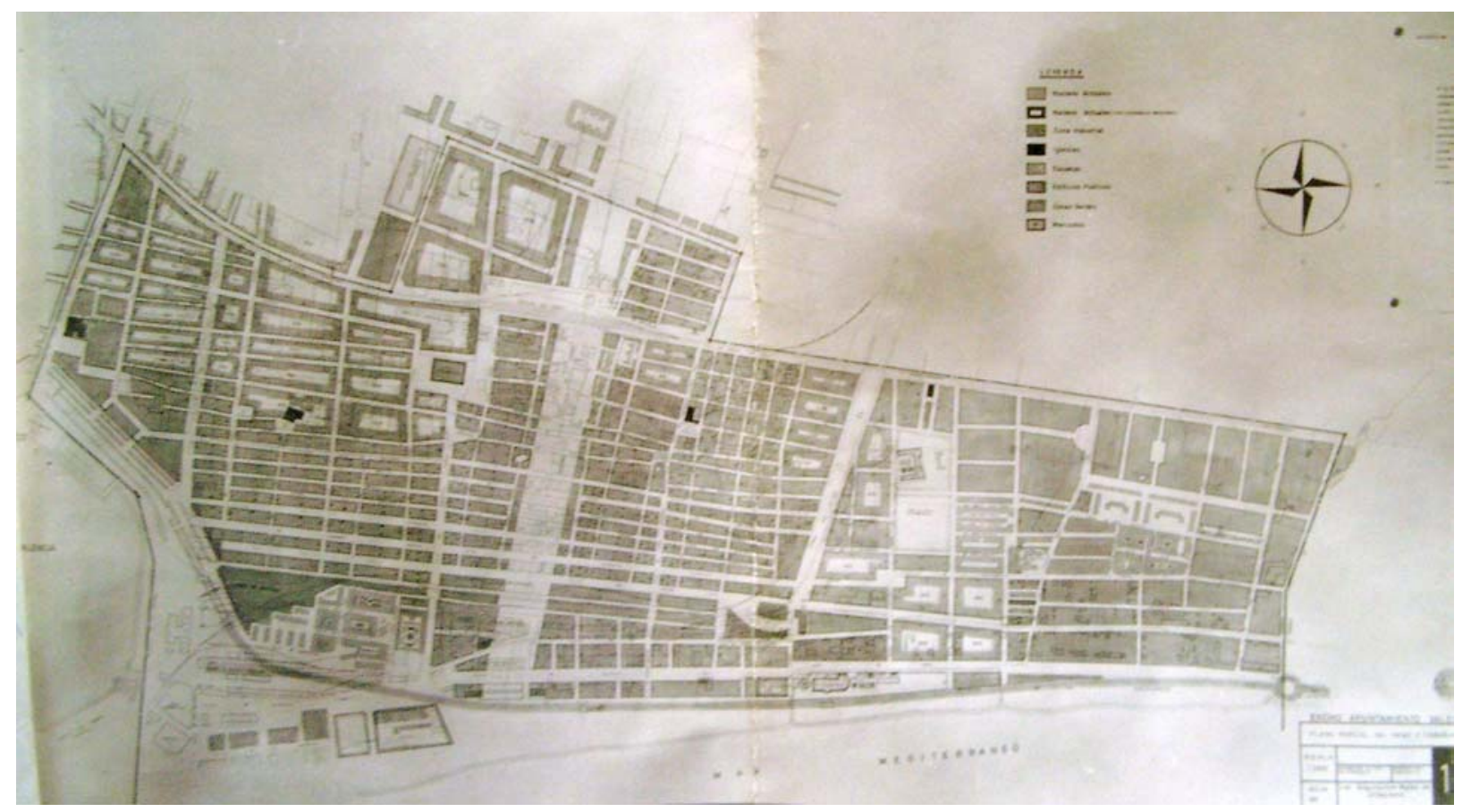



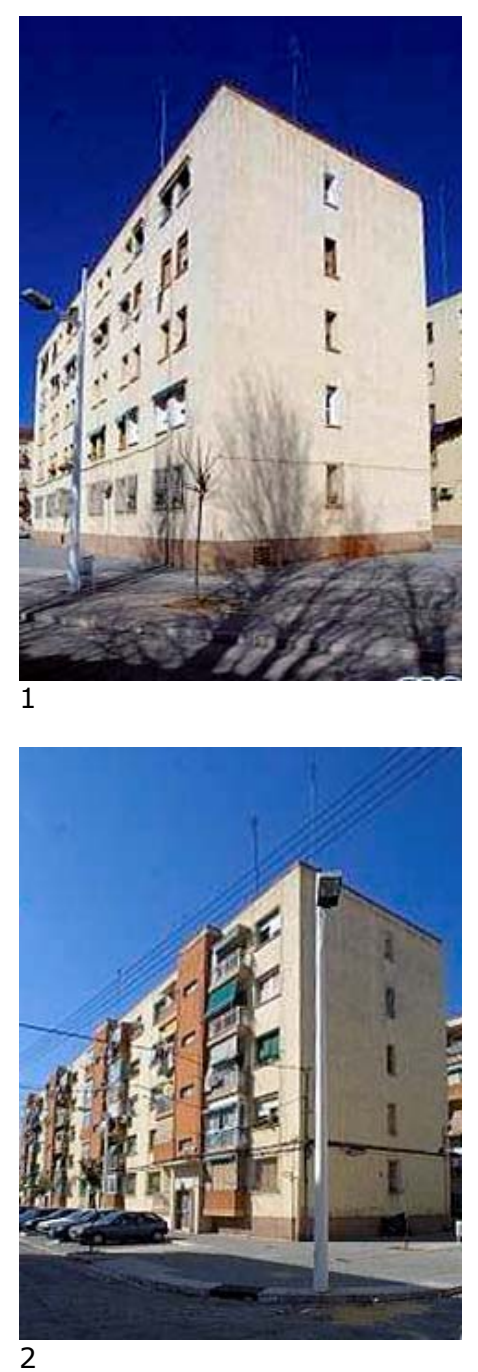

1. Bloque en la calle Chulilla. Fachada sur.

2. Bloque en la calle Benasal. Fachada norte.

3. Vista desde la calle Montanejos.

4. Vista desde la calle Montan.
El plan refleja la única zona de cierta entidad edificada según los principios del orden abierto. Se trata del grupo de bloques lineales de dos crujías situados en el triángulo limitado por las calles de Montanejos, Benasal y Arquitecto Guastavino. Estos bloques, promovidos por la Junta de Obras del Puerto, amplían por el sur el grupo Ramón Laporta, que a su vez ampliaba el grupo Virgen del Castillo, realizado por la Dirección General de Regiones Devastadas entre 1939 y 1945.

Tanto el grupo Virgen del Castillo como el Ramón Laporta están formados por manzanas cerradas con patio ajardinado interior, con la excepción de una de las manzanas que integran el segundo, en la que la continuidad perdida de la edificación perimetral, descompuesta en dos bloques independientes, se recupera mediante el recurso al vallado.

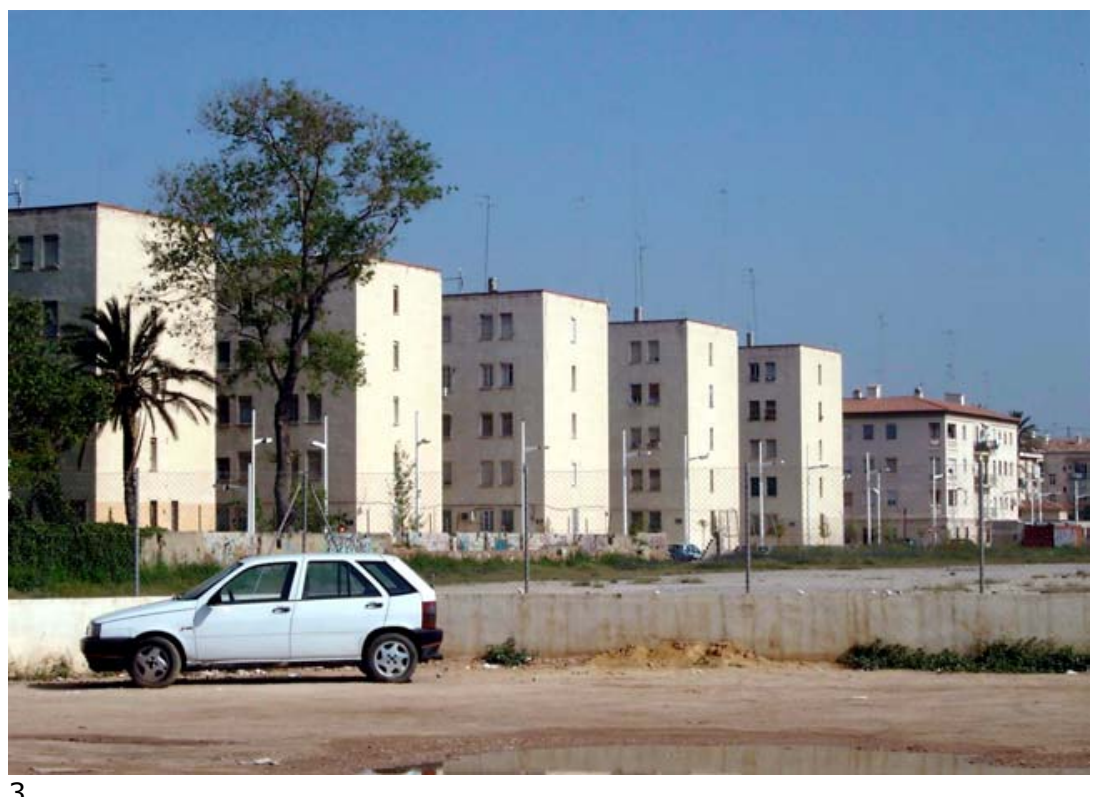

3

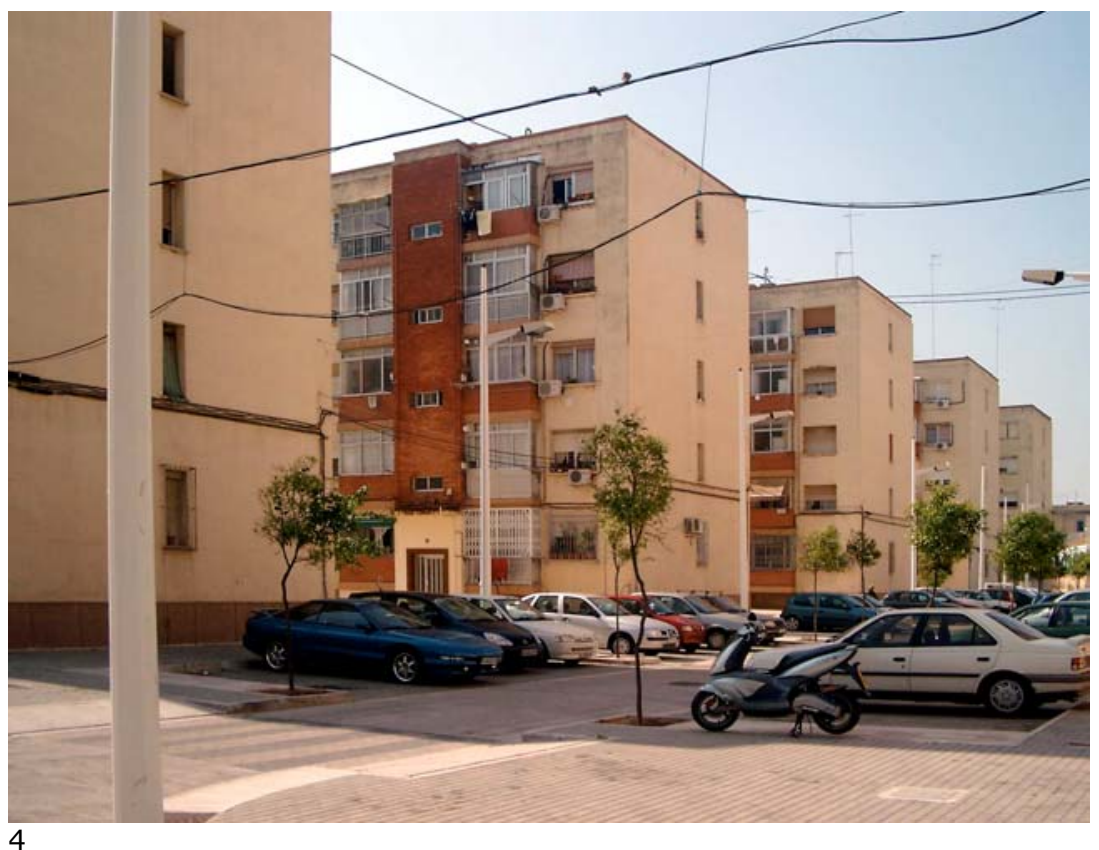


Los bloques situados al sur, en cambio, están dispuestos en su mayor parte según los patrones canónicos del zeilenbau: bloques equidistantes seriados, con acceso por uno de sus lados (en este caso la fachada norte) y orientación uniforme.

De los bloques previstos en el Plan Parcial 13 para formar el frente de la prolongación del paseo al Mar, los tres fragmentos realizados son los recayentes a la actual calle Sánchez Coello, que tienen planta en forma de I. Únicamente el situado más al este es un bloque aislado, ya que los otros dos son realmente meros fragmentos de edificación entre medianeras.

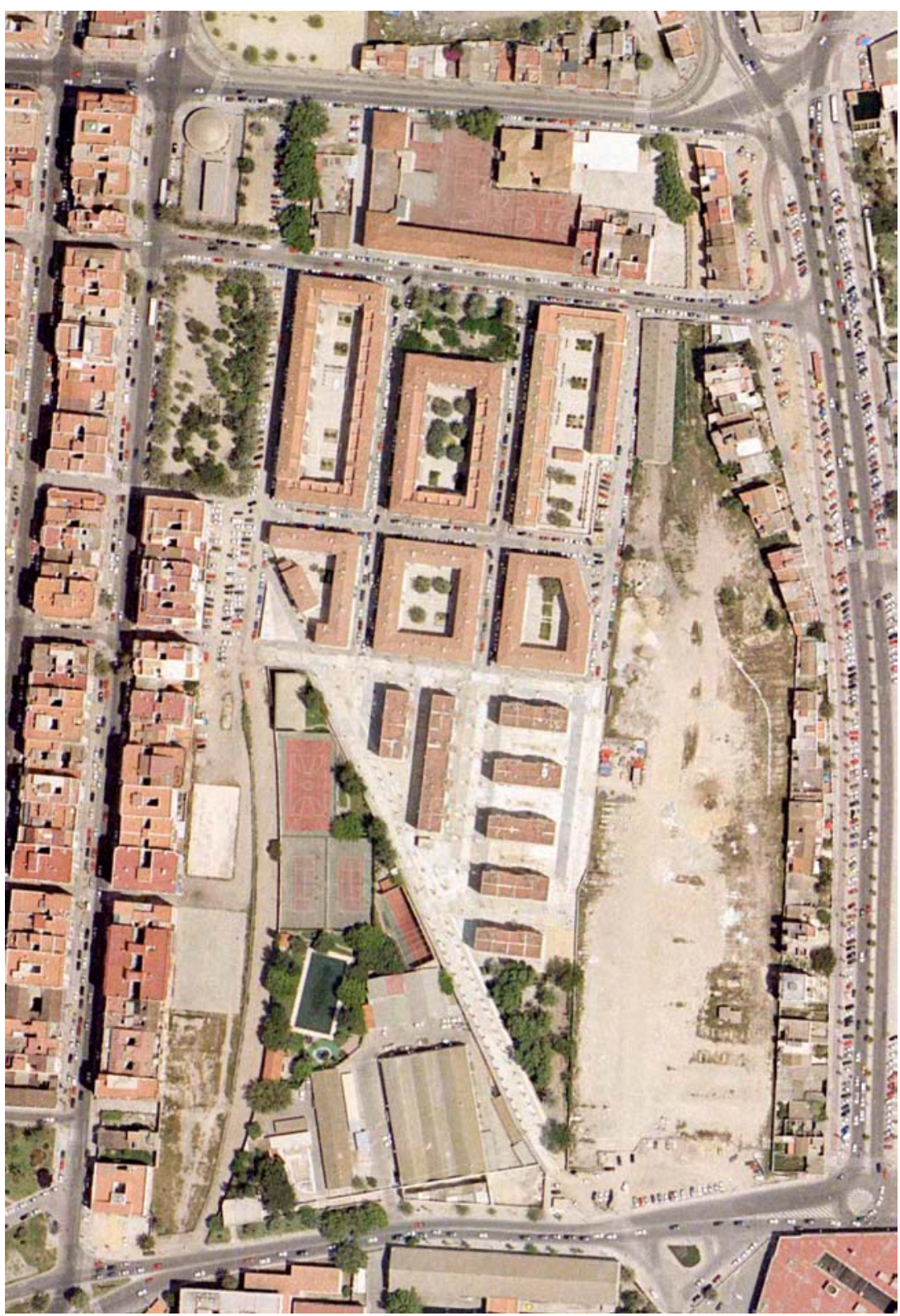

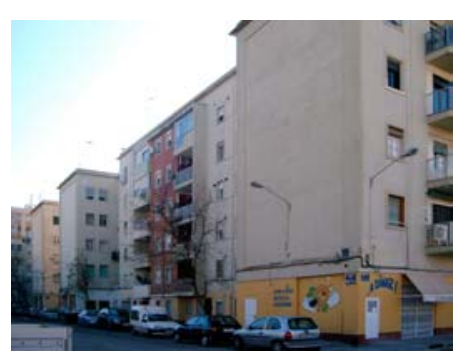

1

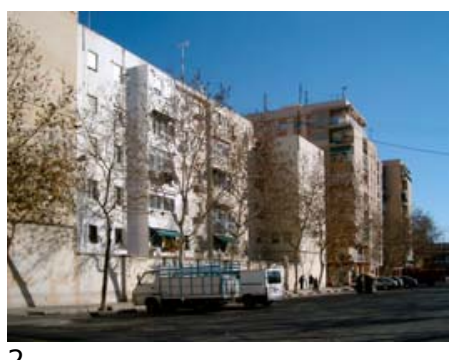

2

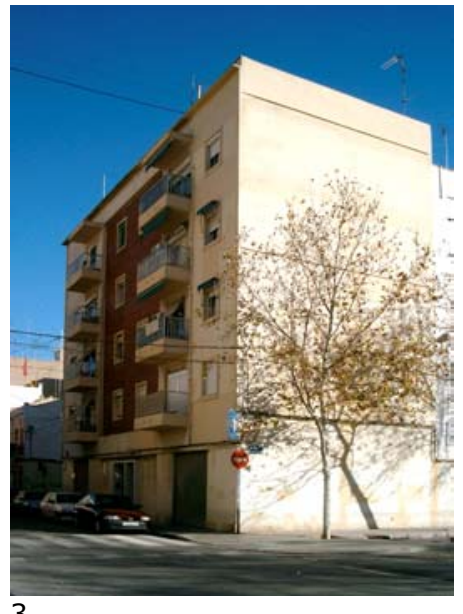

3

1-3. Bloques en la calle Sánchez Coello.

Grupos Virgen del Castillo, Ramón Laporta y zona de edificación abierta al sur de los mismos (Ortofoto 2002, AUMSA). 


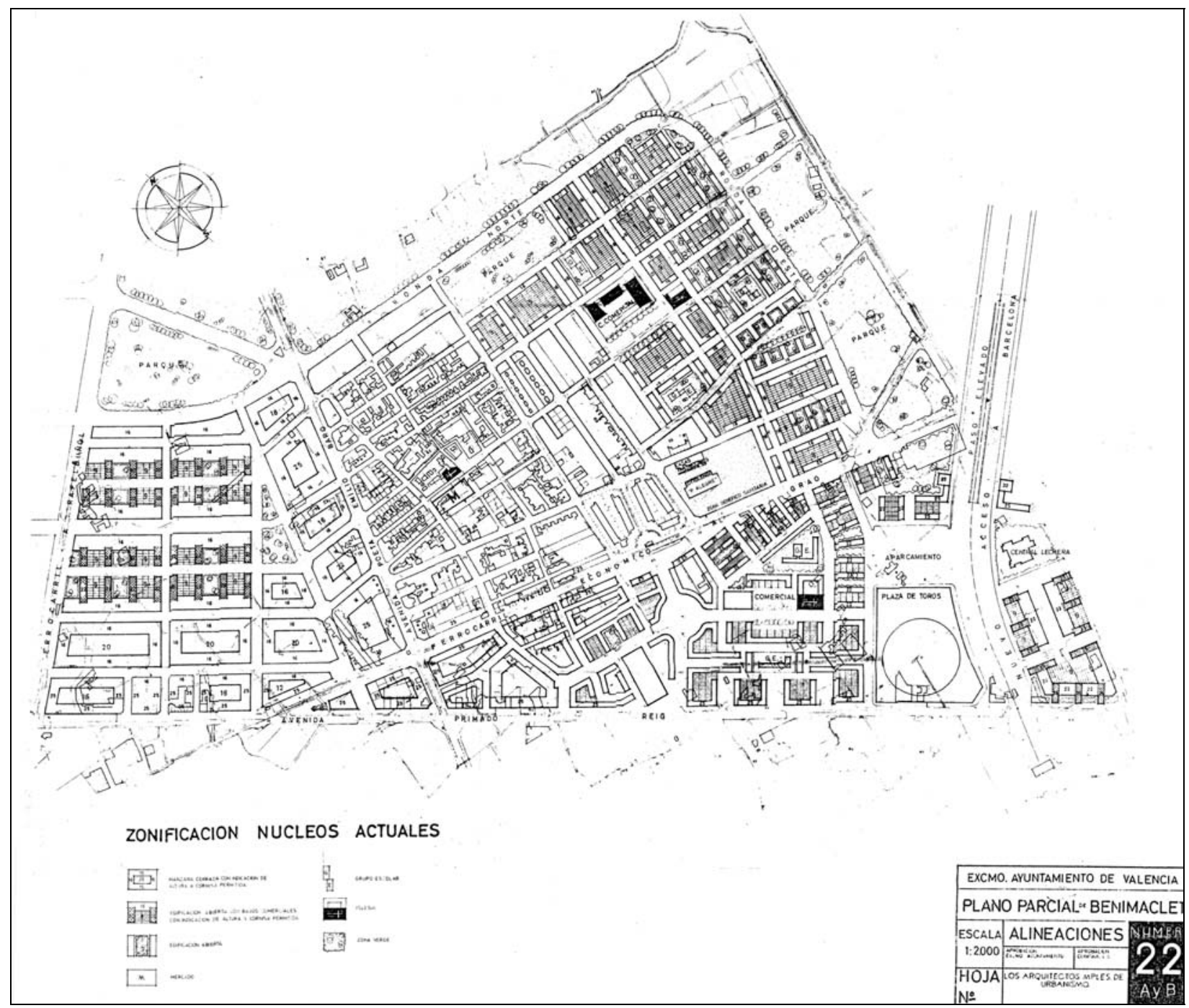

Plan Parcial 22 A+B. Benimaclet, 1962. Ayuntamiento de Valencia

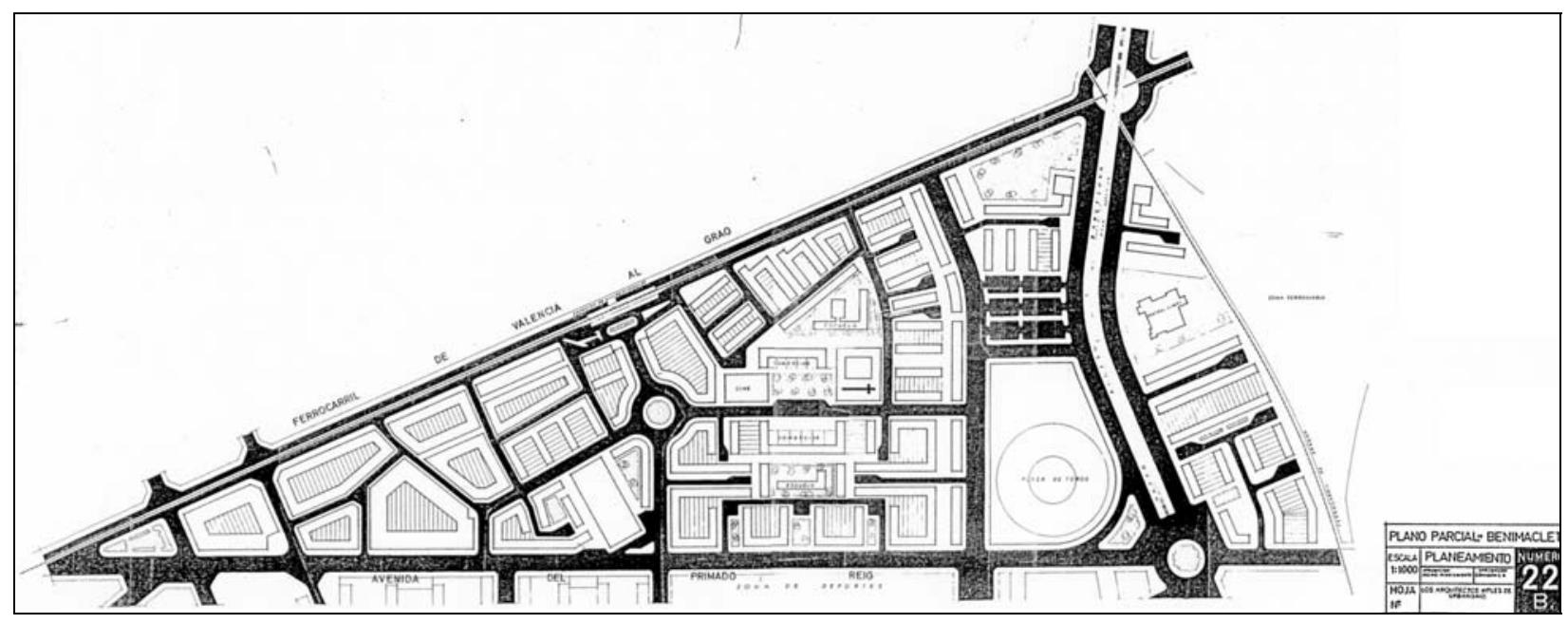

Plan Parcial 22 B. Benimaclet, 1961. Ayuntamiento de Valencia 


\section{BENIMACLET: PLAN PARCIAL 22 (1961/62)}

El Plano Parcial no 22 comprende el poblado de Benimaclet, anexionado desde antiguo al término municipal de Valencia, y sus alrededores. Los límites del plan son el nuevo acceso a Barcelona al este, el Camino de Tránsitos (Avenida de Primado Reig) al sur, la línea de ferrocarril eléctrico a Rafelbuñol al oeste y la ronda de circunvalación (próxima al Camino de Farinós) al norte.

Como hemos indicado anteriormente, esta zona, como otras de la corona periférica norte exterior a Tránsitos, no disponía de planeamiento parcial previo aprobado ${ }^{1}$. El viario dibujado en el plan, por otra parte, es previo al diseño definitivo de la red arterial. Las áreas de edificación abierta previstas en el Plan Parcial 22 son tres, y amplían el poblado de Benimaclet por el oeste, por el noreste y por el sureste.

En la extensión oeste, entre la Avenida Emilio Baró y el ferrocarril de Rafelbuñol, formada por manzanas cerradas, la presencia de la edificación abierta se reduce a cuatro manzanas, en cada una de las cuales se sitúan, a ambos lados de un eje central peatonal, dos bloques de edificación en peine, compuestos por un bloque largo de cinco crujías y $\mathrm{V}$ plantas al que se adosan en perpendicular varios bloques cortos de dos crujías y VII plantas. Los espacios intermedios entre los bloques cortos aparecen en parte destinados a jardines y en parte a bajos comerciales. ${ }^{2}$

En esta zona de extensión oeste no se prevé ningún equipamiento, salvo los pequeños espacios verdes intercalados en los bloques en peine y el parque situado junto a la ronda norte, en una posición marginal. En una de las dos versiones del plan conjunto para las zonas $22 \mathrm{~A}$ y $22 \mathrm{~B}$, un bloque aislado de planta escalonada ocupa parte de los terrenos del parque.

La extensión noreste abarca el espacio comprendido entre el poblado de Benimaclet y la ronda de circunvalación norte, junto a la cual se proyecta un parque a modo de cinturón verde. En esta zona, el plan prevé un viario mallado como soporte de una edificación formada en general por manzanas mixtas: agrupaciones de bloques lineales unidos en planta baja por locales comerciales que ocupan toda la superficie de la manzana. Además, aparecen también en esta zona bloques lineales aislados y, en algunos puntos singulares, bloques con planta en peine. En todos los casos, la profundidad de los bloques es de dos crujías.

En cuanto a equipamientos, el plan prevé en esta zona noreste tres pequeñas parcelas escolares, así como un centro vecinal que incluye un centro comercial y una iglesia agrupados en torno a una plaza. La banda verde continua antes mencionada no puede, debido a su posición periférica, exterior a la ronda norte, asumir el papel de parque vecinal que le correspondería, y es más bien un trozo de campo al que se le ha cambiado el nombre.

La extensión sureste de Benimaclet comprende los terrenos de forma triangular limitados por la línea de ferrocarril eléctrico al Grao (actual calle Doctor Vicente Zaragozá), el Camino de Tránsitos, y el nuevo acceso de Barcelona. Para esta zona se redactó un plan parcial separado, denominado 22-B, en 1961.

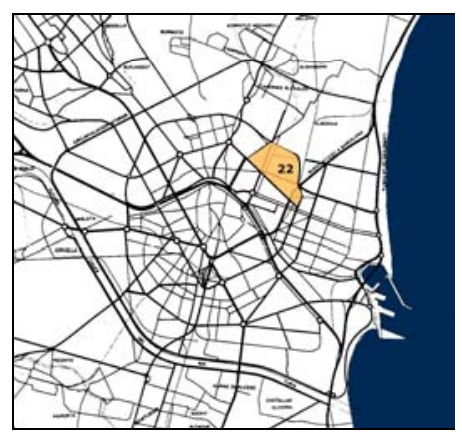

Plan Parcial 22. Localización.

1. En el caso de Benimaclet, hemos localizado en el Archivo de Planeamiento del Ayuntamiento de Valencia la memoria de un plan titulado "Hoja no 22. Benimaclet", fechada en 1954, que probablemente es el que por estar incompleto fue devuelto al Ayuntamiento por la Comisión Central de Sanidad a través de un escrito fechado en 1956.

2. Este tipo de edificio, que aparecía ya en el proyecto del Barrio Residencial de Burjasot-Benimamet de 1946, se utilizará también en otros planes del mismo periodo, como el 8-B o el 12-B. 


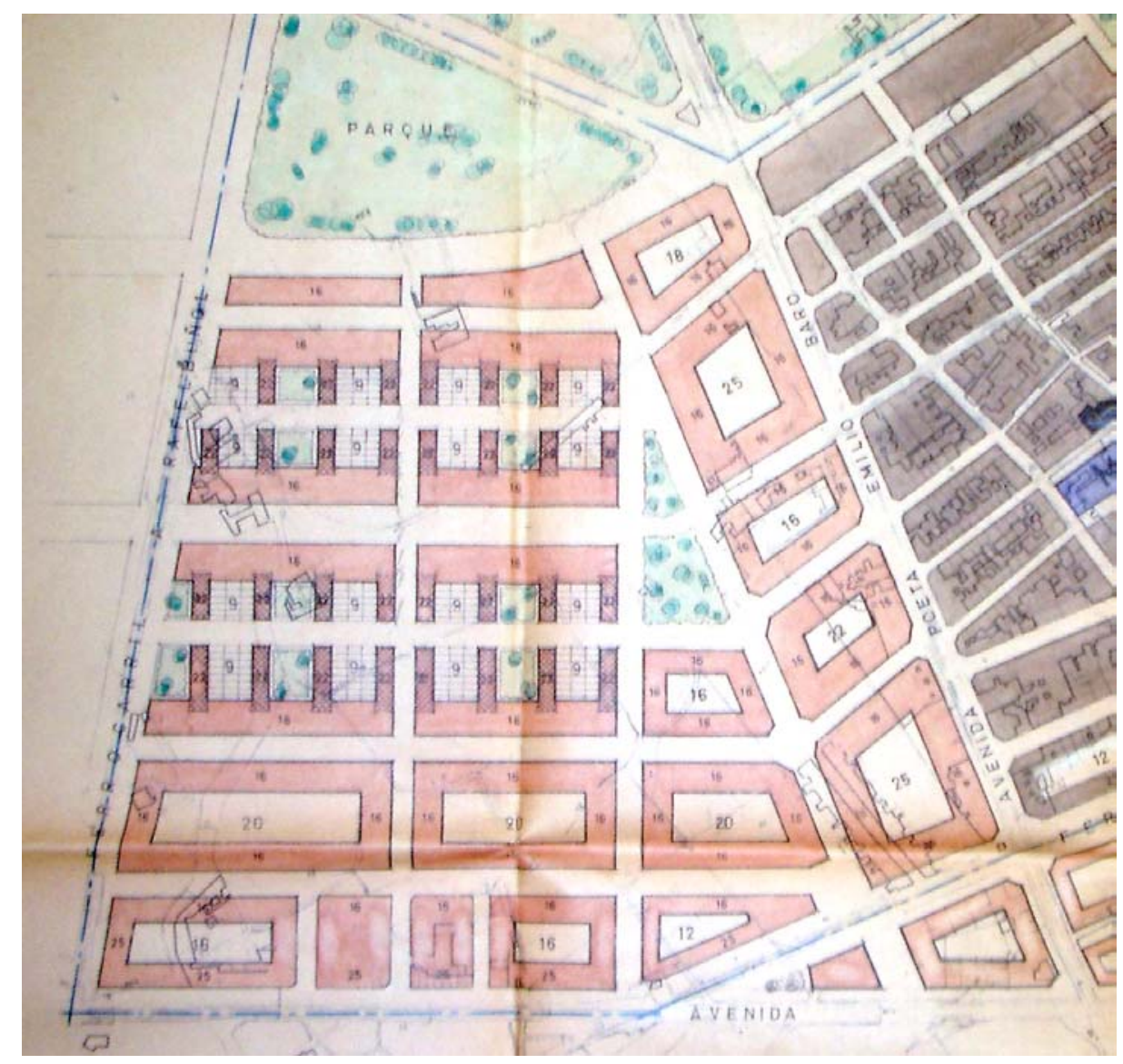

Plan Parcial 22 A+B. Benimaclet, 1962. Detalle de la zona oeste

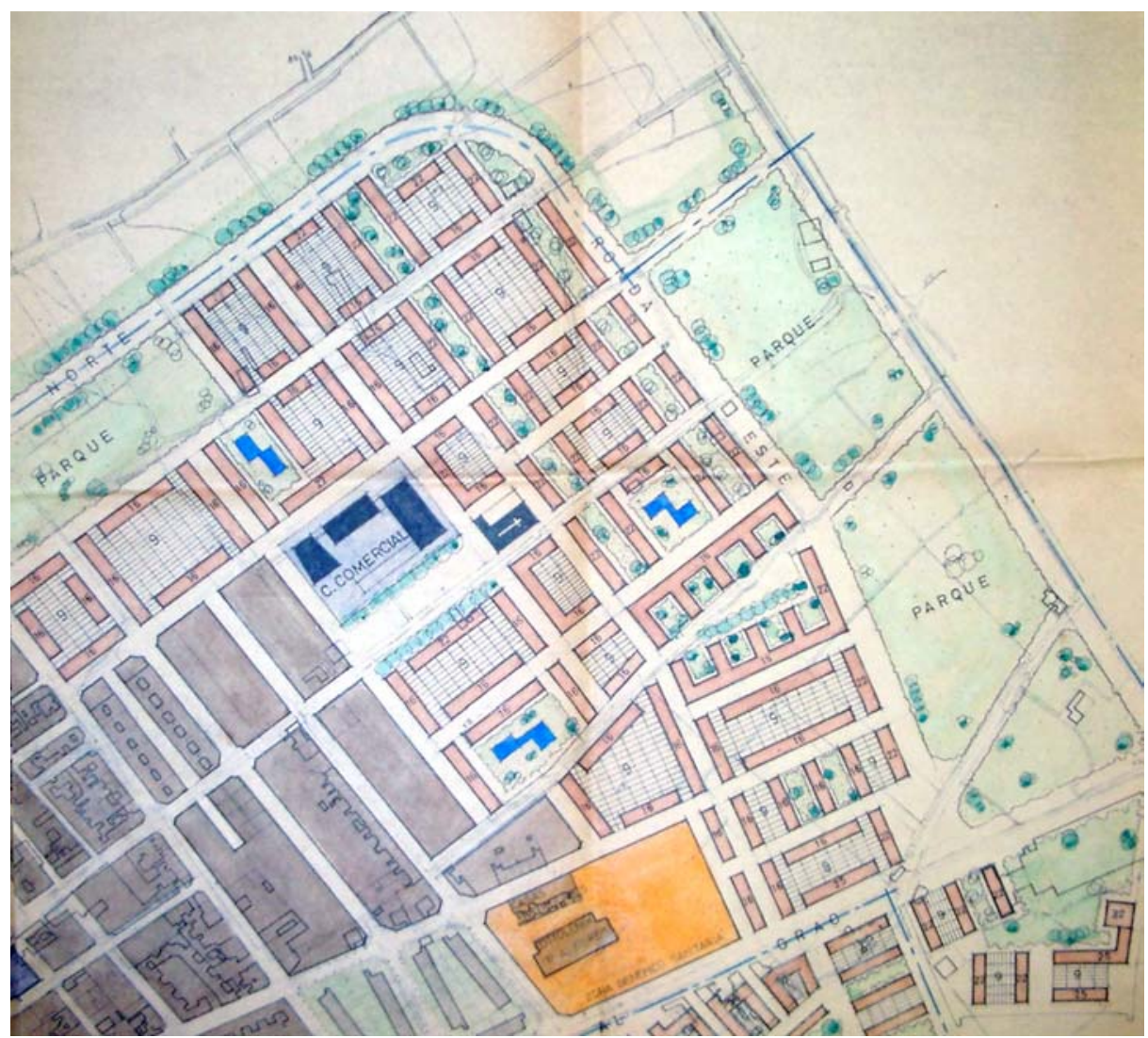

Plan Parcial 22 A+B. Benimaclet, 1962. Detalle de la zona noreste 
El trazado viario proyectado para esta zona tiene dos ejes principales que se cruzan en una plaza de forma circular. El eje este-oeste corresponde a la actual calle Guardia Civil, y el eje transversal norte-sur a la calle Ramón Asensio, cuyo eje desemboca en la estación de FF.CC. para continuar, ya dentro de Benimaclet, por la calle Hermanos Villalonga. El viario secundario previsto para las macromanzanas delimitadas por estos ejes principales es por lo general del tipo ramificado, con ramales sin salida que evitan atravesarlas.

Junto al nuevo acceso de Barcelona, y con un amplio aparcamiento anejo, el plan sitúa la nueva plaza de toros de Valencia. ${ }^{1}$ Además, se prevé un centro vecinal compuesto por una iglesia, un centro comercial y un cine, situados en torno a dos semiplazas abiertas al eje central. Los dos grupos escolares previstos para esta zona se sitúan en el centro de las macromanzanas situadas a norte y sur del centro vecinal, rodeados por calles peatonales.

La edificación proyectada para esta zona es muy variada, y la forma de disponerla no responde enteramente a los patrones del orden abierto, que implican una independencia mayor entre trazado viario y edificación. Así, aquí encontramos bloques de edificación abierta de dos crujías con formas en planta irregulares que derivan de su adaptación a las alineaciones de las calles, como los que delimitan la plaza circular central. Junto a ellos, aparecen otros que adoptan la forma de manzana mixta, formada por dos bloques lineales de dos crujías unidos por un bajo comercial, como los del sector situado al norte del centro vecinal. Igualmente, en la versión conjunta del Plan Parcial $22 \mathrm{~A}+\mathrm{B}$, el sector situado al otro lado del nuevo acceso de Barcelona se resuelve con bloques profundos de planta en peine similares a los utilizados en la extensión oeste, que se sustituyen por bloques lineales formando manzanas mixtas en el Plan Parcial 22-B. Por último, una pareja de torres unidas a bloques lineales en $L$ flanquean el nuevo acceso de Barcelona, a modo de nueva puerta a la ciudad desde del norte.
1. Esta nueva plaza de toros debía sustituir a la existente en el centro de Valencia, cuya demolición liberaba unos terrenos para los que Luís Albert, arquitecto de la Diputación Provincial, propietaria de los mismos, había realizado un proyecto de edificación residencial. Ver Herrero Colás, Adolfo, "Valencia: un modelo no cuestionado. El fantasma de la reforma interior", Historia Urbana, 4, Valencia, 1992.

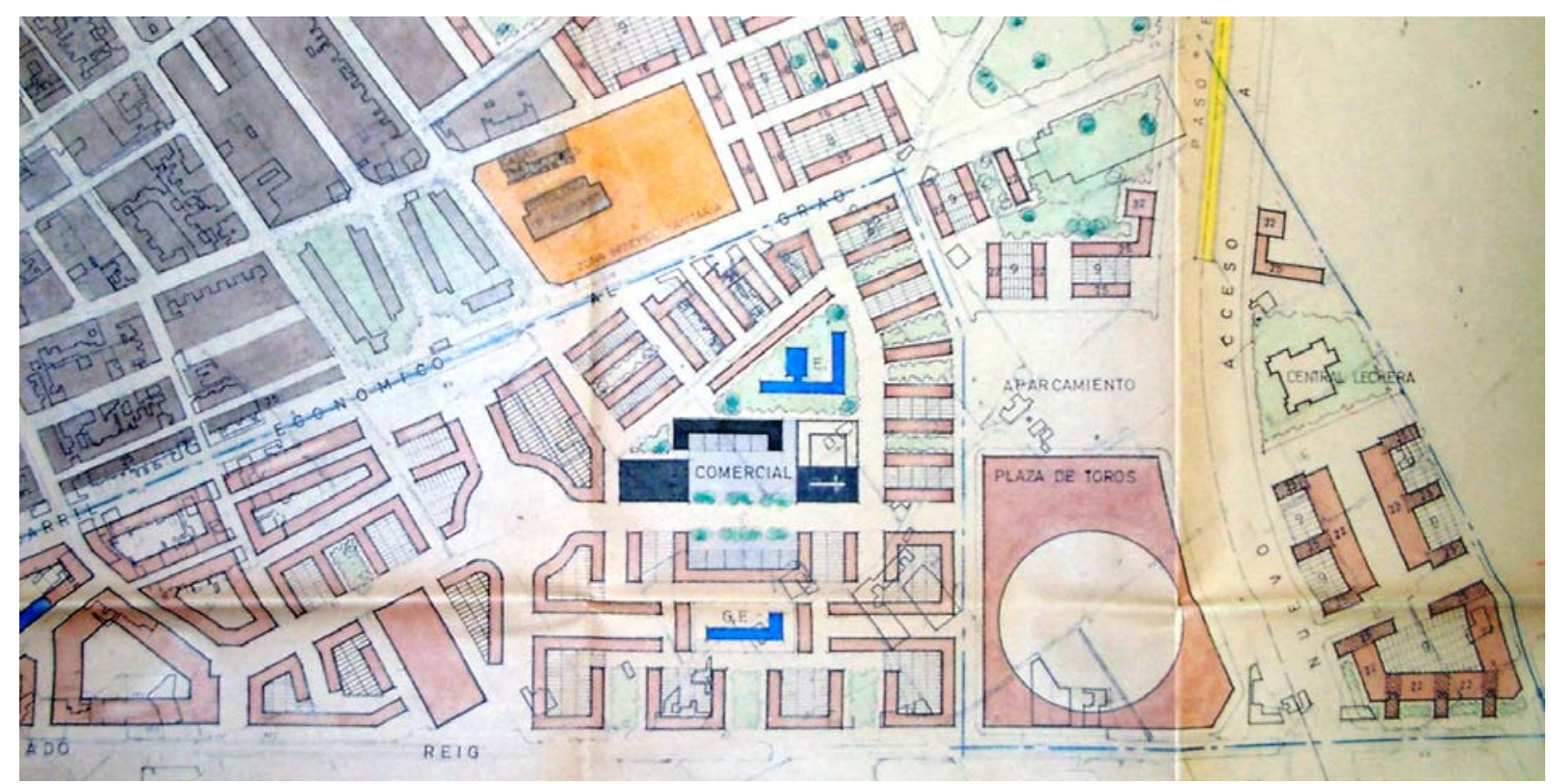

Plan Parcial 22 A+B. Benimaclet, 1962. Detalle de la zona sureste 


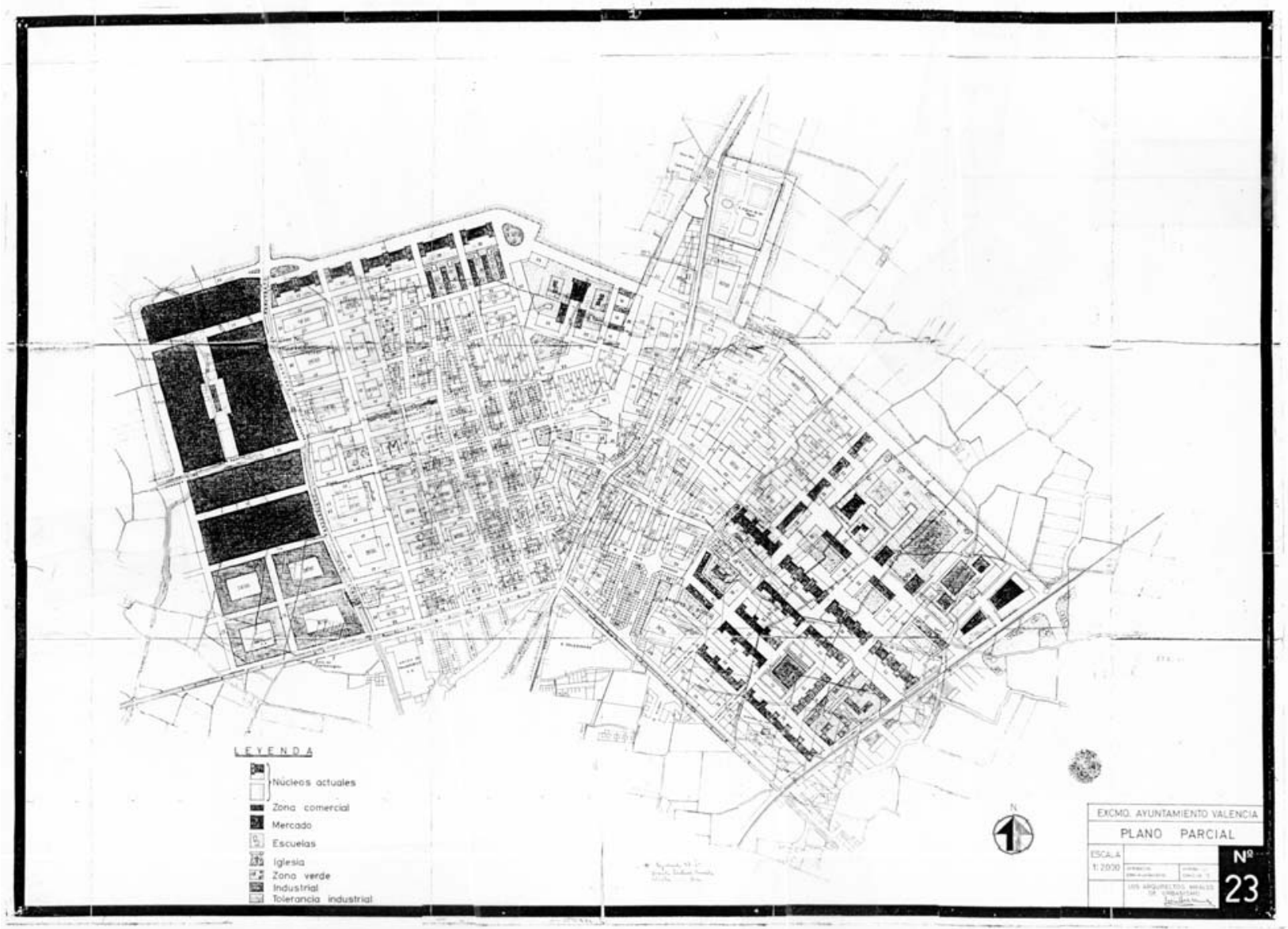

Plan Parcial 23 (1962). Plano de alineaciones.

Plan Parcial 23 (1962). Plano de alineaciones. Detalle de la zona este.

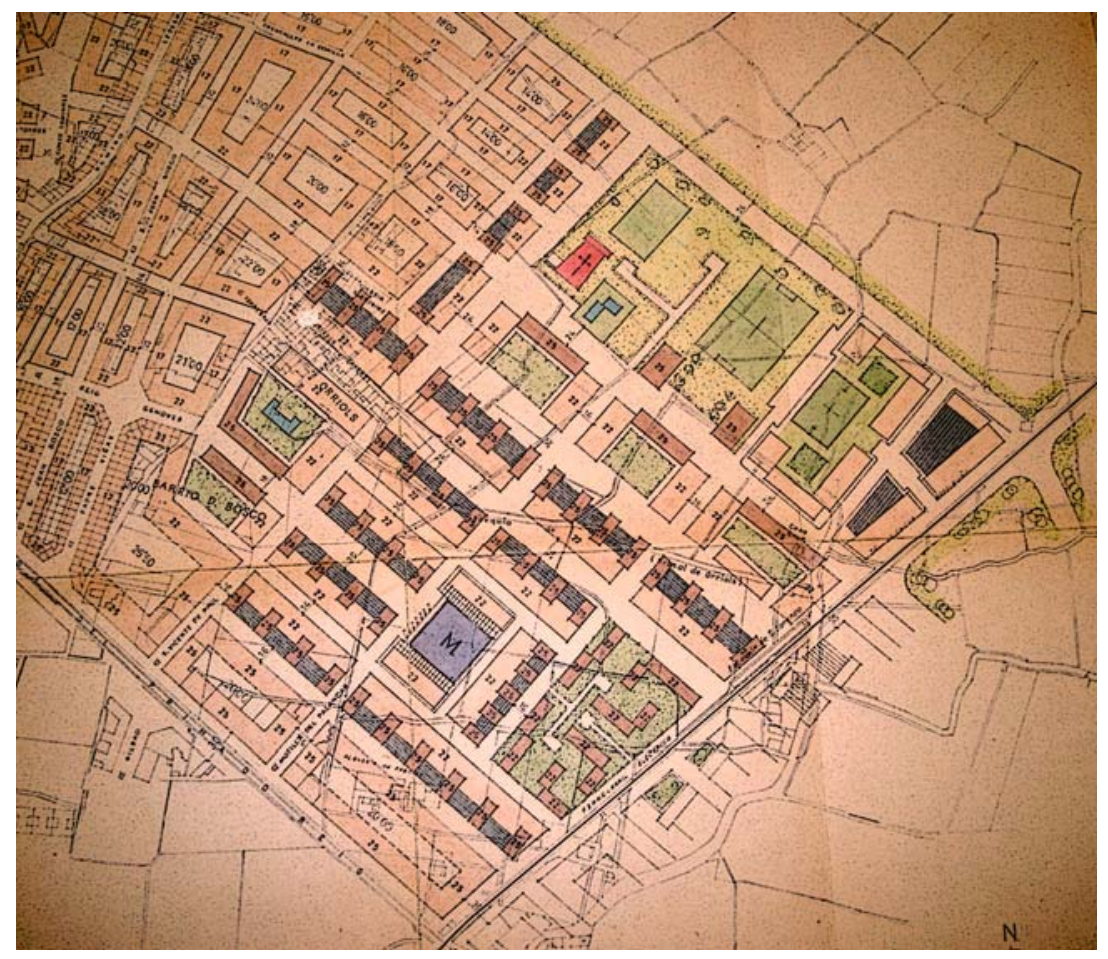




\section{TORREFIEL Y ORRIOLS: EL PLAN PARCIAL 23 (1962).}

El área ordenada por el Plano Parcial no 23 es la de extensión de los poblados de Torrefiel y Orriols, que flanquean por el oeste y por el este, respectivamente, el importante eje viario norte-sur de la carretera de Barcelona. Esta zona de extensión está limitada por el camino de Tránsitos al sur, por el ferrocarril eléctrico a Rafelbuñol (y el Plan Parcial no 22) al este, por la ronda de circunvalación al norte y por el camino de Moncada (y el Plan parcial no 24) al oeste. Al igual que otros planes de la corona periférica exterior a Tránsitos del norte de Valencia, esta zona no disponía de planeamiento parcial previo.

Las áreas proyectadas con edificación abierta en este plan son dos, una más extensa situada al este, entre el poblado de Orriols y la línea de ferrocarril de Rafelbuñol, y otra de menor tamaño situada al norte de Torrefiel, poblado cuya extensión oeste está destinada a usos industriales.

En la zona de edificación abierta del este de Orriols, el tipo edificatorio más repetido es el bloque profundo en peine que ya hemos visto en otros planes, que integra un bloque largo de cinco crujías y varios cortos de dos crujías perpendiculares al primero en una manzana alargada, con toda su superficie ocupada por locales comerciales en planta baja. Además del bloque en peine, se proyectan agrupaciones de bloques lineales de dos y cinco crujías en forma de $U$ o de $L$, envolviendo espacios verdes. Todos estos bloques quedan integrados en una trama viaria mallada de menor tamaño que la de las manzanas cerradas contiguas, formada por calles paralelas y perpendiculares al Camino de Tránsitos.

Los equipamientos se disponen en dos núcleos principales, uno al norte, que incluye extensas zonas verdes y deportivas, así como un centro parroquial y una parcela escolar, y otro central, junto a la continuación proyectada de la calle Reig Genovés, que incluye una parcela escolar, una zona verde y un mercado que cierra dicha calle.

En la extensión de Torrefiel por el norte se utilizan los mismos tipos de edificación que en el este, además de algunos bloques lineales seriados. Junto a la ronda norte se sitúa un centro vecinal que incluye un centro parroquial y dos parcelas escolares.

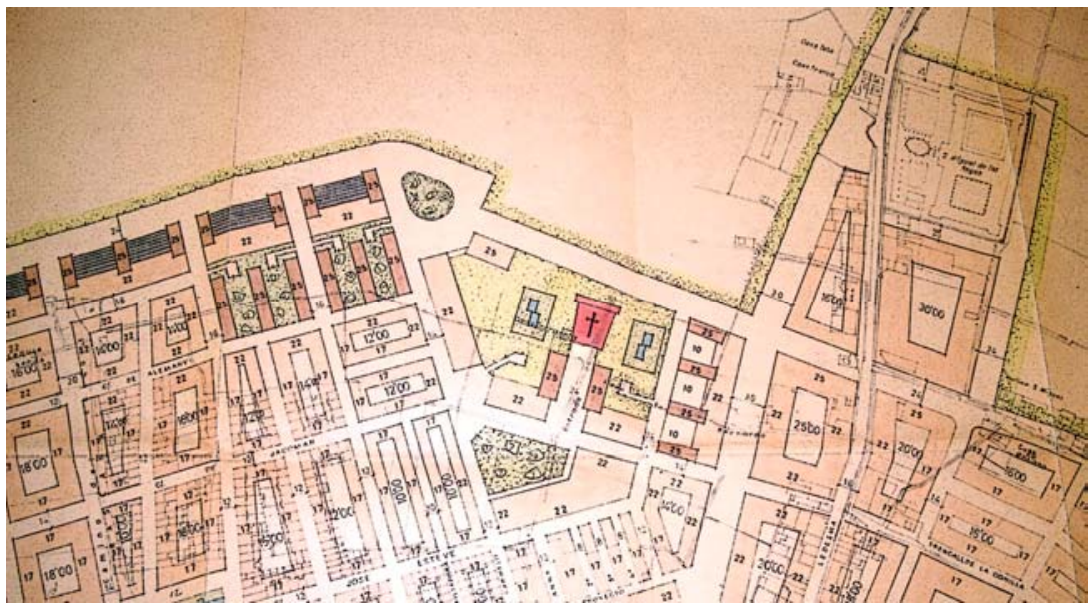

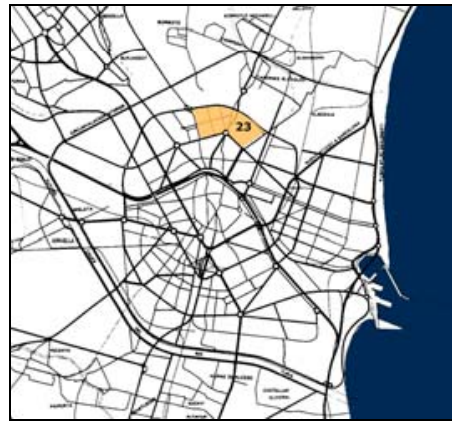

Plan Parcial 23. Localización
Plan Parcial 23 (1962). Plano de alineaciones. Detalle de la zona norte. 


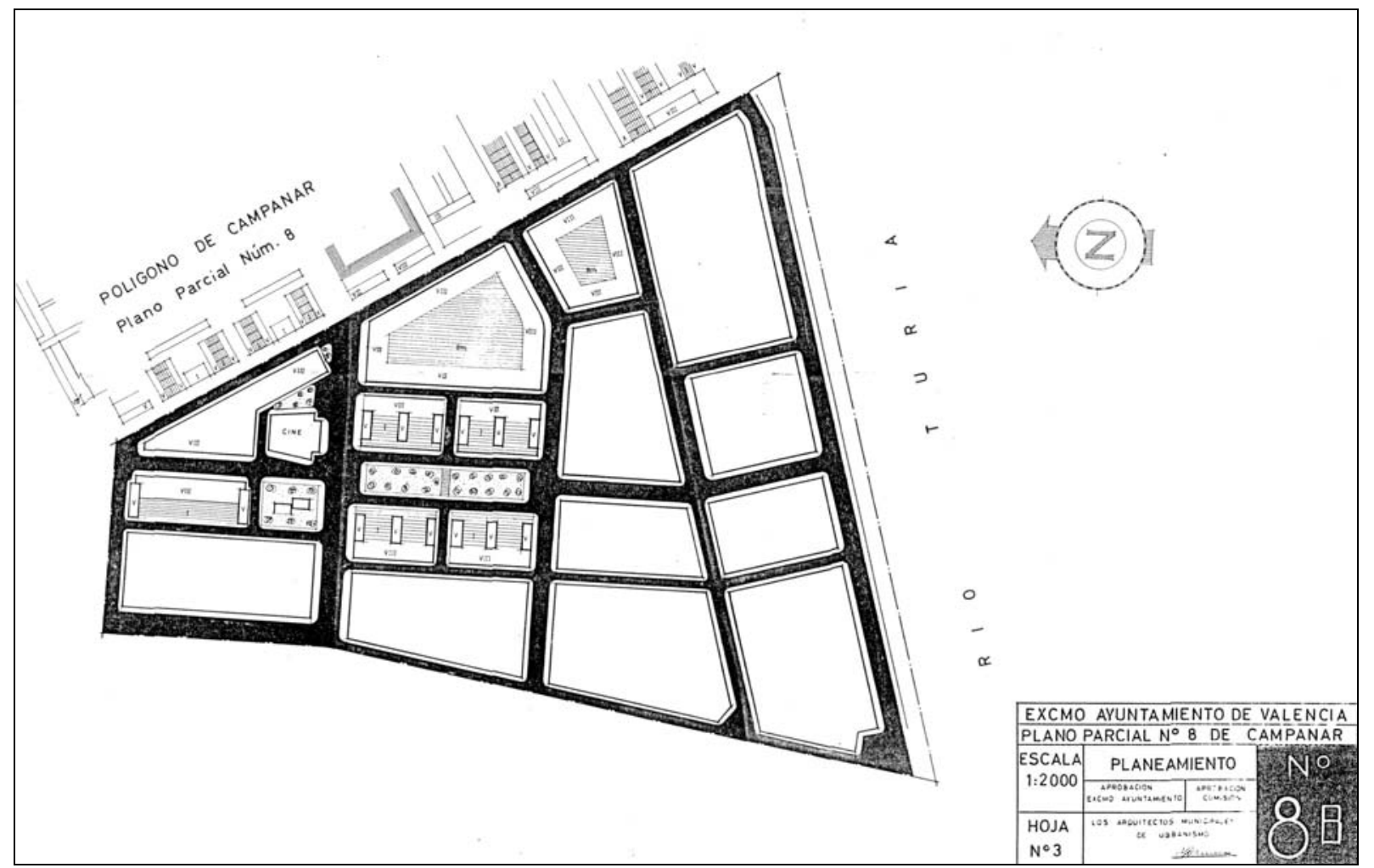

Plan Parcial 8-B (1963). Plano

de planeamiento 
El Plan Parcial 8-B comprende los terrenos situados al oeste del poblado de Campanar, limitados por el río Turia al sur, por la prolongación de la ronda de Tránsitos al Norte, por la prolongación de la Avda. de Pérez Galdós (actual Av. Maestro Rodrigo) al este y por la prolongación, pasado el río, del Camino de las Tres Cruces al oeste. En esta zona no existía planeamiento parcial anterior.

El plan contempla la creación de una zona industrial, ubicada al oeste contra viento reinante, que recoja las actividades industriales de los polígonos residenciales y de edificación abierta creados junto al poblado de Campanar. Esta zona se extiende hasta los bordes sur, al río, y oeste, final de la población de Valencia.

Completando el polígono se establecen manzanas para edificios residenciales, que se sitúan al noreste, junto a la Avenida Maestro Rodrigo y el vecino polígono residencial de Campanar.

La edificación proyectada es de manzanas cerradas en la Avenida Maestro Rodrigo, y de bloques profundos en peine flanqueando un eje viario central de dirección norte-sur. Este eje, que vertebra internamente el conjunto, incorpora una zona verde central en su tramo residencial, así como un pequeño núcleo de equipamientos situado en el cruce con la calle transversal principal.

Los bloques en peine son similares a los que aparecen en otros planes parciales del mismo periodo, como el Plan Parcial 220 el 12-B.

Como veremos más adelante, en la posterior redacción de este plan parcial, tras la aprobación del Plan General de 1966, la zona residencial aumentará su extensión hasta ocupar el frente sur recayente al cauce del río Turia.

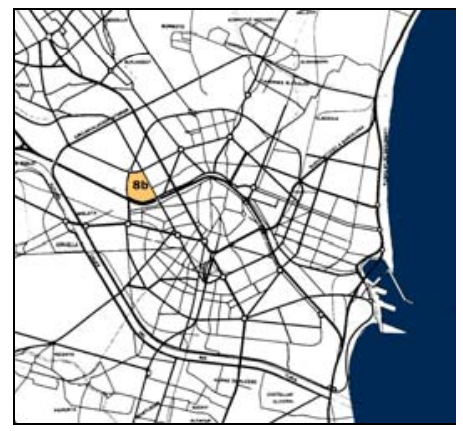

Plan Parcial 8-B. Localización.
Plan Parcial 8-B (1963). Plano de alineaciones.

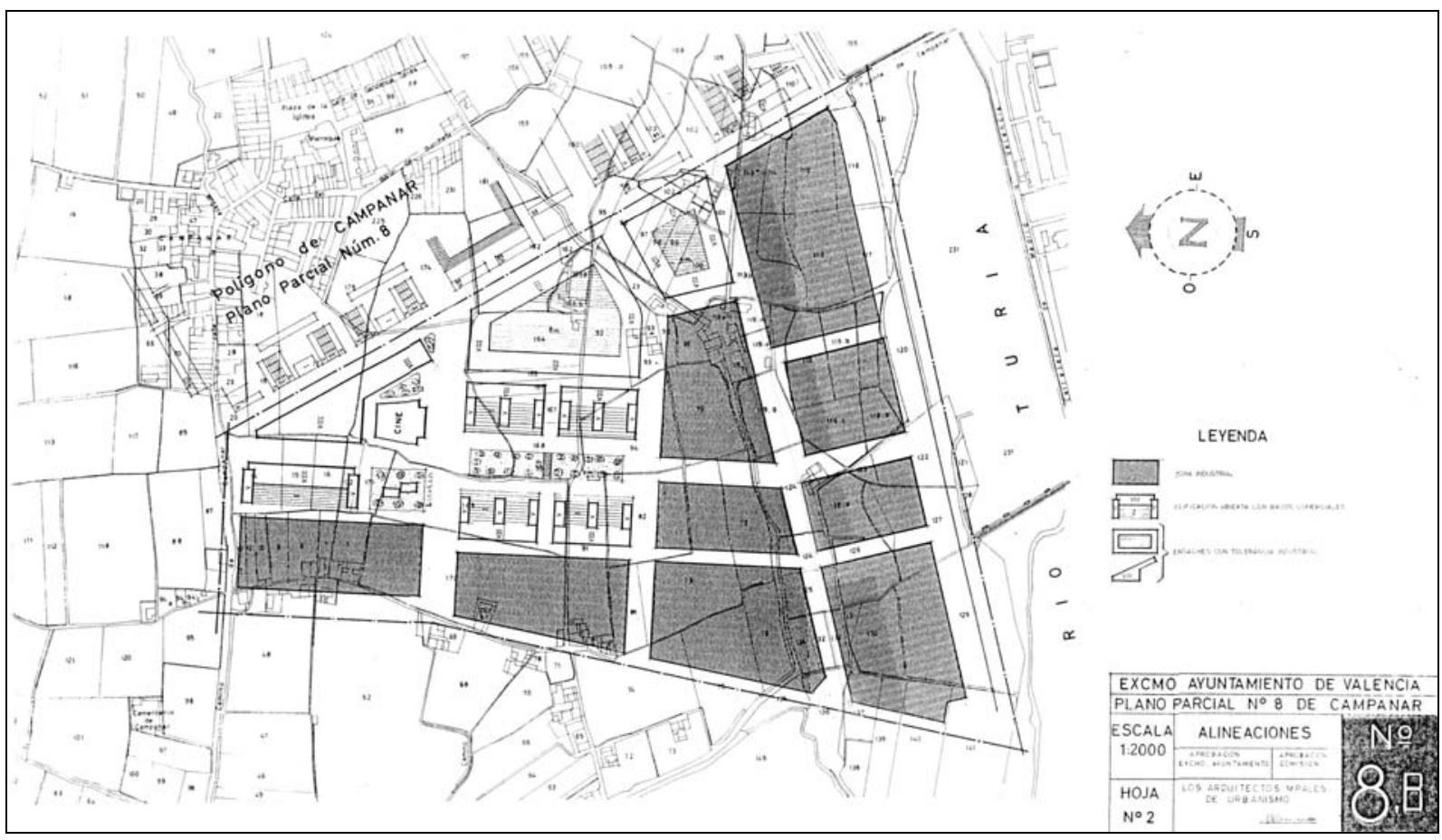




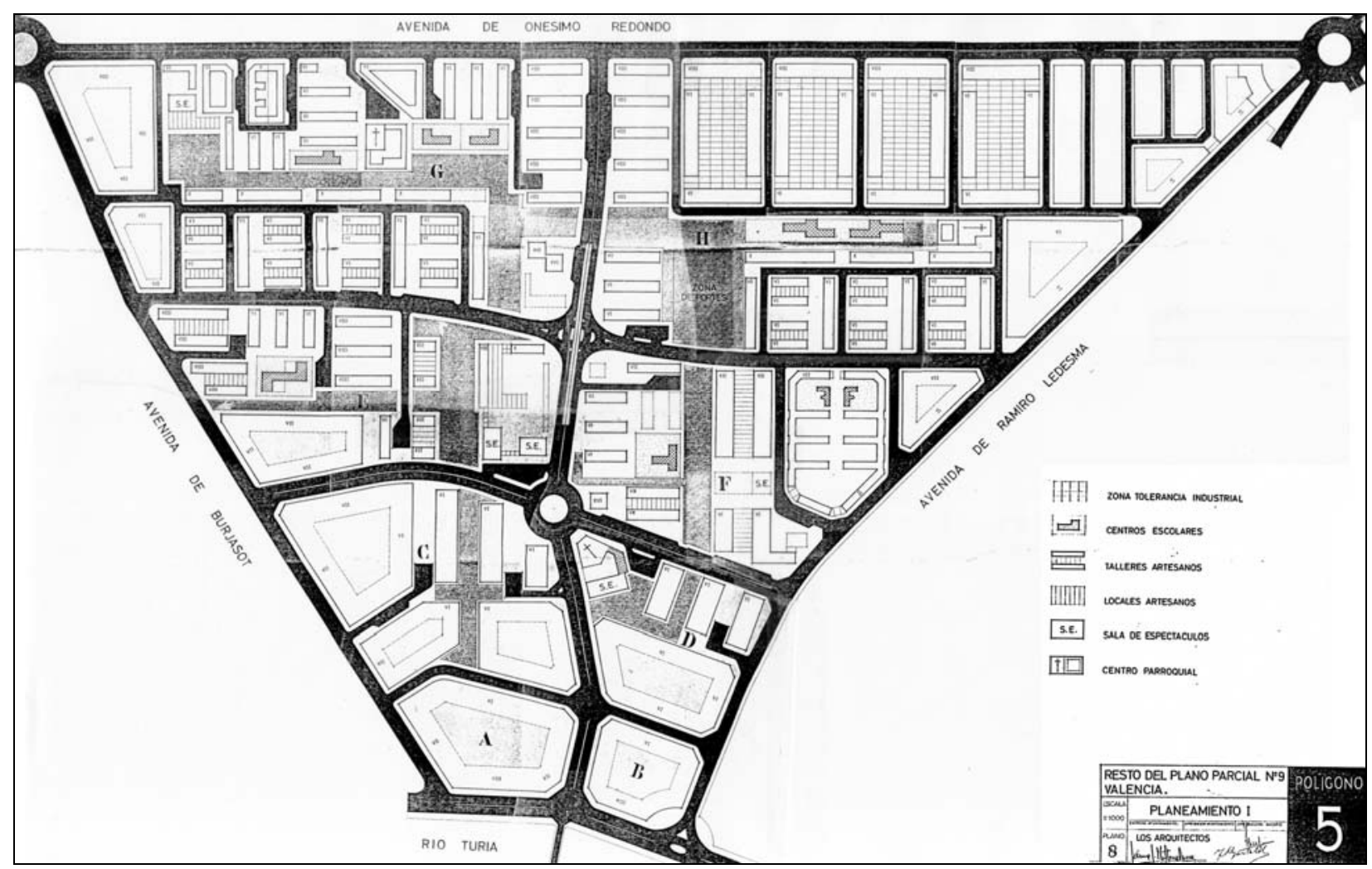

Plano Parcial 9 (1960) Plano de Planeamiento $I$.

Avance de Planeamiento, 1960. Esquema de zonificación.

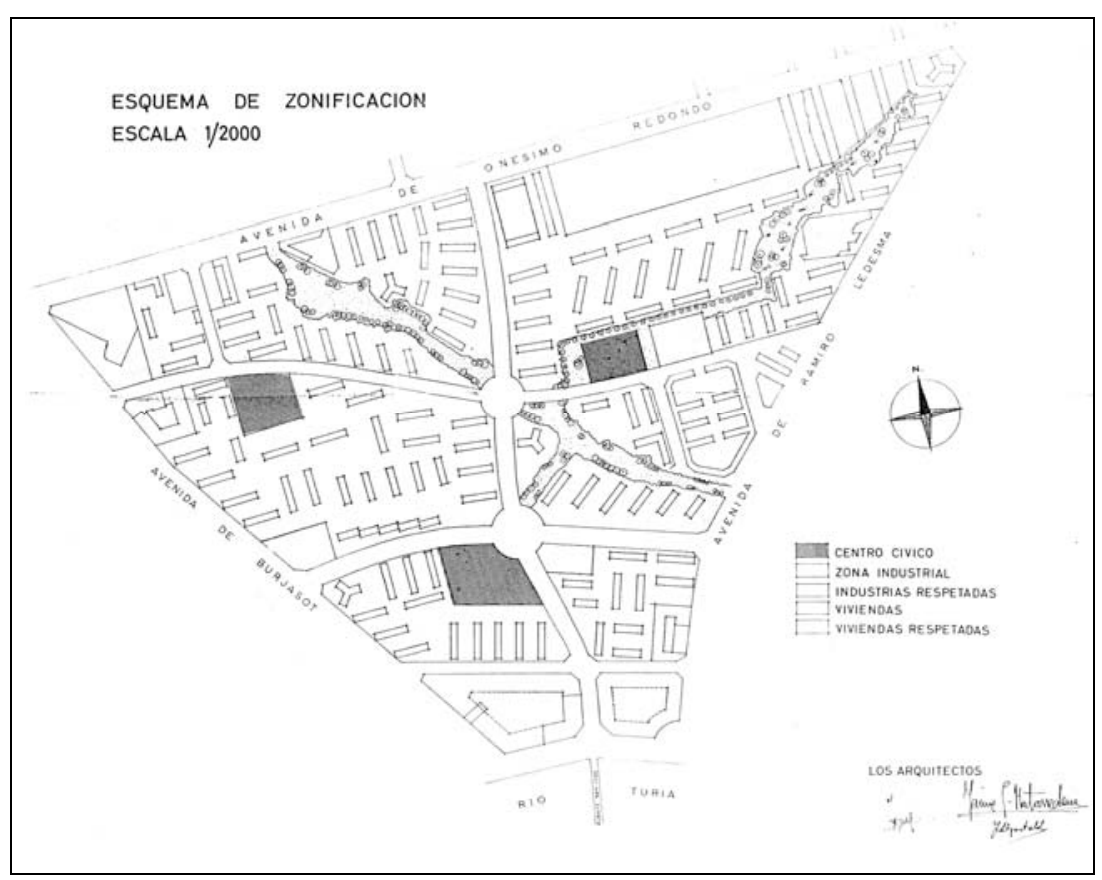


El Plan Parcial 9 fue redactado en 1960 por los arquitectos Jaime García-Matarredona, José Luís Gastaldi, Pablo Navarro y Julio TruIlenque y aprobado por la Dirección General de Urbanismo el 4-111961. El plan ordena un área situada en el margen izquierdo del Río Turia cuyos límites son la Avenida de Burjasot al oeste, el Camino de Tránsitos (Av. Onésimo Redondo) al norte, la Carretera de Barcelona (Av. Ramiro Ledesma) al oeste y el Llano de la Zaidía y el río al sur. Su superficie es de unas $66 \mathrm{Ha}$.

Para esta zona existía un planeamiento anterior, en desarrollo del Plan General de 1946, que ordenaba la zona mediante un tejido de manzanas cerradas de ensanche bastante irregulares, condicionadas por el contorno trapezoidal del área y por la presencia de la línea de Ferrocarriles Económicos y la Estación de Marchalenes, que la cruzan en diagonal por la mitad. De este tejido de ensanche se hallaba ya parcialmente consolidado el correspondiente a la parte sur, junto al río, y algunas manzanas a lo largo de la Avenida de Burjasot y de la carretera de Barcelona. Entre estas últimas se encuentra la manzana del grupo de viviendas de promoción municipal proyectado por Goerlich y construido entre 1944 y 1952 que hemos analizado en la Sección I.

Además, existían en la zona las viviendas e industrias del antiguo poblado de Marxalenes, caserío lineal que discurre a lo largo del camino del mismo nombre y cuya conservación no se prevé en el plan.

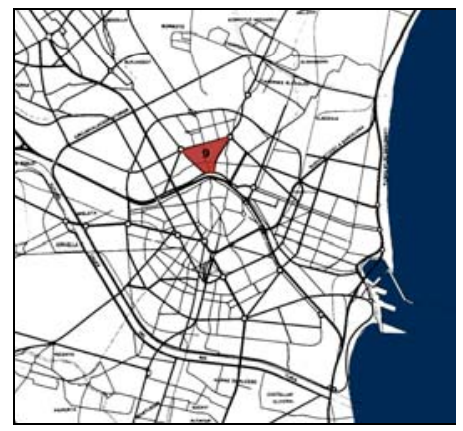

Plan Parcial 9. Localización.

Plan Parcial 9 (1960) Plano de Alineaciones.

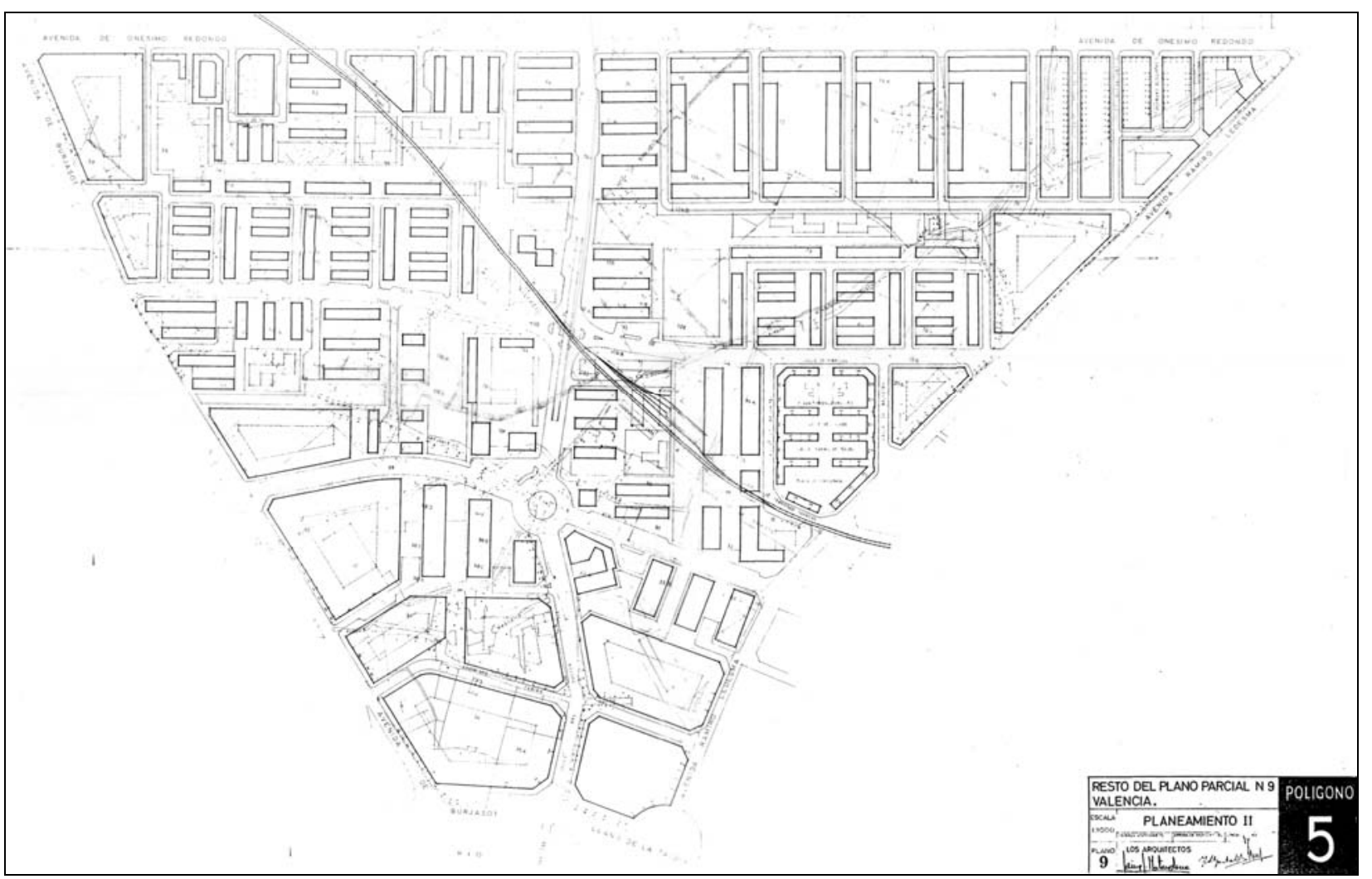



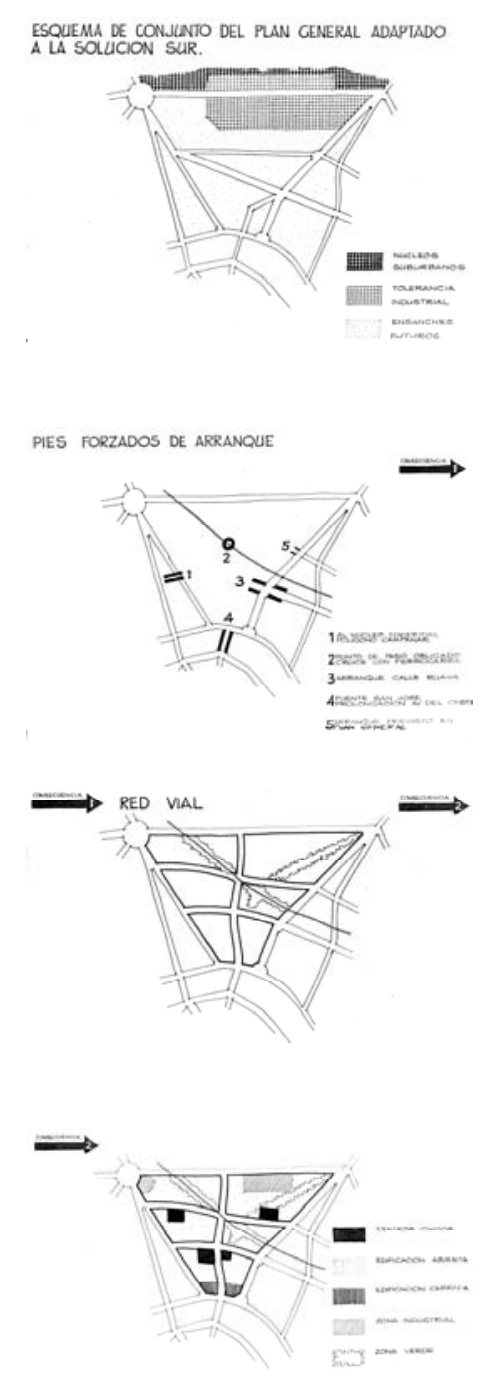

Esquemas del Avance de Planeamiento.

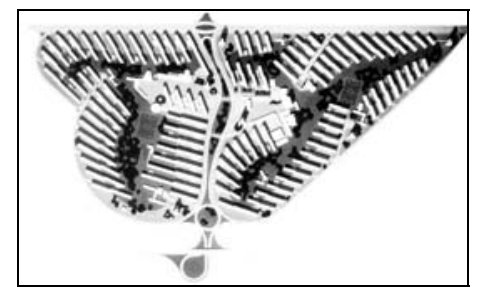

Polígono de Bellvitge, Barcelona, 1957.
En el Plan Parcial de 1960, las manzanas se sustituyen por bloques aislados en la totalidad del suelo vacante, ya que uno de los objetivos declarados de dicho plan, como indica el Avance del mismo, es el de proyectar algo totalmente actual. De hecho, la estructura urbana proyectada en el Avance muestra un cierto parecido con la del plan de 1957 para el polígono de Bellvitge.

El trazado viario proyectado se compone de un eje central norte-sur cruzado por tres vías transversales importantes esteoeste, que dividen la zona en 8 supermanzanas, numeradas de $\mathrm{A}$ a $\mathrm{H}$ en el plan. Las supermanzanas $A$ y $B$, situadas junto al río, son simples manzanas de ensanche. Las restantes, de la $\mathrm{C}$ a la $\mathrm{H}$, van creciendo de tamaño conforme se acercan al norte.

El eje norte-sur está concebido como vía de penetración y acceso al barrio, y corta al Ferrocarril en un solo punto. Las tres vías transversales son las del Arzobispo Fabián y Fuero, Ruaya y Portugal, ya iniciadas. De ellas, la de Ruaya es una vía de conexión entre barrios, que sirve de enlace con el vecino Polígono de Campanar.

Dentro de cada supermanzana, las únicas vías de penetración son en lazo o en fondo de saco. Ello permite configurar en el interior de cada una de ellas un área central peatonal con equipamientos (escuelas e iglesias), comercios y zonas verdes, libre de interferencias con el tráfico rodado.

La Memoria del plan señala que cada supermanzana se concibe como una unidad de barrio con vida propia, para lo que se la dota de los servicios necesarios. Las escuelas, en concreto, se prevén para absorber una población escolar del $10 \%$ del número de habitantes.

Las zonas verdes adoptan una forma lineal, de modo que las supermanzanas están ligadas por un anillo verde para circulación de peatones, que une sus áreas centrales.

Para el adecuado funcionamiento del área como conjunto único, el plan prevé un Centro Cívico importante, corazón del barrio y punto de máxima vitalidad del mismo, situado en su centro de gravedad, a un lado de la vía de penetración norte-sur y conectado con el anillo verde de circulación de peatones. La Memoria del plan señala que este Centro Cívico constará, en su aspecto cultural, de teatro, auditorio y biblioteca; en su aspecto comercial de tiendas de impulso, oficinas y despachos, y en el recreativo de cines, bares, cafeterías y espacios ajardinados.

El plan, como vemos, se enmarca claramente en la idea de integración escalonada de unidades urbanas completas.

En cuanto a la edificación proyectada, la Memoria del plan señala lo siguiente:

En el planeamiento realizado, se ha buscado con interés conseguir una transición entre la manzana cerrada, normal en Valencia y la edificación abierta, considerada en la actualidad como la de mejores condiciones, para ello se ha procedido gradualmente, mediante la interposición de manzanas semiabiertas y bloques de 6 crujías. 


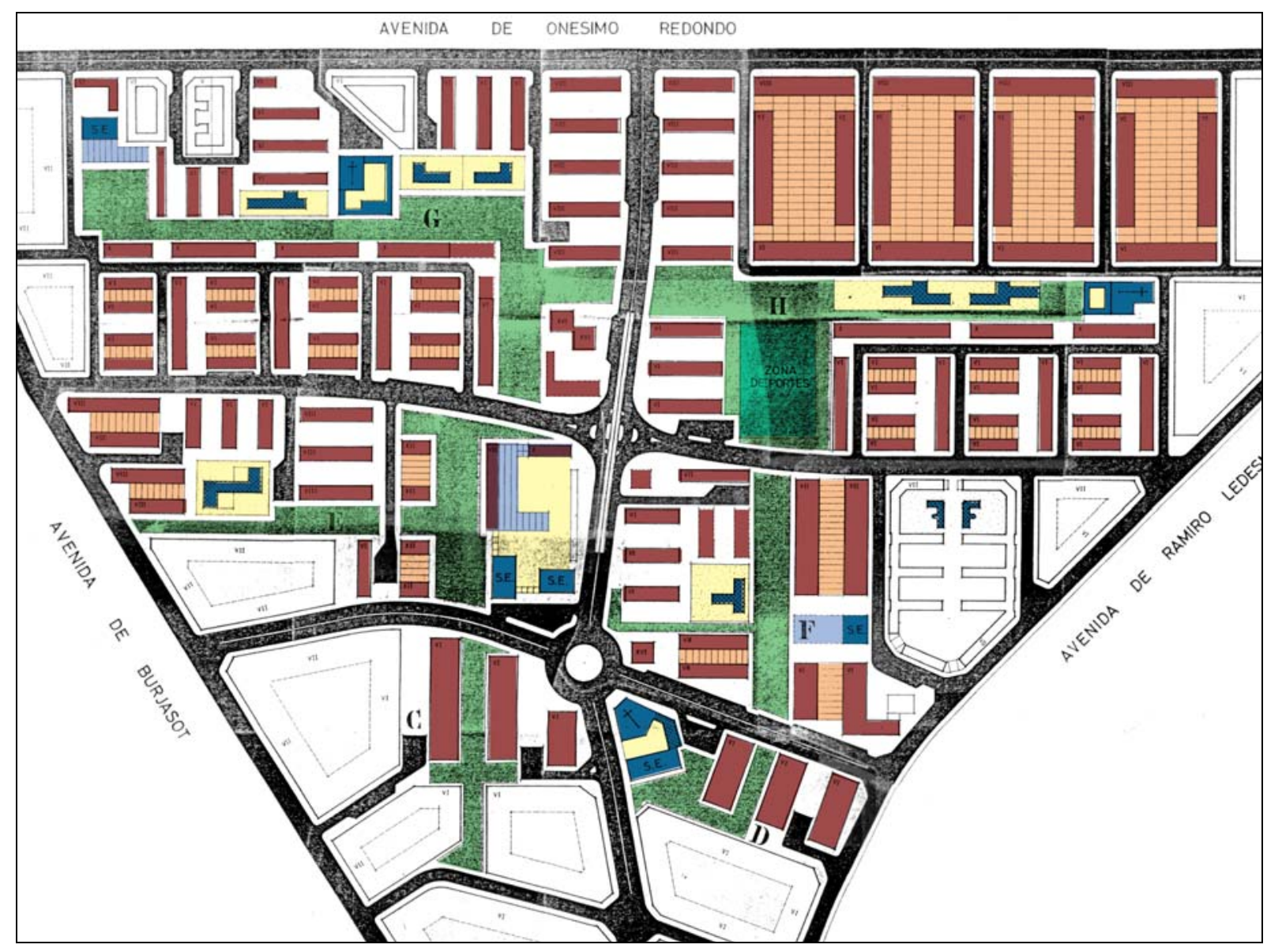

Aunque la edificación en general es abierta, las densidades obtenidas son fuertes, lográndose los $600 \mathrm{hab} / \mathrm{Ha}$. y los $4,72 \mathrm{m3} / \mathrm{m} 2$. , lo cual hace que el aprovechamiento del terreno sea francamente aceptable. Esto nos ha parecido necesario para no defraudar y mover la actuación de la iniciativa privada y para suavizar el paso entre la edificación del casco urbano y la edificación abierta, que en el futuro se desarrollará lógicamente con densidades muy bajas. Aunque la solución aportada no sea la teóricamente ideal, por su excesiva densidad, ya que actualmente se considera que no se deben superar los $300 \mathrm{Hab} / \mathrm{Ha}$., sin embargo nos ha parecido la más adecuada a las circunstancias de lugar y tiempo. ${ }^{1}$

Los bloques profundos aparecen en el lado sur de la calle Ruaya y junto al grupo de Goerlich, como elementos de transición con las manzanas cerradas.

En el resto del área ordenada por el plan, los bloques lineales de dos crujías son el tipo predominante, bien como bloques aislados o bien como bloques unidos por una planta baja comercial. En este segundo caso, existe una gran dispersión de tamaños, ya que podemos encontrar desde grupos de micromanzanas de $25 \times 35$ m formadas por parejas de bloques cortos, como las situadas en el lado norte de la Avenida de Portugal, hasta manzanas de $80 \times 150$ m con cuatro bloques, como las recayentes al Camino de Tránsitos, cuyas plantas bajas estaban destinadas a usos industriales.

El tipo de torre aparece únicamente como edificio singular, situado cerca de las intersecciones más importantes del eje central. ${ }^{2}$

Plan Parcial 9. Edificación y equipamientos (Elaboración propia, sombreado en color sobre Plano de Alineaciones).

1. Planeamiento del resto del Plano No 9. Polígono No 5, 1960. Memoria. Anexo de Documentos, pp. 243-245.

2. La construcción de los edificios previstos en este plan, que comienza inmediatamente después de su aprobación, será estudiada en la sección siguiente. La razón para ello es la de poder comparar la versión original del Plan Parcial 9 de 1960 con las nuevas versiones del mismo redactadas en 1967 y 1973. 


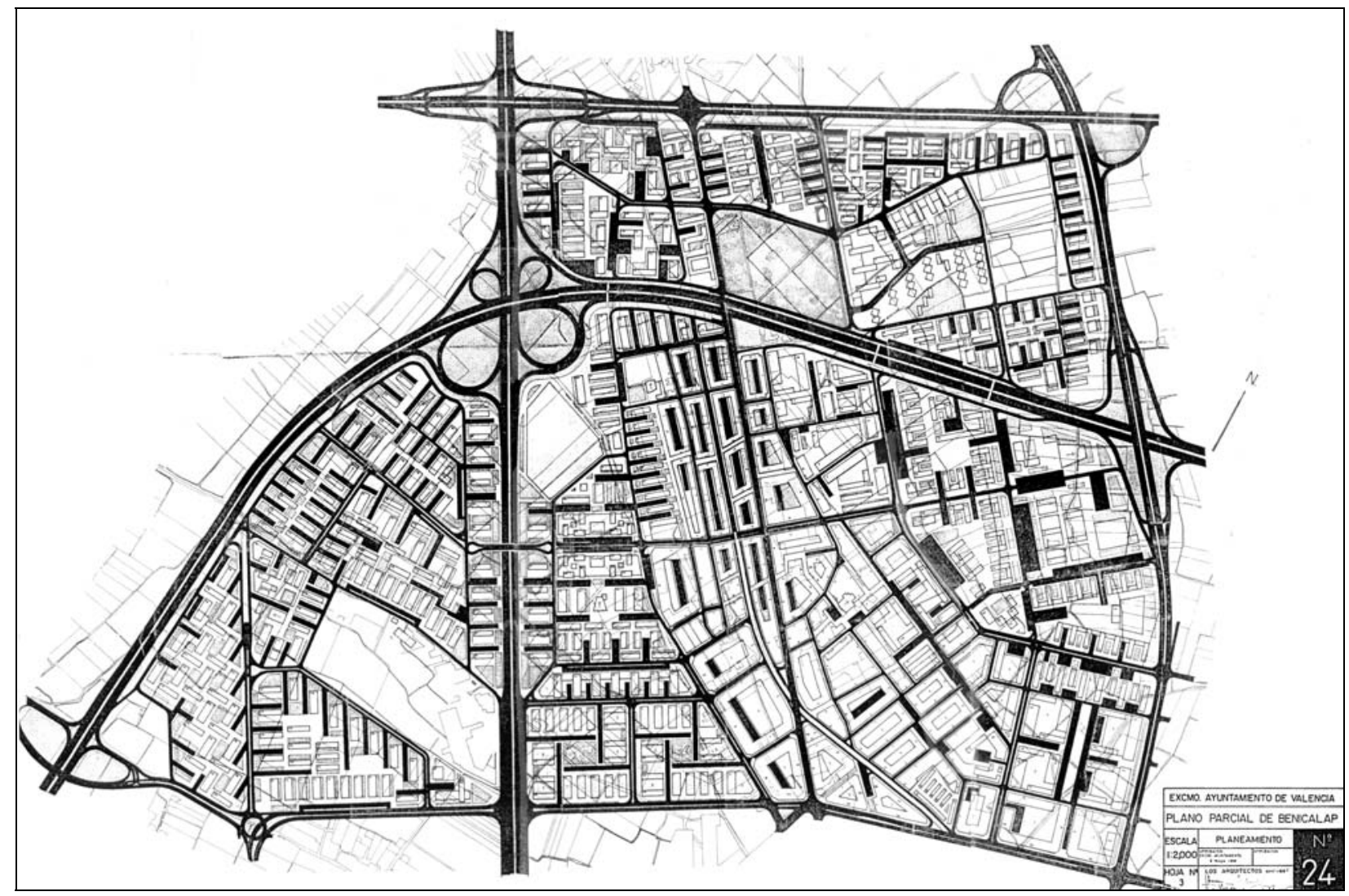

Plan Parcial 24. Ayuntamiento

de Valencia, 1966. Plano de alineaciones. 
El Plan Parcial 24, que ordena las áreas situadas en torno al poblado de Benicalap, en el noroeste de Valencia, fue aprobado inicialmente por el Ayuntamiento de Valencia en octubre de 1966, un mes antes de la aprobación del Plan General adaptado a la Solución Sur. El ámbito del plan, de gran extensión, es el limitado por el camino de Tránsitos y su prolongación al sur, la nueva Circunvalación de Poblados al norte, el nuevo acceso de Moncada y el Plan Parcial 23 al este y la Ronda Interior y el nuevo acceso de Ademuz al oeste.

El área ordenada está cruzada por dos ejes viarios importantes: el eje norte-sur del nuevo acceso de Ademuz y el eje estesuroeste de la Ronda Interior. A ellos se unen los ejes históricos de la Avenida de Burjasot y el Camino de Paterna, a lo largo de los cuales se había ido desarrollando el poblado de Benicalap.

La tardía fecha de redacción de este plan con respecto a los restantes estudiados en esta sección explica el hecho de que el diseño viario que aparece en el mismo sea ya el elaborado por la Jefatura Regional de Carreteras.

Al viario principal señalado se añade una red de calles secundarias que definen una malla de supermanzanas de forma irregular. De esta malla arrancan, en el perímetro de cada supermanzana, ramales sin salida de formas diversas para el estacionamiento y el acceso a las edificaciones.

Además de las edificaciones del poblado de Benicalap, el plan está condicionado por otras preexistencias que ocupan una gran superficie de suelo, como son las Escuelas Profesionales de San José, el enclave de la Ciudad del Artista Fallero y las instalaciones industriales de Saica.

La suma de los condicionantes impuestos por el diseño viario proyectado y por las preexistencias mencionadas es la causa de que las área vacantes en las que se pretende situar la edificación abierta tengan una contorno irregular $y$, además, tengan en su interior grandes bolsas de suelo que rompen la continuidad del nuevo tejido.

La respuesta que da el plan a este problema es la de renunciar a una geometría global predominante de tipo ortogonal, que es la característica del orden abierto, en el que las trazas de los edificios pueden ser independientes del viario y también de los contornos de las parcelas. Frente a ello, se opta por que los bloques se dispongan en cada supermanzana según los ejes que marca el viario perimetral de la misma, o el eje más importante de su contorno.

El resultado de todo ello es que el conjunto presenta una apariencia un tanto caótica, como de cosido de retales, en el que ningún fragmento tiene entidad suficiente para asumir el protagonismo de la composición.

Este hecho se acentúa por las características de la edificación abierta proyectada, a base de bloques lineales de dos o cinco crujías de profundidad pero muy cortos, todos muy parecidos pero dispuestos según orientaciones demasiado variadas.

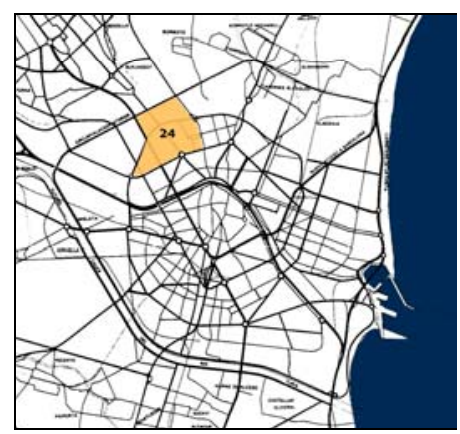

Plan Parcial 24. Localización
1. Plano Parcial No 24, 1966. Ver Anexo de Documentos, pp. 249257. 
Ciudad del Artista Fallero del Plano Parcial no 24, Ayuntamiento de Valencia, julio1963.
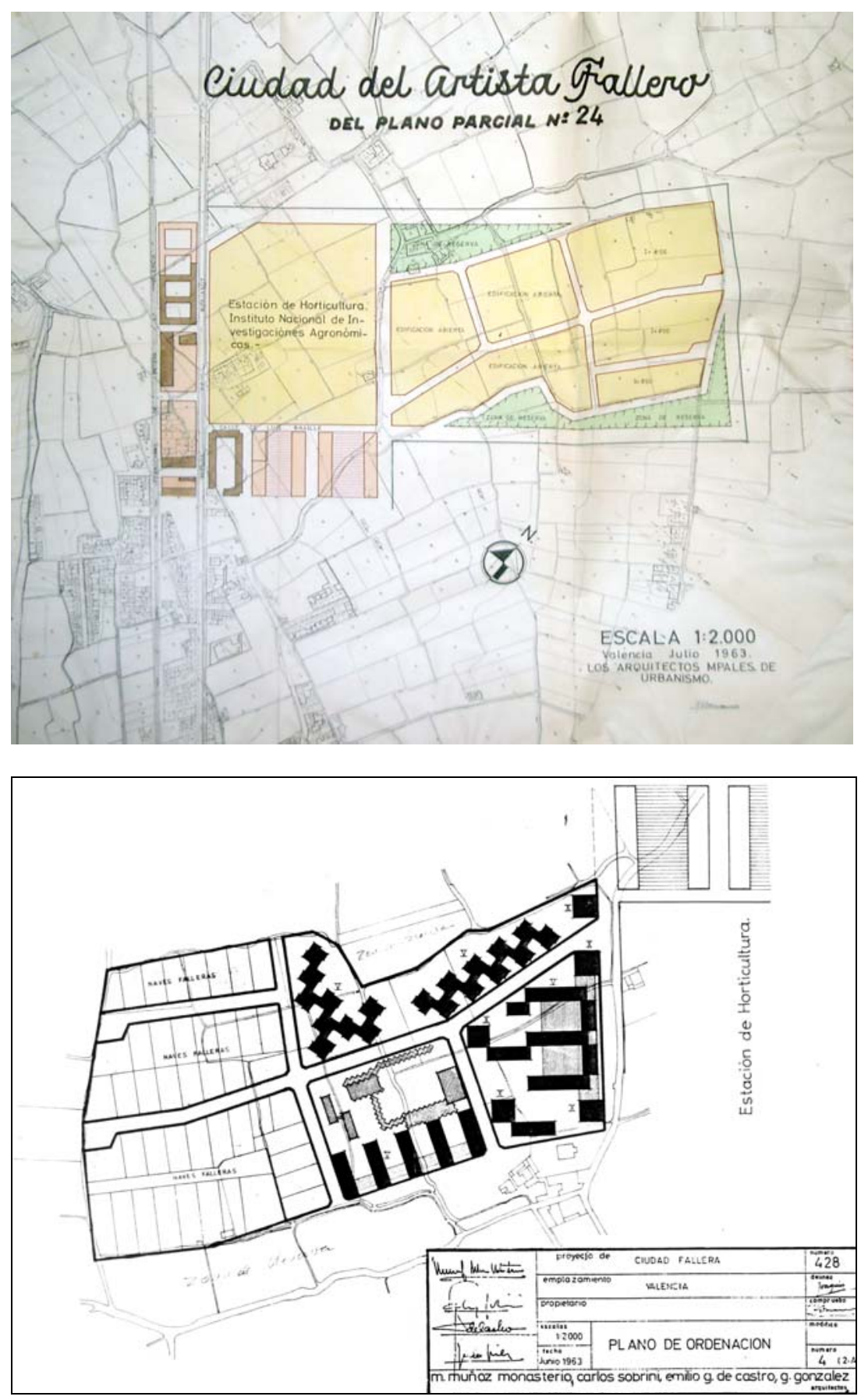

La ausencia casi completa de equipamientos escolares (los únicos son las Escuelas de San José y las de la Ciudad del Artista Fallero) o de zonas verdes que no sean las intersticiales entre bloques, contribuyen a reforzar la imagen del conjunto como relleno masivo de bloques.

El énfasis en la variedad está presente también en el proyecto inicial para la Ciudad del Artista Fallero redactado por Manuel Muñoz Monasterio, Carlos Sobrini, Emilio G. de Castro y G. González en 1963, con anterioridad al Plan Parcial no 24. En unos terrenos no muy extensos, situados a continuación de la Estación de Horticultura recayente a la Avenida de Burjasot, el proyecto prevé tres tipos diferentes de edificación abierta en torno a un núcleo central de equipamientos: bloques lineales equidistantes, bloques lineales de 
traza quebrada combinados con torres, y bloques con planta dentada en forma de cremallera.

Esta variedad de tipos se mantendrá en los proyectos sucesivos para este enclave, que incluye junto a la edificación residencial terrenos para naves de artistas falleros.

Además del Plano Parcial no 24 redactado por la Oficina Técnica Municipal de Urbanismo del Ayuntamiento de Valencia, existe otra versión fechada también en 1966 del Plan Parcial 24, redactada por la Oficina Técnica de la Corporación Administrativa Gran Valencia.

Esta ordenación de Gran Valencia no refleja el diseño viario definitivo para la zona, por lo que cabe suponer que se trata de un proyecto previo al municipal. Su principal diferencia con respecto al plan municipal es la referente al ámbito, ya que amplia considerablemente por el oeste el límite de la zona edificable y, por tanto, de la propia ciudad. Esta ampliación se mantendrá, como veremos, en las nuevas versiones del Plan Parcial 24 que se redactarán con posterioridad a la aprobación en 1966 del Plan General adaptado a la Solución Sur.

En la ordenación de Gran Valencia, la presencia de equipamientos es mucho mayor. Así, en el centro de cada supermanzana, por lo general, se localiza una parcela escolar.
Proyecto Parcial de Benicalap, no 24. Corporación Administrativa Gran Valencia, 1966. Plano de Ordenación

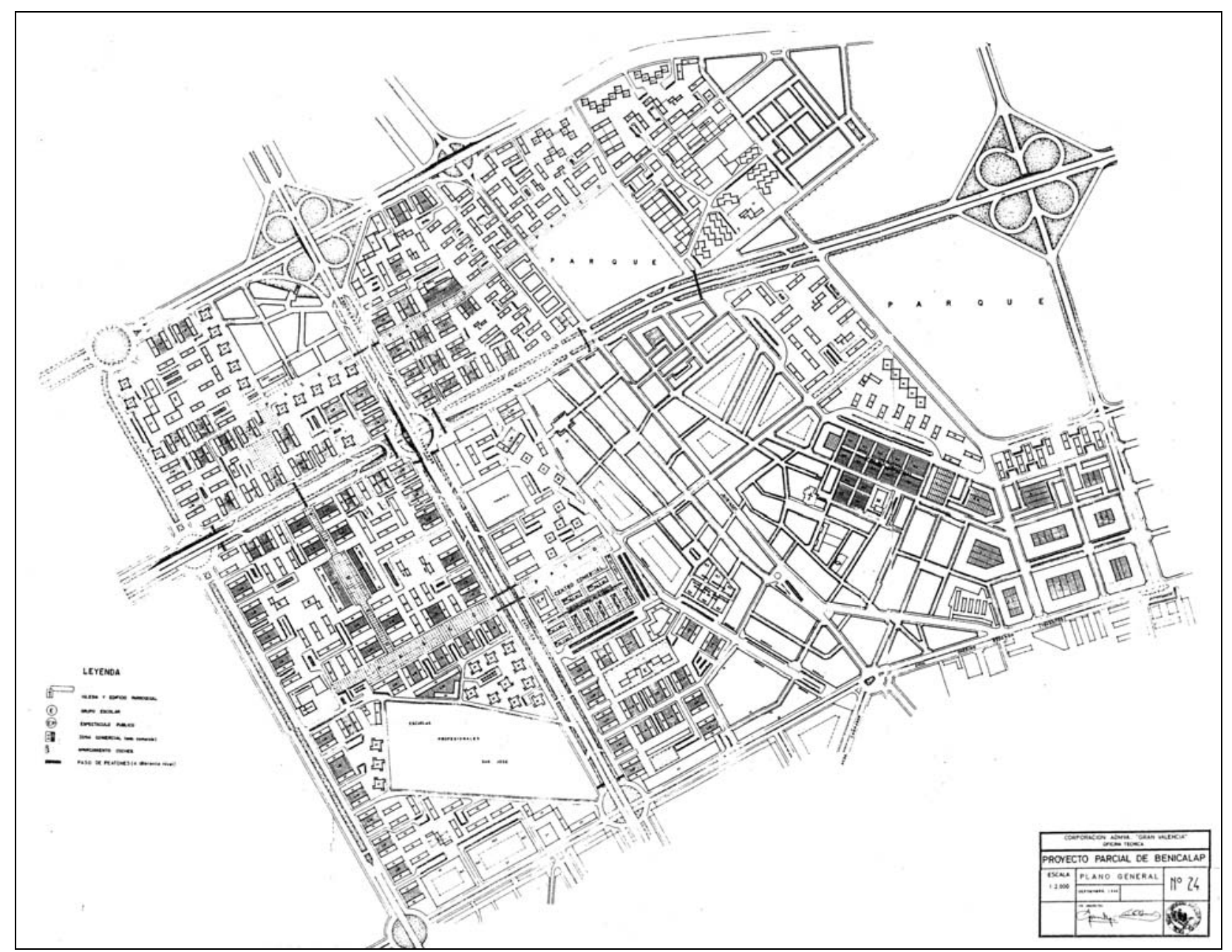


Plan Parcial 24. Ayuntamiento de Valencia, 1966. Plano de alineaciones. Detalle de la zona oeste.
La composición general del plan de Gran Valencia se apoya en unos ejes únicos ortogonales, que son los del nuevo acceso de Ademuz y el perpendicular al mismo, y según estos ejes se disponen todos los bloques y torres, con la única excepción de la zona situada alrededor de la Ciudad del Artista Fallero, en la que se siguen los ejes de la edificación en ella prevista

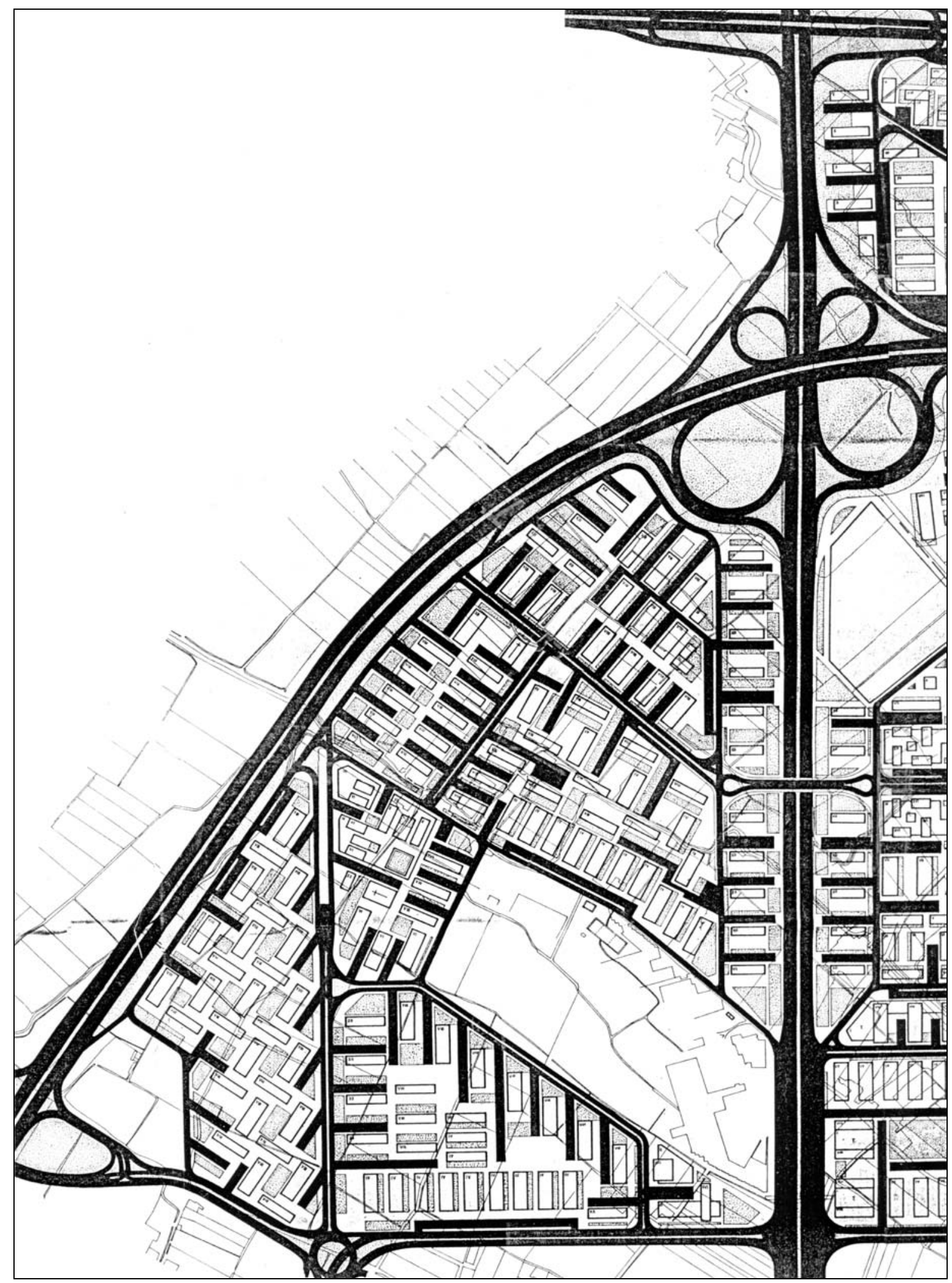


Además, en el plan de Gran Valencia se prevé un sistema de paseos o recorridos peatonales que recorre todas las supermanzanas, formando un anillo superpuesto al trazado en cruz del viario rodado principal, a lo largo del cual se van situando junto a unas plazas diversos equipamientos, tales como centros comerciales, iglesias y zonas verdes ${ }^{1}$.

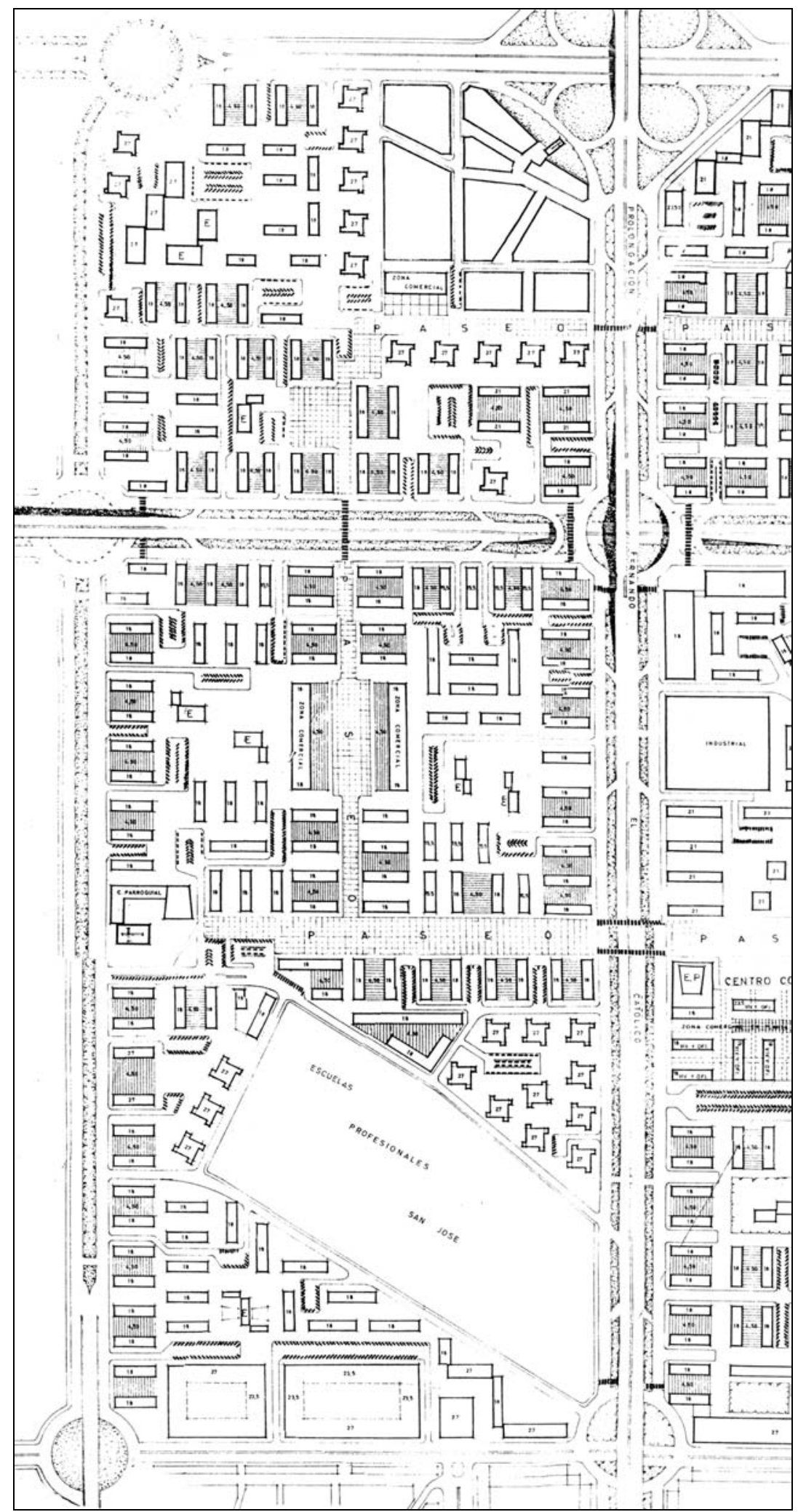

Plan Parcial 24. Corporación Administrativa Gran Valencia, 1966. Plano de Ordenación. Detalle de la zona oeste.
1. Este anillo comienza en un gran parque previsto al este del poblado de Benicalap, continúa en dirección este-oeste a lo largo de las calles Pintor Matarana y Garbí, y entra en la zona de edificación abierta como prolongación de esta última calle. Tras cruzar el acceso de Ademuz mediante pasarelas elevadas, continúa hasta el límite oeste del plan, donde una iglesia cierra su perspectiva El paseo se bifurca hacia el norte, y recorre en esta dirección dos macromanzanas de edificación abierta, en cada una de las cuales se proyecta un centro comercial junto a una plaza. Después, el eje gira hacia el este, vuelve a cruzar el acceso de Ademúz y termina en la Ciudad del Artista Fallero después de atravesar una supermanzana de edificación abierta en la que se sitúa otro centro comercial. 


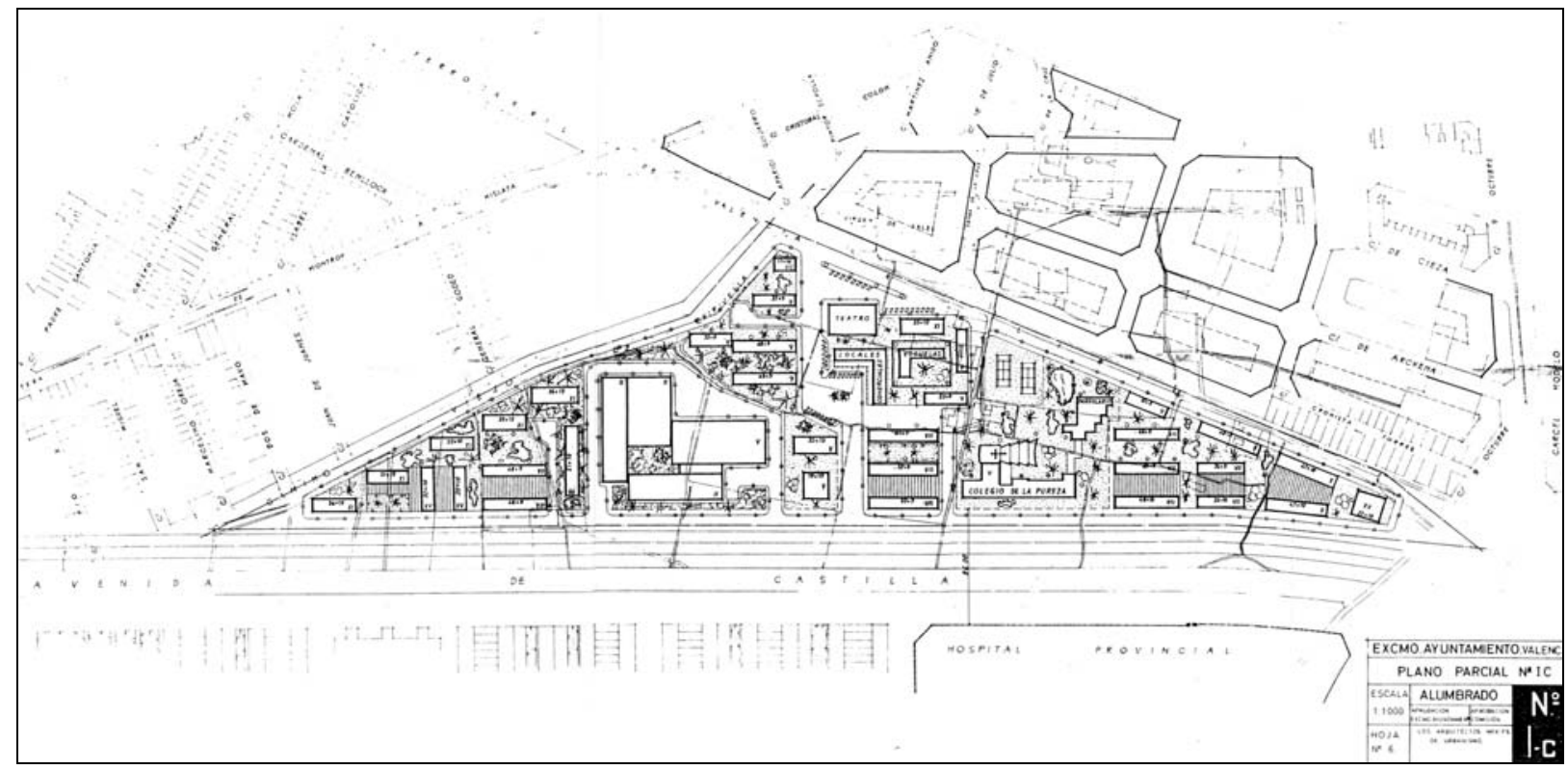

Plano Parcial I-c , 1963.

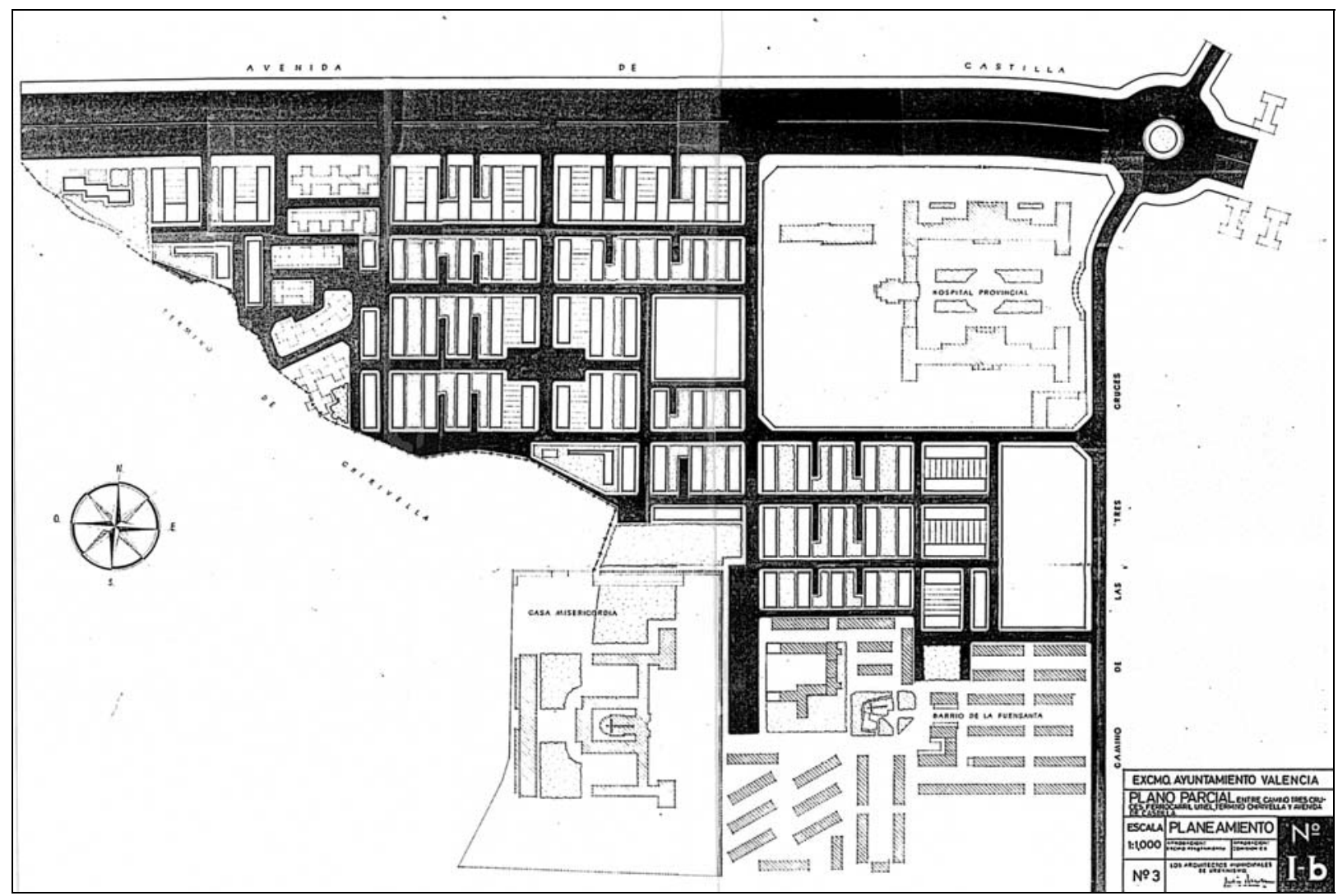

Plano Parcial I-b entre Camino Tres Cruces, Ferrocarril de Utiel, término de Chirivella y Avenida de Castilla, 1962. 


\section{LA ZONA DE LA AVENIDA DE CASTILLA: PLANES PARCIALES I-B Y I-C (1962-63)}

Los planos parciales I-b y I-c ordenan los terrenos sin edificar situados junto a la Avenida de Castilla, al sur y norte de la misma respectivamente, en el tramo comprendido entre la ronda interior y el nuevo cauce. Estos terrenos forman parte de los englobados en el Proyecto Parcial I de desarrollo del Plan General de 1946, y a ello se debe la denominación de los planes, que posteriormente quedarán englobados en el ámbito de los planes parciales 25 (el I-c) y 26-b (el I-b), redactados con posterioridad a la aprobación en 1966 del nuevo Plan General adaptado a la Solución Sur.

\section{Plano Parcial I-b}

El Plano Parcial I-b, redactado en 1962, ordena los espacios intermedios existentes entre el Hospital Provincial, el barrio Virgen de la Fuensanta, la Casa de la Misericordia y el Barrio de la Luz, entre la Avenida de Castilla y el término municipal de Chirivella.

La edificación que se proyecta para esos espacios intermedios es muy uniforme, de bloques lineales muy cortos dispuestos según los principios de la edificación en línea, lo que no resulta nada habitual en los planes parciales de Valencia.

Así, se proyectan bloques lineales equidistantes, orientados casi todos en dirección norte-sur (es decir, con fachadas a este y oeste) y calles de tráfico rodado perpendiculares a los bloques. Los espacios intermedios entre los bloques se destinan a zonas verdes, a ramales sin salida o a locales comerciales. De ello resulta un tejido de manzanas estrechas y alargadas, con la edificación dispuesta en bandas transversales y una densidad de 400 habitantes por hectárea.

En la franja recayente a la Avenida de Castilla, la edificación es de mayor altura, y las parejas de bloques lineales se unen con un cuerpo de edificación transversal, formando una $U$ abierta a la Avenida.

El barrio de la Luz queda englobado en este plan, pero la ordenación del Barrio Residencial no 2 de 1956, que era la que justificaba la disposición de la edificación en dicho barrio, no se tiene en cuenta, y se sustituye por un relleno uniforme de todo el suelo disponible cuya rigidez de zeilenbau es incompatible con la integración de preexistencias que responden a otra lógica compositiva.

En el caso del barrio de la Fuensanta, la integración viaria es mayor, debido a que este barrio estaba proyectado, como el Plano I-b, según los principios de la edificación en línea, y además con unos bloques dispuestos siempre en paralelo o en ortogonal a la Avenida de Castilla.

Las reservas se suelo para equipamientos son muy escasas en el Plano Parcial I-b, y se limitan a dos pequeñas parcelas escolares, que la propia memoria del plan señala que no bastan para cubrir las necesidades previstas, a los espacios verdes intermedios entre bloques, a una plaza con locales comerciales y a un parque previsto junto a la casa de la Misericordia ${ }^{1}$.

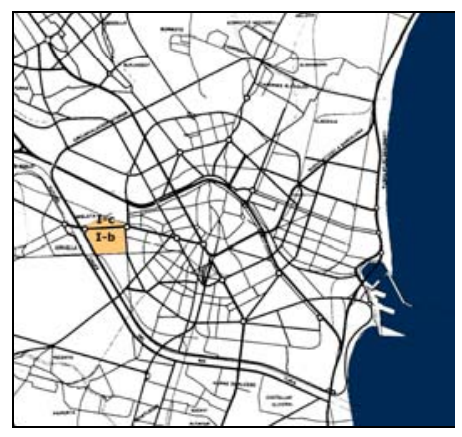

Planes Parciales $I-B$ y $I-C$. Localización
1. En concreto, la Memoria del Plano Parcial I-b señala lo siguiente: "La superficie destinada a escuelas $-4.500 \mathrm{~m} / 2-$, es menor que la necesaria para la zona, que seria de $6.500 \mathrm{~m} 2$, dada una población de 9.125 habitantes, y suponiendo el $15 \%$ de población escolar y $6 \mathrm{~m} / 2$ por niño.

Se hace esto porque los dos grupos proyectados podrían atender las necesidades en el comienzo de la realización y estimo que por la forma de lo proyectado cualquier bloque o grupo de dos con su jardín pueden convertirse en grupo escolar. Es decir, que no habrá verdadera dificultad en el futuro para el establecimiento de un tercer grupo escolar". Ver Anexo de Documentos, pp. 265266. 


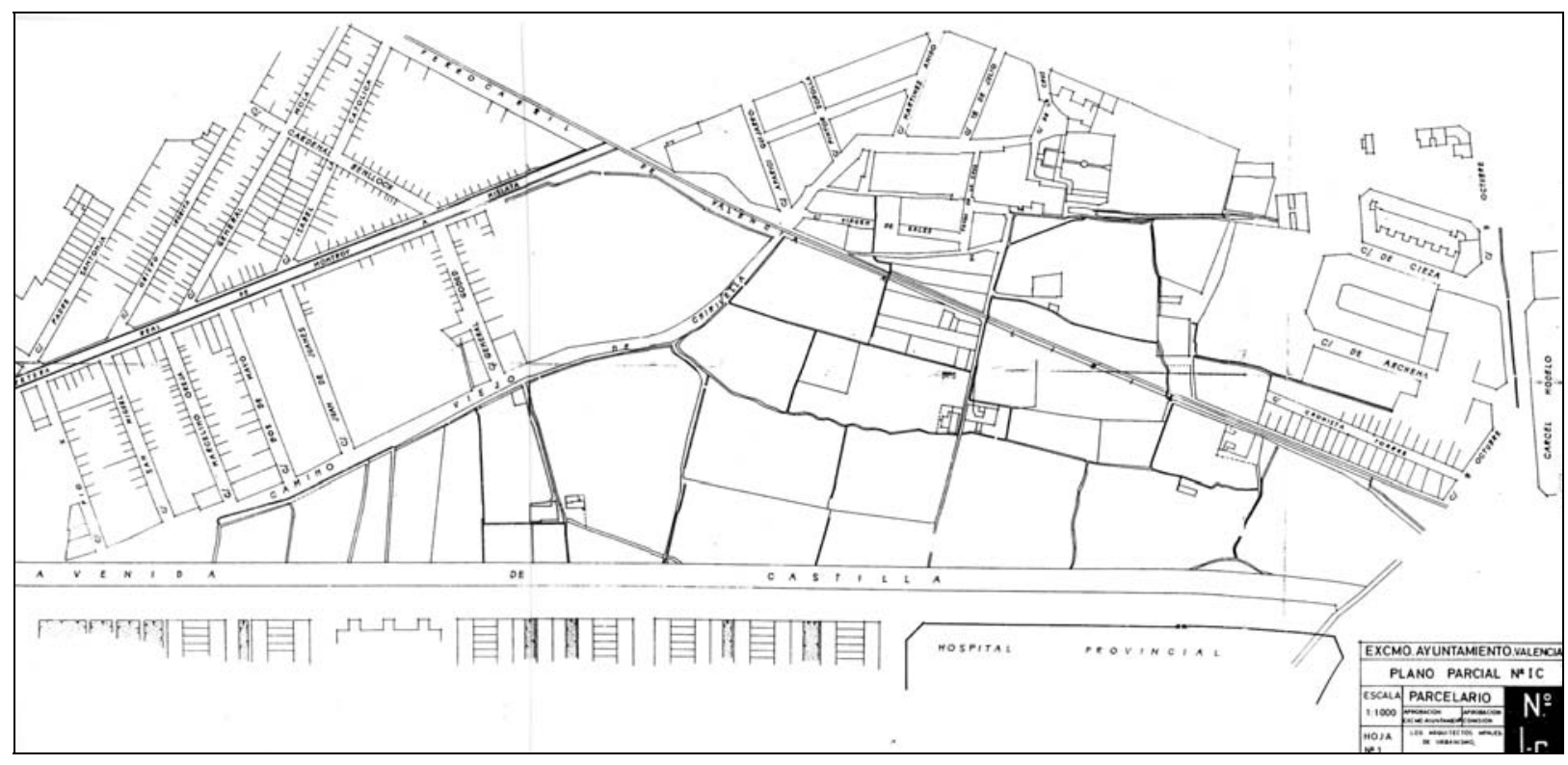

Plano Parcial I-c. Parcelario.

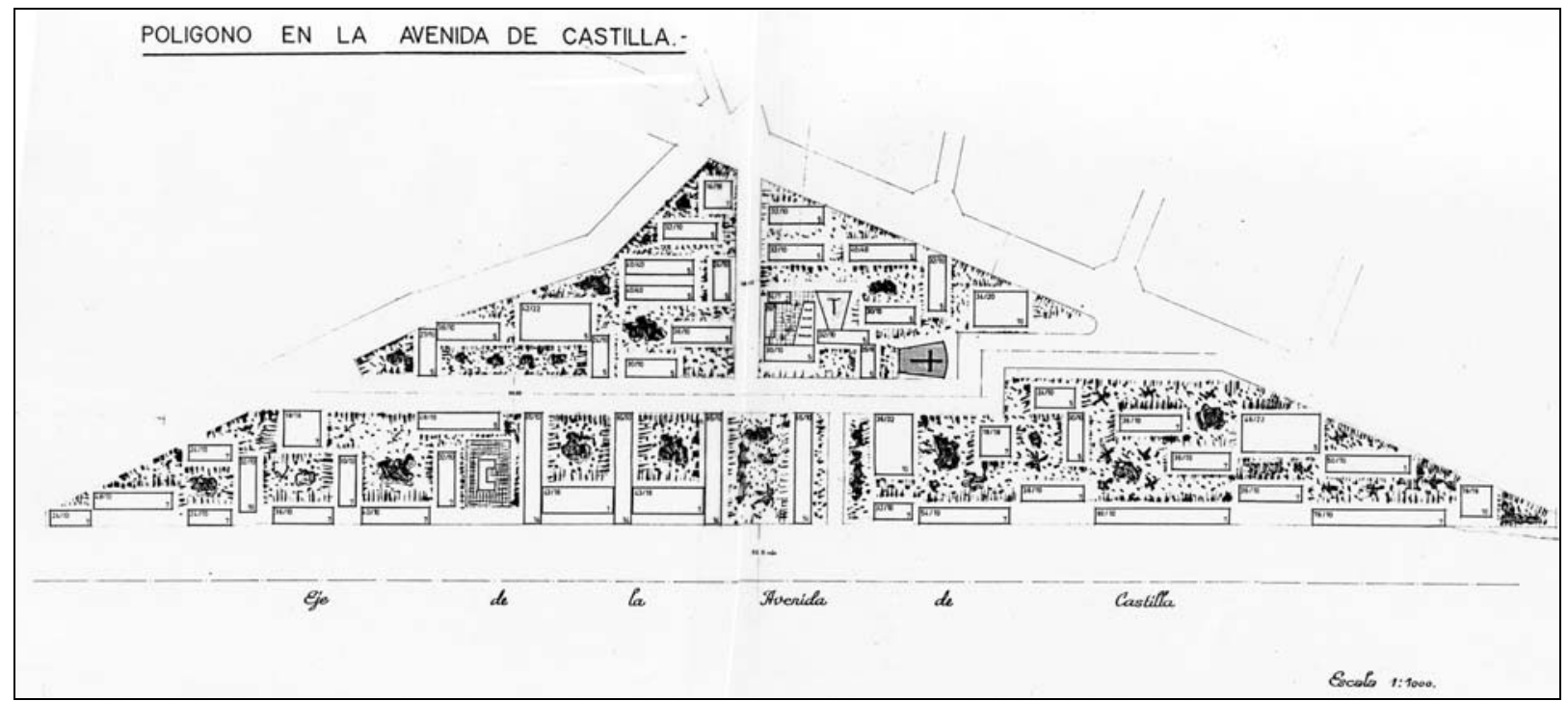

Plano Parcial I-c. Ordenación inicial

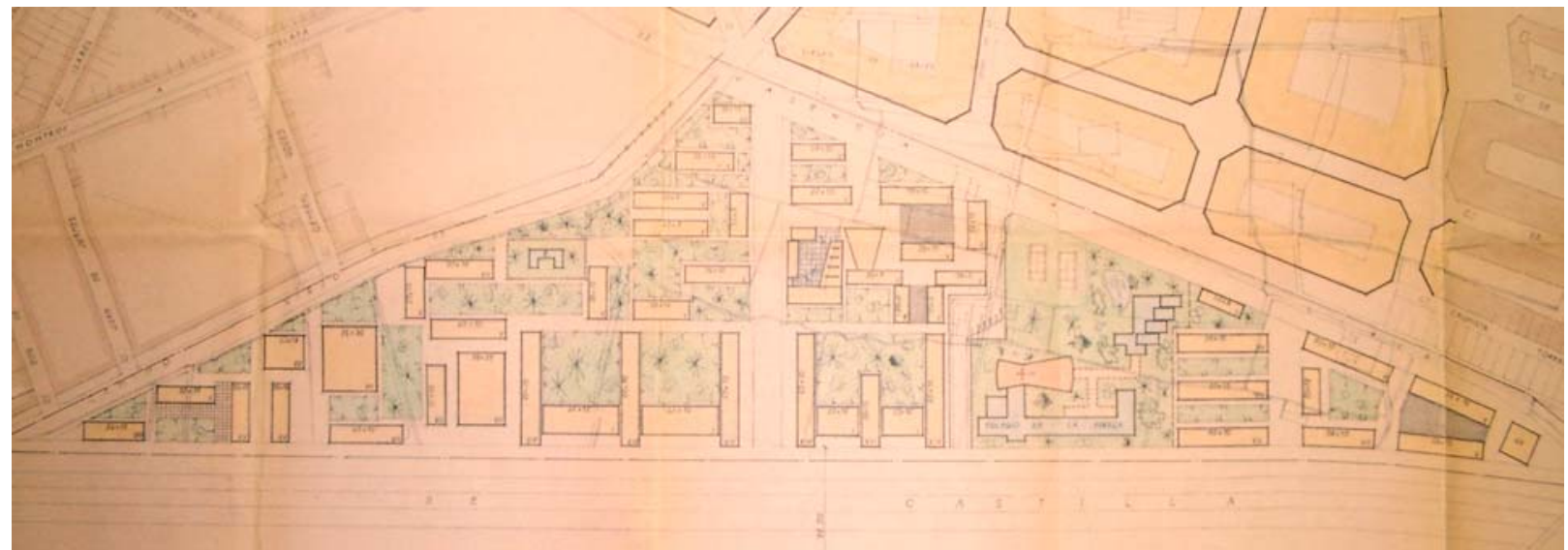

Plano Parcial I-c. Segunda ordenación, que incluye el colegio de la Pureza. 


\section{Plano Parcial I-c}

El Plano Parcial I-c, redactado en 1963, comprende el área triangular limitada al sur por la Avenida de Castilla y al norte por el camino viejo de Chirivella y la línea de ferrocarril de Valencia a Liria (actual calle Alcacer). La ordenación de esta zona que figura en el Plano Parcial I-c de 1963 es el resultado de dos modificaciones sucesivas de la original con edificación abierta, que aparece en un plano sin fecha adjunto al expediente del plan.

En el proyecto inicial, el triángulo ordenado se divide en cuatro partes mediante el trazado de una calle este-oeste paralela a la Avenida de Castilla y dos calles transversales a esta. Estas calles transversales no están dispuestas una en prolongación de la otra, sino que forman sendos cruces en T con la calle central, conectándola con la Avenida de Castilla y con la calle Alcacer. Además, la calle central no es pasante, sino que tiene un quiebro en su trazado que permite acotar las perspectivas, junto al cual se sitúa un centro vecinal integrado por una iglesia y un teatro.

La edificación abierta en este proyecto inicial está formada por bloques lineales de dos o cinco crujías dispuestos según los ejes paralelo y ortogonal a la Avenida de Castilla. Dentro de cada manzana, los bloques adoptan pautas compositivas diferentes (posiciones paralelas desplazadas, ortogonales, uniformes seriadas) pero siempre mantienen su carácter de bloques aislados asentados en un espacio verde continuo. En este espacio verde se localiza, en la manzana suroeste, una parcela escolar.

La implantación del colegio de la Pureza supuso una primera modificación del proyecto original, ya que la extensa parcela trapezoidal de dicho colegio llegaba desde la Avenida de Castilla hasta la calle Alcacer, interrumpiendo y haciendo inviable la calle central longitudinal. La zona quedaba dividida en dos, y el viario se recompuso, estructurándose mediante un eje transversal norte-sur que discurría desde la calle Alcacer hasta la Avenida de Castilla, al que se añadía otro junto a la parcela del colegio. El eje este-oeste del proyecto original se convertía en un eje peatonal circunscrito a la mitad oeste del plan.

Además, esta nueva versión del plan modifica la disposición de la edificación, distorsionando el proyecto original al alinear algunos bloques con el perímetro, como los del vértice este, y al enlazar algunos de ellos con bajos comerciales, con lo que se pierde el carácter continuo de los espacios verdes intermedios. La escuela situada junto a la Avenida de Castilla es trasladada a la manzana trasera y sustituida por un bloque profundo, y la serie de bloques ortogonales a la Avenida queda también desdibujada.

Posteriormente, la ubicación en la zona de las instalaciones industriales de SEAT acabó de desvirtuar el proyecto inicial y eliminó toda posibilidad de estructuración interna. La edificación abierta en la versión definitiva de 1963 del Plano I-c acabó siendo un relleno de espacios triangulares residuales e inconexos con bloques unidos en planta baja por locales. El centro vecinal, integrado por un teatro, locales comerciales y una parcela escolar, se sitúa en la manzana central, limitada por las dos calles de directriz quebrada que cruzan de norte a sur la zona.

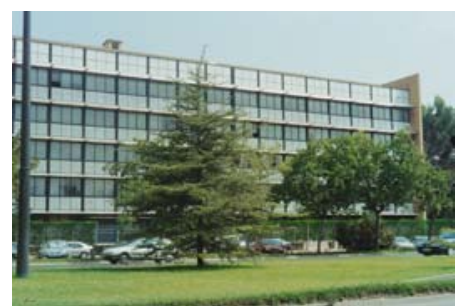

Colegio Pureza de María. Mauro Lleó, 1962. 


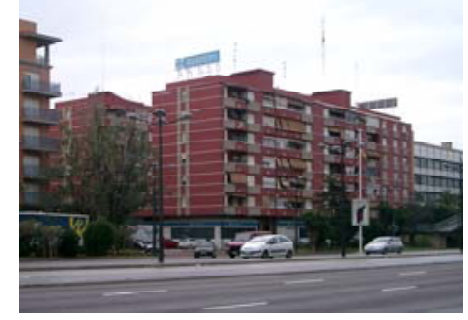

1
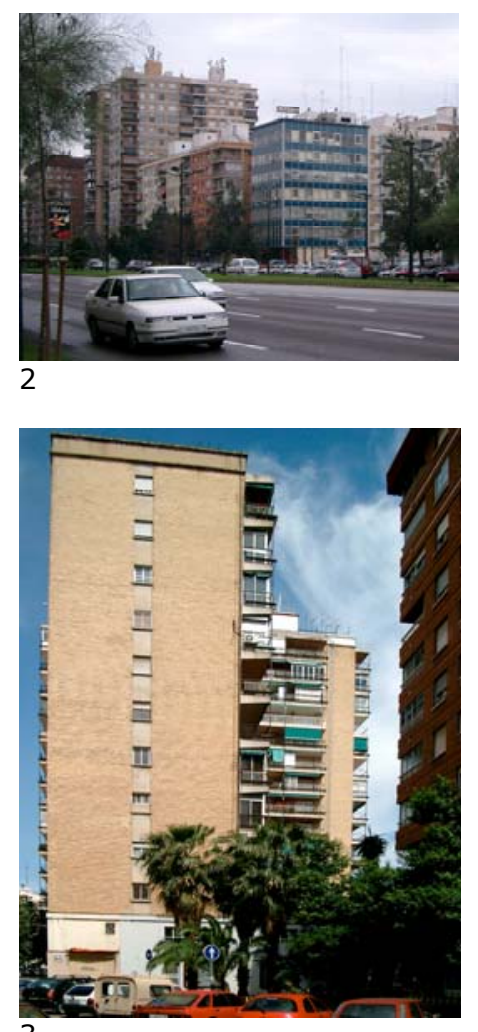

3

1,2. Avenida del Cid.

3. Camino Viejo de Xirivella, vista hacia el norte.

4. Torre en la esquina de la Avenida del Cid con la calle Alcacer.

5. Bloques altos en el camino Viejo de Xirivella.
La mayor parte de los bloques proyectados en la versión del Plano Parcial I-c de 1963 se construyeron entre ese año y 1967, fecha en que se redactará el Proyecto Parcial 25.

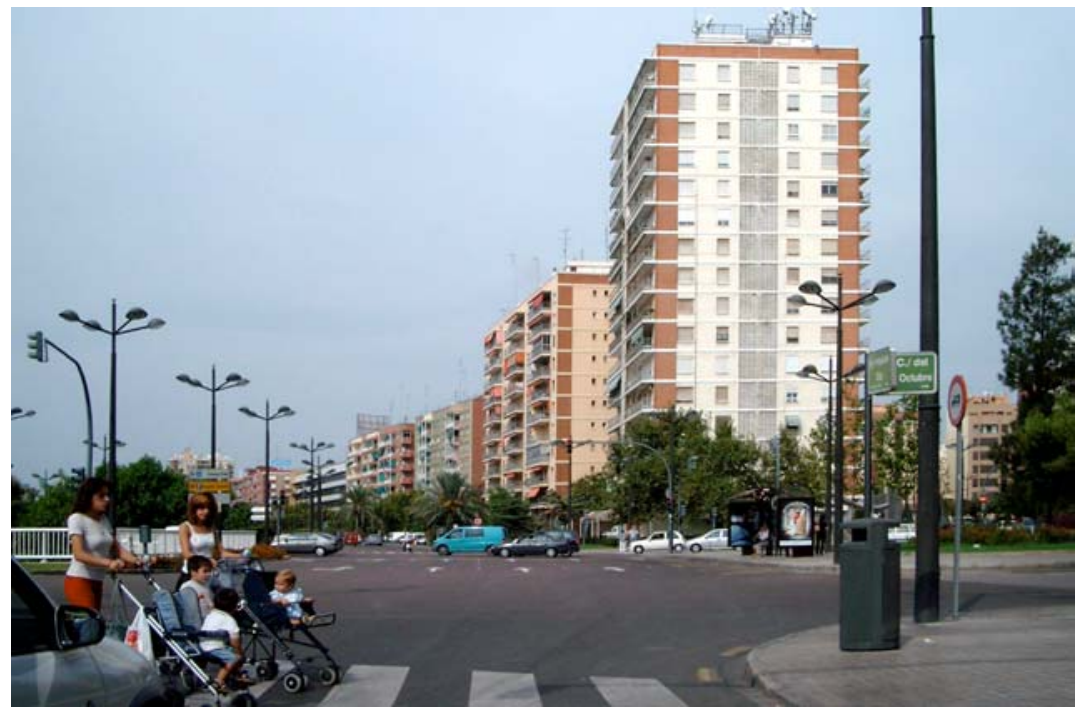

3

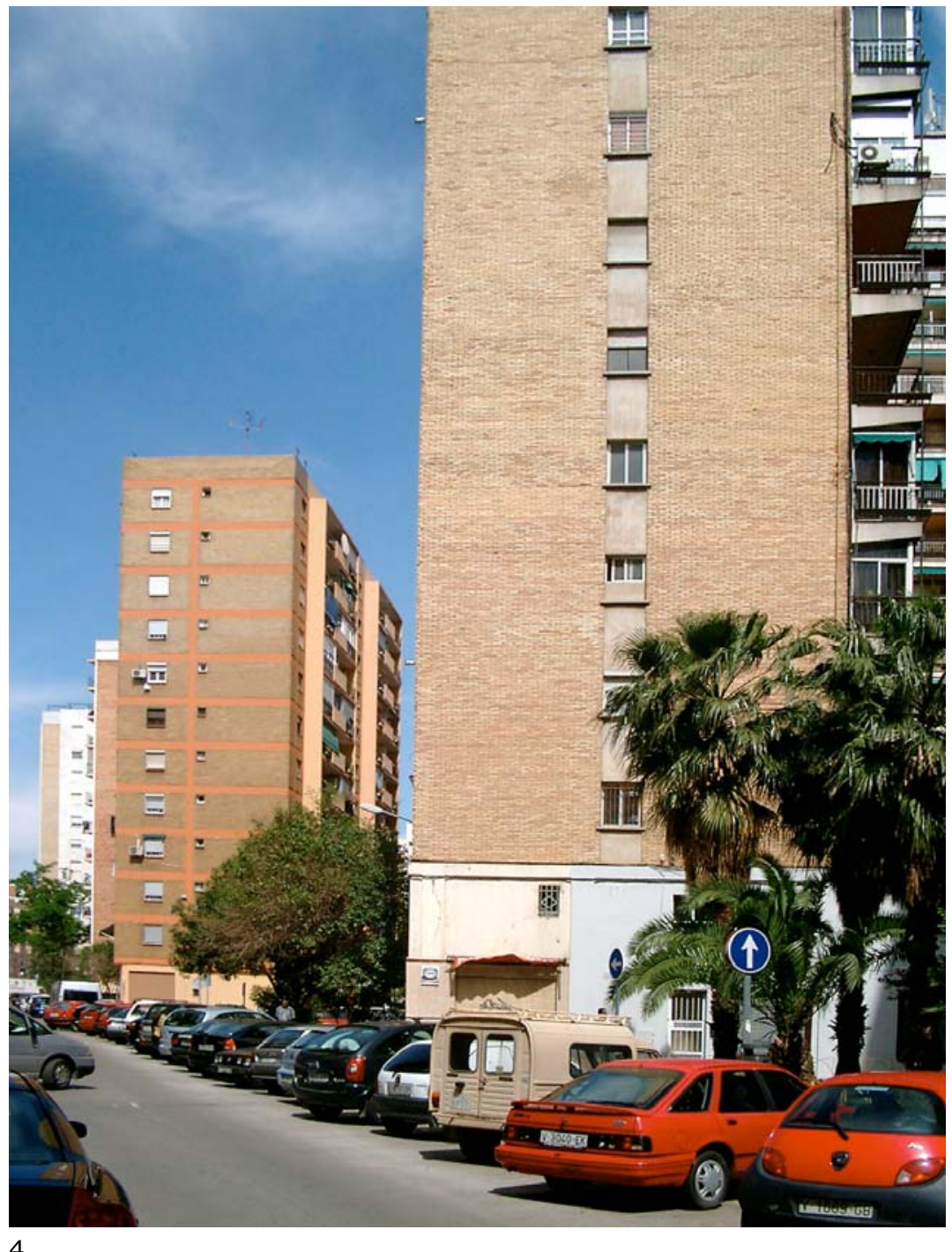

4 
La zona, por ello, constituye uno de los conjuntos de edificación abierta de mayor tamaño entre los de promoción privada construidos con anterioridad a la aprobación en 1966 del Plan General adaptado a la Solución Sur. Únicamente la zona norte del Plan Parcial 11, antes analizada, tiene un desarrollo urbanístico mayor en el mismo periodo.

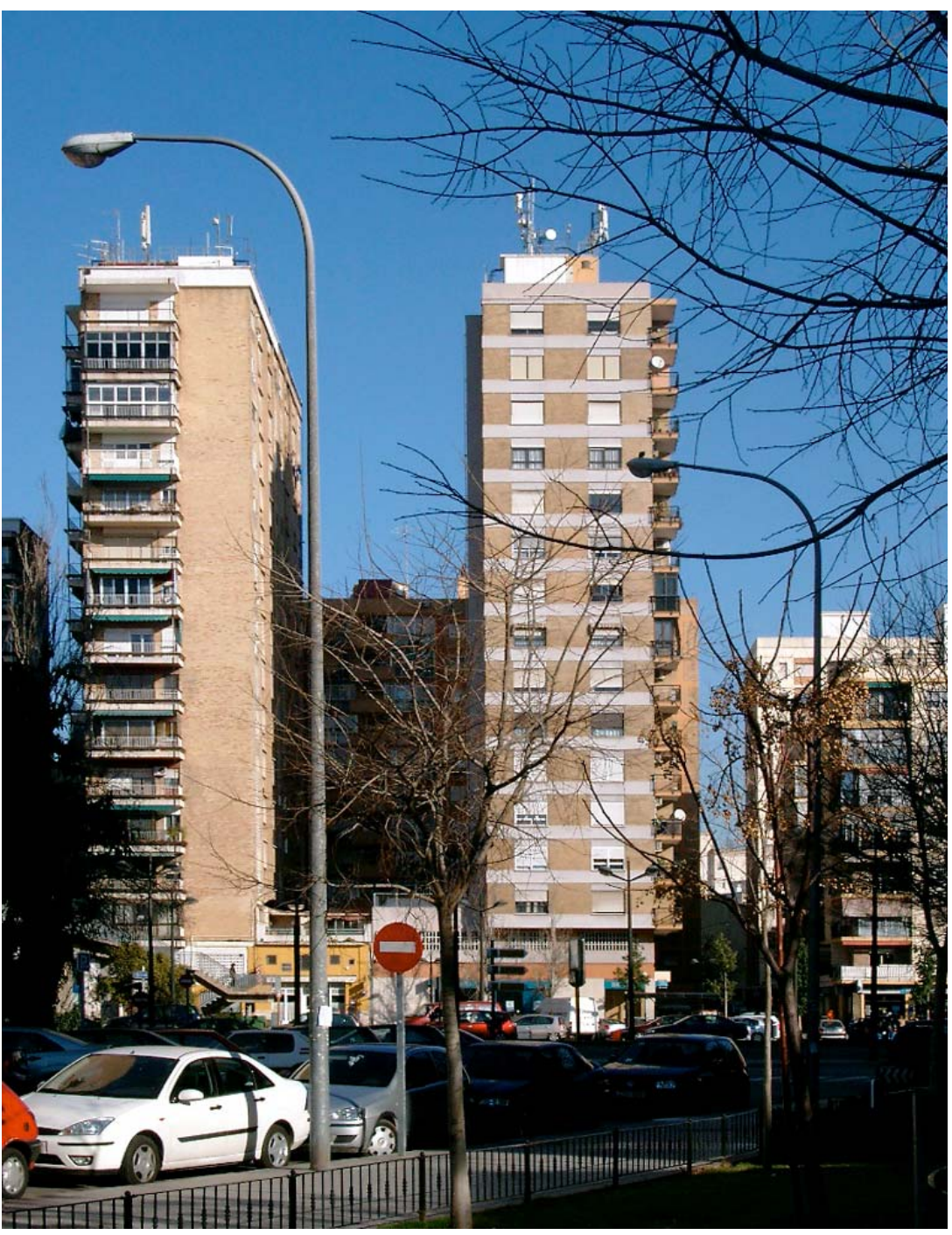

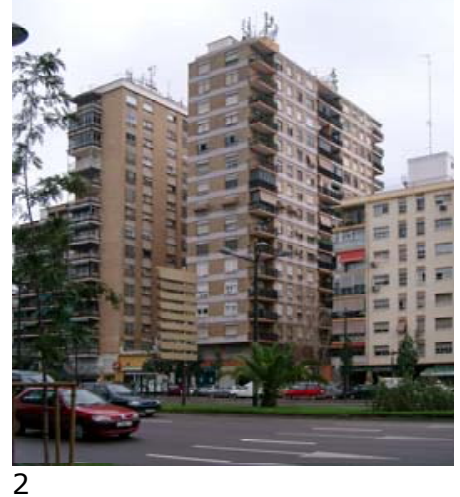

1.2. Bloques altos en la Avenida del Cid.
Zona del Plano Parcial I-c. Fotografía aérea de Valencia, 1980.

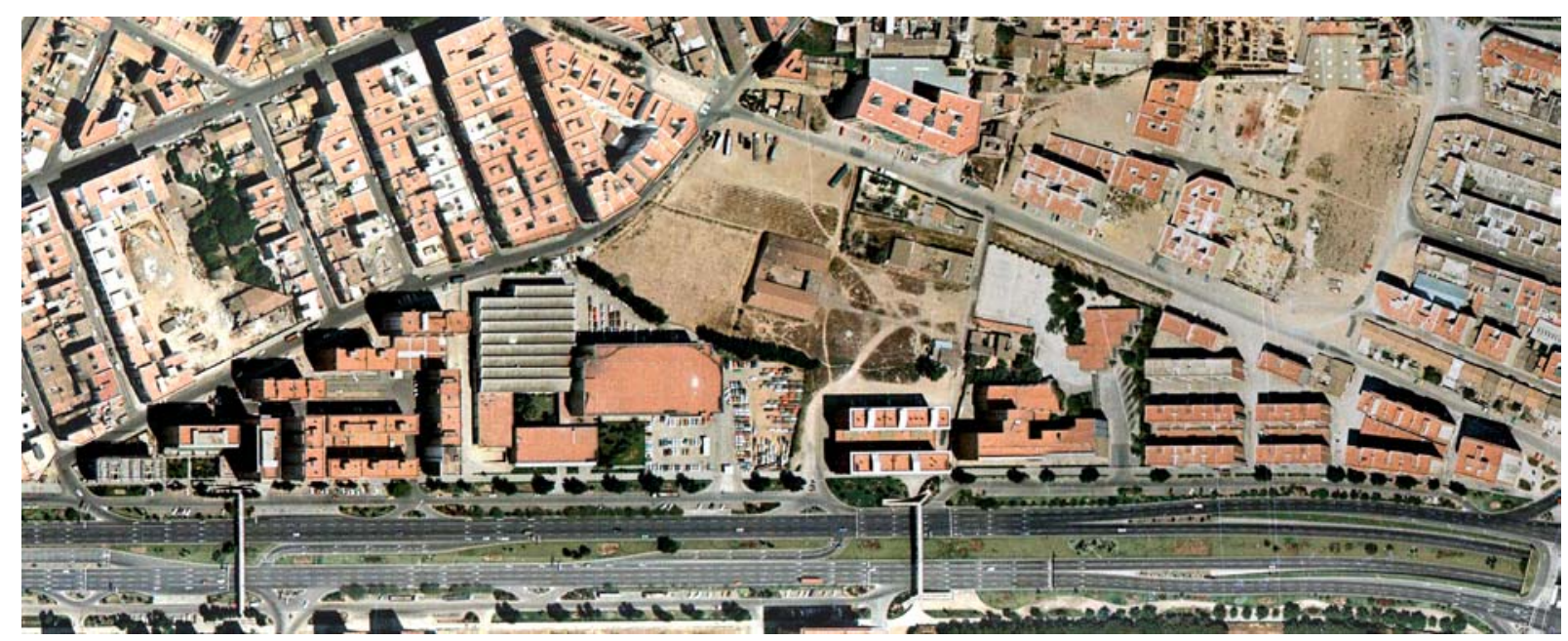




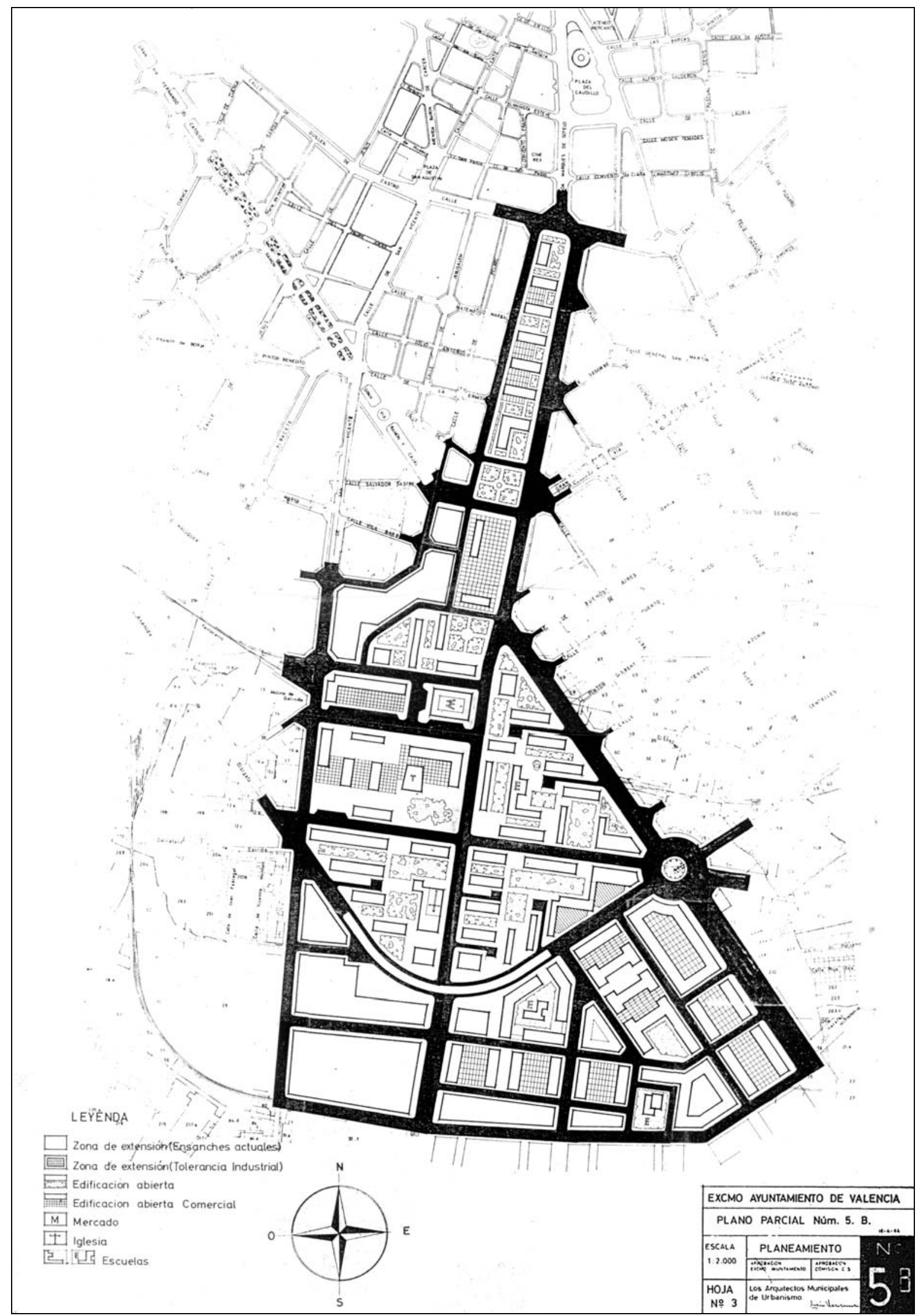

Plan Parcial 5-B, 1963. Ayuntamiento de Valencia. 


\section{LOS TERRENOS DE LA ESTACIÓN DEL NORTE: EL PLAN PARCIAL 5-B (1963).}

En la Ordenación Técnica de Valencia y su Comarca de 1958 aparecía una maqueta del nuevo centro urbano previsto en los terrenos liberados al desplazar la Estación del Norte de su emplazamiento actual. ${ }^{1}$

El Plano Parcial no 5-B, redactado en 1963 y aprobado inicialmente por el Ayuntamiento en julio de 1964, ordena esos mismos terrenos, que debían albergar en su centro la futura estación subterránea de FF.CC. de vía estrecha y que están situados en el encuentro entre importantes vías de comunicación, como el acceso a Alicante (límite oeste), el Camino Real de Madrid (límite este), la unión de las grandes vías de Germanías y Ramón y Cajal, la unión de las Avenidas de Peris y Valero y Cesar Giorgetta, completando el anillo del Camino de Tránsitos. El área ordenada está limitada al sur por la antigua línea de Ferrocarril a Nazaret (actual calle Olta). La Memoria del plan señala que su objetivo es el servir de guía para la futura urbanización de los terrenos de la Estación del Norte, que no se prevé de realización inmediata, $y$, sobre todo, para ordenar la construcción de los terrenos colindantes.

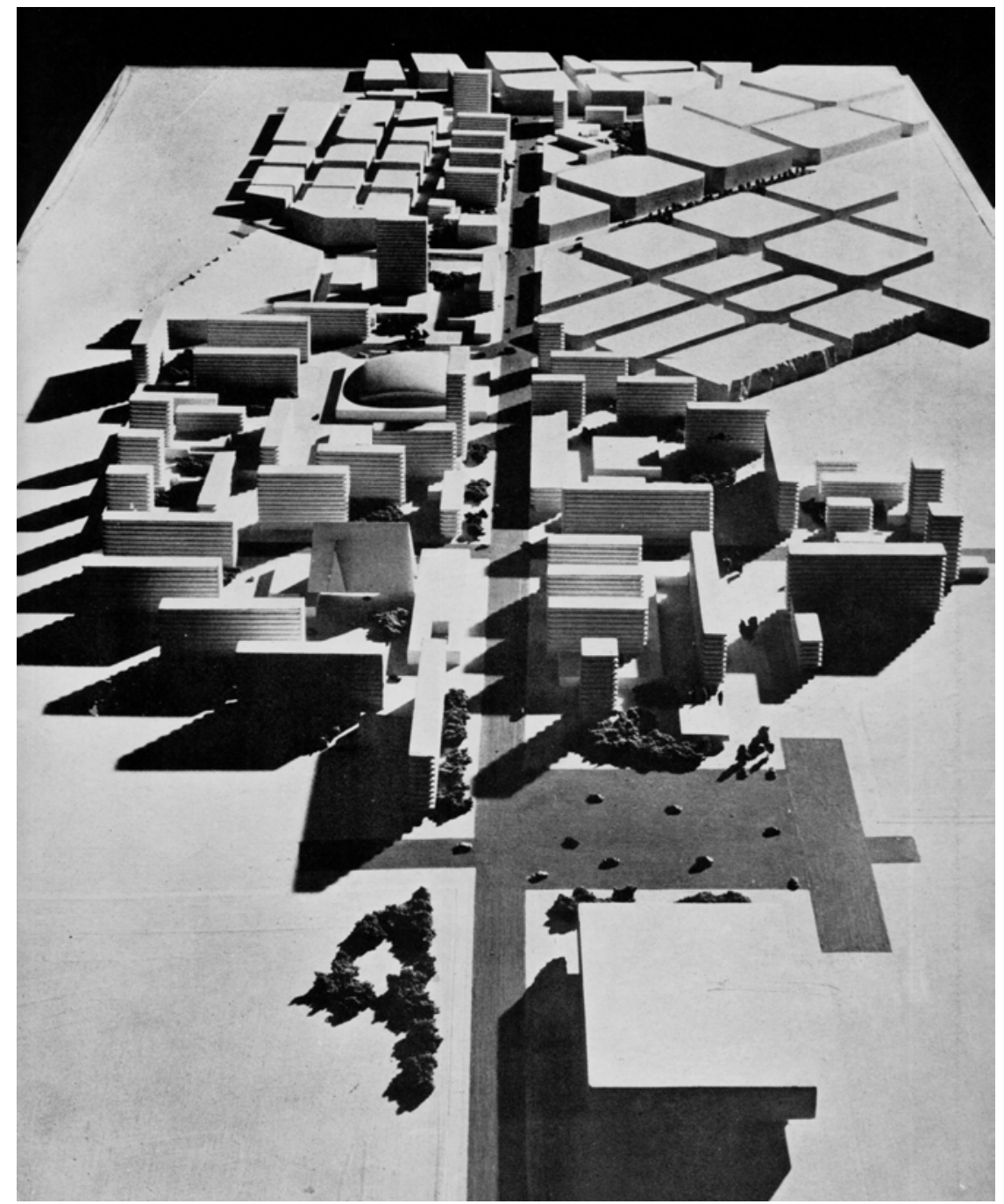

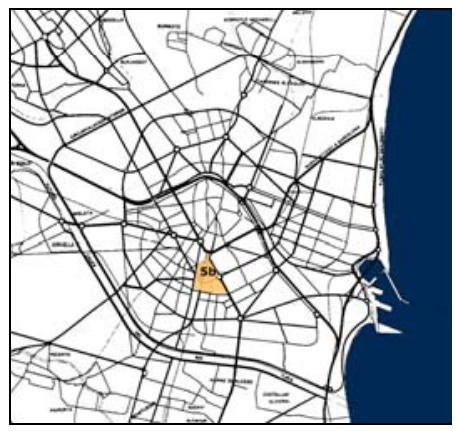

Plan Parcial 5-B. Localización

Nuevo centro urbano en los terrenos de la estación del Norte (Delegación del Gobierno, Valencia. Ordenación técnica de la ciudad y su comarca, 1958).

1. Ver apartado primero de esta sección. 


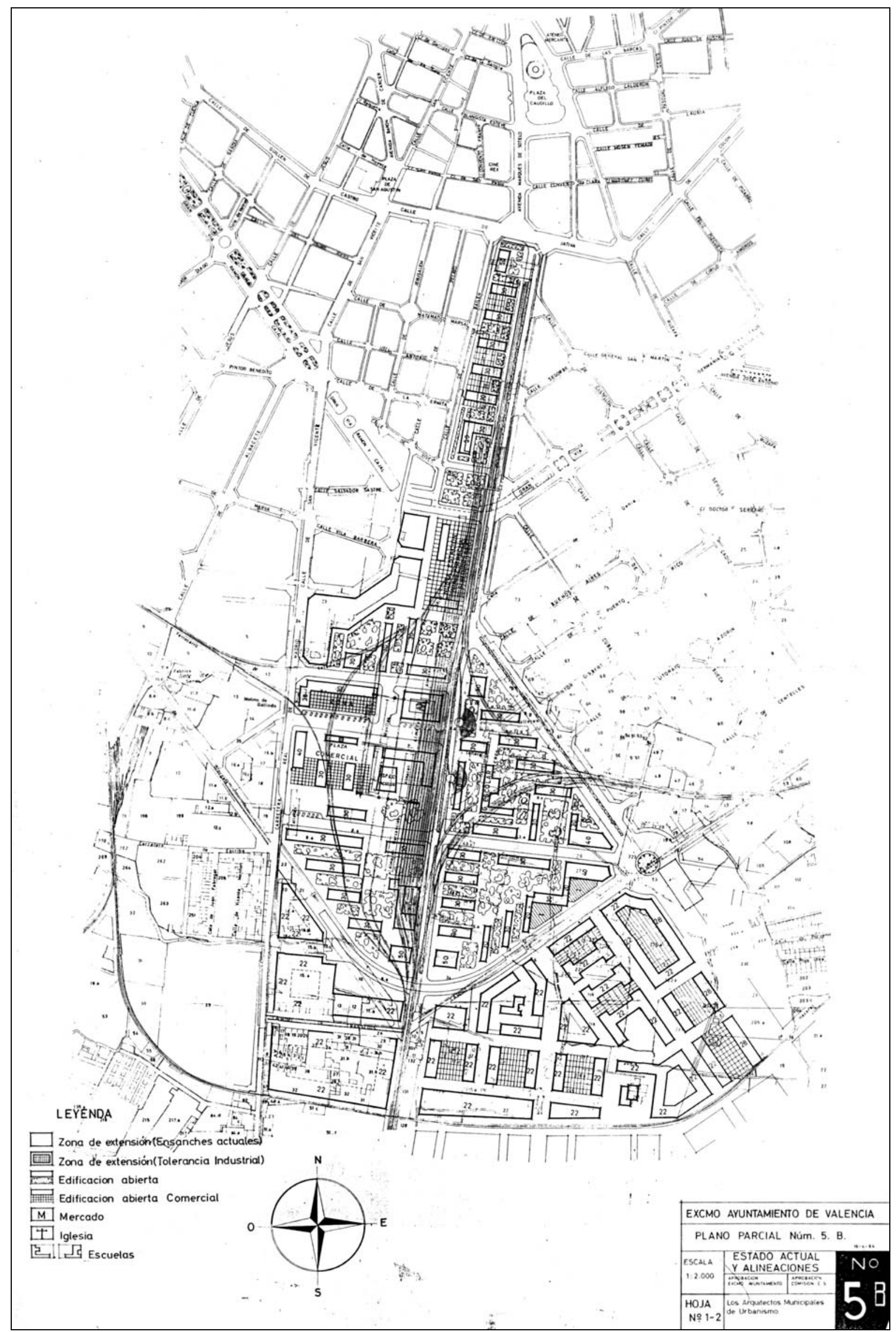

Plano Parcial 5-B. Estado actual y alineaciones. 
Sobre el uso de los terrenos y la características de la edificación, la Memoria del plan señala lo siguiente:

Toma la zona proyectada un carácter mixto residencial y centro cívico central ya que está situada entre ensanches que no gozan de centros definidos.

Se le da un carácter de edificación abierta para aprovechar la coyuntura de disponer de un terreno libre en el futuro de edificaciones, situado entre zonas de manzanas cerradas.

Se divide el total de las subzonas a que obliga la existencia de las vías públicas importantes precitadas dotándolas de los diferentes edificios públicos: escuelas, iglesias, mercado, zona comercial, etc. Deberá dotarse el conjunto de un sistema de pasos de peatones superiores o subterráneos para atravesar dichas vías públicas y que todas las zonas puedan gozar, cómodamente, de todos los servicios. ${ }^{1}$

El plan municipal de 1963 recoge algunos de los elementos del trazado viario y de la edificación de la maqueta de 1958 del Plan Sur. El principal de estos elementos es el sistema de ejes que vertebra la zona, compuesto por un eje norte-sur y un eje este-oeste que se cruzan ortogonalmente. El eje norte-sur comienza en la calle Játiva y discurre por la calle Alicante ensanchada, que se prolonga en línea recta hasta el límite sur del plan. El eje este-oeste se traza como prolongación hacia el oeste de la actual Avenida Doctor Waksmann, eje diagonal del ensanche de Monteolivete. A ello se añade, como viario principal interno, la ronda de Tránsitos.

Los bloques de edificación abierta siguen la dirección de los ejes mencionados, disponiéndose en paralelo o en perpendicular a los mismos. Así, la franja de edificación entre las calle Bailén y Alicante, se resuelve con una serie de bloques equidistantes ortogonales a dichas calles y otros paralelos en las localizaciones más singulares, junto a la calle Játiva y en la plaza proyectada junto al cruce de las grandes vías.

En el sector central del plan, el cruce de ejes delimita tres espacios de forma triangular y otro rectangular. Los espacios triangulares se tratan como supermanzanas con ramales sin salida que penetran en ellas desde algunas de las calles perimetrales pero sin atravesarlas. Los bloques, en estas supermanzanas triangulares, están aislados, y disponen de amplias zonas verdes intermedias entre ellos. En dos de las supermanzanas se incluyen equipamientos (una parcela escolar y un centro parroquial).

La disposición de la edificación en paralelo o en perpendicular al eje norte-sur hace que los frentes recayentes a las calles de borde, junto a las manzanas cerradas del ensanche, estén formados por sucesiones de bloques escalonados y dispuestos en diagonal con respecto a dichas calles.

El espacio rectangular del cuadrante noroeste, que es el destinado a centro cívico, se subdivide en tres manzanas rectangulares y otra trapezoidal, de ajuste con el tejido de ensanche contiguo. En la manzana de mayor tamaño, situada junto al cruce de los ejes principales, se localiza el centro cívico-comercial, y en otra menor junto a ella un mercado.

\footnotetext{
1. Plano Parcial 5-B, 19634. Memoria. Anexo de Documentos, p. 276.
} 
La ordenación del sector exterior a la ronda de Tránsitos es diferente, y está planteada con criterios similares a los que veremos en el Plano Parcial 5-C, que es su continuación por el sur. En lugar de supermanzanas, encontramos aquí un viario mallado convencional, que delimita unas manzanas en las que los bloques siguen alguna de las alineaciones perimetrales, y en particular la del acceso de Alicante.

En la documentación adjunta al expediente del Plano Parcial 5-B hemos encontrado dos propuestas previas de ordenación sin fecha para los terrenos de la Estación del Norte.

La primera de ellas muestra una ordenación mixta, en la que la edificación abierta está circunscrita a la franja central de los terrenos de la Estación. Esta edificación adopta la forma de bloques lineales seriados en peine, unidos por bajos comerciales.

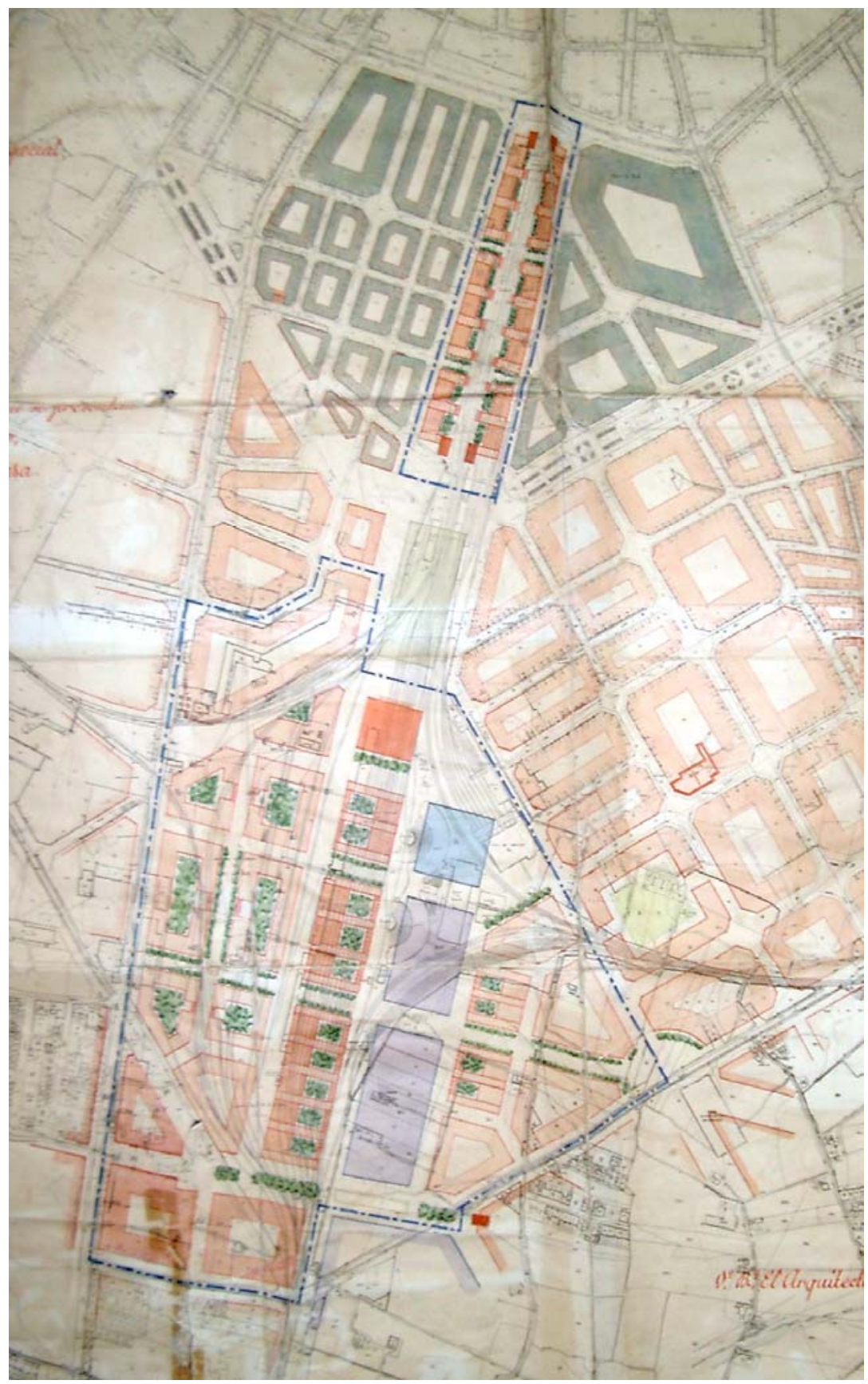


Entre la calle de Játiva y el cruce de las grandes vías, dos bandas de bloques ortogonales muy cortos, rematadas en sus extremos por parejas de torres, flanquean un nuevo eje central intermedio entre las calles de Bailén y Alicante. En el siguiente tramo, hasta la ronda de Tránsitos, el eje se bifurca en dos y los bloques en peine, más largos, ocupan el espacio intermedio entre ambos, junto al cual se sitúa una gran banda de equipamientos.

El otro plano que hemos hallado junto a la documentación del Plano Parcial 5-B parece una versión preliminar del mismo. La ordenación del sector central en esta versión se guía por los mismos criterios que la de la zona exterior a Tránsitos, que es igual a la que figura en el Plano 5-B. El resultado es una composición menos elaborada, en la que la lógica del orden abierto no se asume de forma decidida, sino que se intenta compatibilizar con la de las alineaciones de calles propia de los tejidos de manzanas de ensanche adyacentes.

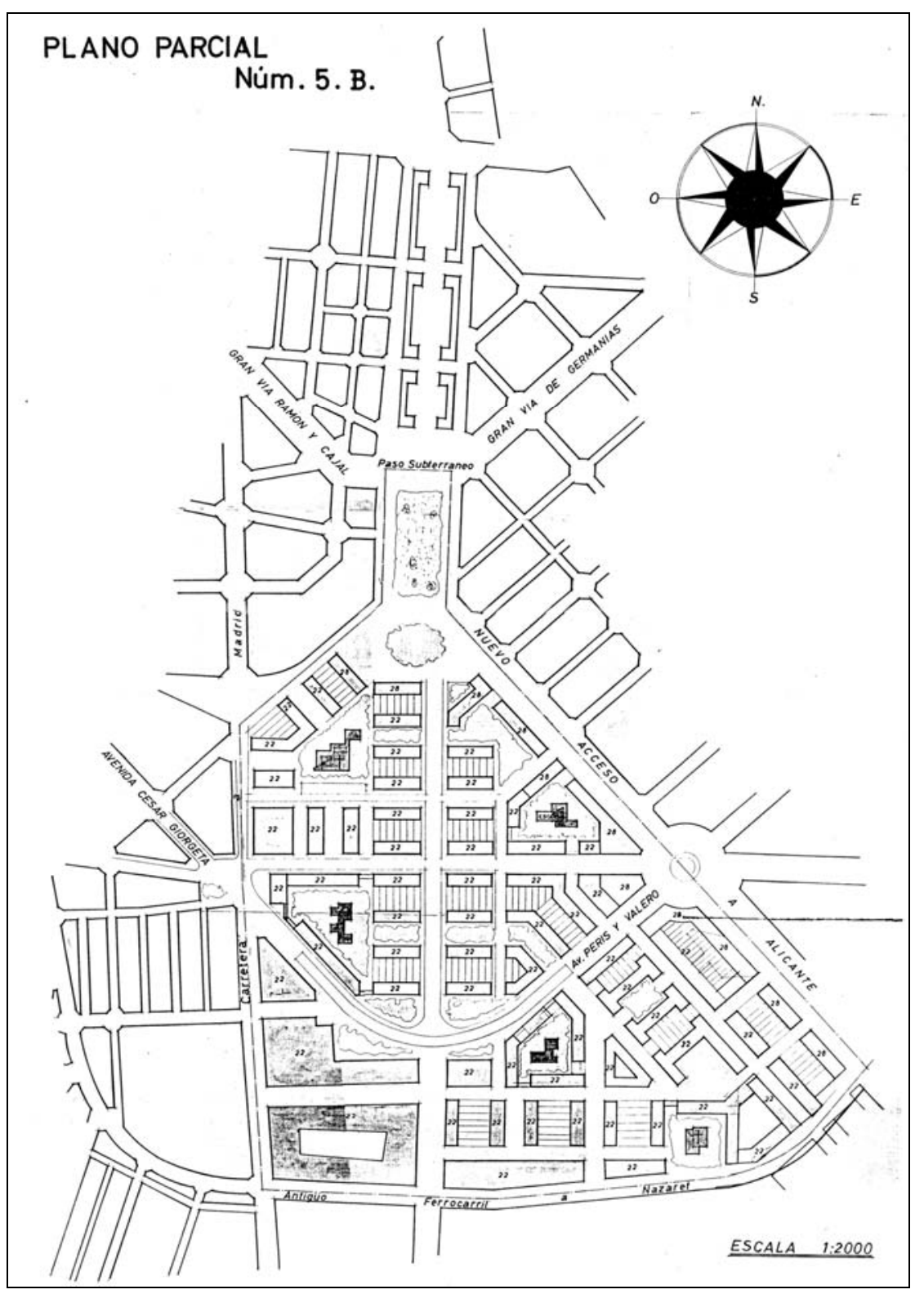

Plano Parcial no 5-B. Versión inicial, s.f. 


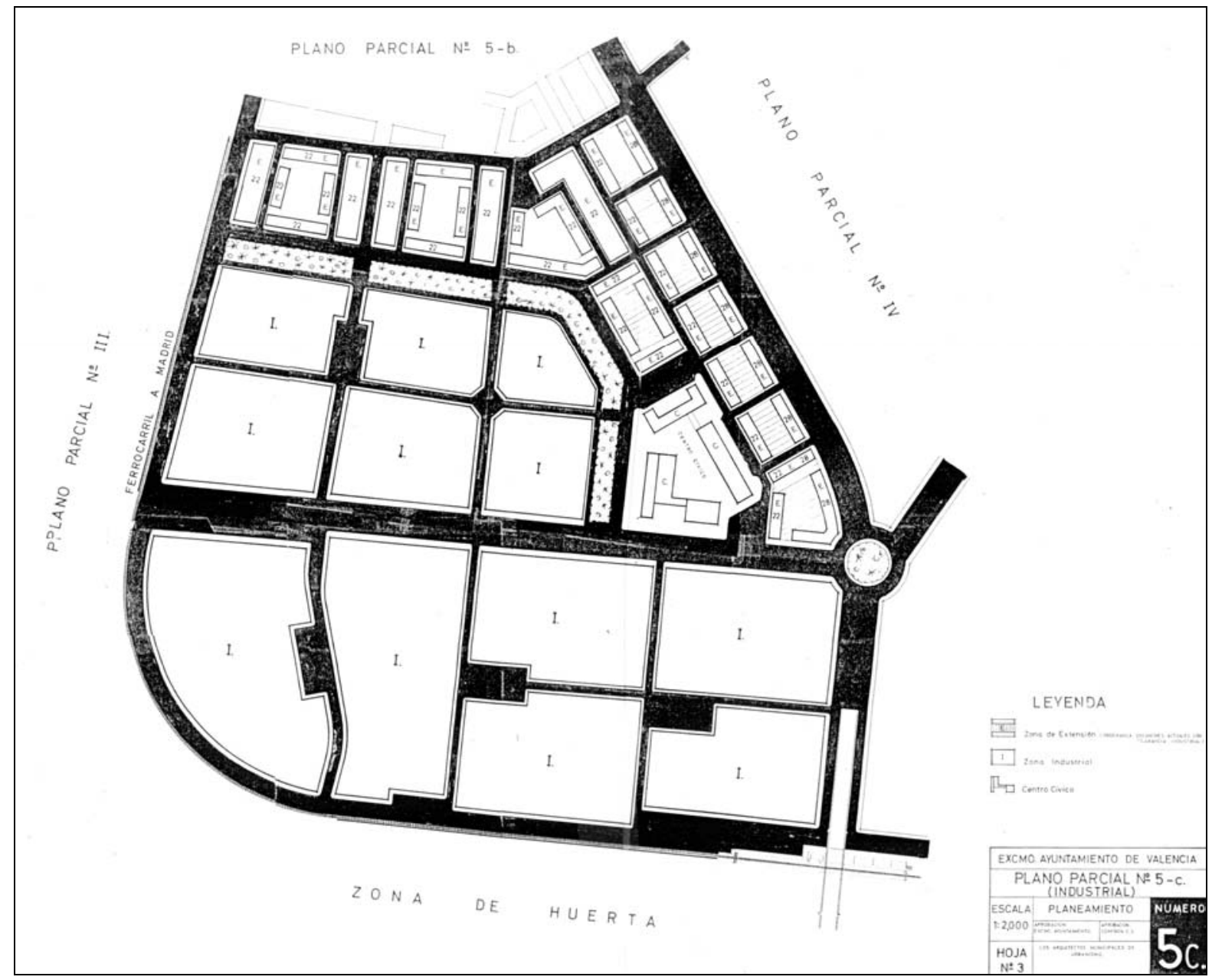

Plano Parcial no 5-C (Indus-

trial). Planeamiento. 
El Plano Parcial 5-C ordena la zona limitada por el nuevo acceso de Alicante al este, la antigua línea de ferrocarril eléctrico a Nazaret al norte, la línea del ferrocarril a Madrid al oeste y el nuevo desvío del ferrocarril a Tarragona al sur. La superficie de la zona, íntegramente de huerta en el momento de redactarse el plan, es de unas $120 \mathrm{Ha}$, de las cuales se destinan $80 \mathrm{Ha}$ a uso industrial y el resto a zona residencial. $^{1}$

Las zonas residenciales se localizan en el borde este, junto al nuevo acceso de Alicante, y en el borde norte, completando la prevista con las mismas características en el Plano 5-B. Entre esta zona residencial y la industrial se proyecta una franja verde de separación, así como un centro cívico con edificios comerciales y administrativos, situado junto al eje viario este-oeste de la ronda interior.

Como ocurre en los otros planes parciales municipales de este periodo, el trazado viario del Plano 5-C, con una rotonda en el cruce del acceso de Alicante y la ronda interior y simples cruces de calles en el resto de las intersecciones, no corresponde al diseño definitivo del mismo de la Jefatura Regional de Carreteras, lo que obligará a una nueva redacción del plan.

La zona residencial está calificada en este plan como de Tolerancia Industrial, y la edificación abierta se dispone en continuidad con la del sector sur, exterior a Tránsitos, del Plan Parcial 5-B. Dentro de un trazado mallado, los bloques lineales se sitúan sobre una planta baja que ocupa la totalidad del suelo de la manzana, y en la que se autorizan industrias menores, almacenes y garajes.

Los bloques se sitúan a lo largo del perímetro de estas manzanas, alineados con las calles. En algunas manzanas, como las que flanquean el acceso de Alicante, las manzanas se componen de dos bloques paralelos unidos en planta baja. En otras, como las del borde norte, el número de bloques se amplía a cuatro.

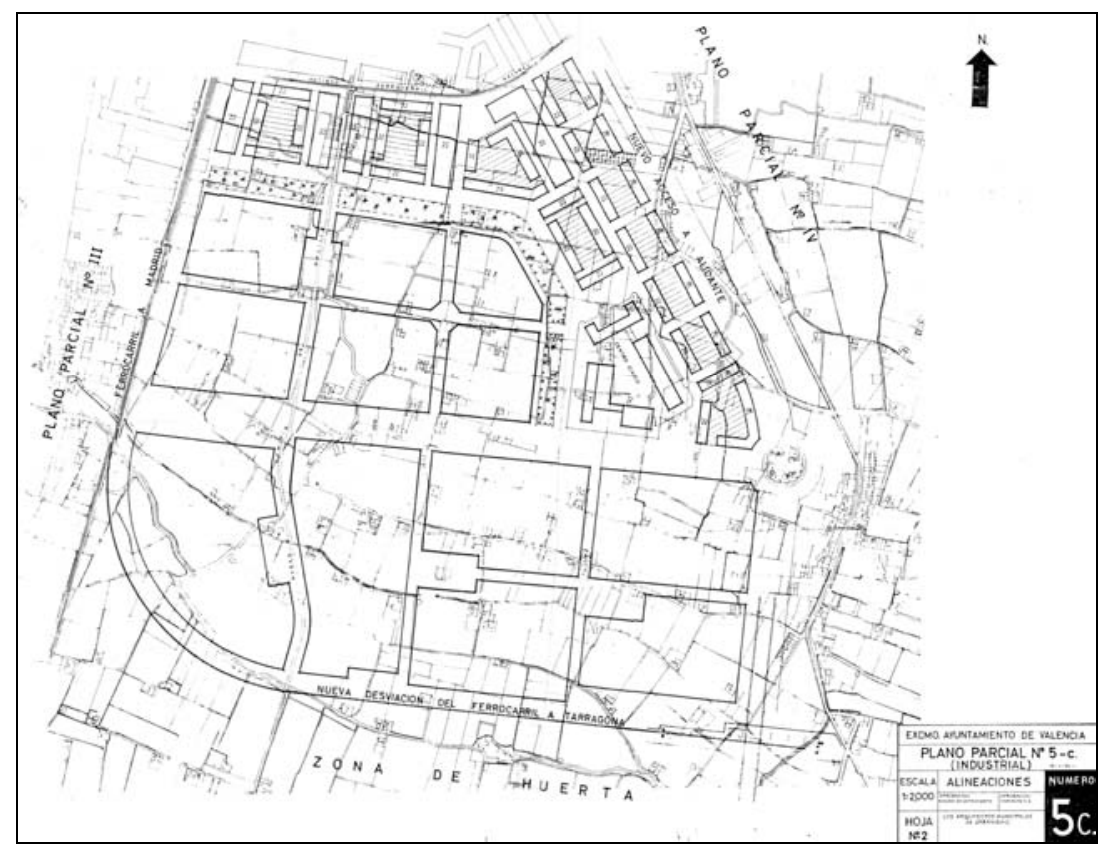

Plano Parcial 5-C. Alineaciones.

1. Plano Parcial No 5-C, 1964. Ver Anexo de Documentos, pp. 283289. 

III. ENTRE EL PLAN GENERAL DE 1966 Y EL PGOU DE 1988 LA CONSOLIDACIÓN DE LA PERIFERIA URBANA 



\section{INTRODUCCIÓN.}

Esta sección está dedicada al estudio de las áreas residenciales de edificación abierta proyectadas en Valencia en el periodo comprendido entre los años 1966 y 1988 . Los dos hitos que marcan el inicio y final del periodo son, respectivamente, la aprobación del Plan General de Valencia y su Comarca adaptado a la Solución Sur y la aprobación del Plan General de Ordenación Urbana de Valencia actualmente en vigor.

En este periodo pueden distinguirse dos etapas. En la primera, entre 1966 y 1979, se redactan y aprueban definitivamente los Planes Parciales de desarrollo del Plan General de Valencia y su Comarca adaptado a la Solución Sur, planes que quedarán obsoletos cuando se aprueben la Reforma de la Ley del Suelo (1975) y el Reglamento de Planeamiento (1978). La segunda etapa, entre 1979 y 1988, es la correspondiente a las actuaciones de remodelación del planeamiento anterior a partir de las primeras elecciones municipales democráticas, que se plasma en diversos Planes Especiales de Reforma Interior que quedarán finalmente refundidos en el nuevo Plan General de Ordenación Urbana.

El Plan General de 1966 es el planeamiento de rango superior al que deben atenerse los Planes Parciales de la etapa 1966-1979. Comenzaremos esta sección, por tanto, con el análisis de las determinaciones de dicho Plan General y, en concreto, del tratamiento dado a la edificación abierta, a través del estudio de sus Normas Urbanísticas y de las Ordenanzas Generales.

Nuestro estudio de las áreas de edificación abierta no está restringido a aquellas que están literalmente calificadas como tales, sino que adoptaremos un uso amplio del término, aplicable a conjuntos urbanos que ostentan otras calificaciones en el planeamiento, como veremos. Con este criterio no restrictivo, identificaremos en primer lugar las áreas de edificación abierta existentes en los distintos Planes Parciales, y haremos algunas consideraciones de carácter general sobre las mismas.

Con respecto a la segunda etapa señalada, entre 1979 y 1988, analizaremos las características generales de los Planes Especiales de Reforma Interior y del Plan General de Ordenación Urbana en el que quedaron encuadrados, que marca el final del ámbito temporal que nos hemos fijado para nuestro trabajo.

El resto de la sección está dedicado al estudio pormenorizado de las áreas de edificación abierta incluidas en los Planes Parciales de desarrollo del Plan General de 1966 que fueron aprobados definitivamente. El largo periodo de vigencia de estos planes como documentos de planeamiento significa que la construcción de la mayor parte de las áreas de edificación abierta de la periferia urbana se realizó de acuerdo con las determinaciones de los mismos.

Nuestro estudio está estructurado, para cada uno de los Planes Parciales, en los apartados siguientes:

a) Datos generales: Identificación del Plan Parcial, localización, y ámbito de actuación. Los datos de extensión, superficies correspondientes a cada tipo de suelo calificado, número de viviendas 
y densidad se recogen en el Anexo de Documentos tal y como vienen reflejados en la documentación escrita original de los Planes.

b) Antecedentes de planeamiento: Se repasan en este apartado las versiones anteriores del Plan Parcial, ya estudiadas en las secciones anteriores, así como las redactadas para el mismo ámbito después de 1966. Asimismo, se analizan las preexistencias y la situación de la zona en el momento de la redacción del Plan Parcial.

c) Tramitación del Plan Parcial y modificaciones sufridas durante la misma: Se documentan, cuando son relevantes, las alegaciones presentadas, las modificaciones requeridas por el Ministerio de la Vivienda y las variaciones introducidas en el Plan como consecuencia de las mismas.

d) Análisis de la zonificación.

e) Análisis del trazado viario.

f) Análisis de los equipamientos.

g) Análisis de la edificación (Planta baja y planta tipo).

h) Análisis del grado de realización del Plan Parcial (comparación del plan con el estado inicial, con la Cartografía Municipal de 1983 y con el PGOU de 1988). Consideraremos que son elementos realizados no sólo los efectivamente construidos, sino también aquellos que se mantienen en los planos del Plan General de 1988 con la misma definición formal que tenían en el Plan Parcial de desarrollo del Plan General de 1966.

i) Fotografía aérea comparada (1980 y Ortofoto 2002 ).

j) Recorrido actual por las zonas de edificación abierta del Plan parcial (documentación fotográfica).

La Fotografía Aérea de 1980 es la imagen que complementa la Cartografía Básica Municipal de 1983: ambas representan por medios gráficos diferentes un mismo momento, que es el previo al cambio de orientación en el planeamiento que supone la redacción de un nuevo Plan General. En este sentido, documentan el grado de realización de los Planes Parciales que desarrollaban el anterior Plan General de 1966, y por tanto el margen de actuación posible para introducir cambios.

La Ortofoto de 2002 de AUMSA (Actuaciones Urbanísticas Municipales S.A.), por su parte, complementa los Planos de Ordenación Urbana del PGOU de 1988, que constituyen el momento final de nuestro estudio. Los planos del PGOU nos permiten observar en qué medida el nuevo Plan General asume las determinaciones de los Planes Parciales anteriores, manteniendo la forma y volumen de algunas edificaciones previstas en dichos planes o modificando e incluso suprimiendo otras. 
La comparación de la Ortofoto de 2002 con la Fotografía Aérea de 1980 nos da una idea clara de la evolución urbana reciente de las diferentes zonas objeto de estudio.

La Ortofoto de 2002 nos permite avanzar un poco más en el tiempo, y comprobar a su vez en que medida edificios que se proyectaron en unos Planes Parciales que desarrollaban el Plan General de 1966, y que se mantuvieron en el Plan General posterior de 1988, han sido finalmente realizados o no al cabo de unos treinta años.

En cuanto al orden del estudio, hemos descartado tanto el cronológico (por año de redacción del Plan Parcial) como el meramente correlativo (de número de Plan). La opción tomada ha sido la de agrupar los Planes Parciales por zonas de la ciudad, es decir, por proximidad entre los mismos. Creemos que esta opción es la más apropiada para contrastar la realidad y el proyecto, que es algo fundamental para analizar el papel de la edificación abierta en la formación de la periferia urbana de Valencia. 


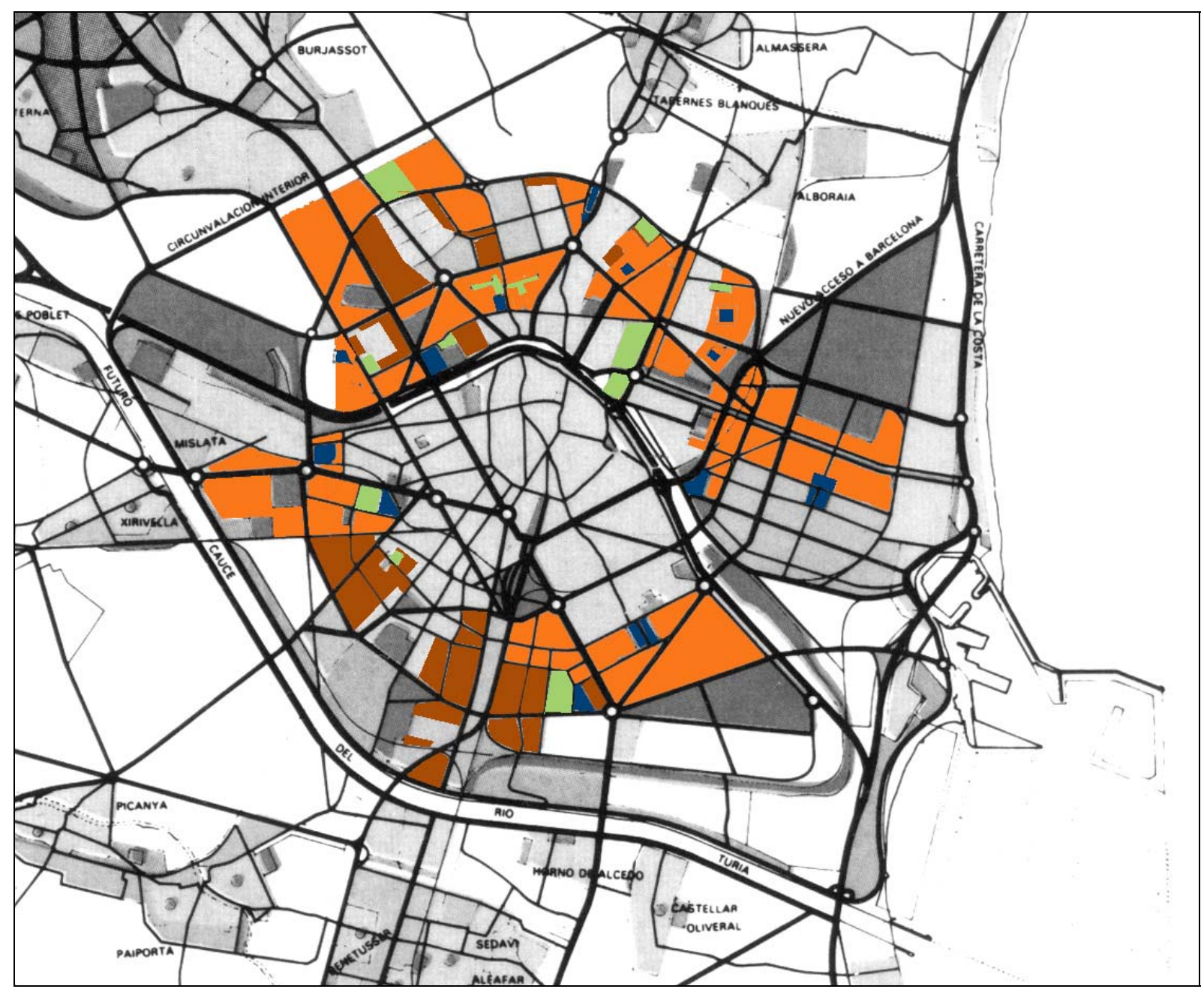

Áreas de edificación abierta en el Plan de Ordenación de Valencia y su Comarca adaptado a la Solución Sur (Elaboración propia sobre planimetría incluida en La Gran Valencia. Trayectoria de un Plan General).

AREAS DE EDIFICACIÓN ABIERTA EN SUELOS CALIFICADOS COMO EDIFICACIÓN ABIERTA

ÁREAS DE EDIFICACIÓN ABIERTA EN SUELOS CON OTRA CALIFICACIÓN.

CENTROS COMERCIALES

ZONAS VERDES 


\section{LA EDIFICACIÓN ABIERTA EN EL PLAN GENERAL DE VALENCIA ADAPTADO A LA SOLUCIÓN SUR DE 1966.}

El "Plan General de Ordenación Urbana de Valencia y su Comarca adaptado a la Solución Sur" fue redactado por los arquitectos Mauro Lleó, Victor Bueso y Antonio Gómez Llopis, para la Corporación Administrativa Gran Valencia. Terminado en 1964, el Plan fue finalmente aprobado en 1966, y afectaba a treinta municipios.

No es objeto de este trabajo el análisis detallado del Plan General de 1966, ya que dicho análisis ha sido ya realizado en diversos estudios $^{1}$, en los cuales la valoración negativa del mismo es prácticamente unánime.

Así, en la publicación del Ayuntamiento de Valencia sobre el Avance del Plan General de 1985, se señala al Plan General de 1966 como la peor herencia de la riada de 1957, afirmando que:

El Plan General de 1966 no responde a un planteamiento racional de óptima utilización del territorio y, lo que es más grave, sus determinaciones son una amenaza latente y un potencial peligro para el funcionamiento de la ciudad. ${ }^{2}$

El Plan General de 1966 es, en realidad, una amalgama de tres elementos. Dos de ellos son los que integraban el Plan Sur para Valencia de 1961: la solución hidráulica del nuevo cauce y el trazado viario definido en el "Plan de Accesos de Carreteras y sus enlaces", aprobado por el Ministerio en 1959. El tercero es el Plano de Zonificación del suelo, que es el único de ordenación del Plan.

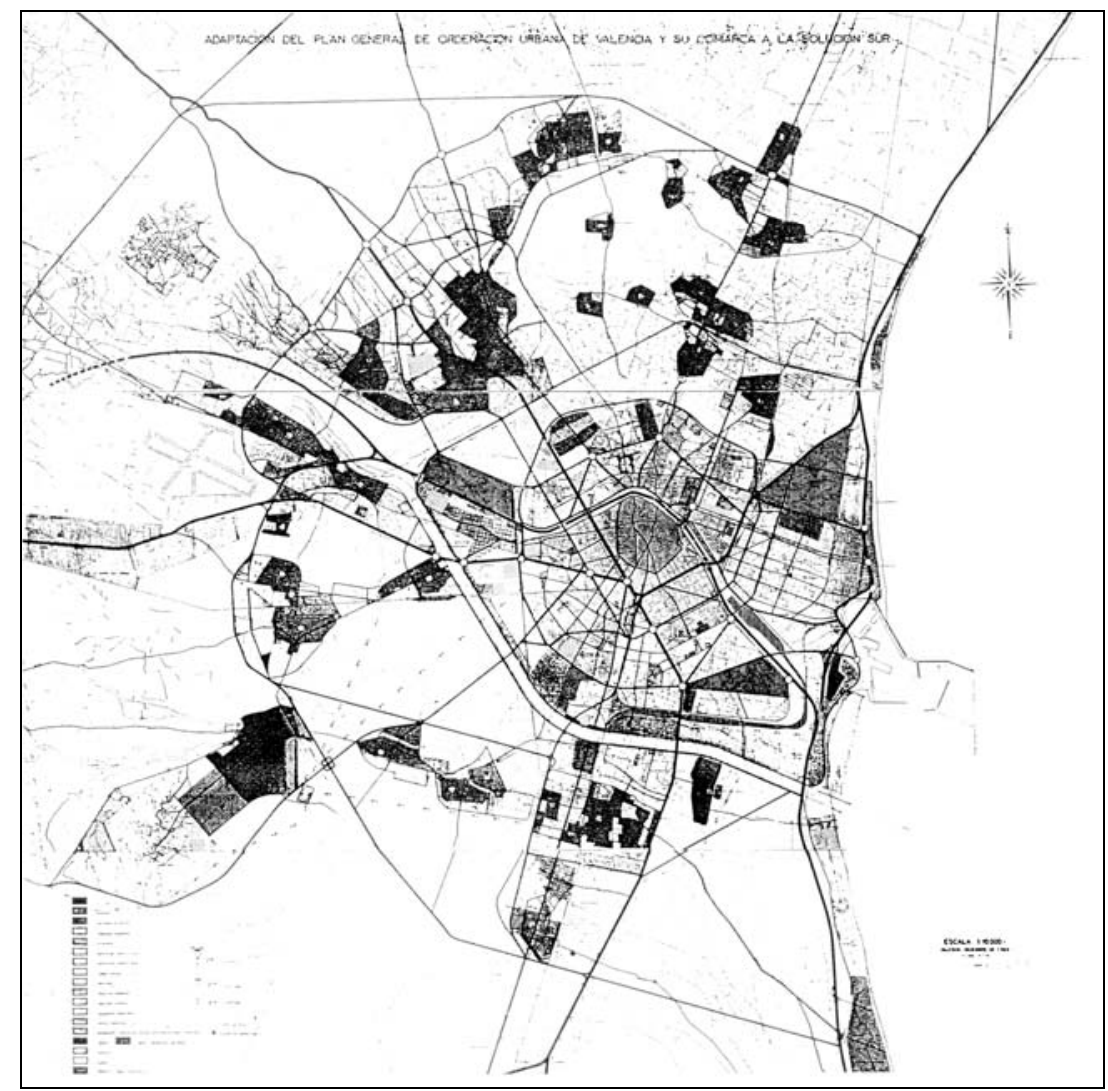

Adaptación del Plan de Ordenación de Valencia y su Comarca a la Solución Sur. M. Lleó, V. Bueso y A. Gómez Llopis, 1966. (Ayuntamiento de Valencia)
1.El análisis más completo del Plan de 1966 es el contenido en Consellería d'Obres Públiques, Urbanisme i Transports, La Gran Valencia. Trayectoria de un Plan General, Generalitat Valenciana, Consellería d'Obres Públiques, Urbanisme i Transports, Valencia, 1986.

2. Ayuntamiento de Valencia, Oficina Municipal del Plan, La ciudad que queremos. Avance del Plan General de Ordenación urbana, Valencia, 1985. Ayuntamiento de Valencia, Valencia, 1985. 

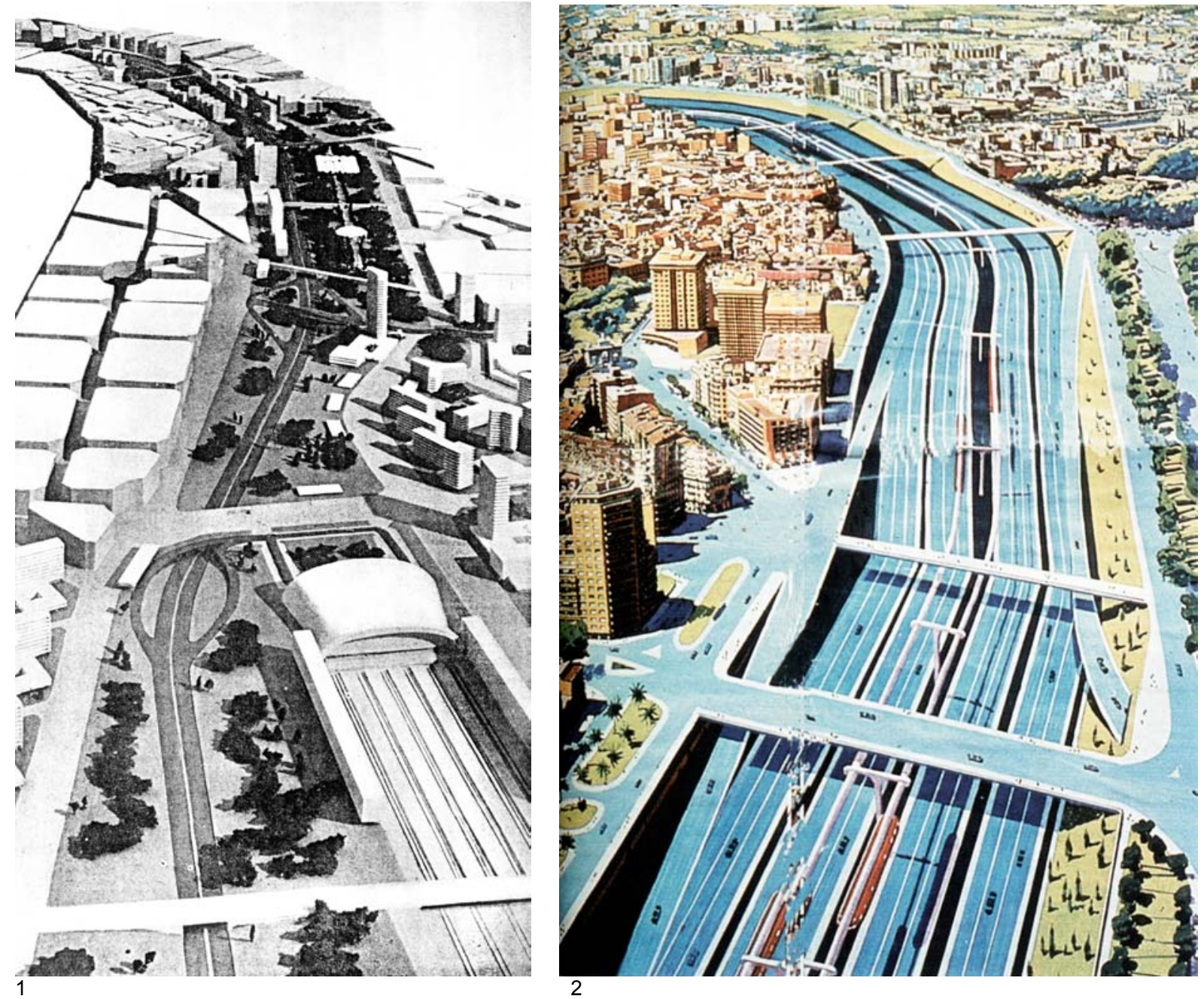

1. Ordenación de los terrenos del cauce del Turia (Delegación del Gobierno, Ordenación Técnica de la ciudad y su comarca, 1958)

2. La autopista del cauce del Turia. (Reportaje sobre Valencia, Gaceta Ilustrada, 1968.)

1. Terán, Fernando de, "Calles y algo más que calles", Urbanismo, 29, Madrid, 1996.
De los tres elementos fundamentales del Plan General de 1966 -nuevo cauce hidráulico, sistema viario y zonificación- ha sido por regla general el segundo el que ha suscitado las mayores críticas. Las imágenes de la prolongación de la autopista de Castilla a lo largo del viejo cauce del Turia, o de la autopista de Cataluña atravesando los barrios marítimos y cruzando la dársena del puerto, han sido ampliamente difundidas como muestra de un urbanismo más atento a la circulación que a la construcción equilibrada de la ciudad.

El Plan de 1966 está estructurado a partir de un sistema viario que muestra, ciertamente, una hipertrofia circulatoria, con profusión de cruces a distinto nivel, bucles de enlace y todo el repertorio de soluciones de la ingeniería de transportes del momento.

Pero, como ha señalado Terán ${ }^{1}$, la ciudad necesita "calles y algo más que calles", y tendría interés estudiar hasta que punto el sistema viario que actualmente se está realizando para la ciudad no guarda un parecido notable con el diseñado para el Plan de 1966, aunque las formas visibles del mismo sean rotondas y bulevares en lugar de bucles y calzadas con vías laterales de servicio.

En todo caso, podemos apuntar que existe una gran diferencia entre el tratamiento de la autopista del cauce del Turia en la maqueta de 1958 y en la imagen que apareció en un artículo de la 
revista Gaceta Ilustrada, que muestra una imagen exagerada del cauce del Turia invadido de lado a lado por el asfalto ${ }^{1}$.

El sistema viario fundamental del Plan General de 1966 se compone de vías de acceso y vías de circunvalación. Las principales vías de acceso y penetración son, por el oeste, la Avenida del Cid (N-III a Madrid) y la autopista de Levante, que se prolonga por el viejo cauce del río; por el norte, el acceso de Ademuz, el acceso Norte, la autopista de Enlace Norte (acceso de Barcelona); por el sur, la carretera de Torrente y el acceso Sur (CN-340 por Silla) y, por el oeste, la autopista del Mediterráneo por la costa. Las vías anulares son las Grandes Vías, la Ronda Interior (anillo de Tránsitos), la Ronda Exterior, la Circunvalación Interior de Poblados y la Circunvalación Exterior.

El establecer unos límites al crecimiento de Valencia es uno de los objetivos mencionados en la Memoria del Plan General de 1966, donde se indica que el casco de la ciudad se limita por el Norte y por el Noroeste por la Circunvalación Interior de Poblados, por el Sur y por el Suroeste por el nuevo cauce del Turia y por el E. por la Carretera de la Costa. Sin embargo, la mayor parte del suelo calificado para usos residenciales queda englobado por la Ronda Exterior ${ }^{2}$, que puede considerarse que marca el límite físico de la ciudad como continuo edificado.

Las bolsas de suelo vacante en la periferia de la ciudad englobada por la Ronda Exterior se aprecian claramente en el plano general que acompaña al Informe PREVASA ${ }^{3}$. Si comparamos este plano con el que hemos presentado de identificación de áreas de edificación abierta en el Plan General de 1966, podemos observar que uno es casi el inverso del otro, o, lo que es lo mismo, que el relleno de suelo vacante se realizó casi exclusivamente con ordenaciones basadas en la edificación abierta.

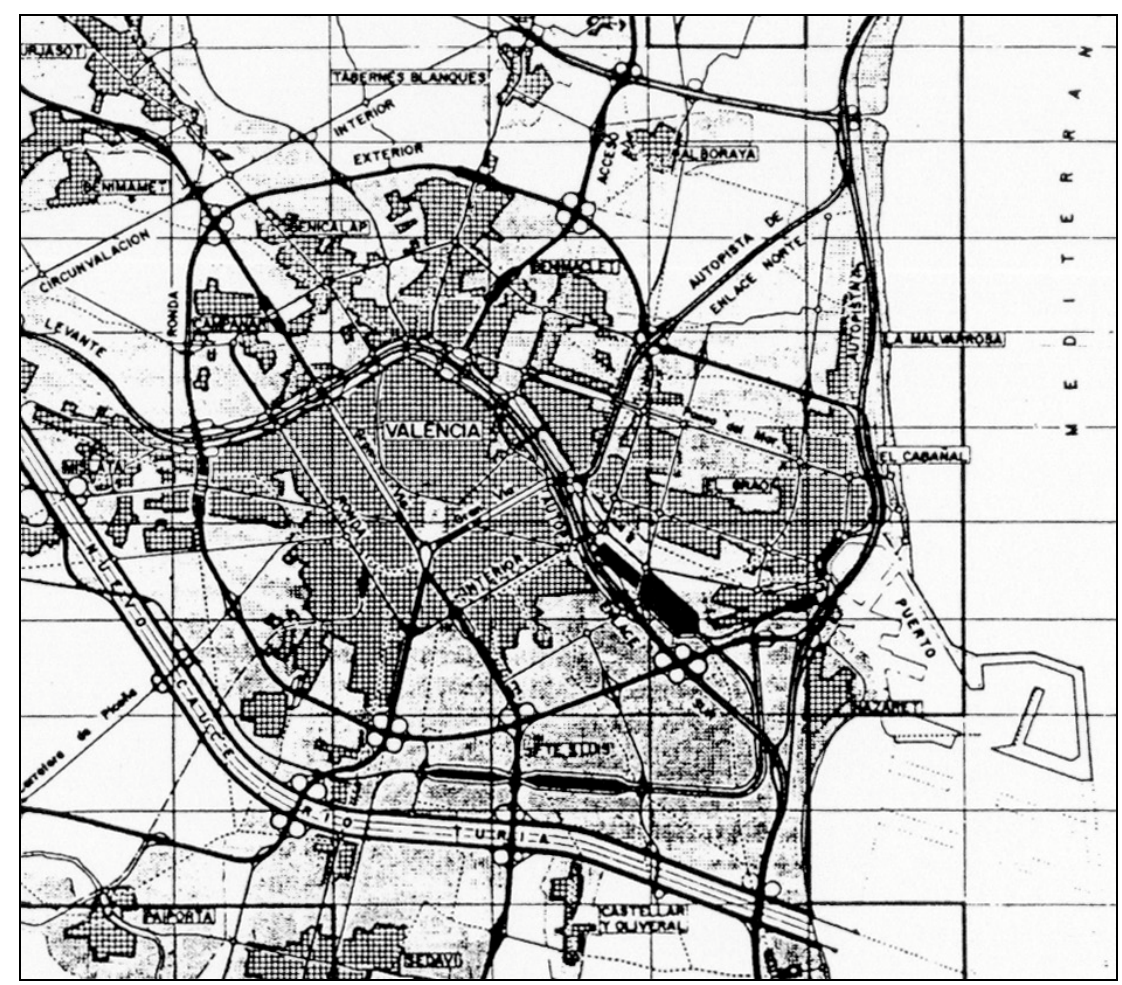

Plano del área metropolitana (fragmento). PREVASA, IV. Información Urbanística.
1.Debe señalarse que este sistema viario es criticado abiertamente, como veremos, en la propia Memoria de algunos Planes Parciales, como el PP 8b y el PP13.

2.Los únicos Planes parciales en los que aparece edificación residencial fuera del límite de la Ronda Exterior son, como veremos, el PP24, el PP26b y el PP3.

3.PREVASA, Comunicaciones del área metropolitana. Valencia, IV. Información urbanística, Caja de Ahorros de Valencia, Valencia, 1974. 
A partir de unas previsiones demográficas poco justificadas, el Plan de 1966 duplica la superficie de suelo calificado con respecto a la del Plan de 1946.

En los Planes Parciales que se redactaron en desarrollo del Plan General, las ordenaciones basadas en la edificación abierta no sólo aparecen en las zonas calificadas en el mismo como de Edificación Abierta, sino también en otras en las que la calificación del suelo es diferente, por lo general de Extensión Exterior a Tránsitos.

La idea de ciudad subyacente en el Plan General de 1966 es la propia del urbanismo funcionalista a partir del CIAM de Hoddesen de 1951 dedicado al Corazón de la Ciudad ${ }^{1}$ : Se entiende la ciudad como un agregado de partes, cada una de las cuales es una unidad vecinal autónoma. Los ejes viarios son los elementos que delimitan esas unidades:

Las triangulaciones señaladas por la malla fundamental de accesos y circunvalaciones, constituyen verdaderas unidades vecinales. Interesa que se las organice lo más introvertidamente posible en beneficio de las circulaciones generales. Es decir, que debiera procurarse que la trama vial de dichos barrios afluya en contados lugares a las circulaciones perimetrales, pertenecientes a la malla fundamental. En lo posible las calles del barrio deben canalizar todas sus necesidades y solo acometerán a las circulaciones perimetrales para conectarse con otros barrios.

Esta disposición favorece al propio barrio, ya que elimina circulaciones de paso ajenas al mismo y permite establecer en su interior, sin derroche de espacios libres, remansos para el reposo, la educación y el comercio.

También sería conveniente que en la estructuración de la unidad vecinal así delimitada, se procurase establecer una estratificación de sus servicios comunales. Las zonas de reposo, enseñanza e Iglesias, podrían ocupar el corazón del mismo. El comercio, los mercados y talleres se ordenarían perimetralmente. El Comercio especialmente al emplazarse en la proximidad de los nudos de la malla fundamental, serían más rentables ya que podrían participar de la clientela de los próximos barrios.

Siempre que fuese posible interesaría envolver exteriormente los barrios con cinturas verdes que, a la par que les protege de las circulaciones rápidas marginales, marcarían claramente su sentido de unidad vecinal, borrando de la ciudad esa tendencia a convertirse en una mancha indefinida de construcciones ${ }^{2}$.

El texto parece una descripción directa del célebre diagrama de una unidad vecinal elaborado por Perry en 1928: barrios autónomos, circulación rodada perimetral, centros vecinales y comercios en los nudos exteriores.

1.Sert, Jose Luís, Tyrwhitt, Jacqueline, Rogers, Ernesto N., The Heart of the City, Lund Humphries, Londres, 1952.

2. Adaptación del Plan General de Ordenación Urbana de Valencia y su Comarca a la Solución Sur, 1964. Memoria. Ver Anexo de Documentos, pp. 295-302. 


\section{Las Normas Urbanísticas del Plan General de 1966.}

En las Normas Urbanísticas del Plan General de 1966, la práctica totalidad de la edificación residencial urbana de Valencia se engloba en dos zonas: la de "Edificación Intensiva" y la de "Edificación Abierta". Las demás zonas que establece el Plan son las de Ciudad Jardín, Industrial, de Tolerancia Industrial, Zonas Especiales, Zonas Verdes, de Huerta y de Reserva

Las zonas de edificación intensiva son, según las Normas Urbanísticas, aquellas en las que se sigue un criterio tradicional de edificación, de modo que los diferentes edificios tienen medianeras comunes y están unidos formando manzanas cerradas, con o sin patio de manzana. Esta zona se divide en los sectores siguientes:

A) Histórico Artístico.

B) Interior hasta la primera Ronda.

C) Ensanche hasta Tránsitos.

D) Extensión exterior a Tránsitos

E) Núcleos periféricos.

Las zonas de edificación abierta, por su parte, se definen del modo siguiente:

ZONA DE EDIFICACIÓN ABIERTA: Son aquellas zonas en que se prodiga la edificación en disposición de bloques aislados de doble, triple o de cinco crujías (en este caso se establecen patios interiores) dando lugar a espacios abiertos o ajardinados, a comercios u otros usos complementarios $^{1}$

Estas zonas de edificación abierta están reguladas en las Normas No 16, 17 y 18, que establecen las determinaciones siguientes:

a) Se distinguen dos grados de edificación abierta, A y B, con coeficientes de edificabilidad de 3,5 y $5 \mathrm{~m} 3 / \mathrm{m} 2$ respectivamente.

b) Los espacios envolventes de los edificios serán ajardinados, salvo en los casos en que se permita la unión de dos o más bloques por construcciones de una planta, con el fin de ubicar talleres de artesanía, aparcamientos cubiertos o garajes, comercios u otros usos permitidos.

c) La altura de la edificación será función del espacio existente entre bloques paralelos, siendo la altura máxima igual a la separación. Sobre la altura permitida sólo se consentirá la caja de escalera, ascensores, cuadro de contadores y vivienda del portero, siempre que puedan retranquearse tres metros como mínimo de los paramentos de la fachada.

d) Se podrán establecer voladizos, con saliente máximo de 1,30 metros, pudiendo partir desde el propio suelo las fachadas que recaigan a jardín privado.

e) En los casos de bloques de cinco crujías, los patios interiores deberán permitir la inscripción de un círculo de diámetro mínimo del cuarto de la altura del mencionado patio.

1. Adaptación del Plan General de Ordenación Urbana de Valencia y su Comarca a la Solución Sur, 1966. Normas urbanísticas. Ver Anexo de Documentos, pp. 303312. 
Como hemos indicado, existen en diversos Planes Parciales áreas ordenadas mediante bloques de edificación abierta dentro de zonas con otra calificación. En las zonas de edificación intensiva y en las de tolerancia industrial la altura, los patios y los voladizos se regulan en función del ancho de la calle. Se fija además una altura máxima total admisible, que es de $21 \mathrm{~m}$. en el sector Interior, de 27 $\mathrm{m}$. en el sector de Ensanche hasta Tránsitos y de 23,5 m. en el de Ensanche Exterior a Tránsitos.

La Norma $3^{a}$, que permite que los voladizos se desarrollen a lo largo de toda la longitud de fachada, permitiendo una ocupación máxima del cincuenta por cien con voladizos tratados en forma cerrada, será decisiva en la configuración formal de la edificación abierta.

Las Normas Urbanísticas del Plan General de 1966 señalan además una serie de reglas que deberán seguirse para la redacción de Planes Parciales:

a) Un Plan Parcial comprenderá, siempre que sea posible, una extensión superior a cincuenta hectáreas y deberá quedar claramente delimitado por vías principales previstas en el Plan General.

b) Será preciso, previamente a la redacción del mismo, determinar las necesidades de servicios sociales, principalmente religiosos y culturales, de acuerdo con las directrices establecidas por el Arzobispado y por el Ministerio de Educación Nacional.

c) Además de las referidas necesidades es obligada la reserva dentro del mismo de un diez por ciento de la superficie total para espacios públicos destinados a parques o deportes.

d) Se proveerá igualmente las necesidades comerciales, que normalmente deberá concentrarse en puntos determinados para crear centros comerciales.

Previsto el anterior programa se procederá al desarrollo viario, siguiendo las directrices del Plan General en cuanto a vias principales y secundarias.

Las vías principales se clasificarán en tres categorías:

a) Trafico rapidísimo.

b) Tráfico rápido

c) Tráfico normal.

En las primeras, que normalmente dispondrán de calzadas laterales complementarias de la principal, no se podrán establecer calles secundarias en relación con ella a distancias menores de $300 \mathrm{~m}$.

En las segundas esta separación podrá reducirse a 200 m, y en las terceras a $100 \mathrm{~m}$.

Dentro del Polígono se establecerá claramente una red viaria al servicio del mismo, que diferencie las calles principales de las secundarias, considerando estas últimas con la única finalidad de acceder a las edificaciones previstas, pudiendo ser en algunos casos en fondo de saco.

Como complemento de la red viaria de tráfico rodado será conveniente establecer, cuando las circunstancias lo permitan, una red peatonal que permita el fácil acceso a las zonas escolares, centro comercial, e igualmente desarrollar vías comerciales sin circulación rodada más que en caso de emergencia ${ }^{1}$.

El texto, como vemos, es una muestra de doctrina funcionalista ortodoxa con todos sus elementos: trazado viario jerarquizado, con distinción entre viario interurbano y viario interno del barrio, y 
dotación de servicios propios de la unidad vecinal que, igual que ocurre con la ley del Suelo de 1956, no están cuantificados salvo en lo referente al $10 \%$ de zonas verdes.

La reserva de áreas de aparcamiento de vehículos prevista en las Normas Urbanísticas se indica en la Norma 33a:

Cuando se trate de barriadas de mayor categoría, considerar la existencia de un vehículo por cada tres familias. y en las barriadas modestas un vehículo por cada cinco familias. Cada vehículo obligará a una reserva de un área de aparcamiento de veinte metros cuadrados.

Se deberá reservar el quince por ciento de la superficie construida en edificios destinados a uso público. excepto los aparcamientos previstos para salas de espectáculos que deberá tener la capacidad de un vehículo por cada cincuenta espectadores ${ }^{1}$.

Esta escasa previsión de aparcamientos será una fuente permanente de problemas no sólo para la tramitación de los Planes Parciales, debido a la exigencia del Ministerio de una plaza por vivienda, sino, sobre todo, para la adecuada utilización del sistema de espacios públicos de los barrios, desbordados por el vertiginoso crecimiento del parque de vehículos privados que no encuentran más alojamiento que las calles 0 , incluso, las supuestas zonas verdes.

Por último, debe destacarse que una de las Normas Urbanísticas, la No 34, incide directamente en aspectos de composición urbanística de los conjuntos residenciales, señalando que:

Cuando se trate de Planes Parciales dentro del concepto de edificaciones abiertas, se procurará lograr agrupaciones de bloques con carácter abierto o semiabierto, dentro de la máxima variedad, para evitar la monotonía que implica la repetición de tipos normalizados en disposición paralela, de forma que el recorrido a través de las calles provoque composiciones agradables y se evite en lo posible la visibilidad desde las mismas de las fachadas secundarias donde establecen los servicios de las viviendas.

Se determinará en forma clara los espacios libres entre bloques que forzosamente deben ser ajardinados. ${ }^{2}$

En los Planes Parciales se seguirá, como veremos, el criterio de variedad en la disposición de los bloques, evitando el zeilenbau o edificación en línea de bloques equidistantes de igual orientación. En cambio, resultará un objetivo casi imposible de lograr el mantener en la edificación abierta la distinción entre la parte delantera y la trasera, que resulta natural en la edificación entre medianeras alineada a las calles.
1.Adaptación del Plan General de Ordenación Urbana de Valencia y su Comarca a la Solución Sur, 1966. Normas urbanísticas. Norma 33a. Anexo de Documentos, p. 310 .

2. Adaptación del Plan General de Ordenación Urbana de Valencia y su Comarca a la Solución Sur, 1966. Normas urbanísticas. Norma 34a. Anexo de Documentos, p. 310 
Tabla III.1 Áreas de edificación abierta incluidas en los Planes Parciales de desarrollo del Plan General de Valencia de 1966.

\begin{tabular}{|c|c|c|c|c|}
\hline ZONA & $\begin{array}{l}\text { PLAN } \\
\text { PARCIAL }\end{array}$ & $\begin{array}{c}\text { AÑo } \\
\text { REDACCIÓN }\end{array}$ & $\begin{array}{c}\text { AÑO } \\
\text { APROBACIÓN }\end{array}$ & $\begin{array}{l}\text { ÁREAS DE EDIFICACIÓN ABIERTA } \\
\text { INCLUIDAS EN EL PLAN }\end{array}$ \\
\hline \multirow{17}{*}{ NORESTE } & \multirow{4}{*}{11} & \multirow{4}{*}{1967} & \multirow{4}{*}{1974} & Jaime Roig-Bachiller \\
\hline & & & & Av. Catalunya - Menendez Pelayo \\
\hline & & & & Av. Aragón - Mestalla \\
\hline & & & & Llano del Real \\
\hline & \multirow{5}{*}{12} & \multirow{5}{*}{1967} & \multirow{5}{*}{1969} & Av. Catalunya - Ruben Darío \\
\hline & & & & Avenida Aragón - Polo y Peyrolón \\
\hline & & & & Prolongación Paseo al Mar. \\
\hline & & & & Isla Perdida (G). \\
\hline & & & & Grupo Virgen del Carmen (G). \\
\hline & 10 & $\begin{array}{l}\text { a) } 1968 \\
\text { b) } 1974\end{array}$ & $1975(\mathrm{~N})$ & Molinell-Tránsitos \\
\hline & \multirow{4}{*}{22} & \multirow{4}{*}{$\begin{array}{l}\text { a) } 1967 \\
\text { b) } 1973\end{array}$} & \multirow{4}{*}{1974} & Guardia Civil \\
\hline & & & & Primado Reig- Av. Catalunya. \\
\hline & & & & Benimaclet Noreste. \\
\hline & & & & Benimaclet Oeste. \\
\hline & 23 & 1967 & 1968 & Orriols \\
\hline & 14 & $\begin{array}{l}\text { a) } 1967 \\
\text { b) } 1975\end{array}$ & - & Camins al Grao \\
\hline & 13 & $\begin{array}{l}\text { a) } 1968 \\
\text { b) } 1974\end{array}$ & $1975(\mathrm{~N})$ & $\begin{array}{l}\text { Noroeste de la Malvarrosa. } \\
\text { Cavite }\end{array}$ \\
\hline \multirow{7}{*}{ NOROESTE } & 8 bis & 1967 & 1968 & Ampliación Campanar \\
\hline & \multirow[t]{2}{*}{8} & a) 1967 & \multirow[b]{2}{*}{1974} & Campanar \\
\hline & & b) 1971 & & Tendetes -Polígono Campanar (P). \\
\hline & 9 & $\begin{array}{l}\text { a) } 1967 \\
\text { b) } 1973\end{array}$ & 1974 & Marxalenes \\
\hline & \multirow{3}{*}{$24-A / B$} & \multirow{3}{*}{$\begin{array}{l}\text { a) } 1970 \\
\text { b) } 1974\end{array}$} & \multirow[b]{3}{*}{1978} & Ciudad del artista fallero. \\
\hline & & & & Benicalap \\
\hline & & & & Salida Ademuz \\
\hline \multirow{7}{*}{ SUROESTE } & 25 & 1966 & 1968 & Soternes \\
\hline & \multirow{3}{*}{26} & \multirow{3}{*}{$\begin{array}{l}\text { a) } 1967 \\
\text { b) } 1973\end{array}$} & \multirow[b]{3}{*}{1974} & G.Virgen de los Desamparados (G) \\
\hline & & & & Polígono Avenida de Castilla $(\mathrm{P})$ \\
\hline & & & & Patraix \\
\hline & \multirow[b]{2}{*}{26 bis } & \multirow[b]{2}{*}{1967} & \multirow[b]{2}{*}{1968} & Grupo Virgen de la Fuensanta (G) \\
\hline & & & & Barrio de la Luz \\
\hline & 3 & 1968 & 1969 & $\begin{array}{l}\text { Ausias March/Juan Ramón Jimenez } \\
\text { La Torre/ Joaquín Benlloch }\end{array}$ \\
\hline \multirow{4}{*}{ SURESTE } & $5-B$ & 1968 & 1969 & Sur de RENFE \\
\hline & $5-\mathrm{C}$ & $\begin{array}{l}\text { a) } 1968 \\
\text { b) } 1973\end{array}$ & 1976 & Malilla \\
\hline & 4 & 1974 & 1974 & Polígono Fuente San Luís (P) \\
\hline & 4bis-16I & $\begin{array}{l}\text { a) } 1968 \\
\text { b) } 1973\end{array}$ & 1975 & Fuente San Luís Sur \\
\hline
\end{tabular}

(G) Grupos de promoción pública.

(P) Polígonos de promoción pública.

(N) Anulado por sentencia judicial. 


\section{LA EDIFICACIÓN ABIERTA EN LOS PLANES PARCIALES DE DESARROLLO DEL PLAN GENERAL DE 1966.}

Para acotar nuestro estudio de los planes parciales de desarrollo del Plan General de 1966 nos hemos fijado tres límites. En primer lugar, nos centraremos en los planes correspondientes a áreas situadas dentro del término municipal de Valencia. De ellos, analizaremos únicamente los planes que incluyen, en mayor o menor medida, áreas residenciales de edificación abierta. Por último, descartaremos los planes parciales propios de poblados que, aun encontrándose dentro del término municipal de Valencia y siendo de uso residencial, sean áreas aisladas del continuo urbano de la ciudad.

El primero de estos límites es puramente operativo, ya que el elemento final de comparación de los Planes Parciales es el PGOU de Valencia de 1988, que es ya un Plan General municipal y no comarcal. Por otra parte, ampliar el estudio a todos los municipios que integraban el Plan de 1966 es algo que excede nuestras posibilidades, aunque es una posible línea de trabajo futura que queda abierta.

El segundo límite deriva sencillamente de considerar que el uso residencial es el sustantivo de la ciudad, y el que merece por tanto una atención prioritaria como objeto de estudio.

El tercer límite es consecuencia del primero, ya que si dejamos fuera de nuestro análisis a los municipios del área metropolitana, deberemos hacer lo mismo con áreas como Nazaret, la Fonteta de San Luís o El Saler, que aunque forman parte del término municipal de Valencia, tienen una relación con la ciudad central similar a la de aquellos.

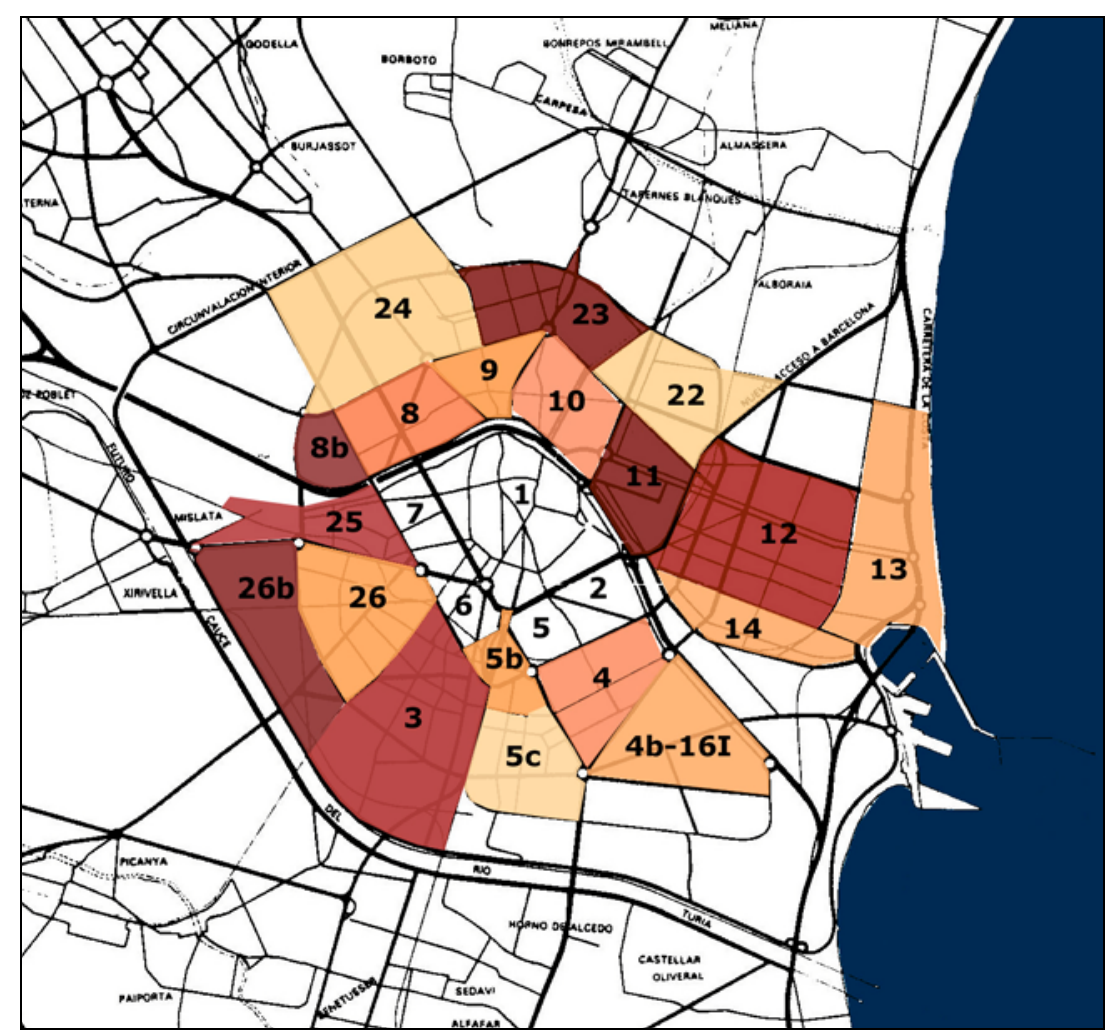

Planes parciales de desarrollo del Plan General de 1966 que contienen zonas de edificación abierta. 
Tabla III.2 Tramitación de Planes Parciales, 1966-1988.

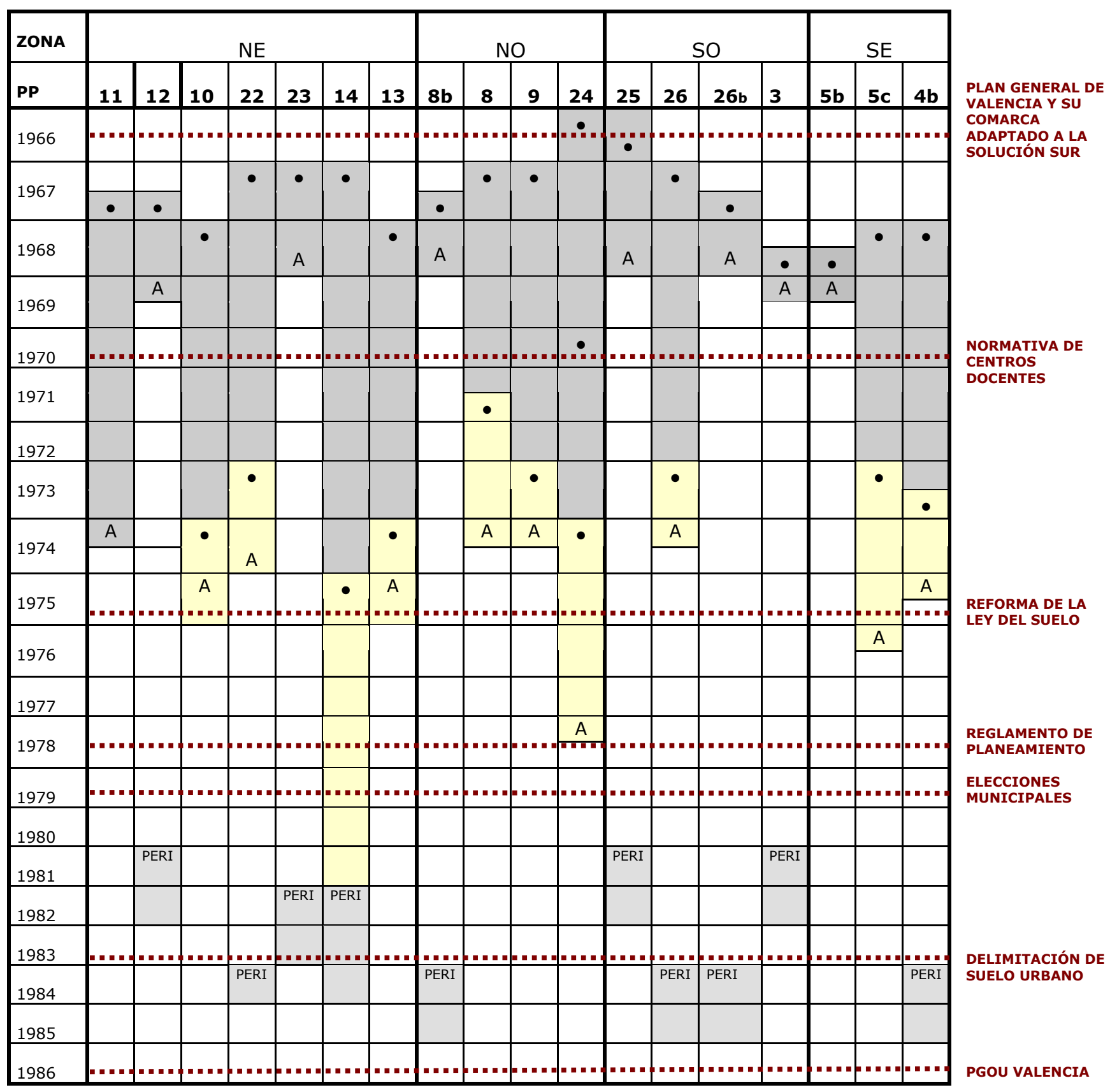

- Redacción de Plan Parcial

A Aprobación definitiva. 
Las zonas en las que agrupamos los planes parciales son el resultado de dividir la ciudad de Valencia en cuadrantes, utilizando como línea de división este-oeste el cauce del río Turia y como línea de división norte-sur el eje de la carretera de Barcelona por un lado y el de las vías de ferrocarril que parten de la Estación del Norte por otro. De ello resultan los cuadrantes Noreste, Noroeste, Suroeste y Sureste, cada uno de los cuales incluye un grupo de Planes Parciales contiguos entre sí.

En la Tabla III.1 se reflejan los Planes Parciales englobados en cada uno de estos cuadrantes, indicando las áreas de edificación abierta más importantes existentes en cada Plan.

Los Planes indicados en la Tabla serán los que estudiaremos con detalle, ya que son los que incluyen áreas de edificación abierta de tamaño significativo.

Debe señalarse que no siempre las áreas ordenadas mediante bloques de edificación abierta están situadas en las zonas de suelo clasificadas como tales en el Plan General, sino que en algunos de planes parciales aparecen en zonas con clasificación de Ensanche Exterior a Tránsitos o Tolerancia Industrial.

En la Tabla III. 2 hemos reflejado en un diagrama de barras el periodo transcurrido entre el inicio de la redacción de cada uno de los diferentes planes parciales por parte de los técnicos municipales y el año de su aprobación definitiva por el Ministerio de la Vivienda, una vez subsanadas las deficiencias observadas. Además, se señalan mediante unas líneas divisorias horizontales unos hitos que corresponden a los hechos más relevantes que afectan al planeamiento en la ciudad de Valencia.

El año de redacción de un plan viene representado por un punto, y el de su aprobación por la letra A. El cambio de color de gris a amarillo en una barra del diagrama se produce cuando se redacta una nueva versión del plan correspondiente.

La observación de la Tabla III.2 permite constatar que entre 1966 y 1968, inmediatamente después de la aprobación del Plan General de 1966, se redactaron nuevas versiones de todos los planes parciales que estamos estudiando. Estas versiones sustituían a las redactadas entre 1958 y 1966, analizadas en la sección anterior y que, en algunos casos, eran bastante recientes, como en el caso del Plan Parcial $24 .^{1}$

Por otra parte, la Tabla III.2 muestra que, en lo referente al periodo de redacción y tramitación, los planes parciales que estamos estudiando pueden englobarse en dos grandes grupos.

El primer grupo es el formado por los planes cuya tramitación fue rápida, ya que su primera versión, redactada entre 1966 y 1968, fue aprobada definitivamente entre 1968 y 1969. A este grupo pertenecen los Planes no 12, 23, 8b, 25, 26b, 3 y 5b.

El segundo grupo es el formado por los planes cuya tramitación resultó larga y compleja, exigiendo en la mayor parte de los casos una nueva redacción de los mismos.
1. Según E.Giménez, la secuencia temporal de los Planes Parciales revela una estrategia de crecimiento que consiste en desarrollar primero los planes de borde, dejando áreas de suelo vacante intermedio que quedan así revalorizadas para un desarrollo urbano posterior. Esta supuesta estrategia queda desmentida por el hecho de que las bolsas de suelo intermedias estaban siendo edificadas con arreglo a Planes Parciales en tramitación, pendientes de aprobación definitiva. Pensamos, por tanto, que la hipótesis del crecimiento uniforme en todas las direcciones es más plausible como idea inspiradora del planeamiento de desarrollo. Ver Giménez Baldrés, Enrique J. Parcelaciones Residenciales Suburbanas. La formación de la periferia metropolitana de Valencia, Universidad Politécnica de Valencia, Valencia, 1996, pp. 553-565. 

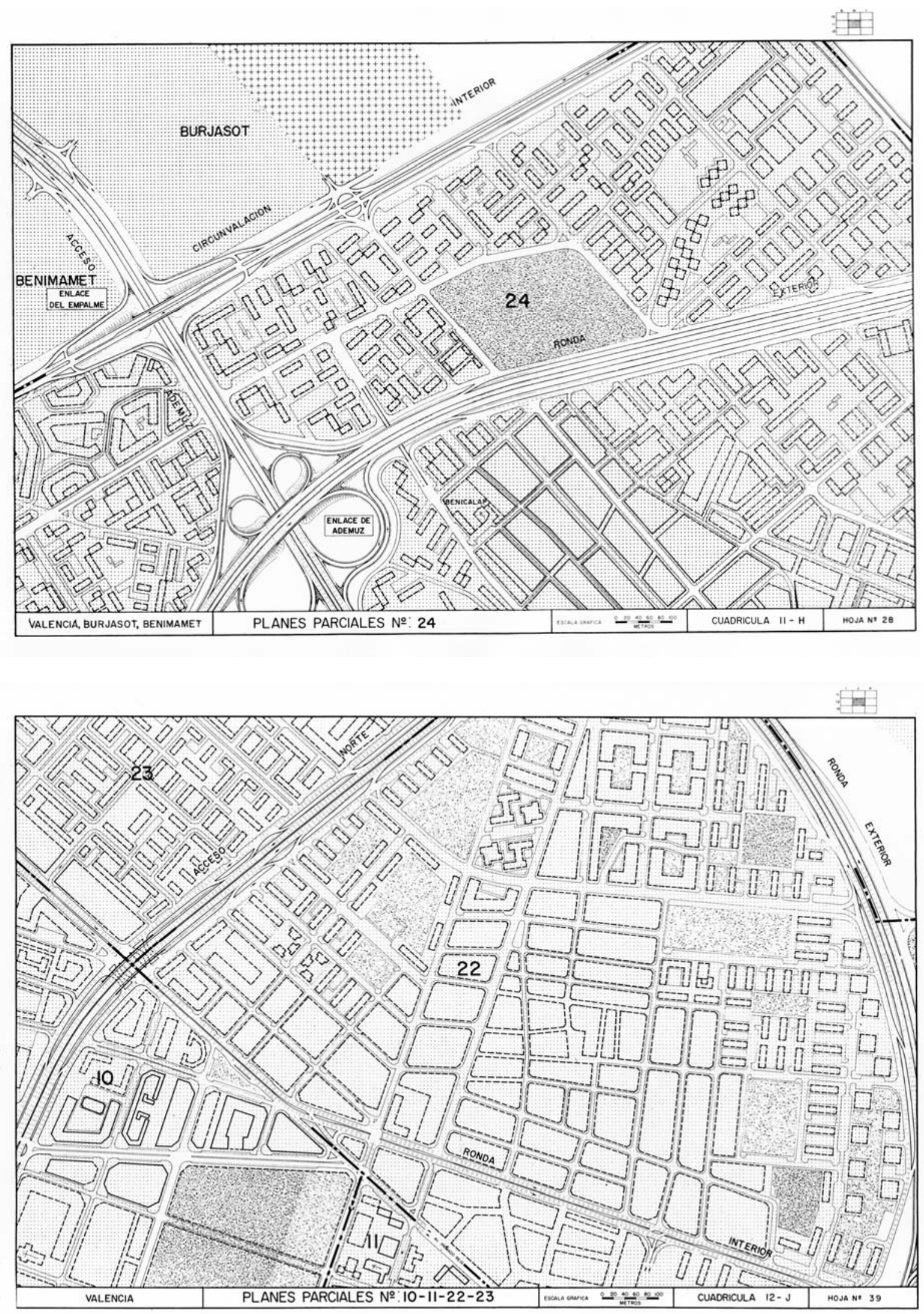

Informe PREVASA, 1974. Información urbanística. Hojas no 28 y 39 
Entre estos, el Plan Parcial 11 constituye un caso aparte, a causa de una accidentada tramitación que, sin embargo, no se tradujo en una nueva redacción del plan, como veremos más adelante.

Los demás planes de este segundo grupo tienen dos versiones sucesivas, ya que a las iniciales, redactadas entre 1968 y 1969, se suman otras redactadas a partir de 1973 y aprobados por lo general antes de 1975, año de la promulgación de la Ley del Suelo. De hecho, la observación de la Tabla III.2 parece sugerir que las segundas versiones de estos planes se redactaron con el objeto de regularizar el planeamiento de las áreas que ordenaban antes de la entrada en vigor de dicha Ley del Suelo. A este grupo pertenecen los planes no $10,22,13,14,8,9,24,26,5$ c y $4 b$.

De todos ellos, los planes que sufrieron una mayor demora en su tramitación fueron el Plan Parcial 24, que tuvo que adaptarse en su redacción final a la nueva Ley del Suelo, como veremos, y el Plan Parcial 14, que no llegó a ser aprobado definitivamente.

Las construcción de las zonas de edificación abierta correspondientes al PP22 (Benimaclet) en la zona Noreste, el PP24 (Benicalap) en la zona Noroeste, el PP 26 (Patraix) en la zona Suroeste y los PP 5-c (Malilla) y 4-b (Fuente San Luís Sur) en la zona Sureste quedará para después de la aprobación nuevo del Plan General de Valencia de 1988, en el que la mayoría de ellas aparecerán con la calificación de "Suelo Urbanizable No Programado", es decir, sin una ordenación urbana definida. Lo mismo ocurrirá, pese a que forman parte del grupo de planes tramitados con rapidez, con los planes parciales 8-b (Oeste de Campanar) y 23 (Orriols-Torrefiel).

El primer documento en el que se dibujan de manera conjunta todos los Planes Parciales de la ciudad, insertos en el nuevo sistema viario resultante del Estudio de la Red Arterial, es el Informe PREVASA (Promociones Económicas Valencianas), encargado por la Caja de Ahorros de Valencia, que tiene como título general el de Comunicaciones del área metropolitana. Su parte IV, titulada "Información Urbanística", incluye un plano de la ciudad de Valencia, desglosado en 104 Hojas de tamaño A3 a escala 1:2.500, que recoge todos los planes parciales, así como un listado final de datos de planeamiento vigentes. ${ }^{3}$

El montaje de hojas del Informe PREVASA nos confirma que se prevé un crecimiento de la ciudad en todas las direcciones, ya que cada uno de los cuadrantes en que hemos dividido la ciudad dispone de planeamiento parcial aprobado o en tramitación a finales de los años 60.

Además, la parte IV del Informe PREVASA incluye planos del planeamiento existente en los municipios del área metropolitana de Gran Valencia. Los datos de los municipios más próximos a Valencia aparecen también transcritos en las Hojas, de modo que podemos obtener una visión muy completa y detallada de la ciudad que se proyectó a través del Plan General de 1966 y sus Planes Parciales de desarrollo.
1.PREVASA, Comunicaciones del área metropolitana. Valencia, IV. Información urbanística, Caja de Ahorros y Monte de Piedad de Valencia, Valencia, 1974. En 1984, el Colegio de Arquitectos de Valencia preparó un plano titulado "Información Urbanística de Valencia", que recogía todos los planes parciales vigentes, así como los PERI que reformaban algunos de ellos. 

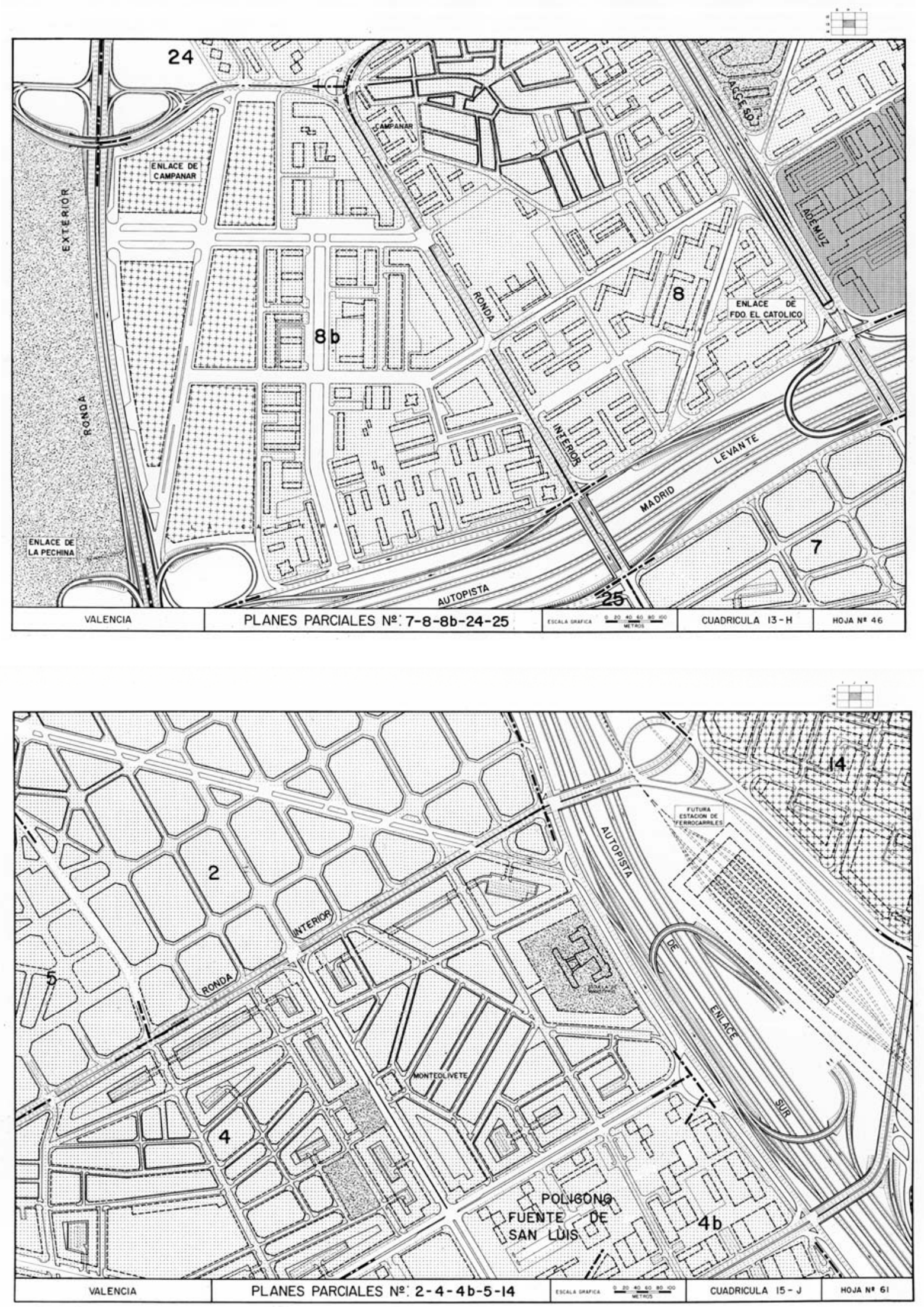

Informe PREVASA, 1974. Información urbanística. Hojas no 46 y 61. 
La sección IV del Informe PREVASA comienza con una parte escrita dedicada al análisis urbanístico del área metropolitana de Valencia. En relación con el anillo de Planes Parciales delimitados por la Ronda Exterior, que son los proyectados en mayor medida mediante edificación abierta, se señala que

Absolutamente toda la superficie incluida dentro de este recinto está calificada como suelo urbano en el Plan General y por tanto, cabría decir de ella que representa la imagen de la ciudad futura, manteniendo el concepto de compacidad directamente vinculado a la definición de ciudad como corresponde a un asentamiento meridional. ${ }^{1}$

Esta referencia a la ciudad compacta es abiertamente contradictoria con la idea de ciudad por partes señalada en la Memoria del Plan General, pero surge inevitablemente, y resulta adecuada, al describir lo que se observa al superponer en un único plano todos los Planes Parciales, ya que no se aprecia realmente una solución de continuidad entre unos barrios y otros. La hipótesis de crecimiento de la ciudad que se deduce de ese plano es la de expansión en todas las direcciones.

Las previsiones del Informe para las zonas más periféricas del sector urbano englobado por la Ronda exterior son de una poderosa dinámica de expansión, caracterizada por una rápida realización de las previsiones de planeamiento en cuanto a la edificación privada y una mucho más lenta ejecución de la urbanización, los servicios y las dotaciones de equipamientos y zonas verdes.

El Informe, de 1974, menciona el proyecto de reforma de la Ley del Suelo, en tramitación en ese momento, y que sería aprobado en 1975, señalando que cuando se quiera aplicar esta nueva Ley, que introduce mecanismos de gestión que permitirían evitar los desequilibrios antes mencionados, se encontrarán probablemente ya edificadas todas las zonas del sector englobado en la Ronda Exterior.

En relación con las zonas verdes, el Informe señala que en las sucesivas redacciones de los planes parciales de este sector se han ido reduciendo los espacios libres destinados a parques y jardines al quedar ocupados por edificación, y añade con cierto sarcasmo que:

...las zonificaciones del Plan General vigente son muy "realistas" sobre este tema y no han incluido en estos sectores grandes parques ni zonas verdes cuya influencia pueda considerarse exterior al barrio en que están localizados. Se trata simplemente de plazas o paseos ajardinados y también de espacios libres entre edificación abierta cuyo destino sobre el plano es para jardín pero de cuya realización como tal, nos permitimos nuestras reservas. ${ }^{2}$
1.PREVASA, Comunicaciones del área metropolitana. Valencia, IV. Información urbanística, Caja de Ahorros y Monte de Piedad de Valencia, Valencia, 1974.

2.Ibid. 


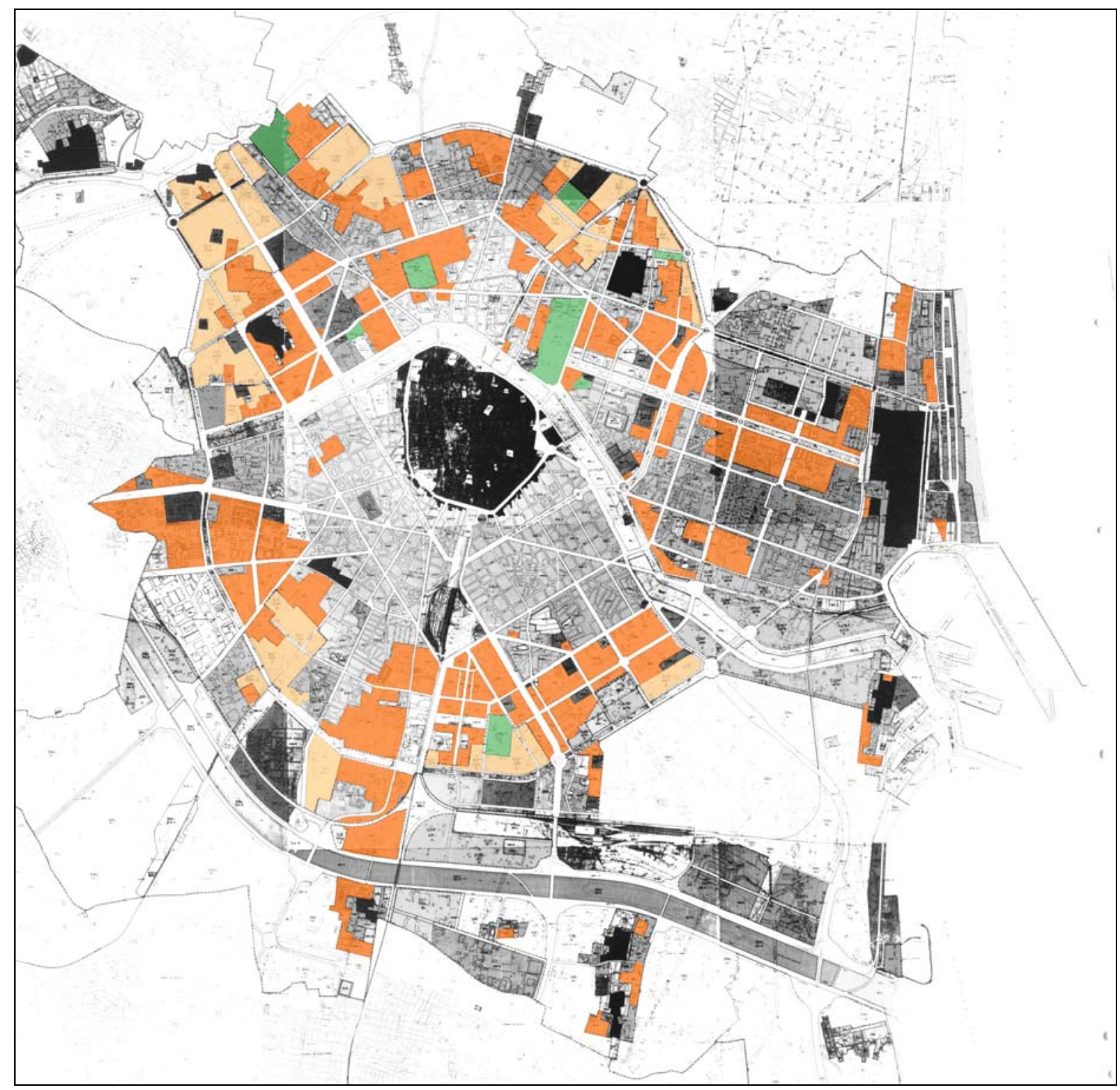

Áreas de edificación abierta en el Plan General de Ordenación Urbana de Valencia de 1988 (Elaboración propia sobre montaje de hojas de la Serie B del PGOU).

AREAS DE EDIFICACIÓN ABIERTA (ZONA EDA)

ÁREAS DE SUELO URBANIZABLE PROGRAMADO QUE TENÍAN CALIFICACIÓN DE EDIFICACIÓN ABIERTA EN EL PLAN DE 1966

ZONAS VERDES 


\section{LA EDIFICACIÓN ABIERTA EN EL PLAN GENERAL DE 1988: LOS RESTOS DEL NAUFRAGIO DEL ORDEN ABIERTO.}

El urbanismo de la austeridad preconizado por Campos Venuti y las propuestas para Bolonia inspiradas por Cervellatti son, junto con las movilizaciones vecinales y profesionales en torno a los conflictos relativos a la urbanización del Saler y la utilización del antiguo cauce del Turia como autopista, algunos de los referentes básicos que marcan el panorama de finales de los años setenta en Valencia. ${ }^{1}$

Para la nueva corporación municipal de izquierdas formada en Valencia como consecuencia de las primeras elecciones municipales democráticas, celebradas en abril de 1979, las tres líneas prioritarias de actuación en materia de urbanismo, recogidas en el Programa de Actuación Municipal, fueron la recuperación del Saler, la rehabilitación del centro histórico y la mejora de las condiciones urbanas de la periferia.

En relación con esta última línea de actuación, el Gabinete de Estudios Urbanos y Territoriales (GEUT), organismo creado para desarrollar el Programa de Actuación Municipal, redactó un Programa de Intervención en la Periferia Urbana, a fin de identificar y medir los principales déficits urbanos de cada uno de los 56 barrios en los que se había subdividido el término municipal, y poder de ese modo establecer prioridades en la intervención.

Como consecuencia de ello, en las áreas que se consideraron más deficitarias en cuanto a reservas de suelo para zonas verdes y equipamientos se redactaron una serie de Planes Parciales de $\mathrm{Re}$ forma Interior (P.E.R.I.) que modificaban los Planes Parciales en vigor, o sectores de los mismos, a fin de adecuarlos en lo posible a los nuevos estándares urbanísticos y a los sistemas de gestión fijados en la Ley del Suelo de 1975 y el Reglamento de Planeamiento de 1978.

El Reglamento de Planeamiento de 1978 fijaba unos estándares de reservas de suelo con destino dotacional muy elevados, sin precedentes en ninguna zona de la ciudad existente. La consecuencia de ello es que todos los planes parciales proyectados en desarrollo del Plan General de 1966 quedaron obsoletos, ya que las reservas para equipamientos en los mismos eran inferiores a las exigidas por el Reglamento, y su edificabilidad superaba la máxima prevista en el mismo.

Por otra parte, el Reglamento de Gestión Urbanística, aprobado también en 1978 , hace que el sistema de cesión de viales habitual en los Planes Parciales de Valencia quede superado por los nuevos sistemas de ejecución del planeamiento.

Entre 1979 y 1983, la revisión de planeamiento mediante Planes Especiales de Reforma Interior afectó a 34 de los 40 Planes Parciales de desarrollo del Plan General de 1966. Los PERI redactados introdujeron importantes incrementos de reservas de suelo dotacional, en espacial para equipamientos escolares y zonas verdes, aprovechando las bolsas de suelo vacante existentes ${ }^{2}$.

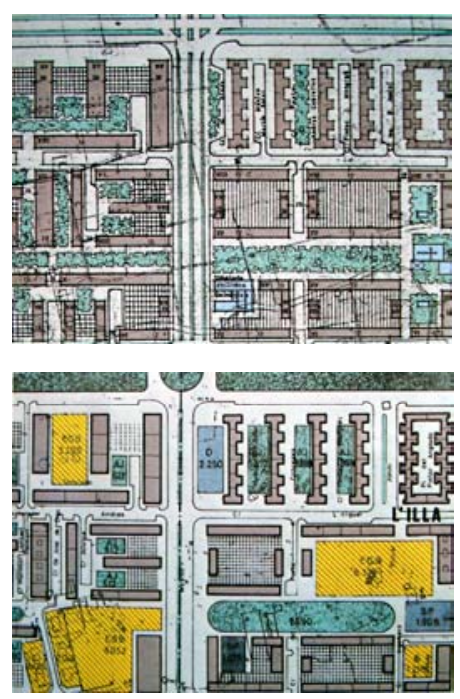

Detalle de la zona de Algirós. Arriba, Plan Parcial de 1968. Abajo, PERI de 1983; mostrando el incremento de zonas escolares (en amarillo), dotacionales (en azul) y jardines (La ciudad que queremos. Avance del Plan General de Ordenación Urbana, Valencia, 1985)

1.Ver González Móstoles, Vicente, "La renovación del urbanismo en los años ochenta", en VV.AA., Historia de la ciudad, II. Territorio, sociedad y patrimonio, Colegio Territorial de Arquitectos de valencia, Ayuntamiento de Valencia, Universidad de Valencia, 2002.

2. Ayuntamiento de Valencia, Libro de la ciudad 1979/1982. Cuatro años de gestión municipal democrática, Ayuntamiento de Valencia, 1982 
Áreas de huerta, calificadas para usos urbanos en el Plan general de1966 y calificadas como suelo no urbanizable en el Avance del Plan General (La ciudad que queremos. Avance del Plan General de Ordenación Urbana, Valencia, 1985)

Áreas con planeamiento revisado mediante Planes Especiales de Reforma Interior entre 1980 y 1984 (Elaboración propia sobre plano viario del Plan General de 1966).
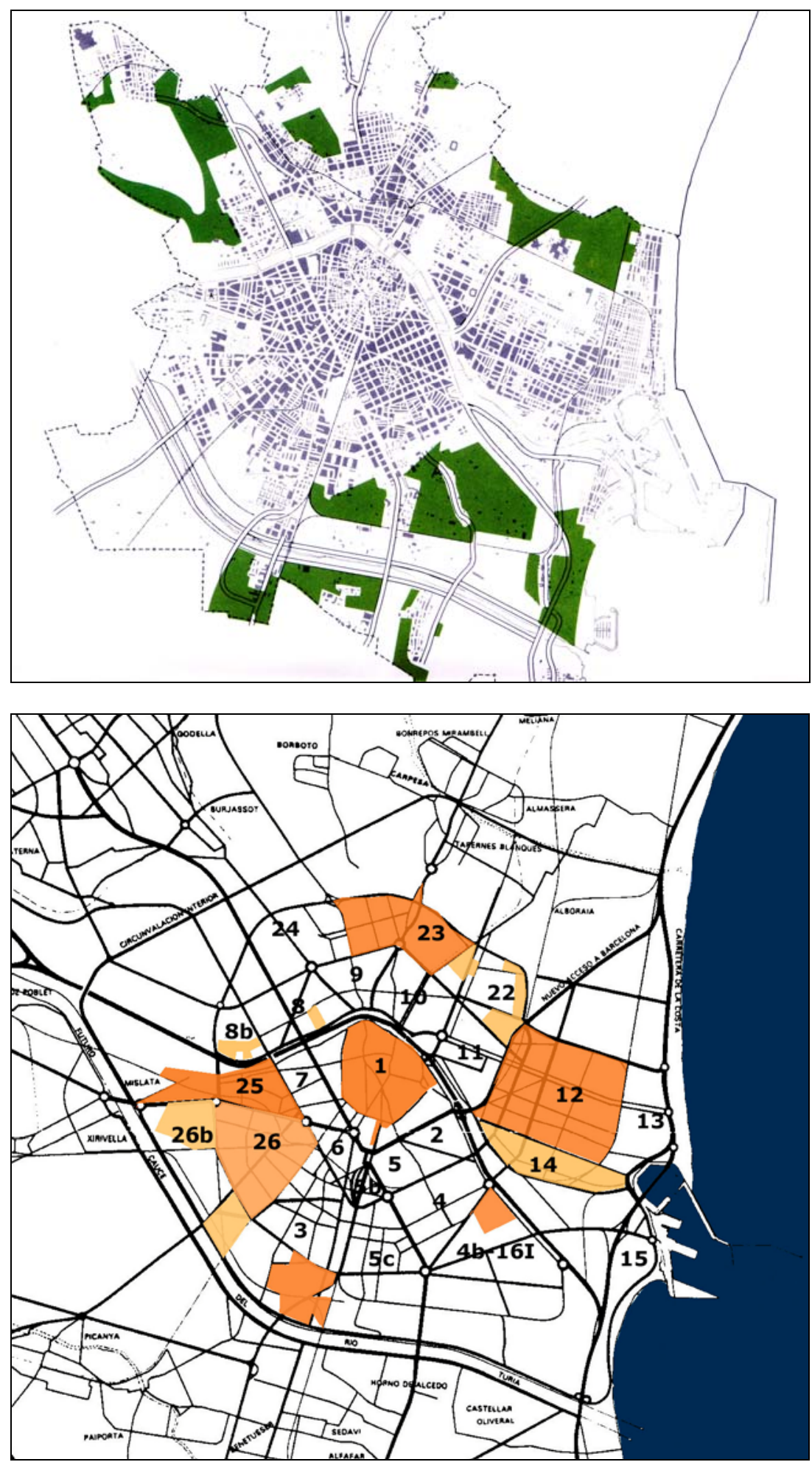

Así, en lugar de abordar la revisión del Plan General vigente de 1966, que era competencia de la Corporación Administrativa Gran Valencia, se optaba en esta primera etapa por una revisión del planeamiento por barrios o sectores.

Después de las segundas elecciones municipales, se creó el Servicio de Arquitectura Urbana, que tenía como tareas centrales la ejecución del Jardín del Turia, la rehabilitación de viviendas en el centro histórico y la realización de una serie de Proyectos de Urba 
nización Integral para subsanar la deficiente situación de la urbanización y los servicios en áreas con planeamiento previamente remodelado mediante PERI, tales como Algirós, Torrefiel y Malilla.

Los PERI redactados, recogidos en la Tabla III.2, fueron finalmente anulados por sentencias judiciales. Sin embargo, la mayor parte de sus determinaciones pasarían a formar parte del nuevo Plan General de Ordenación Urbana de Valencia, cuya redacción, necesaria para adaptar a la Ley del Suelo de 1975 el viejo Plan, sólo pudo abordarse una vez disuelta la Corporación Administrativa Gran Valencia en 1982, tras el cambio del gobierno central como consecuencia de las elecciones legislativas de 1981.

El Avance del nuevo Plan General de Ordenación Urbana, redactado por la Oficina Municipal del Plan creada por el Ayuntamiento al efecto, fue presentado al público en $1985^{1}$. El Avance parte de la consigna "Valencia no debe crecer", de un planteamiento general de restricción del crecimiento urbano de Valencia que pretende favorecer el correcto acabado de la ciudad existente en lugar de promover una extensión de la misma que se considera destructiva para la huerta circundante y sin justificación demográfica ni económica, por el despilfarro de recursos que deben ser empleados en urbanizar y equipar los barrios ya existentes.

En la publicación sobre el Avance del Plan, al comentar el modelos y características del nuevo Plan General se señala lo siguiente:

Inmersos en pleno debate turístico entre los "planes-programa" y los "planes-imagen", en un momento de plena revalorización de los espacios urbanos clásicos y de la arquitectura urbana asociada a ellos, metidos de lleno en los Planes Generales llamados, convencionalmente de "3a generación", superados asimismo los esquemas nacidos de la Carta de Atenas, el Plan General de Valencia nace en un momento especialmente apasionante de la práctica urbanística europea. Y de ninguna manera podía ni debía ser ajeno a un debate cultural de singular trascendencia que amenaza con quebrar para siempre el urbanismo de los últimos 50 años. ${ }^{2}$

En la publicación municipal del Avance encontramos también algunas observaciones relativas a los tipos de edificios que se emplearán en las ordenaciones, como la siguiente, muy crítica con los bloques aislados de edificación abierta:

El nuevo Plan General plantea también nuevos modos de "hacer" la ciudad, nuevos planteamientos respecto al diseño urbano, revalorizando el papel del espacio público, introduciendo nuevos tipos de vivienda, de menores alturas y densidades, con espacios comunitarios e integrando adecuadamente los equipamientos en la trama urbana. Asimismo se implantarán nuevos criterios de ordenación para las áreas de suelo aún vacantes, evitando los bloques aislados (la mal llamada "edificación abierta") responsable en buena medida de la despersonalización de la ciudad y ajena por completo a nuestro entorno cultural. ${ }^{3}$

El urbanismo de la Carta de Atenas y los bloques de edificación abierta, son, pues, descalificados con rotundidad, en línea con la cultura urbanística del momento: el tejido regular de manzanas
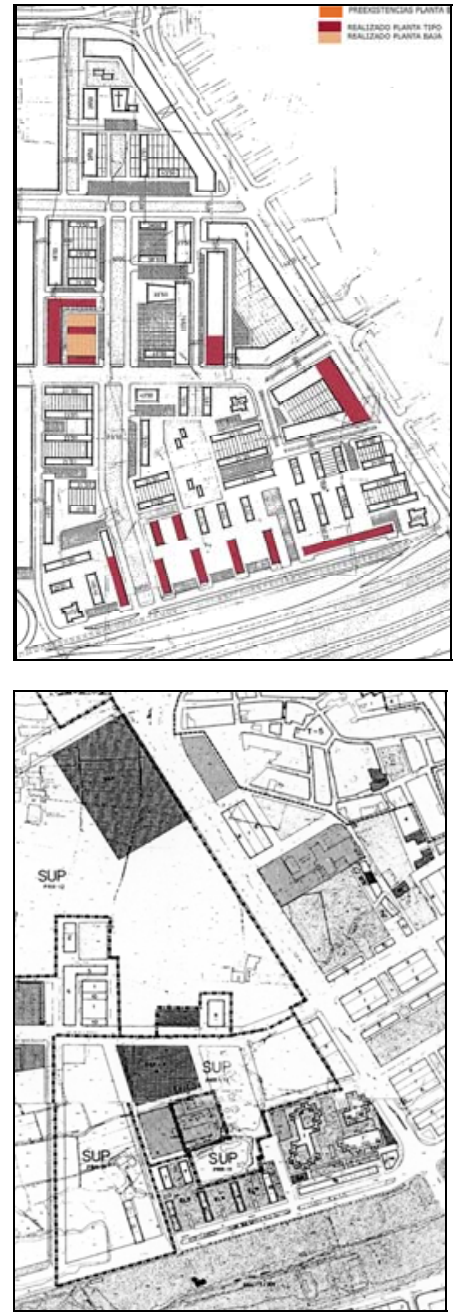

Plan Parcial 8-B. Fragmento del Plan Parcial de 1967 y de la misma zona, calificada cono SUP en el PGOU de 1988.

1.Ayuntamiento de Valencia, Oficina Municipal del Plan, A. Escribano, Dir., La ciudad que queremos. Avance del Plan General de Ordenación Urbana, Valencia, 1985 Ayuntamiento de Valencia, Valencia, 1985.

2.Ibid., p. 58.

3.Ibid. , p. 54 
del ensanche decimonónico es propuesto como modelo, mientras que los bloques aparecen fotografiados como edificaciones que irrumpen en la huerta.

Los objetivos de carácter estructural del Plan, en la versión del Avance, son los de disminuir la superficie de suelo clasificado en el Plan General de 1966, que se considera excesiva, centrar la atención en el suelo urbano y el acabado de la ciudad, proteger el patrimonio histórico y medioambiental, potenciar los sistemas de transporte públicos y establecer mecanismos de gestión adecuados y ágiles para el reparto de cargas y beneficios.

Sin embargo, los objetivos del Avance no se trasladarán al Plan General finalmente aprobado en 1988, en el que la práctica totalidad de las áreas destinadas a usos residenciales previstas en el Plan de 1966 mantienen ese uso, asumiendo los criterios expansivos inherentes al negocio inmobiliario que habían sido censurados en el Avance.

El nuevo marco doctrinal del urbanismo, por otra parte, tampoco se refleja de manera significativa en las ordenaciones nuevas propuestas en el PGOU de 1988, salvo en algunos episodios aislados como los conjuntos formados por manzanas previstos en Benicalap, Campanar o el este de la Fuente de San Luis.

Así, las áreas de edificación abierta (EDA) en suelo urbano del PGOU de 1988 coinciden básicamente con las señaladas en el Plan General de 1966, a excepción de una serie de zonas que tenían una ordenación aprobada mediante el correspondiente Plan Parcial y que, siendo todavía bolsas de suelo vacante en el momento de redactarse el nuevo Plan General, pasan a calificarse en el mismo como suelo urbanizable, tanto programado como no programado.

Estas últimas zonas, extensas áreas de suelo en Orriols, Campanar, Benicalap, Ademuz, Benimaclet, Malilla y sur de Monteolivete, son las que en los años noventa, tras la aprobación de la Ley Reguladora de la Actividad Urbanística de la Comunidad Valenciana, se desarrollarán mediante Programas de Actuación Integrada (PAI). Las ordenaciones planteadas en los PAI quedan fuera del alcance de nuestro trabajo, ya que el PGOU de 1988 marca el final del ámbito temporal que nos hemos fijado para el mismo. 


\section{LAS ÁREAS DE EDIFICACIÓN ABIERTA EN VALENCIA ENTRE 1968 Y 1988.}

Como hemos señalado anteriormente, las zonas en las que agrupamos los planes parciales objeto de estudio son el resultado de dividir las áreas de la ciudad de Valencia exteriores al núcleo formado por el centro histórico y el ensanche en cuadrantes, utilizando como línea de división este-oeste el cauce del río Turia y como línea de división norte-sur el trazado de la antigua carretera de Barcelona por un lado y el de las vías de ferrocarril que parten de la Estación del Norte por otro.

Con este agrupación, los únicos planes que quedan a caballo entre dos de las líneas de división son el Plan Parcial 23, que hemos integrado con los del cuadrante noreste debido a que el sector de edificación abierta de mayor tamaño de este está comprendido dentro de dicho cuadrante, y el Plan Parcial 5-b, englobado por la misma razón en el cuadrante sureste. ${ }^{1}$

Los planes parciales incluidos en cada uno de los cuadrantes, así como la relación de las principales áreas de edificación abierta comprendidas en los mismo, están identificados en la Tabla III.1.

En los siguientes apartados, analizaremos de forma detallada las versiones redactadas entre 1966 y 1975 de cada uno de estos planes parciales, y las compararemos con las anteriores, que hemos estudiado en la sección anterior de este trabajo. Todo ello nos debe permitir, finalmente, realizar una valoración global del papel de la edificación abierta en la formación de la periferia urbana de Valencia.

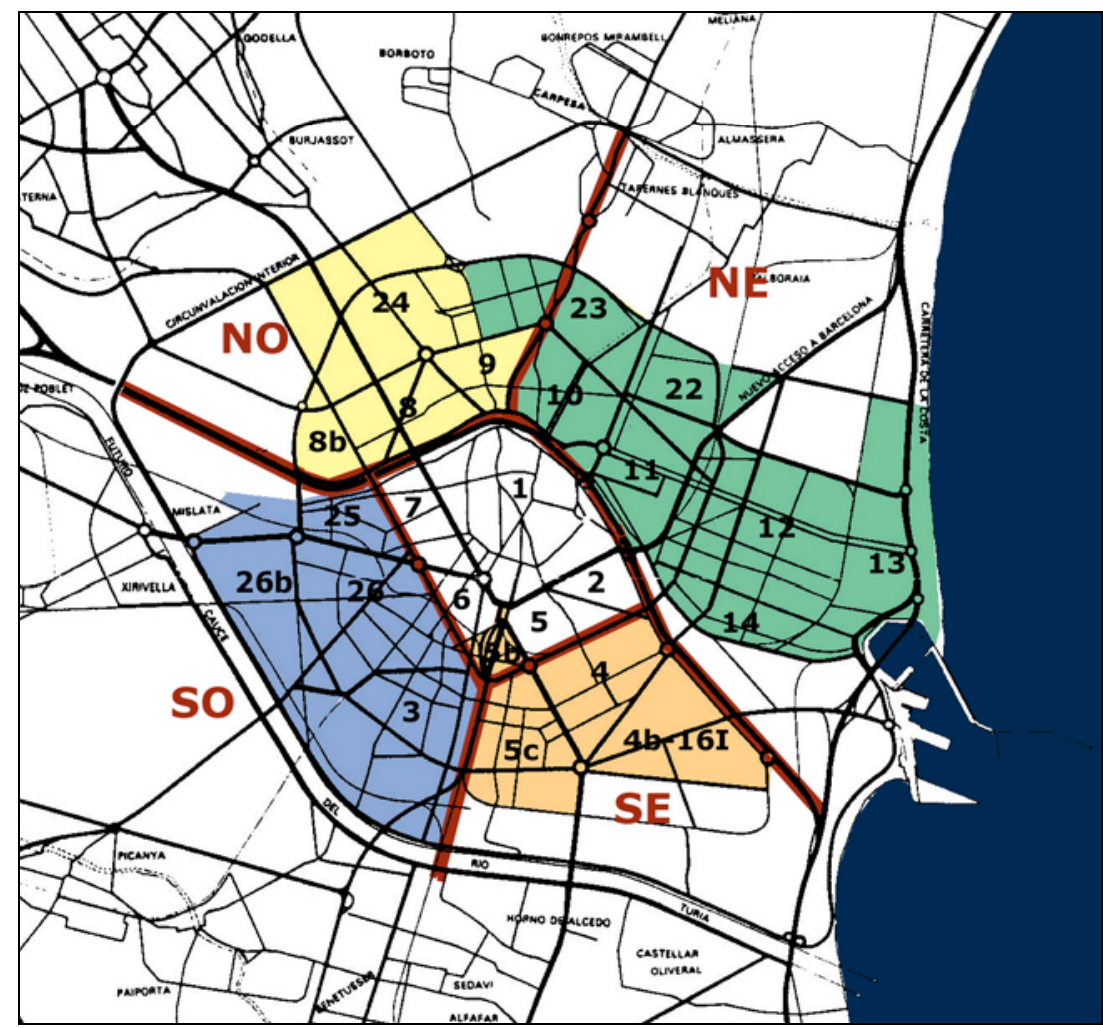

Sectores de la ciudad de Valencia en los que se agrupan los planes parciales de desarrollo del Plan General de 1966.
1. Una línea de división alternativa a la de la carretera de Barcelona podría haber sido la formada por la línea de ferrocarriles eléctricos de Rafelbuñol, que habría dejado al Plan Parcial 10 a caballo entre los cuadrantes noreste y noroeste, y al Plan Parcial 23 englobado en el cuadrante noreste. 


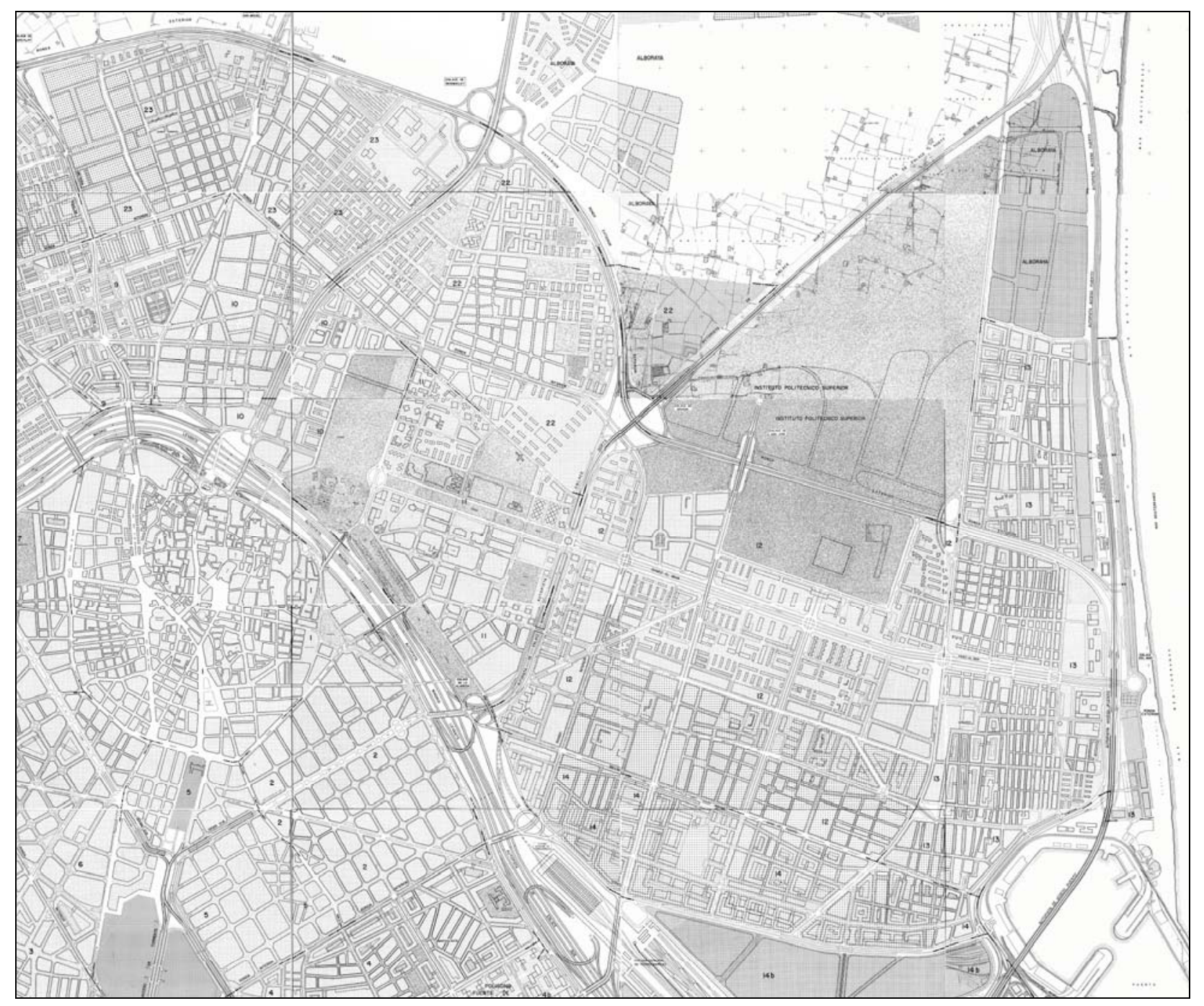

Valencia. Zona noreste: Planes

Parciales no 10, 11, 12, 13, 14,

22, 23 (Montaje de hojas del Informe PREVASA). 


\subsection{LA EDIFICACIÓN ABIERTA EN EL SECTOR NORESTE DE VALENCIA, 1966-1988.}

Los planes parciales que englobamos en al sector noreste de Valencia pueden dividirse en tres grupos por su posición dentro de la estructura general de la ciudad:

a) Planes situados en el interior de la ronda de Tránsitos: Plan Parcial no 10 (Zaidía)

Plan Parcial no 11 (Facultades, Mestalla y Llano del Real).

b) Planes situados entre el límite este de la ronda de Tránsitos y el frente marítimo:

Plan Parcial no 12 (Paseo al Mar-Algirós).

Plan parcial no 13 (Cabanyal-Malvarrosa).

Plan Parcial no 14 (Camins al Grao).

c) Planes situados en el exterior de la ronda de Tránsitos:

Plan Parcial no 22 (Benimaclet).

Plan Parcial no 23 (Torrefiel-Orriols).

La edificación abierta no está presente de modo homogéneo en todos estos planes, como hemos podido ver en la sección anterior al analizar su primera redacción. En los dos planes parciales (10 y 11) situados en el interior del anillo de Tránsitos, por ejemplo, existían amplias zonas ya edificadas con manzanas cerradas de ensanche cuando estos planes se redactaron, y la edificación abierta sólo podía plantearse en la ordenación de los espacios vacantes disponibles en cada caso. Dentro de estos dos planes también hay diferencias, ya que los espacios vacantes son mucho menores en el Plan Parcial 10 que en el 11, y están además separados unos de otros.

El Plan Parcial 13 ordena también una zona, la de los poblados marítimos (Grao, Cabañal y Malvarrosa), muy consolidada, y la edificación abierta es en ella poco relevante. En cambio, en el Plan Parcial 12 y, en menor medida, en el 14, el espacio disponible para la edificación abierta es mucho mayor, pese a que en estos planes existen también amplias zonas ocupadas por tejidos de ensanche preexistentes.

En los planes exteriores a Tránsitos de la zona norte, el espacio disponible sin edificar es el correspondiente a los terrenos situados alrededor de los núcleos de población periféricos existentes (el de Benimaclet en el Plan Parcial 22 y el de Torrefiel-Orriols en el 23), que quedan acotados, como el Plan Parcial 12, por la nueva Ronda Exterior prevista en el Plan General de 1966.

El montaje de las hojas de Información Urbanística del Informe PREVASA correspondientes a este sector noreste de Valencia nos permite observar el conjunto de los planes que lo integran de una manera global. Así, podemos ver que, además de las dos vías anulares que lo delimitan por el norte y el sur (la autopista del cauce del Turia y la Ronda Exterior), y los dos ejes principales intermedios entre ambos del Camino de Tránsitos y del Paseo al Mar, aparecen en este sector varias vías radiales que lo cruzan, la mayor parte de las cuales sirven para fijar la línea divisoria entre dos planes parciales adyacentes. 


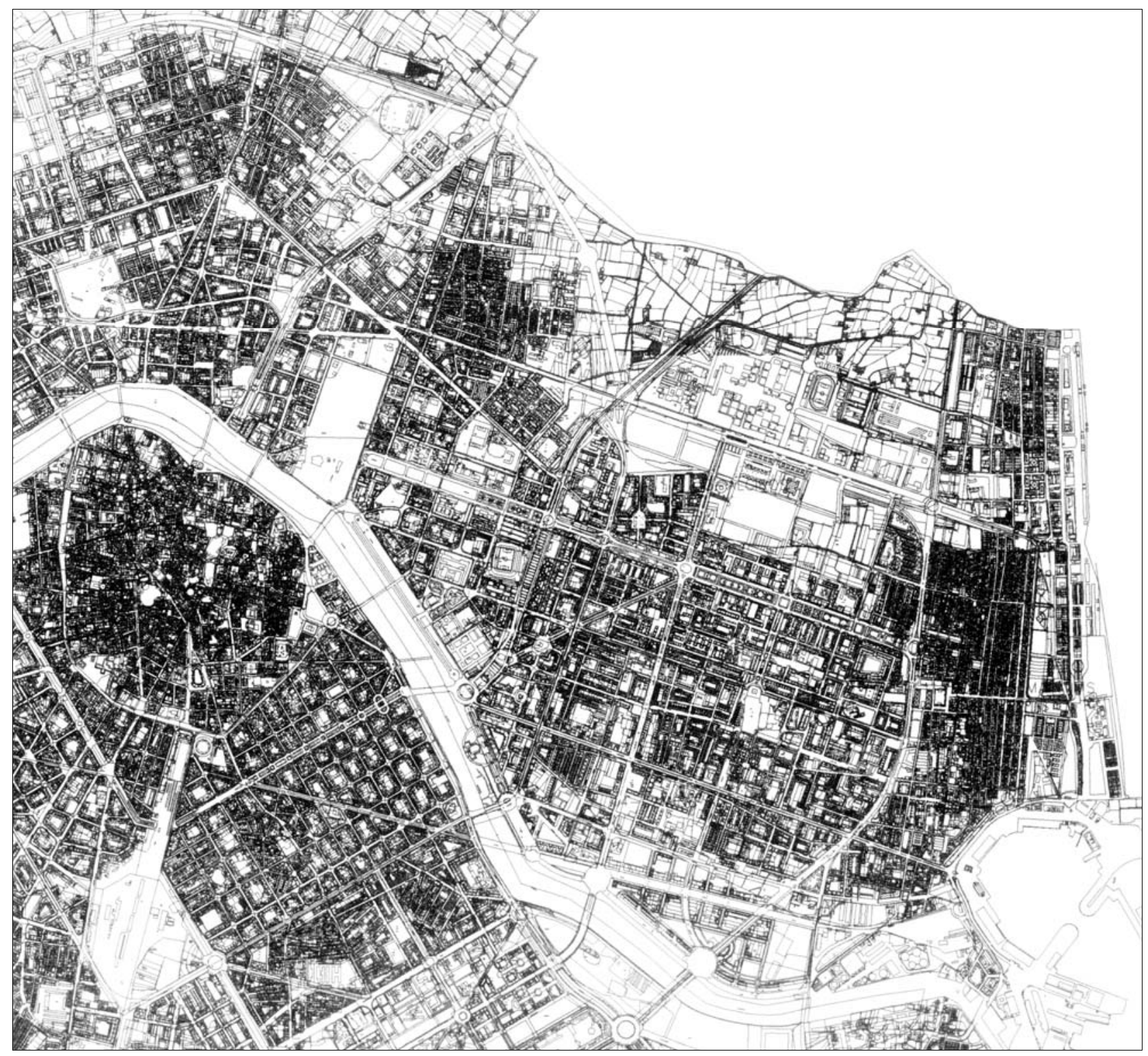

Valencia. Zona Noreste. Cartografía Municipal de Valencia, 2004
Así, el Nuevo Acceso Norte deja a un lado los planes parciales 11 y 22 y al otro el 12 . El nuevo acceso de Alboraya separa a su vez el Plan Parcial 22 y el 23, para continuar atravesando el ámbito del Plan Parcial 10 hasta llegar a la Autopista del viejo cauce. Lo mismo ocurre, a la inversa, con el eje de la carretera antigua de Barcelona, que separa Plan Parcial 10 del 9 para seguir hacia el norte a través de los terrenos del Plan Parcial 23, hasta llegar a la Ronda Exterior.

El límite entre el Plan Parcial 12 y el 13 es el vial previsto en sustitución de la traza del ferrocarril a Barcelona, actual calle Serrería, y la Avenida del Puerto separa a su vez los ámbitos correspondientes a los planes parciales 12 y 14 .

En el Diagrama III.1 hemos reflejado la superficie aproximada de cada uno de los planes parciales del sector noreste de Valencia, indicando para cada uno de ellos la superficie total y la superficie ordenada con edificación abierta, así como la parte de ésta última superficie que se edificó con arreglo a lo previsto en el plan. 
El diagrama nos permite observar que la superficie de los planes parciales no es demasiado homogénea en este sector, ya que oscila entre las $105 \mathrm{Ha}$ del Plan Parcial 11 y las $326 \mathrm{Ha}$ del Plan Parcial 12, que es con diferencia el de mayor tamaño.

En función de la superficie ordenada con edificación abierta, podemos establecer tres grupos de planes. El primero es el formado por los planes parciales 10, 11 y 13, con superficie de edificación abierta comprendida entre 22 y $41 \mathrm{Ha}$. El segundo es el formado por los planes parciales 14, 22 y 23, con superficie entre 60 y 76 $\mathrm{Ha}$, y el último es el integrado por el Plan Parcial 12, único que supera las $100 \mathrm{Ha}$. Los planes del segundo grupo son, por otra parte, los que tienen un porcentaje mayor de suelo proyectado con edificación abierta, debido a que ordenan ámbitos con una mayor extensión de terrenos vacantes. El Plan Parcial 12 puede considerarse también un plan de expansión, aunque su mayor tamaño, resultado de agrupar los dos antiguos sectores denominados 12-A y 12-B, cada uno de los cuales podría haber constituido, por sí solo, un plan parcial independiente, hace que el porcentaje de suelo ordenado con edificación abierta sea menor.

Los planes cuyo grado de realización es mayor son el 11,el 22 y el 10, aunque en éste último la superficie prevista de edificación abierta es menor. En cambio, el grado de realización de los planes parciales 22, 23, 14 y 13 es en general bastante bajo.

\section{Diagrama III. 1}

\section{Planes parciales del sector Noreste. Cuadro de superficies}

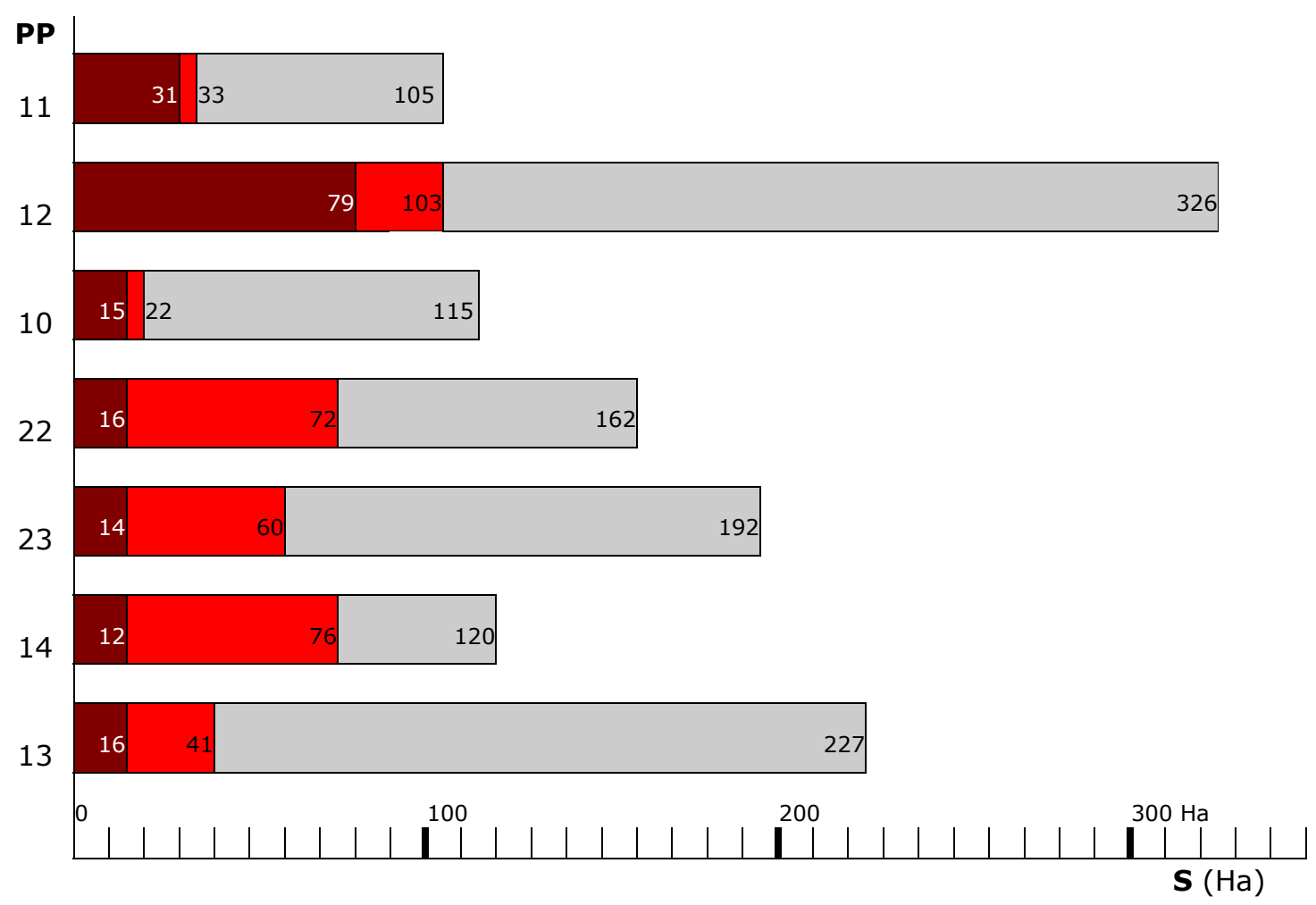

SUPERFICIE TOTAL DEL PLAN PARCIAL

SUPERFICIE ORDENADA CON EDIFICACIÓN ABIERTA

PARTE REALIZADA DE LA SUPERFICIE ORDENADA CON EDIFICACIÓN ABIERTA 


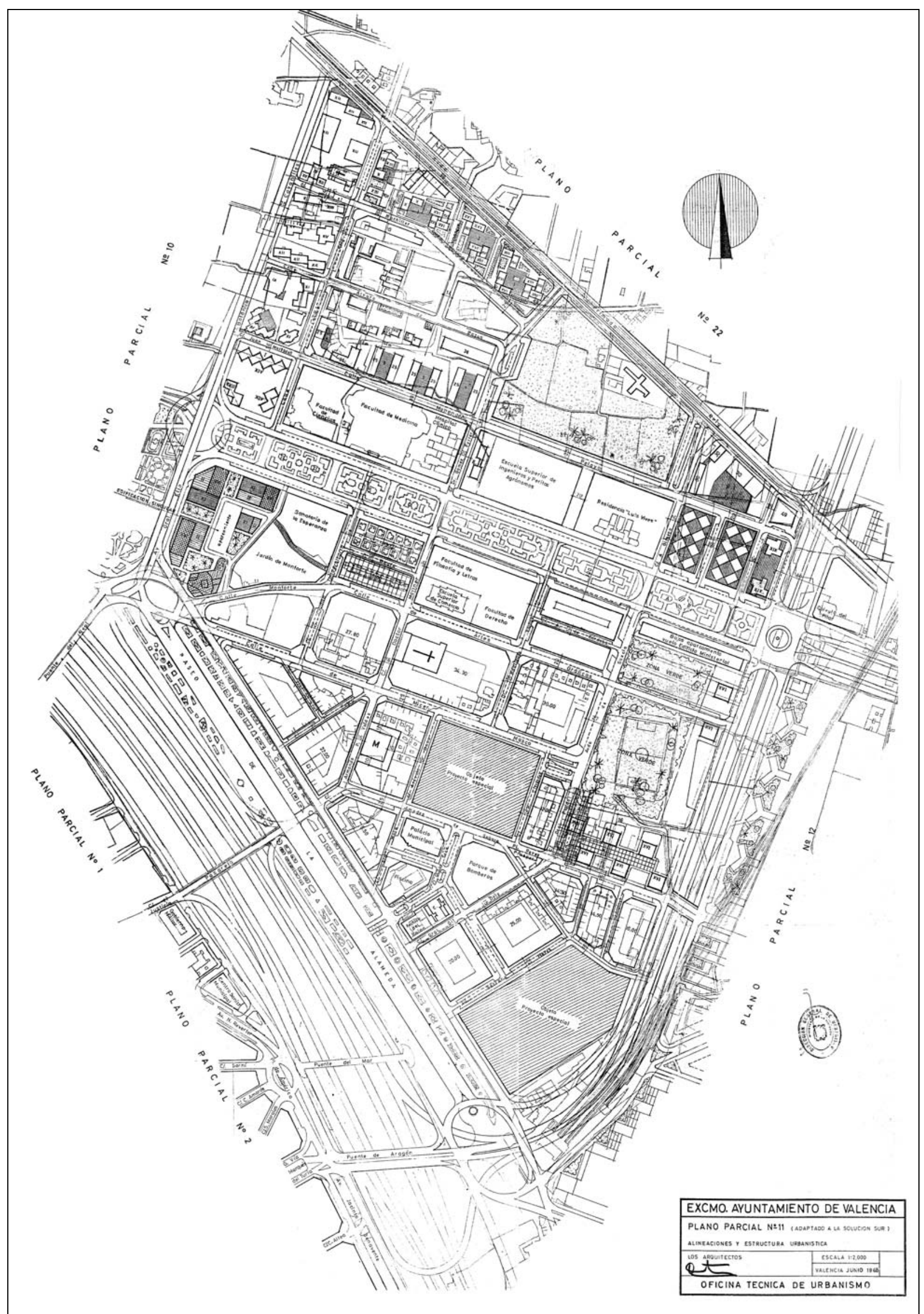

Plan Parcial no 11 adaptado a la Solución Sur, 1968. 


\section{LA ZONA DE LAS FACULTADES, MESTALLA Y EL LLANO DEL REAL: EL PLAN PARCIAL No 11 ADAPTADO A LA SOLUCIÓN SUR (1967-68).}

En la sección anterior hemos analizado las versiones de 1958 y 1960 del Plan Parcial 11, sometidas desde un primer momento a continuas modificaciones puntuales. La aprobación del Plan General adaptado a la solución Sur en 1966 propició la redacción de nuevas versiones de casi todos los planes generales, permitiendo, en el caso del Plan Parcial 11, legalizar las modificaciones introducidas en el mismo. ${ }^{1}$

En el plano de zonificación del plan se diferencian claramente dos zonas de distinto carácter separadas por la principal vía del mismo, el Paseo al Mar. La zona situada al sur del citado Paseo corresponde a la llamada Zona de Ensanches hasta Tránsitos y está formada por manzanas cerradas. Dentro de esta zona, se prevé una zona verde en el espacio ocupado por el campo de fútbol de MestaIla, flanqueada a sur y este por dos zonas de edificación abierta.

La zona situada al norte del Paseo al Mar está considerada en el Plan en su totalidad como Zona de Edificación Abierta Alta. En esta zona están incluidas dos grandes manzanas dotacionales (la destinadas a facultades, Hospital Clínico, etc.) recayentes al citado Paseo y una zona de reserva deportivo-universitaria en los mismos espacios previstos para ello en el Plan Parcial de 1960.

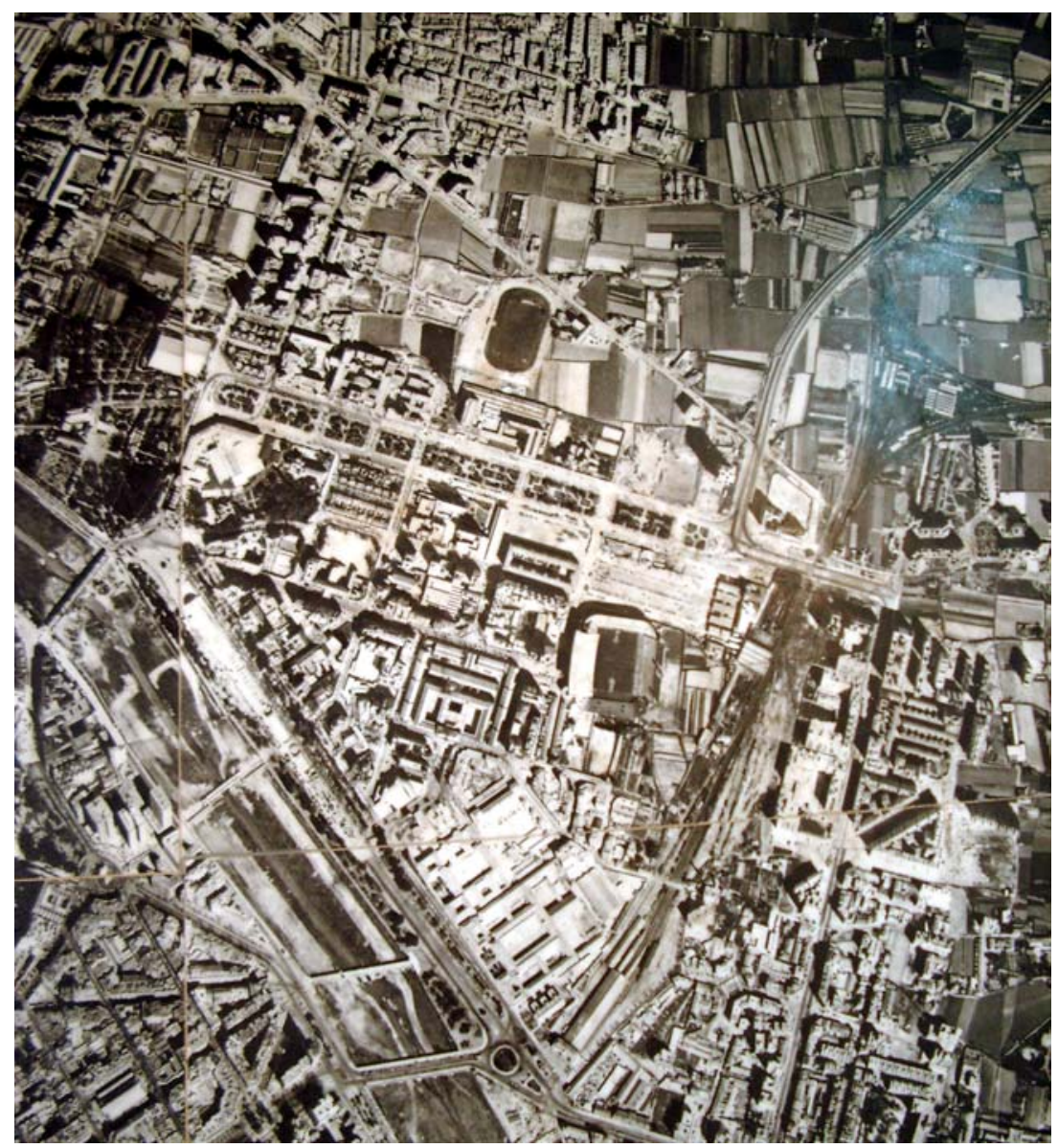

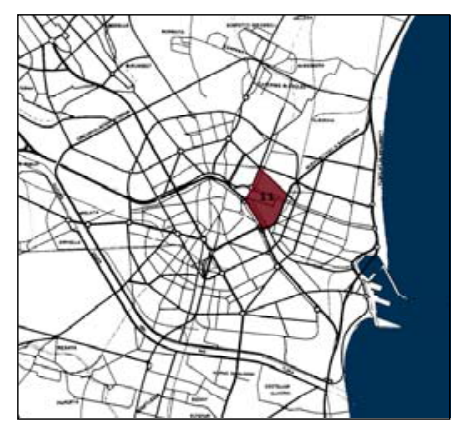

Plan Parcial 11. Localización.

Zona del Plan Parcial 11. Fotoplano, h. 1965 (E.T.S. de Arquitectura de Valencia)

1. Plan Parcial No 11 adaptado a la Solución Sur, 1968. Ver Anexo de Documentos, pp. 343-385. 
Plan Parcial 11, 1968. Plano de zonificación.

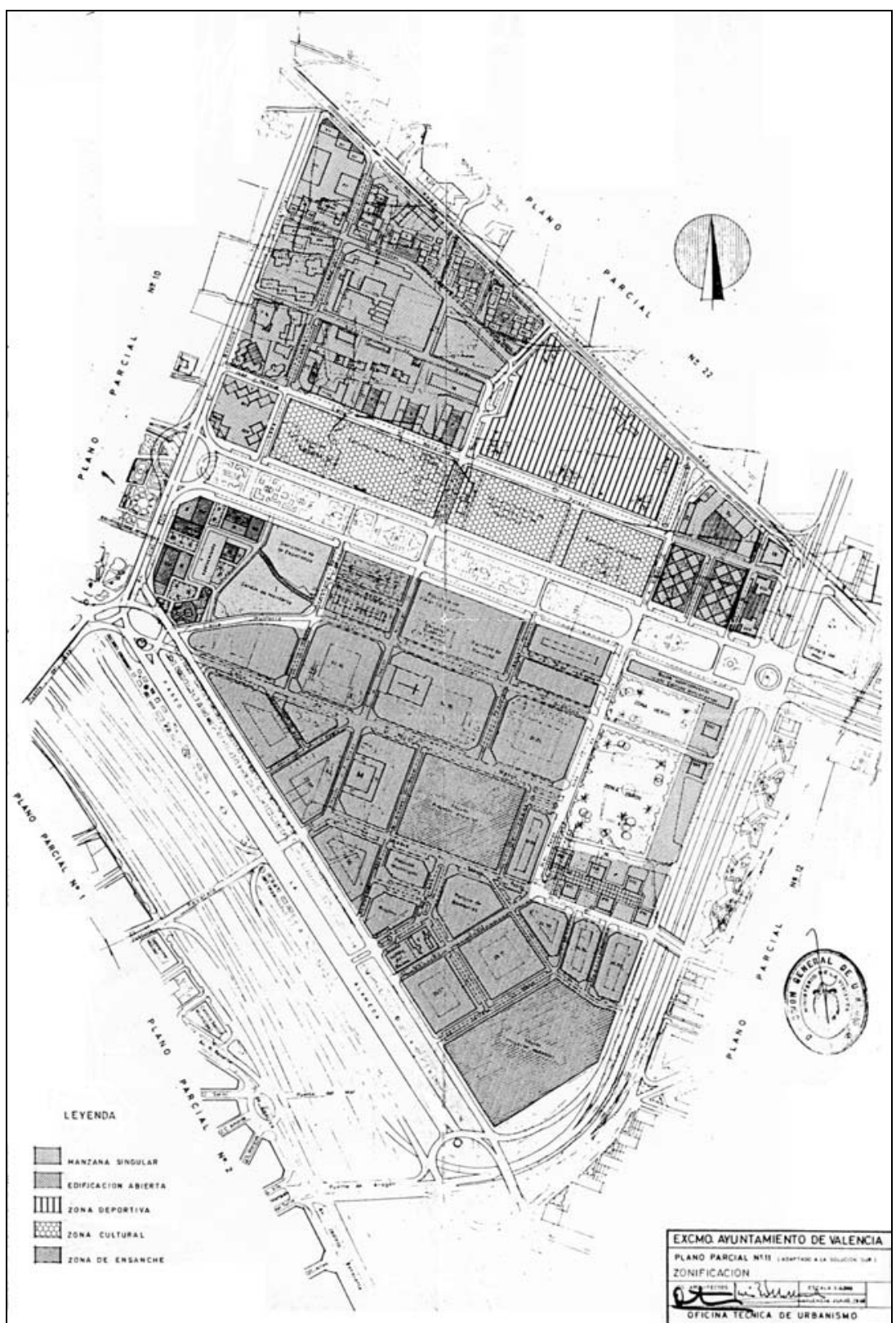

En cuanto a las manzanas de las casas de periodistas y la zona del Llano del Real, la Memoria del Plan indica lo siguiente:

La manzana limitada por las calles, Jaime Roig, Juan Martorell. Botánico Cavanilles y el Paseo al Mar, así como los terrenos donde hoy día se halla ubicada la feria de Muestras y el Palacio de Ripalda, debido a su situación privilegiada -Principio del Paseo al Mar y Paseo de la Alameda, frente al Río y junto al arranque del Puente del Real cuyo ensanchamiento ya está iniciado, y estando situados frente por frente de la zona verde de mayor extensión que posee Valencia: Parque de Viveros Municipales -se ha tratado como zona de edificación abierta alta considerando los edificios allí ubicados como "SINGULARES". ${ }^{1}$

Las zonas de edificación abierta en las que esta nueva versión del Plan Parcial 11 introduce formas y volúmenes diferentes para la edificación con respecto a las previstas en ordenaciones anteriores son tres. La primera de ellas es la franja situada al norte, entre
. Plan Parcial No 11 adaptado a Solución Sur, 1968. Memoria. Anexo de Documentos, p. 345. 
Tránsitos y la calle Bachiller, donde los bloques lineales de planta grecada de ordenaciones anteriores se sustituyen por torres enlazadas por bajos comerciales. La segunda es la zona correspondiente a los edificios Luz, en la manzana situada al sur del colegio Alemán, donde los bloques aislados anteriores se sustituyen por un conjunto de torres sobre un extenso zócalo comercial y de oficinas. La tercera zona es la de las torres junto al estadio de Mestalla, localizadas en un espacio en el que estaban previstas edificaciones de ningún tipo en el planeamiento anterior.

Además, el Plan Parcial 11 de 1968 incorpora la ordenación de Fisac antes analizada para las dos manzanas situadas entre el Paseo al Mar, la calle Menéndez y Pelayo, Gascó Oliag y Almela y Vives, así como modificaciones puntuales de la planta de dos edificios, uno situado junto a la iglesia de los Carmelitas, y otro en la zona del Llano del Real que refleja claramente un proyecto de arquitectura previamente redactado.
Grado de novedad del Plan Parcial 11 de 1968: Edificaciones proyectadas de forma diferente a la prevista en ordenaciones anteriores (Elaboración propia. Color sobre plano de alineaciones).

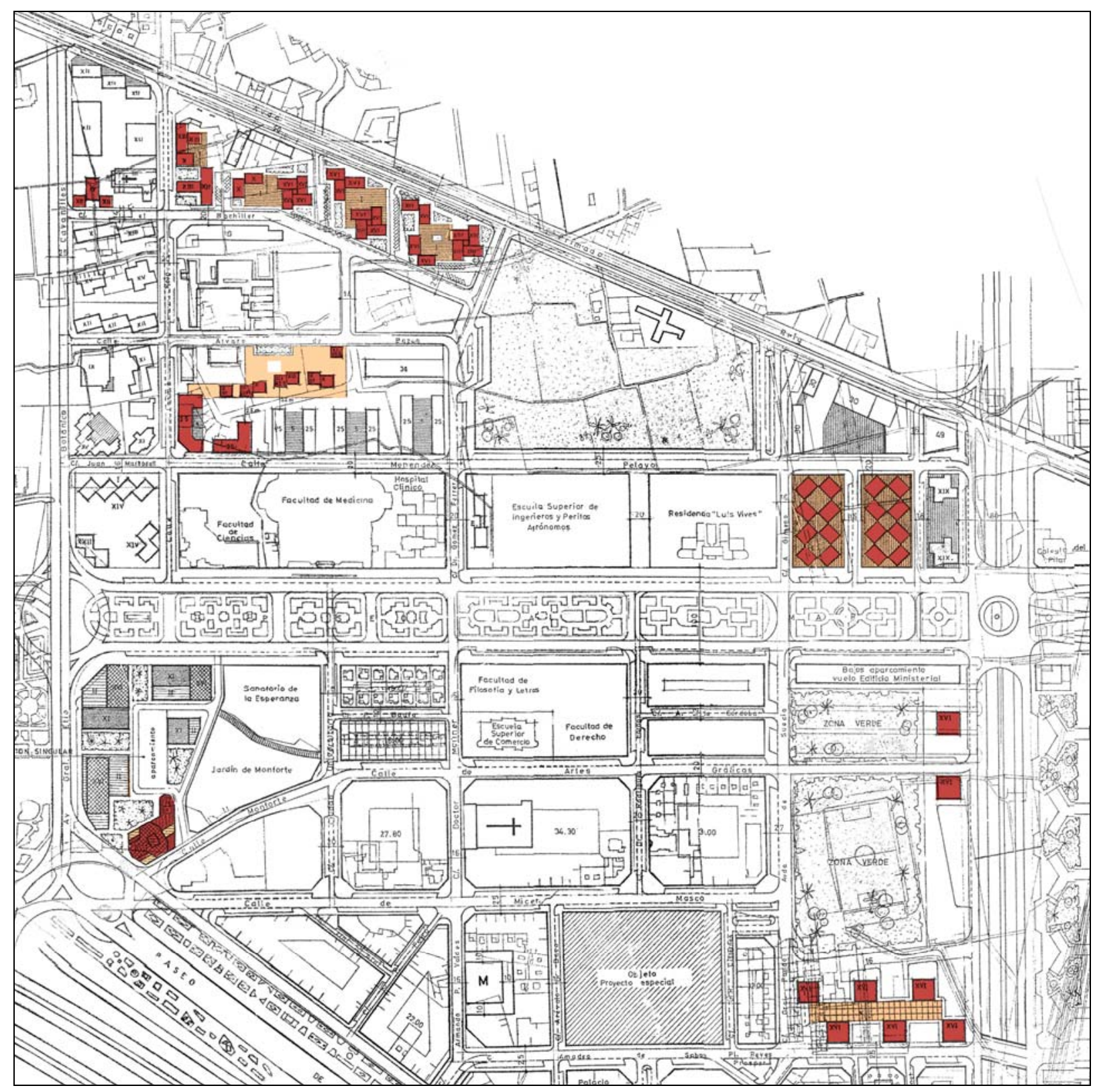


Plan Parcial 11. Plano de edificación en planta tipo (Elaboración propia sobre plano de alineaciones del plan)
Estas modificaciones, en la línea de las anteriores al plan, suponen el progresivo abandono del bloque lineal alargado -que se asocia a la vivienda masiva de menor calidad- como tipo básico de la edificación abierta en esta zona, y la sustitución del mismo por torres aisladas o bloques cortos y escalonados, que permiten obtener una mayor longitud de fachada.

Sin embargo, el modelo con el que se inició la edificación abierta en la zona, de edificios insertos en parcelas con espacios libres privados, vallados y ajardinados, que es el correspondiente a las tres manzanas situadas entre las Calles Jaime Roig y Botánico Cavanilles y que hemos analizado con detalle en la sección anterior, no tendrá continuidad en la versión de 1968 del Plan Parcial 11.

Frente a ese modelo, se optará por el de manzana mixta, en la que el orden cerrado y el orden abierto se superponen en vertical.

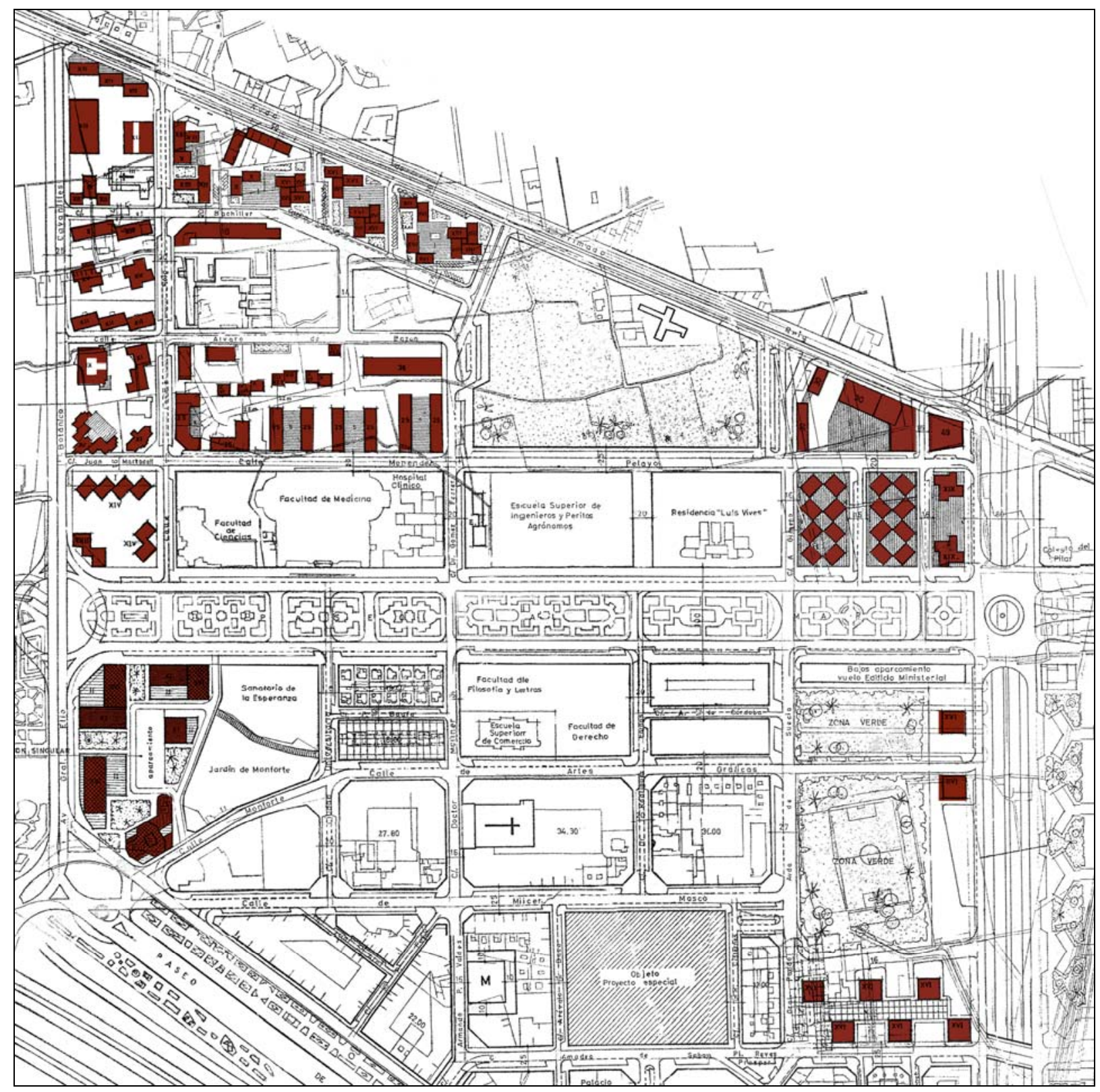


La práctica totalidad de las edificaciones de nuevo diseño corresponden a este modelo, con plantas bajas comerciales y a veces entresuelos de oficinas, configurando un zócalo no residencial cuyos límites se extienden a veces hasta la línea de calle y del que emergen volúmenes aislados que albergan las viviendas, en forma de bloques o torres cuya planta es independiente del trazado del viario.

La consecuencia de esta opción a favor de la manzana mixta será, como podemos apreciar claramente en el plano de edificación en planta baja, la disminución, con respecto a la etapa inicial, del suelo ocupado por espacios libres ajardinados. Al mismo tiempo, los usos se diversifican, y la zona pierde su carácter exclusivamente residencial al incorporarse a la edificación, dentro del modelo de la manzana mixta, amplias superficies destinadas a actividades comerciales y terciarias.
Plan Parcial 11. Plano de edificación en planta baja (Elaboración propia sobre plano de alineaciones del plan)

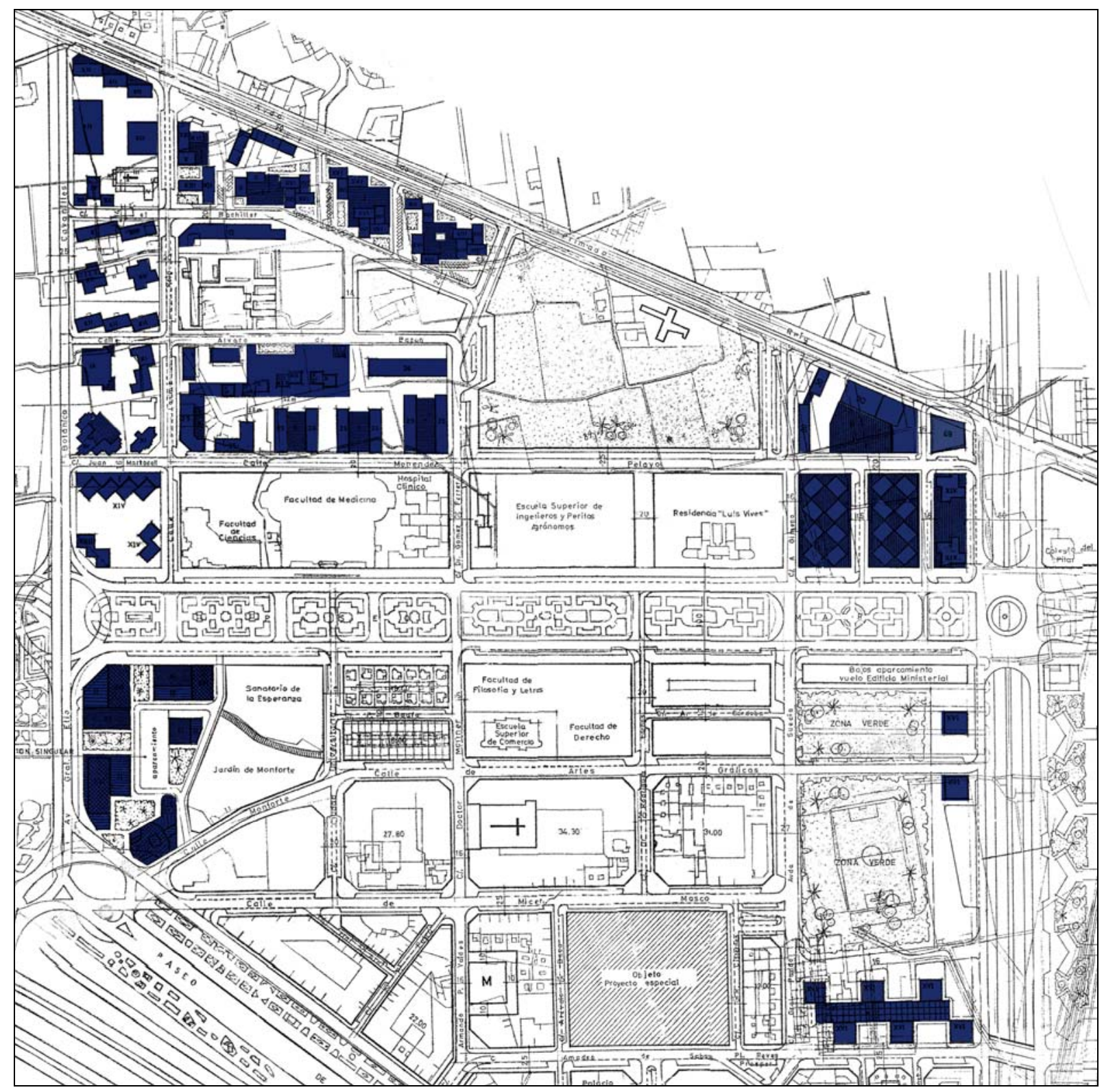


PP-11. Plano de zonas excluidas de aprobación por el Ministerio de la Vivienda

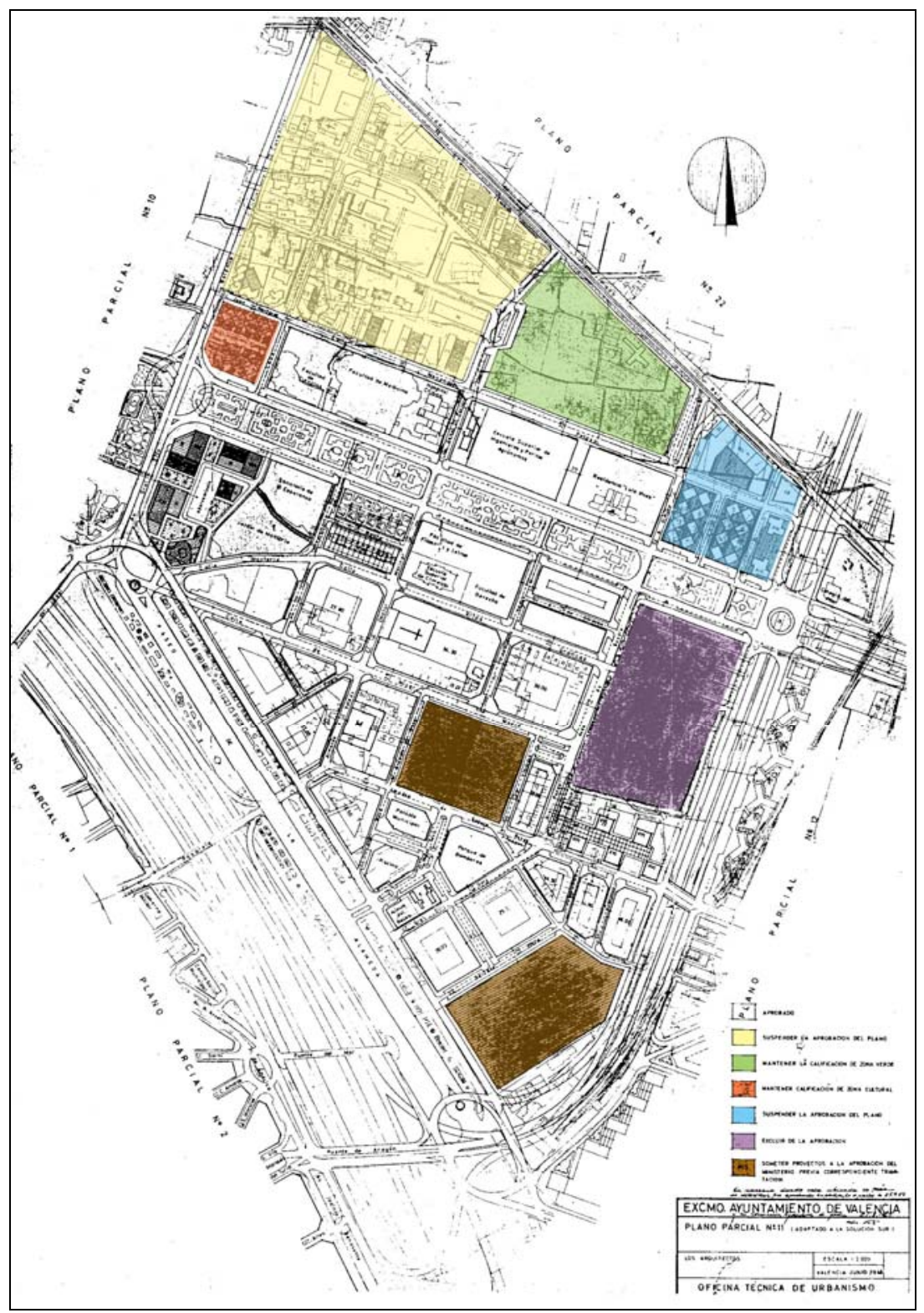

La complicada tramitación del Plan Parcial 11

La versión inicial del Plano Parcial no 11 adaptado a la solución Sur, que se somete a exposición pública y sobre la que se realizan las alegaciones correspondientes, está fechada en Junio de 1967.

La Memoria del Plan señala que la nueva redacción del mismo se produce como consecuencia del estudio de todos los accesos de la Ciudad por carretera y las carreteras de tránsito y circunvalación realizado por parte de la Jefatura de Obras Publicas en su Oficina Regional de Proyectos y Carreteras.

Las alegaciones a esta versión del Plan se desarrollan en dos rondas. En la primera ronda, el Ayuntamiento acepta, entre otras, tres variaciones con respecto al plano inicial elaborado por la Oficina Técnica de Urbanismo relativas a zonas de edificación abierta. 
La primera y principal de las modificaciones aceptadas es la planteada por la Asociación de la Prensa Valenciana para cambiar la calificación de cultural a edificación abierta densa de las dos manzanas de casas unifamiliares limitadas por las calles Juan Martorell al norte, Botánico Cavanilles al oeste, Paseo al Mar al sur y Jaime Roig al oeste, eliminando la calle Bernat y Baldoví intermedia y fundiendo las dos manzanas en una sola sobre la que se sitúan tres edificios de 16 plantas. La segunda modificación, solicitada por los propietarios del Barrio Obrero sito en la calle general Pando, supone sustituir un espacio para aparcamiento por una torre de $25 \times 25$ m y 15 plantas. La tercera, solicitada por los Padres Carmelitas, aumenta ligeramente la volumetría de la parcela propiedad de esa orden situada junto a la calle Bachiller, dentro de una manzana cuyo coeficiente de edificabilidad estaba ya próximo a los $10 \mathrm{m3} / \mathrm{m} 2$.

Una vez incorporadas al plano las modificaciones derivadas de las alegaciones, el Ayuntamiento aprueba en 1968 el Plano Parcial no 11 adaptado a la solución Sur y lo somete a la preceptiva aprobación por el Ministerio de la Vivienda.

La documentación escrita del Plan se reduce a una Memoria de cuatro páginas, unas Ordenanzas de una página y un Plan de Etapas también de una página. Los planos que contiene el Plan son once, de los cuales cuatro son de información (situación en la ciudad y en el plan, fotoplanos y estado actual), cuatro de proyecto (estructura urbana, zonificación, red viaria fundamental y alineaciones y rasantes) y tres de esquemas de redes de servicios urbanos (alcantarillado, aguas potables y alumbrado).

La resolución del Ministerio de la Vivienda de 4-04-1970 que aprueba el Plan Parcial 11 exige unas modificaciones tan sustanciales del mismo que, en la práctica, supone una denegación. Estas modificaciones, por lo que respecta a áreas de edificación abierta, son las siguientes:

1) Suspender la aprobación del Plan en el Sector comprendido entre las calles Menéndez y Pelayo, Juan Martorell, Botánico Cavanilles, Avenida Primado Reig y calle Doctor Gómez Ferrer.

2) Excluir de la aprobación la ordenación de los terrenos en torno al campo de Mestalla, comprendidos entre el Paseo de Valencia al Mar, Avenida de Aragón, calle Juan Reglá y Avenida de Suecia, por no ajustarse al Plan General de Valencia y su Comarca.

3) Mantener la calificación de zona cultural con el volumen de edificación de 0,5 m3/m2 que le corresponde, para la manzana delimitada por las calles Botánico Cavanilles, Juan Martorell, Jaime Roig y Paseo de Valencia al Mar (casas de los periodistas), que en el Plan Parcial se define como manzana singular con un volumen resultante de $9,25 \mathrm{~m} 3 / \mathrm{m} 2$.

4) Mantener la calificación de zona verde determinada por el Plan Comarcal para los terrenos que en el Plan Parcial se destinan a zona de reserva deportivo-universitaria sitos entre la Avda. Primado Reig y la calle Menéndez y Pelayo.

5) Suspender la aprobación del Plan en los terrenos situados entre el Paseo de Valencia al Mar, calle A. Gimeno (actual Gascó
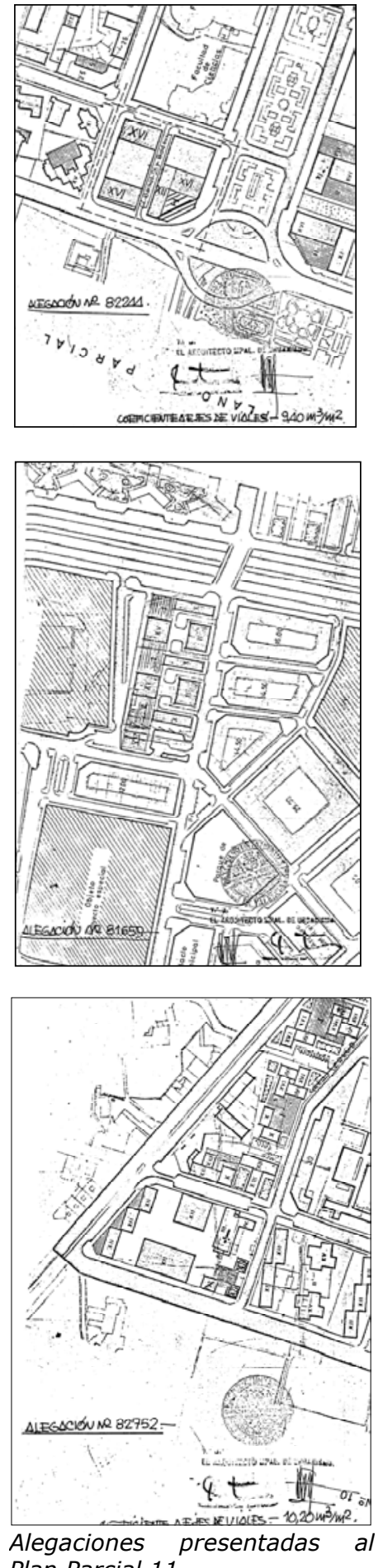

Plan Parcial 11. 
Oliag), calle de Menéndez Pelayo y vía en proyecto (Avenida de Cataluña).

Los argumentos que figuran en diversos informes elaborados desde el Ayuntamiento de Valencia resultan débiles como respuesta a la resolución negativa del Ministerio de la Vivienda. ${ }^{1}$

Así, por ejemplo, el informe del Negociado de Suelo y Ordenación Urbana de 16-10-70 indica que la zona excluida de ordenación en torno al campo de Mestalla coincide sensiblemente con el Plan Parcial de 1960 aprobado por el Ministerio, cuando en realidad en dicho Plan de 1960 en la zona no existía, como hemos visto, edificación residencial alguna, mientras que el Plan de 1968 incluye en ella dos torres de 16 plantas y un edificio dotacional, aparte de declarar zona verde el espacio ocupado por el estadio. Este informe añade que el Ministerio de la Vivienda ya aprobó en su día la ordenación de algunos fragmentos puntuales de las áreas excluidas de aprobación, como la de la manzana comprendida entre las calles Botánico Cavanilles, Jaime Roig, Alvaro de Bazán y Bachiller, o las alineaciones del Colegio mayor Universitario de La Asunción.

Un nuevo informe más extenso redactado con fecha 30-041971 por los Servicios Administrativo y Técnico de la Sección de Urbanismo del Ayuntamiento, acompañado del Plano Parcial no 11 con lavado en color que resume las determinaciones de la resolución del ministerio de la Vivienda, reproduce las anteriores argumentaciones y añade algunas otras. ${ }^{2}$

Este informe indica, por ejemplo, que en los sectores excluidos de aprobación existe un buen número de edificaciones ya construidas $o$ en construcción, basadas en ordenaciones urbanísticas aprobadas por acuerdos del Ayuntamiento que remodelaban diversas zonas sin aumento de edificabilidad, todo ello con anterioridad al nuevo Plan General de 1966.

También señala el informe que las edificaciones que aparecen en la zona en torno a Mestalla son, por una parte, un edificio ministerial ya construido para la Delegación Provincial del Ministerio de Obras Públicas y, por otra, dos bloques de XVI plantas que forman

1., Documento no 11.2: Informes municipales en respuesta a la resolución de 4-04-1970 del Ministerio de la Vivienda. Negociado de Suelo y Ordenación Urbana. Arquitecto Municipal de Urbanismo. Ayuntamiento de Valencia.16-10-70, 16-11-70. Anexo de Documentos, p. 360.

2., Documento no 11.3: Informe relativo a las observaciones y reparos contenidos en la resolución del Ministerio de la Vivienda de 4-04-70. Servicios Administrativo y Técnico de la Sección de Urbanismo del Ayuntamiento de Valencia. 30-04-1971. Anexo de Documentos, p. 364.

3., Documento no 11.4: Resolución negativa con respecto a la aprobación del Plan Parcial No 11. Ministerio de la Vivienda. 19-071972. Anexo de Documentos, p. 367. parte del volumen que el Ayuntamiento aprobó a cambio de la afección de zona verde del campo del Valencia C.F.

En relación con la manzana de las casas de periodistas, este informe afirma incluso que su calificación como zona cultural en el Plan General de Valencia y su Comarca era un error que el Ayuntamiento ha corregido en el Plan Parcial.

El Ministerio de la Vivienda, en su resolución de 10-07-1972, considera inadmisible la argumentación de ese supuesto error, y se reafirma en la necesidad de mantener la calificación de las manzanas de los periodistas como zona cultural. ${ }^{3}$

Además, el Ministerio acuerda denegar definitivamente la aprobación del Plan Parcial 11 en los dos sectores excluidos de aprobación; el comprendido entre las calles Menéndez y Pelayo, Juan Martorell, Botánico Cavanilles, Avenida Primado Reig y Doctor Gómez Ferrer y el comprendido entre el Paseo de Valencia al Mar, calle Gascó Oliag, calle de Menéndez Pelayo y Avenida de Cataluña. 
La denegación se debe a que el plan municipal no justifica que la edificabilidad global es inferior a los $5 \mathrm{~m} 3 / \mathrm{m} 2$ permitidos por el Plan Comarcal, y a que las reservas de suelo para espacios libres es inferior a la prevista en la Ley del Suelo.

Como respuesta a esta resolución negativa definitiva del Ministerio de la Vivienda, se redactan dos informes, uno del Arquitecto Municipal de urbanismo del Ayuntamiento y otro de los Servicios Jurídicos Municipales.

El informe del Arquitecto Municipal de Urbanismo indica, en primer lugar, que "realizada visita de inspección a las zonas afectadas por suspensión de aprobación del Plan, he podido comprobar que se hallan prácticamente construidas en su totalidad según el Plan Parcial aprobado por la Dirección General de Urbanismo con fecha 29 de diciembre de 1.960, con una serie de remodelaciones aprobadas asimismo por el Ministerio de la Vivienda".

En relación con las reservas de suelo para espacios libres, este informe señala lo siguiente:

Como complemento al presente informe, considero oportuno señalar que el Plan Parcial No 11 linda, en sus límites de las calles General Elio y Botánico Cavanilles, con los Jardines del Real (Viveros Municipales) que, aunque perteneciendo al Plan Parcial No 10, superan en $145.000 \mathrm{~m} 2$. la superficie reglamentaria de Zona Verde de este Plan. Esta superficie, inmediata a la zona suspendida de aprobación, contribuye por su influencia directa, a una disminución notable en la densidad de población del Plan Parcial No 11, resultando que la zona aludida tiene una densidad de población muy inferior al resto de la ciudad porque la proporción de espacios libres que le corresponde es muy superior. ${ }^{1}$

El informe de los Servicios Jurídicos Municipales, por su parte, para justificar que no se supera el volumen edificable autorizado por el Plan Comarcal, comienza citando jurisprudencia que afirma que es equivocado calcular el volumen de la edificación autorizada en una parcela aplicando a la misma el coeficiente de edificabilidad total de la zona. ${ }^{2}$

El coeficiente de $5 \mathrm{~m} 3 / \mathrm{m} 2$ permitido por el Plan Comarcal, por tanto, se aplica a la superficie total ordenada por el Plan Parcial 11, y dado que la superficie destinada a zonas verdes y a viario no se edifica, las parcelas edificables incrementan su volumetría en la misma medida en que las parcelas inedificables la pierden, hasta un coeficiente aproximado de $9,60 \mathrm{~m} 3 / \mathrm{m} 2$.

El informe jurídico desarrolla a continuación los mismos argumentos empleados por el Arquitecto Municipal: en primer lugar, la existencia de situaciones de hecho que es conveniente mantener, es decir, las edificaciones ya construidas, que se afirma que se han realizado según las previsiones del Plan Parcial de 1960 y, en segundo lugar, la gran superficie destinada a zonas verdes en el Plan (estimada en el 50\% del suelo, muy superior al preceptivo $10 \%$ de la Ley del Suelo), que linda además con el Parque de los Viveros Municipales.
1. Documento no 11.5: Informe técnico en respuesta a la resolución negativa del Ministerio de la Vivienda con respecto a la aprobación del Plan Parcial No 11. Arquitecto Municipal de Urbanismo. Ayuntamiento de Valencia. 15-01-1973. Anexo de Documentos, p. 369.

2. Documento $n^{0}$ 11.6: Informe jurídico en respuesta a la resolución negativa del Ministerio de la Vivienda con respecto a la aprobación del Plan Parcial No 11. Servicios Jurídicos Municipales. Ayuntamiento de Valencia. 1501-1973. Anexo de Documentos, p. 370 . 


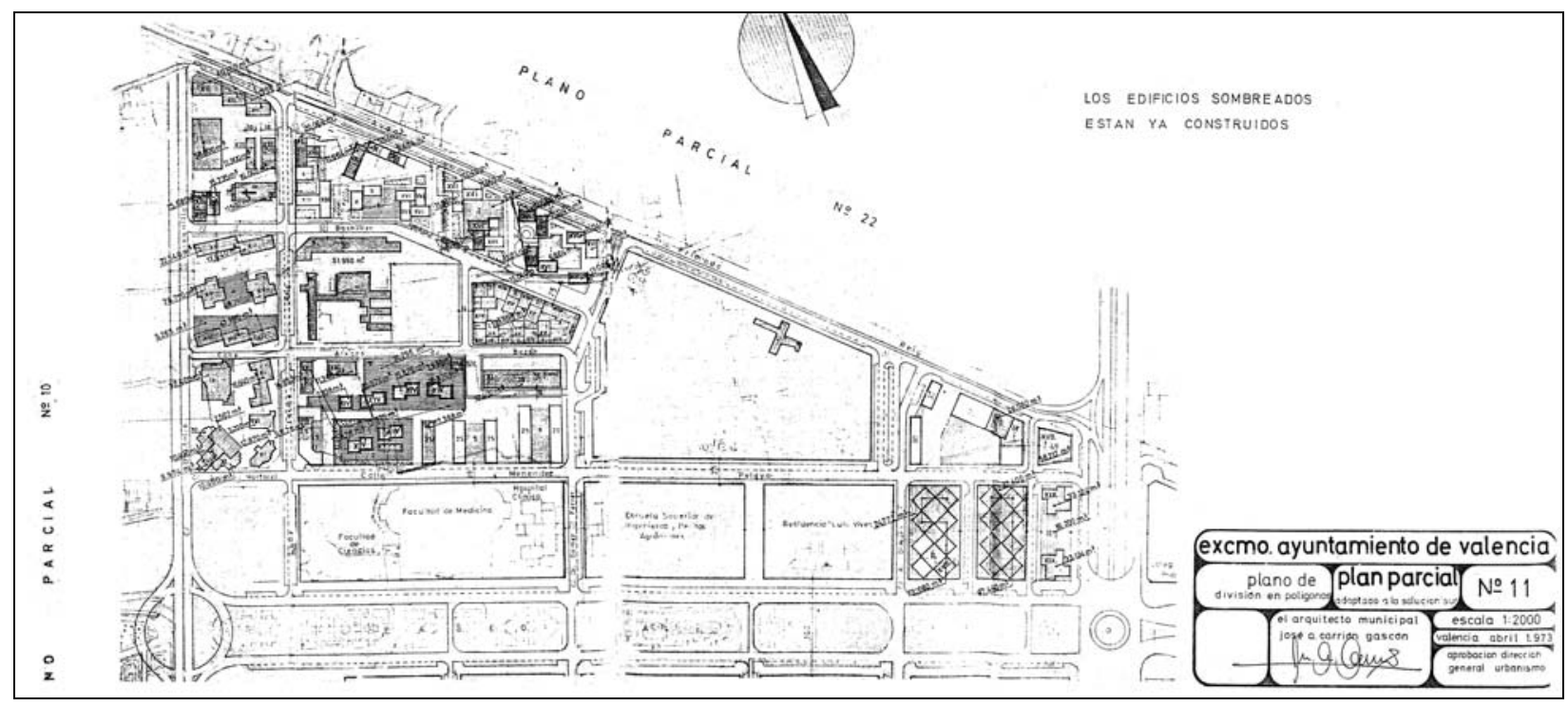

PP-11. Proyecto Técnico de División en Polígonos y Nueva Ordenación Urbanística. Plano de estado actual.

1. Documento no 11.7. Moción proponiendo la división en polígonos del PP 11 para conseguir su aprobación final. Comisión Informativa de Urbanismo. Ayuntamiento de Valencia. 28-03-1973. Anexo de Documentos, p. 378.
En la Comisión Informativa de urbanismo del Ayuntamiento se aprueba el 28-03-1973 una Moción que permitirá conseguir finalmente la aprobación de los dos sectores excluidos y, con ello, la aprobación completa del Plan Parcial 11.

Esta moción propone una división en polígonos del territorio del Plan y una nueva ordenación urbanística en la que no se superen los $5 \mathrm{~m} 3 / \mathrm{m} 2$ y la reserva de espacios libres no sea inferior al 10 $\%$ de la superficie.

Como consecuencia de la moción se redacta en abril de 1973 el Proyecto Técnico de División en Polígonos y Nueva Ordenación Urbanística, que consta de una Memoria de tres páginas y dos planos (Estado actual y División en Polígonos).

En la Memoria de dicho proyecto se resume la situación de la zona de modo siguiente:

El Plan Parcial no 11 de la Ciudad de Valencia anterior al que nos ocupa, tenia una Zonificación de Ensanches Actuales y, basándose en tal calificación se hicieron remodelaciones de volúmenes que fueron aprobadas, ejecutándole las obras en consecuencia.

Aprobado posteriormente el Plan General de Valencia y su Comarca según. B.0.E. del 27 de Julio de 1966, se procedió a una nueva redacción del Plan adaptándolo a la Solución Sur, el cual cambiaba la calificación de la zona que nos ocupa esta delimitación de polígonos de Ensanches Actuales a Edificación Abierta, aplicándole un coeficiente de edificabilidad de $5 \mathrm{~m} 3$ por $\mathrm{m} 2$.

Al no haberse tenido en cuenta en la redacción del Plan General estas edificaciones recientes, dignas y en perfecto estado, ahora se ven depreciadas ya que de por sí alcanzan un coeficiente aproximado de edificabilidad de $7,5 \mathrm{~m} 3 . / \mathrm{m} 2$. superando los $5 \mathrm{~m} 3 . / \mathrm{m} 2$. aprobados posteriormente a su legal construcción.

Por todo lo expuesto anteriormente la Comisión de Urbanismo acordó la división en polígonos de la zona delegada con el fin de que el volumen excedido en ella no afecte los intereses particulares de los administrados que todavía no hayan edificado sus parcelas. ${ }^{1}$ 
La distribución de volúmenes en los polígonos se expresa en el Plano de división en polígonos y en un cuadro incluido en la Memoria (Cuadro A). El resultado de dividir el volumen edificable que figura en el cuadro por la superficie da un coeficiente de edificabilidad de $5 \mathrm{~m} 3 / \mathrm{m} 2$ en todos los polígonos.

La Memoria señala que quedan fuera de ordenación los volúmenes que excedan de los expresados en el cuadro mencionado.

Si observamos el segundo plano, de estado actual, en el que están sombreados los edificios ya construidos, con su volumen correspondiente, podemos elaborar otro cuadro que añade al volumen edificable en cada polígono el volumen ya edificado (Ver Cuadro B).

La conclusión que puede establecerse a partir de estos datos es que el Proyecto Técnico de División en Polígonos y Nueva Ordenación supone una masiva declaración de edificios fuera de ordenación: se deja fuera de ordenación un volumen total de $516.942 \mathrm{~m} 2$, sin señalar qué edificios o partes de los edificios son los que quedan en esa situación. Se trata, pues, de un tácito reconocimiento de la ilegalidad manifiesta de todo lo edificado, sometiendo a trámite un Plan formalmente correcto a sabiendas de que una edificaciones tan recientes no serían demolidas.

\begin{tabular}{ccccc}
$\begin{array}{c}\text { Cuadro } A \\
\text { Polígono }\end{array}$ & $\begin{array}{c}\mathrm{S} \\
\text { Superficie } \\
(\mathrm{m} 2)\end{array}$ & $\begin{array}{c}\text { Volumen } \\
\text { Edificable } \\
(\mathrm{m} 3)\end{array}$ & $\begin{array}{c}\text { Volumen } \\
\text { por edificar } \\
(\mathrm{m} 3)\end{array}$ \\
\hline A & 19.550 & 97.750 & - \\
B & 30.475 & 152.375 & - \\
C & & 55.448 & 277.244 & 146.464 \\
D & d1 & 4.000 & 20.000 & 10.324 \\
& d2 & 21.550 & 107.750 & - \\
E & d3 & 13.332 & 66.660 & 66.660 \\
F & & 16.050 & 80.400 & - \\
G & g1 & 10.880 & 54.400 & - \\
& g2 & 18.900 & 94.500 & - \\
\hline
\end{tabular}

\begin{tabular}{|c|c|c|c|c|c|c|c|}
\hline \multicolumn{2}{|c|}{$\begin{array}{l}\text { Cuadro B } \\
\text { Polígono }\end{array}$} & $\begin{array}{c}\mathrm{S} \\
\text { Superficie } \\
(\mathrm{m} 2)\end{array}$ & $\begin{array}{c}\text { Va } \\
\text { Volumen } \\
\text { edificable } \\
\text { (m3) }\end{array}$ & $\begin{array}{c}\text { Vb } \\
\text { Volumen } \\
\text { edificado } \\
\text { (m3) }\end{array}$ & $\begin{array}{c}\text { Eb } \\
\text { Coef. } \\
\text { Edificabilidad } \\
\mathrm{Vb} / \mathrm{S}(\mathrm{m} / \mathrm{m} 2)\end{array}$ & $\begin{array}{l}\text { Vf } \\
\text { Volumen fuera } \\
\text { de ordenación } \\
\text { Vb-Va (m3) }\end{array}$ & $\begin{array}{c}\text { Vc } \\
\text { Volumen } \\
\text { por edificar } \\
\text { Va-Vb(m3) }\end{array}$ \\
\hline \multicolumn{2}{|l|}{ A } & 19.550 & 97.750 & 174.090 & 8,90 & 76.340 & - \\
\hline \multicolumn{2}{|l|}{ B } & 30.475 & 152.375 & 244.471 & 8,02 & 92.096 & - \\
\hline \multicolumn{2}{|l|}{ C } & 55.448 & 277.244 & 130.780 & & - & 146.464 \\
\hline \multirow[t]{3}{*}{ D } & d1 & 4.000 & 20.000 & 9.676 & & - & 10.324 \\
\hline & d2 & 21.550 & 107.750 & 170.132 & 7,89 & 62.382 & - \\
\hline & d3 & 13.332 & 66.660 & - & - & - & 66.660 \\
\hline \multicolumn{2}{|l|}{$\mathrm{E}$} & 16.050 & 80.400 & 232.298 & 14,44 & 151.898 & - \\
\hline \multicolumn{2}{|l|}{$\mathrm{F}$} & 10.880 & 54.400 & 84.144 & 7,73 & 29.744 & - \\
\hline \multirow[t]{2}{*}{ G } & g1 & 18.900 & 94.500 & 198.532 & 10,50 & 104.032 & - \\
\hline & g2 & 3.500 & 17.500 & - & & - & 17.500 \\
\hline
\end{tabular}

El coeficiente de edificabilidad $\mathrm{Ea}=\mathrm{Va} / \mathrm{S}$ es de $5 \mathrm{~m} 3 / \mathrm{m} 2$ en todos los polígonos 


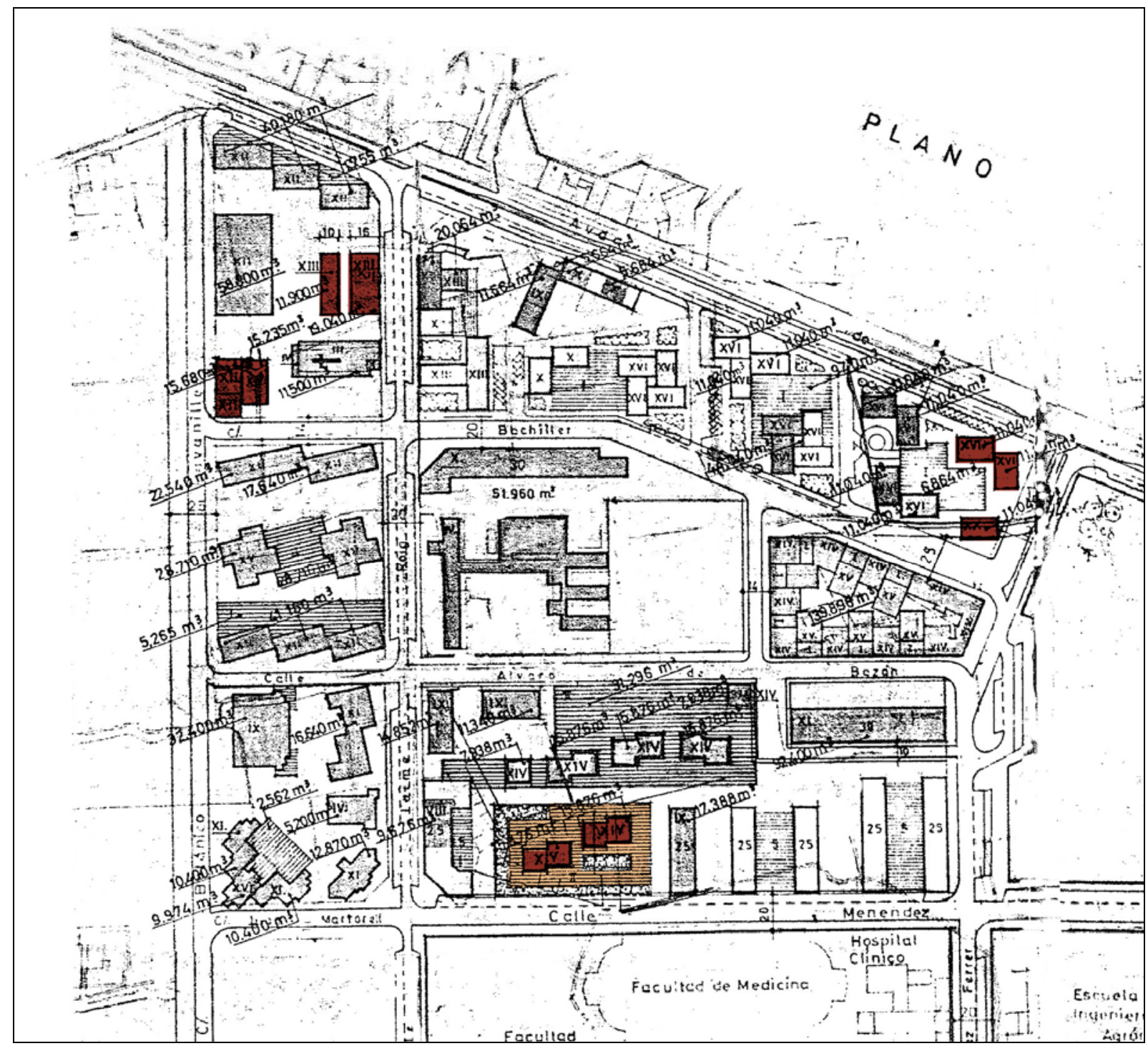

PP-11. Proyecto Técnico de División en Polígonos y Nueva Ordenación Urbanística, 1973. Plano de estado actual. Detalle de la zona de Jaime Roig/Bachiller (Elaboración propia. Sombreado en color de los edificios que se han modificado con respecto al Plan Parcial 11 de 1968).
Hay que señalar que, aunque este hecho no se menciona en la Memoria del plan, el Proyecto Técnico de División en Polígonos y Nueva Ordenación incorpora en su plano de estado actual modificaciones de la edificación prevista en algunas manzanas. Estas modificaciones se realizan obviamente para incluir en el plan edificios ya construidos con ordenaciones diferentes a las que figuran en la versión del mismo de 1968, como lo demuestra el hecho de que la edificación objeto de dichas modificaciones aparece sombreada como ya construida en el plano de estado actual.

Así, podemos ver que, en la manzana comprendida entre las calles Jaime Roig, Alvaro de Bazán, Gómez Ferrer y Menéndez y Pelayo, en la franja de edificación recayente a esta última calle se sustituyen un bloque lineal y otro en L por una manzana similar a la de los Edificios Luz, con torres sobre un basamento comercial.

El edificio situado junto a la Iglesia de los PP. Carmelitas cambia también su configuración en planta inicial (un cuadrado de $32 \times 32 \mathrm{~m}$. y 12 plantas) por otra de dos bloques lineales de $10 \times 32$ y $16 \times 32$, dejando un patio continuo intermedio. 
Igualmente, en la manzana comprendida entre las calles Maestro Catalá, Bachiller, Gómez Ferrer y la Avenida Primado Reig, las dos torres en $\mathrm{L}$ de 16 plantas y una torre con planta en aspa de molino de 13 plantas, enlazadas por un zócalo comercial de una planta, del plan inicial se sustituyen por tres torres en $\mathrm{L}$ de 16 plantas con zócalo de unión entre ellas y otra torre exenta de 20 plantas.

En los polígonos en los cuales queda todavía una reserva de volúmen edificable, el Proyecto Técnico señala que las edificaciones sobre los polígonos C, d1 y g2 se ajustarán al Plano Parcial 11.

En el polígono d3, en cambio, se indica que la edificación tendrá una forma de libre composición, ateniéndose al volumen del cuadro y las normas del Plan General sobre edificación abierta. Esta libertad concedida por el plan permitirá sustituir los bloques lineales previstos por torres en el proyecto finalmente realizado para este polígono, que es el conjunto de las Torres Universidad de 1977.

Por lo que se refiere a las manzanas de las casas de los periodistas, el Ayuntamiento acabaría aceptando la argumentación del Ministerio de la Vivienda para esta zona, calificándose la zona como cultural, rotulada en el plano como "Palacio de la Ópera". Gracias a todo ello, se conservan todavía las dos manzanas completas de la ciudad jardín inicialmente prevista en el Paseo al Mar, cosa que no ocurrió en el lado opuesto de dicho paseo.
PP-11. Proyecto Técnico de División en Polígonos y Nueva Ordenación Urbanística, 1973. Plano de división en polígonos.

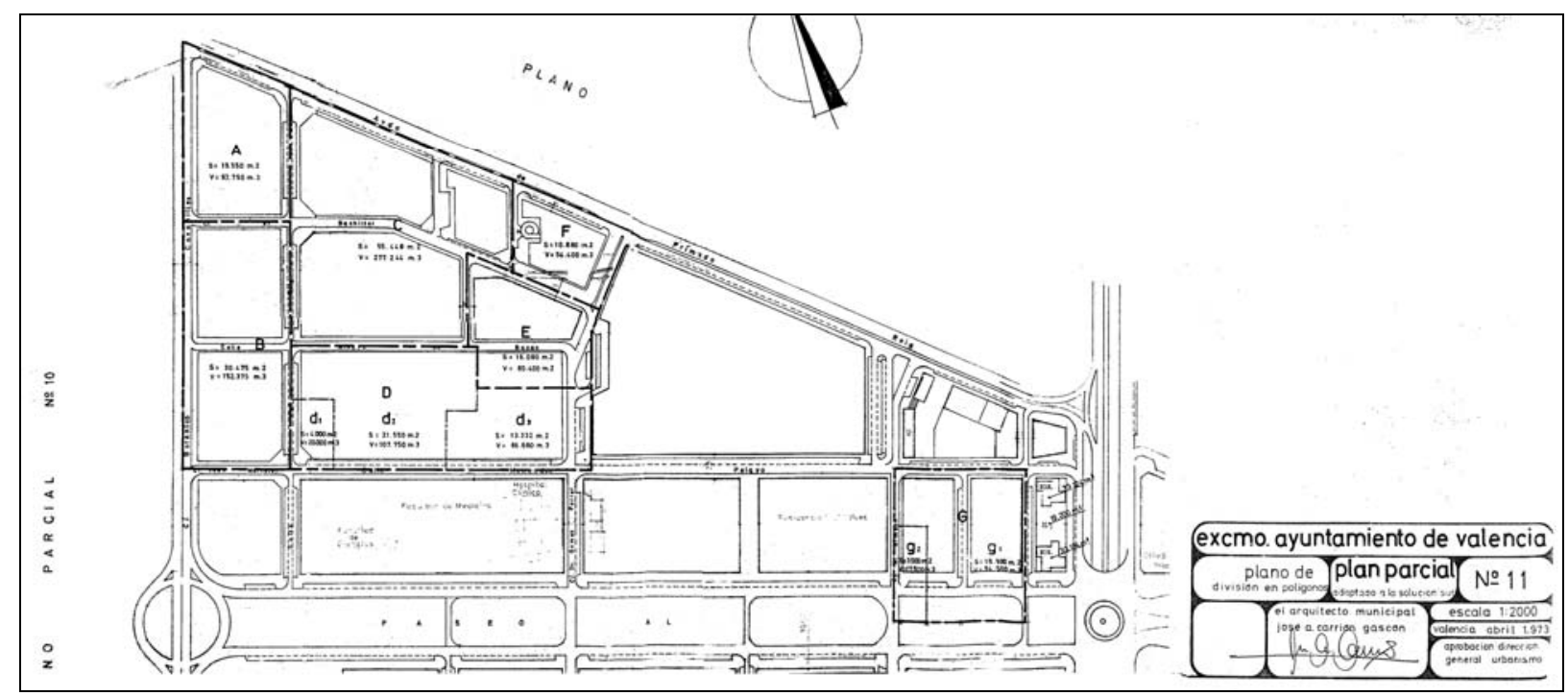




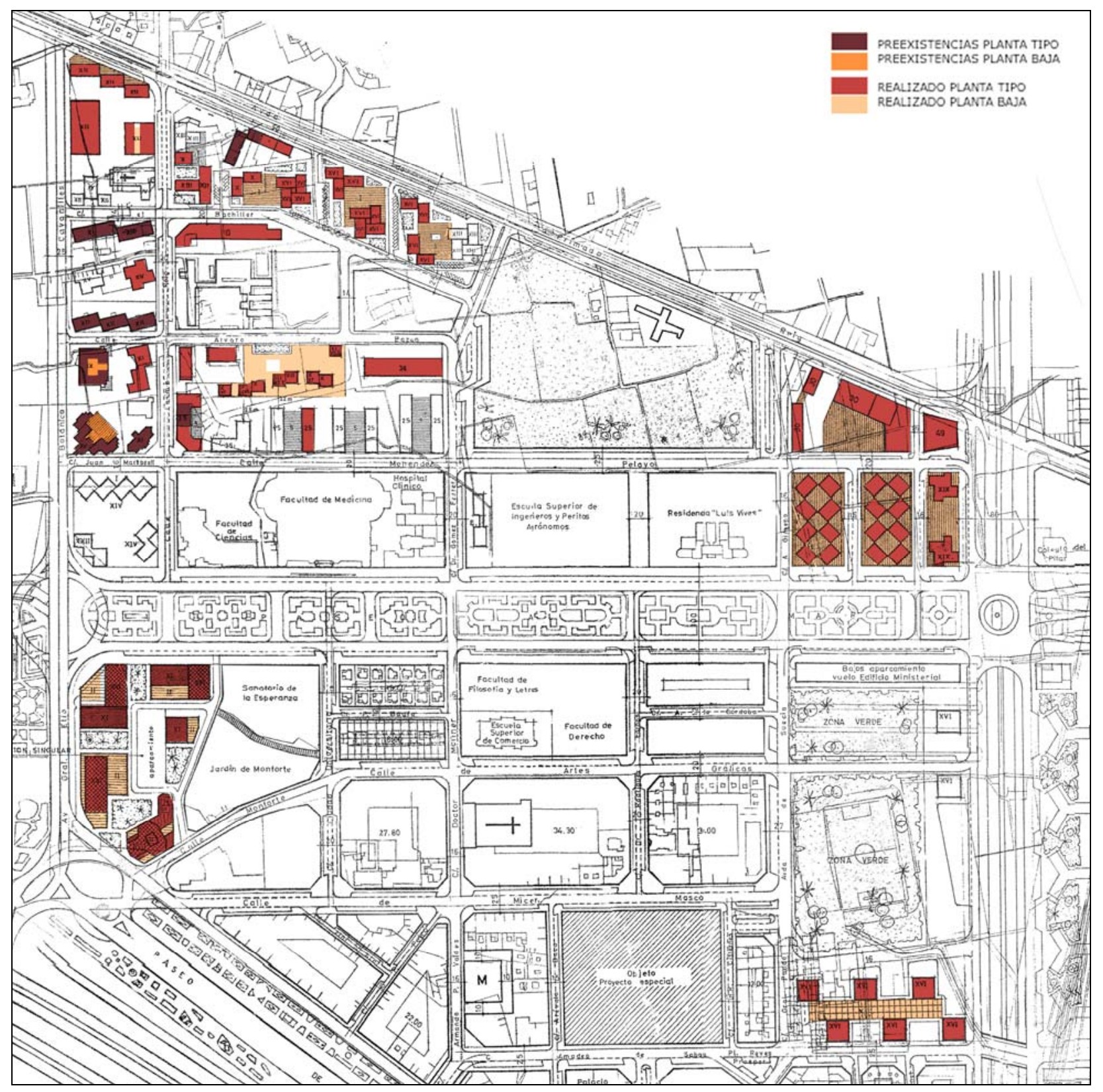

Plan Parcial 11, 1968. Grado de realización (Elaboración propia. Color sobre plano de alineaciones del plan).
1. Sorribes i Monrabal, Josep. Desarrollo capitalista y proceso de urbanización en el País Valenciano (1960-75), Institución Alfonso el Magnánimo, Institució Valenciana d'Estudis i Investigació, Valencia, 1985.

\section{Grado de realización: etapas de la construcción de la zona}

En la construcción de las zonas de edificación abierta comprendidas en el Plan Parcial 11 pueden distinguirse, según Sorribes, cuatro fases bien diferenciadas: ${ }^{1}$

1. Construcción de la zona situada entre Jaime Roig y los jardines de Viveros, según el modelo de edificación abierta en forma de torres o bloques aislados dotados de zonas ajardinadas privadas y garajes subterráneos.

2. Promoción de la zona junto a la Avenida de Cataluña, con las dos torres de la cooperativa de funcionarios municipales.

3. Crecimiento hacia el este y hacia el oeste, respectivamente, de los dos núcleos citados. 


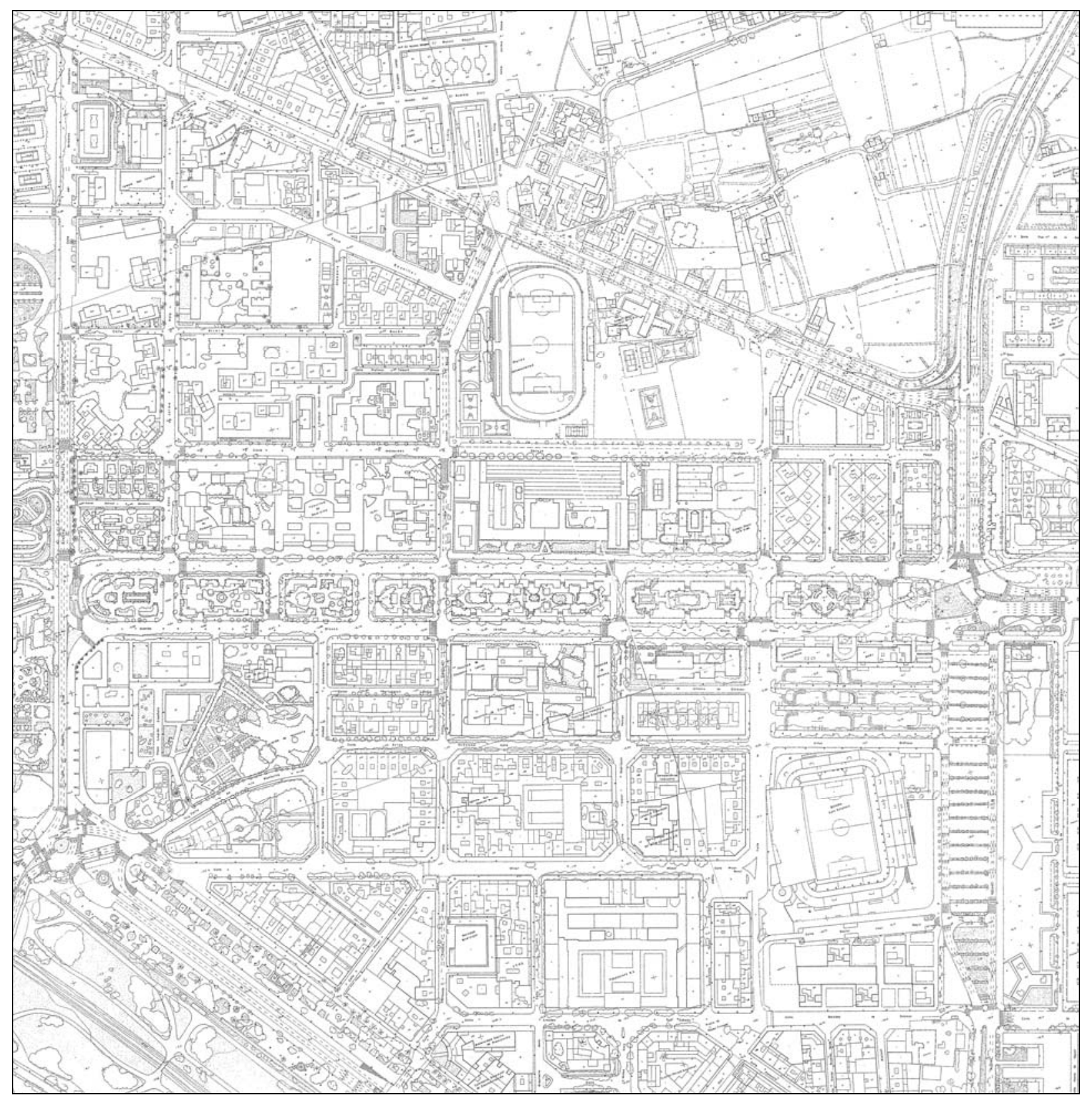

4. Solapado con la fase 3, se desarrolla el espacio de la margen derecha del Paseo al Mar hasta el paseo de la Alameda y la Avenida de Aragón, con los conjuntos del Llano del Real al oeste, la renovación de la edificación entre medianeras formando manzanas en el entorno de la calle Artes Gráficas (barrio de Exposición) y las Torres de Mestalla y las Torres de Aragón al este. Más recientemente, se producirá la extensión de la zona residencial al otro lado de la Avenida Primado Reig, que se enmarca en el Plan Parcial 22.

En la sección anterior de este trabajo hemos estudiado las dos primeras fases, que son previas a la versión del Plan Parcial 11 redactada en 1968. En adelante, por tanto, analizaremos la edificación abierta correspondiente a las fases tercera y cuarta, que es la que se realiza con posterioridad a dicho plan.

Zona del Plan Parcial 11, 1968. Cartografía Básica Municipal de Valencia, 1983. 


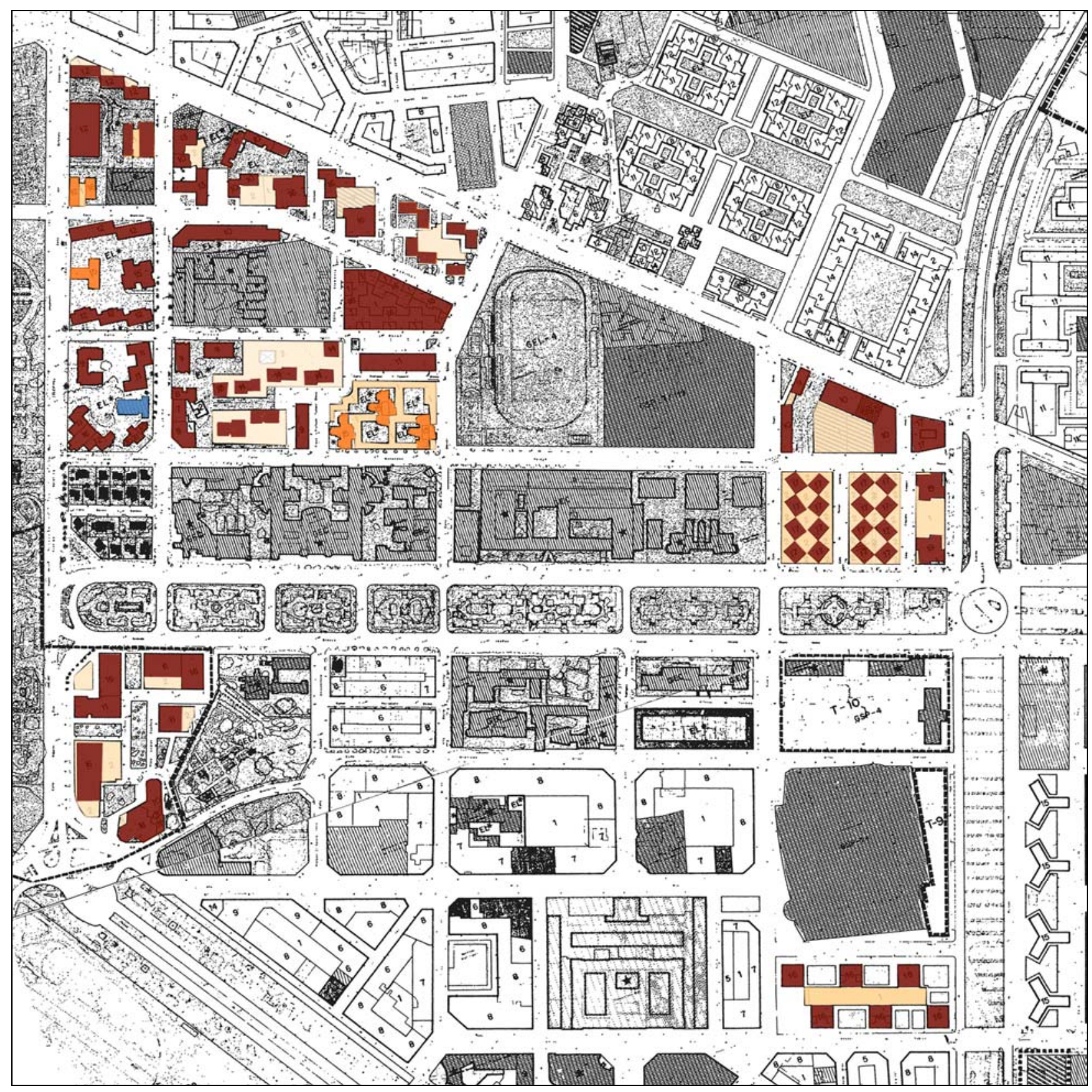

Zona del Plan Parcial 11, 1968. Plan General de Ordenación Urbana de Valencia, 1988.
Con carácter general, puede constatarse que, tal como señala Sorribes, en la zona de Jaime Roig la expansión hacia el este ha supuesto una fuerte densificación. En la zona de la Avenida de Cataluña, la densidad del núcleo inicial formado por las dos torres de promoción municipal ya era muy alta, y así se mantuvo en la expansión hacia el este. La zona de las Torres de Mestalla sigue la misma pauta en cuanto a densificación $y$, por lo tanto, pérdida de calidad relativa con respecto a las etapas iniciales.

En cualquier caso, el grado de realización del Plan Parcial 11 es muy alto, como cabría esperar de un plan que en gran medida no es más que un trámite para legalizar edificaciones ya realizadas o en curso de realización.

Las única zona de edificación abierta construida de forma diferente a lo previsto en el Plan Parcial 11 y en el Proyecto de Delimitación de Polígonos es el conjunto de las Torres Universidad de 1977. 


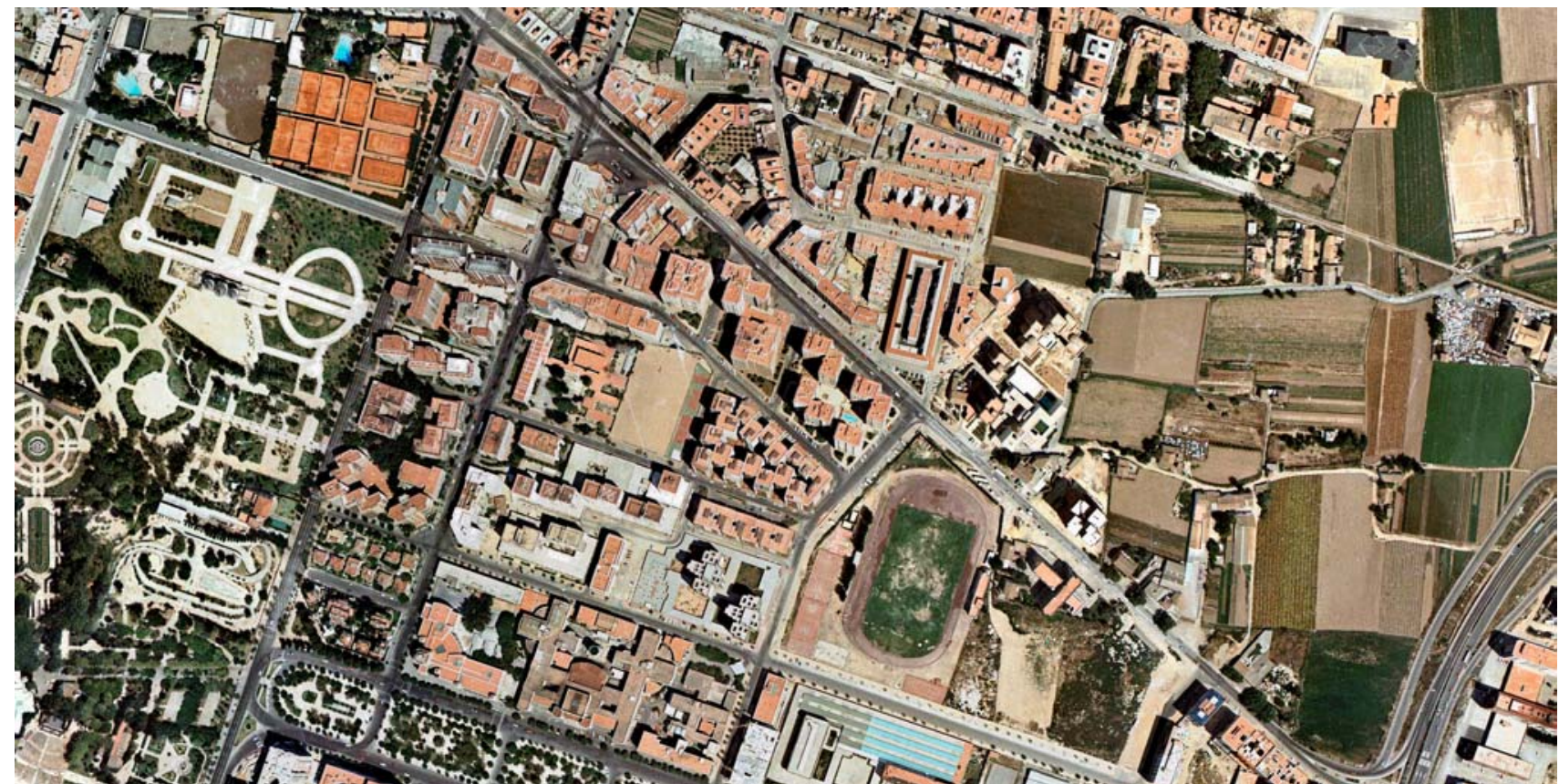

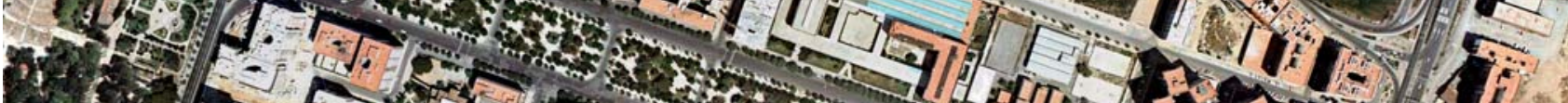

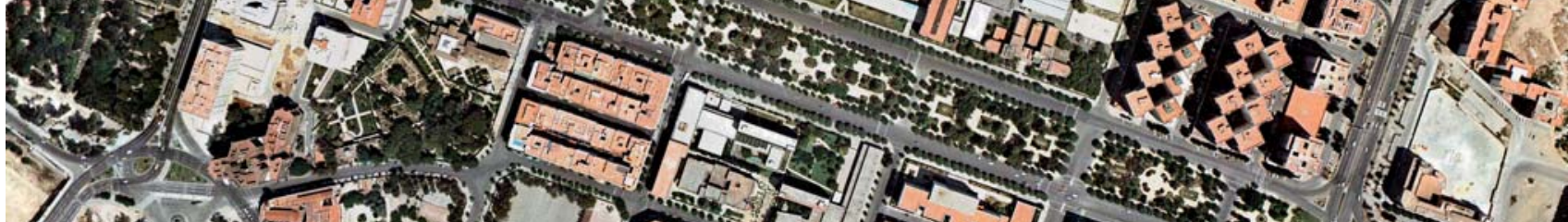

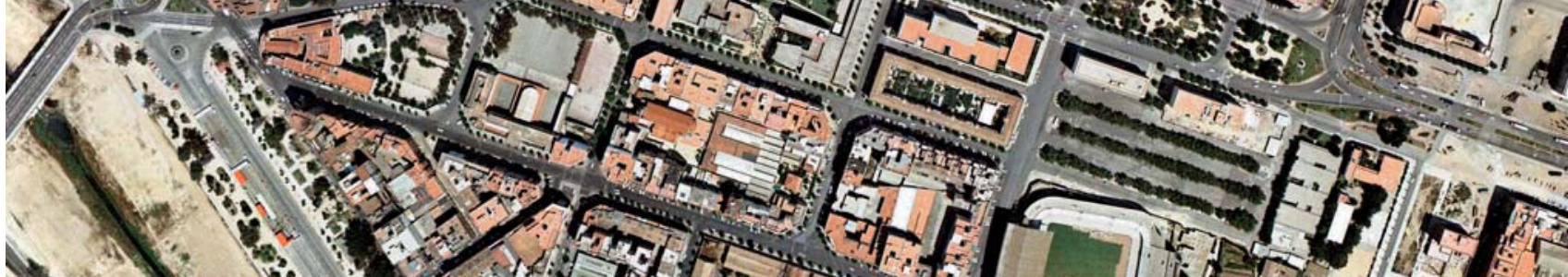
- 1 . (n) 1.

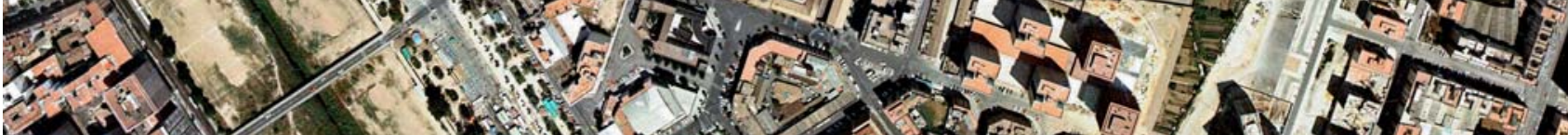

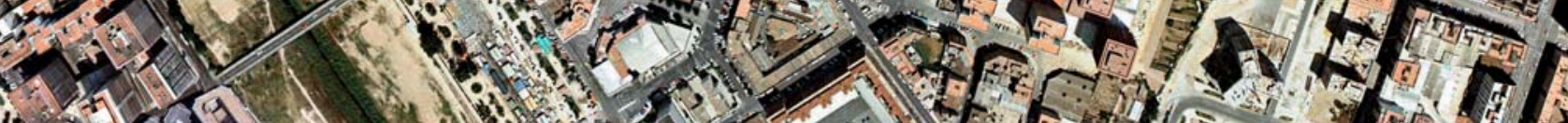

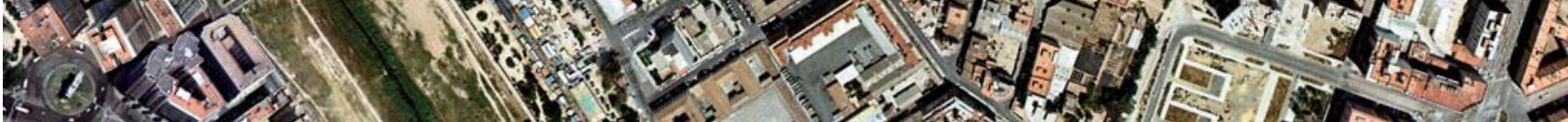

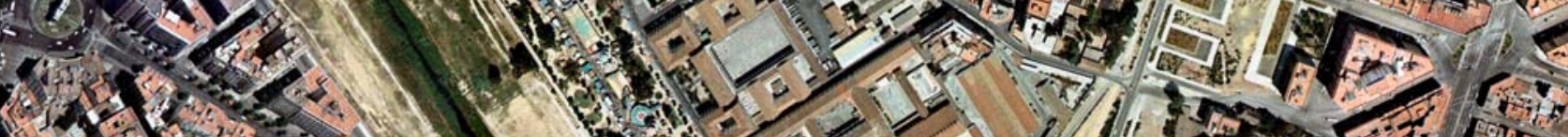

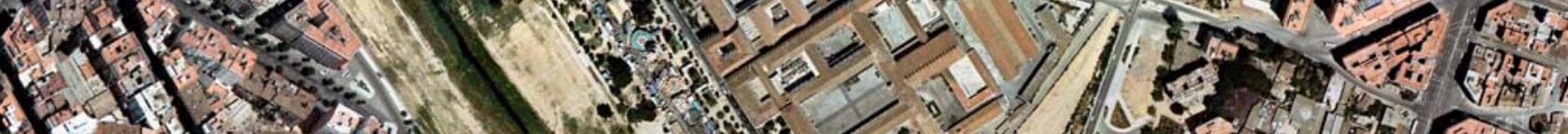

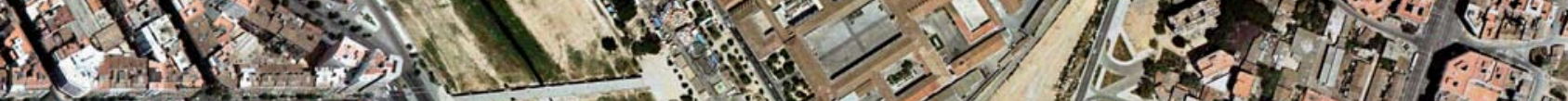

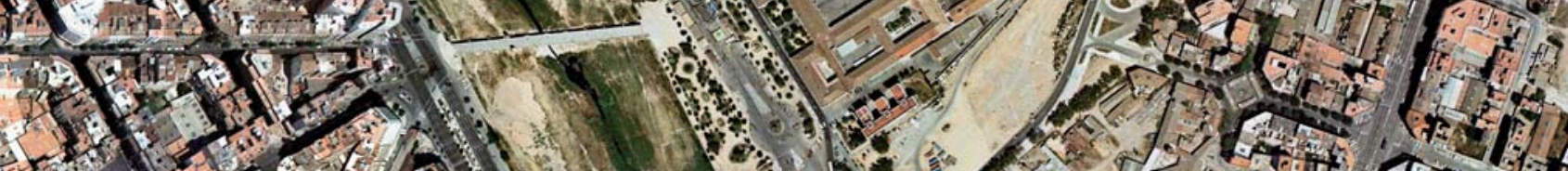

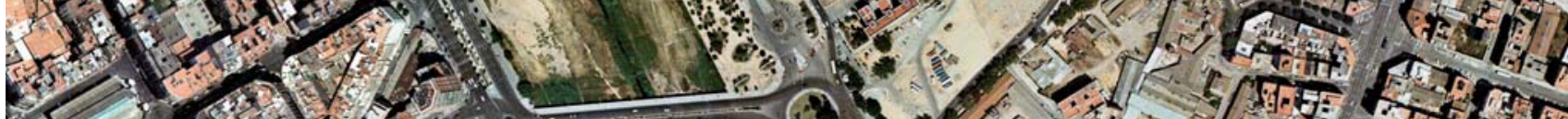
201.

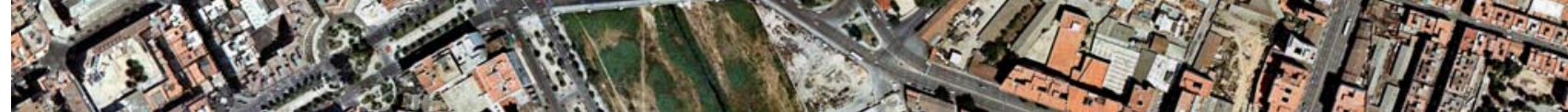



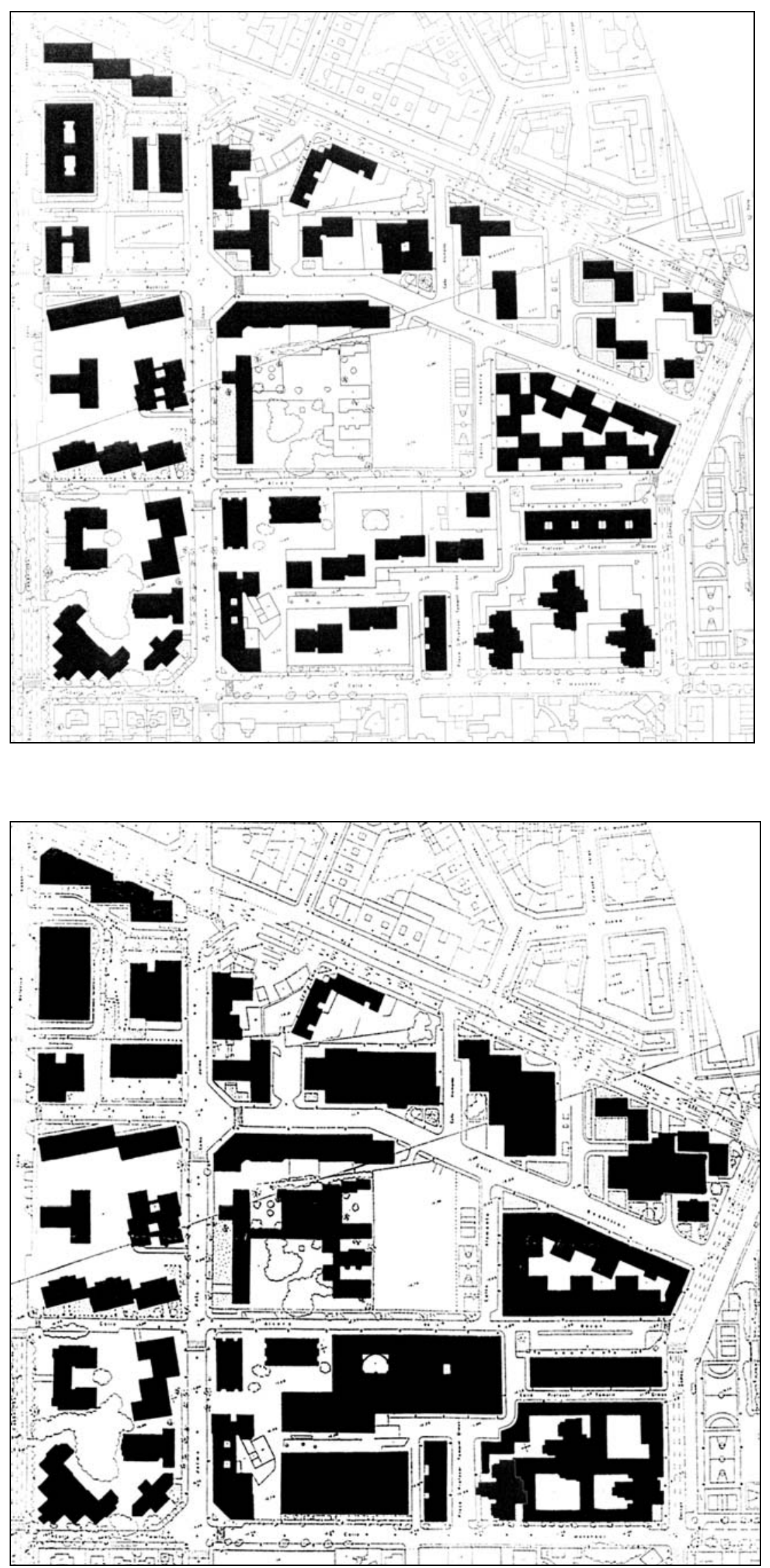

PP-11- Zona de Jaime Roig-Bachiller. Plano de edificación en planta baja y en planta tipo (Elaboración propia sobre Cartografía Básica Municipal, 1983). 


\section{Un recorrido actual por la zona del Plan Parcial 11.}

En la sección anterior hemos analizado la edificación abierta de las cuatro primeras manzanas construidas de la zona del Plan parcial 11, que son las situadas entre la calles Jaime Roig y Botánico Cavanilles. La manzana situada más al norte, que es la que incluye la iglesia de los P.P. Carmelitas, se ocupó con edificación más compacta que las demás, formando grupos de bloques dobles muy juntos y unidos en la planta baja, como el de Luís Marés de la calle Jaime Roig, 25 o el situado en la esquina de la calle Jaime Roig con Botánico Cavanilles. En esta manzana se proyecta, incluso, un edificio con patios interiores.
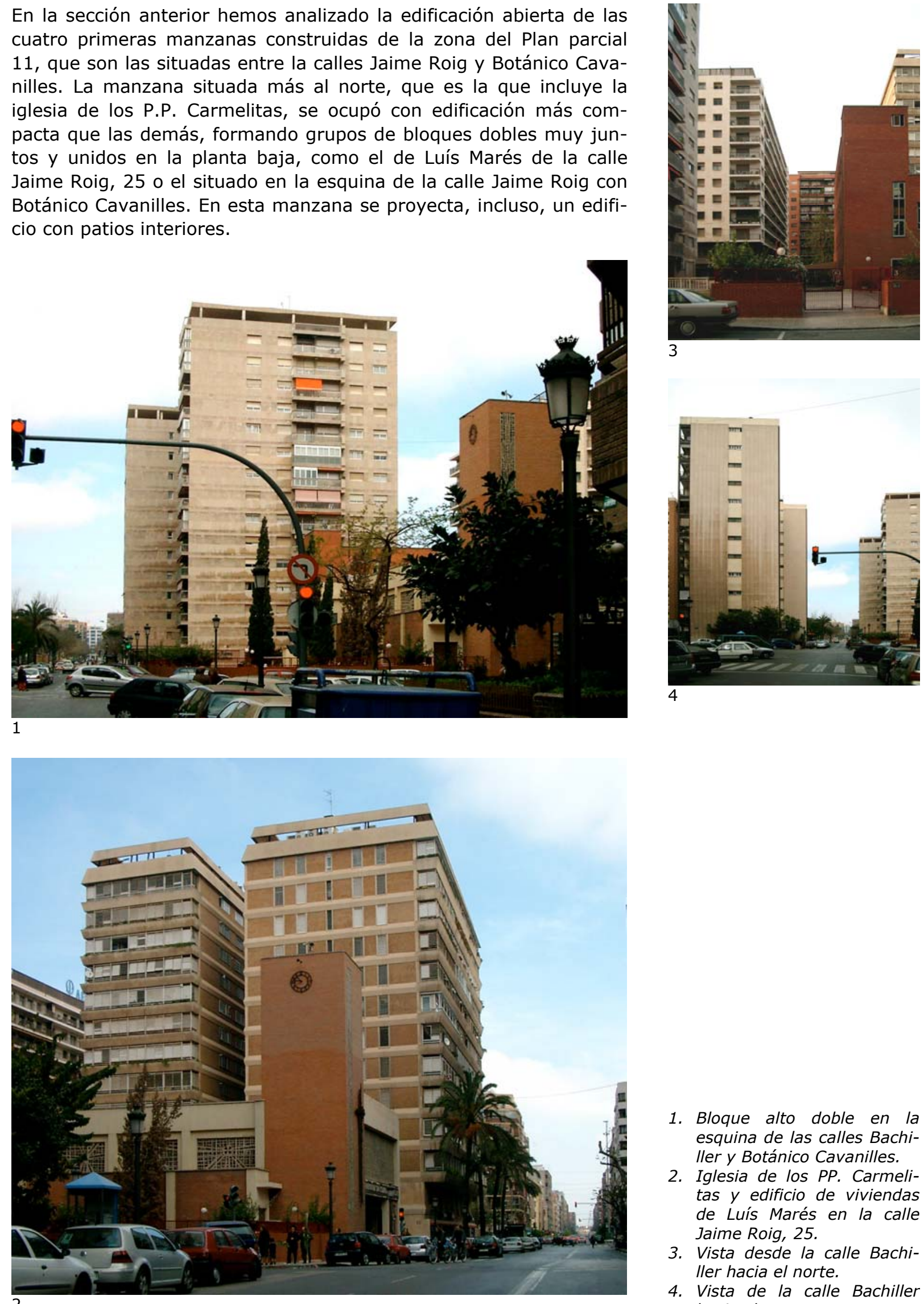

1. Bloque alto doble en la esquina de las calles Bachiller y Botánico Cavanilles.

2. Iglesia de los PP. Carmelitas y edificio de viviendas de Luís Marés en la calle Jaime Roig, 25.

3. Vista desde la calle Bachiller hacia el norte.

4. Vista de la calle Bachiller hacia el oeste. 


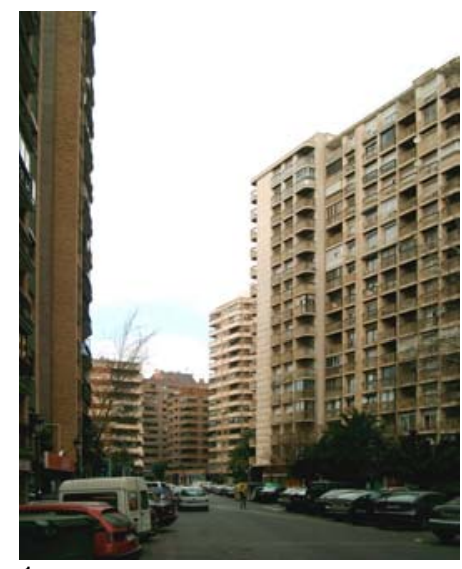

1
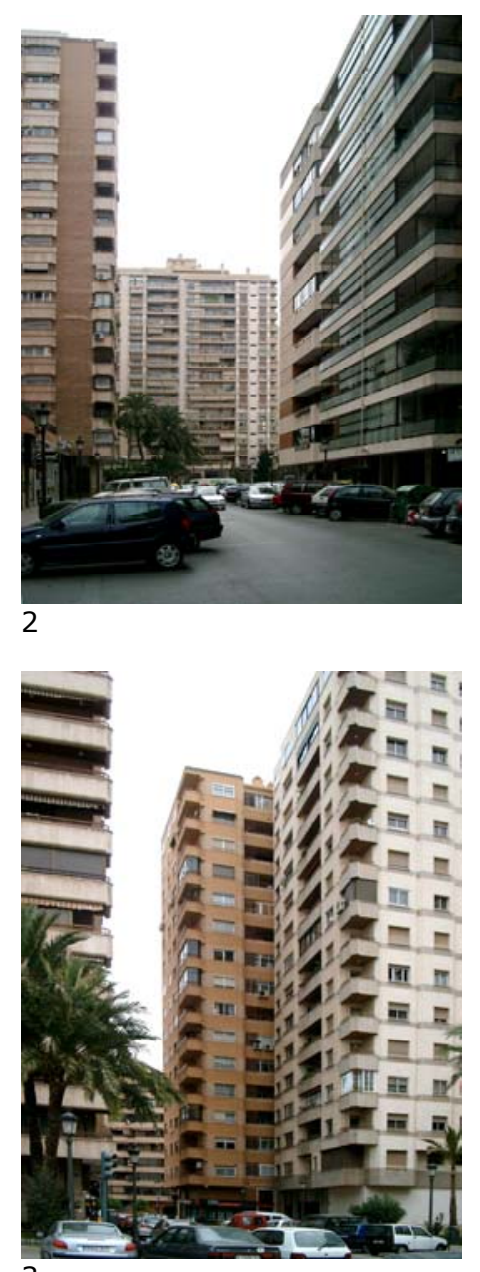

3

1. Calle Bachiller, vista hacia el oeste.

2. Calle Bachiller, vista hacia el este.

3. Calle Alemania, vista hacia la Avenida Primado Reig.

4. Grupo de torres en la calle Alemania.
Los edificios de la franja comprendida entre la calle Bachiller y la Avenida de Primado Reig, realizados según lo previsto en el Plan Parcial 11 de 1968, componen un conjunto abigarrado y sobredensificado, debido a la proporción entre altura y separación que presentan, que hace que el cielo apenas asome como una delgada grieta vertical entre las torres de XVI plantas. El espacio libre del patio de juegos y de las pistas deportivas del Colegio Alemán es el único alivio para esta concentración de edificios, ya que no existe en la zona ningún otro espacio libre público, salvo pequeñas isletas ajardinadas.

Por otra parte, estas torres están unidas en planta baja, y a veces también en la planta de entresuelo, por locales comerciales y de oficias, cuya cubierta se usa en uno de los conjuntos como terraza ajardinada con piscina. La existencia del zócalo no residencial permite recomponer lo suficiente en planta baja las alineaciones de calle, de modo que el conjunto funciona razonablemente bien en cuanto a definición y legibilidad del espacio público: es un fragmento de ciudad que, funcionalmente, presenta la misma mezcla de usos que la ciudad tradicional, aunque con otro tipo de edificación.

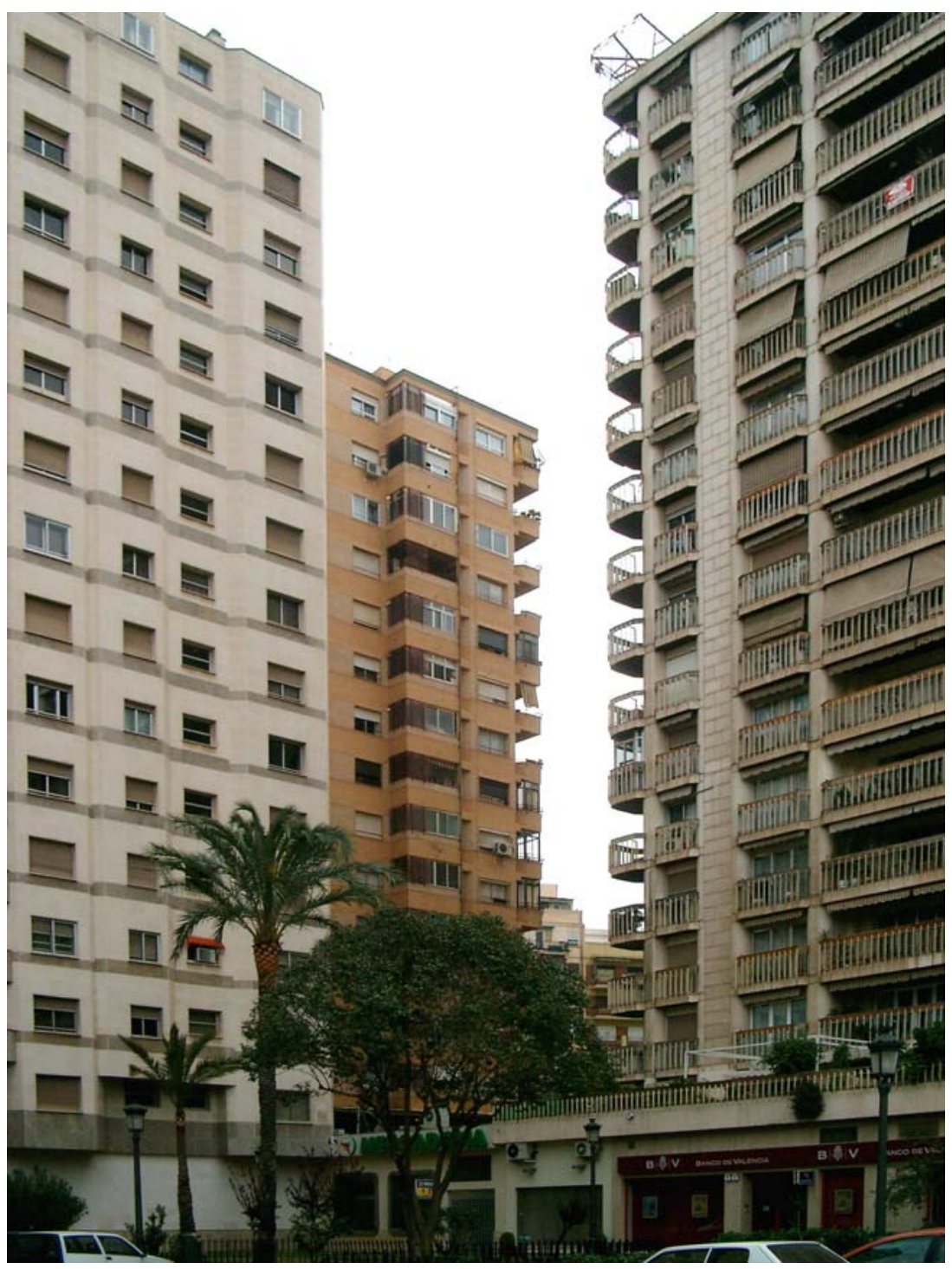

4 
El borde este de la zona, recayente a la calle Doctor Gómez Ferrer y a la amplia zona verde y deportiva contigua prevista en el plan, muestra una masa casi continua de edificación superpuesta, a la que resulta difícil llamar edificación abierta.

Algo similar, aunque un poco menos acusado, ocurre en el borde norte, limitado por la Avenida Primado Reig, donde las torres destacan más como edificios aislados debido a que no están alineadas con dicha Avenida.

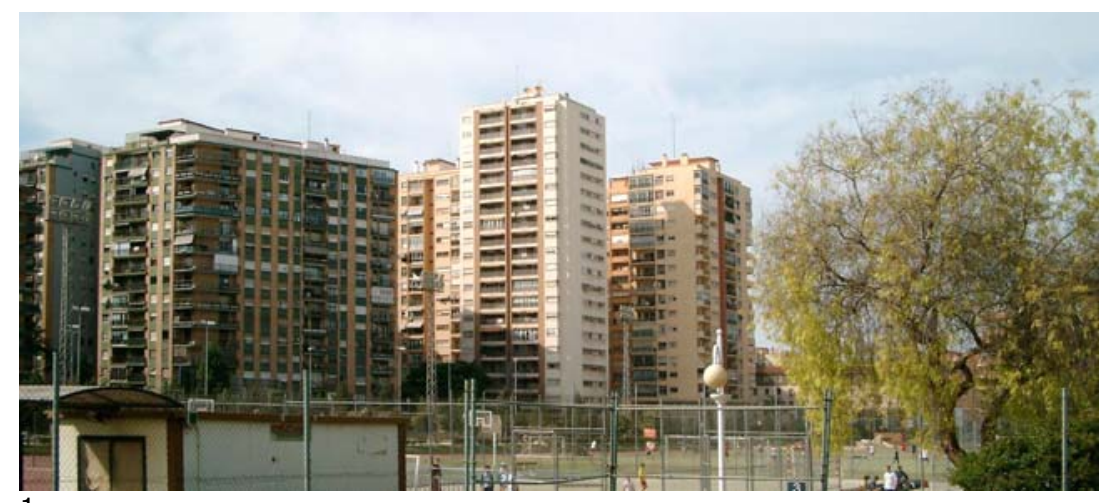

1

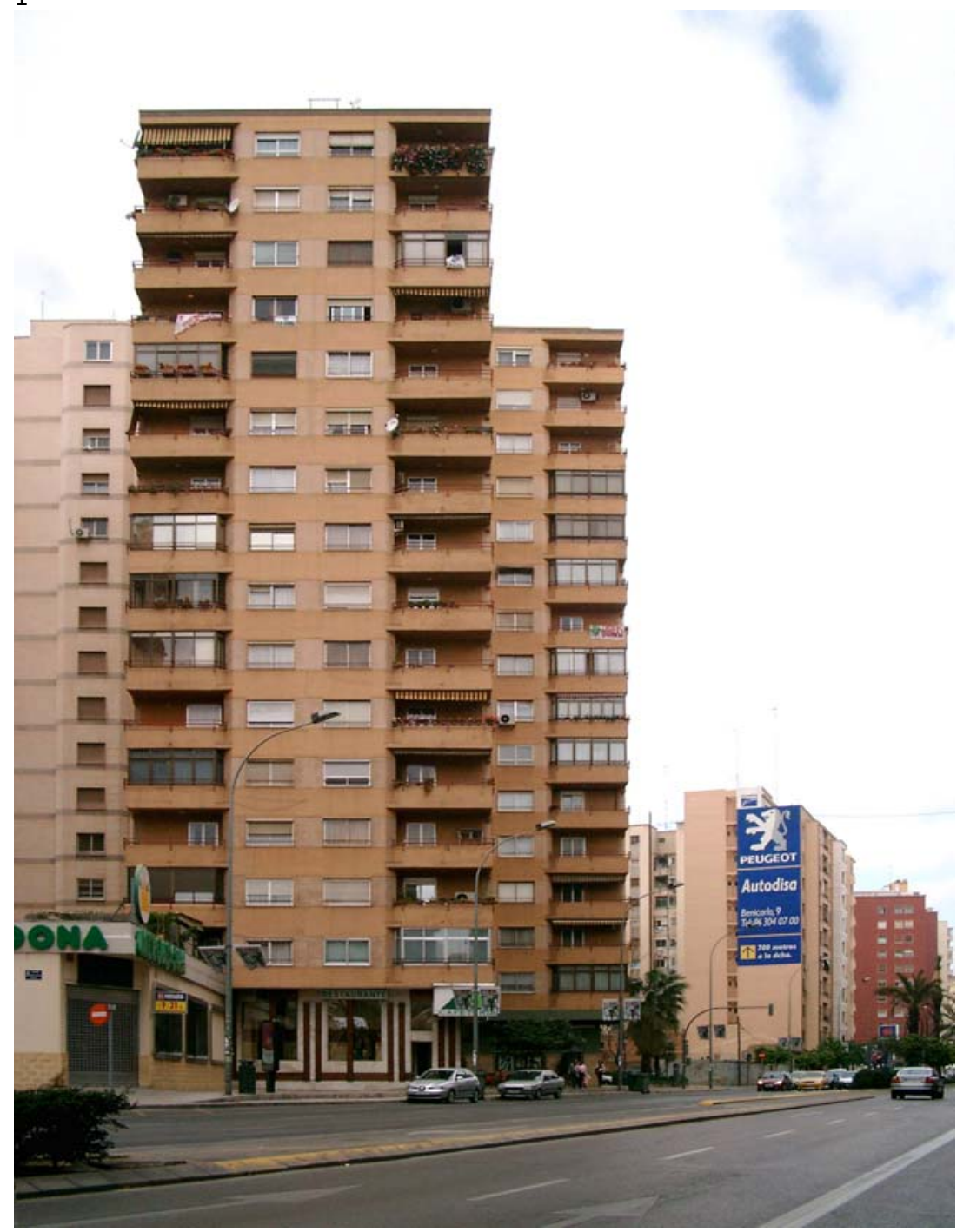

1. Vista del borde este desde las pistas deportivas.

2. Torre en la Avenida Primado Reig.

3. Vista de la calle Maestro Catalá desde la Avenida Primado Reig.

4. Vista de la Avenida Primado Reig hacia el este. 


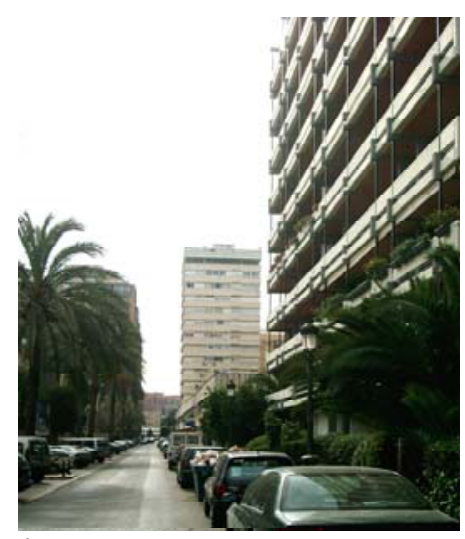

1

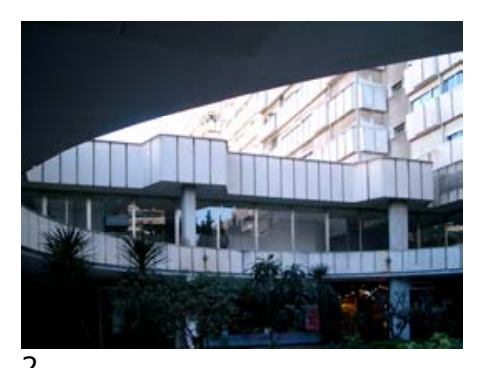

2

En la manzana situada entre las calles Álvaro de Bazán y Menéndez y Pelayo, la edificación abierta no resulta tan densa como en el norte, lo que se debe a que las torres que se disponen sobre el zócalo no residencial son de menos tamaño en planta y, por ello, más esbeltas para la misma altura. Es el caso de los denominados Edificios Luz y de los que ocupan el frente sur, recayente a la calle Menéndez Pelayo. El extenso zócalo proyectado en estos conjuntos, alineado con las calles circundantes, se compone de dos plantas, la baja destinada a locales comerciales y el entresuelo a oficinas. En el caso de los edificios Luz, que constituyen un proyecto unitario, un pasaje con patios interiores que conectan los dos niveles atraviesa la manzana.

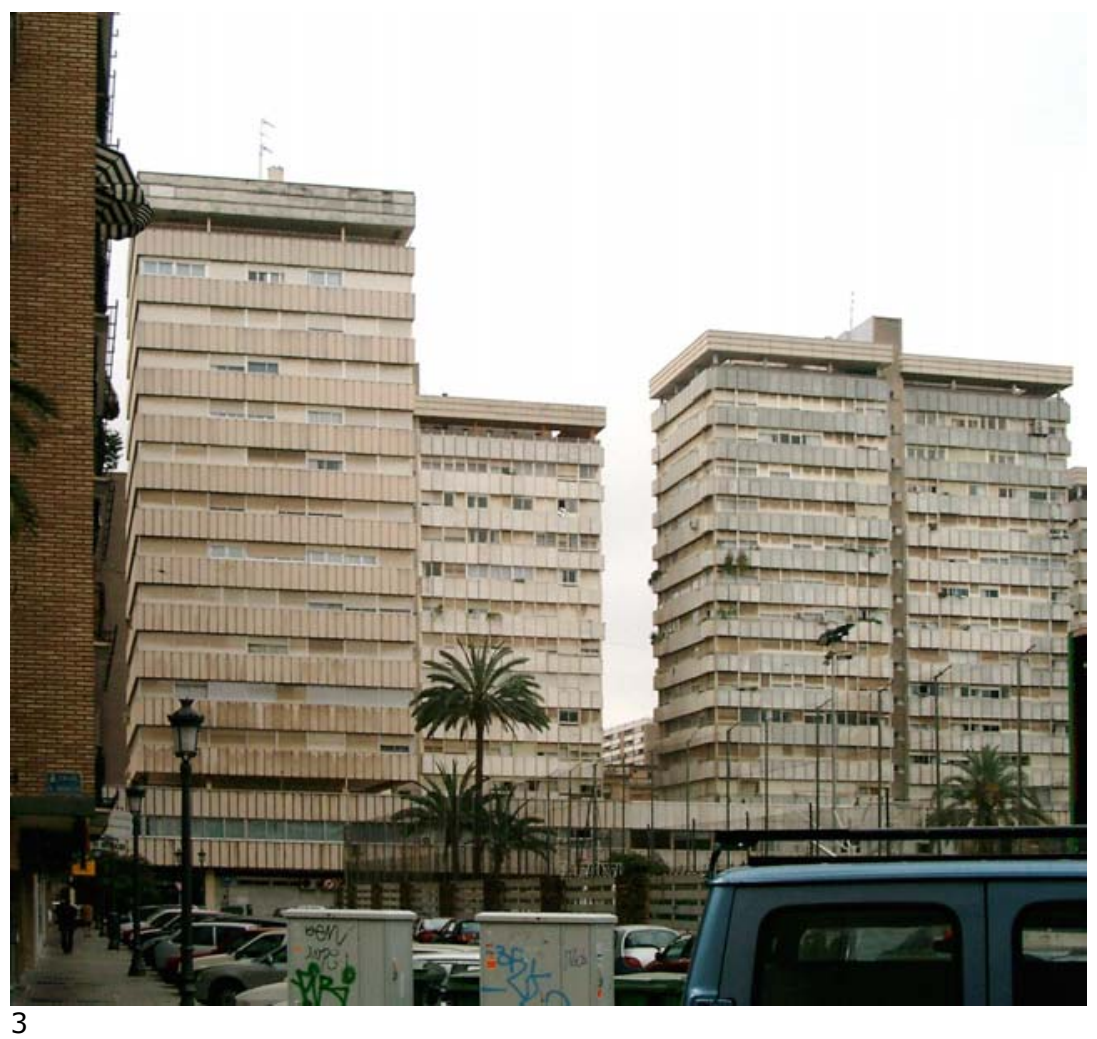

1-4-Vistas del conjunto de los Edificios Luz.

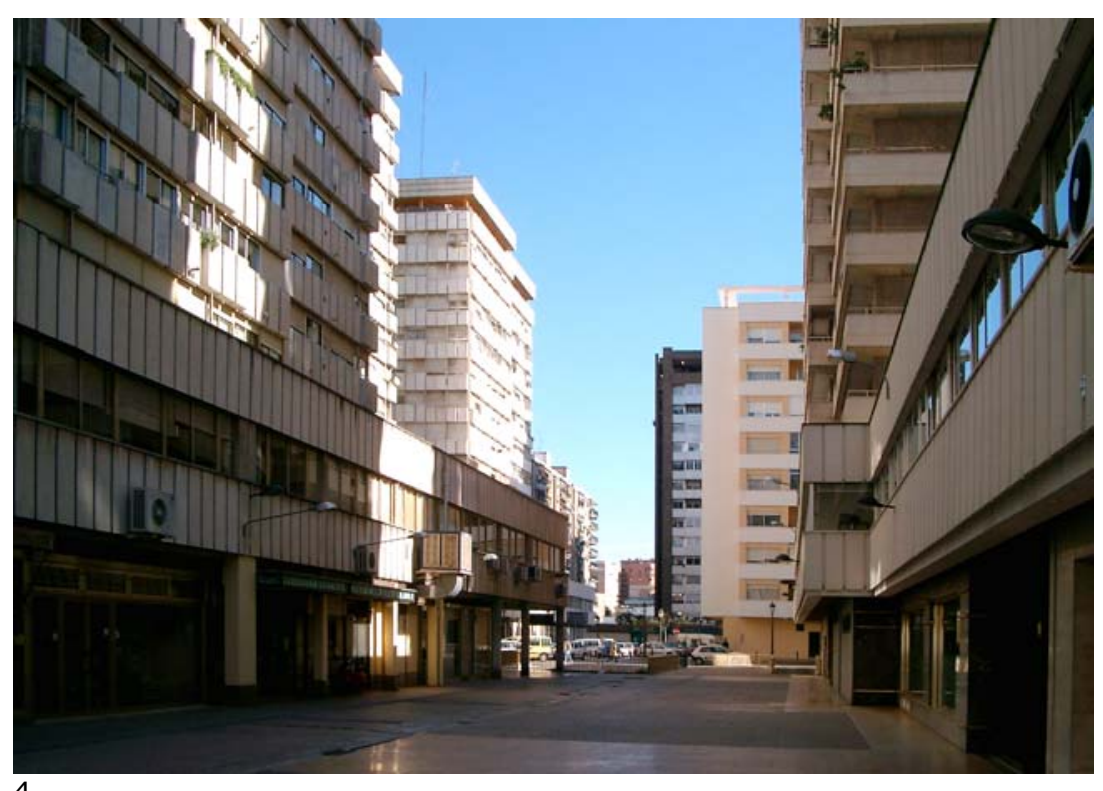


A la calle Menéndez y Pelayo recaen también algunos fragmentos de edificación abierta que no adoptan la forma de manzana mixta con torres, sino la del bloque lineal perpendicular a dicha calle o con planta en forma de $L$.

El conjunto de las Torres Universidad, proyectado por A. Escario en 1977 en la manzana limitada por las calles Menéndez Pelayo, Doctor Gómez Ferrer y Profesor Tamarit Olmos, es la última edificación realizada en la zona. Se compone de tres torres de 14 plantas de altura enlazadas por edificación comercial en planta baja. Lo singular de este conjunto es que esa edificación comercial ocupa únicamente una delgada franja del perímetro de la manzana, dejando espacios libres ajardinados interiores de carácter privado que permiten, además del acceso a los zaguanes de las torres, aportar luz y ventilación al garaje subterráneo mediante patios.

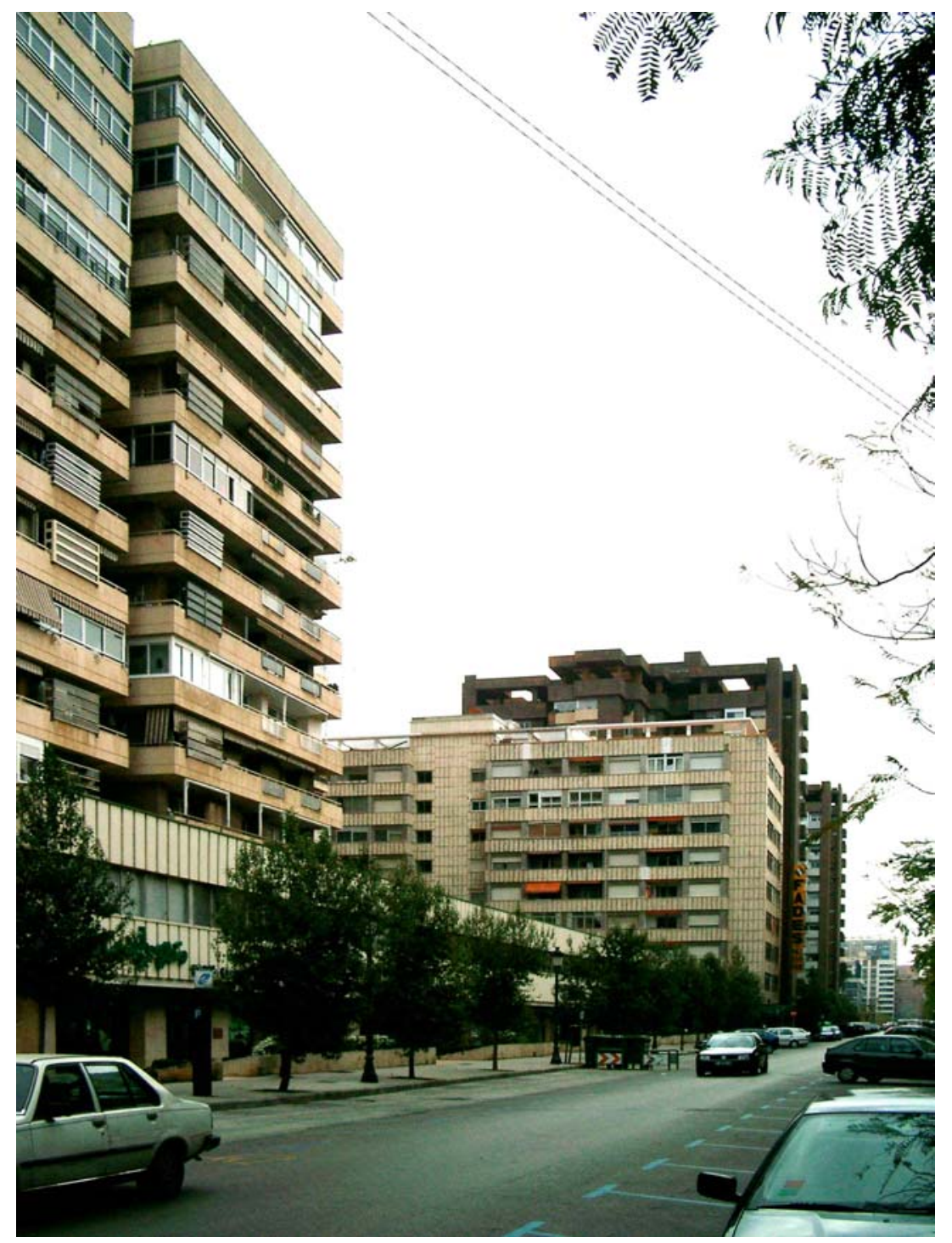

1
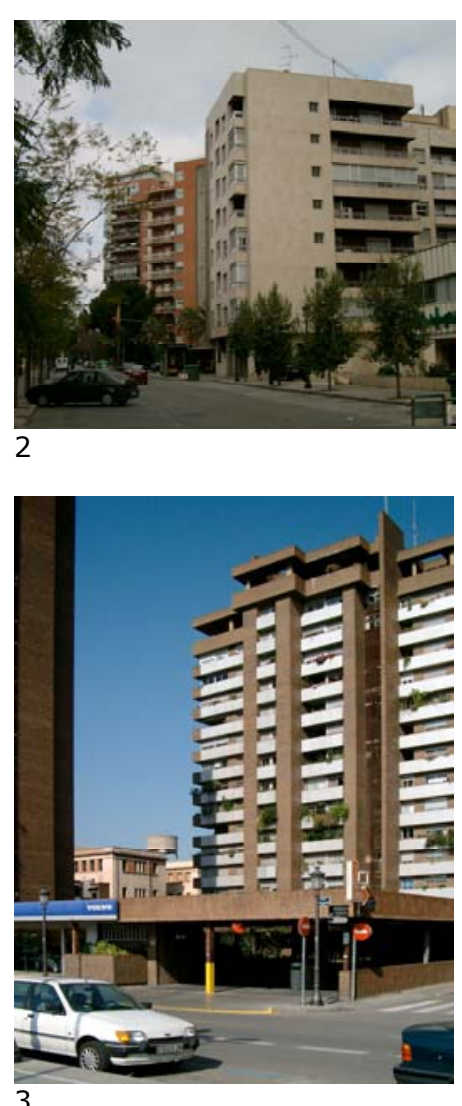

3

1. Vista de la calle Menéndez Pelayo hacia el este.

2 Vista de la calle Menéndez Pelayo hacia el oeste.

3. Vista de las Torres Universidad. 


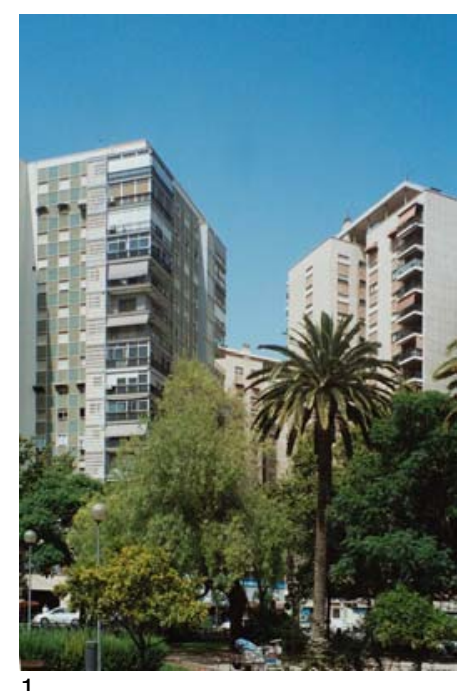

Como hemos señalado en la sección anterior, las dos manzanas situadas entre el Paseo al Mar y las calles Menéndez Pelayo, Gascó Oliag y Almela y Vives, construidas de acuerdo con la ordenación del anteproyecto de Fisac de 1965, no pueden considerarse, en propiedad, como conjuntos de edificación abierta.
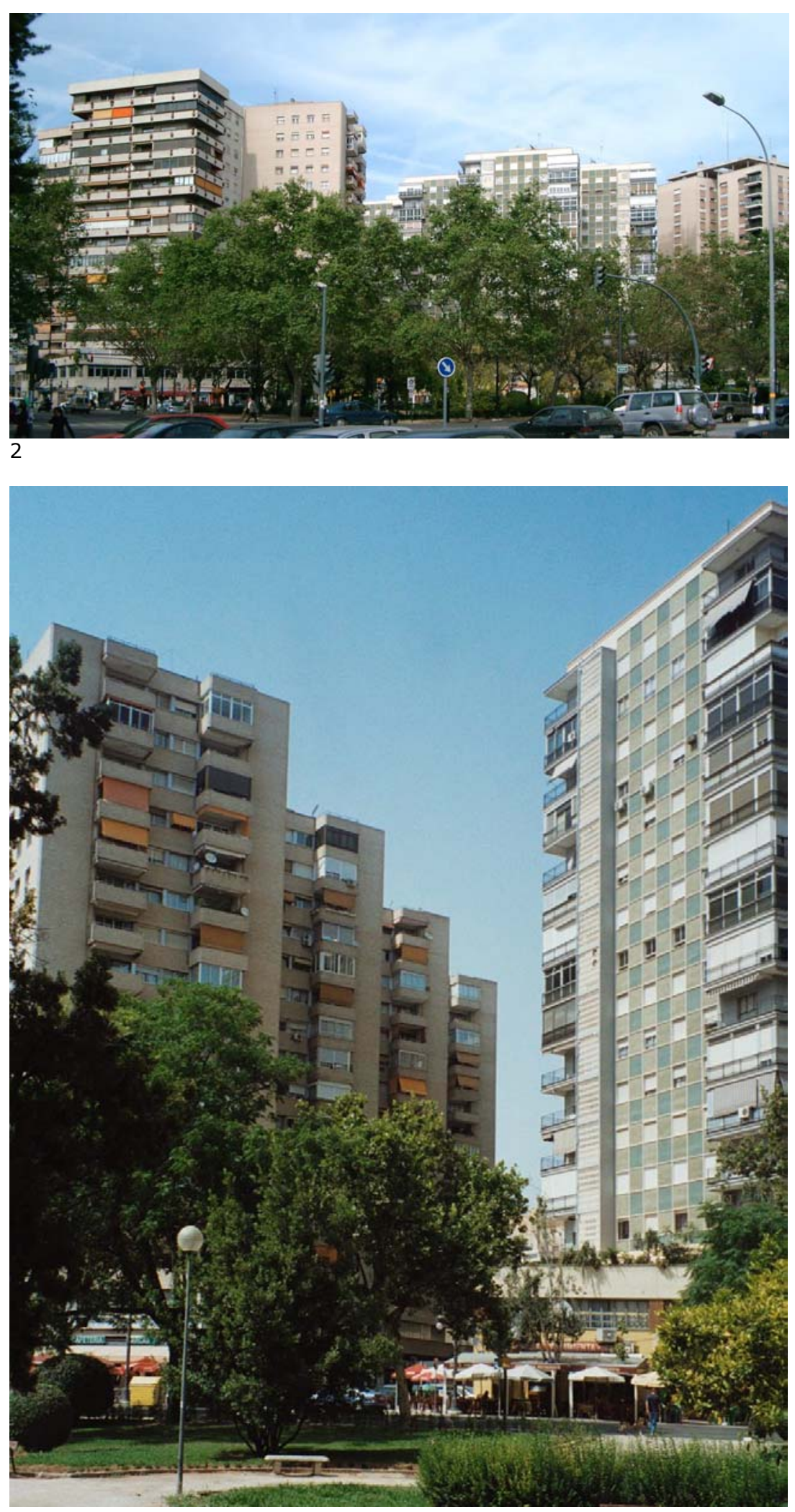

2,3. Vistas de las manzanas situadas entre el Paseo al Mar y las calles Menéndez Pelayo, Gascó Oliag y Almela y Vives. 
Aunque están compuestas por torres situadas sobre un zócalo no residencial, según el modelo de manzana mixta empleado en otras zonas del Plan Parcial 11, las torres no son edificaciones aisladas, sino que se tocan por sus vértices, formando una edificación que en realidad es continua, y que tiene patios interiores.

La disposición diagonal de las torres con respecto a las alineaciones de las calles que circundan a las manzanas contribuye a disimular la continuidad de la edificación, y ayuda a individualizar el volumen de cada una de ellas.

El zócalo situado bajo las torres, que ocupa la totalidad de la superficie rectangular de las manzanas, sigue la misma pauta que la edificaciones próximas antes mencionadas, con una planta baja de locales comerciales y un entresuelo de oficinas.

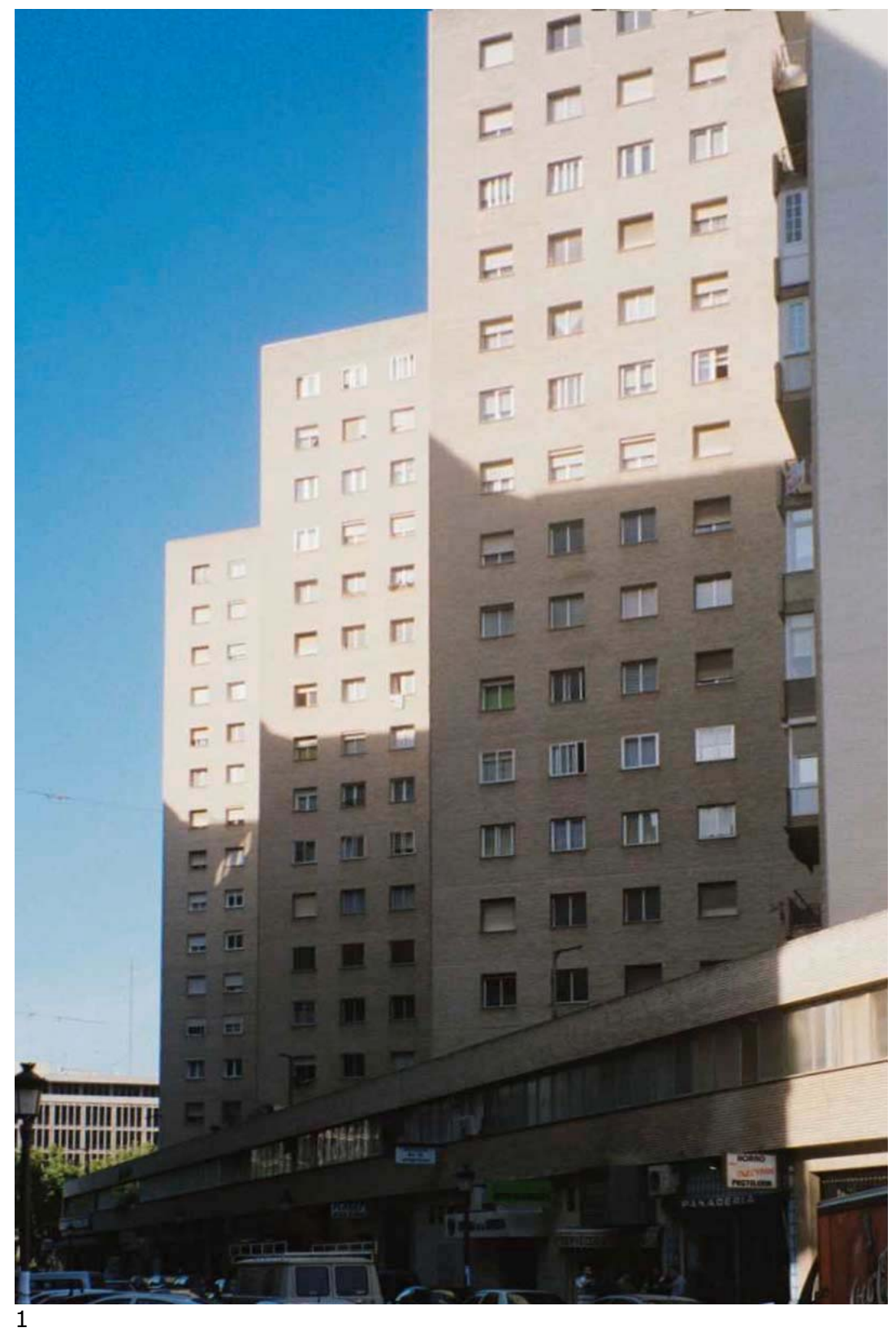

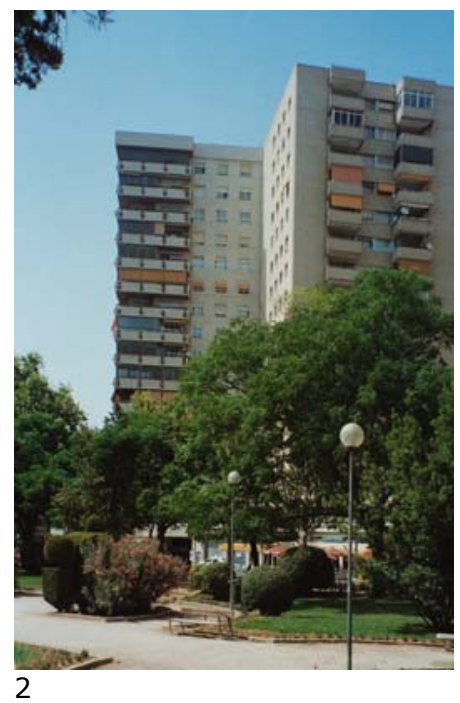

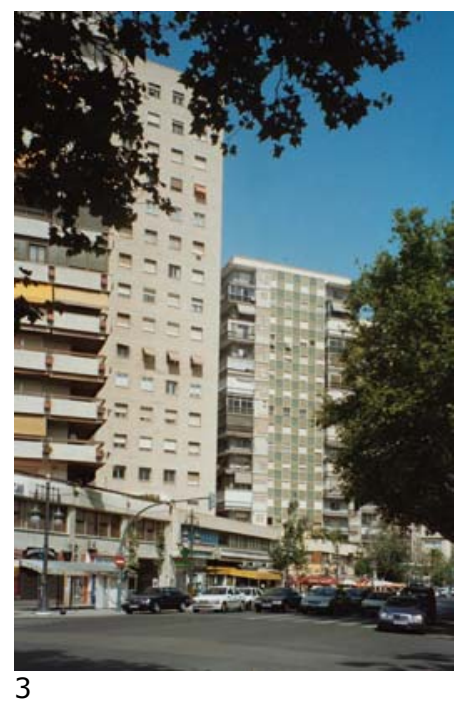

1.,2,3. Vistas de las manzanas situadas entre el Paseo al Mar y las calles Menéndez Pelayo, Gascó Oliag y Almela y Vives. 

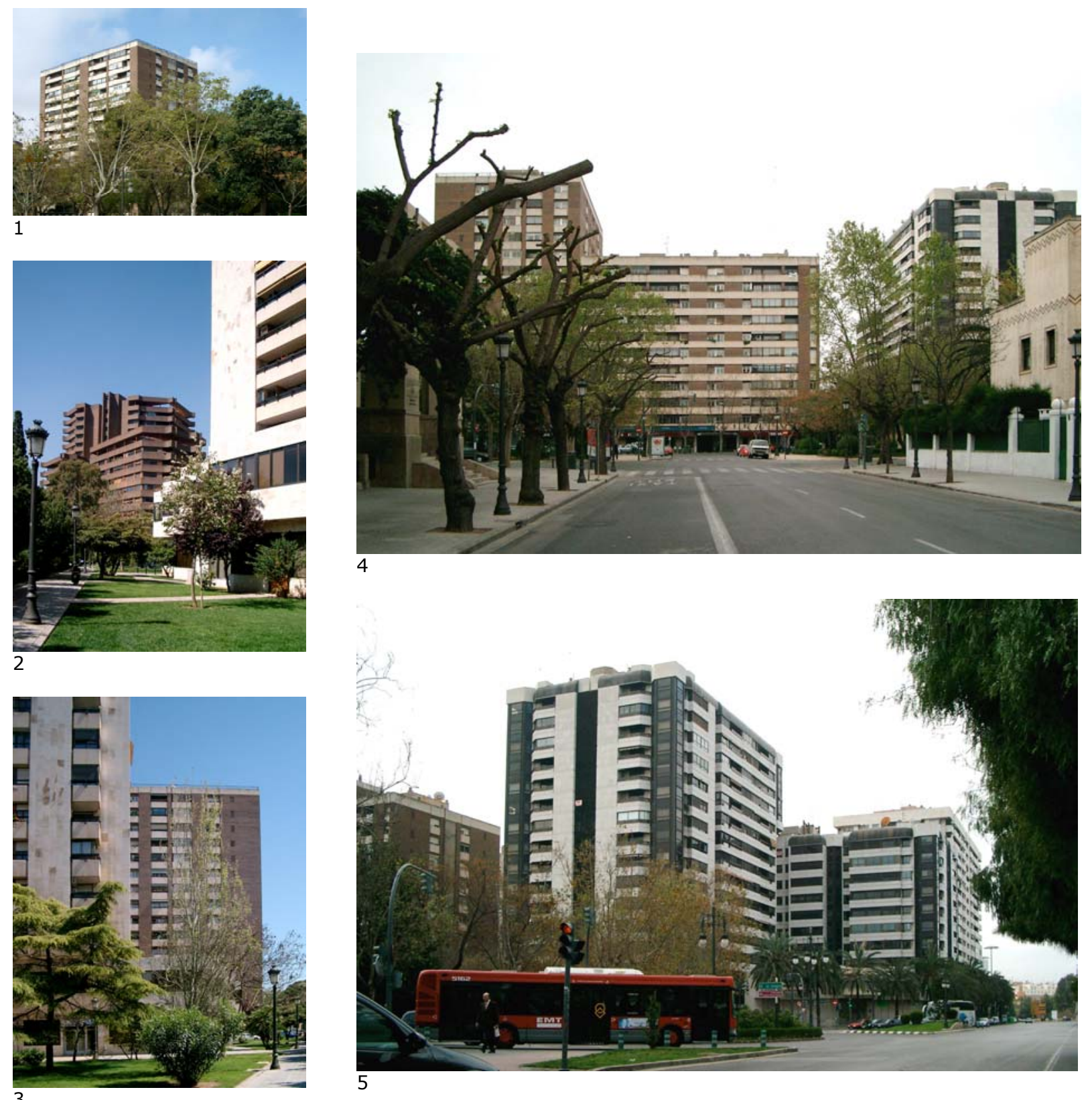

3

1-6. Edificios de la zona del Llano del Real.

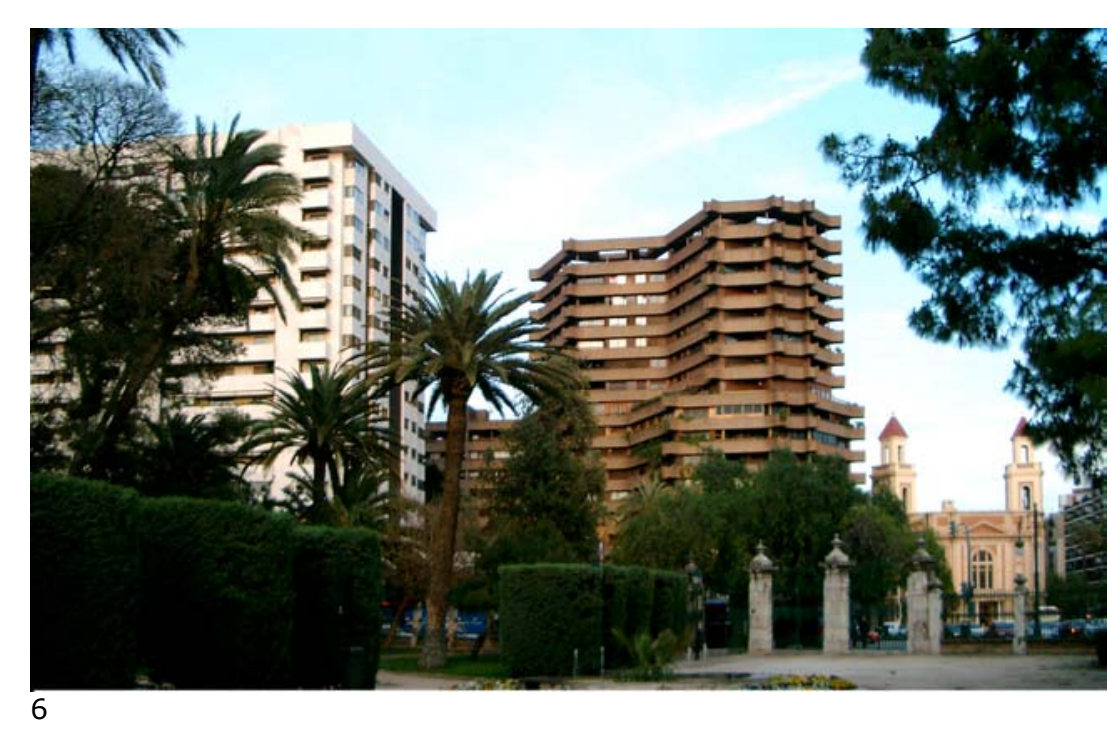


El conjunto del Llano del Real, situado en la zona comprendida entre el Paseo al Mar, la calle General Elio, el inicio de la Alameda y los jardines de Monforte, fue construido de acuerdo con una ordenación previa al Plan Parcial 11 de 1968 que este plan se limita a transcribir y que, por ello, hemos analizado en la sección anterior.

Como hemos visto, la ordenación del Llano del Real de 196566 , distribuye la edificación de la zona en cuatro bloques altos y una torre dispuestos en torno a una plaza central ajardinada. Todos los bloques son profundos, con cinco crujías y patios interiores, y se ajustan al modelo de la manzana mixta, con edificación abierta situada sobre zócalos no residenciales de dos plantas cuya superficie excede la de los bloques.

La forma de los bloques es variada. Los dos situados al norte, junto al Paseo al Mar, tienen una planta en forma de $L$, el recayente a General Elio es un rectángulo y el situado más al sur, denominado la Pagoda, que es también de planta en L en la ordenación de 196566 , se modifica en el Plan Parcial de 1968, reflejando claramente un proyecto arquitectónico previo basado en una planta poligonal y unos volúmenes escalonados.

El conjunto de las Torres de Mestalla, junto al estadio de fútbol, responde también al tipo de manzana mixta, pero en este caso la edificación en planta baja que une los bloques tiene menor peso en la composición, ya que, además de ser de una sola planta, no envuelve a la edificación abierta que se sitúa sobre ella. Esta edificación abierta está formada por torres situadas al tresbolillo cuya planta llega hasta el suelo y resulta perfectamente identificable como huella en el mismo.

La edificación, en planta baja, forma así un frente a redents en el que se alternan los vacíos, ocupados por jardines abiertos a la calle, y los llenos.

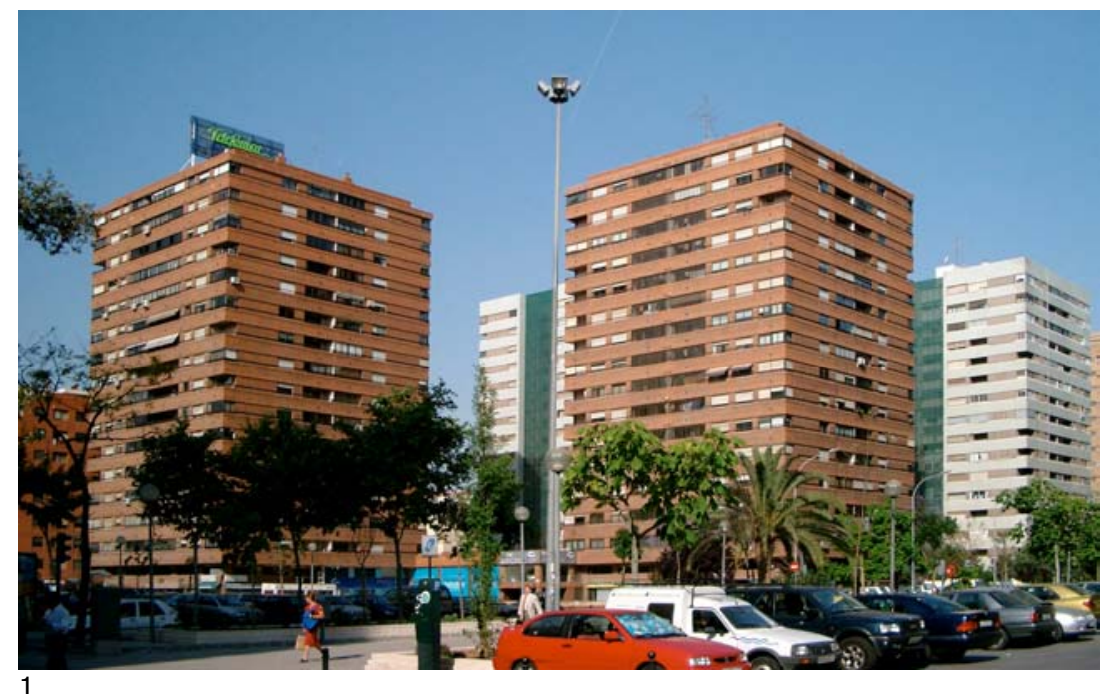

1-3. Torres de Mestalla. Vistas desde la Avenida de Aragón. 


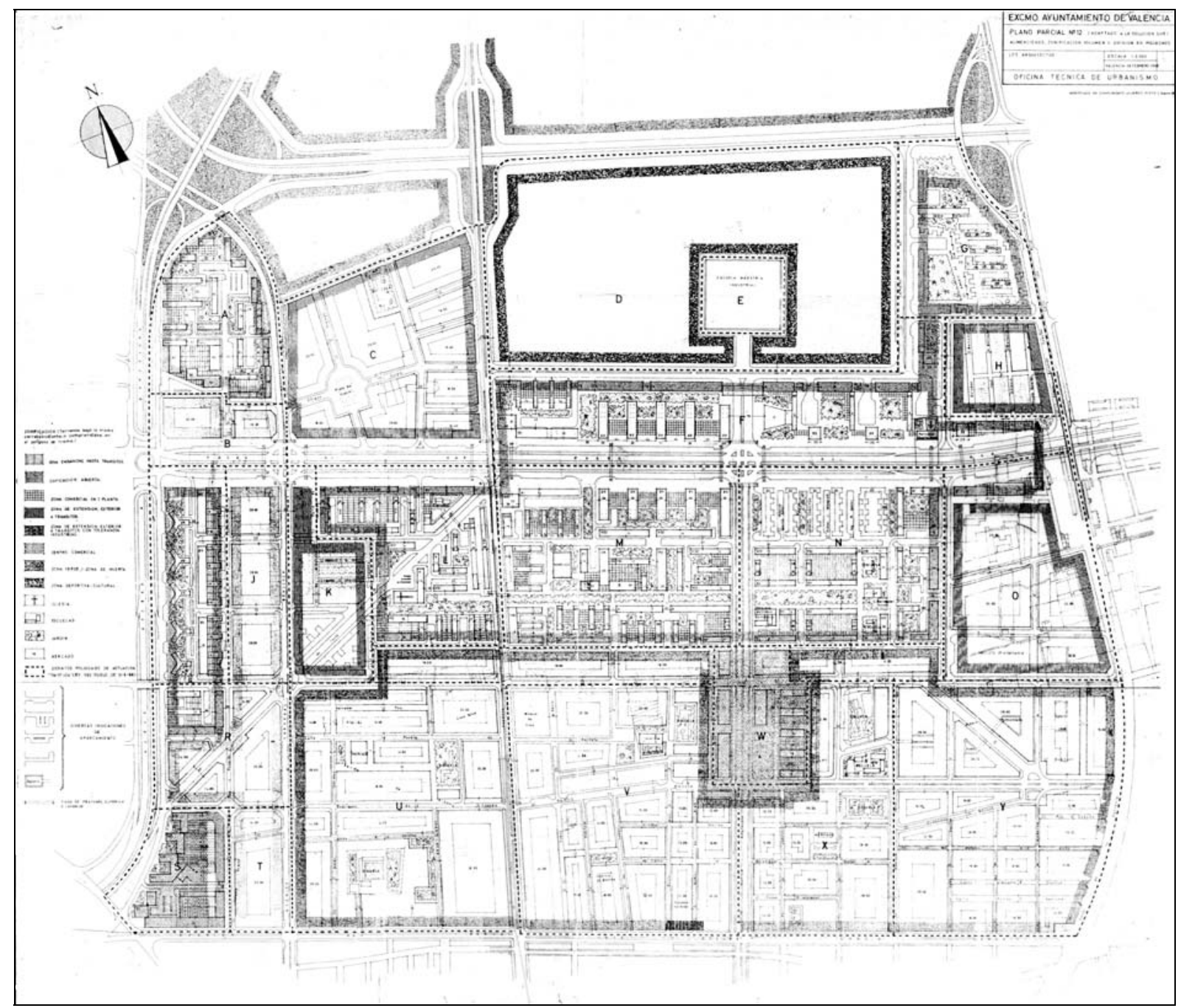

Plan Parcial 12.adaptado a la Solución Sur, 1968.

Plano de Alineaciones, zonificación, volumen y división en polígonos.

ZONIFICACion (Tertenos bajo la trome

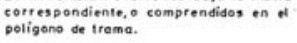

EXTENSION EXTERIOR a tRANSITOO

D. edificacion agierta

InOUSTRIAL

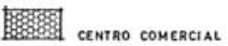

Escueıs

药 IGLESIA

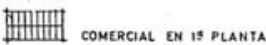

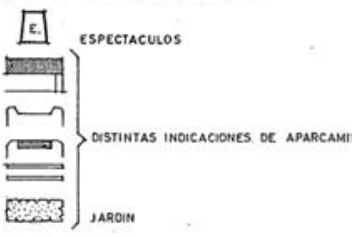

Dastintos pouconos oe ACtuacion
(Ant: 106 LEY DeL SUCLO 12-5-66) 


\section{LA EDIFICACIÓN DE LA PROLONGACIÓN DEL PASEO AL MAR. EL PLAN PARCIAL No 12 (1968)}

El Plano Parcial No 12 adaptado a la solución Sur (PP12) ordena el espacio limitado al oeste por el nuevo acceso a Barcelona y el Plan Parcial 11 (actuales Avenida de Aragón y Avenida de Cataluña), al norte por la Ronda Exterior, al este por la línea de ferrocarril a Barcelona (actual calle Serrería) y al sur por la Avenida del Doncel Luis Felipe García Sanchiz (actual Avenida del Puerto). ${ }^{1}$

La superficie aproximada del Plan es de $326 \mathrm{Ha}$, de las cuales $103 \mathrm{Ha}$ corresponden a edificación abierta. Esta superficie resulta de fusionar los anteriores planes parciales 12-A y 12-B en uno solo, que además amplía su ámbito por el este hasta llegar a la calle Serrería.

La edificación abierta está situada en la mitad norte, correspondiente al ámbito del anterior Plan Parcial 12-B de 1963, que hemos analizado en la sección anterior. En esta zona, las preexistencias más importantes son el conjunto de la Isla Perdida, el barrio Virgen del Carmen, el núcleo de edificación en torno a la plaza Xuquer $y$, frente al mismo, al otro lado del Paseo el Mar, algunos fragmentos de bloques lineales edificados de acuerdo con lo señalado en el Plan Parcial 12-B de 1963.

La mitad sur del plan, entre la Avenida del Puerto y la calle Justo y Pastor, está ocupada por las manzanas edificadas de acuerdo con el Plan Parcial 12-A. En esta zona, la franja de edificación más consolidada es la situada al sur, entre la Avenida del Puerto y la calle Rodriguez de Cepeda.

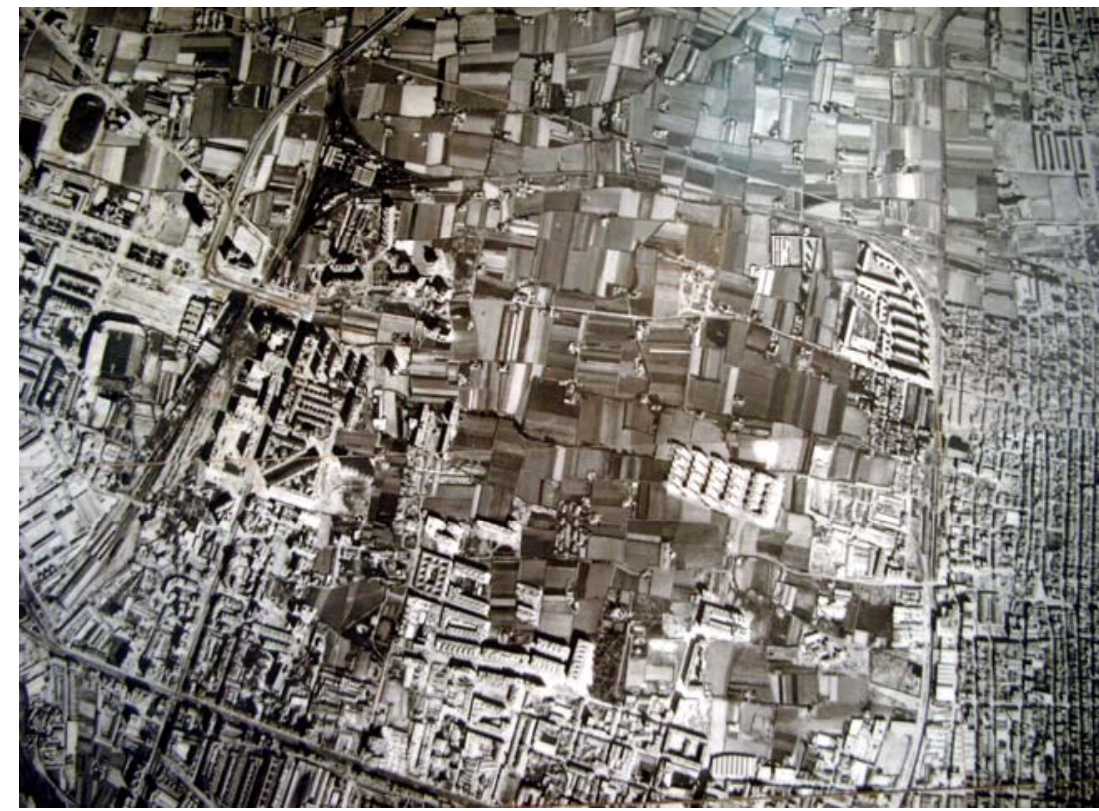

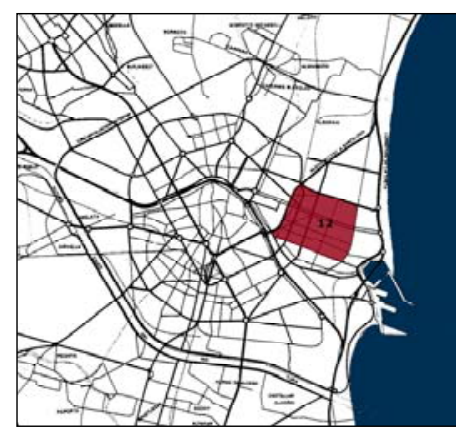

PP 12. Plano de situación

Zona del Plan Parcial 12. Fotoplano, h. 1965 (E.T.S. de Arquitectura de Valencia).

1. Plano Parcial No 12 adaptado a la Solución Sur, 1968. Ver Anexo de Documentos, pp. 387-413. 


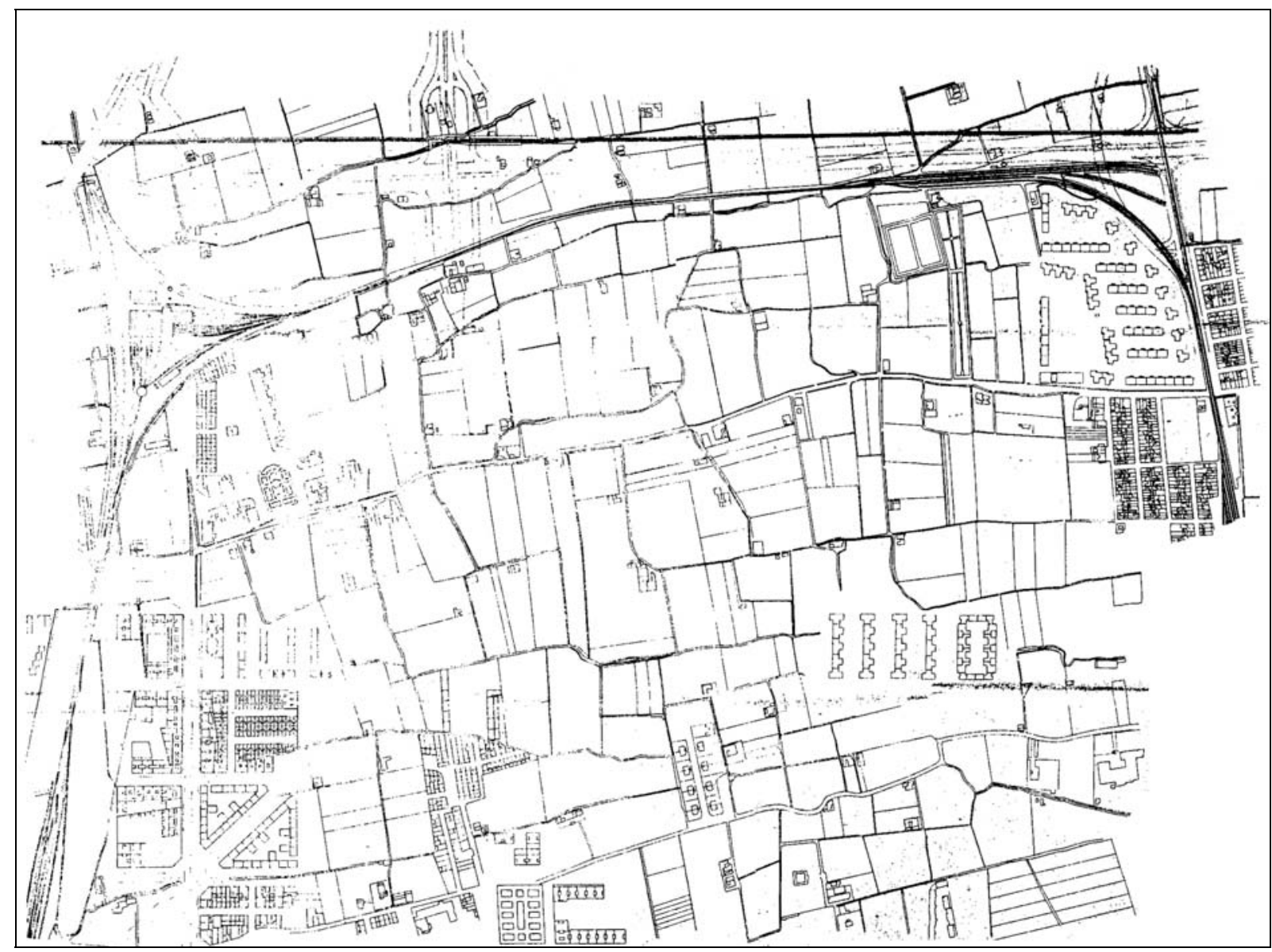

PP-12. Plano de estado actual. Zona $A$ (norte).
1., Informes del Arquitecto Municipal de Urbanismo sobre alegaciones presentadas al Plan Parcial 12, 1967-68. Documentos 12A.1 y 12A.2 y 12A.3. Anexo de Documentos, pp. 403-410.
En cuanto a viario e infraestructuras, en la zona no existe ningún eje viario estructurante consolidado en el momento de redactarse el PP12, a excepción de la actual Avenida del Puerto y el inicio de Cardenal Benlloch. Dos caminos en dirección este-oeste, el del Cabañal y el de Algirós, son el único viario de enlace con cierta continuidad en el interior del ámbito del Plan.

Las vías de ferrocarril existentes son dos: las que arrancan de la Estación de Aragón hacia el norte, ocupando un espacio que, una vez liberado del uso ferroviario, constituirá el nuevo acceso a Barcelona (actual Avenida de Aragón), y las que a partir de una bifurcación de las anteriores discurren hacia el este, bordeando por el norte las edificaciones de la plaza Xuquer y del barrio Virgen del Carmen.

\section{Tramitación del Plan Parcial 12}

La versión inicial del Plan Parcial 12 está fechada en Junio de 1967, siendo en Julio de ese mismo año sometido a información pública. Tras introducirse las modificaciones correspondientes a las alegaciones aceptadas, el plan es aprobado inicialmente por el Ayuntamiento en Diciembre de 1967. Después de una segunda ronda de alegaciones, la versión final del plan, de Febrero de 1968, es enviada al Ministerio de la Vivienda para su aprobación definitiva, que se produce con fecha 24-10-1969. ${ }^{1}$ 
En el periodo de tramitación del plan, las únicas modificaciones que se introducen en el mismo son las que derivan de alegaciones presentadas por particulares y aceptadas por el Ayuntamiento. Entre las que afectan a zonas de edificación abierta cabe destacar las siguientes: ${ }^{1}$

- Modificación del diseño de volúmenes previsto en la manzana identificada como "Centro Comercial" en el plano de Zonificación, limitada por la Avenida de Aragón, la calle Vicente Sancho Tello, la calle Polo y Peyrolón y la Avenida del Puerto. La modificación supone un aumento del volumen edificable, ya que en el frente recayente a la Avenida de Aragón se sustituye una serie de bloques cortos aislados unidos por bajos comerciales por un continuo edificado formado por bloques en $L$ yuxtapuestos. Los espacios interiores de manzana también se modifican: se abre un vial intermedio y se cambia la localización de zonas verdes y bolsas de aparcamiento, de modo que la edificación forme un continuo en planta baja.
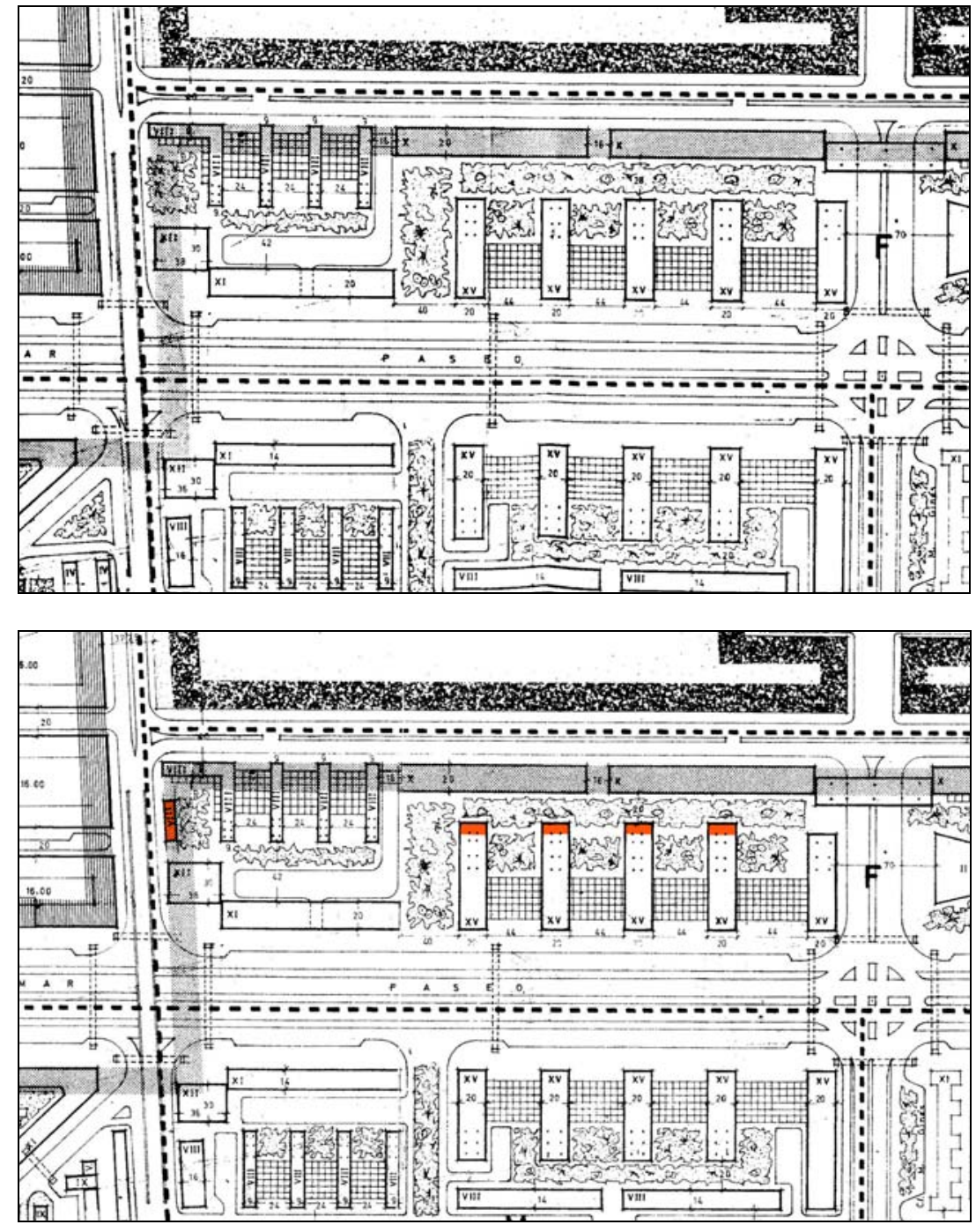

Plan Parcial 12, 1967. Modificaciones derivadas de alegaciones presentadas en el periodo de exposición pública. Arriba, versión inicial. Abajo, versión final.(Elaboración propia, color sobre planos de alineaciones de 1967 y 1968)
1. Resolución de aprobación del Plan Parcial 12. Ministerio de la Vivienda. 24-10-1969. Documento 12.1. Anexo de Documentos, $p$. 413. 


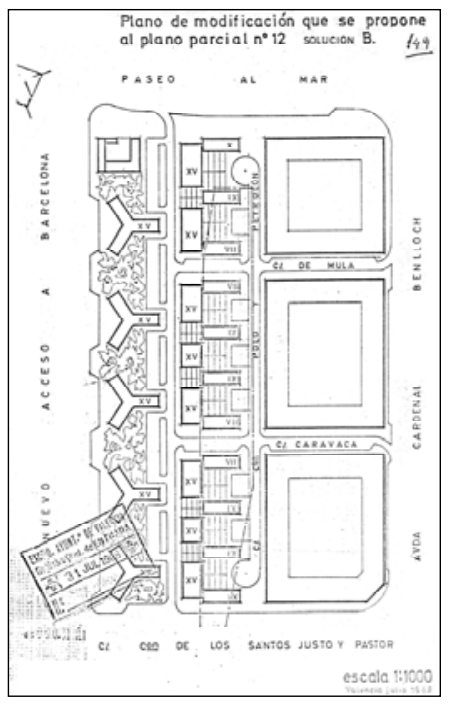

PP-12. Modificación de la zona de la Avenida de Aragón propuesta en el periodo de exposición pública y desestimada por el Ayuntamiento.
- Introducción de un pequeño bloque lineal en la calle Ramón Llull, en un espacio inicialmente previsto como zona verde.

- Aumento de la longitud de cuatro bloques lineales perpendiculares a la calle Honduras, que pasa de 28 a $20 \mathrm{~m}$. de anchura.

- Prolongación de dos bloques paralelos a ambos lados de la calle Beatriz Tortosa, eliminando la zona verde triangular prevista inicialmente al final de dicha calle.

- Modificación de la disposición de los bloques en la manzana limitada por las calles República Argentina, Campoamor, Poeta Más y Ros y Séneca.

- Modificación de la disposición de los bloques y del mercado y zona verde previstos en la manzana limitada por la actual Plaza del Cedro y las calles Explorador Andrés, Impresor Lambert Palmari y Campoamor.

- Modificación de alineaciones y volúmenes del tramo final del Paseo al Mar, en el encuentro con la calle Serrería: se sustituye una torre de 20 plantas por una iglesia y se modifican las dimensiones de los grupos de bloques y torres situados a ambos lados del Paseo.

- En la zona comprendida entre la Avenida de Cataluña, la calle Clariano y el Paseo al Mar, la manzana trapezoidal prevista del Colegio El Pilar se sustituye por otra rectangular. Además, se acorta un bloque lineal para dar continudad en dirección norte-sur a la calle Ruben Darío.

Como puede verse, las modificaciones suponen un aumento del volumen edificable en la práctica totalidad de los casos.
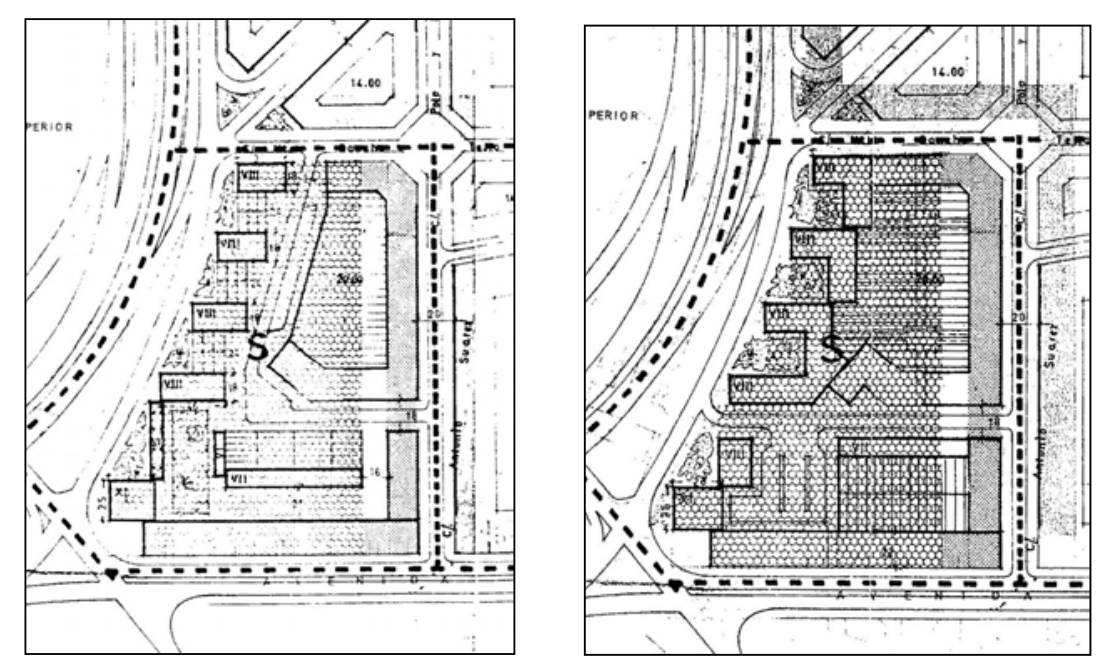

PP-12. Modificación de la manzana destinada a Centro Comercial. Izquierda, versión inicial. Derecha, versión final. 

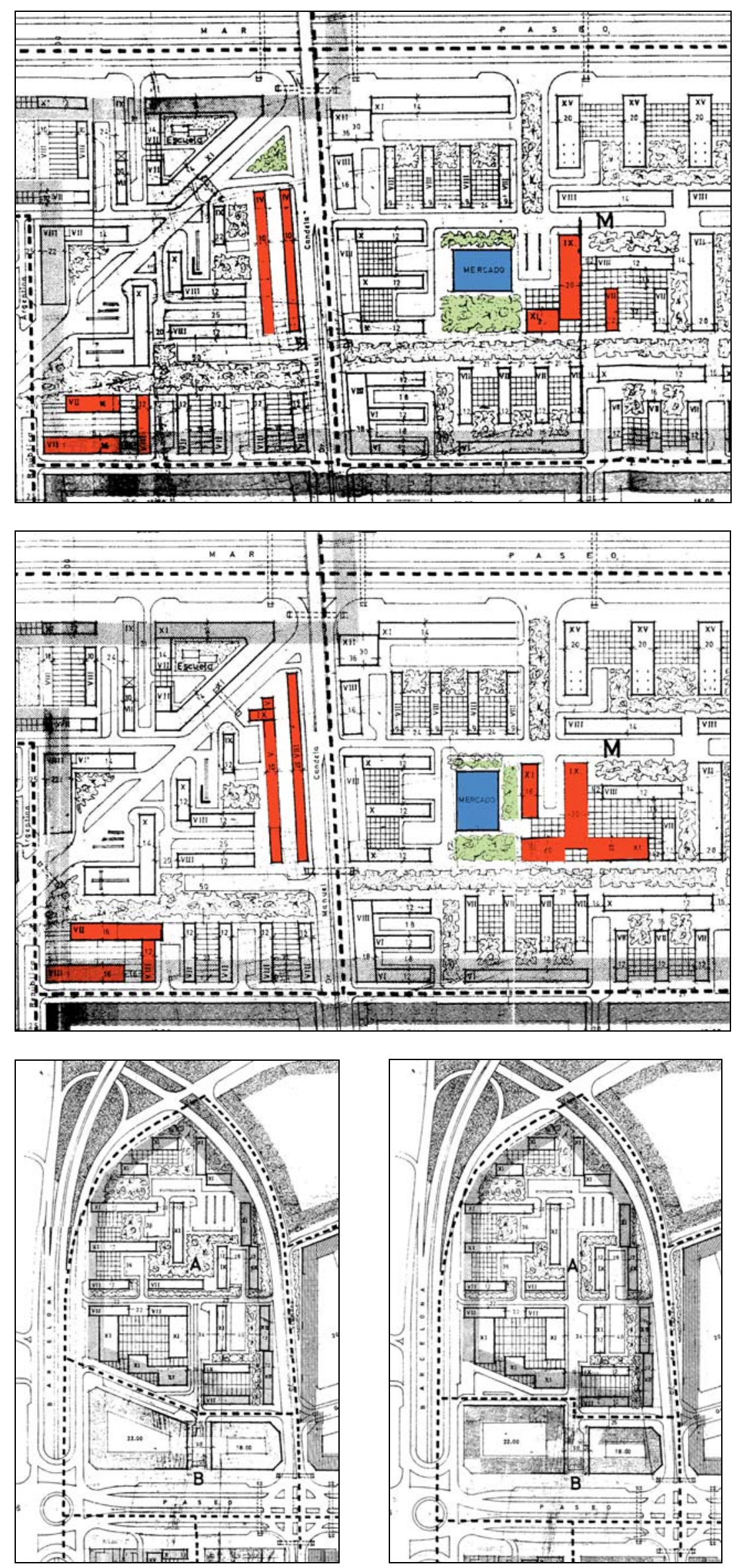

$P P-12$. Modificaciones derivadas de alegaciones presentadas en el periodo de exposición pública. Arriba, versión inicial. Abajo, versión final.

$P P-12$. Modificaciones derivadas de alegaciones presentadas en el periodo de exposición pública. Izquierda, versión inicial. Derecha, versión final. 


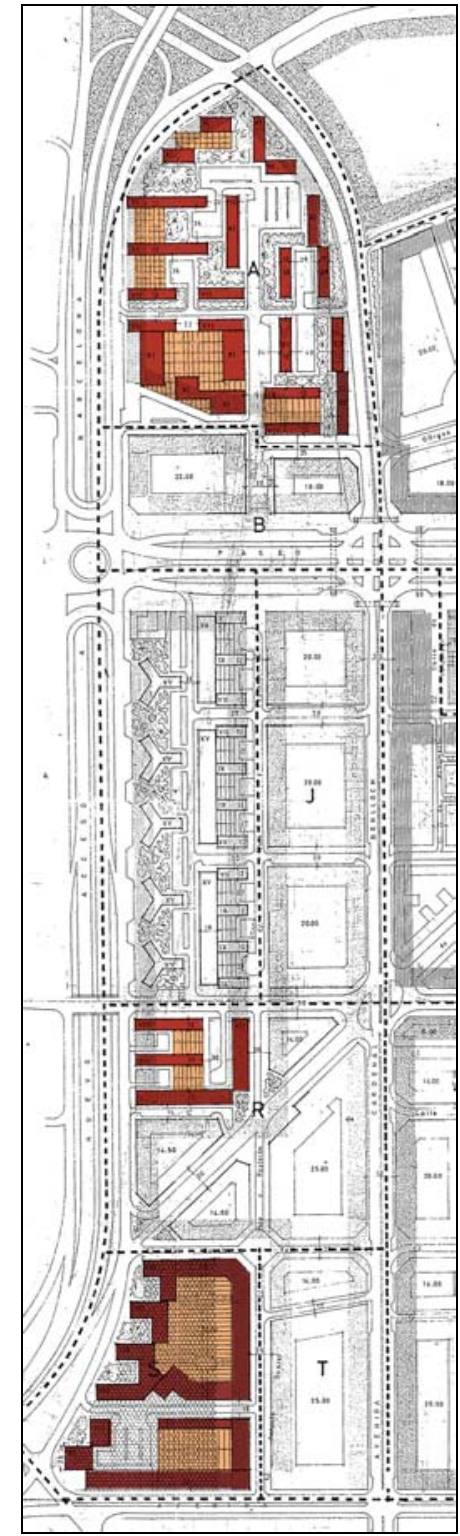

Grado de novedad del PP-12. Edificios proyectados de modo diferente al previsto en ordenaciones anteriores (Color sobre Plano de Alineaciones, zonificación, volumen y división en polígonos). Detalle de la zona oeste (Avenida de Aragón).

\section{Áreas de edificación abierta en el Plan Parcial 12}

En el plano de Alineaciones, zonificación, volumen y división en polígonos del PP12 se delimitan cuatro zonas de Edificación Abierta. El resto de la edificación se califica como zona de Extensión Exterior a Tránsitos.

Las zonas calificadas como edificación abierta son las siguientes:

- Zona de la Avenida de Aragón / Polo y Peyrolón. Limitada por la Avenida de Aragón al oeste, Paseo al Mar al norte, calle Polo y Peyrolón al este y calle Eolo al sur.

- Zona de la Avenida Cataluña / Ruben Darío. Limitada por la Avenida de Cataluña al oeste, calle Clariano a norte y este y calle Gorgos al sur.

- Zona de Paseo al Mar. Incluye las áreas situadas a ambos lados del Paseo al Mar. A un lado, la zona se extiende desde el Paseo al Mar a la calle Serpis y Beniopa por el norte y desde la calle Ramón Llull por el oeste a Serrería por el este. En el lado sur, la zona abarca desde Paseo al Mar hasta la calle Poeta Más y Ros por el sur, y desde Amistat / Dr.Vicente Pallarés y República Argentina por el oeste hasta Serrería / República de Guinea y José Maria Haro por el este.

- Zona del barrio Virgen del Carmen, ya realizado en el momento de redactarse el PP12 y descrito en una sección anterior.

Además de estas zonas, se proyectan en el plan otras dos zonas ordenadas mediante edificación abierta calificadas como "centros comerciales", ninguna de las cuales llegó a realizarse. Son las siguientes:

- Centro comercial Aragón. Limitado por la Avenida de Aragón, la calle Vicente Sancho Tello, la calle Polo y Peyrolón y la Avenida del Puerto.

- Centro comercial Ayora. Limitado por las calles Humanista Furió al oeste, Poeta Más y Ros al norte, nueva calle paralela a Industria al este y Jerónimo Monsoriú al sur.

La superficie ordenada mediante la edificación abierta representa aproximadamente un tercio del total del ámbito del plan. Por otra parte, puede observarse que las seis zonas de edificación abierta antes señaladas, cuatro residenciales (Aragón, Av. Cataluña, Paseo al mar y Virgen del Carmen) y dos comerciales (Aragón y Ayora), están separadas entre sí por zonas resueltas con manzanas cerradas. 


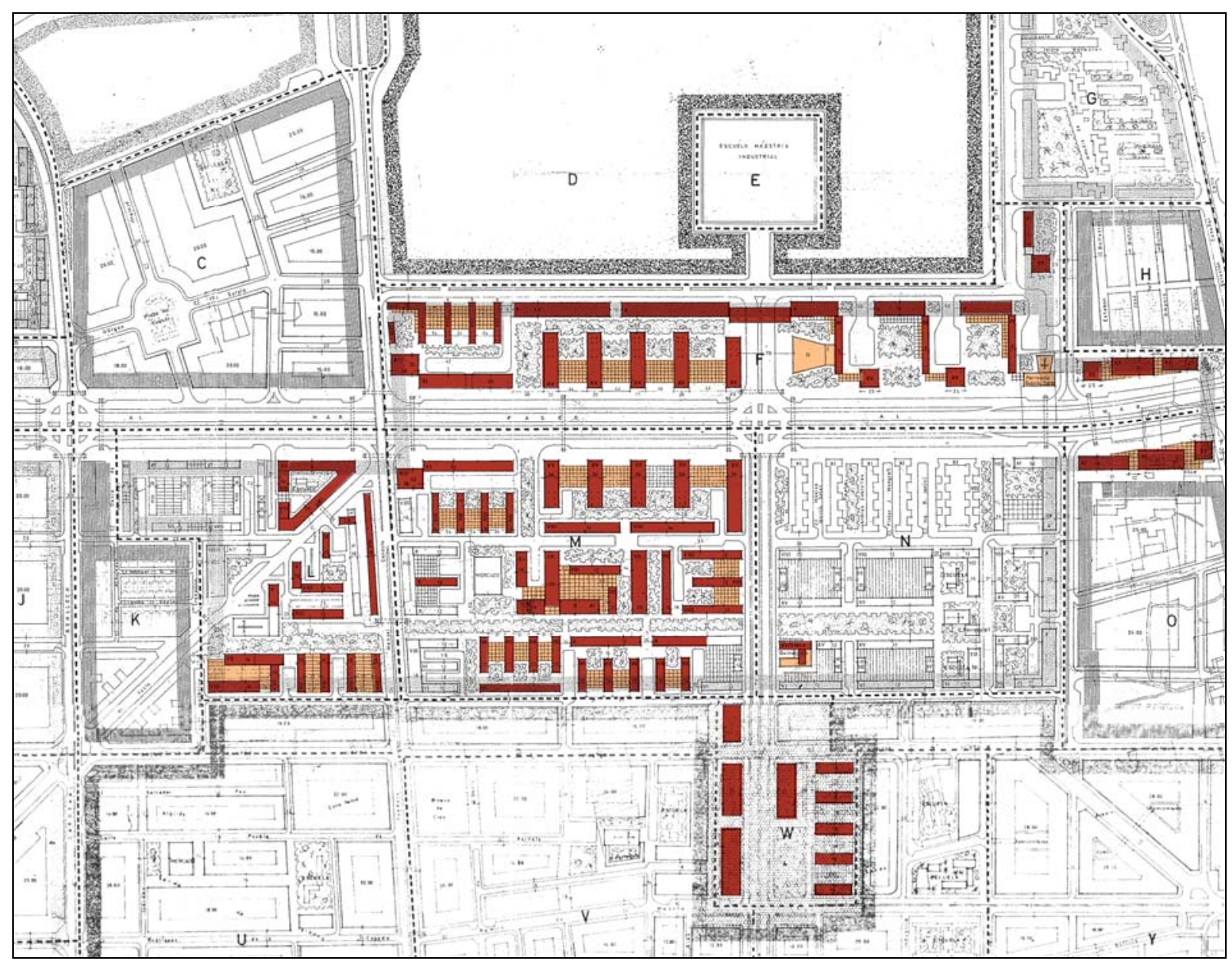

Las únicas zonas de edificación abierta con superficie suficiente para abordar un diseño urbano dotado de un cierto grado de autonomía con respecto a los tejidos de ensanche circundantes son la de Paseo al Mar y, en menor medida, la de Avenida de Cataluña/Ruben Darío. En la primera, la autonomía del proyecto deriva de la gran extensión del ámbito a ordenar, y de la relativa ausencia de condicionantes previos salvo las vías principales. En la segunda, la autonomía es un resultado de su carácter de isla, de enclave rodeado de viario primario.

En estas dos zonas puede observarse que el grado de novedad del Plan Parcial 12 de 1968 con respecto al 12-B de 1963 es importante, ya que un gran número de edificios están proyectados de forma diferente a la prevista en el planeamiento anterior.

La zona de la Avenida de Aragón, por su parte, es un fragmento aislado de edificación abierta, una franja de edificación que forma el frente de una nueva avenida, que correspondería a cuatro manzanas en caso de haberse resuelto con un tejido de ensache convencional. En esta zona, las edificaciones con un nuevo diseño son únicamente las del centro comercial de Aragón y las de la manzana limitada por la Avenida de Aragón y las calles Ernesto Ferrer, Polo y Peyrolón y Eolo.
Grado de novedad del PP-12. Edificios proyectados de modo diferente al previsto en ordenaciones anteriores (Color sobre PP-12. Plano de Alineaciones, zonificación, volumen y división en polígonos. Detalle de la zona de Paseo al Mar 


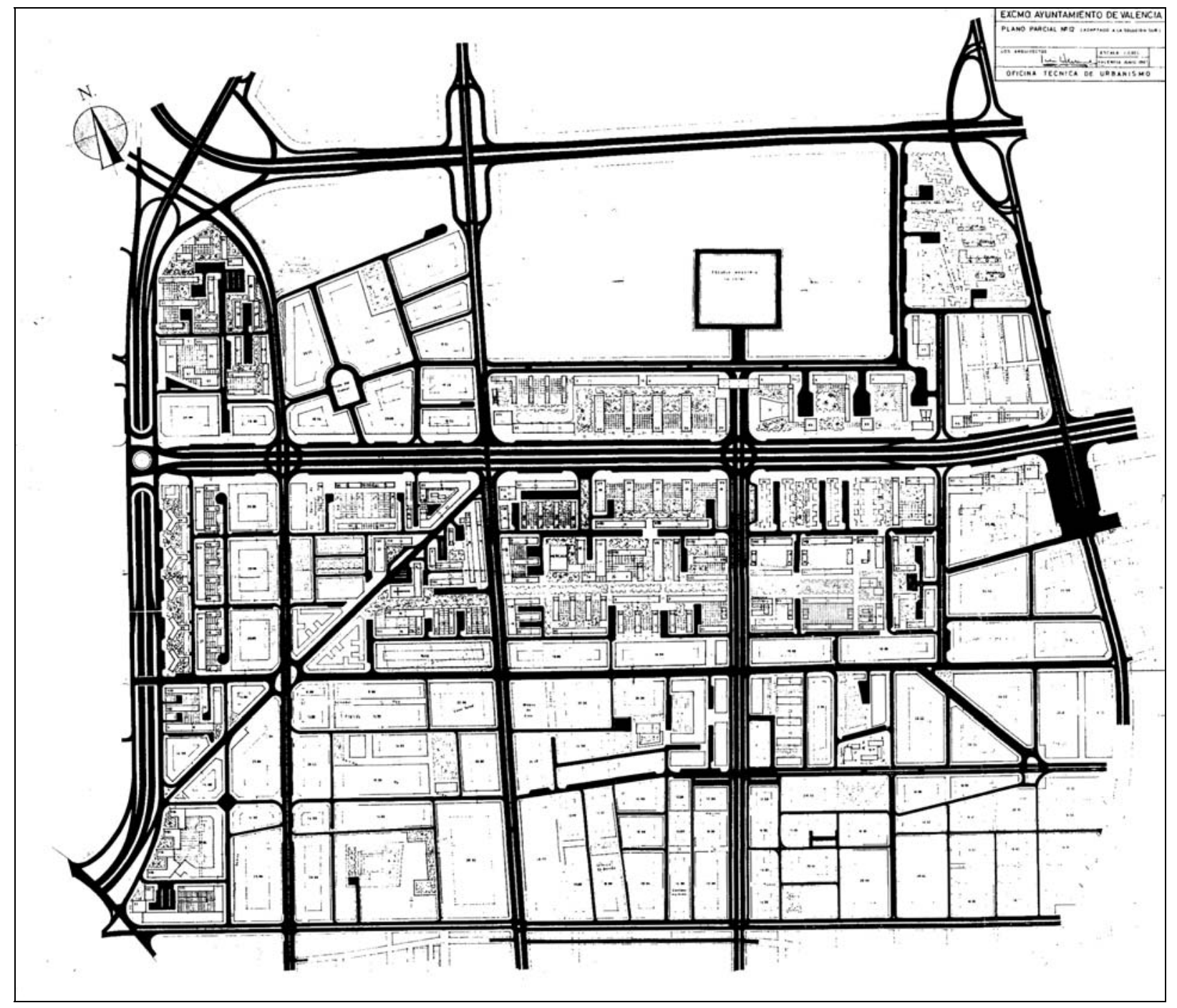

PP-12. Plano de red viaria fundamental.

1. Plano Parcial No 12 adaptado a la Solución Sur, 1968. Memoria. Anexo de Documentos, pp. 388390.

\section{Trazado viario.}

La Memoria del PP12 señala lo siguiente:

En el plano de este Plan Parcial se distinguen perfectamente las vías de Gran Tráfico de las de Tráfico mediano y las de distribución.

Se ve perfectamente que se ha procurado, allá donde ha sido posible, por ser sobre zona poco edificada, adoptar el esquema de supermanzana, ya sea compuesta de bloques abiertos o de manzanas cerradas, procurando para formarla imposibilitar el tráfico veloz de vehículos por su interior, disponiendo fondos de saco o bien calles quebradas, para distribuir en el interior de la manzana o bien llegar a los aparcamientos. $^{1}$

En el plano de red viaria fundamental del PP12 se puede observar que la utilización de un trazado viario como el descrito en la Memoria, de tipo ramificado, sólo se da de hecho en las zonas de edificación abierta. 
Analizaremos a continuación el trazado viario planteado en el PP12 para cada una las zonas de edificación abiertas anteriormente señaladas.

En la zona de Avenida de Aragón / Polo y Peyrolón, la contigüidad con áreas de ensanche hace que el uso de un viario ramificado sea muy reducido, limitándose a dos ramales en cul-de-sac que impiden la continuidad de la calle Polo y Peyrolón tanto hacia el norte (Paseo al Mar) como hacia el sur (Ernesto Ferrer). Las tres manzanas en que se subdivide la edificación entre las calles Bélgica y Polo y Peyrolón se convierten en una única manzana de gran longitud, que ocupa el espacio entre la Avenida de Aragón y la calle Bélgica, atravesada únicamente por espacios peatonales verdes. En relación con el viario perimetral principal, que siempre es mallado, existen en esta zona dos viales internos este-oeste que conectan con la Avenida Cardenal Benlloch (las calles Ciudad de Mula y Caravaca) y un vial norte-sur que conecta con Paseo al Mar y con Ernesto Ferrer (la calle Bélgica)

En la manzana limitada por la Avenida de Aragón y las calles Ernesto Ferrer, Polo y Peyrolón y Eolo, se recurre a los ramales en cul-de-sac que penetran directamente desde las vías perimetrales de forma múltiple y poco coherente con la idea de macromanzana.

En la zona de Avenida Cataluña / Ruben Darío, el trazado viario proyectado consta de dos vías de acceso este-oeste y una via interna norte-sur. Las vías de acceso son las calles de Palancia y Gorgos, que atraviesan la zona en dirección este-oeste, conectando con las vías perimetrales de Clariano y Avenida Cataluña. La vía interior, sin salida a norte ni a sur, es la calle Ruben Darío. Este viario se completa con diversos ramales sin salida acabados en bolsas de aparcamiento.

La zona de edificación abierta de Paseo al Mar es la de mayor extensión, y es en ella donde el trazado viario de tipo ramificado tiene un desarrollo mayor y más coherente con las ideas de jerarquización del tráfico y de creación de supermanzanas indicadas en la Memoria del plan.

Las supermanzanas son los espacios que quedan en el interior de la malla que forman los ejes viarios principales. Estos ejes son, en dirección norte-sur, la Avenida de Cardenal Benlloch, la calle Dr. Manuel Candela/Ramón Llull, la calle Músico Ginés/Guillem Anglesola y la calle Jose María Haro. En dirección este-oeste, los ejes principales son la calle Serpis, el Paseo al Mar y la calle Santos Justo y Pastor.

De estos ejes, el Paseo al Mar y la calle Músico Ginés/Guillem Anglesola están proyectados como vías rápidas, con calzada central con mediana y calzadas laterales diferenciadas, con pasos para peatones a diferente nivel que la calzada.

Esta malla de ejes principales delimita cinco macromanzanas, dos de ellas en el lado norte de Paseo al Mar y tres en el lado sur.

Las dos manzanas del lado norte del Paseo al Mar, que ocupan la franja limitada al norte por la calle Serpis, tienen unas dimensiones aproximadas de $120 \times 490 \mathrm{~m}$ y $120 \times 360 \mathrm{~m}$. En la primera 


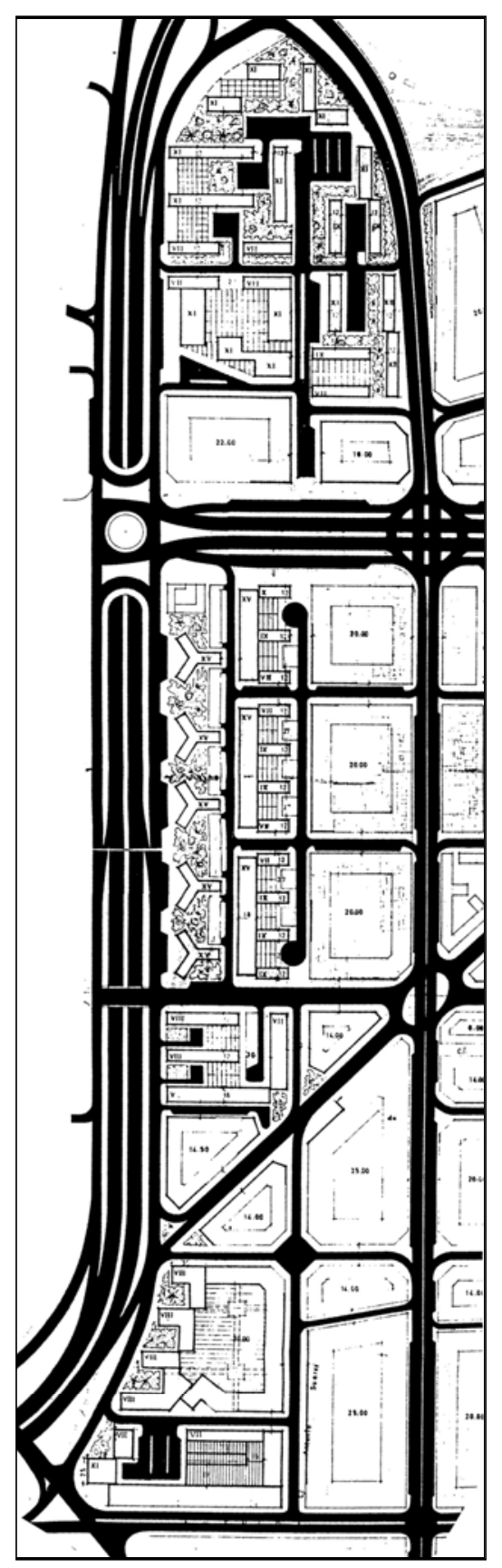

$P P-12$. Plano de red viaria fundamental. Detalle de la zona oeste. de ellas (la situada entre Ramón Llull y Músico Ginés) el viario perimetral es al mismo tiempo viario de acceso a los edificios. En la segunda (la situada entre Músico Ginés y José María Haro) tres ramales en cul-de-sac acabados en bolsas de aparcamiento penetran en la manzana a intervalos regulares. Este trazado viario responde a una disposición de los volúmenes edificados, muy diferente en ambas manzanas, como veremos más adelante.

Las tres macromanzanas rectangulares del lado sur del Paseo al Mar tienen unas dimensiones mayores, de 320x470, 320x380 y $320 \times 400 \mathrm{~m}$, ya que se extienden hasta la calle Santos Justo y Pastor.

Los ejes viarios en dirección norte-sur que delimitan las macromanzanas no son homogéneos, sino que tienen diferentes papeles en la estructura viaria general. Así, la Avenida Cardenal Benlloch continúa en la calle Clariano y se curva en el norte para dar continuidad a la Ronda de Tránsitos. La calle Manuel Candela prolonga su alineación recta a lo largo de la calle Ramón Llull hasta un nudo de enlace con la Ronda Exterior.

El siguiente eje norte-sur, no realizado, enlazaba las actuales calles de Guillem Anglesola y Músico Ginés, terminando frente al recinto de la escuela de Maestría Industrial. Su apertura implicaba la destrucción del jardín y palacete de Ayora, en cuyo enclave estaba previsto en el plan un centro comercial. Por último, la calle José María Haro, de desarrollo menor, no juega un papel tan relevante como eje norte-sur.

De las tres macromanzanas que delimitan los ejes norte-sur, la situada más al oeste (entre la Avenida Cardenal Benlloch y la calle Dr. Manuel Candela) está subdividida en dos manzanas triangulares por una vía diagonal, la calle Yecla. El trazado en esta macromanzana está condicionado por diversas edificaciones existentes.

Tanto las manzanas triangulares como las otras dos macromanzanas rectangulares disponen de vías de penetración que arrancan de los ejes viarios perimetrales. De estas vías de penetración arrancan otras perpendiculares sin salida con bolsas de aparcamientos. No existe ninguna calle que atraviese completamente, de lado a lado, el interior de las macromanzanas, a excepción de la calle Yecla.

En las dos macromanzanas rectangulares, menos condicionadas por las preexistencias, se recupera el eje peatonal central de dirección este-oeste del plan de 1956, transformado ahora en eje lineal verde que discurre a lo largo de la actual calle Campoamor.

El eje central peatonal divide el espacio interior de las macromanzanas en dos franjas (de Paseo al Mar a Campoamor y de ésta a Santos Justo y Pastor). Cada una de esas dos mitades queda dividida a su vez en dos por los los viales de penetración desde los ejes perimetrales norte-sur.

Así, en la franja entre Paseo al Mar y Campoamor los viales en cul-de-sac que arrancan de Manuel Candela, Músico Ginés y Jose María Haro penetran por las calles Explorador Andrés en una manzana y por la calle L'Alguer en la otra, bordeando el conjunto Isla 
Perdida. Y en la franja entre Campoamor y Santos Justo y Pastor, dichos viales penetran en las macromanzanas por la calle Poeta Más y Ros.

Las vías de penetración desde el este y el oeste a las calles de Explorador Andrés, L'Aguer y Poeta Más y Ros no tienen continuidad a lo largo de dichas calles, sino que están proyectadas como calles sin salida, evitando que atraviesen las macromanzanas. De esta vías de penetración arrancan ortogonalmente otros viales también sin salida destinados a bolsas de aparcamientos.

En cada macromanzana, al menos uno de estos viales ortogonales a las vías de penetración se conecta con alguno de los ejes perimetrales situados a norte o a sur (Paseo al Mar o Santos Justo y Pastor).
$P P$-12. Plano de red viaria fundamental. Detalle de la zona de Paseo al Mar

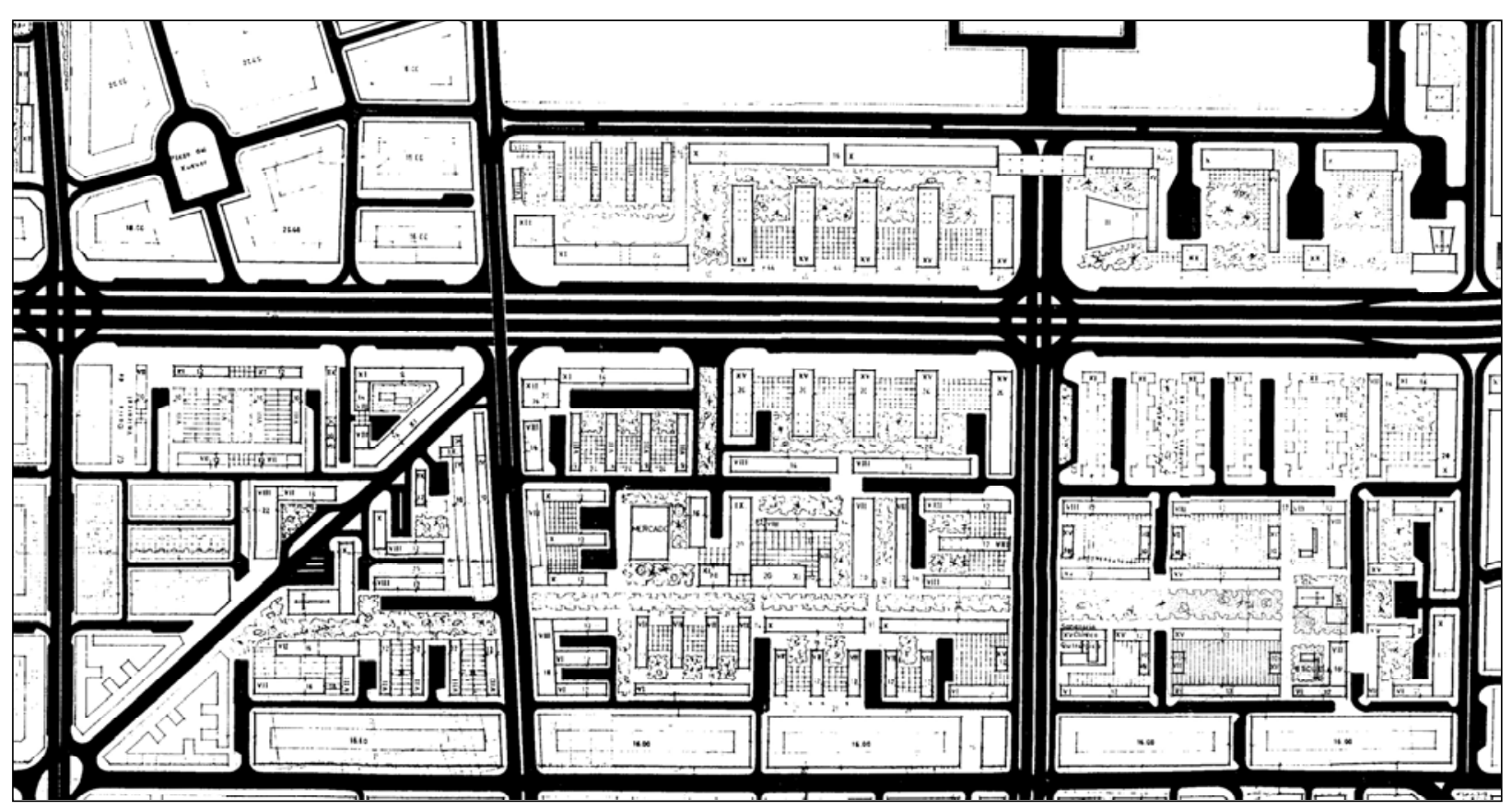




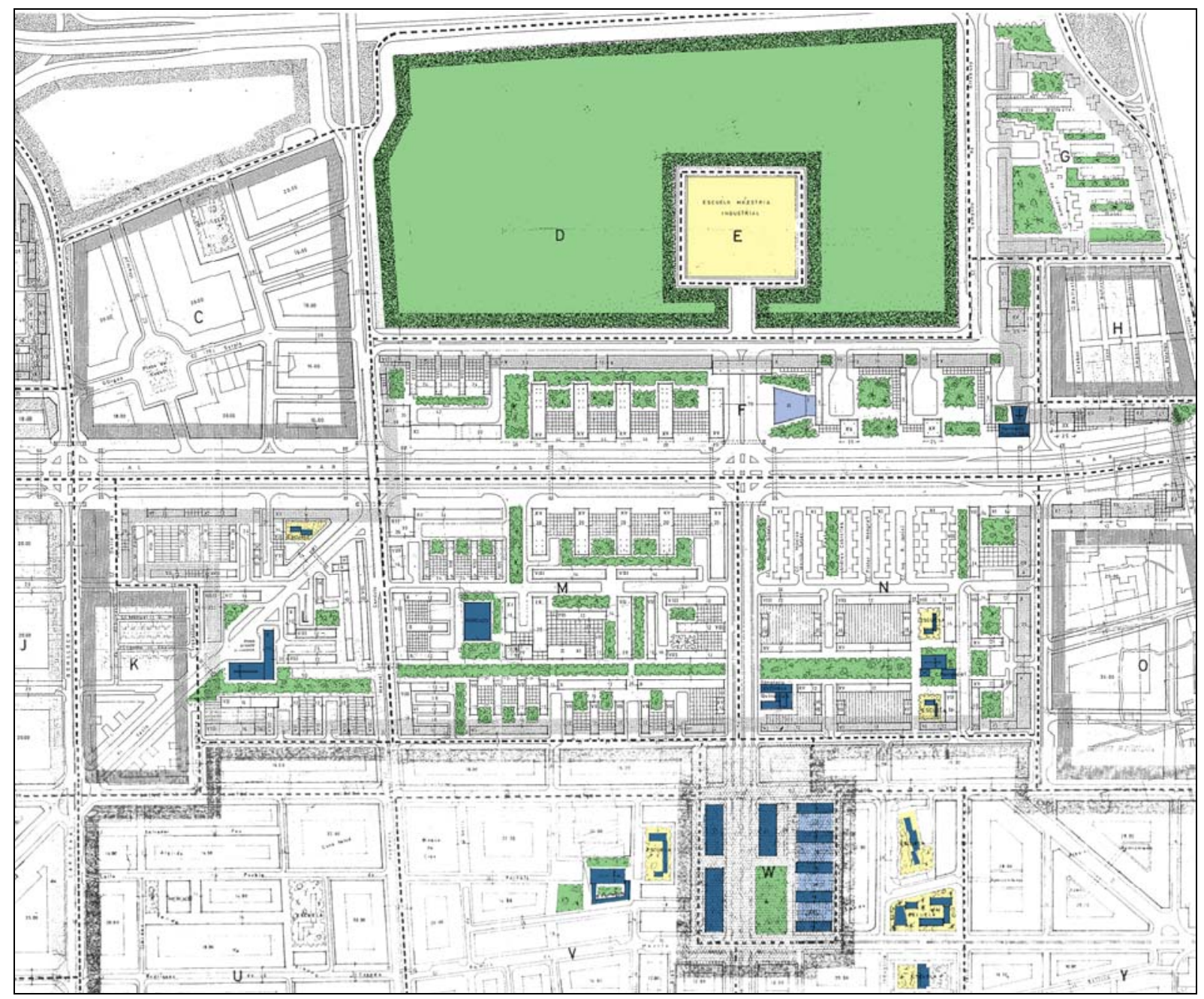

PP-12. Plano de equipamientos. Detalle de la zona de Paseo al Mar

\section{Equipamientos.}

La reserva de suelo para equipamientos en el Plan Parcial 12, tanto en las zonas de edificación abierta como en el plan en su conjunto, es muy escasa. La Memoria incluye la misma frase que se repite en otros Planes Parciales, señalando que en relación con los equipamientos se ha utilizado un criterio de prudencia, evitando señalar en plano más elementos que los que se prevé que el Ayuntamiento pueda construir, o cuyo suelo pueda al menos adquirir, a fin de evitar el recobro del libre ejercicio de las facultades dominicales, establecido en el art. 56 de la Ley del Suelo.

Aparte de los espacios verdes entre bloques, no existen equipamientos de ningún tipo en las zonas de edificación abierta de la Avenida de Aragón y de la Avenida de Cataluña/Rubén Darío.

En la zona de edificación abierta del Paseo al Mar, el eje verde este-oeste, a lo largo de la calle Campoamor, aglutina diversos equipamientos, tales como un centro religioso en el extremo oeste, junto a la calle Yecla, un mercado a la altura de la actual Plaza del Cedro, un centro médico en el cruce con la calle Músico Ginés, y un conjunto de escuelas y centro religioso en el extremo este. 
Además del eje de la calle Campoamor, el único conjunto de equipamientos previsto en el PP12 de cierta entidad e integrado en las áreas residenciales es el formado por el centro comercial de Ayora, cerca del cual, y ya dentro de la zona de Extensión Exterior a Tránsitos, se prevén diversas parcelas para uso escolar y religioso.

Aparte de estos dos núcleos, las reservas de suelo que se prevén en las zonas de edificación abierta del PP12 son, además de los espacios verdes intermedios entre bloques, dos edificios en el Paseo al Mar (para uso comercial y religioso respectivamente) y una gran bolsa situada al norte, constituida por la parcela destinada a Escuela de Maestría Industrial y por la inmensa zona verde que la rodea.

Esta extensa bolsa, por su localización exterior con respecto a las zonas edificadas, no podía asumir ningún papel efectivo como reserva de dotaciones. Llamar zona verde a un espacio de estas características equivale a llamar zona verde a la huerta. De hecho, la Memoria del Plan Parcial 12 remite a esta gran bolsa de equipamientos para justificar el cumplimiento de las reservas de suelo necesarias para escuelas y zonas verdes.

En concreto, la Memoria señala lo siguiente:

La superficie de espacios libres es de $210.447 \mathrm{~m} 2 . \sin$ contar el enorme espacio destinado a escuela de Maestría Industrial que es de $342.350 \mathrm{~m} 2$, lo que supera con mucho el $10 \%$ de la superficie total del plano.

La población escolar. Incluidos maternales, es del $15 \%$ de la población, o sea, 32.196 alumnos, lo que a razón de $6 \mathrm{~m} 2$. por alumno se necesitaría una superficie de $193.179 \mathrm{~m} 2$. La superficie prevista en el plano es de $75.052 \mathrm{~m} 2$ sin contar la gran superficie que se destina a escuela de Maestría Industrial. En la parte nueva del plan se ha dotado todas las manzanas su correspondiente espacio escolar, y se han aprovechado de la parte construida del mismo los espacios libres donde se pudieran ubicar alguna obra con lo previsto nuevo, y los edificios escolares ya en funcionamiento, sitos en la parte construida del plan parcial, se rebasara con mucho las necesidades. ${ }^{1}$

Podemos ver, por tanto, que, como ocurrirá en otros planes parciales, la reserva prevista de suelo para escuelas es incluso inferior a la que resulta de los propios cálculos contenidos en la Memoria del Plan Parcial 12. 


\section{Edificación}

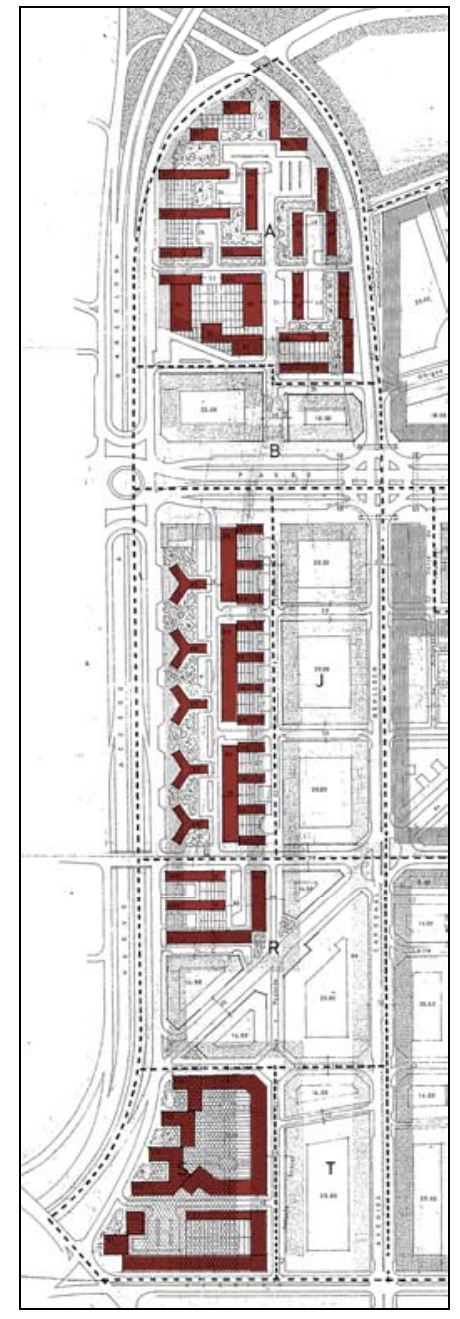

Plan Parcial 12. Plano de edificación en planta tipo. Detalle de la zona oeste (Elaboración propia, color sobre plano de alineaciones del plan).
La edificación abierta en el Plan Parcial 12 está compuesta principalmente por bloques lineales, con alturas que oscilan entre las VII y las XV plantas y longitud entre 30 y $150 \mathrm{~m}$.

Los bloques lineales pueden agruparse en dos categorías principales: bloques de poca profundidad (9, 10, 12 y $14 \mathrm{~m})$, aptos para albergar viviendas pasantes, y bloques profundos (de anchos $16,18,20,24$ y hasta $30 \mathrm{~m}$ ), que implican patios de luces interiores o abiertos a calle.

Los bloques lineales están siempre dispuestos en paralelo o en perpendicular a la malla viaria estructural de la zona, que tiene como eje principal en dirección este-oeste al Paseo al Mar.

Un caso particular de bloque es lo que podemos denominar bloque articulado o unión de bloques, que se forma cuando se yuxtaponen varios bloques lineales de orientaciones diferentes, formando una L o una U.

Además de los bloques lineales, se proyectan en el Paseo al Mar algunas torres de $25 \times 25 \mathrm{~m}$. y XX plantas y, en el frente a la Avenida de Aragón, unas torres con planta en patte de poule de XV alturas, que podrían considerarse también como un caso particular de bloque articulado.

Los bloques lineales tienen en el Plan Parcial 12 dos formas muy diferentes de encontrarse con el suelo, es decir, dos formas de edificación en planta baja. La primera de ellas es la canónica de la doctrina funcionalista: la planta baja es idéntica a la planta tipo, y en teoría debería destinarse también a viviendas, como las plantas superiores, aunque su uso más habitual es en Valencia el de locales comerciales.

La segunda forma de asentar los bloques de edificación abierta en el suelo es la propia de la manzana mixta, con un basamento o cuerpo de edificación de una o dos plantas destinado por lo general a usos comerciales y cuya superficie y perímetro son diferentes a los de los bloques de edificación situados sobre el mismo.

A su vez, dentro de la manzana mixta, podemos diferenciar dos tipos:

a) Planta baja que envuelve los bloques: Manzanas en las que el zócalo comercial forma un rectángulo edificado en su totalidad sobre el que se asientan los bloques de edificación abierta. Es un tipo funcionalmente igual al de las manzanas de ensanche, con la única diferencia de que la edificación en planta tipo no es una edificación perimetral continua, sino una edificación discontinua. El plano de edificación en planta baja es idéntico para una manzana tradicional y para una manzana de este tipo, y es imposible con ese plano obtener información alguna sobre los bloques de edificación abierta de la planta tipo.

b) Planta baja que enlaza los bloques: Manzanas en las que el zócalo comercial es un cuerpo de edificación que enlaza en 
planta baja los bloques, pero sin superar el perímetro de los mismos. El espacio entre los bloques queda, por tanto, parcialmente edificado y parcialmente libre. En el plano de edificación en planta baja los bloques se pueden identificar claramente, y la lectura en planta baja del espacio libre que queda entre los bloques enlazados es similar a la que ofrecería una edificación a redents.

En el plano elaborado de edificación en planta baja se pueden observar los dos tipos de ocupación de suelo señalados: la edificación abierta aislada, en forma de torre o de bloque, que puede ser ser lineal o articulado (en $L$ o U), y los dos tipos de manzana híbrida señalados, con basamento envolvente o de enlace entre bloques.

Además, si observamos conjuntamente los planos de edificación en planta baja y en planta tipo, podemos identificar para la edificación abierta del Plan Parcial 12 tres sistemas de composición o "frases urbanas" ${ }^{1}$ diferentes, con los cuales se proyecta la práctica totalidad del área. Estos sistemas de composición son los siguientes:

1) Sistema pantalla-testeros: Unidad de composición urbana formada por un espacio verde lineal interior al que recaen por un lado un bloque lineal (pantalla) y por el otro una serie de bloques en perpendicular (testeros) enlazados por un basamento edificado en planta baja.

2) Sistema de bloques envolventes: Unidad de composición urbana formada por bloques lineales dispuestos en $\mathrm{L} \circ \mathrm{U}$ que rodean un espacio libre. Equivale a una manzana cerrada con espacio libre interior en la que la edificación perimetral es discontinua y el espacio libre interior es público.

3) Sistema de manzana edificada: Manzana híbrida con planta baja que envuelve los bloques.

En el sistema de bloques envolventes, los bloques pueden envolver en mayor o menor grado el espacio público central. Dos bloques formando una $L$ pueden considerarse como el caso límite de este sistema compositivo.

Los sistemas 2 y 3 son formas de recomponer la manzana con edificación abierta, en el primero disponiendo los bloques de modo que separen un espacio exterior y otro interior y en el segundo edificando completamente la planta baja, de modo que todo el espacio es exterior.

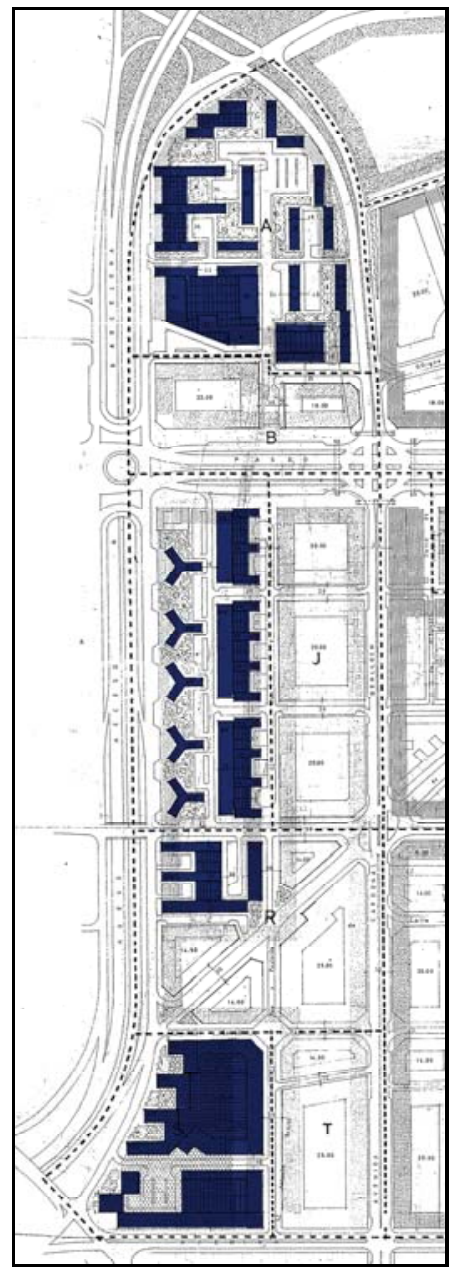

Plan Parcial 12. Plano de edificación en planta baja. Detalle de la zona oeste (Elaboración propia, color sobre plano de alineaciones del plan).

1. Hemos tomado prestado el término "frase urbana" de Serra i Riera, Enric, "Prototipus singulars d'arquitectura residencial del Moviment Modern i temptatives de compromís urbanístic", en VV.AA., Ciutat funcional y morfologia urbana, Edicions UPC, Barcelona, 1994. 

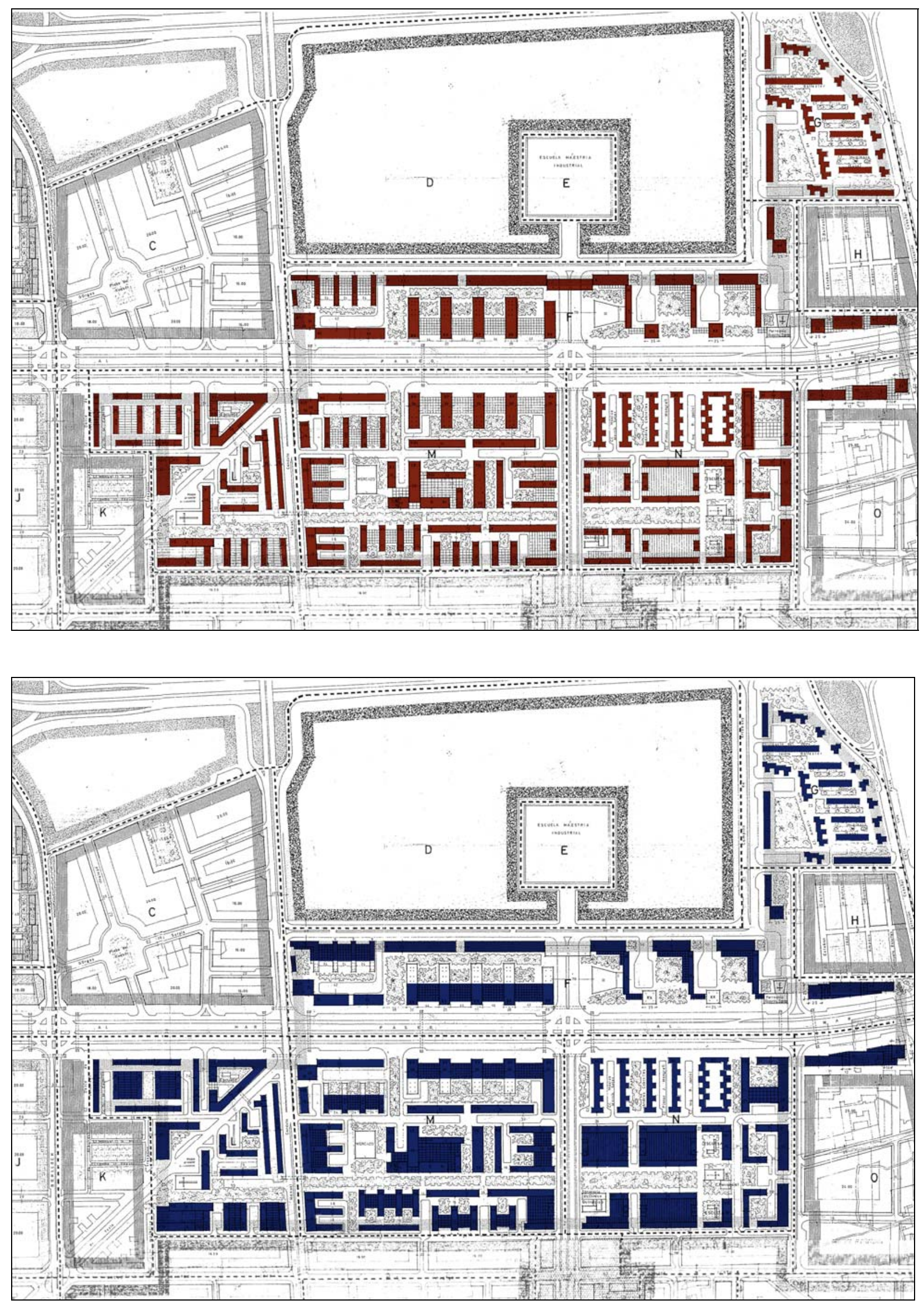
El sistema 1, en cambio, es más ambiguo. El espacio interior es aquí un paseo peatonal ajardinado, al que se abren los espacios libres que existen entre los bloques perpendiculares. Es precisamente el carácter lineal que tiene el paseo ajardinado, lo que dificulta su lectura como "interior": no es un espacio envuelto, sino lineal, una calle peatonal.

En el Plan Parcial 12, el sistema pantalla-testeros aparece principalmente en las macromanzanas comprendidas entre las calles Manuel Candela y Músico Ginés, tanto a uno como al otro lado de Paseo al Mar.

Se puede observar también una voluntad de alternar la posición del bloque lineal del lado sur al lado norte de la unidad urbana, de modo que a lo largo de una calle, como ocurre en Paseo al Mar, en Explorador Andrés, en Campoamor y en Poeta Más y Ros, aparezcan series alternadas de bloques alineados con la calle y bloques en perpendicular a la misma.

En las macromanzanas comprendidas entre Músico Ginés y José María Haro, en cambio, podemos encontrar manzanas con planta baja completamente edificada, como las cuatro recayentes a Campoamor, entre las calles Músico Ginés e Ingeniero Rafael Janini, y bloques envolviendo un espacio público, como los que ocupan el espacio entre el final de Campoamor y Serrería y los que, en el lado norte de Paseo al Mar, forman una serie de tres bloques en $L$ rematados por torres recayentes al Paseo.

\section{Página opuesta:}

Plan Parcial 12. Plano de edificación en planta tipo y en planta baja. Detalle de la zona este (Paseo al Mar).
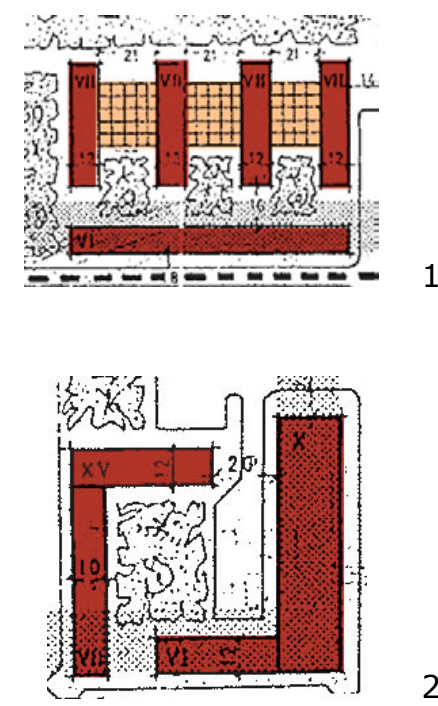

2

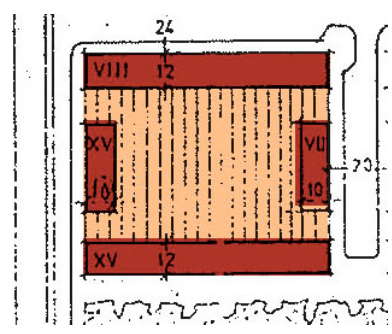




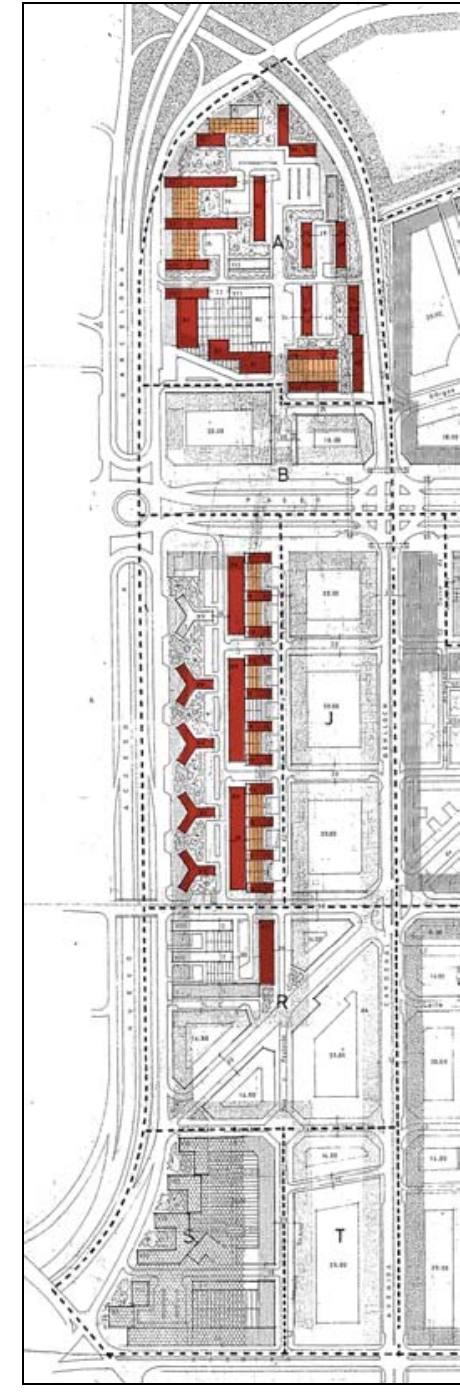

PP-12. Grado de realización. Zona oeste
1.La zona más atrasada en cuanto a edificación en el segundo tramo del Paseo al Mar es la limitada por la calle Campoamor al norte, Músico Ginés al este, Poeta Más y Ros al Sur e Impresor Lambert Palmari al oeste. Es una zona ocupada por un conjunto de casas pareadas dispuestas a los lados de la calle José de Orga, que taponan la apertura de la calle Campoamor hasta Musico rinón

\section{Grado de realización.}

El grado de realización de la edificación abierta del Plan Parcial 12 ha sido muy alto. Puede decirse que la imagen global de la zona es hoy sustancialmente la prevista en el plan, de que quedaron sin ejecutar unas pocas manzanas en la zona de Paseo al Mar, algunos bloques aislados y la parte sur de la zona de la Avenida de Aragón, que incluía un centro comercial.

En la Cartografía Municipal de 1983 las zonas de edificación abierta correspondientes a este plan muestran un grado de realización desigual, ya que junto a sectores con un grado de consolidación relativamente alto hay otros apenas iniciados.

Así, en la zona de Avenida de Cataluña/Rubén Darío, la mitad oeste es la que aparece más consolidada. En la zona de edificación abierta de la Avenida de Aragón, que muestra un grado de consolidación medio, esta cartografía permite apreciar un curioso detalle: la manzana situada entre las calles Ernesto Ferrer y Eolo se halla urbanizada, con unos solares preparados para los bloques lineales previstos para la misma en el Plan Parcial 12, que finalmente no llegarían a realizarse, como veremos más adelante. El encontrar una zona urbanizada con antelación a su edificación resulta insólito y excepcional en este momento del desarrollo urbano de Valencia, ya que lo habitual era lo contrario, una deficiente urbanización como consecuencia del pobre sistema de gestión previsto en los planes parciales, basado en la cesión de viales.

En los dos primeros tramos de la zona del Paseo al Mar, comprendidos entre los ejes viarios de Cardenal Benlloch y Manuel Candela y entre éste y Músico Ginés, respectivamente, el grado de realización de la edificación abierta que muestra la Cartografía Municipal es bastante alto, aunque la urbanización aparece claramente retrasada en el segundo. De hecho, la urbanización de la prolongación del Paseo al Mar (actual Avenida de Blasco Ibáñez) se producirá en los años ochenta, cuando ya están realizados la mayor parte de los edificios que flanquean este importante eje viario. ${ }^{1}$

Los dos tramos restantes de la zona del Paseo al Mar muestran en la Cartografía Municipal un grado de realización menor, tanto en la edificación como en la urbanización, ya que subsiste todavía el Camino de Algirós y los terrenos agrícolas adyacentes al mismo.

El Plan Parcial 12 fue reformado mediante un P.E.R.I. redactado en 1982, cuyas determinaciones, aunque anuladas por sentencia judicial, fueron posteriormente recogidas en el nuevo Plan General de Ordenación Urbana de Valencia de 1988.

En la zona correspondiente al Plan Parcial 12, las principales modificaciones que introduce el PGOU de 1986 afectan a los espacios destinados a equipamientos. 


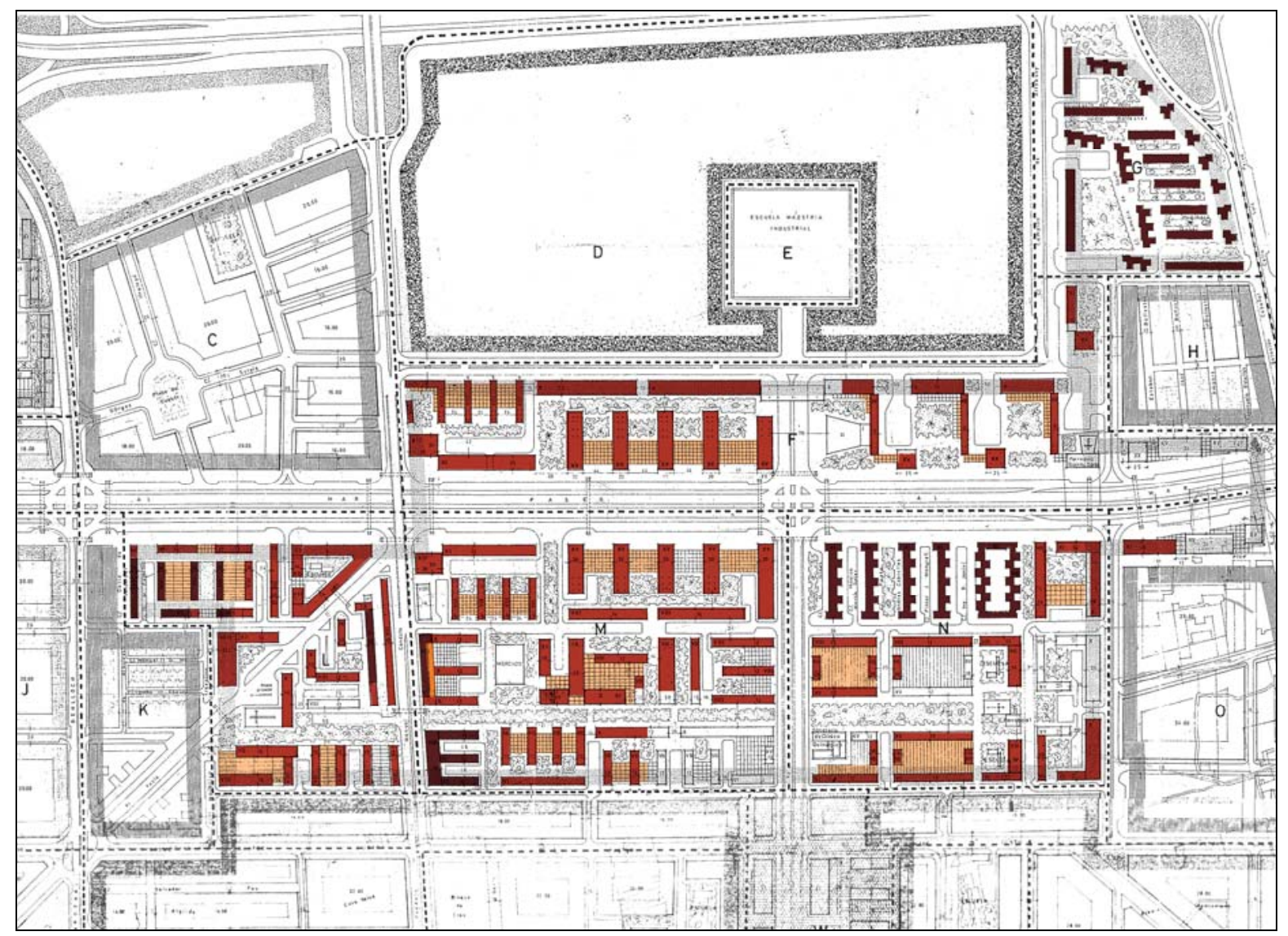

El nuevo Plan General intenta aprovechar cualquier espacio no edificado disponible entre los bloques para insertar parcelas dotacionales, introduciendo como consecuencia de ello modificaciones en la edificación abierta prevista en el Plan Parcial 12.

Algunas de estas modificaciones que merecen destacarse son la la remodelación del eje de la calle Campoamor ${ }^{1}$, intercalando parcelas para equipamientos y zonas verdes en todos los espacios vacantes disponibles, y la supresión de los dos centros comerciales previstos de Aragón y Ayora. En el espacio destinado a éste último, se preserva el histórico Jardín de Ayora y su palacete y se reserva espacio para la ampliación del mismo.

En cuanto al viario, las necesidades de obtener un mayor espacio para aparcamientos y de favorecer una mejor interconexión urbana, unidos al intento de recomponer la manzana, considerada como elemento básico de los tejidos urbanos, desmontaron progresivamente el sistema segregado de trazados rodados ramificados y calles peatonales previsto en el Plan Parcial 12. El trazado mallado convencional se impone pues en el PGOU de 1988, aunque a veces genera ciertas incongruencias con respecto a la edificación abierta, como la que se produce cuando un bloque lineal de poca profundidad queda rodeado de calles por sus cuatro lados.

PP-12. Grado de realización. Zona de Paseo al Mar.
1. En el encuentro de la calle Campoamor con la calle Yecla se prevé, además del edificio público previsto en el PP12, una nueva parcela escolar (actual CP Mestalla); el mercado previsto para la Plaza del Cedro se suprime, y la plaza queda convertida en zona verde; en el tramo entre las calles Impresor Lambert y Músico Ginés se elimina la edificación prevista, dejando únicamente un bloque profundo recayente a la segunda calle y destinando el espacio restante a parcela escolar; igualmente, en el tramo entre Músico Ginés y José María Haro, el espacio que ocupaban los bloques no realizados entre las calles Explorador Andrés y José María Haro se destina a ampliar las parcelas dotacionales previstas en el PP12 y a crear otras nuevas. 
Página opuesta:

Arriba:

Cartografía Municipal 1983. Zona este del PP-12.

Abajo:

PGOU Valencia, 1988. Zona del Paseo al Mar del PP-12.

Zona oeste del PP-12. Cartografía Municipal, 1983.y PGOU 1988.
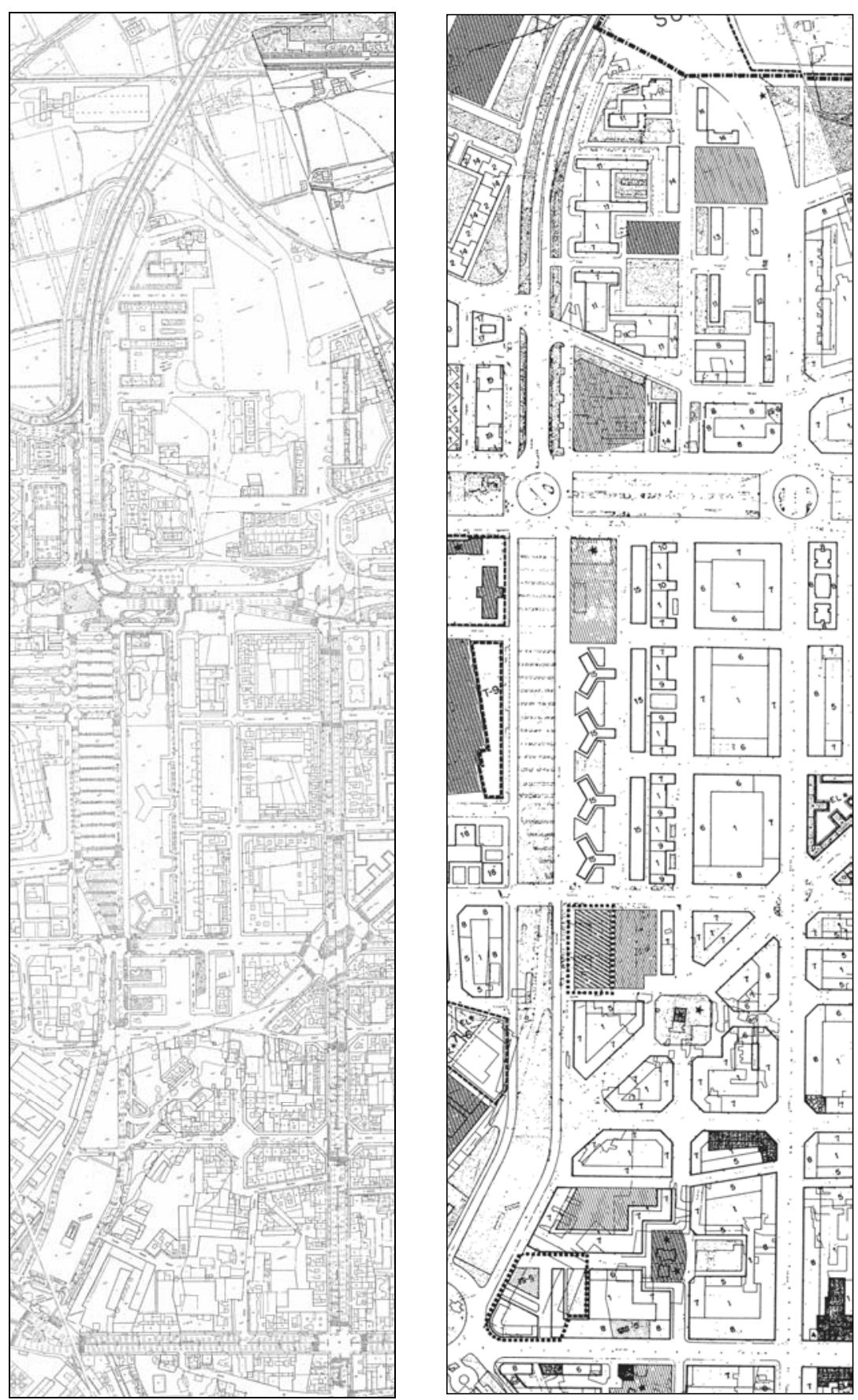

Es importante señalar que en el PP12 los bloques de edificación abierta realizados no siempre son edificios construidos de una sola vez, como una promoción unitaria, sino que en muchos casos, en especial en los bloques más largos y profundos, se produce un fraccionamiento del bloque lineal, un troceado del mismo en varias promociones entre medianeras. La edificación entre medianeras, que era la propia del ensanche, se extrapola como procedimiento operativo a la edificación abierta. 

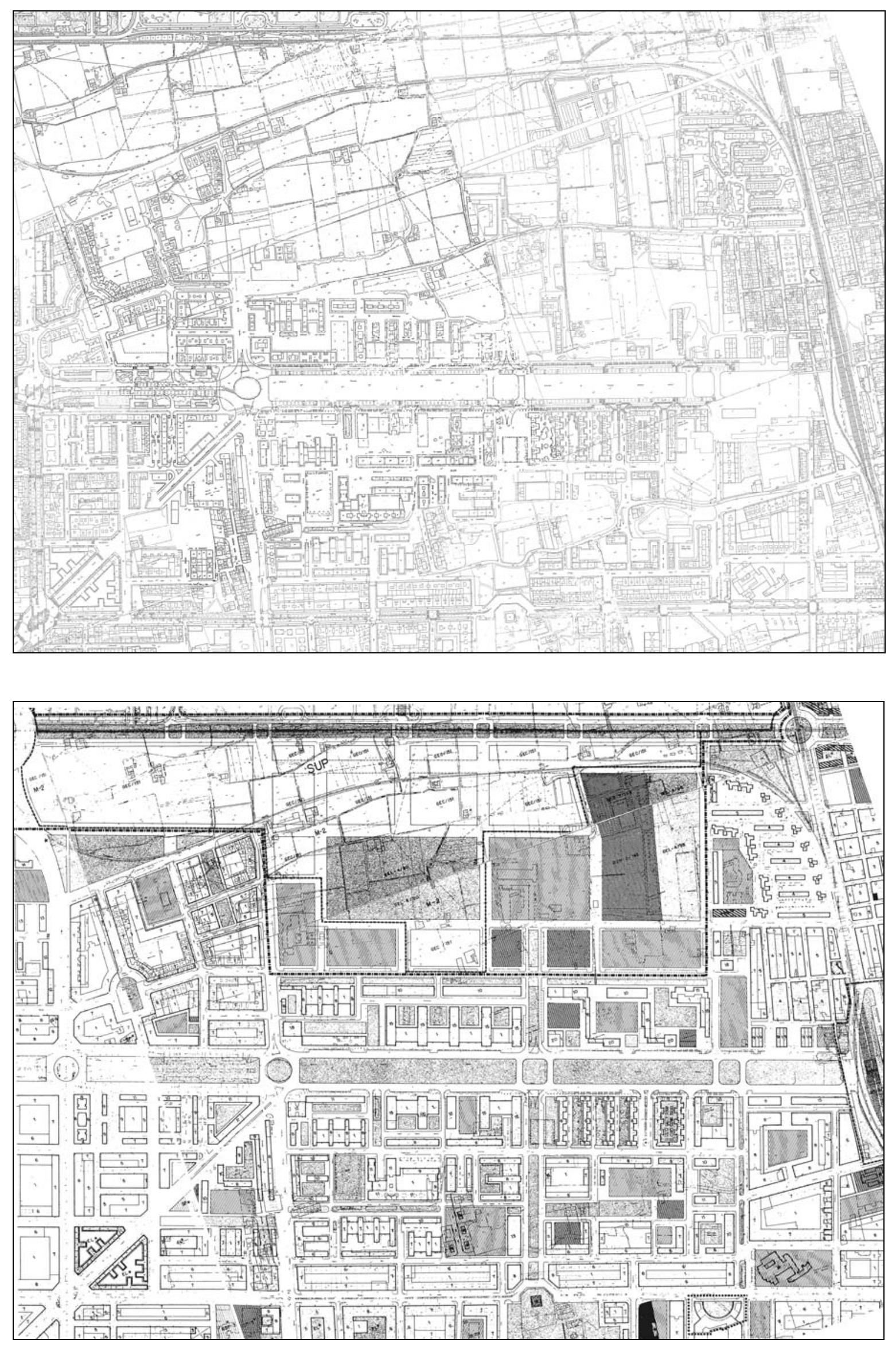


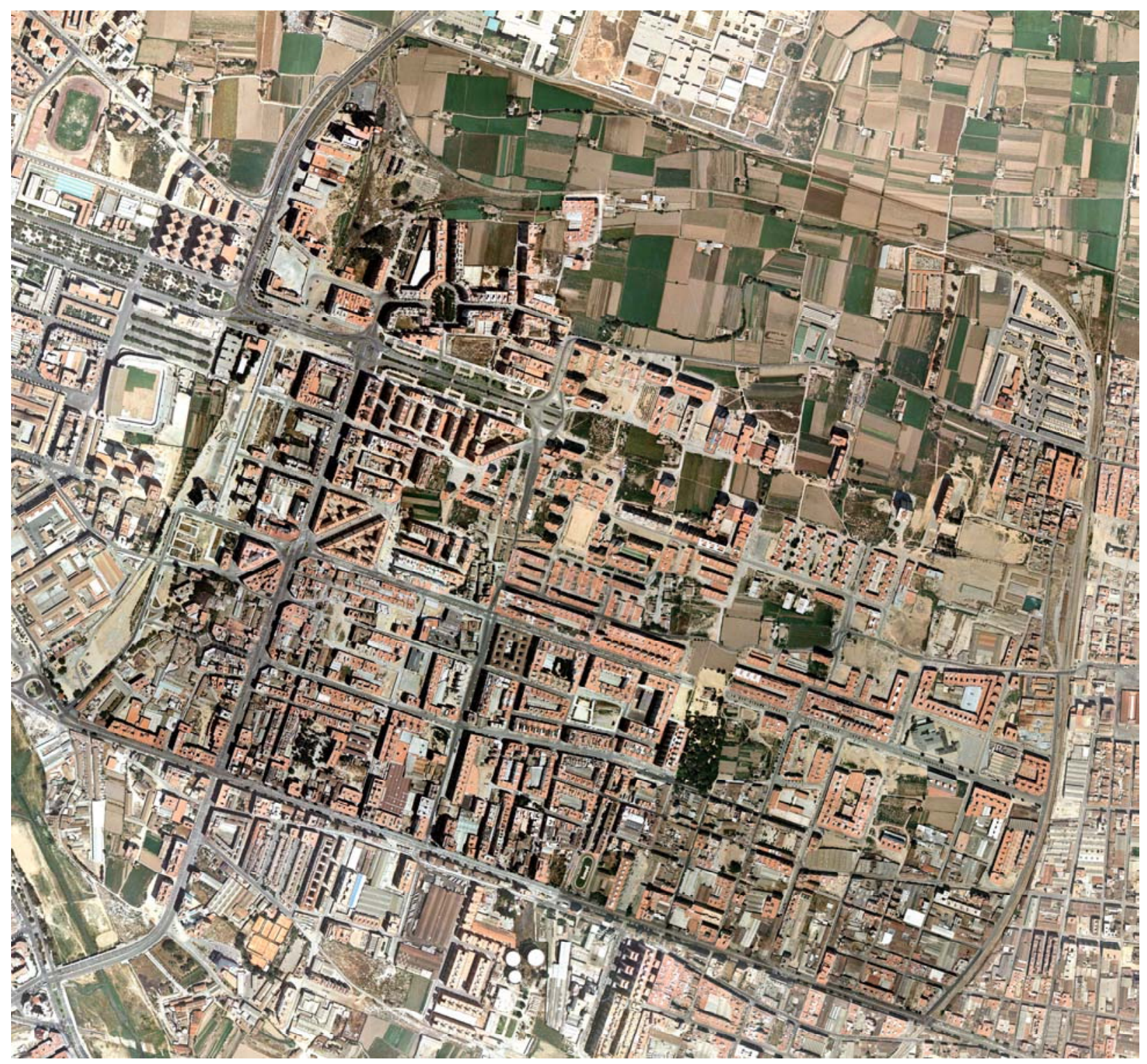

Zona del Plan Parcial 12. Fotografía aérea, 1980 (AUMSA). 


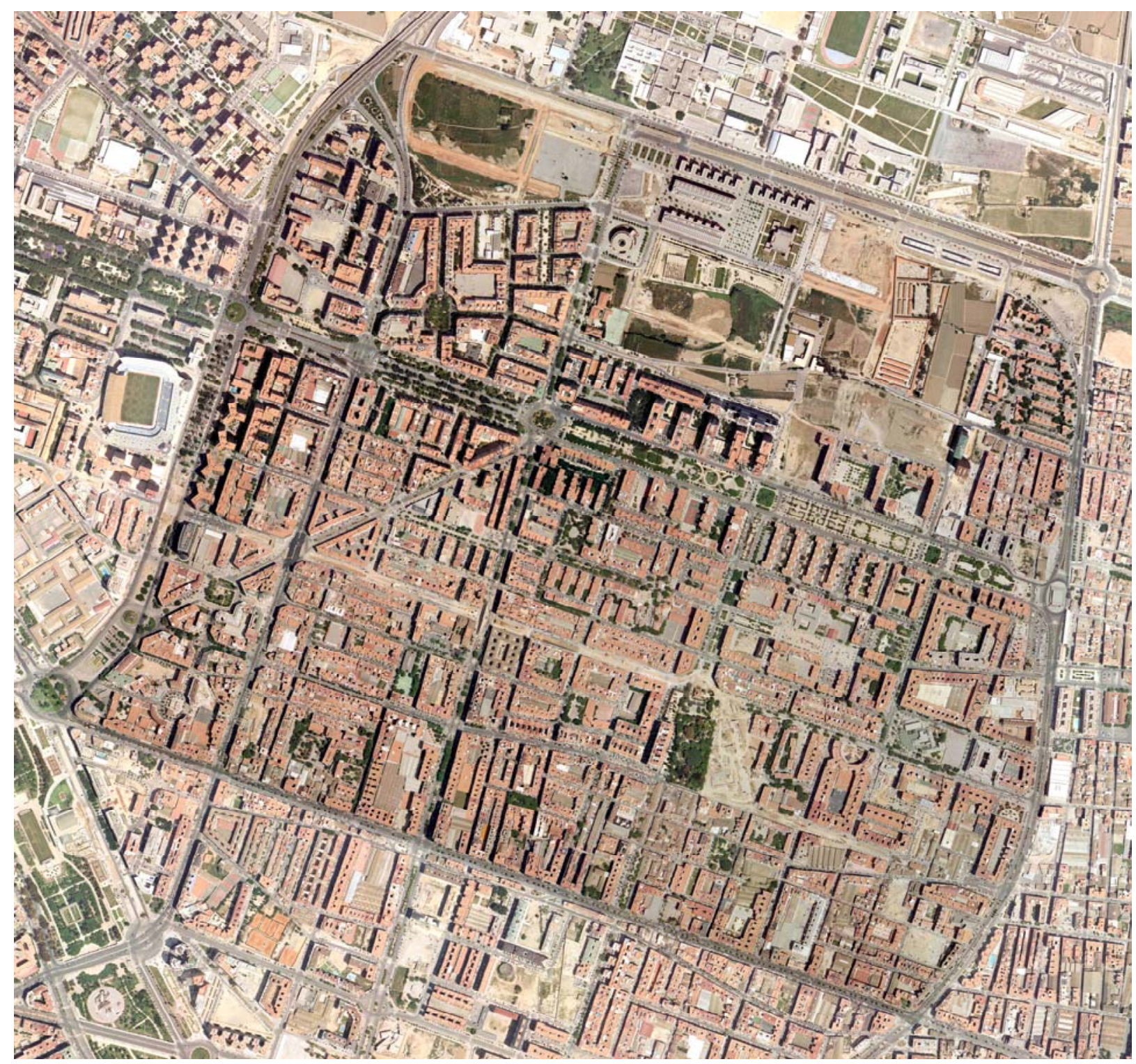

Zona del Plan Parcial 12. Ortofoto 2002. (AUMSA). 

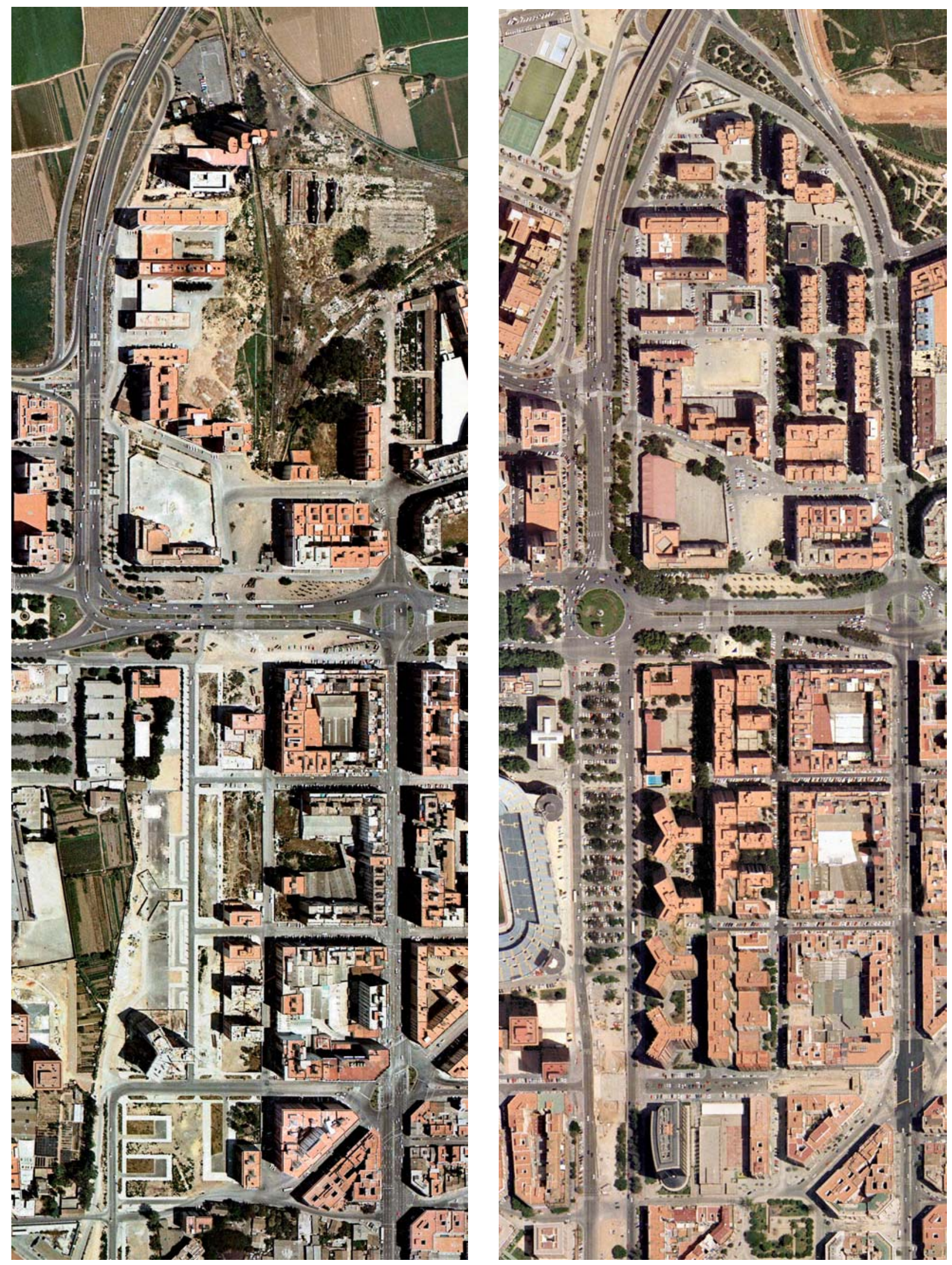

Zonas de edificación abierta del PP12: Avenida de Cataluña/Rubén Darío y Avenida de Aragón. Fotografías aéreas de 1980 y 2002. 


\section{Un recorrido actual por las áreas de edificación abierta de Plan Parcial 12.}

Los bloques lineales situados en la zona de Avenida Cataluña/Rubén Darío, cuyas características en planta hemos analizado en el apartado anterior, han sido construidos en su mayor parte como bloques completos, aunque muy heterogéneos entre sí en cuanto a su arquitectura. La edificación prevista en la zona está ya realizada en su totalidad, excepto un bloque alto previsto junto al colegio El Pilar en el PGOU de 1988. En el centro de la zona, la Ortofoto de 2002 permite apreciar un área sin urbanizar que corresponde a una zona verde todavía sin ejecutar.

El frente a la Avenida de Cataluña está formado por una serie de cuatro bloques ortogonales a dicha Avenida, enlazados por bajos comerciales en los que no hay una orientación preferente de los accesos a los locales comerciales. Dos de los bloques son de XI plantas, y los otros dos de VII, lo que resta fuerza al conjunto como alzado unitario.
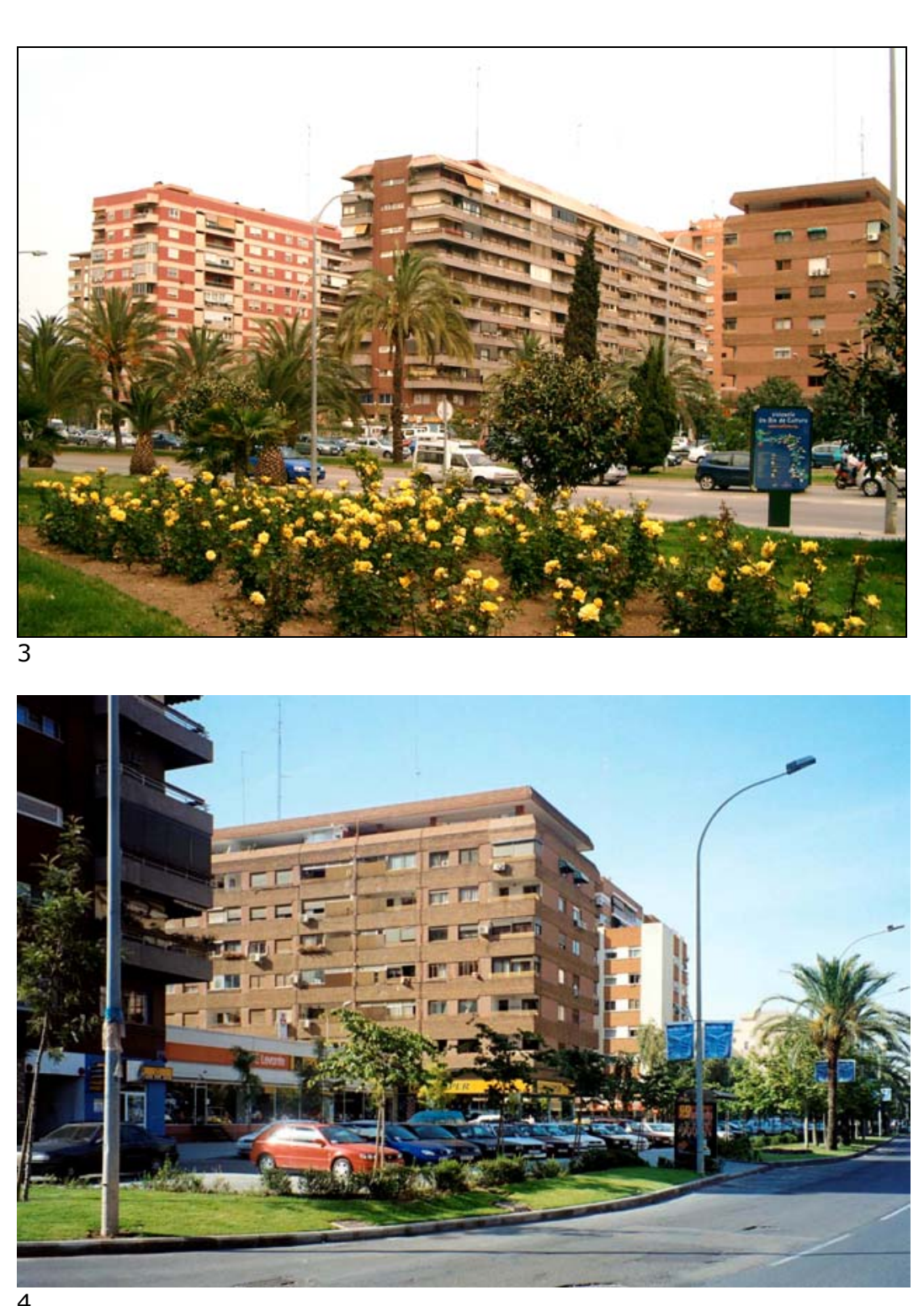

4
3

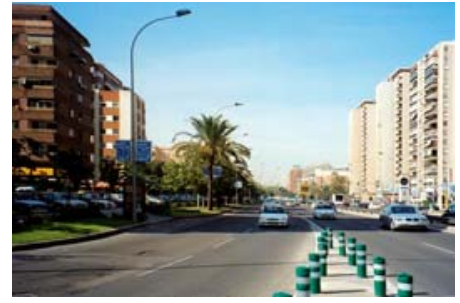

1

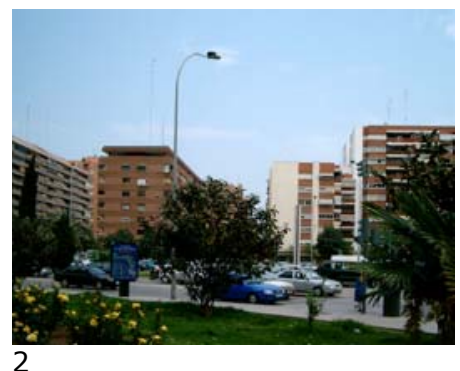

1. Avenida de Cataluña, vista hacia Paseo al Mar.

2,3,4. Edificación abierta en el lado este de la Avenida de Cataluña, 


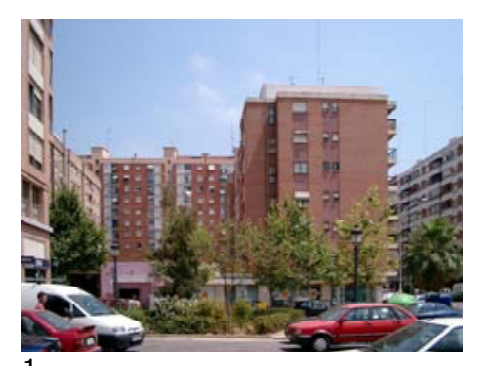

1

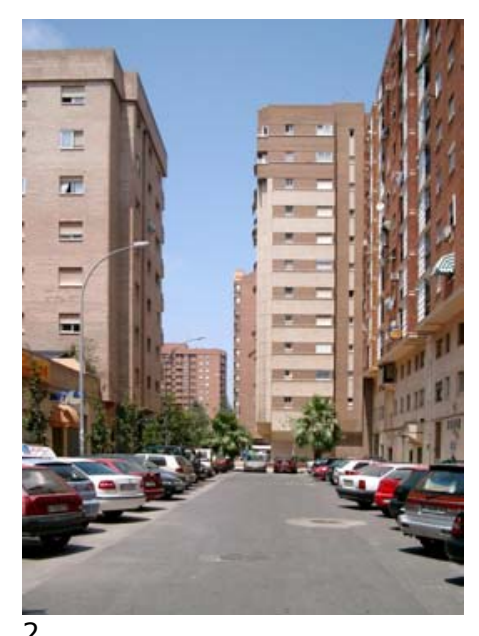

$\overline{2}$

El vértice norte de la zona está ocupado por tres bloques de formas diversas: un bloque corto al oeste, otro en $L$ al este $y$ un tercero en el centro con volúmenes articulados de proporciones muy verticales, correspondiente al Colegio Mayor Ausias March. La silueta que resulta de la yuxtaposición de estos elementos no resulta del todo incongruente con su emplazamiento.

En la mitad este de la zona la mayoría de los bloques lineales, de XI, XII y XIII plantas, están dispuestos en dirección norte-sur, alineados con las calles Rubén Darío y Clariano y formando frentes casi continuos de edificación a lo largo de dichas calles, en las que se concentran por lo general los accesos a zaguanes y los frentes de los locales comerciales. Por ello, el espacio intermedio entre las dos líneas de bloques aparece ocupado por calles cuyo uso principal es de aparcamiento, ya que las fachadas de las plantas bajas recayentes a este espacio son meras traseras de los bloques.

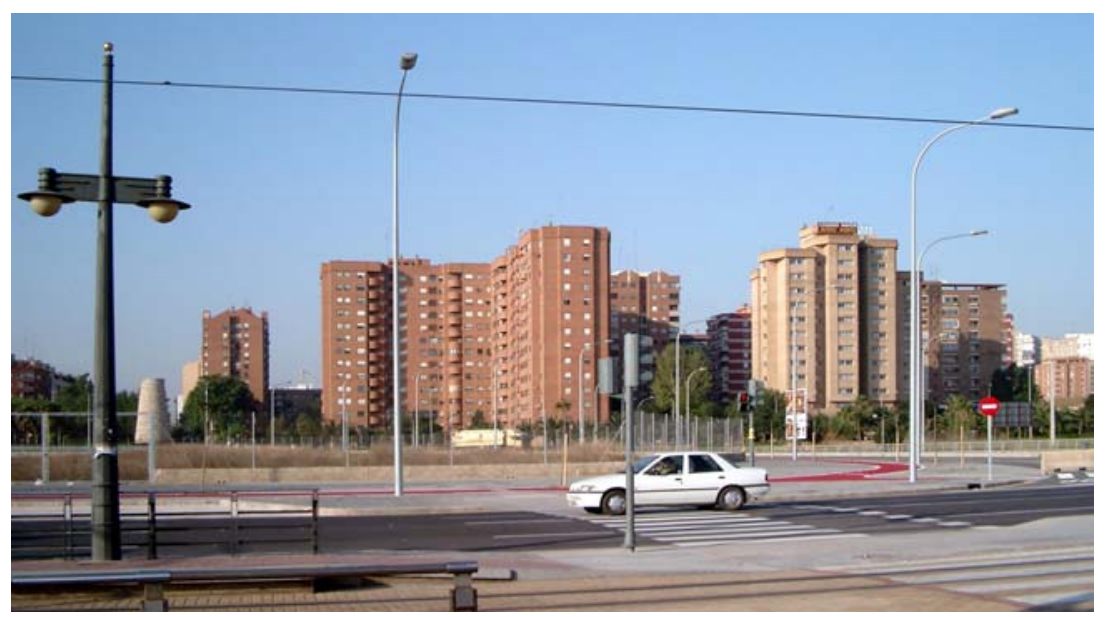

3

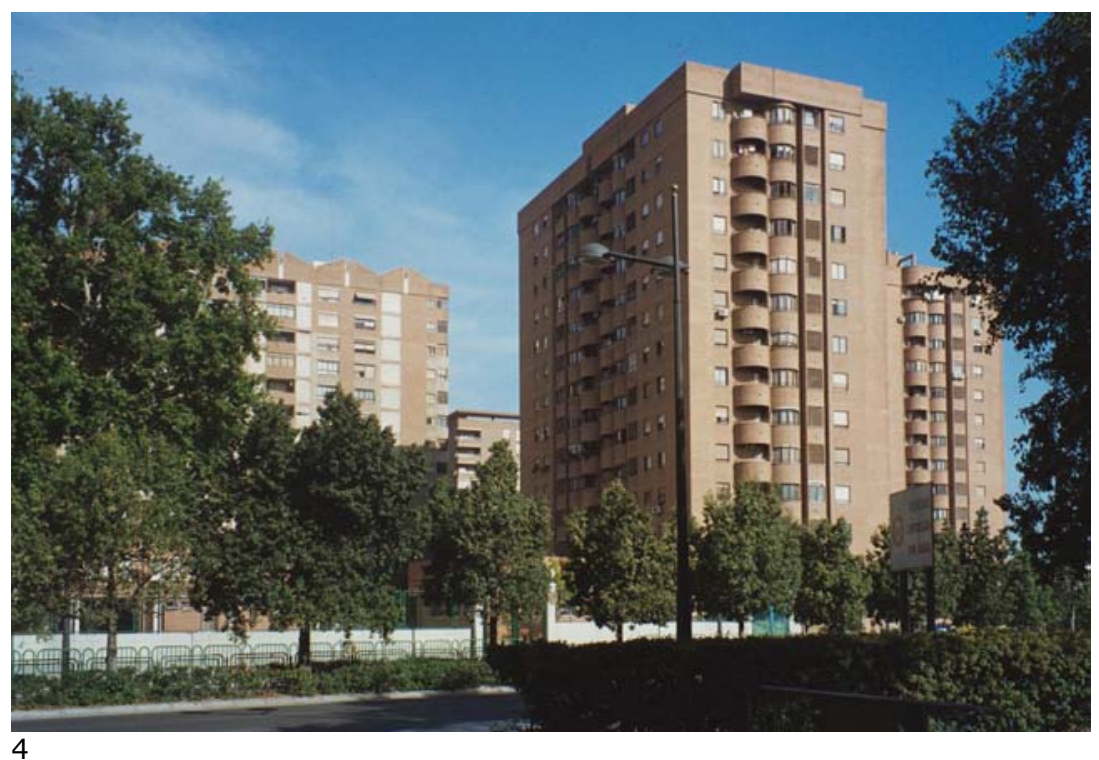




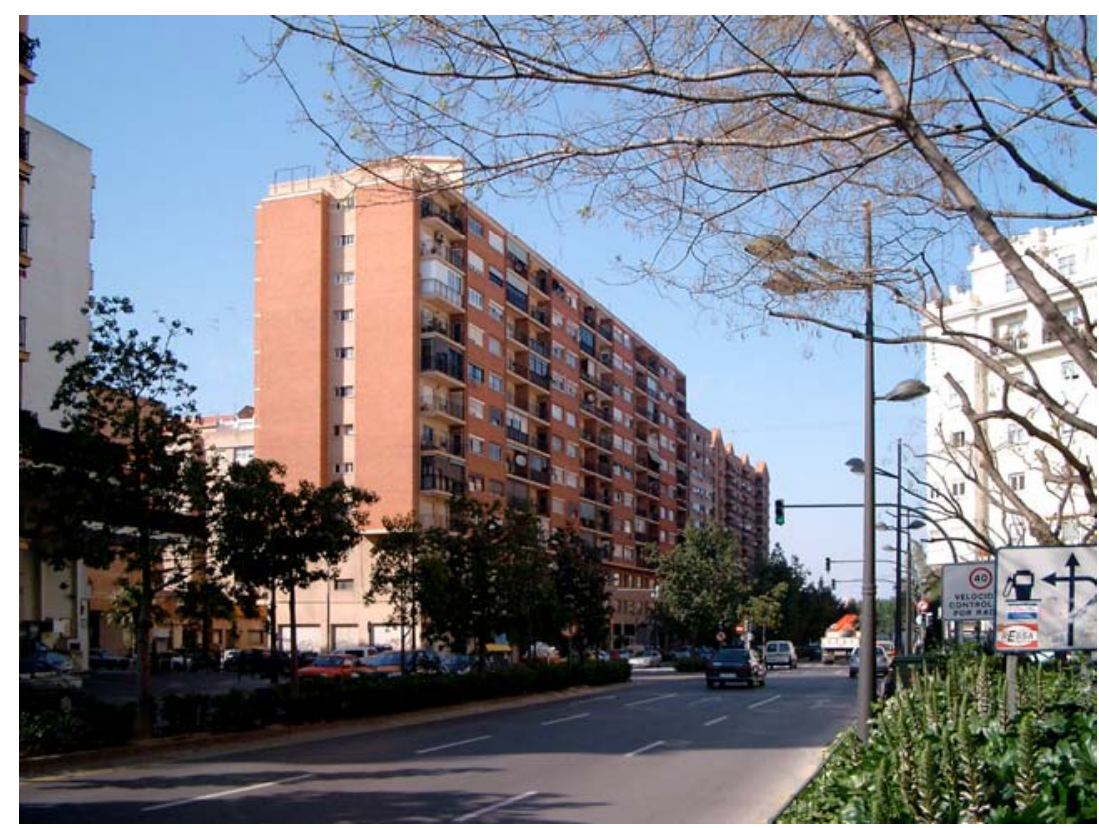

1

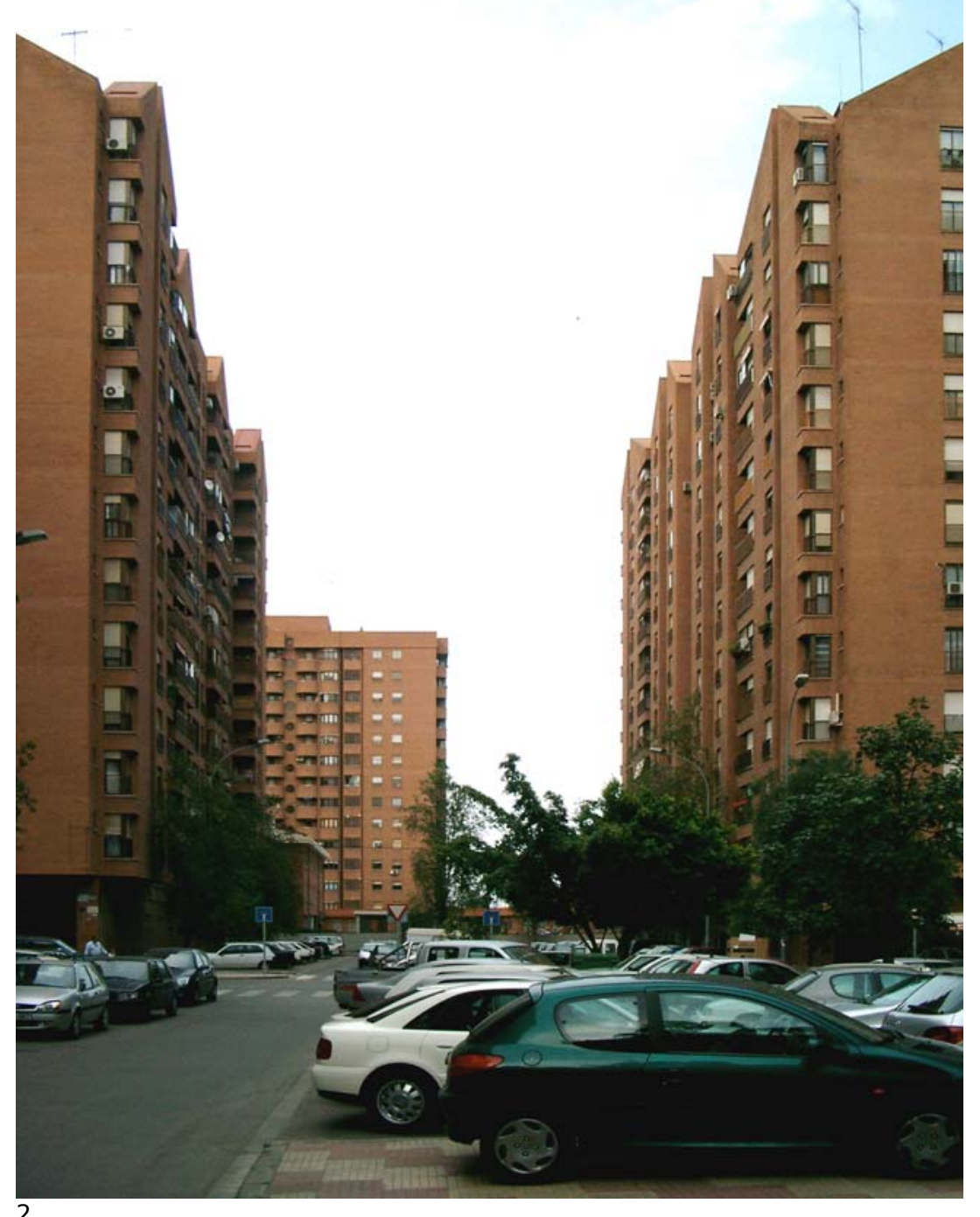

2

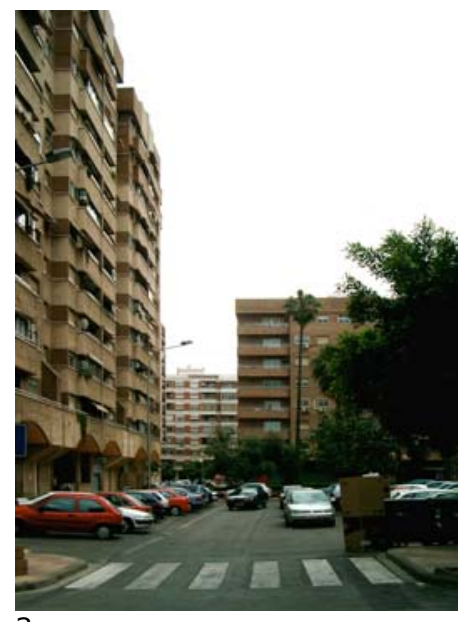

3

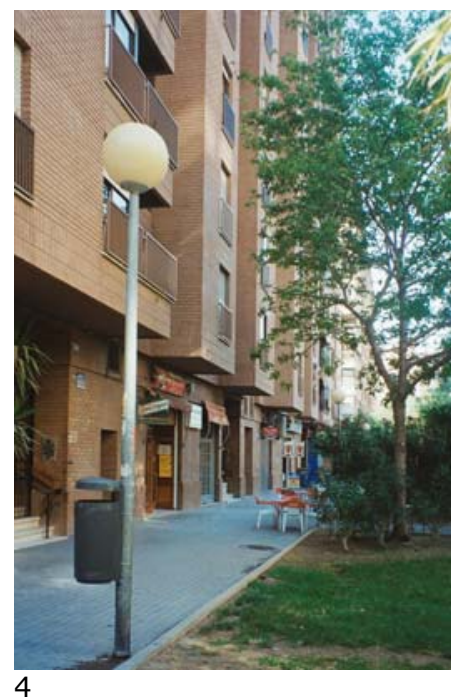

4

1. Bloque lineal en la calle Clariano.

2. Bloques altos en la calle Historiador Claudio Sánchez Albornoz (vista hacia el norte): aplicación de la proporción 1:1 entre distancia entre edificios $y$ altura de los mismos.

3. Bloques altos en la calle Historiador Claudio Sánchez Albornoz (vista hacia el sur).

4. Tramo peatonal de la calle Rubén Darío, junto al Colegio Público García Lorca. 

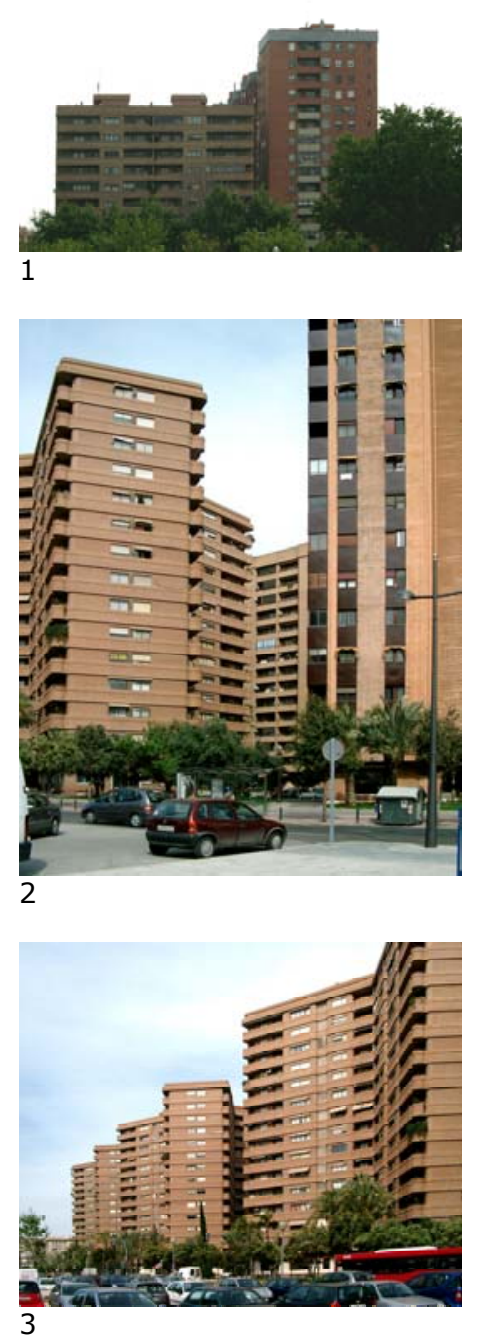

1. Alzado a Paseo al Mar del conjunto edificado entre las calles de Bélgica y Polo y Peyrolón.

2,3,4. Vistas de las torres en "patte de poule" de la Avenida de Aragón.

5. Bloque profundo de XV plantas detrás del colegio Guadalaviar.

En la zona de la Avenida de Aragón, la serie de torres en patte de poule que ocupa la primera línea de edificación de la Avenida muestra hasta que punto es posible degradar una idea: de los rascacielos separados por amplios espacios verdes de Le Corbusier no queda aquí prácticamente nada. Las torres están tan próximas entre sí que el resultado es un frente apelmazado y compacto, una especie de acantilado en el que resulta difícil identificar las torres como edificios independientes, saber donde acaba una y comienza la siguiente: no es posible atisbar fragmentos de cielo entre los edificios.

Sin embargo, siempre es posible empeorar las cosas. La franja de edificación abierta que ocupa la segunda línea de la Avenida de Aragón, entre las calles de Bélgica y Polo y Peyrolón, constituye un desgraciado episodio de barbarie urbanística, y muestra hasta donde puede llegar la degradación de los principios de la edificación abierta.
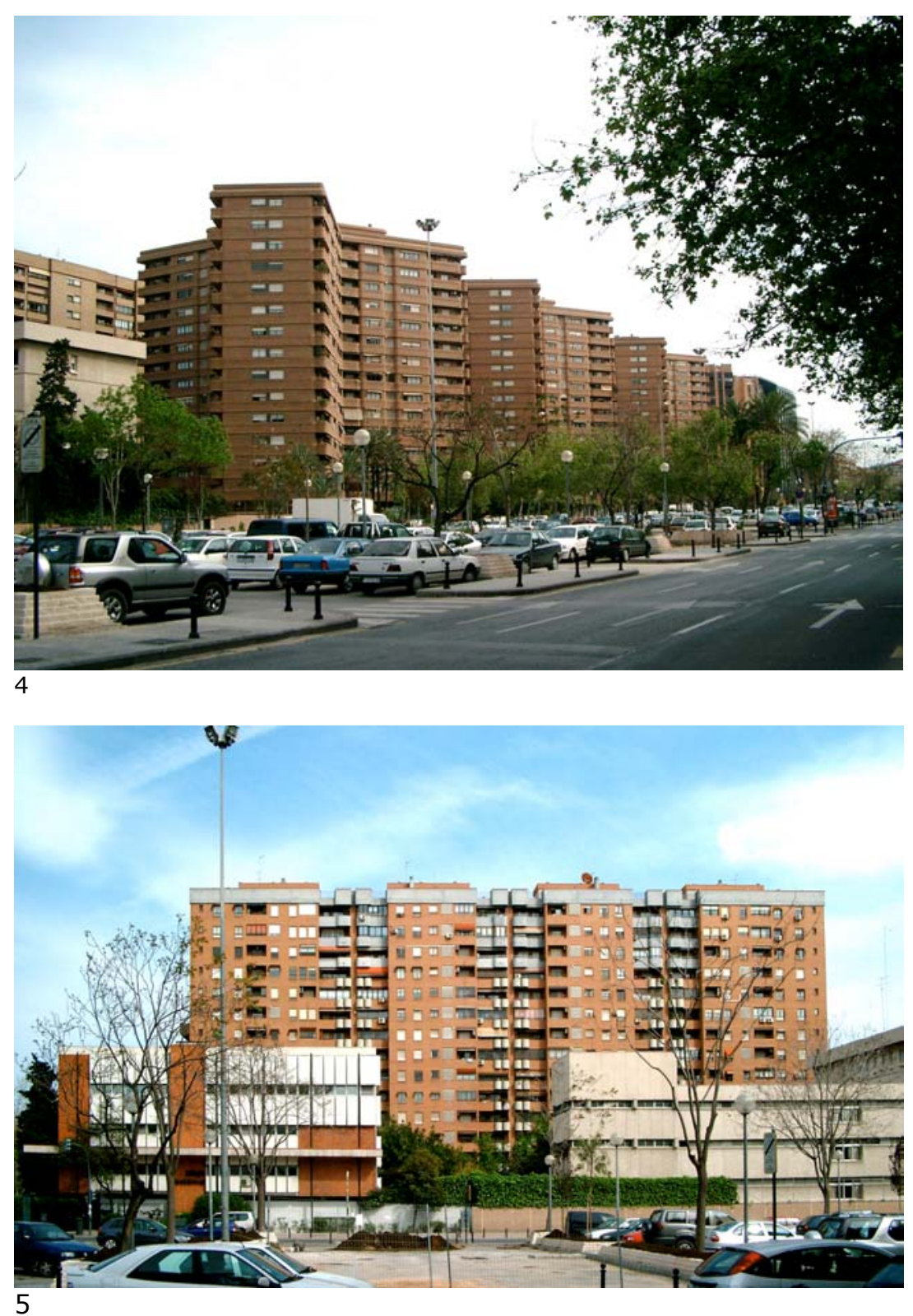
En esta franja, el primer edificio construido fue, como podemos ver en la fotografía aérea de 1980, el segundo de los bloques lineales de VII plantas ortogonales a la calle Polo y Peyrolón. Este edificio fue rodeado y engullido por la masa edificada que creció a su alrededor como un tumor desbocado, formada por una pantalla casi continua de bloques lineales profundos de XV plantas y una serie de bloques cortos perpendiculares de VII y IX plantas sobre un zócalo comercial continuo.

Estos bloques cortos, con los voladizos permitidos, quedaban casi adosados al bloque profundo, y el resultado de ello queda bien patente en las fotografías, tanto por lo que se refiere a la silueta del conjunto vista desde el Paseo al Mar como a la imagen del callejón que queda entre ambas edificaciones (Pasaje Eusebio Sempere).

Si observamos una fotografía de la calle Polo y Peyrolón con la serie de bloques perpendicular a dicha calle en la que no aparezcan los inmensos bloques profundos que arrojan sombra sobre ellos, podemos ver que el conjunto hubiera resultado bastante más apropiado si hubiese estado formado sólo por las torres de la Avenida de Aragón y la serie de bloques lineales mencionada.

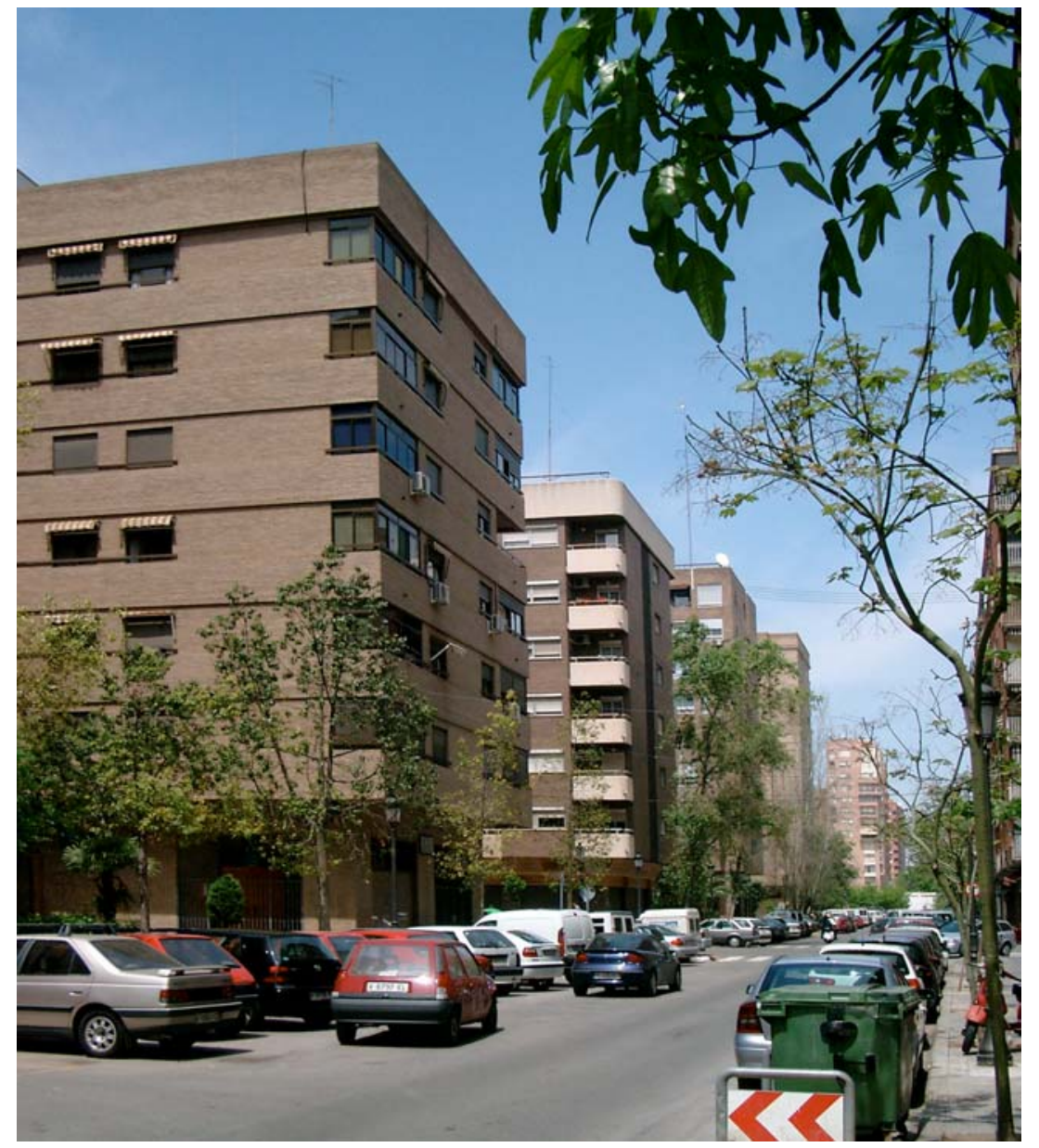

1
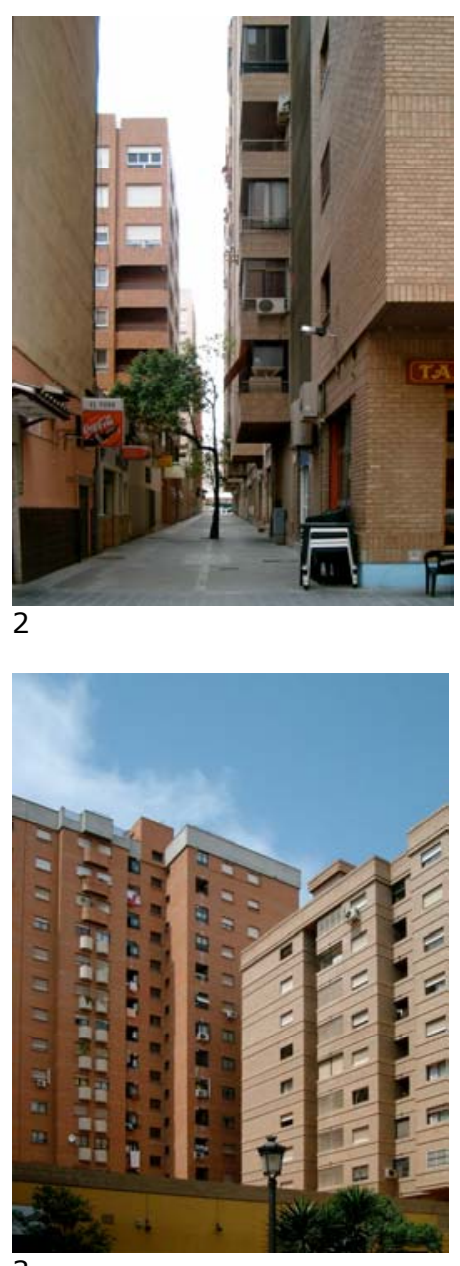

3

1. Bloques en la calle Polo y Peyrolón.

2. Pasaje Eusebio Sempere: callejón entre bloques

3. Vista del bloque profundo de XV plantas desde la calle Polo y Peyrolón. 


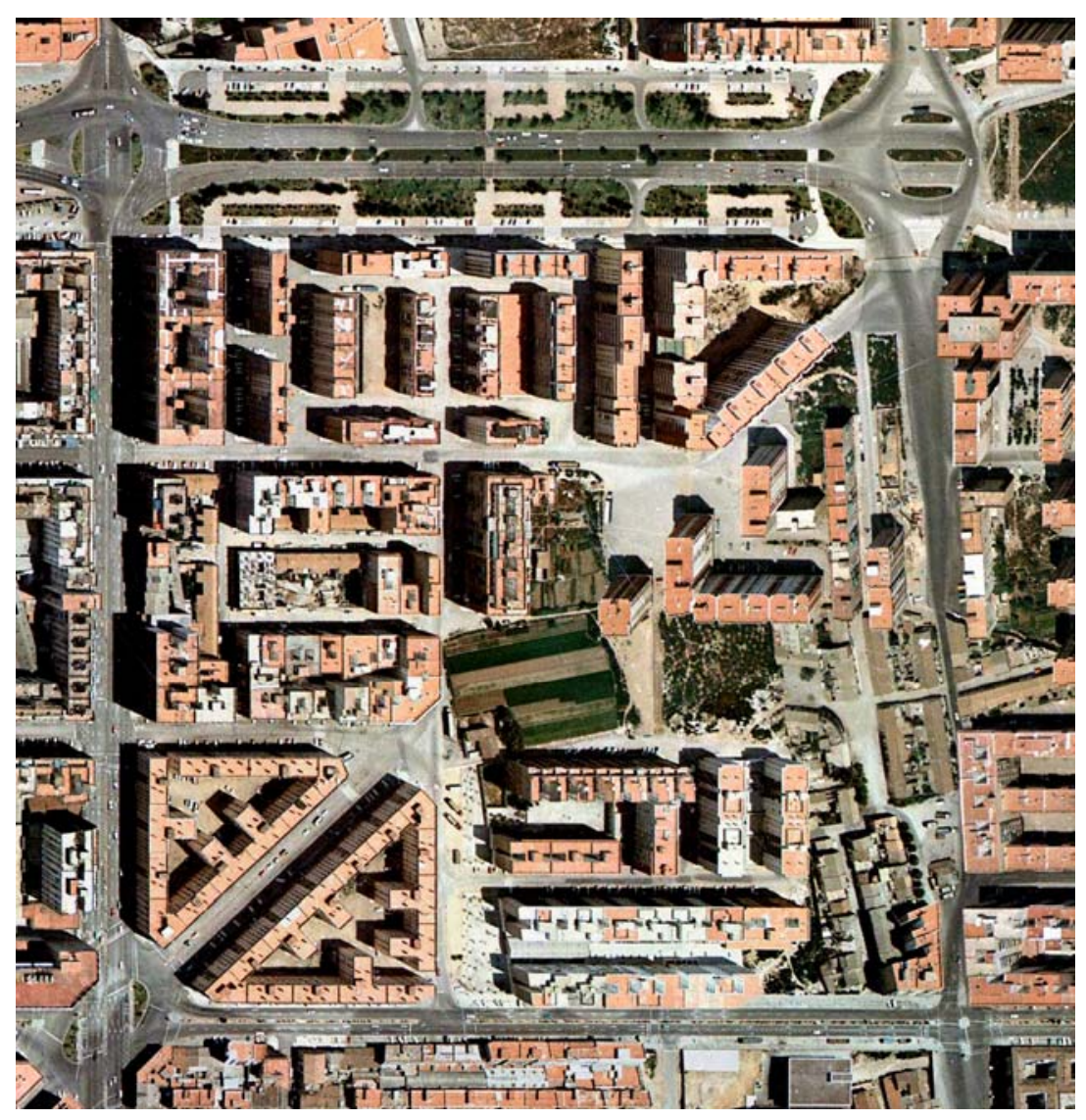

Zonas de edificación abierta del PP12: Zona de I'Amistat. Fotografías aéreas de 1980 y 2002.

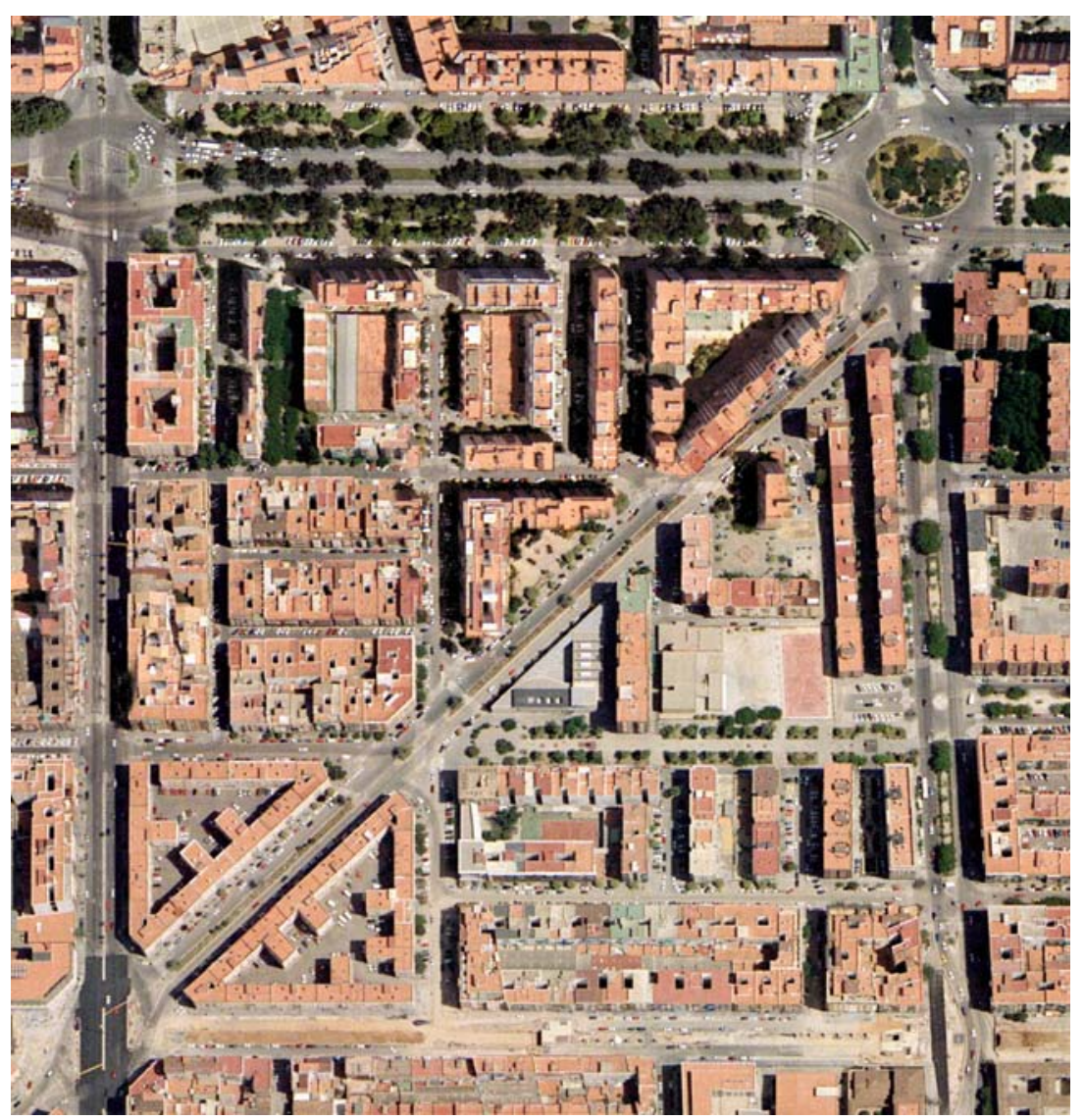


Se suele denominar barrio de I'Amistat al área limitada por el Paseo al Mar (actual Avenida de Blasco Ibáñez) al norte, la calle Santos Justo y Pastor al sur, la calle Dr. Manuel Candela al este y la Avenida Cardenal Benlloch al oeste. El área ocupa, por tanto, el primero de los tres sectores de edificación abierta que podemos identificar en la zona, limitados por los ejes viarios principales ortogonales al Paseo al Mar.

En la zona de I'Amistat, los bloques lineales recayentes al Paseo al Mar están alineados con el mismo, salvo los dos ortogonales de las calles Amistat y Llosa de Ranes. Pese a ello, el alzado al paseo no se percibe como un frente edificado continuo, sino que la separación entre los bloques es lo suficientemente amplia como para que cada uno de ellos aparezca como volumen diferenciado. La gran masa vegetal del paseo central de la Avenida Blasco Ibáñez hace el resto, y podemos obtener imágenes que muestran bloques que emergen entre amplios espacios verdes, de acuerdo con los modelos canónicos de la edificación abierta.

En esta zona se encuentran los únicos fragmentos de edificación abierta realizados con arreglo al Plan Parcial 12-B de 1963. Uno de esos fragmentos, el formado por las manzanas que flanquean la calle República Argentina, iniciado con bloques lineales de V plantas, fue completado con bloques altos recayentes al Paseo al Mar.

Los bloques lineales aislados generan un sistema de parejas de calles paralelas muy próximas entre sí, como ocurre en las calles Amistat y Dr. Modesto Cogollos, en la calles Vicente Pallarés y Pedro J. Núñez, o en las calles Llosa de Ranes y Daoíz y Velarde. En estas parejas de calles, una de ellas es casi siempre innecesaria como elemento de acceso a los zaguanes cuando el bloque, como en este caso, es de poca profundidad.

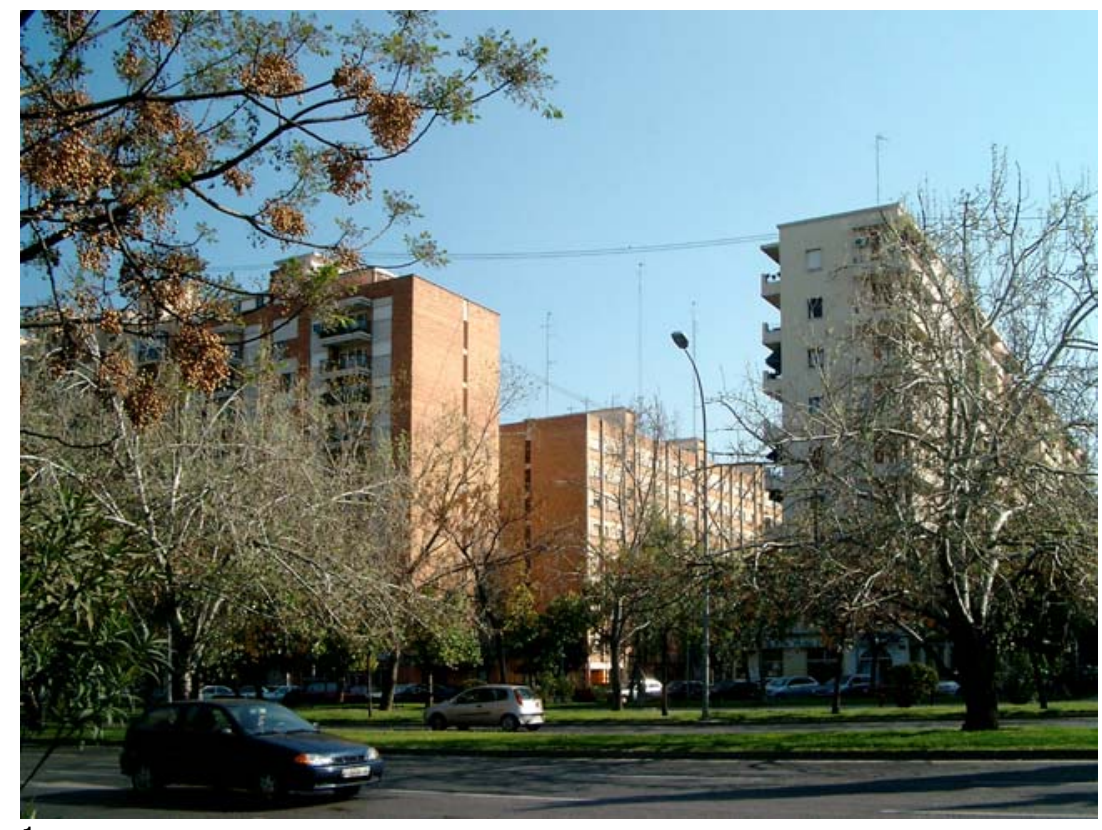

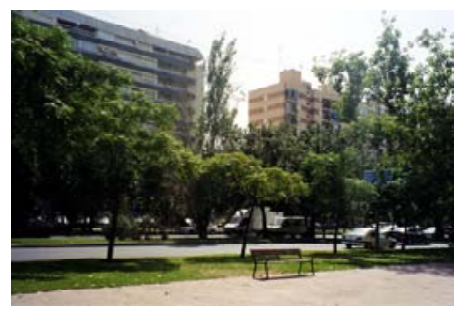

1. Bloques del barrio de I'Amistat. Vista desde Paseo al Mar.

2. Bloques en el Paseo al Mar, entre las calles Dr. Modesto Cogollos y Llosa de Ranes. 


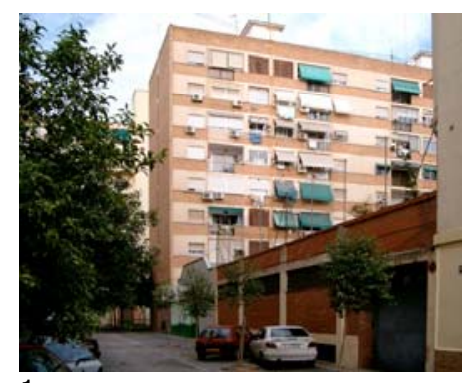

1

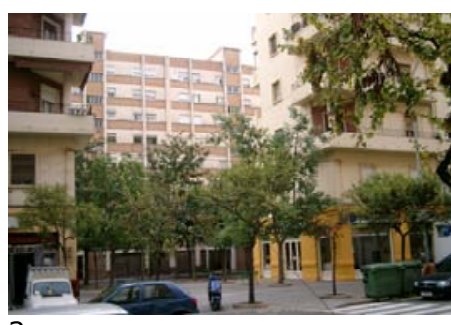

2

1. Calle Pedro J. Núñez vista hacia el oeste, con los bloques lineales unidos por una planta baja comercial.

2. Calle Amistat. Travesía peatonal entre bloques que conduce a la calle Dr. Modesto Cogollos.

3. Bloque en Paseo al Mar, entre las calles República Argentina y Llosa de Ranes.

4. Bloques en el Paseo al Mar, entre las calles Daoíz y Velarde y Manuel Candela.

5. Bloques en el Paseo al Mar, Llosa de Ranes y Daoíz y Velarde.

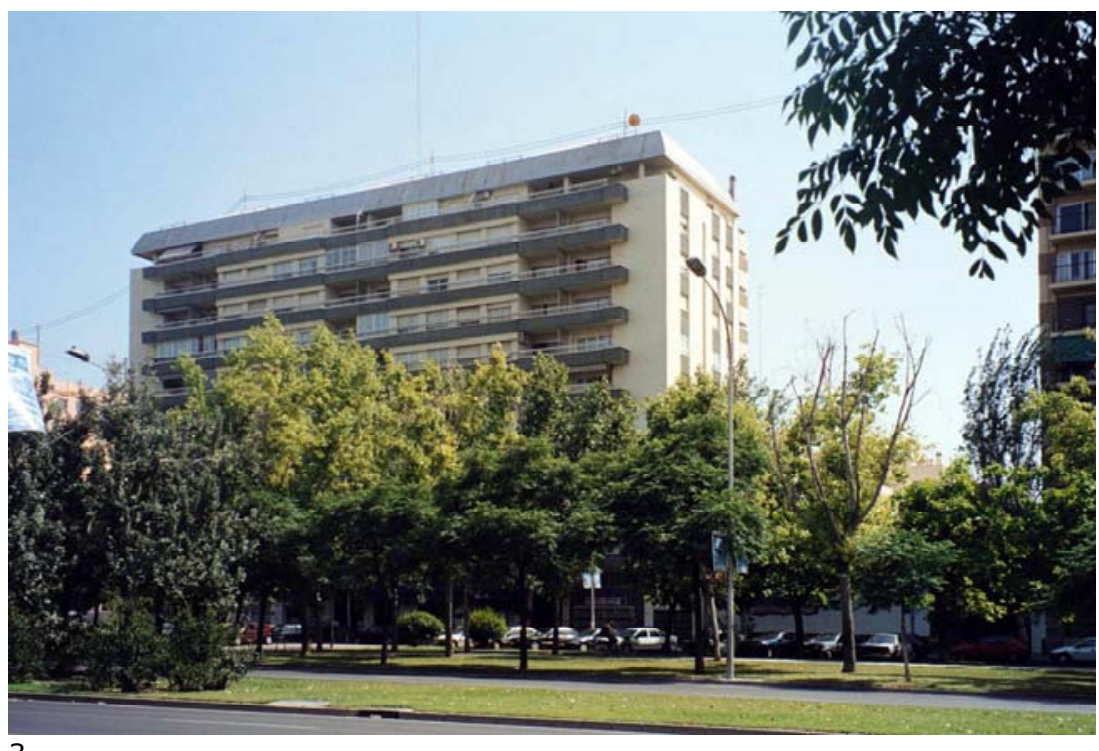

3

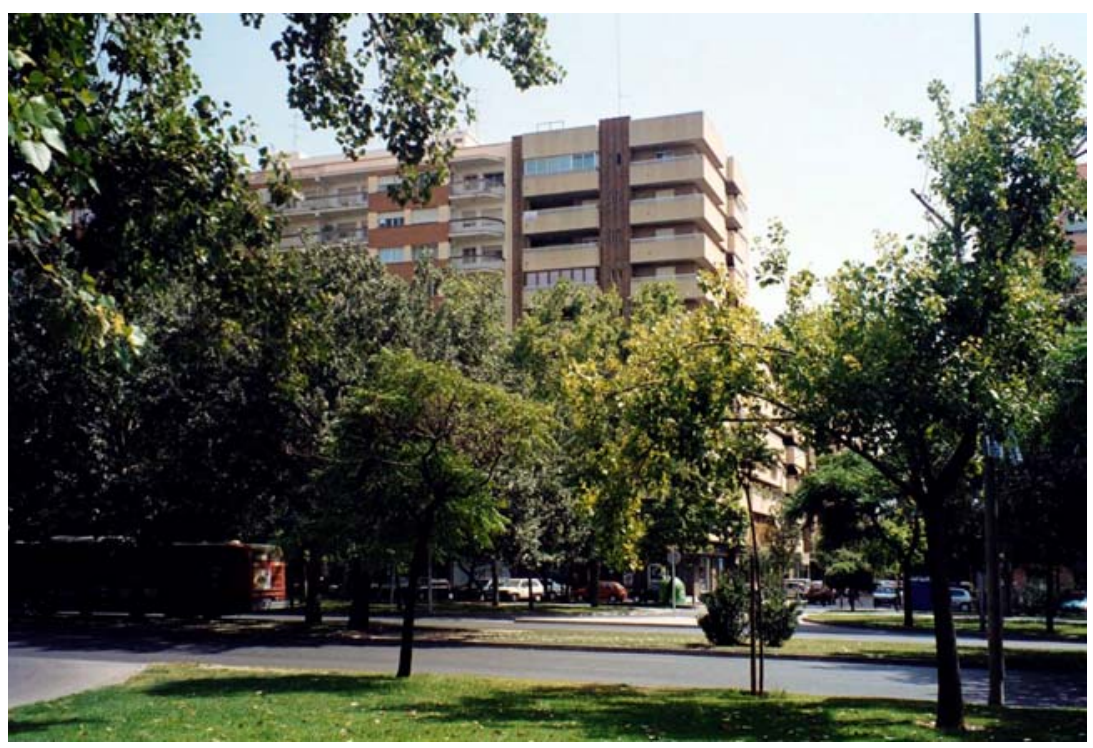

4

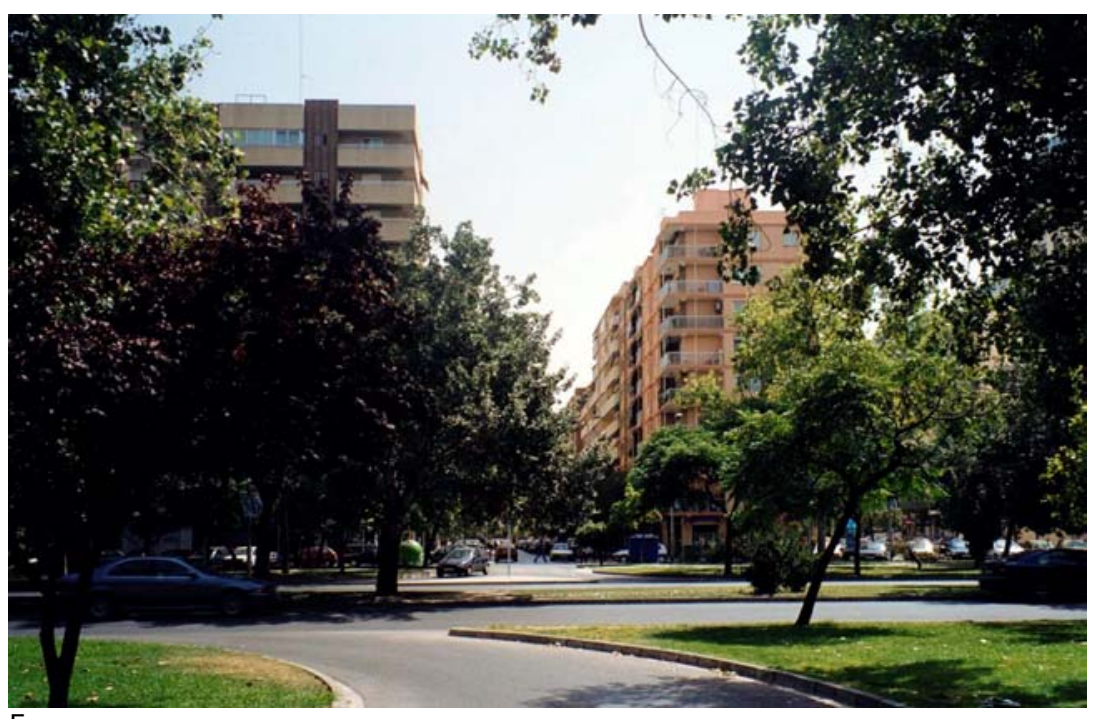

5 
La calle Yecla es un eje diagonal que atraviesa toda la zona y conecta los vértices suroeste y noreste de la misma. Este eje quedó iniciado con las dos manzanas unitarias triangulares del grupo Cardenal Benlloch, construido en el marco del Plan 5000 y terminado en 1960.

Los lados norte y sur de la calle Yecla muestran características diferentes. En el lado norte de la calle, la edificación está alineada con la misma, a excepción del bloque en $L$ del tramo central. En el lado sur, en cambio, los bloques lineales aparecen como bloques oblicuos con respecto a la calle Yecla, ya que mantienen en todos los casos su lado largo ortogonal o paralelo al Paseo al Mar. Los triángulos que quedan entre los testeros de los bloques y la calle se tratan como pequeños espacios ajardinados. La imagen resultante, de "dentado", es muy habitual como sistema compositivo en la edificación abierta, y puede considerarse como una forma particular de la edificación a redents.

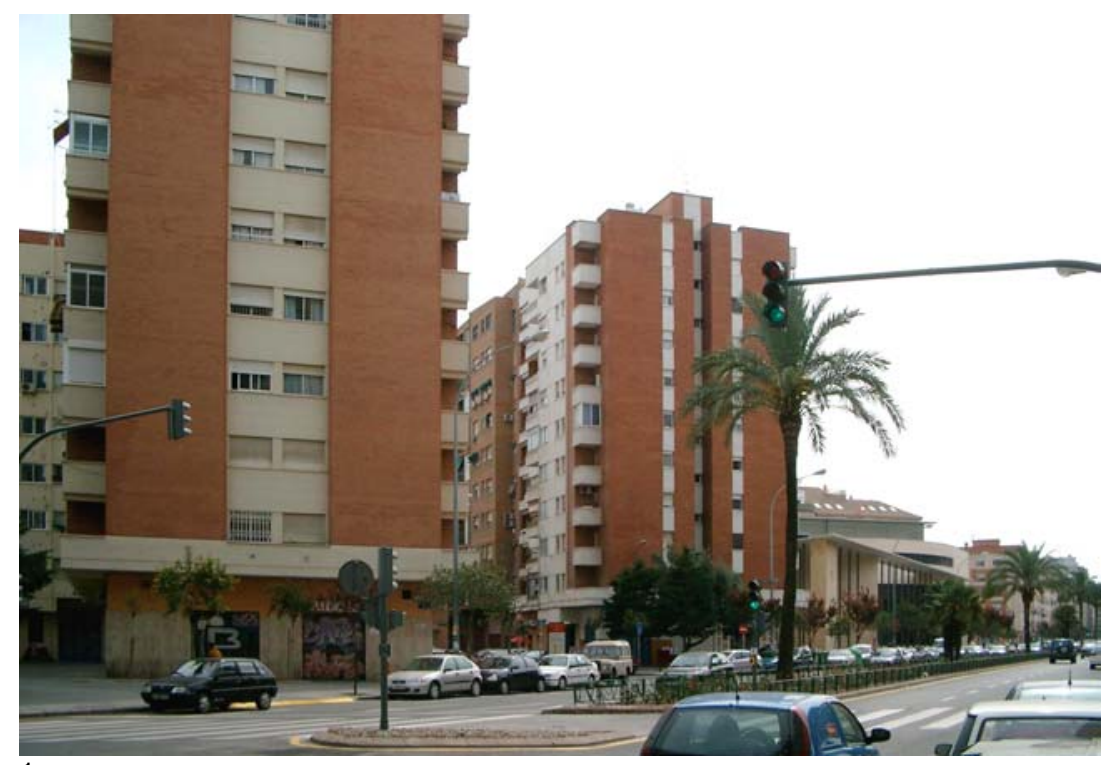

1

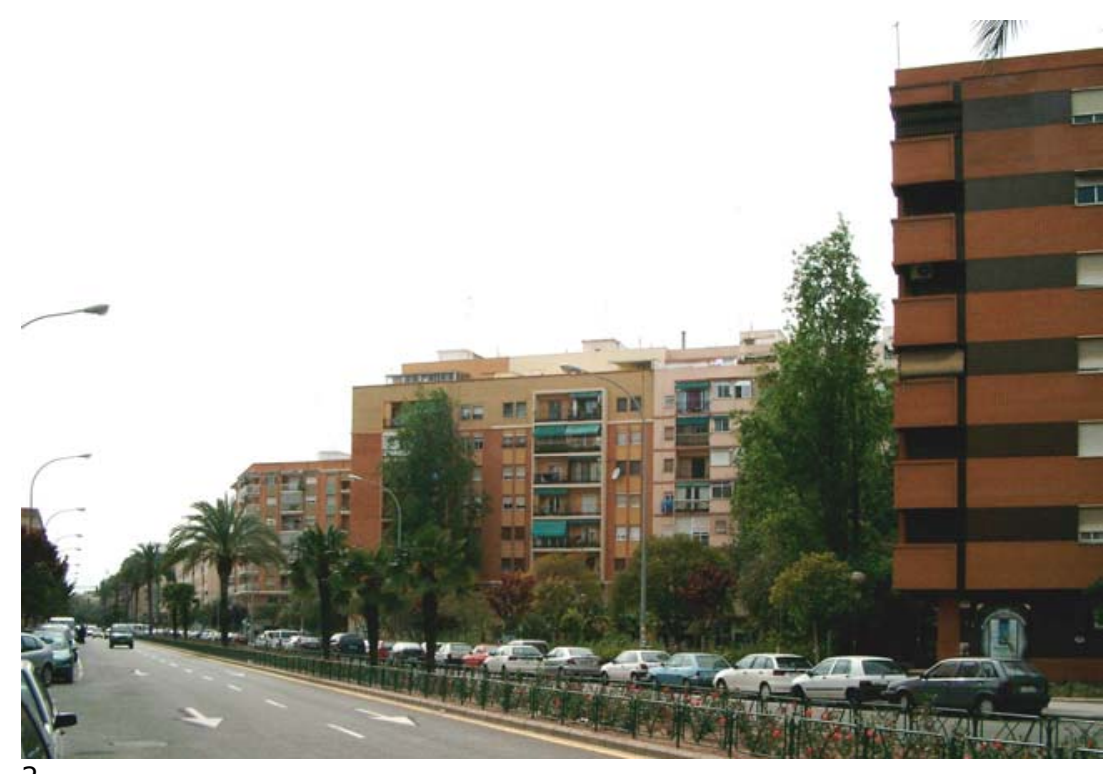

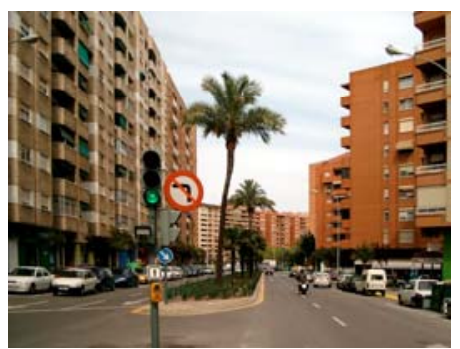

3

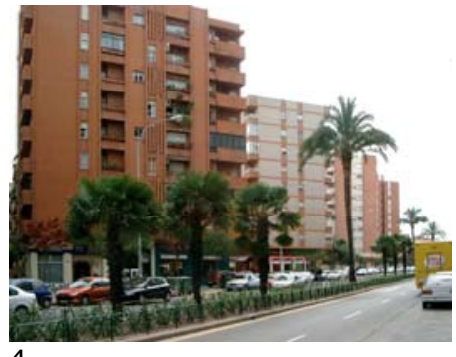

4

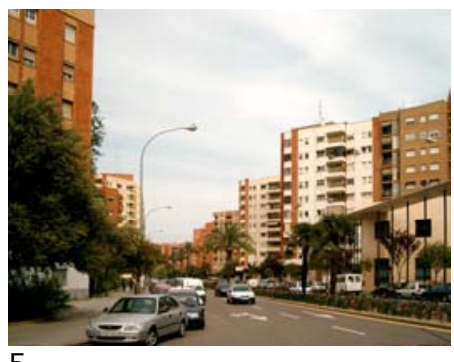

5

1. Bloques en la calle Yecla. Vista hacia el suroeste del lado sur.

2. Bloques en la calle Yecla. Vista hacia el suroeste del lado norte.

3. Calle Yecla. Vista hacia el noreste del lado sur.

4. Calle Yecla. Vista hacia el suroeste del lado sur.

5. Calle Yecla. Vista hacia el noreste del lado sur. 


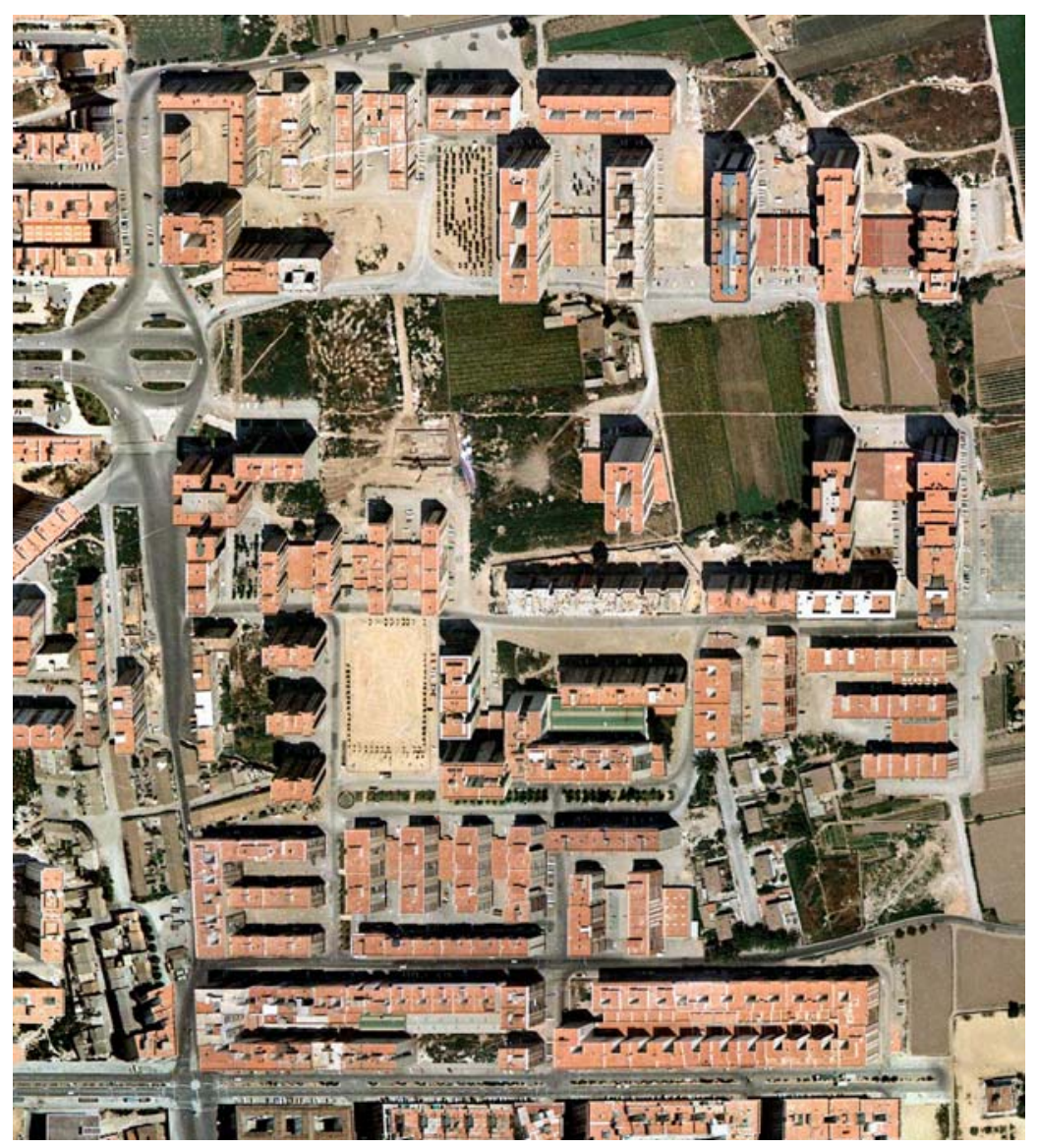

Zona de edificación abierta de la Prolongación del Paseo al Mar. Tramo entre las calles Dr. Manuel Candela y Músico Ginés. Fotografía aérea de 1980 y Ortofoto de 2002

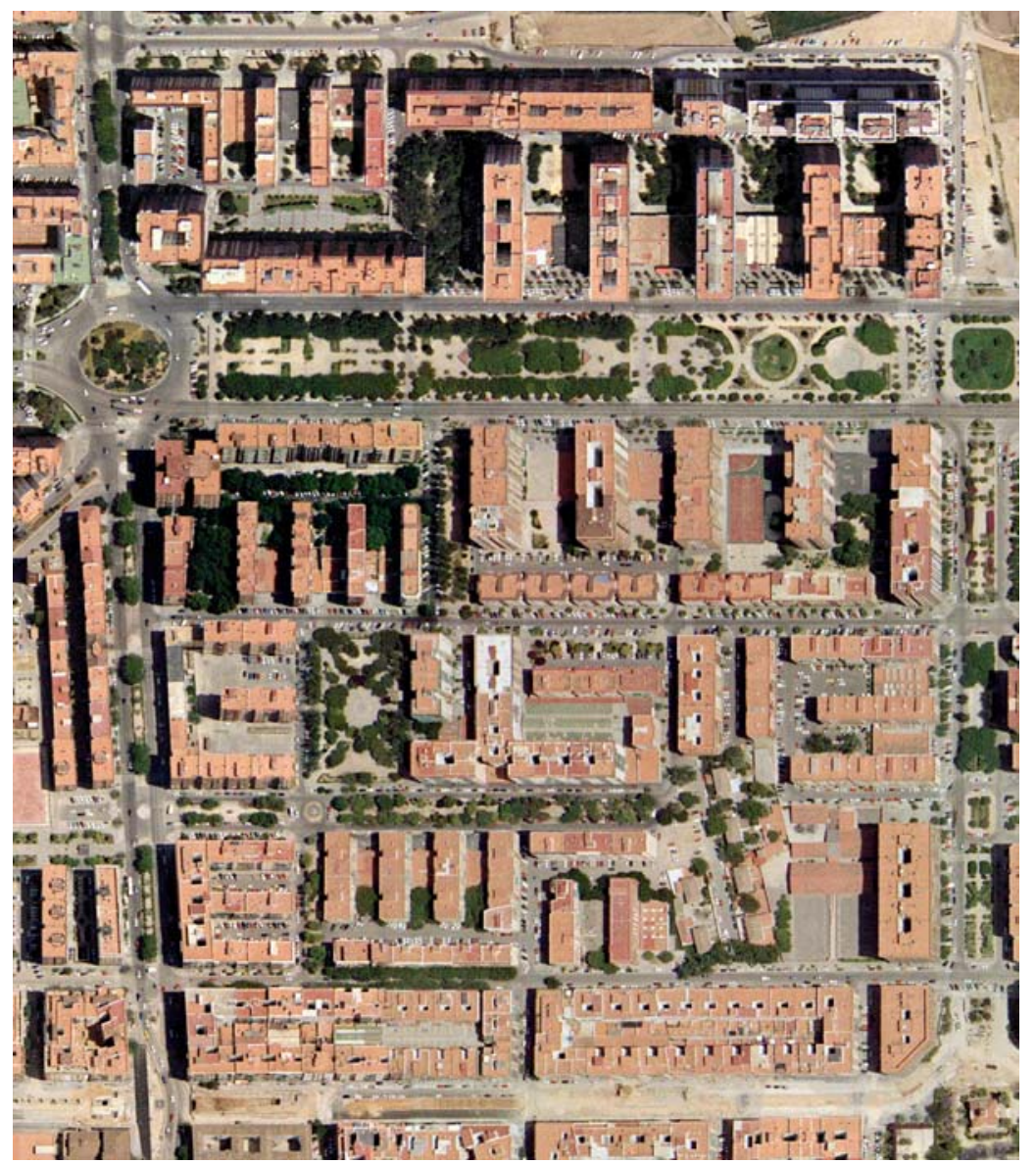


La zona de edificación abierta de la prolongación del Paseo al Mar, entre las calles Doctor Manuel Candela y Serrería, es una de las de mayor extensión entre las realizadas a partir de los planes parciales de desarrollo del Plan General de 1966.

En esta zona, podemos distinguir dos grandes sectores, separados por ejes viarios norte-sur. El primero es el comprendido entre las calles Dr. Manuel Candela y Músico Ginés, y el segundo el comprendido entre esta última calle y la de José María Haro. En el resto de la zona hasta la calle Serrería la edificación abierta se reduce a dos estrechas franjas que flanquean el tramo final del Paseo al Mar.

La forma de combinar los bloques de edificación abierta es muy diferente en cada uno de los sectores indicados. En el primero de ellos, entre las calles Dr. Manuel Candela y Músico Ginés, podemos observar una composición que toma como eje de simetría el Paseo al Mar. Los elementos integrantes de esta composición son, a cada lado, una torre retranqueada unida a un bloque lineal largo alineado con el Paseo y cinco bloques altos profundos ortogonales al mismo.
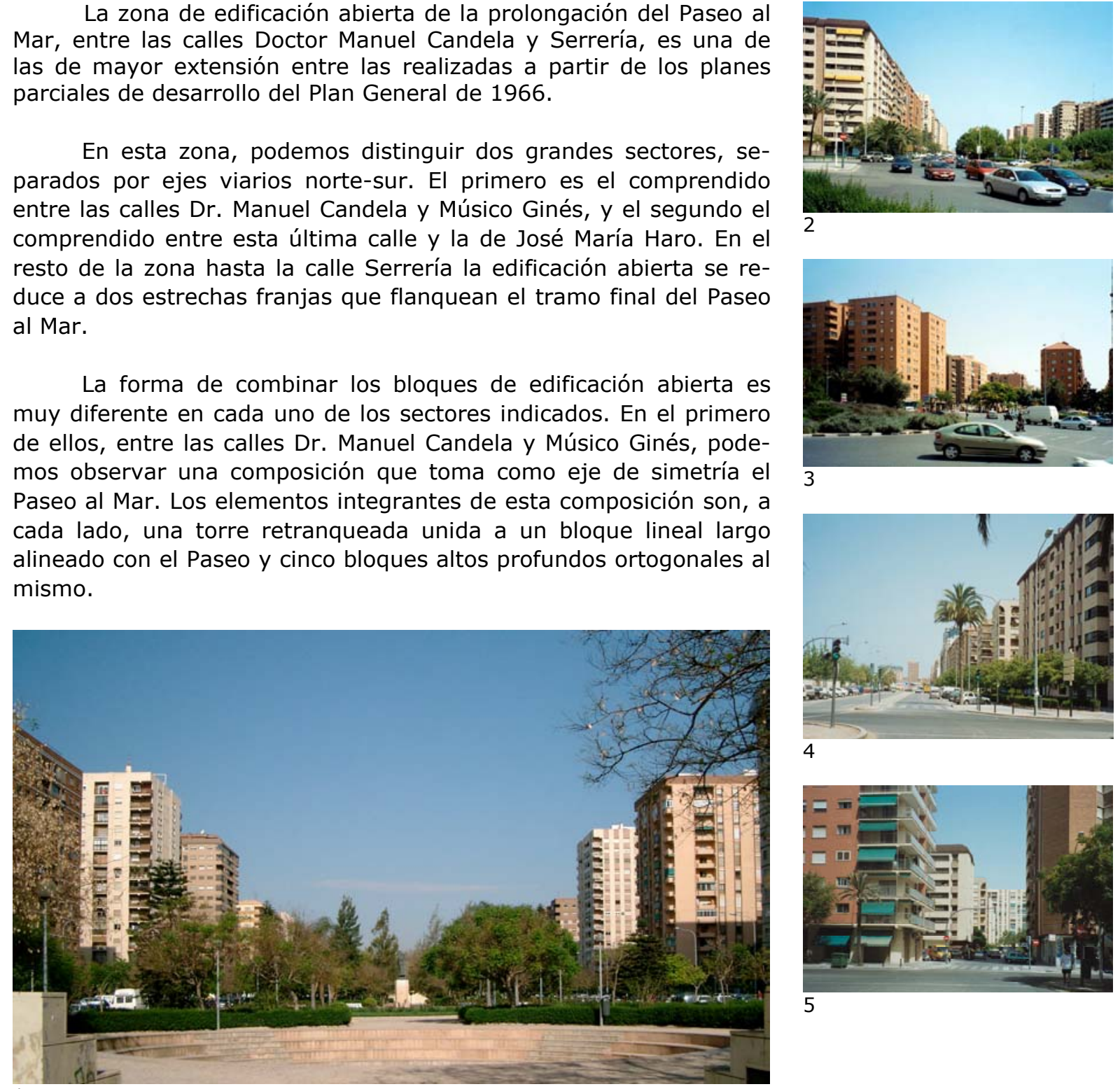

4

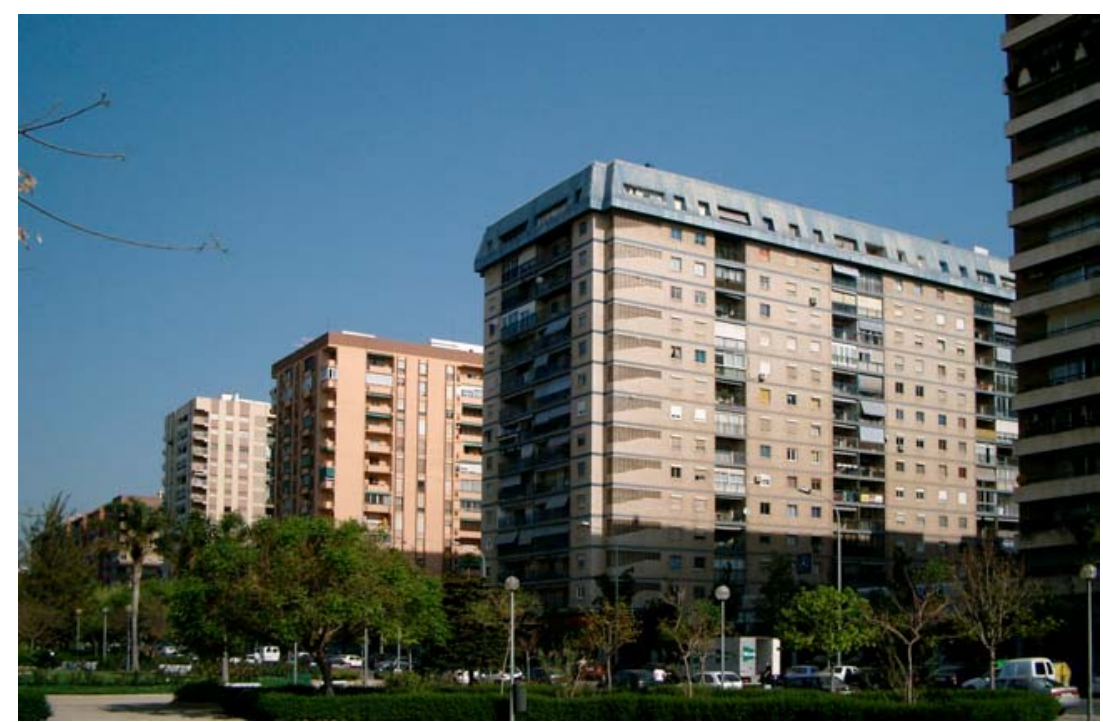

2

1. Paseo al Mar. Vista hacia el oeste desde el jardín central.

2. Paseo al Mar. Vista de los bloques del lado norte.

3. Inicio de la prolongación del Paseo al Mar. Vista hacia el este desde la rotonda de la calle Ramón Llull.

4. Inicio de la calle Dr. Manuel Candela. Vista hacia el sur desde la rotonda de la calle Ramón Llull.

5. Calle Serpis. Vista hacia el este desde la calle Ramón Llull.

6. Bloques en la calle Ramón Llull. Vista hacia la calle Escultor Alfonso Gabino 


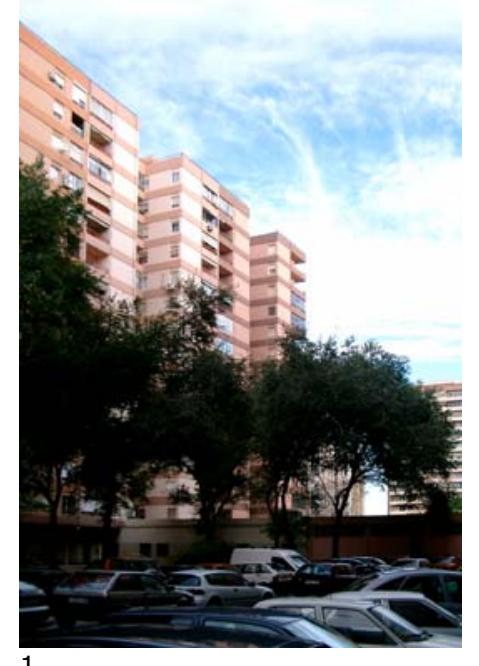

1
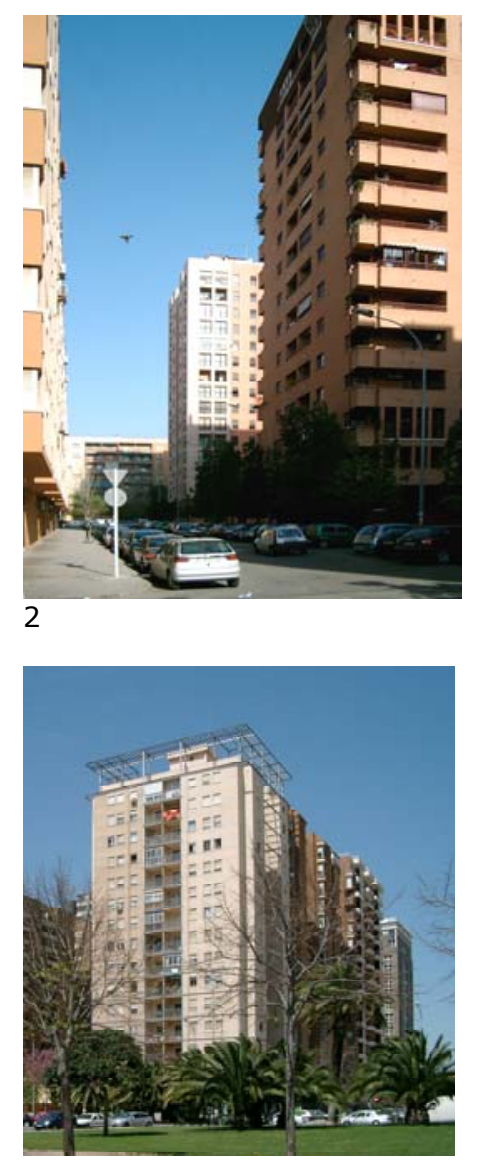

3

\section{1,2. Calle Poeta Durán y Tor-} tajada.

3. Paseo al Mar. Bloque alto del lado norte, compuesto por varias promociones entre medianeras.

4,5. Paseo al Mar. Bloques altos del lado sur
Esta composición simétrica en planta del primer tramo de la prolongación del Paseo al Mar queda, sin embargo, desvirtuada por dos razones. En primer lugar, por la gran anchura (100 metros) del Paseo, que dificulta la percepción como conjunto de los edificios que lo flanquean, ya que están demasiado separados entre sí: de hecho, esta percepción sólo es posible desde el centro del jardín. En segundo lugar, por la fragmentación de los bloques largos en varias edificaciones entre medianeras, que impide una lectura unitaria de los mismos.

Los dos grupos simétricos de cinco grandes bloques lineales altos y profundos, perpendiculares al Paseo al Mar, constituyen tal vez el conjunto de edificación abierta más característico de este paseo. Estos bloques, de XV alturas, tienen una planta de $20 \times 65$ $\mathrm{m}$. en el lado sur y $20 \times 75 \mathrm{~m}$ en el lado norte. Están unidos en planta baja por locales y separados entre sí $40 \mathrm{~m}$ en planta tipo. Algunos de ellos son unitarios, y otros se componen de dos o tres parcelas adosadas.
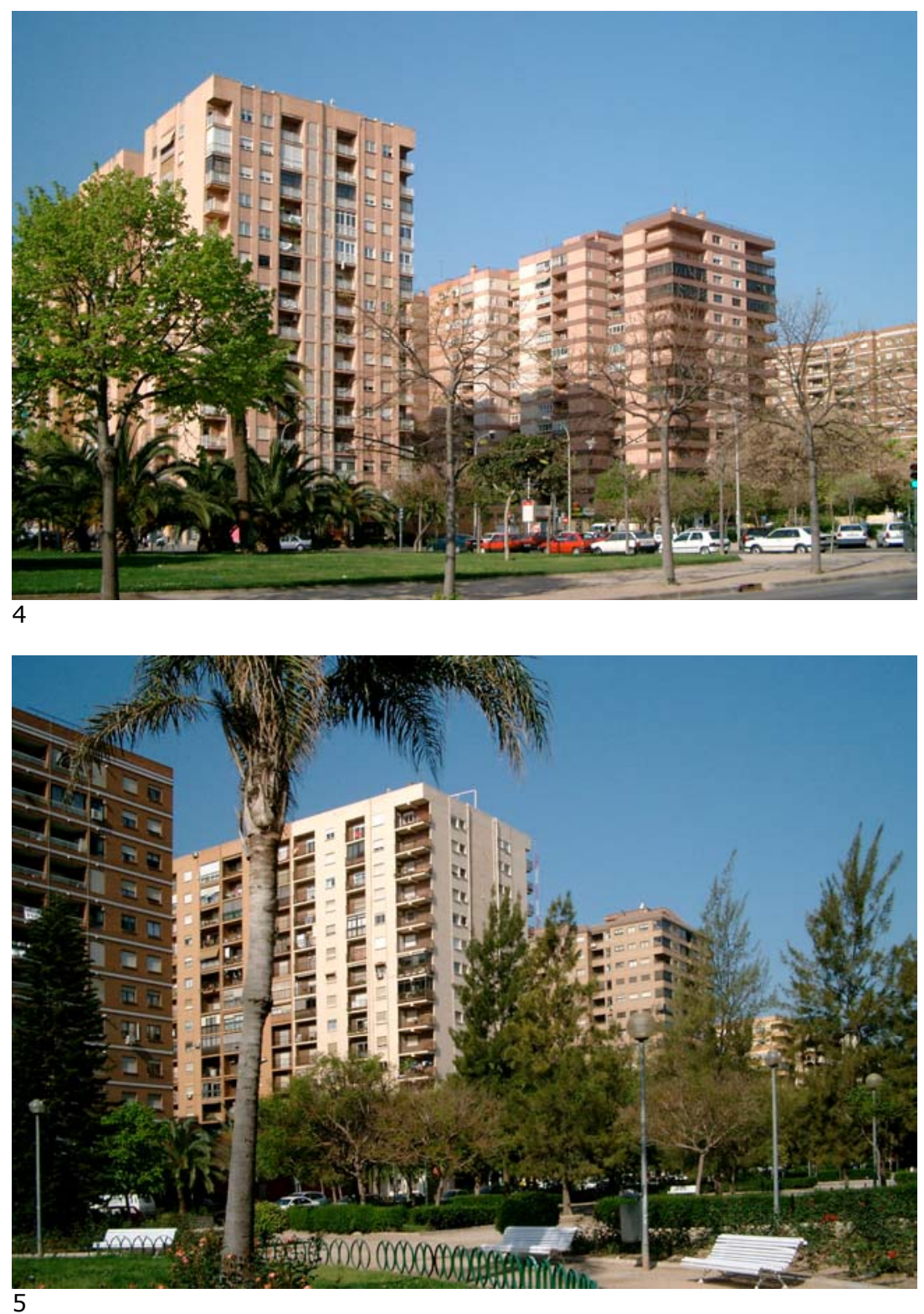
La vista de esta serie de bloques desde el jardín central del Paseo al Mar es la de unos grandes volúmenes prismáticos situados tras una masa vegetal que hoy por hoy, al ser relativamente joven, parece aún un poco aplastada por el peso de una edificación tan densa.

Por contra, los grandes bloques resultan una carga demasiado pesada para las calles de Honduras y de Poeta Durán y Tortajada, paralelas al Paseo al Mar. En estas calles, de $20 \mathrm{~m}$. de anchura, un lateral está formado por los testeros de los bloques altos transversales al paseo, y el otro por bloque lineal continuo, también de gran altura. El resultado es una sucesión de plazas envueltas por grandes edificios por tres de sus lados, siendo el cuarto lado el correspondiente a la franja de locales de planta baja que las separa del Paseo al Mar. Algunas de estas plazas son pequeños jardines y otras bolsas de aparcamiento. Entre dos de los bloques del lado sur, el PERI de 1982 eliminó la franja de locales, sustituyéndola por un espacio libre.

La calle de Explorador Andrés es la equivalente a Serpis en el lado sur del Paseo al Mar. La calle Serpis es una calle con edificación residencial a un lado solamente, y Explorador Andrés, con edificación a ambos lados, tiene un cierto carácter de eje comercial de barrio. Este carácter viene favorecido por la presencia de un buen número de bloques alineados con la calle o, en su defecto, de bajos comerciales que enlazan bloques ortogonales a la misma.

En el lado sur de la calle Explorador Andrés, la manzana situada entre la plaza del Cedro y la calle Impresor Lambert Palmari es un conjunto de edificación abierta poco habitual y muy denso, formado por un bloque profundo en $\mathrm{T}$ combinado con un bloque lineal y otro bloque alto corto.

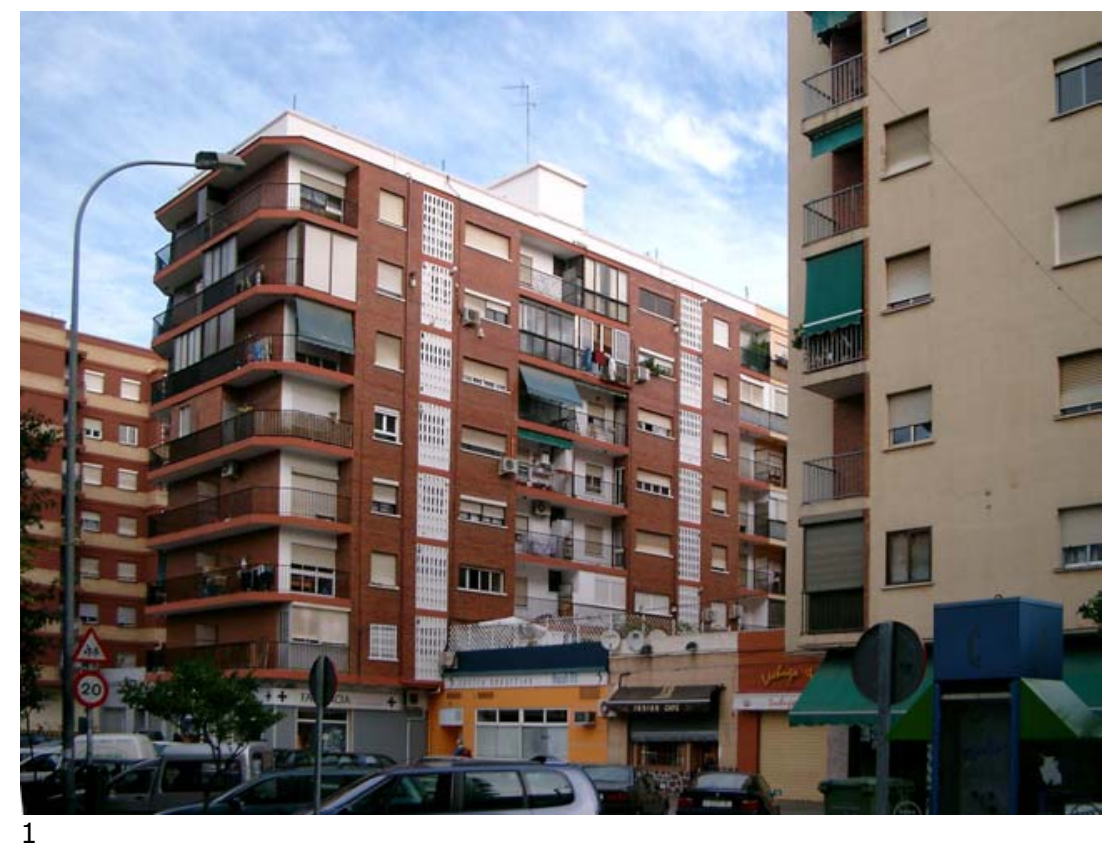

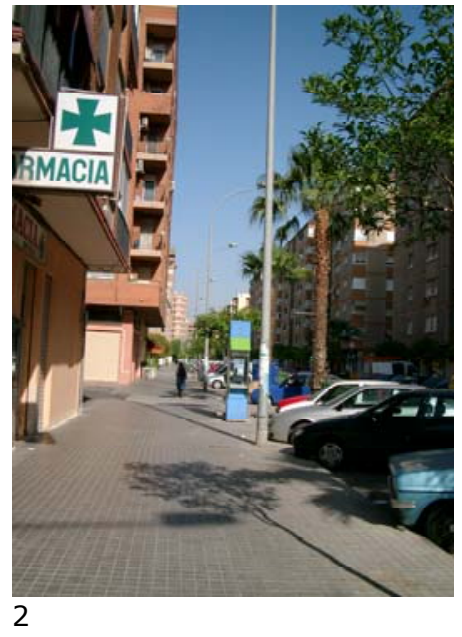

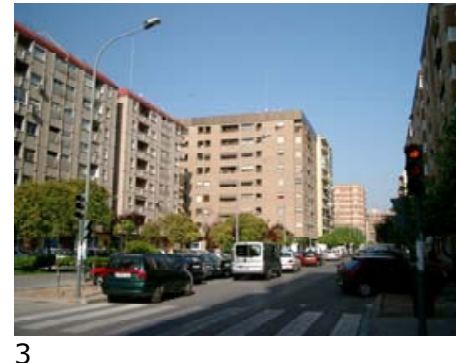

3

1. Calle Explorador Andrés. Bloques del lado norte, perpendiculares a la plaza del Cedro.

2. Calle Explorador Andrés. Acera del lado sur, vista hacia el oeste.

3. Calle Explorador Andrés. Manzana entre la calle Impresor Lambert y plaza del Cedro. 


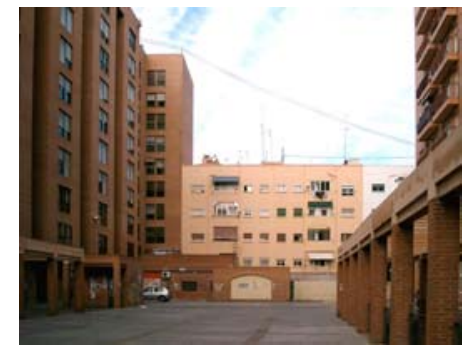

1

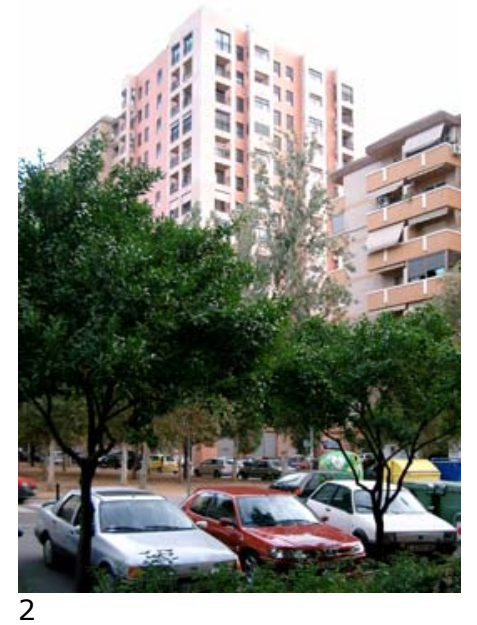

1. Plaza del Cedro. Lado oeste, espacios peatonales entre bloques.

2. Plaza del Cedro, lateral este.

3. Calle Campoamor, lado norte. Manzana entre la Plaza del Cedro y la calle Impresor Lambert.

4. Calle Campoamor. Vista hacia la Plaza del Cedro.

En esta zona, el espacio intermedio existente entre los bloques lineales enlazados en uno de sus extremos por un bajo comercial suele estar destinado a aparcamiento, como ocurre, por ejemplo, en la calle Historiadora Silvia Romeu. En esta calle, al igual que en el lado sur de la calle Campoamor, entre Manuel Candela y Músico Ginés, la edificación abierta adquiere una escala más amable y proporcionada con las dimensiones de los espacios públicos, gracias a la menor altura y profundidad de los bloques lineales.

En general, la disposición de los bloques lineales según la directriz norte-sur o este-oeste no responde al criterio de orientación preferente, sino a una simple búsqueda de variedad en los volúmenes edificados, igual que ocurre en otros planes parciales del mismo periodo.
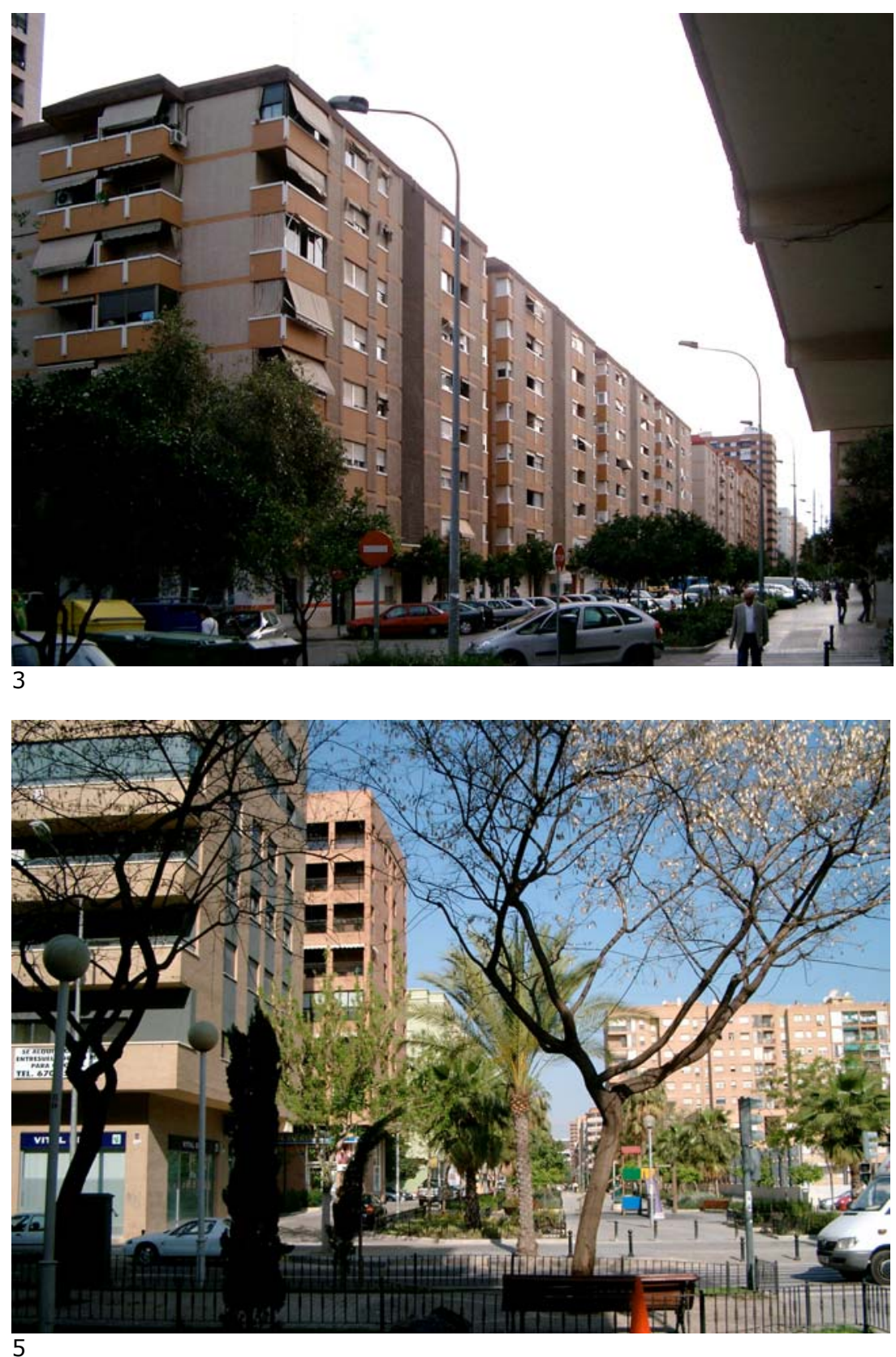


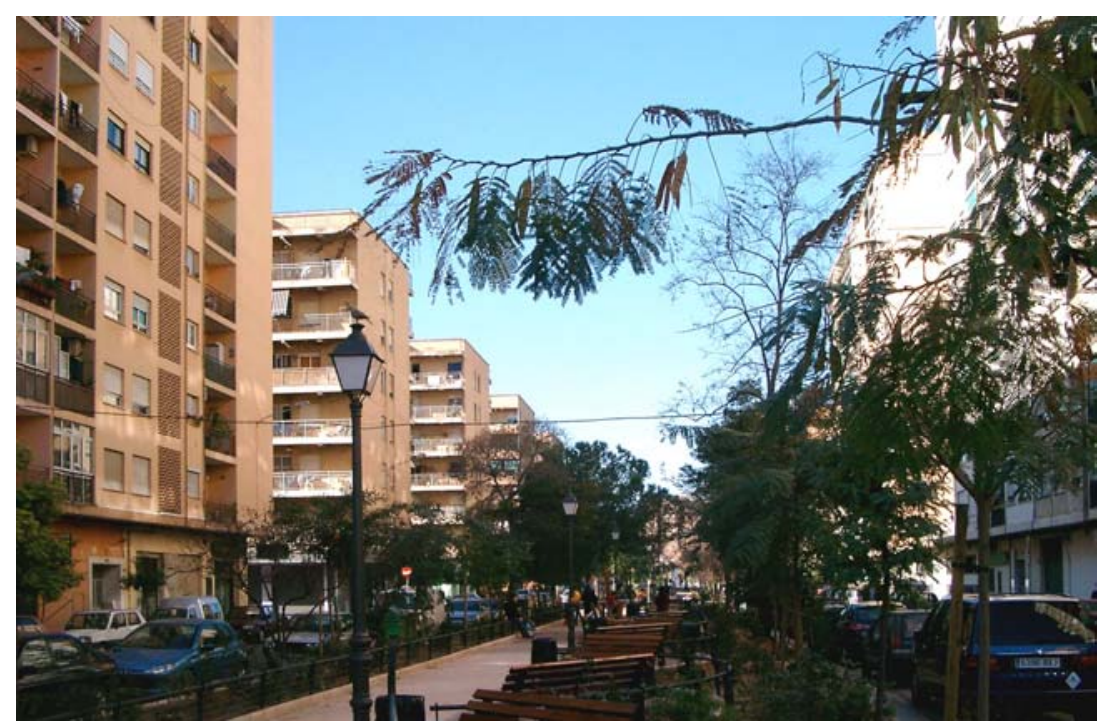

1
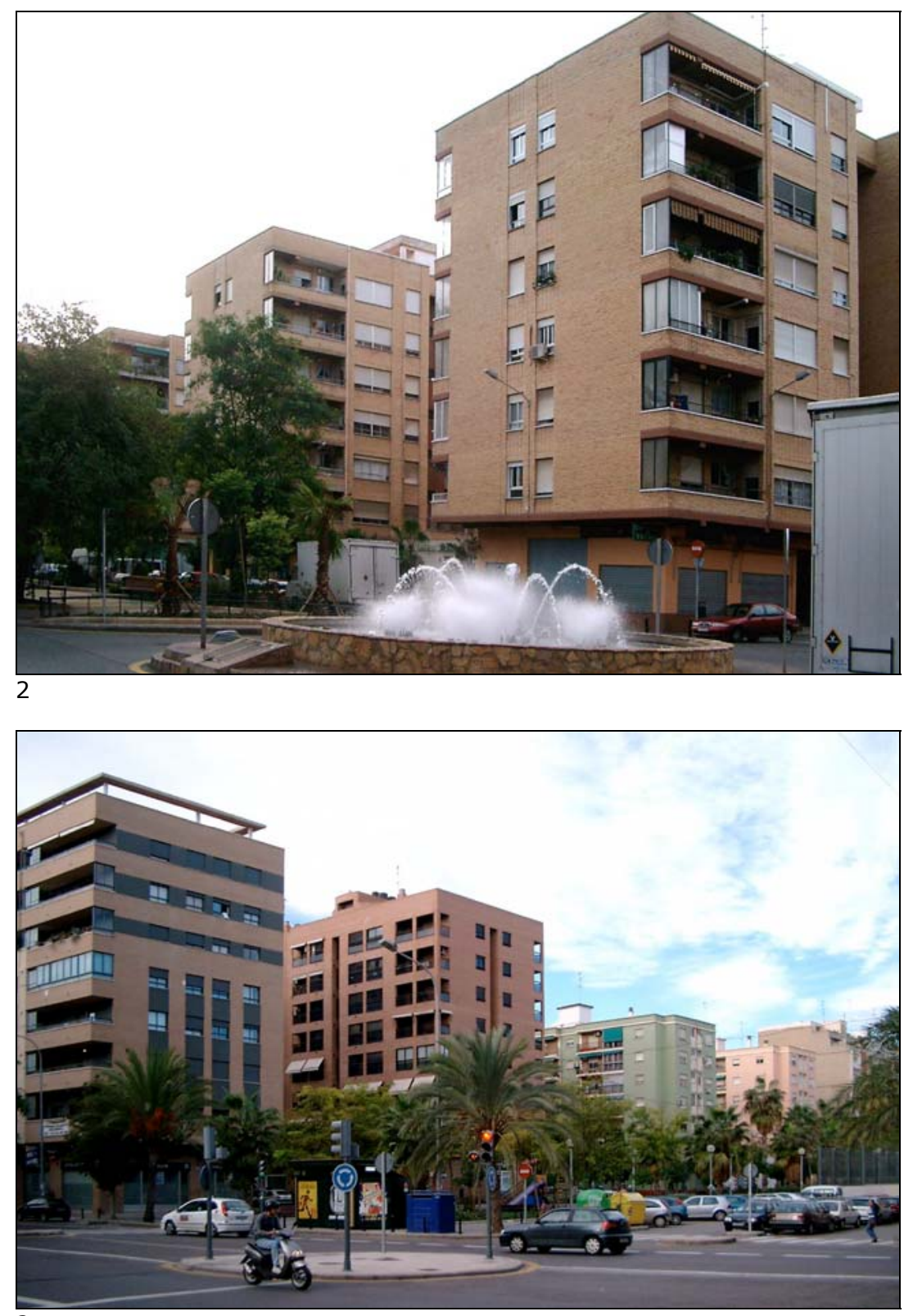

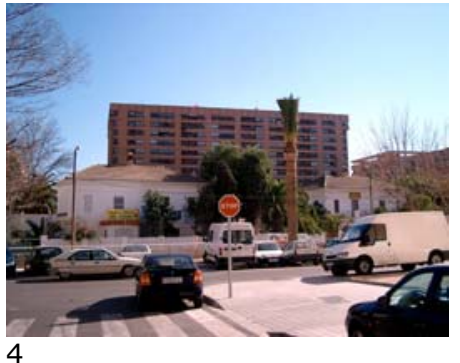

1. Calle Campoamor. Bloques en el lado sur.

2. Calle Historiadora Silvia Romeu.

3. Calle Músico Ginés. Bloques del lado oeste

4. Calle Campoamor. Edificaciones de la calle José de Orga y bloque recayente a Músico Ginés al fondo. 


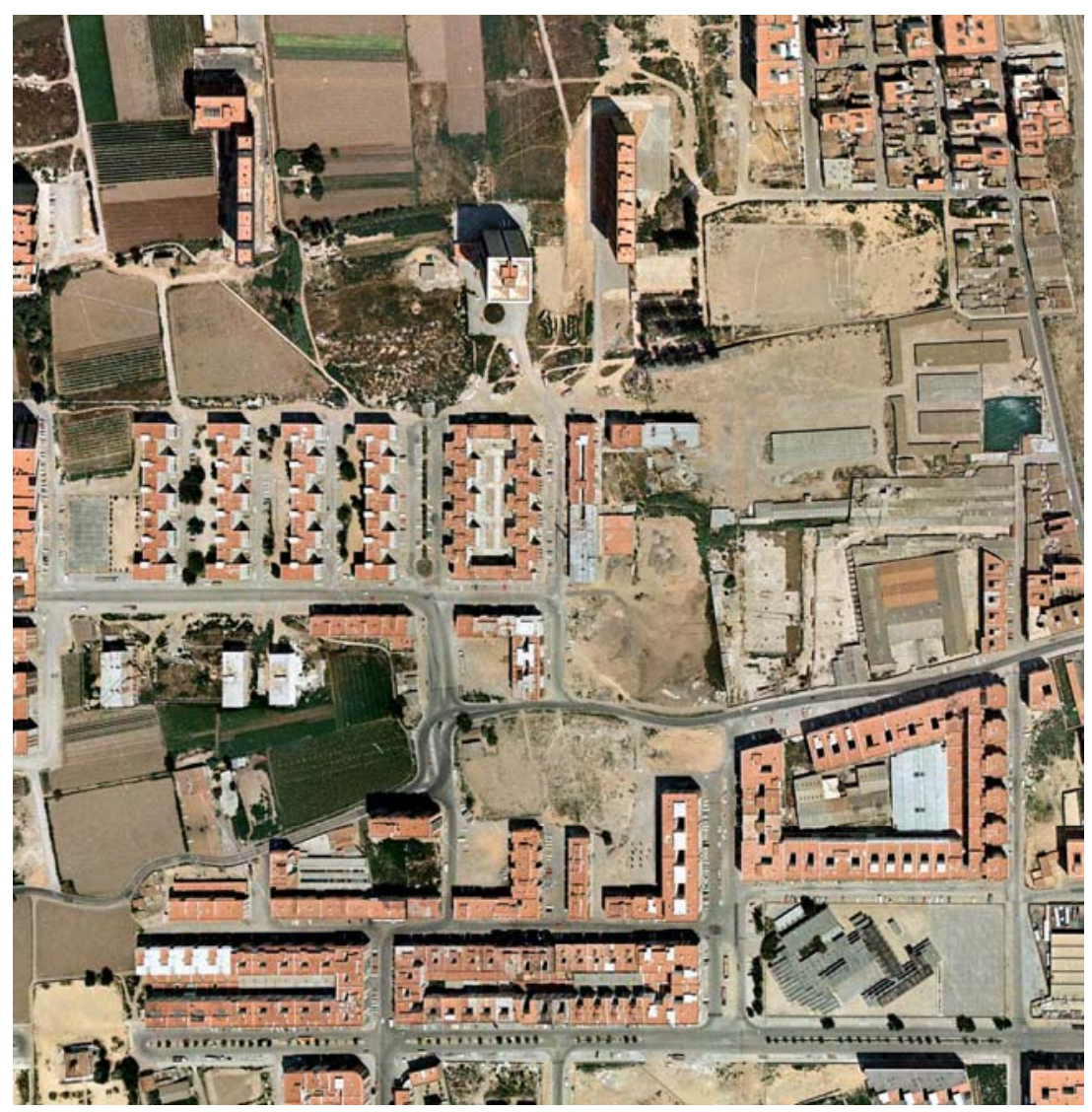

Zona de edificación abierta de la Prolongación del Paseo al Mar. Tramo entre las calles Músico Ginés y Serrería. Fotografía aérea de 1980 y Ortofoto de 2002

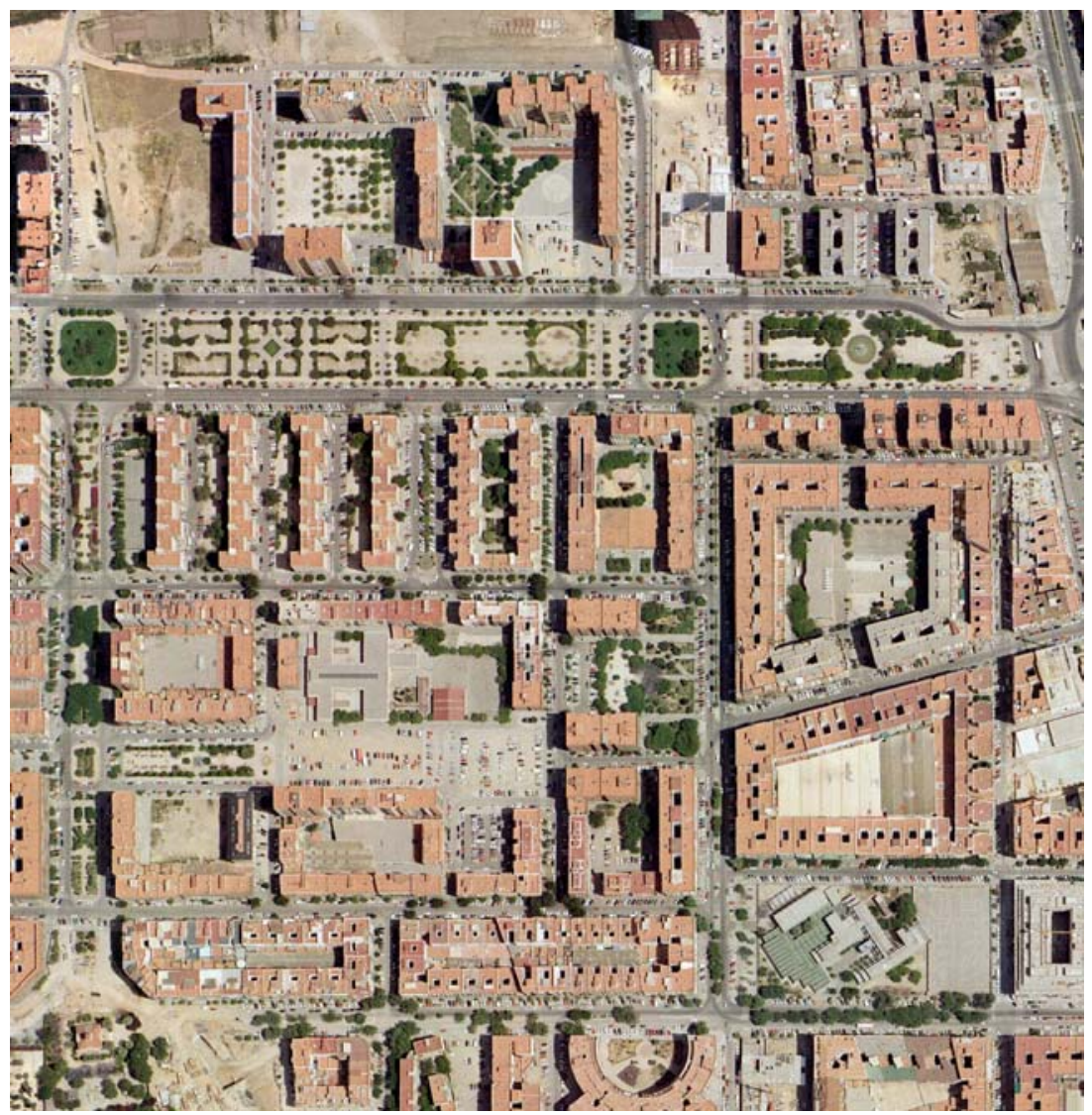


En el tramo del Paseo al Mar comprendido entre las calles de Músico Ginés y José María Haro, el lado sur está ocupado por el conjunto de la Isla Perdida, analizado en una sección anterior. En el lado norte, la edificación abierta realizada es una combinación de bloques altos en $L$ y torres. De los dos cuerpos de edificación que forman la $\mathrm{L}$ en los bloques altos, uno de ellos está alineado con la calle Serpis y el otro es perpendicular al Paseo al Mar. Las torres se sitúan a lo largo del Paseo, cerca del final del brazo del bloque en $L$ y a veces enlazadas con él por bajos comerciales.

Esta composición libera una gran cantidad de suelo abierto al Paseo al Mar: las plazas del Actor Enrique Rambal, de J. María Orense y de Mestre Ripoll, destinadas a jardines y equipamientos. Por contra, el alzado resultante a la calle Serpis queda como una gran cortina continua de edificios altos, evidenciando una línea de corte demasiado drástica con respecto a la zona de equipamientos situada a continuación de dicha calle.

Además, el hecho de que las torres sean de XX plantas y los bloques en $L$ de $X V$ y $X$ plantas, resta protagonismo a las primeras, que no se muestran como un elemento emergente con respecto a la edificación circundante. En conjunto, en todo caso, las distancias entre bloques y torres son coherentes con la idea de edificación abierta, y permiten percibir los edificios, desde del Paseo al Mar, como elementos separados entre sí: la silueta de cada uno de ellos se recorta en el cielo de manera independiente.

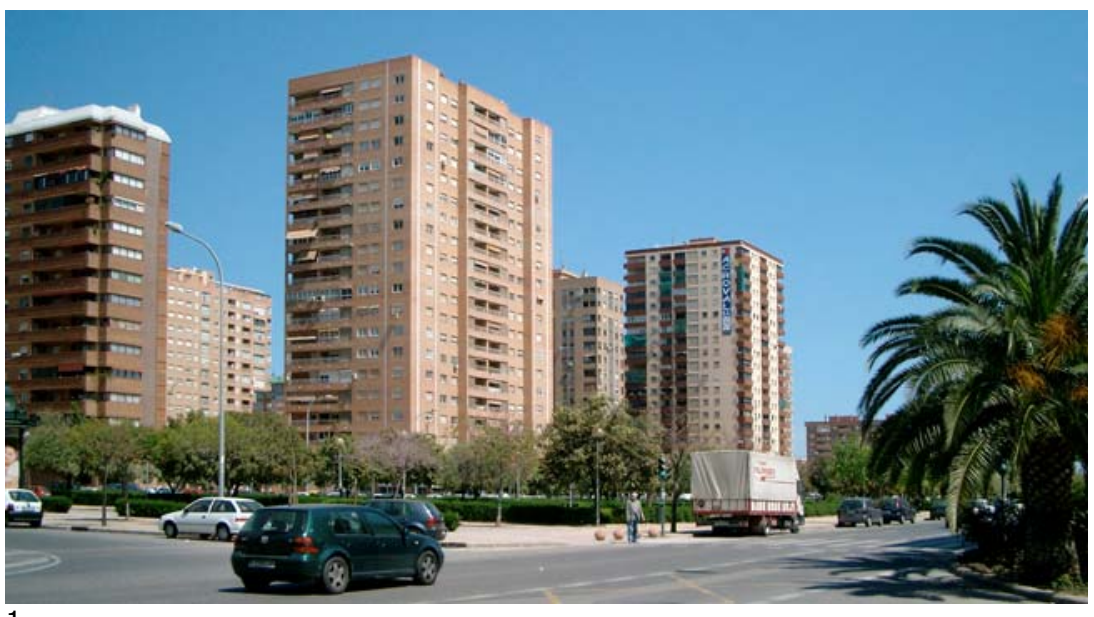

1

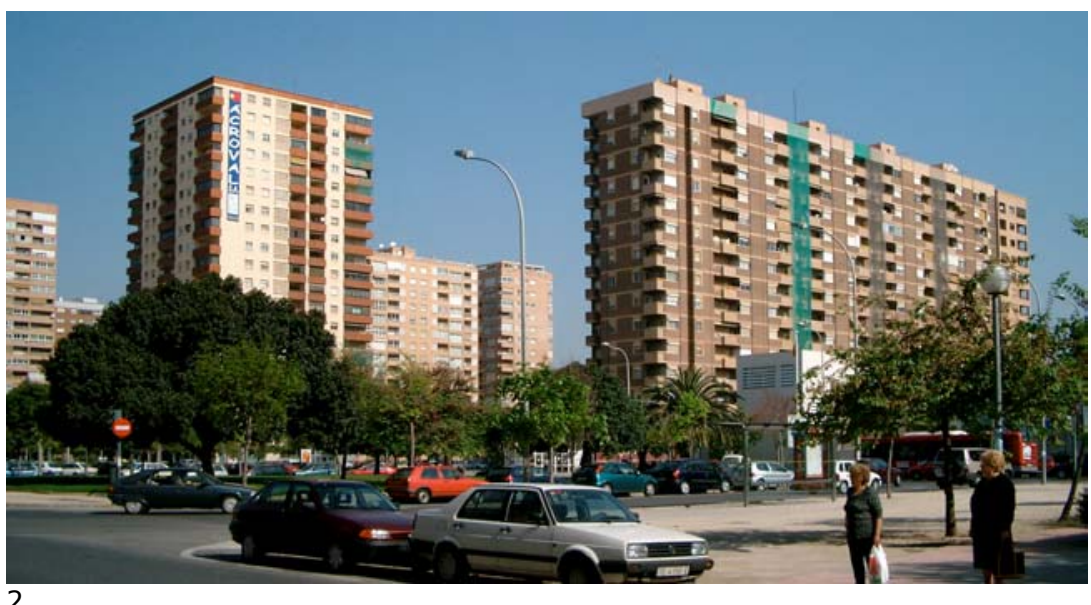

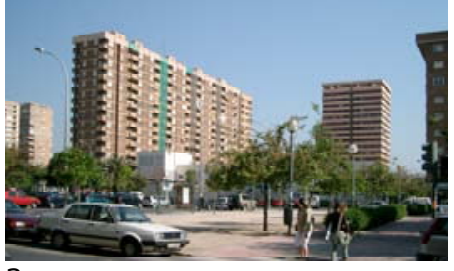

3
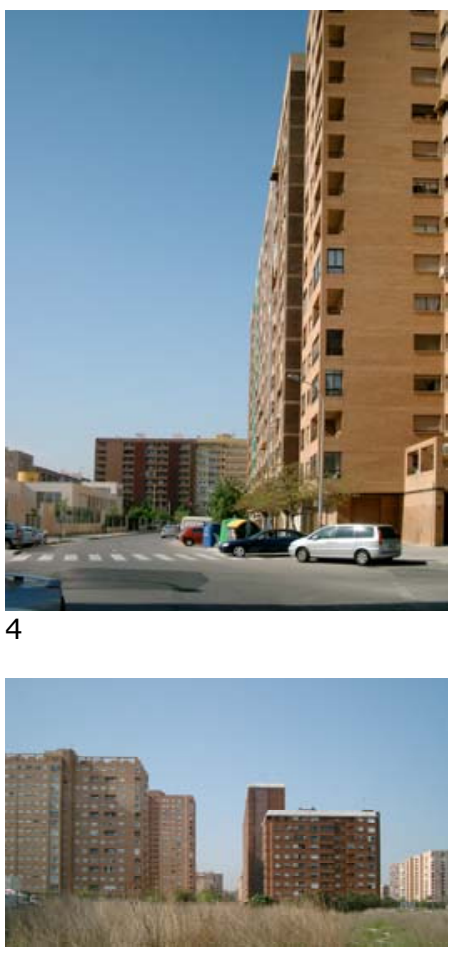

5

1. Paseo al Mar. Torres en el lado norte (Plazas Actor Enrique Rambal $y$ J.María Orense).

2. Paseo al Mar. Torre $y$ bloque alto en L en el lado norte (Plaza Mestre Ripoll).

3. Paseo al Mar. Bloque alto y torre en calle José María Haro.

4. Calle Campillo de Altobuey, esquina con Serpis. Vista hacia el sur (Al fondo, el Paseo al Mar)

5. Bloques altos en $L$ vistos desde la calle Serpis. 


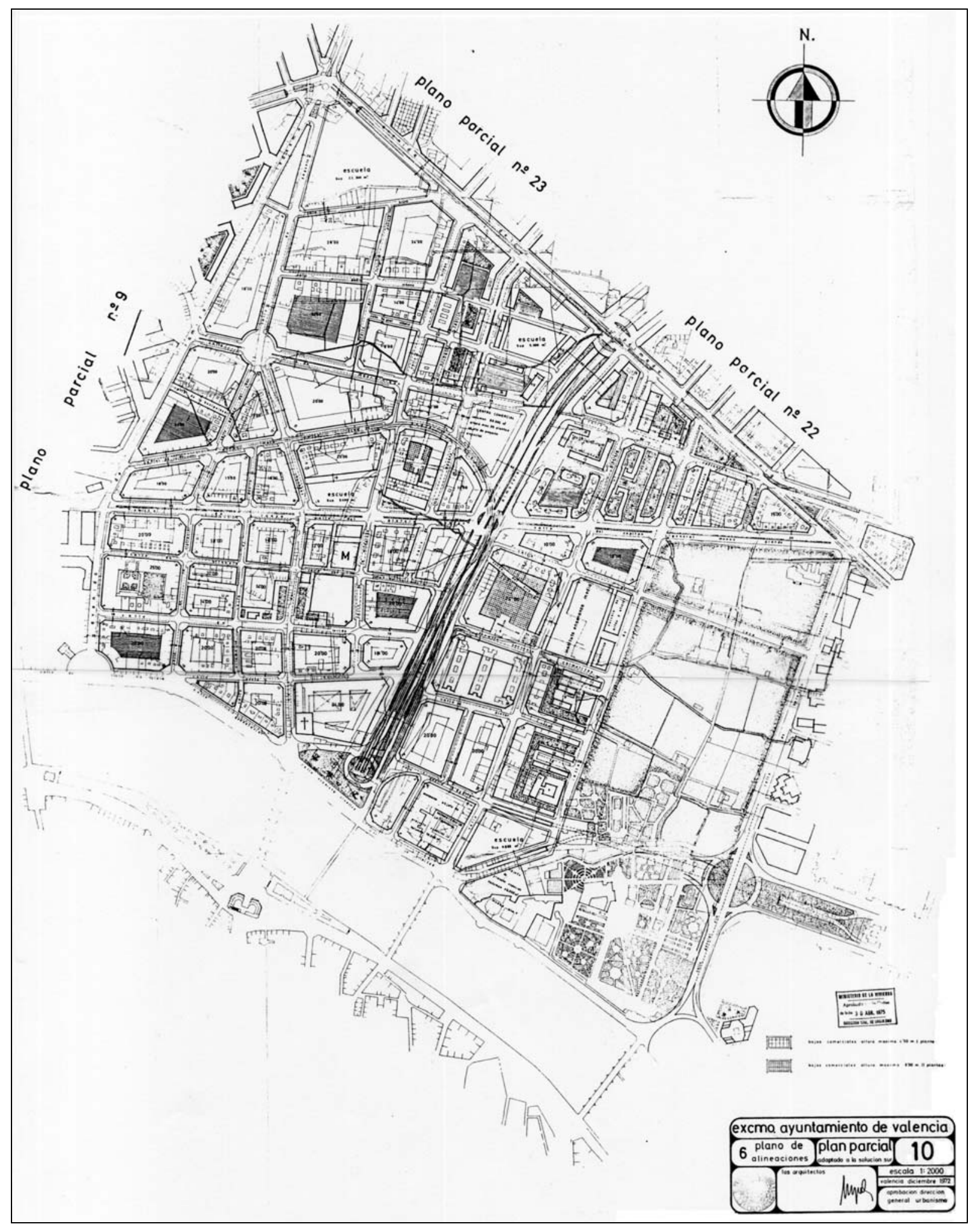

Plan Parcial 10, 1974. Plano de alineaciones. 


\section{EL PLAN PARCIAL 10. EPISODIOS AISLADOS DE EDIFICACIÓN ABIERTA EN EL LLANO DE ZAIDÍA.}

El Plan Parcial 10, aprobado como Hoja 10 del Plan General de 1946 por la Comisión Central de Sanidad Local en 1956, no fue revisado hasta después de la aprobación en 1966 del Plan General adaptado a la Solución Sur.

La primera revisión, fechada en 1968, muestra una versión del plan muy parecida en cuanto a la disposición de la edificación a la de 1956.

Esta primera revisión no fue aprobada y, ya en 1974, se redactó la que sería la versión del plan adaptada a la Solución Sur, que fue aprobada definitivamente en 1975 y anulada en 1982 por sentencia judicial. El tiempo transcurrido entre estas dos versiones evidencia que la zona, realmente, no requería una nueva ordenación global, ya que estaba en su mayor parte ya edificada. De hecho, como ocurre con otros planes cuya tramitación para adecuarlos al Plan General de 1966 quedó interrumpida, el objetivo de la nueva redacción de éste parece el de legalizar su situación antes de la inminente entrada en vigor de la nueva Ley del Suelo.

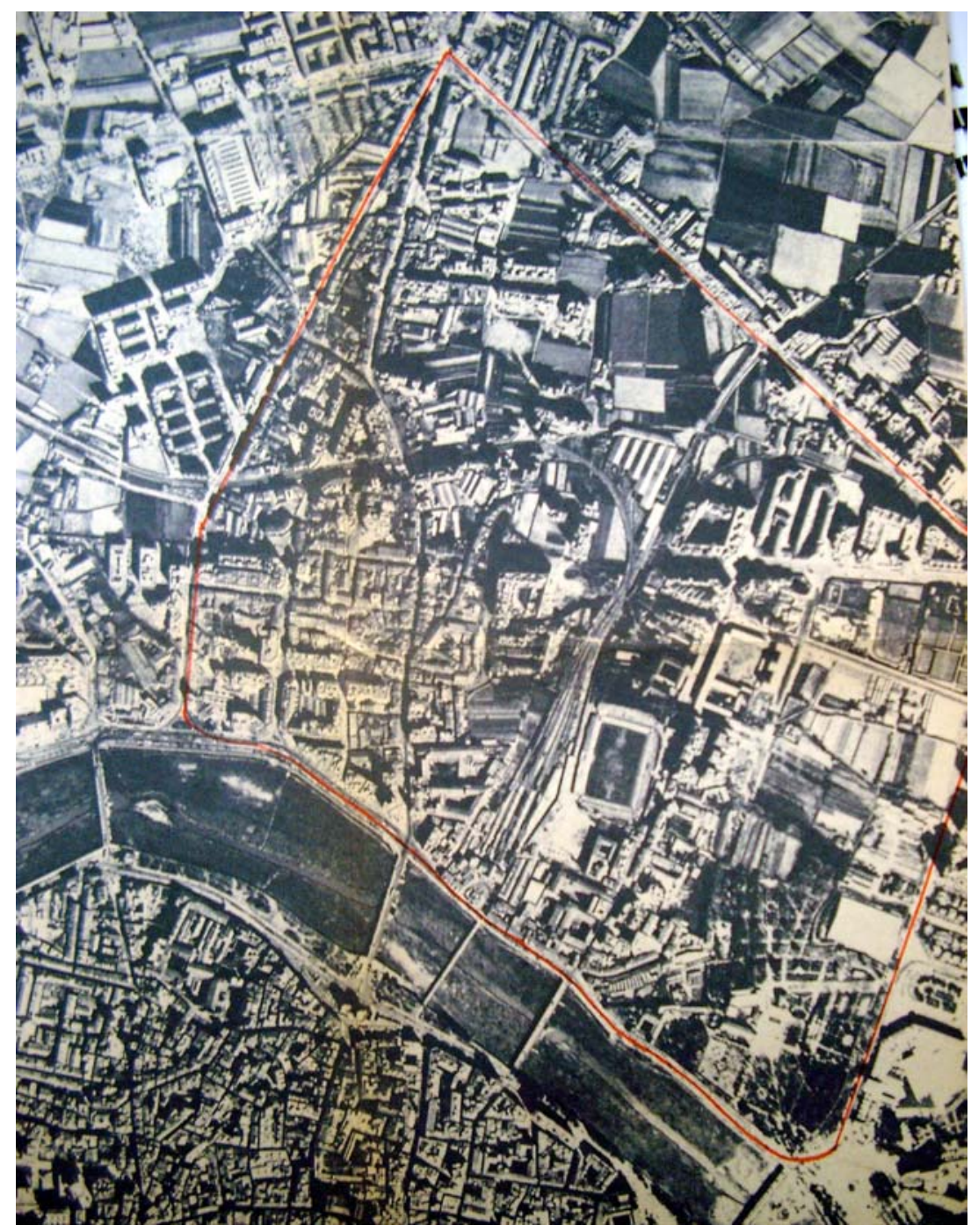

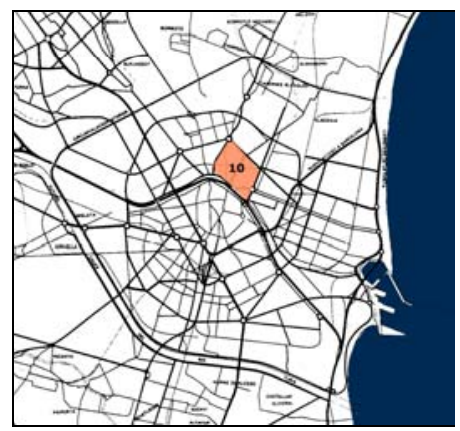

Plan Parcial 10. Localización

Plan Parcial 10. Fotoplano.

1. Plan Parcial No 10 adaptado a la Solución Sur, 1968/1974. Anexo de Documentos, pp. 325-341 


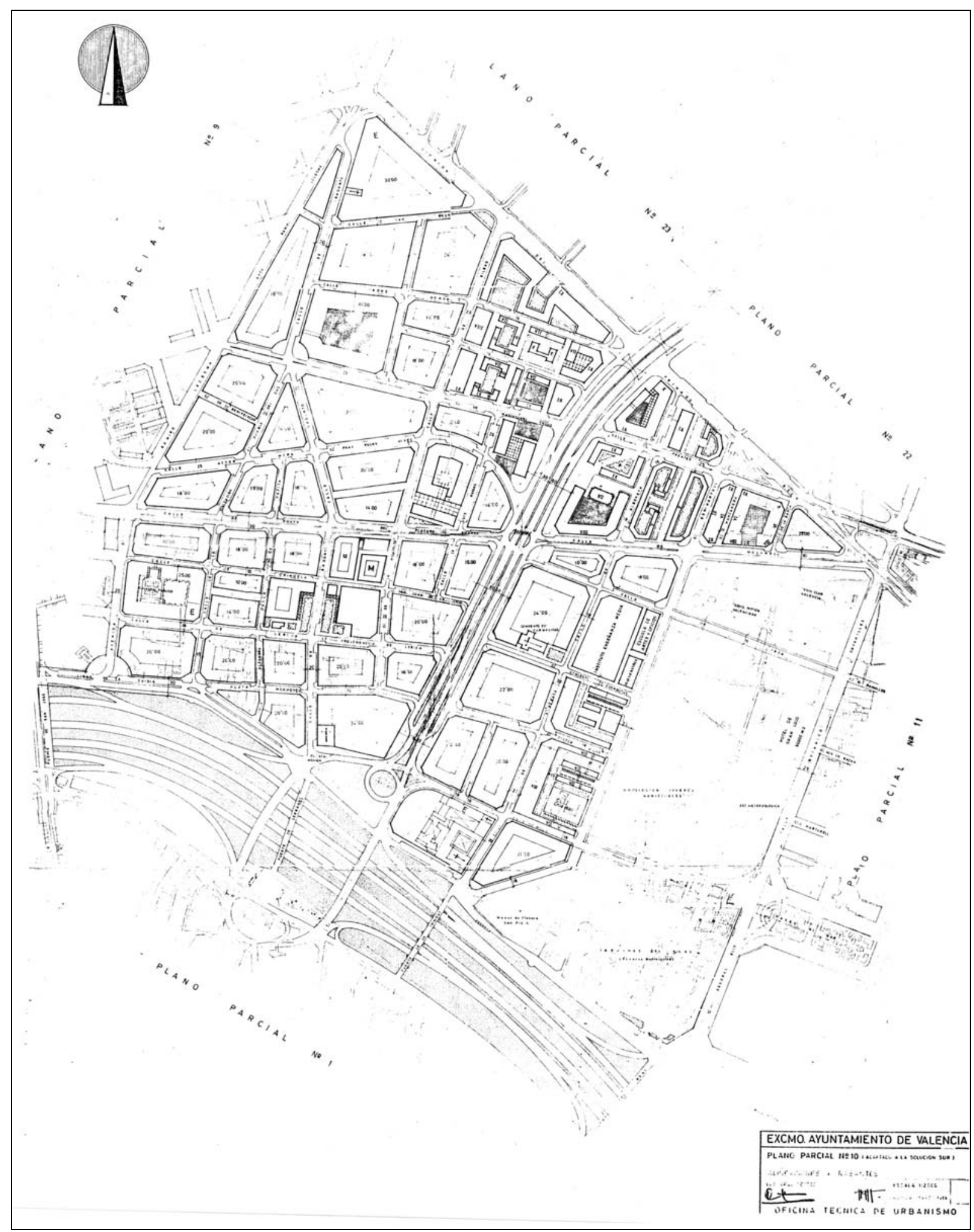

Plan Parcial 10, 1968. Plano de alineaciones.
Las zonas de edificación abierta de la versión de 1968 del Plan Parcial 10 son las mismas que las incluidas en la Hoja 10 de 1956, que hemos analizado en una sección anterior: dos zonas contiguas situadas al norte, en el espacio triangular delimitado por el Camino de Tránsitos al norte, la calle Molinell al sur y la calle Bilbao al oeste, y una tercera zona que ocupa la franja rectangular situada entre la calle Alboraya y los jardines de Viveros. 
Las modificaciones introducidas en el nuevo estudio del plano de 1968 son de pequeña entidad. En las zonas del norte, algunos bloques profundos se convierten en manzanas cerradas, como consecuencia del trazado de la arteria norte-sur que sustituye a la línea de FF.CC. de Rafelbuñol. Además, se modifica la forma en planta de algunos de los bloques aislados, y se suprime una de las semimanzanas resueltas de modo similar a las de grupo Alboraya, que se sustituye por un bloque profundo. En la zona sur, se eliminan algunos bloques lineales de la serie perpendicular a los Viveros para albergar las instalaciones de la Cruz Roja.

El plano de estado actual que acompaña a la nueva redacción del plan de 1974 muestra un alto grado de consolidación de la edificación en la zona, en la que sólo aparecen como terrenos vacantes parte de los destinadas a edificación abierta.

Por otra parte, en este plano de estado actual aparece ya edificada la manzana delimitada por las calles Alboraya, Pintor Vilar, Almazora y Convento Carmelitas, que aunque situada en la zona calificada de Ensanche hasta Tránsitos, es una manzana mixta con bloques profundos dispuestos en peine sobre un zócalo no residencial.

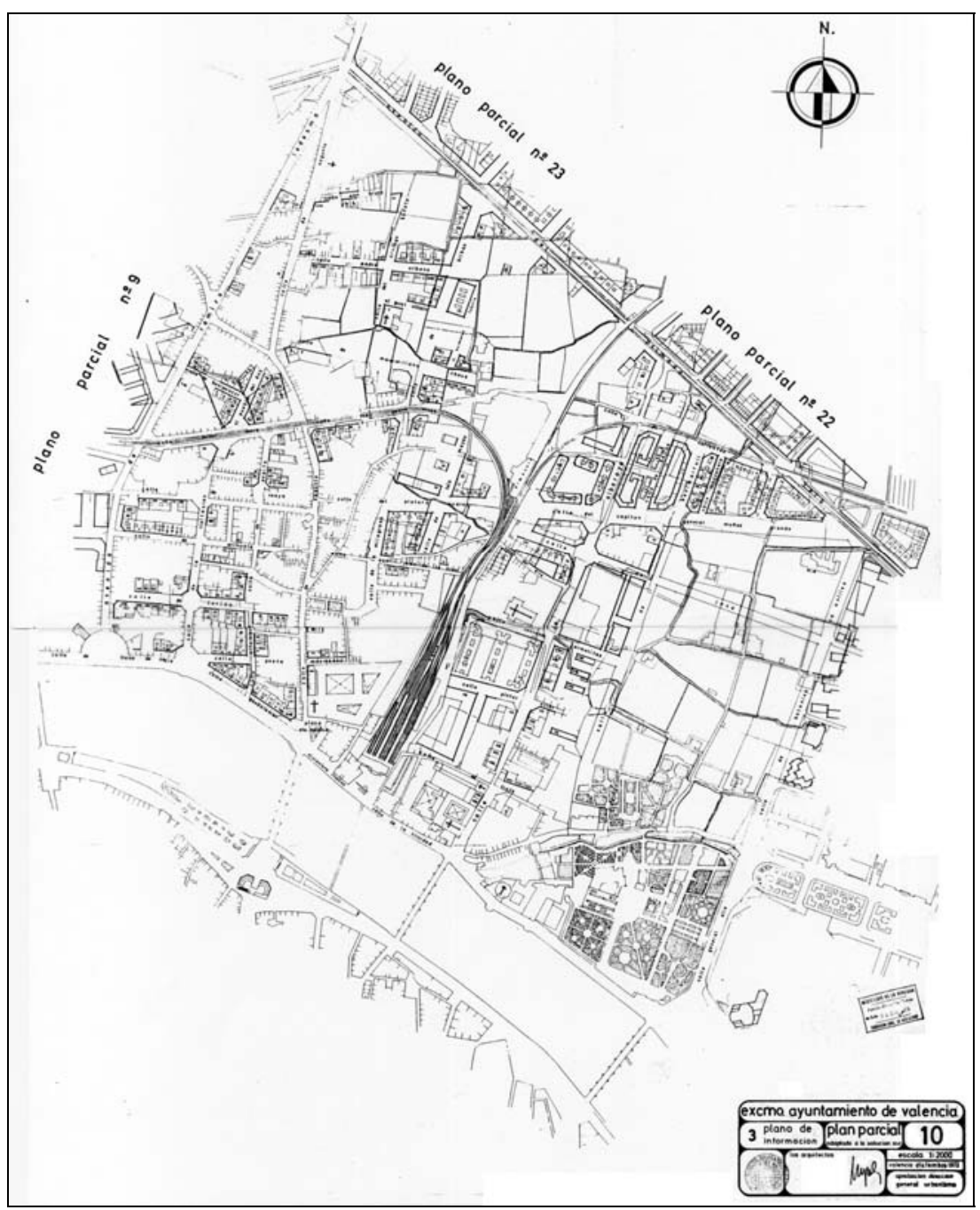

Plan Parcial 10, 1974. Plano de estado actual. 
En la versión de 1974 del Plan Parcial 10, la única manzana que quedaba con una ordenación similar a la del grupo Alboraya se sustituye por bloques aislados. Además, en la zona situada entre las calles Bilbao y Almazora, la disposición de los bloques aislados se modifica nuevamente para aumentar el tamaño de la pequeña parcela escolar prevista en el planeamiento anterior.

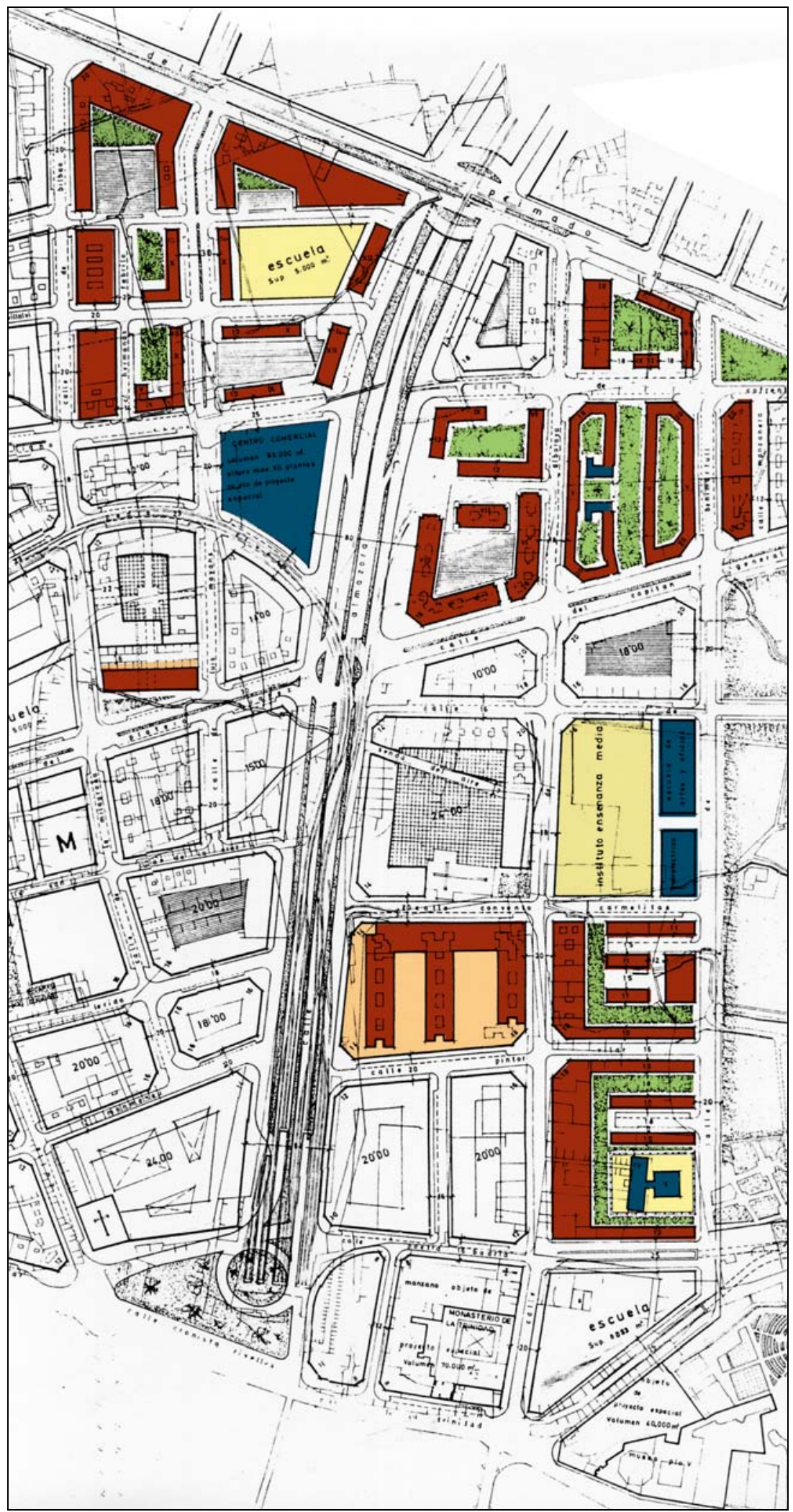


Todas estas zonas están calificadas como Edificación Abierta Alta, de edificabilidad máxima $5 \mathrm{~m} 3 / \mathrm{m} 2$. En cambio, la zona comprendida entre la calle Alboraya y los jardines de Viveros, aunque ordenada con bloques de edificación abierta, está situada dentro de la zona de Ensanche hasta Tránsitos. Lo mismo ocurre con las manzanas mixtas de Pintor Vilar y de Plafisa.

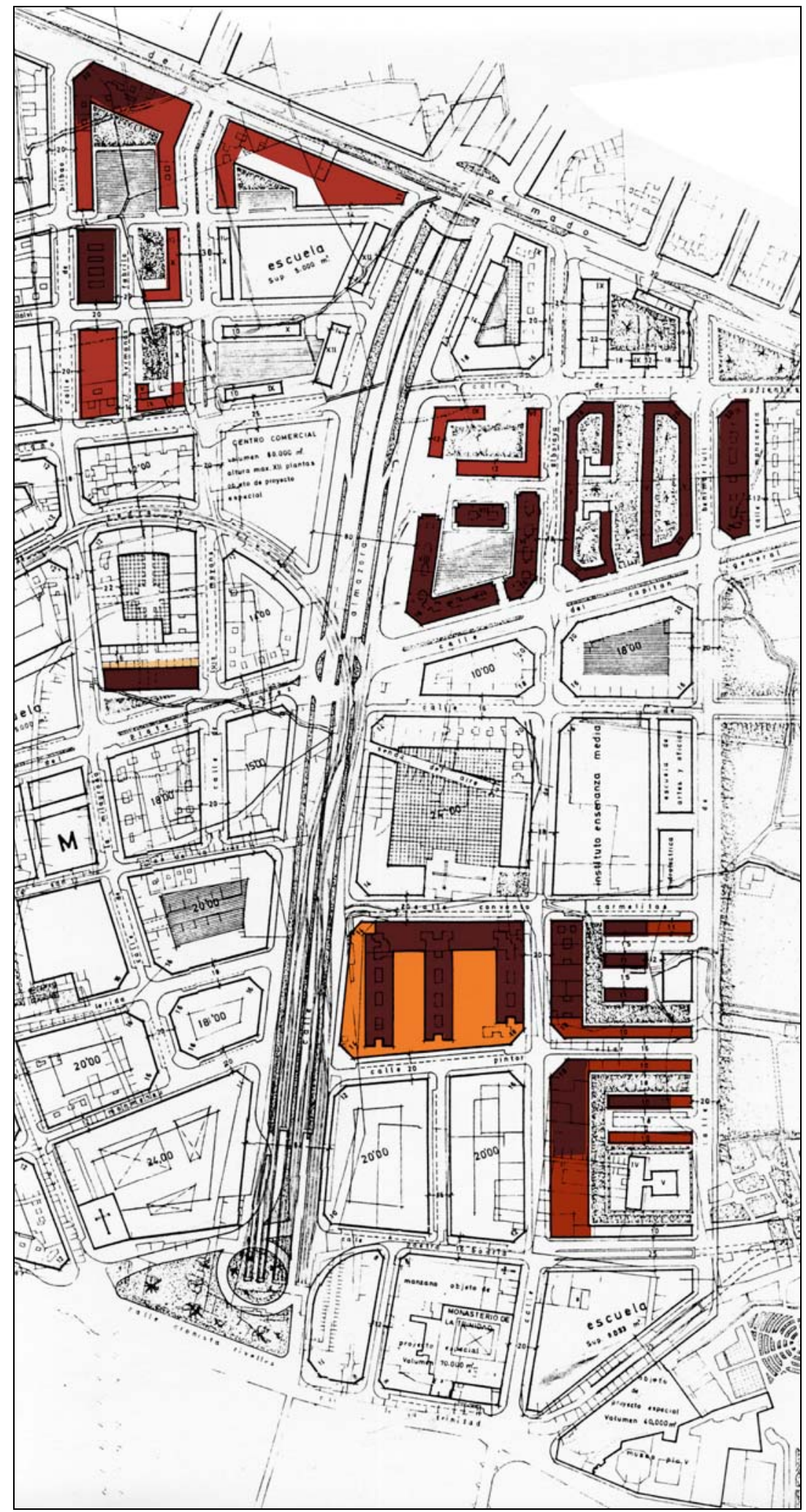

Plan Parcial 10, 1974. Grado de realización de las zonas de edificación abierta (Elaboración propia. Color sobre Plano de alineaciones). 
Los jardines de los Viveros, con una superficie de 263.640 m2, forman parte, según la Memoria del Plan Parcial 10, de las zonas verdes del mismo, de modo que la superficie de las mismas asciende al 23,3\% del total del plan.

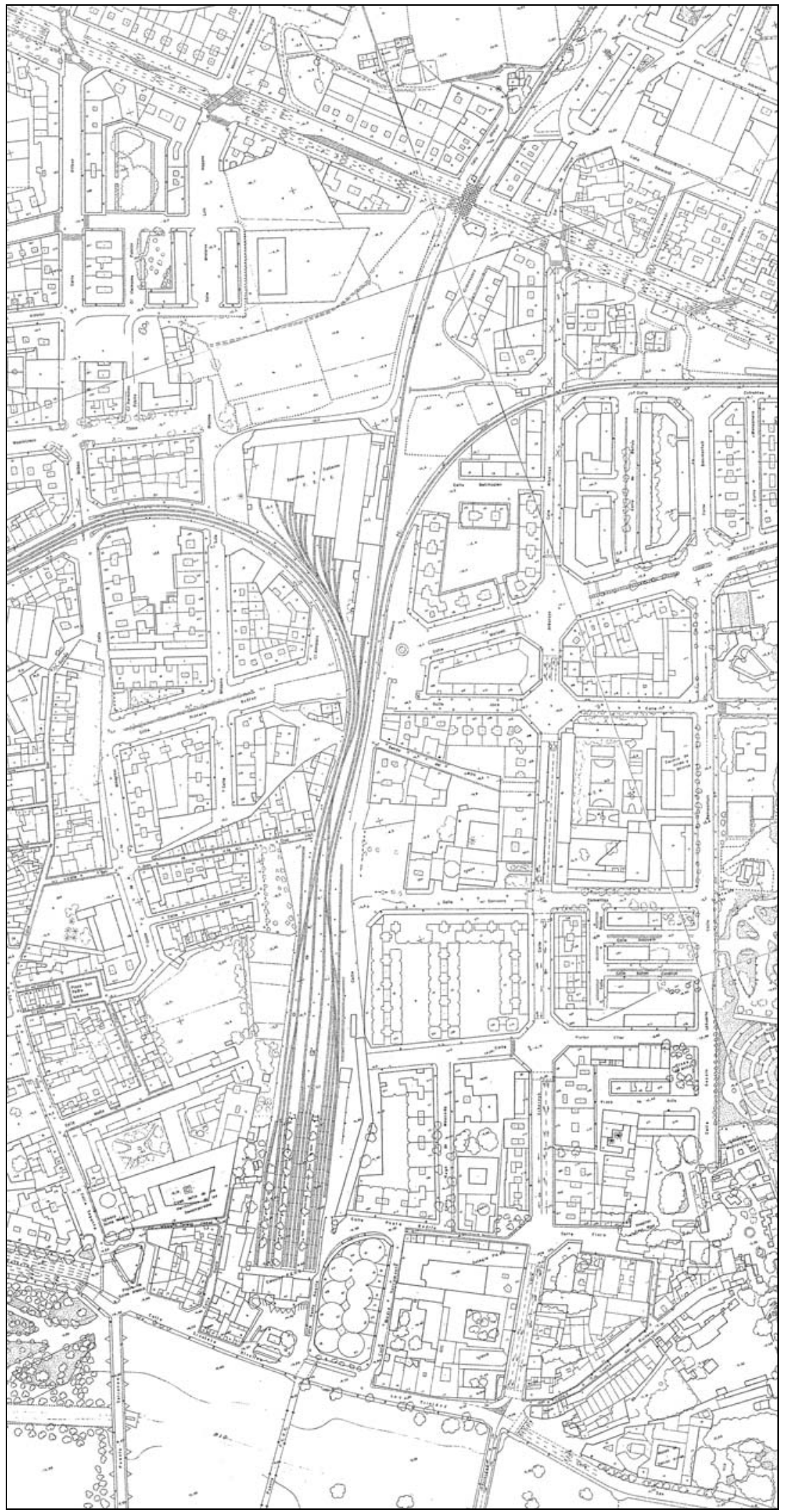


El viario en las zonas de edificación abierta es mallado, como en el resto del ámbito del plan. Los espacios intermedios entre los bloques que componen cada manzana se destinan a bolsas de aparcamientos y a jardines.

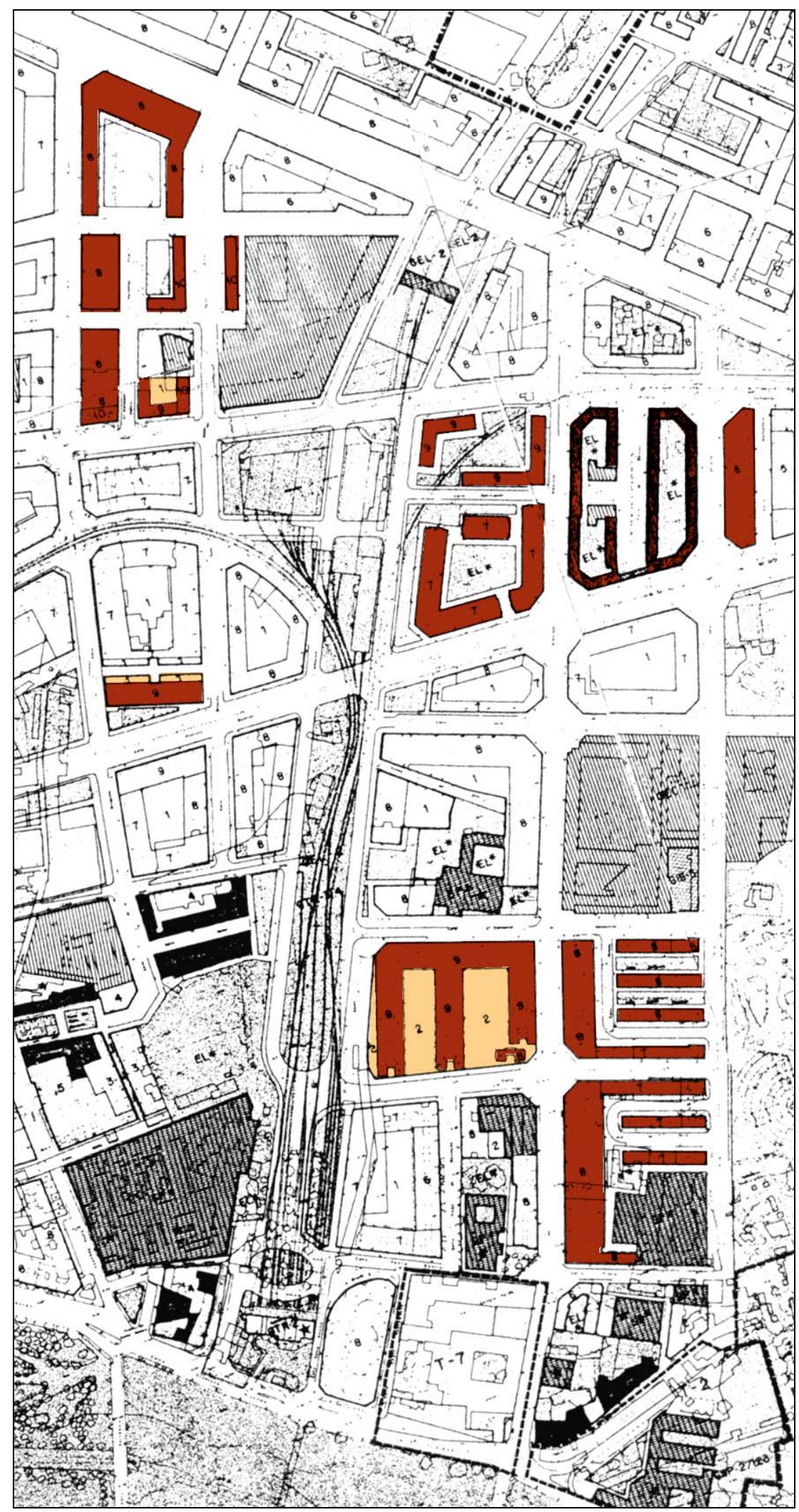

PGOU 1988. Detalle de la zona correspondiente al Plan Parcial 10 (Elaboración propia. Color sobre montaje de hojas Serie C, Planos de Régimen Urbanístico del plan). 

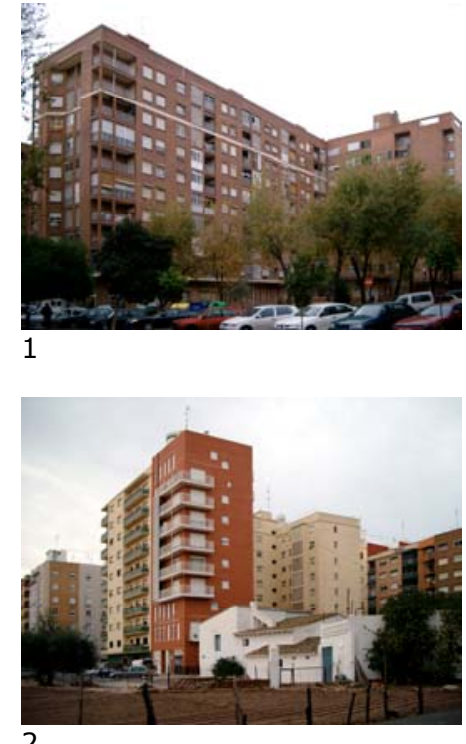

2

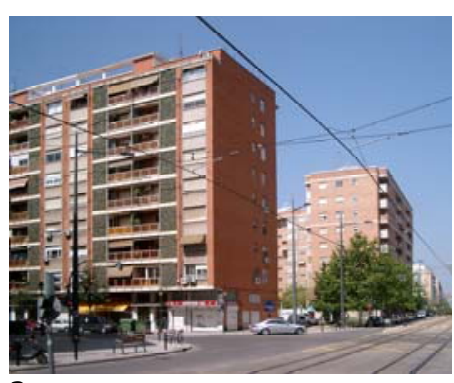

3

\section{Grado de realización}

Los bloques de edificación abierta que quedaron sin edificar de los previstos en el Plan Parcial 11 son los comprendidos entre la calle Molinell y la Avenida de Primado Reig, al norte del grupo Alboraya, y los de la zona delimitada por las calles Almazora, Molinell, Luís Mayans y Padre Urbano, además del bloque lineal situado más al sur de los de la serie ortogonal a los Viveros.

La edificación abierta situada en el ámbito de este plan es, en definitiva, una suma de episodios aislados que no forman un conjunto legible como tal. De hecho, ninguno de esos episodios está completo, ya que lo realizado son únicamente fragmentos, restos de las ordenaciones iniciales.
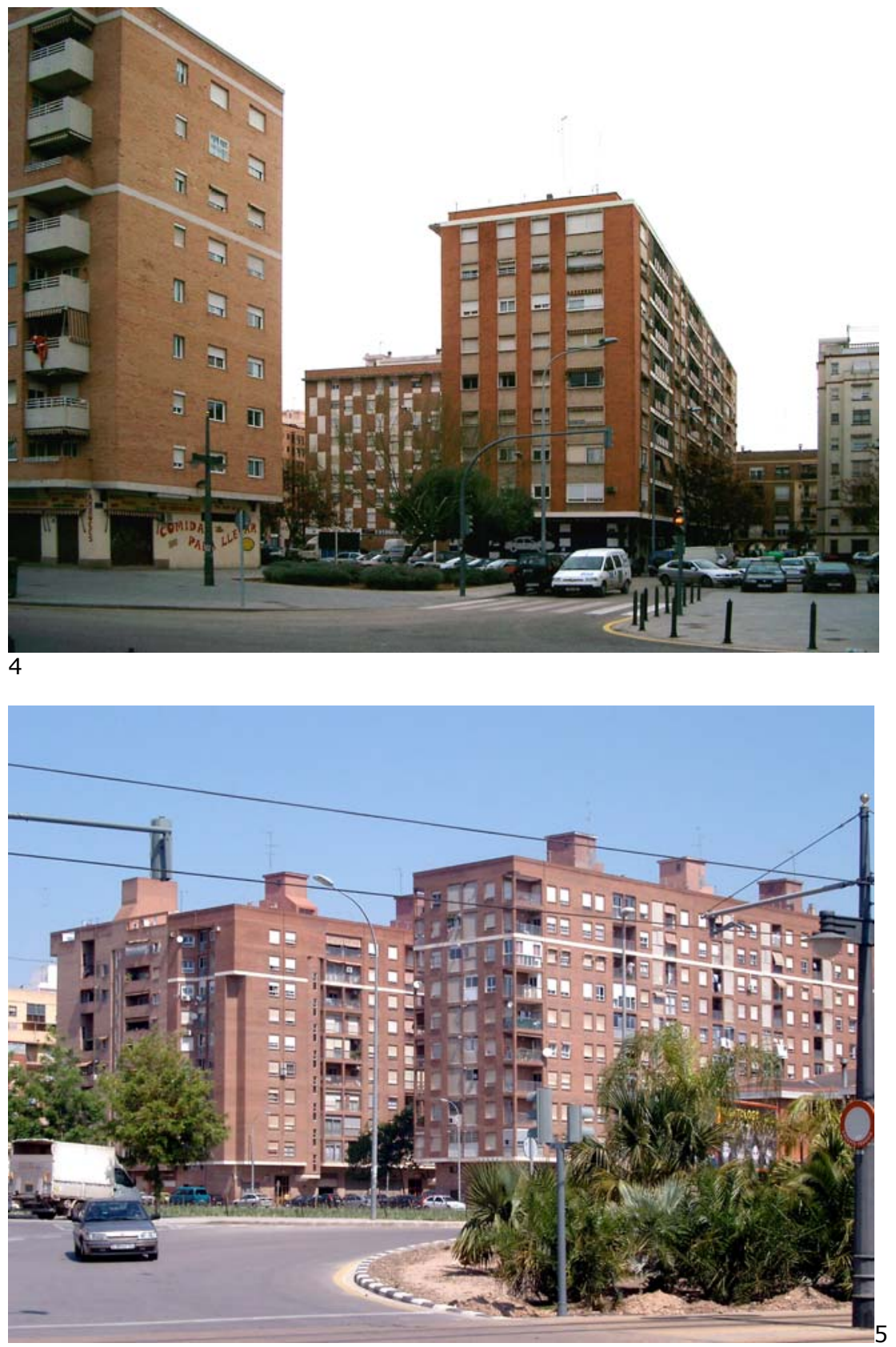

1. Bloque en la calle Hermanos Fabrilo.

2. Bloque junto a la calle Gual Villalbí.

3-4.Bloques en la calle Cofrentes.

5.Bloques de la calle Luís Mayans. 


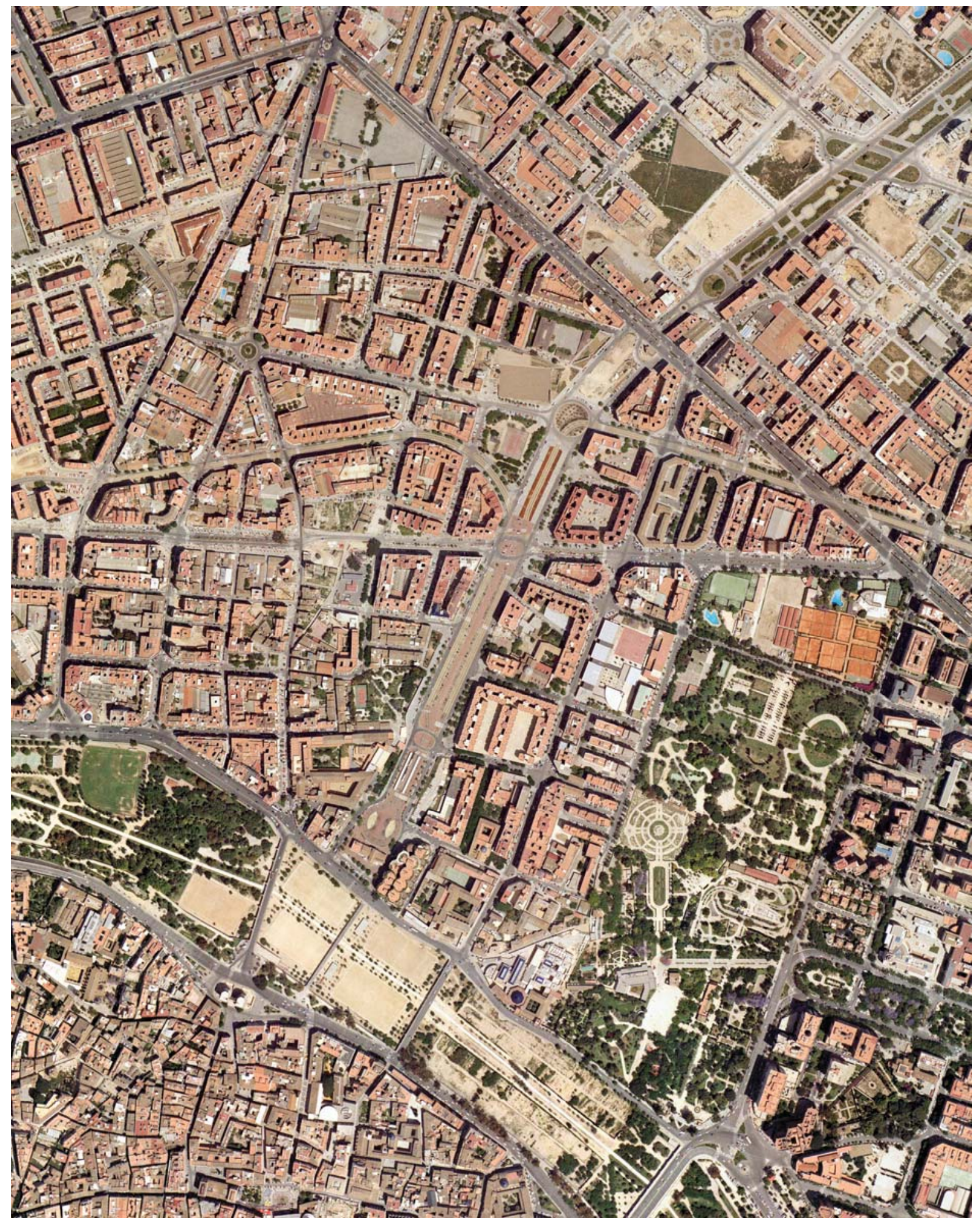

Plan Parcial 10. Ortofoto 2002 (AUMSA). 


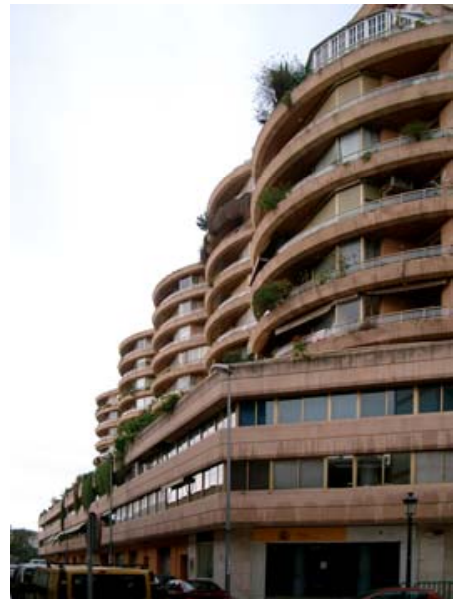

Conjunto Torres del Turia. Vista desde la calle Madre Sacramento.

Conjunto Torres del Turia. Plafisa. Primera propuesta, 1975. GODB Arquitectos.

1. Vista desde el cauce del Turia.

2. Planta tipo de viviendas.

3. Perspectiva.

1. Sorribes i Monrabal, Josep. Desarrollo capitalista y proceso de urbanización en el País Valenciano (1960-75), Institución Alfonso el Magnánimo, Institució Valenciana d'Estudis i Investigació, Valencia, 1985.

El conjunto Torres del Turia, promovido por Plafisa y proyectado por GODB en 1975 para una manzana recayente al cauce del río Turia, junto a la estación de FF.CC. eléctricos, ha sido analizado con detalle en cuanto promoción inmobiliaria por Sorribes ${ }^{1}$. La primera propuesta de volúmenes para el mismo estaba formada por siete torres circulares escalonadas de alturas variables, situadas sobre un basamento comercial de tres plantas, y fue rechazada por el Ayuntamiento debido a que superaba la altura máxima de $27 \mathrm{~m}$. permitida por el Art. no 12 de las Normas Urbanísticas del Plan General para la zona de Ensanche hasta Tránsitos a la que pertenece esta manzana. A fin de mantener la edificabilidad total, se redacta un Estudio de Detalle, aprobado en 1977, que reordena con desafortunados resultados los volúmenes, reduciendo las alturas pero aumentando el número de torres de siete a diez.

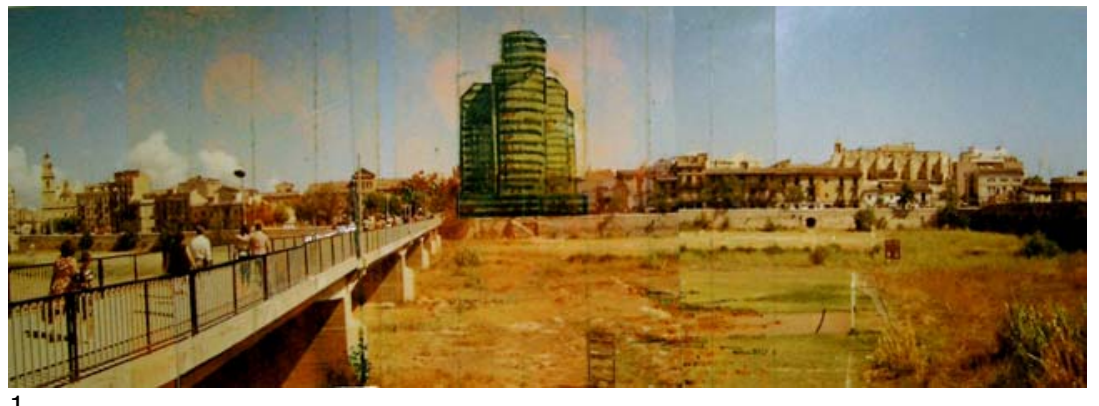

1
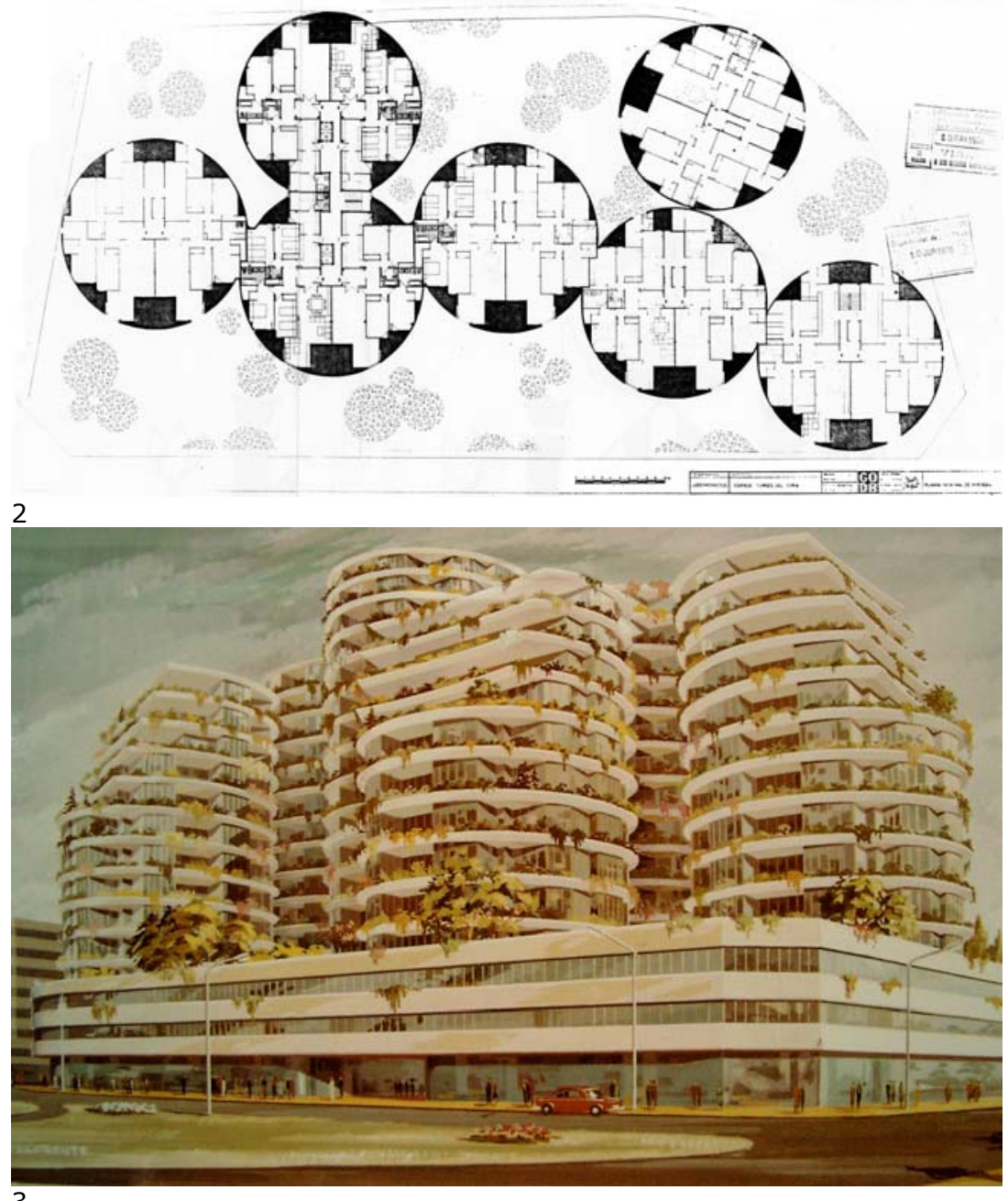

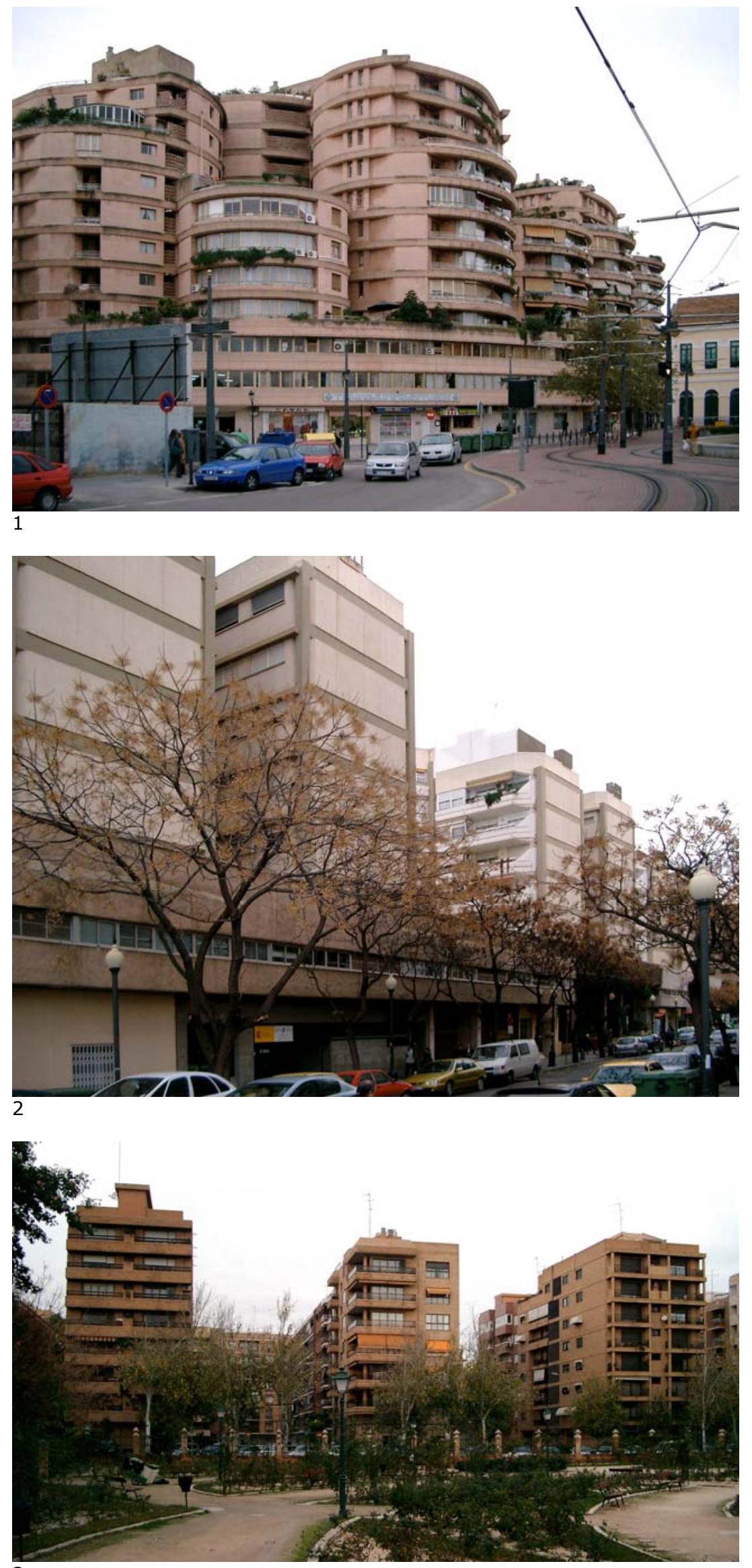

3
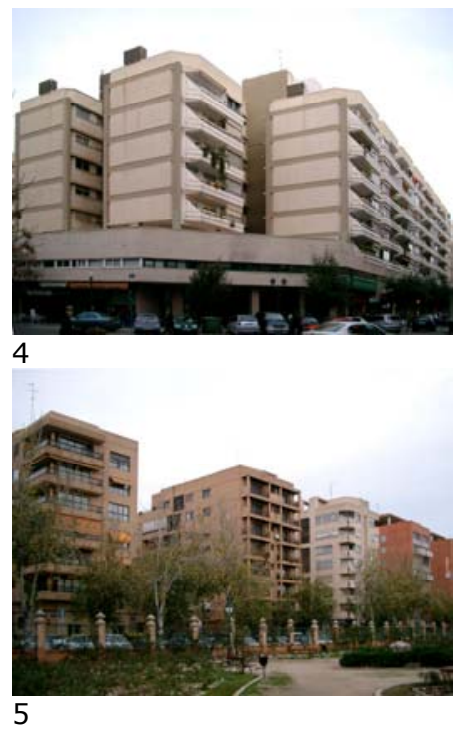

5
1. Conjunto Torres del Turia. 2,4. Conjunto de Pintor Vilar. 3,5. Bloques lineales frente a los jardines de Viveros. 


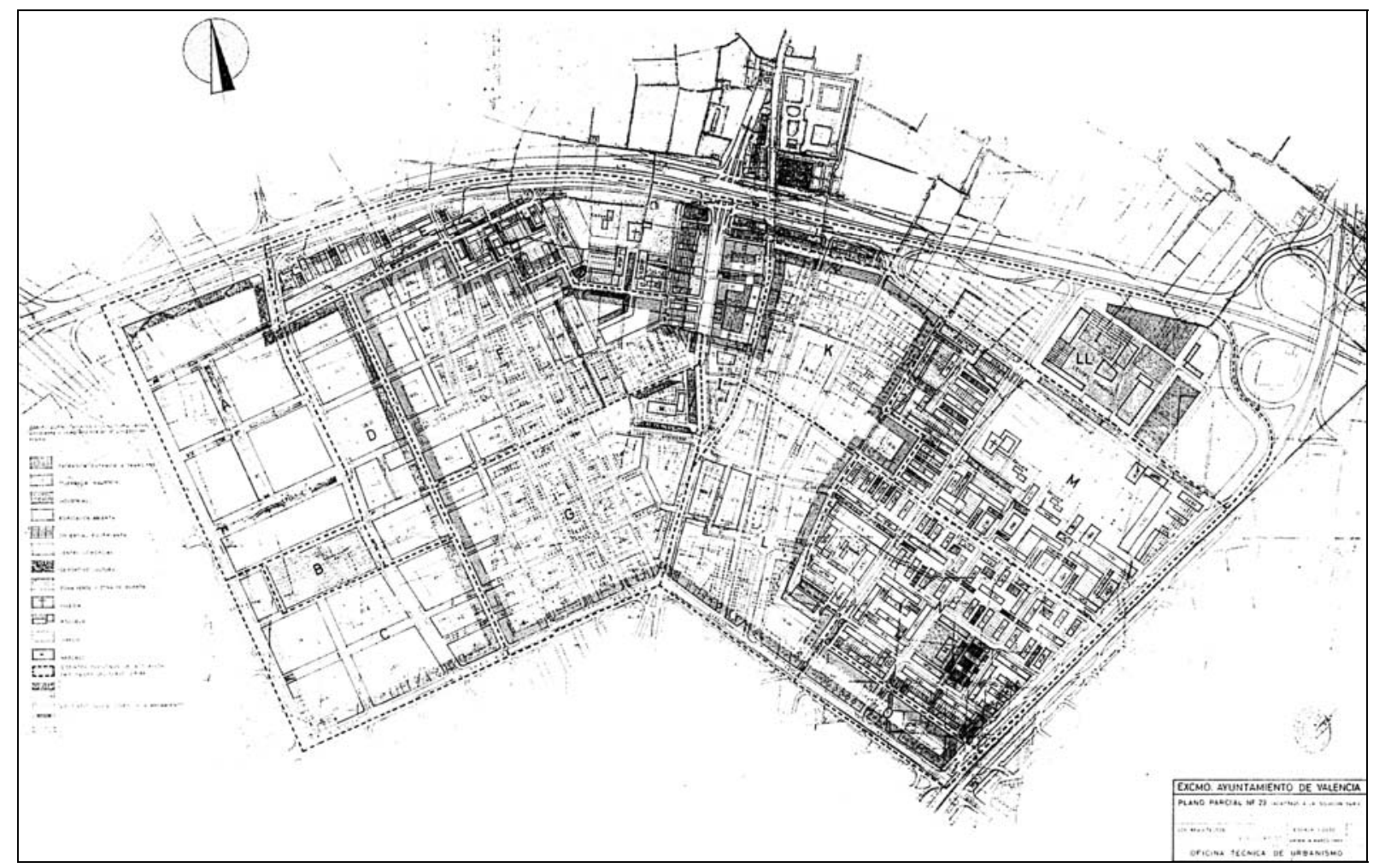

Plan Parcial no 23 adaptado a la Solución Sur, 1967. Plano de zonificación.

ZONificacion (Terrenos bajo la tram
correspondiente, o comprendidos on

correspondiente,
poligono de trama.

EXTENSION EXTERIOR A tranSITOS

D. coiricacion abienta

INDUSTRIAL

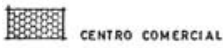

国要 Escuela

固卉 Iotesis

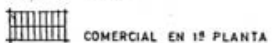

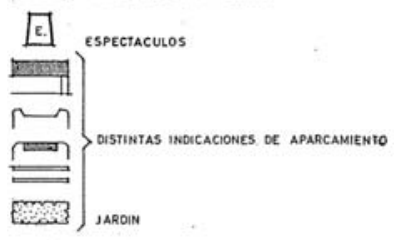

Distintos pougonos oe actuacion 
El área ordenada por el Plano Parcial no 23 adaptado a la Solución Sur (PP23) está limitada al sur por la Ronda de Tránsitos, al norte por la Ronda Exterior, al este por la línea de ferrocarriles eléctricos de Rafaelbuñol (futuro acceso Norte) y al oeste por el camino de Moncada. Esta delimitación coincide con la de la primera versión del plan, redactada en 1962, que hemos analizado en la sección anterior. $^{1}$

El eje de la carretera de Barcelona, que es el que hemos adoptado para delimitar las zonas este y oeste en la mitad norte de la ciudad, está situado en el centro del PP23, atravesándolo de norte a sur. Podemos, por ello, considerar que el ámbito de este plan está a caballo entre las zonas noreste y noroeste. El que lo agrupemos con los planes parciales de la zona noreste se debe al hecho de que el sector este del PP23 es la parte más significativa del mismo proyectada de acuerdo con los principios de la edificación abierta.

En su nueva redacción de 1967, el PP23, que refleja ya el diseño viario elaborado por la Oficina Regional de Proyectos de Carreteras, modifica completamente la edificación prevista en la versión de 1962, así como el trazado del viario interno.

Ello fue posible porque, tal como evidencia el plano de estado actual que acompaña al PP23 de 1967, no se había llegado a construir ninguno de los edificios previstos en las zonas ordenadas con edificación abierta, que permanecían como terrenos vacantes, con su uso agrícola original.

Además, el PP23 de 1967 introduce una modificación en el Plan General de 1966, que consiste en la creación de un nuevo centro comercial con un amplio aparcamiento anejo al noreste, junto a la Ronda Exterior. La Memoria del plan justifica este cambio aduciendo que el centro comercial previsto en el Plan General, junto a la antigua carretera de Barcelona, era inviable por estar localizado en una zona de manzanas cerradas bastante consolidada y sin posibilidad de aparcamientos.

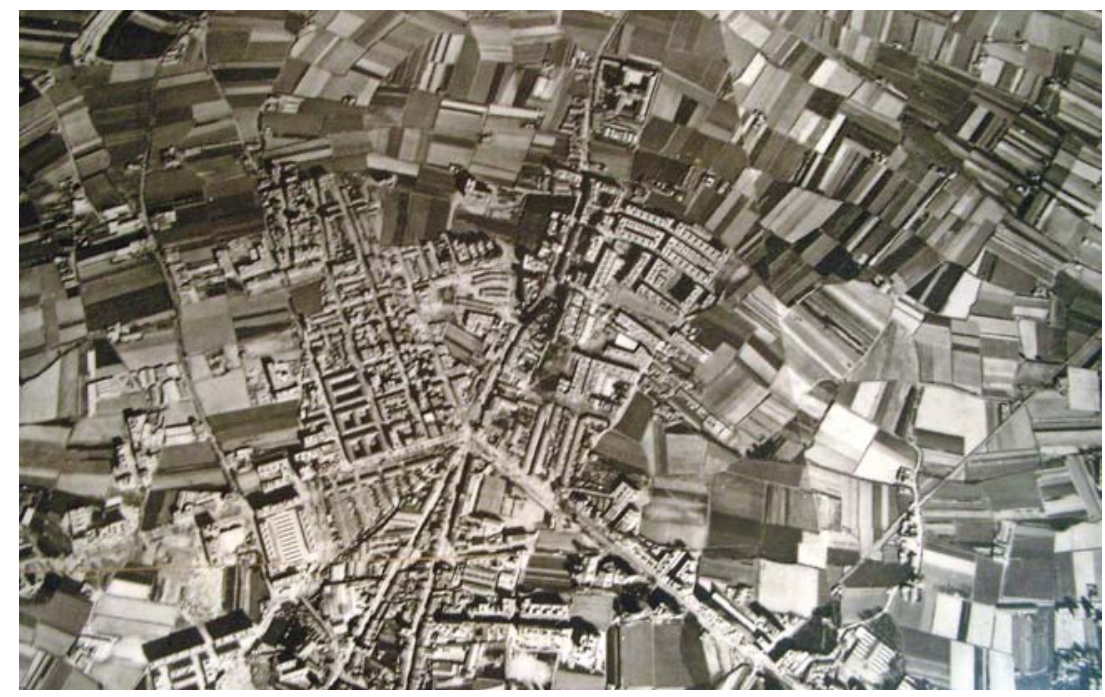

Zona del Plan Parcial 23. Fotoplano, h. 1965 (ETS de Arquitectura, Valencia)

1. Plan Parcial no 23 adaptado a la Solución Sur, 1967. Ver Anexo de Documentos, pp. 487-502. 


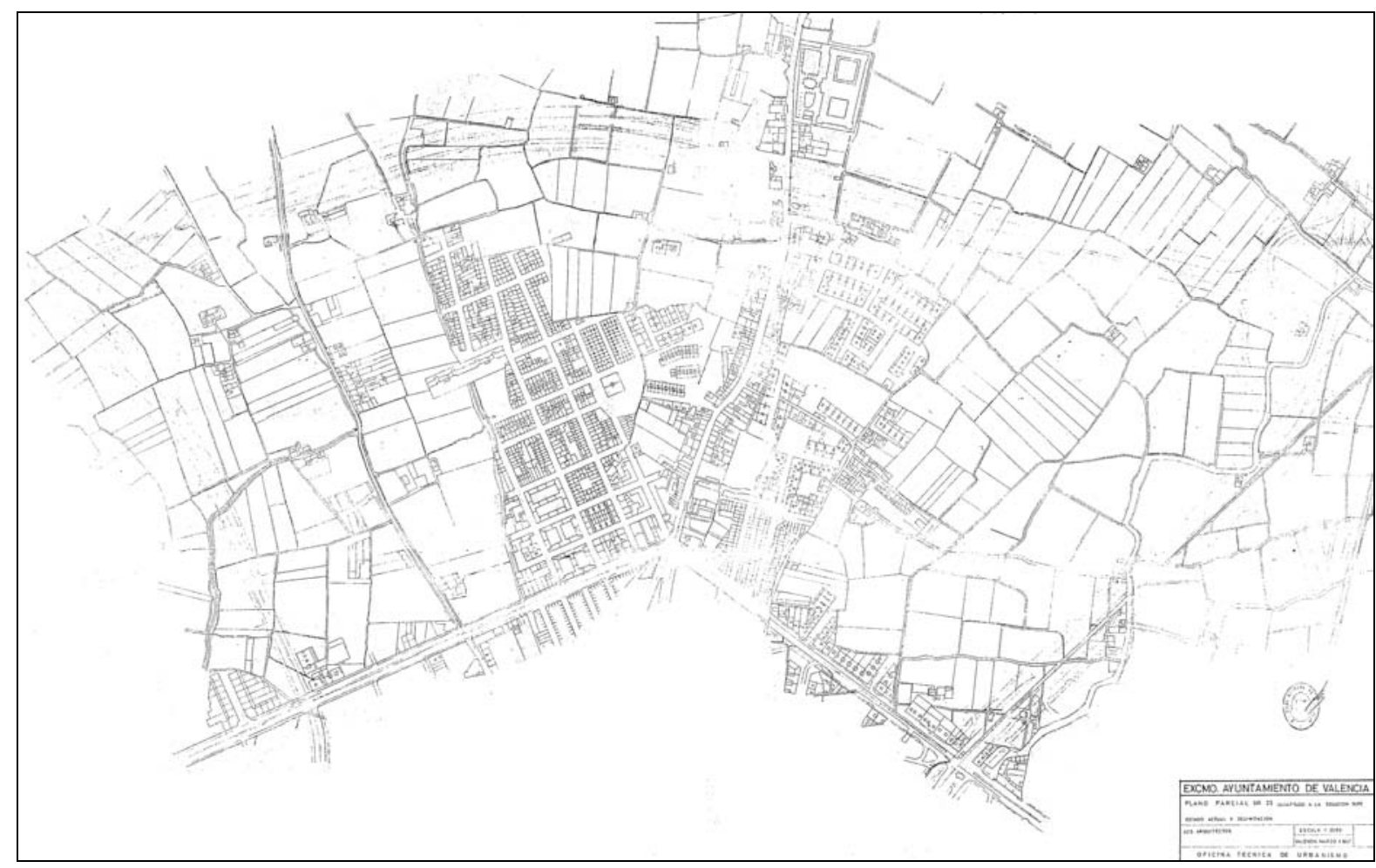

Plan Parcial 23, 1967. Plano de estado actual.

1. Informe sobre alegaciones del Arquitecto mayor, 23-11-1967 y resolución de aprobación del Plan Parcial 23 por el Ministerio de la Vivienda,30-10-1968. Documentos 23A.1 y 23.2. Anexo de Documentos, pp. 497-500.
Las zonas calificadas en el PP23 de 1967 como Edificación Abierta Alta son las mismas que en la versión de 1962: una de menor tamaño al norte de Torrefiel, junto a la Ronda Exterior, y otra más extensa al este de Orriols, hasta el límite con la línea de FF.CC. eléctricos de Rafelbuñol.

Tras las correspondientes rondas de alegaciones, el PP23 fue aprobado definitivamente por el Ministerio de la Vivienda en $1968^{1}$. De la aprobación ministerial se excluyeron tres zonas: el nuevo centro comercial y su aparcamiento, un núcleo de escuelas y centro parroquial que estaba localizado en una zona verde prevista en el Plan General y una zona de edificación abierta adyacente.

La modificación del plan realizada por el Ayuntamiento en respuesta a dicha exclusión deja libre la zona verde del Plan General y crea una zona escolar-deportiva al noreste, albergando el centro parroquial en la manzana contigua. Además, renuncia al nuevo centro comercial y refleja en el solar previsto para el mismo el estadio de fútbol del Levante U.D., con una explicación que no necesita comentarios:

Se ubica en la zona en estudio el nuevo campo del Levante U.D., ya que la redacción y gestión del Plan Parcial no 23 fue simultánea a la gestación de la idea y compra de terrenos para ubicar el campo de fútbol indicado, hecho ignorado por el autor del plano que suscribe, que ahora rectifica con la introducción de tan deseable elemento deportivo.

Por último, a instancia de la Jefatura de Industrias de Valencia, se ubica instalación para reconocimiento de Camiones.

La zona comercial, como aneja a este Plan Parcial, no es realmente necesaria, porque, siendo edificación, en general, cerrada, todos los bajos, tradicionalmente son comercios o pequeñas industrias. No podemos decir lo mismo de zona comercial que sirva a toda la 
ciudad, una o varias, de llegada en vehículos automóviles. Estas zonas comerciales que se van imponiendo podrán establecerse, en cualquier momento en cualquier terreno despejado junto a una gran circunvalación. Por el momento creemos preferible prescindir de la misma. ${ }^{1}$
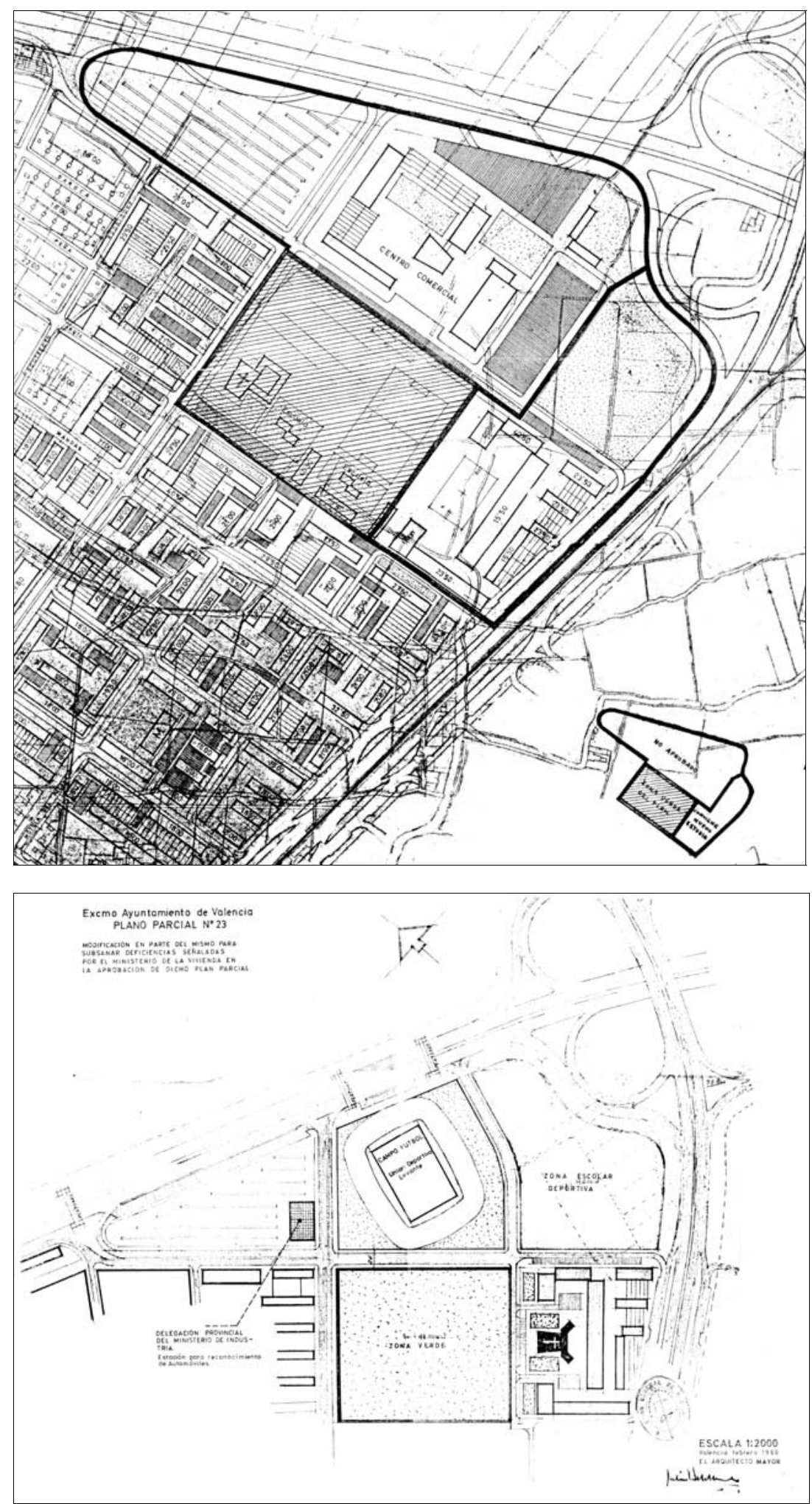

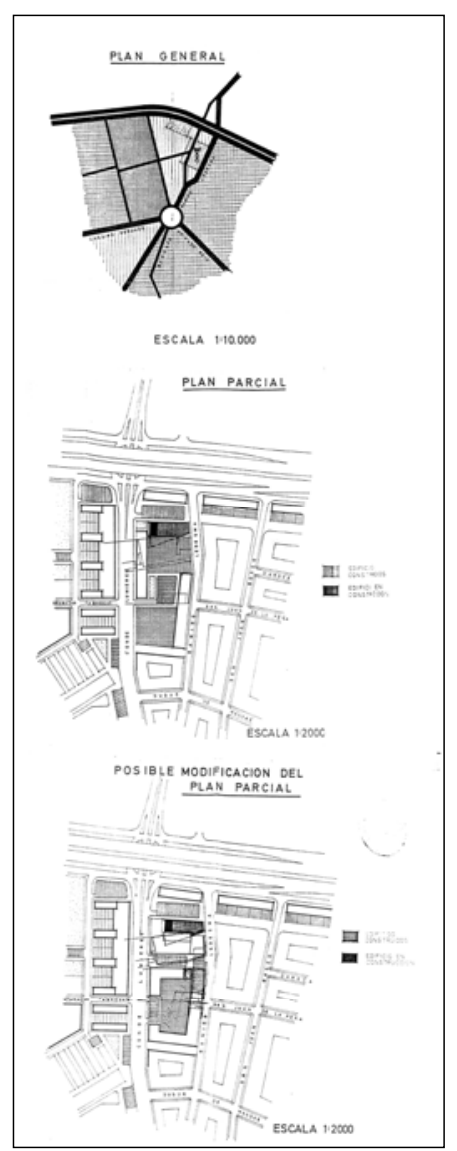

PP 23. Propuesta de modificación del centro comercial previsto por el Plan General en la carretera de Barcelona.

PP23. Zonas excluidas de aprobación por el Ministerio de la Vivienda, 1968.

PP23. Modificación de la zona noreste, 1969.

1. Modificación de la zona norte del Plan Parcial 23, febrero 1969. Documento 23.3. Anexo de Documentos, p. 501. 


\section{Trazado viario.}

La zona este del PP23 es la única, de las dos de edificación abierta previstas, con una extensión suficiente para proyectar en ella un trazado viario diferente de la malla convencional asociada a las manzanas cerradas.

En esta zona, se utiliza para las calles principales un viario en forma de malla, y para el resto se recurre a una serie de viales en forma de lazo que parten del viario principal y vuelven a él. De estos viales en lazo, que delimitan unas manzanas de gran tamaño, nacen, para cada manzana, diversos ramales sin salida que penetran en dichas manzanas pero no las atraviesan.

El núcleo central de las manzanas queda, de este modo, libre de tráfico rodado, lo que permite que todos los bloques estén comunicados peatonalmente entre sí.

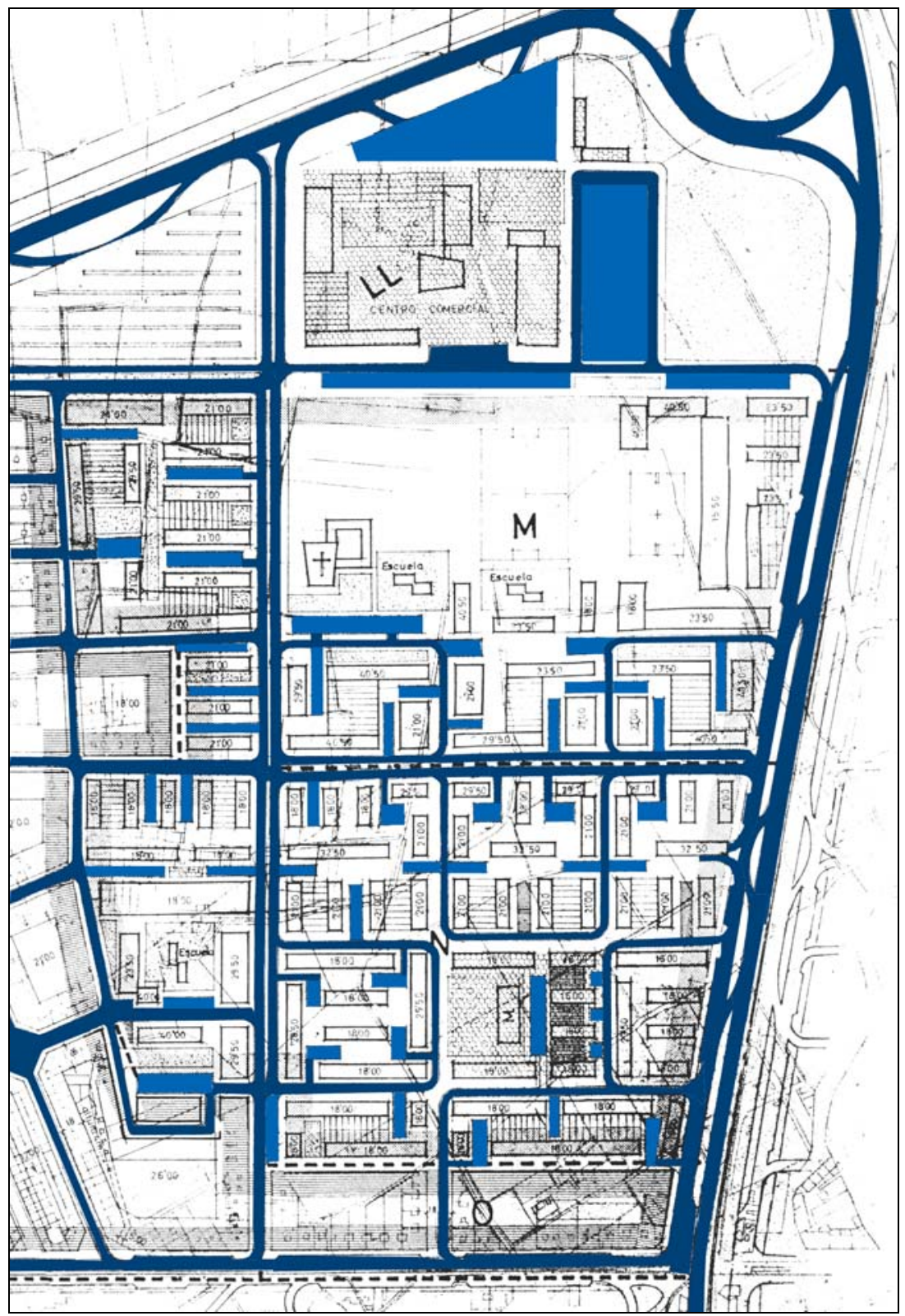


Por otro lado, el sistema de viales en forma de lazo se puede utilizar para enlazar peatonalmente varias manzanas, como ocurre en el caso del mercado situado en la parte sureste, unido por los vértices, con recorridos libres de tráfico, a tres manzanas adyacentes.

En cuanto a las reservas para aparcamientos, la memoria del plan señala que por tratarse de un barrio de condición modesta, se han previsto $20 \mathrm{~m} 2$ cada 5 viviendas, previsión que, como ocurre en los demás planes parciales, es escasa.

\section{Equipamientos}

Los equipamientos comerciales previstos en el PP23 para las zonas de edificación abierta son el centro comercial exterior a la Ronda (inicialmente previsto y finalmente descartado, como hemos visto), el centro comercial situado junto a la antigua carretera de Barcelona y un mercado situado en la zona al este de Orriols.

Además, en las zonas de edificación abierta se reserva suelo para centros escolares y religiosos. En concreto, en la zona al este de Orriols se prevén tres parcelas escolares (dos de las cuales se convertirán, en la modificación del plan, en una parcela deportivoescolar en una localización diferente, como hemos visto) y un centro religioso. En la zona al norte de Torrefiel se proyecta un núcleo de equipamientos formado por una parcela escolar y un centro religioso envueltos por un parque.

En relación con la reserva de suelo para escuelas, la Memoria del PP 23 señala literalmente lo siguiente:

La población escolar, incluido maternales, es del $15 \%$ de la población, o sea, 16.337 escolares, lo que a razón de $6 \mathrm{~m} 2$ por alumno, se necesitarían 98.024 metros cuadrados. En el presente plan se ha alcanzado la cifra de 18.703 metros cuadrados, notoriamente inferior a la necesaria, a pesar de haber dotado todas las agrupaciones nuevas con sus correspondientes escuelas. Ello es debido en gran parte porque el núcleo actual de población tiene resuelto en parte esta necesidad por medio de escuelas en edificios no especiales y de colegios oficiales situados en las manzanas construidas, particulares y religiosos. ${ }^{1}$

En cuanto a las zonas verdes, están todas ellas concentradas en el gran parque situado al noreste, junto a la Ronda Exterior y el nuevo centro comercial. Aparte de este parque, no existen apenas zonas verdes en el resto del ámbito del plan, salvo la que envuelve el núcleo de equipamientos de la zona noroeste formado por la escuela y el centro parroquial y una franja residual situada entre los bloques y la Ronda Exterior.

1. Plan Parcial no 23 adaptado a la Solución Sur, 1967. Memoria. Anexo de Documentos, p. 488. 
$P P$ 23. Edificación y equipamientos. Detalle de la zona norte (Elaboración propia sobre plano de alineaciones del Plan)

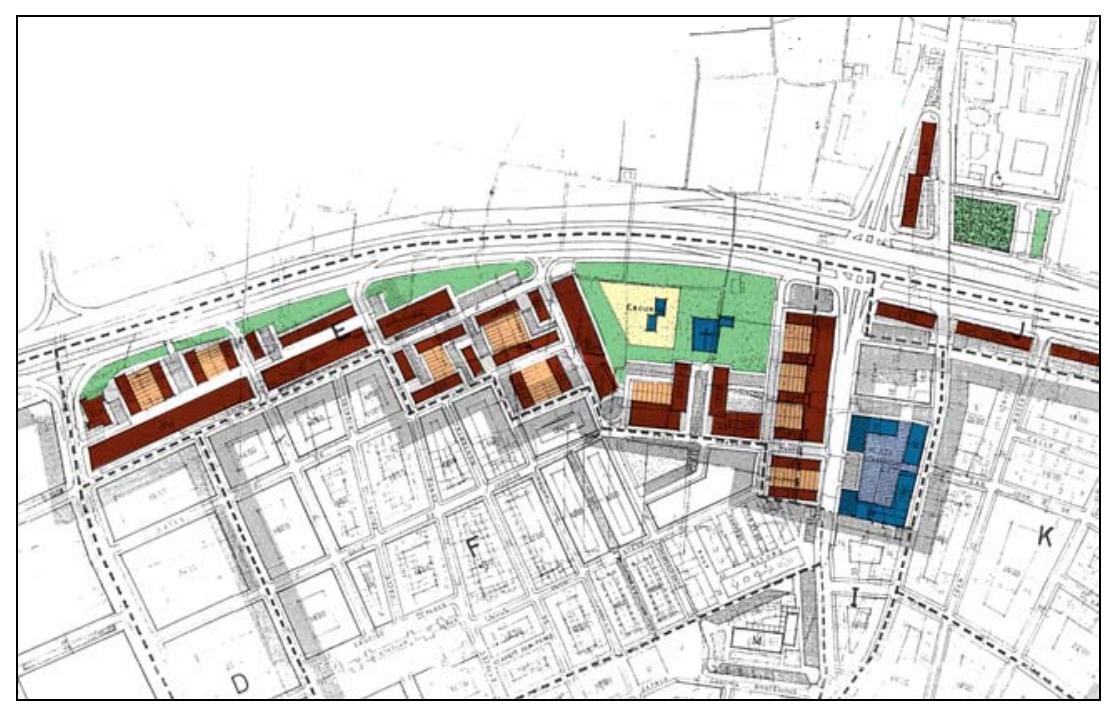

PP 23. Edificación y equipamientos. Detalle de la zona este (Elaboración propia sobre plano de alineaciones del Plan)

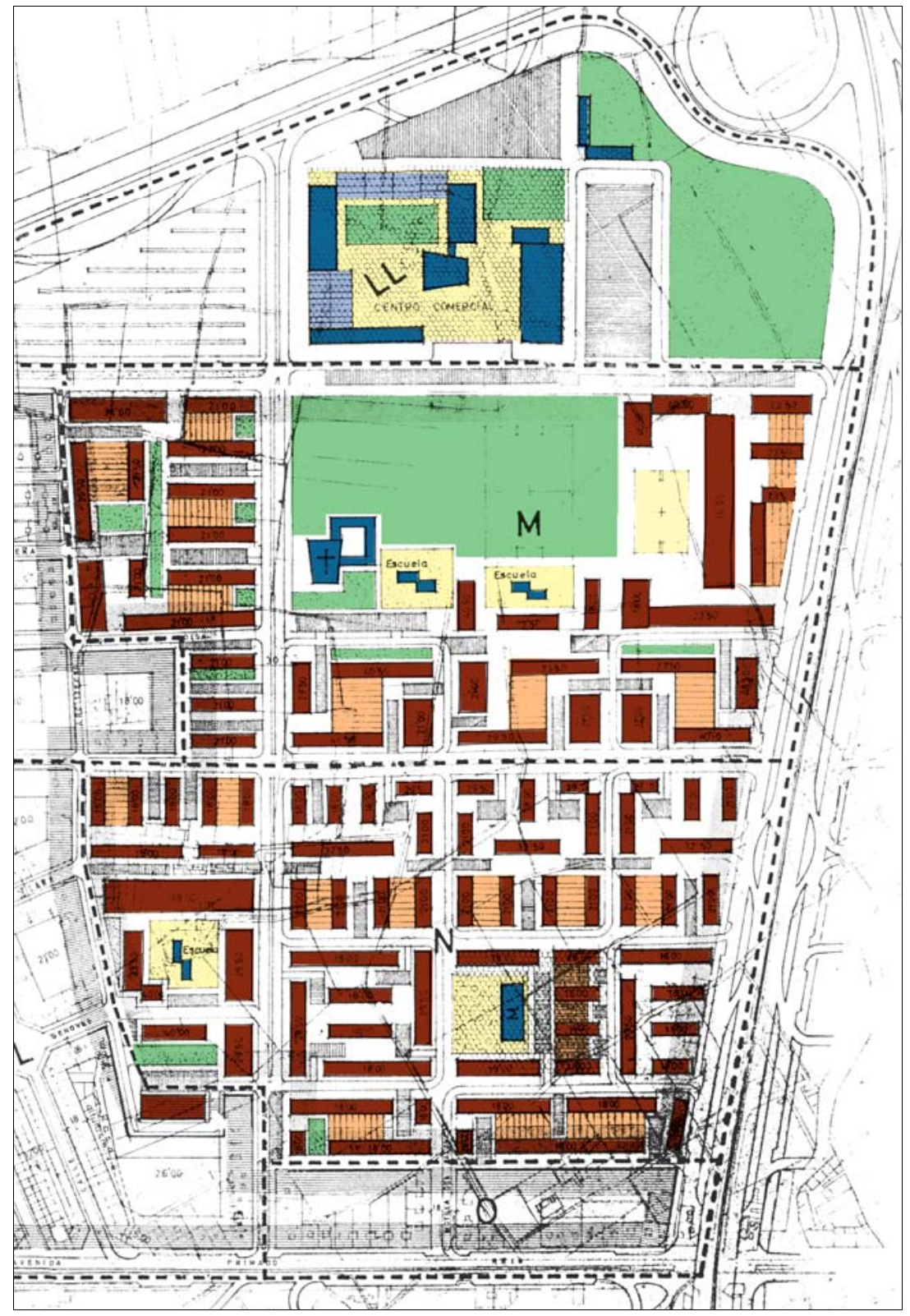




\section{Edificación.}

La Memoria del PP23 señala que en el mismo se distinguen claramente dos zonas de distinto carácter:

Las actuales zonas construidas, compuestas de manzana cerrada que ocupa la mayor parte del centro del conjunto, y que se ha ordenado en lo posible, rectificando las alineaciones y el ancho de las calles principales, y la que por no haber construcciones de gran importancia se ha procurado ordenarla en un plan más orgánico colocándole los servicios y edificios públicos, espacios libres, aparcamientos, etc. ${ }^{1}$

Como hemos señalado, la edificación prevista en las zonas de edificación abierta del PP23 de 1967 responde a un nuevo proyecto, con un viario y unos bloques dispuestos de un modo diferente al de la versión anterior del plan de 1962.

Toda la edificación abierta está resuelta con bloques lineales. La mayor parte de ellos son de dos crujías, aunque también se proyectan algunos de cinco crujías, que a veces se agrupan para configurar una planta en $L$ o en $U$.

Los bloques lineales de dos crujías aparecen de dos maneras: como bloques aislados o como bloques enlazados de dos en dos mediante bajos comerciales. Dentro de este segundo sistema, encontramos, además de la habitual pareja de bloques embebidos en un rectángulo edificado en planta baja, otra disposición que consiste en prolongar los bloques más allá de los límites del rectángulo que los une en planta baja, formando una unidad modular que se completa con dos bloques cortos aislados dispuestos en perpendicular a los anteriores y por lo general de mayor altura.

Los espacios intermedios entre los bloques no se destinan por lo general a zonas verdes, sino que están ocupados en su mayor parte por bolsas de aparcamiento dispuestas al fondo de los ramales sin salida que penetran en las diversas manzanas.

En la zona al este de Orriols, todos los bloques se disponen en paralelo o en perpendicular al eje del Camino de Tránsitos, que constituye el límite sur de la zona. Lo mismo ocurre con los bloques de la zona al norte de Torrefiel, ya que siguen las direcciones de la cuadrícula de las manzanas de este barrio, cuyas calles son también paralelas u ortogonales al Camino de Tránsitos, que cambia de dirección precisamente a partir del eje norte-sur de la antigua carretera de Barcelona.

La elección de la dirección paralela a Tránsitos o de su ortogonal para alinear los diferentes bloques parece responder, simplemente, a la búsqueda de variedad en la composición general, más que a criterios de orientación preferente de las fachadas. 
PP 23. Grado de realización. Detalle de la zona norte (Elaboración propia sobre plano de alineaciones del Plan)
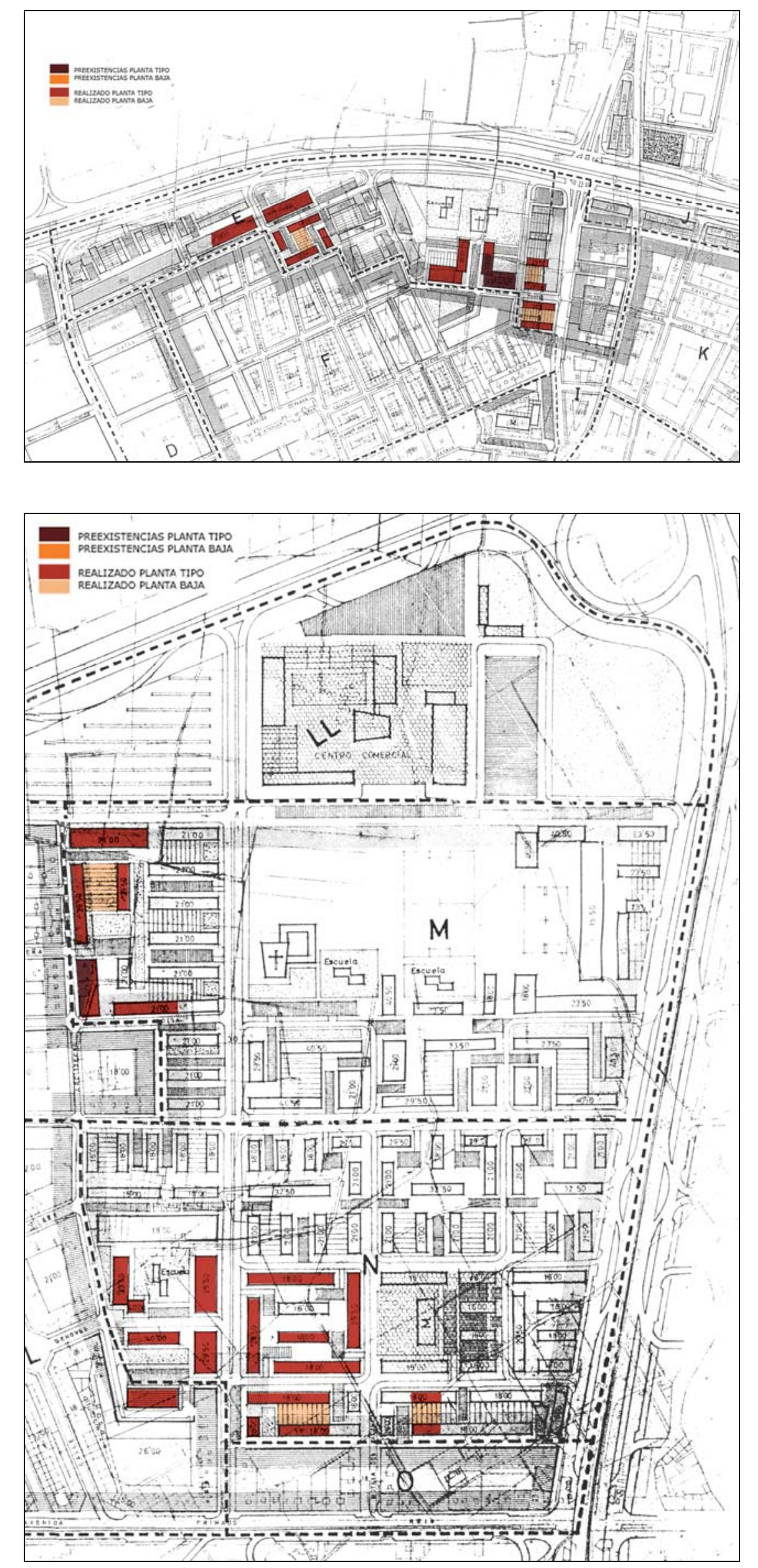

PP 23. Grado de realización. Detalle de la zona este (Elaboración propia sobre plano de alineaciones del Plan) 


\section{Grado de realización}

El grado de realización de las propuestas del PP23 es muy bajo en la zona de edificación abierta más extensa prevista en el plan, que es la situada al este de Orriols. En la zona de edificación abierta situada al norte de Torrefiel, los bloques construidos con arreglo al plan son también pocos, pero constituyen casi la mitad de los previstos en dicha zona, dada su pequeña superficie.

En la zona este, los bloques construidos son los situados a continuación del tejido consolidado de manzanas, y forman dos grupos, uno al sur, próximo al Camino de Tránsitos, y otro en las inmediaciones de la calle Esteban Dolz.

En la zona norte, están completas dos de las unidades modulares de edificación antes descritas, integradas por dos bloques lineales, unidos en su tramo central por bajos comerciales, y dos bloques cortos más altos.

El Plan General de 1988 anuló la ordenación de las áreas sin edificar en ese momento de la zona este de edificación abierta del PP23 de 1927, sin sustituir dicha ordenación por otra diferente; esta zona fue calificada como Suelo Urbanizable Programado, y en la misma se fijaron únicamente las localizaciones previstas para equipamientos y zonas verdes.

La ordenación y posterior edificación de la zona se realizará mediante un Programa de Actuación Urbanística, con unos planteamientos muy diferentes a los previstos en el PP23 y cuyo estudio excede los límites que nos hemos fijado para este trabajo.
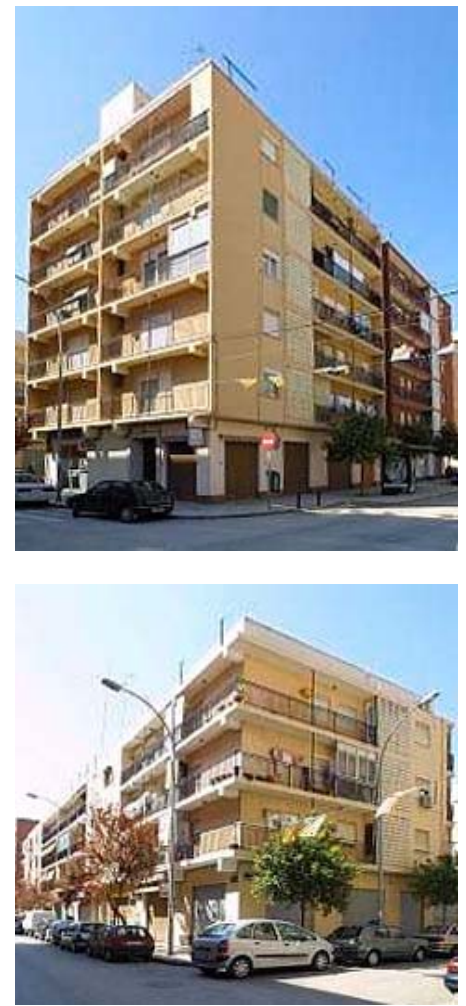

Bloques en la calle Alemany.

Zona del PP23. PGOU Valencia,1988 (Color sobre montaje de Hojas de la Serie C, Planos de Régimen Urbanístico).

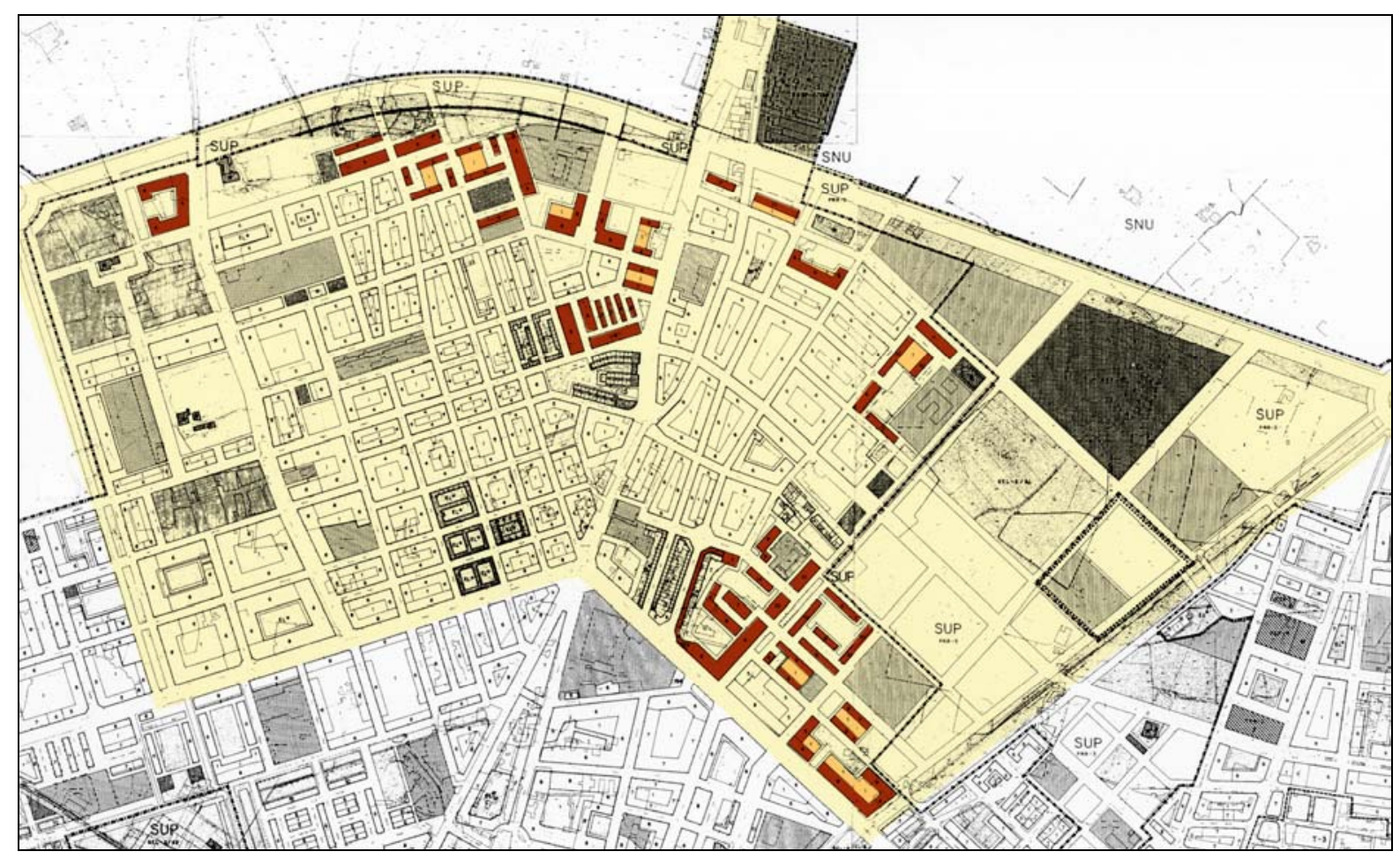



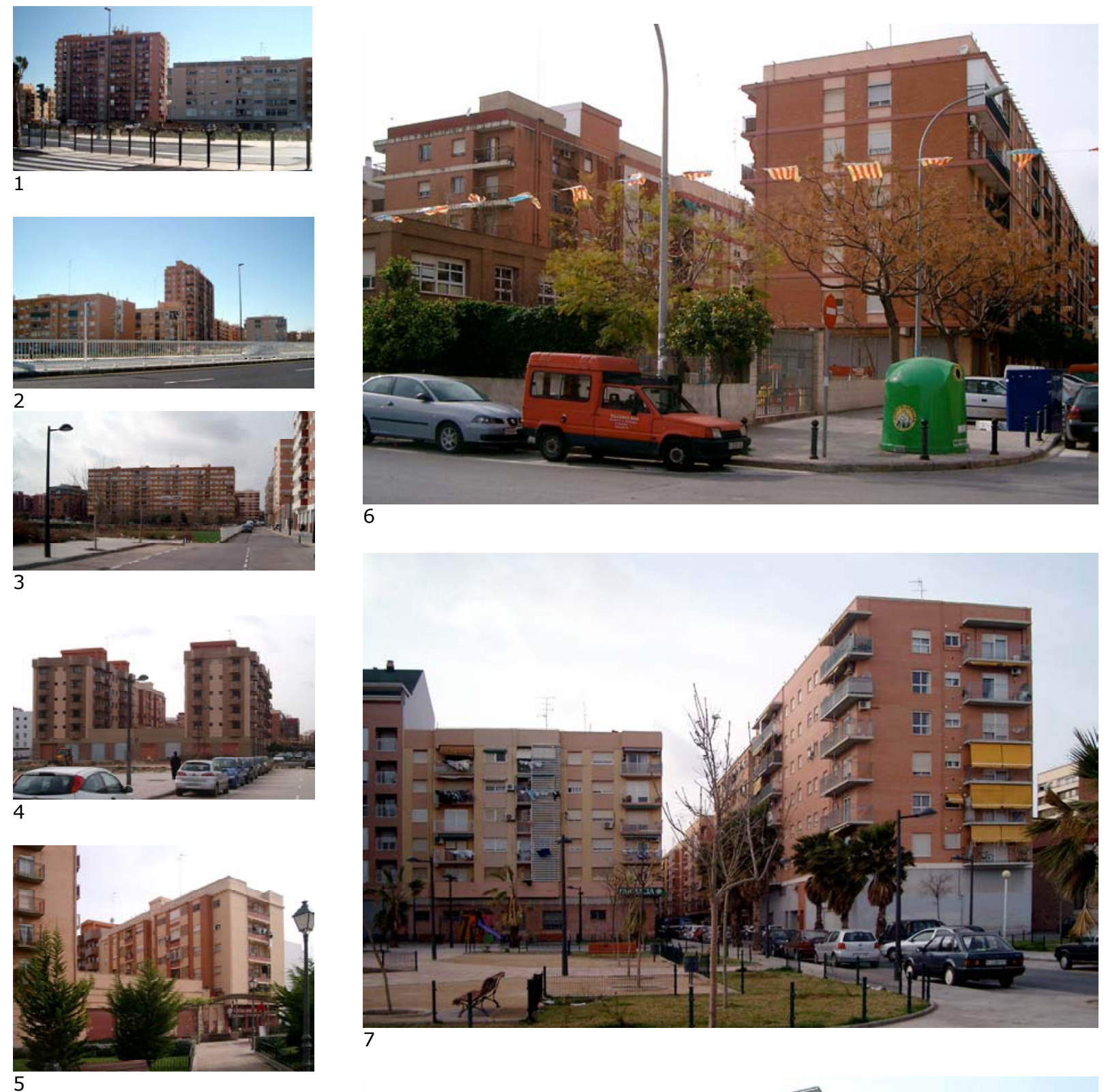

5

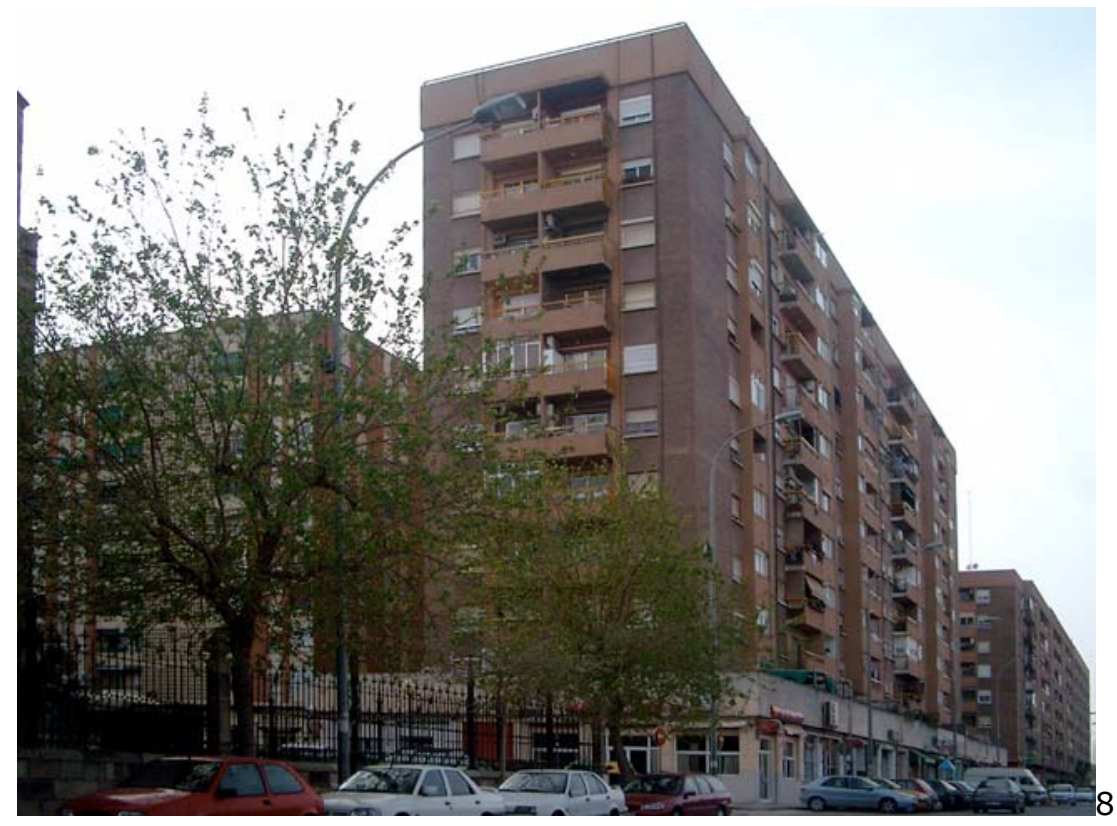

1-2 Bloques en la calle Río Bidasoa, vistos desde la ronda exterior.

3-7. Bloques en la calle Motilla del Palancar.

5. Bloque en Avenida Hermanos Machado. 


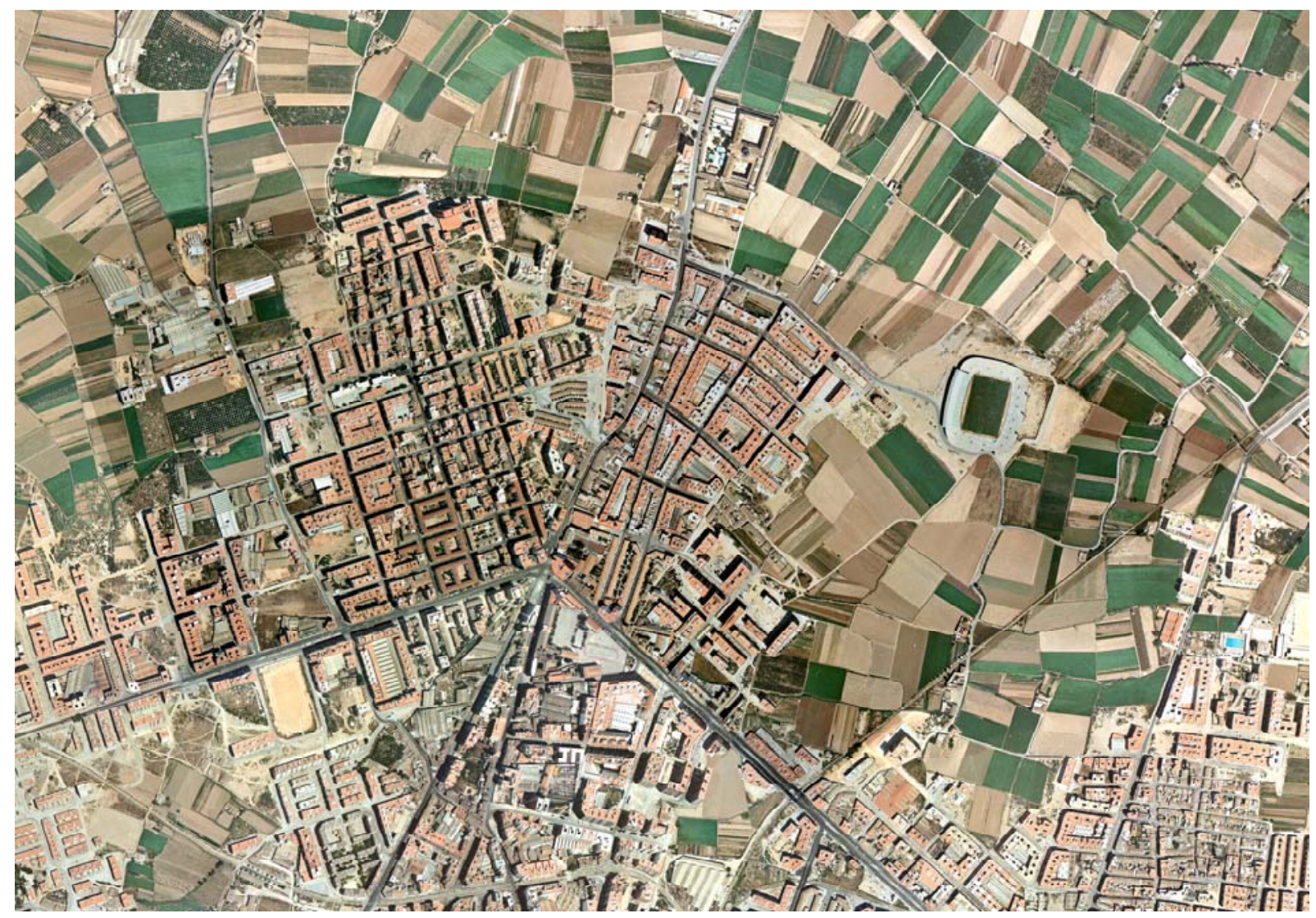

Zona del Plan Parcial 23. Fotografía aérea de Valencia, 1980.

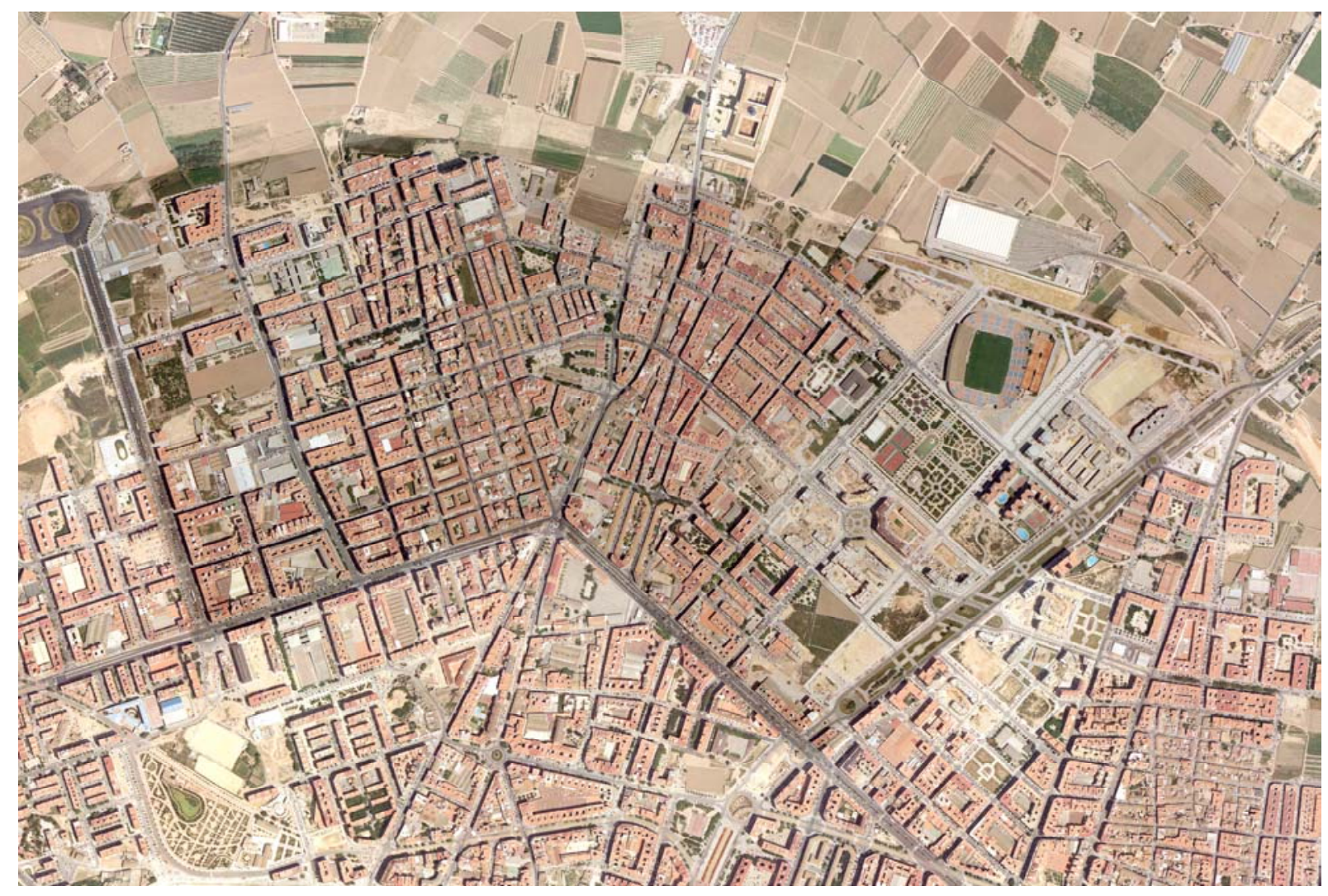

Zona del Plan Parcial 23. Ortofoto de Valencia, 2002 


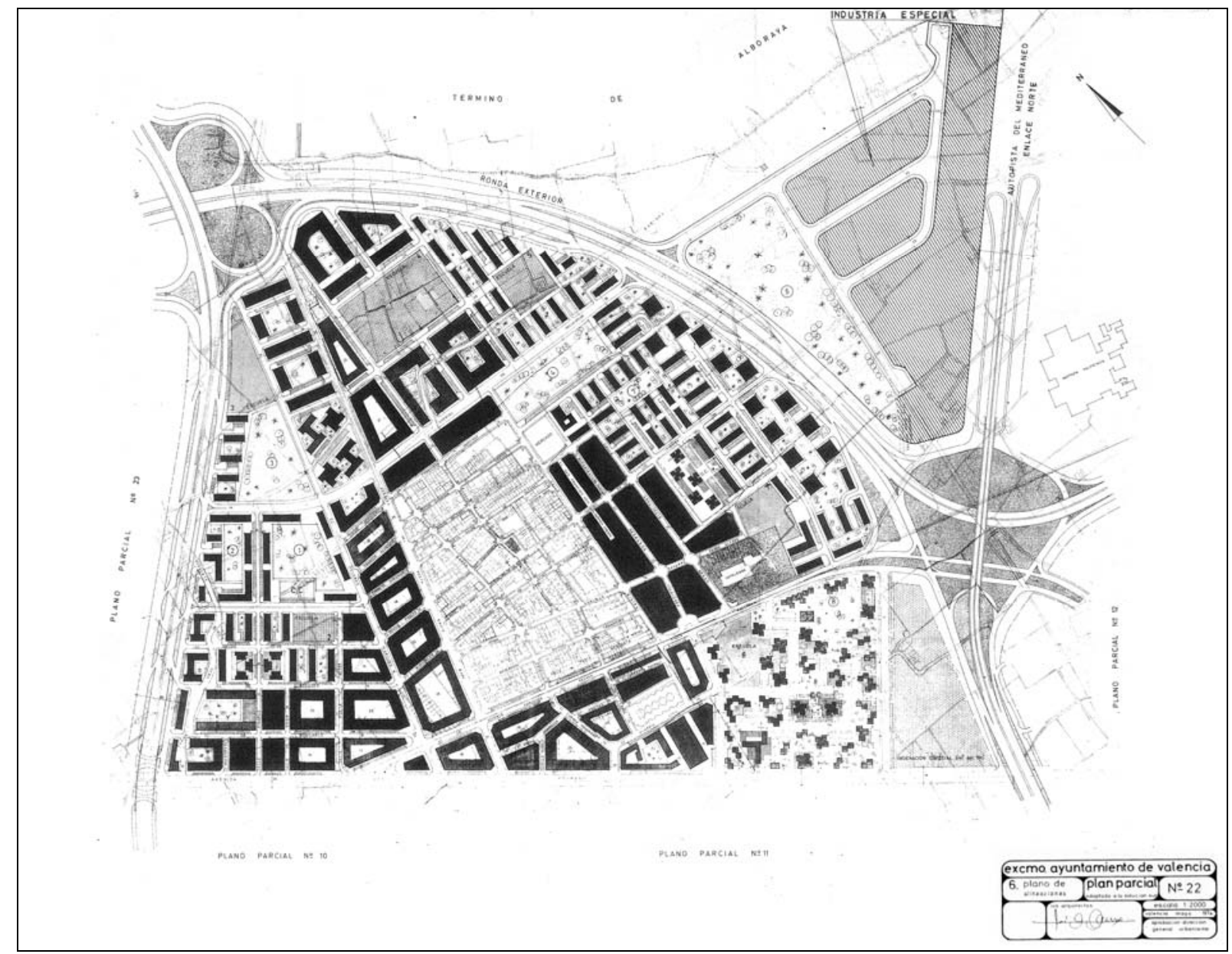

Plan Parcial no 22 adaptado a la Solución Sur, 1972. Plano de alineaciones. 


\section{BENIMACLET: EL PLAN PARCIAL No 22 Y EL P.E.R.I. DEL SECTOR 4.}

El Plan Parcial no 22 comprende el ámbito de la población de Benimaclet y los alrededores de la misma. Sus límites son, al Norte la Ronda Exterior, al Oeste la línea de ferrocarriles eléctricos de Rafelbuñol (futuro acceso Norte según el Plan Comarcal), al Sur la Avenida Primado Reig y al Este la Autopista del Mediterráneo. También está incluida en el Plan una zona industrial en el espacio triangular comprendido entre la Autopista y la Ronda Exterior.

En esta zona existía ya una ordenación previa, correspondiente al Plan Parcial 22 A+B de 1961/62, analizado en la sección anterior. Este plan tenía unos límites diferentes y no reflejaba todavía el diseño viario elaborado por la Oficina Regional de Proyectos de Carreteras ${ }^{1}$.

Por todo ello, tras la aprobación en 1966 del Plan General adaptado a la Solución Sur se redactó una nueva versión del Plan Parcial 22, que es la que aparece en los planos del Informe Prevasa, en el que figura como plan en tramitación. Esta versión, en la que las zonas de edificación abierta responden a un nuevo proyecto que no tiene en cuenta la ordenación prevista en el plan de 1961, será la base sobre la cual se redactará en 1972 el plan que será aprobado definitivamente en $1974^{2}$, poco antes de la entrada en vigor de la nueva Ley del Suelo de 1975.

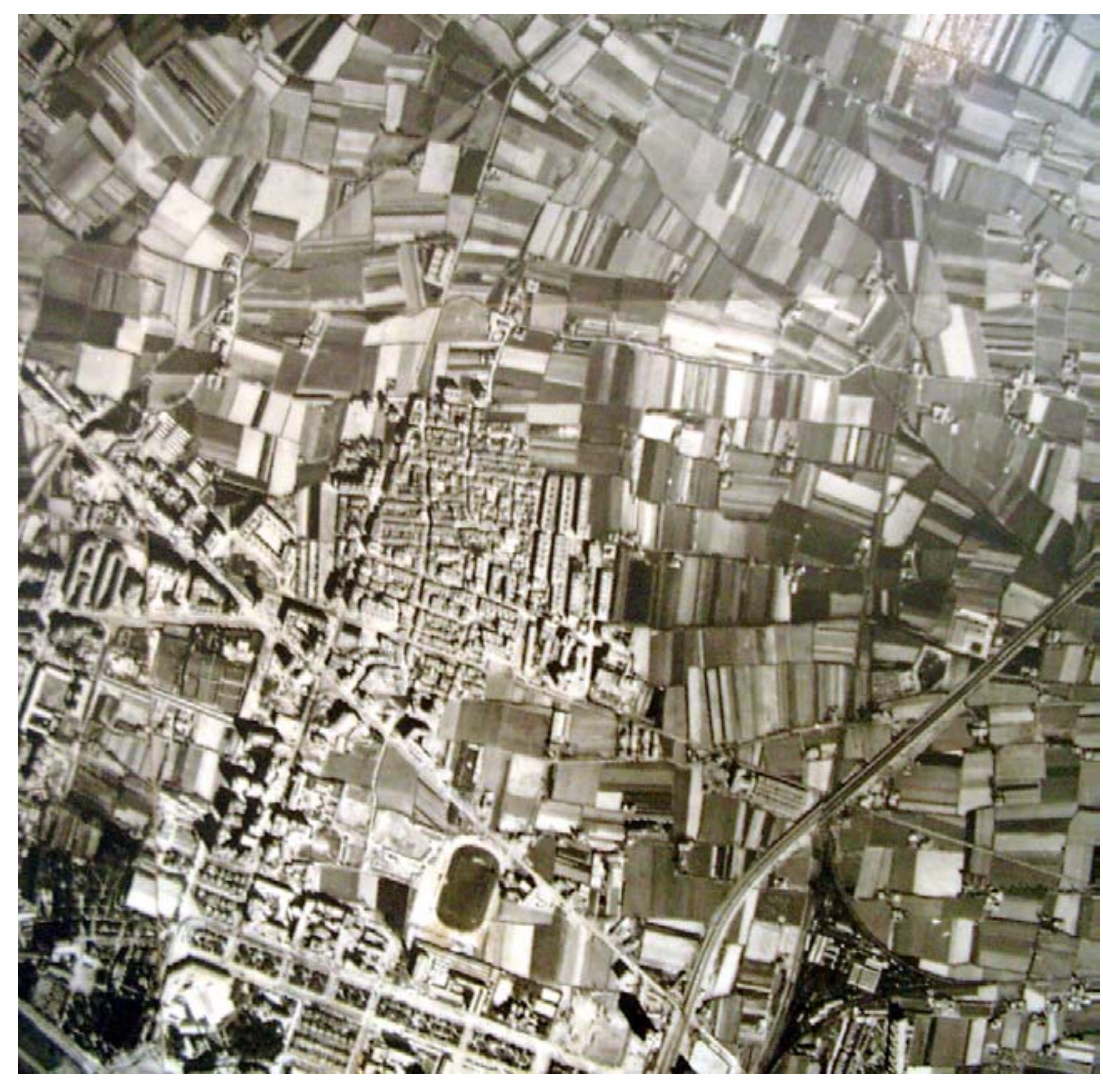

Zona del Plan Parcial 22. Fotografía aérea, h. 1965 (ETS de Arquitectura de Valencia)

1. Ver el apartado dedicado al Plano Parcial 22 de 1961/62 en la sección II de este trabajo, pp. 259 y siguientes.

2. Plan Parcial no 22 adaptado a la Solución Sur, 1972. Ver Anexo de Documentos, pp. 465-486. 


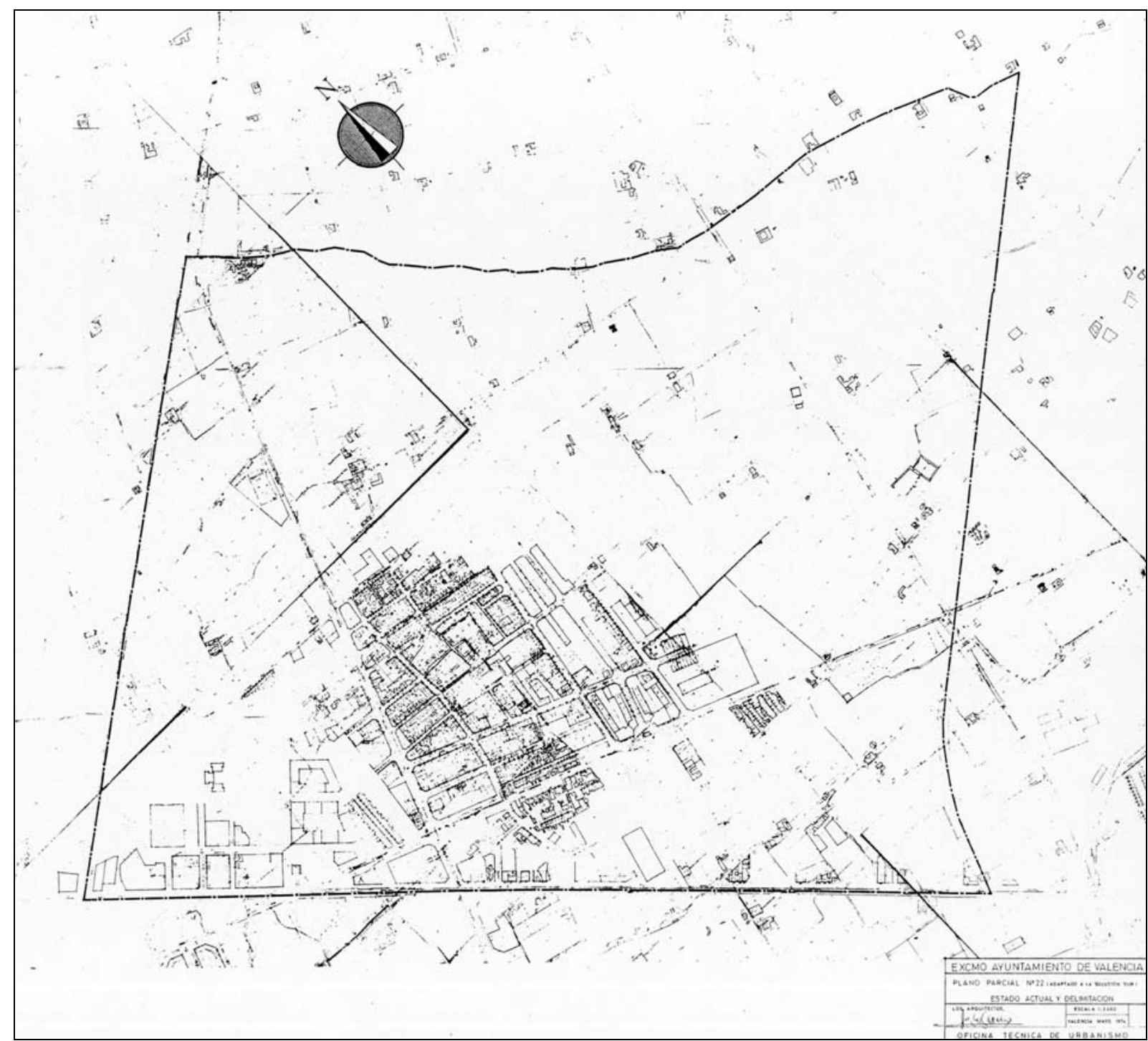

Plan Parcial 22, 1972. Plano de información.
El Plan Parcial 22 redactado en 1972 modifica completamente la ordenación de la edificación abierta del sector sureste, sustituyendo los bloques lineales inicialmente previstos en la versión de 1968 por torres con plantas de formas muy variadas, de corte organicista. Este sector, que es el posteriormente denominado Sector 4, será objeto de una nueva modificación global a través de un Plan Especial de Reforma Interior (PERI) redactado en 1984, como veremos más adelante.

Además, en la versión de 1972 del Plan Parcial 22 se aprecian algunas otras variaciones de menor importancia, como la eliminación de algunos bloques para obtener una mayor reserva de suelo destinado a zonas verdes.

El Ministerio de la Vivienda condicionó la aprobación definitiva de este plan a la introducción de algunas rectificaciones, que consistían en modificar la delimitación de las zonas (de Extensión Exterior a Tránsitos, Edificación Abierta y Especial) y, sobre todo, en prever una plaza de aparcamiento como mínimo por vivienda. 
Esta cuota de aparcamientos excedía con mucho la prevista en el plan, que se ajustaba a las Normas Urbanísticas del Plan General de 1966, cuyo artículo 33 fijaba una reserva de un vehículo por cada tres familias en las barriadas "de mayor categoría" y de un vehículo por cada cinco familias en las barriadas "modestas".

PP22. Versión de 1967-68. (Elaboración propia, montaje de hojas del Informe PREVASA).

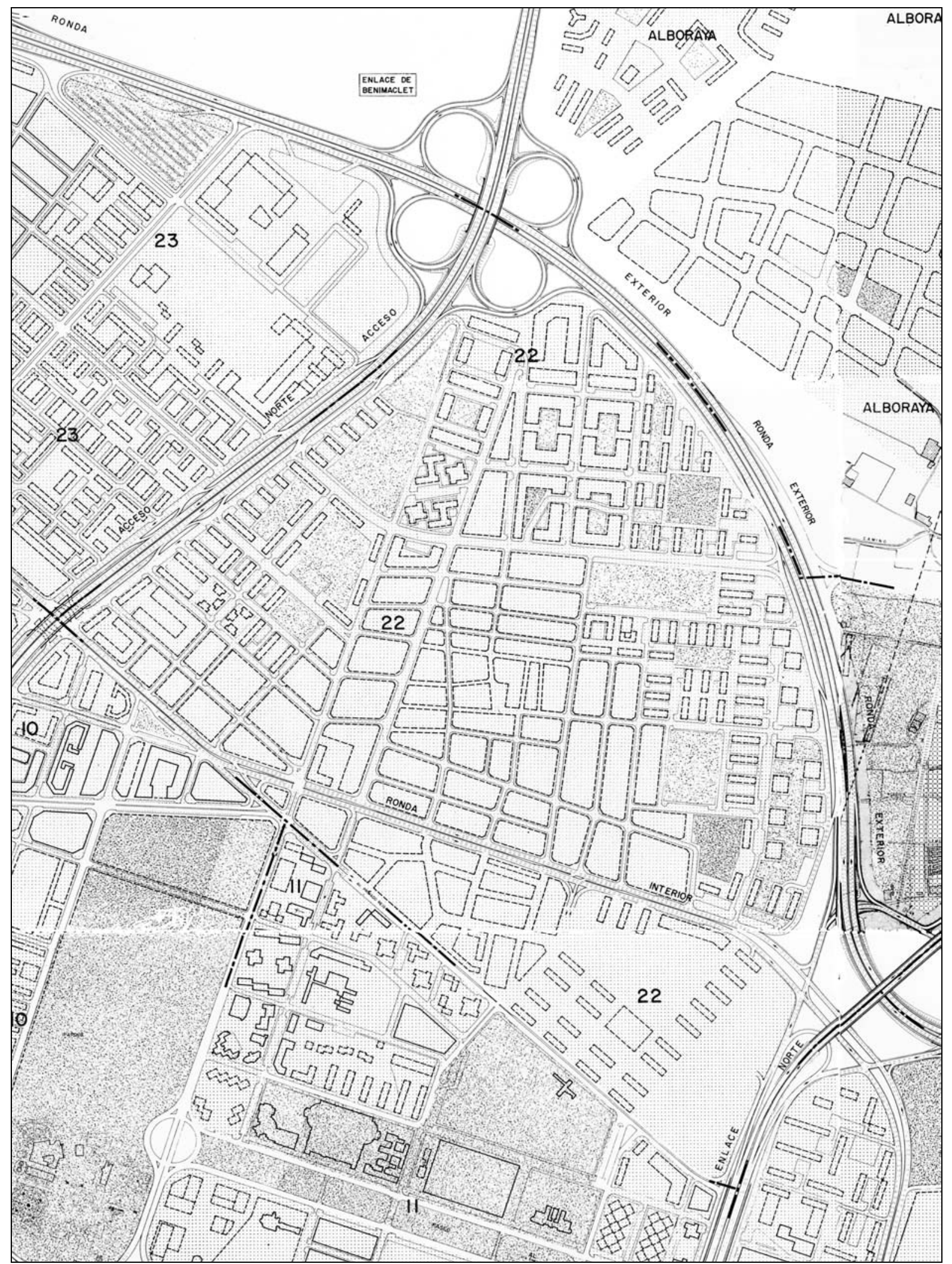




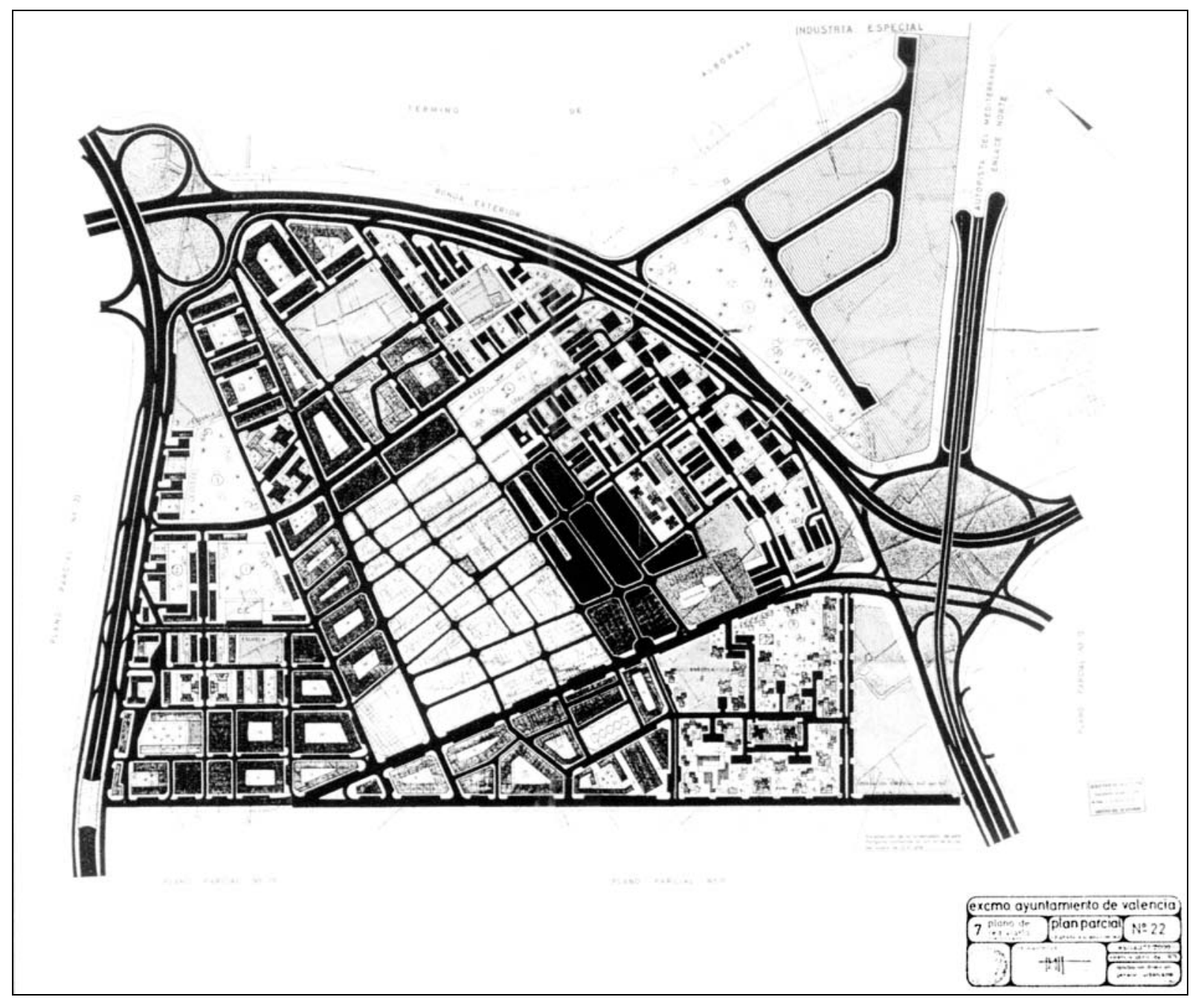

Plan Parcial 22, 1972. Plano de red viaria fundamental.

\section{Trazado viario}

Tal como indica la Memoria del PP22, la Ronda Exterior y el futuro Acceso Norte están tratados como vías con control de accesos reguladas por los servicios de la Dirección General de Carreteras, dotadas de vías de servicio paralelas al acceso principal, y guarnecidas de aparcamientos en toda su longitud. El esquema de viario interno se basa en una jerarquía de redes viarias, que se clasifican en redes amarilla, azul y verde. La red amarilla es de carácter eminentemente local y circunscrita a unidades residenciales reducidas; sin repercusión al exterior y limitada a su función inmediata. La red azul la componen las vías de relación entre barrios: la. Avenida del Poeta Emilio Baró, que es el límite separador entre el ámbito de edificación abierta y el núcleo antiguo de Benimaclet, y la Avenida del Doctor Zaragoza, que no separa zonas de características diferentes. La red verde la componen los colectores de barrio; ordena el tráfico fundamental dentro de los propios barrios y guarnece las arterias principales de uso restringido con aquellos.

El viario planteado para las zonas de edificación abierta es de tipo mallado en la parte oeste y mixto en la parte este, con una retícula que delimita manzanas y ramales en cul-de-sac que penetran en las mismas formando bolsas de aparcamiento. 


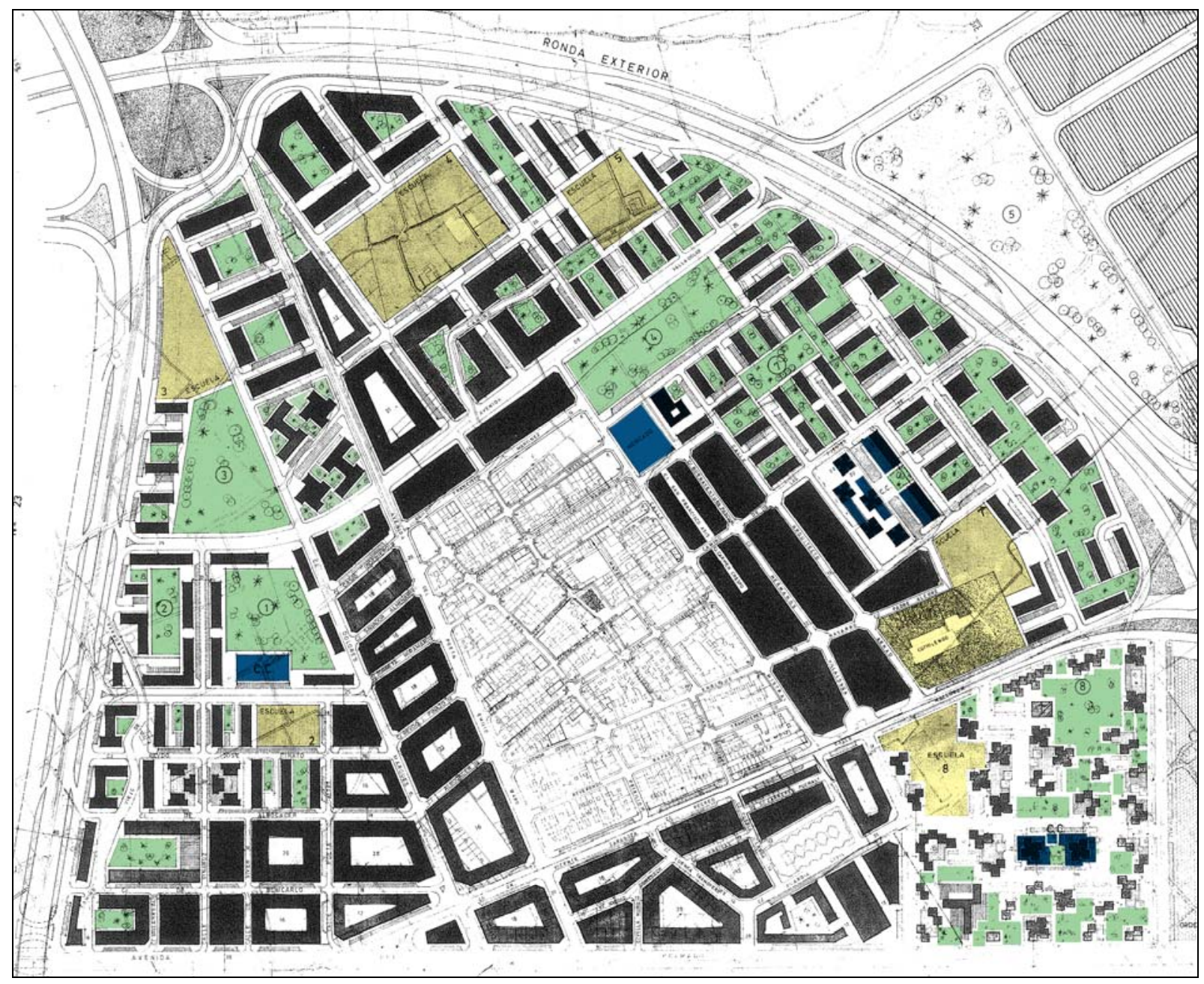

\section{Equipamientos}

El Plan Parcial 22 prevé tres centros comerciales, uno en cada zona de edificación abierta, así como un mercado situado junto al núcleo consolidado de Benimaclet.

En cuanto a las zonas verdes, la Memoria señala que el plan combina pequeños jardines intercalados en la retícula de calles y fajas verdes que enlazan los barrios a lo largo de paseos, con una superficie total superior al $10 \%$ fijado en la ley del Suelo.

En algunas de las zonas verdes, el plan prevé parques de vegetación baja en cuyo subsuelo se disponen dos plantas de estacionamiento de vehículos. Esta es la singular solución adoptada en respuesta a la exigencia del Ministerio de la Vivienda relativa a las plazas de aparcamiento.

El equipamiento escolar está integrado por ocho grupos, distribuidos en el plan parcial de forma que la distancia a recorrer por la población escolar sea la menor posible. Esta distancia es mayor en el sector central del plan, donde no se sitúa grupo alguno por la cantidad de expropiaciones que sería preciso realizar en la zona de edificación compacta del poblado de Benimaclet.
Plan Parcial 22, 1972. Equipamientos. (Elaboración propia sobre plano de alineaciones del Plan) 


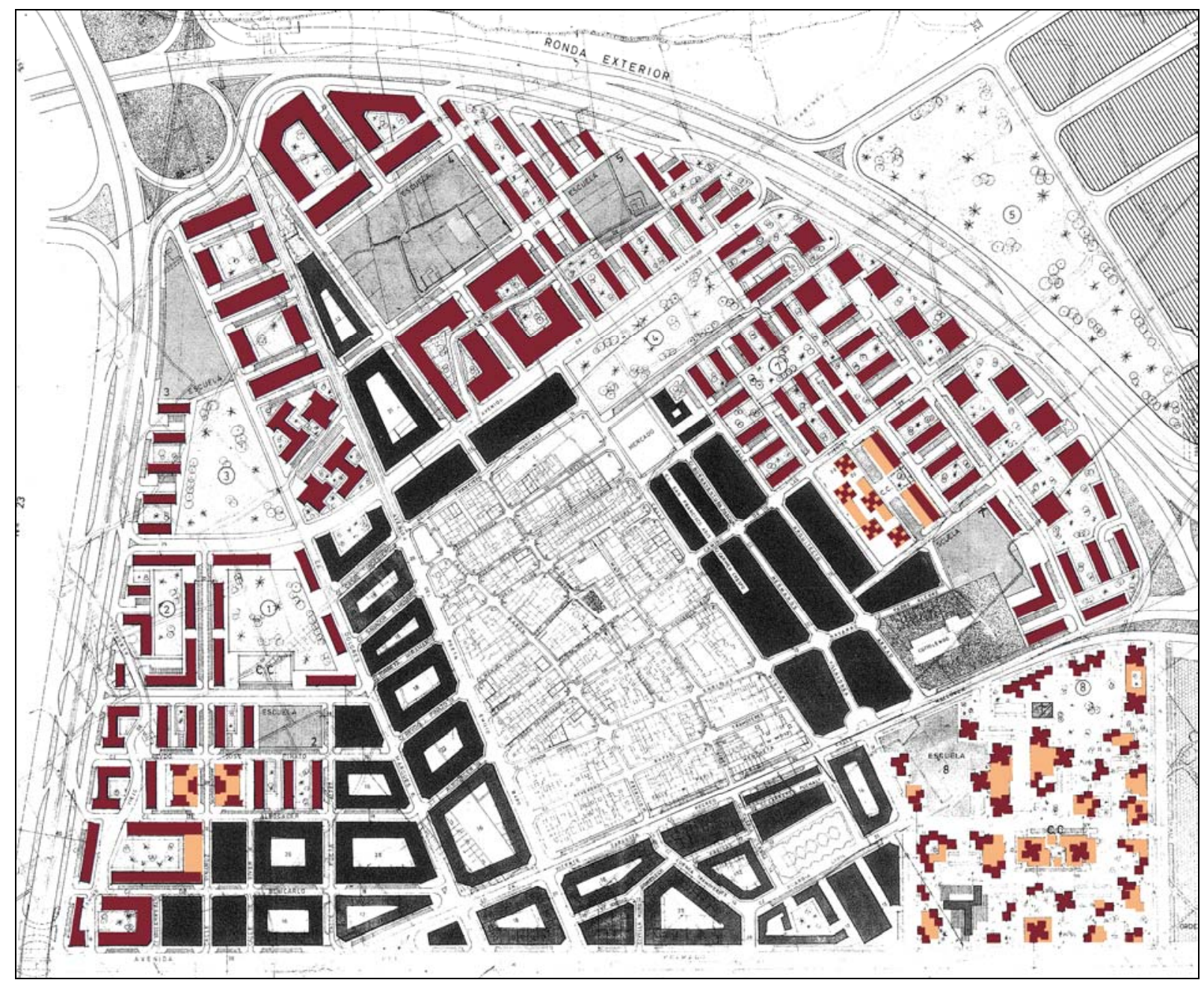

Plan Parcial 22, 1972. Edificación (Elaboración propia sobre plano de alineaciones del Plan)

\section{Edificación}

La edificación abierta del Plan Parcial 22 adopta formas muy variadas. El tipo más repetido es el del bloque lineal de dos crujías, de VII plantas y dimensiones medias de $12 \times 50 \mathrm{~m}$. Estos bloques se proyectan como edificios aislados, dispuestos por lo general según el modelo canónico del zeilenbau, con espacios verdes intermedios. Las plantas comerciales de enlace sólo se prevén en algunos de los bloques situados junto al camino viejo de Alboraya. La orientación de los bloques no es única, sino que se combinan dos direcciones, paralela y ortogonal a los ejes viarios principales, que son el Camino de Tránsitos en el sector oeste y la Avenida de Valladolid en el sector oeste.

La zona situada al norte del poblado de Benimaclet se ordena mediante bloques de cinco crujías que adoptan la forma de manzana abierta, envolviendo un jardín interior de carácter público. En una de las manzanas de esta zona, sin embargo, aparece un grupo de cuatro edificios dispuestos con total independencia del viario circundante, formado por dos edificios con planta en forma de aspa de molino y dos bloques en $Z$.

Un tipo intermedio entre la palazzina y la torre es el que aparece en todo el borde noreste del plan, junto a la Ronda Exterior, resuelto con edificios de planta cuadrada, de $30 \mathrm{~m}$. de lado, y VIII 
plantas, dispuestos en damero sobre espacios verdes. El tipo de la palazzina, por su parte, podemos encontrarlo en dos pequeñas manzanas a los lados de la calle Vinaroz, donde los pequeños inmuebles emergen de una planta baja que los envuelve.

Por último, el tipo de torre, con alturas entre $\mathrm{X}$ y XVI plantas, es el que se utiliza para el sector sureste del plan, así como en el centro comercial próximo al Camino de las Fuentes. En el sector sureste, que es el posteriormente denominado Sector 4, las torres adquieren formas en racimo muy variadas, que resultan de diferentes agrupaciones a partir de un módulo base de $10 \times 10 \mathrm{~m}$. Las edificaciones comerciales en planta baja sobrepasan la superficie de las torres, y llegan a enlazar a veces dos o más de ellas.

\section{Grado de realización}

El grado de realización de las zonas de edificación abierta previstas en el Plan Parcial 22 no es muy alto, como puede verse en el plano que se adjunta, en el que se puede comprobar que no se llegó a completar ninguno de los sectores.

En cuanto a tipos, no se halla realizado ninguno de los bloques de planta cuadrada del borde noreste. De los demás tipos señalados anteriormente, existen ejemplos construidos de todos ellos.
Plan Parcial 22, 1972. Grado de realización (Elaboración propia sobre plano de alineaciones del plan)

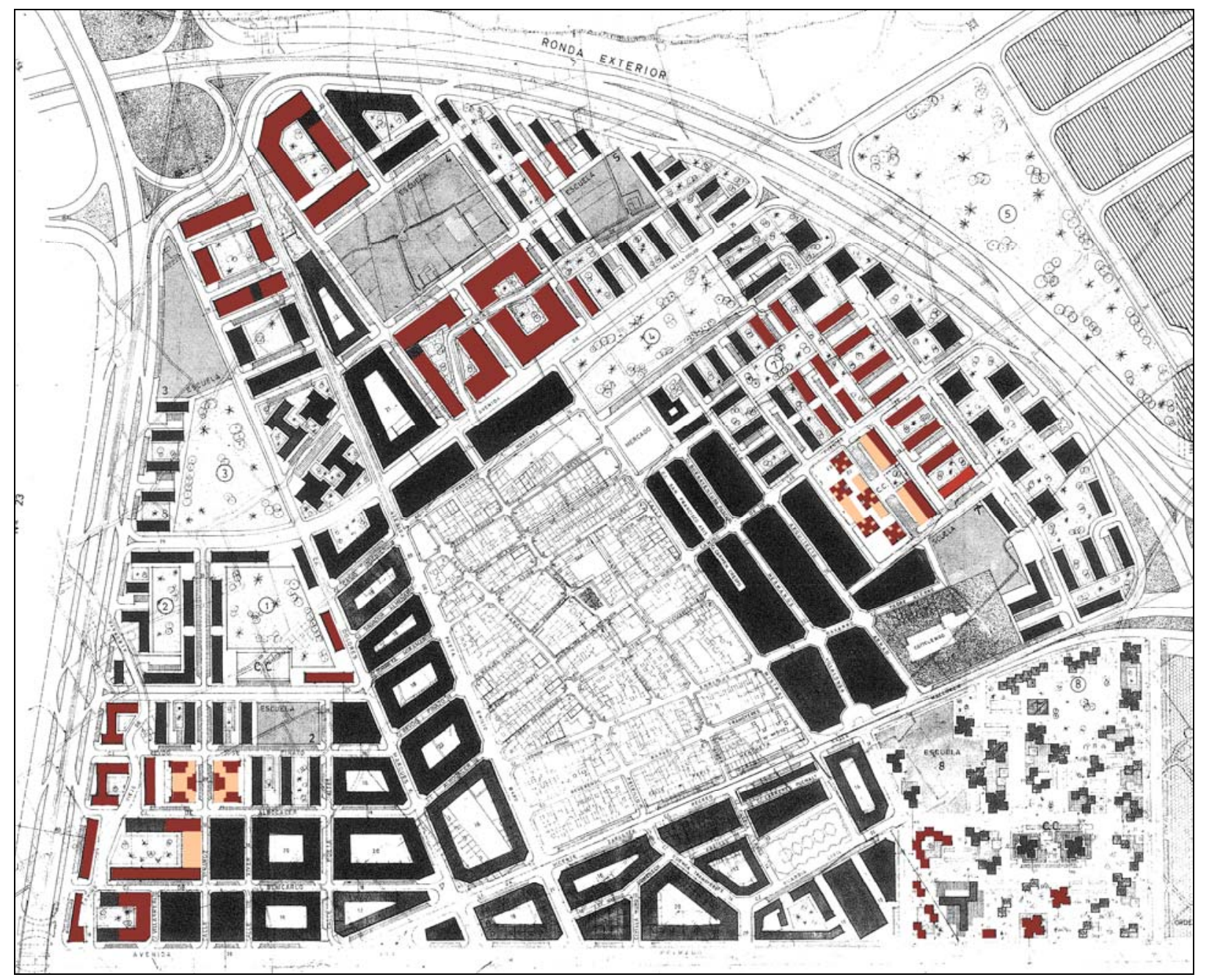




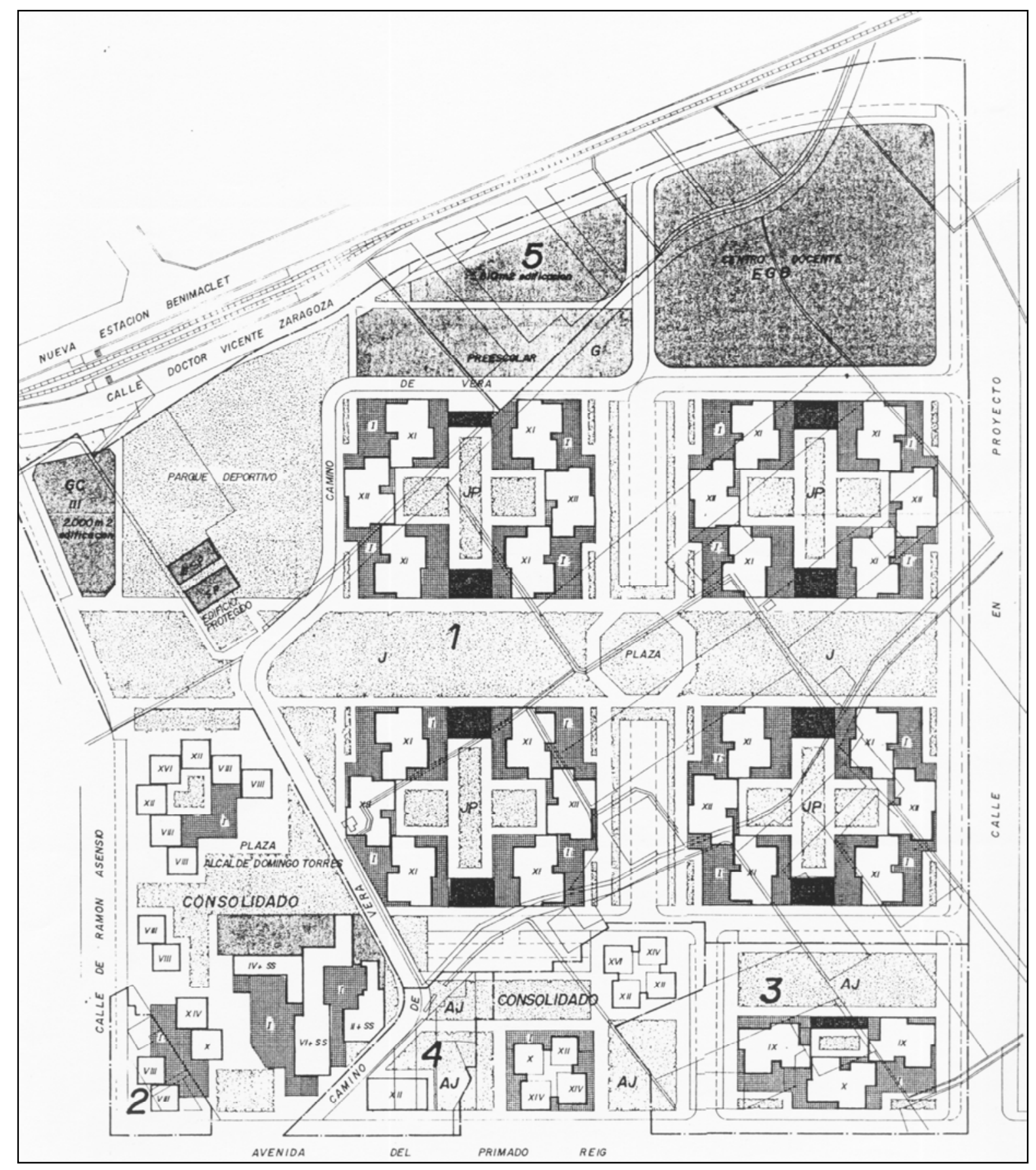

Plan Especial de reforma Interior del Sector 4 del Plan Parcial 22, 1984. Plano de Ordenación. Gestión.

\section{EI PERI del Sector 4 (1984).}

El Plan Especial de Reforma Interior del Sector 4 fue redactado en 1984 por el arquitecto Joaquín Hernández para la promotora Valencia Urbana S.A.. Sus objetivos, según indica la Memoria del plan, son los siguientes:

- Descongestión del Suelo urbano.

- Alcanzar niveles de equipamientos comunitarios, en relación con la población prevista.

- Saneamiento del área constituida por una industria existente.

- Aplicar sistemas de gestión que permitan la obtención gratuita de equipos comunitarios.

- Garantizar la urbanización de su conjunto, mediante un sistema de 
actuación.

- Disminución del volumen edificable y densidad de poolación, mejorando el diseño urbano, con destino principal a viviendas de Protección Oficial, con una mayor racionalidad en la volumetria y en los espacios abiertos. ${ }^{1}$

La ordenación planteada para responder a estos objetivos se basa en la separación de la circulación rodada y la peatonal, creando un paseo ajardinado central y unos viales de acceso que terminan en ramales sin salida destinados a aparcamientos.

En esta zona, se hallaban ya edificadas algunas de las torres previstas por el Plan Parcial 22 de 1974 junto a la Avenida de Primado Reig.

Las edificaciones que responden a un nuevo diseño del Sector 4 son, fundamentalmente, las integradas en las cuatro manzanas que flanquean el paseo central. Cada una de estas manzanas está formada por dos grupos de tres torres yuxtapuestas que se asientan sobre una planta baja destinada a locales comerciales. Los dos grupos de locales situados bajo las torres se unen mediante una pérgola o paso cubierto en el que una cancela controla el acceso desde el paseo central público al espacio interior ajardinado de carácter privado de la manzana, desde el cual se accede a su vez los zaguanes de las viviendas.

Aparte de la zona verde central, los equipamientos previstos en el PERI del Sector 4 son un parque deportivo, dos parcelas escolares y un edificio para servicios públicos. Todos ellos se sitúan en el borde norte del sector, junto a la línea de FF.CC. eléctricos al Grao (actual calle Dr. Vicente Zaragozá).

EI PERI es un documento mucho más completo en todos los sentidos que los planes parciales de desarrollo del Plan General de 1966 , en particular en los apartados dedicados a la gestión urbanística. $^{2}$
1.PERI Sector 4 del PP22. Memoria. Anexo de Documentos, p. 787.

2.PERI Sector 4 del PP22. Ver Memoria, apartado 2.5. Criterios para la gestión y plan de etapas, y apartado 3. Estudio económicofinanciero. Anexo de Documentos, pp. 784-798.
Plan Especial de Reforma Interior del Sector 4 del Plan Parcial 22. Edificación en planta tipo y en planta baja (Color sobre Plano de Ordenación. Gestión).

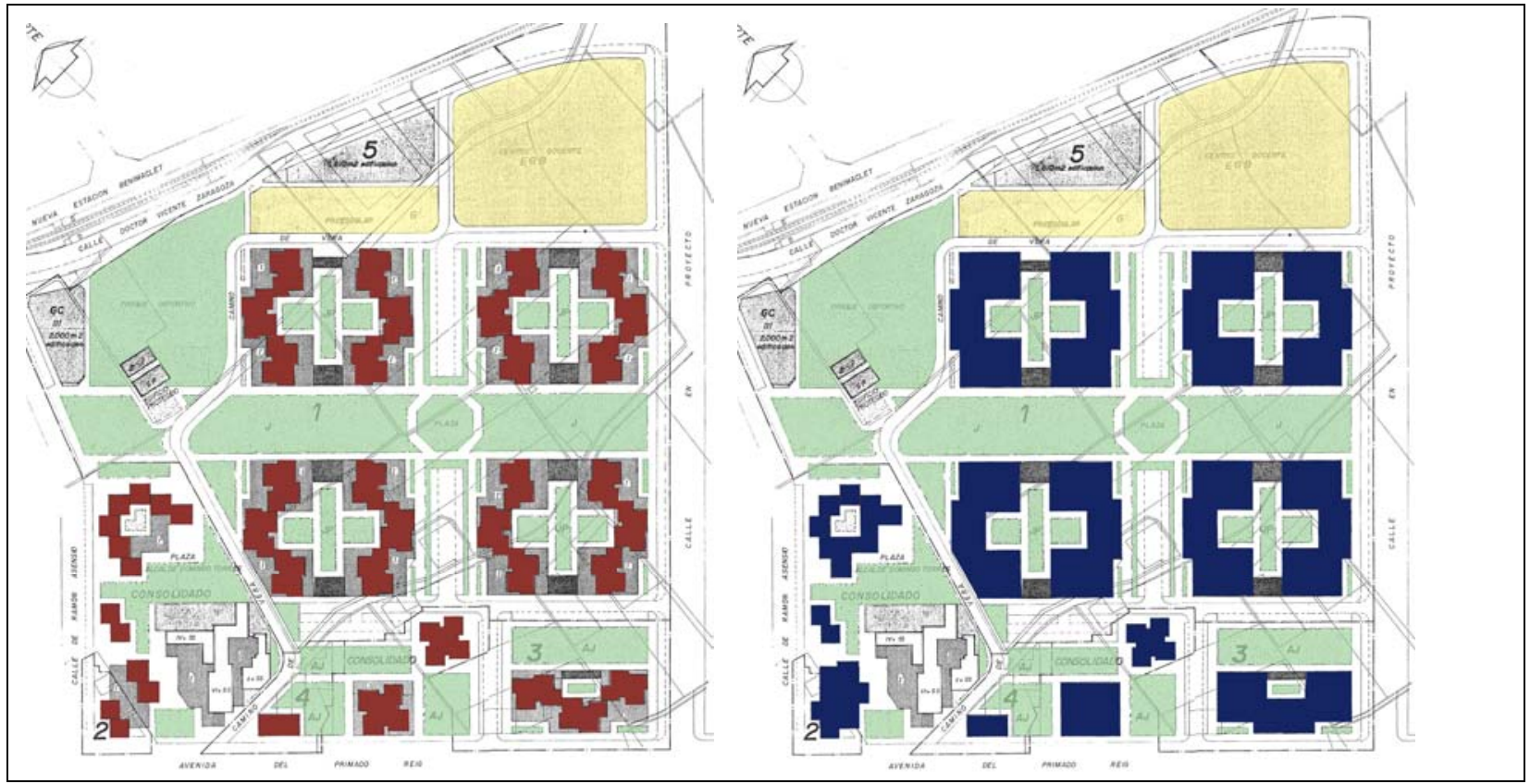


PERI de la zona situada junto al nuevo acceso de Barcelona, Cristina y Camilo Grau García, 1982.

PGOU 1986. Detalle de la zona correspondiente al PP 22. (Color sobre montaje de hojas de la Serie C, Planos de Régimen urbanístico).

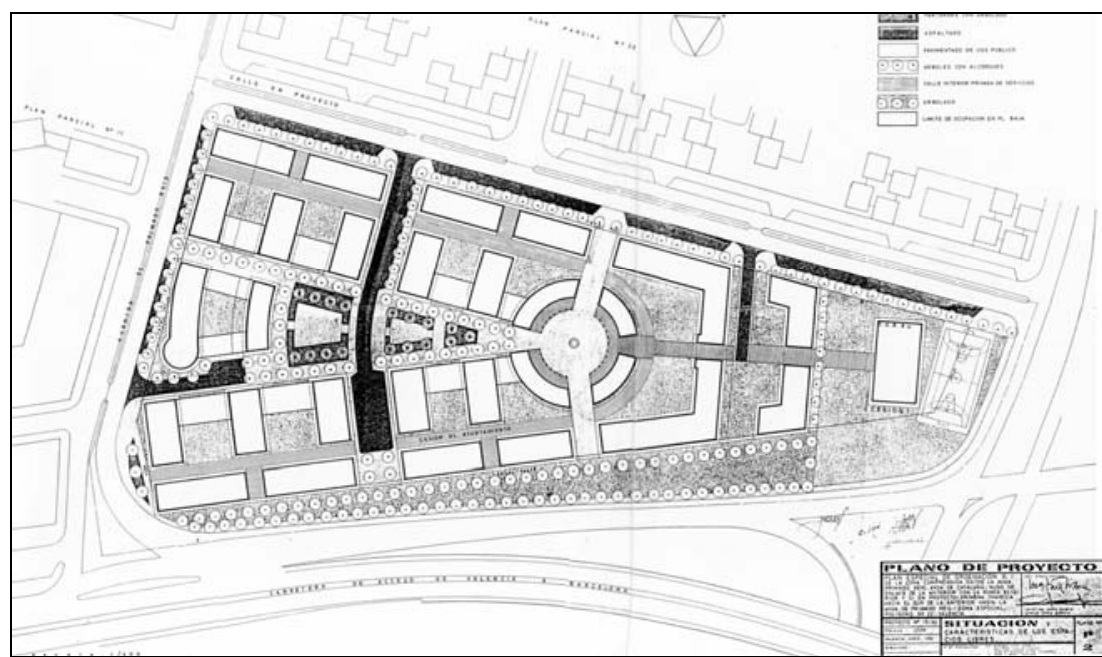

En el espacio trapezoidal situado junto al nuevo acceso de Bercelona, calificado como Zona Especial por el PP22, los arquitectos Cristina y Camilo Grau García redactaron un PERI en 1982 basado en bloques de edificación abierta pero con una composición de conjunto de corte postmoderno. Este PERI fue finalmente descartado en favor de la desafortunada solución que figura en el Plan General de 1988, que es la finalmente construida.

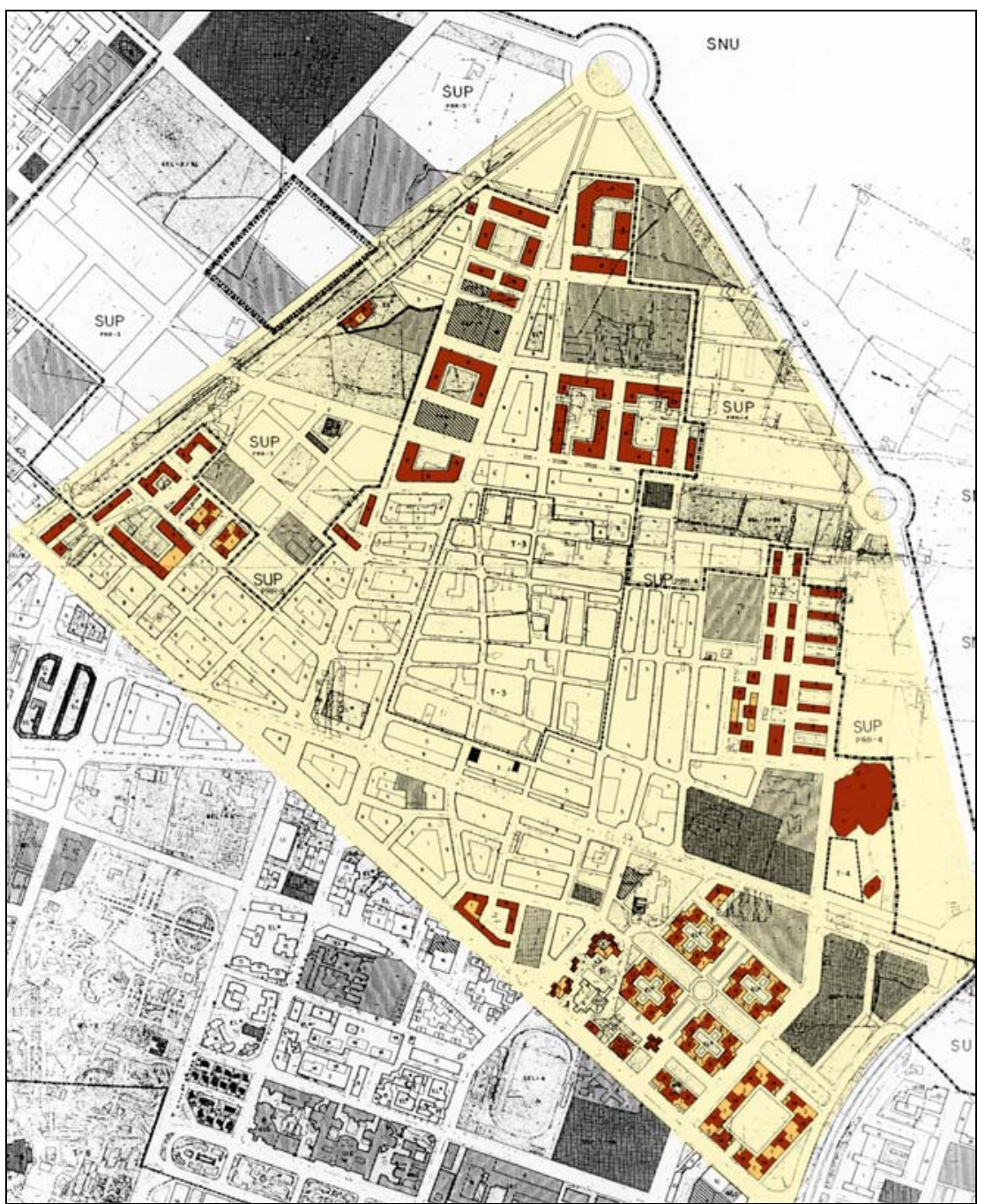




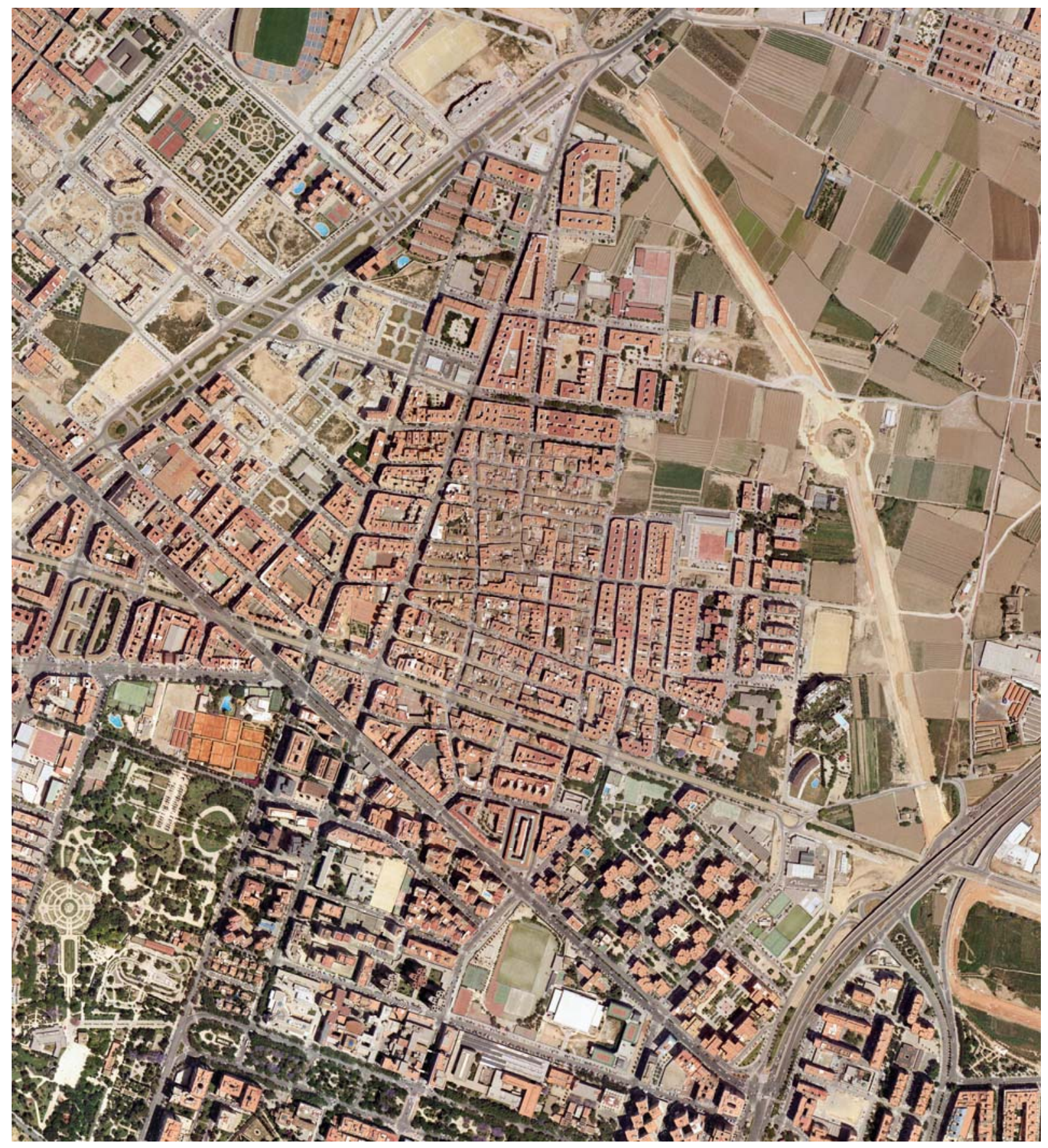

Zona del Plan Parcial 22. Ortofoto 2002 (AUMSA). 


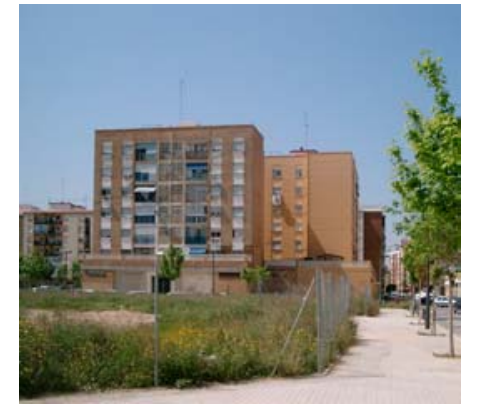

1

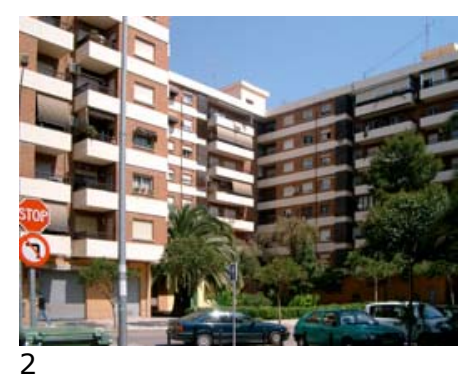

2

\section{Un recorrido actual por los alrededores de Benimaclet.}

Las zona de edificación abierta prevista en el Plan Parcial 22 en las inmediaciones de la línea de FF.CC. eléctricos a Rafelbuñol (actual Avenida de Alfahuir) fue realizada a medias. Están construidos los bloques situados entre dicha Avenida y el camino viejo de Alboraya, en el tramo entre la Avenida de Primado Reig y la calle Torreta. Junto a ellos, existen algunos fragmentos de bloques lineales y el singular conjunto que forman las dos manzanas con palazzinas de las calles Viver y Vinaroz, que ha sido completado recientemente.

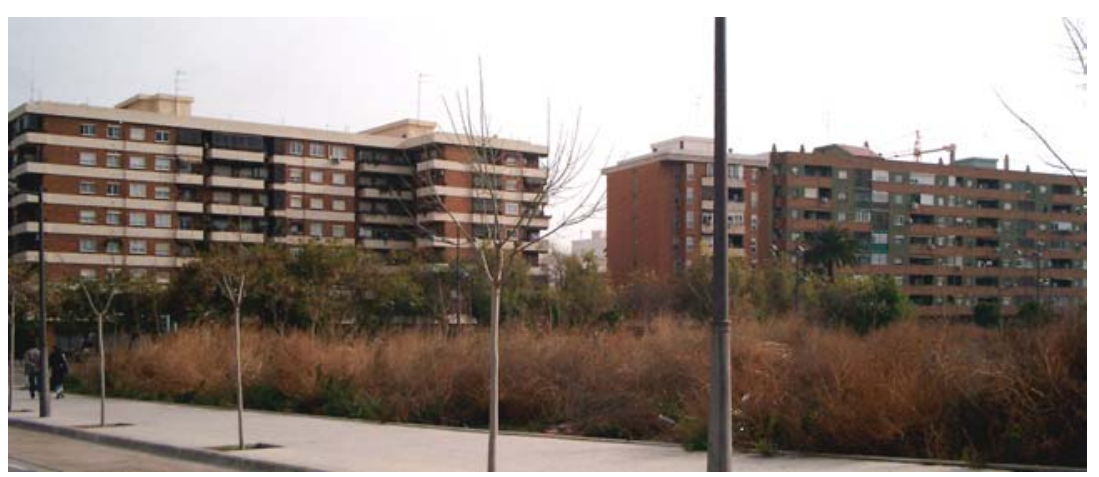

3

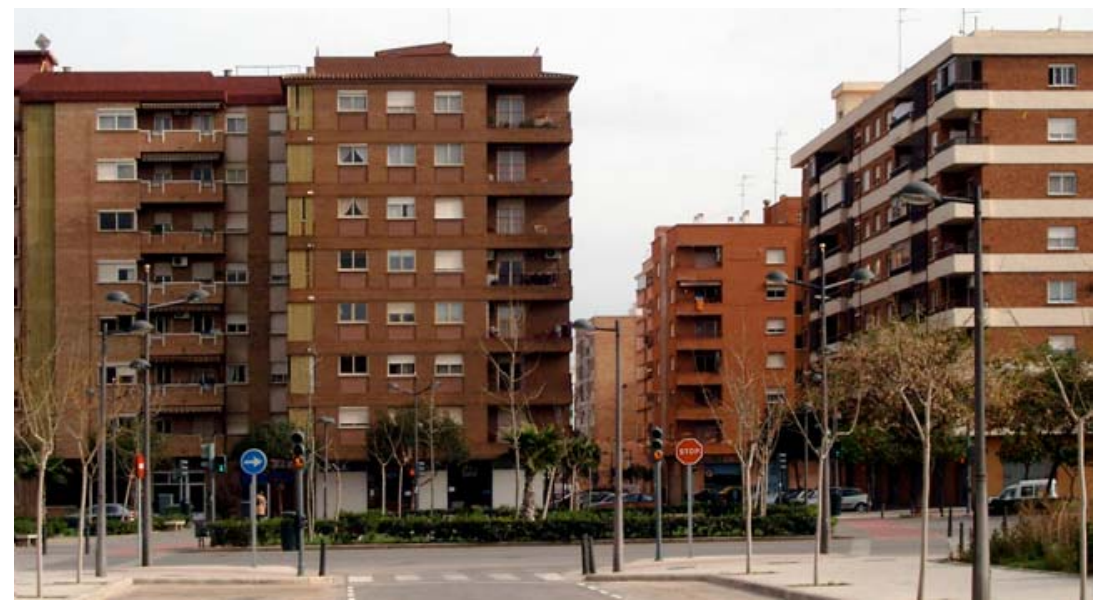

4

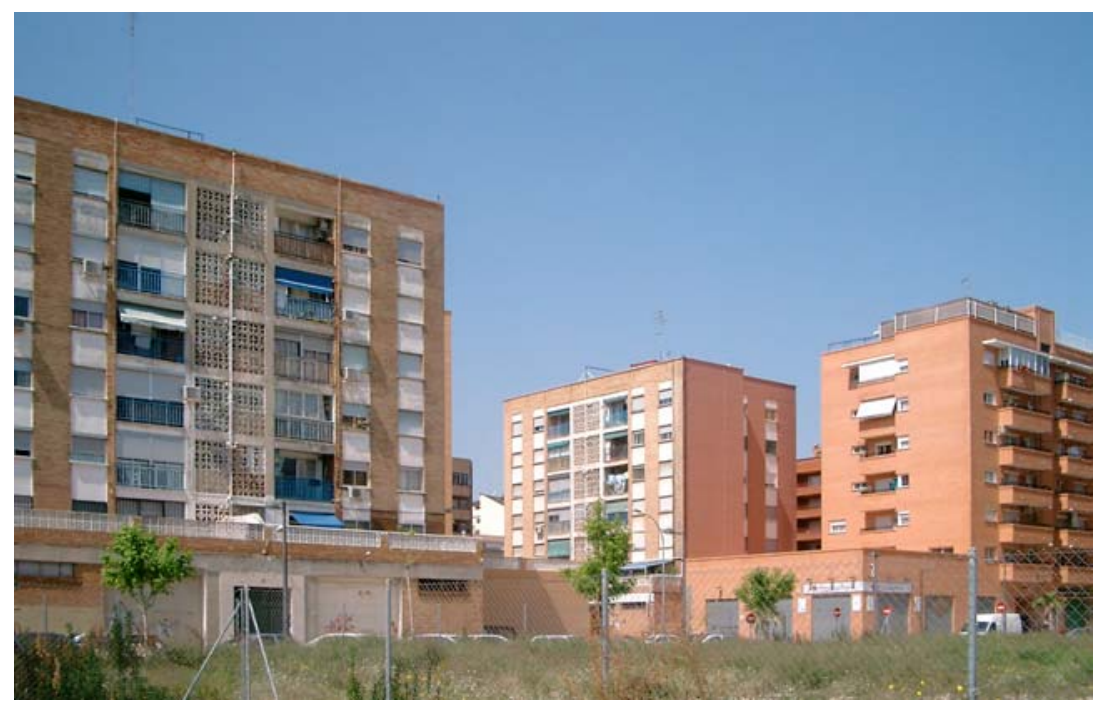

5
1. Palazzinas en la calle Vinaroz.

2. Bloque en $U$ en el Camino Viejo de Alboraya

3-4. Bloques en la Avenida de Alfahuir.

5. Palazzinas sobre zócalo comercial en las calles Viver y Vinaroz. 
En la zona situada al norte de Benimaclet, los bloques lineales llegan hasta el borde de las áreas urbanizadas, y en algunos casos aparecen en medio de terrenos que todavía conservan su uso agrícola. La precariedad de la urbanización y la presencia de descampados muestra claramente, aún hoy, las consecuencias negativas de la falta de una gestión urbanística adecuada.
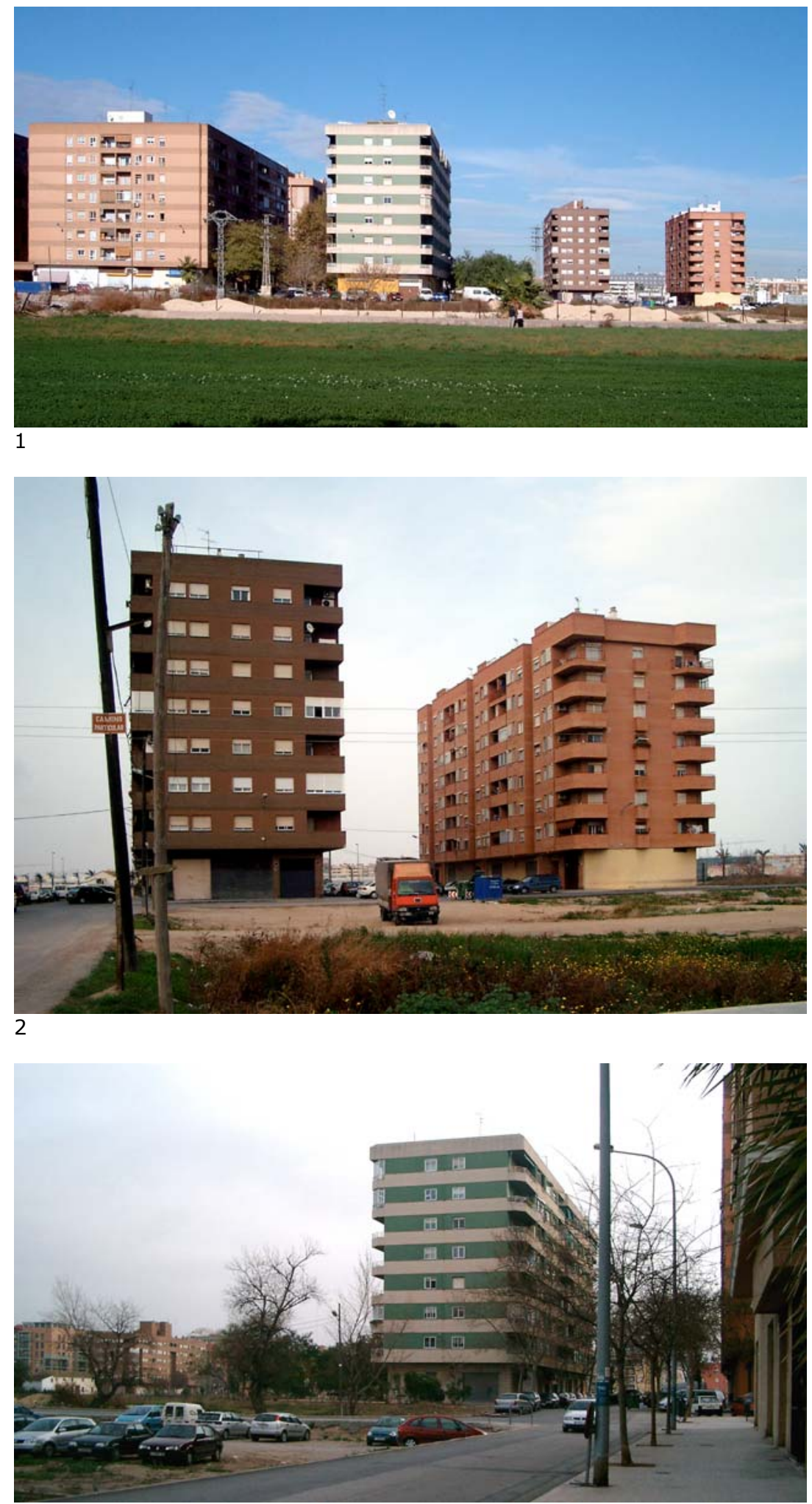

1. Bloques en la Avenida de Valladolid, vista desde el sur

2. Bloques en la calle Ricard Sanmartí.

3. Bloque en el Camino de Farinós.

4. Bloque en la calle General Sanmartí, vista hacia el este. 


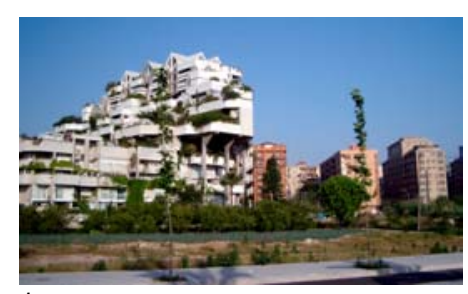

1

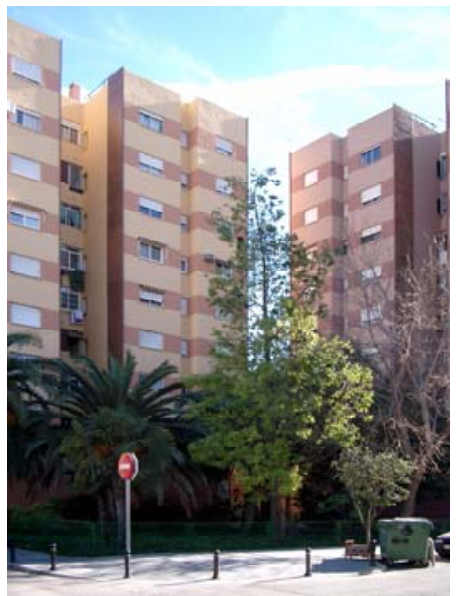

2

La zona más extensa de edificación abierta realizada de acuerdo con las previsiones del Plan Parcial 22 es la situada entre el límite este de Benimaclet y la Ronda Exterior del Plan de 1966, que coincide básicamente en su trazado con la actual Ronda Norte.

En esta zona están construidos buena parte de los bloques lineales, dispuestos en serie, previstos en el plan. Entre ellos y la Ronda Norte, el suelo permanece vacante.

Está construido también en esta zona el conjunto situado en la manzana delimitada por las actuales calles de Marcelino Giner, Camino de las Fuentes, Prudenci Alcón i Mateu y Músico Hipólito, formado por cinco torres unidas por en planta baja por locales comerciales, pero no tiene el carácter de centro comercial previsto en el Plan Parcial 22, ya que su estructura de usos no es diferente de la de las edificaciones colindantes, integradas también por locales comerciales en planta baja y viviendas en las plantas de pisos.

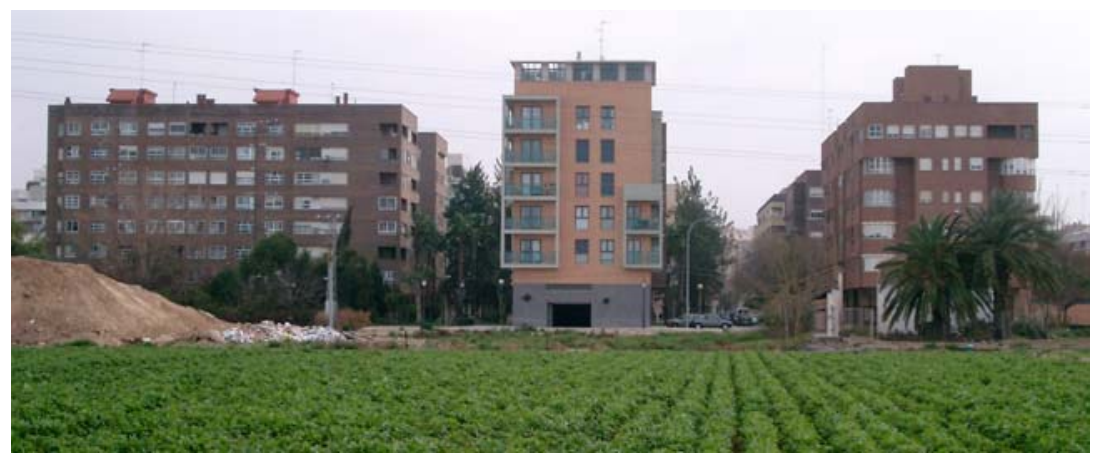

3

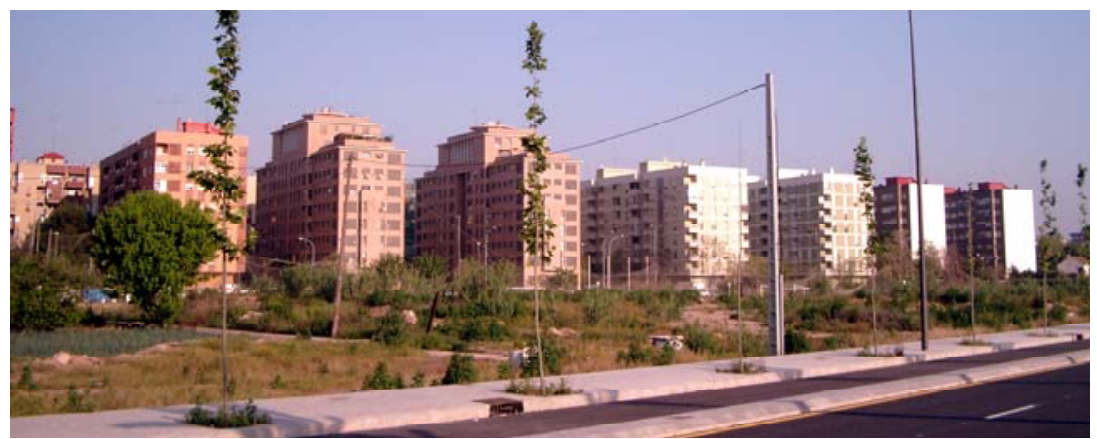

4

1. Edificación abierta en el borde este del PP22, frente a la Ronda Interior.

2. Torres del centro comercial de la calle Marcelino Giner.

3-5. Bloques lineales en el borde este del PP22, frente a la Ronda Exterior.

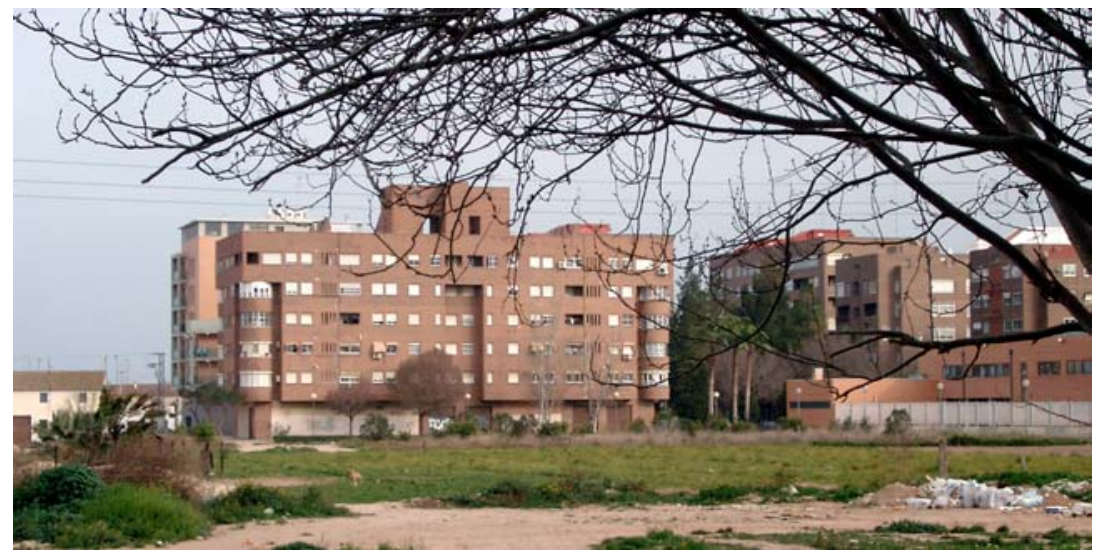


En esta zona, el conjunto denominado "Espai Vert" es un singular y desafortunado ejemplo de megaestructura aplicada a la edificación de viviendas.

Las edificaciones contempladas en el PERI del Sector 4 se haIlan construidas en su totalidad. La mayor parte de ellas forman parte de una promoción inmobiliaria unitaria, en la que las características arquitectónicas de los edificios son homogéneas tanto en las formas como en los materiales utilizados.

Como hemos indicado al analizar el PERI del Sector 4, La principal novedad que esta promoción introduce en Valencia es el recurso a espacios ajardinados privados que se utilizan como área comun de acceso a los bloques de edificación abierta que componen cada manzana, y a los que se accede tras atravesar una cancela que los separa del espacio público de la calle. Junto a esta cancela se sitúa una zona de conserjería y buzones compartida por todos los edificios de la manzana.

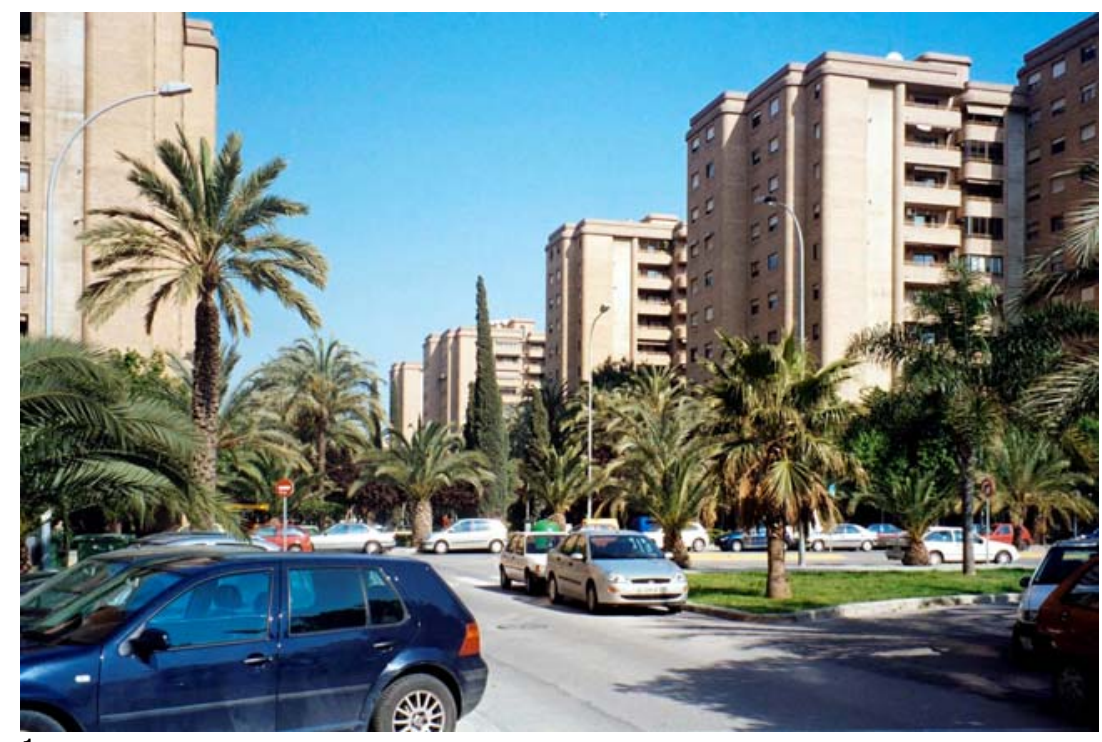

1

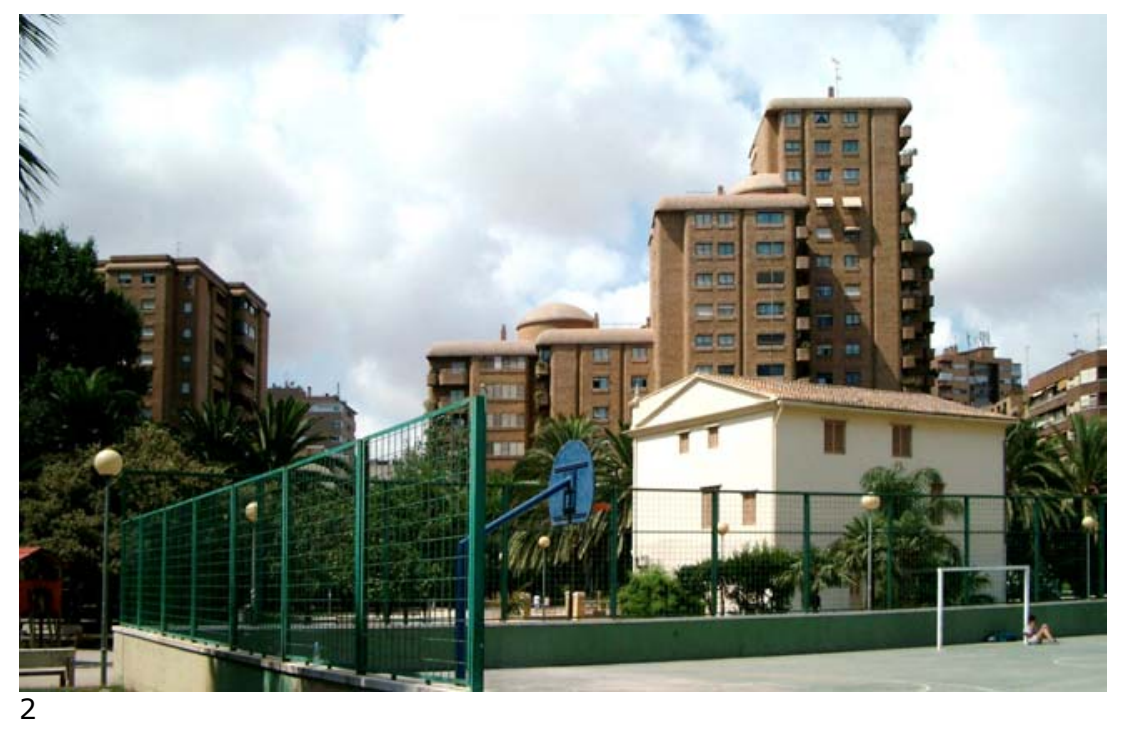

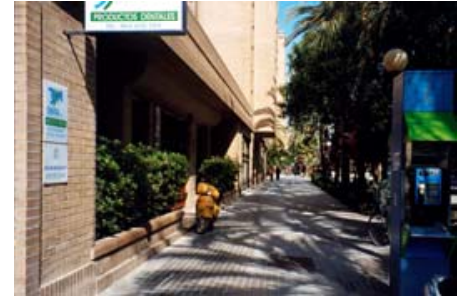

3

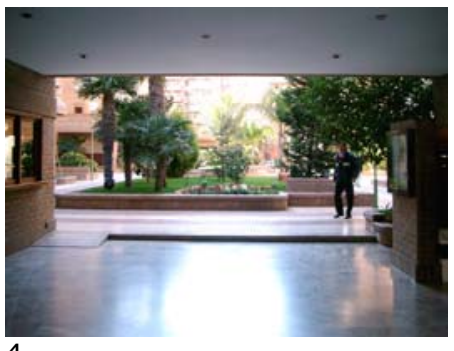

4

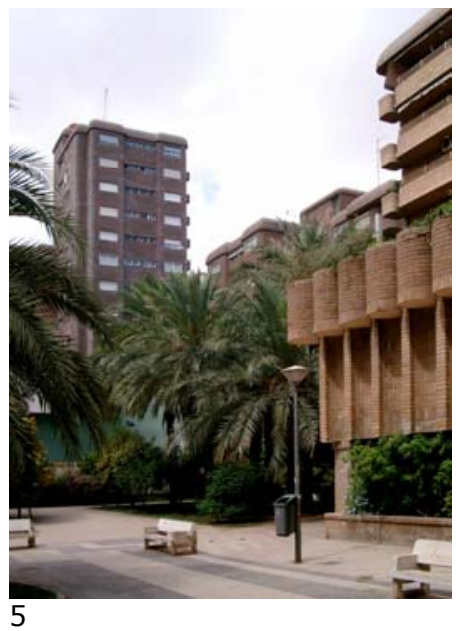

1-2. Torres en la calle Guardia Civil.

3-4. Calle Guardia Civil. Acceso a zaguanes y jardín interior de manzana

5-6. Torres en la plaza Alcalde Domingo Torres, junto al Camino de Vera. 

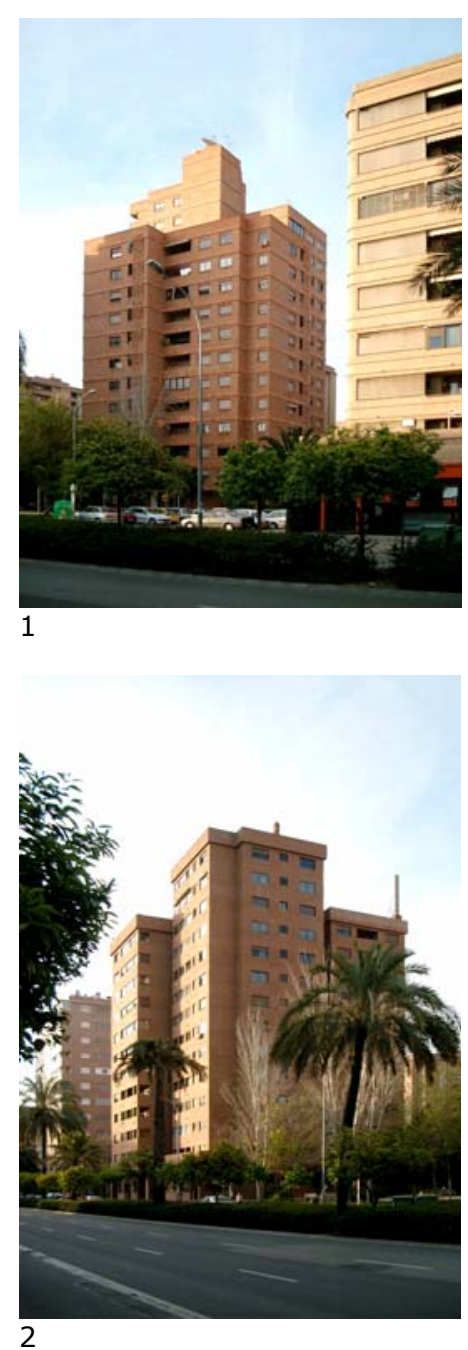

1-5. Torres en el lado sur del Sector 4 del PP22, junto a la Avenida de Primado Reig.
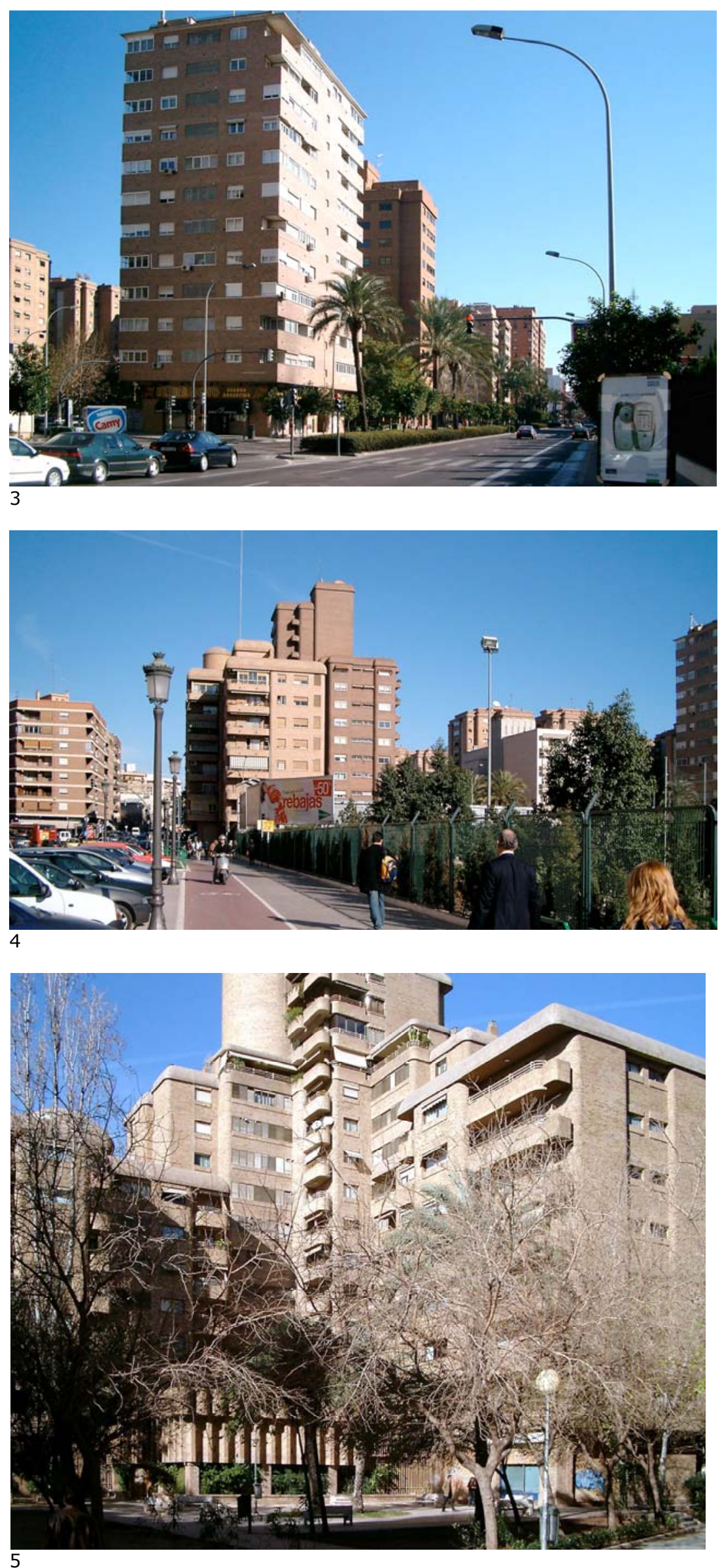
El jardín público central, libre de tráfico rodado, está actualmente flanqueado por diversos locales comerciales, dispuestos en los bajos que ocupan el perímetro de las manzanas, envolviendo el jardín privado de acceso antes mencionado. Un buen número de dichos locales están dedicados a actividades relacionadas con el ocio, tales como cafeterías o restaurantes.

En la zona sur del denominado Sector 4 del PP22, la edificación adopta el modelo de torres en el parque, característico de la edificación abierta. Algunas de estas torres, construidas en base al plan de 1972, tienen unas plantas en forma de racimos formados por agrupaciones de módulos de $10 \times 10$ m, acompañados por construcciones complementarias de menos altura destinadas a usos comerciales y de oficinas por lo general.

El conjunto situado junto a la Avenida de Cataluña, resultado de un Estudio de Detalle que se incorpora al Plan General de 1988, está formado por torres con planta en forma de T situadas sobre un zócalo no residencial continuo que envuelve un jardín público interior. La exagerada densidad de este conjunto, en el que las torres casi se tocan unas con otras, hace que los principios de la edificación abierta queden completamente desvirtuados.

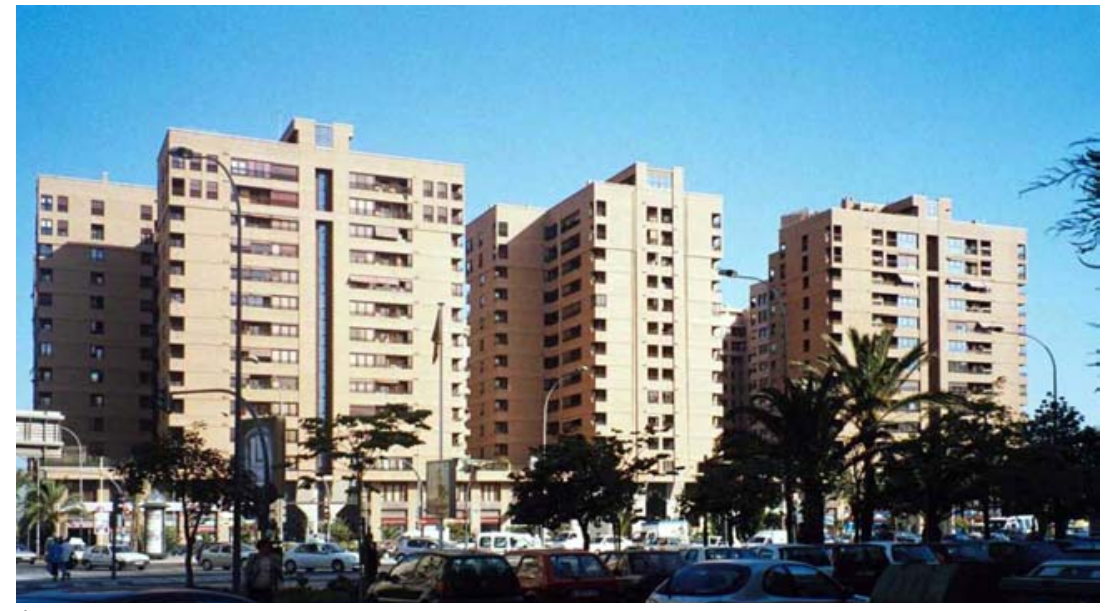

1

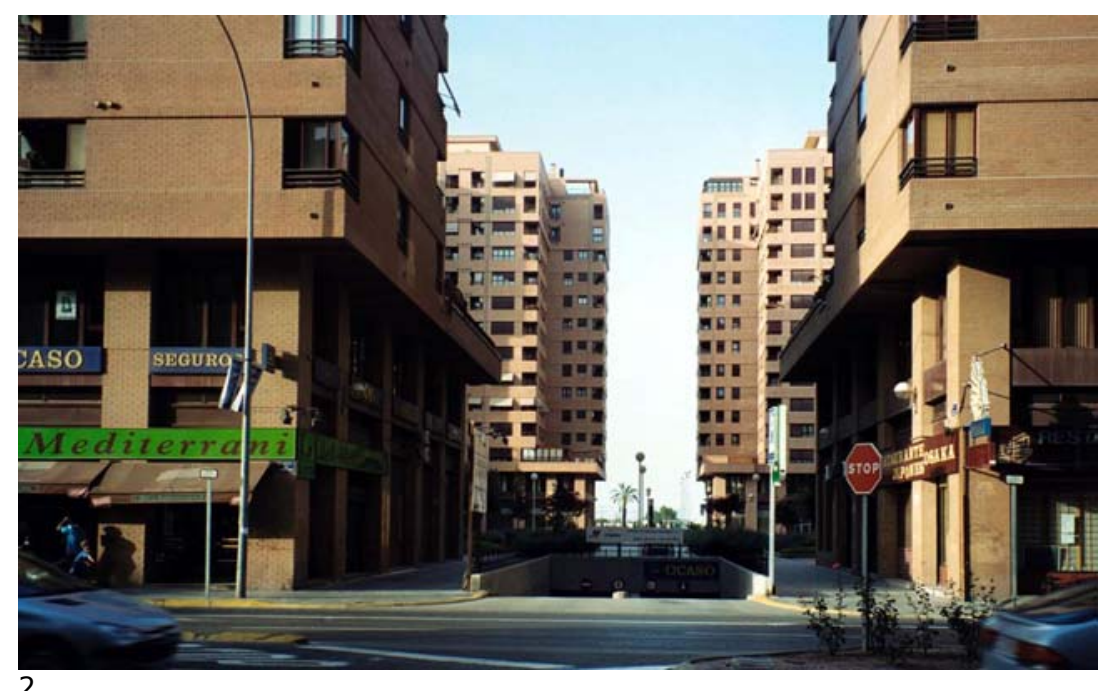

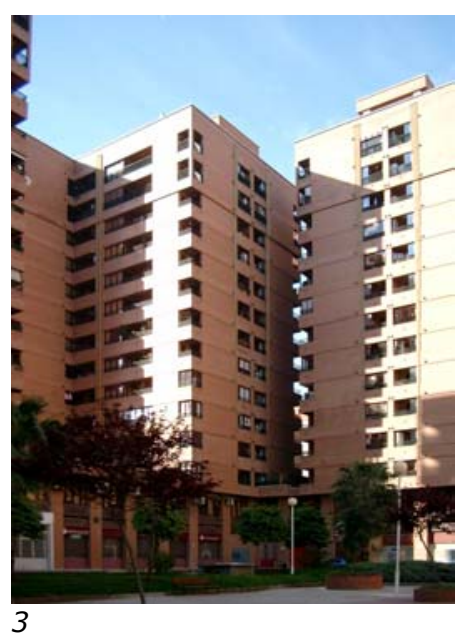

1-5. Torres al oeste del Sector 4 del PP22, junto a la Avenida de Cataluña. 


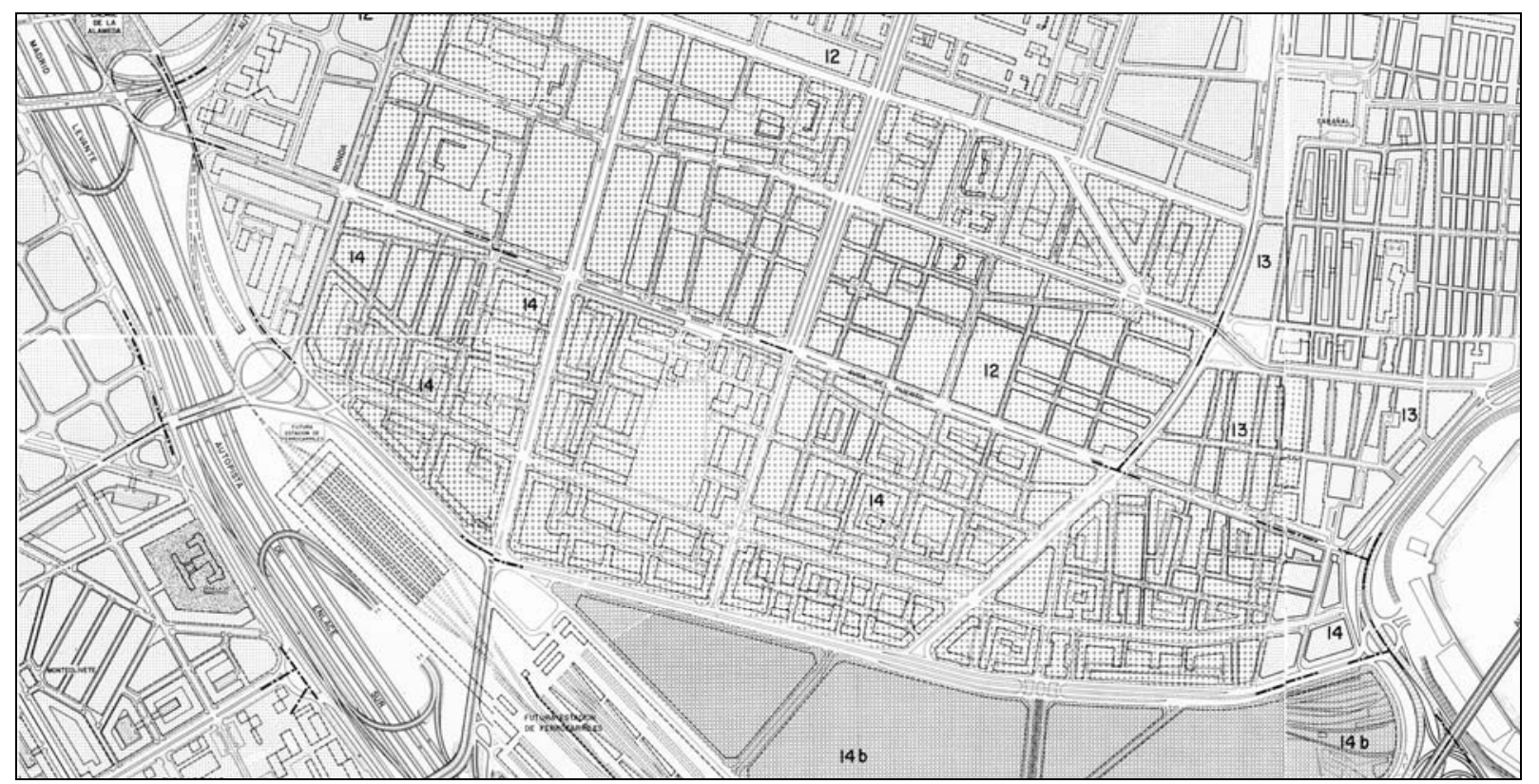

Plan Parcial 14. Versión incluida en el Informe PREVASA.

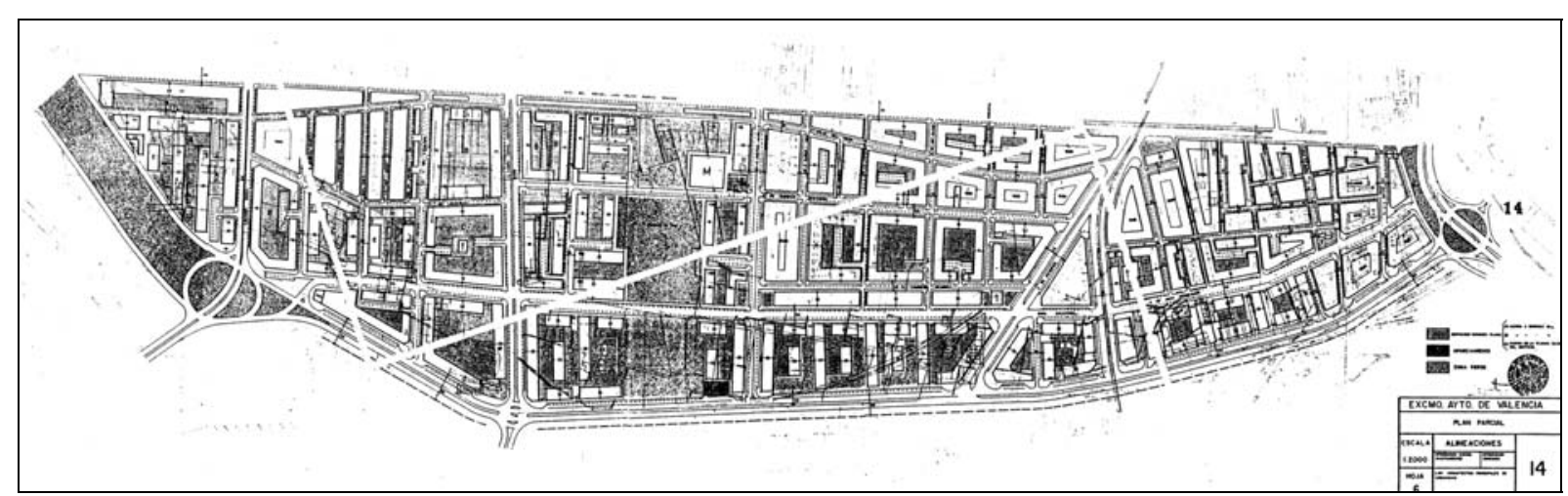

Plan Parcial 14, 1967. Plano de alineaciones.

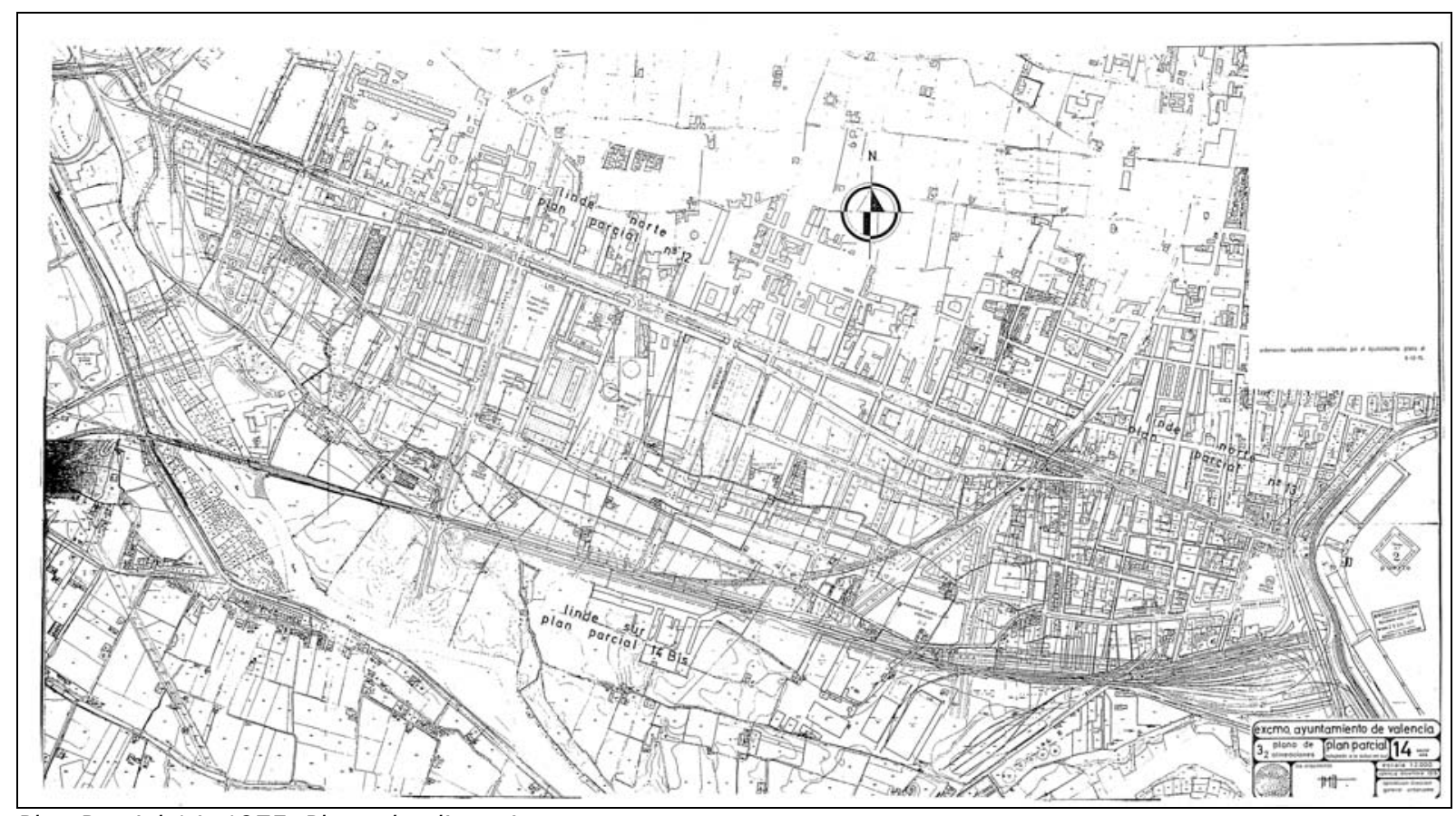

Plan Parcial 14, 1975. Plano de alineaciones. 
CAMINS AL GRAO: EL PLAN PARCIAL 14 (1967-75)

El Plan Parcial 14, que como hemos visto en una sección anterior fue aprobado como Hoja 14 del Plan General de 1946 por la Comisión Central de Sanidad Local en 1954, no fue revisado hasta después de la aprobación en 1966 del Plan General adaptado a la Solución Sur. ${ }^{1}$

La primera revisión, fechada en 1967, muestra una disposición de la edificación abierta completamente diferente a la prevista en la Hoja 14 de 1954. Esta primera revisión no fue aprobada y, ya en 1975, se redactó una nueva versión del plan, que tampoco llegó a aprobarse definitivamente. Además, existe una tercera versión del Plan Parcial 14, que es la que figura en el Informe PREVASA como plan en tramitación. El ámbito ordenado, que es todos los casos el mismo, es el limitado el norte por la Avenida del Puerto, al este por la dársena portuaria, al sur por la línea ferroviaria que coincide con la actual Avenida de Francia y al oeste por el cauce del río Turia.

La Hoja 14, por tanto, es el único documento de planeamiento en vigor para este ámbito entre 1954 y 1988, fecha de aprobación del nuevo Plan General de Valencia. Los pocos bloques de edificación abierta realizados en la zona, sin embargo, no se ajustan a lo previsto en dicha Hoja, sino a la ordenación establecida en la versión del Plan Parcial de 1967 y, en algunos casos, a la de 1975.

El desarrollo urbano del área del PP14 es, pues, tardío, y ello se debe en gran parte a la presencia en la misma de diversas instalaciones industriales de cierta envergadura, entre las que destacan las del Gas Lebón, cuya eliminación o traslado resultarán por lo general lentos y dificultosos.

En esta zona está situado el grupo de la calle Pintor Maella, analizado en el apartado dedicado a los grupos de viviendas de Renta Limitada de promoción privada, que es un ejemplo de edificación abierta inserta en un tejido de manzanas convencionales.

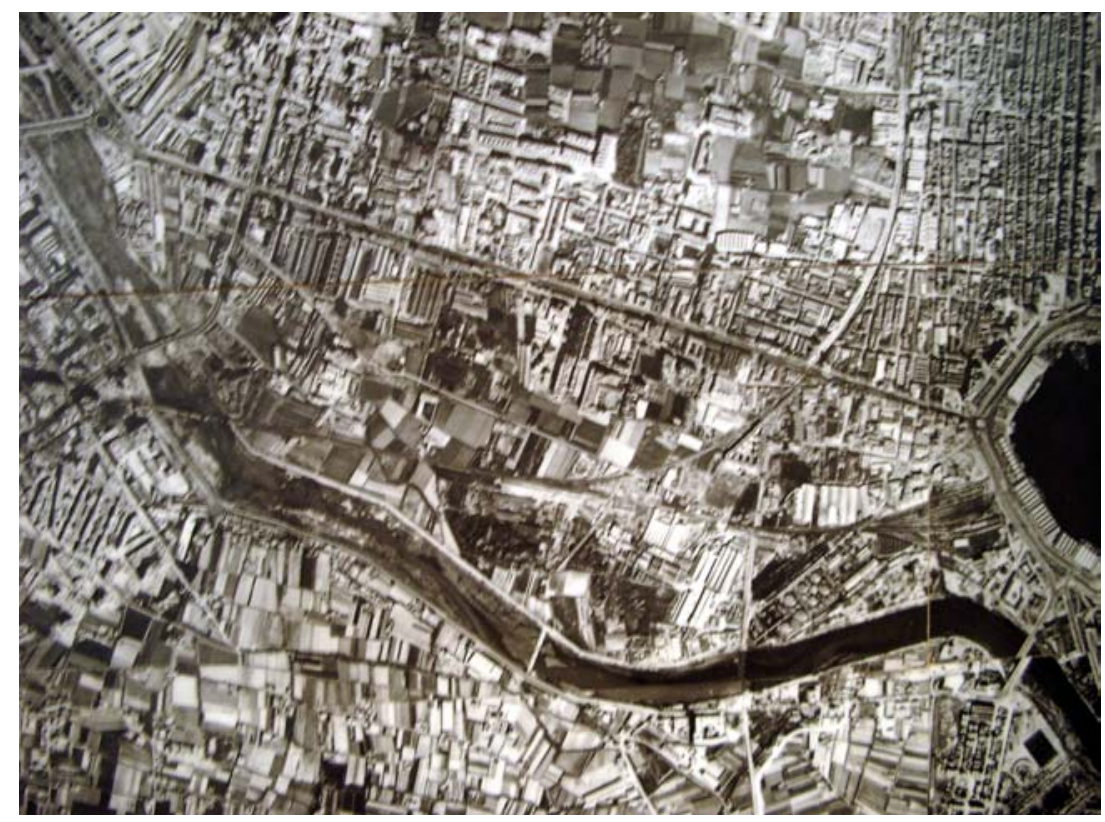

Zona del Plan Parcial 14. Fotoplano, h. 1965 (ETS de Arquitectura de Valencia).

1. Ver Anexo de Documentos, pp. 441-464. 


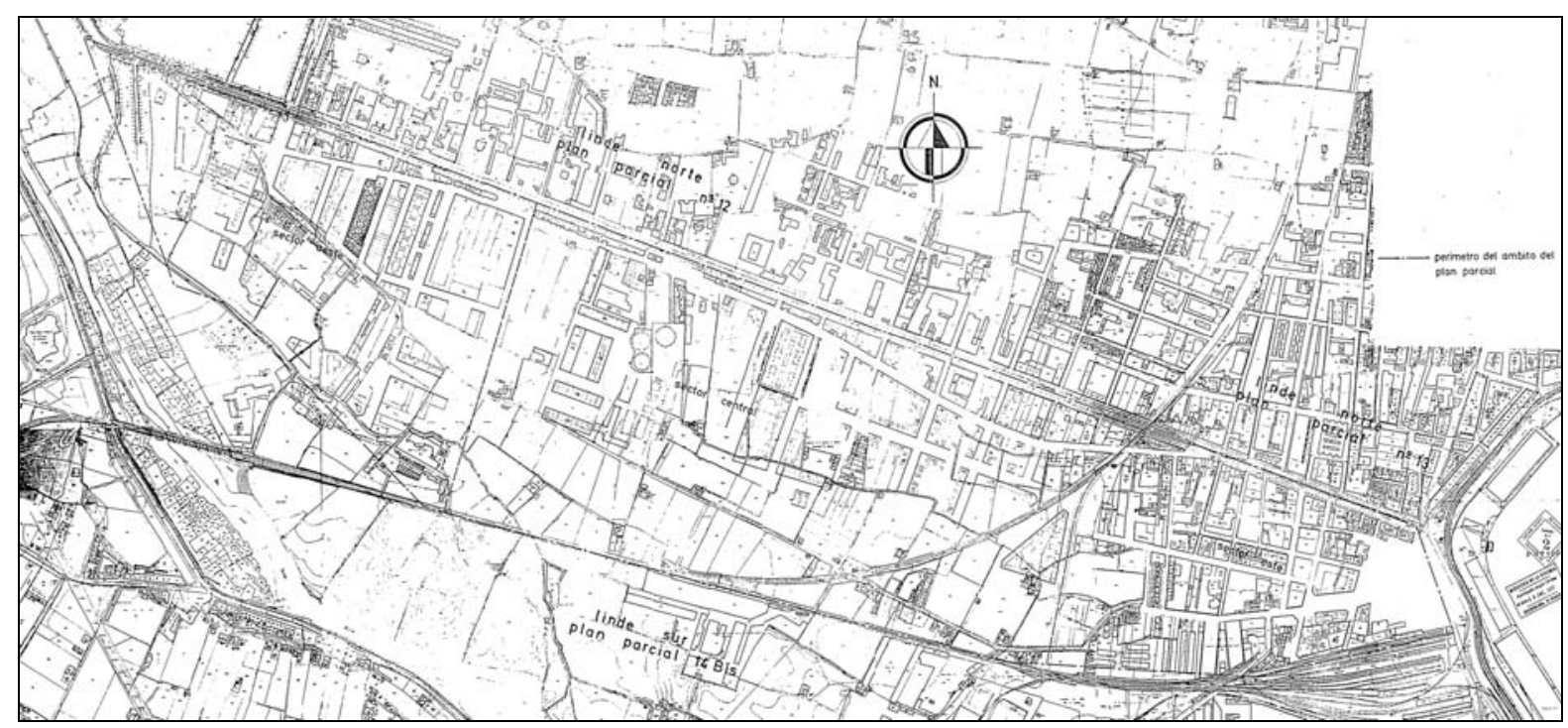

Plan Parcial 14, Sector Este, 1975. Plano de estado actual.

Plan Parcial 14. Versión incluida en el Informe PREVASA. Edificación y equipamientos en las zonas de edificación abierta (Elaboración propia. Color sobre montaje de hojas de información urbanística del Informe).
En la versión del PP14 que figura en el Informe PREVASA es reconocible todavía vagamente el principal conjunto de edificación abierta proyectado en la Hoja 14, situado al sur, entre la Avenida de Baleares y la actual Avenida de Francia. Esta versión parece por ello anterior a la de 1967, ya que en esta última desaparece toda referencia a dicho conjunto.

La presencia de espacios verdes y de equipamientos en la versión del PREVASA del PP14 es muy escasa. La única reserva de suelo importante es la correspondiente a la zona ocupada por las instalaciones de Gas Lebón, donde el plan prevé un parque, junto al que se sitúa un mercado y una iglesia. El resto de equipamientos son algunos pequeños edificios escolares o religiosos dispuestos en espacios interiores de manzana.

La edificación abierta prevista en la versión del PP14 del Informe PREVASA adopta en su mayor parte la forma de manzanas abiertas, con bloques profundos dispuestos alineados con las calles perimetrales que envuelven un espacio interior ocupado por bajos comerciales y atravesado por viales de acceso y aparcamiento. El aspecto del conjunto es parecido al de un tejido de manzanas, del que se diferencia por la discontinuidad del perímetro edificado y por la presencia de viales interiores.

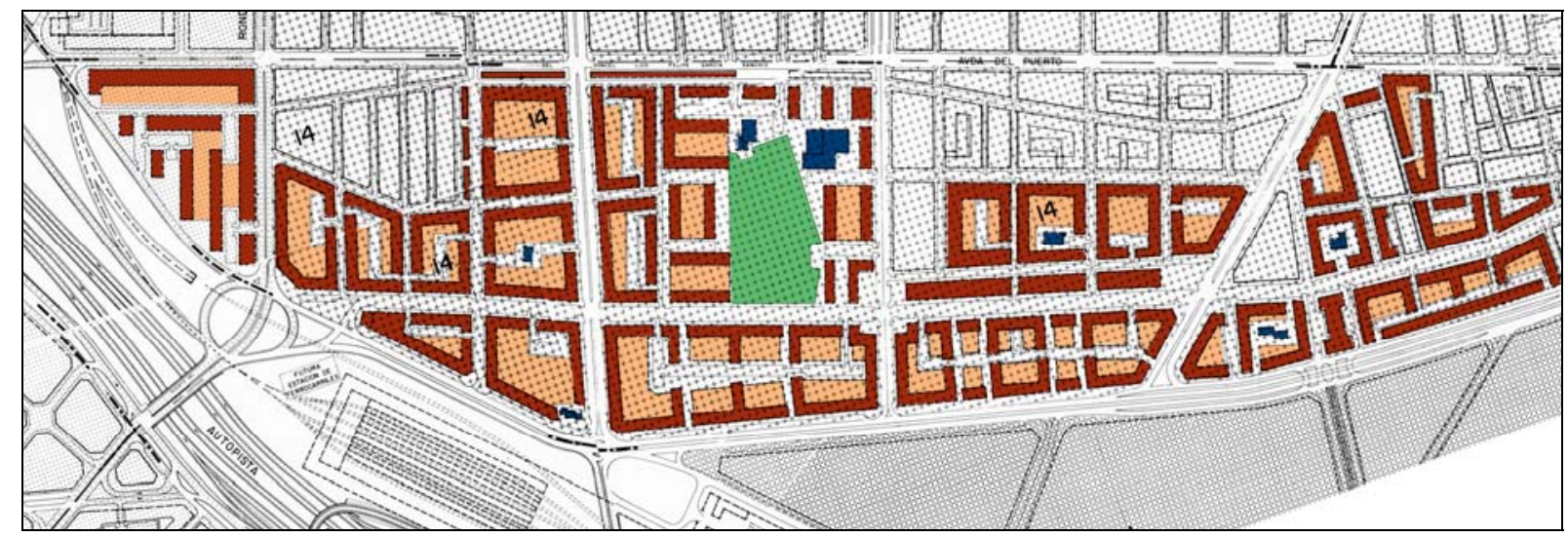




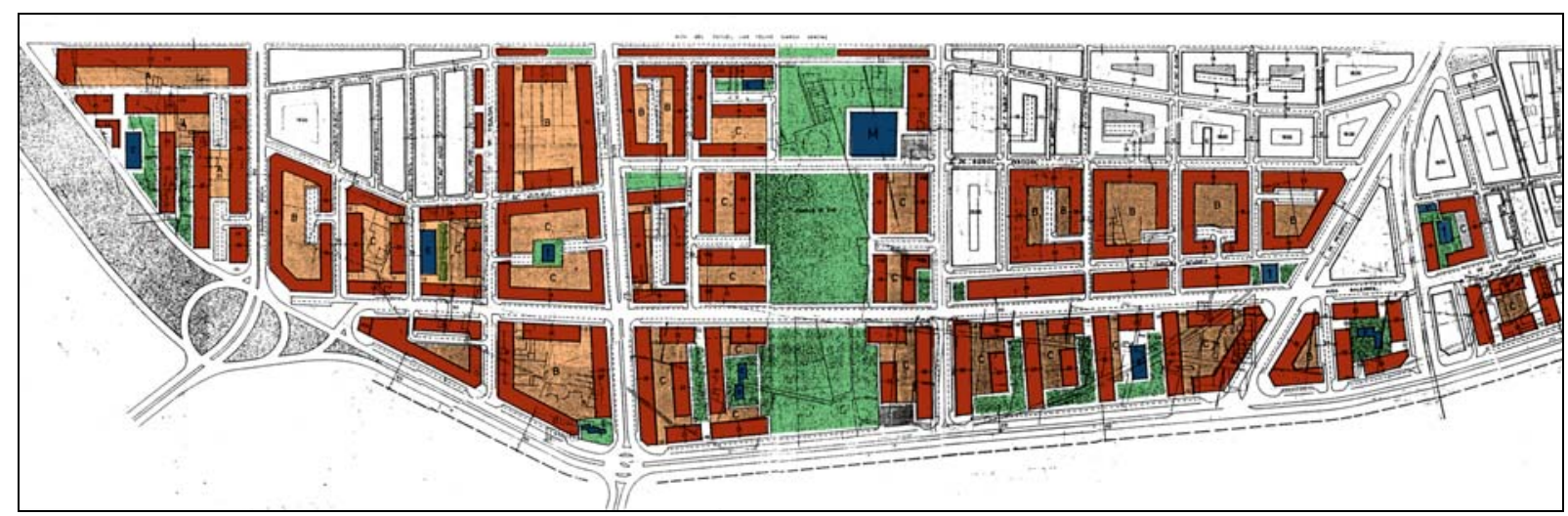

Los bloques lineales se utilizan en únicamente en dos zonas: alrededor del parque central y en el espacio triangular situado en el extremo este, próximo a la localización prevista para la futura Estación Central de Ferrocarriles. En ambos casos, los bloques son de cinco crujías, y requieren patios interiores o bien patios abiertos a fachada.

La ordenación de 1967 es muy similar a la que figura en el Informe PREVASA. La principal modificación que se introduce en ella es la relativa al conjunto de edificación abierta situado al sur antes mencionado, en el que se sustituyen los bloques a redents por agrupaciones de bloques lineales profundos enlazados por bajos comerciales, con espacios verdes intercalados. Además, se amplía la zona verde central hasta el límite sur del plan.

En la versión del PP14 de 1975, varias de las zonas de edificación abierta incluidas en el plan de 1967 quedan calificadas como sectores de ordenación especial diferida, para los que no se dibujan alineaciones.

Por otra parte, la versión de 1975 introduce unas reservas de suelo para equipamientos muy superiores a las previstas en la zona hasta ese momento. Estas dotaciones se concentran sobre todo en la parte sur del plan, donde se prevé una franja verde casi continua $y$, junto a ella, otra banda de parcelas escolares de gran tamaño. Además, la zona verde transversal de la versión anterior se sustituye por una amplia zona de uso deportivo.
Plan Parcial 14, 1967. Edificación y equipamientos en las zonas de edificación abierta (Elaboración propia. Color sobre Plano de alineaciones).
Plan Parcial 14, Sector Este, 1975. Edificación y equipamientos en las zonas de edificación abierta (Elaboración propia. Color sobre plano de alineaciones).

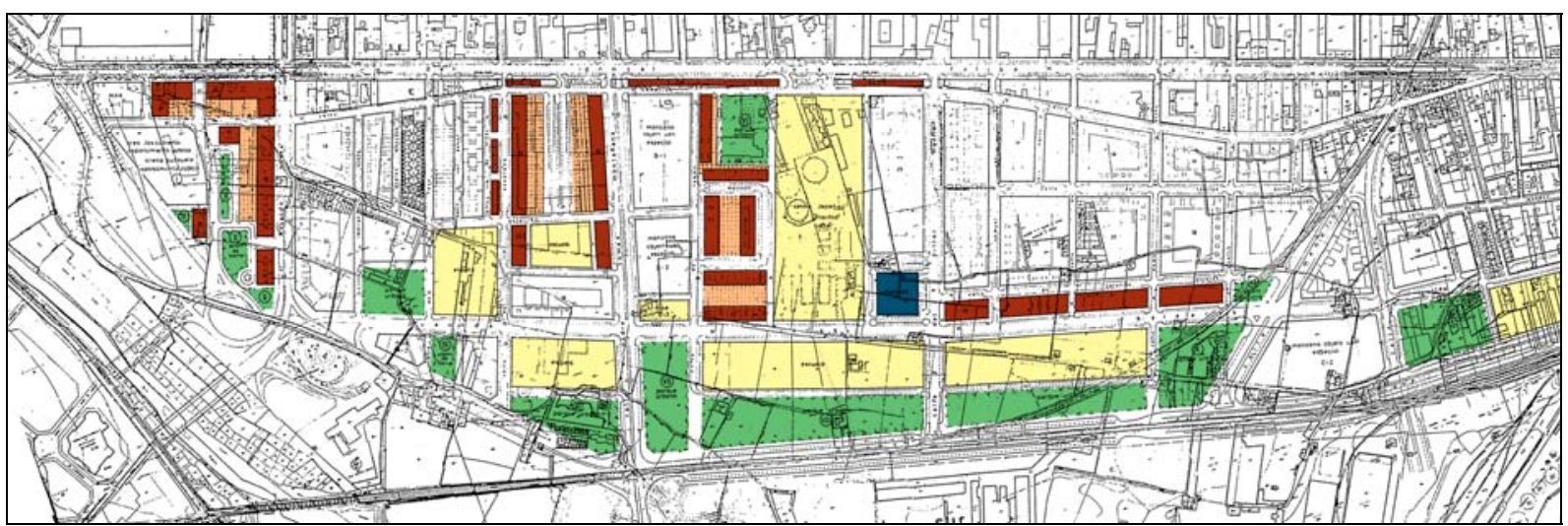




\section{Grado de realización}

De las zonas de edificación abierta previstas en las diferentes versiones del Plan Parcial 14 antes reseñadas, únicamente se construyeron finalmente cuatro manzanas, tres pequeños bloques de dos crujías y algunos fragmentos de bloques profundos.

Los tres bloques lineales aislados, dispuestos en serie, alineados con la calle Río Escalona, se construyeron de acuerdo con las previsiones de Hoja 14 de 1954, en la que ya aparecían.

Las manzanas, por su parte, están formadas por bloques profundos sobre unidos por edificación comercial en planta baja que ocupa la totalidad del suelo. La más extensa es la delimitada por las calles Padre Tomás de Montañana, Asturias, Río Escalona e Islas Canarias. Las otras tres, que responden a un proyecto de arquitectura unitario y que son las únicas que ofrecen una imagen adscribible al orden abierto, son las situadas junto a la fábrica de Gas Lebón, entre las calles Islas Baleares, Fuencaliente y Lebón.

En el Plan General de 1988, la zona situada al sur, entre la Avenida de las Islas Baleares y la actual Avenida de Francia, ordenada con edificación abierta en el PP14, se califica como Suelo Urbanizable No Programado, con lo que su ordenación queda pospuesta.

Por otra parte, el nuevo Plan General refleja la reordenación de algunas de las zonas de edificación abierta del PP14. Así, alrededor de las dos manzanas de la calle Lebón, entre las calles Padre Tomás de Montañana y Pintor Maella, se prevén varias manzanas formadas por bloques profundos, algunas de las cuales disponen de un espacio libre interior. También se remodela completamente la zona situada en el extremo oeste, frente al Palau de la Música.

En cuanto a los espacios verdes, debe mencionarse el hecho

PGOU 1988. Zona del Plan Parcial 14 (Color sobre montaje de hojas de la serie $C$, Planos de Ordenación, del Plan General). de que ninguno de los parques previstos en las diferentes versiones del PP14 ha llegado a realizarse todavía.

No existen en esta zona, por tanto, conjuntos de edificación abierta de tamaño significativo, sino episodios aislados inconexos, tal como ocurría en el Plan Parcial 10.

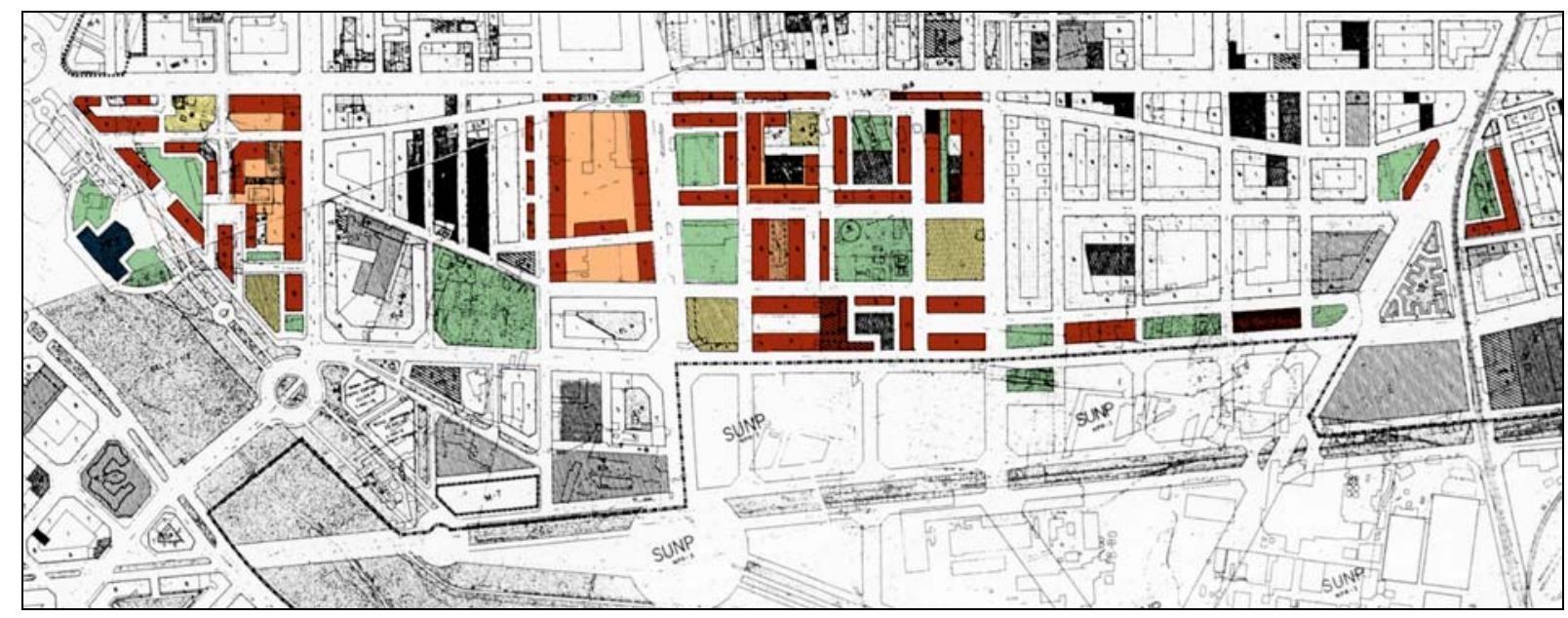




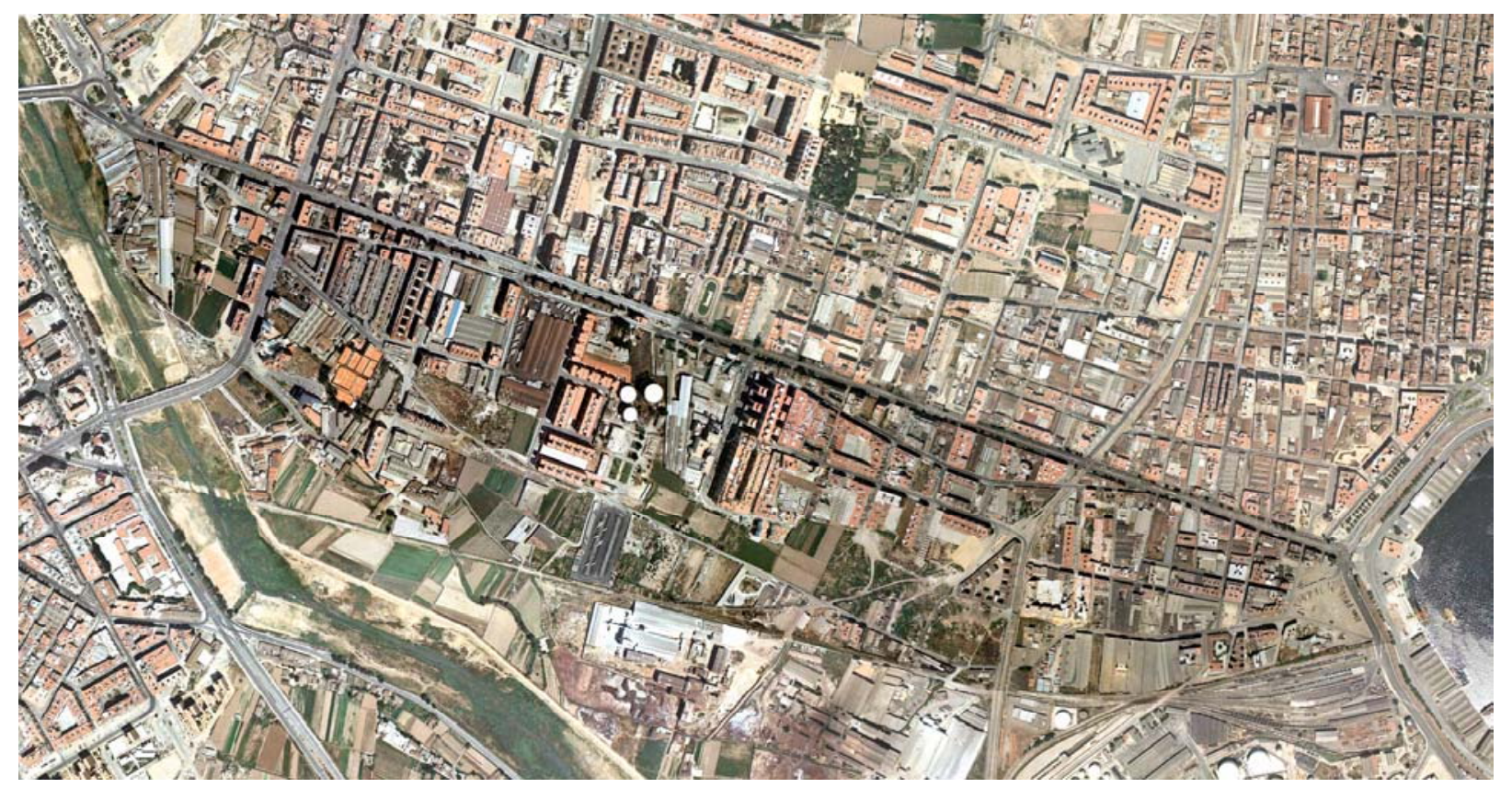

Zona del Plan Parcial 14. Fotoplano, 1980 (AUMSA).

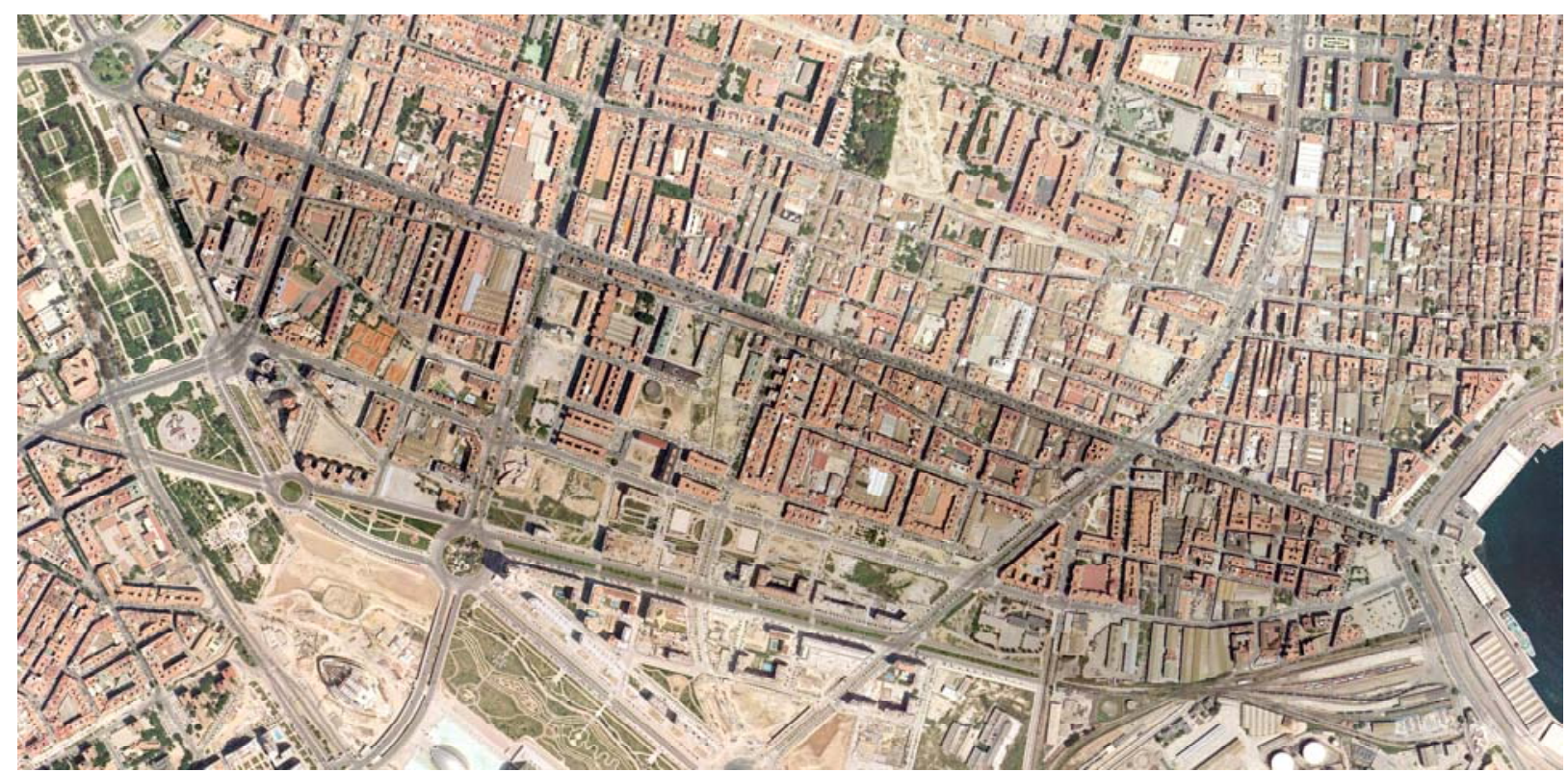

Zona del Plan Parcial 14. Ortofoto 2002 (AUMSA). 


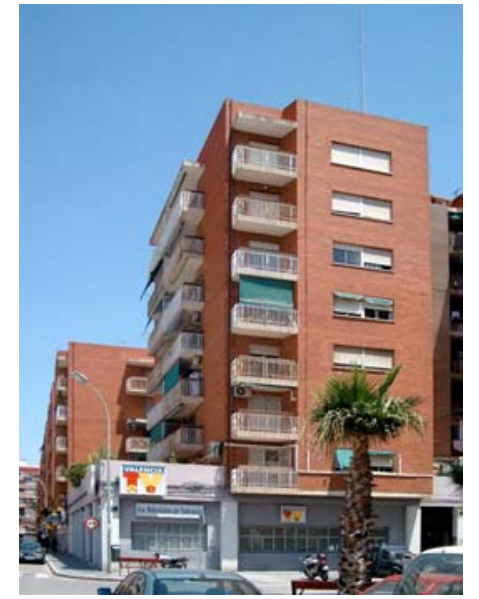

1
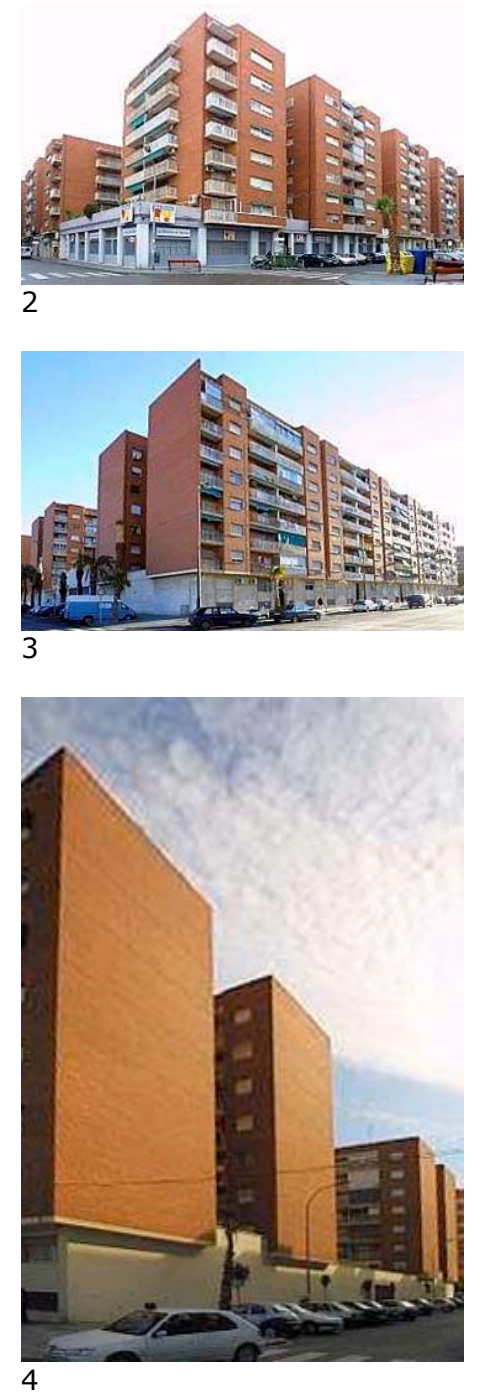

1-6. Bloques de la calle Lebón.
Los bloques profundos de cinco crujías que integran el grupo de tres manzanas situadas junto a la antigua fábrica de Gas Lebón son, como hemos indicado, resultado de un proyecto unitario, al que el recurso al ladrillo rojo y a una composición alterna de terrazas y paños perforados con ventanas apaisadas dota de unidad arquitectónica.

En la manzana situada más al norte, estos bloques profundos no están dispuestos en paralelo sobre el zócalo comercial como ocurre en las otras dos manzanas, sino que se sitúan en perpendicular, formando una L. Además, los patios no se ubican en la crujía central, sino que se abren a fachada, de modo que todas las piezas habitables recaen siempre a calles. Esta solución es la que recomendaban las ordenanzas para la edificación abierta profunda.

En las otras dos manzanas, el tratamiento de los testeros, ciegos y sin cambios de orientación de las piezas, muestran que el bloque profundo, con patios interiores, se concibe como un bloque doble, como una unión de dos bloques de dos crujías cada uno.
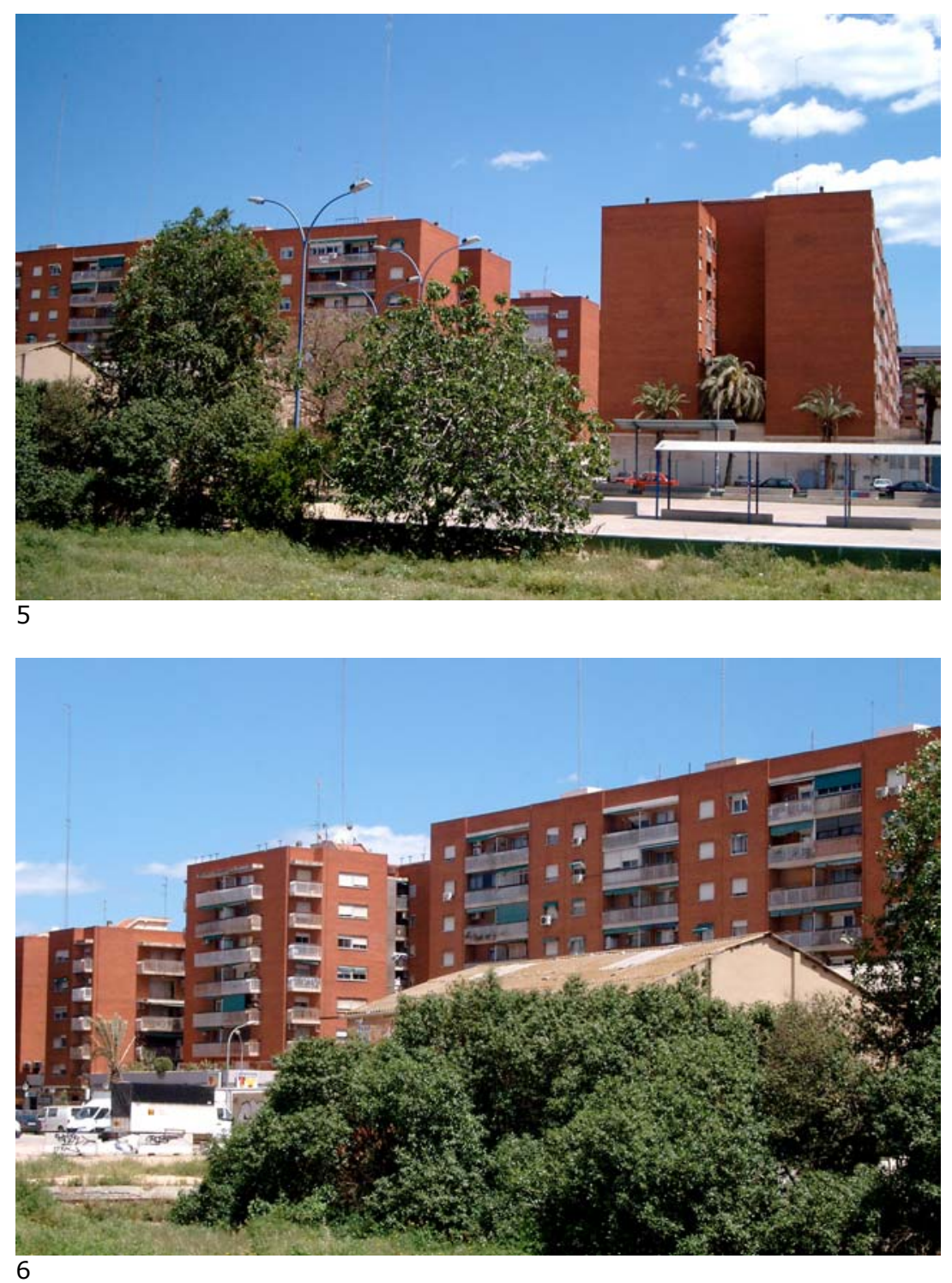


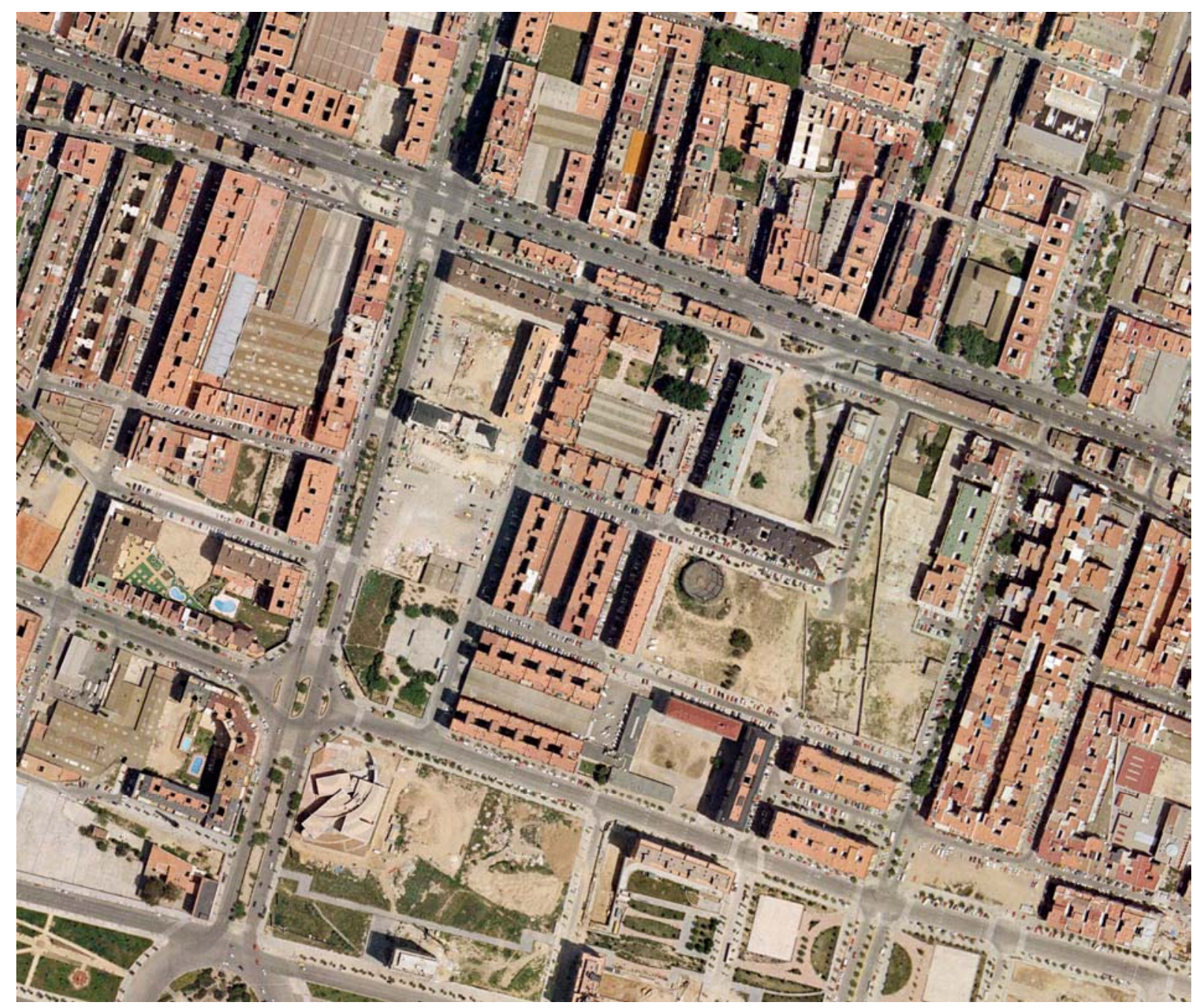

Ortofoto 2002. Detalle de la zona de edificación abierta del PP14. 


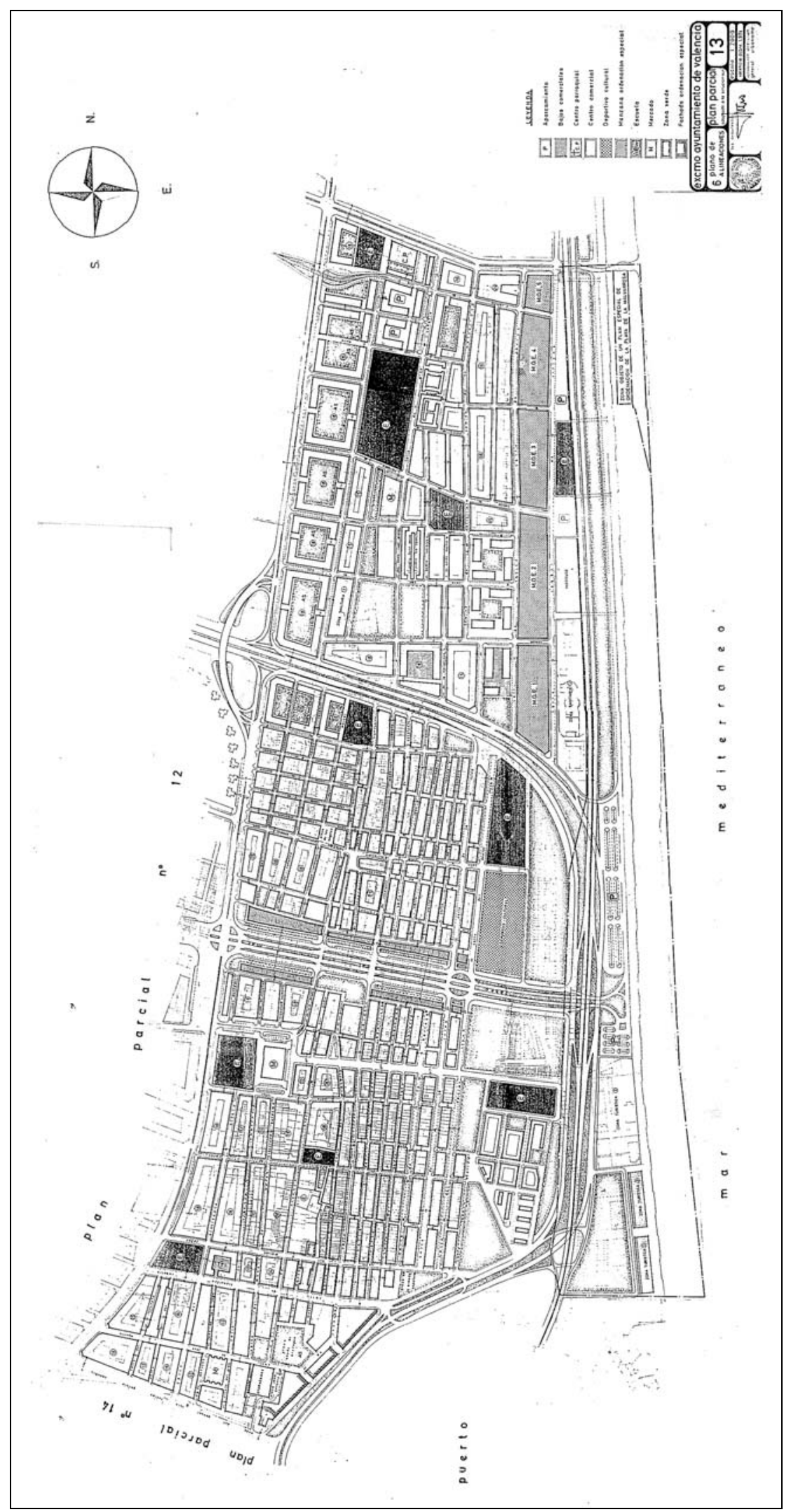

Plan Parcial 13, 1974. Plano de alineaciones. 
GRAO-CABANYAL-MALVARROSA: EL PLAN PARCIAL 13 (1967-74)

Los barrios del Grao, Cabanyal y Malvarrosa son la parte del distrito marítimo de Valencia ordenada en el Plan Parcial 13. Se trata de unos barrios dotados de una vida propia muy intensa, muy edificados, con una trama y tipologías de edificación propias.

El Plan Parcial 13 redactado en 1962, que hemos analizado en la sección anterior, fue revisado en 1967, después de la aprobación en 1966 del Plan General adaptado a la Solución Sur. Esta versión de 1967 fue a su vez modificada por otra redactada en 1974, aprobada definitivamente por el Ministerio de la Vivienda en septiembre de 1975 y anulada en 1982 por sentencia del Tribunal Supremo ${ }^{1}$.

La primera revisión del plan, fechada en 1967, introduce la edificación abierta en algunas zonas todavía vacantes de la Malvarrosa - situada en la mitad norte- que estaban ordenadas con manzanas cerradas en la versión de 1962.

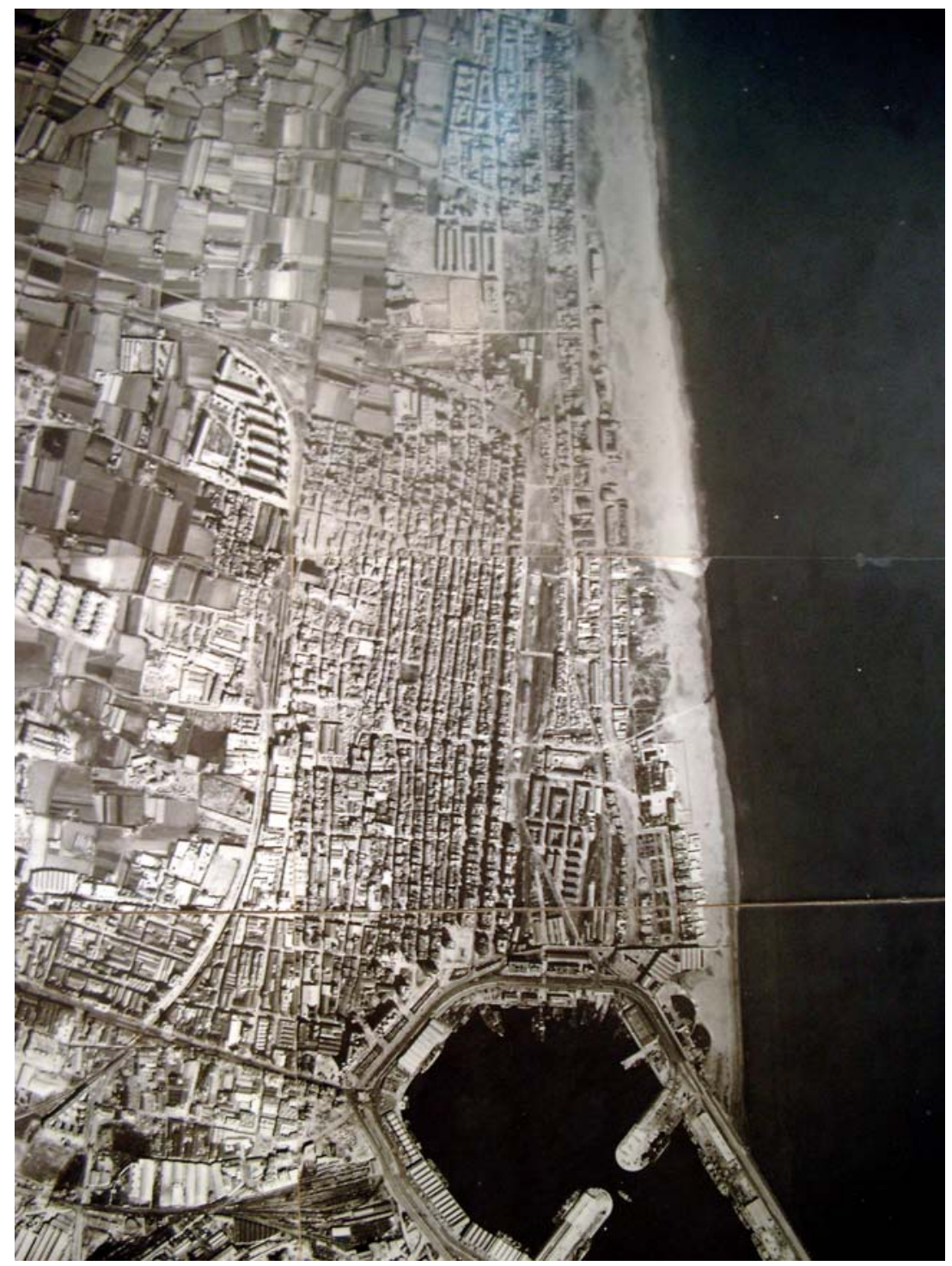

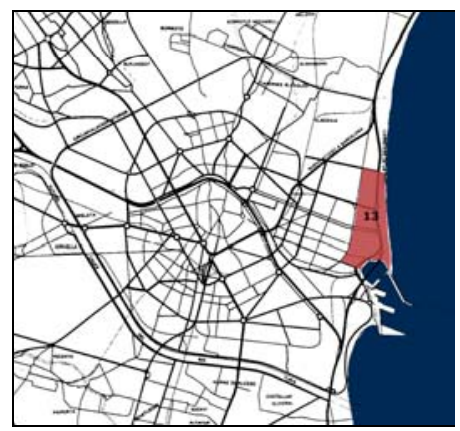

Plan Parcial 13. Localización

Zona del Plan Parcial 13. Fotoplano, h. 1965 (ETS de Arquitectura de Valencia).

1. Plan Parcial no 13 adaptado a la Solución Sur, Ayuntamiento de Valencia, 1968/1974. Ver Anexo de Documentos, pp. 415-439. 


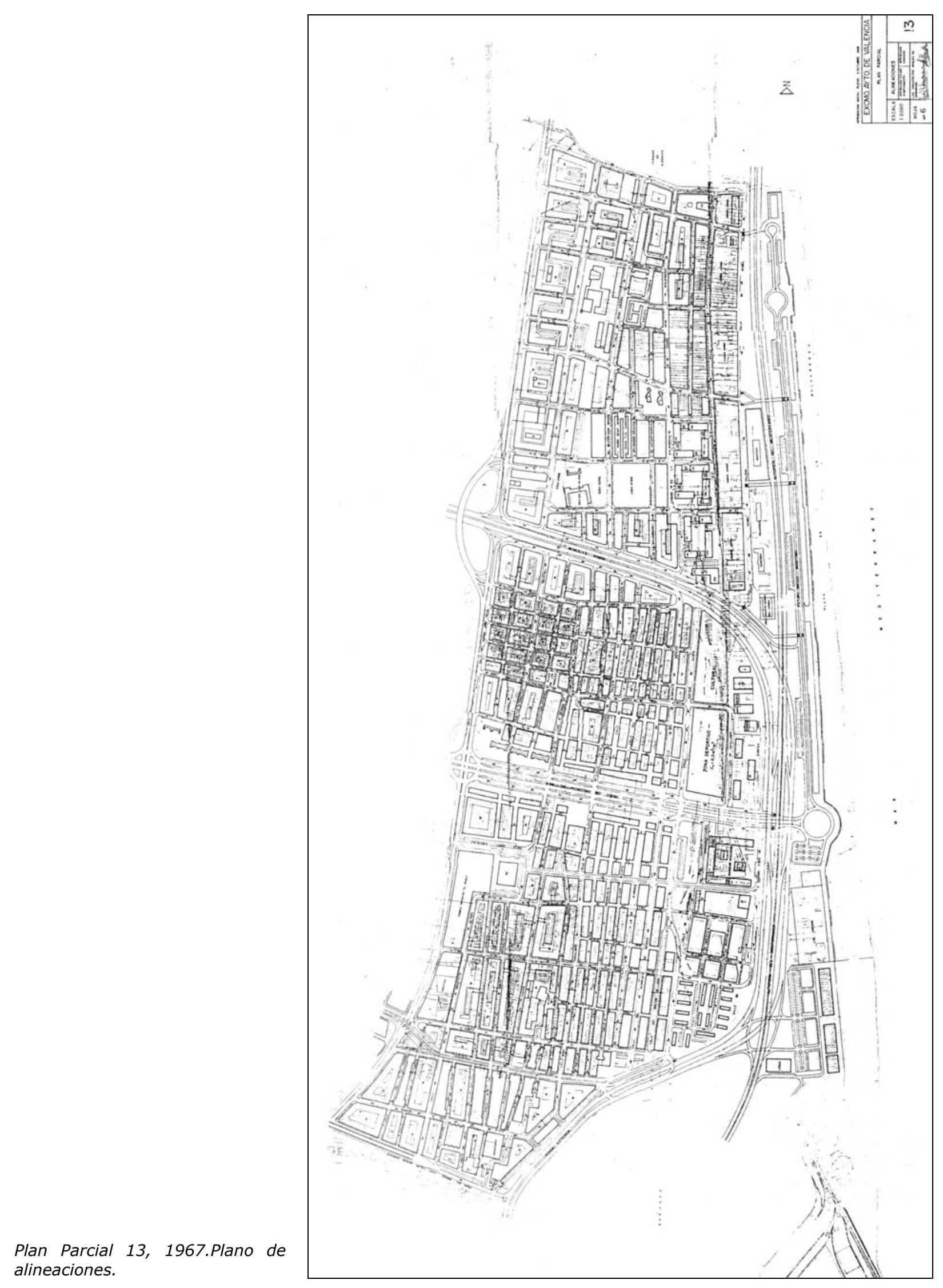
alineaciones.

La primera de estas zonas, y la más extensa, es la que forma el borde oeste de la Malvarrosa, entre la línea del Ferrocarril de Barcelona y la calle Gran Canaria. La forma que adopta aquí la edificación es la de manzanas abiertas, con bloques perimetrales de 
cinco crujías y espacios interiores destinados a aparcamientos y, en algunos casos, a equipamientos escolares o religiosos.

La segunda zona de edificación abierta es la situada entre la Avenida de la Malvarrosa y la calle Cavite, y esta formada por manzanas abiertas que resultan en este caso de la disposición en aspa de molino de cuatro bloques rectangulares de cinco crujías, que envuelven un jardín público.

Estas dos zonas sufrirán algunas modificaciones en la nueva versión del plan de 1974. Así, en el borde oeste de la Malvarrosa se disminuye el número de manzanas inicial para obtener una mayor homogeneidad de las mismas, que pasan a estar formadas mayoritariamente por dos bloques en $U$ que envuelven un espacio verde central. Por otra parte, en la zona de edificación abierta entre la calle Cavite y la Avenida de la Malvarrosa, se suprimen algunos bloques aislados previstos al norte y al sur del grupo de manzanas formadas por bloques en aspa de molino.

Las otras zonas de edificación abierta previstas en la versión de 1967 del Plan Parcial 13 están situadas en el Cabanyal. Se trata, en primer lugar, de los bloques lineales que flanquean la prevista prolongación del Paseo al Mar". A ello se añade la denominada "unidad vecinal autónoma para profesionales de mar", que se sitúa en la zona del Clot, en la que se prevé el derribo de las chabolas existentes y su sustitución por una manzana formada por bloques agrupados en $U$ en torno a un núcleo de equipamientos. Por último, se proyecta un grupo de tres bloques dispuestos al tresbolillo y otro núcleo de equipamientos junto a la autopista del Mediterráneo. Estas zonas de edificación abierta serán suprimidas en la versión de 1974 del plan, que destina a zonas verdes los espacios previstos para las mismas.

En todas las zonas mencionadas, el tipo edificatorio básico es el bloque de cinco crujías, que requiere patios interiores o patios abiertos a fachada. Este es el tipo habitual al que se recurre en este periodo para ordenar las áreas vacantes que no están calificadas en el plano de zonificación del plan como zonas de edificación abierta.

La única zona calificada en el plano de zonificación del PP13 como de edificación abierta es, de hecho, la formada por el grupo de bloques lineales de dos crujías, dispuestos según los patrones del zeilenbau, edificada con anterioridad al plan como ampliación del grupo Ramón Laporta y del barrio Virgen del Castillo, realizado por la Dirección General de Regiones Devastadas entre 1939 y 1945. La versión de 1967 del PP13 propone una ampliación de este grupo de bloques sobre los terrenos ocupados por las vías de ferrocarril de la Junta de Obras del Puerto, manteniendo los principios de la edificación en línea. En la redacción de 1974 del plan, dicha ampliación será descartada, calificándose como zona verde la zona prevista para la misma.

La manzana situada más al oeste de las tres que constituyen el grupo Malvarrosa, construido en el marco del Plan 5000 de 1950, también podría, en cierta medida, considerarse como edificación abierta, ya que está compuesta por dos bloques con planta en forma de $C$ laterales y un tercer bloque lineal central, actualmente demolido.
1. El trazado viario es analizado en el presente trabajo únicamente en tanto que elemento integrante de conjuntos de edificación abierta, lo que no es el caso de los barrios que forman parte del ámbito del Plan Parcial 13, que sufren las agresiones simultáneas de la prolongación del Paseo al Mar, de la Autopista de la Costa y de la Ronda Exterior. Al respecto, la Memoria del Plan Parcial 13 , en la versión redactada en 1974, señala lo siguiente: "El Plan se limita, por un lado a reflejar la red de comunicaciones que el Plan General proyecta en este sector, que realmente lo destroza, y por otro a dotar de los equipamientos mínimos que establece la legislación vigente".( Ver Plan Parcial 13, 1967, Memoria. Anexo de Documentos, $p$ 428). 
Plan Parcial 13, 1967. Edificación abierta (Elaboración propia, color sobre plano de alineaciones del plan).

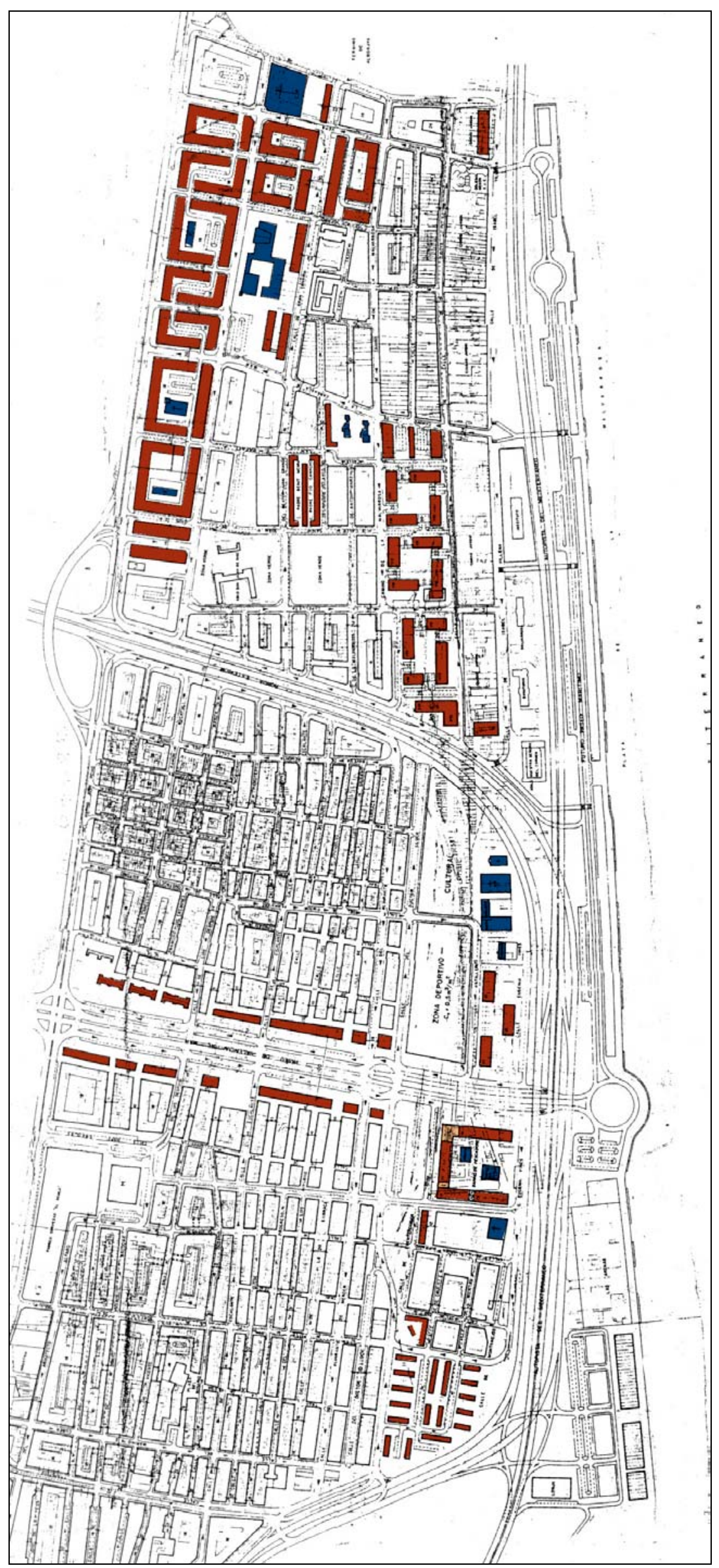




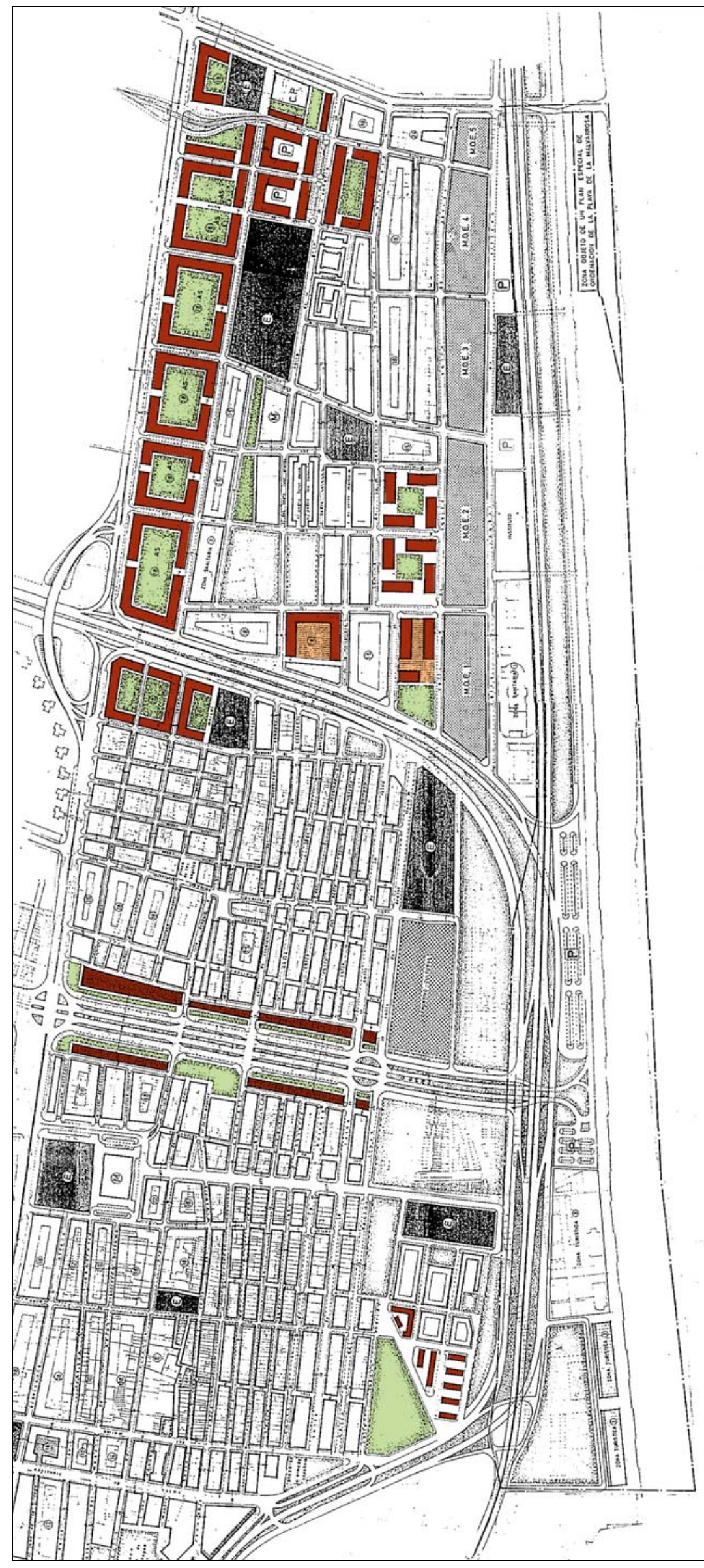

Plan Parcial 13, 1974. Edificación abierta (Elaboración propia, color sobre plano de alineaciones del plan). 


\section{Grado de realización}

De la edificación abierta prevista en las diferentes versiones del Plan Parcial 13 antes reseñadas, el conjunto realizado de mayor tamaño es el grupo de manzanas formadas por bloques dispuestos en forma de aspa de molino entre las calles Cavite y Avenida del Mediterráneo.

La zona de manzanas abiertas prevista en el borde noroeste del plan, junto a la línea de ferrocarril de Barcelona, quedó modificada profundamente en el Plan General de 1988. Sólo un grupo de manzanas abiertas en el extremo norte de la zona, junto al término municipal de Alboraya, y otras dos manzanas se ajustan a las previsiones del PP13. En el resto de la zona se localizan parcelas dotacionales o bien se relegan las parcelas previstas como edificables a un planeamiento diferido.

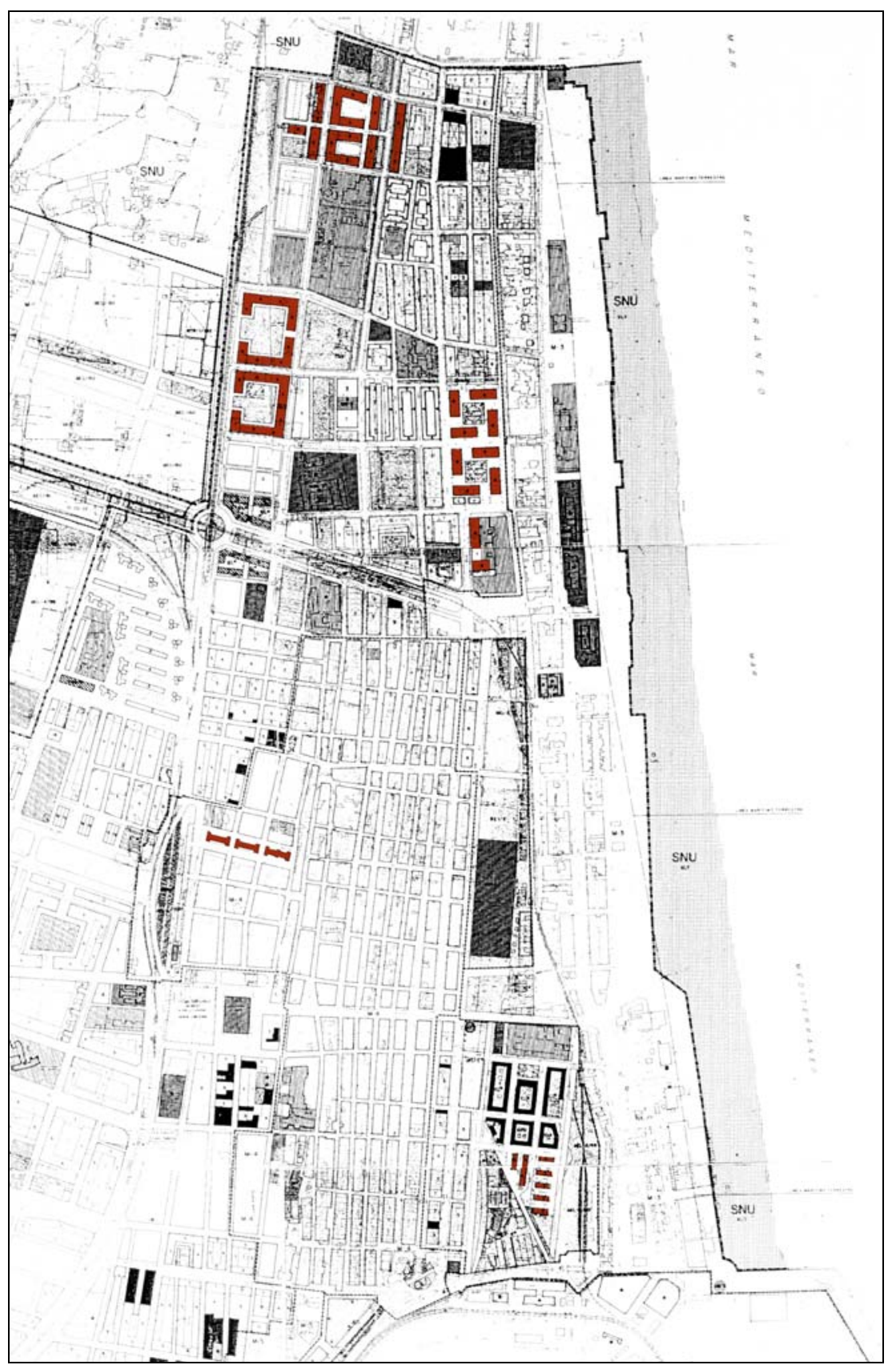




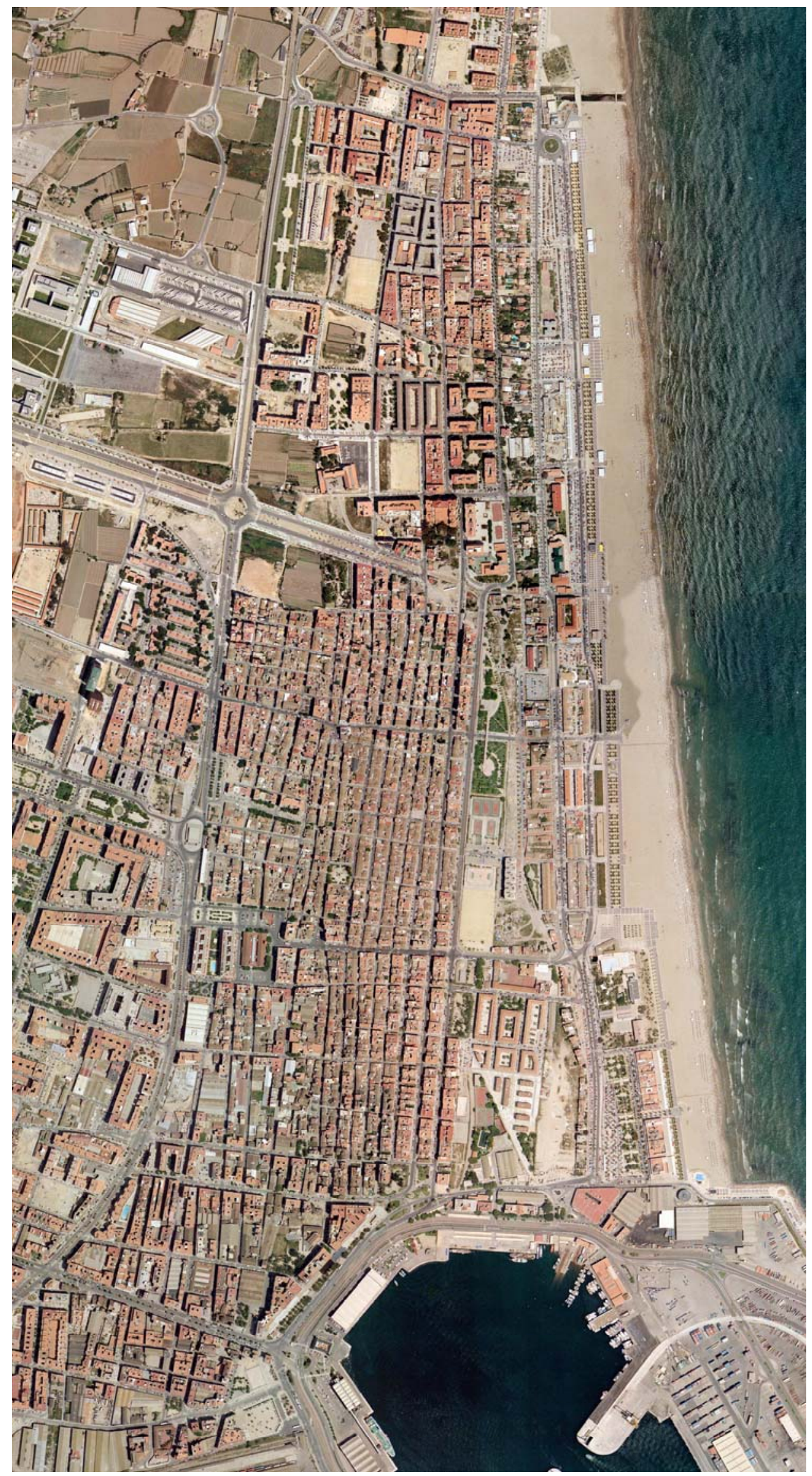

Zona del Plan Parcial 13. Ortofoto 2002 (AUMSA). 
Del grupo de tres manzanas situadas entre la Avenida de la Malvarrosa y la calle Cavite, formadas por agrupaciones de bloques profundos de cinco crujías, dos están completamente ejecutadas y una sólo parcialmente. Los bloques, a excepción de los dos de ésta última manzana y uno de la adyacente, responden a un proyecto arquitectónico unitario. Los espacios verdes internos, por ello, presentan una envolvente uniforme. El carácter público de estos espacios verdes permite considerar como exteriores las viviendas con fachada al mismo. De hecho, estas viviendas se abren a un espacio mayor que las recayentes a las calles perimetrales.
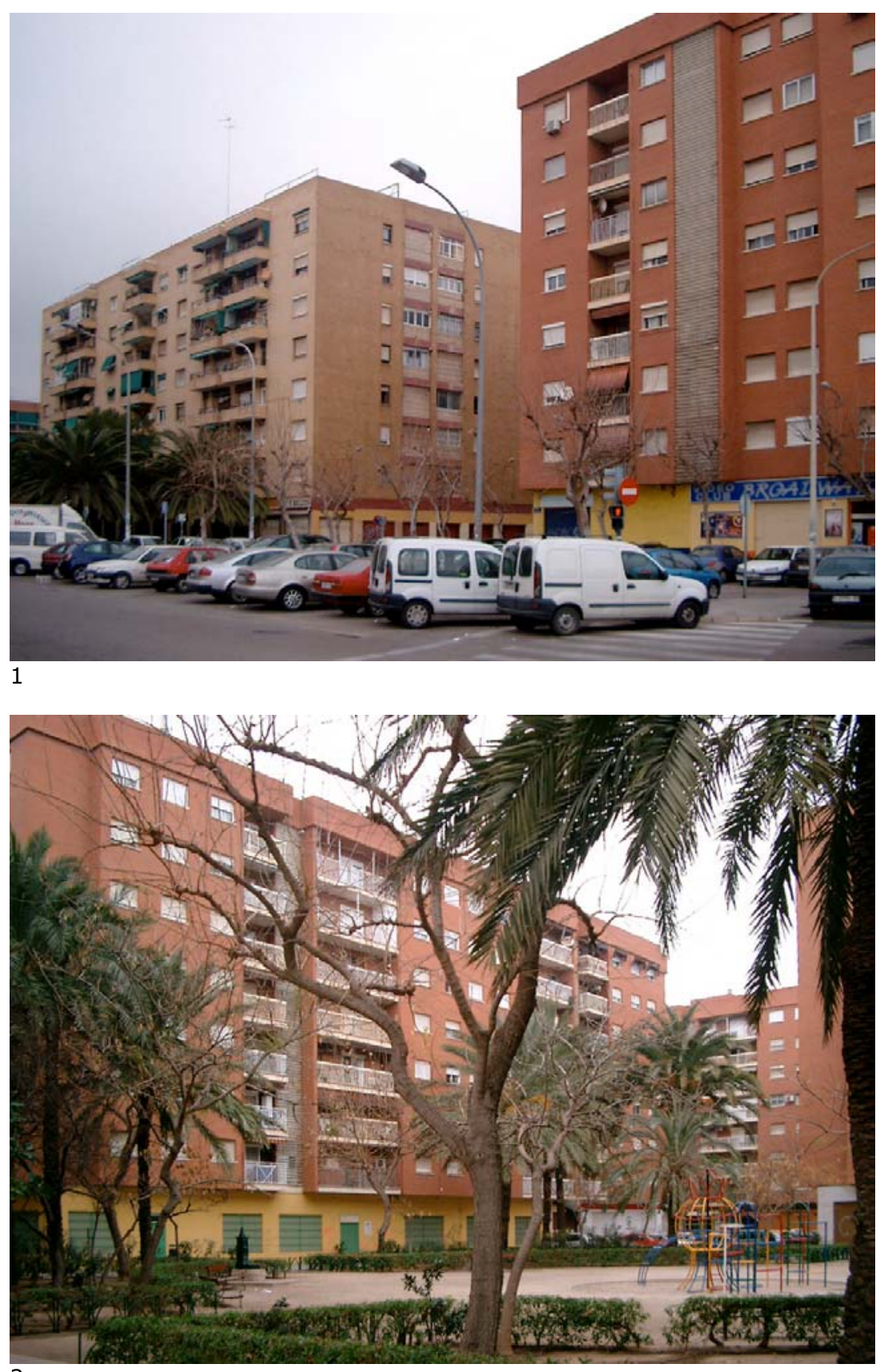

Bloques de la calle Río Tajo.

2. Plaza Cronista Francisco Montblanc. 

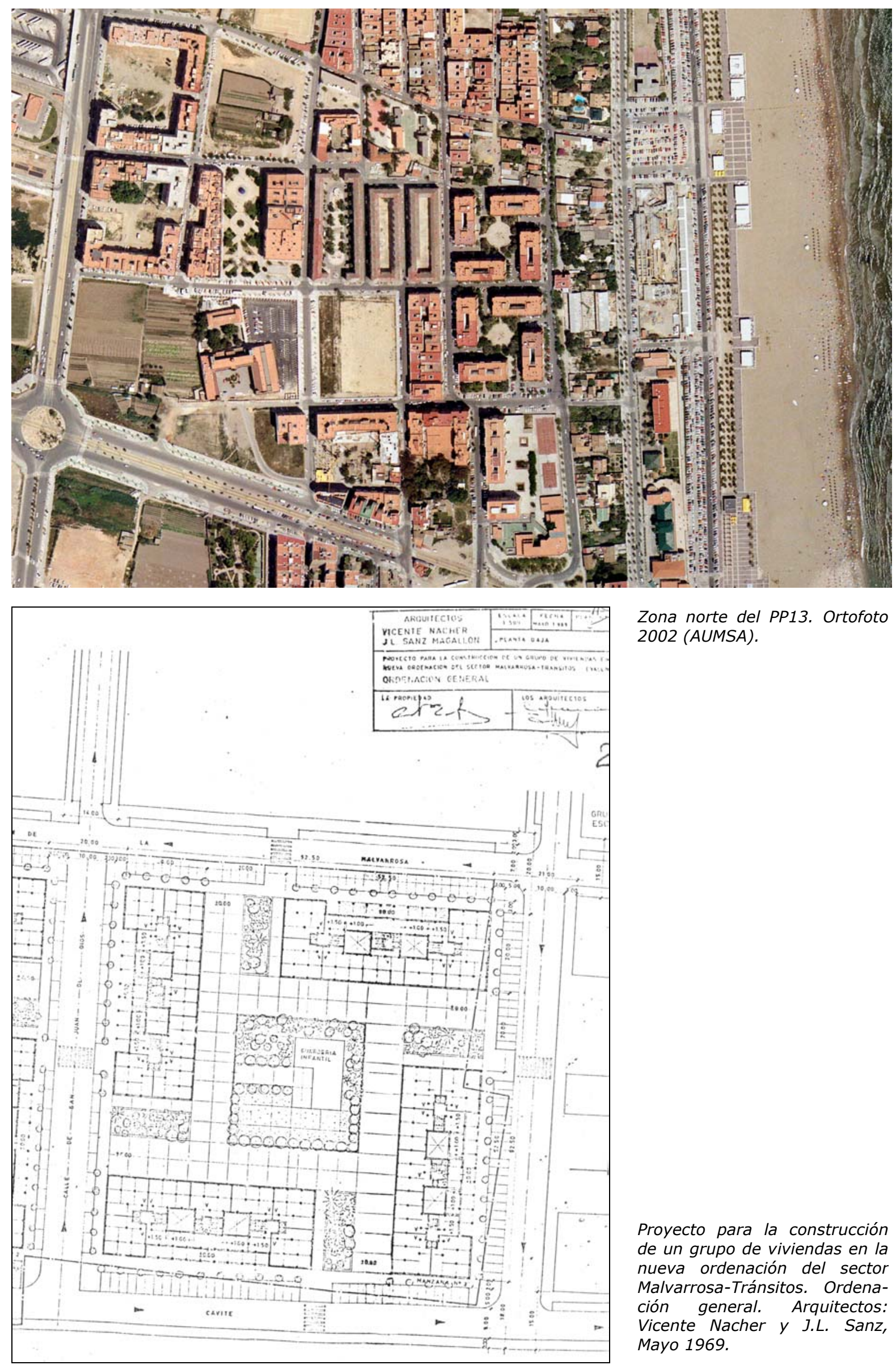

Zona norte del PP13. Ortofoto 2002 (AUMSA).

Proyecto para la construcción de un grupo de viviendas en la nueva ordenación del sector Malvarrosa-Tránsitos. Ordenación general. Arquitectos: Vicente Nacher y J.L. Sanz, Mayo 1969. 


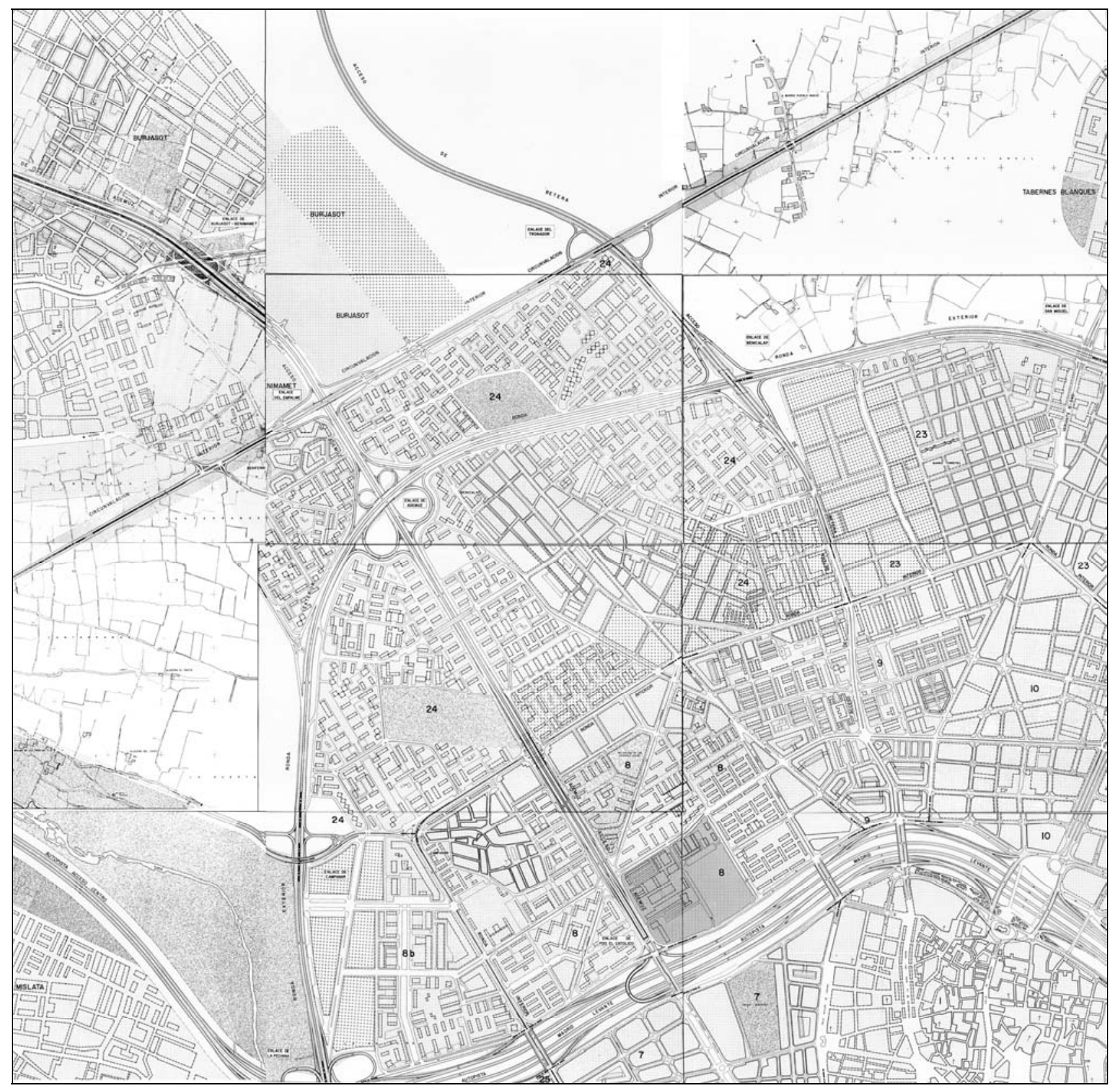

Valencia. Zona noroeste: Pla-

nes Parciales $n^{\circ}$ 8, 8- $b, 9$ y 24

(Montaje de hojas del Informe PREVASA). 


\subsection{LA EDIFICACIÓN ABIERTA EN EL SECTOR NOROESTE DE VALENCIA, 1966-1988.}

Los planes parciales que, con el criterio fijado al principio del presente trabajo, hemos englobado en al sector noreste de Valencia pueden dividirse en dos grupos por su posición dentro de la estructura general de la ciudad:

a) Planes situados en el interior de la Ronda de Tránsitos: Plan Parcial no 9 (Marchalenes). Parte del Plan Parcial no 8 (Campanar)

b) Planes situados en el exterior de la Ronda de Tránsitos: Parte del Plan Parcial no 8 (Campanar) Plan Parcial no 8-B (Oeste de Campanar) Plan Parcial no 24 (Benicalap).

El Plan Parcial 8, cuya delimitación coincide con la del polígono de Campanar proyectado en 1960, se extiende hacia el oeste más allá del Camino de Tránsitos, que lo atraviesa en diagonal. El Plan Parcial 8-B, a su vez, completa la ampliación de Campanar por el oeste, hasta la Ronda Exterior.

El Plan Parcial 24, que es el de mayor extensión, abarca el espacio comprendido entre la Ronda de Tránsitos y la Circunvalación Interior de Poblados, y está cruzado por la Ronda Exterior.

Como ocurría también en los planes del sector noreste situados en el interior del anillo de Tránsitos, en los planes parciales no 9 y en parte del 8 existían zonas ya edificadas con manzanas cerradas de ensanche cuando los planes se redactaron. Lo mismo ocurre con el Plan Parcial 24, ya que engloba el poblado existente de Benicalap. En este sector noroeste, sin embargo, la edificación abierta tiene una mayor presencia en todos los planes, gracias a la mayor superficie disponible en general de espacios libres de edificación. En el caso del PP 8-B esta superficie libre es la de todo el ámbito del plan.

El montaje de las hojas correspondientes a este sector de la ciudad del Informe PREVASA nos permite obtener una imagen global del mismo. Esta imagen nos muestra una zona en la que la proporción de viario estructural que atraviesa los diferentes planes es muy alta, salvo en el caso del Plan Parcial 8-b, de pequeño tamaño. Ello hace que los planes aparezcan troceados en sectores aislados, separados entre sí por vías de tráfico rápido.

Así, el Plan Parcial 9 está cortado en dos por el eje norte-sur del nuevo acceso a Moncada, mientras que el Plan Parcial 8 queda subdividido en cuatro partes por la diagonal final del Camino de Tránsitos y el nuevo acceso de Ademúz. Este último eje y la Ronda Exterior dividen a su vez en cuatro el ámbito del Plan Parcial 24.

Las hojas del Informe PREVASA nos permiten observar también que las direcciones principales en las que se disponen los bloques lineales son la paralela y la perpendicular al eje del Camino de Tránsitos, aunque esta orientación se va perdiendo en la corona mas externa de los planes, junto a la Circunvalación Interior de Poblados.

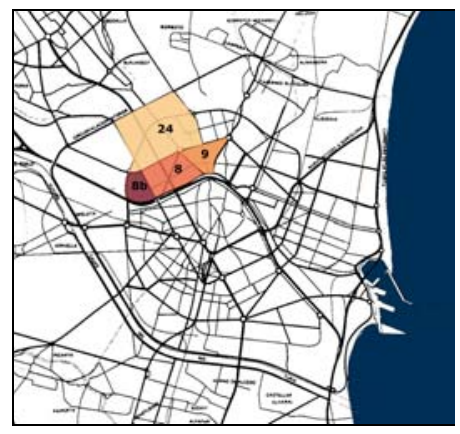

Planes Parciales del sector noroeste. Localización. 


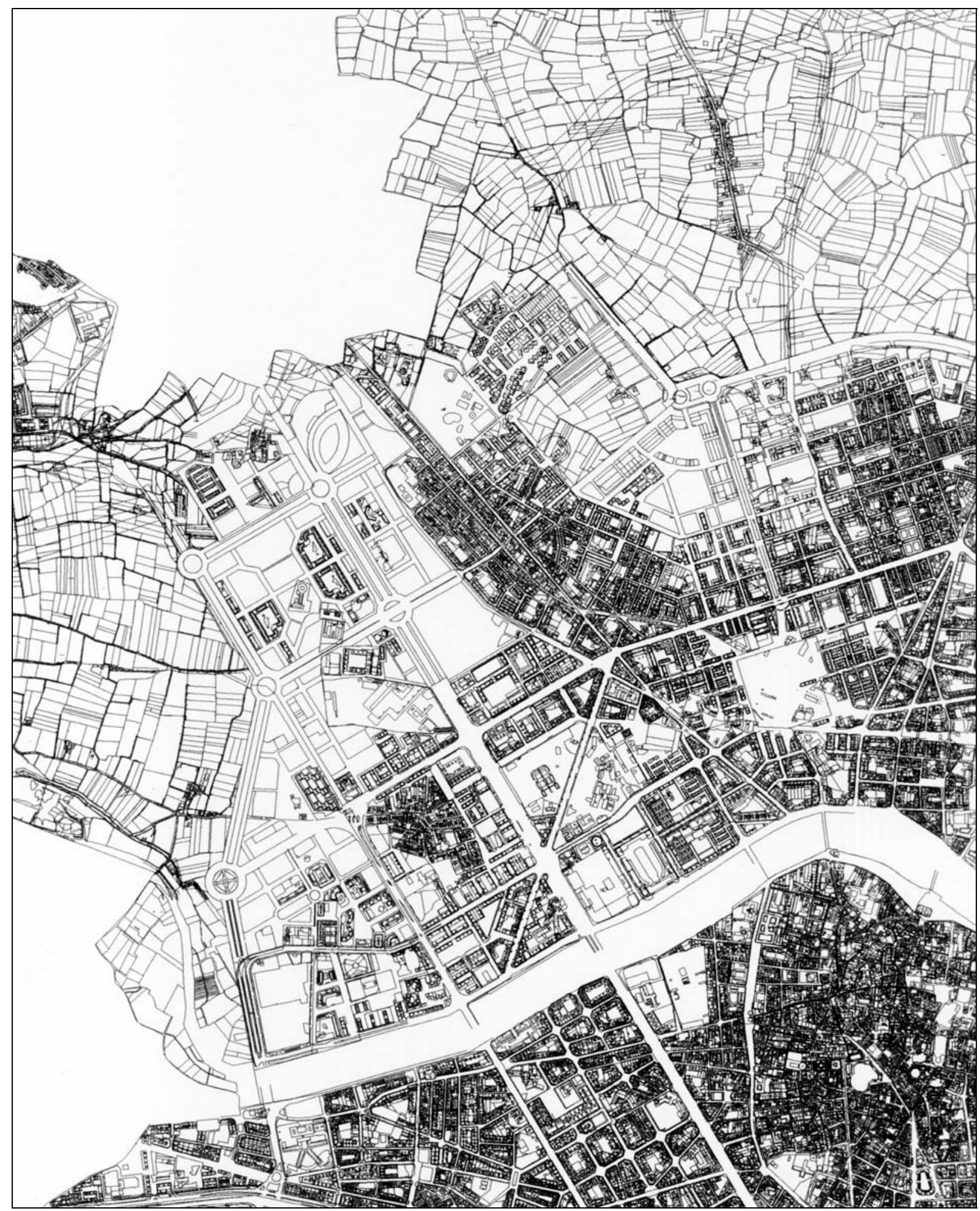

Zona Noroeste. Cartografía Municipal de Valencia, 2004.

La comparación del viario del Plan general de 1966 y el del PGOU de 1988 nos permite constatar que la estructura de ejes principales es la misma en ambos casos, aunque existen variaciones de cierta importancia, como el traslado hacia el sur del cierre de la Ronda Exterior y la supresión del eje que prolongaba hasta el borde del cauce del Turia la carretera de Moncada. 
En el Diagrama III.2 hemos reflejado la superficie aproximada de cada uno de los planes parciales del sector noroeste de Valencia, indicando para cada uno de ellos la superficie total y la superficie ordenada con edificación abierta, así como la parte de ésta última superficie que se edificó con arreglo a lo previsto en el plan.

El diagrama nos permite observar que la superficie total de los planes parciales no es demasiado homogénea en este sector, ya que oscila entre las $57 \mathrm{Ha}$ del Plan Parcial 8-b y las $298 \mathrm{Ha}$ del Plan Parcial 24, que es con diferencia el de mayor tamaño.

El plan que prevé una mayor extensión de terrenos ordenados con edificación abierta es, con diferencia, el Plan Parcial 24, lo que se debe, principalmente, a que ordena un ámbito muy extenso en el que abunda el suelo libre de edificaciones previas.

El plan que tiene un porcentaje mayor de suelo proyectado con edificación abierta es el 9. En los demás, esa superficie oscila en torno al $50 \%$ de la total. En el caso de los Planes Parciales 8 y 24 , las zonas que no están ordenadas con edificación abierta son principalmente las que engloban los poblados de Campanar y Benicalap, respectivamente. En el Plan Parcial 8-b, en cambio, el sector sin edificación abierta es de uso industrial.

El grado de realización de las zonas de edificación abierta proyectadas en los diferentes planes es también bastante desigual: alto en el Plan Parcial 8, medio en el 9 y en el 24, y muy bajo en el 8-b.

Diagrama III. 2.

Planes parciales del sector Noroeste. Cuadro de superficies

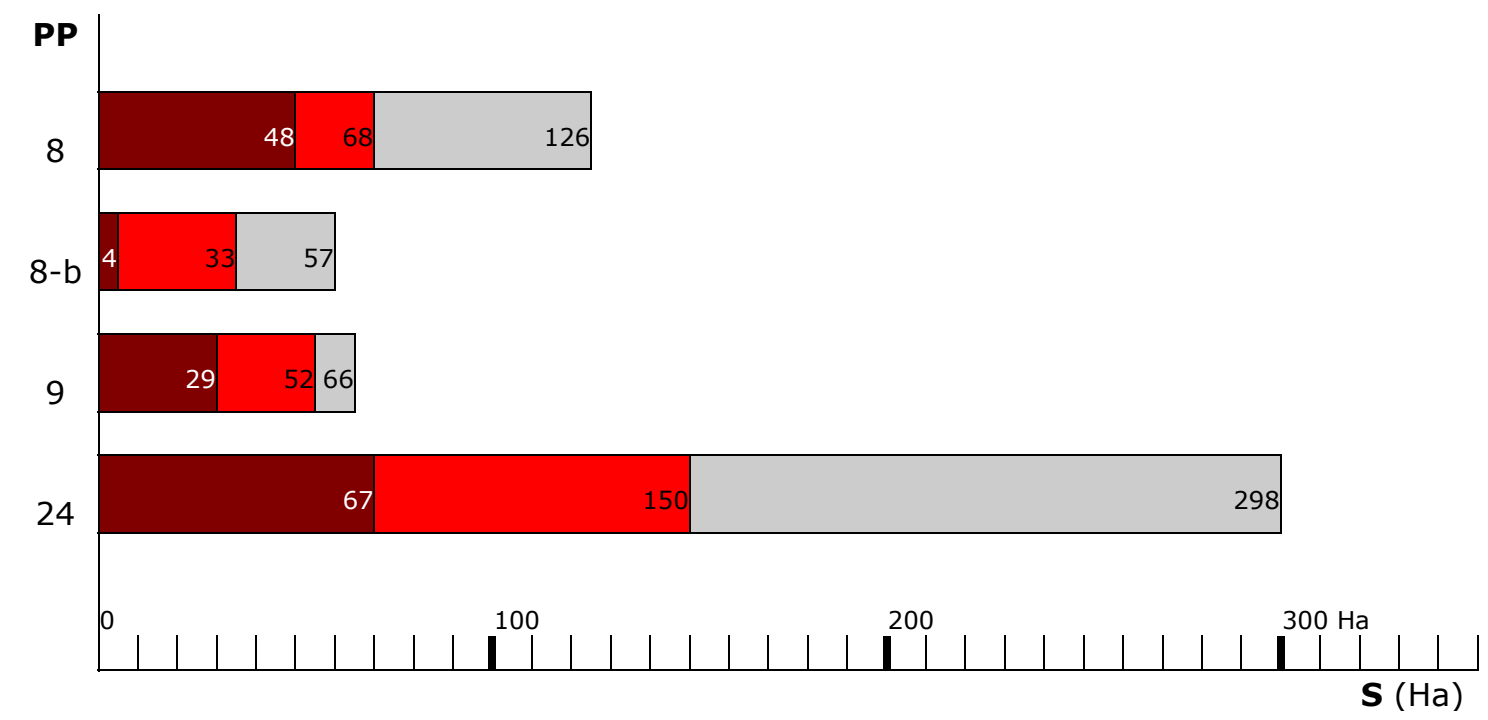

SUPERFICIE TOTAL DEL PLAN PARCIAL

SUPERFICIE ORDENADA CON EDIFICACIÓN ABIERTA

PARTE REALIZADA DE LA SUPERFICIE ORDENADA CON EDIFICACIÓN ABIERTA 


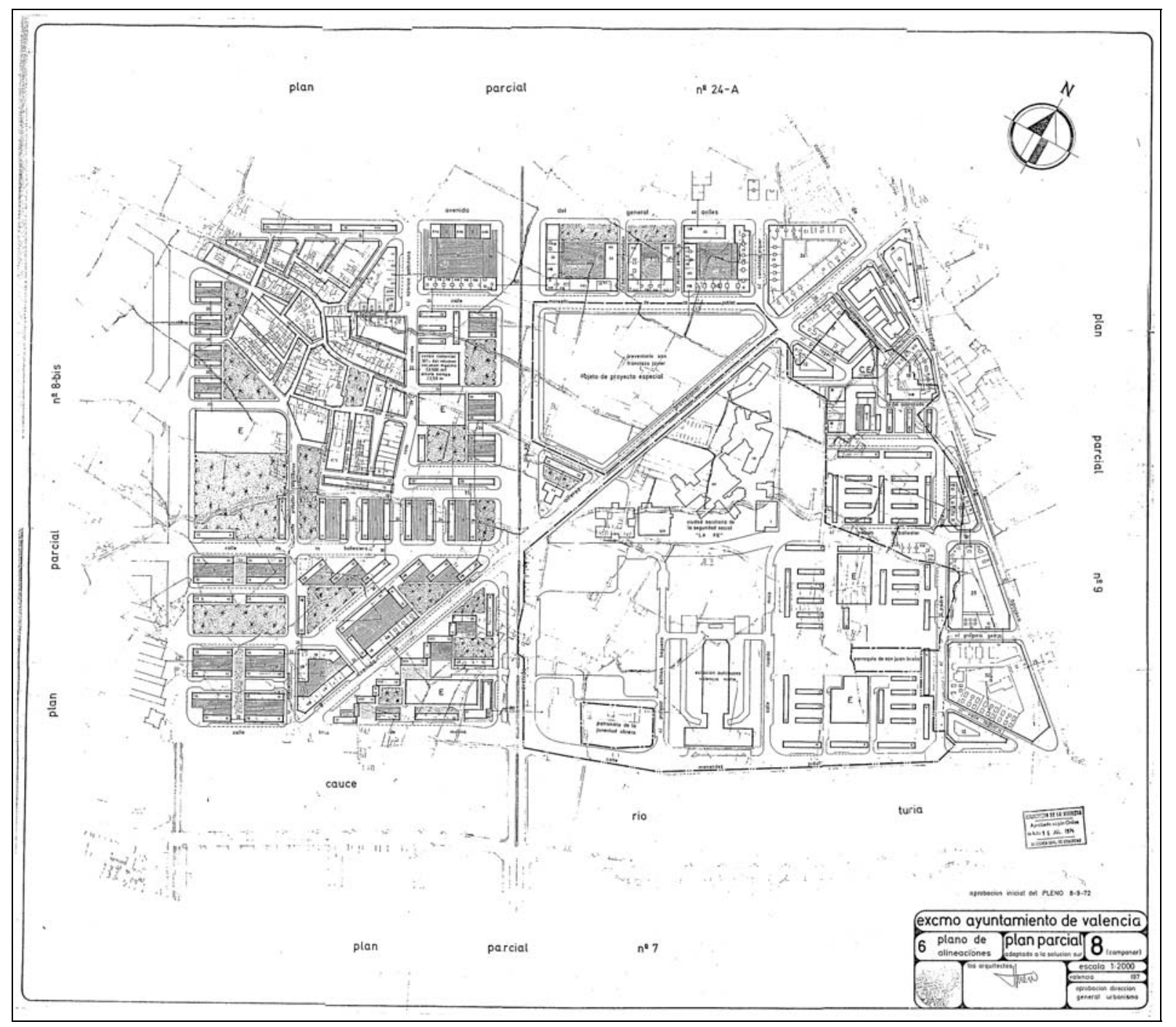

Plan Parcial no 8 adaptado a la Solución Sur, 1972. Plano de alineaciones. 


\section{EL POLÍGONO DE CAMPANAR Y EL PLAN PARCIAL No 8 (1968/1972)}

El Plan Parcial no 8 comprende los terrenos limitados al Sur por el Cauce del Río Turia, al oeste por la Avenida Maestro Rodrigo, al Norte por Avenida del General Avilés y al Este por la Avenida de Burjasot. Esta delimitación es idéntica a la del Plan Parcial del Polígono de Campanar redactado en 1960, que hemos estudiado en la sección anterior ${ }^{1}$.

El Plan Parcial del Polígono de Campanar, en su versión modificada de 1962, es la base sobre la que se redacta en 1967, por parte de la Oficina Técnica Municipal de Urbanismo, una primera versión del Plan Parcial 8 que conserva buena parte de las edificaciones proyectadas en dicho Polígono ${ }^{2}$.

La principal modificación que introduce esta versión de 1967 es la relativa a la gran parcela del Preventorio de S. Francisco Javier, para la que se plantea una zona residencial de edificación abierta. Esta parcela, actual recinto de la Consellería de Cultura y Educación, era propiedad del Estado y estaba calificada como zona especial según el Plan General de Valencia y su Comarca adaptado a la Solución Sur.

Poco después, en 1968, se aprueba por el Ayuntamiento una nueva versión del Plan Parcial 8 que introduce otra modificación sustancial, que es la que resulta de la implantación en la zona de la Ciudad Sanitaria de la Seguridad Social "La Fé", que se sitúa en una extensa parcela triangular junto a la diagonal del Camino de Tránsitos. Esta versión del plan vería denegada su aprobación por el Ministerio de la Vivienda en 1969.

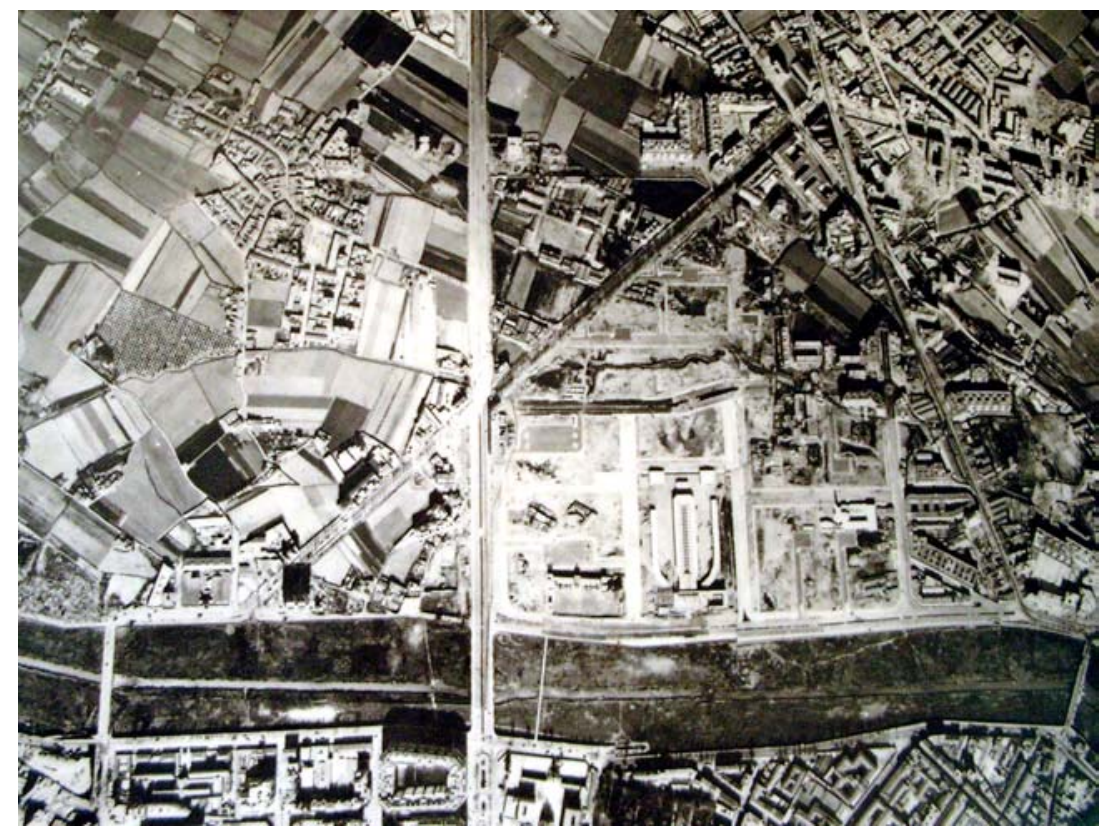

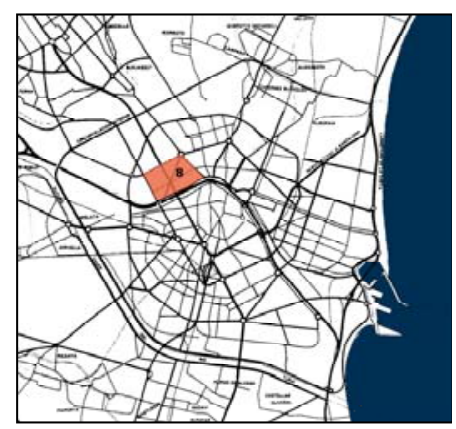

Plan Parcial 8. Localización

Zona del Plan Parcial 8. Fotografía aérea, h. 1965 (ETS de Arquitectura de Valencia).

1. Ver Sección II, pág. 191 y siguientes.

2. Plan Parcial 8, 1967. Ver Anexo de Documentos, pp. 517-523. Esta versión del Plan Parcial 8 es la reproducida en el Informe Prevasa. 


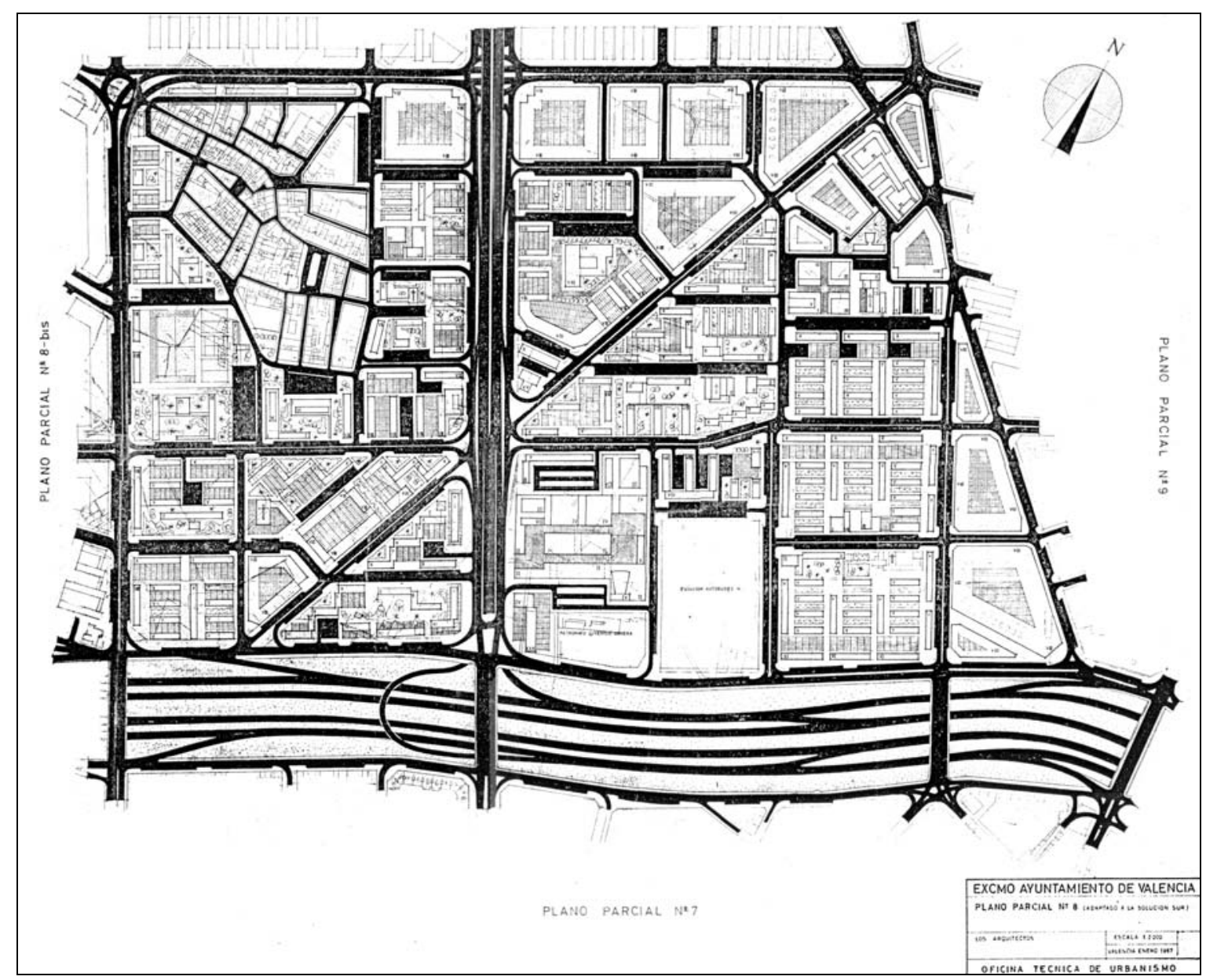

Plan Parcial 8. Versión de 1967.

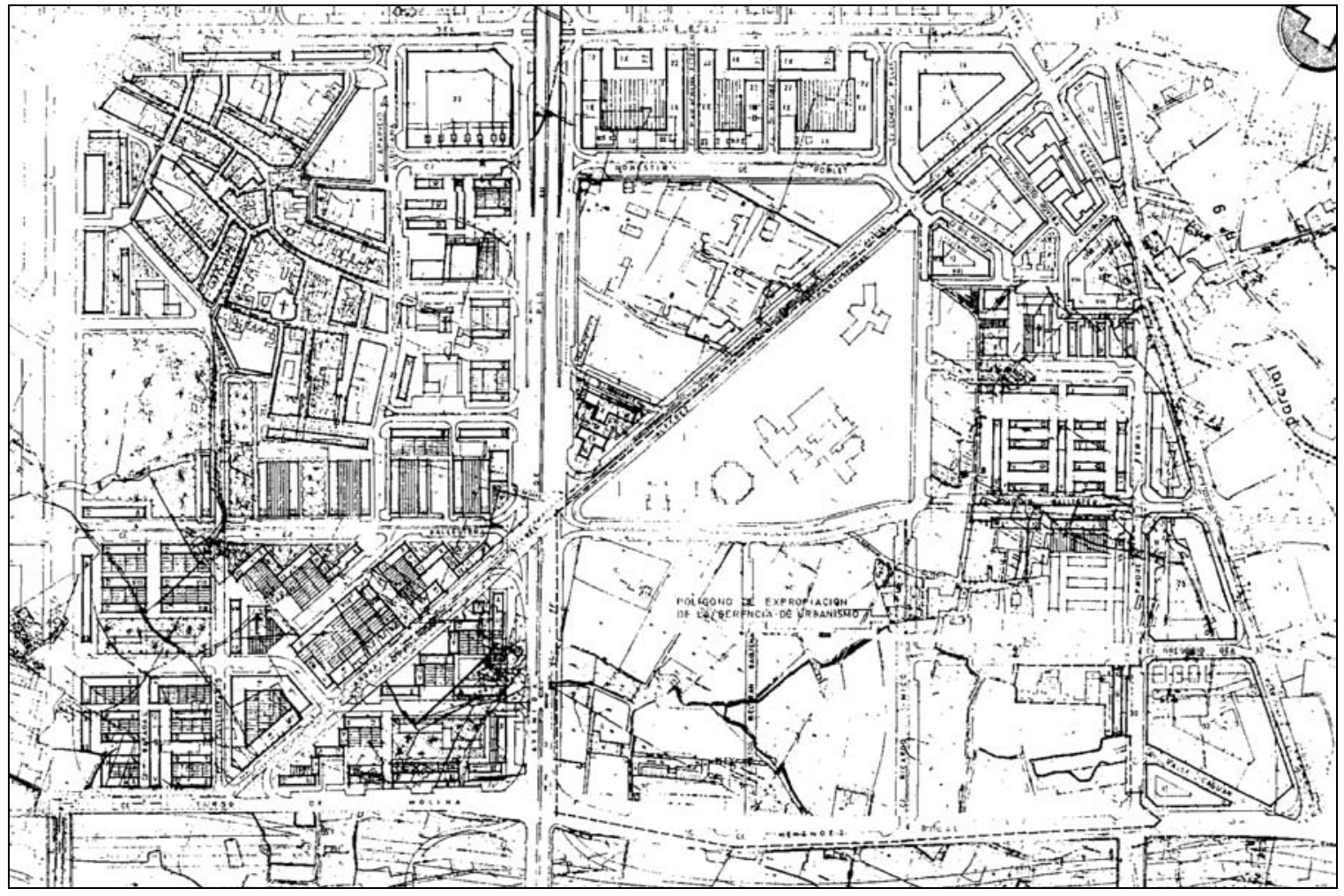

Plan Parcial 8. Versión sometida a información pública, 1971. 
La parcela de la Ciudad Sanitaria La Fé forma parte de los terrenos englobados en la nueva delimitación del Polígono de Campanar, gestionado por la Gerencia de Urbanización del Ministerio de la Vivienda, que incluye, además, las parcelas de la Estación de Autobuses, la del Centro Comercial Valencia Norte (actual "Nuevo Centro") y las del conjunto de edificación abierta que forman el actual barrio de Tendetes. El Plan Parcial del Polígono de Campanar fue aprobado en su versión definitiva de 1971 por la Dirección General de Urbanismo.

En 1971 se redacta por la Oficina Técnica Municipal de Urbanismo una nueva versión del Plan Parcial 8 , que se somete a información pública y que, con pequeñas modificaciones, será aprobada definitivamente en 1972 por el Ministerio de la Vivienda y estará en vigor hasta la aprobación del nuevo Plan General de Valencia en 1988.

En el plano de información del Plan Parcial 8 de 1972 se observa que en la zona ordenada existen numerosas edificaciones, realizadas en base a las anteriores versiones del plan.

En la parte oeste, además de la población de Campanar, cuyo núcleo urbano original estaba ya anexionado a Valencia, pueden observarse manzanas parcialmente construidas, con edificación perimetral profunda, en dos áreas: en las proximidades de la Avenida de Campanar y cerca de la confluencia de las Avenidas General Avilés y Pío XII. Junto a estos fragmentos de manzana aparecen también algunos bloques lineales aislados.
Polígono de Campanar. Plan Parcial reformado, 1971. Plano de Ordenación General.

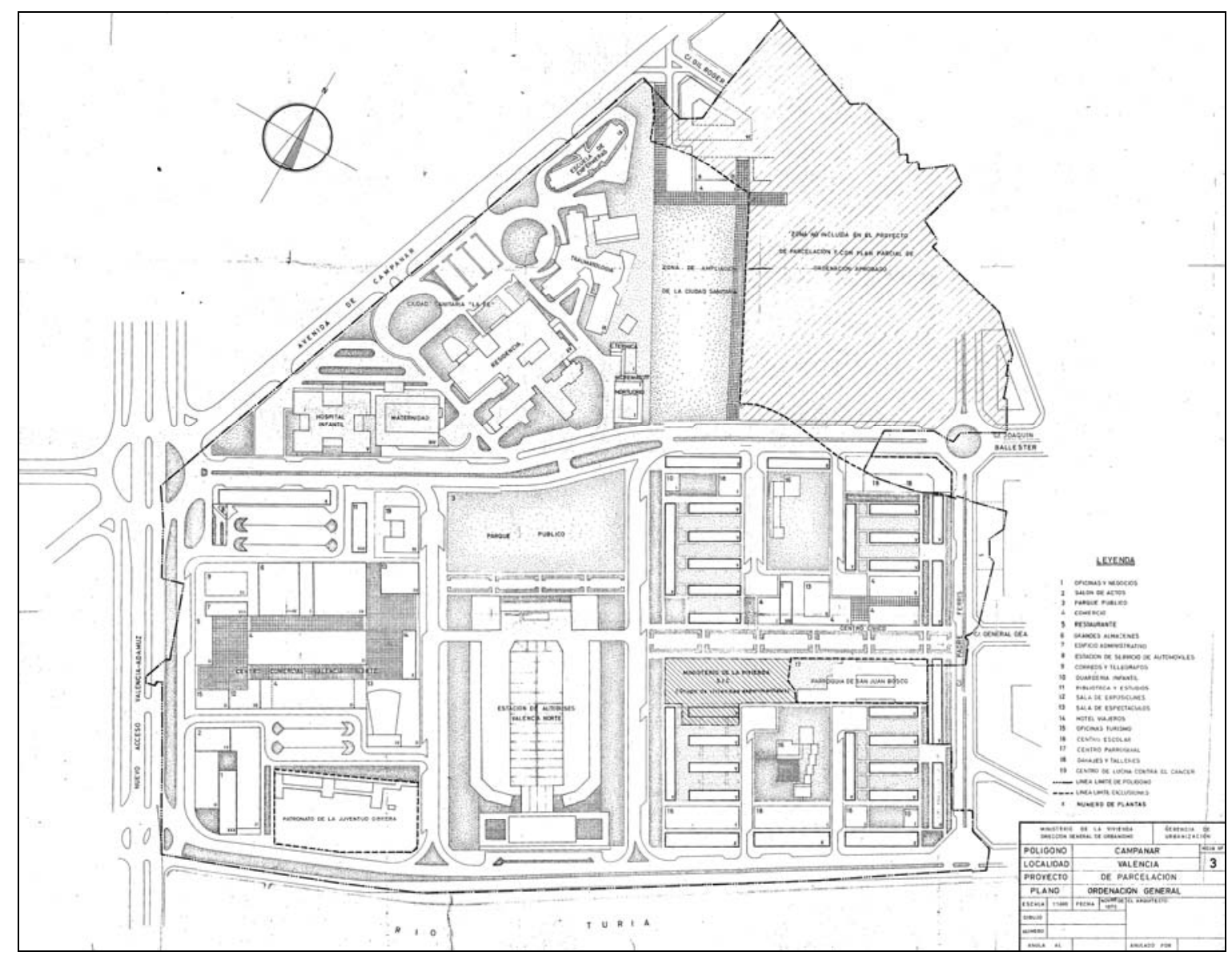




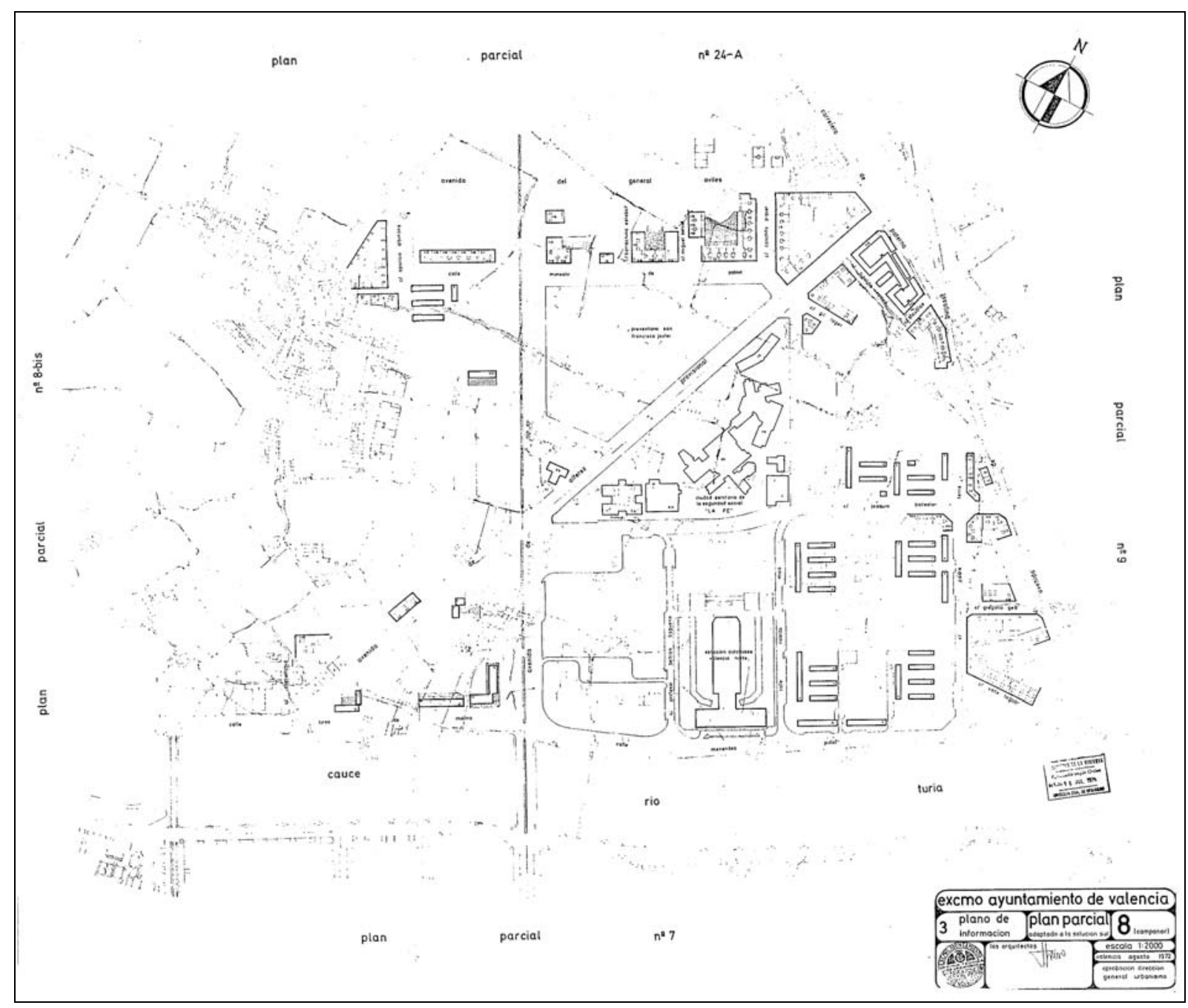

PP-8. Plano de información.

La mitad este del área ordenada por el Plan, entre las Avenidas de Pio XII y de Burjasot, está ocupada en su mayor parte por las edificaciones comprendidas en el Polígono de Campanar de la Gerencia de Urbanización, limitándose el Plan Parcial municipal a transcribir su ordenación definitiva de 1971. Vemos por ello dibujados en el plano de información los bloques lineales que forman el barrio de Tendetes.

Además, en esta mitad este existen con anterioridad a la aprobación del PP8 grupos de manzanas cerradas con edificación perimetral profunda, construidas en mayor o menor medida a lo largo de los ejes de las Avenida del General Avilés y de Burjasot y carretera de Paterna. Junto a esta última vía se halla el grupo Agrifersa, analizado en una sección anterior.

En el plano de información aparece también como preexistencia la torre situada en un espacio triangular recayente a las Avenidas de Pio XII y Alférez Provisional, proyectada en la versión del PP8 de 1967.

Por último, en cuanto a edificios públicos, están reflejadas en el plano mencionado las edificaciones integradas en la parcela correspondiente a la Ciudad Sanitaria La Fé, así como la estación de autobuses. 
Los planos de zonificación de las versiones de 1967/68 y de 1972 del PP8 muestran diferencias importantes en cuanto a la zonificación que, sin embargo, no se reflejan en absoluto en el tipo de edificación proyectada. El caso más evidente es el de los bloques de edificación abierta dispuestos en torno al poblado de Campanar, que tienen calificación de Edificación Abierta en una versión y de Extensión Exterior a Tránsitos en la otra, sin que por ello se modifique su configuración en planta o en volúmenes.
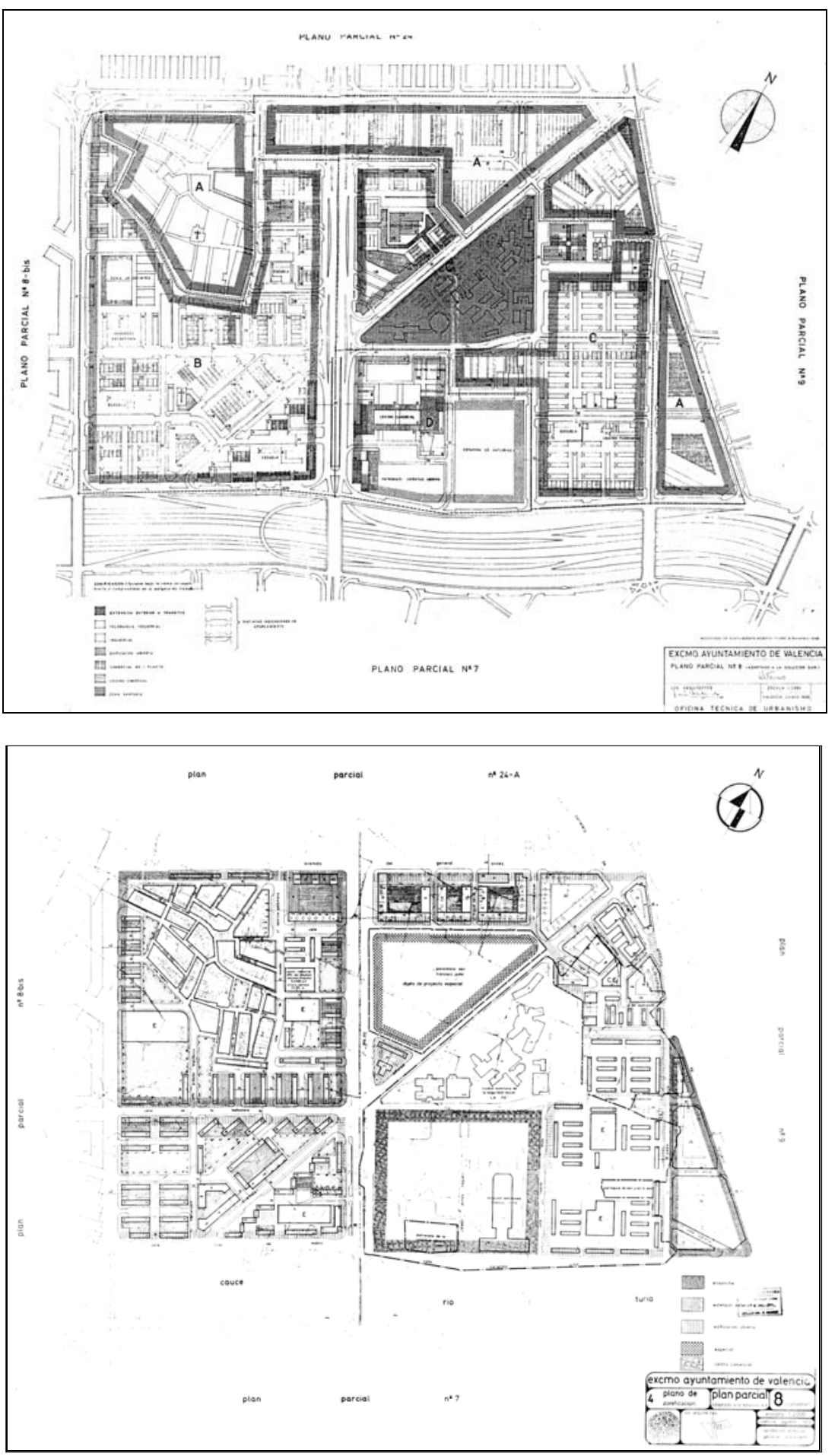

PP 8, 1968. Plano de zonificación.
PP 8, 1972. Plano de zonificación. 


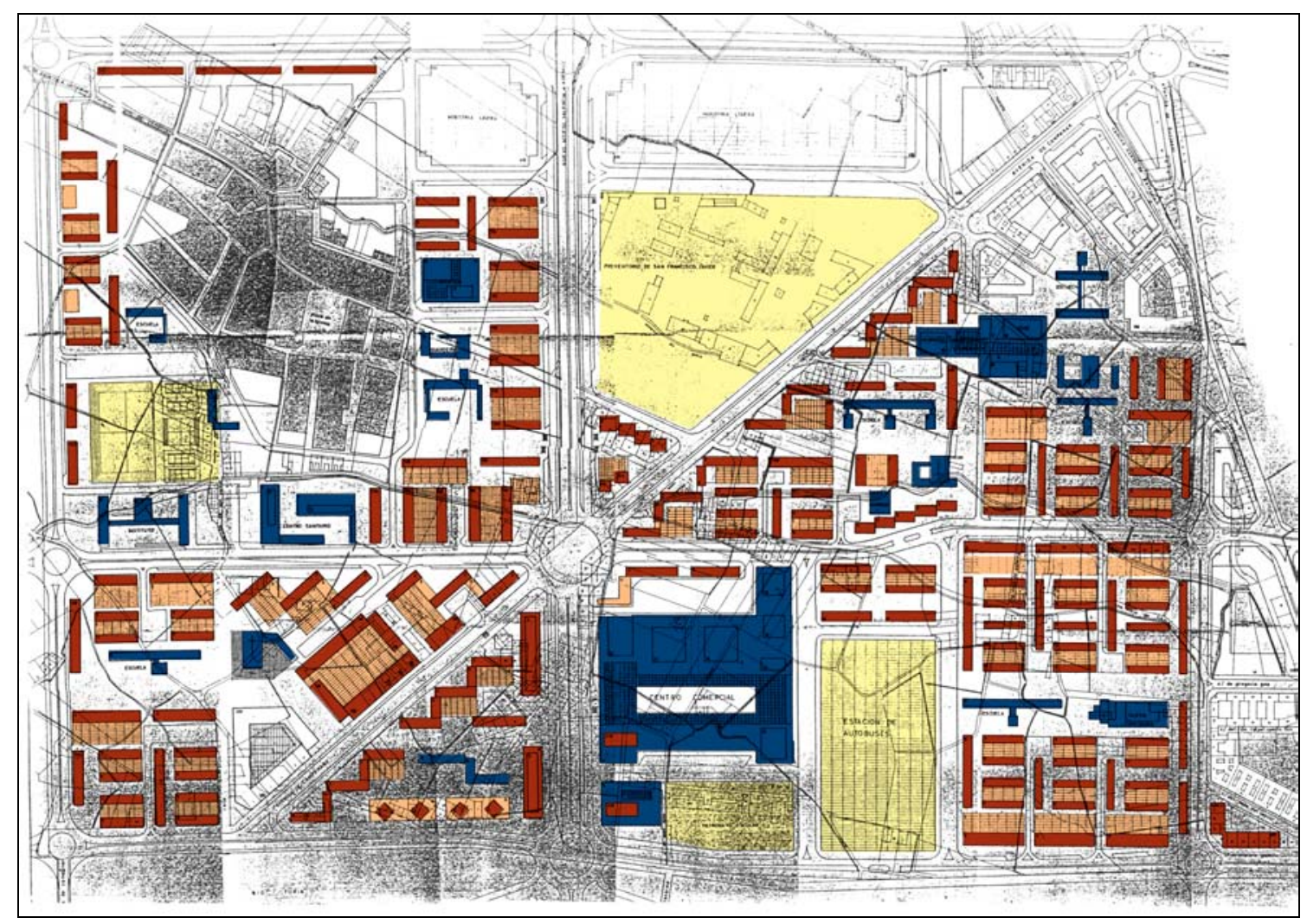

Polígono de Campanar. Plan Parcial Modificado, 1962 (Elaboración propia. Color sobre Plano superpuesto estado actual-proyecto).

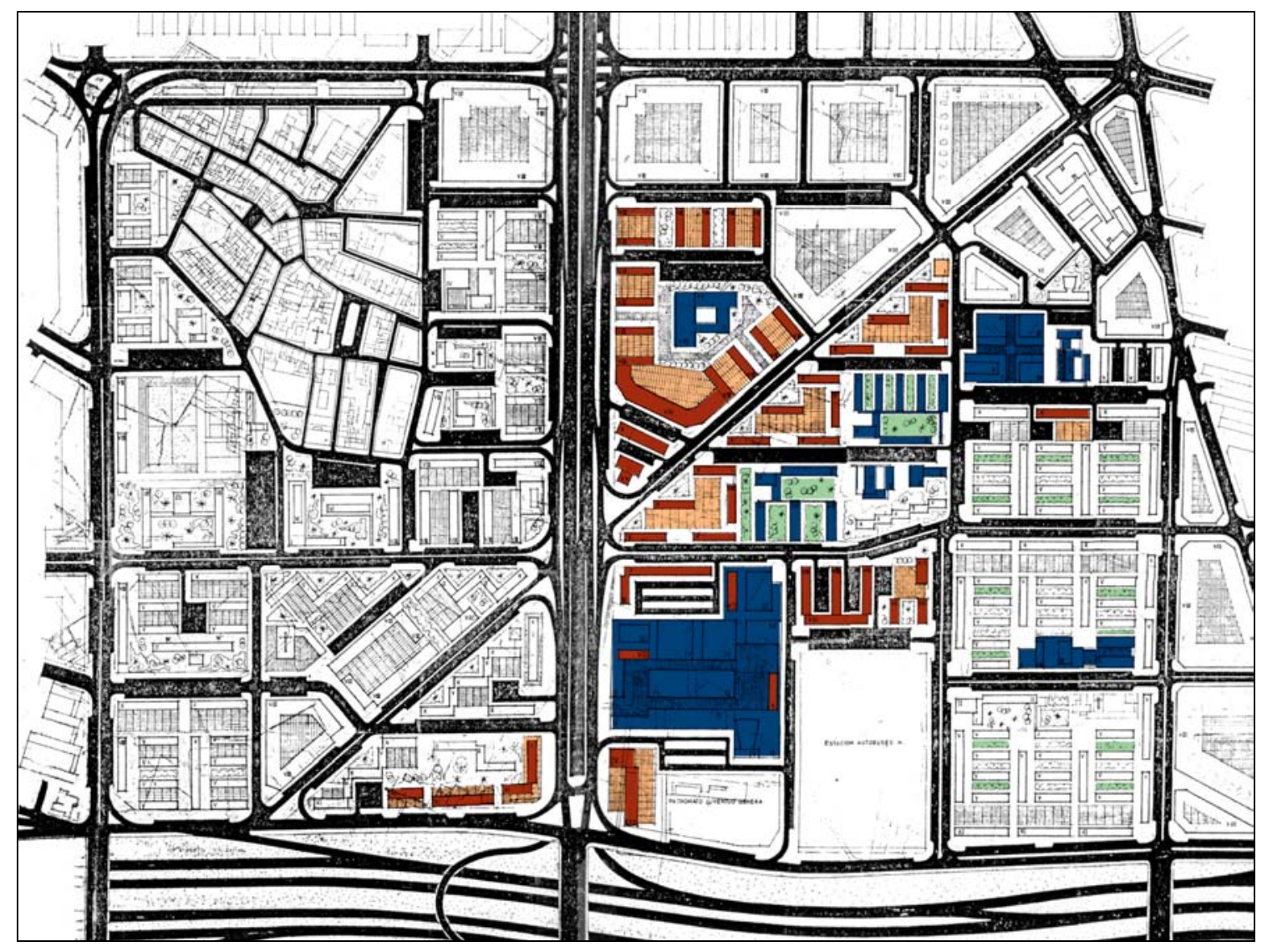

Plan Parcial no 8, 1967. Elementos nuevos (Elaboración propia. Color sobre plano de trazado viario). 


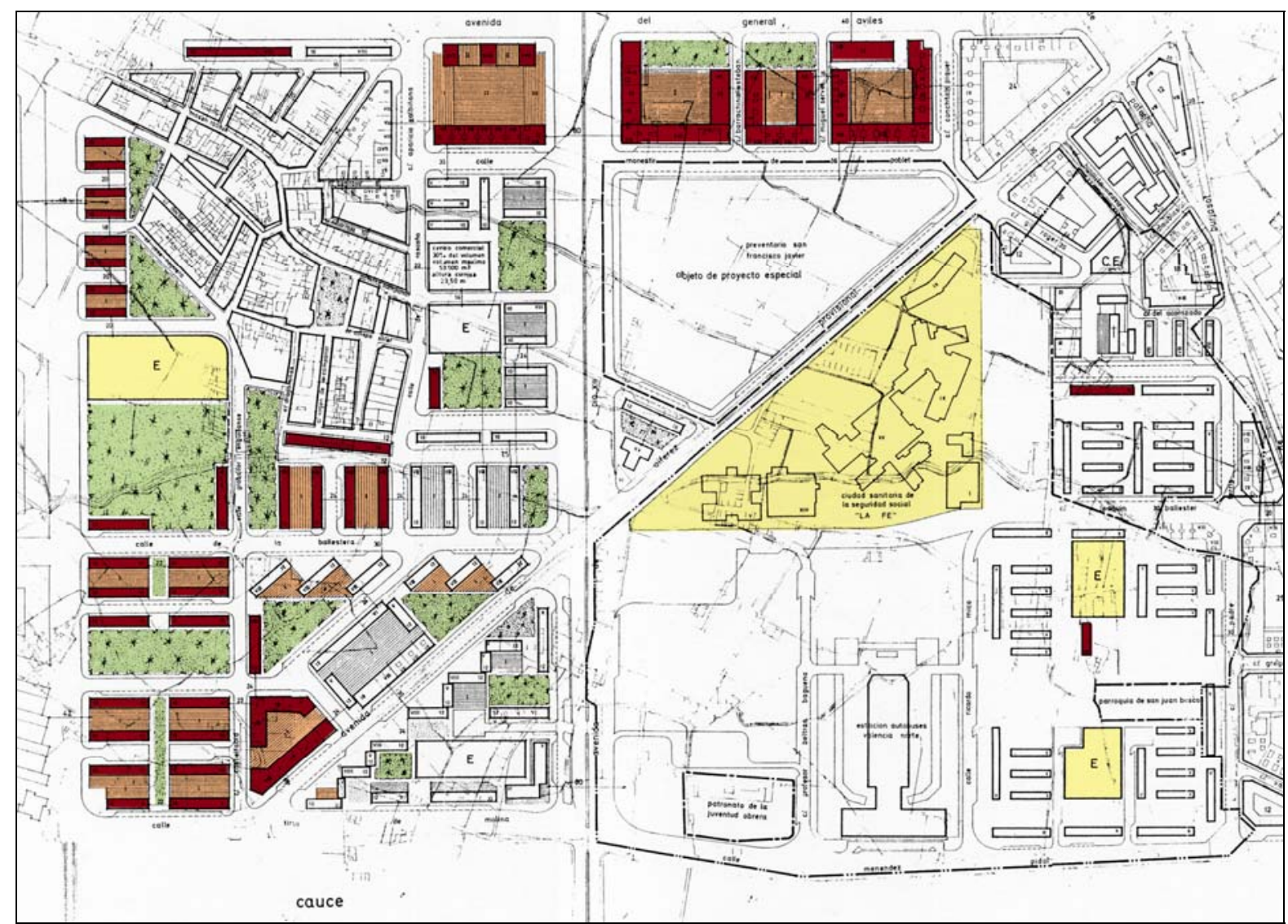

Si comparamos el plano del Polígono de Campanar, en su versión modificada de 1962 , con las versiones del Plan Parcial 8 de 1967 y 1972, podemos observar que el primero de estos planes es el que realmente supone un proyecto global para la ordenación de la zona. Los otros dos introducen modificaciones diversas, unas de gran envergadura, como la implantación de la Ciudad Sanitaria "La Fé", y otras de menor entidad. El resultado de todo ello es una evidente pérdida de coherencia de los elementos que integran la ordenación, que pierden su carácter de partes de un conjunto unitario para pasar a ser fragmentos inconexos yuxtapuestos.

En el Polígono de 1962 y en la versión del PP8 de 1967-68 las reservas de suelo para zonas verdes y equipamientos son inferiores a las previstas en la posterior redacción del Plan de 1972. Al respecto, podemos observar, por ejemplo, que la parcela que se acabaría destinando a la Ciudad Sanitaria aparece ocupada por bloques de edificación abierta, que la parcela destinada al Preventorio San Francisco Javier es mucho más pequeña, que en la zona de Tendetes no existe la franja central de dotaciones y que los espacios situados entre el núcleo original de Campanar y las vías perimetrales del Plan se rellenan casi enteramente con bloques lineales de edificación abierta, sin apenas espacios verdes salvo los interbloques ${ }^{1}$.

En todas las versiones del PP-8 se prevén dos centros comerciales vecinales, uno en la zona oeste y otro en la zona este. Junto a éste último, se sitúa un centro religioso.

Plan Parcial no 8, 1972. Elementos nuevos (Elaboración propia. Color sobre Plano de trazado viario).

1. En relación con las zonas verdes, la Memoria del Plan de 1972 hace la siguiente consideración: "El actual cauce del Río Turia, destinado según el Plan General a viales (enlace de la autopista del mediterráneo con la de Madrid), está en trámite de desafección como cauce de río.

Del estudio de viales, se ha deducido la no necesidad de esta autopista con el cauce, bastando con dos calzadas laterales de tráfico rápido, con lo cual quedaría el 80 \% del cauce como espacio libre, de los cuales al menos el 50 \% sería zona verde $(70.080 \mathrm{~m} 2$ corresponden a este Plan), siendo el resto deportivo-cultural, lo que supone, no sólo para toda la ciudad sino especialmente para las zonas limítrofes con el cauce, una beneficiosa descongestión que habría que considerar como muy beneficiosa, y compensatoria de los posibles aumentos de volumen". Plan Parcial 8, 1972. Memoria. Anexo de Documentos, p. 527. 


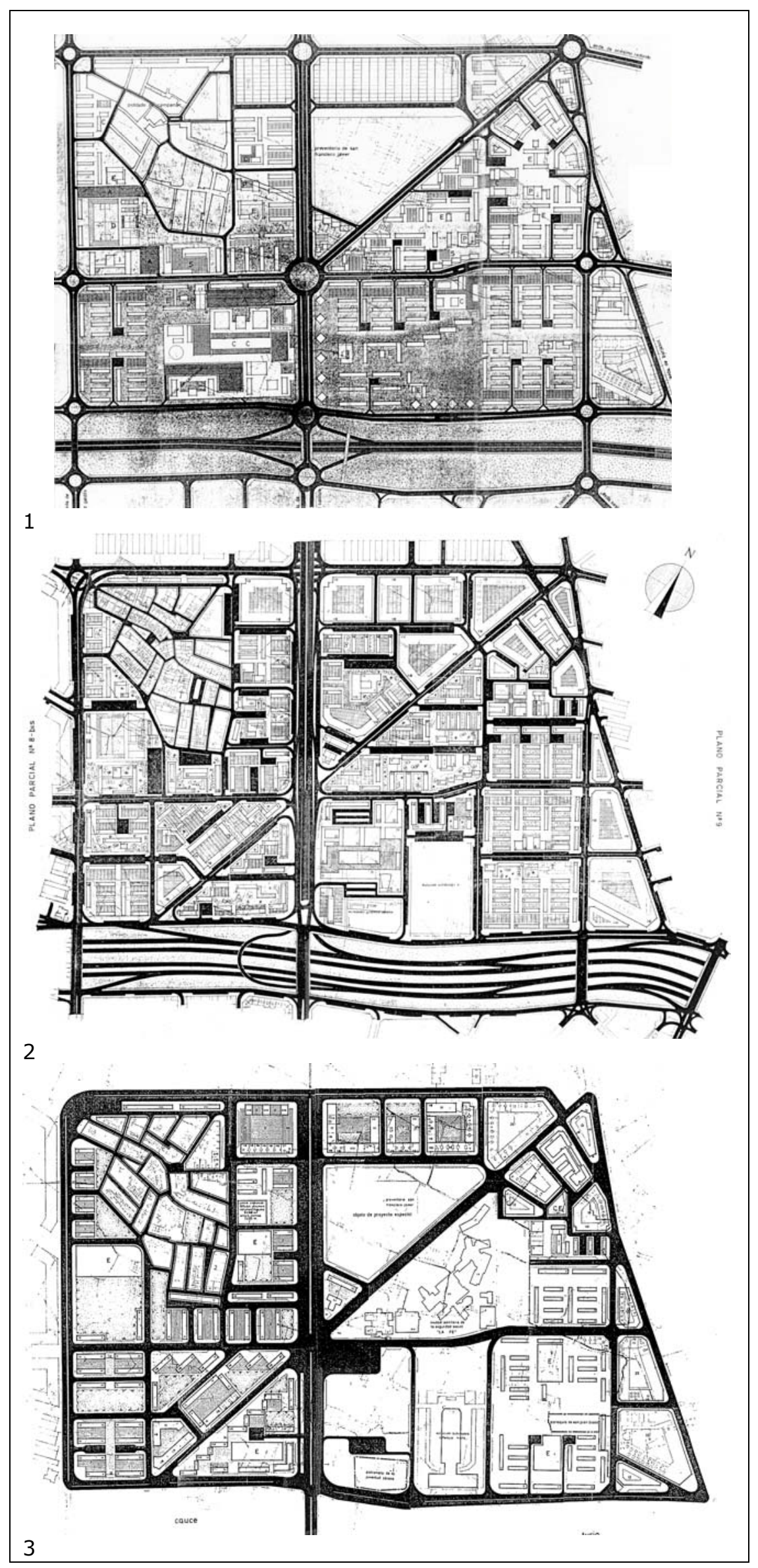




\section{Trazado viario.}

La comparación entre el trazado viario proyectado para el Polígono de Campanar de 1960 y los correspondientes a las versiones de 1967/68 y de 1972 del Plan Parcial 8 evidencia un progresivo abandono del trazado ramificado canónico del urbanismo funcionalista en favor de un trazado mallado convencional.

El sistema de "supermanzanas" con viales de penetración en forma de ramales sin salida previsto en el Polígono de Campanar de 1960 permitía crear una red de itinerarios peatonales independiente de los viales destinados al tráfico rodado.

En la versión de 1967 del Plan Parcial 8 podemos observar que los pocos ramales sin salida que permanecen son anecdóticos, ya que las supermanzanas son atravesadas por vías de tráfico que las trocean en unidades menores. Con ello desaparece toda posibilidad de establecer una segregación del viario rodado y el peatonal.

La eliminación del viario especializado continúa en la versión del PP-8 de 1972, en la que el trazado interno previsto es ya un trazado mallado, cuyos ejes principales son, por este orden, el eje norte-sur de la Avenida de Pío XII, el eje este-oeste de las calles Valle de La Ballestera/Joaquín Ballester y el eje diagonal de la Avenida de Campanar.

En el núcleo de Campanar y en las manzanas cerradas de ensanche el viario es convencional. En las zonas de edificación abierta, el tratamiento del viario es variable. Las manzanas formadas por dos bloques unidos por bajos comerciales aparecen en algunos casos asociadas dos a dos con viales en forma de ramal sin salida: es el caso de las situadas en el borde oeste y sur de Campanar. Otras manzanas de este mismo tipo, en cambio, aparecen bordeadas por calles convencionales, como las recayentes a la calle de La Ballestera, por ejemplo, que sólo se distinguen en planta baja de las de ensanche por su menor tamaño.

El tamaño de manzana mayor, más próximo al modelo de macromanzana con viales de penetración en cul-de-sac aparece únicamente en la zona de Tendetes.

La aprobación de la versión de 1972 del PP8 fue condicionada por el Ministerio de la Vivienda a la exigencia de obtener una dotación mínima de aparcamientos de una plaza por vivienda. En la modificación del plan realizada por el Ayuntamiento para dar respuesta a esa exigencia, la solución adoptada fue la de prever dos plantas de aparcamientos subterráneos bajo las zonas verdes. 


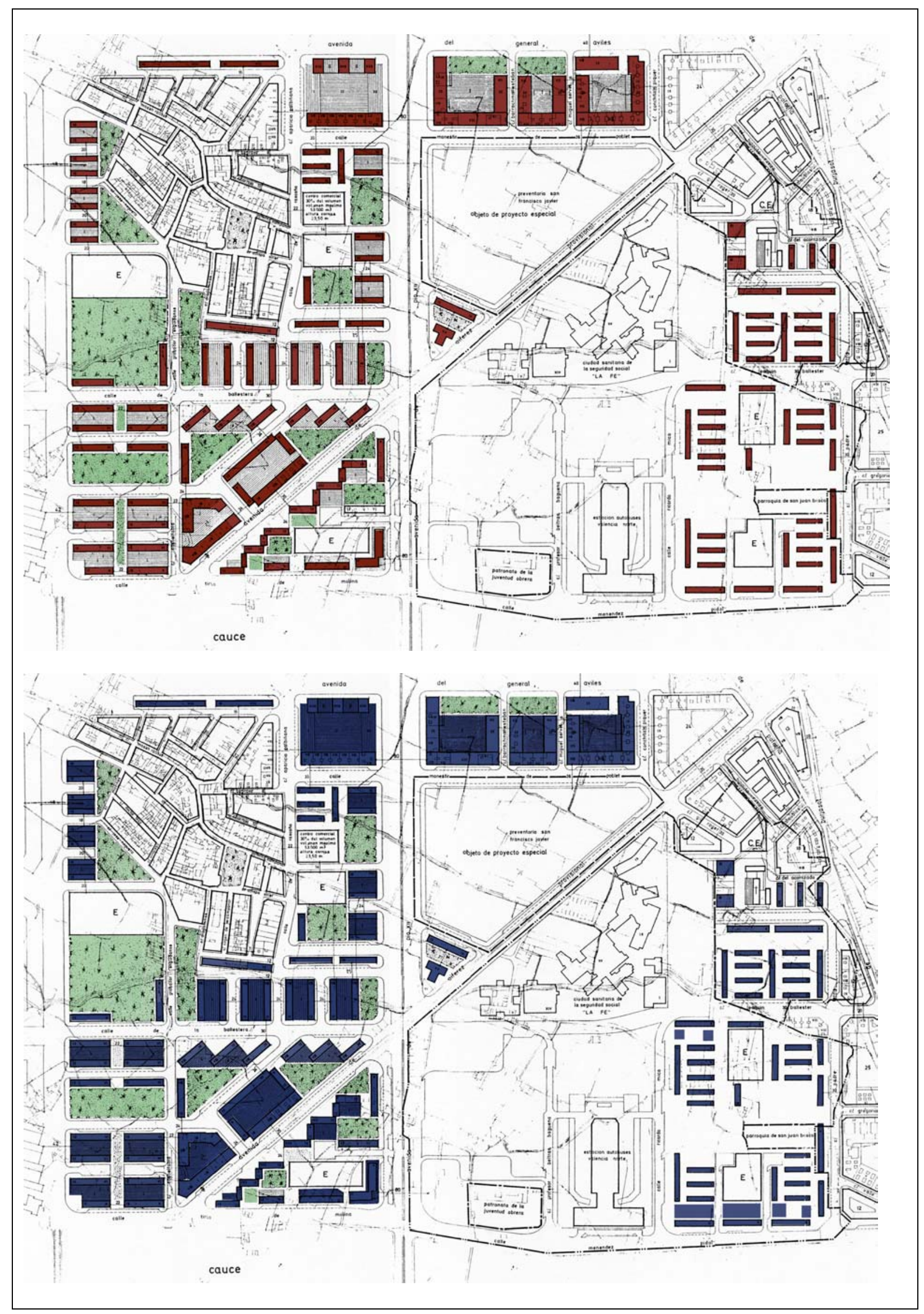




\section{Edificación}

La nueva edificación proyectada en torno al núcleo urbano de Campanar, aunque perteneciente a una zona calificada como Extensión Exterior a Tránsitos en el Plan General, tiene características de edificación abierta. Al respecto, la Memoria del Plan Parcial señala lo siguiente:

Esta zona, dado el estado poco avanzado de las construcciones, se ha diseñado con un tratamiento más higiénico y menos denso que la típica construcción de Ensanche.

A pesar de ello, no se vulnera el Plan General, puesto que la unidad formada por un bloque o por dos bloques unidos por plantas bajas comerciales, son manzanas elementales de ensanche. ${ }^{1}$

Además del tipo básico formado por unidades de dos bloques unidos por una planta baja comercial, que aparece con orientaciones y tamaños diversos, se utilizan también puntualmente bloques lineales aislados, como los edificios-pantalla situados al norte y sur del poblado de Campanar.

Además de este tipo básico, en el cuadrante suroeste, calificado como Edificación Abierta en el plano de zonificación, se proyectan bloques escalonados dispuestos como edificación continua (lado sur de la Avenida de Campanar) o dispuestos en serie y enlazados en planta baja (lado sur de la calle Vall de la Ballestera). En esta zona existen también algunas manzanas semiabiertas en las que se integran solares ya edificados, en las cuales se han previsto unos cortes en la edificación perimetral, formada por bloques profundos.

En el triángulo limitado por la Avda. Alférez Provisional, Avda. Pío XII y c/ En proyecto, el plan refleja los elementos ya previstos en la versión de 1967: una torre de XV plantas y, entre ésta y el Preventorio, un bloque lineal de IX plantas.

Las cuatro manzanas recayentes a la Avda. General Avilés, al norte del plan, se componen de bloques de cinco crujías dispuestos perimetralmente sobre una planta baja que ocupa la totalidad del suelo. La situada más al oeste, calificada como singular, incluye además tres torres de XV plantas.

La zona de edificación abierta del Polígono de Campanar, que forma el barrio de Tendetes, resuelta con bloques lineales de dos crujías, es el único ejemplo construido de la unidad modular de composición definida en el Plan Parcial del Polígono redactado en 1960, que hemos analizado en la sección anterior.

El plano de edificación en planta baja muestra un claro contraste entre el barrio de Tendetes y el resto de zonas de edificación abierta, debido a la existencia en éstas últimas de plantas bajas comerciales que unen parejas o series de bloques, formando un tejido de pequeñas manzanas.
Página opuesta:

PP 8. Edificación en planta tipo y en planta baja (Elaboración propia sobre plano de alineaciones del Plan)
1, Plan Parcial 8, 1972. Memoria. Anexo de Documentos, p. 526. 


\section{Grado de realización}

El grado de realización del Plan Parcial 8 es muy alto, y casi todas las áreas de edificación abierta han sido construidas de acuerdo con lo proyectado en el Plan.

Como áreas no realizadas del PP-8, aparte de algunos bloques aislados o fragmentos de los mismos, pueden señalarse, al oeste, las cuatro manzanas situadas entre el poblado de Campanar y la Av. Maestro Rodrigo; los bloques lineales escalonados del lado sur de la calle Ballestera; al sur, la manzana recayente a la Av. Tirso de Molina y c/ Castielfabib y, al este, los bloques lineales previstos entre las calles Acorazado y Galera. En la manzana calificada como singular, recayente a las Avenidas General Avilés y Pío XII, en la que estaba ya construido con anterioridad a la última versión del plan el bloque profundo del lado sur, un centro comercial ha sustituido a las tres torres no realizadas.

Estas zonas no realizadas coinciden con las escasas áreas vacantes existentes en el momento de redactarse el Plan General de 1988, que aprovechó los vacíos para insertar equipamientos o, en algunos casos, para plantear una disposición diferente de los bloques lineales, evitando su lectura como elementos aislados en favor de otra que los asimila a manzanas abiertas, formadas por edificación perimetral que envuelve espacios libres.

$P P$ 8. Grado de realización (Elaboración propia sobre plano de alineaciones del plan)

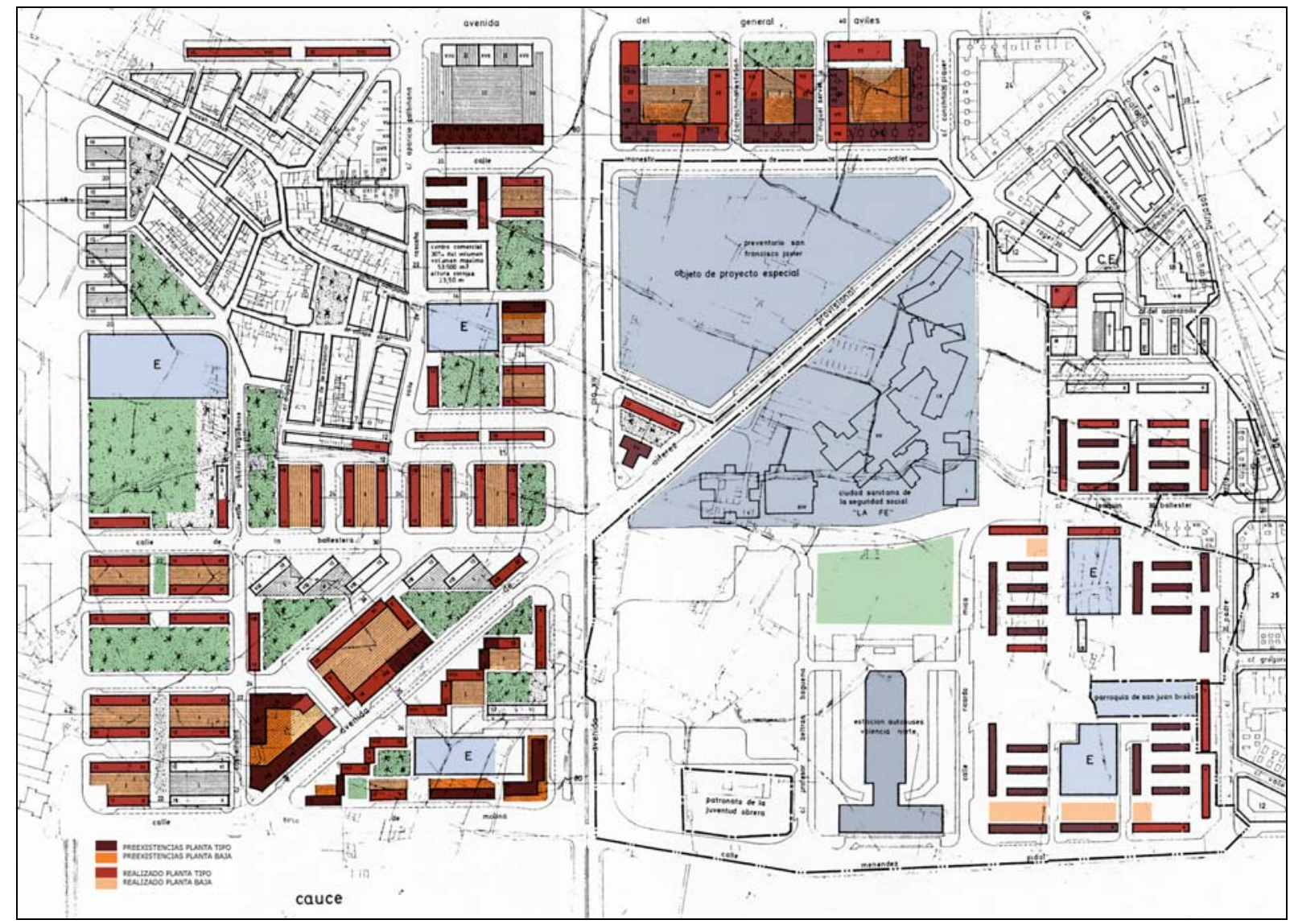




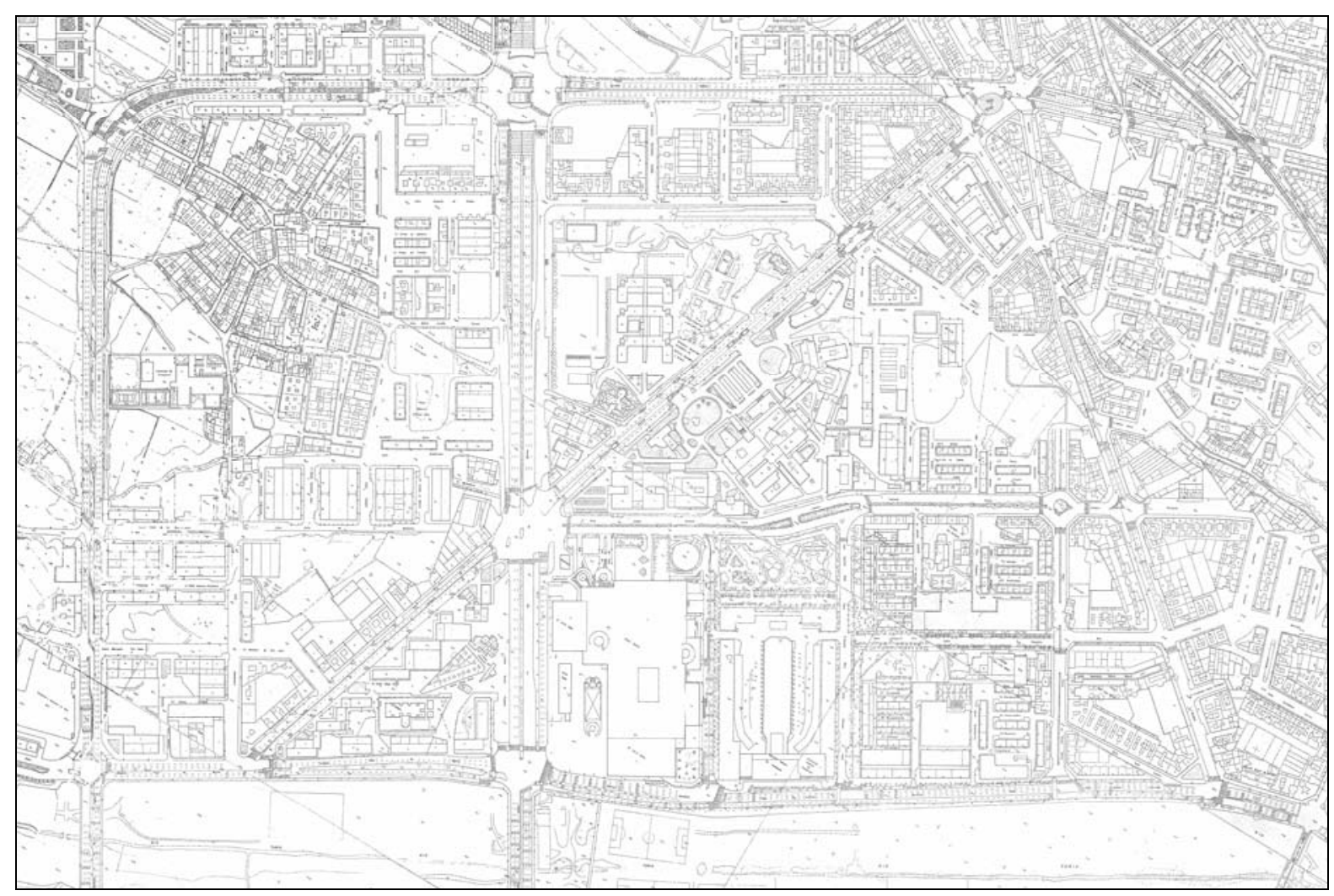

PP 8. Situación en 1983. (Elaboración propia. Montaje de hojas de Cartografía Básica Municipal, 1983.)

PGOU 1986. Detalle del área correspondiente al PP 8 (Elaboración propia, color sobre montaje de hojas de la serie C del PGOU de Valencia).

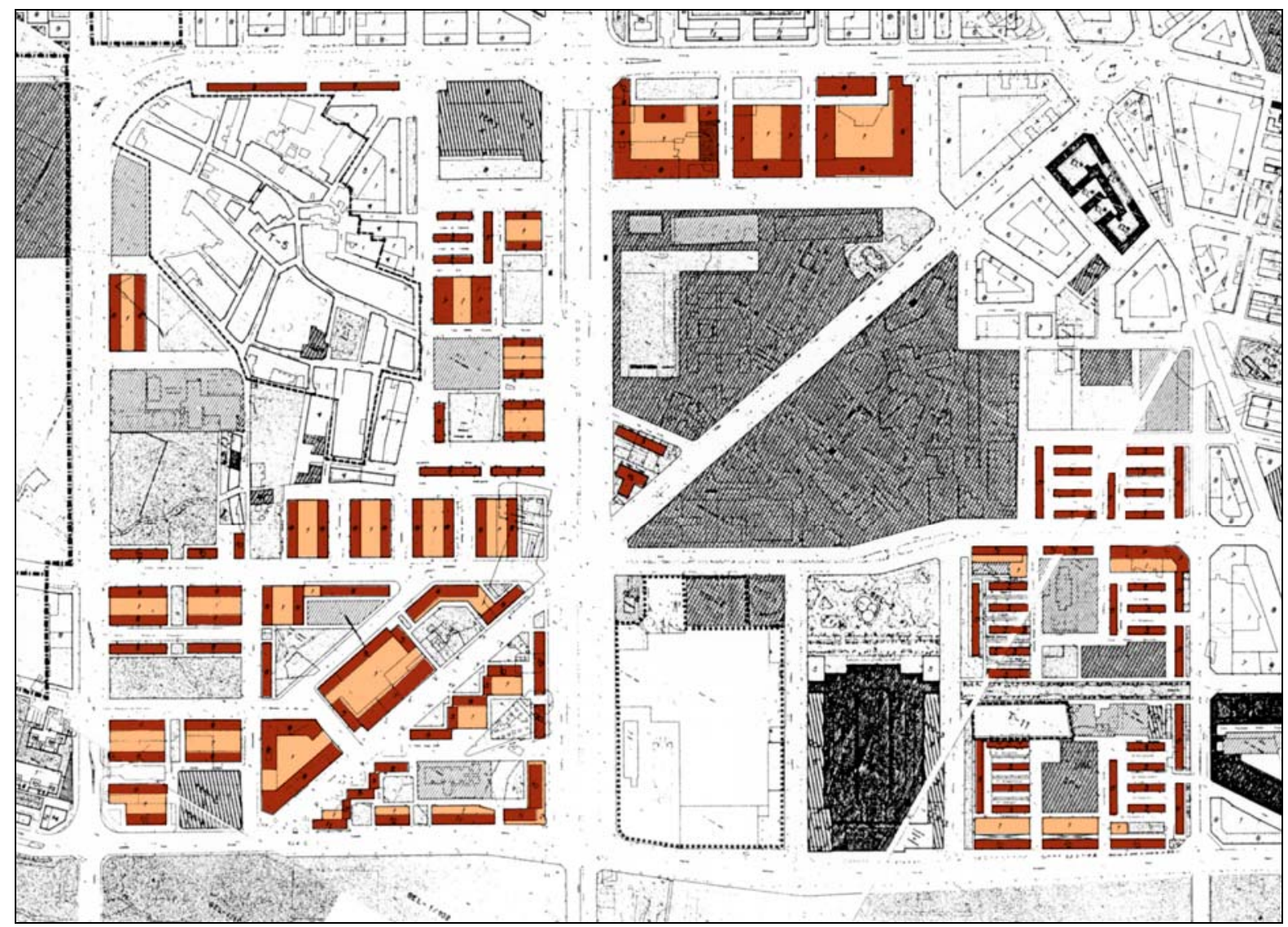



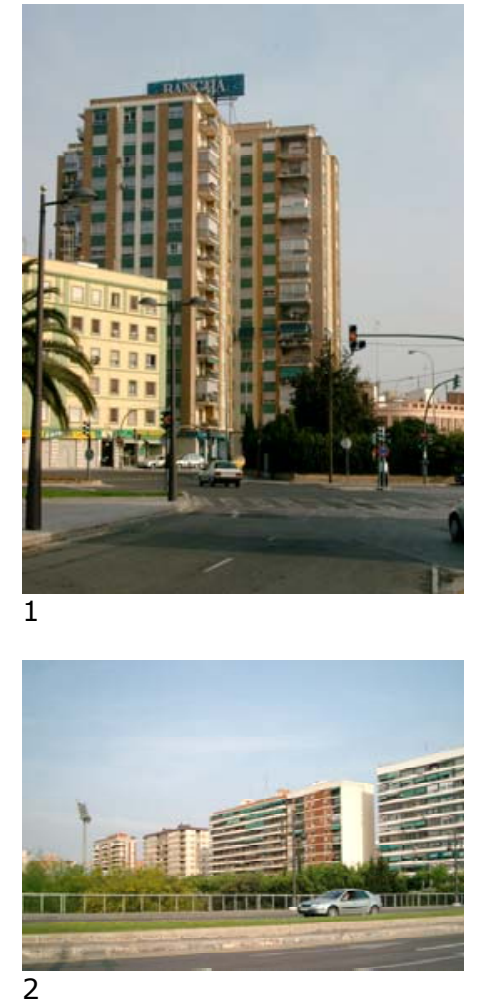

1. Torre en la Avenida Pio XII.

2. Avenida Tirso de Molina, frente al cauce del río Turia.

3. Bloques altos en el lateral oeste de la Avenida Pío XII. Vista hacia el norte.

4. Vista del frente edificado de la Avenida Tirso de Molina desde la marginal derecha del río.

\section{Un recorrido actual por Campanar.}

Como hemos señalado al estudiar las edificación proyectada en el Plan Parcial 8, el bloque lineal es el tipo predominante. La torre con planta en forma de T situada en la Avenida Pío XII es, de hecho, un edificio singular en este plan.

El bloque lineal, con alturas variables entre $\mathrm{V}$ y $\mathrm{X}$ plantas, da lugar a un paisaje urbano muy diferente en el sector oeste y en el sector este. El único elemento común de ambos sectores es el tratamiento del frente sur, recayente al cauce del río Turia, resuelto con bloques altos que forman una pantalla casi continua de edificación.

En el sector oeste, en torno al poblado de Campanar, los bloques son de promoción privada, y se construyen en base a las alineaciones y volúmenes definidos en el Plan Parcial 8. En el sector este, que forma el actual barrio de Tendetes, los bloques, construidos en su mayor parte por cooperativas, se ajustan a las determinaciones del Plan Parcial del Polígono de Campanar, de la Gerencia de Urbanización.
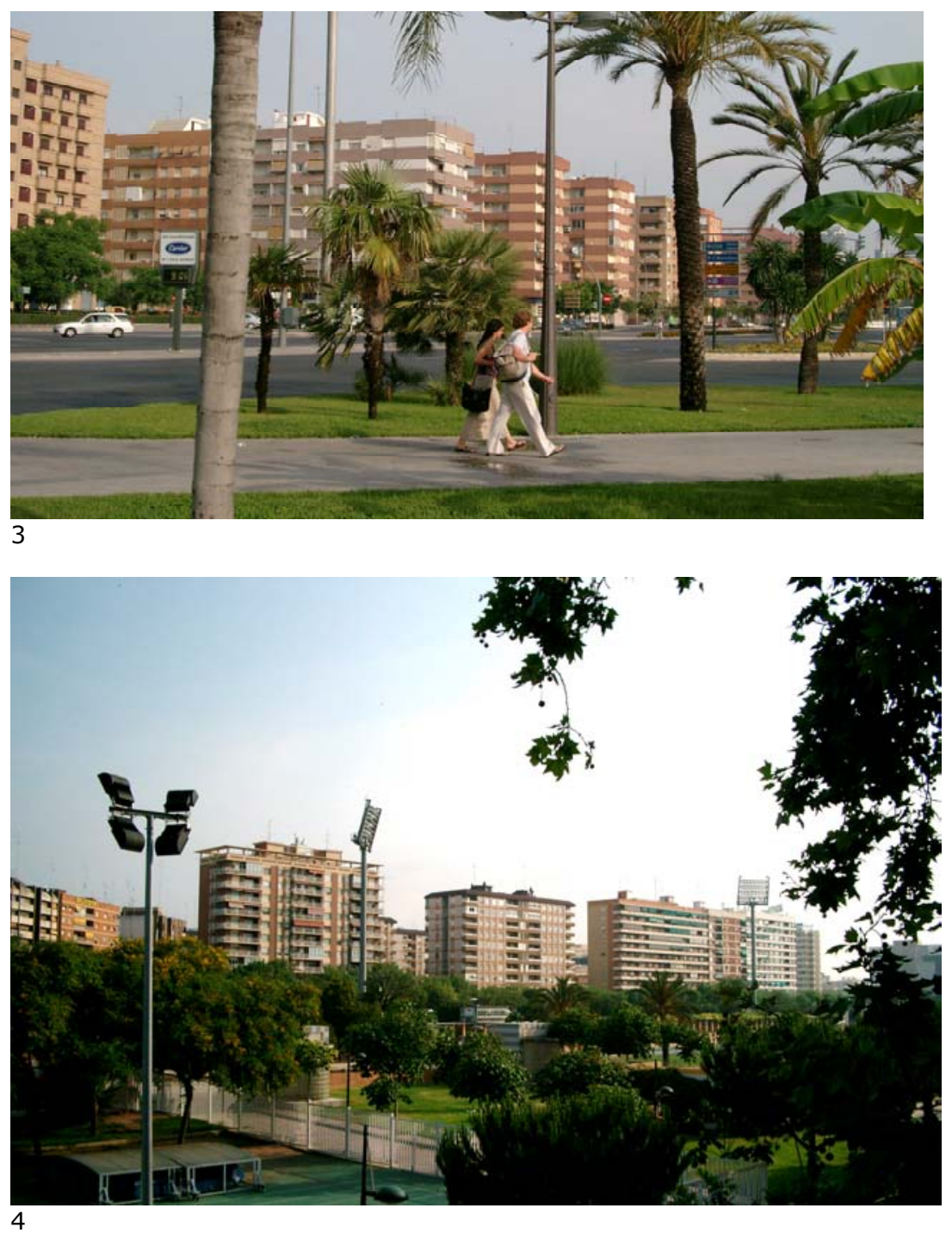


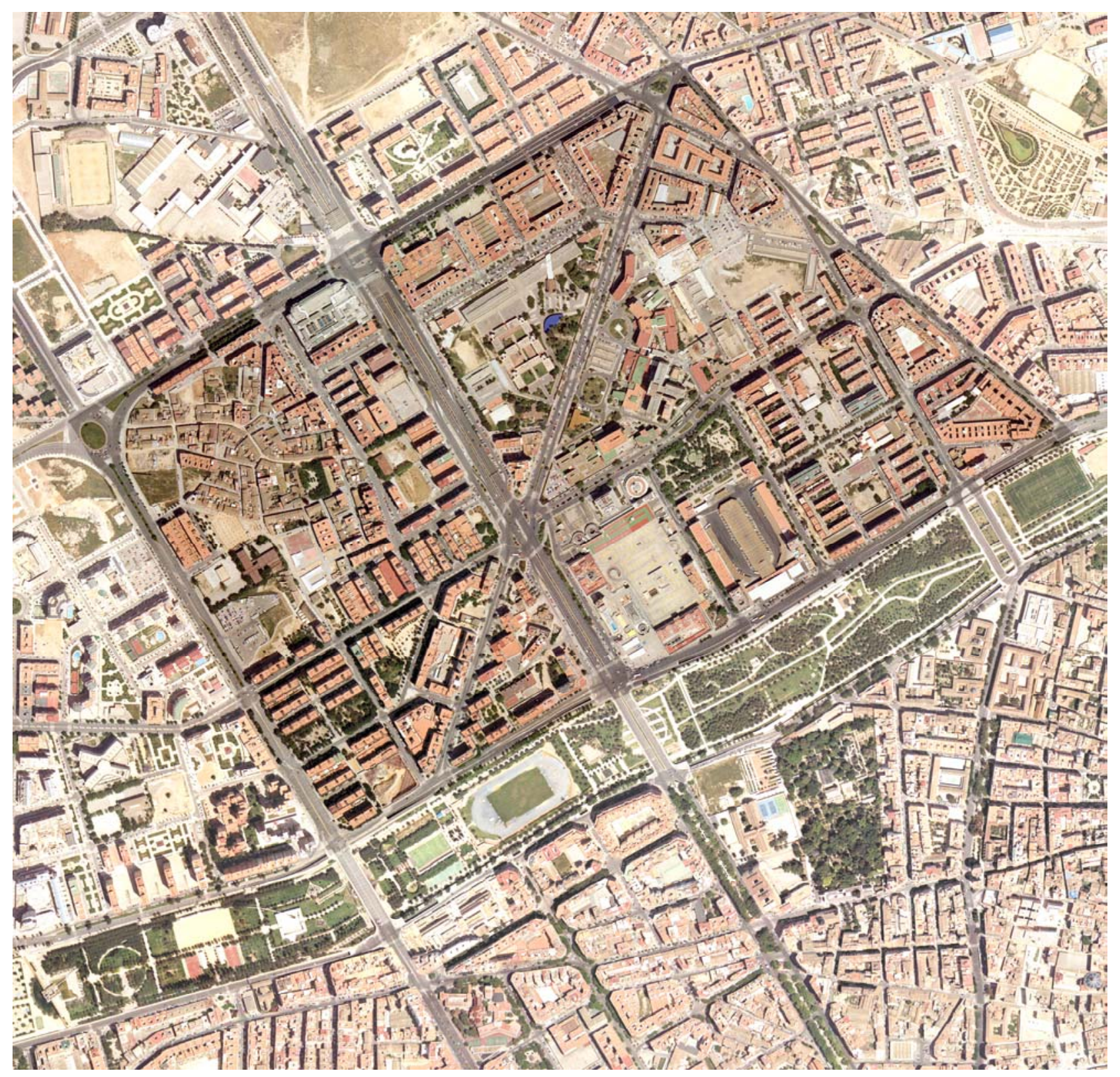

Zona del Plan Parcial 8.

Ortofoto 2002 (AUMSA) 
Zona oeste del PP-8. Fotografía aérea de Valencia, 1980.

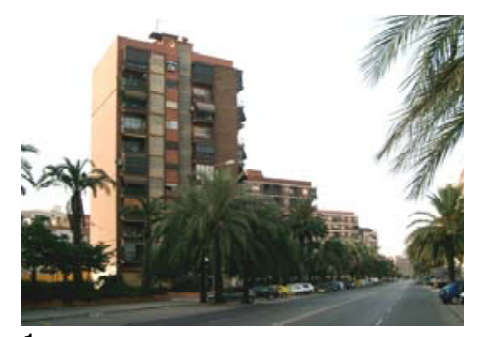

1
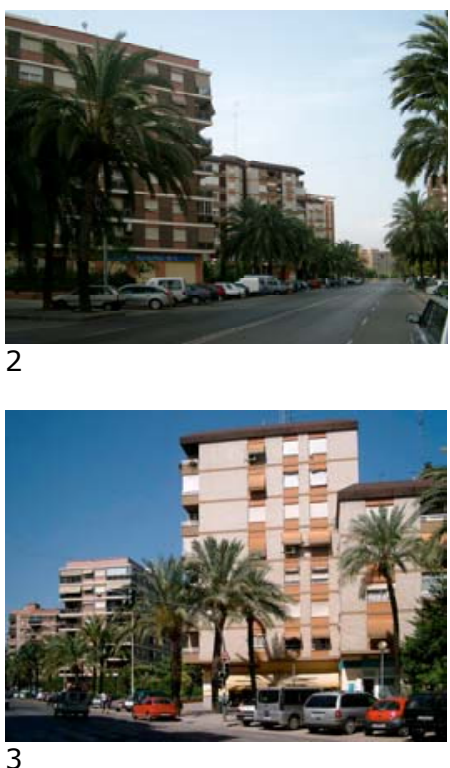

1,2.Avenida de Campanar. Bloques escalonados del lateral sur. Vista hacia el río.

3-4.. Avenida de Campanar. Bloques escalonados del lateral sur. Vista hacia el norte.
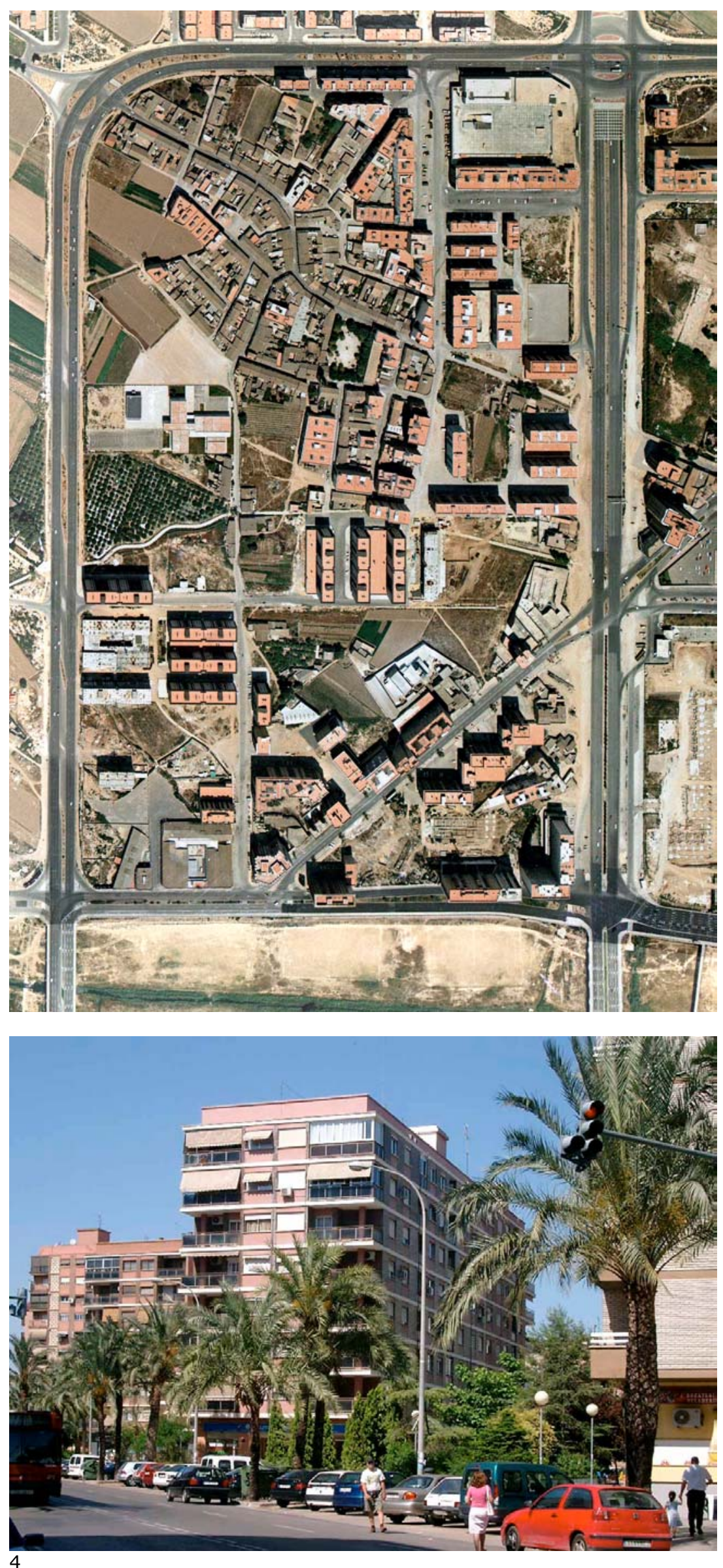


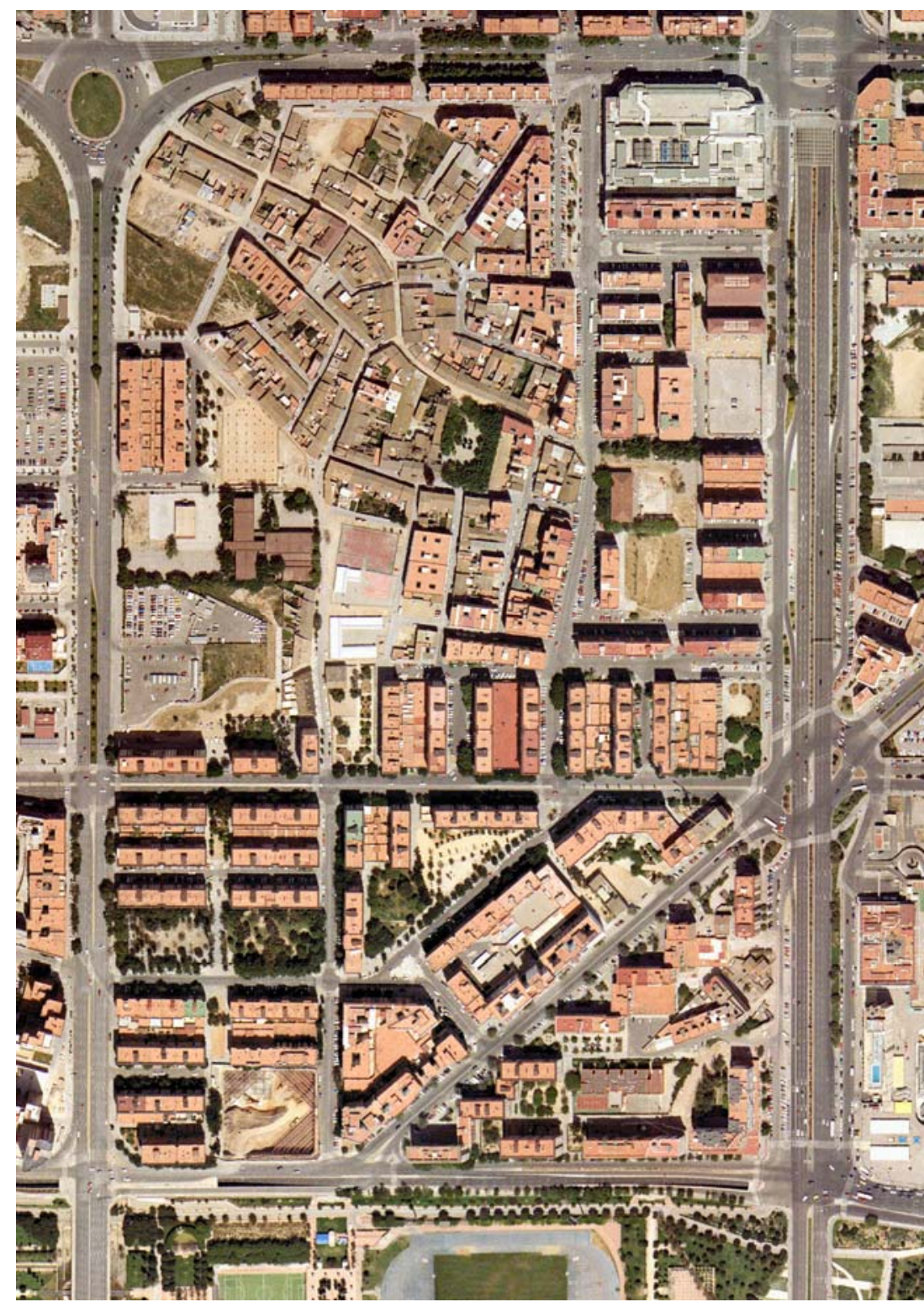

En el sector oeste, el eje diagonal de la Avenida de Campanar está flanqueado en su lado norte por manzanas abiertas alineadas con dicha Avenida, formadas por bloques profundos perimetrales situados sobre una planta baja comercial que ocupa todo el suelo de la manzana.

El lado sur, en cambio, está formado por bloques de dos crujías dispuestos de forma escalonada, formando un dentado que deja espacios ajardinados triangulares junto a la Avenida. De estos bloques, los dispuestos en dirección este-oeste (con fachadas a norte y sur) son de mayor altura (VIII plantas), mientras que los bloques transversales que los enlazan, dispuestos en dirección norte-sur, tienen menor altura ( $\mathrm{V}$ plantas) y menor longitud.

Estos bloques, construidos en algunos casos por unidades completas y en otros en forma de fragmentos unidos por medianeras, albergan locales comerciales en planta baja. La superficie de los locales se extiende a veces más allá del perímetro de la planta tipo
Zona oeste del PP-8 (Ortofoto 2002, AUMSA.

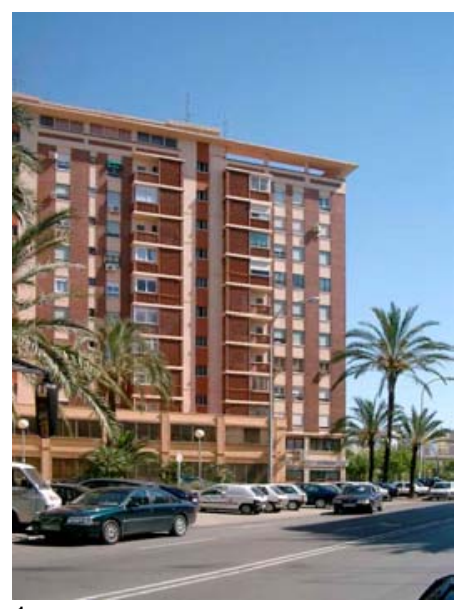

1

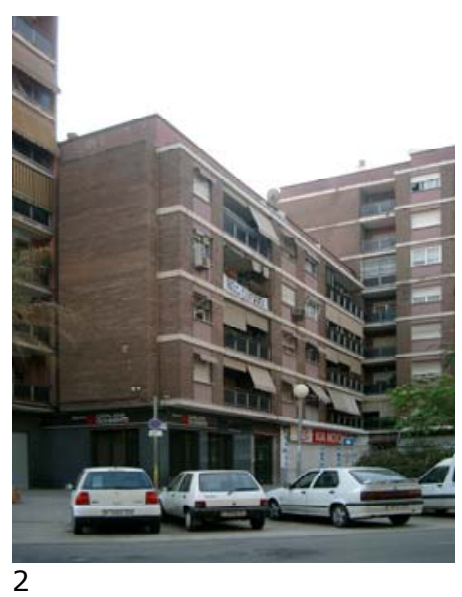

2

1,2. Avenida de Campanar. Bloques escalonados del lateral sur. Vista hacia el río y detalle. 


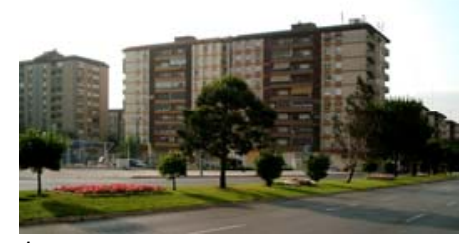

1

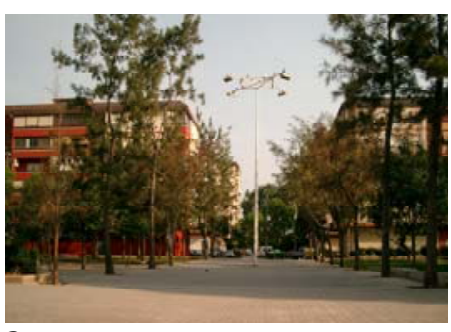

2

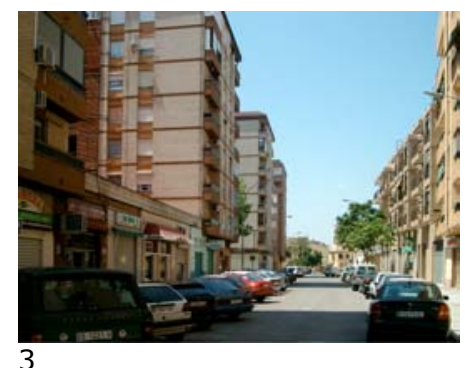

1. Bloques en la calle Vall de la Ballestera, vista desde el norte.

2. Calle Marqués de San Juan.

3. Calle Vall de la Ballestera, lado sur.

4. Avenida Maestro Rodrigo.

5. Calle Vall de la Ballestera, lado norte.

6. Calle Marqués de San Juan.
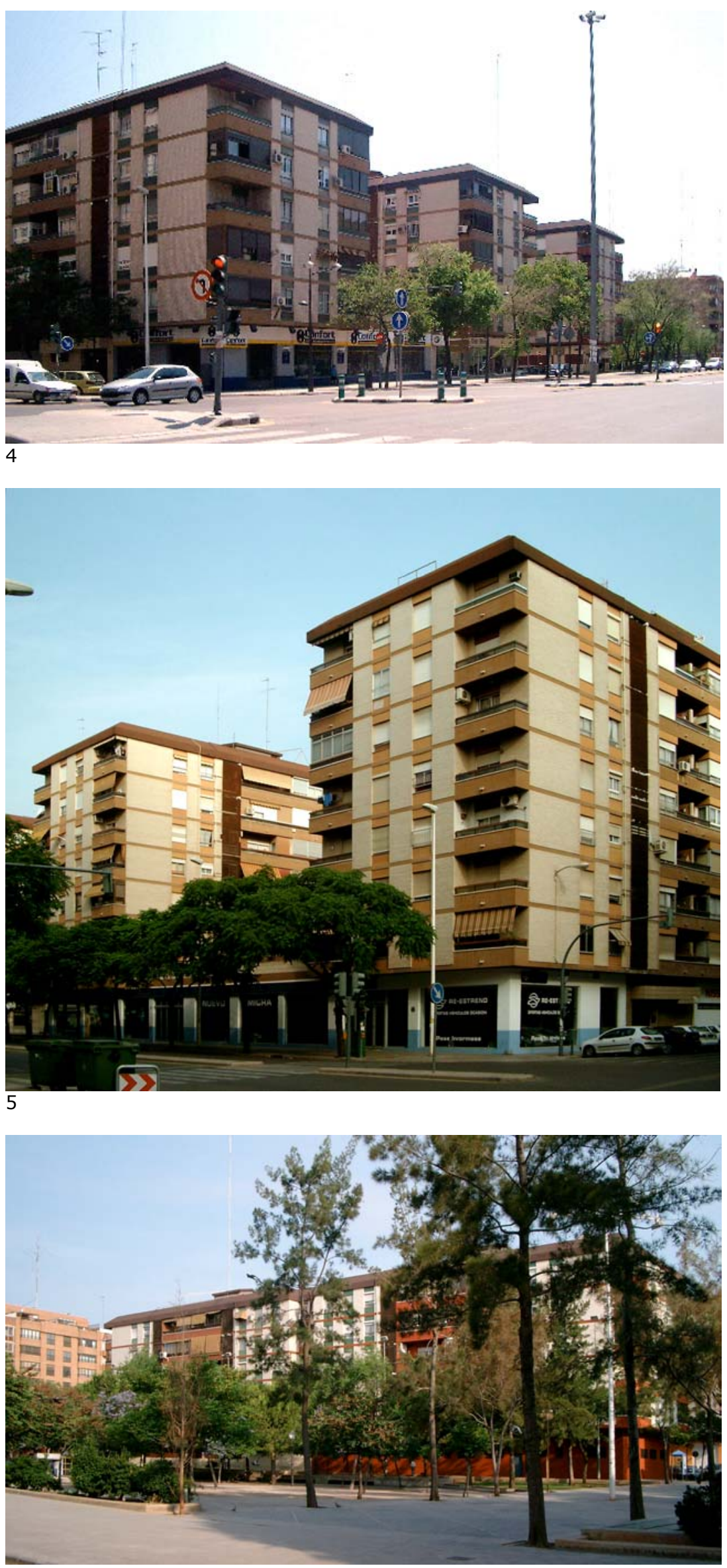
El resto de la edificación abierta en torno al poblado de Campanar esta resuelto con un tipo único de manzana mixta: el de la pareja de bloques paralelos de dos crujías situados sobre un cuerpo de edificación comercial que los une en planta baja, formando un rectángulo cuyas dimensiones oscilan entre $40 \times 40$ y $60 \times 60 \mathrm{~m}$.

Las manzanas son, por tanto, de un tamaño más pequeño que las de los tejidos urbanos de ensanche, y generan como consecuencia un perímetro mayor de frentes de calle, para los que a veces no existe un nivel de actividad comercial en grado suficiente para ocuparlos.

Los bloques dispuestos sobre el zócalo comercial son de alturas variables entre 4 y 7 pisos ( $V$ y VIII totales), y su orientación no es uniforme.

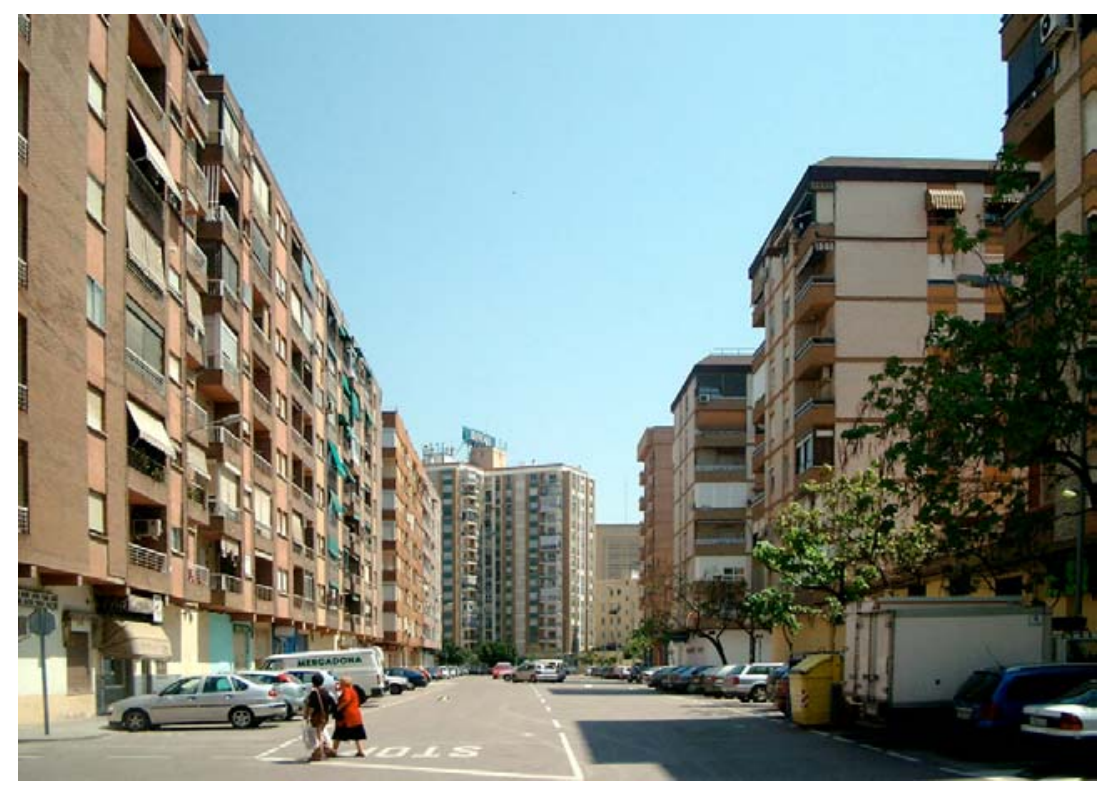

1

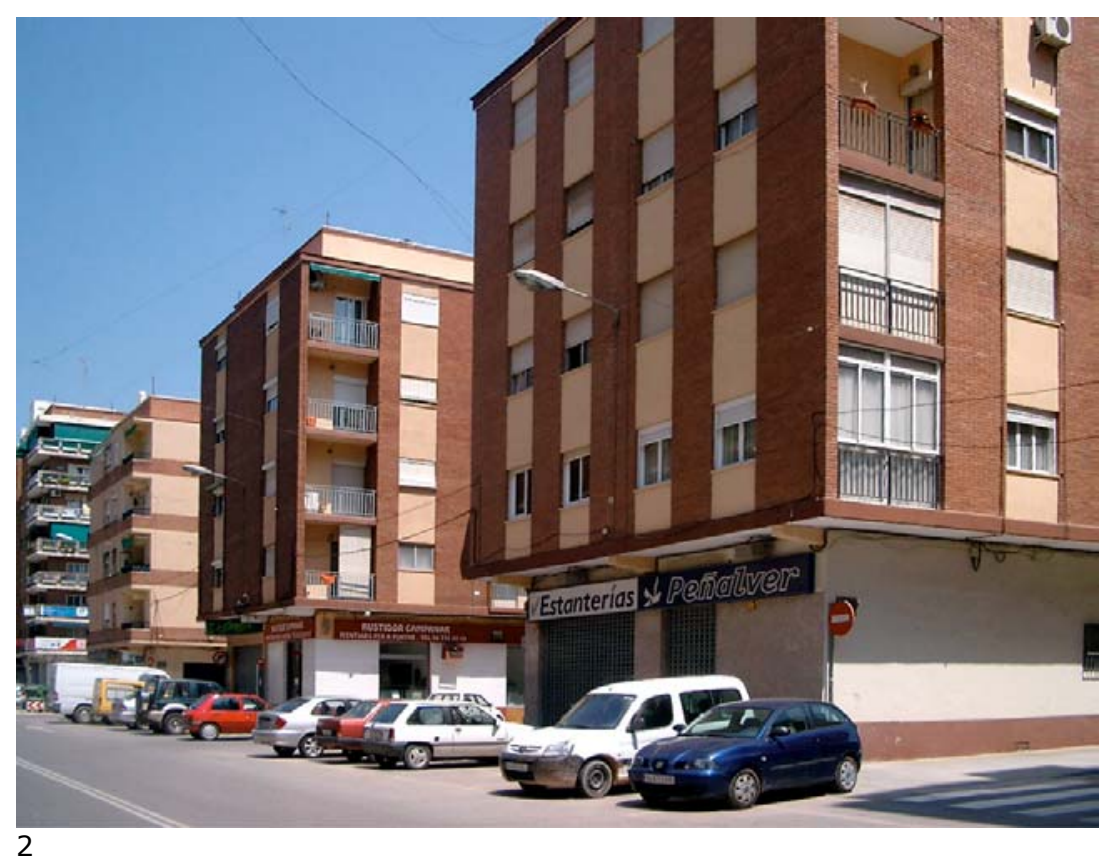

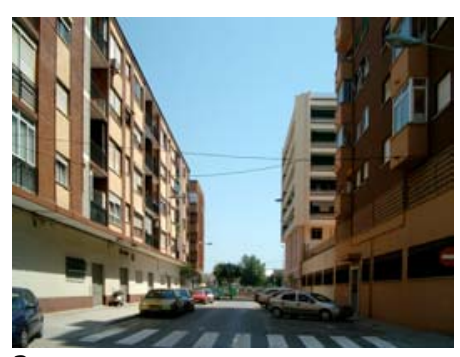

3

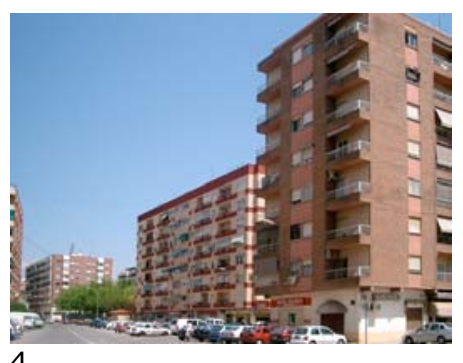

4

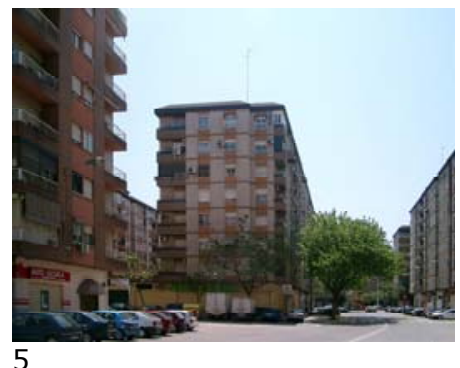

5

1. Calle Valdelinares, vista hacia el este, con la torre de la Avenida Pío XII al fondo.

2. Calle Camino Parra, vista hacia el norte.

3. Calle Obispo Soler, vista hacia el este.

4. Calle Rascaña, vista hacia el norte.

5. Calle Rascaña, vista hacia el sur. 
Plan Parcial Modificado del Polígono de Campanar. Gerencia de Urbanización, 1971. Zona de Tendetes.
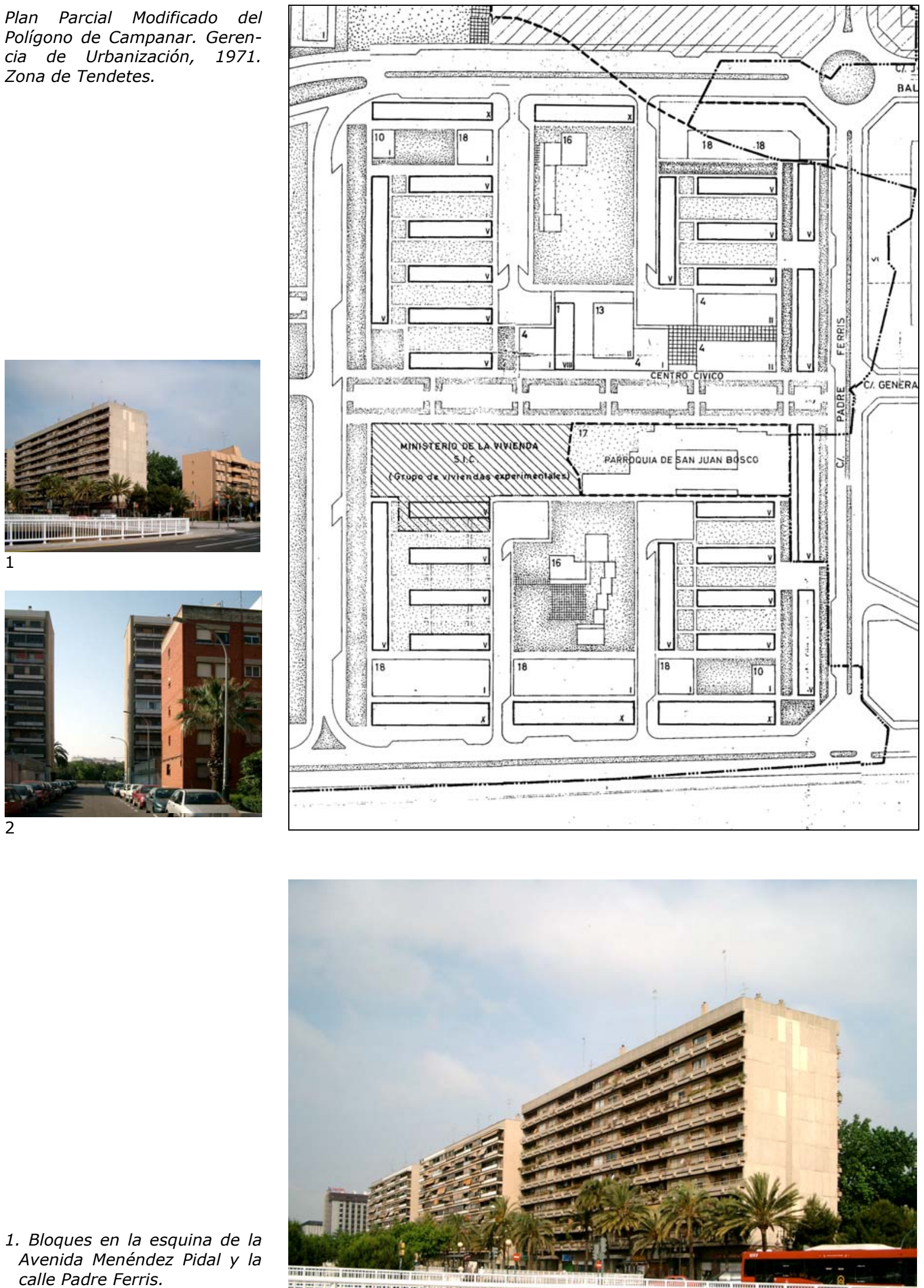

1. Bloques en la esquina de la Avenida Menéndez Pidal y la calle Padre Ferris.

2. Calle Submarino, vista hacia el río.

3. Bloques en la Avenida Menéndez Pidal, frente al río Turia.

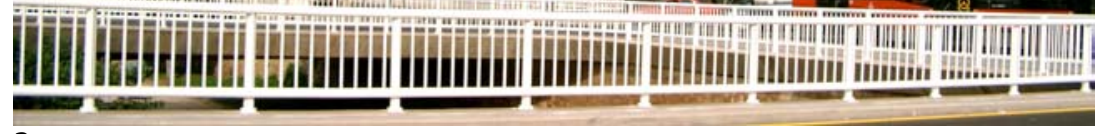




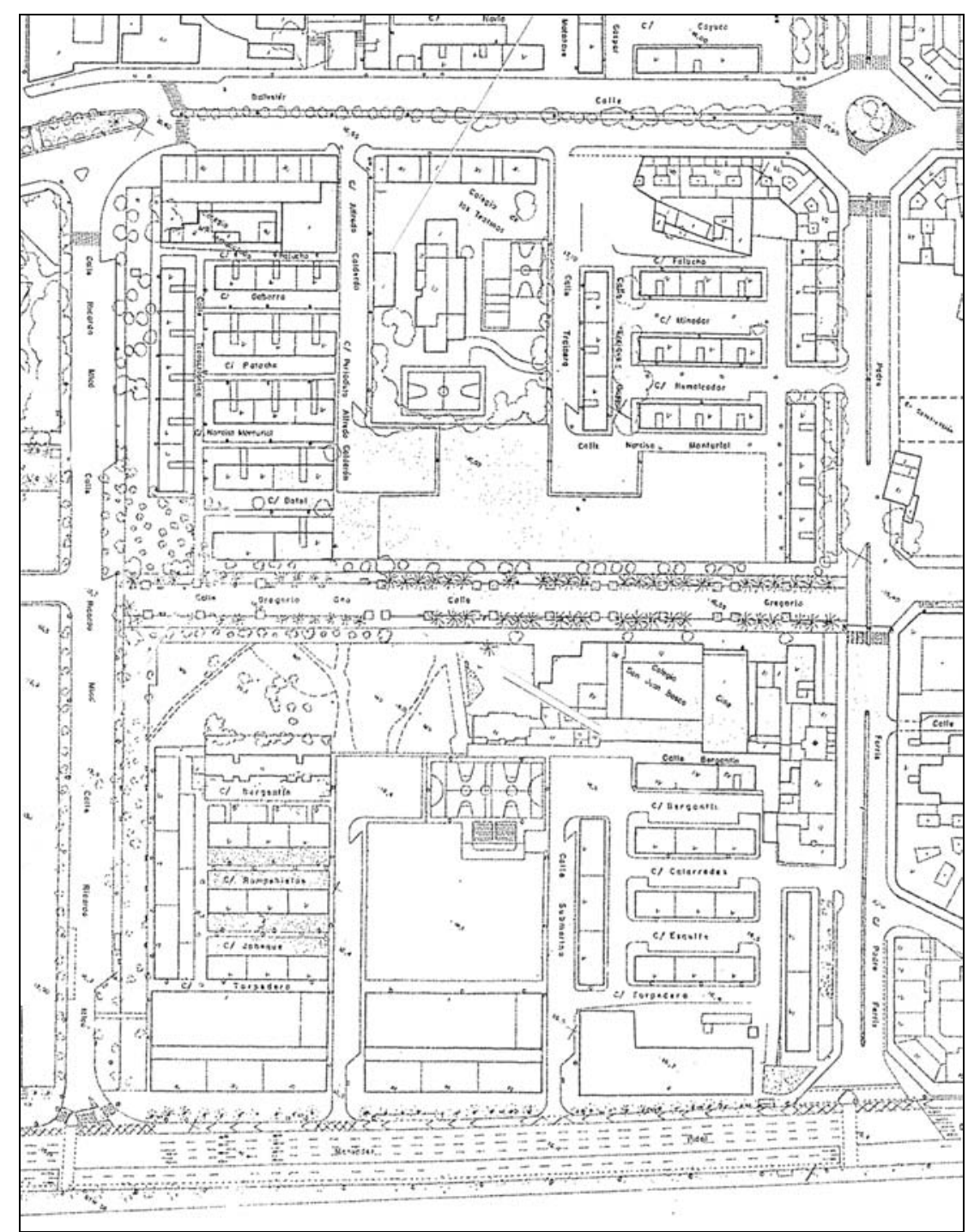

La zona de edificación abierta de promoción pública situada al este, que forma el actual barrio de Tendetes, presenta unas características muy diferentes a la situada alrededor de Campanar. Esta zona, que es el único fragmento construido del Plan Parcial original de 1960 del Polígono de Campanar, se edificó en su mayor parte por cooperativas diversas, de acuerdo con el Plan Parcial modificado de 1971, que en sus ordenanzas señalaba para la edificación abierta lo siguiente:

En la edificación abierta, los usos no se superponen. Se separan las funciones y en consecuencia, los edificios que tienen la misión de cumplirlos. Las distintas funciones tienen un orden jerárquico de subordinación para la mayor eficacia del conjunto.

Así partiendo de la vivienda en bloque, conjunto de bloques y unidad vecinal, se establecen para su servicio las funciones: garajes, talleres, comercial, negocios, cultural y social, educativa, religiosa., en edificios propios, conectados con la unidad pero con absoluta independencia de los edificios de vivienda.

El uso, por consiguiente, queda perfectamente definido y delimitado por la separación de la función familiar (viviendas) de las de relación (edificios públicos o de uso publico y de las de trabajo (oficinas, talleres, etc..$^{1}$
Cartografía Básica Municipal, Valencia, 1983. Zona de Tendetes.
1. Plan Parcial Modificado del Polígono de Campanar, 1971. Ordenanzas. Anexo de Documentos, p. 760. 
Zona oeste del PP-8. Fotografía aérea de Valencia, 1980.

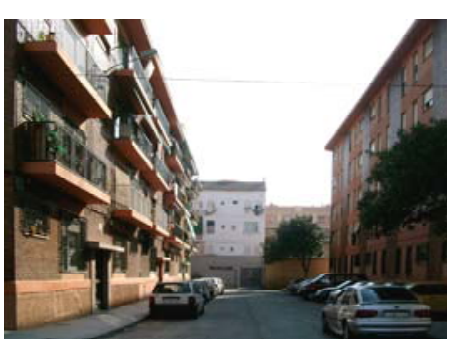

1

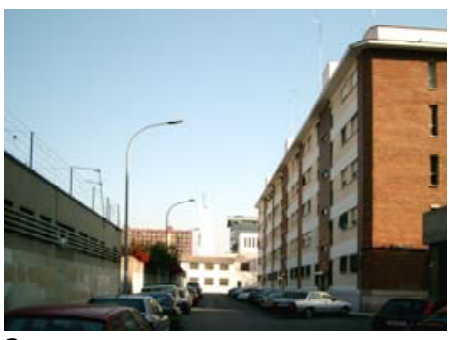

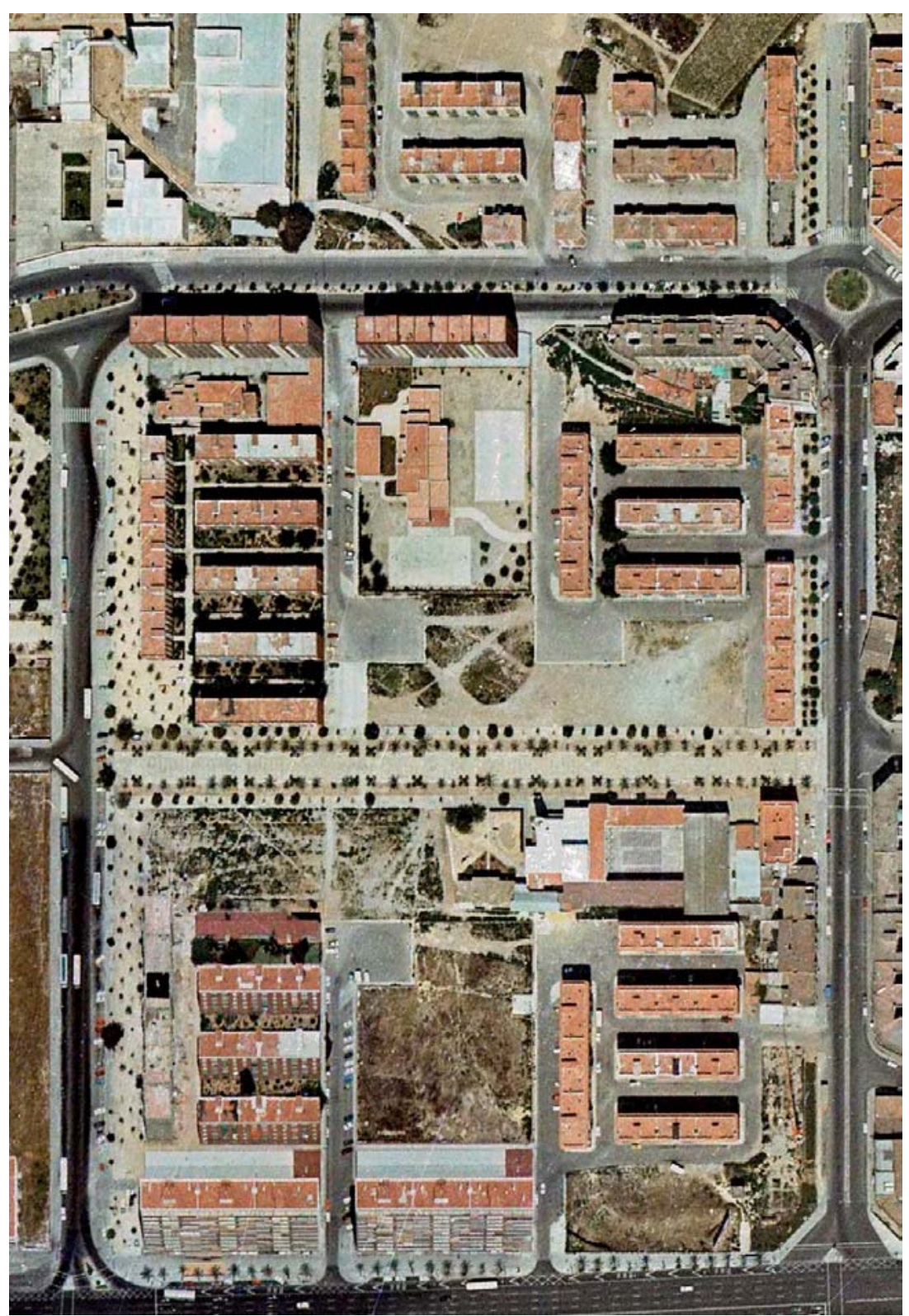

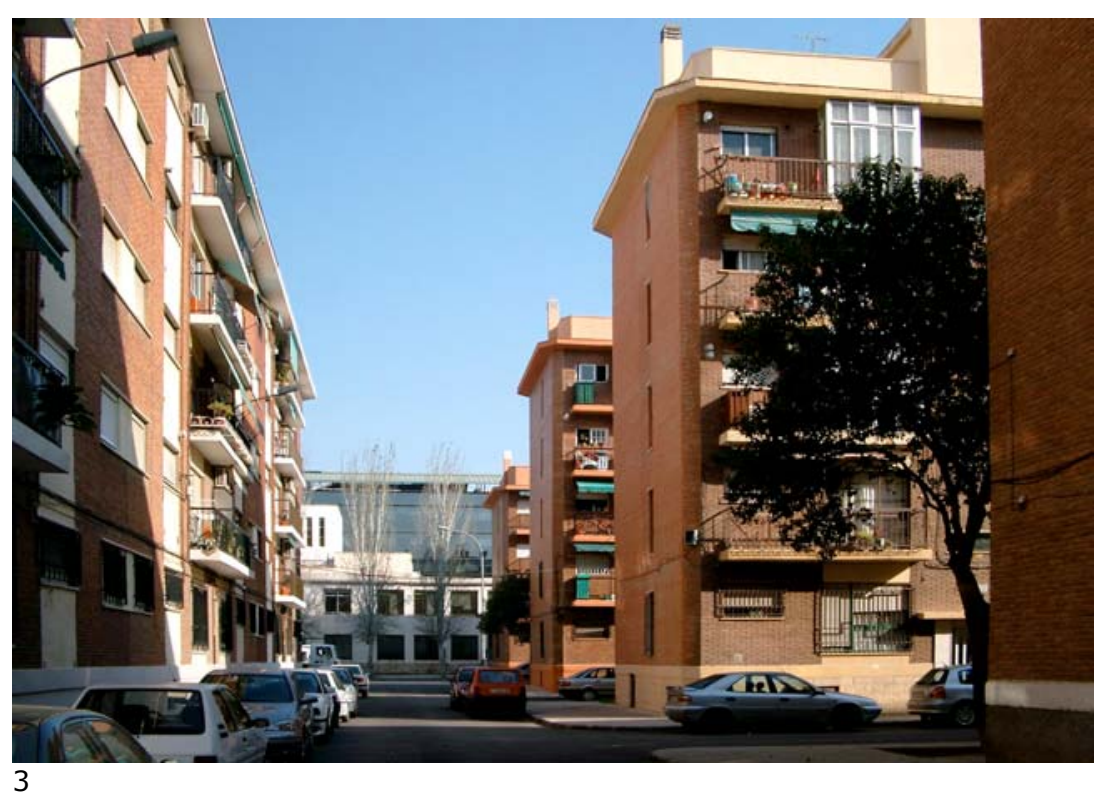

1. Calle Bergantín.

2. Calle Submarino.

3. Calle paralela a Submarino. A la derecha, bloques de las calles Esquife, Carrelades y Bergantín. 


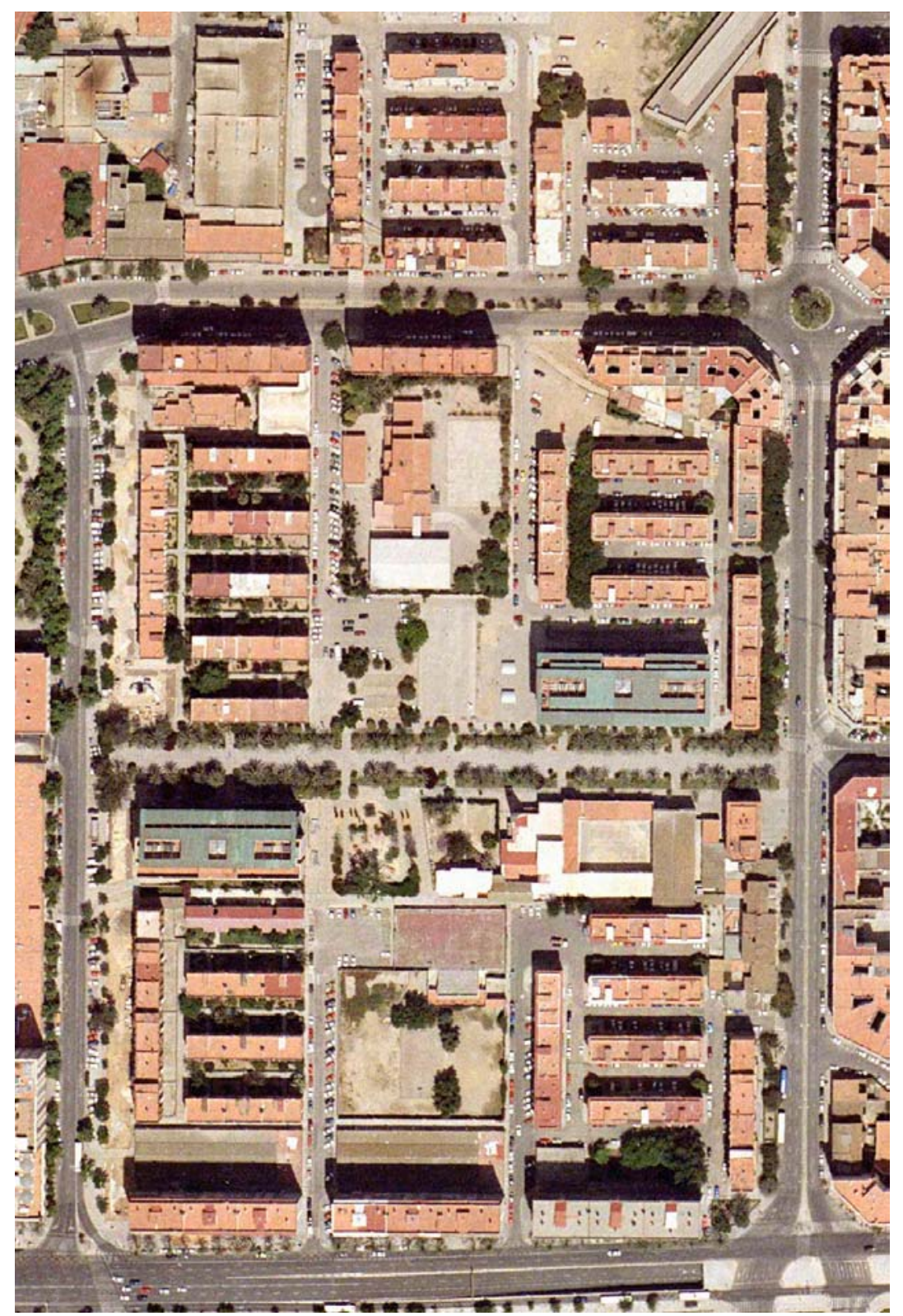

La especialización funcional se circunscribe únicamente, en realidad, a los bloques lineales de $\mathrm{V}$ plantas de la parte central del conjunto, cuyas plantas bajas están ocupadas por viviendas. En los bloques altos de los frentes norte y sur, recayentes a la Avenida Menéndez Pidal y a la calle Joaquín Ballester, en cambio, las plantas bajas tienen usos comerciales.

Las Ordenanzas del Plan Parcial modificado de 1971 prohiben expresamente en la edificación abierta los cuerpos volados que no sean terrazas, así como los patios interiores de ventilación. Además, incluyen un apartado relativo a composición, que señala lo siguiente:

La composición de los bloques para viviendas, será única para cada uno de ellos y ligada al contiguo, caso de que no estuviesen aislados.

Será de líneas sencillas y claras, con expresión actual de la arquitectura, y con correcto y buen acabado en todas sus fachadas. ${ }^{1}$
Zona oeste del PP-8 (Ortofoto 2002, AUMSA. 


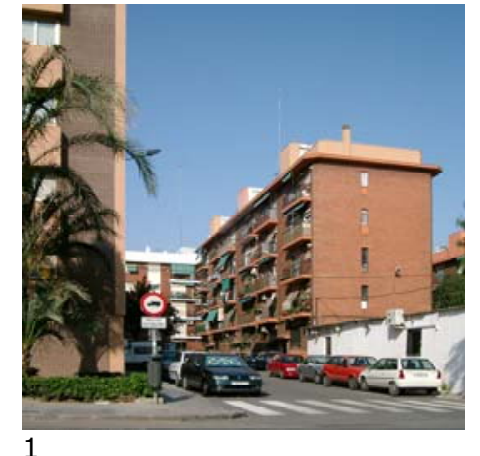

1

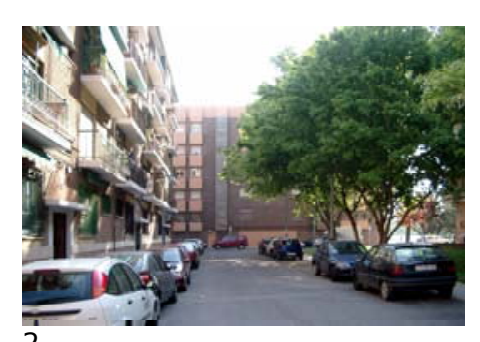

2

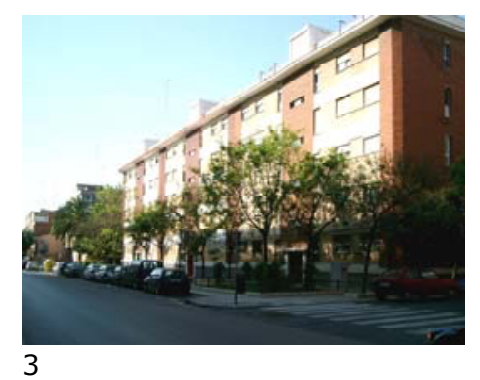

1. Calle Calarredes, desde Padre Ferris.

2. Calle Torpedero.

3. Calle Padre Ferris

4. Calle Remolcador, vista hacia el oeste
Las edificaciones construidas responden, en buena medida, a estos criterios compositivos expresados en las Ordenanzas. La principal diferencia entre las previsiones del plan y la realidad actual de la zona es la concerniente al espacio público.

El trazado viario proyectado, como en otros planes contemporáneos, era del tipo ramificado, con segregación de circulaciones rodada y peatonal. En este caso, el viario rodado estaba formado por dos ramales sin salida que arrancaban de cada uno de los ejes viarios situados a norte y sur (la calle José Ballester y la Avenida Menéndez Pidal, respectivamente), a lo largo de los cuales se sitúan los escasos aparcamientos previstos. ${ }^{1}$

Las circulaciones peatonales están formadas por una red de senderos que unen entre sí los bloques y conducen a los accesos a los mismos. Los espacios intermedios entre los bloques estarían destinados a jardines $y$, además, se prevé un parque lineal central que atraviesa la zona de este a oeste.

El viario proyectado fue modificado en la mitad este, con el fin de obtener más plazas de aparcamiento. Para ello, los espacios ajardinados entre los bloques han sido asfaltados y convertidos en calles convencionales. En la mitad oeste, sin embargo, se conserva la idea original del plan.

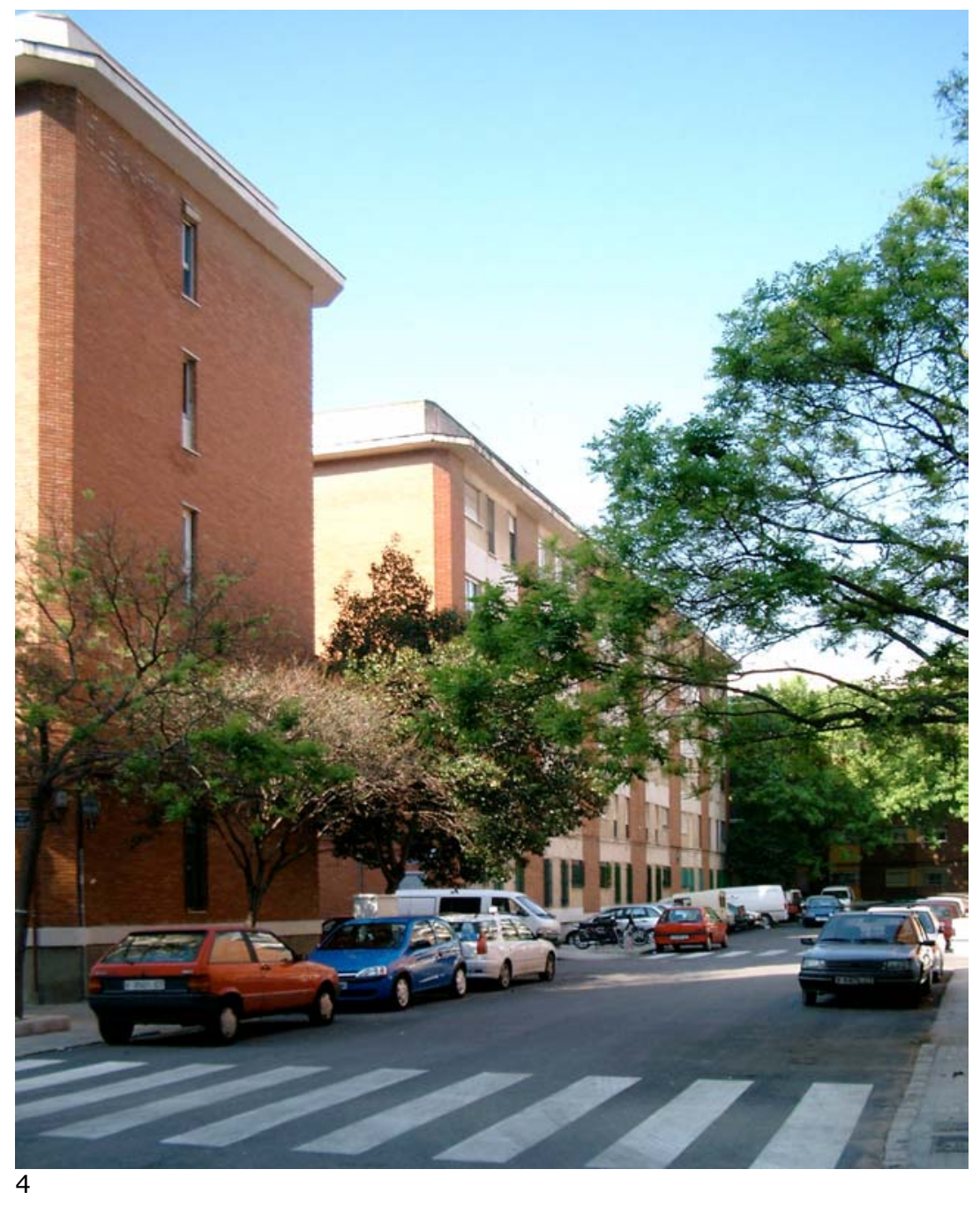




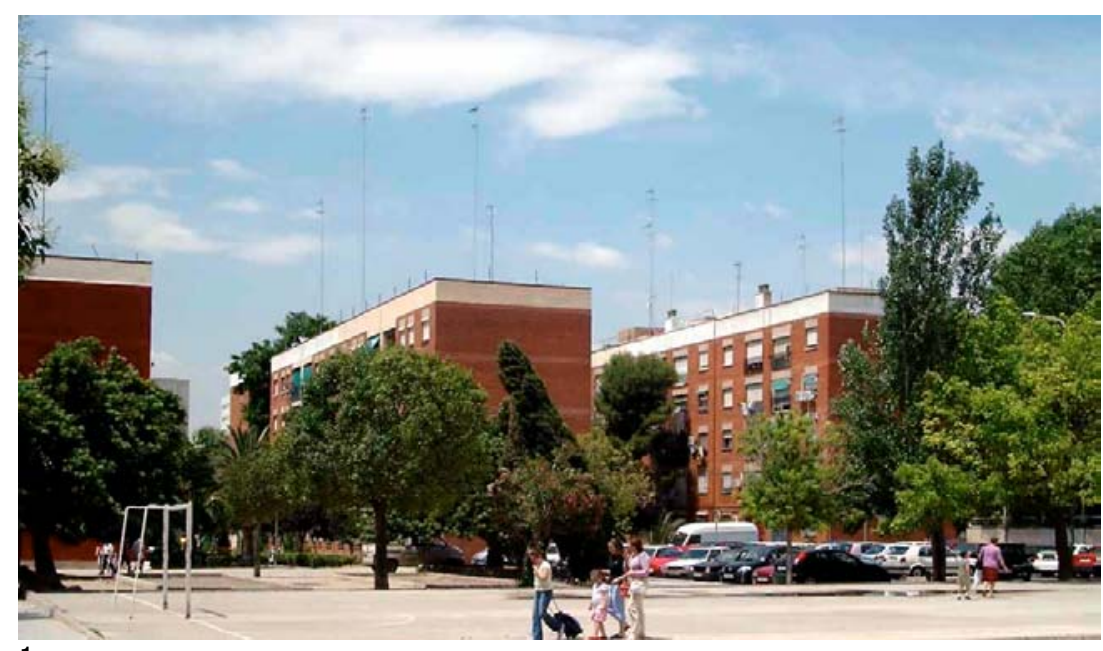

1
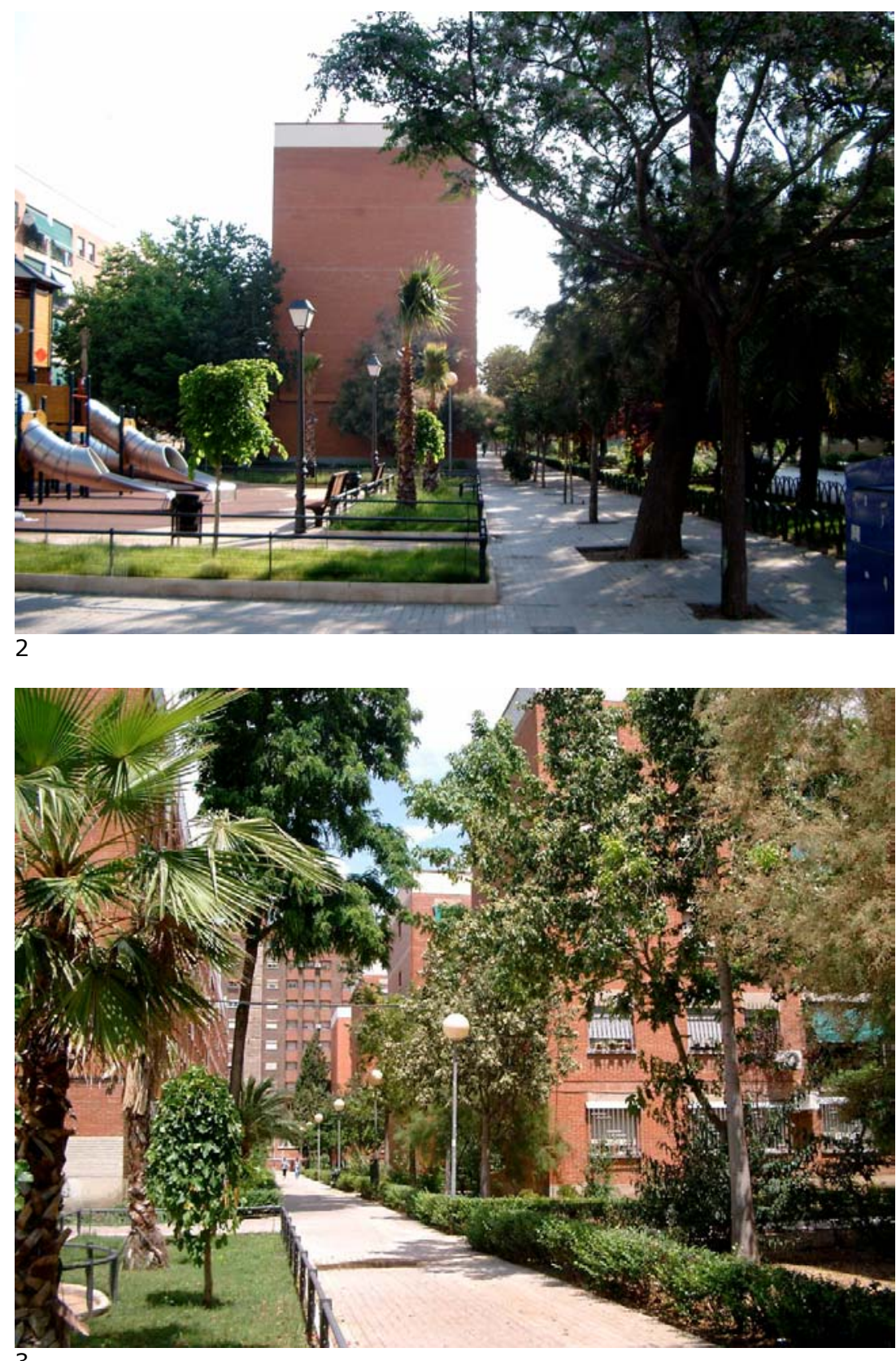

3

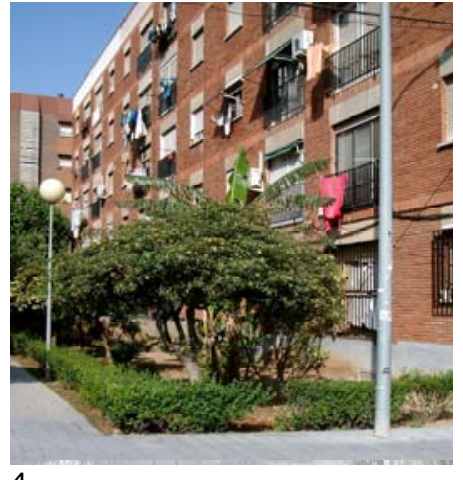

4

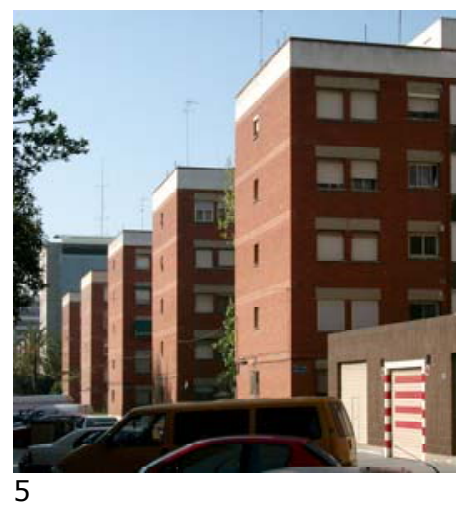

1. Calle Periodista A. Calderón.

2. Calle Gregorio Gea, vista hacia el este.

3. Calle Transatlántico, vista hacia el norte.

4. Calle Rompehielos.

5. Calle Submarino, vista hacia el sur. 

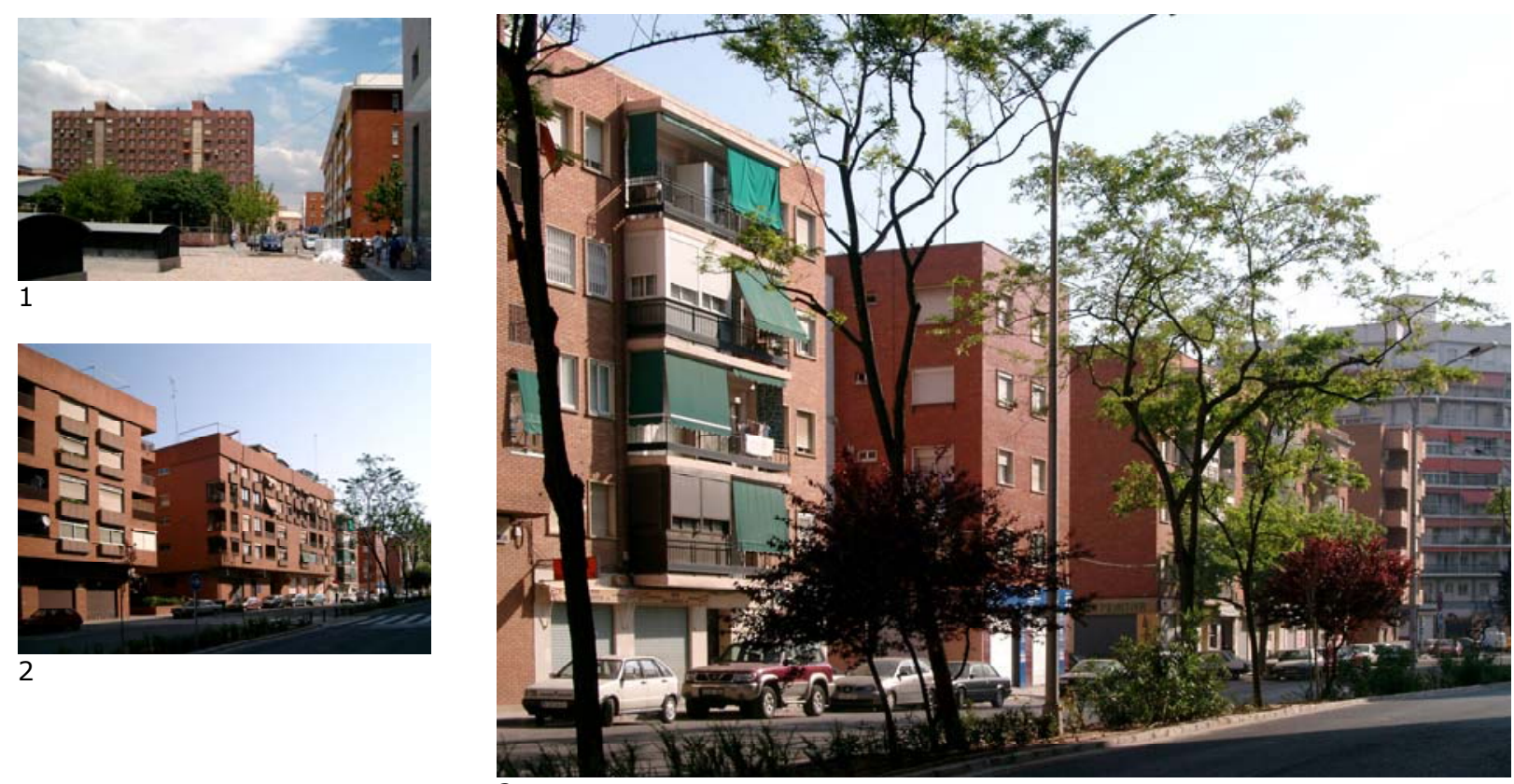

3

1. Bloque alto en el lado sur de la calle Joaquín Ballester, visto desde la calle Gregorio Gea.

2,3. Bloques de altura media en el lado norte de la calle Joaquín Ballester.

4. Bloques ortogonales a la calle Crucero (a la derecha, calles Galera, Canoa y Navío)

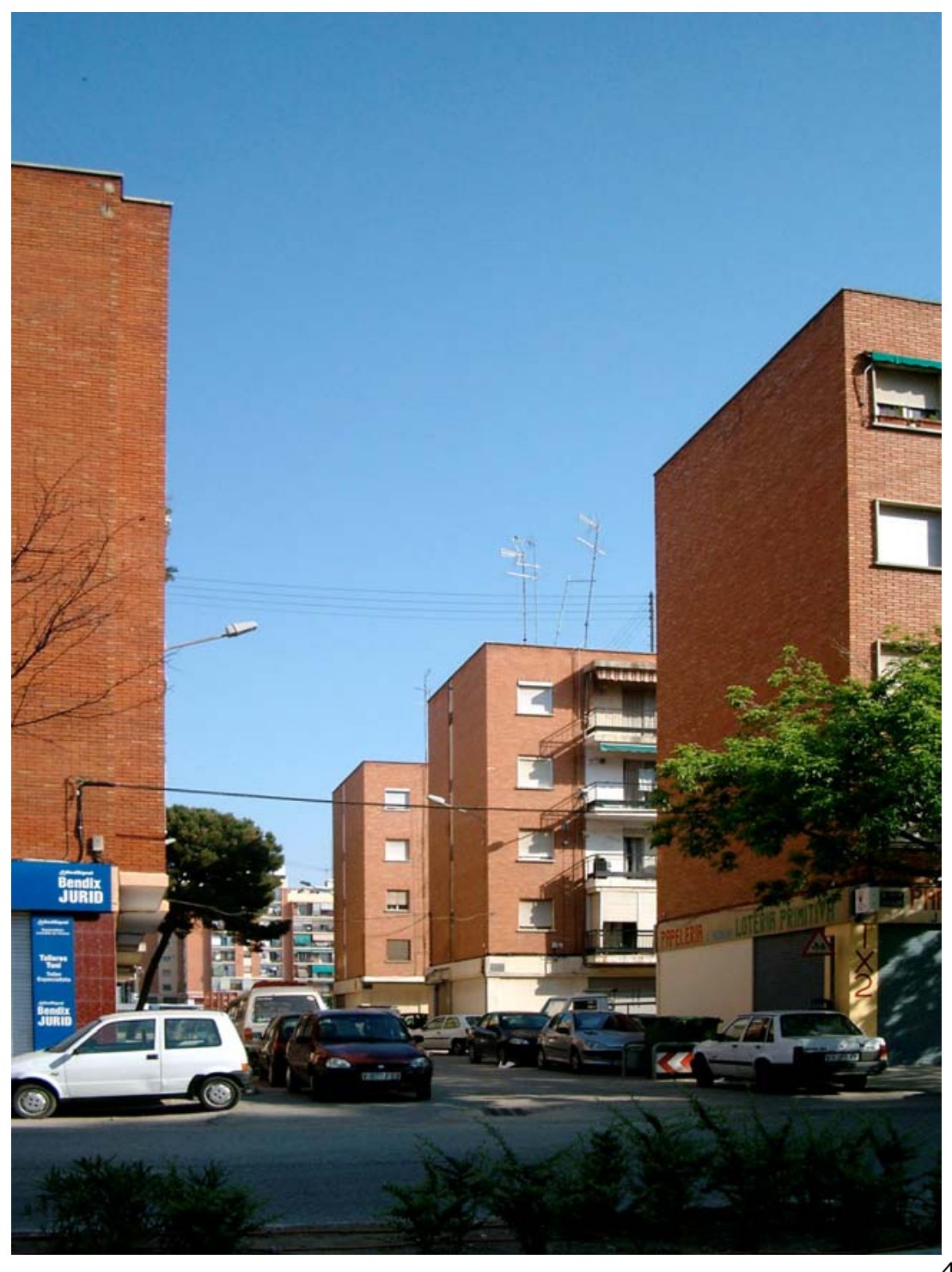


Al norte de Tendetes, entre las calles de Joaquín Ballester, Padre Ferris, Galera y Ricardo Micó, existe un fragmento de edificación abierta que responde también al tipo definido en el proyecto original para el Polígono de Campanar de 1960: series de bloques lineales de dos crujías dispuestos según la dirección este-oste combinados con bloques más largos dispuestos en dirección norte-sur, formando pantallas enfrentadas a los testeros de los anteriores.

En esta zona, a diferencia de lo que ocurre en Tendetes, la planta baja de los bloques se destina a usos no residenciales, y sus límites coinciden con los de la planta tipo.

En el borde norte del plan, el grupo de cuatro manzanas situado entre la Avenida General Avilés y la calle Monestir de Poblet, formado por bloques de cinco crujías situados sobre un extenso zócalo comercial, es más un conjunto de manzanas convencional de ensanche con un perímetro edificado incompleto que un conjunto de edificación abierta.
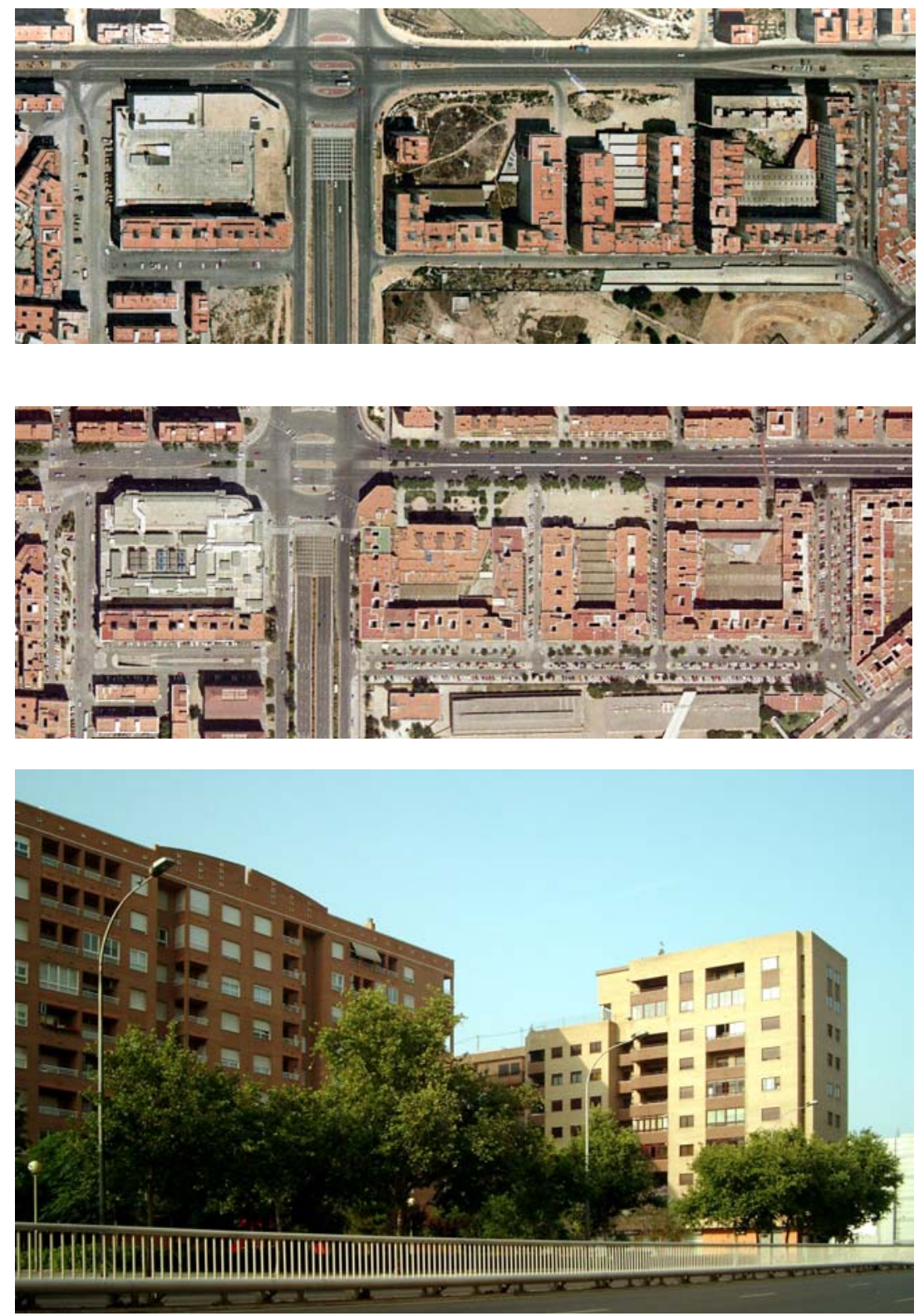

Zona norte del PP8. Fotografía aérea de Valencia, 1980

Zona norte del PP8. Ortofoto 2002, AUMSA.

Bloques en la Avenida General Avilés. 


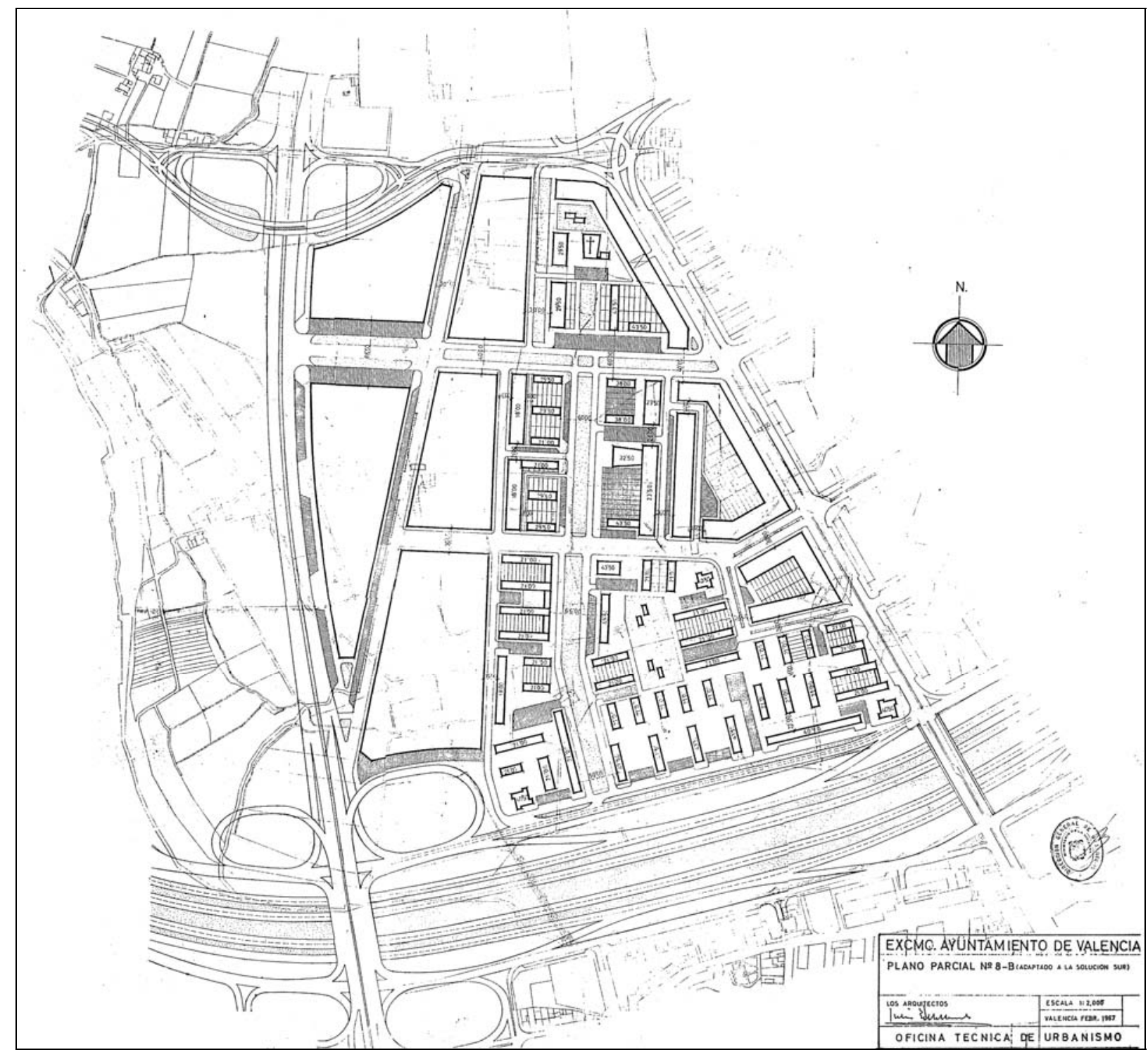

Plano Parcial No 8-B adaptado a la solución Sur, 1967. Plano de alineaciones. 


\section{EL OESTE DE CAMPANAR: PLAN PARCIAL No 8-B.}

El Plano Parcial No 8-B adaptado a la solución Sur (PP12), redactado en 1967, ordena el área limitada al oeste por la Ronda Exterior, al norte por la prolongación hasta la ronda de la Avenida General Avilés, al este por la Avenida Maestro Rodrigo y el Plan Parcial 8, y al sur por la Avenida Manuel de Falla, lateral norte del cauce del río Turia. Su superficie, de 61,97 $\mathrm{Ha}$, es menor que la de la mayor parte de los planes parciales del mismo periodo.

En la sección anterior hemos analizado la anterior versión de este plan, redactada en 1962 y que quedó obsoleta tras la aprobación del Plan General de 1966 y del diseño viario correspondiente.

La nueva redacción del PP8-B está fechada en Agosto de $1967 .{ }^{1}$ El plan no sufrió ninguna modificación relevante durante los dos periodos de exposición al público, antes y después de la aprobación inicial por el Ayuntamiento, de Diciembre de 1967, y su aprobación definitiva por el Ministerio de la Vivienda se produjo con fecha 21-12-1968. ${ }^{2}$

Como puede verse en los fotoplanos y en el plano de estado actual del PP8-B, las únicas edificaciones existentes en la zona que se ordena son las alquerías vinculadas a explotaciones agrícolas de la huerta, alineadas a lo largo de caminos como del de la Alquería Ricos o el camino del cementerio de Campanar. Estos caminos y alquerías no son ni tan siquiera mencionados en la documentación escrita del plan, y su preservación no formaba parte en modo alguno de los objetivos del mismo.

El único elemento previo que condicionaba la ordenación era, por tanto, el trazado viario diseñado por la Oficina Regional de Proyectos de Carreteras para la Red Arterial de Valencia. Este trazado, como ocurre en los restantes planes parciales, no aparece como plano de información previo, sino que se incorpora directamente a los planos de proyecto.

En el plano de Zonificación del PP8-B se pueden diferenciar claramente dos zonas de diferente carácter:

a) Zona industrial: ocupa la totalidad del área situada al oeste, entre la ronda exterior y la actual calle Hernández Lázaro.

b) Zona residencial: ocupa el área triangular restante, entre la zona industrial y la actual Avenida Maestro Rodrigo.

La principal diferencia entre la versión del plan de 1962 y esta de 1967 es el mayor tamaño de la zona residencial, en detrimento de la superficie destinada a usos industriales.

Dentro de la zona destinada a uso residencial, la mayor parte del suelo está calificado como Edificación Abierta. Únicamente en tres manzanas recayentes a la Avenida Maestro Rodrigo, la calificación del suelo es de Extensión Exterior a Tránsitos, aunque pueden considerarse también como edificación abierta si atendemos a su definición de volúmenes.

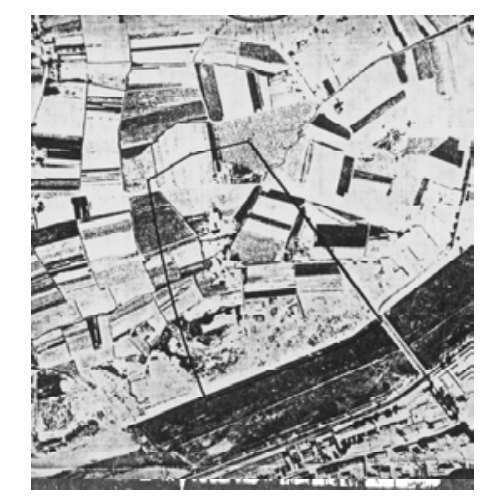

PP 8-B. Fotoplano

1.Plan Parcial 8-b adaptado a la Solución Sur, Ayuntamiento de Valencia, 1967. Ver Anexo de Documentos, pp. 505-515.

2. Resolución de aprobación del Plan Parcial 8-B. Dirección General de Urbanismo. Ministerio de la Vivienda. 11-01-1969. Documento no 8B-1. Anexo de Documentos, p. 515 . 


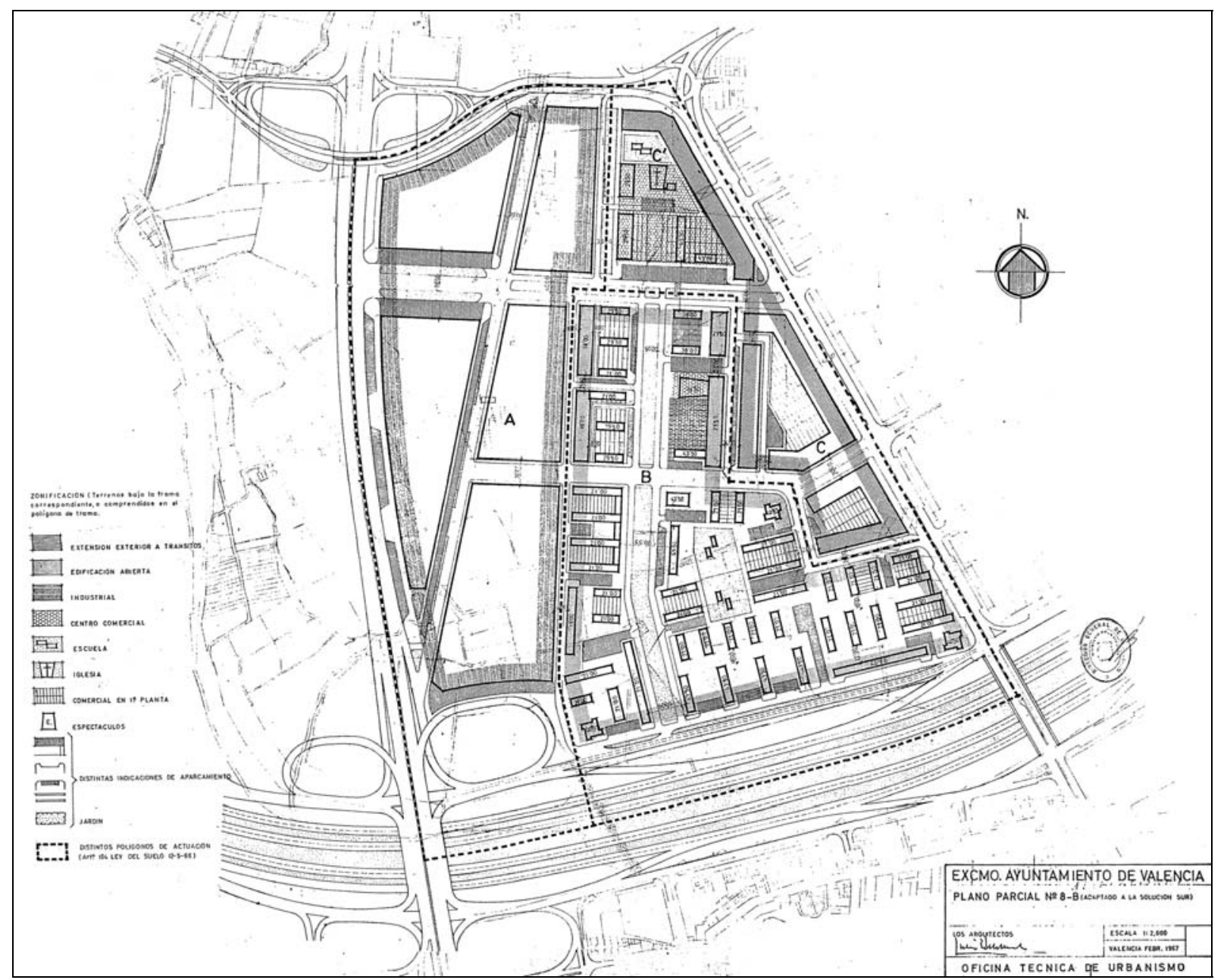

PP 8-B. Plano de zonificación.

El PP 8-B prevé también un Centro Comercial, situado en el emplazamiento señalado por el Plan General, y terrenos destinados a escuelas, jardines y un centro religioso, que analizaremos con más detalle en el apartado dedicado a equipamientos.

\section{Trazado viario.}

La Memoria del PP8-B, igual que ocurría en el PP12, señala que en la zona residencial del Plan se adopta el esquema de supermanzana, integrada por bloques abiertos o por manzanas semiabiertas.

En la zona del plan destinada a edificación residencial, entre las calles Hernández Lázaro y la Avenida Maestro Rodrigo, el viario principal interno del Plan tiene un esquema en $\mathrm{T}$, con un eje nortesur que arranca de la Avenida Manuel de Falla y termina en un eje transversal este-oeste.

El eje norte-sur (que sigue la directriz actual de la Avenida de los Tamarindos) está proyectado como un bulevar, lo que resulta bastante atípico en el urbanismo de la edificación abierta. El ancho del bulevar es variable, de 50, 66 y 60 m., según tramos. El eje este-oeste que completa el esquema en $\mathrm{T}$ tiene una anchura que oscila entre 40 y 60 m., y también está proyectado como un bulevar. El viario principal interno se completa con otro eje dispuesto también en dirección este-oeste, que corresponde a la actual calle 
Vall de la Ballestera, que tiene continuidad a lo largo del PP8 contiguo. El resto de calles son travesías del viario principal o bien ramales sin salida destinados a aparcamiento.

En cuanto a la idea de supermanzana, en realidad, solamente aparece en la zona comprendida entre la calle Vall de la Ballestera y la Avenida Manuel de Falla. En esta zona, al oeste del bulevar nortesur aparece una manzana de unos $350 \mathrm{~m}$. de longitud por 100-120 $\mathrm{m}$. de anchura. Al este del bulevar, una manzana de contorno poligonal ocupa todo el frente del río Turia entre el bulevar y la Avenida Maestro Rodrigo (unos 400 m.) y 300 m. del lado este del bulevar.

La reserva de aparcamientos prevista en el plan es de 1 plaza (20 m2) cada 5 viviendas, que es lo que se considera apropiado, "considerando que el barrio es de condición modesta". ${ }^{1}$

Los aparcamientos se sitúan en los ramales sin salida y en las bandas de aparcamiento junto a las calles. No existe un criterio uniforme de dimensionado de los espacios para aparcamientos, sino que podemos encontrarlos de formas y anchos muy diversos: franjas de aparcamiento de 2, 5 y $10 \mathrm{~m}$. junto a las calles, y ramales sin salida de anchos 15 y 25 m., con longitudes variables.
1. Plan Parcial 8b, 1967 Memoria. Anexo de Documentos, p. 507

PP 8-B. Plano de red viaria fundamental

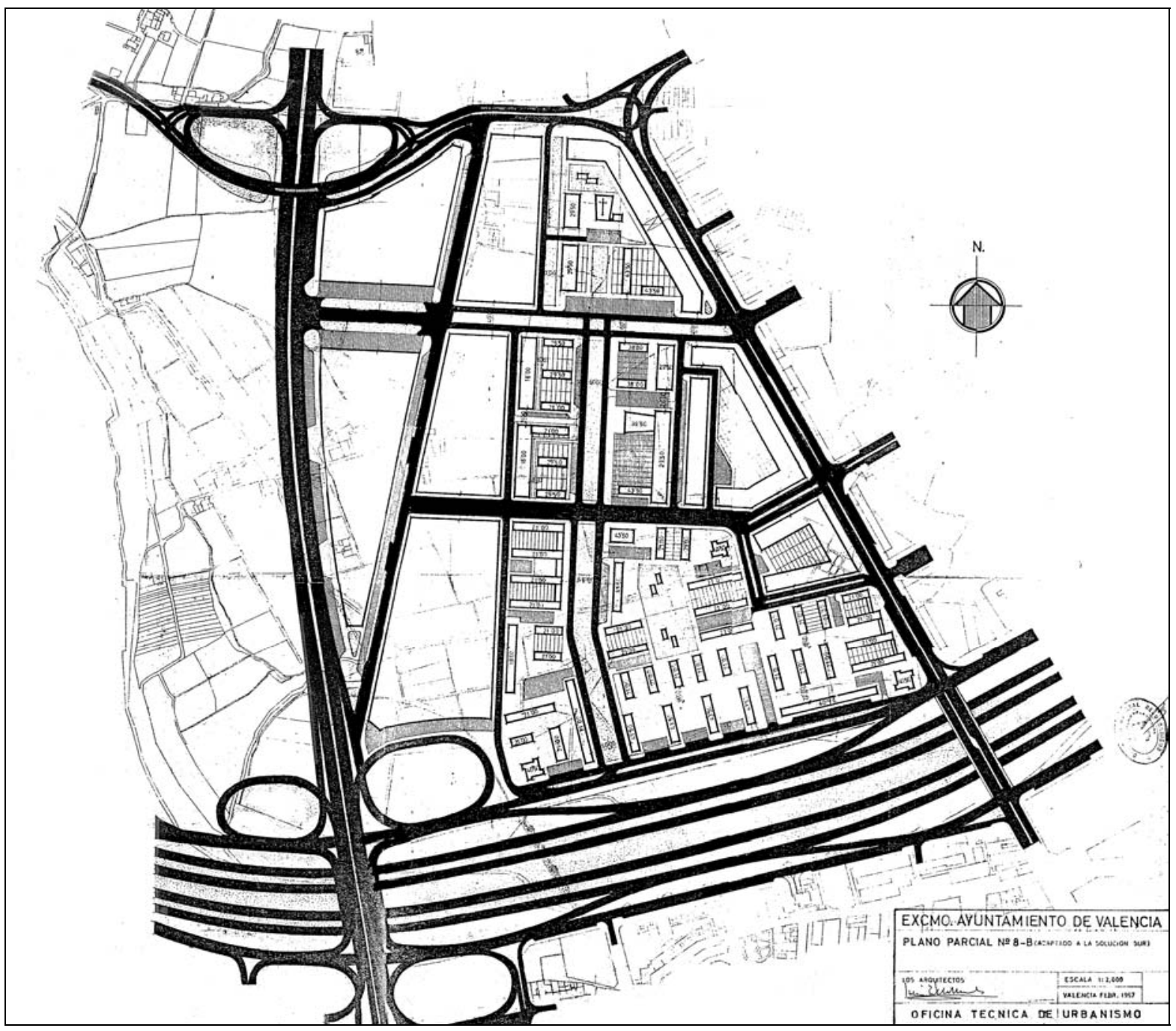




\section{Equipamientos}

Los equipamientos previstos en el PP 8-b son un centro comercial, una iglesia y dos parcelas escolares. En cuanto a espacios libres, el espacio central de los dos ejes viarios internos con sección en forma de bulevar, de ancho $20 \mathrm{~m}$., es en la práctica la única zona verde de cierta entidad que existe el plan, aparte de los espacios libres intermedios entre bloques lineales. ${ }^{1}$ La propia Memoria del PP8-B señala que la superficie reservada para escuelas es insuficiente, pero zanja la cuestión en los términos siguientes:

La población escolar, incluido maternales, es del $15 \%$ de la población, o sea 3.129 alumnos, lo que a razón de $6 \mathrm{~m} 2$ por puesto escolar necesitarían una superficie de $19.317 \mathrm{~m} 2$. La superficie destinada en el presente proyecto es de $8.600 \mathrm{~m} 2$, cifra al parecer insuficiente a pesar de haber ubicado los centros de enseñanza que creemos necesarios en la parte Norte y Sur del polígono. Pero dada la circunstancia de no existir en el mismo ningún centro de enseñanza media, y sí en los próximos relacionados, con el objeto de este proyecto creemos que es suficiente. Ya que si fuera preciso en el futuro podría aprovecharse el excedente de espacios libres para construir algún grupo escolar más. ${ }^{2}$

Para una necesidad estimada de más del doble que la proyectada, y dado que los espacios libres contabilizados como zonas verdes son espacios interbloques o medianas de bulevar, resulta evidente que no es posible ubicar en ellos ninguna parcela escolar adicional de tamaño adecuado.

PP 8-B. Equipamientos (Elaboración propia sobre plano de alineaciones del Plan)

1. En la Memoria del PP8-B aparece también la frase que se repite en la mayoría de los Planes Parciales de desarrollo del Plan de 1966, señalando que en relación con los equipamientos se ha utilizado un criterio de prudencia, evitando señalar en plano más elementos que los que se prevé que el Ayuntamiento pueda construir, o cuyo suelo pueda al menos adquirir, a fin de evitar el recobro del libre ejercicio de las facultades dominicales, establecido en el art. 56 de la Ley del Suelo.

2. Plan Parcial 8-B, 1967. Memoria. Ver Anexo de Documentos, $p$ 507.

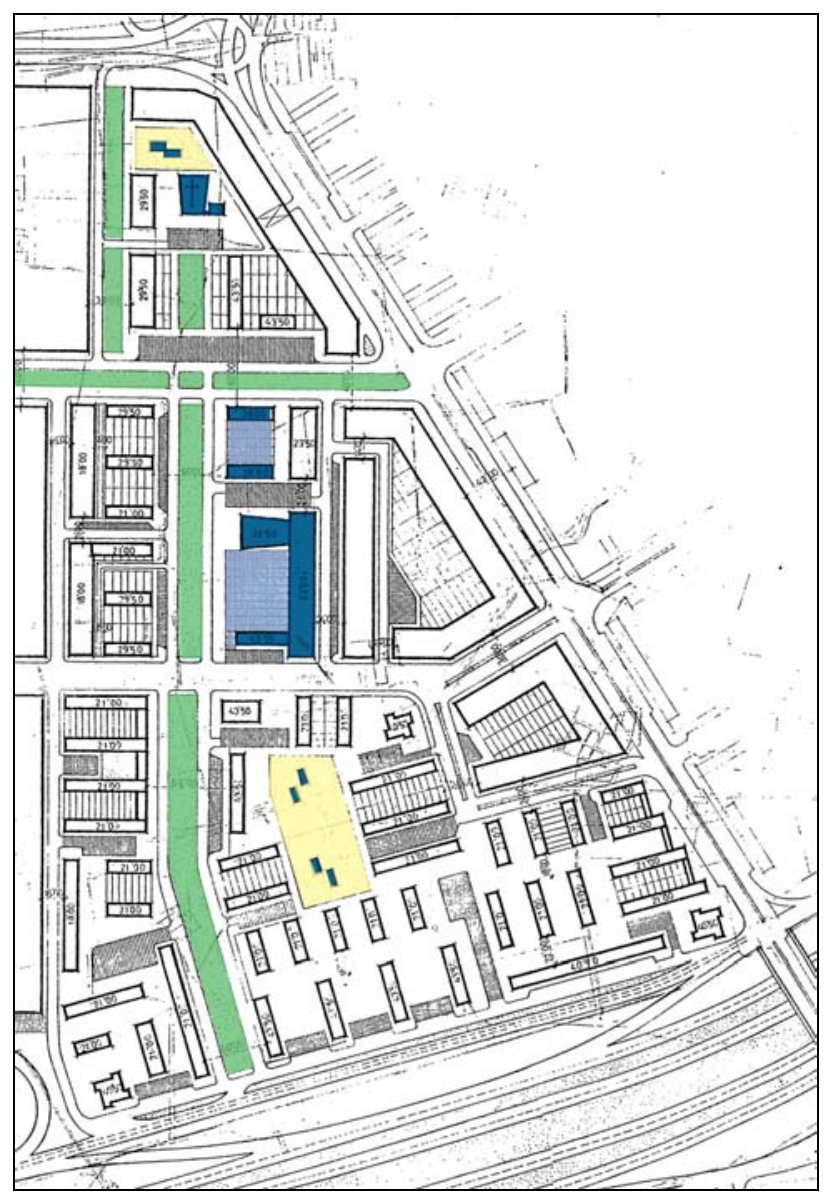




\section{Edificación}

Los tipos de edificios que podemos encontrar en el PP 8-B son los siguientes:

- Bloques lineales de dos crujías de profundidad y longitudes entre 30 y $60 \mathrm{~m}$, dispuestos en línea a intervalos regulares, con una separación igual a la altura de los mismos. Los bloques más altos (de alturas 40,50 y $43,50 \mathrm{~m}$.) son los recayentes al río, tras los cuales se sitúa otra serie de altura $21 \mathrm{~m}$. (8 plantas).

- Bloques profundos, bien lineales o formando manzanas abiertas. Estos bloques están incluidos en la zonificación de Edificación Exterior a Tránsitos.

- Micromanzanas formadas por grupos de dos o tres bloques lineales sobre un zócalo comercial de una planta. El ancho del grupo de dos bloques unidos por locales es de $40 \mathrm{~m}$., con longitudes que oscilan entre 40 y $70 \mathrm{~m}$. La mayor parte de estos bloques son de 8 plantas ( $21 \mathrm{~m}$. de altura), salvo los que aparecen en el lateral oeste del eje principal central, que ala estar más separados, pasan a elevarse a 29,50 m.

- Torres, situadas en los extremos este y oeste del frente al río y junto al centro comercial.
PP 8-B. Edificación en planta tipo y en planta baja. (Elaboración propia sobre plano de alineaciones del Plan)

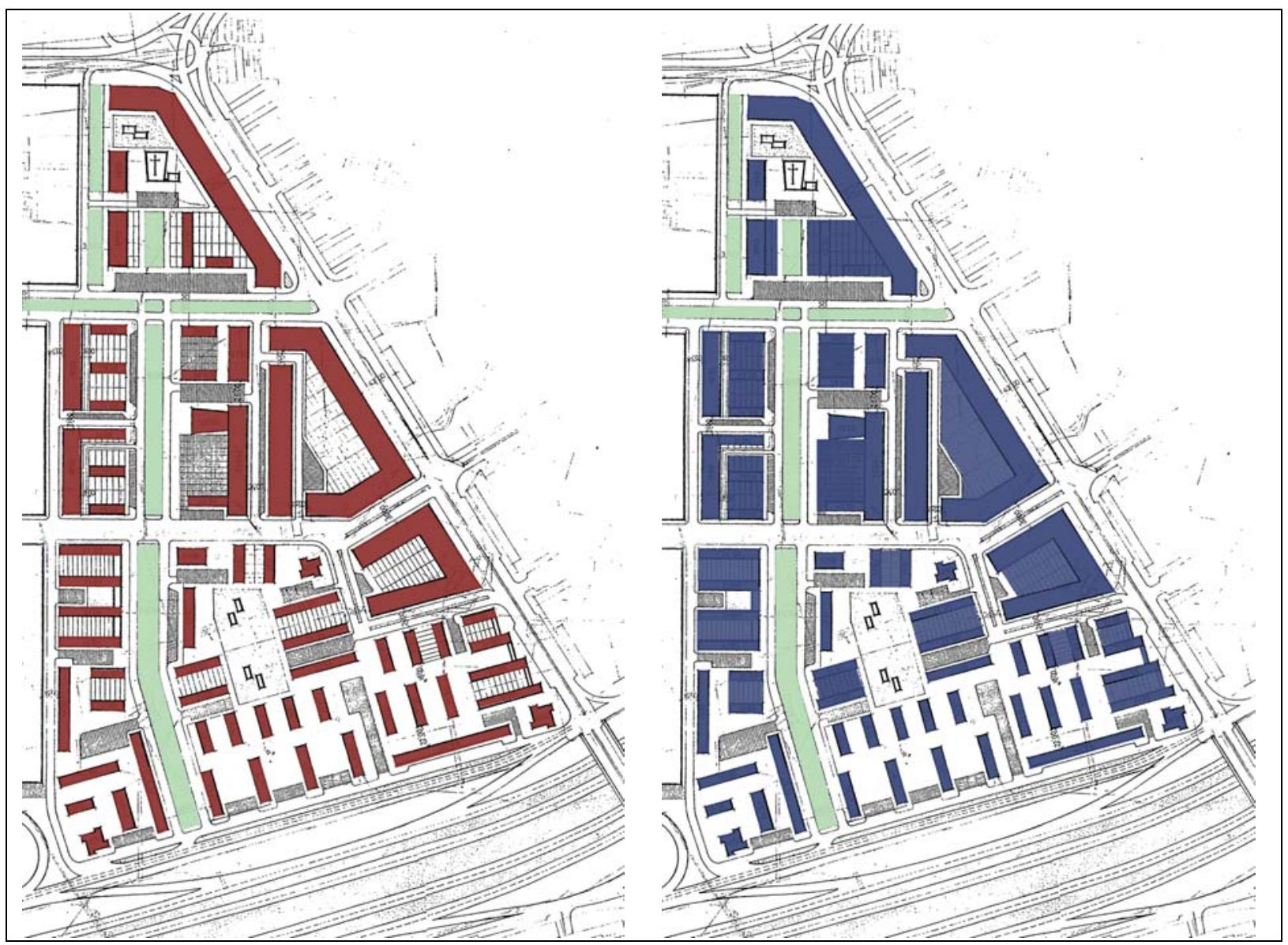




\section{Grado de realización}

Los edificios construidos del PP8-B son, sobre todo, los bloques lineales recayentes a la Avenida Manuel de Falla: cuatro bloques altos y parte de otro dispuestos en perpendicular a la Avenida y otro bloque largo paralelo a la misma, junto con dos bloques más situados en segunda fila. También se construye de acuerdo con el plan una de las manzanas que flanquean el eje central por el oeste, compuesta por dos bloques enlazados por bajos comerciales y otro bloque en $L$ que la envuelve. Finalmente, algunos fragmentos de bloques profundos recayentes a las calles Hernández Lázaro, Vall de la Ballestera y Maestro Rodrigo responden igualmente a la planta prevista en el Plan Parcial.

El grado de realización del PP 8-B es, por tanto, muy pequeño. La mayor parte de los edificios mencionados aparecen ya realizados en la fotografía aérea de 1980.

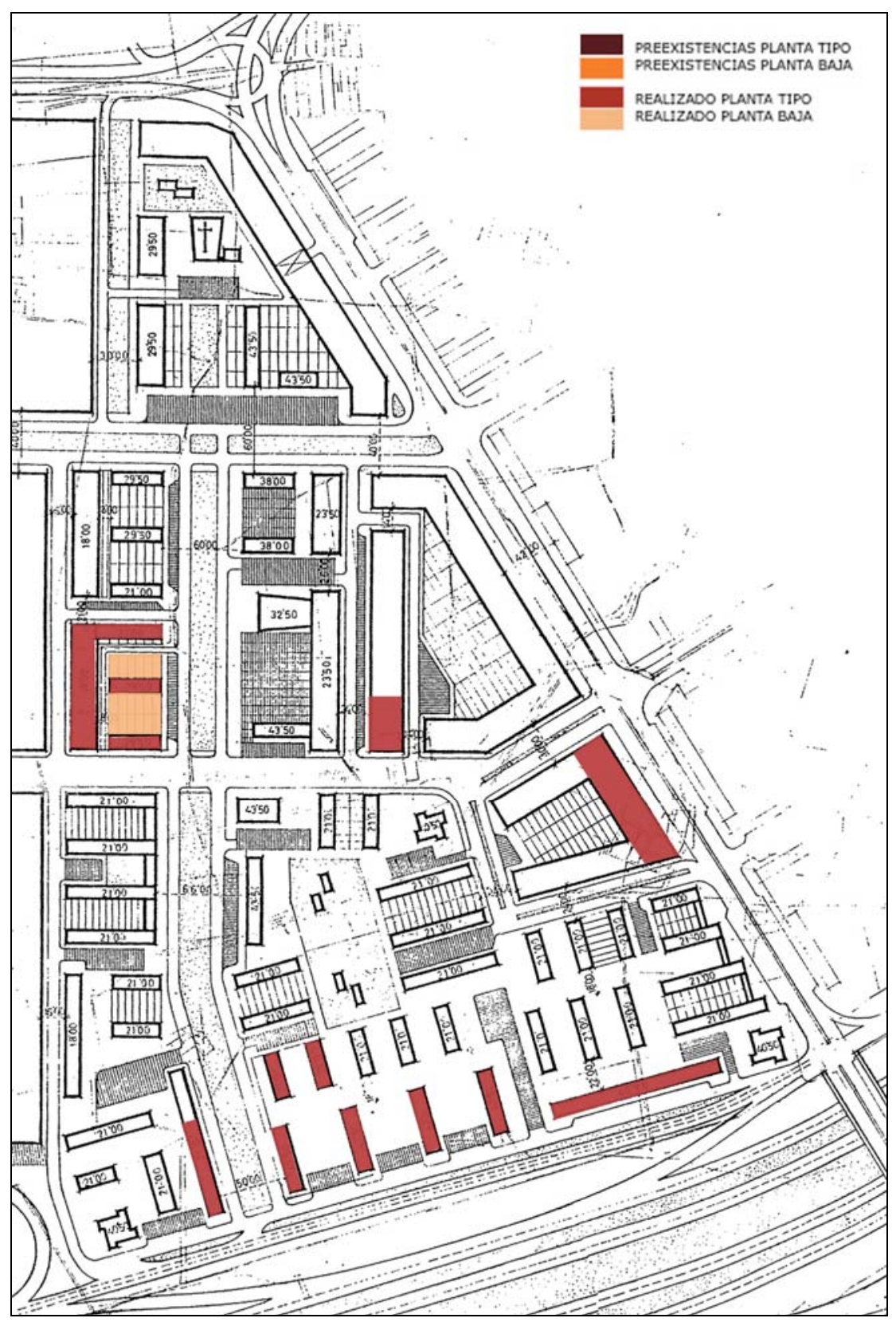


La torre prevista en la esquina sureste fue construida con una planta diferente a la indicada en el PP 8-B, como resultado de una modificación de alineaciones del mismo. La manzana adyacente, entre las calles de Góngora y Marqués de San Juan fue remodelada completamente mediante un Estudio de Detalle recogido posteriormente en el Plan General de 1988, que transformó los bloques lineales en agrupaciones en racimo de edificios escalonados.

El Plan General anuló la ordenación de edificación abierta prevista en el PP 8-B sin sustituirla por otra diferente; la zona fue calificada como Suelo Urbanizable Programado (SUP), y únicamente se fijaron las localizaciones previstas para equipamientos.

La ordenación posterior de la zona mediante un Programa de Actuación Urbanística, cuyo estudio excede los límites del presente trabajo, aunque basada también en la edificación abierta, se realizó con criterios y tipos completamente diferentes a los previstos en el PP 8-B, como puede comprobarse examinando la Ortofoto de 2002 de la zona

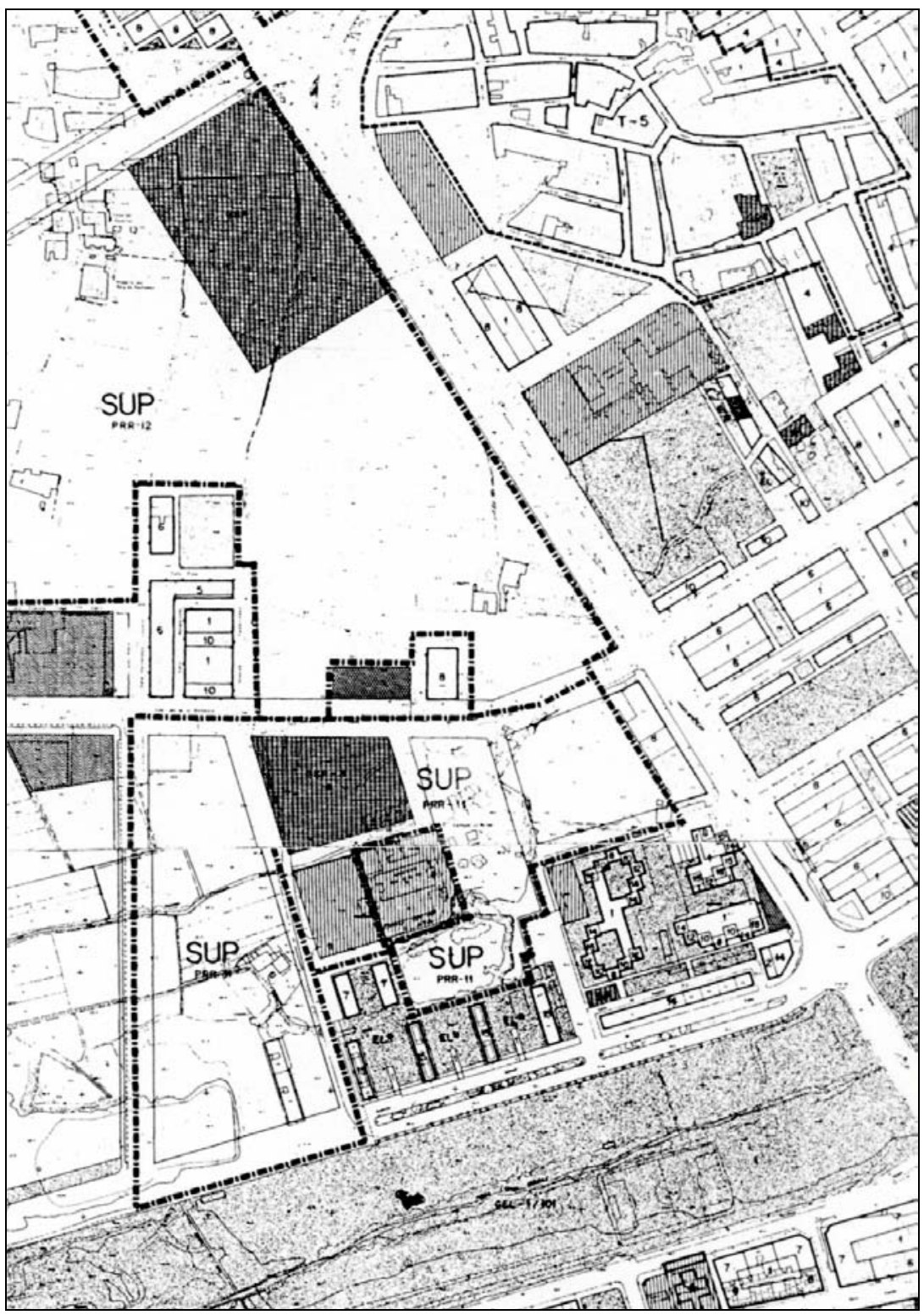

PGOU 1986. Detalle de la zona de correspondiente al PP 8-B. 


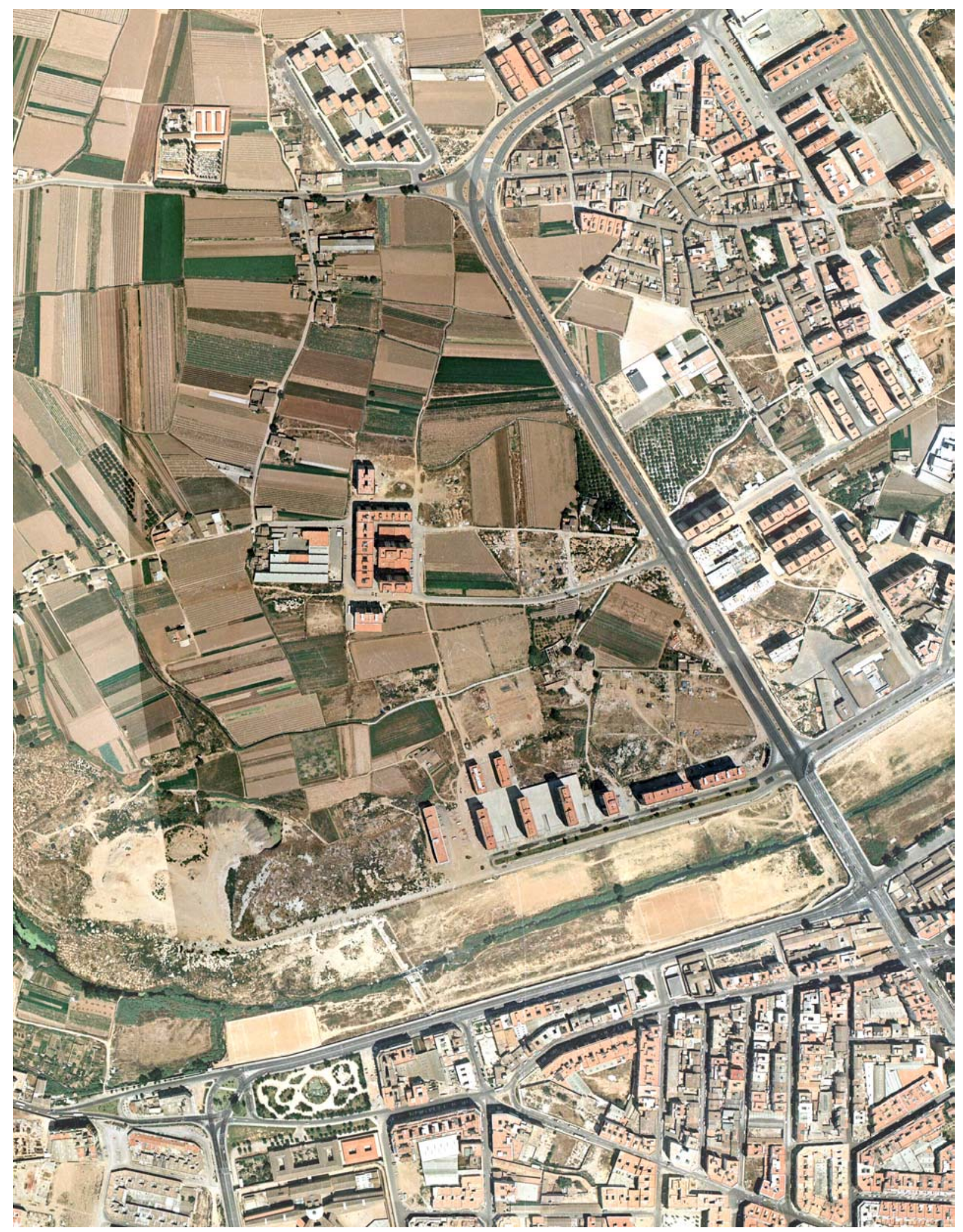

Zona del Plan Parcial 8-B.

Fotografía aérea, 1980 


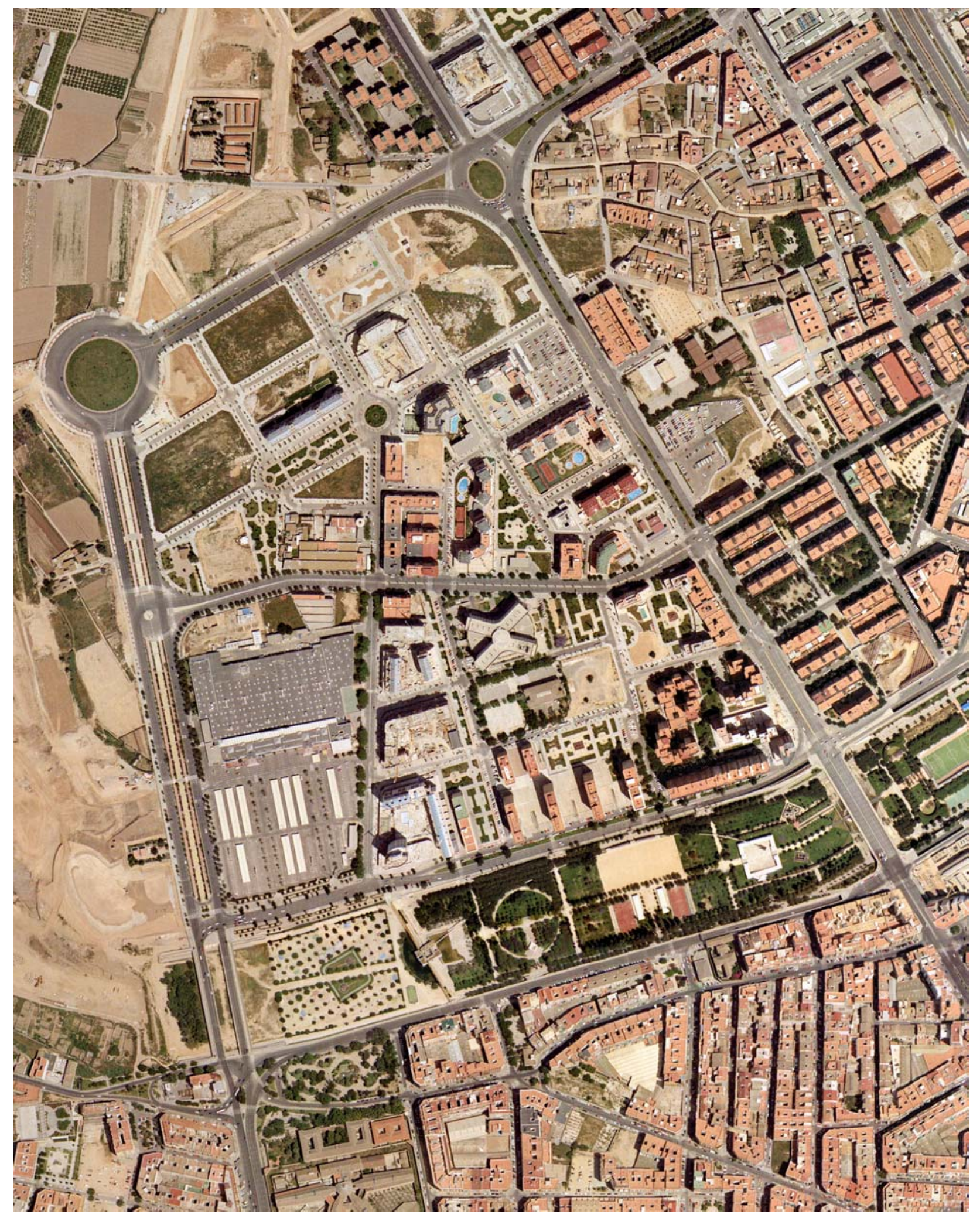

Zona del PP 8-B. Ortofoto 2002 (AUMSA) 

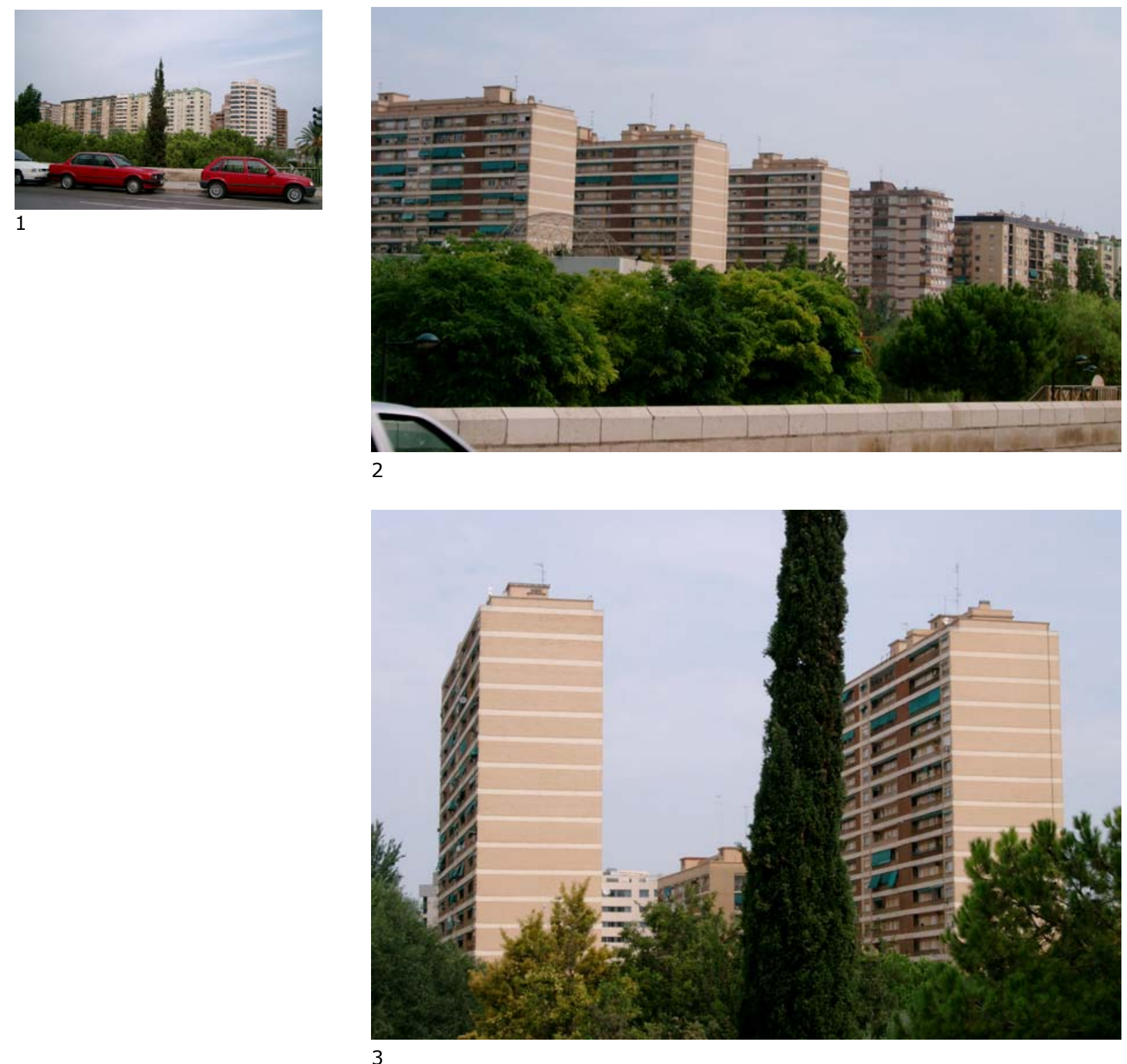

1-3. Bloques altos en la Avenida Manuel de Falla. Vistas desde el al cauce del Turia.

5. Bloques altos. Vista desde la plaza profesor López Ibor.

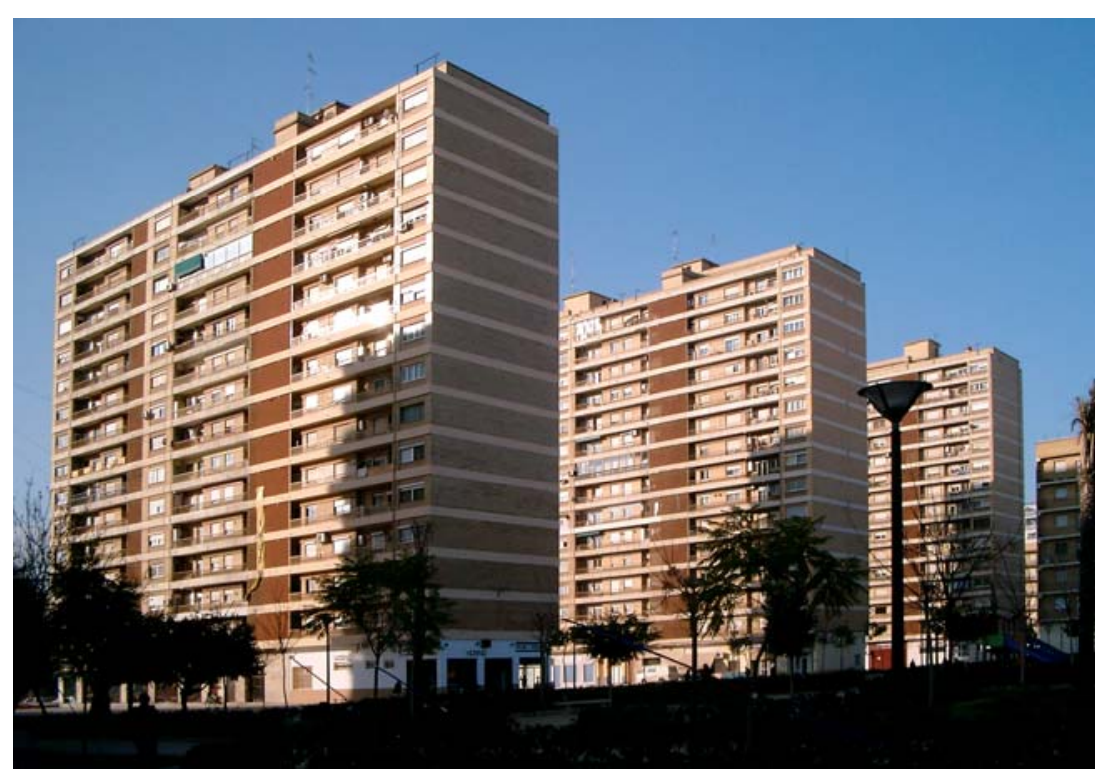


El único conjunto de cierta entidad urbana construido según lo previsto en el Plan Parcial 8-B es el grupo de bloques altos situados frente al río.

De los bloques altos de XV plantas dispuestos ortogonalmente al cauce del río Turia, tres de ellos son consecuencia de un proyecto arquitectónico unitario, y sus altos testeros ciegos tienen una gran presencia urbana incluso desde la marginal derecha.

Esta presencia se acentúa en la parte de atrás, en la plaza López Ibor, donde el importante volumen de los bloques tiene más peso al emerger ante un espacio que, aunque amplio, es menor que el del cauce. En este espacio se halla construida en parte la segunda fila de bloques prevista en el plan, que es de menor altura (VII plantas).

Los bloques altos que ocupan la mitad este del frente recayente al cauce del Turia no están dispuestos en perpendicular a dicho cauce, sino que forman una pantalla de edificación alta alineada con la Avenida Manuel de Falla. Su gran longitud, para los estándares de promoción inmobiliaria de la época, hace que la pantalla esté compuesta por la agregación de varios fragmentos de bloque entre medianeras.

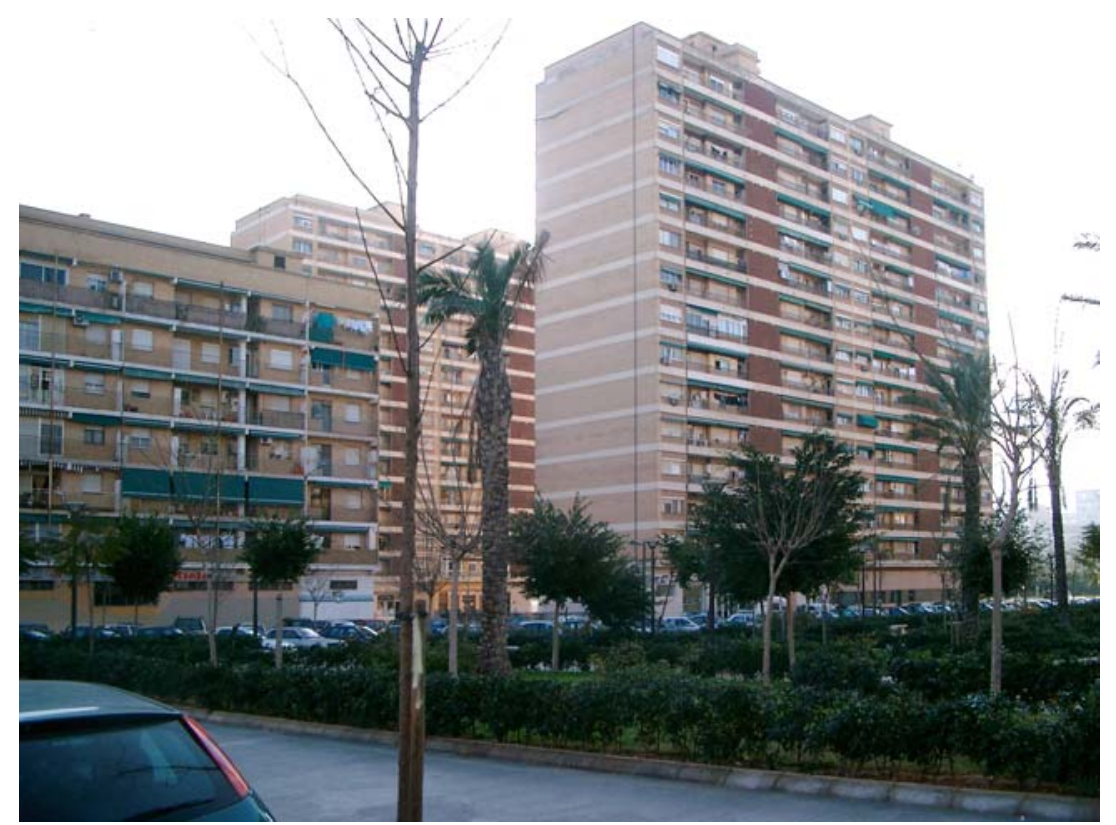

1
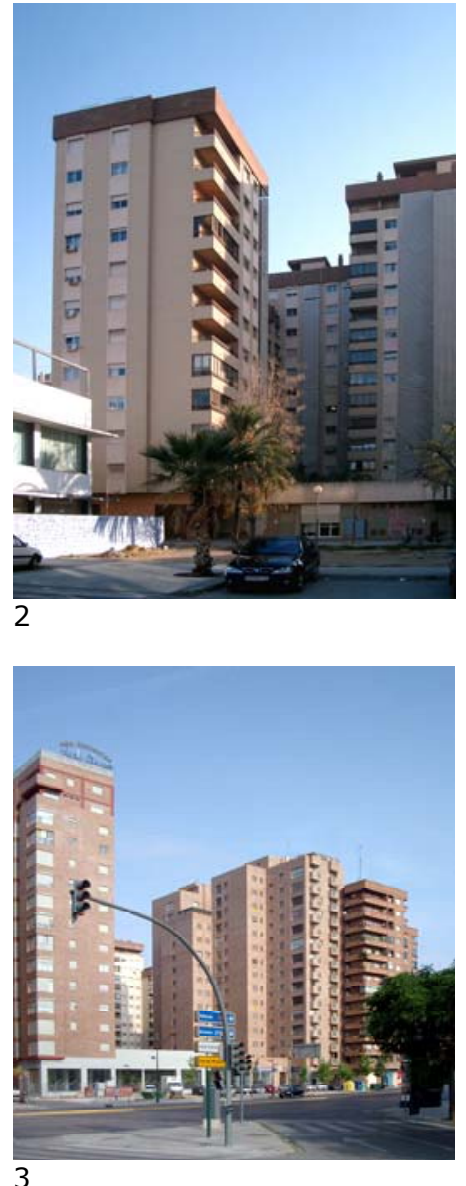

3

1. Bloques altos. Vista desde la plaza profesor López Ibor.

2,3. Edificación abierta escalonada posterior al PP8b. Vistas desde la plaza López Ibor y desde la Avenida Maestro Rodrigo. 


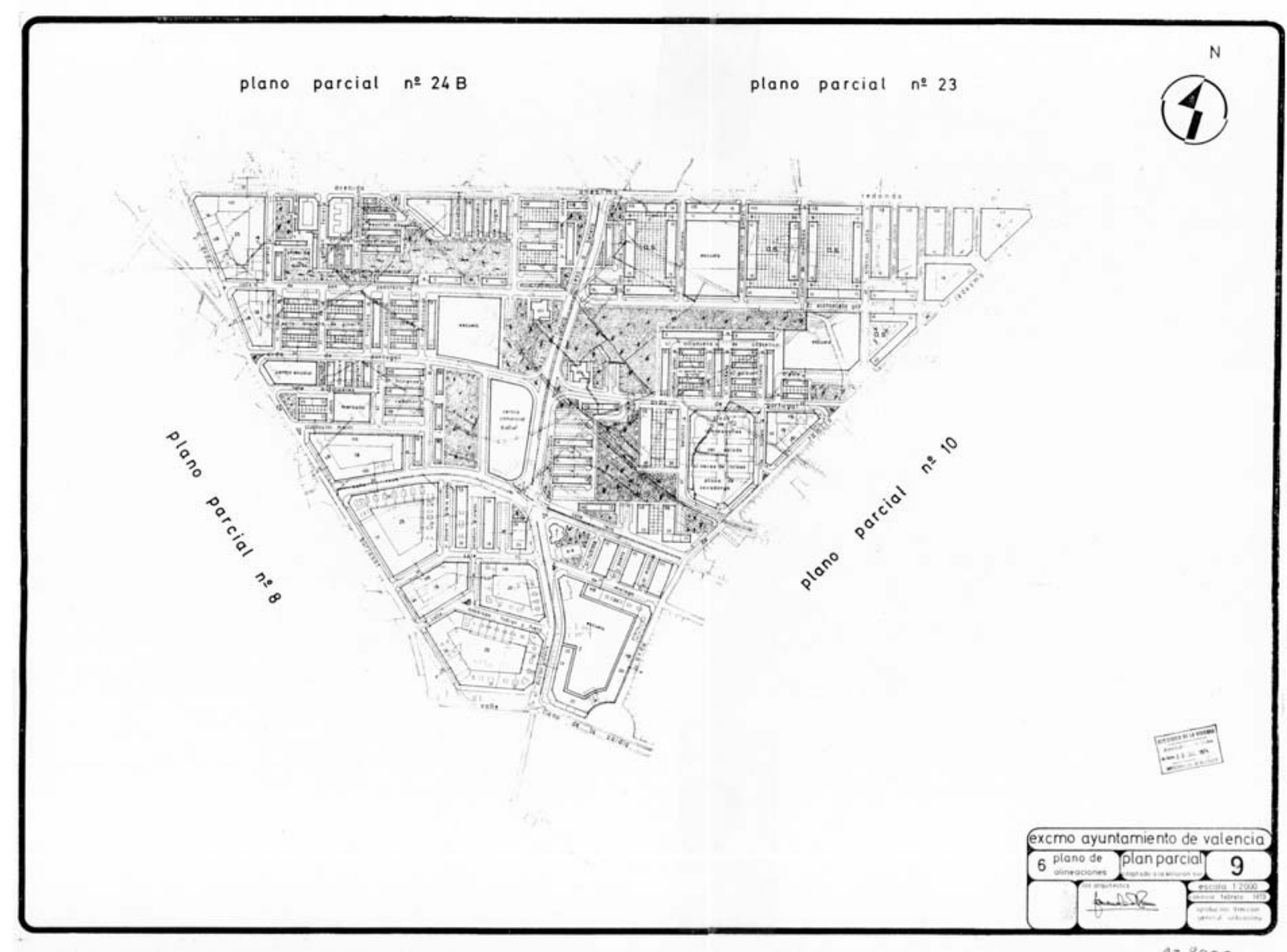

Plan Parcial no 9 adaptado a la Solución Sur, 1973. Plano de Alineaciones. 
El Plan Parcial No 9 comprende los terrenos limitados al Sur por el cauce del Río Turia, al Oeste por la Avenida de Burjasot, al Norte por el Camino de Tránsitos o Ronda Interior (actual Avenida Dr. Peset Aleixandre) y al Este por el antiguo acceso de Barcelona (actual Avenida de la Constitución). Su superficie total es de 66,49 $\mathrm{Ha}$, de las cuales corresponden a zona de edificación abierta 51,74 Ha.

La memoria de la versión definitiva del PP-9 ${ }^{1}$, redactada en 1973, señala que el Plan se realiza sobre la base de la estructura urbanística prevista en el antiguo Plan Parcial 9, Polígono V, aprobado por la Dirección General de Urbanismo en 1961 y que hemos analizado en la sección anterior.

Esta versión original del plan fue modificada ligeramente en una nueva versión redactada en 1967, tras la aprobación en 1966 del PGOU de Valencia y su Comarca adaptado a la Solución Sur. La versión de 1967 es la que figura en el informe PREVASA, donde el Plan Parcial 9 aparece como aprobado con fecha 6-III-68 en el listado de datos urbanísticos vigentes.

Muchas de las alegaciones desestimadas en el periodo de información pública de la versión de 1973 del PP9 pretendían, precisamente, que se mantuvieran las determinaciones fijadas en la versión anterior del plan.

La principal modificación que introduce la revisión realizada en 1973 del PP-9 con respecto a la versión de 1967 es el importante aumento de reservas de suelo para zonas verdes y escuelas, con la consiguiente supresión de los bloques previstos en las parcelas asignadas a las nuevas dotaciones.

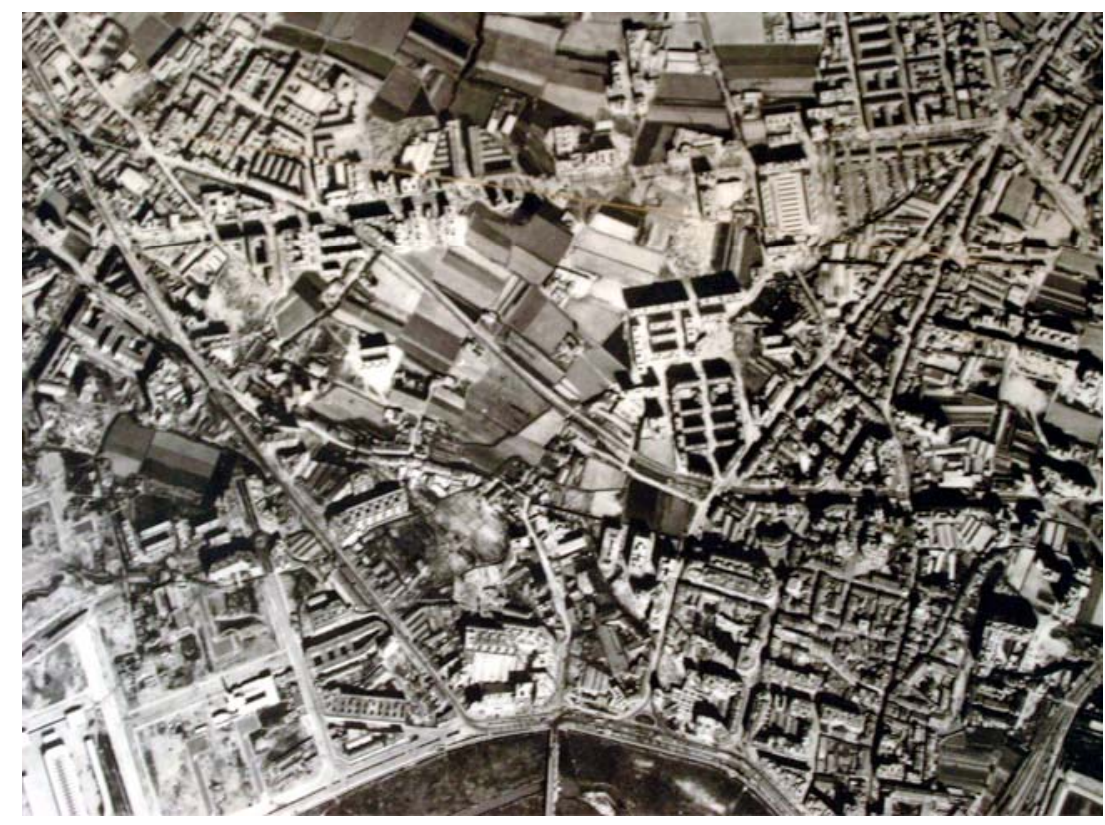

Zona del Plan Parcial 9. Fotografía aérea, h. 1965 (ETS de Arquitectura de Valencia).

1. Plan parcial No9, 1973. Memoria. Ver Anexo de Documentos, pp. 548-554. 
Plan Parcial 9, 1961 (Elaboración propia. Color sobre plano de Planeamiento)

Plan Parcial 9, 1967. Edificación diferente a la proyectada en la versión de 1961 (Elaboración propia. Color sobre plano de alineaciones).

Plan Parcial 9, 1973. Edificación diferente a la proyectada en las versiones anteriores del plan (Elaboración propia. Color sobre plano de alineaciones).
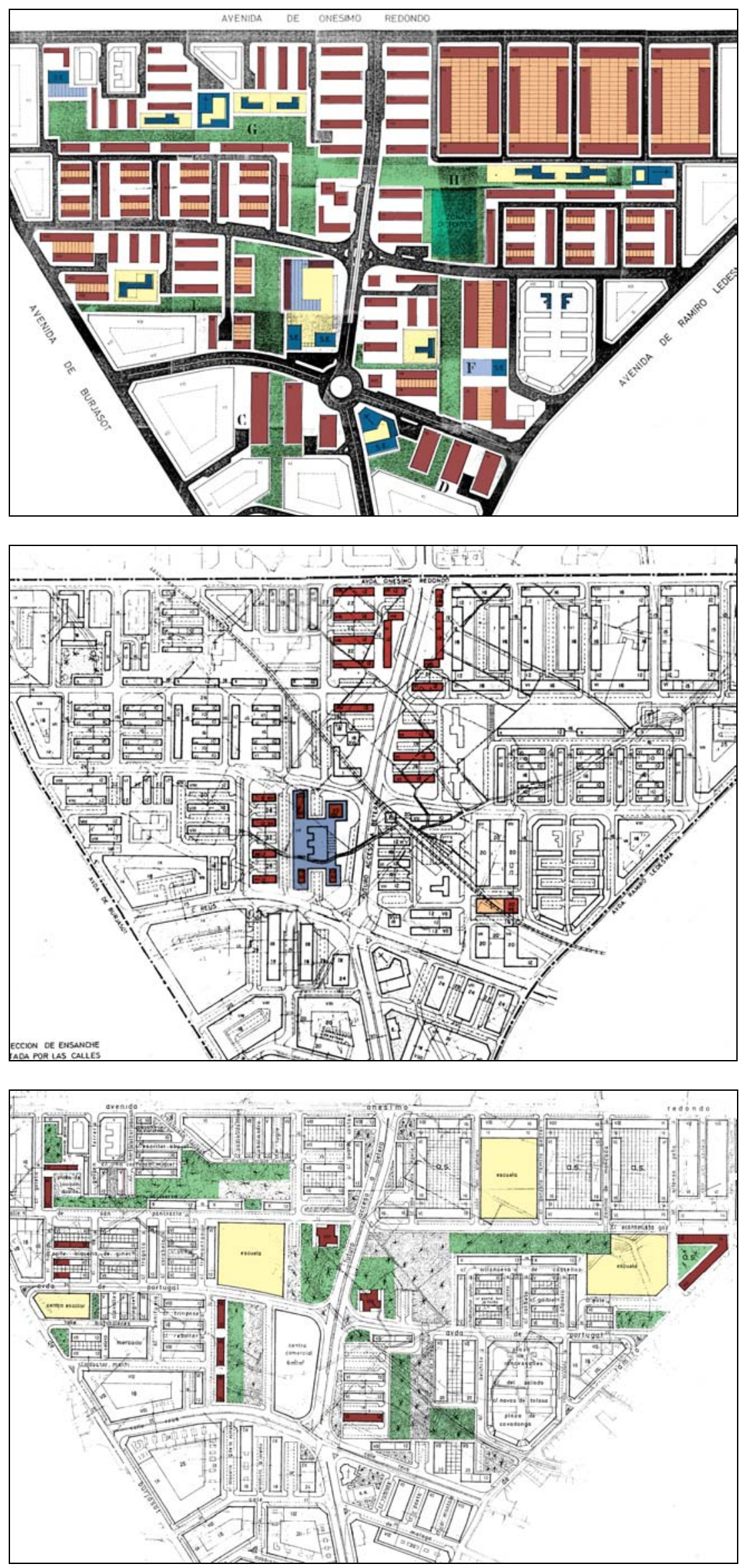
La lectura comparada de las versiones del PP-9 de 1961 y 1973 permite observar que la primera es la que plantea la ordenación global de la zona, y la segunda un ajuste por simple vaciado y eliminación de edificios para dejar espacio para los equipamientos y zonas verdes previstos en el Plan General y exigidos por el Ministerio de la Vivienda.

En el plano de información de la versión de 1973 del PP-9 se observa que en la zona ordenada por el Plan existen numerosas edificaciones, realizadas en base al Plan Parcial anterior de 1961. La memoria del plan clasifica estas edificaciones en tres grupos:

- El poblado de Marxalenes, caserío lineal que discurre a lo largo del camino del mismo nombre, desde el ángulo sureste hasta el Camino de Burjasot, y cuya conservación no forma parte de los objetivos del Plan.

- La edificación antigua a lo largo de las vías más importantes, que flanquea de modo casi continuo los viejos accesos de Burjasot y Barcelona y la margen del cauce del río.

- Edificación reciente, que aparece tanto en forma de fragmentos de manzanas de edificación perimetral profunda como en forma de bloques lineales de edificación abierta o fragmentos de los mismos.

El Plan Parcial 9 transcribe las zonificaciones previstas en su ámbito por el Plan General de 1966, en el cual se distinguen dos sectores claramente diferenciados, separados por el eje este-oeste de la calle Reus.
Plan Parcial 9, 1973. Plano de información.

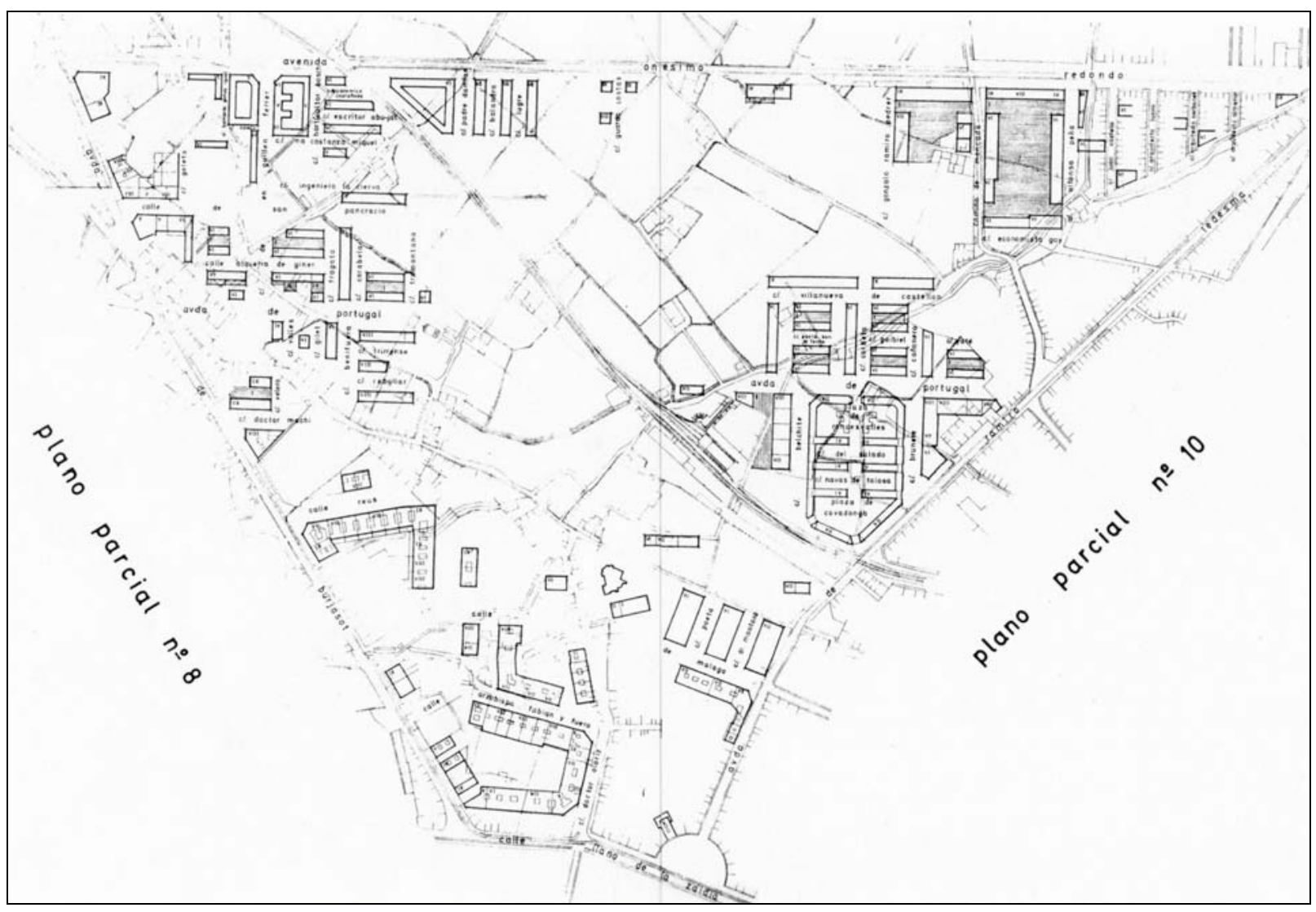


PP-9. Correcciones introducidas en el Plan Parcial 9 por el Ayuntamiento en cumplimiento de la resolución del Ministerio de la Vivienda (Ver Anexo de Documentos, Documento 9.3)

Versión inicial

Versión final

Propuesta alternativa del arquitecto municipal.
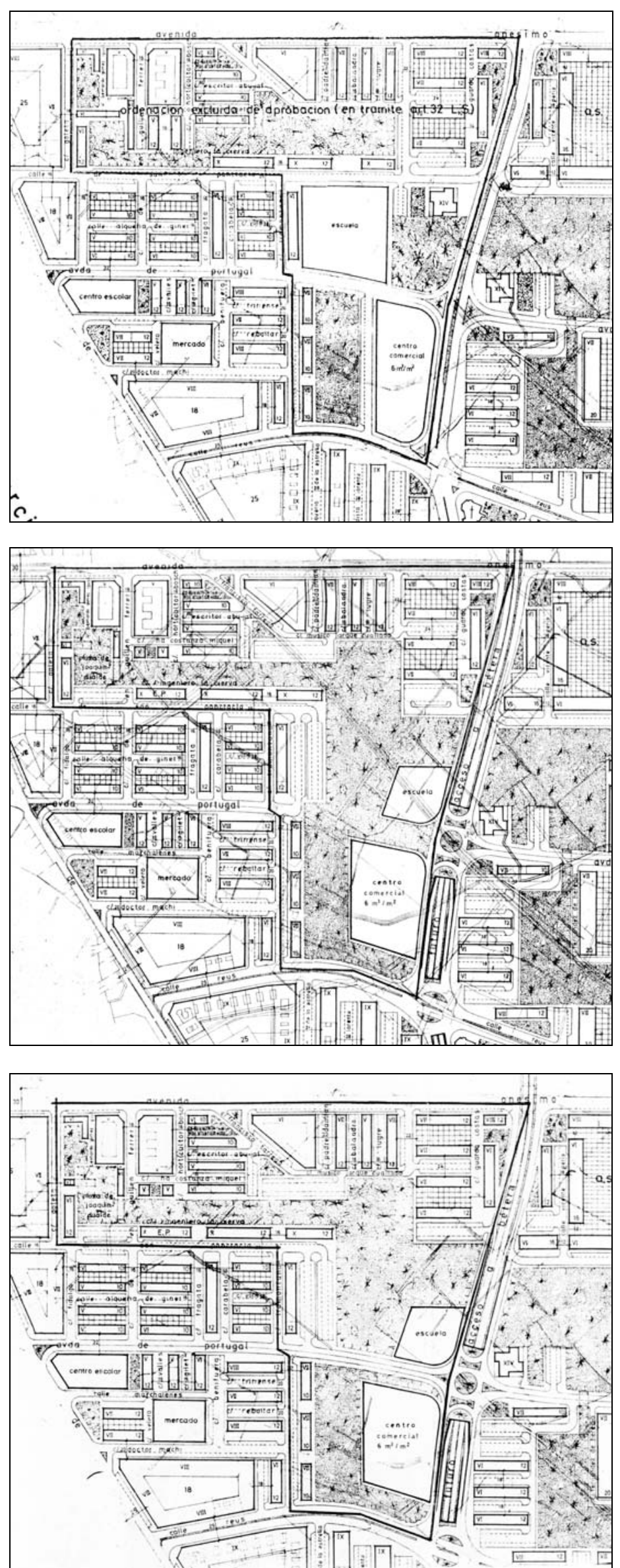
El sector Sur, entre la calle Reus y el Llano de Zaidía, está calificado como Zona Intensiva, Ensanche Hasta Tránsitos.

El sector norte, entre Reus y el camino de Tránsitos, está calificado como Zona de Edificación Abierta Alta, con edificabilidad de $5 \mathrm{~m} 3 / \mathrm{m} 2$. La memoria del PP-9 señala que en este sector de edificación abierta existen algunas manzanas recayentes a las avenidas principales perimetrales que estaban ya realizadas de acuerdo con los modelos de manzana cerrada previstos en la ordenación del antiguo Polígono V.

La versión del PP-9 redactada en 1973 fue aprobada por resolución del Ministerio de la Vivienda con fecha 30-07-1974. Esta resolución obligaba a introducir una serie de rectificaciones, de las cuales la más importante es la referente a la zona de edificación abierta del sector noroeste del Plan,

"cuya aprobación se suspende a fin de que sea objeto de un nuevo estudio de ordenación, en la que se respete la Zona Verde de uso público prevista en el Plan General, que resulta invadida por una parte del Centro Comercial, por la Escuela y por un bloque de catorce plantas, otro de diez y parte de otros de cinco y seis plantas". ${ }^{1}$

El informe del Arquitecto Municipal ${ }^{2}$ sobre el nuevo estudio del PP-9 señala que la continuidad de la zona verde prevista en el Plan General perjudica al normal desarrollo del tráfico rodado en el sector, ya que obliga a la interrumpir no sólo la calle San Pancracio sino también la Avenida de Portugal, que se considera un eje esteoeste importante en la estructura viaria de la zona.

La resolución ministerial exigía también, a efectos de previsión de aparcamientos, la reserva de una plaza por vivienda como mínimo.

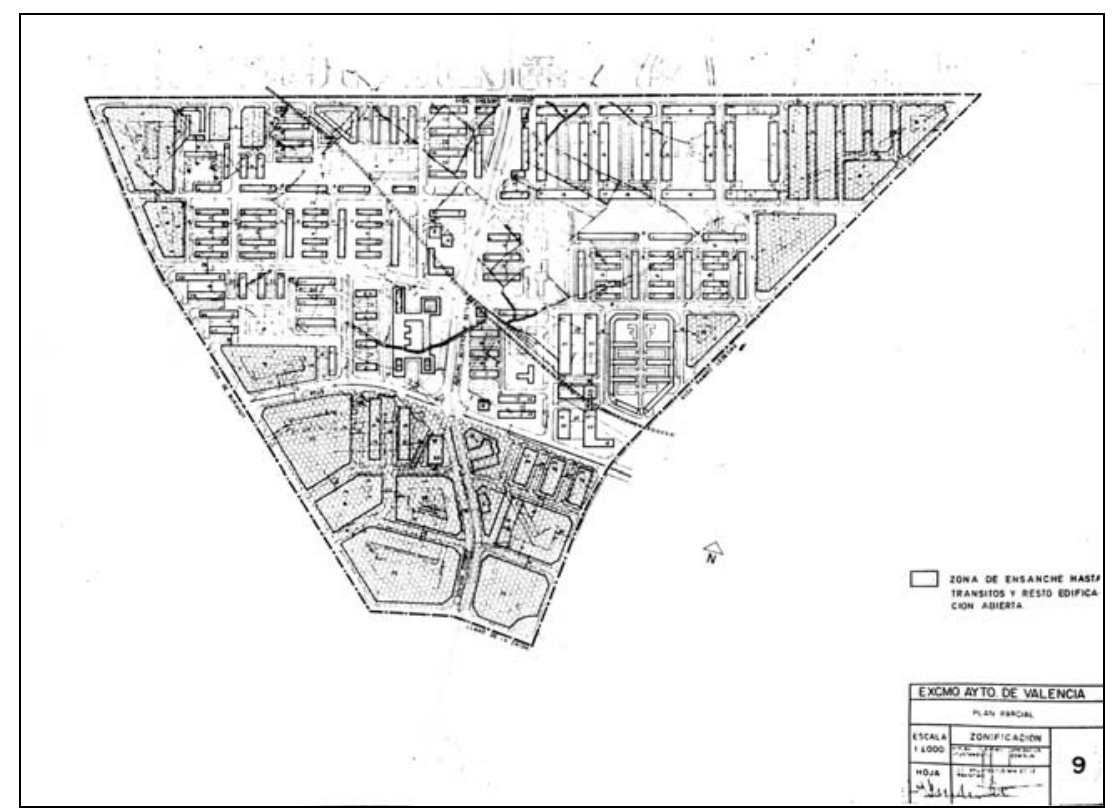

Plan Parcial 9, 1967. Plano de zonificación.

1. Dirección General de Urbanismo del Ministerio de la Vivienda. Resolución de aprobación del Plan parcial 9 con rectificaciones, 3007-1974. Documento 9.1. Anexo de Documentos, p. 569.

2. Informe del Arquitecto Municipal sobre el nuevo estudio del Plan parcial 9, 9-06-1976. Documento 9.3. Anexo de Documentos, p. 573-576. 
Plan Parcial 9, 1973. Viario. (Elaboración propia sobre Plano de red viaria fundamental del plan)

\section{Trazado viario.}

La Memoria del PP-9 clasifica las redes viarias, según su uso y carácter, en los rangos siguientes:

a) Red roja: Es el conjunto de vías establecidas por la Dirección General de Carreteras del Ministerio de Obras Públicas en su Estudio Previo de la Red Arterial. Los viales de esta red son el Camino de Tránsitos, el Llano de la Zaidía, y, en sentido norte-sur, el Nuevo Acceso a Bétera (calle Dr. Olóriz).

b) Red azul: Es el conjunto de vías urbanas cuya función es el enlace de barrios contiguos, y en las que predomina la capacidad de circulación. Los viales de esta red son la calle Reus, eje bidireccional este-oeste, prevista ya en el antiguo proyecto, que separa las dos zonas del plan y conecta toda una cadena de barrios comprendidos entre el camino de Tránsitos y el cauce del Río Turia; también corresponde a este grupo la Avenida de la Constitución (antigua Av. Ramiro Ledesma), eje norte-sur que continúa en el vecino PP-10.

c) Redes Verde y Amarilla: Son el conjunto de vías urbanas cuya función básica es el enlace y distribución dentro del Plan parcial y barrios, de sus diversos sectores o núcleos residenciales. La red amarilla enlaza de forma inmediata la propiedad y unidades de aparcamiento. El trazado de esta red en el PP-9 es mixto, combinando viarios mallados y ramificados en función del tamaño de las manzanas.

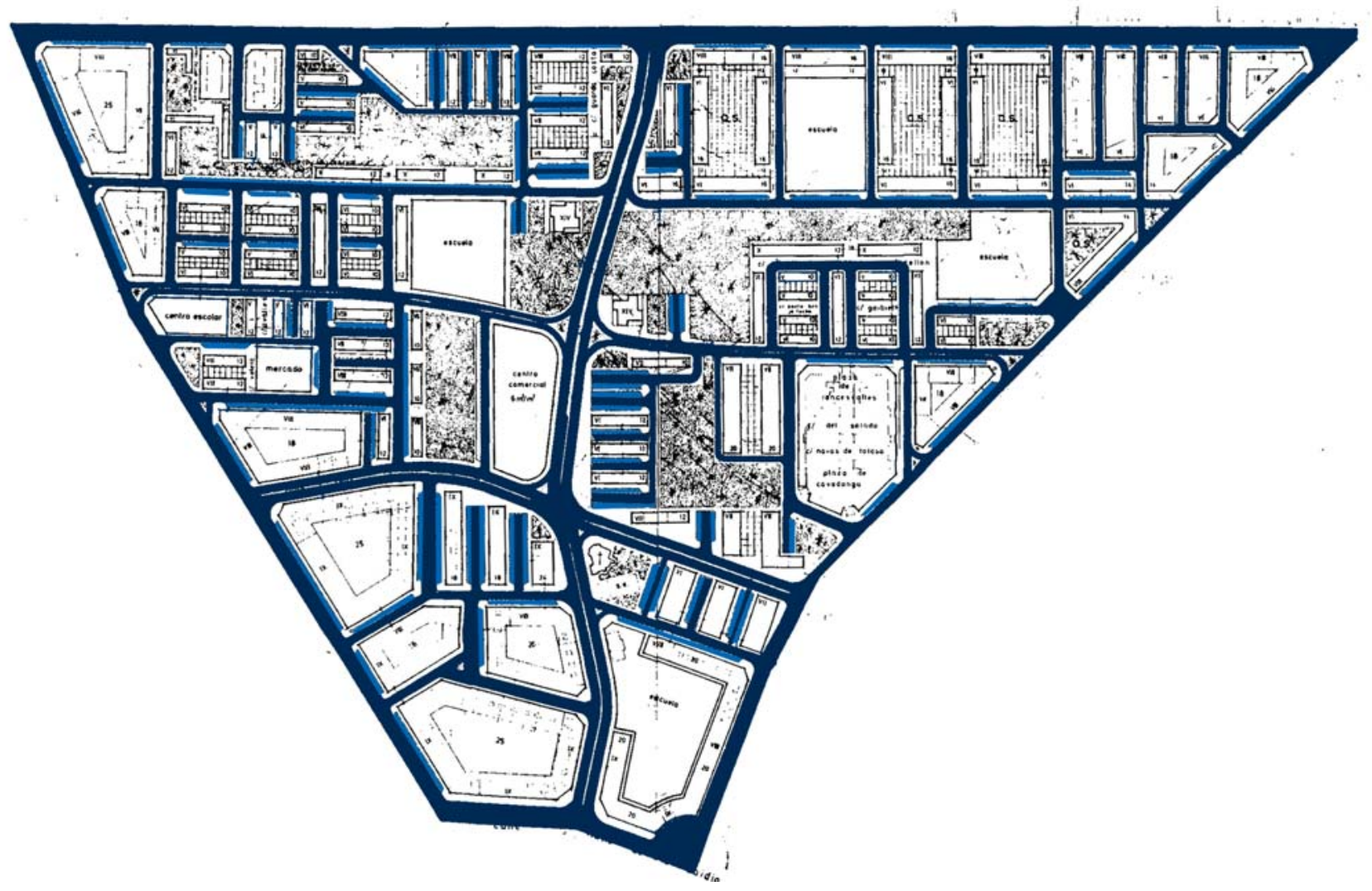




\section{Equipamientos}

La versión de 1973 del PP-9 señala que uno de sus objetivos es corregir las insuficiencias del anterior estudio del Plan en cuanto a reservas de suelo para equipamientos y zonas verdes.

En cuanto a reserva de escuelas, el PP-9 prevé cuatro parcelas, con una superficie total de $45.000 \mathrm{~m} 2$. Todas estas parcelas están situadas en la zona de edificación abierta: una al oeste, más pequeña, en la Av. Burjasot, otra junto a la zona verde central y otras dos en la parte este, a uno y otro lado de la calle Economista Gay.

En el PP-9 se prevén dos centros comerciales, uno en la zona oeste y otro de mayor tamaño en el centro del conjunto, recayente al nuevo acceso a Moncada, que ocupa el espacio entre la calle Reus y la Av. de Portugal. Este centro comercial, que aparece ya en la versión de 1961 del Plan con un diseño más detallado de su planta, es descrito en la Memoria como elemento sujeto a proyecto especial, que tendrá plazas y zonas peatonales y podrá albergar todo tipo de usos públicos (asistenciales, administrativos o culturales) excepto los residenciales. El volumen edificable previsto para el mismo es de $6 \mathrm{~m} 3 / \mathrm{m} 2$. Enfrentado a este centro comercial, junto al cruce de los ejes que forman la calle Reus y el nuevo acceso a Moncada se localiza también un centro religioso.

Por lo que se refiere a zonas verdes, el PP-9, tras las correcciones pertinentes antes comentadas, mantiene lo fijado para la zona por el Plan General, ampliando notablemente las previsiones del Polígono $\mathrm{V}$ de 1961 con respecto a espacios libres.

Plan Parcial 9, 1973. Equipamientos (Elaboración propia sobre plano de alineaciones del plan)

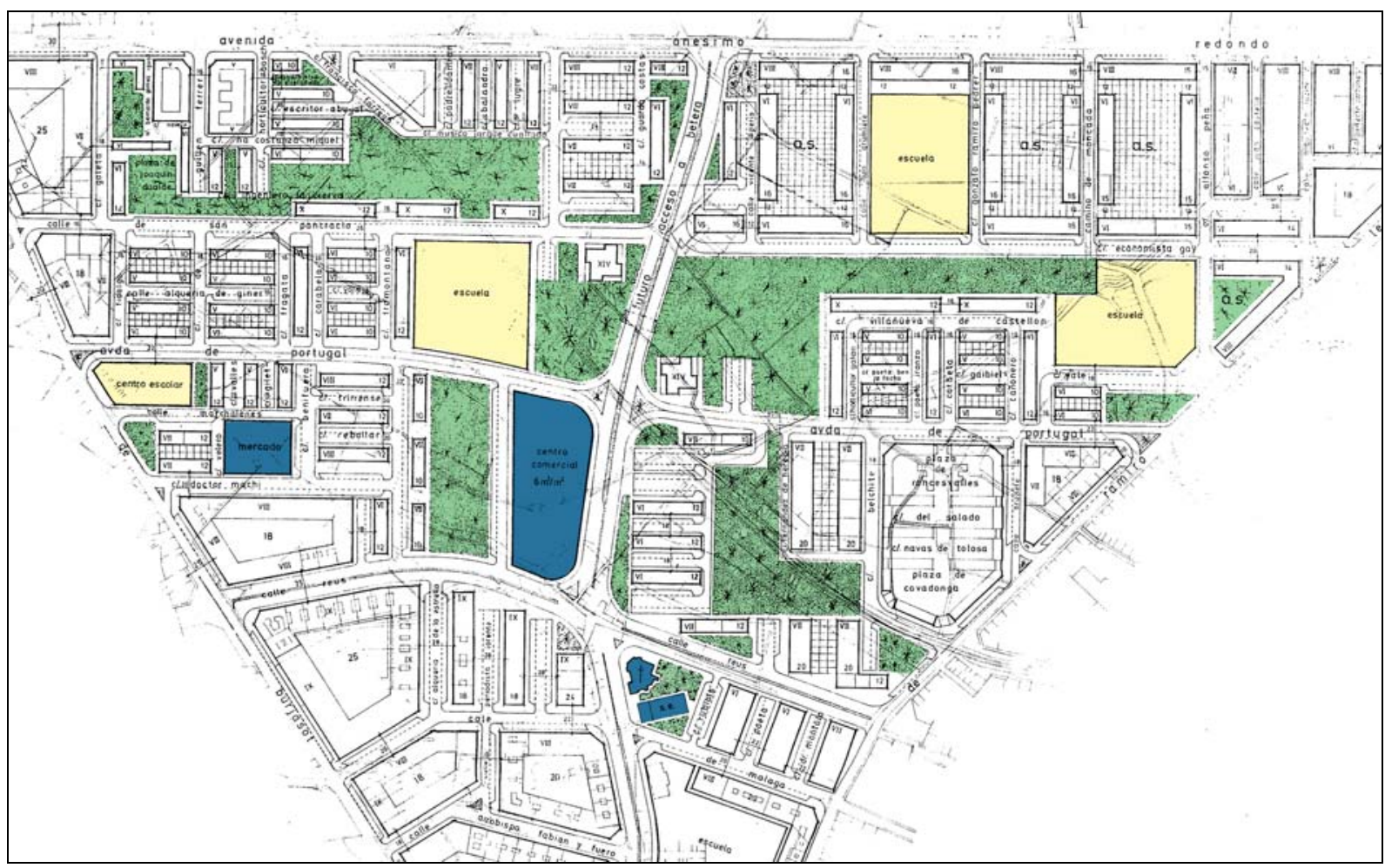




\section{Edificación}

La edificación abierta de la versión de 1973 del Plan Parcial 9 es, como hemos señalado, una simple transcripción de la proyectada en la versión original del plan de 1961, en la que se eliminan las manzanas o bloques necesarios para obtener unas mayores superficies de zonas verdes y equipamientos. En 1973 no se plantea, por tanto, una revisión global del plan de 1961 que, por otra parte sería muy dificultosa debido al gran número de edificios construidos en base al mismo.

La práctica totalidad de los bloques están dispuestos según unos mismos ejes, en paralelo o en perpendicular al Camino de Tránsitos (antigua Avenida Onésimo Redondo y actual Avenida Doctor Peset Aleixandre), que limita el plan por el norte.

La unidad modular tipo definida en el plan original de 1961, como elemento que se repite de este a oeste en la banda intermedia entre la Avenida de Portugal y la calle Economista Gay/San Pancracio, es todavía reconocible en la versión de 1973 en las dos manzanas situadas junto al grupo de la carretera de Barcelona de Goerlich y en las situadas junto a la calle Tramontana, más al oeste. Esta unidad está compuesta por dos micromanzanas de $25 \times 35 \mathrm{~m}$ formadas por parejas de bloques muy cortos de $\mathrm{V}$ o VI plantas dispuestos en dirección este-oeste y unidos por bajos comerciales, combinadas con bloques aislados de VI plantas más largos, dispuestos en dirección norte-sur, perpendiculares a las micromanzanas y

Plan Parcial 9, 1973. Edificaenvolviendo a las mismas.

ción en planta tipo.

(Elaboración propia sobre plano de alineaciones del plan)

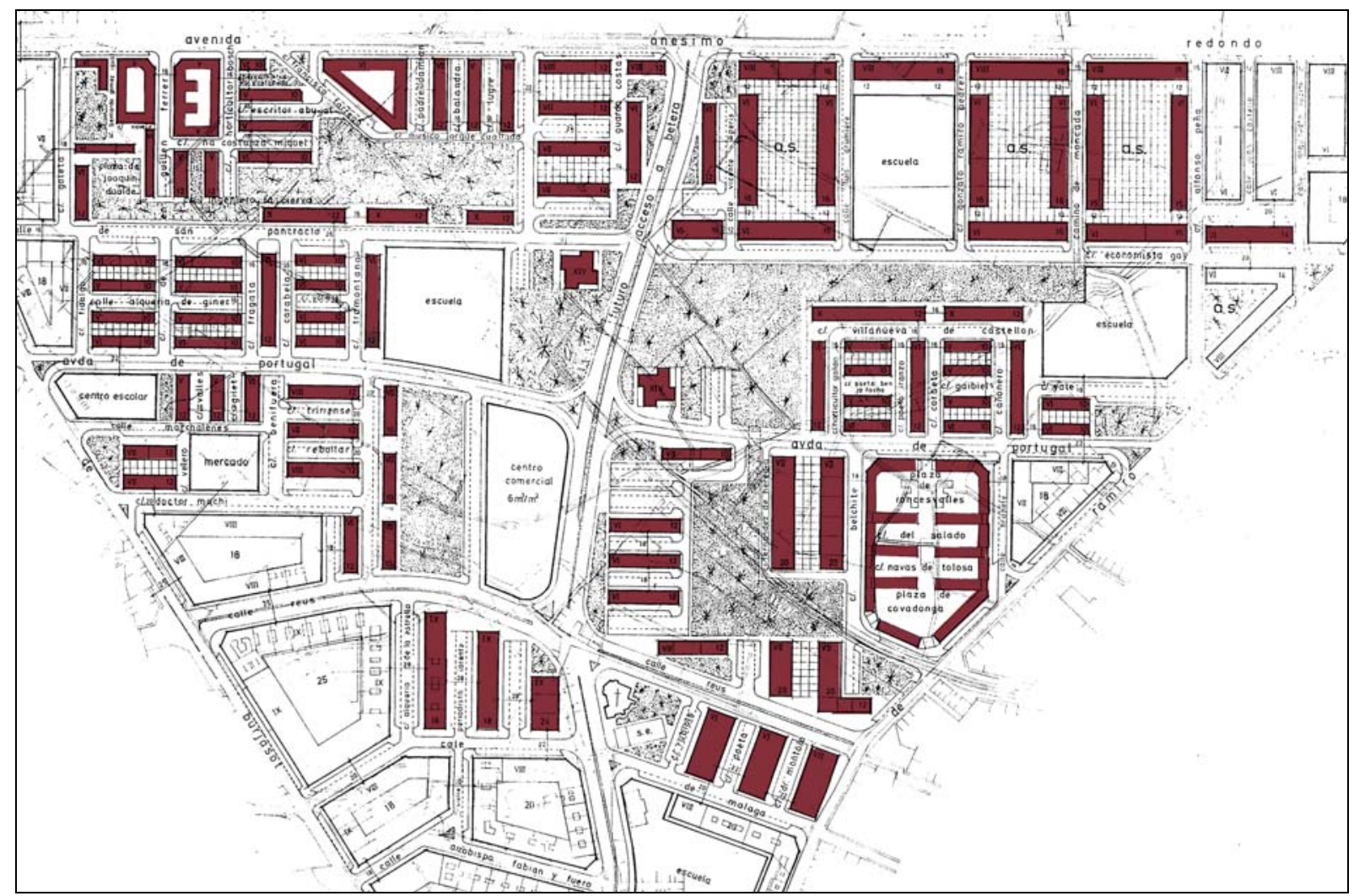


El resto de bloques lineales de dos crujías no sigue una pauta de repetición tan acusada. Por lo general están dispuestos en grupos de dos o más bloques equidistantes, siguiendo en unos casos el eje del Camino de Tránsitos y en otros el ortogonal al mismo. Con este planteamiento están resueltas las zonas situadas en la mitad noroeste del plan, entre el camino de Tránsitos y la calle San Pancracio y entre la Avenida de Portugal y la calle Doctor Machi.

En la zona noreste, la edificación abierta que flanquea el Camino de Tránsitos, se organiza en forma de grandes manzanas rectangulares con cuatro bloques lineales de profundidad media alineados al perímetro dispuestos sobre un zócalo no residencial que ocupa la totalidad de la planta baja. La serie de cuatro manzanas definida en la versión del plan de 1961 quedó interrumpida en la versión de 1973, en la que en una de dichas manzanas la edificación se reduce al bloque alineado con el Camino de Tránsitos, destinándose el resto del suelo a parcela escolar.

Los bloques de cinco crujías, con patios interiores, según un modelo de planta de vivienda semejante al que se utiliza en las manzanas adyacentes de ensanche, ocupan la parte sur del plan, como edificaciones de transición entre la edificación abierta y las manzanas cerradas de ensanche.

Es el caso de la zona situada junto al grupo de Goerlich, donde se proyectan dos manzanas mixtas de parejas de bloques unidos en planta baja, y de la franja comprendida entre las calles de Reus y Málaga, donde aparecen dos series aisladas de tres bloques lineales profundos.
Plan Parcial 9, 1973. Edificación en planta baja (Elaboración propia sobre plano de alineaciones del plan)

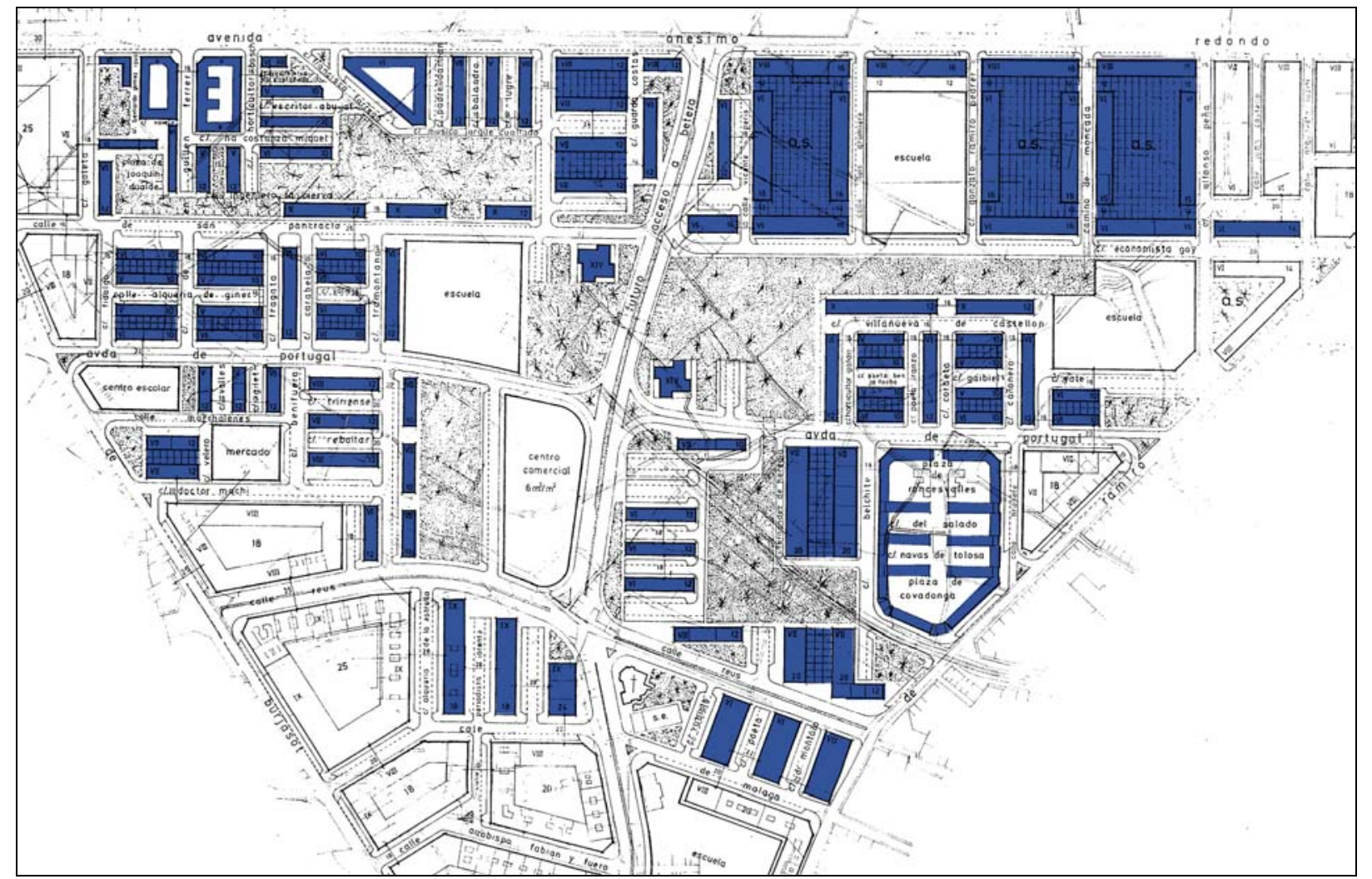




\section{Grado de realización}

El grado de realización del Plan Parcial 9 es alto, y casi todas las áreas de edificación abierta han sido construidas de acuerdo con lo proyectado en las sucesivas versiones del plan, entre 1961 y 1973.

La principal zona no realizada de edificación abierta es la central, en la que el Plan General de 1988 situó una gran zona verde de distrito, que es el parque de Marxalenes, hoy ya realizado. En esa zona, por tanto, quedaron sin construir las torres, los bloques y el centro comercial previstos en el Plan Parcial 9.

La eliminación a finales de los años ochenta de la línea de ferrocarriles eléctricos que cruzaba en diagonal la zona, partiéndola en dos mitades separadas, y su sustitución por la nueva línea de tranvía, puesta en servicio en 1994 con un trazado que bordea el parque central, desbloqueó el desarrollo urbanístico del área, al permitir la ejecución de dicho parque, así como la apertura y prolongación de las calles pendientes de ejecución para completan el viario interno, entre las que cabe destacar el eje este-oeste de Reus-Ruaya, previsto ya en el Plano de Ensanche de 1917.

La edificación abierta proyectada en las zonas que rodean el parque de Marxalenes se halla en la actualidad completamente realizada, a excepción de algún pequeño fragmento de bloque. Como puede verse en el plano de grado de realización, una gran parte de

Plan Parcial 9. Grado de realización (Elaboración propia sobre plano de alineaciones del plan) esa edificación se realizó en base al Plan Parcial de 1961, con anterioridad a la nueva redacción de dicho plan en 1973.

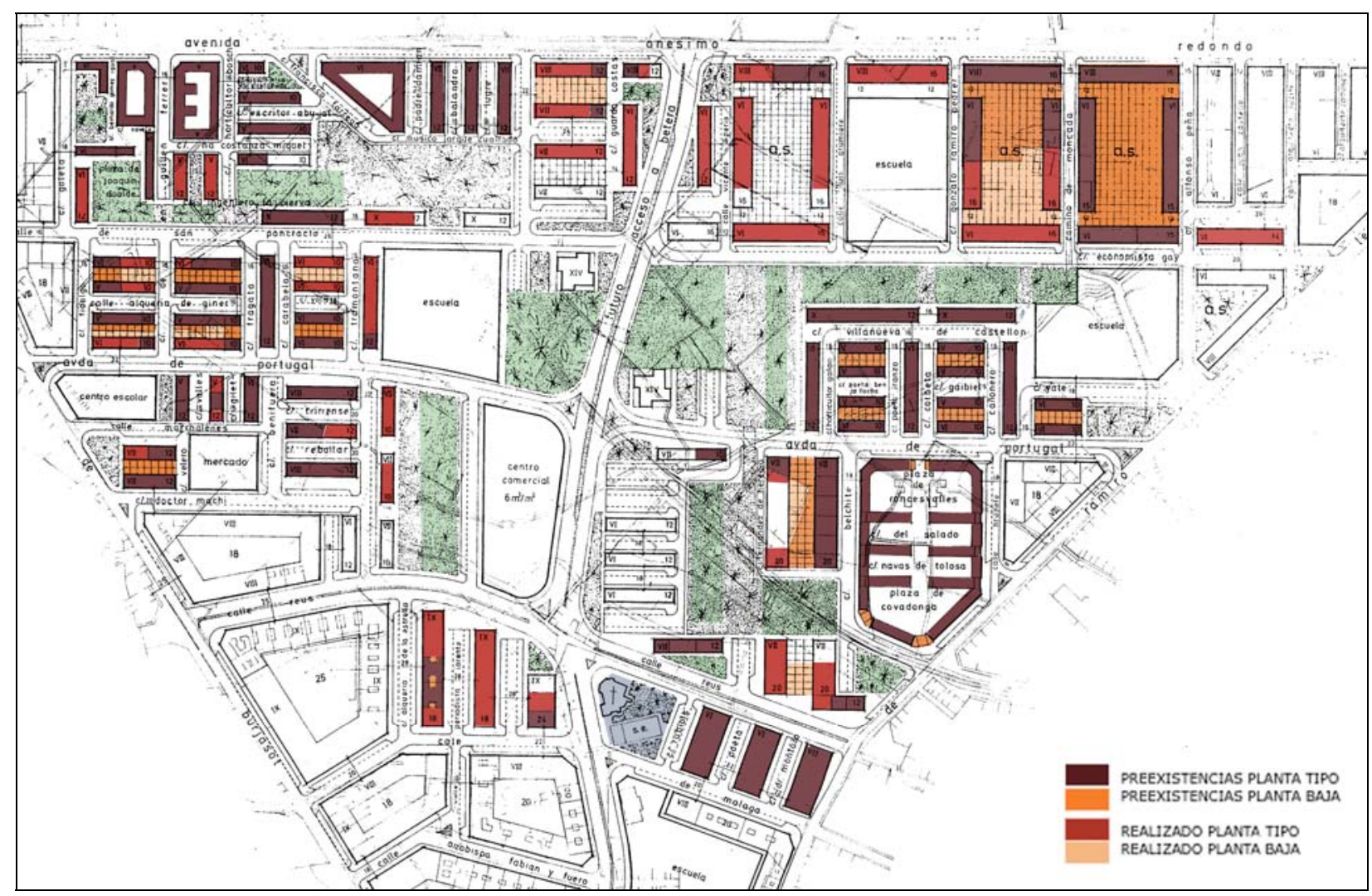




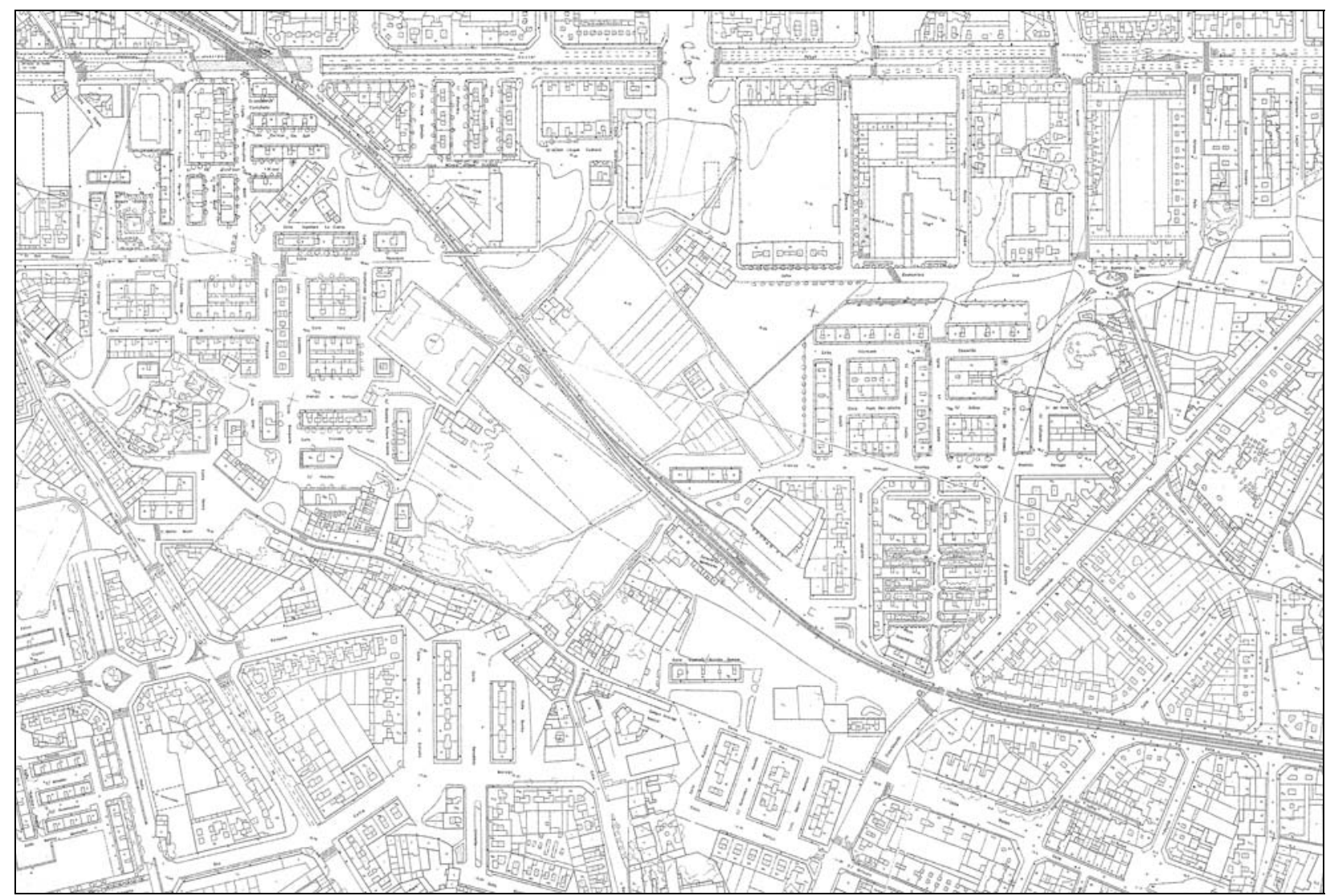

Cartografía Básica Municipal,

1983. Zona del PP-9.

PGOU Valencia 1986. Zona del PP-9. (Color sobre montaje de hojas de la serie $C$ del PGOU).

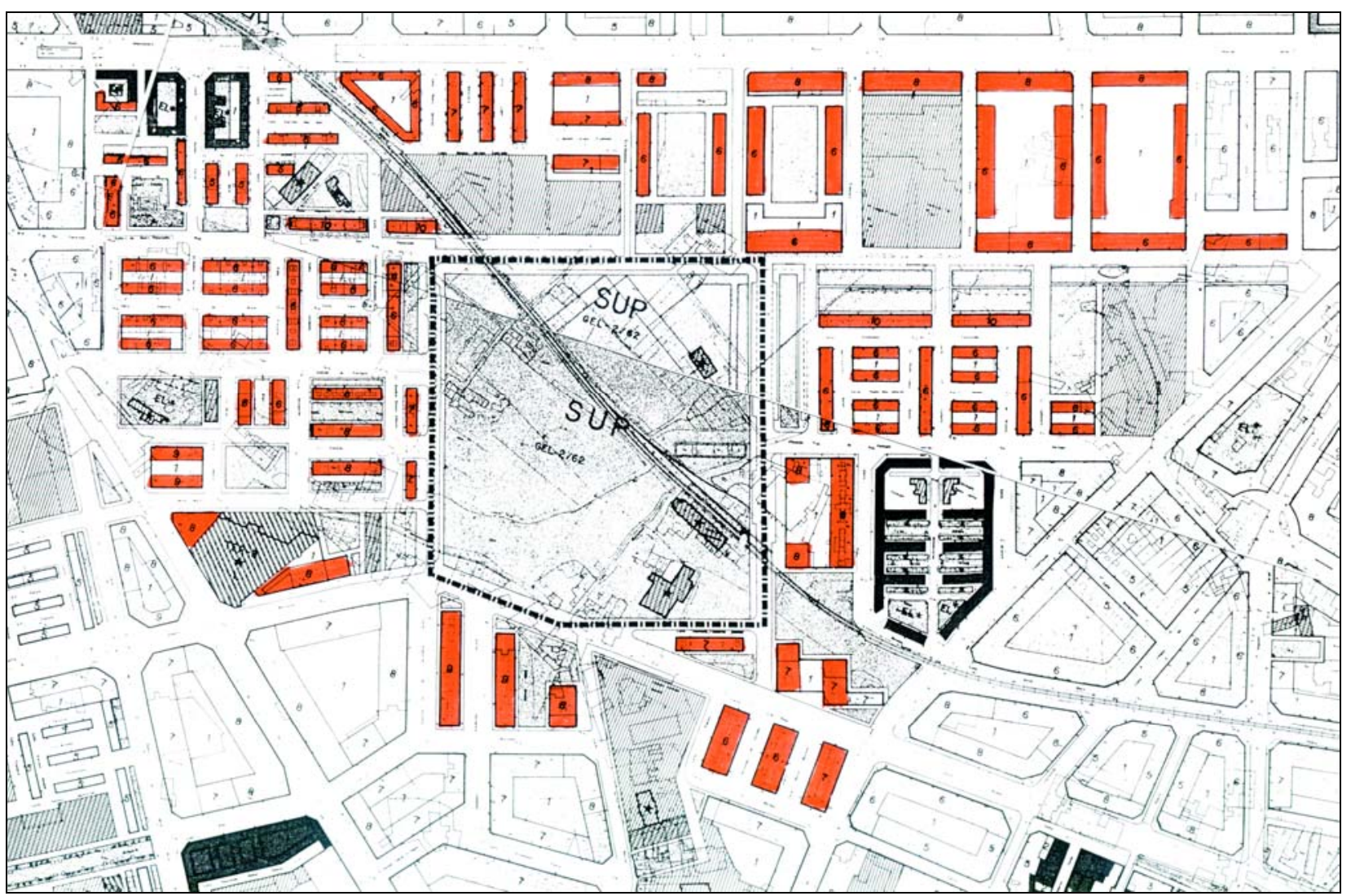




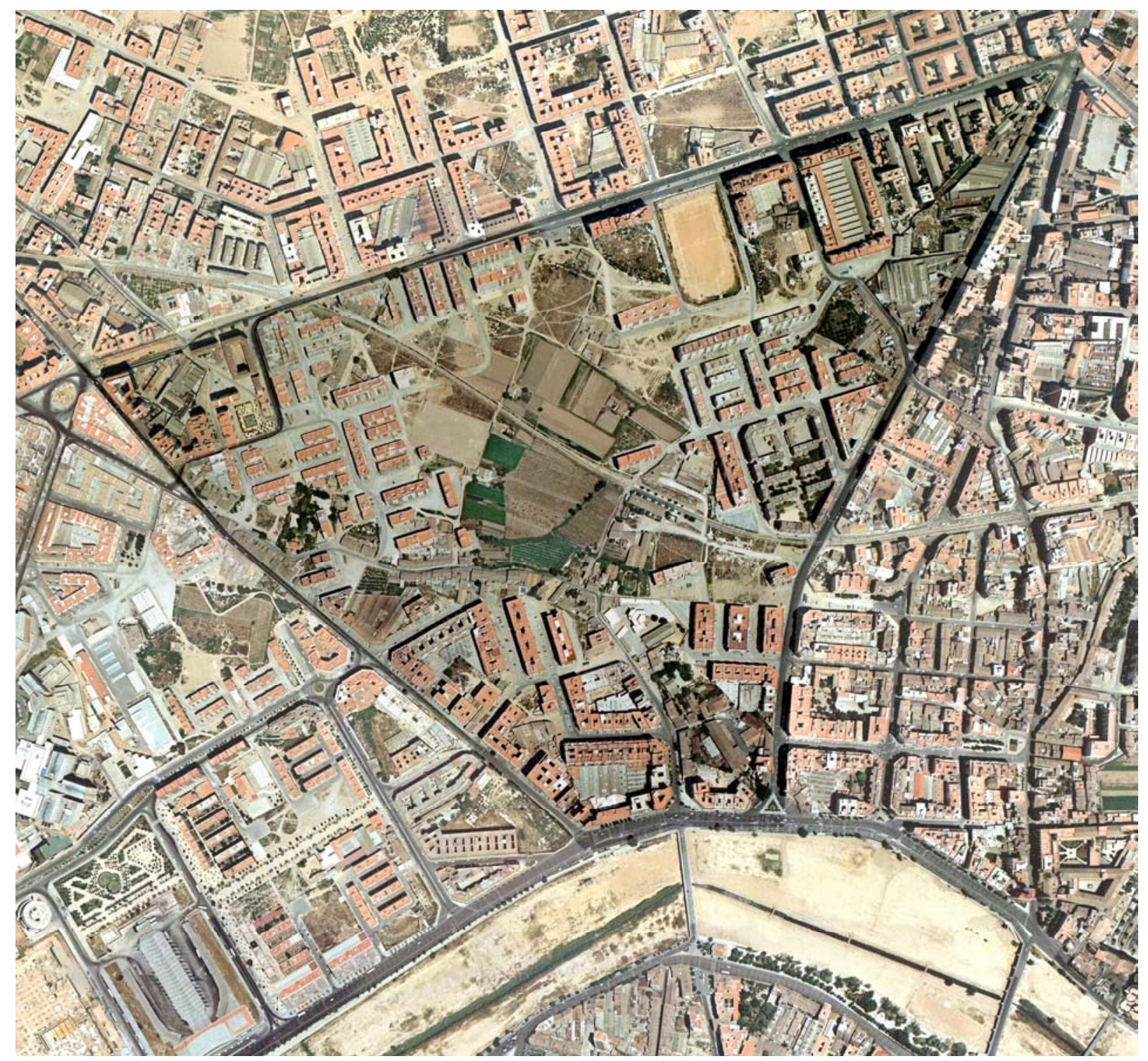

Área del Plan Parcial 9.

Fotografía aérea, 1980. 


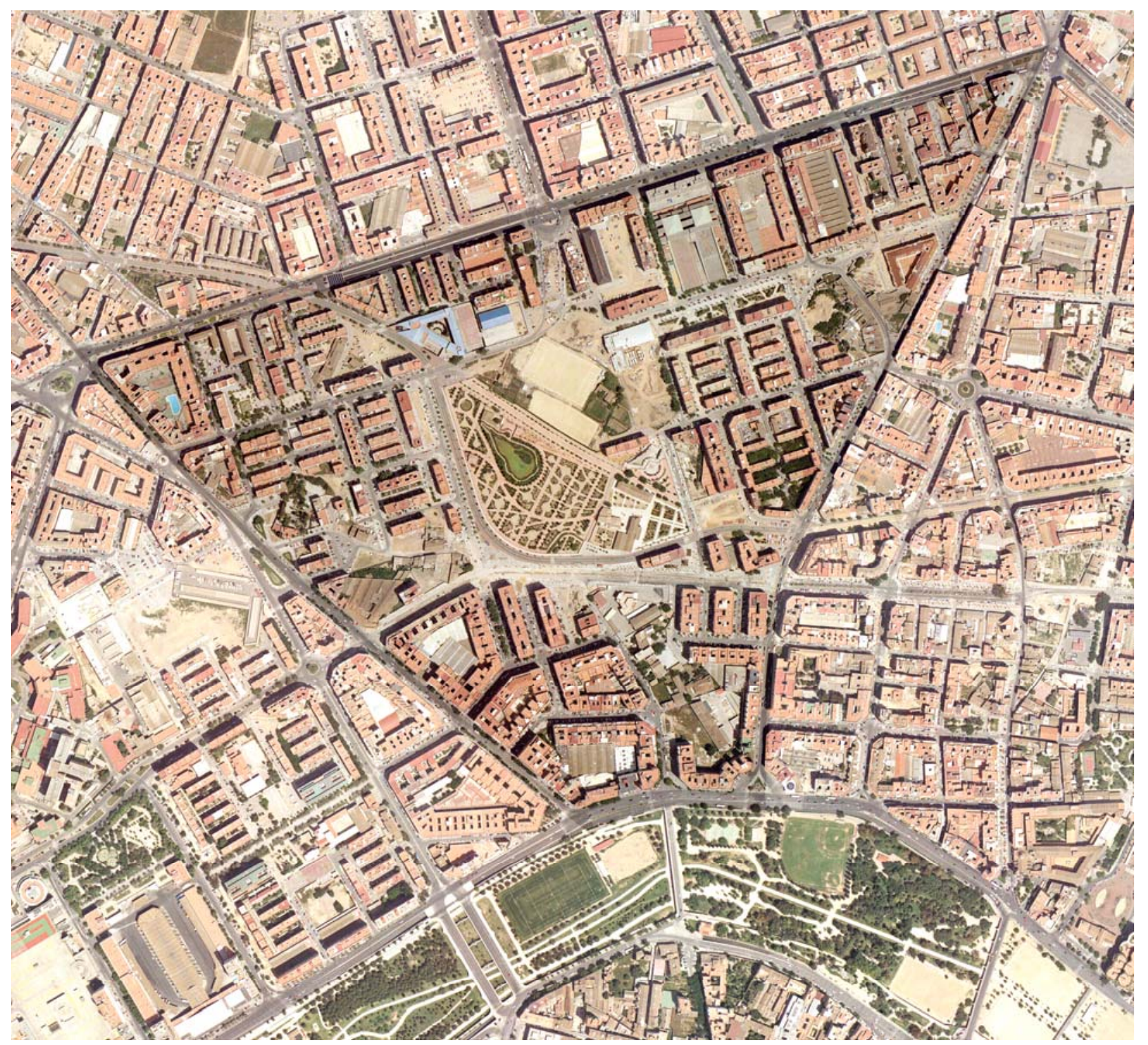

Área del Plan Parcial 9. Ortofoto, 2002 (AUMSA) 


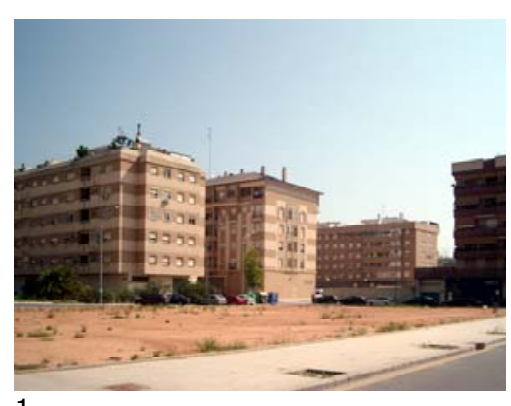

1
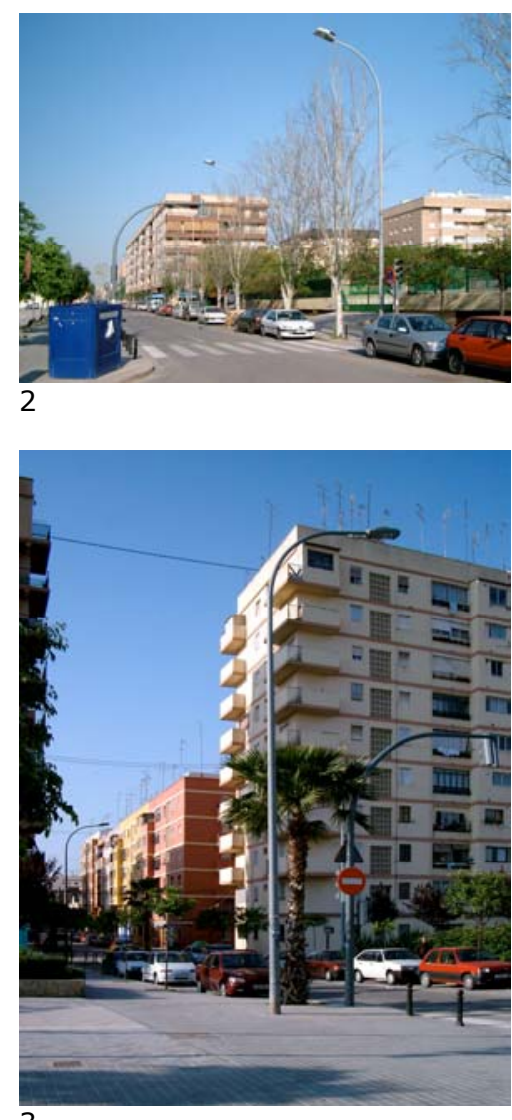

3

1. Calle Economista Gay, vista hacia el este

2. Calle Economista Gay, vista hacia el oeste.

3. Calle Economista Gay. Cruce con calle la Corbeta.

4. Calle Horticultor Galán. Vista hacia el norte.

Detalle del sector este del PP-9. Fotografía aérea, 1980.

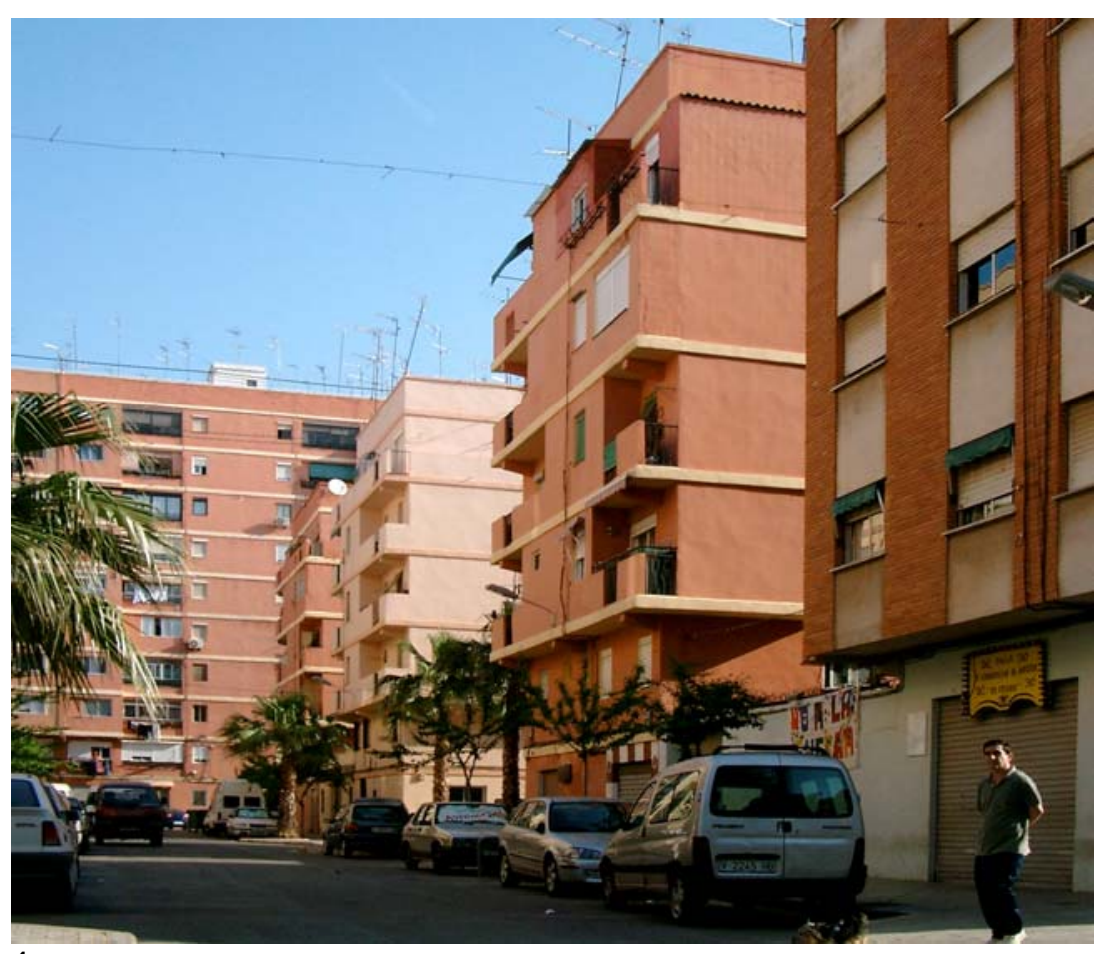

4

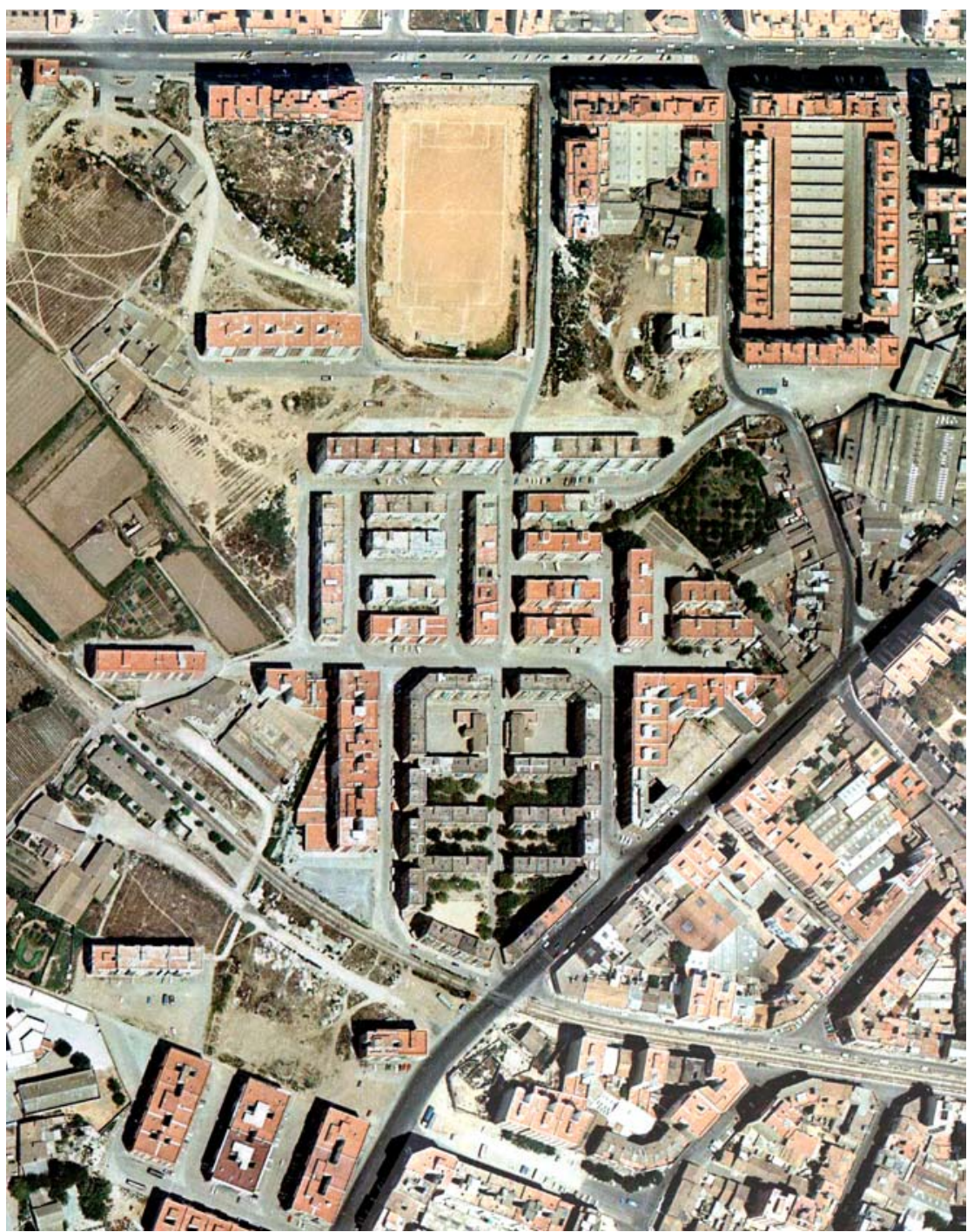




\section{Un recorrido actual por Marxalenes}

En el sector este del ámbito del Plan Parcial 9, cada uno de los tres tipos de agrupaciones de edificación abierta existentes genera un paisaje urbano diferente.

Así, en la zona norte, las manzanas formadas por bloques dispuestos sobre una planta baja continua funcionan igual que una manzana cerrada convencional a efectos de delimitación del espacios público y de configuración de una retícula de calles. Este papel urbano es posible gracias al carácter mixto de estas manzanas y, sobre todo, a su tamaño, ya que sus dimensiones, de $80 \times 150 \mathrm{~m}$ aproximadamente, son comparables a las de un tejido de ensanche.

En la edificación abierta de la zona central, en cambio, a causa del reducido tamaño de las manzanas mixtas, y de la utilización de bloques lineales aislados, el número de calles supera con mucho la proporción habitual que encontramos en un tejido mallado convencional, y además ninguna de las calles previstas como peatonales o como jardín entre bloques ha mantenido este carácter, sino que han acabado siendo bolsas de aparcamientos.

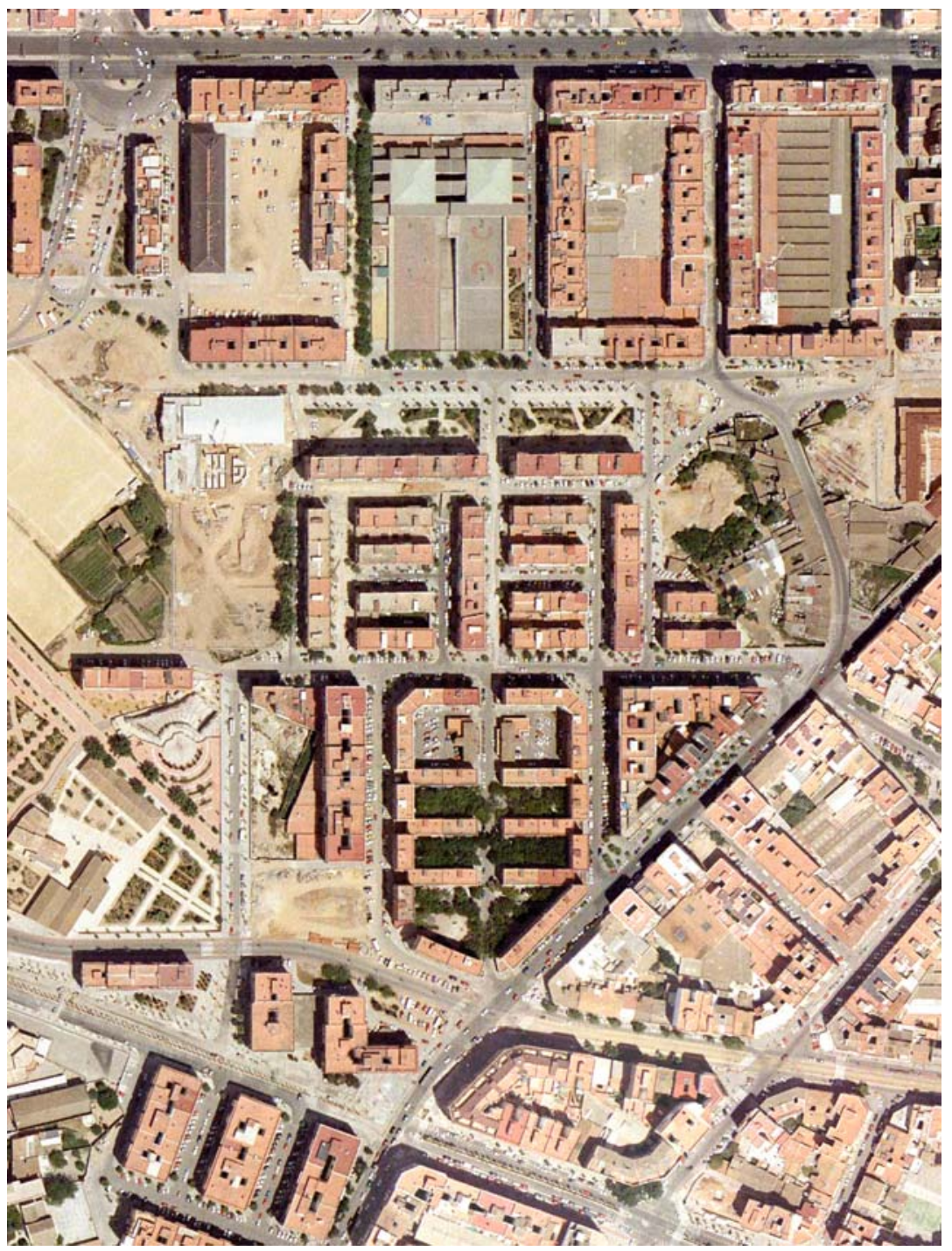

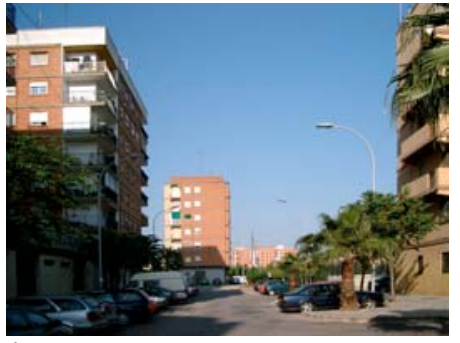

1
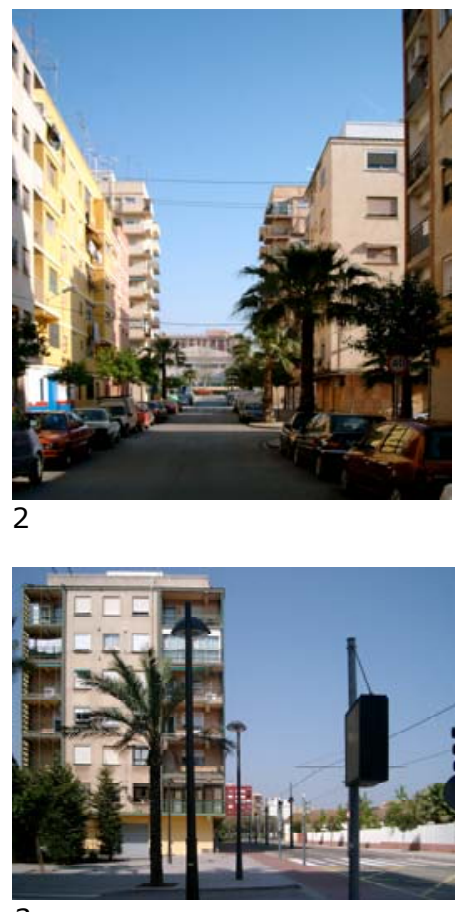

3

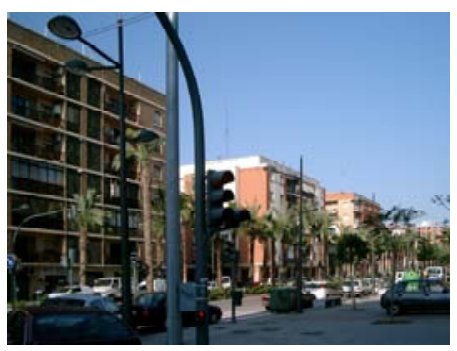

4

1. Avenida de Portugal. Vista hacia el oeste.

2. Calle Corbeta. Vista hacia el norte.

3. Calle Diputado Ricardo Samper, vista hacia el oeste.

4. Calle Ruaya, lado sur.

Detalle del sector este del PP9. Ortofoto 2002 (AUMSA) 
Detalle del sector oeste del PP9. Fotografía aérea, 1980.

Detalle del sector oeste del PP9. Ortofoto 2002 (AUMSA)
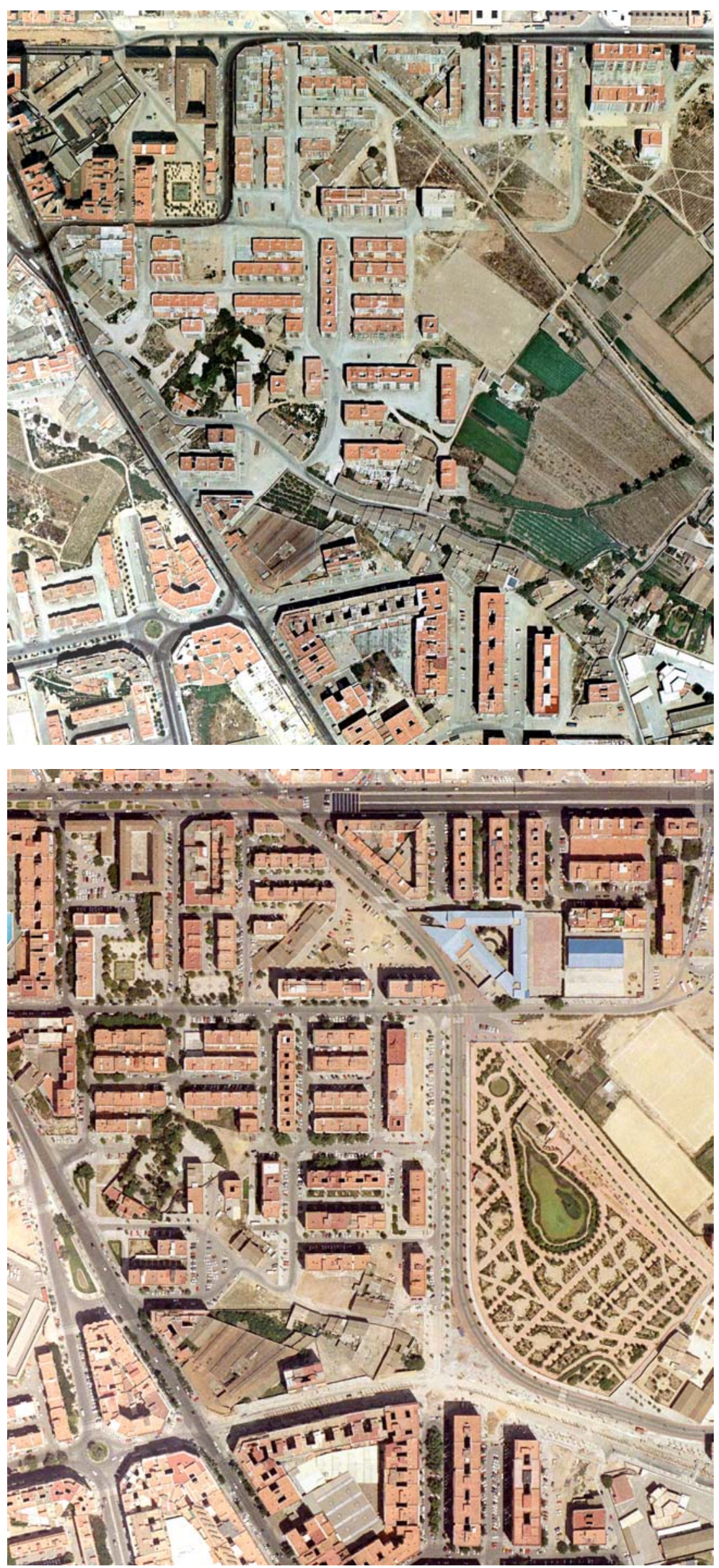
Esta situación se repite en la edificación abierta de la mitad oeste de Marxalenes, donde todo el espacio intermedio entre los bloques se ha destinado a paliar el déficit de aparcamientos derivado de la imprevisión al respecto, habitual en los planes que estamos estudiando.

En esta zona, la fotografía aérea de 1980, en la que aparecen ya construidos la mayor parte de los bloques de edificación abierta de la misma, es una clara evidencia de la ausencia de mecanismos de gestión adecuados en el planeamiento de este periodo, ya que muestra que la edificación de viviendas no va acompañada de la correspondiente urbanización, y mucho menos de la realización de los equipamientos y zonas verdes necesarios.

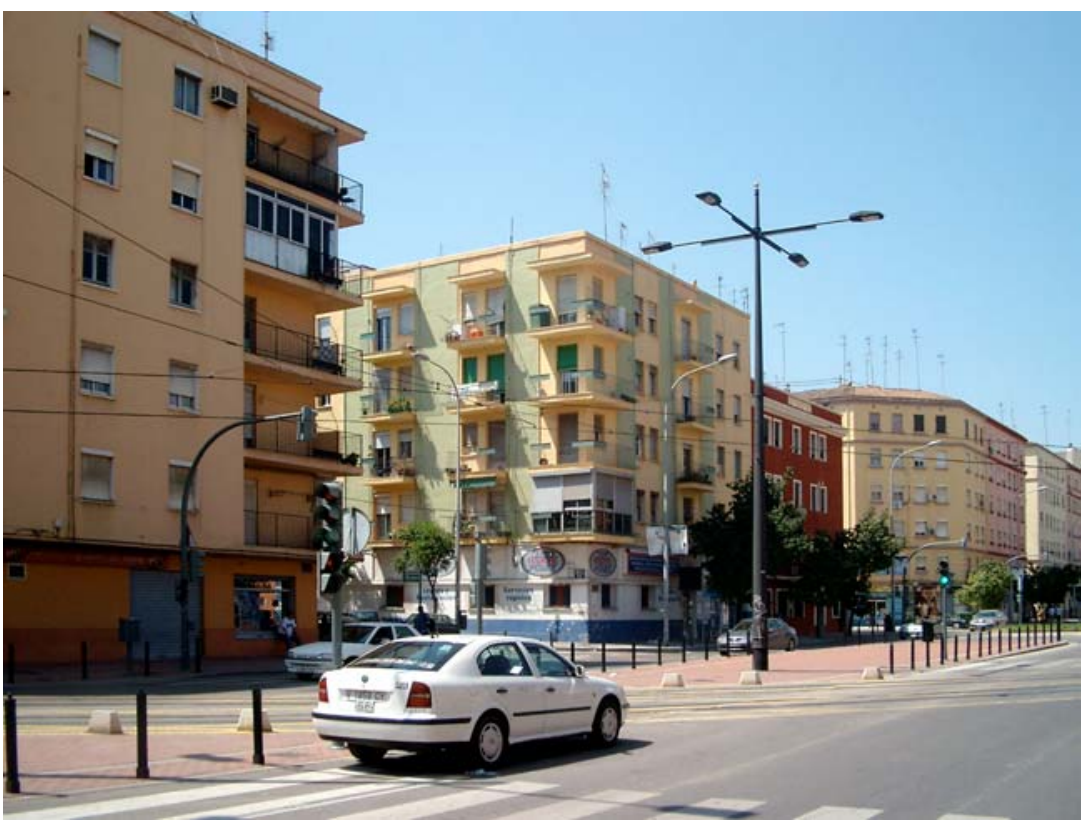

1

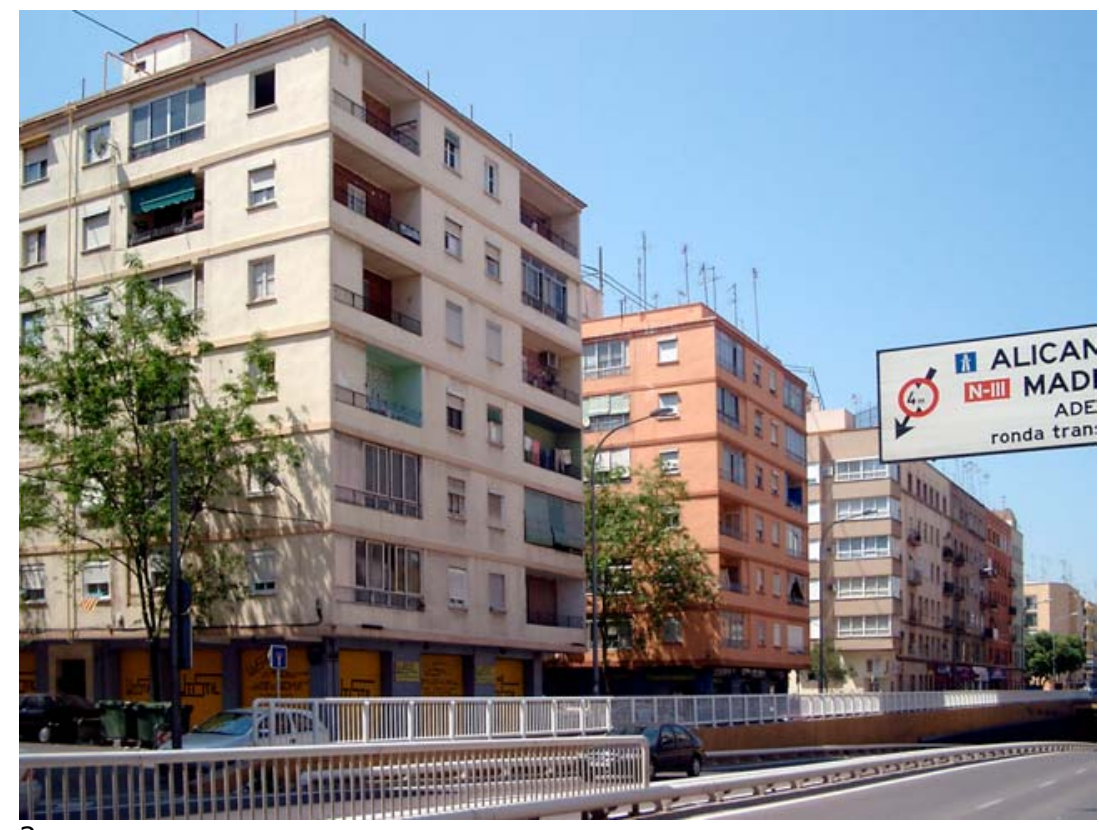

1. Bloques recayentes a la Avenida Dr. Peset Aleixandre, entre las calles Francisco Tárrega y Goleta.

2. Bloques recayentes a la Avenida Dr. Peset Aleixandre, entre las calles Padre Tena y Padre Damián. 


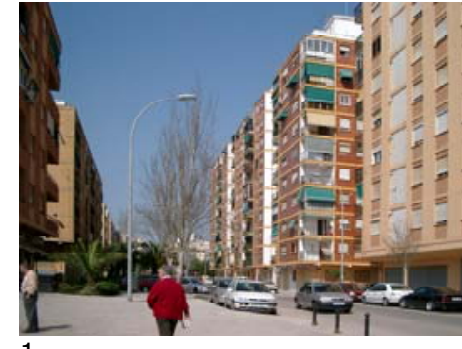

1
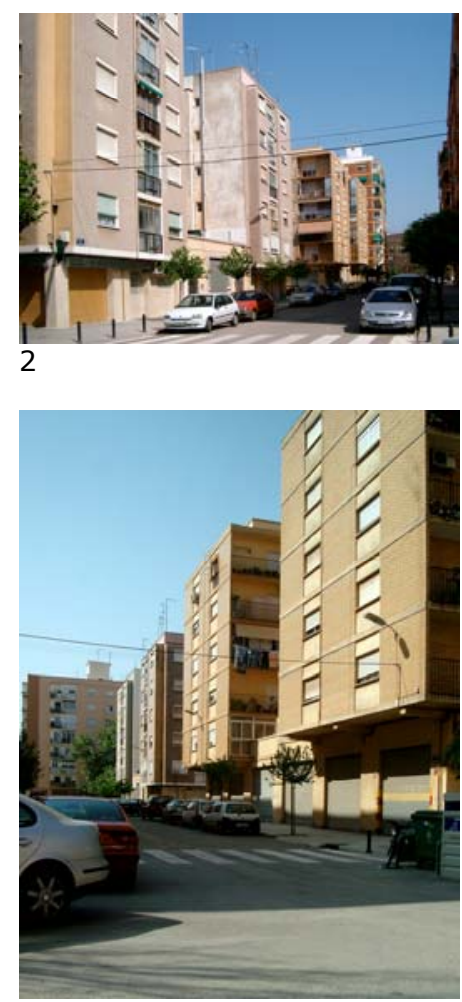

3

1. Calle San Pancracio, vista hacia el oeste.

2. Calle Carabela, vista hacia el sur.

3. Calle Fragata, vista hacia el sur.

4. Calle San Pancracio. Bloques en el lado norte, entre las calles En Guillem y Horticultor Bosch.

5. Plaza Joaquín Dualde.
Esta situación ha mejorado sustancialmente como consecuencia de las diversas actuaciones de urbanización y creación de equipamientos realizadas en los últimos quince años, como se aprecia en la Ortofoto de 2002.

La edificación abierta no es toda ella alta en Marxalenes, sino que además de los bloques de VIII a XII plantas habituales en otros planes, localizados junto a las calles más importantes, se proyectan bloques de altura media ( $V$ plantas, o planta baja y cuatro de piso) en un número apreciable. En algunos casos puntuales, como en los alrededores de la Plaza Joaquín Dualde, estos bloques de altura media aparecen frente a espacios verdes de cierta amplitud, mostrando la imagen urbana que podría haber resultado de un orden abierto menos denso.
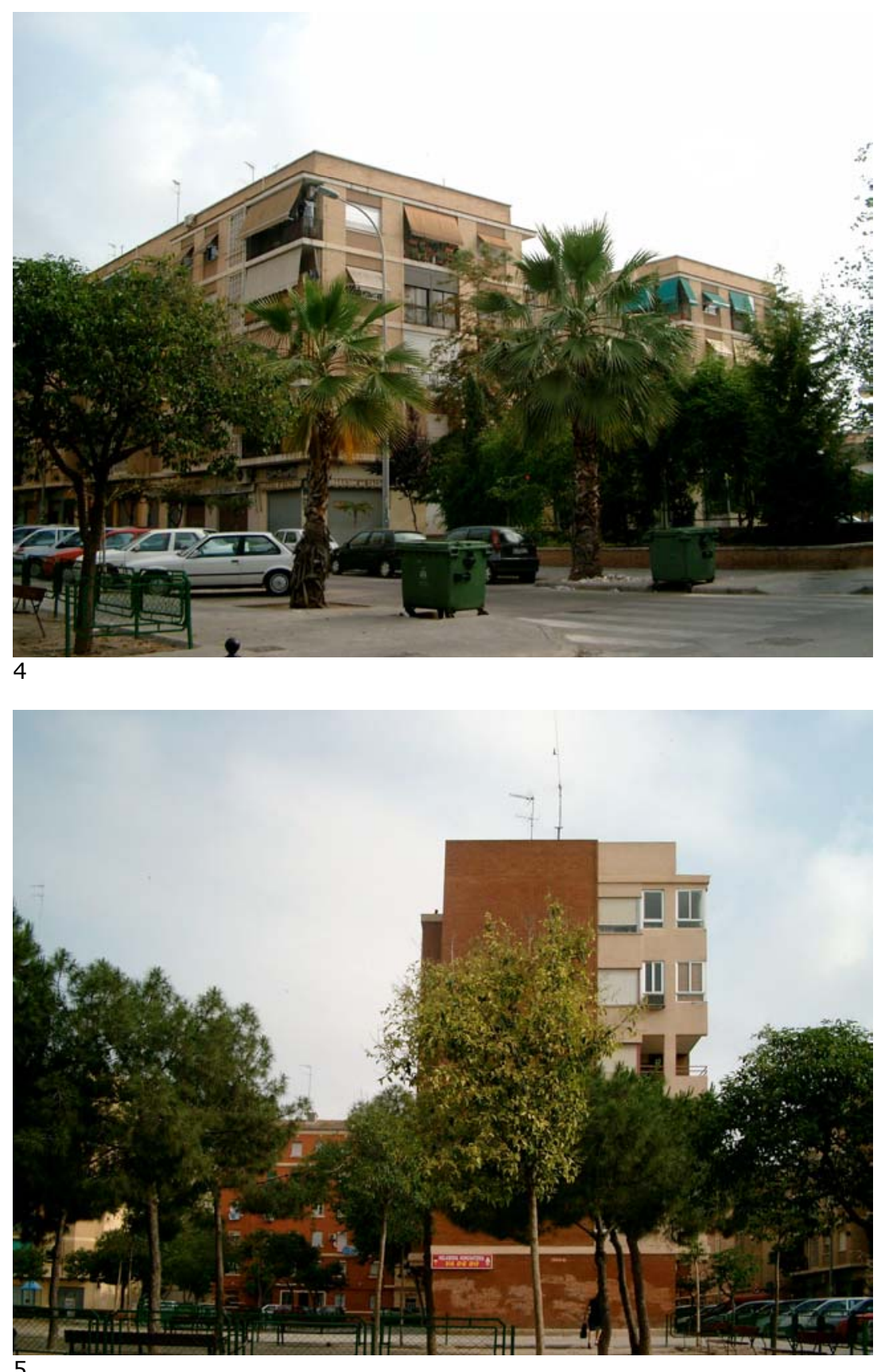

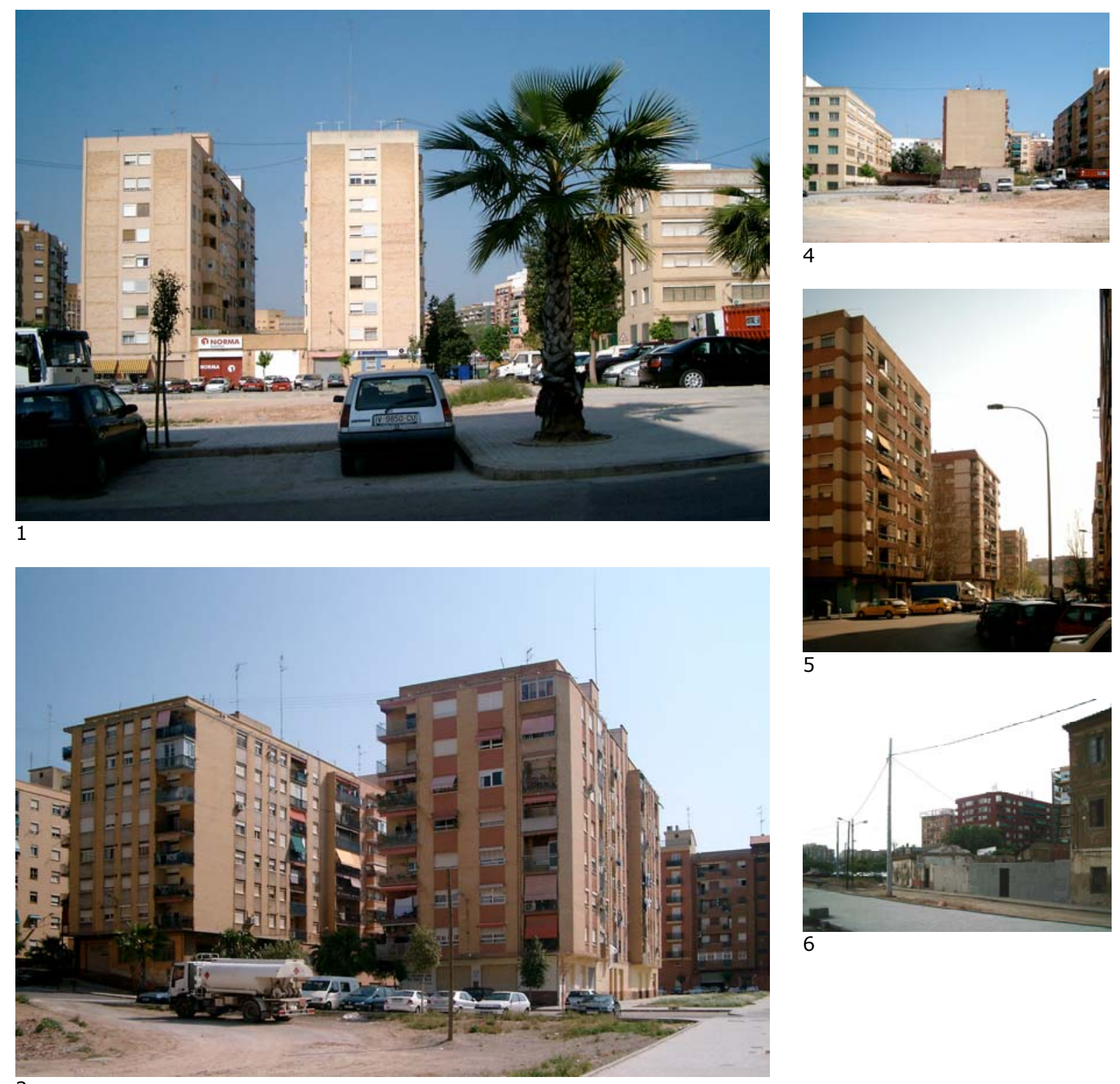

6

2

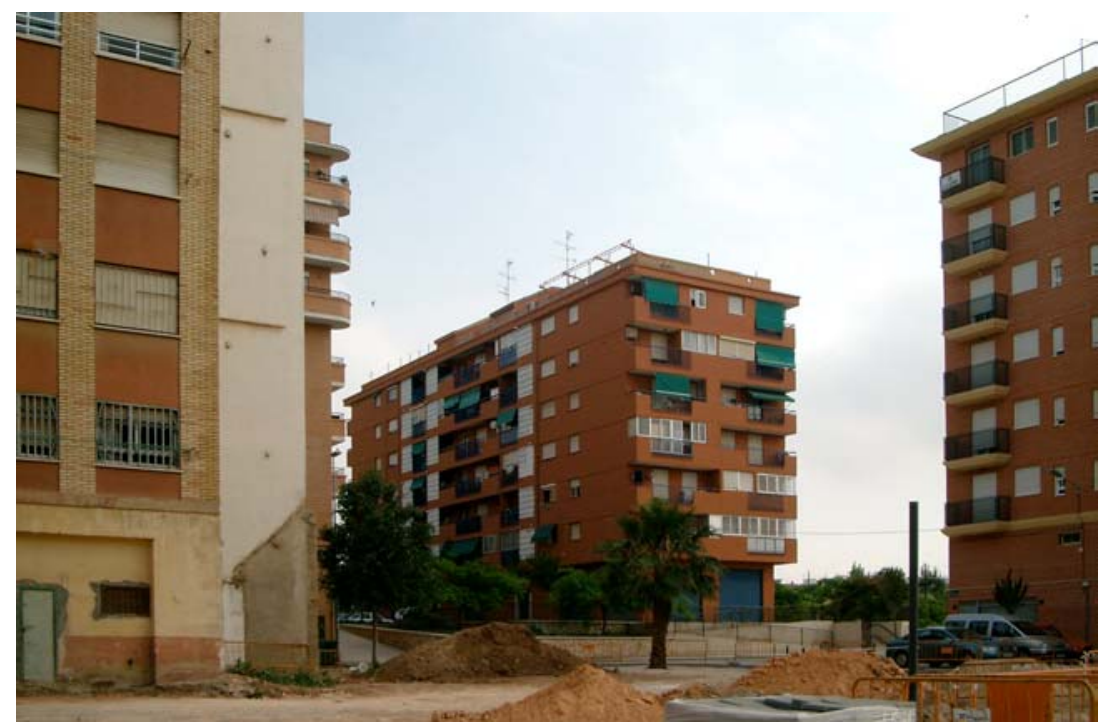

1. Bloques entre las calles Doctor Machi y camino de Marxalenes. Vista desde la calle Vallés hacia el oeste.

2. Bloques entre las calles Trirreme y Doctor Machi. Vista desde la calle Benisuera hacia el este.

3. Calle Bautista Esteve Ximeno, vista hacia el norte.

4. Bloques entre las calles Vallés. Vista hacia el norte.

5. Calle Málaga, vista hacia el este.

6. Bloques de la calle Málaga vistos desde el norte. En primer plano, algunos restos del caserío original del Camino de Marxalenes. 


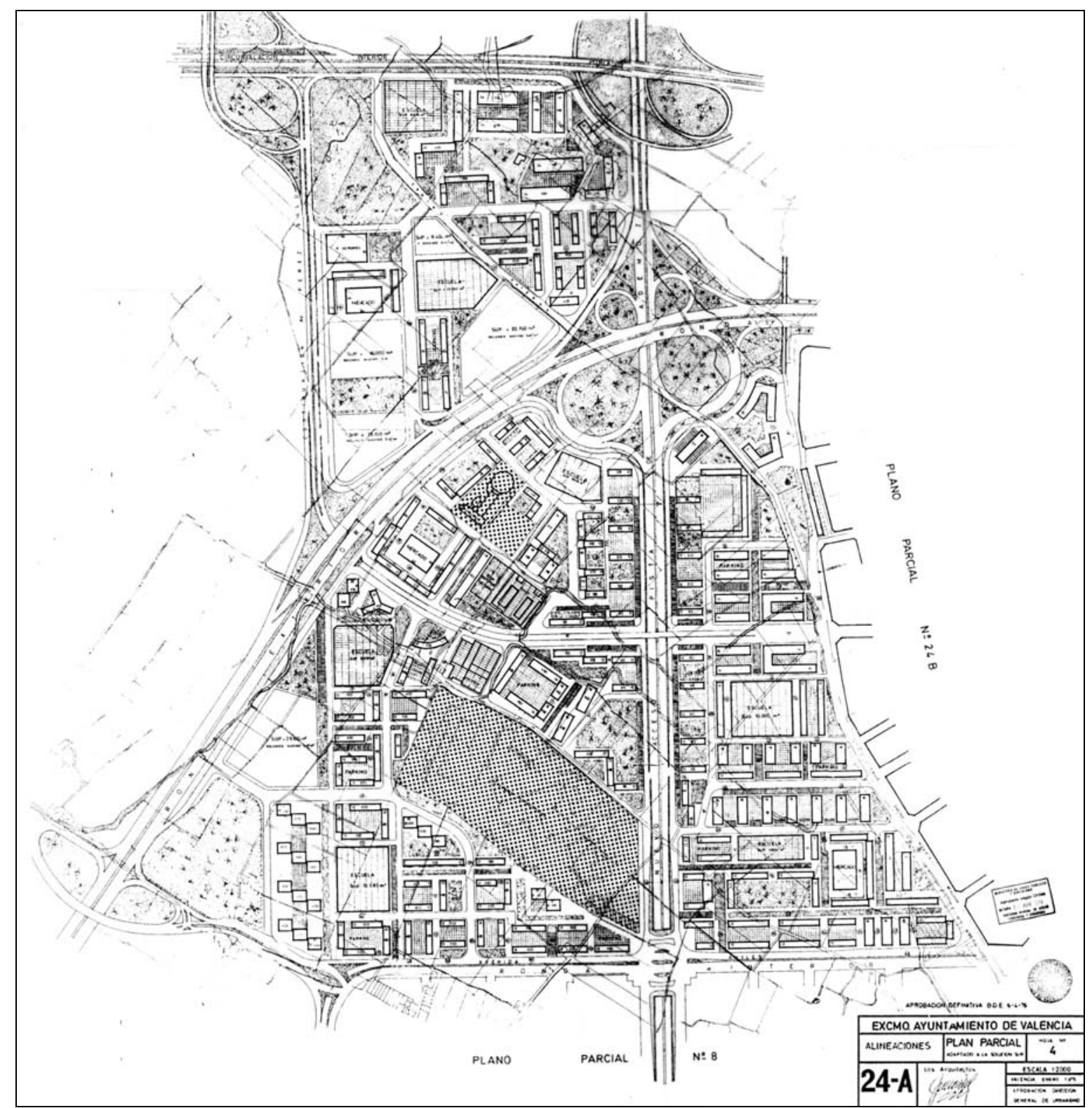

Plan Parcial 24-A, 1975. Plano de alineaciones. 


\section{EL ÁREA JUNTO AL NUEVo ACCeso de ADEMUZ: PLAN PARCIAL NO 24-A (1970/1975)}

La primera versión del Plan Parcial no 24, que hemos analizado en la sección anterior, fue aprobada inicialmente por el Ayuntamiento de Valencia en octubre de 1966, un mes antes de la aprobación del Plan General adaptado a la solución sur ${ }^{1}$. En 1970 se redactó una nueva versión del plan, que llegó a aprobarse por el Ayuntamiento y por la Corporación Administrativa Gran Valencia. Esta versión fue posteriormente sustituida por otra redactada en 1975, que fue aprobada definitivamente en $1976 .^{2}$

La gran extensión del área ordenada hace que, tanto en la versión de 1970 como en la de 1975, el plan se subdivida en dos sectores, A y B, para cada uno de los cuales se representan en juegos de planos separados las determinaciones del plan. La Memoria del plan de 1975 indica que la subdivisión obedece exclusivamente a consideraciones de formato, señalando que el estudio de ambos sectores se ha realizado de modo conjunto. Por la misma razón, estudiaremos también por separado cada uno de los dos sectores que componen el PP24.

El sector A del PP24 comprende los terrenos situados al oeste del poblado de Benicalap, junto al eje viario del nuevo acceso a Ademúz, limitados al Norte por la llamada "Circunvalación interior de poblados", al Oeste por la Ronda Exterior y la llamada "Continuación de la Av. Pérez Galdós", al Sur por la Ronda Interior (Avenida General Avilés) y al Este por la calle Doctor Nicasio Benlloch y con el sector B del Plan.

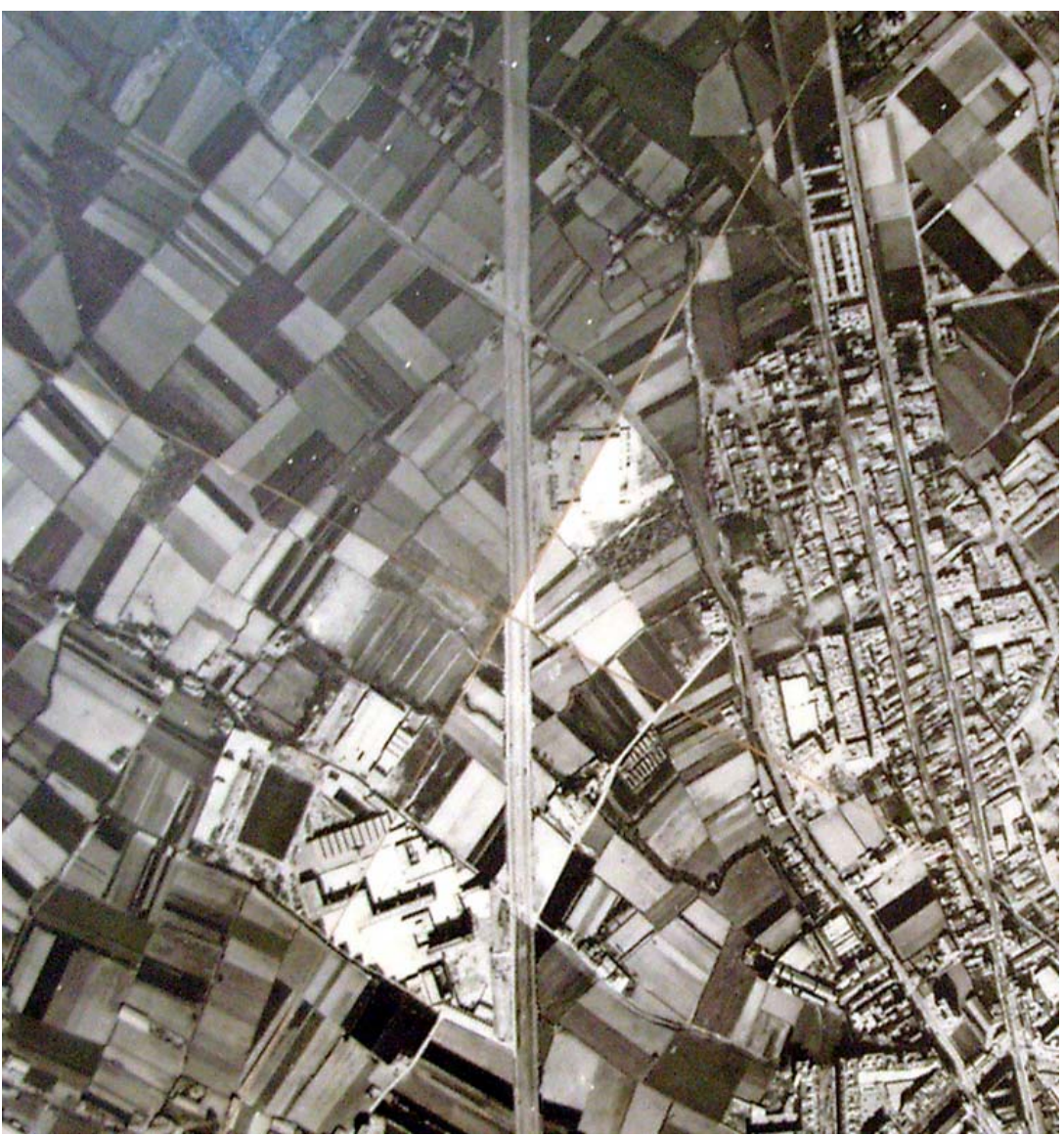

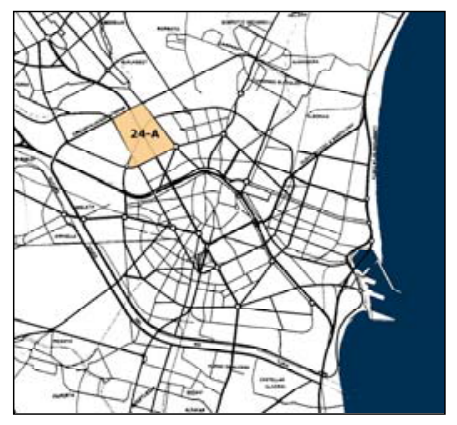

Plan Parcial 24-A. Localización

Zona del Plan Parcial 24-A. Fotografía aérea, h. 1965 (ETS Arquitectura de Valencia).

1. Ver Sección II, pág. 271 y siguientes.

2. Plan Parcial 24, 1970/1975. Ver Anexo de Documentos, pp. 577639. 


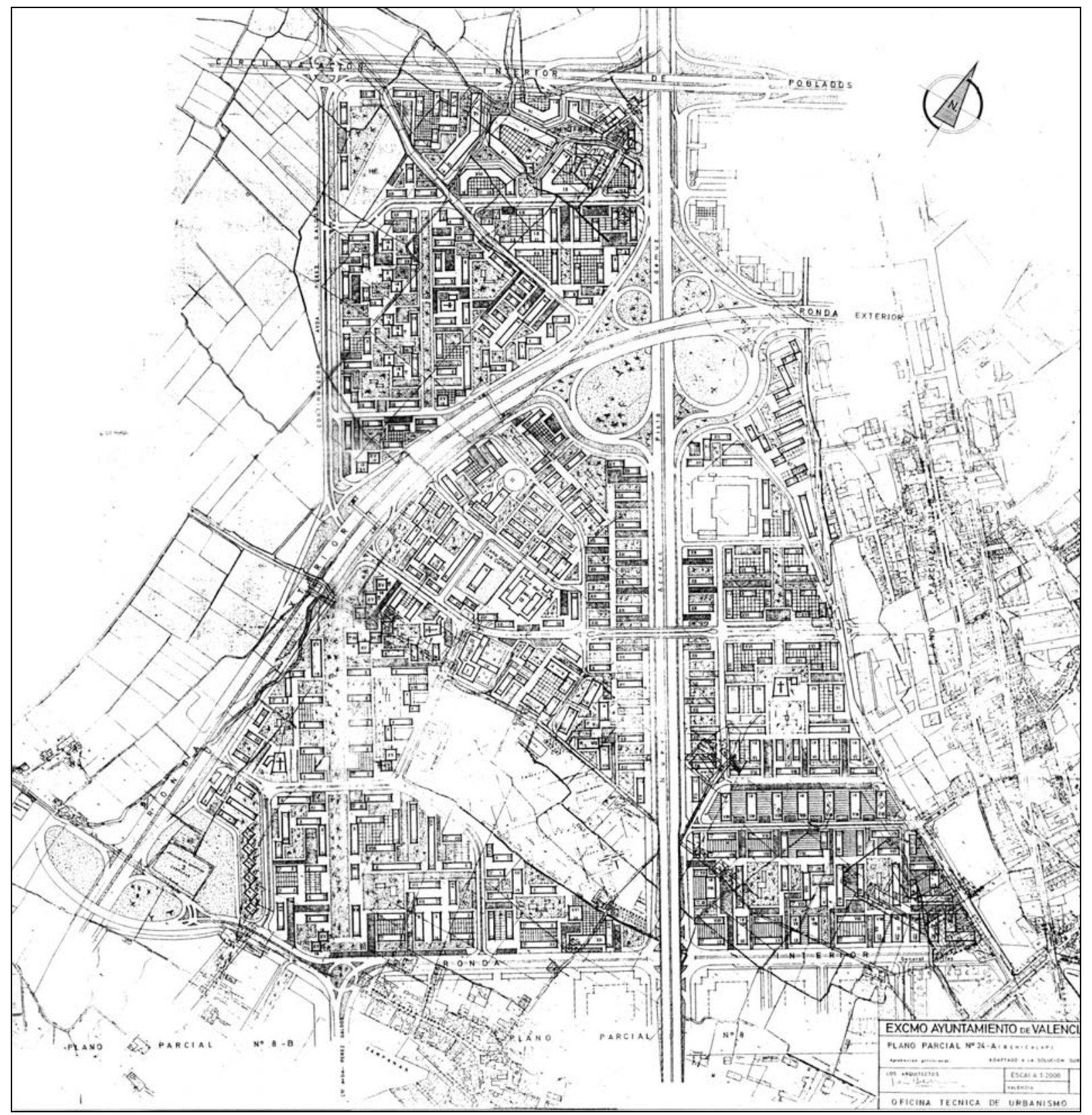

Plan Parcial 24-A, 1970. Plano de alineaciones.
El sector 24-B, por su parte, es el situado al este del poblado de Benicalap. El montaje de las hojas del Informe Prevasa nos permite obtener un plano conjunto de los dos sectores que integran el Plan Parcial 24. La versión del Plan Parcial 24 que figura en el Informe Prevasa es la de $1970, y$ en el listado final aparece como plan en tramitación.

El plano conjunto del Prevasa pone de manifiesto la importante fractura que introducen en el ámbito del Plan Parcial 24 los dos ejes que lo cruzan: el eje norte-sur del nuevo acceso a Ademuz (actual Avenida Pio XII) y el eje este-oeste de la Ronda Exterior.

La versión del plan redactada en 1970 no mantiene ninguno de los elementos de la versión inicial de 1966, salvo aquellos que se encuentran construidos, que son, además de la edificación de manzanas cerradas del poblado de Benicalap, las instalaciones de Saica y la extensa parcela ocupada por las Escuelas Profesionales de San José.
1. Ver Anexo de Documentos. PP24, 1970. Memoria. 
El objetivo del plan, expresado en su Memoria, es el de encauzar la iniciativa particular ${ }^{1}$. Tiene, por tanto, el carácter de plano de alineaciones mas que de plan de realizaciones urbanísticas directas.

La ordenación de las zonas de edificación abierta del Plan Parcial 24 se describe en la Memoria del plan de 1970 en los términos siguientes:

...todas las partes del plano restantes de nuevo esquema, se caracterizan por el intento de formar agrupaciones definidas con elemento ajardinado central, formando lo que se ha dado en llamar supermanzanas, dentro de las cuales el tráfico rodado es tranquilo, ya que las calzadas para el mismo no atraviesan las supermanzanas, sino que entran y salen por la misma calle para distribuir y llegar a los aparcamientos. Al no haber beneficio de acortar camino, por no atravesar, el tráfico es solamente el propio de la supermanzana y por lo tanto lento.

En cada una de estas agrupaciones hay un elemento central de jardín o público, que es el centro de la agrupación y también en el centro se ubica la Escuela Maternal o el Grupo Escolar, para que los niños no tengan que desplazarse ni atravesar calles de tránsito intenso. ${ }^{1}$

El planteamiento es, pues, el mismo que hemos observado en otros planes parciales del mismo periodo.
1. Plan Parcial 24, 1970. Memoria. Anexo de Documentos, p. 579.

Plano conjunto de los sectores 24-A y 24-B del Plan parcial 24. (Montaje de hojas del Informe PREVASA).

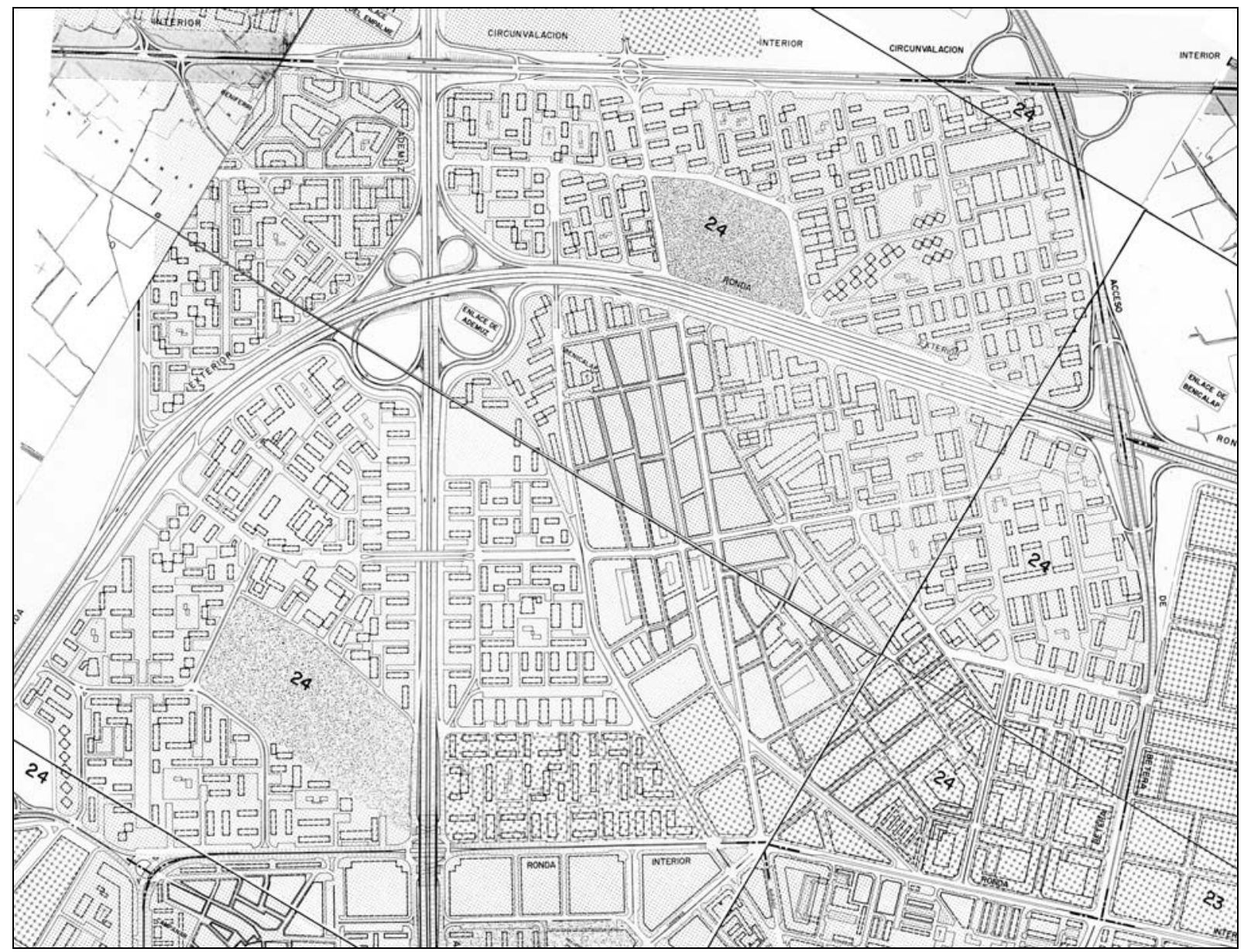




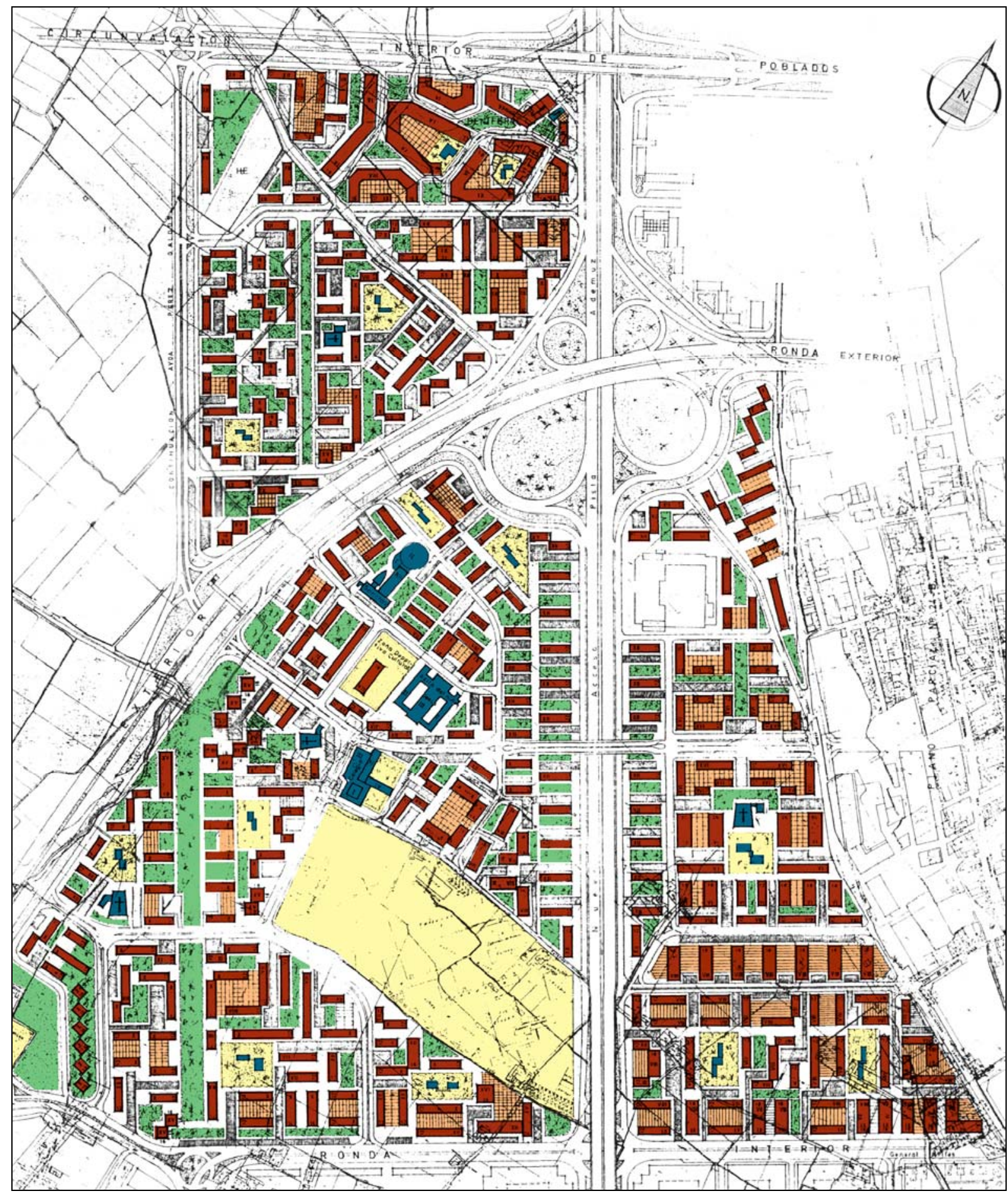

Plan Parcial 24-A, 1970. Edificación abierta y equipamientos (Elaboración propia. Color sobre plano de alineaciones del plan).
En la versión del PP24 de 1970, las reservas de suelo para zonas verdes y equipamientos en el sector A son notablemente inferiores a las previstas en la posterior redacción del Plan de 1975.

En ambas versiones, los tipos edificatorios presentes son los habituales en los planes parciales coetáneos: bloques lineales de dos y cinco crujías, dispuestos de forma aislada, en cadena o unidos por cuerpos de edificación en planta baja, o torres de planta cuadrada, aisladas o formando parejas o racimos de torres unidas por un vértice. Una geometría más libre, basada en líneas oblicuas, se emplea en los bloques profundos previstos para el poblado de Beniferri en la versión de 1970. 


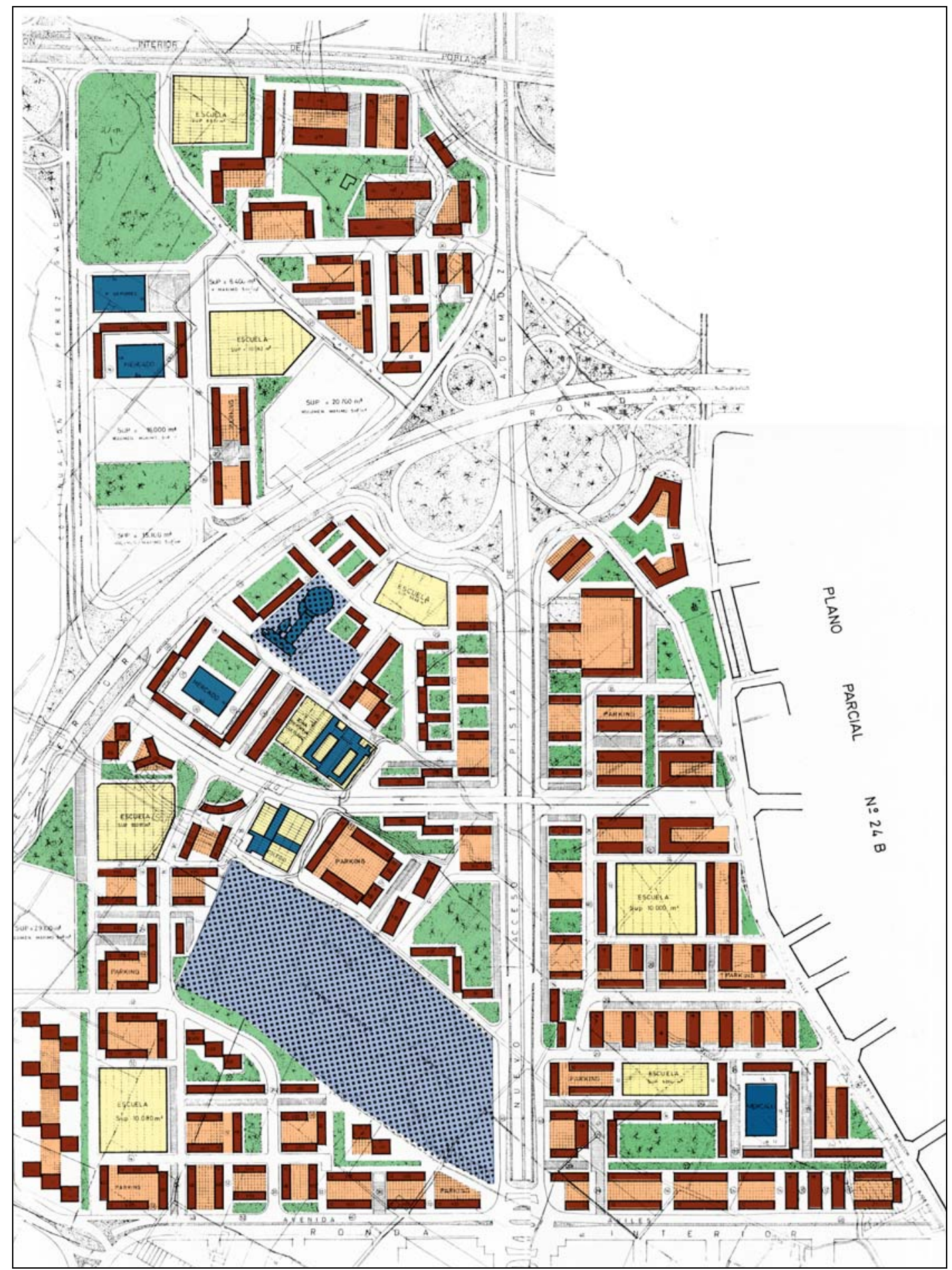

En la versión de 1975 existe también algún bloque aislado de planta más libre, en forma de $\mathrm{Y}$ o de curva.

Los bloques se disponen mayoritariamente según la orientación norte-sur o levante-poniente, siguiendo el ejes del nuevo Acceso de Ademuz o de la Ronda Interior, perpendicular al mismo. Esta orientación sólo se altera a causa de la traza oblicua de la Ronda Exterior y de la parcela de las Escuelas Profesionales de San José, en cuyas proximidades los bloques, tanto en la versión de 1970 como en la de 1975, se alinean con la directriz diagonal de dicha parcela.

Plan Parcial 24-A, 1975. Edificación abierta y equipamientos (Elaboración propia. Color sobre plano de alineaciones del plan). 
PP 24-A, 1975. Plano de estado actual.
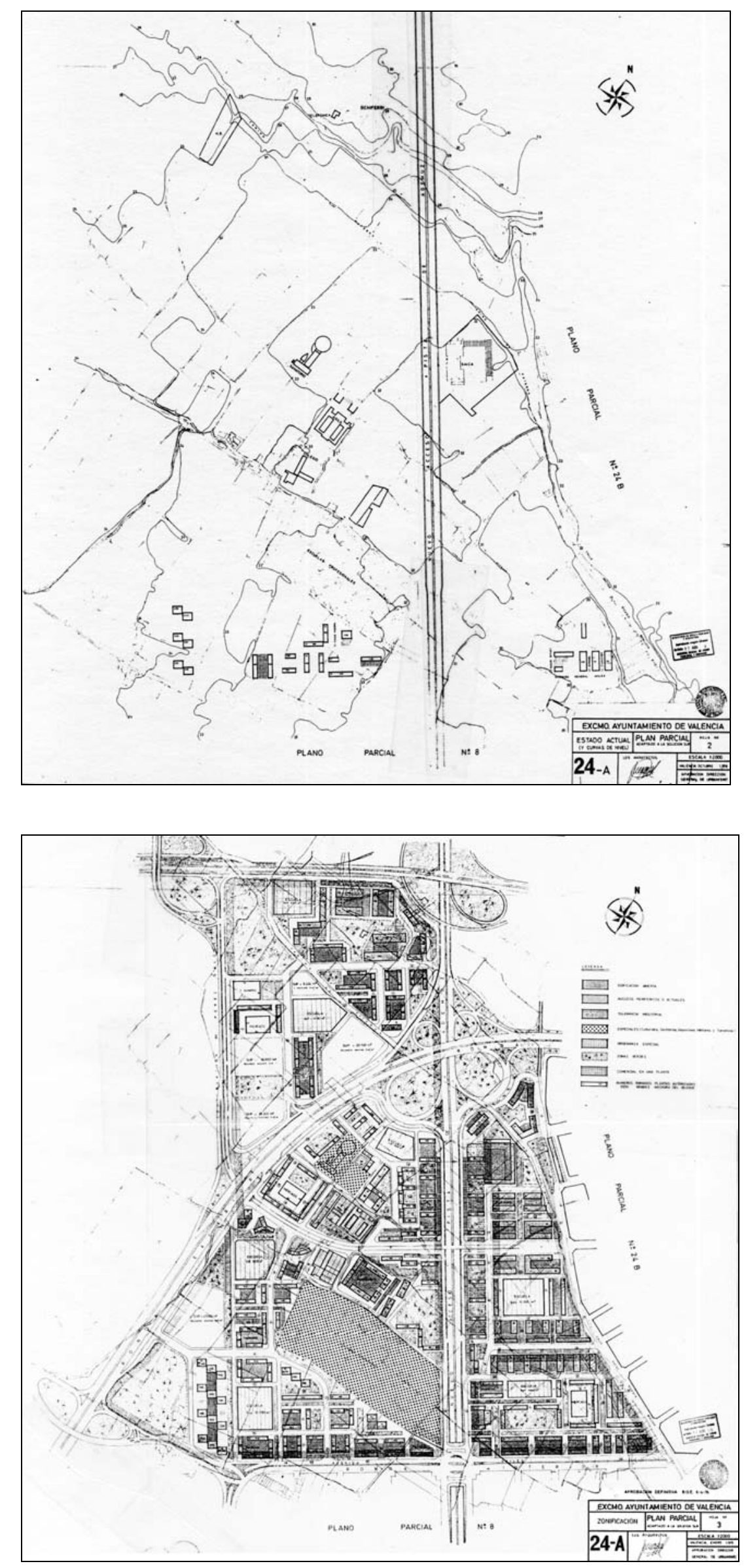

PP 24-A, 1975. Plano de zonificación. 


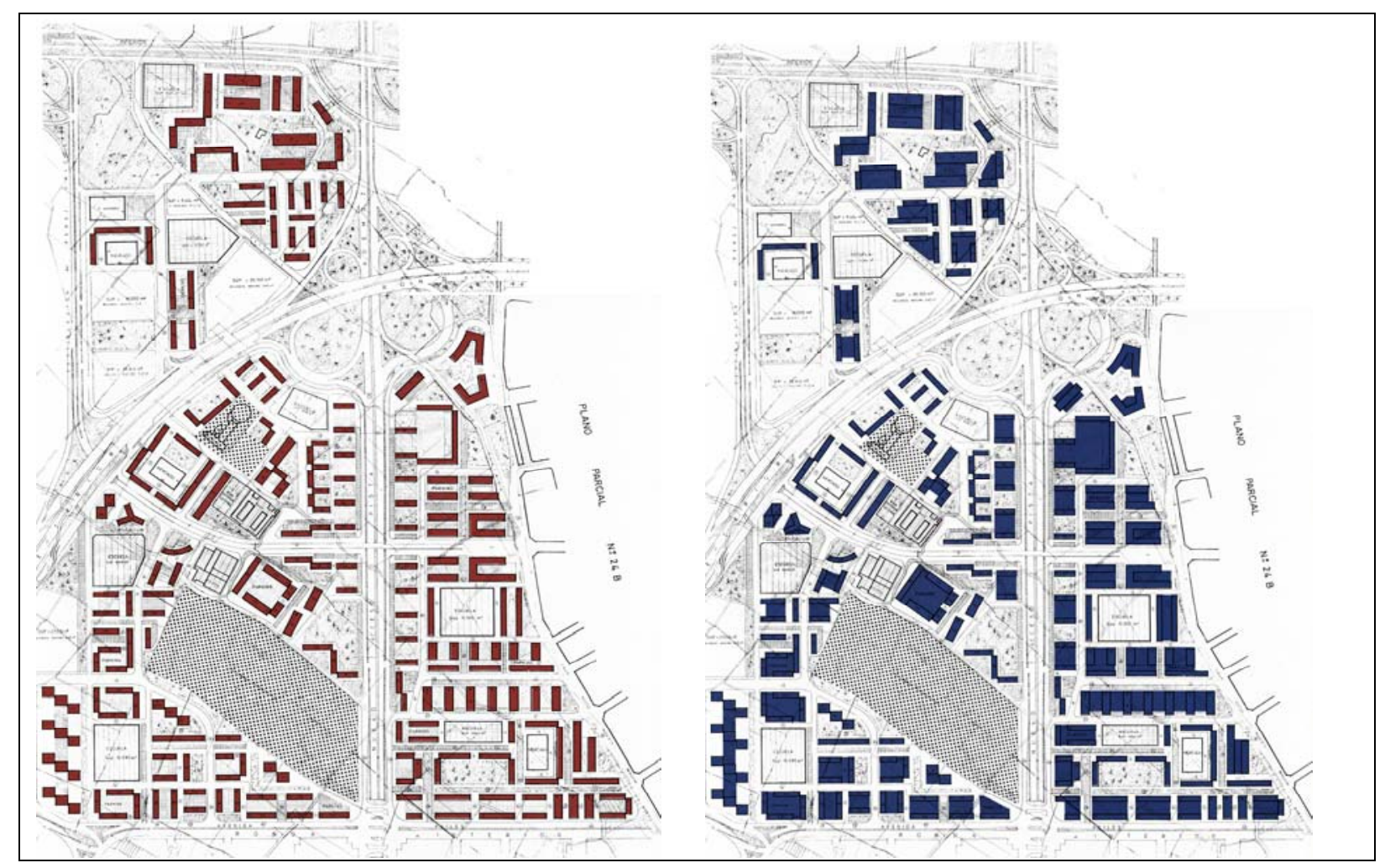

Como conjunto, el sector A, tanto en la versión del plan de 1970 como en la de 1975, muestra un aspecto caótico, como resultado del exceso de variedad introducido en la combinatoria de los tipos básicos edificatorios antes mencionados. La única frase urbana legible es tal vez la secuencia de bloques transversales a ambos lados del nuevo acceso de Ademuz proyectada en la versión del plan de 1970, que queda bastante desdibujada en la de 1975.

A la impresión de desorden contribuye la escasa longitud de los bloques lineales, que parece a veces dictada casi exclusivamente por la intención de que queden situados dentro de los límites de las diferentes parcelas rústicos existentes, a fin de favorecer su construcción como edificios completos, tal como señala la memoria del plan de 1975:

En lo que atañe a la longitud de los bloques, se ha procurado en lo posible dado el minifundio de los terrenos en esta ciudad y zona, el que pueda llegarse en orden a posible a un máximo de dos proyectistas distintos, si bien lo interesante sería que cada bloque poseyera unidad arquitectónica como mejor solución estética. ${ }^{1}$

El desorden de la edificación abierta, no obstante, se evidencia más en el plano de edificación en planta tipo que en el de planta baja, ya que los cuerpos de edificación de una planta destinados a usos comerciales forman unos rectángulos que, pese a su pequeño tamaño, recomponen un tejido legible de manzanas y calles.

En la versión de 1975 se aprecia, además, una voluntad de tratar algunos agrupaciones de bloques lineales como elementos envolventes de jardines o equipamientos, en una tentativa de recomponer la manzana con edificación perimetral.
Plan Parcial 24-A, 1975. Edificación en planta tipo y en planta baja (Elaboración propia sobre plano de alineaciones del Plan).
1. Plan Parcial 24, 1975. Memoria. Anexo de Documentos, p. 590. 

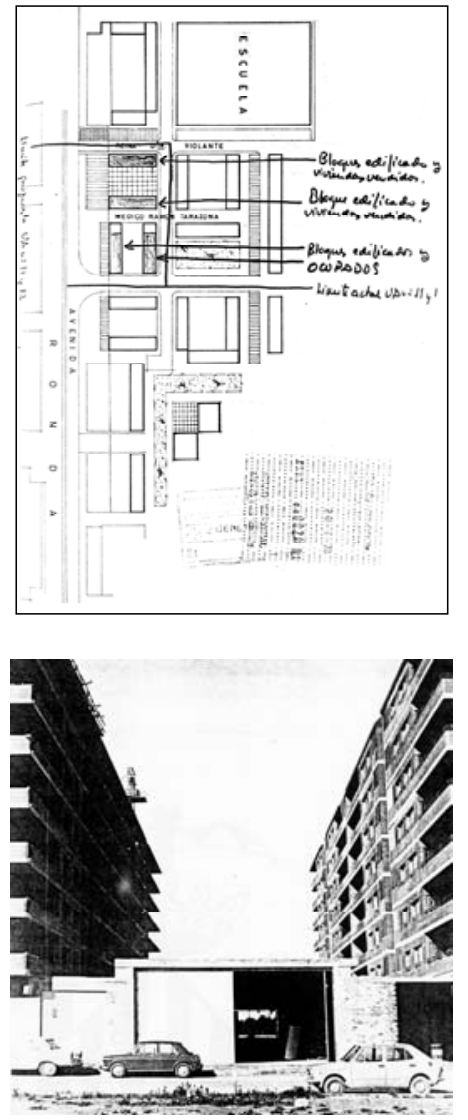

Alegación al PP 24-A.de 1975.

PP 24-A, 1975. Plano de unidades de actuación.

1. Resolución de aprobación del Plan Parcial 24, Dirección General de Urbanismo del Ministerio de la Vivienda, 28-02-1976. Documento 24.2. Anexo de Documentos,p. 626

2. Determinación del Sistema de Actuación en el ámbito del Plan Parcial 24 (sectores A y B), 1977. Memoria. Anexo de Documentos, pp. 598-611.
El Plan Parcial 24 es el más tardío de todos los planes parciales que desarrollan el Plan General de 1966. Es de hecho el único cuya versión definitiva tuvo que ajustarse a las determinaciones de la Ley del Suelo de 1975, al tramitarse en el Ministerio de la Vivienda con posterioridad a la entrada en vigor de la misma.

La resolución de aprobación definitiva de 1976 de la Dirección General de Urbanismo obligaba, entre otras condiciones, a la sustitución del sistema de cesión de viales previsto para la ejecución del plan por alguno de los previstos en la Ley del Suelo ${ }^{1}$. Se redactó para ello por parte del Ayuntamiento un documento anexo al plan para la delimitación de unidades de actuación, indicando para cada una de ellas el sistema de actuación elegido, que fue para las áreas de nueva edificación el de compensación. ${ }^{2}$

Dos de las condiciones de la resolución mencionada se refieren a las zonas verdes, una prohibiendo la posibilidad prevista en el plan de realizar aparcamientos subterráneos bajo zonas verdes y la otra exigiendo la supresión de toda referencia a la posible propiedad privada de las zonas verdes dispuestas entre bloques, ya que todas las zonas calificadas como verdes deben ser de dominio y uso público.

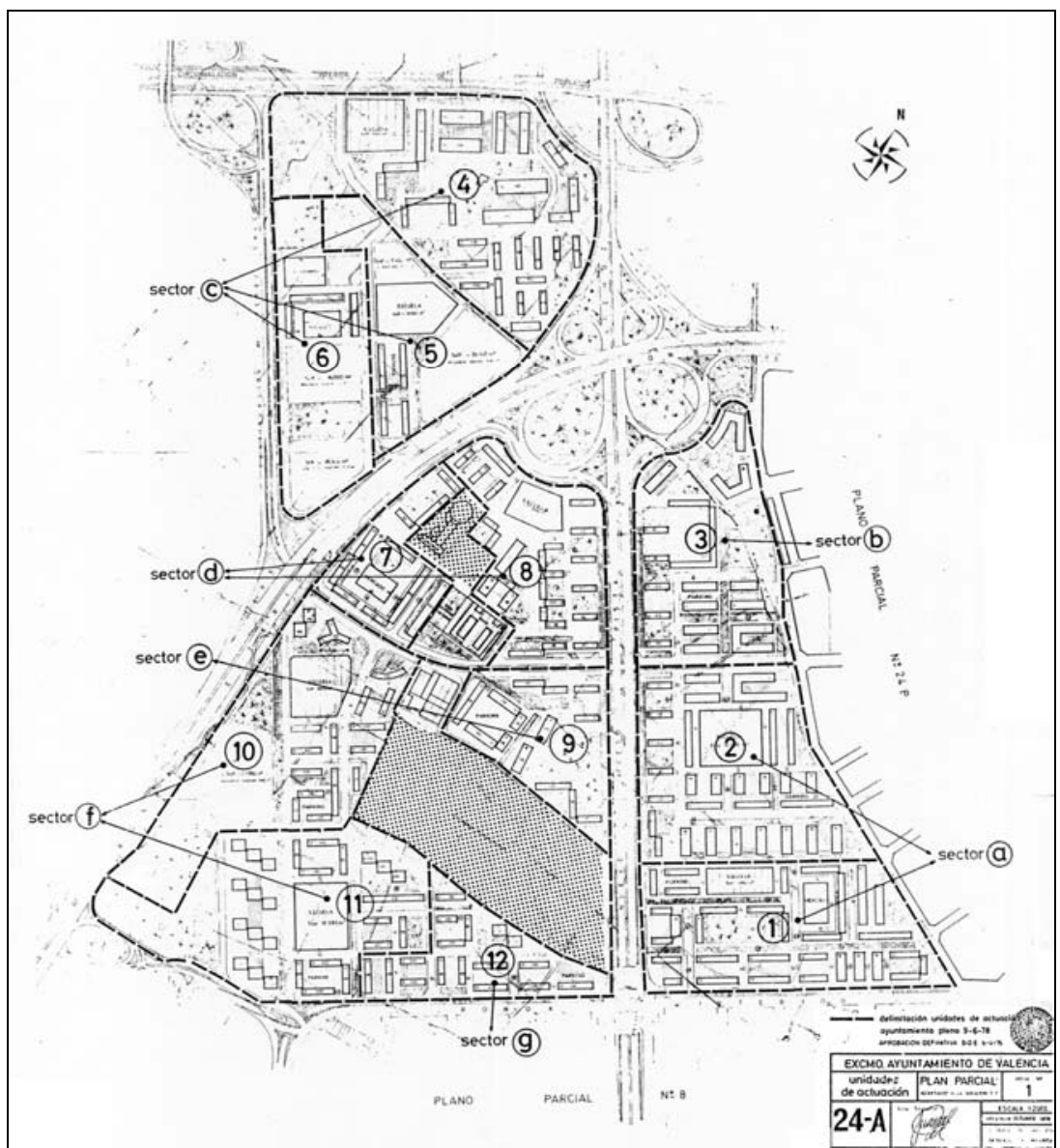




\section{Trazado viario.}

La fractura interna que en el área ordenada por el Plan Parcial 24 introducen los ejes viarios que lo cruzan, y en especial el nuevo Acceso de Ademuz y la Ronda Exterior, es reconocida en la propia documentación del plan cuando se manifiesta lo siguiente:

...tomando como base la propia estructura viaria del plan, reflejo de la prevista en el Plan General, el territorio ámbito del mismo en ningún modo puede conceptuarse como un ente unitario, sino más bien como un conjunto de unidades vecinales o barrios totalmente independientes, ya que las grandes vías que lo atraviesan, trocean y separan, al ser de rango fundamental (autopistas o autovías), constituyen auténticas barreras que imposibilitan la relación de unos sectores con otros. ${ }^{1}$

Dentro de esos sectores, las "supermanzanas" con ramales de penetración sin salida que constituían las unidades de composición del conjunto en la versión del plan de 1970 son en su mayor parte troceadas y atravesadas por un viario que adopta un sistema mallado convencional.

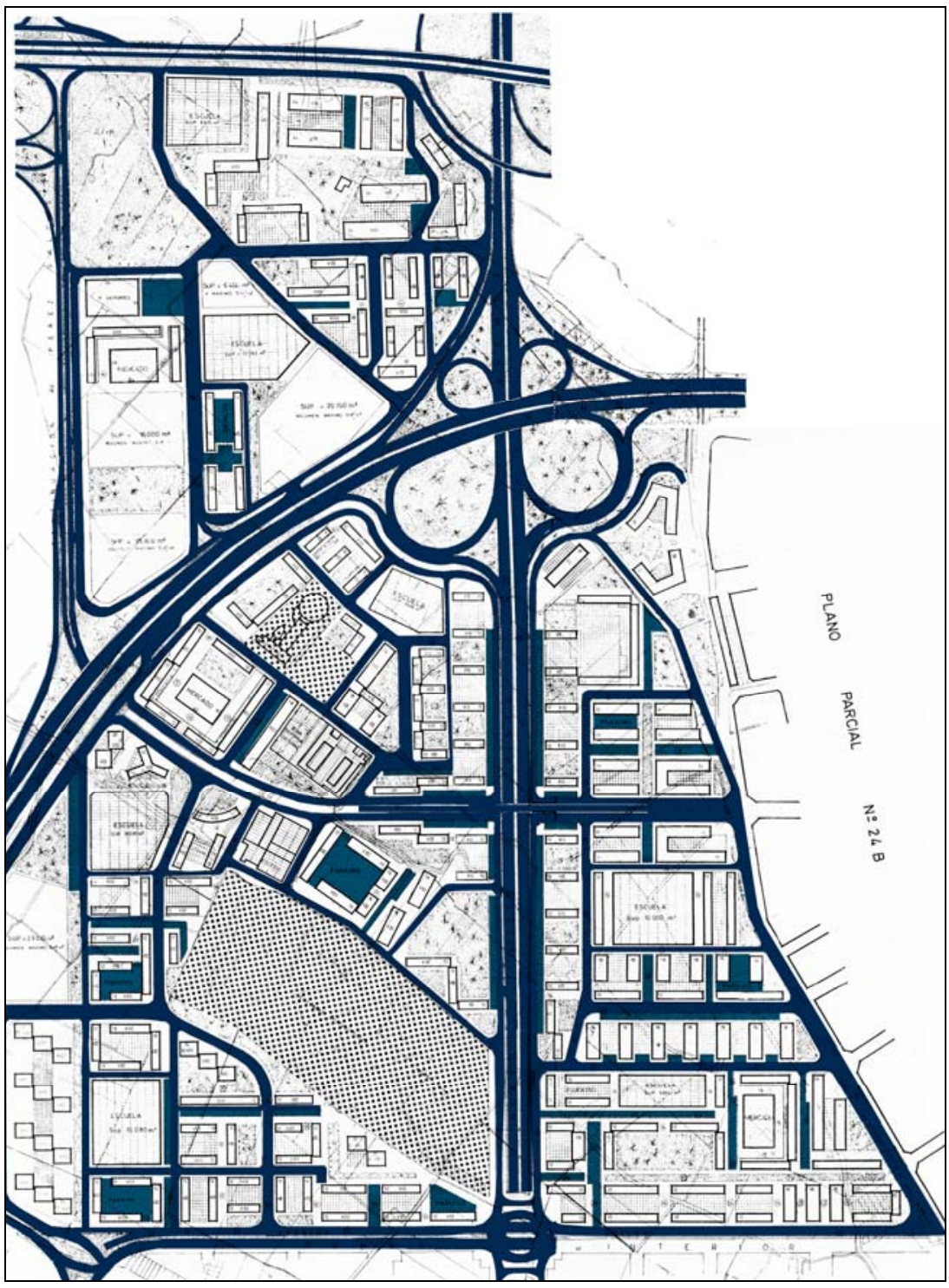

Plan Parcial 24-A, 1975. Trazado viario (Elaboración propia sobre plano de alineaciones del Plan).
1. Memoria de la Determinación del Sistema de Actuación en el ámbito del Plan Parcial 24 (sectores A y B), 1977. Anexo de Documentos, p. 599. 


\section{Grado de realización}

En la versión de 1970 del Plan Parcial 24 toda la edificación prevista en el sector $A$ está definida en cuanto a número de plantas y alineaciones. En cambio, en la versión de 1975 del plan, tal como señala la Memoria del mismo,

...se prevén manzanas sin definir edificación alguna, ofreciéndolas como simple unidad de terreno con un volumen de edificación asignado, para que la agrupación de propietarios pueda resolver según criterio del proyectista los bloques a su conveniencia, siempre acordes con los límites definidos en la Ordenanza correspondiente, previa aprobación Municipal. ${ }^{1}$

Este planteamiento de dejar en blanco, para un estudio urbanístico posterior, zonas que en una versión anterior del planeamiento poseían una ordenación con edificación abierta se mantiene y acentúa en el Plan General de 1988, que califica todo el espacio no edificado del sector A como Suelo Urbanizable Programado.

Plan Parcial 24-A, 1970. Grado de realización de la edificación abierta (Elaboración propia sobre plano de alineaciones del plan).

1. Plan parcial 24, 1975. Memoria. Anexo de Documentos, p. 590.

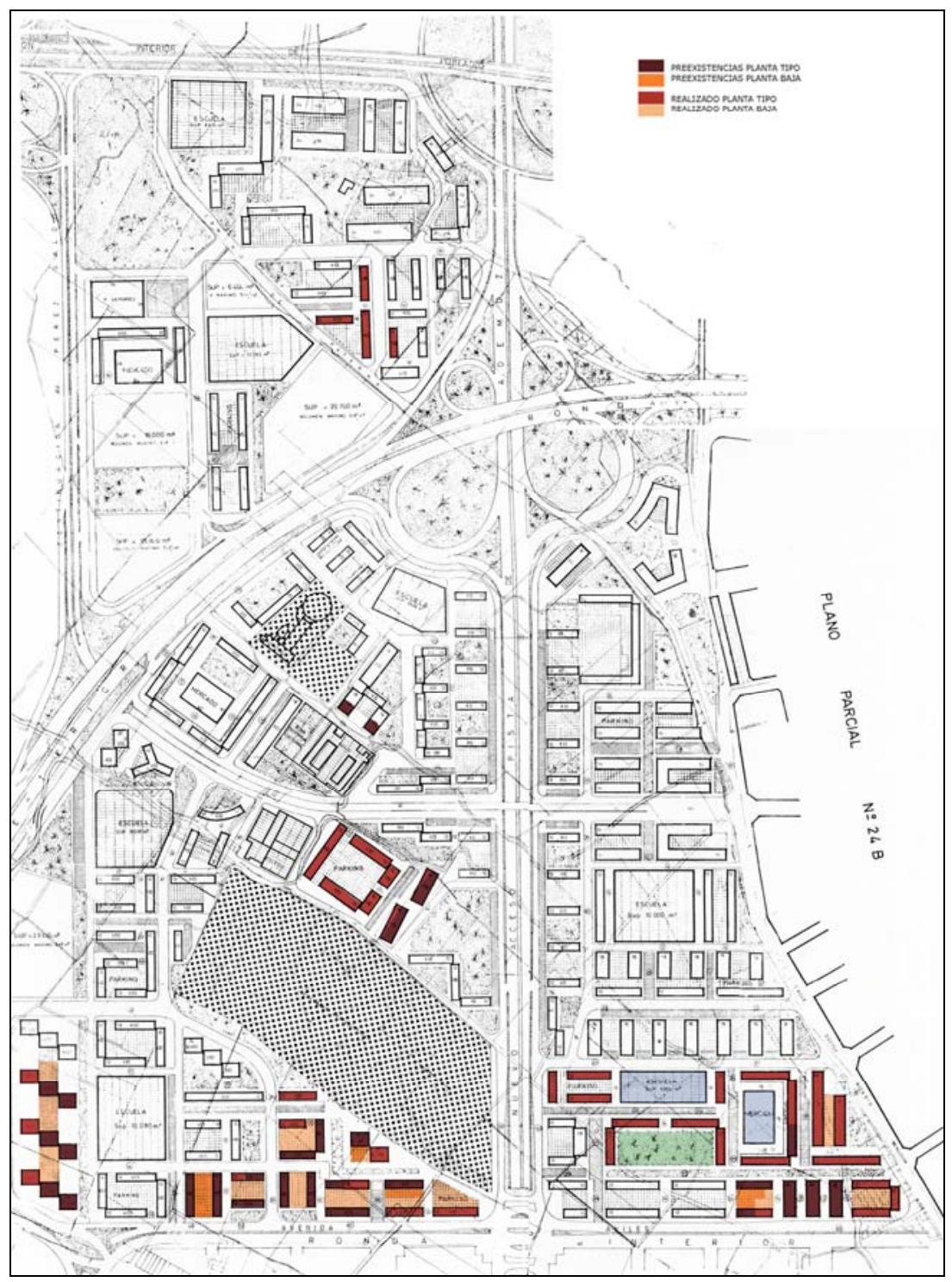


Este suelo sería ordenado posteriormente a través de un nuevo Plan Parcial, denominado "de Accesos a Ademuz" basado en sistemas de trazado y composición de la edificación muy diferentes a los previstos en el Plan Parcial $24 .^{1}$

La zona ha experimentado un importante desarrollo urbanístico en los últimos años, cuyo punto de inicio fue la construcción en ella del nuevo Palacio de Congresos de Valencia. El estudio de esta etapa reciente queda, no obstante, fuera de los límites de nuestro trabajo.

El grado de realización de la edificación abierta prevista en el sector A del Plan Parcial 24 de 1975 es, en consecuencia, muy bajo. Los fragmentos realizados de cierta entidad como conjunto se concentran en la franja sur, junto a la Ronda Interior (actuales Avenidas Dr. Peset y General Avilés). A ellos hay que añadir algunos bloques aislados situados en las proximidades del lado norte del recinto de las Escuelas Profesionales de San José y otros junto al Camino Nuevo de Paterna.

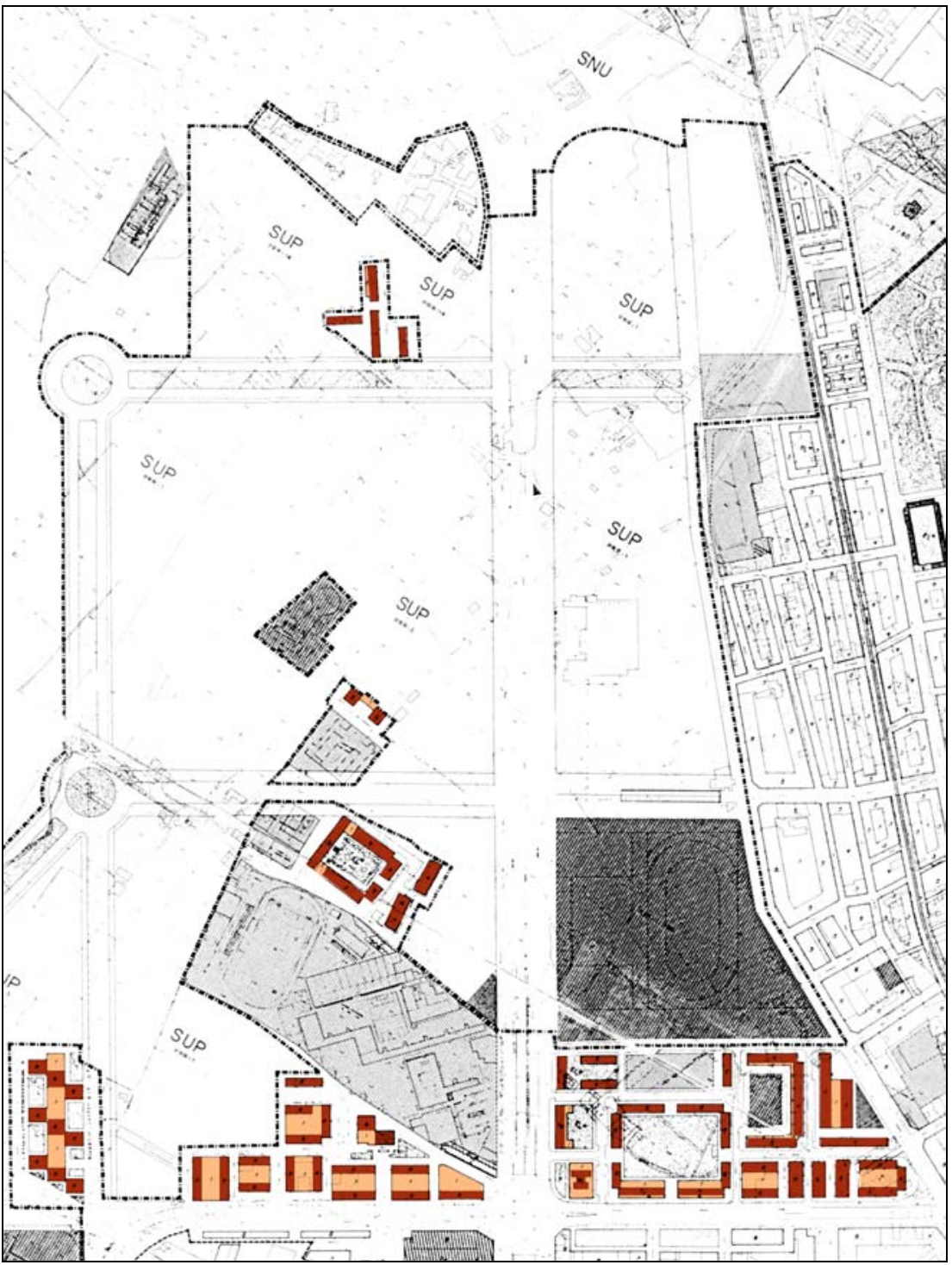

PGOU de Valencia, 1988. Zona del Plan Parcial 24-A (Elaboración propia. Color sobre montaje de hojas de la serie C del PGOU)

1. Este nuevo Plan Parcial, redactado por Luís Alonso de Armiño, quedó por desgracia bastante desdibujado y desvirtuado a causa de las diversas modificaciones que sufrió en el curso de su ejecución. 


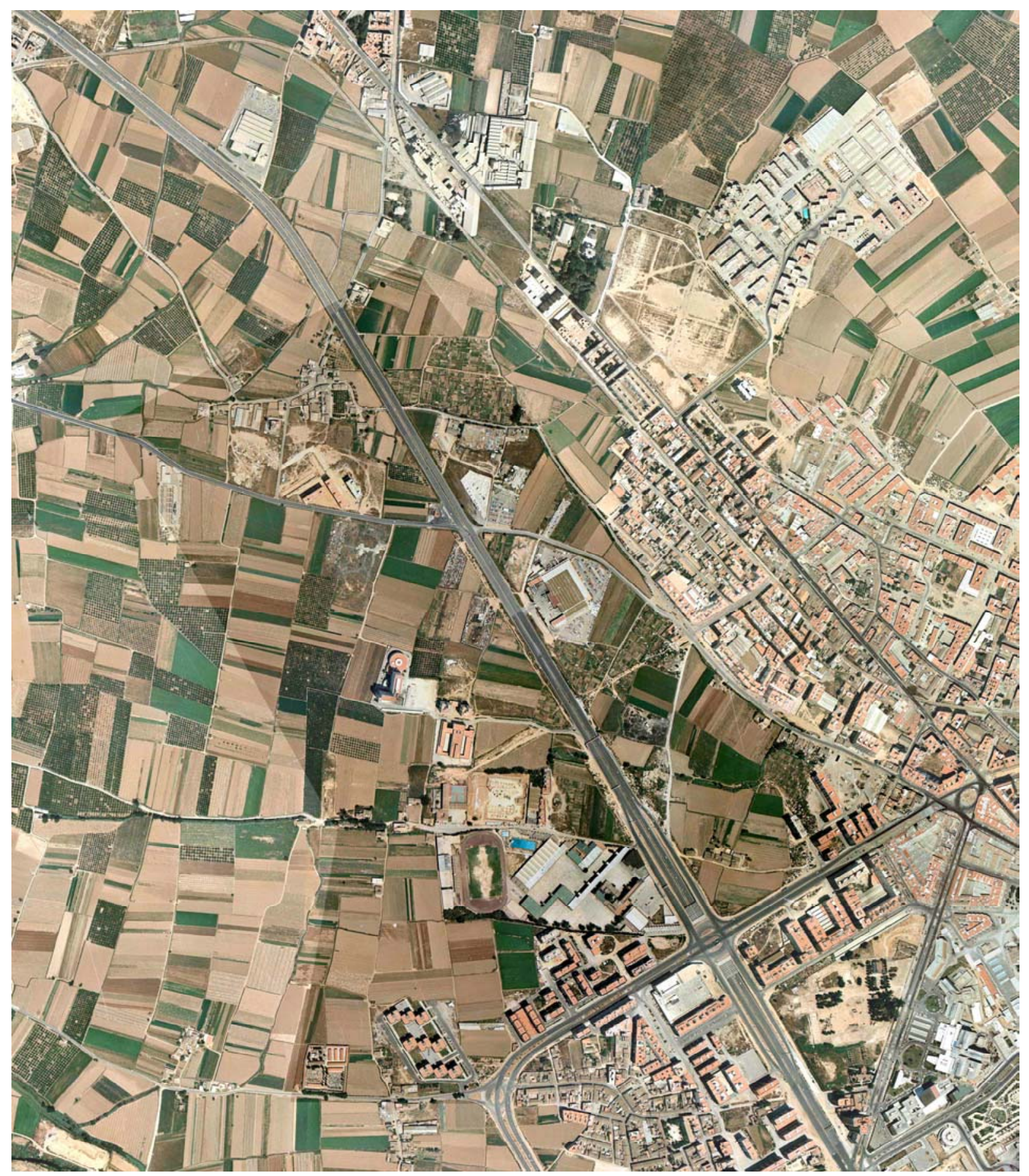

Plan Parcial 24-A. Fotografía aérea, 1980. 


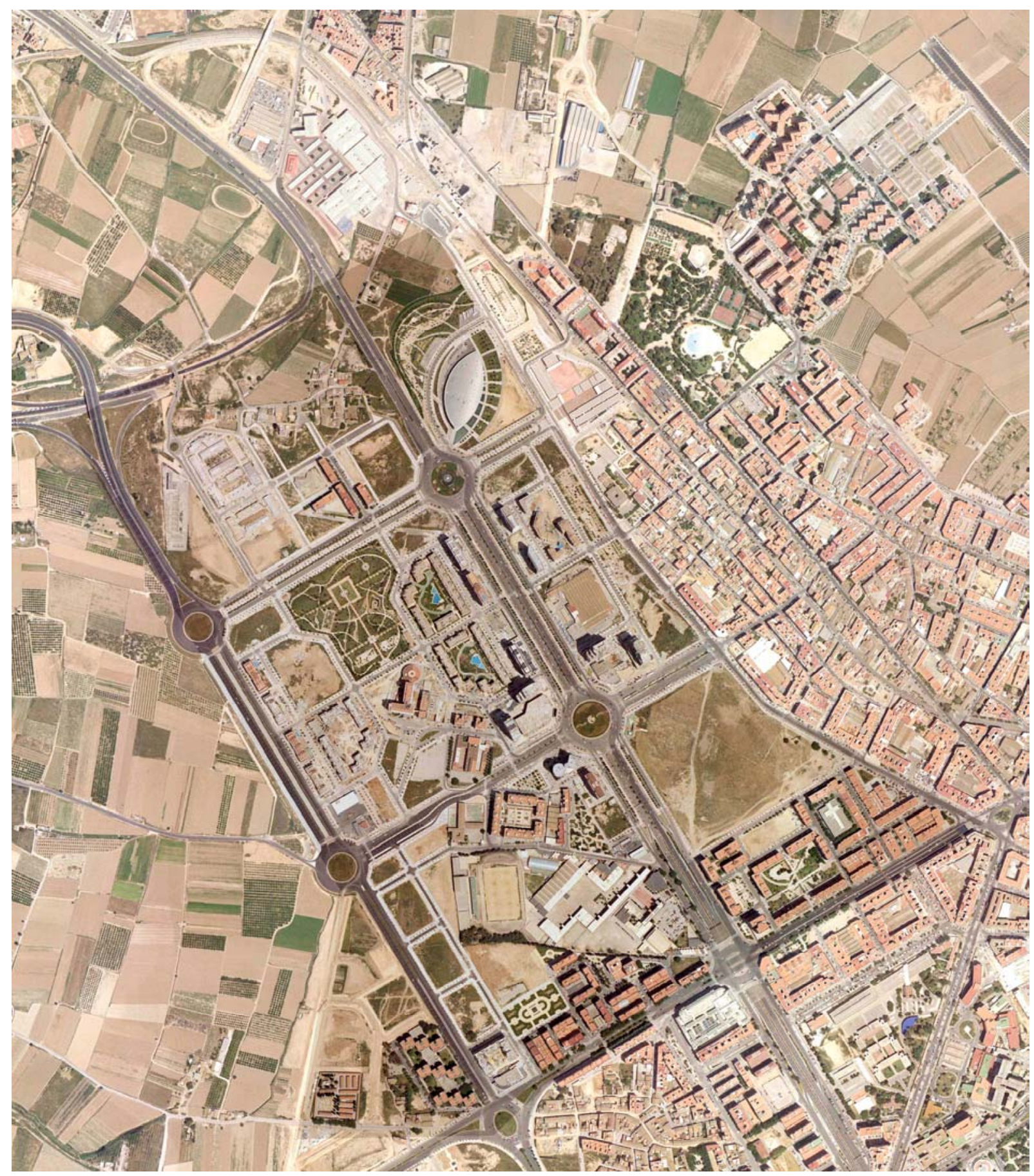

Plan Parcial 24-A. Ortofoto,2002 (AUMSA). 
PP 24-A. Zona sureste. Fotografía aéreas, 1980.

$P P \quad 24-A$

Ortofoto

2002 (AUMSA)
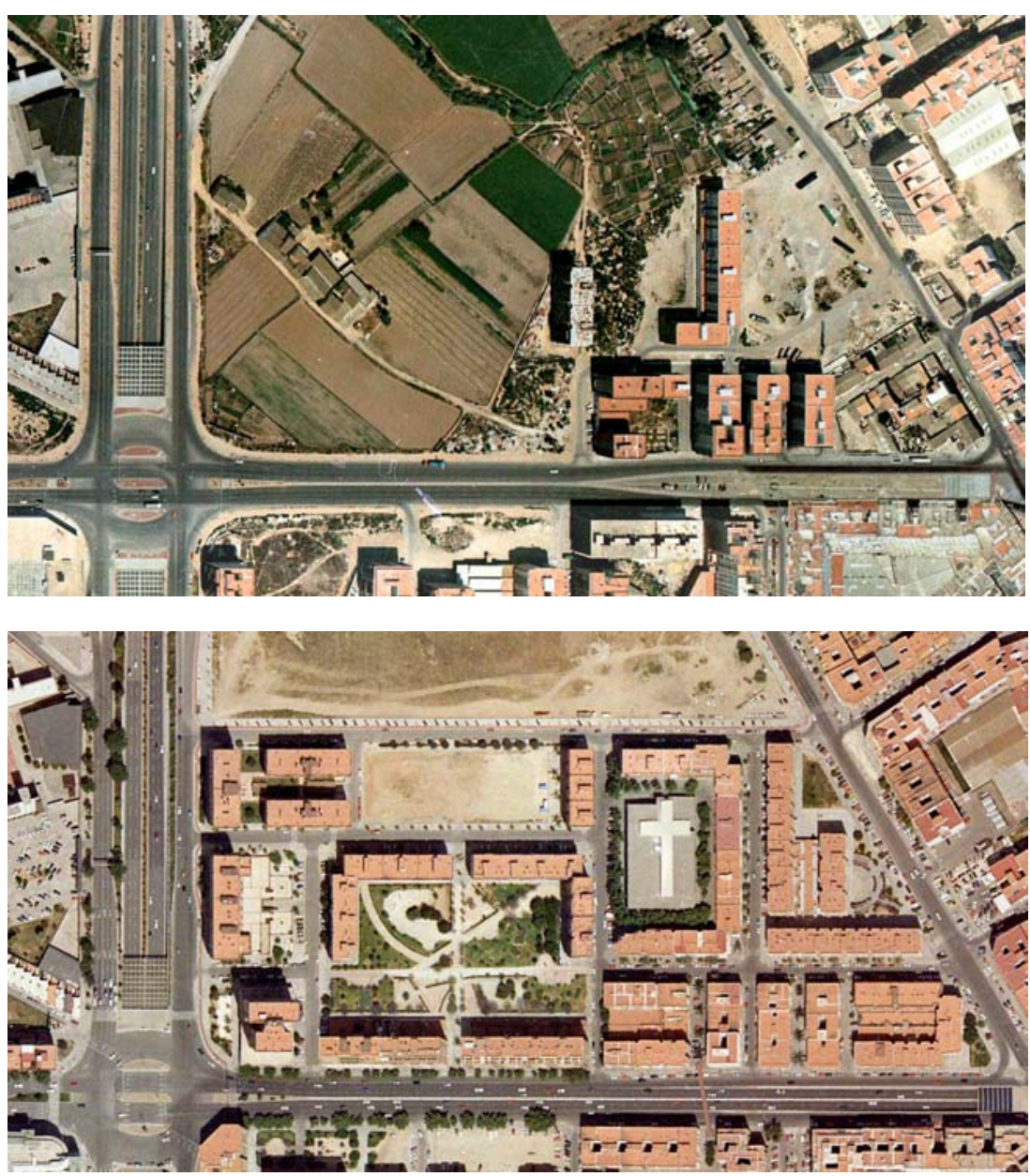

La zona sureste del sector A del Plan Parcial 24 es una de las dos que concentran un conjunto mayor de edificios construidos de acuerdo con las determinaciones de dicho plan.

Junto a la Avenida General Avilés, entre las calles de Tenor y Rafelcofer, existían ya tres bloques de IV plantas y cinco crujías edificados según lo previsto en la versión de 1966 del Plan Parcial 24. Estos bloques, dispuestos en perpendicular a la Avenida, son uno de los escasos ejemplos realizados en Valencia de edificación abierta baja, y muestran lo diferente que habría sido el paisaje urbano de la periferia si no se hubiese adoptado con carácter general el modelo de la edificación abierta alta. Los bloques altos y la torre que ocupan el resto del frente a la Avenida General Avilés, entre la calle Doctor Miguel Servet y la Avenida Pio XII, construidos de acuerdo con lo previsto en el Plan General de 1988, son la muestra evidente de ello.

En la franja de manzanas posterior, entre las calles de Sierra martes y Padre Fernando Casanova, están realizadas las dos grandes manzanas compuestas por bloques altos agrupados en $U$ en torno a un parque y el mercado de Benicalap. El resto del espacio está ocupado por diversos bloques aislados de dos crujías y por una manzana mixta formada por dos bloques profundos de diferente longitud que generan unos volúmenes escalonados en la calle Doctor Nicasio Benlloch. 


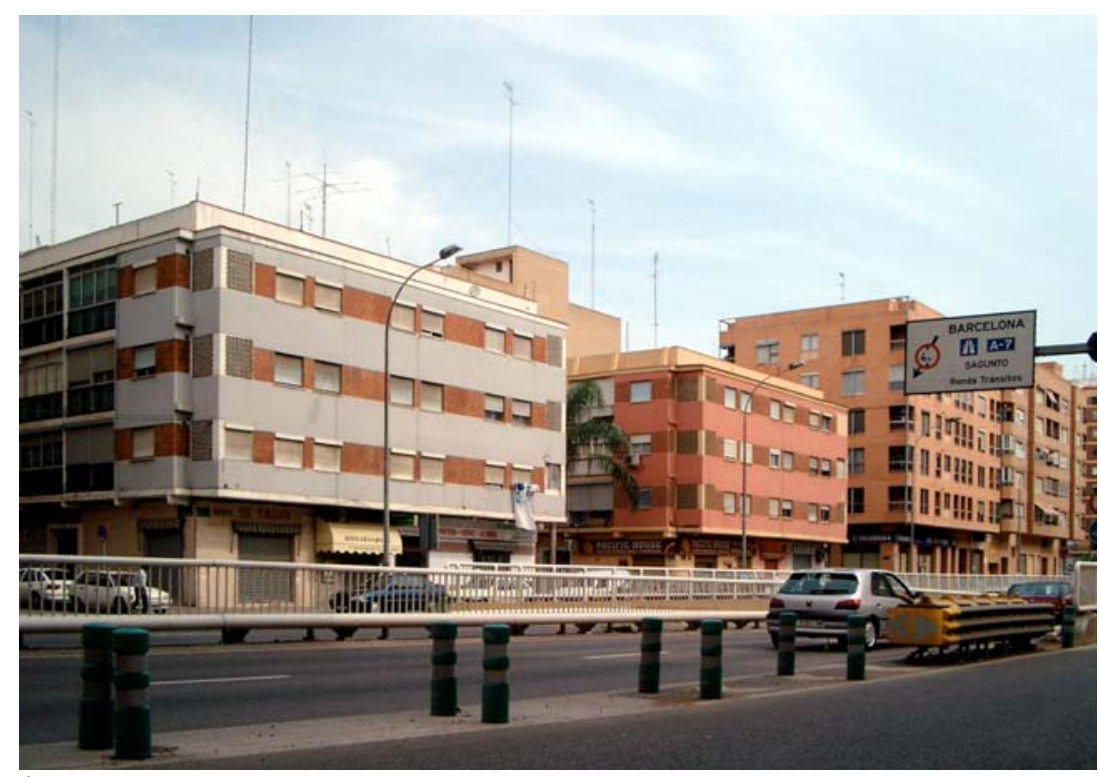

1
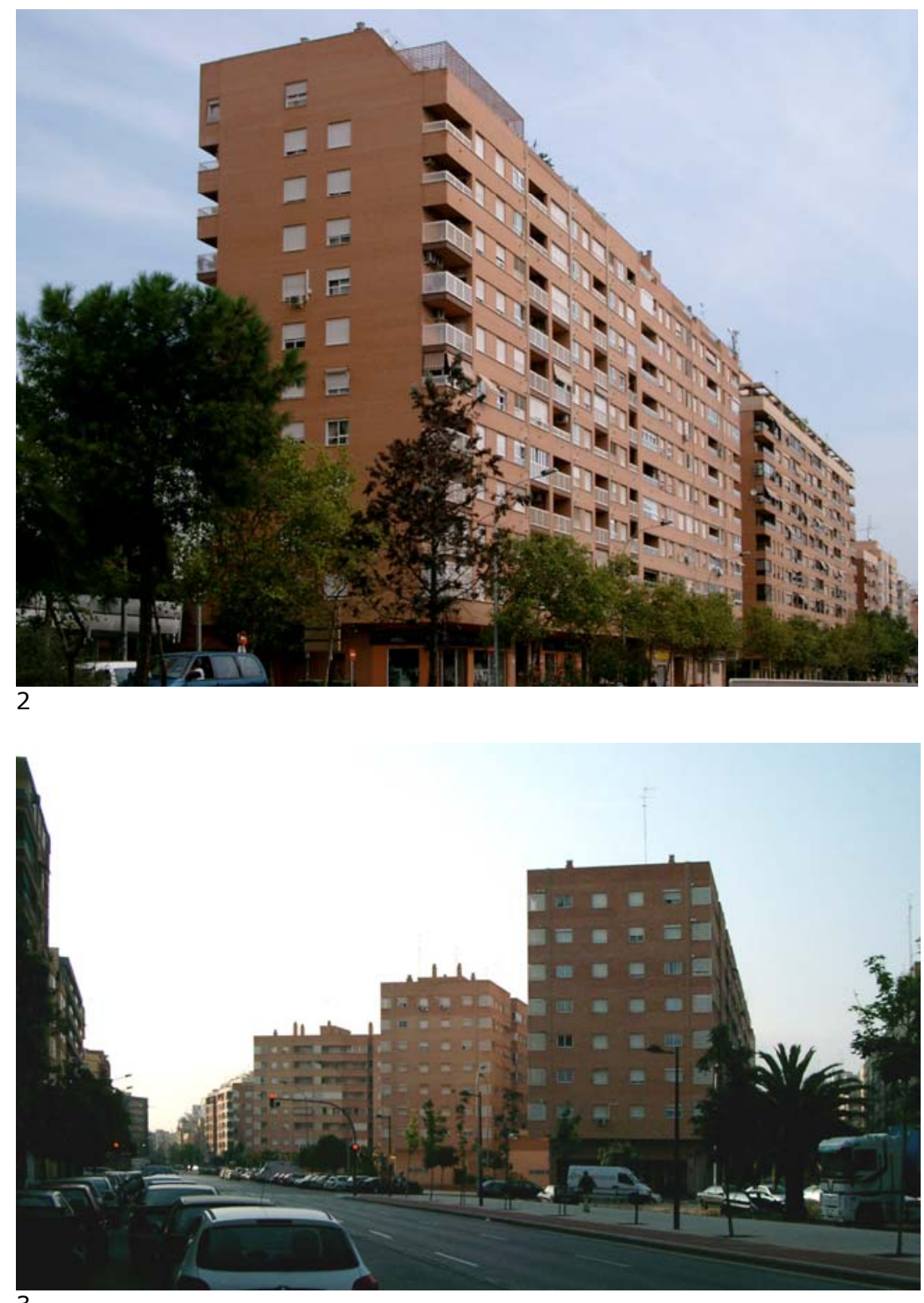

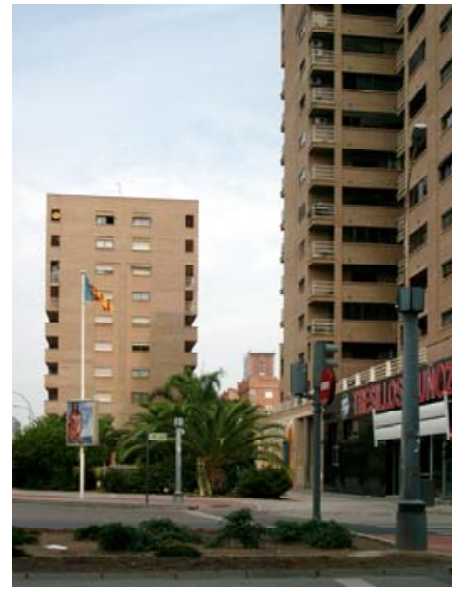

1. Avenida General Avilés. Lado norte. Bloque entre las calles Mirasol y Rafelcofer.

2. Avenida General Avilés.

3. Calle Dr. Nicasio Benlloch. Vista hacia el sur.

4. Bloque y torre en la Avenida Pío XII. 


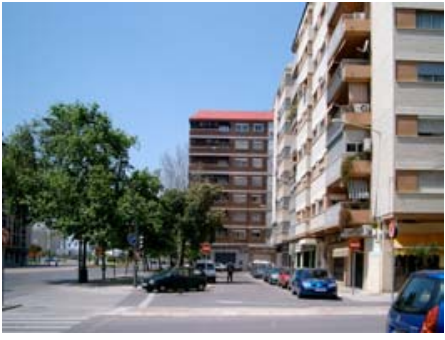

1
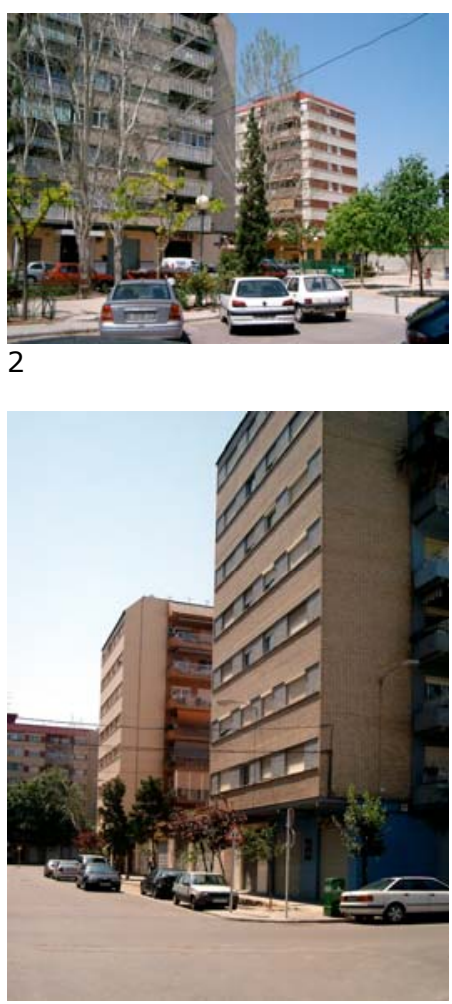

3

En el espacio triangular comprendido entre el recinto de las Escuelas Profesionales de San José y la Avenida General Avilés existe un conjunto significativo de bloques construidos de acuerdo con las determinaciones del sector A del Plan Parcial 24.

La mayor parte de estos bloques responden al tipo de manzana mixta formada por dos bloques de dos crujías unidos en planta baja, con unas dimensiones medias de $45 \times 60 \mathrm{~m}$. La altura de esta edificación de VIII plantas (PB +7).

Los bloques aislados, lineales o agrupados en forma de L, se sitúan en las parcelas triangulares lindantes con las Escuelas Profesionales. En una de estas parcelas se sitúa también un conjunto formado por dos bloques cortos de cinco crujías unidos por el vértice y situados sobre un zócalo comercial.

El extremo oeste de la zona está ocupado por una manzana mixta singular, integrada por tres series de tres bloques escalonados cada una, enlazados por un cuerpo de edificación en planta baja que ocupa sólo la banda central del conjunto, dejando unos jardines abiertos a la Avenida Maestro Rodrigo y a la calle Arturo Ballester.

La realización de un parque vecinal en un espacio que en el Plan Parcial 24 estaba previsto como edificable ha dotado a esta zona de un núcleo central abierto al que se asoman los bloques.

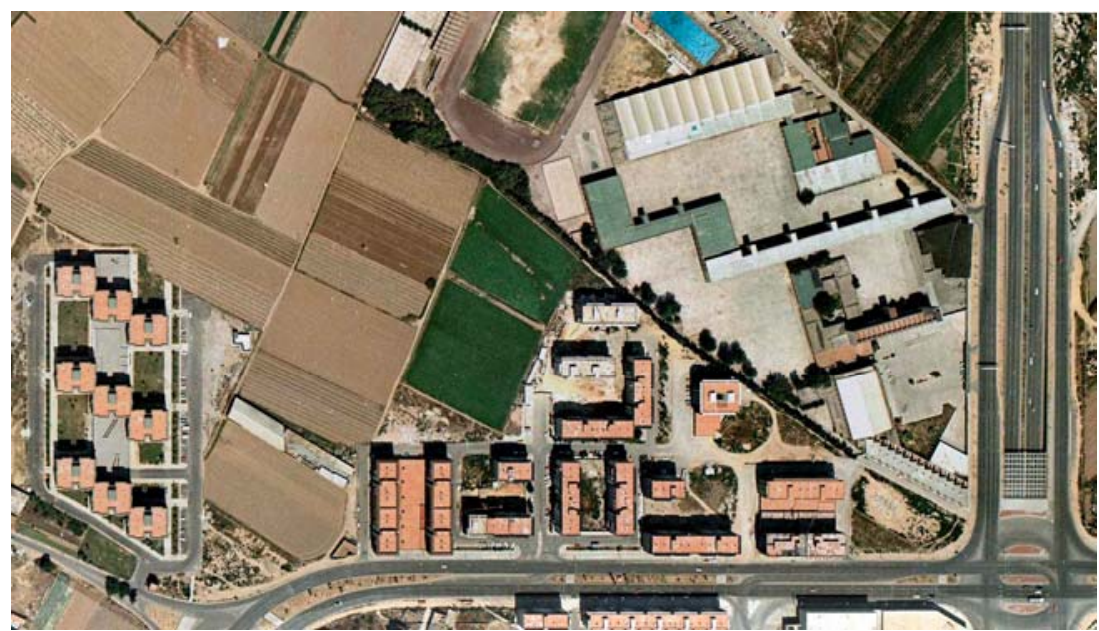

PP 24-A. Zona suroeste. Fotografías aéreas, 1980 y 2002 (AUMSA)

1. Bloques de la Avenida General Avilés.

2. Calle Fornoles, bloques del lado oeste.

3.Calle Aparicio Albiñana, vista hacia el norte.

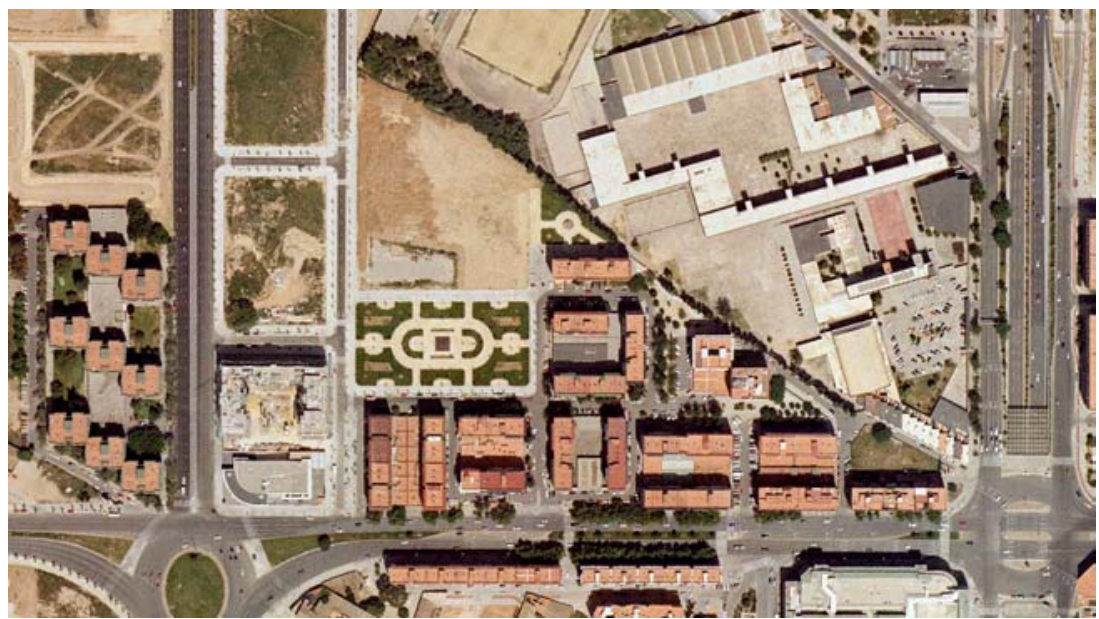




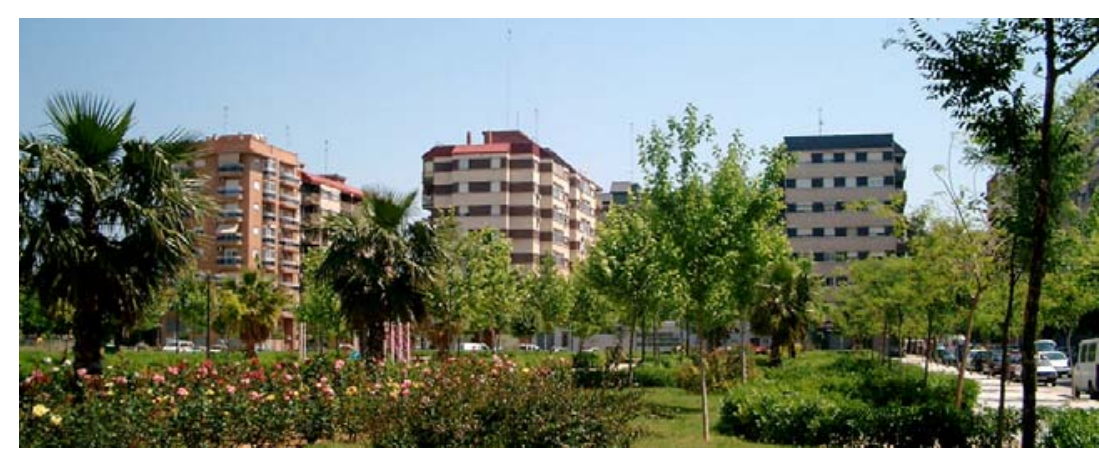

1
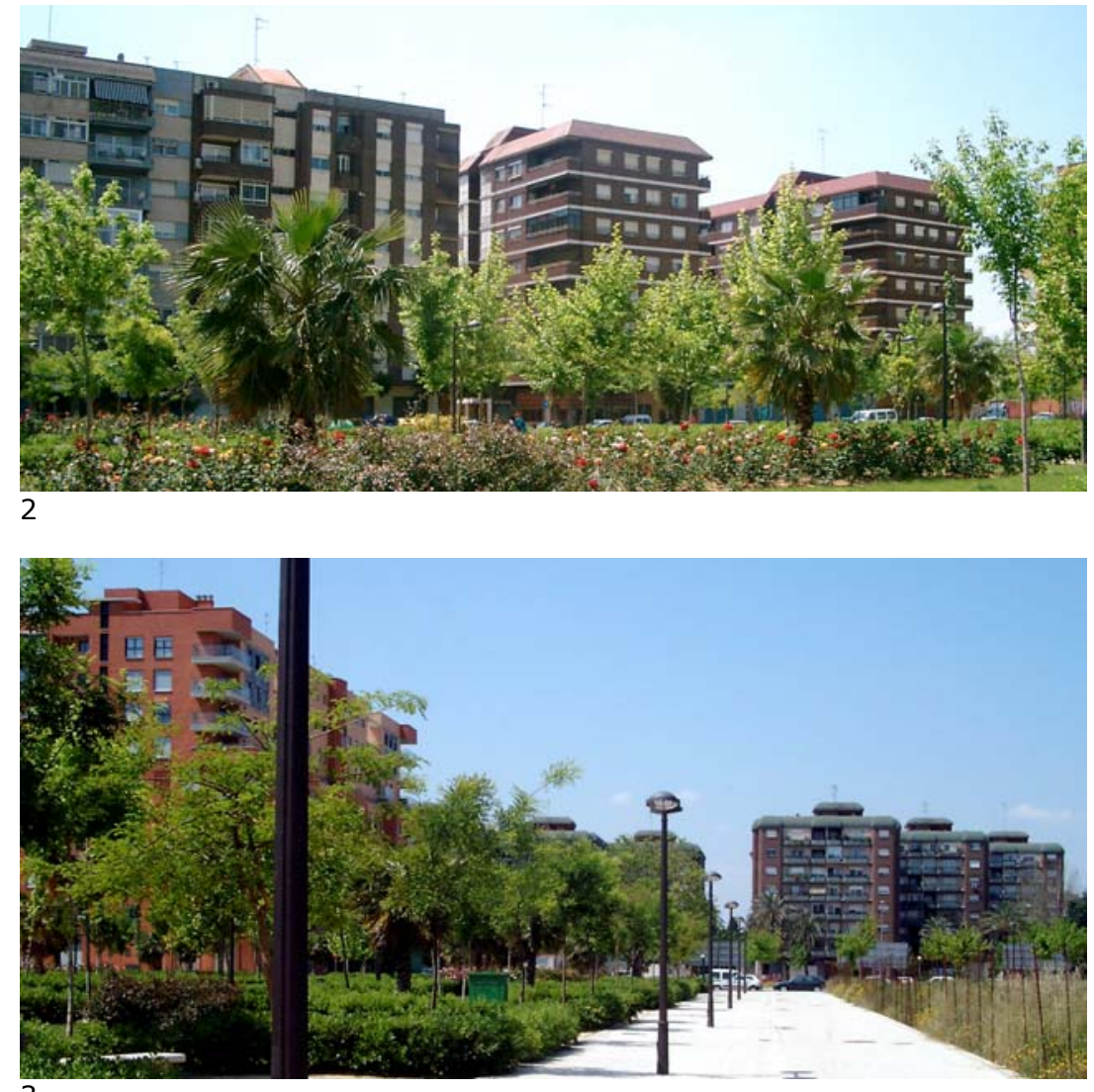

3

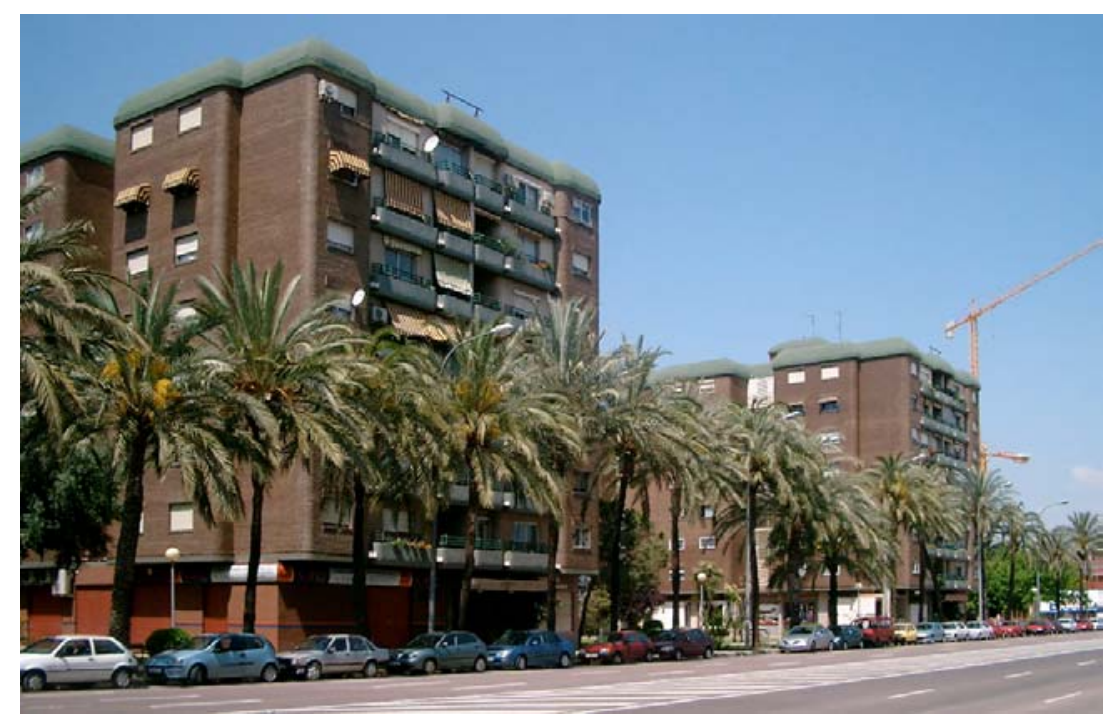

4

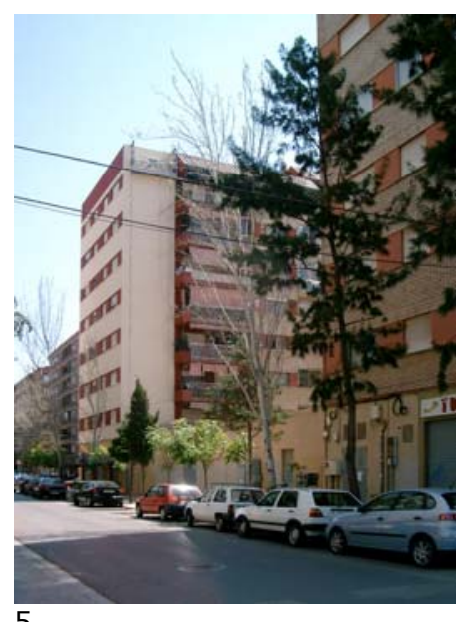

5

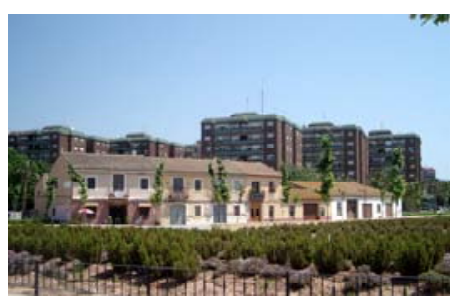

1. Bloques de la calle Puerto de Santa María, vistos desde el nuevo parque vecinal.

2. Bloques de la calle Escultor García Más, vistos desde el parque.

3. Conjunto de la Avenida Maestro Rodrigo, visto desde el parque.

4. Conjunto de la Avenida Maestro Rodrigo.

5. Calle Escultor García Más, vista hacia el este.

6. Vista desde el oeste del conjunto de la Avenida Maestro Rodrigo. 


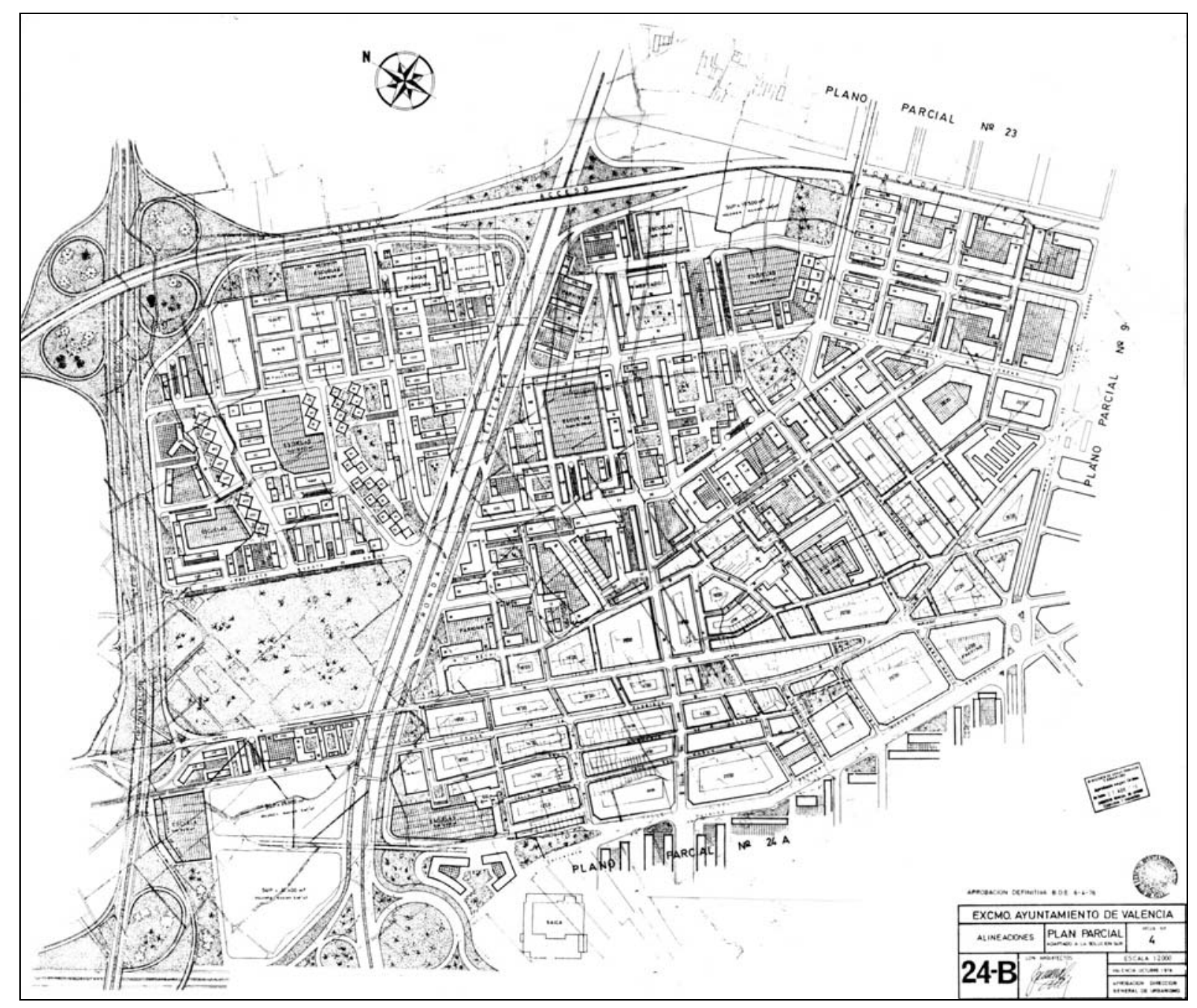

Plan Parcial 24, 1975. Sector B. Plano de alineaciones. 


\section{EL ESTE DE BENICALAP: PLAN PARCIAL No 24-B $(1970 / 1975)$}

El sector B corresponde a la mitad este de las dos en las que se subdivide el Plan Parcial no 24. Como hemos indicado en el apartado anterior, dedicado al sector A, la gran extensión del área ordenada por dicho plan hace necesario que las determinaciones del mismo se representen en juegos de planos separados para cada uno de estos dos sectores.

En concreto, el sector B del PP24 comprende los terrenos limitados al Norte por la llamada "Circunvalación interior de poblados", al Oeste por la calle Doctor Nicasio Benlloch y el sector A del Plan, al Sur por la Ronda Interior (Avenida Onésimo Redondo, actual Av. Dr. Peset Aleixandre) y al Este por el denominado "Nuevo acceso a Moncada".

El sector $B$ está mucho más edificado que el $A$, ya que engloba el poblado de Benicalap, que se extiende a ambos lados del eje norte-sur que forma la Avenida de Burjasot.

Además, en la zona noreste de este sector B se encuentra el conjunto de la Ciudad del Artista Fallero, cuyo plan inicial de 1963 hemos analizado en la sección anterior. Este conjunto estaba ya construido en su mayor parte, con algunas variaciones con respecto a dicho proyecto inicial, en el momento de redactarse la versión de 1970 del Plan Parcial 24 adaptado a la Solución Sur.

En el sector B no se mantiene en esta ordenación de 1970 ningún elemento del plan anterior redactado en 1966, aparte de la Ciudad del Artista Fallero.

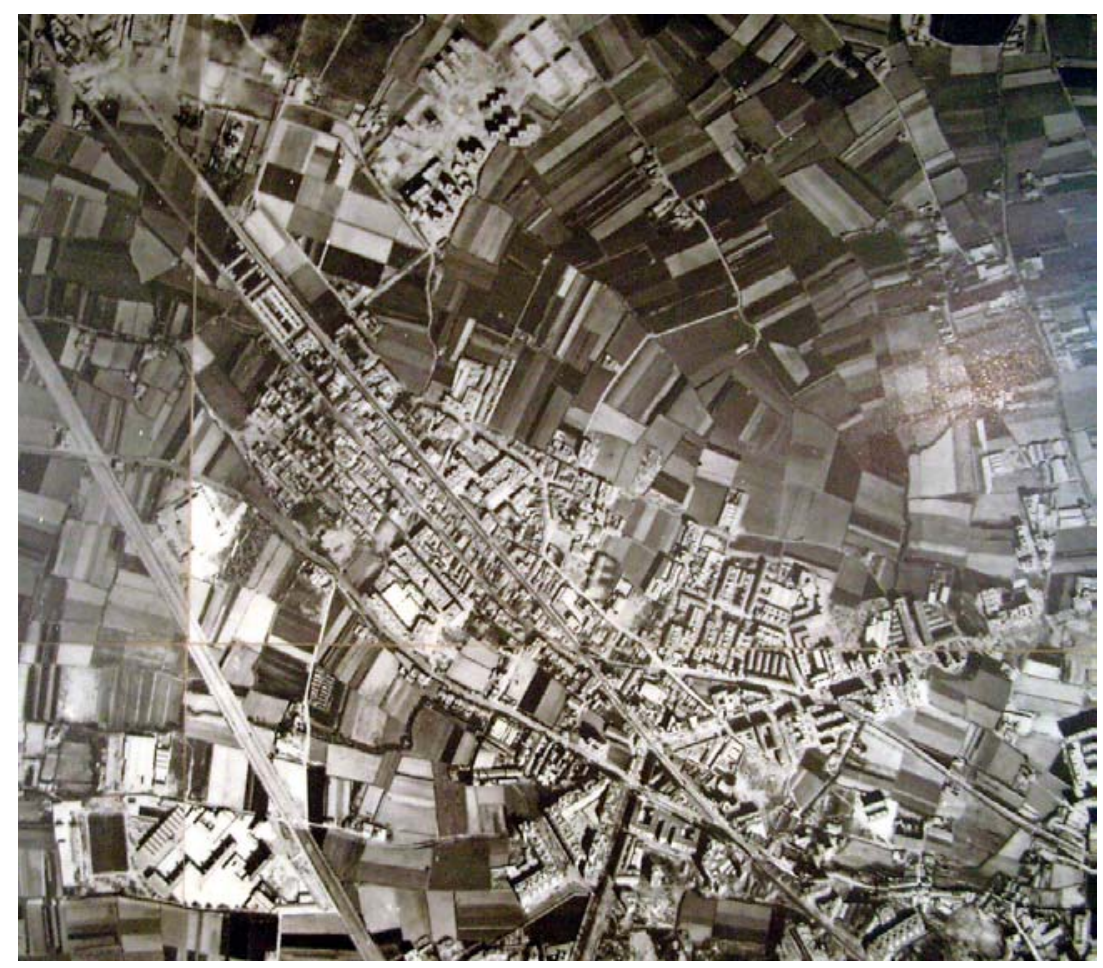

Plan Parcial 24-B. Fotografía aérea, h. 1965 (ETS Arquitectura de Valencia). 
Plan Parcial 24, Sector B, 1970. Edificación y equipamientos (Elaboración propia. Color sobre plano de alineaciones).
Las características de la edificación proyectada para el sector B en esta versión de 1970 del plan son similares a las que hemos visto en la sección A: proliferación de bloques muy cortos y agrupados de formas muy variadas, generando un conjunto de apariencia un tanto desordenada. Estos bloques son en su mayor parte de dos crujías en la zona de edificación abierta, excepto en la zona situado al sur de las naves artesanas de la Ciudad del Artista Fallero.

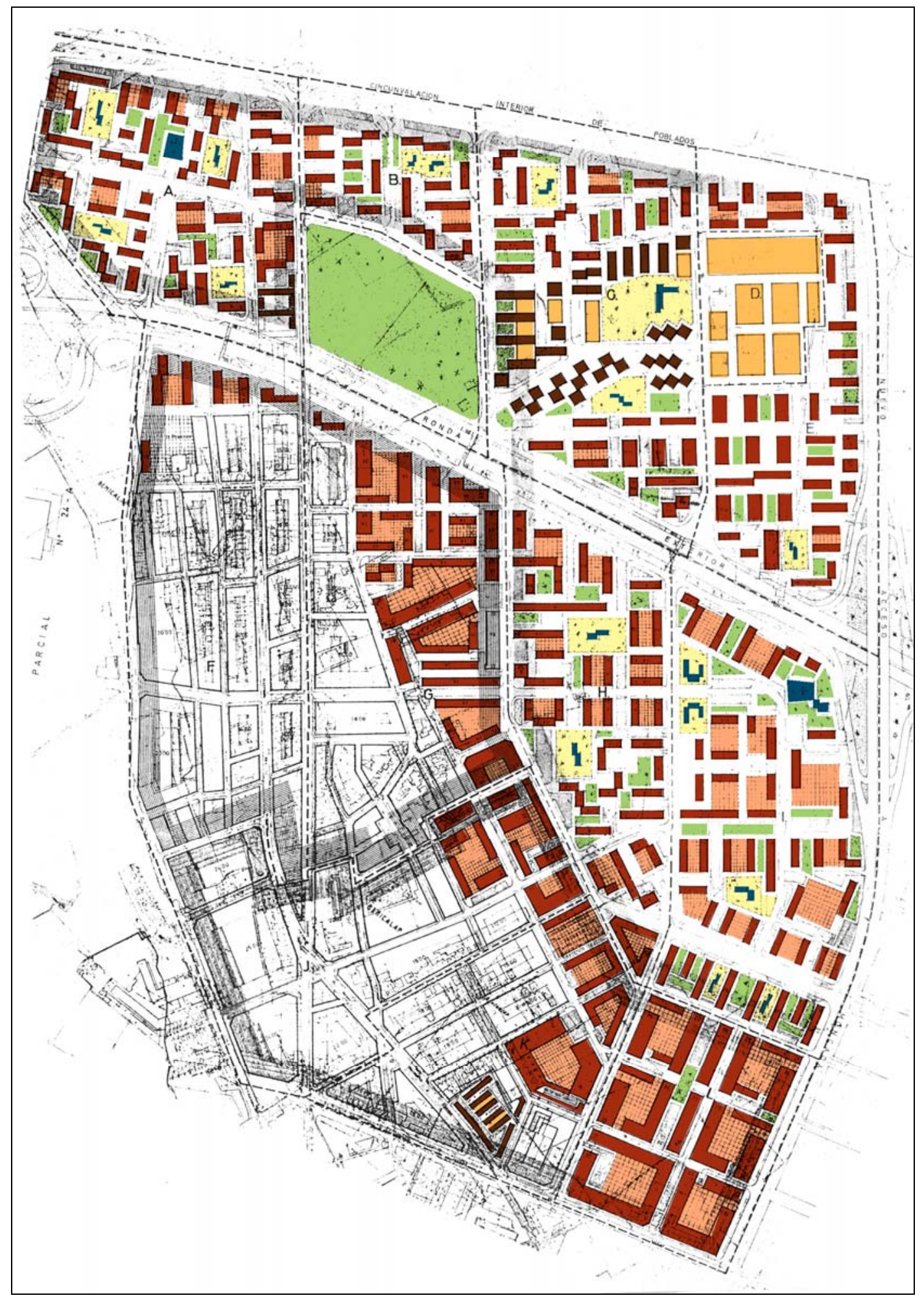


En la franja adyacente al poblado de Benicalap, entre éste y la actual Avenida del Ecuador, predominan en cambio los bloques de cinco crujías, y se agrupan formando manzanas abiertas con la planta baja íntegramente ocupada por locales comerciales.

La principal modificación que introduce la versión del PP24 en su sector B es, como ocurría en el sector A, la relativa a las reservas de suelo para zonas verdes y equipamientos, que aumentan sustancialmente.

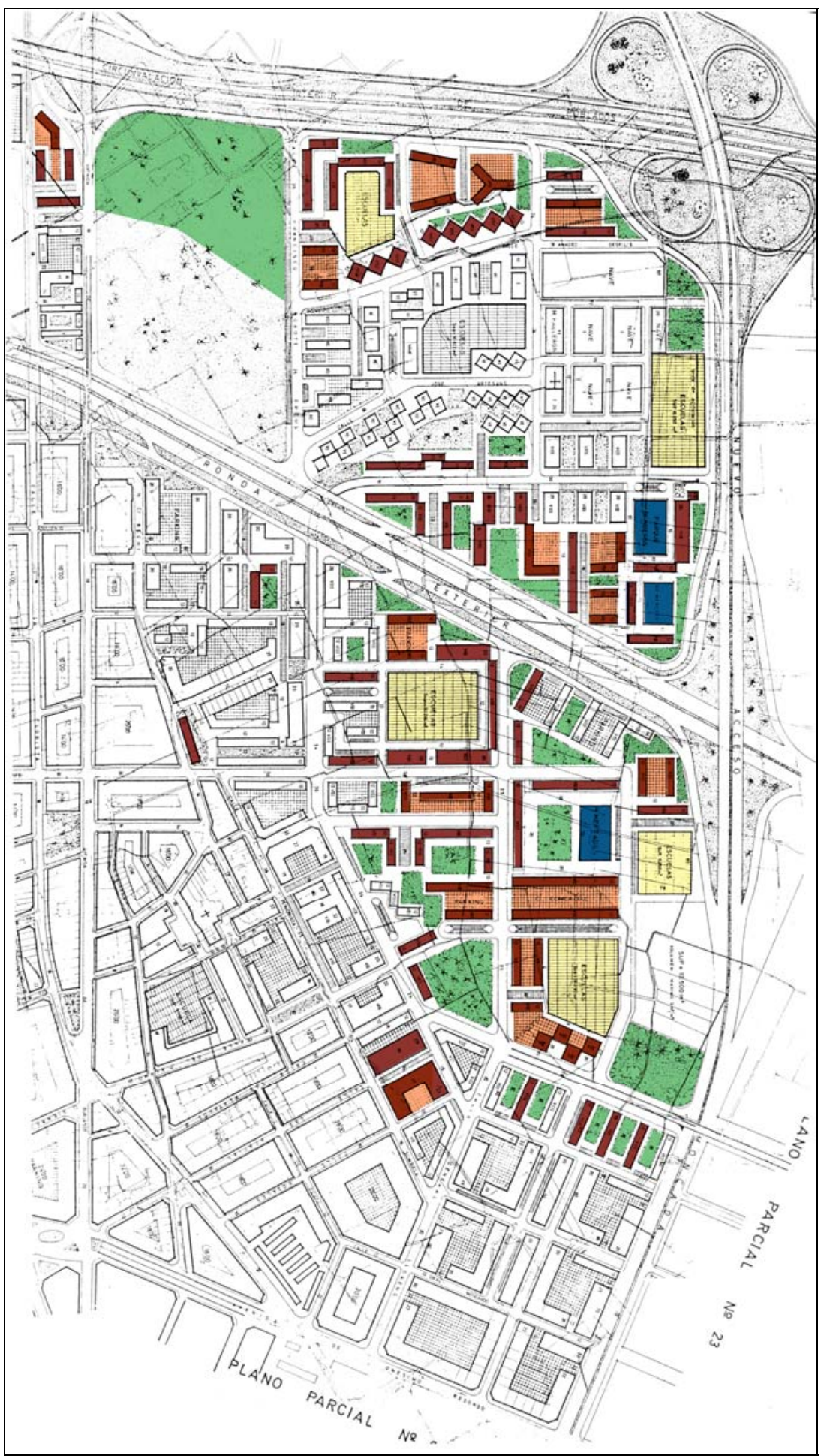

Plan Parcial 24, Sector B, 1975. Grado de novedad: edificación y equipamientos proyectados de modo diferente al previsto en anteriores versiones del plan (Elaboración propia. Color sobre plano de alineaciones). 


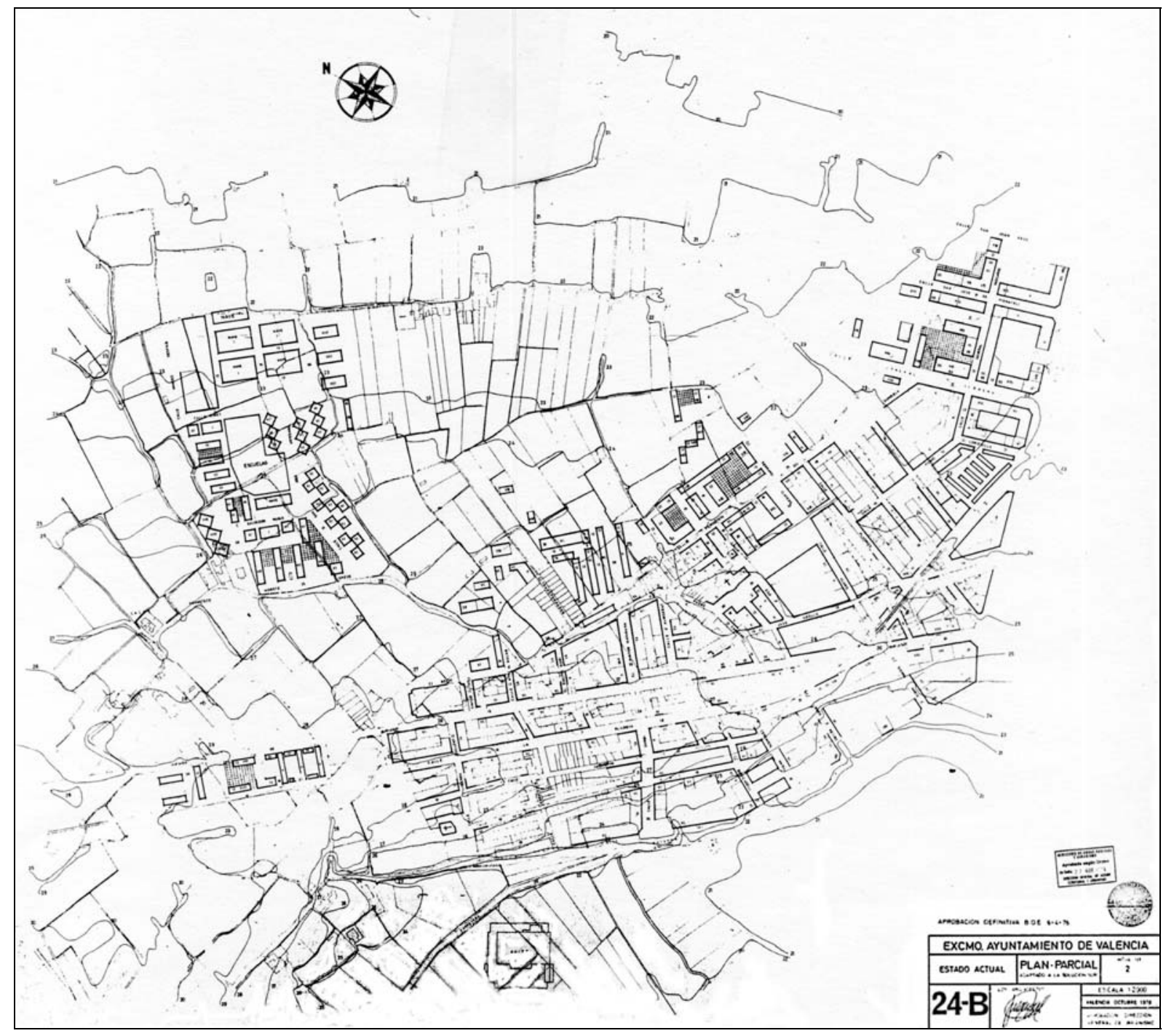

Plan Parcial 24-B, 1975. Plano de información.
Así, por ejemplo, la extensa zona edificable prevista al noroeste del sector, entre las Avenidas de Burjasot y de Pío XII, es suprimida y sustituida por una zona verde.

Igualmente, la zona verde prevista entre la Avenida de Burjasot y la Ciudad del Artista Fallero se amplía hacia el norte, eliminando los bloques previstos y delimitando un recinto que coincide sensiblemente con el del actual parque de Benicalap.

EL resto de zonas verdes, menos extensas, se reparten de manera homogénea en la zona de edificación abierta. Las parcelas escolares, por su parte, se concentran en menos parcelas de más tamaño. Dos mercados y un parque de bomberos, situados cerca del límite este del plan, completan las dotaciones previstas.

En la versión de 1975, los bloques de dos crujías tienen por lo general mayor longitud, y se aprecia, como en el sector A, una tendencia a agruparlos para formar una edificación envolvente de espacios o equipamientos, en lugar de yuxtaponerlos como elementos aislados. 
En el plano de información de la versión de 1975 del sector B del Plan Parcial 24 podemos observar que en la franja situada entre la zona consolidada del poblado de Benicalap y la actual Avenida del Ecuador se reflejan numerosas edificaciones realizadas con arreglo a las alineaciones fijadas en la versión de 1970, pese a que esta versión del plan no llegó a aprobarse definitivamente por el Ministerio de la Vivienda.

En el plano de delimitación de unidades de actuación, estas edificaciones quedaron englobadas con el poblado de Benicalap en el suelo calificado como urbano.
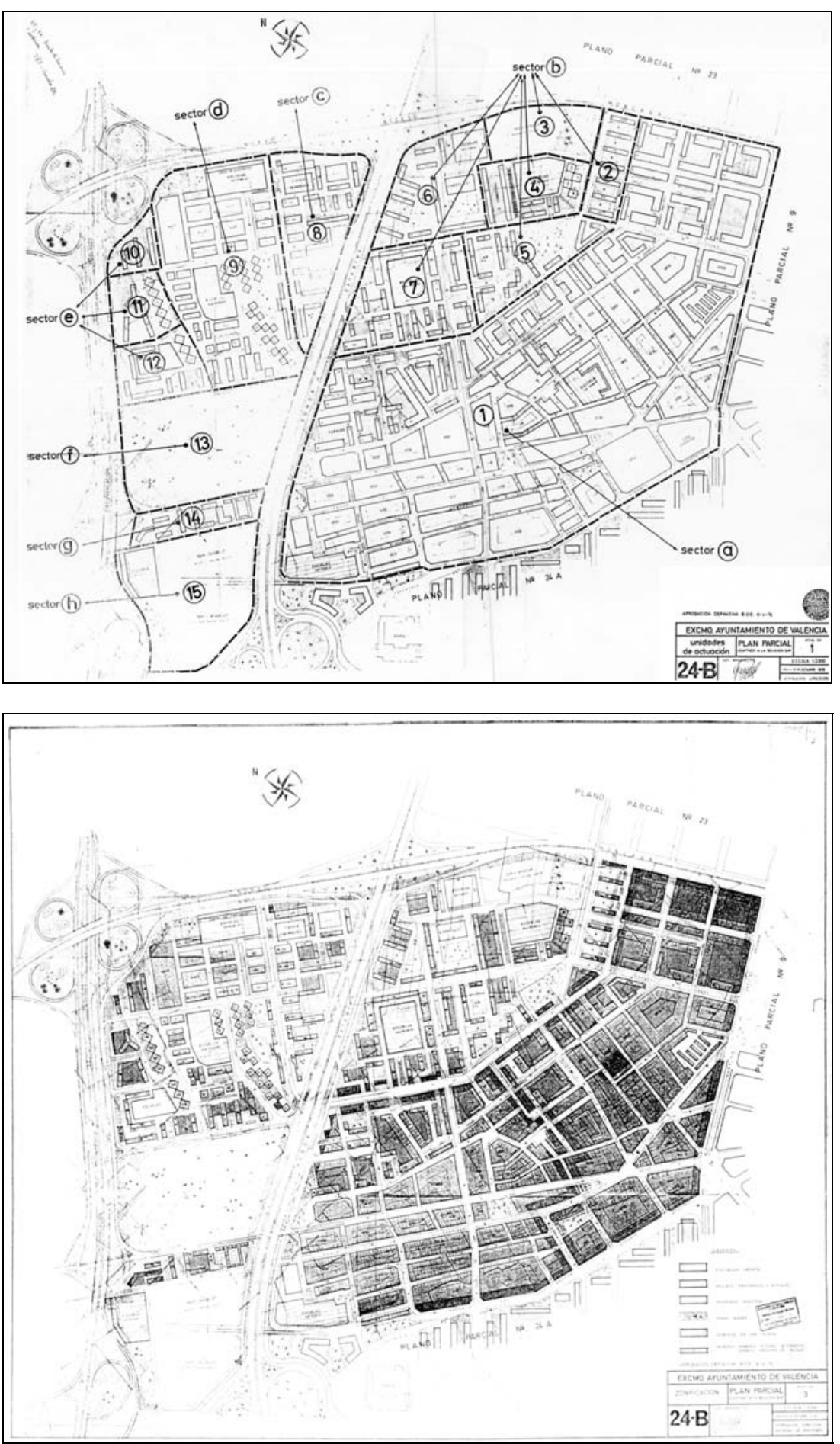

Plan Parcial 24-B, 1975. Plano de Unidades de Actuación.

Plan Parcial 24-B, 1975. Plano de zonificación. 


\section{Trazado viario.}

El viario proyectado para las zonas de edificación abierta del sector B del Plan Parcial 24 presenta características similares a las observadas en el sector A: supermanzanas con ramales sin salida que penetran en ella sin atravesarlas.

Este sistema es perfectamente reconocible en la planta viaria de la versión de 1970 del plan, pese a que las teóricas supermanzanas son a veces demasiado pequeñas o están demasiado llenas de edificios como para albergar en su núcleo un equipamiento o un espacio verde libres de interferencias con el tráfico rodado.

Plan Parcial 24-B, 1970. Trazado viario (Elaboración propia, color sobre montaje de hojas del Informe Prevasa).
La geometría de esta planta viaria se basa en los ejes paralelo y ortogonal a la Avenida de Burjasot y al Nuevo Acceso de Moncada. Esta geometría, sin embargo, queda distorsionada por la ronda interior que parte en dos el sector.

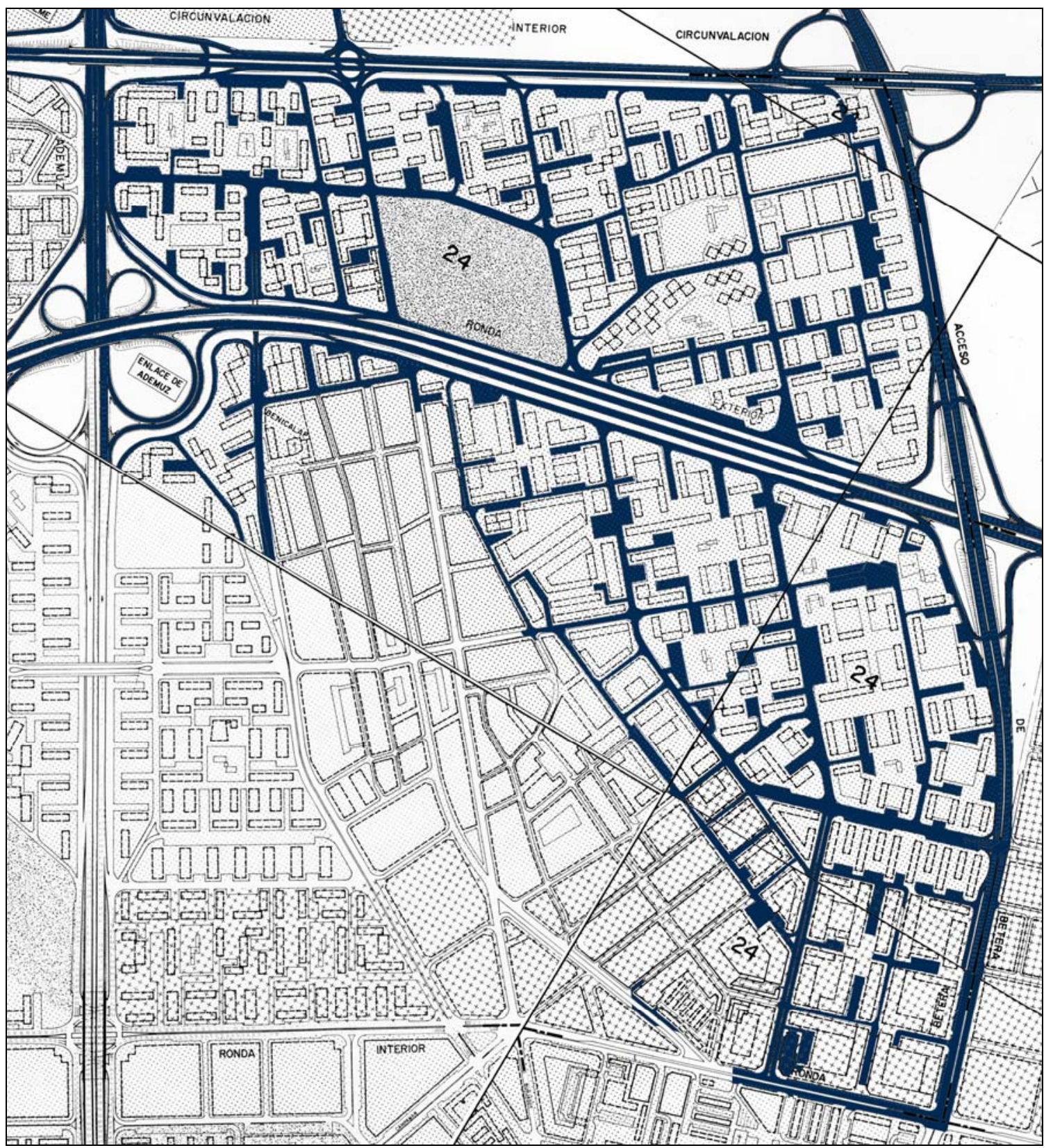


En la versión de 1975, sin embargo, la planta viaria muestra un abandono del sistema de supermanzanas en favor de un trazado mallado. En esta versión, por ello, los ramales sin salida han quedado reducidos a un papel casi testimonial.

En ambas versiones del plan, la franja de edificación adyacente al poblado de Benicalap aparece resuelta con un viario mallado cuyo trazado se basa en la prolongación de las calles existentes. En algunos casos, dos de las manzanas o varios bloques se agrupan, dejando una calle peatonal intermedia.

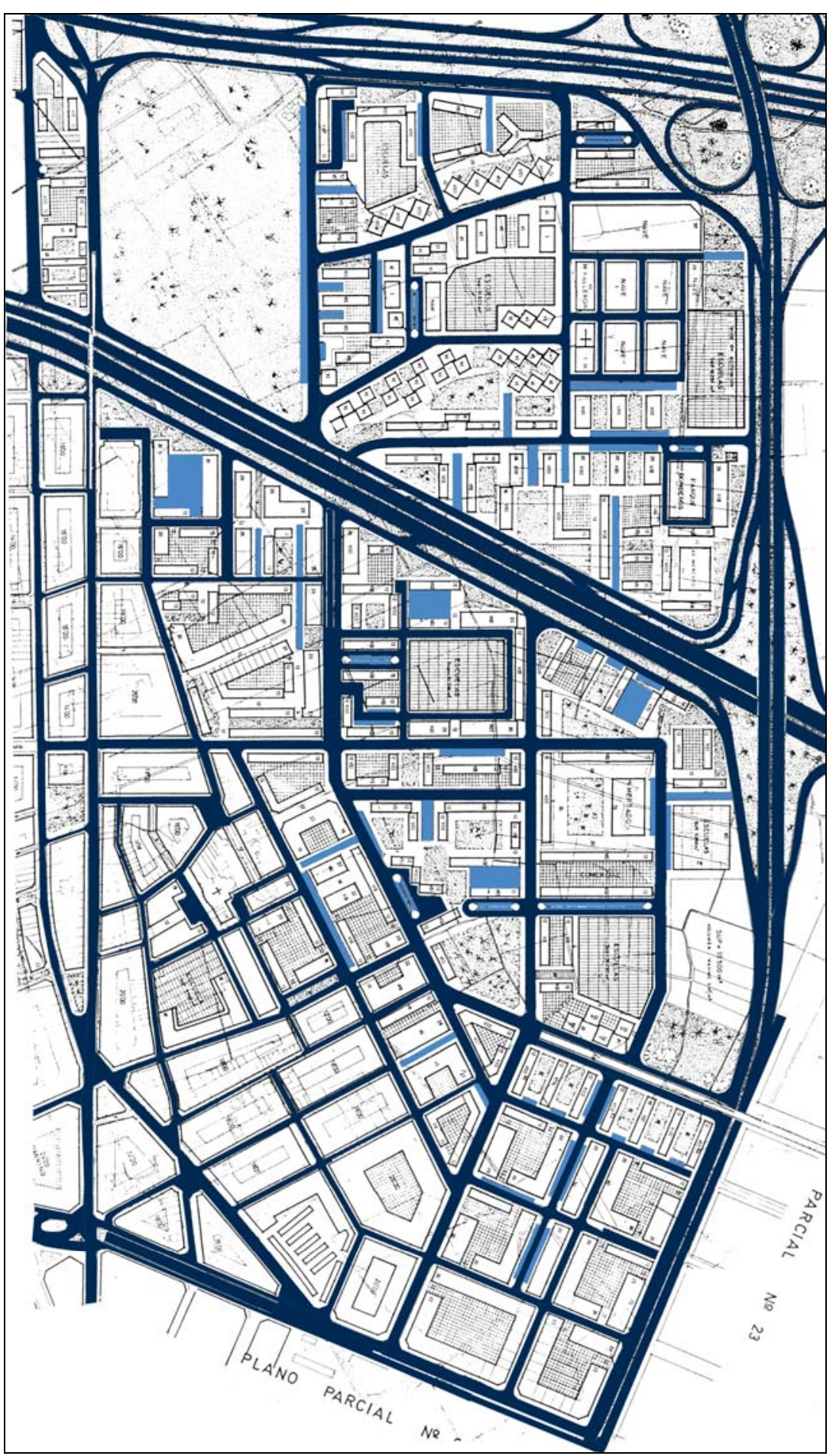

Plan Parcial 24-B, 1975. Trazado viario (Elaboración propia, color sobre plano de alineaciones del plan). 


\section{Edificación}

En la edificación abierta proyectada para el sector B del Plan Parcial 24 no predomina ningún tipo de agrupación de bloques en particular.

Los bloques lineales, de dos y cinco crujías, dispuestos de forma aislada, agrupados en $L$ o en parejas sobre un zócalo comercial, se alternan sin ningún criterio de orden evidente.

Plan Parcial 24-B, 1975. Edificación en planta tipo (Elaboración propia sobre plano de alineaciones del plan)

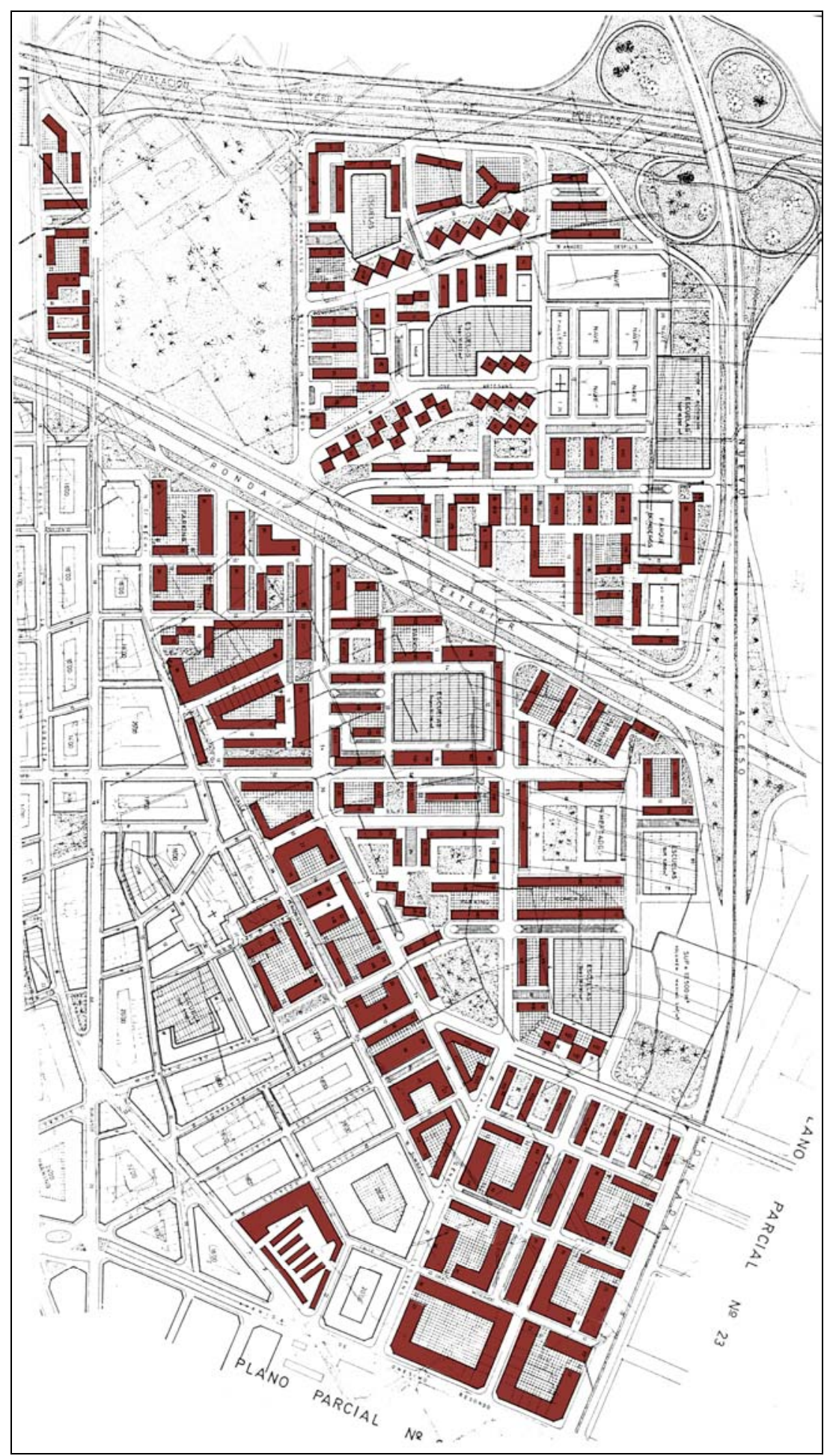


En cuanto a la ocupación del suelo en planta baja, podemos observar que las manzanas mixtas de la franja adyacente al poblado de Benicalap, en las que predominan los bloques profundos superpuestos a un cuerpo de edificación en planta baja, son de mayor tamaño que las existentes en la zona calificada como edificación abierta.

En el sector B, a diferencia del A, sólo existe una zona que se deja para una ordenación posterior.

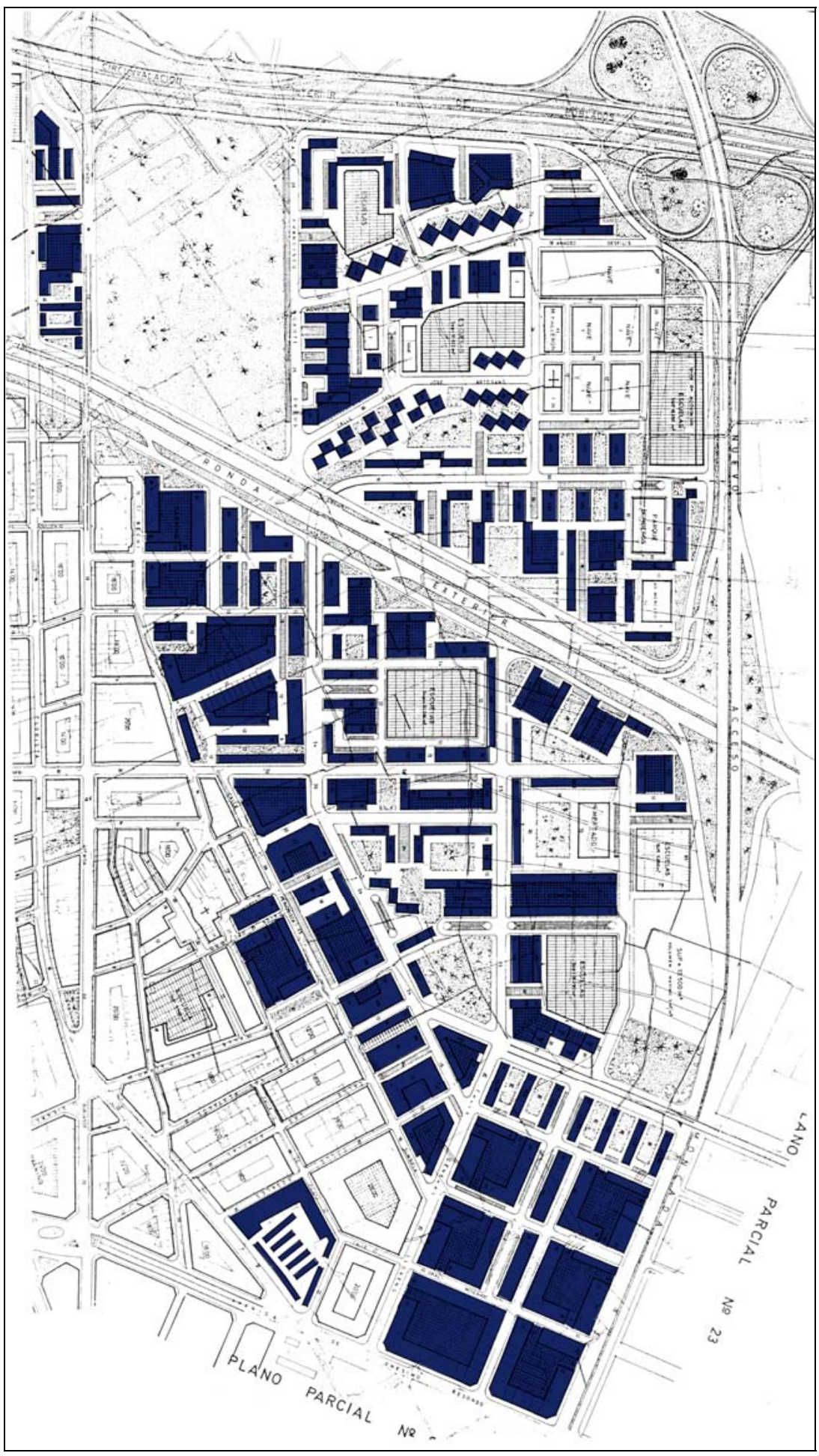

Plan Parcial 24-B, 1975. Edificación en planta baja (Elaboración propia sobre plano de alineaciones del Plan) 


\section{Grado de realización}

La mayor parte de los bloques previstos en la zona de edificación abierta del sector B del Plan Parcial 24 de 1975 no fue realizada. En cambio, como hemos visto, en la franja adyacente al poblado de Benicalap, entre este y la actual Avenida del Ecuador, se construyó un buen número de bloques según lo previsto en la versión del plan de 1970.

Plan Parcial 24-B, 1975. Grado de realización (Elaboración propia sobre plano de alineaciones del plan)

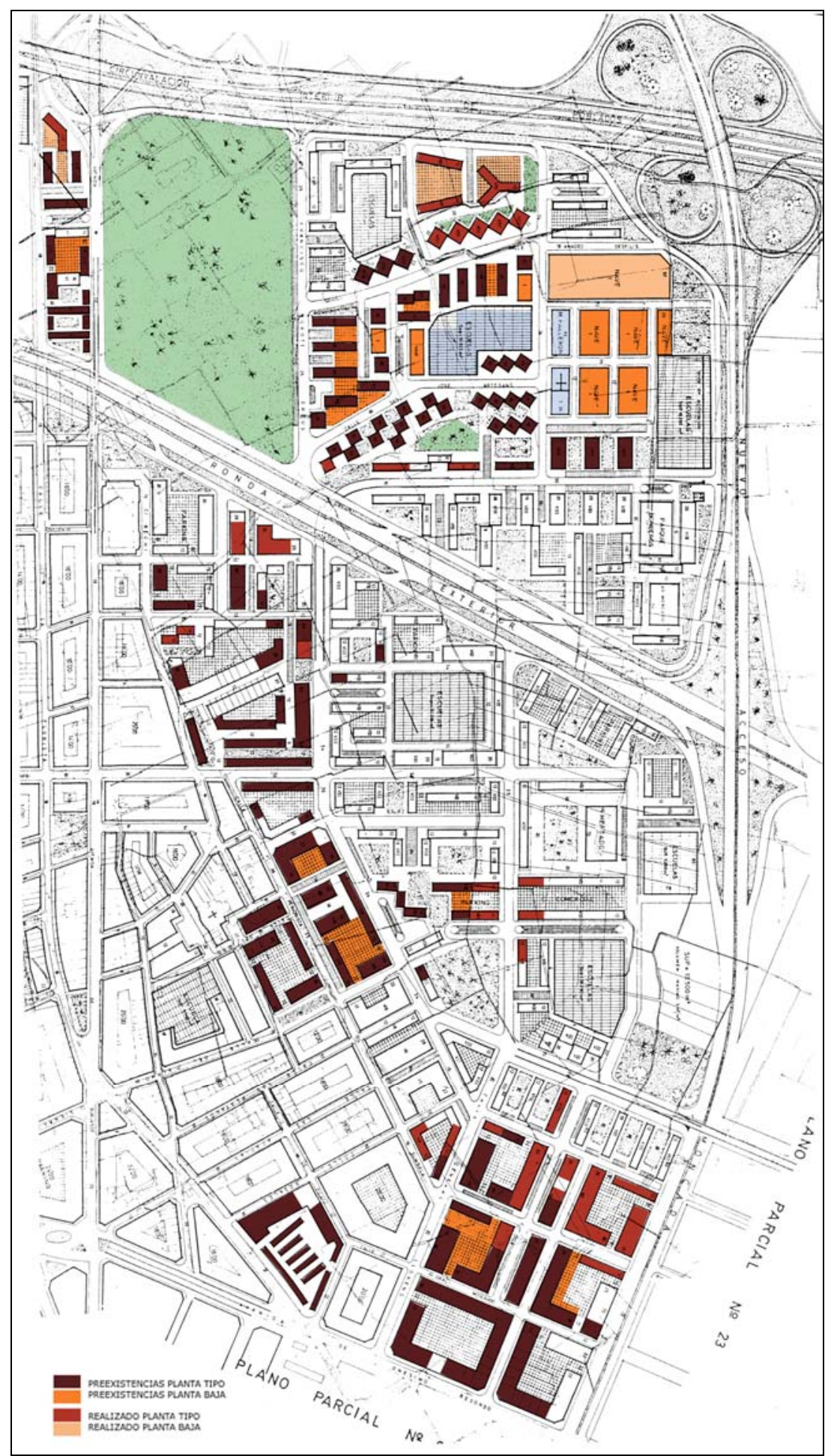


Al igual que ocurrió en otras áreas del arco noroeste de Valencia, como la correspondiente al Plan Parcial 8-B, en la mayor parte de la zona correspondiente al sector B del Plan Parcial 24 la edificación abierta prevista en dicho plan fue eliminada en el Plan General de 1988, que no la sustituye por otra diferente, ya que la zona es, simplemente, calificada como Suelo Urbanizable No Programado, y su ordenación queda pendiente de la redacción del planeamiento de desarrollo posterior.

Los únicos bloques de edificación abierta que se mantuvieron en el nuevo Plan General fueron los que ampliaban por el norte y por el sur la Ciudad del Artista Fallero y los que completaban los fragmentos de bloques existentes en dos zonas situadas junto a la Avenida del Ecuador.

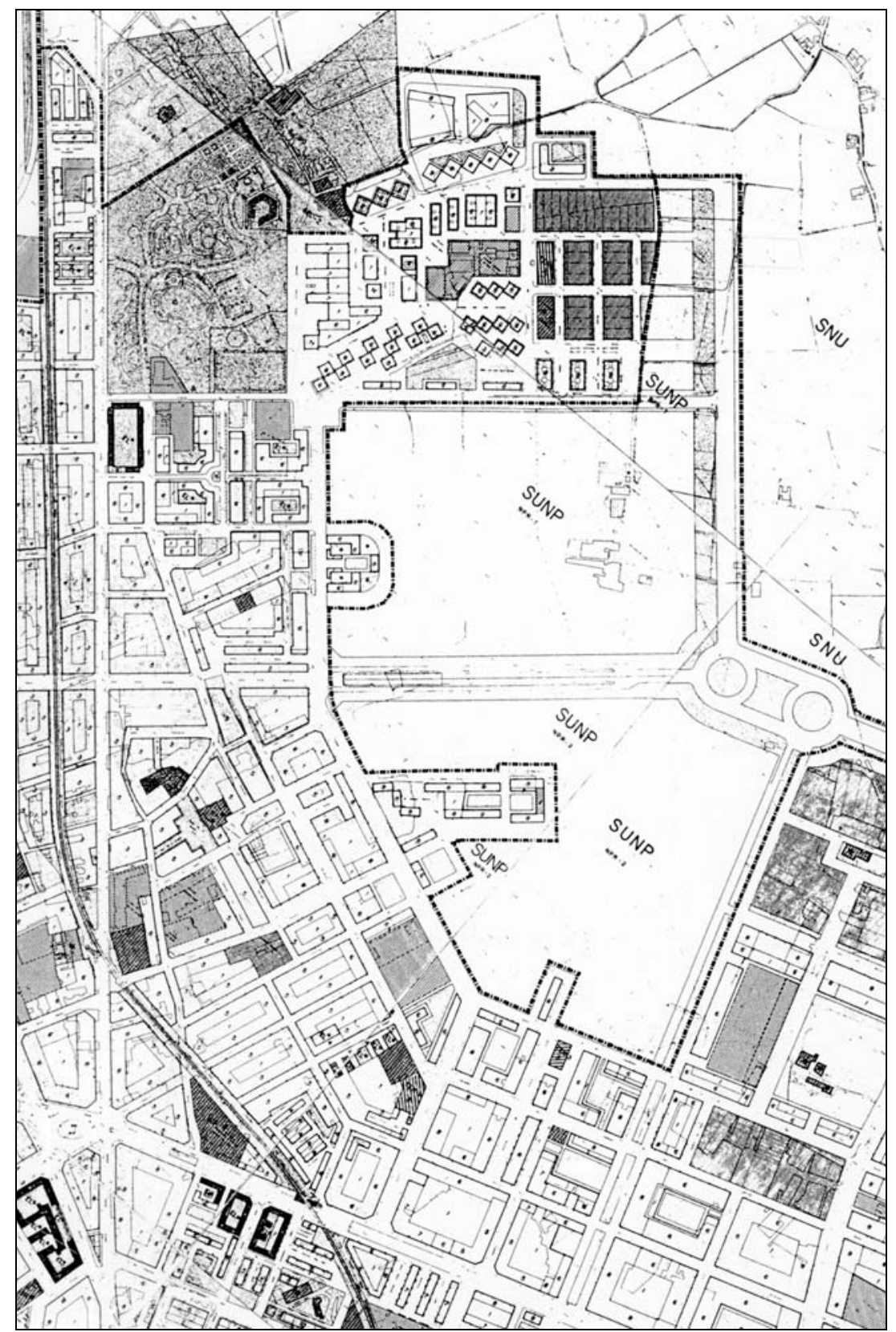




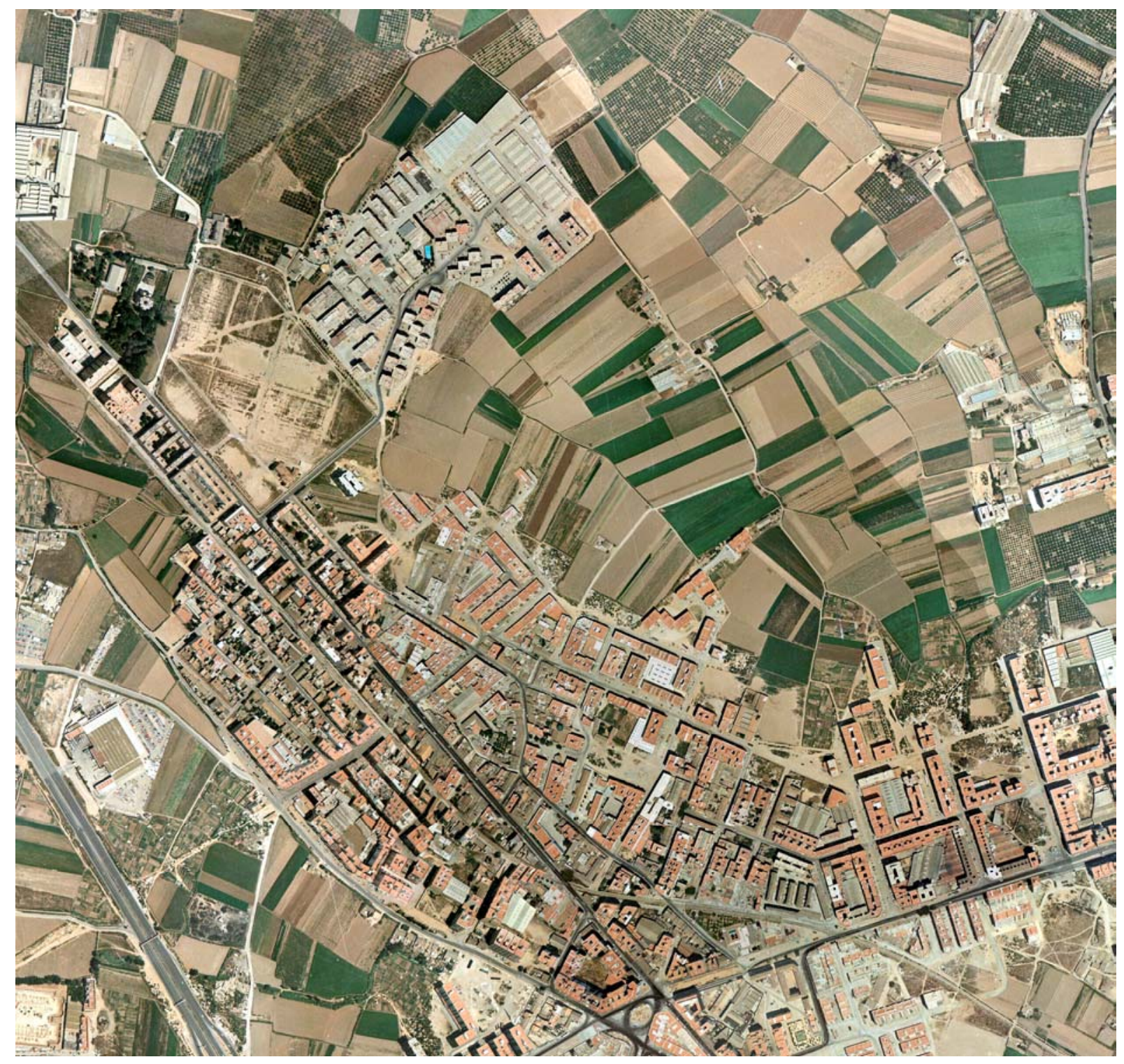

Plan Parcial 24-B. Fotografía aérea, 1980. 


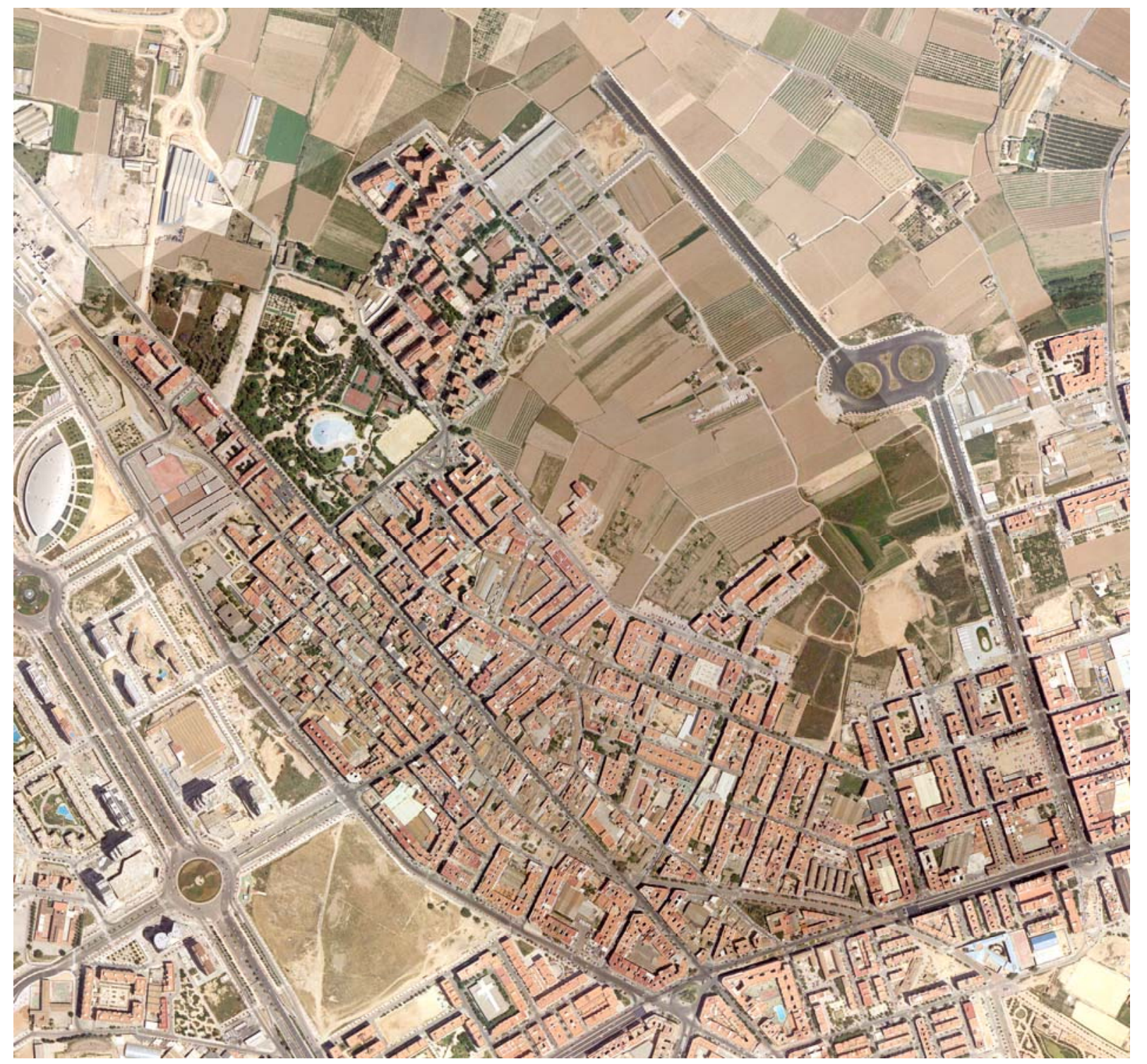

Plan Parcial 24-B. Ortofoto, 2002 (AUMSA) 
Zona de la Ciudad del Artista Fallero (Ortofoto 2002 AUMSA).
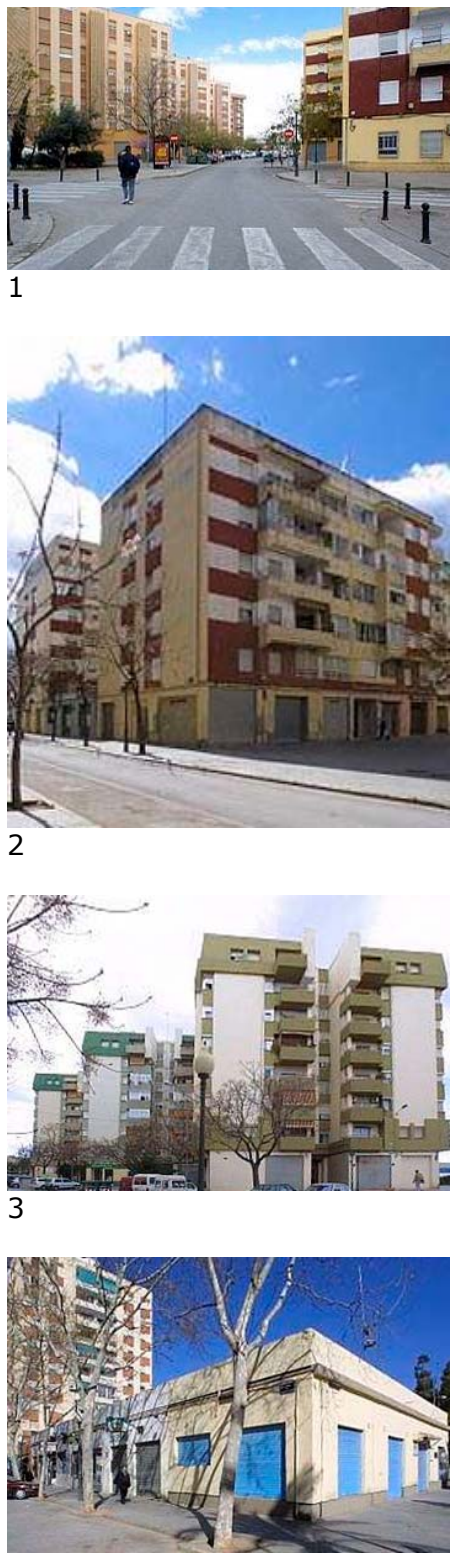

1. Calle Amadeo Desfilis. Vista hacia el este.

2. Bloques del lado sur de la calle Amadeo Desfilis.

3. Bloques escalonados del lado norte de la calle Amadeo Desfilis.

4. Calle.Salvador Rubio.

5. Calle Francisco Morote, vista hacia el sur.

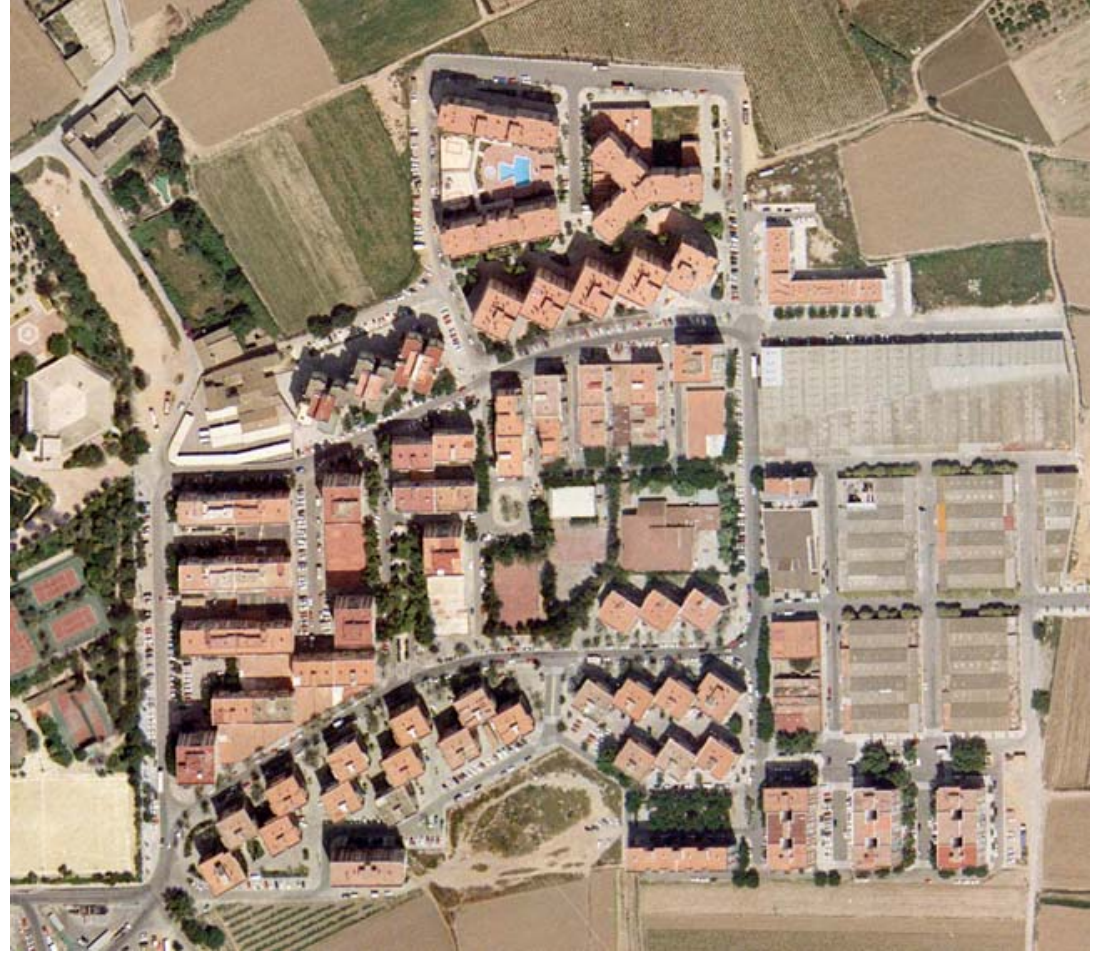

El conjunto de la Ciudad del Artista Fallero presenta algunas diferencias con respecto al plan inicial para el mismo, redactado por Muñoz Monasterio en 1963 y que hemos analizado en la sección anterior. Los tipos de edificio previstos en el proyecto inicial (bloques lineales, palazzinas encadenadas y torres) se mantienen pero integrados en una composición distinta.

Así, por ejemplo, las palazzinas del lado sur de la Avenida de San José Artesano pasan de una yuxtaposición en damero a otra escalonada a partir de una disposición diagonal de las mismas, y ocupan además parte de la parcela destinada inicialmente a escuela en la manzana central.

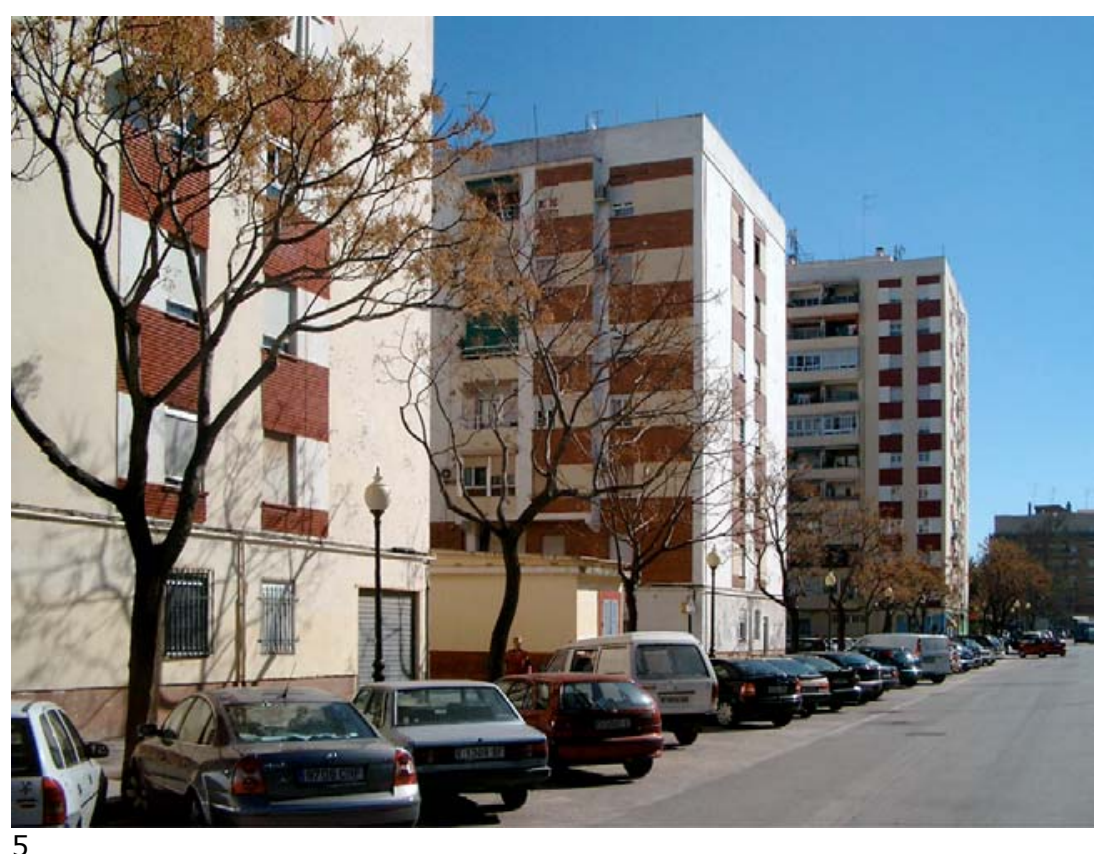


Por otra parte, las torres previstas quedan reducidas a cuatro, una al inicio de la Avenida de San José y las otras tres junto a la calle Salvador Rubio. Además, los bloques lineales perpendiculares a la calle Francisco Morote se simplifican, adoptando una disposición más seriada y repetitiva.
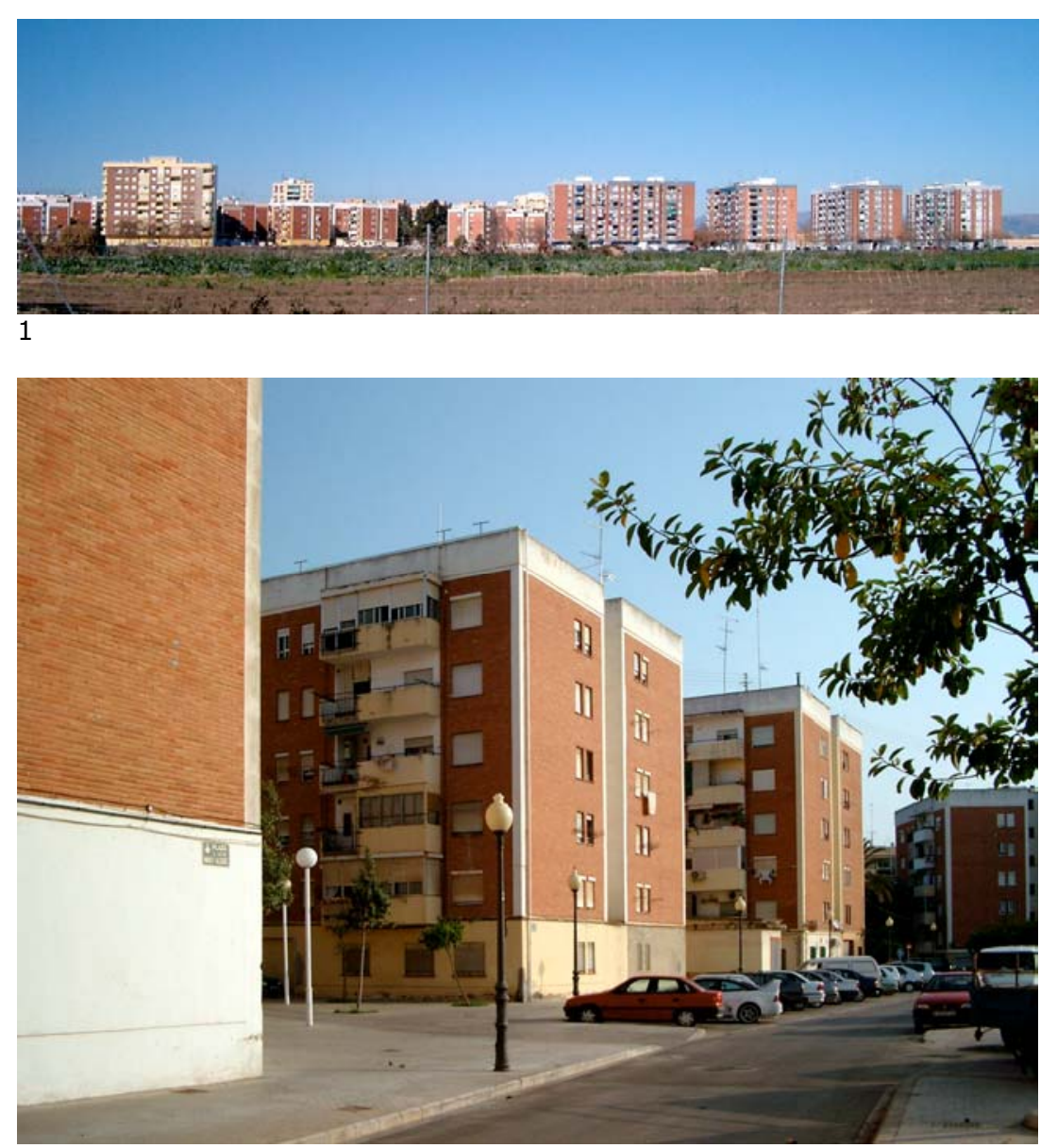

2

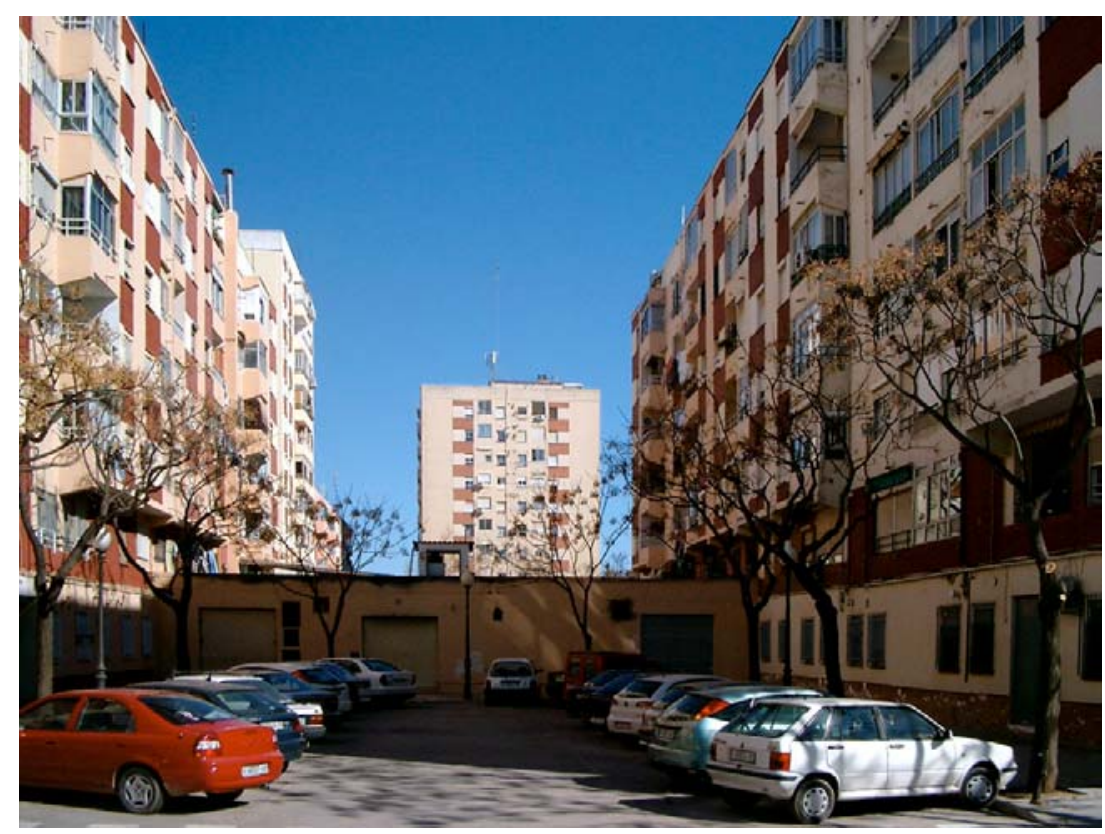

3

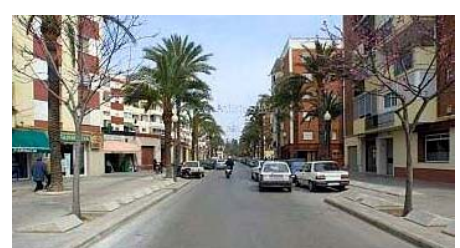

1
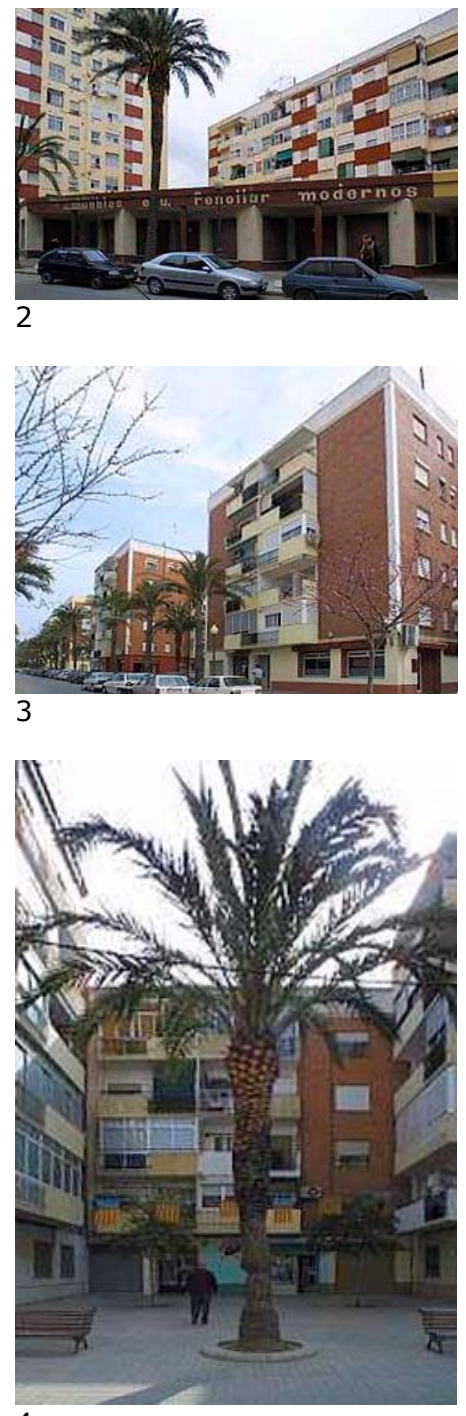

4

1. Avenida San José Artesano, vista hacia el este.

2. Bloques del lado norte de la Avenida San José Artesano.

3,4. Palazzinas en cadena del lado sur de la Avenida San José Artesano. 
Zona del este de Benicalap. (Ortofoto 2002, AUMSA).

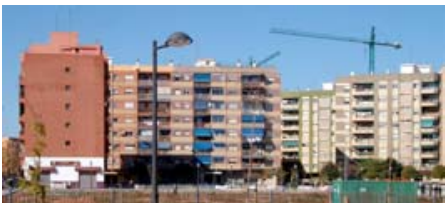

1

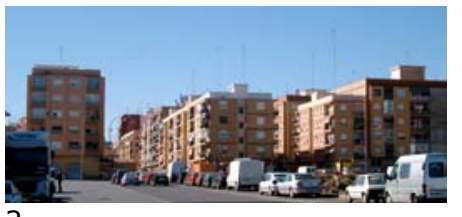

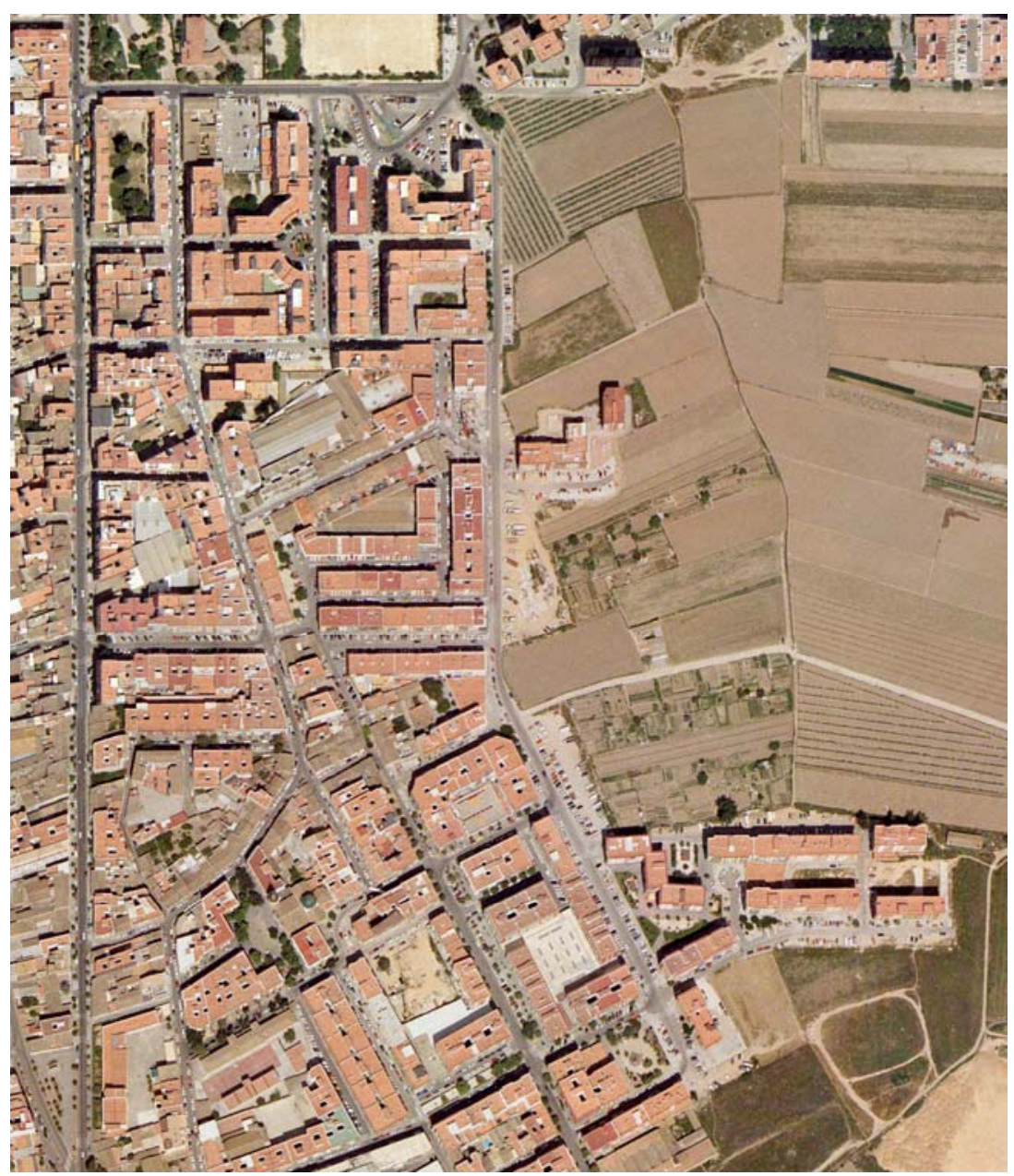
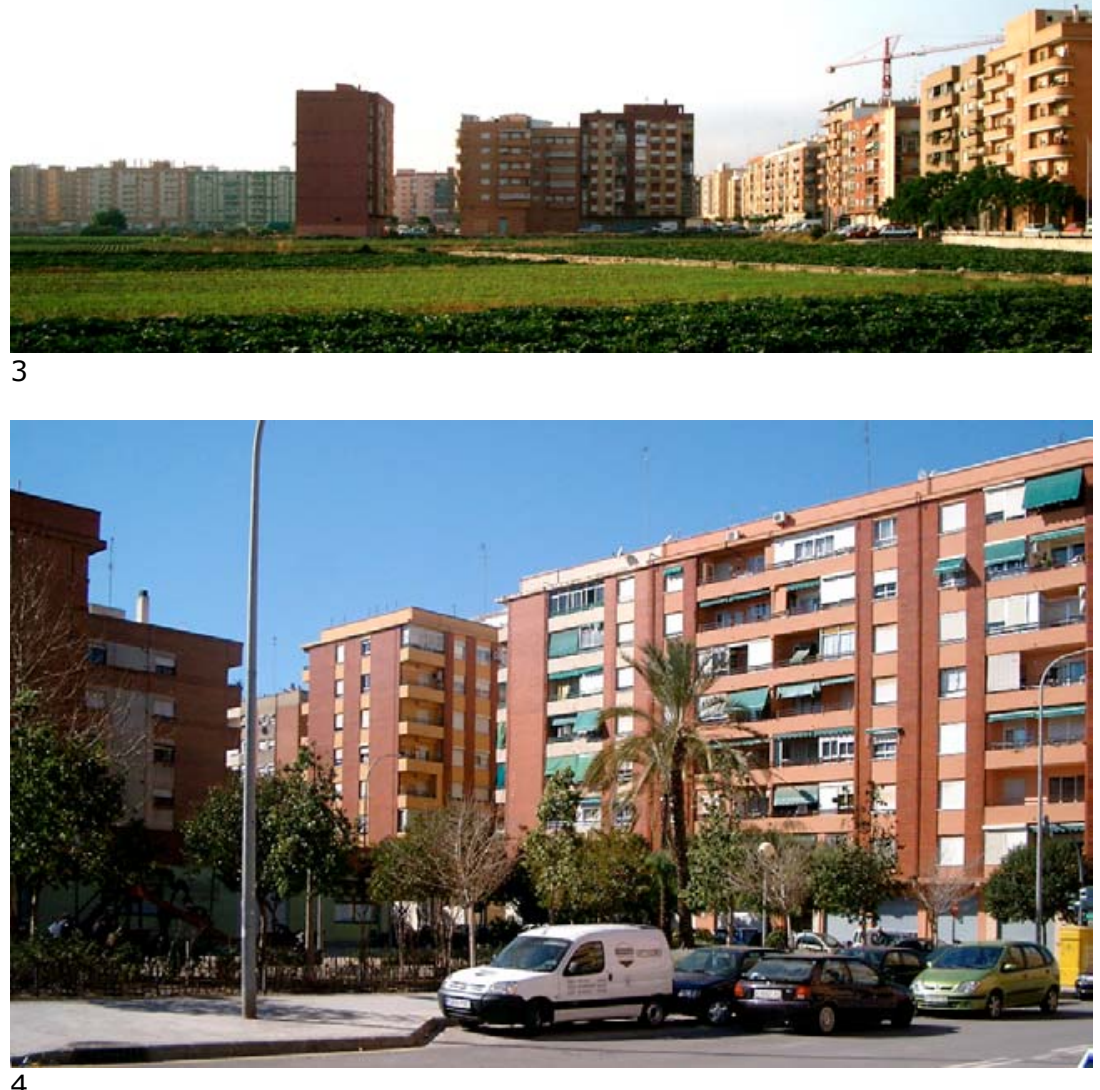

1. Bloques en el lado este de la Avenida del Ecuador.

2. Cruce de la calle Pintor Matarana con la Avenida del Ecuador.

3. Avenida del Ecuador, vista hacia el sur desde la Ciudad del Artista Fallero.

4. Plaza en la calle Clavero, junto a la Avenida del Ecuador 

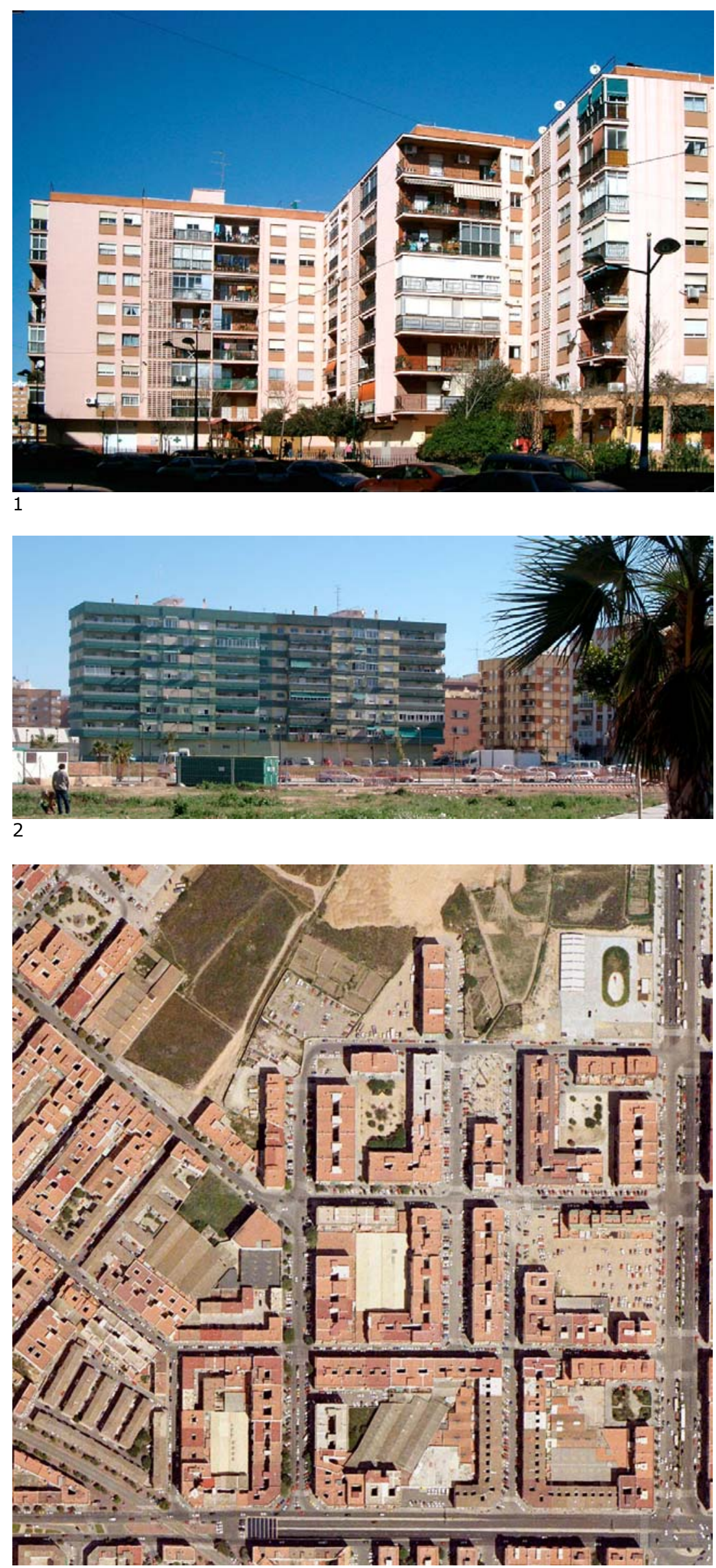
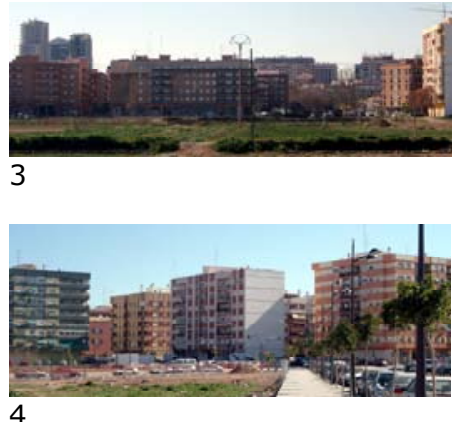

4

Zona del sureste de Benicalap. (Ortofoto 2002, AUMSA).

1. Bloques escalonados en la Avenida del Ecuador. Vista hacia el norte.

2. Bloque en la calle Alfara del Patriarca-Castellonet.

3. Vista general desde el este del frente entre las calles Luís Braille y Pintor Matarana.

4. Calle Castellonet, vista hacia el este. 


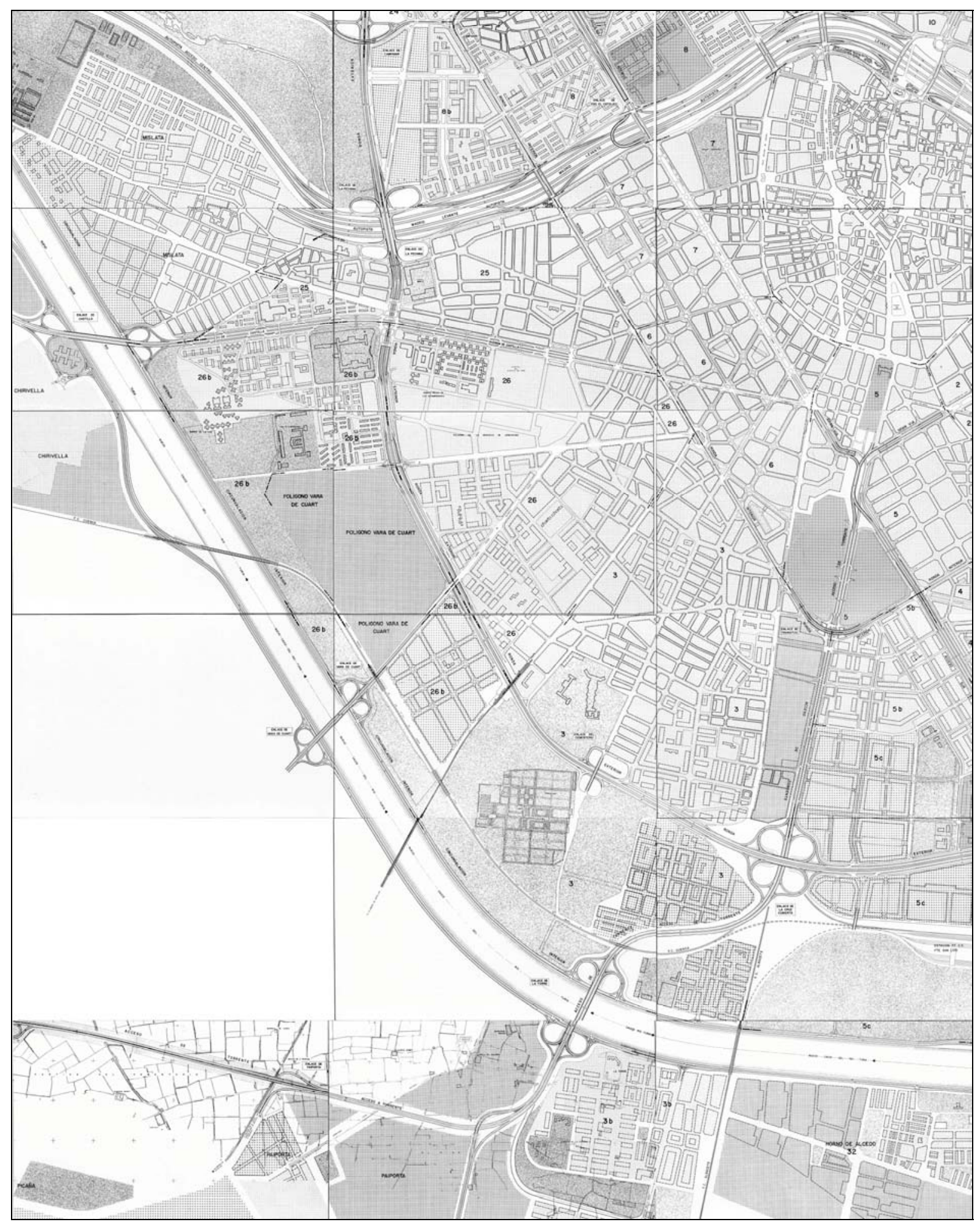

Valencia. Zona suroeste:

Planes Parciales no 25, 26, $26 B$

y 3 (Montaje de hojas del Informe PREVASA). 


\subsection{LA EDIFICACIÓN ABIERTA EN EL SECTOR SUROESTE DE VALENCIA, 1966-1988.}

Los cuatro planes parciales que, con el criterio fijado al principio del presente trabajo, hemos englobado en el sector suroeste de Valencia no presentan un criterio uniforme de delimitación con respecto al viario estructural del Plan General de 1966.

Todos los planes de este sector están comprendidos entre los anillos perimetrales de Tránsitos (Avenidas de Pérez Galdos y Giorgeta) y el Nuevo Cauce del Turia, pero dos de ellos, el Plan Parcial 25 y el Plan Parcial 3, engloban terrenos situados tanto dentro como fuera de la Ronda Exterior, mientras que los otros dos, que son el Plan Parcial 26 y el 26-b, están comprendidos, respectivamente, dentro y fuera de dicha Ronda Exterior, que constituye el anillo viario intermedio entre el de Tránsitos y el Nuevo Cauce.

Como ocurría también en los planes de otros sectores, dentro del ámbito de los planes parciales no 25, 26 y 3 existían zonas ya edificadas con manzanas cerradas de ensanche, como resultado de anteriores planes para las mismas zonas. En el caso del PP 26-b, situado en la corona periférica exterior, las preexistencias eran ya conjuntos de edificación abierta: el grupo del Plan Riada Virgen de la Fuensanta, de 1957, y el barrio de la Luz, de 1958, analizados en la sección II del presente trabajo.

Dos de los planes de este sector incluyen extensos terrenos cuyo uso no es residencial: el Plan Parcial 26-b, que engloba el polígono industrial de Vara de Quart, y el Plan Parcial 3, que incluye en su ámbito el Cementerio General de Valencia y una franja de suelo industrial junto a la línea de ferrocarril que lo limita por el este.

El montaje de hojas del Informe PREVASA nos proporciona una visión global de este sector, que permite constatar, en primer lugar, que la estructura viaria principal definida en el Plan General de 1966 se ha mantenido invariable en el PGOU de 1988, aunque con un diseño diferente de los ejes y de las intersecciones.

Por otra parte, el plano conjunto del Informe PREVASA nos permite observar la importancia de la Avenida de Castilla como eje vertebrador de las áreas de edificación abierta del sector.

Así, podemos ver que junto a este eje se encuentran, en su lado norte, las zonas de edificación abierta del Plan Parcial 25, y, en su lado sur, las del grupo Virgen de los Desamparados, incluido a efectos administrativos en el Plan Parcial 26, y las del Plan Parcial 26-b, que incluye el grupo Virgen de la Luz.

Otro eje radial de similares características es el de la calle Tres Forques, también de dirección este-oeste, flanqueada al norte y sur por áreas de edificación abierta del Plan Parcial 26-b (el grupo Virgen de la Fuensanta), del Polígono de la Avenida de Castilla, que incluye el grupo Antonio Rueda, y del Plan Parcial 26.

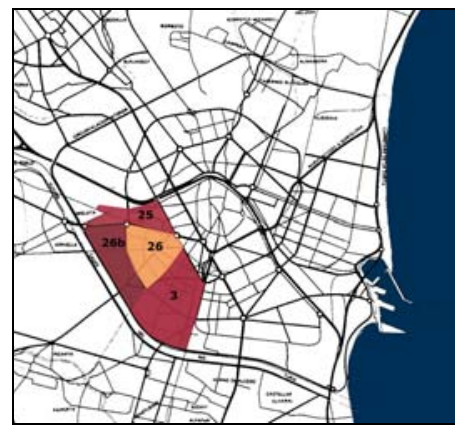

Planes Parciales del sector suroeste. Localización. 


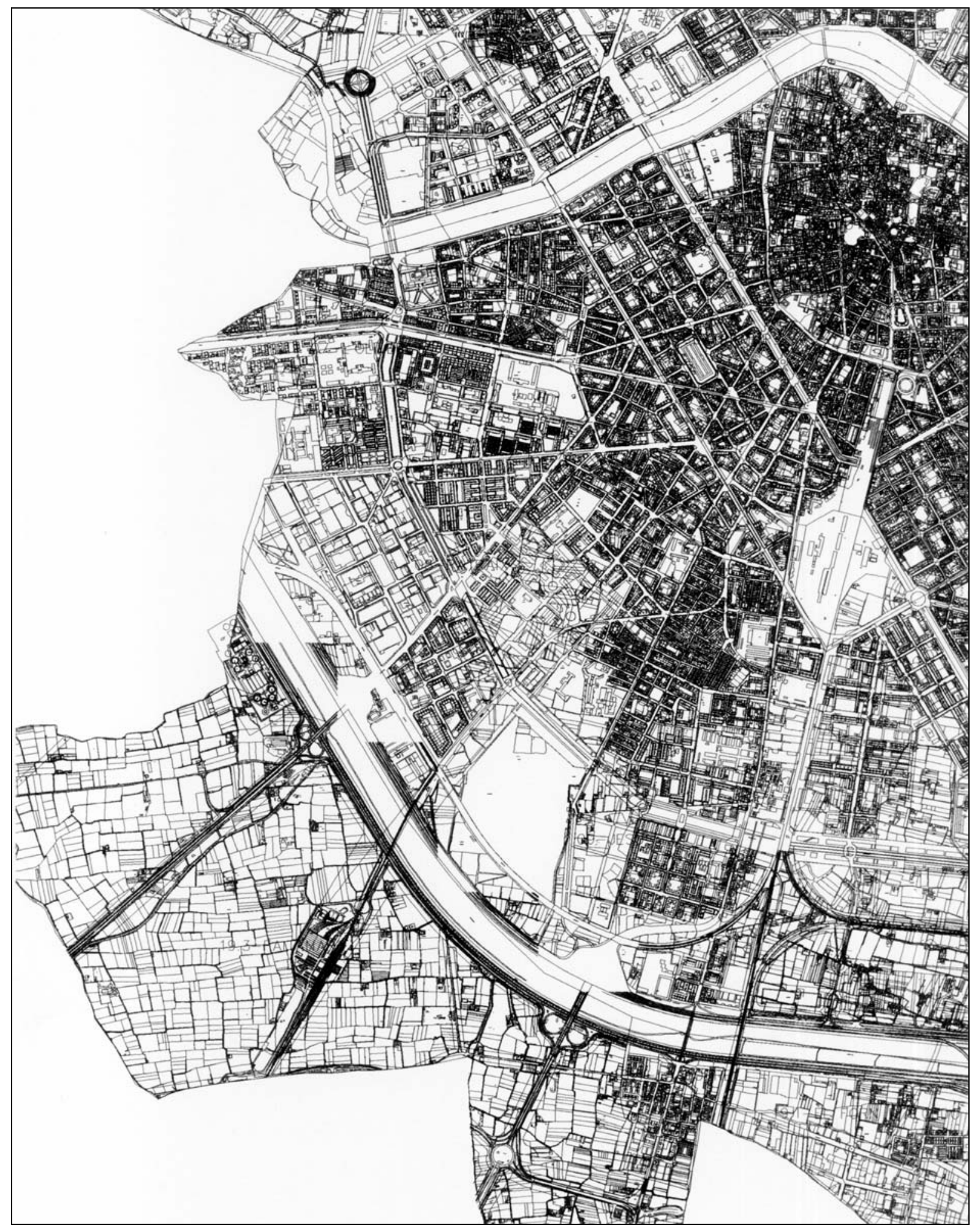

Valencia. Zona suroeste. Cartografía Municipal, 2004.

Igual que hemos hecho en apartados anteriores para los sectores noreste y noroeste, hemos representado en el Diagrama III.3 la superficie aproximada de cada uno de los planes parciales del sector suroeste de Valencia, indicando para cada uno de ellos la superficie total y la superficie ordenada con edificación abierta, así como la parte de ésta última superficie que se edificó con arreglo a lo previsto en el plan. 
El diagrama nos permite observar que, como ocurre en otros sectores, la superficie total de los planes parciales no es demasiado homogénea en este, ya que oscila entre las $94 \mathrm{Ha}$ del Plan Parcial 25 y las $307 \mathrm{Ha}$ del Plan Parcial 3. Los planes parciales 26 y 26-b tienen una superficie total parecida, aunque en el segundo de ellos una parte importante de esa superficie es la ocupada por el polígono industrial de Vara de Quart.

El plan que prevé una mayor extensión de terrenos ordenados con edificación abierta es el Plan Parcial 26, aunque en él hemos cuantificado en el diagrama también como áreas de edificación abierta algunas zonas formalmente calificadas como Extensión Exterior a Tránsitos.

El plan que tiene un porcentaje mayor de suelo proyectado con edificación abierta es el 26 , debido sobre todo a la inclusión en el mismo de los conjuntos de promoción pública (el grupo Virgen de los Desamparados y el Polígono de la Avenida de Castilla). En los planes parciales 3 y 25, el porcentaje de suelo ordenado con edificación abierta es bajo, ya que corresponden a zonas con una importante superficie ya consolidada, edificada con manzanas cerradas de ensanche.

El grado de realización de las zonas de edificación abierta proyectadas en los diferentes planes es mas alto en general que en otros sectores de la ciudad.

Los conjuntos de promoción pública integrados en este sector suponen un $24 \%$ de la superficie total ordenada mediante edificación abierta.

\section{Diagrama III. 3}

Planes parciales del sector Suroeste. Cuadro de superficies

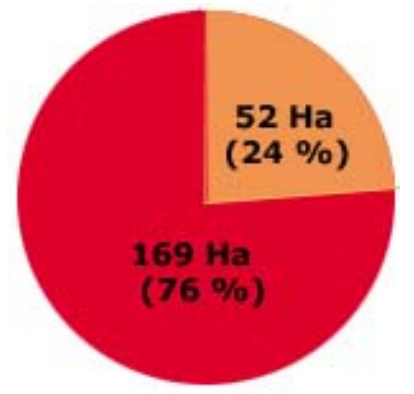

SUPERFICIE TOTAL ZONAS DE EDIFICACIÓN ABIERTA: 221 HA

PROMOCIÓN PÚBLICA PROMOCIÓN PRIVADA

Promoción pública y privada en la edificación abierta del sector suroeste de Valencia.

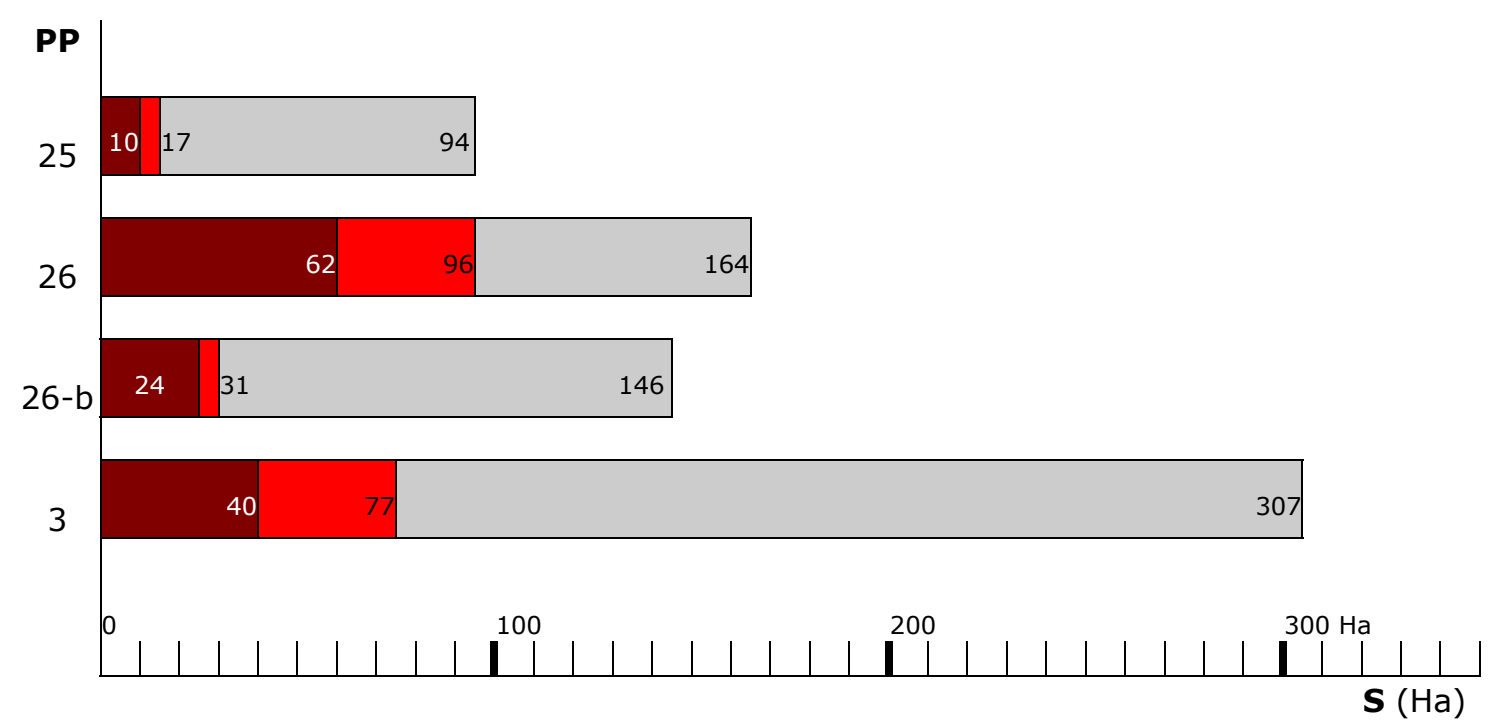

SUPERFICIE TOTAL DEL PLAN PARCIAL

SUPERFICIE ORDENADA CON EDIFICACIÓN ABIERTA

PARTE REALIZADA DE LA SUPERFICIE ORDENADA CON EDIFICACIÓN ABIERTA 


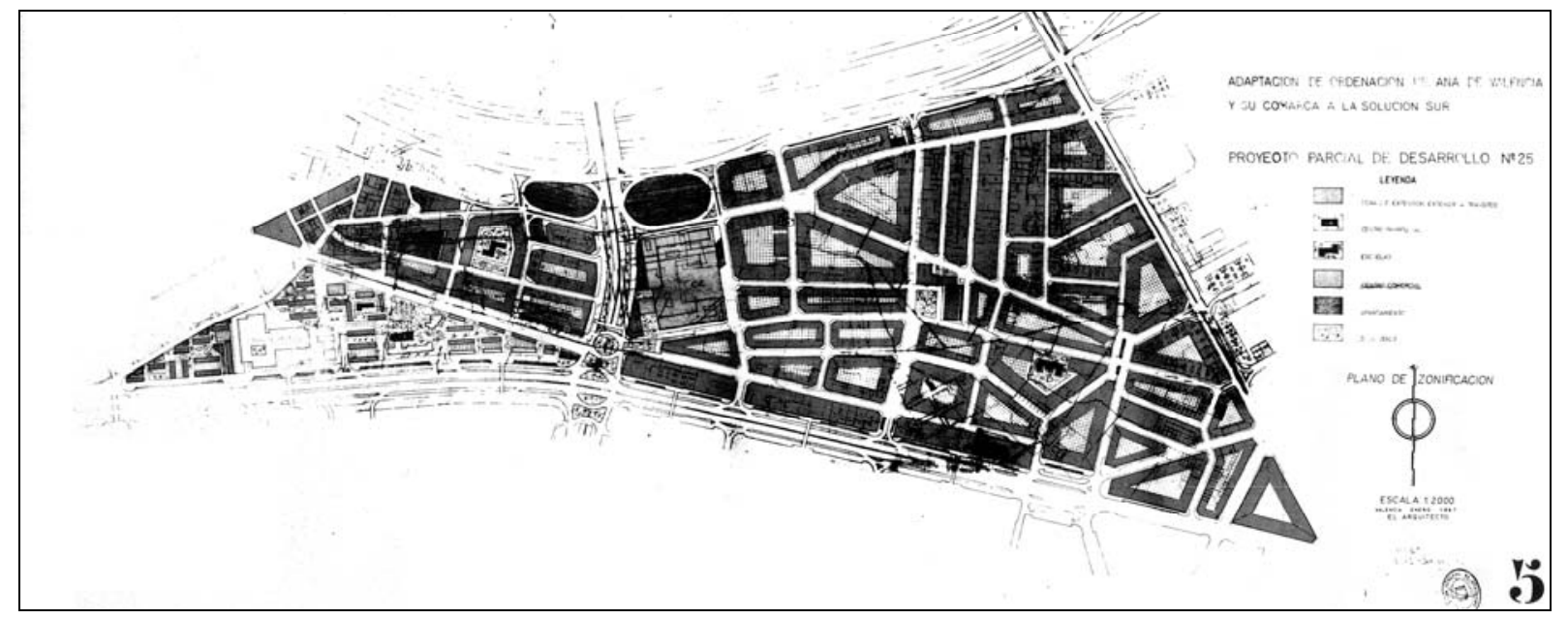

Proyecto Parcial no 25, 1967. Plano de zonificación.

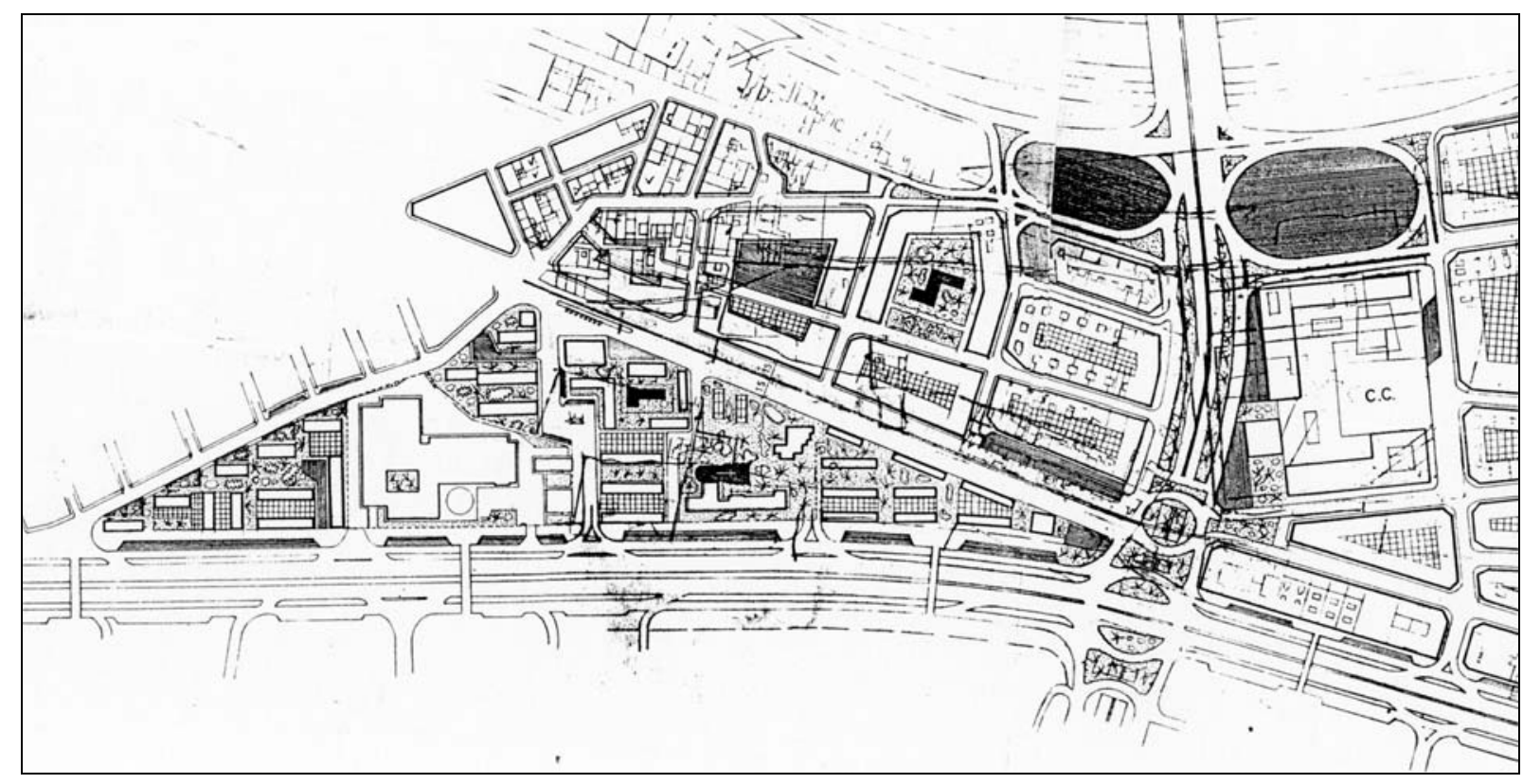

Proyecto Parcial no 25, 1967. Plano de alineaciones (fragmento) 


\section{EL PROYECTO PARCIAL No 25 (1967)}

El Proyecto Parcial no 25, redactado en 1967, engloba los terrenos correspondientes a los anteriores planes I-c, II, y parte del III. La edificación abierta se concentra sobre todo en el ámbito correspondiente al anterior Plan Parcial I-c, que hemos analizado en la sección anterior de este trabajo. ${ }^{1}$ De hecho, en esta zona el Proyecto Parcial 25 es una mera transcripción de la versión definitiva del Plan Parcial I-c, redactada en 1963, lo que se justifica en la Memoria en los términos siguientes:

En lo que respecta al antiguo Proyecto Parcial I-C incluido en el presente proyecto, se ha respetado las alturas de edificios que figuraba en él, por dos razones fundamentales, $1^{a}$, porque en su inmensa mayoría, pues solo falta por construir tres edificios, están terminados o en avanzado estado de construcción, al parecer con Licencia Municipal y, $2^{\circ}$ que si está justificado en algún sitio la ubicación de edificios en altura, es en este polígono, con fachada a la Av. De Castilla, de gran anchura y con calles particulares que no interfieren el tráfico de dicha vía.

Hemos tratado de ser realistas y conservadores en las zonas en donde la promoción de construcciones estaba iniciada, tratando en lo posible, de incluir las normas del Plan General de Adaptación en cuanto a aparcamientos, zonas de uso público y emplazamiento de edificios escolares. ${ }^{2}$

Así, las únicas variaciones que introduce el Proyecto Parcial 25 con respecto al Plano Parcial I-c son unos pequeños desplazamientos de la posición de las torres situadas junto a la parcela de SEAT y en el extremo este del área.

Además de la comprendida en el ámbito del antiguo Plano parcial I-c, el Proyecto Parcial 25 prevé otras dos zonas de edificación abierta, que son la proyectada en el centro comercial previsto en sustitución de la cárcel Modelo y un conjunto de tres manzanas situadas entre la calle Alcacer y el límite con el término municipal de Mislata, con edificación perimetral discontinua de bloques profundos que envuelven parcelas dotacionales, jardines, aparcamientos o, simplemente, viales que las atraviesan.

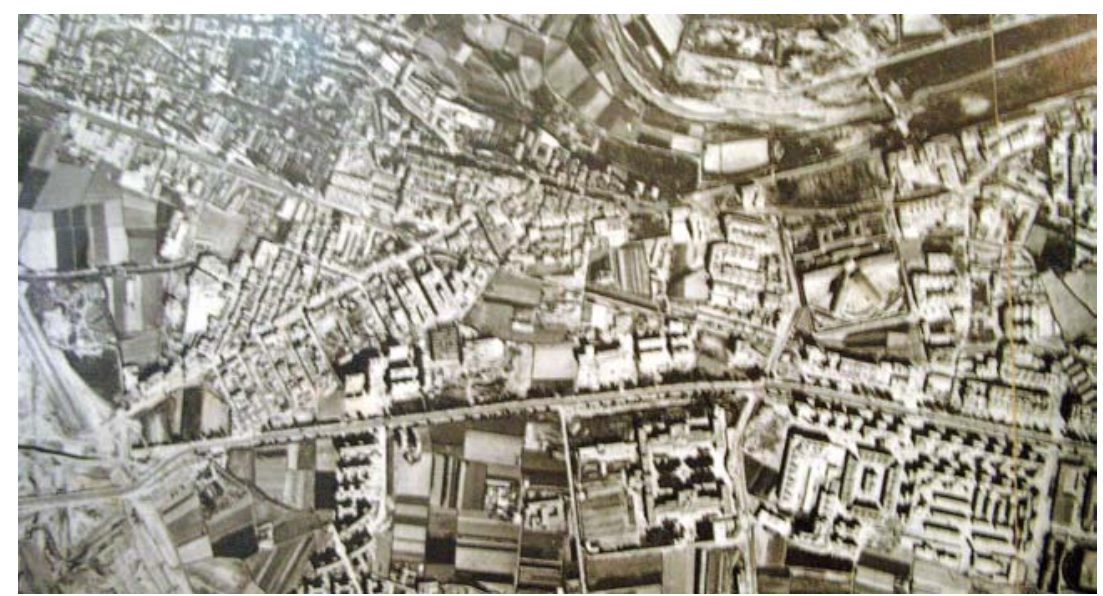

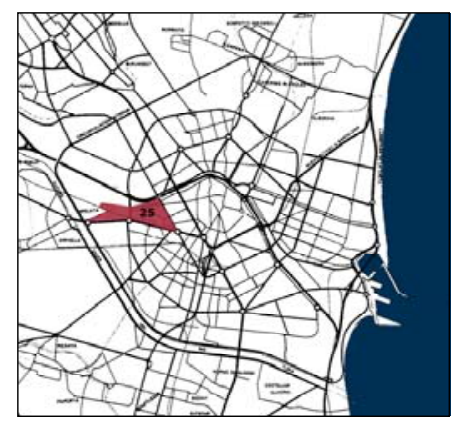

Plan Parcial 25. Localización
Zona del Plan Parcial 25. Fotografía aérea, h. 1965 (ETS de Arquitectura de Valencia)
1. Ver Sección II, pág. 279 y siguientes.

2. Plan Parcial 25, 1967. Memoria. Anexo de Documentos, p. 644 


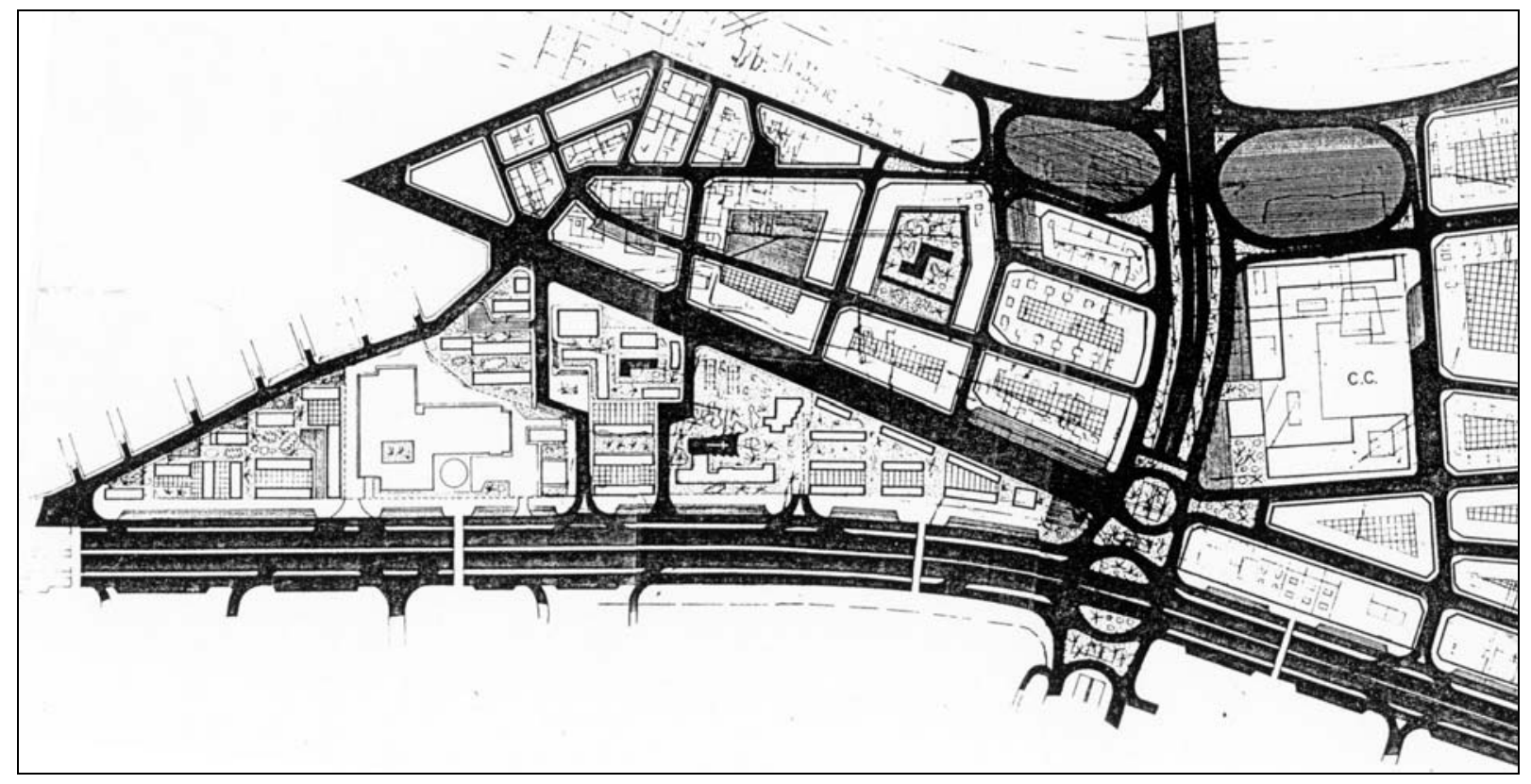

Plan Parcial 25 Trazado viario (fragmento)

1. Plan Parcial 25, 1967. Memoria. Anexo de Documentos, p. 645

Plan Parcial 25 Grado de realización (Fragmento, Elaboración propia. Color sobre plano de alineaciones)
La superficie destinada en el Proyecto Parcial 25 a equipamientos y zonas verdes es escasa, por tratarse de un plan que afecta a un área urbana bastante consolidada. Lo mismo ocurre con los aparcamientos, que no llegan a alcanzar ni siquiera la reserva a todas luces insuficiente fijada en el plan de un vehículo por cada seis familias. Por todo ello, la Memoria incluye el siguiente comentario final:

Creemos conveniente señalar que lindando este polígono, en una parte importante en longitud, con al actual cauce del río que según la Solución Sur desaparece como tal cauce, gran parte de los terrenos ocupados por él podrán ser destinados a zonas verdes o de aparcamientos si ello fuera necesario y las necesidades futuras lo hicieran aconsejable. $^{1}$

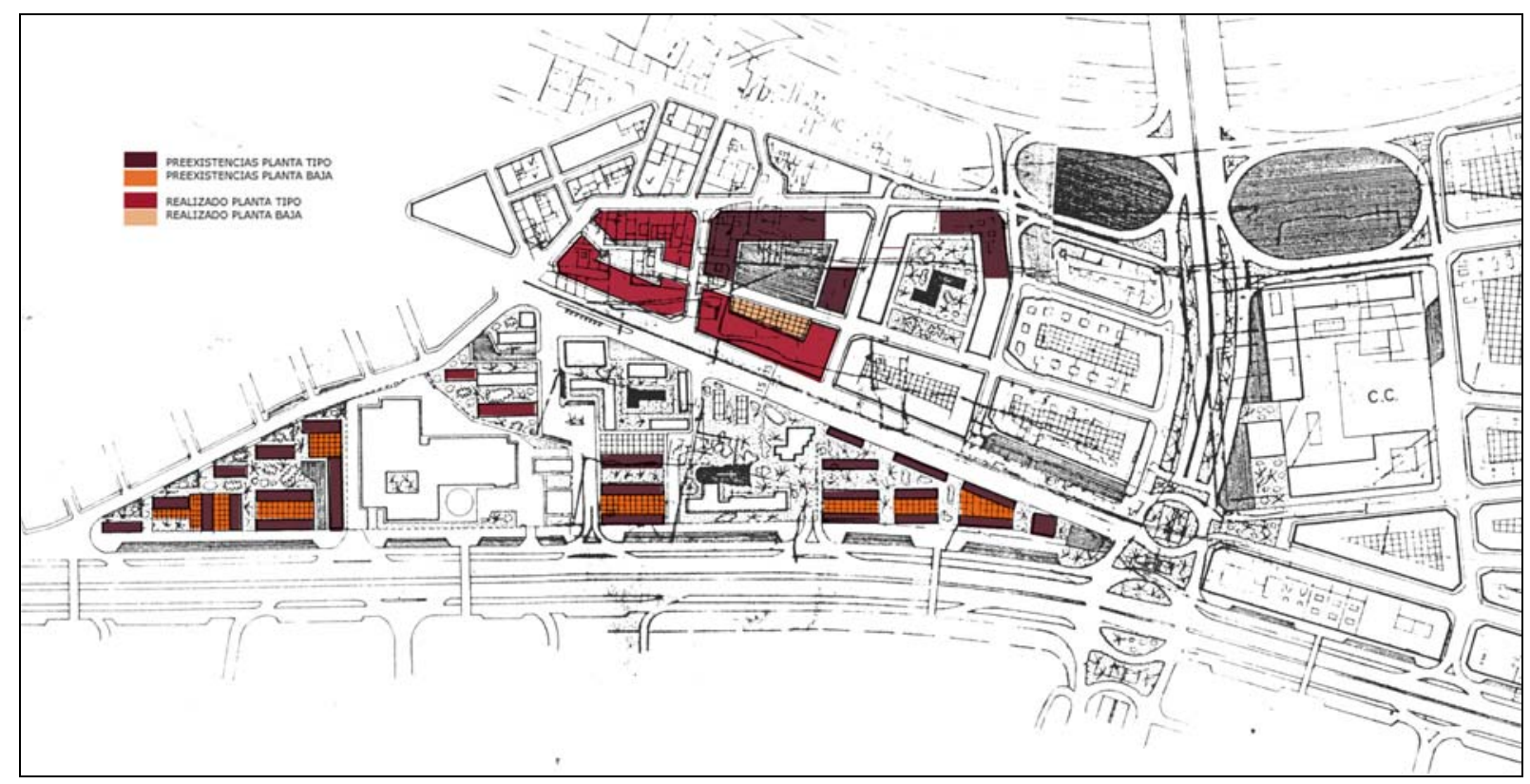




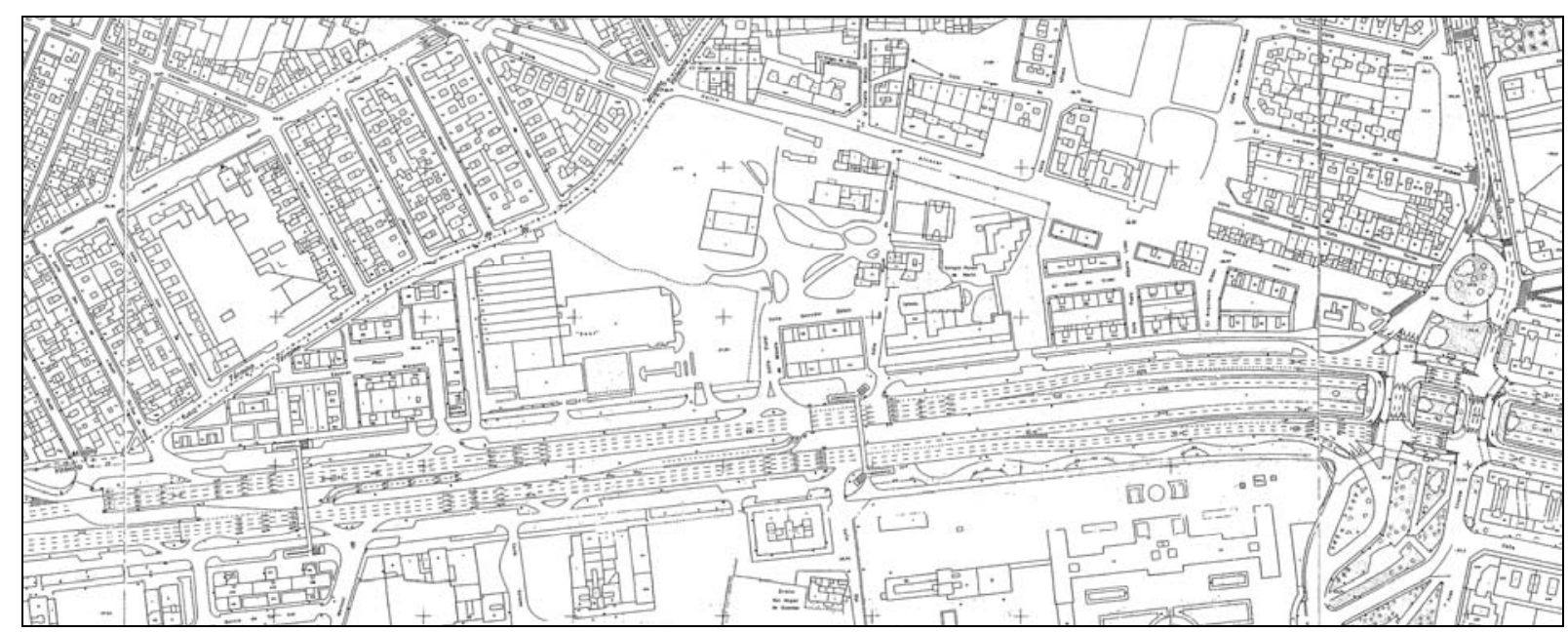

\section{Grado de realización}

Dos de las tres manzanas abiertas situadas entre la calle Alcacer y el límite con el término municipal de Mislata se realizaron en su mayor parte según las previsiones del Plan Parcial 25, con ligeras modificaciones.

En la zona correspondiente al antiguo Plano Parcial I-c, en cambio, los escasos bloques que no había sido edificados en el periodo comprendido entre 1963 y 1967, en el que se edificaron los restantes, fueron sustituidos por equipamientos o por bloques dispuestos de forma diferente en el Plan General de 1988.

Las previsiones del Plan General tampoco serían respetadas finamente, ya que en lugar de los cinco bloques previstos en el Plan se construyeron dos, con una disposición diferente en planta.
Zona del Plan Parcial 25. Cartografía Básica Municipal, 1983.

PGOU 1986. Detalle de la zona correspondiente al Plan Parcial 25. (Elaboración propia. Color sobre montaje de Hojas Serie C, Planos de Régimen Urbanístico)

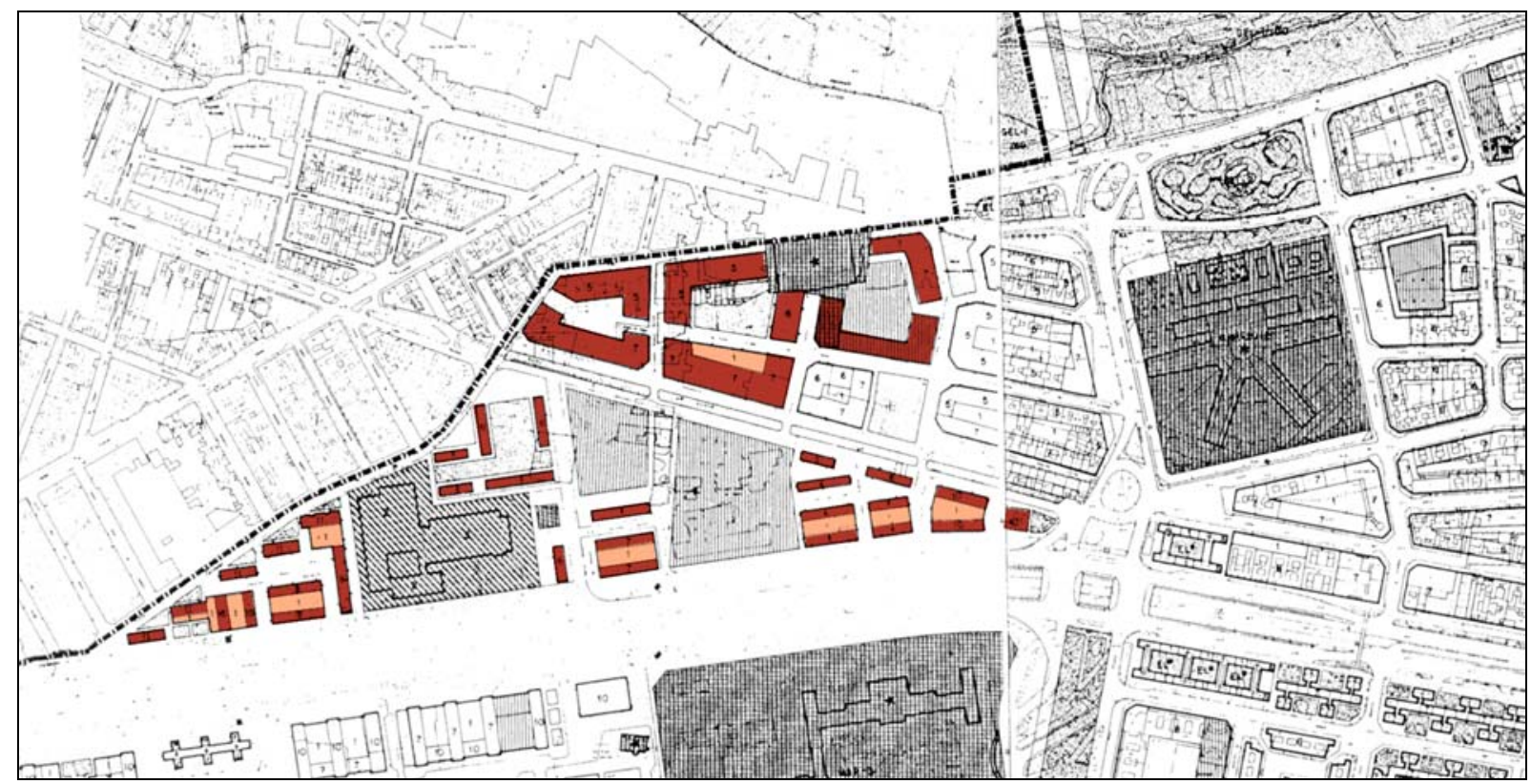


Los dos bloques lineales se sitúan a lo largo de la calle Ciutat de Mislata, que coincide con la línea correspondiente a la altura del triángulo que forma la zona, desde el vértice norte, situado en la confluencia de la calle Alcacer y el camino Viejo de Xirivella, hasta la Avenida del Cid. En los espacios vacantes a ambos lados de los mismos se sitúan un parque y una parcela escolar.

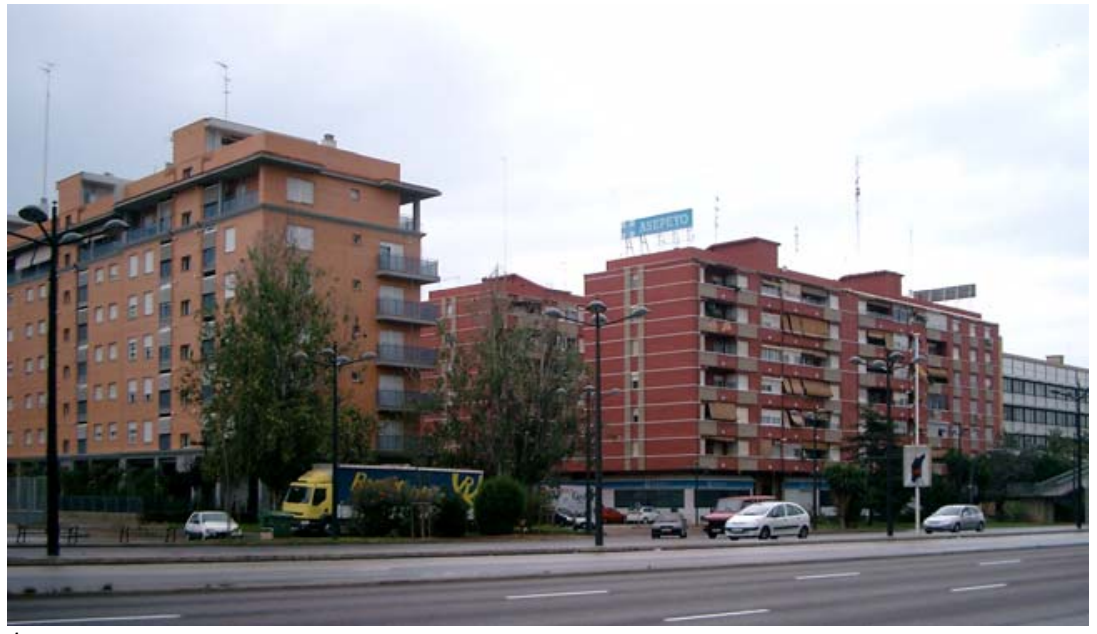

1. Avenida del Cid.

2. Calle Ciutat de Mislata, vista hacia la Avenida del Cid.

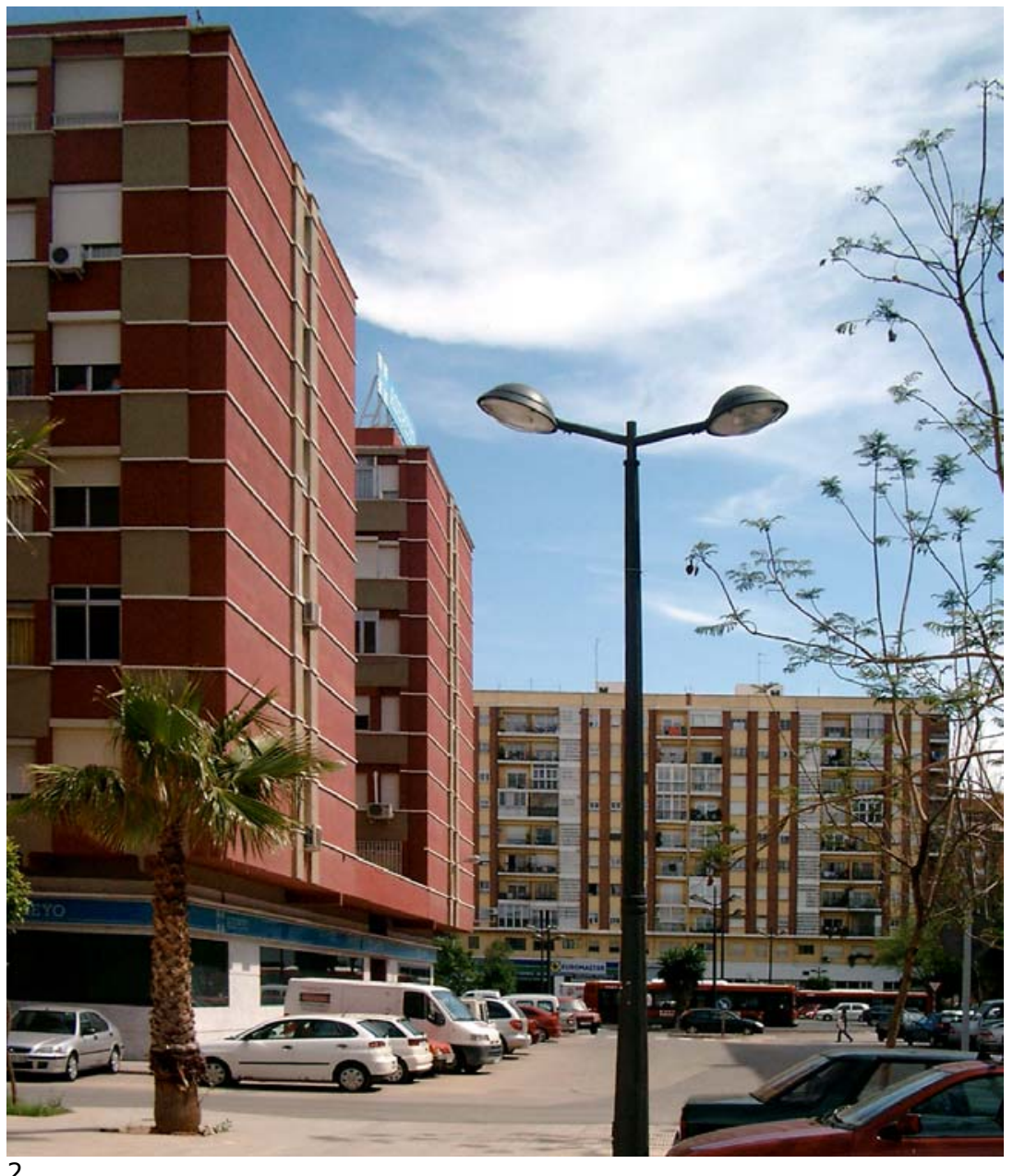




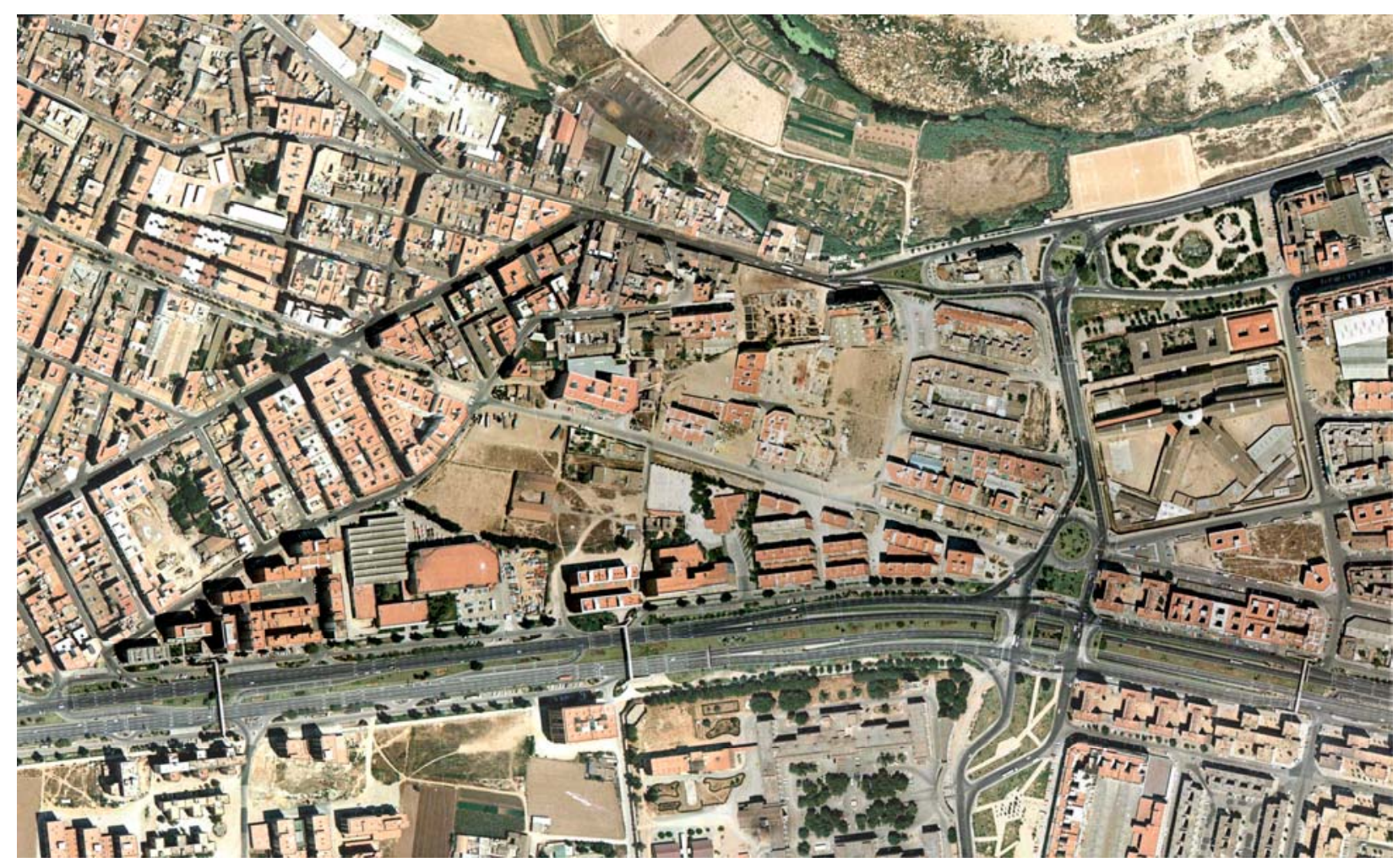

Zona del Plan Parcial 25. Fotografía aérea, 1980.

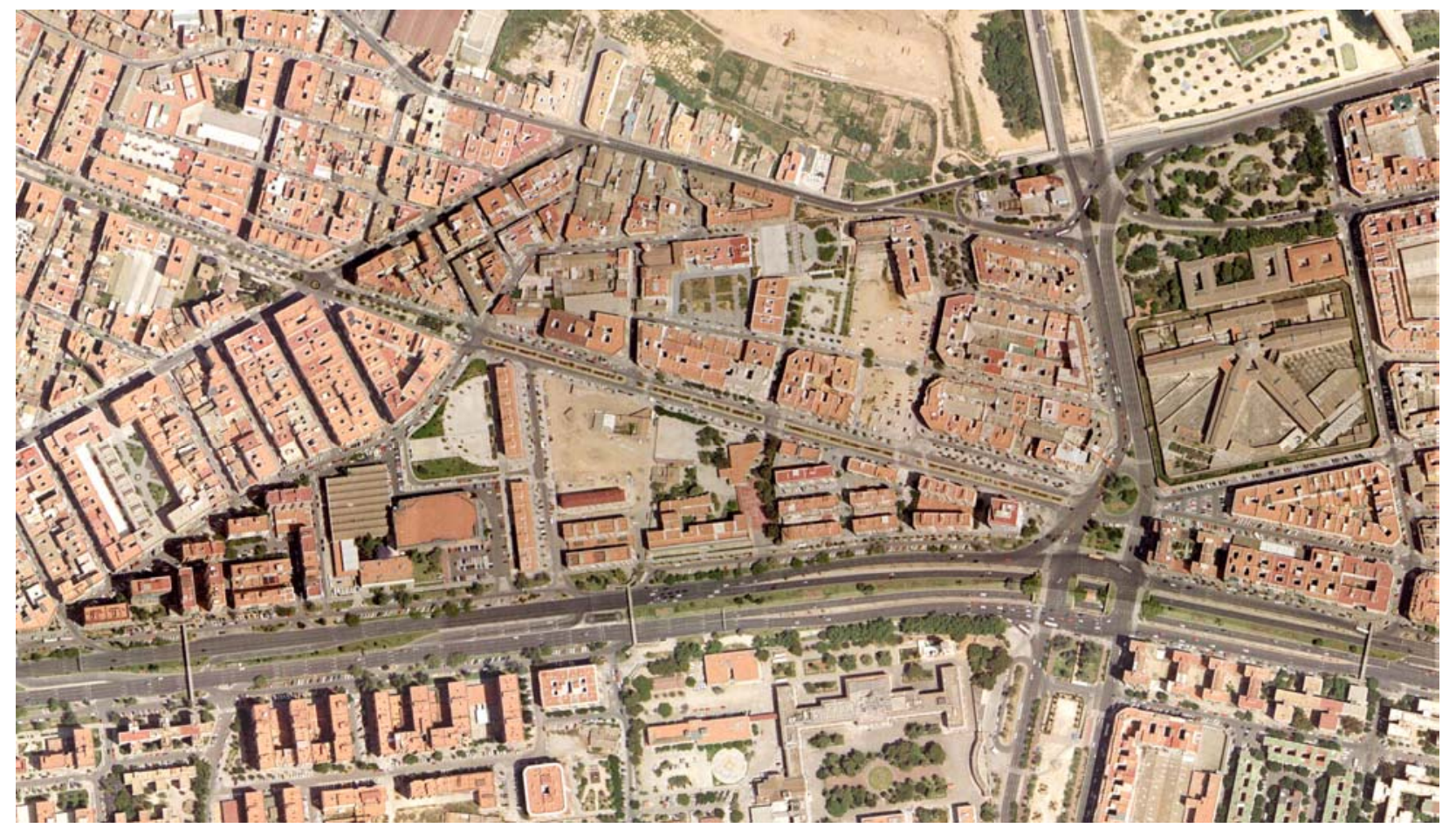

Zona del Plan Parcial 25. Ortofoto 2002 (AUMSA) 


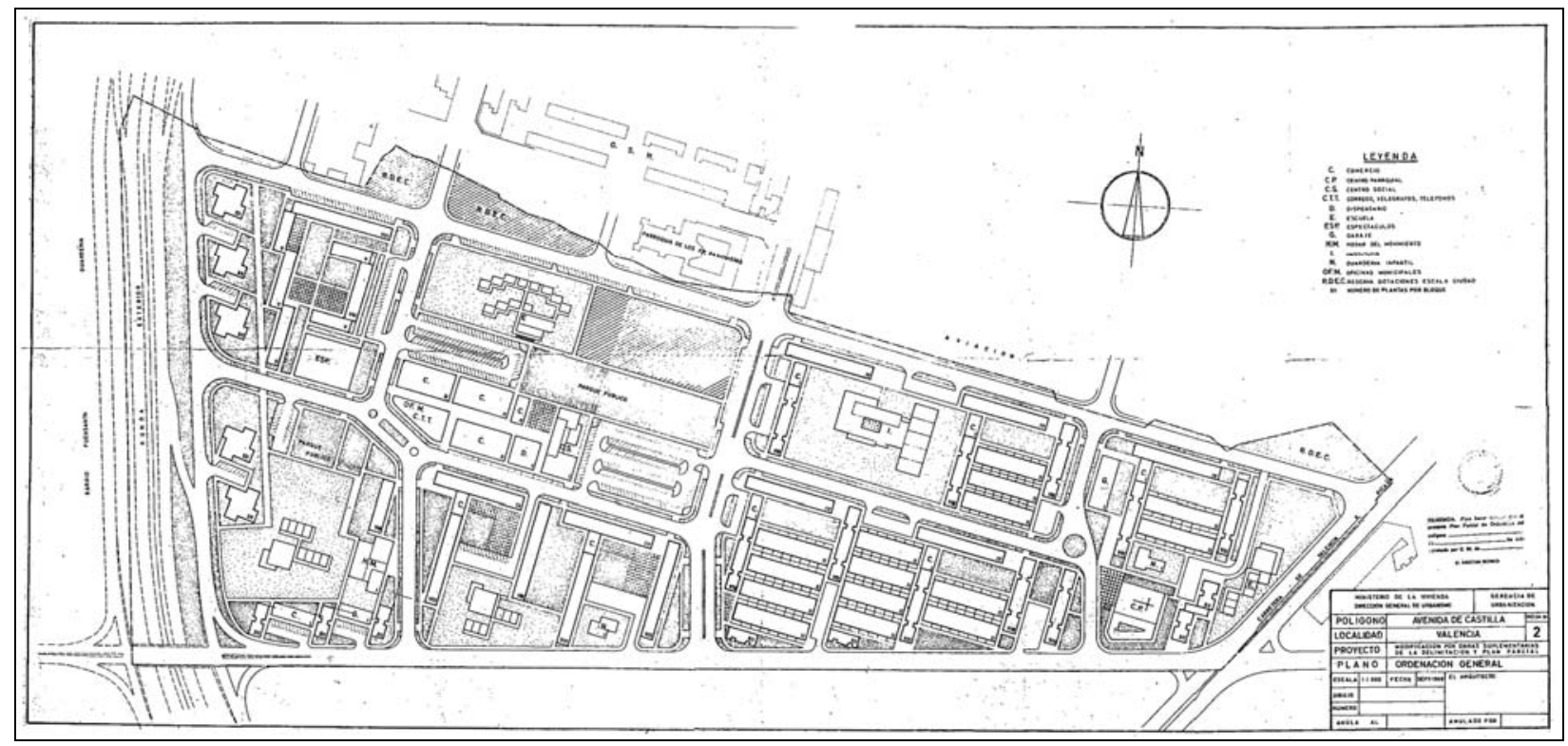

Plan Parcial Modificado del Polígono de la Avenida de Castilla, 1968. Plano de ordenación general. 


\section{EL GRUPO ANTONIO RUEDA Y EL POLÍGONO DE LA AVENIDA DE CASTILLA (1965/68).}

El Plan Parcial de Ordenación del Polígono de la Avenida de Castilla fue redactado en 1960, y comenzó a ejecutarse en base al correspondiente Proyecto de Urbanización, redactado en 1961. Este plan, que hemos analizado en la sección anterior, sufrió dos modificaciones de importancia en su sector este, que fueron, por una parte, la implantación de un Instituto de Enseñanza Media en una parcela inicialmente prevista como residencial y, por otra, la redacción en 1965 del proyecto para el grupo Antonio Rueda, conjunto de viviendas promovido por la Obra Sindical del Hogar que plantea una disposición de la edificación completamente diferente a la prevista en el Plan Parcial del Polígono.

Con ello, todas las parcelas del sector este, que era el destinado a la primera fase de desarrollo del Polígono, quedaron alteradas con respecto a su configuración inicial. Esta circunstancia, que bastaba para justificar la elaboración de una nueva versión del Plan Parcial, no es sin embargo mencionada en la exposición que figura en la Memoria del denominado "Proyecto de Modificación por obras suplementarias de la delimitación y Plan Parcial del Polígono Avenida de Castilla", redactado en 1968.

Los motivos aducidos en este Proyecto para la modificación del plan son dos, y ambos derivan, según la Memoria del mismo, del notable aumento experimentado en el nivel económico de la población. La primera es el importante aumento experimentado por el parque automovilístico en las ciudades españolas, que requiere una completa revisión, al alza, de las superficies de aparcamientos. La segunda es la "posibilidad de acceso de los jóvenes matrimonios a un hogar independiente del paterno, matrimonios que suelen instalarse preponderantemente en los nuevos núcleos residenciales ${ }^{\prime 1}$, lo que hace necesario ampliar las reservas de espacios para dotaciones, y en particular los destinados a enseñanza primaria y secundaria y a guarderías.

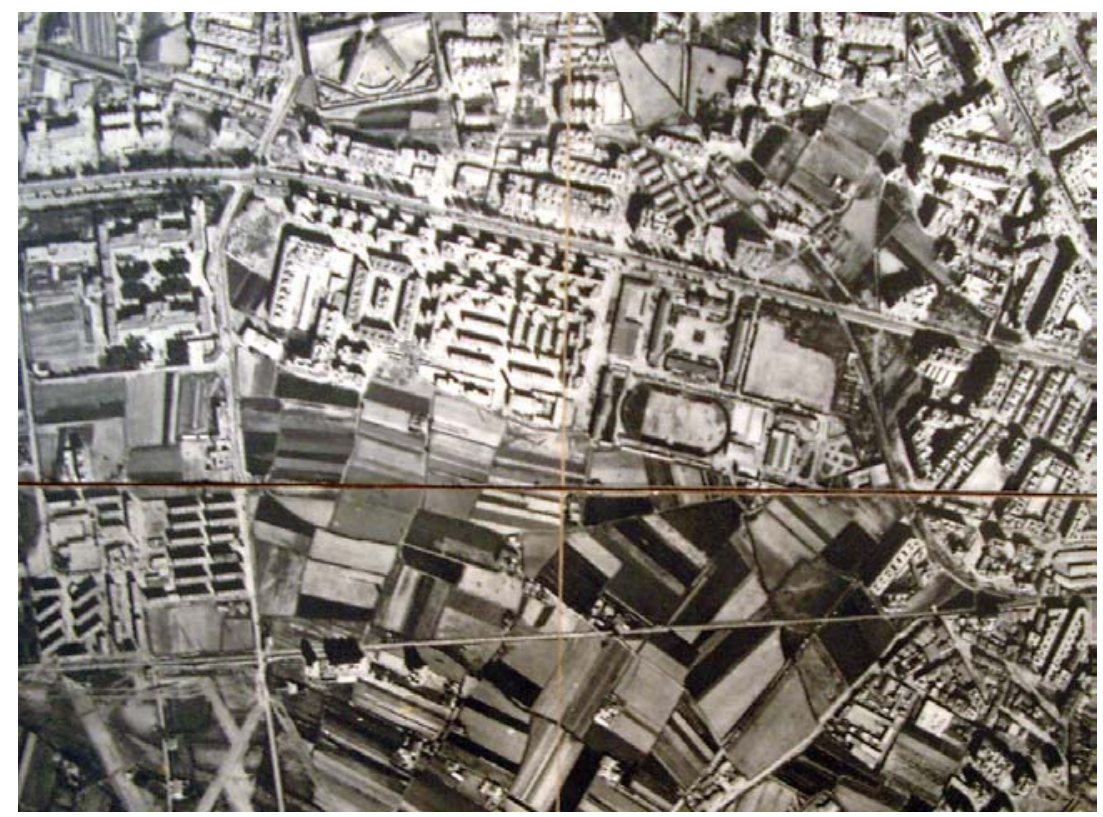

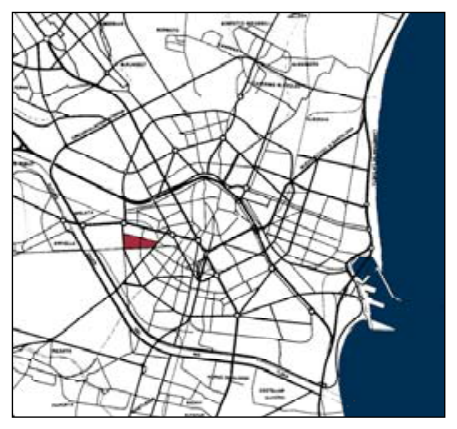

Polígono Av. Castilla. Situación

Zona del Polígono de la Avenida de Castilla. Fotografía aérea, h. 1965 (ETS Arquitectura de Valencia).

1. Memoria del Proyecto de Modificación por obras suplementarias de la delimitación y Plan Parcial del Polígono Avenida de Castilla, 1968. Ver Anexo de Documentos, p. 748 . 

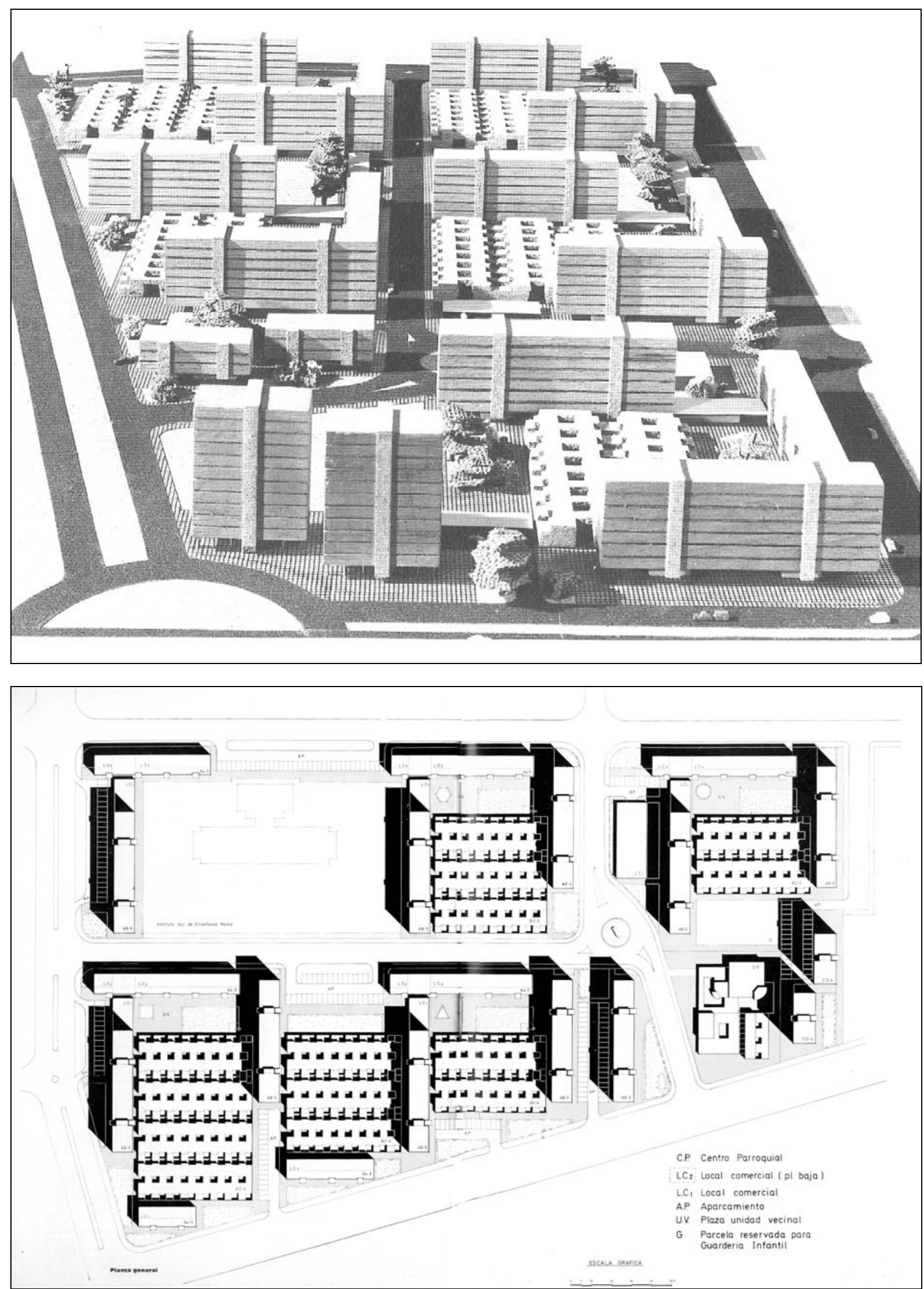

Grupo Antonio Rueda. Maqueta del proyecto original y planta general de ordenación definitiva 


\section{El Grupo Antonio Rueda (1965-72).}

El grupo Antonio Rueda fue proyectado en 1965 por los arquitectos Vicente Valls Abad, Joaquín García Sanz y Luís Marés Feliu, por encargo de la Obra Sindical del Hogar del I.N.V. Las obras del mismo se iniciaron en 1969 y finalizaron en 1972.

El grupo, de 1002 viviendas, ocupa unas 10 hectáreas de las 28 urbanizadas en el Polígono de la Avenida de Castilla por la Gerencia de Urbanización. Limita al norte con la Calle Músico Ayllon y el barrio Virgen de los Desamparados, al sur con la calle Tres Forques, el este con Archiduque Carlos y al oeste con Santa Cruz de Tenerife.

El proyecto, que prescinde de la ordenación de volúmenes vigente en el momento de su redacción, se apoya , según señalan los autores del mismo, en los siguientes criterios generales:

A) Diferenciación de circulaciones peatonales y de vehículos.

B) Máxima ocupación de los terrenos para tratar de eliminar los típicos eriales de las "Zonas verdes".

C) Crear espacios públicos proporcionados que ayuden a la convivencia de los vecinos, y sobre los cuales recayesen los comercios de uso diario. ${ }^{1}$

El grupo Antonio Rueda es un ejemplo tardío del modelo de desarrollos residenciales mixtos teorizado por Bakema y Van den Broek en el CIAM de Aix-en-Provence de 1953. Este sistema, utilizado en conjuntos como los de Pendrech, Klein Driene y t'Hool, consiste en la reformulación de la manzana a partir de la edificación abierta, combinando edificios de forma y volumen diversos (casas patio y en hilera, bloques, torres), que se disponen por lo general en turbina alrededor de un espacio libre central, para crear una unidad modular repetible.

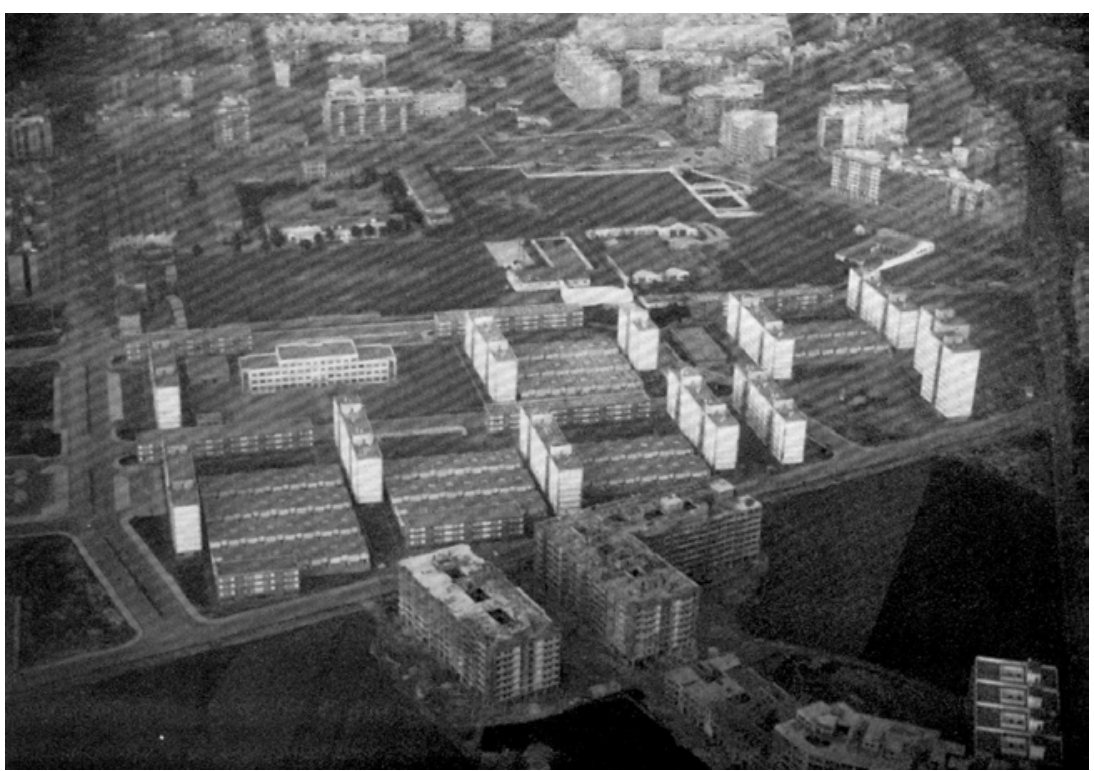

1-5. Grupo Antonio Rueda. (Hogar y Arquitectura, 106, 1973).

1. Valls Abad, Vicente, García Sanz, Joaquín, Marés Feliú, Luís, "Grupo Antonio Rueda de 1.002 viviendas en Valencia", Hogar y Arquitectura 106, Madrid, 1973. 


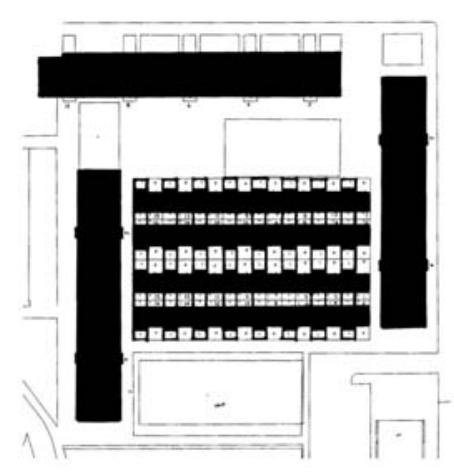

Grupo Antonio Rueda. Unidad modular de edificación abierta mixta.
Grupo Antonio Rueda. Plantas $y$ alzados de los edificios tipo

A. Torre.

B. Bloque lineal de VIII plantas.

C. Bloque lineal de VIII plantas.

D. Casas patio.
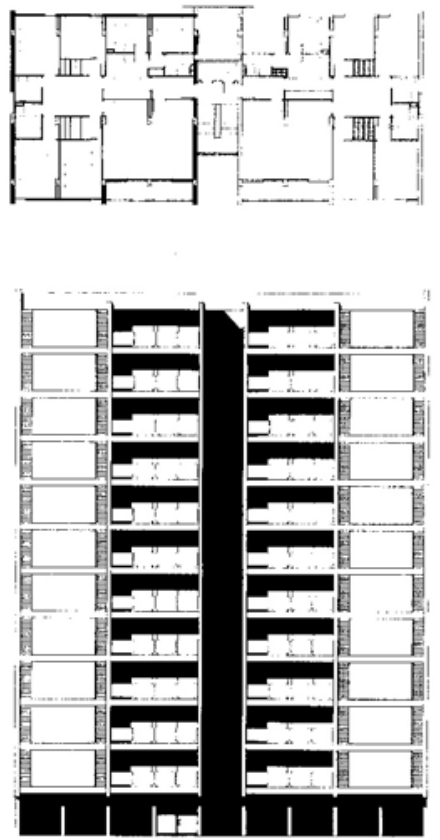

A

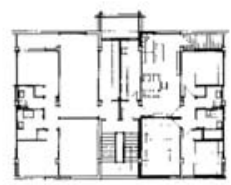

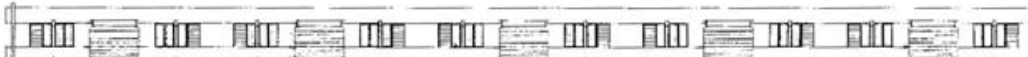

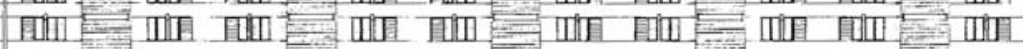

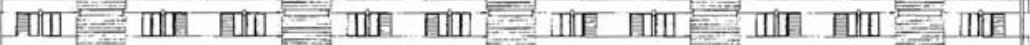

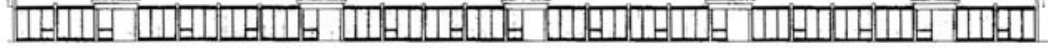
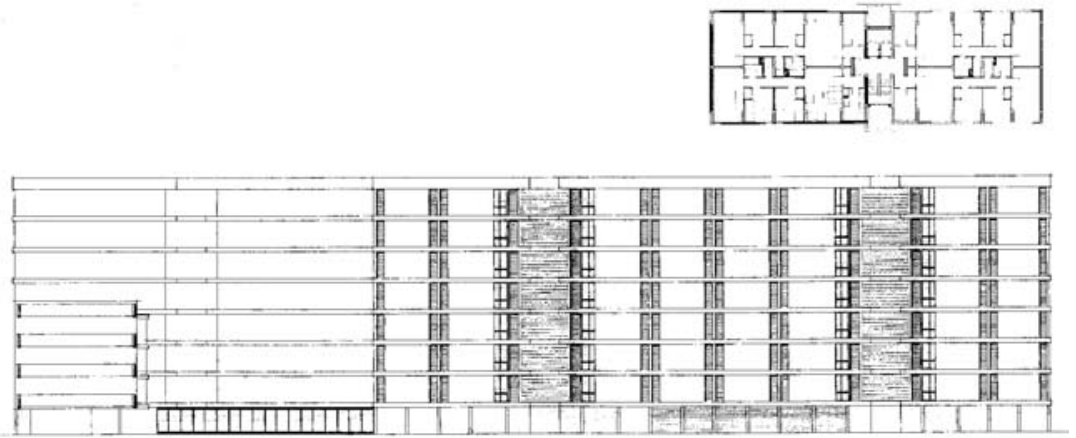

C
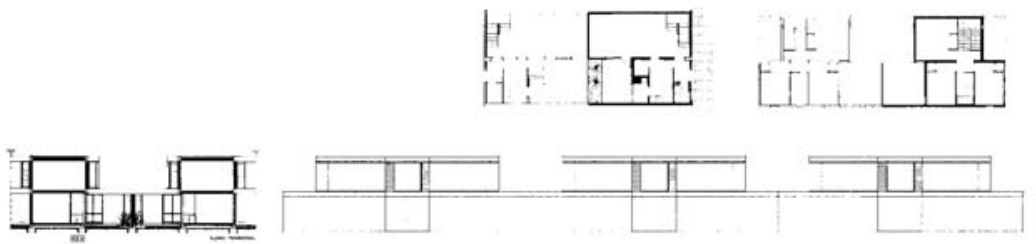

D 
El grupo puede considerarse por ello como la realización más próxima en nuestra ciudad a los supuestos de la arquitectura y el urbanismo europeos contemporáneos.

En el grupo Antonio Rueda, la unidad modular de edificación abierta está compuesta por dos bloques paralelos de VIII plantas de orientación norte-sur, un bloque de IV plantas dispuesto de este a oeste y una agrupación compacta de casas en hilera. Estas edificaciones envuelven una plaza central conectada con la calle del lado oeste a través de una pérgola que ocupa el espacio libre resultante del desplazamiento hacia el sur del bloque alto de ese lado.

A ello se añaden, como bloques singulares para las parcelas irregulares sobrantes del borde este, dos torres de XII plantas.

La unidad modular de manzana abierta, que se lee con claridad en la maqueta del proyecto inicial, resultó distorsionada a causa de la asignación de $10.000 \mathrm{~m} 2$ del sector a un Instituto de Enseñanza Media.

Así, en el proyecto original se identifican claramente seis unidades completas de manzanas abiertas, tres arriba y dos abajo, todas ellas con los tres bloques perimetrales formando una $U$ abierta al sur y el grupo de casas-patio cerrando el lado sur y dejando la plaza interior.

De las tres manzanas que dan a Músico Ayllón se realizaron finalmente dos, las de lado este, una de ellas incompleta al faltarle el bloque este, y un fragmento de manzana formado por dos bloques que quedan sueltos al oeste.

Las tres manzanas recayentes a Tres Forques acabaron perdiendo su individualidad como tales, pasando a formar un conjunto más indiferenciado al ocuparse el espacio previsto para equipamientos entre las dos manzanas originales por un fragmento adicional de plataforma de 2 alturas de casas-patio, fragmento que queda abierto al exterior por el norte, en forma de plaza a la calle central del barrio y cerrado por el sur por un bloque. En la manzana del lado oeste también aparece un bloque corto cerrando el lado sur.
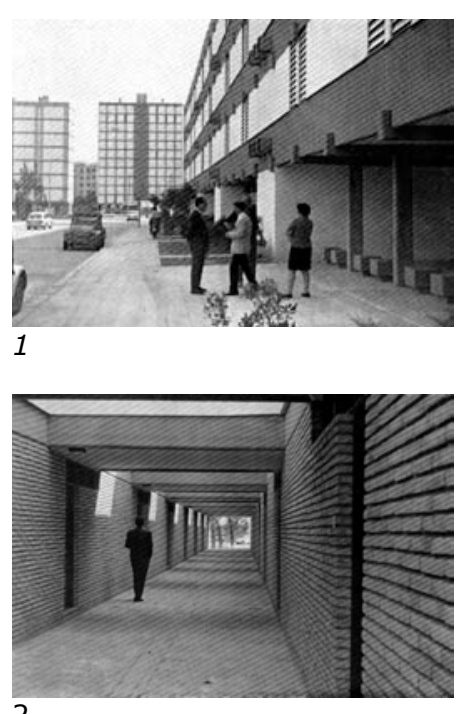

2

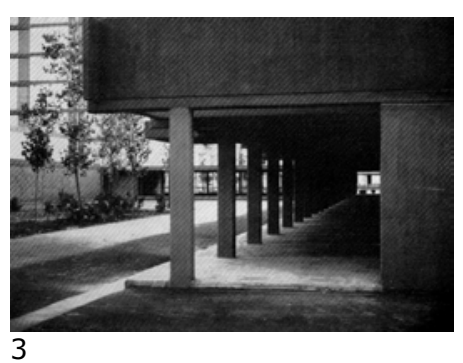

1-4. Grupo Antonio Rueda. (Hogar y Arquitectura, 106, 1973).

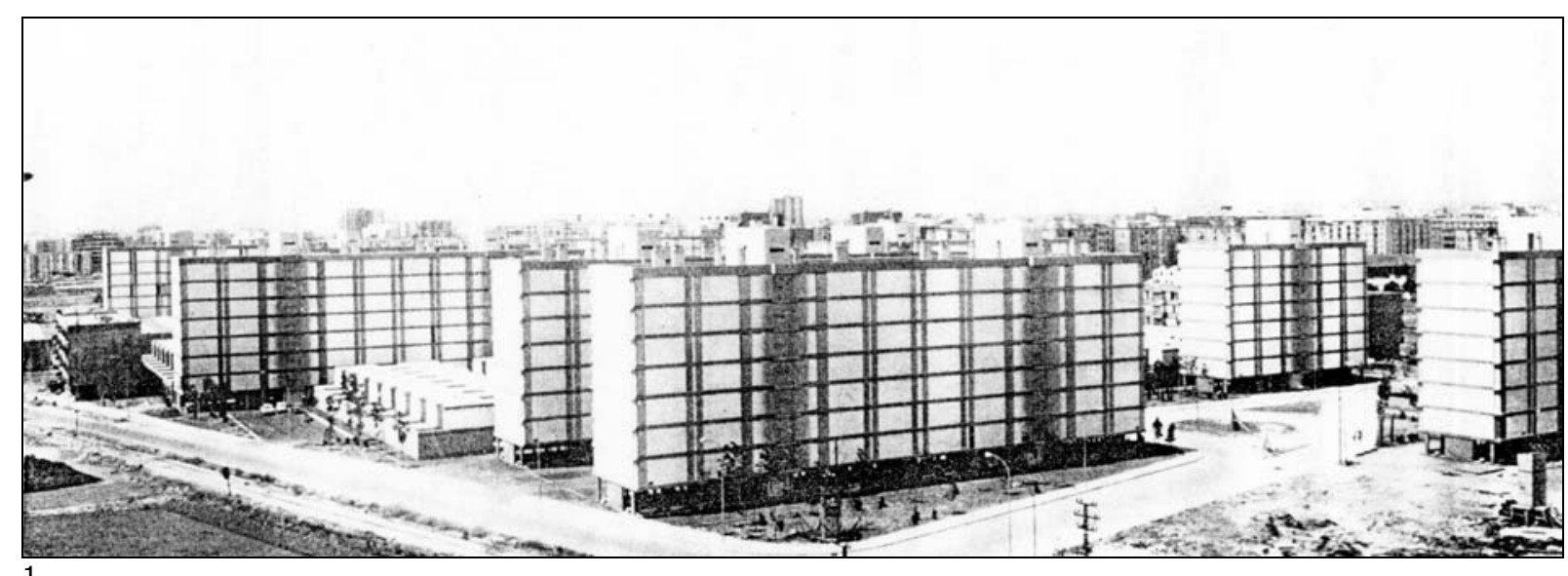




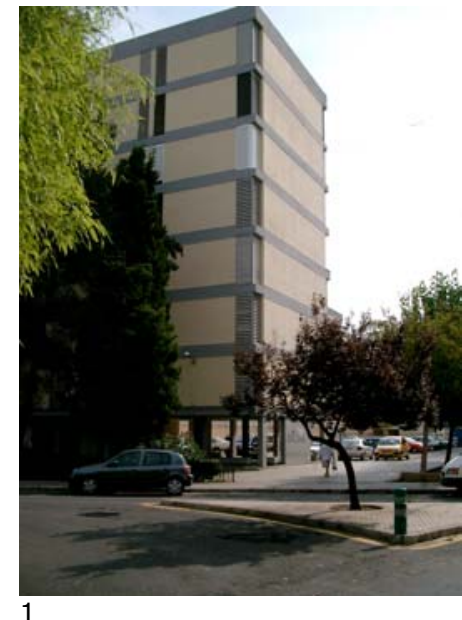

1

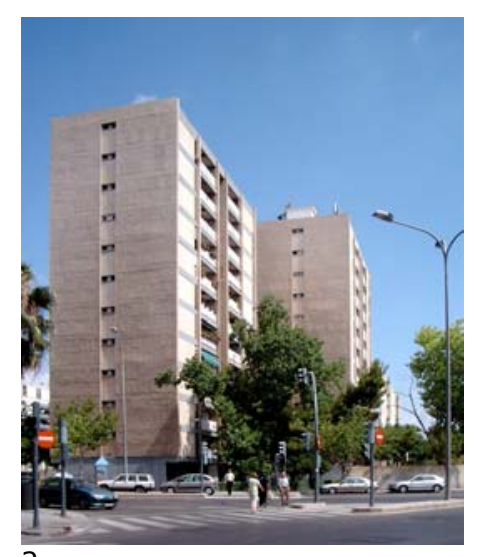

2

Los tipos de vivienda utilizados en los bloques lineales son dos: el canónico de vivienda pasante de dos crujías con caja de escalera para cada dos viviendas por planta y otro, más dudoso, de viviendas a una cara con una caja de escalera compartida por cuatro viviendas en cada planta.

Las viviendas unifamiliares son el tipo más novedoso del conjunto, ya que son el único ejemplo en Valencia de edificación abierta de baja altura. La agrupación, muy compacta, está formada en planta baja por hileras de viviendas desarrolladas alrededor de un patio privado y separadas por calles peatonales de acceso. Sobre estas calles se genera una alternancia de zonas cubiertas y descubiertas al situar sobre las mismas a intervalos regulares las plantas superiores de las viviendas.

Este tipo horizontal permite obtener una cuota de ocupación del suelo mayor que la de la edificación abierta alta, contribuyendo a evitar los espacios verdes residuales.
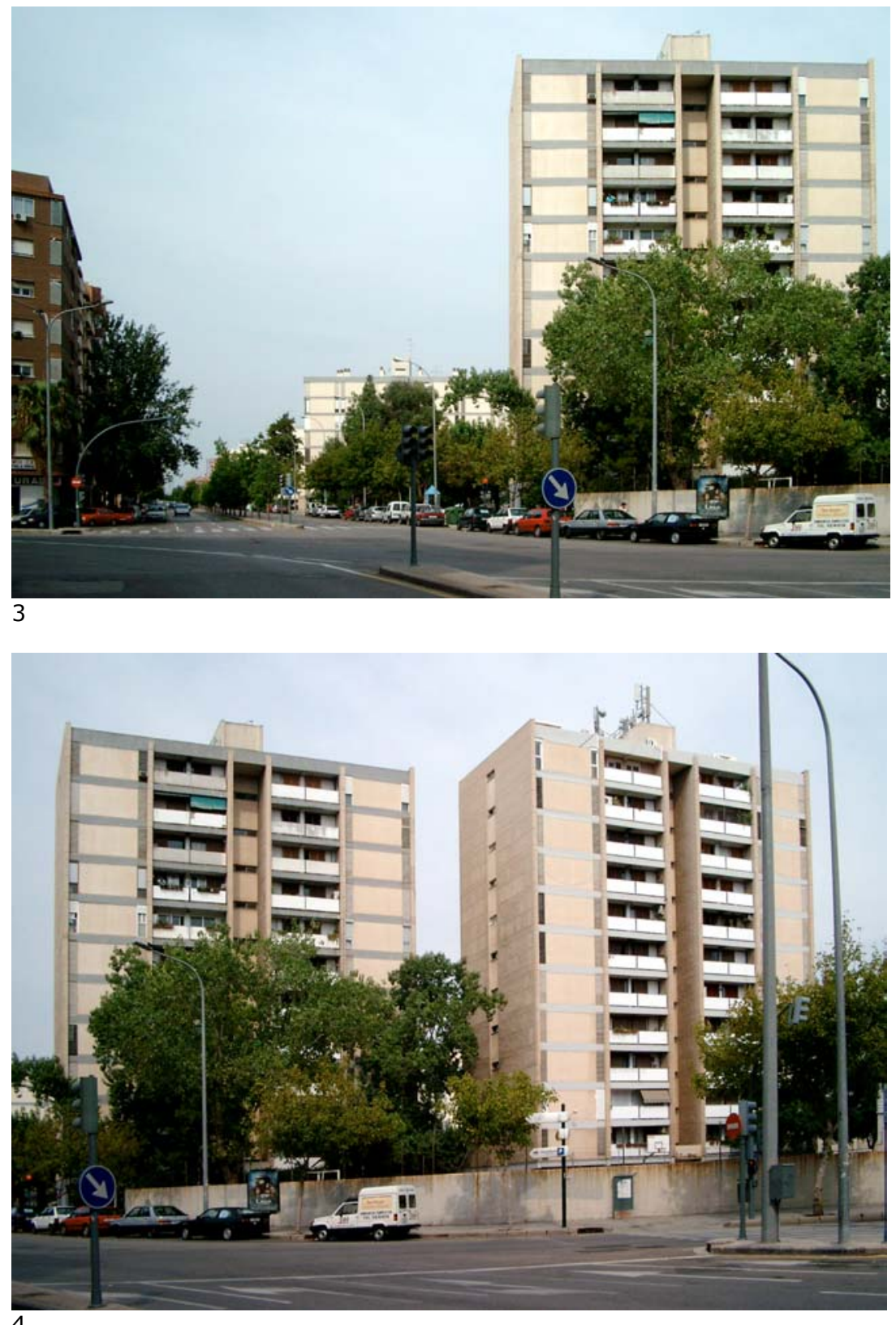

1. Bloque alto en calle Vicente Maroto.

2-4. Torres en la esquina de las calles Archiduque Carlos y Tres Forques. 


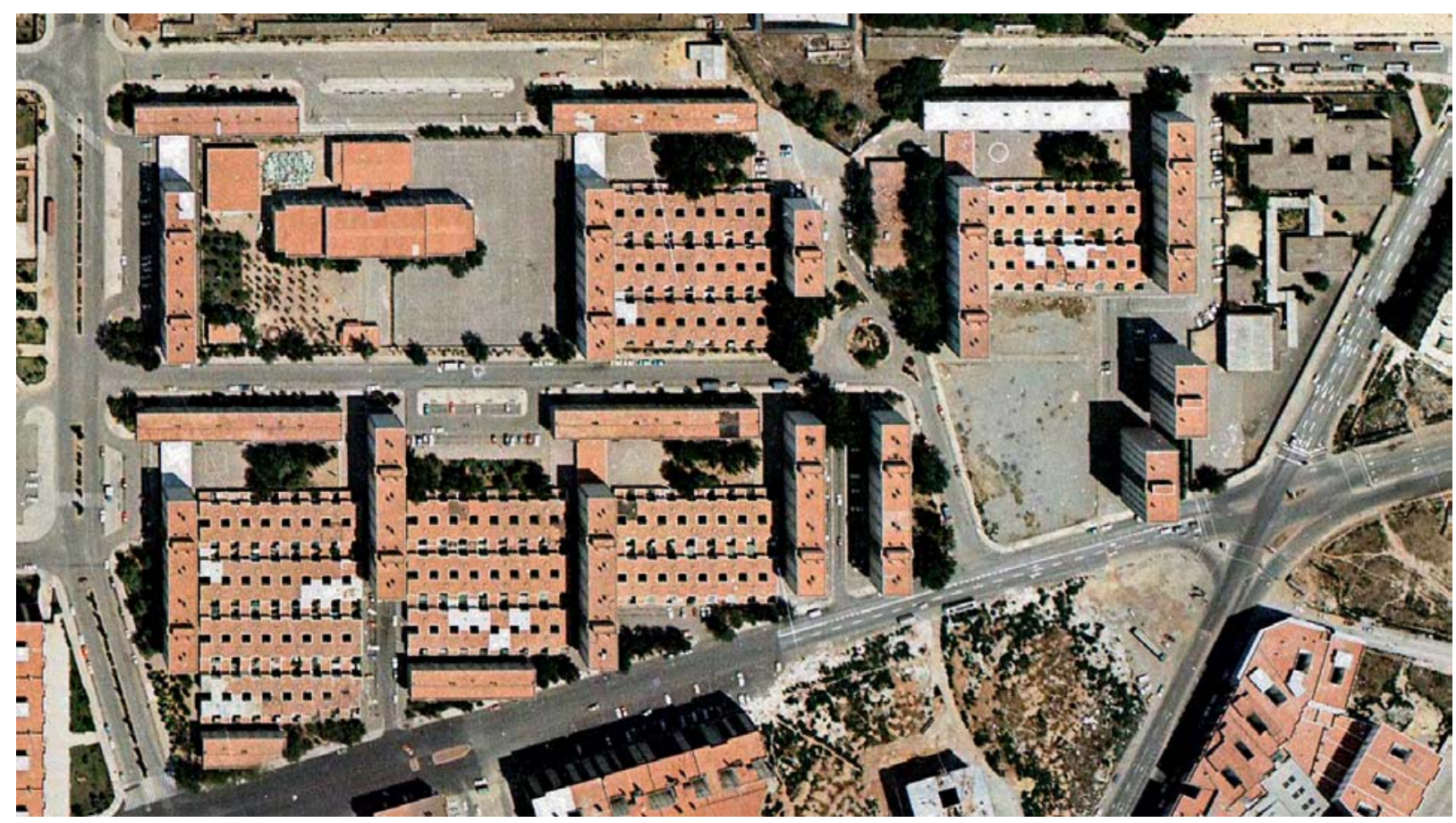

Grupo Antonio Rueda. Fotografía aérea, 1980.

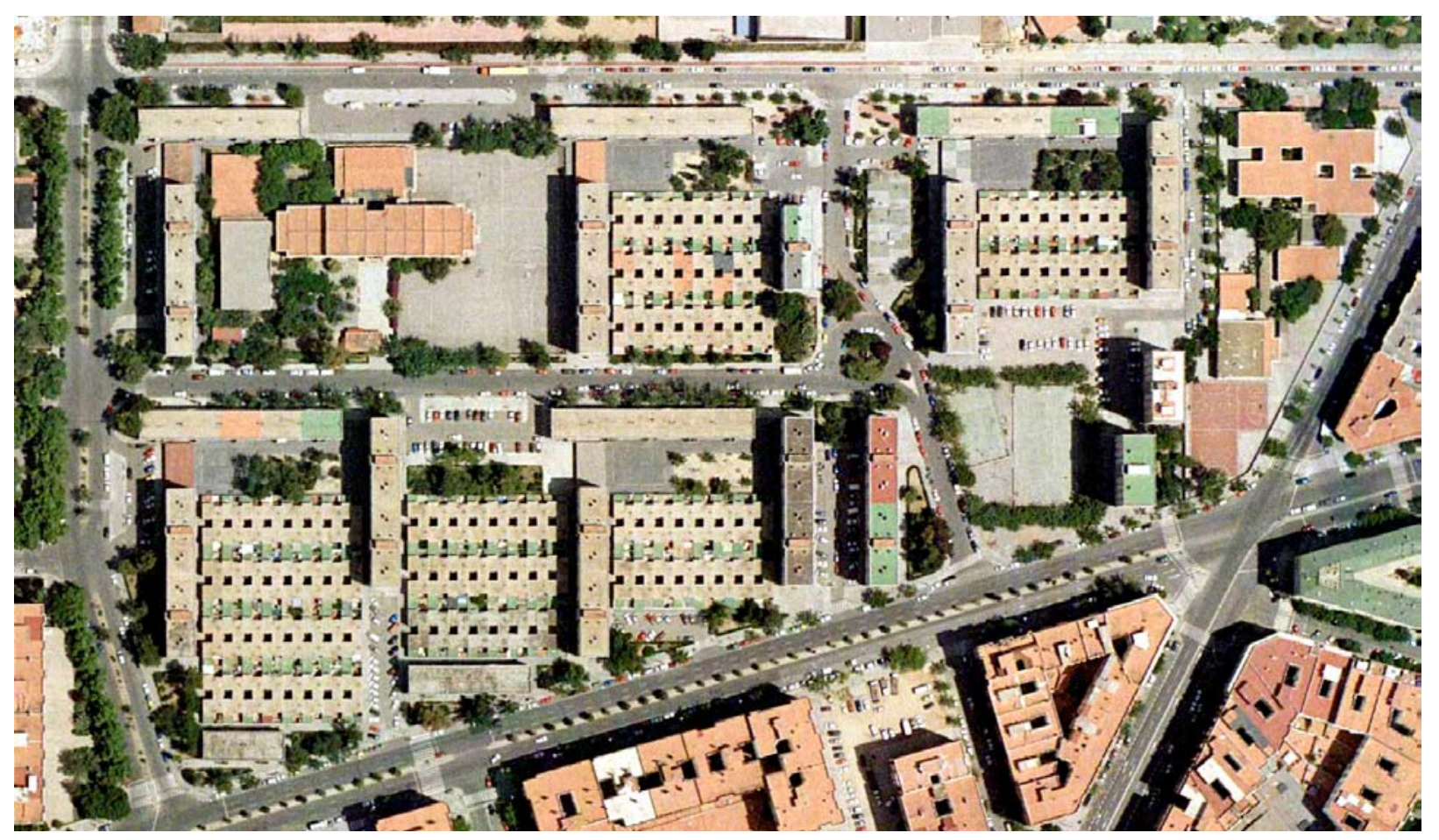

Grupo Antonio Rueda. Ortofoto, 2002 (AUMSA) 

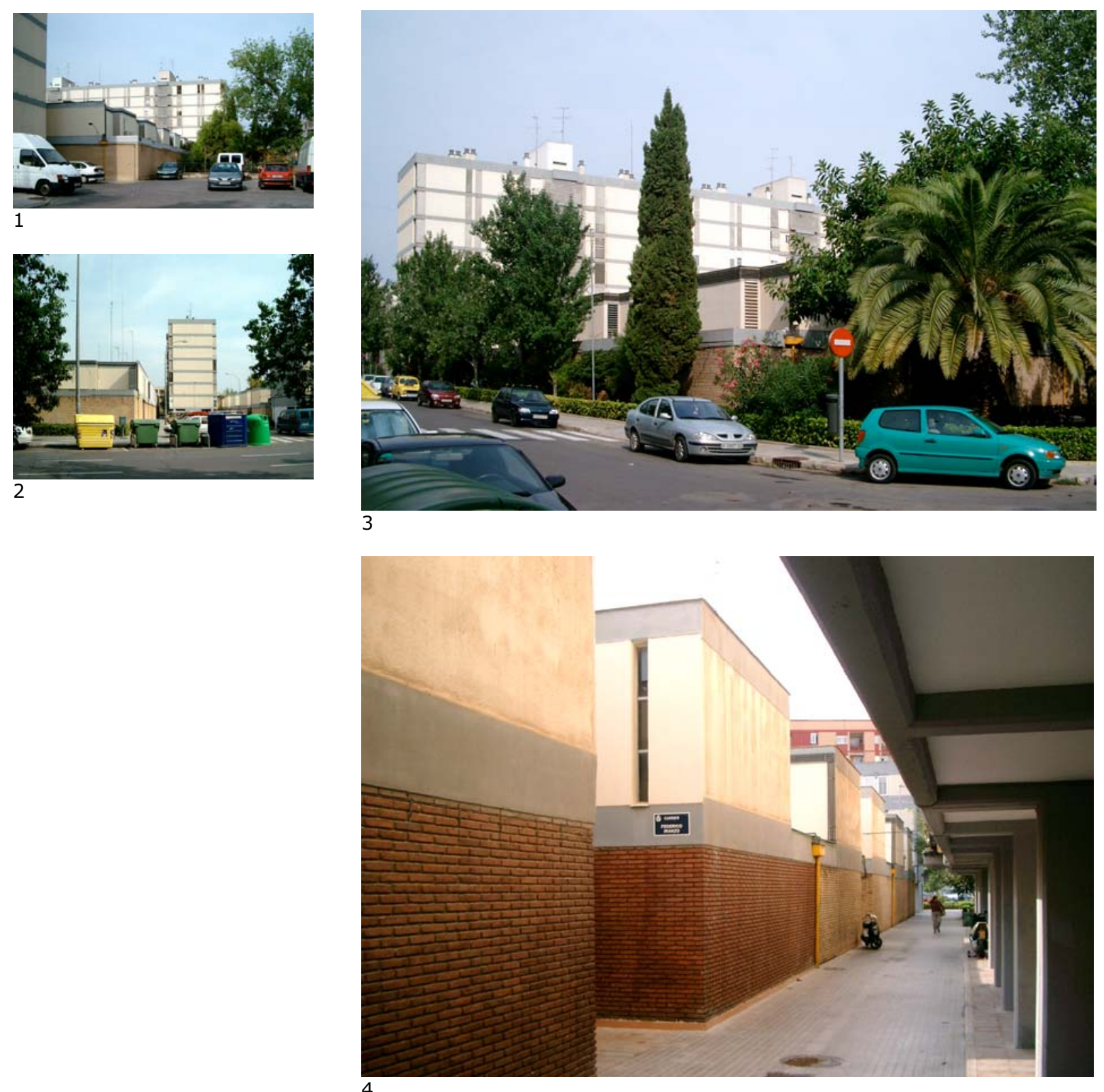

1. Calle Guillem Despuig, esquina con Francisco Dolz.

2. Calle Tres Forques.

3. Calle Guillem Despuig, vista hacia el oeste.

4. Calle Juan Romero, vista hacia el sur.

5. Calle Luís Sanjuan, vista hacia el este.

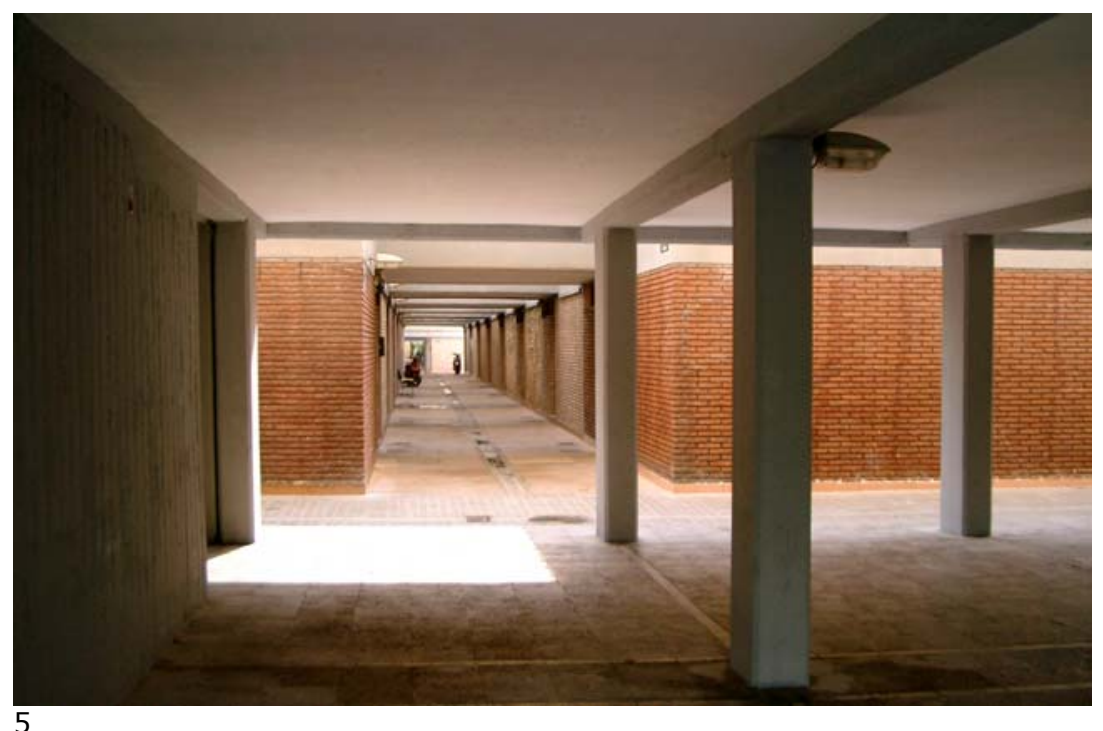


El problema mayor de este conjunto es el derivado de su zonificación funcionalista estricta, que elimina cualquier coexistencia de usos y separa drásticamente vivienda y comercio, dejando vacías las plantas bajas de los bloques, que son tratadas como simples porches cubiertos. Ello es reconocido por los propios autores del mismo cuando señalan lo siguiente:

Por contra, hemos de reconocer que los comercios previstos alrededor de las plazas peatonales de convivencia vecinal se están instalando de forma distinta a la prevista, por cuento el comerciante no se conforma con la clientela vecinal, sino que busca la transeúnte que circula por las calzadas; es decir, que la economía, en su favor, desordena el plan urbanístico previsto, previsión esta que, por ello, nos ha demostrado no ser la adecuada. ${ }^{1}$

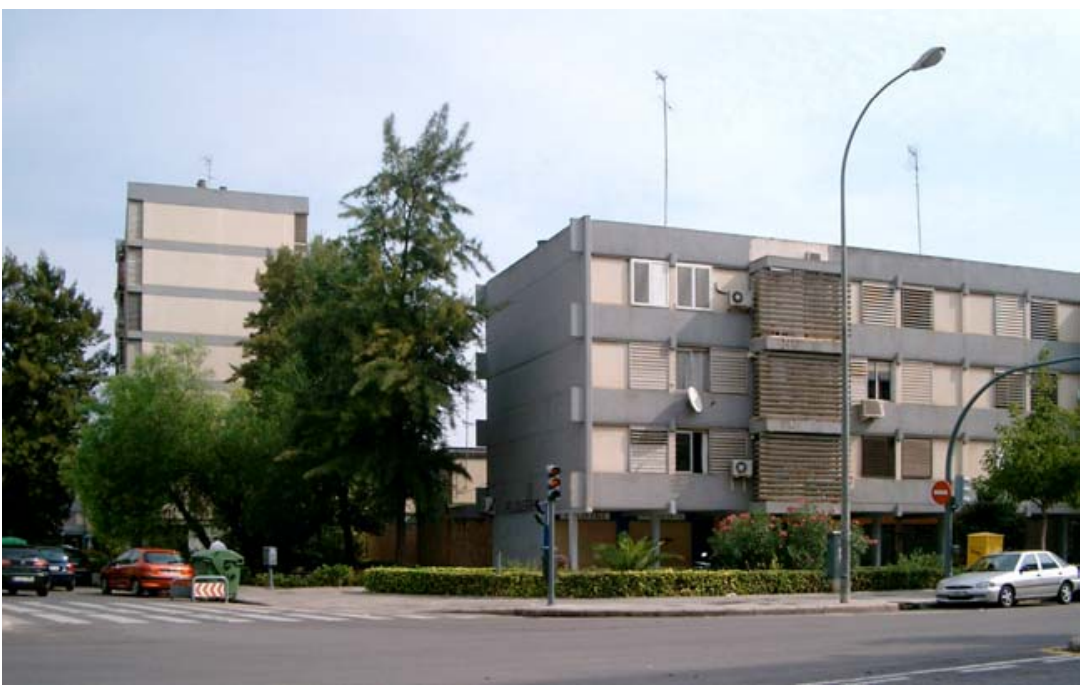

1

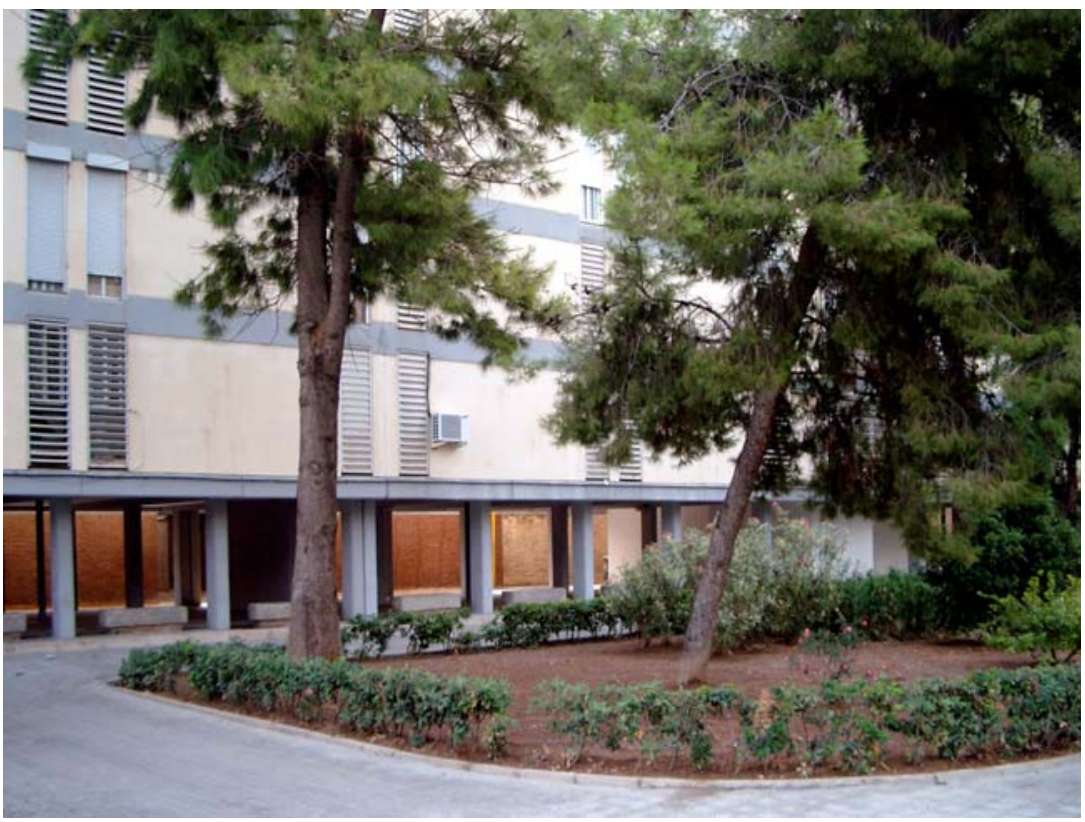

2
1. Calle Tres Forques, esquina con Santa Cruz de Tenerife.

2. Calle Mario Aristoy: Plaza interior en unidad de manzana tipo

1. Valls Abad, Vicente, García Sanz, Joaquín, Marés Feliú, Luís, "Grupo Antonio Rueda de 1.002 viviendas en Valencia", Hogar y Arquitectura 106, Madrid, 1973. 
PP Polígono Av. Castilla, 1968. Red viaria y equipamientos (Elaboración propia sobre plano de alineaciones del plan)

\section{El Plan Parcial de Ordenación Modificado del Polígono Aveni- da de Castilla (1968).}

El aumento de las superficies destinada a aparcamientos y a dotaciones son, como hemos señalado más arriba, las dos razones expuestas en la Memoria del Proyecto de Modificación del Plan Parcial del Polígono Avenida de Castilla para justificar su redacción. En concreto, este proyecto añade $20.000 \mathrm{~m} 2$ para enseñanza media y guarderías a las parcelas escolares previstas en el plan de 1961, y el número de plazas de aparcamiento pasa de 251 a 480.

Estas modificaciones tienen como consecuencia la reducción del número y la densidad de viviendas, que pasan de 3.098 viviendas (136 viv/Ha) en la versión de 1961 a 2.050 viviendas (71 viv/Ha) en la de 1988. La edificabilidad prevista es de 2,44 m3/m2, muy inferior a la de la edificación abierta alta habitual en los planes parciales municipales, de $5 \mathrm{~m} 3 / \mathrm{m} 2$.

El trazado viario es el único elemento que la nueva ordenación de 1988 conserva del plan original para el polígono de 1961. A este viario, que hemos analizado en la sección anterior, se añaden ahora únicamente espacios adicionales para aumentar la superficie destinada a aparcamiento.

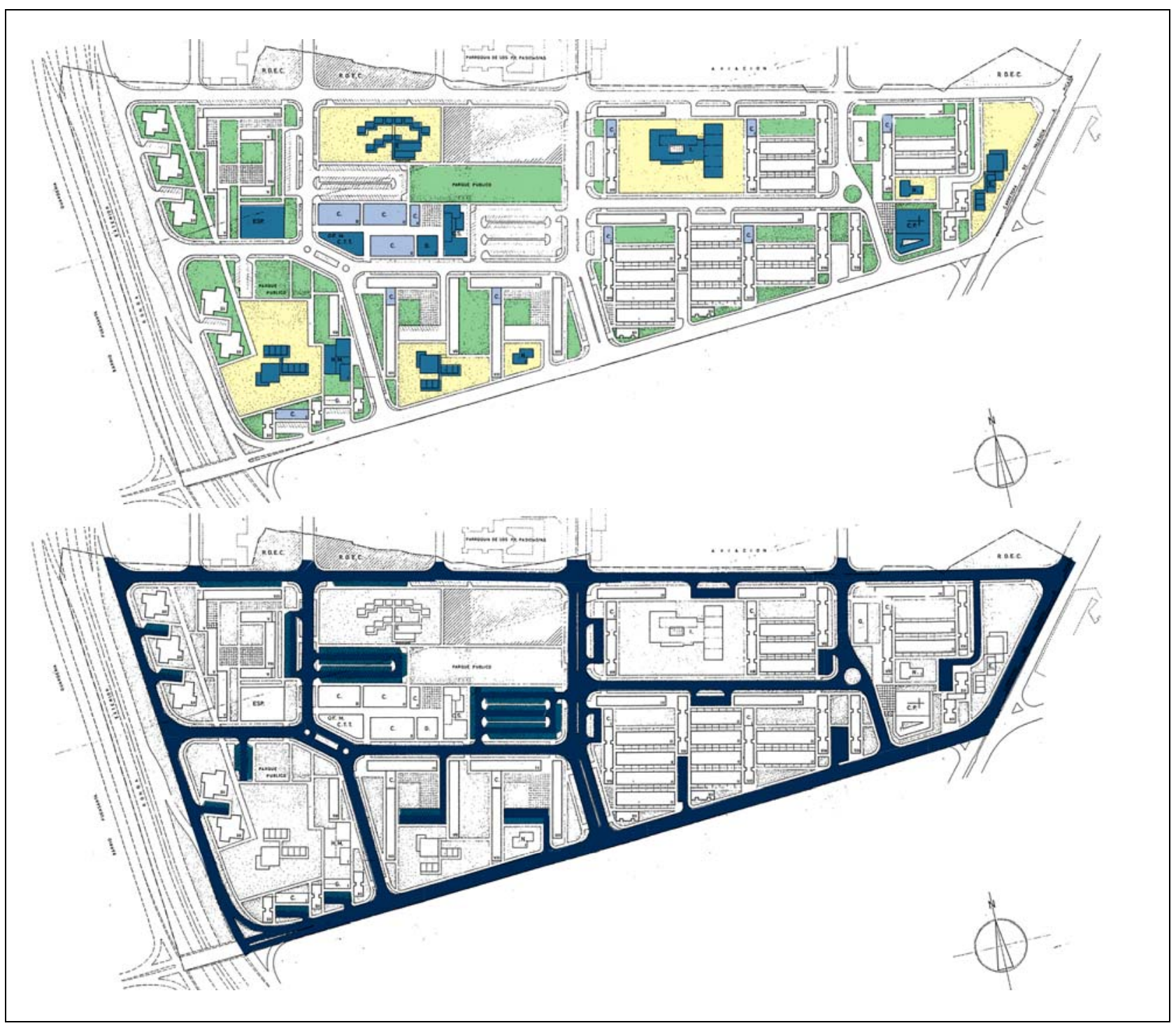


Por lo que respecta a la edificación, la versión del plan de 1968 no se limita a reflejar en el plano de ordenación el proyecto del Grupo Antonio Rueda, redactado en 1965, sino que modifica completamente las características de forma y volumen de los bloques en todo el resto del Polígono.

Así, la edificación de las tres manzanas residenciales del sector oeste del Polígono se resuelve con los tipos siguientes:

a) Bloques lineales dispuestos en torno a un espacio libre, configurando una versión simplificada de la unidad tipo del grupo Antonio Rueda que continúa la serie iniciada por este en el frente de la calle Tres Forques.

b) Torres de planta igual a las dos proyectadas en el grupo Antonio Rueda, y situadas en el extremo opuesto de la calle Tres Forques.

c) Torres con planta en forma de aspa de molino, alineadas a lo largo del frente oeste del Polígono, recayente al camino de Tres Cruces.

d) Bloques envolventes de un espacio central, completando la manzana de torres situada junto a la calle Musico Ayllón.
PP Polígono Av. Castilla, 1968. Edificación en planta tipo y en planta baja. (Elaboración propia sobre plano de alineaciones del plan)

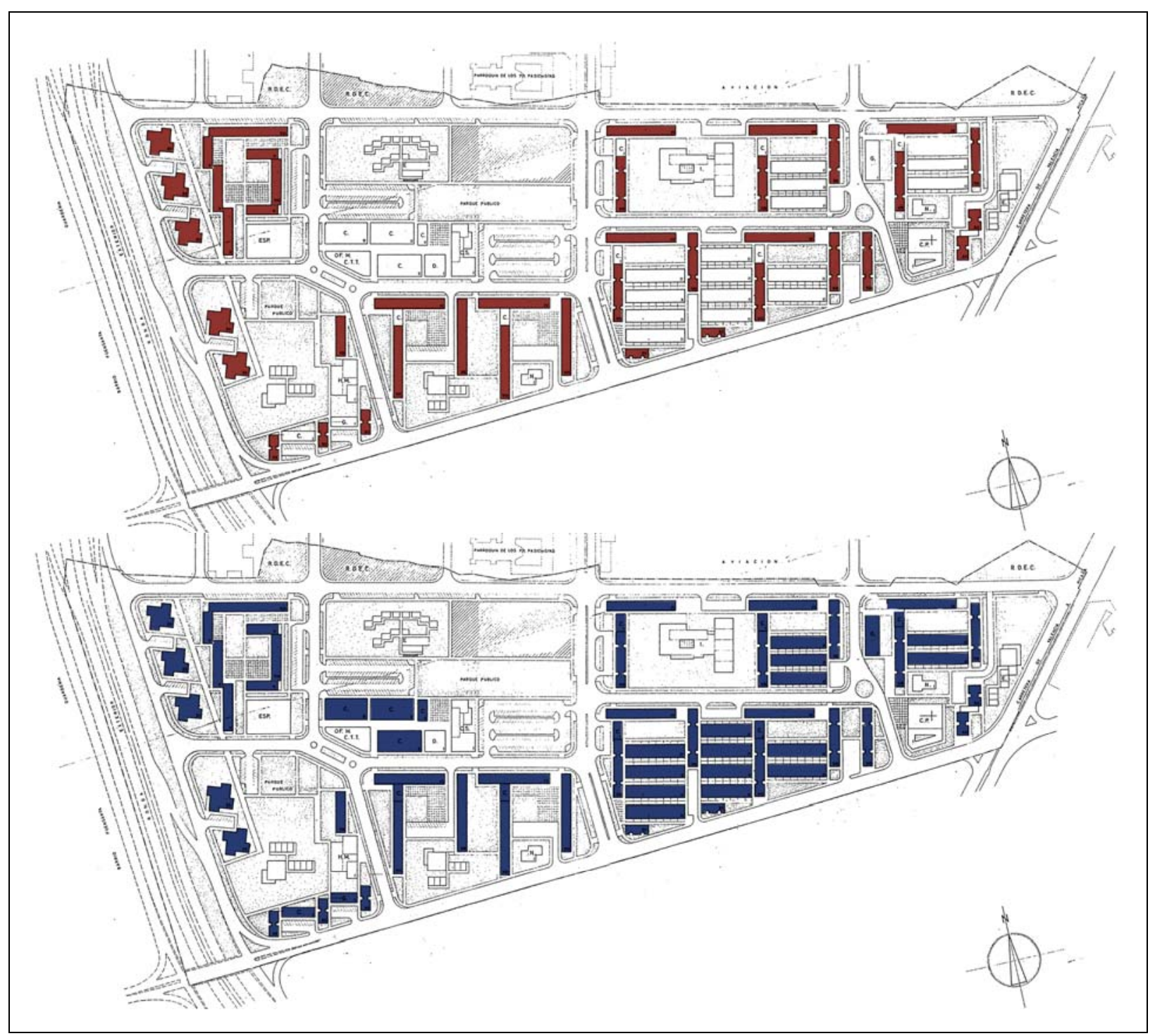




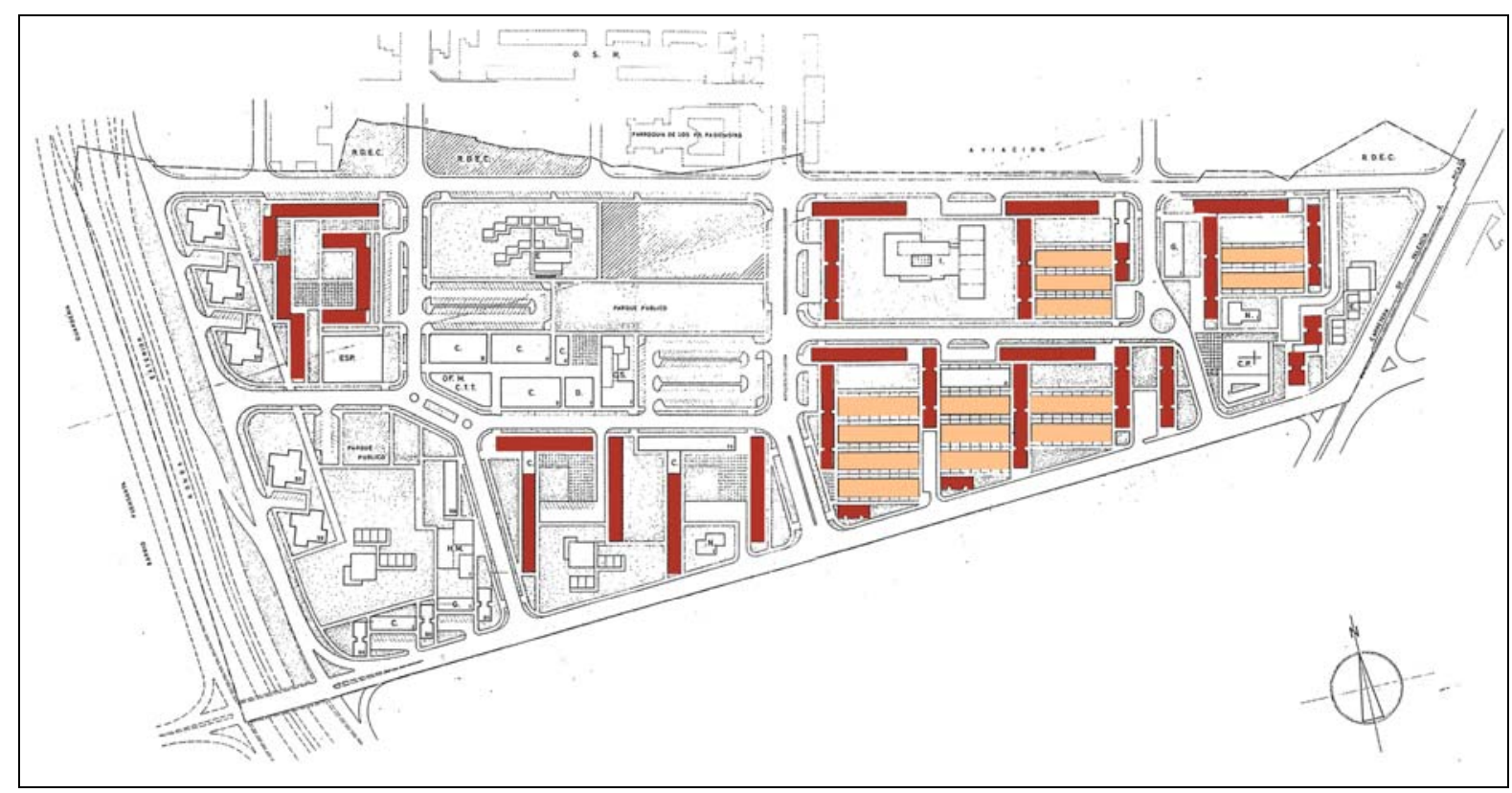

PP Polígono Av. Castilla. Grado de realización (Elaboración propia sobre plano de alineaciones del plan

PGOU 1986. Zona del Polígono Av. Castilla

\section{Grado de realización}

Además del Grupo Antonio Rueda, que figura como conjunto protegido, el Plan General de 1988 refleja las edificaciones del Polígono de la Avenida de Castilla ya construidas en el momento de su redacción. Las únicas edificaciones eliminadas por el Plan General son las que estaban pendientes de realizar, que son las tres torres y el bloque previstos en el frente a la calle Tres Forques de la supermanzana suroeste del polígono y una de las cinco torres previstas junto al Camino de Tres Cruces.

De estas torres, las cuatro que se realizaron tienen todas ellas formas en planta diferentes a la de aspa de molino prevista en el plan.

Las dos manzanas formadas por bloques en torno a un espacio interior situadas entre las calles Tres Forques y Llombay se construyeron según lo previsto en el plan con la excepción del bloque norte de la manzana situada más al este, que es un bloque doble con planta en $\mathrm{C}$.

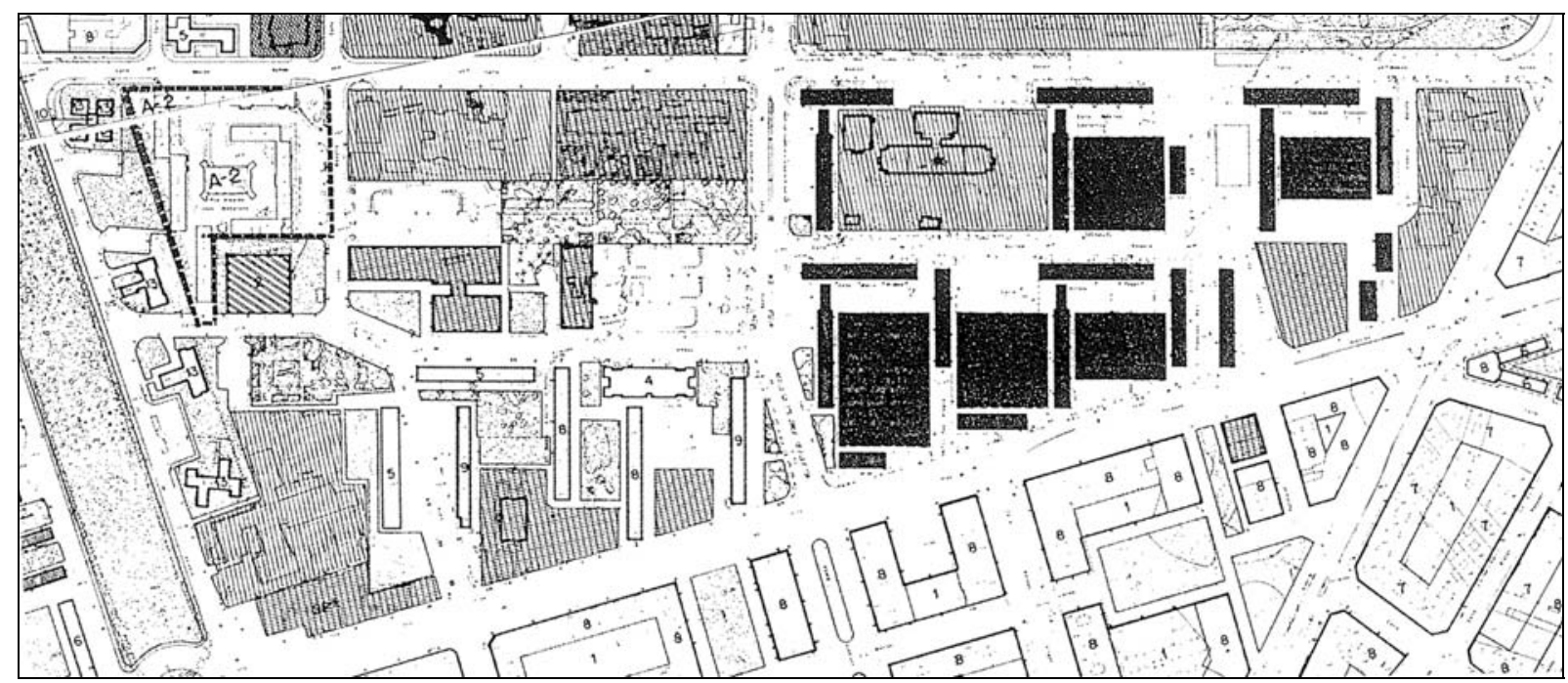




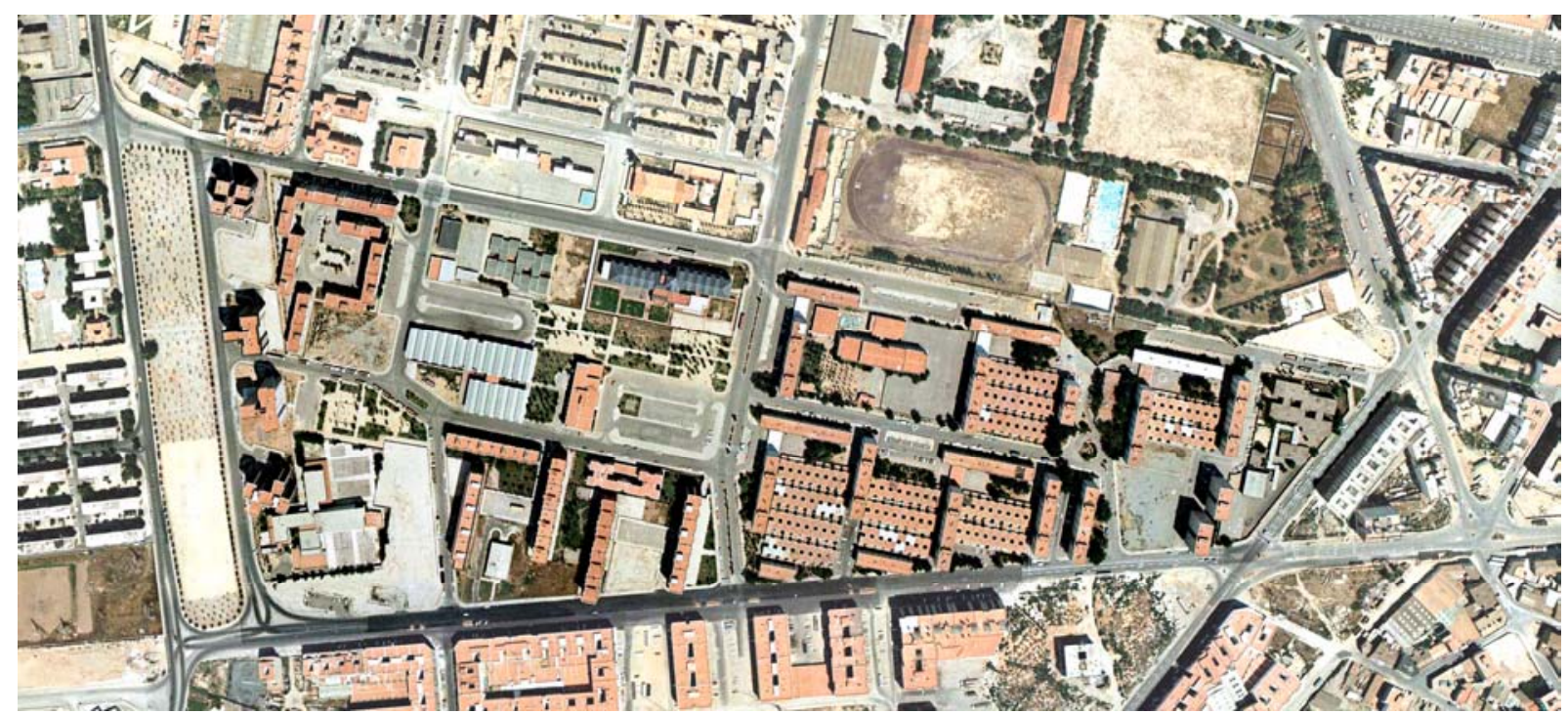

Zona del Polígono de la Avenida de Castilla. Fotografía aérea, 1980.

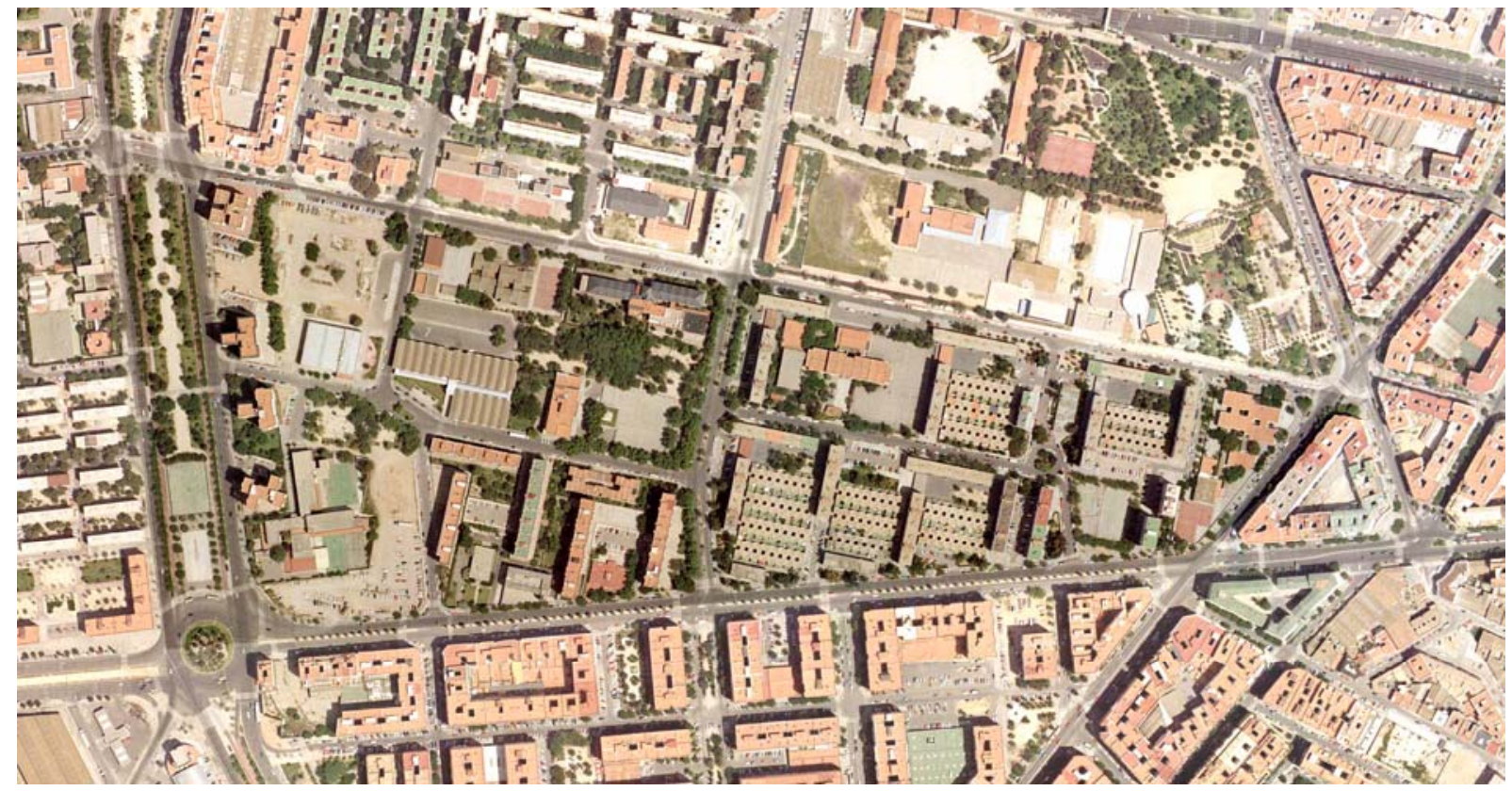

Zona del Polígono de la Avenida de Castilla. Ortofoto, 2002. 


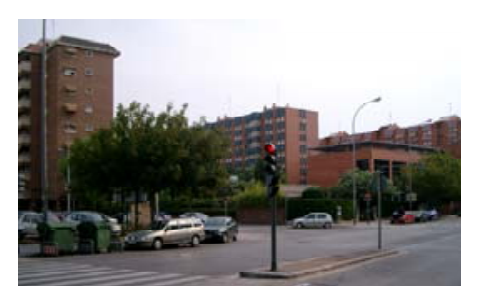

1

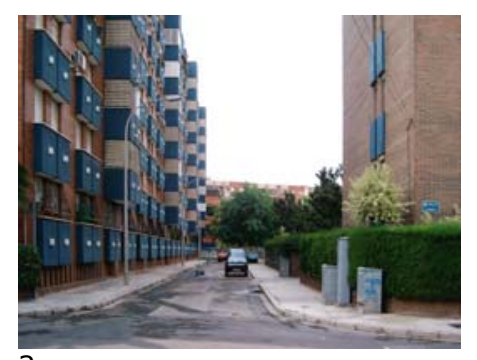

$$
2
$$

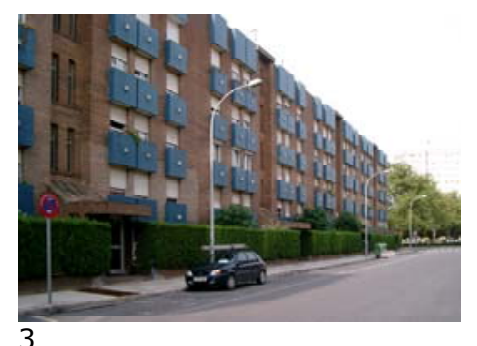

3

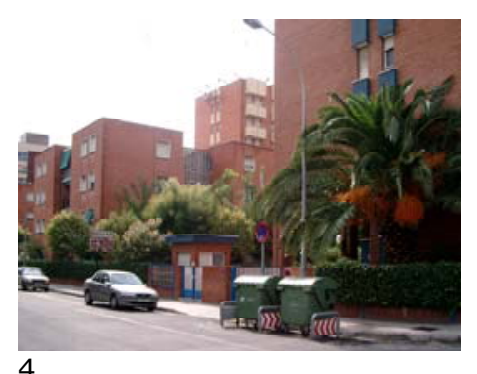

4

1, Calle Tres Forques, vista hacia el este.

2. Vial de acceso a espacio interior de manzana, visto desde la calle Llombay.

3,4. Calle Llombay.

5. Calle Tres Forques.

6. Calle Santa Cruz de Tenerife, vista hacia el sur.
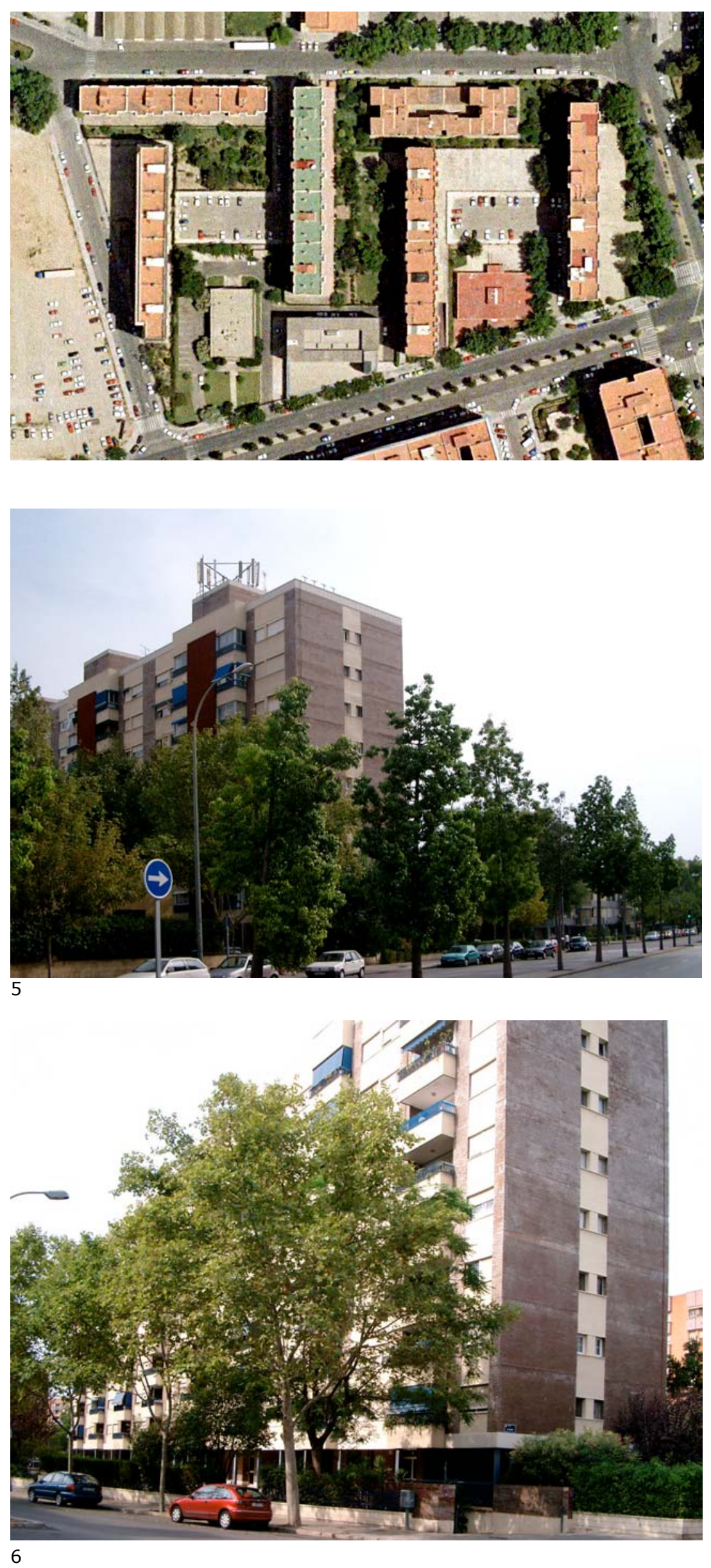
Las dos manzanas formadas por bloques lineales en torno a un espacio central presentan la particularidad de que dicho espacio libre es de carácter privado, y está destinado en parte a jardín y en parte a garaje. Los bloques disponen también de franjas ajardinadas privadas, valladas, que los separan de las calles perimetrales.
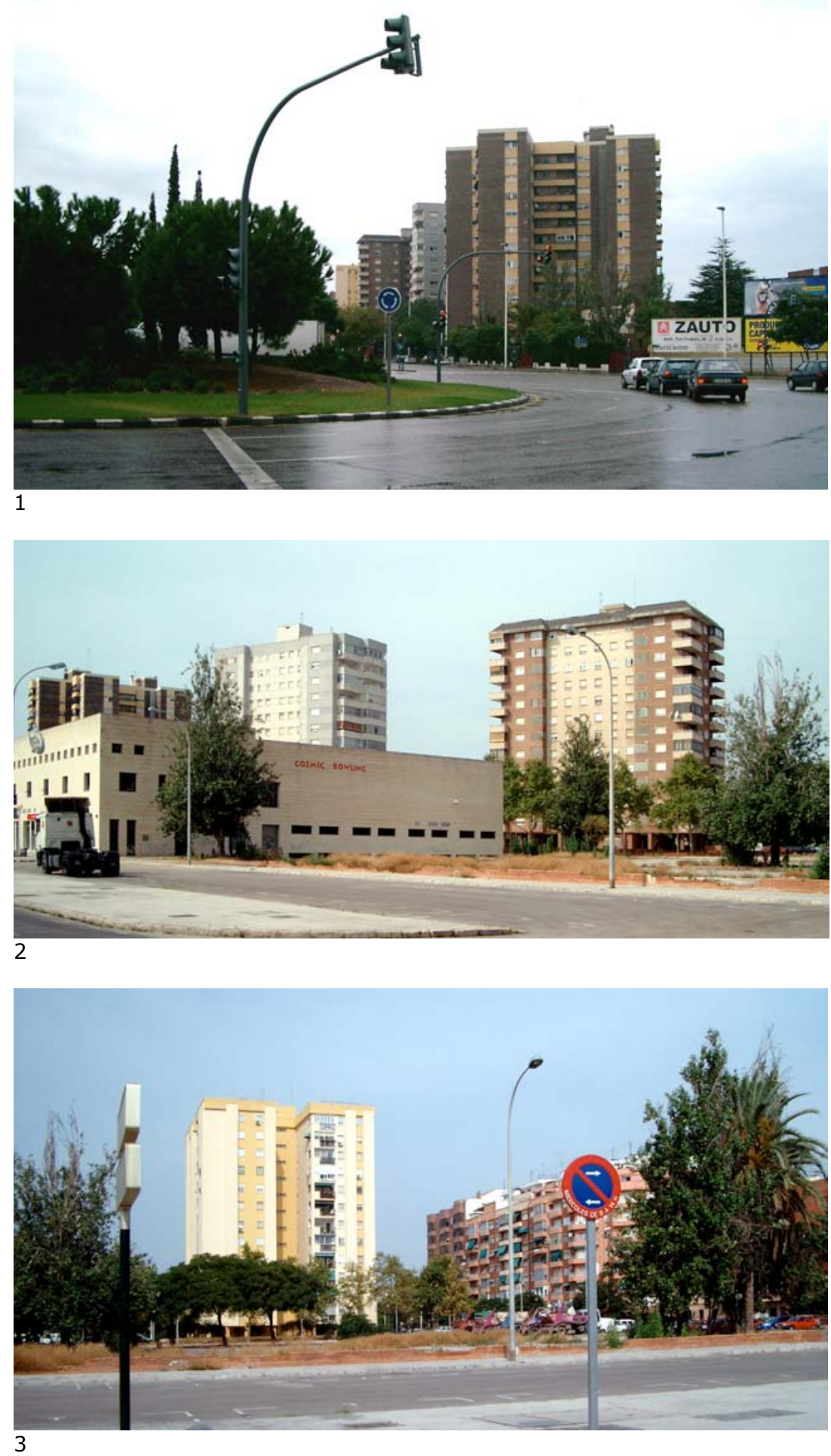
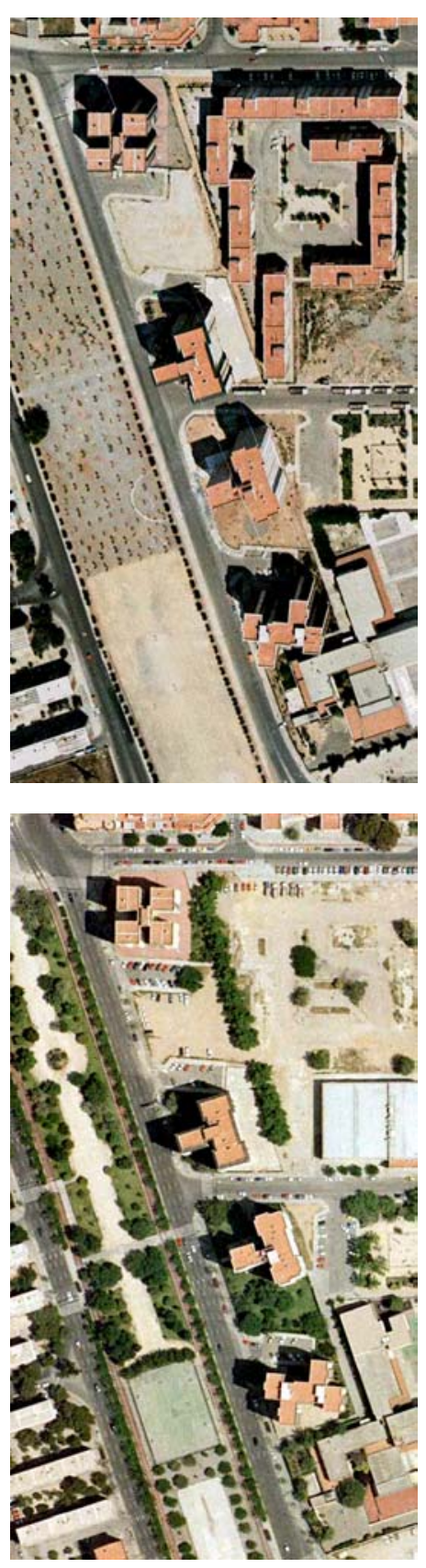

Torres junto al Camino de Tres Cruces. Fotografía aérea, 1980 y Ortofoto 2002 (AUMSA)

1-3. Torres en el Camino de Tres Cruces. 


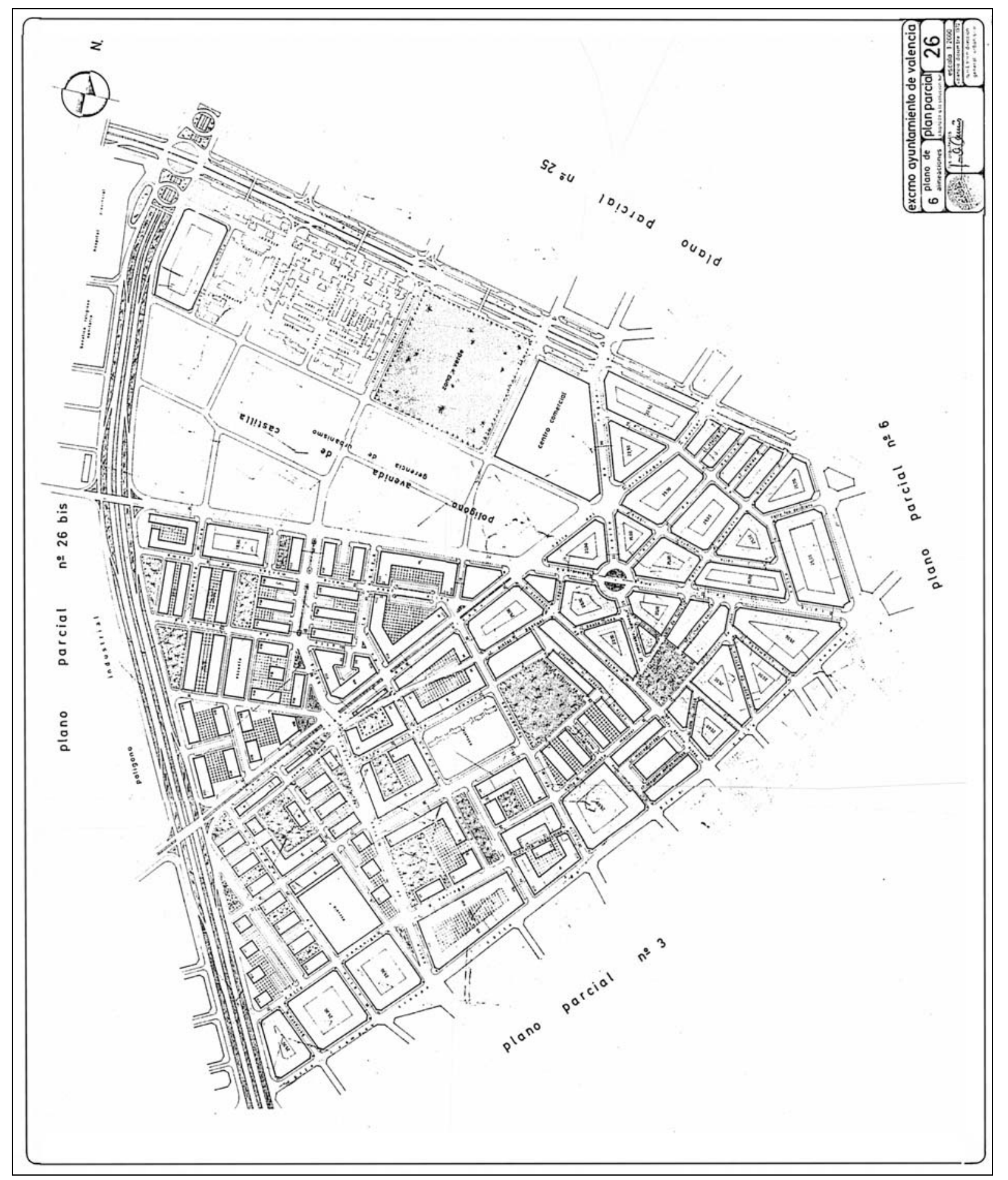

Plan Parcial 26 adaptado a la Solución Sur, 1973. Plano de alineaciones. 


\section{EL PLAN PARCIAL No 26 (1967/1973)}

El Proyecto Parcial de Desarrollo no 26, redactado en 1967, después de la aprobación en 1966 del Plan General de Valencia y su Comarca adaptado a la Solución Sur, proviene del antiguo Plan Parcial no I, aprobado en 1950 por la Comisión Central de Sanidad Local.

El cambio de denominación es consecuencia de un cambio en la delimitación del área ordenada, ya que, como hemos visto más arriba, la antigua zona I-c, situada al norte de la Avenida de Cid, pasaba a formar parte del Plan Parcial 25, junto con el antiguo Plan parcial no II.

El Proyecto Parcial 26 queda, así, limitado por la Avenida del Cid al norte, la Avenida Pérez Galdós al noreste, la prolongación de la calle Cuenca al sureste y la Ronda Exterior (camino de Tres Cruces) al oeste.

La Memoria del Proyecto Parcial no 26 de 1967 señala que esta zona ha quedado muy afectada por el Plan General de 1966 debido a que ésta cambia dos grandes áreas que pasan de las calificaciones de Industrial y Ciudad Jardín a la de Extensión Exterior a Tránsitos.

Dentro del ámbito del plan quedan englobados el Polígono de la Avenida de Castilla, gestionado por la Gerencia de Urbanización, los terrenos del Cuartel del Ejército del Aire y los del grupo Virgen de los Desamparados.

El sector comprendido entre la Avenida del Cid, Pérez Galdos, la prolongación de la calle Cuenca, Salavert, venerable Agnesio y Engera, se hallaba casi totalmente construido en el momento de redactarse el Proyecto Parcial 26, con un tejido de ensanche sin espacios previstos para escuelas, zonas verdes $u$ otros equipamientos.

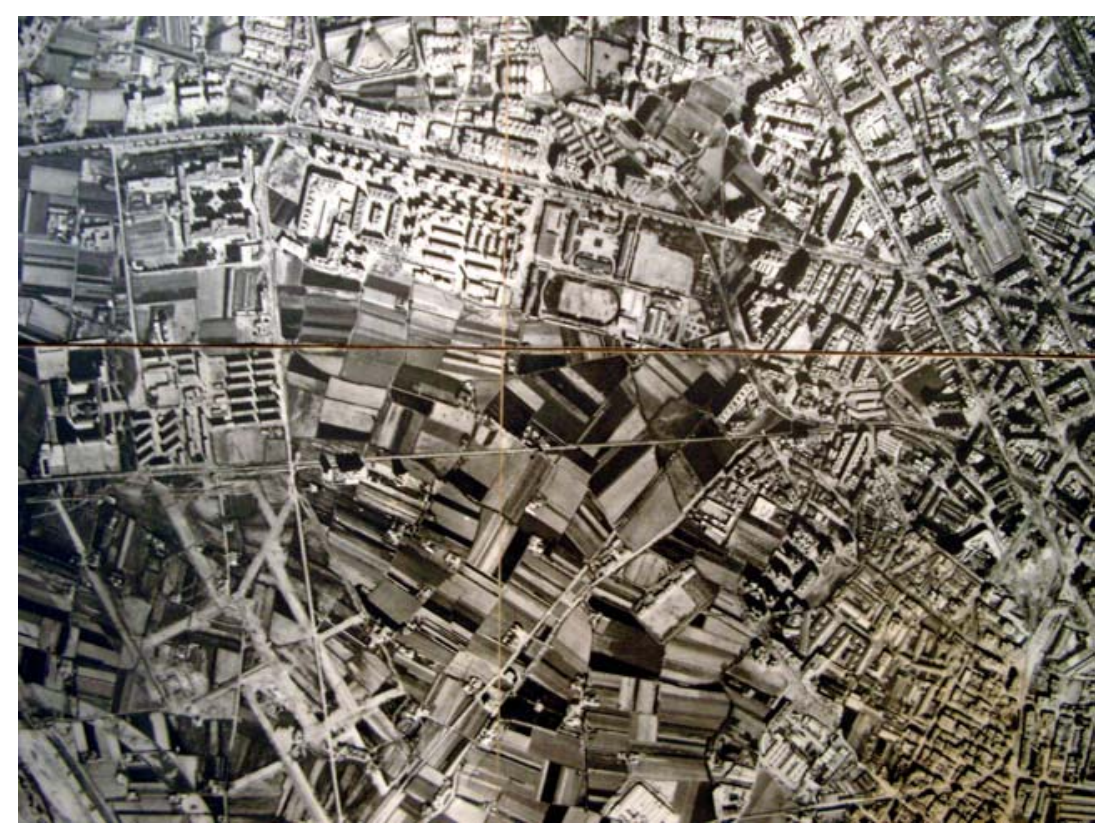

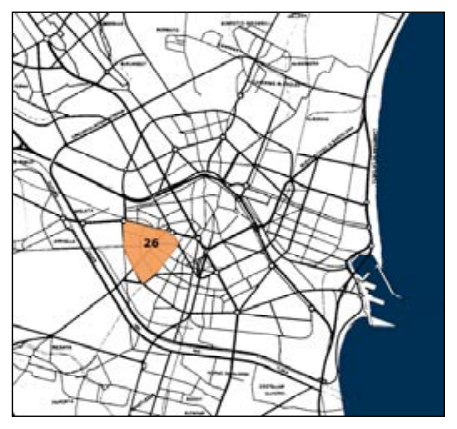

Plan Parcial 26. Localización.

Zona del Plan Parcial 26. Fotografía aérea, h. 1965 (ETS de Arquitectura de Valencia). 


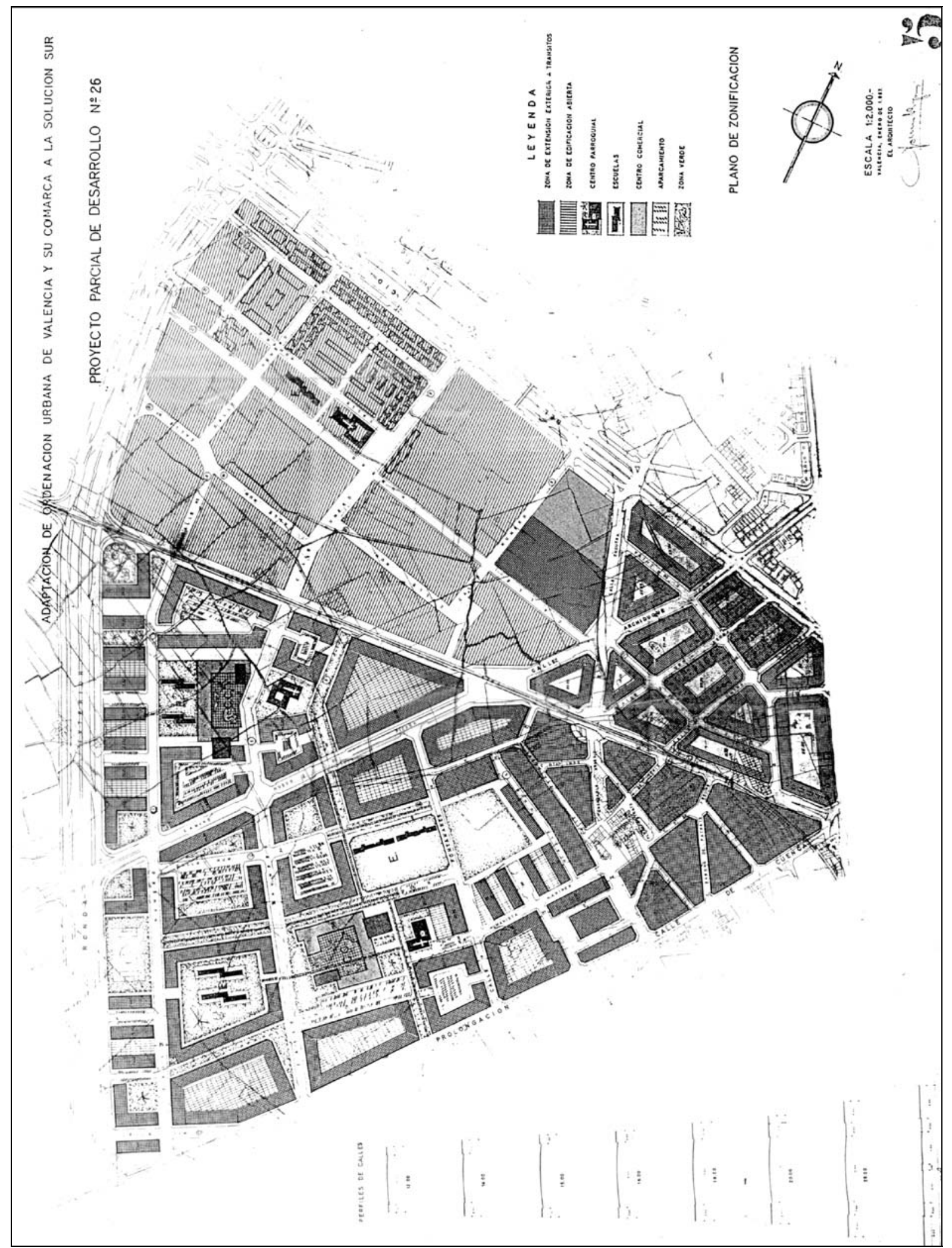

Proyecto Parcial no 26, 1967. Plano de zonificación.
La edificación abierta, por ello, se centra en los espacios vacantes disponibles, que son los comprendidos entre la calle Tres Forques, la Ronda Exterior, la prolongación de la calle Cuenca y la calle Fontanares.

La edificación en la mayor parte de estos espacios se resuelve mediante manzanas abiertas, con bloques perimetrales discontinuos 
alineados con las calles. De ello resultan unas manzanas irregulares, similares a las existentes en las zonas próximas ya edificadas.

Los bloques lineales aparecen únicamente en dos zonas: junto a la plaza Enrique Granados y en el borde oeste, recayente a la Ronda Exterior. Algunos de estos bloques, que son siempre de cinco crujías, son edificios aislados, y otros se agrupan de dos en dos sobre un zócalo comercial de planta baja, formando micromanzanas.

El Proyecto Parcial no 26 de 1967 no se llegó a aprobar definitivamente, y fue finalmente sustituido por otro, denominado Plan Parcial no 26 adaptado a la Solución Sur, redactado en 1973, que sería aprobado definitivamente en 1974.

La versión del Plan Parcial 26 del Informe Prevasa, donde figura como plan en tramitación, coincide ya sensiblemente con la de 1973.

La principal diferencia con respecto a la versión de 1967 es la sustitución de la mayor parte de las manzanas abiertas irregulares con bloques perimetrales por agrupaciones de bloques lineales. Estos bloques, todos ellos de cinco crujías, son por lo general cortos, y aunque algunos aparecen como edificios aislados, lo habitual es que estén enlazados por cuerpos de edificación de formas diversas en planta baja.

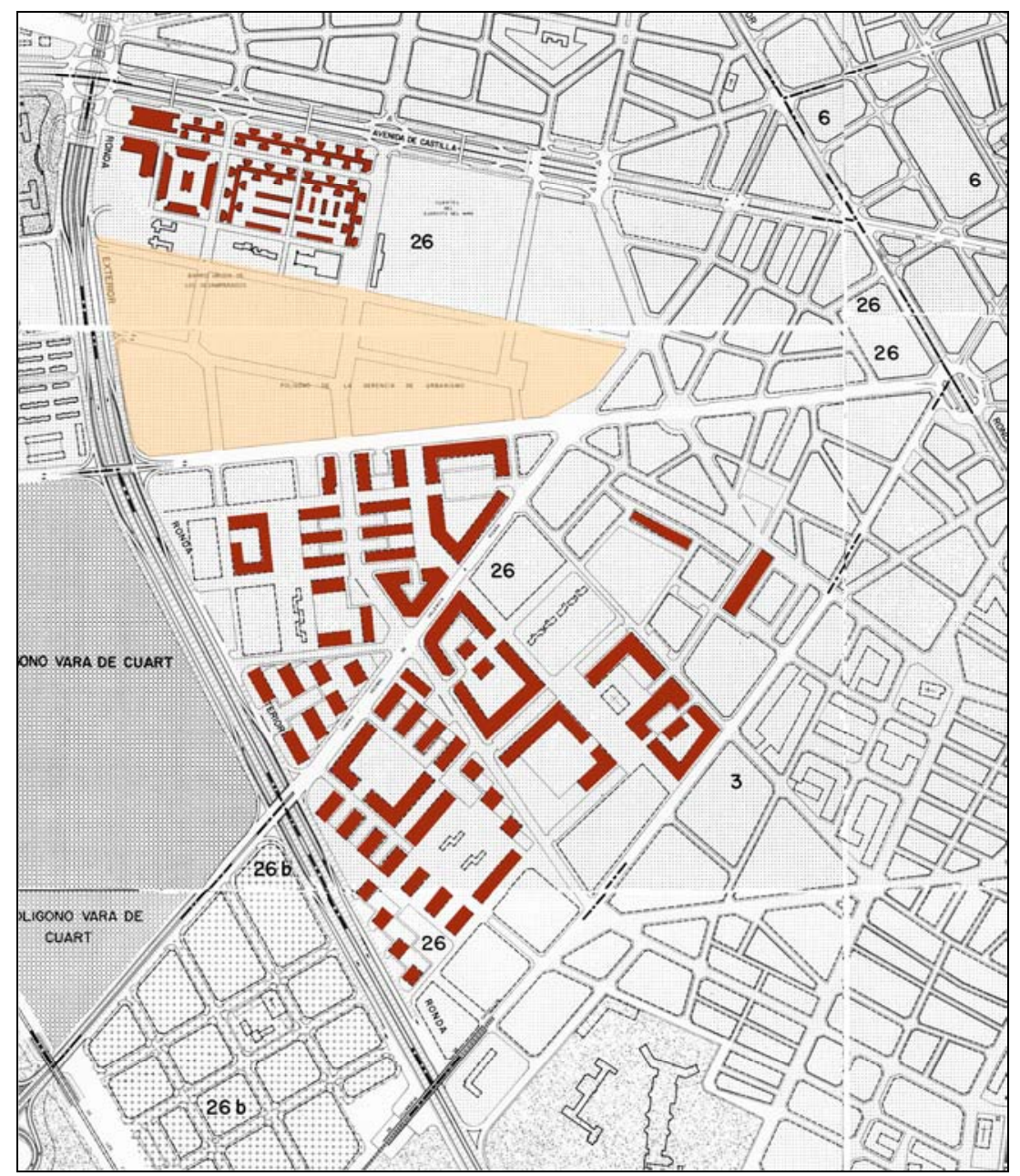

Zona del Plan Parcial 26 (Elaboración propia. Color sobre montaje de hojas del Informe PREVASA). 
Plan Parcial 26, 1973. Plano de información.

1. Ver Documento 26.1, Resolución de aprobación con modificaciones $y$ exclusiones del PP26 por el Ministerio de la Vivienda, 23-09-1974. Anexo de Documentos, p. 665.

2. Ver Documentos 26.2 a 26.5 , Informes municipales, Recurso de reposición interpuesto por el Ayuntamiento de Valencia y Resolución del Ministerio del Obras Públicas y Urbanismo de 1977. Anexo de Documentos, pp. 667676.

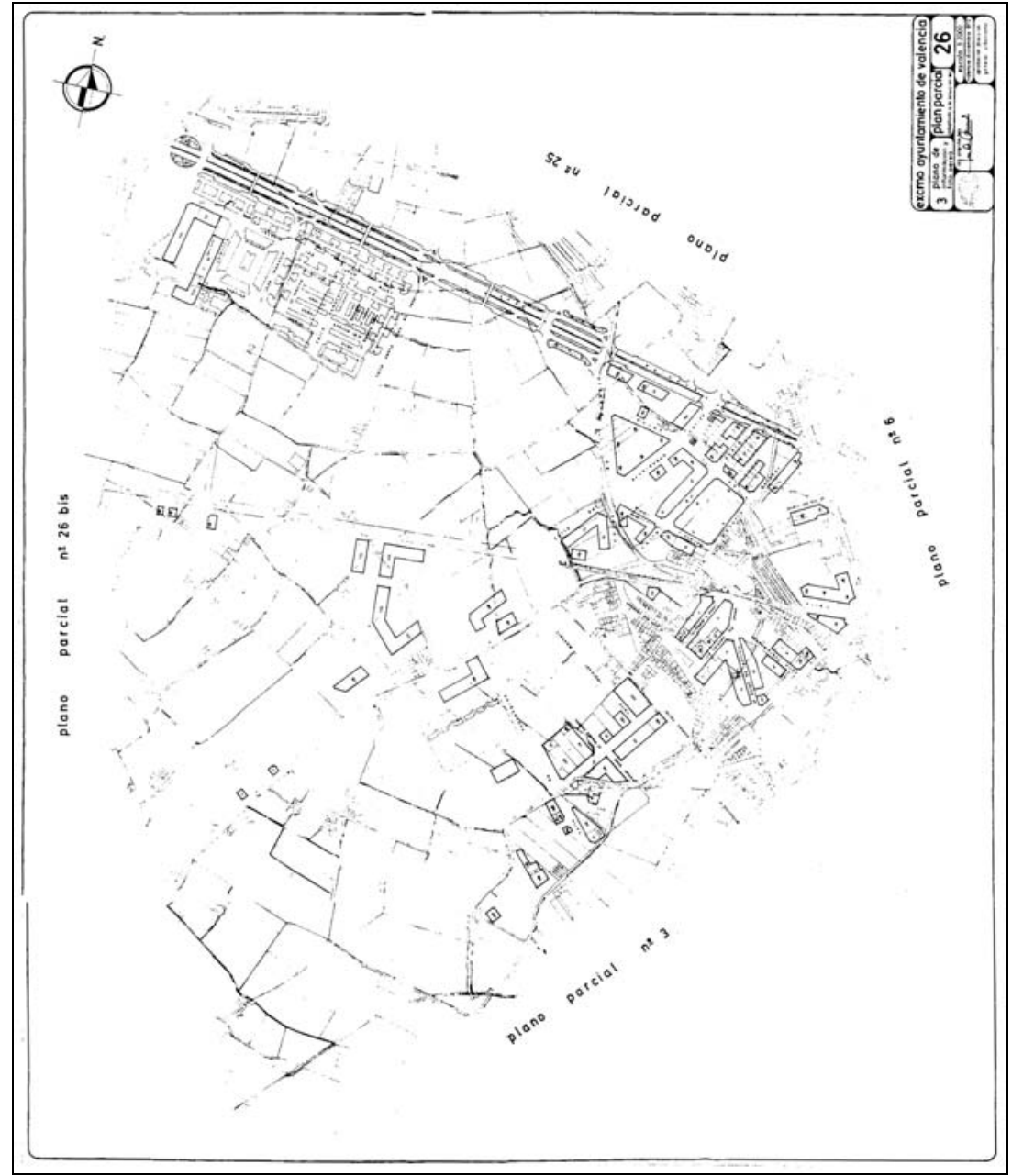

La aprobación en 1974 del Plan Parcial por parte del Ministerio de la Vivienda quedó condicionada a una serie de modificaciones, entre las que cabe destacar la de obtener una plaza de aparcamiento por vivienda y la de reservar terrenos para dotaciones escolares en proporción adecuada a la población prevista, además de mantener la calificación de zona verde prevista en el Plan general de 1966 para la manzana situada en la calle Fontanares, junto a la plaza de Enrique Granados, en la que se hallaba ya edificada una escuela. ${ }^{1}$

El déficit de aparcamientos estimado en un informe del propio Arquitecto Municipal era de 3.700 plazas. En cuanto a reserva de suelo para uso escolar, la previsión del Plan Parcial 26 era de 20.000 y las necesidades, según ese mismo informe, de 120.000 $\mathrm{m} 2$.

El Ayuntamiento de Valencia interpuso ante el Ministerio de la Vivienda un recurso de reposición, resuelto en 1977 por el Servicio Central de Recursos del Ministerio, que ratificó las obligaciones antes mencionadas. ${ }^{2}$

Todo ello alargó el proceso de tramitación del plan, que acabó solapándose con el nuevo periodo de revisión del planeamiento mediante Planes Parciales de Reforma Interior iniciado a partir de 1980. 
El plano de información del Plan Parcial 26 de 1973 muestra que en el momento de la redacción de esta versión únicamente estaban construidos unos pocos fragmentos de los bloques que debían formar las manzanas abiertas previstas en la versión de 1967.

Aparte del Grupo Virgen de los Desamparados y del Polígono de la Avenida de Castilla, el área que podemos asimilar a la edificación abierta en el Plan Parcial 26, aunque está calificada en el plano de zonificación como Extensión Exterior a Tránsitos, es la comprendida entre las calles Tres Forques, la Ronda Exterior, la Calle campos Crespo y la calle Fontanares, a lo que hay que añadir los bloques situados en el lado sur de la plaza Enrique Granados.

El trazado viario proyectado en el Plan Parcial 26 para esa zona es de tipo mallado, delimitando unas manzanas de tamaño similar a las contiguas de ensanche. Los ejes internos principales de este viario son, en sentido norte-sur, la calle Fray Junípero Serra, que arranca por el sur desde la calle Campos Crespo y que tiene continuidad hasta la Avenida del Cid por la calle Santa Cruz de Tenerife, a través del Polígono de la Avenida de Castilla. En sentido noreste-suoeste, el eje de la calle Archiduque Carlos divide en dos la zona de edificación abierta.

Los aparcamientos se sitúan con frecuencia en los espacios intermedios entre los bloques, que pierden con ello su condición canónica de zonas ajardinadas.

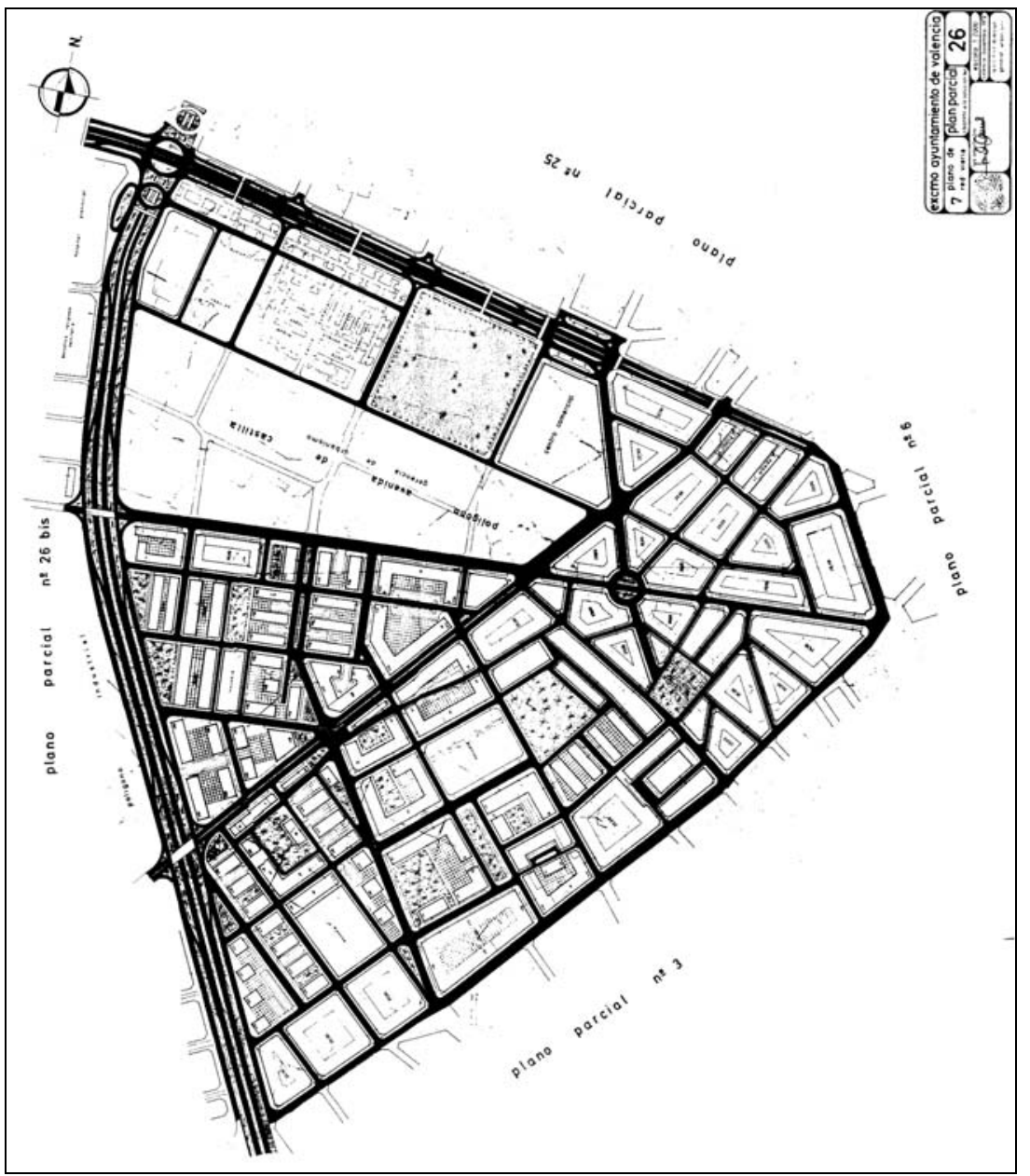

Plan Parcial 26, 1973. Plano de red viaria 
Plan Parcial 26, 1973. Equipamientos. Zona sur (Elaboración propia sobre plano de alineaciones del plan)

Plan Parcial 26, 1973. Edificación en planta tipo. Zona sur (Elaboración propia sobre plano de alineaciones del plan)

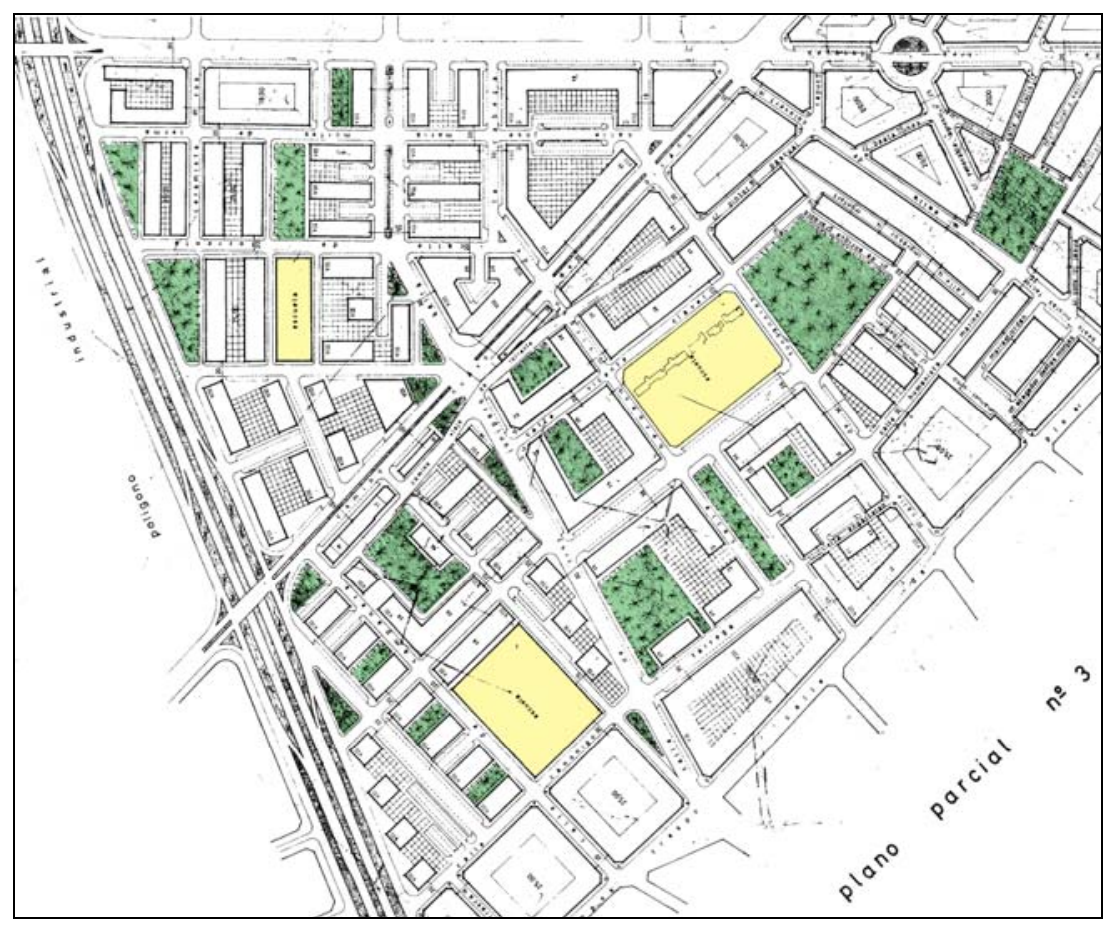

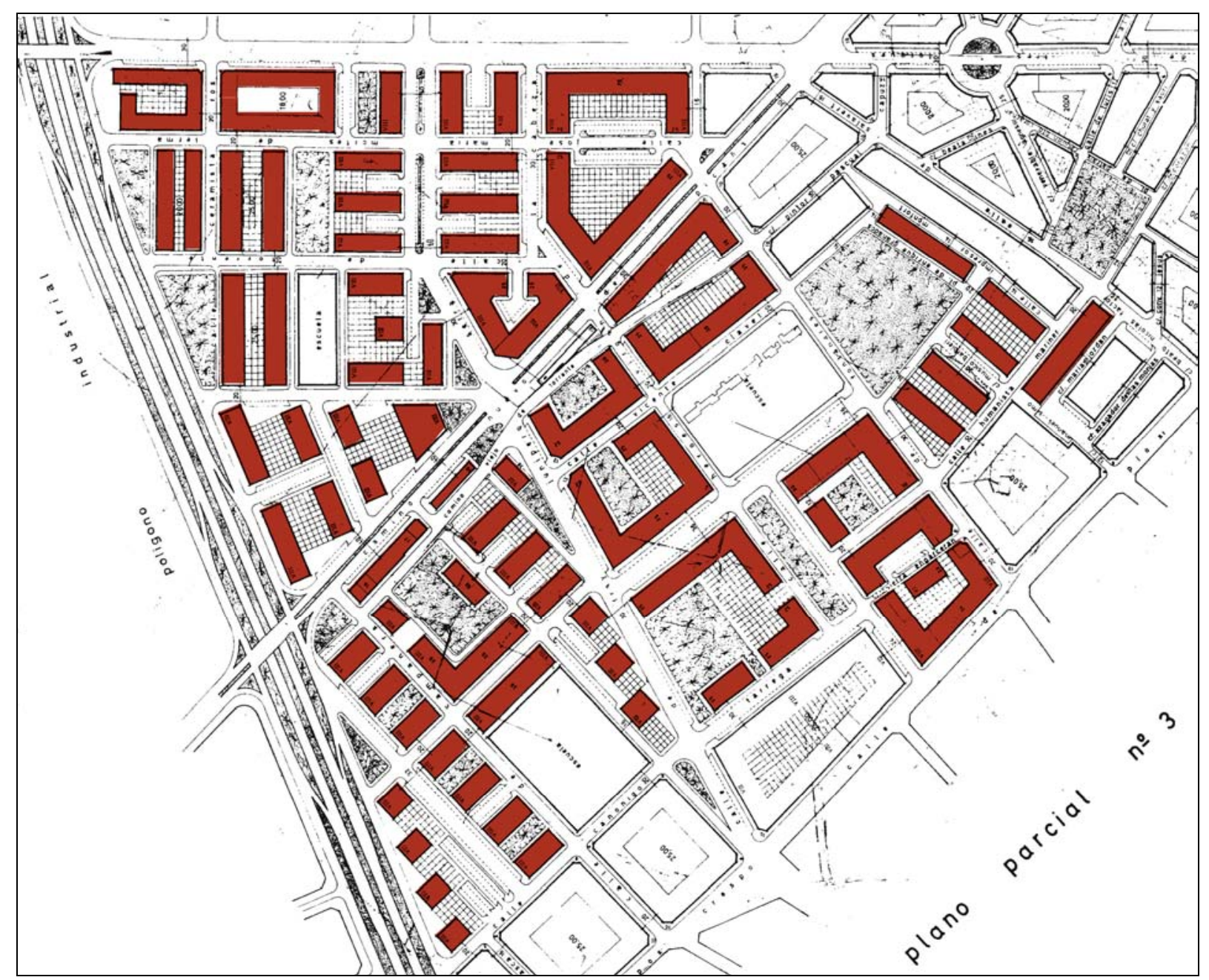




\section{Edificación}

En la calle Tres Forques se aprecia una gran diferencia entre la edificación abierta de su lado norte y la de su lado sur. En la primera, construida según las previsiones del Plan Parcial del Polígono de la Avenida de Castilla, predominan los bloques lineales altos de dos crujías, y entre ellos se sitúan espacios verdes, equipamientos o las casas bajas del Grupo Antonio Rueda. En la segunda, en cambio, realizada según las alineaciones y volúmenes previstos en el Plan Parcial 26, los bloques altos de cinco crujías forman un conjunto más compacto y abigarrado.

La zona de edificación abierta proyectada en el Plan Parcial 26, pese a utilizar como tipo edificatorio único el bloque de cinco crujías, no aparece en el plano como un conjunto coherente. Ello se debe, en parte, al hecho de estar dividida en dos por el eje diagonal de la calle Archiduque Carlos. También contribuye a la heterogeneidad del conjunto la presencia simultánea de cuatro ejes diferentes con respecto a cada uno de los cuales se alinea -en paralelo u ortogonal- un grupo diferente de bloques: el de la calle Tres Forques, el de la calle Fontanares, el de la calle Campos Crespo y el de la Ronda Exterior.

Las plantas bajas que enlazan los bloques, no obstante, permiten recomponer parcialmente un tejido de manzanas y una red de calles que, aunque irregular, resulta legible.
Plan Parcial 26, 1973. Edificación en planta baja. Zona sur (Elaboración propia sobre plano de alineaciones del plan)

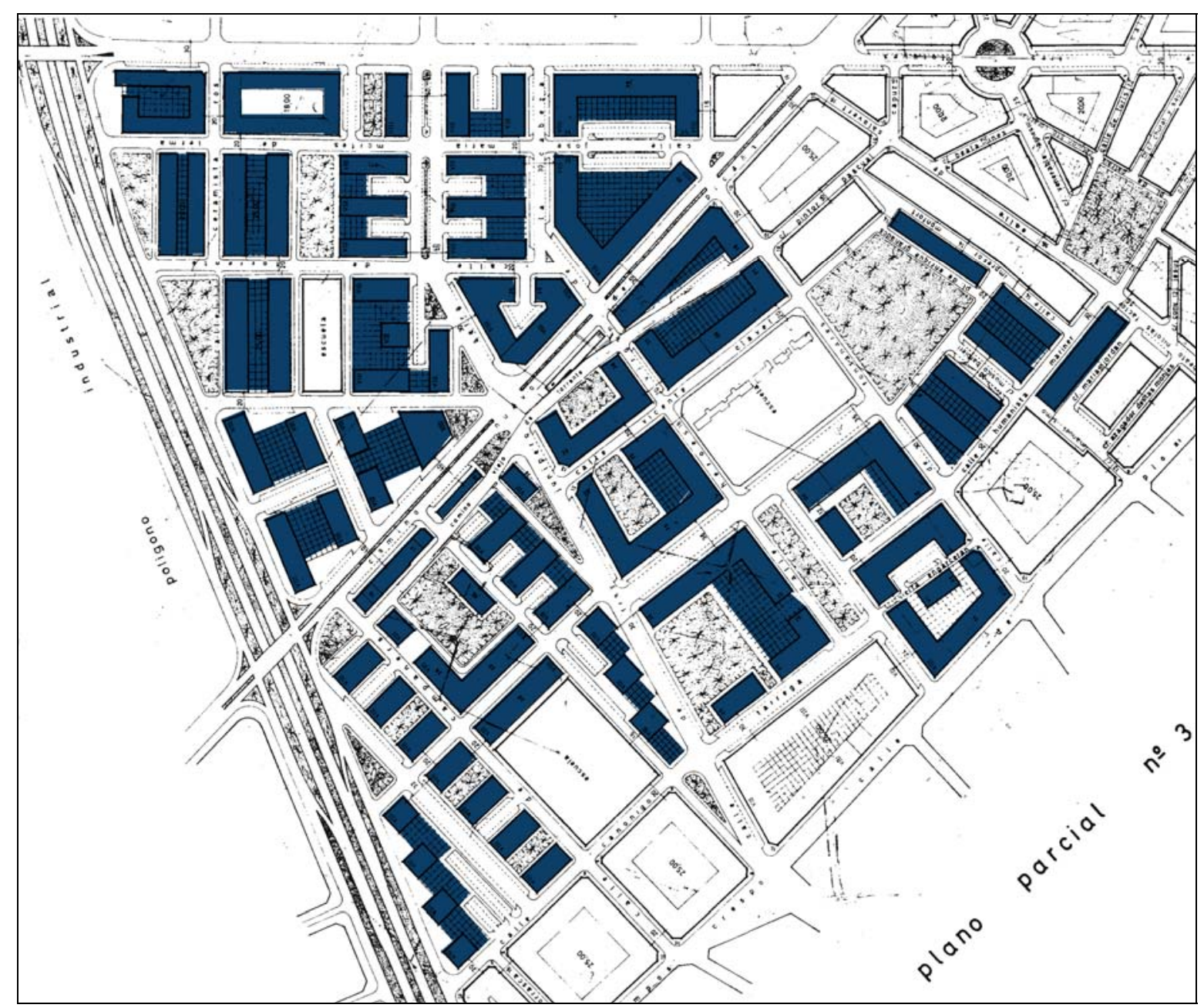




\section{Grado de realización}

El grado de realización de la edificación abierta prevista en el Plan Parcial 26 es muy diferente al norte y al sur de la calle Archiduque Carlos.

El sector norte, dentro del triángulo limitado por la calle Tres Forques, la Ronda Exterior y la calle Archiduque Carlos, se encuentra construido en su práctica totalidad con arreglo al plan. En este sector, el Plan General de 1988 suprimió únicamente parte de los bloques todavía no realizados en el momento de su redacción, sustituyéndolos por parcelas dotacionales.

En la mitad sur, en cambio, sólo se realizaron según lo previsto en el Plan Parcial 26 dos fragmentos: el situado en los alrededores de la plaza Enrique Granados y el que ocupa el espacio adyacente al cruce de la Ronda Exterior con la calle Archiduque Carlos, entre esta calle y la de Argenters.

La ordenación prevista en el Plan Parcial 26 para el resto de la

Plan Parcial 26, 1973. Grado de realización (Elaboración propia sobre plano de alineaciones del plan) edificación abierta del sector sur es sustituida en el Plan General de 1988, que califica esta zona como Suelo Urbanizable Programado, por un tejido de manzanas rectangulares que se apunta como propuesta no vinculante para la misma.

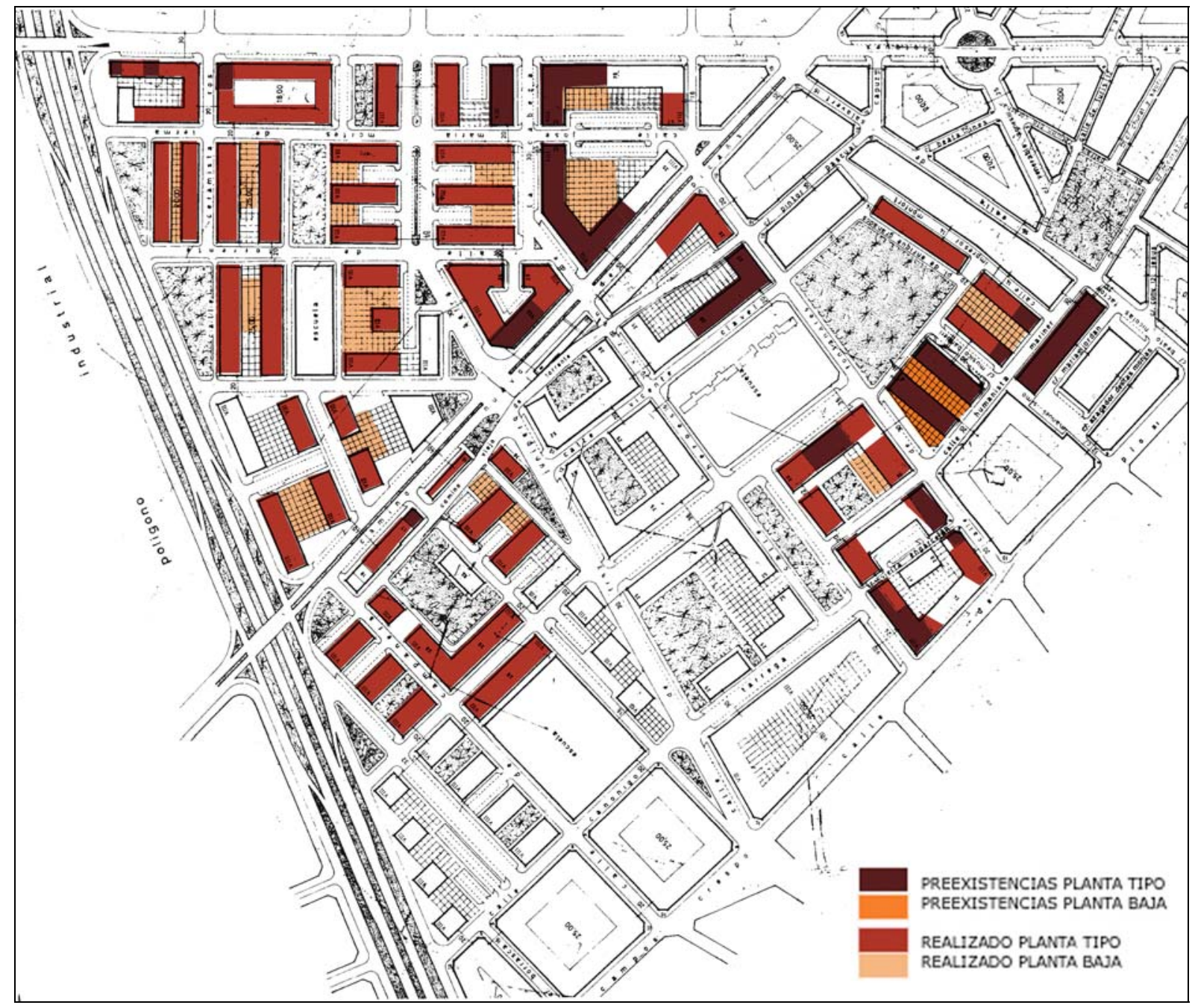




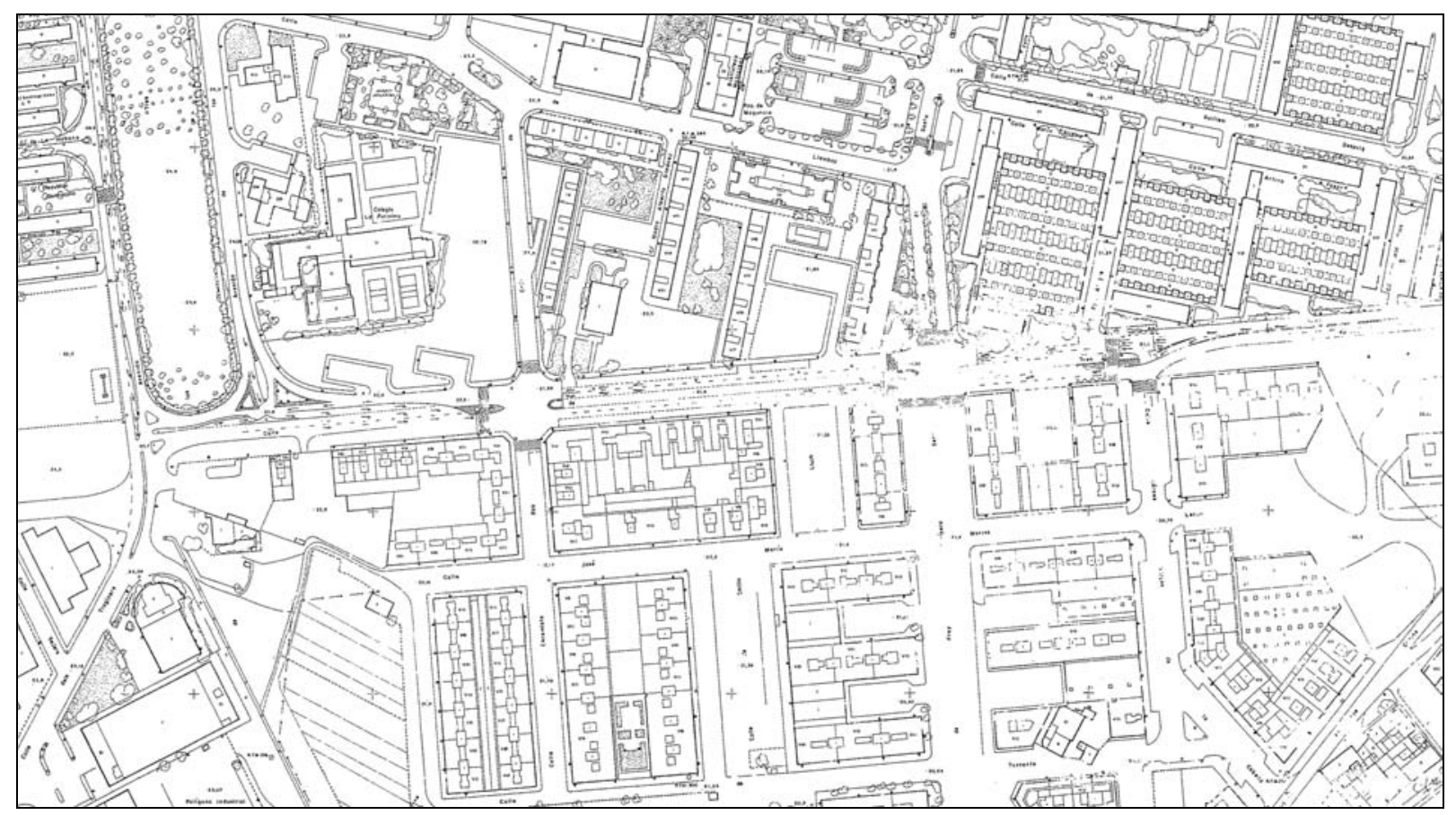

Edificación abierta en la calle Tres Forques.(Cartografía Básica Municipal,1983, Hoja 6E-5)

PGOU 1986. Zona del PP 26 (Elaboración propia. Color sobre montaje de hojas de la serie C).

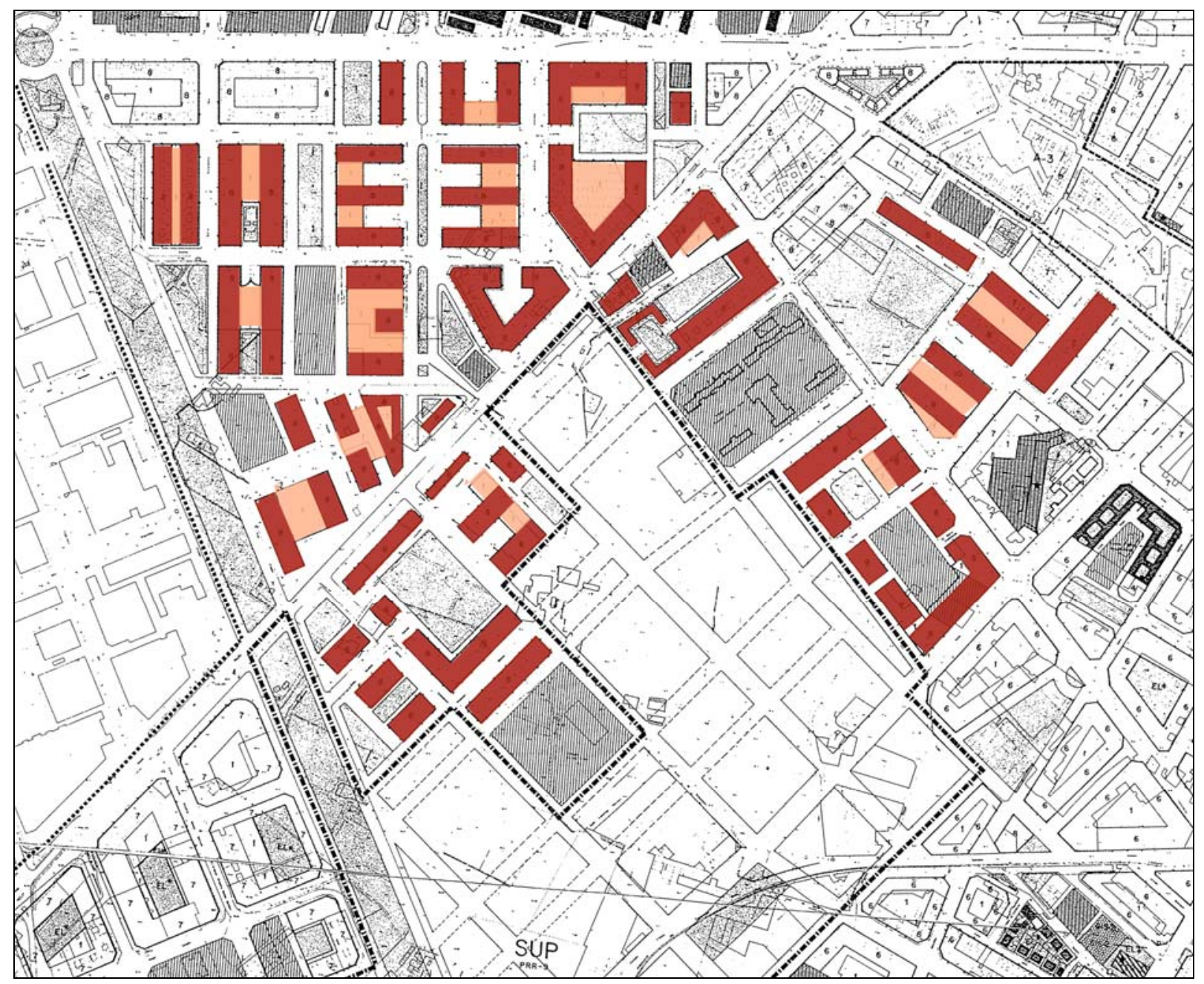




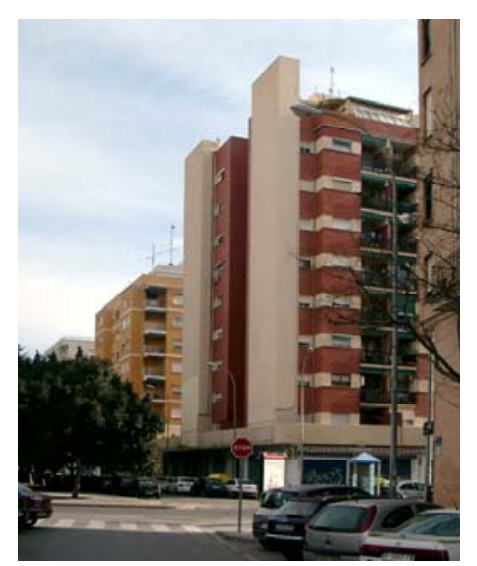

1

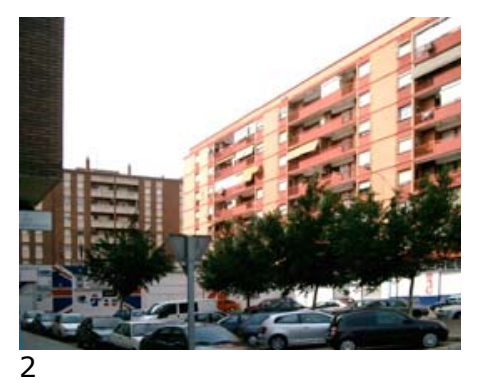

2

1. Bloque en la esquina de la calle Fontanares y la plaza Enrique Granados.

2. Calle Tres Forques. Espacio entre bloques destinado a aparcamientos.

3. Bloques en peine en la calle Fray Junípero Serra.

4. Bloques en la calle Tres Forques.

5. Bloques en la plaza Enrique Granados.
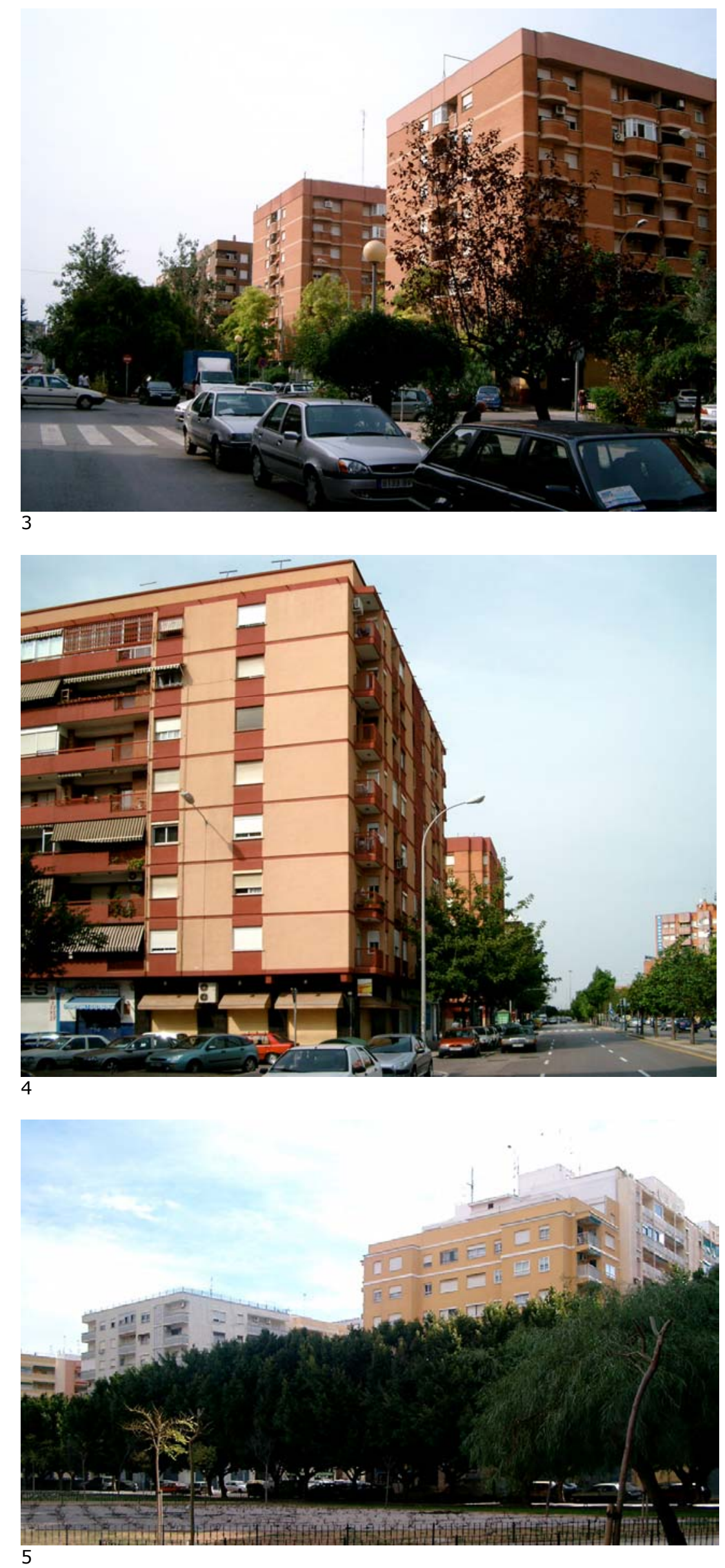


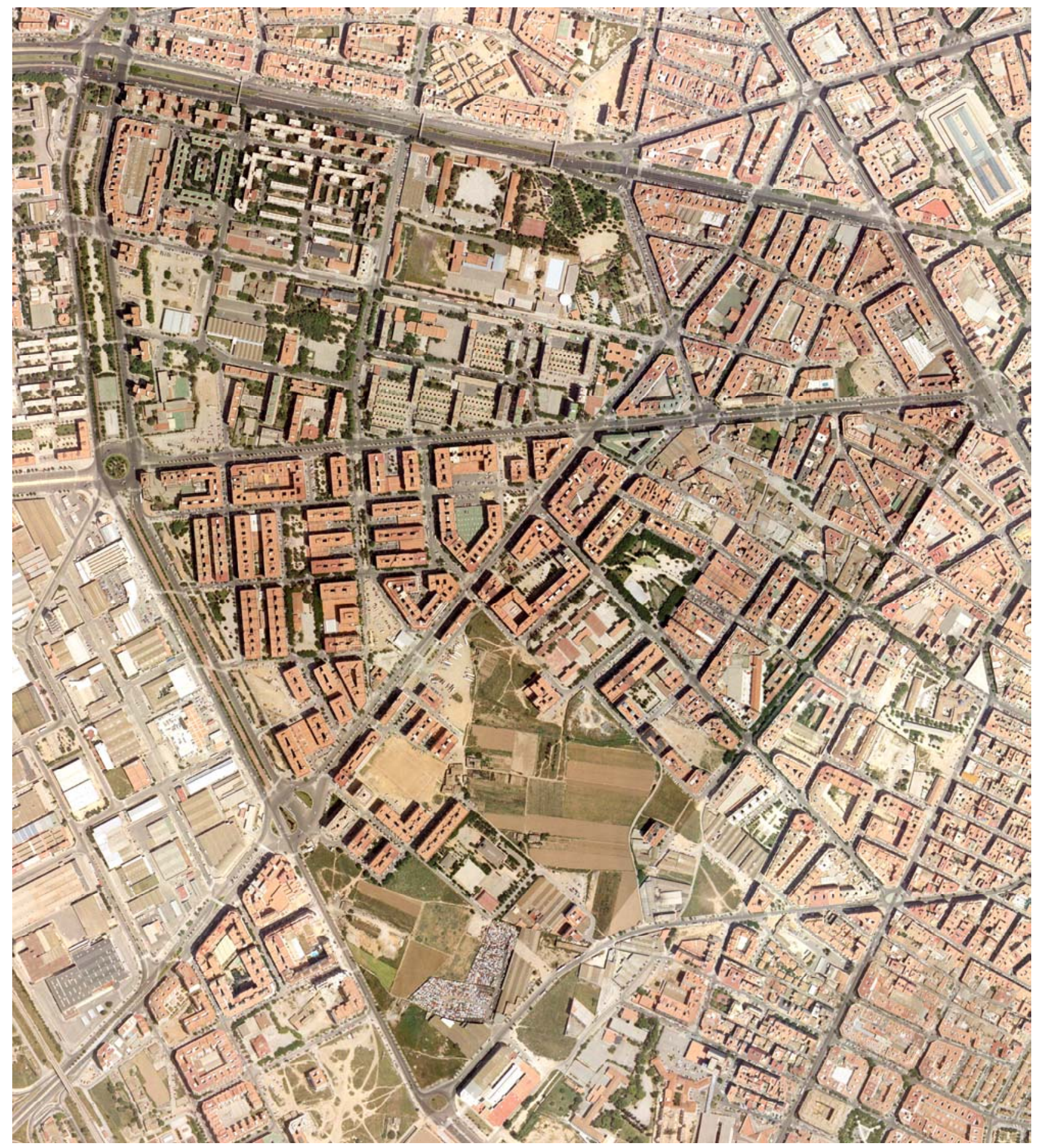

Zona del Plan Parcial 26. Ortofoto, 2002 (AUMSA). 


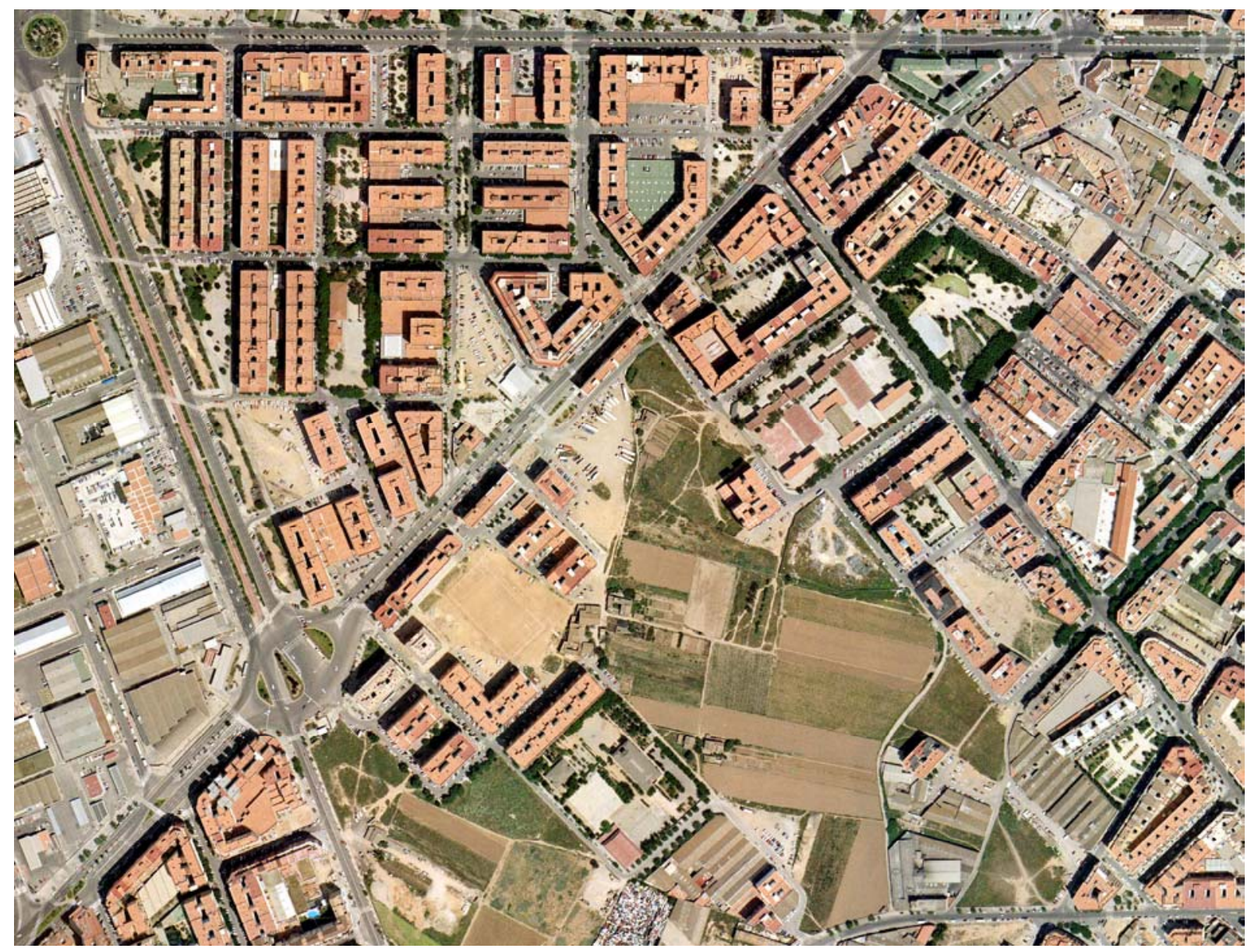

PP 26. Zona sur. Ortofoto 2002 (AUMSA)

Los bloques lineales dispuestos en peine a ambos lados de la calle Fray Junípero Serra forman la única secuencia de volúmenes digna de mención en la zona del PP26, además de las series de bloques aislados dispuestos a intervalos regulares en perpendicular a la Ronda Exterior (actual Bulevar Sur) y a la calle Tres Forques.

En estos bloques, los testeros son una fachada más, y presentan, para las alturas de VIII plantas, unas proporciones casi cuadradas, muy diferentes a las verticales de los bloques de dos crujías.

Bloques en el inicio de la calle Archiduque Carlos, lado norte

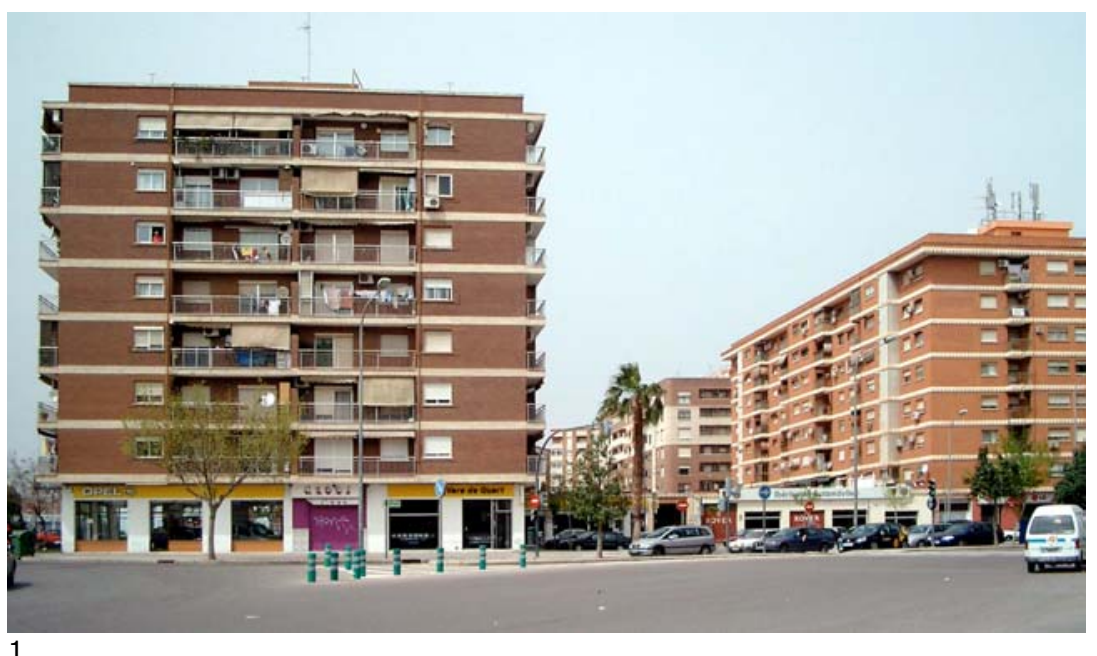




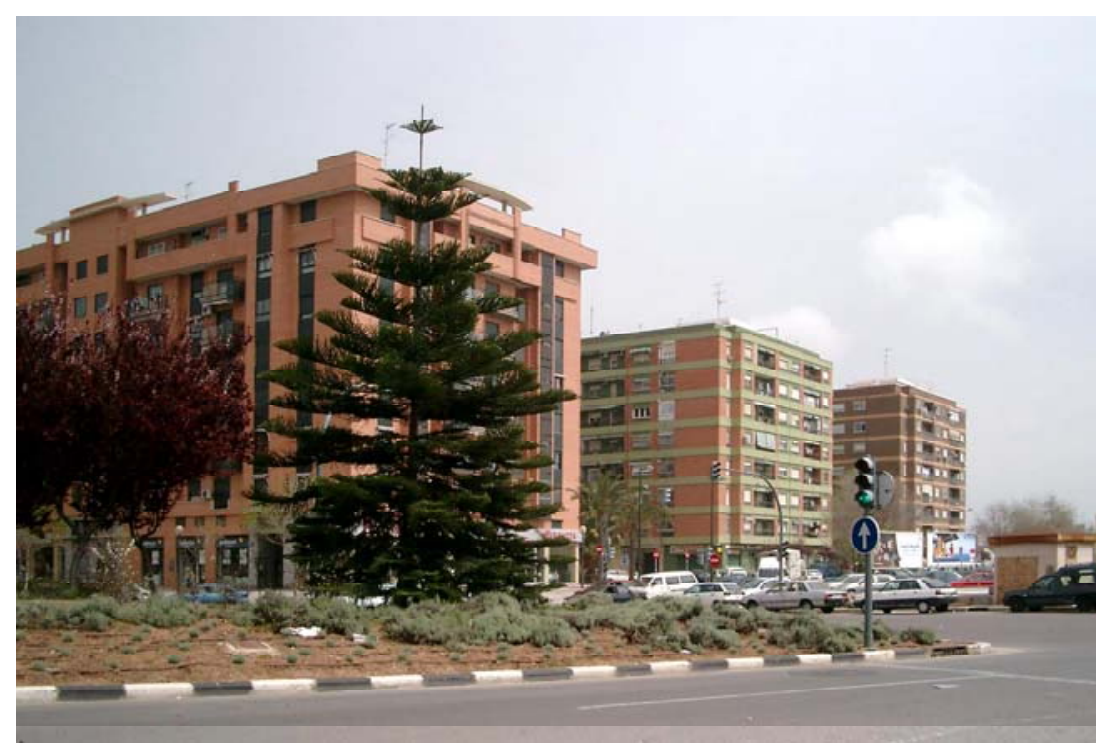

1
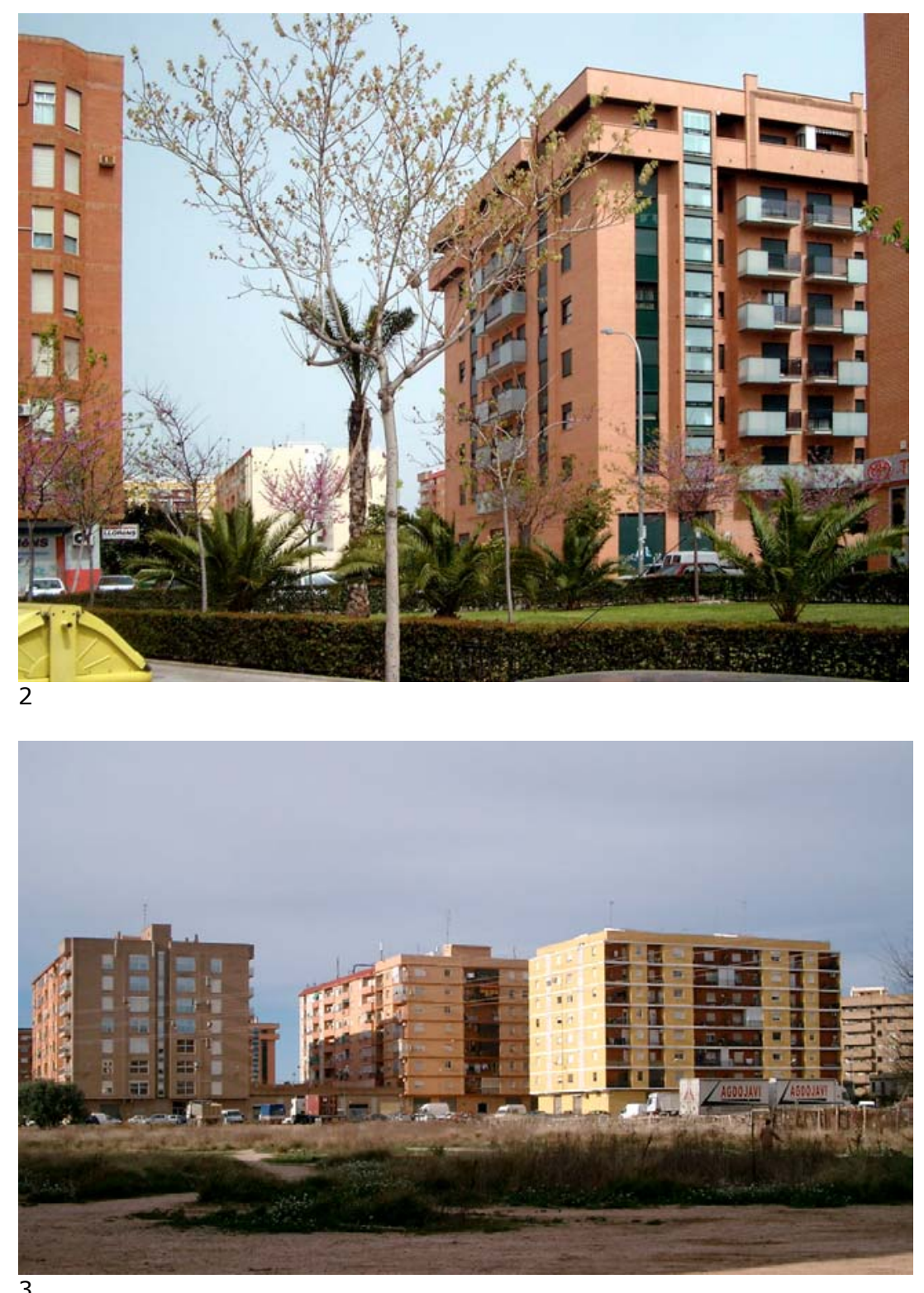

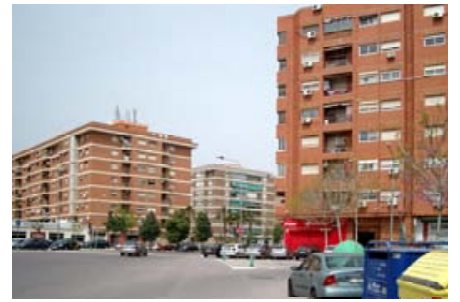

4
1. Bloques en el Bulevar Sur.

2. Calle Campaners. Espacios libres entre bloques.

3. Bloques del tramo sur de la calle Fray Junípero Serra.

4. Cruce del Bulevar Sur 


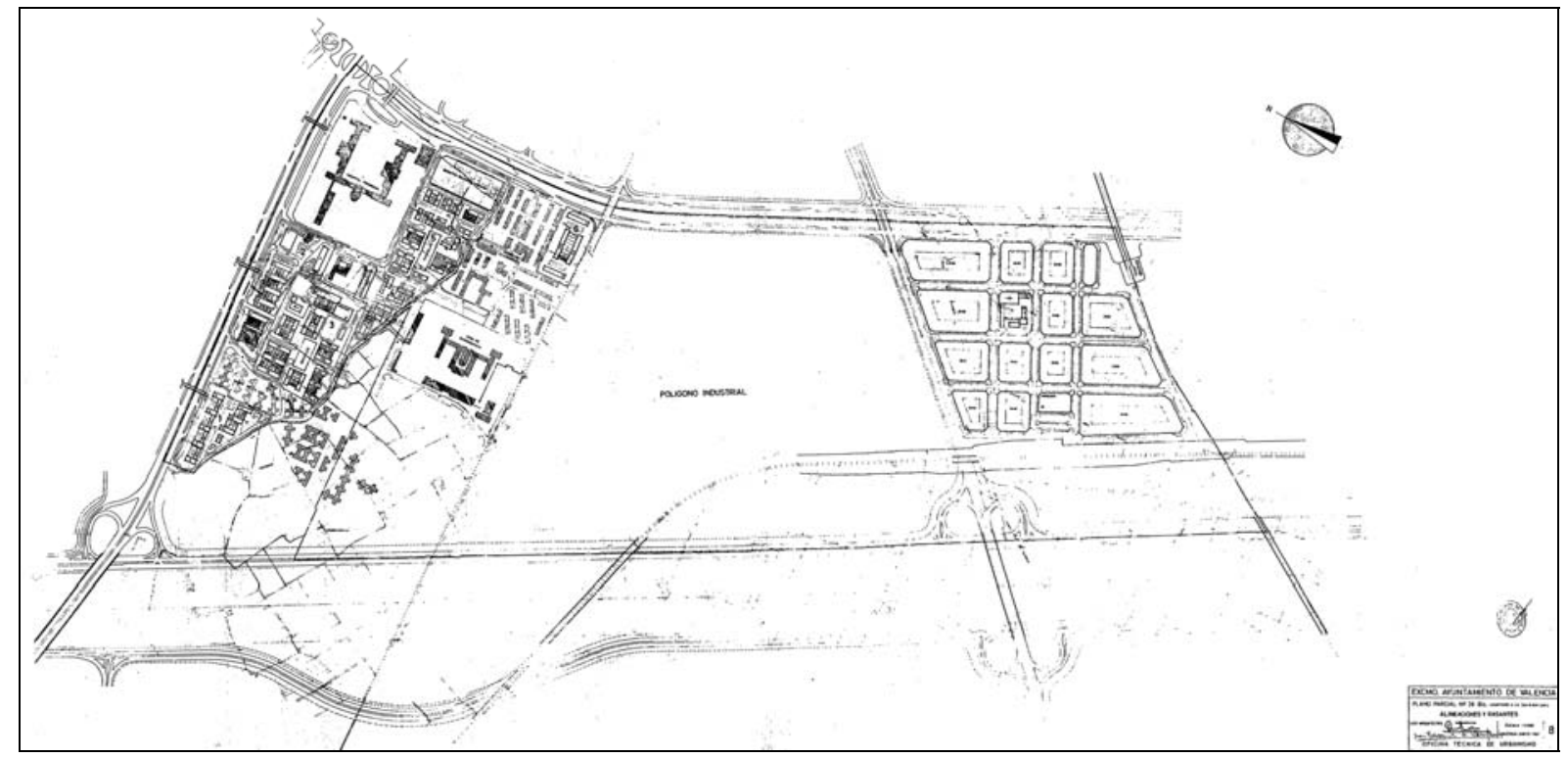

Plan Parcial 26-B, 1967. Plano de alineaciones.

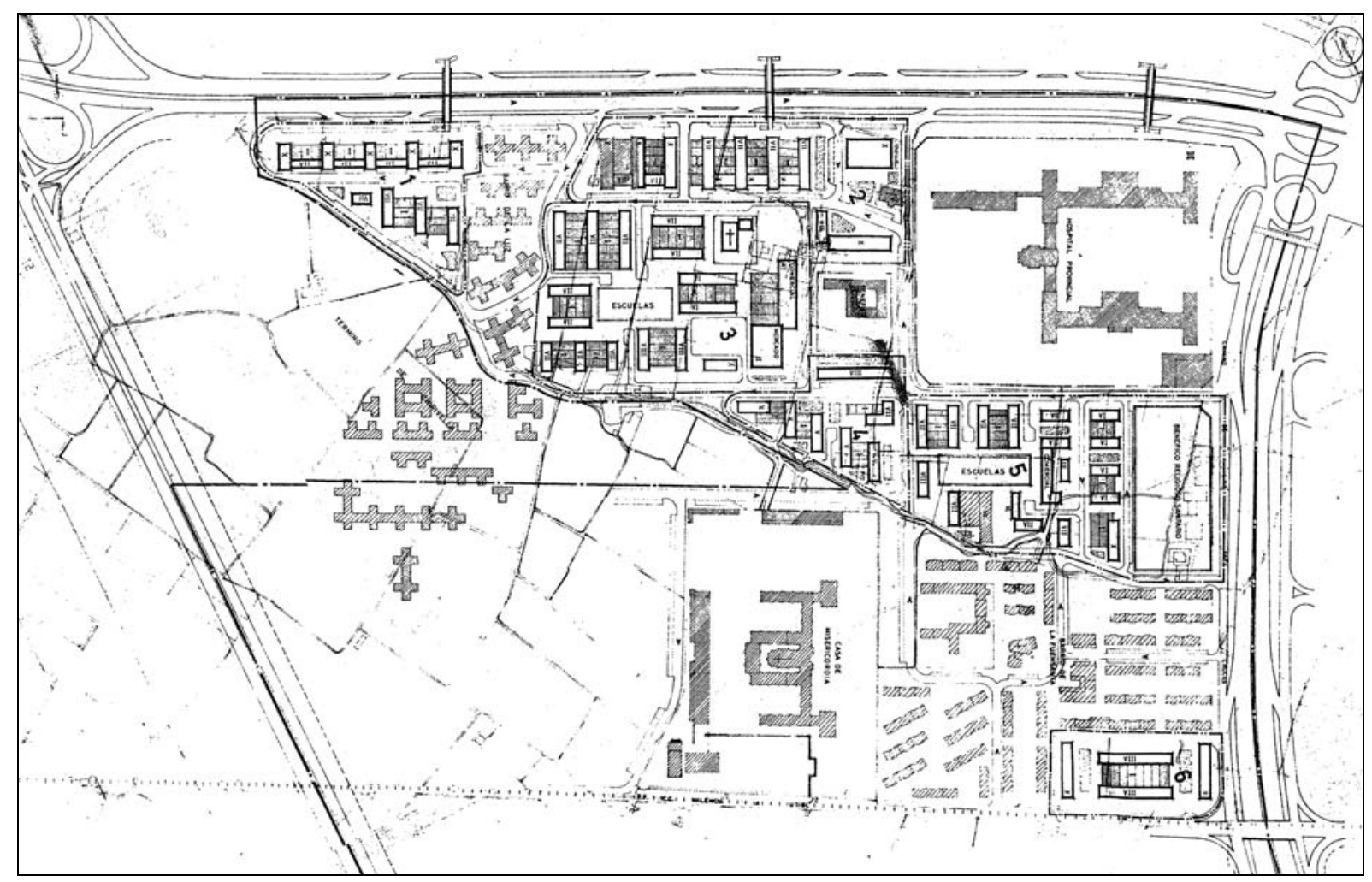

Plan Parcial 26-B, 1967. Plano de alineaciones. Detalle de la zona norte. 


\section{ENTRE LA FUENSANTA Y LA LUZ: EL PLAN PARCIAL No 26-B (1967)}

Los límites del Plano Parcial no 26 bis son los definidos por la Avenida del Cid al Norte, la vía de ferrocarriles de Villanueva de Castellón al Sur, la Ronda exterior al Este y el nuevo cauce del río al Oeste.

En este ámbito el Plan General de Valencia y su Comarca de 1966 identificaba tres zonas diferentes. En la parte norte, lindante con la Avenida del Cid, la zonificación es de edificación abierta baja con coeficiente de edificabilidad $3,5 \mathrm{m3} / \mathrm{m} 2$, y la parte sur está ocupada por una zona de tolerancia industrial, resuelta con manzanas cerradas. Entre estas dos áreas está situado el Polígono Industrial Vara de Quart, aprobado por la Gerencia de Urbanismo.

Para la zona norte, que formaba parte anteriormente del Plano Parcial I, se redactó en 1962 el Plano Parcial I-b, analizado en la sección anterior. Las determinaciones de este plan de 1962 no se mantuvieron en el plan de 1967, salvo en algunos de los bloques racayentes a la Avenida del Cid, que estaban construidos en parte.

La ordenación de 1962, como hemos visto, estaba basada en la disposición seriada de bloques lineales con orientación uniforme, dispuestos todos ellos según la dirección norte-sur, perpendicular a la Avenida del Cid. Esta disposición, que resulta bastante atípica en los planes parciales municipales del periodo que estamos estudiando, es sustituida en la versión de 1967 por otra, más habitual, en la que los bloques en dirección norte-sur se combinan con otros en dirección este-oeste, buscando un efecto de variedad en la composición del conjunto.

Tal como ocurría en el Plano Parcial I-b, la ordenación de la zona de edificación abierta de Plan Parcial 26-b no contempla entre sus objetivos la integración de los conjuntos existentes del grupo Virgen de la Fuensanta y del barrio Virgen de la Luz, pese a que abarcan una porción importante de la superficie del área.

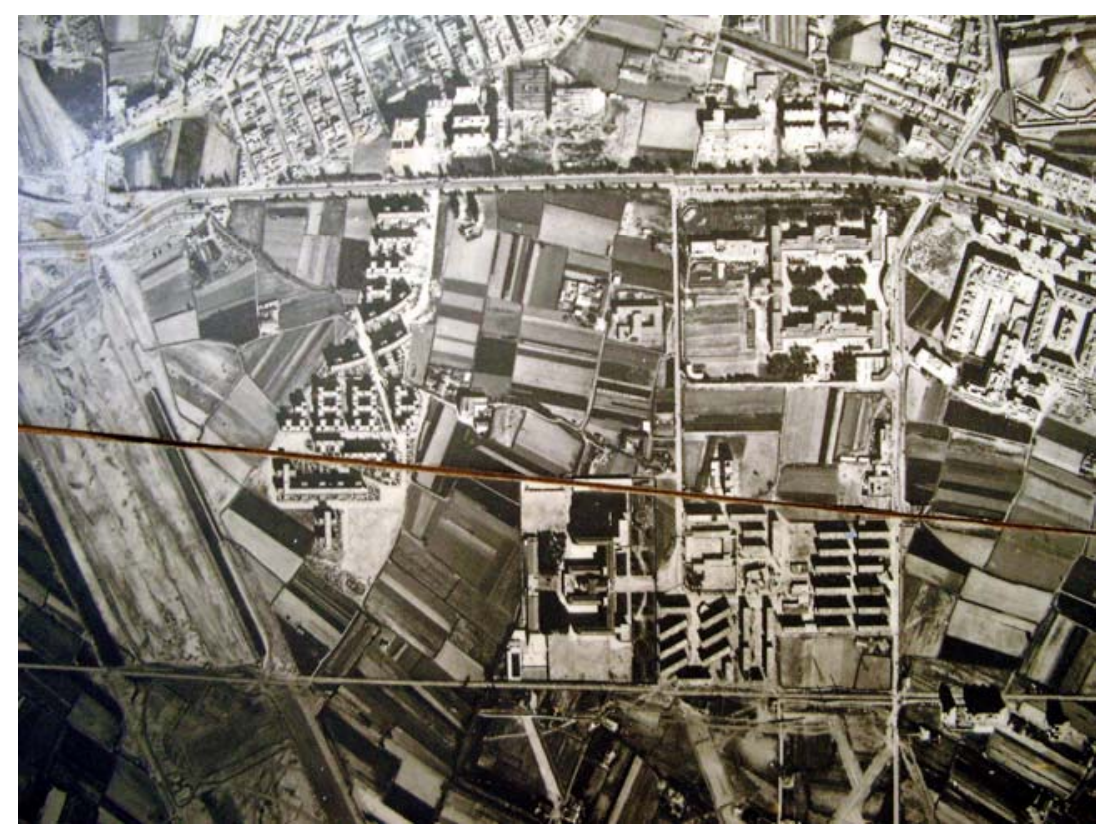

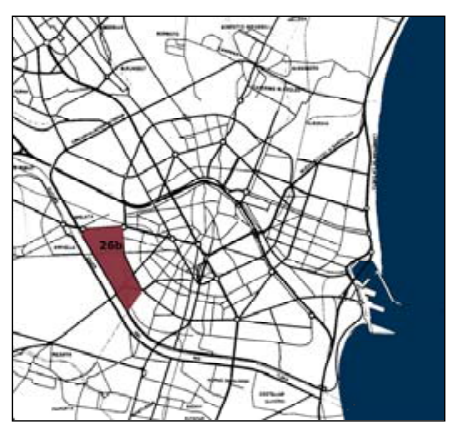

Plan Parcial 26-B. Localización.

Zona norte. Plan Parcial 26-B. Fotografía aérea, h. 1965 (ETS de Arquitectura de Valencia). 


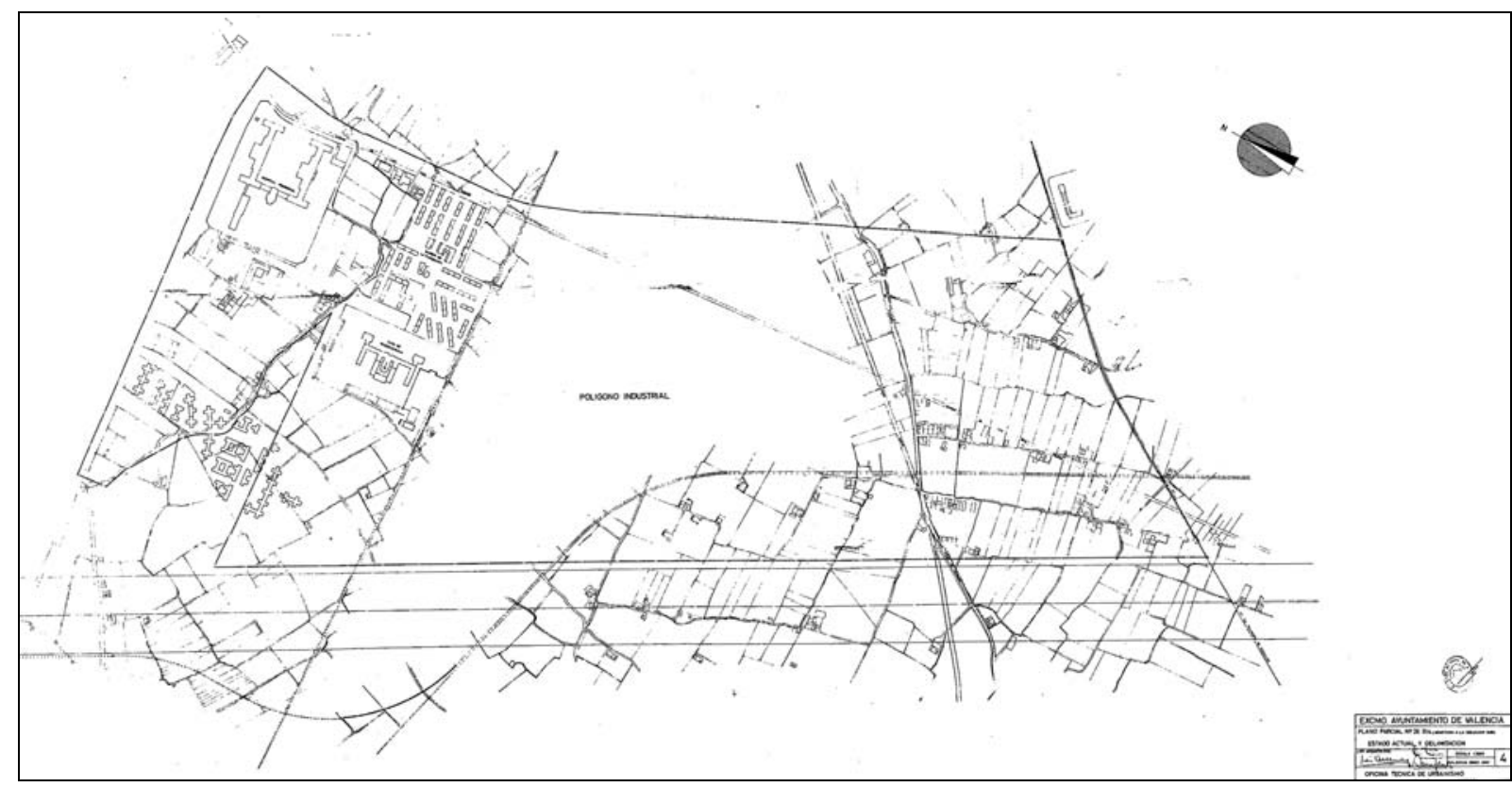

Plan Parcial 26b. Plano de estado actual y delimitación.

Plan Parcial 26b.Plano de red viaria.

Detalle de la zona norte.
La zona de edificación abierta proyectada en el Plan Parcial 26b, que ocupa los espacios intermedios entre el Hospital Provincial (hoy Hospital General) y los barrios Virgen de la Fuensanta y Virgen de la Luz, está estructurado mediante un trazado que delimita dos supermanzanas y varias manzanas que completan la superficie ordenada. Del perímetro de las supermanzanas arrancan ramales de penetración sin salida, reservando el centro de las mismas, de carácter peatonal, para sendas parcelas escolares.

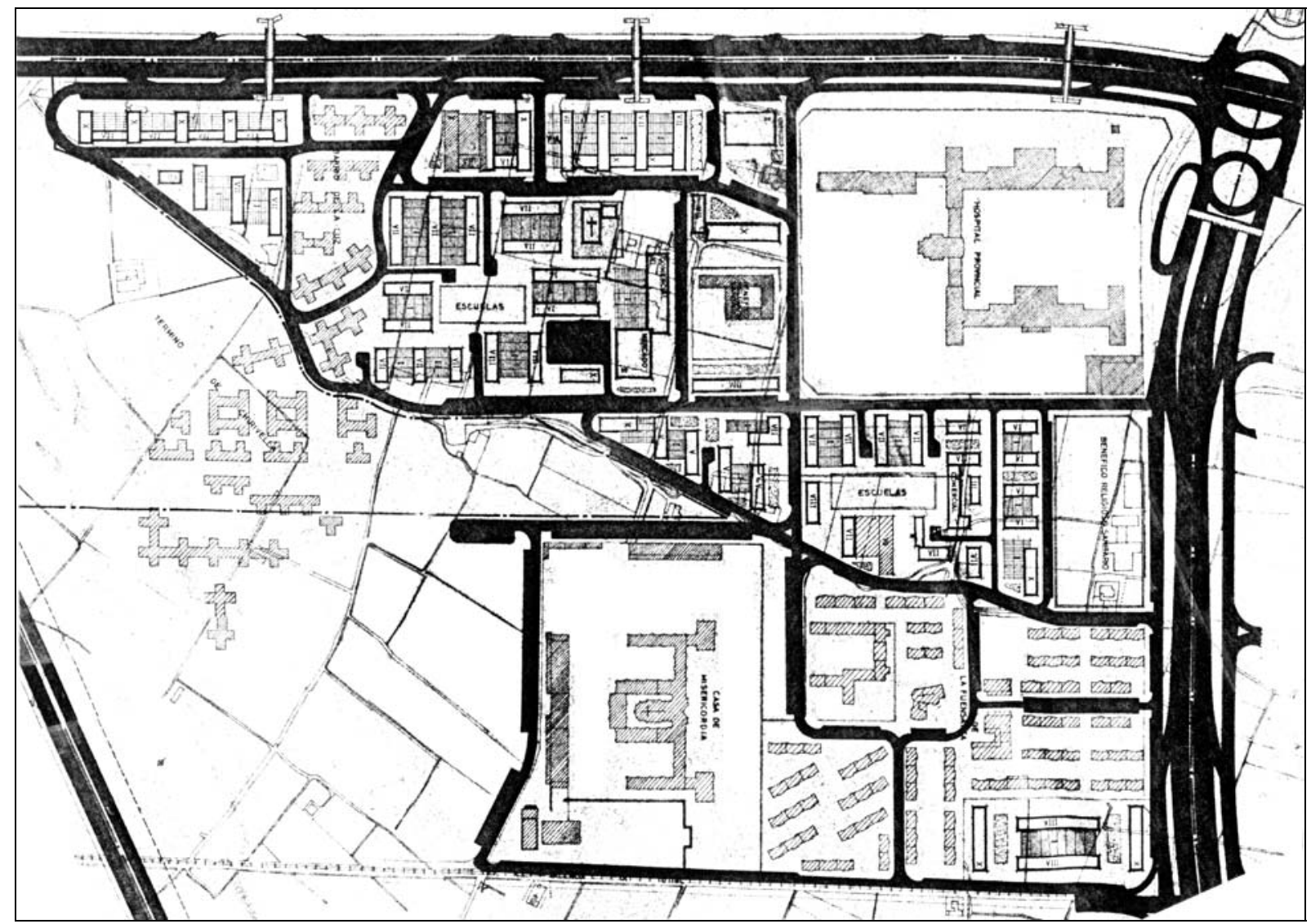


Las manzanas de menor tamaño son, al norte, las que forman el frente a la Avenida del Cid, a uno y otro lado del barrio Virgen de la Luz; en el centro, una manzana destinada a centro comercial y, entre el Hospital General y el barrio de la Fuensanta, dos manzanas que flanquean a este y oeste la supermanzana que ocupa la parte central de este espacio.

La estructura urbanística de la zona norte del Plan Parcial 26b esta, en todo caso, muy condicionada por el importante espacio que en ella ocupan diversos equipamientos, como el Hospital General o la Casa de la Misericordia, cuya escala trasciende la del barrio. Con respecto a los equipamientos propiamente vecinales, la Memoria del Plan parcial 26-B señala lo siguiente

En el Planeamiento anterior existían tres zonas para escuelas, actualmente se han dejado dos, pero con mayor superficie por considerar suficientemente resuelto el problema escolar. En cuanto a Centros Parroquiales se ha mantenido uno y se ha suprimido otro, por estar en construcción en el término de Chirivella un Centro parroquial muy cerca del ubicado en el anterior Planeamiento.

Se han mantenido los centros comerciales y mercado, ampliando las zonas para aparcamiento. ${ }^{1}$

En cuanto a las zonas verdes, las únicas identificables en el plano tienen un carácter intersticial, en forma de pequeñas isletas ajardinadas en las aceras o franjas intermedias entre bloques. No existe realmente en todo el ámbito del plan ninguna reserva de suelo que sea susceptible de aprovechamiento como parque vecinal.
1.Plan Parcial 26bis, 1967. Memoria. Ver Anexo de Documentos, pp 678-679.

Plan Parcial 26b. Equipamientos. Zona norte. (Elaboración propia sobre plano de alineaciones del plan)

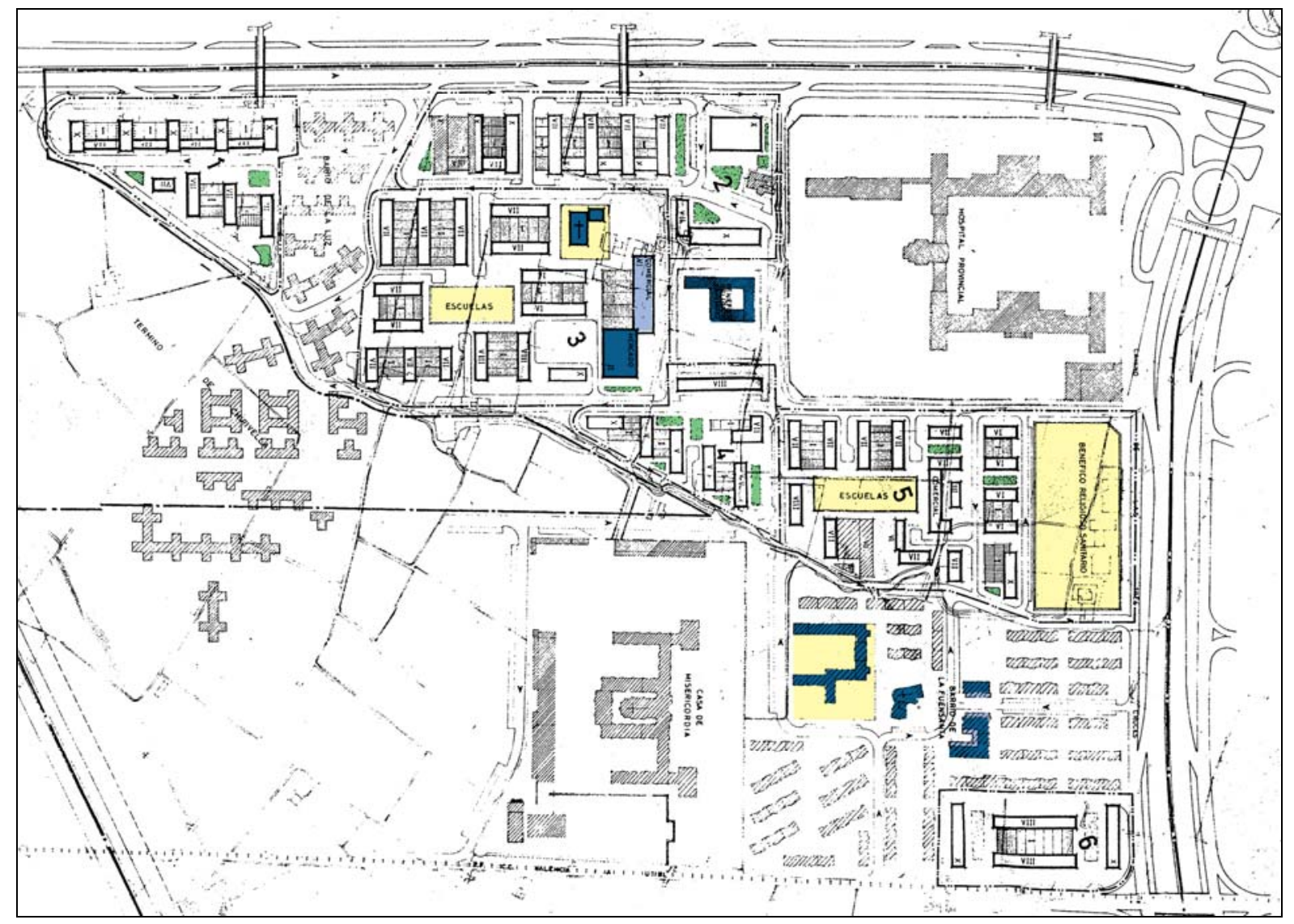




\section{Edificación}

La calificación asignada a la zona norte del Plan Parcial 26-b de "edificación abierta baja", con coeficiente de edificabilidad de 3,5 $\mathrm{m} 3 / \mathrm{m} 2$, no se traduce en menores alturas de los bloques.

Así, las alturas son de VI y VII plantas en la mayor parte de los bloques, y aumentan a $\mathrm{X}$ plantas en aquellos recayentes a espacios más amplios, como los que integran el frente a la Avenida del Cid o los situados junto al centro comercial vecinal.

La edificación abierta adopta en el Plan Parcial 26b, como hemos señalado, la forma de bloques, orientados en paralelo o en perpendicular a la Avenida del Cid. Los bloques, de longitud variable entre 30 y 60 metros, son siempre de dos crujías, excepto un bloque de cinco crujías situado junto al Hospital General.

Los bloques situados a lo largo del eje diagonal del Camino del Molino de Xirivella, que marca el límite del término municipal de valencia y su continuación hasta la calle Escultor Salzillo, se disponen de forma escalonada, conservando también los ejes paralelo y ortogonal a la Avenida del Cid.

Los bloques recayentes a la Avenida del Cid no son bloques

Plan Parcial 26b. Edificación en planta tipo. Zona norte (Elaboración propia sobre plano de alineaciones del plan). lineales aislados, sino que forman un continuo edificado en peine, con bloques de menor altura perpendiculares a la Avenida unidos por otros paralelos a la misma.

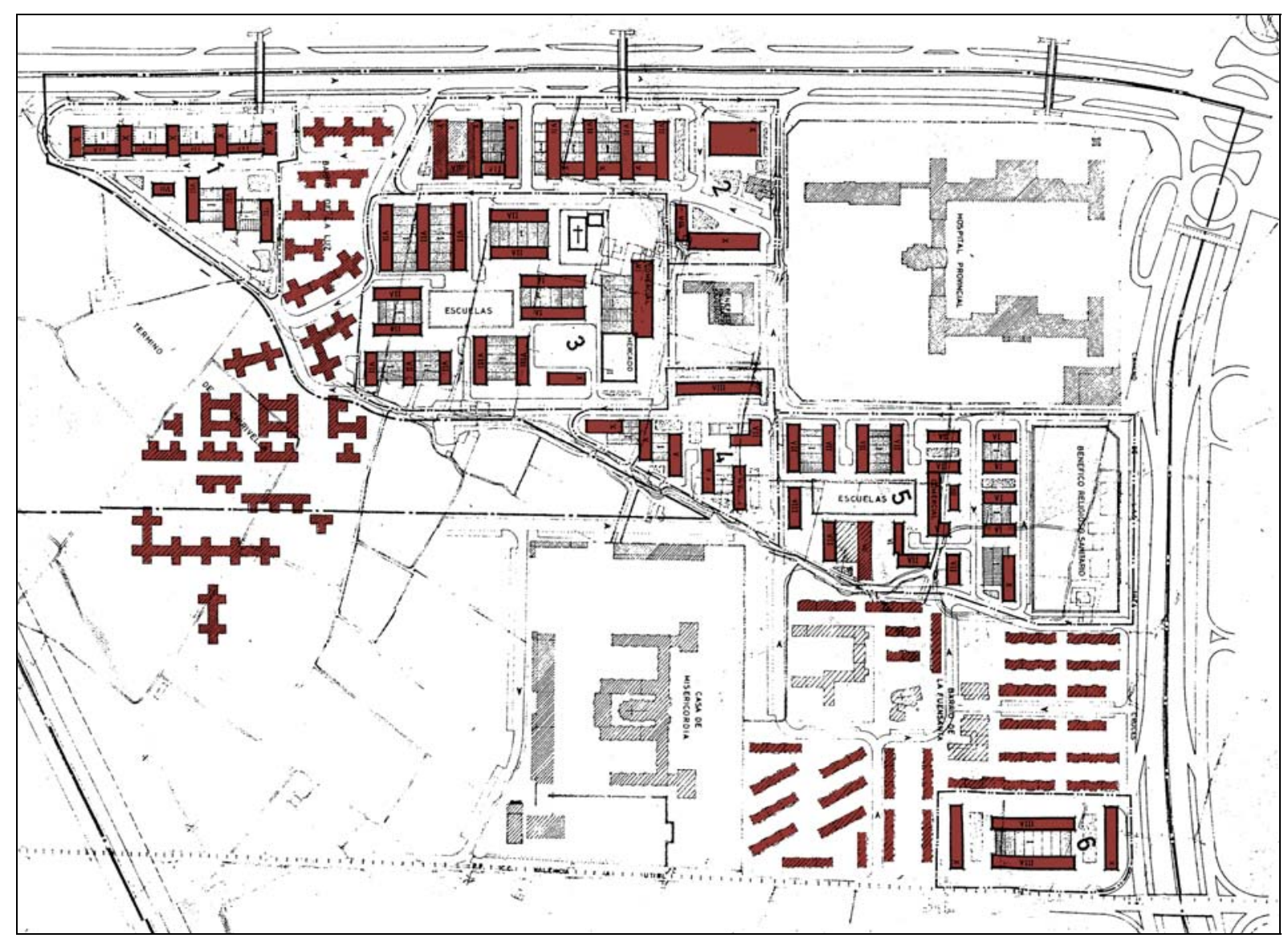


El plano de edificación en planta baja muestra un claro contraste entre las zonas de los barrios de la Fuensanta y de la Luz, en los que los bloques albergan viviendas en planta baja, y la zona de edificación abierta propia del Plan Parcial 26-b, en la que la mayor parte de los bloques están agrupados en manzanas con la planta baja destinada a locales comerciales.

De estas manzanas, las que agrupan sólo dos bloques son de tamaño muy pequeño, especialmente cuando los bloques son cortos. En cambio, las que integran tres o más bloques, dispuestos en serie o en $U$ sobre el cuerpo de edificación que los engloba en planta baja, alcanzan un tamaño más adecuado como unidad urbana repetible.

Así, por ejemplo, en la zona intermedia entre el Hospital General y el grupo Virgen de la Fuensanta, podemos encontrar micromanzanas de hasta $30 \times 36 \mathrm{~m}$. En cambio, las manzanas que envuelven el centro vecinal situado entre el Hospital y el barrio de la Luz tienen unas dimensiones que oscilan entre los $50 \times 50$ y los $50 \times 110 \mathrm{~m}$.

El carácter intersticial del Plan Parcial 26b, como relleno del espacio vacante existente entre las grandes parcelas dotacionales de la zona y los barrios de la Fuensanta y la Luz, sin tener en cuenta la ordenación de éstos conjuntos residenciales, se hace patente al observar los grupos de bloques previstos en las esquinas sureste y noroeste.
Plan Parcial 26b. Edificación en planta baja. Zona norte (Elaboración propia sobre plano de alineaciones del plan)

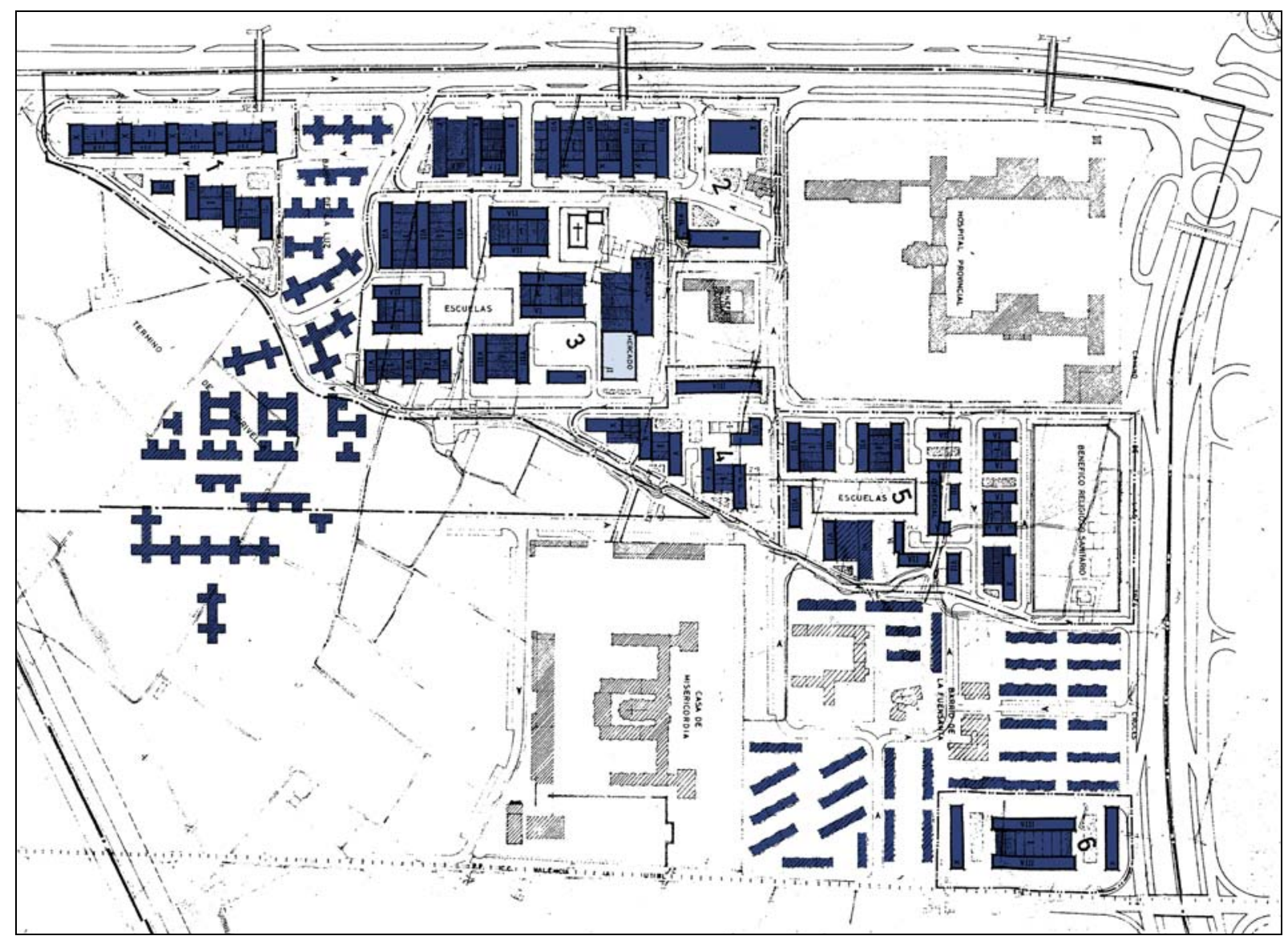




\section{Grado de realización}

El grado de realización de la edificación abierta prevista en la zona norte del Plan Parcial 26b es bastante alto. Los bloques no construidos son los que formaban una manzana triangular junto al Camino del Molino de Xirivella, una parte de los situados junto al centro vecinal de la supermanzana situada entre el Hospital General y el barrio de la Luz y algunos más aislados, como los situados al sur del barrio de la Fuensanta y dos de los que formaban el frente en peine recayente a la Avenida del Cid.

Como ocurre en otros planes parciales, el Plan General de 1988 destina los espacios vacantes disponibles a paliar el déficit de equipamientos, y en particular de zonas verdes, proyectando tres parques vecinales en espacios anteriormente previstos como edificables.

Estas zonas verdes están situadas en los dos espacios previstos para centro comercial en las supermanzanas del Plan Parcial 26b, y en la manzana de la esquina sureste, junto al cruce del camino de Tres Cruces y la calle Tres Forques. Estos parques se envuelven con bloques de nueva planta con planta en forma de L.

Otro grupo de bloques en L sustituye a los bloques escalona-

Plan Parcial 26b. Grado de realización

Zona norte (Elaboración propia sobre plano de alineaciones del plan) mino del Molino de Xirivella, en cuyo interior se sitúa una nueva parcela escolar.

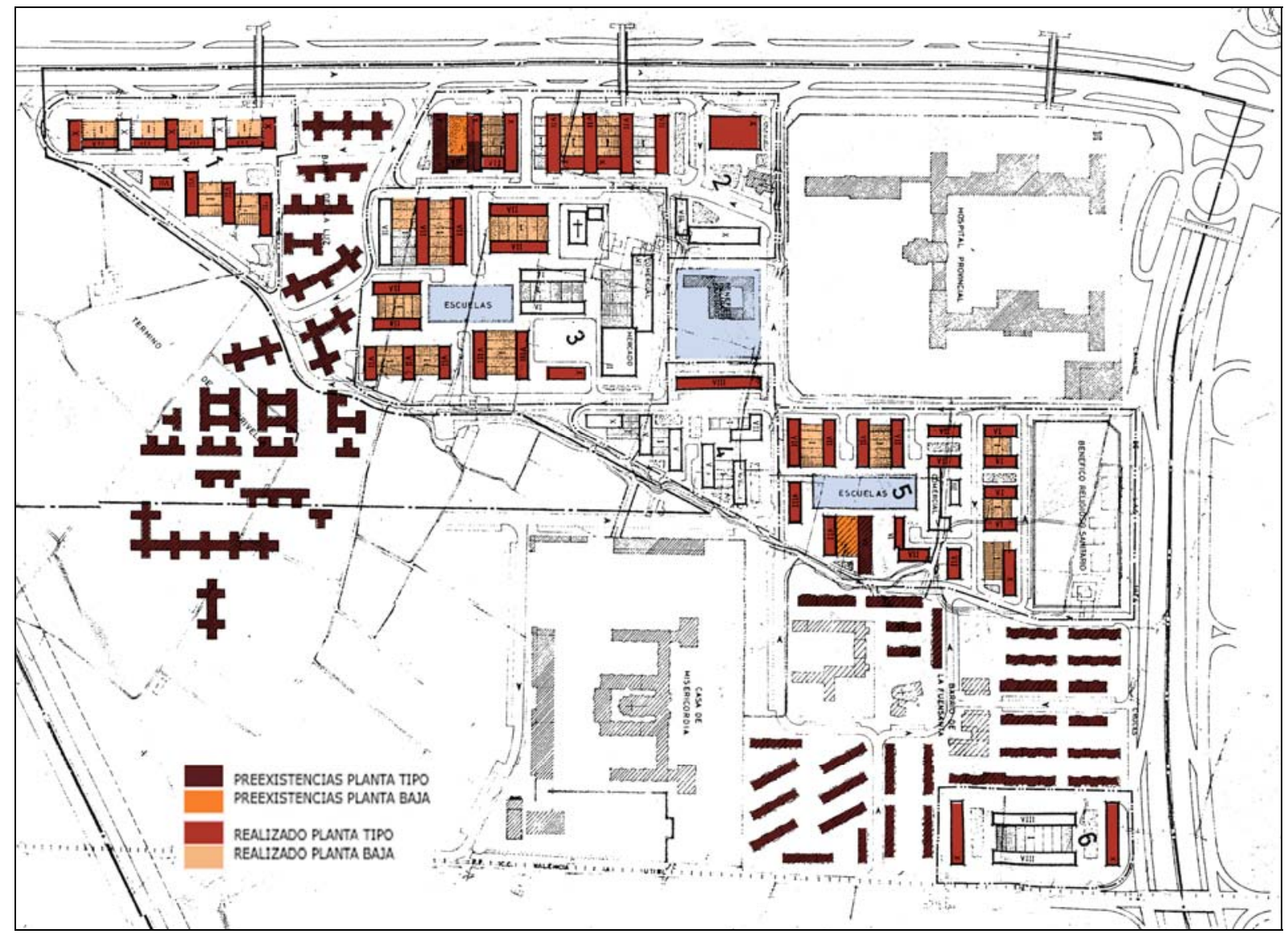




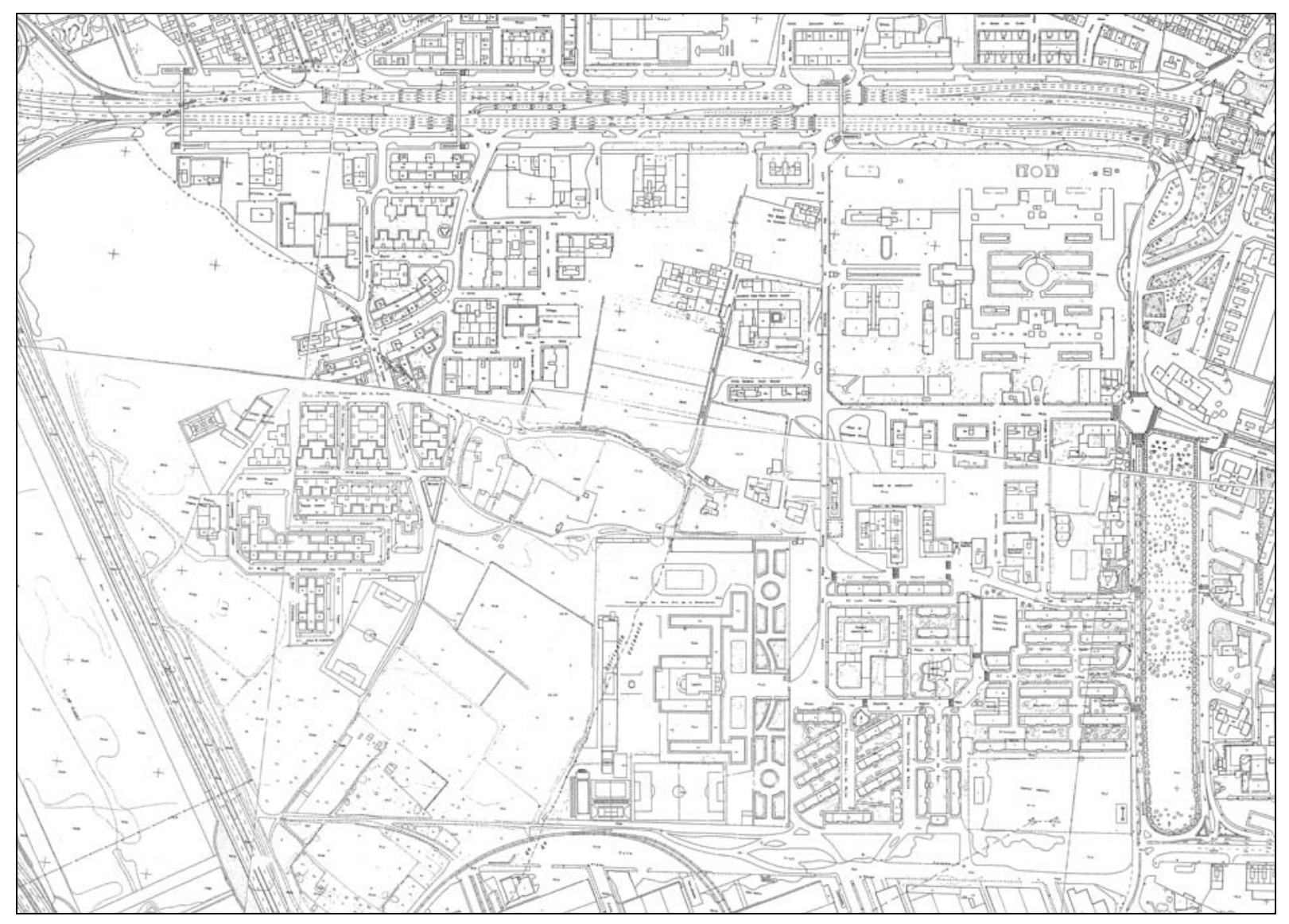

Zona del Plan Parcial 26b. Cartografía Básica Municipal, 1983.

PGOU 1986. Zona del Plan Parcial 26-B

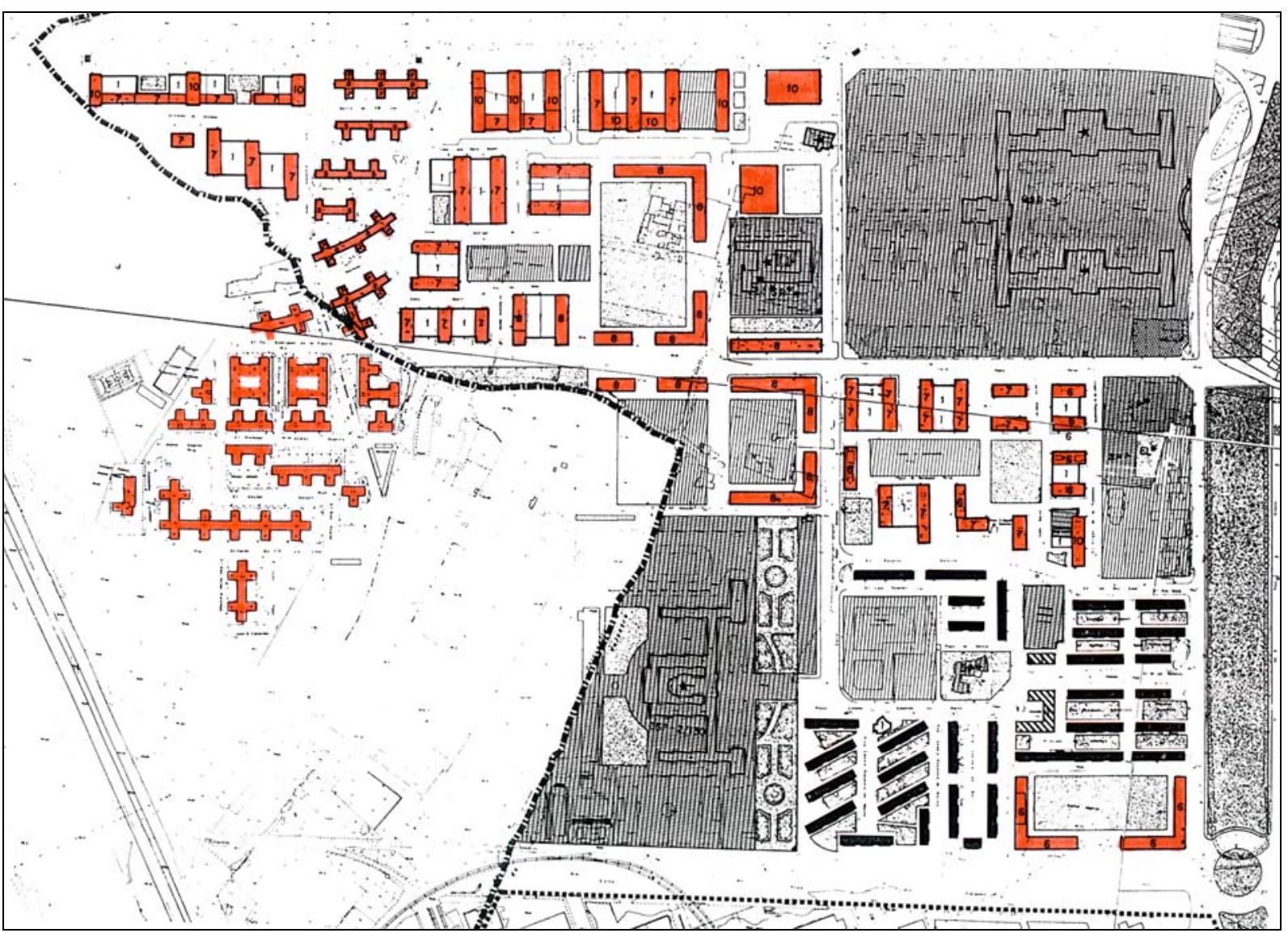




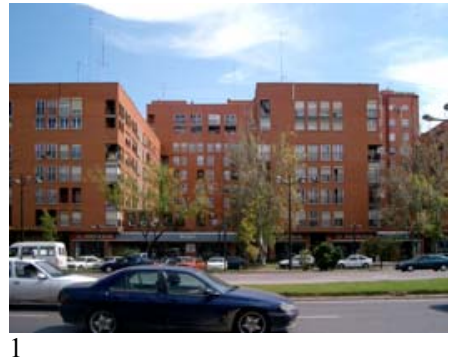

En la Avenida del Cid, las dos series de bloques en peine proyectadas en el Plan Parcial 26b, al este y al oeste respectivamente del barrio de la Luz, forman grupos de edificación a redents. La segunda serie, de edificación más reciente, es más homogénea y menos densa, al combinar bloques de VII y $\mathrm{X}$ plantas.
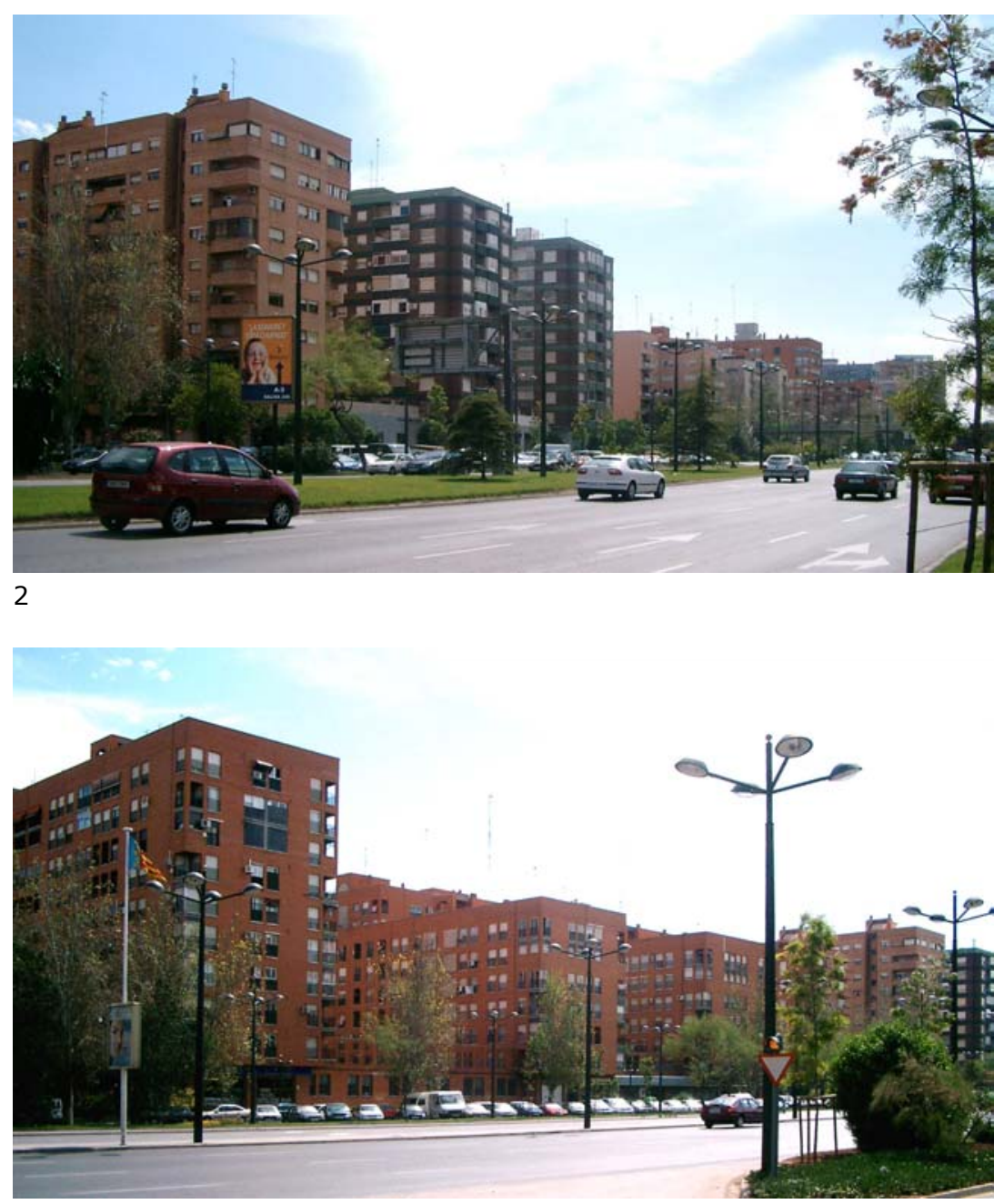

1-4. Bloques en peine en el lado sur de la Avenida del Cid.

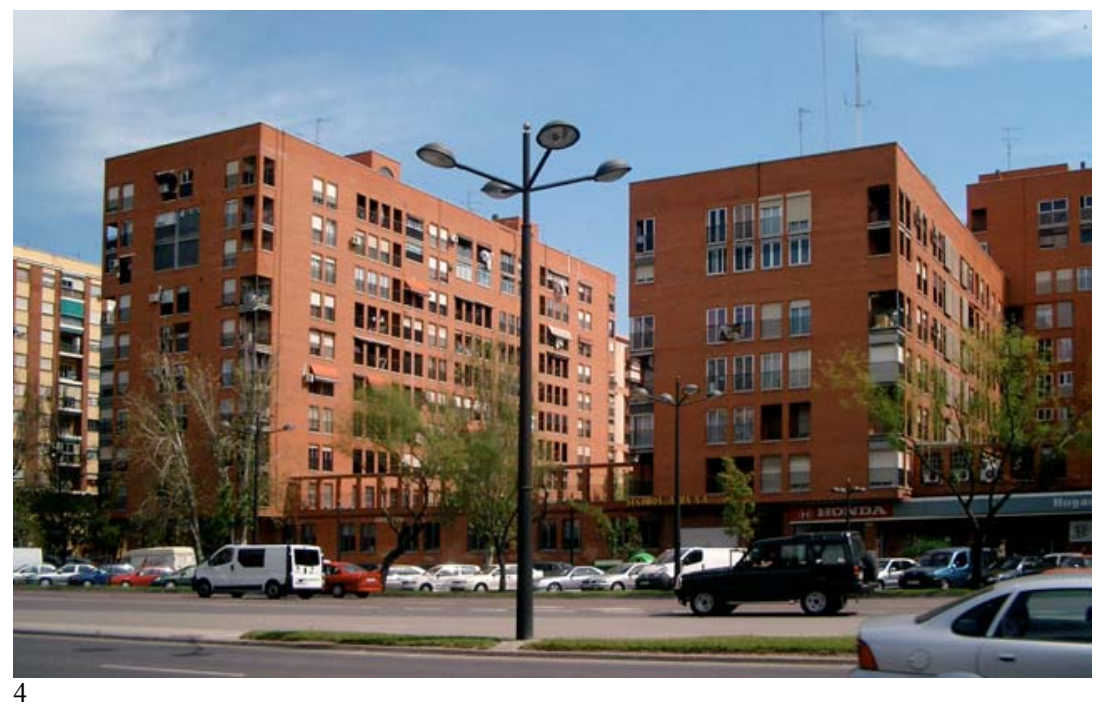




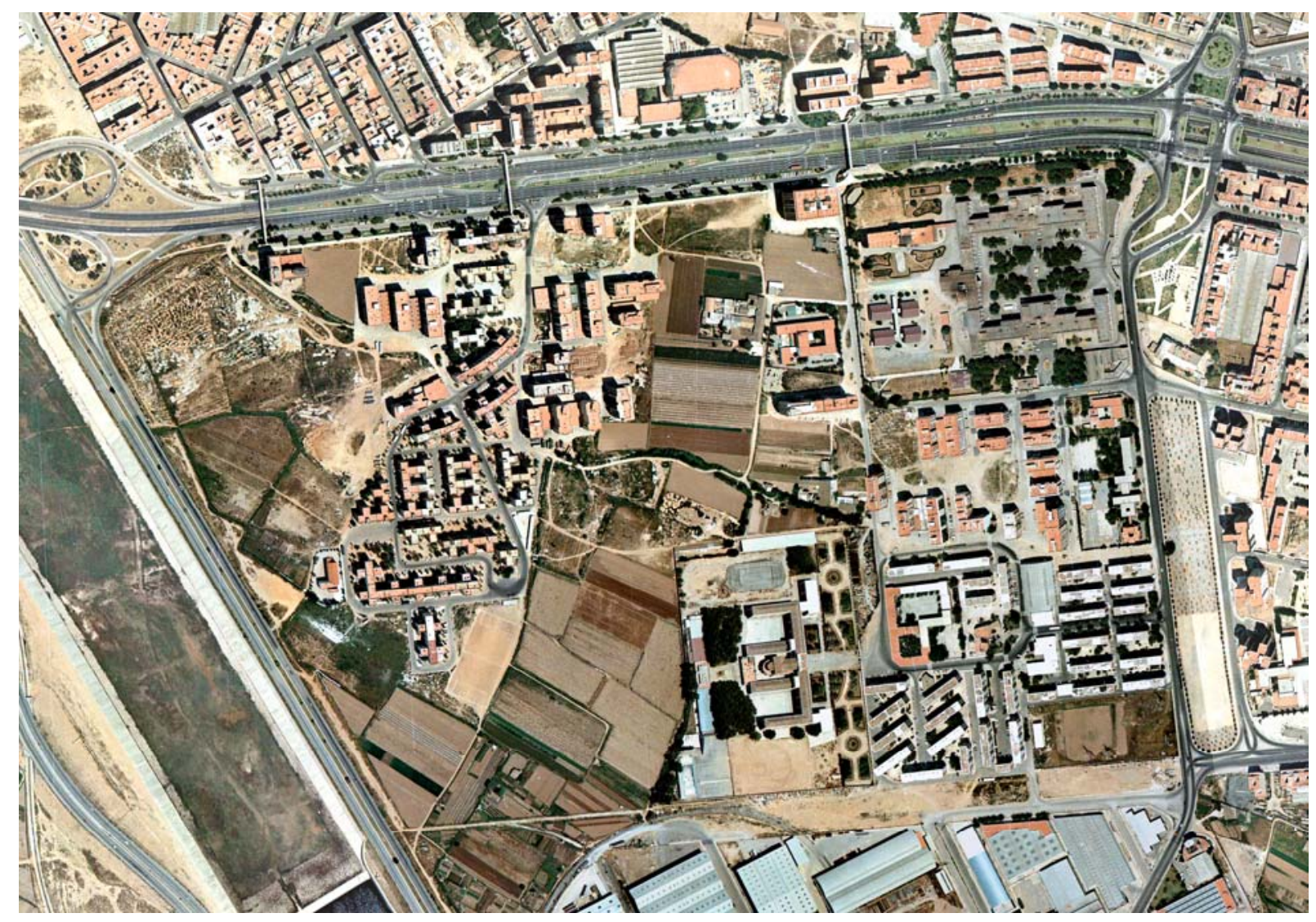

Zona norte del Plan Parcial 26-b. Fotografía aérea, 1980

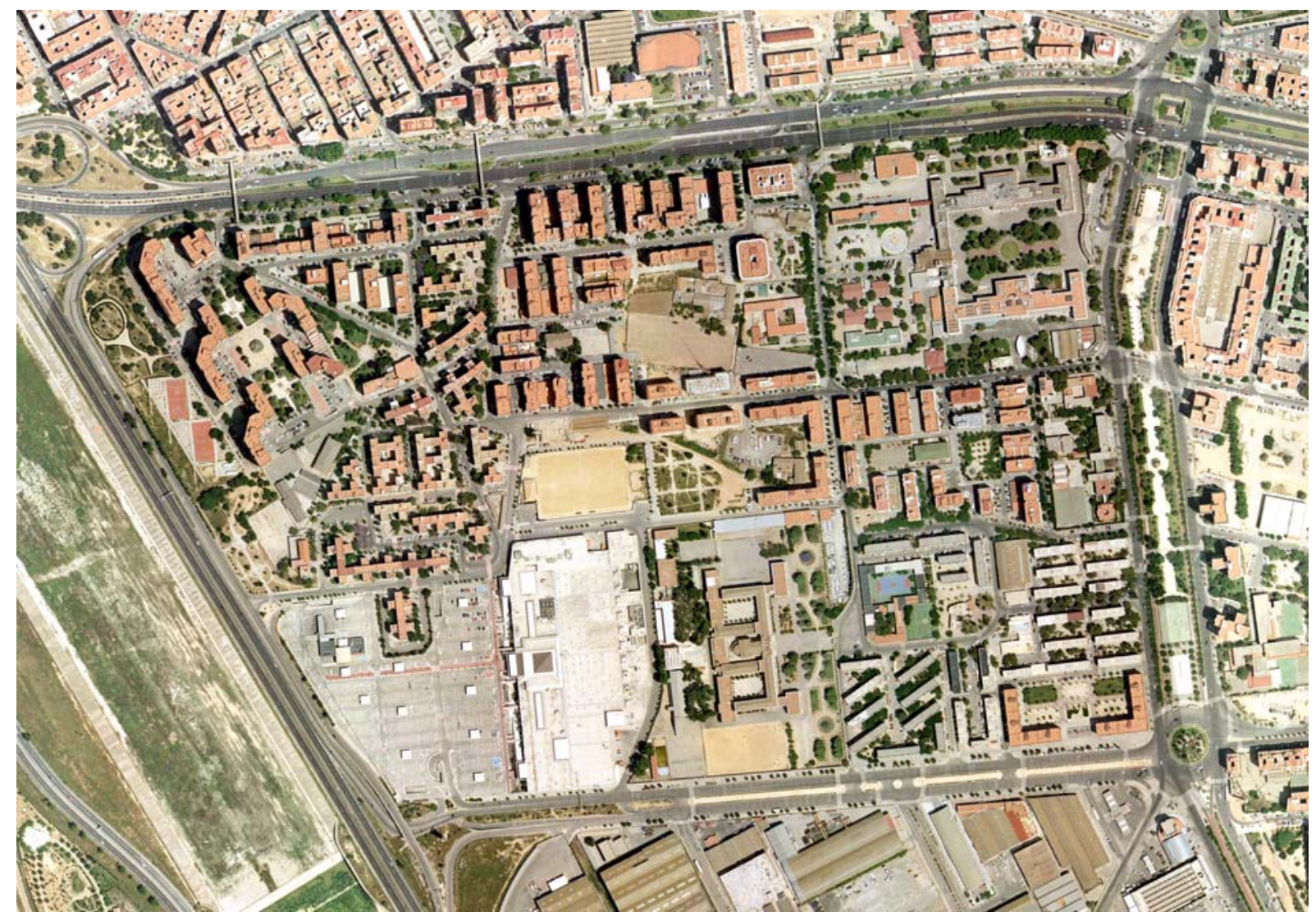

Zona norte del Plan Parcial 26-b. Ortofoto 2002 (AUMSA) 


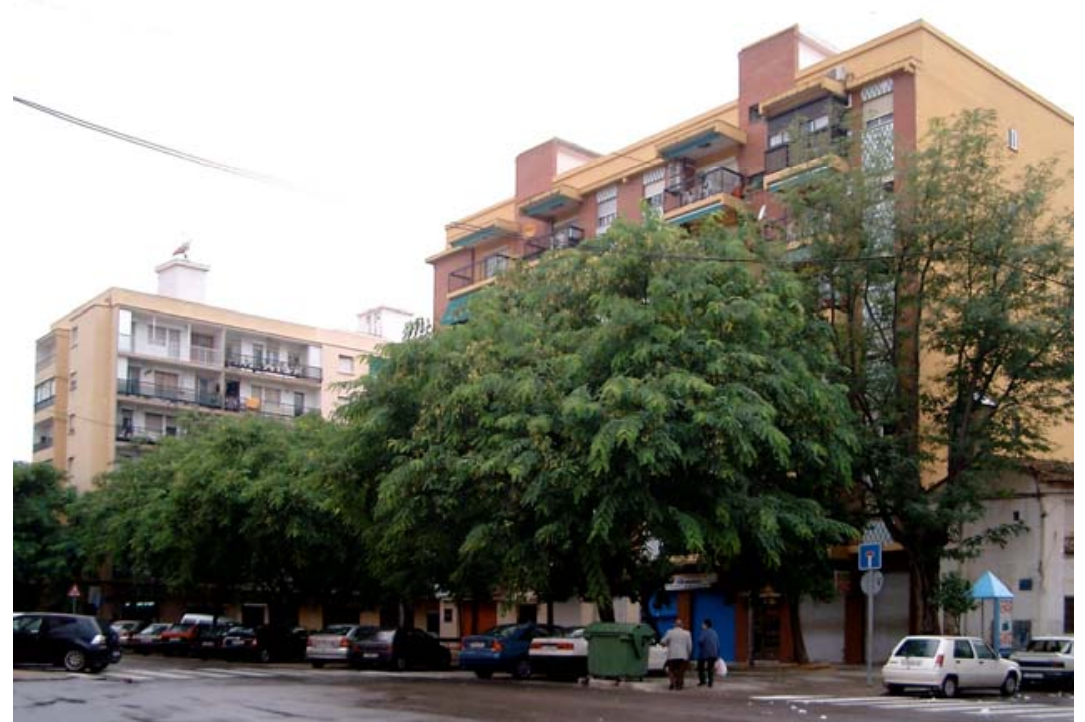

1

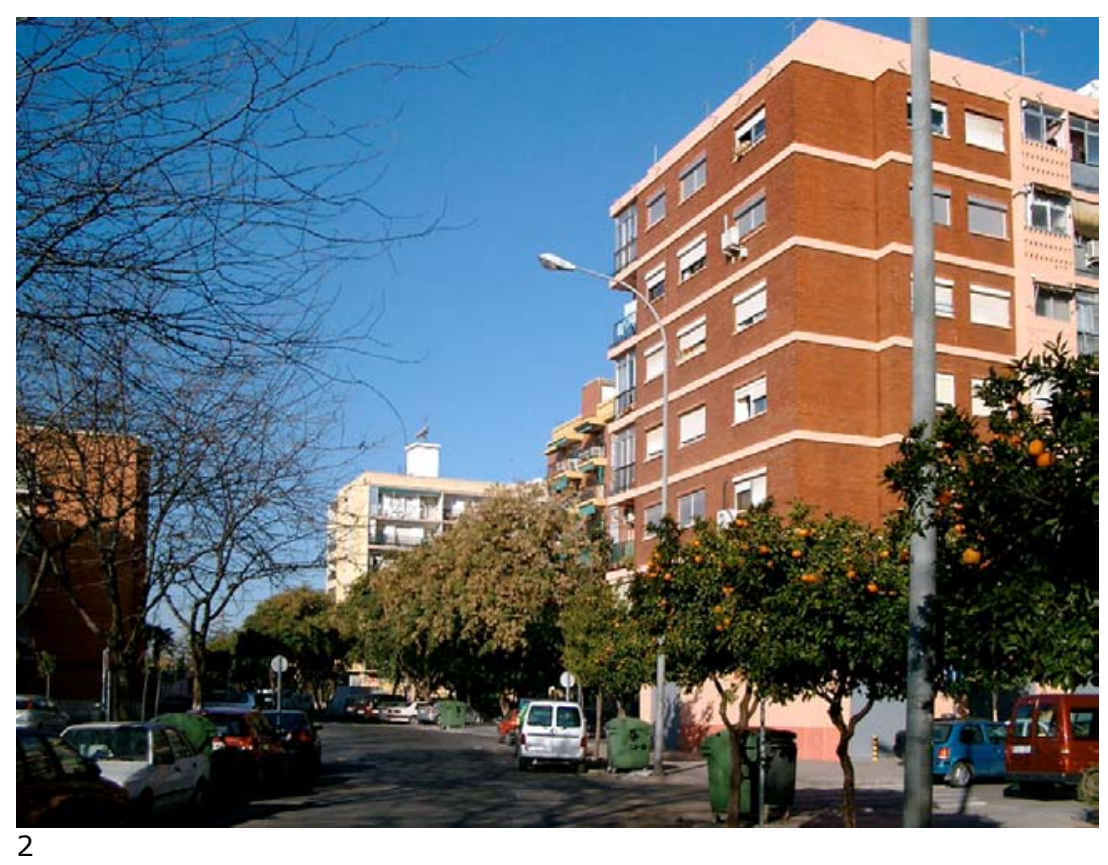

1,2. Calle Escultor Salzillo, vista hacia el oeste.

3. Calle Garza Imperial, vista hacia el norte.

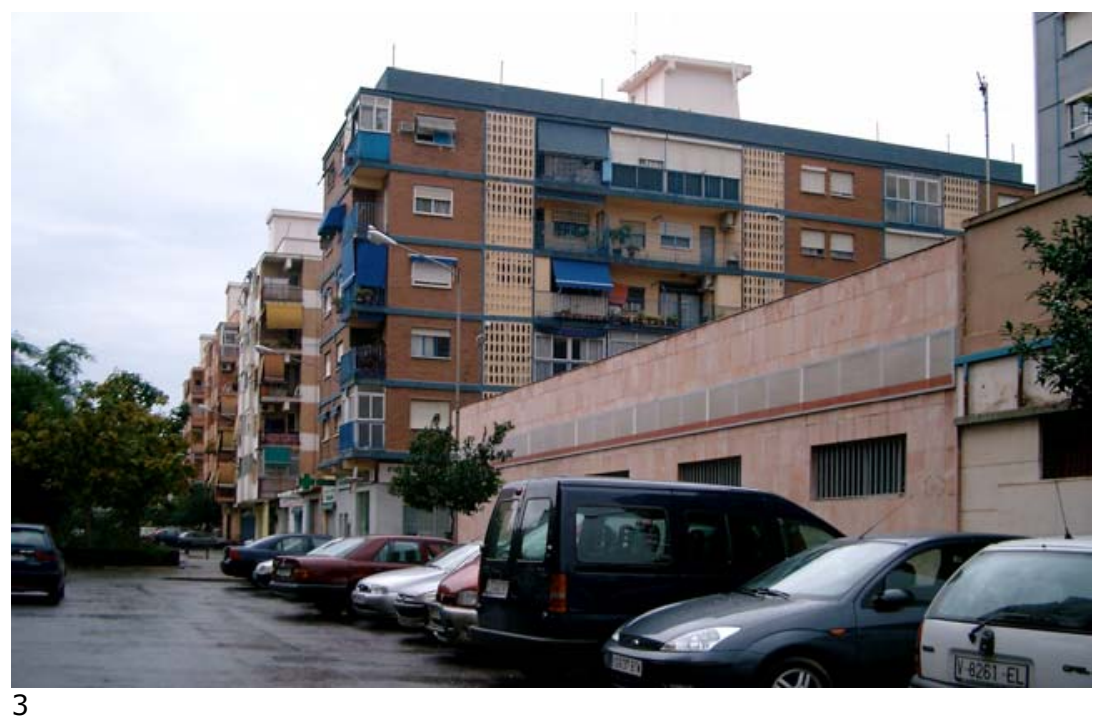


La zona de edificación abierta intermedia entre el barrio Virgen de la Fuensanta y el Hospital General, proyectada como supermanzana en el Plan Parcial 26b, ha mantenido en parte ese carácter, pese a que el viario la atraviesa en parte, gracias a la presencia del núcleo central de equipamientos de la plaza Dr. Berenguer Ferrer, formado por una escuela y por un parque que sustituye al centro comercial inicialmente previsto.

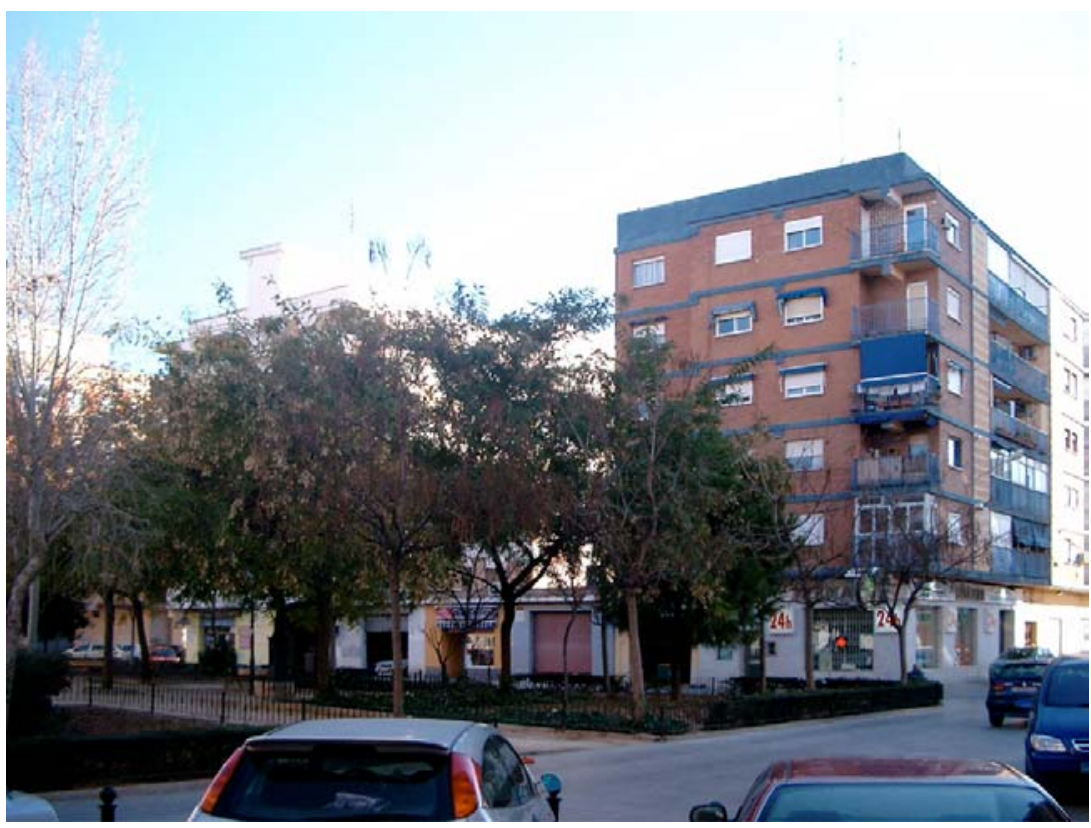

1

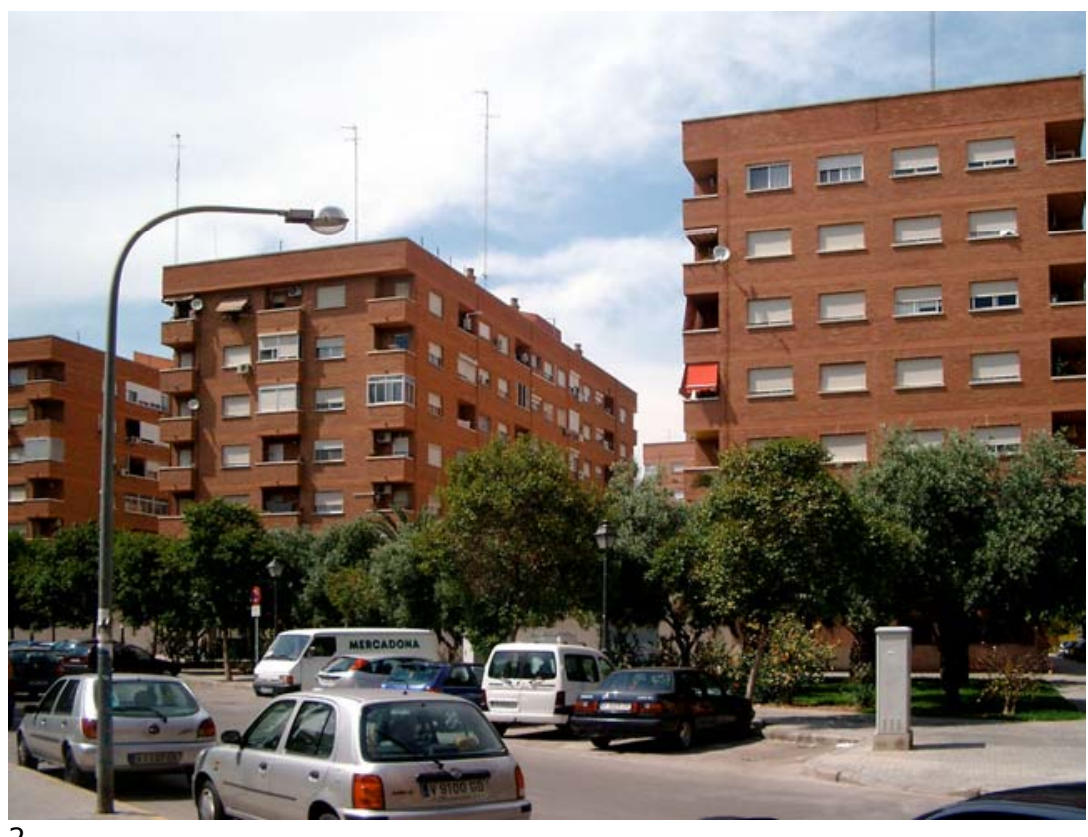

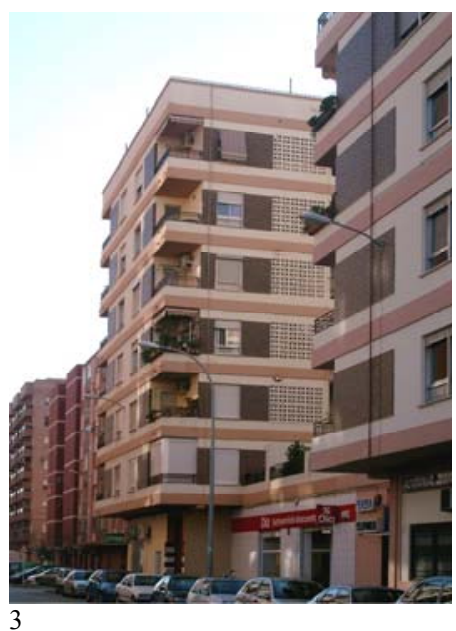

1. Plaza Dr. Berenguer Ferrer.

2. Camino del Molino de Xirivella, bloques escalonados del lado norte.

3. Calle José María Bayarri, vista hacia el este. 


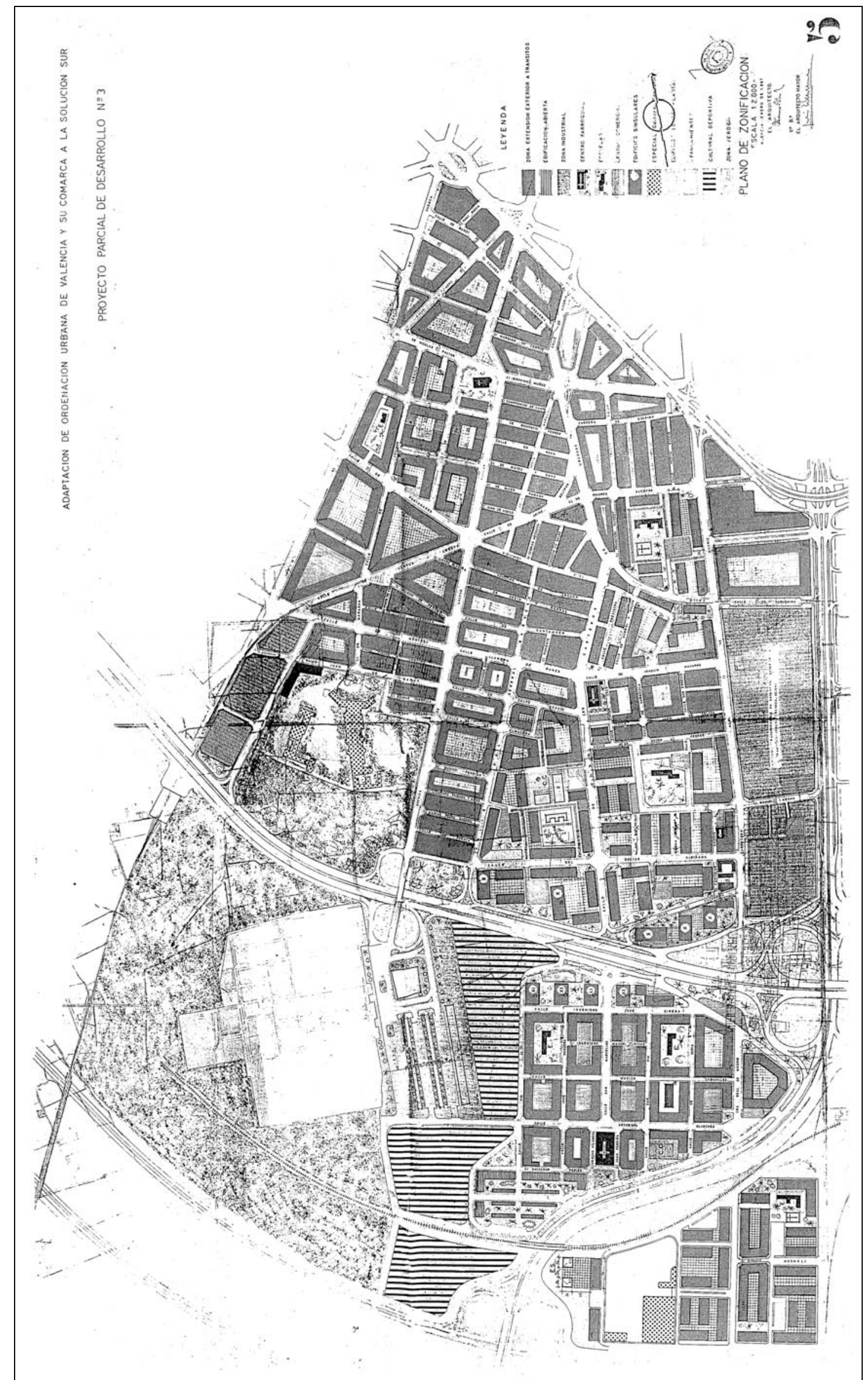

Plano Parcial no 3 adaptado a la Solución Sur, 1968. Plano de zonificación. 


\section{LA CRUZ CUBIERTA Y SAN MARCELINO: EL PLANO PARCIAL NO 3 (1967).}

El ámbito del Plano Parcial no 3 adaptado a la Solución Sur, redactado en 1967 por la Oficinal Técnica Municipal de Urbanismo, comprende todos los terrenos antes englobados en el Proyecto Parcial de Desarrollo no III de 1951, excepto los exteriores al Nuevo Cauce del Turia, cuya ordenación queda asignada al Plan Parcial 3-b ${ }^{1}$. El plan, por tanto, está limitado al norte por la Avenida de Giorgeta, al este por las líneas de ferrocarril de RENFE (futuro acceso de Torrente), al oeste por la Avenida de Gaspar Aguilar y al sur por el Nuevo Cauce.

El Proyecto Parcial de Desarrollo no III resultaba afectado en gran medida por diversas determinaciones del Plan General adaptado a la Solución Sur de 1966, que incidían en su ámbito: el nuevo cauce del Turia, el nuevo trazado del ferrocarril, el nuevo trazado de la Ronda Exterior y el desdoblamiento del acceso sur. Todo ello hacía necesaria una nueva redacción del mismo.

El Plano Parcial de 1967, aprobado definitivamente por el Ministerio de la Vivienda en $1969,^{2}$ sustituye las manzanas cerradas previstas para toda la zona en el Proyecto Parcial III de 1951 por manzanas abiertas o bloques en todos los espacios vacantes disponibles en el momento de su redacción.

Además, la ordenación proyectada en algunas áreas ya tratadas como edificación abierta en el Proyecto Parcial de 1951 es descartada y sustituida por otra diferente.

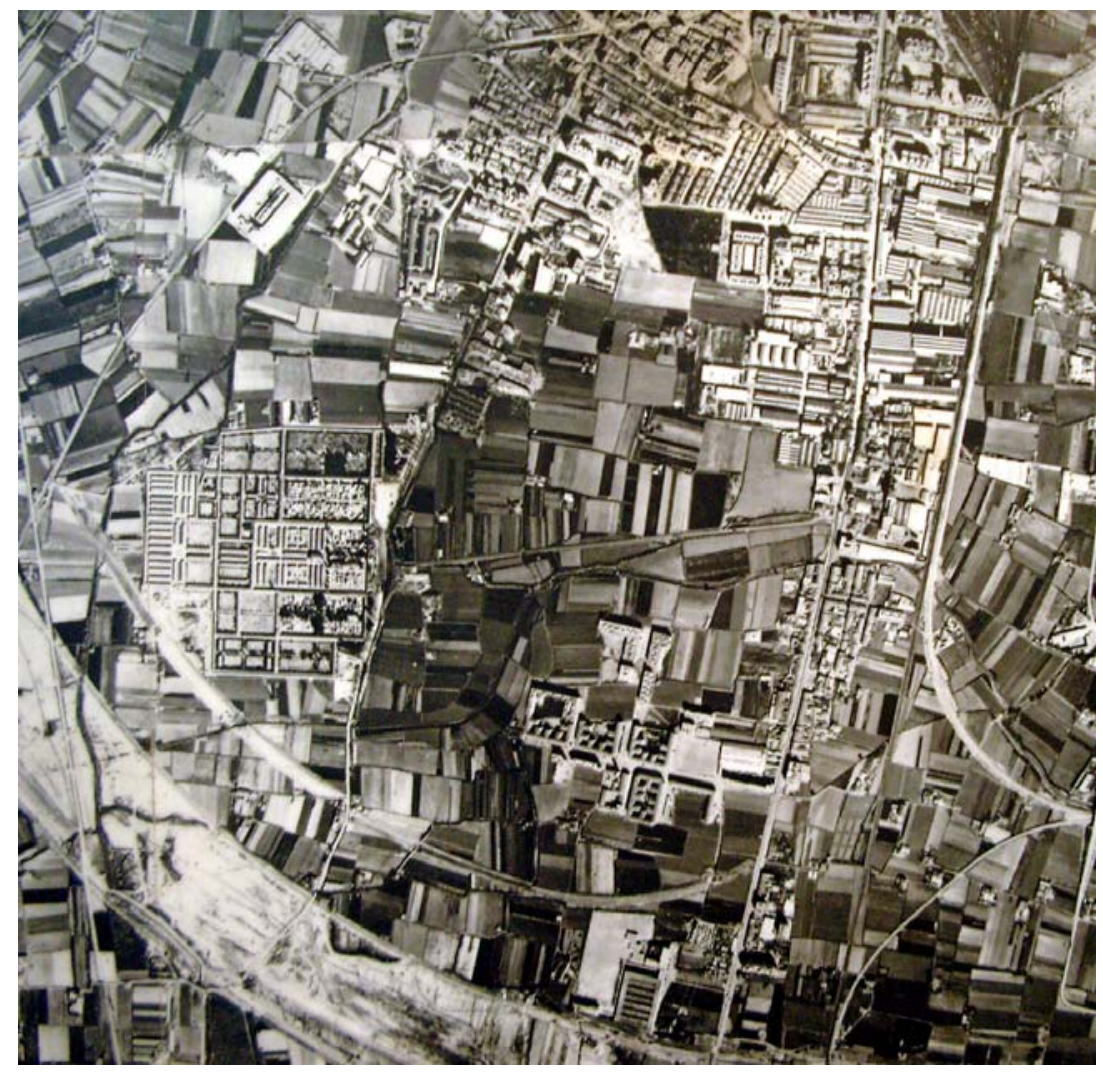

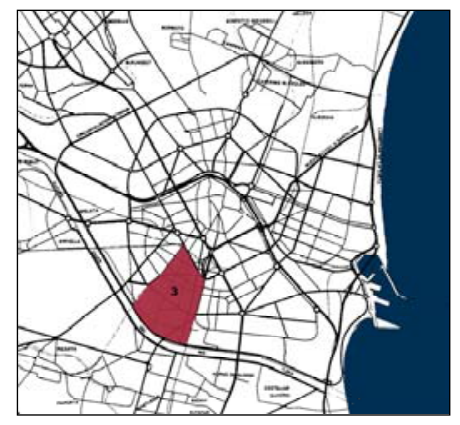

Plan Parcial 3. Localización.

Zona del Plan Parcial 3. Fotografía aérea, h. 1965 (ETS de Arquitectura de Valencia).

1. Este Plan Parcial 3-b queda fuera del ámbito del presente trabajo, por las razones que hemos señalado en la introducción a esta sección.

2. Resolución de aprobación del Plan Parcial 3 por la Dirección General de Urbanismo, firmada por Bidagor. Documento 3.1. Anexo de Documentos, p. 699. 


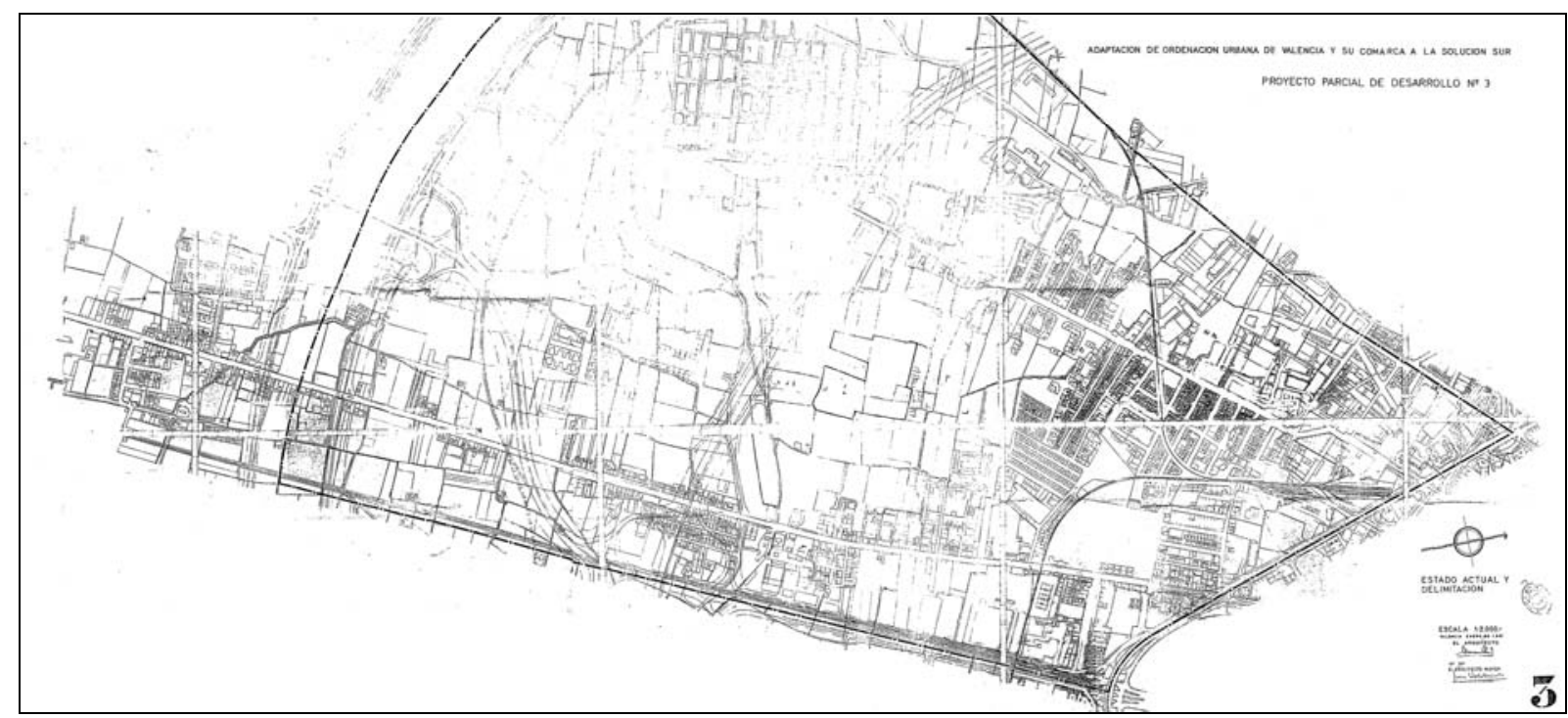

Plan Parcial 3. Plano de estado actual y delimitación.
Así, dentro del ámbito del plan se pueden identificar tres zonas que podemos considerar como de edificación abierta. La primera es la limitada al este por el Camino Real de Madrid, al oeste por la calles General Barroso y Carteros, según tramos, al norte por la calle Dolores Alcayde y al sur por la Ronda Exterior. La segunda zona es la ampliación del barrio de San Marcelino, que se prevé en todas las direcciones a partir del núcleo de manzanas original de 1949 situado entre la Ronda Exterior y el acceso de Torrente. La tercera es la denominada Ciudad del Aprendiz, situada entre el acceso de Torrente y el Nuevo Cauce.

Todas estas zonas están calificadas en el plan como Extensión Exterior a Tránsitos, y, al igual que ocurre en otros planes que incluyen zonas con esta calificación, la edificación de las mismas se resuelve mediante bloques de cinco crujías, dispuestos de modo aislado o unidos por plantas bajas comerciales. Únicamente una parte de la ampliación de San Marcelino por el sur está proyectada con bloques de dos crujías, y ostenta la calificación de edificación abierta.

En el momento de la redacción del Plano Parcial 3, la edificación abierta existente se reducía a los pequeños bloques situados junto a la Cruz Cubierta, único fragmento realizado del Proyecto Parcial III en esa zona, a algún fragmento de las manzanas abiertas que debían ampliar el barrio de San Marcelino por el Norte y al grupo Virgen de la Vallvanera, formado por un bloque en $U$ y otro lineal situados alrededor del mercado del mismo nombre.

El viario proyectado en el plan para las zonas de edificación abierta no es del tipo ramificado, sino que forma un tejido mallado que se completa ramales sin salida en algunas manzanas, como las dos que flanquean el cruce de la calle carteros con la Ronda Exterior, o las que incluyen en su interior una parcela escolar.

La previsión de aparcamientos del plan es de un vehículo por cada cinco familias, previsión común a otros planes del periodo y que bien pronto quedaría absolutamente desfasada. 
Por lo que se refiere a los equipamientos, el plan se limita a cubrir la reserva del $10 \%$ de suelo para zonas verdes exigida por la legislación, y prevé muy poco suelo para otras dotaciones tales como parcelas escolares, sobre todo si se tiene en cuanta la densidad de los tejidos de ensanche adyacentes.

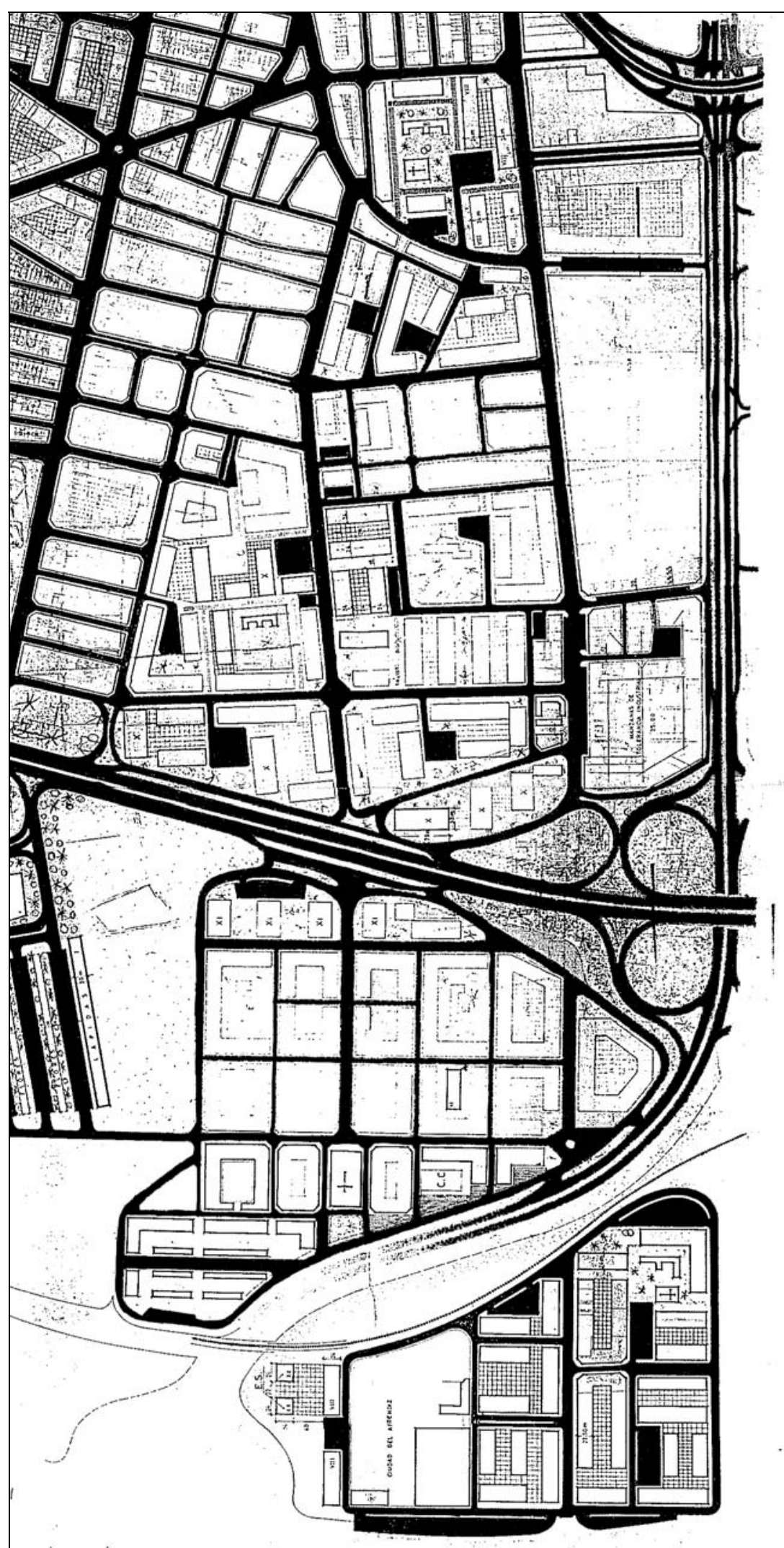

Plan Parcial 3.Plano de red viaria. Detalle de la zona sureste. 


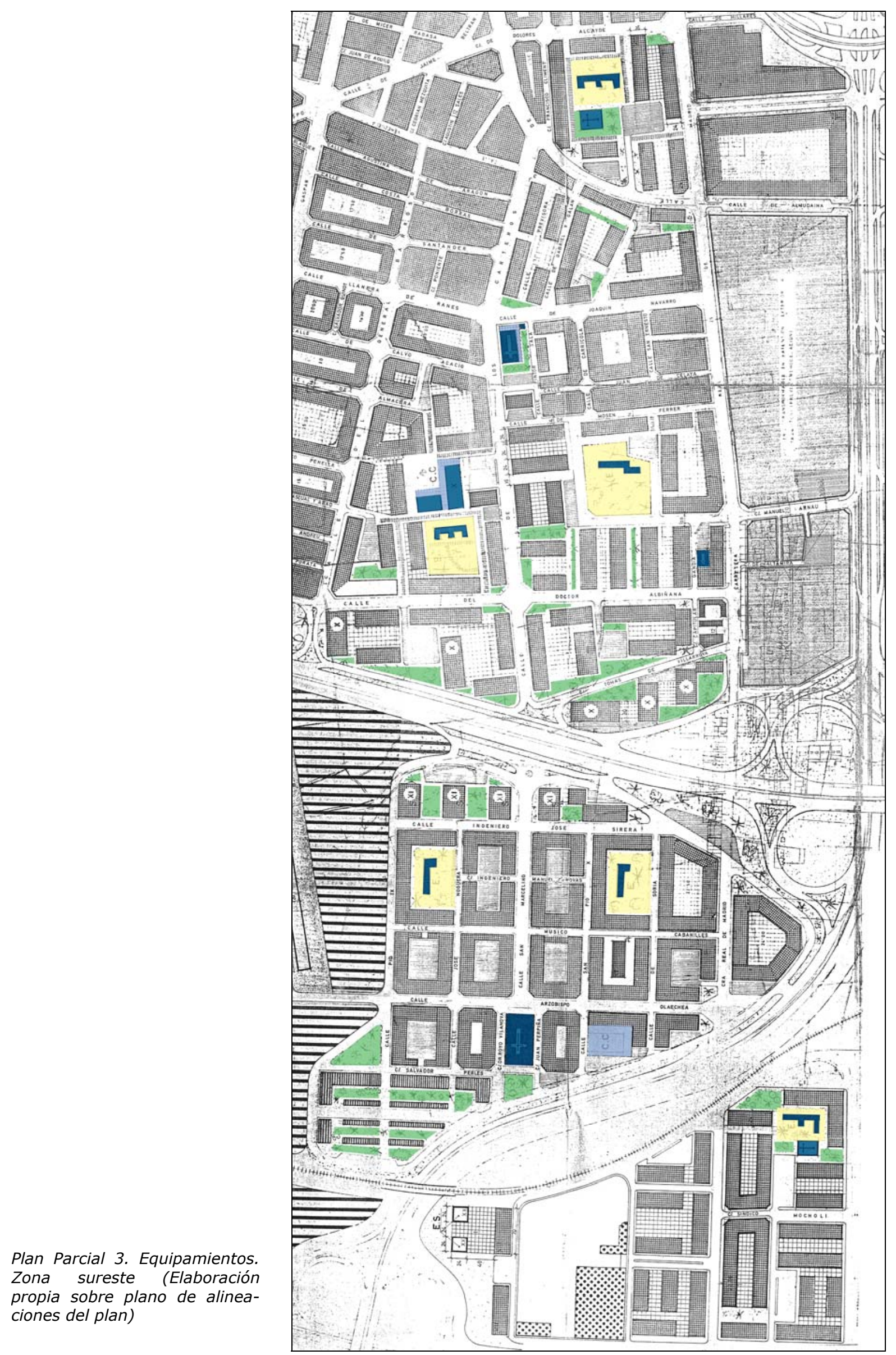


Las características de la edificación prevista en las zonas que, aunque calificadas en el plan como Extensión Exterior a Tránsitos, hemos considerado como edificación abierta son descritas en la Memoria del mismo en los términos siguientes:

Las manzanas previstas antiguamente, se mantienen idénticas en las zonas en que se ha iniciado la construcción. En las más libres de construcciones pero rodeadas de zonas ya construidas se han tratado de mejorar, abriendo en parte las manzanas, de tal forma que se consigue mayor aireación e insolación y posibilidad de viviendas recayentes a estos patios abiertos.

La profundidad de $22 \mathrm{mts}$. en los bloques permite un sistema muy útil de 4 viviendas por escalera y con muy buenas condiciones de insolación y ventilación.

En las grandes zonas, hoy dedicadas a huerta o en manos de una sola propiedad se proponen supermanzanas con aparcamientos, servicios y pocas vías pavimentadas. ${ }^{1}$

Este texto es la única justificación escrita que hemos encontrado en el planeamiento parcial de Valencia del recurso al bloque de cinco crujías, tan frecuente por otro lado, como tipo edificatorio básico del mismo. La apertura del perímetro de la manzana será también un procedimiento para obviar la ordenanza que prohibe las viviendas interiores, con piezas recayentes sólo a patio de manzana, inevitables cuando se proyectan cuatro viviendas por caja de escalera en cada planta.

La memoria del plan justifica la localización junto a la Ronda Exterior de los edificios altos:

A la zona que atraviesa la Ronda, se trata de darle cierta categoría, $y$ al tener una anchura superior a los cien mts. es el único emplazamiento lógico para edificios singulares de altura. ${ }^{2}$

Estos edificios altos adoptan la forma de bloques cortos seriadas de $X$ plantas en el lado sur de la Ronda Exterior y de bloques cortos escalonados enlazados en planta baja en el lado norte.

El plano de edificación en planta baja permite observar el diferente tratamiento dado a los bloques lineales. En la zona de la Cruz Cubierta y en la Ciudad del Aprendiz predominan los bloques dispuestos sobre una extensa planta baja comercial que los engloba, formando unas manzanas de tamaño comparable a las del ensanche.

En la extensión de San Marcelino, en cambio, predominan los bloques profundos que envuelven un espacio libre destinado a escuelas o aparcamientos En la zona de ampliación situada junto a la Ronda Exterior, encontramos además, como hemos señalado más arriba, una pequeña agrupación de bloques seriados de dos crujías, envueltos por un perímetro de bloques profundos.

La geometría de la ordenación sigue una pauta uniforme en las zonas de la Ciudad del Aprendiz y del barrio de San Marcelino, en las que los ejes de la trama original de este barrio son los que, en paralelo o en perpendicular, siguen los bloques. En cambio, en la zona de la Cruz Cubierta los bloques siguen diversas alineaciones de calles, lo que resta claridad a la ordenación en su conjunto.

1. Plano Parcial 3, 1967. Memoria. Anexo de Documentos, p. 688.

2. Ibid. p. 689. 


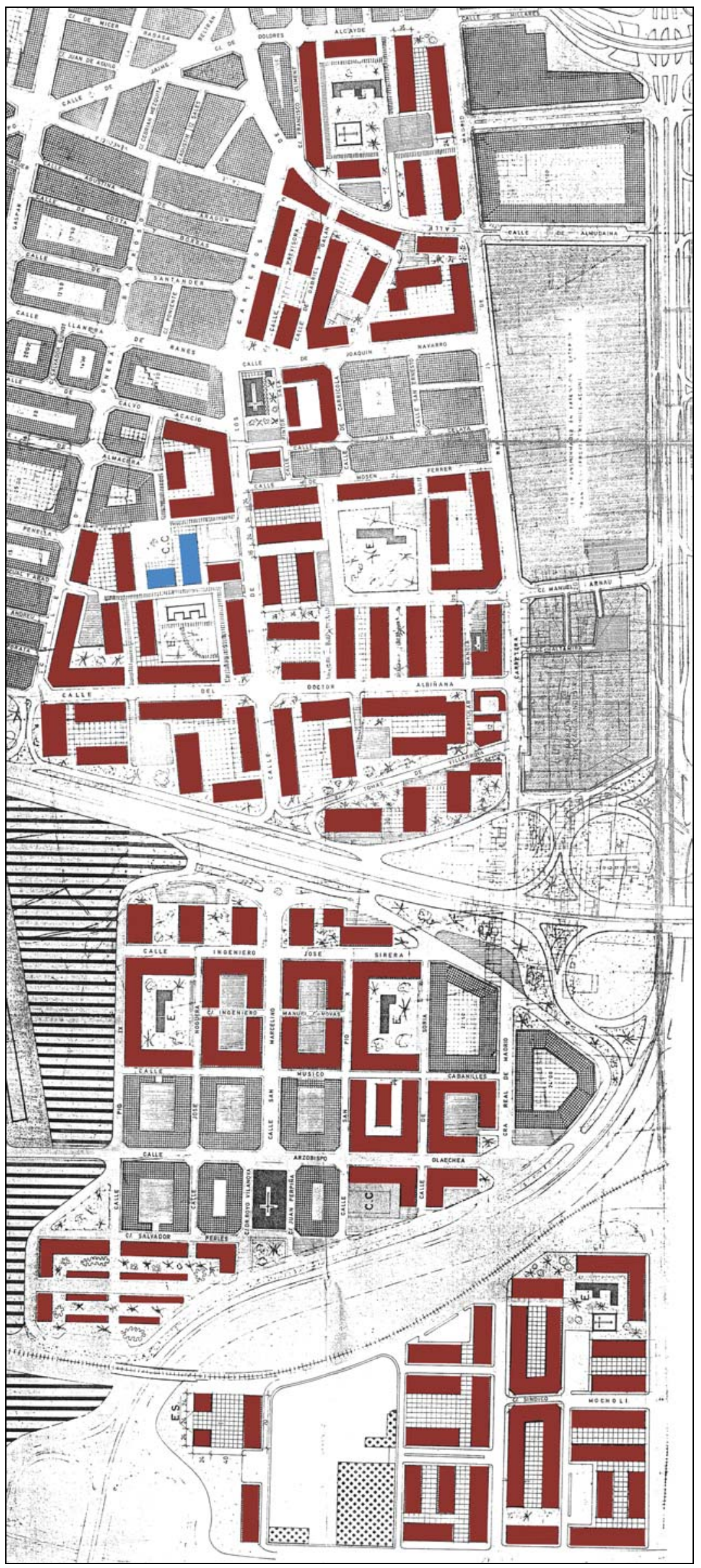




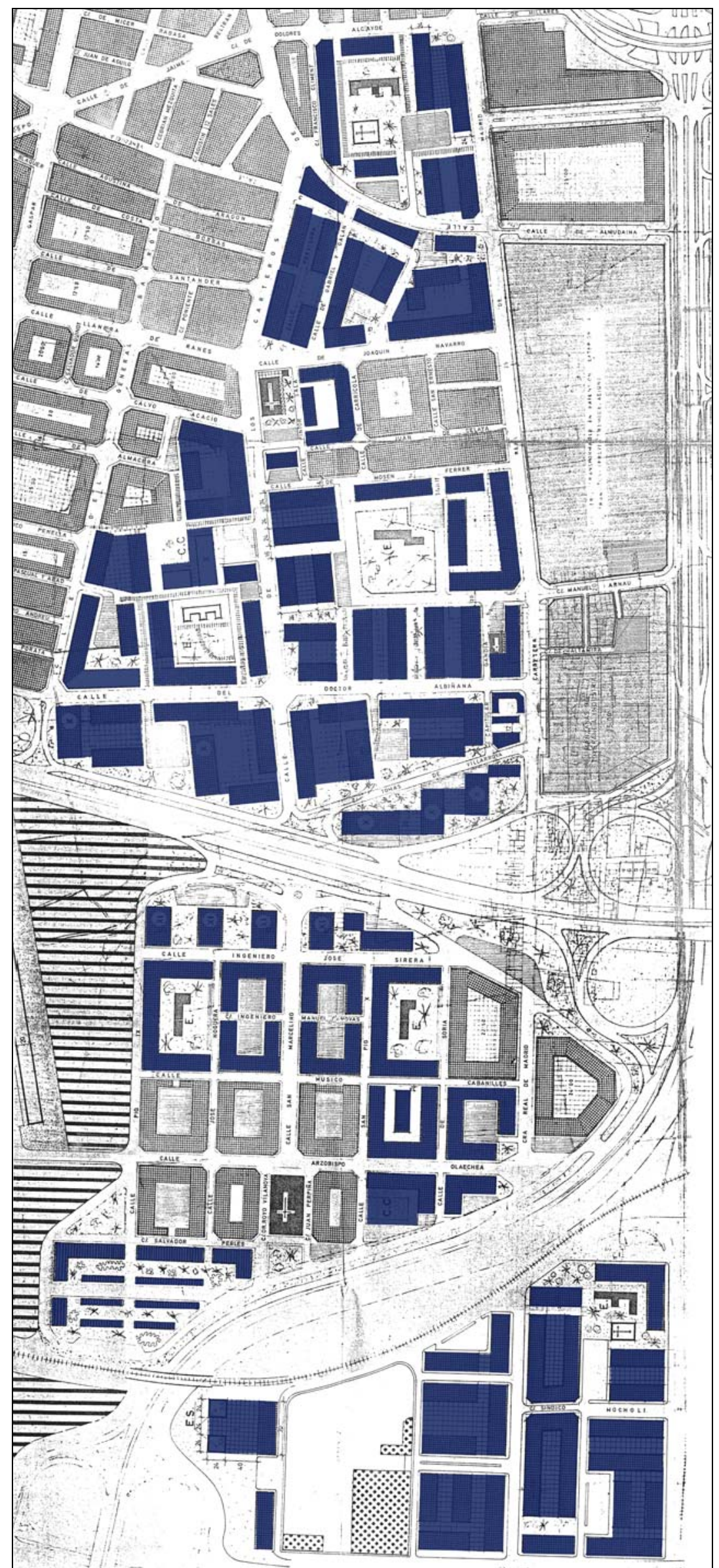

Plan Parcial 3. Edificación en planta baja. Zona sureste (Elaboración propia sobre plano de alineaciones del plan) 
Plan Parcial 3. Grado de realización. Zona sureste (Elaboración propia sobre plano de alineaciones del plan)

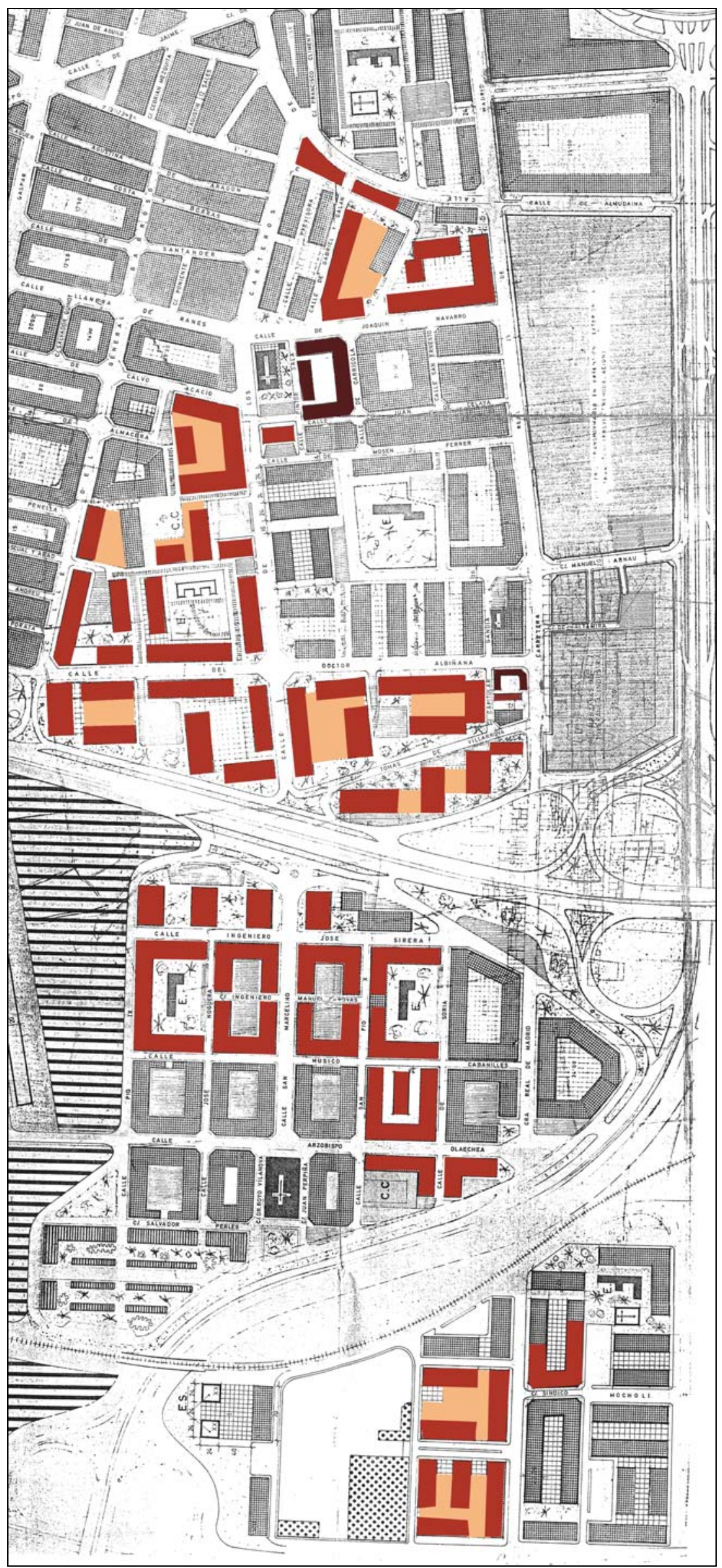




\section{Grado de realización}

La superficie global de las zonas de edificación abierta realizadas con arreglo al Plano Parcial 3 es aproximadamente de la mitad de la prevista en el mismo.

En la zona de la Cruz Cubierta, la zona no realizada es la correspondiente al recinto del Parque de Artillería del Ejército, que ocupa todo el sector central de la misma y para la que el Plan general de 1988 no realiza ninguna propuesta de ordenación nueva.

En la zona de San Marcelino, la extensión realizada es la situada al norte del barrio, entre éste y la Ronda Exterior, y una parte de la ampliación por el este.

Por último, en la Ciudad del Aprendiz de se realizaron únicamente dos manzanas y un fragmento de una tercera.

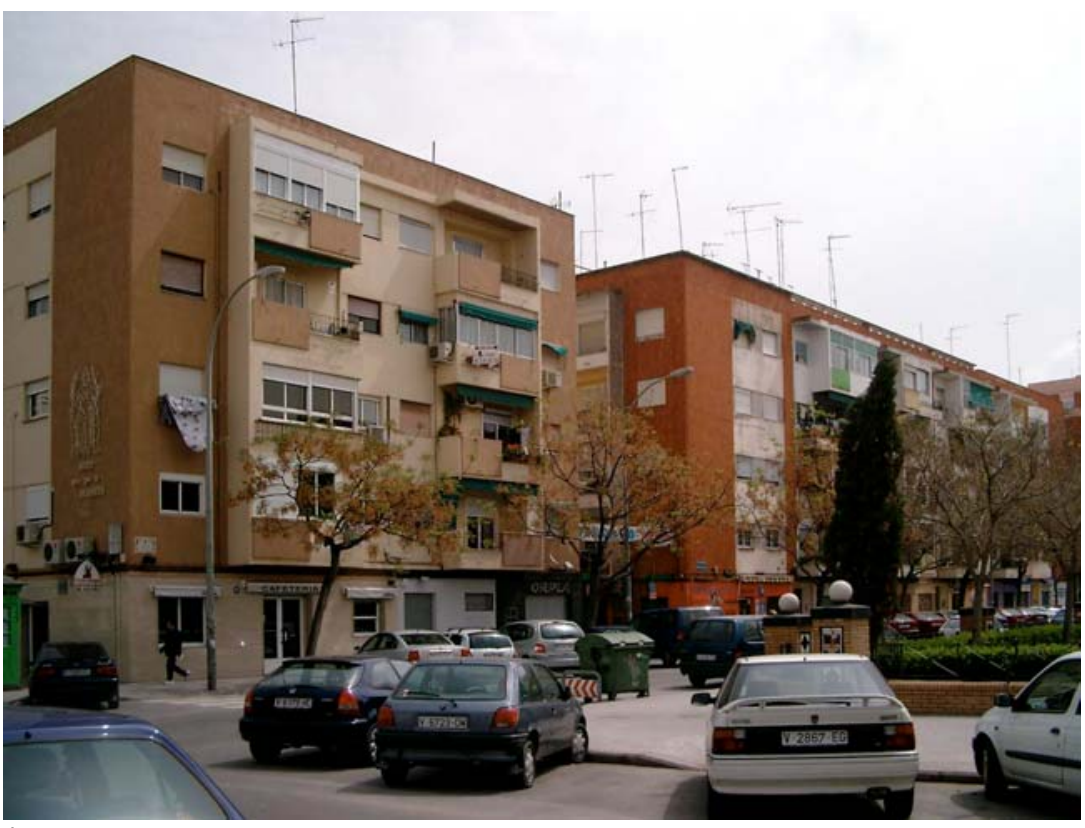

1

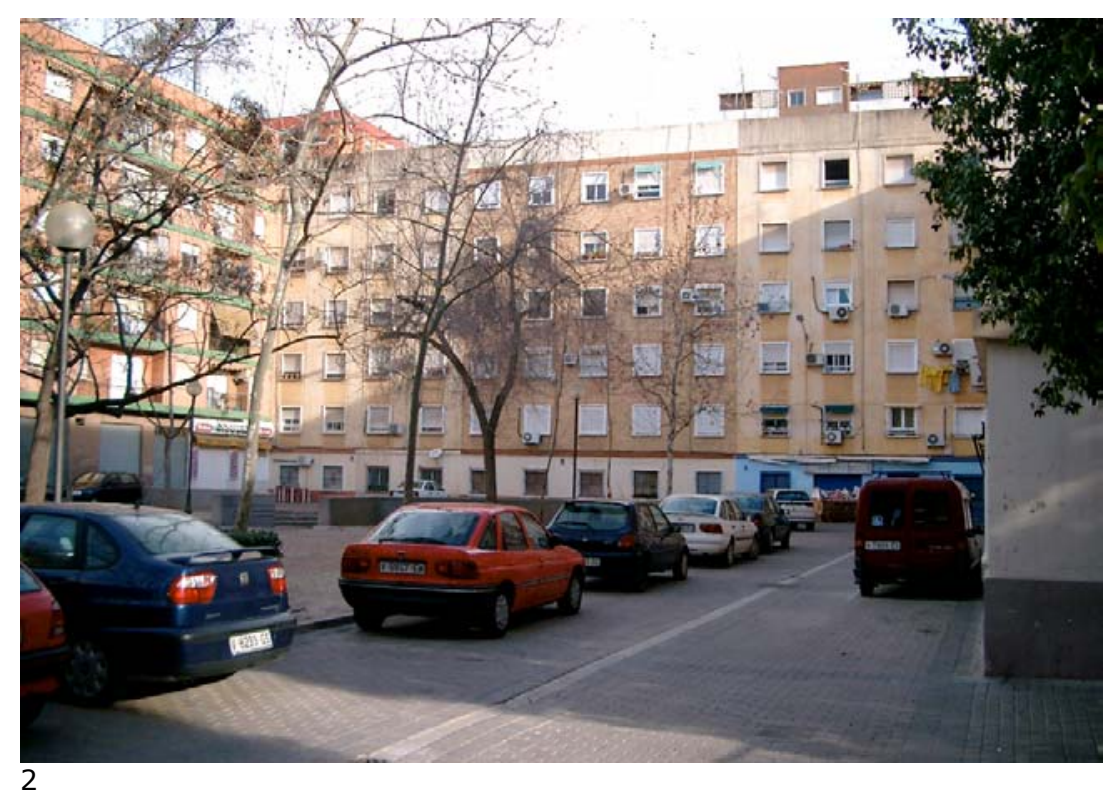

1. Grupo Virgen de la Vallvanera.

2. Plaza Monseñor Oscar A. Romero. Interior de manzana abierta de extensión de San Marcelino. 


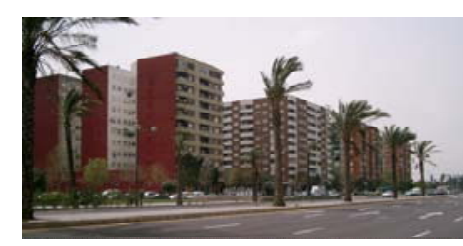

1
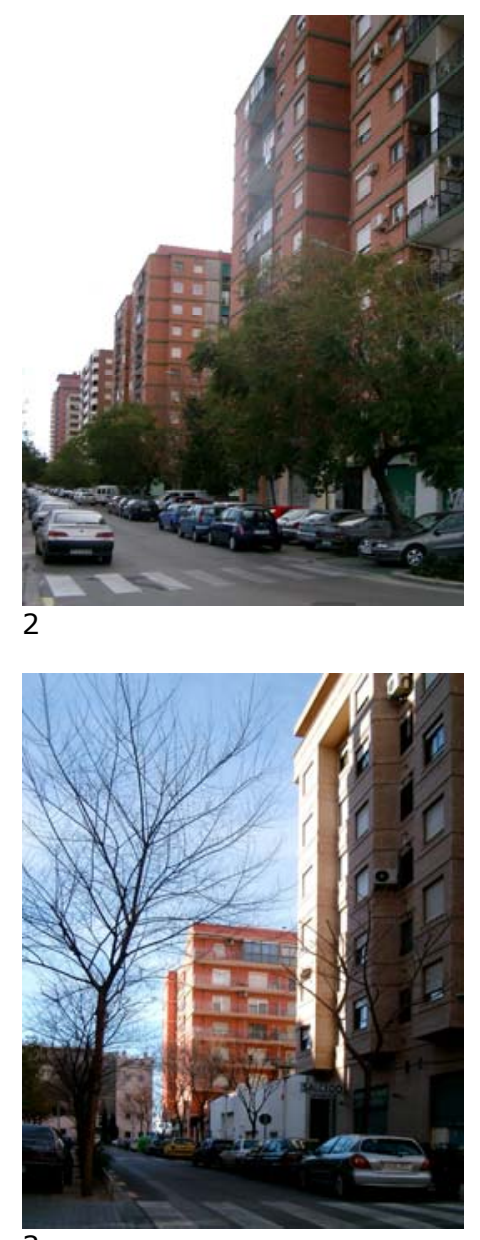

3
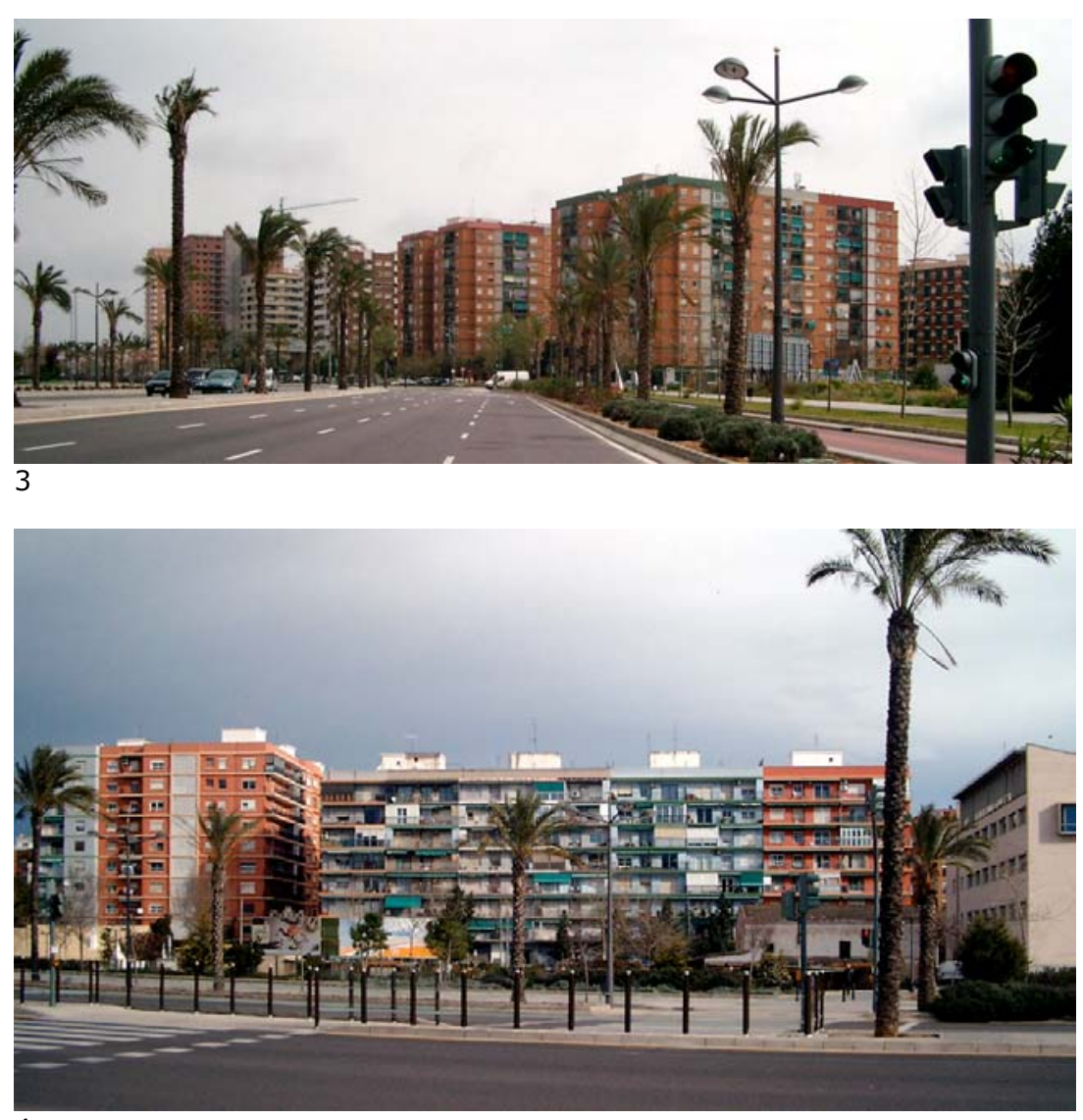

4
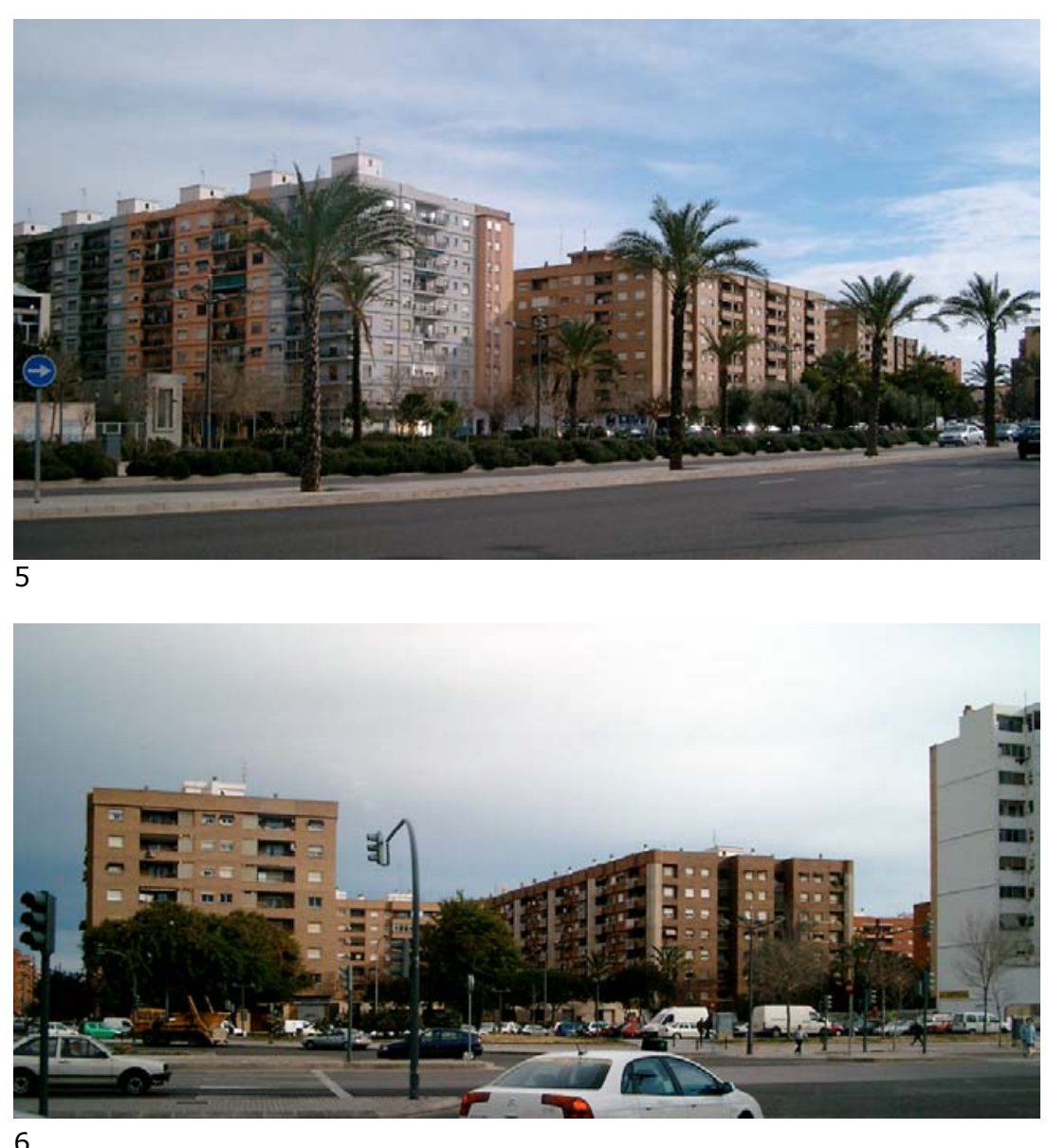

6 
En las zonas no realizadas de San Marcelino y Ciudad del Aprendiz, el Plan General de 1988 prevé también bloques de edificación abierta, aunque con un diseño diferente al del Plan Parcial 3.

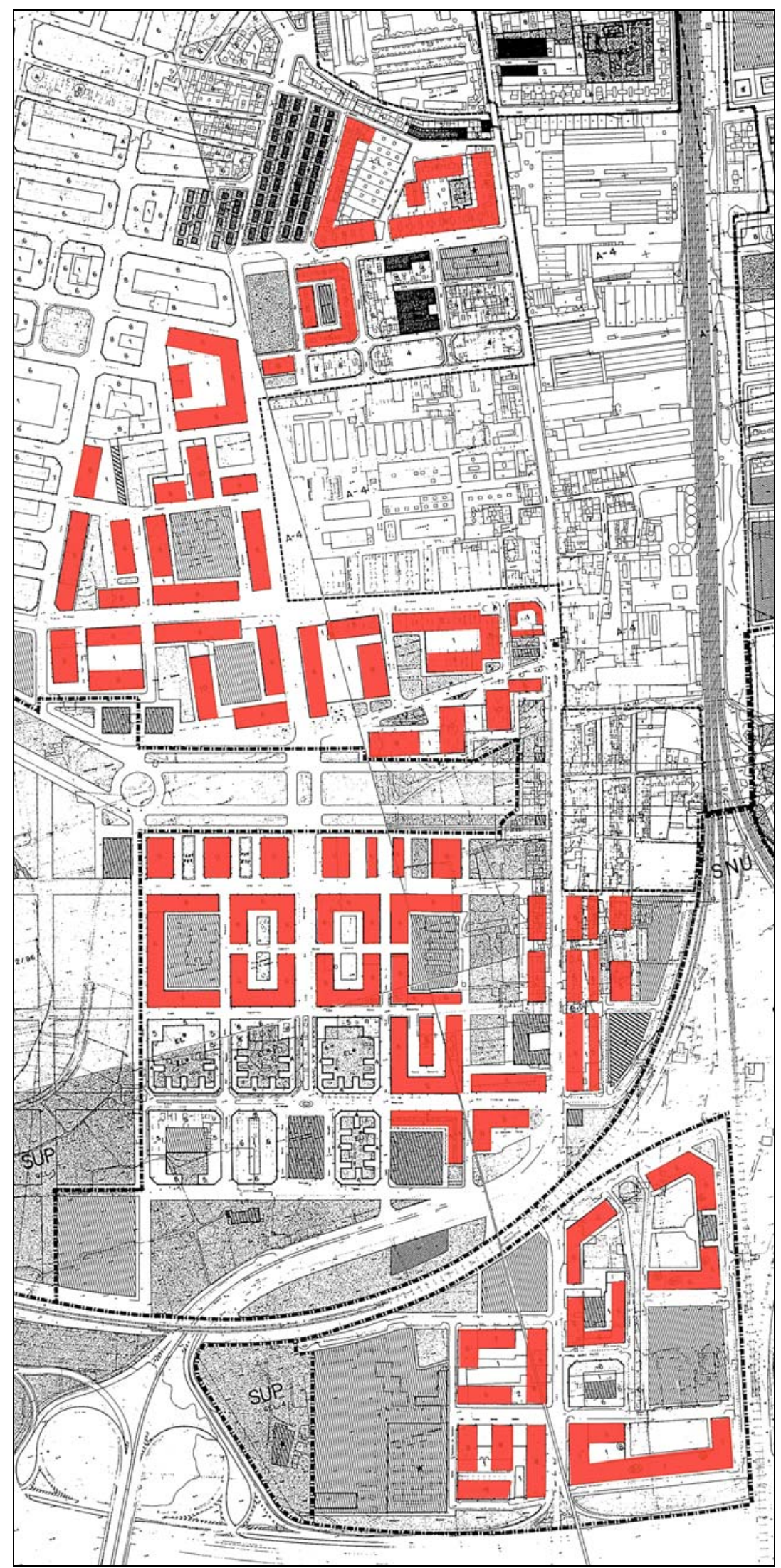

Zona sureste del PP 3. PGOU Valencia, 1988. (Elaboración propia. Color sobre planos de estructura urbanística del Plan) 


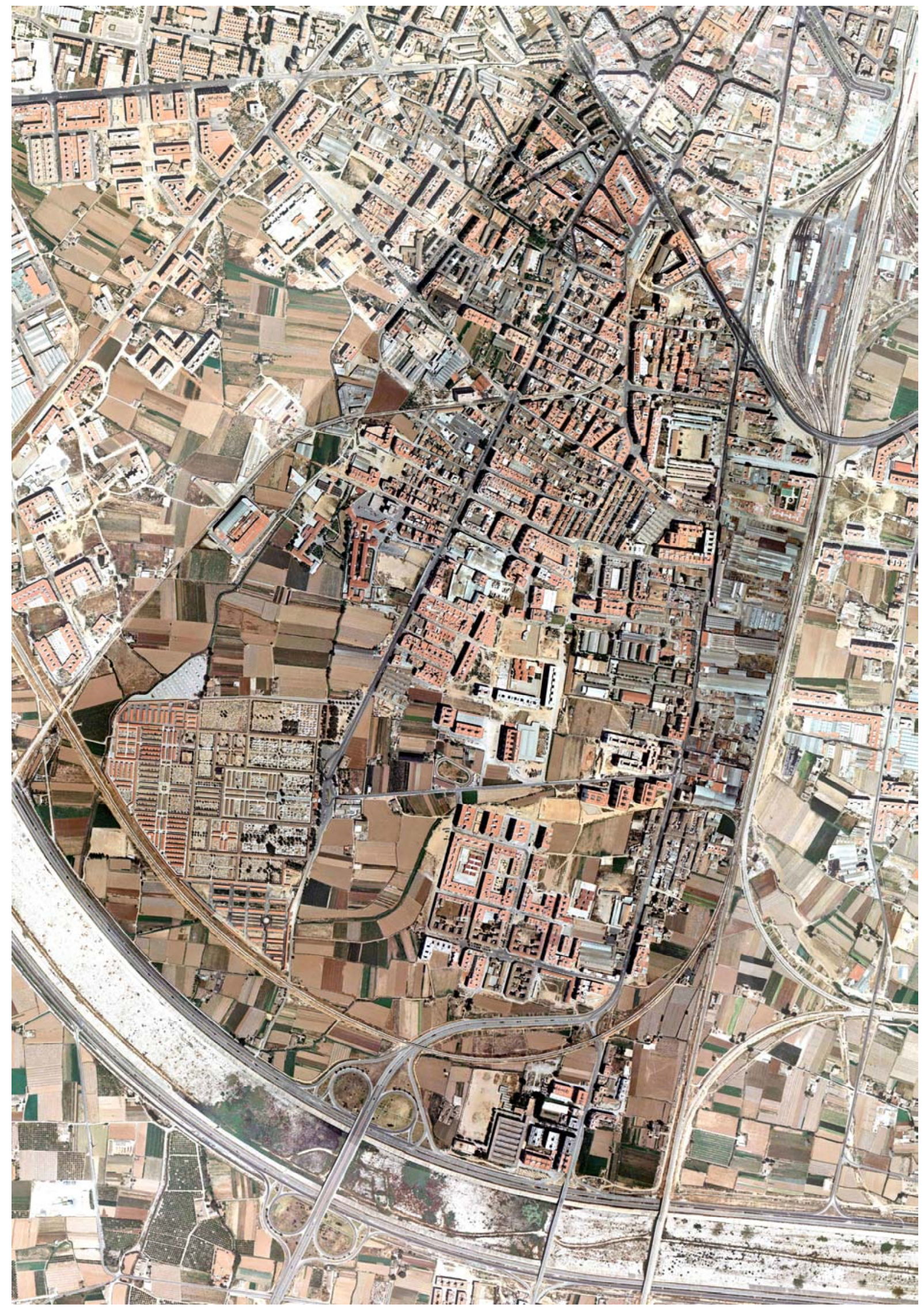

Zona del Plan Parcial 3. Fotografía aérea, 1980. 


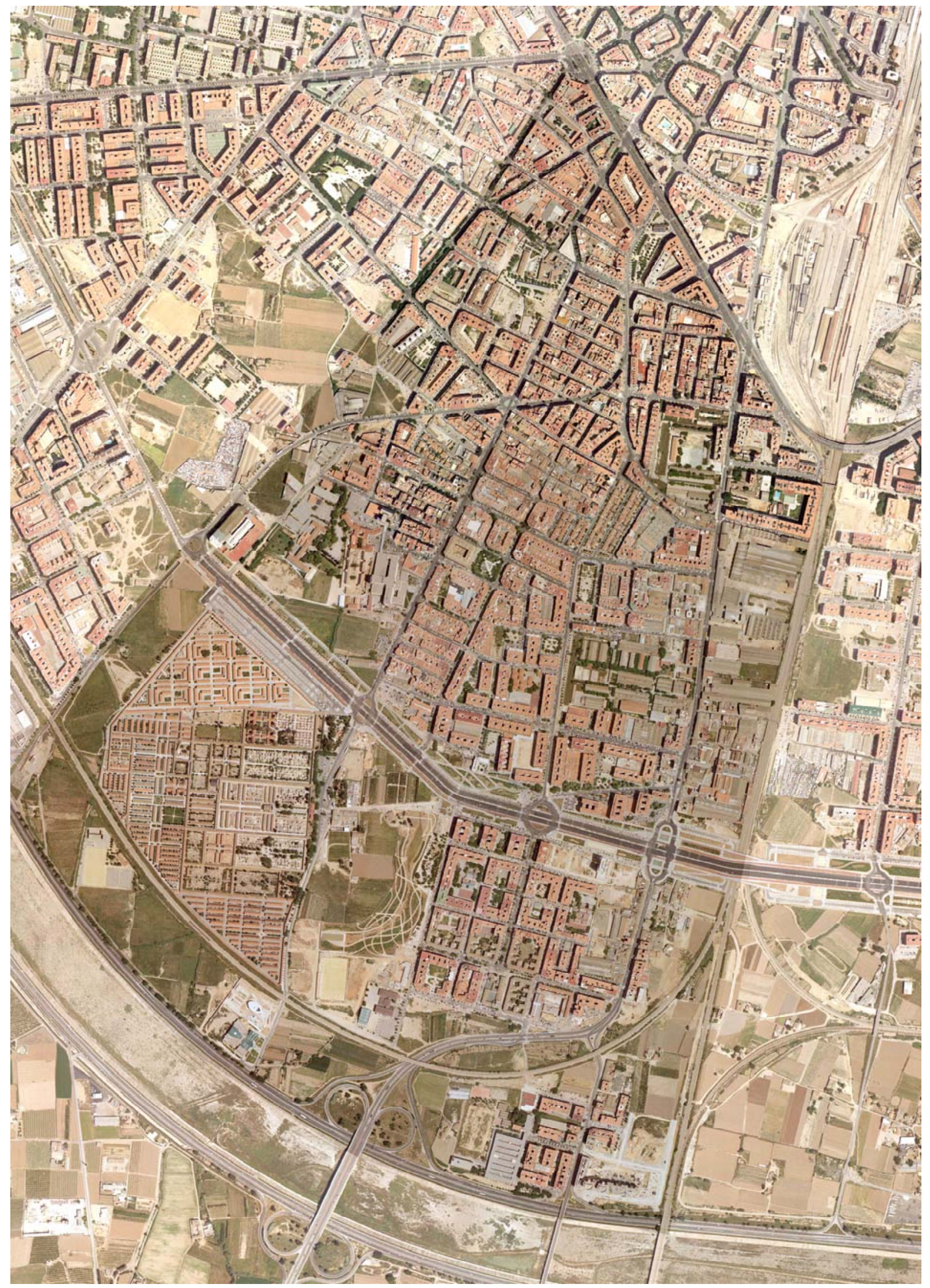

Zona del Plan Parcial 3.Ortofoto 2002 (AUMSA). 


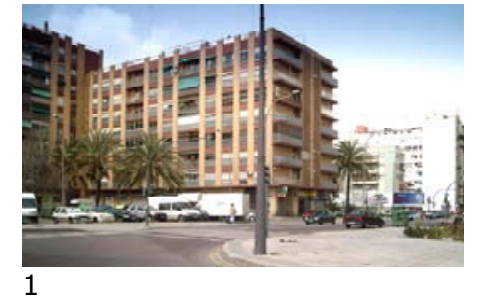

1

Por otra parte, algunos espacios previstos en el Plano Parcial 3 como bolsas de aparcamiento al final de ramales sin salida han servido finalmente para crear plazas ajardinadas, como la de Holanda o la del Escultor Frechina.

En el frente al Bulevar Sur, eje viario que coincide aproximadamente con la Ronda Exterior prevista en el Plan General de 1966, hay perspectiva suficiente, debido a su amplitud, para apreciar la composición de volúmenes global de los bloques profundos dispuestos sobre una planta baja comercial. En cambio, en las calles más interiores, la alineación con las mismas de los bloques hace que el paisaje urbano no resulte muy diferente del que se obtendría a partir de un sistema de manzanas cerradas.
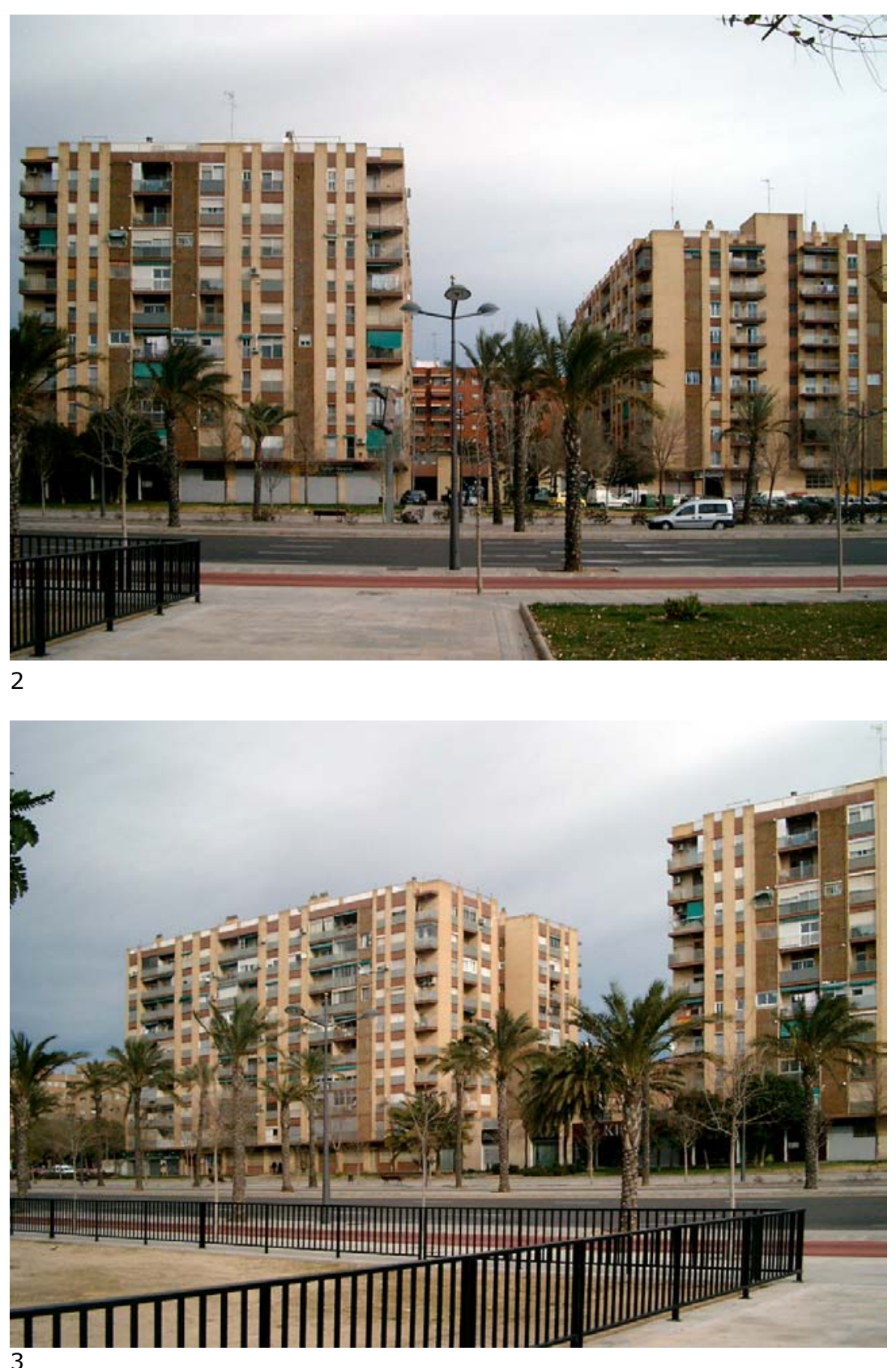
tramo entre la calle Carteros y San Vicente del Bulevar Sur. 

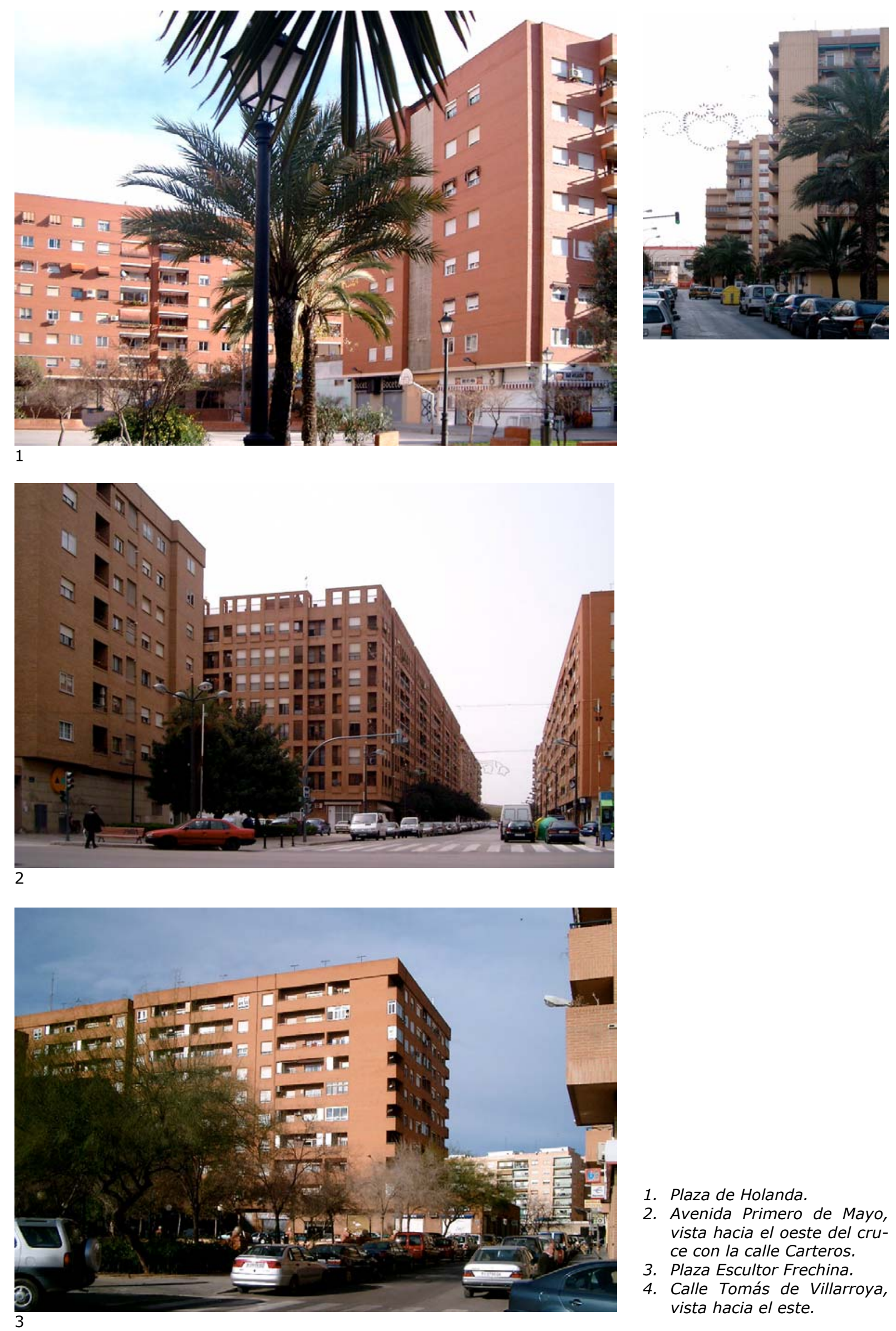

1. Plaza de Holanda.

2. Avenida Primero de Mayo vista hacia el oeste del cruce con la calle Carteros.

3. Plaza Escultor Frechina.

4. Calle Tomás de Villarroya, vista hacia el este. 


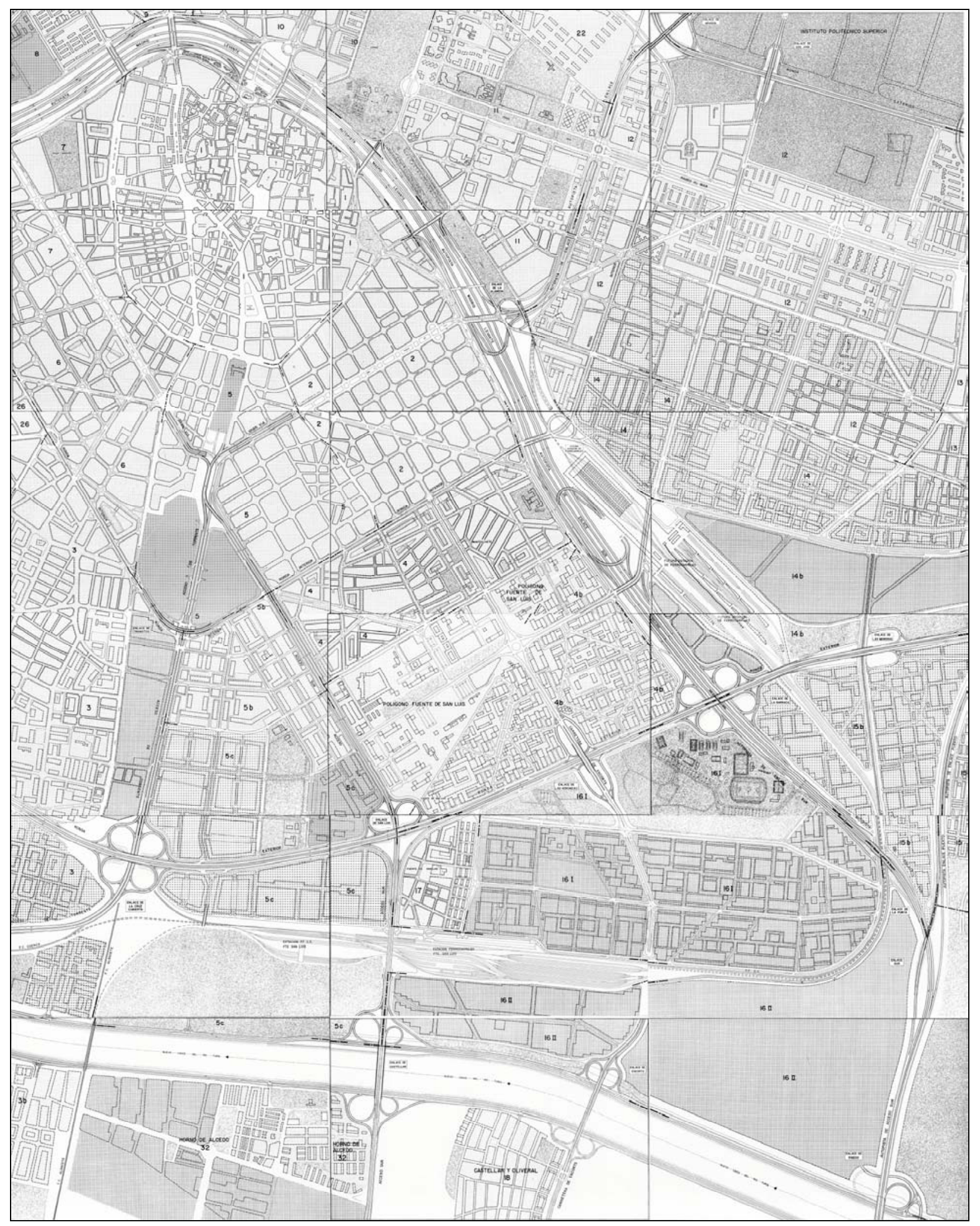

Valencia. Zona sureste: Planes

Parciales no 5-B, 5-C, 4B-16I y

Polígono Fuente de San Luís

(Montaje de hojas del Informe

PREVASA). 


\subsection{LA EDIFICACIÓN ABIERTA EN EL SECTOR SURESTE DE VALENCIA, 1966-1988.}

Las áreas residenciales de edificación abierta proyectadas en los planes parciales que, con el criterio fijado al principio del presente trabajo, hemos englobado en el sector sureste de Valencia están todas comprendidas entre las vías denominadas Ronda Interior y Ronda Exterior en el Plan General de 1966.

Dos de los planes, el Plan Parcial 5-B y el 4b-16I, abarcan además sendas áreas no residenciales que se extienden más allá de los límites marcados por las vías mencionadas. Estas áreas son, en el Plan Parcial 5-b, los terrenos de la Estación Central de Ferrocarriles, y en el Plan Parcial 4b-16I los terrenos calificados como deportivo-dotacionales situados fuera de la Ronda Exterior.

El Plan Parcial del Polígono de la Fuente de San Luís, aunque forma parte a efectos administrativos del Plan Parcial 4, no es un plan municipal, sino que está promovido por la Gerencia de Urbanización del Ministerio de la Vivienda. El resto del área comprendida en el Plan Parcial 4 es la correspondiente al tejido de manzanas de ensanche de Monteolivete. Esta zona, que es la única con edificación preexistente en el sector, queda fuera de nuestro estudio, por lo que todos los planes parciales de este sector se desarrollan en suelo vacante, libre de edificaciones previas.

El plano de conjunto del sector sureste que resulta del montaje de hojas del Informe PREVASA permite observar que la delimitación de planes guarda coherencia con la estructura viaria principal del sector, ya que los ejes de la Ronda Exterior o del nuevo Acceso Sur son los que constituyen la línea de separación entre planes.

La única delimitación cuestionable es, tal vez, la que resulta de la vía diagonal que separa el Polígono de Fuente de San Luís del Plan Parcial 4-b, ya que dicha vía es un eje secundario, que no tiene continuidad ni conexiones en sus extremos con los nudos de enlace principales.

El montaje de hojas del Informe PREVASA permite constatar, además, que las zonas residenciales de los planes 5 -b y 5 -c tienen un diseño unitario, por lo que en realidad pueden considerarse como partes de un único plan, y así las analizaremos.

En el plano conjunto del sector podemos ver también la ordenación prevista para la expansión hacia el este del antiguo poblado de la Fonteta de San Luís, correspondiente al Plan Parcial 17. Esta ordenación, de concepción muy simplista, consta de una serie uniforme de bloques que ocupan la franja intermedia entre el poblado y la zona industrial adyacente.

La comparación del Informe PREVASA con el Plan General de 1988, aparte de proporcionar una idea general del grado de realización de la edificación abierta prevista en el Plan General de 1966, nos permite, si comparamos el viario, observar que los ejes principales, aunque con distintos diseños de su sección y de los nudos de enlace, siguen siendo los mismos. Así, por ejemplo, el Bulevar Sur, recientemente realizado, coincide, con alguna modificación de trazado, con el de la Ronda Exterior del Plan de 1966.

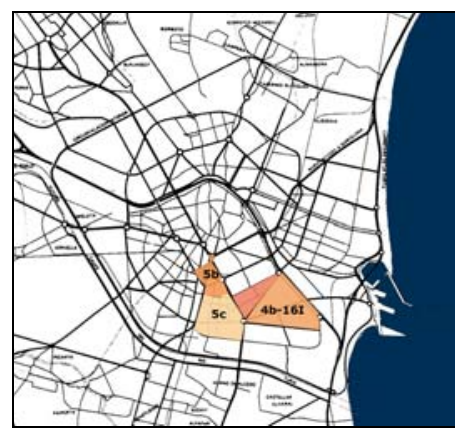

Planes Parciales del sector sureste. Localización. 


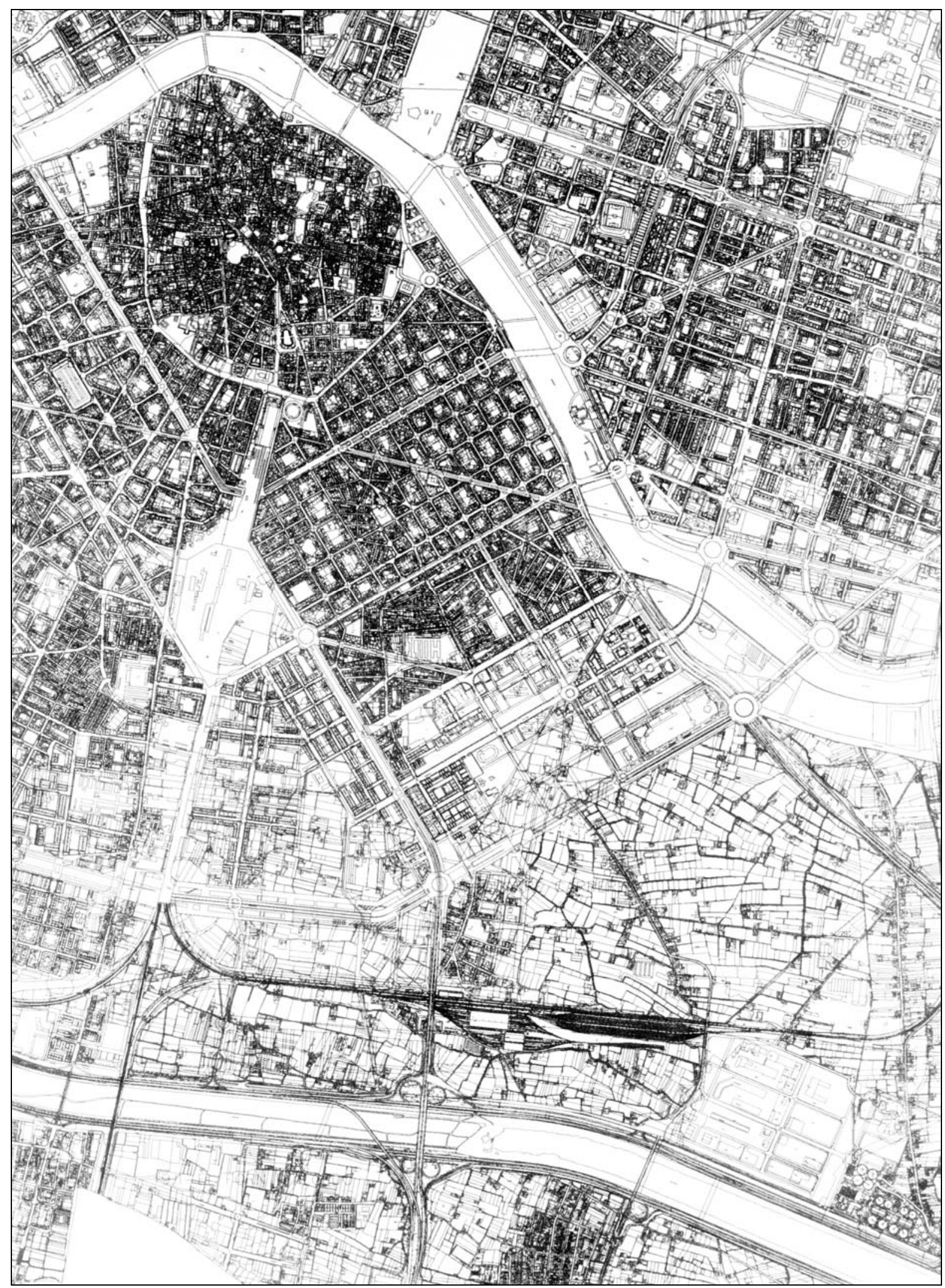

Valencia. Zona sureste. Cartografía Municipal, 2004. 
Igual que hemos hecho para los demás sectores de la ciudad, hemos representado en el Diagrama III.4 la superficie aproximada de cada uno de los planes parciales del sector noreste de Valencia, indicando para cada uno de ellos la superficie total y la superficie ordenada con edificación abierta, así como la parte de ésta última superficie que se edificó con arreglo a lo previsto en el plan.

El diagrama nos permite observar que la superficie de los planes parciales no es demasiado heterogénea en este sector, ya que oscila entre las 73 Ha del Plan Parcial 5-b y las 132 Ha del Plan Parcial 5-c.

La superficie correspondiente al sector $16-\mathrm{I}$, que se tramitó conjuntamente con el 4-b, no se recoge en el diagrama, ya que dicho sector no está destinado a uso residencial.

Las superficies no ordenadas con edificación abierta son la de los terrenos de la Estación Central en el Plan Parcial 5-b, una zona industrial en el $n^{\circ} 5$-c y el ensanche de Monteolivete en el $n^{0} 4$.

El Plan Parcial 4b es el único, de todos los planes parciales municipales del periodo que estamos estudiando, en el que toda la superficie está ordenada con edificación abierta. Al mismo tiempo, es un plan que presenta un grado de ejecución casi nulo.

El grado de realización de las zonas de edificación abierta es variable. La del Polígono de Fuente de San Luís, incluida en el diagrama en el Plan Parcial 4, se ejecutó en su práctica totalidad, mientras que en los planes 5-b y 5-c el grado de realización es más bien bajo. La gran extensión del Polígono de Fuente de San Luís hace que la proporción de edificación abierta de promoción pública en este sector alcance el $24 \%$.

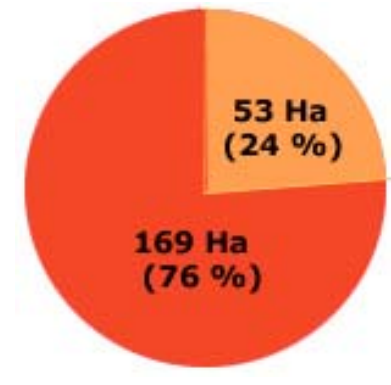

SUPERFICIE TOTAL ZONAS DE EDIFICACIÓN ABIERTA: 222 HA

PROMOCIÓN PÚBLICA

PROMOCIÓN PRIVADA

Promoción pública y privada en la edificación abierta del sector sureste de Valencia.

\section{Diagrama III. 4}

\section{Planes parciales del sector Sureste de Valencia. Cuadro de superficies}

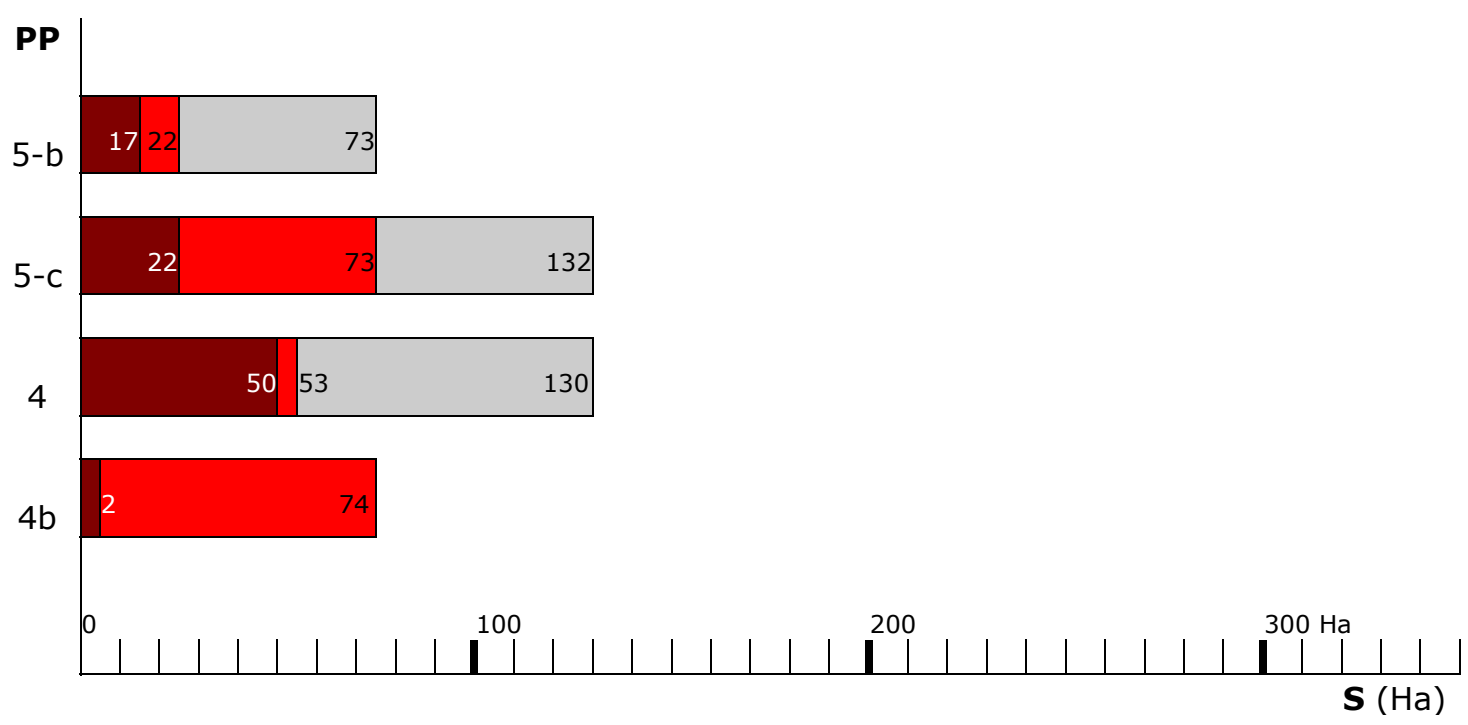

SUPERFICIE TOTAL DEL PLAN PARCIAL

SUPERFICIE ORDENADA CON EDIFICACIÓN ABIERTA

PARTE REALIZADA DE LA SUPERFICIE ORDENADA CON EDIFICACIÓN ABIERTA 
Plan Parcial 5B, 1968. Plano de alineaciones.

Plan Parcial 5C, 1973. Plano de alineaciones.
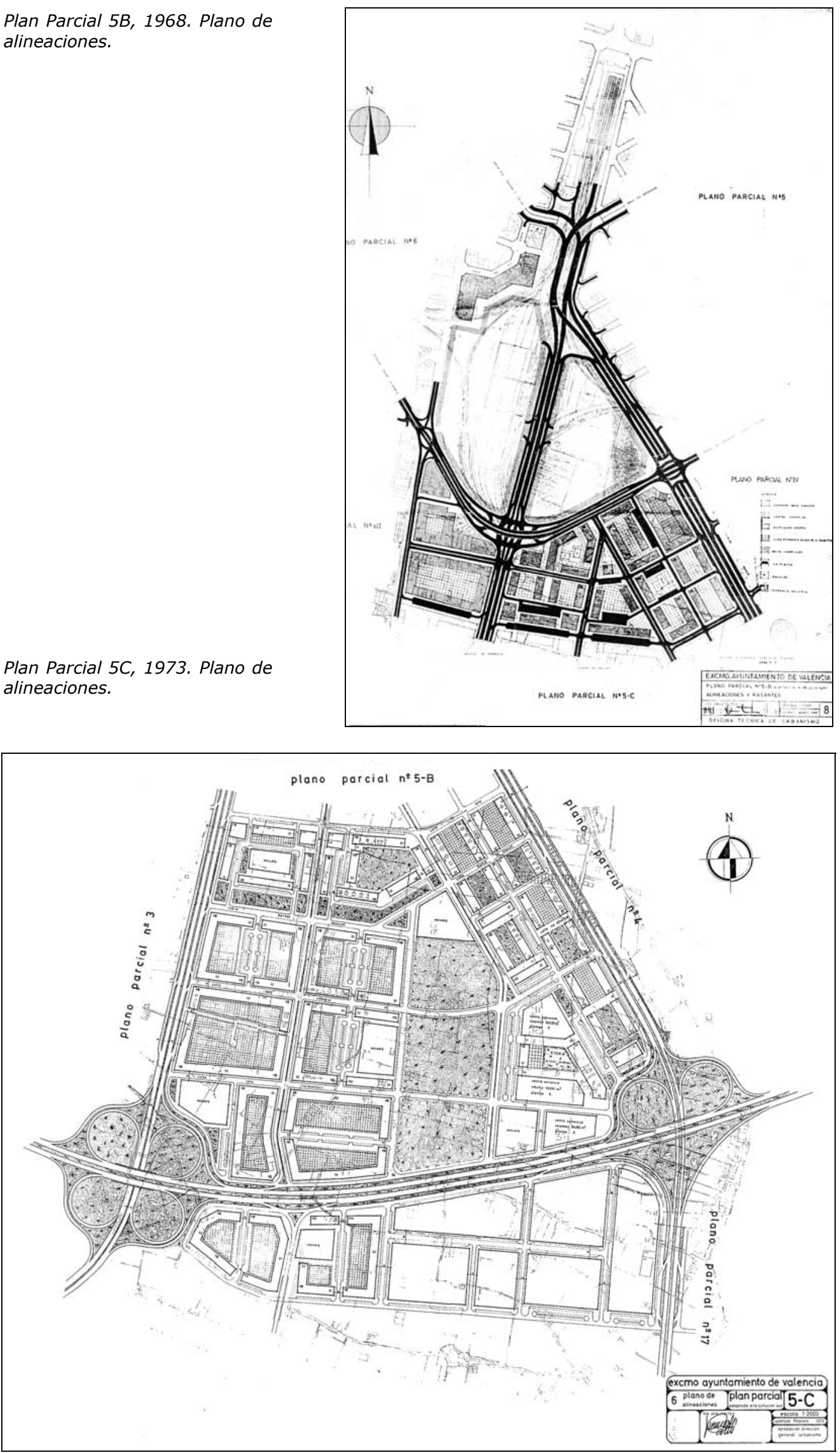


\section{MALILLA: LOS PLANES PARCIALES No 5-B Y 5-C (1967/1973)}

En la sección anterior hemos analizado las versiones de los Planes Parciales 5-B y 5-C redactadas, respectivamente, en 1963 y 1964. Estos planes fueron revisados tras la aprobación del Plan General de 1966 y del diseño viario detallado de la Oficina Regional de Carreteras.

La nueva ordenación de los terrenos comprendidos en el ámbito de estos planes se redacta entre 1967 y 1968. La aprobación definitiva del Plan Parcial 5-B se produce en $1969^{1}$, mientras que la del Plan Parcial 5-C se retrasará hasta 1976, tras redactarse otra versión del mismo en 1973.

El Plan Parcial 5-B, en la versión de 1967, excluye de la ordenación los terrenos de la Estación central de RENFE, calificados como Centro Comercial en el Plan General y para los cuales la versión del plan de 1963, como hemos visto en la sección anterior, planteaba una ordenación basada en la edificación abierta. La Memoria del plan de 1967, en cambio, señala que la importancia de estos terrenos para el futuro de Valencia hace que se reserven para un futuro y más detenido estudio.

Tanto en el Plan Parcial 5-B como en el 5-C se mantienen algunos de los bloques proyectados en las versiones anteriores de los mismos, y en particular los que forman la franja de manzanas que flanquea la salida de Alicante (actual Avenida Ausias March).

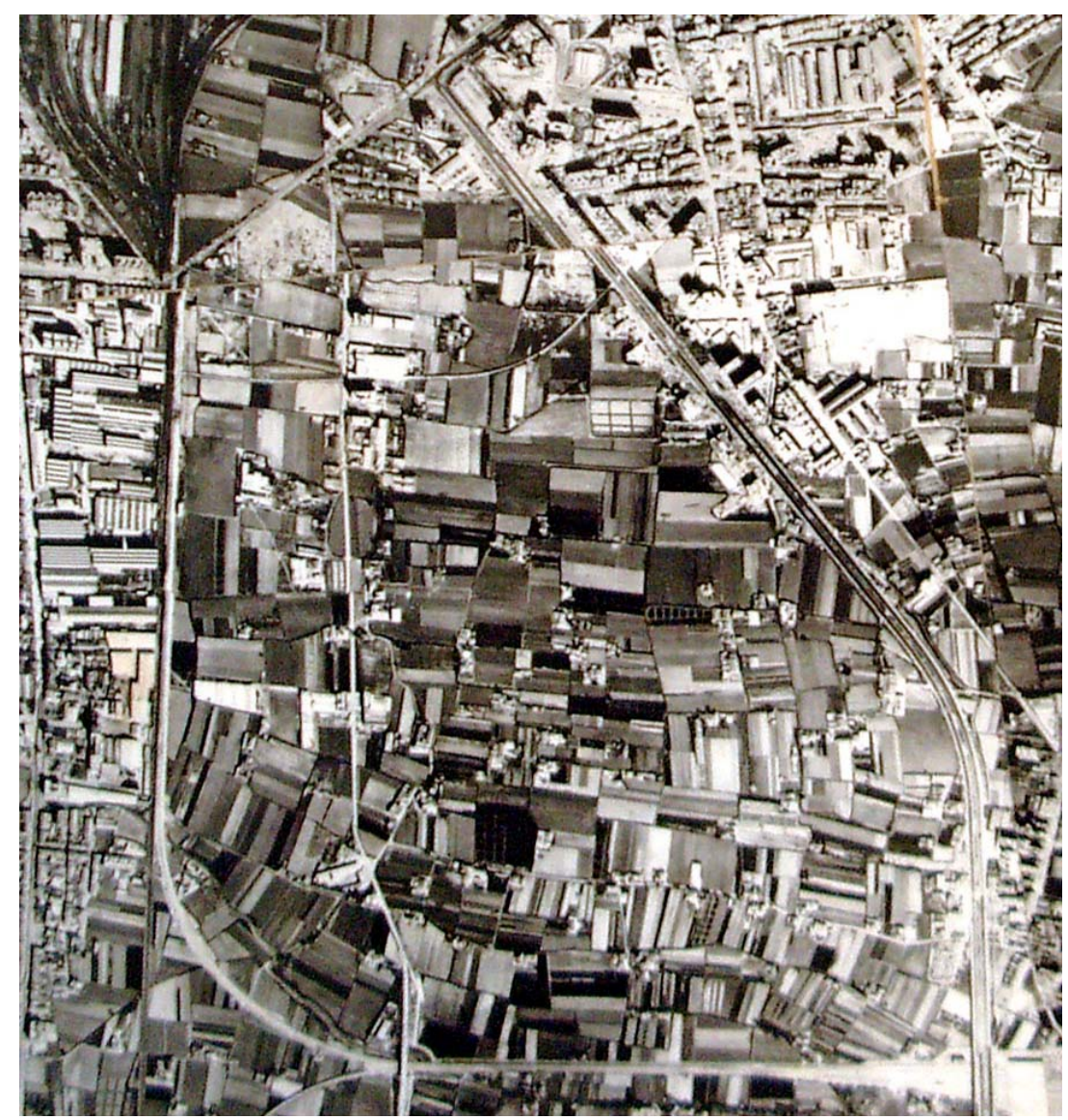

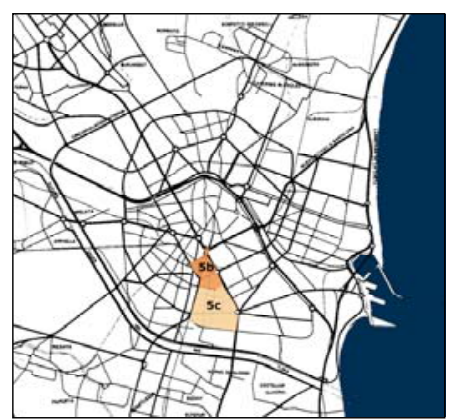

Planes Parciales 5-B y 5-C. Localización.

Zona del PP 5B/5C. Fotografía aérea, h. 1965.(ETS Arquitectura de Valencia).
1. Resolución de aprobación del Plan Parcial 5-B, Ministerio de la Vivienda, 14-10-1969. Ver Documento 5B.1. Anexo de Documentos, p. 711. 
Plan Parcial 5B. Plano de estado actual y delimitación (fragmento).
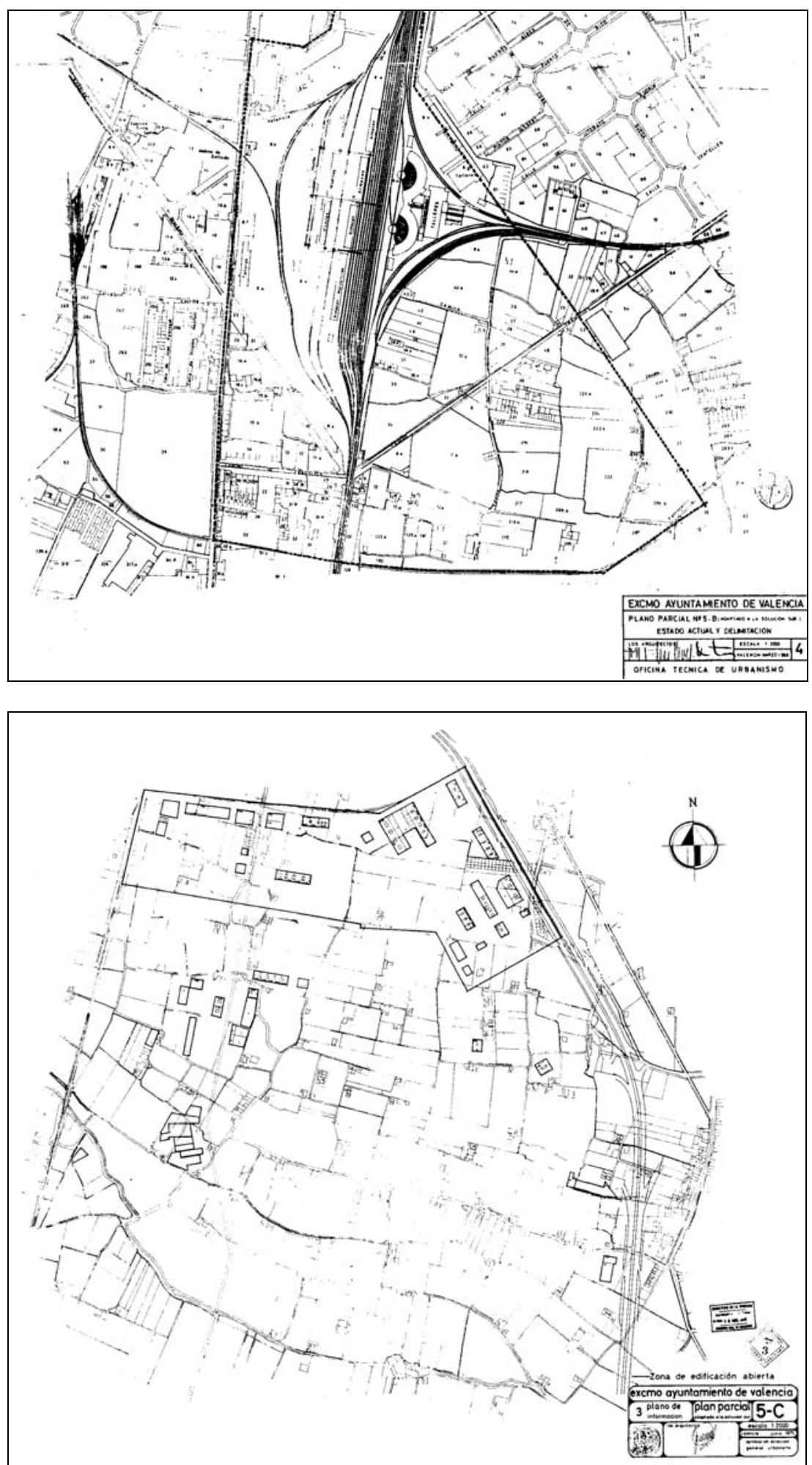

Algunos de estos bloques aparecen ya realizados de forma más o menos fragmentaria en los planos de Información de estos planes parciales.

Tanto en las versiones anteriores al Plan General de 1966 como en las posteriores, el tipo edificatorio básico - y único- de los Planes Parciales 5-B y 5-C es el bloque profundo, de cinco crujías y con patios interiores. En algunos casos, los bloques se agrupan de 
dos en dos sobre una planta baja comercial que los envuelve, formando manzanas mixtas, y en otros aparecen en forma de elementos aislados. Los bloques se reparten en dos zonas, una calificada como Edificación Abierta Alta en la que los bloques son por lo general lineales y otra de Tolerancia Industrial, con manzanas más grandes y bloques alineados con el perímetro.

A diferencia de lo que ocurrió con el Plan Parcial 5-B, la tramitación del Plan Parcial 5-C resultó muy larga y complicada. La versión de 1967 de este plan es la que figura en los planos del Informe Prevasa, en cuyo listado aparece como plan en tramitación.

La versión de 1967 del Plan Parcial 5-B fue modificada en una nueva redacción del mismo realizada en 1973. Las diferencias entre ambas versiones no son muy grandes, y afectan sobre todo a la ordenación del centro comercial previsto en la zona sureste, junto al enlace viario de San Luís entre la Ronda Exterior y el nuevo acceso Sur.

Las modificaciones exigidas por el Ministerio de la Vivienda para la aprobación del plan motivaron la redacción de una versión modificada del mismo, fechada en 1975. Estas modificaciones consistían, en primer lugar, en la supresión de dos calles en sentido este-oeste que partían en tres la extensa zona verde central. Además, se eliminaba la edificación residencial en una manzana adyacente a la parcela escolar situada al norte de la zona verde, sustituyéndola por un mercado y un edificio para aparcamiento, a fin de cumplir la exigencia ministerial de obtener una plaza por vivienda.
Plan Parcial 5-C, 1967. Plano de alineaciones.

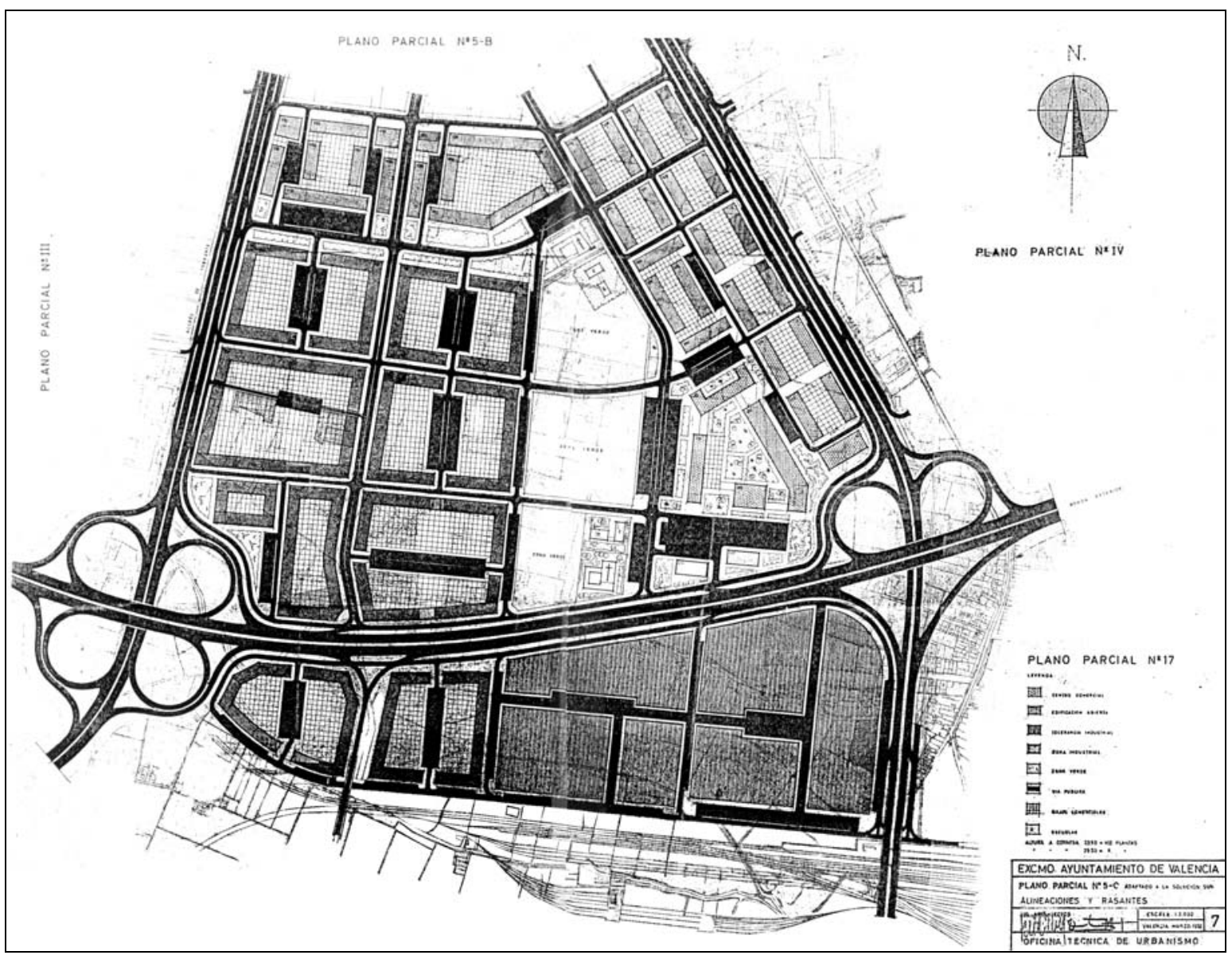




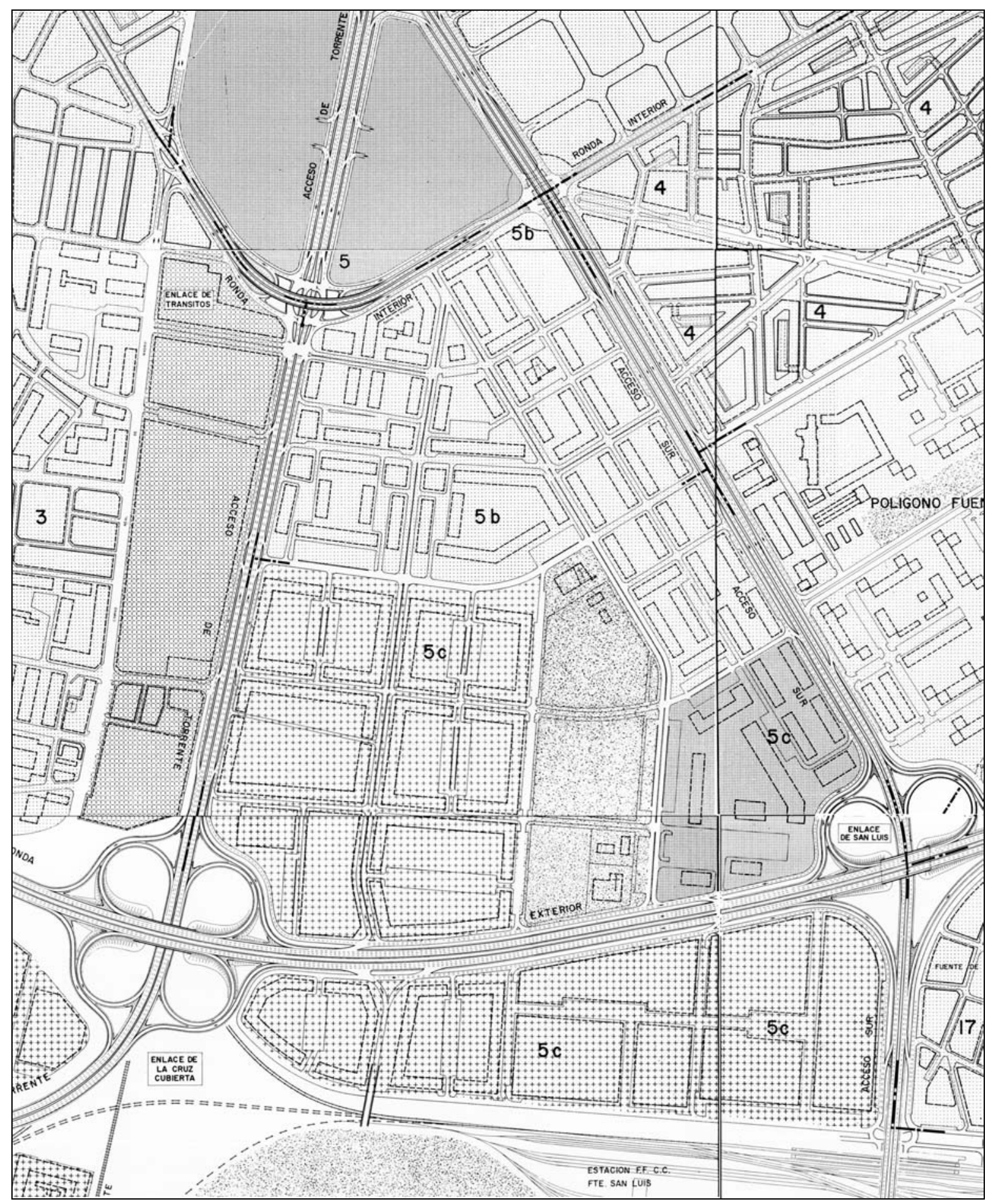

Planes Parciales 5B/5C (Montaje de hojas del Informe PREVASA).
1. Memoria Complementaria del Plan Parcial 5-C, 1975, Anexo de Documentos, p. 714 . Documento 5C.2. Informe del Arquitecto Municipal, 29-09-1974, Anexo de Documentos, p. 723.
Con ello se persigue también responder al reparo más importante planteado por la resolución ministerial de 1974, que era el de dejar en suspenso la ordenación de la zona de edificación abierta por alcanzarse en ella una edificabilidad de $5,40 \mathrm{~m} 3 / \mathrm{m} 2$, superior a la máxima permitida por el Plan General para las zonas de Edificación Abierta Alta, que era de $5 \mathrm{~m} 3 / \mathrm{m} 2$.

En el Informe del Arquitecto Municipal de 1974 y en la Memoria Complementaria de 1975 se señala que el sector suspendido de aprobación se hallaba edificado en un 80 \% con edificios acogidos a protección oficial, que se respetan en la modificación introducida en el plan. ${ }^{1}$ 
Los bloques construidos son en su mayor parte los situados junto al nuevo Acceso Sur y junto al paso elevado de la Ronda Interior, realizados en base al diseño del Plan Parcial 5-B de 1964.

En el plano que hemos elaborado para reflejar el grado de novedad de los Planes Parciales 5-B y 5-C, podemos observar que los bloques proyectados de forma diferente a las versiones previas de estos planes son, principalmente, los que forman la segunda línea de manzanas con respecto al Acceso Sur y la Ronda Interior, además de los que integran las manzanas del área calificada como zona de Tolerancia Industrial.

El Centro Comercial del Plan Parcial 5-C cambia también en la versión de 1973 de este plan, en la que se elimina parte de la edificación y el gran aparcamiento previstos para introducir en la zona una parcela escolar. Además, se renuncia a la definición de las alineaciones en varias parcelas residenciales, para las que se señalan únicamente unos volúmenes máximos edificables.
Planes Parciales 5B/5C. Grado de novedad: edificaciones diferentes a las previstas en el planeamiento anterior (Elaboración propia sobre plano de alineaciones de los planes)

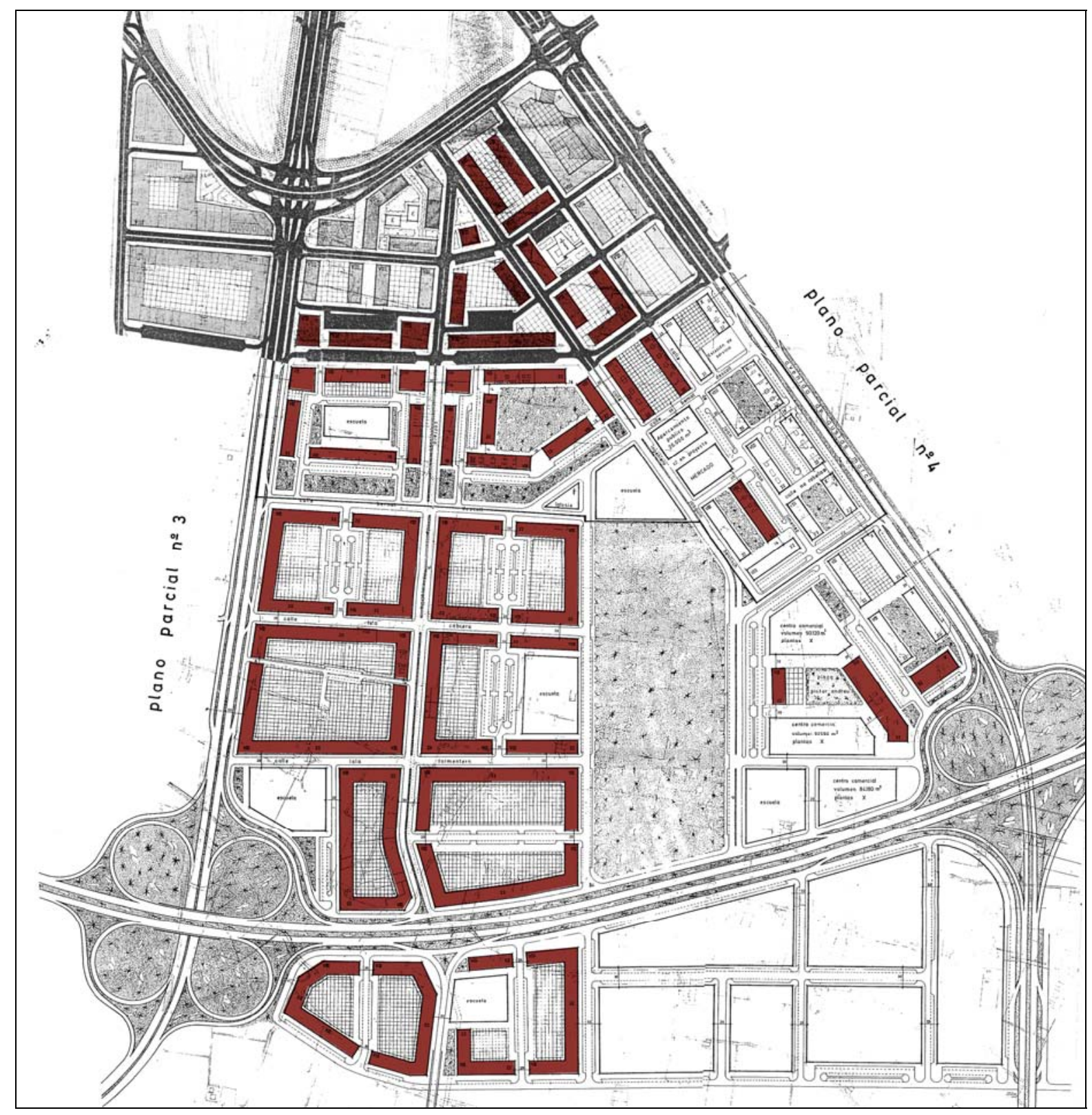


Planes Parciales 5B/5C. Trazado viario (Elaboración propia, montaje de planos de red viaria fundamental de los planes)
El trazado viario tiene continuidad en los Planes Parciales 5-B y $5-C$, lo que viene a confirmar que estos planes no son el resultado de dos ordenaciones independientes sino de una sola desglosada en dos documentos de planeamiento.

El viario proyectado es de tipo mallado, lo que resulta coherente con el tipo de edificación más frecuente, que es el de manzana mixta formada por bloques superpuestos a una planta baja comercial que los engloba.

La retícula es de menor tamaño en las manzanas de la zona de Edificación Abierta, compuestas por lo general por parejas de bloques profundos. En la zona de Tolerancia Industrial, en cambio, la retícula principal tiene el doble de tamaño, ya que la unidad de composición está formada por dos manzanas con bloques perimetrales en $U$ en cada una, separadas por un vial central de acceso y aparcamiento.

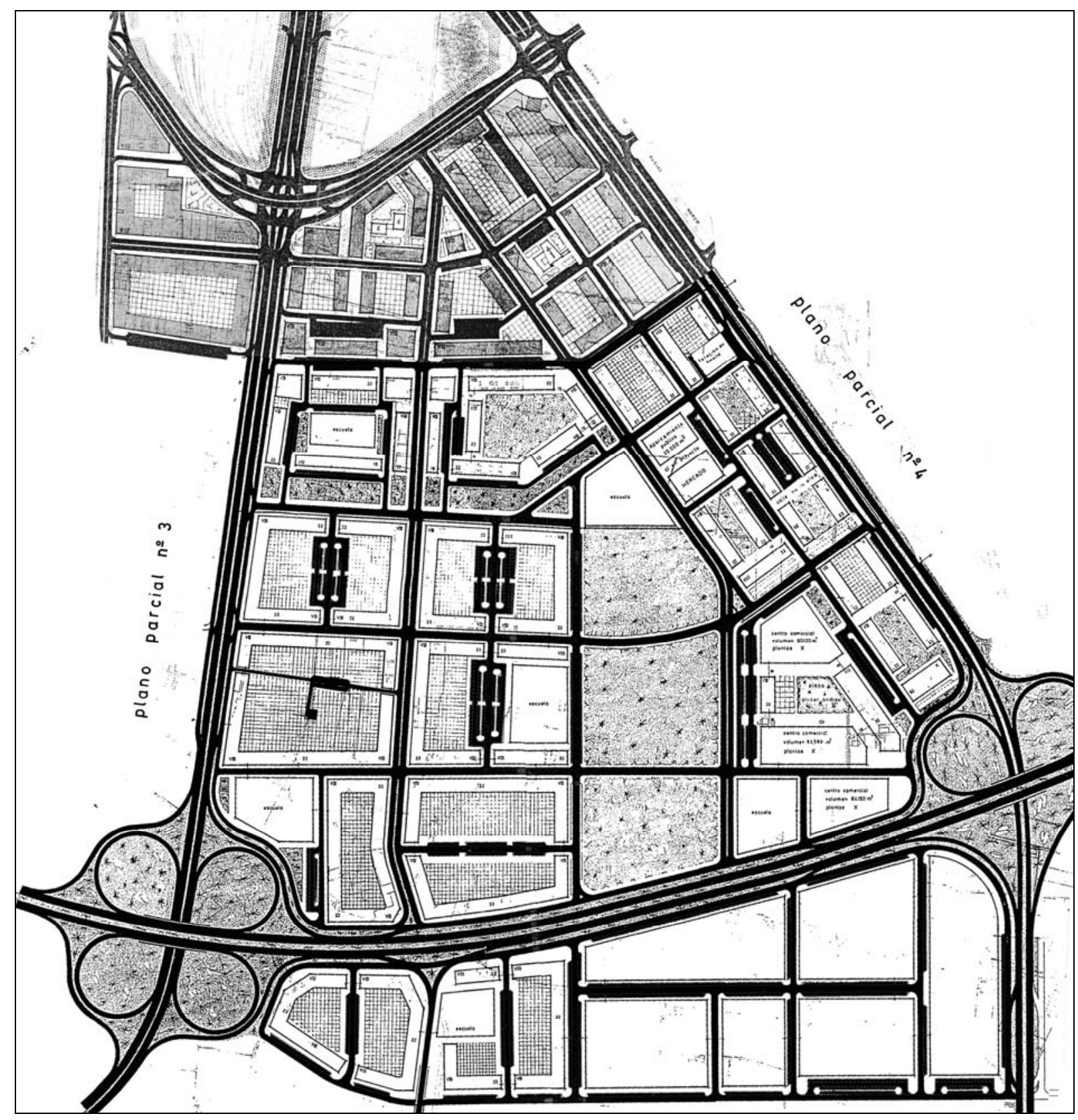


En cuanto a los equipamientos, los previstos en las versiones de 1967 son similares, e igual de escasos, en el Plan Parcial 5-B y en el $5-C$, con la única excepción de la gran zona verde que es un requisito del Plan General.

Las versiones de 1973 y 1975 del Plan Parcial 5-C, en cambio, incorporan unas mayores reservas de suelo para equipamientos, y en especial para parcelas escolares.

Así, además de las variaciones antes señaladas en relación con el Mercado, el edificio de aparcamientos y el Centro Comercial, podemos ver que el espacio interior de algunas manzanas de la zona de edificación abierta, ocupado por comerciales en la versión de 1967 , se convierte en zonas verdes o en parcelas escolares.
PP 5B/5C. Equipamientos.. (Elaboración propia sobre plano de alineaciones del plan)

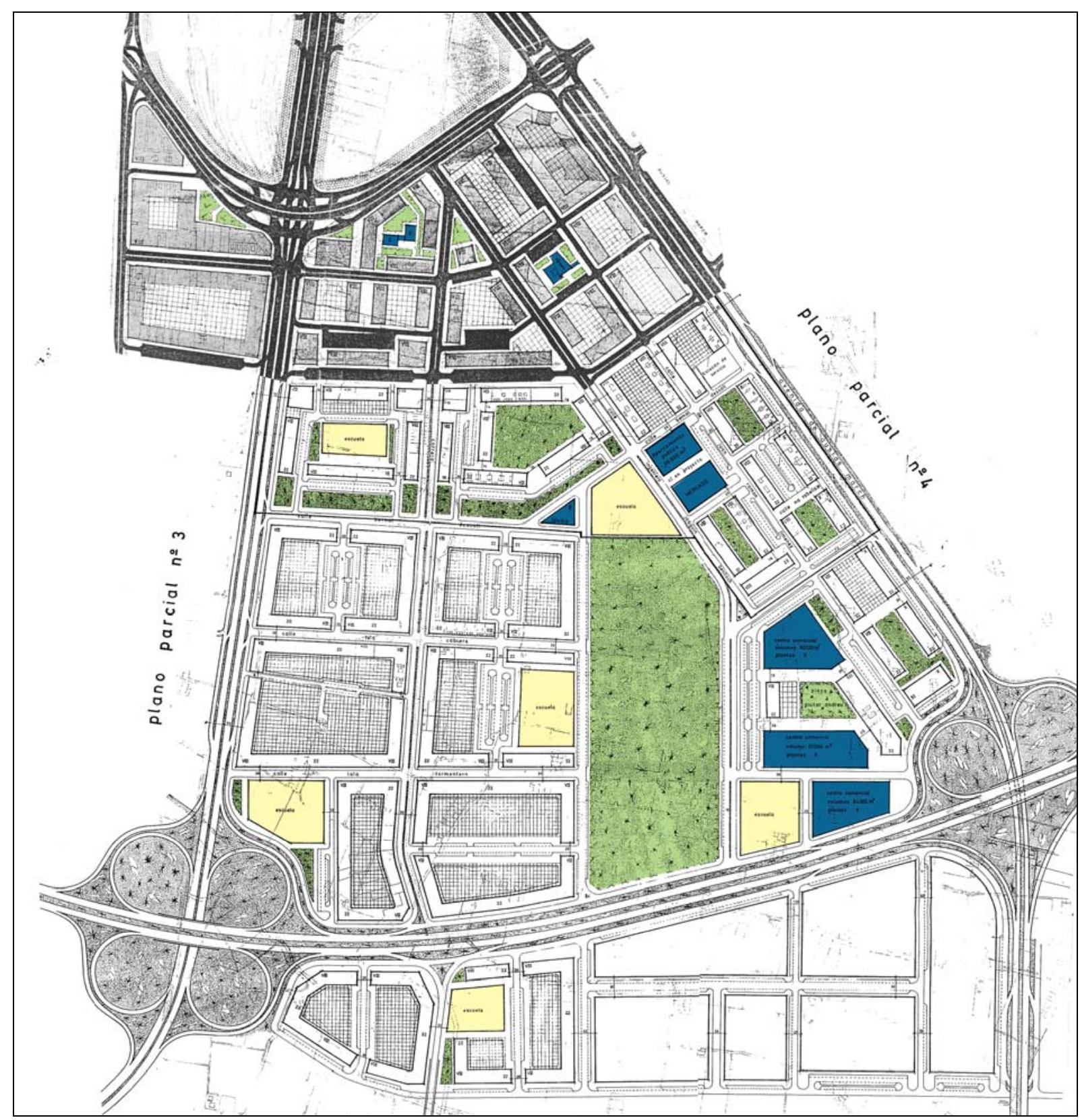




\section{Edificación}

El bloque profundo, de cinco crujías y con patios interiores, es, como hemos señalado, el único tipo de edificio que se utiliza para ordenar todo el ámbito de los Planes Parciales 5-B y 5-C.

En la franja recayente al eje viario del Nuevo Acceso Sur (actual Avenida Ausias March), calificada como Edificación Abierta, los bloques son lineales, y aparecen bien de forma aislada, con jardines intermedios, o bien unidos de dos en dos por una planta baja comercial, generando unas manzanas rectangulares de dimensiones que oscilan entre los 80-90 m. de ancho y 90-150 m. de largo.

Las manzanas mixtas adoptan formas trapezoidales más irre-

PP 5B/5C. Edificación en planta tipo. (Elaboración propia sobre plano de alineaciones del plan). gulares en la zona de edificación abierta del noroeste, limitada por la vía del ferrocarril, las calles Ingeniero Joaquín Benlloch y Bernat Descoll y la Avenida Peris y Valero.

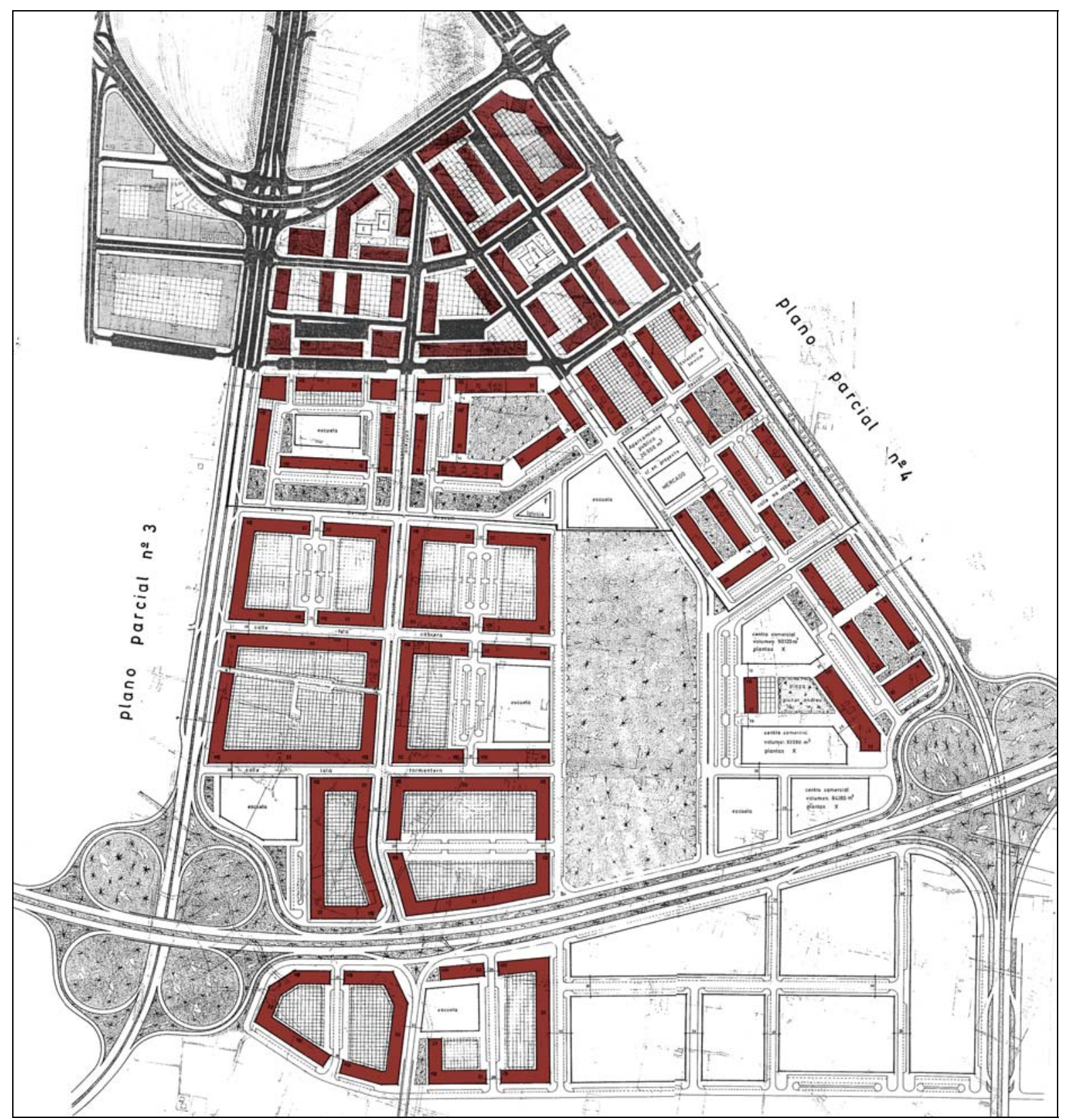


Los bloques de estas manzanas, manteniendo su condición de bloques lineales aislados, se alinean con las calles perimetrales de cada manzana, por lo que no existe una orientación homogénea de los mismos.

En la zona calificada como de Tolerancia Industrial, en cambio, los bloques ya no se proyectan como elementos lineales aislados, sino como envolvente casi continua de unas manzanas de mayor tamaño. Es el caso de la unidad compositiva tipo de esta zona, formada por dos manzanas mixtas con bloques perimetrales cuya planta en $U$ permite afirmar las esquinas, de modo que la calle intermedia entre las dos manzanas se percibe como una mera interrupción de una unidad urbana de mayor tamaño que las engloba a ambas.

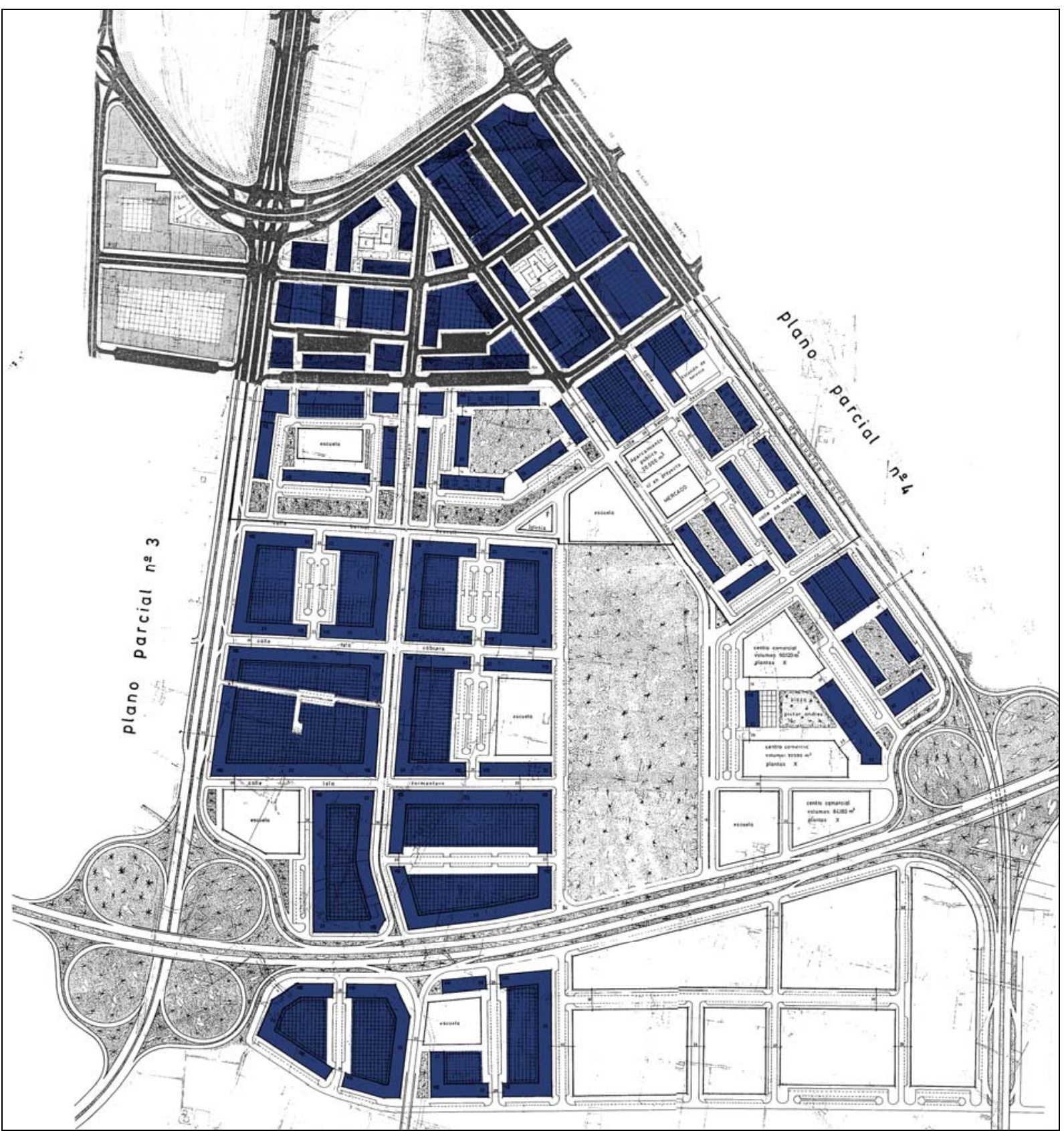

PP 5B/5C. Edificación en planta baja. (Elaboración propia sobre plano de alineaciones del plan). 
Planes Parciales 5B/5C.Grado de realización (Elaboración propia sobre montaje del plano de alineaciones de los planes)

\section{Grado de realización}

El grado de realización de la edificación abierta es muy alto en el Plan Parcial 5-B e irregular en el Plan Parcial 5-C.

Los bloques integrados en las dos hileras de manzanas paralelas a la Avenida Ausias March están construidos en su práctica totalidad de acuerdo con lo previsto en el Plan Parcial 5-C, excepto los correspondientes al Centro Comercial. En cambio, de los bloques previstos en la zona de Tolerancia Industrial están construidos únicamente los que flanquean un tramo de la Carrera de Malilla y los transversales a éstos de las calles Bernat Descoll, Isla cabrera y de parte de la calle Isla Formentera.

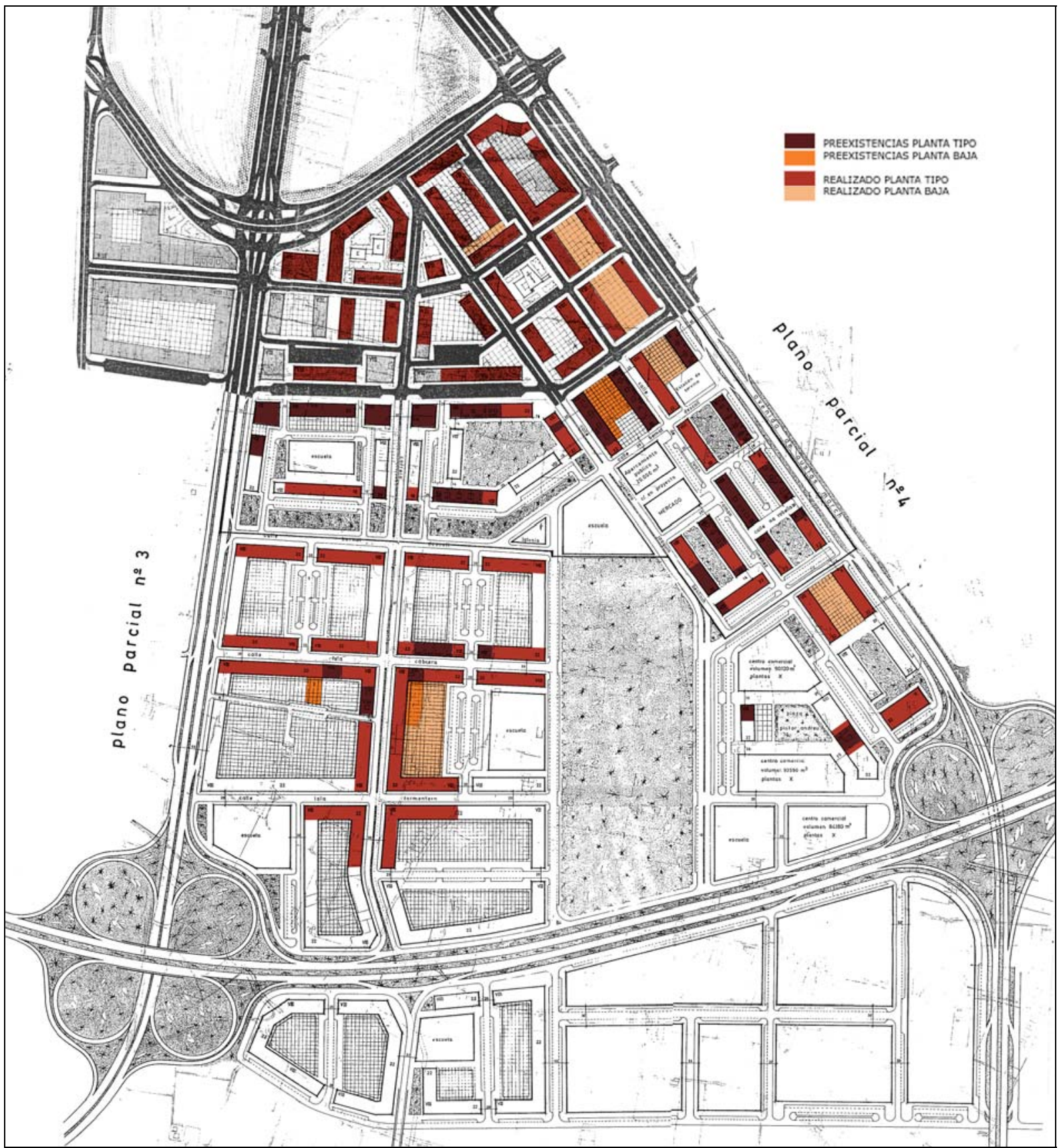


El Plan General de 1988 plantea una nueva ordenación para la zona prevista como centro comercial en el Plan Parcial 5-C, aprovechando el espacio ganado al sustituir el bucle viario previsto en el Plan General de 1966 por una rotonda.

Además, el nuevo Plan General sustituye el sistema de manzanas con bloques profundos perimetrales previsto en la zona de Tolerancia Industrial del Plan parcial 5-C por otro que conserva únicamente los bloques ya construidos e intercala entre los mismos viviendas en hilera o espacio para dotaciones y zonas verdes.

La superficie del gran parque previsto en el Plan Parcial 5-C se ve reducida en su parte sur en el Plan general de 1988, que califica esta zona, junto con la adyacente que correspondía al centro comercial, como Suelo Urbanizable Programado.
PGOU 1988 . Zona de los Planes Parciales 5B/5C (Elaboración propia. Color sobre montaje de hojas de la Serie $C$, Estructura urbanística, del PGOU).

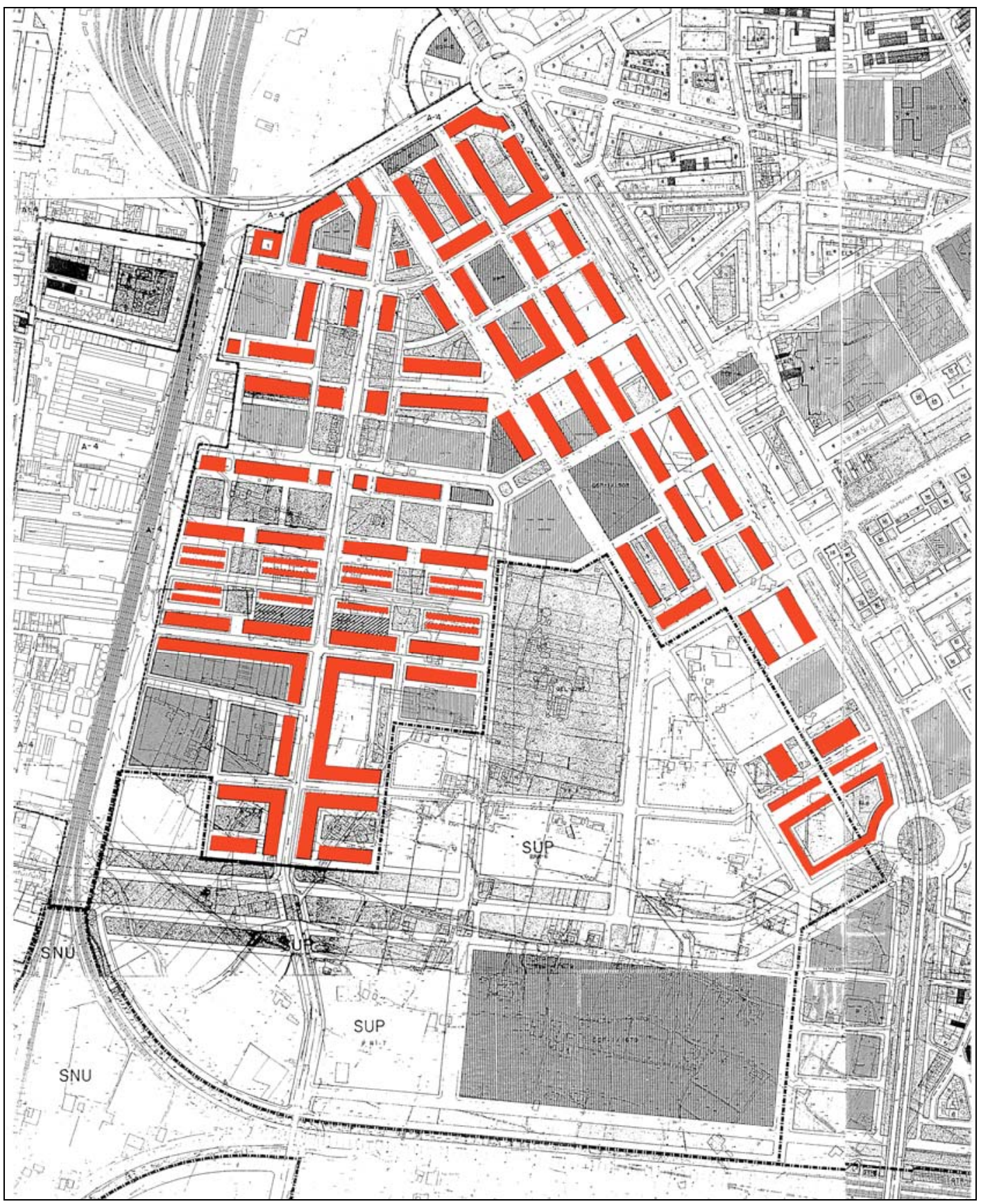




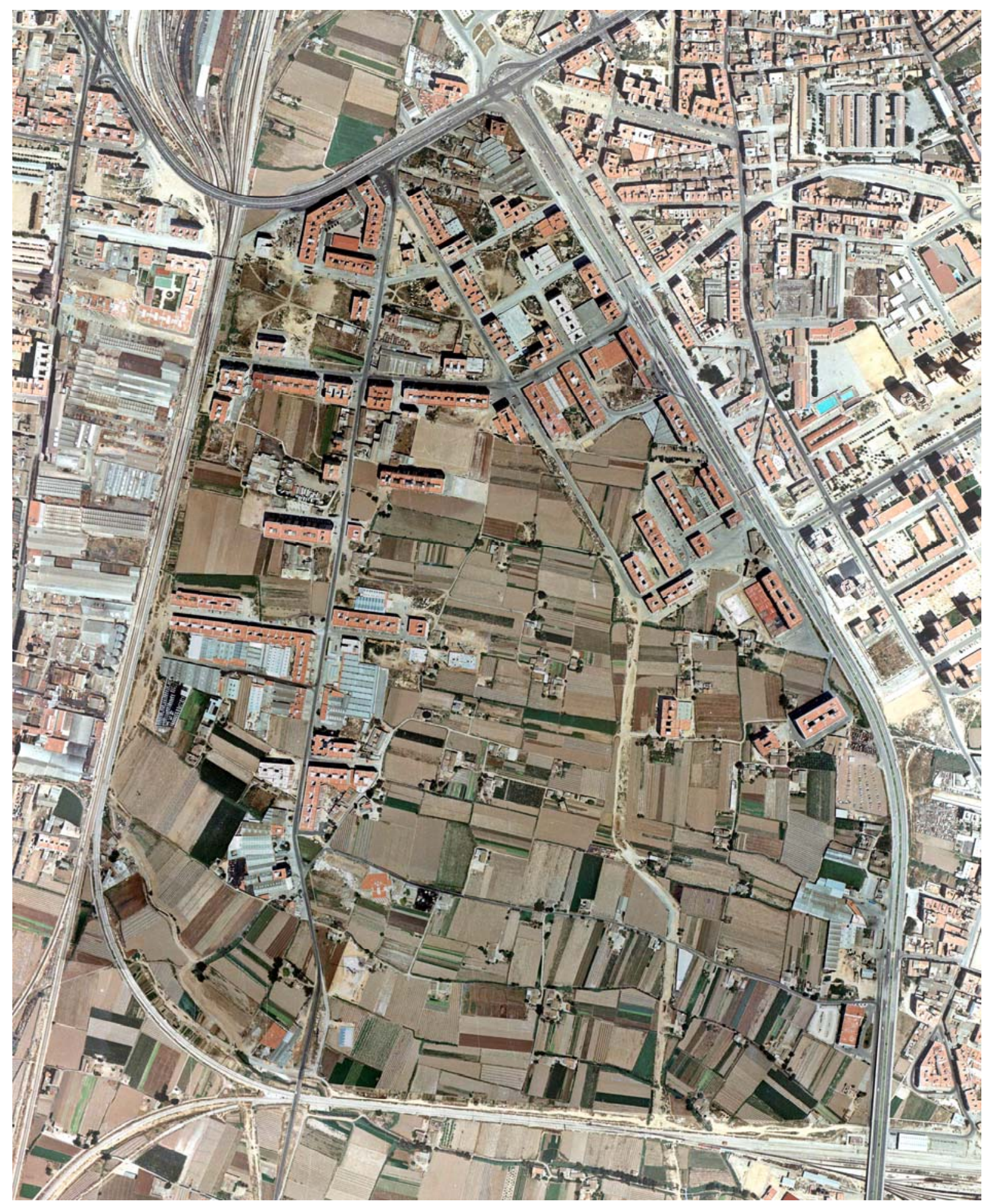

Zona de los Planes Parciales 5B y 5C. Fotografía aérea de Valencia, 1980. 


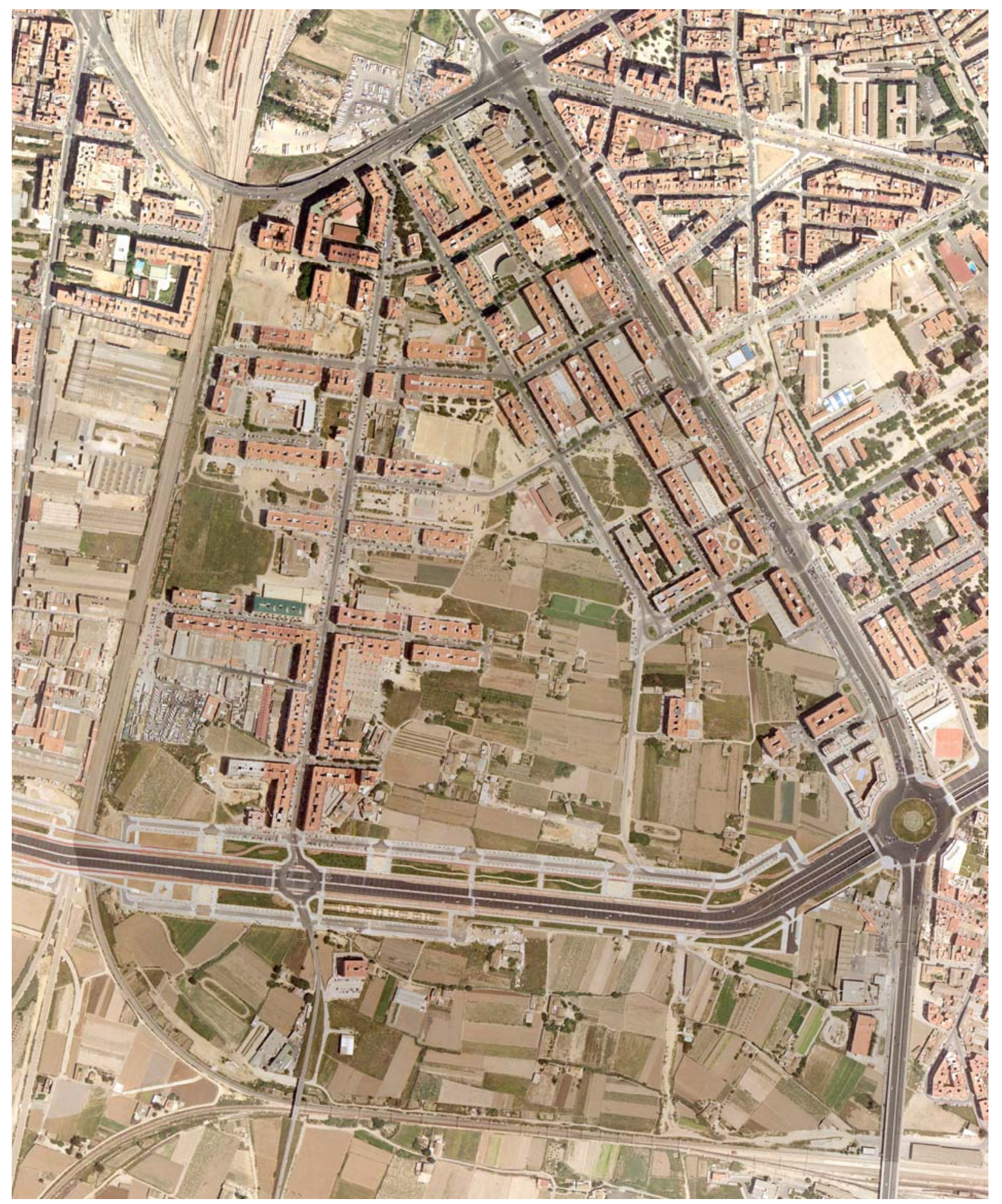

Zona de los Planes Parciales 5B y 5C. Ortofoto 2002 (AUMSA). 

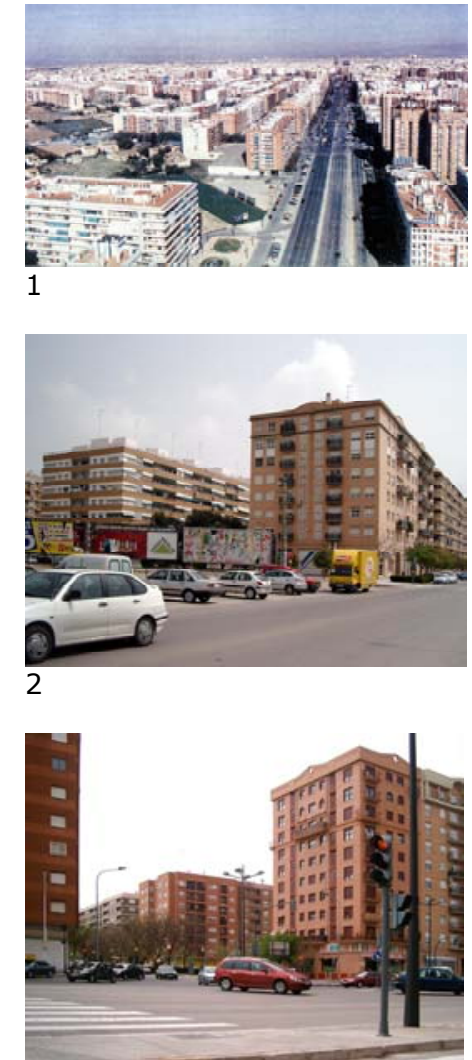

3

La gran compacidad del modelo de manzana mixta formada por bloques de cinco crujías unidos en planta baja o, simplemente, dispuestos en torno a un espacio libre, es evidente en los frentes edificados a la Avenida Ausias March o a las calles paralelas y perpendiculares a ésta, como las del Ingeniero Joaquín Benlloch, $\mathrm{Na}$ Robella y otras.
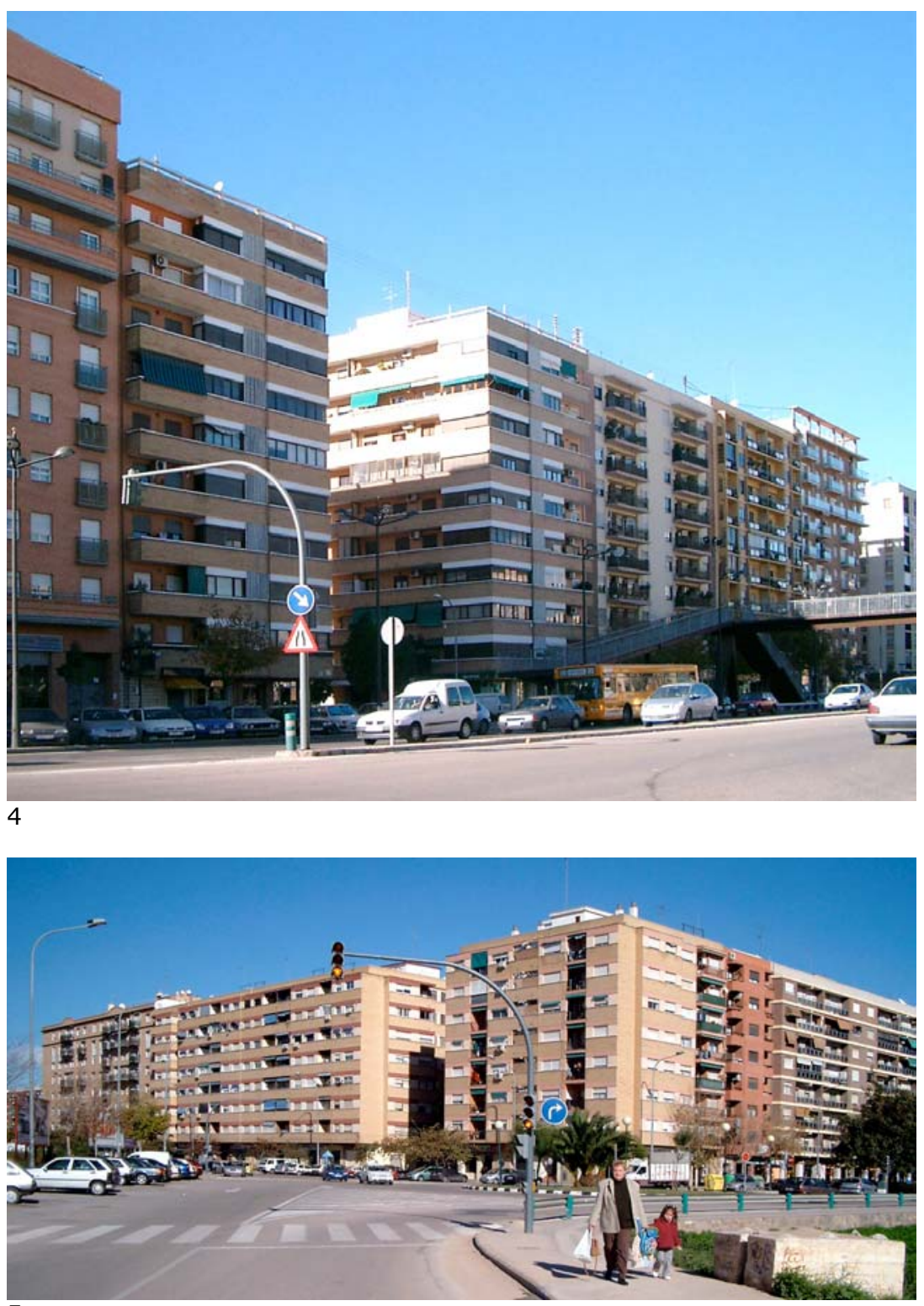

5

1. Avenida Ausias March.

2. Calle Ingeniero Joaquín Benlloch, vista hacia el sur.

3. Calle Isla cabrera, cruce con la Avenida Ausias March.

4. Calle Ingeniero Joaquín Benlloch, vista desde el oeste.

5. Bloques aislados en la zona sureste, vistos desde el Bulevar Sur.

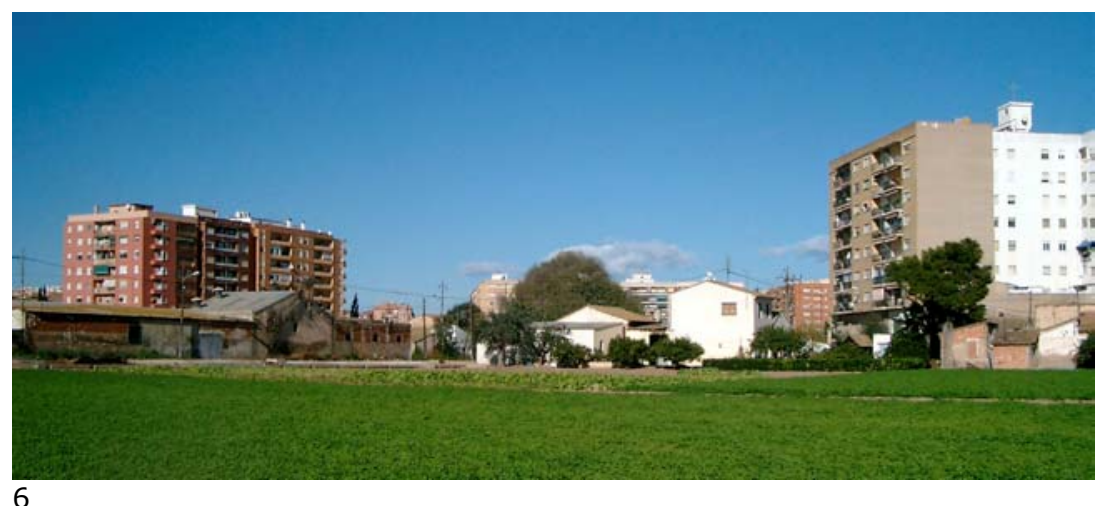


La reciente apertura del Bulevar Sur, eje viario previsto en el Plan General de 1988 en sustitución de la Ronda Exterior del Plan General de 1966, ha mejorado sensiblemente la conexión del área de Malilla con el resto de la ciudad.

Los bordes este -Avenida Ausias March- y sur adquieren así su configuración definitiva, y queda pendiente la de los bordes oeste y norte, afectados por la remodelación de los terrenos de la Estación Central de RENFE.

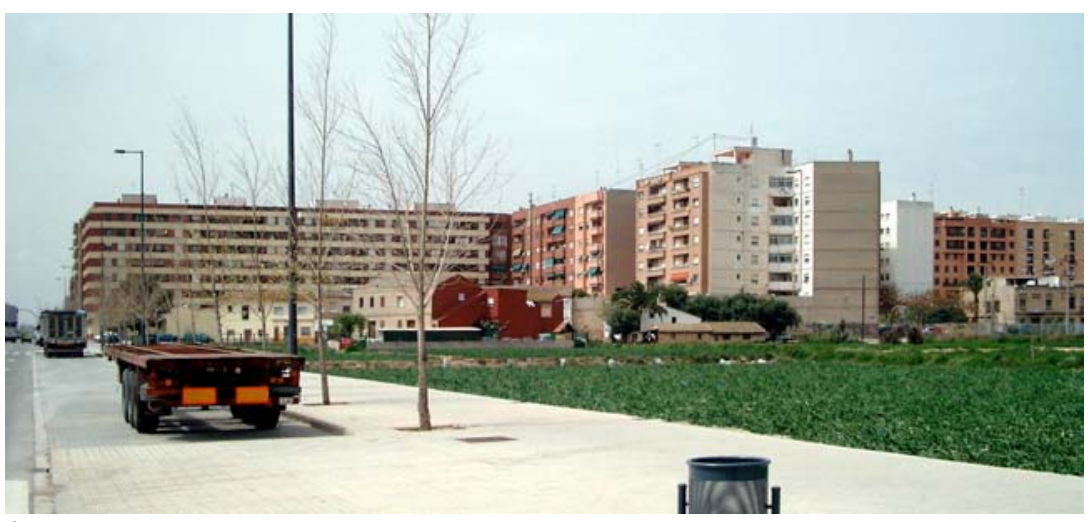

1

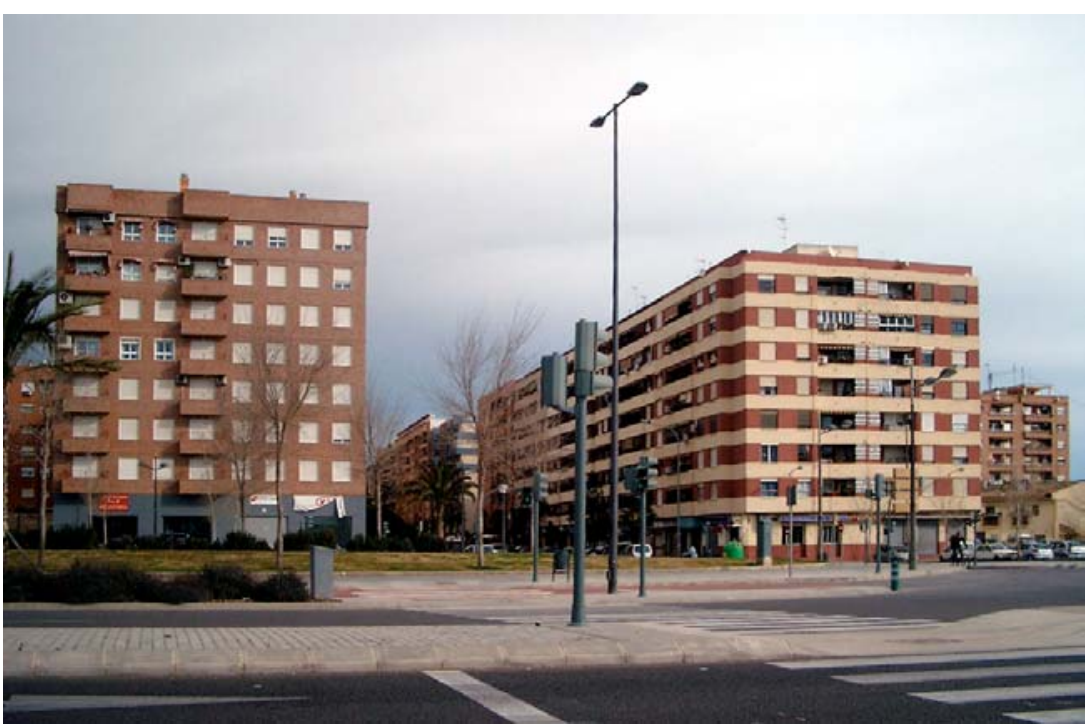

2

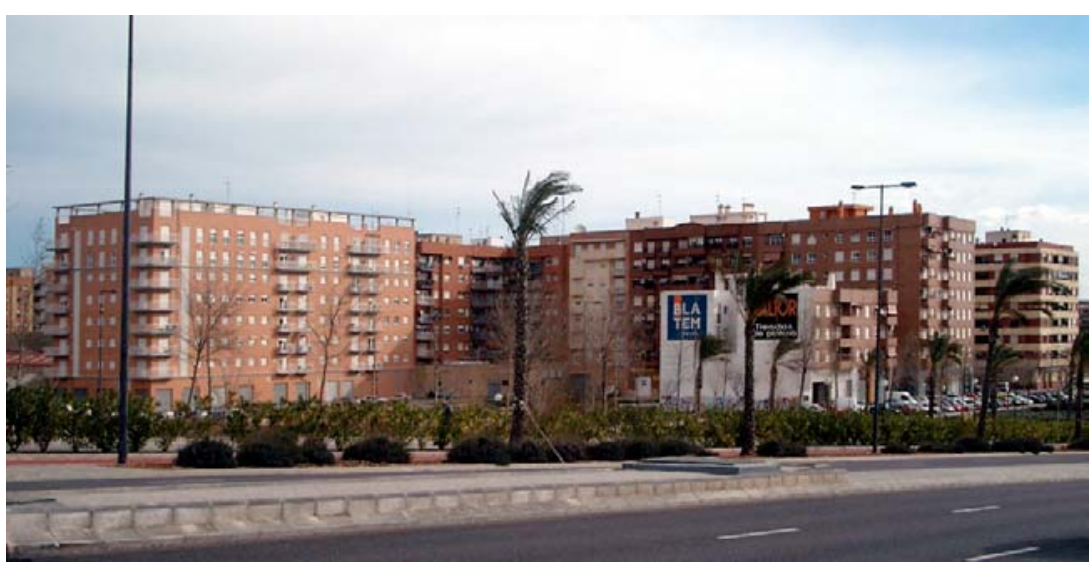

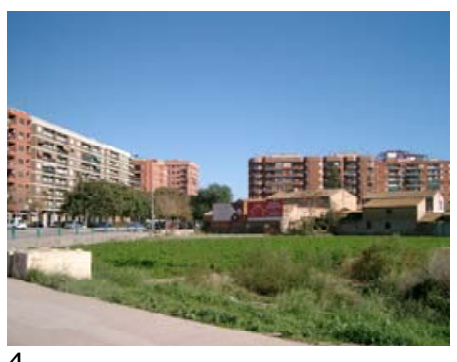

4 

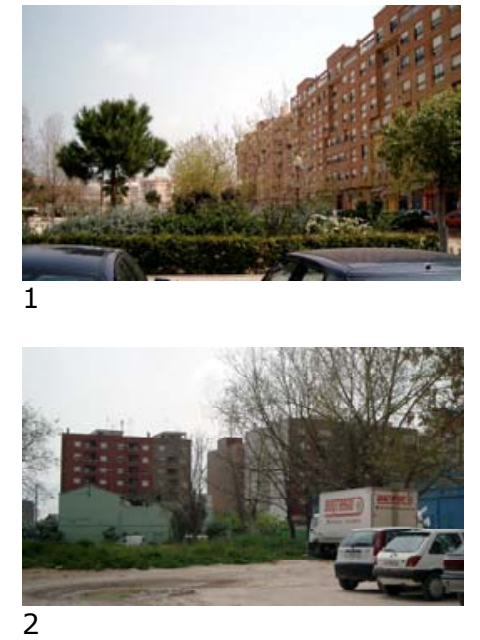

Los bloques de la Carrera de Malilla, en definitiva, forman una delgada franja urbana, a modo de una escenografía, tras la cual se encuentran, a unos pocos pasos, los terrenos en espera de convertirse en parte de la ciudad: descampados, solares sin edificar, casas y huertas, en torno al vacío actualmente existente en el lugar previsto en todos los sucesivos planes para la zona, desde el año 1966, como gran parque de distrito.
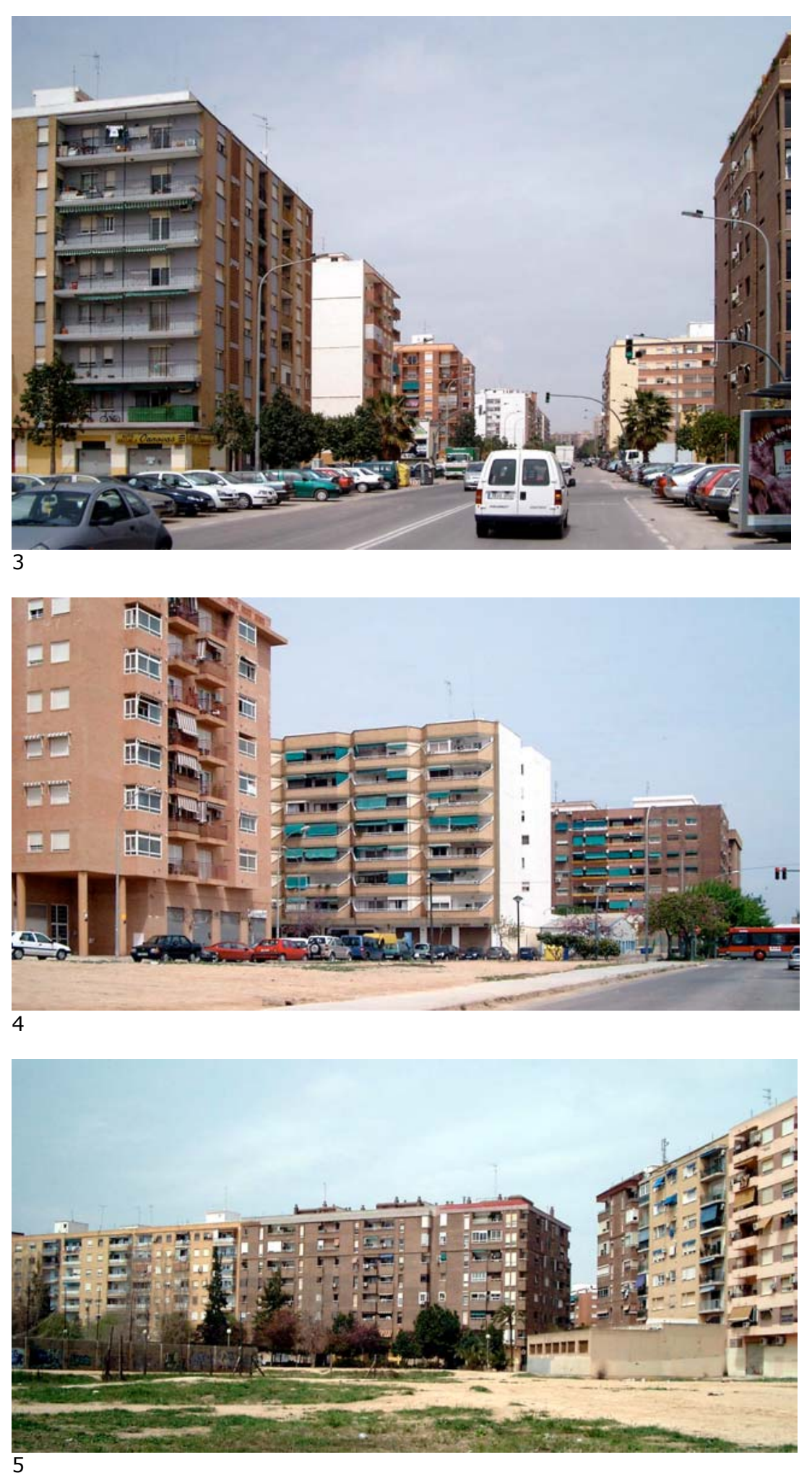

1. Parque lineal en la calle Bernat Descoll.

2. Espacios sin urbanizar tras la pantalla de bloques de la Carrera de Malilla.

3,4. Carrera de Malilla, vistas hacia el norte.

5. Plaza Escultor Victor Hino. 


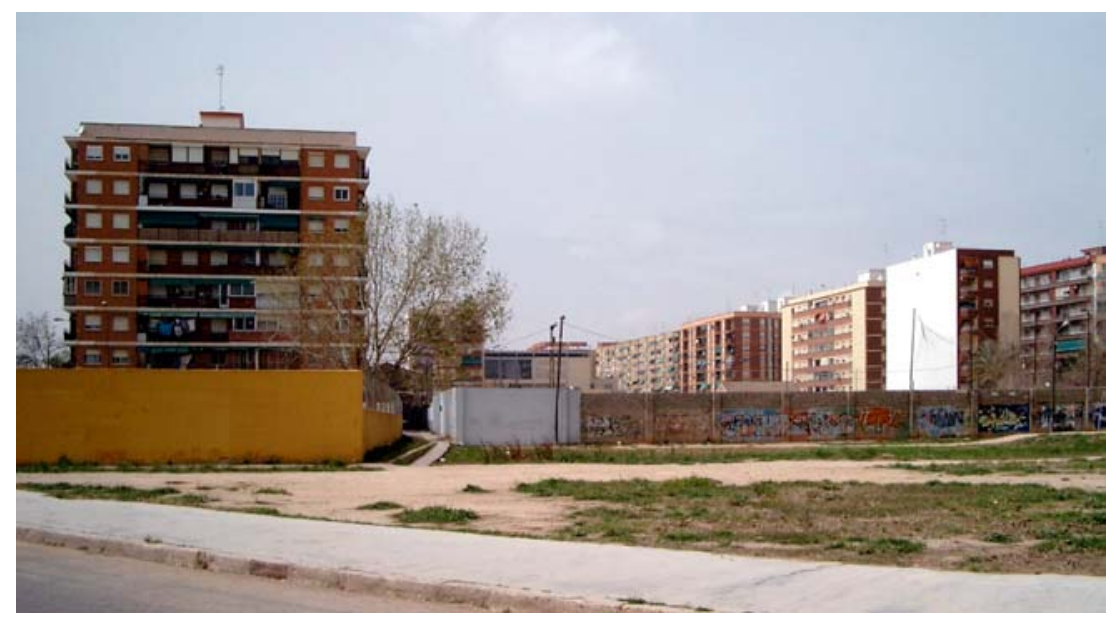

1

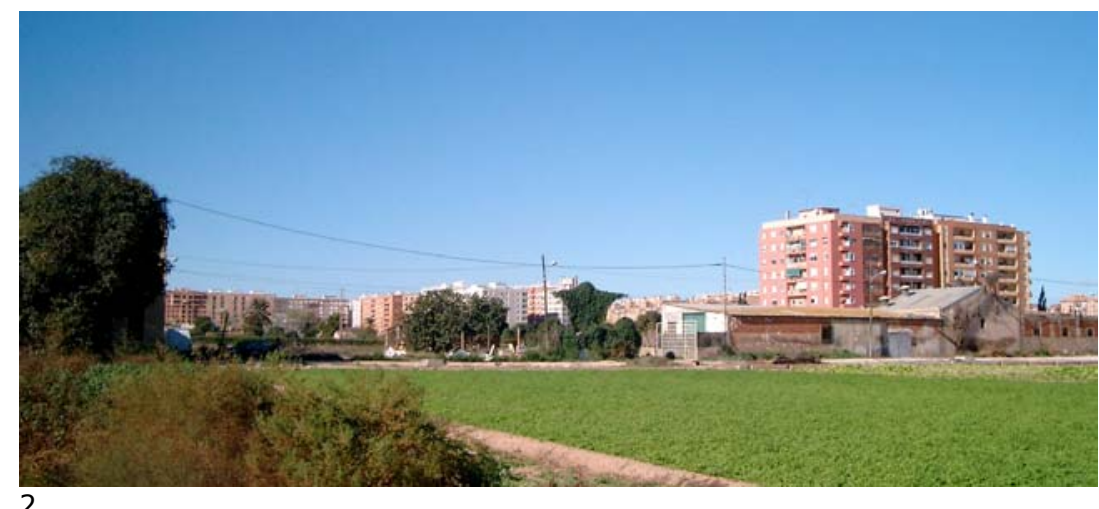

2

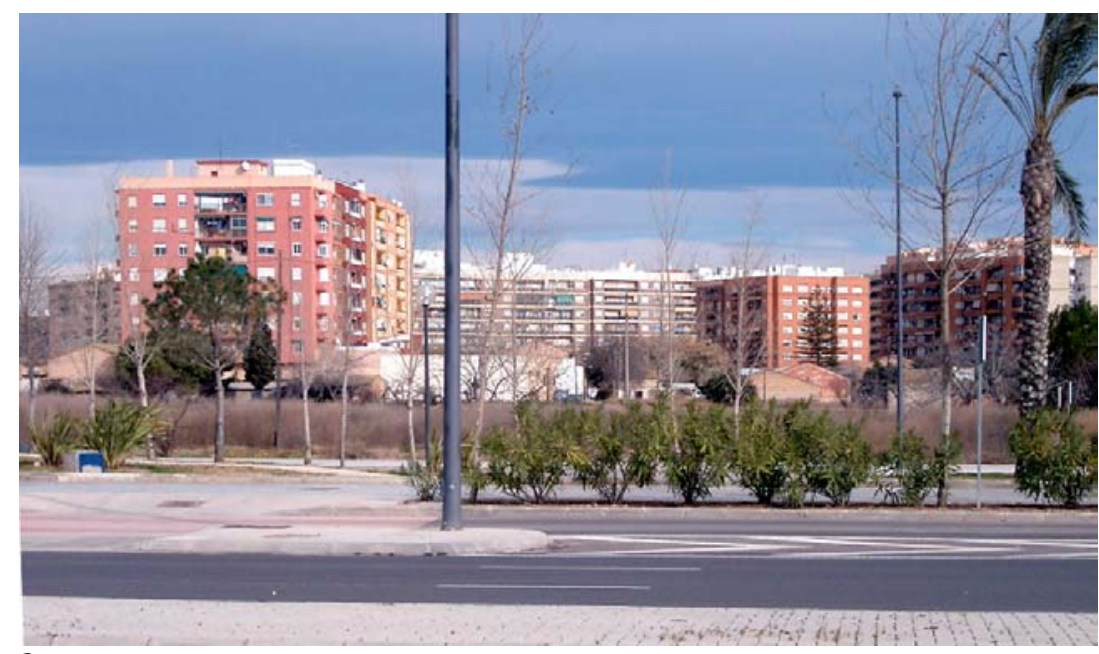

3

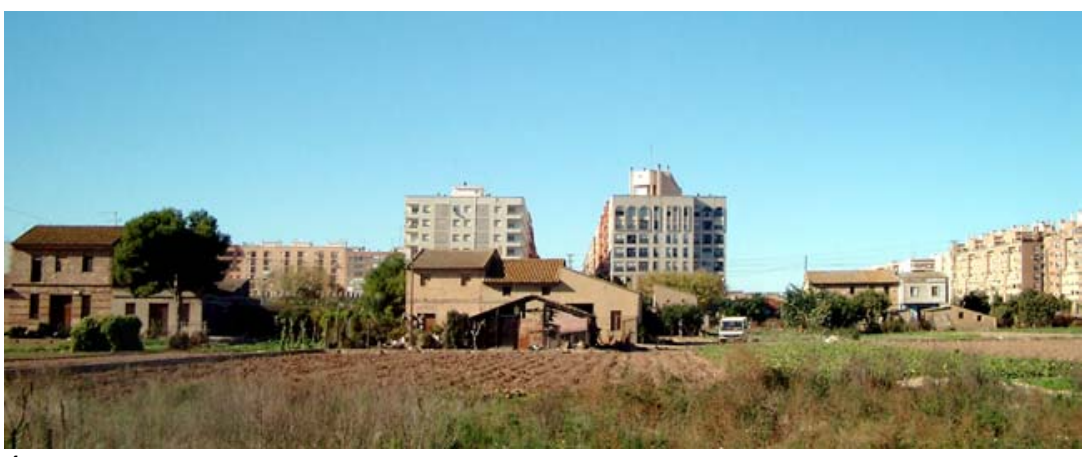

1. Calle Bernat Descoll, vista hacia el oeste.

2,3. Bloque aislado en la zona prevista como centro comercial en el Plan Parcial 5C.

4. Bloques de la calle Isla Cabrera, vistos desde el este. 


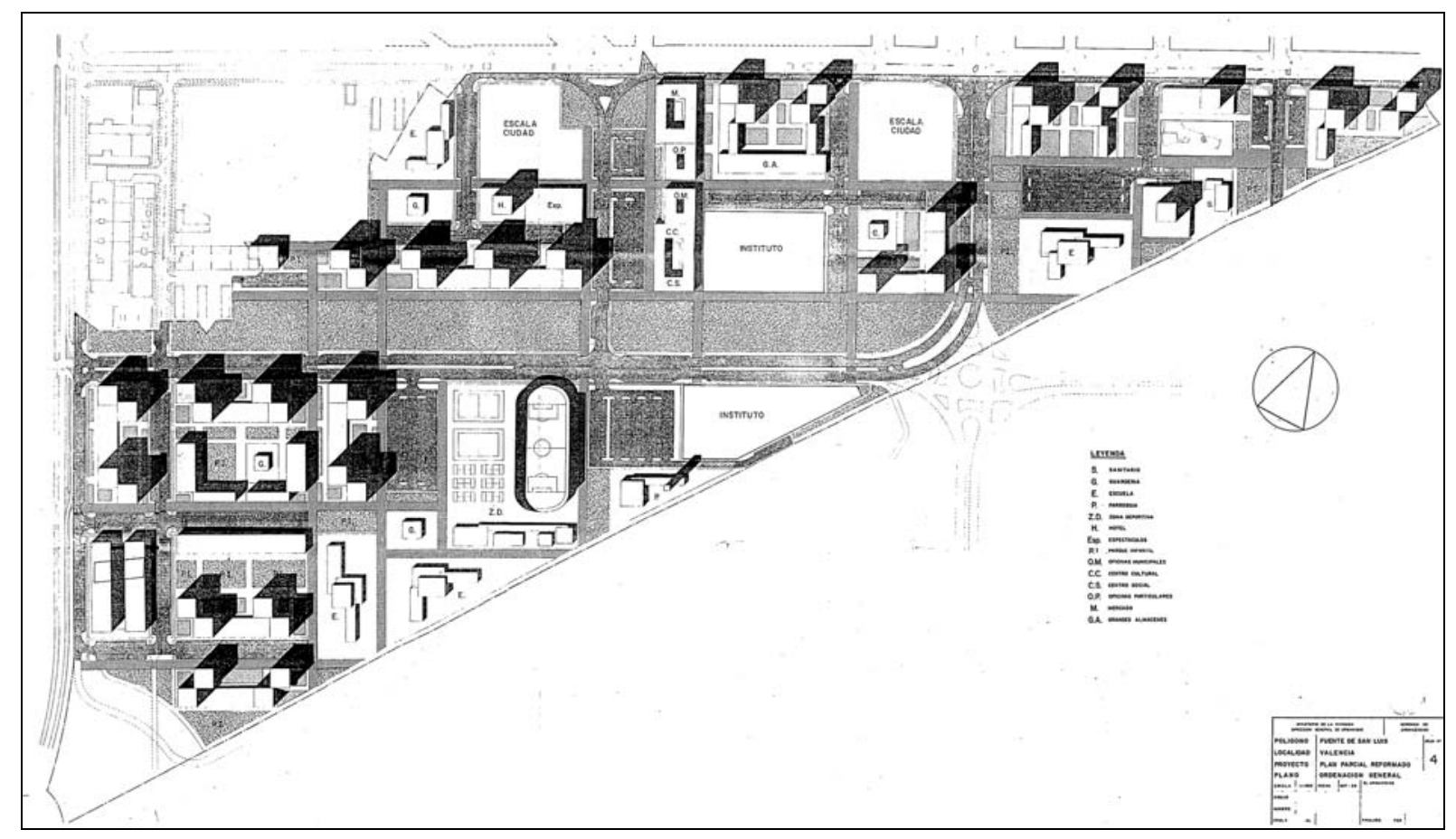

Plan Parcial Reformado del Polígono Fuente de San Luís, 1969. Plano de ordenación general. 


\section{EL PLAN PARCIAL REFORMADO DEL POLÍGONO FUENTE DE SAN LUÍS (1969).}

En la sección anterior de este trabajo hemos analizado el plan inicial para el Polígono de la Fuente de San Luís (antes denominado de Monteolivete), redactado en 1960. Este plan fue sustituido por otr que, pese a su denominación -Plan Parcial Reformado- era completamente diferente.

El Plan Parcial Reformado del Polígono fue redactado en 1969 por la Gerencia de Urbanización del Ministerio de la Vivienda, y aprobado en $1971^{1}$. Todos sus elementos responden a un nuevo diseño, ya que no llegó a realizarse ningún edificio de los previstos en el plan de 1960.

La zona ordenada, de 57,3 $\mathrm{Ha}$, tiene forma de triángulo rectángulo, cuyo lados son la Avenida de la Plata, al norte, y el Nuevo Acceso Sur de la Red Arterial de Valencia, al este, y su hipotenusa una antigua vía diagonal del Plan General anterior en sentido noreste-suroeste, ya suprimida. En esta zona no existían en el momento de redactarse en 1971 el Plan Parcial del Polígono más edificaciones que las ya existentes cuando se redactó en 1960 la primera versión de dicho plan.

La Memoria del Proyecto Modificado de 1971 transcribe directamente el apartado relativo a justificación de la ordenación de la Memoria del plan de 1960. Los factores que se destacan en favor del emplazamiento del Polígono, y como condicionantes de las soluciones adoptadas, son su proximidad al nuevo eje viario que acompañará al Nuevo Cauce del Turia, la contigüidad a la nueva Estación Central de Ferrocarriles prevista al este de Monteolivete, la facilidad de salida de los habitantes hacia los centros rurales e instalaciones fabriles y portuarias, la descongestión de otros sectores periféricos de expansión y, por último, "la rotura del cinturón suburbial que, en forma de edificaciones anárquicas y mal ordenadas, amenazaba el vértice Sureste de la capital". ${ }^{2}$

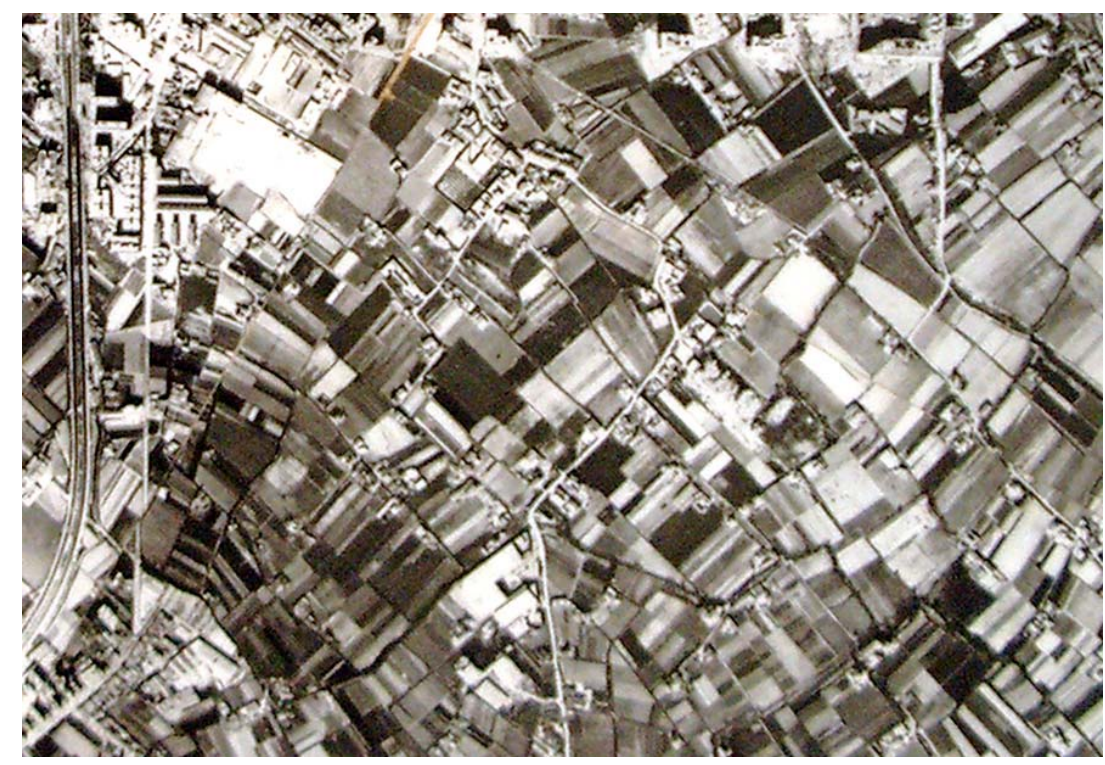

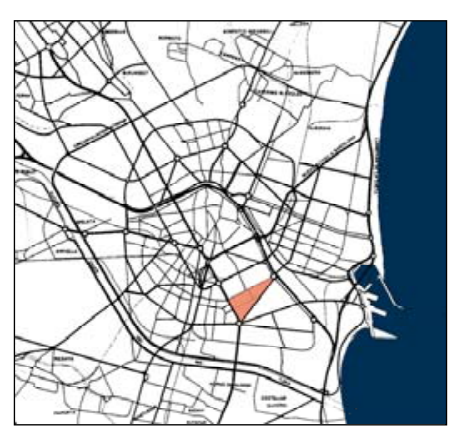

Polígono Fuente de S. Luís. Localización.

Zona del Polígono Fuente de San Luís. Fotografía aérea, $h$. 1965 (ETS de Arquitectura de Valencia).

1. Plan Parcial Reformado del Polígono Fuente de San Luís, 1969. Anexo de Documentos, pp. 767779.

2. Ibid. Memoria. Anexo de Documentos, p. 769 .. 


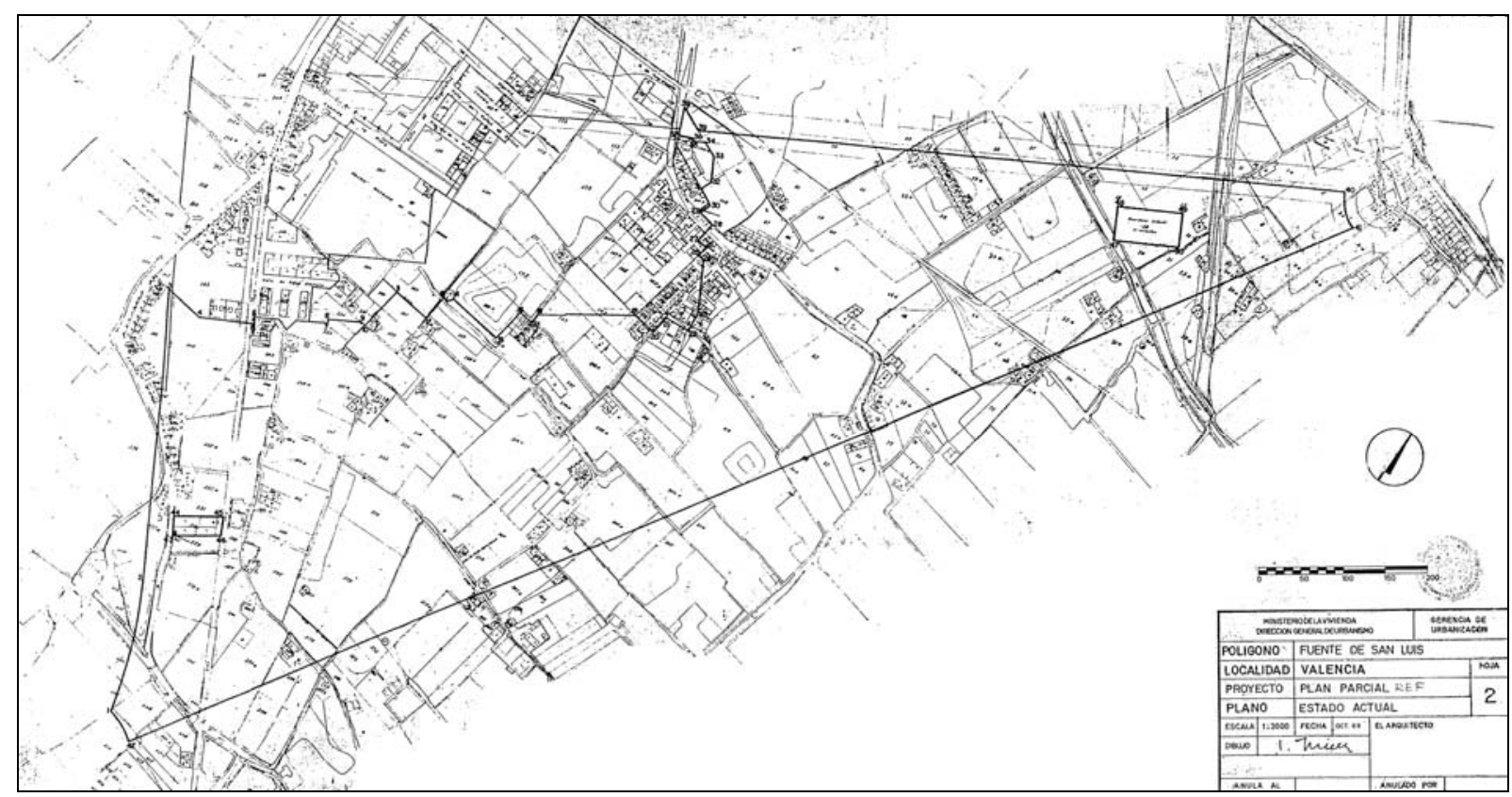

PP Polígono Fuente San Luís, 1969. Plano de estado actual.

PP Polígono Fuente San Luís, 1969. Plano de parcelación.
El Polígono se plantea, según señala la memoria del plan de 1969, como una unidad residencial autónoma para una población total de 15.000 personas, frente a las 28.000 personas previstas en el plan de 1960.

El Polígono de la Fuente de San Luís quedó englobado, a efectos únicamente de delimitación administrativa, en el Plan Parcial no 4, correspondiente al barrio de Monteolivete, que es el que regulaba la ordenación de la zona situada en la parte noroeste del Polígono, en la que está situado el recinto del Colegio Salesiano y la mayor parte de las edificaciones ya construidas con anterioridad al plan, como el grupo Felipe Rinaldi, analizado en una sección anterior.

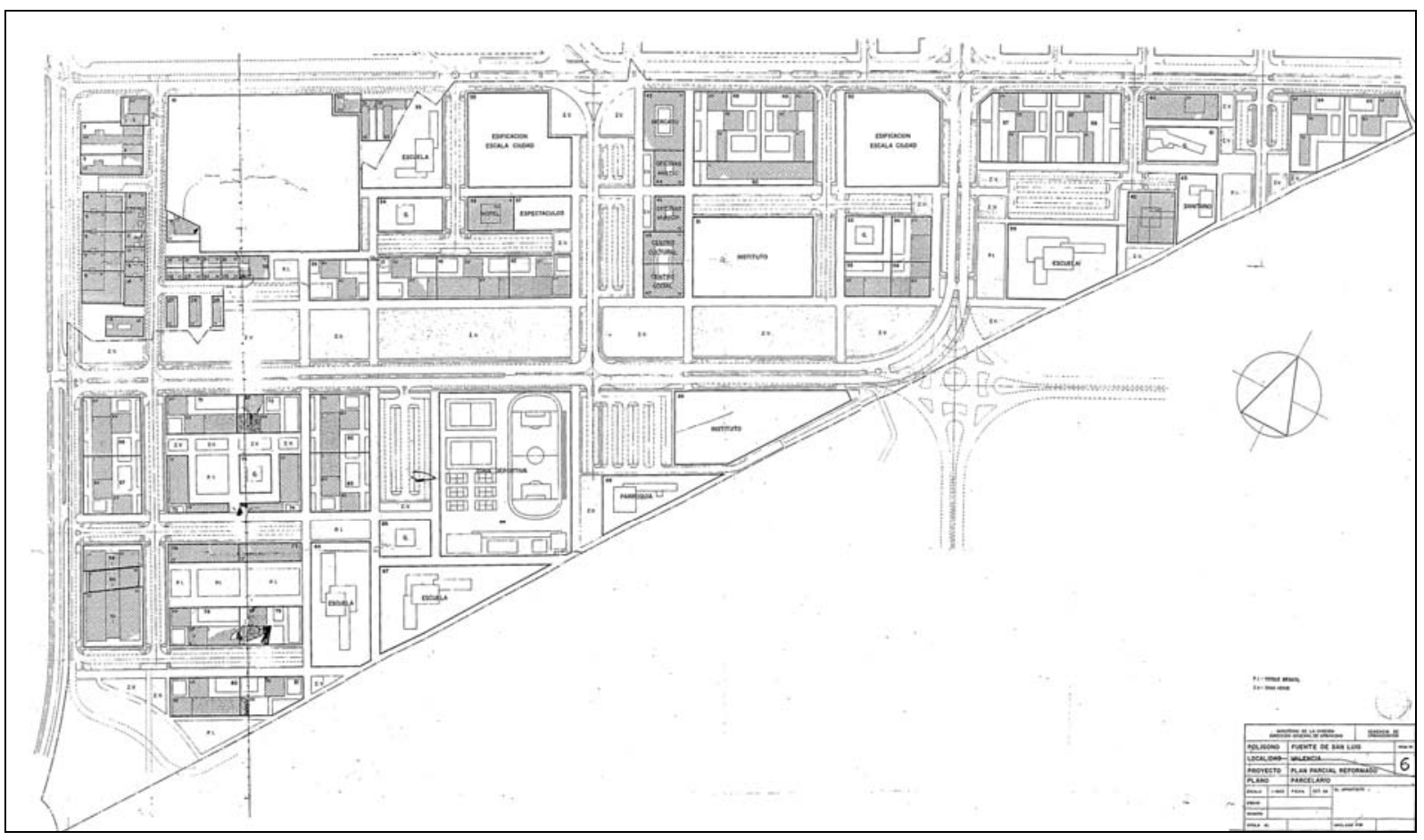




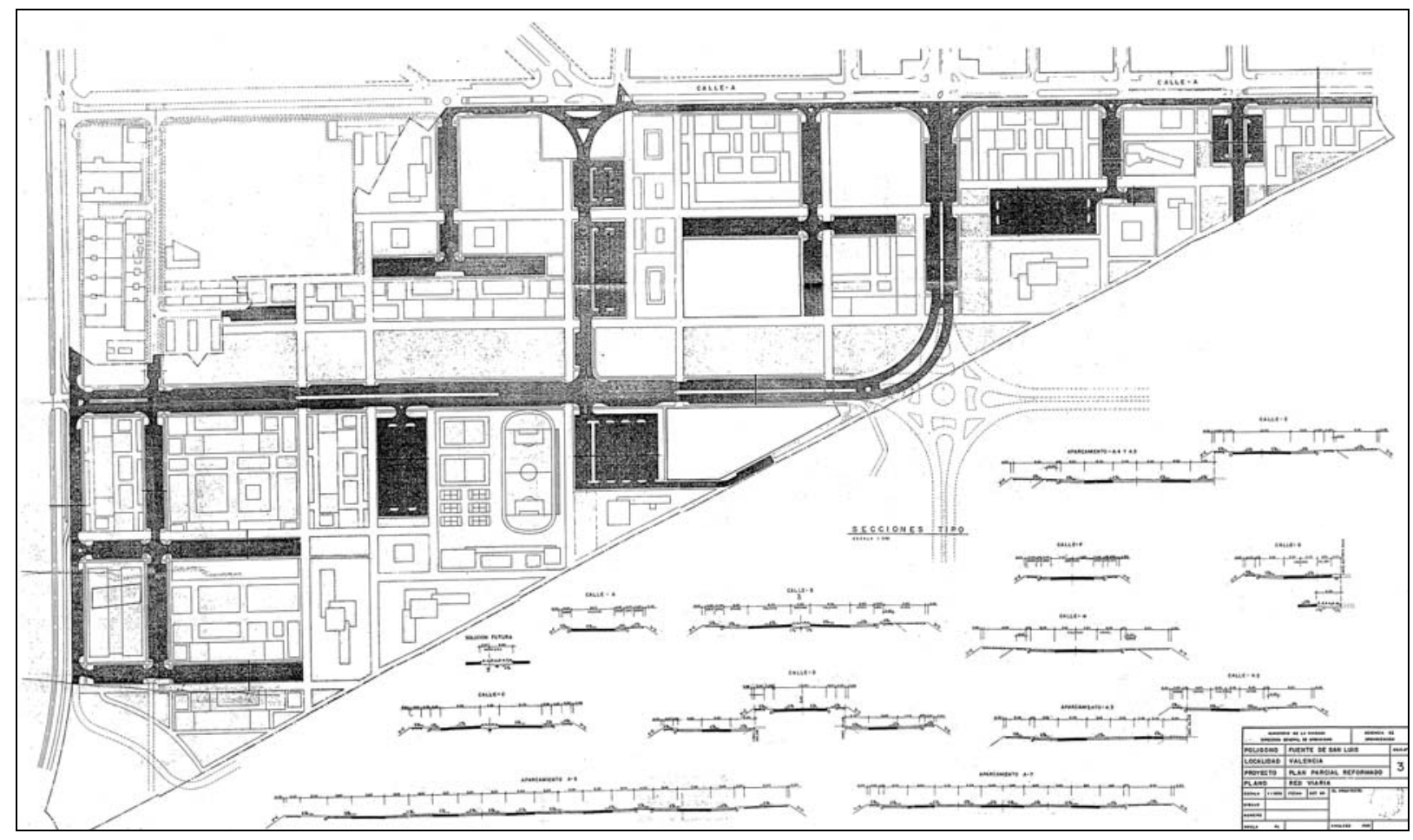

La estructura viaria proyectada para el Plan Parcial Reformado del Polígono Fuente de San Luís de 1969 está descrita con bastante precisión en la Memoria del mismo:

Cuatro vías fundamentales constituyen la red de penetración en el polígono. Tres de ellas nacen en la Avda. de la Plata, y son paralelas al acceso Sur. La cuarta, perpendicular al Acceso Sur, divide el polígono longitudinalmente en dos partes. En el lado Norte de esta vía se proyecta un parque o paseo central, de unos 50 metros de anchura, paralelo a ella.

De las tres vías perpendiculares a la Avda. de la Plata, la primera, al Oeste, coincide sensiblemente con la carrera de San Luis. La segunda, en el centro del polígono, termina en una gran plaza de aparcamiento, contigua a la zona deportiva, a la parroquia y a uno de los institutos de Enseñanza Media; pero al oeste de la parcela de la Parroquia se ha reservado terreno, con el fin de hacer posible un enlace futuro con los terrenos existentes al Sur del Polígono.

La tercera vía, más al Este, con $40 \mathrm{~m}$. de distancia entre fachadas, es prolongación de la Avda. del General Urrutia, quedando enlazada al eje longitudinal paralelo al parque.

Se han previsto además, otros accesos al polígono que terminan en fondos de saco y amplias zonas de aparcamiento.

La red de peatones también es importante, constituida por vías de $9 \mathrm{~m}$. de anchura, y en contacto con la red de circulación rodada sólo en los puntos indispensables. ${ }^{1}$

El sistema viario es, pues, mixto, combinando un trazado en malla de gran tamaño con un trazado ramificado secundario de ramales sin salida terminados en bolsas de aparcamiento.

Las previsiones de aparcamiento, como es lógico dada la fecha de redacción del plan, son muy superiores a las que hemos podido observar en otros planes parciales.
PP Polígono Fuente San Luís, 1969. Plano de red viaria.
1. Plan Parcial Reformado del Polígono Fuente de San Luís, 1969. Memoria. Anexo de Documentos, p. 769. 

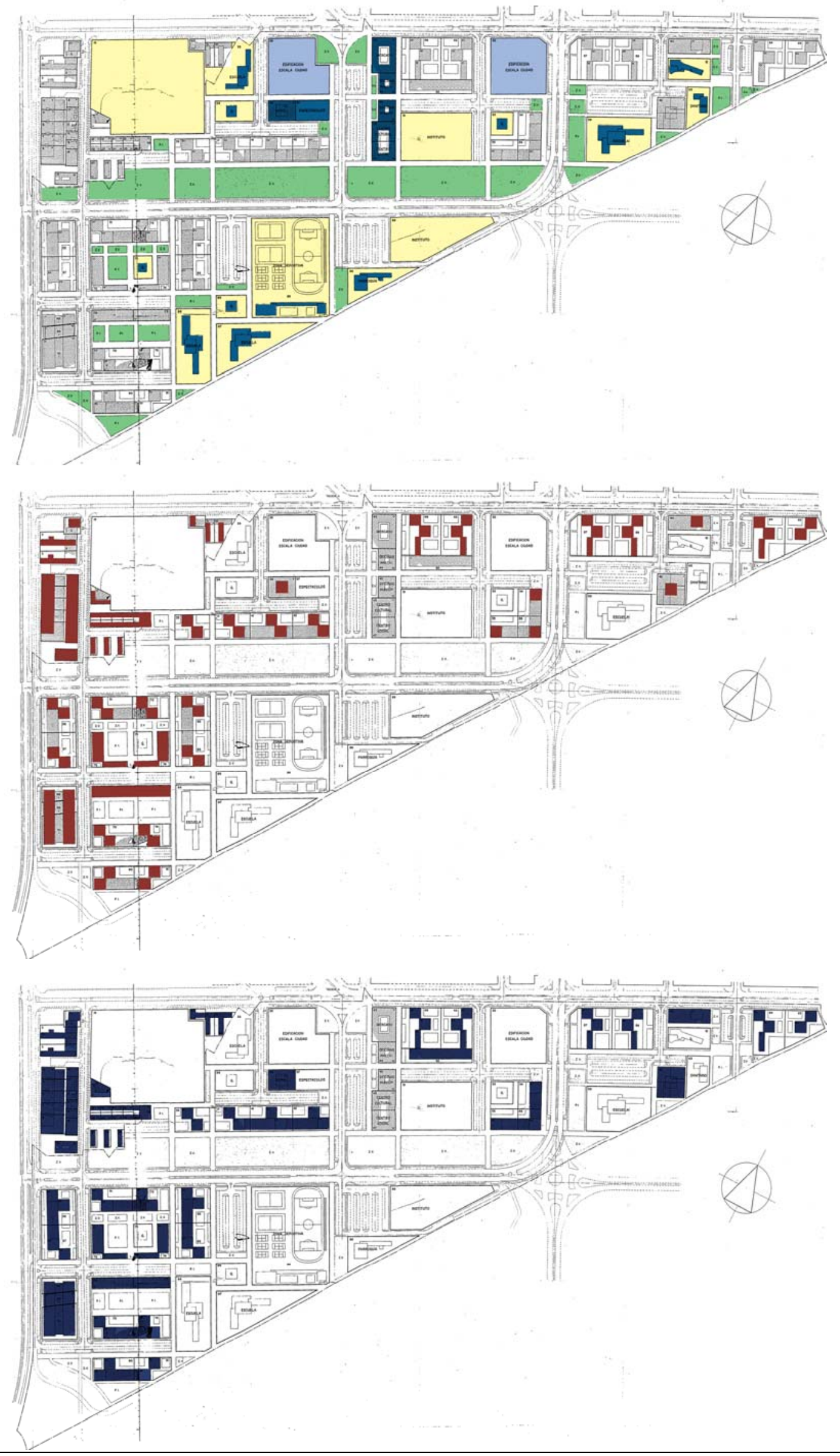
El Polígono está dividido en dos partes, separadas por la vía longitudinal este-oeste (actual Avenida Hermanos Maristas) y el parque público que la acompaña.

La parte sur, de forma triangular, concentra en su mitad oeste, según señala la Memoria del plan, un $42 \%$ de la población del Polígono, en torres de XII y XV plantas y bloques de IV y VI plantas. Este conjunto de edificaciones será el que integrará el grupo de viviendas "Fuente de San Luís", promovido por el Instituto Nacional de la Vivienda en 1973.

En esta zona se prevén dos parcelas para Enseñanza Primaria, dos para guarderías, una para Instituto de Enseñanza Media, una zona deportiva y un centro parroquial. Además, se reservan terrenos en el interior de las manzanas para juegos infantiles.

La zona norte del Polígono, que forma una franja paralela a la Avenida de la Plata, se ordena también mediante una combinación de torres de XII y XV plantas y bloques de altura media de IV plantas. Esta zona constituirá el otro grupo de viviendas de promoción pública del Polígono, que es el denominado "Vicente Mortes", promovido por la Obra Sindical del Hogar en 1971.

Esta zona norte alberga el centro cívico del Polígono, situado, como en el plan de 1960, a ambos lados del eje norte-sur de la actual calle Bombero Ramón Duart, entre la Avenida de la Plata y el parque central. Este centro vecinal, servido por grandes bolsas de aparcamientos, incluye edificios para oficinas municipales, mercado, comunicaciones, centros cultural y social, oficinas privadas, sala de espectáculos, hotel y grandes almacenes.

Cerca del centro vecinal se prevén también otras parcelas destinadas a equipamientos a escala de ciudad, que están ocupadas actualmente por el Colegio de Médicos y por un parque de bomberos.

Además, en esta la zona norte del Polígono se prevé una reserva de parcelas escolares equivalente a la señalada para la zona sur, junto con un centro sanitario y algunos parques infantiles.

La disposición de la edificación no es tan concentrada en la zona norte como en la zona sur, sino que forma unidades mixtas que se alternan con parcelas dotacionales, con una composición en damero de vacíos y llenos.

El modelo de edificación concentrada va asociado en este plan, por tanto, a unas reservas de suelo para equipamientos y zonas verdes muy superiores a las previstas en cualquier otro plan parcial de la ciudad.

En cambio, el suelo destinado a locales comerciales es mucho menor que el existente en otros planes, y se reduce a los cuerpos bajos que unen algunas de las torres y a construcciones aisladas de una planta entre bloques de edificación.

La densidad del Polígono es de 67,25 viviendas/Ha, y la edificabilidad promedio de $2,56 \mathrm{~m} 3 / \mathrm{m} 2$.
Página opuesta: Polígono Fuente S. Luís, 1969. Equipamientos y edificación en planta baja y en planta tipo (Elaboración propia sobre plano parcelario del plan) 


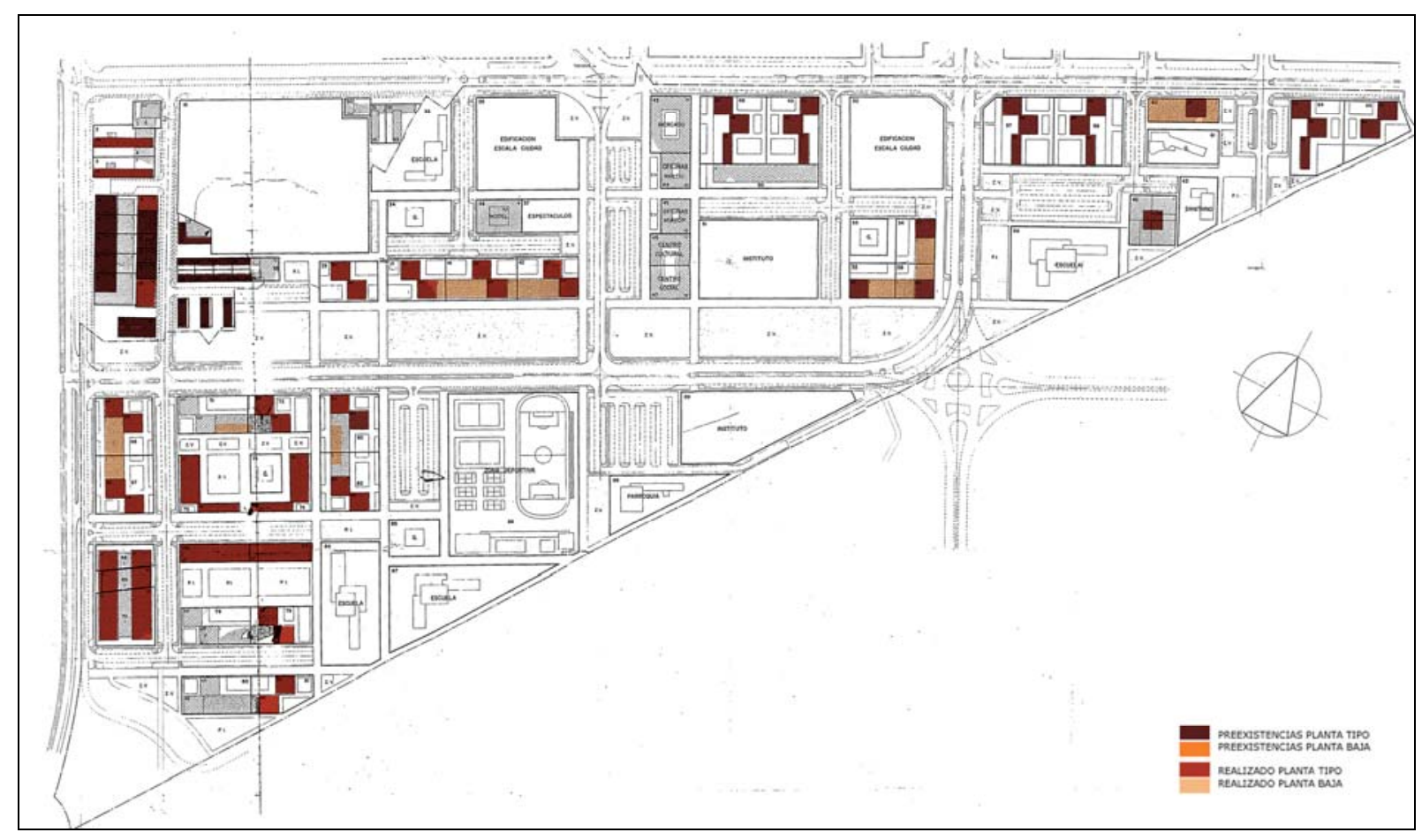

PP Polígono Fuente de S. Luís. Grado de realización (Elaboración propia sobre plano parcelario del Plan)

\section{Grado de realización}

La edificación abierta prevista en el Plan Parcial Reformado del Polígono de la Fuente de San Luís de 1969 se halla realizada en su totalidad, aunque algunas de las torres no siguen exactamente la disposición prevista en dicho plan.

La completa realización de la edificación según lo previsto en un plan parcial es algo insólito en el planeamiento de desarrollo de la ciudad de Valencia, y lo que lo ha hecho posible ha sido sin duda el carácter público de la promoción en los dos grupos de viviendas en que se subdividió la ejecución del plan.

Fuente de S. Luís.

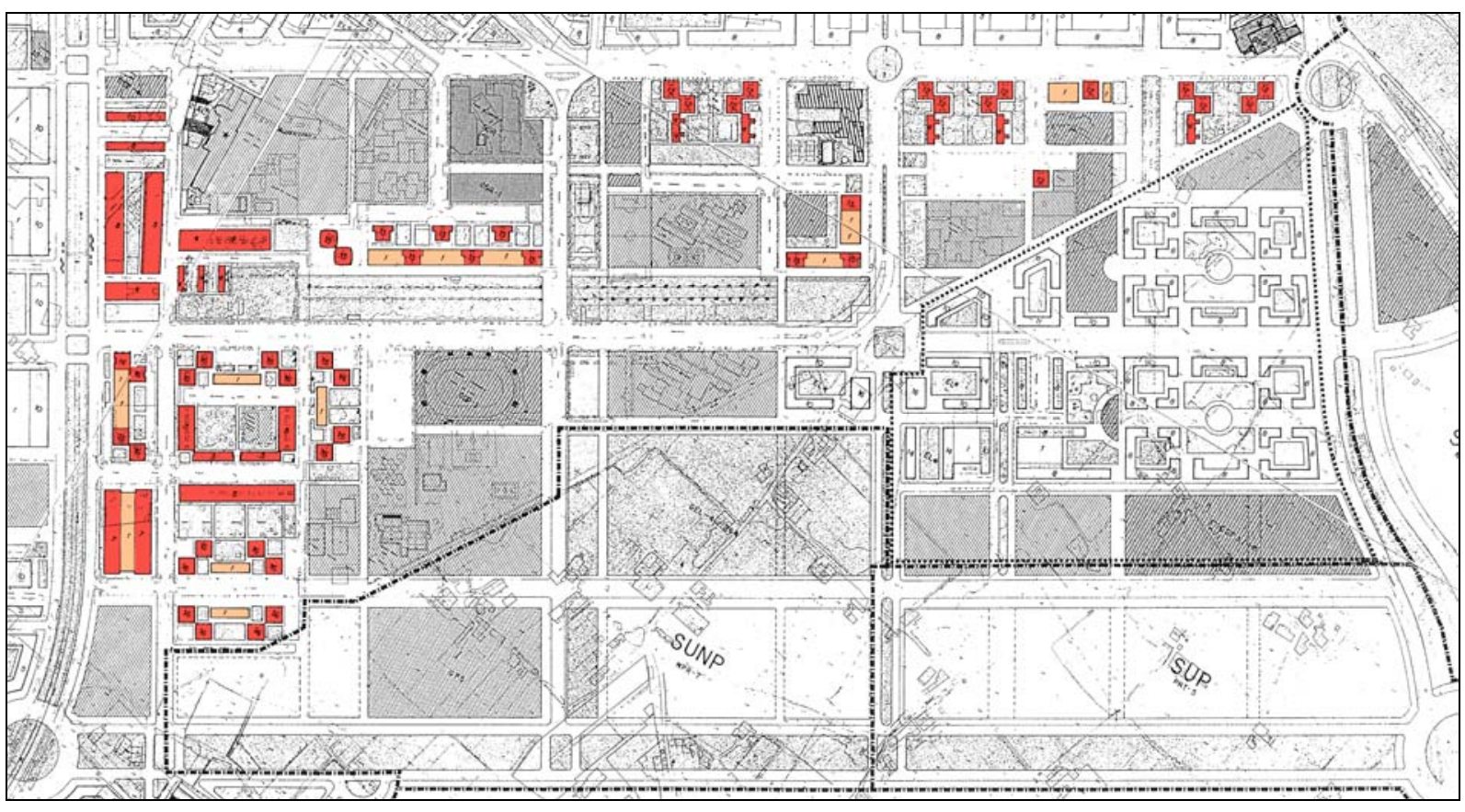




\section{El Grupo Vicente Mortes (1971-76)}

El grupo denominado Vicente Mortes, integrado por 1.200 viviendas y locales comerciales, es el primer conjunto de edificios construido en el Polígono de la Fuente de San Luís. El proyecto, que constituye la última promoción de la Obra Sindical del Hogar en Valencia, fue redactado en 1971 por los arquitectos Vicente Valls Abad, Joaquín García Sanz y Francisco Mensua Fernández. Las obras, iniciadas en 1972, quedaron finalizadas en 1976.

En el texto que acompaña la publicación del grupo en la revista Hogar y Arquitectura, los autores del mismo se muestran muy críticos con el Plan Parcial de Polígono, basado en la edificación abierta, al que tuvieron que ajustarse, señalando acerca del mismo lo siguiente:

Su ordenación tiene en cuenta los problemas higienísticos, y se resuelve con criterios geométricos y perspectivistas. Adolece, a nuestro juicio, como la mayoría de las ordenaciones de aquella época -y también de épocas posteriores- de la creación, a escala adecuada, de espacios urbanos habitables que estimulen la convivencia de las personas y en donde puedan realizar con naturalidad el desarrollo de las distintas funciones urbanas. Los edificios previstos en este plan son de tipología rígida y poco variada. ${ }^{1}$

Las parcelas asignadas a la Obra Sindical del Hogar para la construcción del grupo, situadas en la mitad norte del Polígono, tenían una superficie total de unas $4,5 \mathrm{Ha}$. Las alineaciones y volúmenes de los edificios previstos en estas parcelas estaban completamente definidos en el Plan Parcial de 1969, que contemplaba tres sistemas de composición diferentes para las mismas.

Estas parcelas no tenían contigüidad entre sí, sino que, como hemos señalado más arriba, estaban alternadas con parcelas dotacionales, en una composición alternada al tresbolillo de vacíos y llenos.

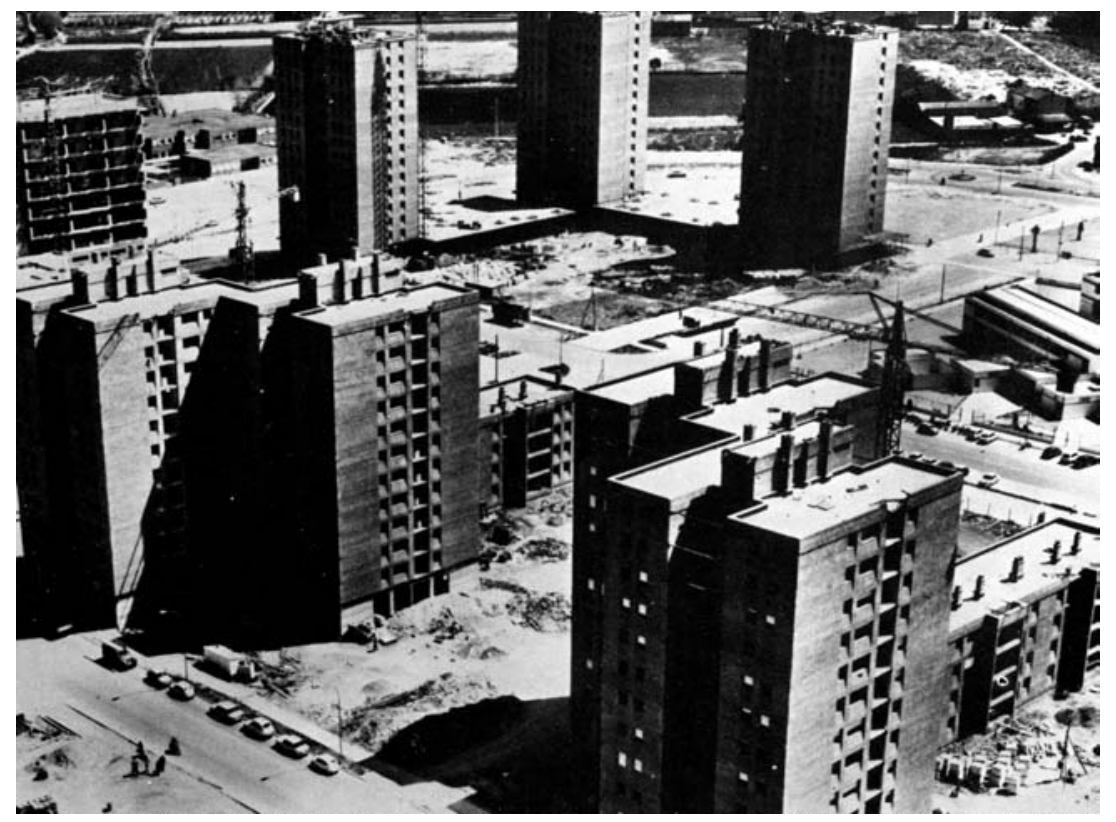

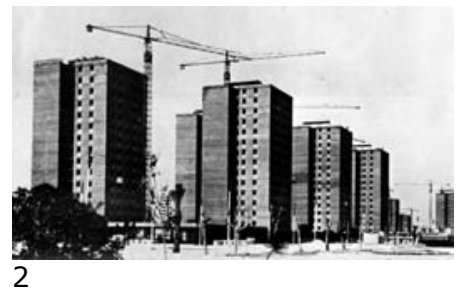
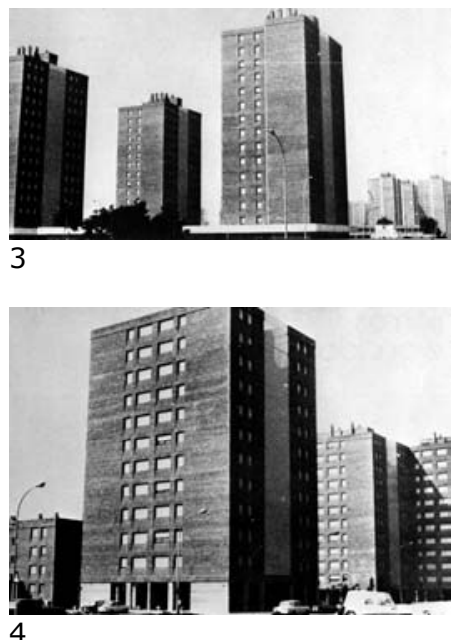

1-4. Grupo Vicente Mortes. Fotografías (Hogar y Arquitectura, 121, Madrid, 1977).

1. Valls Abad, Vicente, García sanz, Joaquín, Mensua Fernandez, Francisco, "Grupo de 1.200 viviendas en el Polígono de la Fuente de San Luís (Valencia)", Hogar y Arquitectura, 121, Madrid, 1977. 

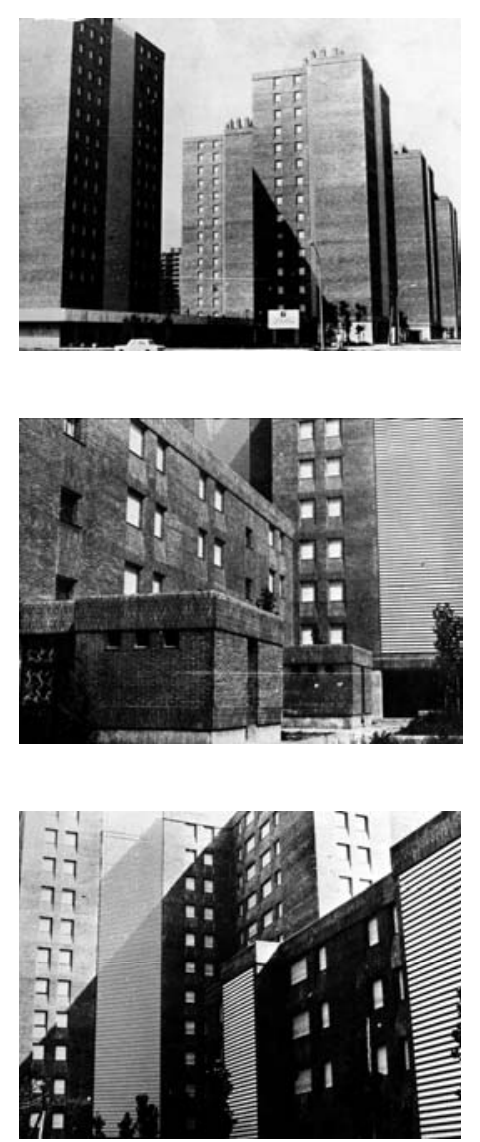

Grupo Vicente Mortes. Fotografías, planta de conjunto $y$ plantas de los tres tipos de edificios (Hogar y Arquitectura, 121, Madrid, 1977)
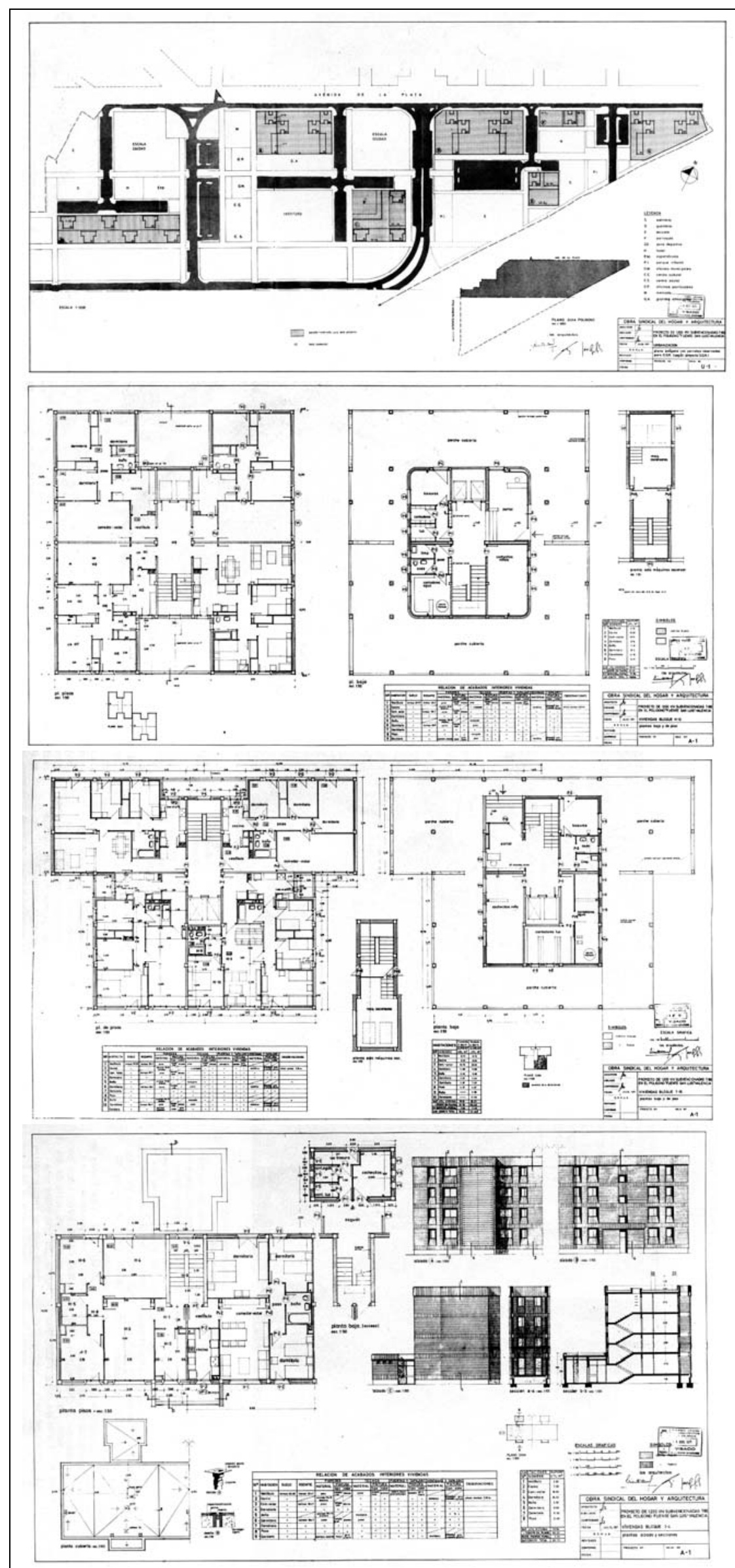
El primer sistema de composición de la edificación, previsto para la mayor parte de las parcelas recayentes a la Avenida de la Plata, consistía en formar una especie de manzanas abiertas integradas por dos grupos de edificios, cada uno de los cuales estaba formado por una pareja de torres de XII plantas tangentes por el vértice y un bloque lineal de IV plantas adosado a una de las torres también por el vértice. La planta de estas torres era en forma de $\mathrm{H}$, con cuatro viviendas por piso y patios abiertos al exterior, cuyo cierre mediante lamas permitía recuperar la forma cuadrada de la planta prevista en el plan.

El segundo sistema era también de parejas de torres de XII plantas, pero sin bloques lineales. Se utiliza en el frente recayente a la Avenida Hermanos Maristas, donde las cuatro parejas de torres previstas se enlazan por un cuerpo bajo comercial.

El tercer sistema, que se utilizaba en la parcela de esquina entre la Avenida Hermanos Maristas y la calle General Urrutia, así como en otras dos parcelas más al este, era el de torres de XV plantas, enlazadas en planta baja por locales comerciales. La planta de estas torres, cuadrada en el plan parcial, fue transformada en una planta en forma de $\mathrm{T}$ en el proyecto del grupo Vicente Mortes, para adecuarlas a las exigencias de distribución y superficies de la OSHA.

Las plantas bajas de las torres, igual que los cuerpos bajos de edificación previstos para usos comerciales, se dejaron exentos, sin cerramiento de fachadas.

\section{El Grupo Fuente de San Luís.}

El grupo denominado Fuente de San Luís, integrado por 1.168 viviendas y locales comerciales, es el último grupo promovido en la ciudad de Valencia por el INV. El proyecto fue redactado en 1973 por los arquitectos José A. Pastor Pastor, Mauro Lleó Serret y Luís Gay Ramos en 1973, y las obras quedaron finalizadas en $1978 .^{1}$

El grupo Fuente de San Luís ocupa las parcelas edificables de la mitad sur del Polígono, excepto las correspondientes a las dos manzanas recayentes a la Avenida Ausias March, una de las cuales estaba ocupada por bloques profundos preexistentes y la otra por dos parejas de torres de XV plantas unidas por comerciales en planta baja, que sería adjudicada a una cooperativa. ${ }^{2}$

La edificación del grupo Fuente de San Luís se ajusta a lo previsto en el Plan Parcial del Polígono, combinando torres de XII y $\mathrm{XV}$ plantas con bloques lineales de IV y $\mathrm{V}$ plantas y comerciales exentos de I planta. La mayor parte de los bloques lineales son de cinco crujías con un patio interior alargado en el que se van intercalando las cajas de escalera, que sirven a cuatro viviendas en cada planta, aunque también existen algunos bloques lineales de dos crujías.

Las plantas bajas de las torres no se destinaron a viviendas ni a locales comerciales, sino que se dejaron exentas, a modo de porches.
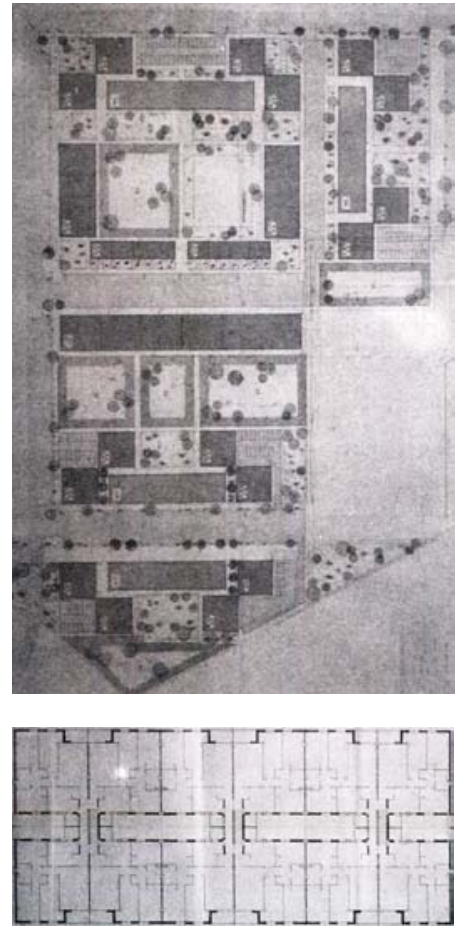

Grupo Fuente de San Luís. Planta general y planta tipo de los bloques lineales de cinco crujías.

1.Ver Gaja Díaz, Fernando, La promoción pública de la vivienda en Valencia (1939-1976), Generalitat Valenciana, Consellería d'Obres Públiques, Urbanisme i Transports, 1989.

2. Una de estas parejas de torres, obra de Luís Alonso de Armiño y Vicente Vidal, está publicada en Heras, Artur, ed., Arquitectura valenciana (1974-82), Sala ParpaIló, Valencia, 1983. 


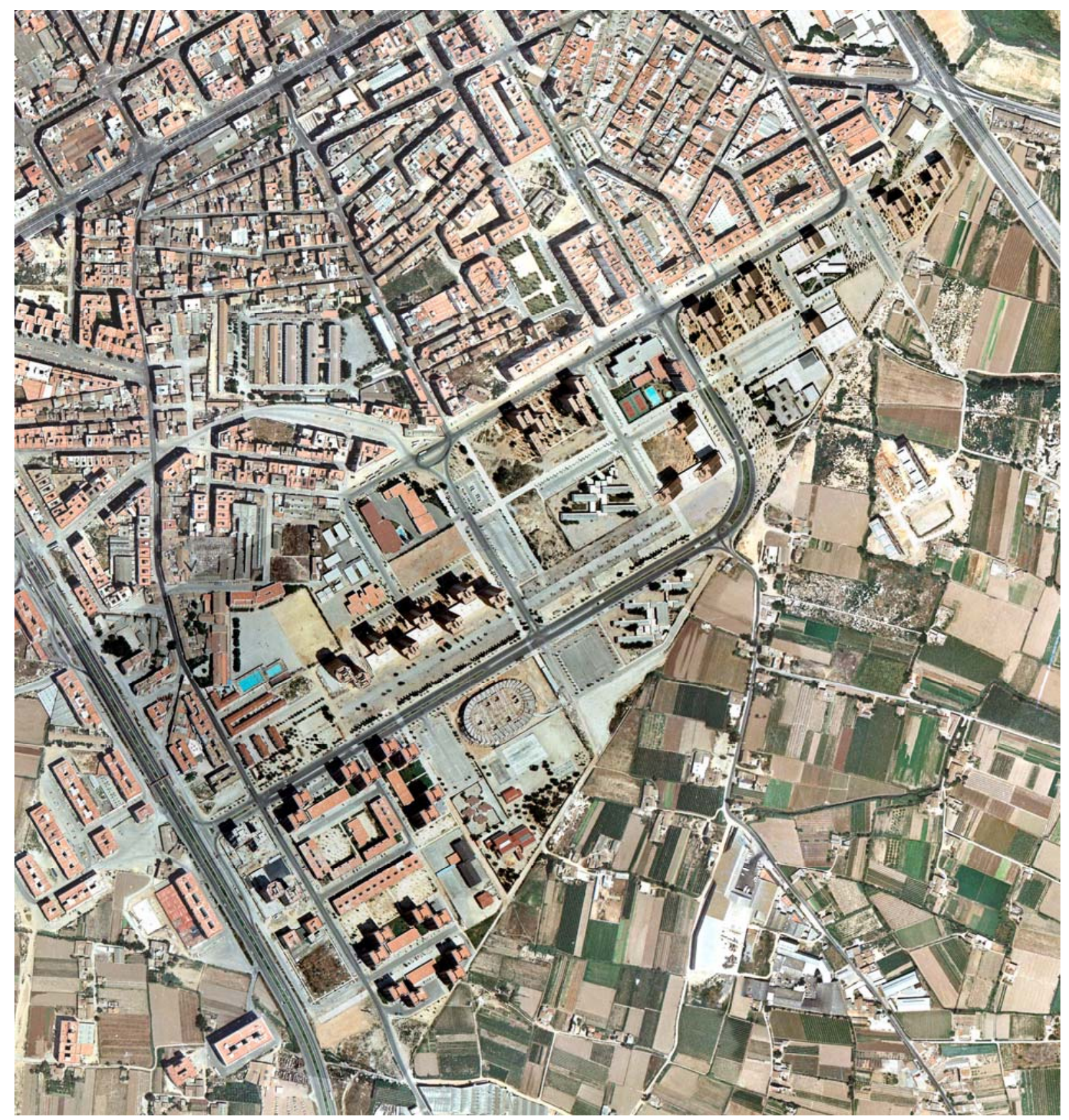

Zona del Polígono de la Fuente de San Luís. Fotografía aérea, 1980. 


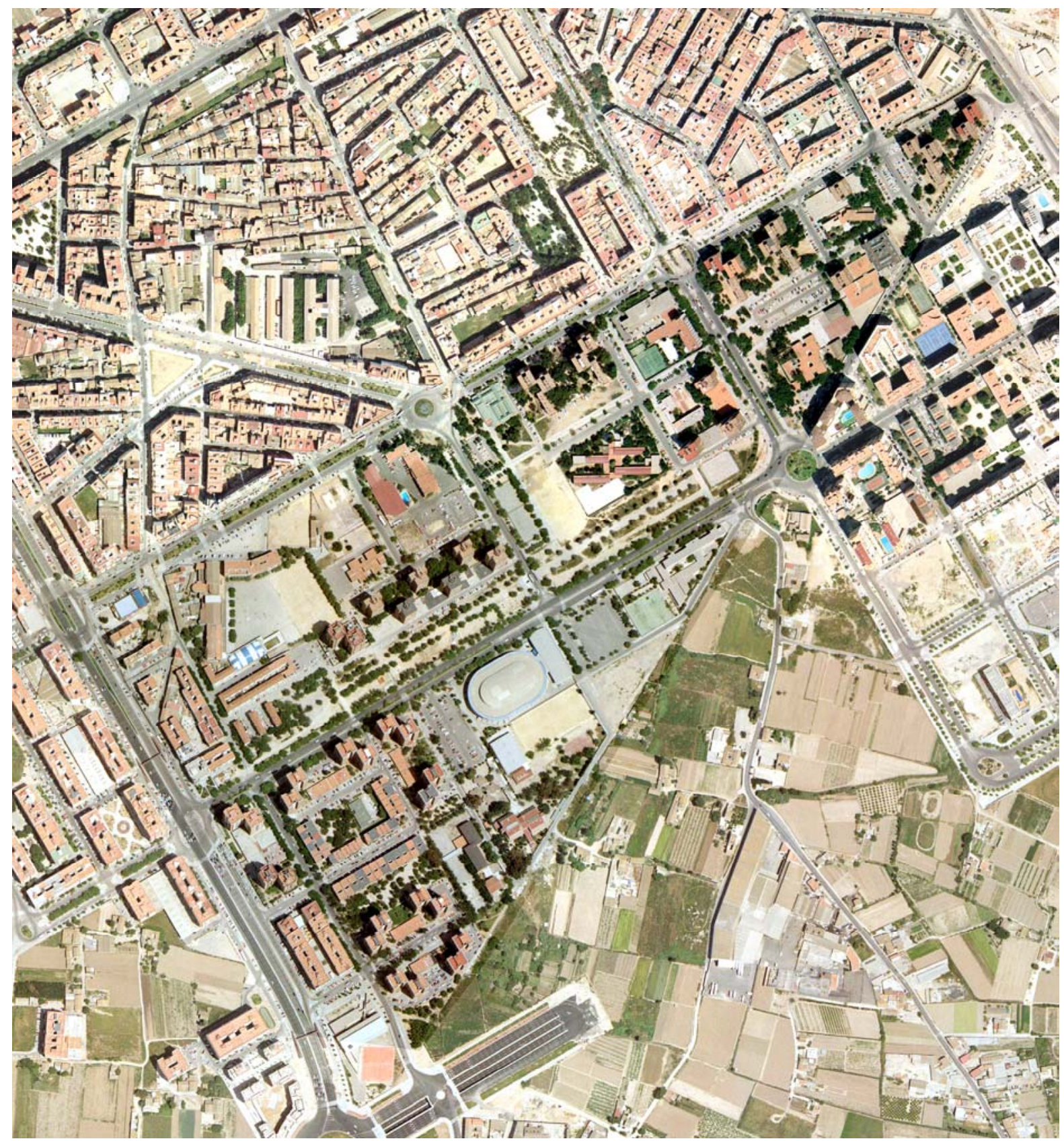

Zona del Polígono de la Fuente de San Luís. Ortofoto, 2002.(AUMSA) 

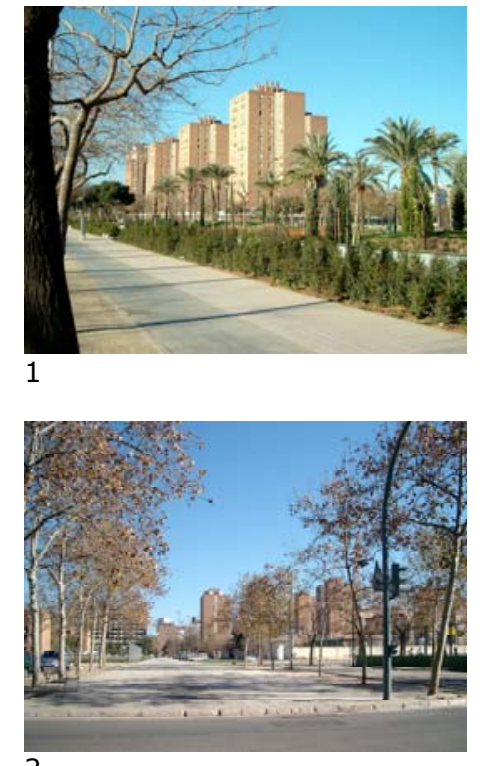

2

Las torres y bloques del grupo Vicente Mortes tienen fachadas de ladrillo visto, y una composición de huecos neutra, sin voladizos o elementos que rompan su volumetría básica. Todo ello contribuye a que unas edificaciones que están dispuestas en unidades relativamente aisladas unas de otras se perciban como parte de un único conjunto.

Por otra parte, los espacios libres públicos intermedios entre dichas edificaciones, cuya sobreabundancia y abandono centraban buena parte de las críticas al urbanismo del orden abierto en los años ochenta, han sido en los últimos años mejorados sensiblemente, y presentan el aspecto que cabe esperar en una zona verde adecuadamente urbanizada.
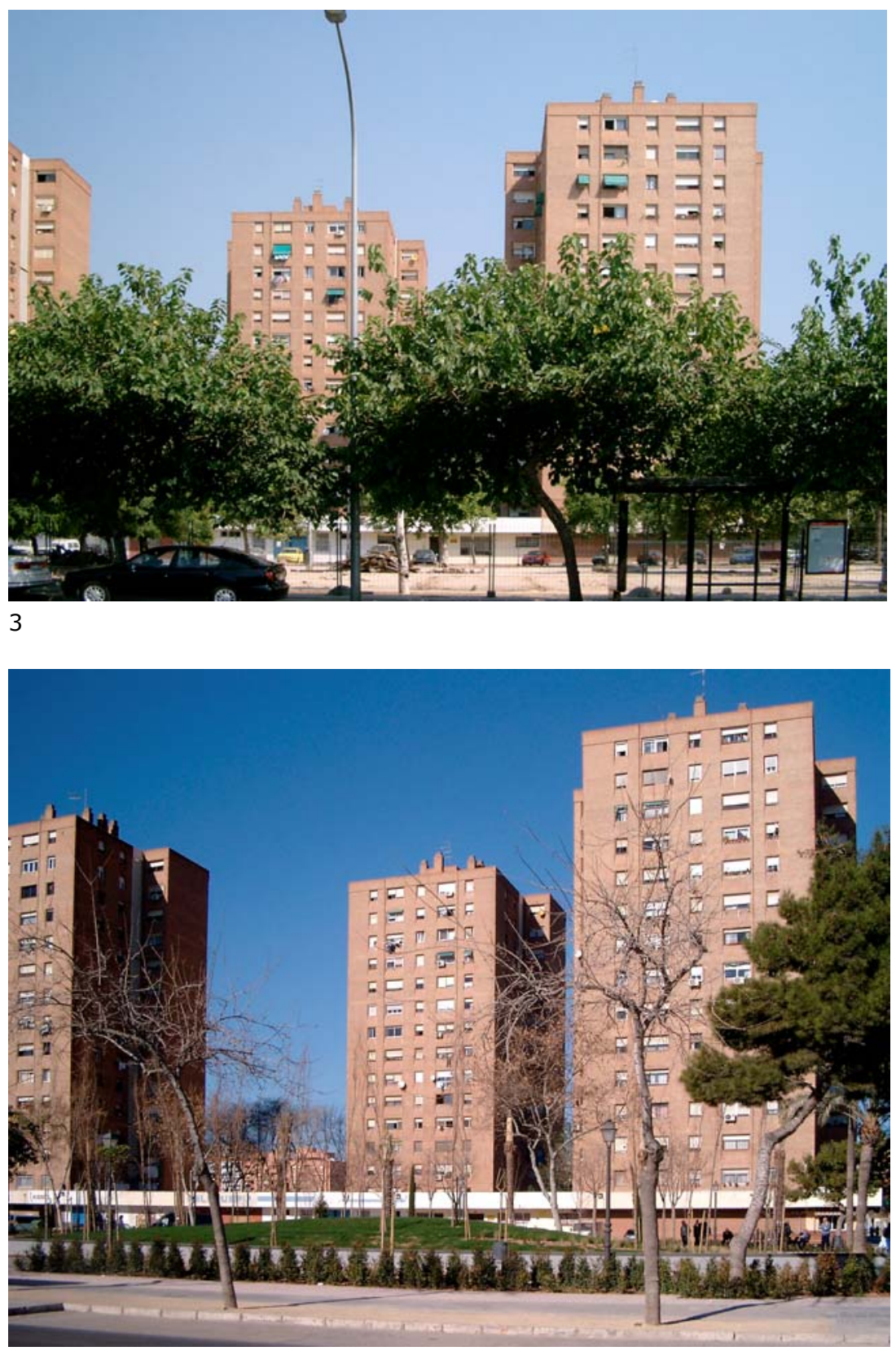


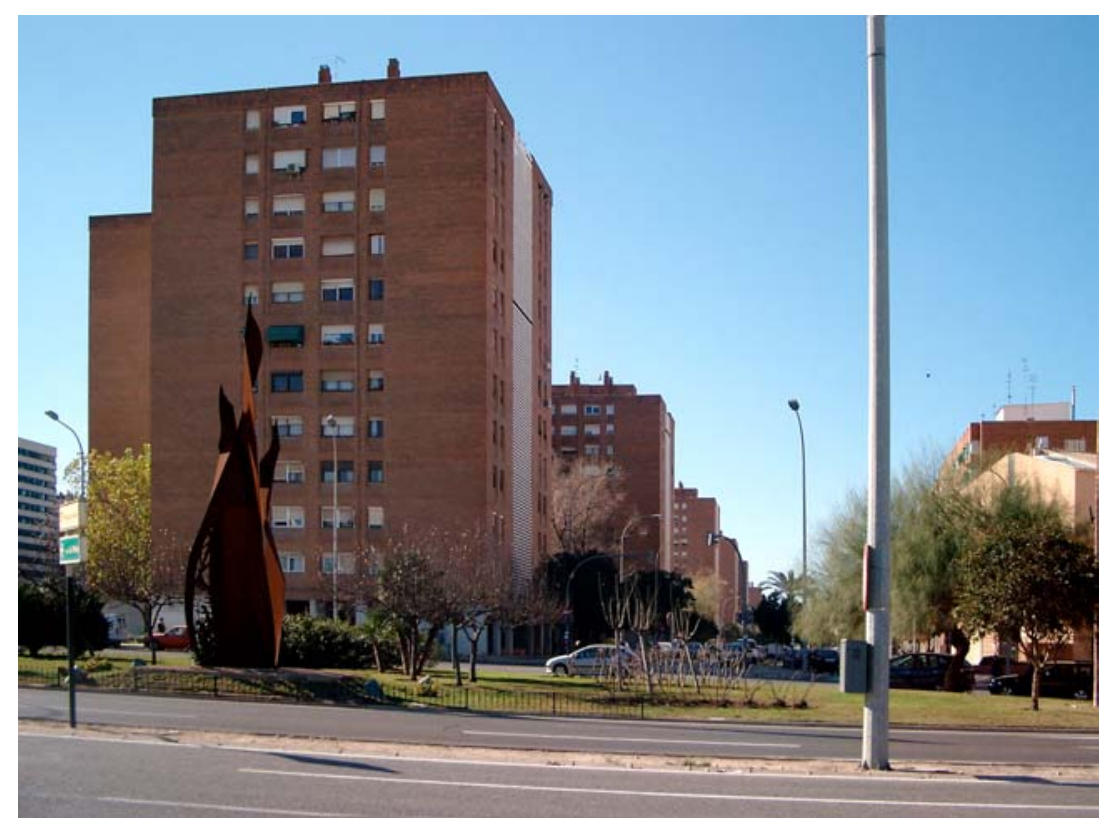

1

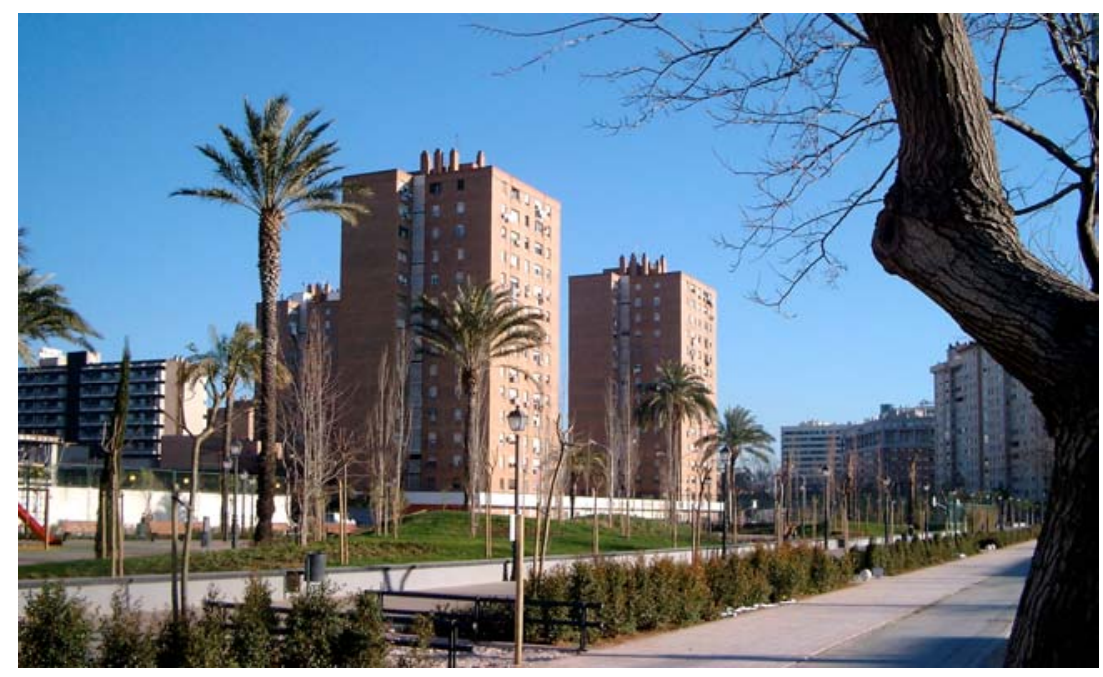

2

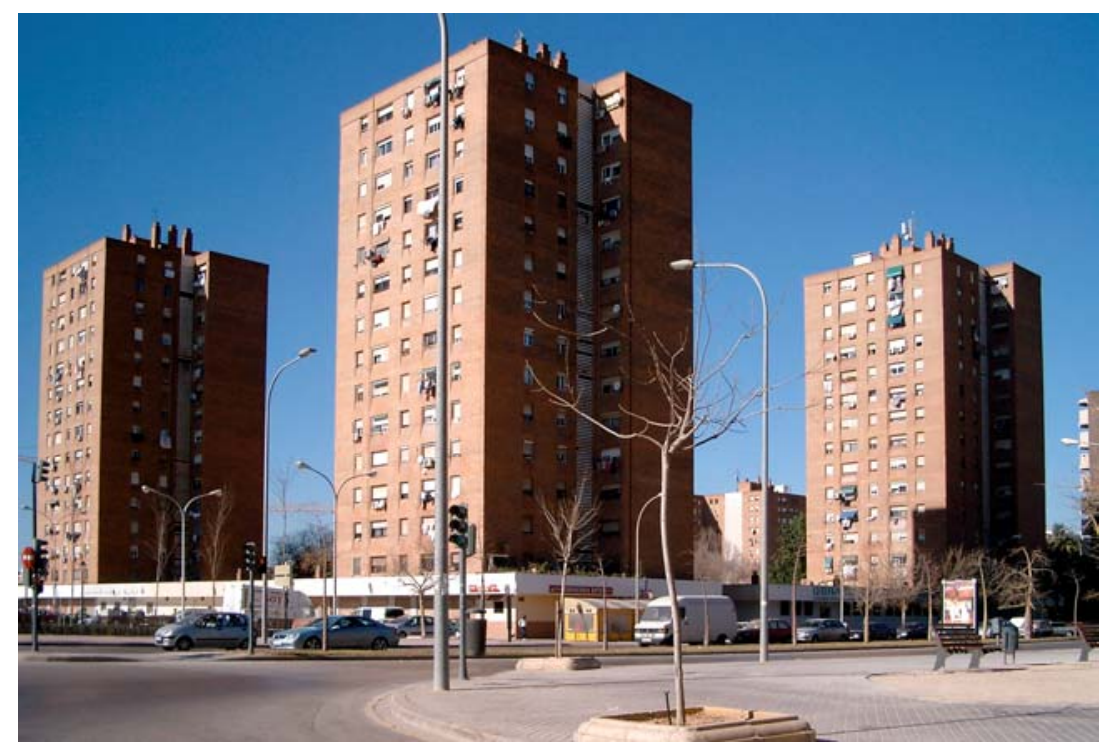

3
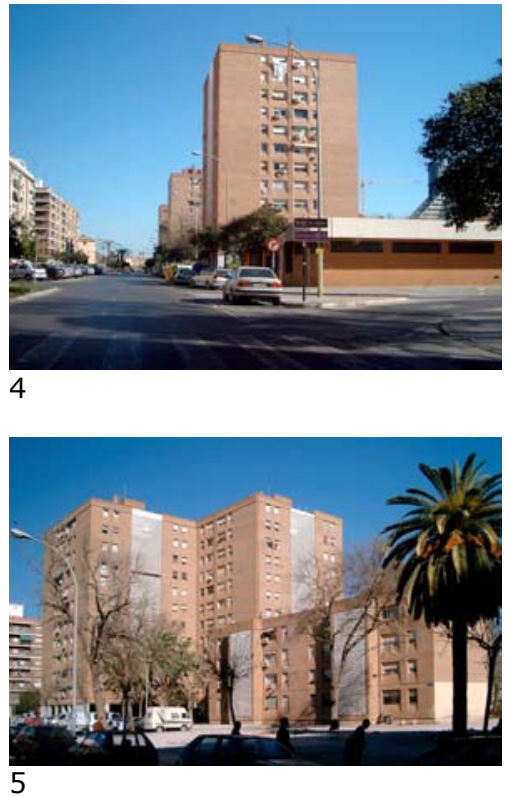

5

1. Torres de XII plantas en la Avenida de la Plata, vista hacia el oeste.

2,3. Torres de XV plantas en la Avenida Hermanos Maristas.

4 Avenida de la Plata, vista hacia el este.

5. Bloques lineales combinados con torres en la calle General Urrutia 

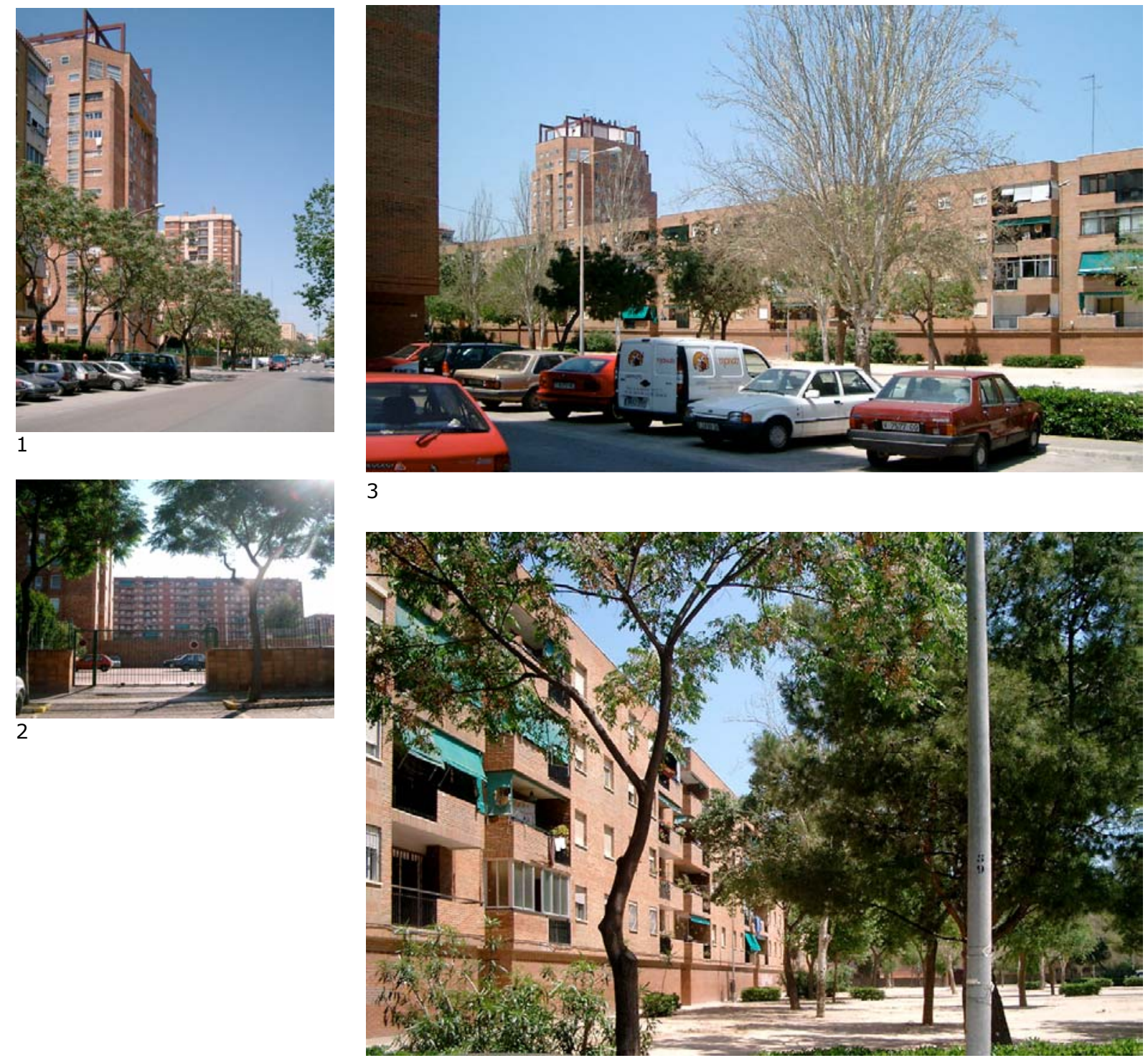

4

1. Torres en la Carrera de San Luís, vista hacia el norte.

2. Vallado de parcela en una de las torres promovidas por cooperativas.

3. Calle Doctor Julián Celma vista hacia el oeste.

4. Calle Doctor Julián Celma, vista hacia el este.

5. Calle Paco Piera, vista hacia el oeste.

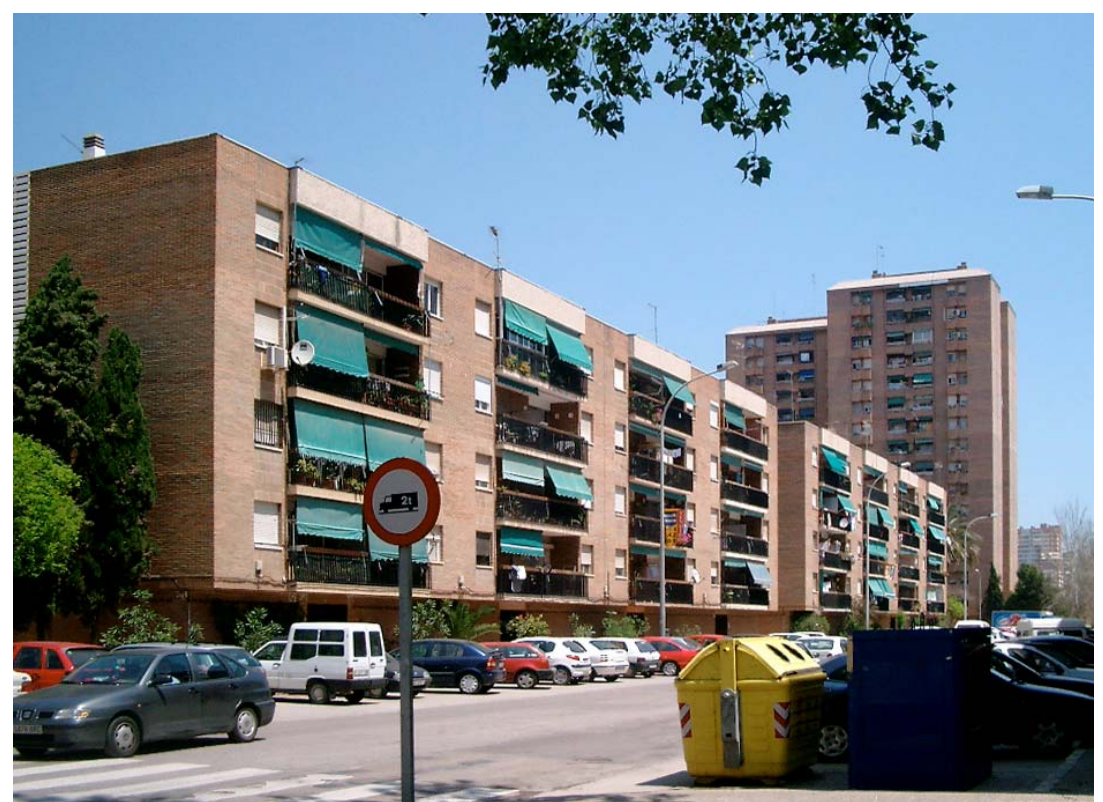


Las torres promovidas por cooperativas junto a la Avenida Ausias March disponen de una parcela propia en planta baja, vallada perimetralmente y destinada en algunos casos a jardín y otros a aparcamientos. La adscripción a la edificación de estos espacios libres de carácter privado marca una diferencia fundamental con respecto a las torres de promoción pública directa de los grupos Vicente Mortes y Fuente de San Luís, en las cuales los espacios ajardinados adyacentes en planta baja son de carácter público, y adoptan la forma de pequeñas isletas verdes intercaladas en las aceras.

En los dos grupos de promoción pública, las plantas bajas porticadas y sin más elementos que los zaguanes de acceso a viviendas de las torres y bloques pronto resultaron un elemento problemático a efectos de seguridad, por lo que han acabado siendo cerradas en su mayor parte.

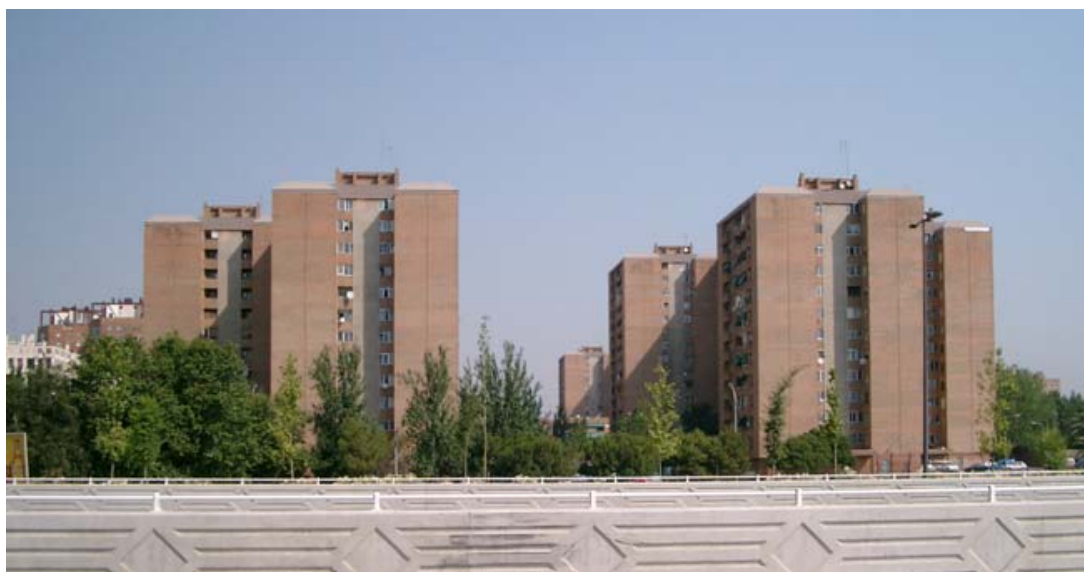

1

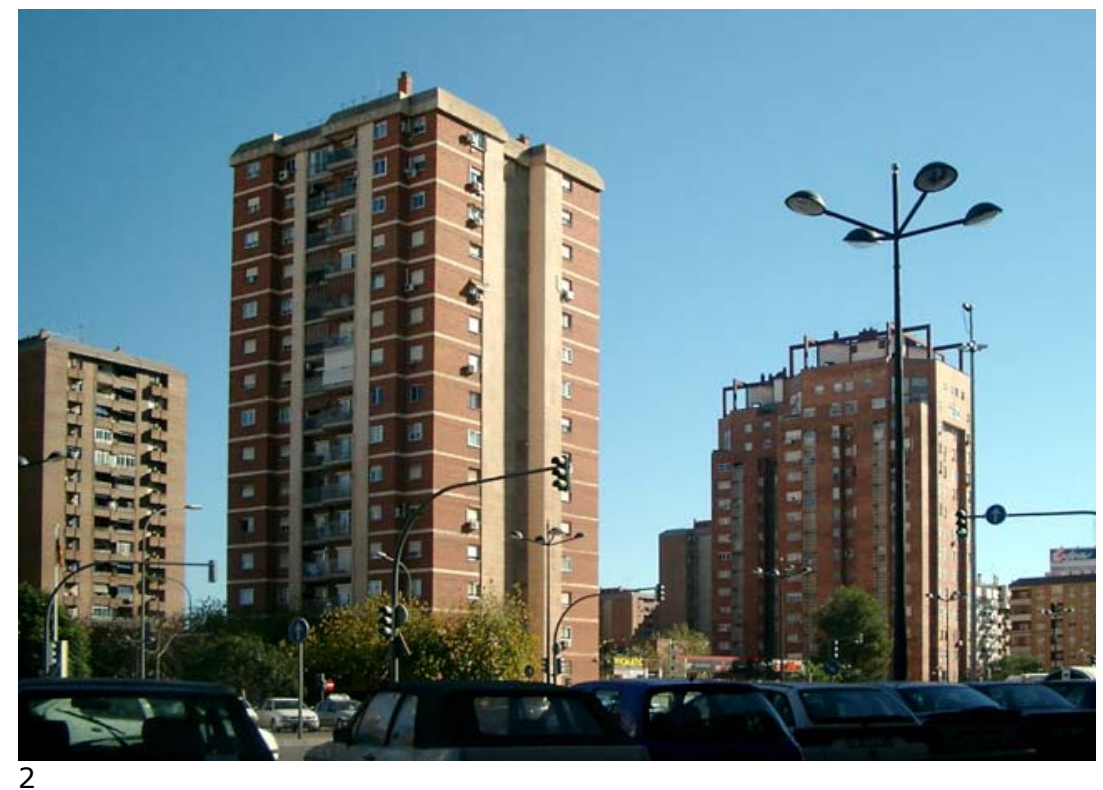

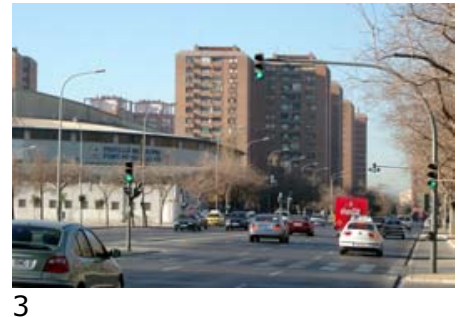
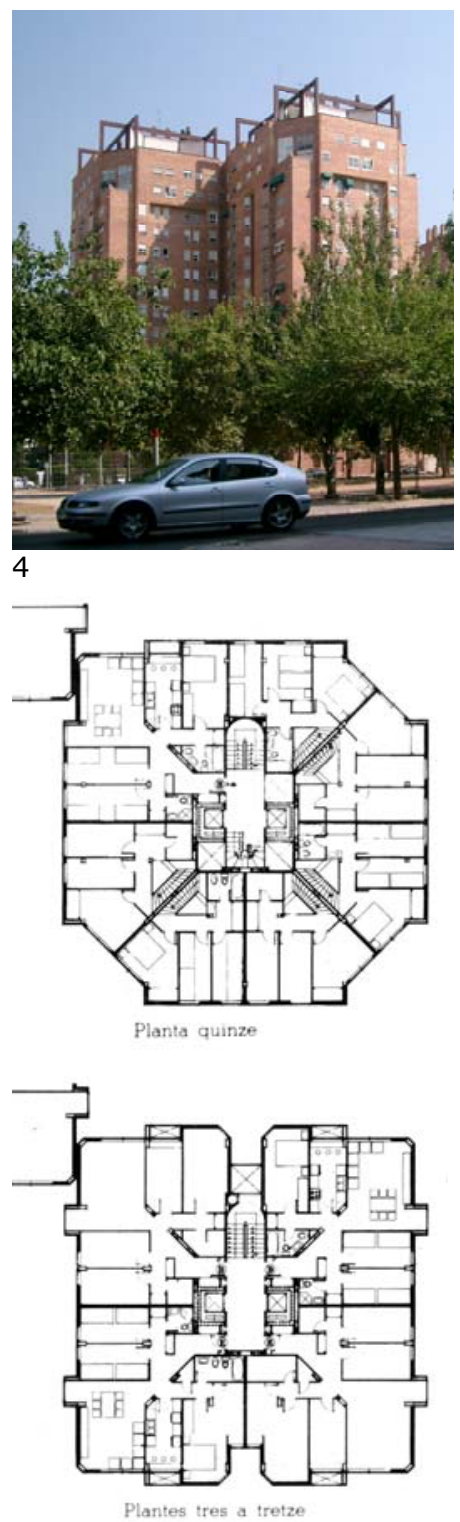

1. Torres del grupo Fuente de San Luís, vistas desde el Bulevar Sur.

2. Torres promovidas por cooperativas en la Avenida Ausias March, vista hacia el sur.

3. Torres del grupo Fuente de San Luís.

4,5. Torres en la Avenida Hermanos Maristas. Vista $y$ plantas. Arquitectos: V. Vidal y L. Alonso de Armiño, 1978-80. 


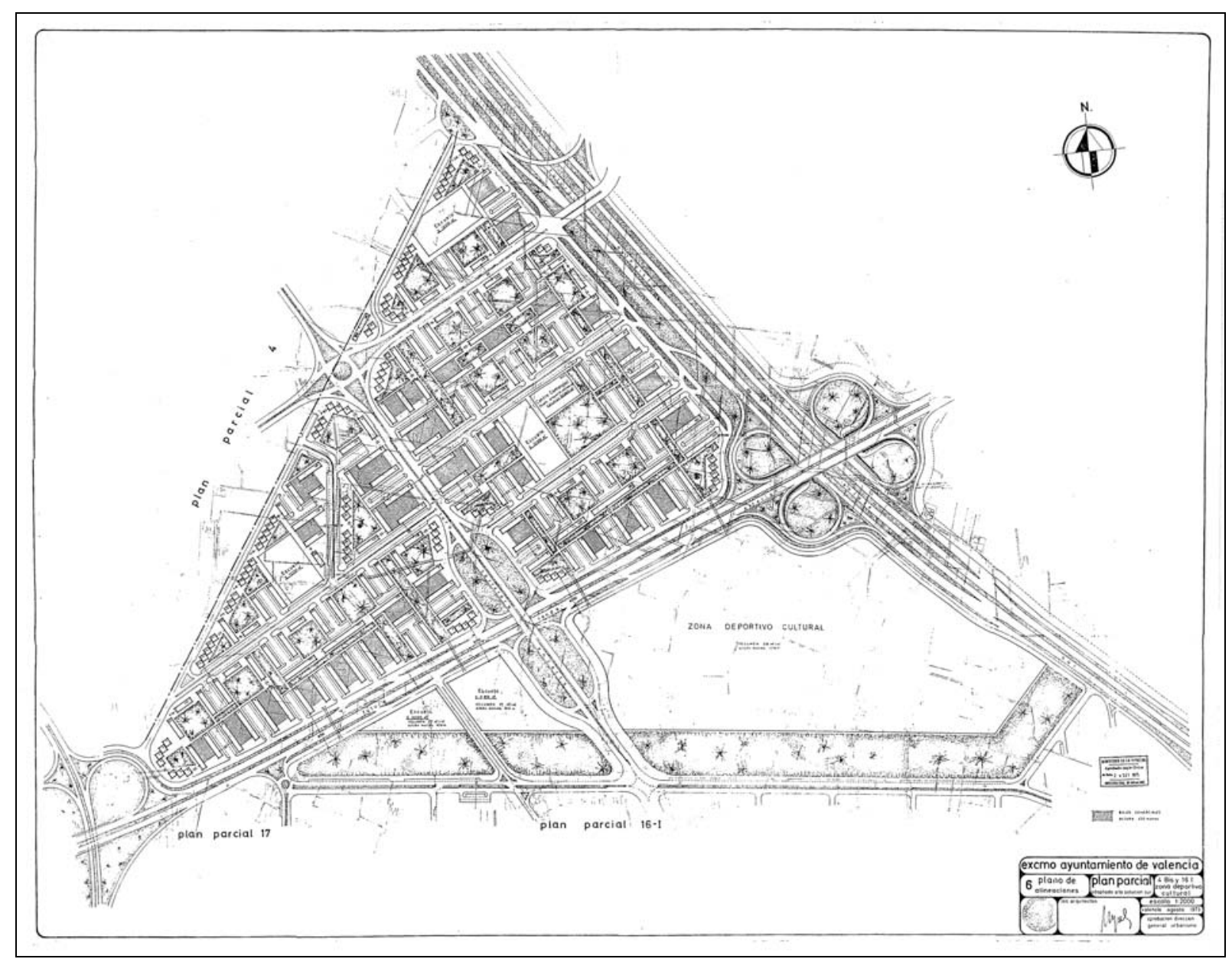

Plan Parcial 4b-16I, 1973. Plano de alineaciones. 


\section{EL PLAN PARCIAL No 4b-16I (1968/1973)}

El Plan Parcial no 4bis ordena un espacio de forma triangular limitado al Sur por la Ronda Exterior proyectada en el estudio de la red Arterial, al este por el tramo sur de la Autopista de enlace de la de Madrid-Levante, trazada por el viejo cauce del Turia, con la del Mediterráneo, y al norte por el Polígono Fuente de San Luís.

El Plan Parcial 16I, contiguo al anterior, ordena una zona situada entre la Ronda Exterior y la línea del enlace sur del ferrocarril. Esta zona, en el Plan General de 1966, está calificada en parte como dotacional-deportiva y en parte como industrial.

Los Planes Parciales 4bis y $16 \mathrm{I}$ fueron redactados por separado en 1968, y estas versiones son las que aparecen dibujadas en las hojas del Informe PREVASA, donde figuran como planes en tramitación en el listado final de la sección de Información Urbanística. $^{1}$

Posteriormente, como ocurrió también en otros planes que no habían llegado a aprobarse definitivamente, se redactó un nuevo Plan Parcial que englobaba los anteriores 4 bis y la parte calificada como dotacional-deportiva del $16 \mathrm{I}^{2}$. Esta versión, redactada en 1973, fue aprobada definitivamente por el Ministerio de la Vivienda en septiembre de $1975 .^{3}$

La zona, en el momento de redactarse la versión del plan de 1973, estaba todavía libre de construcciones, ya que de la ordenación previa para la misma, que es la del Polígono para Viviendas de Renta Limitada de 1956, no había llegado a realizarse ningún edificio antes de que quedara descartada como consecuencia de la nueva delimitación y ordenación del Polígono Fuente de San Luís en 1960.

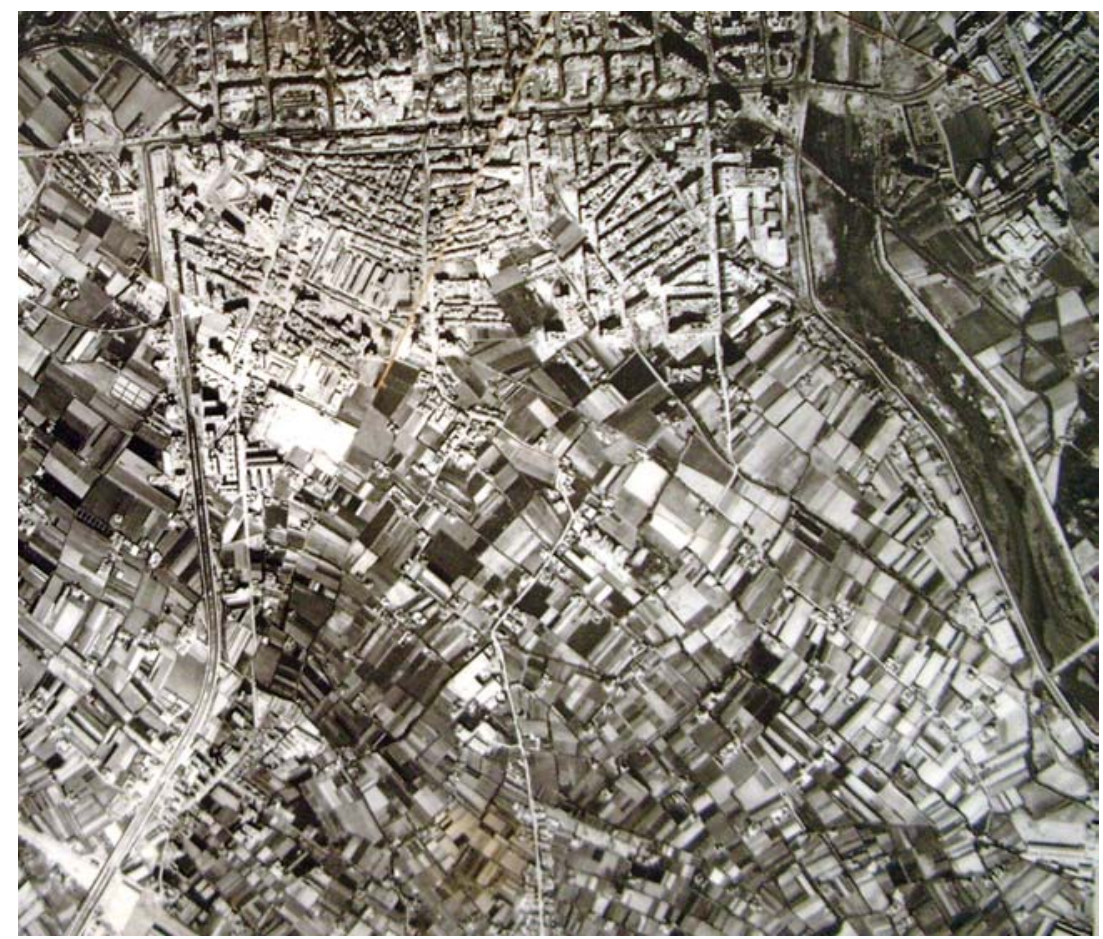

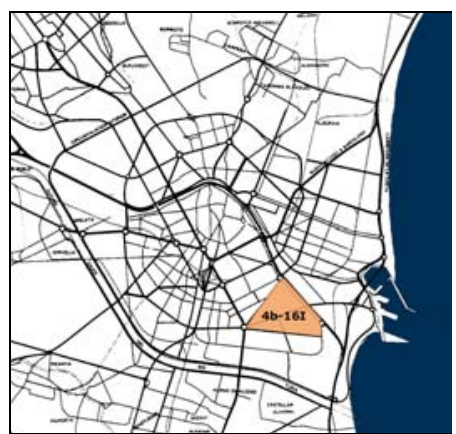

Plan Parcial 4b/16I. Situación

Zona del Plan Parcial 4b/16I. Fotografía aérea, h. 1965 (ETS de Arquitectura de Valencia)

1.Plan Parcial 4bis, 1968. Anexo de Documentos, pp. 725-732.

2. Plan Parcial 4b/6I. Anexo de Documentos, pp. 733-743.

3. Ver Documentos 4b-16I.1, Informe de la Corporación Administrativa Gran valencia sobre el PP 4bis-16I y Documento 4b-16I.2, Resolución del Ministerio de la Vivienda de aprobación del PP 4b16I. Esta resolución hace ya referencia a la Reforma de la Ley del Suelo de 1975, aprobada con anterioridad a la misma. Anexo de Documentos, pp. 742-743. 


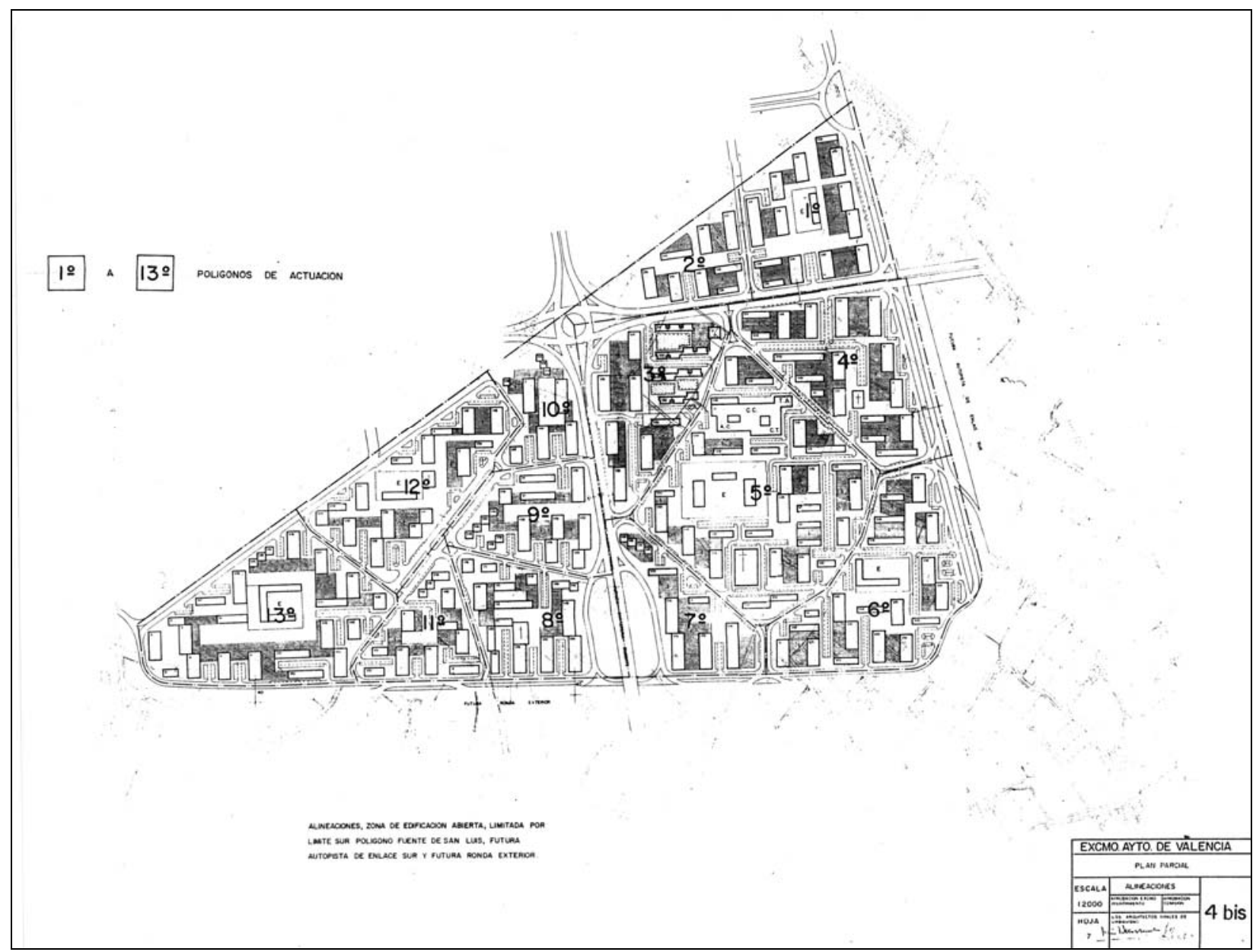

Plan Parcial 4 bis, 1968. Plano de alineaciones.

Plano Parcial no 16I, Zona deportivo-cultural, 1968. Plano de alineaciones.

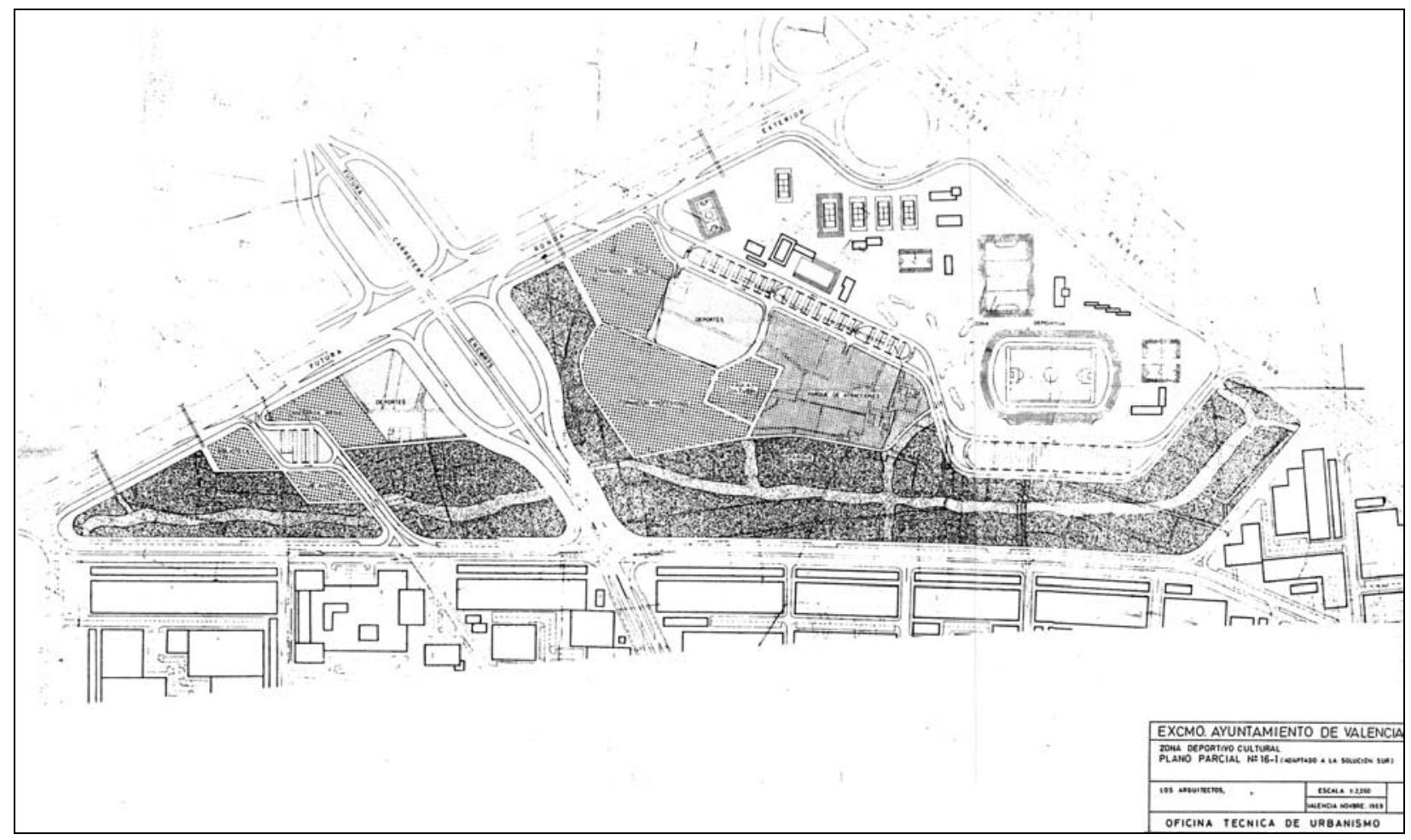


El Plan Parcial 4bis adaptado a la Solución Sur, redactado en 1968 , es un plan atípico dentro del conjunto de planes parciales del periodo que estamos estudiando.

El primer elemento que diferencia este plan con respecto a otros es el viario interno, para el que se proyecta un trazado coincidente con el de los principales caminos existentes en la zona, formando una red de anillos de forma irregular, previstos para un tráfico unidireccional. Esta red es la denominada en la memoria del plan red verde, de calles colectoras de barrio, y constituye la categoría de viales intermedia entre la red azul, de conexión entre barrios, y la amarilla, de acceso a la propiedad y aparcamientos. Además, el plan prevé una red peatonal que enlaza las distintas unidades vecinales que delimitan los anillos antes mencionados.

En cuanto a la forma de la edificación, en el Plan Parcial 4bis de 1968 los bloques lineales son la base de la composición. La mayoría de los bloques son de cinco crujías, aunque hay también bastantes bloques de dos crujías. De modo puntual, se emplea también el tipo de bloque escalonado que hemos visto anteriormente en el Plan Parcial 22. Los bloques se enlazan unos con otros en planta baja mediante cuerpos de edificación destinados a usos no residenciales (comerciales, talleres, garajes, etc.), formando agrupaciones de varios bloques en la mayor parte de los casos. El objetivo de estas agrupaciones, cuyo tamaño es mayor que el de la habitual manzana mixta formada por dos bloques unidos por una planta baja comercial, está explicado en la Memoria del modo siguiente:

En la disposición de los bloques y edificaciones además de las orientaciones, alturas, óptimas distribuciones posibles de viviendas, etc., se ha pretendido crear ambientes públicos de alto grado compositivo dentro de cada supermanzana, definiendo al mismo tiempo los espacios verdes, viarios de peatones, superficies de aparcamiento público, plazas para juegos infantiles y plazas de convivencia ciudadana. ${ }^{1}$

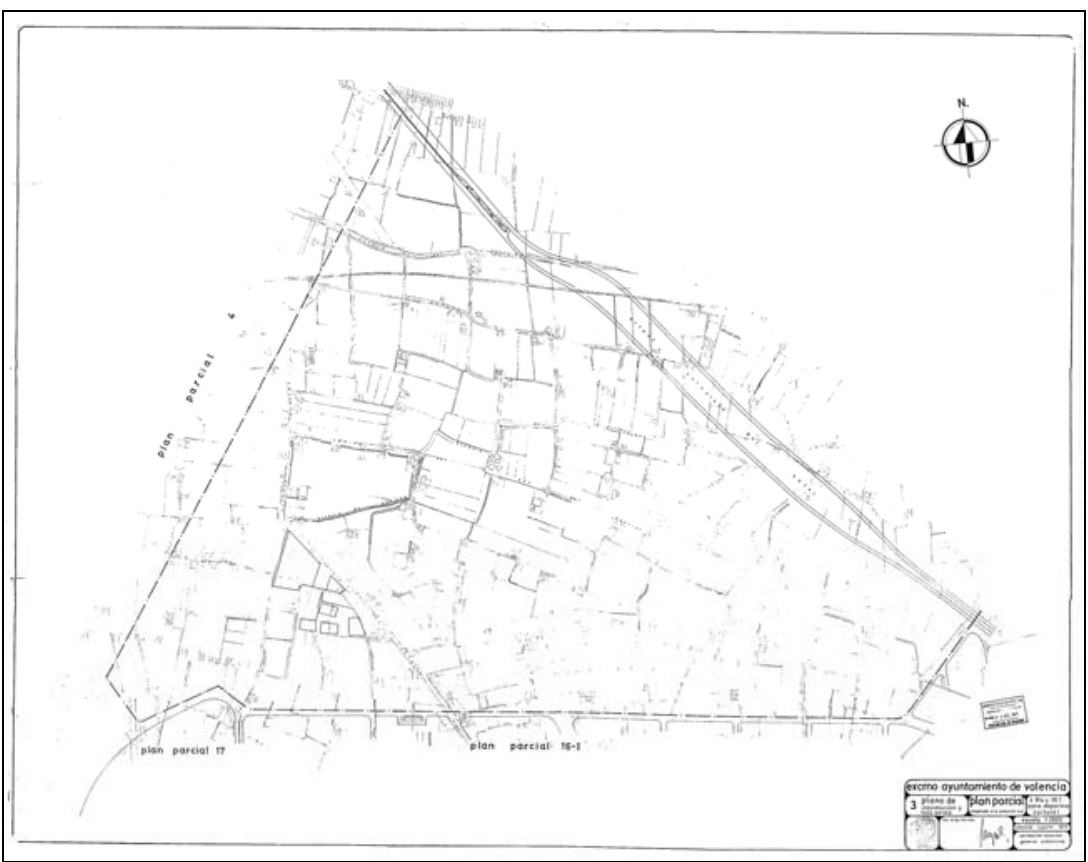

Plan Parcial 4b-16I, 1973. Plano de información.
1.Plan Parcial 4bis, 1968. Memoria. Anexo de Documentos, p. 727. 


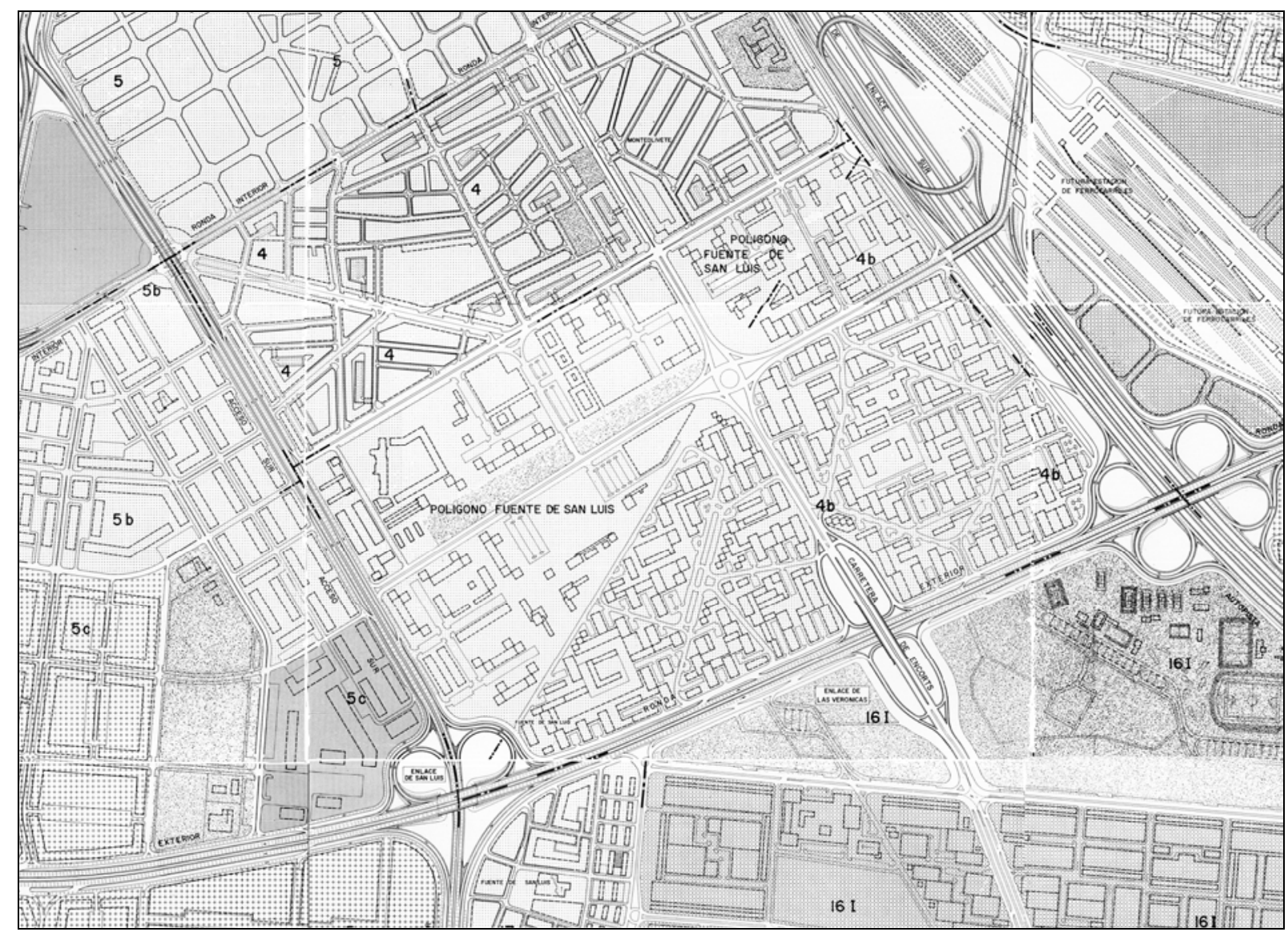

Zonas de los Planes Parciales 4bis y 16I, 1968. (Montaje de Hojas del Informe PREVASA).
Los bloques lineales, muy cortos, adoptan posiciones muy variadas, y se enlazan en planta baja con cuerpos de edificación que componen formas cóncavas, envolviendo espacios libres en forma de plazas o parcelas dotacionales.

La mayor parte de los bloques lineales se disponen según las direcciones paralela u ortogonal al eje de la Ronda Exterior, a excepción de los situados en el sector noreste, que siguen los ejes del ensanche de Monteolivete. Estos ejes del ensanche son también los que orientan la edificación abierta en el Polígono contiguo de la Fuente de San Luís, así como los de los ejes viarios estructurales de la zona, como la Avenida Hermanos Maristas o la calle general Urrutia, que atraviesa la zona del Plan Parcial 4bis hasta llegar a la Ronda Exterior. Por todo ello, la opción de orientación elegida en este plan no parece la más afortunada desde el punto de vista de la coherencia geométrica de la nueva extensión hacia el sur de esta zona de la periferia.

Por lo que respecta a los equipamientos, la Memoria del Plan Parcial 4bis señala que para su cuantificación se ha partido de las determinaciones del Plan Nacional de la Vivienda. En concreto, el plan prevé cuatro centros parroquiales, cinco grupos escolares y un centro comercial. En cambio, las zonas verdes en forma de parques vecinales son prácticamente inexistentes.

En el plan se delimitan, para su ejecución, trece polígonos de actuación independientes. La Memoria indica que para la urbanización y concesión posterior de licencias en estos polígonos deberá tramitarse previamente un expediente de reparcelación. 


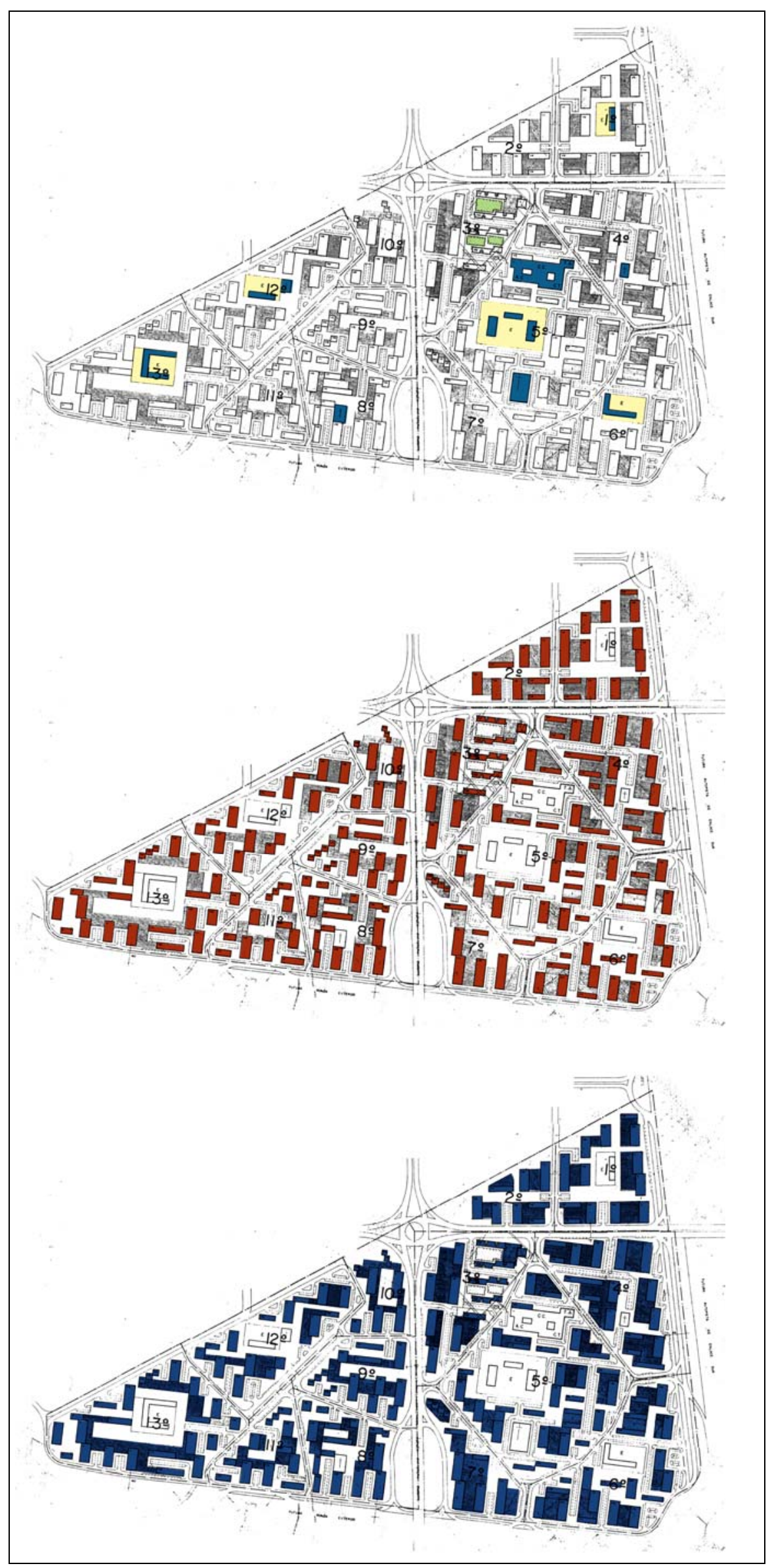

Plan Parcial 4bis, 1968. Equipamientos y edificación en planta baja y planta tipo (Elaboración propia, color sobre plano de alineaciones del plan). 
Plan Parcial 4b-16I, 1973.

Viario (Elaboración propia sobre Plano de red viaria fundamental del plan)

El Plan Parcial 4bis-16I de 1973 sustituye la ordenación revista en la versión de 1968 por otra completamente diferente.

La nueve ordenación se basa en un trazado viario que sigue los ejes iniciados en el Polígono de la Fuente de San Luís, paralelos y ortogonales al ensanche de Monteolivete. Así, el viario interno principal se compone de cuatro ejes transversales a la calle General Urrutia, uno por el oeste y tres por el este, que delimitan supermanzanas. De estos ejes, así como de las calles de servicio que discurren en paralelo a la Ronda Exterior y al Enlace Sur, arrancan, en perpendicular, una serie de ramales sin salida que penetran a intervalos regulares en las supermanzanas sin atravesarlas, y cuya función es de acceso y aparcamiento.

La edificación prevista en esta versión del plan es toda ella de bloques lineales de dos crujías, combinados con bloques escalonados recayentes a las vías diagonales. Los bloques lineales aparecen como edificios aislados, separados por zonas verdes, o bien agrupados de dos en dos formando pequeñas manzanas mixtas con locales comerciales en planta baja.

El plan muestra, en la disposición de la edificación, una mayor atención de lo habitual en cuanto al proyecto del espacio público, como lo demuestra la composición sensiblemente simétrica a ambos lados de los ejes principales que forman la calle General Urrutia o la Avenida Hermanos Maristas, o el tratamiento unitario de los bordes del área.

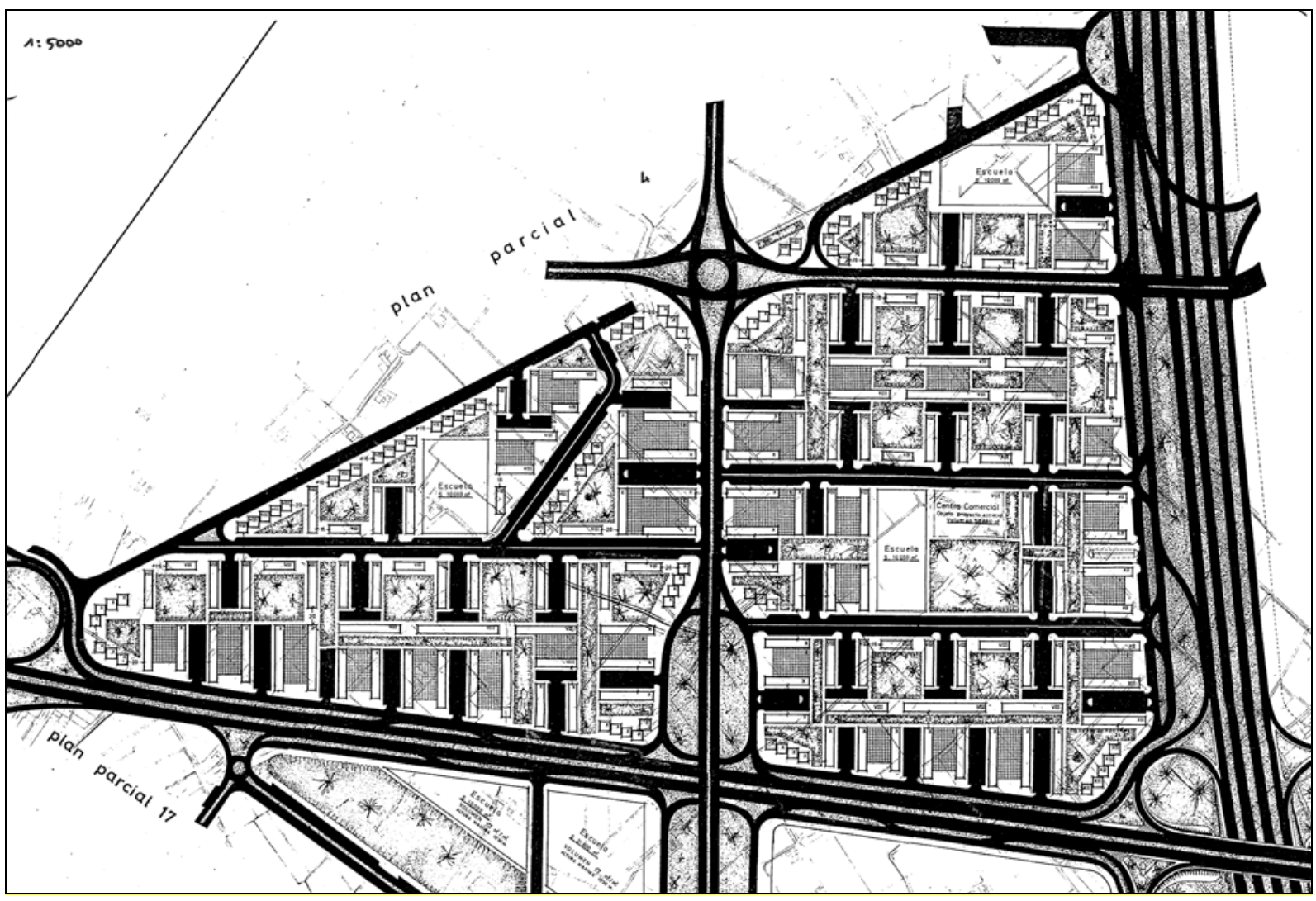




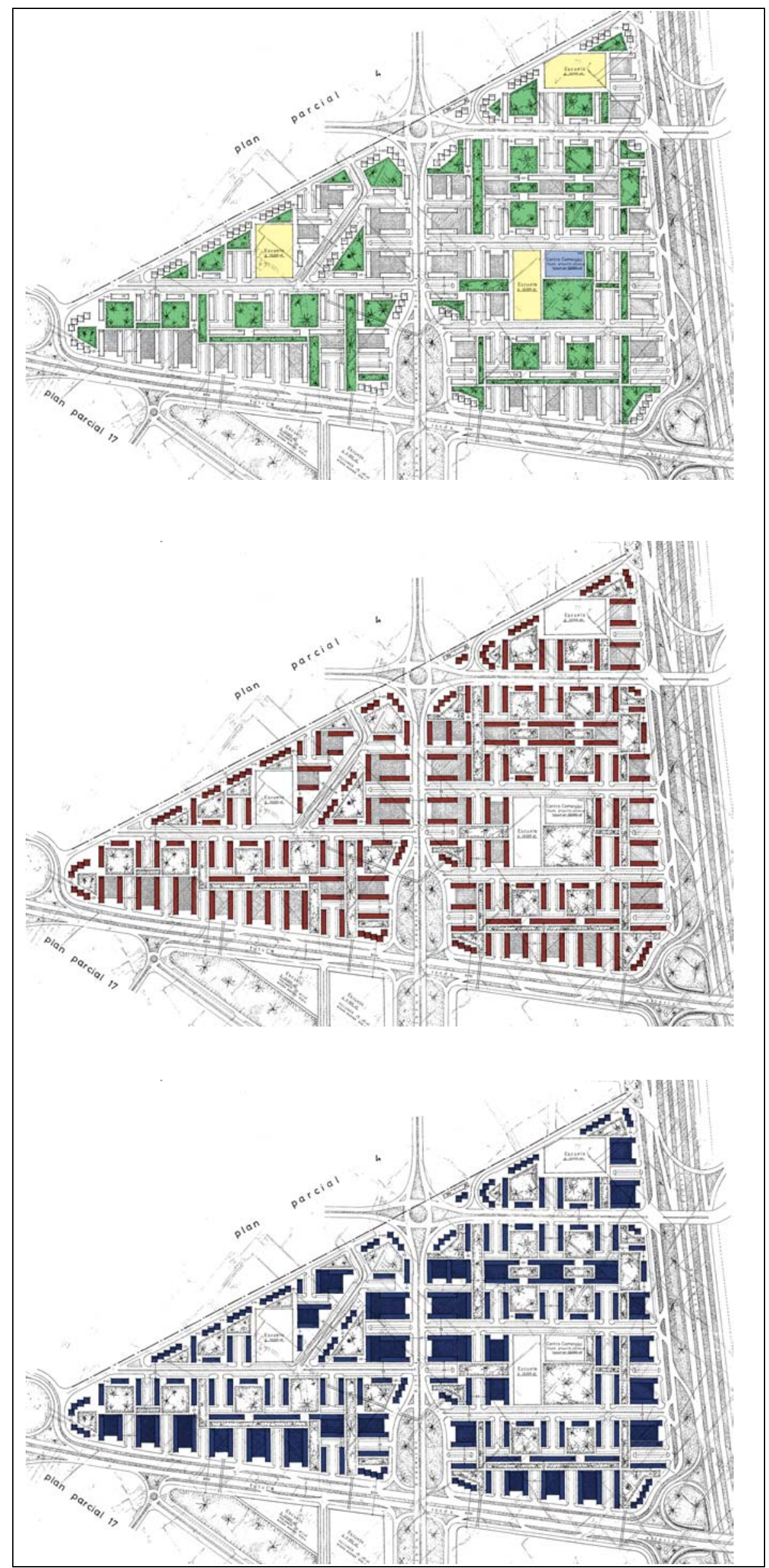

Plan Parcial 4b-16I Equipamientos, edificación en planta tipo y en planta baja (Elaboración propia, color sobre plano de alineaciones del plan) 


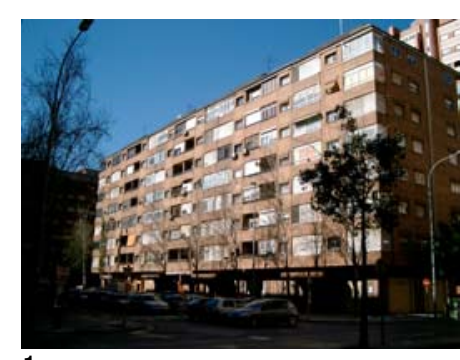

1

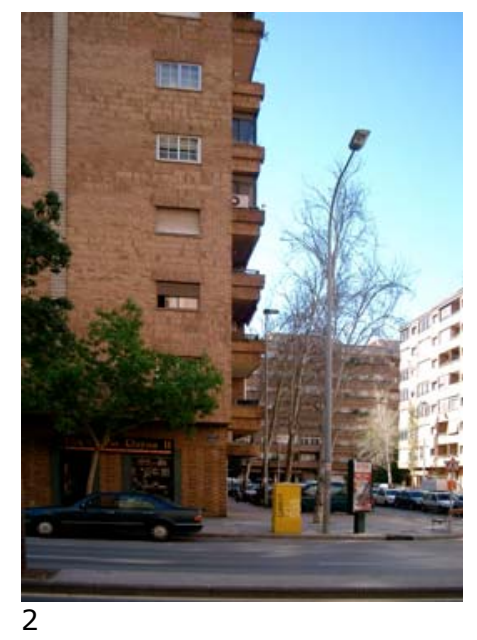

1,2. Bloques en la calle Marqués de Lozoya.

Plan Parcial 4b/16I. Grado de realización (Elaboración propia sobre plano de alineaciones del plan)

PGOU Valencia 1986. Área del Plan Parcial 4B/16I (Color sobre montaje de hojas de la serie $C$ del PGOU).
La presencia de parcelas dotacionales es, como cabe esperar por la fecha de redacción del plan, mucho más abundante que en los planes parciales redactados en el periodo inmediatamente posterior a la aprobación del Plan General de 1966.

En relación con las zonas verdes, el plan plantea una combinación de parques repartidos por toda la zona combinados con unas franjas verdes lineales que acompañan los recorridos peatonales de enlace entre las diversas parcelas dotacionales. El verde no es, pues, residual, sino estructurante.

\section{Grado de realización}

El grado de realización del Plan Parcial 4bis-16I fue prácticamente nulo, ya que se limita a unos pocos bloques lineales al este de la calle General Urrutia.

La zona ordenada por el plan, no obstante, no es precisamente un suelo vacante en la actualidad, sino que ha tenido en los últimos años un desaforado desarrollo urbanístico, realizado sobre unas bases completamente diferentes y con unos resultados que no mejoran, sino más bien al contrario, el Plan Parcial 4bis. Su análisis detallado, no obstante, excede los límites del presente trabajo.
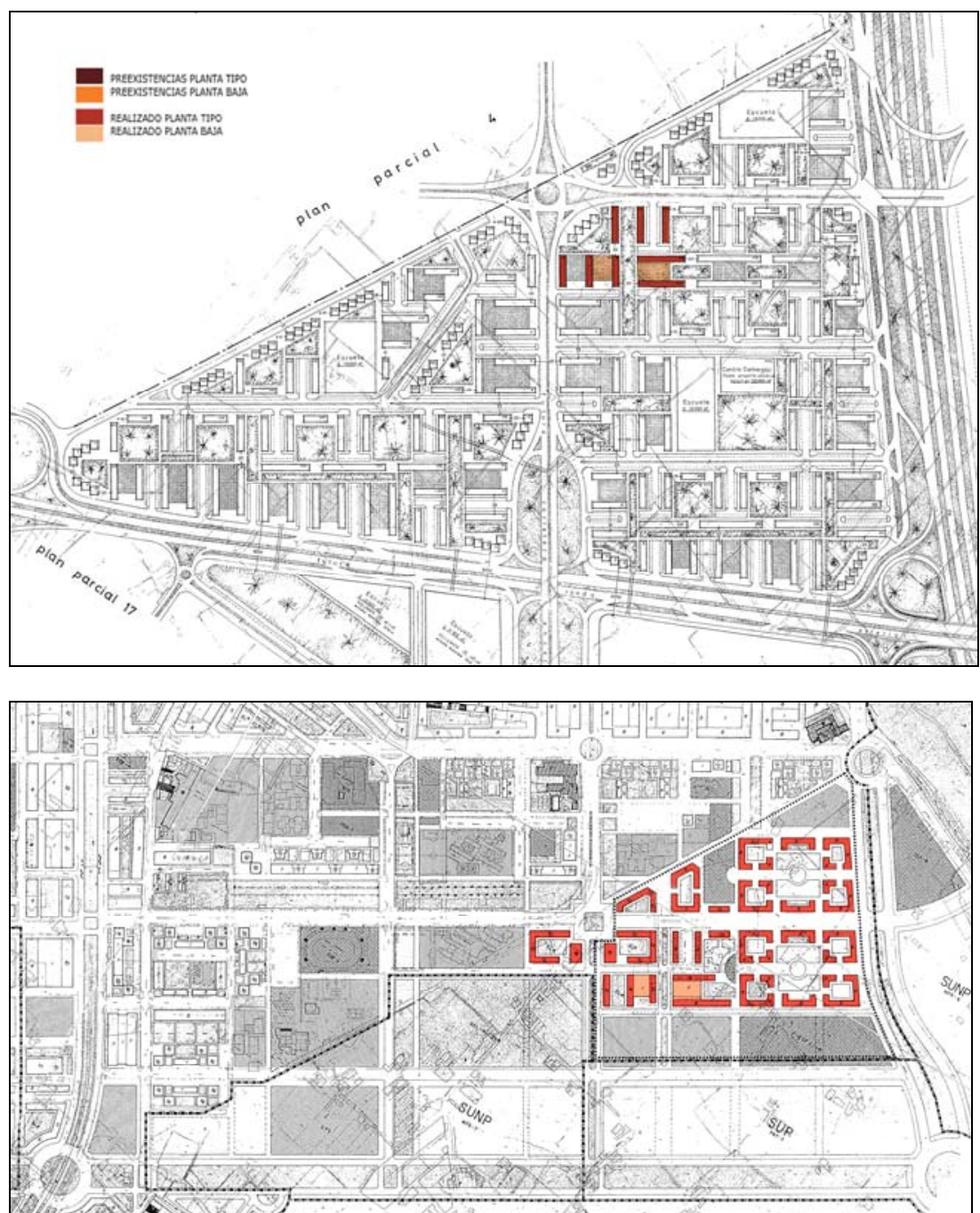


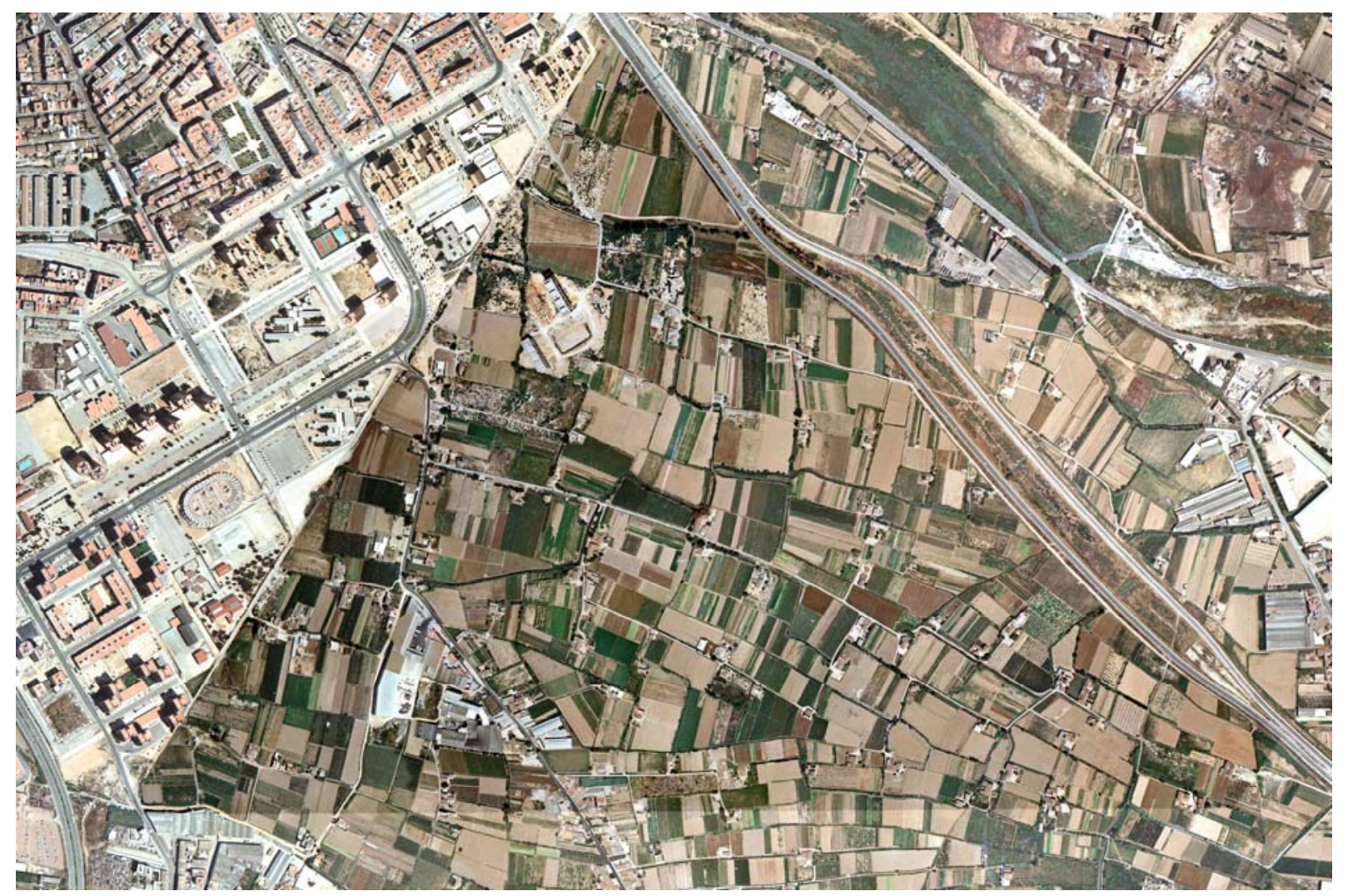

Zona del Plan Parcial 4b-16I. Fotografía aérea 1980.

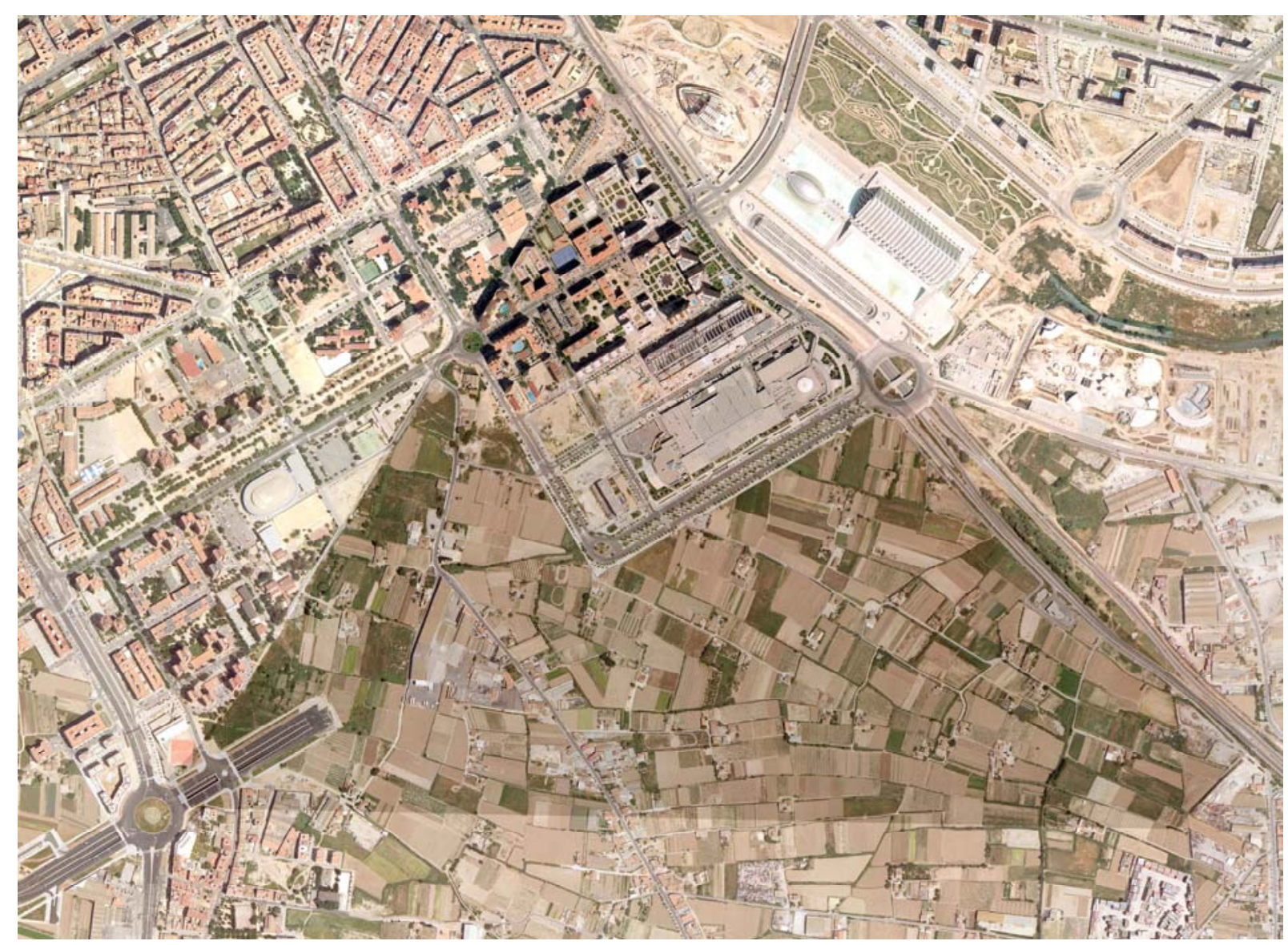

Zona del Plan Parcial 4b-16I. Ortofoto 2002 (AUMSA). 

RECAPITULACIÓN Y CONCLUSIONES 

El objetivo principal de este trabajo, que, tal como señalábamos en la introducción al mismo, era el de aportar documentación para conocer con un grado de detalle suficiente las áreas periféricas de edificación abierta de Valencia, ha quedado cubierto, a nuestro juicio, con el estudio que hemos realizado de las mismas, que ha permitido sacar a la luz un buen número de planes y proyectos urbanos relegados al olvido tras el cambio en la orientación del urbanismo derivado de la crisis del modelo de ciudad funcionalista de la Carta de Atenas, cambio que en nuestra ciudad coincide con los años previos a la gestación del Plan General de Ordenación Urbana de 1988.

Aunque consideramos que esa labor documental y de análisis pormenorizado podría bastar por sí sola para justificar el trabajo, no debemos darlo por finalizado sin una valoración de conjunto de la edificación abierta en Valencia y unas conclusiones, que expondremos a continuación.

\section{ETAPAS DE LA EDIFICACIÓN ABIERTA EN VALENCIA.}

La documentación que a lo largo del presente trabajo hemos ido presentando nos permite conocer de un modo bastante preciso la evolución del planeamiento parcial basado en la edificación abierta en Valencia, ya que abarca desde el primero hasta el último de los diferentes planes parciales realizados para las áreas residenciales periféricas de la ciudad entre 1946 y 1976. Los planes parciales que hemos analizado, redactados en este periodo, pueden englobarse en tres etapas, cada una de las cuales corresponde a una sección del trabajo. Dentro de cada etapa, pueden distinguirse varios grupos de planes.

I) Entre el Plan General de 1946 y la riada de 1957.

La primera etapa es la de introducción progresiva de los principios del orden abierto, que se produce inicialmente a pequeña escala en los grupos de viviendas de promoción pública y también en una serie de planes y proyectos urbanos no realizados. En esta etapa hemos incluido los conjuntos de planes y proyectos siguientes:

- Grupos de viviendas de promoción pública municipal o estatal, de los cuales el de mayor importancia es el Virgen de los Desamparados, de la Obra Sindical del Hogar.

- Proyectos que formaban parte del Plan General de 1946: Barrio residencial en Burjasot-Benimamet y Ensanche Sureste, que pueden considerarse como los primeros planes urbanísticos basados en la edificación abierta.

- Hojas y Proyectos Parciales de Desarrollo del Plan General de 1946, algunos de los cuales ordenan zonas de suelo vacante mediante edificación abierta, en vez de con manzanas.

- Proyectos de Ejecución de Polígonos para la construcción de Viviendas de Renta Limitada, redactados entre 1955 y 1956 para los sectores de Paseo al Mar, Campanar, Avenida de 
Castilla y Monteolivete. Estos proyectos, no realizados, suponen una primera aproximación a la idea de crecimiento de la ciudad por partes o unidades vecinales característica del urbanismo funcionalista.

II) Entre el Plan Sur de 1958 y el Plan General de 1966.

En esta segunda etapa el orden abierto se afianza como forma de crecimiento propia de la periferia urbana, utilizándose no sólo para áreas de suelo vacante, sino para rehacer zonas ya dotadas de planeamiento anterior a base de manzanas, que se sustituyen por edificación aislada.

Los grupos de planes y proyectos incluidos en esta etapa son los siguientes:

- Edificación abierta incluida en las propuestas del Plan Sur de 1958: nuevos centros comerciales y edificación proyectada junto al antiguo cauce del Turia.

- Grupos de viviendas del Plan Riada: Virgen de la Fuensanta y Virgen del Carmen. Son los primeros conjuntos de viviendas construidos en Valencia de acuerdo con los principios del orden abierto y con el lenguaje arquitectónico asociado al mismo. Con ellos se introduce en la ciudad el modelo de crecimiento urbano propio de la ciudad funcional, por adición de partes completas, de unidades residenciales integradas por viviendas y equipamientos, proyectadas y construidas de modo unitario.

- Barrio Virgen de la Luz y diversos episodios aislados de edificación abierta en grupos de viviendas de Renta Limitada, como los grupos Stella Maris o Santa María Micaela, que señalan el inicio del predominio de la promoción privada.

- Planes parciales municipales de desarrollo del Plan Sur de 1958. En estos planes, en los que se aplican de forma incipiente los criterios establecidos por la Ley del Suelo de 1958, se introduce de manera generalizada la edificación abierta en todas las zonas no consolidadas de la periferia de Valencia, tanto en las ordenadas anteriormente con manzanas como en las de suelo vacante exteriores a la Ronda de Tránsitos, que no disponían de planeamiento parcial previo, e incluso en algunas operaciones de renovación urbana en el centro histórico. Estos planes quedarán obsoletos en 1966 al aprobarse el Plan General adaptado a la Solución Sur y, sobre todo, el nuevo trazado viario definido en el proyecto de Red Arterial de Valencia.

- Planes parciales iniciales de los Polígonos de Valencia al Mar, Campanar, Avenida de Castilla y Monteolivete, redactados entre 1960 y 1961 y gestionados por la Gerencia de Urbanización. Estos planes, que fueron finalmente sustituidos por otros o transformados hasta hacerlos irreconocibles, se basan en la idea de unidad vecinal, y reflejan un conocimiento preciso de los instrumentos compositivos propios del orden abierto. 


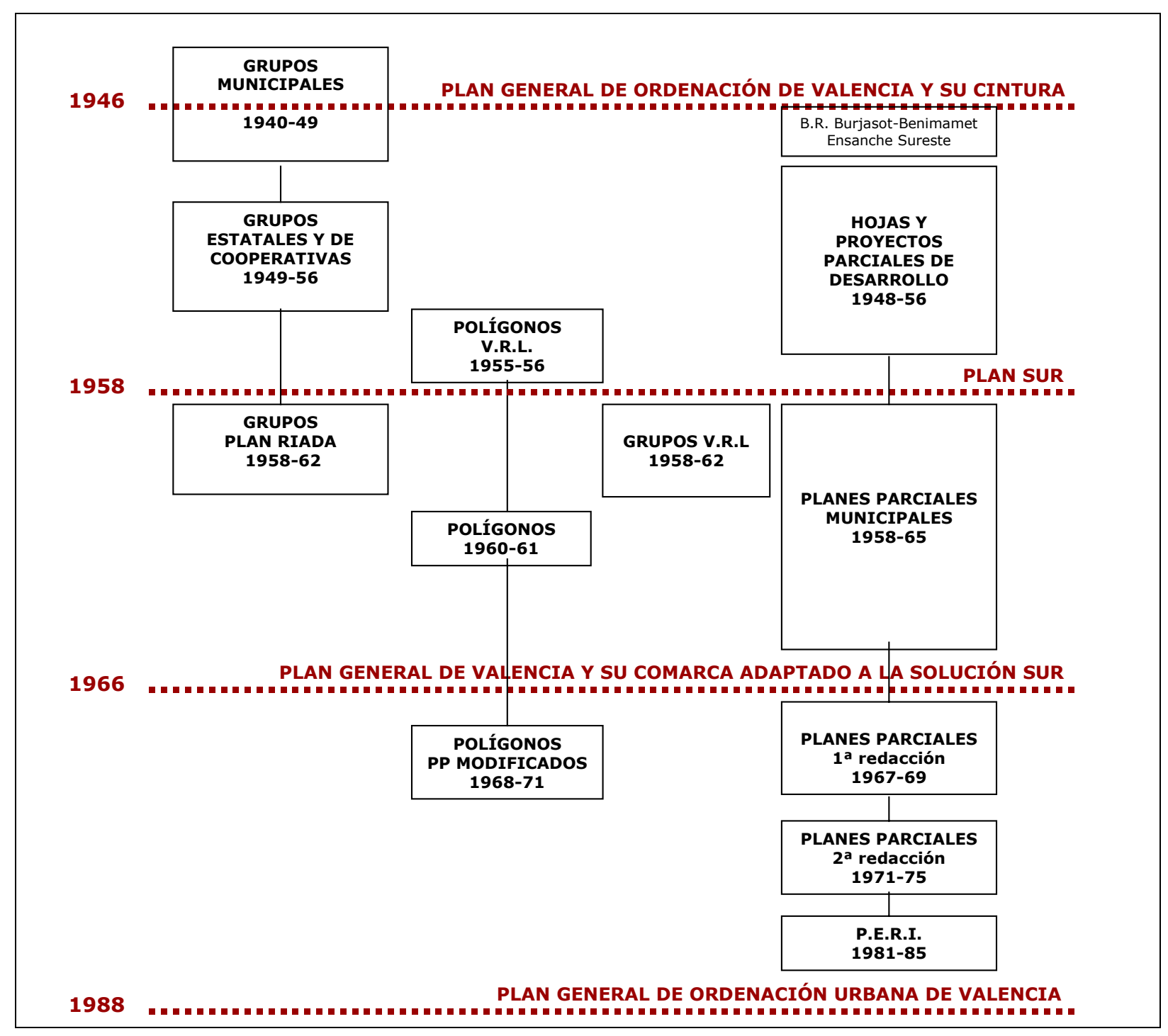

III) Entre el Plan General adaptado a la Solución Sur de 1966 y el PGOU de 1988.

Es una etapa que podemos caracterizar por una cierta desfiguración del modelo de la edificación abierta en los planes, que coincide con un momento de expansión económica y de construcción acelerada de la periferia. Los diseños que aparecen en los nuevos planes municipales, salvo alguna excepción, son a menudo rutinarios y de poco interés, cuando no una mera modificación, por lo general poco afortunada, de un plan previo.

En esta etapa se incluyen los grupos de planes siguientes:

- Planes parciales municipales de desarrollo del Plan General de 1966 . Son las nuevas versiones de todos los planes parciales, que se redactan para adaptarlos al Plan General adaptado a la Solución Sur y al nuevo trazado viario definido en el proyecto de Red Arterial de Valencia. La mayor parte de la edificación abierta construida en Valencia responde a las alineaciones y volúmenes fijados en este grupo de planes. En algunos casos, las nuevas versiones no son más que una modificación, de mayor o menor entidad, de los planes
Etapas de la edificación abierta en Valencia. Esquema de evolución del planeamiento parcial. 
parciales municipales de la etapa anterior. En otros, en cambio, la nueva redacción se aprovecha para redactar un plan completamente diferente. De estos planes, los que no fueron aprobados entre 1967 y 1969, fueron redactados nuevamente entre 1973 y 1975, antes de la entrada en vigor de la nueva Ley del Suelo.

- Planes parciales modificados de los Polígonos de Campanar, Avenida de Castilla y Monteolivete, redactados entre 1968 y 1973 y gestionados por la Gerencia de Urbanización. Son nuevas versiones de los planes para estos polígonos, con arreglo a las cuales se construirán los edificios de los mismos. En ellas no se conserva ningún elemento de la edificación prevista en las versiones anteriores en los polígonos de Avenida de Castilla y Monteolivete, y sólo una pequeña parte de la misma en el de Campanar.

- Planes Especiales de Reforma Interior, redactados entre 1981 y 1983 . Marcan el cambio de orientación en el urbanismo, y plantean modificaciones de los planes parciales para adaptarlos a los nuevos estándares urbanísticos y de gestión fijados en la Ley del Suelo de 1975 y el Reglamento de Planeamiento de 1978. Sus determinaciones quedarán finalmente incorporadas en su mayor parte al Plan General de Ordenación Urbana de Valencia de 1988, que marca el final de ámbito temporal de nuestro trabajo.

La primera etapa es, por tanto, de introducción de la edificación abierta, la segunda de difusión y generalización de los nuevos principios urbanísticos, que se aplican de forma más elaborada, y la tercera de banalización de dichos principios como consecuencia de su aplicación rutinaria y simplista, que es uno de los factores determinantes de su descrédito posterior.

\section{Diagrama IV.1}

\section{Formas urbanas en Valencia. Cuadro de superficies}

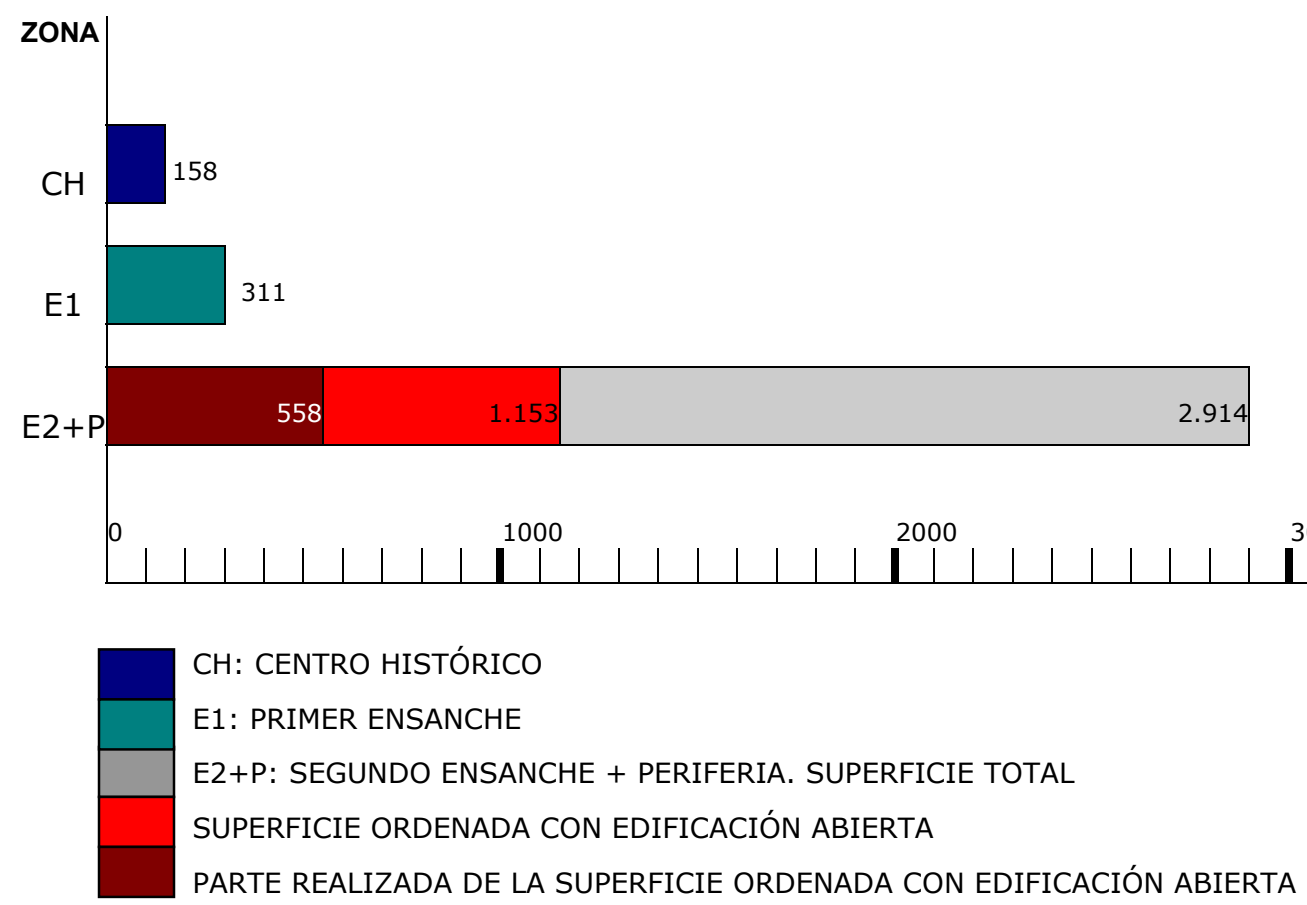




\section{LA EDIFICACIÓN ABIERTA COMO FORMA URBANA: SU PAPEL EN LA FORMACIÓN DE LA PERIFERIA DE VALENCIA.}

La importancia cuantitativa de superficie ordenada mediante edificación abierta a través de los planes parciales que hemos estudiado para el conjunto de la ciudad de Valencia, en relación con las formas urbanas precedentes de centro histórico y ensanche queda reflejada en el Diagrama IV.1 adjunto, que resume los anteriormente elaborados para los diferentes sectores en los que hemos desglosado nuestro estudio.

En este diagrama podemos observar, en primer lugar, que, frente a las $158 \mathrm{Ha}$ del centro histórico y las 311 del primer ensanche, la corona residencial periférica tiene una extensión aproximada de $2.914 \mathrm{Ha}$. De esta superficie, la correspondiente a edificación abierta es de aproximadamente $1.153 \mathrm{Ha}$, lo que supone un $34 \%$ del total de la ciudad.

El diagrama nos permite observar, por otra parte, que la superficie de edificación abierta efectivamente realizada de acuerdo con lo previsto en los planes parciales que hemos estudiado es de $558 \mathrm{Ha}$, lo que supone solamente un $48 \%$ de la proyectada. ${ }^{1}$

La conclusión que podemos extraer de ello es, en primer lugar, que la edificación abierta tiene un peso importante en al configuración actual de la ciudad y, en segundo lugar, que la mayor parte de la periferia de Valencia exterior al primer ensanche no está formada mayoritariamente por edificación abierta, sino por una combinación de poblados preexistentes y tejidos de ensanches secundarios formados por manzanas más densas y menos regulares que las del primer ensanche.

La edificación abierta, por tanto, no es la forma urbana predominante en la periferia urbana de Valencia. Aparte de los polígonos de la Avenida de Castilla y Fuente de San Luís y, como antecedentes, de los grupos del Plan Riada, los únicos planes parciales municipales compuestos íntegramente por edificación abierta son el 24-A y el 4b.

Es a estos tejidos, más que a la edificación abierta, a los que cabría atribuir un mayor grado de responsabilidad con respecto a los problemas de congestión y de carencias de equipamientos y servicios en la periferia urbana, ya que, con $1.761 \mathrm{Ha}$, ocupan aproximadamente un $60 \%$ de la superficie de la misma.

La comparación entre el plano de conjunto de todos los planes parciales de desarrollo del Plan General de 1966 aprobados definitivamente y el plano de grado de realización de los mismos refleja claramente que la ciudad de la edificación abierta, en los términos en los que se planteó en ese periodo, es en gran medida un proyecto inacabado, que quedó cancelado en el Plan General de 1988.

En este nuevo Plan General fue calificada como Suelo Urbanizable Programado una importante superficie de suelo periférico que contaba ya con ordenación pormenorizada a través de diferentes planes parciales.
1. La superficie contabilizada en el diagrama es la envolvente de las edificaciones construidas con arreglo al plan parcial, sin tener en cuenta el grado de realización del viario previsto. 


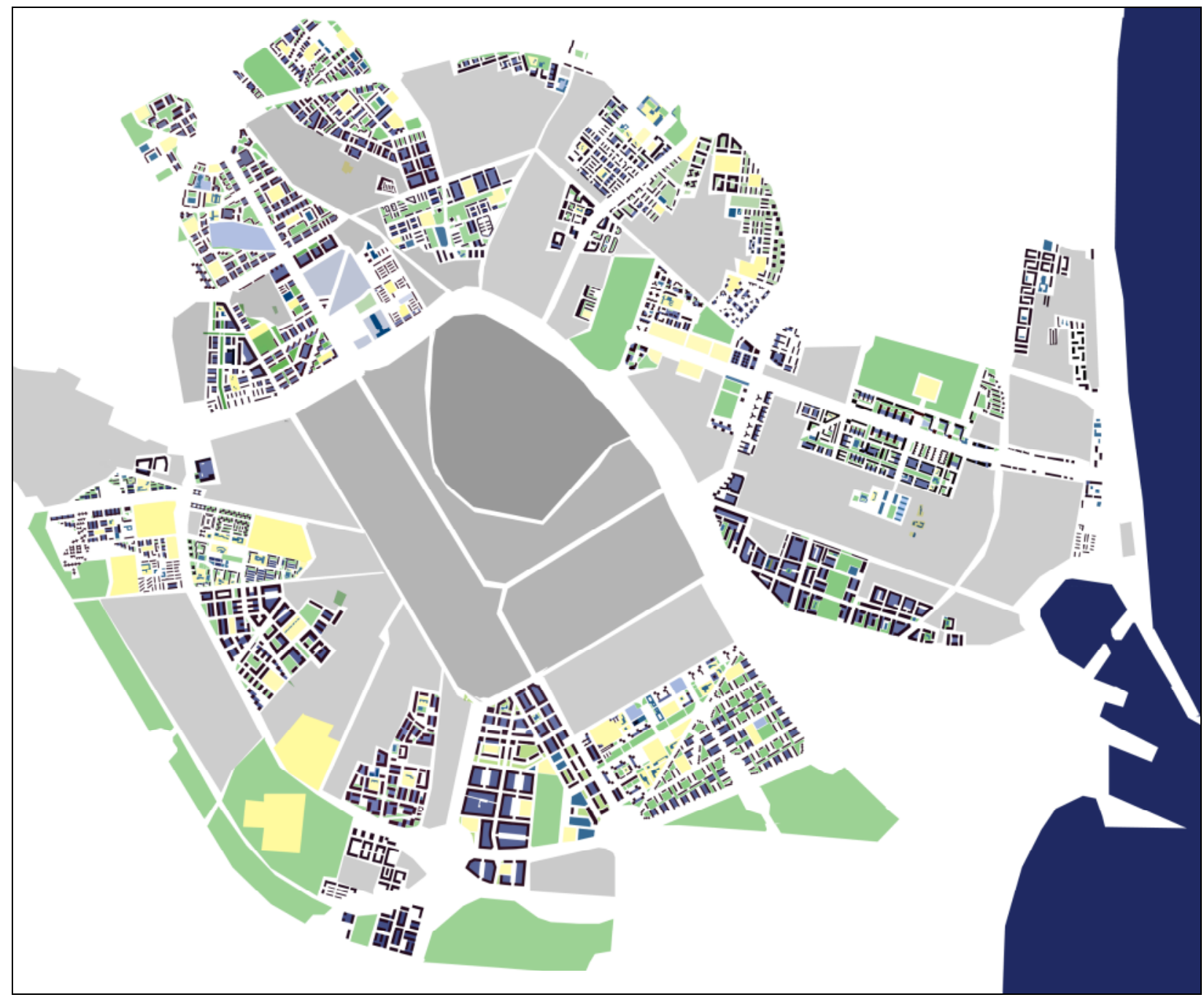

Valencia. Plano conjunto de áreas de edificación abierta proyectadas en planes parciales de desarrollo del Plan General de 1966.

\section{EDIFICACIÓN ABIERTA Y MODELO DE CIUDAD.}

El estudio realizado permite concluir que la creación de nuevas áreas de edificación abierta no supone en Valencia entre 1946 y 1976 una ruptura con el modelo de ciudad continua, de crecimiento en mancha de aceite, sino una simple sustitución de tipos residenciales en la corona periférica exterior al ensanche decimonónico. La ciudad de la edificación abierta es una ampliación más de la ciudad, y se construye sin solución de continuidad con ella, de la misma manera que el ensanche con respecto al centro histórico.

Como hemos podido comprobar a lo largo del presente trabajo, en las áreas urbanas situadas dentro de la Ronda de Tránsitos o Circunvalación Interior las nuevas ordenaciones basadas en la edificación abierta sustituyen a otras previamente aprobadas, realizadas con tramas de ensanche de manzanas cerradas, mientras que entre la Ronda de Tránsitos y la Ronda Exterior, la edificación abierta se utiliza para ordenar el suelo vacante, de carácter agrícola, situado alrededor de poblados periféricos anexionados al municipio de Valencia, como los de Benimaclet o Benicalap. 


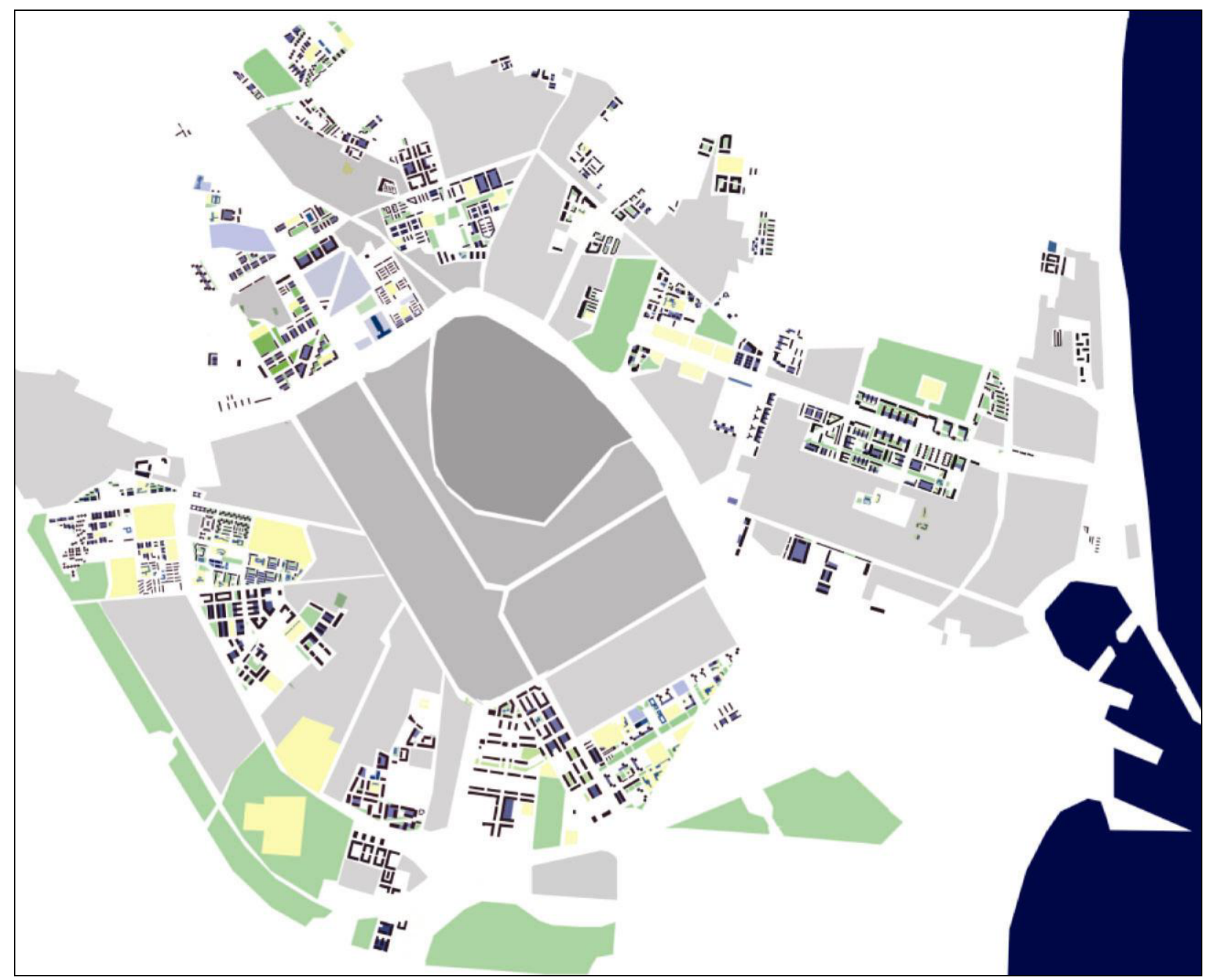

Por otra parte, del estudio realizado de la secuencia temporal de las diferentes versiones redactadas de planes parciales de desarrollo del Plan General de 1966 se desprende que la hipótesis más plausible como idea inspiradora de dicho planeamiento de desarrollo es la del crecimiento uniforme en todas las direcciones.

Entre 1966 y 1968, inmediatamente después de la aprobación del Plan General de 1966, se redactaron nuevas versiones de todos los planes parciales, cubriendo la totalidad de la superficie calificada, y la redacción de nuevas versiones de algunos de estos planes entre 1971 y 1975 se debe a problemas encontrados en la tramitación de las primeras, que imposibilitaron su aprobación definitiva.

La supuesta estrategia de crecimiento que consiste en desarrollar primero los planes de borde, dejando áreas de suelo vacante intermedio que quedan así revalorizadas para un desarrollo urbano posterior queda desmentida por el hecho de que las bolsas de suelo intermedias estaban siendo edificadas en muchos casos con arreglo a planes parciales en tramitación, pendientes de aprobación definitiva.
Valencia. Plano conjunto de áreas de edificación abierta realizadas con arreglo a planes parciales de desarrollo del Plan General de 1966. 


\section{POLÍGONOS O PLANES PARCIALES: PROMOCIÓN PÚBLICA Y PROMOCIÓN PRIVADA. LA GESTIÓN DEL CRECIMIENTO.}

La primera aproximación en Valencia a la idea de crecimiento de la ciudad por partes o unidades vecinales característica del urbanismo funcionalista son los planes promovidos por el Ayuntamiento y desarrollados en los denominados "Proyectos de Ejecución de Polígonos para la construcción de Viviendas de Renta Limitada", redactados entre 1955 y 1956 para los sectores de Paseo al Mar, Campanar, Avenida de Castilla y Monteolivete, que hemos analizado en la sección I. En esos planes, no realizados, se propone una sustitución generalizada del planeamiento anterior, con tejidos de ensanche formados por manzanas cerradas, por nuevas ordenaciones basadas en los tipos de la edificación abierta y dotadas de mayores reservas de suelo para equipamientos y espacios libres, abarcando áreas de la periferia de una extensión considerable.

Estos primeros planes fueron sustituidos por otros, también centrados en los sectores de Paseo al Mar, Campanar, Avenida de Castilla y Monteolivete, aunque con delimitaciones diferentes. A su vez, dichos planes para polígonos, redactados en 1960, fueron sustituidos por unos nuevos planes para los mismos o menores ámbitos, redactados entre 1968 y 1970, en base a los cuales se realizó finalmente la edificación de promoción pública de dichos sectores.

En la Tabla IV.1 hemos reflejado la evolución de la superficie ordenada mediante polígonos. Como podemos observar en la tabla, dicha superficie es decreciente en cada nueva redacción de los planes para los polígonos, reduciéndose en las versiones finales de los mismos, de 1968-71, a un tercio de la prevista inicialmente en 1956.

La superficie de edificación abierta en polígonos de promoción pública, comparada con la de edificación abierta de promoción privada, que se construye por los particulares de acuerdo con las determinaciones de alineaciones y volúmenes fijadas en los planes parciales municipales, en el periodo comprendido entre 1966 y 1988, está reflejada en la Tabla IV.2 para los diferentes sectores de la ciudad en los que hemos desglosado nuestro estudio.

Tabla IV.1

Evolución de la superficie reservada para polígonos.

\begin{tabular}{|l|c|c|c|}
\hline POLÍGONO & $1955-56$ & $1960-61$ & $1968-71$ \\
\hline Paseo al Mar & 72 & 50 & - \\
\hline Campanar & 90 & 102 & 32 \\
\hline Av. Castilla & 34 & 29 & 29 \\
\hline Monteolivete & 127 & $57+9\left(^{*}\right)$ & 57 \\
\hline Total & 323 & 247 & 118 \\
\hline
\end{tabular}

(*) Polígono residencial + centro comercial 
Podemos observar que la edificación abierta proyectada en polígonos de promoción pública supone únicamente un $11 \%$ del total, porcentaje que asciende al $23 \%$ si consideramos la superficie efectivamente construida. Por sectores, los que concentran un mayor porcentaje de promoción pública son los de la mitad sur de la ciudad: el polígono Fuente de San Luís en el sector sureste y el polígono Avenida de Castilla y los grupos Virgen de los Desamparados y Virgen de la Fuensanta en el sector suroeste.

El grueso del crecimiento de la periferia de Valencia, por tanto, no se produce principalmente mediante la creación de polígonos, sino mediante el tradicional casa por casa, a partir de unos planes parciales que, pese a su parecido formal con los de los polígonos, debido al recurso a la edificación abierta como base del diseño, son en realidad meros planos de alineaciones y volúmenes.

Por otra parte, estos planes parciales, redactados por el Ayuntamiento para encauzar la iniciativa particular, son documentalmente muy pobres, sobre todo en lo referente a mecanismos de gestión urbanística. El sistema tradicional de cesión de viales será sustituido por los nuevos sistemas de gestión previstos en la Ley del Suelo de 1975 únicamente en aquellos planes cuya tramitación se alargó más allá del año de aprobación de dicha Ley.

Todo ello, al final, significa que en Valencia, en el periodo objeto del presente trabajo, aunque aparecen los tipos edificatorios de la ciudad moderna (más o menos desvirtuados), no se consigue realizar una gestión del crecimiento por adición de nuevos sectores urbanos completos y, por ello, resulta imposible controlar las condiciones de la transformación urbana: no se puede garantizar la obtención de superficies importantes de suelo para usos públicos, no se puede garantizar la urbanización completa de las nuevas áreas urbanas y no se pueden ajustar los estándares de densidad en relación con las infraestructuras y servicios existentes. El resultado es la ciudad de los setenta que conocemos bien, hecha a "troços i mossos", que queda bien representada por el habitual fragmento de bloque en medio de la huerta con urbanización precaria alrededor y descampados en los solares previstos para equipamientos no construidos.

Tabla IV.2

Promoción pública y privada en la edificación abierta en Valencia, 1966-1988.

\begin{tabular}{|c|c|c|c|}
\hline & $\begin{array}{c}\text { A- POLÍGONOS } \\
\text { (PROMOCIÓN } \\
\text { PÚBLICA)(*) }\end{array}$ & $\begin{array}{c}\text { B- PLANES PARCIALES } \\
\text { (PROMOCIÓN } \\
\text { PRIVADA) }\end{array}$ & $\begin{array}{c}\text { A+B } \\
\text { EDIFICACIÓN } \\
\text { ABIERTA }\end{array}$ \\
\hline $\mathrm{NE}$ & $7 \mathrm{Ha}$ & $400 \mathrm{Ha}$ & $407 \mathrm{Ha}$ \\
\hline $\mathrm{NO}$ & $18 \mathrm{Ha}$ & $285 \mathrm{Ha}$ & $303 \mathrm{Ha}$ \\
\hline $\mathrm{SO}$ & $52 \mathrm{Ha}$ & $169 \mathrm{Ha}$ & $221 \mathrm{Ha}$ \\
\hline $\mathrm{SE}$ & $53 \mathrm{Ha}$ & $169 \mathrm{Ha}$ & $222 \mathrm{Ha}$ \\
\hline Proyectado & $130 \mathrm{Ha}(11 \%)$ & $1.023 \mathrm{Ha}(89 \%)$ & $1153 \mathrm{Ha}$ \\
\hline Construido & $130 \mathrm{Ha}(23 \%)$ & $428 \mathrm{Ha}(77 \%)$ & $558 \mathrm{Ha}$ \\
\hline
\end{tabular}

$(*)$ Se incluyen en esta superficie los grupos de promoción pública, como los del Plan 5000 y el Plan Riada, entre otros. 


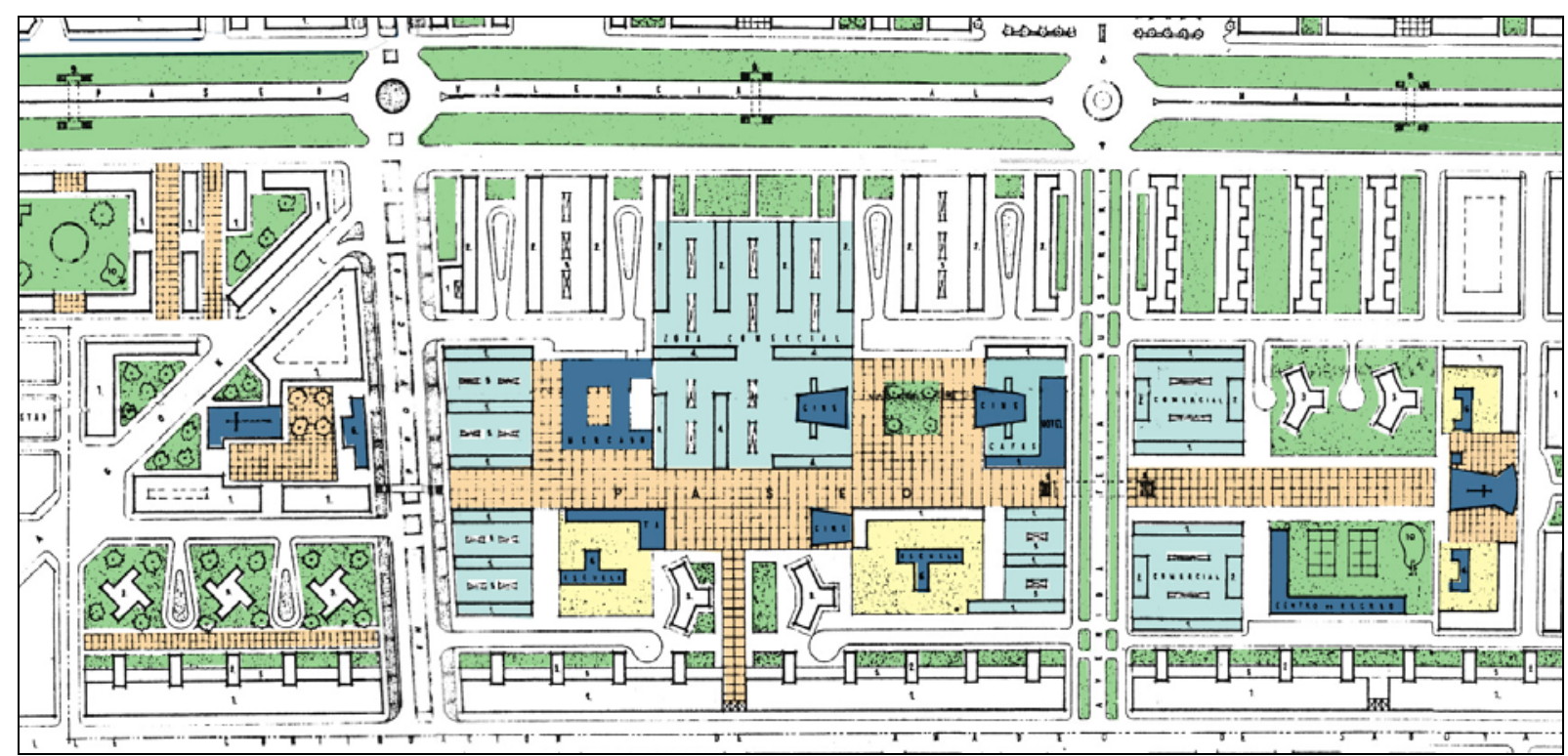

Polígono de Valencia al Mar, 1956. Disposición de los equipamientos según un modelo lineal..

\section{ESTRUCTURA URBANÍSTICA INTERNA DE LOS PLANES PARCIALES: LOS EQUIPAMIENTOS.}

La Ley del Suelo de 1956, que constituye el marco general de la mayor parte de los planes del estudiados en este trabajo, no fijaba unos estándares urbanísticos mínimos en función del número de viviendas o de habitantes, ni detallaba las necesidades en cuanto a espacios para uso deportivo, asistencial, cultural o recreativo. La única reserva cuantificada por esta ley era la de zonas verdes, que se fijaba en un mínimo de un $10 \%$ de la superficie del terreno ordenado.

El Plan Nacional de la Vivienda de 1961 fijaba también unas reservas de suelo para edificaciones complementarias, obligatorias para los conjuntos de viviendas de promoción estatal, que se toman como referencia en algunos planes parciales de Valencia, como el PP 4bis de $1968 .^{1}$

En los planes parciales municipales, la alta densidad edificatoria va unida por lo general a una evidente escasez de reservas de suelo para equipamientos y servicios. Así, hemos visto como, por ejemplo, las reservas para escuelas previstas son en muchos casos inferiores a las que resultan de los propios cálculos de necesidades realizados en la Memoria de los planes.

En relación con los espacios verdes, la crítica que Jane Jacobs hace de la veneración de los mismos por el urbanismo funcionalis$\mathrm{ta}^{2}$, que genera una sobreabundancia de los mismos con efectos negativos para la cohesión urbana, no afectaría obviamente a los planes parciales municipales que hemos estudiado, ya que en ellos no encontramos precisamente una sobreabundancia, sino más bien lo contrario. Estos espacios verdes son con frecuencia de carácter intersticial, atomizados en multitud de pequeños fragmentos situados entre los bloques, y adquieren dimensiones de parque público únicamente cuando la reserva estaba prevista ya en el Plan General.

Además, no se observa una voluntad de organizar los equipamientos de modo que jueguen un papel estructurante en la composición interna, sino que se adopta por lo general un modelo dis- 
perso: las reservas de suelo para dotaciones aparecen aquí y allá, salpicando el suelo ordenado, y el único criterio que se aprecia para localizarlos es el de situar las escuelas en el centro de las supermanzanas.

Aparte de las escuelas y las zonas verdes, los únicos equipamientos que se incluyen en los planes parciales municipales de desarrollo del Plan General de 1966 son los centros religiosos, los mercados y los centros comerciales. Estos últimos, que se sitúan en las localizaciones previstas para ellos en el Plan General, no alcanzan la consideración de centro vecinal debido a que resultan redundantes cuando la práctica totalidad de las plantas bajas de los bloques se destina a locales comerciales, como es habitual en Valencia.

Las plantas bajas han servido, como en otras ciudades españolas, para paliar temporalmente, aunque fuese en condiciones de precariedad, algunos déficits de equipamientos. En los años setenta, las iglesias, ambulatorios y escuelas localizados en plantas bajas eran componentes habituales del paisaje urbano de la ciudad.

Los polígonos, en cambio, muestran unas reservas dotacionales muy superiores y más diversificadas, ya desde sus primeros planes de 1956 y 1960, así como un grado de elaboración mucho mayor de la estructura interna del sistema de equipamientos, que se organizan generalmente según un modelo nuclear o lineal. Ejemplo de ello son los ejes de los Polígonos de Monteolivete y de Valencia al Mar. Este último todavía es legible en la versión del Plan Parcial 12 de 1968, en la que queda algo desdibujado por haber sido privado de gran parte de los edificios públicos que lo flanqueaban y reducido casi a mera franja verde.

La idea de nucleización interna, de composición por agregación de unidades vecinales, está presente en algunos de los planes para polígonos, como el de Campanar de 1960, en el que se representan incluso las unidades vecinales en un plano.
Polígono de Campanar, 1960. Subpolígono $A$, formado por 3.868 viviendas, que incluye dos unidades vecinales, cada una con sus dotaciones propias de escuelas, iglesia $y$ zonas verdes, $y$ un parque $y$ centro cívico-cultural comunes a ambas.

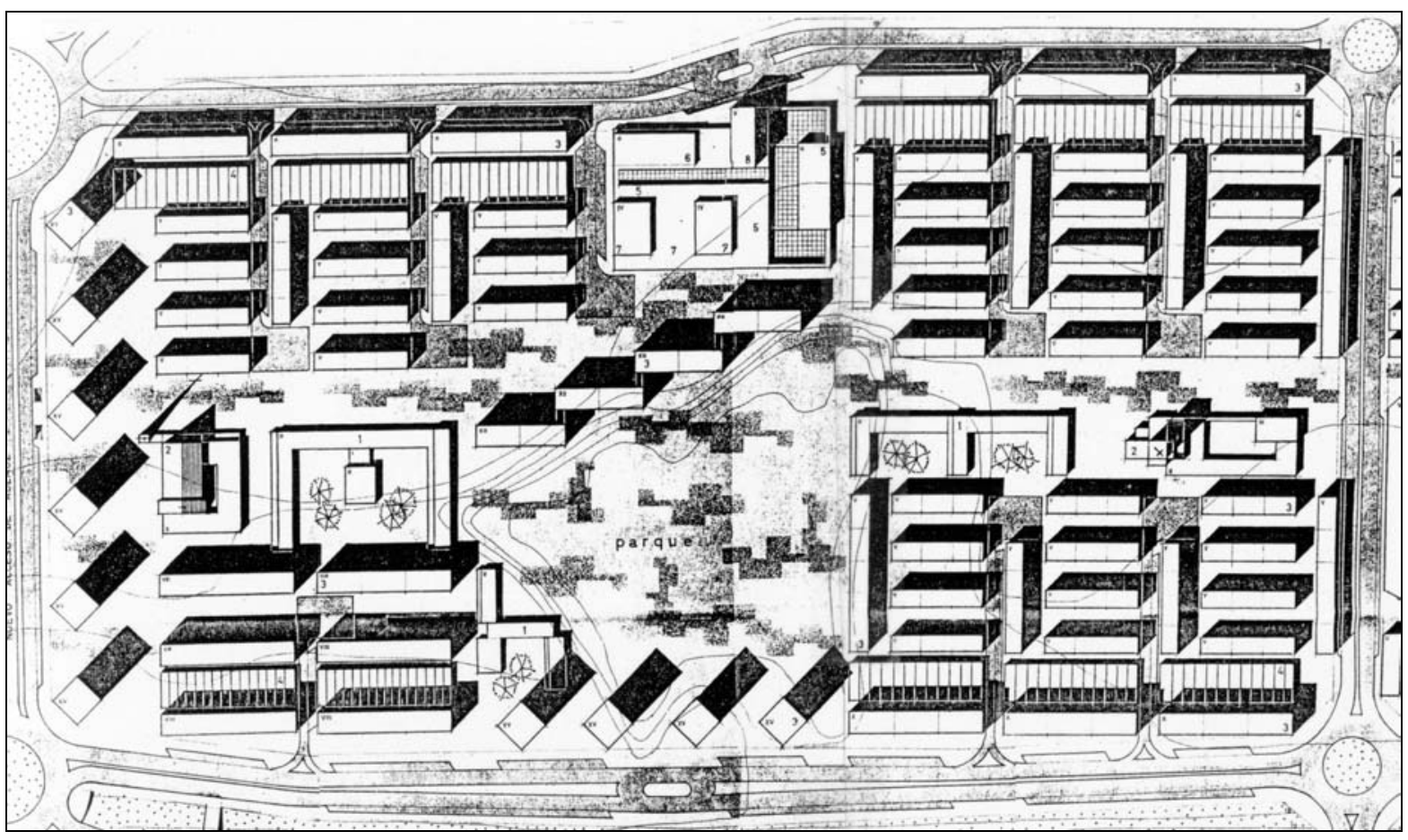




\section{EL VIARIO DE LA EDIFICACIÓN ABIERTA: TRAZADO RAMIFICADO Y SUPERMANZANAS.}

La ordenación general de las zonas de edificación abierta de la periferia de Valencia está muy condicionada por su carácter de extensión urbana, por su contigüidad con tejidos de ensanche o de poblados anexionados al término municipal, consolidados en mayor o menor medida, con cuyo viario los nuevos planes suelen establecer conexiones.

En cambio, el parcelario rústico original no tiene apenas incidencia en el trazado de los planes parciales, y resulta por lo general ilegible tras la realización de los mismos, como es lógico en un sistema compositivo como el del orden abierto, uno de cuyos puntos de partida habituales es el del carácter isótropo y público del territorio en el que se asienta la edificación, que no está sujeta a las subdivisiones de la propiedad.

La excepción que confirma esta regla, en el periodo estudiado, es el Plan Parcial 4-bis, en su versión de 1968, que es el único en el que se utiliza la partición original del parcelario rústico como base para el trazado proyectado.

En el resto de los planes parciales, el condicionante básico del trazado, aparte de las preexistencias edificadas, es sobre todo la estructura viaria general diseñada en el proyecto de la Red Arterial de Valencia de 1966, y así se expresa en la memoria de los mismos.

El trazado diseñado como sistema de carreteras o vías rápidas, y la hipertrofia del tráfico rodado como referente básico del proyecto en detrimento de otros elementos urbanos, han centrado buena parte de las críticas al orden abierto. Pero la realidad es que, al menos en Valencia, ese viario apenas existe: gran parte del mismo, especialmente el vecinal, no se ha llegado a realizar, y el realizado, que es sobre todo el viario principal, no sigue los trazados ni los diseños de intersecciones proyectados en la Red Arterial de

Plan Parcial 12-B, 1956. Trazado viario ramificado y supermanzanas con eje peatonal de equipamientos. 1966. La comparación entre ambos, que no estamos seguros de que sea favorable para el actual, es un interesante tema pendiente de estudio, que excede los límites de nuestro trabajo.

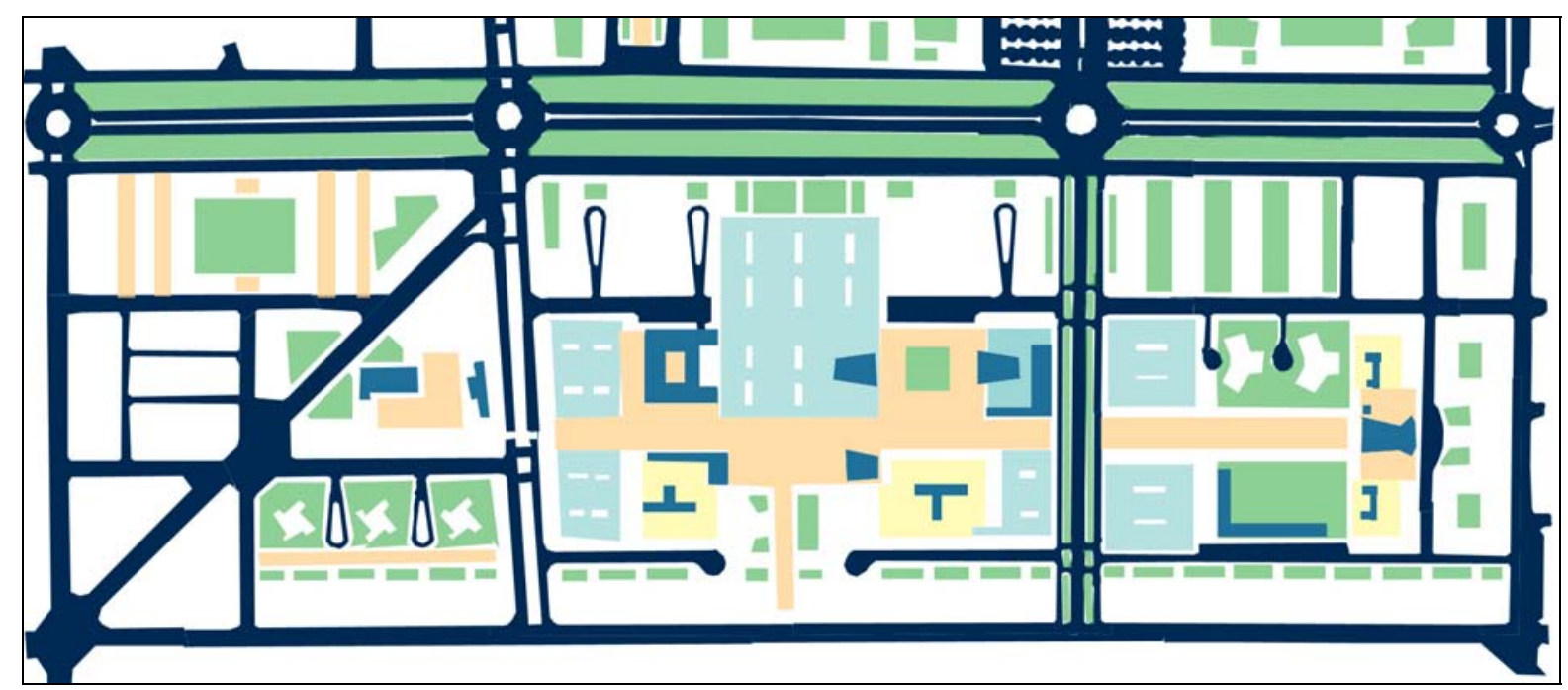




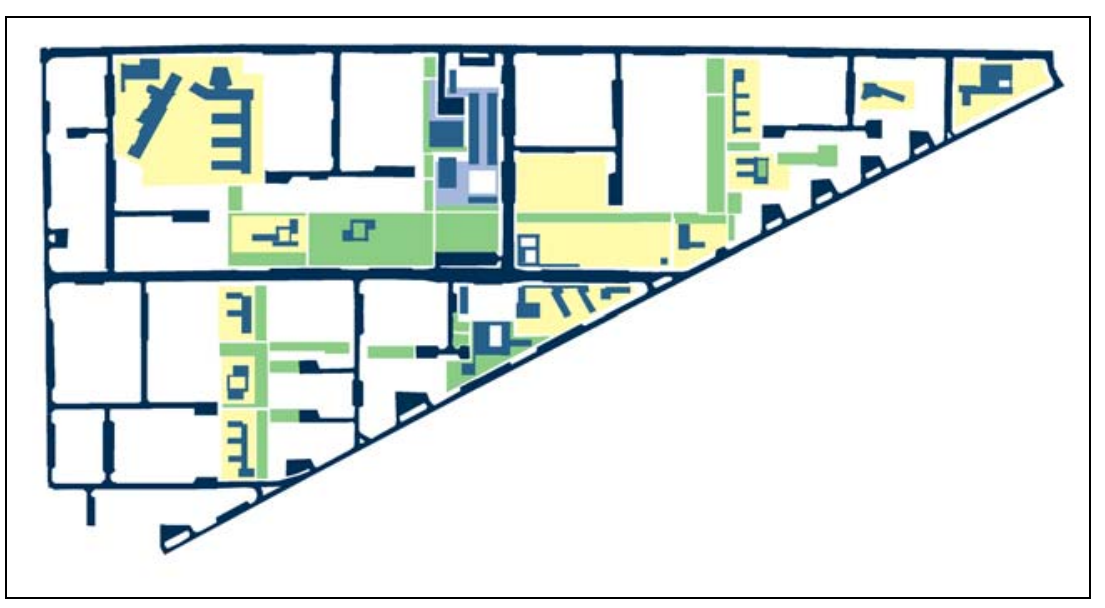

En la mayor parte de los planes parciales del periodo objeto de nuestro estudio, tanto en los municipales como en los de los polígonos de promoción pública, el trazado viario interno de las zonas de edificación abierta se basa en el principio de separación del tráfico rodado y el peatonal, principio característico del urbanismo funcionalista.

El viario mallado, por su parte, es el más frecuente en las zonas de edificación abierta que ostentan la calificación de Extensión Exterior a Tránsitos, resueltas en su mayor parte con manzanas mixtas formadas por bloques profundos unidos en planta baja.

La separación de tráficos se obtiene por lo general con sistemas de trazado ramificado, que se basan en la existencia de una serie de culs-de-sac o ramales sin salida que impiden la circulación a partir de un determinado punto. De ello resultan las denominadas "supermanzanas", cuya zona central es de carácter peatonal y, libre del ruido y las molestias asociadas al tráfico rodado, se puede destinar a escuelas, parques y otros equipamientos vecinales.

Los sistemas de trazado ramificado, iniciados en Radburn por Stein y Wright, inducen, automáticamente, una jerarquización en el viario, de modo que éste puede escalonarse en diversos tipos según su intensidad, optimizándolo funcional y económicamente para el papel que debe cumplir (acceso a viviendas, enlace entre grupos de ellas, etc.).

El principio de separación de tráficos y la idea de supermanzana, que son las ideas más comúnmente expresadas en los planes con respecto a su composición interna, resultaron un absoluto fracaso, principalmente debido a la falta de previsión de las consecuencias urbanísticas del auge del vehículo privado como medio principal de transporte, que condujo a un enorme déficit de espacio para aparcamientos. A resultas de ello, los trazados ramificados fueron convertidos en trazados mallados y los espacios libres entre bloques, teóricas zonas verdes, fueron sustituidos por calles asfaltadas.

El fracaso de la especialización funcional del viario, sin embargo, puede considerarse como algo positivo desde el punto de vista de la recuperación de la idea de calle como lugar mixto, en el que coexisten tráficos y actividades diversos.
Polígono de Monteolivete, 1960. Trazado viario ramificado y supermanzanas con ejes peatonales de equipamientos.
Plan Parcial 23, 1967. Trazado viario con lazos y ramales sin salida.

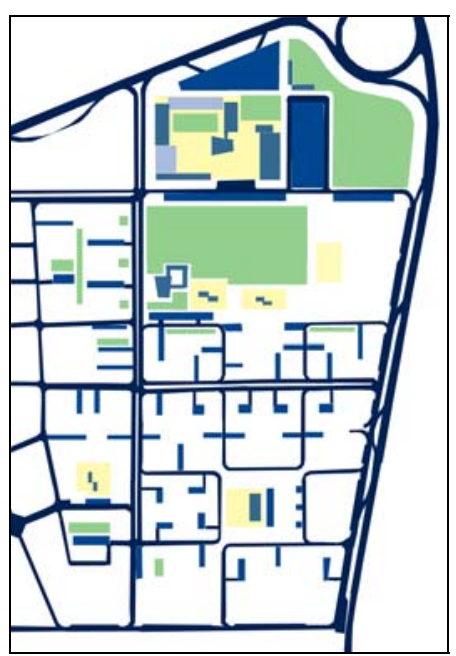




\section{LA EDIFICACIÓN DEL ORDEN ABIERTO}

La valoración de la edificación abierta que realizaremos en este apartado se desglosa en aspectos cuantitativos y cualitativos. Los primeros se refieren a la cantidad edificada, y los segundos a la forma, tipos y disposición de los edificios.

\section{Edificabilidad y densidad.}

La mayor parte de los planes parciales redactados en Valencia por la Oficina Técnica Municipal de Urbanismo en el periodo objeto de estudio se basan en la edificación abierta alta, con un coeficiente de edificabilidad de $5 \mathrm{~m} 3 / \mathrm{m} 2(1,66 \mathrm{~m} 2 / \mathrm{m} 2)$, salvo en algún caso aislado, como en el Plan Parcial 26-b, en el que se adopta el de 3,5 $\mathrm{m} 3 / \mathrm{m} 2(1,16 \mathrm{~m} 2 / \mathrm{m} 2)$. Estos coeficientes son los máximos fijados por el Plan General de 1966.

La edificación abierta alta con coeficiente de edificabilidad próximo a $5 \mathrm{~m} 3 / \mathrm{m} 2$ va asociada a unas densidades de edificación en torno a las 150 viviendas/hectárea. Es el caso de planes como el PP12 (157 viv/Ha y $4,75 \mathrm{m3} / \mathrm{m} 2$ ), el PP9 (156 viv/Ha y 4,71 $\mathrm{m} 3 / \mathrm{m} 2$ ) o el 24 (147 viv/ha y $4,40 \mathrm{~m} 3 / \mathrm{m} 2$ ).

Las áreas de edificación abierta formadas por manzanas mixtas de bloques profundos enlazados con plantas bajas comerciales, que aparecen en los planos de zonificación con calificación de Ensanche Exterior a Tránsitos, alcanzan densidades superiores. Así, el Plan Parcial 26, por ejemplo, alberga $183 \mathrm{viv} / \mathrm{Ha}$, con un coeficiente de edificabilidad de $6,61 \mathrm{~m} 3 / \mathrm{m} 2$.

Los polígonos de promoción pública, en cambio, presentan un índice de edificabilidad mucho menor, en torno a $2,5 \mathrm{~m} 3 / \mathrm{m} 2(0,83$ $\mathrm{m} 2 / \mathrm{m} 2$ ), y las densidades oscilan entre las 67 viv/ha del Polígono Fuente de San Luís y las 71 viv/ha del de la Avenida de Castilla, inferiores a las 75 viviendas por hectárea.

Estos índices generan un evidente contraste entre las áreas residenciales de promoción privada, en las que los edificios más habituales son de VIII o más plantas, y las de los polígonos de promoción pública, en las que podemos encontrar un mayor número de bloques de altura media, o una mayor separación entre las torres cuando se recurre a ellas. La presencia de edificación abierta baja es casi nula en los conjuntos residenciales de Valencia, ya que la única muestra de ella es, como hemos visto, la agrupación de casas con patios del grupo Antonio Rueda.

Debe señalarse, en todo caso, que la densidad de las áreas de edificación abierta es siempre inferior a la de los tejidos contiguos de ensanche.

La Carta de Atenas estaba a favor de los edificios altos, siempre que estuviesen separados entre sí lo suficiente. En los planes parciales de Valencia objeto de nuestro estudio la relación entre distancia y altura de los edificios se ajusta por lo general, como hemos visto, a la proporción 1:1 fijada en las Normas Urbanísticas de la Comisión Central de Sanidad Local de 1955 y en las del Plan General de 1966: los bloques altos quedan bastante juntos. Ello se 
justifica en algunos planes, como el PP9 de 1960 y el 12-B de 1956, por el alto coste del suelo de huerta, debido a su gran valor agrícola.

Como ha señalado Amador Ferrer, el coeficiente de edificabilidad es una medida del volumen cuya utilización proyectual presupone unos tipos de edificación específicos, y adquiere sentido cuando la edificación se libera de las condiciones que impone la parcela y su envolvente no puede ya definirse mediante los parámetros de fachada mínima, altura reguladora y profundidad edificable, como ocurría en los tejidos de manzanas sujetos a alineaciones viarias. ${ }^{1}$

La densidad residencial es un dato que no se deduce directamente del coeficiente de edificabilidad. Como señalaba Jane Jacobs, en su clásico libro de crítica radical al urbanismo funcionalista, Death and Life of Great American Cities, no debe confundirse alta densidad de edificación con hacinamiento. ${ }^{2}$ Sin embargo, cuando el tipo de vivienda es prácticamente único, ambos conceptos resultan equiparables.

Los aspectos contradictorios de la alta densidad, que por una parte coincide con los objetivos del negocio inmobiliario y, al mismo tiempo, es un factor de vitalidad urbana, han sido acertadamente puestos de relieve por Ferrer:

Si bien la elevada densidad de población que resulta en un Plan puede connotar la presencia de unos intereses que actúan en el sentido de maximizar el volumen edificado (...), esta misma elevada densidad ha sido, precisamente, en los barrios españoles de la periferia de los núcleos urbanos el factor determinante de la relativa vitalidad que se observa en ellos. Basta compararlos con los "Grands Ensembles" franceses, en los que los espacios libres se encuentran en mayor proporción y en los que la densidad es menor. A pesar de que los Planes Parciales españoles derivan en muchos aspectos de estos "Grands Ensembles" (aunque en éstos la calidad de la construcción es mayor y el equipo público más abundante), la consecuencia de esta superior densidad en los conjuntos españoles, resultado de intereses dominantes que nunca buscaron este efecto, es la de una cierta intensidad de vida urbana que les da un aspecto menos aburrido y desolado que el de los conjuntos franceses. La alta densidad de población tiene, pues, en este sentido, un valor positivo para el barrio urbanizado, en cuanto posibilita una cierta diversidad urbana y la animación de los espacios públicos, lo que repercute, a su vez, en la progresiva complejidad funcional del sector. Sin embargo, en la medida en que esta elevada densidad no va acompañada de una suficiente previsión de equipo público y espacios verdes, adquiere de nuevo una significación negativa. ${ }^{3}$

Estas observaciones siguen vigentes, y pueden añadirse a las conclusiones de nuestro trabajo, ya que son aplicables a la mayor parte de los planes parciales municipales que hemos analizado.
1. Ferrer i Aixalà, Amador, Els polígons de Barcelona, Edicions Universitat Politécnica de Catalunya, Barcelona, 1996.

2.Jacobs, Jane, The Death and Life of Great American Cities, Random House, New York, 1961 (Muerte y vida de las grandes ciudades, Península, Barcelona, 1967).

3. Ferrer Aixalà, Amador, Oficina de Información Urbanística, Presentación y estadística de los Planes Parciales de la provincia de Barcelona (1956-1970), La Gaya Ciencia, Barcelona, 1974. 
De la manzana al bloque. Implicaciones del cambio en la célula tipo de vivienda en el tamaño de la unidad edificatoria mínima.

1. Manzana con edificación perimetral de cinco crujías: dos viviendas profundas por escalera y patios de luces. Ejemplo: manzana de ensanche convencional.

2. Manzana con edificación perimetral de cinco crujías: cuatro viviendas por escalera, dos con fachada a calle y dos a espacio interior ajardinado. Patios de luces aislados. Ejemplo: Finca Roja.

3-A. Manzana con edificación peri metral de dos crujías: dos viviendas por escalera. El espacio interior aumenta de tamaño y se destina a equipamientos. Ejemplo: Grupo Federico Mayo.

3-B. Manzana con edificación perimetral de cinco crujías: cuatro viviendas por escalera, dos con fachada a calle y dos a espacio interior ajardinado. Patio intermedio casi continuo. Ejemplo: Lexington Terraces.

4-A. Manzana con edificación perimetral de dos crujías: dos viviendas por escalera. Disminución del tamaño de la manzana para recuperar una proporción razonable entre edificación y espacio libre interior. Ejemplo: Manzanas de Amsterdam Sur.

4-B. Descomposición de la manzana en bloques, sin pérdida de tamaño. Utilización del bloque seriado de dos crujías como relleno del espacio intermedio entre dos bloques profundos. Ejemplo. Barrio residencial de Burjasot-Benimamet

5. Edificación abierta en línea (Zeilenbau). Bloques lineales de dos crujías dispuestos a intervalos regulares con orientación uniforme.

6. Edificación abierta con bloques de dos y cinco crujías dispuestos libremente.
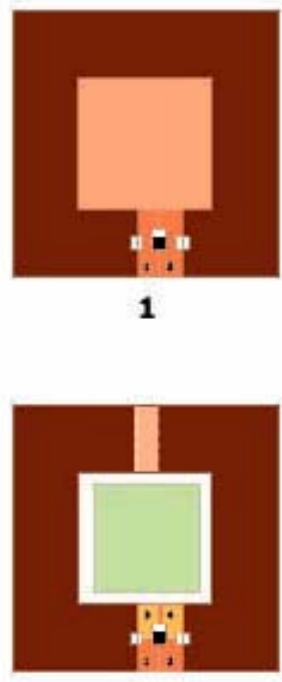

2

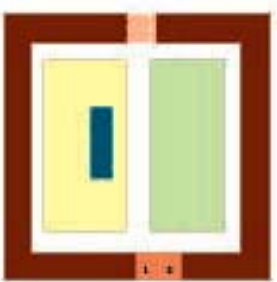

3 A
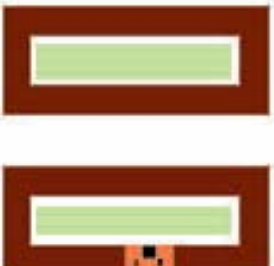

4 A

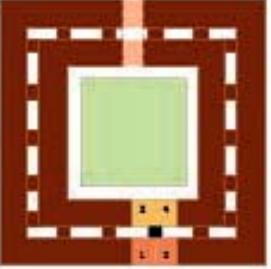

3 B

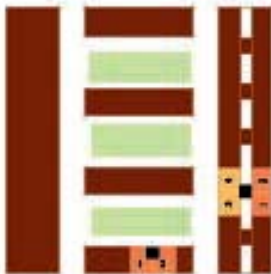

4 B

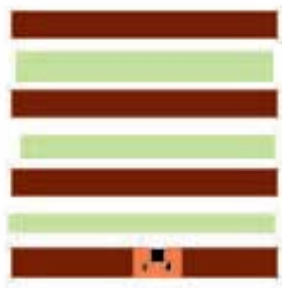

5

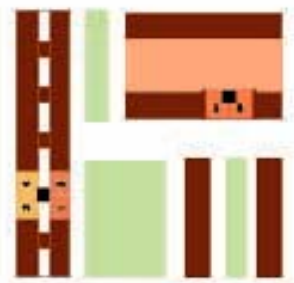

6 
Las formas de la edificación abierta.

En la primera sección del presente trabajo hemos visto como, entre 1946 y 1957, se realiza la transición de la manzana al bloque como tipo básico edificatorio para el crecimiento urbano de Valencia.

La manzana era en el ensanche la unidad modular de la edificación, y marcaba como tal la agregación máxima posible de viviendas entre medianeras. En esa unidad, de superficie superior a 1 hectárea por lo general, la vivienda tipo era grande, profunda y con patios de luces.

En cambio, la célula tipo de vivienda que se utilizará para la edificación de la corona periférica exterior al ensanche será más pequeña, poco profunda, con dos fachadas opuestas y ventilación cruzada, sin patios de luces. El cambio de célula tipo implica necesariamente un cambio drástico en las características del conjunto edificado resultante de la agrupación de las viviendas. ${ }^{1}$

Si las nuevas células de vivienda se disponen en torno a un espacio libre central, formando una manzana, la edificación perimetral resulta tan poco profunda que el espacio libre central entra en crisis por pura falta de densidad, ya que, aunque a veces su mayor tamaño se aprovecha para localizar en el mismo algunos equipamientos, como las escuelas del grupo Federico Mayo, esta no es obviamente una solución generalizable.

Una de las vías para poder recomponer una proporción razonable entre la edificación perimetral y el espacio libre interior es la de reducir del tamaño de la manzana. Esta vía es la utilizada en el plan de Berlage para Amsterdam Sur y en numerosas manzanas holandesas del mismo periodo, como la de Tusschendyjken (Rotterdam, 1920-23) de J.J.P. Oud.

Para mantener un tamaño de manzana como la de ensanche utilizando células tipo de viviendas de dos crujías, y sin que la proporción de espacio libre interior sea excesiva con respecto a la edificación perimetral, la solución empleada en ejemplos como los de las Lexington Terraces (Chicago, 1901) de Wright y la Casa de las Flores (Madrid, 1931-32) de Zuazo es la de formar dos coronas de edificación perimetral concéntricas, una de viviendas recayentes a la calle y otra de viviendas recayentes al espacio interior de manzana, separadas por patios en los que se intercalan las cajas de escaleras, cada una de las cuales sirve a cuatro viviendas por planta. ${ }^{1}$

En los primeros planes y proyectos basados en la edificación abierta en Valencia es frecuente, como hemos visto, encontrar un nuevo modelo de manzana formada por una combinación de dos bloques laterales de cinco crujías entre los que se sitúan varios bloques transversales de dos crujías. A los bloques profundos, por lo general, se les asigna una función de delimitar espacios, ya que están alineados con las calles principales, mientras que los bloques delgados son un relleno neutro del espacio intermedio. Este modelo es una alternativa a la manzana cerrada de ensanche como unidad modular del crecimiento urbano, y permite utilizar células tipo de viviendas de dos crujías sin tener que reducir por ello el tamaño de la manzana.

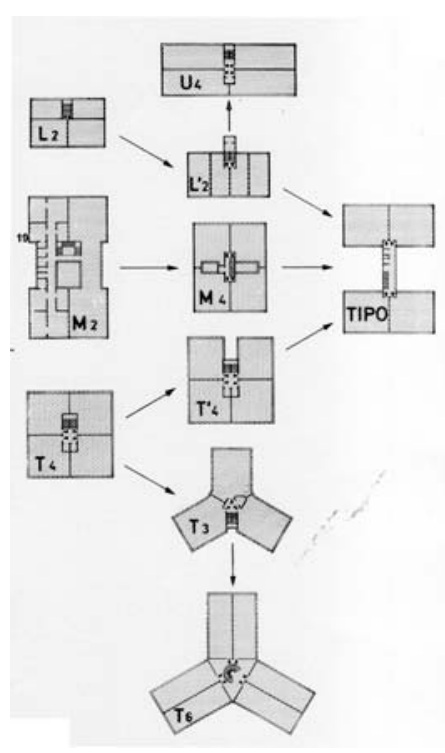

Esquema de evolución de los tipos de agrupación de viviendas (Paricio, 1973).
1. Ver Paricio, Ignacio, "Las razones de la forma en la vivienda masiva", Cuadernos de Arquitectura, 96, Barcelona, 1973.

2. En las hoffe vienesas, la corona perimetral está formada por viviendas a una cara, fachada a patio o a calle, agrupadas a razón de cuatro por escalera en cada planta. En la Finca Roja (Valencia, 1929-33) de E. Viedma, hay también cuatro viviendas por escalera, dos abiertas a la calle y dos al patio interior, lo que obliga a crear unos pasos a dicho patio accesibles a los bomberos. Sin embargo, la mayor profundidad edificada, típica de las manzanas de ensanche, permite mejorar las viviendas con respecto a las de las hoffe al proporcionarles ventilación adicional a través de patios de luces intermedios. 


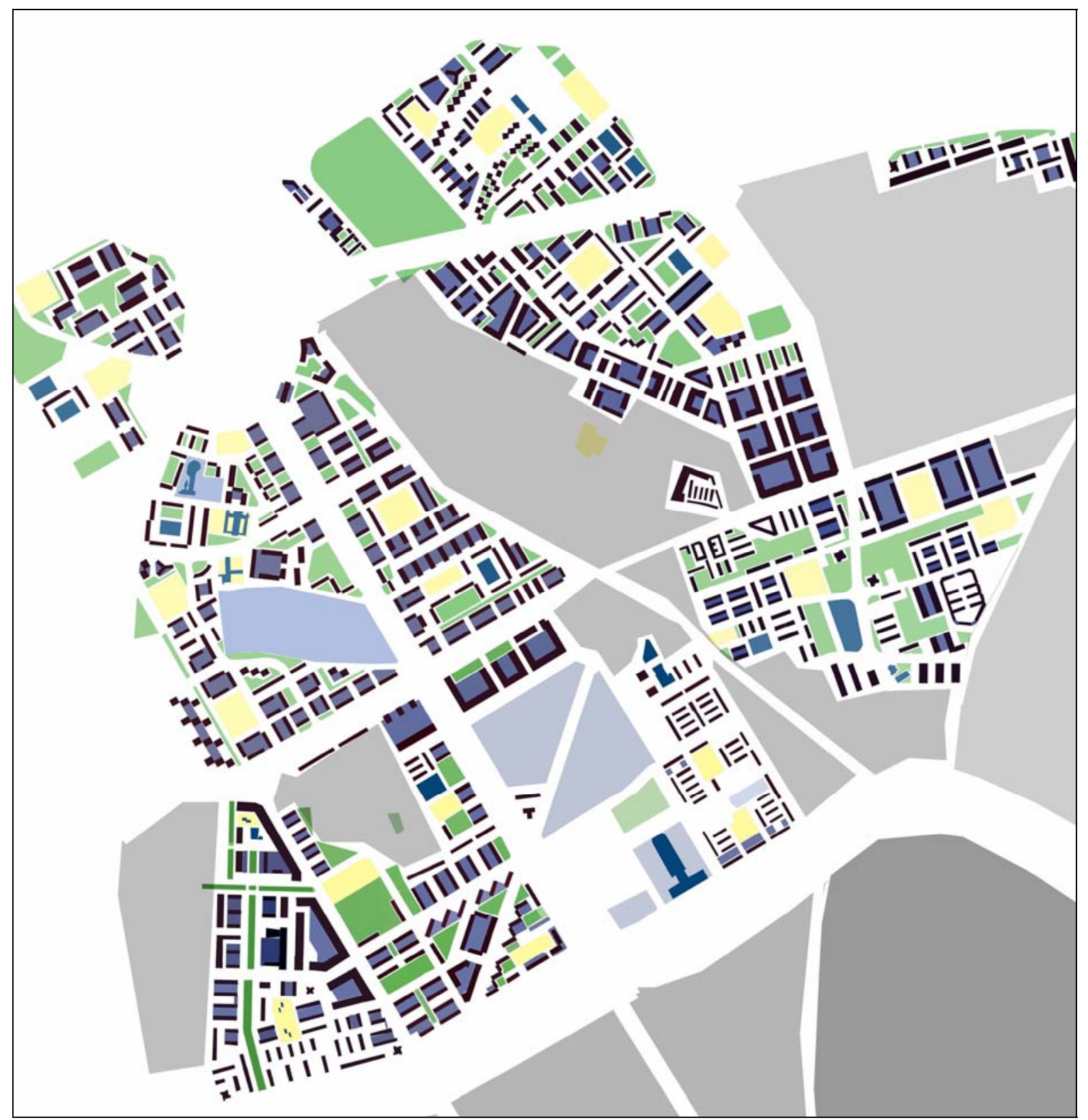

Valencia. Plano conjunto de áreas de edificación abierta proyectadas en planes parciales de desarrollo del Plan General de 1966. Detalle de la zona noroeste.
Un ejemplo construido de este sistema de agrupación de bloques es el conjunto Virgen de los Desamparados, con manzanas abiertas en las que se combinan bloques profundos (en este caso a redents, con patios a fachada) en el perímetro y un relleno interior de bloques lineales de dos crujías.

Más adelante, la unidad modular descrita se descompone y los bloques, de dos o de cinco crujías, empiezan a disponerse de una forma más libre, buscando un efecto de variedad que prima sobre el criterio de orientación homogénea. A partir de ese momento, el bloque pasa a constituir por sí solo la nueva unidad modular de la edificación, de tamaño mucho menor que el de la manzana cerrada.

Como hemos indicado anteriormente, los sistemas de agrupación más utilizados en los planes parciales objeto de estudio, a partir de la unidad del bloque lineal, son los siguientes: 


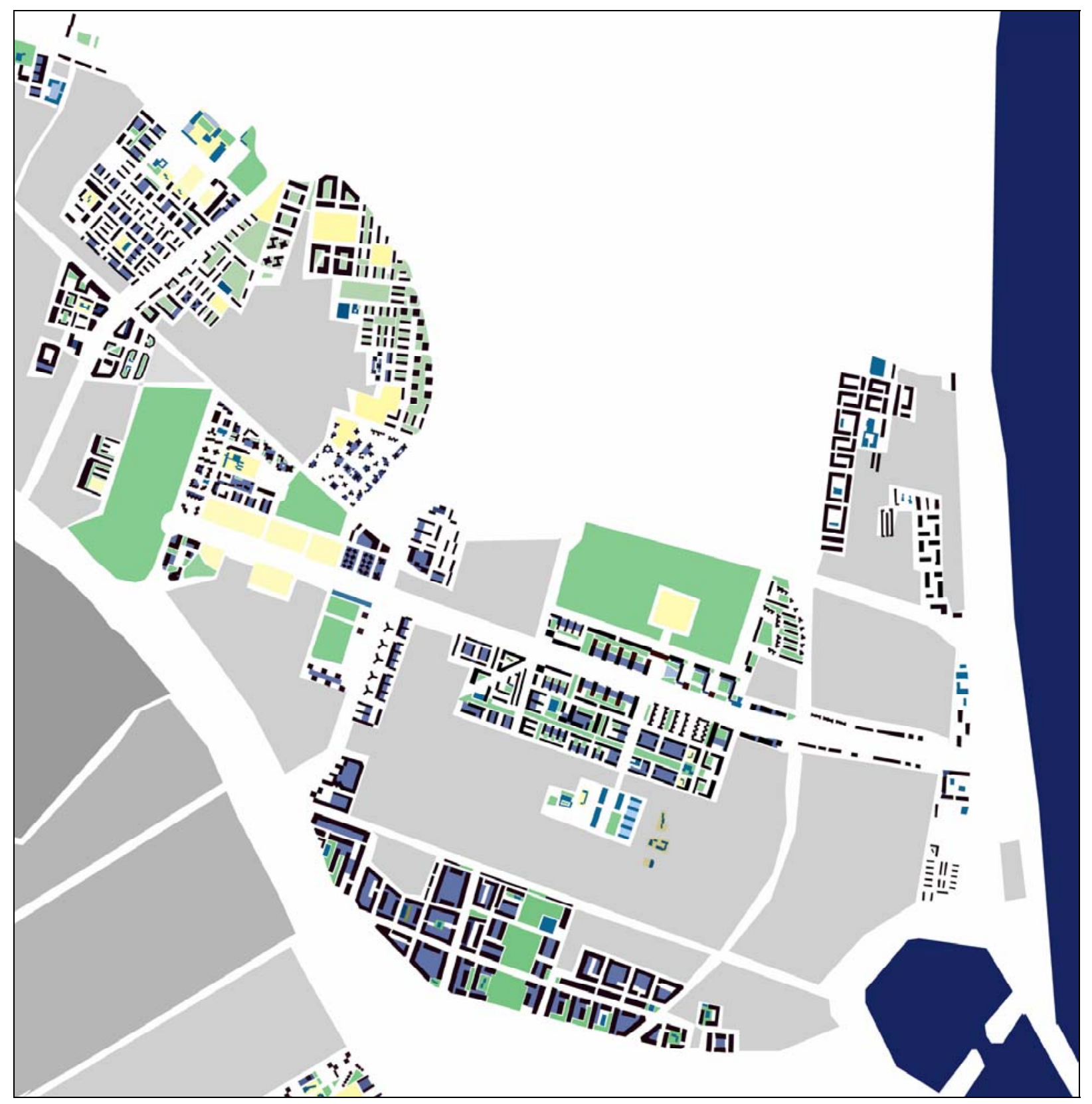

- Seriación de bloques: es el clásico procedimiento de la edificación en línea, o zeilenbau, que sitúa los bloques a intervalos regulares, con orientación uniforme y separados por espacios verdes intermedios.

- Articulación de bloques: consiste en yuxtaponer o unir por sus extremos varios bloques lineales de orientaciones diferentes, formando una $L$, una $C$ o una $U$, de modo que el espacio verde público queda envuelto por los bloques.

- Unión de bloques: los bloques quedan unidos por un cuerpo de edificación bajo, de una o dos plantas, destinado a usos comerciales y cuya superficie y perímetro son diferentes a las de la planta tipo de los bloques. Es el sistema de manzana híbrida, equivalente a las propuestas por Hilberseimer para su Ciudad Vertical de 1929. Dentro de este sistema, podemos distinguir dos formas de unir los bloques:

Valencia. Plano conjunto de áreas de edificación abierta proyectadas en planes parciales de desarrollo del Plan General de 1966. Detalle de la zona noreste. 


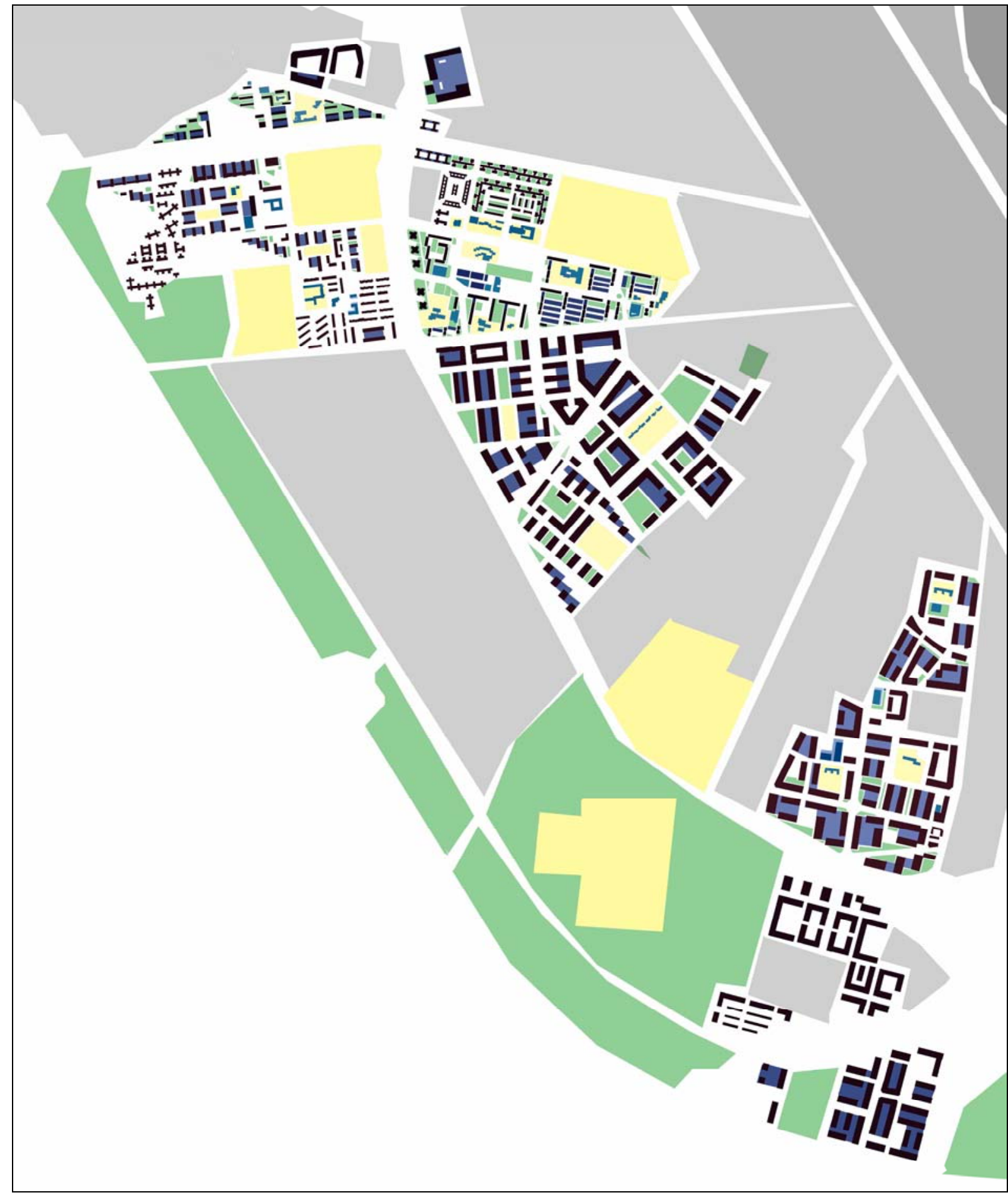

Valencia. Plano conjunto de áreas de edificación abierta proyectadas en planes parciales de desarrollo del Plan General de 1966. Detalle de la zona suroeste. a) Planta baja que envuelve los bloques: el zócalo comercial forma un rectángulo edificado en su totalidad sobre el que se asientan los bloques de edificación abierta. Es un tipo funcionalmente igual al de las manzanas de ensanche, con la única diferencia de que la edificación en planta tipo no es una edificación perimetral continua, sino una edificación discontinua. El plano de edificación en planta baja es idéntico al de una manzana tradicional, y es imposible obtener a partir de ese plano información alguna sobre las características de los bloques de edificación abierta de la planta tipo. 
b) Planta baja que enlaza los bloques: el zócalo comercial es un cuerpo de edificación que enlaza en planta baja los bloques, pero sin superar el perímetro de los mismos. El espacio entre los bloques queda, por tanto, parcialmente edificado y parcialmente libre. En el plano de edificación en planta baja los bloques se pueden identificar claramente, y la lectura en planta baja del espacio libre que queda entre los bloques enlazados es similar a la que ofrecería una edificación a redents.

Además del bloque lineal, en la edificación abierta del periodo estudiado se utiliza también la torre, aunque es un tipo menos frecuente. Las formas en planta más habituales en las torres son la cuadrada o rectangular, la planta en forma de aspa de molino y la planta en forma de $\mathrm{Y}$.

Las torres se proyectan como elementos aislados o se agrupan para formar unidades urbanas de mayor tamaño, por procedimientos similares a los que se utilizan en los bloques: uniendo las torres mediante cuerpos de edificación en planta baja que en unos casos las enlazan y en otros las envuelven.

Un tipo que se utiliza también, aunque en contadas ocasiones, en las áreas de edificación abierta de Valencia, es el de la palazzina, edificio aislado con planta igual a la de una torre pero de menor altura.

La edificación abierta con parcela propia, rodeada por un jardín privado, es un modelo muy poco usado, y se reduce prácticamente a tres manzanas de la calle Jaime Roig y a otras dos promovidas por cooperativas en el polígono de la Avenida de Castilla
Valencia. Plano conjunto de áreas de edificación abierta proyectadas en planes parciales de desarrollo del Plan General de 1966. Detalle de la zona sureste.

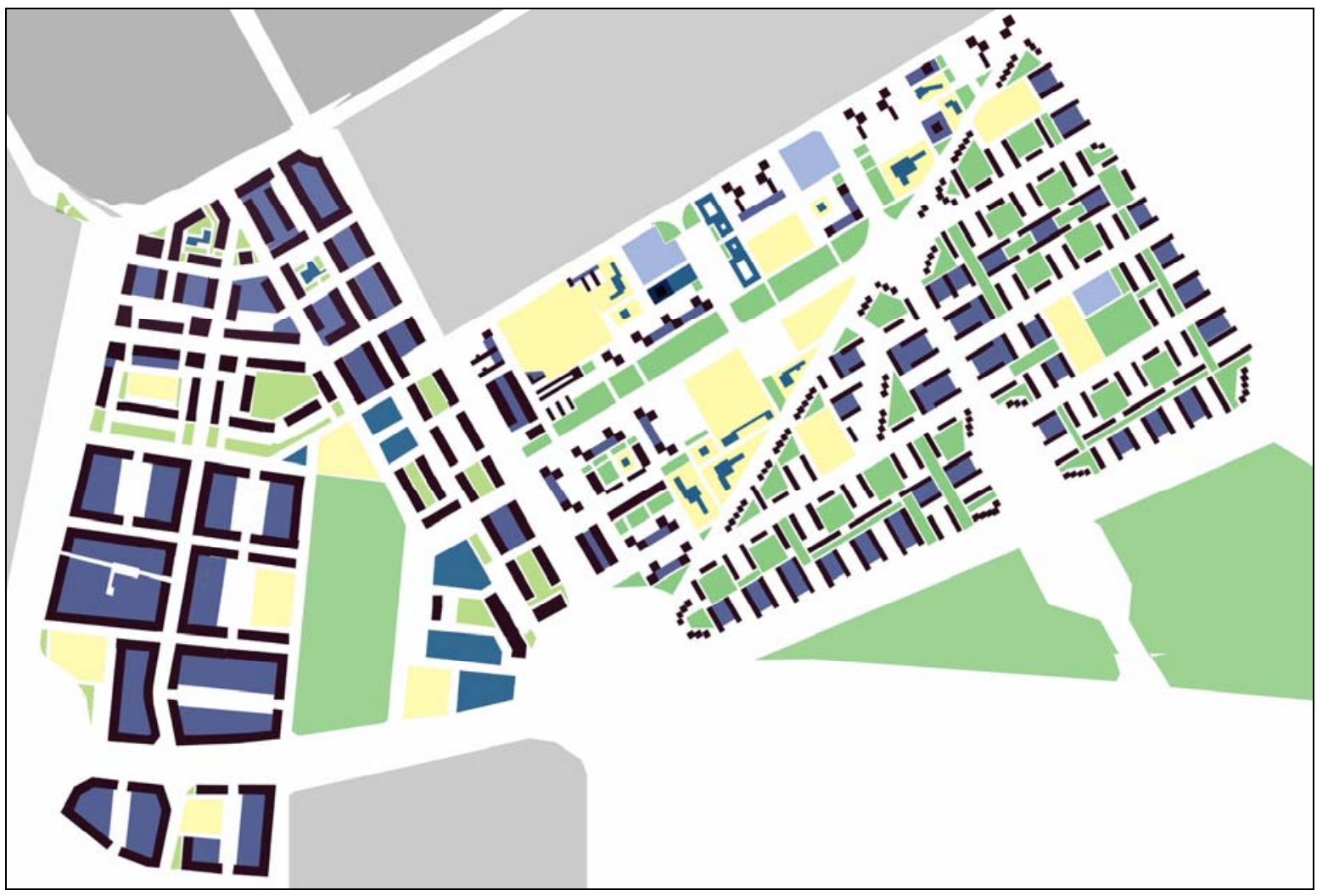




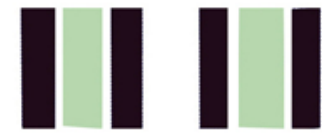

Seriación de bloques

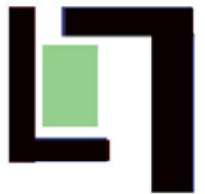

Articulación de bloques.

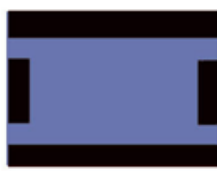

Unión de bloques. a)Planta baja envolvente.

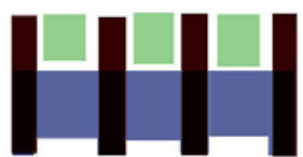

Unión de bloques. b)Planta baja de enlace.

Sistemas de agrupación de bloques lineales.
El trabajo de análisis realizado nos permite concluir que la edificación abierta presenta en los planes parciales objeto de nuestro estudio una serie de características que suponen una clara vulneración de algunos de los principios básicos del orden abierto, tal como fueron expresados en la Carta de Atenas. La vulneración de esos principios, sin embargo, hace que, como veremos, esa edificación abierta quede a resguardo de algunas de las críticas realizada contra el orden abierto a partir de finales de los años sesenta, como la de Jane Jacobs en su libro ya citado o la de Colin Rowe y Fred Koetter más tarde, en su clásico Ciudad Collage. ${ }^{1}$

\section{Estas características son las siguientes:}

1) Uso indistinto de bloques lineales de dos o de cinco crujías como elementos básicos de la edificación abierta.

En ambos casos, la célula tipo de vivienda es similar, pero en los bloques profundos las dos fachadas de dicha célula no se abren a espacios exteriores, sino que una de ellas da a un patio de luces. Con ello se vulnera el principio según el cual en la edificación abierta no deben existir patios interiores de ventilación, ya que son, junto con las alineaciones de las calles, formas "absolutamente contrarias al bien de los hombres", según Le Corbusier. ${ }^{2}$

En las versiones menos especulativas, los bloques profundos son bloques dobles, es decir, edificios formadas por dos bloques lineales de dos crujías separados por un espacio intermedio en el que se intercalan únicamente las cajas de escalera, cuya posición central les permite servir a cuatro viviendas por planta. Este es el "tipo único" de la vivienda masiva identificado por Paricio.

El bloque profundo, con patios (interiores o a fachada) o como bloque doble, es un tipo arquitectónico de uso muy extendido en España en el periodo que nos ocupa. Este tipo de edificio tiene una doble lectura urbana, ya que puede entenderse como un tipo que expande el bloque lineal, al integrarlo en grupos de dos, y también como una manzana de edificación perimetral en la que el espacio central se comprime y reduce a un patio lineal interrumpido por las cajas de escaleras.

2) Predominio de la unidad edificatoria mixta o híbrida, en la que se superponen en vertical usos comerciales y residenciales.

La utilización generalizada de las plantas bajas para usos comerciales en la promoción privada, que es consecuencia de la escasa aceptación de las viviendas en planta baja en Valencia, implica que los bloques de edificación abierta mantienen el carácter mixto de las manzanas cerradas de ensanche, con tiendas situadas bajo las viviendas. Con ello se vulnera el principio de especialización funcional de la edificación propio del orden abierto, según el cual la separación de funciones implica la separación de los edificios proyectados para cumplirlas. Este principio únicamente se respeta en los polígonos de promoción pública, en los que los bloques son exclusivamente residenciales, y albergan viviendas también en planta baja.

La manzana híbrida en la que se superponen en vertical el orden cerrado y el orden abierto, cuyo prototipo de laboratorio es, 
como hemos señalado, la propuesta por Hilberseimer para la Ciudad Vertical, permite recuperar en planta baja las alineaciones perdidas cuando la edificación se dispone libremente, de acuerdo con su propia lógica interna de agregación y orientación, en las plantas superiores. Con ello se vulnera el principio de independencia entre viario y edificación propio del orden abierto, y reaparece parcialmente, en planta baja, la vieja calle corredor denostada por Le Corbusier.

La superposición de usos y la recuperación de las alineaciones, que son aspectos negativos de la manzana híbrida desde el punto de vista de los principios del orden abierto, son en cambio aspectos positivos si lo que se desea es recuperar la calle y el espacio público como elementos estructurales generadores de la forma urbana.

Ya hemos señalado, además, que las plantas bajas no residenciales de la edificación mixta ha servido para paliar déficits de equipamientos. En todo caso, aunque durante determinados periodos los bajos no estén en uso como locales comerciales, su potencial persiste, y posibilita la evolución hacia la plurifuncionalidad en los conjuntos residenciales, lo que no ocurre en los bloques exclusivamente destinados a viviendas de los polígonos de promoción pública.

3) El bloque lineal no es un edificio unitario, sino que aparece con bastante frecuencia como una suma de fragmentos edificados de manera independiente y unidos por medianeras.

Con ello se vulnera la lógica compositiva interna del bloque residencial propio del orden abierto, que se proyecta de dentro a fuera, por agregación de células tipo que no son el resultado de la aleatoriedad de las divisiones de la propiedad, sino de la investigación previamente realizada sobre la distribución racional de las viviendas.

Por contra, la fragmentación del bloque lineal comporta una mayor variedad formal, frente a la excesiva repetición y seriación de bloques iguales propia de los polígonos de promoción pública, que genera falta de identidad.

Las parcelas resultantes del troceado de un bloque lineal son de tamaños más variados, por lo que las distribuciones interiores no son necesariamente tan repetitivas como las que resultan de componer un bloque por agregación de células previamente definidas.

4) La disposición de los bloques no responde a un criterio de orientación, sino que su eje o lado mayor es casi siempre paralelo u ortogonal a los ejes viarios principales que delimitan o atraviesan el ámbito del plan parcial.

Así, por ejemplo, podemos ver que en la mayor parte de los planes situados en el arco norte que limitan con el Camino de Tránsitos, tales como el Plan Parcial 8b, 8, 9, 22 o 23, la geometría básica de la edificación abierta está dictada por el paralelismo o la ortogonalidad con respecto a dicho eje viario, lo que, dado su trazado poligonal, implica que las orientaciones de los bloques van cambiando de unos planes a otros.

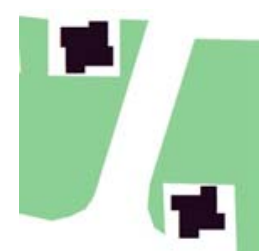

Torres aisladas

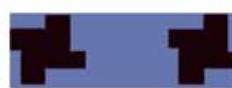

Unión de torres a)Planta baja envolvente.

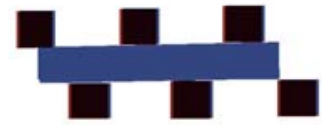

Unión de torres. b)Planta baja de enlace.

Sistemas de agrupación de torres. 
Con ello se vulnera el principio de independencia entre la edificación y el viario propio del orden abierto. El edificio no responde a la lógica de la orientación uniforme de las viviendas, sino a otra lógica, más urbana, de ajuste de su directriz a uno de los dos ejes de una trama ortogonal subyacente derivada del contorno del área ordenada.

Este planteamiento permite, cuando los bloques están enlazados o envueltos en planta baja por un cuerpo bajo de edificación comercial, recuperar un trazado mallado equivalente desde el punto de vista funcional al de los tejidos de manzanas cerradas.

\section{POR UNA VALORACIÓN EQUILIBRADA DE LA CIUDAD DE LA EDIFICACIÓN ABIERTA.}

El tiempo, que, como ha señalado acertadamente Solá-Morales, es una materia compositiva fundamental del proyecto urbano, ha jugado, a nuestro juicio, a favor de la edificación abierta. ${ }^{1}$

La edificación abierta fue descalificada con rotundidad a partir de mediados de los años setenta. Fue descalificada, probablemente, demasiado pronto, aunque razones para ello no faltaron en su momento. De hecho, si se contempla la evolución que sufren en sus sucesivas redacciones algunos de los planes parciales de Valencia que hemos analizado, se comprueba que cada una de ellas estropeaba un poco más la anterior: los mejores proyectos no son por lo general los que finalmente se realizaron, sino más bien al contrario. Este hecho adquiere consecuencias desastrosas cuando el proyecto inicial tampoco es especialmente brillante, como ocurre en más de un caso.

Los resultados insatisfactorios de las realizaciones basadas en el orden abierto condujeron a planteamientos que hacían hincapié en la necesidad de volver a centrar la atención del urbanismo en el proyecto del espacio público, recuperando los modelos urbanos tradicionales de tejidos de manzanas cerradas con edificios alineados a calles y los instrumentos del trazado y las ordenanzas.

Sin embargo, vistas desde la perspectiva actual, las áreas residenciales de edificación abierta, y especialmente aquellas con una ocupación del suelo equilibrada, con un porcentaje suficiente de espacios libres, han mostrado en Valencia una evidente capacidad para mejorar, que contrasta con la relativa inmovilidad y falta de pulso de los tejidos de manzanas, en los cuales cualquier mejora de las condiciones urbanísticas generales resulta muy dificultosa, cuando no imposible, por pura falta de espacio físico para ello: no es lo mismo suprimir un bloque para obtener un parque que suprimir un fragmento de edificación entre medianeras o liberar espacio en un interior de manzana.

La crítica a los espacios libres sobreabundantes intercalados entre los bloques, que debían ser zonas verdes y eran descampados, no se sostienen hoy. La inversión pública en urbanización y

1. Solá-Morales i Rubió, Manuel de, Les formes de creiximent urbà, Edicions UPC, Barcelona, 1993. jardinería ha conseguido evidentes mejoras con el paso del tiempo en el acabado del espacio público. 
El verde público puede considerarse, en cierta forma, como una prestación pública, asistencial: el ayuntamiento aporta el espacio libre directamente vinculado a las viviendas y asume su cuidado y mantenimiento, que no puede ser costeado por la población sin recursos. Este espacio libre inmediato a las viviendas es conceptualmente diferente al del parque vecinal, y si nos planteásemos su privatización y anexión a los bloques que lo envuelven, es probable que su destino fuese el de garaje, más que el de jardín.

Puede pensarse por todo ello que, tal vez, el orden abierto es una forma urbana que requiere un determinado grado de desarrollo de la sociedad, y de hecho donde ha funcionado mejor desde un primer momento es en los barrios de viviendas de rentas altas, y particularmente en los modelos en los que la edificación dispone de una parcela anexa destinada a jardín privado, cuya conservación está garantizada sin necesidad de recursos públicos.

Como ha puesto de relieve con gran agudeza Carles Martí, los nuevos sectores residenciales construidos en España en los años ochenta a partir de supuestos contrarios a los del orden abierto, mediante tejidos de manzanas y calles, como los denominados nuevos ensanches de Madrid, no han logrado alcanzar el umbral de urbanidad que se pretendía para ellos, a causa de su localización discontinua con respecto a otros tejidos, de la falta de densidad y compacidad de los tejidos a causa de la gran proporción de suelo requerido para equipamientos y zonas verdes, y del predominio del uso residencial, que hace entrar en crisis el zócalo comercial y, con él, la propia idea de calle como lugar público. ${ }^{1}$

Paradójicamente, según estos parámetros, las áreas residenciales de edificación abierta estudiadas en nuestro trabajo, pese a su morfología, tienen más puntos en común con los ensanches tradicionales que los nuevos ensanches periféricos, ya que tienen una localización continua con respecto a los demás tejidos urbanos de Valencia, son muy densas y compactas a causa de la escasa previsión de reservas de suelo para equipamientos y, además, incluyen una proporción muy alta de manzanas mixtas, con bloques o torres situados sobre zócalos comerciales, que por su extensión permiten además recomponer, al menos en planta baja, los lados de la calle, todo ello sin renunciar a los tipos de vivienda derivados de la experiencia moderna.

El orden abierto basado en la edificación aislada no es pues, contrariamente a lo que se pudo creer en los años ochenta, un desafortunado episodio ya cerrado de la historia de la ciudad, sino que mantiene su vigencia como alternativa de proyecto para las áreas residenciales, aunque sin el carácter de dogma excluyente que tuvo en su día, sino en pie de igualdad con otras formas urbanas, a las que no debe tratar ya de desplazar.
1. "Con estos ingredientes es imposible superar, en los nuevos sectores residenciales, la denostada condición de barrios-dormitorio que, a menudo, se ha querido atribuir en exclusiva a los polígonos de ordenación abierta. Este acaba siendo un dato de partida de carácter estructural que no depende de la elección morfológica y del que la periferia no puede redimirse por el simple hecho de construirse imitando las formas del ensanche", Martí Arís, Carlos, "Ensanches en la periferia, el caso de Madrid", en Lopez de Lucio, Ramón, Hernández-Aja, Agustín, Los nuevos ensanches de Madrid. La morfología residencial de la periferia reciente 1985-1993, Ayuntamiento de Madrid, 1995. 



\section{BIBLIOGRAFÍA Y FUENTES}





\section{BIBLIOGRAFÍA}

\subsection{BIBLIOGRAFÍA GENERAL.}

Alonso de Armiño Pérez, Luís, Intervención pública y transformación del espacio: una aproximación teórica a la producción del espacio territorial y urbano en el capitalismo avanzado. Tésis Doctoral. Dir. Fernando Ramón Moliner. Universidad Politécnica de Valencia, 1980.

Alonso de Armiño Pérez, Luís, Pérez Igualada, Javier, Análisis de unidades residenciales, Vol. I y II., , Universidad Politécnica de Valencia, Valencia, 1990.

Aymonino, Carlo, Il significato delle città, Gius. Laterza \& Figlio, Roma-Bari, 1975 (El significado de las ciudades, Hermann Blume Ediciones, Madrid, 1985).

Aymonino, Carlo, ed., L'abitazione razionale: atti del congressi CIAM 1929-1930. Marsilio, Padova, 1971 (La vivienda racional. Actas de los congresos CIAM, Gustavo Gili, Barcelona, 1973).

Banham, Reyner, Megastructure. Urban futures of the recent past, Thames \& Hudson, Londres, 1976 (Megaestructuras. Futuro urbano del pasado reciente, Gustavo Gili, Barcelona, 1978).

Benévolo, Leonardo, Melograni, Carlo, Giura Longo, Tomasso, La progettazione della città moderna, Laterza, Bari, 1977 (La proyectación de la ciudad moderna, Gustavo Gili, Barcelona, 1978)

Benévolo, Leonardo, Storia dell'architettura moderna, Laterza, Roma-Bari, 6a Ed. 1975 (Historia de la arquitectura moderna, Gustavo Gili, Barcelona, 1977).

Buchanan, Peter. "Oltre il mero abbellimento", Casabella, 597-598, Milán, 1993.

Casciato, Maristella, ed., Diotallevi e Marescotti. Il problema sociale costruttivo ed económico dell'abitazione, Officina edizioni, Roma, 1984.

Esteban Noguera, Juli, La ordenación urbanística: conceptos, herramientas y prácticas, Electa, Barcelona, 2003.

Ezquiaga, José María, "Formas construidas, formas del suelo", Geometría, 9, Málaga, 1990.

Ezquiaga, José María, "Las afueras. Transformaciones del paisaje periférico", Arquitectura COAM, 286-287, Madrid, 1990.

Frampton, Kenneth, Modern Architecture: A Critical History, Thames \& Hudson, Londres, 1980 (Historia crítica de la arquitectura moderna, Gustavo Gili, Barcelona, 1993)

Galantay, Ervin Y., New Towns: Antiquity to the Present, George Braziller Inc, Nueva York, 1975 (Nuevas ciudades: de la antiguedad a nuestros días, Gustavo Gili, Barcelona, 1977).

Garnier, Tony. Une cité industrielle, Philippe Sers Editeur, París, 1998.

Gibberd, Frederick, Town Design (Diseño de núcleos urbanos, Editorial Contémpora, Buenos Aires, 1956). 
Hilberseimer, Ludwig, Groszstadt Architektur, Verlag Julius Hoffmann, Stuttgart, 1927 (La arquitectura de la gran ciudad, Gustavo Gili, Barcelona, 1979)

Hoffmann, Hubert, Conjuntos residenciales de baja densidad, Blume, Barcelona, 1967.

Jacobs, Jane, The Death and Life of Great American Cities, Random House, New York, 1961 (Muerte y vida de las grandes ciudades, Península, Barcelona, 1967)

Johnson-Marshall, Percy, Rebuilding Cities, Aldine Publishing Company, Chicago, 1966 (Renovación de ciudades, Instituto de Estudios de la Administración Local, Madrid, 1979).

Kleihues, Joseph Paul, "Edilizia chiusa ed edilizia aperta", Lotus, 19, Milán, 1978.

Klein, Alexander, Vivienda mínima: 1906-1957, Gustavo Gili, BarceIona, 1980.

Krier, Leon, "Quarta lezione. Analisi e progetto dell'isolato urbano tradizionale", Lotus, 19, Milán,1978.

"La manzana residencial", Urbanismo COAM, 30, Madrid, 1997.

Le Corbusier, La Charte D'Athenes, Fondation Le Corbusier y Éditions de Minuit, Paris, 1957 (Principios de urbanismo. La Carta de Atenas, Ariel, Barcelona, 1971).

Le Corbusier, Propos d'urbanisme (A propósito del urbanismo, Paidós, Barcelona, 1978).

Le Corbusier et Pierre Jeanneret, Oeuvre complete 1910-1929. Les Editions d'Architecture, Zurich, 1964.

López de Lucio, Ramón, Ciudad y urbanismo a finales del siglo $X X$, Universitat de Valencia, Valencia, 1993.

Lozano Velasco, José María, La vivienda social, entre utopía y realidad, Editorial UPV, Valencia, 2002.

"L'isolato urbano", Lotus, 19, Milán, 1978.

Martí Arís, Carlos, Las formas de residencia en la ciudad moderna, Servicio de Publicaciones de la UPC, Barcelona, 1991.

Mausbach, Hans, Introducción al urbanismo, GG, México, 1985.

Martínez Sarandeses, José, Herrero Molina, Maria Agustina, Medina Mauro, María, Guía de diseño urbano, Ministerio de Fomento, Dirección General de la Vivienda, la Arquitectura y el Urbanismo, 1999.

Merlin, Pierre, Les villes nouvelles, Presses Universitaires de France, 1969 (Las nuevas ciudades, Laia, Barcelona, 1978)

Monteys, Xavier, La gran máquina. La ciudad en Le Corbusier, Demarcación de Barcelona del Colegio de Arquitectos de Cataluña, Ediciones del Serbal, Barcelona, 1996.

Ostrowski, Waclaw, L'urbanisme contemporain. Des origines a la Charte $d$ 'Athenes, Centre de Recherche d'Urbanisme, Paris, 1968. 
Panerai, Philippe R., Castex, Jean, Depaule, Jean Charles, Formes Urbaines: de I'ilot à la barre, Bordas, París, 1980 (Formas urbanas: de la manzana al bloque, G.Gili, Barcelona, 1986).

Panerai, Philippe y Mangin, David, Projet Urbain, Editions Parenthèses, Marsella, 1999 (Proyectar la ciudad, Celeste Ediciones, Madrid, 2002)

Paricio, Ignacio, Sust, Xavier, La vivienda contemporánea. Programa y tecnología, Institut de tecnología de la Construcció de Catalunya, Barcelona, 1998.

Pérez Igualada, Javier, "Otra vuelta de tuerca. Nuevos objetos en el espacio de la arquitectura moderna", Geometría, 24, Málaga, 1997.

Pérez Igualada, Javier, Manzanas, bloques y casas. Formas construidas y formas del suelo en la ciudad contemporánea, Universidad Politécnica de Valencia, Valencia, 2003.

"Periferias urbanas", Geometría, 9, Málaga, 1990.

Peters, Paulhans, Wohnquartiere Neuestadte, Georg D.W. Callwey, Munich, 1966 (Nuevos barrios residenciales, G. Gili, Barcelona, 1969).

Prinz, D. Planificación y configuración urbana. Gustavo Gili, México, 1983.

Rowe, Colin y Koetter, Fred, Collage City, MIT Press, Cambridge \& London, 1978 (Ciudad Collage, G.Gili, Barcelona, 1981).

Ravetllat, Pere Joan, Bloques de viviendas, Gustavo Gili, Barcelona, 1992.

Rowe, Colin, "La IBA entre res publica y res privata", A\&V, 2, Madrid, 1985.

Rowe, Colin, "Talent and ideas. A conference", Lotus, 62, Milán, 1989.

Rowe, Colin, "Introducción", Five Architects, Oxford University Press, 1972 (Five Architects, G. Gili, Barcelona, 1975).

Rowe, Peter G., Modernity and Housing, The MIT Press, Cambridge, Massachusetts, Londres, 1983.

Schneider, Friederike, ed., Floor Plan Atlas. Housing, Birkhäuser Verlag, Basilea, 1994.

Schwab, G., Differenzierte Wohnanlagen. Internationale Beispiele, Karl Krämer Verlag, Stuttgart, 1975 (Unidades residenciales. Conjuntos diferenciados de viviendas, Gustavo Gili, Barcelona, 1975).

Serra i Riera, Enric, "Prototipus singulars d'arquitectura residencial del Moviment Modern i temptatives de compromís urbanístic", en VV.AA., Ciutat funcional y morfologia urbana, Edicions UPC, BarceIona, 1994.

Sert, Jose Luís, Tyrwhitt, Jacqueline, Rogers, Ernesto N., The Heart of the City, Lund Humphries, Londres, 1952.

Sherwood, Roger, Modern Housing Prototypes, Harvard University Press, Cambridge, 1978 (Vivienda: Prototipos del Movimiento Moderno, Gustavo Gili, Barcelona, 1983). 
Solá-Morales, Ignasi, "Territorio construido. La ciudad desde la arquitectura", Arquitectura Viva 35, Madrid, 1994.

Solá-Morales, Manuel de, "La segunda historia del proyecto urbano", Urbanisme, 5, Barcelona, 1987.

Solá-Morales, Manuel de, "Projectar la periferia", Urbanisme, 9-10, Barcelona, 1992.

Solá-Morales, Manuel de, "Les parcel.les de la ciutat moderna", en VV.AA., Ciutat funcional y morfologia urbana, Edicions UPC, BarceIona, 1994.

Solá-Morales i Rubió, Manuel de, Les formes de creiximent urbà, Edicions UPC, Barcelona, 1993.

Stein, Clarence S., Towards New Towns for America, University Press of Liverpool, 1951.

Terán, Fernando de, "Calles y algo más que calles", Urbanismo, 29, Madrid, 1996.

Terán, Fernando de, Ciudad y urbanización en el mundo actual, Blume, Madrid, 1969.

Trebbi, Giorgio, ed., Housing in Europa (prima parte 1900-1960, seconda parte 1960-1979), Edizioni Luigi Parma, Bolonia, 1978.

Valdés, Alfonso, "La ciudad funcionalista", Geometría, 13, Málaga, 1992.

"Vivienda en detalle", AV Monografías, 86, Madrid, 2000.

"Vivienda europea", AV Monografías, 56, Madrid, 1995.

"Vivienda mejor", AV Monografías, 67, Madrid, 1997.

"Vivienda: nuevas ideas urbanas", Quaderns, 211, Barcelona, 1996.

"Viviendas: nuevas alternativas", Quaderns, 210, Barcelona, 1995.

"Vivienda varia", Arquitectura Viva, 36, Madrid, 1994.

"Vivienda y ciudad", Geometría, 17, Málaga, 1994.

"Vivienda y flexibilidad (I)", a+t, arquitectura + tecnología, 12, Vitoria, 1998.

"Vivienda y flexibilidad (II)", a+t, arquitectura + tecnología, 13, Vitoria, 1999.

Unwin, Raymond, Town Planning in Practice, Londres, 1909 (La práctica del urbanismo, Gustavo Gili, Barcelona, 1984)

VV. AA., Ciudad para la sociedad del siglo XXI, Icaro, Colegio Territorial de Arquitectos de Valencia, Valencia, 2001. 


\section{2. BIBLIOGRAFÍA SOBRE PAÍSES, CIUDADES O PERIOdOS ESPECÍ́FICOS.}

\section{ALEMANIA}

"Berlín IBA' 87", AV Monografías, 1, Madrid, 1985.

"Berlín Metrópolis", AV Monografías, 50, Madrid, 1994.

Dolff-Bonekämper, Gabi, Das Hansaviertel. Internationale Nachkriegsmoderne in Berlin, Verlag Bauwesen, Berlín, 1999.

Dreysse, DW, Ernst May Housing States. Architectural Guide to Eight New Frankfort States (1926-1930), Verlag Dieter Fricke, Frankfurt, 1988.

Grassi, Giorgio, ed., Das neue Frankfurt 1926-1931, Dédalo, Bari, 1975.

Huse, Norbert, ed., Vier Berliner Siedlungen der Weimarer Republik: Britz, Onkel Toms Hütte, Siemensstadt, Weissestadt, Argon Verlag, Berlín, 1984 (Cuatro siedlungen berlinesas en la República de Weimar: Britz, Onkel Toms Hütte, Siemensstadt, Weissestadt, Fundación Cultural COAM, 1992).

Piccinato, Giorgio, La costruzione dell 'urbanistica. Germania 18711914, Officina Edizioni, Roma, 1977 (La construcción de la urbanística. Alemania 1871-1914, Oikos-Tau, Barcelona, 1993).

VV.AA., Berliner Wohnquartiere. Ein Führer durch 70 Siedlungen, Dietrich Reimer Verlag, 1990.

\section{AUSTRIA}

Steiner, Dietmar, "10.000 nuovi alloggi per Vienna", Casabella, 610, Milán. 1994.

Tafuri, Manfredo, ed., Vienna Rossa. La politica residenziales nella Vienna socialista, 1919-1933, Electa Editrice, Milán, 1980.

\section{DINAMARCA}

Faber, Tobías, Neue dänische Architektur, Verlag Gerd Hatje, Stuttgart, 1968 (Nueva arquitectura danesa, Gustavo Gili, Barcelona, 1968).

\section{ESPAÑA}

Aballanet, Albert, Castiñeira, Isabel, Monteys, Xavier, Paricio, Antoni, Residencia urbana en Barcelona 1945-1970. El área de La Bonanova (Sarrià-Sant Gervasi), Edicions UPC, 2000.

Alonso Velasco, J.M., "El equipo urbano en el plan parcial de ordenación", Ciudad y Territorio, 1, Madrid, 1969.

Bidagor Lasarte, Pedro, "Situación general del Urbanismo en España. 1939-1964", Arquitectura, 62, Madrid, 1964.

Bohigas, Oriol, "El Polígono de Montbau", Cuadernos de Arquitectura, 61, Barcelona, 1965. 
Busquets, Joan, Barcelona. La construcción urbanística de una ciudad compacta, Ediciones del Serbal, Barcelona, 2004.

Cano Lasso, Julio, "La Gerencia de Urbanización del Ministerio de la Vivienda", Arquitectura, 62, Madrid, 1964.

Díaz, César y Ravetllat, Pere Joan, Habitatge $i$ tipus a l'arquitectura catalana, Col.legi d'Arquitectes de Catalunya, Barcelona, 1989..

Durán Loriga, Manuel, "Urbanismo", Temas de Arquitectura, núms. 52-59, Madrid, 1963-64.

Fernández-Galiano, Luis, Isasi, Justo F., Lopera, Antonio, La quimera moderna. Los poblados dirigidos de Madrid en la arquitectura de los 50, Hermann Blume, Madrid, 1989.

Ferrer i Aixalà, Amador, Els polígons de Barcelona, Edicions Universitat Politécnica de Catalunya, Barcelona, 1996.

Ferrer Aixalà, Amador, Oficina de Información Urbanística, Presentación y estadística de los Planes Parciales de la provincia de BarceIona (1956-1970), La Gaya Ciencia, Barcelona, 1974.

Font, Antonio, "Territorio y ciudad en la Cataluña de los sesenta", en Pizza, Antonio y Rovira, Josep Ma, Desde Barcelona arquitecturas y ciudad 1958-1975, Col.legi d'Arquitectes de Catalunya, Barcelona, 2002.

Gaviria, Mario, Campo, urbe y espacio del ocio, Siglo XXI, Madrid, 1971.

Jaén i Urban, Gaspar, Formació de la moderna ciutat d'Elx: 17401962, del Pont i Raval de Santa Teresa al Plá General d'Ordenació Urbana, Tesis Doctoral inédita, Dir. Luís Alonso de Armiño Pérez, Universidad Politécnica de Valencia, 1990.

López de Lucio, Ramón, Hernández-Aja, Agustín, Los nuevos ensanches de Madrid. La morfología residencial de la periferia reciente 1985-1993, Ayuntamiento de Madrid, 1995.

López de Lucio, Ramón, "De la manzana cerrada al bloque abierto", en Sambricio, Carlos, ed., Un siglo de vivienda social (1903-2003). Vol. II. Nerea, San Sebastián, 2003.

Lozano Velasco, José María, La vivienda unifamiliar de protección estatal en España. Evolución, antecedentes y propuestas para un medio rural, Tesis Doctoral, Dir. Miguel Colomina Barberá, Universidad Politécnica de Valencia, 1987.

Martí Arís, Carlos, "Ensanches en la periferia, el caso de Madrid", en Lopez de Lucio, Ramón, Hernández-Aja, Agustín, Los nuevos ensanches de Madrid. La morfología residencial de la periferia reciente 1985-1993, Ayuntamiento de Madrid, 1995.

Moya González, Luís, Barrios de promoción oficial. Madrid, 19391976, Colegio Oficial de Arquitectos de Madrid, Madrid, 1983.

Moya González, Luís, "Polígonos de viviendas", en Sambricio, Carlos, ed., Un siglo de vivienda social (1903-2003). Vol. II. Nerea, San Sebastián, 2003.

Nadal, Luís, "Reflexiones en torno a la Gineueta", Cuadernos de Arquitectura, 61, Barcelona, 1965. 
Paricio, Ignacio, "Las razones de la forma en la vivienda masiva", Cuadernos de Arquitectura, 96, Barcelona, 1973.

Ribas Piera, Manuel, "La planificación urbanística en España", Zodiac, 15, Milán, 1965.

Roca, Francesc, El Plá Macià, Edicions de la Magrana, Barcelona, 1977.

Sabaté Bel, Joaquín, "De la casa aislada a los bloques y la manzana cerrada en el proyecto Cerdá", Historia Urbana, 4, Valencia, 1992.

Sambricio, Carlos, ed., Plan Bidagor 1941-1946, Consejería de Urbanismo y Transportes, Comunidad de Madrid, 2003.

Sambricio, Carlos, ed., Un siglo de vivienda social (1903-2003). Nerea, San Sebastián, 2003.

Sambricio, Carlos, Moure, Lilia y Ezquiaga, José Ma, Madrid, urbanismo y gestión municipal 1920-1940, Ayuntamiento de Madrid, Área de Urbanismo e Infraestructuras, Gerencia Municipal de urbanismo, Madrid, 1984.

Serratosa i Palet, Albert, Com., Tarragó i Cid, Salvador, Dir., Cerdà. Urbs i territori. Una visió de futur. Catálogo de la Muestra, Fundació Catalana per a la Recerca, Electa, Barcelona, 1994.

Solá-Morales, Manuel de, "Fábulas de la Mar Bella. Sobre la consulta de cinco manzanas en el frente marítimo", Quaderns d'Arquitectura i Urbanisme, 210, Barcelona, 1995.

Solá-Morales, M., Busquets, J., Domingo, M., Font, A., Gómez, J.L., Barcelona, remodelación capitalista o desarrollo urbano en el Sector de la Ribera Oriental, Gustavo Gili, Barcelona, 1974.

Terán, Fernando de, "Evolución del planeamiento de núcleos urbanos nuevos", Ciudad y Territorio 1-1969, Centro de Estudios Urbanos del IEAL, Madrid, 1969.

Terán, Fernando de, Planeamiento urbano en la España contemporánea Historia de un proceso imposible, Gustavo Gili, Barcelona, 1978 (Ed. revisada, Planeamiento urbano en la España contemporánea (1900-1980), Alianza Editorial, Madrid, 1982).

Torres i Capell, Manuel de, La formació de la Urbanística Metropolitana de Barcelona. L'Urbanisme de la diversitat, Mancomunitat de Municipis de I'Àrea Metropolitana de Barcelona, Barcelona, 1999.

Varela Botella, Santiago, Los barrios de viviendas en Alicante y provincia 1940-1970, Colegio Oficial de Arquitectos de la Comunidad Valenciana, Valencia, Consellería d’Obres Públiques, Urbanisme i Transports, 1998.

VV.AA., La arquitectura del sol, Colegios de Arquitectos de Cataluña, Comunidad Valenciana, Islas Baleares, Murcia, Almería, Granada, Málaga y Canarias, Barcelona, 2002.

Zuazo, Secundino y Jansen, Hermann, Anteproyecto del trazado viario y urbanización de Madrid (Estudio preliminar de Lilia Moure Rubio), Colegio Oficial de Arquitectos de Madrid, 1986. 


\section{EE.UU.}

Ciucci, Giorgio, Dal Co, Francesco, Manieri-Elia, Mario y Tafuri, Manfredo, La città americana, Gius. Laterza \& Figlio, Roma-Bari, 1975 (La ciudad americana, Gustavo Gili, Barcelona, 1975).

Plunz, Richard, "Las formas del bloque en los orígenes de la vivienda pública", en UR Urbanismo Revista, 3, Laboratorio de Urbanismo, ETS de Arquitectura de Barcelona, Barcelona, 1985.

\section{FRANCIA}

Candilis, Georges, Josic, Alexis y Woods, Shadrach, Toulouse le Mirail, Karl Krämer Verlag, Stuttgart, 1975 (Toulouse le Mirail. El nacimiento de una ciudad nueva, Gustavo Gili, Barcelona, 1976).

Chapel, Enrico, "Parigi: Progetti di ZAC", Casabella, 581, Milán.1991.

Croset, Pierre Alain y Milesi, Silvia, "A Bercy e Villejuif: due quartieri parigini a confronto", Casabella 617, Milán. 1994.

"Francia fría", AV Monografías, 65, Madrid, 1997.

Preteceille, Edmond, La production des grands ensembles, École Pratique des Hautes Études (VI Section) and Mouton \& Co., paría-La Haya, 1973 (Región de París. La producción de los Grands Ensembles, Gustavo Gili, Barcelona, 1976).

VV. AA., L'urbanisation française, Centre de Recherche d'Urbanisme, París, 1964 (La urbanización en Francia, Instituto de Estudios de la Administración Local, Madrid, 1970).

\section{FINLANDIA}

Tempel, Egon, Neue Finnisch Architektur, Verlag Gerd Hatje, Stuttgart, 1968 (Nueva arquitectura finlandesa, Gustavo Gili, Barcelona, 1968).

\section{HOLANDA}

Amsterdamse Federatie van Woningcorporaties, The Amsterdam Social Housing Atlas, Architectura \& Natura, Amsterdam, 1990.

Bruijne, Dick, et al, Amsterdam Southeast, Thoth Publishers, Bussum, 2002.

Casciato, Maristella, Ponzini, Franco y Polano, Sergio, eds., Olanda 1870-1940. Città, Casa, Architettura, Electa Editrice, Milán, 1980.

Galindo González, Julián, Cornelis van Eesteren. La experiencia de Amsterdam 1929-1958, Colección Arquithesis, Fundación Caja de Arquitectos, barcelona, 2003.

Ibelings, Hans, Nederlandse Stedenbouw van de 20ste eeuw, Nai Uitgevers, Rotterdam, 1999

Ibelings, Hans, "Nei Paesi Bassi, sei quartieri habitativi modello", Casabella,. 603, Milán. 1993. 


\section{ITALIA}

Mantero, Enrico, ed., Il Razionalismo Italiano, Nicola Zanichelli Editore, Bolonia, 1984.

\section{RUSIA}

Quilici, Vieri, Città russa e città sovietica, Gabriele Mazotta Editore, Milán, 1976 (Ciudad rusa y ciudad soviética, Gustavo Gili, Barcelona, 1978).

\subsection{BIBLIOGRAFÍA SOBRE VALENCIA.}

Alonso de Armiño Pérez, Luís; Pérez Igualada, Javier; Almazán P. De Petinto, Gonzalo V., El proyecto de vivienda colectiva y el hábitat urbano, Universidad Politécnica de Valencia, Valencia, 1994.

Artal Ríos, S., "Grupo de viviendas en Valencia", Arquitectura, 34, Madrid, 1961.

Aubán Nogués, Carlos y Palau Navarro, José Manuel, Guía básica para la redacción de Planes Parciales en el ámbito de la Comunidad Valenciana, ICARO-CTAV, 1999.

Ayuntamiento de Valencia, Libro de la ciudad 1979/1982. Cuatro años de gestión municipal democrática, Ayuntamiento de Valencia, 1982

Ayuntamiento de Valencia, Ordenanzas Generales, Valencia, 1955.

Ayuntamiento de Valencia, Oficina Municipal del Plan, La ciudad que queremos. Avance del Plan General de Ordenación Urbana, Valencia, 1985. Ayuntamiento de Valencia, Valencia, 1985.

Banyuls Gacía, Jeroni, Valencia barrio a barrio. La Fontsanta y La Llum, Ayuntamiento de Valencia, 1986.

Blat Pizarro, Juan, Vivienda obrera y crecimiento urbano (Valencia 1856-1936), Generalitat Valenciana, Consellería d'Obres Públiques, Urbanisme i Transports, Colegio Oficial de Arquitectos de la Comunidad Valenciana, Valencia, 2000.

Colomer Sendra, Vicente, Ed., Registro de Arquitectura del siglo XX, Comunidad Valenciana, Colegio Oficial de Arquitectos de la Comunidad Valenciana, Consellería d'Obres Públiques, Urbanisme i Transports, Instituto Valenciano de la Edificación, Valencia, 2002.

Consellería d'Obres Públiques, Urbanisme i Transports, La Gran Valencia. Trayectoria de un Plan General, Generalitat Valenciana, Consellería d'Obres Públiques, Urbanisme i Transports, Valencia, 1986.

Delegación del Gobierno, Valencia. Ordenación técnica de la ciudad y su comarca, Imp. Tipografía Artística, Valencia, 1958.

Esteban Chapapría, Julián, Vicente-Almazán, José Luís, Javier Goerlich Lleó, Arquitecto (1886-1913-1972), Colegio Oficial de Arquitectos de Valencia, Valencia, 1982. 
Ferrer Pérez, Antonio, "Transformaciones urbanas del Plan general de 1944", en VV.AA., En tránsit a gran ciutat, actas del I Congreso de Historia de la Ciudad de Valencia, Siglos XIX-XX, tomo II, Ayuntamiento de Valencia, Valencia, 1988.

Gaja Díaz, Fernando, La promoción pública de la vivienda en Valencia (1939-1976), Generalitat Valenciana, Consellería d’Obres Públiques, Urbanisme i Transports, 1989.

Gaja Díaz, Fernando, "La transformación de Valencia", I y II, Urbanismo, 28 y 29, Madrid, 1996.

García Heredia, Antonio, "Planeamiento entre 1957 y 1979", en VV.AA., En tránsit a gran ciutat, actas del I Congreso de Historia de la Ciudad de Valencia, Siglos XIX-XX, tomo II, Ayuntamiento de Valencia, Valencia, 1988.

García Ordóñez, Fernando M., "El Plan Sur visto desde 30 años después", en VV.AA., En tránsit a gran ciutat, actas del I Congreso de Historia de la Ciudad de Valencia, Siglos XIX-XX, tomo II, Ayuntamiento de Valencia, Valencia, 1988.

García Ordóñez, Fernando M., Dexeus Beatty, Juan Ma, "Grupo de viviendas Virgen del Carmen. Valencia", Informes de la Construcción, 149, Instituto Eduardo Torroja de la Construcción y del Cemento, Madrid, 1963.

Giménez Baldrés, Enrique J. Parcelaciones Residenciales Suburbanas. La formación de la periferia metropolitana de Valencia, Universidad Politécnica de Valencia, Valencia, 1996.

Giménez, Emilio y Llorens, Tomás, "La imagen de la ciudad. Valencia", Hogar y Arquitectura, 86, Madrid, 1970.

Gómez-Ferrer Bayo, Álvaro, "Una contradictoria etapa de transició 1979-83", en VV.AA., En tránsit a gran ciutat, actas del I Congreso de Historia de la Ciudad de Valencia, Siglos XIX-XX, tomo II, Ayuntamiento de Valencia, Valencia, 1988.

González Móstoles, Vicente, "La renovación del urbanismo en los años ochenta", en VV.AA., Historia de la ciudad, II. Territorio, sociedad y patrimonio, Colegio Territorial de Arquitectos de Valencia, Ayuntamiento de valencia, Universidad de Valencia, 2002.

Heras, Artur, ed., Arquitectura valenciana (1974-82), Sala Parpalló, Valencia, 1983.

Herrero Colás, Adolfo, "Valencia: un modelo no cuestionado. El fantasma de la reforma interior", Historia Urbana, 4, Valencia, 1992.

Jordá Such, Carmen, ed., 20x20. Siglo XX. Veinte obras de arquitectura moderna, Catálogo de exposición, Generalitat Valenciana, Colegio Oficial de Arquitectos de la Comunidad Valenciana, Valencia, 1997.

La Roca, Francesc, Klein, rainer, "L'evolució de la periferia de la ciutat. 1939-1987", en VV.AA., En tránsit a gran ciutat, actas del I Congreso de Historia de la Ciudad de Valencia, Siglos XIX-XX, tomo II, Ayuntamiento de Valencia, Valencia, 1988.

Llopis, Amando y Dauksis, Sonia, eds., Arquitectura del siglo $X X$ en Valencia, Institució Alfons el Magnánim-Diputació de Valencia, Valencia, 2000. 
Llorens, Tomás, "El moviment modern i el racionalisme a I'arquitectura i I' urbanisme valencians", en "El Pais Valenciá, 19311939", Arguments, 1, L'estel, Valencia, 1974.

Martínez García-Ordóñez, Fernando, Análisis de los aspectos urbanísticos del Plan Sur de Valencia, VIII Asamblea de Cronistas del Reino de Valencia, Valencia, 1972.

Peñín Ibáñez, Alberto, Valencia 1874-1959. Ciudad, arquitectura y arquitectos, Escuela Técnica Superior de Arquitectura de Valencia, Valencia, 1978.

Peñín Ibáñez, Alberto, La ordenación del territorio en la Comunidad Valenciana; la Planificación urbanística, IEAL, Madrid, 1982.

Peñín Ibáñez, Alberto, Luís Albert, Arquitecto, 1902-1968, Colegio Oficial de Arquitectos de la Comunidad Valenciana, Valencia, 1984.

Pecourt, Enrique, "Notas sobre soleamiento", I y II, Boletín del Colegio Oficial de Arquitectos - Zona de Valencia, no 2 y 3, Valencia, 1933

Pecourt, Juan, ed., Ciutat Vella: Materiales para el Urbanismo, Catálogo de exposición, Colegio Oficial de Arquitectos de la Comunidad Valenciana, Valencia, 1992.

Pecourt, Juan, Piñón, Juan Luís, Dirs., La Valencia marítima del 2000. Estudio del frente marítimo desde Sagunt hasta Cullera, Colegio Oficial de Arquitectos de la Comunidad Valenciana, Valencia, 1997.

Piñón Pallarés, Juan Luís, "La ciudad y el mar. Notas para una historia", en Pecourt, Juan, Piñón, Juan Luís, Dirs., La Valencia marítima del 2000. Estudio del frente marítimo desde Sagunt hasta Cullera, Colegio Oficial de Arquitectos de la Comunidad Valenciana, Valencia, 1997.

Piñón Pallarés, Juan Luís, ed., Bulevares. Introducción al estudio de los nuevos bulevares de Valencia, Colegio Oficial de Arquitectos de la Comunidad Valenciana, Valencia, 1997.

Plan de Ordenación de Valencia y su comarca. Solución Sur. Normas Urbanísticas, Colegio Oficial de Arquitectos de la Comunidad Valenciana, Valencia, 1966.

PREVASA, Comunicaciones del área metropolitana. Valencia, IV. Información urbanística, Caja de Ahorros y Monte de Piedad de Valencia, Valencia, 1974

Reglamento de Planeamiento de la Comunidad Valenciana, Decreto 201/1998, de 15 de diciembre, del Gobierno Valenciano. DOGV 29$1-99$.

Sorribes i Monrabal, Josep. Desarrollo capitalista y proceso de urbanización en el País Valenciano (1960-75), Institución Alfonso el Magnánimo, Institució Valenciana d’Estudis i Investigació, Valencia, 1985.

Temes Riancho, Vicente, Vivanco Bergamín, L. Felipe, Cano Lasso, Julio, "Proyecto de ordenación turística de la Albufera y playas de Saler", Arquitectura, 65, Madrid, 1964 
Teixidor de Otto, Ma Jesús, Funciones y desarrollo urbano de Valencia, Institut de Geografía, Institución Alfonso el Magnánimo, Valencia, 1976.

Teixidor de Otto, Ma Jesús, Valencia, la construcció de una ciutat, Institución Alfonso el Magnánimo, Valencia, 1982.

Valls Abad, Vicente, García Sanz, Joaquín, Marés Feliú, Luís, "Grupo Antonio Rueda de 1.002 viviendas en Valencia", Hogar y Arquitectura 106, Madrid, 1973.

Valls Abad, Vicente, García Sanz, Joaquín, Mensua Fernandez, Francisco, "Grupo de 1.200 viviendas en el Polígono de la Fuente de San Luís (Valencia)", Hogar y Arquitectura, 121, Madrid, 1977.

Vila Gómez, Juan Francisco et.al., Valencia barrio a barrio. Nou Moles-Soternes, Ayuntamiento de Valencia, 1987. 


\section{FUENTES}

FUENTE PRINCIPAL:

- ARCHIVO DE PLANEAMIENTO DEL AYUNTAMIENTO DE VALENCIA.

FUENTES COMPLEMENTARIAS:

- ARCHIVO HISTÓRICO MUNICIPAL DE VALENCIA.

- ARCHIVO DE CARTOGRAFÍA DE LA E.T.S. DE ARQUITECTURA DE VALENCIA.

- BIBLIOTECA DEL COlEgIO OfICIAL DE ARQuitectos DE LA COMUNIDAD VALENCIANA.

- BIBLIOTECA CENTRAL DE LA UNIVERSIDAD POLITÉCNICA DE VALENCIA.

- CENTRO DE INFORMACIÓN ARQUITECTÓNICA DE LA E.T.S. DE ARQUITECTURA DE VALENCIA.

\section{PROCEDENCIA DE LAS ILUSTRACIONES}

Las ilustraciones de planes y proyectos que aparecen en el presente trabajo proceden principalmente de las fuentes indicadas en el pie de las mismas, que son el Archivo de Planeamiento del Ayuntamiento de Valencia y, ocasionalmente, el Archivo Histórico Municipal y algunas revistas de arquitectura de la época. De ellas, todas las procedentes del Archivo de Planeamiento están recogidas en el Anexo de Documentos. Las imágenes elaboradas por el autor del trabajo a partir de las de los planes y proyectos originales aparecen identificadas como tales en el pie de las mismas.

Las imágenes de planes parciales sin referencia expresa al pie proceden en su totalidad del Archivo de Planeamiento del Ayuntamiento de Valencia. Las restantes fotografías, gráficos, tablas e imágenes que aparecen en el presente trabajo han sido realizadas por el autor del mismo, excepto las procedentes de las fuentes bibliográficas que se indican a continuación, que se utilizan en su mayor parte en los apartados dedicados al análisis de los grupos de viviendas.

- Esteban Chapapría, Julián, Vicente-Almazán, José Luís, Javier Goerlich Lleó, Arquitecto (1886-1913-1972), Colegio Oficial de Arquitectos de Valencia, Valencia, 1982: Pág. 40. Pág. 42, abajo. Pág. 48, abajo. Pág. 88, arriba.

- Gaja Díaz, Fernando, La promoción pública de la vivienda en Valencia (1939-1976), Generalitat Valenciana, Consellería d'Obres Publiques, Urbanisme i Transports, 1989: Pág. 42, planta viviendas. Pág. 82, abajo. Pág. 84, abajo. Pág. 99, arriba. Pág. 141, arriba.

- Giménez Baldrés, Enrique J. Parcelaciones Residenciales Suburbanas. La formación de la periferia metropolitana de Valencia, Universidad Politécnica de Valencia, Valencia, 1996: Pág. 60, 2. Pág. 70, 1-2. Pág. 74, arriba. 
- Herrero Colas, Adolfo, "Valencia: un modelo no cuestionado. El fantasma de la reforma interior". Historia Urbana, 4, Valencia, 1992. Pág. 178, arriba izda. Pág. 225, arriba.

- Jordá Such, Carmen, ed., 20x20. Siglo XX. Veinte obras de arquitectura moderna, Catálogo de exposición, Generalitat Valenciana, Colegio Oficial de Arquitectos de la Comunidad Valenciana, Valencia, 1997. Pág. 175, arriba. Pág. 566.

- Llopis, Amando y Dauksis, Sonia, eds.. Arquitectura del siglo $X X$ en Valencia, Institució Alfons el Magnánim-Diputació de Valencia, Valencia, 2000. Pág. 52, centro. Pág. 169, abajo.

- Peñín Ibáñez, Alberto, Valencia 1874-1959. Ciudad, arquitectura y arquitectos, Escuela Técnica Superior de Arquitectura de Valencia, Valencia, 1978. Pág. 82, arriba izda. y centro. Pág. 100, arriba. Pág. 170, centro.

- QDQ. Callejero Fotográfico Virtual: Pág. 77, 1-3. Pág. 97, arriba. Pág. 98, centro. Pág. 101, 3-5. Pág. 102, 1-2. Pág. 103, arriba. Pág. 104, 1-3. Pág. 105, 3-6. Pág. 413, 1-2. Pág. 440, 2-4. Pág. 548, 1-4. Pág. 549, 4-7. En estas fotografías se ha realizado una corrección de perspectiva mediante un programa informático de tratamiento de imágenes.

- W.AA., Registro de Arquitectura del siglo XX, Comunidad Valenciana, COACV, COPUT, IVE, Valencia, 2002. Pág. 83, centro. Pág. 90, planta tipo. Pág. 92, planta tipo. Pág. 168, foto. Pág. 170, abajo.

Las fotografías aéreas que aparecen en el presente trabajo son fragmentos de las realizadas por el Ayuntamiento de Valencia en 1980 y 2002 . Además, se ha utilizado la fotografía aérea existente en la E.T.S. de Arquitectura de Valencia, donación del Profesor D. José Luís Molina, que fue realizada probablemente alrededor de 1965, ya que coincide en líneas generales con la situación de la ciudad reflejada en los planos de estado actual de los primeros planes parciales redactados tras la aprobación del Plan General de 1966. 


\section{LA CIUDAD DE LA EDIFICACIÓN ABIERTA VALENCIA, 1946-1988}

Javier Pérez Igualada 



\section{ANEXO DE DOCUMENTOS}

\section{Í N D I C E.}

NOTA PRELIMINAR

1. ORDENANZAS GENERALES DE LA COMISIÓN CENTRAL DE SANIDAD LOCAL, 1955

2. PROYECTOS PARCIALES DE DESARROLLO DEL PLAN GENERAL DE $1946 \quad 21$ NUEVO BARRIO ENTRE C. TRÁNSITOS, P. VALENCIA AL MAR Y NUEVO ACCESO DE BARCELONA, 1952

HOJA 12-B (PASEO VALENCIA AL MAR), 1952

BARRIOS RESIDENCIALES No 2 Y 3 EN LA AVENIDA DE CASTILLA, 1956

3 PROYECTOS DE EJECUCIÓN DE POLÍGONOS PARA VIVIENDAS

DE RENTA LIMITADA, 1955-56

SECTOR PASEO VALENCIA AL MAR, 1956

SECTOR CAMPANAR, 1956

SECTOR AV. CASTILLA, 1956

SECTOR MONTEOLIVETE, 1956

4. POLÍGONOS, 1960-62.

POLÍGONO VALENCIA AL MAR, 1960.

$\begin{array}{lr}\text { POLÍGONO DE CAMPANAR, } 1961 & 95\end{array}$

$\begin{array}{lr}\text { POLÍGONO AV. CASTILLA, } 1961 & 131\end{array}$

POLÍGONO MONTEOLIVETE, $1960 \quad 137$

POLÍGONO MONTEOLIVETE, CENTRO COMERCIAL, 1960

5. PLANES PARCIALES MUNICIPALES, 1958-1965 163

5.1. ZONA CENTRO 165

PLAN PARCIAL 1-3-4, 1958 Y $1960 \quad 167$

PLAN PARCIAL 1-3-4 RESTO. AREA DEL HOSPITAL PROVINCIAL 173

5.2. ZONA NORESTE $\quad 179$

PLAN PARCIAL 11, 1950 Y $1960 \quad 181$

PLAN PARCIAL 12-B, 1958 Y $1963 \quad 201$

PLAN PARCIAL 13, $1962 \quad 213$

PLAN PARCIAL 22B, $1961 \quad 219$

PLAN PARCIAL 23, $1962 \quad 225$

5.3. ZONA NOROESTE 229

PLAN PARCIAL 8-B, $1963 \quad 231$

PLAN PARCIAL 9, $1960 \quad 237$

PLAN PARCIAL 24, $1966 \quad 249$

5.4. ZONA SUROESTE 261

PLAN PARCIAL IB, 1962

PLAN PARCIAL IC, $1963 \quad 269$

5.5. ZONA SURESTE 273

PLAN PARCIAL 5-B, $1964 \quad 275$

PLAN PARCIAL 5-C, 1964 
6. PLAN GENERAL DE ORDENACIÓN URBANA DE VALENCIA Y SU

COMARCA ADAPTADO A LA SOLUCIÓN SUR, 1966

7. PLANES PARCIALES DE DESARROLLO DEL PGOU DE 1966

Y PLANEAMIENTO COMPLEMENTARIO

7.1. ZONA NORESTE

PLAN PARCIAL No 10 (ZAIDIA), 1967/1974
PLAN PARCIAL No 11 (PLA DEL REAL), 1967

325

343

PLAN PARCIAL NO 12 (PASEO AL MAR/ALGIRÓS), 1968

PLAN PARCIAL NO 13 (CABANYAL-MALVARROSA), 1968/1974

PLAN PARCIAL NO 14 (CAMINS AL GRAO), 1977

441

PLAN PARCIAL NO 22 (BENIMACLET), 1974

465

PLAN PARCIAL NO 23 (ORRIOLS-TORREFIEL), 1967

487

7.2. ZONA NOROESTE

PLAN PARCIAL NO 8-B (CAMPANAR OESTE), 1967

505

PLAN PARCIAL NO 8 (CAMPANAR-TENDETES), 1967/1972

517

PLAN PARCIAL NO 9 (MARXALENES), 1967/1973

547

PLAN PARCIAL NO 24 (BENICALAP-ACCESO ADEMUZ), 1970/1974

577

7.3. ZONA SUROESTE

641

PLAN PARCIAL NO 25 (NOU MOLES/SOTERNES), 1969

643

PLAN PARCIAL NO 26 (PATRAIX), 1967/1973

547

PLAN PARCIAL NO 26-B (LA LUZ/FUENSANTA/S.ISIDRO), 1967

677

PLAN PARCIAL NO 3 (PATRAIX-CAMI REIAL), 1968

7.4. ZONA SURESTE

PLAN PARCIAL NO 5-B (ESTACION CENTRAL), 1969

713

PLAN PARCIAL NO 5-C (MALILLA), 1968/1975

713

PLAN PARCIAL NO 4B-16I (FUENTE SAN LUIS), 1968/1973

725

8. POLÍGONOS, 1968-71

POLÍGONO AV. CASTILLA, 1968

POLÍGONO DE CAMPANAR, 1971

755

POLÍGONO FUENTE DE SAN LUÍS, 1970 


\section{NOTA PRELIMINAR}

La principal fuente utilizada para obtener la documentación contenida en este Anexo es el Archivo de Planeamiento del Ayuntamiento de Valencia. Los únicos documentos obtenidos de otras fuentes son las Ordenanzas de 1955, transcritas de la publicación realizada en su día por el Ayuntamiento de Valencia, y el Plano de Zonificación del Plan General de 1966, que procede del Informe PREVASA.

La documentación correspondiente al periodo comprendido entre 1952 y 1966 que hemos localizado es muy desigual para los diferentes planes, y en algunos de ellos no es completa, sobre todo en lo referente a la parte escrita. La mayor parte de estos planes se halla en la sección de expedientes antiguos del Archivo de Planeamiento.

De los planes parciales redactados en desarrollo del Plan General de 1966, los aprobados definitivamente por el Ministerio de la Vivienda tienen asignado en el Archivo de Planeamiento un número que remite al archivador en el que se guarda la documentación correspondiente a los mismos. Las versiones de estos planes que fueron descartadas o que no alcanzaron la aprobación definitiva están guardadas en los archivadores de la serie denominada OM, o bien en la sección de expedientes antiguos.

Cada plan parcial tiene asignado un número de expediente correspondiente al registro del Negociado de Suelo y Ordenación Urbana, que era la sección municipal encargada de su tramitación.

Cada uno de los expedientes del Negociado de Suelo y Ordenación Urbana relativos a planes parciales aprobados definitivamente incluye, por regla general, los siguientes documentos:

a) La versión inicial o avance del Plan Parcial, que consta usualmente un Plano, que es el que se somete a exposición públi$\mathrm{ca}$, y una memoria justificativa.

b) Las alegaciones de particulares y organismos al Plan Parcial, en dos rondas sucesivas, antes y después de la aprobación provisional

c) Los informes de los Arquitectos Municipales en relación con las alegaciones al Plan.

d) Las actas de sesiones de la Comisión de Urbanismo que recogen acuerdos relativos a la tramitación del Plan Parcial y propuestas para el Pleno del Ayuntamiento.

e) El Plan Parcial, tal como es aprobado inicialmente por el Ayuntamiento, que se compone de documentación escrita, (Memoria, Ordenanzas, Estudio Económico-Financiero, Plan de Etapas) y Planos.

f) Las resoluciones del Ministerio de la Vivienda de aprobación de los Planes Parciales, con o sin modificaciones.

g) Los informes técnicos (de los Arquitectos Municipales) y jurídicos relativos a dichas resoluciones ministeriales $y$, eventualmente, los recursos presentados contra las mismas.

h) Los documentos revisados o modificados del Plan como consecuencia de las resoluciones del Ministerio de la Vivienda, que constituyen la versión del Plan Parcial que se aprueba definitivamente. 
Para cada uno de los planes parciales aprobados definitivamente se transcriben a continuación todos estos documentos, excepto los señalados en los apartados b) y d) de la relación anterior, es decir, el texto de las alegaciones de particulares, que por lo general queda resumido en el informe del Arquitecto Municipal, y las actas de sesiones de la Comisión de Urbanismo, puesto que por lo general coinciden con lo planteado en los Informes técnicos. Cuando ello no es así, se añade a la documentación transcrita el acta de la sesión correspondiente.

La Memoria, Estudio Económico-Financiero y Plan de Etapas de los Planes se transcribe siempre íntegramente. De las Ordenanzas, en cambio, en los pocos casos en que constituyen un documento extenso, se reproducen sólo las correspondientes a la edificación abierta.

Las versiones previas descartadas de los planes parciales se transcriben con mayor o menor extensión en función del interés que presentan debido a sus diferencias con las aprobadas definitivamente.

Con el apoyo de un programa informático, y a fin de facilitar la lectura de los textos, se ha realizado una transcripción de las copias mecanografiados de los documentos originales, unificando el tipo de letra con el utilizado en el resto de este trabajo y reproduciendo las firmas y sellos existentes al pie. La transcripción es literal en cuanto al contenido, ya que nos hemos abstenido de realizar correcciones ortográficas o de cualquier otro tipo.

En cuanto a los planos, se reproducen en cada Plan los que resultan más relevantes. Por lo general, se reproducen siempre los planos de situación en la ciudad y en el Plan General, de estado actual, de zonificación, de alineaciones y de trazado viario.

No se reproducen los planos de estructura urbanística, que no suelen aportar información nueva con respecto a los de alineaciones, ni los de redes fundamentales de servicios (alumbrado, saneamiento y abastecimiento de agua), que no son relevantes a efectos de nuestro estudio.

Los Planes Parciales se han agrupado por zonas, y dentro de cada una de ellas se presentan en la medida de lo posible por orden cronológico.

La documentación técnica de los polígonos de promoción pública estatal, que es mucho más completa y elaborada que la de los planes parciales municipales del mismo periodo, se transcribe en dos apartados, correspondientes a los planes iniciales de 1960-62 y a las versiones modificadas de los mismos de 1968-71.

Este Anexo concluye con la transcripción, a título de ejemplo, de uno de los Planes Especiales de Reforma Interior (PERI) redactados a partir de 1981, cuyas determinaciones quedaron, por lo general, incorporadas al PGOU de 1988. 
1. ORDENANZAS GENERALES DE LA COMISIÓN CENTRAL DE SANIDAD LOCAL, 1955. 



\section{OG 55}

ORDENANZAS GENERALES DE LA COMISIÓN CENTRAL DE SANIDAD LOCAL

Redactores: Comisión Central de Sanidad Local.

Fecha aprobación: Ordenanzas 1-6, aprobación 23-10-1950; ordenanzas 7-12, aprobación 26-01-1955.

\section{Contenido:}

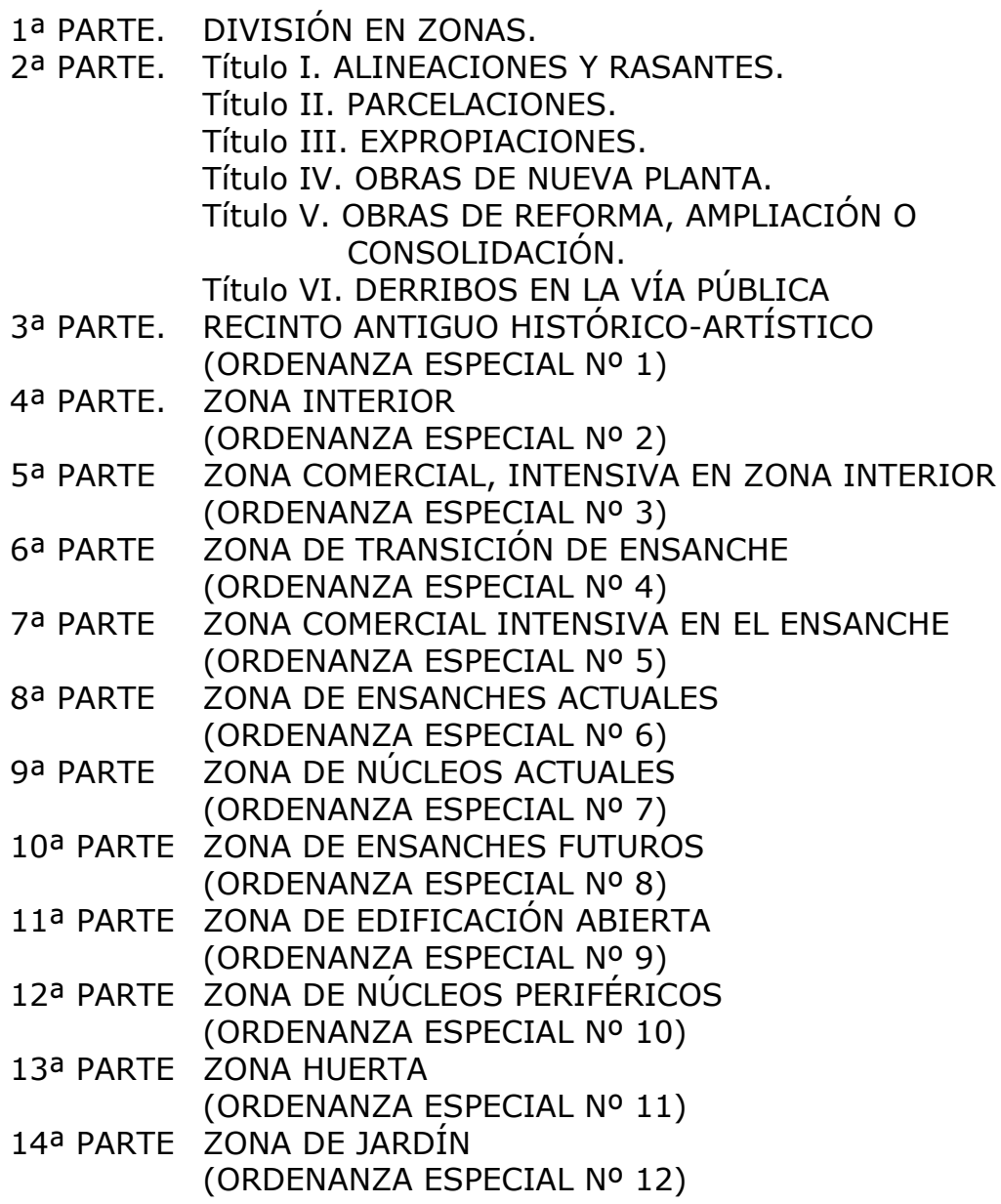

Fuente: Ayuntamiento de Valencia. Publicación sin fecha.

\section{Notas:}

Se transcriben a continuación únicamente los artículos de las Ordenanzas relacionados con las zonas de edificación abierta (Preámbulo, Parte $1^{a}$, División en Zonas y Parte $11^{a}$, Ordenanza especial No 9) 



\section{Ordenanzas Generales}

Ordenanzas núms. 1 al 6

Aprobadas por la Superioridad en virtud de acuerdo de Fecha 23 de Octubre de 1950, adoptado por la Comisión Central de Sanidad, introduciendo las siguientes modificaciones:

«Con respecto al artículo 51, que la instalación obligatoria de depuración de las aguas, ha de ser por pozo séptico y filtro».

«Que las dimensiones de los patios fijadas en los artículos $86,110,121$ y 139 han de ser de tres metros como mínimum en cumplimiento de lo preceptuado en la Orden de $1^{\circ}$ de Enero de 1944».

Valencia, Noviembre de 1950.

Ordenanzas núms. 7 al 12

Aprobadas por la Comisión Central de Sanidad Local en 26 de Enero de 1955.

Valencia, 1 Enero de 1955.

\section{Plan General de Ordenación de Valencia y su Comarca Ordenanzas Reguladoras de la Edificación PREÁMBULO}

El Plan de Ordenación de Valencia y su cintura, redactado por la Oficina Técnica dependiente de la Comisión Superior del Plan de Ordenación de la Provincia, fue aprobado por el Gobierno en 27 de julio de 1946, y declarado preceptivo por Ley de 18 de diciembre del propio año. En dicho Plan General de Ordenación quedaron comprendidos, además de los planos y zonificación, un proyecto de bases generales para las Ordenanzas reguladoras de la edificación en el ámbito territorial a que la ordenación se extiende.

Inspirándose en tal proyecto de bases generales de Ordenanzas y considerando los problemas de todo orden que en armonía con el Plan General han de resolverse, especialmente los que por referirse a la edificación ofrecen destacada relevancia urbanística, el Consejo General, ejercitando funciones de su propia competencia, que su Ley reguladora le atribuye para la aprobación de Reglamento y Ordenanzas Generales ha estimado inaplazables las prescripciones y normas a que han de someterse en general cuantas situaciones puedan suscitarse con motivo de la edificación actual o futura en la extensión territorial a que alcanza el Plan de Ordenación.

No pueden considerarse estas Ordenanzas como obra definitiva y acabada, pues comprendiendo complejas materias, tanto urbanísticas como jurídicas, que ofrecen módulos de solución nuevos o que implican modificación importante en las prescripciones que sobre la materia han venido aplicando los Ayuntamientos interesados, sólo la experiencia y los resultados de su aplicación, determinarán los términos en que resulte aconsejable una ampliación o modificación de estas Ordenanzas, hasta conseguir las que sean más perfectas y adecuadas para el mejor cumplimiento de todos los fines a que aspira el Plan General.

Comprende también el citado Plan General la apropiada y conveniente zonificación, a efectos de diferencias, en cuanto a uso y volumen de las edificaciones en las diferentes zonas. Especialmente 
la labor de zonificación se fija y establece en la forma más idónea y apropiada para alcanzar los fines siguientes:

1. ${ }^{\circ}$ Conseguir una ciudad ordenada en su conjunto y en sus detalles, considerada como una comunidad natural de personas y bienes, que vive, funciona y se desarrolla organizadamente.

2. ${ }^{\circ}$ Lograr una densidad de población de acuerdo con el carácter de los diferentes barrios o conjuntos y con las necesidades generales de la ciudad de Valencia y su comarca.

3. o Defensa, exaltación y mantenimiento de todo el sector urbano de interés histórico-artístico de edificaciones y lugares con el mismo carácter, sin perjuicio de establecer en los ensanches futuros, zonas representativas que deberán cuidarse.

4. 0 Regular debidamente los usos de vialidad, edificación y demás convenientes, estableciendo los casos de incompatibilidad con los que se opongan al Plan General; y

5. . Lograr una organización adecuada en distritos y barrios, señalando en cada uno el carácter de la edificación predominante según su situación y fijando emplazamiento adecuado para edificios públicos (parroquias, tenencias de alcaldía, mercado, grupos escolares, campos de deportes).

Inspirándose en todos los motivos expuestos y en los de la Lev de Ordenación, puestos todos al servicio de la futura gran Valencia y municipios comarcanos, el Consejo General ha aprobado las siguientes:

\title{
Ordenanzas Generales
}

\author{
PRIMERA PARTE \\ DIVISIÓN EN ZONAS
}

Articulo $1^{\circ}$. La edificación en Valencia y su comarca ha de sujetarse a la siguiente división de zonas:

\section{1. a RECINTO ANTIGUO O DE CONSERVACIÓN HISTORICO- ARTISTICO.}

Queda sometido principalmente a una ordenanza restrictiva, con la finalidad de conservar y revalorizar los conjuntos urbanos de mayor interés.

\section{2. a ZONA INTERIOR.}

Se establece una Ordenanza más amplia pero regulando debidamente la edificación para lograr el mejoramiento de la salubridad y la defensa, igualmente de aquellos sectores de interés históricoartístico.

\section{3. a ZONA COMERCIAL INTENSIVA EN EL CASCO ANTIGUO.}

Comprende un sector delimitado del mismo, donde se establecerán edificios de carácter comercial y público, bancarios, de oficinas, espectáculos, hoteles, etc., con una tolerancia más amplia en cuanto a la altura y a la superficie de patios.

\section{4. a ZONA DE TRANSICIÓN DE ENSANCHE.}

Comprende dos sectores de la zona actual de ensanche, donde conviene conservar las características de la construcción, dentro de un tono de transición entre la edificación de la zona interior y la del ensanche propiamente dicho, especialmente en lo que con las alturas hace referencia. 


\section{5. a ZONA COMERCIAL INTENSIVA DE ENSANCHE.}

Comprende un sector delimitado en el plano de zonificación, donde con preferencia se establecerán edificios de carácter comercial y públicos, con una tolerancia más amplia en cuanto a la altura de la edificación y a la superficie de patios.

\section{6. a ZONA DE ENSANCHES ACTUALES.}

Se refiere a la parte no interesada por la transición ni la de comercio intensivo y para la que se mantienen, con ligeras modificaciones, los principios que inspiran las ordenanzas anteriores vigentes, estableciendo la debida compatibilidad de usos de tipo industrial o de almacenamientos.

\section{7. a ZONA DE NÚCLEOS ACTUALES.}

Se refiere este concepto al de aquellas zonas periféricas, cuyos trazados y ordenanzas no han seguido la trayectoria de los ensanches existentes, y que por el trazado de sus calles y la dimensión en general reducida de sus manzanas, exige una ordenanza diferente al ensanche.

\section{8. a ZONA DE ENSANCHES FUTUROS.}

Son las zonas provistas, casi en su totalidad como terrenos disponibles, que quedaran sujetos u una ordenanza más restringida en cuanto altura y dimensiones de patios, así como a la compatibilidad con usos industriales, a fin de mejorar con relación a los ensanches actuales las zonas futuras.

\section{9. a ZONA DE EDIFICACIÓN ABIERTA.}

Son las emplazadas dentro de los ensanches futuros, donde por el valor de los terrenos se trata de establecen tipos abiertos de edificación con mayor abundancia de espacios libres.

10. ZONAS DE NÚCLEOS PERIFÉRICOS.

Son los que al margen de los ensanches futuros constituyen núcleos de edificación modesta en general, cuyas alturas y superficies aprovechables reclaman un carácter particular.

11. ZONA DE HUERTA.

Comprende la que lindando con el casco urbano tiene el único destino de su finalidad exclusivamente agrícola.

12. ZONAS DE CIUDAD-JARDIN.

Son las que se establecen en el plano con tal carácter y quedan incorporadas indistintamente a los ensanches y núcleos periféricos.

13. ZONAS DE TOLERANCIA INDUSTRIAL.

Obedecen a un plan de conjunto que permite en determinadas zonas de los ensanches y núcleos periféricos establecer compatibilidad de viviendas y determinadas industrias.

\section{ZONAS INDUSTRIALES.}

Obedecen igualmente a un plan de conjunto, incompatibilizándose en las mismas la vivienda y la industria, la que, a su vez, queda regulada en cuanto al aprovechamiento de los terrenos por ordenanzas especiales, lo mismo que las zonas de almacenes y portuarias. 
15 ZONAS DE ORDENANZA ESPECIAL.

Son aquellas que por constituir elementos fundamentales de la ciudad futura, quedan sujetas no sólo a una ordenanza que regule su uso y aprovechamiento, sino a unas normas generales de composición inspiradas en la arquitectura tradicional valenciana.

Aparte de las zonas señaladas y que llevan consigo las ordenanzas correspondientes, se determinan las que deberán destinarse a parques públicos, zonas deportivas, militares y sanitarias, y las ferroviarias, cuya situación exacta y delimitación corresponde a la Comisión de Enlaces Ferroviarios, que tiene a su cargo el estudio del Plan Ferroviario.

\section{$[\cdots]$}

\section{UNDÉCIMA PARTE \\ ZONAS DE EDIFICACIÓN ABIERTA \\ (ORDENANZA ESPECIAL NÚM. 9)}

\section{Art. 172. DELIMITACIÓN.}

Se regulan por la presente Ordenanza las zonas marcadas en los planos parciales de líneas y zonificación aprobados con el carácter de edificación abierta, por medio del signo, notación o color correspondiente.

Art. 173. DEFINICIÓN.

(Véase gráfico XIV.) En las zonas a que se refiere la presente Ordenanza estará constituida, en general, la edificación por bloques sin patios interiores de ninguna clase, rodeados de espacio abierto, excepto en los casos en que los planos indiquen lo contrario, al establecerse, en partes de la zona, bloques de más de dos crujías o manzanas cerradas para situar comercios, garages, salas de espectáculos, etc., o bien para limitar vías de tráfico.

Las formas permitidas de edificación serán siempre las derivadas del edificio a doble crujía, sin patios interiores ni de manzana, constituyendo, por lo tanto, bloques alargados, de la profundidad que indiquen los planos. La forma principal de bloque lineal podrá doblarse y ramificarse. Cuando este previsto en los planos parciales de alineación y zonificación puede también realizarse bloques alargados de más de dos crujías.

Art. 174. CASOS DE REALIZACIÓN.

En los proyectos de edificación de estas zonas pueden presentarse los siguientes casos:

a) Realización de toda una manzana, considerando como tal el espacio comprendido entre calles de tráfico o bien bloque entero o conjunto de bloques, por una sola persona o todos los propietarios del terreno necesario. En este caso se puede solicitar variaciones, con respecto a lo proyectado en los planos de líneas y zonificación, siempre que se cumplan los preceptos urbanísticos comprendidos en el plano (jardín de manzana, plaza, centro, escuela, etc.) y aprobación por el Excmo. Ayuntamiento previo informe de la Sección de Urbanismo y Comisión correspon 
diente. Las variaciones no deben suponer aumento de volumen respecto a la disposición que consta en los planos.

b) Realización de parte de un bloque, uno o varios edificios, por un propietario. En este caso deberá ajustarse a la linea y altura marcada en los planos y prescripciones de estas Ordenanzas.

c) realización de parte de una manzana, cuando en el plano no está prevista la forma de los bloques de edificación, deberá ajustarse a estas Ordenanzas y a lo prescrito en el art. 11 de las Ordenanzas Generales relativo a parcelación previa.

\section{CONDICIONES DE LAS PARCELAS.}

El terreno de estas zonas, destinado a la edificación por particulares, se divide en dos partes: la de construcción propiamente dicha y parte delantera o posterior arbolada o ajardinada. Este terreno ajardinado, mientras no sea propiedad municipal, deberá cercarse en las condiciones que se indicaran y junto con el edificable, constituyendo la parcela edificable cuyas condiciones ha de determinar este artículo.

Sin perjuicio de lo dispuesto en los arts. 10 y 11 de las Ordenanzas Generales, la parcela, para ser edificable, deberá lindar con la calle en línea igual o mayor de 7 metros y sus líneas medianeras deberán ser perpendiculares a la línea de la calle, hasta encontrar a la calle o calle de servicio paralela, si existe, o de manera regular a las parcelas colindantes. Entre dos calles no paralelas, las medianeras serán perpendiculares al eje del bloque proyectado, si la realización es como se marca en el caso b), pudiendo tomar otras formas de regularidad, cuando se trate de construcciones comprendidas en los casos a) o c). En los casos b) cada parcela deberá permitir la formación de otras edificables a ambos lados sin comprometer la parcelación general de todo bloque ni los derechos de los restantes propietarios, y deberá dejar completamente libre, o bien contener totalmente el nudo de encuentro de dos alineaciones de bloque y el terreno necesario para luces $y$ vistas y regularidad de la parcela de dicho nudo.

Los solares en que no se cumplan las condiciones antedichas, y cuando no se logre el acuerdo entre propietarios para la regularización de parcelas, serán expropiados por el Excmo. Ayuntamiento para su parcelación y venta, con derecho preferente de adquisición por los primitivos propietarios, en la forma que se establece en el Reglamento de la Gran Valencia.

(Véase gráfico XV.)

Art. 175. USOS.

Estas zonas son de carácter residencial y, por lo tanto, solamente se permitirán comercios en las calles comerciales señaladas en los planos y pequeños comercios, garages con capacidad máxima de seis coches y actividades arte 
sanas en las plantas bajas de las edificaciones de las restantes calles.

Para estas industrias se permitirá la instalación de motores eléctricos hasta 2 H.P. No se permitirá ninguna industria o almacén considerado como insalubre, incómodo o peligroso. Los servicios necesarios de garages y espectáculos ubicados en manzanas cerradas o semicerradas previstas en los planos, se regirán por la Ordenanza de Ensanches Futuros (especial núm. 8). Cuando la zona de edificación abierta sea relativamente pequeña, tendrá este carácter de abierta en toda su pureza, ubicando garages y salas de espectáculos en las zonas colindantes.

Los espacios comprendidos entre edificación y calle, estarán ajardinados o arbolados y deberán cerrarse con muro de 0'80 m. de altura, con o sin verja, o bien con seto vivo recortado de 0'80 a $1 \mathrm{~m}$. de altura.

Los espacios comprendidos entre edificaciones no podrán cercarse más que para separarlos de la calle y serán destinados a jardín y juego de niños.

Podrán establecerse calles particulares, que podrán cerrarse con verja o seto, como se ha dicho, y de la misma forma las parcelas recayentes a ellas.

Art. 176 VOLUMEN.

La altura de los edificios, mientras en los planos no se especifique otra cosa, queda regulada por la distancia entre ellos en la siguiente forma: la distancia mínima entre las fachadas de dos bloques alargados, cuyos ejes sean paralelos, será igual a la altura, cuando la orientación de los ejes esté en el cuadrante N.E.-S.E. y de una vez, más un cuarto de la altura, cuando esté en el cuadrante N.O. La distancia entre la fachada de un bloque y otro de dirección normal será igual a $2 / 3$ de la altura. La distancia entre bloques alineados, es decir, cuyos ejes están en la misma dirección, será de $1 / 2$ de la altura. Se considerará u estos efectos paralelo, aunque no lo sea exactamente, cuando el ángulo de los ejes sea menor o igual o de $30^{\circ}$. La altura de que se habla es la altura a cornisa sobre la cual sólo podrá edificarse la baranda del terrado, de 1'20 m. Sobre esta altura el resto de protección que se desea será verja metálica. La escalera no podrá acusar torre en fachada, para evitar sea visible desde el exterior y se rompa la línea de coronación de los bloques.

Los espacios entre bloques situados en manzanas distintas se contarán por mitad a partir del eje de la calle.

Las alturas mínimas de pisos, que serán a su vez máximas, o sea fijas, cuando la realización sea como se previene en el caso b), serán: planta baja, 3'60 m., comprendiendo zócalos y entramado; pisos, 3 m., comprendiendo el espesor del entramado, con una tolerancia por planta de $5 \mathrm{~cm}$. y total de la mitad de la suma de las parciales.

La distancia entre bloques que ramifiquen otros, en forma de peines, o simples redientes, quedan resueltas aplicando las reglas anteriores a los elementos que se forman. El número mínimo de plantas permitidas es de cuatro.

Para poder dejar un patio interior de manzana, utilizable con los usos permitidos en la Ordenanza de Ensanches 
Futuros, podrá formarse esta manzana cerrada, con bloques a dos crujías sobre un polígono que retira a sus lados paralelamente a los de la manzana y que ocupe el tercio de la superficie total de la manzana. De las fachadas de esta manzana podrán salir en forma de peines, con la debida regularidad, otros bloques de edificación que cumplan todas las otras condiciones y dejen entre ellas espacios ajardinados a la calle.

\section{Art. 177. ÁTICOS.}

No se consentirá sobre la altura permitida ninguna construcción acusada a fachada, salvo la caja de la escalera debidamente tratada como elemento decorativo. Sin acusarse a fachada se permitirán las construcciones necesarias para proteger los mecanismos de ascensores y para llegada de escalera. Por último, en el caso de que haya porteros, se ubicara en una de las plantas permitidas.

\section{Art. 178. VOLADIZOS.}

Podrán establecerse voladizos de fábrica en forma de miradores, que puedan llegar hasta el terreno cuando el bloque no linda con la calle, sino con su jardín delantero, que no ocupe en planta la mitad de la línea de fachada y tengan saliente máximo de $1 \mathrm{~m}$.

No se permitirán estos salientes cuando el espacio entre bloques sea menor de $16 \mathrm{~m}$.

Los balcones se consentirán desde segunda planta, sin más limitaciones que las de separarse $0^{\prime} 60 \mathrm{~m}$. del predio vecino y tener el saliente de $1 \mathrm{~m}$. como máximo. Cada vivienda podrá tener una terraza con desarrollo lineal máximo de $6 \mathrm{~m}$. y saliente de $1^{\prime} 30 \mathrm{~m}$. Este voladizo, para ser considerado terraza, tendrá que tomar hacia dentro por lo menos $0,70 \mathrm{~m}$.

Art. 179. CALLES LIMITE DE ZONA.

Se regirán por estas Ordenanzas en la parte correspondiente a su zona, aún cuando en la Ordenanza de la zona colindante se prevea lo contrario.

Art. 180. ORNATO.

Ambas fachadas de cada bloque ostentarán la misma categoría decorativa en cuanto a materiales, elementos y composición, y cuando la casa no se cubra con terraza practicable deberá preverse en los pisos una terraza con balcón, que sirva de tendedero de ropa, limitada por baranda poco calada, que oculte en parte lo tendido, para que no se vea directamente y en primer término desde, la calle, produciendo un aspecto indiscreto y de mal efecto. Además, estas terrazas, cuando haya calle principal y calle particular, se situarán en la fachada que recae a estas calles de menor importancia. 


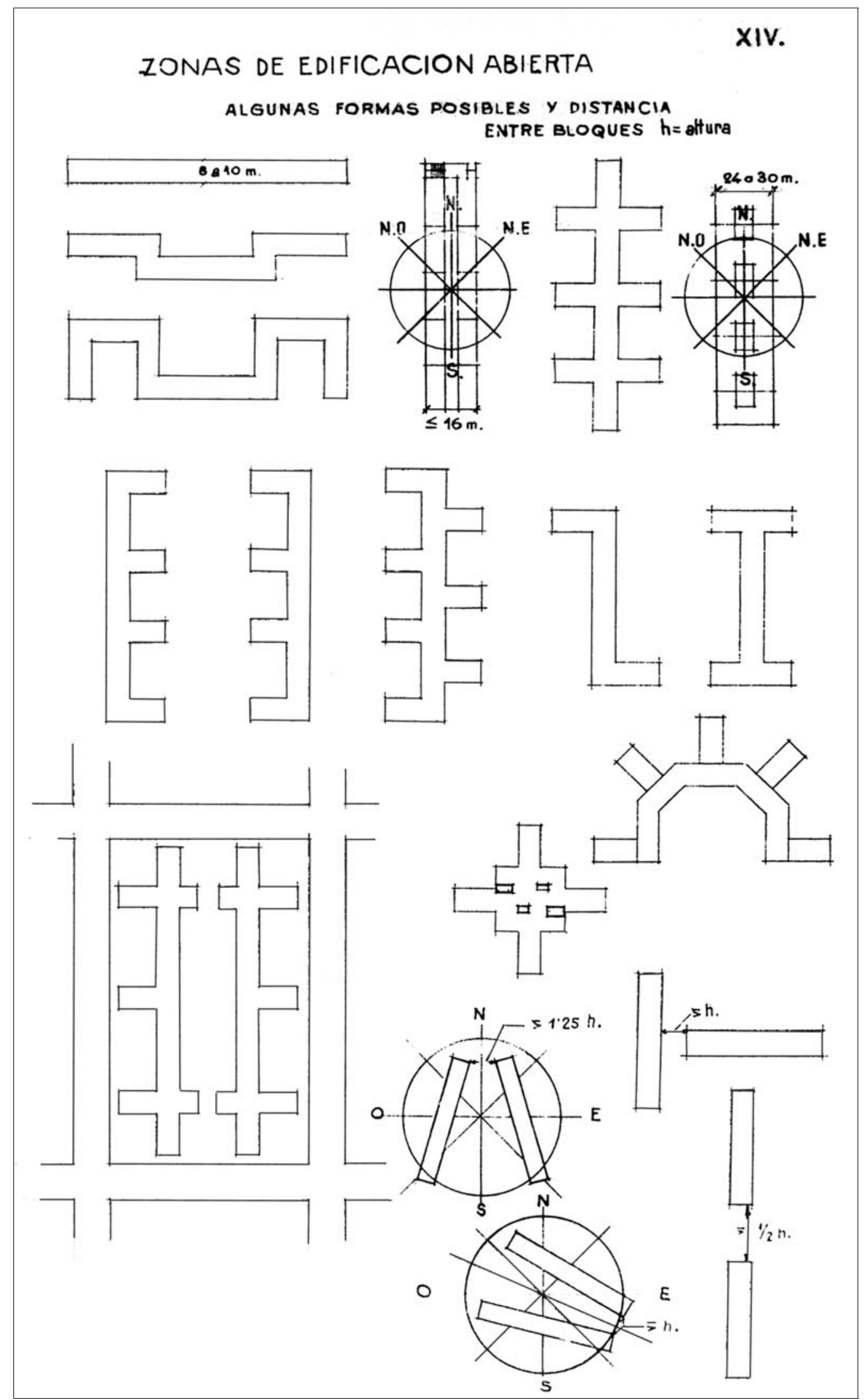

Ordenanzas 1955. Anexo gráfico. Tabla XIV. 

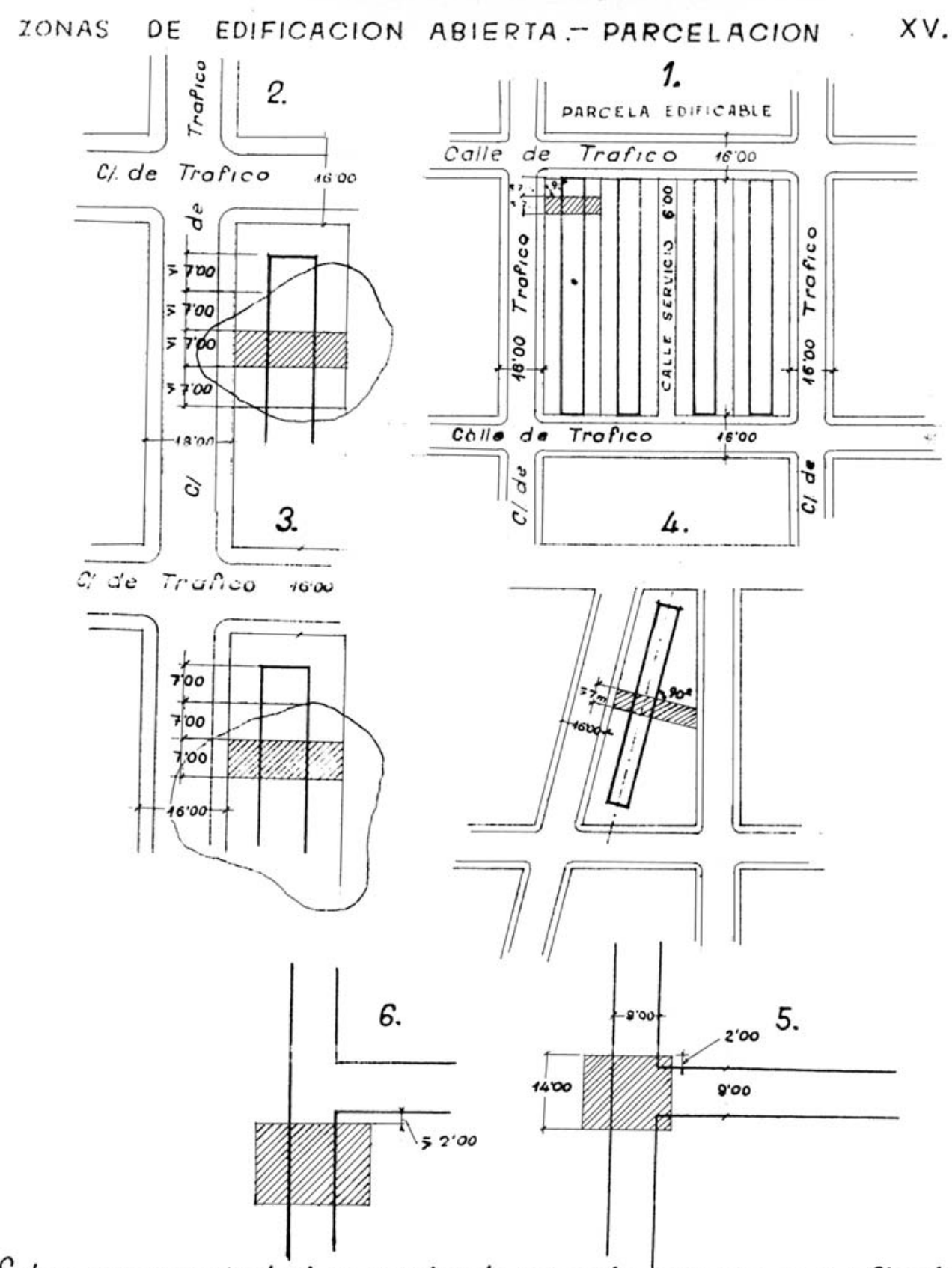

Sobre una propiedad irregular la parcela rayada es edificable

(2) inmediatamente porque no comprbmete la posibilidad do parcela. cion del Bloque. sobre una propiedad innegular la pancela nayada es edifciable inme-

(3) diatamente porque facilytala formbcion de farceic edificable ? ambos lados.

(4) Paricela carricubie entre cailes no paraieias.

5. La parcela rayada es ediricable porque contiene totnImente el mudo de encueritro yespocios de luces y yistas.

(6) La parcela rayada es edificable porque deja completamente libre el nudo de encuentro y el terreno de luces y vistas del mismo.

Ordenanzas 1955. Anexo gráfico. Tabla XV. 

2. PROYECTOS PARCIALES DE DESARROLLO DEL PLAN GENERAL DE 1946. 

PROYECTO DE "NUEVO BARRIO" ENTRE CAMINO DE TRÁNSITOS, PO VALENCIA AL MAR Y ACCESOS DE BARCELONA $\quad 1952$

Redactores: Ayuntamiento de Valencia. Oficina Técnica Municipal de Urbanismo.

Fecha: 1952.

\section{Contenido:}

\section{PLANOS:}

PROYECTO DE "NUEVO BARRIO" ENTRE CAMINO DE TRÁNSITOS, PO VALENCIA AL MAR Y ACCESOS A BARCELONA

E 1:2.000

Fuente: Ayuntamiento de Valencia. Archivo de Planeamiento (OM 57.1)

Nota: No se ha localizado la memoria de este proyecto. 

PROYECTO DE "NUEVO BARRIO" ENTRE CAMINO DE TRÁNSITOS, Po VALENCIA AL MAR Y ACCESOS A BARCELONA

Escala original: 1:2000

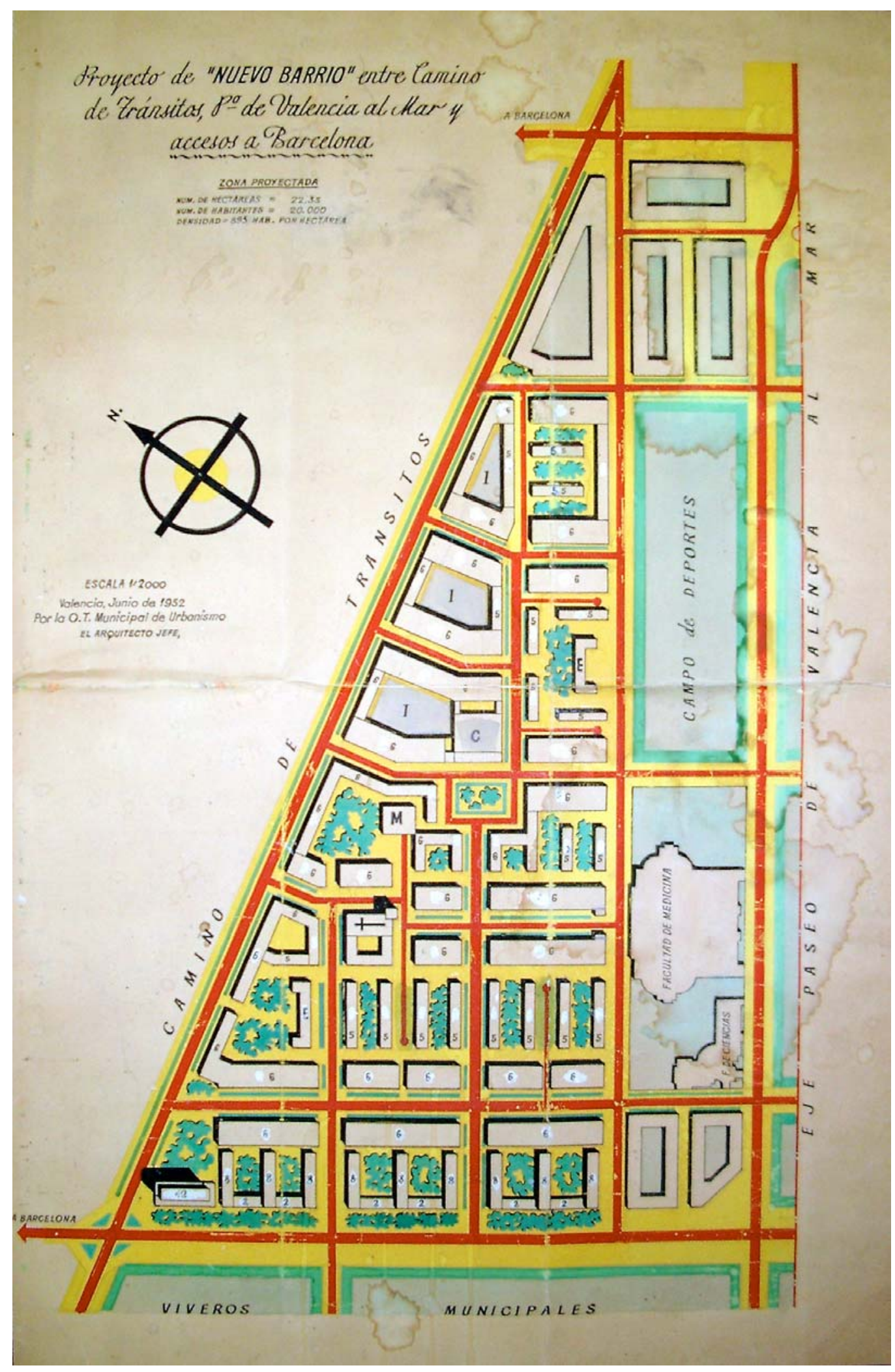





\section{H 12-B}

HOJA No 12-B. PLANO DE ALINEACIONES Y ZONIFICACIÓN DEL SECTOR COMPRENDIDO ENTRE EL NUEVO ACCESO DE BARCELONA, F.C. ECONOMICOS Y DE ARAGON AL PUERTO, ACTUAL F.C. DE TARRAGONA Y CONTINACION DE C/ AMADEO DE SABOYA

Redactores: Excmo. Ayuntamiento de Valencia. Oficina Técnica Municipal de Urbanismo.

Fecha redacción: Diciembre 1952.

Contenido:

MEMORIA

FOTOGRAFÍAS DE LA MAQUETA $(*)$

Fuente: Ayuntamiento de Valencia. Sección de Urbanismo. Negociado de Suelo y Ordenación urbana. (Archivo de Planeamiento, sección de expedientes antiguos)

\section{Notas:}

(*) No se han localizado los planos correspondientes a este plan. 

PLANO DE ALINEACIONES Y ZONIFICACIÓN DEL SECTOR COMPRENDIDO ENTRE EL NUEVO ACCESO DE BARCELONA, F.C. ECONOMICOS Y DE ARAGON AL PUERTO, ACTUAL F.C. DE TARRAGONA Y CONTINACION DE C/ AMADEO DE SABOYA

\section{MEMORIA DESCRIPTIVA}

10.- OBJETO DE ESTE ESTUDIO.- La mayor parte de esta Zona, todo el centro del plano, estaba destinado, en los del Plan General de Ordenación de Valencia y su Comarca, a Zona de reserva atravesada por una continuación del primer tramo del Paseo de Valencia al Mar, reduciendo la anchura de éste a la de una calle ordinaria y bordeándola de edificación de Ciudad-Jardín. Modificación tan profunda que hacía desaparecer el Paseo de Valencia al Mar como tal.

Se pensó, y así queda plasmado en el plano, la conveniencia de continuar el Paseo, que estaba ya, por así decirlo, grabado y aceptado en la mente de los valencianos como obra o empeño importante para el futuro embellecimiento y mejora de la Ciudad, y destinar ya la Zona de reserva a un barrio modelo de salubridad y belle$z a$, con modos de edificación que desearíamos ver extendidos a otras partes de la Ciudad y que no son posibles más que en las Zonas vírgenes de construcción, por causa del gran realismo que la práctica del urbanismo impone.

Se ha dedicado pues, el centro de la zona, a Edificación Abierta o sea edificación, en general, sin patios de luces ni patio central de manzana, quedando los edificios rodeados de jardín, o simplemente zonas arboladas.

Al norte del Paseo de Valencia al Mar, después de una serie de bloques abiertos, parece que quedarían muy bien ubicados, un gran Estadio Municipal y la futura Feria Muestrario, que gozaría de amplitud para poder ser muy ajardinada y de magníficas comunicaciones por ferrocarril para mercancías.

El resto de la zona es, por la derecha Núcleos Actuales y Tolerancia Industrial y por la izquierda Ensanches futuros, como continuación de la Zona Norte de la Alameda.

$2^{\circ}$.-DIRECTRICES DEL ESTUDIO REALIZADO.- Son los tres principios fundamentales de la actuación urbanística:

Utilidad, belleza y salubridad. En la práctica, la primera la dividimos en dos, con lo cual tenemos como directrices de éste estudio: A- Tráfico.-

B- Sociología.-

C- Salubridad.-

D- Belleza.-

A- TRAFICO.- Los cuatro límites del enunciado del Sector son vías de tráfico del esquema general vario de la Ciudad. Además es atravesado el Sector de Oeste a Este, por la Avd. de Valencia al Mar de $100 \mathrm{mts}$. de anchura y de Norte a Sur por la Avd. Cardenal Benlloch de $30 \mathrm{mts}$. de ancho; por la Avd. del Nuevo Ferrocarril en zanja (o en alto) de $60 \mathrm{mts}$. de anchura; Avd. del Estadio de $50 \mathrm{mts}$. de anchura y continuación de calle de Maestro Valls de $30 \mathrm{mts}$. de anchura. Para estudiar el tráfico del Sector hay que verlo, además de su trabazón con el resto de la Ciudad, íntimamente ligado con el plano 12-A.

El problema de elegir entre desarrollo en radio o diagonales, vivo 
y dinámico pero que produce manzanas triangulares y formas difíciles de edificación o desarrollo en la clara y fácil pero estática cuadrícula, importante el primero si se tiene en cuenta que en una esquina del sector tenemos el Puerto y en la opuesta el co de Tránsitos y en las otras dos esquinas el Puente de Aragón y Carretera por la costa, se resuelve aquí ligando ambas tendencias. Se ha trazado en el plano, un centro cuadriculado del cual salen cuatro diagonales: Una desde Estación de Aragón(contenida en el plano 12-A); otra hacia el Paseo de Colón y Puerto (contenida en el plano 12-A); otra el actual $C^{\circ}$ de Tránsitos desde el Norte al Paseo de Valencia al Mar, por último otra a Carretera por la Costa y Zona Industrial del Norte.

B- SOCIOLOGIA.- División en barrios- En este Sector pueden distinguirse claramente tres barrios:

a) Izquierda de la Avd. del ferrocarril en zanja.-

Forma cuatro grupos de manzanas, cerradas en general, de Ensanches futuros, que quedan separados por Avd. de Valencia al Mar y Avd. del Cardenal Benlloch. Se sitúa en uno de dichos grupos de manzana, el que comprende la diagonal al Paseo de Valencia al Mar, un centro cívico con Iglesia, Centro Parroquial y Escuelas y en otro un grupo que comprende las edificaciones Devis, un grupo Escolar.

b) Barrio Central.-

Está tratado, en su mayor parte, con edificación abierta, con densidad no muy baja, siguiendo en las distancias entre edificaciones lo que prescriben las Ordenanzas de Zonas de Edificación abierta, que es igual a la altura de la Edificación, para orientación Este y Oeste y vez y cuarto la altura de la edificación, para orientación N.S. (Valencia, donde los terrenos que han de ser edificables comienzan con las características de ser de huerta y precio superior a 25.000 ptas. la hanegada, para ir luego subiendo con la calificación de solares, no puede permitirse distancias entre los bloques de dos veces o dos veces y media la altura de la edificación, como es corriente en otras ciudades, y deberá buscar para sus barrios modelos, formas de gran salubridad pero de buena densidad. De otra forma se llegaría a cubrir excesiva huerta.

Así pues, los bloques recayentes al Paseo de Valencia al Mar, tendrán la altura correspondiente a 14 plantas, por lo cual se proyecta cada planta en forma de grupos de viviendas con calle interior servida por una escalera, un grupo centralizado de ascensores y dos escaleras supletorias a los lados, como se ve en los planos de planta que de estos grupos se presentan. Tendrán estos bloques una profundidad de $14 \mathrm{mts}$. , sin patios interiores.

Tiene este barrio además del Estadio dicho y Feria Muestrario, que corresponden a lo general de la Ciudad, como elementos propios una Iglesia y Centro Parroquial, Mercado, Sala de Espectáculos y cinco grupos escolares.

c) Derecha de calle continuación a la de Maestro Valls.-

Está destinado en parte Núcleos Actuales, barrio del Beteró, con una Escuela, al Norte del Paseo de Valencia al mar, y al Sur se forma un Grupo de manzanas, unas de Tolerancia Industrial y otras puramente Industriales, en el cual tenemos noticias de que van a realizarse unas Escuelas junto a los terrenos de Campsa.

C) SALUBRIDAD.- Espacios libres.- Basta ver el plano para apreciar que los Espacios libres son abundantísimos por lo que nos atrevemos a decir que, en este aspecto será este Sector el más salubre de la Ciudad. Todas las edificaciones abiertas, comprenden entre ellas Zonas arboladas que necesariamente tienen que ser dedicadas 
a sitios de estar y juego de niños. Las grandes vías llevan todas, fajas ajardinadas, lo que contribuirá a mejorar el aspecto que se está estudiando.

Todos los edificios públicos tendrán sus anteplazas ajardinadas lo que aumentará también la salubridad y por último el tener su límite con zona de huerta abona a favor de la salubridad del Sector. También hay una zona de reserva junto al Estadio que podría ser destinada a aparcamiento en caso de tomar enorme incremento los espectáculos en el mismo.

Al mismo aspecto de salubridad contribuye el que gran parte de construcciones del barrio sean de edificación abierta, sin patios interiores.

D) BELLEZA.- Se confía, en gran parte, a la sensación de libertad y amplitud que ha de producir, para todo aquel que circule por el Sector, el hecho de no quedar casi nunca enclaustrado por dos paramentos de edificaciones. En las vías principales, además de su gran anchura y zonas ajardinadas, los bloques de edificación son perpendiculares al eje de la vía, de tal manera que la perspectiva de jardines y arbolados dará la sensación de no tener fin. La sensación que producirá, será la de un gran parque con bloques de edificación aislados.

La situación de los edificios públicos como final de perspectiva de las calles interiores o de barrio, las torres final de perspectiva del Paseo de Valencia al Mar, la torre del Estadio como final de la Avd. que va al mismo y las edificaciones de entrada a la Feria Muestrario y sus torres serán también elementos de Belleza del conjunto.

Por último la acertada disposición del suelo de las calles, en las que se procurará que quede la mayor cantidad posible de tierra viva, que lleve o pueda llevar una planta, reservando el asfaltado para lo estrictamente necesario de circulación de vehículos y el enlosado, o pavimento idóneo, para la de peatones; la ordenación de las edificaciones, que en gran parte serán unificadas ya que tendrán, como luego se verá, que ser construidas por una sola Entidad y en otros casos se unificarán lo suficiente por efecto de los artículos de la Ordenanza de Edificación abierta, que a esto tiende, contribuirán también a la belleza del Sector.

30.- URBANIZACION.- En cuanto merezca este plano la aprobación del Excmo. Ayuntamiento y Organismos competentes, se procederá al estudio detallado de perfiles longitudinales y transversales, abastecimientos de agua, pavimento y alumbrado, que completen el proyecto.

En cuanto al alcantarillado según manifestaciones de Ingenieros de Regiones Devastadas encargados de realizar proyecto y ulteriormente la obra del alcantarillado de los Barrios del Cabañal y Cañamelar, para esta obra se ha de realizar proyecto en conjunto con el Sector de este plano por lo que el proyecto se ajustará en un día a las directrices que se marquen en el citado de Regiones Devastadas.

40.- PROCEDIMIENTOS DE EJECUCION.- Sin prejuzgar el procedimiento por que pueda llevase a cabo la urbanización de este importante Sector remarcaremos como más importante lo referente al Sector comprendido entre el nuevo F.C. en zanja y calle continuación de la de Maestro Valls o sea la Zona tratada con edificación abierta.

La urbanización de toda esta Zona pudiera ser realizada por el 
Excmo. Ayuntamiento con expropiación de terrenos y construcción posterior o bien mixta entre Ayuntamiento y Empresa particular. Esto es imprescindible en las edificaciones recayentes al Paseo de Valencia al Mar, en que por su naturaleza no puede permitirse la diversidad que la edificación por particulares implica. De todas maneras en toda la Zona, la intención de brillantez y de barrio modelo que la vista del plano indica llevará anejo, en la urbanización, una actuación total por parte del Excmo. Ayuntamiento sobre solares. Deberá estudiarse la parte con que cada elemento del barrio sirve a la Ciudad o al mismo barrio o parte de él, para estudiar los porcentajes de su coste que deben cargarse sobe los terrenos edificables y poder determinar el valor de estos para ser edificados por Excmo. Ayuntamiento, entregados a Empresa mixta o a la iniciativa particular.

Con todo lo dicho, creemos dar una idea clara del alcance del estudio realizado, que sometemos a la consideración del Excmo. Ayuntamiento, para que, si así lo estima lo eleve a la superioridad.

Valencia, diciembre de 1952.

Los Arquitectos de la O.T. Municipal de Urbanismo,

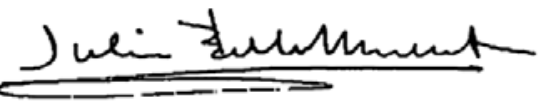

Vo $B^{\circ}$

El Arquitecto Mayor,

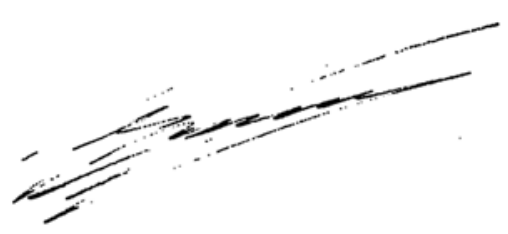



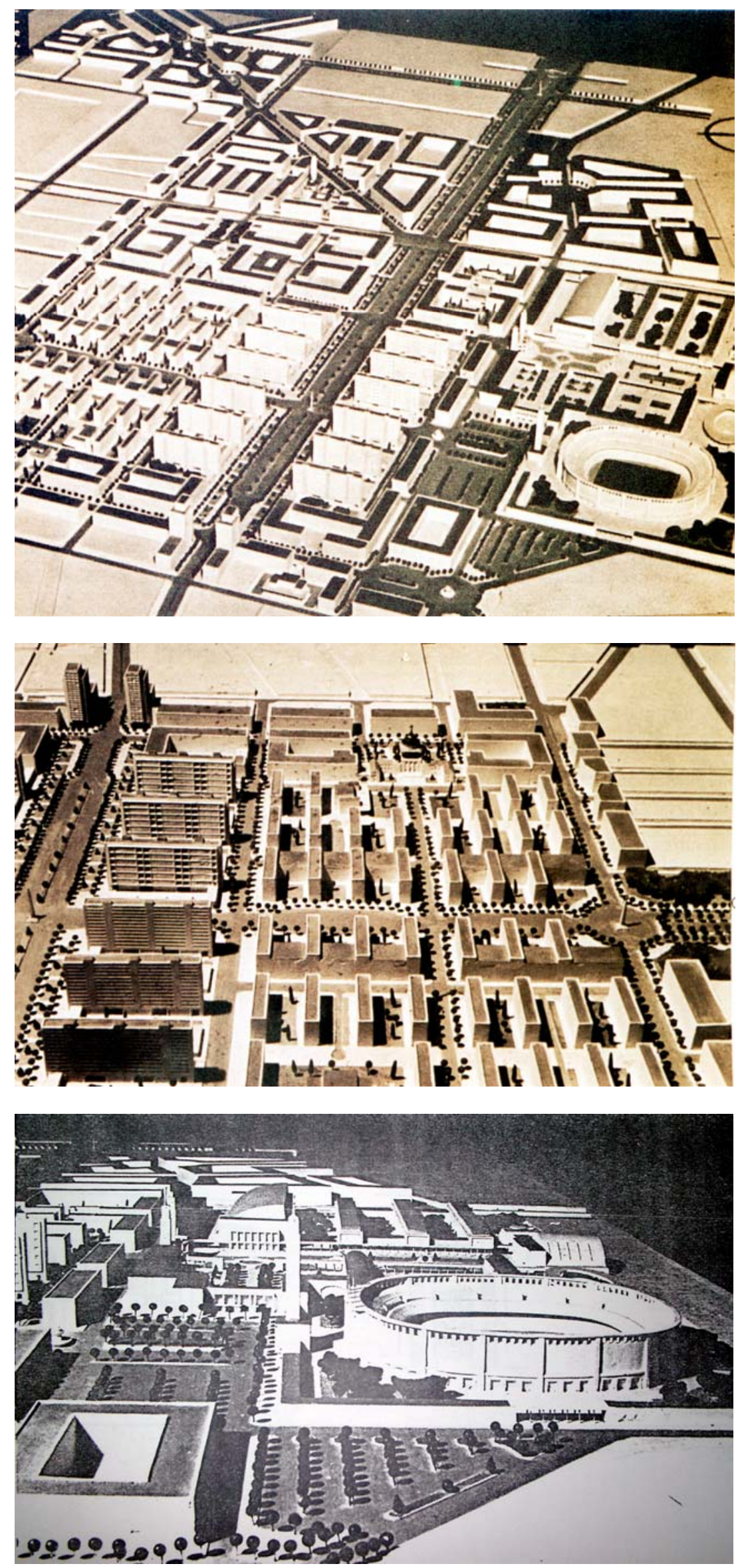



\section{BR 2 y 3. Av. Castilla}

BARRIOS RESIDENCIALES No 2 Y 3 EN LA AVENIDA DE

CASTILLA

1956

Redactores: CORPORACIÓN ADMINISTRATIVA GRAN VALENCIA.

Fecha: 1956.

\section{Contenido:}

PLANOS:

BARRIO RESIDENCIAL No 2 EN LA AVENIDA DE CASTILLA

E 1:2.000

S/N (BARRIO RESIDENCIAL NO 2 EN LA AVENIDA DE CASTILLA CON INSERCIÓN DEL BARRIO DE LA LUZ).E 1:2000

BARRIO RESIDENCIAL No 3 EN LA AVENIDA DE CASTILLA

E 1:1.000

BARRIO RESIDENCIAL EN QUART. E 1:2000

Fuente: Ayuntamiento de Valencia. Archivo de Planeamiento (Sector de expedientes antiguos)

Notas: No se ha localizado documentación escrita correspondiente a estos proyectos. 

BARRIO RESIDENCIAL No 2 EN LA AVENIDA DE CASTILLA.

Escala original: 1:2000
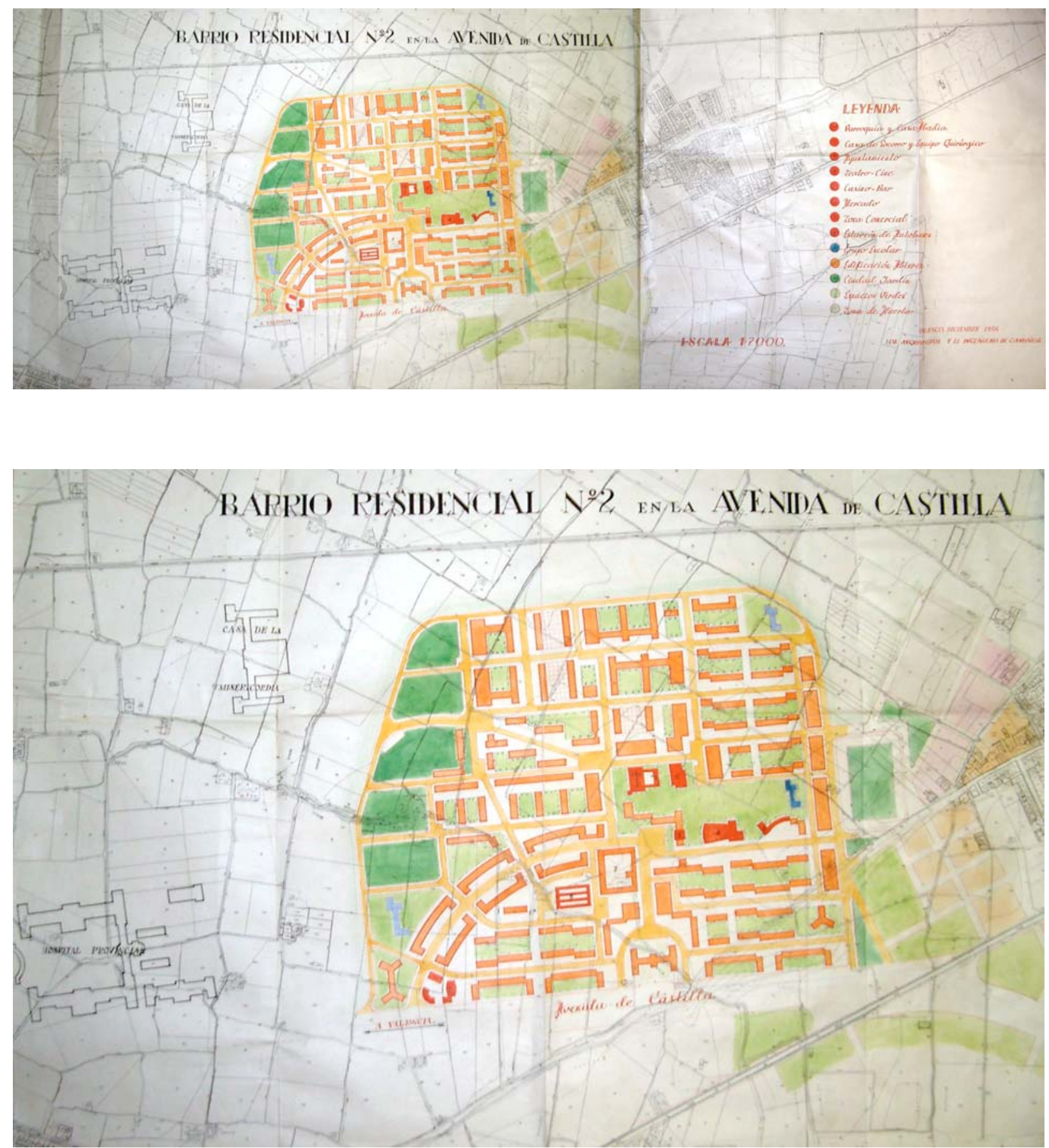

Detalle del Barrio Residencial No 2. 
S/N (BARRIO RESIDENCIAL No 2 EN LA AVENIDA DE CASTILLA CON INSERCIÓN DEL BARRIO DE LA LUZ).

Escala original: 1:2000

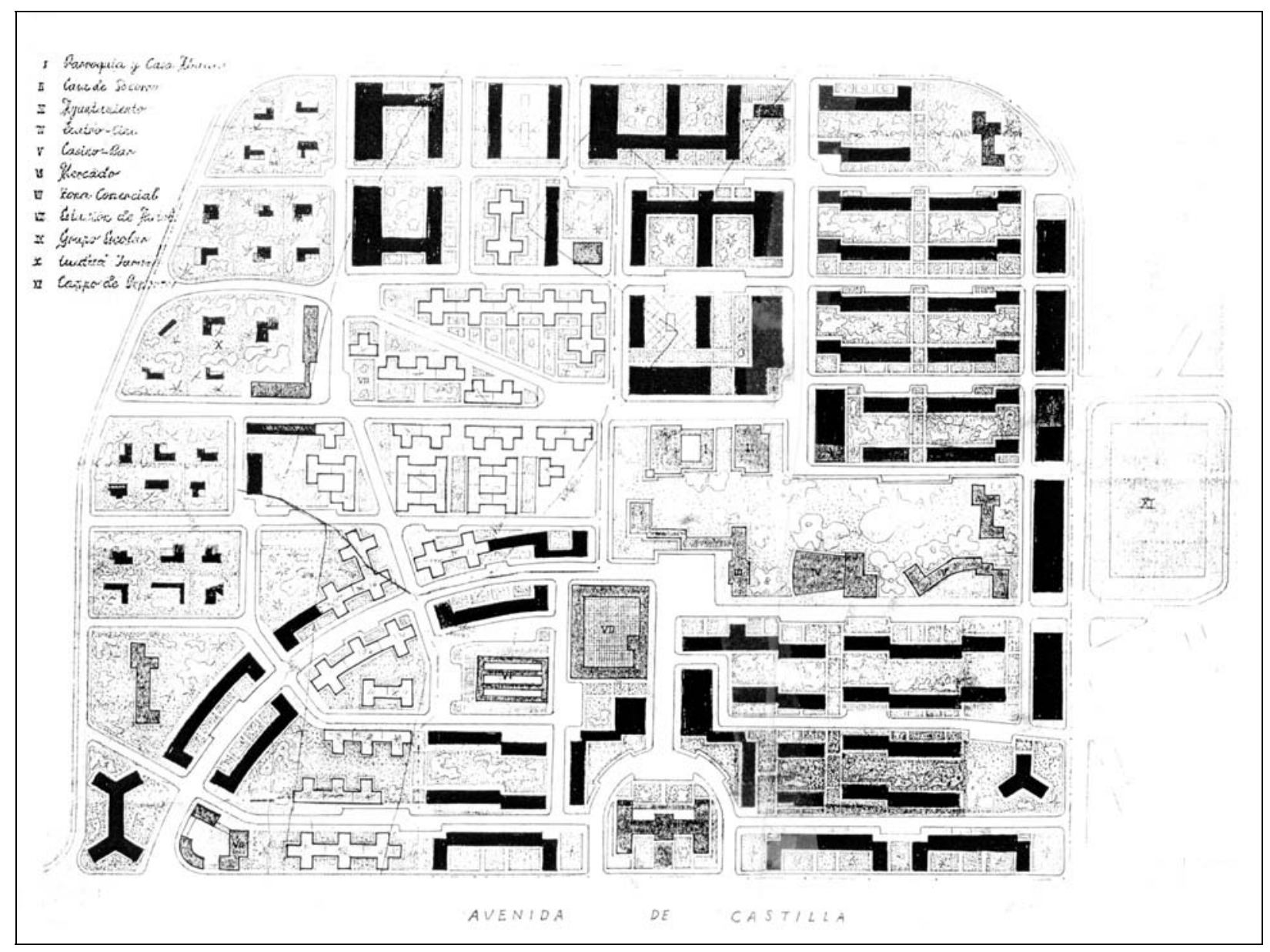


ZONA RESIDENCIAL DE "CUART DE POBLET".

Emplazamiento. Escala original: 1:25.000

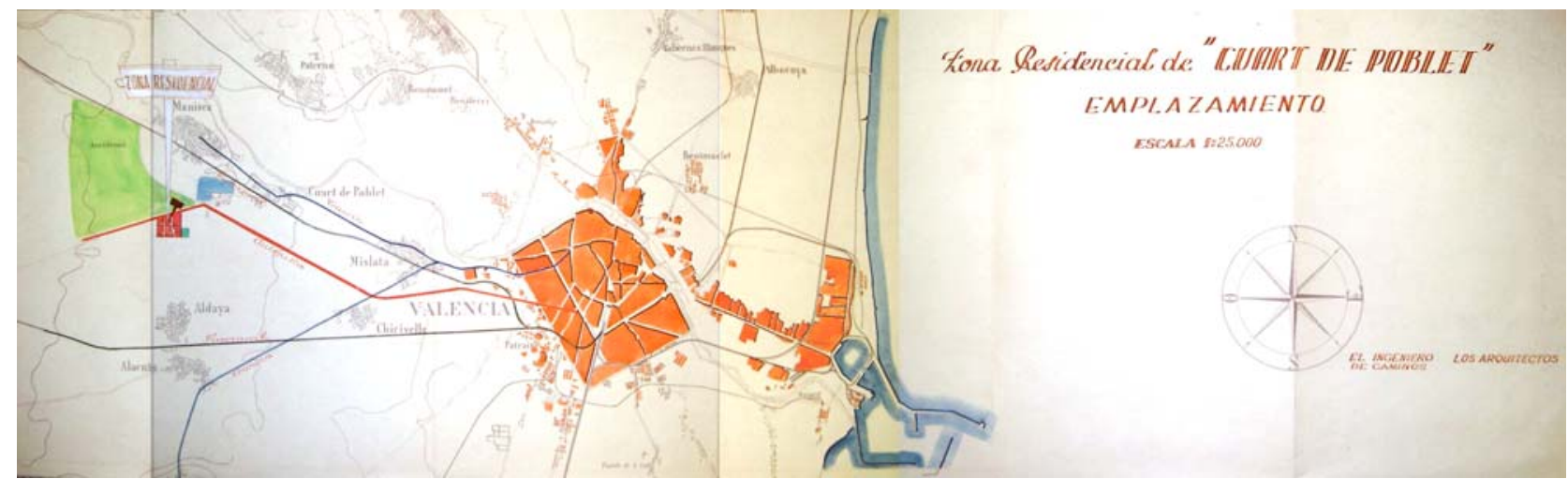

BARRIO RESIDENCIAL No 3 EN LA AVENIDA DE CASTILLA.

Escala original: 1:2000

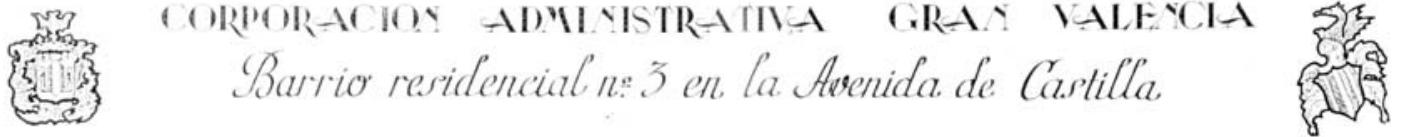

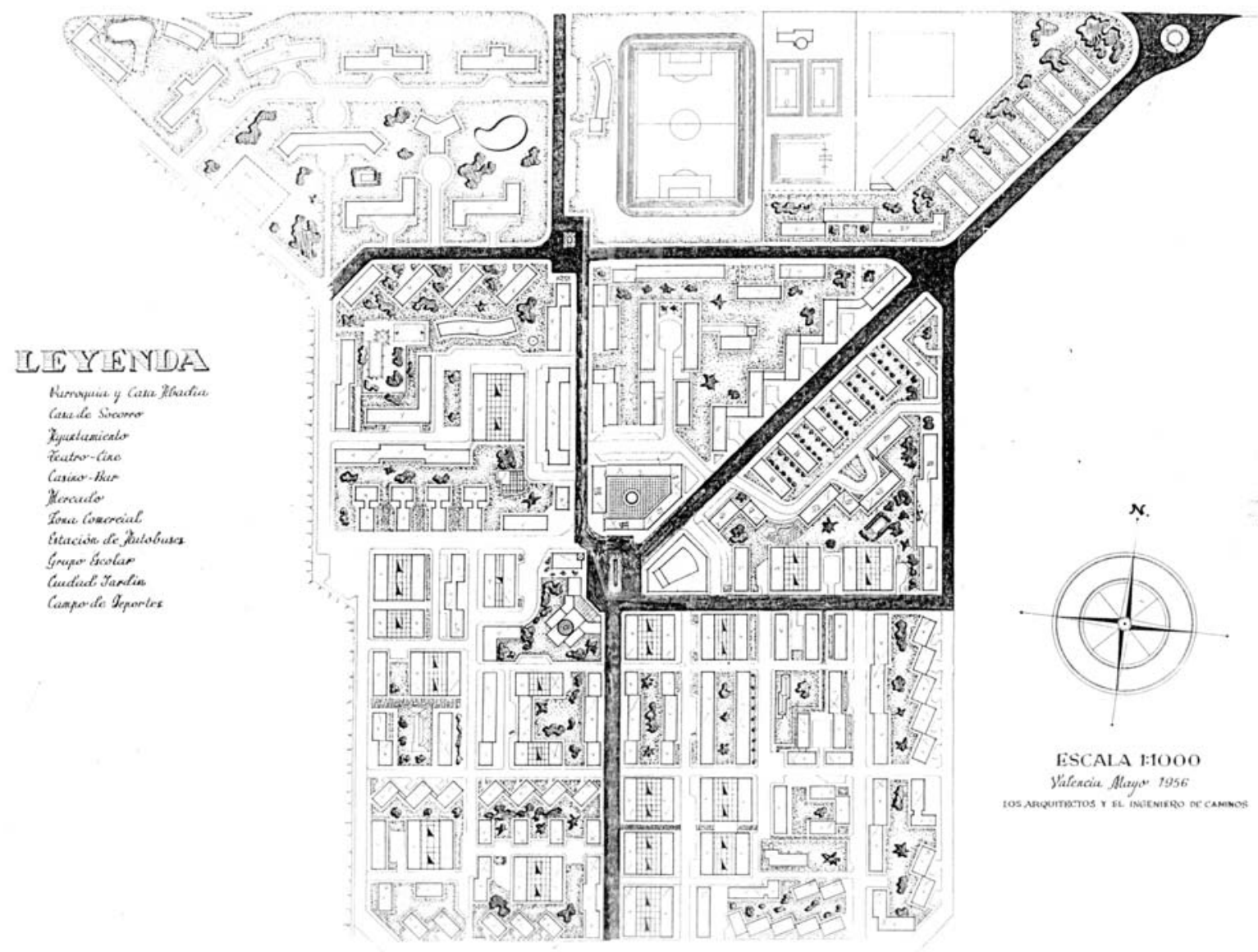



3. PROYECTOS DE EJECUCIÓN DE POLÍGONOS PARA VIVIENDAS DE RENTA LIMITADA, 1955-56. 



\section{PE Polígono Valencia al Mar.}

PROYECTO DE EJECUCIÓN DEL POLÍGONO DEL SECTOR DE PASEO DE VALENCIA AL MAR CON DESTINO A LA FORMACIÓN DE SOLARES PARA EMPLAZAMIENTO DE VIVIENDAS DE RENTA LIMITADA 1956

Redactores: EXCMO. AYUNTAMIENTO DE VALENCIA. Arquitectos: Vicente Valls Gadea, Julio Bellot Senent.

Fecha redacción: 1956.

Contenido:

PLANOS:

PLANTA GENERAL

SECCIONES VIARIAS

$1: 200$

Fuente: Ayuntamiento de Valencia. Archivo de Planeamiento (Zona de expedientes antiguos).

Nota: No se ha localizado documentación escrita de este proyecto. 
PLANTA GENERAL

Escala original: 1:2000
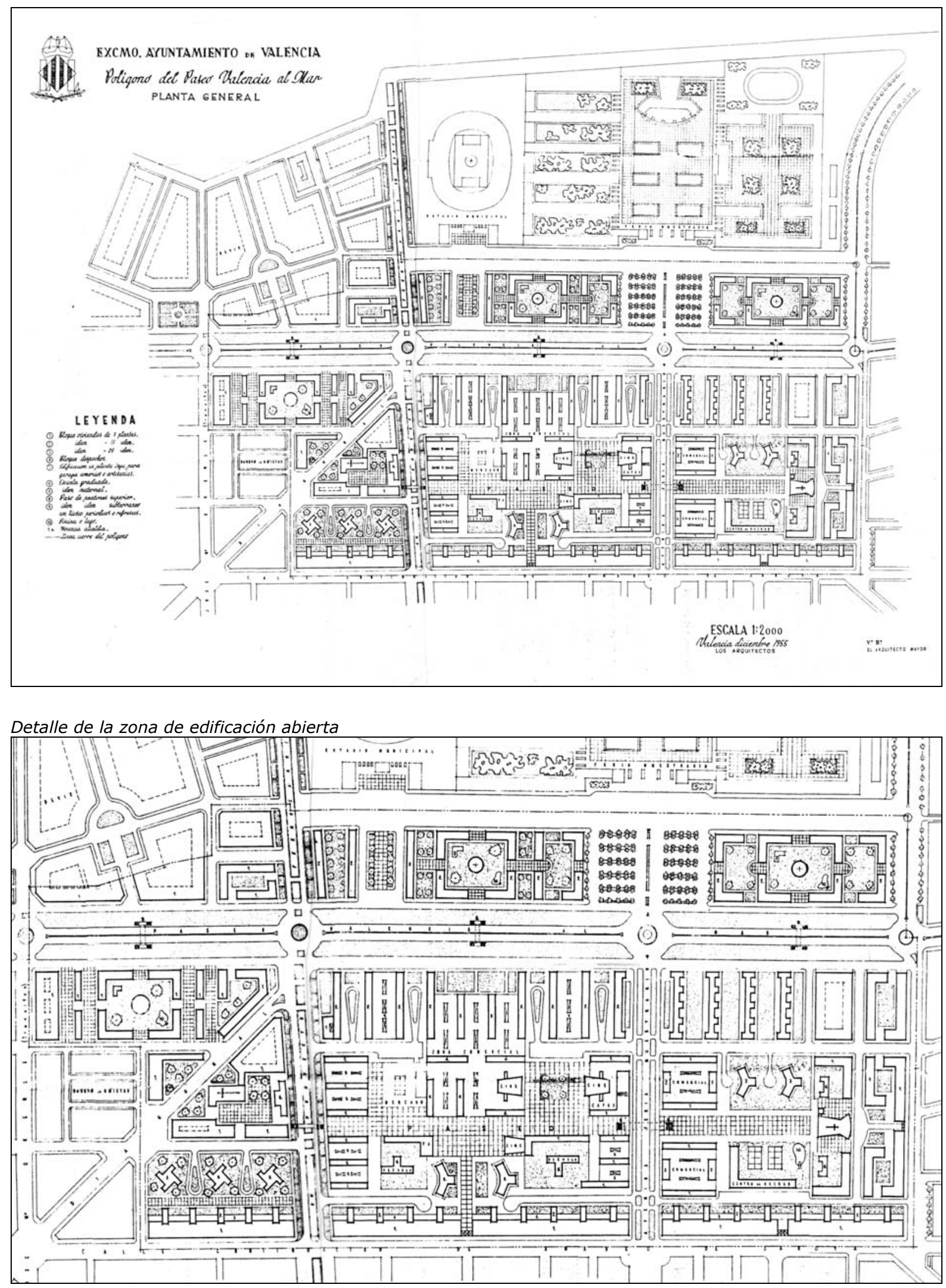
SECCIONES VIARIAS

Escala original: 1:200

EXCMO. AYUNTAMIENTO DE VALENCIA Poligono del Pateo Malencia al Mar SECCIONES TRANSVERSALES

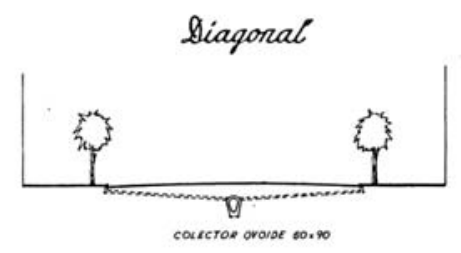

Averida Deria Muestrarid

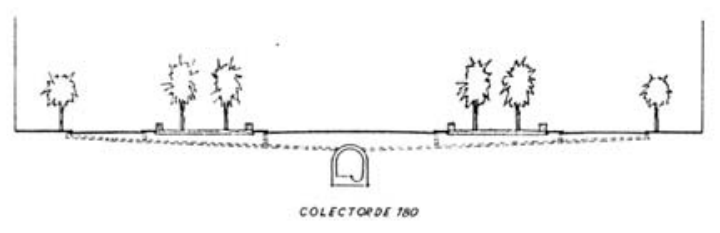

averida de X:C. en Zarja

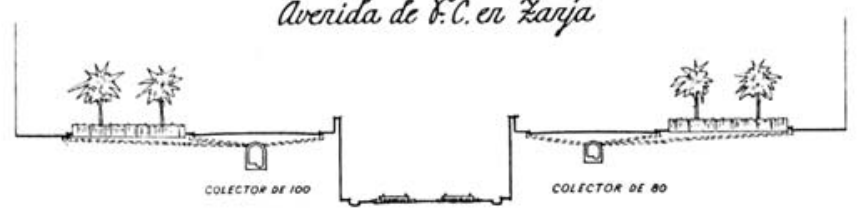

Paseo de Valencia al Mar

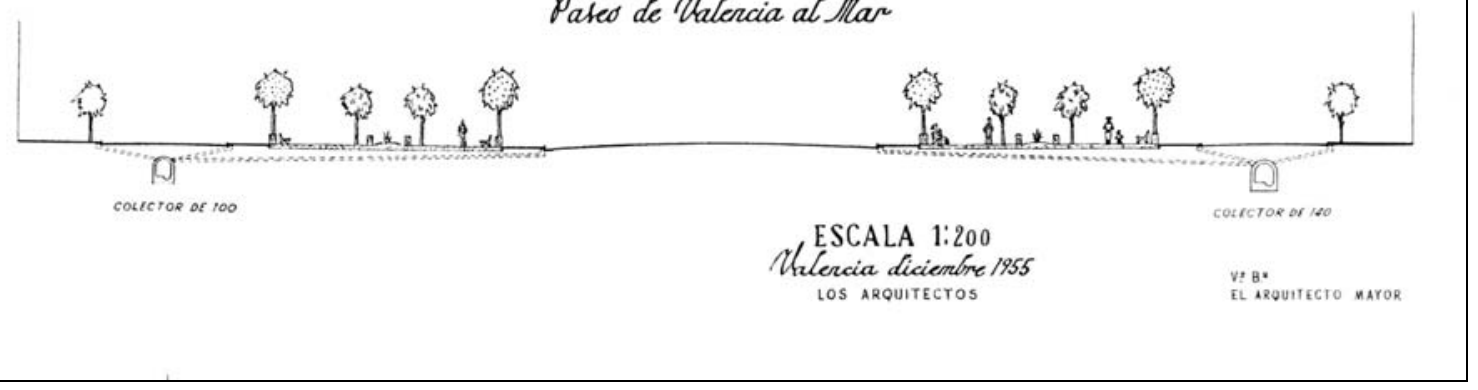

45 



\section{PE Polígono Sector Campanar}

PROYECTO DE EJECUCIÓN DEL POLÍGONO DEL SECTOR DE

CAMPANAR CON DESTINO A LA FORMACIÓN DE SOLARES

PARA EMPLAZAMIENTO DE VIVIENDAS DE RENTA LIMITADA

1956

Redactores: EXCMO. AYUNTAMIENTO DE VALENCIA. Arquitectos: José Pedrós Ortiz, Camilo Grau Soler.

Fecha redacción: 1956.

Contenido:

PLANOS:

POLÍGONO DE CAMPANAR, Mayo $1955 \quad 1: 2.000$

POLÍGONO DE CAMPANAR, Noviembre $1955 \quad 1: 2.000$

POLÍGONO DE CAMPANAR. DELIMITACIÓN DE SOLARES

PARA VIVIENDAS DE RENTA IMITADA, $1956 \quad 1: 2000$

Fuente: Ayuntamiento de Valencia. Archivo de Planeamiento (Sección de expedientes antiguos).

Notas: No se ha localizado documentación escrita de este proyecto. 

POLÍGONO DEL SECTOR DE CAMPANAR. Mayo 1955

Escala original: 1:2000

Boligono del Yector de CAMPANAR cuya aprobación se propone al Exemo: Clyuntamiento para solicitar de la Shperio ridad por GRAN VALENCIA se hagan eatensivos al mismo, los bereficios de la Ley de 3 de Diciembre de 1953.

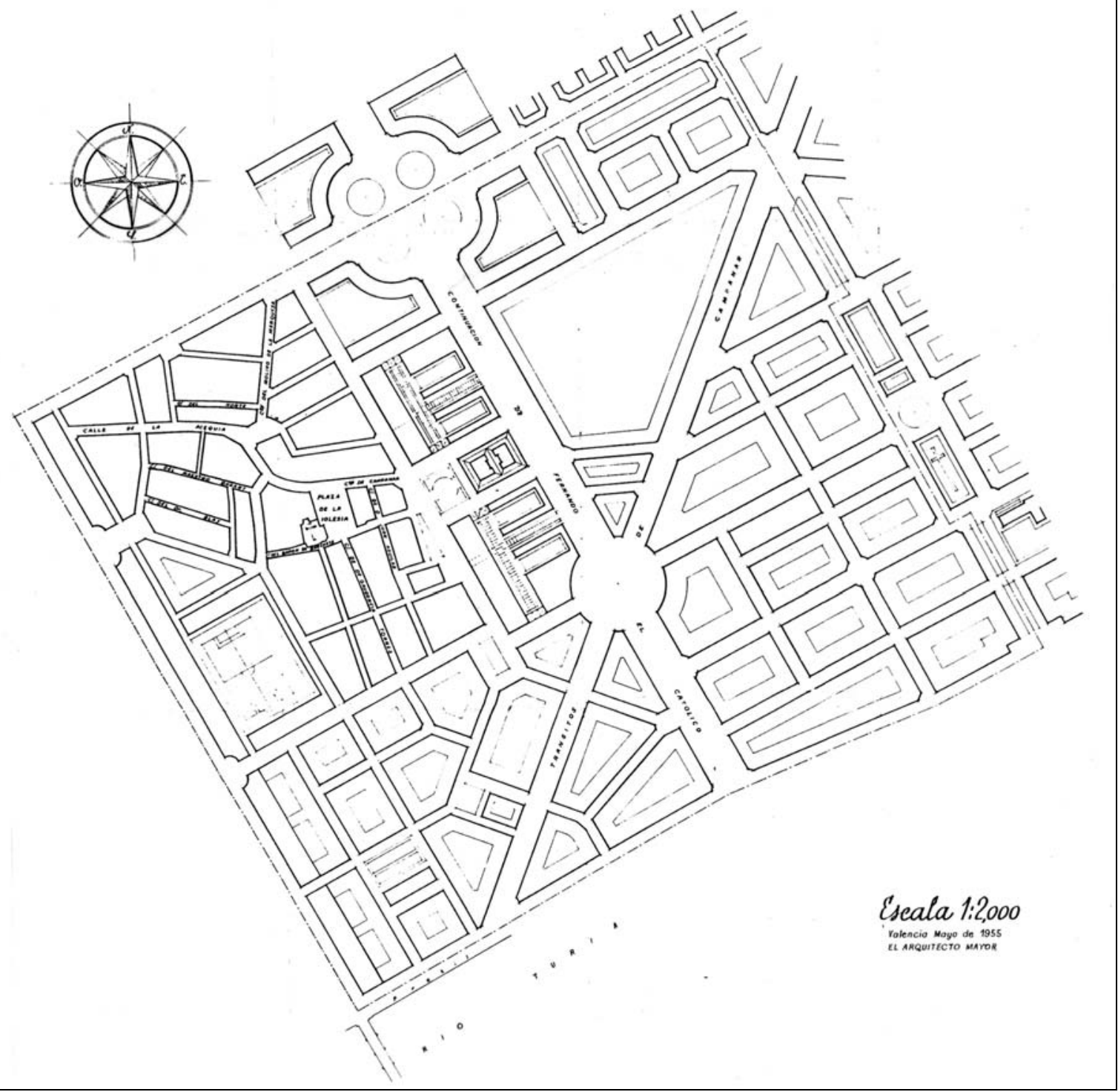


POLÍGONO SECTOR CAMPANAR. Noviembre 1955.

Escala original: 1:2000

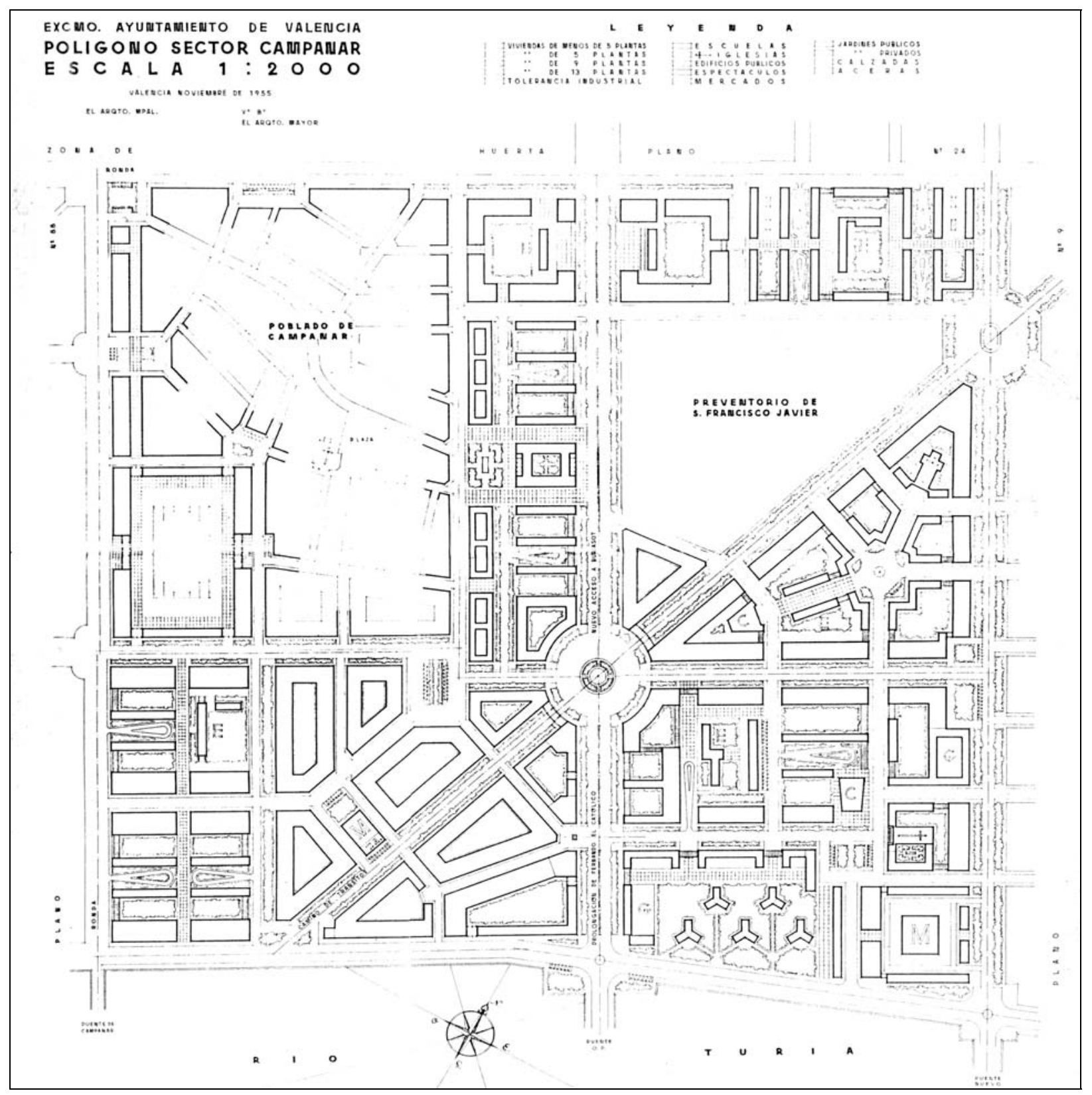


POLÍGONO SECTOR CAMPANAR. DELIMITACIÓN DE SOLARES

PARA VIVIENDAS DE RENTA LIMITADA, 1955.

Escala original: $1: 2000$

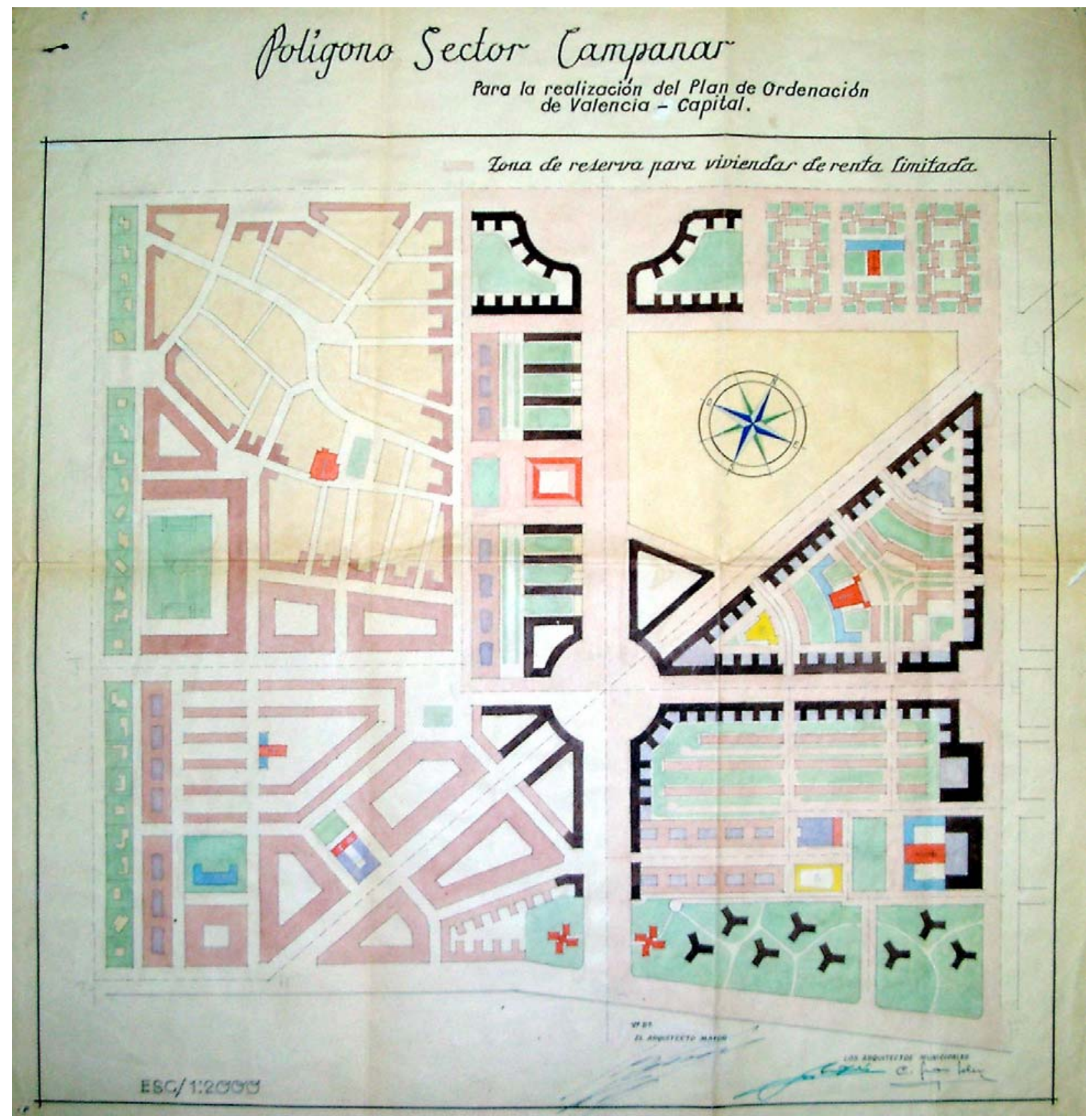





\section{PE Polígono Sector Av. Castilla}

PROYECTO DE EJECUCIÓN DEL POLÍGONO DEL SECTOR DE LA AVENIDA DE CASTILLA CON DESTINO A LA FORMACIÓN DE SOLARES PARA EMPLAZAMIENTO DE VIVIENDAS DE RENTA LIMITADA

Redactores: EXCMO. AYUNTAMIENTO DE VALENCIA. Arquitectos: Javier Goerlich Lleó, Camilo Grau Soler.

Fecha redacción: Noviembre 1956.

Contenido:

I. MEMORIA DESCRIPTIVA

II. PLANOS:

ALINEACIONES VIGENTES

$1: 2.000$

NUEVAS ALINEACIONES PROPUESTAS

$1: 2.000$

DELIMITACIÓN SOLARES PROPUESTOS

$1: 2000$

Fuente: Ayuntamiento de Valencia. Archivo de Planeamiento (Sección expedientes antiguos). 

EXCMO. AYUNTAMIENTO DE VALENCIA

\author{
POLIGONO DEL SECTOR DE LA "AVENIDA DE CASTILLA"
}

Documentación segregada para la aprobación de las nuevas alineaciones del sector.

\title{
MEMORIA DESCRIPTIVA
}

Por orden de la Alcaldía Presidencia de 6 de Agosto de 1955, dando traslado a un acuerdo de la Comisión Municipal Permanente, los Arquitectos municipales que suscriben procedieron al desarrollo del proyecto de ejecución del polígono del sector de la "Avenida de Castilla", destinado a la formación de solares para emplazamiento de viviendas de renta limitada, de acuerdo con la delimitación del citado polígono, aprobadas por el Excmo. Ayuntamiento en 22 de Noviembre del propio año 1955.

En la Memoria del proyecto aludido, razonaba la disposición de las alineaciones adoptadas de acuerdo esquemáticamente en el proyecto parcial de alineaciones y zonificación del sector de la llamada "Avenida de Castilla" del Plan de Ordenación de Valencia y su Comarca rectificadas sus alineaciones previa consulta a la Comisión Municipal de Urbanismo, teniendo en cuenta la nueva Ley para la construcción de viviendas de renta limitada de 15 de Julio de 1954 (posterior a la aprobación del sector aludido) y que se creyó conveniente acoger a las disposiciones de dicha Ley, con el fin de facilitar la formación, aplicación y destino de la nueva parcelación que había de resultar de la adaptación propuesta.

Resultado de este nuevo estudio, el Excmo. Ayuntamiento en sesión de su Comisión Permanente de 19 de Octubre de 1955 y en Sesión Plenaria del propio mes y año, aprobó las nuevas alineaciones, para el polígono referido, tal como se representan en la hoja de planos No 2 que se adjunta.

En el trazado de las nuevas alineaciones, se tuvo en cuenta que la construcción de núcleos numerosos de viviendas, no se puede realizar con garantía de éxito sin tener en cuenta, anticipandose a las variadas necesidades de sus futuros usuarios, el aplicar la diversificación necesaria que permita satisfacer las necesidades del conjunto en orden al trazado y construcción de los servicios generales preparados a su vez, para los futuros desarrollos que el completo servicio de ellos han de exigir en el mañana.

No puede olvidarse la necesidad y conveniencia de realizar a su vez un estudio económico y financiero, con la amplitud necesaria para facilitar el desarrollo del proyecto general del polígono.

Y siendo propósito del Excmo. Ayuntamiento llevar a cabo la expropiación de los terrenos del polígono del sector de la "Avenida de Castilla" para que urbanizados permitan a la Corporación desarrollar sus planes de construcción de viviendas y sobretodo el disponer de solares para ceder a los particulares con este mismo fin, precisa proceder con toda urgencia a la aprobación de las nuevas alineaciones adoptadas al desarrollar el proyecto.

A los efectos de la expropiación inmediata, se adjunta también una nota con los datos estadísticos referentes al sector que ha de ser de expropiación inmediata.

Valencia 5 de Noviembre de 1956. LOS ARQUITECTOS MUNICIPALES,

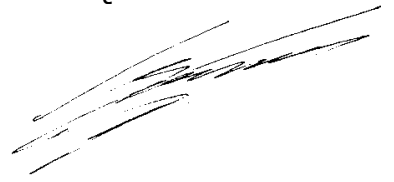




\section{ALINEACIONES VIGENTES.}

Escala original: 1:2000

\section{Sineas vigentes del Sector de la AVDA. DE CASIILLA,} destinado a la urbaniración y formación de solares.

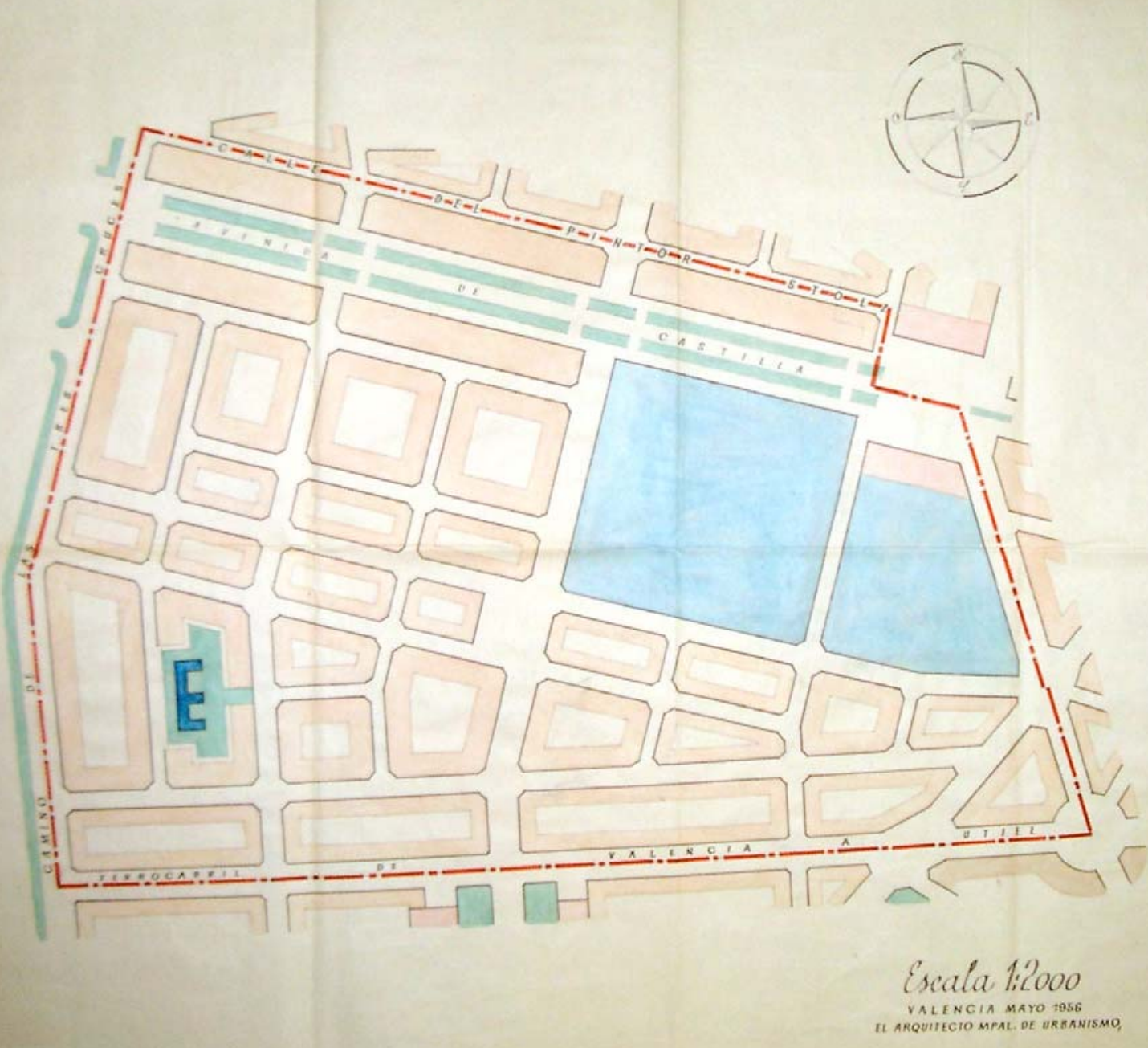


NUEVAS ALINEACIONES PROPUESTAS.

Escala original: 1:2000

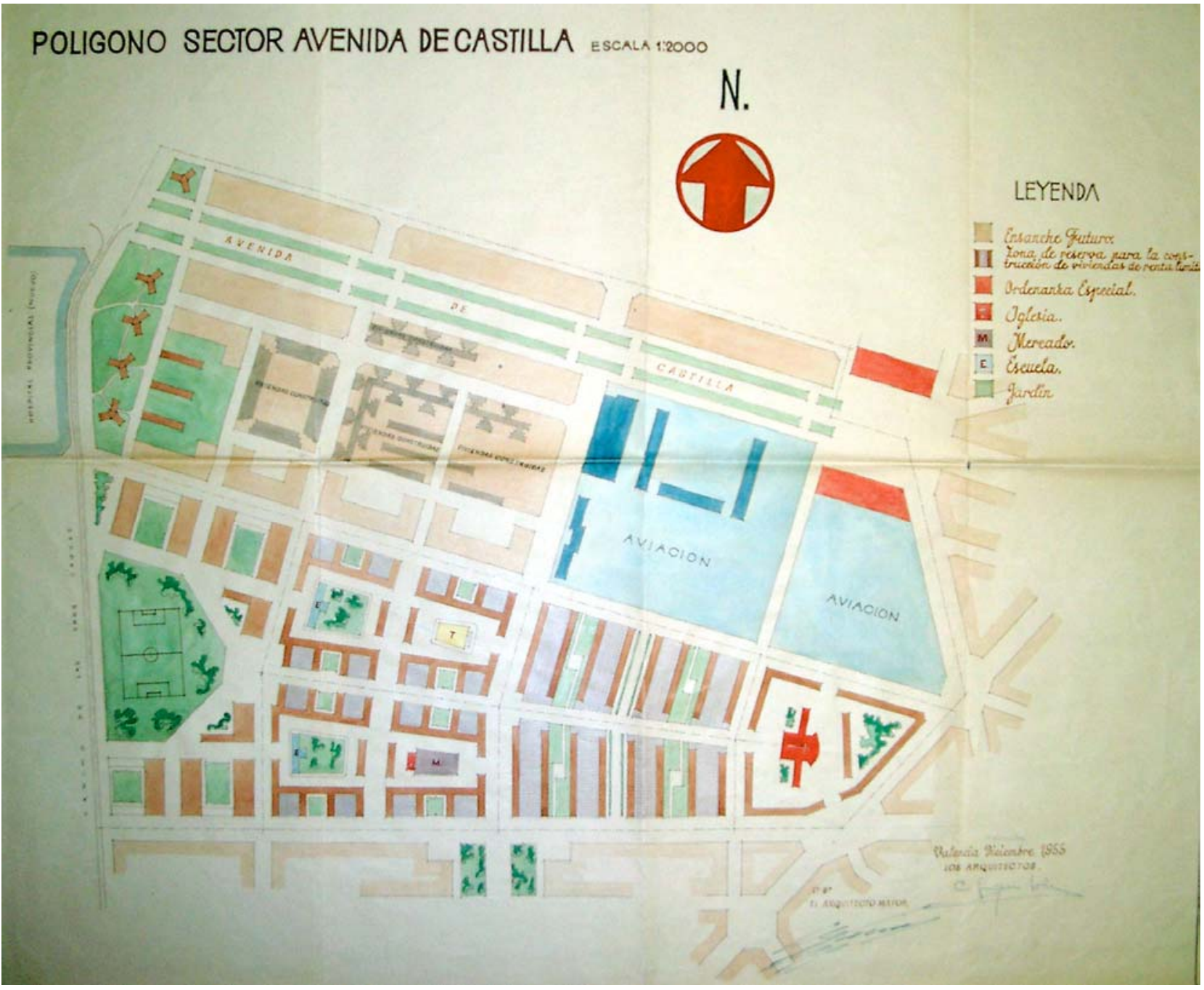





\section{PE Polígono Sector Monteolivete}

PROYECTO DE EJECUCIÓN DEL POLÍGONO DEL SECTOR DE MONTEOLIVETE CON DESTINO A LA FORMACIÓN DE SOLARES PARA EMPLAZAMIENTO DE VIVIENDAS DE RENTA LIMITADA

1956

Redactores: EXCMO. AYUNTAMIENTO DE VALENCIA. Arquitectos: José Luís Testor Gómez, Emilio Artal Fos.

Fecha redacción: Marzo 1956.

Contenido:

1. MEMORIA DESCRIPTIVA

2. PLANOS:

$\begin{array}{ll}\text { EMPLAZAMIENTO DEL SECTOR } & 1: 10.000 \\ \text { EDIFICACIÓN ACTUAL (HOjas) } & 1.1000 \\ \text { ALINACIONES VIGENTES } & 1: 2000 \\ \text { PLANO DE VOLUMEN } & 1: 2000 \\ \text { PLANO DE NUMERACIÓN DE MANZANAS Y CALLES } & 1: 2000 \\ \text { PLANO DE RED DE DESAGÜES } & 1: 2000 \\ \text { SECCIONES LONGITUDINALES Y TRASVERSALES } & \\ \text { PLANO DE PAVIMENTACIÓN } & 1: 2000 \\ \text { PLANO DE ILUMINACIÓN } & 1: 2000\end{array}$

3. PRESUPUESTO

Fuente: Ayuntamiento de Valencia. Archivo de Planeamiento (Sección de expedientes antiguos). 



\author{
PROYECTO \\ de \\ EJECUCIÓN del POLÍGONO \\ del \\ SECTOR DE MONTEOLIVETE
}

\title{
MEMORIA DESCRIPTIVA
}

Se trata de describir en la presente Memoria, el objeto del Proyecto que remitimos a la Alcaldía Presidencia de este Excmo. Ayuntamiento, a virtud de la orden de la misma sobre su redacción, de fecha 6 de Agosto de 1955, que no es otro, que proceder al desarrollo de las expropiaciones y consiguientes obras de Urbanización, para que pueda ser un hecho el Proyecto de Alineaciones presentado en su día y aprobado por la superioridad, que constituye el Sector denominado de Monteolivete, y con lo que quedarán los suficientes y necesarios solares, dotados de todos los servicios, para la construcción sobre ellos, de Viviendas de todos los Grupos y Categorías, de las comprendidas en la Ley de 15 de Julio de 1954, sobre protección de Viviendas de Renta Limitada.

Este Sector de Monteolivete queda delimitado de la siguiente forma: Por el norte, por la Avenida de Peris y Valero, y la Avenida de la Plata; por Sur, con la nueva calle que constituirá el desvío del Ferrocarril de Valencia a Tarragona, Avenida $\underline{C}$ del Plano; por Este, con el actual Camino Nuevo del Saler, hasta la Iglesia de Monteolivete, y la continuación de este Camino, siguiendo la proyectada desviación del Rio Turia; y por Oeste, con la calle prolongación de la del Doctor Sumsi, hasta la Avenida de la Plata, y el Nuevo Acceso de Alicante.

Del citado sector excluidos de momento, la realización de algunas expropiaciones de edificios con fachada a la Avenida de Peris y Valero que dependerá su ejecución del aspecto Estético de la misma, ya que se realizan las necesarias, para el debido enfoque de las calles de penetración en el mismo de las calles que llevan la dirección Norte Sur, así como otras expropiaciones de fincas situadas en la parte izquierda del Valladar, (aguas abajo del mismo), por realizarse parte de ellas, por el Ministerio de Instrucción Pública.

RED VIARIA. El Sector queda constituido por la unión de dos rectángulos de desigual superficie (en la proporción 1 á 3), el superior de menos extensión que el inferior, unidos por la Avenida de la Plata, y su continuación en la Avenida $\underline{A}$ del Proyecto, teniendo ambos el linde Este común, ya que lo constituye el Camino Nuevo de Monteolivete ó del Saler, y lo que será la prolongación del mismo.

Las calles que comprenden el Sector y que constituyen sus límites son: La Avenida de Peris y Valero, actualmente abierta en toda su longitud, con un ancho de 30 metros; El Camino Nuevo de Monteolivete, abierto en la parte que coincide con las alineaciones del Sector con un ancho de 30 metros, y que en su continuación a partir de la Iglesia de Monteolivete, se Proyectó con el ancho de 56 metros; el nuevo desvío del Ferrocarril de Valencia a Tarragona, que lo constituirá una calle junto al mismo, no determinada hasta el momento, pero que nunca será su ancho inferior a los 30 metros; y el nuevo acceso de Alicante, que está abierto ya en parte en la actualidad, con un ancho de 40 metros. 
EJE NORTE SUR. Lo constituye la denominada Gran Avenida, que se ha Proyectado con el ancho de 40 metros, siguiendo su eje el de la actual calle de Luis Santángel y naciendo en la Avenida de Peris y Valero, a continuación de una gran Plaza proyectada para que le sirva de embocadura.

Esta Avenida, es perpendicular a la Avenida de Peris y Valero y mide una longitud de 1 Kilometro, terminando y por ello constituye un fondo de perspectiva, un Parque, en el que se emplaza un gran edificio de 25 alturas.

CALLES PRINCIPALES. Paralelas a esta Avenida (o sensiblemente paralelas, por torcer un poco la prolongación de la calle de Ciscar) existen las calles No 1, con ancho de 24 metros, las № 6 y No 7, continuación de la actual Carrera de Encorts, con ancho de 36 metros; y la No 18 y la continuación de la actual calle de Ciscar, y también la calle No 15, que miden todas ellas un ancho de 20 metros.

CALLES SECUNDARIAS. El resto de las calles que se proyectan en el sentido Norte Sur, No 2, 3, 4, 5, 8, 9, 10, 11, 12, 13, 16, 17, 18 y 19 , miden diferentes anchos, aunque ninguna inferior a los $18 \mathrm{me}-$ tros. Asimismo hay otras muchas calles que podemos denominar como de servicios o separación de bloques, de distintos anchos.

EJE ESTE OESTE. En realidad lo constituye la Gran Avenida $\underline{A}$ unida por una Gran Plaza a la actual Avenida de la Plata, Plaza a la que también incide una calle transversal, proyectada en diagonal, por junto al Cuartel de Ingenieros. Esta Avenida mide 40 metros.

Paralela a ella y además de las Avenidas de Peris y Valero, y la Avenida $\underline{C}$ descritas anteriormente por constituir los limites Norte y Sur del Sector, se ha Proyectado la Avenida $\underline{B}$ de 30 metros de ancha, intermedia entre la Gran Avenida $\underline{A}$ y el linde Sur.

Como calles Principales y Secundarias del Sector, Proyectadas según la dirección del eje Este Oeste, aparecen las designadas con las letras D, E, F. G. H. J, K, L. M. H, H, O, P y Q, con distintos anchos en relación con sus dimensiones y construcción recayente a las mismas.

VOLUMEN. En el Plano General del Sector pueden apreciarse, la diversidad de Tipos de manzanas que se han Proyectado, y el Volumen aparece dibujado en otro, en el que además del sombreado correspondiente, que da una clarísima idea de él, con números romanos constan el número de plantas de cada una de las manzanas.

ZONA COMERCIAL. Aparte del aprovechamiento de muchas Plantas Bajas, para ubicar pequeños Comercios, como es costumbre su desarrollo, se ha Proyectado una Zona ó Sector Comercial, que comprenderá el máximo de ellos, y en la que se instalarán pequeños depósitos de mercancías etc. Todo ello está situado entre las calles No 1 y la No 6, Avenida de la Plata y la Avenida B.

En esta Zona aparece colocado el Mercado principal, y todo lo complementario a sus instalaciones, como Frigoríficos. Almacenes etc.y aunque la limitan, algunos edificios laminares recayentes a la Avenida $\underline{B}$, las plantas bajas que se han Proyectado porticadas, todas ellas se destinan a Comercios, pudiendo circularse por esta Zona por completo a cubierto.

EDIFICIOS PÚBLICOS En el Sector aparecen diseminados los si 
guientes:

Dos Iglesias.

Cuatro Grupos Escolares.

Dos Mercados.

Un Teatro.

Una Pista para Espectáculos al aire libre, junto al Teatro y a la

zona de Cafés.

Dos Tenencias de Alcaldía, con Retén de Bomberos.

Dos Casas de Socorro.

PARQUE PUBLICO. Como se aprecia en el Plano, junto al linde Sur se ha Proyectado un Gran Parque, en el que podrá construirse Un Stadium para toda clase de competiciones Atléticas.

También se instalan en el Parque, otras Pistas, para Tennis, Baloncesto Patinage etc. Asimismo se podrá construir una Piscina , y existe una pequeña Playa para niños.

ZONAS AJARDINADAS En el Plano General se observan las distintas manchas verdes, de mayor o menor importancia, que constituirán pequeños jardines, junto a la Iglesia, y otras, que limitarán Aparcaderos de coches. Pistas de Tennis para los usuarios de las Viviendas próximas, y otros jardincitos un tanto privados, frente a los Bloques de construcción.

DENSIDAD DE EDIFICACION. Aunque no de un nodo definitivo, ya que no se ha podido entrar en el estudio de detalles, sino en el del Conjunto, el aprovechamiento de los terrenos que son edificables, estará comprendido entre los coeficientes de 3,5 a 6 . siendo siempre superior al primero, y procurando no llegar al segundo.

El Sector comprende una Superficie aproximada de 1.274.700 metros cuadrados.

EXPROPIACION. Este Sector que es extensísimo, ubica ó comprende un gran numero de edificios, generalmente desperdigados por la huerta y construidos de forma un poco anárquica, ó bien agrupados principalmente junto a los Caminos sinuosos que comunican el campo con la Ciudad, o determinando ó iniciando calles particulares y que solo en parte algunas de ellas fueron incluidas en los Planos de Alineaciones.

Habrá pues necesidad de expropiar gran numero de viviendas algunas, como las emplazadas con fachada a la Avenida de Peris y Valero, que aunque están a línea, o han estado con respecto a esta Avenida, son necesarias para abrir o iniciar las calles de penetración de la Zona.

Y asimismo habrán de desaparecer las situadas, en línea casi ininterrumpida, junto a los Caminos de Encorts, Carrera de San Luis, Camino Viejo de Castellar, así como otras a Caminos secundarios, pues a todas ellas las comprende el Sector.

También desaparecerán los edificios que hemos mencionado en el primer párrafo de este Título, construidos muchos de ellos por los arrendatarios de los distintos predios, y en gran numero, ya que las fincas no son de macha superficie, viviendo de ellas muchísimas familias. Junto a estas Casas-Alquerías, y aún muchas de ellas Barracas típicas de nuestra huerta, existen agrupadas pequeñas construcciones, como almacenes, cuadras, pocilgas de mayor ó menor importancia, etc. para el mejor servicio del campo, al que han consagrado su vida.

Se han redactado unos cuadros ó relaciones copiados de los 
datos ó Polígonos que figuran cono complemento del Plano Topográfico levantado por el Instituto Geográfico, en los que constan todas las fincas a expropiar de las distintas hojas que comprende el Sector, con sus superficies, caracteristicas de la construcción existente, nombre del Propietario etc. Y por separado en otro cuadro se han efectuado la valoración de las fincas.

De un modo concreto no pueden indicarse el precio medio global que se aplicó a loa terrenos, aunque como el Sector aparece como dividido en tres secciones en el sentido Norte Sur, a la zona media se la valoró a unas 40.000 Pts la Hanegada, pero siempre se han tenido en cuenta, las características especiales de los terrenos y sobre todo la proximidad a zonas de edificación ó agrupación de edificios, aumentando este valor, y aproximándolo a los precios incluso de los solares.

OBRAS DE URBANIZACION. ALCANTARILLADO. Por tratarse de zona próxima al Mar, por la que discurre la Colectora General de la Ciudad (Valladar) que se encuentra emplazado a lo largo de la calle continuación de la Ciscar, que aparece construido actualmente en una longitud de $\underline{800}$ metros aproximadamente, se dispone en el Sector de lo necesario para la evacuación de las aguas residuales (blancas, y negras), habiendo por ello redactado un anteproyecto de alcantarillado de la totalidad del Sector, entre la calle continuación de la de Ciscar, y el limite Oeste del mismo, ó Nuevo Acceso de Alicante, y ya se procurará cuando se desarrolle el Proyecto, que se aproveche al máximo la profundidad a que discurre el Valladar, preparando asimismo para que viertan a él, las aguas residuales del otro lado del indicado Acceso de Alicante.

[...]

Destacamos que en relación con lo expuesto sería muy interesante la realización de un ESTUDIO ECONOMICO FINANCIERO de la ZONA, con el fin de que se pusieran en evidencia los factores económicos que incidiendo en el conjunto de la operación, pusieran a la vista tanto las posibilidades, cono la conveniencia de la realización de la Ordenación de la Zona que se proyecta.

Van unidos a la presente Memoria, una hoja RESUMEN, en la que figuran relacionados los distintos planos, estudios, cuadros y presupuesto de todo lo que comprende el Sector y sus obras de Urbanización, que tenemos el honor de entregar al Excmº. Sr. Alcalde Presidente del Excm ${ }^{\circ}$. Ayuntamiento de VALENCIA.

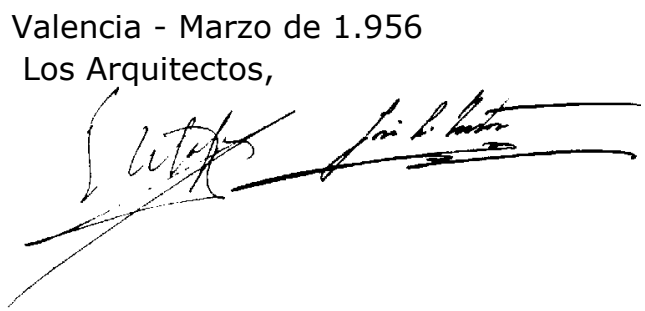


EMPLAZAMIENTO DEL SECTOR

Escala original: 1:10000

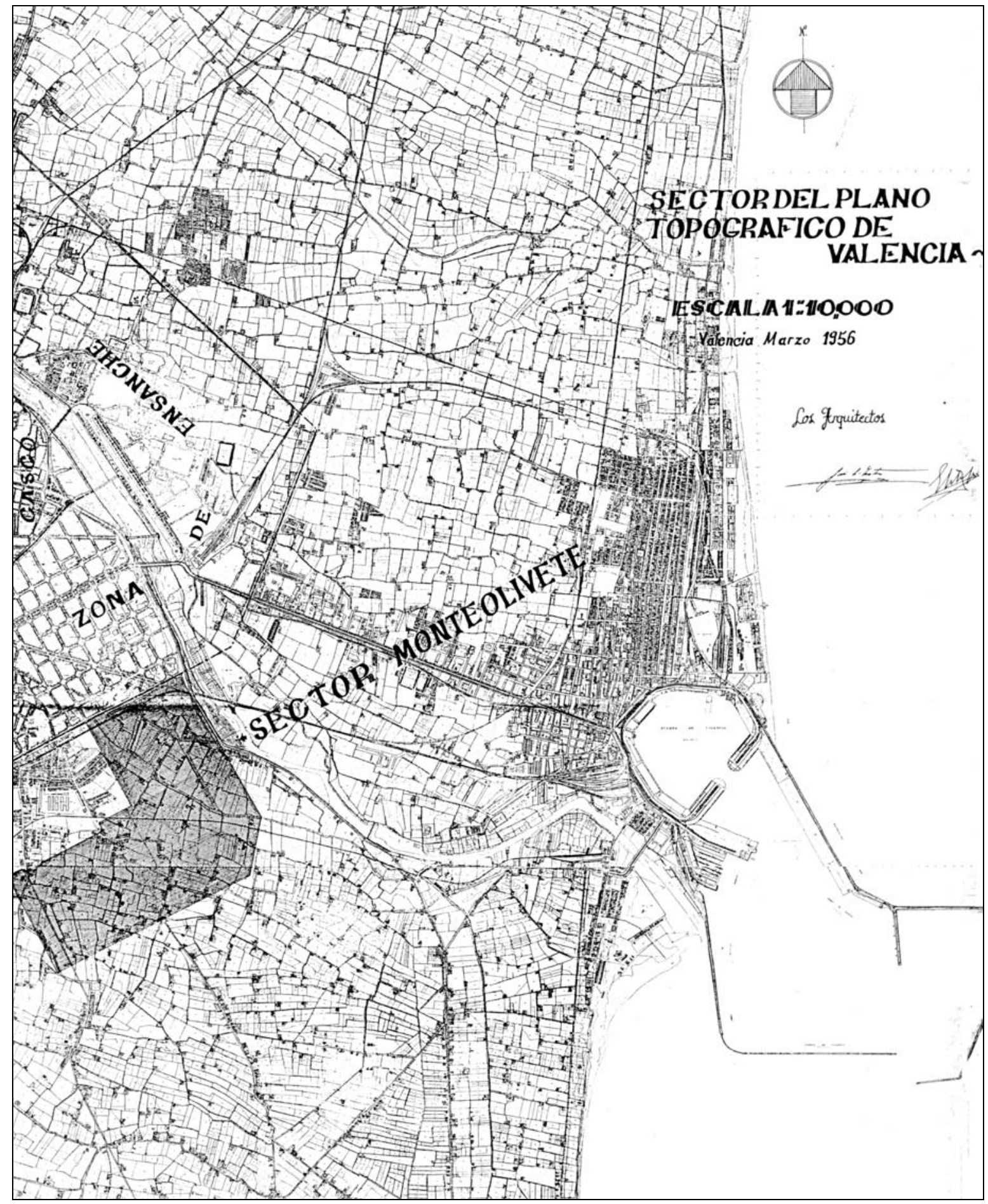


PLANO DE VOLUMEN

Escala original: 1:2000

\section{VALENCIA CAPITAL : ordenación del sector de Monteolivete}
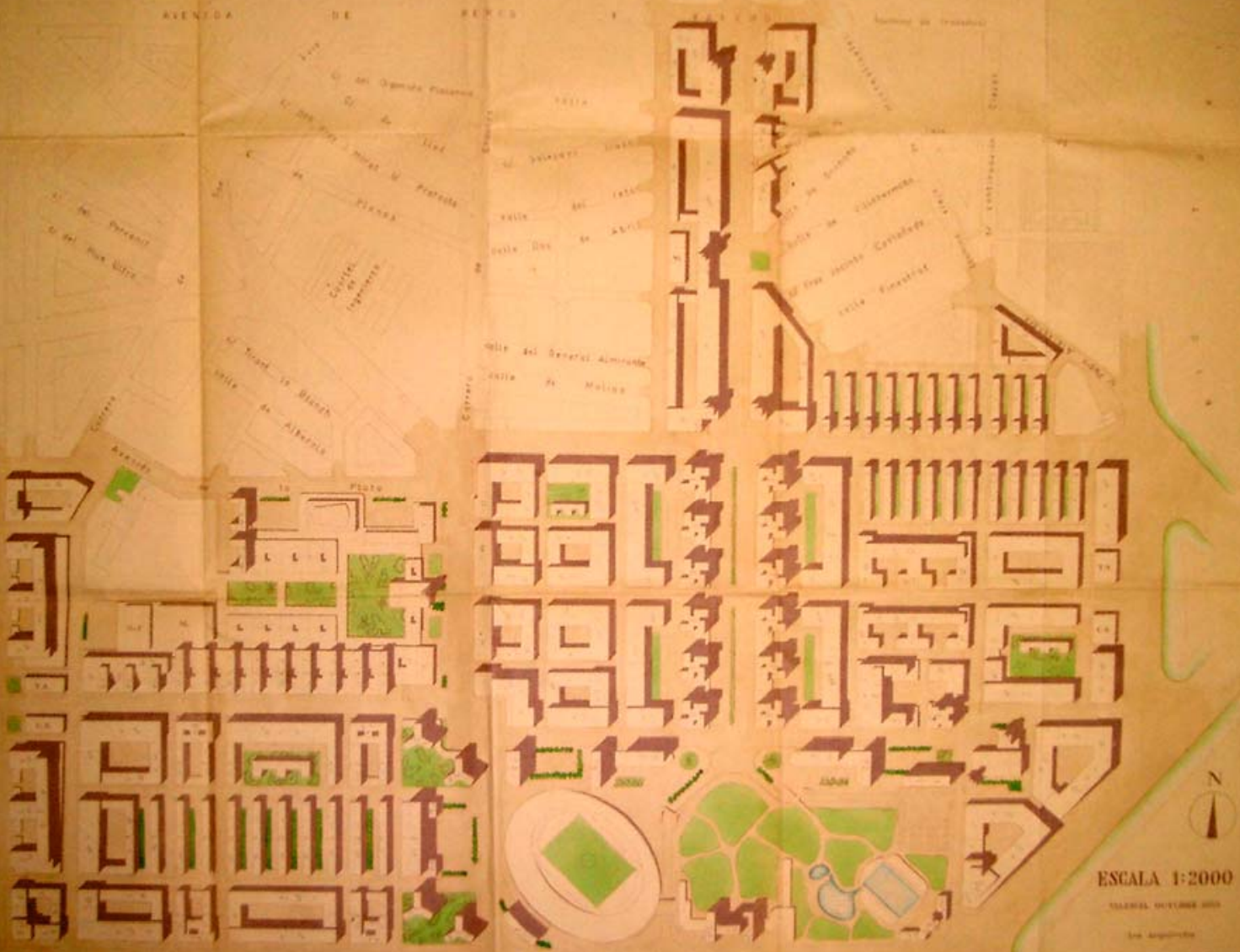
PLANO DE PAVIMENTACIÓN ACERAS Y CALZADAS

Escala original: $1: 2000$

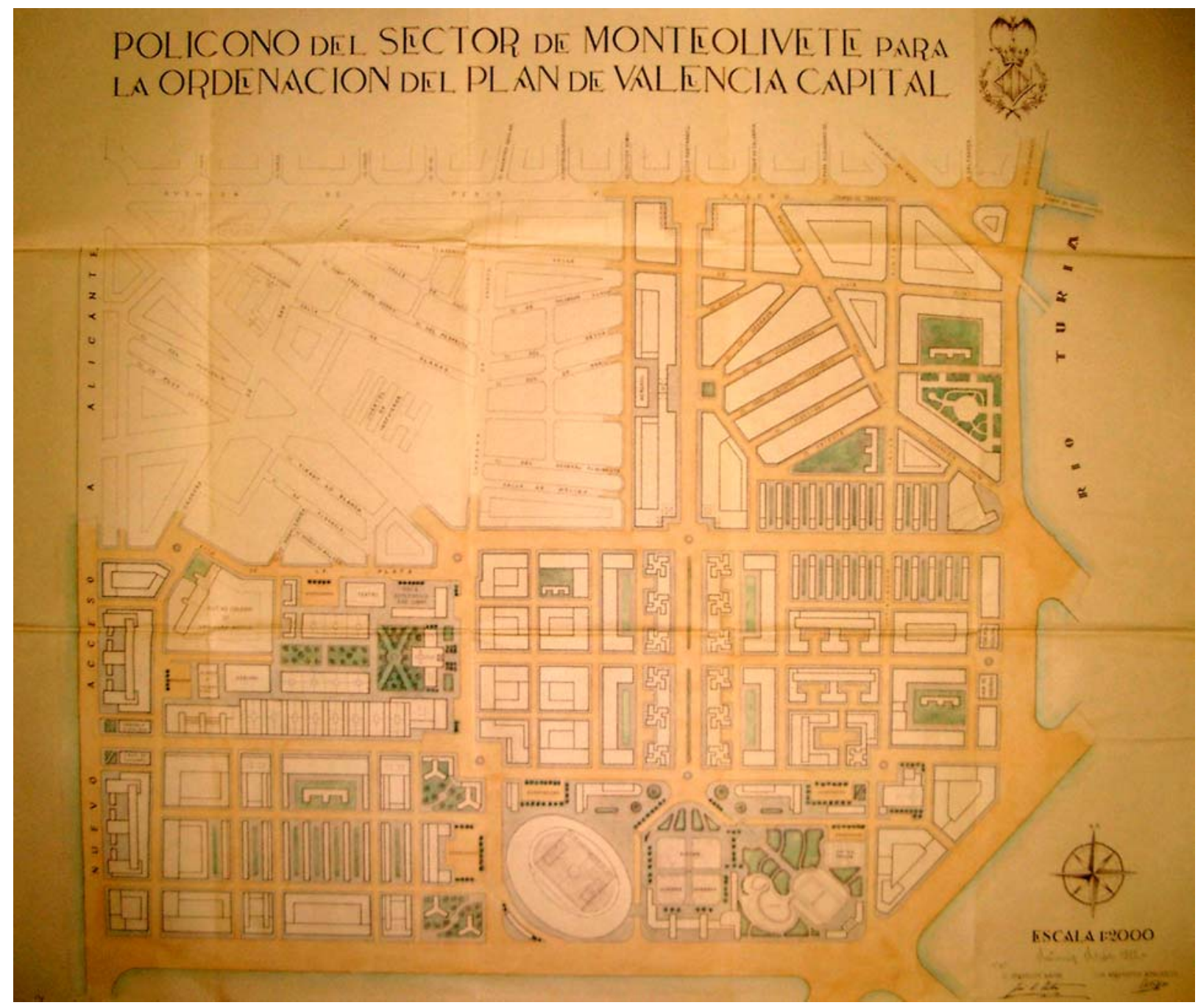




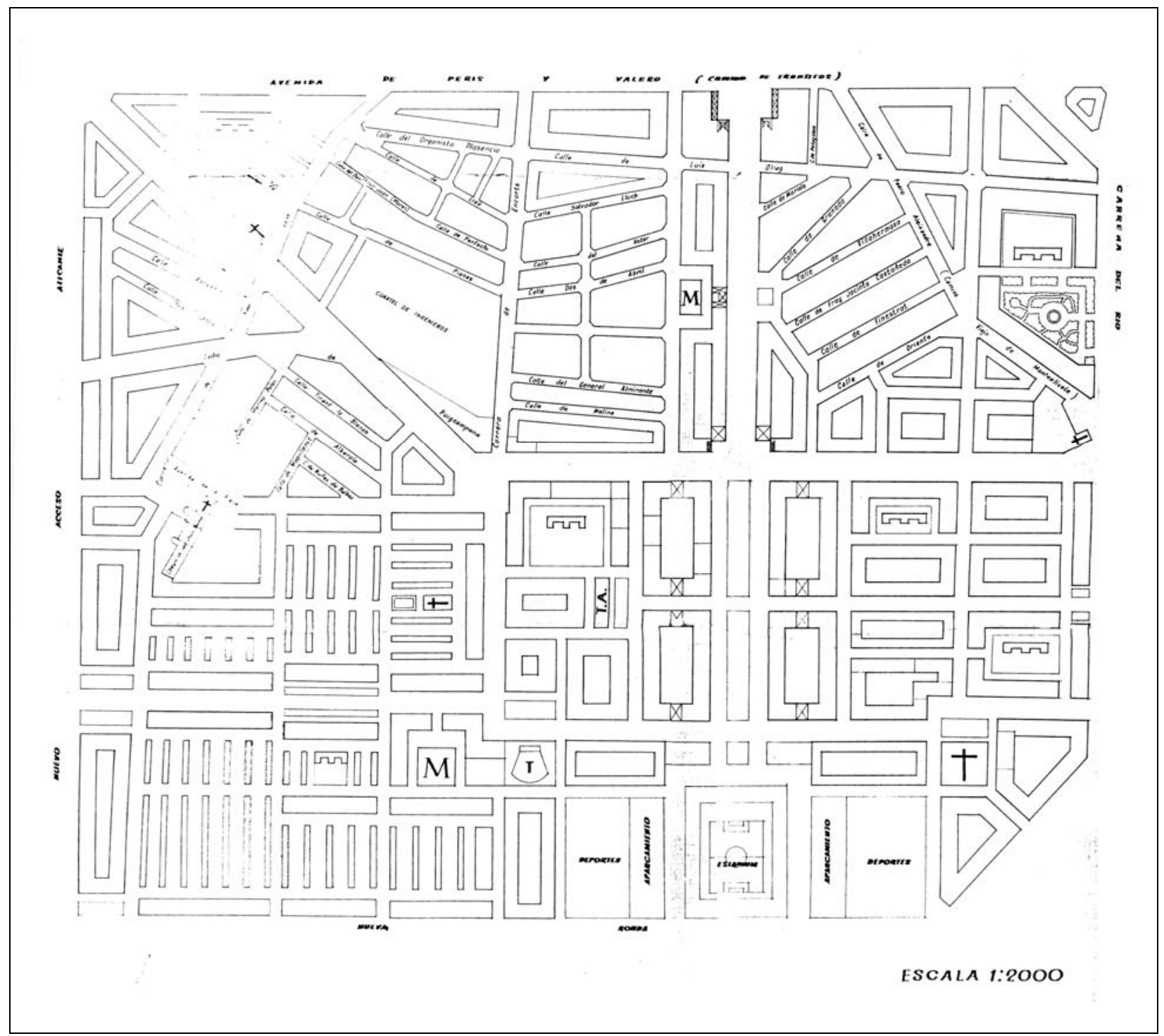


HOJA DE ALINEACIONES PROPUESTAS SUPERPUESTA A ESTADO ACTUAL

Escala original: 1:1000

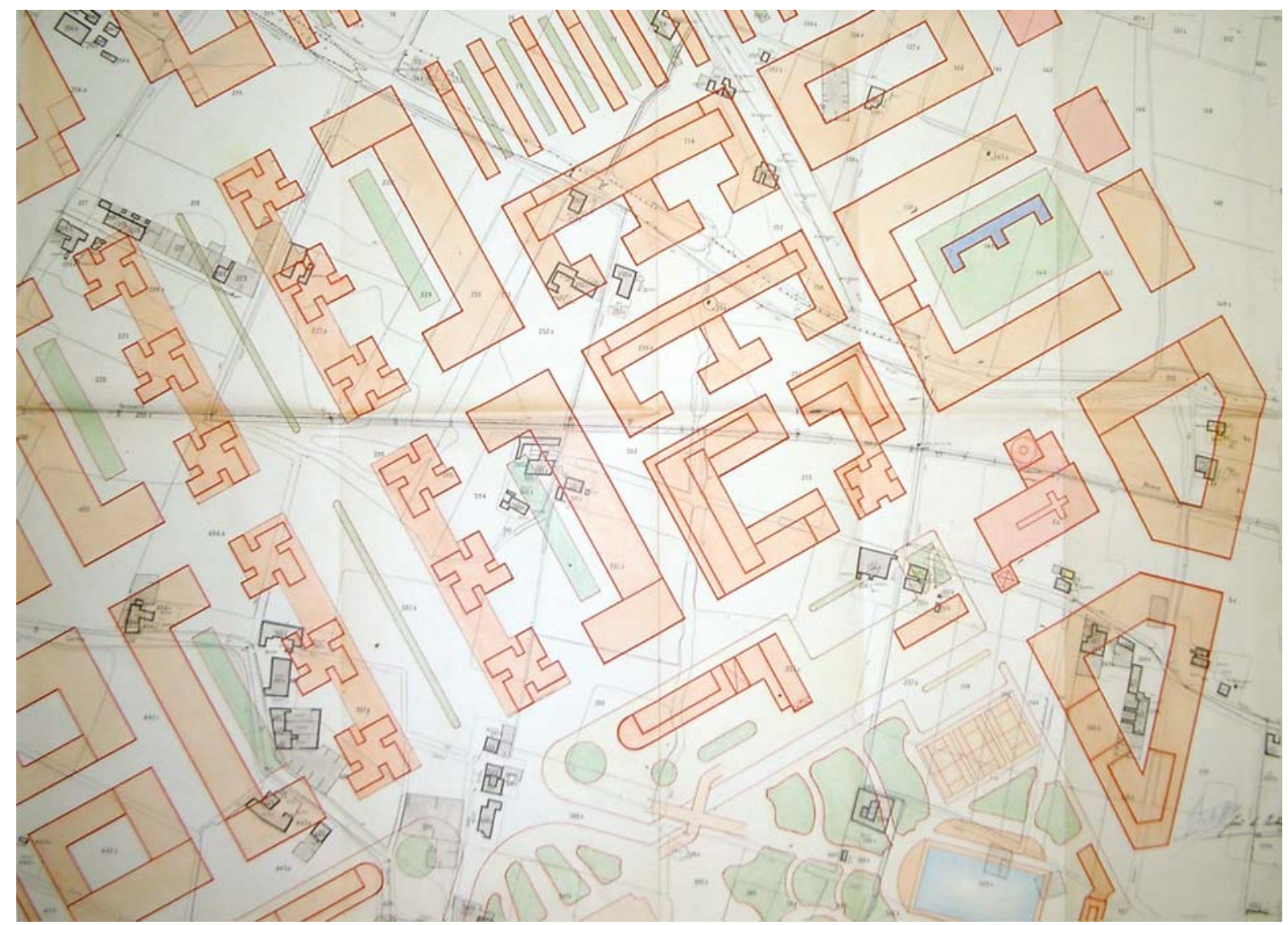



4. POLÍGONOS, 1960-62 



\section{Polígono Valencia al Mar}

Arquitecto Redactor: Fernando Moreno Barberá.

Fecha redacción: Junio 1960.

Fecha aprobación: -

Contenido:

I. INFORMACIÓN.

CARPETA No 1

Explicación de los planos de información.

Volumen y densidades actuales.

Licencias concedidas.

CARPETA No 2

Relación de propietarios

II. VALORACIÓN

CARPETA NO 3

1. Criterios de Valoración

2. Relación de indemnizaciones por traslado de industrias.

3. Relación de valores de solares y edificios

CARPETA No 4

Planos de información y valoración.

\section{III.PROYECTO}

CARPETA NO 5:

Memoria

Ordenanza reguladora

CARPETA No 6:

Estudio económico

CARPETA No 7:

Planos de proyecto
11. RELACION CON LA CIUDAD
$1: 10.000$
12. PLAN GENERAL DE ORDENACIÓN
$1: 2000$
13. CIRCULACIONES
$1: 2000$
14. ALZADOS Y PLANTA PILOTO
$1: 2000$
15. SOLARES RESULTANTES
$1: 2000$
16. ORDENANZAS DE USO
17. RED DE ALCANTARILLADO
$1: 2000$
18. RED DE DISTRIBUCIÓN DE AGUA
$1: 2000$
19. ELECTRICIDAD; ALUMBRADO PÚBLICO
$1: 2000$

\section{Fuente:}

Ayuntamiento de Valencia. Sección de Urbanismo. Negociado de Suelo y Ordenación urbana. (Archivo de Planeamiento, No OM-87.3) 


\author{
TRABAJO NO 405.- POLÍGONO \\ EMPLAZAMIENTO.- PROLONGACIÓN DE LA AVENIDA \\ DE VALENCIA AL MAR. \\ CIUDAD.- VALENCIA
}

\title{
MEMORIA
}

\section{OBJETO DEL PROYECTO}

Es el estudio del polígono urbanístico de la prolongación de la Avenida de Valencia al Mar.

Este polígono consiste esencialmente en una zona de un ancho de 300 metros a partir de la prolongación del eje de la referida avenida, con una superficie aproximada según el Sr. Arquitecto Municipal de Urbanismo de 29 Ha. 60 a.

\section{ANTECEDENTES}

El desarrollo del proyecto se efectúa de acuerdo con la escritura de contrato de servicios otorgada por el Excmo. Ayuntamiento de Valencia y el Arquitecto autor del proyecto a diecisiete de Diciembre de 1.959 ante el Notario D. Antonio Perelló de la Peña.

Con fecha 25 de febrero, conforme al capítulo 70 (Tramitación de los proyectos) de los Pliegos de Condiciones, se remitió un plano original y cuatro copias de varias soluciones del avance de planeamiento con su correspondiente Memoria y fotografías de maquetas, con objeto de que el Ayuntamiento aprobase o pusiese reparos en el plazo de quince días prescrito por dichas bases.

Con fecha 29 de Abril de 1.960, se recibió escrito de la Sección de Urbanismo del Ayuntamiento en el cual se aprobaba el siguiente dictamen de la Comisión Informativa de Urbanismo:

"Esta Comisión ha procedido a examinar el avance del planeamiento de la prolongación del Paseo de Valencia al Mar, desarrollado por el Arquitecto D. Fernando Moreno Barberá, estimando que entre las soluciones propuestas resulta la más acertada la número dos, por lo que acordó se acepte en principio dicha solución, así como su trazado y esquema de composición, con las siguientes observaciones a tener en cuenta en el estudio definitivo: 10 Procurar que el eje del Paseo corte perpendicularmente a la calle de la Reina y que se conserve ésta por ser eje importante del Barrio y único acceso actual a la Malvarrosa.- $2^{\circ}$ Encajar en el Polígono el trazado definitivo del nuevo acceso a Barcelona por la costa poniéndose para ello de acuerdo con la Jefatura de Obas Públicas.-30.- Prever el emplazamiento de un Instituto de Enseñanza Media, unto a la actual calle de Martín Grajales o sea al S. del bloque recayente al Paseo de Valencia al Mar, después del ferrocarril a Tarragona.- 40.- Completar el estudio con un esquema de la solución de transición entre el sector estudiado y la ordenación actual, hasta la Avenida de Mare Nostrum por el S. y la calle del Pintor Ferrándis por el N.; aconsejando que en los límites del Polígono estudiado se sitúen unos bloques paralelos al eje del Paseo que delimiten y separen las zonas en contacto de características distintas.- $5^{\circ}$.- Prever el emplazamiento de los edificios públicos necesarios.- 60.- Completar la información del estado actual y de las licencias teniendo en cuenta especialmente la posibilidad de respetar y encajar en la ordenación unos importantes bloques de viviendas cuya construcción e está terminando actualmente, así como aquellas otras importantes construcciones que puedan existir en el sector y cuya conservación no resulte inadecuada ni descomponga la ordenación del sector estudiado. Esta Comisión acordó igualmente proponer se 
notifiquen las anteriores observaciones al Arquitecto autor del estudio para que se pueda proceder a completarlo con la mayor rapidez, con el fin de que se realice la información pública a la brevedad posible."

La fecha de recepción de aquel informe y de los datos a suministrar por la Jefatura de Obras Públicas condicionan las fechas ara la terminación del proyecto.

\section{RELACION CON LOS POLIGONOS ACTUALMENTE APROBADOS}

No tiene ninguna relación con ellos. Sólo se encuentra en contacto con el Plan de Ordenación de la Avenida de Valencia al Mar, representado en el plano núm. 12-B, que no establece más dependencias ni relación con la zona que se estudia, que la de encontrarse en la Avenida citada.

\section{ACCESOS Y CIRCULACIONES}

a) Trazado de la Avda. de Valencia al Mar. Siguiendo la observación $1^{\text {a }}$ del dictamen antes reproducido, se modifica el trazado de la solución preliminar, haciendo que la Avda. corte perpendicularmente a la actual calle de la Reina que interesa conservar como vía de acceso secundaria a la Barriada del Cabañal.

Esto obliga geométricamente a trasladar el eje de la Avenida de Valencia al Mar hacia el Sur para cortar perpendicularmente la calle de la Reina, desplazando el polígono respecto al proyecto preliminar. Con ello quedará limitado por la calle Mare Nostrum por el Sur y por la Travesía del Progreso por el Norte.

- Este trazado condicionado pues, geométricamente da lugar a que un bloque alto de viviendas quede exactamente en el centro de la Avenida, de forma que ésta se podrá urbaniza, terminando todos sus servicios sin necesidad de expropiar y derribar dicho bloque hasta el último momento con lo que se facilitan las posibilidades de urbanización.

Perfil transversal de la Avenida de Valencia al Mar.

- Es un hecho comprobado que las grandes avenidas con amplios jardines centrales y aceras estrechas junto a los edificios, no son agradables a la circulación, disminuyen el valor de las edificaciones, especialmente su valor comercial, ya que alejan a los transeuntes de los edificios y sus comercios, espectáculos, etc.

- Como comprobación de esta teoría no basta más que observar las avenidas principales de las grandes ciudades como los Campos Elíseos de París o el Durfürdendamm de Berlín consistentes en una línea central generalmente de vegetación que separa las circulaciones, dos calzadas amplias para tráfico rápido y cómodo de los vehículos y a continuación enormes aceras cuya parte más próxima a la circulación se dedica a estacionamientos. En algunos casos como en los Campos Elíseos de París, es frecuente que el acceso a los estacionamientos no se haga directamente desde la calzada principal, sino desde las transversales y recorriendo los coches una zona de acera destinada para este fin. Las edificaciones quedan alejadas del tráfico y de los gases y ruido de los vehículos. La acera se convierte en un local de estancia de los habitantes de la ciudad, quedando amplio espacio para colocar terrazas con mesas de los cafés, vitrinas, etc.

- No pretende el Arquitecto que suscribe, defender un cri 
terio personal, sino que considera más conveniente citar ejemplos de dos ciudades como las antes citadas totalmente logradas en ese aspecto. Existiendo soluciones de éxito robado y difícilmente superables, se estima prudente adoptarlas.

\section{b) Circulaciones transversales}

-1) Calle de una anchura de 40 mts. que corta a la Avenida por la situación actual de la Estación del Ferrocarril y que se llamará Calle del Ferrocarril. Según manifestaciones obtenidas de la Jefatura Superior de Ferrocarriles, y como solución provisional es posible que mientras se termina en su totalidad la solución Sur aprobada, se construya un paso elevado del Ferrocarril, siguiendo el trazado de esta calle, cuya anchura permite llevar las vías por el centro y el tráfico automóvil por ambos lados de las mismas.

-2) La calle la Reina que se mantiene como vía secundaria de acceso a la barriada del Cabañal según propone el dictamen (punto $1^{\circ}$ ).

Autopista de Barcelona

Al desplazar el eje de la Avenida de Valencia al Mar, se desplaza hacia el Sur el cruce de esta con la carretera a Barcelona por la costa, en una distancia aproximada de $100 \mathrm{mts}$. Considerando que en el proyecto del Ministerio de Obras Públicas se establece un quiebro en el trazado de dicha carretera en el punto en que cruza a la Avenida de Valencia al Mar, se propone modificar ligeramente el trazado de dicha carretera, en la zona próxima al cruce con la Avenida en proyecto.

- Se considera obligado el Arquitecto que suscribe a hacer observar que el trazado de la futura Autopista Valencia a Tarragona, que le ha sido entregado por la Jefatura de Obras Públicas, si bien puede facilitar a dicha Jefatura la construcción de la misma, ahorrándole trámites de expropiación, etc. causa un grave perjuicio a los intereses de la Ciudad al eliminar una plaza, que si bien por el momento no está excepcionalmente cuidada ni dispone de los servicios necesarios, con muy poco trabajo e inversión de dinero podría convertirse en un excelente atractivo turístico de la ciudad.

- El construir la carretera sobre la playa, tal como se propone, obligará no sólo a un muro de contención, sino a una escollera al pie del mismo y a proyectar tal vez malecones o estribos salientes con objeto de romper la violencia e las tormentas contra dicho muro de contención lo que destrozará definitivamente la playa.

- Esto es tanto menos justificable cuando existe una amplia calle a una distancia aproximada de $50 \mathrm{mts}$. de la que se pretende construir, bordeada por edificaciones de una o dos plantas como máximo y de escaso valor que, salvo las pequeñas molestias de tener que efectuar algunas expropiaciones, permite con oda facilidad llevar dicha carretera por un lugar en que no cause dichos perjuicios.

La instalación que se proyecta, en vez de servir, como ocurriría en el caso de llevarla separada de la línea de playa, para mejorar las circunstancias turísticas de la 
ciudad creando solares y zonas edificables y explotables para el descanso de los habitantes, causa un grave perjuicio y es contrario a los intereses de la misma. A pesar de ello el proyecto que se adjunta está proyectado de acuerdo con el proyecto de la Jefatura de O.P., ya que no es misión del Arquitecto que suscribe el estudiar el trazado de dicha pista.

\section{Cruce con la Autopista}

En el plano preliminar confeccionado por la Jefatura de Obras Públicas, se prevé una circulación tipo carrusel. Tanto la Jefatura de Obras Públicas como el Arquitecto que suscribe, conocen los inconvenientes y peligros de dicho sistema de circulación y los atascos a que da lugar así como la gran superficie que ocupan. Carecen además de ambiente y calidad urbanística.

- El efectuar un encuentro en T conforme a las normas de tráfico rápido, resuelto en repetidos casos, tampoco se considera oportuno puesto que no se trata, como ya hemos dicho antes de dar al automóvil que llega por la Avenida de Valencia al Mar la facilidad de desaparecer a altas velocidades por la autopista de Barcelona, sino de que llegue a un lugar en el cual se queda, bien a bañarse, bien a contemplar el paisaje o a continuar por la playa. No se trata, volvemos a decir, de un cruce de carreteras, sino de una autopista que se encuentra con una vía urbana. La solución perfecta para este caso como se ha hecho en numerosas ciudades, es el paso superior o inferior de la autopista. En el caso que nos ocupa sería lógico efectuar un paso superior, ya que el nivel del agua del subsuelo crearía grandes dificultades para el paso inferior.

- Mientras se efectúa este paso superior, se resuelve el cruce de una manera urbana, es decir, con luces de control que permitan la circulación sin dificultades en las dos direcciones y $\mathrm{n}$ las de giro, dejando espacio para la acumulación de coches que forzosamente se producirá al disminuir la velocidad, dar la vuela, etc. Véase el plano de circulaciones.

\section{c) Circulaciones secundarias}

Paralelamente a la Avenida de Valencia al Mar se mantienen dos calles de circulación secundaria, una la calle de Mare Nostrum que se prolonga hasta la calle que limita el polígono 12-B, proyectado por el Ayuntamiento, y otra la Travesía del Progreso por el Norte que se conserva ensanchándola para mejorar la circulación, aún cuando ésta será muy reducida ya que se rata exclusivamente de circulación de acceso a viviendas.

d) Estacionamientos

Además de los espacios destinados a garajes y artesanía que prescriben las normas de la Dirección General de Urbanismo, se proyectan estacionamientos a lo largo de la Avenida de Valencia al Mar y de la mayoría de las calles secundarias, en proporción superior a la correspondiente a la actual densidad de coches por habitante en España. 
La Avenida de Valencia al Mar se proyecta tratarla no como una arteria de circulación únicamente sino como un elemento de la ciudad definido estéticamente, que produzca impresiones sucesivas al recorrerlo tanto de estrechez como de amplitud, de cerrado y diáfano, cuyos edificios responderán a ritmos alternados, tanto en dirección como en altura, etc.

A continuación se describen los efectos que se pretenden obtener.

Ambiente " $\mathrm{A}$ "

Próximo a la zona dedicada a Feria en el Proyecto 12-B del Ayuntamiento, se proyecta un sector de una longitud media de $250,00 \mathrm{mts}$. con edificaciones compactas que actúan como pilonos o portalón del conjunto urbanístico que se proyecta.

A la izquierda (Sector I) se proyecta una abertura en el centro de la zona considerada, por la cual se penetra en una plaza, con un edificio elevado al fondo, y dos edificios bajos laterales, con lo que se forma un ambiente definido y sicológicamente cerrado. A derecha ó izquierda de esta plaza, se proyectan bloques en peine.

En el lado derecho (Sector II), se persigue el efecto contrario que es oponer a la abertura de entrada a la plaza que antes se ha citado, un edificio macizo elevado, retrasado de la alineación de la calle, y de ritmo vertical. Este volumen elevado es contrapunto de la entrada a la plaza situada enfrente. Detrás de este edificio, se proyectan construcciones en peine de densidad elevada orientadas Norte-Sur con objeto de que dispongan de soleamiento todas las fachadas.

\section{Ambiente "B"}

Continuando por la Avenida, se penetra en el espacio urbanístico definido por los Sectores III y IV. Este ambiente urbanístico ha sido estudiado con sumo cuidado teniendo en cuenta la curvatura de la Avenida para valorarlo. Está definido por cuatro edificios de 16 plantas paralelos al eje de la Avenida, que lo limitan. A continuación de ellos, dos hileras de 10 edificios colocados en peine, retranqueados $10,00 \mathrm{mts}$. de la alineación anterior, producen un ensanchamiento entre los cuatro edificios antes citados, creando la impresión de encontrarse en un espacio definido.

Uniendo los edificios en peine, se proyecta una edificación de dos alturas con la parte baja en porche, destinada a fines comerciales, tiendas, oficinas, etc. Estos espacios comerciales de fachada se prolongan en los patios que quedan entre las edificaciones, pudiéndose utilizar para garaje, industrias no molestas para el vecindario, artesanía, almacenes, etc.

El acceso de peatones a cada uno de estos bloques de efectúa desde la Avenida de Valencia al Mar donde quedarán estacionados los vehículos. El acceso tanto de automóviles como de suministros que quieran llegar hasta la puerta, se efectúa por la calle posterior.

El tipo de edificación que aquí se propone se ha utilizado con éxito en urbanizaciones efectuadas en varios países, especialmente en Suecia y en la reconstrucción de Inglaterra. El objetivo que se persigue, es que esta Avenida no sea una calle desierta, sino un lugar lleno de vida con tiendas, oficinas, espectáculos y viviendas.

La pretendida rigidez de los bloques paralelos y repetidos no 
existe. Sólo la repetición de elementos da escala y grandeza a las composiciones, siempre que estén debidamente acentuadas como en el caso presente.

El Arquitecto que suscribe ha efectuado urbanizaciones, que puede mostrar, que se recorren a pié, en que un peine de 10 elementos no produce monotonía. Tanto menos en este caso en que se recorre rápidamente en un automóvil y los peatones tienen edificaciones bajas comerciales que enlazan los elementos en peine como se ve en las perspectivas.

Entre cada uno de los bloques del peine, que dan acceso a las viviendas, se define un pequeño ambiente urbanístico, que lo limita con una torre de 16 plantas que hace de pantalla para velar la actual edificación existente de baja calidad. Se efectuará una intensa plantación de arbolado entre estos bloques.

\section{Ambientes secundarios}

Detrás de los cuatro edificios altos paralelos a la Avenida se definen cuatro ambientes retirados y tranquilos.

El del sector III se utiliza para situar un local de espectáculos incorporado en una amplia zona baja comercial, que ocupa casi toda la superficie.

El del sector $V$ dispone asimismo de otra zona comercial, con otro posible edificio de espectáculos, sala de fiestas, etc. que tendrá el atractivo de que desde su vestíbulo podrá disfrutarse de la vista de la zona verde que se dispone en dicho sector.

En el sector IV el informe recibido del Ayuntamiento, prescribe que se sitúe un Instituto en dicho lugar y cerca de la calle Martín Grajales de lo que se efectúa como asimismo una iglesia, creando con ello una plaza tranquila. Si se efectúa aunque se estima que el terreno resulta demasiado valioso para destinarlo a edificaciones no rentables.

Por último en el sector VI se disponen dos bloques paralelos para viviendas, con edificaciones comerciales entre dichos bloques, tal como se ha efectuado en los sectores III y $\mathrm{V}$.

\section{Ambiente " $\mathrm{C}$ "}

Continuando la Avenida de Valencia al Mar y después del espacio limitado por los cuatro edificios, tantas veces citados, se disuelve la edificación intencionadamente, formando dos zonas verdes a derecha e izquierda con poca densidad de edificación y ésta repartida en edificios elevados, con objeto de obtener superficies libres para descanso, juegos de niños, etc.

Este ambiente urbanístico, está cerrado intencionadamente por dos bloques perpendiculares a la Avenida de Valencia al Mar, de manera que constituya una sorpresa al extender la mirada repentinamente en toda la longitud de la carretera de Valencia a Barcelona por la costa.

El coste de urbanización hace aconsejable aumentar la densidad de esta zona en los edificios marcados de trazos.

\section{Ambiente "D" (Plaza Terminal)}

Efectuado el cruce de esta carretera, nos encontramos en el ambiente " $\mathrm{D}$ ", que si por una parte debe mantener libre la vista del mar como desea la Jefatura de Obras Públicas, por otra, debe marcar claramente que allí no termina la Avenida. Una Avenida de esta importancia y dimensiones debe terminar llegando a alguna parte, no disolverse en un simple nudo de circulación, ya que su objetivo no es el de proporcionar una llegada rápida a la carretera de Bar 
celona, sino que tiene valor en sí misma.

El sector VII se edifica en un bloque cerrado en la misma alineación de la Avenida de Valencia al Mar.

La carretera o paseo costero podrá arrancar en cualquier punto, pasando bajo este bloque, introduciendo otro elemento de sorpresa al pasar de la oscuridad de nuevo a la luz.

En el sector VIII, se proyecta un edificio aislado de la máxima altura posible, sin limitación, y en el eje de la acera de la Avenida. Este edificio aunque está fuera del eje de la circulación rodada, sirve de límite visual evidente, ya que se percibe dada la curvatura de la Avenida desde una distancia superior a $2 \mathrm{kms}$. La zona en cambio, situada a eje de la Avenida estará limitada por una plantación de palmeras formando un balcón sobre el Mediterráneo.

En este conjunto se forma un sub-ambiente urbanístico constituído por un jardín o estanque delante del edificio alto.

\section{SERVICIOS SOCIALES}

La zona cuyo estudio se efectúa, no constituye realmente un polígono, en el sentido urbanístico y orgánico, de la palabra, sino una zona de la anchura aproximada de una manzana a derecha e izquierda de la Avenida. A pesar de ello se presentan todos los problemas inherentes al elevado número de personas que han de habitar en ella.

Según las normas de la Dirección General de Urbanismo, son necesarios los servicios y superficies que se indican más adelante.

El dedicar a determinados centros parte del valioso espacio situado a $100 \mathrm{~m}$. derecha e izquierda de la Avenida, haría insostenible la construcción de ésta y además no resultaría aconsejable su proximidad a la calle de circulación rápida. Conscientemente y como criterio se estima que, las Escuelas, Mercados, Iglesias, etc. cuya capacidad se indica a continuación y cuyas superficies figuran en el plano correspondiente deben situarse fuera de la zona del polígono que se estudia.

Sólo en Instituto de $2^{a}$ Enseñanza que el informe de la Sección de Urbanismo del Ayuntamiento prescribe explícitamente que ha de situarse en la calle Martí Grajales, ha sido situado en la zona estudiada aún cuando se efectúa la indicación de que tal emplazamiento se considera antieconómico y que sería mucho más razonable situarlo al otro lado de la calle Mare Nostrum, en terrenos hoy día de escaso valor y sin edificar, dejando el espacio que ocupa tanto este edificio como la Iglesia, para una edificación remuneradora económicamente. Con el Instituto y la Iglesia podría formarse una Plaza tranquila, en el cruce de la calle Mare Nostrum con la del ferrocarril, con mayor espacio para ambos centros.

\section{RELACIÓN DE LOS SERVICIOS SOCIALES NECESARIOS}

\section{1) IGLESIAS}

- Capacidad: $5 \%$ de 40.000 habitantes $=2.000$ plazas.

- Se proponen 2 iglesias de 1.000 plazas con un terreno asignado de $2.500 \mathrm{~m} 2$ a cada una.

2) ESCUELAS

- Población Escolar $15 \%$ de $40.000=6.000$ plazas.

- Número grados: $6.000 / 40=150$ clases

- Terreno a reservar 150 clases x $240 \mathrm{~m} 2 /$ clase $=35.600 \mathrm{~m} 2$ equivalente al $13,6 \%$ de la superficie útil del polígono.

- Se proponen 12 escuelas de las siguientes capacidades: 


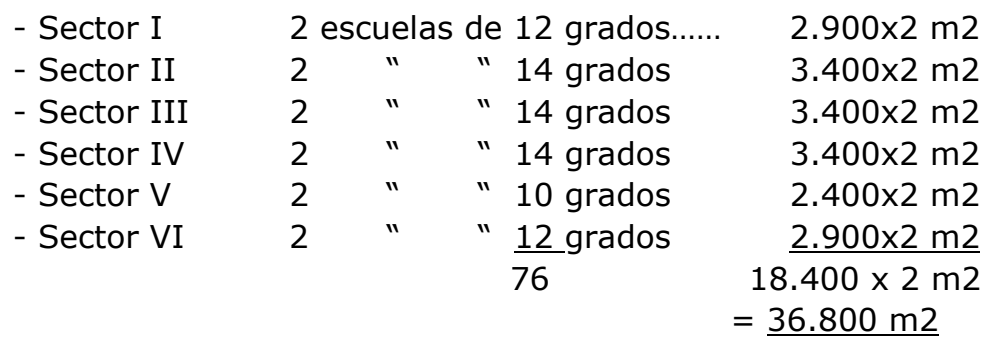

3) COMERCIOS

- 1 comercio cada 20 viviendas: $10.000 / 20=500$ comercios (para unidad comercial en línea $5 \mathrm{ml}$ )

- Se proyectan:

a) Tres centros comerciales en dos plantas a $50 \mathrm{~m} 2$ por local.

Sector III $\quad 2 \times 640 \mathrm{~m} 2 \ldots . \quad 25$ comercios

Sector V $\quad 2 \times 520 \mathrm{~m} 2 \ldots . .11$ id.

Sector VIII $\quad 2 \times 420 \mathrm{~m} 2 \ldots . \quad 17$ id.

b) Comercio en línea.

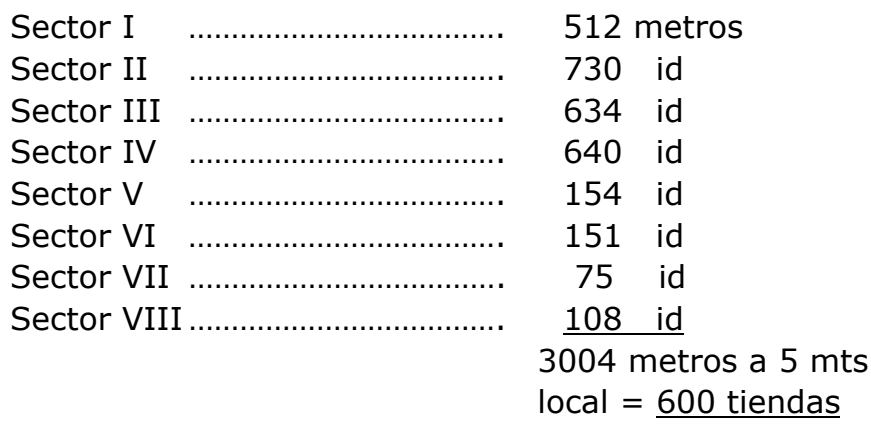

Cifra superior a la mínima exigida que se justifica con que la Av. De Valencia al Mar absorberá un tráfico de paso y de los barrios próximos superior al de los habitantes del polígono.

4) ARTESANIA Y GARAJES

1 local de $200 \mathrm{~m} 2$ cada 100 viviendas.

Superficie necesaria: $10.000 / 100 \times 200=20.000 \mathrm{~m} 2$.

Superficies proyectadas

- Sector I

- Sector II

- Sector III

$3.750 \mathrm{~m} 2$.

- Sector IV

$8.200 \mathrm{~m} 2$.

- Sector V

$8.200 \mathrm{~m} 2$.

- Sector VI

- $\mathrm{m} 2$.

- Sector VII

$3.150 \mathrm{~m} 2$.

- Sector VIII

- $\mathrm{m} 2$.

- $\quad \mathrm{m} 2$.

TOTAL........ $23.000 \mathrm{~m} 2$

5) SALAS DE ESPECTÁCULOS

- Capacidad $10 \%$ de los habitantes del polígono. $10 \%$ de $40.000=4.000$ plazas.

- Se proyectan dos locales de espectáculos en los sectores III y IV de una capacidad de 1.500 plazas para que tengan la mejor rentabilidad con posibles salas de fiestas anejas.

- Existen numerosos emplazamientos en que se pueden situar 2 cines de 500 plazas, para completar la capacidad exigida.

6) CENTROS ADMINISTRACION, ETC. 
- Se reserva para este fin la planta superior de la zona comercial en línea de los sectores III y IV con una superficie total:

$$
\begin{array}{lr}
\text { - Sector III ............ } & 5.500 \mathrm{~m} 2 \\
\text { - Sector IV ............. } & 5.800 \mathrm{~m} 2 \\
& 11.300 \mathrm{~m} 2
\end{array}
$$

- Estos locales podrán ser tanto de administración u oficinas como comerciales anejos a as plantas bajas y con escaleras interiores de comunicación.

\section{7) ZONAS DEPORTIVAS Y VERDES}

- Norma general: $2 \mathrm{~m} 2$ por habitante.

- Superficie necesaria: $40.000 \times 2=80.000 \mathrm{~m} 2=8 \mathrm{Ha}$.

- Se ha proyectado que la edificación intensiva de la Avenida se vaya diluyendo lateralmente como transición a la edificación baja actual. Por ello se construye torres o bloques independientes en la parte posterior, que irán envueltos en plantaciones intensivas de arbolado entre el cual se efectuará la circulación por calles y senderos particulares, fuera del tráfico rodado.

- Como intención buscada se hace contrastar la intensa urbanización de los sectores 3 y 4 con una amplia masa verde (sectores V y VI) que se debe ver a continuación de aquella edificación intensa. En ella se forman unos amplios parques destinados a juegos de niños, accesibles, fácilmente desde los sectores $3,4,5$ y 6 sin cruzar ninguna vía de tráfico rápido.

- Los sectores 1 y 2 tendrán que utilizar las zonas verdes correspondientes a la Feria proyectada por el Ayuntamiento (sector 12-B) y las pequeñas plazas situadas delante de los edificios altos que figuran en el plano, con objeto de que no tengan que cruzar los niños la Avenida de Valencia al Mar ni la calle del Ferrocarril.

- El Polígono que se proyecta tendrá que completarse con el estudio de las zonas colindantes en las que se deberán emplazar las zonas deportivas, verdes, etc. a las que no se debe destinar el terreno de elevado coste de urbanización próximo a la Avenida de Valencia al Mar.

- La extensa superficie de la Av. De Valencia al Mar se puede considerar, si no como zona verde, sí como espacio libre a efectos de aireamiento al que hay que sumar los es-

\begin{tabular}{|c|c|c|}
\hline Sector II & & $10.000 \mathrm{~m} 2$ \\
\hline Sector III & … & $10.500 \quad "$ \\
\hline Sector IV & ……………… & 15.000 \\
\hline Sector V & 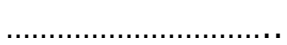 & 18.700 \\
\hline Sector VIII & … & $\frac{2.600 "}{56.800 \mathrm{~m} 2}$ \\
\hline
\end{tabular}
pacios no edificados destinados a jardín entre los bloques. Las zonas verdes pasivas representan:

Considerando que la Avenida de Valencia al Mar, propiamente dicha, ocupa $134.086 \mathrm{~m} 2$ de los cuales $83.000 \mathrm{~m} 2$ se destinan a aceras y faja central arbolada, se puede afirmar que el polígono dispone de un elevado porcentaje de espacios libres. 


\section{CARACTERISTICAS GENERALES DE LA URBANIZACION}

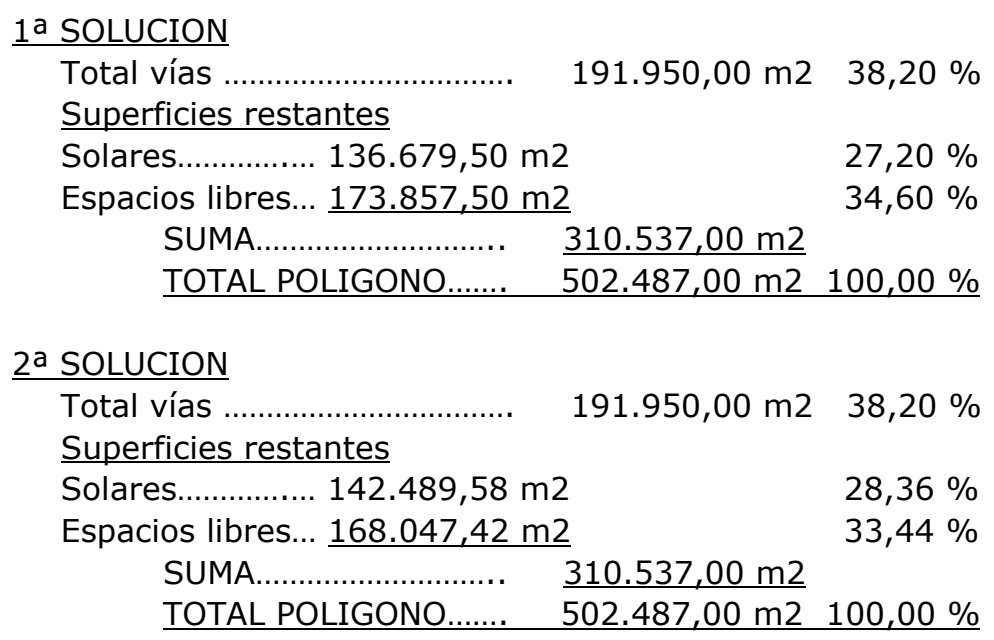




\section{INFORME DEL SERVICIO DE PLANEAMIENTO DE LA DIRECCION GENERAL DE URBANISMO}

El Sr. Arquitecto Jefe del Servicio de Planeamiento de la Dirección General de Urbanismo, con la conformidad de la misma ha emitido informe sobre Avance de Planes Parciales de varios Polígonos para el desarrollo del Plan de Ordenación de Valencia, cuyo contenido en lo referente al Polígono por Vd. Estudiado es del tenor siguiente:

"POLIGONO DE LA AVENIDA DE VALENCIA AL MAR: Arquitecto Sr. Moreno Barberá.- No presenta estudio informativo y ofrece 4 soluciones, de las cuales la mejor resuelta en cuanto a trazado es la que presenta el acuerdo en curva, que permite llegar normalmente a la Vía Marítima.- La Ordenación de bloques es de dos orientaciones, de gran rigidez, y no se plantea el acuerdo de la nueva ordenación con la actualmente existente. Sería aconsejable acoplar los límites de la ordenación a las calles de Pintor Ferrandiz y Mare Nostrum y resolver adecuadamente el enlace de la red viaria actual, especialmente la calle de la Reina con la nueva ordenación.- Es conveniente diferenciar la ordenación de bloques repetidos, dando entrada a algún edificio de carácter público, organizando algún control comercial y previendo un Instituto. En principio cabe distinguir tres zonas dentro de la ordenación, en las que se podría diferenciar la composición urbanística: una industrial, con bloques pantalla; otra de viviendas de clase media, y la última en contacto con la zona marítima, que pudiera ser objeto de composición brillante a tono con su situación.- Es preciso en la ordenación de este sector contar con las características del subsuelo, que puede limitar los edificios de altura. Es fundamental prever la incorporación del paseo de Valencia al Mar a la autopista a Sagunto por la costa, que debe cortar normalmente y en paso superior la referida vía. Estos extremos deben estudiarse en colaboración con Obras Públicas.

"CONCLUSION.- En conjunto, del examen de los Avances de Planeamiento se desprende que el enfoque técnico de los problemas urbanísticos está bien planeado y supone una base suficiente para el desarrollo total de los mismos.- El criterio seguido es unánime, en cuanto a conceptos se refiere, tratando de conseguir barrios organizados en construcción abierta. Sin embargo es preciso pensar que este Camino es revolucionario en Valencia, y provoca un excesivo contraste con las costumbres locales, derivadas en parte de la gran carestía del suelo.- Por este motivo creemos aconsejable sin perder el concepto actual introducir en lugares justificados algunas manzanas más densas, con bloques de seis crujías que puedan organizarse con patios interiores cubiertos, pues de esta forma podría aumentarse la cubicación en $\mathrm{m} 3$ por $\mathrm{m} 2$ y mantener densidad inferior en el resto del polígono. No debe olvidarse tampoco la monotonía que puede derivarse de prodigar y repetir los bloques lineales aunque lleven diferentes alturas, por lo que es importante establecer ambientes y provocar contrastes para acentuar la variedad en conjunto y detalle. El establecimiento previo de porcentajes de vivienda de lujo, media y modesta sería conveniente en cada polígono.Es preciso señalar con carácter fundamental la importancia que debe tener el planteamiento económico financiero que garantice la posibilidad de su ejecución. A estos efectos, se estima que es preciso una orientación clara por parte del Ayuntamiento de Valencia, sobre el sistema de ejecución que va a aplicarse en cada uno de los polígonos.- Ello ha de influir en la estimación de los medios económico-financieros disponibles y que deben quedar afectos a la ejecución de los Planes pues estos medios dependen de la forma de ejecutar las urbanizaciones.En principio, y salvo que el Ayuntamiento tenga capacidad suficiente para aplicar con carácter general el sistema de expropiación parece conveniente que en buena parte de los polígonos de vaya a los sistemas de cooperación, compensación o cesión de viales. Ello obliga a plantear con carácter inmediato y previo la declaración del sistema aplicable a los proyectos y reparcelación al objeto de coordinar eficientemente la iniciativa privada.- Se estima por tanto que es urgente la determinación del sistema de actuación conveniente para cada polígono, al objeto de que se tenga en cuenta en la terminación de los estudios de planeamiento y en la estimación de los medios económico-financieros disponibles.- debe señalarse asimismo que en el desarrollo definitivo de los planes parciales deberá tenerse en cuenta lo prescrito en el Artículo 10 de la vigente Ley de 12 de Mayo de 1.956 sobre Régimen del Suelo y Ordenación Urbana."

Dicho particular concuerda con la copia del informe del referido Servicio de Planeamiento fecha 1 de abril último, que le fue cursada oficialmente en unión de la notificación del cuerdo plenario de esta Corporación de primero de Abril último.

Lo que en cumplimiento de lo ordenado por la Alcaldía en el día de hoy me complazco en trasladar a Vd. Para su conocimiento y efecto.

Dios guarde a Vd. Muchos años.

Valencia, 6 de Junio de 1.960.

EL SECRETARIO GENERAL ACIDENTAL 
AVANCE DE PLANEAMIENTO. ALTERNATIVA 1

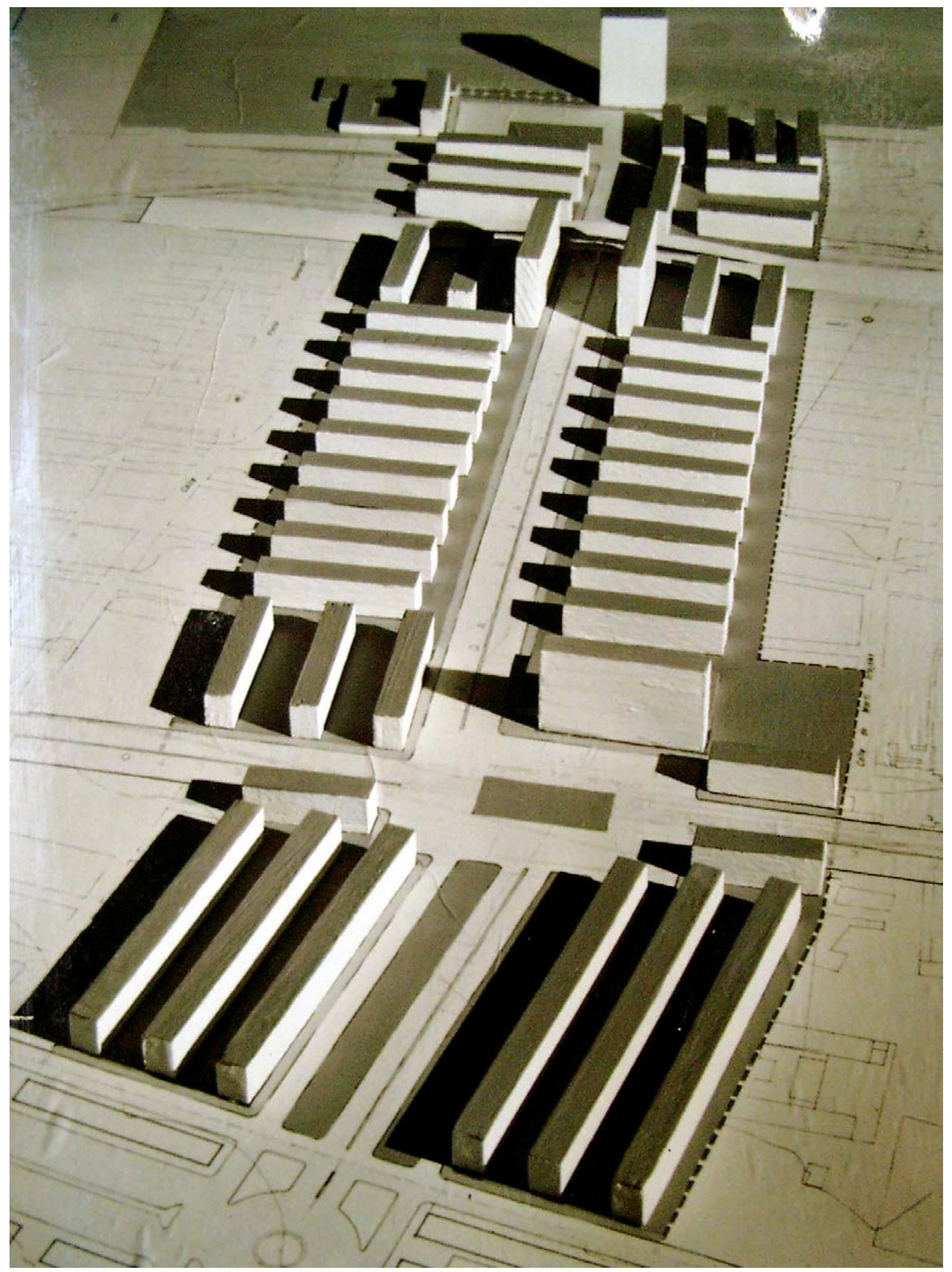


AVANCE DE PLANEAMIENTO. ALTERNATIVA 2

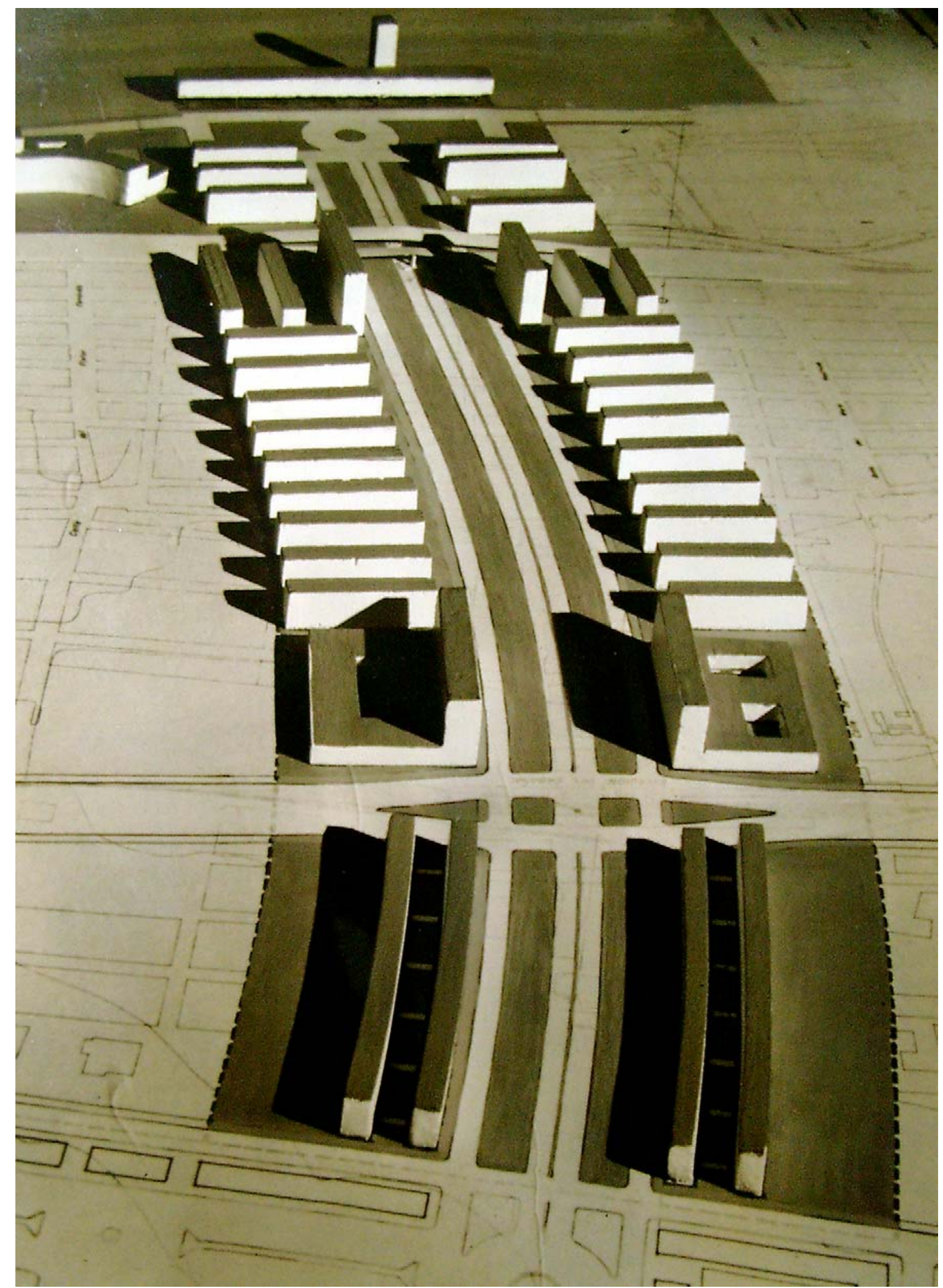



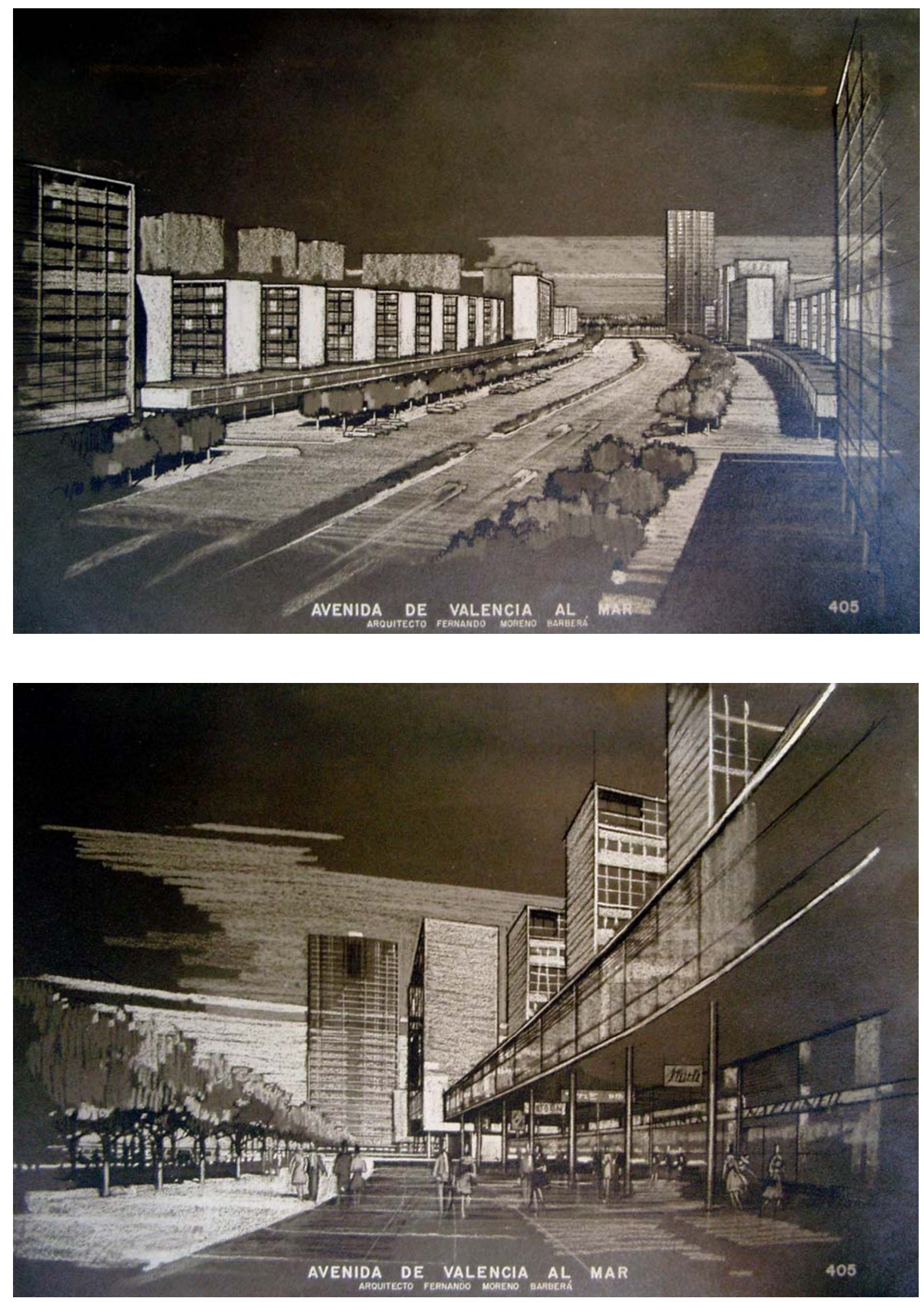


\section{P O L I G O N O U R B A N O DE LA AVENIDA DE VALENCIA AL MAR}

Tendrá una superficie de 502.407 metros cuadrados, diez mil viviendas y cuarenta mil habitanies

Escuelas, iglesias, instituto de segunda enseñanza, restaurantes, salas de espectáculos, zonas deportivas...
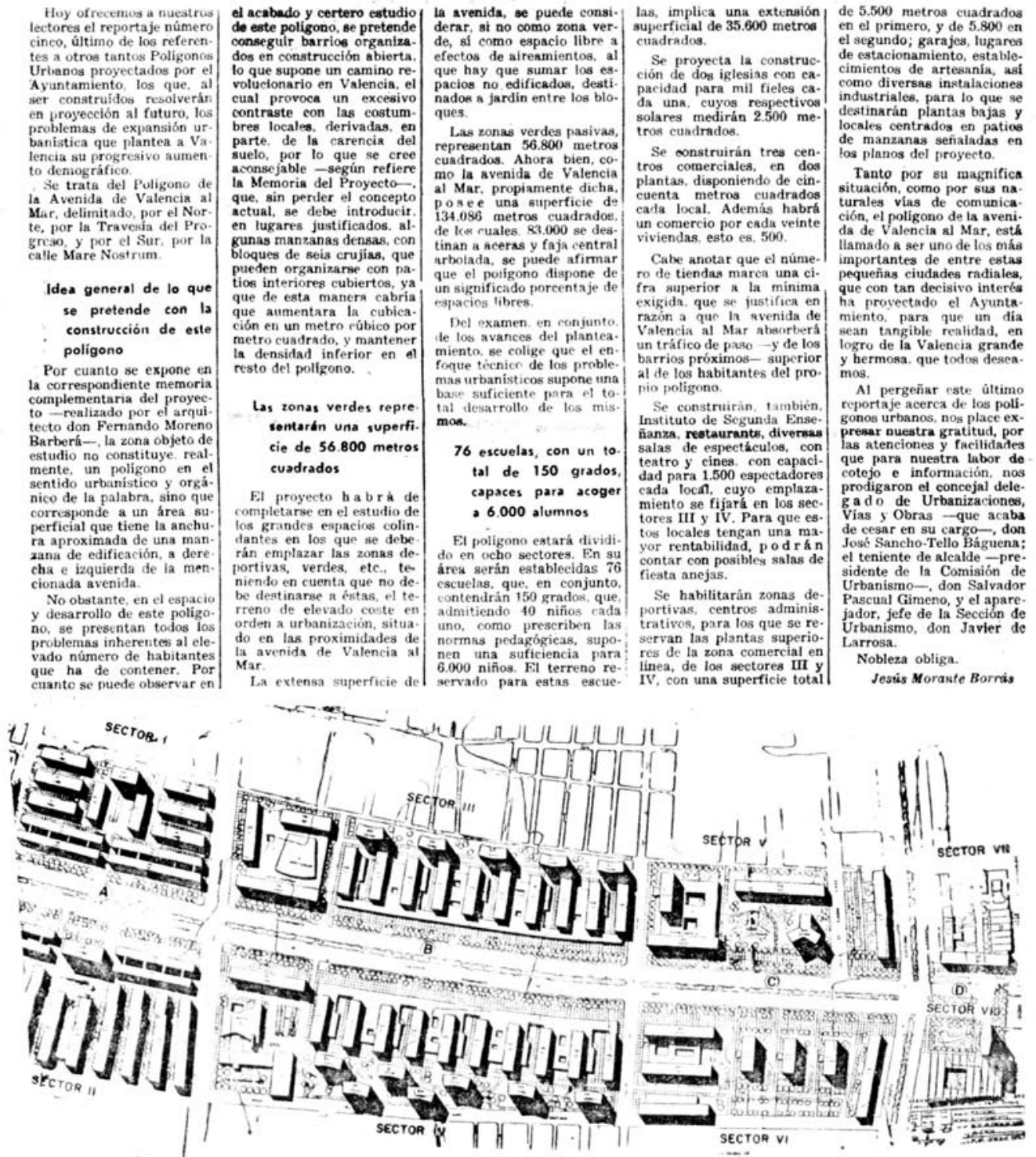
11. RELACIÓN CON LA CIUDAD (Fragmento) Escala original 1:10.000

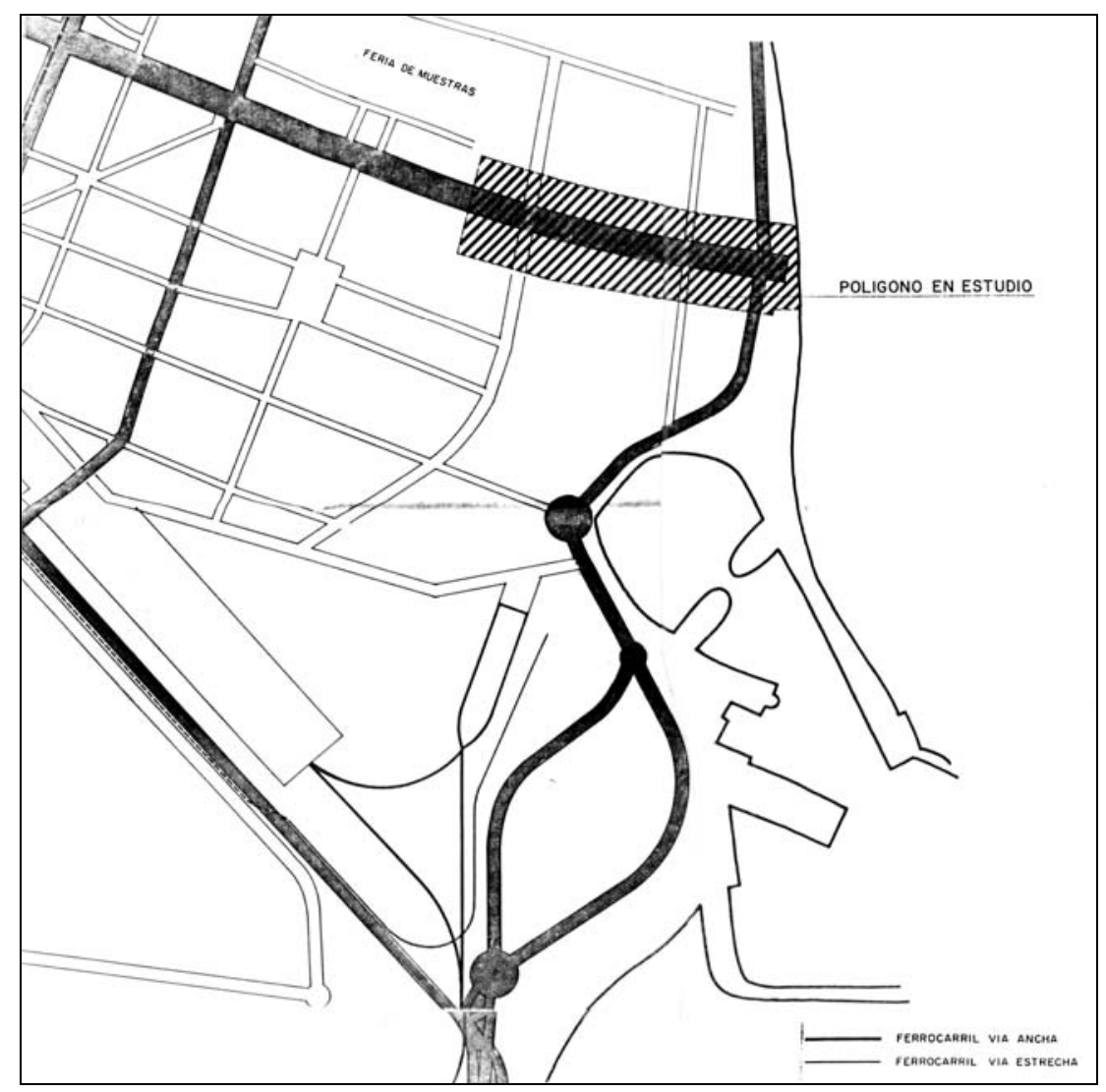

ESTADO ACTUAL

Escala original 1:2000

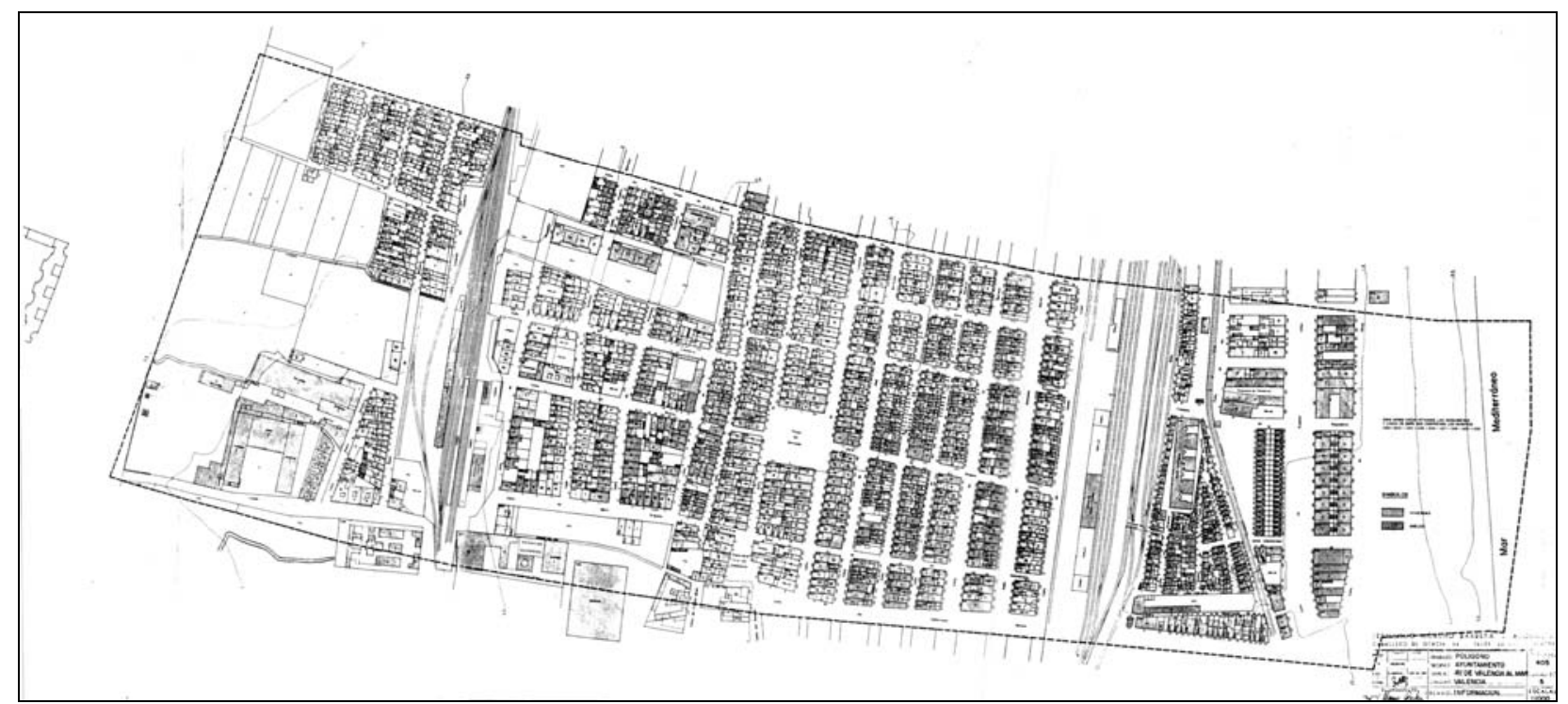


12. PLAN GENERAL DE ORDENACIÓN

Escala original 1:2000
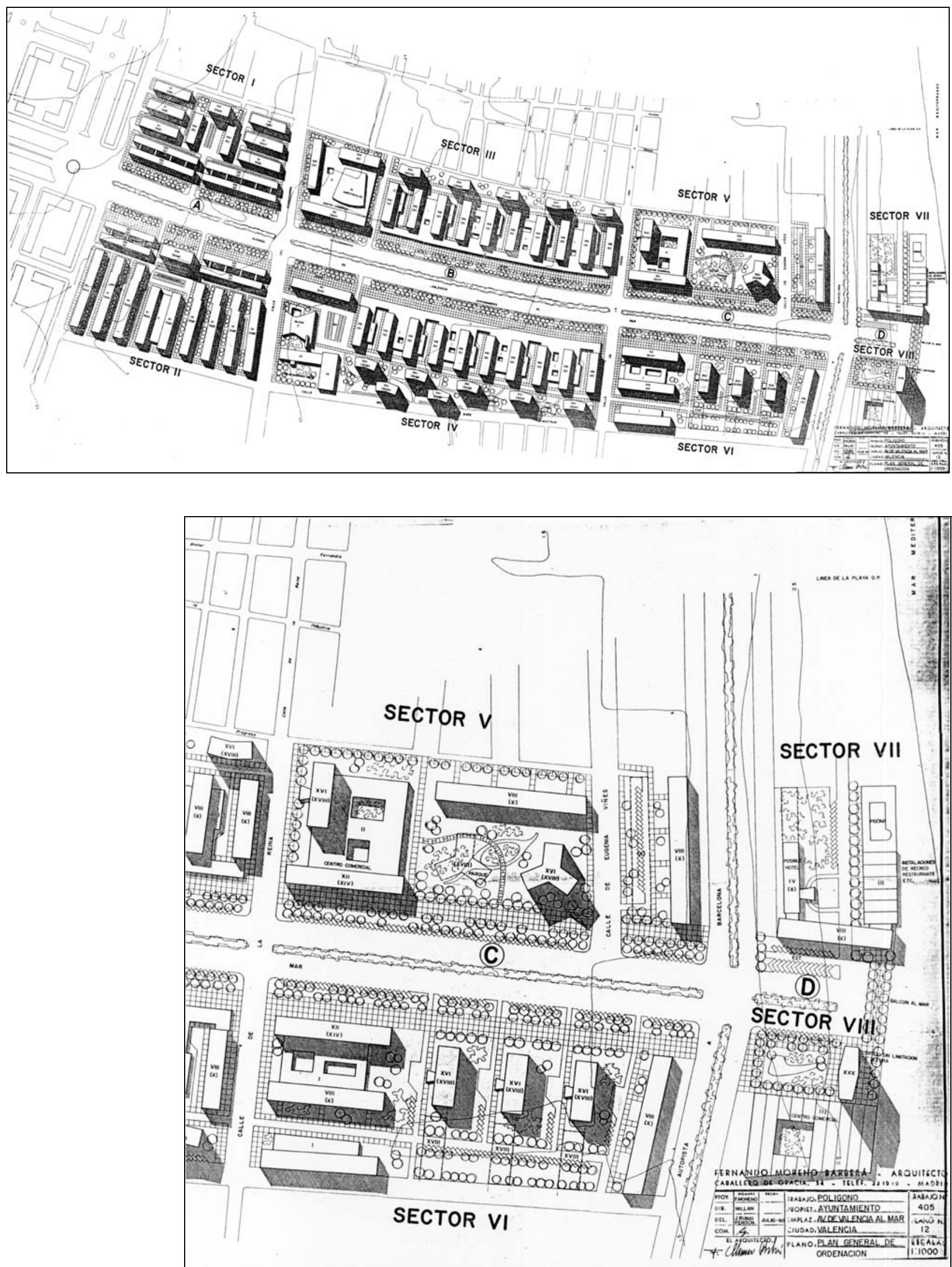

Plan General de Ordenación. Detalle de la zona este. 


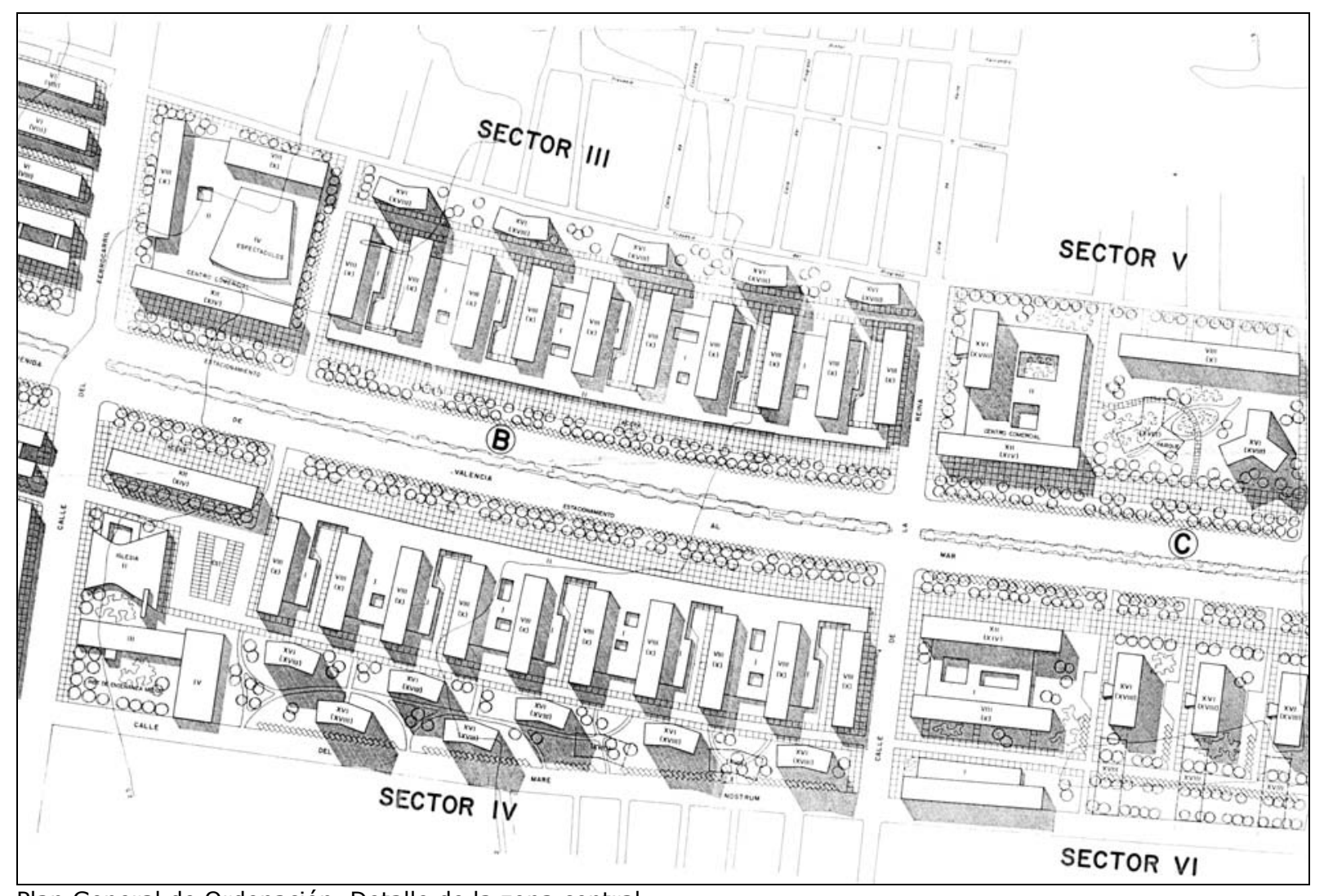

Plan General de Ordenación. Detalle de la zona central.

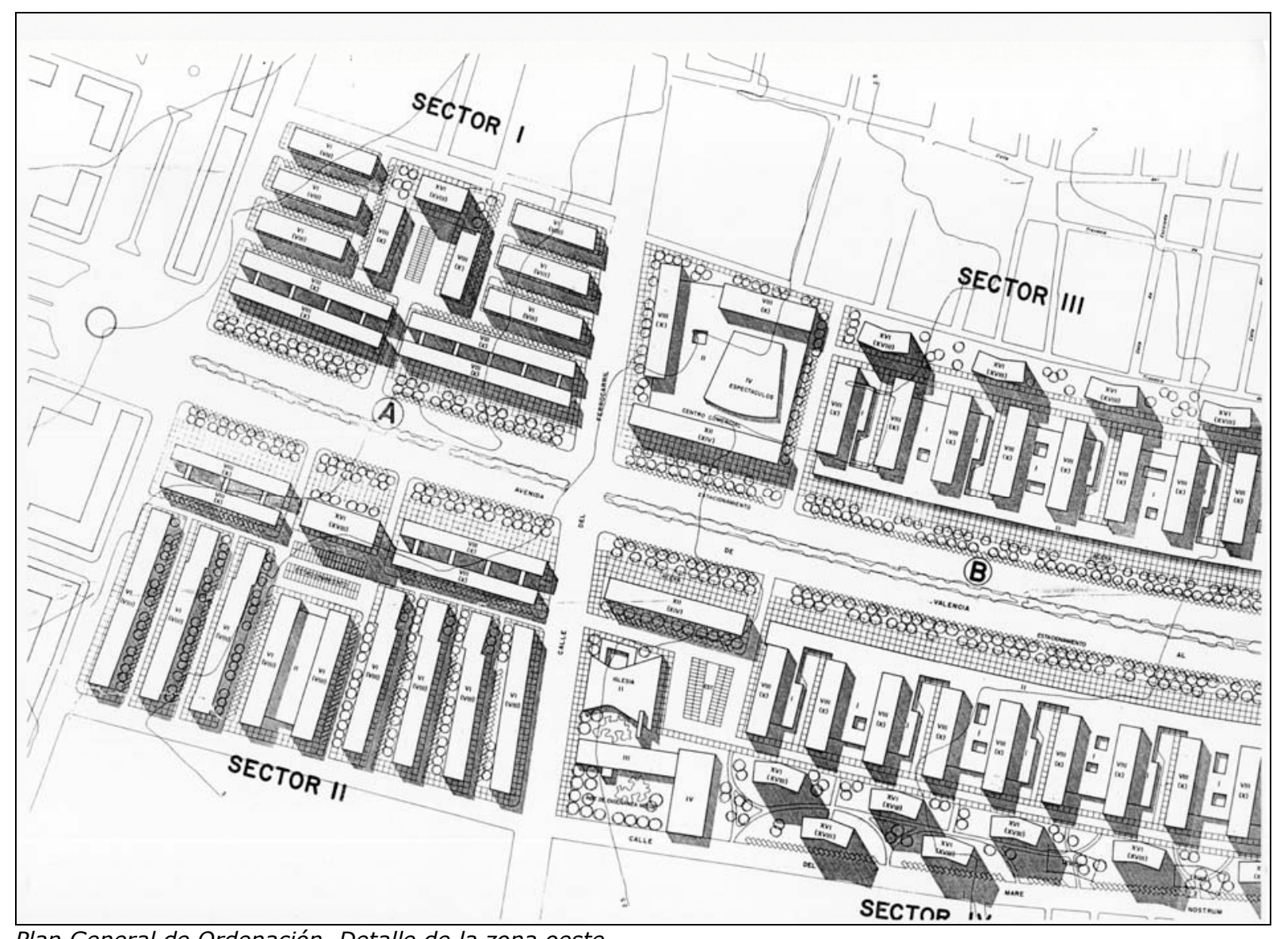

Plan General de Ordenación. Detalle de la zona oeste. 
13. CIRCULACIONES

Escala original 1:2000

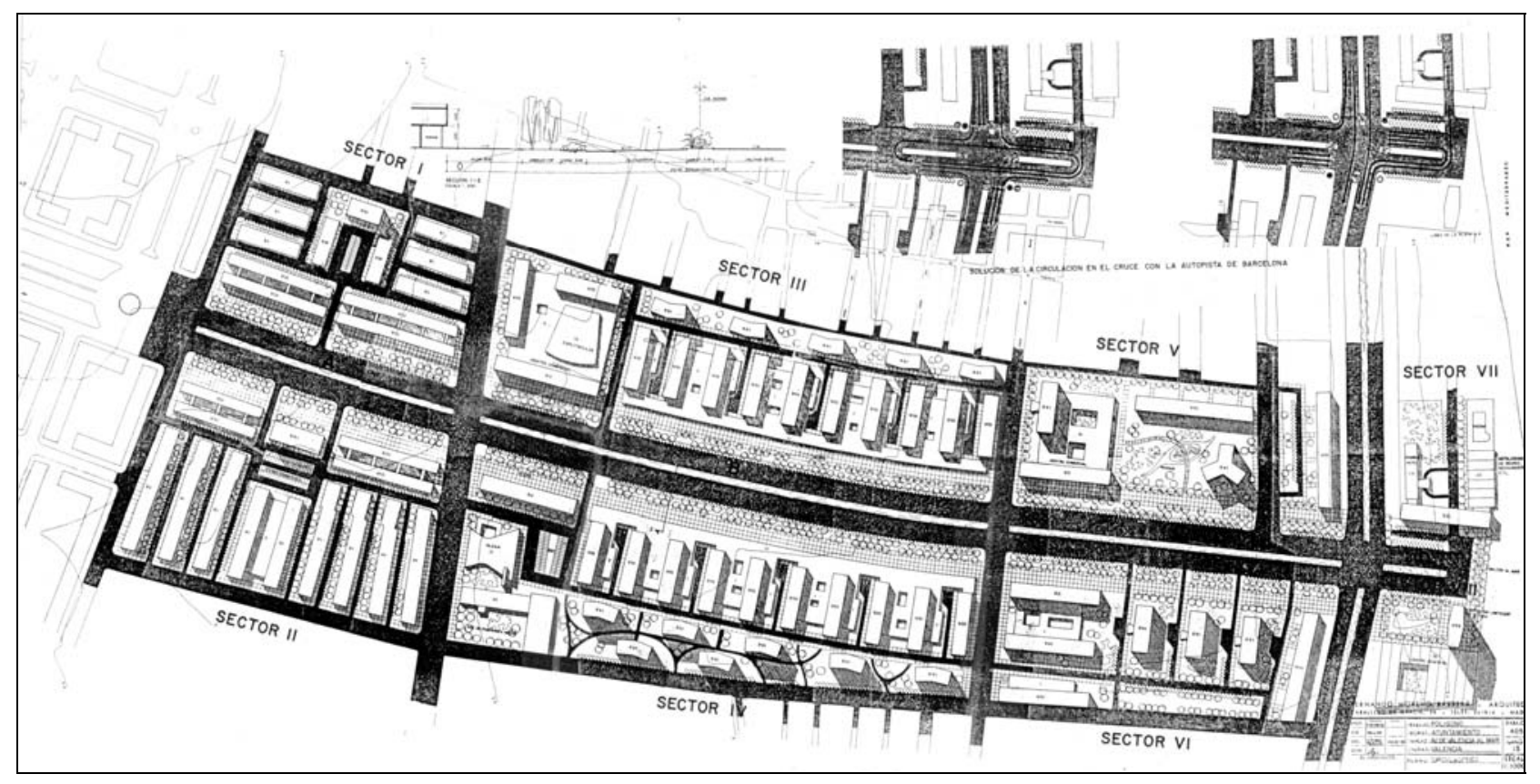

14. ALZADOS Y PLANTA PILOTO

Escala original 1:2000

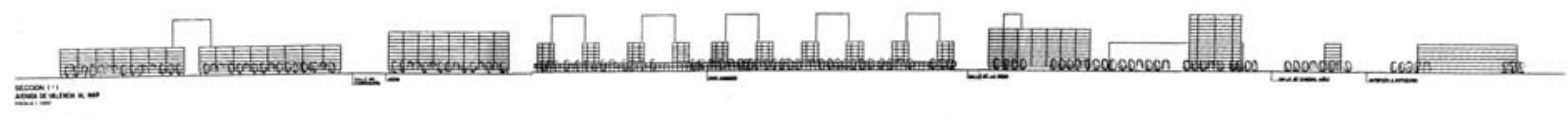

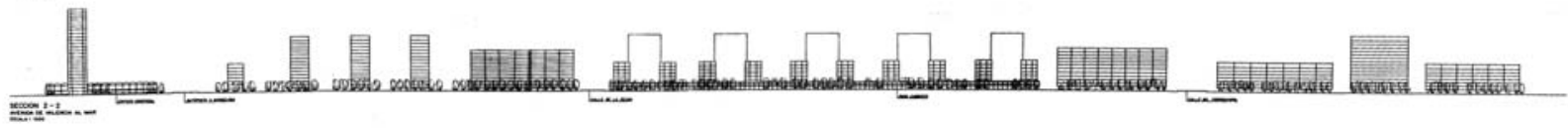
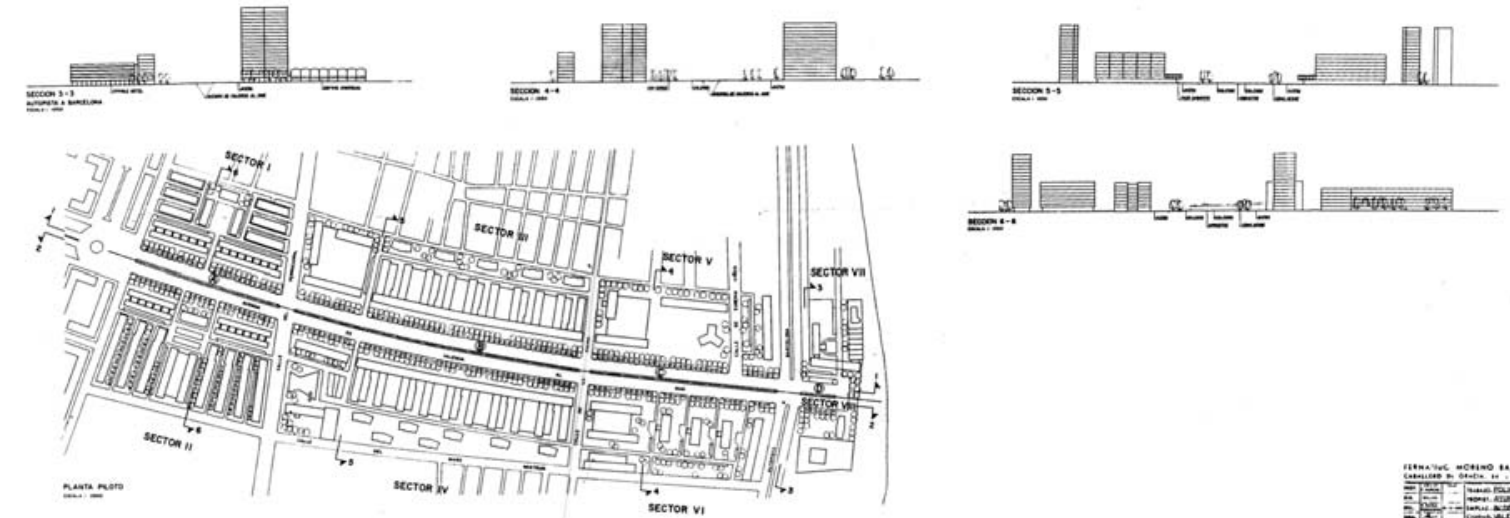
16. ORDENANZAS DE USO

Escala original 1:2000
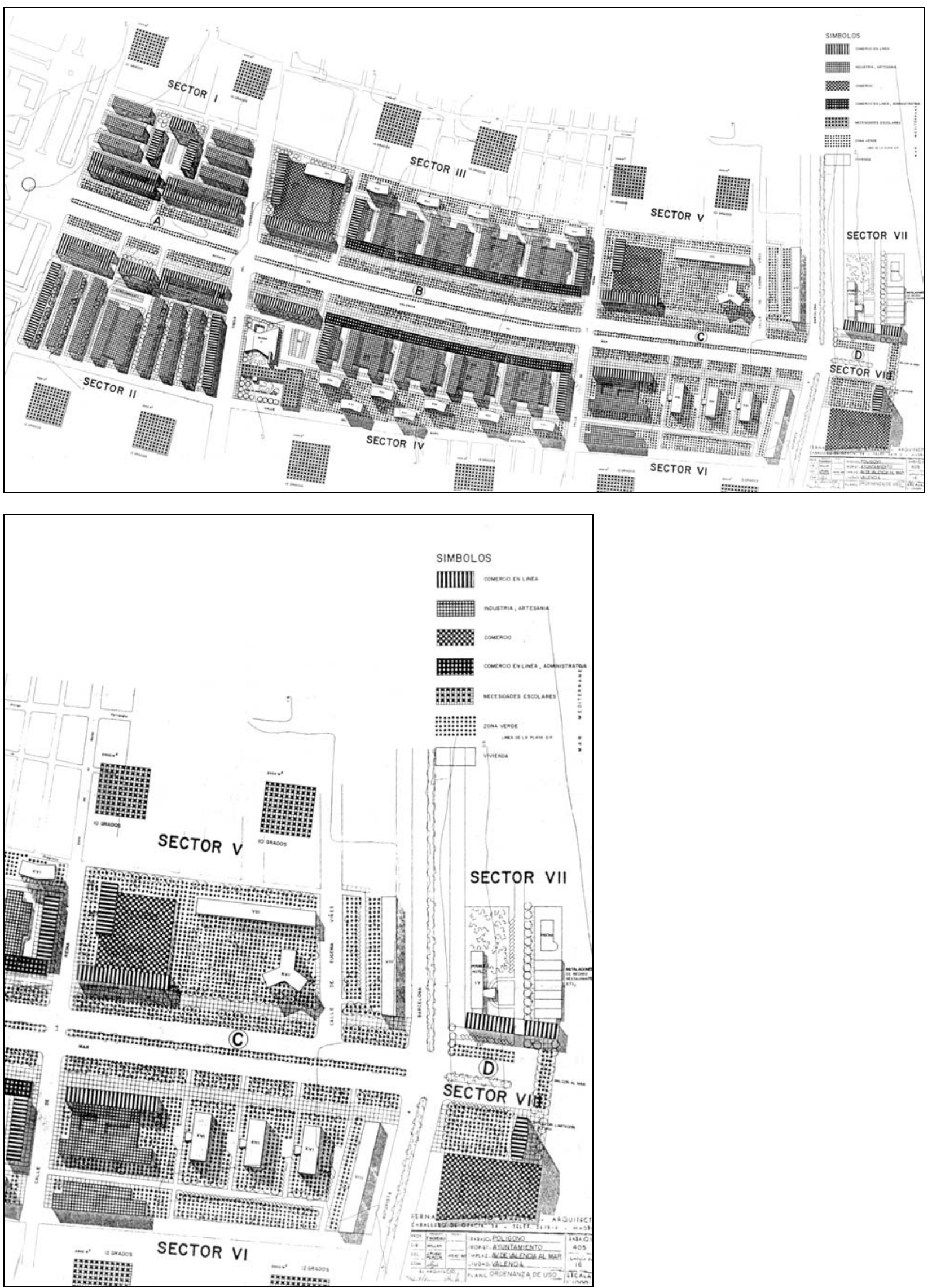

Detalle de la zona este. 



\section{Polígono de Campanar}

Redactores: Joaquín García Sanz, Vicente Valls Abad, Manuel Blanc Díaz, Camilo Grau García.

Fecha redacción: 1960-61 (*).

Fecha aprobación: 1962

Contenido:

I. MEMORIA DESCRIPTIVA.

II. ORDENANZAS DE USO, VOLUMEN Y COMPOSICIÓN.

III. PLAN DE ETAPAS.

IV. SISTEMAS DE ACTUACIÓN.

V. VALORACIÓN DE PARCELAS Y ESTUDIO ECONÓMICO

VI. PLANOS:

1. SITUACIÓN

2. PLANO GENERAL DE EDIFICACIONES SOBRE PARCELAS EXISTENTES

3. ORDENACIÓN GENERAL SUBPOLÍGONO A $1: 1000$

4. ORDENACIÓN GENERAL SUBPOLÍGONO B $1: 1000$

5. ORDENACIÓN GENERAL SUBPOLÍGONO C $1: 1000$

6. ORDENACIÓN GENERAL SUBPOLÍGONO D $1: 1000$

7. ESTRUCTURA, ZONIFICACIÓN

Y CIRCULACIONES $1: 2000$

8.1. SOLUCIÓN $1 \quad 1: 2000$

8.2. SOLUCIÓN $2 \quad 1: 2000$

8.3. SOLUCIÓN $3 \quad 1: 2000$

9. EJEMPLO DE REPARCELACIÓN

10. UNIDADES VECINALES

Y SISTEMAS DE ACTUACIÓN $1: 2000$

11. PERFILES DE CALLES $1: 100$

12. ESQUEMA DE LA RED DE AGUA POTABLE $1: 2000$

13. ESQUEMA GENERAL DE ENERGÍA ELÉCTRICA $1: 2000$

14. ESQUEMA GENERAL DE SANEAMIENTO $1: 2000$

\section{Fuente:}

Ayuntamiento de Valencia. Archivo de Planeamiento (Sección de expedientes antiguos).

Nota:

(*)El avance es de 1960 y el plan definitivo de 1961. 



\section{Memoria Descriptiva}

\section{I. - ANTECEDENTES.}

Los Arquitectos que suscriben, encargados por el Excmo. Auntamiento de Valencia, para el estudio del planeamiento general del Polígono de Campanar, como resultado del concurso convocado al efecto por la Corporación Municipal, presentó a la misma durante el mes de marzo del corriente año, toda la documentación relativa a la fase de información del citado polígono, acompañando al propio tiempo un avance del planeamiento para que pudieran emitir su informe la Corporación Municipal y la Dirección General de Urbanismo, dando base con ello al estudio del proyecto definitivo del planeamiento general, lo cual constituye el objeto del presente trabajo.

Los informes antes citados son los siguientes:

a) Informe del Excmo. Ayuntamiento:

"Esta Comisión ha procedido a examinar detenidamente el planeamiento parcial del Polígono de Campanar, que según el oportuno acuerdo han desarrollado los equipos de arquitectos encabezados por D. Vicente Valls Abad y D. Camilo Grau García, encontrándolo acertado en sus líneas generales, y estimando que en la segunda fase de su estudio deben ser tenidas en cuenta las siguientes observaciones:

1. ${ }^{a}$ - Restablecer la vía orientada de NO a SE que figura en el Plan general, entre la Prolongación de la Gran Vía de Fernando el católico y del padre Ferris y que no descompone la ordenación propuesta; teniendo además la ventaja de que bajo ella puede situarse el adecuado desagüe para el Barranco de Paterna, que debe ser tenido en cuenta en el planeamiento definitivo, en evitación de posibles inundaciones del sector.

$2^{a}$.- Aconsejar la supresión de uno de los dos centros comerciales secundarios que se sitúan en el sector E. del Polígono.

$3^{a}$.- Situar en el Subpolígono D., una vía transversal secundaria, que delimite el Gran centro Comercial y separe este de la zona de viviendas, facilitando al mismo tiempo el acceso a unas y otras.

4a.- Afinar el estudio de la colocación de los bloques situados en el antedicho subpolígono D., que resulta demasiado monótono; así como los que delimitan el actual poblado de Campanar, que deben disponerse de modo que éste quede delimitado con toda claridad.

5a.- Por lo que respecta a la anchura del nuevo acceso de Ademuz, se sugirió por el Sr. Pascual la conveniencia de ampliarlo hasta sesenta y cinco metros; manifestando el Sr. Sancho Tollo haber cambiado impresiones sobre este extremo con el Ingeniero de la Jefatura de Obras Públicas Sr. Oñate y haber estado de acuerdo en que no es aconsejable esta ampliación por responder el ancho de cincuenta y dos metros previsto en el planeamiento, a precedentes, acuerdos firmes adoptados por el Ayuntamiento, Corporación Gran Valencia y Jefatura de Obras Públicas y Comisión Técnica Especial que realiza el estudio del nuevo plan de ordenación, adaptado a le Solución Sur, de desviación del Río; porque la disposición de los bloques perpendiculares al eje del acceso permite disponer los aparcamientos fuera del ancho total previsto cuando esto sea necesario; porque caso 
de haber licencias concedidas se habrán ajustado a dicha anchura en cumplimiento de los acuerdos firmes adoptados; y porque en definitiva dicha anchura se considera más que suficiente, según lo demuestran las secciones transversales oportunamente estudiadas, no siendo aconsejable ampliarlas, por implicar un importante aumento de coste de la urbanización de las calzadas laterales, así como disminución del aprovechamiento del terreno y coeficiente de edificabilidad.

Esta Comision acordó igualmente expresar su satisfacción por el meritorio trabajo desarrollado y que se notifique con urgencia a los autores del estudio, los observaciones anteriormente expuestas, con el fin de que pueden proceder cuanto antes a desarrollar la fase final del trabajo, que permita realizar la información publica del planeamiento a la brevedad posible."

b) Informe de la Dirección General de Urbanismo:

"POLIGONO DE CAMPANAR.- Arquitectos Sres. García Sanz, Valls Abad, Blanc Díaz y Grau García.- En este Polígono se presenta un estudio completo y detallado. Se suprime el último tramo del Camino de Tránsitos, previsto en el Plan General, y efectúa la ordenación en grandes supermanzanas con un conjunto de indudable mérito.- Habida cuenta de la reforma que supone la supresión del Camino de Tránsitos, sería aconsejable verificar una nueva propuesta a base de conservar su trazado, planteando el Centro Comercial el otro lado de la prolongación de Fernando el Católico, en contacto con la zona verde prevista.- Es aconsejable reducir el número de calles en fondo de saco y revisar la afección de varios edificios ya existentes, así como aumentar las zonas de industria en las proximidades del poblado de Campanar. Debe garantizarse el desagüe del barranco de Paterna, aprovechando la zona contigua a una vía de peatones ya prevista.

CONCLUSIÓN.- En conjunto, del examen de los Avances de Planeamiento se desprende que el enfoque técnico de los problemas urbanísticos esta bien planteado y supone una base suficiente para el desarrollo total de los mismos.- El criterio seguido es unánime, en cuanto a los conceptos se refiere, tratando de conseguir barrios urbanizados en construcción abierta. Sin embargo es preciso pensar que este Camino es revolucionario en Valencia y provoca un excesivo contraste con las costumbres locales, derivadas en parte de la gran carestía del suelo.- Por este motivo creemos aconsejable, sin perder el concepto actual, introducir en lugares justificados algunas manzanas más densasy con bloques de seis crujías que puedan organizarse con patios interiores cubiertos, pues de esta forma podría aumentarse la cubicación en $\mathrm{m} 3$ por $\mathrm{m} 2$ y mantener densidad inferior en el resto del polígono.- No debe olvidarse tampoco la monotonía que puede derivarse de prodigar y repetir los bloques lineales, aunque lleven diferentes alturas, por lo que es importante establecer ambientes y provocar contrastes para acentuar la variedad en conjunto y detalle. El establecimiento previo de porcentajes de vivienda de lujo, media y modesta sería conveniente en cada polígono.- Es preciso señalar con carácter fundamental la importancia que debe tener el planteamiento económico financiero que garantice la posibilidad de su ejecución. A estos efectos se estima que es preciso una orientación clara por parte del Ayuntamiento de Valencia sobre el sistema de ejecución que va a apli 
carse en cada uno de los polígonos.- Ello ha de influir en la estimación de los medios económico-finacieros disponibles y que deban quedar afectos a la ejecución de los Planes, pues estos medios dependen de la forma de ejecutar las urbanizaciones.- En principio, y salvo que el Ayuntamiento tenga capacidad suficiente para aplicar con carácter general el sistema de expropiación, parece conveniente que en buena parte de los polígonos se vaya a los sistemas de cooperación, compensación o cesión de viales. Ello obliga a plantear con carácter inmediato y previo la declaración del sistema aplicable a los proyectos de reparcelación, al objeto de coordinar eficientemente la iniciativa privada.- Se estima por tanto que es urgente la determinación del sistema de actuación conveniente para cada polígono, al objeto de que se tenga en cuenta en la determinación de los estudios de planeamiento y en la estimación de los medios económico-financieros disponibles.- Debe señalarse asimismo que en el desarrollo definitivo de los planes parciales deberá tenerse en cuenta lo prescrito en el Articulo 10 de la vigente Ley de 12 de Mayo de 1956, sobre Régimen del Suelo y Ordenación Urbana."

\section{II.- PROGRAMA DE NECESIDADES}

a) DESCRIPCION GENERAL

El Plan General de Ordenación Urbana de Valencia adaptado a la Solución Sur, preveía como situación forzada la de un Gran Centro Comercial, denominado de Valencia-Norte, frente al río y al Oeste del acceso Valencia-Ademuz, como elemento necesario para la descongestión de la zona comercial del centro de Valencia, que al propio tiempo diera adecuado servicio al gran contingente de habitantes de los pueblos del cinturón Norte-Oeste de Valencia, cuya entrada a la capital debe verificarse por el nuevo acceso de Valencia a Ademuz, vía de tráfico rápido que divide al polígono en sentido $\mathrm{N}-\mathrm{S}$.

Asimismo, además del sistema general de viales, establecido en el Plan, fijaba que debían respetarse el Preventorio de San Francisco Javier y el actual poblado de Campanar. El resto quedaba a resolver con absoluta libertad por parte de los técnicos encargados del planeamiento del polígono.

Sentada esta premisa, se estima que el polígono a estudiar debe prever el siguiente programa:

\section{$1^{\circ}$. Zonas residenciales}

Formadas por viviendas, como elemento fundamental de composición y volumen, divididas en diversas categorías: buena, media y modesta, las cuales forman por agrupación los barrios o unidades vecinales, que dotados de una serie de servicios complementarios, deben funcionar con absoluta autonomía dentro de su área.

Estos servicios complementarios son de dos tipos: la unidad escuela Centro Parroquial por una parte y los pequeños centros cívicos secundarios en los que se agrupan los servicios siguientes:

a) Edificios para oficinas privadas, instalaciones bancarias, etc.

b) Centros secundarios de cultura, encaminados al desarrollo da estas actividades, tales como centro de formación de Juventud y salas de reunión para conferencias, exposiciones, etc.

c) Edificios administrativos que alberguen las tenencias de alcaldía, comisaría de policía y servicios judiciales, estafetas de correos, teléfonos y telégrafos. 
d) Centros comerciales secundarios, con tiendas, supermercados de abastecimiento, bares y restaurantes.

e) Edificios de diversión, tales como salas de espectáculos.

f) Pequeños centros sanitarios para casas de socorro y ambulatorios.

Las escuelas deben fijarse en número suficiente para la población escolar, previéndose la educación de ambos sexos, maternales y guarderías infantiles. Generalmente van ubicadas junto a los Centros Parroquiales, en los cuales además del templo propiamente dicho, deben preverse locales anejos para oficinas parroquiales, viviendas de párroco, centros de formación, Cáritas y sala de actos.

Finalmente debe completarse el programa de las unidades vecinales con edificaciones de una sola planta destinadas a garages y talleres artesanos y de reparación de vehículos.

\section{$2^{\circ}$ Espacios libres}

Deben estudiarse amplios espacios verdes y parques, que permitan el paso de peatones sin interferencias con vías de tráfico rodado y sirvan al propio tiempo de zona de esparcimiento de las distintas unidades vecinales. Es interesante el logro de soluciones que permitan establecer una clara comunicación de estas zonas entre los distintos barrios y supermanzanas.

\section{$3^{\circ}$ Aparcamientos y accesos secundarios}

Es fundamental el que se estudien accesos para las distintas agrupaciones de viviendas y talleres, generalmente en fondo de saco, permitiendo al propio tiempo el aparcamiento de vehículos, sin interferir los espacios libres.

Los aparcamientos deben preverse en número suficiente al número de vehículos y estudiándose a lo largo de las vías principales y colocando también zonas de mayor importancia junto a los centros cívicos de las unidades vecinales.

\section{$4^{\circ} \underline{\text { Zona deportiva }}$}

Estará formada por un gran campo de fútbol apto para la práctica de otros deportes; como elemento fundamental. También deben establecerse pistas de tenis, baloncesto y balonmano, hockey y piscina, con unos edificios destinados a vestuarios, completando el programa amplios aparcamientos de vehículos para los grandes actos deportivos.

\section{$5^{\circ}$ Enseñanza Media}

Un centro de Enseñanza Media para 1.400 alumnos, completado con un centro de menor importancia, dedicado a la formación profesional. Deberán preverse además campos de deportes anejos.

\section{$6^{\circ}$ Zona sanitaria}

La magnitud del polígono requiere una zona destinada a albergar con amplitud los servicios sanitarios, tales como: policlínico, maternidad, hospitalización, centro de reconocimiento sistemático y sanatorio quirúrgico y psiquiátrico.

Debe procurarse su emplazamiento en zonas tranquilas y rodeadas de espacios libres.

\section{Zona industrial}

Es indudable que en un gran conjunto urbanístico como el 
que nos ocupa, debe preverse el establecimiento de una zona destinada a industrias ligeras, que permitan absorber un gran contingente de mano de obra del polígono, sin que los obreros tengan que desplazarse a otros núcleos de población, agravando con ello el problema de transportes y pérdida de tiempo consiguiente.

Es interesante su ubicación en zonas separadas de las zonas residenciales por espacios verdes y muy en contacto con el extrarradio de la Ciudad.

A continuación incluimos un estudio numérico y en él queda justificado el programa de necesidades expuesto.

\section{b) ESTUDIO NUMERICO}

\section{1) Equipo Escolar}

Para el estudio de las escuelas necesarias, se parte de la base de considerar que la población escolar entre 3 y 10 años es el $15 \%$ de los habitantes.

No total habitantes polígono .... 48.685

Población escolar polígono $15 \%$ s/48.685 = 7.303 niños, que a razón de 40 niños por grado arrojan un total de 182 grados.

La superficie por grado la fijamos en $40 \mathrm{~m} 2$, a los cuales hay que añadir la superficie ocupada por pasos, servicios, salón de actos, biblioteca, oficinas, etc., que ascenderá a un mínimo de $70 \mathrm{~m} 2$ por grado, con lo cual la superficie total por grado es de $130 \mathrm{~m} 2$.

La superficie total necesaria para escuelas será:

182 grados $\times 130 \mathrm{~m} 2=23.660 \mathrm{~m} 2$, cifra ligeramente superior a los $23.445 \mathrm{~m} 2$ previstos en el proyecto; desglosando esta superficie en 10 grupos escolares a razón de 700 niños de media en cada uno de ellos.

Las normas francesas estiman que para un gran conjunto de 10.000 viviendas debe preverse un Instituto de Enseñanza Media para 1.400 alumnos. La superficie de esta edificación a razón de $3,20 \mathrm{~m} 2$ por alumno, ascenderá a $4.480 \mathrm{~m} 2$. En el proyecto se prevé un centro de $2^{a}$ Enseñanza con superficie de $6.558 \mathrm{~m} 2$, pensando en completar el programa con un centro de formación profesional anejo al Instituto.

\section{2) Centros Parroquiales}

La parroquia media estimamos debe oscilar entre los 6.000 y 10.000 feligreses, en función de la superficie asignada a cada uno de ellas, que varia en cada caso. El termino medio adoptado es el de 8.000 feligreses por parroquia, que en número de 6 , previstas en el proyecto cubren las necesidades de los 48.665 habitantes del polígono.

La superficie prevista en el proyecto es de $14.747 \mathrm{~m} 2$, contando no solo con el templo, sino con los servicios completos que debe reunir todo centro parroquial. Ello da una media de 2.500 $\mathrm{m} 2$ de superficie para cada parroquia.

\section{3) Centros comerciales secundarios}

Las normas francesas aconsejan que la superficie de los centros comerciales secundarios debe ser de $2 \mathrm{~m} 2$ por vivienda. En virtud de ello, la superficie necesaria en el polígono sería:

9737 viviendas $\times 2 \mathrm{~m} 2=19.474 \mathrm{~m} 2$

La superficie prevista en este plan y ocupada por los 3 centros comerciales de barrio y pequeñas tiendas dispersas asciende 


\section{a $14.860 \mathrm{~m} 2$.}

Habida cuenta de la proximidad de algunas zonas al gran centro comercial de Valencia-Norte, que se incluye en el presente polígono, consideramos que la diferencia resultante de superficies puede ser absorbida en el mismo. También hemos de considerar que en la edificación que existe y que se conserva, las plantas bajas están destinadas a estos fines.

\section{4) Centros.culturales y de diversión secundarios}

Quedan comprendidos en este apartado los servicios siguientes: centros de acción social, hogares para jóvenes, pequeñas bibliotecas y salas de espectáculos; todos ellos situados en los centros cívicos de cada uno de los barrios.

La media de las normas generales para un gran conjunto de 10.000 viviendas, aconseja la superficie de $0,8 \mathrm{~m} 2$ por vivienda, que en este caso da la superficie siguiente:

9737 viviendas $\times 0,8 \mathrm{~m} 2=7.769 \mathrm{~m} 2$

Se han previsto $5,822 \mathrm{~m} 2$, considerando que la diferencia de superficies debe quedar absorbida en el centro cultural del gran centro comercial de Valencia-Norte.

\section{5) Administración y oficinas}

Tienen este carácter las tenencias de alcaldía de cada barrio, comisarias de policía, teléfono, telégrafos y estafetas de correos. Además se preven algunos edificios para alojar oficinas de carácter privado, situando todos los servicios reseñados en los centros cívicos de barrio.

La superficie ideal que figura en las normas generales para un gran conjunto de 10.000 viviendas, es la de $6.000 \mathrm{~m} 2$. En nuestro caso la superficie fijada es de 7,480 m2.

\section{6) Talleres y garages}

Los estudios hechos para Valencia capital, con previsión para un futuro práximo, ascienden a 1 coche para cada 3 viviendas.

En nuestro caso el numero de coches sería:

$$
9737 \text { viviendas } / 3=3.245 \text { coches }
$$

Consideremos que se albergan en garages los $2 / 3$ de la totalidad, lo cual nos da una cifra de 2.163 coches. El número de motocicletas, lo fijamos en un $50 \%$, que en este caso será de 1.081.-

La superficie necesaria de garages, tomando las normas alemanas es la siguiente:

2,163 coches $\times 10 \mathrm{~m} 2=21.630 \mathrm{~m} 2$

1.081 motos $\times 2 \mathrm{~m} 2=2.163 \mathrm{~m} 2$

Superficie total garages ..23.793 m2

La superficie prevista para estos servicios en el polígono es de $33.150 \mathrm{~m} 2$. La diferencia de $9.357 \mathrm{~m} 2$, se destina a talleres en sus modalidades: pequeñas industrias artesanas y reparación de vehículos.

\section{7) Zona deportiva}

Las normas francesas aconsejan que para un gran conjunto de 10.000 viviendas, la superficie ocupada por el equipo deportivo debe ser de 6,5 Ha., incluyendo, aparcamientos, edificaciones y campos de juego.

En el presente estudio, se prevé una superficie de 2,25 Ha., lo que resulta a todas luces insuficiente. No obstante, el valor del suelo y la necesidad de lograr un máximo aprovechamiento para 
la edificación, obliga a reducir considerablemente la cifra fijada como superficie ideal.

\section{8) Equipo sanitario}

Para un gran conjunto de 10.000 viviendas, son aconsejables una serie de edificios sanitarios, cuya superficie según las antedichas normas francesas asciende a $9.400 \mathrm{~m} 2$.

Se prevé en el estudio que nos ocupa una superficie construida de $8.715 \mathrm{~m} 2$, repartidos entre un gran centro sanitario de $7.387 \mathrm{~m} 2$ y otros secundarios de barriada, de mucha menor importancia, cuya superficie asciende a $1.328 \mathrm{~m} 2$

9) Equilibrio empleo-población

La población activa, como resumen de estadísticas consultadas, se cifra en el $40 \%$ de la población total.

Población activa $=40 \%$ s/ 48.685 hab. $=19.474$ hab.

De ellos, una parte quedará absorbido por los empleos residenciales (servicios del polígono) y el resto se absorberá en ia zona Industrial y Gran Centro Comercial de Valencia-Norte, considerados como extraresidenciales en este caso.

\section{$1^{\circ}$ Empleos residenciales}

Equipo escolar 500

Equipo parroquial $\quad 90$

Servicios comerciales $\quad 750$

Centros culturales y diversión $\quad 200$

Administración y oficinas $\quad 700$

Talleres y garages $\quad 300$

Equipo sanitario 200

Transportes $\quad \underline{800}$

TOTAL....... 3.540 empleados

Quedan para los empleos extraresidenciales:

$19.474-3.540=15.934$ habitantes

$2^{\circ}$ Zona Industrial

En industrias ligeras, se cifra la mano de obra necesaria a razón de 500 obreros $\mathrm{Ha}$. En este caso sería:

$8,64 \mathrm{Ha}$. zona Industrial $\times 500 \mathrm{hab} .=4.320$ obreros

\section{$3^{\circ}$ Centro comercial. Valencia-Norte}

\begin{tabular}{lr}
\hline Comercios & 2.000 \\
Espectáculos y diversión & 250 \\
Locales culturales & 300 \\
Oficinas públicas y privadas & 3.360 \\
Hotel y apartamentos & 300 \\
Administración, teléfonos, correos, etc & $\underline{600}$ \\
\multicolumn{1}{c}{ TOTAL ....... } & 6,810
\end{tabular}

El total de empleados en el presente plan, asciende a 14.670. Existe pues una diferencia entre la población activa calculada y el número de empleados previstos que es de 5.204 cantidad que puede ser absorbida por la proximidad del centro de la población. La población activa absorbida en el polígono representa el 75,3\%.

10. Aparcamientos

Para su cálculo hemos partido de la misma base que nos ha servido para el calculo de garages, es decir, 3 coches por vivienda. Al excluir en el presente apartado, el aparcamiento del Gran Centro Comercial de Valencia-Norte, es evidente que en los sub 
polígonos del proyecto, el volumen predominante es el de las viviendas, respecto del resto de edificios que componen los centros cívicos, parroquiales y escolares de las distintas unidades de manzana, y por tanto, después de unos estudios realizados, el numero de coches para estos ultimos es insignificante comparados con el que corresponde a las viviendas.

Considerados como horas punta, las horas del mediodía, que coinciden con la comida, cifrando el numero de coches a aparcar en el $80 \%$ del número total de los mismos. Como se puede comprobar en el cuadro que a continuación se expone, el numero de aparcamientos previsto es mayor, considerando que lógicamente deben aparcarse motos y que en el futuro debe aumentar el número de vehículos.

\begin{tabular}{ccccc} 
& $\ldots . .$. &. &. & Aparcamiento \\
Subpoligono No de viviendas & $N^{\circ}$ coches & $80 \%$ coches & $\begin{array}{c}\text { Aparcamiento } \\
\text { prev.y coche }\end{array}$ \\
\hline A & 3.868 & 1.289 & 1.031 & 1.3000 \\
B & 3.319 & 1.106 & 886 & 1.050 \\
C & 1.386 & 462 & 369 & 500 \\
D & 1.004 & 334 & 267 & 320
\end{tabular}

Como dato complementarlo, en el subpolígono $\mathrm{C}$, se preven para la zona deportiva dos aparcamientos, capaces para un total de 500 coches, considerando que el aforo del campo de deportes es de 10.000 espectadores y que existe un coche por cada 20 de ellos.

\section{Espacios libres}

Están formados en este caso por los pasos de peatones y zonas de esparcimiento de los distintos subpolígonos, además del parque situado en el subpolígono A y excluyendo la zona deportiva.

La superficie ocupada por los mismos es la siguiente:

\begin{tabular}{lr} 
Subpolígono & Superficie Ha \\
\hline A & 5,84 \\
B & 3,40 \\
C & 2,67 \\
D & 2,95
\end{tabular}

Suma 14,86 Ha., lo cual representa respecto de la superficie total del polígono el $14,60 \%$, cifra bastante superior al mínimo del $10 \%$ que fija la Ley del Suelo.

\section{Espacios viales}

Se tienen en cuenta para su determinación, las calzadas, aparcamientos y aceras.

Red viaria fundamental........... 21,98 Ha.- 21,70 \%

Fondos de saco y aparcamientos... $7,20 \mathrm{Ha}$.

$$
\text { TOTAL..............29, } 18 \mathrm{Ha} \text {. }
$$

Esta cifra representa el $28,50 \%$ de la superficie total del polígono, pero contando sólo con la red viaria fundamental, que es la única que debe de presupuestarse en la urbanización, representa tan sólo el $21,7 \%$ de la superficie del polígono. 


\section{SOLUCION PROYECTADA}

\section{A) ESTRUCTURACION URBANISTICA}

1) Red viaria.- Siguiendo el trazado da la red viaria previsto en el Plan General de Ordenación Urbana de Valencia, acoplada a la Solución Sur, hemos dividido el polígono en una serie de supermanzanas, limitadas por lo red viaria fundamental, lo cual queda reflejado en el esquema que acompaña a la presente memoria.

De N. a S. y paralelamente al río Turia, la red viaria es la siguiente: nuevo camino de Tránsitos, prolongación de la calle de Joaquín Ballester (como vía de comunicación transversal rápida entre los distintos polígonos) y una nueva avenida junto al río Turia como elemento límite del polígono.

De E. a O. se respeta la Avenida de Burjasot y se prolonga la actual calle del Padre Ferris, quedando después el nuevo acceso de Valencia a Ademuz como vía principal de trafico muy rápido y una vía limite del polígono en su lado 0.

Por ultimo el Camino de Tránsitos atraviesa diagonalmente el polígono en dirección $\mathrm{N}-\mathrm{E}, \mathrm{S}-\mathrm{O}$.

Estas vías son todas ellas de trafico rápido y han sufrido en el presente estudio las modificaciones que a continuación se expresan.

Queda relegada a vía de segundo orden la Actual Avenida de Burjasot, pasando a ser vía de primer orden la actual calle del Padre Ferris, que e través de un nuevo puente sobre el rio unirá el polígono en su parte Este con la desembocadura de la Avenida del Oeste y Guillem de Castro. Su ancho pasa a ser de $25 \mathrm{~m}$.

Se interrumpe el actual Camino de Tránsitos en el tramo comprendido desde su confluencia con el acceso de Valencia a Ademuz hasta la orilla del Río Turia, en atención a dos razones fundamentales: $1^{\circ}$ ) al aparecer el nuevo acceso de Valencia a Ademuz todo el tránsito queda incorporado a esta nueva vía, que a su vez permite su comunicación con el resto de las calles transversales del polígono, perdiendo por tanto su razón de ser como tal vía principal de circulación.

$\left.2^{\circ}\right)$ Su conservación partiría en dos triángulos el espacio destinado a Centro Comercial, con el consiguiente trastorno para lograr una buena estructuración y aprovechamiento del terreno en esta zona de ordenación especial, que por su carácter específico necesita buenos accesos, pero ninguna penetración viaria de tránsito rodado.

En los planos adjuntos, se acompañan unos esquemas con las seccionas estudiadas para el sistema viario del polígono.

\section{2) Supermanzanas y unidades vecinales}

Con esta red viaria se forman grandes supermanzanas y otras de dimensiones inferiores, situadas en el lado E. del polígono, que por sus características peculiares constituyen un elemento de transición entre la zona edificada con carácter masivo y la zona de nueva ordenación en edificación abierta que se proyecta en el resto del polígono.

Dentro de cada una de estas supermanzanas, se crean las unidades vecinales (dos por cada supermanzana, por regla general) cuyas viviendas se agrupan alrededor de los pequeños centros comerciales y del Centro cultural y religioso integrado por la escuelas y parroquia respectivamente.

Hemos procurado que la circulación de peatones y la comuni 
cación entre los centros de unidades vecinales, se realice a través de amplios espacios verdes, que, dispuestos en sentido perpendicular, atraviesan las supermanzanas creando espacios de expansión sin más interferencias que los cruces del sistema principal de viales a que antes aludimos, proyectándose subterráneos los que atraviesa al nuevo acceso de Ademuz que por su naturaleza requiere esta solución.

a) Zona residencial

Podremos definir 3 modalidades diferentes:

1) Edificación masiva.-

Responda a la conveniencia de conservar una serie de edificios construidos recientemente, que por su volumen, estado de conservación y en atención a la función social que cumplen, merecen especial cuidado, aun cuando descomponen la ordenación general del polígono, cuyo carácter es totalmente abierto. El resto de edificaciones existentes por la anarquía de su ordenación, mala conservación y aspecto, estimamos deben quedar fuera de la ordenación estudiada en el presente proyecto.

La zona a conservar forma dos núcleos fundamentales: uno situado en la parte N.E. del polígono y otro en la parte S.E., coincidiendo con el comienzo de la Av. de Burjasot hasta la prolongación de la calle Joaquín Ballester.

El criterio seguido en la composición de estos núcleos, es el de completar los edificios ya construidos, cerrando las manzanas iniciadas con edificios de gran profundidad edificable (alrededor de 6 crujías), con objeto de evitar las vistas de medianerías y patios de manzana de los ya construidos.

2) Poblado de Campanar.-

Por su espacial configuración y extensión superficial queda respetado en su casi totalidad, estudiando el complemento de las manzanas ya edificadas y sin terminar, para regularizar su perímetro y colocando a su alrededor una vía de tráfico que permita el fácil acceso a sus calle interiores desde las vías principales del polígono. Este aislamiento vial se completa con el establecimiento de una zona verde perimetral que, a la vez que sirve de zona de esparcimiento, aísle el aspecto poco afortunado que, en general, ofrecen las fachadas de los edificios del poblado.

3) Edificación abierta.-

La ordenación de las supermanzanas y unidades vecinales en general es bastante rígida, como consecuencia de la fijación de unos módulos, los cuales sirven de base a la ordenación general de volúmenes de la zona residencial. En particular desaparecen estos módulos en algunas zonas en atención a las siguientes razones:

a) Imposibilidad de repetirlas motivadas por la forma irregular de algunas zonas (Avda. de Campanar y pequeñas manzanas junto a la Avenida de Burjasot) y

b) Conveniencia de destacar puntos singulares y evitar la monotonía de la composición general buscando el cambio de ambientes, especialmente en las calles de largo recorrido. Ello se produce fundamentalmente en los edificios recayentes al primer tramo del acceso de Ademuz y en los alrededores del parque, dando frente al rio $y$ en todo su perímetro.

Los módulos antes citados, ocupan una superficie que oscila entre 0,5 y $1 \mathrm{Ha}$., siendo su numero de habitantes de 500 
a 900. En ellos la orientación dominante de los bloques es la S.E., colocando los de mayor altura en la zona N. para evitar la falta de soleamiento de los bloques de menor altura, situados al S. de los mismos.

Se completa el programa de los módulos con edificaciones de 1 planta destinadas a garages, talleres y pequeñas industrias artesanas. El acceso a estas unidades se verifica por medio de calles en fondo de saco, que cumple la doble función de entrada a los bloques de viviendas y la de aparcamiento de vehículos.

\section{b) Centros cívicos, parroquiales y escolares}

Las unidades vecinales constan, además de la zona residencial propiamente dicha, de los centros cívicos secundarios, los cuales al igual que las escuelas y Centros Parroquiales, permiten la autonomía en la vida de estas unidades, tal y como ya describimos en el apartado "Programa de necesidades".

\section{3) Otros elementos}

a) Parque.- En la supermanzana señalada en los planos con la letra $\mathrm{A}$, existe una depresión del terreno de $4 \mathrm{Ha}$. de superficie y unos $5 \mathrm{~m}$. de profundidad, lo cual no permite la edificación, por ser imposible la evacuación de residuos, al estar la rasante a cota inferior a la prevista para el gran colector que discurre paralelamente al río y cuya construcción ya se inició. Por ello proponemos la colocación de un parque que sirva de esparcimiento y espacio libre para este polígono y especialmente para la superficie en que está enclavado.

b) Zona deportiva. - Instituto - Sanitario

El Excmo. Ayuntamiento es propietario de unos terrenos situados en el subpolígono $\mathrm{C}$, junto al poblado de Campanar, los cuales deben destinarse a campo de deportes. Basándonos en ello hemos proyectado una zona deportiva cuyo elemento fundamental es el campo de deportes antedicho, el cual queda rodeado de una serie de instalaciones deportivas complementarias que corresponden a las ya enunciadas en el programa de necesidades.

Por otra parte estas Instalaciones quedan situadas junto al nuevo Instituto de Enseñanza Media, con el fin de que puedan ser utilizadas también por los alumnos de este Centro docente.

Este Instituto responde al programa del Ministerio de Educación Nacional para crear nuevos Centros de Enseñanza Media, para lo cual hemos reservado unos terrenos de superficie aproximada a $1 \mathrm{Ha}$. y cuyo programa ya quedó descrito con anterioridad.

Queda por último el centro sanitario, cuya necesidad es evidente para el gran conjunto urbanístico que se proyecta y que situado en une zona tranquila, rodeada de espacios libres, alberga en su interior los servicios indicados en el programa de necesidades.

\section{c) Zona Industrial}

Para prever le absorción de la mano de obra y el traslado de industrias actualmente existentes en el polígono con carácter ligero, se crea en la parte $\mathrm{N}$. de los subpolígonos B y C una zona reservada para industria ligera, separada de las zonas residenciales por un espacio libre, y circundada por vías 
de trafico rodado de ancho capaz para dos circulaciones de camiones.

4) Gran Centro Comercial de Valencia-Norte

1) Programa de necesidades

a) Descripción general.-

Obedece a una ordenanza especial como necesidad de crear un Centro Comercial en la zona N.O. de la ciudad. Esta organizado a base de 4 núcleos fundamentales: zona administrativa, zona comercial de tiendas, zona de esparcimiento y espectáculos y núcleo cultural.

b) Estudio numérico del programa

El área de influencia para el gran centro comercial, de Valencia-Norte, se ha previsto en la Solución Sur, que sea toda la zona comarcal de los poblados de secano situados al norte de Valencia. Se prevé que para un futuro próximo el número de habitantes de todos estos poblados ascenderá a 600.000 , y si contamos además la influencia urbana, actual y futura, de la ciudad que se puede cifrar en 200.000 habitantes, obtendremos la influencia total

influencia comarcal .........600.000 habitantes

" urbana ..............200.000

" total.................800.000 habitantes

estas cifras reducidas a viviendas nos dan:

influencia comarcal ........ 120.000 viviendas

" urbana ......... 40.000 "

" total $\quad . . . . . . . .160 .000$ viviendas

Esta influencia podemos suponer que en las viviendas comarcales se reduce a un día por cada dos semanas, y consideramos que en las viviendas situadas en la ciudad sea la de un día semanalmente, y pensando en una distribución uniforme, deduciremos el número de viviendas que afluyen diariamente al centro comercial de Valencia-Norte.

Influencia diaria.-

comarcal $\underline{120.000 \text { viv. }}=10.000$ viviendas

12 días

urbana $\quad 40.000$ viv. $=6.660$ viviendas

6 días

total ....................... 16.660 viviendas

Con este cifra hipotética pero hallada razonablemente basaremos el estudio numérico del programa.

$1^{\circ}$ Centro Comercial.-

Las normas aconsejan para tanteo de la superficie de los comercios, el prever $2 \mathrm{~m} 2$ por vivienda, en nuestro caso será:

16.660 viviendas $\times 2 \mathrm{~m} 2=33.320 \mathrm{~m} 2$ de superficie

La superficie con destino a comercios y tiendas prevista en el proyecto del centro comercial de Valencia-Norte es de $32.718 \mathrm{~m} 2$.

$2^{\circ}$ Centro cultural.-

En este centro se incluye una gran sala para museo, salas secundarlas de exposiciones, biblioteca y oficinas generales, así como un auditorium de música.

Aplicando las normas generales que, para un conjunto de viviendas señala la superficie de $0,8 \mathrm{~m} 2$ por vivienda, obtenemos que

16.660 viviendas $\times 0,8 \mathrm{~m} 2=13.328 \mathrm{~m} 2$

La superficie para estas instalaciones, se ha previsto en 
nuestro proyecto en $15.260 \mathrm{~m} 2$, ligeramente superior a la calculada.

$3^{\circ}$ Espectáculos y locales diversión.-

En este apartado quedan incluidos: cines, teatros, salas de baile, restaurantes, etc.

En nuestro proyecto se ha previsto una gran sala para distintos espectáculos, 2 cines y anejos, con una superficie total construida de $11.460 \mathrm{~m} 2$.

Según las normas la capacidad media solo para locales de espectáculos estará fijada por el $10 \%$ del no de habitantes y con $1 \mathrm{~m} 2$ por espectador. En nuestro caso esto supondrá la cifra de $9.000 \mathrm{~m} 2$ de superficie edificada.

$4^{\circ}$ Administración, teléfonos, correos, etc.-

Se sitúan en este apartado, la representación municipal de la ciudad, comisarías de policía, centrales telefónica, telegráfica y de correos, oficinas de turismo, etc. Para estas instalaciones se destinan $10.120 \mathrm{~m} 2$ de superficie edificada.

$5^{\circ}$ Oficinas estatales, públicas y privadas.-

Quedan enclavadas en este apartado, todas las representaciones ministeriales, así como las representaciones de entidades bancarias, públicas y privadas. La superficie destinada para estos servicios asciende a $33.600 \mathrm{~m} 2$.

$6^{\circ}$ Hotel, apartamentos y anexos.-

Se han previsto $33.800 \mathrm{~m} 2$ de superficie para la instalación de un hotel de viajeros de 300 habitaciones y la posible instalación de unos apartamentos, que podrían convertirse en viviendas.

70 Aparcamientos.-

Para su estudio partimos de las siguientes cifras:

a) Viviendas -------- 1 coche cada 3 viviendas

b) Hotel -------- Para las primeras 20 habitaciones 1 coche cada 2 habitaciones; para las 40 siguientes 1 coche cada 8

c) comercios ------- 1 coche cada $80 \mathrm{~m} 2$

d) teatros -------- 1 coche cada 10 espectadores

e) Oficinas privadas 1 coche cada $24 \mathrm{~m} 2$ de oficina

f) Oficinas públicas 1 coche cada 30 funcionarios

Estas cifras base, aplicadas al programa del Centro Comercial, nos dan el numero total de coches a aparcar, el cual es el siguiente:

\begin{tabular}{|c|c|c|c|}
\hline Viviendas & -০-০-০-০-০-০- & 53 & coches \\
\hline Hotel & ------------- & 35 & \\
\hline Comercios & -------------- & 400 & " \\
\hline Teatros & ----০--০-০--- & 600 & " \\
\hline Oficinas pri & vadas ------ & 300 & $"$ \\
\hline & blicas ------ & 356 & " \\
\hline
\end{tabular}

Consideramos ahora las posibilidades de aparcamiento durante la mañana, noche y horas punta, en función de las actividades que se desarrollan en el centro comercial Mañana.-

Comercio $60 \%$-------- 240 coches

Oficinas públicas -------- 356 "

" privadas ------- 300 "

Hotel .-------------- 35 "

Viviendas $60 \%$---------- $\underline{31 " ~}$ 


\begin{tabular}{|c|c|c|}
\hline & Suma & 962 coches \\
\hline \multicolumn{3}{|l|}{ Noche } \\
\hline Teatros & ------------ & 600 coches \\
\hline Hotel & ------------ & $35 "$ \\
\hline Viviendas & 20\%-------- & $\underline{10 "}$ \\
\hline & Suma & 645 coches \\
\hline \multicolumn{3}{|c|}{ Hora punta. ( 7 tarde) } \\
\hline Teatros & ---------- & 600 coches \\
\hline Comercio & ----------- & $400 "$ \\
\hline Viviendas & 20\%---------- & $10 "$ \\
\hline Hotel $20 \%$ & ------------ & $7 "$ \\
\hline Oficinas $\mathrm{p}$ & ivadas $50 \%$ & $150 \quad "$ \\
\hline & cum? & 1.167 coches \\
\hline
\end{tabular}

La más desfavorable es la hora punta, con 1.167 coches, habiéndose previsto en el proyecto dos grandes aparcamientos y otros perimetrales cuya capacidad es de 1.150 coches.

2) Solución Proyectada.-

Dando frente al río y en sentido perpendicular al mismo se colocan 4 edificios de 20 plantas, cuyo destino previsto es el siguiente: hotel, aparcamientos, oficinas particulares y oficinas de carácter administrativo y oficial con dependencias anejas de 1 o 2 plantas y un amplio aparcamiento capaz para unos 500 vehículos.

En la zona primera de espectáculos, se sitúa alrededor de una plaza, un edificio administrativo (tenencia de alcaldía, telégrafos, correos, teléfonos, etc.) y dos salas de espectáculos con sus servicios comunes.

A continuación siguen dos calles de comercios a ambos lados, edificados a 2 alturas, con una zona posterior más amplia con posibilidad de instalar grandes almacenes y supermercados, a cuyas espaldas se sitúa otro gran aparcamiento capaz para 500 vehículos.

Como elemento final se forma otra plaza más tranquila en la que se prevé la construcción de edificios de carácter cultural, tales como auditorium, museos, bibliotecas, conferencias, etc.

\section{B ZONIFICACION}

Aparece claramente en el esquema que se adjunto a escala $1: 2000$. Se distinguen en él las siguientes zonas:

a) Zona de ensanches actuales en edificación masiva que se conserva, completándose algunos puntos con edificios de características similares a los ya existentes.

b) Resto de viviendas en edificación abierta, característica dominante en todo el polígono, acusando el esquema la categoría de las viviendas. Esta, como ya se hace constar en las Ordenanzas de uso y volumen, no dependerá solamente de la superficie de las mismas, sino de la categoría del acabado de la construcción e instalaciones y del módulo de superficie útil por habitante. En general, estimamos que dada la categoría del polígono, el reparto ideal de categorías debe ser la siguiente:

$$
\begin{array}{cc}
\text { vivienda } & \text { buena }----20 \% \\
\text { " } & \text { media }----45 \% \\
\text { " } & \text { modesta }---.35 \%
\end{array}
$$

c) Poblado de Campanar, cuyo trazado se respeta y se delimita, 
debe considerarse como núcleo actual, en el que los complementos de manzanas a construir deben tener dos plantas como máximo por las razones siguientes:

$\left.1^{\circ}\right)$ No descomponer el volumen actual del poblado

$\left.2^{\circ}\right)$ Dejar posibilidades de una remodelación, si las circunstancias así lo aconsejan, lo cual sería únicamente posible, limitando a rajatabla su altura dentro del núcleo, sea cual fuese el ancho de la calle.

d) Gran Centro Comercial de Valencia-Norte

e) Centros cívicos, escolares y parroquiales de las distintas unidades vecinales unidos por zonas verdes para paso exclusivo de peatones.

f) Zona deportiva, Instituto Enseñanza Media y Sanitaria

g) Zona industrial con carácter ligero, al N. del polígono, con exclusión de industrias pesadas e insalubres, en la que convenientemente modulada, tengan cabida las industrias del polígono llamadas a desaparecer y aquellos otras de nueva creación que absorban la población activa del polígono.

\section{C) ESQUEMAS DE SERVICIOS}

Estos esquemas comprenden:

10- Red general de saneamiento

$2^{\circ}$ - Red general de agua potable

30- Red general de energía eléctrica

Se acompañan planos de los esquemas antes citados.

10 -Para el estudio del esquema de saneamiento nos hemos servido de los colectores (actualmente en construcción) de la Avenida de Burjasot y Colector Norte de la orilla del rio Turia, y a ellos hacemos acometer todos los ramales interiores del polígono.

20- Análogamente, en el estudio del esquema de la instalación de agua potable, nos hemos servido de la red actualmente existente y de la prevista por la Sociedad de Aguas Potables, ampliándola y modificándola ligeramente en aquellas zonas donde la edificación proyectada lo necesita.

30- Para la red de energía eléctrica, presentamos un esquema pensando que dicha instalación debe de realizarse subterráneamente, ya que la instalación aérea estropea mucho la vistosidad de la edificación abierta, teniendo en cuenta además que a largo plazo la instalación subterránea resulta más económica por los pocos gastos de entretenimiento y por la mayor duración de sus instalaciones.

D) INFORMES OFICIALES DEL ANTEPROYECTO

Justificación de las soluciones adoptadas en relación con los informes oficiales.

a) Informe del Excmo. Ayuntamiento

La Corporación Municipal, estimando meritorio en general el anteproyecto presentado en el mes de marzo del corriente año, deja traslucir en su informe la preocupación que supone el establecimiento de grandes supermanzanas en que se divide el polígono, pensando sin duda en el carácter revolucionario que esta ordenación sin precedentes hasta la fecha tendrá en Valencia; y por ello en algunos de sus puntos del informe sugiere ideas referentes a la conveniencia de proyectar calles que subdividan en sentido perpendicular al río, algunos de los subpolígonos.

Realmente esta ordenación, aceptada actualmente en el extranjero y en otras ciudades españolas, está de acuerdo 
con las tendencias del urbanismo moderno, pero es revolucionaria en Valencia, lo cual, a nuestro juicio no supone un motivo de peso suficiente como para hacer cambiar una ordenación. Estimamos que estas soluciones a desarrollar a largo plazo, deben acometerse con carácter revolucionarlo, si se quiere lograr una serle de conjuntos urbanísticos, que dentro de muy pocos años no resulten ya anticuados.

Por otra parte el esquema de viales proyectado es sumamente claro y queda complementado con el sistema secundario de accesos en fondo de saco, que garantizan el servicio de todas las zonas residenciales y centros secundarios de las unidades vecinales, sin necesidad de establecer nuevas vías de tráfico rodado que interfieran con frecuencia las vías principales, todas ellas de tráfico rápido.

Para nosotros tiene gran importancia el sistema octogonal proyectado de pasos de peatones y espacios verdes, el cual garantiza la comunicación entre los centros secundarios de las unidades vecinales, sin interferencias repetidas hasta la exageración con las vías de tráfico rodado. Se trata aquí de crear ambientes libres y ajardinados que permitan el esparcimiento y desenvolvimiento autónomo de estas unidades vecinales y este, a nuestro juicio, producirá consecuencias sumamente agradables para los habitantes de las mismas, siendo realmente el punto revolucionario del sistema de comunicaciones.

En resumen: Si el sistema de viales es claro, el tráfico se desarrolla con rapidez y sin interferencias, el acceso a las viviendas y centros secundarlos queda resuelto y se proyectan espacios libres que aseguren el paso de peatones y el esparcimiento de los habitantes sin preocupaciones de trafico, parece aconsejable el aceptar una solución que, si bien es revolucionaria en Valencia, tiende a mejorar sensiblemente la manera de vivir y de funcionar en un gran conjunto urbanístico.

Sentada esta premisa que sometemos no obstante al criterio de la Superioridad, pasamos a justificar la solución proyectada, comentando los distintos puntos del informe de la Corporación Municipal.

10) Por las razones antedichos creemos que tiene fundamento suficiente la supresión de la vía que figura en el Plan General, entre la Prolongación de la Gran Vía de Fernando el Católico y del Padre Ferris, la cual en el proyecto queda sustituida por un amplio paso de peatones y espacios libres, lo que supone además una considerable economía el ahorrar la pavimentación de una nueva calle.

En cuanto a la ventaja de que pueda situarse bajo ella el adecuado desagüe para el Barranco de Paterna, creemos que este puede verificarse igualmente bajo el paso de peatones y espacios libres que figuran en el proyecto.

$\left.2^{\circ}\right)$ En el estudio numérico que figura en el programa de necesidades, se aprecia claramente que la superficie necesaria para centros comerciales anda escasa y que la diferencia debe considerarse absorbida por el Gran Centro Comercial de Valencia Norte. Por ello seguimos conservando el centro comercial secundario que figuraba en el anteproyecto.

30) Con el espacio libre y paso de peatones que separa el Gran Centro Comercial, queda asegurada la independencia debida entre éste y la zona residencial al O. del mismo. El ac 
ceso a las viviendas queda resuelto con los fondos de saco y el del Centro Comercial con los aparcamientos al N.E. y S.O. del mismo, todo lo cual funciona con absoluta independencia. En realidad, ello es consecuencia de las consideraciones generales expuestas con anterioridad.

40) En la solución estudiada, se ha cambiado la colocación de los bloques al $\mathrm{O}$. del Centro Comercial, evitando así la monotonía que ofrecían en el anteproyecto presentado.

Ha quedado afinada la colocación de los bloques en el perímetro del poblado de Campanar, regularizando el propio tiempo la vía que circunda al mismo y destinando las irregularidades resultantes a espacios libres.

$5^{\circ}$ ) En realidad parece deducirse del informe del Excmo. Ayuntamiento, que éste se muestra de acuerdo en respetar el ancho de $52 \mathrm{~m}$. para el acceso de Ademuz, en virtud de las razones expuestas en su informe, criterio que compartimos plenamente por estimar que no debe aumentarse el coste urbanización, siendo así que de acuerdo con las distintas variantes que estudiamos de la sección del acceso, el número de vehículos que por él puede circular, así como los aparcamientos previstos, son sumamente holgados, no ya para la actualidad, sino pensando en un futuro a muy largo plazo.

En una de dichas soluciones se suprimen los espacios laterales para circulación de bicicletas, puesto que estimamos que estos vehículos deben circular por las calzadas laterales dentro del casco de la población y tener su zona correspondiente al salir fuera del mismo, una vez cruzado el nuevo Camino de Tránsitos, que limita al N. del polígono, a partir del cual se debe prever también el tránsito de carros, medio de locomoción y transporte llamado a desaparecer en el futuro.

b) Informe de la Dirección General de Urbanismo

10) El punto fundamental, de este informe, es a nuestro juicio la situación del Gran Centro Comercial Valencia-Norte y la conveniencia de conservar o no el tramo de la Avenida de Campanar en la zona comprendida entre la orilla del Rio y el cruce con el acceso de Ademuz.

Realmente nuestra opinión a este respecto es que, en líneas generales el actual trazado de la Avenida de Campanar en toda su longitud, descompone totalmente el sistema de viales de polígono, ya que esta Avenida, trazada como elemento límite de circunvalación de la Ciudad, ha quedado rebasada, pasando a ser una calle más de la misma, especialmente en esta zona en que ya se prevé un nuevo Camino de Tránsitos en la parte Norte del polígono. Por ello, llevando a ultranza el sistema de viales proyectado, debería suprimirse en su totalidad. Si no lo hacemos en su primer tramo desde la Av. de Burjasot hasta el cruce con el acceso de Ademuz, es porque existe un pie forzado del Preventorio de San Francisco Javier y porque en la zona próxima a la Avenida de Burjasot existe un núcleo de edificaciones bastante importante, que por su numero, reciente construcción y finalidad social que cumplen, aconsejan su conservación.

Sin embargo estas razones de indudable peso ya no existen en el segundo tramo de la Avenida de Campanar, y por ello estimamos que debe suprimirse, ya que su conservación descompone de manera alarmante la zona interesada por esa vía en el polígono, produciendo dos zonas triangulares de 
aprovechamiento complicado y de solución estética poco acertada en la ordenación de volúmenes (sumamente clara en la mayoría de las supermanzanas del polígono) y creando por otra parte una vía de trafico que pierde totalmente su razón de ser al existir ya el acceso de Ademuz, que debe absorber el mayor contingente de trafico desde Valencia a los pueblos del Norte de la Ciudad.

Por otra parte, al situar el Gran Centro Comercial de Valencia-Norte en esta zona, tal y como figura en el Plan General, las interferencias de tráfico serían tales que el tránsito de peatones (fundamental en este caso) sufriría una serie de impactos que inutilizarían el sistema de pasos de peatones del polígono y el recorrido a través del Centro Comercial.

En resumen, proponemos como solución más acertada la colocación del Centro Comercial en el emplazamiento previsto en el Plan General, suprimiendo el tramo final de la Avenida de Campanar.

No obstante y ateniéndonos a los deseos de la Dirección General presentamos dos variantes, estudiadas como anteproyecto, para que puedan ser consideradas por el citado organismo.

En la primera, que figura en los planos con el no 2, desplazamos el Gran Centro Comercial a la supermanzana A, pero seguimos suprimiendo el tramo último de la Avenida de Campanar, organizando una nueva unidad vecinal en la supermanzana $D$, que sustituye al espacio ocupado por el Centro Comercial en la solución incluída en el proyecto con el no 1.

Esto solución hace más viable la expropiación de terrenos que debe realizar el Ayuntamiento para la construcción del Centro Comercial, por cuanto se ahorraría el coste de expropiación de tres edificios (alguno de los cuales está en construcción) y que, considerados como fuera de ordenación, cabría conservarlos en la actualidad hasta su extinción, substituyéndolos en la nueva reparcelación por bloques nuevos cuyo volumen serla el mismo que el de las edificaciones actuales. Por otra parte la supresión del ultimo tramo de la Avenida de Campanar supondría una ayuda económica a la expropiación de los terrenos para el Centro Comercial, puesto que dicha vía es propiedad del Excmo. Ayuntamiento.

En la segunda variante, que figura con el no 3 en los planos, se conserva el tramo de la Avenida de Campanar, organizándose entonces las temidas manzanas triangulares, en las que se sitúan dos pequeñas unidades vecinales. En ellas se sigue un criterio parecido en cuanto a la conservación de los tres edificios citados anteriormente y su solución posterior.

Aparte de las razones expuestas con carácter general, esta conservación del tramo de la Av. de Campanar, motiva un encarecimiento en la expropiación de terrenos para el Centro Comercial y considerando su deficiente resultado de ordenación desde todos los puntos de vista, hacemos constar que ésta no nos satisface en absoluto y que si se estudia es por el deseo antes expuesto de satisfacer una justa aspiración de la Dirección General mostrada en el informe que comentamos.

$2^{\circ}$ ) En el presente estudio hemos aumentado ligeramente el coeficiente de edificabilidad hasta $4 \mathrm{~m} 3 / \mathrm{m} 2$.

$3^{\circ}$ ) En cuanto a la monotonía en la repetición de bloques lineales estimamos que, puesto que el establecimiento de módulos le da bastante rigidez a la ordenación, ésta debe ser 
alterada en una serie de puntos singulares, lo cual ya hemos tenido en cuenta en el presente estudio definitivo, provocando ambientes y contrastes.

$4^{9}$ ) Aun cuando el Ayuntamiento no se ha definido claramente respecto de los sistemas de ejecución, acompañamos en el presente estudio un ejemplo de reparcelación de una unidad vecinal, (que completado con el apartado referente a sistemas de ejecución y plan de etapas, permitirá sin duda, fijar un criterio a seguir en la realización del polígono.

Valencia Junio 1960

los arquitectos

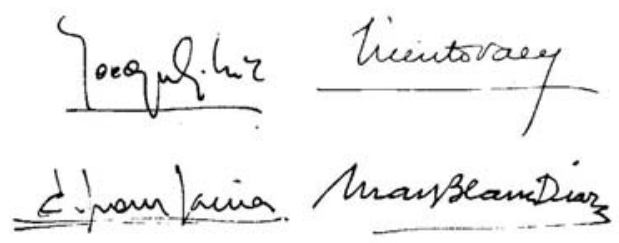


POLÍGONO DE CAMPANAR - VALENCIA

Plan Parcial de Ordenación

MEMORIA

Se redacta el presente estudio en cumplimiento del acuerdo del Excmo. Ayto.,Pleno de 4 de Agosto de 1961 y Dictamen de la Comisión Informativa de Urbanismo de 23 de Octubre de 1961, en los que examinando las reclamaciones presentadas durante la información publica del Planeamiento del Polígono de Campanar, se admiten una serie de ellas que se nos comunican en fechas 27 y 24 de Octubre respectivamente, y para que se de cumplimiento a lo previsto en la base VII, Condición General 14a, epígrafe F. del Pliego de Condiciones, que regió en la contratación para la redacción del proyecto de planeamiento del polígono citado.

En el plano a escala 1:1000 que se aporta, se vé claramente que:

$\left.1^{\circ}\right)$ Quedan graficadas las soluciones correspondientes a las reclamaciones presentadas por D. José Planchadell, respetando el bloque proyectado; por D. Manuel Casanova, con referencia a dar una profundidad edificable uniforme e igual a la que tienen actualmente los edificios de SOCUSA; por D. Vicente Llosa, en idénticas condiciones a las de D. José Planchadell, con $14 \mathrm{~m}$. de profundidad de bloque y respetando los terrenos de la Escuela Patronato de la Juventud Obrera, en su forma, situación, volumen y utilización actual, situando igualmente la zona acordada por el Excmo. Ayto., para emplazamiento de la futura estación de autobuses.

$2^{\circ}$ ) Queda atendida la reclamación de D. Vicente Seguí Palmer y otros en el sentido de transformar la manzana de edificación abierta en cerrada y con VI plantas.

$\left.3^{\circ}\right)$ Se grafica igualmente la resolución Municipal sobre la reclamación presentada por D. Jesús y Dna. Carmen Benedito Miralles, y que denominan $2^{\circ}$ solución, consistente en un bloque de 45 $\times 11$ plantas de altura.

$\left.4^{\circ}\right)$ Los bloques recayentes al $C^{\circ}$ de Tránsitos son de 5 y 10 plantas en su paramento derecho, conservando de VIII plantas los del izquierdo.

$5^{\circ}$ ) La zona edificable recayente a fachada en las manzanas industriales al Norte del Preventorio de San Francisco Javier, se aumentan a VIII plantas.

$\left.6^{\circ}\right)$ En el paramento de prolongación del Puente de Campanar, se igualan las alturas de los bloques a VIII plantas, hasta el fin del Campo de Deportes.

$7^{\circ}$ ) Que aun cuando estimábamos, que el Plan Parcial aportado tenia toda la documentación que exige el Arto 10 de la Ley del Suelo, e incluso se aportó un estudio económico; por las dificultades que entrañaba la interpretación literal que da la Ley, exigiendo que en el estudio económico-financiero del proyecto se indiquen además los medios disponibles afectos a la ejecución del plan, aspecto que estimamos no ser de nuestra competencia por desconocer la potencia económica del Excmo. Ayto.; no tenemos pues, otra solución para cumplir con dichos proyecto que concretar el estudio a un sistema que lo haga viable para una Empresa privada que tuviese las facultades legales de expropiación de los terrenos, para que, añadiendo al valor de estos el coste de la urbanización consiguiente y 
dividiendo el total por los $\mathrm{m}^{2}$ de parcelas disponibles, se llegará a saber el coste unitario a los efectos de enajenación como partida de futuros ingresos y entonces, dado el volumen de gastos (terrenos y urbanización) y los medios económicos disponibles, se podrá desarrollar la ejecución en una serie de etapas que fueran soportables económicamente y pudieran conjugarse con las demandas de solares en el mercado, para que el capital circulante fuese el mínimo.

Como consecuencia del respeto al Patronato de la Juventud Obrera y quedar disminuido el espacio previsto para Centro Comercial, se estudia dentro de los terrenos sobrantes, un nuevo Centro Comercial, más reducido, sin afectar en absoluto a las edificaciones proyectadas de carácter privado, fuera del mismo.

El nuevo Centro Comercial se organiza a base de edificios de negocios y oficinas de carácter privado, comercios y supermercados, edificios de espectáculos públicos y culturales y edificios de tipo administrativo (correos/ telégrafos, tenencia de alcaldía, comisaria, etc.). La zona comercial forma el eje longitudinal del conjunto, uniendo dos plazas, la de negocios y espectáculos y la administrativa. Tangencialmente a las zonas comerciales se sitúan aparcamientos en dos zonas suficientemente amplias.

Habiendo solucionado las reclamaciones del D. Vicente Planchadell y de D. Vicente Llosa en el sentido de ampliar a $14 \mathrm{~m}$. la profundidad de los mismos, nos hemos permitido dejar también con la misma profundidad el bloque situado al Oeste de los anteriores, con objeto de obtener una solución uniforme, toda vez que ello no supone perjuicio para tercero,

Este mismo criterio se aplica a los bloques paralelos al de D. Jesús y $\mathrm{D}^{\mathrm{a}}$ Carmen Benedito Miralles, en el sentido de aumentar la profundidad a $11 \mathrm{~m}$. y altura de 10 plantas, en la zona lindante con la Avda, de Campanar, entre la orilla del Rio y el Acceso de Ademuz, y formando conjunto con la edificación de los Sres. Benedito Miralles.

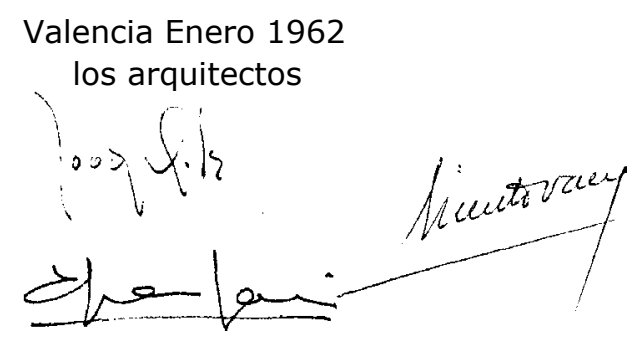


POLIGONO DE CAMPANAR

ORDENANZAS DE USO, VOLUMEN Y COMPOSICION

TITULO I. DEFINICIONES.

[‥]

TITULO II. ZONA DE EFDIFICACIÓN EN MANZANAS CERRADAS O SEMI-CERRADAS CON PATIO DE MANZANA.

\section{TITULO III.- EDIFICACIÓN ABIERTA}

Arto $18^{\circ}$.- LÍMITES.-

En el plano de zonificación queda claramente especificadas las zonas con destino a edificación abierta.

Arto $19^{\circ}$.- USOS

En la edificación abierta, los usos no se superponen.

Se separan las funciones y en consecuencia, los edificios que tienen la misión de cumplirlos.

Las distintas funciones tienen un orden jerárquico de subordinación para la mayor eficacia del conjunto.

Así partiendo de la vivienda, bloque, conjunto de bloques y unidad vecinal, establecemos para su servicio las funciones comercial, cultural, social, asistencial en edificios propios, conectados con la unidad pero con absoluta independencia de los edificios de vivienda.

Igualmente ocurre con los garages, almacenes o pequeños talleres propios y necesarios para el funcionamiento de la unidad, pero con absoluta independencia de la vivienda.

Y cuando llegamos a la agrupación de unidades vecinales para formar barrios y a la agrupación de estos para grandes conjuntos, surgen necesidades de tipo colectivo que hay que prever, como son: Centros culturales de mayor importancia, Centros Comerciales, Centros Sanitarios, Recreativos, Deportivos, etc.

El uso, por consiguiente al quedar perfectamente definido y delimitado por la separación de la función familiar (viviendas) de las de relación (edificios públicos o de uso publico y de las de trabajo, huelga insistir en este aspecto.

$Y$ finalmente las zonas industriales, encargadas de absorber el excedente de empleos propios de las zonas de viviendas con sus servicios, y encargadas del equilibrio empleo-población quedan lo suficientemente aisladas para no suponer interferencias molestas, ni demasiado lejanas que compliquen el problema del transporte en común.

Arto $20^{\circ} .-$ VOLUMENES

El volumen de las edificaciones previstas, tanto las destinada a vivienda, como a edificios públicos o de uso público queda definido en los planos.

1) Viviendas

a) por el tamaño en planta de las edificaciones.

b) Por el $n^{\circ}$ de plantas que figura en números romanos supuesto en $3 \mathrm{~m}$. la altura de cada planta, incluido el espesor del forjado.

2) Edificios públicos

En los Centros Parroquiales, la nave principal de 
cultos se supone de $9 \mathrm{~m}$. de altura, las dependencias parroquiales, abadía, etc. 2 plantas o $6 \mathrm{~m}$. de altura.

En las Escuelas, se suponen 2 plantas incluyendo el salón de actos.

En los cines, 2 plantas, con excepción de la sala con $9 \mathrm{~m}$. o su equivalente de 3 plantas.

En los Centros Comerciales, las tiendas de una sola planta y los supermercados de 2.

En los Edificios administrativos, de servicios, como telegrafos, etc. y de negocios, se indica el $n^{0}$ de plantas.

En los centros sanitarios, 2 plantas y en las Guarderías 1.

Los garages o almacenes de una planta de $4 \mathrm{~m}$ de altura.

Los pequeños talleres y tiendas de $3 \mathrm{~m}$.

No se podrá, variar el volumen previsto en los edificios destinados a vivienda, ni en cada bloque ni en su conjunto. Unicamente cuando se plantee un gran conjunto de edificación que comprende una unidad vecinal con todos sus edificios complementarios y servicios por una empresa única o agrupación de propietarios con pies de construcción por el sistema de compensación, podrá reconsiderarse la forma de agrupación de bloques y variar sus volúmenes relativos, pero sin aumentar el coeficiente de edificabilidad de la unidad vecinal.

en los planos se especifican.

Arto 210.- VOLADIZOS

Habida cuenta de que:

En los bloques de más de $\mathrm{V}$ plantas con ascensor, se fija una anchura de bloque de $11 \mathrm{~m}$. y en los de $\mathrm{V}$ plantas de 9 m. resulta:

Que el volumen está perfectamente previsto y no cabe aumentarlo, ahora bien, los pilares pueden enrrasarse con los límites del ancho permitido o retranquearse y construir con voladizos y eso es perfectamente posible por cianto no supone aumento de volumen. Es más, podrá construirse la edificación sobre pilotes y dejar libre la planta baja, si bien esto supondrá pérdida de volumen pero no se opondría al concepto.

Los voladizos se permitirán únicamente en forma de terraza, con un vuelo máximo de $5 \%$ de la distancia entre bloques, pero con la condición de que en la misma longitud del voladizo se retranquee una profundidad igual incorporada al voladizo.

Arto $22^{\circ}$.- PATIOS

No caben más que chimeneas de ventilación, cuando sean necesarias y sólo para aseos.

Arto $23^{\circ}$.- COMPOSICIÓN

Unica para cada bloque y ligada al contiguo si no estuviese aislado.

Será de líneas sencillas y claras, con sentido actual y con un buen acabado en todas sus fachadas.

a) Componer los elementos que forzosamente han de salir de la altura utilitaria para viviendas del bloque, como son escalera, ascensor, depósitos, chimeneas y quedando prohibidas las piezas habitables (portería y trasteros) 
TITULO IV. Del actual poblado de Campanar.

[...]

TITULO V. De industria Ligera incompatible con vivienda.

$[\cdots]$

TITULO VI. Centro Comercial de Valencia-Norte.

[...]

TITULO VII. Centros Sanitario-Enseñanza Media y Deportivo. [‥]

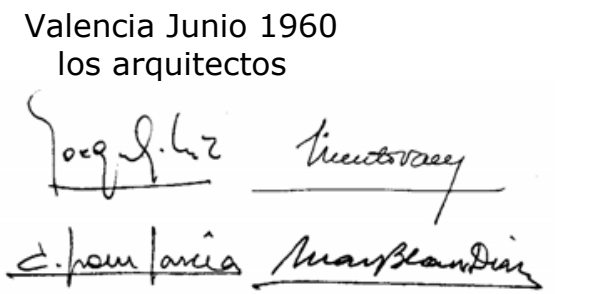




\section{El poligono urbano de Campanar tendrá una superície de 1.020.000 metros cuadrados} Comprenderá unas 10.000 viviendas y una población de 48.685 habitantes

\section{Segin se expone en la me:
moria referida al Poligono}

Urbano que ha de ser levan-
tado en Camplanar, el Plan
General de Ordenación Urba.

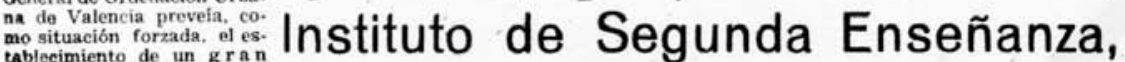
centro comereial denominado

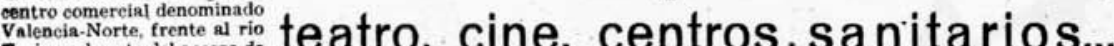
Turia y al oeste del acceso de
Valencia-Ademuz, como eleValencia-Ademuz, como elemento indispenhable para lo-
grar la descongestión de la zona cometcial del centro de tiempo, diera adecuado servicio al gran contingente de habitantes de la serie de puera entrada a la capital de verificarse por el ya indicado quevo acceso de Valencia-
Ademux, vial de tráfico rápiAdemuz, via de trafico rápito que dividira el Poligono Norte-Sur

Ea dichó Poligono no sólo e atienden las necesidades de orien comercial y de trá. ferentes a la cultura, culto eeligioso, deportes, servicio de cotnunicaciones, industria viviendes.

- SUPERMANzanas $r$ UNIDADES VECINA LES

Para el mejor orden urba. aistico, de acuerdo con los planes formules supermanzanas as inferiores, giturdas en el nuevo acceaso atravesarán el teas límites: Norte, nuevo ca- de Segunda Enseñanza, con campos de deportes anejos: crages lustrial, talleres miento y ugares de aparca. una población de $48.685 \mathrm{ha}$.
una bitantes, cifra que se calcula han de poder residir en este nmenso núcleo urbano, que grandes sectores. en cuatro En orden al tipo de las viof recer los datos siguientes: Serán de edificación abier. ta y se dividirán en tres categorias. Las de primera, constarán de vestibulo, gala de estar, despacho, comedor. $y$ servicio de aseo. Los de segunda categoria, constarín de vestíbulo, dormitorios, comédor, cocina y anexos y servicio de aseo. Los de tercera eategoria, comprenderín vestíbulo, dor. mitorios, cocina, eomedor $y$ servicios de aseo. La superficie útil, por ha. bitante, será: en las viviendas de primera categoria, 20 segunda, 15, y en las de tercera, 10 .

Por cuanto hemos expues. o, se deduce la extraordinaria importancia que revestirá la realizaciôn de este Poriosas necesidades de expan. ciudad.

Jesiis Mtorante Borris

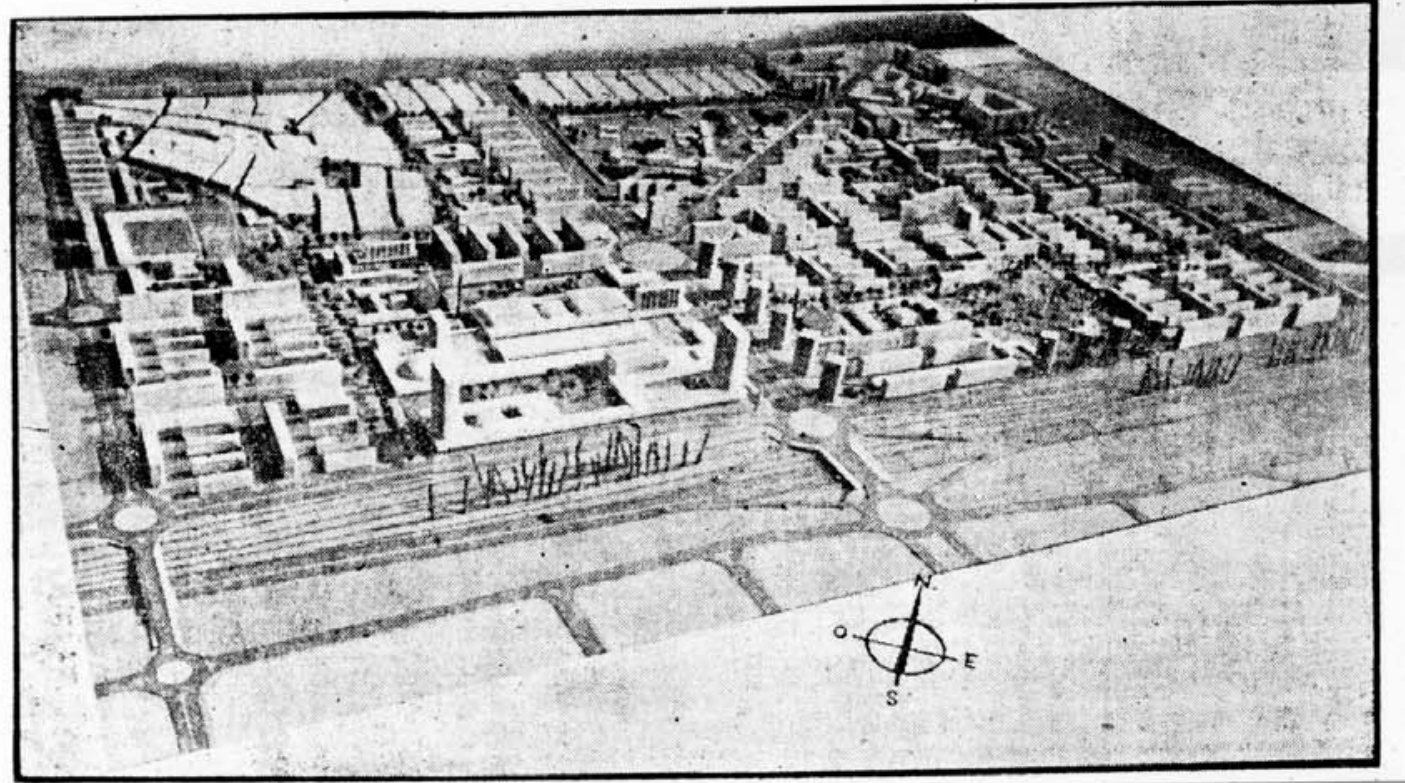



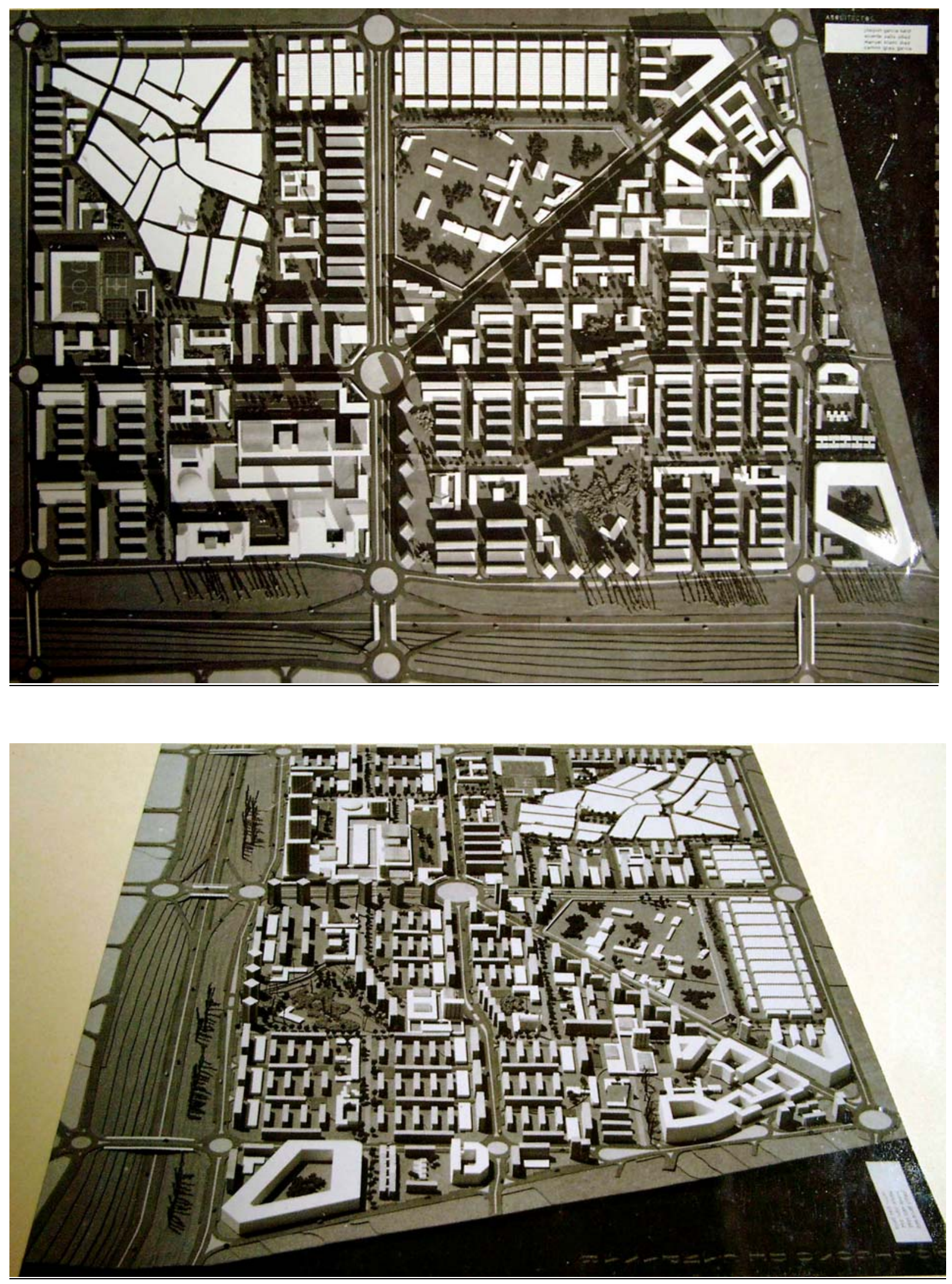

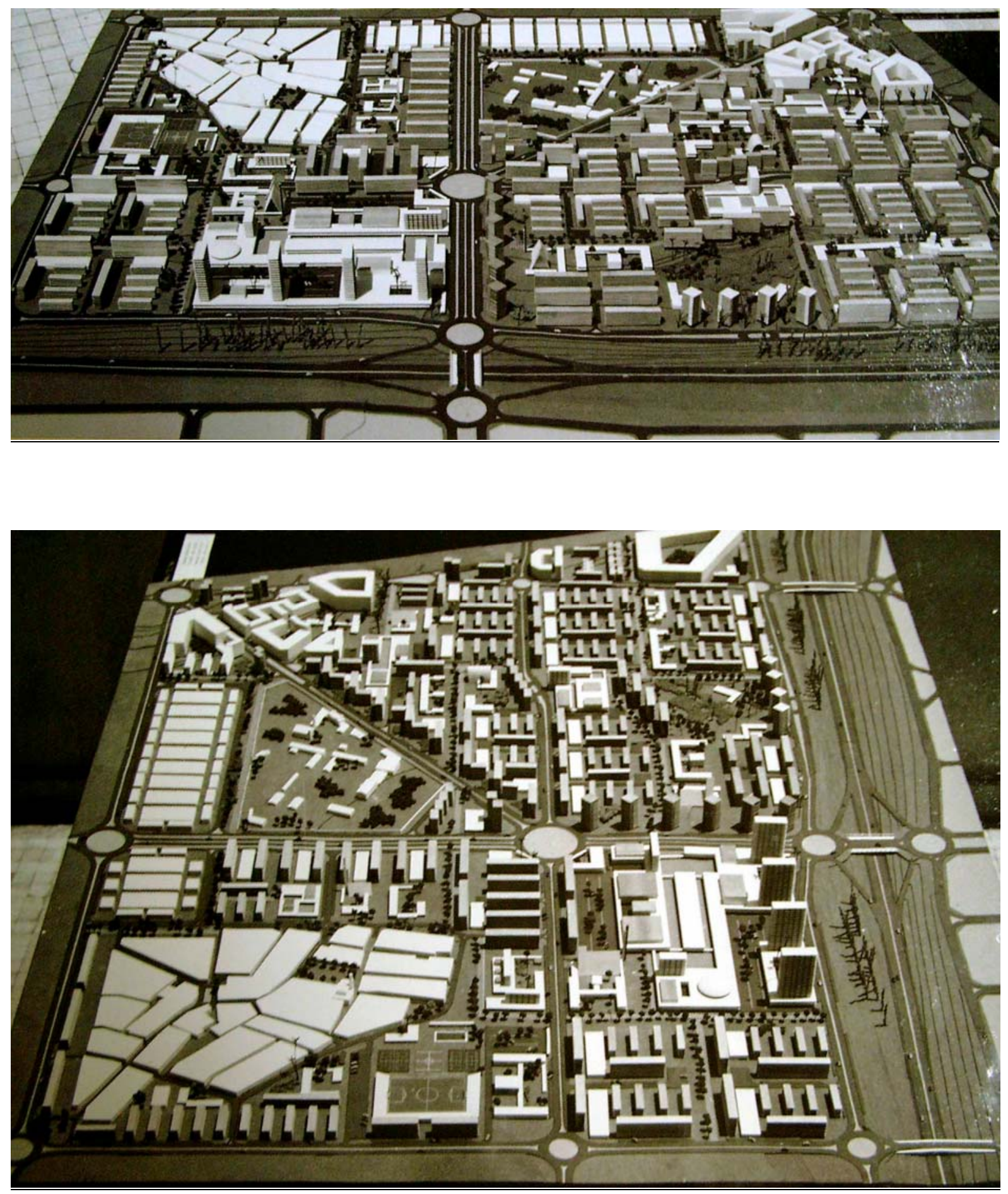
3. PLANO GENERAL DE ORDENACIÓN GENERAL- SUBPOLÍGONO A. Escala original: $1: 1000$

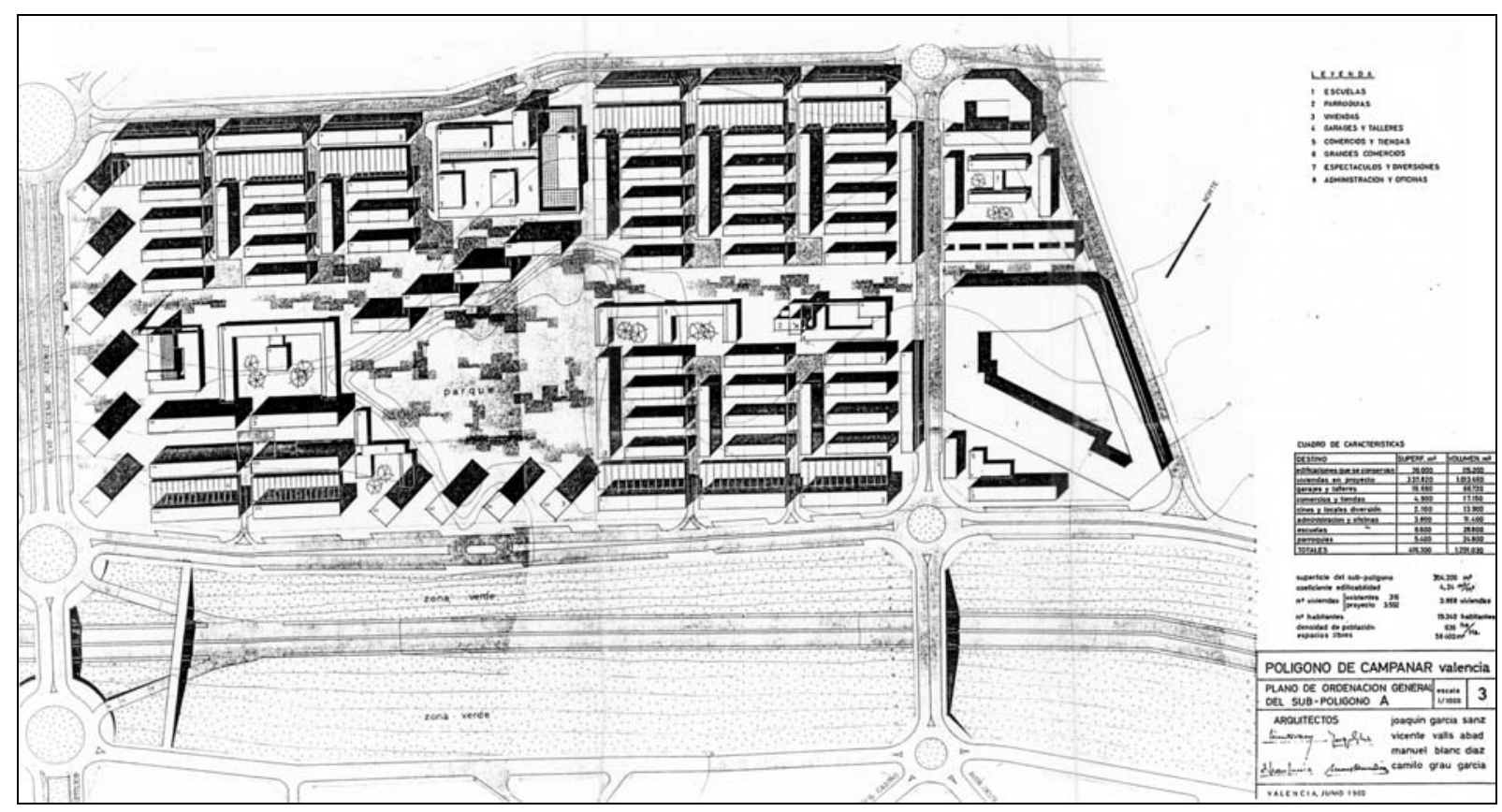

4. PLANO GENERAL DE ORDENACIÓN GENERAL- SUBPOLÍGONO B. Escala original: $1: 1000$

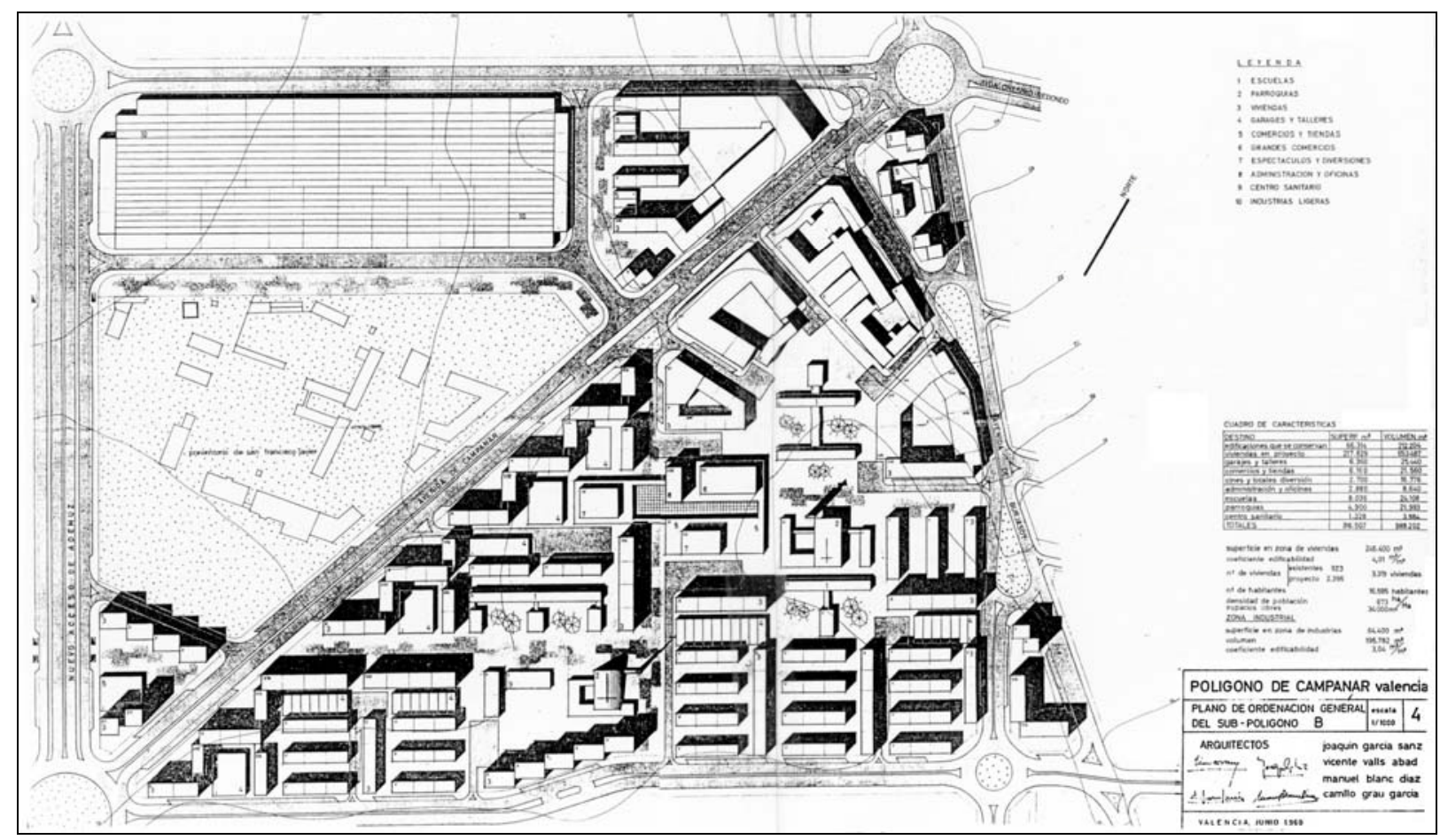


5. PLANO GENERAL DE ORDENACIÓN GENERAL- SUBPOLÍGONO C.

Escala original: 1:1000

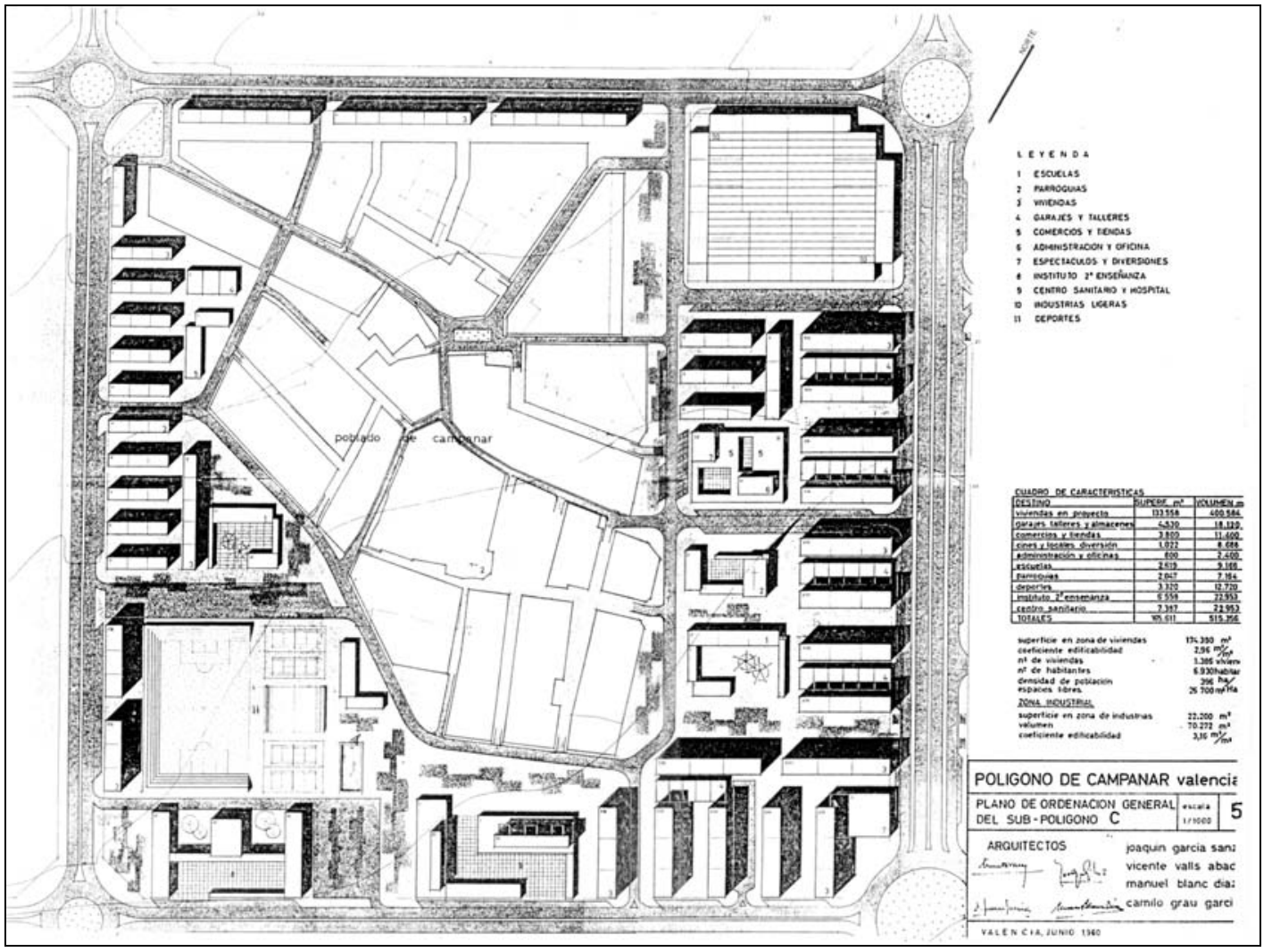

6. PLANO GENERAL DE ORDENACIÓN GENERAL- SUBPOLÍGONO D.

Escala original: $1: 1000$

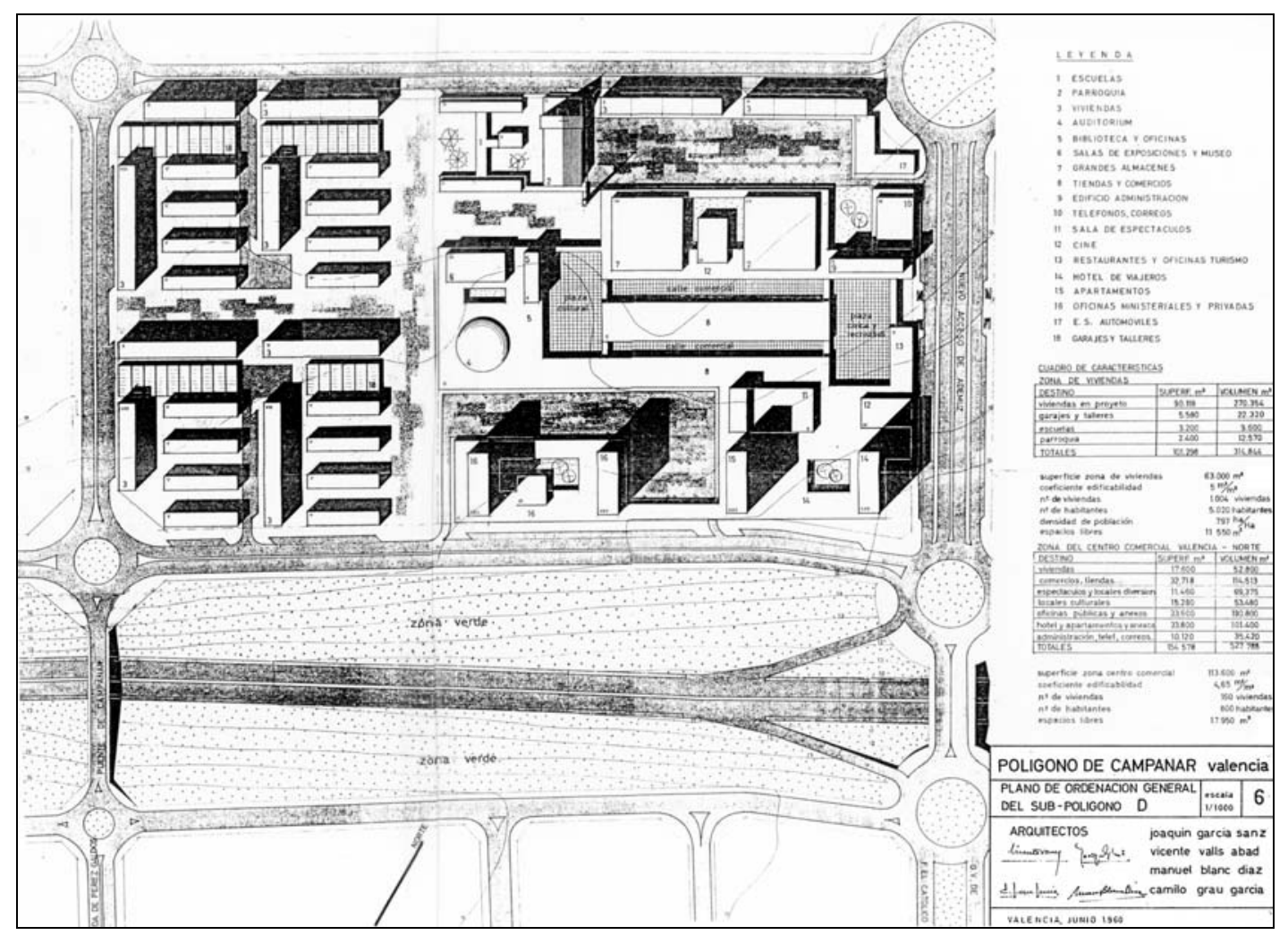


7. PLANO DE ESTRUCTURA, ZONIFICACIÓN Y CIRCULACIONES.

Escala original: $1: 2000$

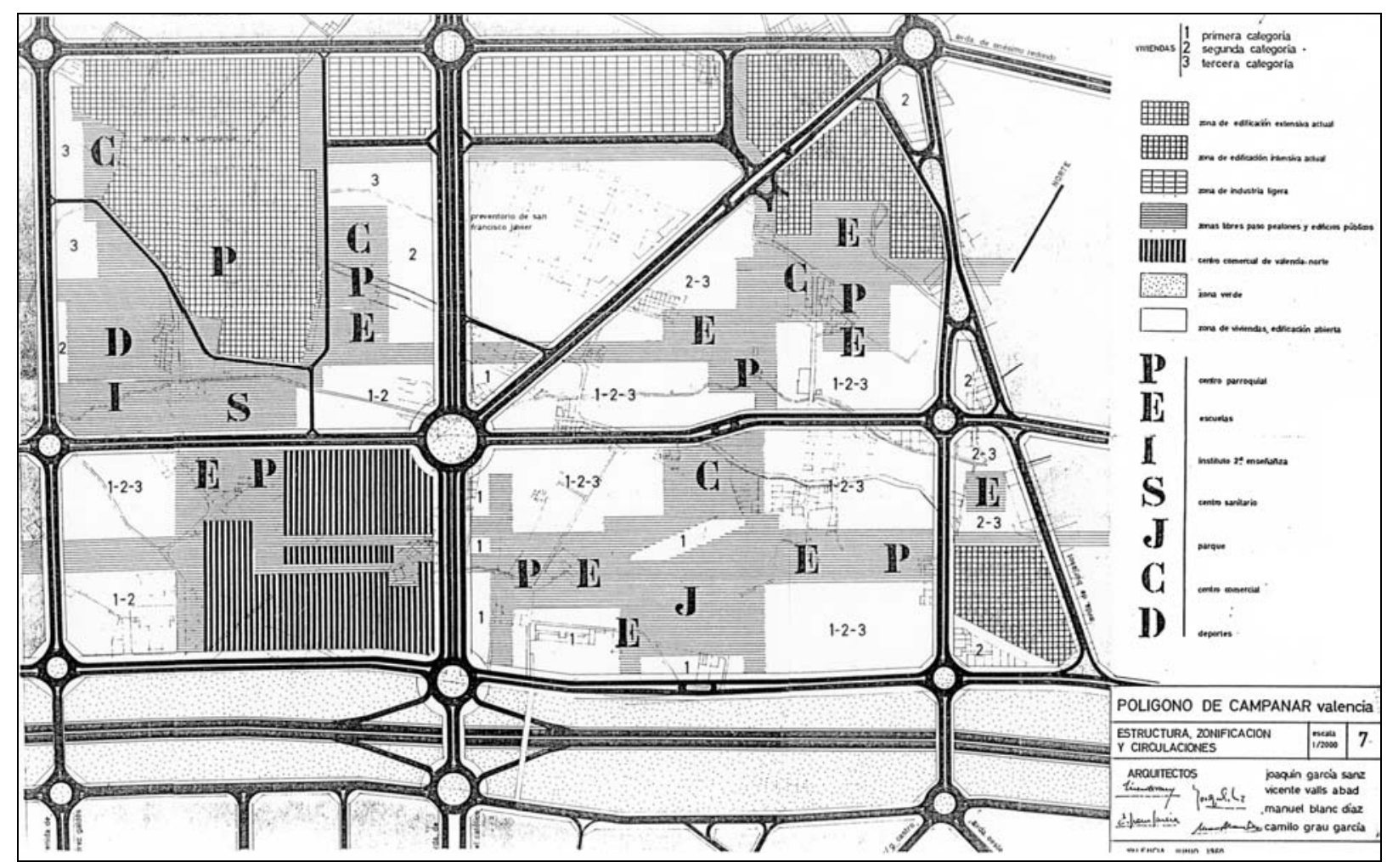

8.1. PLANO DE SOLUCIÓN 1.

Escala original: 1:2000

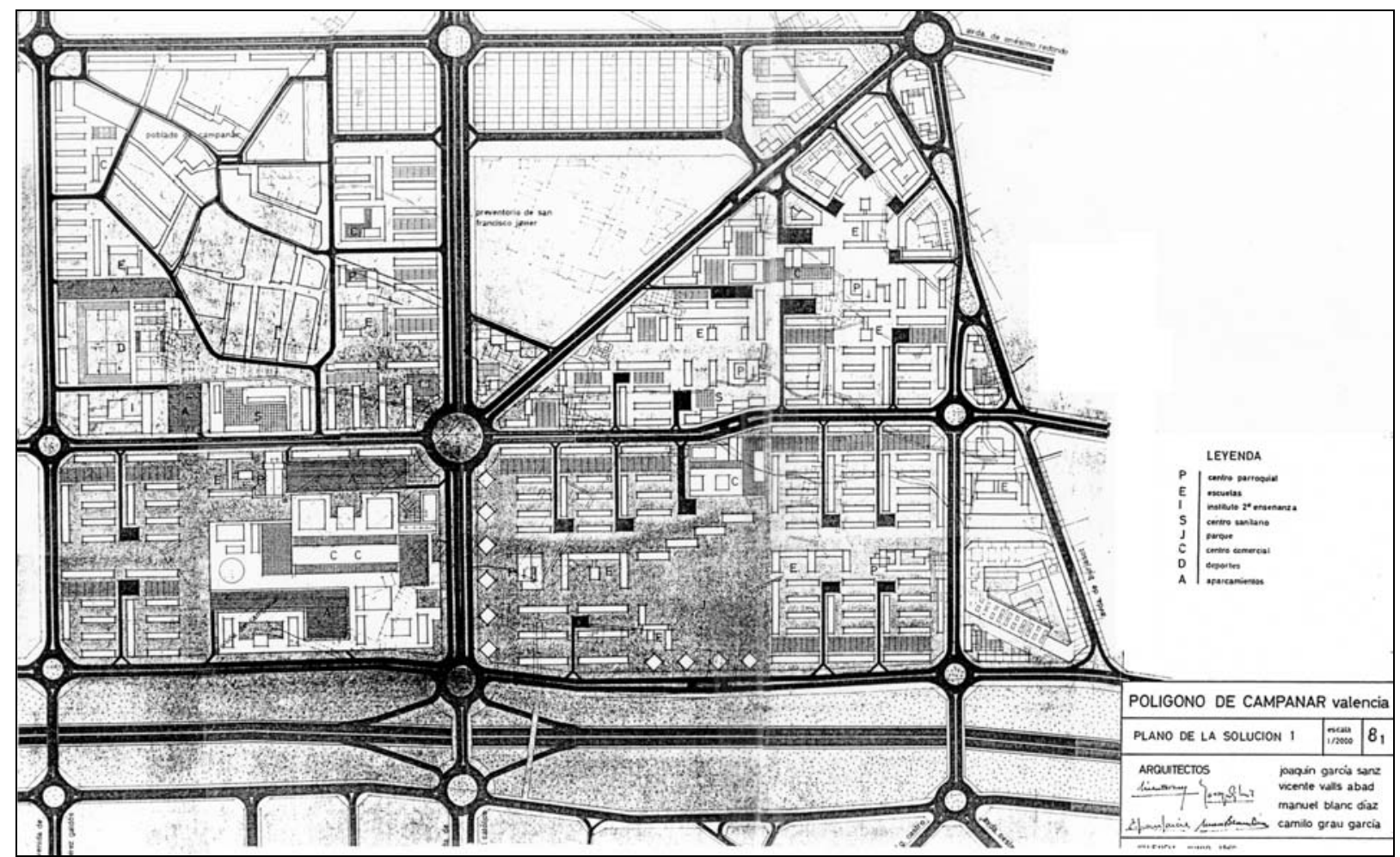




\subsection{PLANO DE SOLUCIÓN 2.}

Escala original: 1:2000

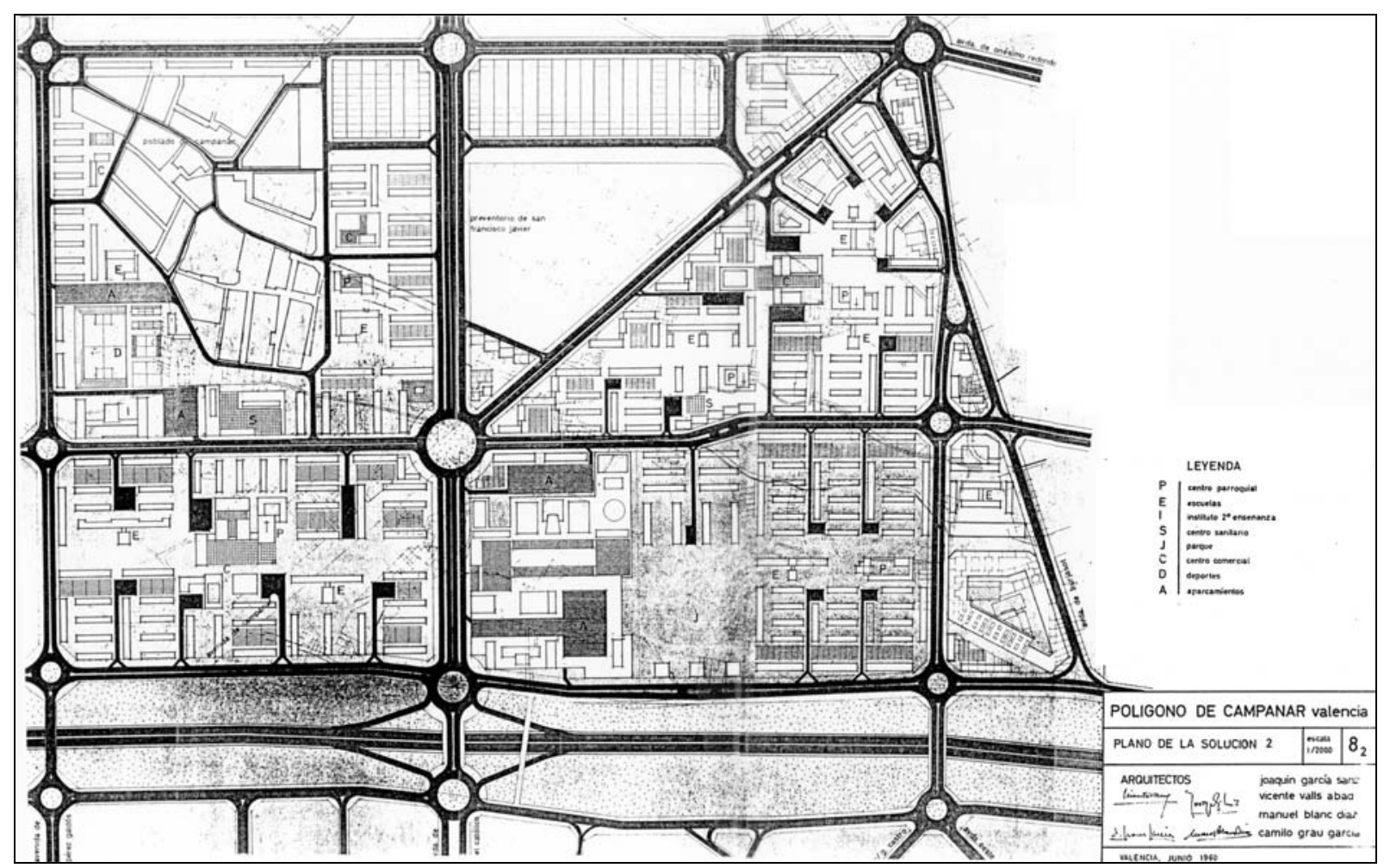

8.3. PLANO DE SOLUCIÓN 3.

Escala original: 1:2000

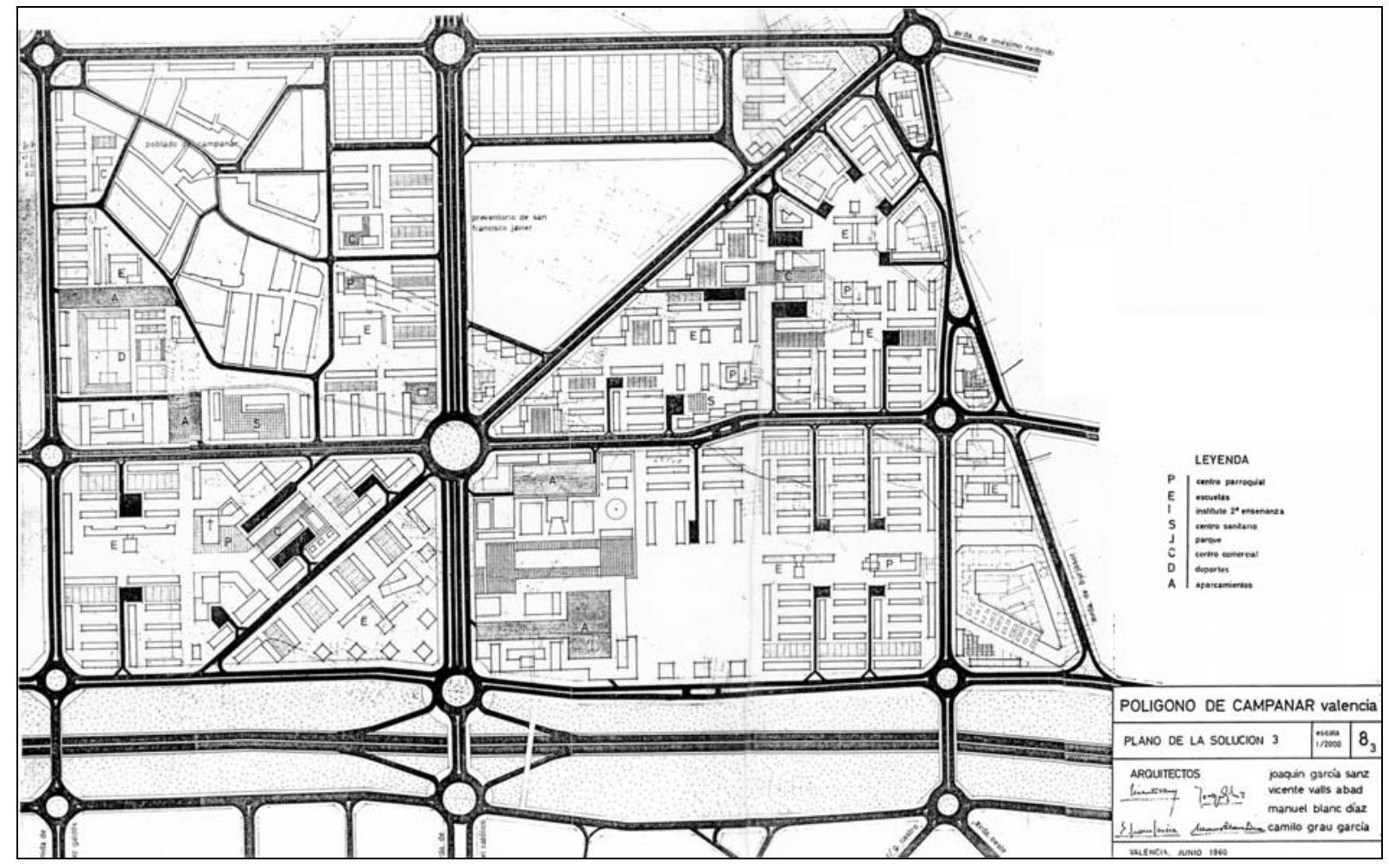


10. PLANO DE UNIDADES VECINALES Y SISTEMAS DE ACTUAIÓN Escala original: 1:2000

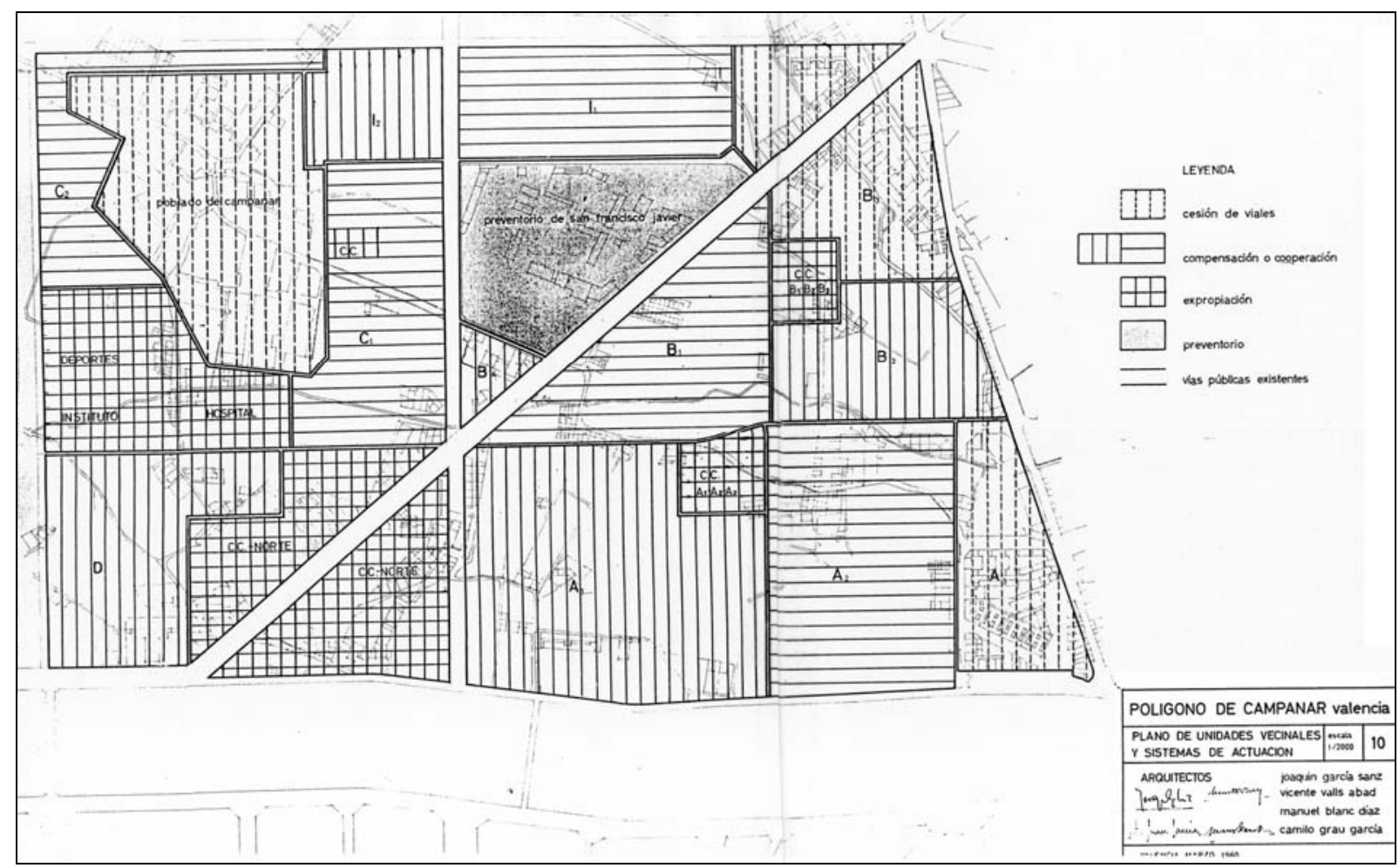

11. PLANO DE PERFILES DE CALLES

Escala original: 1:100

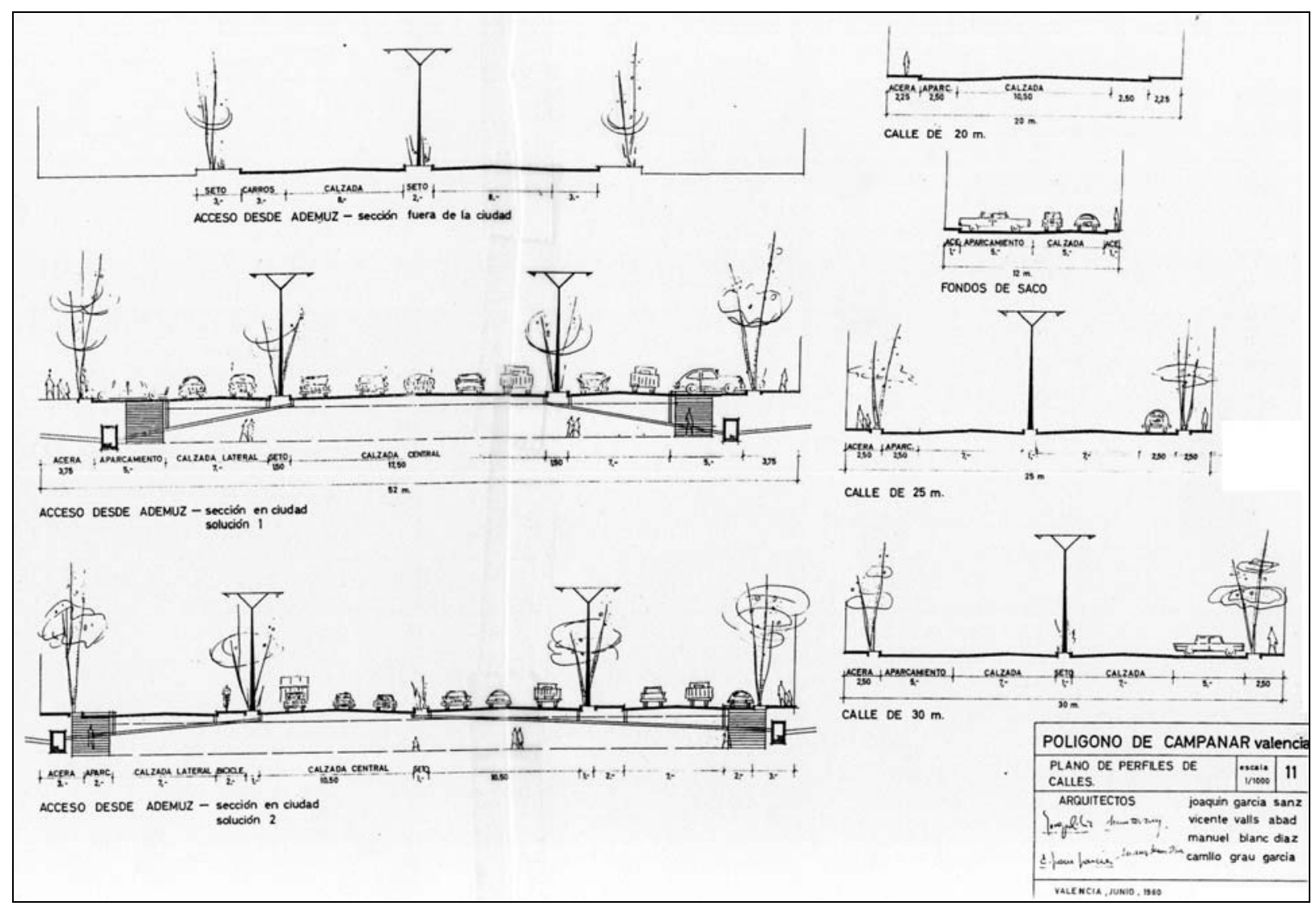


AMPLIACIÓN DEL ACCESO DESDE ADEMUZ A 65 M-

Escala original: 1:1000

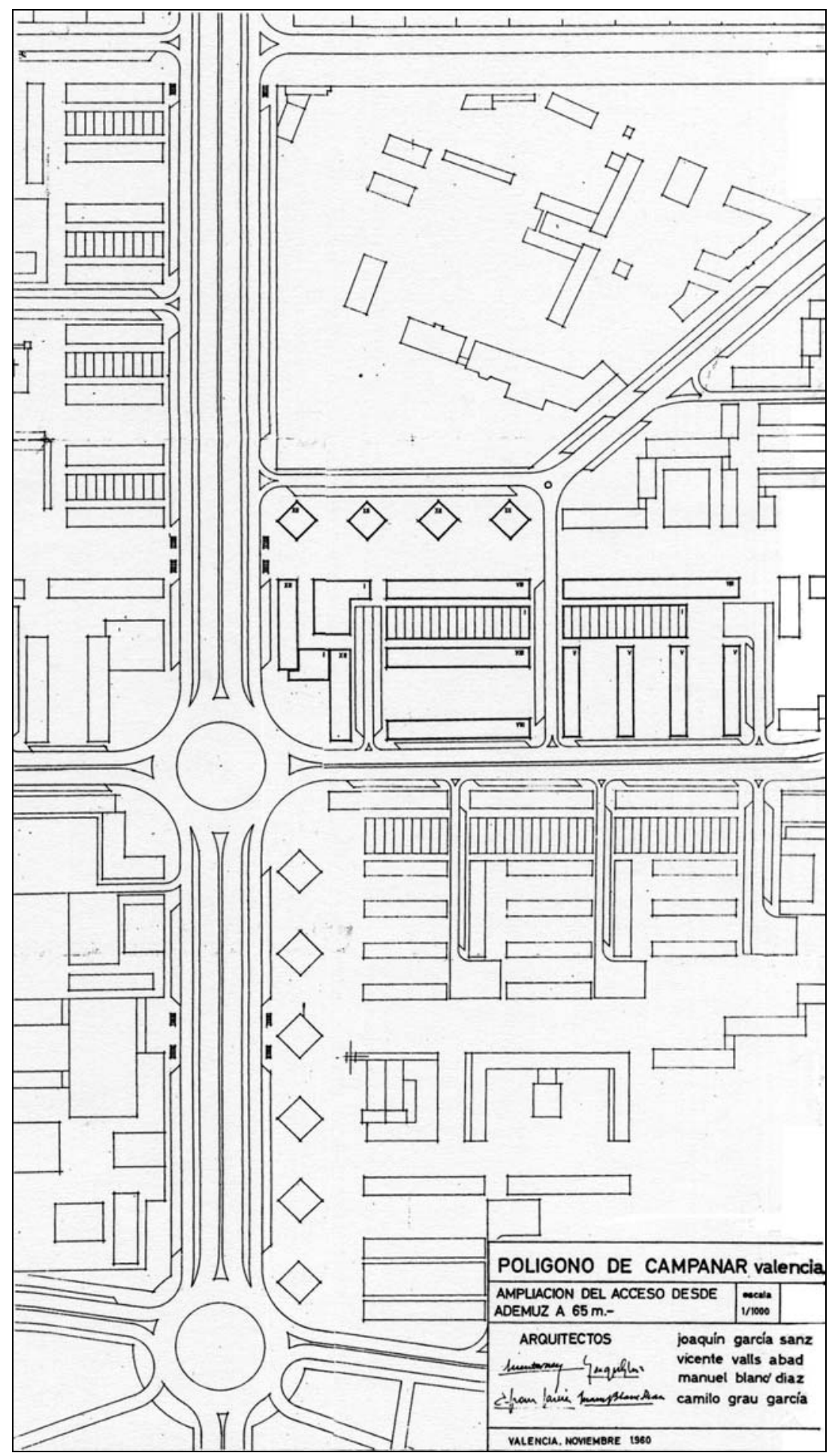


PLANO GENERAL DE EDIFICACIONES SOBRE PARCELAS EXISTENTES (Versión modificada de 1962).

Escala original: 1:1000
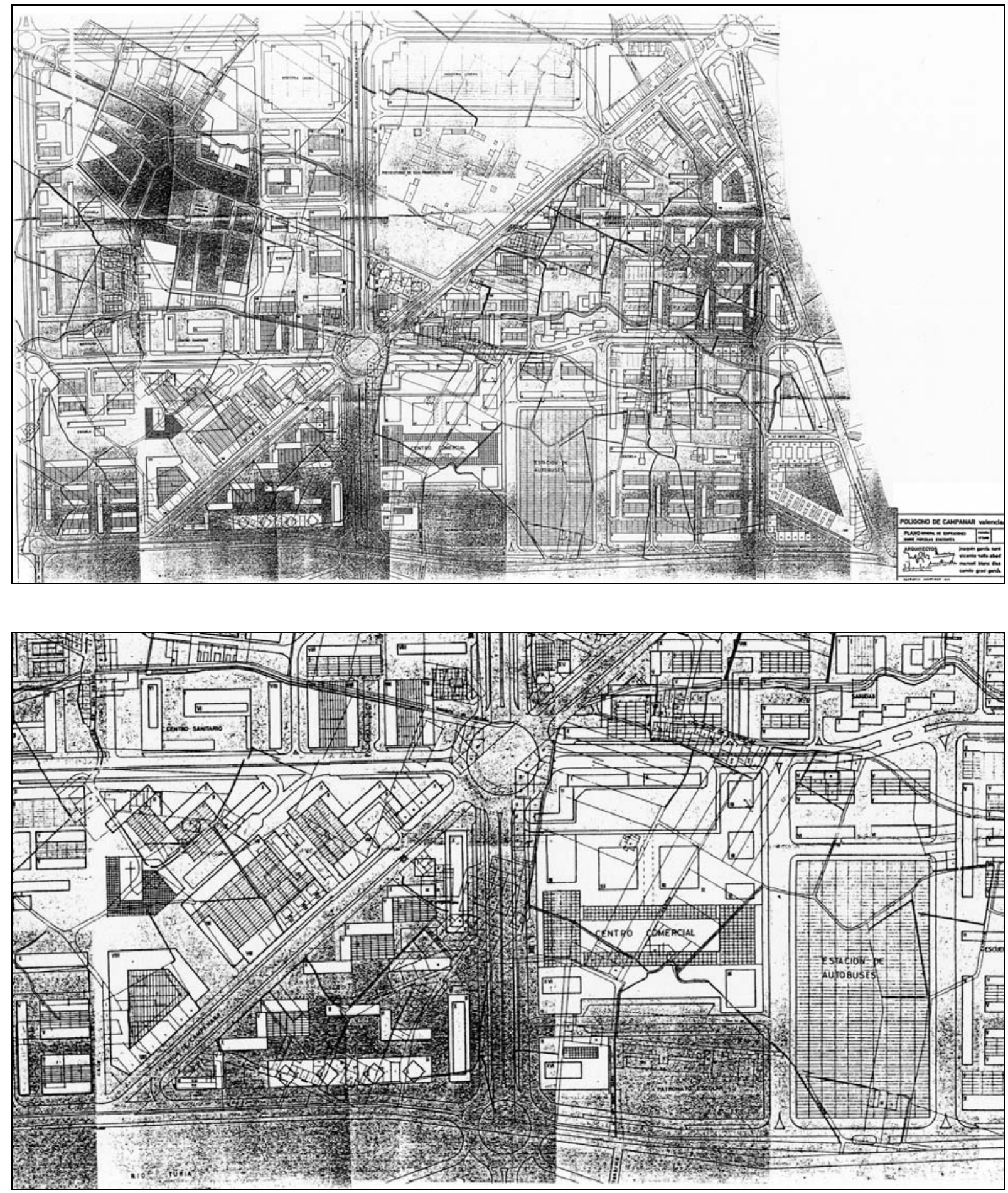

Detalle de las zonas modificadas 


\section{Polígono Avenida de Castilla}

Redactores: GERENCIA DE URBANIZACIÓN. MINISTERIO DE LA VIVIENDA.

Fecha redacción: Abril 1961.

Fecha aprobación: O.M. 25-10-1961.

Contenido:

I. MEMORIA. $\left({ }^{*}\right)$

II.PLANOS: $(* *)$

- PLANO DE SITUACIÓN

$1: 10.000$

- PLANO GENERAL 1a ETAPA

$1: 500$

- PLANO GENERAL 2a ETAPA

$1: 500$

- PLANO DE PARCELAS RESULTANTES

$1: 1000$

\section{Fuente:}

Ayuntamiento de Valencia. Sección de Urbanismo. Negociado de Suelo y Ordenación urbana. Expte. 2.214/1959 (Archivo de Planeamiento, No OM-287)

\section{Notas:}

$\left.{ }^{*}\right)$ No se ha localizado la documentación escrita de este plan.

$\left.{ }^{* *}\right)$ Además de los planos correspondientes al Plan Parcial, el expediente del Archivo de Planeamiento dispone de los planos siguientes:
- PARCELACIÓN. HOJAS 1,2 Y 3. (1960)
$1: 500$
- PLANOS CORRESPONDIENTES AL PROYECTO DE PAVIMENTADO (REFORMADO):
- PLANO DE REPLANTEO
$1: 1000$
- PERFILES LONGITUDINALES
- PLANO TOPOGRÁFICO
S/E
- PLANO GENERAL DE REPLANTEO DEFINITIVO
(Julio 1963)
$1: 1000$ 

1. PLANO DE SITUACIÓN

Escala original: 1:10.000

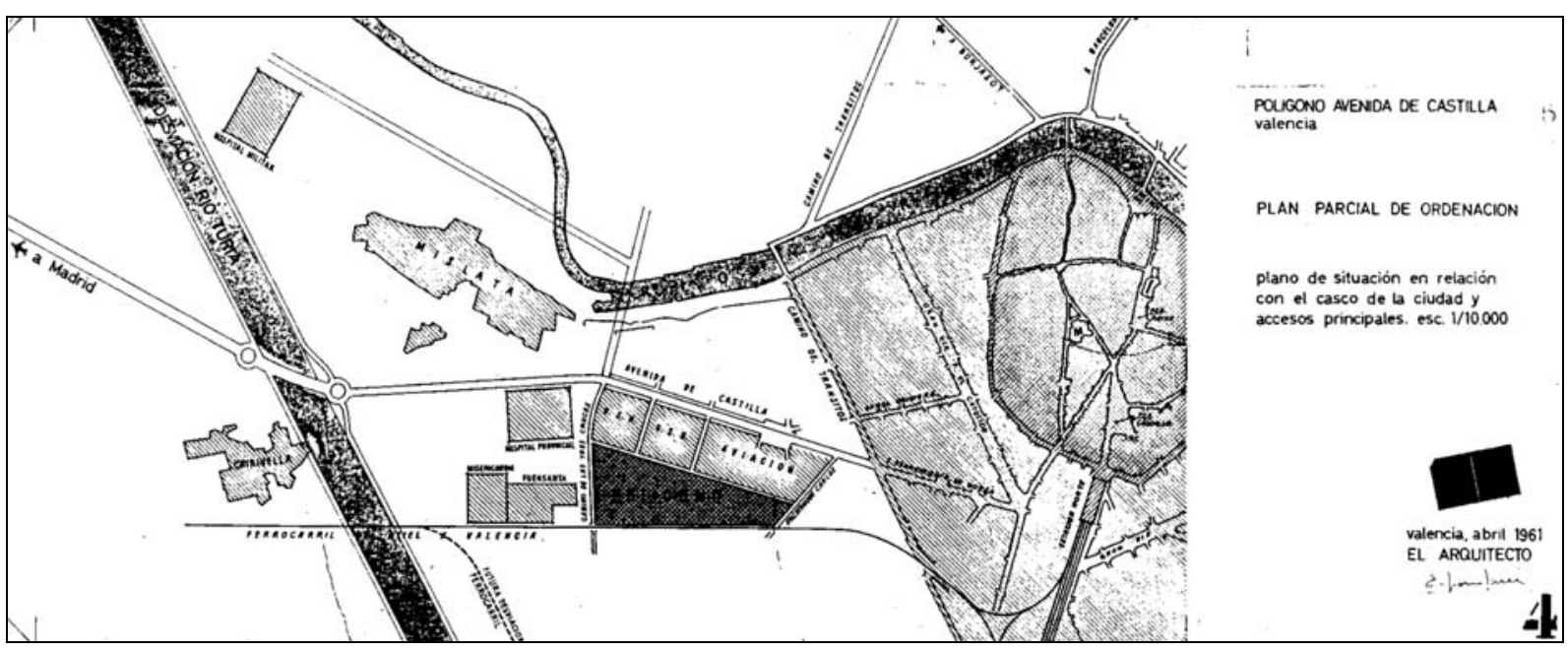

2. PLANO DE PARCELACIÓN

Escala original: 1:500

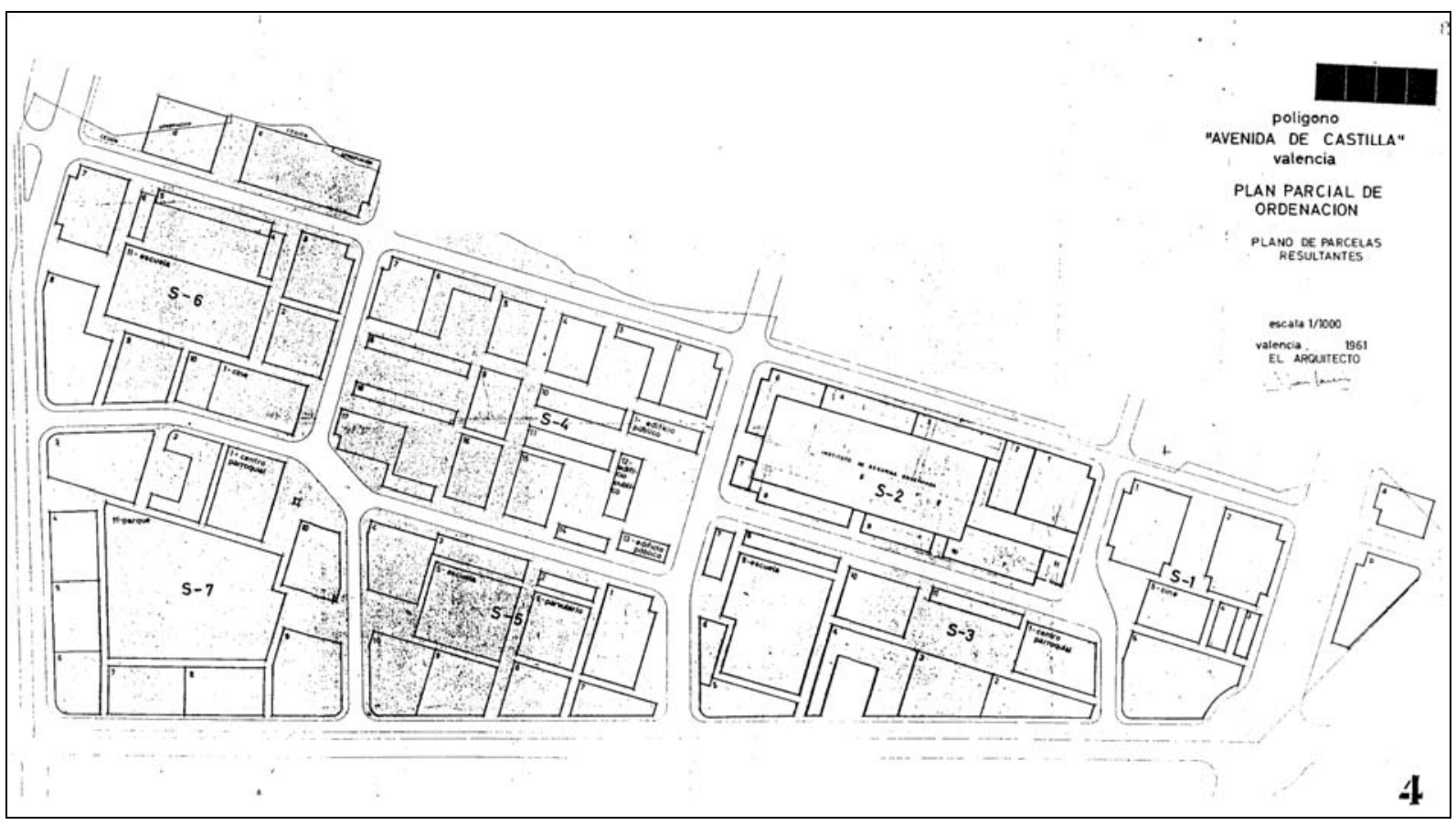


3. PLANO GENERAL $1^{\text {a }}$ ETAPA

Escala original: 1:500

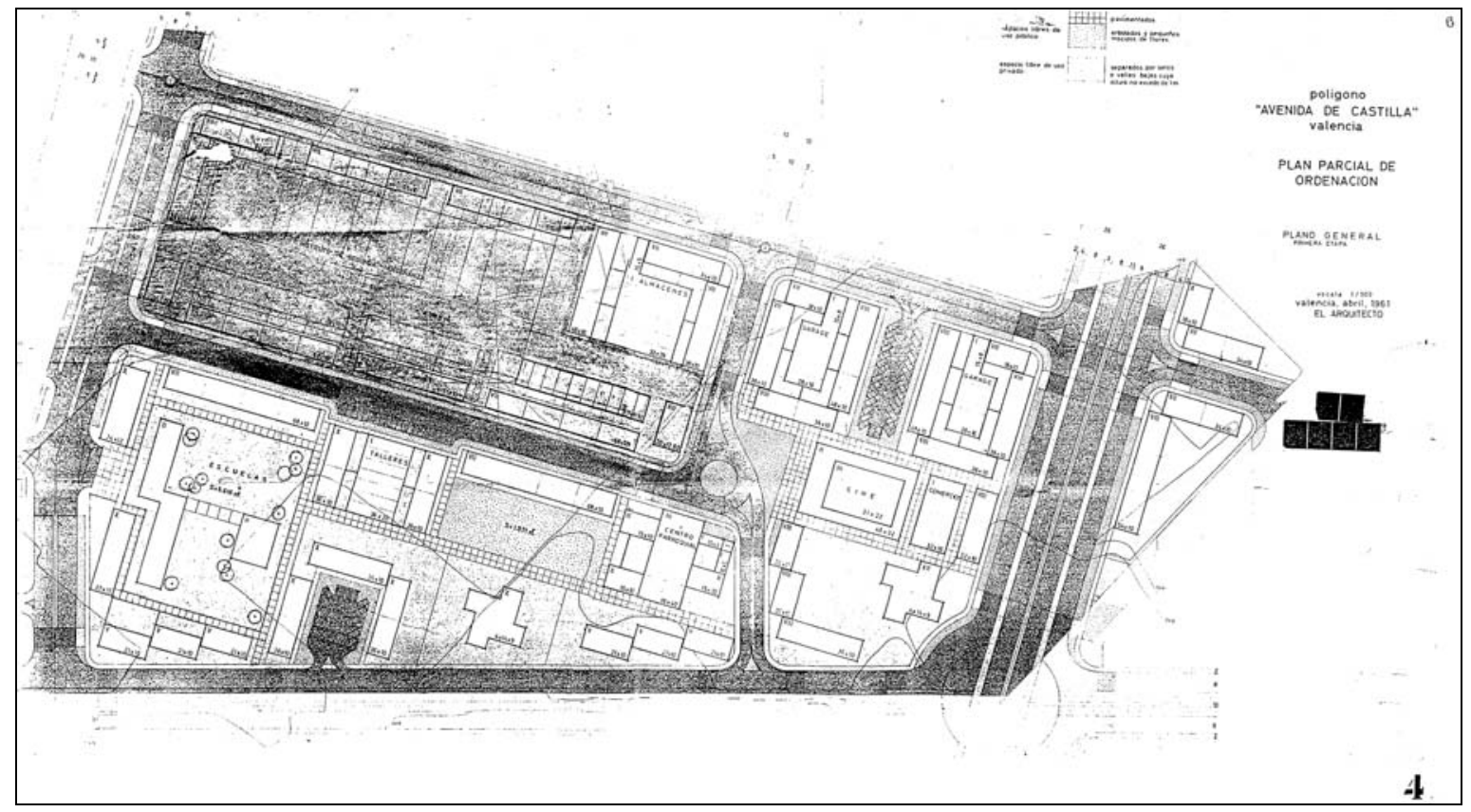

4. PLANO GENERAL $2^{a}$ ETAPA

Escala original: 1:500

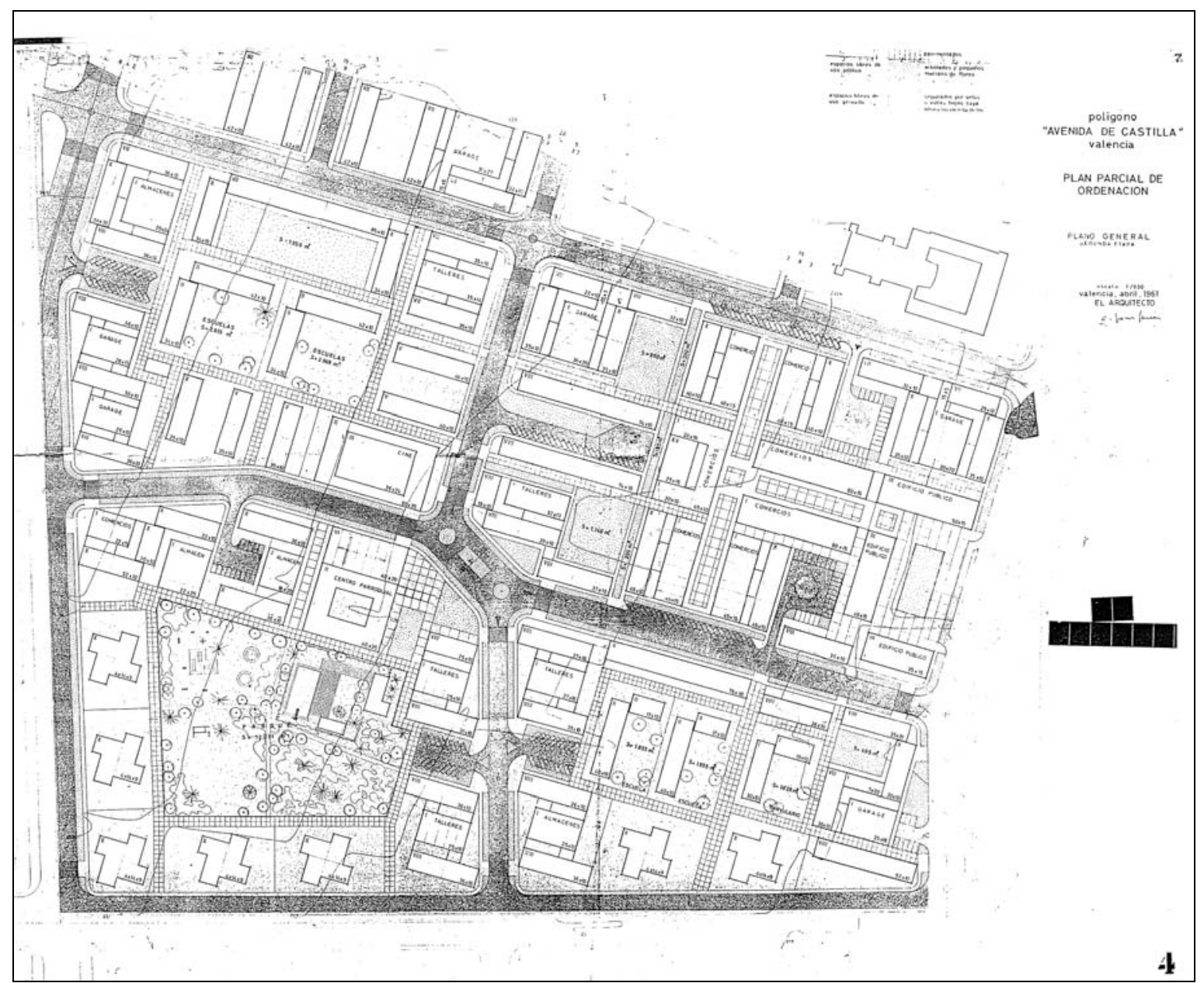


PROYECTO DE URBANIZACIÓN.

PLANTA DE ORDENACIÓN GENERAL. Noviembre 1961.

Escala original: 1:1000

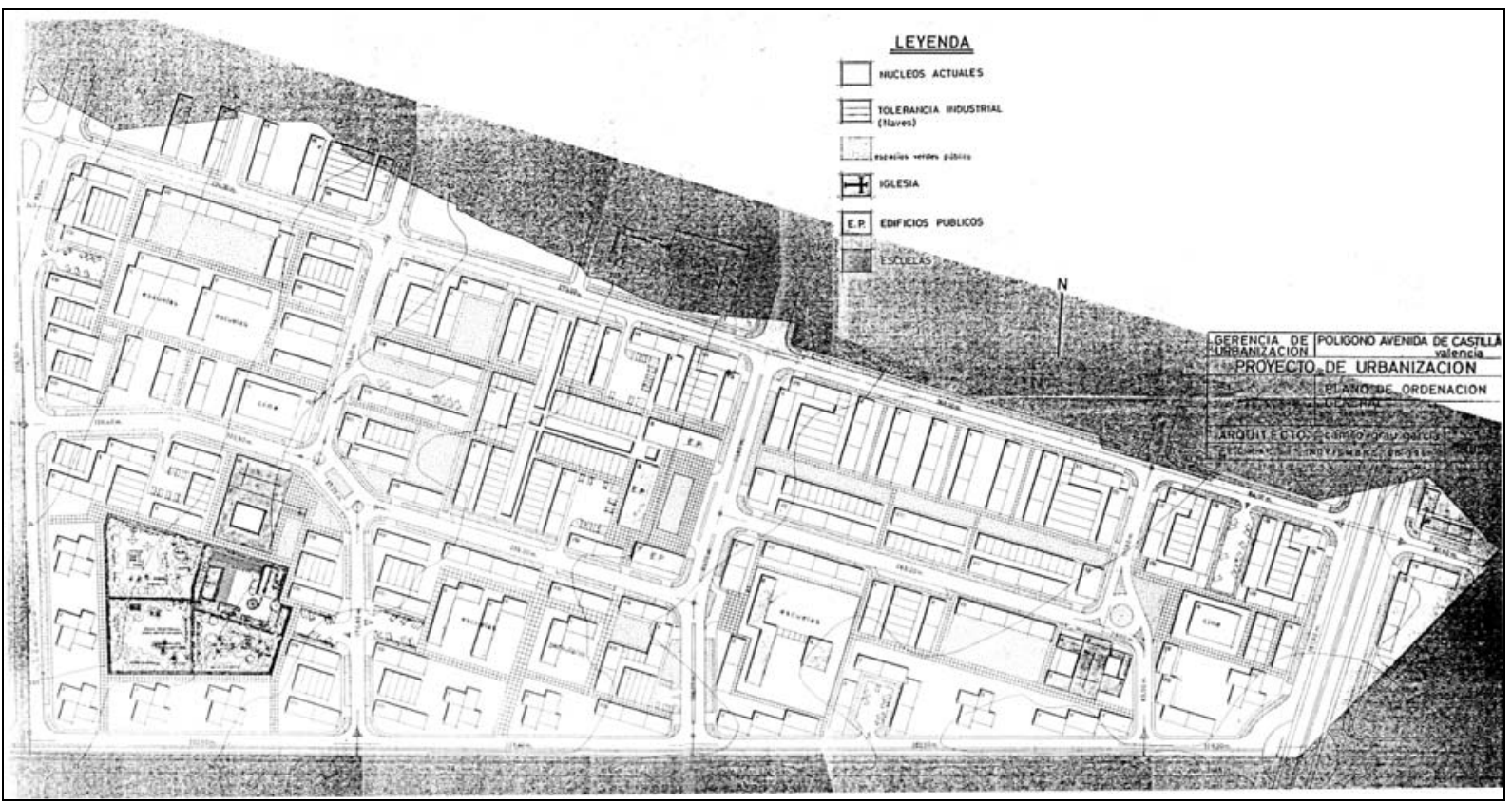

4. PLANO GENERAL DE REPLANTEO DEFINITIVO. Julio 1963.

Escala original: 1:1000

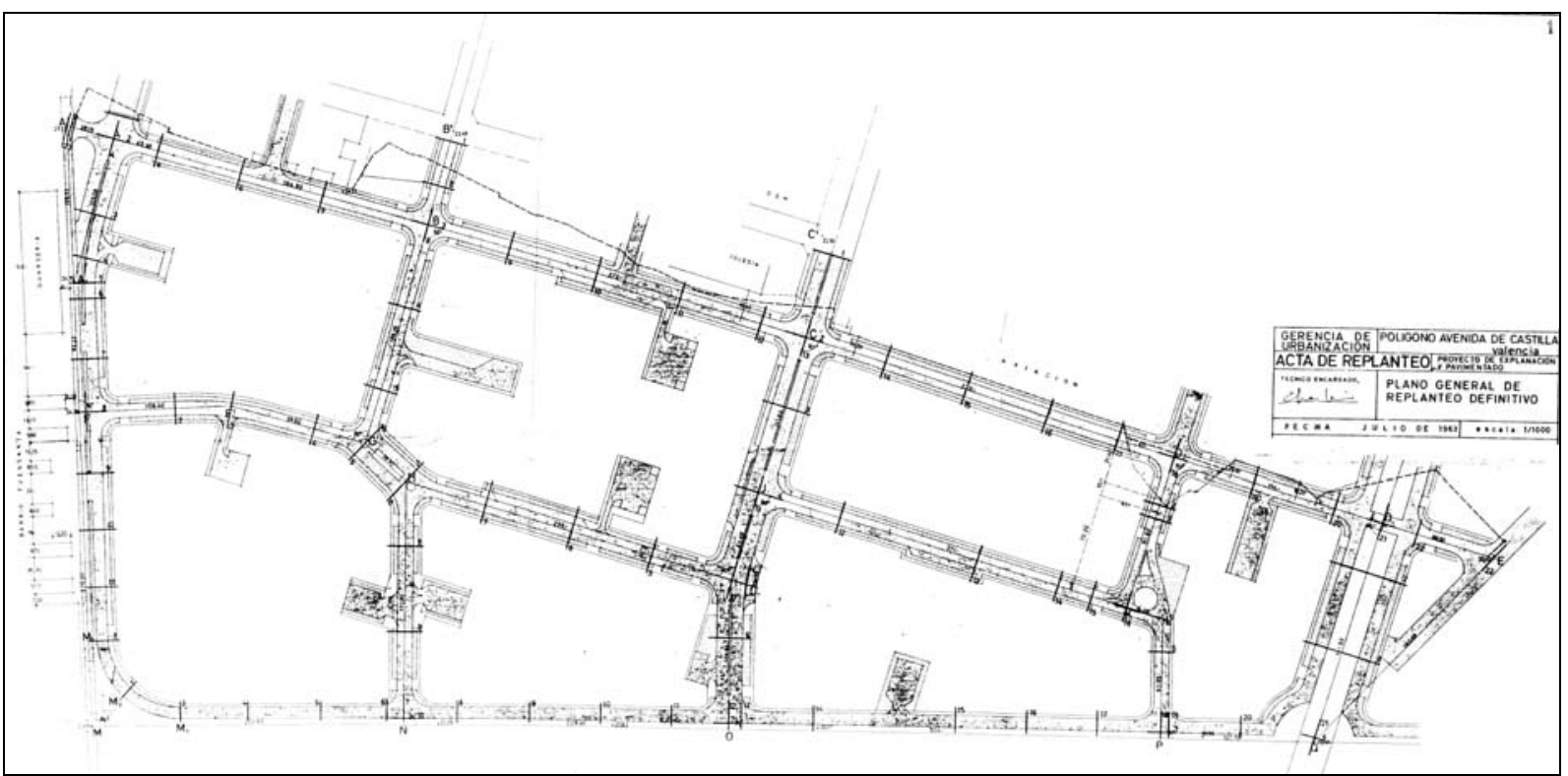





\section{Polígono Monteolivete}

Redactores: GERENCIA DE URBANIZACIÓN. MINISTERIO DE LA VIVIENDA. Arquitectos: Luís García Camarero, Luís Martínez Lebrato, José Ma Pagola de la Puente.

Fecha redacción: Junio 1960.

Fecha aprobación : 1962

\section{Contenido:}

I. MEMORIA.

II. ORDENANZAS

III. ESTUDIO ECONÓMICO

IV. CUADRO DE CARACTERÍSTICAS

V. PLANOS:

- INFORMACIÓN: TOPOGRAFÍA.

EDIFICIOS, NO DE PLANTAS Y USOS

ACEQUIAS

RED ELÉCTRICA EN ALTA

- PROYECTO: ESTRUCTURA URBANÍSTICA.

RED VIARIA.

PLANO PARCELARIO.

PLANO TOPOGRÁFICO ACTUAL Y PROYECTO

ESQUEMAS DE SERVICIOS:

ABASTECIMIENTO AGUA.

ELECTRICIDAD.

SANEAMIENTO.

TRANSPORTES.

\section{Fuente:}

Ayuntamiento de Valencia. Archivo de Planeamiento (Sección expedientes antiguos, No 41b) 

PLAN PARCIAL DE ORDENACION DEL POLÍGONO

"FUENTE DE SAN LUIS". V A L E N C I A.

\section{MEMOR I A}

Por encargo de la Gerencia de Urbanización del Ministerio de la Vivienda se ha procedido al estudio del Plan Parcial correspondiente al citado polígono, cuyo emplazamiento se encuentra al Sureste de la ciudad, entre el río Turia y el nuevo acceso a la carretera de Alicante.

\section{EMPLAZAMIENTO Y ACCESOS}

El polígono presenta la forma de un triángulo rectángulo resultante del trazado viario del Plan General de Ordenación de la ciudad en ese sector. Por el Suroeste aparece delimitado con el nuevo acceso de la carretera de Alicante (en ejecución), por el Este con la vía que enlazara la citada penetración con la carretera de Barcelona y por el Noroeste con la avenida de nuevo trazado prevista también en el Plan de Ordenación.

Sus accesos son pues, muy claros desde el exterior, apareciendo los vértices del polígono como nudos de circulación que habrán de tener gran importancia en el esquema viario general de la ciudad.

\section{CARACTERISTICAS GENERALES DEL POLIGONO}

La superficie total del polígono objeto del estudio asciende a $574.011,00 \mathrm{~m} / 2$ aunque el área de la zona delimitada por la Gerencia para la expropiación es solo de 414.895,60 m/2. La explicación viene dada por la necesidad de desarrollar la unidad urbanística completa dentro de los limites naturales constituidos por las tres vías, ya citadas, de circulación rápida, previstas en el Plan General de Ordenación de Valencia y en fase de ejecución. En el Plano C-3 aparecen reflejados con toda precisión los límites del Plan Parcial proyectado y la delimitación de la zona a expropiar que, como puede verse, coincide con la primera, a excepción del ángulo N.O. no incluido en tal delimitación por encerrar buen número de edificaciones de reciente construcción y una urbanización que puede integrarse en el conjunto del Plan Parcial.

El terreno es prácticamente horizontal con ligeros desniveles que principalmente corresponden a los límites de las parcelas cultivadas, por lo que loa movimientos de tierras para realizar los trabajos de urbanización habrán de ser prácticamente inapreciables. En general se presenta un ligero declive hacia el Este que no llega a rebasar los tres metros en las cotas extremas. Esta circunstancia unida a que la contextura del terreno es aceptable en cuanto a su calidad y resistencia (tierras arcillosas compactas) permitirán que loe gastos de urbanización resulten muy pequeños.

Por lo que respecta al clima puede hacerse extensivo cuanto se tiene estudiado para la Capital, dada su proximidad al casco urbano. Conviene apuntar únicamente que, por su posición al Este de la ciudad, recibe de un modo más directo el influjo de las brisas marinas que, aunque no pueden calificarse de vientos dominantes, contribuyen a condicionar el clima de la zona y precisa tener en 
cuenta a efectos de la disposición y orientación de los bloques residenciales.

La distancia al casco urbano de la Capital, entendiendo como tal la zona totalmente urbanizada, es aproximadamente de unos cuatrocientos metros; para ello se considera como límite de dicha zona el llamado camino de Tránsitos que, a modo de ronda, delimitó el perímetro de la Capital hasta fecha muy reciente. En contacto con el polígono, solamente existen algunos núcleos de edificación dispersa, mas bien inconexa, urbanísticamente hablando, que no pueden servir de pauta para una ordenación.

\section{ESTADO ACTUAL}

Grado de Urbanización.- No puede hablarse con propiedad de la existencia en el polígono de áreas urbanizadas; tan solo aparecen dos áreas edificadas contorneando la Carrera de Encorts y la Carrera de San Luis, como consecuencia del interés que lógicamente ofrecen las vías rodadas para la edificación. En estas dos arterias que constituyen penetraciones secundarías de la ciudad, desde zonas de carácter marcadamente rural, se encuentra un $90 \%$ de las construcciones existentes. El resto se presenta en forma de edificación rural dispersa, ligada íntimamente al terreno cultivado.

Distribución del suelo.- La propiedad del terreno está dividida, como es normal en toda la huerta valenciana. Esta circunstancia que, de entrada ofrece dificultades muy grandes para la urbanización futura, hace aconsejable acudir, para la realización del Plan, al sistema de Expropiación -más adecuado y eficaz que los demás previstos en la Ley del Suelo.

Edificaciones predominantes.- Salvo algunas excepciones, son de carácter fundamentalmente rural, oscilando sus alturas entre una y tres plantas, y abundando las construcciones secundarias (naves, cobertizos, corrales, etc.) de escaso valor estético y económico. La mayoría corresponde al tipo de inmueble de dos plantas, con vivienda en la superior y taller artesano o almacén en la inferior. No existen industrias de importancia ni por su extensión ni por al valor de sus instalaciones cuya desaparición sea aconsejable por exceso de volumen o de maquinaria gruesa instalada. En cuanto al número de locales comerciales, puede decirse que es bastante escaso y realmente insuficiente, aun para la reducida cifra de habitantes del sector. El número de estos se ha calculado con hablante aproximación en 2.700 correspondientes a las 600 viviendas habitadas. Existe un claro predominio de familias dedicadas a los trabajos agrícolas y operarios industriales.

Por lo que respecta al estado de vida de las construcciones, puede asegurarse que predomina, en general, el tipo de inmueble de cuarenta a cincuenta años, deficientemente construido y mal conservado, y que, además, carece de las condiciones higiénicas impuestas por los Reglamentos Vigentes, en muchos casos.

Edificaciones de reciente construcción.- Como consecuencia de una ordenación de origen Municipal realizada hace unos años, se presentan algunas construcciones de nueva planta o de vida muy reciente en el ángulo Noroeste del polígono, precisamente a lo largo de la carrera de San Luis, que es, sin duda, la zona del terreno de mayor valor actual; estas edificaciones cuya altura oscila entra las cuatro y seis plantas, son de segunda y tercera categoría, pero, 
desde luego, quedan por encima del mínimo exigible en cuanto a condiciones higiénicas y estéticas.

Servicios existentes.- Existen redes de abastecimiento de agua y de alimentación eléctrica en las áreas construidas, si bien con una disposición bastante anárquica y absolutamente insuficientes para un planteamiento de la envergadura del que se proyecta.

En cuanto al saneamiento, se realiza de un modo que por desgracia tan frecuente, a través de las acequias, que, recogiendo las aguas residuales que proceden de la Capital, se utilizan para el riego de las tierras cultivadas. El eterno problema de las aguas de riego obligará a encauzar tales acequias y a entubarlas, para que, a la salida del polígono, puedan seguir utilizándose por los agricultores del contorno. En la prolongación de la calle de Císcar (límite este del polígono), aparece un colector-emisario que procede de la $\mathrm{Ca}$ pital y que, con sus grandes dimensiones (túnel abovedado de 2,50 metros de flecha y 4,00 metros de base), permitirá su utilización para la recogida de gran parte de las aguas residuales.

Existe un abastecimiento de gas en algunos puntos de la zona Norte, pero, por las razones antedichas, será preciso acudir a una acometida general, con la ventaja de la proximidad de la fábrica, situada frente al polígono, al otro lado del río.

\section{a-1.- JUSTIFICACION DE LA ORDENACION.}

Conviene destacar, antes de iniciar el estudio detenido del planeamiento proyectado, las características fundamentales que reúne el polígono como base de una urbanización. Entre los factores mas destacados que abonan la elección del emplazamiento y condicionan las soluciones adoptadas, destacan:

a) Proximidad de los terrenos al nuevo eje de Valencia que habrá de discurrir en forma de gran avenida, por el antiguo cauce del río (solución Sur), recientemente aprobado en Consejo de Ministros.

b) Contigüidad a la estación central de los ferrocarriles, proyectada como terminal de todas las líneas importantes.

c) Facilidad de salida da sus habitantes hacia los centros fabriles, rurales e instalaciones portuarias.

d) Descongestión de los sectores que, por diversas causas, resultaban mas atractivos urbanísticamente en la zona Oeste de la ciudad.

e) Rotura del cinturón suburbial que, en forma de edificaciones anárquicas y mal ordenadas, amenazaba el vértice Sureste de la capital.

\section{Zonificación.}

La urbanización del polígono se plantea, de acuerdo con sus condiciones naturales y los factores determinantes citados, como una unidad residencial autónoma en la que, teniendo en cuenta el aprovechamiento volumétrico y de habitantes marcados en las Normas Generales, se podrá llegar a una población total de 28.000 personas.

División funcional .- Se ha previsto la diferenciación del con junto en tres supermanzanas, como unidades residenciales menores dotadas de vida propia, y cada una de éstas, a su vez, en dos veci 
nales (sectores) con los servicios propios para el abastecimiento cotidiano. En el centro de gravedad de cada supermanzana se establecerá, como elementos esenciales $y$ definitorios de uso común, las escuelas, una guardería y un pequeño dispensario, debidamente aislados en el seno de la zona verde correspondiente.

Las condiciones climáticas permiten y aconsejan un planteamiento urbanístico abierto (especialmente hacia el Este, de donde proviene el influjo moderador de la brisa) y la disposición de masas verdes que, penetrando entre las áreas edificables, han de condicionar, en gran manera, el clima interior del poblado. A este efecto, se ha decidido la implantación de una zona verde central con ramificaciones en ambos terminales, para la interpenetración con loa bloques de viviendas; esta zona verde constituirá el pulmón del polígono, permitiendo la situación de todas las instalaciones de tipo escolar, cultural, cívico y deportivo, que han de resumir la vida íntima del polígono.

Centro Comercial.- Se coloca tangente a la vía semirrápida del Noroeste, en el punto de contacto con las ultimas avanzadas de la ciudad actual y a la llagada desde la misma que, lógicamente se producirá, en mayor escala, a través de la vía diagonal proyectada que allí ha de desembocar. Con este emplazamiento, se trata de conseguir que todos los habitantes del polígono puedan acudir a este sector comercial y recreativo con el menor desplazamiento, ya que su posición viene a coincidir sensiblemente, con el centro de gravedad del polígono.

Centro Cívico-Religioso.- Se dispone de una zona tranquila más al interior $y$ casi en coincidencia con el vértice común de las tres supermanzanas. Se intenta con ello lograr una plaza de carácter representativo en la zona más estratégica del poblado por su fácil accesibilidad y aislamiento de los sectores residenciales. La proximidad de la zona verde general del polígono, permite rodear a loa edificios de un ambiente vegetal que ha de resaltar la importancia de los volúmenes construidos, destacando su primacía jerárquica. Por otra parte, esta plaza cívica, tratada al modo clásico como el foro de esta microciudad, se encuentra en el punto crucial de las dos arterias fundamentales que han de canalizar las circulaciones rodadas del polígono, con lo que se facilita la llega y estacionamiento a los vehículos que han de utilizar sus servicios.

La estructuración urbanística estudiada, se ha obtenido como una consecuencia fundamental de la forma del polígono que, de un modo natural, obligaba a una disposición equilibrada, en triángulo. Con ello se ha conseguido situar los elementos generales de uso común en el centro del trébol constituido.

El esquema viario define y delimita las tres unidades vitales del sector, con acceso principal desde la vía Noroeste y penetraciones desde los otros dos lados del triángulo.

\section{a-2.- TRAZADO VIARIO.}

Se ha seguido con fidelidad el principio urbanístico actual de diferenciar netamente las circulaciones rodadas y de peatones, lo que ha conducido a ese elemental trazado de calzada de circulación continua. Consideramos que los dos ejes de tráfico son suficientes para los accesos a los sectores residenciales $y$ las conexiones entre ellos, ya que la extensión y forma del polígono con su contorno definitivo por vías de circulación semirrápida, dotadas, en dos casos, 
de calzadas laterales, resuelve de modo completo, la llegada de vehículos a los bloques de viviendas.

Se ha pretendido, por otro lado, que los accesos rodados a la unidad residencial que se proyecta, fueran muy definidos y que, interfirieran en el menor grado posible, las circulaciones exteriores; este principio, conjugado con el criterio, actualmente insoslayable, de evitar en lo posible la circulación rodada en el interior del "habitat", han condicionado, fundamentalmente, el trazado de la red viaria.

La llegada a los bloques de viviendas, dentro ya de los sectores residenciales, se ha de producir a través de una serie de penetraciones en fondo de saco, estratégicamente distribuidas. No se cortan de este modo, en ningún lugar, las circulaciones rápidas de las vías perimetrales y solamente se acomete a las calzadas laterales en escasos puntos.

Los perfiles transversales de las vías interiores, han sido estudiados desde un punto de vista funcional, considerando que el porcentaje de vehículos que, en un momento dado podrán circular simultáneamente por ellas, no habrá de rebasar el cinco por ciento del total, ya que el mayor numero de conexiones circulatorias se ha de producir entre el polígono y el exterior, quedando para las comunicaciones interiores el caudal constituido por los abastecimientos a tiendas y talleres, y el poco frecuente desplazamiento reducido de habitantes motorizados entre uno y otro sector; por ello se han fijado unas calzadas de catorce metros entre bordillos, lo que permitirá el trafico con circulación en dos sentidos, con posible adelantamiento, teniendo en cuenta un improcedente pero muy normal y probable estacionamiento en ambos laterales de la calzada.

Se ha estudiado la posible trayectoria de los transportes colectivos, pensando que, fundamentalmente, habrán de ligar esta unidad residencial con el centro de Valencia y con las zonas fabriles. Teniendo en cuenta la forma del polígono, y considerando que la distancia de cualquier punto habitable del mismo al perímetro, no rebasa en ningún caso los doscientos metros, parece lógico que las líneas $\mathrm{d}$ « transporte a establecer por los servicios Municipales no hayan de tener necesidad de penetrar dentro del mismo. Esta circunstancia permite la instalación de paradas y esperas en el contorno, que contribuirán a evitar una tensión circulatoria elevada dentro del recinto.

Estacionamientos.- Se han estudiado las superficies útiles para el aparcamiento de vehículos en función del porcentaje previsible de estos en relación con el número de habitantes para un período de 50 años. En todos los terminales de las raquetas de penetración, se han dispuesto zonas de estacionamiento, en cordón o en batería que, junto a las que se establecen en las vías de contorno, totalizan para cada sector, una capacidad aproximada del diez por ciento de los habitantes del mismo.

Hay que destacar que, los estacionamientos previstos en las aceras del acceso de Alicante y de la Avenida Sur, permiten un ensanchamiento futuro de las calzadas laterales, ya que del sistema de aparcamiento en batería, se puede pasar al de cordón.

Circulación de peatones .- La red circulatoria establecida para los peatones, se ha dispuesto en función del acceso necesario a los portales de los bloques y a la conexión entre las zonas vitales dentro del sector. Se ha procurado que los recorridos sean mínimos y que, además, queden protegidos del efecto del sol por pantallas 
de arboles situadas en el Sur. Los citados pasos, tratados como aceras, muy simples, de tres metros de anchura y fabricadas con hormigón o baldosas prefabricadas de terrazo rugoso, servirán, en general, para la delimitación de las futuras parcelas, dejando interespacios de terreno que habrán de tratarse con jardinerías de arbustos y plantas.

\section{a-3.- ZONIFICACION.}

Proyectados como la unidad residencial elemental, se han dispuesto con la densidad suficiente para que, dentro de las normas volumétricas establecidas, pueda llegarse al coeficiente de aprovechamiento medio y al número de habitantes por hectárea marcados en el Plan General.

Sus dimensiones generales se han fijado de tal modo que, la profundidad (potencia) del área edificable sea como máximo de 200 metros (tres minutos andando) entre espacios libres, para asegurar el acondicionamiento climático y evitar que los desplazamientos de sus habitantes hacia los centros de aprovisionamiento cotidiano, de enseñanza y paradas de transporte colectivo rebasen acuella distancia. Con ello se trata de evitar también la sensación de agobio que producen loa complejos urbanos masivos, abriendo los bloques hacia los espacios libres y proporcionando la expansión psicológica precisa a los habitantes con vistas agradables, abundante aireación y permeabilidad de tránsito.

Para la disposición de los bloques, cuyas dimensiones se detallan y Justifican en las Ordenanzas Reguladoras, se ha operado en función de la orientación y de la estructuración orgánica. Como puede observarse, la mayoría de los edificios se emplazan con una orientación de eje N.E.-S.0. que permite abrir las fachadas principales al S.E., óptima desde el punto de vista del soleamiento y de la aireación. El escaso número de bloques con orientación girada ortogonalmente, resulta obligado por la creación de espacios libres y ámbitos conectados y por facilitar el trazado de la red circulatoria de peatones.

La distribución en planta de terreno de los edificios, se ha realizado de acuerdo con dos determinantes fundamentales: funcional $y$ estética. En cuanto al primero, ya se han citado los factores de orientación y circulaciones; hay que destacar también el estudio realizado para que las sombras arrojadas de los bloques no puedan proyectarse sobre las fachadas de las edificaciones contiguas y, sobre todo, el criterio seguido en cada sector de establecer en su centro de gravedad (próximamente) una plaza que, a modo de la antigua ágora constituya el núcleo vital de la unidad residencial. En ella irán emplazados los locales comerciales de sector y, en su proximidad, si bien ocultos de vistas directas los garajes y talleres artesanos. Para las naves de la industria compatible y talleres de mayor envergadura, se ha previsto una disposición, similar al patio de manzana en la que dos bloques-pantalla de viviendas enmarcan y ocultan las cubiertas de los mismos.

Por lo que respecta al estudio estético realizado, basta con reseñar sucintamente loa factores que se han tenido presentes: expresión de ritmos, estudio de rompimientos y contrastes, articulación de espacios libres, cerramiento de perspectivas, definición de siluetas a implantación de elementos focales. No hay que decir que, como es natural, se ha dirigido el enfoque del estudio plástico de los sectores hacia el punto de vista del viandante, despreciando la es 
pectacularidad de las panorámicas aéreas que no tienen interés para el habitante de la ciudad.

El número aproximado de viviendas que resulta en el total del polígono, considerando un volumen medio por cada una de aquellas de 270,00 metros cúbicos, es de 7.094 que, aplicando el índice de 4,5 personas por vivienda, permitirá albergar un total aproximado de 31.923 habitantes.

Zonas verdes.- El sistema de zonas verdes se puede considerar dividido en los espacios interiores a las supermanzanas y en la masa verde general dispuesta en el centro del polígono. Su razón funcional es doble: creación de las áreas tranquilas y apartadas de la circulación rodada para establecer escuelas, guarderías, paseos $y$ zonas de recreo $y$, por otro lado, fomento del microclima preciso para mejorar las condiciones ambientes en el núcleo de la urbanización. Es preciso insistir en el aprovechamiento de estas áreas para la construcción de edificios de uso comunitario, por lo que, su reserva no supone una perdida considerable de terreno a efectos económicos. Se ha considerado que la anchura mínima de estas zonas verdes, para que su función sea eficaz, es de 60 metros; a la vista de este mínimo, se han fijado los anchos de las diferentes fajas que constituyen la masa verde general. En el centro mismo del polígono, precisamente entre los centros comercial y cívico, queda dispuesta la zona absolutamente libre de parque, para el disfrute de sus espacios ajardinados; su situación es estratégica, además, parque aparece como una prolongación de la zona de espectáculos, donde esta prevista la instalación de un hotel residencia, un cine y cafeterías,

La disposición longitudinal de la masa verde, ha permitido disponer un paseo que, a modo de alameda, recorre paralelamente a una de las arterias del polígono. Con espacio suficiente para un desarrollo amplio, se sitúan las instalaciones deportivas, provistas de gradas para espectadores y de los necesarios cuerpos de vestuarios; en íntimo contacto con los campos de deportes se ha proyectado un edificio bajo previsto para el alojamiento de un club, a modo de ateneo que, aparte de sus seccionas de tipo intelectual y recreativo, pueda alojar la administración y control de las instalaciones deportivas citadas.

Escuelas.- Para el cálculo de las escuelas, se han tenido en cuenta los porcentajes que indica el Ministerio de Educación Nacional en cuanto a cifra de alumnado de un sector residencial. Determinados el número de grados precisos, se han seguido aplicando, para la obtención de los volúmenes requeridos, los datos del citado Ministerio que marcan las superficies mínimas exigidas por alumno. Todos los edificios escolares están rodeados por una zona propia para la instalación de sus campos de juegos y jardines, habiéndose determinado en las normas constructivas que los cerramientos de tales parcelas se deberán realizar con setos vegetales o muretes bajos que no interrumpan la continuidad visual de la zona verde.

Centro Cívico-Religioso.- Para su emplazamiento se ha buscado un lugar tranquilo aunque tangencial a una de las arterias circulatorias principales del polígono. Se ha tratado de integrar con edificios de carácter oficial y de uso comunitario una plaza representativa que, a modo del foro romano compendiara un poco las actividades de tipo social y cívico para los habitantes del poblado. Componen el Centro los siguientes edificios: la iglesia parroquial, como elemento fundamental $y$ eje simbólico y estético de la plaza; el ins 
tituto de secunda enseñanza y un bloque en el que irán instalados los servicios públicos. Por razones funcionales, se ha buscado la conexión directa con el Centro Comercial y de oficinas, del que queda separado, únicamente, por el parque Central. Una serie de aparcamientos suficientemente amplios para absorber el número de vehículos que, en casos extraordinarios puedan concentrarse, se dispone estratégicamente junto a la plaza.

El centro parroquial constituye un conjunto en el que, destacan el volumen diferenciado de la iglesia y al que acompañan el edificio destinado a los locales de la Acción Católica, con su sala de actos, catequesis y escuela parroquial, y el pequeño bloque que ha de alojar la vivienda rectoral; todo ello ligado de un modo orgánico y encerrando con atrio y pasos cubiertos un jardín claustral interior. Como instalaciones anejas al Instituto de Enseñanza Media se prevé un cuerpo de edificio que puede llevar un local para biblioteca y una sala de exposiciones.

En el lateral derecho se ha de levantar el bloque que ha de albergar los servicios públicos previstos. Estos son las oficinas Municipales. Las de Correos, Telégrafos y Teléfonos, con los locutorios y salas de maquinarias indispensable, la Comisaría y retén de Policía, las oficinas recaudadoras de Hacienda $y$, en un cuerpo secundario adosado, los servicios municipales de policía Urbana, limpieza y el necesario retén de bomberos.

Centro comercial.- Justificado ya su emplazamiento desde el punto de vista de las necesidades del poblado y de la proximidad a los accesos más directos desde la Capital, conviene describir sus edificios integrantes y su disposición en el conjunto.

El elemento fundamental queda. constituido por la galería de locales comerciales que, tratada de un modo funcional queda formada por dos bloques bajos limitando una calle que, tradicionalmente entronca con la calle mayor de nuestras villas; a la entrada de ella se abre una amplia lonja que, precedida de un extenso aparcamiento, ha de facilitar el acceso a un sector que, por su índole ha de atraer a un numero elevado de personas. Un bloque-torre de 20 plantas cierra la lonja, sirviendo para instalar el contingente obligado de oficinas; al propio tiempo constituye un volumen plástico de contraste y elemento focal interesante desde la avenida que ha de conectar con el polígono la Capital.

El mercado se establece en un punto estratégico para facilitar su acceso desde las zonas limítrofes y, de tal manera, que no ofrece sus aspectos molestos al paso habitual de peatones: queda servido a efectos de abastecimiento por una penetración terminada en amplia raqueta que, al propio tiempo servirá para el aprovisionamiento de los comercios y almacenes.

Al fondo del Centro Comercial y abriéndose ya a la zona verde, se disponen los volúmenes destinados a una sala de espectáculos y un hotel, ligadas con un cuerpo bajo previsto para la instalación de bares y cafeterías.

Da un modo especial se ha estudiado la circulación de peatones en este sector para evitar que, por su lentitud $y$ densidad, so produzcan interferencias y aglomeraciones.

\section{Redes Servicios.}

A continuación se describen, de un modo sucinto, las características más destacadas de saneamiento, distribución de agua y alimentación eléctrica. 
Red de distribución de agua potable.- Comprobada la insuficiencia de una sola acometida para el abastecimiento del polígono, se ha decidido acudir a la solución de una arteria maestra en anillo con alimentación desde los tres puntos en que, actualmente existen acometidas de importancia: Carrera de San Luis, Carrera de Encorts y prolongación de la calle de Císcar. Desde este anillo que, además permite el equilibrio de presiones, se procede a la distribución general por medio de una red en malla, que, extendida por todo el polígono, permitirá el abastecimiento necesario a todos los bloques. En los puntos de entronque, derivación o cambio brusco de trayectoria, se establecerán pozos de registro con llaves de compuerta.

Se ha previsto ( $y$ así figura en el plano correspondiente), el trazado de una red de distribución para el agua de riego, de importancia vital si se quiere conservar el conjunto de zonas verdes en debidas condiciones.

Las acometidas a los bloques, que habrán de situarse en un punto fácilmente accesible de la finca, llevaran un registro con las llaves de paso y los contadores para el control de consumo.

Red de saneamiento.- El problema planteado (como en toda la ciudad) por la falta, casi absoluta de pendientes naturales en el terreno, se ha resuelto, creemos que del mejor modo posible, estableciendo tres puntos distintos de desagüe. Como, por otra parte era preciso seguir adoptando el sistema de utilizar como afluentes las principales acequias que, prácticamente ejercen la función de colectores, se ha decidido utilizar las tres de aquellas más importantes que atraviesan el polígono. El colector principal que, en forma de galería visitable recorre la Avenida Linde del Noroeste, debajo de su acera, recogerá las aguas residuales de los sectores 1,2 y 3 y del Centro Comercial, vertiendo en la acequia del Valladar (debidamente entubada) que, finalmente desemboca en el emisario de la calle Císcar.

El colector que ha de recoger las aguas del sector número 4 , recorrerá la línea que, actualmente ocupa la Carrera de San Luis, desembocando en la acequia Fabiana en el lateral Suroeste del polígono; bastará con una sección ovoide por no tener un excesivo campo de acción. El sector número 5 y parte del número 6, irán servidos por otro colector de sección ovoide que acometerá a la acequia Roll de la Barca. Finalmente, un área pequeña, coincidente con el Centro Cívico y zonas adyacentes, quedará saneada por un pequeño colector que puede acometer al Ilamado Brazo de San Jerónimo.

En el avance económico establecido para considerar los gastos unitarios de urbanización, se ha tenido en cuenta, como una de las partidas fundamentales, la cubrición, encauzamiento y, en algunos casos, desviación de todas las acequias y brazales que surcan el terreno. En general se tenderá a modificar en el menor grado posible, la trama actual, realizando estas desviaciones únicamente, cuando el cauce pueda estorbar o dificultar notoriamente la ejecución da las cimentaciones.

El caudal de recogida de aguas pluviales, no ha de ser muy considerable dado al tipo de urbanización proyectada, ya que al existir una bastante reducida superficie construida de bloques en planta de terreno y una mínima área de calzadas y acera, resulta reducida la superficie de recogida; la mayor parte de las aguas de lluvia que han de caer sobre los espacios libres, filtraran a través de las capas permeables del terreno. 
Red de distribución eléctrica.- Como puede observarse en el plano de servicios, se ha previsto una red de distribución en anillo, estableciendo tres transformadores de $250 \mathrm{Kw}$., subterráneos a intervalos señalados por el cálculo. Las líneas de alimentación a los bloques de mayor volumen y altura, se realizaran con cables subterráneos; el resto de las edificaciones $y$, especialmente las que correspondan a los sectores 4 y 5 , irán alimentadas por medio de cables aéreos, fijando palomillas y postes en puntos poco visibles, de tal modo, que el conjunto de la instalación resulte inapreciable desde las calles.

El alumbrado publico deberá resolverse con candilejas de vapor de mercurio (color corregido), utilizando columnas esbeltas en los espacios amplios y brazos murales para recibir en las fachadas donde la separación de bloques sea reducida.

Red de distribución de gas.- Resulta perfectamente realizable, $y$ de ello se nos informo por parte de la Compañía suministradora, dada la relativa proximidad del gasómetro a los límites del polígono. Las acometidas actuales son totalmente insuficientes, por lo que sería preciso realizar un estudio independiente que, lógicamente, corresponde a los servicios técnicos de la citada empresa.

No se presenta ninguna propuesta sobre la instalación de paradas de autobuses y estaciones de servicios, por considerar que su emplazamiento ha de desprenderse de un estudio conjunto de las necesidades de la Capital y las corrientes de tráfico generales, saliéndose por tanto, del estudio concreto del polígono.

Madrid, Junio de 1.960

Los Arquitectos,

\section{Firmado:}

Luís García Camarero

Luís Martínez Lebrato

José Ma. Pagola de la Puente. 
1. PLANO DE PROYECTO. ESTRUCTURA URBANÍSTICA

Escala original: 1:1000

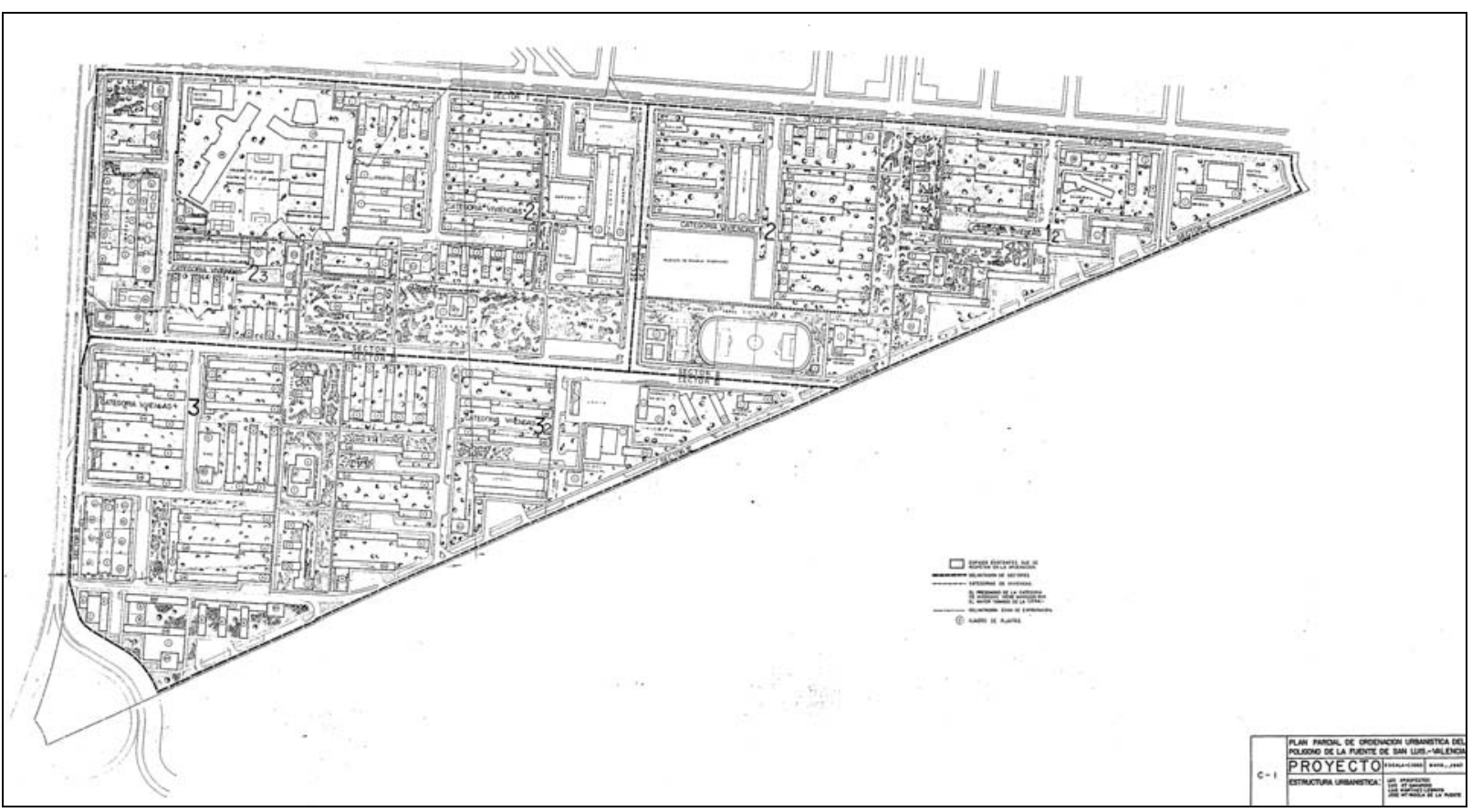

2. PLANO DE PROYECTO. ZONIFICACIÓN

Escala original: 1:1000

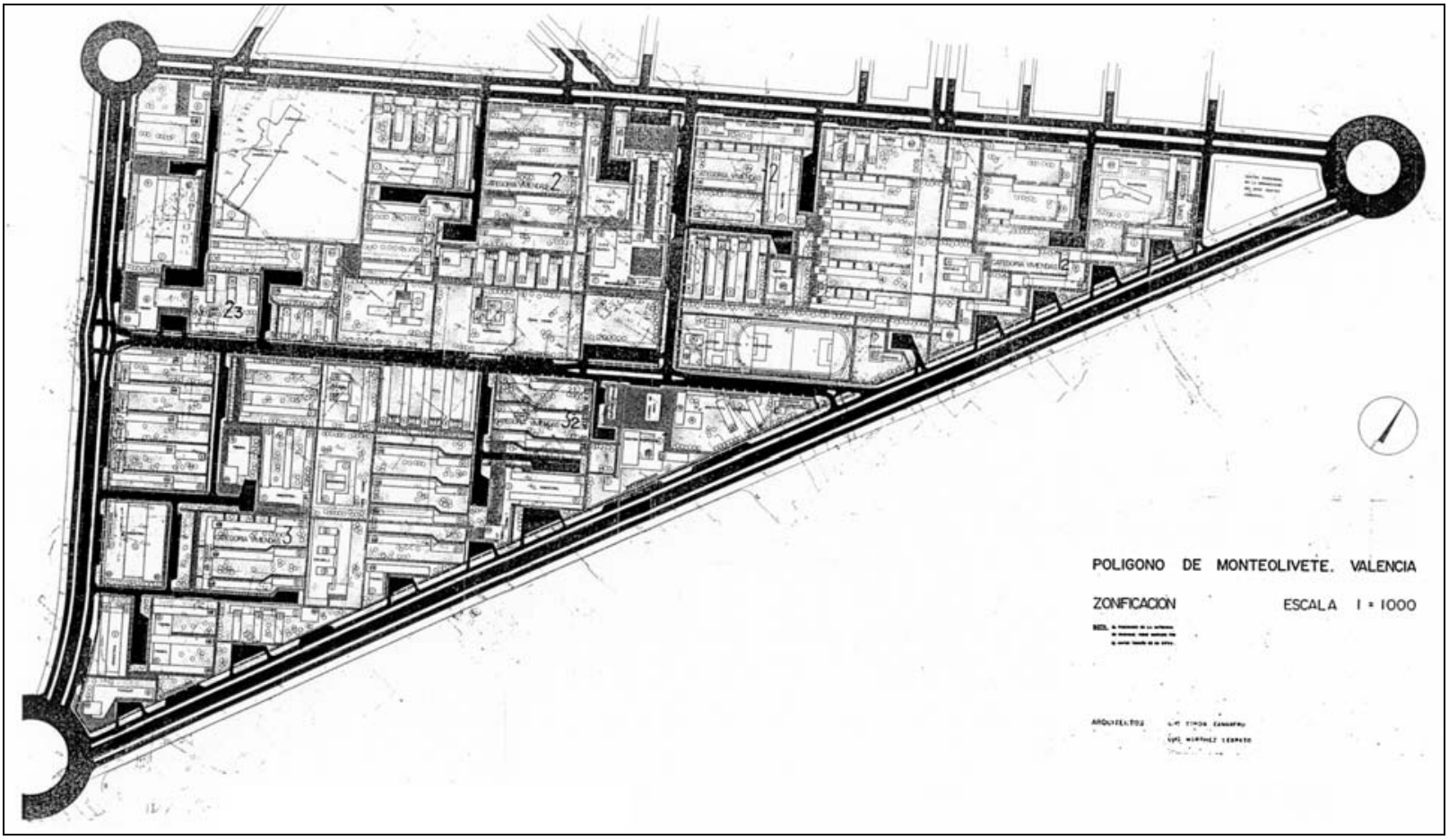




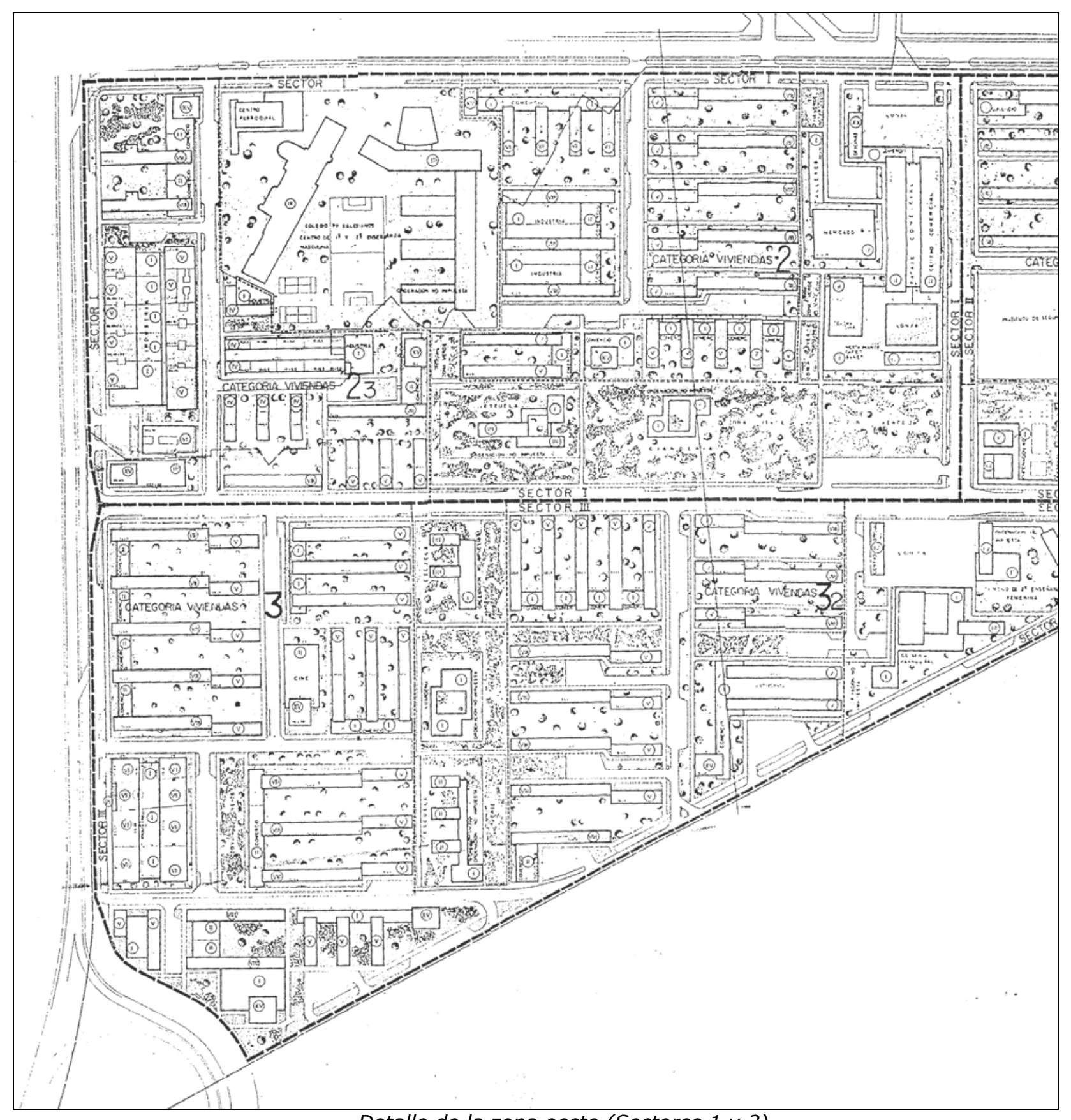

Detalle de la zona oeste (Sectores 1 y 3) 


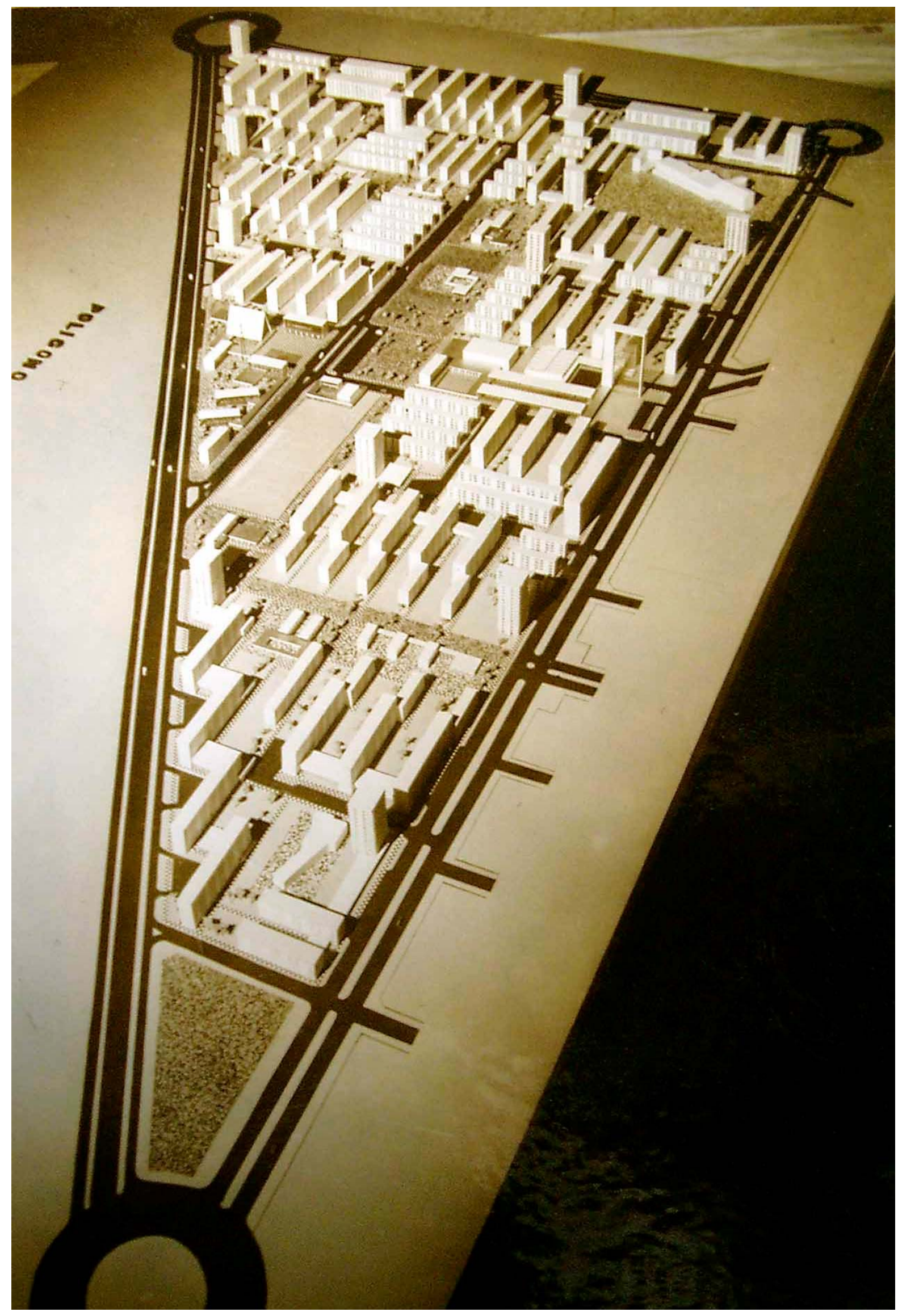



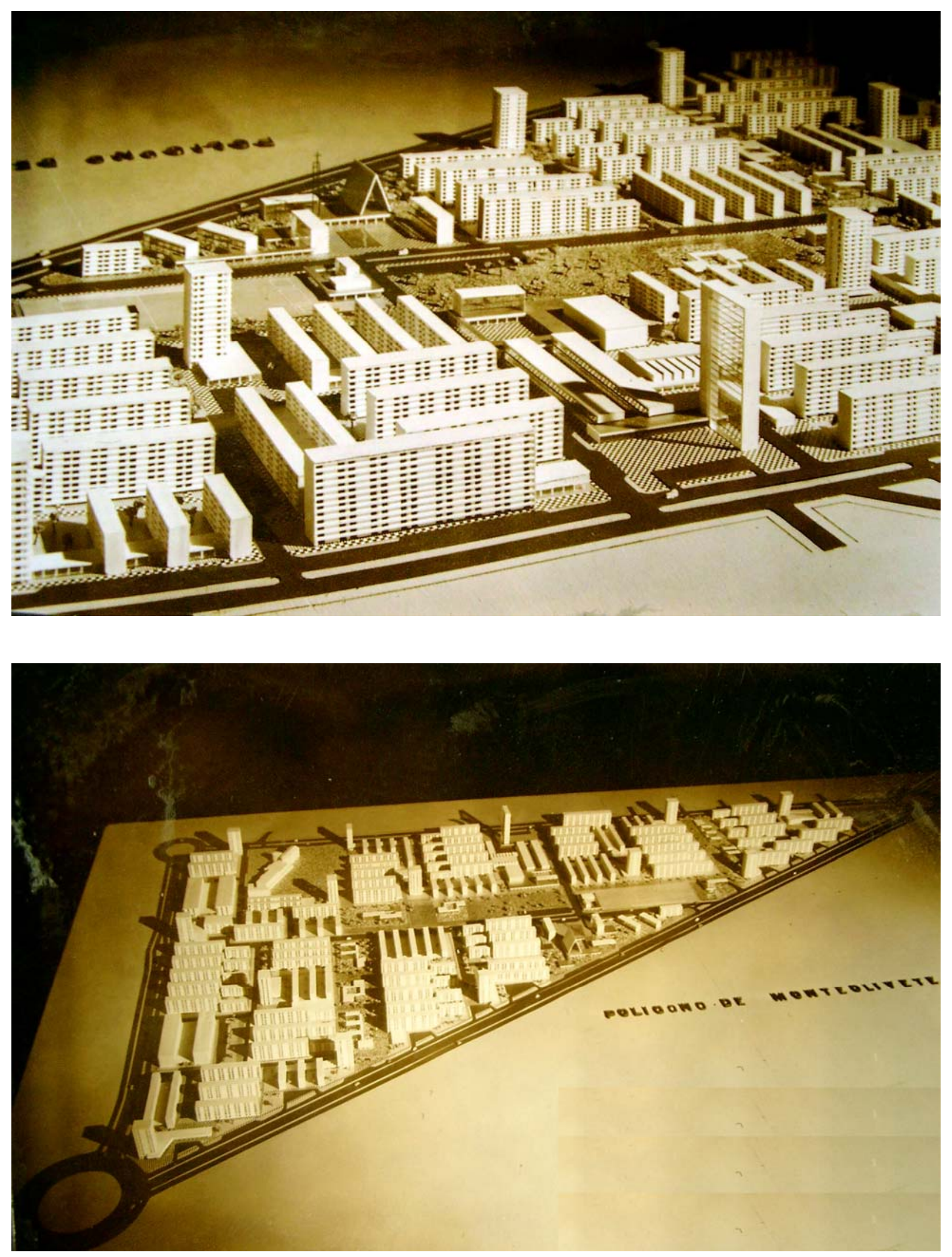


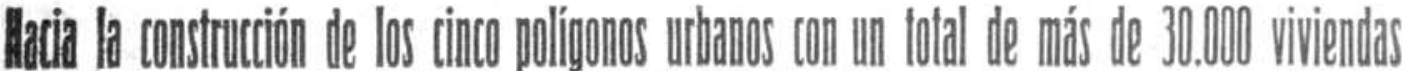
Enclavados en Monteolivete, Avenida de Valencia al Mar, Campanar, Avenida de Castilla y el Industrial, en el Camino de las Tres Cruces Sucinta idea del que se proyecta construir en Monteolivete

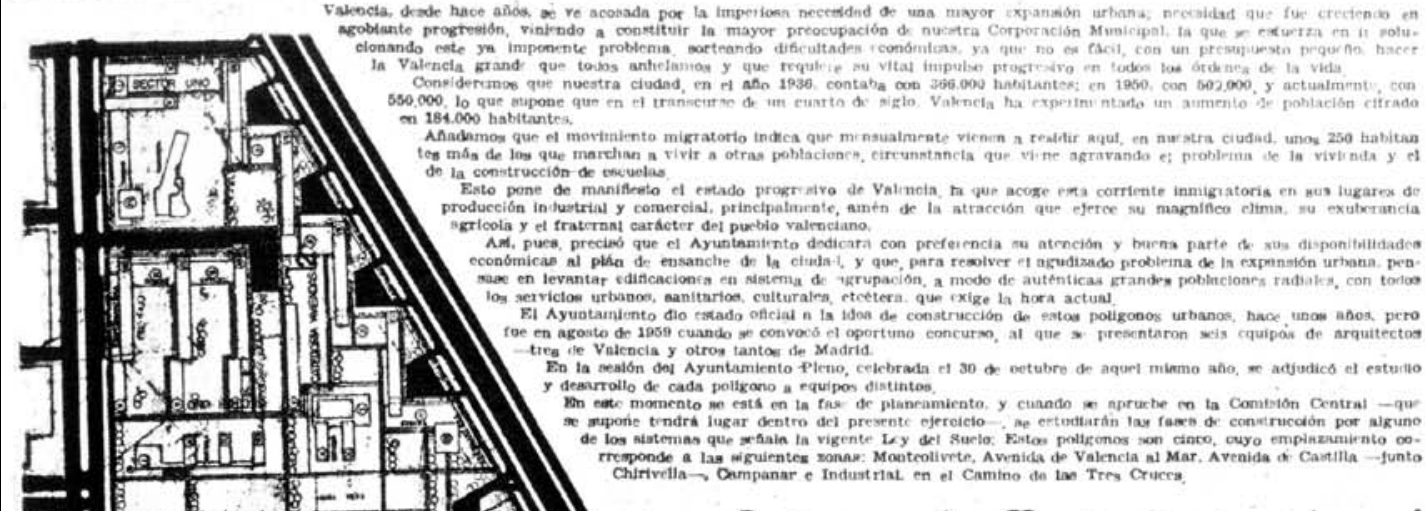
द 1 as 7 [. 5 F. Con iglesios, escuelos, teatro, Instituto Femenino, centros sanitarios

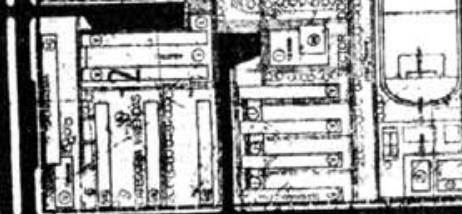

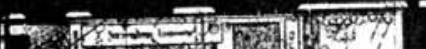
7 $8 \mathrm{k}=\mathrm{k}=\mathrm{k}$

1 1

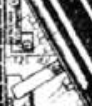

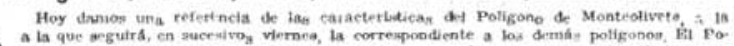

thori

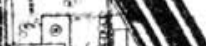

Fing

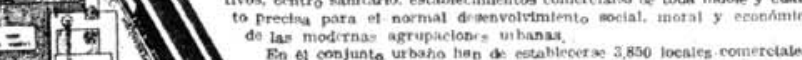

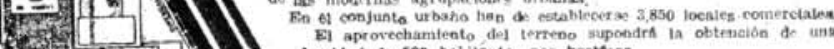

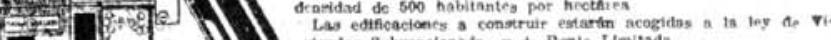

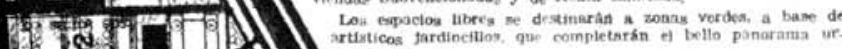

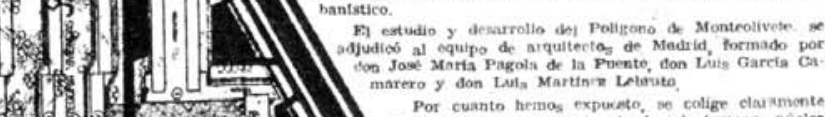
1 1. 1.

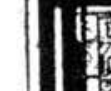
हा? $\frac{1}{2}$

His. tin $=2$
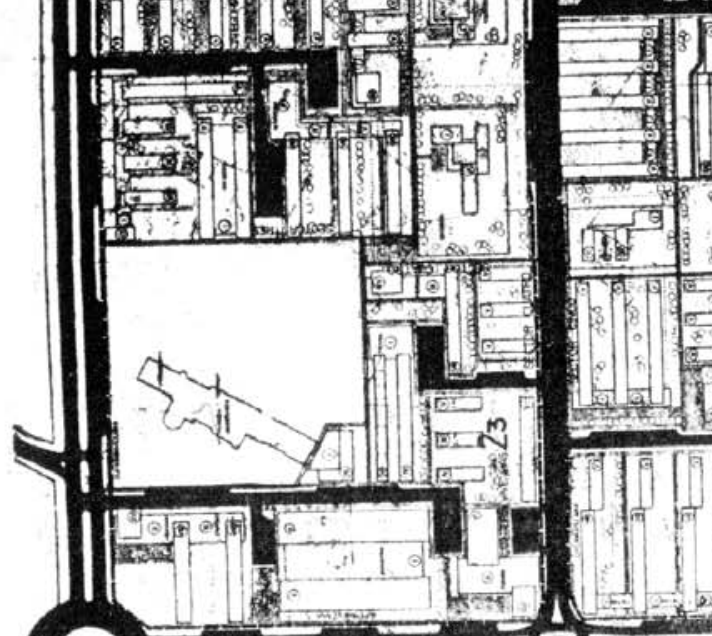

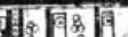

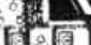

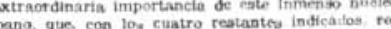

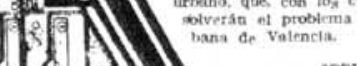
(a)

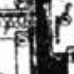

$1-15$
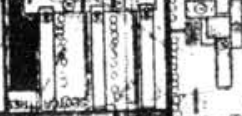



\section{Monteolivete}

ORDENACIÓN PARCIAL DEL POLÍGONO DE MONTEOLIVETE

(CENTRO COMERCIAL)

1960

Redactores: GERENCIA DE URBANIZACIÓN. MINISTERIO DE LA VIVIENDA. Arquitectos: Luís Pérez Mínguez, Luís Laorga, José López Zanón.

Fecha redacción: 1960.

Fecha aprobación: -

\section{Contenido:}

MEMORIA.

ORDENANZAS

PLANOS:
1. PLAN GENERAL DE ORDENACIÓN
E 1:1000
2. ORDENANZA DE USOS
E $1: 1000$
4. ALZADOS GENERALES
E $1: 1000$
11. PARCELACIÓN ACTUAL
E 1:1000

Fuente:

Ayuntamiento de Valencia. Archivo de Planeamiento (Sección de expedientes antiguos) 


\section{ORDENACION PARCIAL DEL POLÍGONO DE MONTEOLIVETE EN VALENCIA}

\section{MEMORIA}

Refiriéndonos a la zonificación urbana de la solución Sur, la parte del Polígono no 1 que nos ha sido encomendado en este estudio, ocupa una posición central entre el bario de Ruzafa, el Polígono de Monteolivete y el sector triangular a lo largo del actual cauce del Turia, y situado frente a la proyectada estación central de Valencia.

En la memoria de ordenación Técnica de la Ciudad, Solución Sur, esquema no 2 , se sitúa en las inmediaciones de la futura estación central, uno de los cuatro centros comerciales previstos.

Por estas razones, se ha considerado necesario dar un carácter intensivo en funciones comerciales, representativas y residenciales, adecuadas a la importancia que en un futuro próximo tendrá el Polígono.

\section{Ordenación General de Usos.}

Por orden de importancia de volumen de edificación se establecen los siguientes usos:

$1^{\circ}$.- Vivienda en sus distintos tipos, que van del apartamento al piso de lujo, debiendo excluir la vivienda modesta.

$2^{\circ}$.- Uso comercial, que comprende calles y recintos de tiendas, con unidades modulares de instalación de comercios, superficies cubiertas para circulación de peatones, oficinas, bancos, etc.

30.- La instalación de bares, cafeterías, restaurantes y otros, enlazará la zona comercial con la cultural. En esta, se incluyen edificios destinados a exposiciones, espectáculos, conferencias, conciertos, bibliotecas e incluso una plaza destinada a representaciones al aire libre. Entre todos estos elementos destaca por su importancia, una sala de grandes dimensiones.

Igualmente deben instalarse edificios dedicados a la atracción turística, hotel de viajeros, oficinas de información, agencias de viaje, etc.

40.- Zona representativa, con un edificio para dependencias municipales de barrio, con servicios de seguridad, sanitarios, judiciales, comunicaciones, etc.

50.- Uso religioso. En el triángulo formado por dos calles de nuevo trazado y la del escultor Capuz, se propone la construcción de una parroquia con programa completo de servicios de acción pastoral, y gran generosidad de espacios abiertos que sin modificar sustancialmente la idea de zona verde le dé un aprovechamiento necesario.

Todos estos usos ya enumerados se ordenan de la siguiente manera: las viviendas se sitúan en las construcciones ya terminadas e iniciadas sobre las calles de escultor Capuz y Avenida de Peris Valero, en bloques sueltos sobre la terraza que cubre los edificios comerciales, y en cuatro torres de veintisiete plantas alineadas a lo largo de la composición.

La zona comercial ocupa el centro del sector, organizado a base de edificios de dos plantas, que cierran espacios con diferentes ambientes, con una calle comercial exclusivamente de peatones y diversas placitas.

Entrando en el polígono por la Avenida de Peris Valero, se sitúa en una gran plaza el edificio representativo de la Administración Municipal y servicios ya reseñados. En el extremo opuesto, al final de la calle comercial, y cerrando el conjunto, se agrupan formando dos plazas, una abierta y otra cerrada, todos los edificios de tipo 
cultural y turístico, entre los que destaca en altura el Hotel de viajeros y en volumen la sala de espectáculos.

\section{Circulaciones.}

Separación de la circulación rodada, de las superficies exclusivamente dedicadas a peatones, situando los estacionamientos en zonas marginales próximas a los lugares de máxima concentración pública, siguiendo el esquema en boga de peines encontrados.

\section{Estacionamientos.}

Se han consultado diversos índices de motorización europeos y americanos, sacando como cifras aplicables a Valencia las siguientes:

Viviendas.- Un coche para dos familias.

Hotel.- Una plaza cada dos habitaciones, en las 20 primeras, una más cada ocho habitaciones, hasta cuarenta; una más cada doce habitaciones, por encima de cuarenta.

Comercios.- Un aparcamiento cada $250 \mathrm{~m} 2$.

Teatro.- Un coche cada diez personas.

Aplicándolas a la zona comercial se obtienen los siguientes datos:

\section{Viviendas.}

\begin{tabular}{|c|c|c|c|c|}
\hline \multirow{3}{*}{$\begin{array}{l}\text { En torres........................... } \\
\text { Casa esquina Peris Valero } \\
\text { y J. Benavente } \\
\text { Casa esquina Peris Valero }\end{array}$} & \multirow{2}{*}{\multicolumn{4}{|c|}{200 V................. 100 plazas }} \\
\hline & & & & \\
\hline & (A) & $100 \mathrm{~V} . . . \ldots \ldots \ldots . . . .$. & 50 & $"$ \\
\hline $\begin{array}{l}\text { y escultor Capuz } \\
\text { Casa en escultor Capuz }\end{array}$ & (B) & $100 \mathrm{~V} \ldots \ldots \ldots \ldots . . . .$. & 50 & $"$ \\
\hline $\begin{array}{l}\text { esquina a Luis Oliag } \\
\text { Casa en escultor Capuz }\end{array}$ & (C) & $80 \mathrm{~V} \ldots \ldots \ldots \ldots$ & 40 & $"$ \\
\hline $\begin{array}{l}\text { esquina a Finestrat } \\
\text { Ultima casa en la }\end{array}$ & (D) & $120 \mathrm{~V} \ldots .$. & 12 & $"$ \\
\hline $\begin{array}{l}\text { C/ escultor Capuz } \\
\text { Bloque sobre la }\end{array}$ & $(E)$ & $60 \mathrm{~V} . . \ldots \ldots \ldots \ldots$ & 30 & " \\
\hline comercial & (3) & $80 \mathrm{~V} \ldots$ & 40 & $"$ \\
\hline Total. & 740 & Vivienda & & \\
\hline
\end{tabular}

* En esta zona se ha considerado un coche cada diez viviendas, teniendo en cuenta que se trata de una construcción modesta.

Hotel

(25) 240 habitaciones

29 plazas

\section{Comercios}

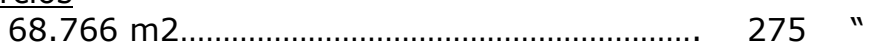

\section{Teatro}

(23) 2.000 butacas.............................................. 200

$\underline{\text { Administrativo }}$

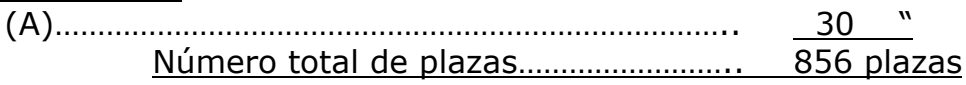

\section{Simultaneidad de uso}

Por la noche puede simultanear un uso el $50 \%$ de las viviendas, hotel y teatro y durante la mañana el $60 \%$ comercio, administración y un veinte por ciento de viviendas, hotel y durante la tarde el teatro, el comercio y el $20 \%$ de viviendas y hotel o sea:

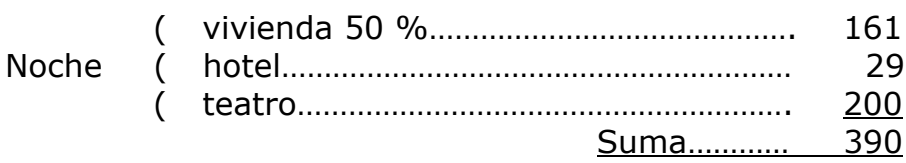




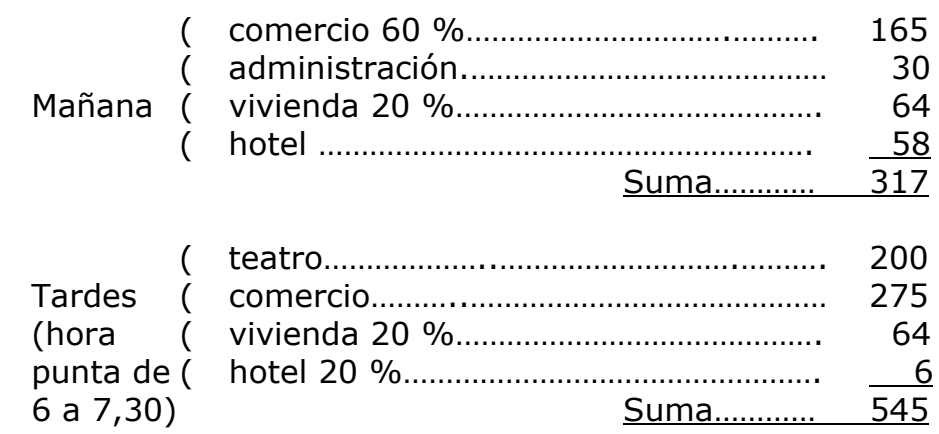

En la zona comercial se prevé, por ordenanza la existencia de dos garajes como mínimo, capaces para 40 coches aparte del hotel que tendrá el suyo propio.

Los estacionamientos previstos, son capaces para aparcar 489 coches, con lo cual queda resuelto el problema, sin contar con el posible aparcamiento a lo largo de las calles y avenidas.

A lo largo de la calle "Alcalde Reig" y al nivel del cauce del Turia, puede disponerse en el futuro un gran aparcamiento capaz de absorber nuevas necesidades si ello fuere necesario.

\section{Composición.}

Se ha huido de las normas en desuso de composición uniforme de volúmenes y trazado, manejando formas de características variadas, buscando armonías equilibradas por compensación.

Como idea general se ha buscado un escalonamiento progresivo de alturas con vistas desde la orilla opuesta del Turia.

Se considera interesantísimo cuidar al máximo el cauce del río, con establecimiento de una zona verde o parque inundable que forme tapiz o pedestal sobre el cual asiente y destaque en profundidad el conjunto.

Densidad de construcción en m3/m2.

Edificios de vivienda incluso hoteles

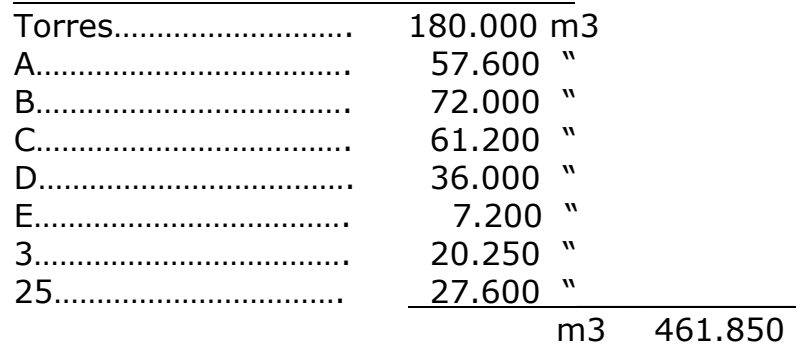

Administración local.

4.

$$
\frac{26.400 "}{m 3 \quad 26.400}
$$

Comercial y recreativa.

8 y 9

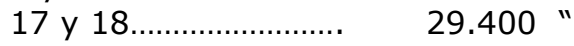

$3,14,15,20,21,22,26$,

$20^{\prime}, 21^{\prime}, 22^{\prime}, 14^{\prime}$ y $15^{\prime} 144.640 . . "$

m3 202.240

Culturales.

23

$48.500 "$

24

28.800

Total de m3 construidos

\begin{tabular}{ll}
$\mathrm{m} 3$ & 77.300 \\
\hline
\end{tabular}

767.790 
Que sobre los $96.200 \mathrm{~m} 2$. da una densidad de $8 \mathrm{~m} 3$. por $\mathrm{m} 2$. repartidos en la siguiente forma:

Viviendas.

Administración local.......

Comercial y recreativo...

Cultural...
$5,2 \mathrm{~m} 3 / \mathrm{m} 2 \ldots . .65 \%$

$0,275 \quad " \quad \ldots . . . \quad 3 \%$

$1,730 " \quad \ldots . .21 \%$

$\underline{0,804 \quad \text { "...... } 10 \%}$

$8,009 \mathrm{m3} / \mathrm{m} 2 \quad 100 \%$

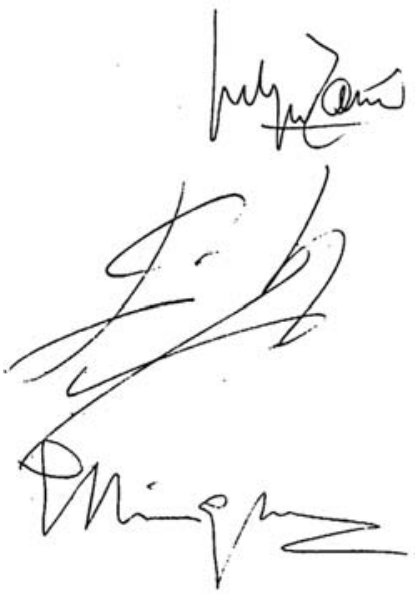


11. PARCELACIÓN ACTUAL

Escala original: 1:1000

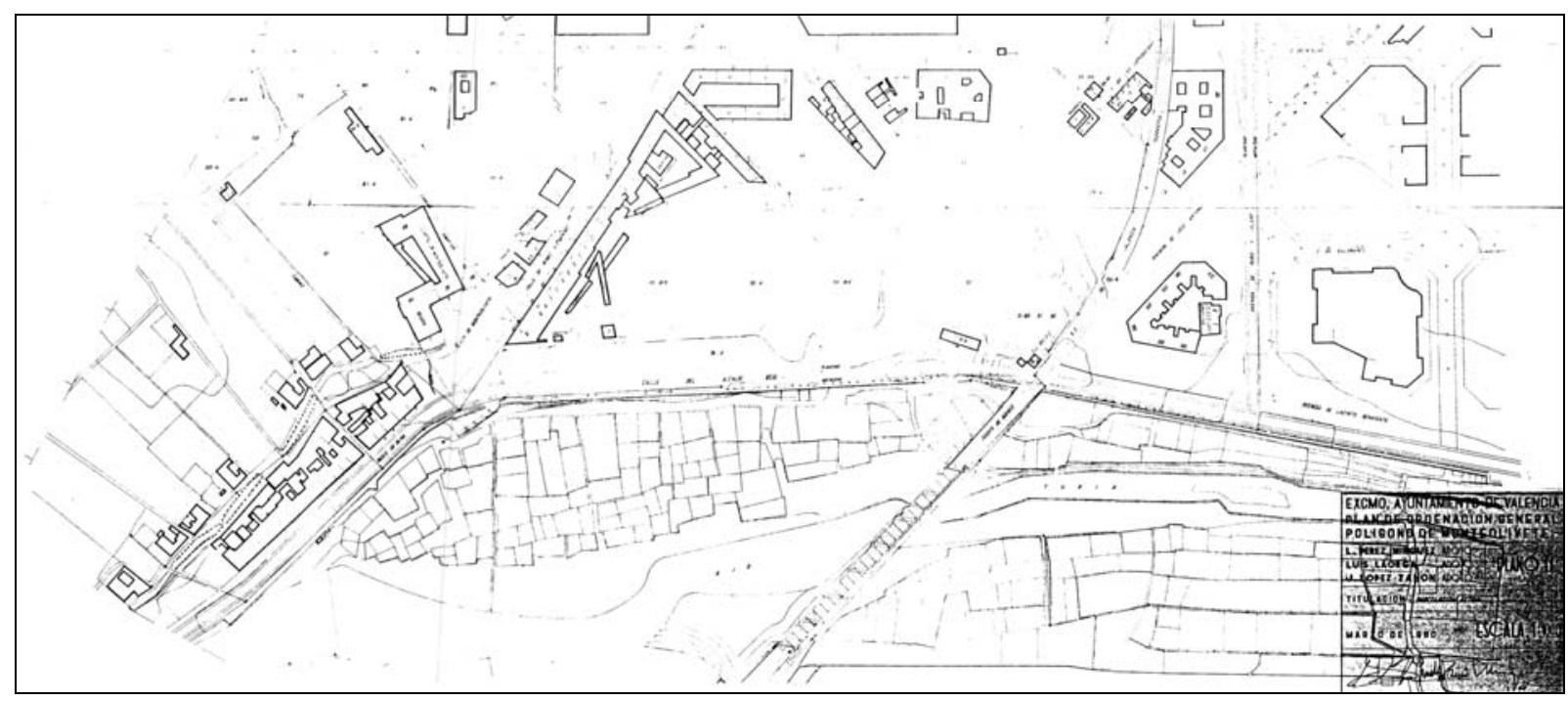

4. ALZADOS GENERALES

Escala original: 1:1000

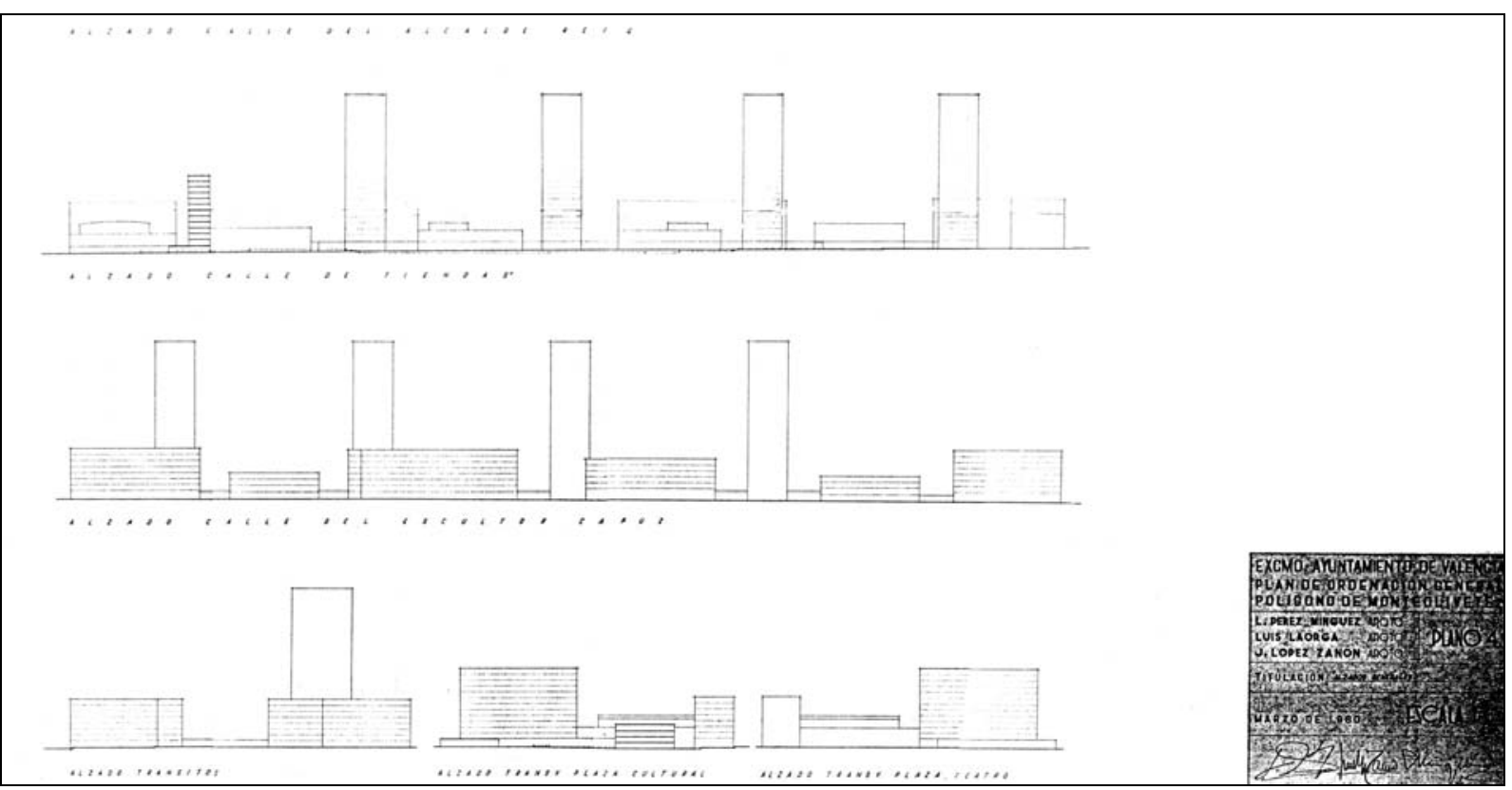


1. PLAN GENERAL DE ORDENACIÓN

Escala original: 1:1000

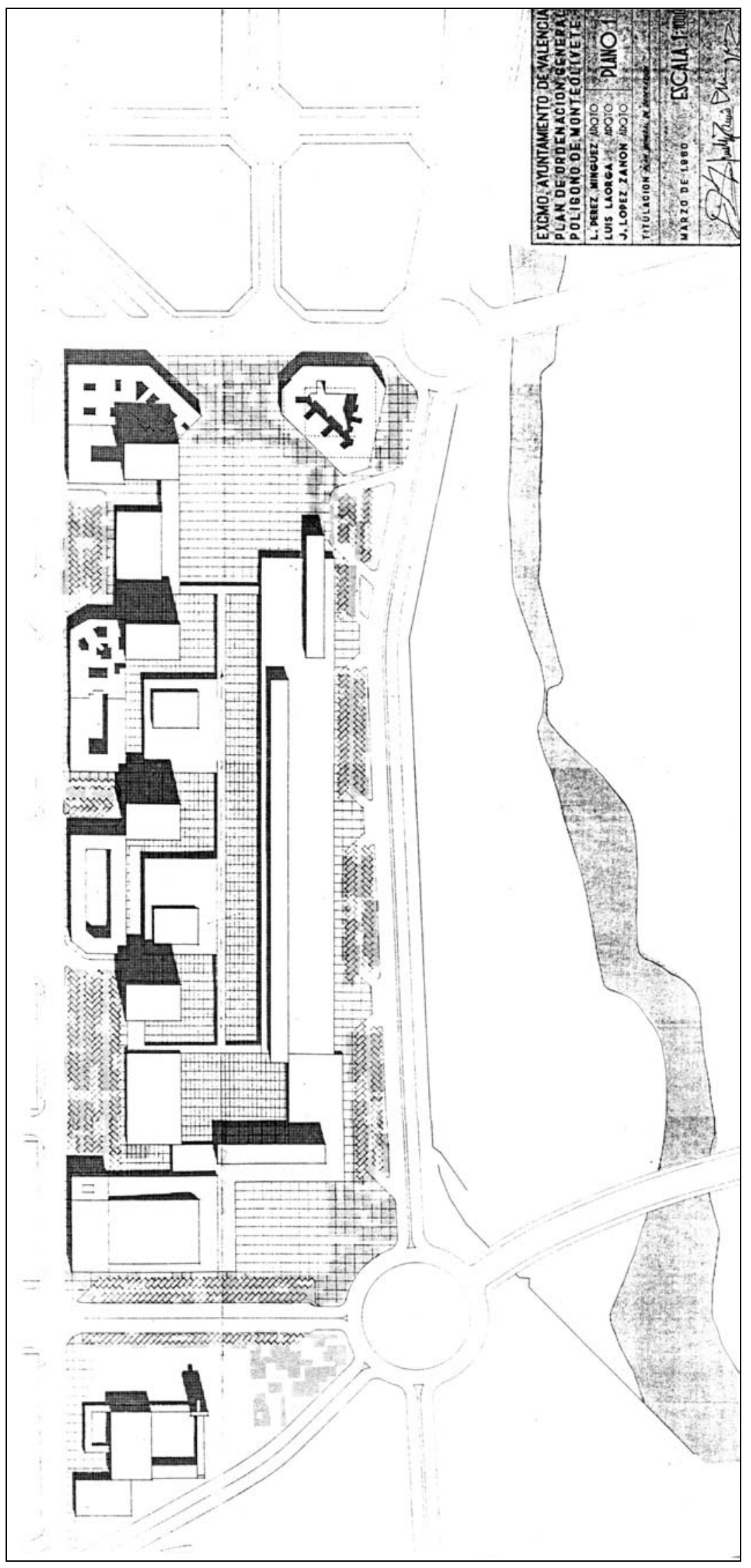



5. PLANES PARCIALES MUNICIPALES, 1958-1965 



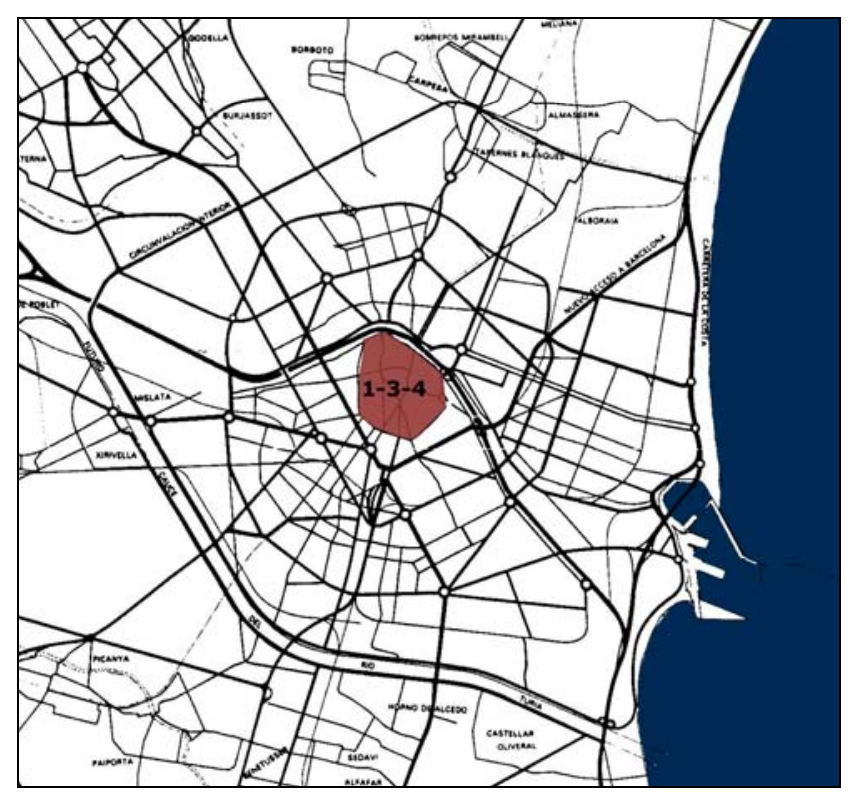

\subsection{ZONA CENTRO}

PLAN PARCIAL No 1-3-4 (CENTRO HISTÓRICO), 1958/1960 PLAN PARCIAL No 1-3-4 (HOSPITAL), 1961 



\section{PP 1-3-4 Barrio del Carmen}

PLANP PARCIAL 1-3-4 SECTOR OESTE CASCO ANTIGUO

1958-1961

Redactores: AYUNTAMIENTO DE VALENCIA. Oficina Técnica de Urbanismo.

Fecha redacción: 1958-1961.

Fecha aprobación:

Contenido:

-PLANO PARCIAL 1-3-4. BARRIO DEL CARMEN, $1958 . \quad$ E 1:1000

- PLAN PARCIAL 1-3-4, SECTOR OESTE CASCO ANTIGUO, 1960:

PLANO DE TRAZADO CON ESTUDIO DE VOLÚMENES Y RED VIARIA

E 1:1000

PLANO DE ESTADO ACTUAL Y PROYECTO

E 1:1000

\section{Fuente:}

Ayuntamiento de Valencia. Sección de Urbanismo. Negociado de Suelo y Ordenación urbana (Archivo de Planeamiento, No AN-4)

Notas:

No se ha localizado documentación escrita de este plan. 
PLAN PARCIAL 1-3-4 PARTE. BARRIO DEL CARMEN,. 1958.

Escala original 1:2000.

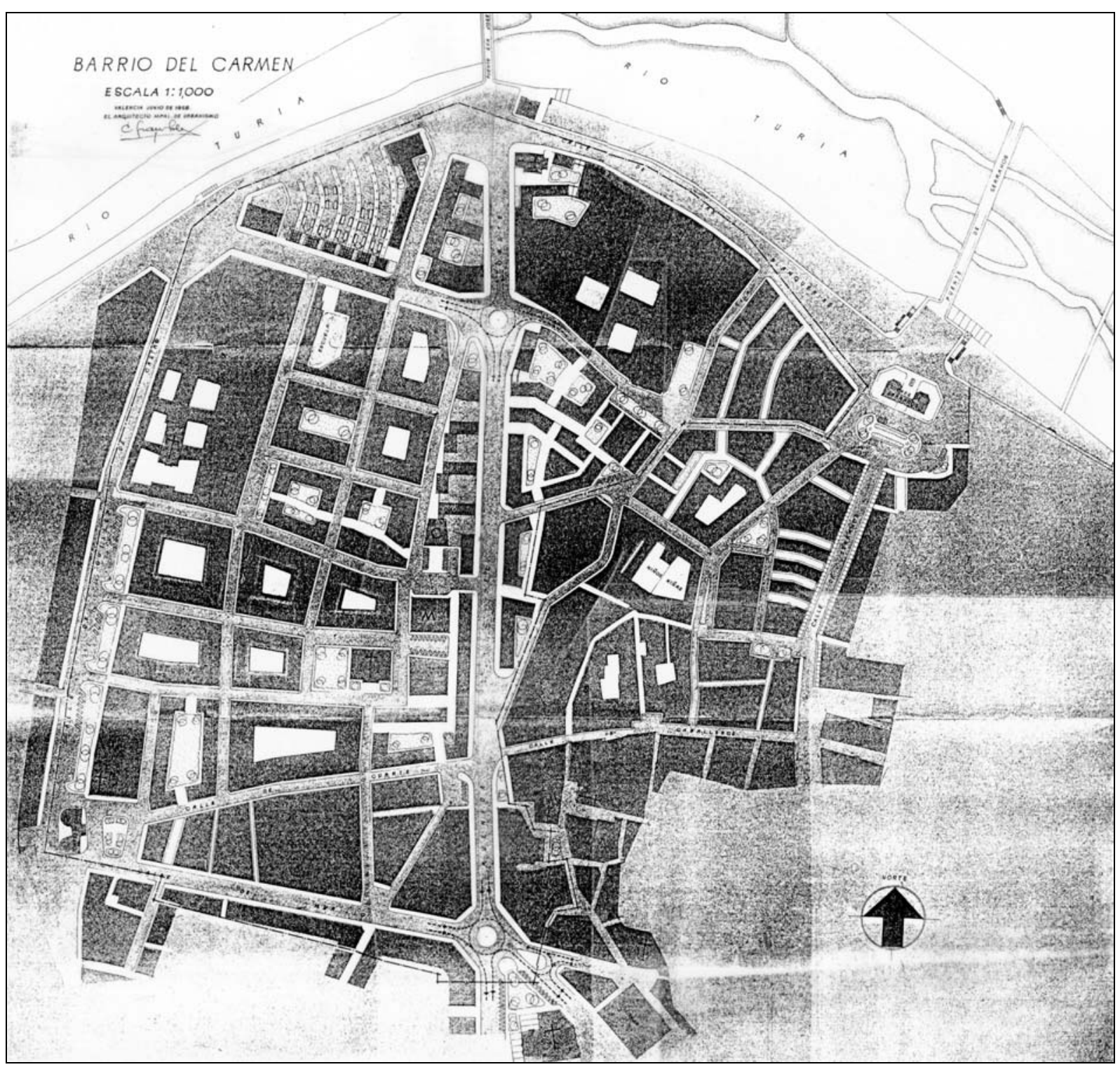


PLAN PARCIAL 1-3-4 PARTE. BARRIO DEL CARMEN,.1958.

Escala original 1:2000.

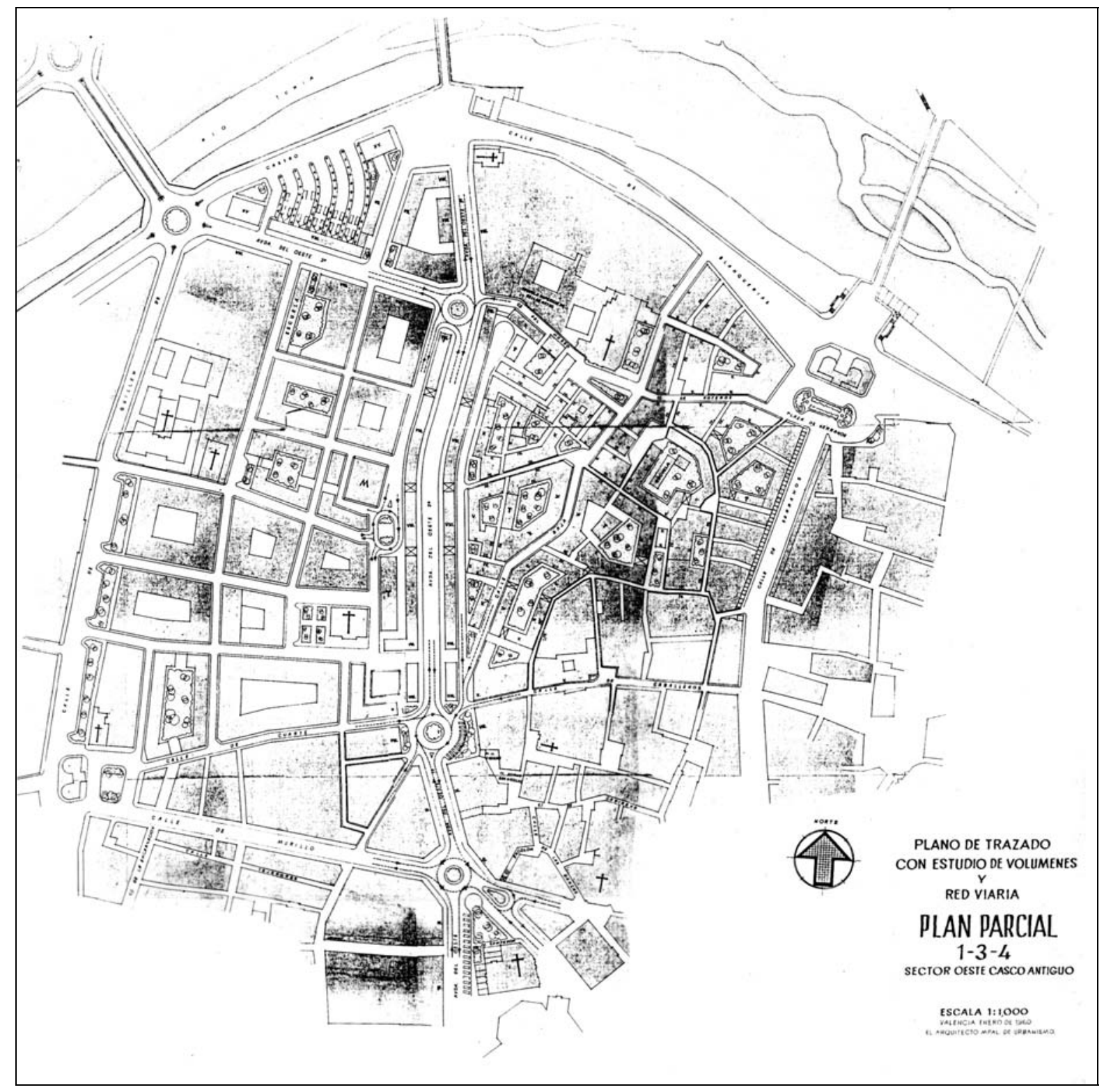


PLAN PARCIAL 1-3-4 PARTE. BARRIO DEL CARMEN,.1960.

Escala original 1:2000.

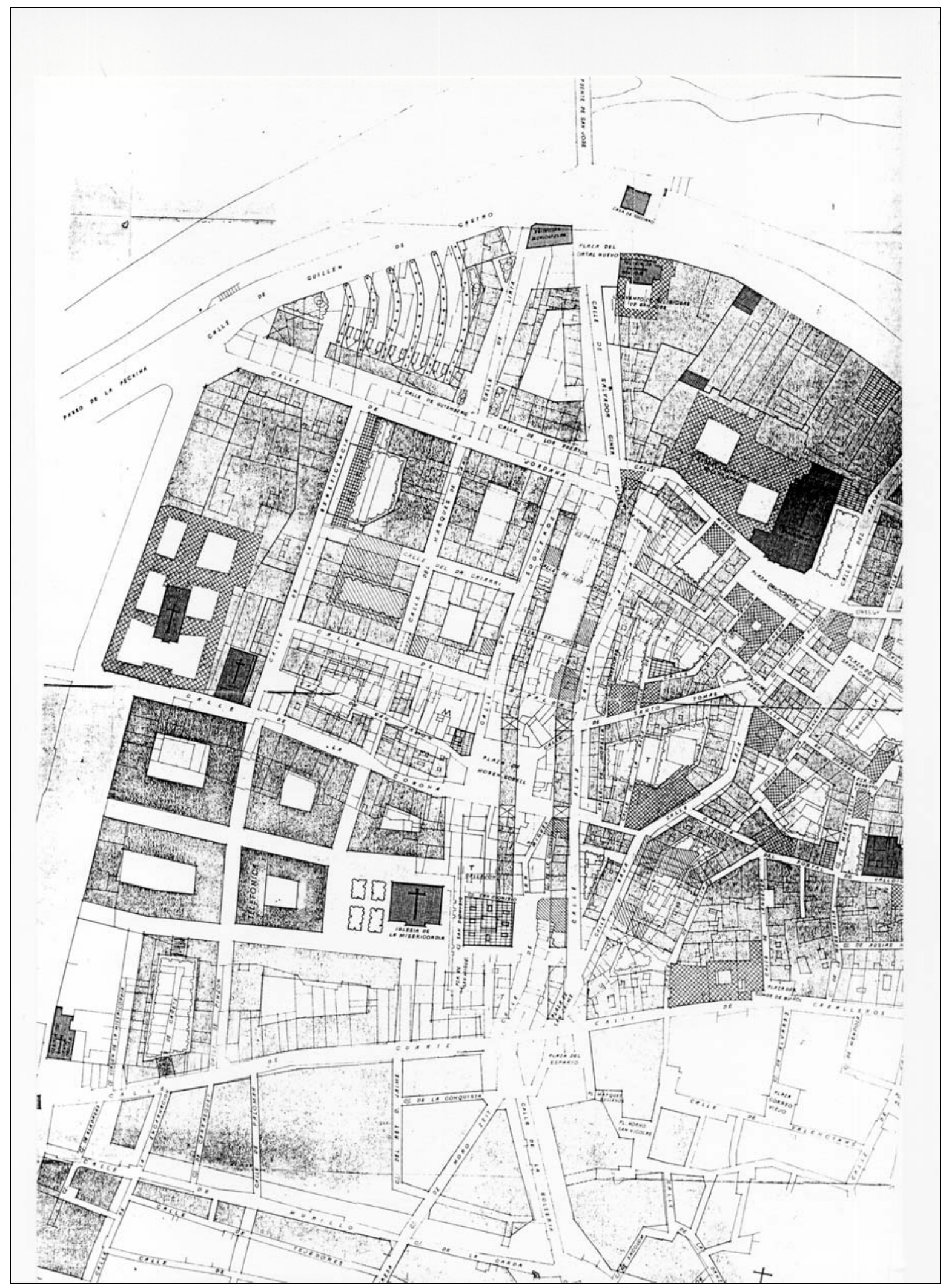



Redactores: AYUNTAMIENTO DE VALENCIA. Oficina Técnica de Urbanismo. Arq. Julio Bellot Senent.

Fecha redacción: Noviembre 1961.

Fecha aprobación: -

\section{Contenido:}

1. MEMORIA.

2. ORDENANZAS

3. PLANO DE SITUACIÓN Y TRANSPORTE $1: 2000$

4. ESTADO ACTUAL $1: 1000$

5. PLANO DE ORDENACIÓN $1: 1000$

6. ESQUEMA DE ALCANTARILLADO $1: 1000$

7. ESQUEMA DE ILUMINACIÓN $1: 1000$

8. ESQUEMA DE SUMNISTRO DE AGUA $1: 1000$

\section{Fuente:}

Ayuntamiento de Valencia. Sección de Urbanismo. Negociado de Suelo y Ordenación urbana (Archivo de Planeamiento, No OM380bis)

\section{Notas:}

En el expediente del Archivo de Planeamiento aparece además la documentación siguiente:

- PROYECTO DE URBANIZACIÓN DE LOS SOLARES RESULTANTES DEL DERRIBO DEL HOSPITAL PROVINCIAL DE VALENCIA. Excma. Diputación Provincial de Valencia. Arquitecto Provincial: Luís Albert Ballesteros. Julio 1958

- PLANO: ORDENACIÓN HOSPITAL. E 1:1000. Noviembre 1968. Firma: E. Rieta y otra ilegible. 


\section{EXCMO. AYUNTAMIENTO DE VALENCIA}

PROYECTO DE ORDENACION DE LOS SOLARES RESULTANTES DEL DERRIBO DEL HOSPITAL PROVINCIAL, PARTE DEL PLANO 1-3-4

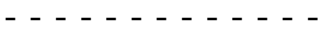

MEMOR I A

SECTOR QUE COMPRENDE.- El limitado por calle de Guillem de Castro, calle del Hospital, Avenida del Barón de Cárcer y calle de Quevedo.

OBJETO DEL ESTUDIO.- Este sector fue excluido de la aprobación del Plano 1-3-4, por la Comisión Central de Sanidad Local en 7 de diciembre de 1.956, por considerarse inadecuada la forma en que se ordenó. Varios estudios se han realizado posteriormente para ordenarlo entre ellos el propuesto por la Excma. Diputación Provincial, aceptando las modificaciones propuestas por dicha Comisión Central, al proyecto y rectificándolo con arreglo a las mismas.

El objeto del presente es pues, la precitada ordenación, teniendo en cuenta dichas propuestas y procurando realizar un conjunto, en lo que cabe más movido y atractivo que la primitiva ordenación consistente en una simple división en manzanas por calles.

JUSTIFICACION DE LA ORDENACION.- Nos encontramos con un conjunto de forma irregular, con las calles de límite ya establecidas y con algunos elementos a respetar como son las Capillas. La ordenación se limita a establecer el grupo de manzanas con miras a que constituya una unidad, con un espacio libre amplio interior y a ordenar las alturas de tal manera que la densidad no sea excesiva, el porcentaje de espacio libre suficiente y superior al $10 \%$.

A la calle de Guillem de Castro se hace recaer, retranqueando un pequeño jardín y algunas alteraciones de línea de fachada que proporcionen movimiento al conjugarse con las de altura de los edificios.

Al interior de la zona podría llegarse por una serie de pasajes comerciales que la comunican con calle de Guillem de Castro y que proporcionan una unión, en cuanto a tránsito de peatones, entre en ensanche y centro de la Ciudad.

No se establece ningún centro cívico porque en realidad esta subzona forma parte del Centro General de Valencia.

ETAPAS.- La realización será dependiente del momento en que se derribe el Hospital, por lo que no pueden establecerse; la suponemos inmediata a que el derribo se produzca por el gran interés comercial de la zona.

MEDIOS ECONOMICO-FINANCIEROS.- Serán los ordinarios del presupuesto de Urbanismo del Excmo. Ayuntamiento o los especiales que puedan establecerse.

Con lo dicho creemos suficientemente expuesto el alcance del estudio realizado para que, si merece la aprobación del Excmo. Ayuntamiento, sea elevado a la aprobación de la superioridad.

Valencia, noviembre de 1.961

EL ARQUITECTO MUNICIPAL DE URBANISMO, 
5. PLANO DE ORDENACIÓN

Escala original $1: 1000$

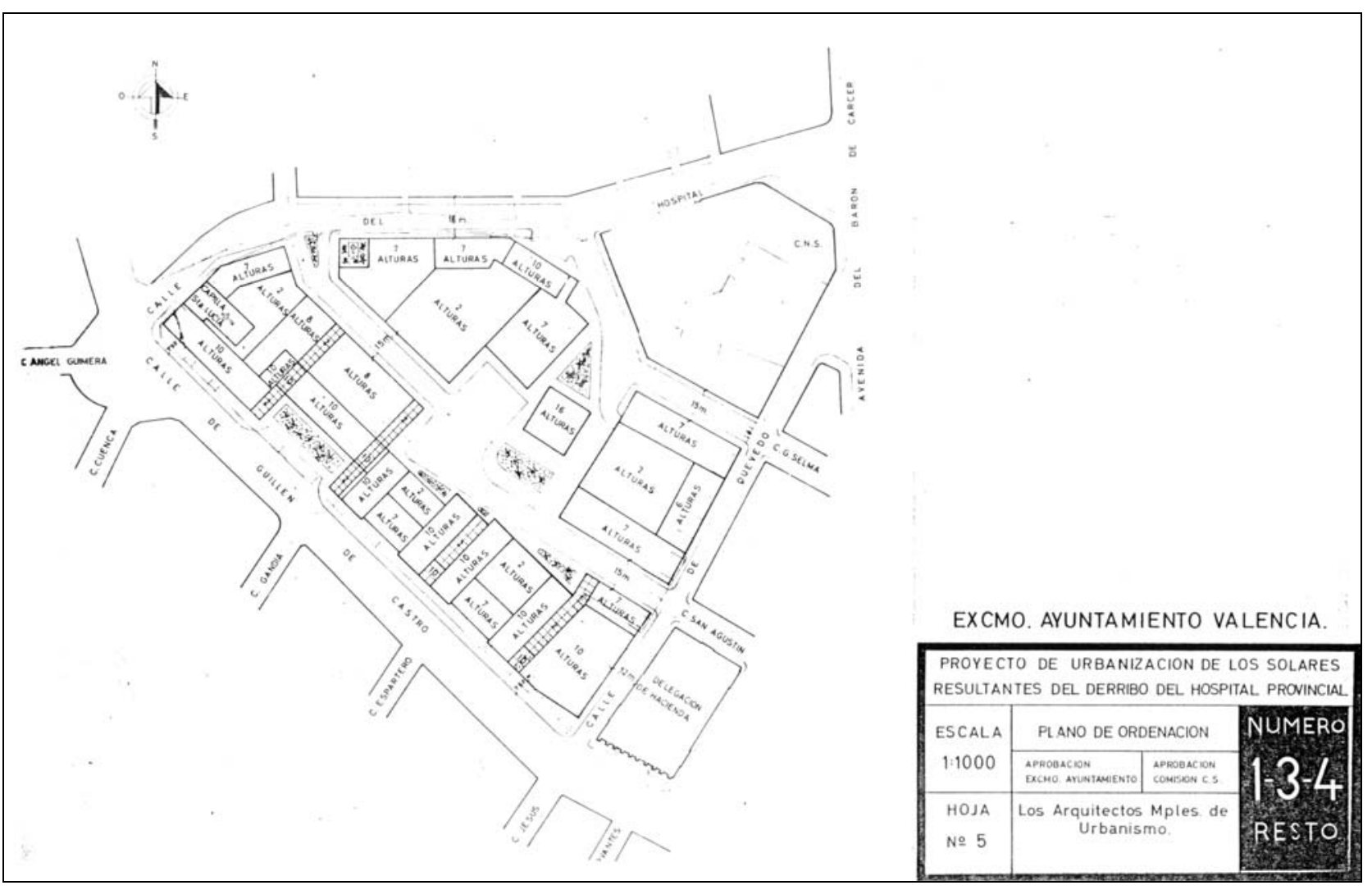


PROYECTO DE URBANIZACIÓN DE LOS SOLARES RESULTAN-TES DEL DERRIBO DEL HOSPITAL PROVINCIAL DE VALENCIA. Excma. Diputación Provincial de Valencia. Arquitecto Provincial: Luís Albert Ballesteros. Julio 1958

PLANO DE ESTADO ACTUAL.

Escala original $1: 300$

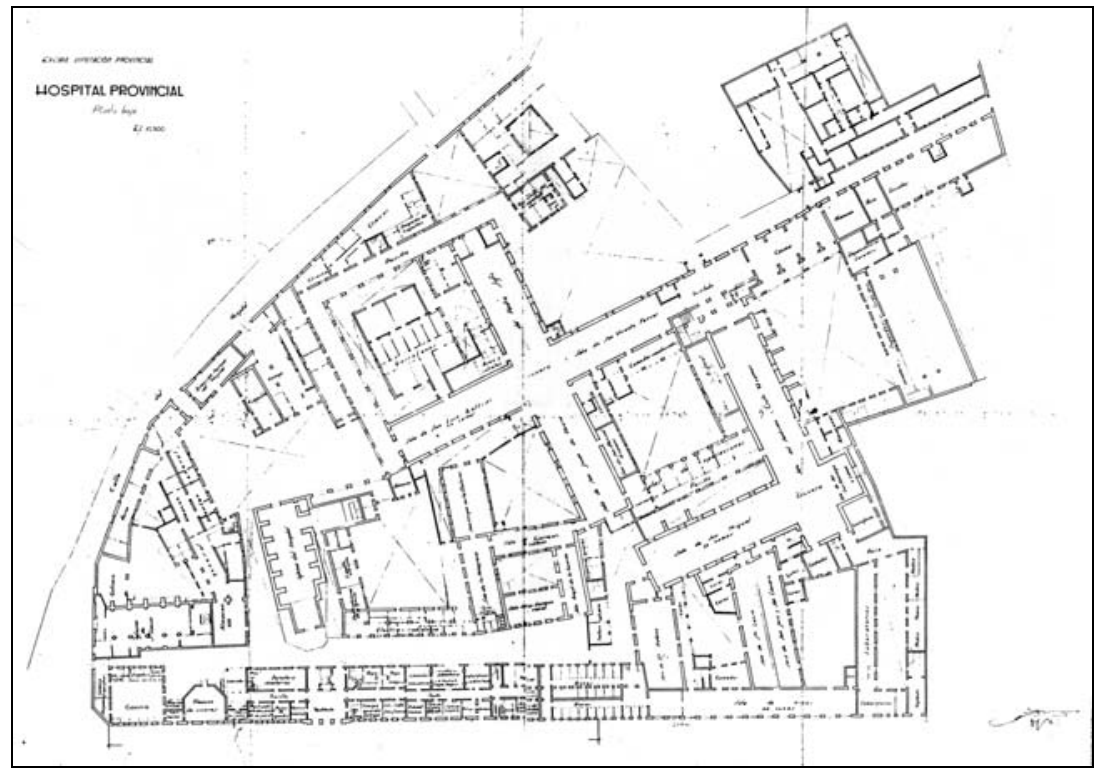

PLANO DEL PROYECTO

Escala original 1:300

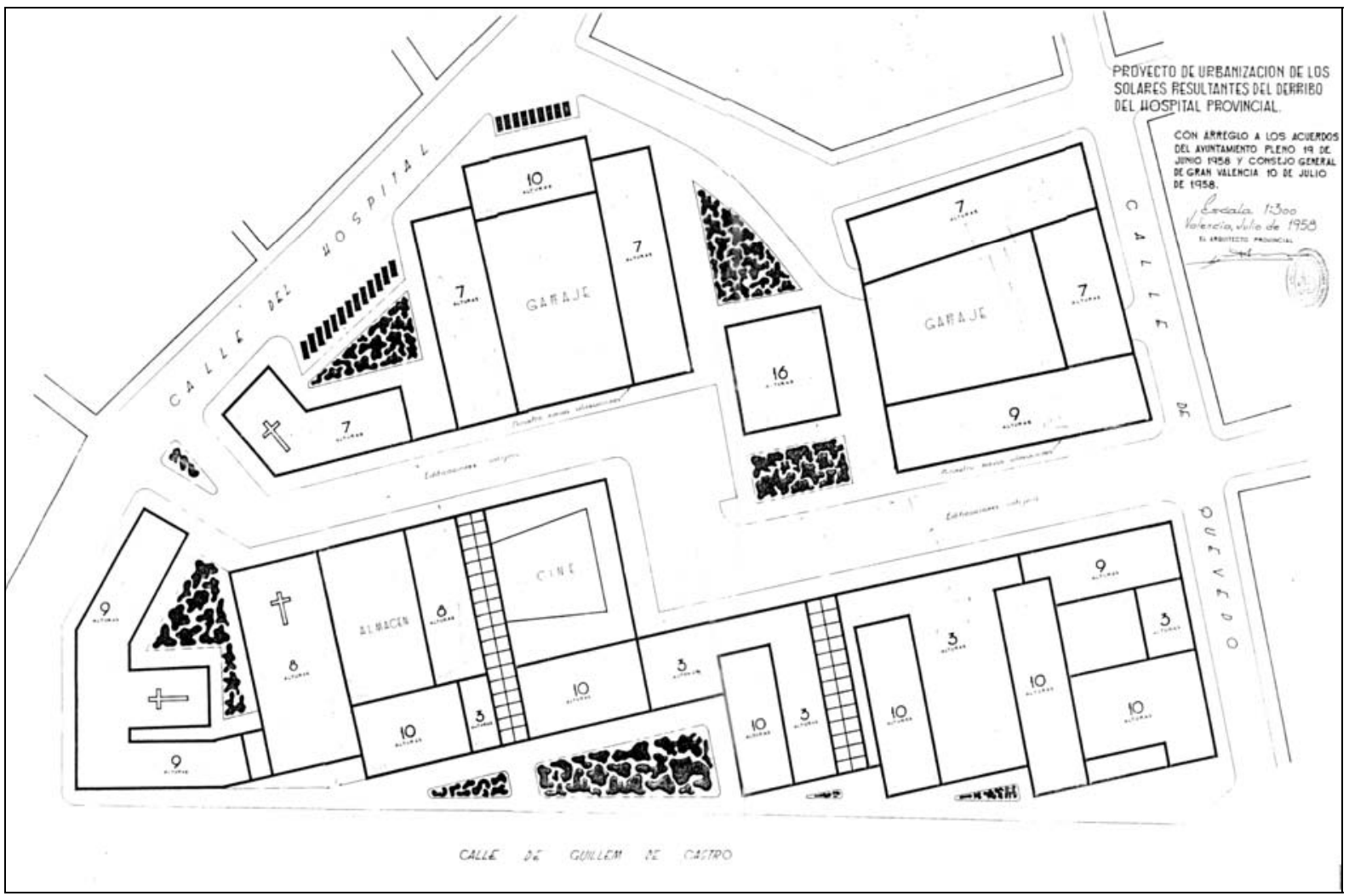


ORDENACIÓN HOSPITAL. Noviembre 1968.

Escala original 1:1000

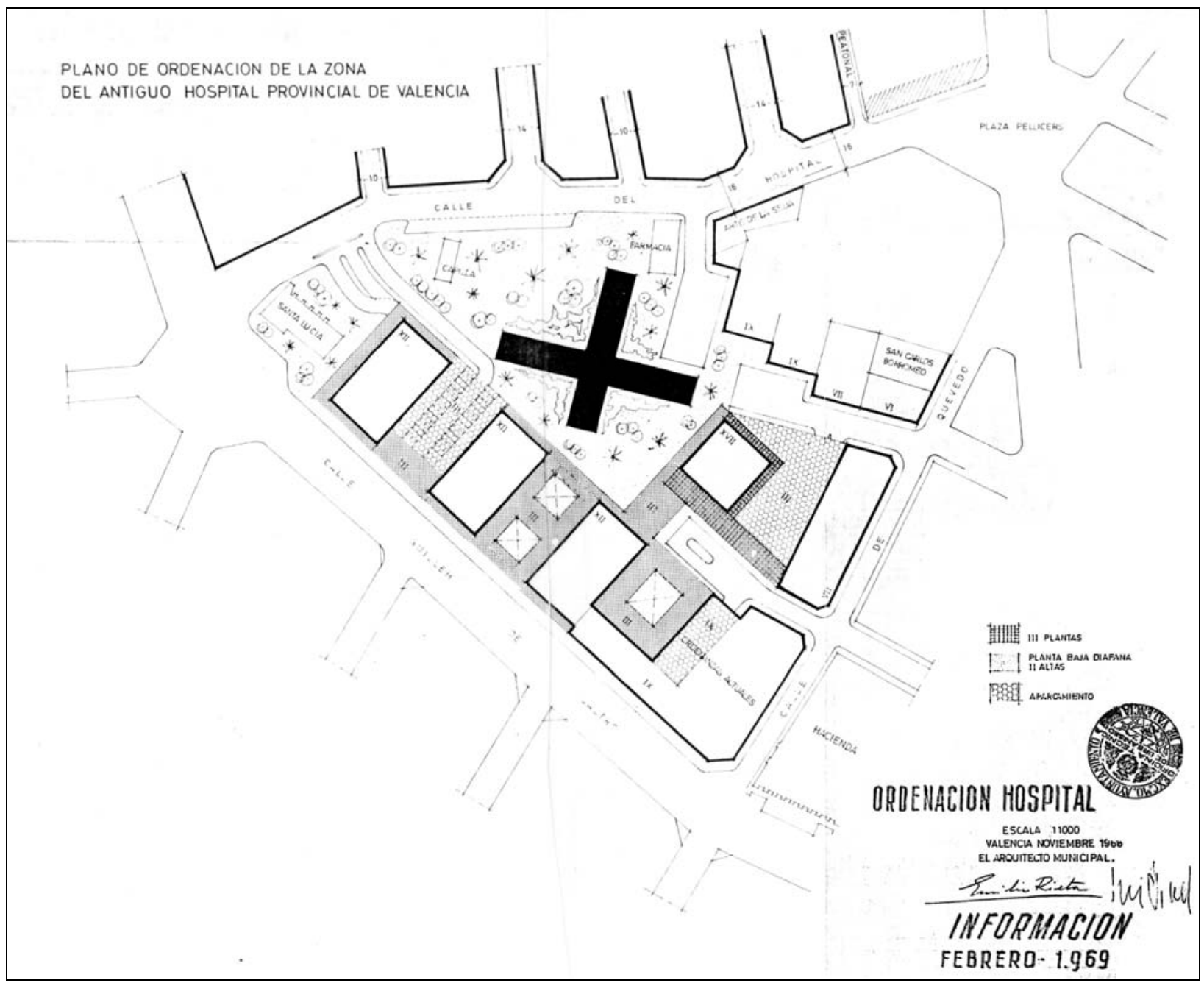





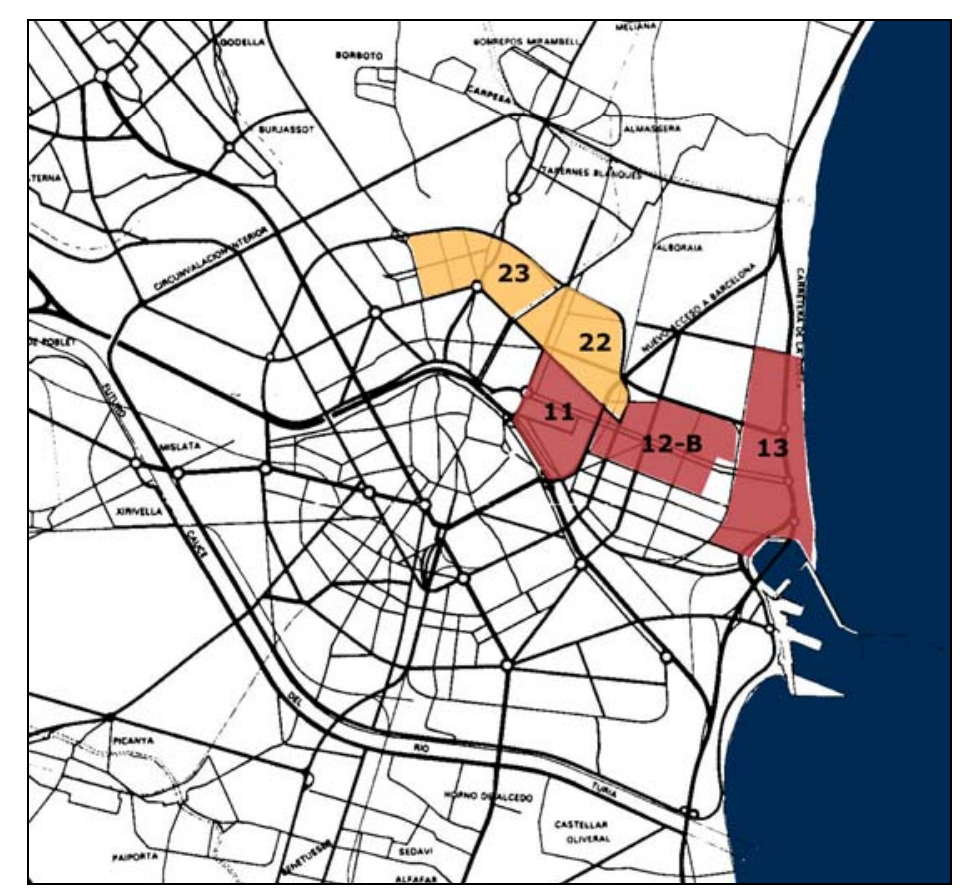

\subsection{ZONA NORESTE}

PLAN PARCIAL No 11 (PLA DEL REAL), 1958/1960 PLAN PARCIAL No 12-B (PASEO AL MAR), 1958/1963 PLAN PARCIAL NO 13 (GRAO-CABANYAL), 1962 PLAN PARCIAL No 22 Y 22-B (BENIMACLET), 1961 PLAN PARCIAL NO 23 (ORRIOLS-TORREFIEL), 1962 



\section{PP 11}

Redactores: AYUNTAMIENTO DE VALENCIA. Oficina Técnica de Urbanismo. Arquitecto: Julio Bellot Senent.

Fecha redacción: Noviembre 1960.

Fecha aprobación: O.M. 29-12-1960.

\section{Contenido:}

Documento 1. MEMORIA.

Documento 2. PLANO DE INFORMACIÓN $1: 2000$

Documento 3. PLANO DE PROYECTO $1: 2000$

Documento 4. SERVICIOS

$\begin{array}{ll}\text { ALCANTARILLADO } & 1: 2000 \\ \text { AGUA Y LUZ } & 1: 2000\end{array}$

Documento 5. ORDENANZAS

\section{Fuente:}

Ayuntamiento de Valencia. Sección de Urbanismo. Negociado de Suelo y Ordenación urbana (Archivo de Planeamiento, No OM-57 y OM-58)

Notas:

(*) Además de los planos correspondientes al Plan Parcial, el expediente del Archivo de Planeamiento dispone de los planos siguientes:

- PLAN PARCIAL 11, Septiembre 1958. E 1:2000. (Plano expuesto al público hasta el 19-12-1960).

- MODIFICACIÓN DE MANZANA EN ZONA NORTE, 1962.

- MODIFICACIÓN DE LÍNEAS EN MANZANA LIMITADA POR C/ JAIME ROIG, BACHILLER, BOTÁNICO CABANILLES Y ÁLVARO DE BAZÁN. Enero 1965

-MODIFICACIÓN DE LÍNEAS EN MANZANA LIMITADA POR C/ JAIME ROIG, TRÁNSITOS, BOTÁNICO CABANILLES Y BACHILLER. Enero 1965.

- MODIFICACIÓN ZONA LLANO DEL REAL. Mayo 1965.

- MODIFICACIÓN ZONA LLANO DEL REAL. Enero 1966 



\title{
EXCMO. AYUNTAMIENTO DE VALENCIA
}

\author{
PLANO PARCIAL 11
}

\section{MEMOR I A}

$1^{0}$ Objeto de este estudio.- El sector que se incluye en este planeamiento es el comprendido entre Paseo de la Alameda, Avenida del general Elio, Camino de Tránsitos y nuevo Acceso de Barcelona.

Este sector está en gran parte urbanizado. Todo o casi todo el espacio comprendido desde el Paseo al Mar a la Alameda, lo está ya, e incluso construidos los edificios quedando solamente aproximadamente un $20 \%$ sin construir. En cambio la zona al norte del Paseo al Mar está virgen de urbanizaciones y construcciones excepto algunas de Avda. de General Elio y la paralela contigua, camino de Benimaclet.

El sector perteneció al ensanche de Valencia, y a ello se debe el tipo de construcción, en manzana cerrada, ya construida, de toda la parte sur del plano.

En el sector se han ubicado y hay proyectados la mayor parte de los edificios de enseñanza superior de Valencia y otro gran número de edificios no residenciales como son campo de fútbol y otros deportes de Mestalla, Feria Muestrario, Sanatorio, cuarteles, Bomberos, Fábrica de Tabacos, etc., etc., amén de varios colegios.

Así pues, el objeto de este estudio es simplemente ordenar en lo posible todo lo existente y crear, hoy más bien completar por haberse ya iniciado, una zona de edificación abierta al norte del Paseo de Valencia al Mar de carácter residencial propio y muy apto para la clase intelectual, que la concentración de edificios de enseñanza superior señala como habitante probable de la zona. Establecer la zona deportiva universitaria con la importancia que requiere, ya que la escuela de Ingenieros Agrónomos, va a ocupar el actual campo de deportes universitario, es otro de los objetivos de este estudio.

20.- Directrices del estudio realizado.- Son las siguientes:

A) TRAFICO: Los cuatro límites del sector que nos ocupa son vías de tráfico del esquema general viario de la Ciudad. Además es atravesado el sector de Oeste a Este por el Paseo de Valencia al Mar de $100 \mathrm{~m}$. de anchura. Es decir, la circulación rápida del sector queda resuelta. Constituye problema el aparcamiento en días de partido de fútbol, el cual queda resuelto con la zona e aparcamientos establecida al Norte del Campo de Mestalla y a lo largo del Paseo de Valencia al Mar.

B) SOCIOLOGIA: Ya al principio hemos apuntado el carácter de las zonas de este sector de carácter residencial y edificios públi$\cos$ y de enseñanza.

Se supone un solo centro comercial en la parte sur. Este centro no puede organizarse como elemento independiente sino que está ya creado en los bajos de los edificios. En la parte Norte en que, por no estar construido, podría hacerse, no se sitúa ningún centro, por ser de pequeño tamaño.

Lo mismo se ha de decir en lo referente a centro religioso. 
Una iglesia parroquia en el centro de la zona sur lo constituye.

La densidad de población será en la zona de manzanas cerradas aproximadamente de 900 hab. por hectárea. Así pues, la primera con una superficie aproximada de 30 hectáreas alberga una población de 27.000 hab. y la zona de edificación abierta con una superficie aproximada de 14 hectáreas albergará aproximadamente 7.000 hab. Así pues la densidad total siendo la superficie de 100 hectáreas será de 340 habitantes por hectárea. Cifra muy baja pero que asegura el aspecto de la salubridad del sector.

C) SALUBRIDAD: Espacios libres.- Aunque no se han establecido en forma de parque, ya que lindando con el sector tenemos el de Viveros, el más importante de la Ciudad, los espacios libres ajardinados son abundantes. Están constituidos por todo el centro del Paseo de Valencia al Mar, Alameda, alrededores del Campo de fútbol, la zona deportiva y los espacios ajardinados, entre bloques de edificación abierta. Estos espacios libes de uso público tienen na superficie superior al $10 \%$.

Además, existen los jardines privados, siendo el más importante el de Monforte de estilo neoclásico y gran belleza.

D) BELLEZA: Se confía en los sectores abiertos a la sensación de libertad y amplitud. Los sectores cerrados rodeados de avenidas muy arboladas bien tratados en cuanto suelo y edificaciones bastante cuidadas, tanto en los edificios públicos como privados, no tienen nada de antiestético. Acentuarán su belleza a medida que vayan siendo completados.

E) INSTALACIONES: Toda la parte sur tiene ya completas o casi completas las instalaciones así como el Paseo de Valencia al Mar. Así pues no falta más que completar la zona al norte del Paseo.

En cuanto a alcantarillado las instalaciones ya realizadas habrá que rehacerlas con motivo de la construcción del colector norte ya que todo el sistema antiguo está basado en colectores que eran antiguas acequias y por tanto superficiales y que permiten poca pendiente.

Con lo dicho y con los planos que se acompañan, creemos haber dado idea bastante exacta del estudio realizado, que, si no brillante porque se basa en zona muy construida, hemos procurado que responda a las exigencias urbanísticas actuales.

Valencia, Noviembre de 1960

EL ARQUITECTO

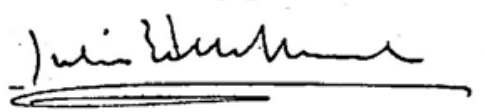




\section{EXCMO. AYUNTAMIENTO DE VALENCIA}

$\underline{P L A N O}$ PARCIAL 11

\section{ORDENANZAS REGULADORAS}

Artículo $1^{\circ}$.- LIMITES.- Los límites del Polígono no 11 regulado en cuanto a uso, volumen y composición por estas Ordenanzas son: Sur: Paseo de la Alameda; Norte: Camino de Tránsitos; Este: Nuevo Acceso de Barcelona; y Oeste: Avenida del General Elio.

Artículo 20.- ZONIFICACION.- Al Sur del Paseo de Valencia al Mar se zonifica como Ensanches Actuales, rigiendo are él las Ordenanzas correspondientes aprobadas para Valencia. Al Norte del Paseo cabe distinguir dos zonas que son: Todas las manzanas que lindan con el Paseo, que se zonifican como Ensanches Actuales y al Oeste de la Zona Deportiva, que será zona de Edificación Abierta, para lo cual se seguirán las prescripciones de la Ordenanza aprobada correspondiente.

Artículo $3^{\circ}$.- ORDENANZA ESPECIAL.- Por su situación y otras causas diversas, se han señalado algunos edificios como de "Edificio de Altura". En ellos esta altura podrá llegar solamente hasta la de sesenta metros con veinte plantas, pudiendo ser menor.

Valencia, Noviembre de 1960

EL ARQUITECTO

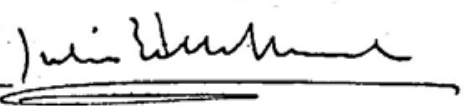




\section{PLANO DE INFORMACIÓN}

Escala original 1:2000

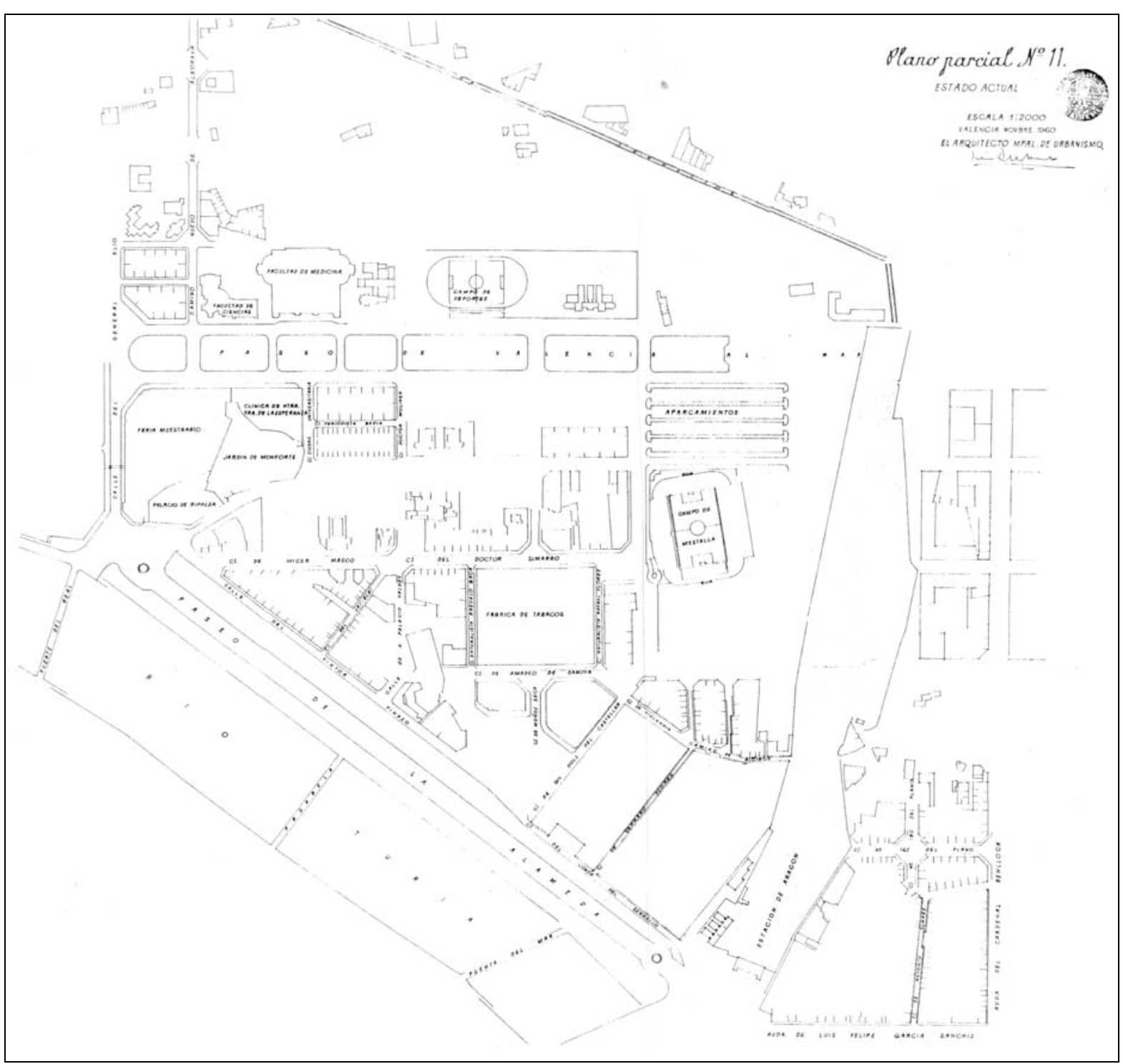


3. PLANO DE PROYECTO

Escala original 1:2000

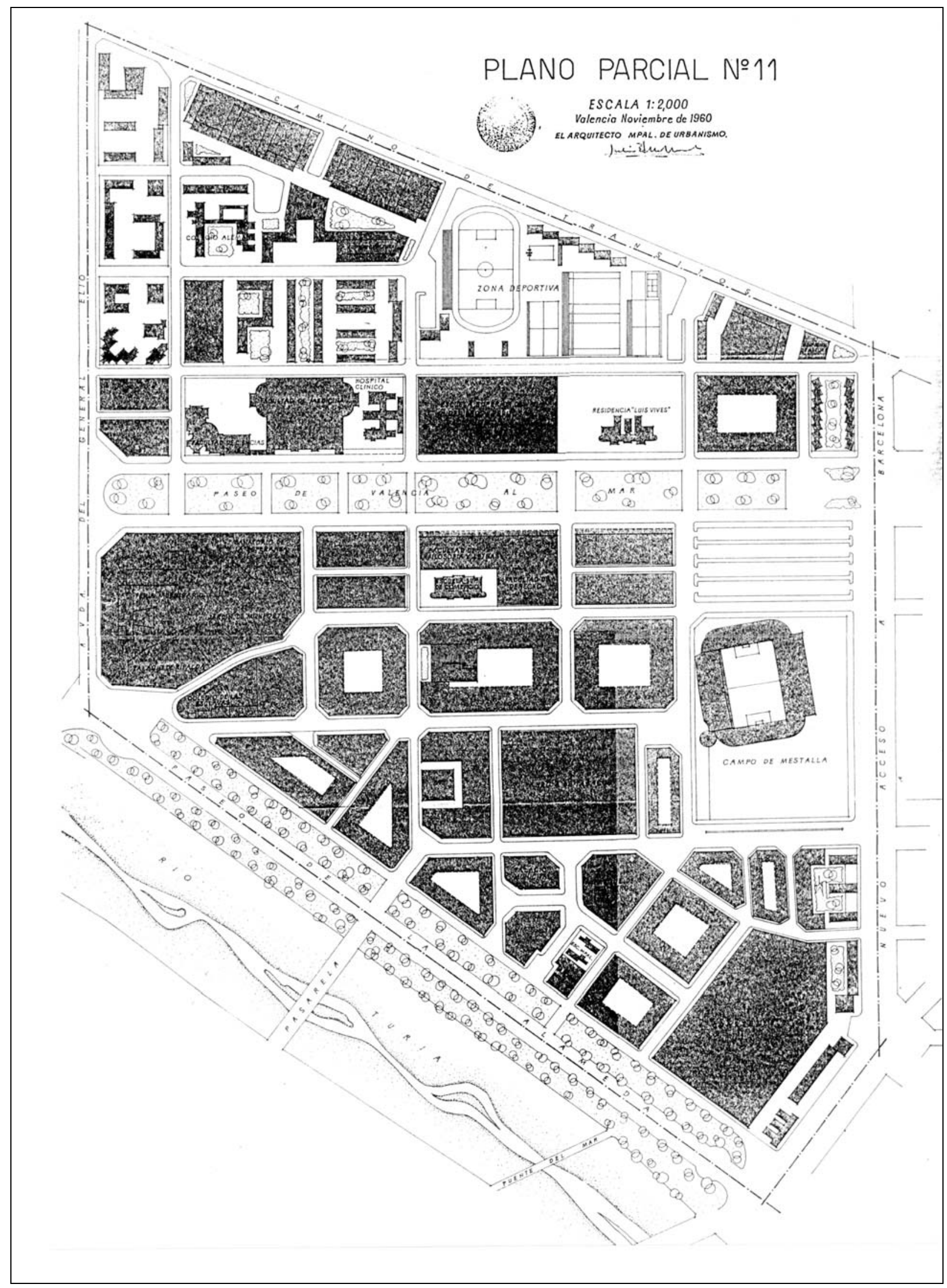


Redactor: Oficina Técnica Municipal de Urbanismo. Ayuntamiento de Valencia.

Fecha: Redacción: 23-8-1962. Aprobación Ministerio Vivienda, 1964

Asunto: MODIFICACIÓN DEL PLANO PARCIAL 11 CON MOTIVO DE ENSANCHE DE 50 A 80 M. DEL ACCESO A BARCELONA.

Fuente: Archivo de Planeamiento. Ayuntamiento de Valencia. OM-60

EXCMO. AYUNTAMIENTO DE VALENCIA PLANO PARCIAL NO 11

MODIFICACION DEL PLANO CON MOTIVO DEL ENSANCHE DE 50 A 80 M. DEL ACCESO DE BARCELONA

\section{MEMOR I A}

JUSTIFICACION DE LA ORDENACION.- Es objeto de este estudio la modificación del plano parcial no 11 de desarrollo del Plan General de Valencia y su comarca por causa del acuerdo del Excmo. Ayuntamiento de ensanchar el acceso de Barcelona de 50 a $80 \mathrm{~m}$. con motivo de nuevo estudio por O.P. de los accesos.

Este plano parcial fue aprobado por el Ministerio de la Vivienda en 29 de Diciembre de 1960 por lo que el actual estudio sólo tiende a la aprobación de la modificación precitada.

Se introduce también la modificación de convertir en edificable parte de los aparcamientos del Campo de Fútbol de Mestalla, siguiendo la parte baja con su mismo destino de aparcamientos y las plantas altas con destino a edificio ministerial.

Al realizar el ensanche del acceso a costa solamente de los solares del lado de este plano, ya que la alineación de la derecha, saliendo de Valencia, queda en la misma situación que tenía, hemos procurado compensar el retiro con un aumento de altura según se especifica en el plano.

Se han introducido también en el plano las pequeñas modificaciones necesarias para acoplar al plano a realidades del mismo.

ETAPAS.- La calzada principal del nuevo acceso a Barcelona es a realizar por el Ministerio de Obras Públicas y la suponemos de realización inmediata en una primera etapa, podíamos decir. El resto del acceso o sea las calzadas laterales y aceras serán realizadas a continuación por el Excmo. Ayuntamiento, por el mismo procedimiento que el esto de la urbanización del sector, dando preferencia a estas obras por tratarse de un elemento importante.

MEDIOS ECONOMICO-FINANCIEROS.- Son los del presupuesto ordinario de urbanismo y de los extraordinarios que se establezcan en los que se incluirán las obras proyectadas.

Con lo expuesto y dada la sencillez del problema, no obstante su gran magnitud, creemos suficientemente expresado el alcance del estudio realizado para que si lo estima el Excmo. Ayuntamiento se eleve a la superioridad para su aprobación.

Valencia, 23 de Agosto de 1.962.

LOS ARQUITECTOS MUNICIPALES DE URBANISMO,
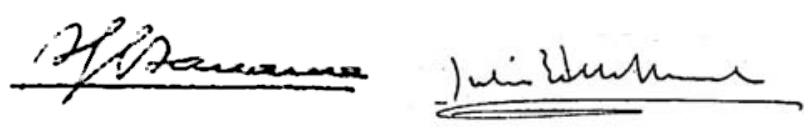


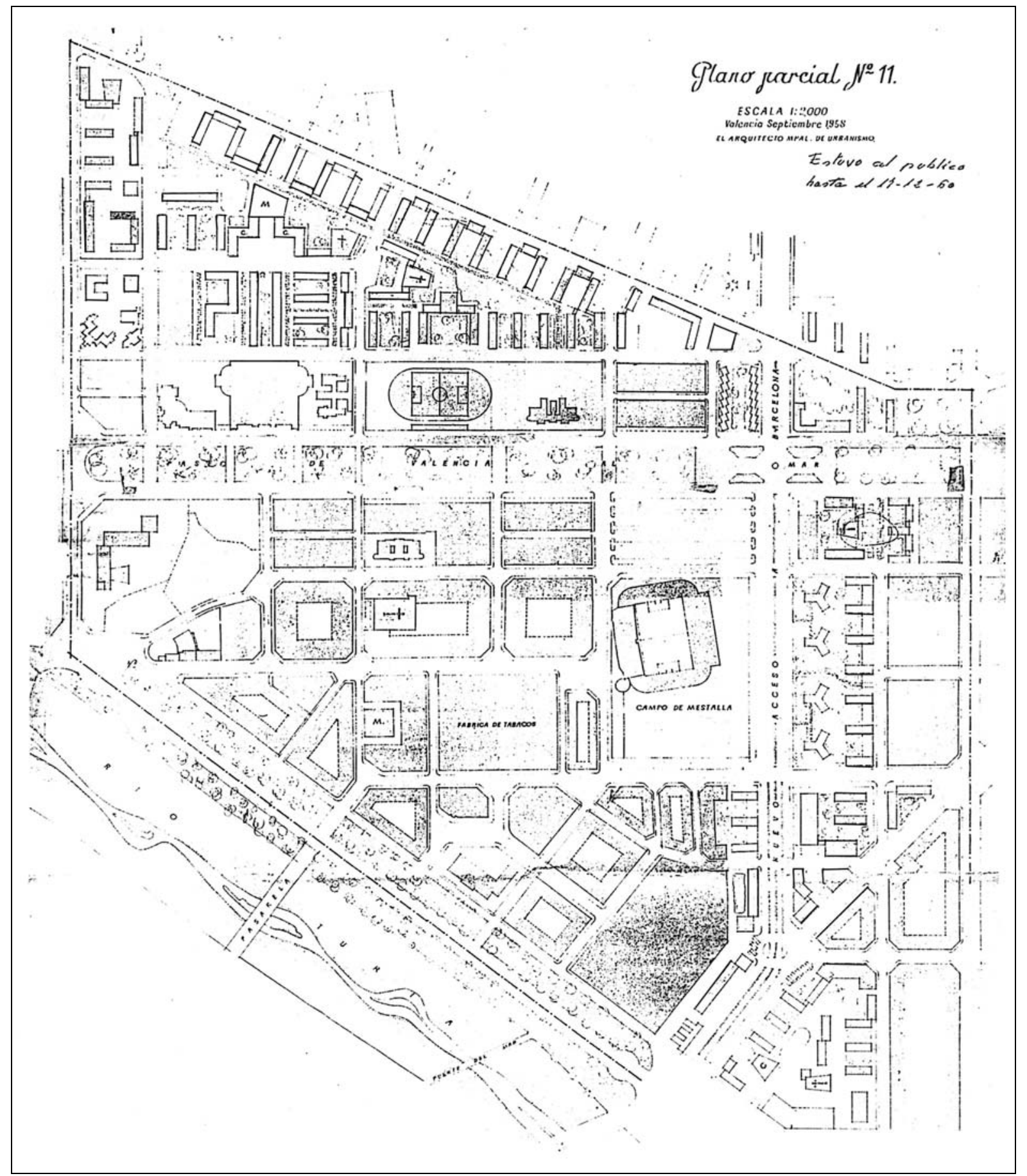


MODIFICACIÓN PP11 POR ENSANCHE DEL NUEVO ACCESO DE BARCELONA, 1962.

Fragmento de Plano de Proyecto. Escala original 1:2000

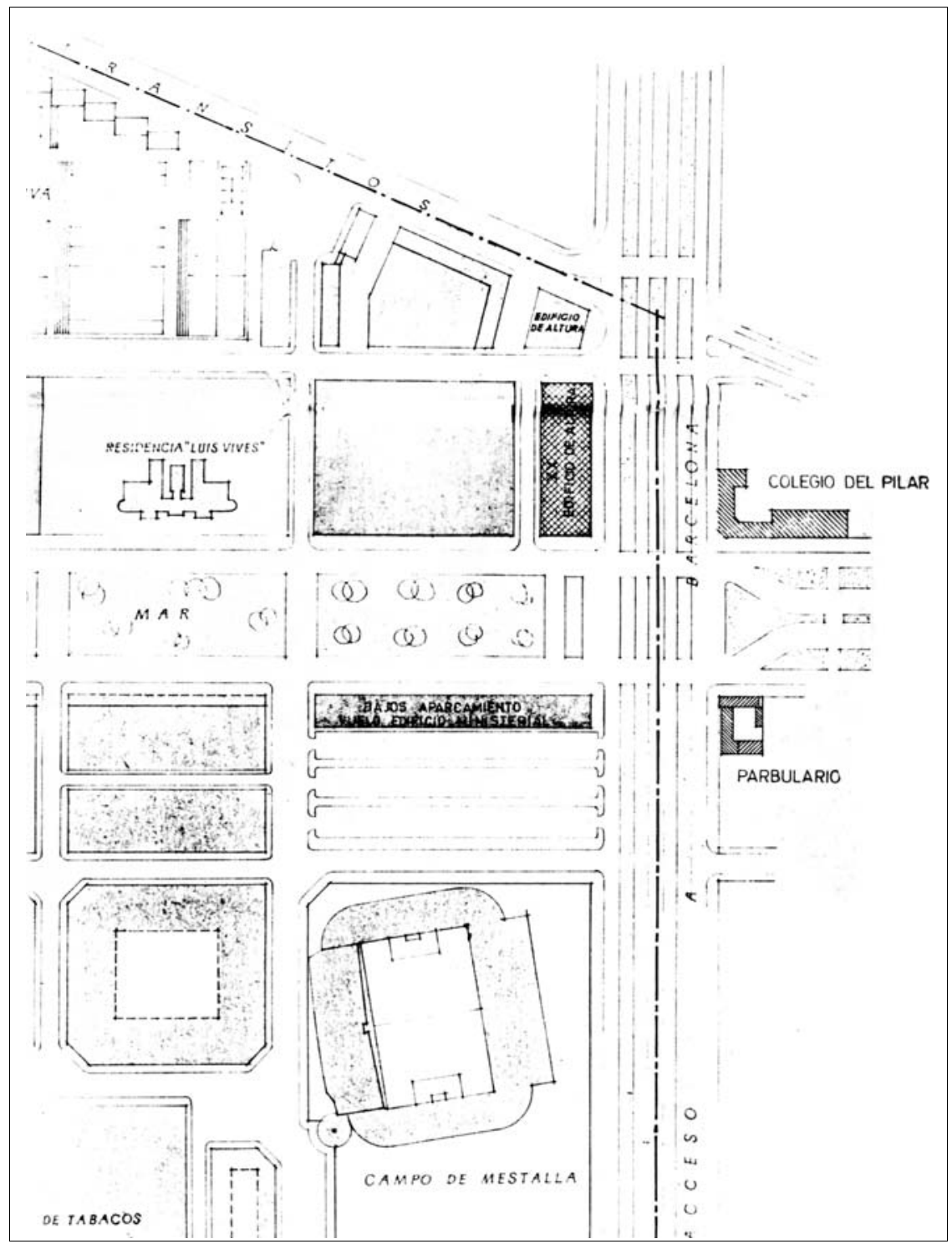


Redactor: Arquitecto Municipal de Urbanismo. Ayuntamiento de Valencia.

Fecha: 20- 7-1963.

Asunto: INFORME SOBRE MODIFICACIONES EN LA ZONA NORTE DEL PP11.

Plano adjunto: PLANO ZONA NORTE PP11, julio 1963.

Fuente: Archivo de Planeamiento. Ayuntamiento de Valencia. OM-57.1

El Arquitecto que suscribe, tiene el honor de informar:

El plano no 11 por su carácter de edificación abierta y el interés de la zona, que contiene las edificaciones docentes de mayor importancia; las instalaciones deportivas de la ciudad y las universitarias; el parque de los viveros, feria muestrario, etc., viene siendo objeto de solicitudes varias de modificación para adaptarlo a las necesidades de los que se construyen en él.

Al presente tenemos tres de ellas que estimo pueden ser tramitadas conjuntamente, previa aprobación, ya que suponen aumento de espacios libres -aunque de carácter privado-, y aumento de salubridad amén de estar dotadas de gran brillantez. Al objeto se ha confeccionado el plano que presentamos adjunto.

Las modificaciones son:

$1^{0}$.- La objeto inicial del presente expediente, presentada por la Orden Carmelita Calzada y por D. Banjamín y D. Luís Muñoz Rodrigo conjuntamente, de la manzana limitada por calles de General Elío, en proyecto, Jaime Roig y Avenida de Primado Reig.

En esta manzana se ha edificado la Iglesia de la Orden Carmelita y ha de edificarse convento y residencia. La modificación resulta apropiada tanto en cuanto a los edificios de la Orden Carmelita como en los destinados a viviendas. Recaen todos ellos a espacios ajardinados, entre ellos Viveros municipales, podrán tener zonas de aparcamientos y forman bloques abiertos.

$2^{\circ}$.- Colegio Alemán. Solicitó cambio de zonificación para poder realizar campo de deportes, anejo al colegio, en zona de edificación. Esto trae consigo modificaciones de las alineaciones de edificaciones. Se proporciona mayor espacio abierto.

30.- Edificios del grupo de Ingenieros al sur del Colegio Alemán. En parte de una manzana cerrada se pretende edificar edificios torre mucho más convenientes.

Por todo ello estimo que puede ser aprobada la modificación que se solicita en este expediente, y el plano que se presenta con las modificaciones que implica.

V.E. resolverá.

Valencia, 23 de julio de 1.963.

EL AQUITECTO MPAL. DE URBANISMO,

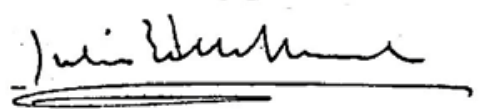


MODIFICACIÓN DE MANZANA EN ZONA NORTE, 1962

Plano de situación. Escala original 1:1000

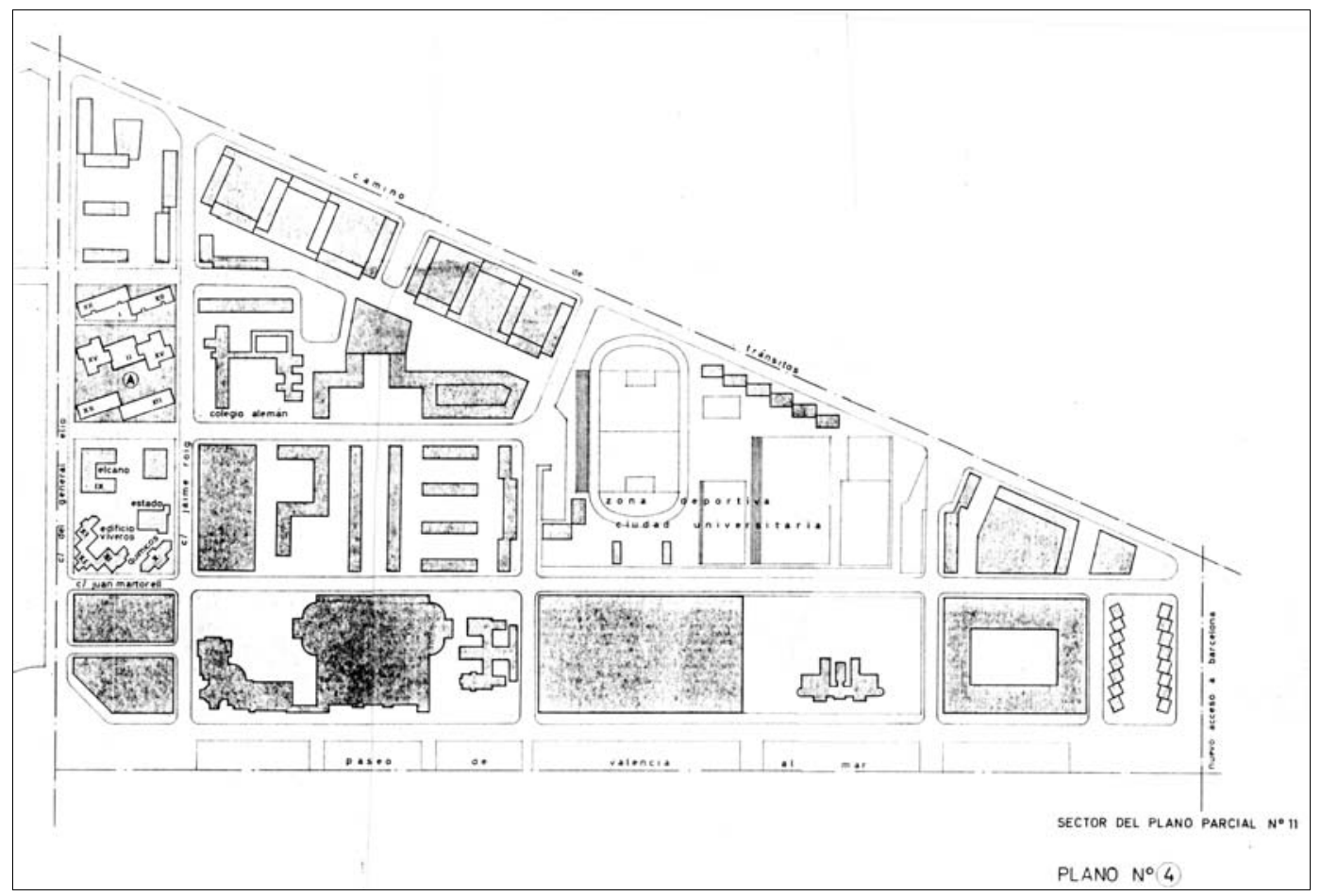

PP11. MODIFICACIÓN ZONA NORTE, junio 1963.

Plano adjunto a Documento 11.1. Escala original 1:1000

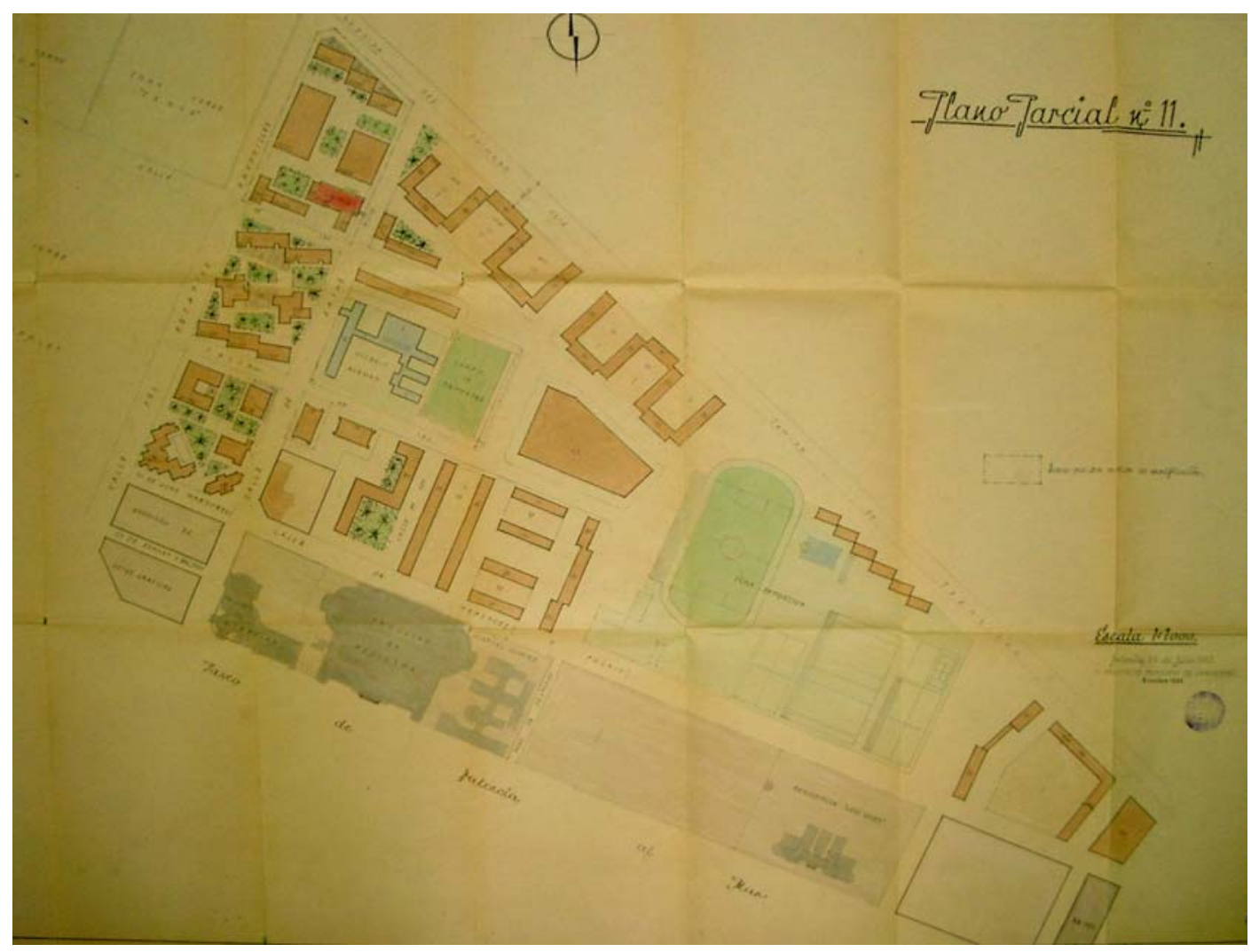


PROPUESTA DE MODIFICACIÓN ZONA NORTE, 1964

Escala original 1:1000

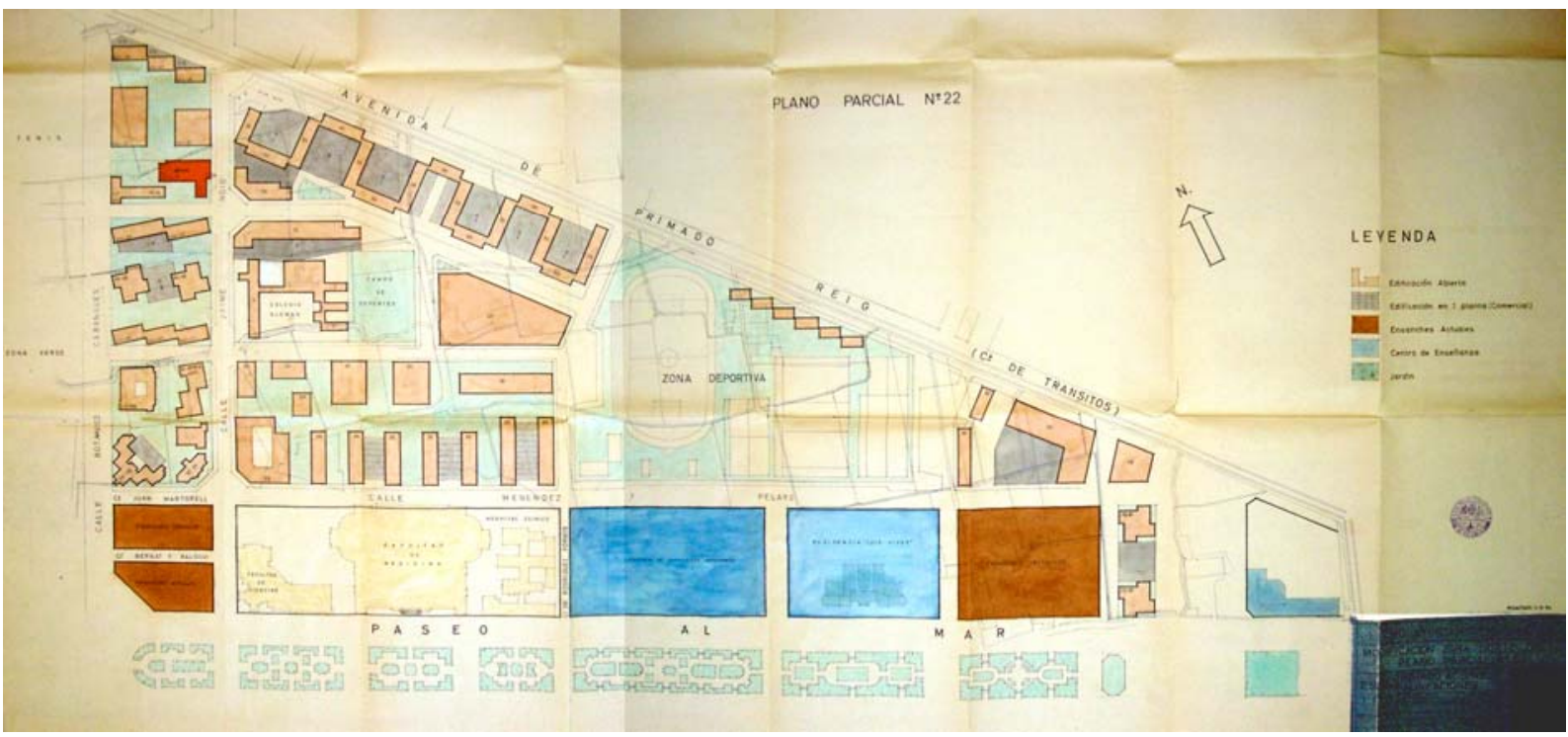

MODIFICACIÓN DE LÍNEAS EN MANZANA LIMITADA POR C/ JAIME ROIG, BACHILLER, BOTÁNICO CABANILLES Y ÁLVARO DE BAZÁN. Enero 1965. Escala original 1:1000

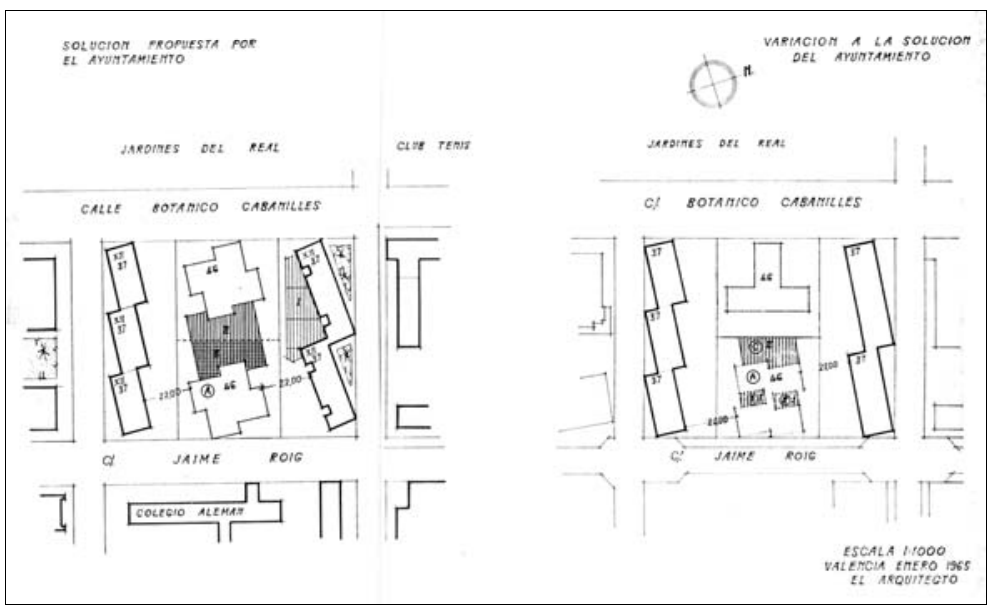

MODIFICACIÓN DE LÍNEAS EN MANZANA LIMITADA POR C/ JAIME ROIG, TRÁNSITOS, BOTÁNICO CABANILLES Y BACHILLER.

Enero 1965. Escala original 1:1000

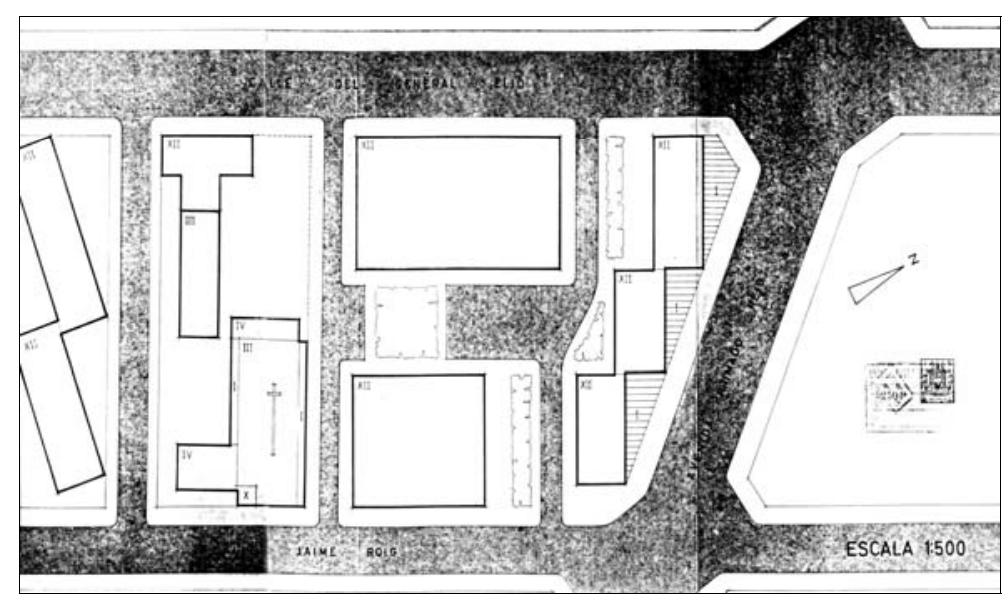


MODIFICACIÓN ZONA LLANO DEL REAL. Mayo 1965.

Escala original 1:2000

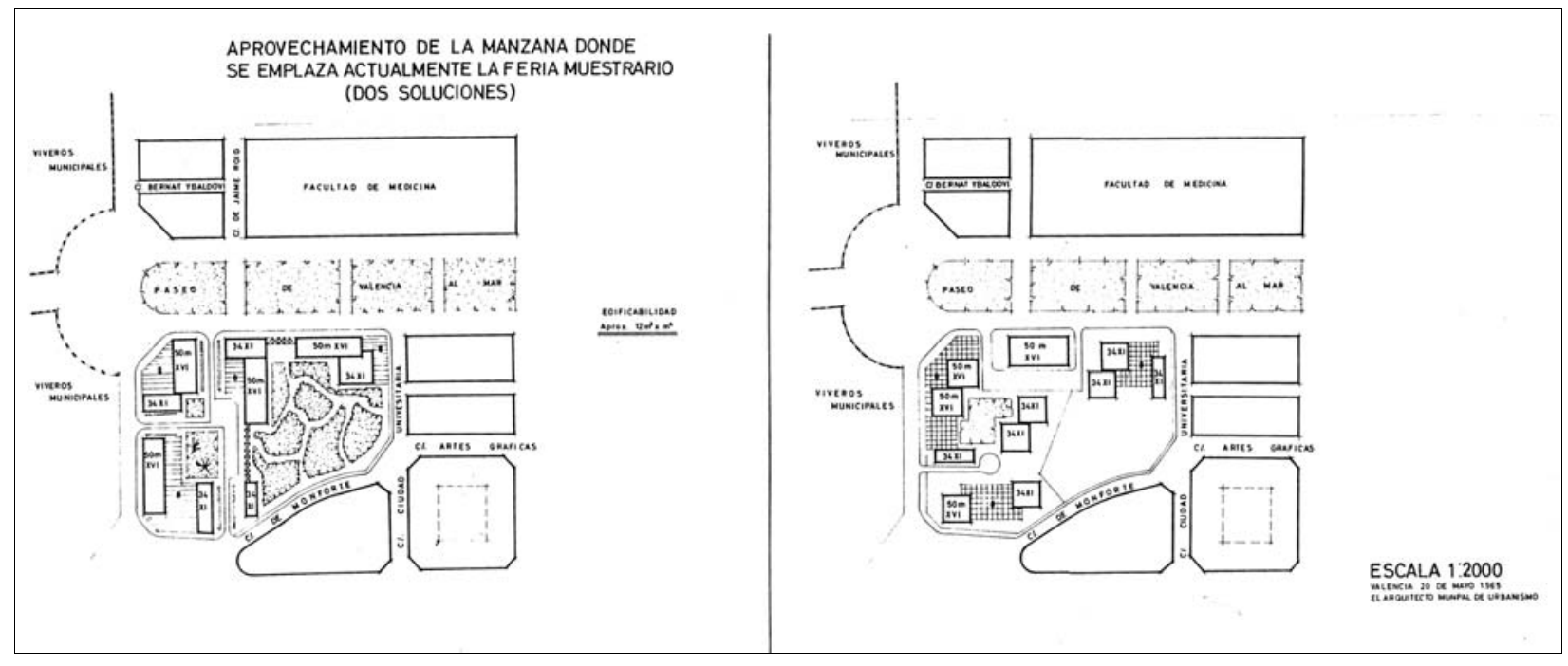

MODIFICACIÓN ZONA LLANO DEL REAL. Enero 1966.

Plano adjunto a Documento 11.3. Escala original 1:1000

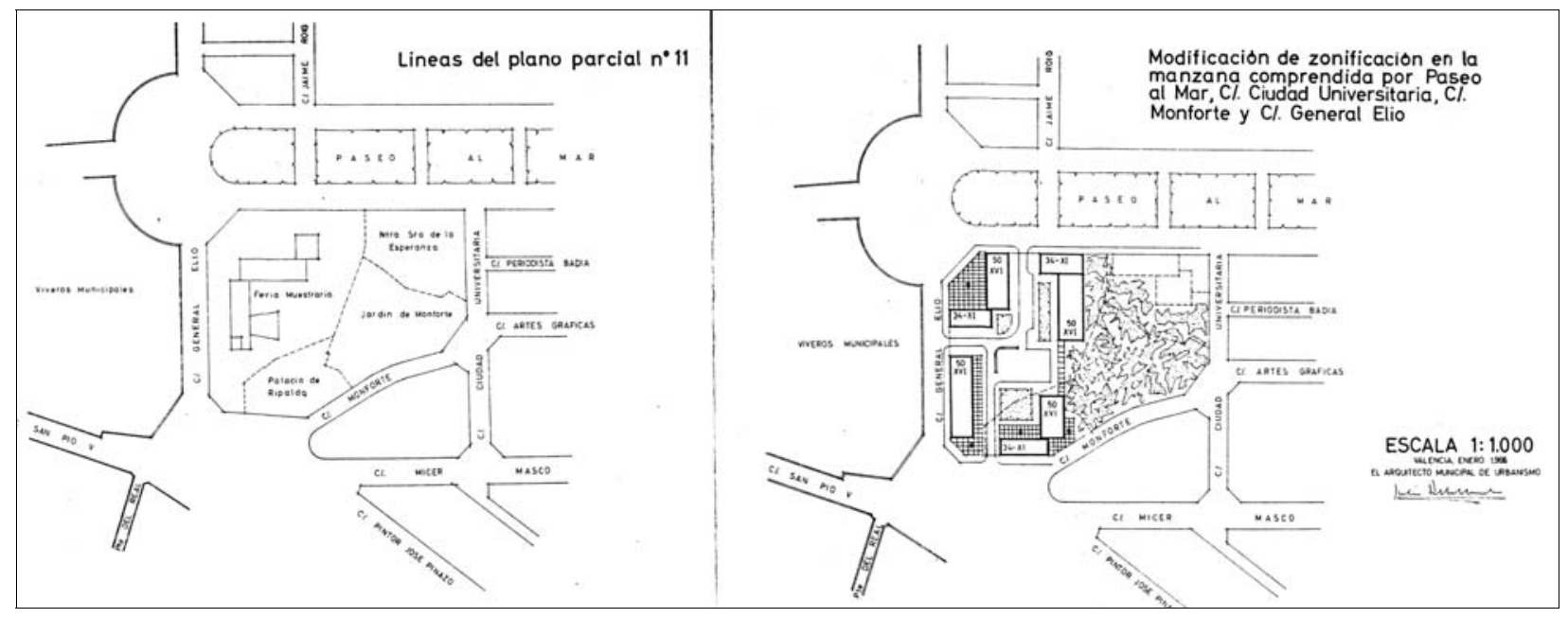


Redactor: Arquitecto Municipal de Urbanismo. Ayuntamiento de Valencia.

Fecha: 28- 1-1966.

Asunto: NUEVA ORDENACIÓN DE LA ZONA DEL LLANO DEL REAL DEL PP11.

Plano adjunto: MODIFICACIÓN DE LA ZONIFICACIÓN EN LA MANZANA COMPRENDIDA POR PASEO AL MAR, C/CIUDAD UNIVERSITARIA, C/MONFORTE Y C/GENERAL ELIO, enero 1966.

Fuente: Archivo de Planeamiento. Ayuntamiento de Valencia. OM-63.

EXCMO. AYUNTAMIENTO

DE

VALENCIA

PLANO PARCIAL No 11

TERRENO DEL PALACIO DE RIPALDA-ZONIFICACION

\section{MEMORIA}

En la redacción del Plano Parcial no 11 se zonificó la manzana entre Paseo al Mar y calle del jardín de Monforte, con los usos ya existentes por la existencia del Jardín de Monforte de carácter Histórico-Artístico y por suponer que los otros elementos de la manzana Feria Muestrario, Sanatorio de Nuestra Señora de la Esperanza y Palacio de Ripalda, no serían modificados.

El Palacio de Ripalda es construcción relativamente moderna y el deseo de sus propietarios así como el proyecto de convertir la actual Feria Muestrario en zona de edificación, ha de bastar para convertirlo en zona de edificación particular ya que ninguna consideración de elemento necesario a la zona motivó su zonificación en el plano parcial que se aprobó por la Dirección General de Urbanismo el 29 de Diciembre de 1.960.

Se trata pues de determinar qué formas pueden construirse en el solar que hoy ocupa el Palacio de Ripalda.

Se ha estudiado en conjunto con los terrenos de la Feria Muestrario actual formando un grupo de edificaciones abiertas con una plaza central de jardines y aparcamientos. Una de esas edificaciones es la que corresponde al Palacio de Ripalda, o sea que su forma responde a un conjunto.

Sobre etapas, servicios y medios económicos-financieros nada hay que añadir a lo establecido en el Plano Parcial no 11 en que se ubica.

ORDENANZA A SEGUIR EN LA EDIFICACION.-

Salvo en la altura que es la marcada en el Plano de este proyecto se seguirá la ordenanza especial de Ensanches Actuales.

Valencia, 28 de enero de 1.966

EL ARQUITECTO MPAL. DE URBANISMO,

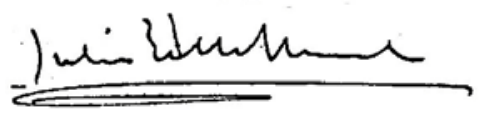


MODIFICACIÓN ZONA LLANO DEL REAL. Julio 1966.

Escala original 1:2000

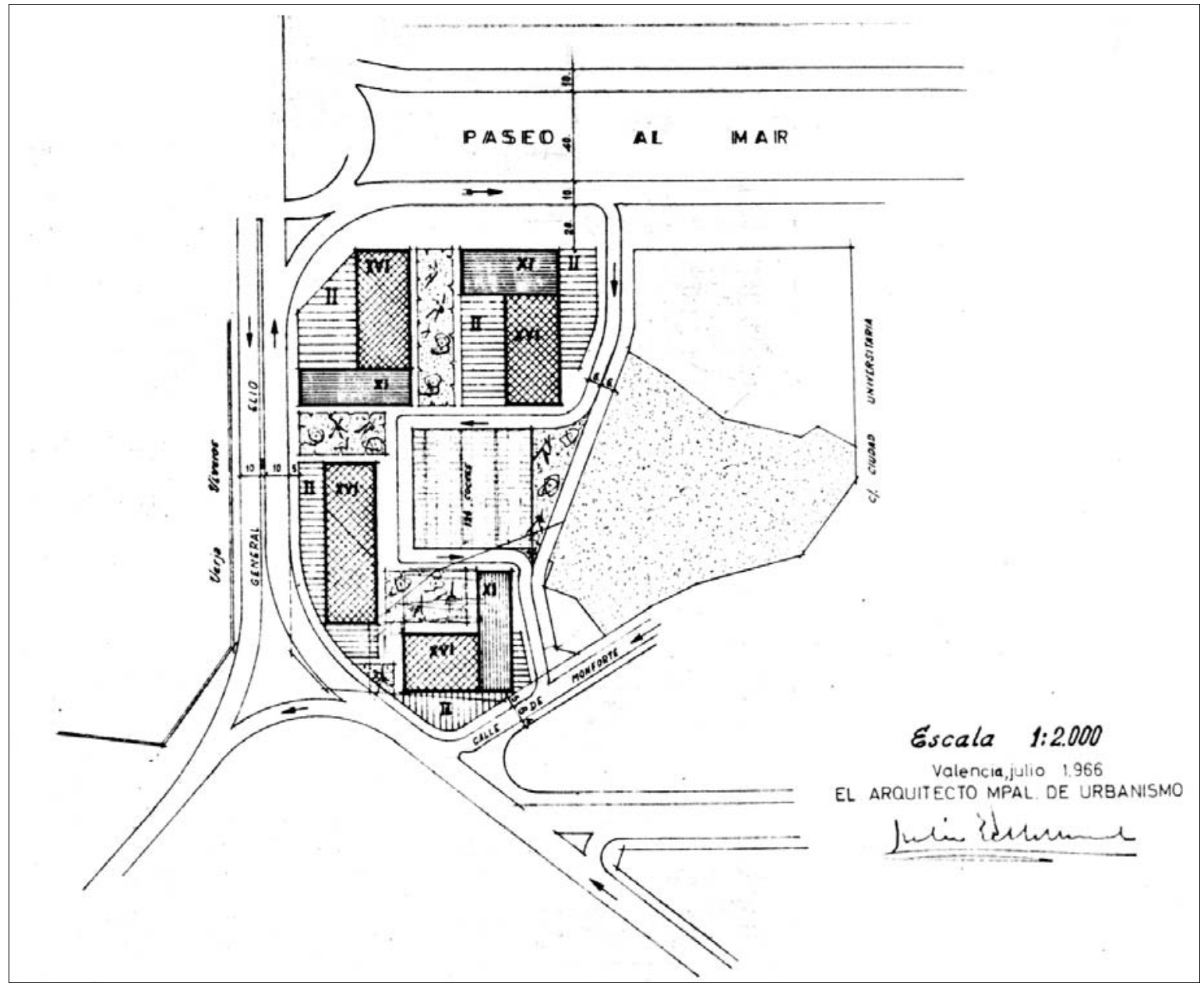


Redactor: Arquitecto Municipal de Urbanismo. Ayuntamiento de Valencia.

Fecha: 21- 6-1968.

Asunto: REORDENACIÓN DE LA ZONA DEL LLANO DEL REAL DEL PP11.

Plano adjunto: REORDENACIÓN DE LA ZONA DEL LLANO DEL REAL, junio 1968.

Fuente: Archivo de Planeamiento. Ayuntamiento de Valencia. OM-63.

\section{MEMORI A}

La presente reordenación trata de estudiar en su totalidad la manzana limitada por las calles de Monforte, General Elío, Paseo al Mar y Universidad.

Para ello hay que agrupar a los solares ya estudiados propiedad del Ayuntamiento y Ripalda, los correspondientes a la familia Monforte y Sanatorio de la Esperanza.

Respecto a este último hay que remitirse al informe de 14 de febrero de 1.967 en el que se dice: "El Sanatorio de la Esperanza cumple una de las necesidades de la ciudad, de manera que establecer un esquema sobre su terreno sería dejarlo fuera de Ordenación, y en cambio comprendemos la conveniencia de que pueda trasladarse a otro lugar cuando así convenga". Esto se soluciona zonificándolo como extensión, según marca el Plan general, con una edificabilidad de $10,5 \mathrm{~m} 3 / \mathrm{m} 2$. igual que el resto de la manzana y ocupación del $45 \%$ de la manzana y separación de bloques igual a su altura.

En cuanto a los terrenos de la familia Monforte constan de: 10.- El Jardín de Monforte propiamente dicho tal como se describe en el Decreto de 30 de Mayo de 1.941 grafiado en el parcelario, letra D. $2^{\circ}$.- Una casa situada en la esquina que forma la calle de Monforte con la Universidad, con sus anejos y corrales y una parcela de terreno situada a espaldas de la casa. Esta parcela fue permutada por otra de similar extensión situada en lo que actualmente constituye el Pabellón Marroquí (letra E). $3^{\circ}$.- Una parcela en que se halla edificada una casa con sus anexos y corrales en la calle de Monforte (letra C).

La superficie total de estas parcelas es aproximadamente de $2.000 \mathrm{~m} 2$. Con una edificabilidad igual al resto de la manzana le corresponde un volumen de $20.500 \mathrm{~m} 3$.

La proximidad de estas parcelas al Jardín y su peculiar configuración no hacen aconsejable el edificar en ellas, por lo que se ha tratado de conservar la anterior Ordenación, creando una calle peatonal que deje totalmente exento el Jardín e introducir esta edificabilidad dentro de la parcela señalada con la letra (a) en el plano parcelario.

Se conserva el volumen y alturas de la solución anterior modificando ligeramente su disposición para dar cabida al nuevo bloque que sobre la parcela (a) absorbe el volumen edificable correspondiente a las parcelas $\mathrm{E}$ y $\mathrm{C}$.

Con esta solución los espacios libres de la manzana quedan incorporados al Jardín de Monforte, dando una sensación de mayor amplitud. La disposición de los bloques suficientemente separados 
del Jardín para no agobiarlo, garantiza su perfecto soleamiento.

Se sustituye un tramo del anterior vial que atravesaba la manzana por una calle peatonal, exclusivamente a fin de dejar más integrado el Jardín al resto de la manzana.

Con el mismo criterio se traza una nueva calle de peatones que delimita el Jardín de Monforte con la parcela del Sanatorio.

Las ligeras modificaciones introducidas en la disposición de los bloques se ha hecho a fin de aumentar la separación entre ellos y garantizar la apertura de vistas del nuevo bloque introducido hacia la Alameda y el Jardín de Viveros.

El aparcamiento situado en el centro de la manzana se prevé realizarlo en sótano y semisótano, a fin de garantizar una superficie de aparcamiento suficiente para la densidad posible, y cubierto por una plaza peatonal que quedará integrada al esto de los espacios libres a través de pasos elevados de peatones.

ESTUDIO DE VOLUMENES: El volumen que se proyecta sobre las parcelas $A, a, B, C$, E, es aproximadamente de $10,5 \mathrm{~m} 3 / \mathrm{m} 2$. sensiblemente inferior al que le correspondería con un aprovechamiento de manzana cerrada con $27 \mathrm{~m}$. de altura.

Dada la situación privilegiada de la manzana que nos ocupa, creemos que queda perfectamente justificada esta Ordenación que se propone.

FORMA DE EJECUCION: Cada bloque queda ubicado en parcelas de fácil independización con lo cual no crean problema de actuación conjunta sobre parcelas diferentes.

Esto se ha conseguido plenamente al ubicar el nuevo bloque que absorbe la edificabilidad de las parcelas C y E sobe la parcela a, siendo por tanto necesaria la permuta de las citadas parcelas $\mathrm{C}$ y $\mathrm{E}$ propiedad de la familia Monforte, por la parcela -a- propiedad del Ayuntamiento, de superficie igual a la suma de las otras dos.

Con esta solución creemos interpretar la sugerencia de la Comisión Central de Urbanismo en su oficio de fecha 28 de mayo de 1.968.

Consiguiendo así una Ordenación total de la manzana con una distribución equitativa de volúmenes.

El Excmo. Ayuntamiento, si así lo estima, puede aprobar esta iniciación de reparcelación entre los terrenos de Monforte y los municipales, que quedará sin efecto hasta aprobación del esquema urbanístico, pero puede ser firme a partir de dicha aprobación.

Valencia, 21 de junio de 1.968.

El Arquitecto Mayor, 
MODIFICACIÓN ZONA LLANO DEL REAL. Junio 1968.

Planos adjuntos a Documento 11.4. Escala original 1:2000
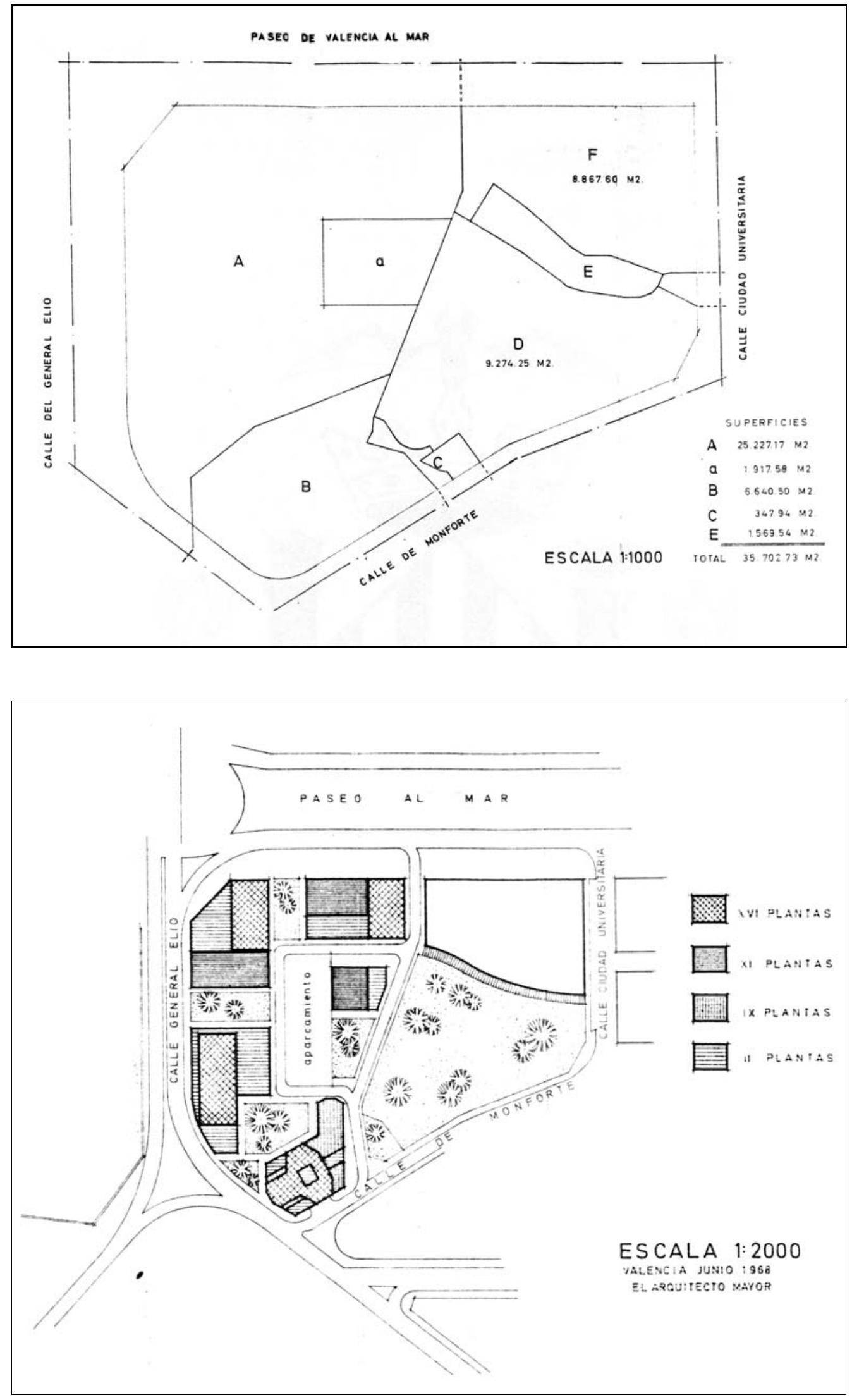

Redactores: AYUNTAMIENTO DE VALENCIA. Oficina Técnica de Urbanismo.

Fecha redacción: Marzo 1963

Fecha aprobación: 7-12-1962 (Aprobación inicial Modificación motivada por la Solución Sur), 1-07-1966 (Aprobación inicial modificación por creación de nueva zona escolar) $(*)$

\section{Contenido:}

MEMORIA.

ORDENANZAS

PLANOS: $(* *)$
1. PARCELARIO
$1: 2000$
2. ALINEACIONES
$1: 2000$
3. PLANEAMIENTO
$1: 2000$
4. ALCANTARILLADO
$1: 2000$
5. RED DE AGUA
$1: 2000$
6. ALUMBRADO
$1: 2000$
7. UBICACIÓN Y TRANSPORTE
$1: 2000$

\section{Fuente:}

Ayuntamiento de Valencia. Sección de Urbanismo. Negociado de Suelo y Ordenación urbana (Archivo de Planeamiento, No OM-83.1)

\section{Notas:}

(*) La "modificación motivada por la solución sur" consiste en incluir en el PP 12-b la edificación proyectada para los terrenos de la Estación de Ferrocarril de Aragón. La nueva zona escolar se prevé en la zona de reserva situada al norte.

(**)Además de los planos correspondientes al Plan Parcial, el expediente del Archivo de Planeamiento dispone de los planos siguientes:

\footnotetext{
- PLANO PARCIAL DE ORDENACIÓN PARTE PASEO VALENCIA AL MAR , (Apr. inicial Ayuntamiento, 29-09-1958) 1:2000

- PLANO DEL ÁREA ESTE DE VALENCIA (S.F.) 1:4000

- PLANO DE ZONAS DE UNIÓN DE LOS

PLANES 11, 12-B Y 22 (MARZO 1964) $1: 2000$

- PLANO DE ZONAS DE UNIÓN DE LOS

PLANES 11, 12-B Y 22 (S.F.)

$1: 2000$
} 



\title{
EXCMO. AYUNTAMIENTO \\ DE \\ VALENCIA
}

\author{
PLANO PARCIAL $12-B$ \\ PASEO AL MAR
}

\section{MEMORI A}

ANTECEDENTES.- El Plano Parcial 12-B fue redactado primeramente por el Excmo. Ayuntamiento de Valencia, como polígono de ejecución inmediata ya que se esperaba auxilio del Ministerio de la vivienda. Se aprobó además como plano parcial por el Excmo. Ayuntamiento en aquella forma, que dejaba un exceso de zonas de destino fijo en relación con el carácter actual que es el de plano de alineaciones, destinado a la ejecución por particulares.

Lo anterior y la necesidad de respetar, bajo este nuevo aspecto, edificaciones realizadas, así como la supresión de un proyecto de ferrocarril subterráneo que había de atravesar, de norte a sur, los terrenos de este plano nos obliga a esta nueva redacción que presentamos.

JUSTIFICACION DE LA ORDENACION.- Las dos arterias principales comprendidas en este plano: El Paseo al Mar y la que limita por el sur el plano, forman parte de un sistema que junto con la Avenida del Doncel Luís Felipe García Sanchiz, Avenida de Tráfico rápido y continuación de Avenida de José Antonio, destinadas a la unión del casco y ensanches con los distritos marítimo y puerto por lo que las creemos de la mayor importancia. La del Paseo al Mar ostenta una anchura de $100 \mathrm{~m}$. necesaria para el establecimiento de zonas ajardinadas y como previsión para el futuro. Las vías Norte y Sur responden: La del Oeste, límite del plano, llamada Avenida del Cardenal Benlloch, forma parte del Camino de Tránsitos, nudo importante de Valencia; la central es resultado del proyecto, hoy abandonado, de ferrocarril subterráneo; la siguiente a la derecha, también central en el plano, es el acceso a la zona de Reserva que está destinada a futuro estadio y Feria Muestrario.

La forma de la edificación es principalmente Edificación Abierta reservándose la de manzana cerrada para las zonas ya iniciadas en esta forma y para las contiguas a otras ya construidas.

Las superficies libres son superiores al $10 \%$ de la superficie total.

El centro comercial será junto al mercado en la manzana central y los religiosos en los laterales unidos, los dos que se establecen por un paseo interno.

La superficie, excluyendo la zona de reserva, es aproximadamente de $90 \mathrm{Ha}$., que a razón de 400 habitantes por Ha. dará una población de 36.000 habitantes. Se establece en los planos el emplazamiento de cinco grupos escolares que, si con su superficie no cubren las necesidades para la población escolar, serán completados con facilidad, dado el carácter abierto de la edificación.

Los medios económico-financieros, en virtud de lo dicho en el párrafo anterior, son los del presupuesto ordinario de Urbanismo del Excmo. Ayuntamiento de Valencia y los extraordinarios que se establezcan para acometer las obras de mayor envergadura. 
Con lo dicho creemos suficientemente expuesto el alcance del estudio realizado para que, si el Excmo. Ayuntamiento lo estima, lo eleve a la superioridad para su aprobación.

Valencia, 13 de marzo de 1.963.

EL ARQUITECTO MPAL. DE URBANISMO,

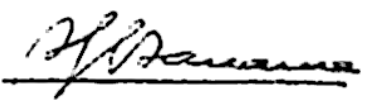


PLANO PARCIAL No $12-\mathrm{B}$

Escala original 1:2000
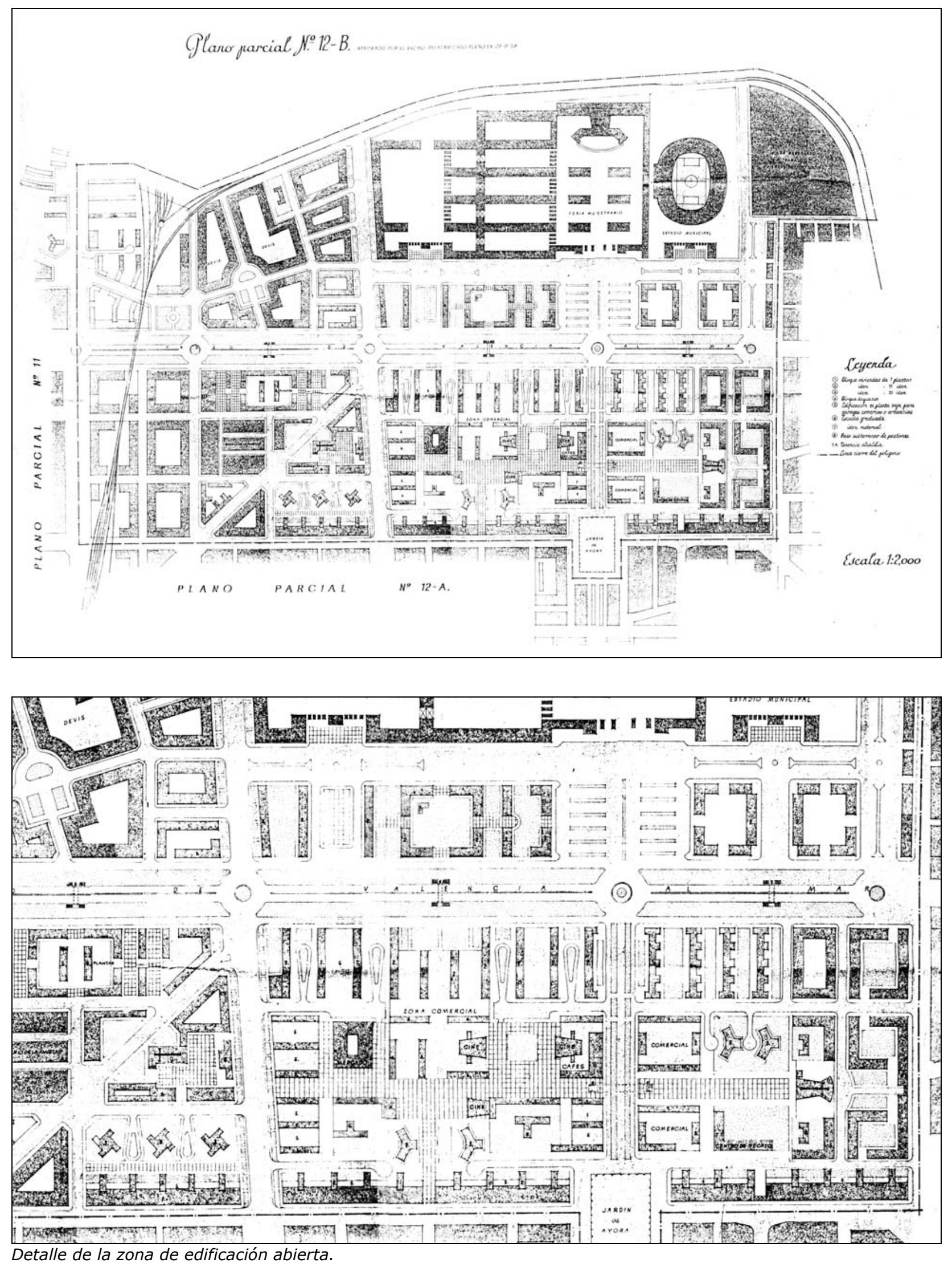


\section{UBICACIÓN Y TRANSPORTE}

Escala original 1:2000

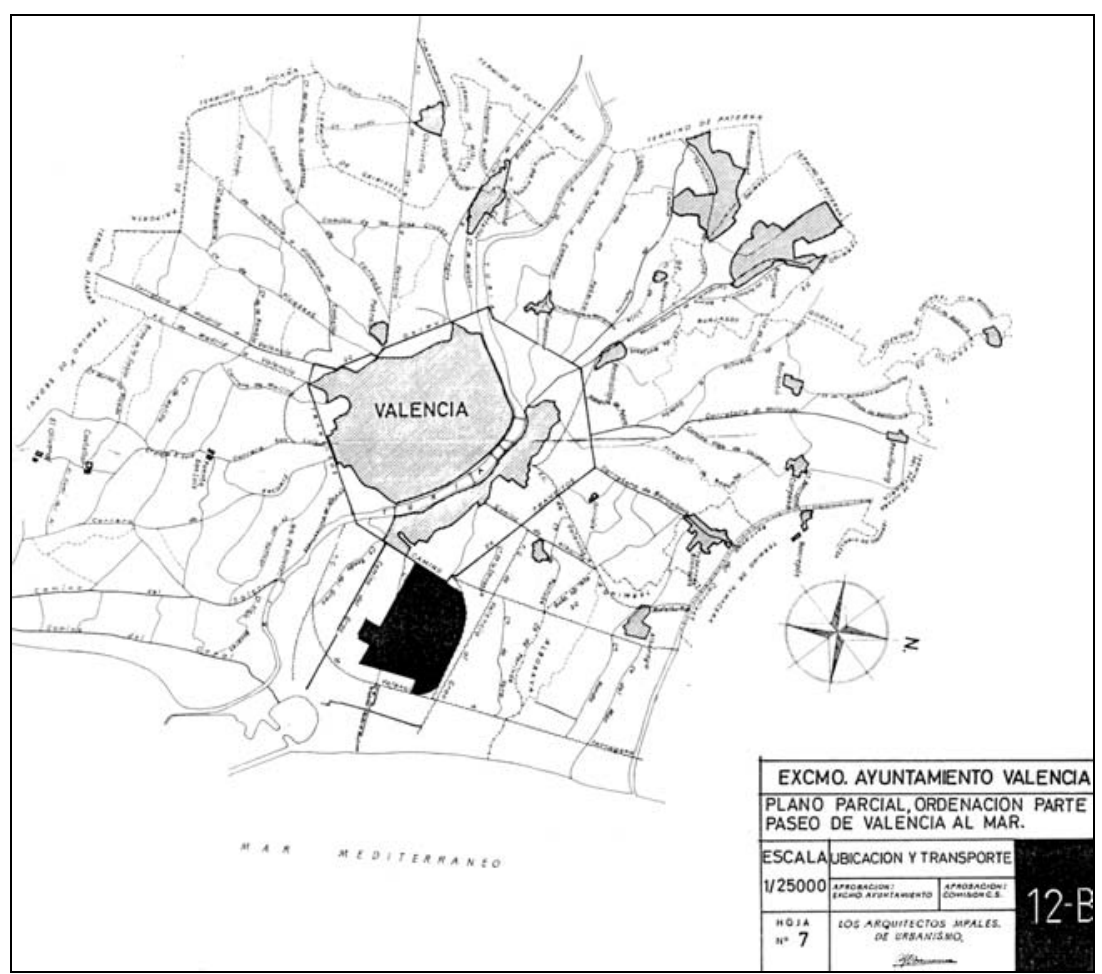

1. PARCELARIO

Escala original 1:2000

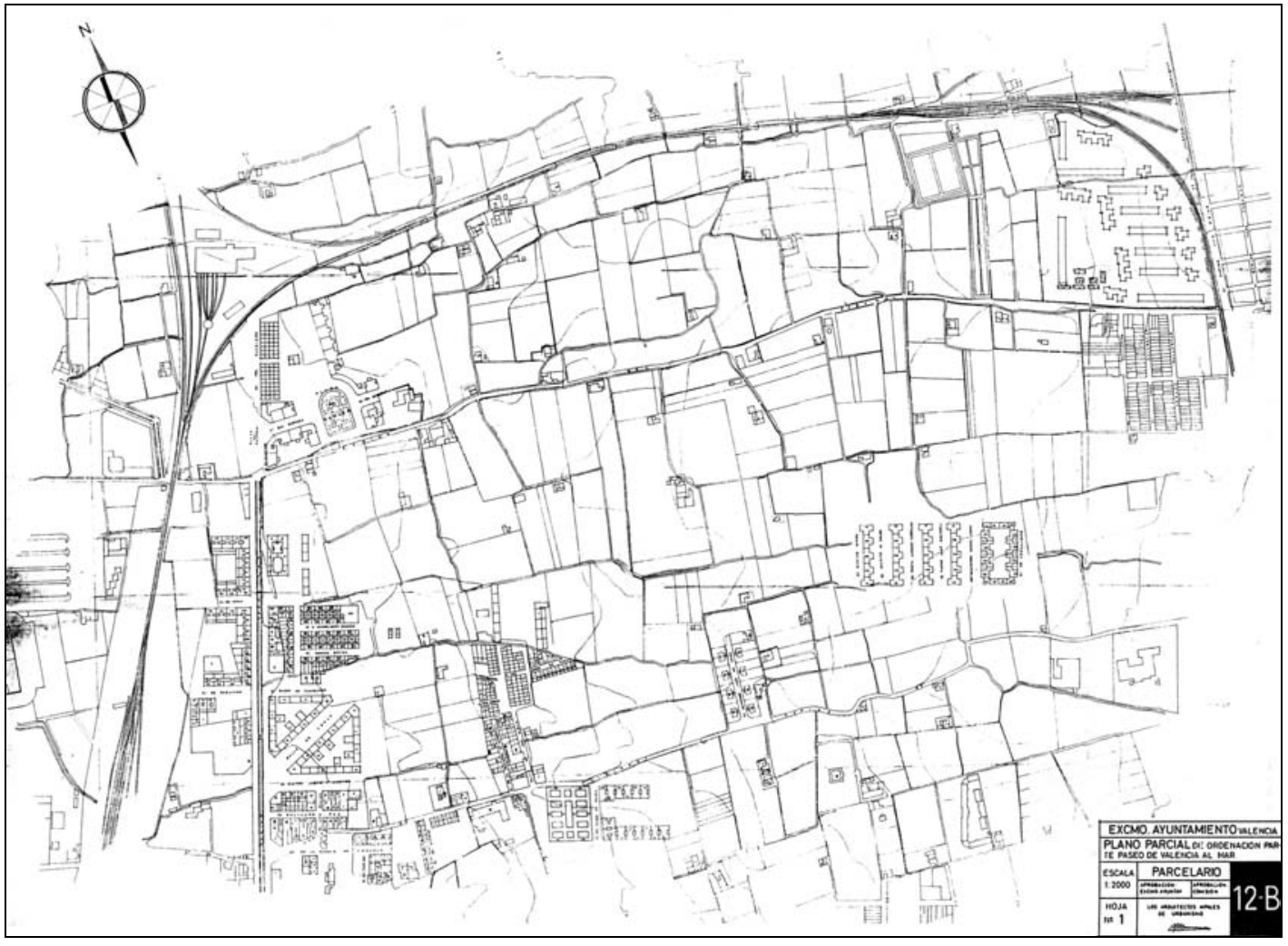




\section{ALINEACIONES}

Escala original 1:2000
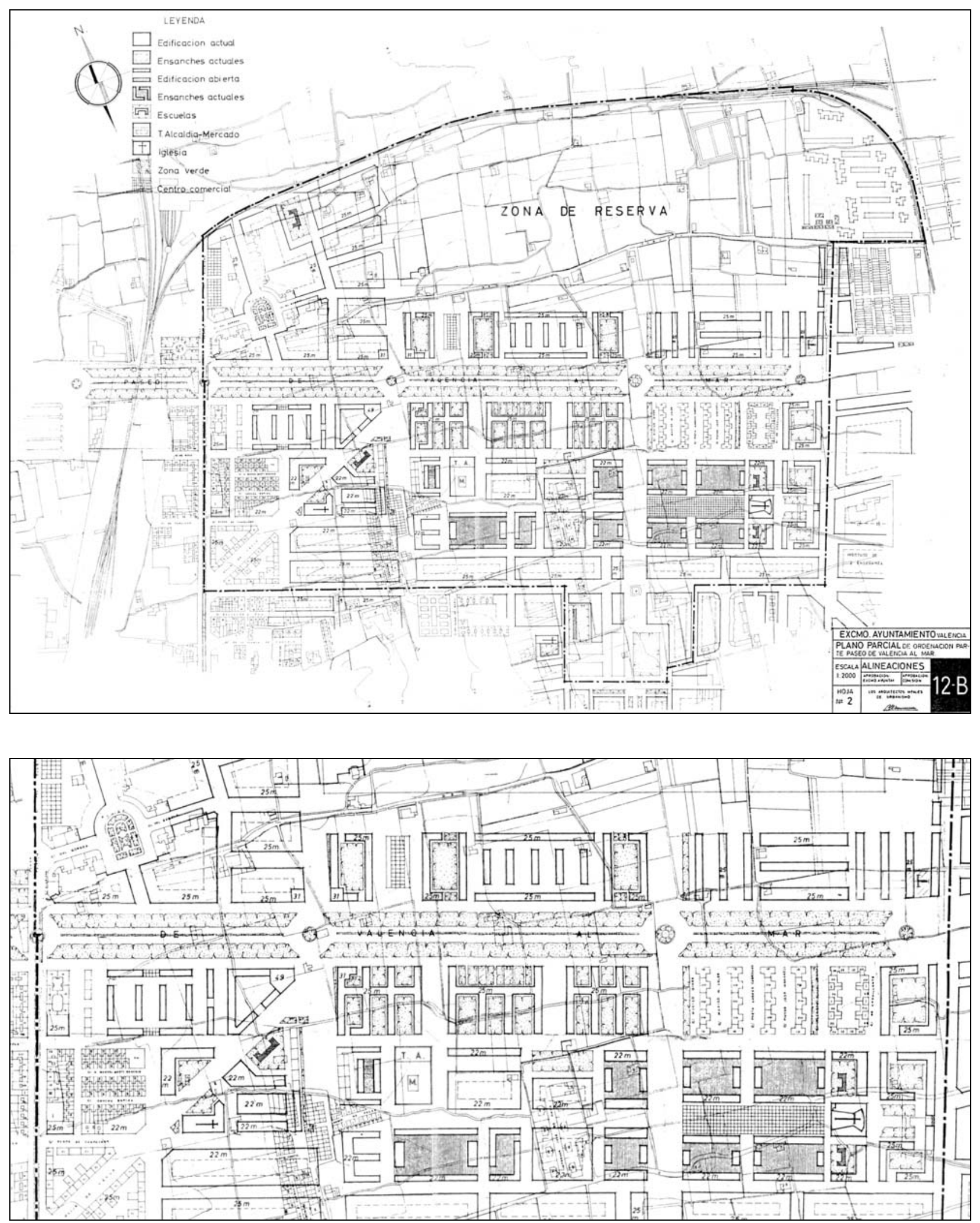

Detalle de la zona de edificación abierta. 
3. PLANEAMIENTO

Escala original 1:2000

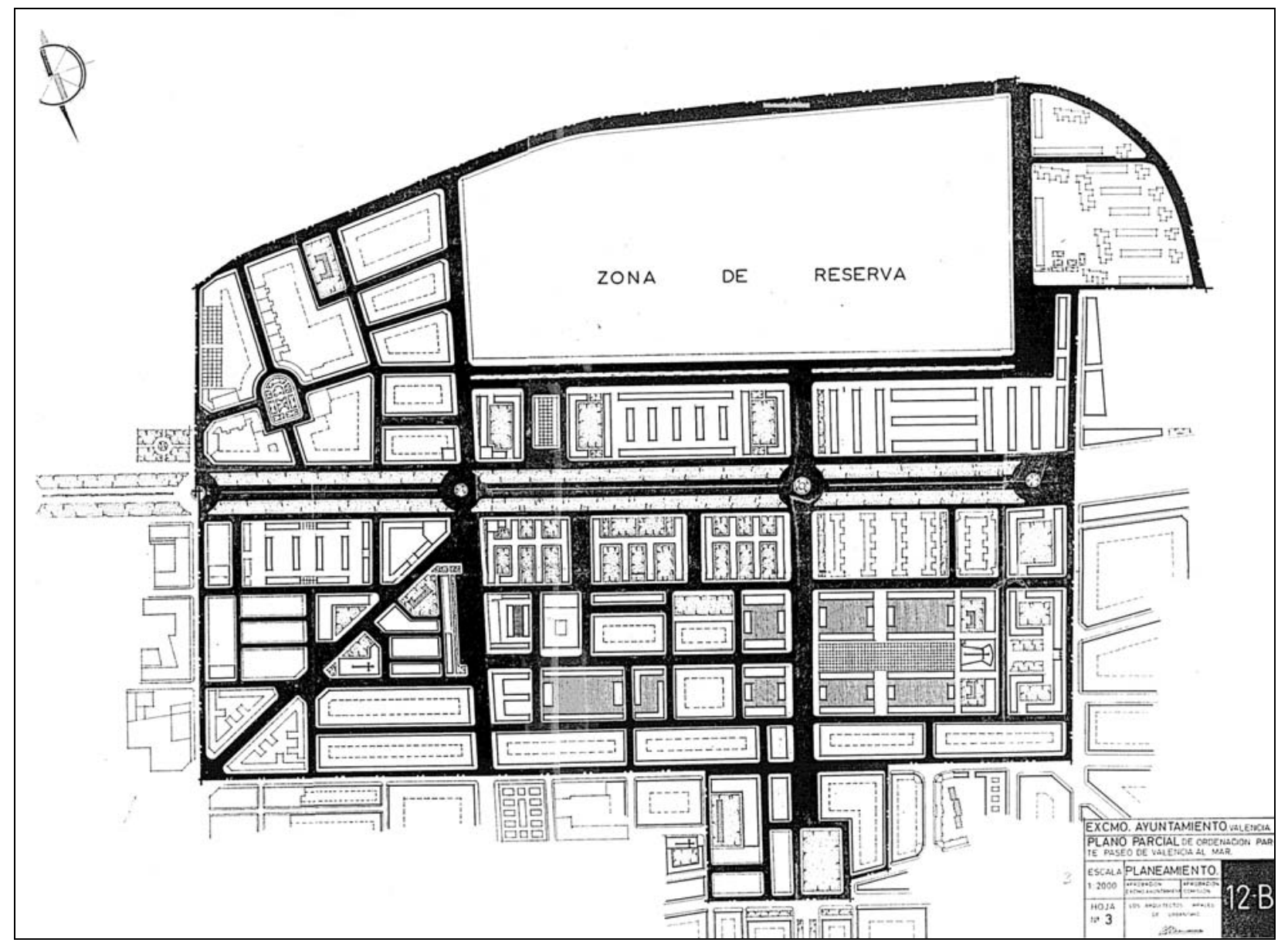


ALINEACIONES.

MODIFICACIÓN MOTIVADA POR LA SOLUCIÓN SUR(Fragmento)

Escala original 1:2000

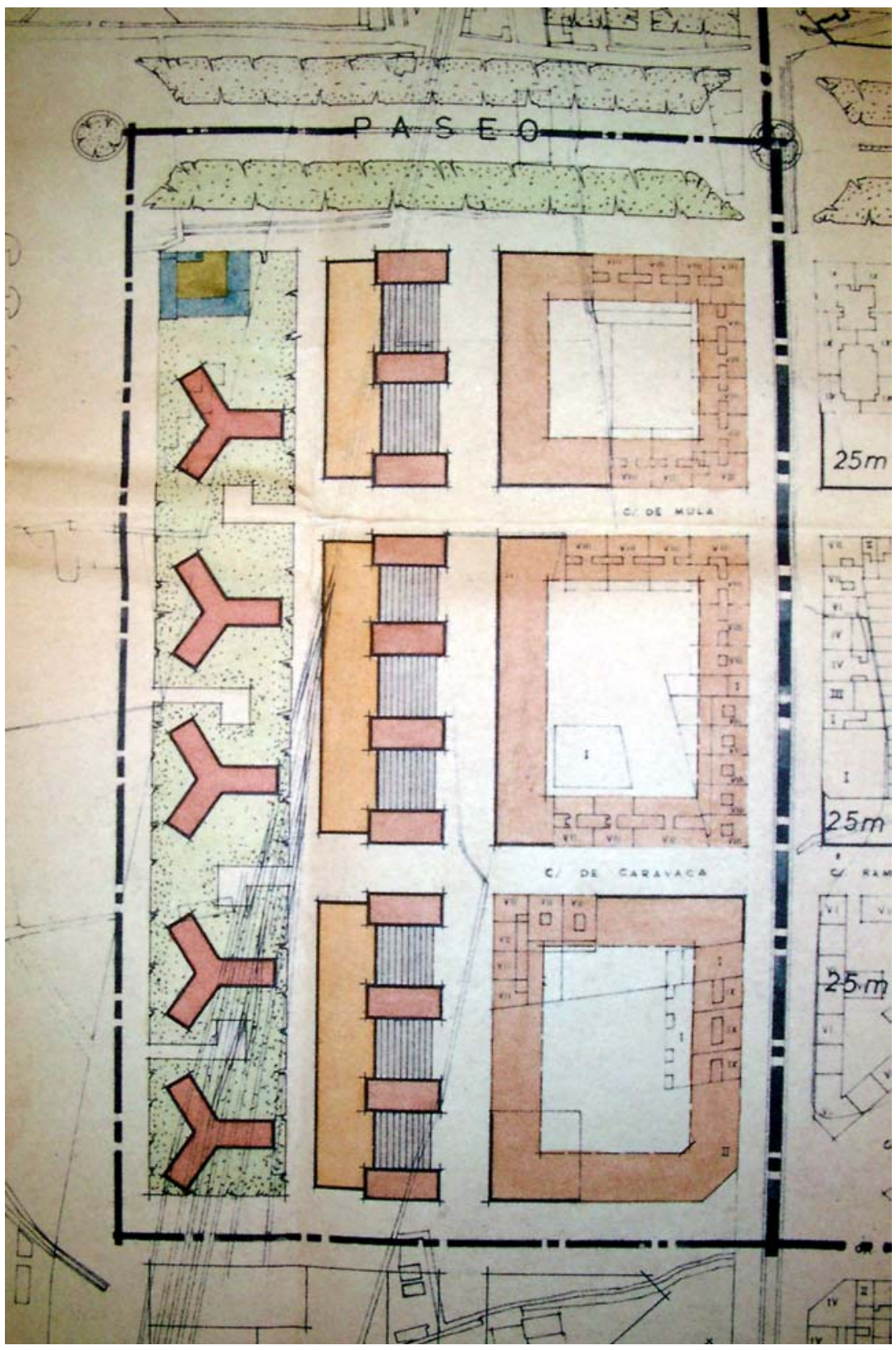




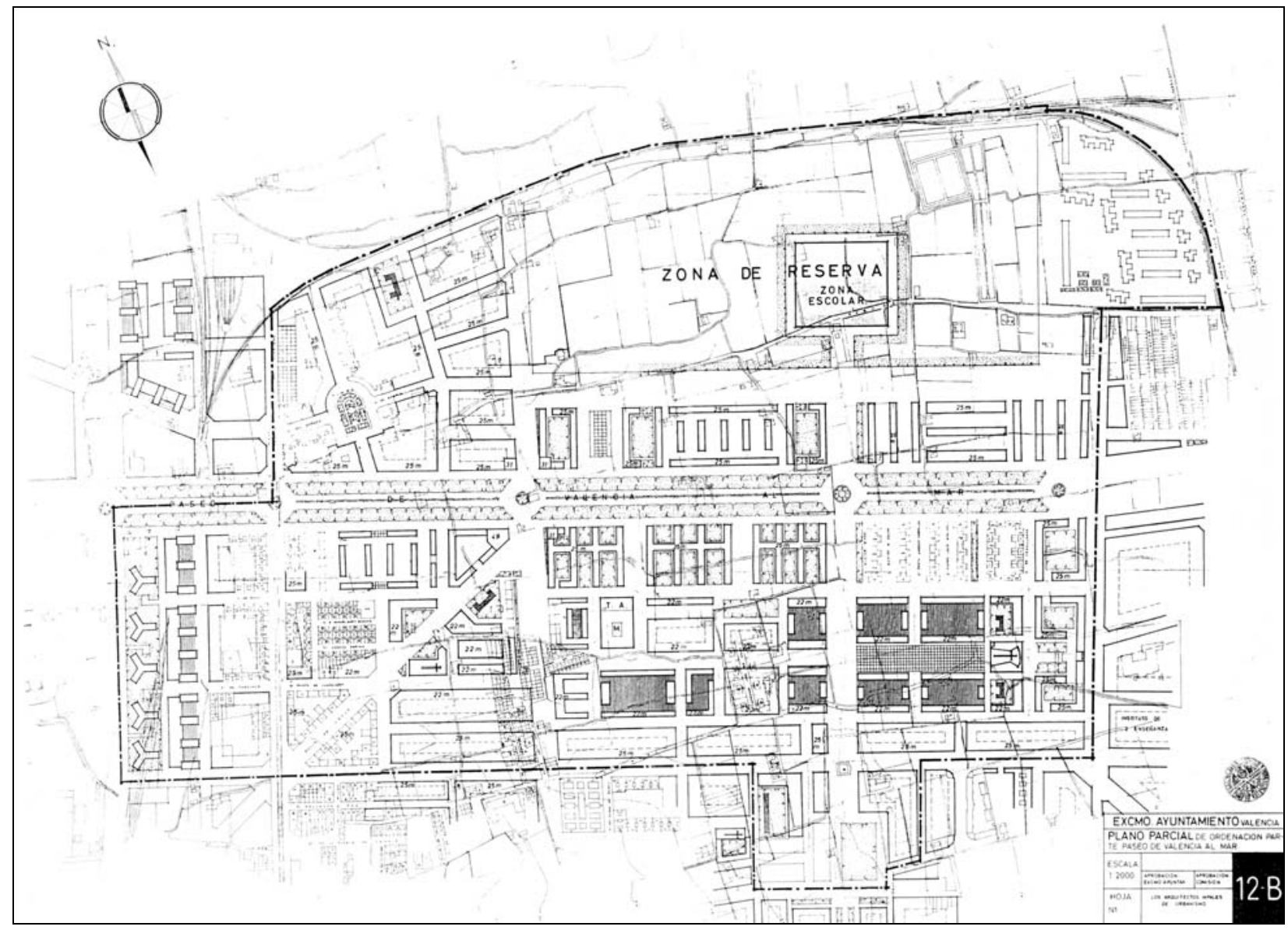


ZONAS DE UNIÓN DE LOS PLANES 11, 12-B Y 22

Escala original 1:2000

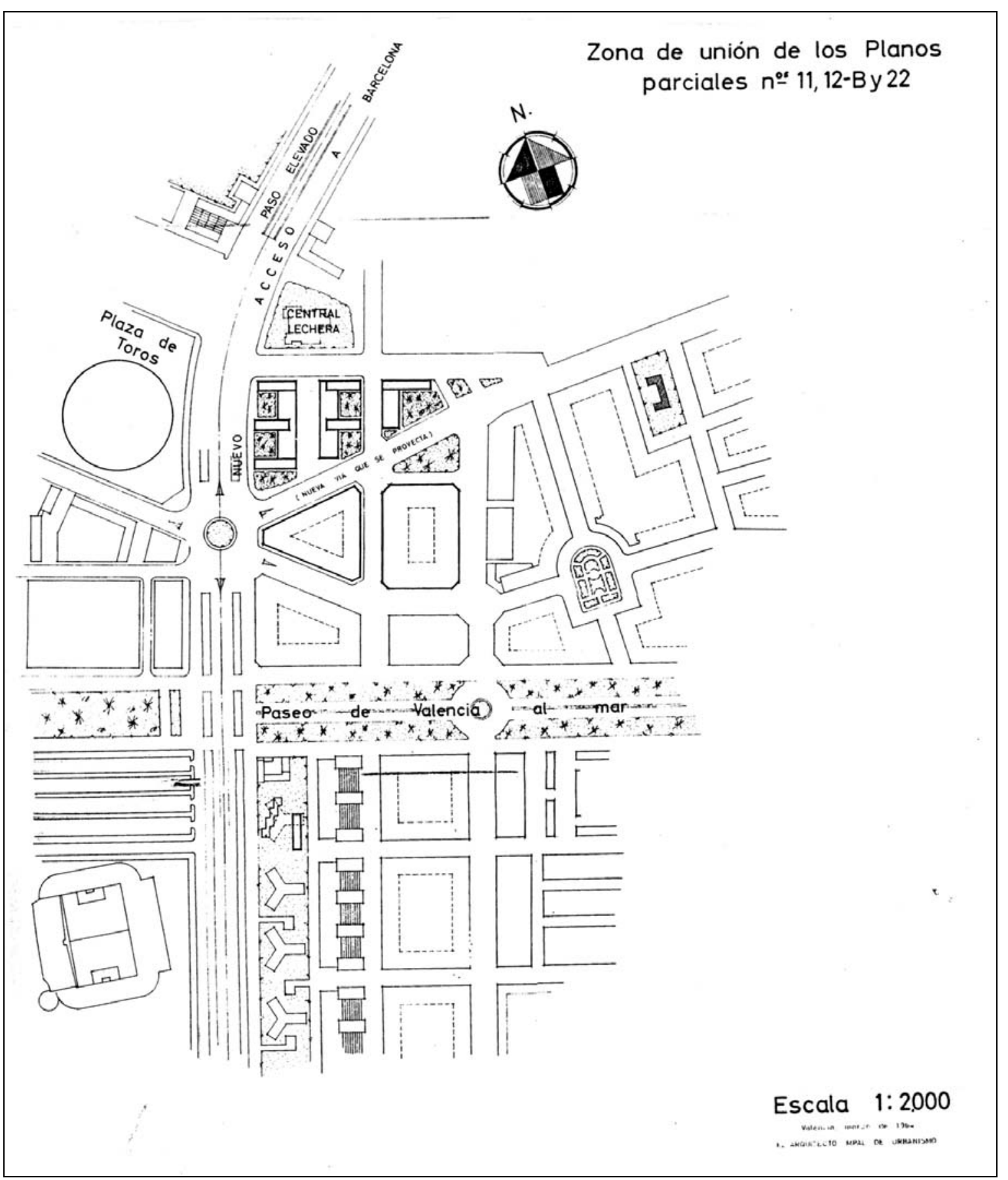





\section{PP 13}

Redactores: AYUNTAMIENTO DE VALENCIA. Oficina Técnica Municipal de Urbanismo. Arq. Julio Bellot Senent.

Fecha redacción: Octubre 1962.

Fecha aprobación: 9-11-1963 (Aprobación inicial Ayuntamiento) Contenido:

MEMORIA.

ORDENANZAS

PLANOS:
1. ESTADO ACTUAL Y ALINEACIONES
$1: 2000$
2. PLANEAMIENTO
$1: 2000$
3. ESQUEMAS DE SERVICIOS
$1: 2000$
4. UBICACIÓN Y TRANSPORTE
$1: 2000$

\section{Fuente:}

Ayuntamiento de Valencia. Sección de Urbanismo. Negociado de Suelo y Ordenación urbana. Expte. 1670/1962 (Archivo de Planeamiento, Sección de expedientes antiguos) 


\title{
EXCMO. AYUNTAMIENTO \\ DE VALENCIA
}

\author{
PLANO PARCIAL 13 \\ GRAO Y CABAÑAL
}

\section{MEMOR I A}

ANTECEDENTES.- El Plano Parcial No 13 es uno de los primeramente redactados por la Oficina Municipal de Urbanismo de Valencia, en desarrollo del Plan de Ordenación de Valencia y su Comarca.

Ajustándose a sus alineaciones, se han realizado un sin número de edificaciones, ya que coincidente, en su mayor parte, con las alineaciones del Plan General, ha podido ser considerado como Plano legal. Pero la aprobación de este Plano, ha estado impedida por causa del tramo final del Paseo al Mar, que, teniendo na anchura de $100 \mathrm{mts}$. a todo lo largo, al llegar a esta zona completamente construida, deja en futura vía pública un gran número de edificios, a no ser que se reduzca en anchura, cosa que ha repugnado a la mayor parte de los que hemos tenido que tratar este problema porque, aunque el Paseo no conduce a ninguna vía de su misma anchura, termina en el acceso por la costa y el mar, siendo aspiración el que lo haga con la misma magnificencia, por su anchura, que muestra en el comienzo.

Se trata pues al presentar el plano a la aprobación municipal, de confirmar la ordenación ya existente en los poblados marítimos, excepto en lo concerniente al Paseo al Mar.

JUSTIFICACION DE LA ORDENACION.- La Zona, como hemos dicho en el anterior, está casi completamente construida, excepto en la Zona Norte, llamada de la Malvarrosa. Las modificaciones son mínimas excepto en la ya citada del Paseo al Mar, la fachada del Puerto ya casi construida, y el acceso de Barcelona por la playa.

La ordenación antigua, tiene buen sentido aunque con calles estrechas, particularmente las transversales, siendo las de circulación, paralelas a la playa, con lo que las casas tienen orientación a levante y poniente. Las manzanas son pequeñas pero de proporción alargada muy conveniente dado su tamaño.

Por lo anterior y lo dicho de estar muy construido, se ha mantenido la urbanización anterior, con las únicas variantes citadas. Estas han venido impuestas por la delimitación con la Junta de Obras del Puerto, la de la fachada al puerto; por el Ministerio de Obras Públicas, la del acceso a Barcelona y por la necesidad de continuación del Paseo al Mar la correspondiente a este Paseo.

CENTROS Y EDIFICIOS PUBLICOS.- Como zona construida que es, tiene los centros comerciales establecidos, con mercado de reciente construcción y otros centros de menor importancia. El Ayuntamiento ha ido estableciendo los grupos escolares necesarios así como el Arzobispado los centros Religiosos.

AGUA, ALCANTARILLADO, ALUMBRADO Y TRANSPORTE.Existe el servicio de agua potable al mismo nivel que el resto de Valencia. La zona tiene alcantarillado antiguo que está siendo reno 
vado por el Ministerio de la Vivienda. El alumbrado existe en la zona, en la del Puerto y calle de la Reina ha sido renovado y por último en cuanto a transporte como zona urbana tiene su comunicación con el centro por la Ava. Del Doncel Luís Felipe García Sanchiz, recientemente y espléndidamente urbanizada por el Ministerio de la Vivienda y otras secundarias servido el transporte por tranvías, autobuses y F.F.C.C. de vía estrecha.

Por todo ello, por estar todo establecido y suficientemente servida la zona, no se presentan esquemas.

MEDIOS ECONOMICO-FINANCIEROS.- Para las modificaciones que se establecen y urbanizaciones en la Malvarrosa los medios económicos financieros serán los del presupuesto ordinario de Urbanismo del Excmo. Ayuntamiento.

ETAPAS.- No se establecen por el carácter del Plano. El Ayuntamiento realizará como ya realiza las urbanizaciones que por renovación o nuevo establecimiento sean necesarias para adelantarse a la iniciativa particular.

Con lo dicho queda suficientemente expuesto el alcance del proyecto para que si el Excmo. Ayuntamiento lo estima, lo eleve a la superioridad para su aprobación.

Valencia, 22 de Octubre de 1.962.

EL ARQUITECTO MPAL. DE URBANISMO,

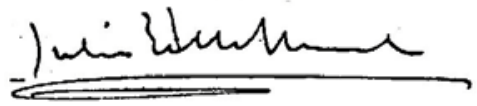

EXCMO. AYUNTAMIENTO

DE

VALENCIA

$$
\frac{\text { PLA N O PAR C I A L } 13}{\underline{\text { GRAO Y CABAÑAL }}}
$$

\section{ORDENANZAS}

Art. ${ }^{0}$ - único.- Se regirá la zona por lo prescrito en las Ordenanzas Reguladoras de la Edificación Vigente en Valencia en su Zonificación de NUCLEOS ACTUALES excepto en la fachada del Puerto que tiene Ordenanza Especial aprobada.

Valencia, 22 de Octubre de 1.962.

EL ARQUITECTO MPAL. DE URBANISMO,

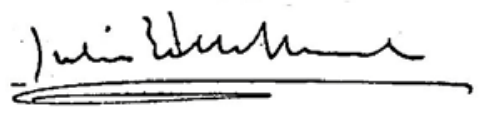


7. UBICACIÓN Y TRANSPORTE (Fragmento)

Escala original 1:2000

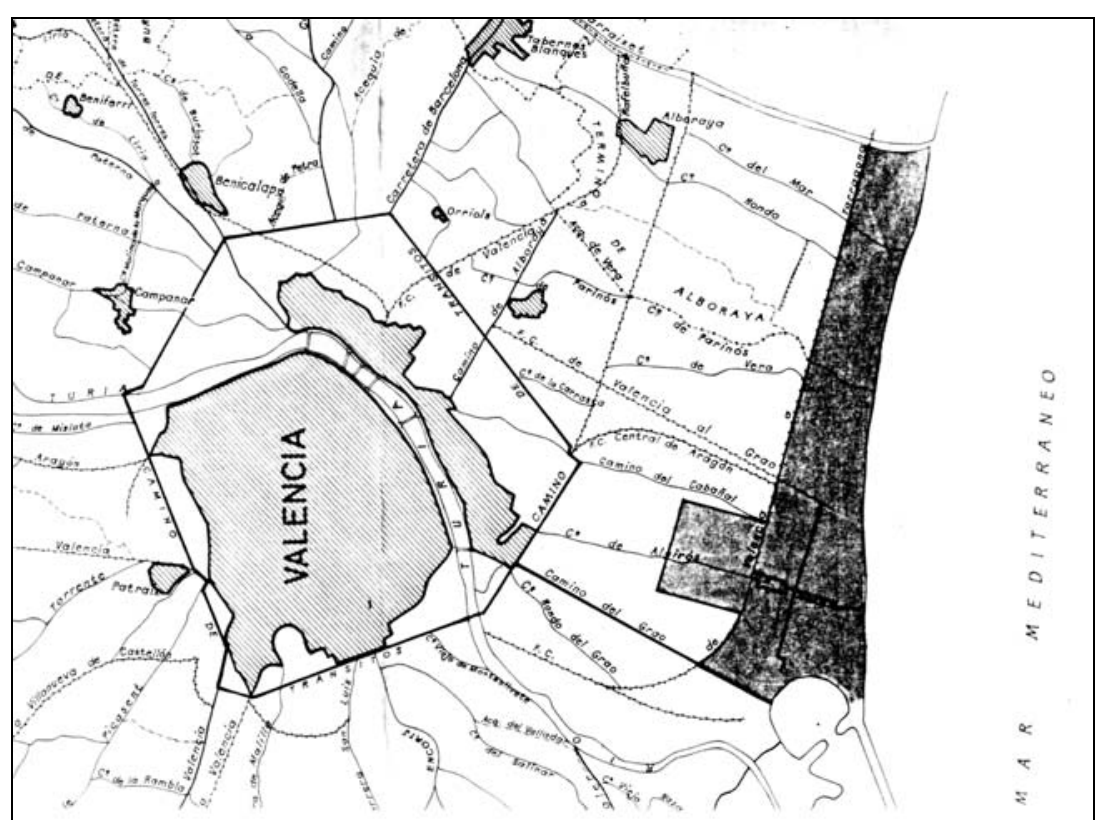

1. PLANEAMIENTO

Escala original 1:2000

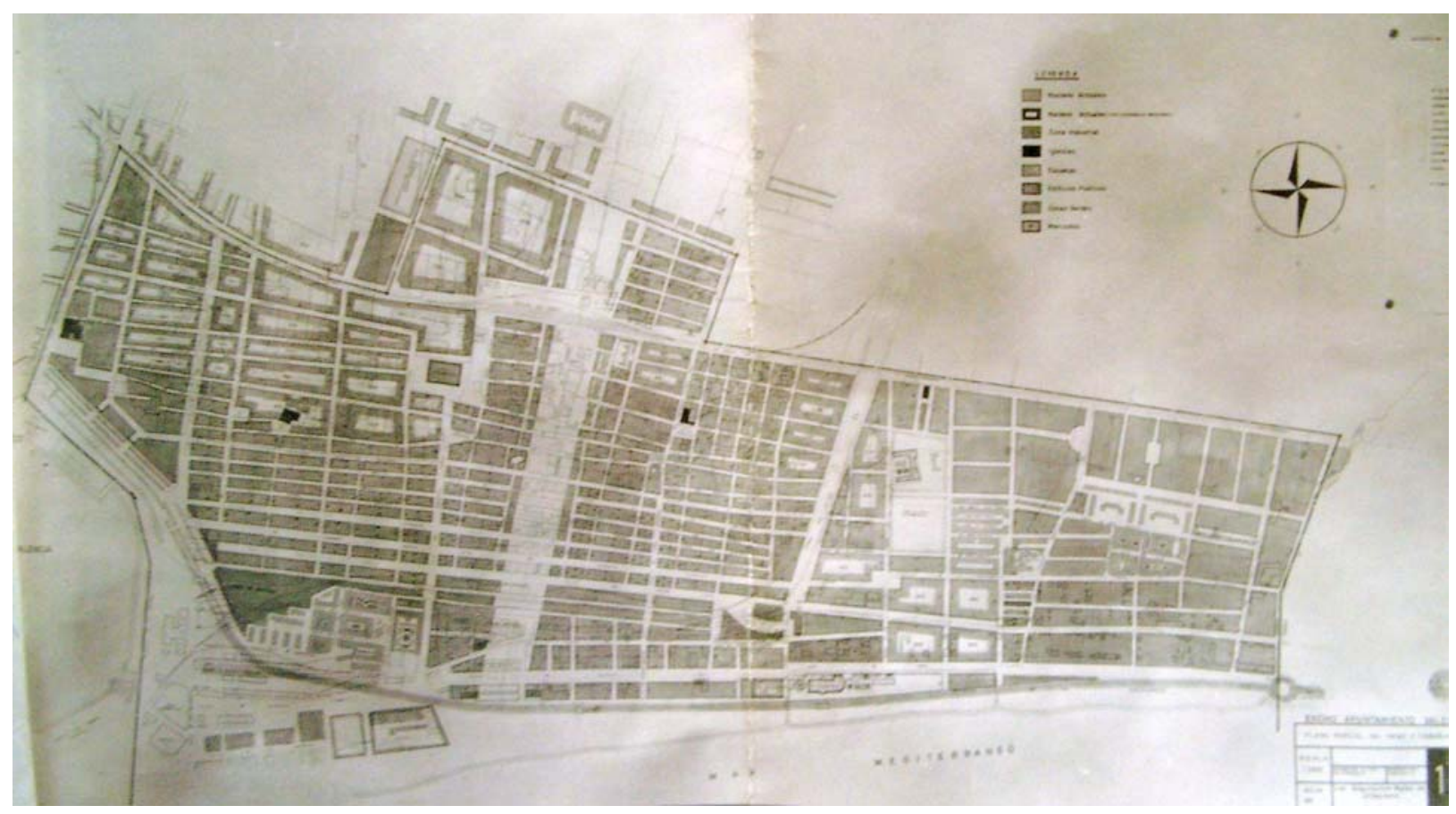




\section{ALINEACIONES}

Escala original 1:2000

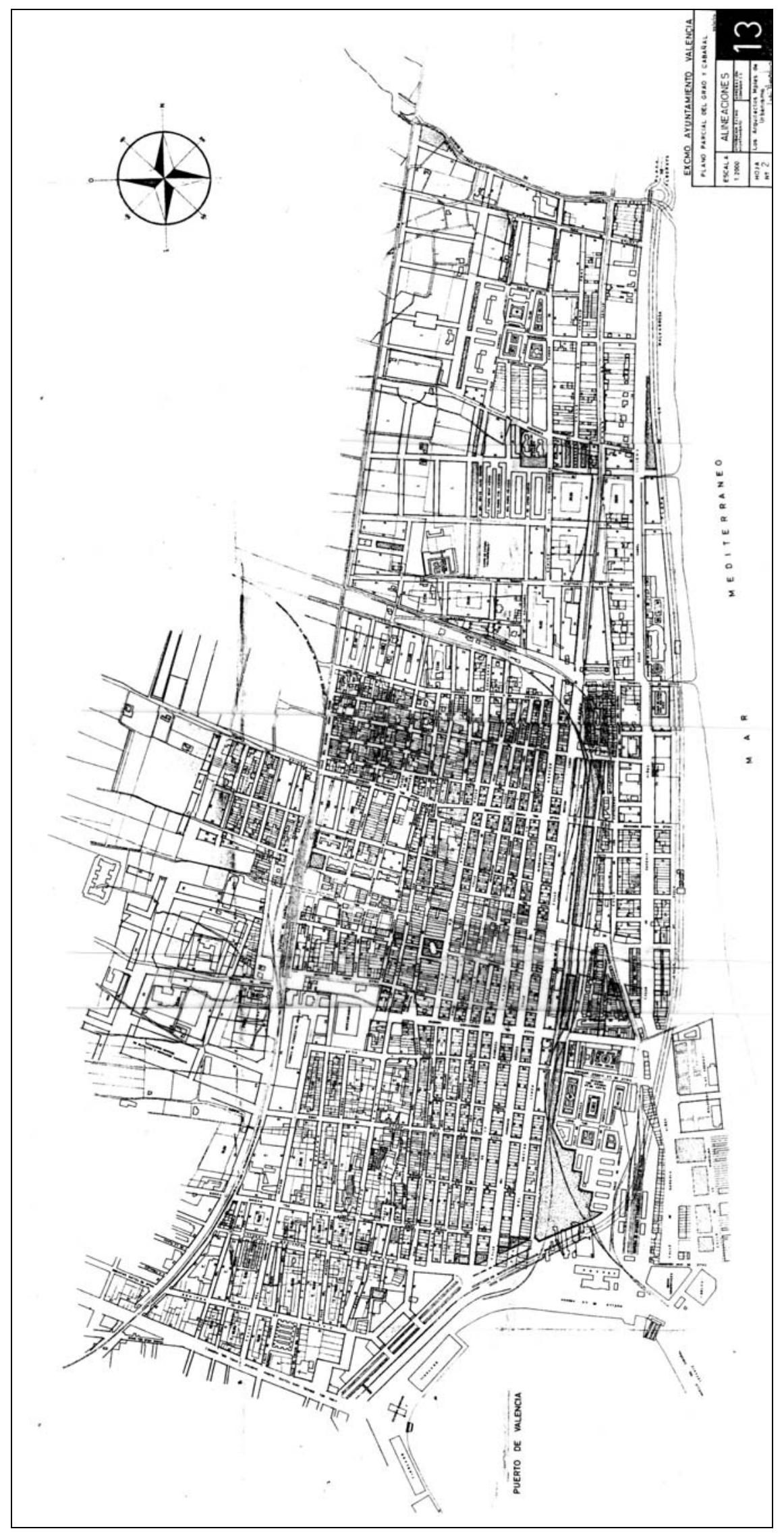





\section{PP 22-B}

Redactores: EXCMO. AYUNTAMIENTO DE VALENCIA. OFICINA TÉCNICA DE URBANISMO.

Fecha redacción: 1961.

Fecha aprobación: Aprobación inicial Ayuntamiento, 19-08-1961.

Contenido:

MEMORIA $(*)$.

ORDENANZAS.

PLANOS $(* *):$

1. ESTADO ACTUAL $\quad 1: 2000$

2. PLANEAMIENTO $1: 2000$

3. ALINEACIONES $1: 2000$

4. RED ALCANTARILLADO $1: 2000$

5. RED DE AGUA $1: 2000$

6. ALUMBRADO $1: 2000$

7. UBICACIÓN Y TRANSPORTE $1: 2000$

\section{Fuente:}

Ayuntamiento de Valencia. Sección de Urbanismo. Negociado de Suelo y Ordenación urbana (Archivo de Planeamiento, Sección de expedientes antiguos).

\section{Notas:}

$\left.{ }^{*}\right)$ No se ha localizado documentación escrita de este plan.

${ }^{* *}$ En el expediente del plan figura también el plano siguiente:

PLAN PARCIAL 22 A+B. BENIMACLET. 1962. 

1. ALINEACIONES

Escala original 1:2000

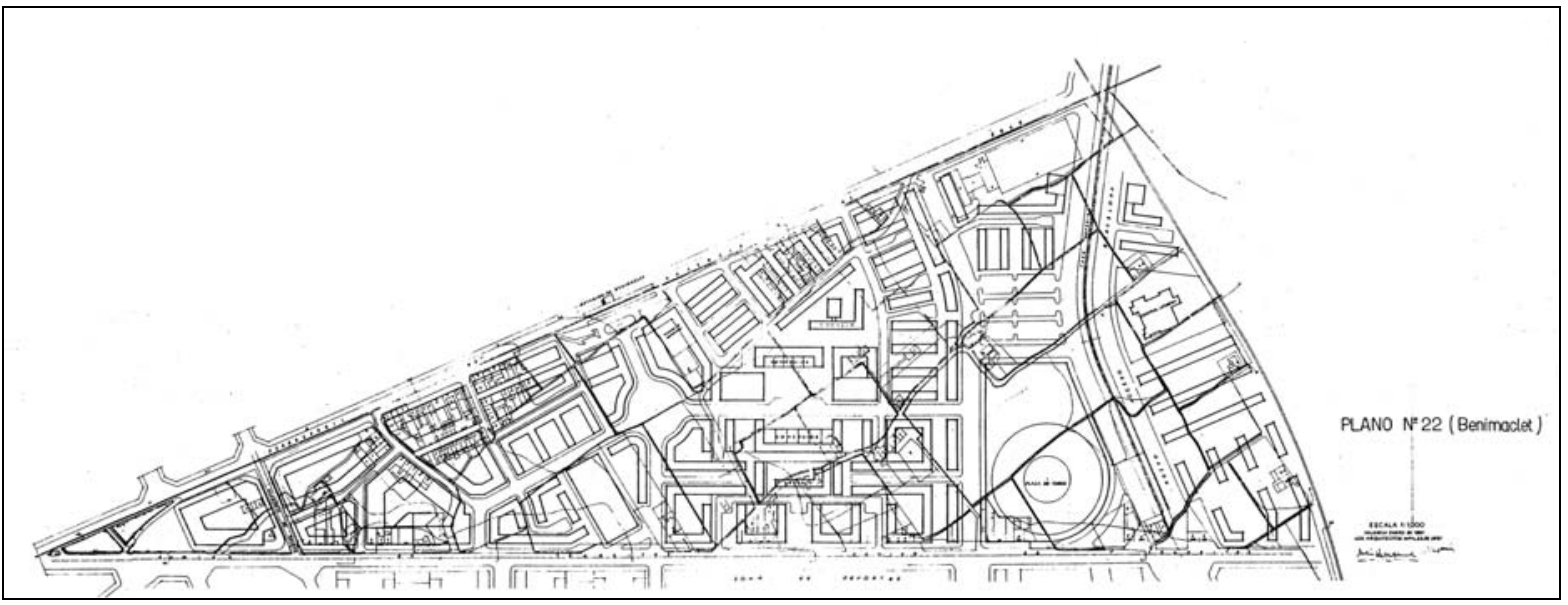

2. PLANEAMIENTO

Escala original $1: 2000$

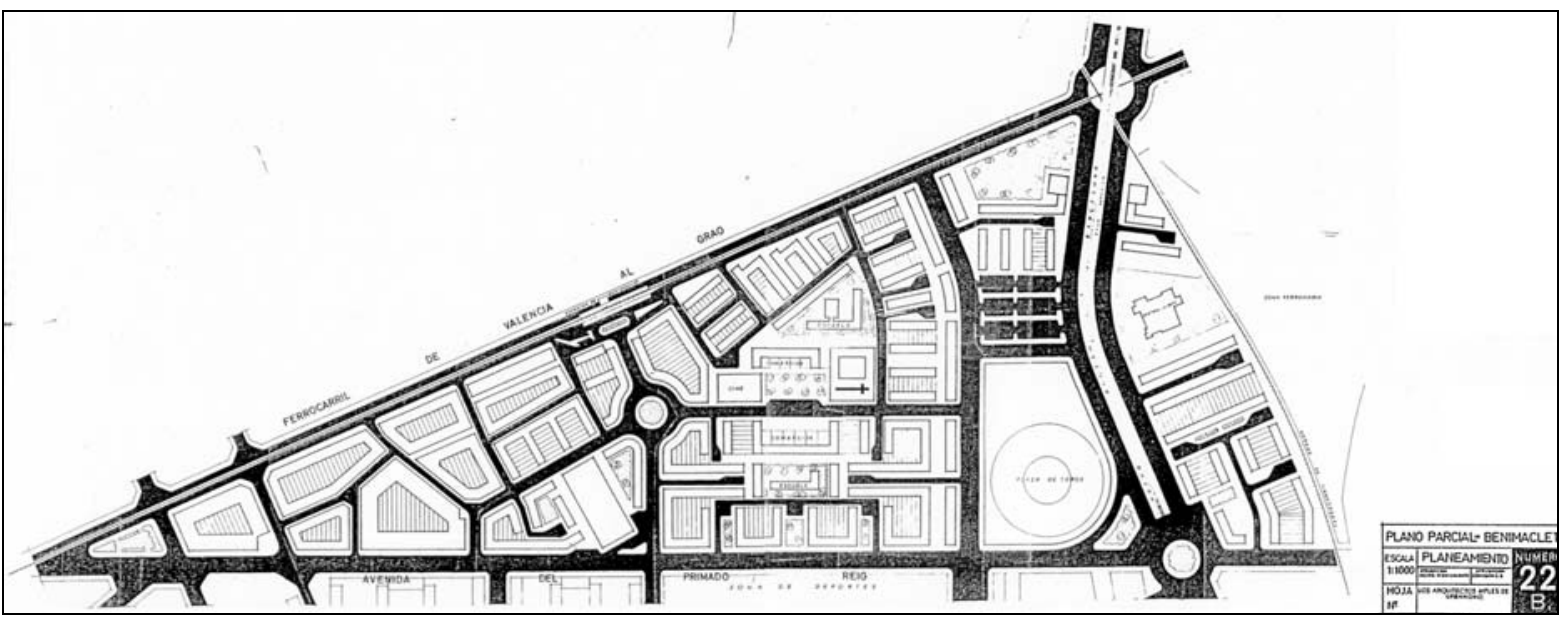



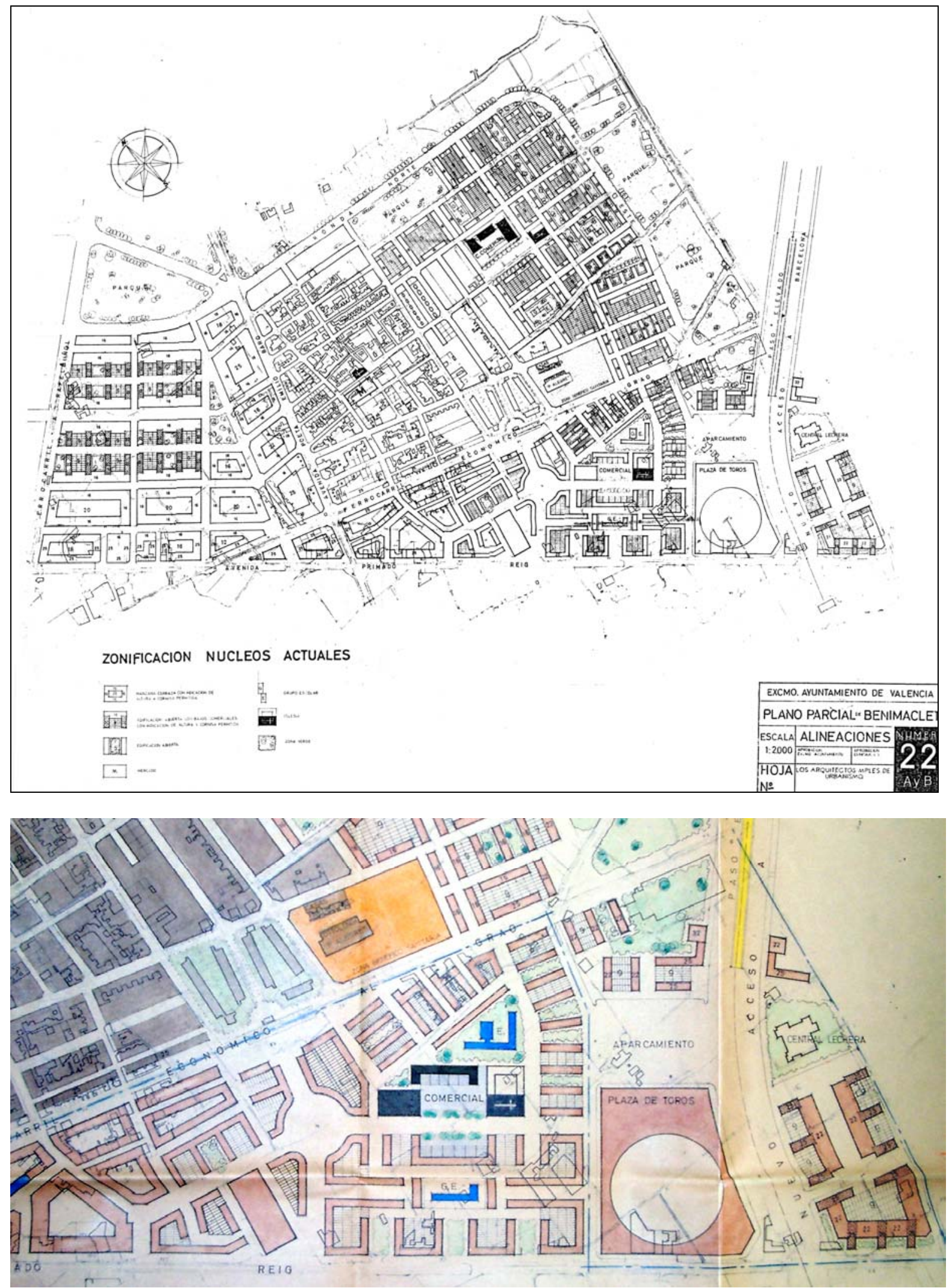

Detalle zona sureste. 


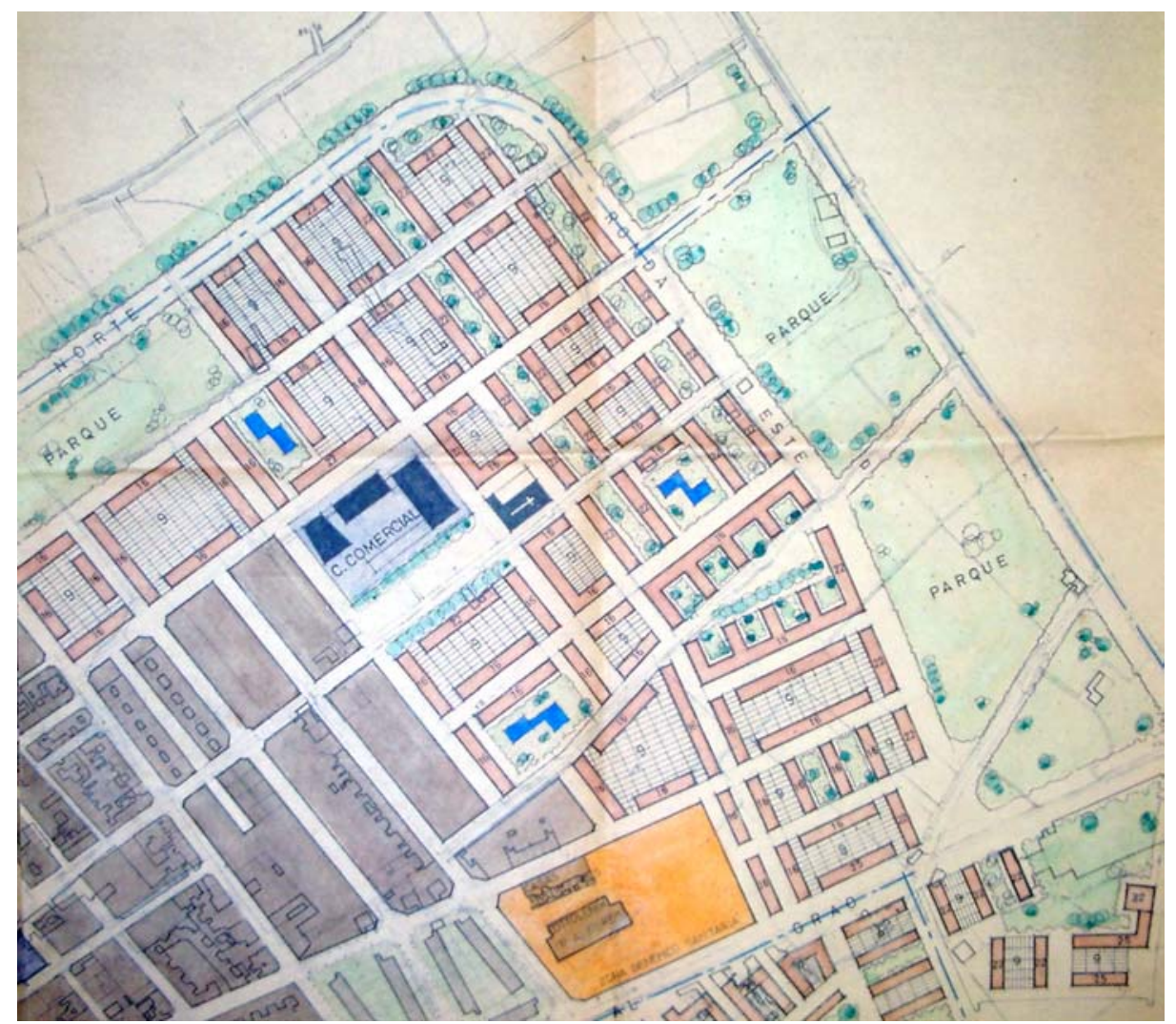

Detalle zona noreste

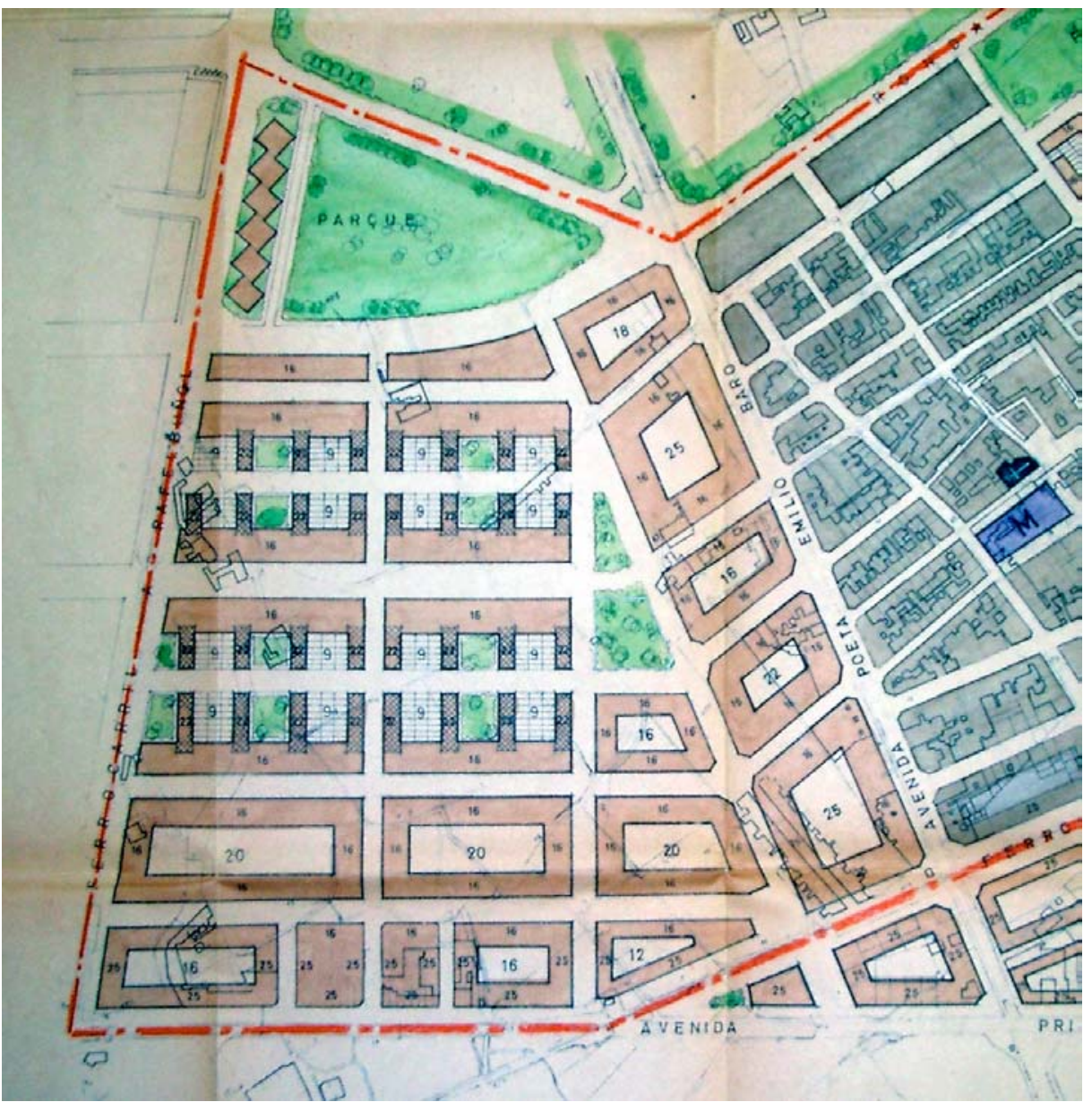

Detalle zona oeste. 



\section{PP 23}

Redactores: EXCMO. AYUNTAMIENTO DE VALENCIA. OFICINA TÉCNICA DE URBANISMO.

Fecha redacción: 1962.

Fecha aprobación: Aprobación inicial, 2-08-1963.

Contenido:

MEMORIA (*).

PLANO DE ORDENACIÓN E 1:2000

\section{Fuente:}

Ayuntamiento de Valencia. Sección de Urbanismo. Negociado de Suelo y Ordenación urbana. Expte. 1671/1962. (Archivo de Planeamiento No OM-254).

\section{Nota:}

(*) No se ha localizado documentación escrita de este plan. 

1. PLANO PARCIAL 23. 1962.

Escala original 1:2000
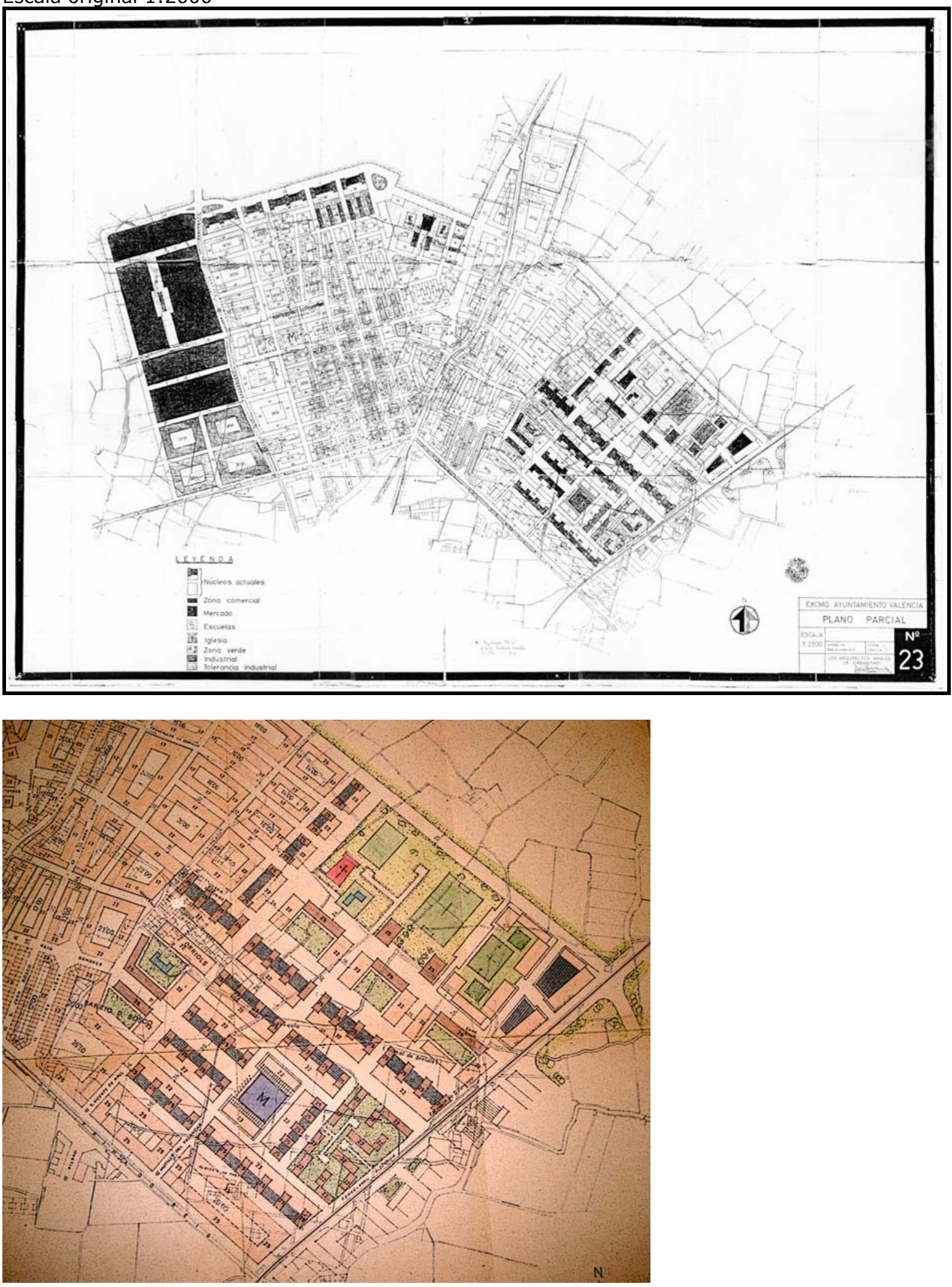

Detalle del plano anterior. 



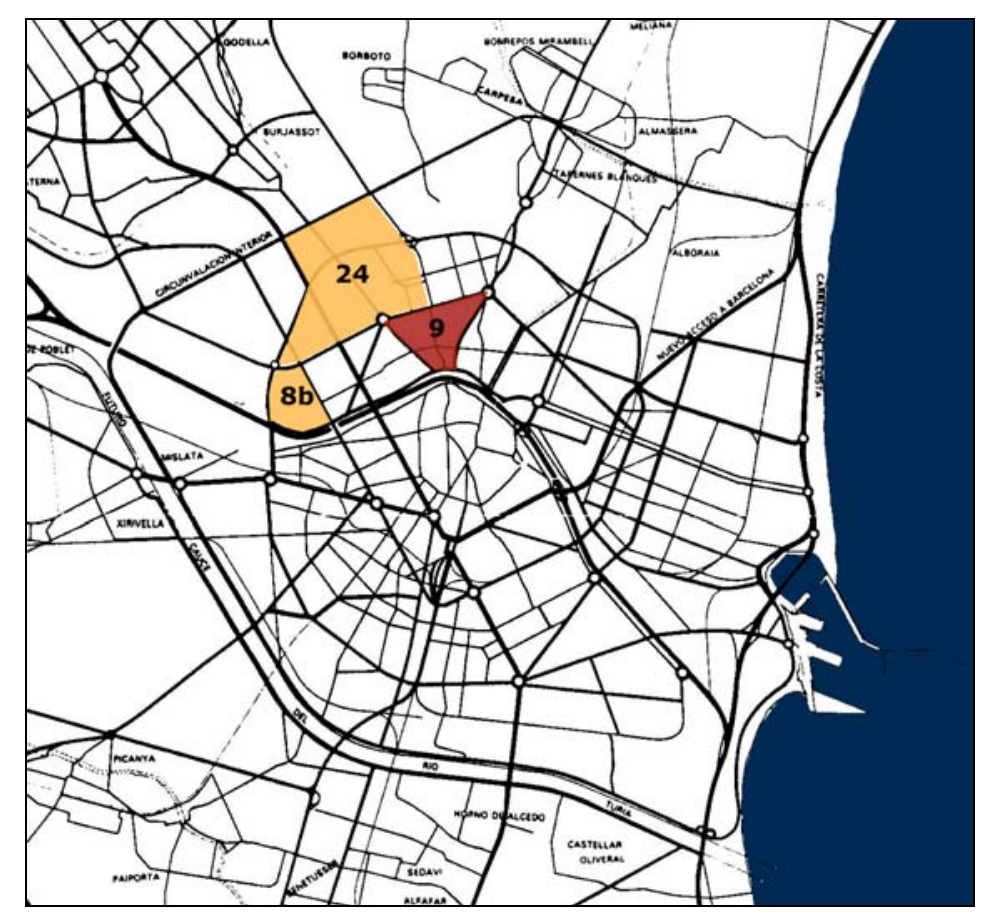

\subsection{ZONA NOROESTE}

PLAN PARCIAL No 8-B (OESTE DE CAMPANAR), 1963

PLAN PARCIAL NO 9 (MARXALENES), 1958/1960

PLAN PARCIAL NO 24 (BENICALAP), 1966 

Redactores: AYUNTAMIENTO DE VALENCIA. Oficina Técnica Municipal de Urbanismo.

Fecha redacción: Junio 1963.

Fecha aprobación: 5-07-1963 (Aprobación inicial Ayuntamiento)

\section{Contenido:}

MEMORIA.

ORDENANZAS

PLANOS:

1. ESTADO ACTUAL

$1: 2000$

2. ALINEACIONES

$1: 2000$

3. PLANEAMIENTO

$1: 2000$

4. RED DE ALCANTARILLADO

$1: 2000$

5. RED DE AGUA

$1: 2000$

6. ALUMBRADO

$1: 2000$

7. UBICACIÓN Y TRANSPORTE

$1: 2000$

\section{Fuente:}

Ayuntamiento de Valencia. Sección de Urbanismo. Negociado de Suelo y Ordenación urbana (Archivo de Planeamiento, Sección de expedientes antiguos) 



\section{EXCMO. AYUNTAMIENTO DE VALENCIA}

Proyecto de Plano Parcial No 8-B

\section{MEMORIA}

Comprende este plano los terrenos limitados: al sur por el Río Turia; al Norte por la prolongación del camino de Tránsitos del Norte; por el Este por la prolongación del Camino de Tránsitos, Avda. de Pérez Galdós y por el Oeste prolongación, pasado el Río, hacia el Norte, del Camino de las Tres Cruces.

Esta Zona límite está determinada por la necesidad de una pequeña zona industrial ubicada al oeste contra viento reinante que recoja las actividades industriales de los polígonos residenciales y de edificación abierta creados junto al poblado de Campanar. Completando el polígono se establecen manzanas para edificios residenciales.

Estas manzanas para edificios de viviendas se establecen al este en contacto con el polígono residencial de Campanar para mejor estética del mismo y Avenida de separación, continuación de la de Pérez Galdós, quedando las manzanas industriales al oeste, límite del plano y de la población de Valencia.

Las manzanas industriales se proyectan de mediano tamaño ya que no es de esperar el establecimiento de grandes industrias.

La circulación interior será tranquila porque las calles de gran tráfico son las que bordean la zona y siendo de gran anchura y recayendo a dos de ellas las manzanas industriales el tráfico interior será local.

Este tráfico queda asegurado por el eje Norte-Sur central del plano y varias calles transversales continuación del polígono de Campanar.

La parte residencial tiene una superficie aproximada de 15 Ha., y por el tipo de edificación imponemos una densidad de 400 hab/Ha., lo que da una población de 6000 habitantes.

La escuela prevista es solamente para los grados inferiores, ya que los grupos escolares del adjunto polígono absorberán los de esta pequeña zona. Así pues el cálculo del $9 \%$ de la población es suficiente para la población escolar bajo estos aspectos, resultando de 540 escolares y a $6 \mathrm{~m} 2$ por cada uno, $3240 \mathrm{m2}$. El campo escolar previsto en el plano es de $3200 \mathrm{~m} 2$.

En el centro del plano, cruce de sus avdas. centrales, se establece el centro comercial con los comercios y garages en extensas plantas bajas y con un cine y un paseo ajardinado.

SERVICIOS PUBLICOS.- Se unen a estos proyectos esquemas de alumbrado, alcantarillado y servicio de agua potable.

ETAPAS.- No se establecen etapas ya que destinada la zona a ser impulsada, por el momento, por la iniciativa particular. El ayuntamiento realizará las pequeñas urbanizaciones necesarias en consonancia con la marcha de la construcción de edificios.

MEDIOS ECONOMICO-FINANCIEROS.- Son los ordinarios del presupuesto de Urbanismo del Excmo. Ayuntamiento y los que se incluyan en los presupuestos extraordinarios para urbanizaciones.

Con lo dicho creemos suficientemente expuesto el alcance del proyecto que se presenta para que el Excmo. Ayuntamiento si lo 
aprueba, lo eleve a la aprobación superior.

Valencia, 25 de junio de 1.963

Los Arquitectos Mpales. de Urbanismo,

HPDannm 


\section{ALINEACIONES}

Escala original 1:2000

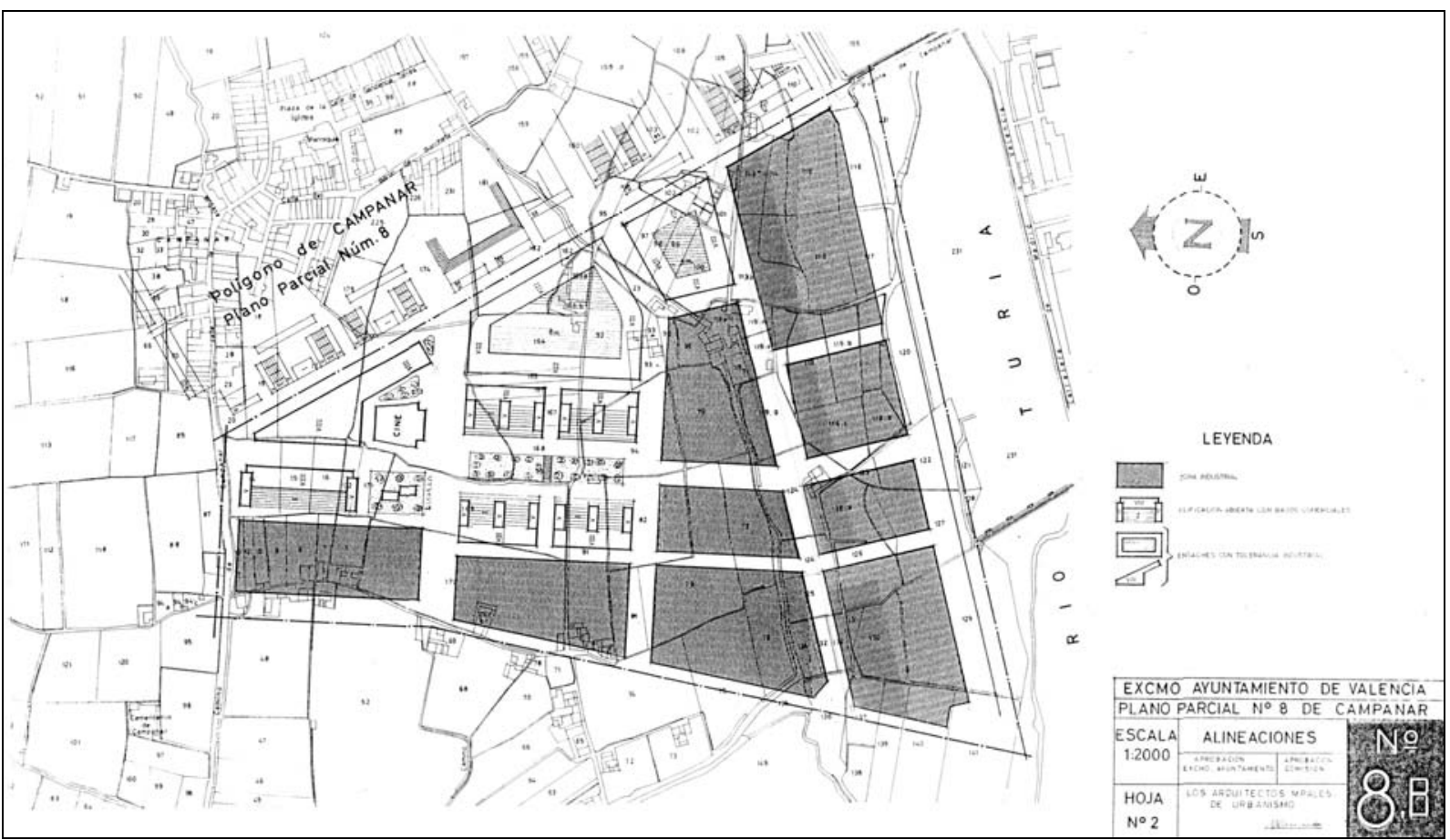

3. PLANEAMIENTO

Escala original 1:2000

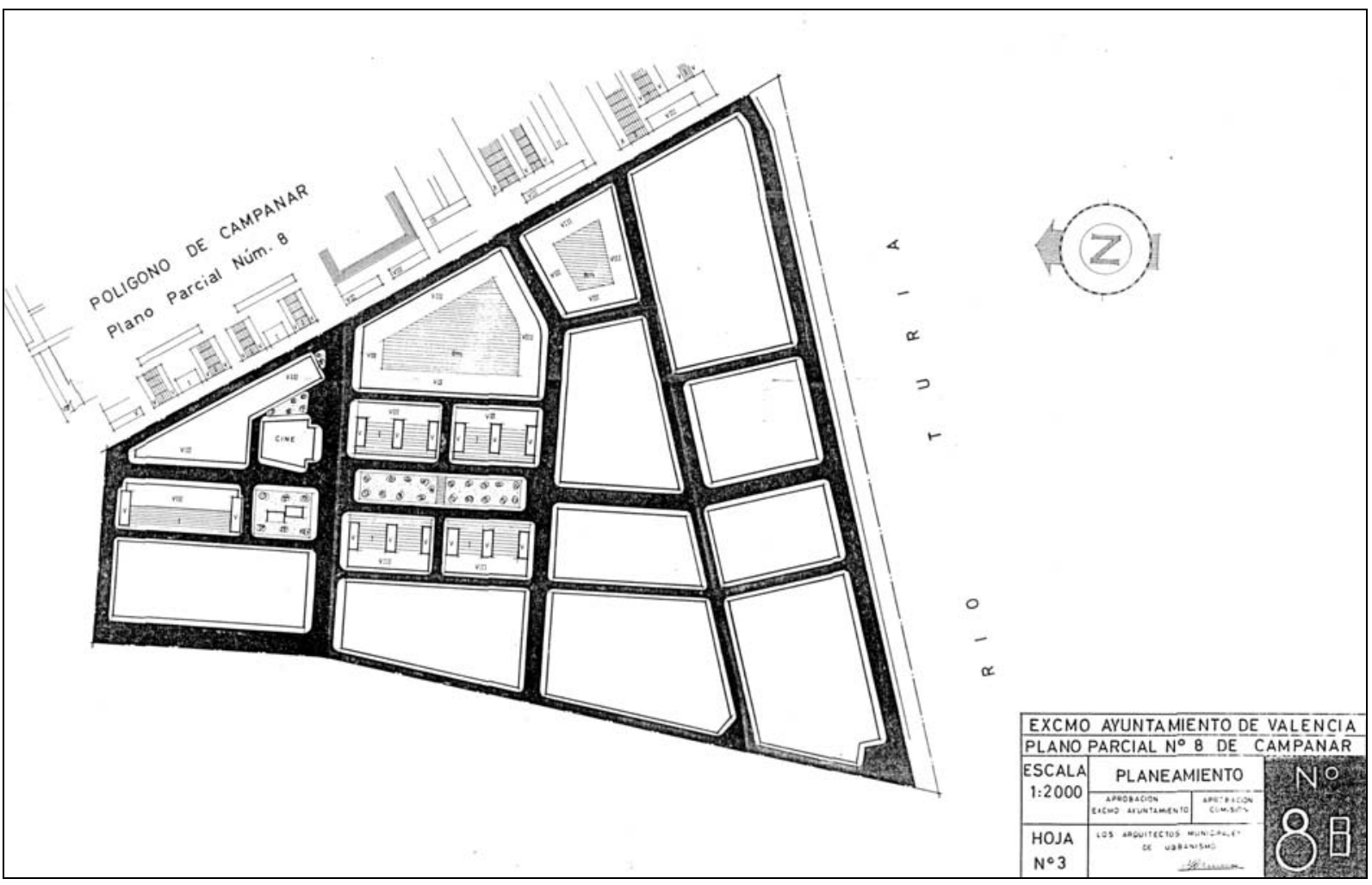





\section{PP9}

PLANEAMIENTO DEL RESTO DEL PLANO No 9

POLÍGONO NO 5

Redactores: EXCMO. AYUNTAMIENTO DE VALENCIA. Arquitectos: García-Matarredona, Gastaldi, Navarro, Trullenque.

Fecha redacción: Avance: Marzo 1960, Planeamiento: Junio 1960.

\section{Contenido:}

AVANCE DE PLANEAMIENTO:

MEMORIA DESCRIPTIVA

ESQUEMA DE ZONIFICACIÓN.

PLANEAMIENTO:

MEMORIA

ORDENANZAS

VALORACIONES

PLAN DE ETAPAS Y PROPUESTA DE REPARCELACIÓN.

PLANOS:

4. PROPUESTA DE REPARCELACIÓN

8. PLANEAMIENTO I

9. PLANEAMIENTO II

10. DETALLE DE PERFILES Y NUDOS

11. ESQUEMA ELÉCTRICO

12. ESQUEMA DE ALCANTARILLADO

$1: 1000$

13. ESQUEMA DE AGUA POTABLE

$1: 1000$

14. ESQUEMA DE GAS

$1: 1000$

15. VALORACIONES

Fuente: Ayuntamiento de Valencia. (Archivo de Planeamiento. Sección de expedientes antiguos). 


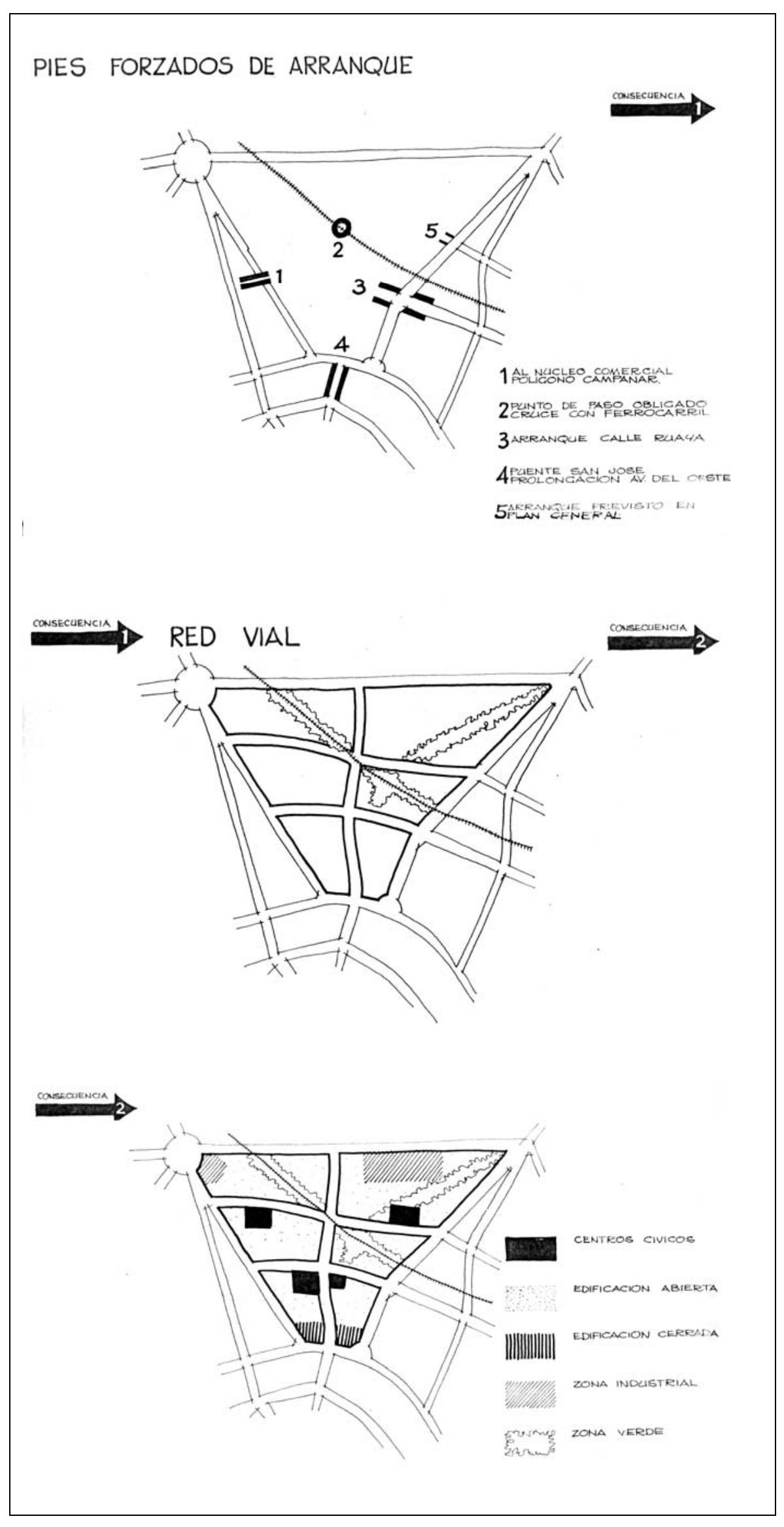




\section{AVANCE DE PLANEAMIENTO}

\section{MEMORIA}

En el planeamiento del Polígono se ha pretendido hacer algo cuya realización posterior sea lo más factible posible, pero totalmente actual.

A las dificultades normales se unen las de ser una zona en la que hay bastantes viviendas e industrias.

Dada la anarquía que existe en las edificaciones no hay más remedio que sacrificar algunas construcciones para conseguir un plan armónico. Por todo lo cual se le ha dado una importancia capital a la toma de datos.

Interesaba conocer con todo detalle lo que realmente es digno de ser salvado y lo que no importaba gran cosa que se sacrificase o incluso convenía.

Respecto a las viviendas se han salvado todas las clasificadas como modernas o actuales en el Plano no 3 de la toma de datos. Son las que lógicamente están en mejor estado y concentran el mayor número de viviendas (ver planos núms. 5 y 6 de la toma de datos).

Las viviendas sacrificadas son las clasificadas como medias y antiguas y en general su estado de conservación es muy regular, proporcionando además densidades muy pobres.

El Monasterio de la Zaidía, actualmente en venta, no se ha considerado de suficiente interés histórico-artistico para conservarlo, ya que creaba un grave problema urbanístico debido fundamentalmente a que existe un bloque de construcción moderna realizado con poco sentido urbanístico y respeto al edificio antiguo. Ha parecido muy conveniente suprimir las viviendas de la zona del camino de Moncada, por su pésimo estado actual.

Respecto a las industrias, después de un detallado estudio de su importancia y características (ver estadillos de industrias) se han respetado las más importantes e inamovibles y menos molestas (Abrasivas, S.A., Bombas Gens y Bombas Ideal). Se han sacrificado las más fáciles de cambiar de ubicación o aquellas que resultan molestas.

También se han dejado fuera de líneas el Molino Estela a pesar de su gran importancia, porque su situación resulta totalmente inadecuada y no es excesivamente difícil su cambio de ubicación a un lugar más adecuado ya que su maquinaria no es demasiado pesada. Industrias de cierta importancia como las situadas en la carretera de Barcelona entre los números 75 a 135 se dejan fuera de zona, para que en el futuro se vayan trasladando a lugares más adecuados, todo ello de acuerdo con el Plan de Zonificación de la Solución Sur.

Otra de las dificultades fundamentales para el planeamiento es la que crea el ramal de los ferrocarriles Económicos y la Estación de Marchalenes. Se ha pensado que aunque está previsto su cambio de situación, no es probable que esto ocurra en plazo breve, por lo que se ha dado una solución urbanísica contando con la existencia de dicho ferrocarril, tendiendo previsto, claro está, el aprovechamiento oportuno cuando sea suprimido.

En los esquemas que se acompañan se expresan gráficamente las principales premisas y pies forzados que se han encontrado para el planeamiento del Polígono. 


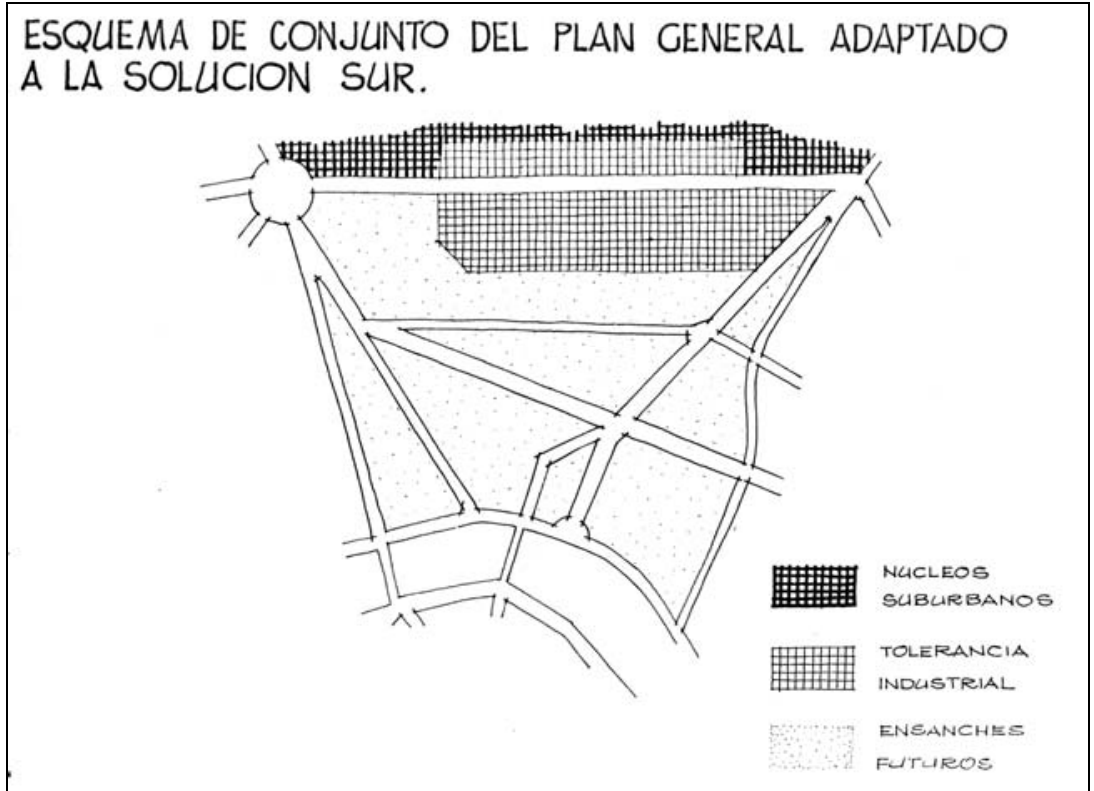

Se ha considerado fundamental crear una vía de penetración importante que unirá la prolongación de la Avenida del Oeste, el puente de San José, el Centro Cívico principal y acabará de momento en el camino de Tránsitos. Se ha pensado que probablemente el éxito de este plan dependa de la efectiva realización de esta vía, pues está demostrado que alrededor de una vía importante la iniciativa privada edifica rápidamente. Por eso se ha estudiado concienzudamente el trazado de dicha vía para que encuentre los mínimos obstáculos, para lo cual se ha adaptado a varias premisas (solar posesión de la Parroquia y lugar muy obligado de cruce con el ferrocarril, fundamentalmente). En realidad, el trazado de todas las vías tiene un carácter muy orgánico, debido no a la adaptación a la topografía del terreno, como es normal, ya que en este caso el terreno es prácticamente llano, sino a circunstancias debidas a las edificaciones o industrias existentes o al ferrocarril.

La calle de Ruaya creada en el plan general y ya iniciada, se desvía ligeramente en su acometida con la Avenida de Burjasot para que sirva de ía de comunicación interbarrios, ya que ligará con el Centro Cívico del Polígono de Campanar que tendrá una importancia enorme.

Se han creado un Centro Cívico importante y dos subcentros, pensando que en el Polígono llegarán a vivir unas 30.000 personas y se opina que para que un barrio pueda tener vida propia no debe pasar mucho de una población de 10.000 personas.

En el centro Cívico están previstos: Un cine, un recinto de tiendas y locales comerciales de impulso, cafeterías y bares y un edificio de altura para oficinas y despachos. El centro parroquial está situado al otro lado de la vía de penetración porque ya tiene la Parroquia de Santiago Apóstol los solares adecuados.

En los subcentros se preveen prácticamente las mismas funciones aunque todo ello con una importancia menor, y en uno de ellos se situará un Instituto de $2^{a}$ Enseñanza.

Los subcentros cívicos están ligados entre sí por una calle secundaria que se cruza con el ferrocarril en el punto más fácil, al que también concurre la vía de penetración, con lo cual se ligan éstos con el centro cívico importante.

También está prevista la comunicación entre los centros cívicos con caminos para peatones, con sus convenientes arbolados y 
zonas verdes.

Como se ve en el esquema, la vía de penetración y las secundarias crean unas supermanzanas bien proporcionadas en las cuales resulta fácil la composición y volúmenes y sencillo el separar las circulaciones de coches y de peatones.

El tipo de edificación, como es lógico, es de bloques aislados, excepto en algunas zonas que por estar ya iniciadas las edificaciones con patio central, no ha habido más remedio que cerrar las manzanas.

En cuanto a orientaciones se ha ido generalmente a las que tienen claramente ejes $\mathrm{N}-\mathrm{S}$ o $\mathrm{E}-\mathrm{O}$, que con distribuciones estudiadas dan muy buenos soleamientos. También se han colocado unos bloques siguiendo el eje isotérmico.

Los tipos de construcciones normales en este polígono son:

a) Viviendas de 5 ó 6 plantas, sin ascensor, modestas, de unos 80 á $100 \mathrm{~m} 2$.

b) Viviendas de 8 ó 9 plantas, con ascensor, de más categoría y una superficie de unos $125 \mathrm{~m} 2$.

c) Bloques de altura, de unas 15 plantas, muy escasos y en zonas convenientemente dispuestas para no crear inconvenientes urbanísticos.

La zona industrial está situada dando al camino de Tránsitos, según la zonificación del Plan Sur, aparte de esta zona concentrada, quedan tres industrias importantes ya existentes, aisladas, por considerar que no resultan molestas, ni crean ningún problema urbanístico importantes, aislándolas debidamente.

Las zonas verdes, pulmones del polígono, no están concentradas sino más bien de enlace y están situadas en zonas que parece que perjudican lo menos posible.

Hay una densidad aproximada de unos 500 habitantes por hectárea que suponen $4 \mathrm{~m} 3 / \mathrm{m} 2$. Es posible que sea una densidad un poco fuerte para edificación abierta, pero parece adecuada a las condiciones sociales y económicas de Valencia.

Valencia 15 de marzo de 1.960.-

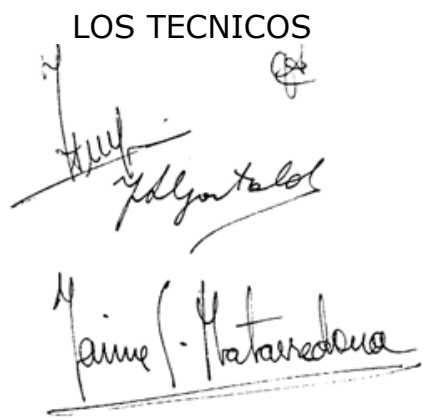


ESQUEMA DE ZONIFICACIÓN

Escala original: 1:2000

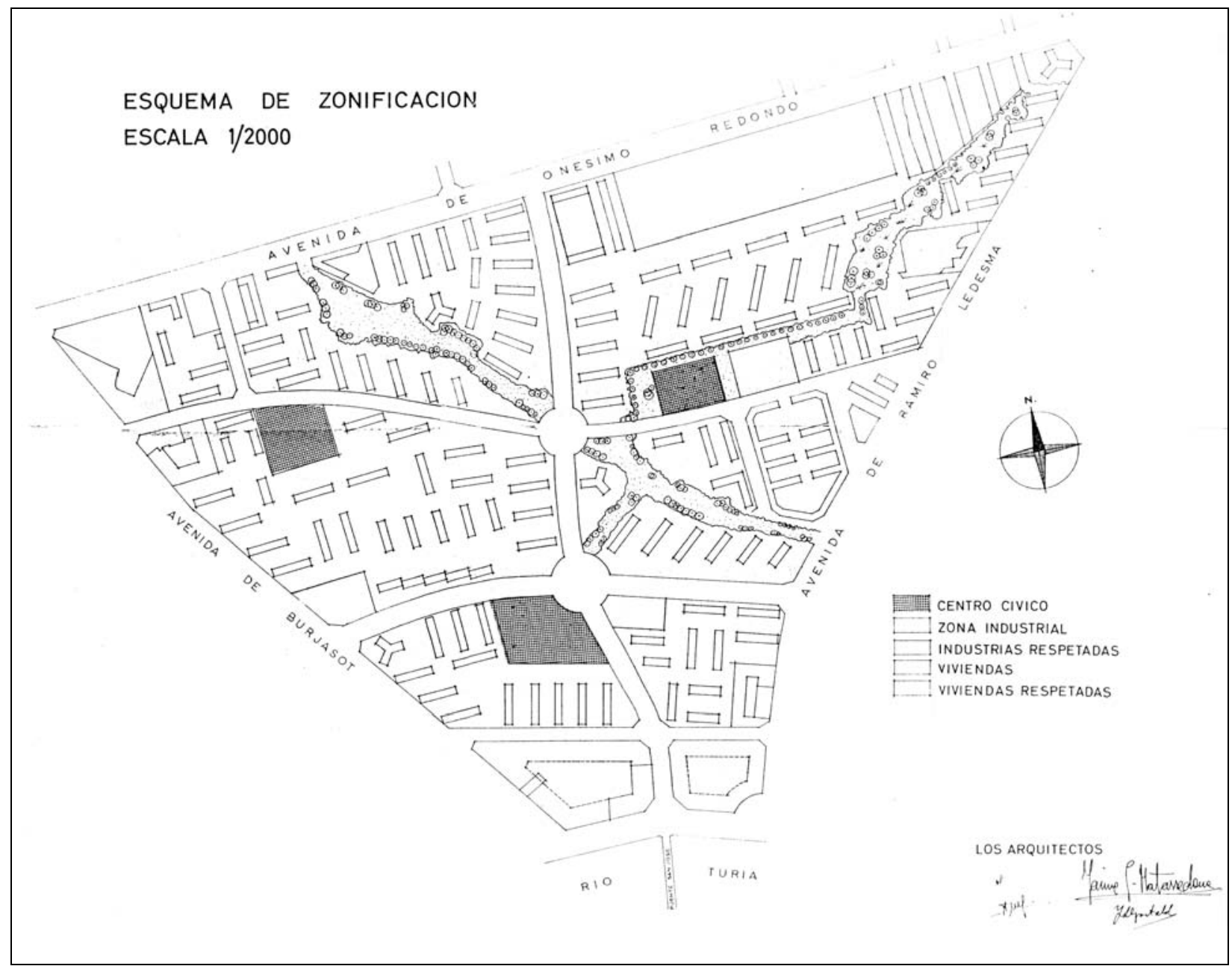




\section{MEMOR I A}

\section{PLANEAMIENTO DEL RESTO DEL PLANO NO 9 POLIGONO No 5}

El área afectada por este planeamiento esta situada en el margen izquierdo del Río Turia y queda definida por la Avda. de Burjasot, Avda. de Onésimo Redondo (Camino Tránsitos), la Avda. de Ramiro Ledesma (Carretera de Barcelona) y el Llano de la Zaidia.-

Su superficie es de unas $66 \mathrm{Ha}$. aproximadamente. El plan General la ha calificado como Zona de ensanche futuro con edificación semiintensiva y zona industrial junto al Camino de Tránsitos.-

En el planeamiento del Polígono, se ha pretendido hacer algo cuya realización posterior fuese lo más factible posible y al mismo tiempo totalmente actual.

Se ha tropezado con serias dificultades, tales como: lo irregular del contorno que complica seriamente la buena composición de las supermanzanas, el ramal de los Ferrocarriles Económicos y la Estación de Marchalenes, que dividen por completo el área del Polígono y multitud de viviendas e industrias existentes anárquicamente dispuestas.-

El criterio seguido, en general es el de mantener todos los elementos de importancia y en buen estado de conservación, para lo cual se le concedió gran valor a la toma de datos.

Respecto al Ferrocarril y Estación de Marchalenes, aunque está previsto su cambio de situación en el Plan General, se ha pensado que no es probable que esto ocurra en plazo breve, por lo cual la solución dada, cuenta con su existencia y provee su posterior aprovechamiento.-

En el planeamiento realizado, se ha buscado con interés conseguir una transición entre la manzana cerrada, normal en Valencia y la edificación abierta, considerada en la actualidad como la de mejores condiciones, para ello se ha procedido gradualmente, mediante la interposición de manzanas semiabiertas y bloques de 6 crujías.-

Aunque la edificación en general es abierta, las densidades obtenidas son fuertes, lográndose los 600 hab/Ha. y los 4,72 $\mathrm{m} 3 / \mathrm{m} 2$. , lo cual hace que el aprovechamiento del terreno sea francamente aceptable.- Esto nos ha parecido necesario para no defraudar y mover la actuación de la iniciativa privada y para suavizar el paso entre la edificación del casco urbano y la edificación abierta, que en el futuro se desarrollará lógicamente con densidades muy bajas.- Aunque la solución aportada no sea la teóricamente ideal, por su excesiva densidad, ya que actualmente se considera que no se deben superar los $300 \mathrm{Hab} / \mathrm{Ha}$., sin embargo nos ha parecido la mas adecuada a las circunstancias de lugar y tiempo.-

A continuación se acompañan esquemas que expresan las principales premisas y pies forzados encontrados en el Planeamiento del Polígono, así como su evolución y esquema final.

Las circulaciones de vehículos y peatones se han separado, tratando de evitar interferencias.-

El esquema viario es en forma de espinazo, el eje es una autentica vía de penetración en el Polígono, pensado no como vía rápida, sino como acceso al mismo, su punto de intersección con el 
Ferrocarril, es muy obligado ya que se pretende cortar a este en un solo punto y en él se ha proyectado un paso superior a lo largo del eje de penetración. Dicho eje está cruzado por tres vías importantes, que lo dividen en 8 supermanzanas.-

Estas tres vías son las del Arzobispo Fabián y Fuero, Ruaya y Portugal, que están ya iniciadas pero su carácter ha sido renovado. Concretamente la de Ruaya cobra una gran importancia al servir de enlace con el Polígono de Campanar, transformándose en una vía interbarrio.-

Las 8 supermanzanas así definidas están ligadas por un anillo verde para circulación de peatones, que une sus áreas centrales en donde están situados los usos y servicios corrientes y que no son accesibles a los coches, pues las únicas vías de penetración serán en fondos de saco.-

Está proyectado el Polígono pensando en su funcionamiento en conjunto, pero también está estudiada cada supermanzana como una unidad de barrio con vida propia.-

Todas ellas tienen previstos los usos y servicios necesarios para su desenvolvimiento normal. En cuanto al funcionamiento del Polígono como un conjunto único, se ha previsto un Centro Cívico importante, corazón del barrio y punto de máxima vitalidad del mismo. Está situado a un lado de la vía de penetración, en el centro de gravedad del Polígono y enlazado con el anillo verde de circulación de peatones, con lo cual su acceso es cómodo para coches y peatones.-

Este Centro Cívico constará en su aspecto cultural, de teatro, auditorium y biblioteca; en su aspecto comercial de tiendas de impulso, oficinas y despachos y en. el recreativo de cines, bares, cafeterías y espacios ajardinados.-

Para la totalidad del Polígono, hay previstos tres Centros Parroquiales, convenientemente ubicados. La capacidad total de las Iglesias, es de 1.800 fieles que corresponde al 5\% de la población total.-

En el aspecto escolar, se han proyectado 14 grupos escolarea de 6 aulas cada uno, capaces para 3.500 niños, que es aproximadamente el $10 \%$ del numero de habitantes del Polígono.-

Respecto a deportes, está pensado una zona deportiva situada en el área verde y cubre las necesidades mínimas.-

Las tiendas se han concentrado en zonas para darles mayor vitalidad, cada supermanzana cubre sus propias necesidades de uso diario, reservándose las de impulso para el Centro Cívico.-

Aparte de las salas de espectáculos del centro Cívico, hay otras convenientemente dispuestas en el Polígono, se han tenido en cuenta las áreas de influencia de las ya existentes en el exterior del mismo.-

Dado el carácter actual del barrio, con multitud de pequeñas industrias y talleres artesanos, se ha pensado su conveniente ordenación, teniendo previsto en lugares adecuados el aprovechamiento de bajos con este carácter.-

En el anexo de las Ordenanzas Reguladoras del Polígono, se indican los lugares en donde están previstas la ubicación de garajes. El cálculo se ha hecho suponiendo que cada 10 familiares pueden tener un coche.-

La zona industrial, industrias ligera, está situada de acuerdo con las Ordenanzas de Zonificacion, del Plan General, junto a la Avda. de Onésimo Redondo, al norte del Polígono, lo cual es muy adecuado teniendo en cuenta que los vientos de mayor frecuencia en Valencia son los SO y SE, y que los NO, tienen menor importan 
cia, porque aunque muy intensos son de muy poca duración. Se ha tomado un modulo mínimo de 500 metros cuadrados, con posibilidad de agrupación según las necesidades de cada industria. Las manzanas industriales subdivididas inicialmente en 24 parcelas mínimas, tienen unas dimensiones de $84 \times 150 \mathrm{~m}$. rodeados por vías exclusivas para el tráfico industrial.-

Una franja verde separa y aísla la zona industrial del resto del Polígono.-

La zona verde total ocupa $70.000 \mathrm{M} 2$, que corresponde a $10,6 \%$ de la superficie total.-

En el Proyecto se da cabida a unas 7.000 viviendas, clasificadas en los siguientes tipos:

$\begin{array}{cc}\text { Tipo social .............. } & 30 \% \\ \text { Tipo Medio Social ... } & 30 \% \\ \text { Tipo Medio ............... } & 30 \% \\ \text { Tipo Lujo ............... } & 10 \%\end{array}$

La densidad total del Polígono es de 525 habitantes por hectárea y su aprovechamiento es de $4,72 \mathrm{~m} 3 / \mathrm{m} 2$. Prescindiendo de la zona industrial la densidad es de 600 habitantes por hectárea.-

El estudio detallado de estos datos aparece en el siguiente cuadro:

\begin{tabular}{lrcccc}
$\begin{array}{l}\text { Super } \\
\text { Manzana }\end{array}$ & Superficie & $\begin{array}{c}\text { Valoración } \\
\text { Construido M3 }\end{array}$ & $\begin{array}{c}\text { Densidad } \\
\mathrm{m3} / \mathrm{m} 2\end{array}$ & $\begin{array}{c}\text { No de } \\
\text { habitantes }\end{array}$ & $\begin{array}{c}\text { Densidad } \\
\text { Hab/Ha. }\end{array}$ \\
\hline A & 22.605 & $175.450,00$ & 7,76 & 1,830 & 810 \\
B & 15.300 & $105.820,00$ & 6,92 & 1.140 & 745 \\
C & 62.237 & $425.262,50$ & 6,83 & 4.650 & 745 \\
D & 37.929 & $199.278,50$ & 5,25 & 1.950 & 512 \\
E & 81.615 & $311.902,40$ & 3,82 & 3.760 & 460 \\
F & 83.867 & $319.182,00$ & 3,80 & 5.250 & 624 \\
G & 155.122 & $675.119,00$ & 4,35 & 9.765 & 630 \\
H & 112.125 & $441.122,00$ & 3,93 & 6.490 & 580 \\
I & 90.900 & $472.400,00$ & 5,21 & - & - \\
\hline TOTAL & 661.700 & $3.125 .536,40$ & 4,72 & 34.835 & 525 \\
\hline
\end{tabular}

Prescindiendo de la zona industrial, obtenemos una densidad da 600 habitantes por hectárea.

A la vista de estos datos, conviene hacer notar que en la supermanzana $D$ hay un gran Centro Parroquial que disminuye la densidad, lo mismo ocurre con la $\mathrm{E}$, en donde está incluido en Centro Cívico y con $\mathrm{E}$, en la que se ubica la Zona Deportiva.

Valencia 17 de Junio de 1.960

LOS ARQUITECTOS.

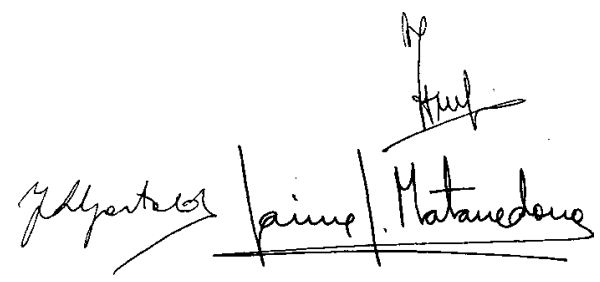


8. PLANEAMIENTO I

Escala original: 1:1000

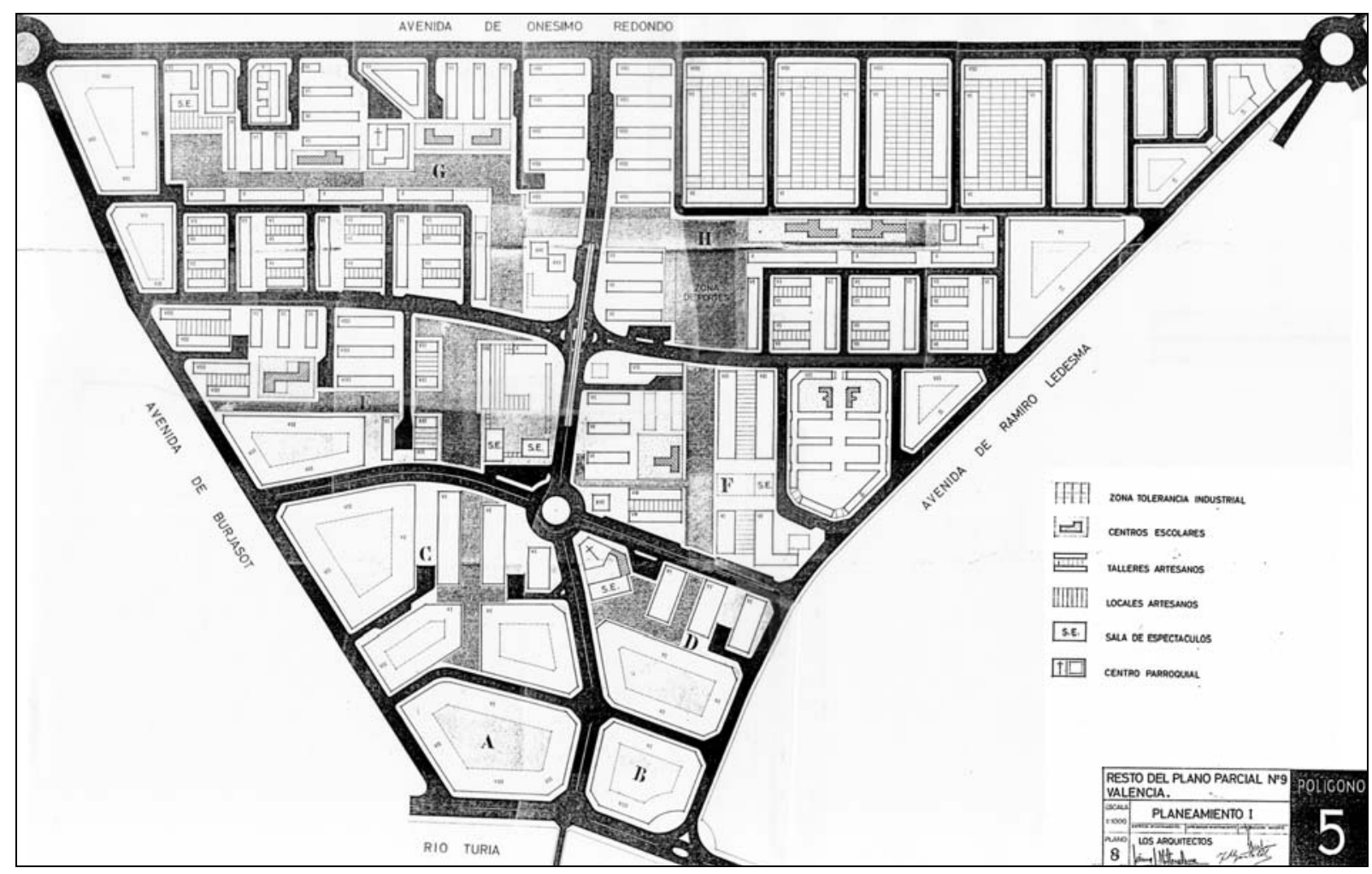

9. PLANEAMIENTO II

Escala original: 1:1000

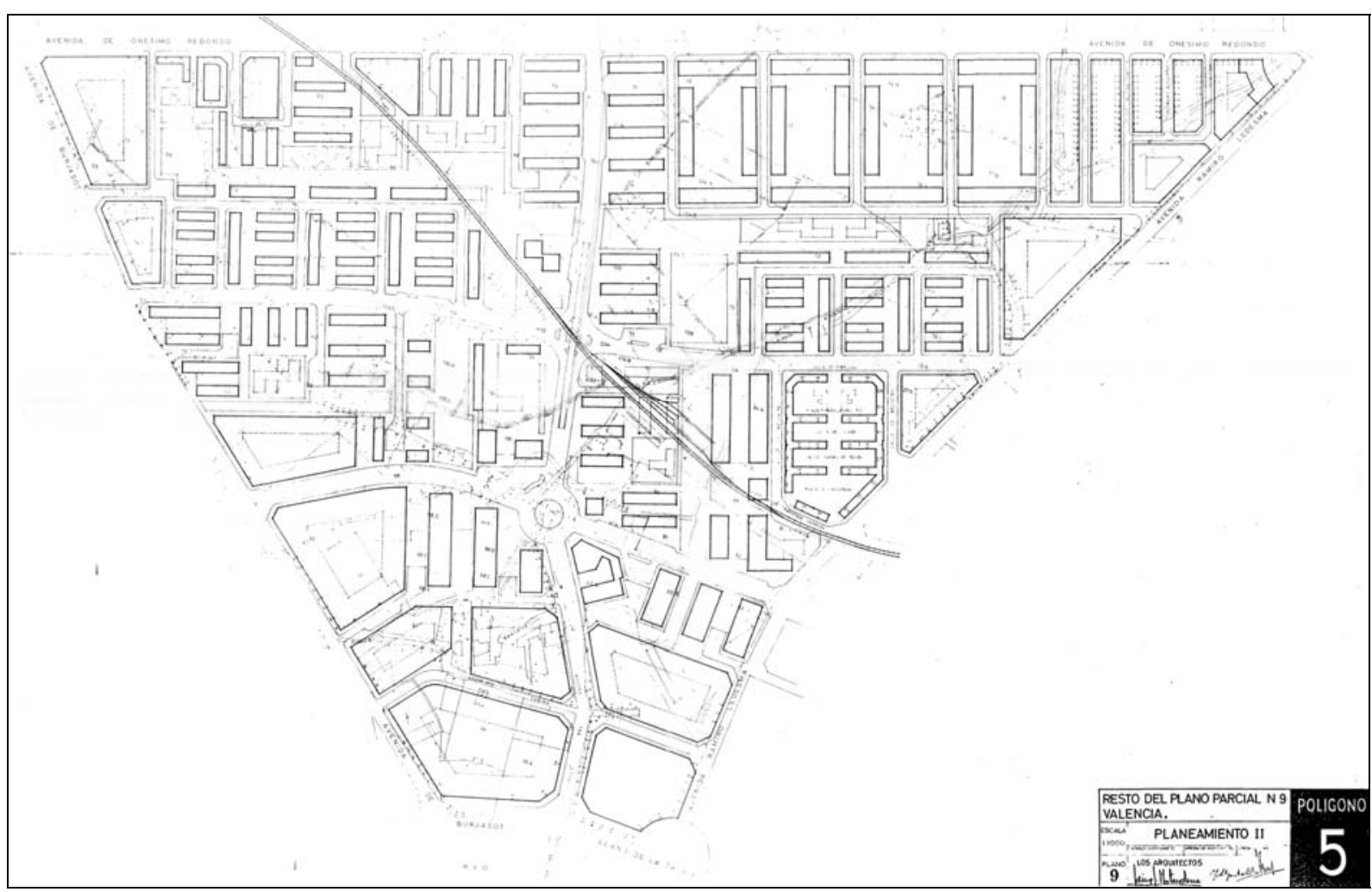




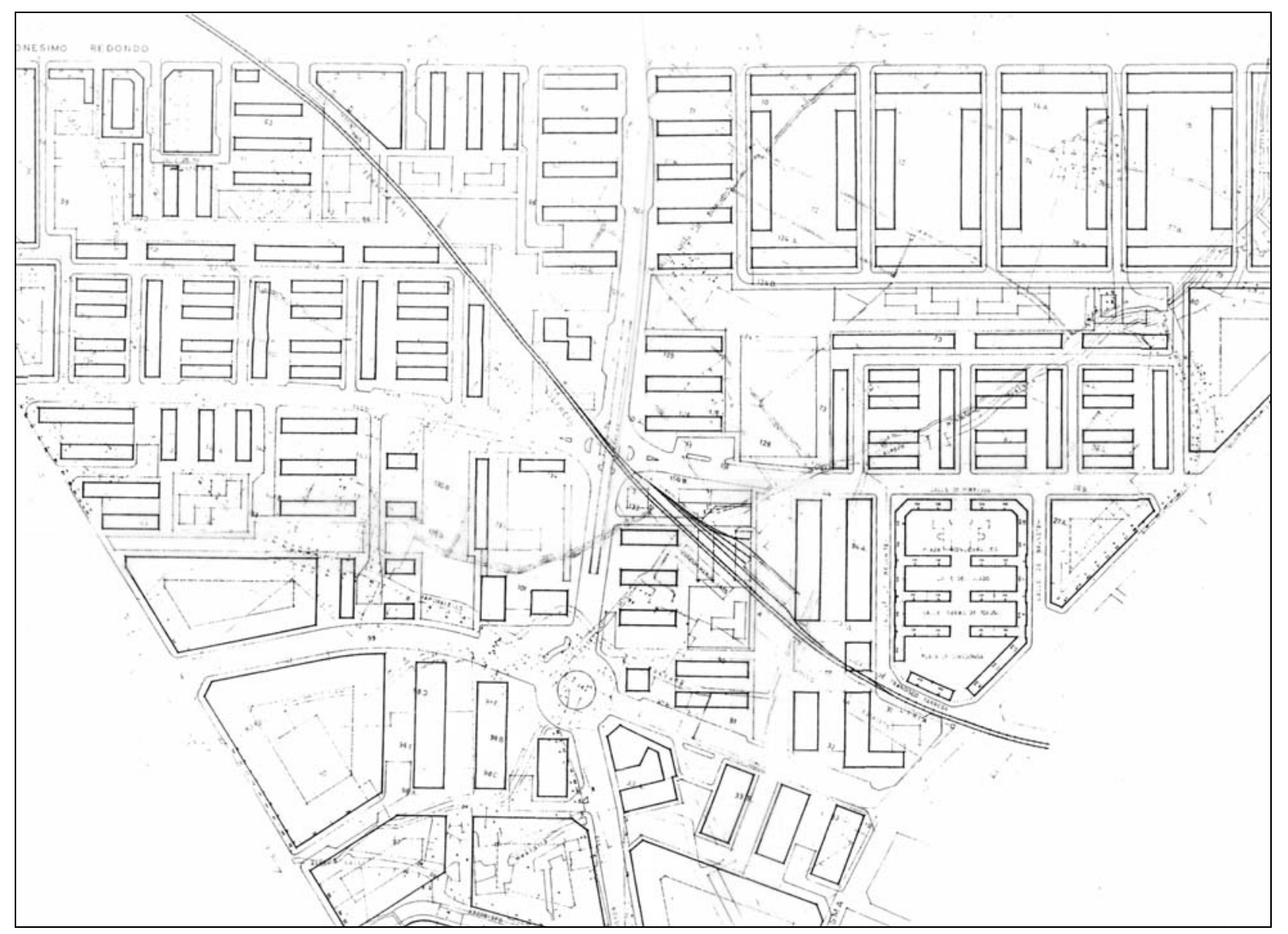

Planeamiento II. Detalle de la zona de edificación abierta. 



\section{PP 24}

Redactores: AYUNTAMIENTO DE VALENCIA. Oficina Técnica de Urbanismo.

Fecha redacción: 1966.

Fecha aprobación: 7-10-1966 (Aprobación inicial Ayuntamiento)

\section{Contenido:}

MEMORIA $(*)$

ORDENANZAS

PLANOS: $(* *)$

1. ESTADO ACTUAL $1: 2000$

2. PLANEAMIENTO $1: 2000$

3. ALINEACIONES $1: 2000$

4. RED ALCANTARILLADO $1: 2000$

5. RED DE AGUA $1: 2000$

6. ALUMBRADO $1: 2000$

7. UBICACIÓN Y TRANSPORTE $1: 2000$

\section{Fuente:}

Ayuntamiento de Valencia. Sección de Urbanismo. Negociado de Suelo y Ordenación urbana (Archivo de Planeamiento, Seción de expedientes antiguos)

Notas:

(*) No se ha localizado documentación escrita de este plan.

(**) El expediente contiene además los planos siguientes:

- PROYECTO PARCIAL DE BENICALAP, No 24. Corporación Administrativa Gran Valencia, 1966.

- CIUDAD DEL ARTISTA FALLERO DEL PLANO PARCIAL No 24. Julio 1963.

- CIUDAD DEL ARTISTA FALLERO. PLANO DE ORDENACIÓN. Arquitectos: M. Muñoz Monasterio, Carlos Sobrini, Emilio G. De Castro, G. González. Junio 1963.

- PROPUESTA DE MODIFICACIÓN DEL PLANO PARCIAL 24 PARA SAICA. Enero 1958. 



\section{PLANEAMIENTO}

Escala original 1:2000

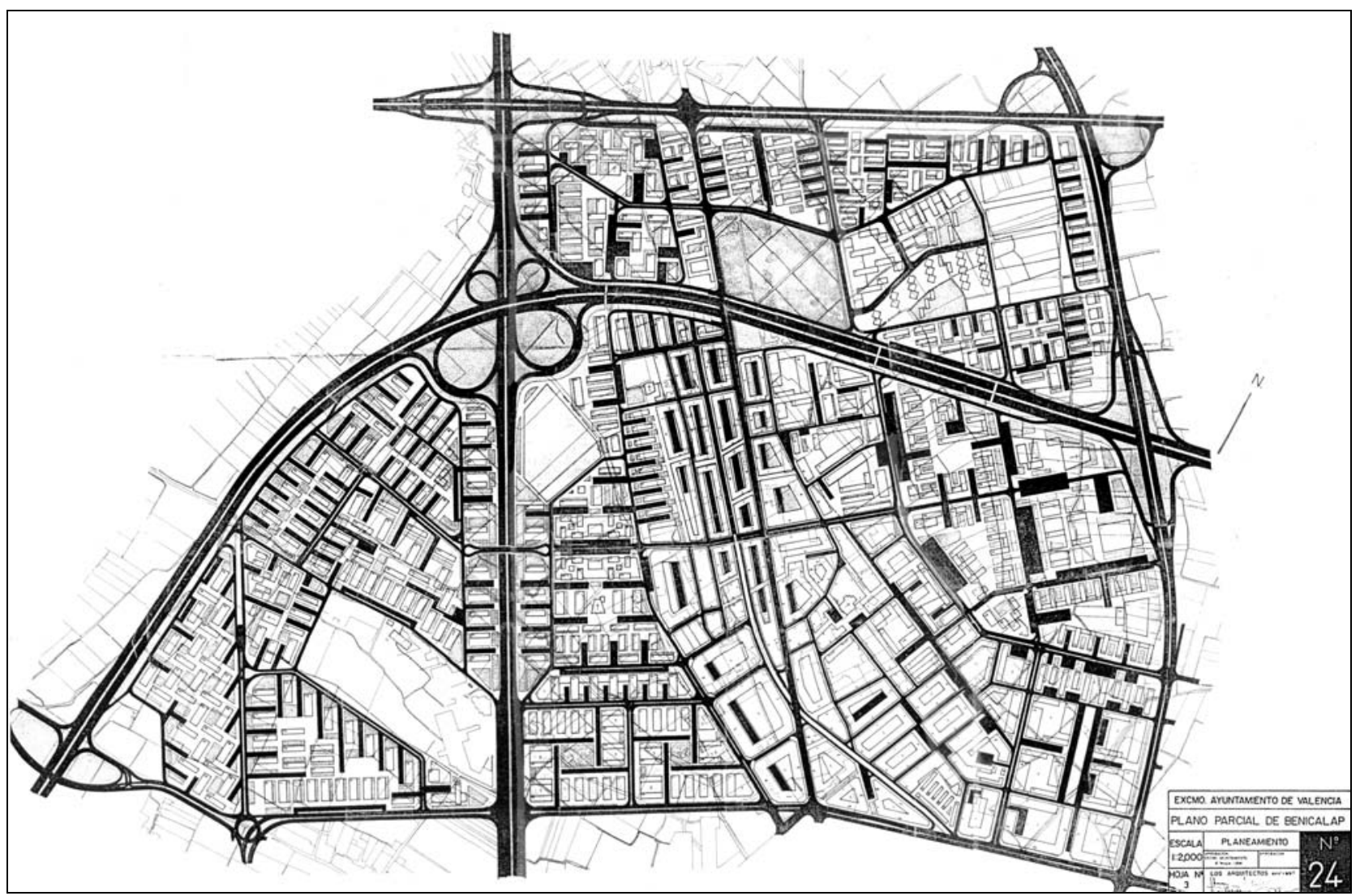




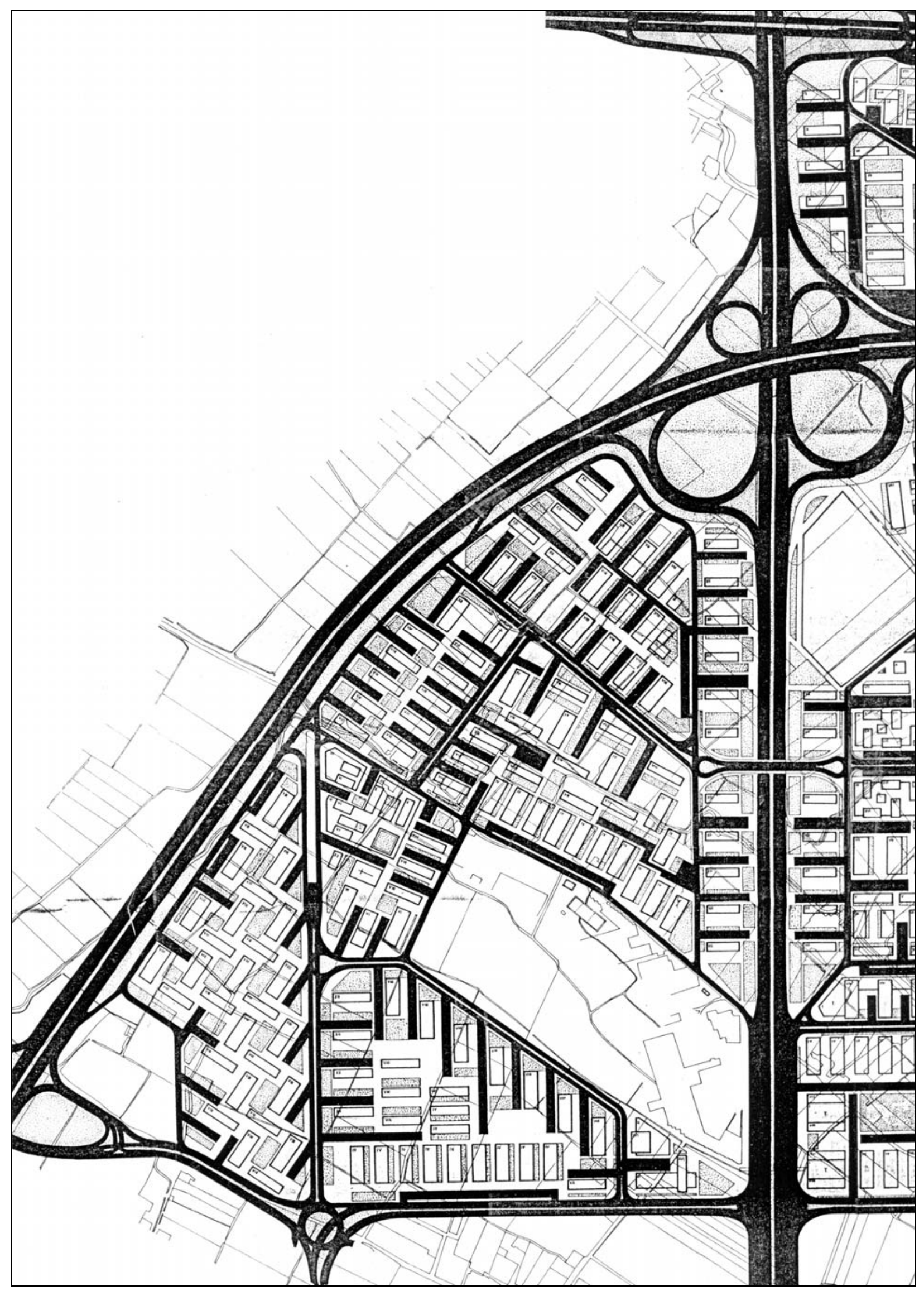

Detalle zona oeste 


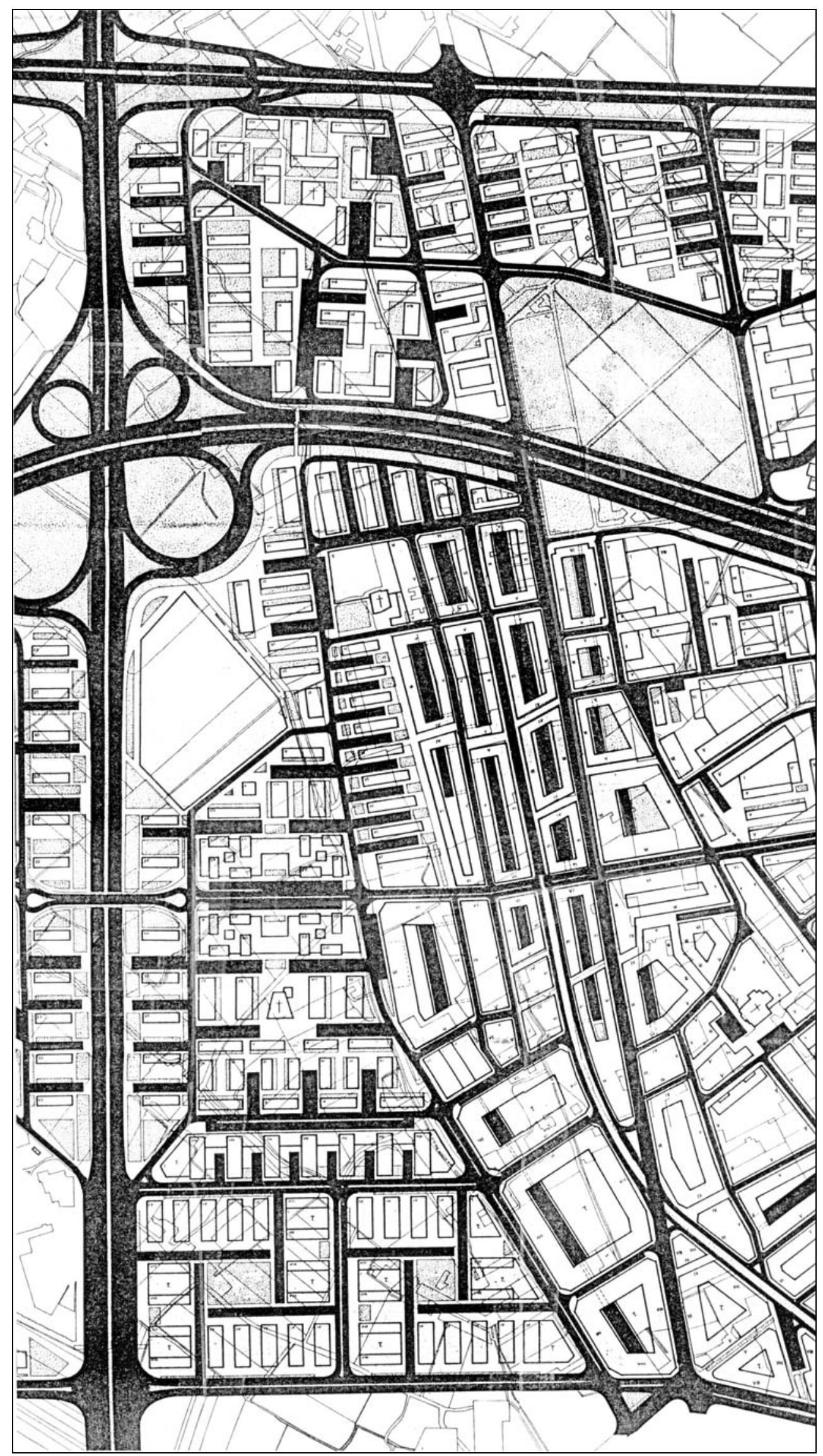

Detalle zona centro 


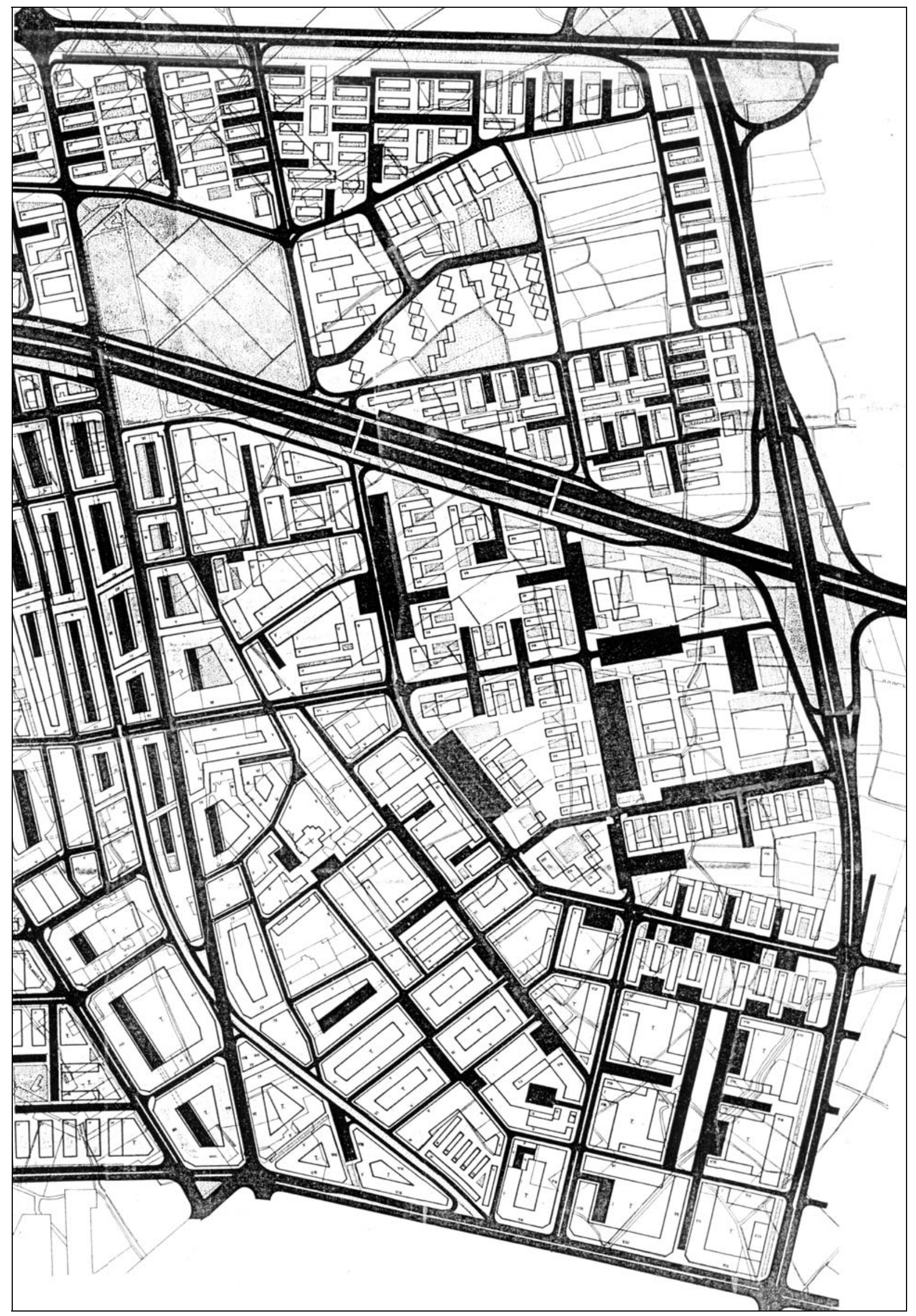

Detalle zona este 
CIUDAD DEL ARTISTA FALLERO DEL PLANO PARCIAL No 24.

Julio 1963. Escala original 1:2000

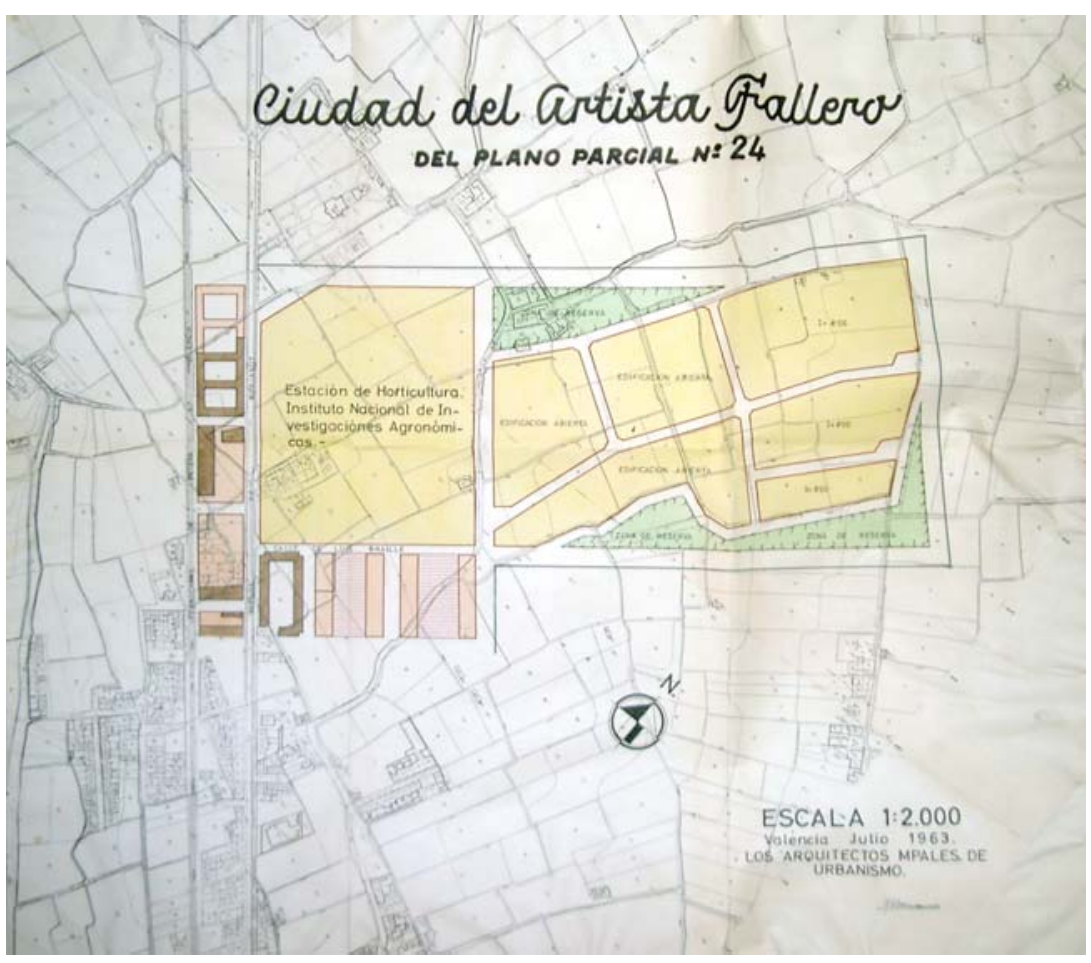

CIUDAD DEL ARTISTA FALLERO. PLANO DE ORDENACIÓN.

Arquitectos: M. Muñoz Monasterio, Carlos Sobrini, Emilio G. De Castro, G. González.

Junio 1963. Escala original 1:2000.

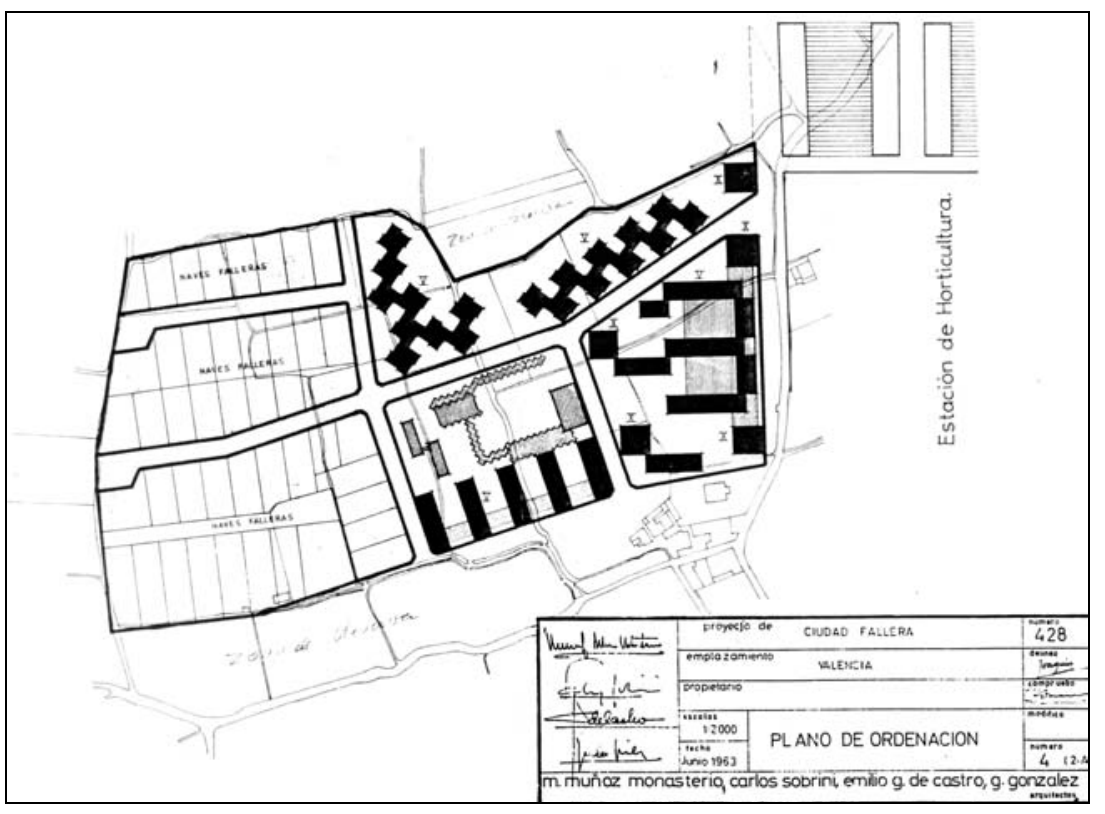


PROPUESTA DE MODIFICACIÓN DEL PLANO PARCIAL 24 PARA SAICA. Enero 1958. Escala original 1:2000.
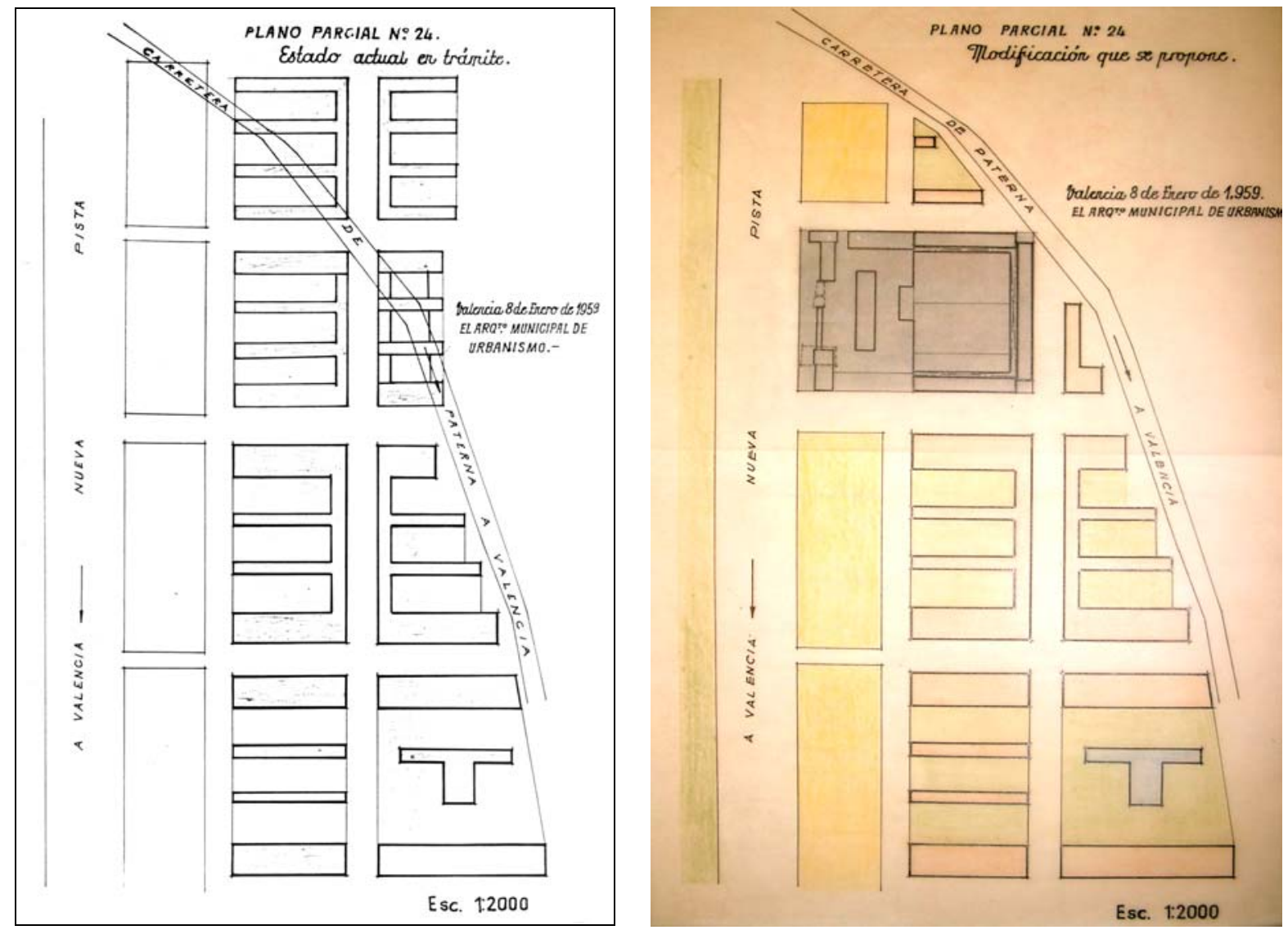
PROYECTO PARCIAL DE BENICALAP, No 24.

Corporación Administrativa Gran Valencia, Septiembre 1966.

PLANO DE ORDENACIÓN.

Escala original 1:2000

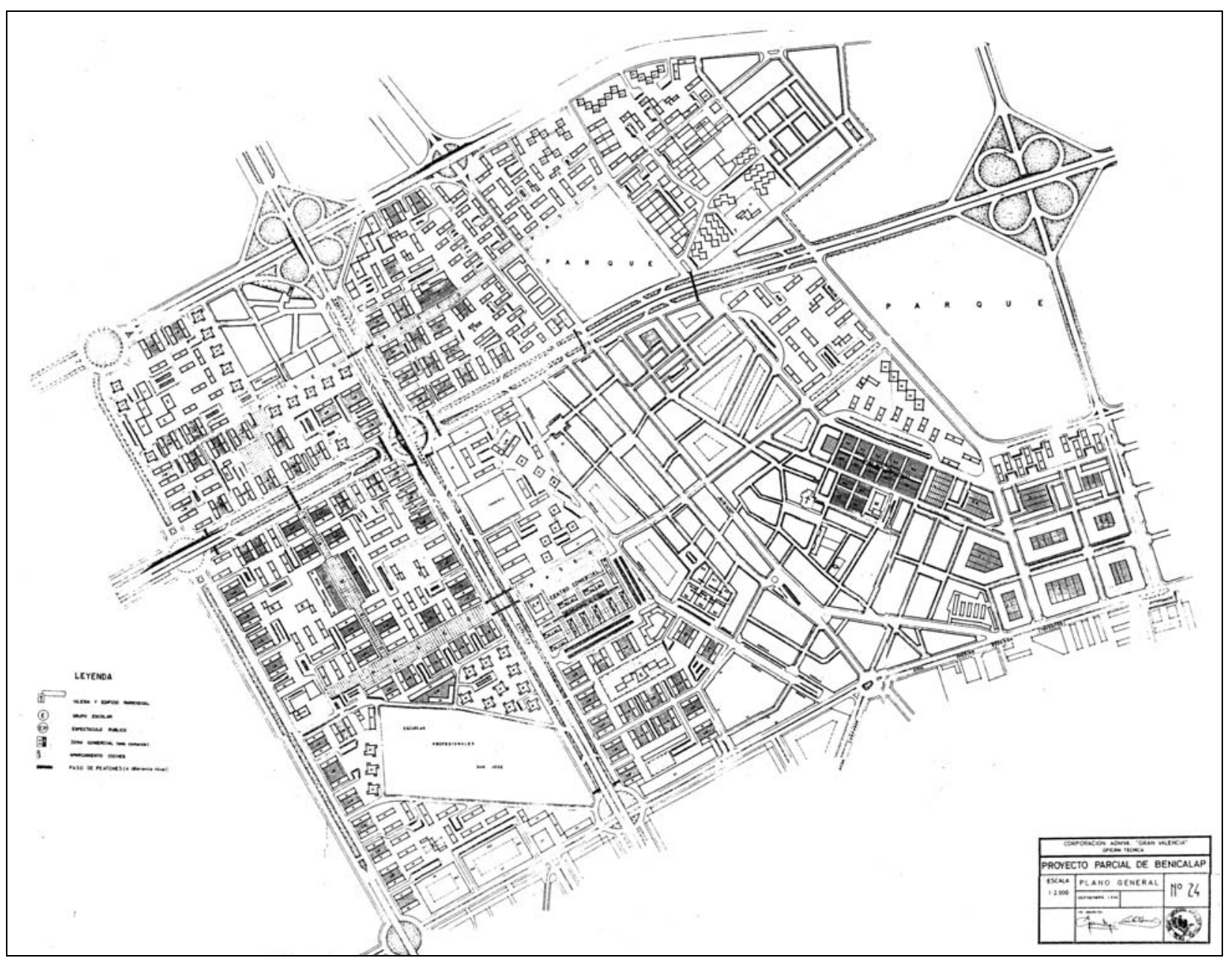




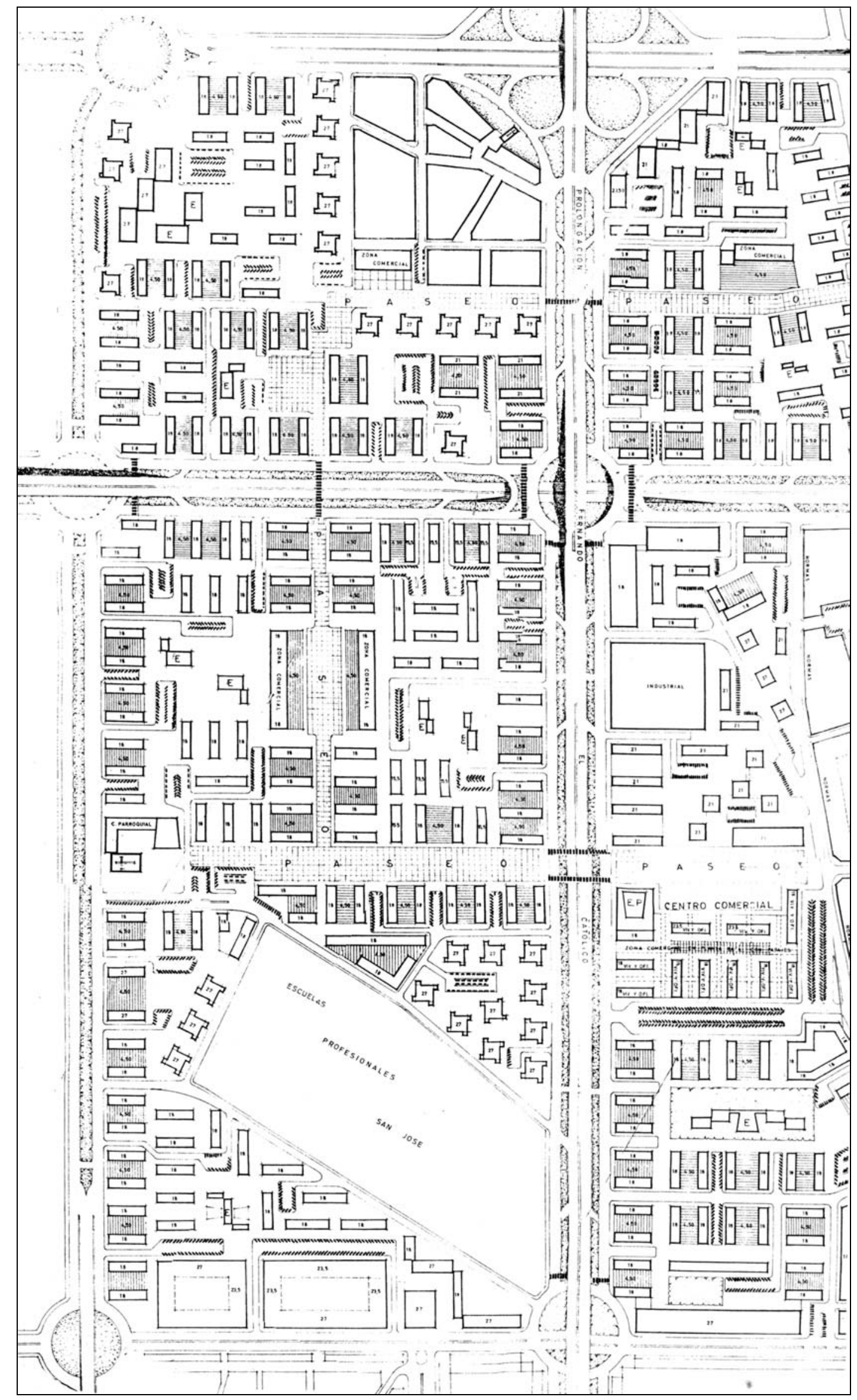

Detalle de la zona oeste 


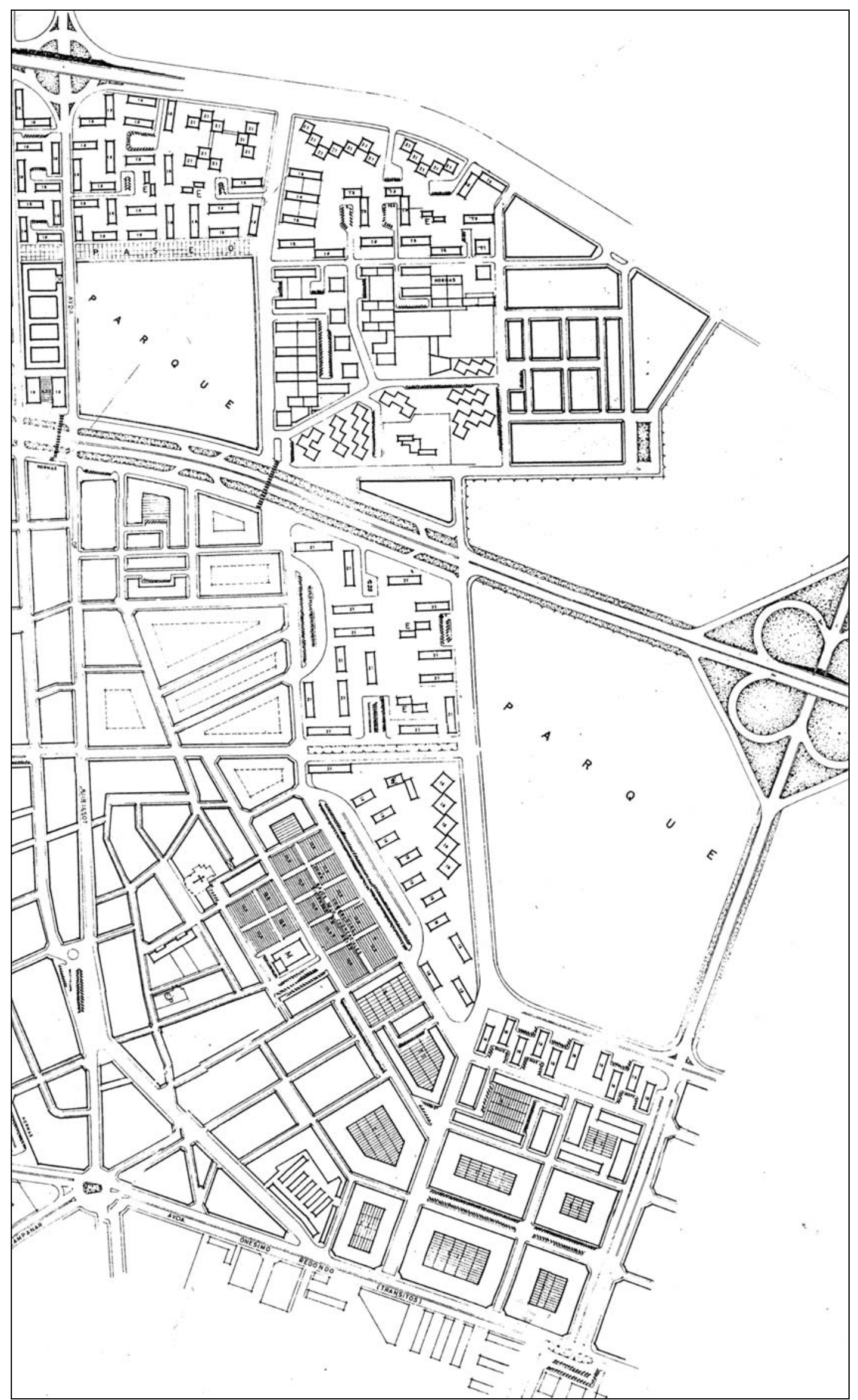

Detalle de la zona este 



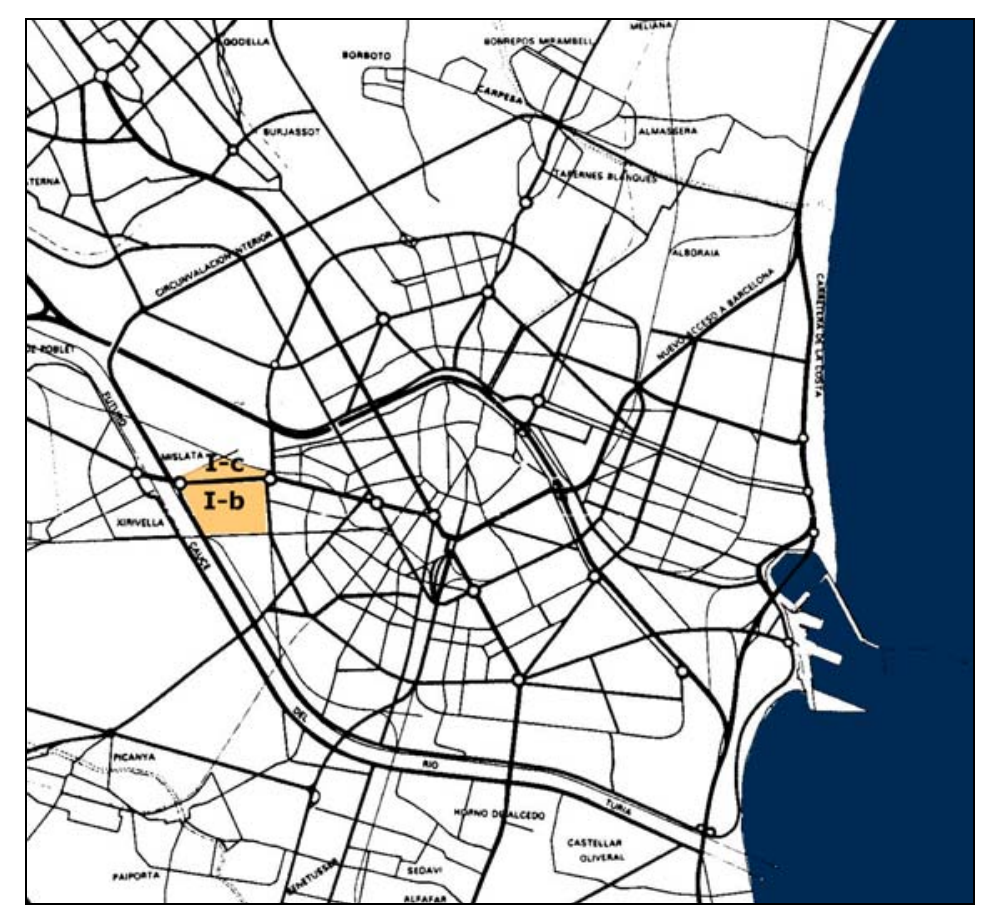

\subsection{ZONA SUROESTE}

PLAN PARCIAL NO I-B (SUR DE AVENIDA DE CASTILLA), 1962 PLAN PARCIAL NO I-C (NORTE DE AVENIDA DE CASTILLA), 1963 

PLANO PARCIAL ENTRE CAMINO DE TRES CRUCES, FERROCARRIL UTIEL, TERMINO CHIRIVELLA Y AVENIDA DE CASTILLA

1962

Redactores: AYUNTAMIENTO DE VALENCIA. Oficina Técnica Municipal de Urbanismo. Arquitecto: Julio Bellot Senent.

Fecha redacción: Octubre 1962.

Fecha aprobación: -

\section{Contenido:}

MEMORIA.

ORDENANZAS

PLANOS:
1. PARCELARIO
$1: 2000$
2. ALINEACIONES
$1: 2000$
3. PLANEAMIENTO
$1: 2000$
4. ALCANTARILLADO
$1: 2000$
5. RED DE AGUA
$1: 2000$
6. ALUMBRADO
$1: 2000$
7. UBICACIÓN Y TRANSPORTE
$1: 2000$

\section{Fuente:}

Ayuntamiento de Valencia. Sección de Urbanismo. Negociado de Suelo y Ordenación urbana (Archivo de Planeamiento, Sección de expedientes antiguos) 



\title{
EXCMO. AYUNTAMIENTO DE VALENCIA
}

PLANO PARCIAL DE LA ZONA COMPRENDIDA ENTRE EL CAMINO DE TRES CRUCES, F.C. A UTIEL, TERMINO DE CHIRIVELLA Y AVENIDA DE CASTILLA.

\author{
PLANO PARCIAL I-B
}

\section{$\underline{\text { ME MOR I A }}$}

OBJETO DE ESTE ESTUDIO.- Peticiones de licencia para establecer instituciones Benéfico-Sanitarias y otras, la magnífica situación de la zona y el hecho de ser zona edificable, según el proyecto de SOLUCION SUR, movieron a la Comisión de Urbanismo de éste Excmo. Ayuntamiento, a ordenar la redacción de este plano parcial.

Con este plano se une lo construido por el Ministerio de la Vivienda en el Barrio Virgen de la Fuensanta, con otro realizado, por la iniciativa particular que edificó el llamado Barrio de la Luz, que ahora queda absorbido formando con ambos un núcleo suficientemente grande para tener vida propia.

CARÁCTER DE LA ZONA.- En la zona se emplaza el nuevo Hospital Provincial, la Casa de Nuestra Señora de la Misericordia y algunos establecimientos religiosos Benéfico-Sanitarios. El resto de a zona es de carácter puramente residencial. La situación del Hospital y Misericordia, es ya antigua con respecto a este plano y los centros religiosos Benéfico-Sanitarios, están ubicados en la situación en que pidieron emplazarse, por ser propietarias las comunidades de los terrenos.

La casi totalidad de la zona se ha tratado como edificación abierta con una plaza en el centro dando preponderancia de altura a los edificios recayentes a la Avenida.

La superficie total de la zona, descontando al Hospital Provincial y desde el eje de la Avenida hasta Barrio de la Fuensanta es de $18,25 \mathrm{Ha}$. y las superficies a construir son las siguientes:
Destinado a religioso-sanitario
12.976.- $\mathrm{m} / 2$
" " "edificación en una planta 14.220.- $\mathrm{m} / 2$
" "Barrio de la Luz 3.032.- $\mathrm{m} / 2$
" " bloques
53.068.- $\mathrm{m} / 2$

Resulta un total de 8,33 $\mathrm{Ha}$. Es decir, que los espacios abiertos son muy superiores al $10 \%$ de la superficie total.

La superficie destinada a escuelas $-4.500 \mathrm{~m} / 2$-, es menor que la necesaria para la zona, que sería de $6.500 \mathrm{~m} 2$, dada una población de 9.125 habitantes, y suponiendo el $15 \%$ de población escolar y $6 \mathrm{~m} / 2$ por niño.

Se hace esto porque los dos grupos proyectados podrían atender las necesidades en el comienzo de la realización y estimo que por la forma de lo proyectado cualquier bloque o grupo de dos con su jardín pueden convertirse en grupo escolar. Es decir, que no habrá verdadera dificultad en el futuro para el establecimiento de un tercer grupo escolar.

La densidad prevista es de 400 habitantes Ha.

SERVICIOS PUBLICOS.- Figuran en el proyecto esquema de alcantarillado, agua, luz. Todos ellos fáciles de establecer por existir posibilidad de conexión. 
ETAPAS.- No pueden establecerse en un plano de alineaciones que trata de encauzar la iniciativa particular. El futuro puede hacer interesante establecerlas para ultimar lo que se haya ido realizando. El Excmo. Ayuntamiento atenderá a la urbanización en las zonas de porvenir inmediato.

MEDIOS ECONOMICO-FINANCIEROS.- Son los ordinarios del presupuesto de Urbanismo del Excmo. Ayuntamiento de Valencia.

Valencia, octubre de 1.962.

LOS ARQUITECTOS MUNICIPALES DE URBANISMO,

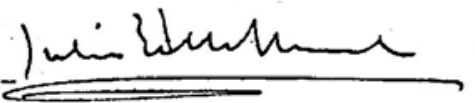




\section{PLANEAMIENTO}

Escala original 1:2000

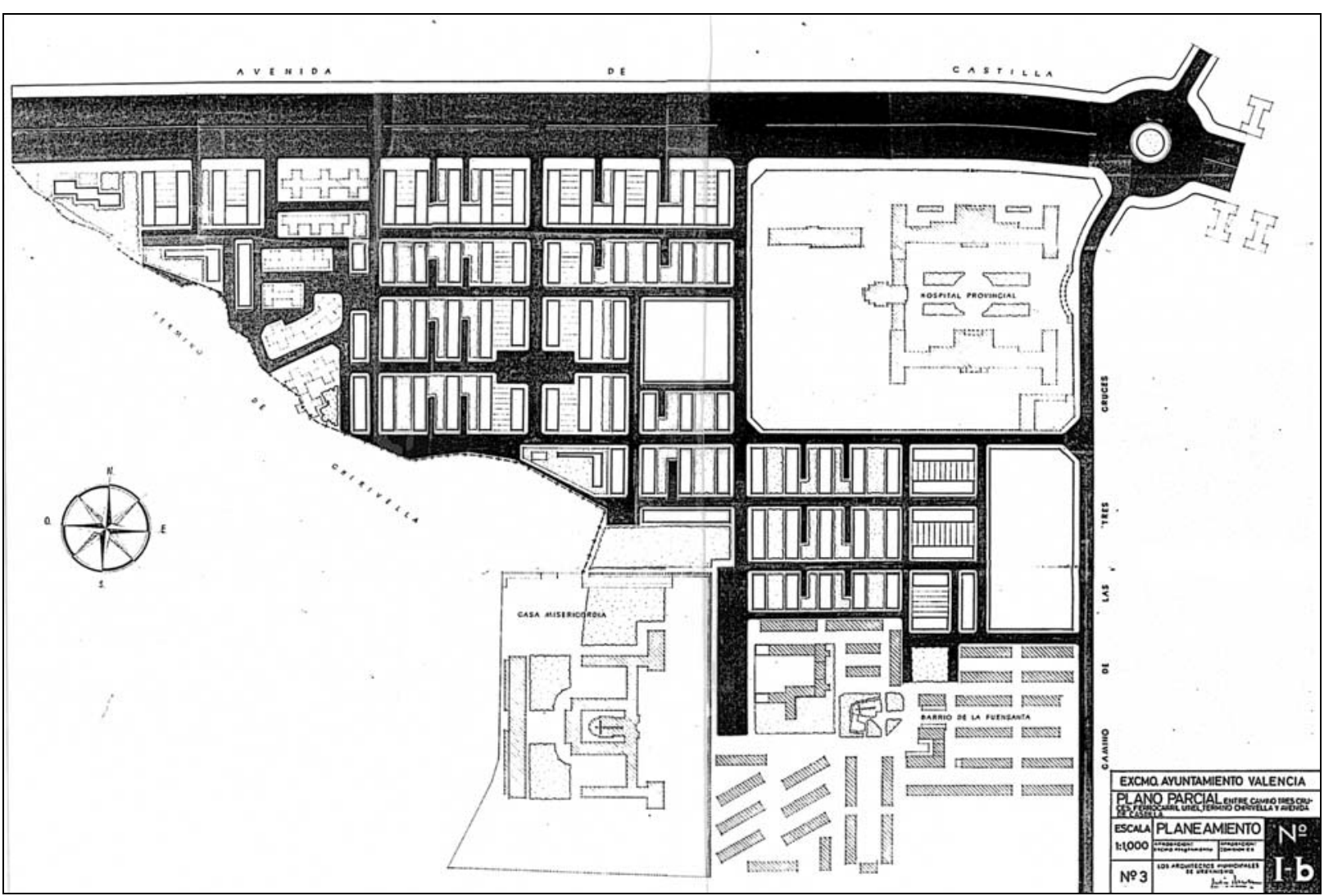



Redactores: AYUNTAMIENTO DE VALENCIA. Oficina Técnica de Urbanismo.

Fecha redacción: 1963.

Fecha aprobación: 4-10-1963 (Aprobación inicial Ayuntamiento)

\section{Contenido:}

$\operatorname{MEMORIA}(*)$

ORDENANZAS

PLANOS: $(* *)$

1-2. ESTADO ACTUAL Y ALINEACIONES $1: 2000$

3. PLANEAMIENTO $1: 2000$

4. RED ALCANTARILLADO $1: 2000$

5. RED DE AGUA $1: 2000$

6. ALUMBRADO $1: 2000$

7. UBICACIÓN Y TRANSPORTE

\section{Fuente:}

Ayuntamiento de Valencia. Sección de Urbanismo. Negociado de Suelo y Ordenación urbana (Archivo de Planeamiento, Sección de expedientes antiguos)

\section{Notas:}

(*) No se ha localizado documentación escrita de este plan.

(**) El expediente contiene además los planos siguientes:

- $\quad$ PLAN PARCIAL I-c (Sin fecha)

- MODIFICACIÓN DEL PLAN PARCIAL I-C (Sin Fecha) 

1. PARCELARIO

Escala original 1:2000

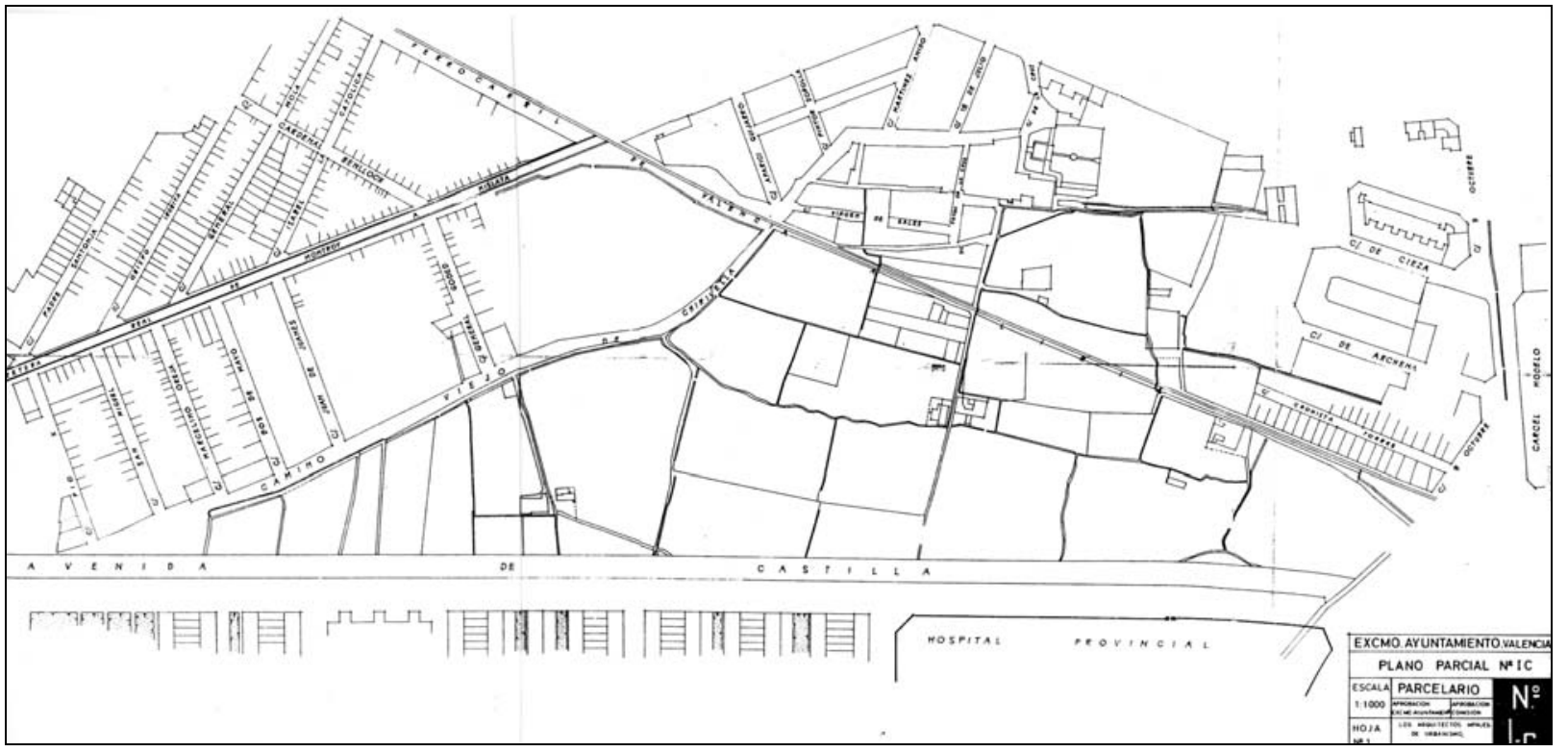

\section{ALUMBRADO}

Escala original 1:2000

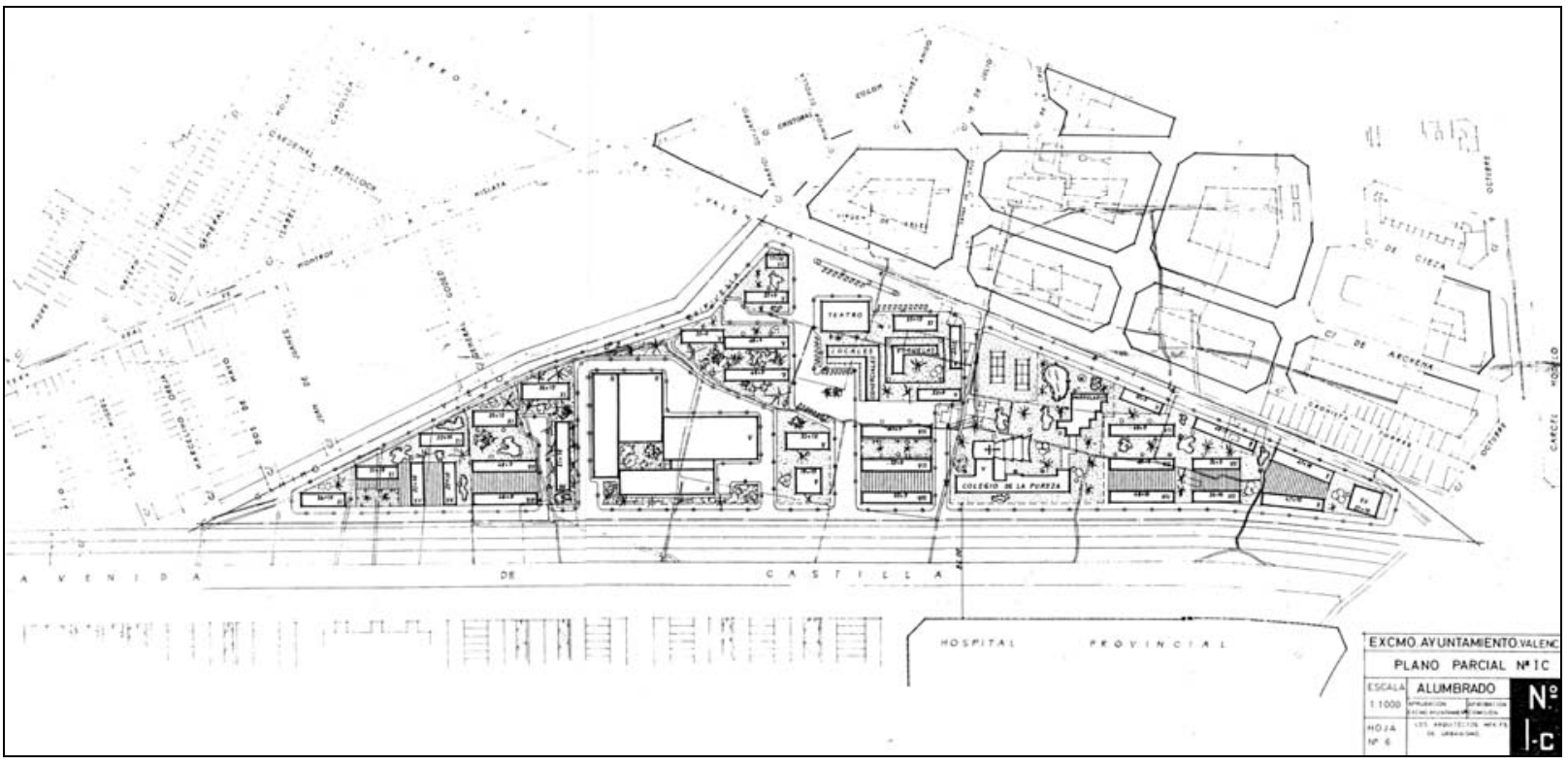


PLANO PARCIAL NO I-C (S.F.)

Escala original 1:2000

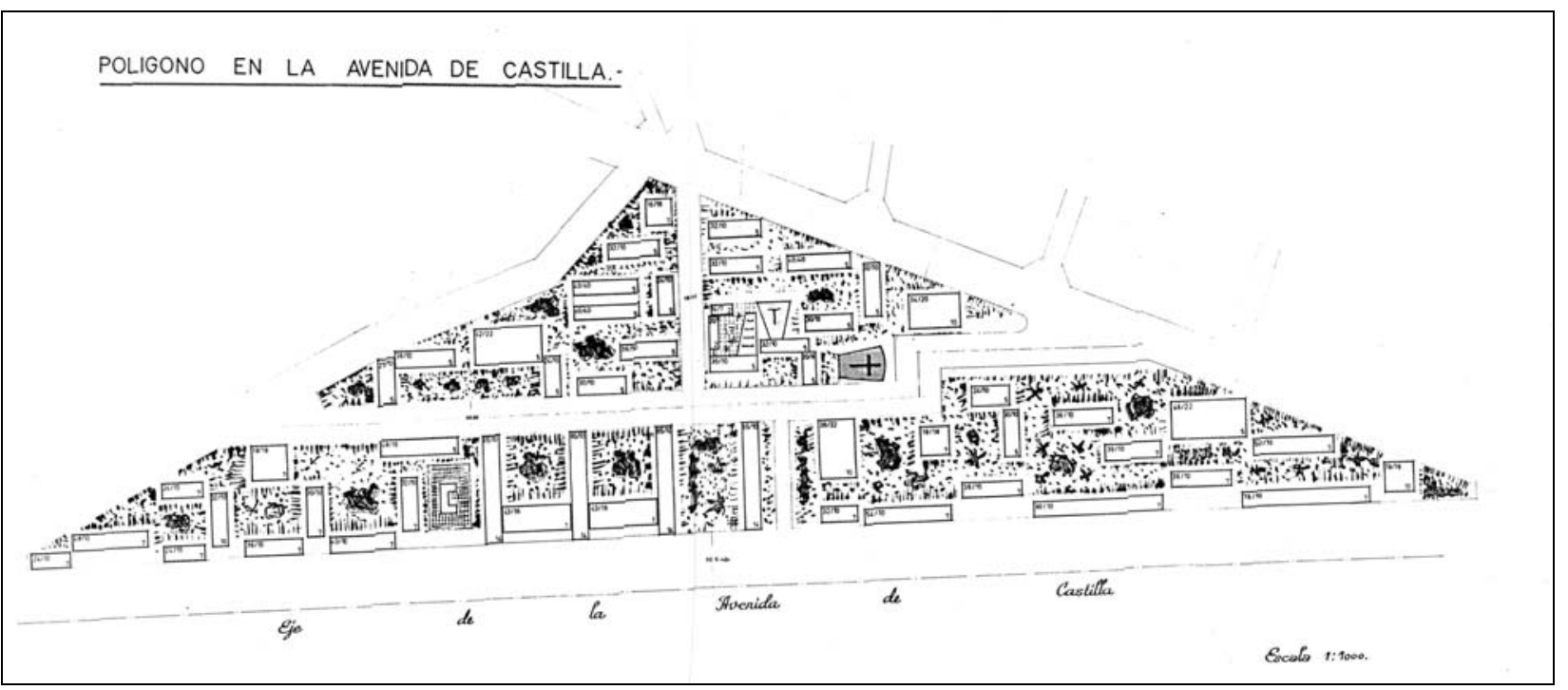

MODIFICACIÓN DEL PLANO PARCIAL NO I-C (S.F.)

Escala original 1:2000

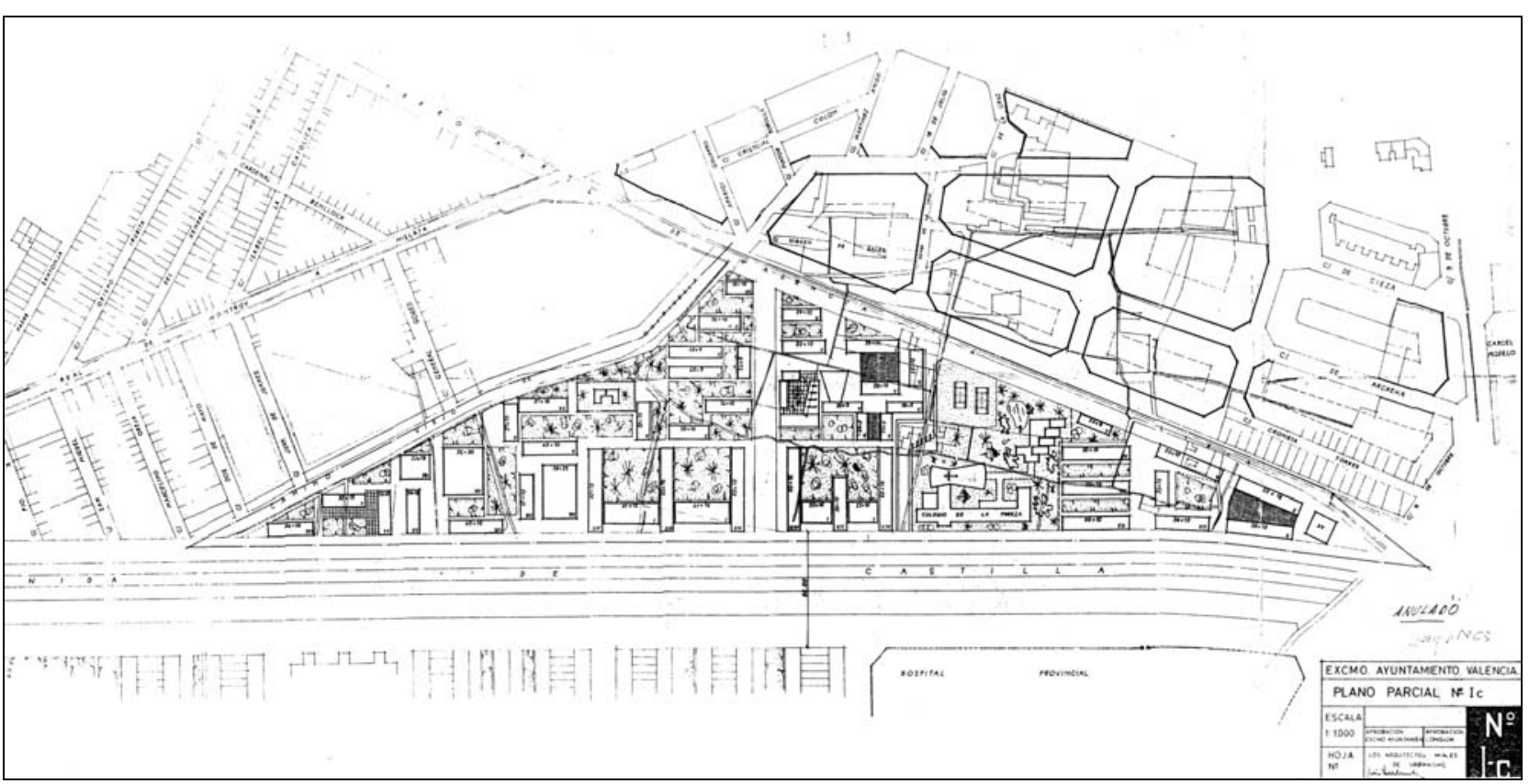




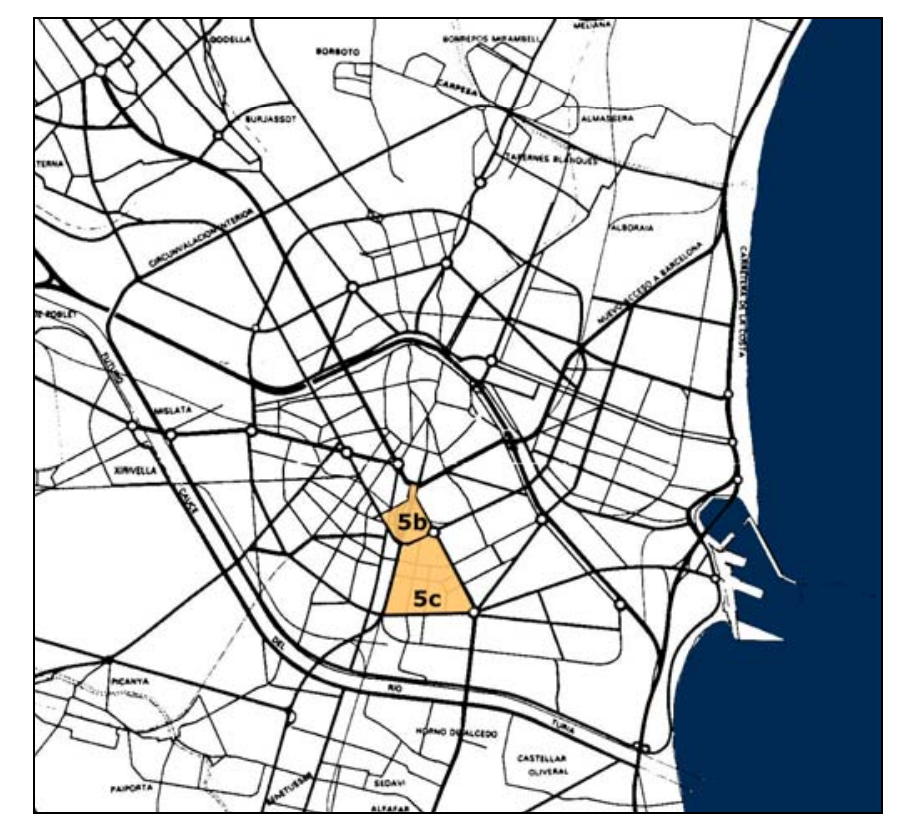

5.5. ZONA SURESTE

PLAN PARCIAL NO 5-B (ESTACIÓN CENTRAL), 1963 PLAN PARCIAL NO 5-C (MALILLA), 1964

273 



\section{PP 5-B}

Redactores: AYUNTAMIENTO DE VALENCIA. Oficina Técnica Municipal de Urbanismo. Arq. Julio Bellot Senent.

Fecha redacción: Octubre 1963.

Fecha aprobación: 3-07-1964 (Aprobación inicial Ayuntamiento)

\section{Contenido:}

MEMORIA.

ORDENANZAS

PLANOS: $(*)$

1-2. ESTADO ACTUAL Y ALINEACIONES $1: 2000$

3. PLANEAMIENTO $1: 2000$

4. RED ALCANTARILLADO $1: 2000$

5. RED DE AGUA $1: 2000$

6. ALUMBRADO $1: 2000$

7. UBICACIÓN Y TRANSPORTE

\section{Fuente:}

Ayuntamiento de Valencia. Sección de Urbanismo. Negociado de Suelo y Ordenación urbana (Archivo de Planeamiento, Sección de expedientes antiguos)

\section{Notas:}

(*) El expediente contiene además el plano siguiente:

PLAN PARCIAL 5-B (Sin fecha)

- HOJA ENTELADA 


\section{EXCMO. AYUNTAMIENTO \\ DE \\ VALENCIA}

\section{PLANO PARCIAL NO 5-B}

\section{MEMOR I A}

Comprende este plano, en su mayor parte los terrenos de la actual estación principal de la Renfe en Valencia. Por esta causa y por estar proyectado el centro de Valencia en el Plan General de Valencia y su Comarca, se aisló la zona que ocupa la estación para posterior estudio. Es de suponer que la realización de este plano no va a ser inmediata pero existen terrenos colindantes que exigen ser definidos en cuanto a uso y alineaciones y elementos especiales como la unión entre caminos de tránsitos por paso superior sobre el F.C. que si necesitan posibilidad de realización inmediata.

Por todo ello se redacta este plano con la aspiración de servir de guía para la futura urbanización de los terrenos de la estación del Norte y ordenar la construcción en los terrenos colindantes.

JUSTIFICACION DE LA ORDENACION.- La zona está en el encuentro de importantes vías de comunicación. El acceso de Alicante y el Camino Real de Madrid cruzan con unión de Gran Vías y con la de Camino de Tránsitos. Ha de llevar en su centro la futura estación subterránea de F.C. económicos de vía estrecha. La zona resulta un importante nudo de comunicación por lo que, tanto en la zona desde calle de Játiva a Gran Vía como en el resto del plano se establecen gran cantidad de espacios libres para servir de aparcamiento entre arbolados.

Toma la zona proyectada un carácter mixto residencial y centro cívico central ya que está situada entre ensanches que no gozan de centros definidos.

Se le da un carácter de edificación abierta para aprovechar la coyuntura de disponer de un terreno libre en el futuro de edificaciones, situado entre zonas de manzanas cerradas.

Se divide el total de las subzonas a que obliga la existencia de las vías públicas importantes precitadas dotándolas de los diferentes edificios públicos: escuelas, iglesias, mercado, zona comercial, etc. Deberá dotarse el conjunto de un sistema de pasos de peatones superiores o subterráneos para atravesar dichas vías públicas y que todas las zonas puedan gozar, cómodamente, de todos los servicios.

ETAPAS.- No pueden establecerse etapas porque es imposible determinar desde aquí el momento en que terminadas la reforma ferroviaria queden libres para destinarlos a los usos que indica el plano, la mayor parte de los terrenos que son los de la estación.

MEDIOS ECONOMICO-FINANCIEROS.- Son los del presupuesto ordinario de Urbanismo en lo que respecta a los terrenos externos a la estación. En cuanto a estos se determinarán cuando queden libres para edificar en el proyecto de ejecución que se realicen con probable presupuesto extraordinario.

Con lo dicho creemos suficientemente expuesto el alcance del estudio realizado para que si el Excmo. Ayuntamiento lo estima conveniente lo eleve a la aprobación por la superioridad.

Valencia, octubre de 1.963

EL ARQUITECTO MPAL. DE URBANISMO, 


\section{EXCMO. AYUNTAMIENTO}

DE VALENCIA

\section{PLANO PARCIAL NO 5 -B}

\section{ORDENANZAS}

Art. 10.- Regirá en la edificación que se realice en los terrenos que comprende este plano las Ordenanzas Reguladoras de la Edificación vigente en Valencia, excepto en lo referente a alturas cuando sean expresamente marcadas en el plano.

Art. $2^{\circ}$.- Los bloques manzanas o edificio sobre los cuales de marca la altura con un número ostentarán como máximo la altura en metros, a cornisa, que marque dicho número.

Art. 30.- La indicación en número romano sobre manzana bloque o edificio indica el número de planas permitido con altura a cornisa igual, en metros, al resultado de multiplicar dicho número por tres añadir una unidad. Obtenida la altura podrá subdividirse en mas plantas o menos siempre dentro del Reglamento de viviendas de Renta limitada según el acuerdo municipal obre la materia.

Art. 40.- Sobre las alturas permitidas expresamente se podrá edificar la sala de máquinas de ascensor, el cuarto de contadores y la portería. Esta última, solamente cuando pueda establecerse en segunda crujía.

Valencia, octubre de 1.963

EL ARQUITECTO MPAL. DE URBANISMO,
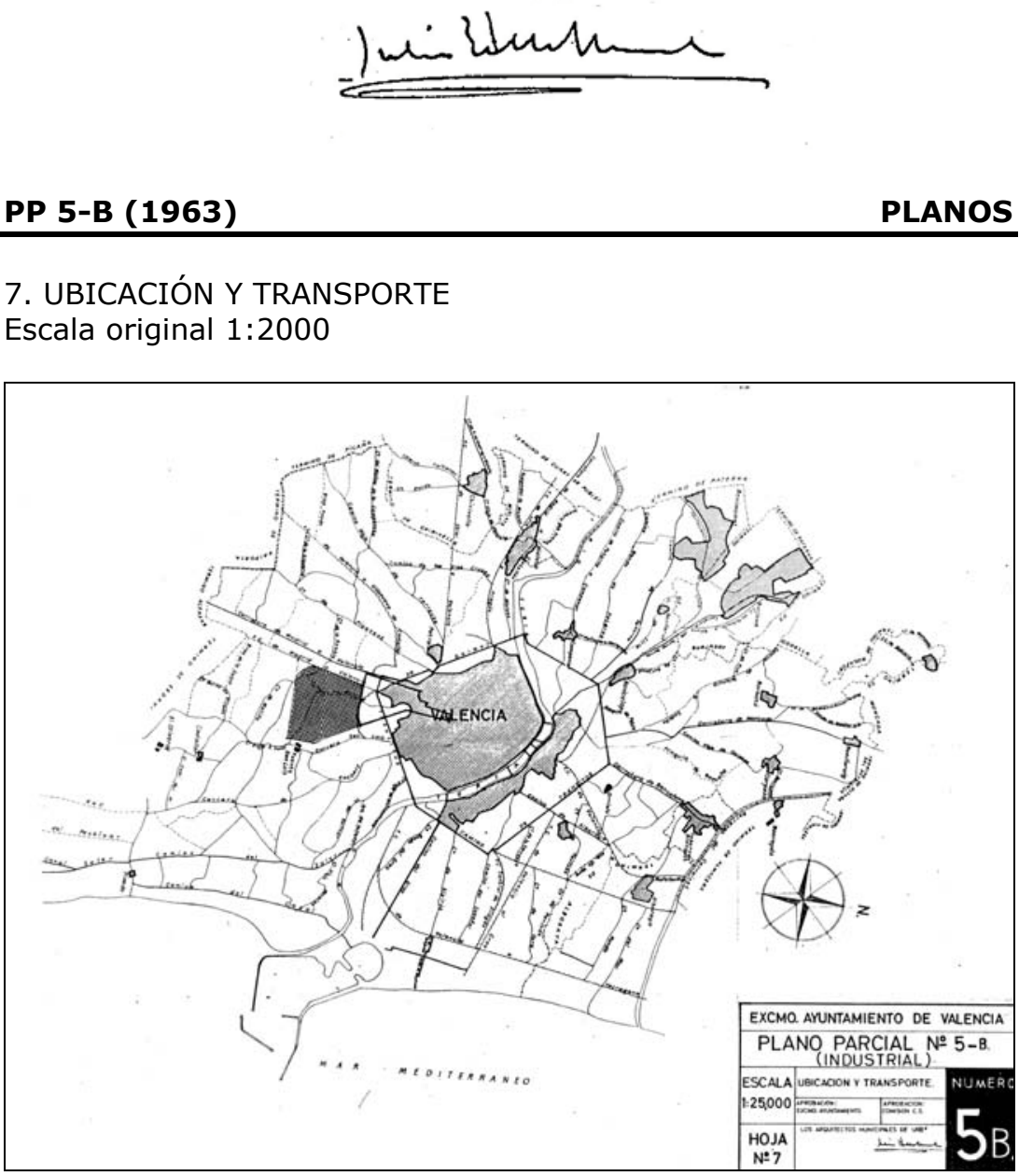
2. ESTADO ACTUAL Y ALINEACIONES

Escala original 1:2000

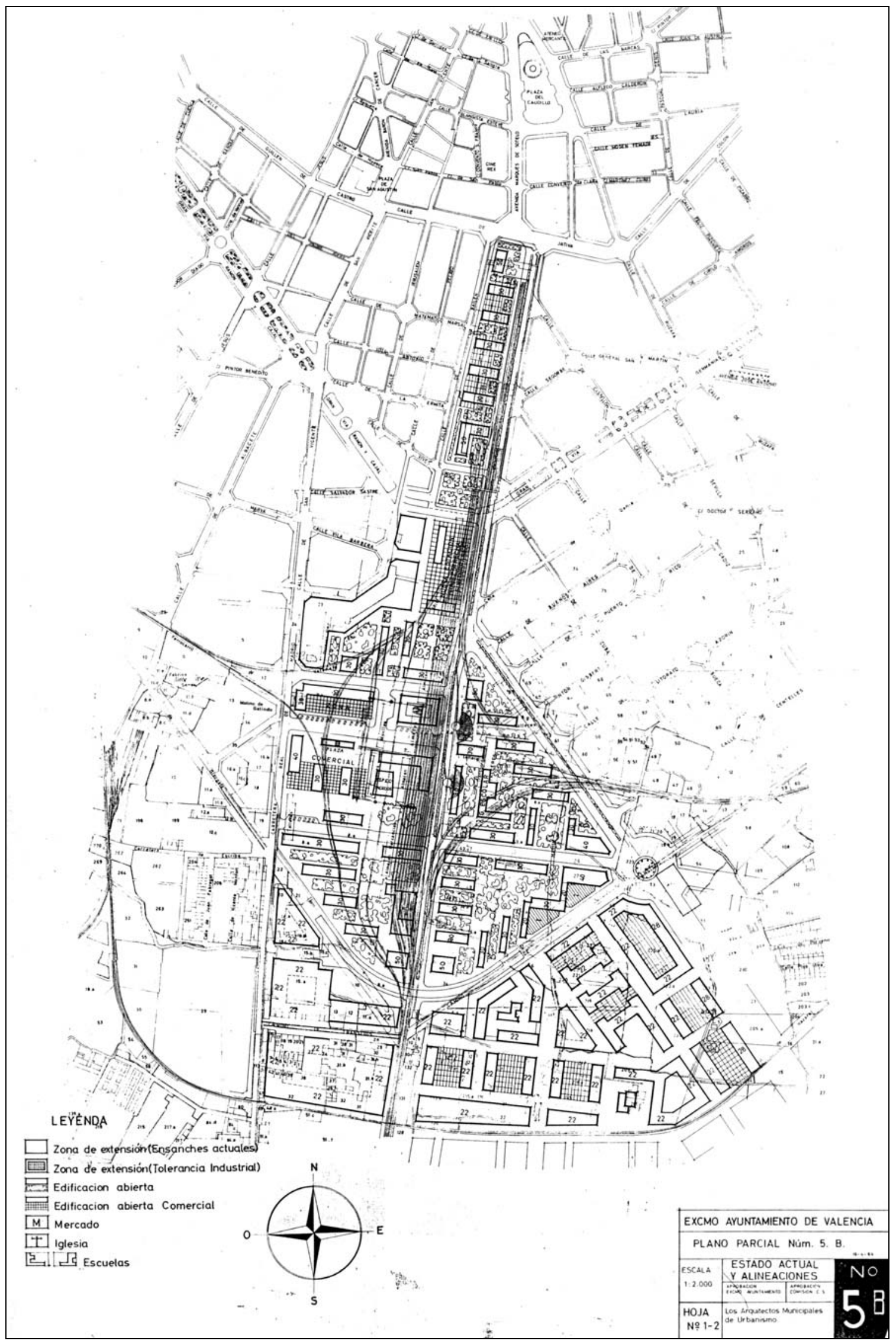




\section{PLANEAMIENTO}

Escala original 1:2000

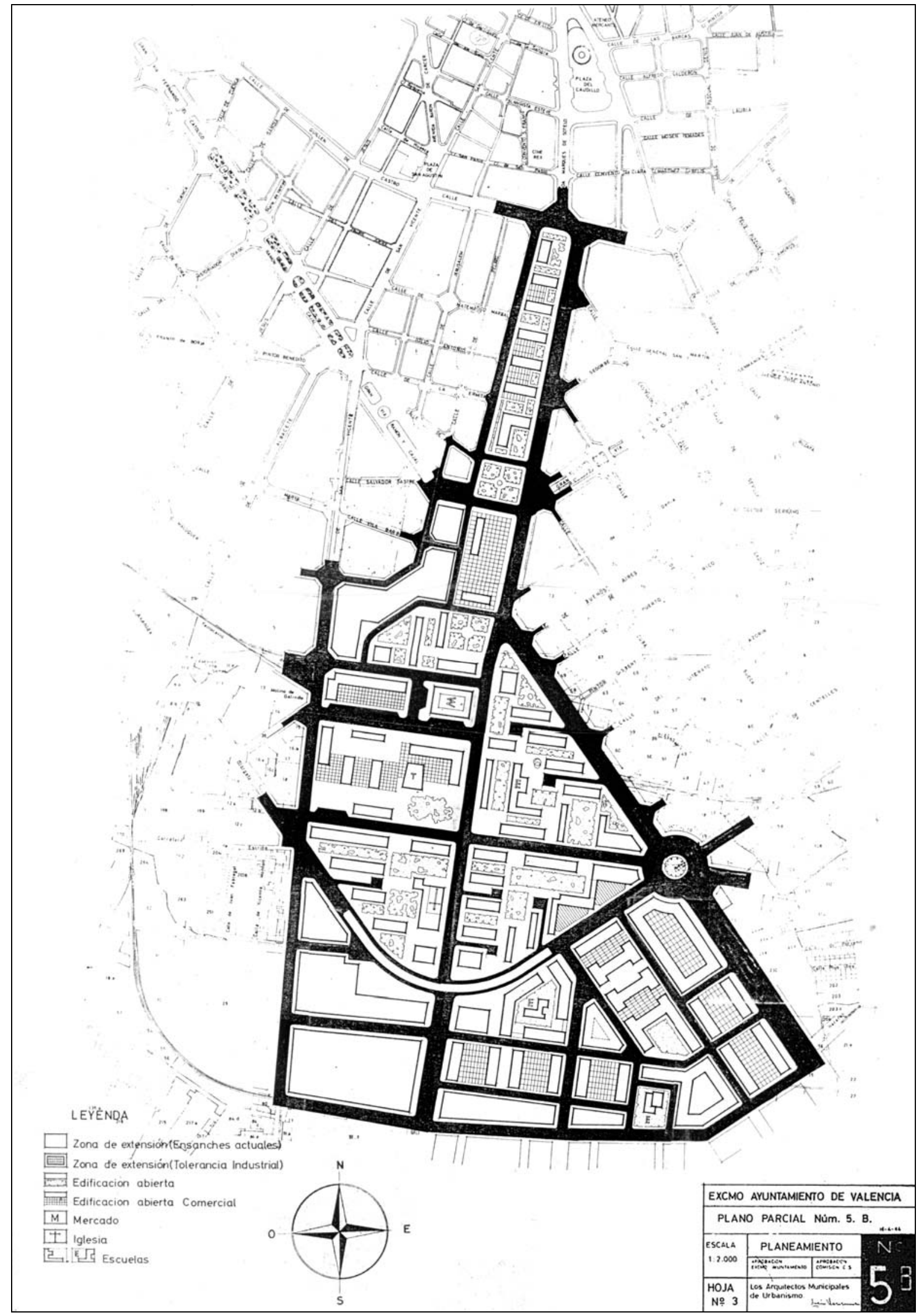


PLANO PARCIAL NO 5-B (S.F.)

Escala original 1:2000

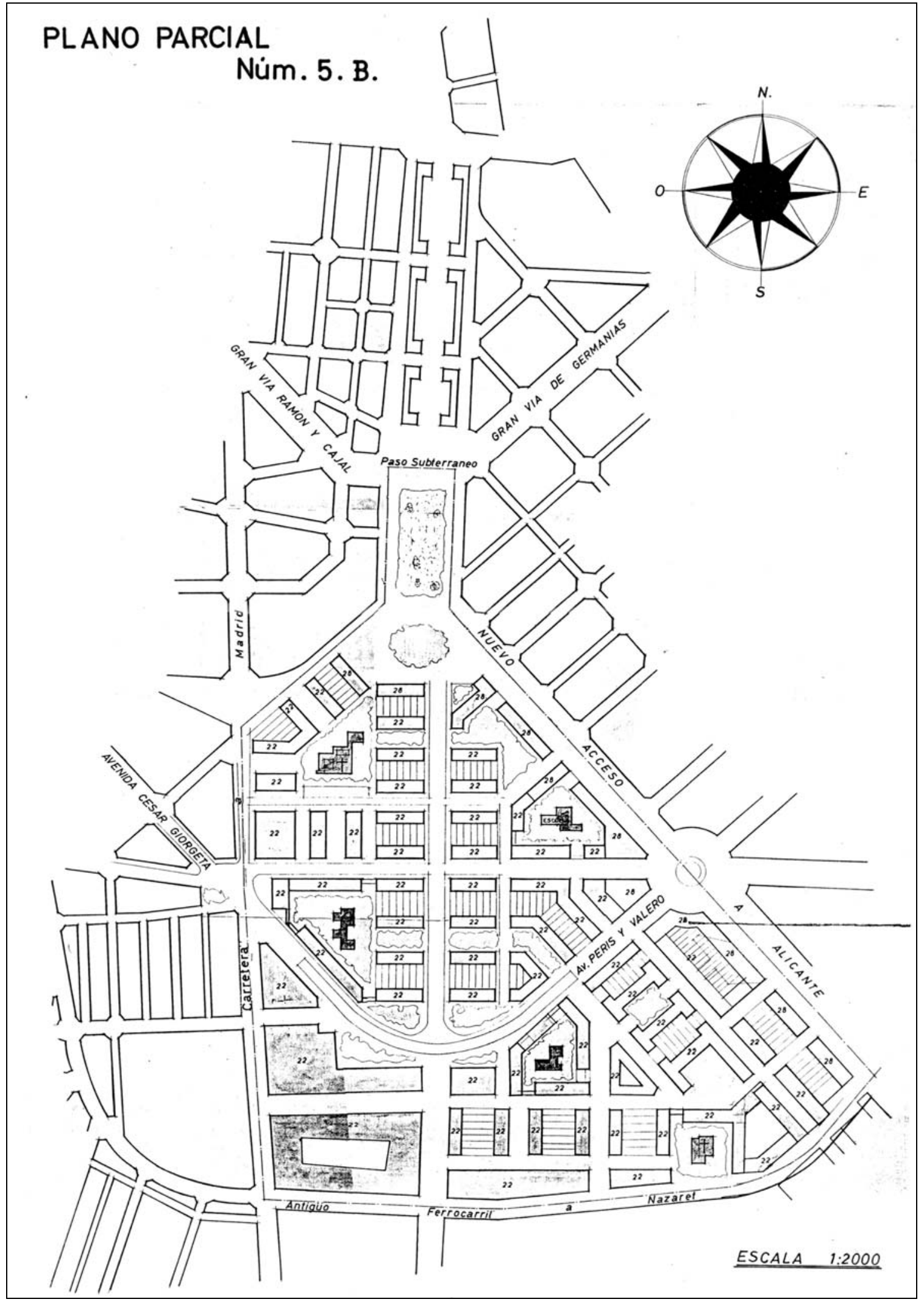


PLANO PARCIAL NO 5-B (S.F.)

Escala original 1:2000

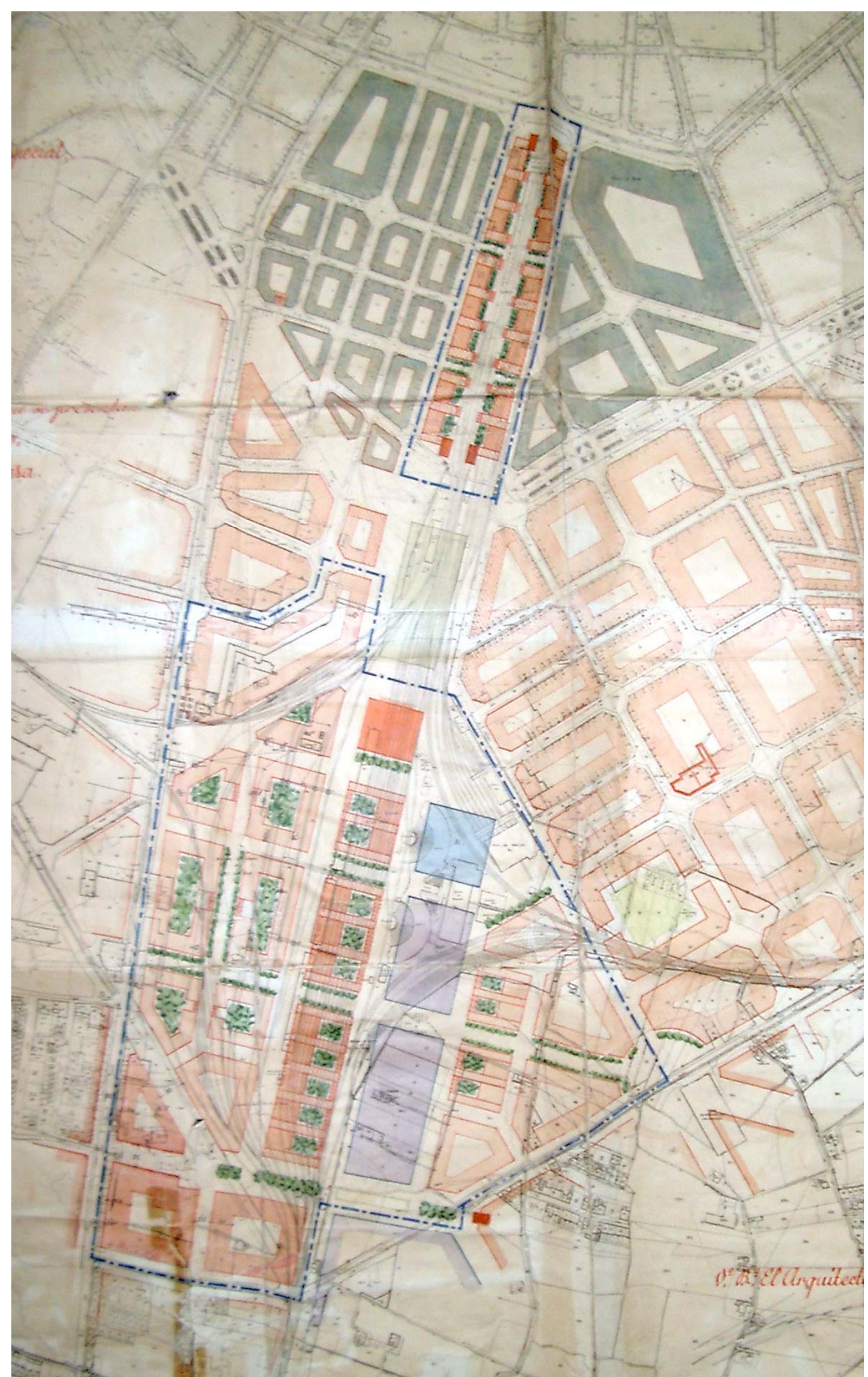





\section{PP 5-C}

Redactores: AYUNTAMIENTO DE VALENCIA. Oficina Técnica de Urbanismo. Arq. Julio Bellot Senent.

Fecha redacción: Abril 1964.

Fecha aprobación: 5-03-1965 (Aprobación inicial Ayuntamiento)

\section{Contenido:}

MEMORIA.

ORDENANZAS

PLANOS:

1. ESTADO ACTUAL

$1: 2000$

2. ALINEACIONES

$1: 2000$

3. PLANEAMIENTO

$1: 2000$

4. RED DE ALCANTARILLADO

$1: 2000$

5. ESQUEMA ABASTECIMIENTO DE AGUA

$1: 2000$

6. ESQUEMA DE ALUMBRADO

$1: 2000$

7. UBICACIÓN Y TRANSPORTE

$1: 2000$

\section{Fuente:}

Ayuntamiento de Valencia. Sección de Urbanismo. Negociado de Suelo y Ordenación urbana (Archivo de Planeamiento, sección de expedientes antiguos) 


\section{EXCMO. AYUNTAMIENTO \\ DE \\ VALENCIA}

\section{PLANO PARCIAL 5-C}

\section{MEMOR I A}

La zona industrial que comprende es una de las marcadas en el Plano de Zonas Industriales que redactado por la Oficina Técnica de la Corporación Administrativa Gran Valencia, fue presentado al Consejo General de la Corporación para su conocimiento y consideración.

Respondía este plano a la necesidad sentida de terrenos para zona industrial ya que el desarrollo industrial así lo exige y la extensión de la ciudad va amortizando los terrenos que estaban dedicados a este uso industrial. Por ello el Ayuntamiento ordenó la redacción del presente plano para comenzar a dar cauce a la solución del problema.

La zona queda limitada por antigua vía F.C. eléctrico a Nazaret; línea del F.C. a Madrid, nueva desviación de F.C. a Tarragona y nuevo acceso a Alicante.

Mide aproximadamente $120 \mathrm{Ha}$., de las que se dedican a industrial 80 y el resto a zona residencial de transición con el resto de la ciudad y a lo largo de la carretera de Alicante; a zona de separación ajardinada entre las dos anteriores y centro cívico.

Queda situada la zona junto a dos vías de F.C. y estación de Fuente de S. Luís, o sea que tiene buena comunicación por F.C. y por contacto con acceso de Alicante, además de ser atravesada por futura ronda muy importante de la ciudad y muy buena comunicación por carretera. La citada ronda desemboca en la autopista de Alicante en gran plaza de estrella que permitirá fácil acceso a pesar del rápido tráfico.

La parte residencial del plano es de tolerancia industrial o sea que podrán establecerse industrias menores y almacenes y garages en los bajos completando el sistema.

Se realiza la zona industrial con amplias calles, plazas de aparcamiento y grandes manzanas, en tamaño apropiado para industrias relativamente importantes.

Se dota la zona de un centro cívico en que se sitúan los edificios comerciales y de administración.

El servicio de suministro de energía tiene grandes posibilidades por estar próxima a la zona industrial del Camino Real de Madrid, naturalmente ampliándolo en muchas veces, pero con la posibilidad de fácil comienzo.

ETAPAS.- Por el momento el plano parcial es solamente un plano de alineaciones que encauce la iniciativa particular por ello no pueden establecerse etapas y sí solamente avanzar el Ayuntamiento en la urbanización procurando adelantarse a las construcciones particulares.

MEDIOS ECONOMICO-FINANCIEROS.- Son los del presupuesto ordinario de Urbanismo del Excmo. Ayuntamiento y los extraordinarios que se establezcan para realización de proyectos parciales de urbanización. 
Con lo dicho creemos suficientemente expuesto el alcance del estudio realizado para que, si el Excmo. Ayuntamiento lo estima conveniente lo eleve a la aprobación por la superioridad.

Valencia, 10 de abril de 1.964

EL ARQUITECTO MPAL. DE URBANISMO,

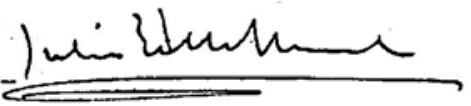




\section{EXCMO. AYUNTAMIENTO \\ DE \\ VALENCIA}

\section{PLANO PARCIAL 5-C}

\section{ORDENANZAS}

Art. 10.- Los edificios de zona residencial con tolerancia industrial se ajustarán a lo prescrito en las Ordenanzas Reguladoras de la edificación, vigentes en Valencia, excepto en lo relativo a altura que podrá ser como máximo la indicada en el plano con un numeral, que expresa el número de metros a cielo raso de última planta. Sobre esta última sólo podrán construirse cajas de ascensor y cuarto de contadores, y también porterías cuando puedan quedar retiradas a 3.- $\mathrm{mts}$. de las fachadas.

Art. $2^{\circ}$.- En las zonas de Tolerancia Industrial se permitirá la industria en las plantas bajas, pudiendo edificarse viviendas en los pisos del edificio a fachada.

La industria que se permita no será peligrosa o insalubre y tampoco de tal volumen que no sea compatible con zona de viviendas.

Se asegurará siempre el aislamiento de toda clase de ruidos y olores, tomando las debidas precauciones contra incendios.

Art. 30.- En las Zonas de Industria Normal, podrán instalarse toda clase de industrias excepto as que han de estar aisladas por su extremado peligro gran insalubridad.

Se autoriza un aprovechamiento máximo de los terrenos del $70 \%$ y un volumen máximo de $7 \mathrm{~m} 3$ por $\mathrm{m} 2$ de superficie de la parcela.

Se asegurarán la ventilación e iluminación de todos los locales y el aislamiento de oficinas y despachos.

Se seguirán las prescripciones del Reglamento de Seguridad e Higiene en el trabajo.

Art. 40.- El centro cívico será desarrollado en principio en su proyecto y ejecutado por el Excmo. Ayuntamiento y los terrenos necesarios expropiados. El Ayuntamiento podrá ceder la ejecución a los propietarios de los terrenos en primer lugar o a otras personas cuando su iniciativa sea aceptada y aprobada por el Ayuntamiento.

Valencia, 10 de abril de 1.964

EL ARQUITECTO MPAL. DE URBANISMO,

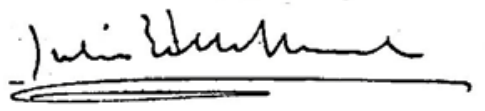




\section{UBICACIÓN Y TRANSPORTE}

Escala original $1: 2000$

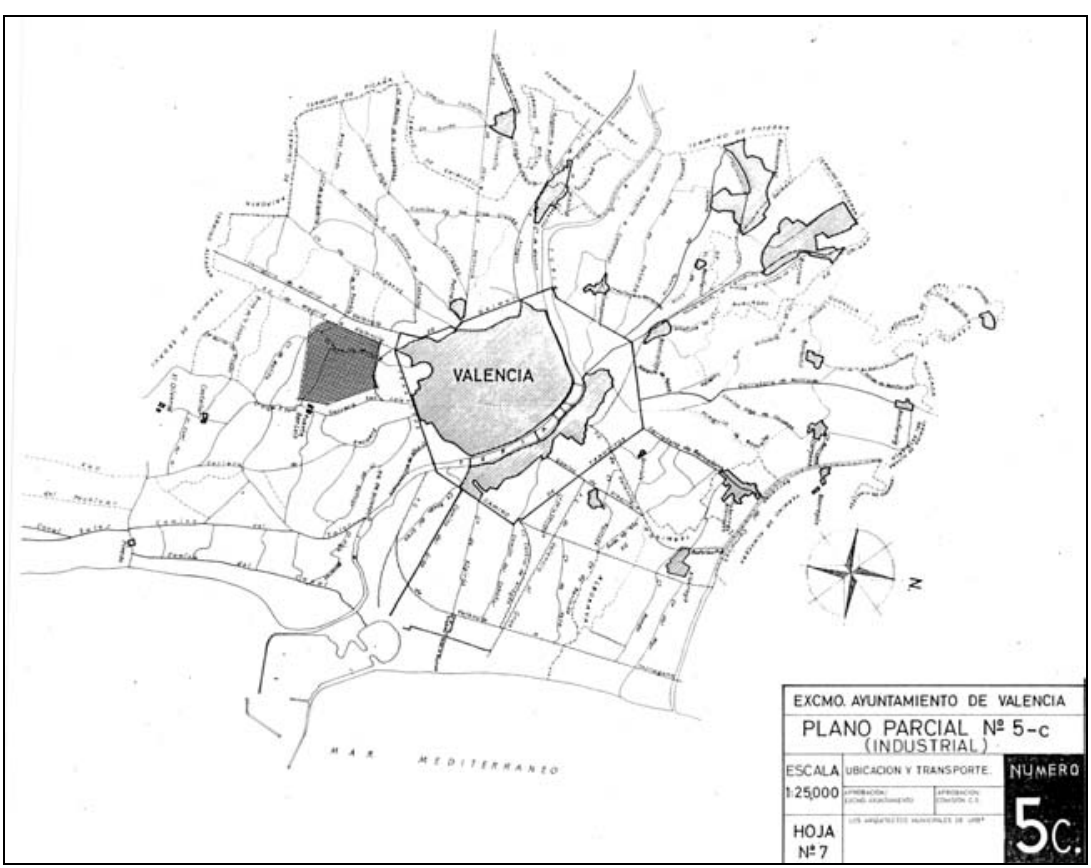

1. ESTADO ACTUAL

Escala original 1:2000

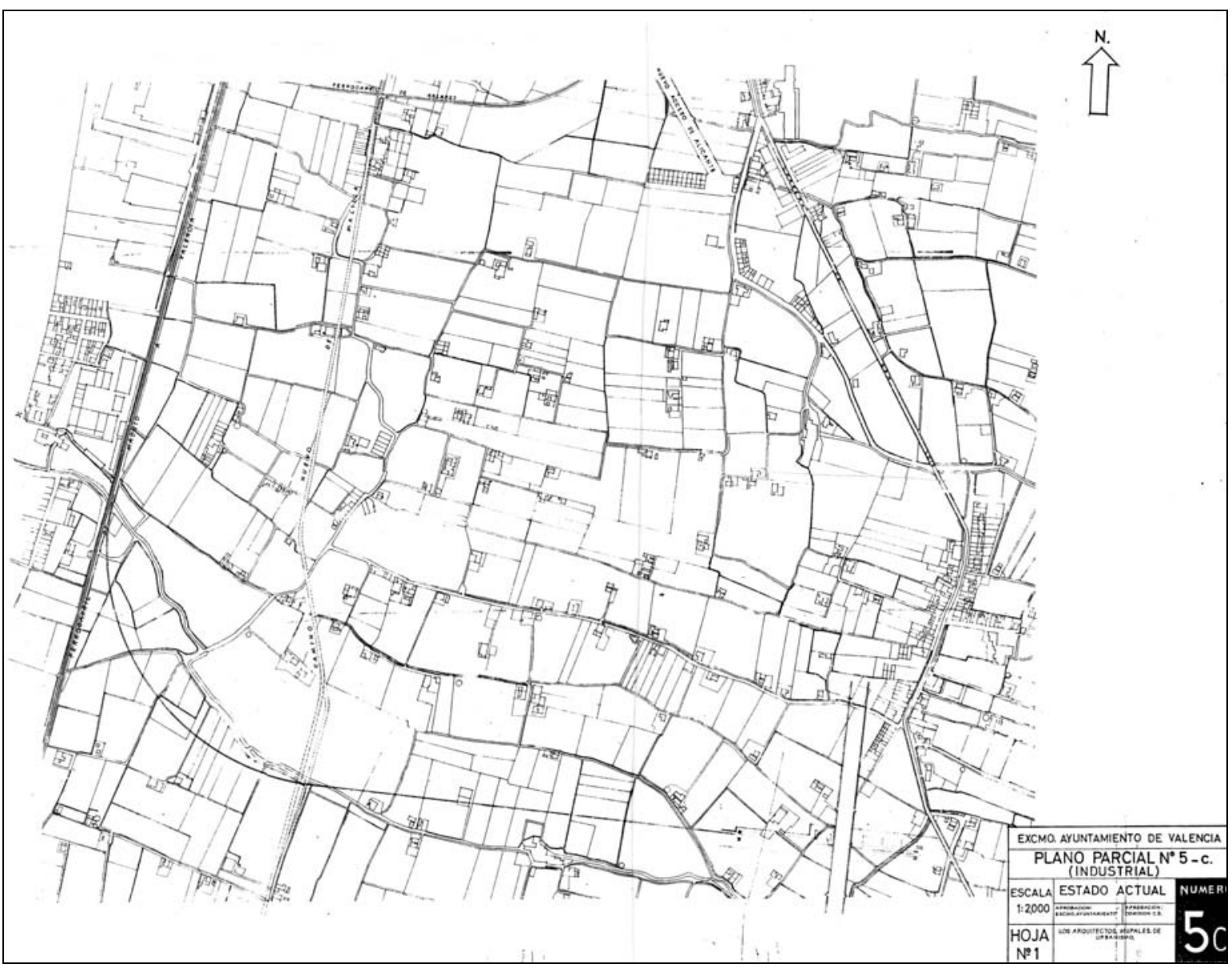


2. ALINEACIONES

Escala original 1:2000

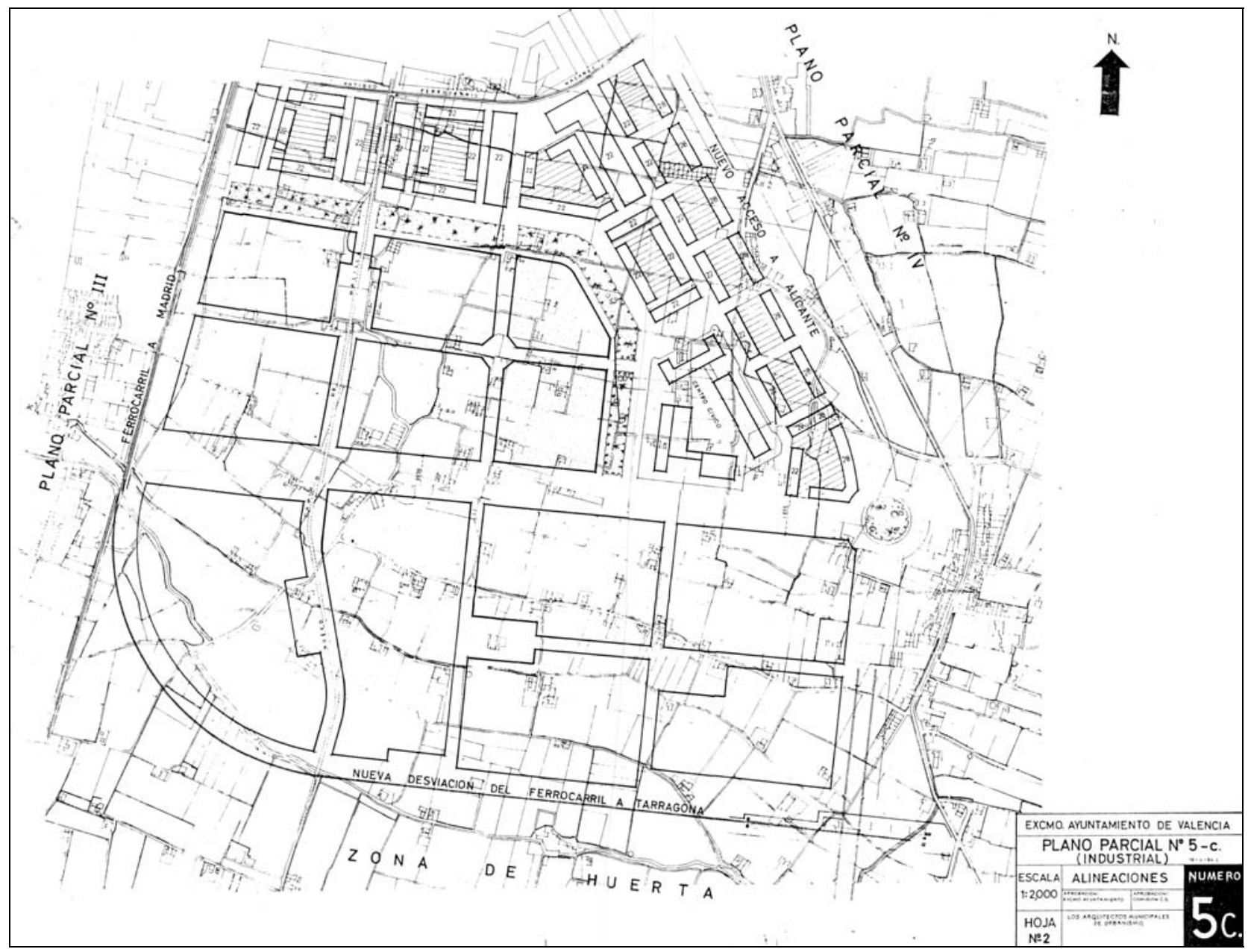


3. PLANEAMIENTO

Escala original 1:2000

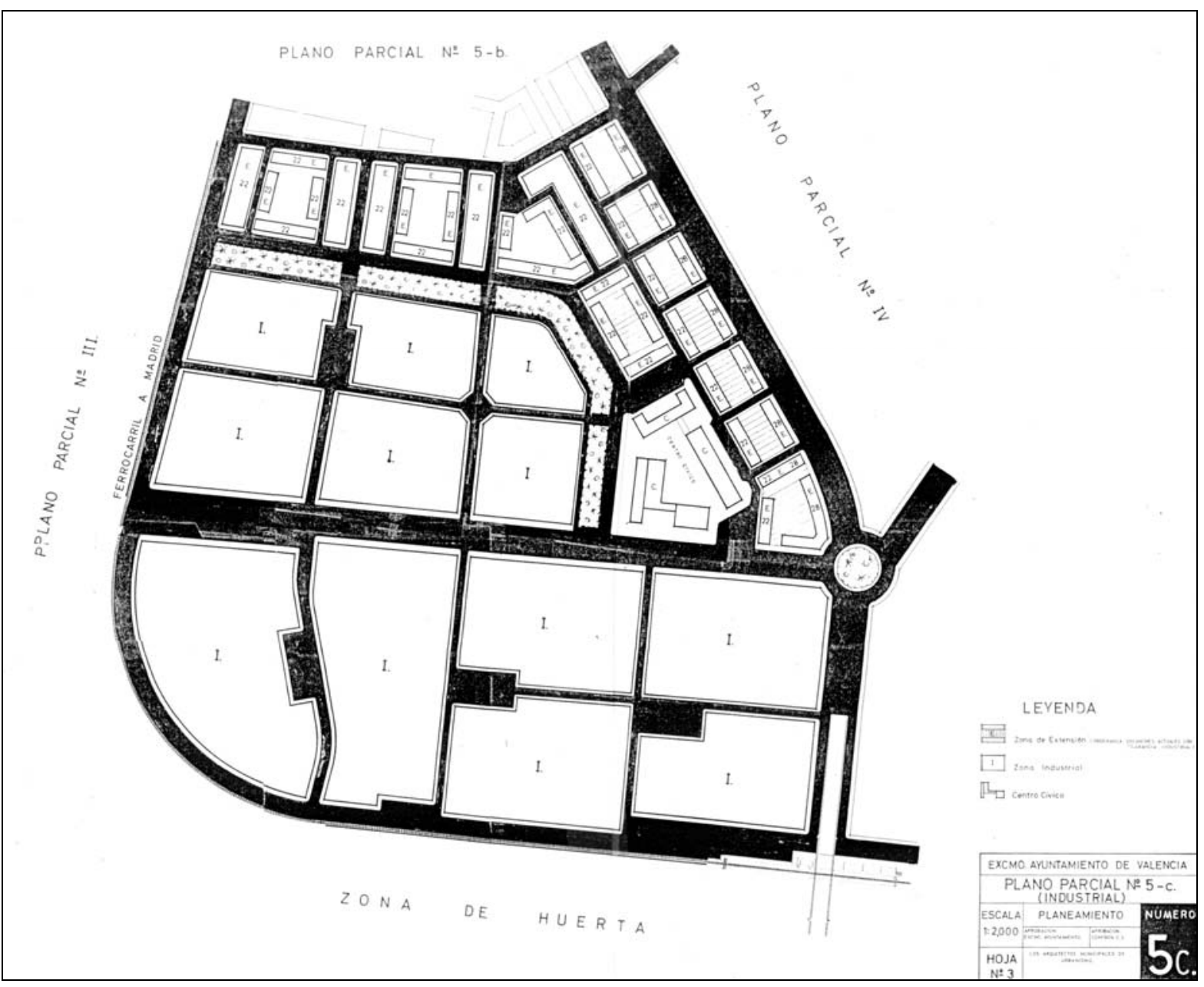



6. PLAN GENERAL DE ORDENACIÓN URBANA DE VALENCIA Y SU COMARCA ADAPTADO A LA SOLUCIÓN SUR, 1966 



\section{PGOU 66}

ADAPTACIÓN DEL PLAN GENERAL DE ORDENACIÓN URBANA

DE VALENCIA Y SU COMARCA A LA "SOLUCIÓN SUR".

1966

Redactores: CORPORACIÓN ADMINISTRATIVA GRAN VALENCIA. Arquitectos: Mauro Lleó, Víctor Bueso y Antonio Gómez llopis.

Fecha redacción: Noviembre de 1964.

Fecha aprobación: 30-06-1966.

Contenido:

I. MEMORIA

II. NORMAS URBANÍSTICAS **

III. PLANOS: *

1. PLANO TOPOGRAFICO

2. RED VIARIA

3. RED VIARIA ACTUAL Y FUTURA

4. ZONIFICACIÓN

5. ZONAS VERDES

6. PLAN DE ETAPAS

7. SERVICIOS URBANOS

8. RELACIÓN CON LA COMARCA

9. SERVICIOS URBANOS "ELECTRICIDAD"

10. SERVICIOS URBANOS "AGUAS POTABLES"

Fuente: Ayuntamiento de Valencia (Archivo de Planeamiento No 261).

Notas:

* Los planos no figuran en el expediente del Archivo de Planeamiento.

** Las Normas Urbanísicas fueron editadas por la Corporación Administrativa Gran Valencia y por el Colegio de Arquitectos de Valencia. 



\section{MEMORIA}

\section{$\underline{\text { ANTECEDENTES }}$}

Por acuerdo del Consejo de Ministros del 22 de julio de 1.958, para resolver los problemas planteados por las inundaciones del río Turia en valencia y su comarca, se estipula que:

a) "Se invita a las Direcciones Generales de los Ministerios de Obras Públicas, Agricultura y Vivienda, a que procedan a la formación de los Planes necesarios para adaptar sus actividades a las Bases conjuntas establecidas por el Plan aprobado" (solución Sur).

b) "Invitar a la Dirección General de Urbanismo para que revise el Plan de Ordenación urbana de valencia y su Comarca, adaptándolo a la solución aprobada con el auxilio de los Servicios de la Corporación Administrativa Gran Valencia y los técnicos de los diferentes departamentos que han intervenido en el estudio del Plan conjunto".

\section{CRITERIOS SEGUIDOS EN EL PLAN}

Nos encontramos con un Plan General relativamente reciente, ya que fue aprobado en el año 1.946, y que establecía una organización basada en una Red viaria, en una zonificación y en unas Ordenanzas. Y como organismo administrativo, que lo desarrolla al mismo tiempo que coordina en materia urbanística la labor de los Municipios de toda la Comarca, la Corporación Gran Valencia.

Muchos Proyectos Parciales, tanto de la ciudad como de los pueblos, y que desarrollan el Plan están aprobados. Por otro lado, el desvío del río Turia lleva consigo una modificación muy importante en la estructuración de la ciudad. Debemos, pues, conjugar todo lo aprovechable del Plan vigente hasta la fecha y que no se oponga a la "Solución Sur" con todas las posibilidades que ofrece el desvío del río.

La solución hidráulica aprobada permite la creación de una vía sensiblemente Este-Oeste que atraviesa la ciudad y que por sus características podrá ser de tráfico rápido. Esto es fundamental en este Plan de adaptación; es una posibilidad magnífica y que no estaba resuelta debidamente con anterioridad. El antiguo cauce, desde Cuart de Poblet hasta las proximidades de los Poblados Marítimos, se transformará en la vía mencionada, que por estar a cota inferior de las que la crucen, permitirá una fluidez de tráfico sin puntos de conflicto.

Por otro lado, la coordinación con la Oficina Regional de Proyectos de Carreteras, que ha estudiado el Plan de accesos y red viaria de carreteras y con los Ingenieros que han estudiado la red ferroviaria, ha dado el fruto de las soluciones propuestas en este Plan de Adaptación.

Los criterios seguidos en el Plan son los siguientes:

10.- Partir de un planteamiento general.

20.- Favorecer el desarrollo de núcleos urbanos en zona de secano. 
30.- Previsión de las áreas urbanas para una población de 2.500.000 habitantes.

40.- Limitación de la ciudad.

50.- Organización de áreas industriales en el grado preciso y conveniente en relación con las previsiones de un futuro de cuarente años.

60.- Destacar como vías importantes las situadas sobre el actual cauce, la circunvalación exterior y la marítima o de la costa.

70. - Establecimiento de una red viaria con una clara diferenciación en sus diversas importancias.

$8^{\circ}$.- Reducción de las zonas a establecer en relación con la simplificación de las Bases de Ordenanzas.

90.- Sistemas de espacios libres y parque públicos que permitan lo previsto en la Ley del Suelo.

100.- Establecimiento de un criterio unificador en los Poblados.

110.- Localización de centros representativos y comerciales para lograr el adecuado funcionamiento de la ciudad.

120.- Respetar en todo lo posible los Proyectos Parciales vigentes y Polígonos de ejecución.

Iremos explicando por orden cada uno de estos puntos.

PLANTEAMIENTO COMARCAL. - Es lógico que así sea. Ya que el Plan es comarcal; pero la Comarca que circunda a la ciudad tiene unas características muy peculiares y es de gran importancia. Son treinta los municipios que integran la Comarca y están muy próximos a la ciudad.

Estando situados la mayoría en la huerta, casi todos tienen un origen agrícola, pero con el tiempo, y motivado por su proximidad a la ciudad, han evolucionado muchos de ellos, siendo en la actualidad eminentemente industriales.

Los mejor comunicados, como son los del espolón de secano de Burjasot, Godella,y Rocafort y Moncada, se han ido transformando en residenciales de gentes que trabajan en la Ciudad. La importancia de estos pueblos representa doscientos veinte mil habitantes; la riqueza de la huerta y la realidad de la unidad que representa la comarca impone este planteamiento.

FAVORECER EL DESARROLLO DE NÚCLEOS URBANOS EN ZONA DE SECANO.- Este criterio es aconsejable por varios motivos: primero, porque son los mejor comunicados por medio de los ferrocarriles eléctricos suburbanos; segundo, por ser el suelo más económico; tercero, por ser los más sanos; y cuarto, por ser un medio de defensa de la huerta que abastece y hace necesario disponer de una extensión en hectáreas de 7600 que son las conseguidas en este estudio.

PREVISIÓN DE LAS AREAS URBANAS PARA UNA POBLACION DE UN MILLÓN NOVECIENTOS MIL HABITANTES: Se han hecho estudios para averiguar la densidad de población de Valencia y su Comarca; como datos fundamentales se han tomado los del año 1959:

Valencia:

Extensión

Población 1959

Pobla. Relat.

Alacuas:
Extensión

Población.

Población relat.
$1.319 \mathrm{Ha}$.

$559.000 \mathrm{Hab}$

$426 \mathrm{Hab} / \mathrm{Ha}$.

49,5 Ha.

6.011.- Hab.

$122 \mathrm{Hab} / \mathrm{Ha}$ 


\begin{tabular}{|c|c|c|}
\hline Catarroja: & 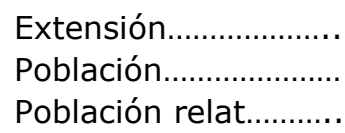 & $\begin{array}{l}\text { 55,9 Ha. } \\
\text { 12.552.- Hab. } \\
225 \mathrm{Hab} / \mathrm{Ha}\end{array}$ \\
\hline Alboraya: & 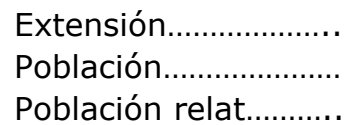 & $\begin{array}{l}\text { 16,5 Ha. } \\
7.419 .-\mathrm{Hab} . \\
450 \mathrm{Hab} / \mathrm{Ha}\end{array}$ \\
\hline
\end{tabular}

Siguiendo el mismo criterio de crecimiento que se tuvo en el Plan anterior, consideramos que la población, en el plazo de cuarenta años, ascenderá a un millón novecientos mil habitantes.

Hemos supuesto una densidad de doscientos cincuenta habitantes por hectárea, como promedio de todas las zonas residenciales de Valencia y su Comarca.

LIMITACION DE LA CIUDAD: Tiene la ventaja de posibilitar su organización y plan de etapas.

El casco se limita por el N. y por el N.O. por la circunvalación interior, por el S. y por el S.O. por el futuro cauce, y por el E. Por la carretera de la costa.

La comarca quedará limitada por la futura carretera que, partiendo por el S. entre Silla y Beniparrell, pasando entre Torrente y Alacuás, dejando al E. El aeropuerto y Manises, tomará la dirección de Puzol. Fuera de este límite, solamente quedarán tres apéndices: Torrente, la zona industrial del O. y La Cañada.

ORGANIZACIÓN DE ZONAS INDUSTRIALES EN EL RANGO PRECISO Y CONVENIENTE CON LAS PREVISIONES EN UN FUTURO DE CUARENTE AÑOS: La industrialización de la comarca de Valencia es un hecho que en los últimos años se ha caracterizado por su rápido crecimiento. La demanda de suelo apto para el montaje de estas industrias crea un problema que es preciso resolver cuanto antes.

Los estudios realizados sobre estas necesidades de zonas industriales y el interés de sus emplazamientos, nos han llevado a la conclusión de que se deben disponer de 2.100 hectáreas destinadas a este fin.

Partiendo de estos cálculos, se han creado cinco grandes zonas industriales. La primera, situada al N., entre Meliana y el actual ferrocarril de Tarragona, con una extensión de 174 hectáreas. La segunda prevista, limitada al N. por la vía que pasará por las proximidades de la Fuente de San Luís, al E. Por la carretera de la Costa, al S. por el futuro cruce en las proximidades de su desembocadura, y por el O. quedará limitada por el poblado de la Fuente de San Luís y el nuevo acceso de Alicante por Silla. Esta zona tendrá gran importancia por su proximidad al Puerto y será aumentada por la también grafiada en los planos y ubicada en los terrenos ganados al mar con las obras de ampliación del Puerto.

La anterior zona tendrá una extensión de 130 hectáreas.

La tercera, está situada al S., entre los pueblos de Masanasa y Catarroja, y el nuevo acceso de Alicante por Silla, ya en funcionamiento. Esta zona industrial tiene la gran ventaja de que puede ejecutarse en plazo inmediato, pues sus accesos son una realidad, y tiene la posibilidad de la futura carretera que comunicará con la de la Costa, facilitando extraordinariamente el acceso al Puerto. La extensión prevista es de 250 hectáreas.

La cuarta, se proyecta a caballo del actual acceso de Madrid y queda, como antes indicábamos, fuera de la circunvalación exterior. Es una realidad en los actuales momentos, pues son muchas las 
importantes industrias ubicadas en esta zona. El futuro acceso de Madrid, por el S.de La Cañada, y que entre Manises y Paterna accederá a la vía de trafico situada sobre el antiguo cauce, hace totalmente previsible la creación de esta cuarta zona industrial. Su extensión será de 450 hectáreas.

La quinta zona industrial está prevista entre Paterna y La Cañada. Tiene las ventajas de su acceso actual resuelto, aunque pobremente, y unos futuros magníficos: suelo económico, por ser totalmente secano, y facilidad de desagüe. En la actualidad, está en construcción un Polígono de la Gerencia de Urbanismo.

La extensión será de 130 hectáreas.

Además de estas cinco importantes zonas industriales, que podrán alojar toda clase de industrias pesadas, excepto las nocivas y peligrosas, se han previsto otras de menos importancia, algunas de ellas con las características de "especiales", por estar situadas próximas a accesos importantes y que hay que cuidar en su arquitectura y en su urbanización.

La extensión de todas estas zonas incluidas las cinco primeras, es de 966 hectáreas.

DESTACAR COMO VÍAS IMPORTANTES LAS SITUADAS SOBRE EL ACTUAL CAUCE, LA CIRCUNVALACIÓN EXTERIOR Y LA MARÍTIMA O DE LA COSTA; ESTABLECIMIENTO DE UNA RED VIARIA CON UNA CLARA DIFERENCIACIÓN EN SUS DIVERSAS IMPORTANCIAS: Unimos los puntos $6^{\circ}$ y 70 en esta exposición, al considerarlos totalmente ligados.

El establecimiento de una red viaria es fundamental en todo planeamiento urbano, y que ésta está diferenciada con relación a la importancia, es elemental.

Entre esta red viaria tenemos que destacar los accesos, que son las importantes carreteras que se transforman en vías urbanas de penetración. En este punto, la colaboración de la Oficina Regional de Proyectos de Carreteras ha sido de gran eficacia.

La vía que discurrirá por el antiguo cauce tendrá una importancia decisiva, permite una estructuración que anteriormente considerábamos imposible. Esta vía servirá de acceso de Madrid por el N.O. y de Alicante por el S.E. Su cota inferior permitirá una solución fácil de los cruces.

La de la Costa y la Circunvalación Exterior las consideramos fundamentales; una rápida ojeada a los planos de conjunto hace ver su gran importancia.

El acceso de Barcelona, que, partiendo de la carretera de la Costa, en el Barranco de Carraixet entra en diagonal a buscar la vía sobre el antiguo cauce y la Gran Vía del Marqués del Turia, es también otra vía de penetración urbana de grandísima importancia, que destacamos. Esta vía será un eje N.E.-S.O. al aprovechar las grandes vías de Marqués del Turia y Germanías, y la futura penetración por el Sur, que pasará por el O. de Catarroja, Masanasa y Benetuser, y, después de cruzar el futuro cauce en diagonal, se unirá a la penetración por la actual zona ferroviaria hasta el futuro centro situado entre las dos uniones de los Tránsitos actuales y grandes vías de Fernando el Católico y Germanías.

Otro acceso y eje importante será la continuación de Fernando el Católico (nuevo acceso de Ademuz), que unirá con el nuevo acceso de Alicante por Silla. La Avenida del Cid, actual acceso de Madrid, es otra de las importantes vías de penetración E.-O. que accederán hasta el futuro centro cívico y comercial. 
REDUCCIÓN DE LAS ZONAS A ESTABLECER EN RELACIÓN CON LA SIMPLIFICACIÓN DE LAS BASES DE ORDENANZAS:

Se establecen las siguientes zonas:

Zona interior.

" histórico-artística.

" comercial intensiva en el interior.

" de extensión.

" de edificación abierta.

" de núcleos periféricos.

" de tolerancia industrial.

" industrial.

$"$ industrial especial.

" ciudad jardín.

" deportivo-cultural.

" de huerta.

Han quedado suprimidas las zonas de ensanche, de transición de ensanche, de ensanches futuros y de núcleos periféricos.

Estas calificaciones se han unificado en las zonas de Extensión. Con ello, conseguimos una simplificación en las ordenanzas y en su aplicación.

Los accesos y las circunvalaciones constituirán en la periferia de la Ciudad una malla triangulada [que ha de ser rellenada] por nuevos proyectos parciales de desarrollo.

En el programa que esta Memoria describe se han fijado unas cuantas determinaciones en dichos nuevos proyectos parciales.

1.- Para la protección de accesos y nudos fundamentales se establecen zonas verdes de uso agrícola o parques públicos a lo largo de alguna de sus bandas. Se recomienda respetar estas zonas aunque a veces en una ligera mirada de los planes parezcan inoportunas.

Ha sido empeño llevar los accesos no interferidos lo más adentro posible.

2.- Las triangulaciones señaladas por la malla fundamental de accesos y circunvalaciones, constituyen verdaderas unidades vecinales. Interesa que se las organice lo más introvertidamente posible en beneficio de las circulaciones generales. Es decir, que debiera procurarse que la trama vial de dichos barrios afluya en contados lugares a las circulaciones perimetrales, pertenecientes a la malla fundamental. En lo posible las calles del barrio deben canalizar todas sus necesidades y solo acometerán a las circulaciones perimetrales para conectarse con otros barrios.

Esta disposición favorece al propio barrio, ya que elimina circulaciones de paso ajenas al mismo y permite establecer en su interior, sin derroche de espacios libres, remansos para el reposo, la educación y el comercio.

También sería conveniente que en la estructuración de la unidad vecinal así delimitada, se procurase establecer una estratificación de sus servicios comunales. Las zonas de reposo, enseñanza e Iglesias, podrían ocupar el corazón del mismo. El comercio, los mercados y talleres se ordenarían perimetralmente. El Comercio especialmente al emplazarse en la proximidad de los nudos de la malla fundamental, serían más rentables ya que podrían participar de la clientela de los próximos barrios.

Siempre que fuese posible interesaría envolver exteriormente los barrios con cinturas verdes que, a la par que les protege de las circulaciones rápidas marginales, marcarían claramente su sentido de unidad vecinal, borrando de la ciudad esa tendencia a convertirse en una mancha indefinida de construcciones. 
Por ser excesivamente onerosa la adquisición y conservación de dichas zonas verdes y parques, convendría transformarlos en áreas más rentables. Un parque puede servir de base para establecer enél tiendas, cines, mercados e incluso algún tipo de talleres, asentados en edificaciones muy sueltas y de poco volumen. A tales establecimientos suele convenir el uso de terrenos libres marginales.

3.- Se ha procurado categorizar los accesos y algunas áreas fundamentales mediante los denominados "Polígonos de edificación impuesta", entendiendo por tales, terrenos expropiados y proyectados como unidad de conjunto. Contendrán edificación de máxima categoría y casi siempre pueden servir de base para zonas comerciales.

Estos poligonos se encuentran: Terrenos de la Estación del Norte, terrenos de la Estación de Aragón, frente a la futura Estación Central, terrenos en el acceso de Ademuz y edificaciones en el cauce abandonado.

SISTEMAS DE ESPACIOS LIBRES Y PARQUE PÚBLICOS QUE PERMITAN LO PREVISTO EN LA LEY DEL SUELO.

Se han mantenido los espacios verdes que figuran en el Plan anterior y se proponen con este otros amplios que aislan las zonas industriales de las residenciales.

En los planos de zonificación, las zonas no afectadas por ninguna trama, son las destinadas a uso agrícola.

Los terrenos de huerta que permanecen en el uso rural, entre el perfil urbano futuro y el cauce desviado por el Sur y la carretera de circunvalación por el Norte, deben ser especialmente controlados, tanto en sus cultivos como en su edificación. Dicha huerta cultivada con esmero y saneada de construcciones, especialmente en la proximidad de los accesos, podrá servir de amable encuadre para una ciudad que como ésta es capital de una poderosa área agrícola.

En consecuencia de este propósito se tendrán en cuenta varios aspectos:

a) Uso agrícola. Puesto que no se trata de grandes extensiones de huerta, se puede controlar sin lesión de intereses el tipo de cultivo, especialmente en los terrenos colindantes con los accesos. Los campos de flores, los naranjos, el limonero, etc. Son otros tantos motivos de ornamentación a tener en cuenta.

b) En las bases de Ordenanzas se especifica el grado de utilización para vivienda que se debe permitir. Interesa solo que dichos terrenos de huerta próximos s la ciudad sean residenciados por sus colonos o braceros y en modo alguno por otro tipo de población. Con este fin deberán limitarse las licencias de construcción en torno a los actuales caseríos, al cupo estricto necesario para cubrir el incremento demográfico o la renovación de viejas viviendas.

c) Siguiendo las normas en vigor de tiempo atrás, debe continuarse la campaña para el adecentamiento externo de las casas de labor, especialmente las más próximas a los accesos. A este fin incluso podría encontrarse algún tipo de estímulo que acelerase este proceso en beneficio del paisaje. En la campiña colindante con la ciudad, se echa de menos el grupo arbolado (palmerales) que rompa con la monotonía de su enorme plana.

D) Por exigencias de las obras hidráulicas, carreteras o ferroviarias, habrán de expropiarse un buen número de casas de labor. En muchas ocasiones por aniquilarse totalmente los terrenos base de una economía doméstica, habrán de buscarse nuevas formas de vida para dichas familias. En otras, sólo será precisa la remoción de viviendas. Con este motivo, convendría replantear el tipo más con 
veniente de ubicación; ya como pequeña agrupación de viviendas con una dotación de servicios concentrada, y por tanto más económica, o bien como unidad laboral familiar aislada. Esta última modalidad es sin duda más conveniente al sistema de cultivos intensivos en pequeñas parcelas, propio de la Comarca. Sin embargo, es mucho más costos en su dotación de servicios. Por todo lo cual, solo parece apropiada para quienes explotan directamente sus fincas.

ESTABLECIMIENTO DE UN CRITERIO UNIFICADOR EN LOS POBLADOS. Son muchos los pueblos que, teniendo Municipio propio, están unidos entre sí y urbanísticamente no se los puede considerar independientes. Tales como Benetuser, Alfafar y Sedaví. Otro ejemplo es Burjasot, Godella y Benimamet (este último es municipio de Valencia), Rocafort y Masarrochos.

En los proyectos parciales, deberán estudiarse estos núcleos en conjunto, con un criterio de unidad urbana.

LOCALIZACIÓN DE CENTROS REPRESENTATIVOS Y COMERCIALES PARA LOGRAR EL ADECUADO FUNCIONAMIENTO DE LA CIUDAD.Valencia es una ciudad eminentemente "centrípeta"; la Plaza del Caudillo es el centro de esta atracción, los grandes comercios están en esta zona o en sus proximidades, los Bancos, el Ayuntamiento, el edificio de Correos y Telégrafos, la Telefónica, los bares más importantes, y, por último, las más importantes salas de espectáculos también están en esta zona. La red viaria que afluye a la misma es insuficiente y con todo ello la congestión en el actual centro de la ciudad es tan grande como intolerable.

Es propio de Valencia asumir dentro de su comarca de influencia un importante papel comercial. Las gentes de pueblos bastante distantes van a las tiendas y almacenes de la ciudad, como si se tratase de sus comercios locales. Por esta razón, el volumen comercial es muy superior al de las exigencias estrictamente urbanas. En la Ciudad existe -como antes hemos dicho- un área central con carácter más señaladamente comercial; pero en el resto de la misma, esta función se encuentra dispersa y con escasa categoría.

En el Plan de Adaptación se prevén tres tipos de centros comerciales distribuidos de la siguiente forma: un centro comarcal que se sitúa en el gran centro cívico situado entre las uniones de las dos Grandes Vías y los Tránsitos. Por este centro, el paso del acceso Sur será subterráneo. La unión de los dos Tránsitos será elevada; este paso elevado será una de las primeras obras a ejecutar, pues resolverá de una manera eficiente el tráfico actual y el futuro desarrollo del centro cívico. Este complejo comercial se extenderá por los terrenos de la actual Estación hasta la calle de Játiva.

El segundo tipo de centro comercial será el de distrito y se han previsto siete. Uno, situado frente a la futura Estación. Estos terrenos hoy se encuentran libres y por tanto sería ocasión de actuar sobre ellos con rapidez ya que su urbanización y puesta en mercado por la iniciativa municipal o estatal permitiría obtener pingües ingresos con que financiar el ramal de salida hacia las playas del Saler, altamente necesario para la Ciudad y para la mayor vitalización de esta zona. Con la construcción de la Estación Central en el cauce del río, cobrará plena significación el uso de la zona. Este polígono de "edificación impuesta" podrá contener un cierto volumen comercial, recreativo, hotelero y residencias de categoría.

El segundo, situado en el acceso de Ademuz, desempeñará un cometido análogo respecto a todos del Noroeste y Oeste, y a la vez podrá atraer la demanda comercial de parte de la población urbana 
situada en la margen izquierda del río. Para hacer posible todo este programa a largo o medio plazo, convendrá que el Municipio congele las licencias en todos los terrenos comprometidos por el plan comercial, que, como ya se dijo, se asienta siempre sobre "'olígonos de edificación impuesta""

El tercero se sitúa en el Polígono de la Gerencia "Avenida de Castilla".

El cuarto, en el Distrito marítimo, en la unión del Paseo de Valencia al mar con la carretera de la Costa.

Los tres últimos centros de distrito se sitúan en los núcleos de poblados más importantes, tales como Burjasot, Benimamet, GodeIla y Rocafort, por un lado; Torrente, Alacuas y Aldaya, por otro; y por último, los situados al Sur, con Catarroja, Masanasa y Alfafar.

Por último, los centros de barrio, que serán diecisiete, situados en los lugares más convenientes.

Además de los centros comerciales, existen seis centros representativos que hay que destacar, tales como el Histórico-artístico, la Ciudad Universitaria, la Feria Muestrario, el Puerto, el Aeropuerto y, por último, el centro turístico de la Albufera.

Los planos que forman parte del presente Plan de Adaptación son los siguientes:

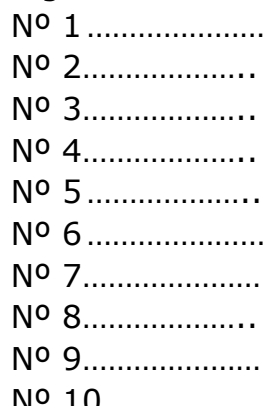

PLANO TOPOGRAFICO
RED VIARIA
RED VIARIA ACTUAL Y FUTURA
ZONIFICACION
ZONAS VERDES
PLAN DE ETAPAS
SERVICIOS URBANOS
RELACION CON LA COMARCA
SERVICIOS URBANOS "ELECTRICIDAD".
SERVICIOS URBANOS "AGUAS POTABLES".

Plano topográfico: Nos hemos basado en el Plano Topográfico a escala 1:10.000, levantado por los Servicios Cartográficos del Ejército. Hemos elegido este plano topográfico por ser de levantamiento reciente y por la escala, muy adecuada para este planeamiento comarcal.

Red viaria: Se ha estudiado asimismo a escala 1:10.000. El estudio se ha hecho con una visión no solo de la Comarca, sino teniendo muy en cuenta la relación de esta en lo que respecta a tráfico con toda la región $y$, en definitiva, con todos los accesos. Los criterios seguidos se han expresado con detalle en párrafos anteriores.

El único Plano que no es de la escala ya mencionada es el número 8 de relación con la Comarca, que por la extensión que abarca se ha redactado a 1:25.000.

Los documentos que forman este Plan de Adaptación so los siguientes: I, Memoria; II, Bases de Ordenanzas; III, Estudios económicos; IV, Planos.

Valencia, noviembre de 1.964.

LOS ARQUITECTOS,
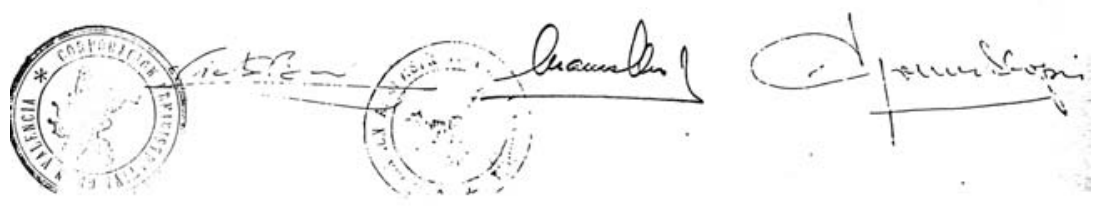


\section{PLAN DE ORDENACIÓN DE VALENCIA Y SU COMARCA} ADAPTADO A LA "SOLUCION SUR"

\section{NORMAS URBANISTICAS}

\section{ZONIFICACION}

El Plan General de Valencia y su Comarca, que ahora se adapta a la Solución Sur, contaba, entre los elementos que lo integran, con las bases de Ordenanzas para regulación de la edificación, necesarias para que el desarrollo del mismo condujera a los fines que el Plan proponía.

Se pasaba en aquel momento de su redacción, en virtud de dicho Plan, de una edificación anárquica en cuanto a zonificación se refiere, a una edificación zonificada con establecimiento, principalmente, de zonas industriales y distintos tipos de residenciales.

Aquellas Bases de Ordenanzas fueron desarrolladas por los Ayuntamientos que integran la Comarca y por la Corporación Administrativa Gran Valencia, de tal manera que hoy nos encontramos con prescripciones pensadas para regular y armonizar la edificación en Valencia y su Comarca y con una experiencia de aplicación.

El Plan General establece la diferenciación adecuada en zonas, para alcanzar los fines siguientes:

$1^{\circ}$. Conseguir una ciudad ordenada en su conjunto y en sus detalles que funcione orgánicamente.

$2^{\circ}$. Lograr la densidad de población adecuada al carácter de los diferentes barrios.

30. Defender el carácter del sector urbano histórico artístico-

40. Regular debidamente los usos y régimen del suelo.

50. Lograr una organización adecuada en Distritos y Barrios, señalando en cada uno el carácter de la edificación predominante y fijando el emplazamiento adecuado para los edificios públicos.

A estos efectos se establecen en Valencia las siguientes zonas:

ZONA DE EDIFICACIÓN INTENSIVA: Comprende las zonas en las que se sigue un criterio tradicional de edificación en las que los diferentes edificios tienen medianeras comunes, están unidos formando manzanas cerradas, con o sin patio de manzana. Esta zona se dividirá en los diferentes sectores que a continuación se detalla:
A) Histórico Artístico.
B) Interior hasta la primera Ronda.
C) Ensanche hasta Tránsitos.
D) Extensión exterior a Tránsitos
E) Núcleos periféricos.

ZONA DE EDIFICACIÓN ABIERTA: Son aquellas zonas en que se prodiga la edificación en disposición, de bloques aislados de doble, triple o de cinco crujías (en este caso se establecen patios interiores) dando lugar a espacios abiertos o ajardinados, a comercios u otros usos complementarios.

Se establecen dos grados:

A) Coeficiente de edificabilidad $=3^{\prime} 5 \mathrm{~m} 3 / \mathrm{m} 2$.

B) Coeficiente de edificabilidad $=5 \mathrm{~m} 3 / \mathrm{m} 2$.

ZONA DE CIUDAD JARDÍN: Destinadas a viviendas unifami 
liares, generalmente rodeadas de jardín. También se esta-blecen dos grados:

A) Coeficiente de edificabilidad $=1^{\prime} 50 \mathrm{~m} 3 / \mathrm{m} 2$.

B) Coeficiente de edificabilidad $=1^{\prime} 00 \mathrm{~m} 3 / \mathrm{m} 2$.

ZONAS INDUSTRIALES: En las que se permiten el establecimiento de industrias, quedando excluidas las viviendas. Se establecen tres grados:

A) Normal. Coeficiente de edificabilidad $=8 \mathrm{~m} 3 / \mathrm{m} 2$.

B) Especial. Coeficiente de edificabilidad $=6 \mathrm{~m} 3 / \mathrm{m} 2$.

C) Dispersa. Coeficiente de edificabilidad $=3 \mathrm{~m} 3 / \mathrm{m} 2$.

ZONA DE TOLERANCIA INDUSTRIAL: En las que cabe .la compatibilidad de ciertas industrias y viviendas según se determine en los Planes Parciales.

ZONAS ESPECIALES: Son aquellas que deban reunir condiciones especiales en cuanto a su edificación, en uso y volumen y que deben ser reguladas previo Proyectos singulares, como por ejemplo: Comerciales, Sanitarias, Militares, Turísticas y Deportivo-Culturales.

ZONAS VERDES: Comprende los parques públicos y privados.

ZONAS DE HUERTA: Son aquellas que su uso será exclusivamente agrícola, que por dominar en la comarca la huerta. Se denominarán por tradición como huerta aunque estarán incluidas en esta zona los secanos.

ZONA DE RESERVA: Son aquellas zonas que por sus condiciones actuales no se considera conveniente zonificar, pero susceptibles de transformar en zona urbana aprovechable.

\section{USO Y APROVECHAMIENTO DEL SUELO}

NORMA 1a.- La altura de los edificios, los patios, tanto interiores como de manzana y los voladizos son los factores que proporcionan el volumen. Las limitaciones quedarán reguladas por el cuadro que forma parte de estas normas.

En las zonas de edificación intensiva y en las de tolerancia industrial quedan reguladas la altura, los patios y los voladizos, en relación con el ancho de la calle y se establece como diferencia para los distintos sectores, la altura máxima o techo.

Los núcleos periféricos tendrán normas diferentes.

Sobre la altura permitida solo podrá construirse la caja de la escalera, cuarto de máquinas de los aparatos elevadores, cuarto de contadores, depósito de agua y vivienda del portero con un máximo de sesenta metros cuadrados.

NORMA 2a.- En los patios interiores, se seguirá el criterio de que en los mismos se puede inscribir un círculo que tenga como mínimo un diámetro de un sexto de la altura del patio y la superficie del patio expresada en metros cuadrados será igual o mayor a la altura del mismo expresada en metros lineales.

Se permitirá la construcción de patios mancomunados, previo acuerdo entre propietarios colindantes, cumpliendo las dimensiones señaladas en el párrafo anterior.

Los patios de manzana deberán quedar grafiados y acotados en los Proyectos Parciales. 
NORMA 3a.- En los voladizos en fachadas se distingue el voladizo en disposición de balcón o terraza y el cerrado en disposición de mirador. (1)

A efectos de regulación de salientes máximos se estará a lo dispuesto en el cuadro.

En el caso de voladizos tratados en forma cerrada se permitirá una ocupación máxima del cincuenta por cien de la superficie del voladizo, pudiendo desarrollarse este voladizo en toda la longitud de fachada.

Los voladizos en patio de manzana se tratarán en forma de galerías abiertas y su vuelo máximo permitido será función del diámetro del círculo inscribible en el patio de manzana con arreglo a la siguiente escala:

Diámetro del círculo

Igual o mayor de 50 metros ... ... 2,00 metros.

$\begin{array}{ccccccc}" & " & 40 & & \ldots & \ldots & 1,60\end{array}$

NORMA 4a.- Los garajes y talleres serán regulados como consecuencia de su situación, bien bajo edificación en patio de manzana o autónomos, estableciéndose como consecuencia la superficie a autorizar y potencia en máquinas.

Las condiciones serán más rígidas para la zona interior y edificación abierta, y más tolerante en zonas de ensanche y extensión.

NORMA 5a.- En las calles que son límite de zona deben tener las mismas alturas ambos paramentos aunque correspondan a distintas zonas, aplicándose la que determine mayores alturas.

SECTOR HISTÓRICO ARTÍSTICO: Comprende la zona señalada en Ios planos.

NORMA 6a.- Las edificaciones tendrán un carácter exclusivamente residencial y exenta totalmente de industrias y talleres, permitiéndose únicamente actividades artesanas.

NORMA 7a.- Las condiciones de composición de fachada a que puede obligarse en las construcciones, son las siguientes:

A) Establecer voladizos únicamente a base de balcones o rejas, continuando la tradición de los tipos más característicos.

B) Tratamiento tradicional de todos los elementos decorativos (molduración, cerrajería, .carpintería, revocos).

C) Se atenderán las disposiciones de la Dirección General de Bellas Artes.

NORMA 8a.- Toda solicitud de licencia de obra. bien sea de nueva planta, reforma o demolición se obliga previamente a una consulta a efectos de que por el Excmo. Ayuntamiento se determinen las condiciones de uso, volumen y características de composición, ya que deberán sujetarse a la preocupación fundamental de lograr la armonía con los edificios existentes y servir de marco a los que tengan carácter histórico o monumental.

La contestación que reciba el solicitante seré puramente informativa, no crea derechos que vulneren estas normas, ni supone concesión de licencia.
(1) La Norma $3 a$ fue modificada como consecuencia de una reclamación presentada por la Cámara Oficial de la Propiedad Urbana de Valencia, quedando redactada en los términos siguientes:

"SEGUNDA.-En cuanto a la Norma 3, que se refiere a los voladizos de fachada, se estiman correctos los que figuran en las diversas categorías, pero deben diferenciarse concretamente dos extremos: Primero, que cuando sean estrictamente balcones, pueden autorizarse en toda la longitud de fachada, salvo las prescripciones legales de separación de los predios colindantes. Segundo, en cuanto a los denominados miradores, o sea, voladizos cerrados con obra de fábrica, sólo deberán autorizarse los fijados en las Ordenanzas a voluntad del constructor, reduciendo su vuelo, pero nunca autorizándose la construcción de los mismos en todo el largo de la fachada, siempre que la superficie de ellos no excediera de la autorización máxima citada al 50 por 100 de fachada, ya que de no ser así conduciría al renacimiento de las fachadas cajón, que en tan elevado número ocupan el ensanche de la ciudad, construidas cuando se autorizaba la realización de miradores en toda la longitud de la fachada y que con tan buen criterio quedó suprimida por las Ordenanzas actuales". 
SECTOR INTERIOR HASTA PRIMERA RONDA.- Es el delimitado por las calles de Colón, Játiva, Guillen de Castro. orilla derecha del rio, plaza de Tetuán. General Palanca y plaza del Marqués de Estella, a excepción del sector histórico-artístico.

NORMA 9a.- A los efectos de volumen, el máximo de altura será de veintiún metros.

NORMA 10a.- En los casos en que se considere oportuno, previo estudio especial, se obligará a mantener o crear patio común mancomunado, a efectos de lograr unas mejores condiciones sanitarias. Serán incluidos en el Plan Parcial correspondiente.

Cuando el destino de las plantas sea exclusivamente comercial, se permitirá cubrir los patios a la altura de las referidas plantas, siempre que se aseguren las condiciones de iluminación y ventilación directa de todos los locales.

NORMA $11^{a}$.- Se permitirá, a propuesta de particulares, calles con este carácter y con un ancho mínimo de ocho metros si se trata de vías descubiertas y de cuatro metros cuando se trate de pasajes cubiertos comerciales.

SECTOR ENSANCHE HASTA TRÁNSITOS.-Es el sector delimitado por la primera Ronda y los Caminos de Tránsitos actuales.

NORMA 12a.- A los efectos de volumen, el máximo de altura será de veintisiete metros.

NORMA 13a.- Las alineaciones de patios de manzana quedarán grafiadas en los Planes Parciales, pudiendo ser utilizados éstos, hasta una altura de ocho metros, para edificaciones con usos compatibles con el carácter residencial de la zona y asegurando en todo momento las condiciones exigibles de iluminación y ventilación de todos los locales.

\section{SECTOR EXTERIOR A TRÁNSITOS}

NORMA 14a.- Este sector obedecerá a las mismas características del anterior, con la única diferencia de que el techo máximo no rebase los 23.50 metros.

SECTOR NÚCLEOS PERIFÉRICOS.-Son éstos los grafiados en los planos de esta adaptación a la solución Sur, y que corresponden en su mayoría a los actuales Poblados de la Comarca.

NORMA 15a.- La regulación del volumen se rige por una escala de alturas más restrictivas y el techo será de dieciocho metros. Sólo se permitirán alturas mayores de dieciocho metros en aquellos sectores que. formando unidades completas, se traten aplicando los conceptos de la edificación abierta, y limitando los metros cúbicos por metro cuadrado y regulando las separaciones entre bloques bajo las normas correspondientes, que en todo caso serán previamente aprobadas.

\section{ZONA DE EDIFICACIÓN ABIERTA}

NORMA 16a.- Comprenden aquellas zonas de carácter totalmente residencial y que por ser aptas para este tipo de edificación, 
se han grafiado en los planos. Se distinguen dos grados, A y B, según el coeficiente de edificabilidad sea de $3.50 \mathrm{~m} 3 / \mathrm{m} 2$ ó $5 \mathrm{~m} 3 / \mathrm{m} 2$ respectivamente.

Los espacios envolventes serán ajardinados, salvo en los casos en que se permita la unión de dos o más bloques por construcciones de una planta, con el fin de ubicar talleres de artesanía, aparcamientos cubiertos o garajes, comercios u otros usos permitidos. Todos estos casos deberán quedar grafiados en los Proyectos Parciales.

NORMA 17a.- La altura de la edificación será función del espacio entre bloques paralelos, siendo la altura máxima igual a la separación. Sobre la altura permitida sólo se consentirá la caja de escalera, ascensores, cuadro de contadores y vivienda del portero, siempre que puedan retranquearse tres metros como mínimo de los paramentos de la fachada.

Se podrán establecer voladizos, con saliente máximo de 1,30 metros, pudiendo partir desde el propio suelo las fachadas que recaigan a jardín privado.

NORMA 18a.- En los casos de bloques de cinco crujías, los patios interiores deberán permitir la inscripción de un círculo de diámetro mínimo del cuarto de la altura del mencionado patio.

\section{ZONA DE CIUDAD JARDÍN}

NORMA 19a.- Son las zonas señaladas en el plano como tales, destinadas -a viviendas unifamiliares y rodeadas, en todo o en parte, del jardín situado entre los lindes de la parcela. Su carácter es exclusivamente residencial, no permitiéndose más usos que el dicho y actividades artesanas.

La característica general es la separación del edificio de la linea de fachada por una distancia mínima de cuatro metros. Las edificaciones pueden ser en fila, pareadas o aisladas, pero coincidiendo las medianeras por acuerdo entre propietarios para no quedar al descubierto.

NORMA 20a.- Se establecerán dos grados: El primero con un aprovechamiento de $1,50 \mathrm{~m} 3 / \mathrm{m} 2$ y el segundo con $1 \mathrm{~m} 3 / \mathrm{m} 2$.

En las zonas de Ciudad Jardín de grado segundo sólo se podrán construir viviendas aisladas; las de grado primero se podrá construir en todas las formas descritas.

\section{ZONA INDUSTRIAL}

NORMA $21^{a}$.- Son las marcadas en los planos y se distinguen tres grados:

A) Normal.

B) Especial

C) Dispersa:

NORMA 22a.- En las zonas de Industria Normal, podrá instalarse toda clase de Industrias excepto aquellas que por su calificación deban de estar aisladas. Se autoriza un aprovechamiento máximo de los terrenos del setenta por ciento y un volumen máximo de ocho metros cúbicos por metro cuadrado de la superficie de la parcela. Se asegurarán la ventilación e iluminación de todos los locales. 
NORMA 23a.- Son zonas de Industria Especial las que se crean junto a accesos importantes, situación por la que algunas industrias sienten atracción por las facilidades de comunicación y a efectos de propaganda. La característica principal ha de ser la dignidad y excelencia de sus jardines y edificios. El coeficiente de edificabilidad será de $6 \mathrm{~m} 3 / \mathrm{m} 2$ de la superficie de la parcela. No podrán instalarse industrias peligrosas, nocivas ni insalubres.

NORMA 24a.- Son zonas de Industrias Dispersa aquellas en las que autorizándose la instalación de industrias no se considera conveniente que el índice de edificabilidad sea elevado. En estos casos cada fábrica o factoría se resolverá su acceso y urbanización, no haciéndose preciso una alineación determinada. El índice será de $3 \mathrm{~m} 3 / \mathrm{m} 2$ de parcela.

NORMA 25a.- En las zonas de Tolerancia Industrial se permitirá la industria en las plantas bajas, pudiendo edificarse viviendas en los pisos del edificio a fachada. La industria que se permita deberé tener características que la hagan compatible con las viviendas. Se tendrá en cuenta el Reglamento vigente sobre la clasificación do industrias. La parte de edificación para viviendas se hará con las condiciones prescritas para zona de Extensión o Periférica, según esté enclavado en un conjunto u otro.

\section{ZONAS ESPECIALES}

NORMA 26a.- Se entiende por tales todas aquellas .que en !a Ciudad o en la Comarca deban obedecer a criterios especiales de orden estético o funcional. Son éstas: La Ciudad Universitaria, las márgenes actuales del río Turia a su paso por la Ciudad. Centros comerciales, tanto sea el Comarcal, de Distrito o de Barrio, todas las plazas que estarán o serán presididas por edificios públicos de carácter religioso, administrativo o cultural.

Todas estas zonas deberán ser objeto de Planes especiales, disponiendo los volúmenes, regulando los usos y la composición, de acuerdo con las tendencias actuales, salvo en las plazas del sector Histórico-Artístico, donde se establecerán normas tradicionales.

NORMA 27a.- Los sectores Turísticos afectan principalmente a las costas, y requieren proyectos especiales que los regulen en los volúmenes, usos y composición, estableciendo principalmente vías de acceso, áreas de aparcamiento, zonas deportivas, edificios singulares, conservación de arbolado y criterio para nuevo arbolado y jardinería.

NORMA 28a.- Las zonas Deportivo-Culturales son las destinadas a conseguir espacios de muy pequeña densidad de edificación, ajardinadas, y en donde únicamente pueden establecerse construcciones con fines culturales o de enseñanza, e instalaciones deportivas. El aprovechamiento o índice de edificabilldad de estas zonas no sobrepasará la $1 \mathrm{~m} 3 / \mathrm{m} 2$.

\section{ZONA DE HUERTA}

NORMA 29a.- La Huerta de Valencia, en general, requiere una protección paisajística que debe reflejarse en el volumen máximo permisible y en el referido volumen que obedezca a unas caracte 
rísticas de construcción tradicional. El volumen se ajustará a lo que la Ley del Suelo determina para zonas rústicas, o sea un aprovechamiento de un metro cúbico por cada cinco metros cuadrados. Con este volumen podrá edificarse con un máximo de dos plantas, con destino a vivienda, almacén o uso complementario, al servicio exclusivo de la explotación agrícola. Toda edificación será aislada. con separación mínima de diez metros de los limites de la parcela, sin dar lugar a medianeras y siguiendo el modelo de las construcciones tradicionales. Sería muy aconsejable volver a desarrollar tipo de construcción barraca, aunque fuera con materiales incombustibles.

Las zonas de huerta influidas por accesos principales y secundarios de acuerdo con el Plan establecido por Obras Públicas, cumplirán las siguientes normas:

a) El aprovechamiento de terreno no será superior a un metro cúbico por cada cinco metros cuadrados, dentro de cada parcela, en forma aislada y con separaciones mínimas de los linderos de diez metros.

b) Su uso será exclusivamente agrícola, para vivienda al servicio de la explotación agrícola u otros usos que requiera la referida explotación.

c) Las edificaciones serán hasta de dos plantas, con una altura máxima de ocho metros, con ambiente tradicional en su arquitectura, prodigándose los tonos blancos, y los tejados cuando los haya de teja curva o siguiendo la tradición de la antigua barraca valenciana.

No se admite ninguna edificación en las zonas de influencia de las vías principales o secundarias, a contar desde el eje de las mismas, a distancias menores de cincuenta metros.

Las industrias que por sus características no puedan ubicarse en otras zonas, podrán hacerlo en la zona agrícola. pero con distancia mínima de cualquier edificación al límite de la parcela de quince metros, y cumpliendo todo lo dispuesto en las disposiciones vigentes.

NORMA 30a.- En las plazas, como norma general, la altura de la edificación será la que corresponde a la calle de mayor ancho que en ella desemboque, salvo en aquellas plazas que por estar enclavadas en sector Histórico-Artístico o ser presididas por un edificio público de carácter religioso, administrativo o cultural, se acuerde una norma de coronación inferior. En las plazas que con el carácter de centro comercial o cívico deberán desarrollarse en los futuros Proyectos Parciales, se estudiará una disposición de volúmenes y alineación en plantas que traducidas en maquetas serán preceptivas.

\section{ZONAS VERDES}

NORMA 31a.- Los parques y zonas verdes pueden tener carácter publico o privado.

En las de carácter público, aparte de fijar el criterio conveniente para la jardinería y paseos públicos, se podrá interpolar edificaciones con destino a restaurantes, bares y teatros al aire libre, zonas deportivas y en general construcciones de tipo recreativo, compatibles con el destino de uso público del Parque. El volumen máximo de las edificaciones a desarrollar no sobrepasará un metro cúbico por cada cinco metros cuadrados. 


\section{PLANES PARCIALES}

NORMA 32a.- En la redacción de Proyectos Parciales se atenderá a las siguientes normas:

a) Un Plan Parcial comprenderá, siempre que sea posible, una extensión superior a cincuenta hectáreas y deberá quedar claramente delimitado por vías principales previstas en el Plan General.

b) Sera preciso, previamente a la redacción del mismo, determinar las necesidades de servicios sociales, principalmente religiosos y culturales, de acuerdo con las directrices establecidas por el Arzobispado y por el Ministerio de Educación Nacional.

c) Además de las referidas necesidades es obligada la reserva dentro del mismo de un diez por ciento de la superficie total para espacios públicos destinados a parques o deportes.

d) Se proveerá igualmente las necesidades comerciales, que normalmente deberá concentrarse en puntos determinados para crear centros comerciales.

Previsto el anterior programa ss procederá al desarrollo viario, siguiendo las directrices del Plan General en cuanto a vias principales y secundarias.

Las vías principales se clasificarán en tres categorías:

a) Trafico rapidísimo.

b) Tráfico rápido

c) Tráfico normal.

En las primeras, que normalmente dispondrán de calzadas laterales complementarias de la principal, no se podrán establecer calles secundarias en relación con ella a distancias menores de 300 $\mathrm{m}$.

En las segundas esta separación podrá reducirse a 200 m, y en las terceras a $100 \mathrm{~m}$.

Dentro del Polígono se establecerá claramente una red viaria al servicio del mismo, que diferencia las calles principales de las secundarias, considerando estas últimas con la única finalidad de acceder a las edificaciones previstas, pudiendo ser en algunos casos en fondo de saco.

Como complemento de la red viaria de tráfico rodado será conveniente establecer, cuando las circunstancias lo permitan, una red peatonal que permita el fácil acceso a las zonas escolares, centro comercial, e igualmente desarrollar vías comerciales sin circulación rodada más que en caso de emergencia.

NORMA 33a.- Será obligatorio el prever áreas de aparcamiento de vehículos, con arreglo a las siguientes normas:

Cuando se trate de barriadas de mayor categoría, considerar la existencia de un vehículo por cada tres familias. y en las barriadas modestas un vehículo por cada cinco familias. Cada vehículo obligará a una reserva de un área de aparcamiento de veinte metros cuadrados.

Se deberá reservar el quince por ciento de la superficie construida en edificios destinados a uso público. excepto los aparcamientos previstos para salas de espectáculos que deberá tener la capacidad de un vehículo por cada cincuenta espectadores.

NORMA 34a.- Cuando se trate de Planes Parciales dentro del concepto de edificaciones abiertas, se procurará lograr agrupaciones de bloques con carácter abierto o semiabierto, dentro de la máxima variedad, para evitar la monotonía que implica la repetición de tipos normalizados en disposición paralela, de forma que el recorrido a 
través de las calles provoque composiciones agradables y se evite en lo posible la visibilidad desde las mismas de las fachadas secundarias donde establecen los servicios de las viviendas.

Se determinará en forma clara los espacios libres entre bloques que forzosamente deben ser ajardinados.

NORMA 35a.- Los centros comerciales a establecer en los Planes Parciales serán de dos categorías.

La primera corresponde a aquellos señalados en el Plan General que constituyen unidades al servicio del concepto Distrito (más de cien mil habitantes). Estos centros comerciales deberán ser objeto de un Plan estudiado con todo detalle, diferenciando dentrode él las áreas para tráfico, aparcamiento, de las peatonales, que deberán tener gran desarrollo. Se permitirán en ellos usos comerciales de todo orden, edificios de espectáculos, hoteles, oficinas, apartamentos y viviendas, pero como mínimo el uso comercial representará el treinta por ciento del volumen previsto.

En las áreas de aparcamiento al servicio de estos centros será obligatorio justificar, previo estudio, el número de vehículos que pueden atraer cómo consecuencia de los usos que en él se establezcan.

El área mínima que deberá reservarse para estos centros comerciales será de seis hectáreas.

Los centros comerciales de segunda, en cuanto a usos. podrán desarrollar los mismos referidos para los de primera, debiendo tenerse en cuenta los mismos aspectos en cuanto a aparcamientos y áreas peatonales se refiere, pero en proporciones más reducidas. La superficie de estos centros será por lo menos de dos hectáreas.

Los volúmenes en aprovechamiento serán de cinco y seis metros cúbicos por metro cuadrado respectivamente. Siendo obligatorio desarrollar los volúmenes sin alteración tai como se prevea en el Proyecto de detalle.

\section{EDIFICIOS SINGULARES}

NORMA 36a.- Se califican edificios singulares los que por aprovechamiento del suelo o subsuelo, volumen de edificación y uso a que se destinen constituyen una excepción de las normas establecidas en el Plan General de Ordenación y en las Ordenanzas aplicables.

Podrán construirse edificios singulares en los casos siguientes:

$1^{\circ}$. Si están concretamente establecidos y grafiados con expresión de su respectivo emplazamiento, volumen y uso en un Plan Parcial aprobado.

$2^{\circ}$. Si no están previstos en el Plan Parcial, podrán autorizarse con carácter excepcional y restrictivo, en los casos siguientes:

a) Los edificios que se construyan sobre la superficie de una manzana completa perteneciente al mismo propietario o comunidad de propietarios y se ordenen en forma libre, pero sin superar en su conjunto el volumen edificable total que en la manzana se autorice por la Ordenanza vigente en la zona o sector de que se trate.

b) Los edificios que formando chaflán o esquina a dos calles de más de quince metros de anchura, constituyen un final o término de perspectiva de excepcional y muy calificada importancia que mejore el conjunto urbano. Cuando el edificio singular recaiga a una plaza podrá autorizarse su construcción si constituye una importante y muy calificada mejora del conjunto armónico de la plaza y sector correspondiente. 
NORMA 37a.- El expediente sobre autorización de edificios singulares no previstos en los Planes Parciales se tramitará en la forma siguiente:

a) Petición del interesado describiendo el emplazamiento y demás características del solar, volumen de la construcción que proyecta y usos. con obligación de establecer aparcamiento propio, acompañando dos maquetas de la futura edificación más los documentos que estime conveniente.

b) Información pública durante un mes de la petición de edificación singular.

c) Informe del Ayuntamiento respectivo y de la Oficina Técnica de Gran Valencia.

d) Vista del expediente al solicitante interesado durante diez días para que pueda formular alegaciones.

e) Acuerdo del Consejo General de la Cooperación Administrativa Gran Valencia, que concederá o denegará discrecionalmente la calificación de edificio singular, sin que pueda vincular precedente alguno.

f) Si el acuerdo del Consejo General fuera favorable. se someterá a la aprobación definitiva de la Comisión Central de Urbanismo.

g) Obtenida la autorización definitiva para construir el edificio singular, el Ayuntamiento, respectivo expedirá la correspondiente licencia de obra nueva, pudiendo exigir el arbitrio sobre aumento de volumen de edificación que establece el articulo 187 de la Ley del Suelo.

Si con infracción de estas normas se realizasen obras de edificación, serán demolidas a costa del propitario.

\section{DISPOSICIÓN FINAL}

Las presentes normas urbanísticas entrarán en vigor en el momento de su aprobación en todos los Municipios que forman parte de la Corporación Administrativa Gran Valencia.

Aquellos casos que no se hallen previstos en las anteriores normas se regirán en primer lugar por las Ordenanzas definitivamente aprobadas para los respectivos Municipios y como supletorio de estas Ordenanzas las Bases que forman parte del Plan General de Ordenación Urbana de Valencia y su Comarca aprobado por Ley de dieciocho de diciembre de mil novecientos cuarenta y seis.

Valencia, julio de 1965.

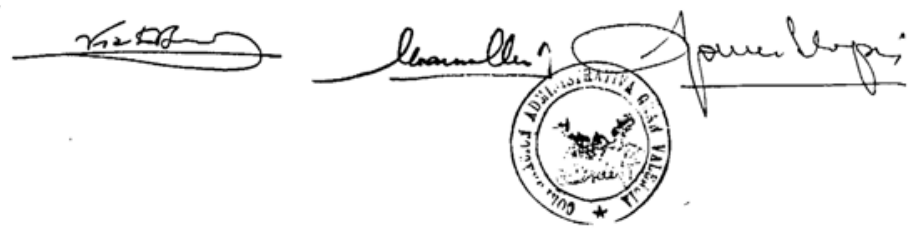



SU COMARCA A LA SOLUCIÓN SUR

\section{ESTUDIO ECONOMICO-FINANCIERO}

Para proceder a este estudio, debemos conocer el crecimiento demografico en los últimos años.

Hemos dibujado las curvos que representan el número de habitantes en la Capital y en la Comarca, desde el año 1.940 al 1.963 . Asimismo hemos obtenido la línea que representa en el mismo espacio de tiempo la suma de habitantes de Valencia y Comarca.

Es interesante hacer constar, que el crecimiento de la Comarca queda representado por una curva sin inflexiones. Desde el año 1.940 al 45 hubo un pequeño descenso, apenas perceptible, pero desde este año al 63, el crecimiento es continuo y siguiendo una curva similar a una catenaria.

En el año 1.940 la comarca tenía 125.000 habitantes, legando en el año 1.963 a 210.000 , lo que representa un aumento de 95.000 habitantes.

El crecimiento de la Capital en cambio es muy irregular, quedando muy afectado por los estados de estabilización o desarrollo de la Industria. Del año 1940 al 45 se observa un a notable crecimiento; desde 1.945 a 1.955 se estabiliza, sufre un pequeño descenso en los cinco años posteriores, y desde 1.960 al 1.963 se aprecia un crecimiento espectacular que coincide con la reactivación. La capital pasa en estos 23 años de 450.000 habitantes a 560.000 habitantes. El gráfico de la capital más la comarca es una linea más uniforme en el que se acusa asimismo el crecimiento de los últimos tres años. El conjunto pasa en los 23 años, desde 580.000 habitantes a 770.000 habitantes.

El desarrollo industrial de Valencia, extraordinario en este último trienio, el Plan de Desarrollo de toda la Nación, actualmente en marcha, y las posibilidades urbanísticas que ofrece el desvío del río, obra esta de realización inmediata, nos permiten aceptar la hipótesis de que la curva de crecimiento iniciada en el año 1960, seguirá ascendiendo, aún con mayor rapidez en los próximos años, pasando posteriormente a ser una línea parabólica que es lo ideal para el crecimiento demográfico de una Comarca que funciona correctamente.

La función lineal, que representa el crecimiento de los últimos siete años es la que se ha considerado más posible, para que represente el crecimiento de los próximos 80 . Esta línea recta, tiene superior pendiente a la que representa el promedio de los últimos 25 años, pero inferior al de los últimos tres, que representa un periodo de próspera reactivación.

Una vez dibujada esta curva, obtenemos el siguiente número de habitantes de Valencia y su Comarca por décadas.

Año 1965 770.000 habitantes.

Año 1.970 990.000

Año 1.980 1.225 .000

Año 1.990 1.405 .000

Año 2.000 1.560 .000

Año 2.010

1.695 .000

Año 2.020

1.805 .000

Año 2.030 1.895 .000

"

"

"

"

"

" 
Año 2.040 1.965 .000

Año 2.050 .

Estos números y suponiendo en término medio de 5 habitantes por vivienda no proporcionan el número de viviendas de nueva construcción para absorber los crecimientos calculados.

Periodo Viviendas de nueva construcción

\begin{tabular}{rr}
$1965-1970$ & 44.000 \\
$1970-1980$ & 47.000 \\
$1990-2000$ & 31.000 \\
$2000-2010$ & 27.000 \\
$2010-2020$ & 22.000 \\
$2020-2030$ & 18.000 \\
$2030-2040$ & 14.000 \\
$2040-2050$ & 14.000 \\
\hline TOTAL..............257.000
\end{tabular}

De todas estas viviendas a construir en un futuro, supondremos que un $90 \%$ lo harán sobre suelo de nueva urbanización, siendo el $10 \%$ restante, viviendas que se construirán sobre solares, procedentes del derribo de viejas construcciones con aumento del número de éstas.

Cálculo de la densidad.

Zona Extensión: Supondremos una manzana normal del ensanche de $100 \times 100$, que con la inclusión de la mitad de las calles tiene una superficie de $120 \times 120=14.400 \mathrm{~m} 2$.

De una totalidad de espacio urbanizado, en la zona de extensión consideramos que un $10 \%$ se debe dedicar a espacios verdes y un $15 \%$ a zonas comerciales, edificios públicos, de enseñanza, recreativos y religiosos, lo que nos da una superficie total de manzana incluidas vías públicas, porcentaje de espacios verdes y suelo dedicado a otras actividades de $19.200 \mathrm{~m} 2$.

El aprovechamiento máximo de una manzana tipo de $100 \times 100$ con patio de manzana, una vez descontado este es de $7.500 \mathrm{M} 2$. Con el sistema tradicional de viviendas recayentes a calles y patios de manzana se obtendrá un aprovechamiento, a razón de 5 plantas destinadas a viviendas y una planta (la primera) a otras actividades de 210 viviendas con 1050 habitantes. Lo que nos da una densidad en el caso del máximo aprovechamiento de 549 habitantes por Ha.

En los casos de extensión exterior, con viviendas más reducidas es posible que se empleen, parcelas que permitan la construcción de 4 viviendas por planta, dos recayentes a la calle, dos al patio de manzana, esta parcela de $18 \times 25$ permitirá con su repetición un número de viviendas por manzana tipo que ascenderá a 1.670 , lo que podría representar una densidad en casos excepcionales de 870 habitantes $\mathrm{Ha}$. El promedio de $700 \mathrm{Hab} / \mathrm{Ha}$ parece el justo para un cálculo de densidades.

Zona de edificación abierta. El promedio del índice de edificabilidad en esta zona es de $2,5 \mathrm{~m} 3$. Y suponiendo que la vivienda media tendrá una cubicación de 210 M3 y representa el $70 \%$ de la edificación, obtenemos una densidad de $400 \mathrm{Hab} / \mathrm{Ha}$.

Zona de Ciudad Jardín.- Consideramos que la densidad según categorías podrá oscilar entre 30 y $120 \mathrm{Hab} / \mathrm{Ha}$ después de hacer un estudio de la posible distribución hemos llegado a la cifra media de $75 \mathrm{Hab} / \mathrm{Ha}$.

Zona de tolerancia Industrial .- El no de habitantes por Hectárea que utilizamos será el de 300 .

Debemos tener en cuenta que las nuevas urbanizaciones creando suelo apto para construir, nunca se saturan al máximo, sobre todo 
en la primera etapa de su función y debemos contar con un margen en el cálculo de suelo urbanizado preciso, para ello disminuiremos la densidad, hasta un $85 \%$ de lo calculado para el máximo aprovechamiento, obteniendo con ello las siguientes densidades para el cálculo:

Zona interior y de extensión......

Zona edificación abierta

$600 \mathrm{Hab} / \mathrm{Ha}$

Zona tolerancia industria

340 "

255

Zona Núcleos Periféricos, no edificado...... 500

Zona " " edificados............ 300

Zona Ciudad Jardín....................................... "

Zona de extensión....................... 1.029 Ha a $600 \quad 617.400$

Zona interior.............................. $124 \mathrm{Ha}$ a $600 \quad 74.400$

Zona Comercial........................... $\quad 31,4 \mathrm{Ha}$ a $600 \quad 18.840$

Zona edificación abierta............. $\quad 33,00 \mathrm{Ha} \quad 340 \quad 285.220$

Zona tolerancia industrial.......... 986.- Ha $255 \quad 251.430$

Zona Ciudad jardín.................... 1222.- Ha $60 \quad 73.320$

Zona Núcleos Periféricos no

Edificados..................... 2595,50 Ha $500 \quad 1.297 .750$

Zona id. Id Edificado.... $755,40 \mathrm{Ha} 300 \quad \underline{232.620}$

TOTAL........................ 2.848 .980

SUPERFICIES DE ZONAS RESIDENCIALES A URBANIZAR QUE SE PRECISAN EN CADA DECADA DESDE 1970 HASTA EL AÑO 2050.-

Superficie de zonas residenciales en el Plan

de Adaptación, en el que está incluido el $10 \%$

de zona verde

$7.596,30 \mathrm{Ha}$

Superficie de Zonas Industriales.

Superficie de la 4 zonas culturales y deportivas.....

La densidad media del conjunto de zonas residenciales que forman

el Plan es de $\underline{2.848 .980}=375 .-\mathrm{Hab} / \mathrm{Ha}$

$$
7.596,30
$$

La densidad media de la totalidad de la zona urbana del Plan, incluidas Zonas Industriales es de $\underline{2.848 .980}=280 \mathrm{Hab} / \mathrm{Ha}$

$$
10.189,30
$$

Periodo hasta el año 1970.-

Crecimiento 220.000 hab. El $90 \%=198.000$ hab.

Se precisarán $\underline{198.000}=528 \mathrm{Ha}$. urbanizadas de zonas residenciales. 375

Década 1970- 1980.

Crecimiento 235.000 hab. El $90 \%=212.000$ hab.

Se precisarán $\underline{212.000}=565 \mathrm{Ha}$. urbanizadas de zonas residenciales. 375

Década 1980- 1990.

Crecimiento 180.000 hab. El $90 \%=162.000$ hab.

Se precisarán $\underline{162.000}=423 \mathrm{Ha}$. urbanizadas de zonas residenciales.

$$
375
$$

Década 1990- 2000.

Crecimiento 155.000 hab. El $90 \%=139.500$ hab.

Se precisarán $\underline{139.500}=372 \mathrm{Ha}$. urbanizadas de zonas residenciales. 375

Década 2000- 2010.

Crecimiento 135.000 hab. El $90 \%=121.500$ hab.

Se precisarán $\underline{121.500}=324 \mathrm{Ha}$. urbanizadas de zonas residenciales. 375 
Década 2010- 2020.

Crecimiento 110.000 hab. El $90 \%=99.000$ hab.

Se precisarán $99.000=264 \mathrm{Ha}$. urbanizadas de zonas residenciales.

$$
375
$$

Década 2020- 2030.

Crecimiento 90.000 hab. El $90 \%=81.000$ hab.

Se precisarán $\underline{81.000}=216 \mathrm{Ha}$. urbanizadas de zonas residenciales.

$$
375
$$

Década 2030- 2040.

Crecimiento 70.000 hab. El $90 \%=63.000$ hab.

Se precisarán $\underline{63.000}=168 \mathrm{Ha}$. urbanizadas de zonas residenciales. 375

VALORACIONES DE LAS OBRAS DE URBANIZACIÓN Y ZONAS VERDES A REALIZAR EN CADA DECADA

Consideramos que el costo de las obras de urbanización será de 150 $\mathrm{ptas} / \mathrm{m} 2$ en las zonas residenciales y de 100 ptas/m2 en las Industriales.

El costo posible y medio de los terrenos destinados a zonas verdes de uso público lo consideramos de $220 \mathrm{ptas} / \mathrm{m} 2$. La superficie de zonas verdes será el $11 \%$ de la suma de zonas residenciales o industriales.

Periodo hasta 1.970.-

Urbanización zonas Residenciales: $5.280 .000 \times 150=629.000 .000$. " $\quad$ "Industriales: $1.440 .000 \times 100=144.000 .000 .-$

Zonas verdes: $\quad 739.200 \times 220=126.624 .000 .-$

Total pesetas Urbanización y zonas verdes............... 962.624.000.-

Década 1.970 - 1.980.-

Urbanización zonas Residenciales: $5.650 .000 \times 150=857.500 .000$." " Industriales: $1.540 .000 \times 100=154.000 .000 .-$

Zonas verdes: $\quad 790.900 \times 220=173.998 .000 .-$

Total pesetas Urbanización y zonas verdes............... 1.185.498.000.-

Década 1.980 - 1.990.-

Urbanización zonas Residenciales: $4.320 .000 \times 150=648.000 .000$." " Industriales: $1.180 .000 \times 100=118.000 .000$.-

Zonas verdes: $\quad 605.000 \times 220=133.100 .000 .-$

Total pesetas Urbanización y zonas verdes................ 899.100.000.-

Década 1.990 - 2.000.-

Urbanización zonas Residenciales: $3.720 .000 \times 150=558.000 .000$." " Industriales: $1.014 .000 \times 100=101.400 .000$.

Zonas verdes: $\quad 520.740 \times 220=114.562 .800 .-$

Total pesetas Urbanización y zonas verdes................ 773.962.800.-

Década 2.000 - 2.010.-

Urbanización zonas Residenciales: $3.240 .000 \times 150=486.000 .000$." " Industriales: $884.000 \times 100=88.400 .000$.

Zonas verdes: $\quad 453.640 \times 220=99.800 .800$.-

Total pesetas Urbanización y zonas verdes............... 674.200.800.-

Década 2.010 - 2.020.-

Urbanización zonas Residenciales: $2.640 .000 \times 150=396.000 .000$." " Industriales: $720.000 \times 100=72.000 .000 .-$

Zonas verdes: $\quad 369.600 \times 220=81.312 .000$.-

Total pesetas Urbanización y zonas verdes............... 549.312.000.- 
Década 2.020 - 2.030.-

Urbanización zonas Residenciales: $2.160 .000 \times 150=324.000 .000$.-

" " Industriales: $590.000 \times 100=59.000 .000 .-$

Zonas verdes: $\quad 302.500 \times 220=66.550 .000$.-

Total pesetas Urbanización y zonas verdes................ 449.550.000.-

Década 2.030 - 2.040.-

Urbanización zonas Residenciales: 1.680 .000 x $150=252.000 .000$.-

" $\quad$ Industriales: $460.000 \times 100=46.000 .000 .-$

Zonas verdes: $\quad 235.400 \times 220=51.788 .000 .-$

Total pesetas Urbanización y zonas verdes................ 349.788.000.-

\section{FINANCIACION}

Para estudiar los recursos con que se puede contar para cubrir las atenciones que suponen las obras de urbanización y zonas verdes, calculadas en este estudio económico, debemos fundarnos en el importe de loa presupuestos municipales ordinarios, tomando como base, por ejemplo, los que regirán en el año 1965, ya que es de suponer que las alteraciones de orden económico serán paralelas entre los ingresos y los gastos, pero la cantidad a que ascenderán los presupuestos municipales de 1965, la hemos do calcular por deducción, ya que en esta fecha habrá un buen numero de ayuntamientos que no tendrán aprobados sus presupuestos ordinarios para el año próximo.

La deducción la hacemos partiendo del importe de los presupuestos municipales de la comarca de Gran Valencia en el año 1963, que ascendían a la cantidad de 413 millones de pesetas, y observando en el año 1964 ascendieron estos mismos presupuestos a 577 millones, resulta que, de un año a otro, tuvieron un aumento de ciento sesenta y cuatro millones, y calculando que en el año siguiente tendrán un parecido aumento, resultará que en el año 1965 el importe total de los presupuestos ordinarios municipales de la comarca ascenderá a la cantidad de 741 millones, y como quiera que con arreglo a la Ley del Suelo estos presupuestos tendrán unas consignaciones para atenciones urbanísticas equivalentes al diez por ciento de su importe total y resultará que anualmente ese diez por ciento ascenderá a la cantidad de setenta y cuatro millones de pesetas, por lo que bastará multiplicar el importe de esta consignación por el número de años que comprende cada periodo, para saber la parte con que los presupuestos municipales podrán contribuir a atender las obras de urbanización y zonas verdes calculadas para ese mismo periodo.

Resultará también, que con estas consignaciones municipales cubriremos sobradamente los gastos totales que se calculan para los últimos periodos a que alcanza este estudio económico, en cambio, habrá un déficit considerable en los primeros, que habrá de atenderse por medio de presupuestos extraordinarios que los ayuntamientos habrán de formular.

Debe también tenerse en cuenta para el momento de fijar la cantidad exacta de los gastos que el plan supone, aquellos que son atendidos directamente por la Gerencia de Urbanización y que invierte en los Polígonos que ella misma lleva a cabo, es decir, que del importe total de gastos calculado para cada periodo, habrá de deducirse los que sufraga la Gerencia de Urbanización; efectuada que esta deducción, la cantidad líquida que resulte ha de sufragarse de la forma antedicha, o sea, en primer lugar, con las aportaciones municipales sacadas de sus presupuestos ordinarios y los restantes, 
si hubiere lugar, con los presupuestos extraordinarios que al efecto formularán los ayuntamientos.

Sirva de ejemplo para efectuar la liquidación con arreglo a lo anteriormente expuesto, la que practicamos a continuación relativa al primer período de este estudio económico, que comprende los años 1965 a 1970, ambos inclusive, o sea, seis años naturales.

Importan los gastas calculados en este estudio económico la cantidad de 962 millones con 624 mil pesetas (962.624.000,00 pts); el importe de los gastos de urbanización a cargo de la Gerencia en las zonas residenciales ascienden a la cantidad de 453.890 .000 pts. y las zonas Industriales, 189.920 .000 pts., por lo que en total los gastos de la Gerencia suman la cantidad de 643.810 .000 pts. , que, deducidas de los gastos calculados en el estudio económico para este periodo queda un liquido de 318.814 .000 pts., $y$, como quiera que las consignaciones para atenciones urbanísticas de los presupuestos municipales ordinarios durante los seis años del periodo, ascienden a la cantidad de $444 \mathrm{mi}-$ llones de pesetas, quedan cubiertos con estas consignaciones solamente las atenciones calculadas en el estudio económico, $y$, por tanto, los ayuntamientos no tendrán necesidad de recurrir a presupuestos extraordinarios para cubrir tales atenciones.

En los sucesivos periodos, se seguirá el mismo procedimiento para efectuar las correspondientes liquidaciones, pero como quiera que en todos estos periodos se comprende décadas completas, resultará que la cantidad representativa de las consignaciones para atenciones urbanísticas de los presupuestos municipales ordinarios ascenderá a la cantidad de 740 millones de pesetas, y, por tanto, la deducción que se hará en loa gastos por este concepto, será la indicada cantidad, previa la deducción si procediere de los gastos que haya de invertir la Gerencia de Urbanización.

Valencia, noviembre de 1964.

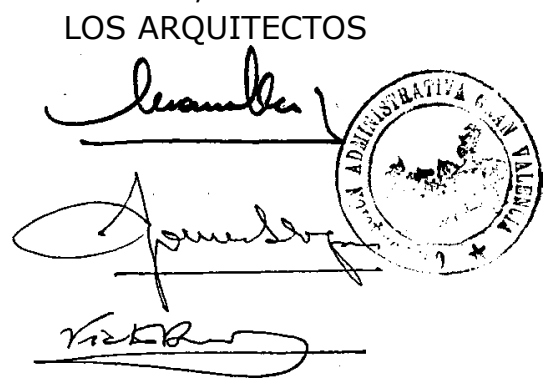

EL. SECRETARIO GENERAL. 
1. PLANO DE ZONIFICACIÓN.

Escala original 1:10.000

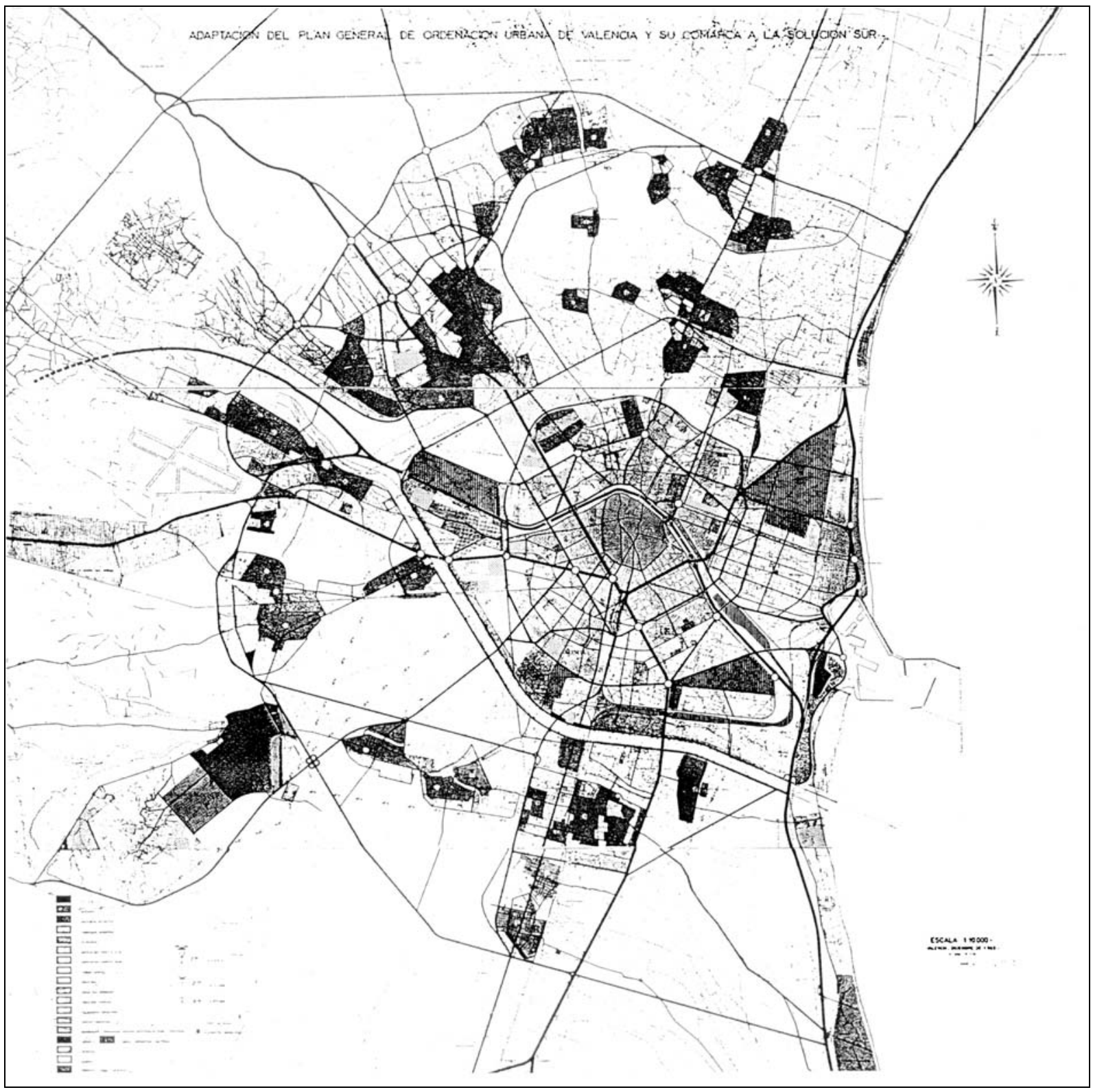



7. PLANES PARCIALES DE DESARROLLO DEL PGOU DE 1966 



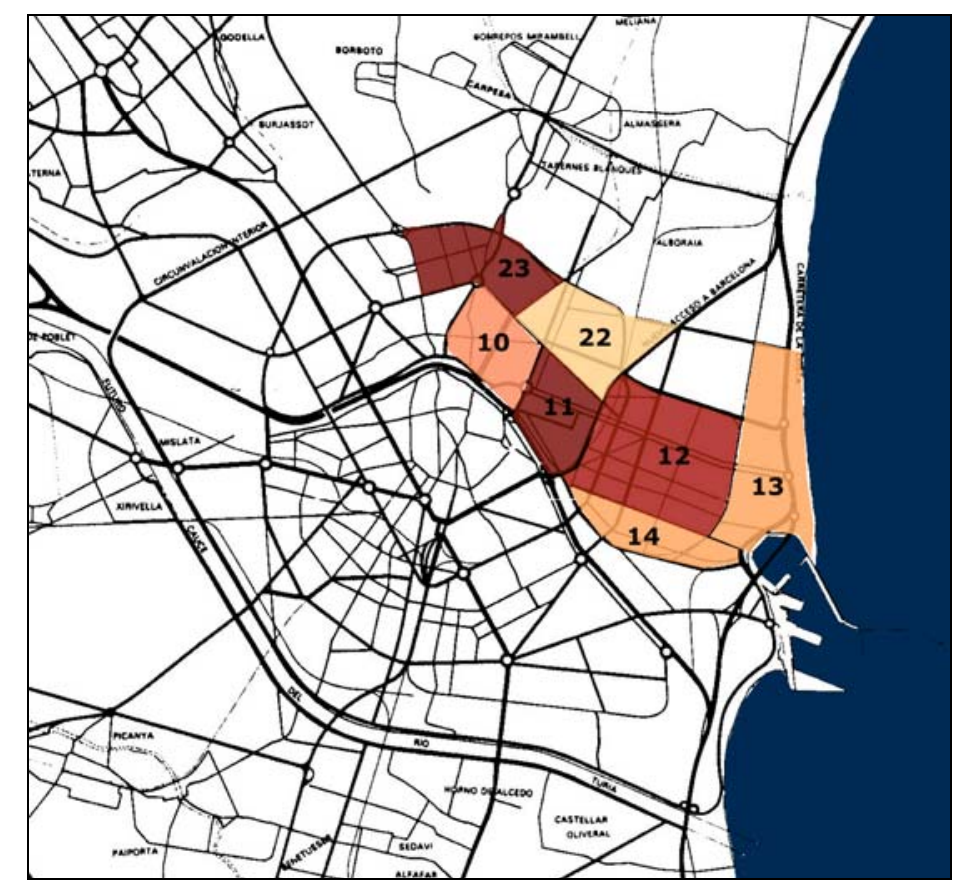

\subsection{ZONA NORESTE}

PLAN PARCIAL NO 10 (ZAIDIA), 1967/1974

PLAN PARCIAL No 11 (PLA DEL REAL), 1967

PLAN PARCIAL No 12 (PASEO AL MAR/ALGIRÓS), 1968

PLAN PARCIAL NO 13 (CABANYAL-MALVARROSA), 1968/1974

PLAN PARCIAL NO 14 (CAMINS AL GRAO), 1968/1977

PLAN PARCIAL NO 22 (BENIMACLET), 1967/1974

PLAN PARCIAL NO 23 (ORRIOLS-TORREFIEL), 1967 



\section{PP10}

PLAN PARCIAL No 10 (ADAPTADO A LA SOlUCIÓN SUR). 1974.

Redactores: EXCMO. AYUNTAMIENTO DE VALENCIA. OFICINA TÉCNICA DE URBANISMO.

Fecha redacción: Septiembre 1974.

Fecha aprobación: O.M. 30-04-1975. Anulado por sentencia T.S. 9-02-1982.

Contenido:

I. MEMORIA

II. ORDENANZAS.

III. PLANOS:

1. PLANO DE SITUACIÓN DENTRO DE LA CIUDAD.

$1: 10.000$

2. SITUACIÓN EN EL PLAN GENERAL

$1: 22.500$

3. INFORMACIÓN Y FOTO AÉREA

$1: 2000$

4. ZONIFICACIÓN

$1: 2000$

5. ESTRUCTURA URBANA

$1: 2000$

6. ALINEACIONES

$1: 2000$

7. RED VIARIA

$1: 2000$

8. RED DE ALUMBRADO

$1: 2000$

9. RED DE AGUAS POTABLES

$1: 2000$

10. RED DE ALCANTARILLADO

$1: 2000$

Fuente: Ayuntamiento de Valencia. Sección de Urbanismo. Negociado de Suelo y Ordenación urbana. Expte. 11/73 (Archivo de Planeamiento No 190).

\section{Nota:}

Se adjuntan los planos siguientes, pertenecientes a la versión del Plan Parcial 10 redactada en 1968:
- PLANO DE ALINEACIONES
$1: 2000$
- PLANO DE ZONIFICACIÓN
$1: 4000$ 



\title{
EXCMO. AYUNTAMIENTO \\ DE \\ VALENCIA
}

\author{
OFICINA TECNICA DE URBANISMO \\ PLAN PARCIAL NO 10 - ADAPTADO A LA SOLUCIÓN SUR
}

\section{MEMORIA}

1.1. El Plan Parcial no 10 fue aprobado en 14 de Mayo de 1.956 por la Comisión Central de Sanidad Local.

El nuevo estudio del citado Plan se reduce a las modificaciones pertinentes para adaptarlo al Plan General de Ordenación Urbana de Valencia y su Comarca, Solución Sur.

Los límites de dicho Plan Parcial no han sufrido variación alguna, siendo los siguientes:

Norte: Avenida de Primado Reig.

Sur : Cruce actual del Rio Turia.

Este : Calle General Elío y Botánico Cavanilles.

Oeste: Avenida de Ramiro Ledesma.

Como consecuencia de la redacción, por parte de la Jefatura de Obras Públicas en su Oficina Regional de Proyectos y Carreteras, del estudio de todos los accesos de la Ciudad, así como de las Rondas Exteriores, este Plan Parcial se ha visto afectado, teniendo que adaptarlo a estas modificaciones, así como también ha habido que actualizarlo para que cumpliese con las nuevas Zonificaciones y Normas establecidas en el Plan General.

Esta adaptación en algunos casos ha revestido especial dificultad, ya que según se puede comprobar en el plano correspondiente al Estado Actual, la edificación -adaptándose al Plan aprobado en 1.956- se ha desarrollado con gran intensidad y dispersión

\subsection{ZONIFICACION.}

Existen según el Plan General las siguientes zonificaciones:

Ensanche hasta Tránsitos

Edificación Abierta Alta.

Centro.Comercial.

Zona Especial.

Zona Verde.

\subsubsection{Ensanche hasta Tránsitos.}

Comprende esta zonificación la mayoría del Plan Parcial en ella la edificación se desarrolla en manzanas cerradas, salvo en algunos sitios determinados en donde se han dispuesto bloques abiertos. Tanto en un caso como en otro la altura máxima viene en función del ancho de la calle.

\subsubsection{Edificación Abierta Alta.}

Esta zonificación viene delimitada por las calles Primado Reig y prolongación Padre Urbano por el norte; Maximiliano Thous y Capitán General Muñoz Grandes por el sur; Benimarfull por el este; y Almazora y Hnos. Fabrilo por el oeste.

Se ha estudiado un sensible reajuste en los límites de esta zona con referencia al Plan General, para delimitar algunas manzanas que estaban parcial o totalmente construidas con una clara 
tipología de edificación intensiva.

Los bloques llevan grafiada la altura máxima, que señala el numero de plantas en las que se incluye la planta baja.

El volumen para esta zona según el Plan General es de 5 m3./m2. Según el Plan Parcial se ha ocupado una superficie de $117.466 \mathrm{~m} 2$., con un volumen total de $550.821 \mathrm{~m} 3$. Io que nos da el siguiente coeficiente de edificabilidad:

coeficiente de edificabilidad $=550.821 \mathrm{m3} .=4,69 \mathrm{~m} 3 . / \mathrm{m} 2$. $117.466 \mathrm{~m} 2$.

\subsubsection{Centro Comercial.}

En el Plan General, en la zona limitada por las calles Maximiliano Thous, Almazora, Platero Suárez y Bilbao, que comprende cuatro manzanas, se ha ubicado un Centro Comercial. Solamente una de las cuatro manzanas citadas puede ser destinada totalmente a edificio comercial, las otras tres están construidas parciamente, algunas de ellas en más de un $80 \%$, por esta razón, se destinan las plantas bajas a locales comerciales y se ha proyectado, en la limitada por las calles Bilbao, Fray Pedro Vives, Luis Mayans y Platero Suárez, unas galerías comerciales.

En la manzana destinada totalmente a edificio comercial se ha establecido de acuerdo con la Norma 35 del Plan General un volumen máximo edificable de $60.000 \mathrm{~m} 3$. y una altura reguladora máxima de XII plantas. En el supuesto de que se proyectaran varios bloques, se aplicarán para la separación entre ellos, las mismas ordenanzas que rigen para la edificación abierta.

\subsubsection{Zona Especial.}

Esta Zonificación hace referencia al actual Museo de San Pío $\checkmark$ que data del siglo XVII y de sus aledaños, que serán objeto de un proyecto especial, respetando el actual Museo. El volumen máximo de la zona es de $40.000 \mathrm{~m} 3$.

Igualmente será objeto de proyecto especial, aunque no venga reflejado en el Plan General, la manzana delimitada por las calles de Alboraya, Poeta Bodría, Trinidad y en proyecto. En esta manzana se encuentra el Convento de Religiosas Franciscanas de la Santísima Trinidad que data del año 1.446 y que fue fundado por la Reina Doña María, mujer de Alfonso $V$ de Aragón. El proyecto especial contemplará la conservación de este edificio. El volumen máximo de la manzana es de $70.000 \mathrm{~m} 3$.

\subsubsection{Zona Verde.}

Comprende los Viveros Municipales. Su superficie es de $263.640 \mathrm{~m} 2$.,que representa aproximadamente el $23,33 \%$ del total del Plan Parcial.

\subsection{Red Viaria.}

Esta limitado el Plan por cuatro importantes vías de comunicación según se ha apuntado en el preámbulo de esta Memoria. Además, en la dirección Norte-Sur discurre una arteria que enlaza con las futuras Rondas Exteriores y de Este a Oeste existen otras dos importantes redes de 30 y $25 \mathrm{~m}$. de anchura. El resto del viario esta compuesto por calles de 25 a $10 \mathrm{~m}$., según las necesidades del Plan y en función de la fluidez del tráfico.

1.4. Densidad de población.

Se ha realizado este estudio con arreglo a los siguientes datos: 
Superficie ocupada por los edificios de viviendas... $203.308 \mathrm{~m} 2$.

Número medio de plantas por edificio....

Superficie total

$1.219 .848 \mathrm{~m} 2$.

Porcentaje ocupado por las viviendas $(70 \%)$, el

resto se prevee para usos comerciales.

$853.893 \mathrm{~m} 2$.

Superficie media de vivienda, considerando patios

interiores, elementos comunes, etc, .

Número de viviendas $=853.893: 200=$

4.269

Número medio de personas por vivienda

4

Número total de habitantes $=4.269 \times 4=$

17.076

\subsection{Servicios urbanos.}

El Plan Parcial esta suficientemente dotado de servicios urbanos, según se puede comprobar en el plano correspondiente a la Estructura urbanística.

Se han ubicado cuatro escuelas, dos de ellas de $5.000 \mathrm{~m} 2$. una de $8.033 \mathrm{~m} 2$. y otra de $22.300 \mathrm{~m} 2$. De acuerdo con las últimas normas establecidas por el Ministerio de Educación y Ciencia, la capacidad total de alumnos para estas escuelas será de 2.800 .

Se ha dotado de áreas de aparcamiento y además se ha previsto que en las zonas grafiadas en los planos como aparcamientos en superficie o zonas verdes, puedan construirse aparcamientos subterráneos.

Los aparcamientos que existen proyectados en superficie en el Plan, tienen una superficie total de $26.240 \mathrm{~m} 2$. dando cabida a unas 1.312 plazas.

Las superficies exigidas para aparcamientos en el interior de los edificios según las Normas del Plan General son:

$5 \%$ de superficie destinada a vivienda:

$$
0,05 \times 853.893 \mathrm{~m} 2 .=\ldots \ldots \ldots \ldots . .42 .694 \mathrm{~m} 2 .
$$

$15 \%$ de superficie destinada a otros usos:

$$
0,15 \times 365.955 \mathrm{m2} .=\ldots \ldots \ldots \ldots . \quad \frac{54.893 \mathrm{~m} 2}{\text { Total }} \quad .
$$

que a una media de $20 \mathrm{~m} 2$. por plaza de aparcamiento, representan 4.879 plazas, que junto con las anteriores previstas en superficie ascienden a 6.191 .

1.6. Medios Económicos-Financieros.

Constituyen estos medios el presupuesto ordinario de urbanismo del Excmo. Ayuntamiento más los presupuestos extraordinarios que sean establecidos para promover y fomentar el desarrollo de la zona.

Con todo lo descrito creemos haber expresado suficientemente el alcance de este estudio que proponemos al Excmo. Ayunta miento para que si lo estima conveniente, lo eleve a la aprobación por la Superioridad.

Valencia, Septiembre de 1.974

LOS ARQUITECTOS

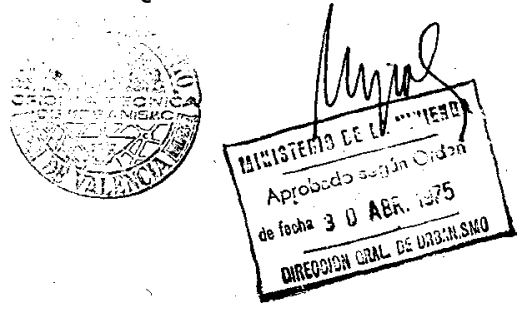


EXCMO. AYUNTAMIENTO

DE

VALENCIA

\author{
OFICINA TECNICA DE URBANISMO \\ PLAN PARCIAL NO 10 - ADAPTADO A LA SOLUCIÓN SUR
}

\title{
ORDENANZAS
}

Hasta que no se aprueben las Ordenanzas adaptadas a la Solución Sur, en estudio, se aplicarán las vigentes, aprobadas por la Comisión Central de Sanidad, en 23 de Octubre de 1.950 y 26 de Enero de 1.955, en los casos no previstos en las Normas Urbanísticas del Plan de Ordenación de Valencia y su Comarca, adaptadas a la "Solución Sur" por las que tendrá que regirse actualmente este Ayuntamiento.

A este Plan Parcial le corresponden las zonificaciones de Ensanche hasta Tránsitos, Edificación abierta alta, Centro Comercial, Zona Especial y Zona Verde.

Valencia, Diciembre de 1.972

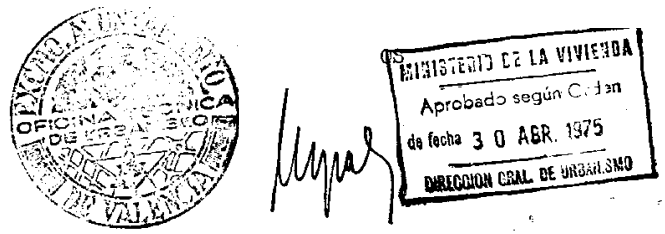


4. ZONIFICACIÓN

Escala original: 1:4.000

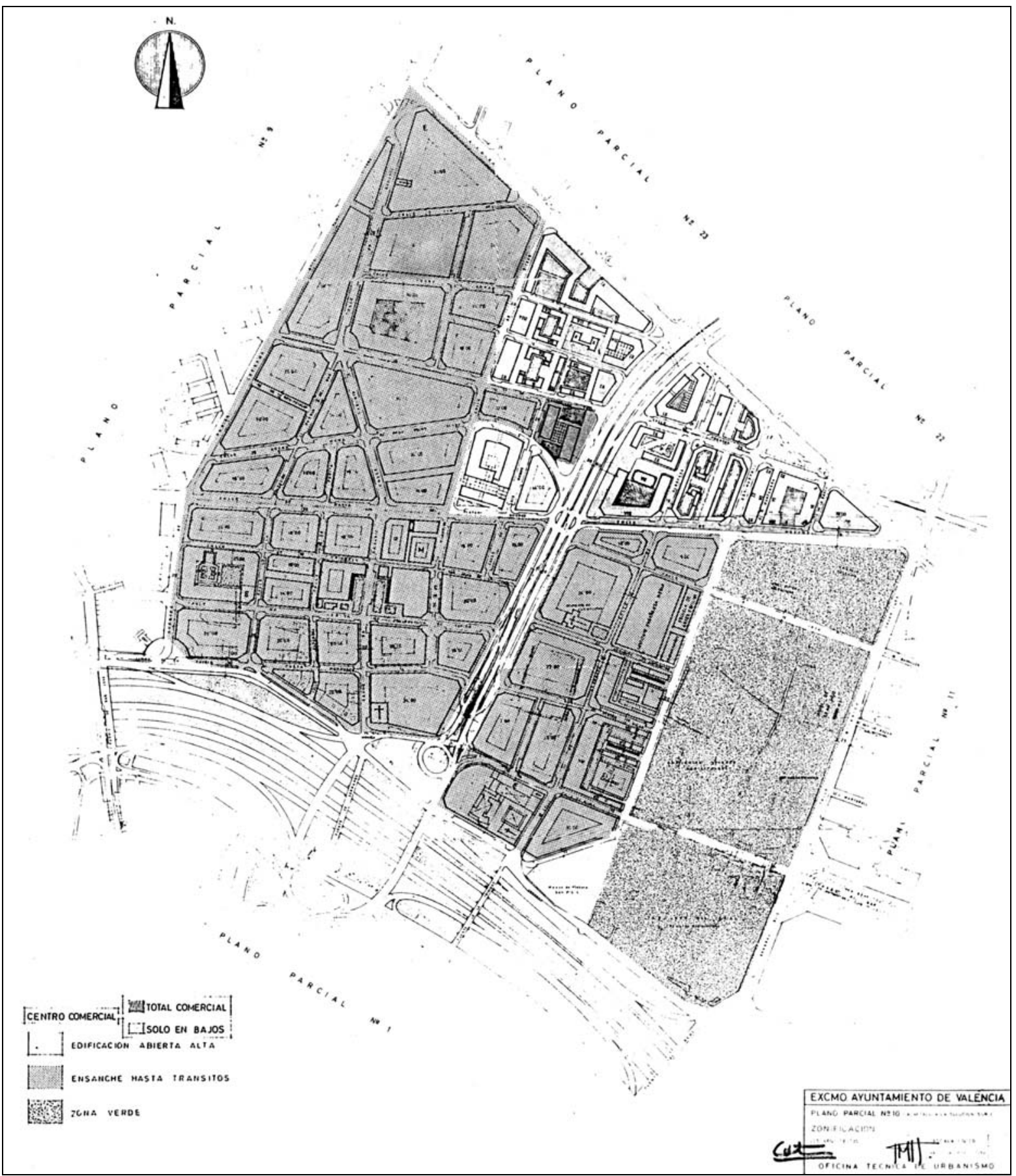


6. ALINEACIONES.

Escala original 1:2000

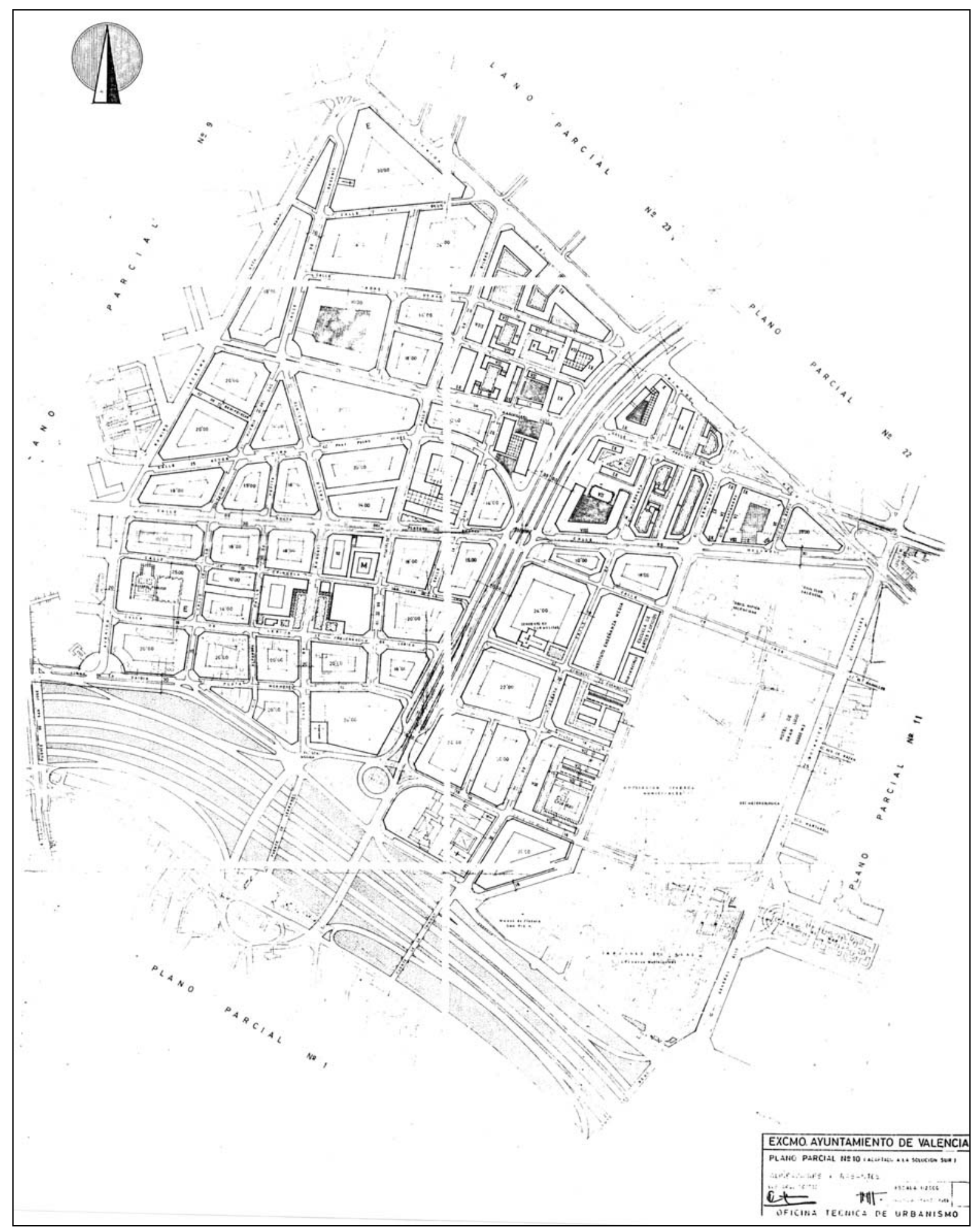


1. PLANO DE SITUACIÓN EN LA CIUDAD

Escala original: $1: 10.000$

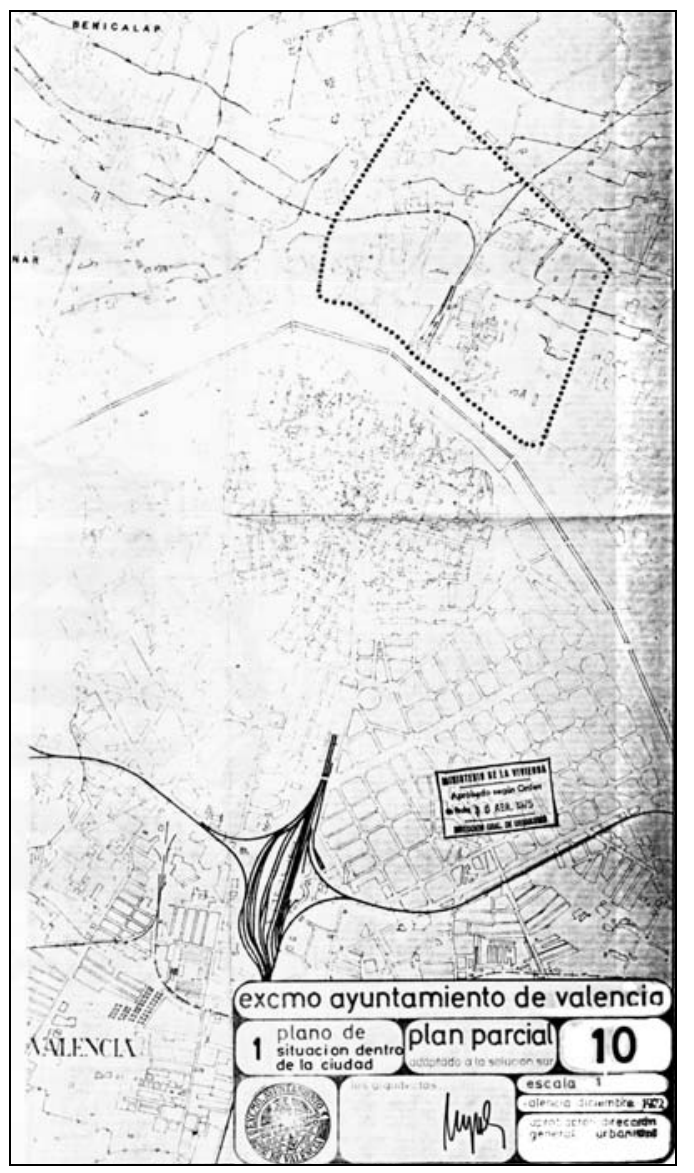

2. PLANO DE SITUACIÓN EN EL PLAN GENERAL (Fragmento)

Escala original: $1: 22.500$

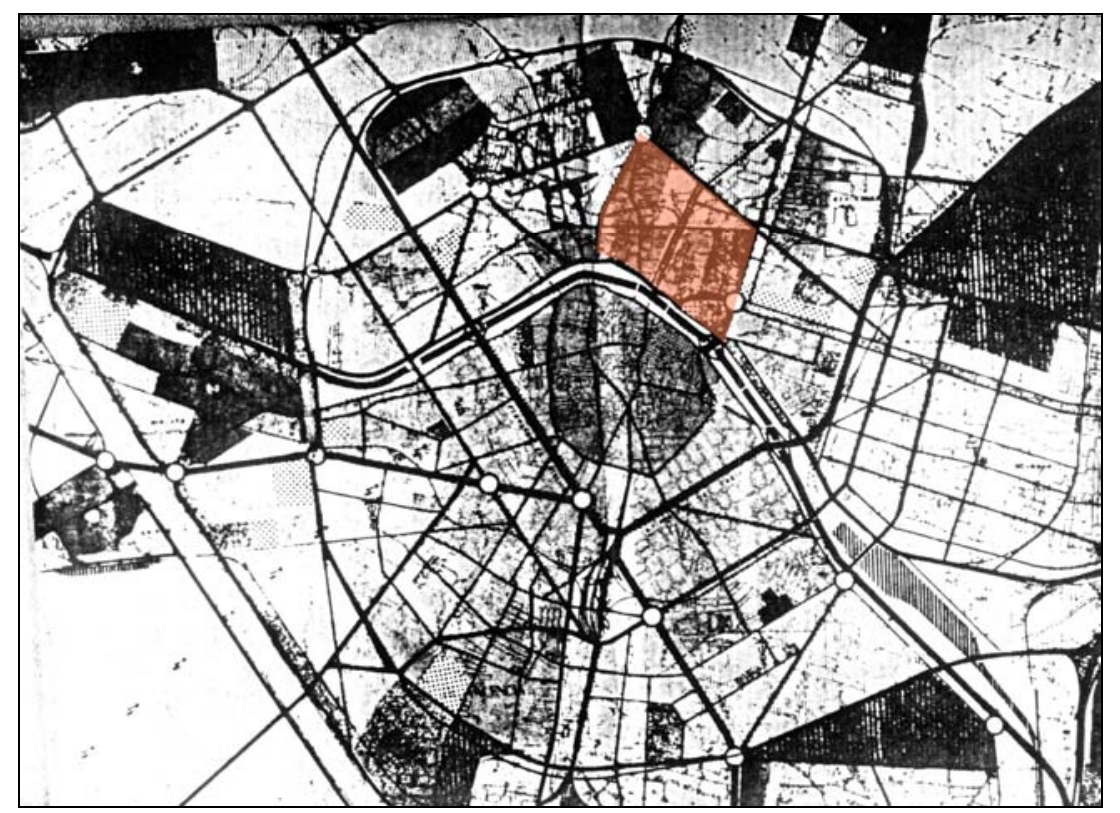




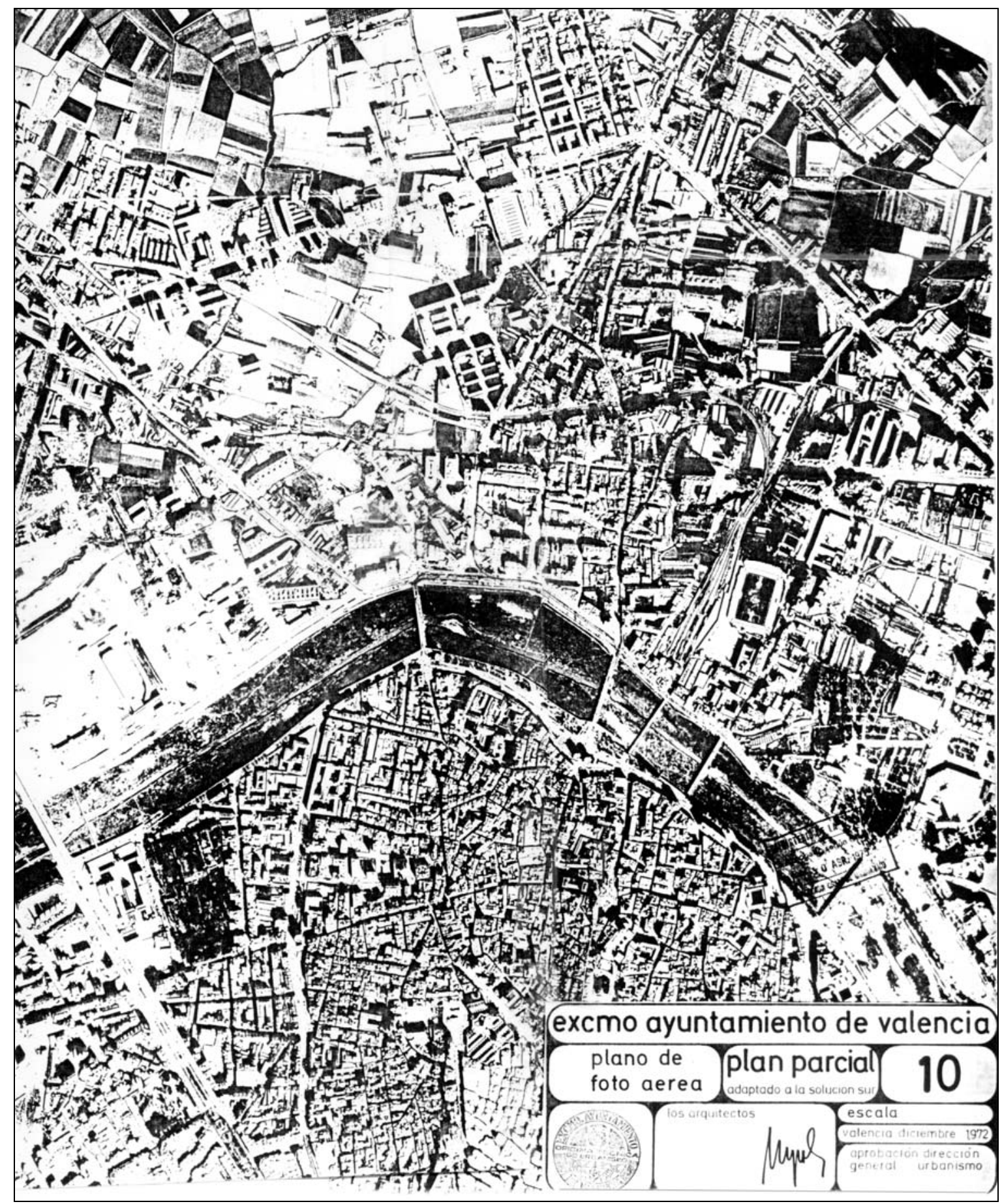




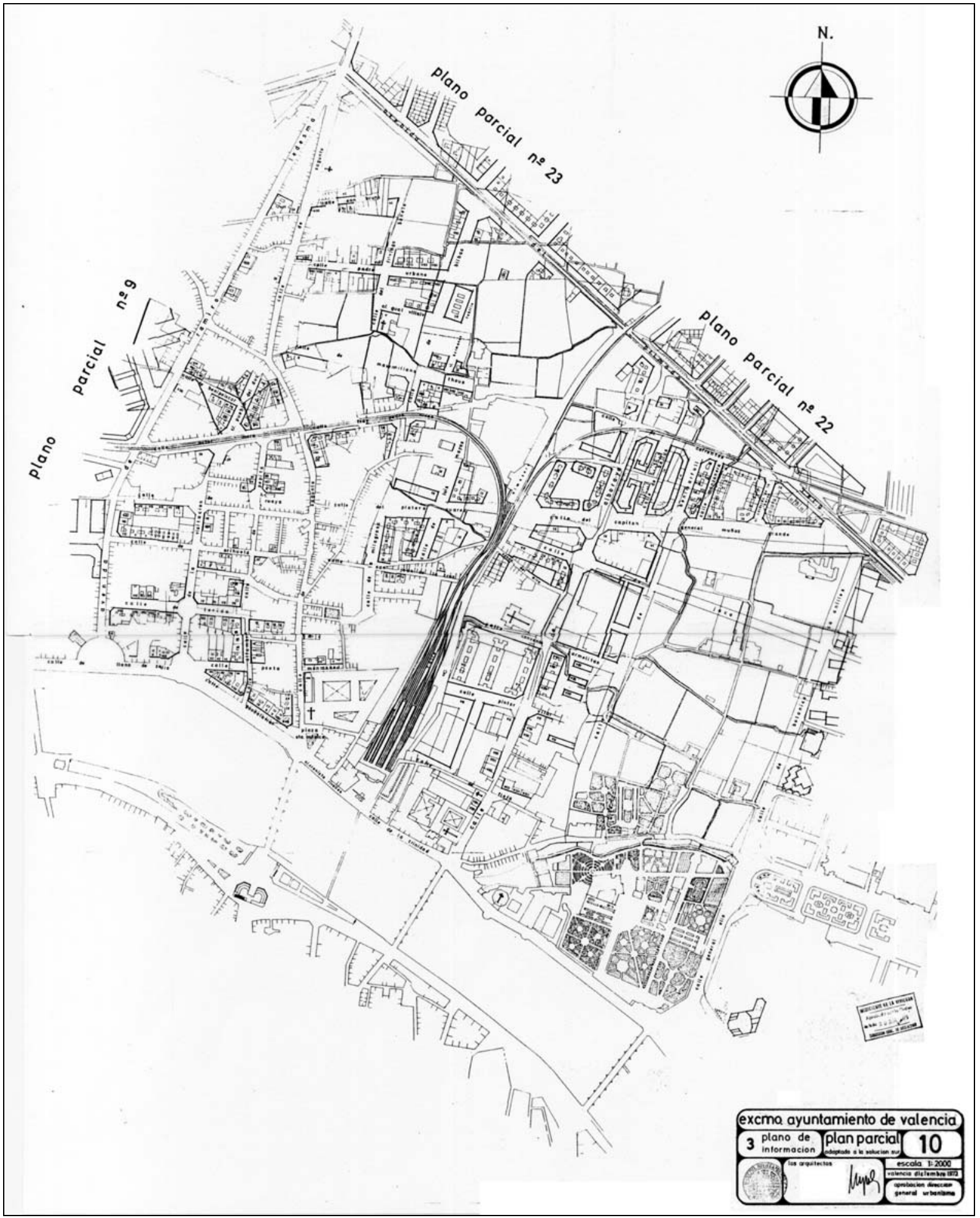


4. ZONIFICACIÓN.

Escala original: 1:2000

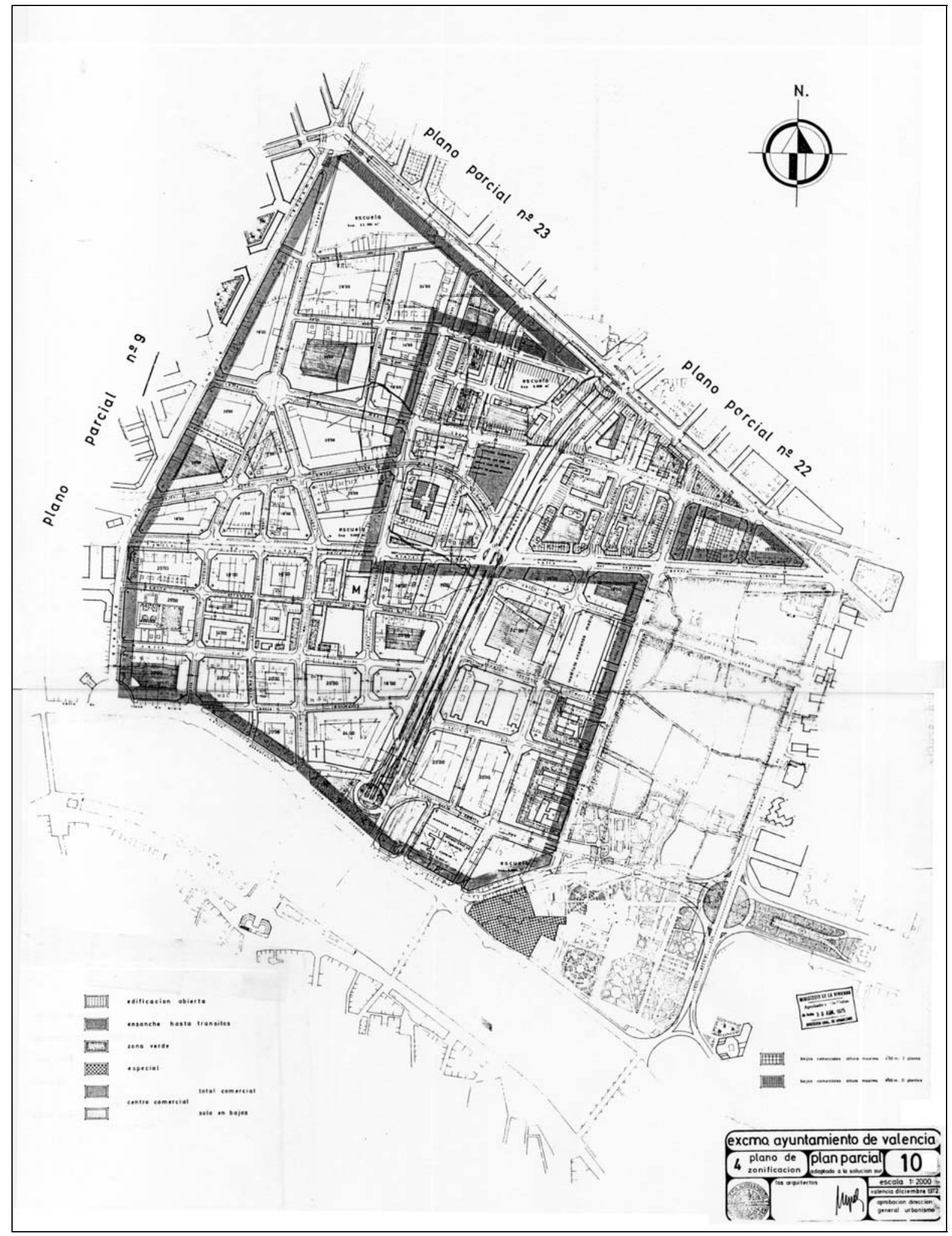


6. ALINEACIONES.

Escala original 1:2000

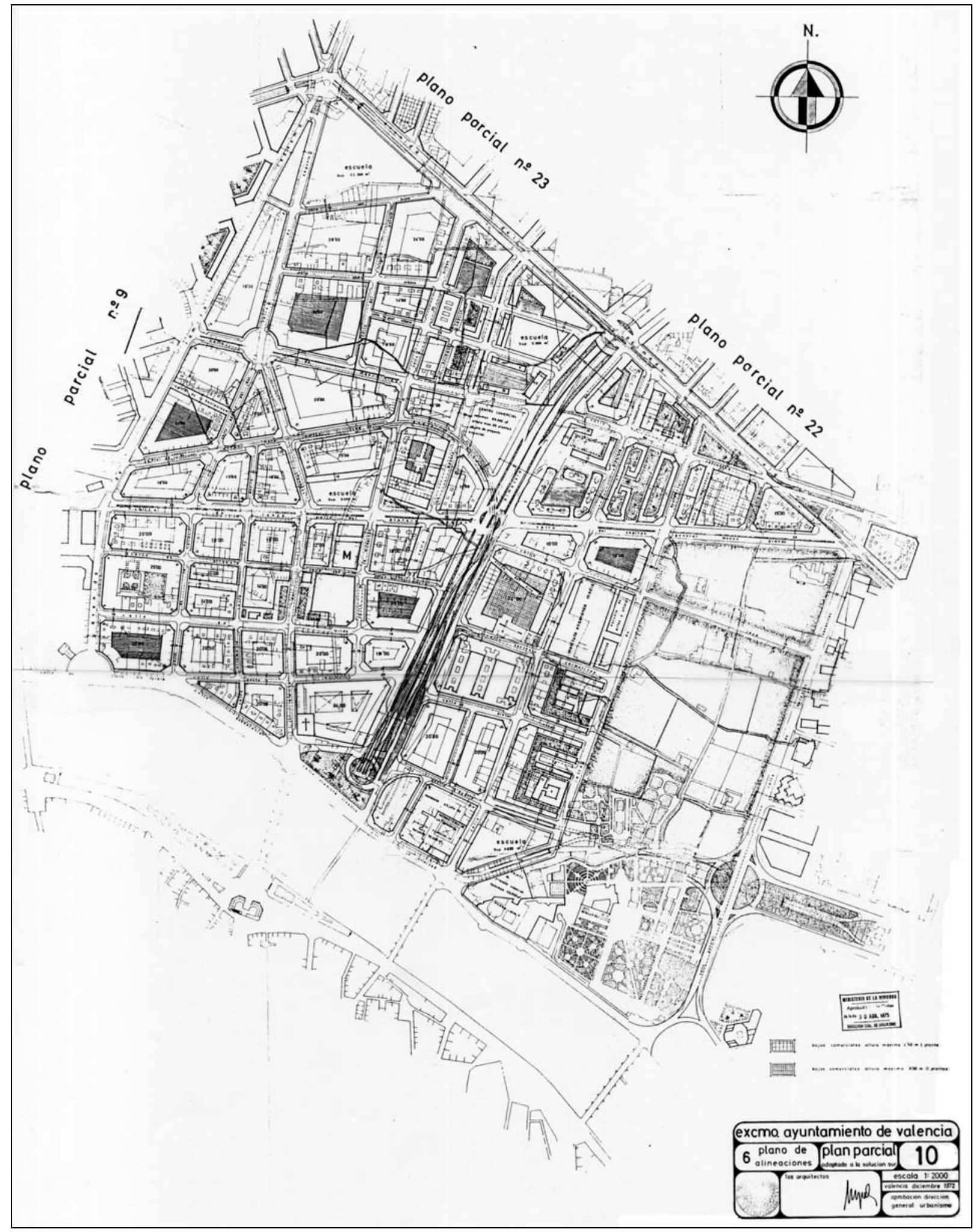




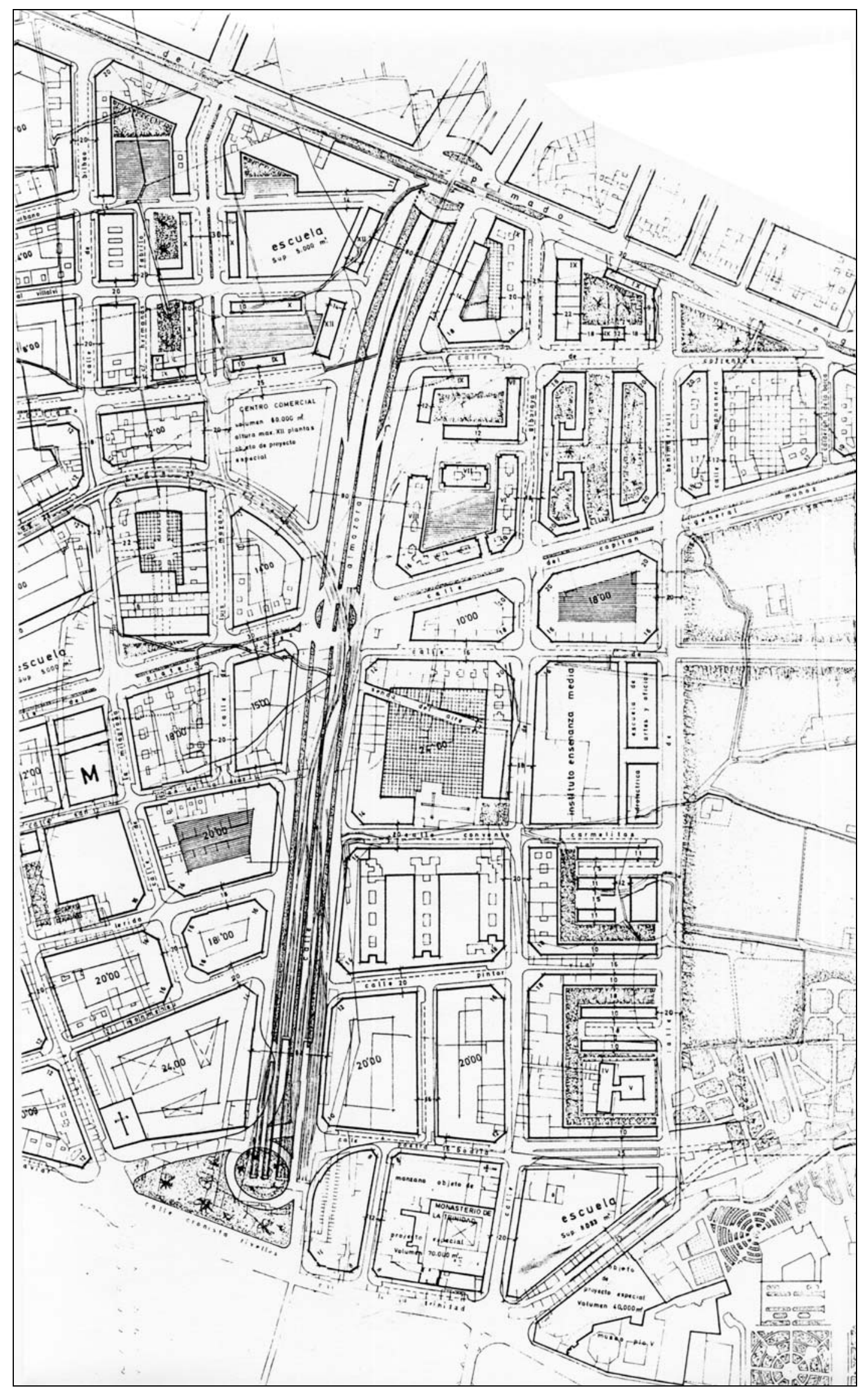

Detalle del Plano de Alineaciones. Zona de edificación abierta. 
7. RED VIARIA

Escala original: 1:2000

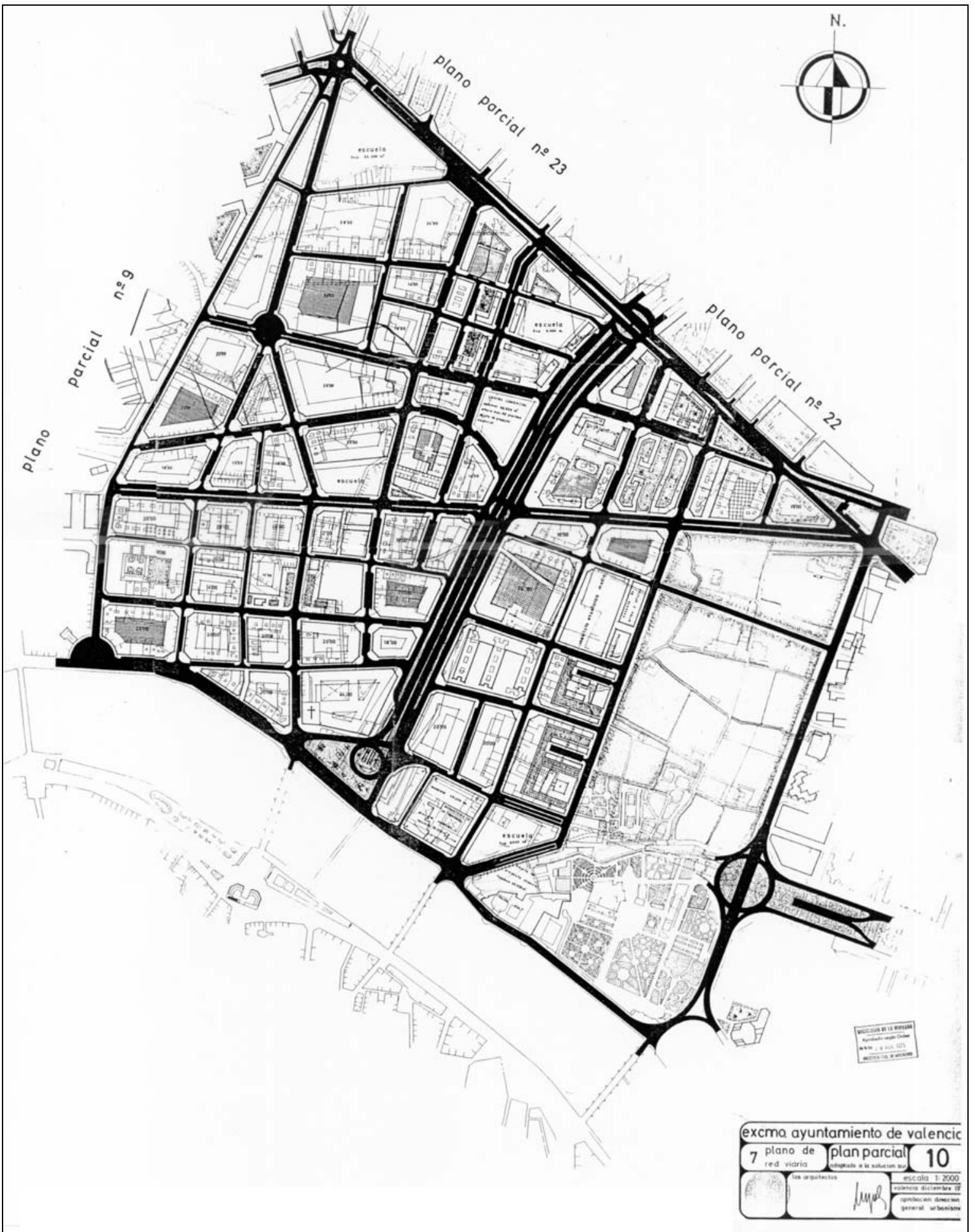


Redactor: Arquitecto Municipal. Ayuntamiento de Valencia

Fecha: 3-07-1973.

Asunto: Informe sobre alegaciones al Plan Parcial No 10.

Fuente: Ayuntamiento de Valencia. Sección de Urbanismo. Negociado de Suelo y Ordenación urbana. Expte. 11/73 (Archivo de Planeamiento No 190).
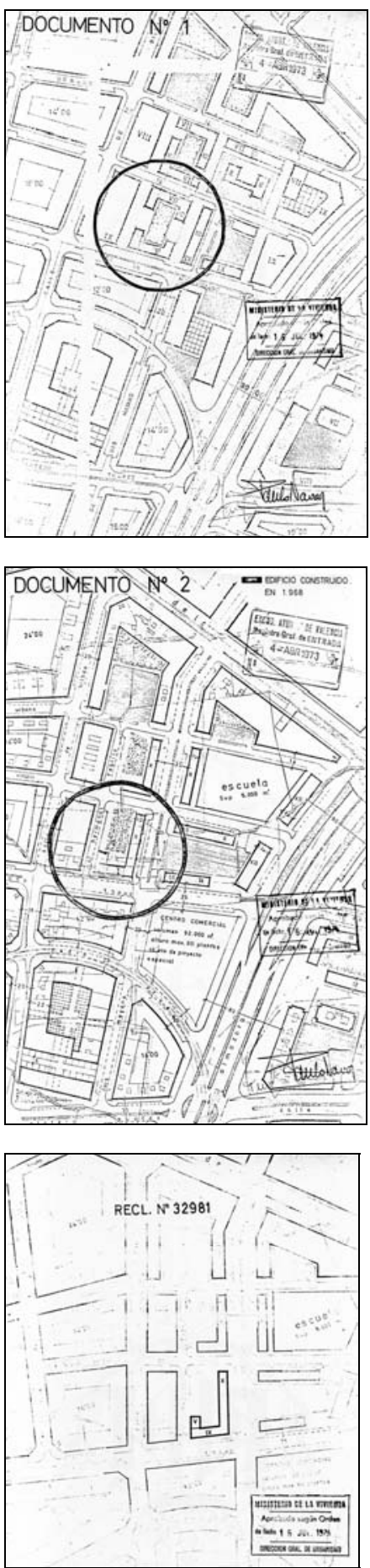

Reclamación No 32.981.
El Arquitecto Municipal que suscribe, a la vista de las reclamaciones presentadas con motivo de la exposición a información pública del nuevo estudio del Plan parcial 10, una vez estudiada su posible aceptación, tiene el honor de informar:

No 27.249. - D. VICENTE PORCAR BLAS Y OTROS.

Reclaman contra la desafectación de la celle Federico Tomás. Esta solución ya corresponde al Plan Parcial aprobado en 14-V1.956.

No 31.099.- D. SILVERIO ROYO LLISO.

Reclama contra la ubicación del mercado previsto en las calles San Guillem, San Juan de la Cruz y Milagrosa.

Esta solución ya corresponde al Plan Parcial aprobado en 14-V1.956.

NO 32.531.- Da MARIA LUISA MERCADER SANCHIS

Alega poseer una parcela con fachada a la calle Jaca sin indicar cual es. Dice que anteriormente hubo otro acuerdo inicial de aprobación. Por otra parte señala que una parcela recayente a las calles de Benimarfull y Jaca se ha visto invadida por una obra en construcción.

La nueva aprobación inicial es debida a que el Plan Parcial no fue aprobado por Gran Valencia y ha habido que realizar nuevo estudio. En cuanto a la referencia que hace a la construcción en la parcela esquina a Jaca y Benimarfull, se hace notar que no existe graficado en el Plan Parcial que se expuso al público ningún tipo de construcción.

No 32.979.- D. MIGUEL Y Da AMPARO COLLADO PEREZ.

No 33.517.- Da ELVIRA COLLADO SELMA.

Solicitan que no se ubique la escuela recayente a las calles Sagunto, Platero Suárez, Bilbao y en proyecto.

No 33.508.- Da VICENTA BARRERA GINER.

Solicita lo mismo que los anteriores, o que en su defecto se efectue la reparcelación.

Esta escuela es necesaria para cumplir con las dotaciones escolares de acuerdo con las normas dictadas por el Ministerio de Educación y Ciencia para la Educación General Básica.

No 32.980.- D. JOSE CAMPS PANACH.

Sugiere que se ubique un bloque entre otros dos situados en terrenos de su propiedad.

No hay posibilidad, pues no se cumplen las distancias que según las ordenanzas rigen para edificación abierta.

No 32.981.- D. AGUSTIN MIRAVET REDO.

Propone dos soluciones sobre un bloque de edificación abierta en la calle Maximiliano Thous, que queda parcialmente fuera de ordenación.

Se estima que puede aceptarse la segunda propuesta. Se acompaña plano donde se ha graficado esta solución.

No 32.982.- D. SANTIAO BERMEJO HERNANDEZ.

Reclama contra la desaparición de las vías y dependencias 
anexas de la Estación Central de Ferrocarriles Eléctricos de Valencia, y alega que no existe ningún nuevo emplazamiento proyectado.

Esta solución ya corresponde al Plan Parcial aprobado en 14-V$1.956, y$ al Plan general vigente.

No 32.983.- D. SALVADOR-LUIS BRUGGER AUBAN Y Da MARIAAMPARO ALBALAT BATALLER.

Dicen no cumplir el Plan Parcial 10 con la vigente Ley del Suelo (art. 10,e) y formulan consulta para que se les indique normas de alzado, volumen y estilo, a los que deberá sujetarse un proyecto de edificio a levantarse junto al museo de Bellas Artes.

El terreno está calificado como Zona Especial con destino a Centro Cultural. Según las normas del Plan General estas zonas deben ser reguladas por Proyectos singulares.

No 33.505.- D. FELIPE PICH AGUILERA.

NO 33.506.- Da TERESA DE LA TRINIDAD BRUÑO.

NO 33.509.- D. MANUEL AZNAR BOSQUE.

NO 33.510.- Da PILAR TEJEDOR BORRAS.

NO 33.511.- Da JOSEFA SAVAL PEREZ.

NO 33.512. - Da AMPARO FARINOS MONTORO.

NO 33.513.- D. MIGUEL MARI HERRERO.

No 33.514.- Da ANTONIA GARCIA BELLVER.

NO 33.515.- D. JULIAN PERALES CASTELLO.

NO 33.928.- OBRA SINDICAL DEL HOGAR.

NO 33.930.- D. JOSE FOLGADO SENA.

Solicitan que no se ubique la escuela recayente a las calles Alboraya, Flora y Vuelta del Ruiseñor ${ }^{1}$.

No 33.929.- D. MARIANO ANDREU LLOBAT.

Dice que no es correcto el establecimiento de zona escolar en la calle Alboraya, salvo que este destinado a concederse a las Madres Marianistas.

Esta escuela es necesaria para cumplir con las dotaciones escolares de acuerdo con las normas dictadas por el Ministerio de Educación y Ciencia para la Educación General Básica.

No 33.516.- FRAY JUAN FRANCISCO SAERA FERRADA.

Reclama contra el nuevo trazado de la Senda del Aire, ya que disminuye la disponibilidad de terreno de la Comunidad, edificable junto a la calle de Alboraya.

Se acompaña una nueva solución, dejando un pasaje que de acceso a la Senda del Aire y cuya altura libre no deberá ser inferior a $4 \mathrm{~m}$.

No 33.931.- D. RAMON SANZ HERNANDEZ.

Pide que en su momento se le venda el tramo de calle que enfrenta a las casas 8 y 10 de Palau y Quer y que queda desafectado por las nuevas alineaciones.

La petición es correcta, está regulada en el art. 100 del Reglamento de Bienes de las Entidades Locales.

NO 42.472.- D. JOSE GIL TERRON.

Dice que prolongando la alineación que se dio en su momento resulta un chaflán de $13 \mathrm{~m}$.

Se acompaña solución en la que se grafica chaflán de $11 \mathrm{~m}$. no afectándose ningún bloque circundante.

Valencia, 3 de Julio de 1.973.

EL ARQUITECTO MUNICIPAL,

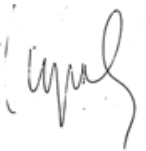
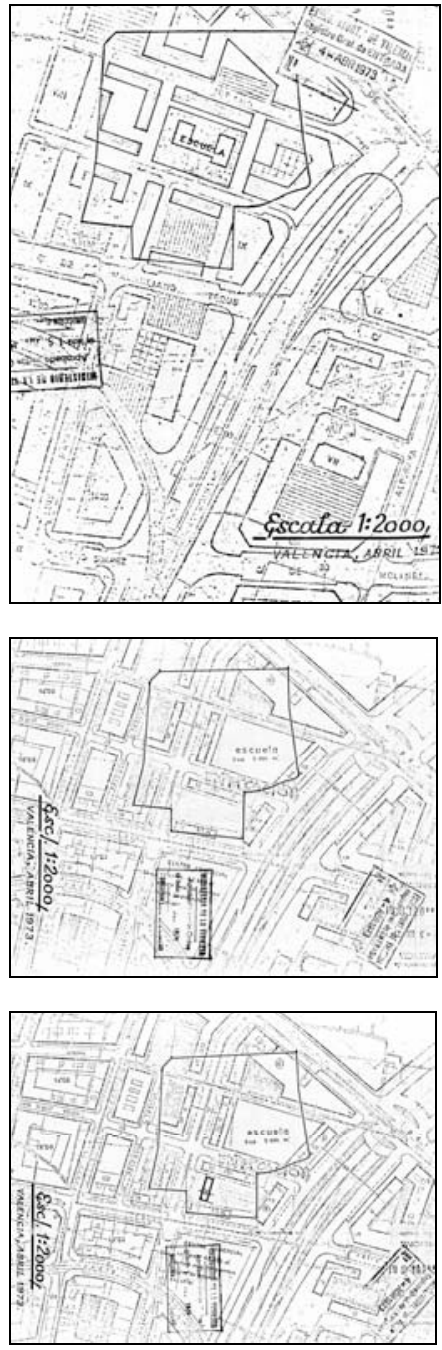

Reclamación No 32.980

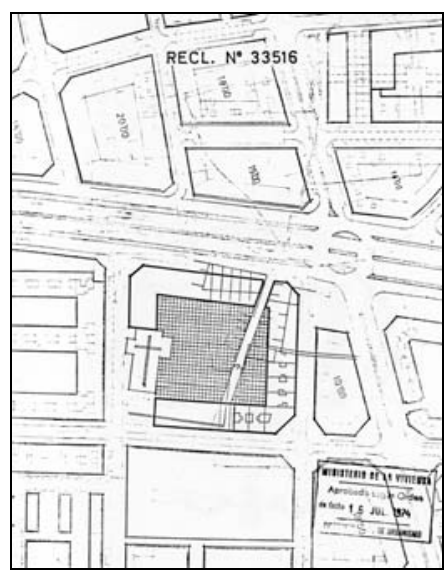

Reclamación No 33.516

1. Esta reclamación es la que, trasladada al Tribunal Supremo, ocasionó la anulación por éste del PP 10. 



\section{PP11}

PLANO PARCIAL No 11 (ADAPTADO A LA SOLUCIÓN SUR).

1968

\section{Redactores:}

EXCMO. AYUNTAMIENTO DE VALENCIA. OFICINA TÉCNICA DE URBANISMO. ARQUITECTOS: Julio Bellot, Cándido Orts, J.L. Quinzá $(*)$.

Fecha redacción: Junio $1968(* *)$.

Fecha aprobación: O.M. 15-04-70 (B.O.E. 26-05-70).

Contenido:

I. MEMORIA

II. ORDENANZAS.

III. PLANOS:

1. PLANO DE SITUACIÓN DENTRO DE LA CIUDAD. $1: 10.000$

2. SITUACIÓN EN EL PLAN GENERAL $1: 22.500$

3. FOTOPLANO. S/E

4. ESTADO ACTUAL Y DELIMITACIÓN. $1: 2000$

5. ESTRUCTURA URBANA $1: 2000$

6. ZONIFICACIÓN $1: 4000$

7. RED VIARIA FUNDAMENTAL $1: 2000$

8. ALINEACIONES Y RASANTES. $1: 2000$

9. REDES FUNDAMENTALES DE SERVICIO.

$\begin{array}{ll}\text { RED DE ALCANTARILLADO. } & 1: 2000 \\ \text { ESQUEMA DE RED DE AGUAS POTABLES. } & 1: 2000 \\ \text { ESQUEMA DE ALUMBRADO. } & 1: 2000\end{array}$

IV. PLAN DE ETAPA DE ACTUACIÓN.

Fuente: Ayuntamiento de Valencia. Sección de Urbanismo. Negociado de Suelo y Ordenación urbana. Expte. 376/1967. Reg. General 72.334 (Archivo de Planeamiento No 91).

\section{Notas:}

* Los nombres de estos arquitectos no figuran en los planos, sino únicamente en la carpeta del expediente del PP 11.

** Esta versión del PP 11 es la redactada una vez introducidas en la versión inicial las modificaciones derivadas de las dos rondas de alegaciones, antes y después de la aprobación inicial municipal, de fecha 16-11-1967. 
EXCMO. AYUNTAMIENTO

DE VALENCIA

\author{
OFICINA TÉCNICA DE URBANISMO \\ PLAN PARCIAL NO 11 -ADAPTADO A LA SOLUCIÓN SUR-
}

\title{
MEMOR I A
}

\section{OBJETO DE ESTE ESTUDIO}

La redacción del Plan Parcial no 11 se debe a la adaptación del Plan General de Ordenación Urbana de Valencia y su Comarca a la Solución Sur.

El Plano Parcial no 11 se halla limitado por la Avda. de Primado Reig, margen izquierda del Rio Turia, Nuevo acceso de de Barcelona y la Av. General Elío -calle Botánico Cabanilles.

Como consecuencia de la redacción, por parte de la Jefatura de Obras Publicas en su Oficina Regional de Proyectos y Carreteras, del estudio de todos los accesos de la Ciudad por carretera y las carreteras de tránsito y circunvalación, este Plan Parcial se ha visto también afectado teniendo que adaptarlo a las modificaciones que han traído consigo el citado estudio, estableciendo aparcamientos posibles, sin producir exceso de trastornos a la propiedad particular -puesto que este Plano ha estado en uso durante mucho tiempo en el Ayuntamiento-, así como pequeñas modificaciones parciales del esquema urbanístico para mejorarlo.

El Camino de Tránsitos o Ronda Interior -Av. del Primado Reig-. Esta vía limita al Plan Parcial por su lado Norte, como se dijo anteriormente y lleva consigo unas exigencias en lo que se refiere a cruces de calles y embocadura de las mismas. Además de facilitar el acceso directo a la propiedad, posibilita el estacionamiento marginal de vehículos en algunas partes importantes.

Nuevo acceso de Barcelona: Este acceso lo limita por el Este siendo esta arteria incorporada al Plan Parcial con todas las características del trazado que para ella se ha previsto.

El resto de calles se ha estudiado con el fin de conseguir una mayor fluidez en el trafico definiendo las secciones transversales y radio de giro necesarios.

Parte muy importante en este Plan Parcial ha sido también el convertir la Pasarela de la Exposición -anteriormente solo para peatones- en paso para vehículos.

Se ha pretendido que el Paseo al Mar adquiera mas carácter de paseo aumentando su zona central de paseo con la eliminación de alguna de las vías que cruzaban. 


\section{JUSTIFICACIÓN DE LAS ORDENANZAS}

Lo dicho anteriormente justifica por sí solo la ordenación propuesta. Además el Plan General, aunque prescindiendo seguir en todo las zonificaciones establecidas en los planos parciales que el Ayuntamiento tenía redactado y en redacción, ha modificado pequeñas zonas, ha establecido zonas comerciales, etc.

Todo ello se ha plasmado en la redacción del Plan Parcial presente y aunque parece que haya alguna modificación sobre el Plan General, no es así ya que, en los polígonos que se forman en el Plan General, éste tiende a generalizar zonificaciones sin las particularidades que existían y deben continuar, y, dada la escala del Plan General, si consideramos que el Plan General ya lo dice todo, resultará que el Plan General no será un. Plan General sino la suma de planos parciales en pequeño, que no necesita, para su desarrollo mas que aumentarlo de tamaño. Sabemos que esto no es así sino que el Plan general en su adaptación a la Solución Sur ha redactado respetando al planos parciales existentes anteriormente $o$ pendientes de aprobación.

Por todo ello la justificación de la ordenación es la de desarrollar el Plan General y adaptarse a él.

En el Plan Parcial se diferencian claramente dos zonas de distinto carácter separadas por la principal vía de este Plan Parcial: El Paseo al Mar.

La zona situada al sur del citado Paseo y limitada además por el Nuevo acceso de Barcelona, margen izquierda del Río Turia y Av. del General Elío, corresponde a la llamada Zona de ensanches hasta Tránsitos. En el vértice de esta zona, limitado por el Paseo de la Alameda y el nuevo acceso de Barcelona se halla emplazado un Centro Comercial.

Incrustada en esta Zona se halla una zona verde -actual campo de fútbol, Mestalla- y lindando por dos de los lados de ésta y formando una ele se ubica una zona de edificación abierta alta.

La Zona situada al norte del Paseo al Mar comprende: Zona especial -Cultural, Sanitaria, Deportiva, etc.- y comprende dos manzanas recayentes al citado Paseo. Zona de reserva deportivo-universitaria, y el resto Zona de edificación abierta alta.

La manzana limitada por las calles, Jaime Roig, Juan Martorell. Botánico Cavanilles y el Paseo al Mar, así como los terrenos donde hoy día se halla ubicada la feria de Muestras y el Palacio de Ripalda, debido a su situación privilegiada -Principio del Paseo al Mar y Paseo de la Alameda, frente al Río y junto al arranque del Puente del Real cuyo ensanchamiento ya está iniciado, y estando situados frente por frente de la zona verde de mayor extensión que posee Valencia: Parque de Viveros Municipales -se ha tratado como zona de edificación abierta alta considerando los edificios allí ubicados como "SINGULARES".

La Zona Ensanche hasta Tránsitos, casi totalmente construida en la actualidad, está formada por manzanas cerradas donde se ha respetado la profundidad edificable indicándoles en 
aquellas que no tenían anteriormente este destino.

Se ha reservado terreno para escuelas, centros comerciales, aparcamientos, jardines, centros religiosos, etc.

En todo ello se ha procurado que domine la prudencia, si bien es cierto que no señalar el futuro emplazamiento de algún edificio público, compromete su futura situación, también es cierto que señalar mas elementos de los que se prevé que el Municipio construya, o por lo menos adquiera los terrenos, tiene el inconveniente de que a los diez años se recobra el libre ejercicio de las facultades dominicales, según el artículo 56 de la Ley del Suelo, haciendo inútil el plano.

Con todo lo dicho creemos suficientemente expuesto el alcance el estudio realizado para que, si el Excmo. Ayuntamiento lo estima conveniente, lo eleve a la aprobación por la Superioridad.

Valencia, mayo de 1969.

LOS ARQUITECTOS MUNICIPALES.

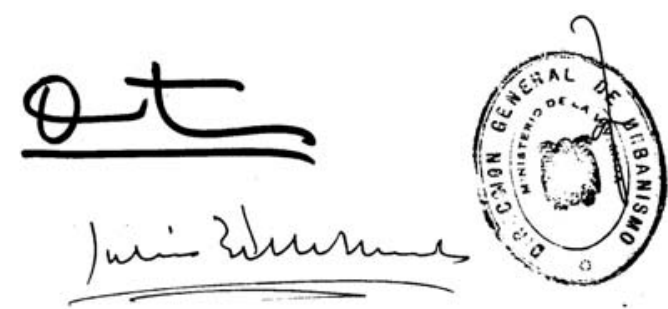


EXCMO. AYUNTAMIENTO

DE

VALENCIA

\section{PLANO PARCIAL NO 11}

Proyecto de Alineaciones y Zonificación del Sector limitado por el perímetro de las calles siguientes:

NORTE: Avenida de Primado Reig.

SUR: Paseo de la Alameda.

ESTE: Prolongación del Nuevo Acceso a Barcelona.

OESTE: Avda. General Elío y Botánico Cavanilles.

\section{ORDENANZAS}

Hasta que no se aprueben las ordenanzas adaptadas a la Solución Sur en estudio, se aplicarán las vigentes aprobadas por la Comisión Central de Sanidad en 23 de octubre de 1.950 y 26 de enero de 1.955, en los casos no previstos en las normas urbanísticas del Plan de Ordenación de Valencia y su Comarca, adaptada a la "Solución Sur" por la que tendrá que regirse actualmente este Ayuntamiento.

A este Plano Parcial le corresponde la zonificación de Ensanche hasta Tránsitos, Edificación abierta.

Valencia, marzo de 1967.

LOS ARQUITECTOS MPLES.,

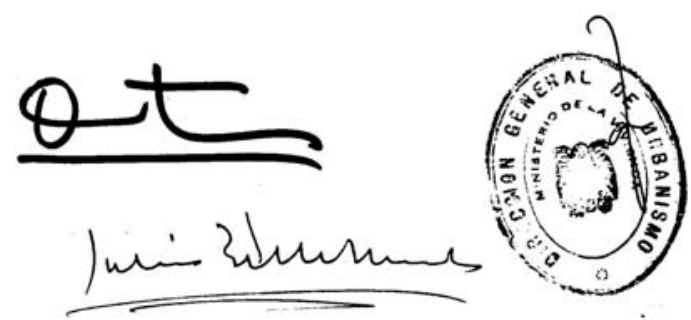


EXCMO. AYUNTAMIENTO

DE

VALENCIA

PLANO PARCIAL NO 11

\section{PLAN DE ETAPAS}

Siendo este Plan Parcial destinado por el momento a la edificación por particulares, no pueden marcarse etapas de realización que dependerán de la actividad constructiva de los mismos. Sin embargo, el Excmo. Ayuntamiento, además de construir los elementos urbanísticos generales en una primera etapa, se mantendrá siempre en la urbanización adelantando sobre la iniciativa particular, urbanizando zonas que se prevea edificación inmediata

\section{MEDIOS ECONÓMICO FINANCIEROS}

Son los del presupuesto ordinario de Urbanismo del Excmo. Ayuntamiento de Valencia y los extraordinarios que se establezcan a medida que se cumpla lo dicho en. el párrafo anterior y se disponga de proyectos detallados de urbanización»

Valencia, marzo de 1967.

LOS ARQUITECTOS MPLES. DE URBANISMO,

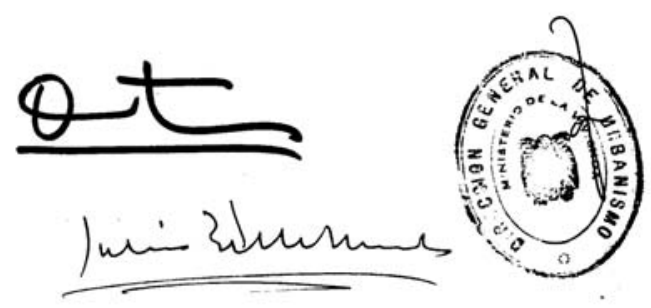


1. PLANO DE SITUACIÓN EN LA CIUDAD

Escala original: $1: 10.000$

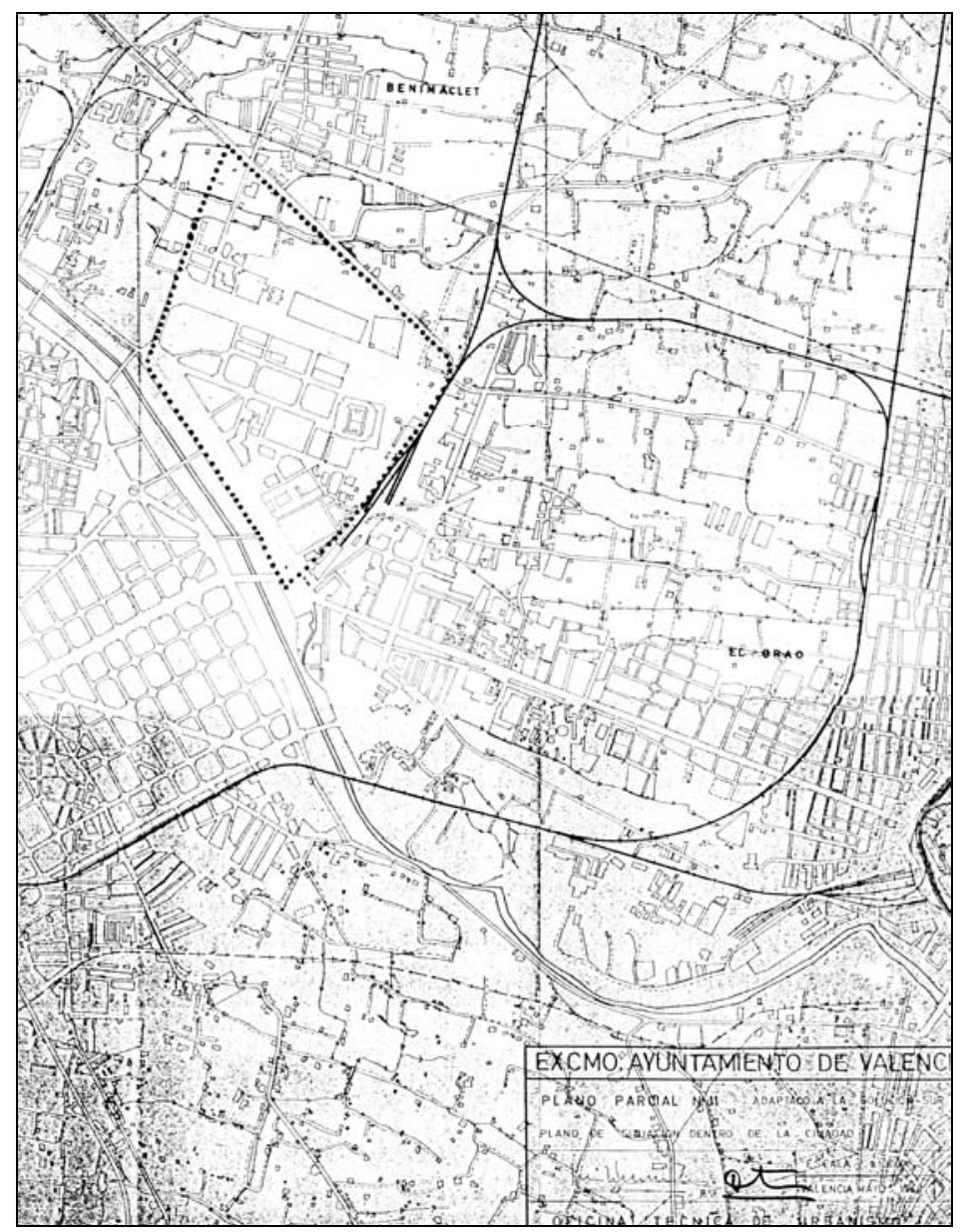

2. PLANO DE SITUACIÓN EN EL PLAN GENERAL (Fragmento) Escala original: $1: 22.500$

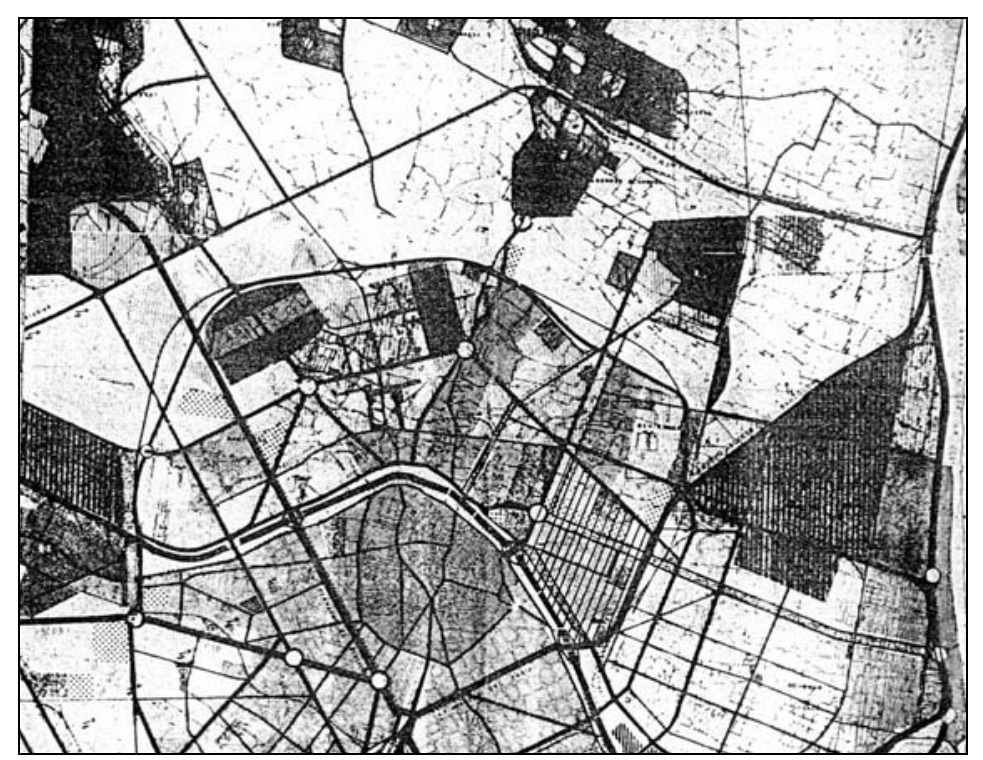



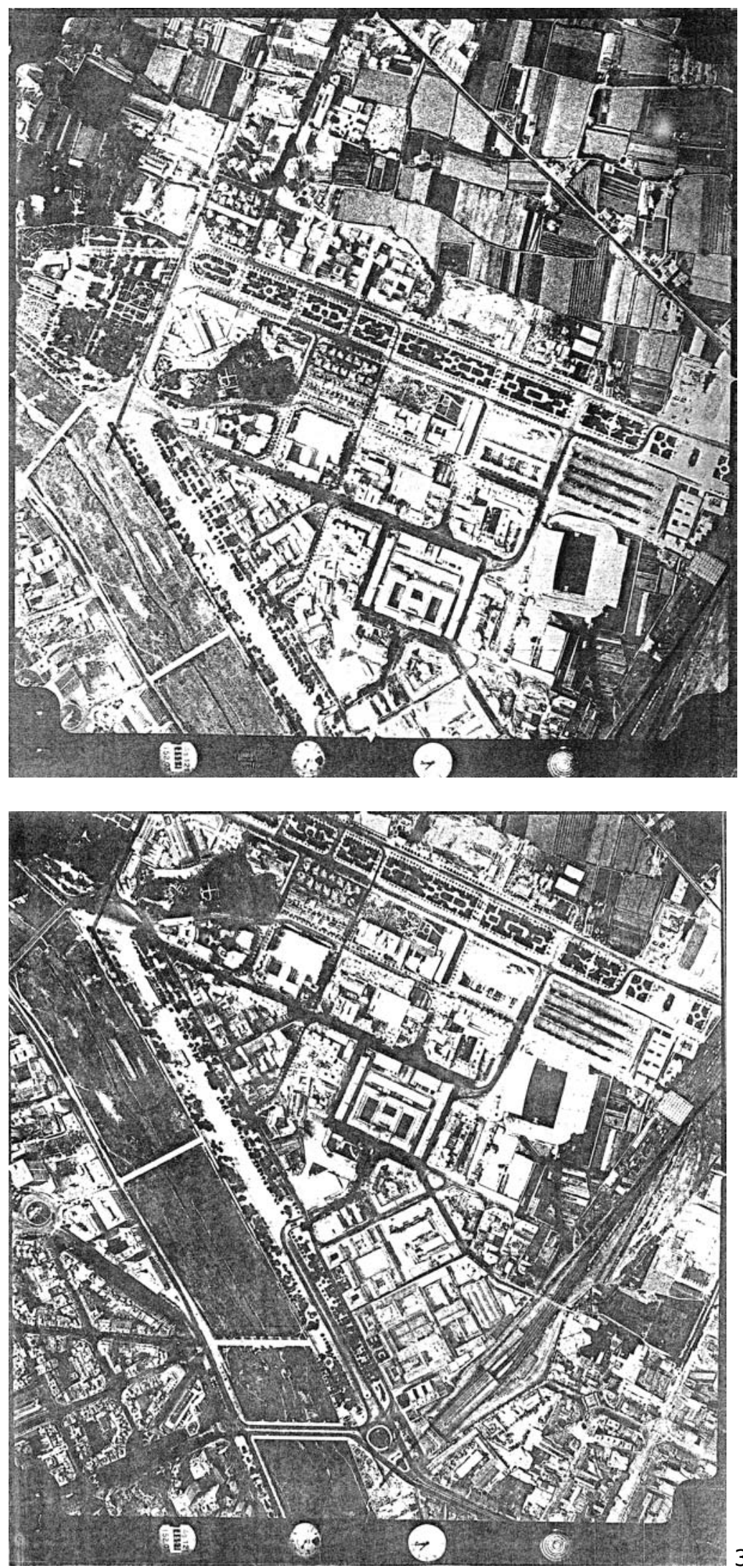
6. ZONIFICACIÓN.

Escala original: 1:4000

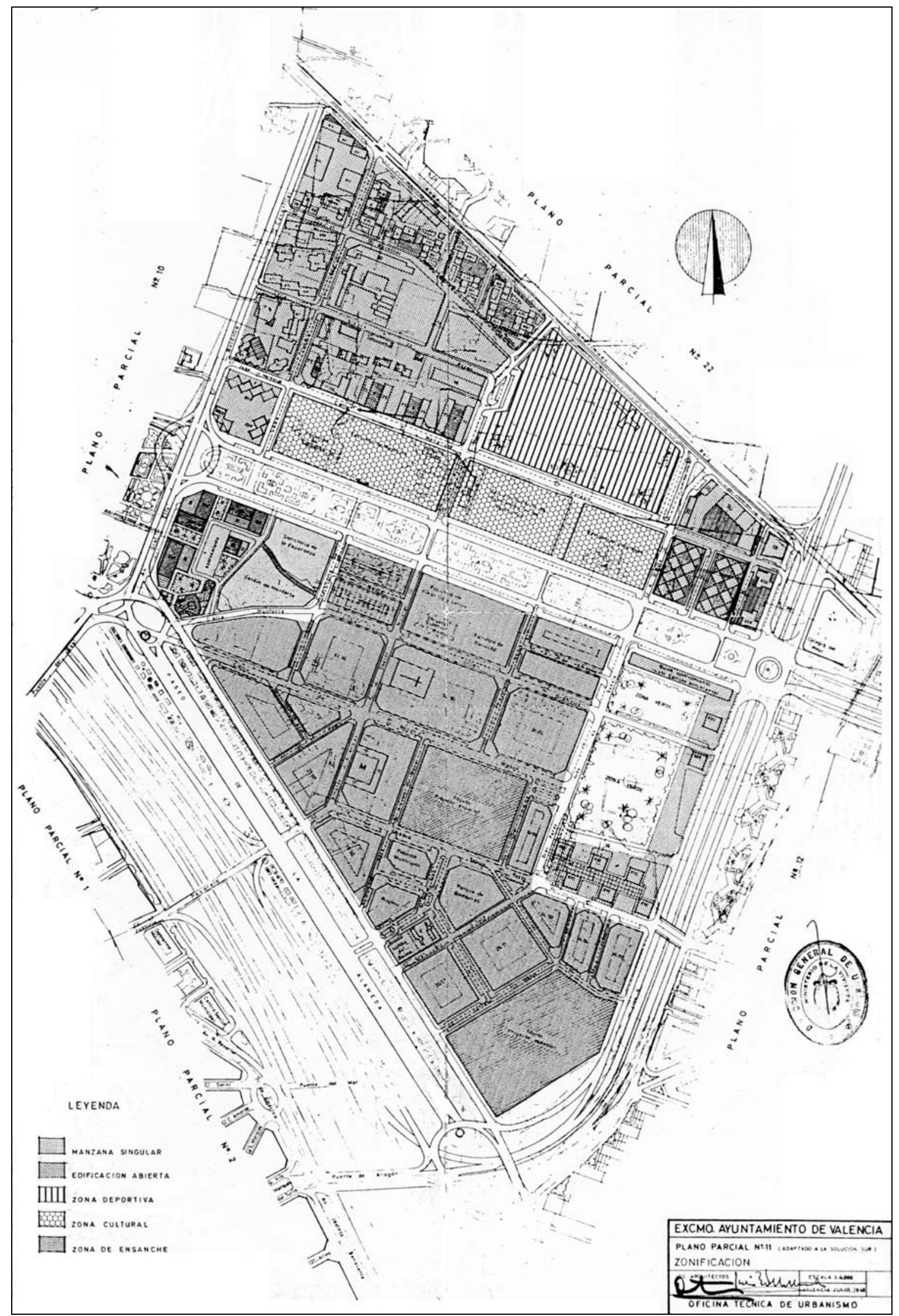


8. ALINEACIONES Y RASANTES.

Escala original 1:2000

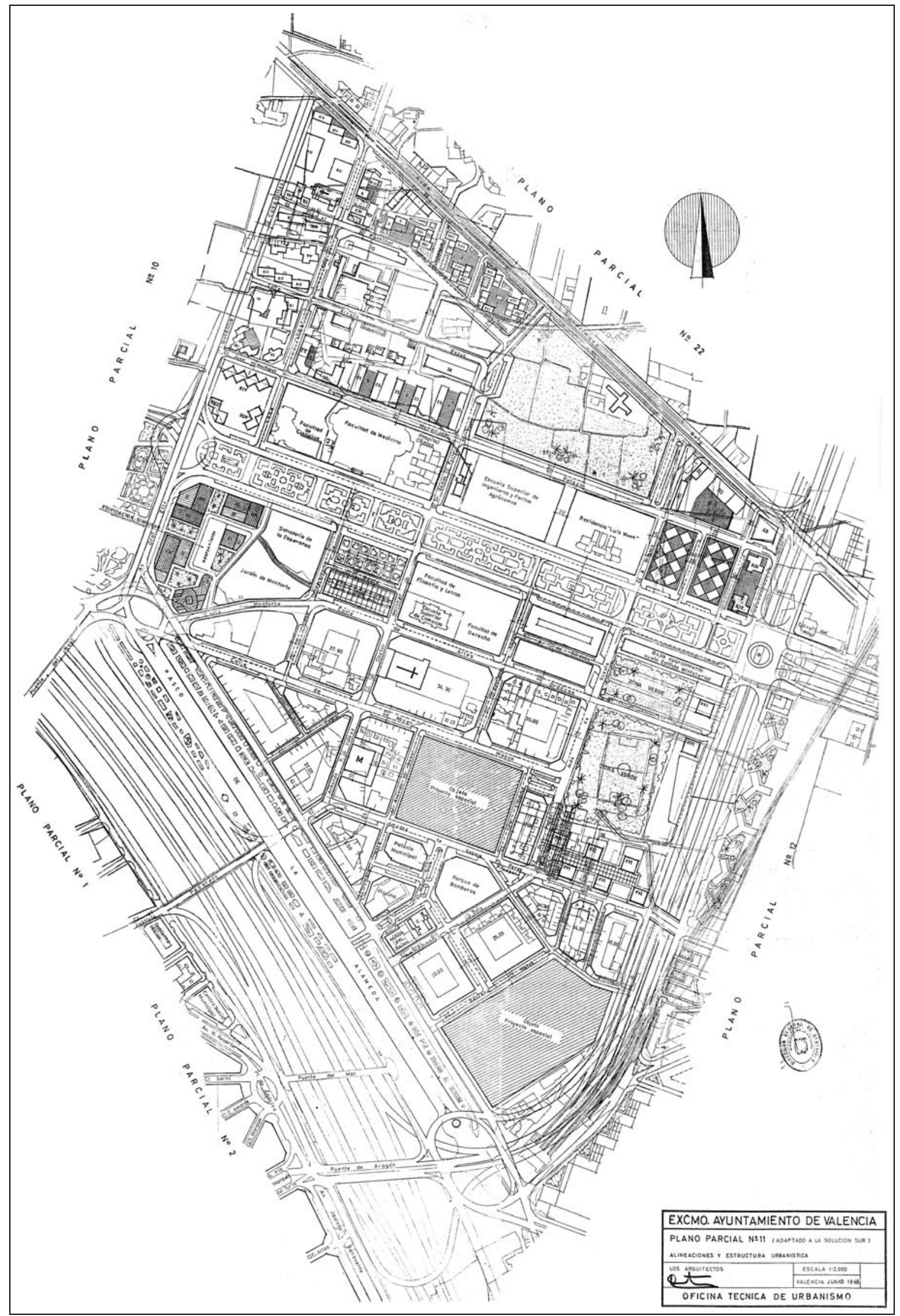




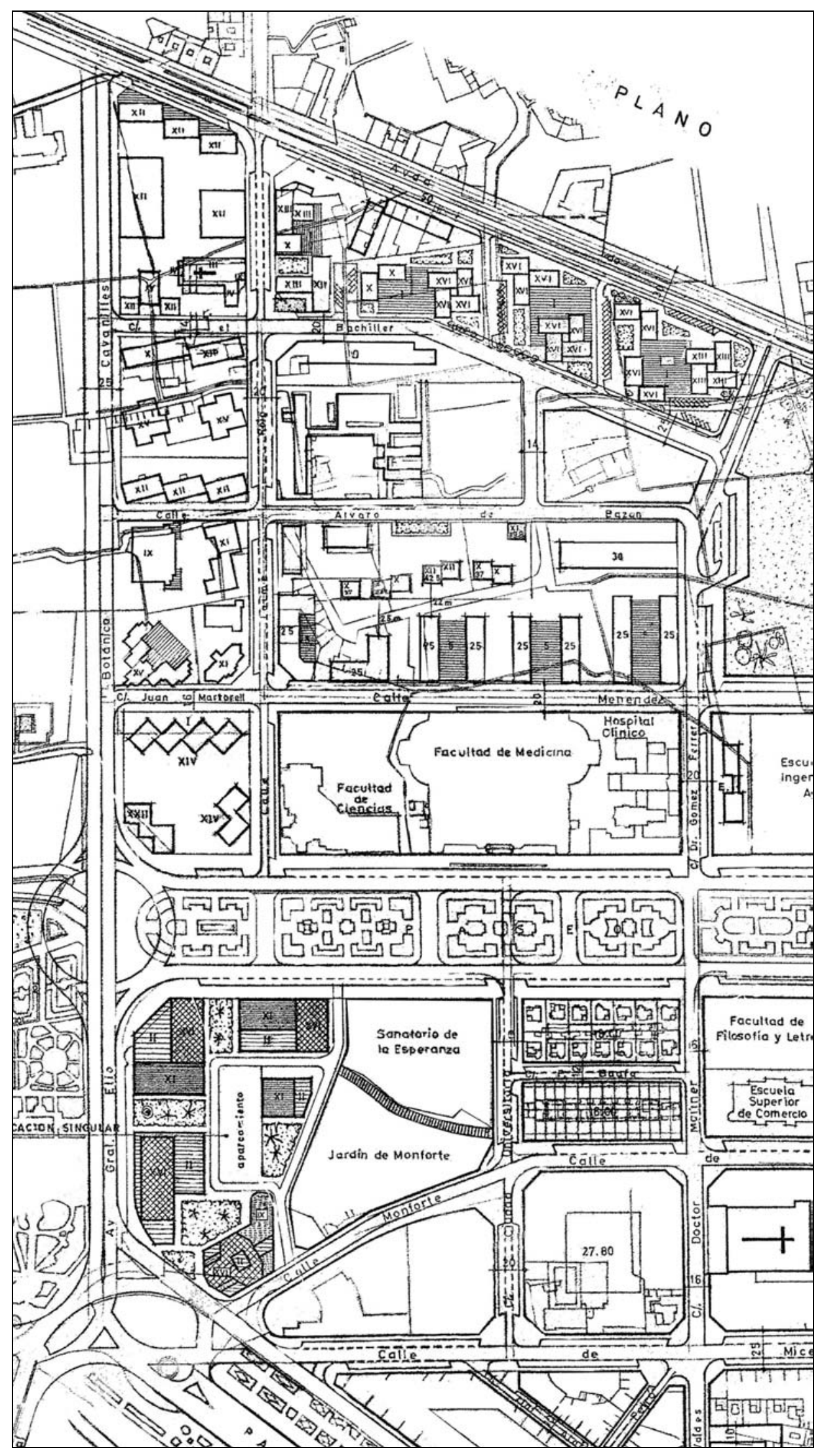

Plano de alineaciones. Detalle de las zonas de Jaime Roig y Llano del Real. 


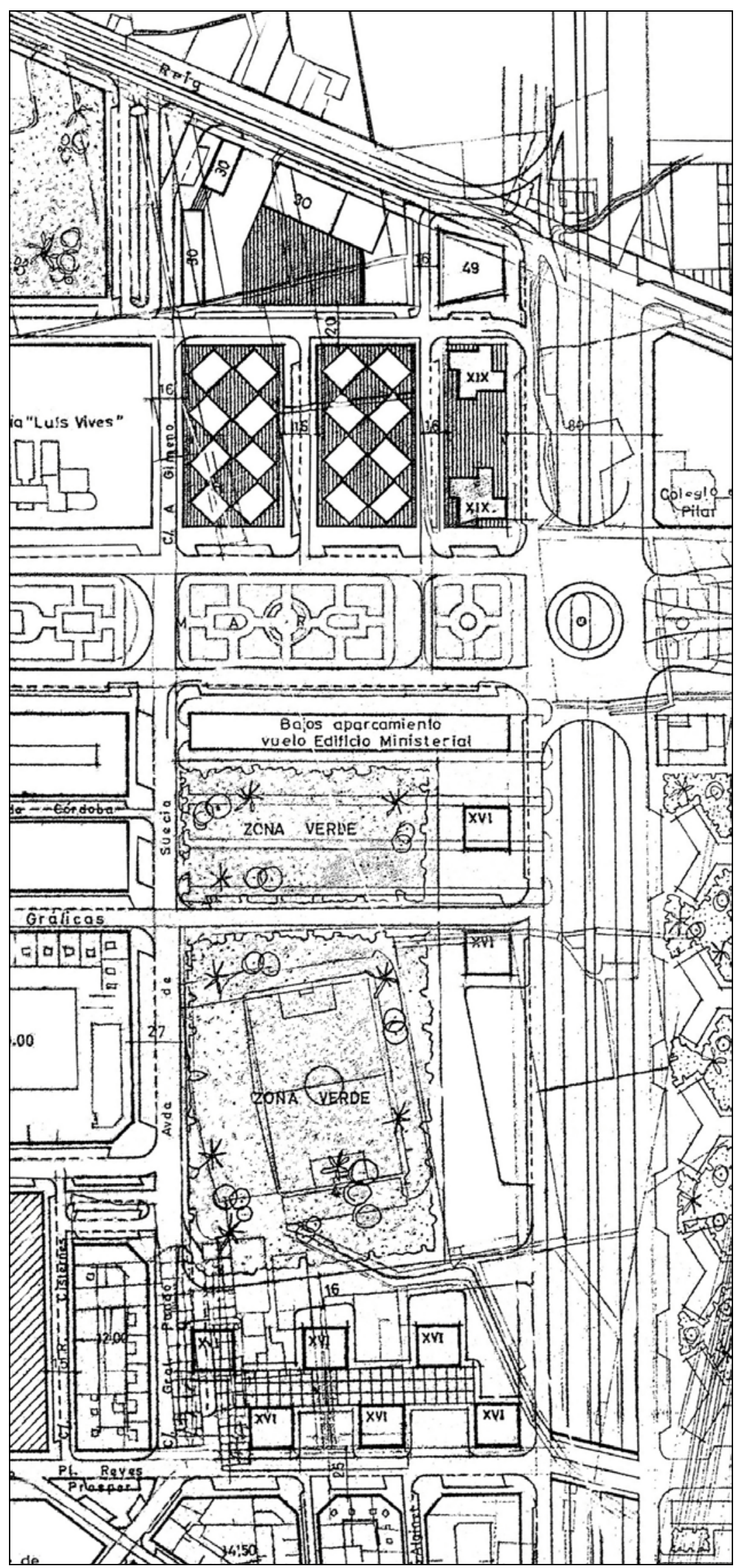

Plano de alineaciones. Detalle de las zonas de Menéndez Pelayo y Mestalla. 
Redactor: El Arquitecto Municipal de Urbanismo. Ayuntamiento de Valencia.

Fecha: 31-10-1967

Asunto: Informe sobre la primera ronda de alegaciones presentadas al nuevo estudio del Plano Parcial No 11.

Fuente: Ayuntamiento de Valencia. Sección de Urbanismo. Negociado de Suelo y Ordenación urbana. Expte. 376/1967. Reg. General 72.334 (Archivo de Planeamiento, No 91).

El Arquitecto Municipal que suscribe, ante las alegaciones motivadas por la exposición a información publica del nuevo estudio del plano parcial $n^{\circ} 11$ con motivo de la tramitación del vigente plan general de ordenación urbana de Valencia y su comarca a la solución sur de 30 de Junio de 1966, una vez estudiadas las mismas y sus posibles aceptación y soluciones, tiene el honor de informar:

86151.- D. Francisco.Ripoll Carbonell.-

Debe desestimarse por tratarse de una incidencia de vias importantes y deben por tanto permitir los chaflanes una buena visibilidad en el cruce, así como por el carácter del uso de la. edificación, estación de servicio, debe disponer de espacio a efectos de maniobras de los vehículos. Por otra parte no se trata de rectificación respecto al plano parcial aprobado por la superioridad.

79731.- D.. José Feliciano Peris.-

82245.- D. Salvador Sales Martí.-

02248.- D. Juan Martí Diez.-:

Estas alegaciones se refieren a la solución dada a la manzana comprendida entre Avda. Primado Reig, calle Jaime Roig, calle Bachiller y prolongación calle Dr. Gómez Ferrer.

La solución dada a esta manzana en la nueva redacción del plano parcial 11 mantiene el mismo aprovechamiento en cuanto a coeficiente de edificabilidad que la solución propuesta en el plano parcial 11 anteriormente aprobado, y estimamos supera a ésta en cuanto a espacios libres diáfanos, suprimiendo el efecto de pantalla, y creando volúmenes de una más clara solución arquitectónica sin perjudicar a terceros.

Por todo ello estimamos que, tras una previa reparcelación entre todos los propietarios de la manzana, debe mantenerse esta solución u otra de este tipo que puede ser objeto de una propuesta por parte de los mismos.

82596.- D. Pedro y Edmundo Veyrat Colin.-

81912.- D. Pedro y Edmumdo Veyrat Colín.-

Estas alegaciones se refieren al ancho del nuevo acceso de Barcelona impuesto por razón de viario y por tanto no estimable por parte de este Excmo. Ayuntamiento.

\section{7.- Dña. Teresa Sancho Báguena.-}

Esta alegación es reproducción de la formulada con ocasión. de la ordenación de la manzana de la Feria de Muestras que ya ha sido aprobada por el Excmo. Ayuntamiento Pleno, debiendo hacer constar que dicha ordenación es independiente, $a$ efectos de coeficiente, de la superficie ocupada por jardín de Monforte y Sanatorio 


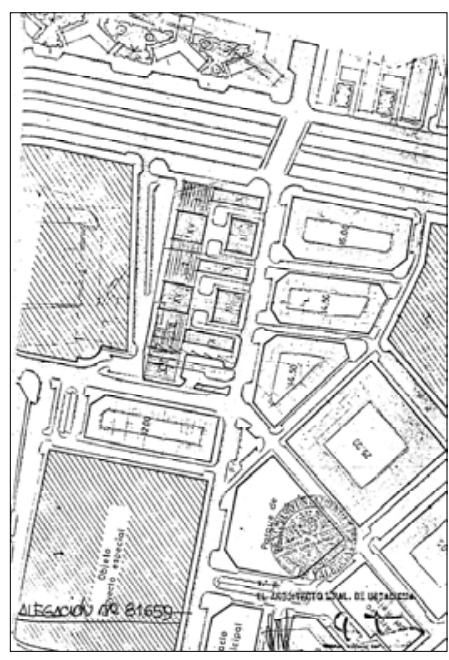

Alegación 81659. Propietarios del Barrio Obrero sito en $\mathrm{C} /$. General Pando de la Esperanza, pudiendo ser estos terrenos, en su día, objeto de ordenación por su parte.

80241.- D. Daniel Moret Plaza.-

Debe desestimarse esta alegación por cuanto la separación de este bloque con el situado próximo a él en el solar de las P.P. Carmelitas debe considerarse a testa y no separación de fachadas principales de bloques con lo que cumple sobradamente dicha separación a efectos de ordenanzas. Por otra parte la aprobación por parte del Excmo. Ayuntamiento de un bloque de tales dimensiones y aprovechamiento como el reclamante no puede ser objeto de daños a terceros mientras no incumpla con ordenanzas vigentes cosa que estimo no ocurre.

Sin embargo la propuesta de nueva disposición de bloques por parte do los P.P. Carmelitas acepta y resuelve de hecho esta alegación.

\section{6. - Valencia Club de. Fútbol.-}

Debe mantenerse la solución expuesta a información pública pues la propuesta por el interesado ya fue objeto de estudio y rebasa el coeficiente autorizado en esta zona.

\section{7.-D. Manuel Sais Calatayud.-}

Debe desestimarse por rebasar la solución propuesta el coeficiente de edificabilidad y suponer reforma innecesaria del plano anterior.

79732.- D. Francisco y Dña. Amparo Belenguer Julia.-

El vigente plan general marca esta zona con zonificación de zona verde deportiva de la Ciudad Universitaria.

El plano parcial $n^{\circ} 11$ aprobado por la Dirección General de Urbanismo en 29 de Diciembre de 1.960 fijaba ya el aparcamiento en cuestión.

El Arquitecto que suscribe estima que debe mantenerse dicho aparcamiento y uso, como servicio de la zona universitaria y especialmente como deslinde y separación clave entre esta zona y los intereses privados, restando injerencias de estos en aquella.

\section{3.- D. Augusto Dobler Santer.-}

Debe aceptarse esta alegación de reducción del ancho de la calle que une a Alvaro de Bazán con calle Bachiller, de 20,00 metros a 14,00 metros y a que la consulta sobre viario realizada a obras públicas obro en el sentido de lo innecesario de este ancho dada la escasa circulación de la misma y el ensanche tendría que hacerse por el lado del reclamante por estar construyendo el paramento opuesto.

81659.- Propietarios del Barrio Obrero sito en C/. General Pando.

Dado el carácter de este barrio y a efecto de concederle un cierto aprovechamiento del solar que actualmente ocupa, estimo podría aceptarse esta reclamación trasladando la superficie de aparcamiento proyectada y colocando un bloque edificable tal como se gráfica en el croquis de solución, que se adjunta, y tras una previa re parcelación entre todos los propietarios.

82244.- Cooperativa de la Asociación de la Prensa Valenciana.- 
tural, dado su emplazamiento y carácter de esta zona entre grupos de edificación abierta densa, y el valor de dichos solares, podría aceptarse la alegación en el sentido de zonificarla como edificación abierta con un coeficiente similar a los de la zona en que se enclava, cuya solución acompañamos en croquis adjunto.

82752.- Padres Carmelitas A.O. de Aragón y Valencia.-

La solución expuesta al público daba a la manzana en que se ubica este emplazamiento un coeficiente próximo a los 10,00 $\mathrm{m} 3 / \mathrm{m} 2$. No obstante debido al relativo bajo coeficiente en la parcela propiedad de esta orden, podría aceptarse un ligero aumento del mismo en el sentido apuntado en croquis adjunto al efecto.

\section{3.- Cooperativa de Agentes Comerciales Sección H.-}

Se traslada la posición del bloque objeto de esta alegación hasta situarlo a línea del contiguo.

Es cuanto .creo poder informar.

V.E. no obstante, resolverá.

Valencia 31 de Octubre de 1.967

El Arquitecto Municipal de Urbanismo

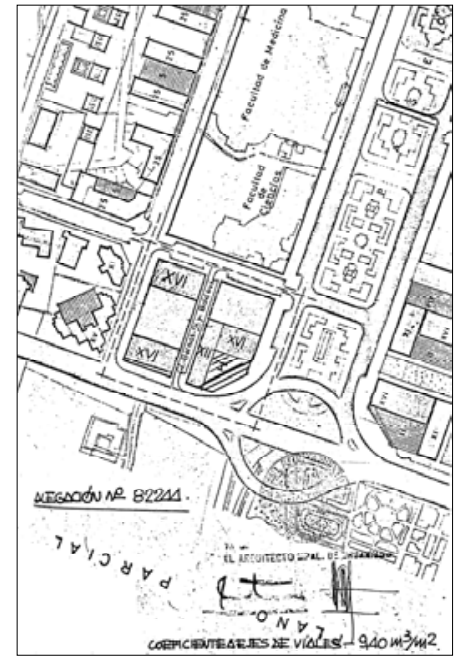

Alegación 82244. Cooperativa de la Asociación de la Prensa Valenciana

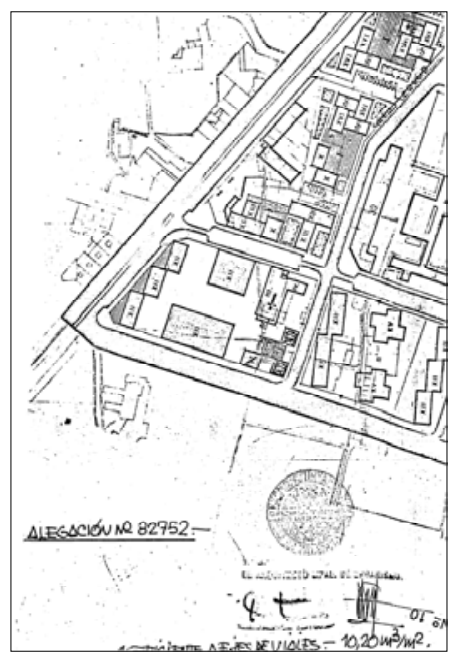

Alegación 82752. Padres Carmelitas A.O. de Aragón y Valencia 
Redactor: Dirección General de Urbanismo del Ministerio de la Vivienda / Ministerio de la Vivienda.

Fecha: 4-04-1970 / 15-04-1970.

Asunto: Resolución de aprobación del Plan Parcial 11 condicionada a modificaciones sustanciales del mismo.

Fuente: Ayuntamiento de Valencia. Sección de Urbanismo. Negociado de Suelo y Ordenación urbana. Expte. 376/1967. Reg. General 72.334 (Archivo de Planeamiento No 91).

MINISTERIO DE LA VIVIENDA

Dirección General de Urbanismo.

Excmo. Sr.:

Visto el Plan Parcial de Ordenación. Urbana núm. 11, de Valencia, adaptado al Plan General de Ordenación Urbana de Valencia y su Comarca, revisado, presentado por el Ayuntamiento de la citada localidad, y

Visto el informe emitido por los Servicios competentes de la Dirección General de Urbanismo.

Esta Dirección General, teniendo en cuenta lo dispuesto en la Ley sobre Régimen del Suelo y Ordenación Urbana de 12 de Mayo de 1956, en la Ley 15.8/1963 de 2 de Diciembre y en el Decreto $63 / 1968$, de 18 de Enero, tiene el honor de proponer a V.E. la aprobación del referido Plan con las siguientes modificaciones:

$1^{a}$.- Suspender la aprobación del Plan en el Sector comprendido entre las calles Menéndez y Pelayo, Juan Martorell, Botánico Cavanilles, Avenida Primado Reig y calle, uniendo esta Avenida con la calle Menéndez y Pelayo, separa a este sector de una zona verde destinada en el Plan. Parcial a uso deportivo, en tanto no se justifique suficientemente, ante este Departamento, por la Corporación Local, que el volumen de edificación asignado a dicho sector se ajusta a las previsiones del Plan Comarcal, o, en otro caso, se presente la documentación por la que se expongan los motivos en los que se hubiera basado la modificación pretendida, demostrativos del carácter concreto y excepcional del supuesto y el cumplimiento de la exigencia legal de la previsión de mayores espacios libres, conforme a lo establecido en los artículos 46 núm. 2 y 39 num. 2, de la Ley de 12 de Mayo de 1956.

$2^{a}$.- Excluir de la aprobación la ordenación de los terrenos comprendidos entre el Paseo de Valencia al Mar, vía que separa el Plan Parcial núm. 11 del Plan Parcial núm. 12, calle que une esta vía con la calle General Pando, calle General Pando y Avenida de Suecia por no ajustarse a las previsiones del Plan Comarcal. Si por el. Ayuntamiento de Valencia se considera necesaria y suficientemente justificada la alteración del planeamiento del sector reseñado, deberá tramitarse el correspondiente expediente de modificación del Plan Comarcal, teniendo en cuenta que toda variación de la ordenación que afecte a zonas verdes o espacios libres, ha de someterse a lo dispuesto en la Ley 158/1963, de 2 de Diciembre.

3a.- Mantener la calificación de zona cultural, que establece el 
Plan Comarcal con el volumen de edificación de $0,5 \mathrm{~m} 3 / \mathrm{m} 2$., que le corresponde, para la manzana delimitada por las calles Botánico Cavanilles, Juan Martorell, Jaime Roig y Paseo de Valencia al Mar, que en el Plan Parcial se define como manzana singular con un volumen resultante de $9,25 \mathrm{~m} 3 / \mathrm{m} 2$, lo que supone, además de una modificación del Plan Comarcal realizada por medio de un Plan Parcial, que por su finalidad debe respetar las disposiciones del General que desarrolla un importante aumento del coeficiente de edificabilidad sin cumplimentar lo dispuesto en el art. 39 de la Ley del Suelo.

4a.- Mantener la calificación de zona verde determinada por el Plan Comarcal para los terrenos que en el Plan Parcial se destinan a zona de reserva deportivo-universitaria sitos entre la Avda. Primado Reig y la calle Menéndez y Pelayo, habida cuenta de que, como se expone en el apartado anterior el Plan Parcial no es instrumento hábil para modificar el Plan Comarcal y de lo dispuesto en el art. 1 de la Ley $1-58 / 1963$, de 2 de diciembre, cuyo preámbulo establece que las alteraciones de estas zonas sólo pueden obedecer a razones de interés general, debidamente justificada.

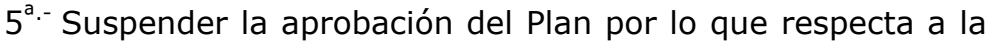
ordenación de los terrenos situados entre el Paseo de Valencia al Mar, calle A. Gimeno, calle de Menéndez Pelayo y vía en proyecto o hasta la presentación en este Departamento y correspondiente aprobación de la documentación justificativa de que el volumen de edificación no sobrepasa el autorizado por el Plan Comarcal, dado que en el Plan Parcial no se concreta este extremo al no señalar la altura máxima permitida,. Esta rectificación no requiere nueva tramitación, siendo de aplicación lo preceptuado en el art ${ }^{\circ}$. 32.3 de la Ley del Suelo.

6a.- Los proyectos especiales que según el Plan Parcial deberán redactarse para la manzana destinada a Comercial de $2^{a}$. categoría, y para la manzana situada entre las calles de Micer Mascó,Arévalo Baca, Amadeo de Saboya y R. Cisternes, habrán de ser sometidos a la aprobación de este Ministerio previa su correspondiente tramitación con arreglo a lo dispuesto en las Leyes de 14 de octubre de 1949 y 12 de mayo de 1,956.

Esta resolución deberá notificarse al Ayuntamiento de Valencia.

No obstante V.E. resolverá.

Dios guarde a V.E. muchos años.

Madrid, 4 de abril de 1.970.

EL DIRECTOR GENERAL,

Conforme. Madrid, 15 de abril 1970

EL MINISTRO DE LA VIVIENDA, 
Redactor: Negociado de Suelo y Ordenación Urbana. Arquitecto Municipal de Urbanismo. Ayuntamiento de Valencia.

Fecha: 16-10-70, 16-11-70.

Asunto: Informes municipales en respuesta a la resolución de 404-1970 del Ministerio de la Vivienda (Documento 11.1).

Planos adjuntos:

- Plano Parcial no 11 con lavado en color de zonas, que resume las determinaciones del Documento 11.1.

- Plano Parcial no 11, aprobado el 29-12-1960 por el Ministerio de la Vivienda.

- Modificación de manzana respecto al PP 11 (1960) limitada por las calles Jaime Roig, Bachiller, Botánico Cavanilles y Álvaro de Bazán, aprobada por el Ministerio de la Vivienda el 17-12-1962.

Fuente: Ayuntamiento de Valencia. Sección de Urbanismo. Negociado de Suelo y Ordenación urbana. Expte. 376/1967. Reg. General 72.334 (Archivo de Planeamiento No 91).

\section{Excmo. Sr.:}

A la vista de la resolución del Ministerio de la Vivienda de fecha 4 de Abril de 1970, sobre el Plan Parcial $n^{\circ} 11$ y del plano de alineaciones iluminado por la Sección Técnica de Urbanismo para reflejar las suspensiones y exclusiones a las que se refiere la resolución ministerial, el Negociado tiene el honor de informar lo siguiente:

El sector lavado en morado que, según dicha resolución, se excluye de la aprobación, y en el que figura el campo de Mestalla, coincide sensiblemente con el Plan aprobado definitivamente por el Ministerio de la Vivienda en 29 de Diciembre de 1960, según consta en expedientes $1.061 / 58$ y $72 / 60$.

Por lo que se refiere a la segunda manzana lavada en amarillo -Botánico Cavanilles, Jaime Roig, Alvaro de Bazán y Bachiller- tal como figura en el plano actual fue aprobada definitivamente por el Ministerio de la Vivienda en 17 de Noviembre de 1962, según expediente 303/61. Por otra parte la manzana del. Colegio Alemán, también lavada en amarillo, fue aprobada por el Excmo. Ayuntamiento Pleno en $1^{\circ}$ de Marzo de 1963, según expediente 1.741/62. Finalmente, el sector también lavado en amarillo en el que figura la Iglesia de los Padres Carmelitas fue incorporado al Plan con algunas modificaciones de lo solicitado, según expediente 575/63.

En cuanto a la ordenación de las manzanas marcadas en azul fue aprobada inicialmente en 3 de diciembre de 1965 y provisionalmente en 4 de Marzo de 1966, previa la exposición al público durante la que no se presentó reclamación alguna. El expediente de gestión fue remitido a Gran Valencia en 16 de Marzo de 1966, según consta en el expediente 287/65. Por lo que respecta a la zona lavada en verde hay que hacer constar que en dicha zona fue construido el Colegio Mayor Universitario femenino de La Asunción, según alineaciones aprobadas definitivamente por el Ministerio de Vivienda en 30 de Mayo de 1966, según expediente 184/65,

Es cuanto puede informar el funcionario que suscribe respecto a las citadas zonas urbanas. 
Valencia, 16 de Octubre de 1970.

El Jefe del Negociado

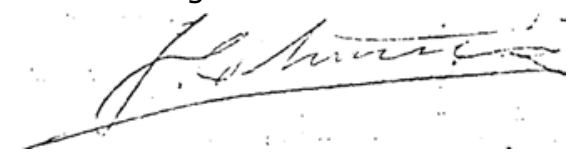

Conforme:

El Jefe de la Sección

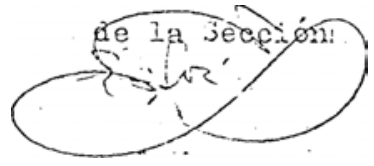

A la. Vista de lo manifestado por el Jefe del Negociado de Suelo y Ordenación Urbana, que precede, el Arquitecto Municipal de Urbanismo, complementando el informe en cuestión, adjunta plano parcial núm. 11, iluminado con los mismos colares que el adaptado a la Solución Sur, aprobado en 29-XII-1960 por el Ministerio de la Vivienda, según expedientes 1061/58 y 72/60.

Igualmente se adjunta modificación de la manzana, respecto del Plan Parcial anteriormente citado, limitada por las calles Jaime Roig, Bachiller, Botánico Cavanilles y Alvaro de Bazán, y que fué aprobada por el Ministerio de la Vivienda en 17-XI-1962, según expediente núm. 303/61.

Con todo lo cual espera el Arquitecto Mpal. de Urbanismo que suscribe, quede debidamente ampliada la información precedente.

Valencia, 16 de noviembre de 1970.

EL ARQUITECTO MUNICIPAL DE URBANISMO,

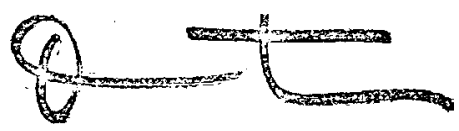




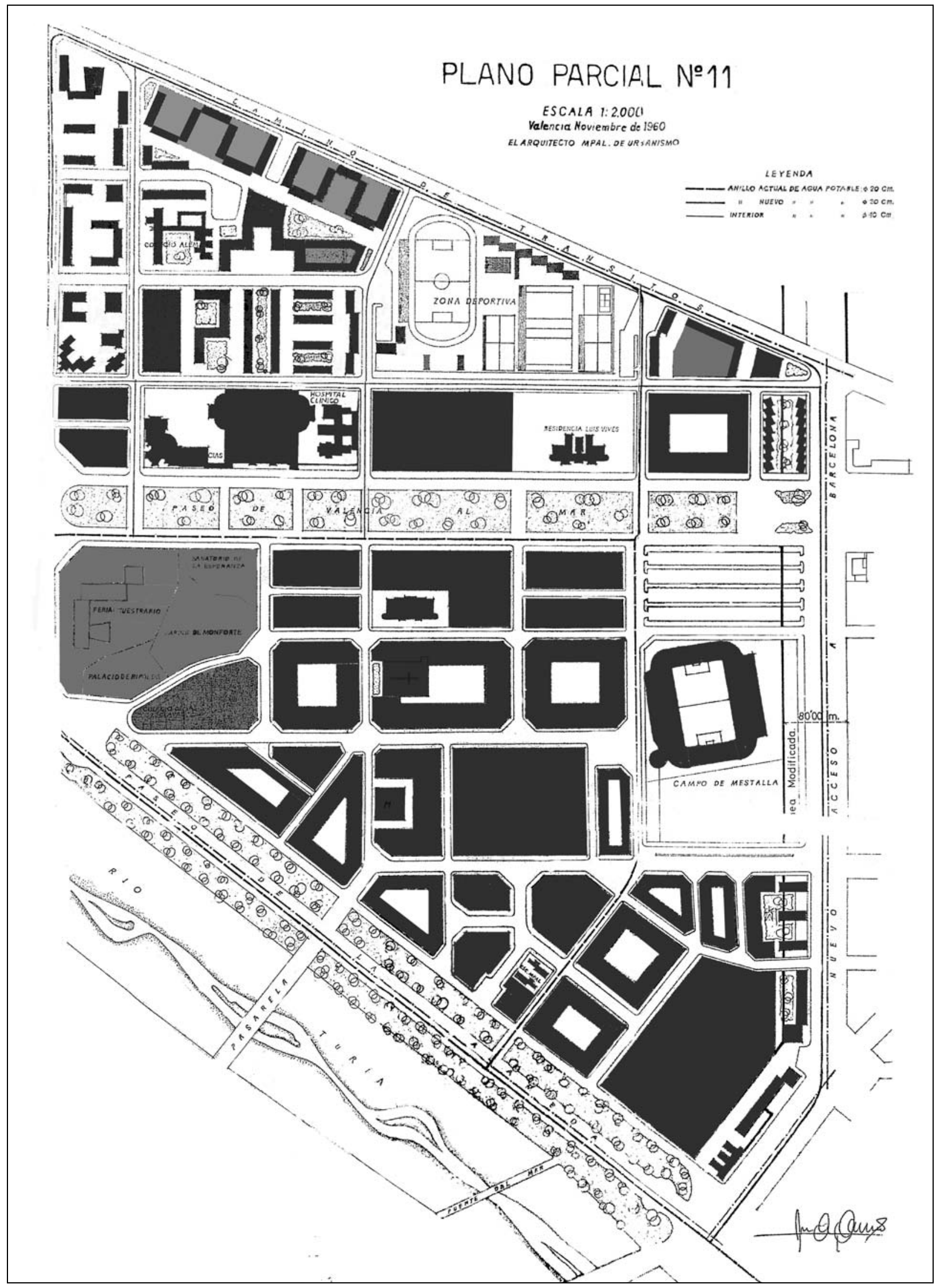

Plan Parcial 11, 1960.

Dibujo restaurado a partir de la copia adjunta al Documento 11.2, en la cual aparecen coloreados los mismos sectores señalados en el plano correspondiente al Plan Parcial 11 de 1968. 


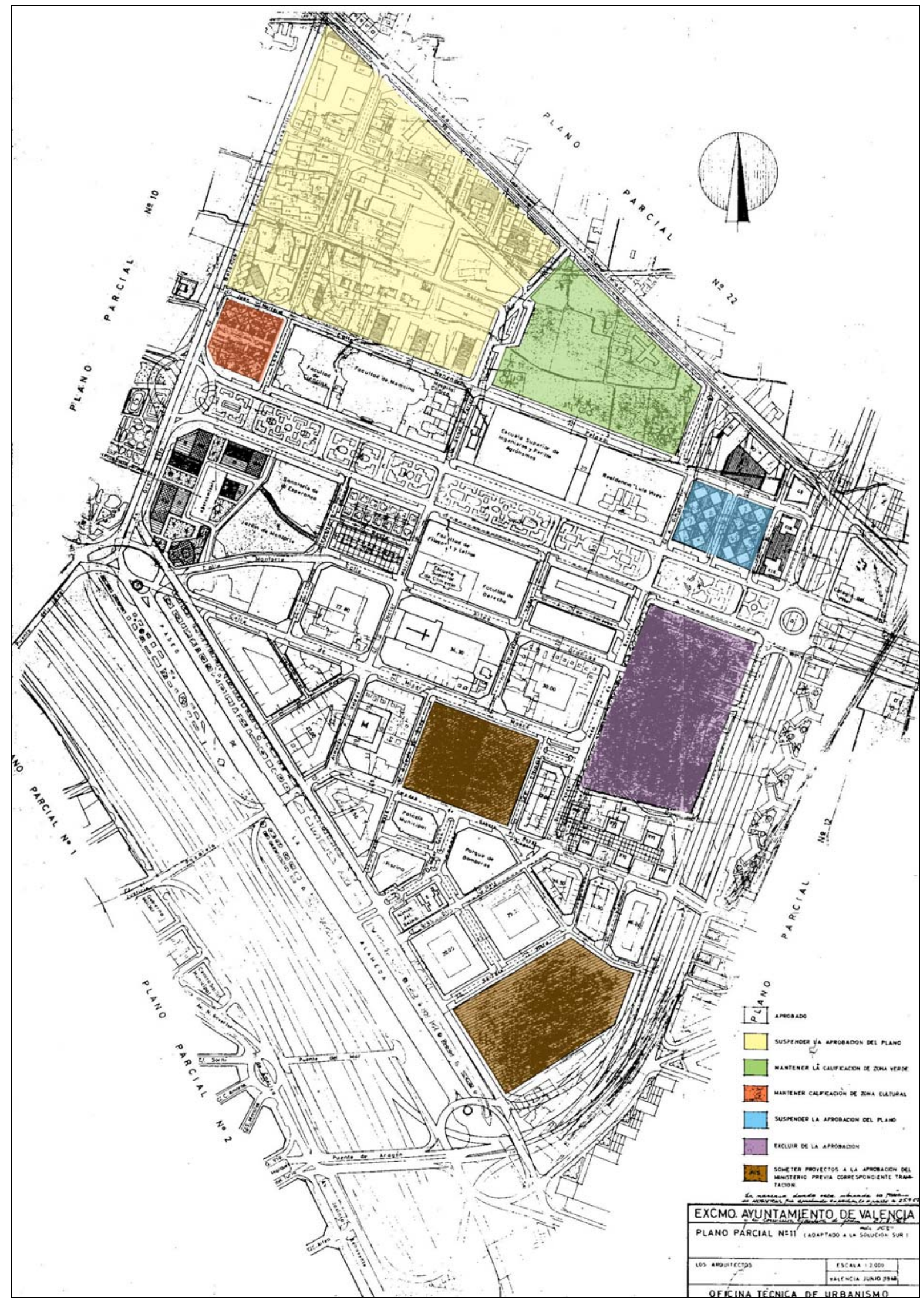

Plano Parcial No 11, 1968

Plano resumen de modificaciones exigidas por el Ministerio de la Vivienda.

(Copia y sombreado de color con los mismos colores que el original). 
Redactor: Servicios Administrativo y Técnico de la Sección de Urbanismo del Ayuntamiento de Valencia.

Fecha: 30-04-1971.

Asunto: Informe relativo a las observaciones y reparos contenidos en la resolución del Ministerio de la Vivienda de 4-04-70 (Documento 11.1).

Planos adjuntos:- Plano Parcial no 11 con lavado en color de zonas, que resume las determinaciones del Documento 11.1. (Ya reproducido en Documento 11.2)

Fuente: Ayuntamiento de Valencia. Sección de Urbanismo. Negociado de Suelo y Ordenación urbana. Expte. 376/1967. Reg. General 72.334 (Archivo de Planeamiento No 91).

En cumplimiento de lo ordenado por V.E. se ha procedido por los servicios administrativo y técnico de la Sección de Urbanismo, al estudio de las observaciones y reparos contenidos en la resolución del Ministerio de la Vivienda de fecha 4 de Abril de 1.970, referente al Plan Parcial $n^{\circ} 11$ para desarrollo del Plan General de Valencia y su Comarca adaptado a la Solución Sur, uniéndose al expediente, para mayor claridad, un plano en el que se han lavado en distintos colores los sectores afectados por dicha resolución; y siguiendo el mismo orden de ésta, tienen el honor de informar lo siguiente:

$1^{\circ}$.- Sector comprendido entre las calles Menéndez y Pelayo, Juan Martorell, Botánico Cavanilles, Avenida Primado Reig y calle que lo separa de la zona verde destinada a uso deportivo. Se ha señalado en color amarillo en el plano adjunto, y se distinguen varias manzanas $\mathrm{A}$ a $\mathrm{F}$.

Con relación a la manzana $A$, limitada por las calles Botánico Cavanilles, Alvaro de Bazán, Jaime Roig y Juan Martorell, se ha de hacer constar que antes de la aprobación del Plan General revisado, de fecha 30 de Junio de 1.966, estaba ya completamente edificada, al igual que la manzana $B$ que obtuvo aprobación definitiva por ese Ministerio el 17 de Noviembre de 1962 (expediente 303/61).

En la manzana $C_{\text {, }}$ se promovió su ordenación a instancia de loa Padres Carmelitas, para construir Iglesia y distintas dependencias parroquiales, motivando a este efecto que se tramitara el expediente 576 de 1963, y como resultado del mismo se incorporó dicha ordenación al correspondiente Plan Parcial y por ello en la redacción presente se ha mantenido, por cuanto en desarrollo de tal ordenación se habían realizado gran parte de las construcciones. Y asimismo en terrenos pertenecientes al Estado, con fachada a la Avenida Primado Reig, de los tres bloques grafiados, se han construido dos de ellos en su totalidad y el tercero está en adelantada fase de construcción, con destino a viviendas militares.

En la manzana $D_{1}$ cuya ordenación urbanística fue aprobada por ese Ministerio en 17 de Noviembre de 1962, se inició la construcción con arreglo a la misma $y$, al proceder a la redacción del presente Plan se han tenido que respetar las edificaciones ya existentes, remodelándose dicho sector de tal modo que más bien se ha disminuido el volumen de edificabilidad atribuído en su aprobación 
precitada.

En la manzana $E_{1}$ se ubica el denominado "Colegio Alemán", construido en fechas muy anteriores a la de la Revisión del Plan General del año 1966 y con mucho menor volumen de edificación al que le hubiera correspondido con arreglo a la ordenación urbanística aplicable en dicho momento. Por ello, al formar la manzana $E$ junto con la que se grafía con letra $G$ un todo unitario y al sustituirse, como se ha indicado, parte de la construcción prevista en dicho Colegio, por un campo de deportes, esta edificabilidad residual ha permitido que se planifique el repetido sector $G$, donde por otra parte, ya en las anteriores redacciones del año 1963 figuraba un edificio "en altura", con el volumen y características cuya aprobación se pretende actualmente.

En cuanto a la zona $F$, la ordenación aprobada en la anterior redacción del Plan $\mathrm{n}^{\circ} 11$ (aprobado por el Ministerio en 29 de Diciembre de 1960) fue remodelada, respetando volúmenes por acuerdos del Excmo. Ayuntamiento, anteriores a la aprobación del Plan General adaptado a la Solución Sur, hallándose parte de este sector construido cuando se aprobó dicho Plan General.

$2^{\circ}$.- Las edificaciones que aparecen en la manzana comprendida entre Paseo al Mar, futuro Acceso Norte, calle que une con la de General Pando y Avda. de Suecia (sector lavado en morado en el plano) son de dos tipos; una de ellas es un edificio ministerial que alberga a una Delegación Provincial del Ministerio de Obras Públicas, hoy ya construido y visto para su ocupación inmediata; los dos bloques de XVI plantas ubicados con fachada al futuro Acceso Norte forman parte del volumen que el Excmo. Ayuntamiento aprobó a cambio de la afección de zona verde de lo que es actual Campo del Valencia C.F. Ello no obstante, el Excmo. Ayuntamiento tramitará oportunamente la notificación reglamentaria tal y cono señala la Dirección General en su apartado nº 2.

$3^{\circ}$.- La manzana grafiada en rojo comprendida entre las calles Juan Martorell, Jaime Roig, Paseo al Mar y Botánico Cavanilles, lleva sin duda en el Plan General de Valencia y su Comarca la zonificación de cultural por un error, ya que la zonificación antes de la adaptación a la solución Sur era de edificable; y se ha corregido en el Plan Parcial por estimarlo así la Corporación, evitando que se desconociesen derechos establecidos en el Planeamiento anterior, ya que la adaptación a la Solución Sur debe ser, como su nombre indica, una adaptación y no una modificación de zonas que tenían calificación de edificables para viviendas y que en el momento del estudio del Plan general ya se hallaban construidas.

En lo que se refiere a volumen de la edificación propuesta a la aprobación, no supera el coeficiente de $6 \mathrm{~m} 3 / \mathrm{m} 2$. y queda con mucho por debajo de la edificación existente en la manzana contigua, que se menciona en el punto $1^{\circ}$.

$4^{\circ}$. - Con relación a este sector manchado en verde, se ha de manifestar que en la ordenación aprobada por el Ministerio de la Vivienda en 17 de noviembre de 1.962, se consideraba como zona deportiva. Con posterioridad, fecha 30 de Mayo de 1.966, según expediente 184/65, fue aprobada por ese Ministerio la construcción de Colegio Mayor universitario femenino de la Asunción, como que 
da reflejado en la actual ordenación, bien entendido que en el resto se respetará la calificación de Zona Verde, según lo manifestado por ese Ministerio.

$5^{\circ}$.- Sector señalado en azul. En el Plan Parcial $n^{\circ} 11$ aprobado en 29 de Diciembre de 1.960, estaba constituido por una manzana cerrada de $266.961 \mathrm{~m} 3$. de volumen.

Solicitada remodelación por los propietarios afectados aprobó el Excmo. Ayuntamiento la que figura en el plano actual y que supone un volumen total de torres y plantas bajas de $249.340 \mathrm{m3}$., no superando por tanto dicha ordenación el volumen que tenía aprobado en el planeamiento anterior a la Solución Sur.

$6^{\circ}$.- Los dos sectores señalados en marrón corresponden a edificios estatales: uno de ellos, el edificio de Tabacalera, S.A. y el otro, que en el Plan General se destina a comercial de $2^{a}$ categoría, es en la actualidad Cuarteles del Ejercito.

Cuando en el futuro se derriben, o se desafecten de los destinos indicados, se tramitará y someterá a aprobación superior, la ordenación de los mismos, conforme a lo dispuesto en las Leyes de 14 de Octubre de 1949 y 12 de Mayo de 1956.

Lo que tienen el honor de exponer los funcionarios que suscriben.

Valencia, 30 de Abril de 1.971.

El Arquitecto Mupal.de Urbanismo Por el Negociado de Suelo y Ord. Urb.

El Jefe de Sub-Sección,

Conforme:

El Jefe de la Sección de Urbanismo.

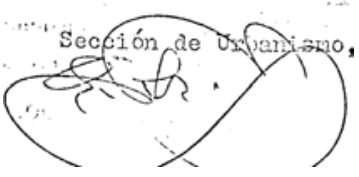


Redactor: Ministerio de la Vivienda.

Fecha: 19-07-1972.

Asunto: Resolución negativa con respecto a la aprobación del Plan Parcial No 11.

Fuente: Ayuntamiento de Valencia. Sección de Urbanismo. Negociado de Suelo y Ordenación urbana. Expte. 376/1967. Reg. General 72.334 (Archivo de Planeamiento No 91).

\section{MINISTERIO DE LA VIVIENDA}

Iltmo. Sr.:

VISTO el expediente presentado por el Ayuntamiento de Valencia para subsanar las deficiencias apreciadas en Plan Parcial de Ordenación Urbana no 11 de dicha Capital de Valencia, adaptado al Plan General de Ordenación Urbana de Valencia y su Comarca, aprobado con determinadas modificaciones por Orden Ministerial de fecha 15 de abril de 1.970,

RESULTANDO que en la precitada Orden de 15 de abril de 1970 se aprobó el citado Plan con determinadas modificaciones y exclusiones, suspendiendo la aprobación en dos sectores, uno comprendido entre las calles Menéndez y Pelayo, Juan Martorell, Botánico Cavanilles, Avda. Primado Reig y calle uniendo esta Avenida con la calle Menéndez y Pelayo, y otro constituido por los terrenos situados entre el Paseo de Valencia al Mar, calle A. Gimeno, calle de Menéndez y Pelayo y vía en proyecto, hasta tanto no se justificase suficientemente ante este Departamento por la Corporación Local interesada, que los volúmenes de edificación asignados a dichos sectores se ajustaban a las previsiones del Plan Comarcal o, en otro caso, se presentase la documentación por la que se expongan los motivos en los que se hubieran basado las modificaciones pretendidas, demostrativas del carácter concreto y excepcional de los supuestos, y el cumplimiento de la exigencia legal de previsión de mayores espacios libres, conforme a lo establecido en los artículos 43 no 2 y 39 de la Ley del Suelo.

CONSIDERANDO que en la mentada Orden, además, se excluyó de aprobación en su pronunciamiento 20, la Ordenación de los terrenos comprendidos entre el paseo de Valencia al Mar, vía que separa el Plan parcial no. 11 del Plan parcial no. 12, calle que une esa vía con la calle General Pando, calle General Pando y Avenida de Suecia, por no ajustarse a las previsiones del Plan Comarcal, y se mantuvieron en los pronunciamientos $3^{\circ}$ y $4^{\circ}$ las calificaciones de zona cultural que establece el Plan Comarcal con el volumen de edificación de 0,15 m3/m2 para la manzana delimitada por las calles Botánico Cavanilles, Juan Martorell, Jaime Roig y Paseo de Valencia al Mar, y de zona verde para los terrenos que se destinan a zona de reserva deportiva, sitos entre la Avenida de Primado Reig y la calle Menéndez Pelayo.

CONSIDERANDO que examinadas las presentes actuaciones, se observa que para aquellos sectores en que se suspendió la aprobación de la ordenación presentada, faltan los datos completos so 
bre los volúmenes construidos y proyectados, por lo que no se ha demostrado que la suma del volumen edificado y el previsto para las nuevas edificaciones, no sobrepasa los $5 \mathrm{m3} / \mathrm{m} 2$, que es la edificabilidad máxima permitida por el Plan Comarcal, como se exigió en la precitada Orden Ministerial o, en otro caso, la mayor previsión de espacios libres establecida en el Art. 39 de la ley del Suelo, por lo que habida cuenta del carácter resolutorio de la condición impuesta procede denegar definitivamente la aprobación de la ordenación pretendida para dichos sectores.

CONSIDERANDO que con respecto a los puntos $2^{\circ}, 4^{\circ}$ y $6^{\circ} \mathrm{de}$ la precitada resolución, el Ayuntamiento interesado acepta las modificaciones y observaciones señaladas en estos puntos, por lo que este Departamento se remite a lo dispuesto en los citados pronunciamientos.

CONSIDERANDO que en relación con el argumento expuesto por el Ayuntamiento de que existía un error en el Plan Comarcal al calificar como zona cultural la manzana delimitada por las calles Botánico Cavanilles, Juan Martorell, Jaime Roig y Paseo de Valencia al Mar, es inadmisible en el momento procesal presente cuando aquel Plan ha adquirido el carácter de firme y ejecutivo, por todo lo cual debe respetarse la calificación señalada de zona cultural.

VISTOS la Ley sobre Régimen del Suelo y Ordenación Urbana de 12 de mayo de 1.956 y el Decreto 63/1968, de 18 de enero.

Este Ministerio acuerda denegar definitivamente la aprobación del Plan parcial de Ordenación Urbana no 11 de Valencia, en lo que respecta a los dos sectores, uno comprendido entre las calles Menéndez y Pelayo, Juan Martorell, Botánico Cavanilles, Avda. Primado Reig y calle uniendo esta Avenida con la calle Menéndez y Pelayo, y otro constituido por los terrenos situados entre el Paseo de Valencia al Mar, calle A. Gimeno, calle de Menéndez y Pelayo y vía en proyecto, remitiéndose en todo lo demás a los pronunciamientos 20 , $3^{\circ}, 4^{\circ}$ y $6^{\circ}$ de la Orden Ministerial de fecha 15 de abril de 1.970.

Esta resolución deberá notificarse al Ayuntamiento de Valencia.

Lo que comunico a V.I. para su conocimiento y efectos.

Dios guarde a V.I.

Madrid, 19 de julio de 1.972 .

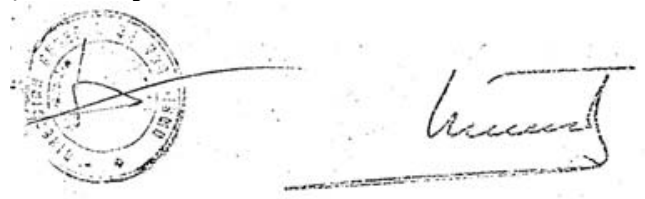

Ilmo. Sr. Director General de Urbanismo. 
Redactor: Arquitecto Municipal de Urbanismo. Ayuntamiento de Valencia.

Fecha: 15-01-1973.

Asunto: Informe técnico en respuesta a la resolución negativa del Ministerio de la Vivienda con respecto a la aprobación del Plan Parcial No 11 (Documento 11.4).

Fuente: Ayuntamiento de Valencia. Sección de Urbanismo. Negociado de Suelo y Ordenación urbana. Expte. 376/1967. Reg. General 72.334 (Archivo de Planeamiento No 91).

Expte. 376/67

Leída la denegación del Plan Parcial No 11 por el Excmo. Sr. Ministro de la Vivienda de fecha 19 de julio de 1972, y estudiado el expediente, tengo a bien. informar:

Que, realizada visita de inspección a las zonas afectadas por suspensión de aprobación del Plan, he podido comprobar que se hallan prácticamente construidas en su totalidad según el Plan Parcial aprobado por la Dirección General de Urbanismo con fecha 29 de diciembre de 1.960 , con una serie de remodelaciones aprobadas asimismo por el Ministerio de la Vivienda según se expone en los folios 149,149 bis, 150,150 bis y 151 de este expediente.

Como quiera que las licencias de obra se concedieron según el Plan Parcial aprobado con anterioridad por la Dirección General de Urbanismo con fecha 29 de diciembre de 1960 y estar prácticamente edificado en su totalidad, propongo:

Que se levante la suspensión de aprobación en las zonas afectadas, conservando las aprobaciones ministeriales anteriores a la aprobación del Plan General, reflejadas en los folios 149, 159 bis, 150,150 bis y 151 , que en esta zona -como se puede comprobarno fueron tenidas en cuenta para la redacción del Plan General adaptado a la Solución Sur de Valencia y su Comarca. Asimismo, propongo que se conserve la calificación de Zona Verde que se menciona en la denegación.

Como complemento al presente informe, considero oportuno señalar que el Plan Parcial No 11 linda, en sus límites de las calles General Elio y Botánico Cavanilles, con los Jardines del Real (Viveros Municipales) que, aunque perteneciendo al Plan Parcial No 10 , superan en $145.000 \mathrm{~m} 2$. la superficie reglamentaria de Zona Verde de este Plan. Esta superficie, inmediata a la zona suspendida de aprobación, contribuye por su influencia directa, a una disminución notable en la densidad de población del Plan Parcial No 11, resultando que la zona aludida tiene una densidad de población muy inferior al resto de la ciudad porque la proporción de espacios libres que le corresponde es muy superior.

Es cuanto tiene el honor de informar a V.E a los efectos oportunos.

Valencia, .15 de enero de 1.973

EL ARQUITECTO MUNICIPAL DE URBANISMO

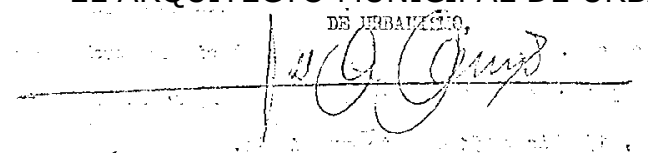


Redactor: Servicios Jurídicos Municipales. Ayuntamiento de Valencia.

Fecha: 16-01-1973.

Asunto: Informe jurídico en respuesta a la resolución negativa del Ministerio de la Vivienda con respecto a la aprobación del Plan Parcial No 11 (Documento 11.4).

Planos adjuntos:

Croquis de zonas verdes en el ámbito del PP 11 y zonas adyacentes. Fuente: Ayuntamiento de Valencia. Sección de Urbanismo. Negociado de Suelo y Ordenación urbana. Expte. 376/1967. Reg. General 72.334 (Archivo de Planeamiento No 91).

\section{Excmo. Señor:}

El letrado que suscribe, cumplimentando lo dispuesto por V.E., tiene el honor de emitir el siguiente informe:

Primero.- Como ha transcurrido ya, con exceso, el plazo legal para poder impugnar judicialmente los actos administrativos objeto de este informe, resaltamos que vamos a limitarnos exclusivamente a exponer un planteamiento nuevo del problema contemplado basándonos en antecedentes que no fueron expuestos al Ministerio de la Vivienda, pensando que estos nuevos elementos de juicio pudieran inducir al Excmo. Sr. Ministro de la Vivienda (atento siempre a conseguir la mejor ordenación urbanística más que a la rigidez de los plazos) a una nueva consideración de la resolución definitiva a adoptar en relación con el Plan Parcial $n^{\circ} 11$.

Segundo.- El Ministerio de la Vivienda ha acordado, por resolución de 19 de julio de 1972, denegar la aprobación definitiva del Plan Parcial de Ordenación Urbana $\mathrm{n}^{\circ} 11$ en los dos sectores comprendidos, uno entre las calles M. Pelayo, J. Martorell, Botánico Cavanilles, Avenida Primado Reig y calle que une esta Avenida con la calle M. Pelayo; y otro sector entre Paseo Valencia al Mar, calle A. Gimeno, calle $M$. Pelayo y vía en Proyecto, remitiéndose expresamente a los pronunciamientos $2^{\circ}, 3^{\circ}, 4^{\circ}$ y $6^{\circ}$ de la Orden ministerial de 15 de abril de 1970.

Esta última resolución ministerial en relación con la de 15 de abril de. 1970, constituye el estado de hecho y. de Derecho actuales, situación fáctico-jurídica a contemplar prescindiendo de los demás problemas por estar de acuerdo en ello el Ministerio y la Corporación municipal. Del examen de las precitadas resoluciones ministeriales se concluye que la motivación de las mismas se fundamenta básicamente en el supuesto aumento del aprovechamiento volumétrico del Plan Parcial que se dice supera al permitido por el Plan Comarcal. Estudiemos pues esta cuestión que constituye el principal obstáculo para la aprobación del Plan Parcial pero contemplémosla desde su verdadera perspectiva jurídica:

I

Iniciemos el estudio de esta cuestión admitiendo que no se han expuesto al Ministerio de la Vivienda los antecedentes necesa 
rios para haber conseguido una resolución distinta a la acordada. Si. el Ministerio hubiera conocido los antecedentes y los datos que van a exponerse es posible que hubiera resuelto en forma diferente.

A sus efectos comenzamos exponiendo que no puede limitarse el estudio de este problema a la contemplación aislada de una manzana o polígono del Plan Parcial, haciendo abstracción del resto del territorio objeto de la planificación, pues este enfoque nos lleva inexcusablemente a una conclusión errónea. Hacemos esta afirmación porque este problema ya ha sido contemplado y resuelto por los Tribunales, y precisamente en relación con licencias de edificación referentes al sector cuya aprobación definitiva deniega el Ministerio en base a que se superan los cinco $\mathrm{m} 3 / \mathrm{m} 2$ que es la edificabilidad máxima permitida por el Plan Comarcal (así lo expone acertadamente la resolución ministerial de 19 de julio de 1972).

En efecto la Sala de lo Contencioso-Administrativo de la Audiencia Territorial de. Valencia, en su sentencia de 10 de julio de 1968, sienta la doctrina siguiente: "CONSIDERANDO: Que otorgada la licencia con arreglo a las normas de adaptación del Plan de Ordenación de la ciudad de Valencia y su Comarca a la solución Sur, sería necesario para que el recurso prospere acreditar que en el solar para el que la licencia se ha conferido, no cabe la volumetría que la licencia autoriza y que los funcionarios técnicos municipales consideran dentro de las posibilidades del Plan; a este respecto, hay que considerar que el Plan Parcial correspondiente a la zona en que se halla ubicada el edificio a construir ha de reglamentar el volumen edificable en la zona, no en cada una de las parcelas que la componen; es decir, teniendo en cuenta el destino que la zona ha de tener se establece la volumetría total que la zona admite, sin distinguir para nada entre terrenos edificables y no edificables; así, cuando en la Norma 16 que el actor cita, aunque no acredita, dice que a las zonas residenciales les corresponde un coeficiente de edificabilidad de cinco metros cúbicos por metro cuadrado, no puede entenderse el absurdo de que toda la zona sólo admite edificaciones de planta baja, prácticamente, sino que el volumen total admitido por la zona viene dado por la superficie total de éste multiplicando por cinco; en consecuencia, al repartirse posteriormente tal volumetría sobre los solares edificables, aparecerá el volumen que a cada uno corresponde, el que, como es natural, excederá en mucho de la aplicación rígida que el actor pretendía; esa, y no otra, es la interpretación que resulta de los preceptos de la ley de Régimen del Suelo, tales como los artículos 10,80 y 81 , y ella la que, en el caso, debe aplicarse y la que obliga a desestimar la demanda articulada al no haberse acreditado la ilegalidad de la licencia con arreglo a las normas cuya aplicación se pretende, pues no se ha demostrado en momento alguno que el volumen autorizado por la licencia exceda del total autorizado al adicionarse con los demás correspondientes a otras parcelas edificables de la zona."

Esta sentencia de la Audiencia fue confirmada por el Tribunal Supremo en su sentencia de 3 de febrero de 1971 que ratifica la precitada doctrina de la Sala de lo Contencioso-Administrativo referente, como hemos dicho, a terrenos incluidos en el Plan Parcial no 11. Y no se trata de una sentencia aislada pues se han dictado dos más por la Sala de la Audiencia Territorial precisamente referidas también a terrenos del sector cuya aprobación deniega el Ministerio. En efecto, en recursos contenciosos Administrativos inter 
puestos por el Colegio de Arquitectos de Valencia contra licencias de obra concedidas a Mutua Levantina de Viajantes y Representantes sobre el terreno cuya aprobación es denegada, la Sala de la Jurisdicción de la Audiencia de Valencia dictó la sentencia de 8 y 17 de octubre de 1969 en la que desestima los recursos y confirma las licencias concedidas, ratificando la doctrina antes expuesta en el siguiente "CONSIDERANDO: Que examinadas las alegaciones actuadas por la representación del Colegio profesional demandante, a la vista de lo establecido en la alegación precedente, es visto que la primera de ellos, relativa a la volumetría total autorizada es planteada en los mismos términos en que lo fue en el proceso que queda resuelto por la sentencia de esta Sala de 10 de Julio de 1968; y en este caso como en aquél, es pertinente rechazar la alegación efectuada, porque la misma se apoya en una equivocada manera de calcular el volumen del edificio autorizado, cual es la de aplicar a la parcela a edificar el coeficiente de edificabilidad de la zona total".

Es decir, que según tal doctrina jurisprudencial, la norma indicativa permitida por el Plan Comarcal $(5 \mathrm{~m} 3 / \mathrm{m} 2)$ se distribuye entre las edificaciones señaladas por. el Plan Parcial lo que deja a algunas parcelas sin volumen edificable (jardines, calles, plazas, etc, ) y como consecuencia las parcelas edificables incrementan su volumetría en la misma medida en que las parcelas inedificables la pierden. Sería absurdo que todas y cada una de las parcelas del Plan fueran edificadas en la misma proporción de $5 \mathrm{~m} 3 / \mathrm{m} 2$ ya que entonces no sería posible ni siquiera la existencia de zonas verdes o espacios libres, calles, plazas, etc, elementos que son obligatorios y que incluso la Ley del Suelo preceptúa la obligatoriedad de reservas al menos el $10 \%$ para zona verde, (artículos 9, 1-b) y 10, 1-c. Es pues evidente que el Plan Parcial distribuye el volumen de $5 \mathrm{~m} 3 / \mathrm{m} 2$ autorizado para la zona, señalando espacios libres y características y ubicación de edificaciones privadas que, necesariamente, por su finalidad, han de tener volumetría diferente. $Y$ buena prueba de la posible desigualdad, en el Plan Parcial de volúmenes edificables nos la da el hecho de que el legislador para evitar una injusta distribución de beneficios y perjuicios derivados del planeamiento, instituye la reparcelación no sólo por el destino a viales, jardines o zonas verdes, "sino también (art. 81, párrafo 2, de la Ley del Suelo) "cuando el volumen edificable en un Polígono o Manzana no se distribuyera entre estos o sus parcelas según la superficie de las mismas y la anchura de la vía a que dieran frente y SE CONCENTRARE EN ALGUNAS." Ello prueba de forma indiscutible que puede concentrarse el volumen edificable en algunas parcelas, las cuales superarán el aprovechamiento volumétrico medio de $5 \mathrm{m3} / \mathrm{m} 2$, insistiéndose en que éste es el volumen asignable a todo el Plan que consta también de zonas verdes, viales, etc, inedificables y carentes por tanto de aprovechamiento volumétrico que es concentrado en otras parcelas.

Confirma tal doctrina la sentencia del T.S. de 14 de marzo de 1967 (Aranzadi 3.461) en cuyo penúltimo Considerando rechaza "la objeción de que el edificio proyectado rebasaría el índice de edificabilidad previsto para el Polígono; tesis municipal frente a la cual debe prevalecer la eficacia, no contrarrestada, de las dos observaciones razonadas en el Considerando $5^{\circ}$ de la Sentencia recurrida; a) la de que es el Plan Parcial del Polígono, que aún no existe, el que reglamentará en su día, con arreglo a lo que dispone el art. 10, $\mathrm{n}^{\circ} 1$, letra e), lo relativo al volumen de las construcciones; y b) que 
la argumentación del Ayuntamiento aplica al área propiedad del Sr.E, lo que el Plan General establece para el Polígono en total."

Como se ha visto en dicha sentencia el T.S. coincide con la tesis de que no se debe determinar la volumetría considerando únicamente la superficie de una parcela sino el Polígono o Plan total.

Por tanto, se incurre en error al contemplarse aisladamente el volumen asignado a una manzana o sector puesto que desde la perspectiva jurídica conduce inexcusablemente al error que señala el Tribunal Supremo.

La aplicación práctica de la invocada doctrina de los Tribunales es la siguiente: En el Plano adjunto, xerocopia del Comarcal, aparece la superficie y zonificación correspondiente a Plan Parcial $\mathrm{n}^{\circ} .11$

Los sectores con color verde constituyen las zonas ajardinadas o verdes (polígonos-2, 5, 7 y 10) que suman en total 335.553 m2,(sin contar la amplísima zona verde del Parque público llamado Viveros Municipales que linda con nuestro Plan y sirve por tanto a la población del mismo).

Los restantes polígonos edificables $(1,3,4,6,8$ y 9 ocupan una superficie de $627.568 \mathrm{m2}$. (De esta área se deducirán los terrenos con destino vial).

Así pues la superficie total regida por el Plan 11 queda de $963.121 \mathrm{~m} 2$ y como el volumen autorizado es el de $5 \mathrm{~m} 3 / \mathrm{m} 2$ resulta como volumen total del Plan Comarcal el de 4.815.785 (963.121 por 5).

Este volumen total permitido se distribuye por el Plan Parcial entre las parcelas edificables, es decir, entre el terreno que resta después de deducir las superficies verdes y viales que no son edificables o sea que en $963.121 \mathrm{~m} 2$ menos $335.553 \mathrm{~m} 2$ (zonas verdes), más el. $15 \%$ para viales (aunque la doctrina señala el $30 \%$ para evitar objeciones y en perjuicio de nuestra argumentación fijamos la deducción vial en el $15 \%$ redondeando en menos, es decir, fijándola en $127.568 \mathrm{~m} 2$ ) lo que nos da como resto una superficie realmente edificable de $500.000 \mathrm{~m} 2$ entre la cual distribuye el volumen autorizado para el Plan 11 de $4.815 .785 \mathrm{~m} 3$, lo que representa un coeficiente aproximado de $9^{\prime} 60 \mathrm{~m} 3 / \mathrm{m} 2$.

No se infringe por tanto en el Plan 11, el volumen permitido por el Plan Comarcal mientras no se rebasen esos 9,60 m3 por m2 $y$ en consecuencia creemos que no existe inconveniente jurídicourbanístico para que el Excmo. Sr. Ministro de la Vivienda acceda a aprobar definitivamente la ordenación propuesta para los sectores denegados puesto que no se supera en ellos el volumen autorizado por el Plan Comarcal, según la interpretación de los Tribunales que hemos invocado. 
Conviene señalar que la ciudad de Valencia se encuentra en especiales circunstancias, distintas a las de los casos corrientes ó generales en los cuales se contempla un Plan General de Ordenación Urbana nuevo que va desarrollándose en diferentes Planos Parciales.

No es ese nuestro caso. En Valencia desde el año 1946 ya existía un Plan General definitivamente aprobado por ía superioridad que fue desarrollado, en gran parte, por los correspondientes Planes Parciales que fueron estudiados, tramitados y finalmente aprobados por las Autoridades superiores en materia de urbanismo, entre los cuales se encuentra el Plan Parcial $n^{\circ} 11$ que fue aprobado definitivamente; por el Ministerio de la Vivienda en 29 de diciembre de 1960, es decir, en calenda anterior a la de la aprobación del Plan General adaptado a la Solución Sur.

De todos es conocida la trágica inundación que sufrió nuestra ciudad motivadora del proyecto y realización de diferentes obras públicas estatales denominadas Solución Sur de desviación del rio Turia y, como es lógico, el Ayuntamiento de Valencia hubo de adaptar su ordenación urbanística a las precitadas obras estatales. Pero esta adaptación no supone que el nuevo Plan General tenga como objetivo suprimir toda la ordenación urbanística prevista en los Planes Parciales anteriores puesto que en tal caso quedarían fuera de ordenación y habrían de demolerse todos los edificios, viales y servicios urbanísticos existentes, interpretación que conduce al absurdo y por tanto debe ser rechazada.

Lo lógico es pensar que el objetivo del nuevo Plan General es el de adaptar la ordenación a las nuevas obras públicas del Estado, conservando lo realizado con tanto esfuerzo y sacrificio. Su propia denominación así lo indica: "Plan General ADAPTADO a la Solución Sur".

Significamos también que las previsiones urbanísticas del Plan General son meramente indicativas y han de ser desarrolladas por los Planes Parciales que marcan para cada zona su alineación, altura, volumen y destino o uso. Invocamos el art. 10 de la Ley del Suelo que en su epígrafe 1, e), previene que los planes Parciales contendrán, entre otros extremos, la "reglamentación del uso de los terrenos".

Luego la regulación específica de cada sector, la atribuye el legislador a los Planes Parciales. En efecto, el Tribunal Supremo, en sentencia de 27 de junio de 1964 ha sentado doctrina según la cual el Plan General es la base de la ordenación del suelo, y solamente puede trazar los principios fundamentales, sin descender al detalle del futuro urbanismo de las poblaciones, correspondiendo al Plan Parcial la concreción del volumen y aprovechamiento del suelo para cada zona del Plan General.

Debe considerarse que el Plan General señala directrices indicativas para cada zona y es propio del Plan Parcial distribuir los volúmenes señalando zonas verdes, escuelas, mercados, iglesias; campos deportivos, viviendas, aparcamientos, etca, etc, es decir, 
que la norma indicativa permitida se distribuye entre las edificaciones señaladas por el Plan Parcial.

Es pues, evidente, que el Plan Parcial distribuye el volumen autorizado para la zona, señalando espacios libres y características y ubicación de edificaciones públicas y privadas que, necesariamente, por su finalidad, han de tener volumetría diferente.

A mayor abundamiento exponemos que el Tribunal Supremo ha sentado la doctrina de que es admisible incluso la modificación del Plan Comarcal al desarrollarse en Planes Parciales (sentencias de 8 febrero 1969; 17 mayo, y 22 noviembre 1963; 14 mayo 1964; etca, etc,).

En atención a lo expuesto debemos significar que el Plan Parcial $n^{\circ} 11$ no es un planeamiento urbanístico proyectado sobre terreno hasta entonces rústico o sin ordenar sino que existe un Plan Parcial anterior definitivamente aprobado por el Ministerio a cuyo amparo se han realizado numerosas construcciones.

Se presenta pues un grave problema si no se aprueba el Plan Parcial 11 denegado que recoge esa situación legal anterior puesto que, según informa el Arquitecto municipal, en las zonas afectadas ha podido comprobar que se hallan prácticamente construídas en su totalidad según el Plan Parcial aprobado por la Dirección General de urbanismo con fecha de $1^{\circ}$ de diciembre de 1960.

El problema indicado presenta dos vertientes:

$1^{\text {a }}$. Si el Ministerio de la Vivienda aprueba definitivamente el Plan Parcial en 29 de diciembre de 1960 y posteriormente, una vez prácticamente edificado en su totalidad, lo anula sustituyéndolo por otra ordenación distinta es visto que va contra sus propios actos.

La doctrina considera que la estabilidad del Plan es una de las características esenciales de los mismos, en el sentido de que los Planes urbanísticos sólo pueden ser modificados cuando exigencias públicas de notable importancia y diligentemente atinadas lo reclamen.

Janer considera que para alterar la ordenación del casco urbano son necesarias razones más poderosas y, sobre todo, soluciones mucho más acertadas que las que concurran para modificar la ordenación de zonas rústicas o sin urbanizar. La estabilidad, dice, debe ser respetada pues sólo con ella pueden conseguir los Planes los fines que en su concepción se persiguieron.

Carceller dice que la inestabilidad de la ordenación, provocada por la modificación de los Planes, desgraciadamente tan frecuente, es uno de los males que aquejan a nuestro urbanismo y ponen en peligro el derecho a edificar. La modificación de los Planes, aparte de denunciar -si efectivamente se hace para mejorar la ordenación- una falta de previsión o un desacierto por parte de los redactores de la primera versión del planeamiento, origina inconvenientes de ejecución gravísimos, porque, destinados los Planes a ser llevados a la práctica, sucede, como es lógico, que al producirse la modificación existen ya situaciones de hecho (originadas, sin em 


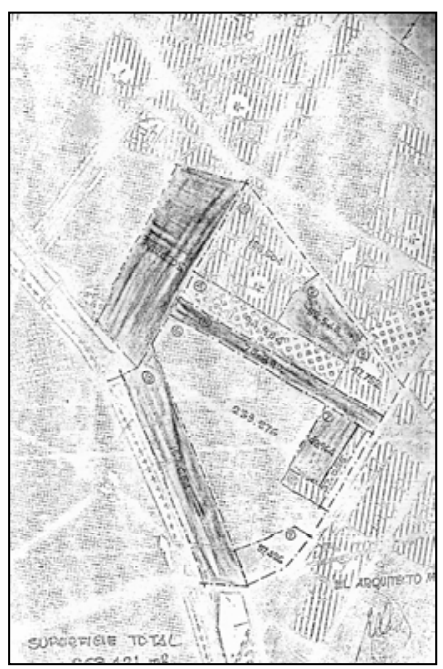

Croquis adjunto al informe jurídico, señalando las zonas verdes adyacentes al PP11 (Viveros, Paseo al Mar y Alameda) bargo, conforme a Derecho), que frecuentemente se desconocen por los autores del Plan modificado, y que son otros tantos inconvenientes, especialmente por su trascendencia económico-financiera, para el desarrollo ordenado de las ciudades.

El urbanismo, ha escrito Martín Retortillo, implica constante y progresiva renovación, pero ha de efectuarse con prudencia, sin atropellar y menos sin aniquilar situaciones creadas al amparo de una legalidad vigente, que si ciertamente no deben constituir obstáculos insalvables, su remoción ha de efectuarse conforme a principios de justicia y atendiendo siempre al bien común.

En consecuencia, aparte de que -como decimos- no se supera el volumen autorizado por el Plan Comarcal, resulta acertado mantener las situaciones de hecho, originadas conforme a Derecho, por haberse realizado las construcciones según las previsiones del Plan Parcial a la sazón en vigor aprobado definitivamente por el Ministerio de la Vivienda en 29 de diciembre de 1960.

Segunda vertiente. Si el terreno se halla casi totalmente edificado según el precitado Plan Parcial del año 1960 resulta que según el art.48, de la Ley del Suelo los edificios e instalaciones erigidos con anterioridad a la aprobación del Plan que resultaren disconformes con el mismo, serán calificados como fuera de ordenación, y no podrán realizarse en ellos obra de consolidación, aumento de volumen, modernización o incremento de su valor de expropiación. En consecuencia, cada, vez que se niegue licencia de obras para alguno de estos supuestos, se producirá un daño causado por mera cesación del ejercicio as un derecho o interés. patrimonial, situación protegida por el art. 1 de la vigente Ley de Expropiación Forzosa y por tanto se habrá de indemnizar a los titulares perjudicados, supuesto que puede tener grave trascendencia económica por estar construida la zona prácticamente en su totalidad según informa el Arquitecto municipal.

Debemos exponer que en nuestra opinión si bien es dudosa la posibilidad de indemnización por la simple aprobación del Plan, no obstante creemos que puede ser exigible la misma, en los supuestos contemplados por el precitado art. 4:8. El problema por tanto existe, surgiendo la siguiente pregunta: ¿Quien debe pagar estas indemnizaciones el Ayuntamiento que quiere autorizarlas o el Ministerio que causa la limitación del derecho?.

\section{III}

No queremos terminar este informe sin hacer observar que el simple exámen de la xerocopia que acompañamos, que reproduce parte del Plan Comarcal, nos obliga inexcusablemente a reconoce que las zonas verdes asignadas por dicho Plan al sector correspondiente al Plan Parcial $n^{\circ} 11$ es quizás la de mayor proporción entre todas las de Valencia. En efecto, de $963.121 \mathrm{~m} 2$ superficie total del Plan Parcial no 11 - se destinan, como hemos dicho, solamente $500.000 \mathrm{~m} 2$ a edificaciones y el resto a zonas verdes y a viales, es decir, que los espacios libres o abiertos ascienden en el Plan 11 a casi el $50 \%$ de su territorio, superándose, por tanto, con exceso las previsiones del art. $\left.3^{0}-1-g\right)$ de la Ley del Suelo que solamente exige la reserva del $10 \%$. 
Huelgan pues las previsiones del art. 39-2 de la Ley citada puesto que, de una parte, no se incrementa el volumen edificable como hemos probado- $y$, de otra parte, porque además de destinarse el $50 \%$ a espacios libres linda el Plan 11 con los Viveros Municipales, Parque Público de uso general con gran extensión y verdadero pulmón de la zona colindante con el mismo, circunstancias que por sí solas permiten una mayor densidad de población.

No obstante lo expuesto, V.E. resolverá.

El Abogado del Servicio Jurídico,

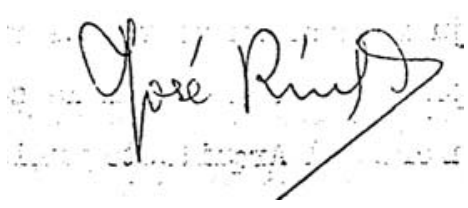


Redactor: Comisión Informativa de Urbanismo. Ayuntamiento de Valencia.

Fecha: 28-03-1973.

Asunto: Moción proponiendo la división en polígonos del PP 11 para conseguir su aprobación final.

Fuente: Ayuntamiento de Valencia. Sección de Urbanismo. Negociado de Suelo y Ordenación urbana. Expte. 376/1967. Reg. General 72.334 (Archivo de Planeamiento No 91).

\section{MOCION}

Que somete el Presidente de la Comisión Informativa de Urbanismo a estudio y dictamen de la misma, en relación con la adaptación del Plan Parcial de Ordenación Urbana $n^{\circ} 11$ a las resoluciones del Ministerio de la Vivienda de fechas 15 de abril de 1970 y 19 de julio de 1972.

El Excmo. Sr. Ministro de la Vivienda, en las resoluciones precitadas, acordó aprobar el meritado Plan Parcial $n^{\circ} 11$, con excepción de los dos sectores a que se refiere la resolución ministerial.

Nos encontramos por tanto con un Plan Parcial aprobado que contiene dos sectores pendientes de planificación. Conviene pues a los intereses municipales estudiar y proyectar nueva ordenación de esos sectores para que después de cumplir los requisitos procesales pertinentes sea posible someter la nueva ordenación modificada a la superior aprobación ministerial, con lo que conseguiríamos la planificación total del territorio del Plan 11, resolviéndose los problemas de ordenación urbanística pendientes de solución legal.

\section{II}

a) La ordenación urbanística proyectada completa las previsiones del Plan Parcial 11, a cuyo efecto debe proponerse ahora la división del territorio del Plan en los Polígonos que se considere conveniente para atender las necesidades y posibilidades de actuación urbana.

Fundamentará la división poligonal la homogeneidad de las características de edificación en cada sector (rodeado por otros de régimen distinto) y el hecho de integrar cada uno de los polígonos núcleos unitarios de edificaciones y servicios, considerándose además que existe iniciativa oficial para su urbanización con la necesaria colaboración privada y que gran parte del territorio se halla ya urbanizado y edificado desde hace varios años bajo la normativa del Plan Parcial $n^{\circ} 11$ que aprobó definitivamente el Ministerio de la Vivienda el 29 de diciembre de 1960.

La división poligonal que se proyecte sobre tales bases cumplirá en forma plena los requisitos previstos en el art. 104 de la Ley del Suelo.

b) Como premisa previa señalamos que en la nueva ordenación urbanística debe partirse' de una triple consideración:

Ia. Que las Normas Urbanísticas del Plan General asignan, a las zonas a ordenar, un aprovechamiento volumétrico de 5 $\mathrm{m} 3 / \mathrm{m} 2$. 
$2^{\mathrm{a}}$. Que la Ley del Suelo, en su art. 3-1-g), obliga a reservar para parques y jardines públicos el 10 por 100 de la superficie del Plan.

$3^{a}$. Que el Plan Parcial $n^{\circ} 11$ reserva para tal destino casi el 50 por 100 de su superficie, aparte de que linda con el gran Parque de los Viveros que funciona para el servicio de extensión territorial superior a la de un Plan Parcial (por lo que puede integrarse en un polígono comprensivo de nuestro Plan 11 y el colindante 10, según art. 104 apartado 3, de la Ley del Suelo), supuestos tácticos que permiten una mayor densidad de población proporcionalmente al aumento de espacios verdes sobre el 10 por 100 que la Ley considera adecuado y suficiente.

Aunque tales premisas permiten un incremento de volumen constructivo -autorizado por el art. 39-2 de la Ley del Suelo- no obstante, y para disipar cualquier duda interpretativa del invocado precepto legal exponemos:

a) Que realizado el cálculo de volúmenes proyectados en la nueva ordenación resulta que oscila sobre los $5 \mathrm{m3} / \mathrm{m} 2$ autorizados para zonificación abierta con sólo el 10 por 100 de reserva para parques y jardines.

b) Que, a mayor abundamiento, se destinará una nueva zona, no prevista en el Plan General, a espacio libre inedificable (situada junto al Colegio Alemán) lo que constituye una reserva nueva compensadora de cualquier moderado aumento de volumen, previsión nueva de reserva que permite el funcionamiento del invocado art. 39 de la Ley del Suelo.

Insistimos, por su trascendencia, que en general en la nueva ordenación no se superan los $5 \mathrm{~m} 3 / \mathrm{m} 2$, y si hubiera algún pequeño sector con ligero aumento volumétrico debe considerarse que queda compensado con el nuevo espacio libre y que además no puede limitarse el estudio de este problema a la contemplación aislada de una manzana o polígono del Plan Parcial, haciendo abstracción del resto del territorio objeto de la planificación, pues este enfoque nos lleva inexcusablemente a una conclusión errónea. $Y$ hacemos esta afirmación porque este problema ya ha sido contemplado y resuelto por los Tribunales, y precisamente en relación con licencias de edificación referentes al sector cuya aprobación definitiva deniega el Ministerio en base a que se superan los $5 \mathrm{~m} 3 / \mathrm{m} 2$.

En efecto, la Sala de lo Contencioso-Administrativo de la Audiencia Territorial de Valencia, en sus sentencias de 10 de julio de 1968, 8 y, 17 de octubre 1969 y T.S. 3 de febrero 1971, sientan la doctrina siguiente: El volumen total admitido por la zona viene dado por la superficie total de éste multiplicando por cinco; en consecuencia, al repartirse posteriormente tal volumetría sobre los solares edificables, aparecerá el volumen que a cada uno corresponde, el que, como es natural, excederá en mucho de la aplicación rígida que el actor pretendía: esa, y no otra, es la interpretación que resulta de los preceptos de la Ley de Régimen. del Suelo, tales como las artículos 10, 8081 , y ella la que, en el caso, debe aplicarse.

Es decir, que según tal doctrina jurisprudencial, la norma indicativa permitida por el Plan Comarcal $(5 \mathrm{~m} 3 / \mathrm{m} 2)$ se distribuye entre las edificaciones señaladas por el Plan Parcial que deja a algunas parcelas sin volumen edificable (jardines, calles, plazas, etc, ) y como consecuencia las parcelas edificables incrementan su volumetría en la misma medida en que las parcelas inedificables la pierden. Sería absurdo que todas y cada una de las parcelas del Plan fueran edificadas en la misma proporción de $5 \mathrm{~m} 3 / \mathrm{m} 2$ ya que entonces no 
sería posible ni siquiera la existencia de zonas verdes o espacios libres, calles, plazas, etc, elementos que son obligatorios y que incluso la ley del Suelo preceptúa la obligatoriedad de reservas al menos el 10 por 100 para zona verde (artículos 9, 1-b) y 10, 1-c).

Y buena prueba de la posible desigualdad, en el Plan Parcial de volúmenes edificables nos la da el hecho de que el legislador para evitar una injusta distribución de beneficios y perjuicios derivados del planeamiento, instituye la reparcelación no sólo por el destino a viales, jardines o zonas verdes, sino también (art. 81, párrafo 2, de la Ley del Suelo) "cuando el volumen edificable en un Polígono o Manzana no se distribuyera entre estos o sus parcelas según la superficie de las mismas y la anchura de la vía a que dieran frente y SE CONCENTRARE EN ALGUNAS." Ello prueba la forma indiscutible que puede concentrarse el volumen edificable en algunas parcelas, las cuales superarán el aprovechamiento volumétrico medio de $5 \mathrm{n} 3 / \mathrm{m} 2$, insistiéndose en que éste es el volúmen asignable a todo el Plan que consta también de zonas verdes, viales, etc, inedificables y carentes por tanto de aprovechamiento volumétrico que es concentrado en otras parcelas.

Confirma tal doctrina la sentencia del T.S. de 14 de marzo de 1967 (Aranzadi, 3.461).

III

Por último y a efectos de procedimiento, se significa que tanto en el caso de considerar a la nueva ordenación que se proyecta como modificación del Plan Parcial 11 o en el de estimar que se trata del cumplimiento de la Orden ministerial denegatoria o de la actuación por polígonos a que se refiere el art. 104 de la Ley del Suelo, procede, en cualquiera de dichos supuestos, tramitar el nuevo proyecto de ordenación urbanística con estricta sujeción a lo prevenido en los arts. 39 y 32 de la Ley del Suelo.

Valencia, 28 de Marzo de 1973.

EL PRESIDENTE,

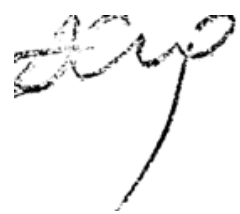




\section{PP11(M)}

PLANO PARCIAL NO 11 (ADAPTADO A LA SOLUCIÓN SUR). PROYECTO TÉCNICO DE DIVISIÓN EN POLÍGONOS Y NUEVA ORDENACIÓN URBANÍSTICA

Redactores: EXCMO. AYUNTAMIENTO DE VALENCIA. OFICINA TÉCNICA DE URBANISMO.

Fecha redacción: Abril 1973.

Fecha aprobación: O.M. 23-09-74 (B.O.E. 25-10-74).

Contenido:

I. MEMORIA

II. PLANOS:

1. ESTADO ACTUAL

2. DIVISIÓN EN POLÍGONOS

Fuente: Ayuntamiento de Valencia. Sección de Urbanismo. Negociado de Suelo y Ordenación urbana. Expte. 376/1967. Reg. General 72.334(Archivo de Planeamiento No 91).

Notas: 


\section{PP11 PROYECTO TÉCNICO DE DIVISIÓN EN POLÍGONOS Y NUEVA ORDENACIÓN URBANÍSTICA \\ MEMORIA}

\section{MEMORIA}

El Plan Parcial no 11 de la Ciudad de Valencia anterior al que nos ocupa, tenia una Zonificación de Ensanches Actuales y, basándose en tal calificación se hicieron remodelaciones de volúmenes que fueron aprobadas, ejecutándole las obras en consecuencia.

Aprobado posteriormente el Plan General de Valencia y su Comarca según. B.0.E. del 27 de Julio de 1966, se procedió a una nueva redacción del Plan adaptándolo a la Solución Sur, el cual cambiaba la calificación de la zona que nos ocupa esta delimitación de polígonos de Ensanches Actuales a Edificación Abierta, aplicándole un coeficiente de edificabilidad de $5 \mathrm{~m} 3$ por $\mathrm{m} 2$.

Al no haberse tenido en cuenta en la redacción del Plan General estas edificaciones recientes, dignas y en perfecto estado, ahora se ven depreciadas ya que de por sí alcanzan un coeficiente aproximado de edificabilidad de $7,5 \mathrm{~m} 3 . / \mathrm{m} 2$. superando los 5 m3./m2. aprobados posteriormente a su legal construcción.

Por todo lo expuesto anteriormente la Comisión de Urbanismo acordó la división en polígonos de la zona delegada con el fin de que el volumen excedido en ella no afecte los intereses particulares de los administrados que todavía no hayan edificado sus parcelas.

La división en polígonos es realizada con un criterio uniforme diferenciando lo edificado y las parcelas pendientes de edificar, como se puede comprobar en los planos que se adjuntan de estado actual y división en polígonos. La distribución de volúmenes en los polígonos se expresa en el cuadro siguiente:

\begin{tabular}{|c|c|c|c|c|}
\hline \multicolumn{2}{|c|}{ Polígono } & Superficie & $\begin{array}{l}\text { Volumen } \\
\text { edificable }\end{array}$ & $\begin{array}{l}\text { Volumen } \\
\text { por edificar }\end{array}$ \\
\hline \multicolumn{2}{|l|}{ A } & $19.550 \mathrm{~m} 2$ & $97.750 \mathrm{~m} 3$ & --- \\
\hline \multicolumn{2}{|l|}{ B } & $30.475 \mathrm{~m} 2$ & $152.375 \mathrm{~m} 3$ & --- \\
\hline \multicolumn{2}{|l|}{ C } & $55.448 \mathrm{~m} 2$ & $277.244 \mathrm{~m} 3$ & $146.464 \mathrm{~m} 3$ \\
\hline \multirow[t]{3}{*}{ D } & d1 & $4.000 \mathrm{~m} 2$ & $20.000 \mathrm{~m} 3$ & $10.324 \mathrm{m3}$ \\
\hline & d2 & $21.550 \mathrm{~m} 2$ & $107.750 \mathrm{~m} 3$ & --- \\
\hline & d3 & $13.332 \mathrm{~m} 2$ & $66.660 \mathrm{~m} 3$ & $66.660 \mathrm{~m} 3$ \\
\hline \multicolumn{2}{|l|}{ E } & $16.050 \mathrm{~m} 2$ & $80.400 \mathrm{~m} 3$ & --- \\
\hline \multicolumn{2}{|l|}{$\mathrm{F}$} & $10.880 \mathrm{~m} 2$ & $54.400 \mathrm{~m} 3$ & --- \\
\hline \multirow[t]{2}{*}{ G } & g1 & $18.900 \mathrm{~m} 2$ & $94.500 \mathrm{m3}$ & --- \\
\hline & g2 & $3.500 \mathrm{~m} 2$ & $17.500 \mathrm{~m} 3$ & $17.500 \mathrm{~m} 3$ \\
\hline
\end{tabular}

Quedan fuera de ordenación los volúmenes que excedan de los expresados en el cuadro anterior.

Cualquier modificación de lo previsto en este expediente se hará en base a las superficies expresadas aplicando el coeficiente de $5 \mathrm{m3} . / \mathrm{m} 2$. y las normas del Plan General referentes a Edificación Abierta. 
Las edificaciones sobre el polígono " $\mathrm{C}$ " seguirán la ordenación prevista en el Plano Parcial 11 ya que este polígono cumple con los requisitos de $5 \mathrm{m3}$./m2.; sobre el polígono "D", d1, se seguirá también la ordenación prevista en el plan. Sobre el polígono " $D$ " d3, la edificación se realizará ateniéndose al volumen expresado en el cuadro anterior y las normas del Plan General referentes a Edificación Abierta, siendo la forma de libre composición. Polígono "G" g2, sobre el se edificará siguiendo la ordenación prevista en el Plano Parcial.

Como la nueva división poligonal que se proyecta supone exclusivamente una disminución de los volúmenes propuestos anteriormente, proyectándose ahora un aprovechamiento volumétrico adaptado a las previsiones del Plan General ( $5 \mathrm{m3} . / \mathrm{m} 2$.) y una declaración de edificios fuera de ordenación a los ya construidos, según normas del Plan Parcial anteriormente aprobado por el Ministerio de la Vivienda, que superan dicho volumen constructivo, resulta que no se produce modificación alguna de la documentación complementaria exigida por el artículo 10 de la Ley del Suelo, por lo que en aras a la economía procesal y para no incurrir en repeticiones innecesarias se dan por reproducidos ahora los documentos de referencia que se acompañaron en su día al Plan Parcial no 11 que fue definitivamente aprobado, en parte, por el Ministerio de la Vivienda, según resolución de 4 de abril de 1.970.

Con todo lo anteriormente expuesto se considera aclarada la situación de la zona denegada de aprobación del Plan Parcial nº11 que nos ocupa.

Valencia, abril de 1.973

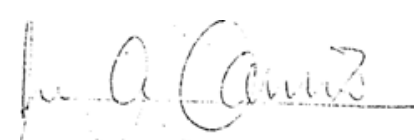

Fdo. El Arquitecto Municipal José A. Carrión Gascón 
1. ESTADO ACTUAL

Escala original: $1: 2.000$

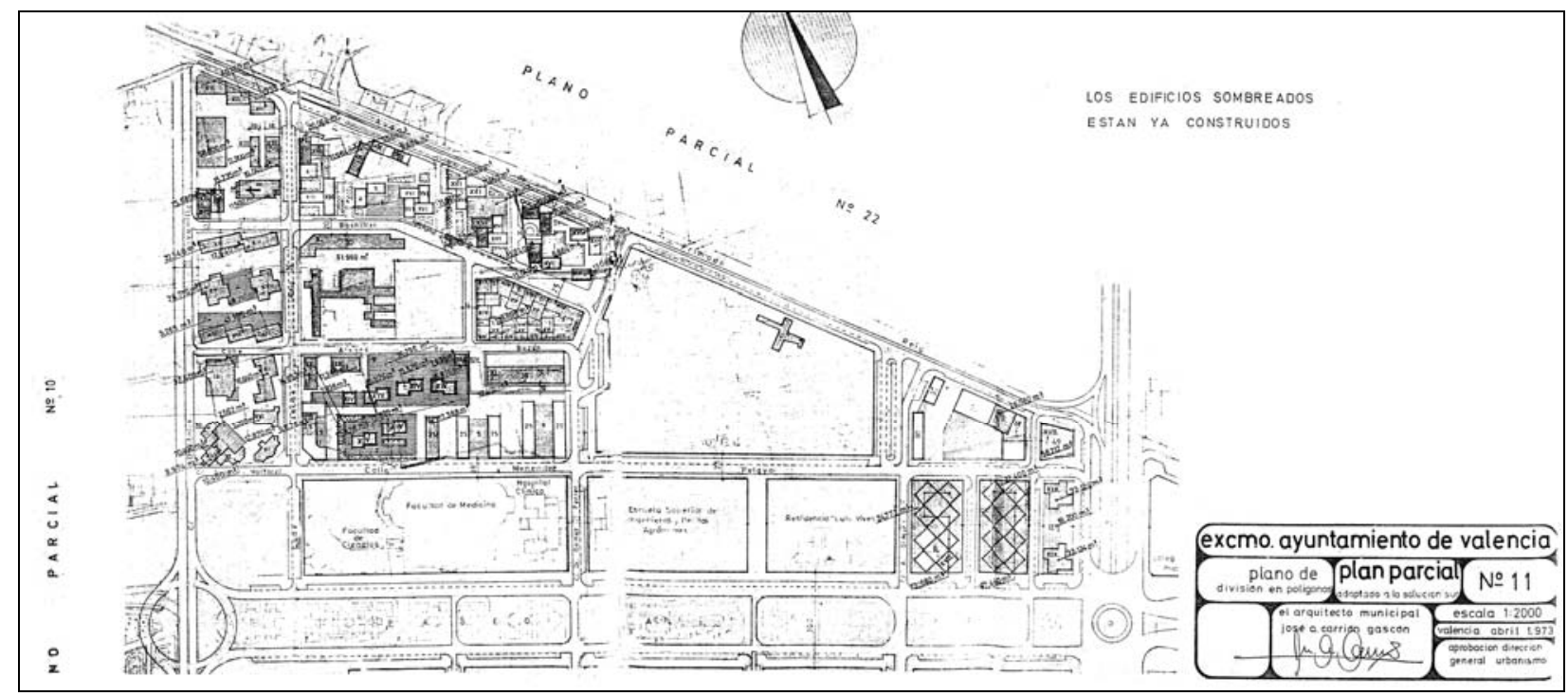

2. DIVISIÓN EN POLÍGONOS

Escala original: $1: 2.000$

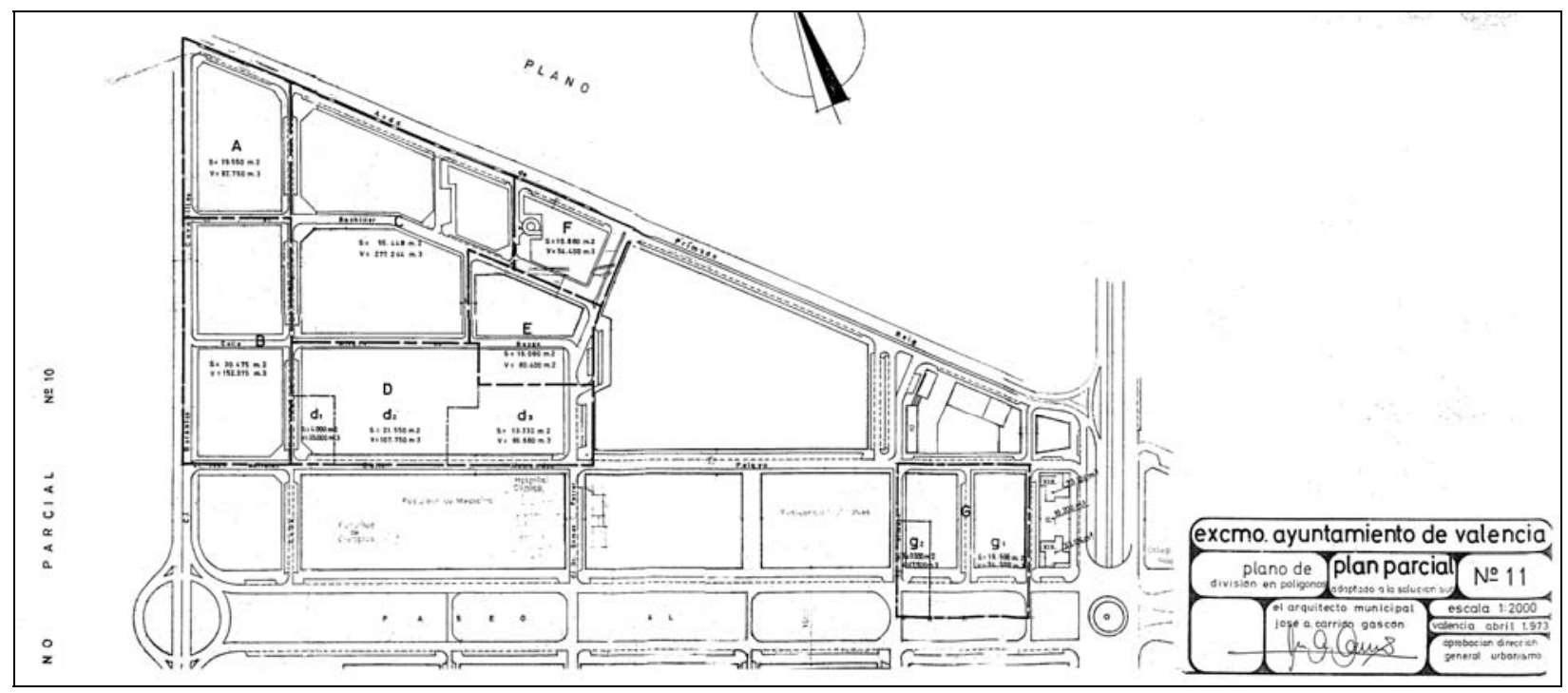




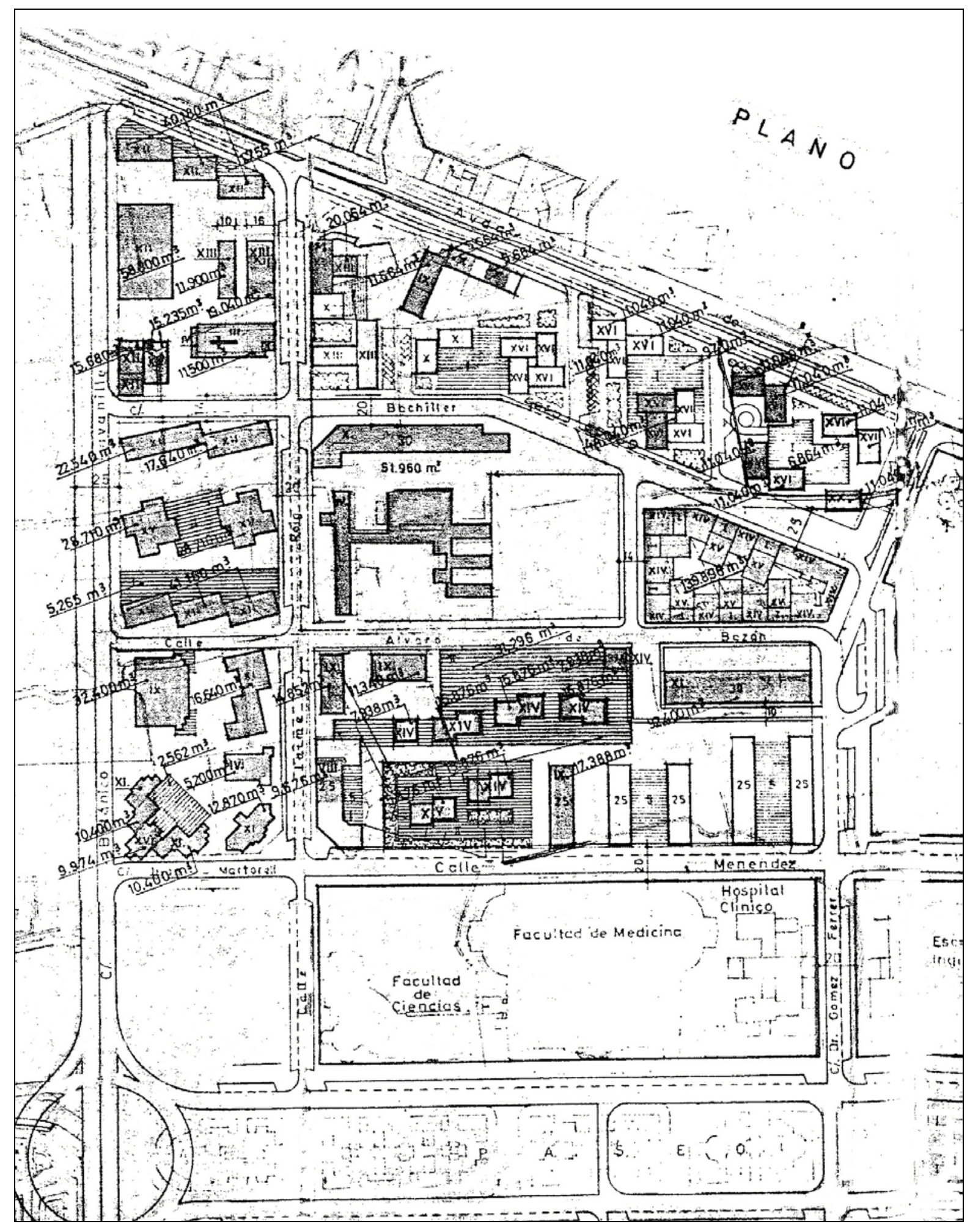

Plano de estado actual. Detalle de la zona de Jaime Roig. 



\section{PP12}

PLANO PARCIAL No 12 (ADAPTADO A LA SOlUCIÓN SUR). 1968.

Redactores: EXCMO. AYUNTAMIENTO DE VALENCIA. OFICINA TÉCNICA DE URBANISMO.

Fecha redacción: Febrero $1968(*)$.

Fecha aprobación: O.M. 24-10-1969 (B.O.E. 15-11-69).

Contenido: (Fecha documentos Julio 1967)

I. MEMORIA

II. ORDENANZAS.

III. PLANOS:

1. PLANO DE SITUACIÓN DENTRO DE LA CIUDAD. $1: 10.000$

2. SITUACIÓN EN EL PLAN GENERAL $1: 22.500$

3. FOTOPLANOS.

4. ESTADO ACTUAL Y DELIMITACIÓN (3 planos) 1:2000

5. ESTRUCTURA URBANA $1: 2000$

6. ZONIFICACIÓN $1: 2000$

7. RED VIARIA FUNDAMENTAL $1: 2000$

8. ALINEACIONES Y RASANTES. $1: 2000(* *)$

9. REDES FUNDAMENTALES DE SERVICIO.

RED DE ALCANTARILLADO

ESQUEMA DE RED DE AGUAS POTABLES.

ESQUEMA DE ALUMBRADO.

Fuente: Ayuntamiento de Valencia. Sección de Urbanismo. Negociado de Suelo y Ordenación urbana. Expte. 330/67. Reg. General 60.885 (Archivo de Planeamiento No 96).

\section{Notas:}

* Esta versión del PP 12 es la redactada una vez introducidas en la versión inicial las modificaciones derivadas de las dos rondas de alegaciones, antes y después de la aprobación inicial en Diciembre de 1967.

** El plano de Zonificación y Alineaciones es único, y se denomina "ALINEACIONES, ZONIFICACIÓN, VOLÚMEN Y DIVISIÓN EN POLÍGONOS". 


\author{
EXCMO. AYUNTAMIENTO DE VALENCIA \\ DESARROLLO DEL PLAN GENERAL DE ORDENACIÓN DE VALENCIA Y \\ SU COMARCA, ADAPTADO A LA SOLUCIÓN SUR
}

PLANO PARCIAL NO. 12

\author{
M E M O R I A
}

\title{
OBJETO DE ESTE ESTUDIO
}

La redacción y aprobación en 28 de Junio de 1.966 del Plan General de Ordenación de Valencia y su Comarca, adaptado a la Solución Sur, ha traído consigo, además del cambio del Río y de algunos elementos, la sujeción a las nuevas exigencias del momento urbanístico, principalmente en lo que se refiere a tráfico de vehículos y aparcamiento de los mismos.

Como consecuencia, la Jefatura de Obras Públicas en su Oficina Regional de Proyectos de Carreteras, redactó un estudio de todos los accesos a la Ciudad por carretera y las carreteras de tránsito y circunvalación, con gran anchura (80 metros en la mayor parte) y uniones a niveles distintos con gran superficie, amen de la autopista por el cauce actual del Río.

Naturalmente, casi todos los planos parciales han resultado afectados con mayor o menor intensidad, no habiendo sido una excepción el que nos ocupa, por lo que el objeto de este estudio es la adaptación a las modificaciones precitadas, el establecimiento de los aparcamientos posibles, sin producir exceso de trastornos a la propiedad particular (en consideración de que este plano ha estado en uso durante mucho tiempo en el Ayuntamiento) y pequeñas modificaciones parciales del esquema urbanístico para mejorar aspectos estrictamente necesarios

\section{JUSTIFICACIÓN DE LA ORDENACIÓN}

Lo dicho anteriormente justifica ya por sí solo la ordenación propuesta.

Además el Plan General, aunque pretendiendo seguir en todo las zonificaciones establecidas en los planos parciales que el Ayuntamiento tenía redactados y en redacción, ha modificado pequeñas zonas, ha establecido zonas comerciales y ha añadido zona periférica.

Todo ello se ha plasmado en la redacción del Plan Parcial presente y aunque parece que haya alguna modificación sobre el Plan General, no es así ya que, en los polígonos que se forman en el Plan General, este tiende a generalizar zonificaciones sin las particularidades que existían y deben continuar, y, dada la escala del Plan General, si consideramos que el Plan General ya lo dice todo, resultará que el Plan General no será un Plan General sino la suma de planos parciales en pequeño, que no necesita, para su desarrollo, mas que aumentarlo de tamaño.

Esto no es así, por el contrario los que hemos seguido atentamente la redacción del Plan General sabemos que éste se ha trazado respetando al máximo en los planos parciales existentes anteriormente, o pendientes de aprobación. 
Por todo ello la justificación de la ordenación es la de desarrollar el Plan General y adaptarse a él.

En este plano hay que señalar, en relación con lo expresado anteriormente, y como más extraordinario, la zonificación de edificable de una pequeña manzana en la conjunción de Camino de Tránsitos con el Paseo al Mar donde se emplaza una Estación de Servicio de automóvil y han de emplazarse diversos edificios solicitados.

Esto se ha hecho concordando con el plano anterior aprobado en una zona que comprende este emplazamiento por el Pleno Municipal de 3 de enero de 1.964 .

En esta misma latitud, pero el norte del Plano y ya en su límite, zonificamos como Edificación abierta, poco densa, en consideración de que antes era edificable y destinado a Central Lechera. Todo ello, como se ha dicho, porque creemos que el Plan General no ha pretendido modificaciones no necesarias y las establecidas son errores.

Se han establecido algunas modificaciones en relación con expedientes en curso, como zona del Colegio de Santa Ana (Expediente $n^{\circ} 72 / 19.65$ ).

En el plano de este Plan Parcial se distinguen perfectamente las vías de Gran Tráfico de las de Tráfico mediano y las de distribución.

Se ve perfectamente que se ha procurado, allá donde ha sido posible, por ser sobre zona poco edificada, adoptar el esquema de supermanzana, ya sea compuesta de bloques abiertos o de manzanas cerradas, procurando para formarla imposibilitar el tráfico veloz de vehículos por su interior, disponiendo fondos de saco o bien calles quebradas, para distribuir en el interior de la manzana o bien llegar a los aparcamientos.

Se han establecido los centros comerciales en los emplazamientoe que marca el Plan General, pudiendo construirse en ellos mas de dos metros cuadrados por habitante por lo que resultarán holgados.

Se ha reservado terreno para escuelas.

Se ha reservado terreno para aparcamientos.

Se ha reservado terreno para jardines.

Se han ubicado los centros religiosos.

En todo ello se ha procurado que domine la prudencia, si bien es cierto que no señalar el futuro emplazamiento de algún edificio público, compromete su futura situación, también es cierto que señalar mas elementos que los que se prevé que el Municipio construya, o por lo menos adquiera los terrenos, tiene él inconveniente de que a los diez años se recobra el libre ejercicio de las facultades dominicales, según el artículo 56 de la Ley del Suelo, haciendo inútil el plano.

La superficie que abarca el plano y desde el eje de las caIles que lo limitan, es de 313,63 hanegadas.

La superficie de edificación destinada a vivienda es de 5.366.107 m2, lo que destinando a cada vivienda $100 \mathrm{~m} 2$, incluidos los patios y escaleras, da un total de 53.661 viviendas:

El número de habitantes, calculando un promedio de cuatro habitantes por viviendas, es de 214.644 habitantes.

La densidad del polígono es aproximadamente de 680 habitantes por hanegada.

La superficie de aparcamientos, considerando que el barrio es de condición modesta, es de $20 \mathrm{~m} 2$. por cada cinco viviendas, lo que daría una superficie de aparcamientos de $214.700 \mathrm{~m} 2$. Los 
aparcamientos especiales existentes en el plan alcanzan la superficie de 84.516, m2, sin contar viales, calculando un $20 \%$ de la superficie de viales destinada a aparcamiento, rebasaríamos con mucho la superficie necesaria.

La superficie de espacios libres es de 210.447 m2.sin contar el enorme espacio destinado a escuela de Maestría Industrial que es de $342.350 \mathrm{~m} 2$, lo que supera con mucho el $10 \%$ de la superficie total del plano.

La superficie destinada a edificación abierta es de $1.156 .078 \mathrm{~m} 2$ y el volumen de la edificación que se puede construir en la misma, es de $5.432 .490 \mathrm{m3}$. lo que da un coeficiente de edificabilidad de 4,75 m3 por metro cuadrado, inferior a los $5 \mathrm{~m} 3$ por m2. necesarios.

La superficie destinada a zona de extensión exterior a Tránsitos, es de $1.270 .000 \mathrm{~m} 2$ aproximadamente.

La población escolar. Incluidos maternales, es del $15 \%$ de la población, o sea, 32.196 alumnos, lo que a razón de $6 \mathrm{~m} 2$. por alumno se necesitaría una superficie de $193.179 \mathrm{~m} 2$. La superficie prevista en el plano es de $75.052 \mathrm{~m} 2$ sin contar la gran superficie que se destina a escuela de Maestría Industrial. En la parte nueva del plan se ha dotado todas las manzanas su correspondiente espacio escolar, y se han aprovechado de la parte construida del mismo los espacios libres donde se pudieran ubicar alguna obra con lo previsto nuevo, y los edificios escolares ya en funcionamiento, sitos en la parte construida del plan parcial, se rebasara con mucho las necesidades.

En documentos aparte se desarrollan las Ordenanzas de uso de los terrenos y edificación, planos topográficos, de ubicación, de alineaciones y de ordenación, así cono los esquemas de servicios de agua, alcantarillado y alumbrado.

\section{ETAPAS}

Siendo este plan parcial destinado, por el momento, a la edificación por particulares, no pueden marcarse etapas de realización que dependerán de la actividad constructiva de los mismos. Sin embargo, el Excmo. Ayuntamiento, además de construir los elementos urbanísticos generales en una primera etapa, se mantendrá siempre en la urbanización adelantando sobre la iniciativa particular, urbanizando zonas que se prevea edificación inmediata.

\section{MEDIOS ECONÓMICOS FINANCIEROS}

Son los del presupuesto ordinario de Urbanismo del Excmo. Ayuntamiento de Valencia y los extraordinarios que se establezcan a medida que se cumplo lo dicho en el párrafo anterior y se disponga de proyectos detallados de urbanización.

Con lo dicho creemos suficientemente expuesto el alcance del estudio realizado para que, si el Excmo. Ayuntamiento lo estima conveniente, lo eleve a la aprobación por la superioridad.

Valencia, Junio de 1967.

LOS ARQUITECTOS MUNICIPALES,

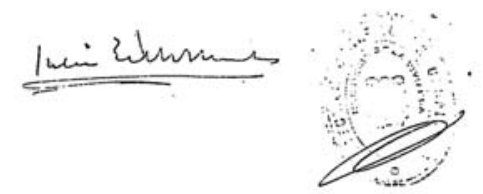


EXCMO. AYUNTAMIENTO DE VALENCIA

OFICINA TÉCNICA DE URBANISMO

DESARROLLO DEL PLAN GENERAL DE ORDENACIÓN ADAPTADO A LA SOLUCION SUR

\section{PLAN PARCIAL No 12}

\section{ORDENANZAS}

Preámbulo:

De acuerdo con el artículo $10^{\circ}$ de la Ley de 12 de Mayo de 1.956 sobre Régimen del Suelo y Ordenación Urbana, se establece las presentes Ordenanzas Reguladoras de uso de los terrenos en cuanto a volumen, destino, condiciones sanitarias y condiciones estéticas de las construcciones y elementos naturales de cada zona en el ámbito de este Proyecto Parcial.

Estas Ordenanzas toman como base y punto de partida las Normas Urbanísticas del Plan General de Ordenación de Valencia adaptado a la Solución Sur. Dado que la función propia de las Normas referidas determina la pauta a seguir en la redacción de los planes parciales, estas Ordenanzas, recogiendo aquellas directrices, tienden a concretar y delimitar las condiciones implícitas en las mismas para una correcta configuración de las estructuras urbanas. Así, estas Ordenanzas precisan aquellos extremos exigibles para el recto desenvolvimiento de los proyectos de urbanización y de edificación en el área de alcance de las mismas.

Estas Ordenanzas se agrupan en dos capítulos, el primero de los cuales, titulado como "Ordenanzas Comunes", reúne aquellas condiciones genéricas que afectan a las estructuras urbanas al margen de su ubicación y zonas a las cuales pertenecen, en tanto el segundo agrupa, con el título de "Ordenanzas Específicas", aquellas otras condiciones afectas con carácter exclusivo a determinadas zonas o sectores.

Estas Ordenanzas se suman a aquellas que tiene dictadas el Excmo. Ayuntamiento en orden a tramitación; a los reglamentos de escaleras y ascensores; a lo legislado en cuanto a condiciones de las viviendas, viviendas de portero, sótanos y semisótanos, cuartostrastero y desvanes; a las Normas concernientes a instalaciones en general, instalaciones de saneamiento y conductos de humos; y a las Ordenanzas Particulares para obras de reforma, ampliación, consolidación y demolición.

Del mismo modo, se hace referencia a aquellas Ordenanzas Generales que conciernen a Edificios Públicos y Edificios Singulares así como a aquellas normas que convienen o pueden convenir a Zonas Especiales.

Por ultimo, tienen plena vigencia aquellas Normas Urbanísticas que no vengan desarrolladas o especialmente puntualizadas en estas 
Ordenanzas.

0. ORDENANZAS COMUNES $[\ldots]$

3. ENSANCHE HASTA TRÁNSITOS (EXTENSIÓN INTERIOR A TRÁNSITOS) $[\ldots]$

4. EXTENSIÓN EXTERIOR A TRÁNSITOS. [...]

5. NÚCLEOS PERIFÉRICOS. [...]

\section{ORDENANZAS DE EDIFICACIÓN ABIERTA}

Art. 6.1 DELIMITACIÓN.

Se regula por la presente Ordenanza las zonas señaladas en los planos de zonificación y alineaciones de los proyectos parciales aprobados con este carácter por medio de la trama o distintivo correspondiente.

La altura de los edificios recayentes a calle límite de esta zona obedecerá a esta Ordenanza.

Art. 6.2 DEFINICIÓN.

Se entiende por edificación abierta aquella cuya disposición de volúmenes permite el contacto directo con el medio exterior de amplios paramentos de la misma.

Las formas de esta edificación so determinan normalmente en los planos de alineaciones. En aquellos tipos o modelos edificatorios cuya forma exija el complemento de patios de ventilación, se estima como muy apropiado el empleo de retranqueos en fachada (antiguos "patios de fachada").

Las Normas Urbanísticas establecen dos grados de edificación abierta, señalados con las letras A y B y que hacen referencia al coeficiente de edificabilidad respectivo de 3,5 $\mathrm{m} 3 / \mathrm{m} 2$ y $5 \mathrm{~m} 3 / \mathrm{m} 2$. En las zonas marcadas como de edificación abierta sin expresión del grado prescrito, se entenderá que éste obedece al grupo D.

Art. 6.3 PROCEDIMIENTOS DE REALIZACIÓN.

a) Si una manzana (espacio continuo comprendido entre vías de tráfico rodado) o bloque independiente pertenece a un solo propietario o existe acuerdo expreso de los diversos propietarios de los terrenos afectados, cabe por parte de estos solicitar una variación de volúmenes dentro de las condiciones subsiguientes:

$1^{\text {a) }}$ Que el volumen proyectado no supere al que se deduce de la aplicación directa de los planos y Ordenanzas de este Proyecto Parcial.

2a) Que las nuevas alineaciones queden totalmente inscritas en el polígono cerrado formado por las alineaciones grafiadas en los planos, prolongadas hasta en 
contrarse.

$\left.3^{a}\right)$ Que los paramentos que conservan las alineaciones de los planos no rebasen la altura que a ellos corresponde y aquellos otros que quedan retirados se eleven solamente en función de su retiro.

$\left.4^{a}\right)$ Que no exista perjuicio de tercero.

Este proyecto de variación de volúmenes deberá ser aprobado por el Excmo. Ayuntamiento previo informe de la Sección de Urbanismo y Comisión correspondiente.

b) Si un bloque se realiza en partes diversas, éste deberá ajustarse a las líneas y alturas establecidas en los planos y Ordenanzas de este Proyecto Parcial.

\section{Art. 6.4 SOLAR EDIFICABLE.}

Los solares destinados a edificación abierta comprenden una parte edificable normalmente intercalada entre otras dos de uso ajardinado.

Las parcelas incluidas en esta zona deberán cumplir las condiciones de tipo general establecidas en el artículo 0.5 de estas Ordenanzas y ser tales que su línea lindante con la vía de tráfico no sea inferior a 7 metros y sus líneas medianeras sean perpendiculares a aquella. Igualmente toda parcela, para ser edificable deberá permitir a sus costados la formación de parcelas igualmente edificables.

Cuando no concurran las condiciones impuestas en el párrafo anterior, el Excmo. Ayuntamiento procederá según lo establecido en el artículo 3.3 de estas Ordenanzas.

Art. 6.5 USOS PERMITIDOS.

Estas zonas son de carácter eminentemente residencial. Cuando la extensión de las mismas sea reducida, se mantendrá el criterio antedicho en toda su pureza. En zonas de mayor desarrollo, se dispondrá garajes y edificios públicos, así como grandes comercios, en las manzanas cerradas $O$ semiabiertas previstas en los planos a este efecto.

Los pequeños comercios y actividades artesanas podrán ser ubicados en las plantas bajas de los bloques de edificación abierta. En todos los casos, no se permitirá industria alguna ni almacén que presente incomodidades a la comunidad residencial.

Los espacios libres deberán establecerse y conservarse ajardinados o arbolados.

\section{Art. 6.6 ALTURA DE LA EDIFICACIÓN.}

Los bloques de edificación abierta pueden entenderse a partir de dos tipos básicos: torre y bloque lineal. El predominio de una dimensión en planta diferencia el segundo 
tipo del primero. Todo bloque ramificado en planta puede así descomponerse en bloques elementales de los tipos prefijados.

Las condiciones de altura impuestas en este artículo son pues de aplicación directa a los elementos básicos de esta edificación.

La altura de dos bloques lineales de ejes paralelos no excederá de la distancia entre las alineaciones encaradas de los mismos. Cuando los dos paramentos principales de un bloque lineal distan longitudes distintas de otros dos bloques paralelos al primero, será determinante de la altura la mayor distancia. Una condición semejante se aplicará a bloques cuyos ejes formen ángulo no superior a 30 grados, midiéndose la distancia entre los puntos medios de los paramentos o porciones de paramento encarados, siempre que la mínima distancia no sea inferior a la mitad de dicha distancia media.

La distancia entre bloques de ejes perpendiculares medida desde la testa de uno de ellos hasta el paramento principal del otro no será inferior al ancho de la testa del primero. La distancia entre bloques cuyos ejes estén en prolongación uno de otro no será inferior a 6 metros. Las alturas de bloques son independientes de estas distancias.

La altura de torres formando agrupaciones se medirá considerando bloques lineales hipotéticos que envuelvan aquellas torres y aplicando las reglas descritas en los párrafos anteriores.

Los bloques recayentes a vías divisorias de supermanzanas medirán su altura duplicando la semidistancia al eje de la calzada antedicha.

\section{Art. 6.7 MEDICIÓN DE LA ALTURA.}

La dimensión definida en el artículo anterior hace referencia a la altura de cornisa y por encima de ella podrá realizarse un nuevo forjado o pérgola que envuelva los elementos permitidos como sobresalientes a plano de cornisa, extendiéndose a la, totalidad de la planta y con una altura máxima de 3,50 $\mathrm{m}$. por encima de dicho plano de cornisa.

\section{Art. 6.8 ELEMENTOS SOBRESALIENTES A CORNISA.}

Se regirán por lo establecido en el artículo 0.4 de estas Ordenanzas, permitiéndose la ubicación de viviendasportería siempre que ello sea posible con un retiro de 3 metros de los paramentos de fachada.

Art. 6.9 VOLADIZOS.

Las dimensiones de vuelo en planta se regulan por las distancias entre bloques de ejes paralelos, de acuerdo con el cuadro subsiguiente: 


\begin{tabular}{c|c}
$\begin{array}{c}\text { Distancia mínima entre } \\
\text { bloques }\end{array}$ & $\begin{array}{c}\text { Dimensión máxima de } \\
\text { vuelo }\end{array}$ \\
\hline 25 & 1,50 \\
16 & 1,00 \\
9 & 0,70 \\
- & No se permiten
\end{tabular}

La dimensión frontal (paralela a línea de fachada) de los voladizos de obra de fábrica en forma de miradores no excederá de la cuarta parte de dicha línea de fachada. Los balcones plenamente abiertos podrán extenderse a todo el paramento de fachada.

Art. 6.10 ORNATO.

Todos los paramentos de fachada de los bloques ostentarán el mismo rango decorativo en composición y material. Se preverá en todos los casos oportunos tendederos que permitan el soleamiento directo sin ofrecer visibilidad alguna desde la vía publica.

\section{CIUDAD JARDÍN [...]}

\section{ZONAS INDUSTRIALES $[\ldots]$}

\section{ZONAS DE TOLERANCIA INDUSTRIAL [...].}

\section{ZONAS DE HUERTA [...].}

\section{EDIFICIOS PÚBLICOS Y SINGULARES Y ZONAS ESPECIALES}

EDIFICIOS PÚBLICOS.- En la Memoria se ha hablado de loe Edificios públicos que se han establecido fijando sus porcentajes, pero no se ha puntualizado las Ordenanzas a que su construcción ha de acogerse. Por todo ello se proyectan las siguientes prescripciones.

Art. 11.1 ESCUELAS.- Quedan marcados en el plano por medio de un esquema de edificio, cuya forma sugiera la corriente de las escuelas, con el rótulo "Escuela" sobre el mismo o próximo al terreno escolar que es el que rodea al edificio hasta la vía pública y edificios próximos, excepto el espacio normal para paso entre el jardín escolar y edificación privada. Este espacio será una calle de seis (6) metros de anchura, si hay tráfico rodado, o un pasillo de tres (3) metros de anchura si solo han de circular peatones.

El volumen, así como las demás condiciones de la edificación de las escuelas, será el que corresponda según el tamaño del campo escolar y los reglamentes específicos de esta clase de edificios.

Art. 11.2 IGLESIAS.- Quedan marcados en el plano, por esquema de edificios sobre el que se sitúa una cruz. La superficie será la marcada en plano y las condiciones de la edificación las que marquen las Ordenanzas y Reglamentos específicos de construcción de esta clase de edificios. 
Lo mismo que se dice de la Iglesia, ha de entenderse para los Centros Parroquiales anejos.

Art. 11.3 ZONAS COMERCIALES.- Son las marcadas en el plano con la trama correspondiente y estarán constituídos por planta baja y entresuelo comerciales, formando plataformas extensas sobre las que puedan situarse loa bloques, marcados en los planos, para viviendas. Los pasajes comerciales dejarán libre el bajo y el piso y tendrán las claraboyas y patinillos necesarios. Podrán construirse también, cuantos sótanos convengan.

Art. 11.4 EDIFICIOS ESPECIALES Y ZONAS ESPECIALES.- Se proyectan en algunos puntos edificios en forma de torre u otra, con altura que sobrepasa el techo corriente del plano. Son los edificios especiales que se han señalado, de acuerdo con los criterios de las normas.

Solamente podrán construirse los señalados en el plano.

Art. 11.5 APARCAMIENTOS.- Aparecen grafiados en el plano con esquemas sugeridores de dichos elementos.

Los grafiados en los planos serán de obligatoria construcción por el Municipio, o bien por los particulares propietarios del terreno si les conviniera cumplir así las obligaciones sobre Aparcamientos dimanantes de la construcción de edificios.

Todos los marcados en el plano serán de carácter público, si se construyen según lo dicho en el párrafo anterior.

\section{Valencia}
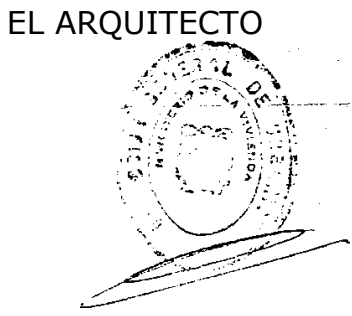
1. PLANO DE SITUACIÓN EN LA CIUDAD

Escala original: $1: 10.000$

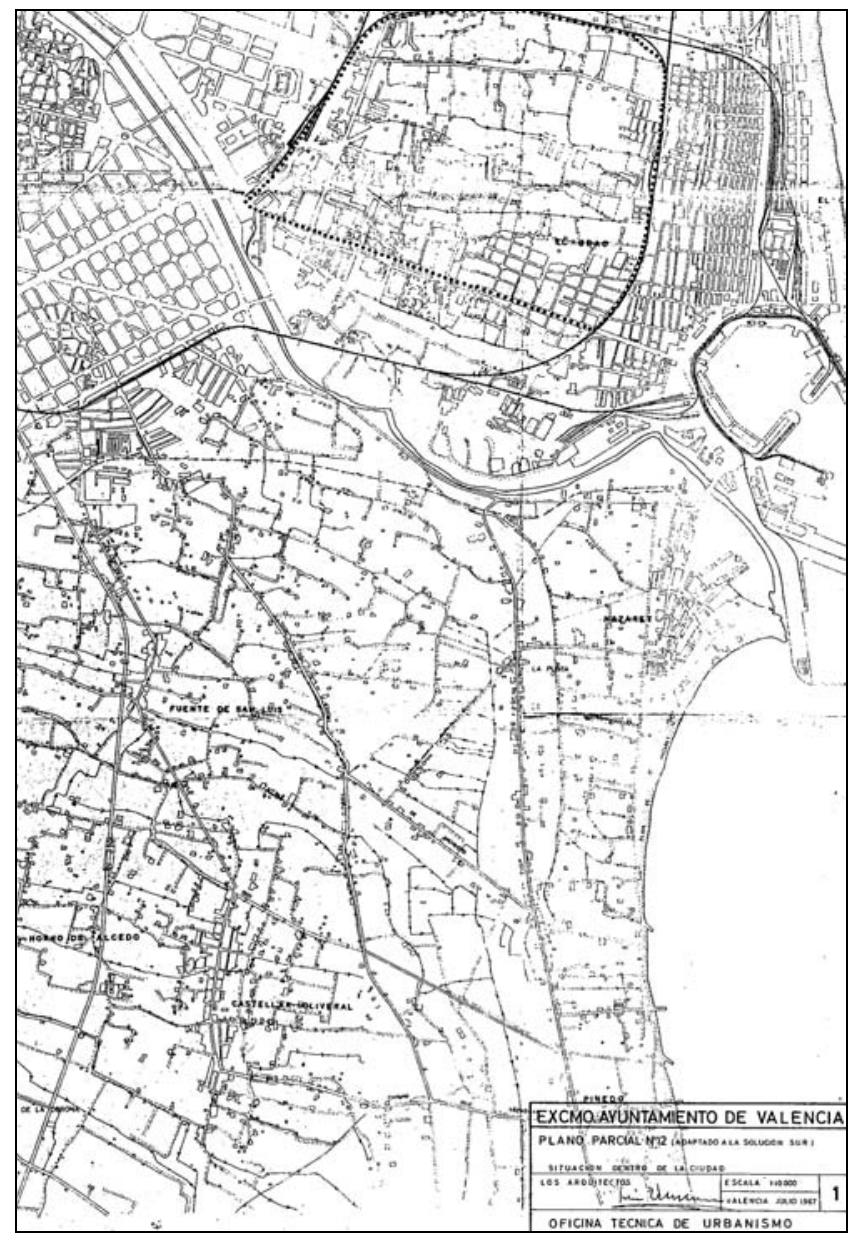

2. PLANO DE SITUACIÓN EN EL PLAN GENERAL (Fragmento) Escala original: $1: 22.500$

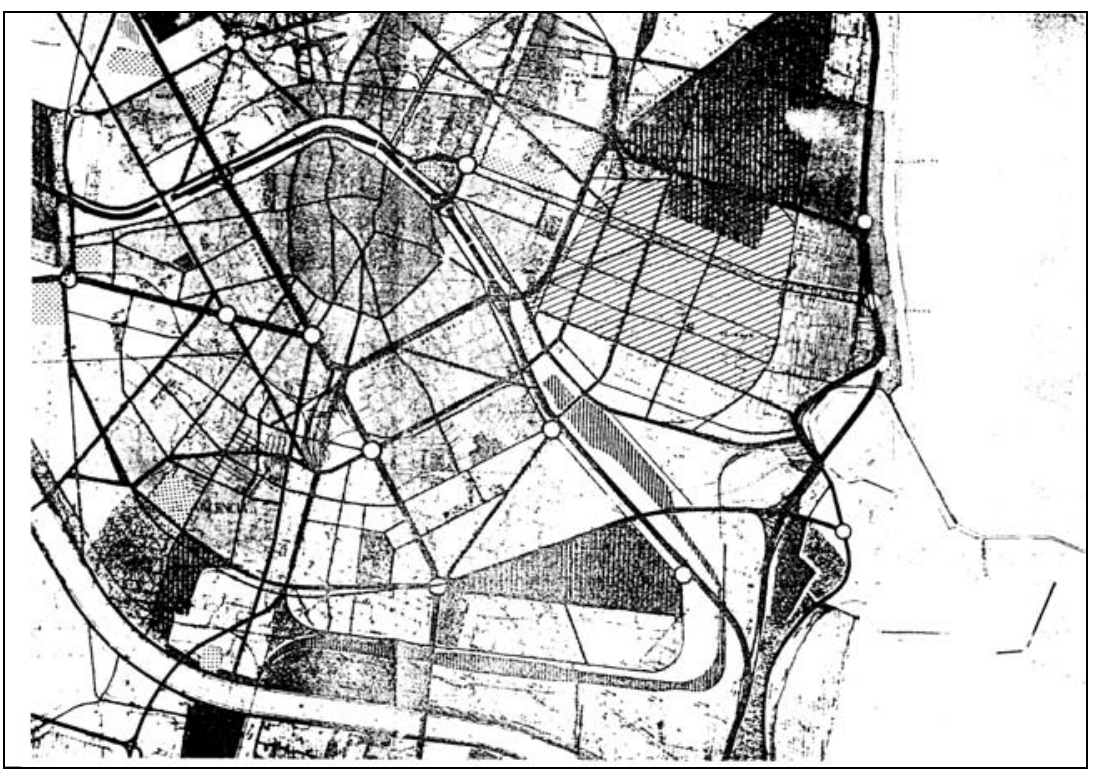




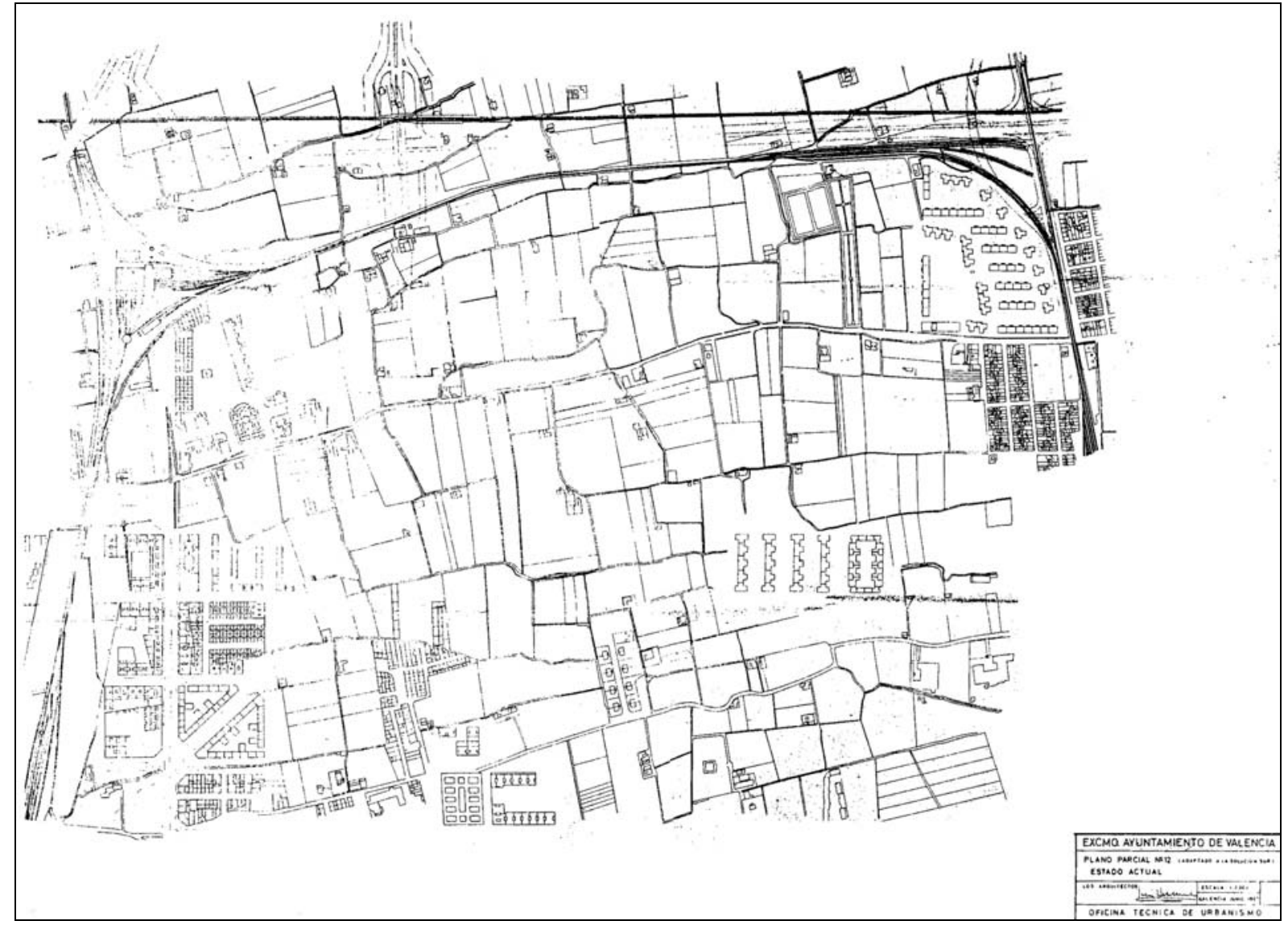

Zona A

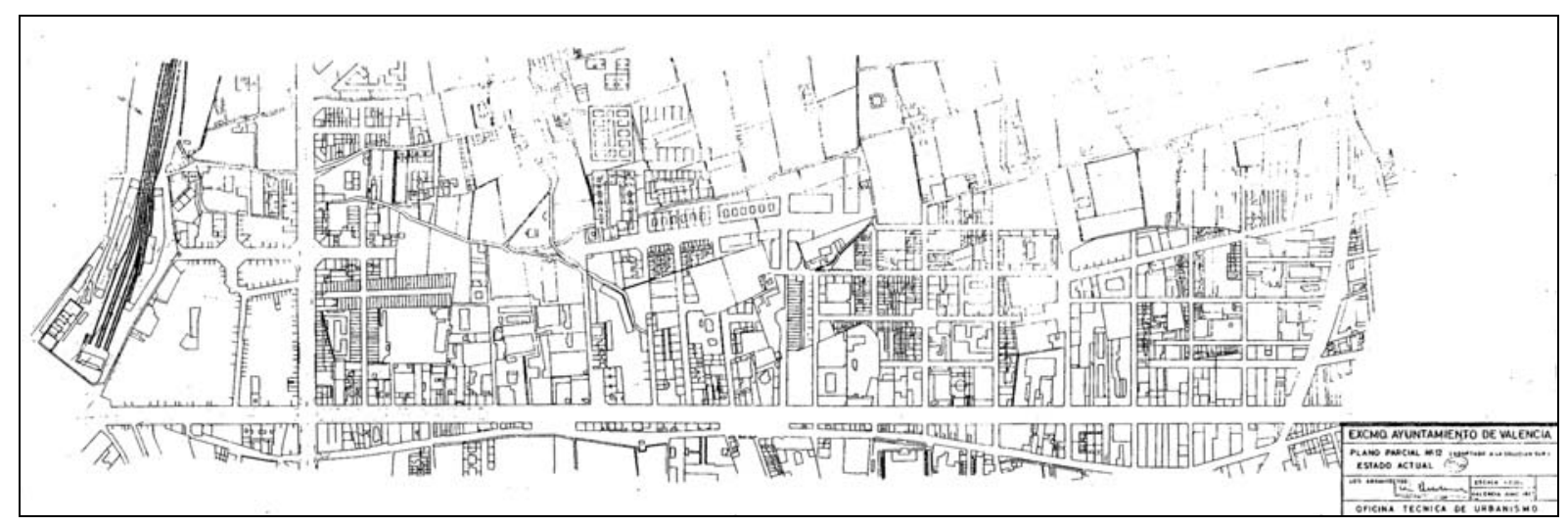

Zona B 
7. RED VIARIA FUNDAMENTAL

Escala original: 1:2000
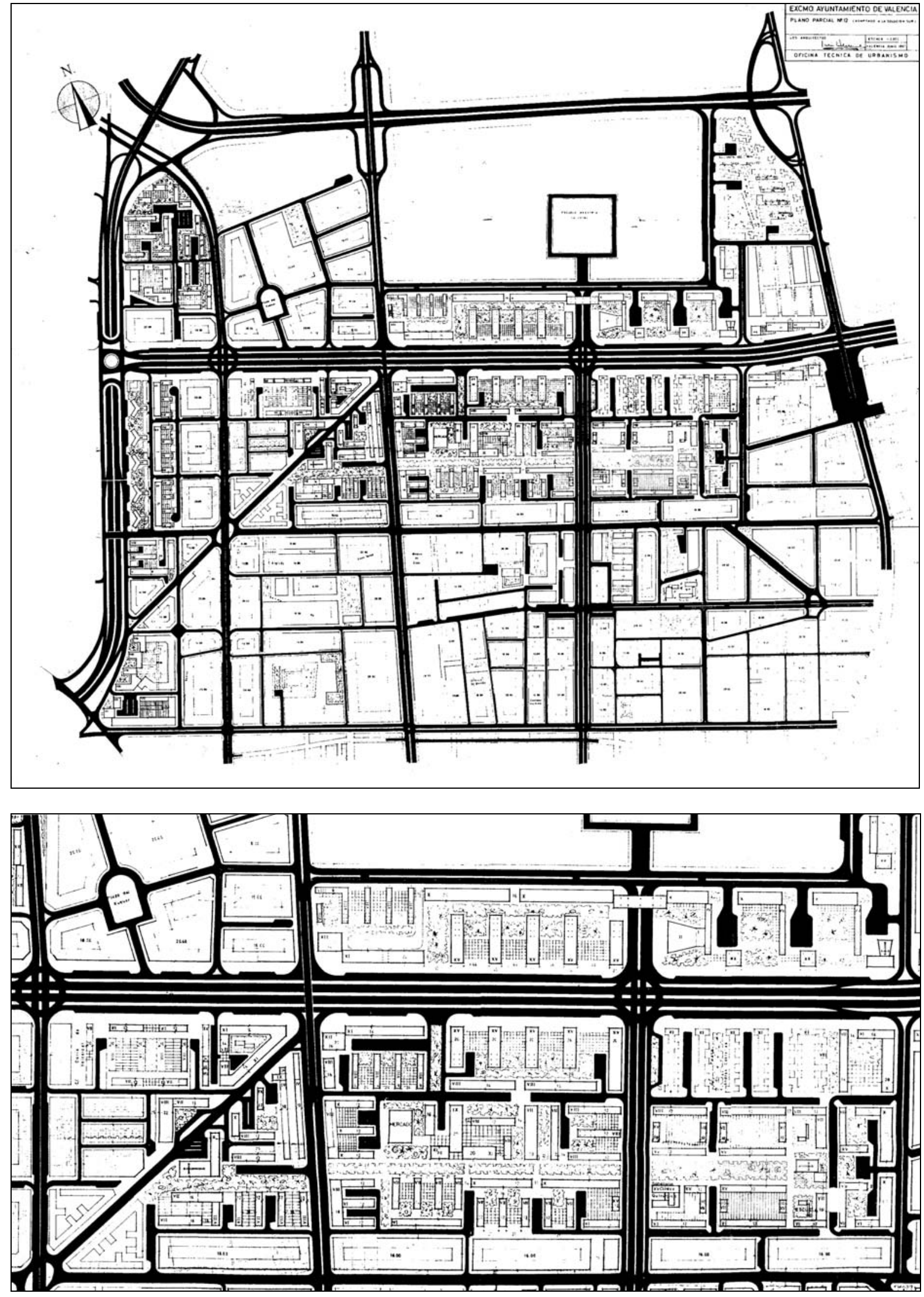

Detalle de viario. Zona de Paseo al Mar. 


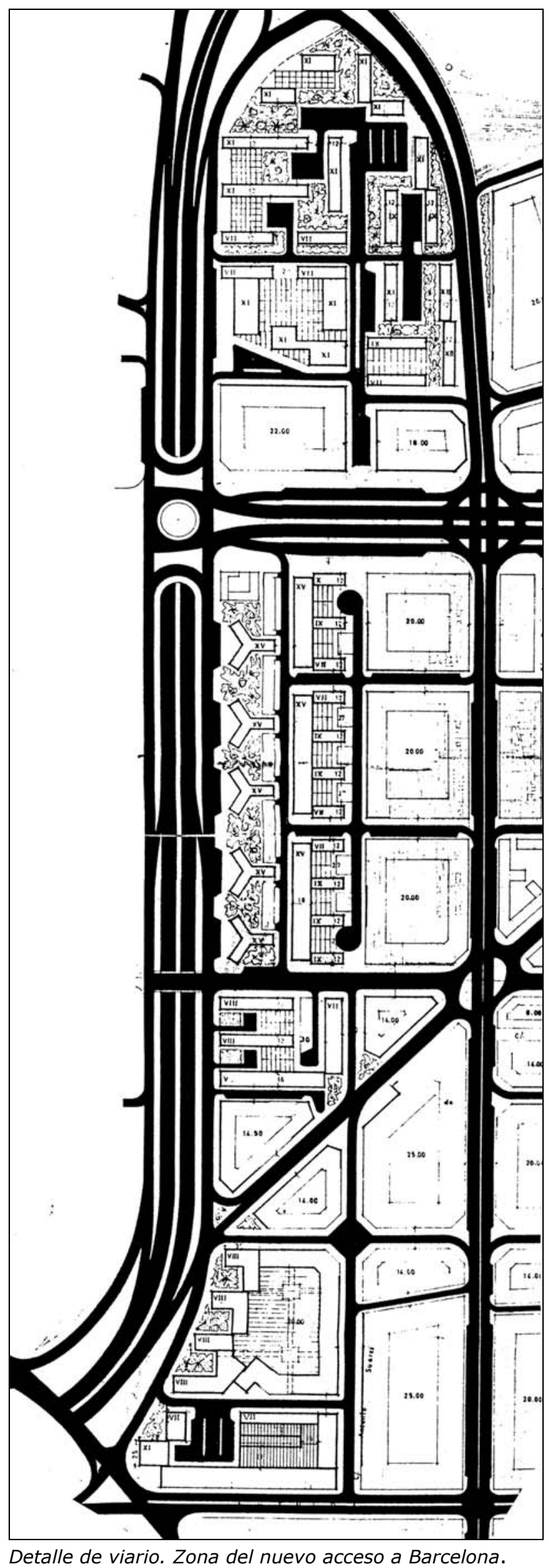


8. ALINEACIONES, ZONIFICACIÓN, VOLUMEN Y DIVISIÓN EN POLÍGONOS.

Escala original: 1:2000
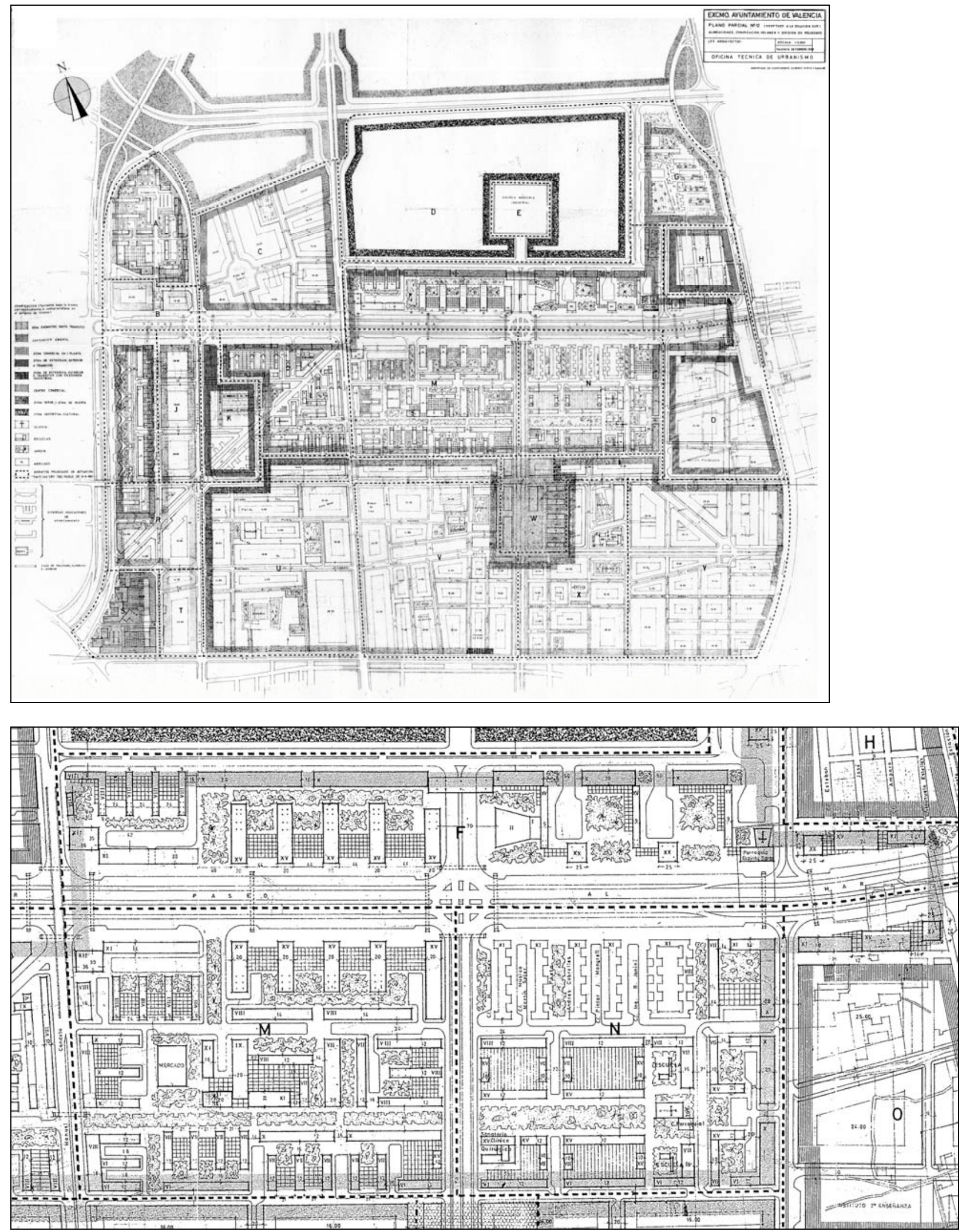

Detalle del plano de alineaciones. Zona de Paseo al Mar. 


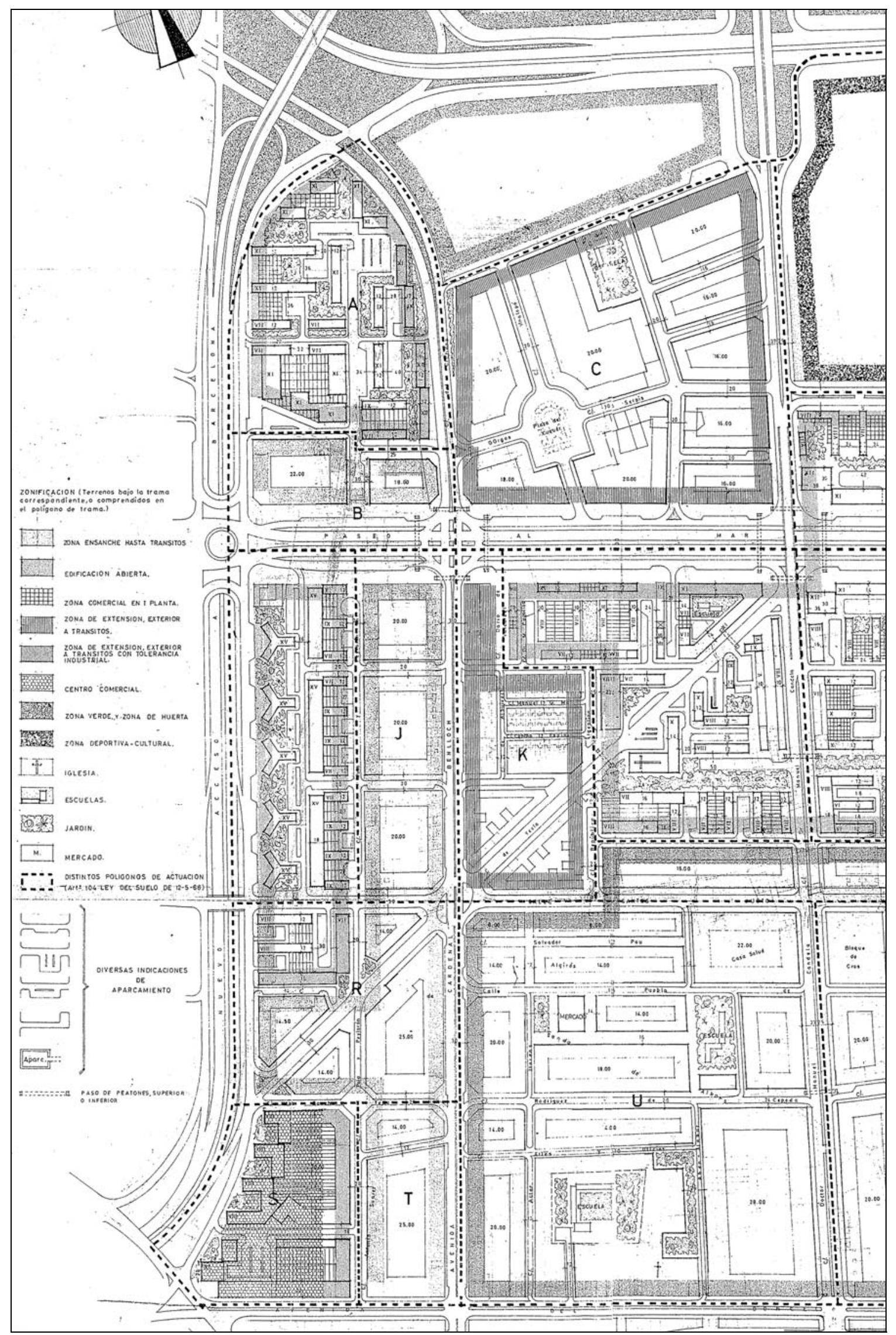

Detalle del Plano de alineaciones. Zona del nuevo acceso a Barcelona.. 
Redactor: El Arquitecto Municipal de Urbanismo. Ayuntamiento de Valencia.

Fecha: 8-11-1967

Asunto: Informe sobre la primera ronda de alegaciones presentadas a la versión inicial del Plano Parcial No 12.

Fuente: Ayuntamiento de Valencia. Sección de Urbanismo. Negociado de Suelo y Ordenación urbana. Expte. 330/67. Reg. General 60.885 (Archivo de Planeamiento No 96).

El que suscribe, a la vista de las reclamaciones, tiene el honor de informar:

Reclamación de don Jaime Bofill Campmajó

Remédela muy bien la zona, se adapta a la realidad muy bien y se adopta muy bien el carácter de zona comercial. Estimo que puede aceptarse modificándola por causa de la reclamación de don Manuel Serra. Se une croquis como entendemos debe quedar

Reclamación de don Manuel Serra

Se queja de que se destina excesivo terreno a vía pública. Es cierto, porque puede corregirse sin desvirtuar el plano, por lo que puede aceptarse. Se une al mismo croquis de la anterior de don Jaime Bofill.

Reclamación de la 6a, Jefatura Regional de Carreteras

Consta de dos partes:

Por la primera recomiendo la supresión de la calle, sustituyéndola por "cul de sac", estimo que debe aceptarse. Con este motivo denuncia que la zona a que afecta está marcada edificable, siendo zona verde según el plan. Es cierto, aunque la zona es muy pequeña y la edificación en ella poquísimo densa, y el motivo es que en el plano anterior era edificable, con volumen parecido, destinado a central lechera. Esto se justifica en la Memoria del plan parcial, diciendo que el plan general ha querido respetar todo lo establecido en los planes parciales anteriores, salvo las modificaciones necesarias por el Plan Sur y nuevas exigencias urbanísticas, por lo que consideramos error material esta zonificación. Por ello, creo que puede quedar como en el Plan Parcial establecido, salvo opinión en contrario del Excmo. Ayuntamiento, que ahora ha de aprobar el Plan Parcial.

La segunda porte de la reclamación, se refiere a vía pública inmediatamente al Norte del Paseo al Mar. Estimo que puede atenderse en la forma que se grafía en el croquis, en consideración a que hay peticiones de licencia que se verían afectadas. Se une un croquis de solución posible.

Reclamación de don Francisco Cuenca Ballester

Estimamos puede atenderse, dado que la densidad de población y edificabilidad, se han ido debilitando hacía el Norte y en a zona es pequeña. Se une croquis de la solución.

Reclamación de don Enrique Lladró Estelles

Puede atenderse por la poca edificabilidad de la parcela en la forma que se indica en el croquis de solución que se une.

Reclamación de don Vicente Gaya Sanz

Es cierta la reclamación, aunque los edificios son de altura reducida. Puede atenderse con solución parecida a la segunda que se presenta. Se une croquis. En éste se grafía, como mas importante todavía que lo relativo a la reclamación, solución al defecto observado en la unión de las dos direcciones del Paseo al Mar.

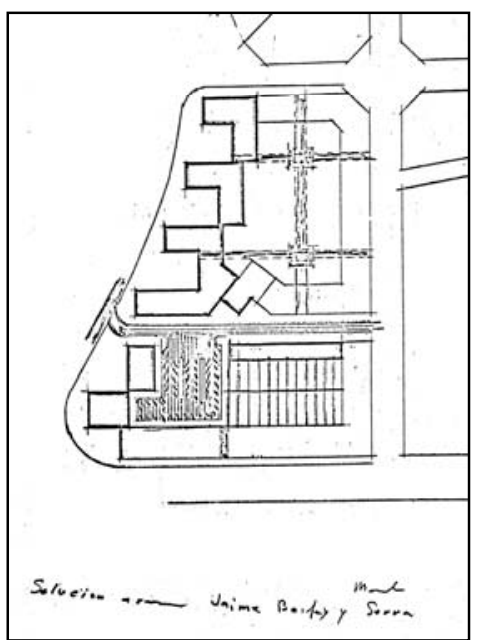

Reclamaciones de D. Jaime Bofill y D. Manuel Serra.

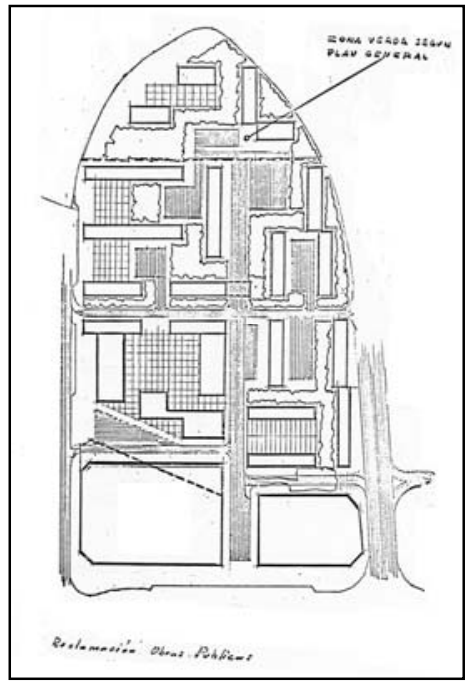

Reclamación de la Jefatura Regional de Carreteras. 
Reclamaciones de D. Francisco Cuenca y D. Juan Llopis.

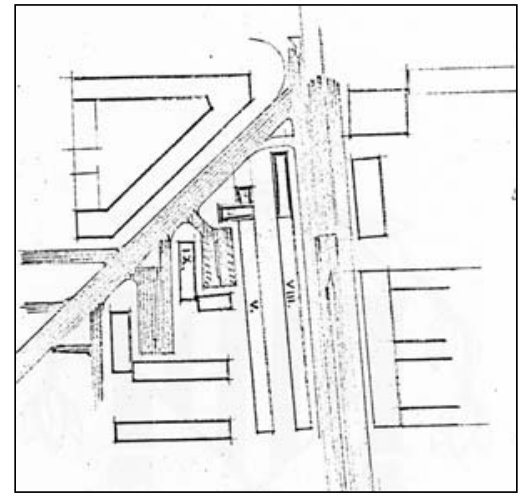

Reclamación de D. Enrique Lladro Estellés

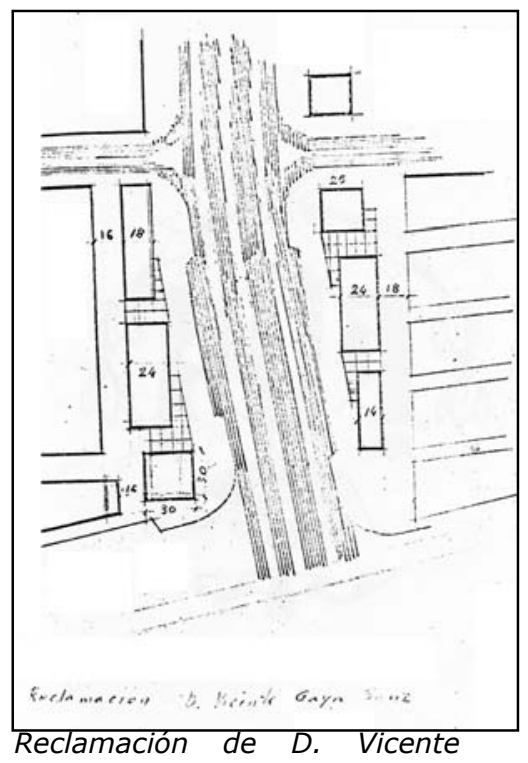

Gaya Sanz.

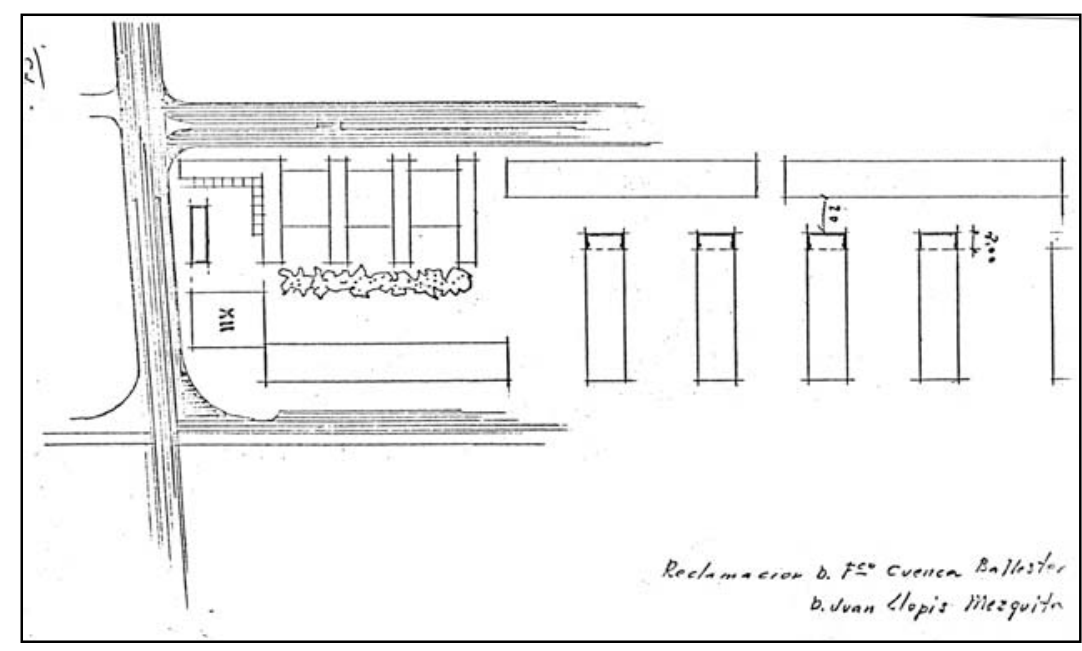

Reclamación vecinos CASAS DE AMALIA

Dicen que las nuevas líneas impiden el acceso a sus viviendas. Es inadmisible el argumento en contra, porque es evidente que las nuevas alineaciones no podrán ser efectivas hasta que las servidumbres de paso se extingan. Luego no se cierra ningún paso.

Reclamación de don José Sala Marco

Presenta solución que, aunque es interesante, no puede aceptarse, porque la forma nueva afectaría al bloque construido al noroeste del encuentro de calles.

Reclamación de don Francisco Darder Salcedo

No puede admitirse, porque las alineaciones que ahora se han grafíado, se ajustan a lo construido dentro de la mayor exactitud posible, con defecto o no, con arreglo al Plan Parcial 12-A, aprobado anterior.

Reclamación de don Enrique Martínez

En representación de la Cooperativa de Casa Baratas "La Señera". En el Plan Parcial se ha modificado las líneas antiguas de la Cooperativa, por ser de directrices completamente distintas de las del proyecto actual. Estimo que no puede conjugarse el carácter de estas casas con lo proyectado y, en todo caso, solamente podría mantenerse dos partes de grupo, pero con carácter completamente distinto al resto del Plan y Plan General. La alegación de haber entregado la vía pública, puede hacerse valer para el caso de reparcelación.

Reclamación de Talleres Dacar y otros sobre dar salida a la calle de Beniganim

No puede atenderse por ser la calle de Beniganim a extinguir, según este plano y el anterior aprobado por la Superioridad, $12 \mathrm{~A}$. Reclamación de doña Trinidad Moret Aparisi

Sobre retiro de Avenida del Doncel Luis Felipe García Sanchiz, junto a la calle de Serrería. El retiro éste consta ya en los planos anteriores aprobados por la Superioridad. Tiene por objeto el retiro formar plaza en el cruce de dos vías de gran tráfico. Estimo que debe quedar como está aprobado.

Reclamación de doña Amparo Pérez Duyos

En el plan Parcial 12-A, aprobado por la Superioridad, consta cono se ha marcado en el plano objeto de este estudio. Es terreno necesario en el cruce de dos grandes vías. Estimo que debe quedar como estaba aprobado, ya que para la supresión de espacio libre, hace falta tramitación distinta.

Reclamación de don Vicente Juliá Cubells.

Su aceptación afectaría a otros terrenos y teniendo la parcela 
parte edificable en buena proporción, estimo que debe quedar como está en el plano.

Reclamación de Yute Industrial S.A.

Deberá ser informada por la Oficina de Proyectos de Carreteras del Ministerio de Obras Públicas, en el sentido de si es o no posible estrechar esta calle de Clariano a la vista de estas construcciones.

La Reclamación de J.R. Pons Ibáñez

Puede admitirse por las razones que indica, si bien manteniendo la posibilidad de entrada a la Iglesia por la parte posterior, en la forma que indica el croquis que se une. Se ha de añadir que esta zona es de las pocas que se han modificada de la zona Sur de este plano, es decir del 12-A, y la modificación ha consistido en supresión de una calle, a petición muy justificada, del Parque Colegio de Santa Ana, en expediente no 15017 del Registro General. La reclamación de doña Asunción Santabárbara Luis

Es muy justificada y puede aceptarse en su totalidad tal y como se ha presentado en el plano, pero sin disminuir la superficie en planta baja de otros propietarios, con el fin de no motivar otras reclamaciones.

V. E. no obstante, resolverá.

Valencia 8 de noviembre de 1967.

El Arquitecto Mayor,

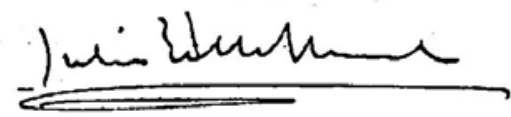

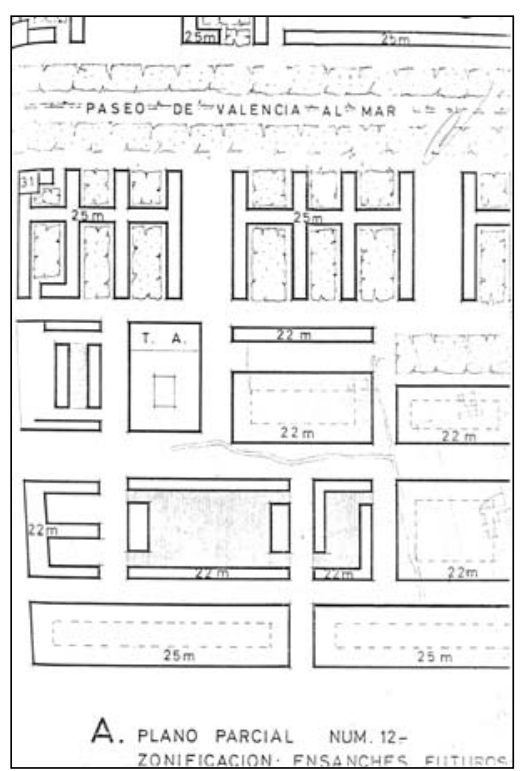
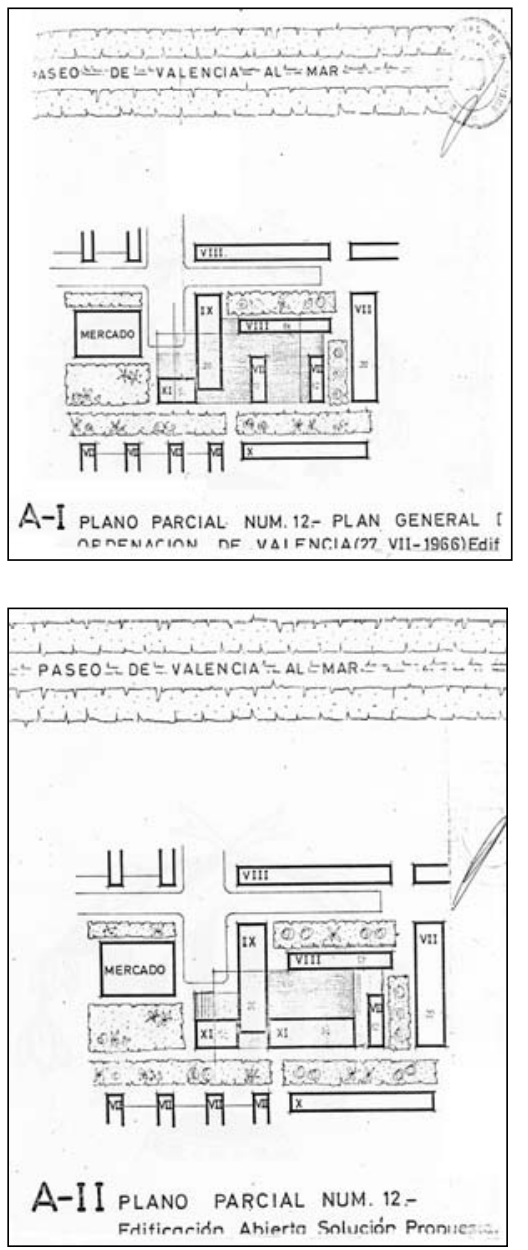
Redactor: El Arquitecto Municipal de Urbanismo. Ayuntamiento de Valencia.

Fecha: 26-02-1968

Asunto: Informe sobre modificaciones realizadas en la versión inicial del PP12.

Fuente: Ayuntamiento de Valencia. Sección de Urbanismo. Negociado de Suelo y Ordenación urbana. Expte. 330/67. Reg. General 60.885 (Archivo de Planeamiento No 96).

El Arquitecto que suscribe, tiene el honor de informar:

Se han realizado las modificaciones ordenadas por la Comisión de Urbanismo, a la vista de las sugerencias presentadas en la exposición pública realizada al objeto.

Además, como acoplamiento a la realidad, se ha acotado el lado de la manzana y ancho de calle en la segunda manzana al Norte de Paseo al Mar, comenzando a contar desde el límite Oeste del plano. También para subsanar el olvido se ha situado la parroquia del Espíritu Santo al Norte del Paseo al Mar y prolongación de calle José Aguilar.

Por último, porque así constaba en los planos aprobados anteriores, se ha zonificado como tal, el mercado próximo al cruce de calles de Puebla de Farnals y Actor Llorens.

V. E. no obstante, resolverá.

Valencia 26 de febrero de 1968.

El Arquitecto Mayor,

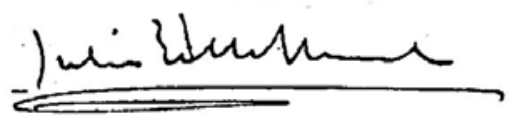

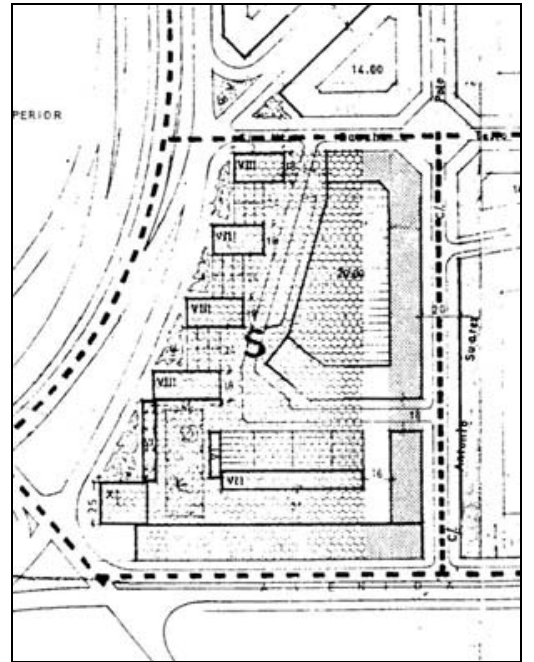

Plano inicial.

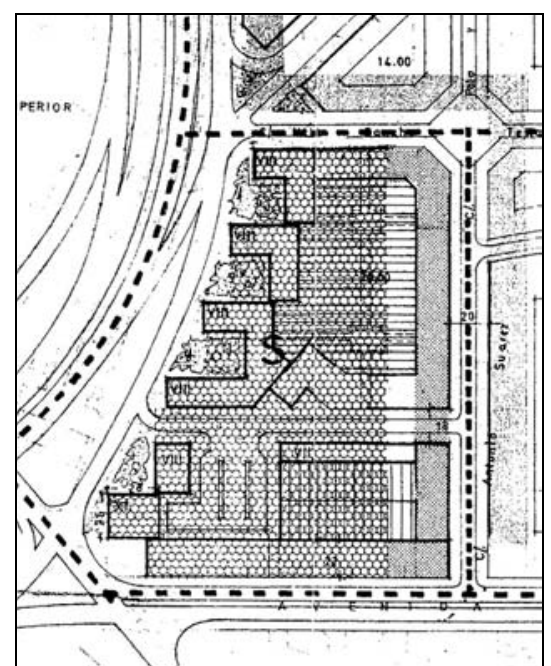

Plano modificado

Modificación derivada de las reclamaciones de D. Jaime Bofill y D. Manuel Serra. 


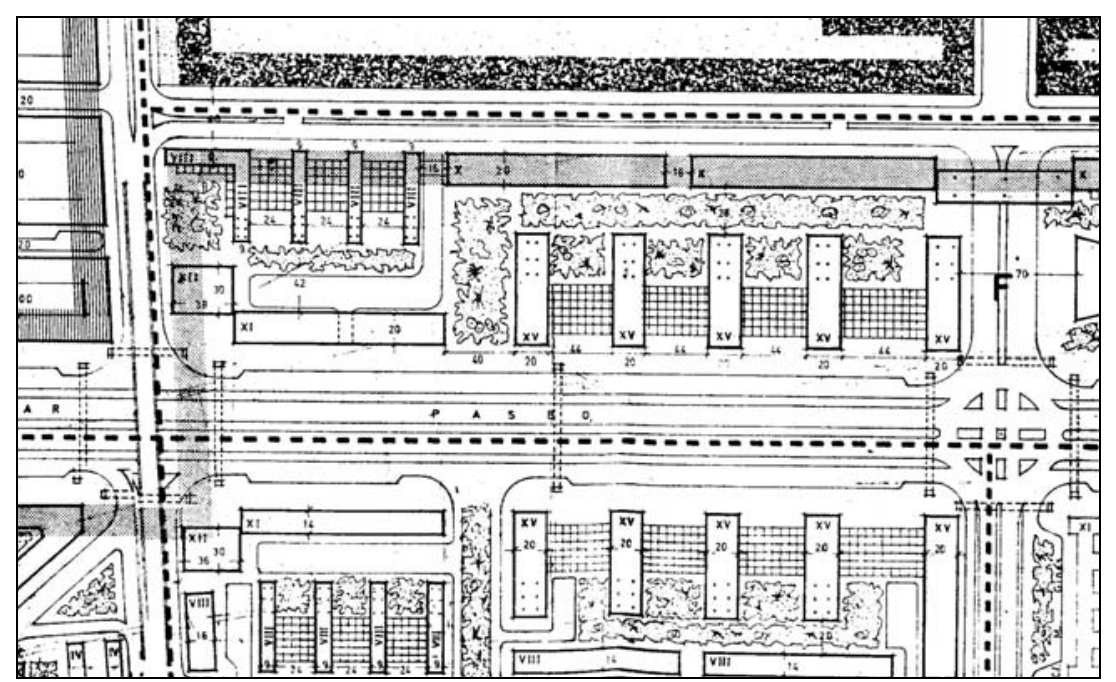

Plano inicial

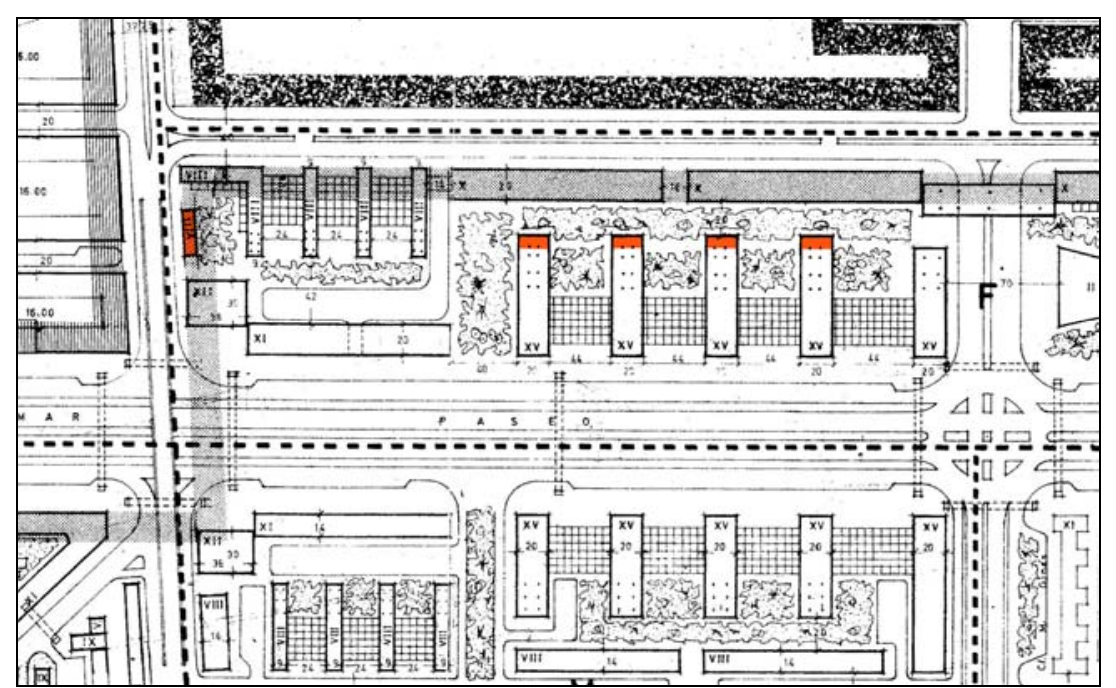

Plano modificado

Modificación derivada de las reclamaciones de D. F. Cuenca y J. Llopis.

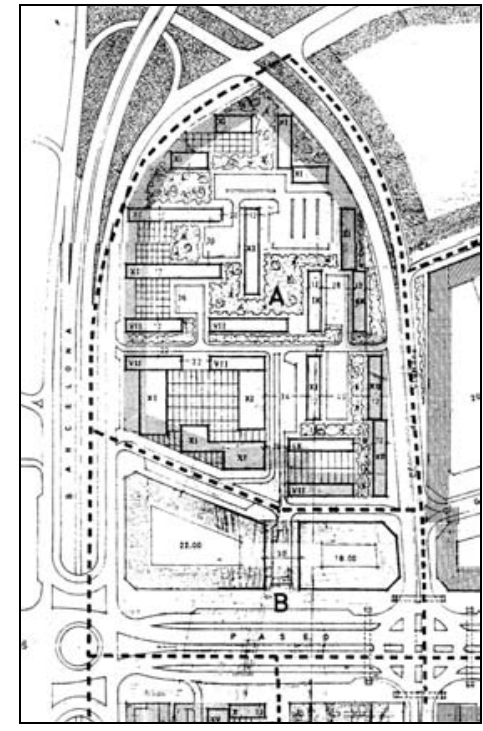

Plano inicial.

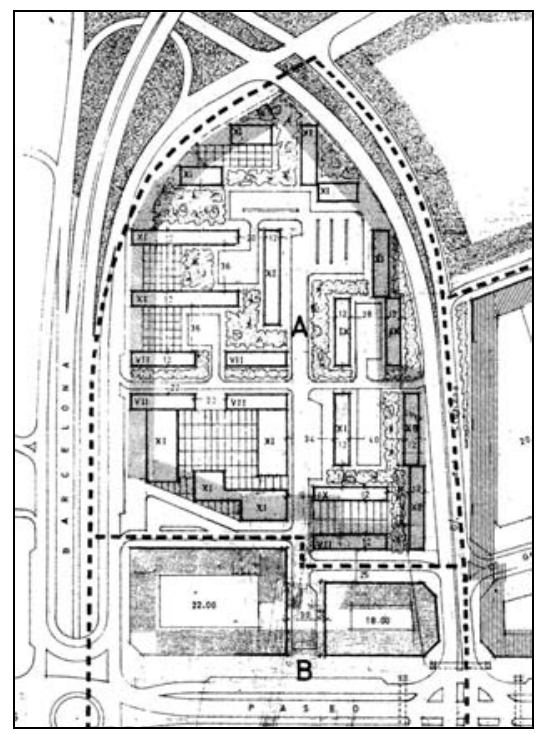

Plano modificado

Modificación derivada de las reclamaciones de la Jefatura de Carreteras. 


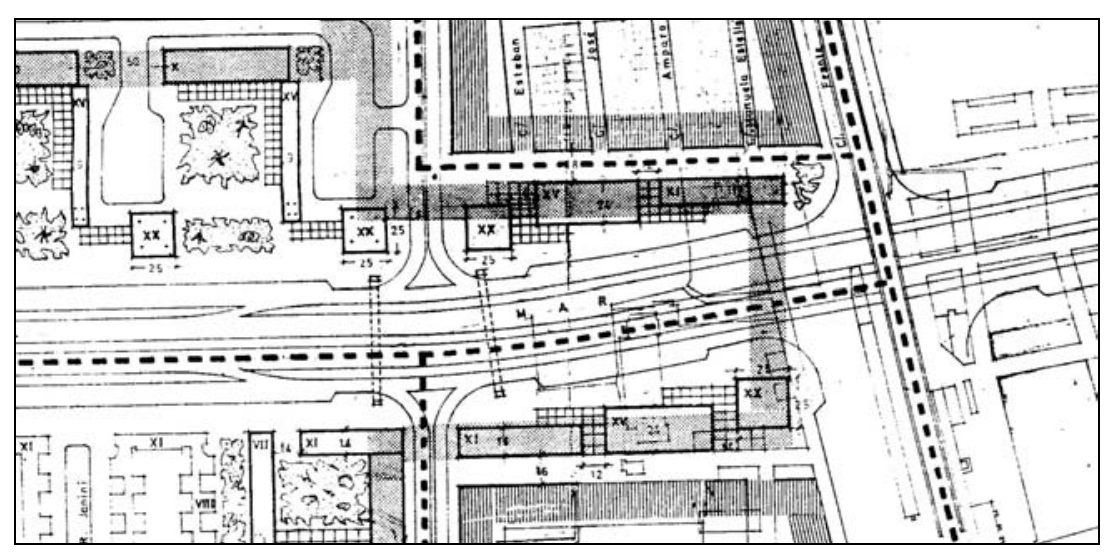

Plano inicial

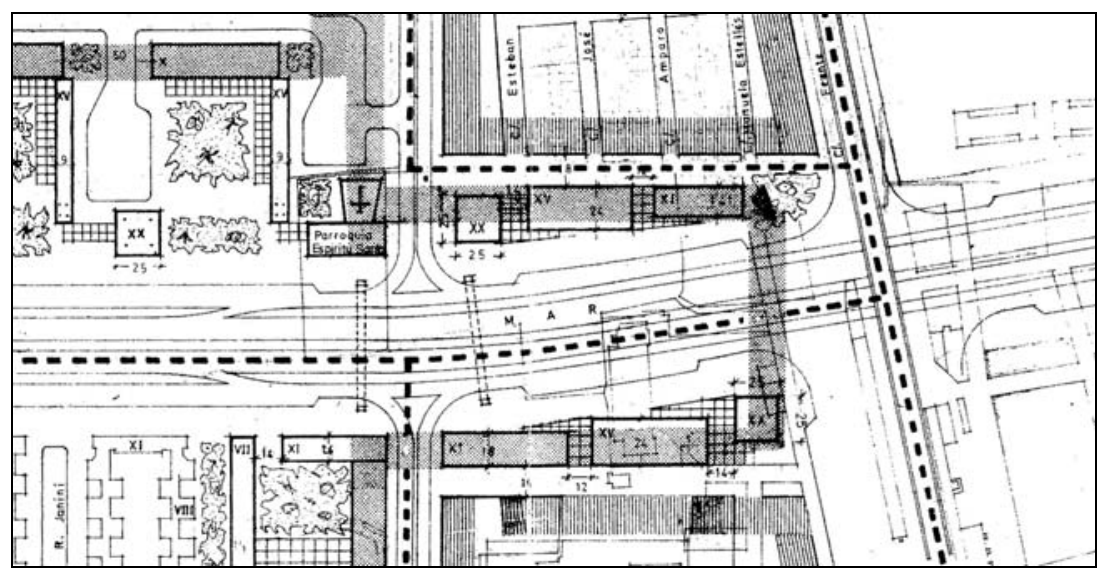

Plano modificado

Modificación derivada de las reclamaciones de D.Vicente Gaya. 
Redactor: El Arquitecto Municipal de Urbanismo. Ayuntamiento de Valencia.

Fecha: 19-08-1968

Asunto: Informe sobre la segunda ronda de alegaciones presentadas a la versión inicial del Plano Parcial No 12.

Fuente: Ayuntamiento de Valencia. Sección de Urbanismo. Negociado de Suelo y Ordenación urbana. Expte. 330/67. Reg. General 60.885 (Archivo de Planeamiento No 96).

El arquitecto que suscribe, tiene el honor de informar:

La reclamación de VICENTE BARRAQUER PEREZ (hoja no 87 de este expediente) pide profundidad edificable de 22 metros, que estimo aceptable. Es en manzana recayente a Paseo y entre calles de Clariano y en Proyecto.

La siguiente reclamación, (hoja 88 de este expediente) del mismo anterior, pide mayor altura en función del ancho de calle. Estimo puede concederse.

La reclamación de Doña JUANA ROIG ARNAL (hoja 89), la de don BLAS GINER QUILES (hoja no 91) y la de don PEDRO Y DON EDUARDO VEYRAT (hoja no 124) si se aceptan quedarían resueltas en el croquis que se une.

La reclamación de don JOSE CASTRO (hoja no 93 de este expediente) podría quedar resuelta, si se acepta con el croquis que se une adjunto a este expediente.

La reclamación de don FRANCISCO DARDER SALCEDO (hoja no 96 de este expediente) es lógica, es un error de redacción y se expresa en el croquis que unimos.

La reclamación de don JUAN LLOPIS MEZQUITA (hoja no 102) es reproducción de la presentada en el periodo de sugerencias y recuerda que no se le ha contestado. Por si se estima tomarla en consideración, reproduzco el croquis de solución.

Estimo que la reclamación de don LUIS MARTI ALEGRE, (hoja no 103) puede ser atendida en la forma que indica el croquis adjunto.

La reclamación de doña LUISA GARRIGUES VILLACAMPA, (hoja no 112) es atendible, cono se indica en el croquis que unimos

La reclamación de dona TRINIDAD MORET APARISI, (hoja 116) ya se presentó en periodos anteriores, siendo denegada. Se refiere a la plaza que se forma en el cruce de Avenida del Doncel Luis Felipe García Sanchíz y calle de la Serrería, solicitando doña Trinidad Moret alineación que regularice la plaza y le proporcione mayor solar edificable.

La de don FRANCISCO MANDINGORRA y otros pretende que se siga la alineación de la calle de la Serrería, en lugar de la plaza que se forma como unión (imperfecta) de la prolongación de Ramiro de Maeztu y calle de Cubells.

La reclamación de don ANTONIO GIRONA (hoja no 128) es atendible en la forma que el mismo indica y que consta en el croquis que unimos.

Atender a la reclamación de doña TERESA BONORA BENLLOCH, traería consigo la disminución del patio central de manzana en que se ubican Escuelas y Aparcamientos, por eso, si se concediera mayor profundidad edificable, debería ser en este lado de la manzana solamente y solamente dos metros mas de profundidad, quedando en 16 metros

La reclamación de don RAFAEL CARDONA PEREZ, solicita la declaración de edificable del terreno entre calle en proyecto y Es

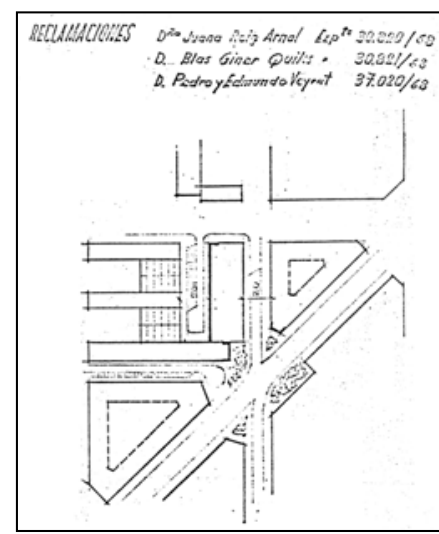

Reclamación de Da Juana Roig, D. Blas Giner y D. Eduardo Veyrat.

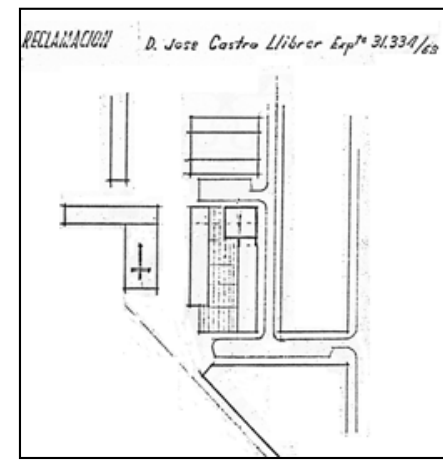

Reclamación de D. José Castro

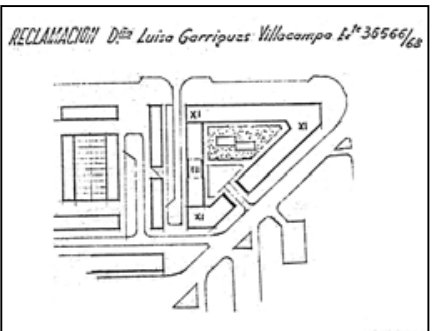

Reclamación de $D^{a}$ Luisa Garrigues 

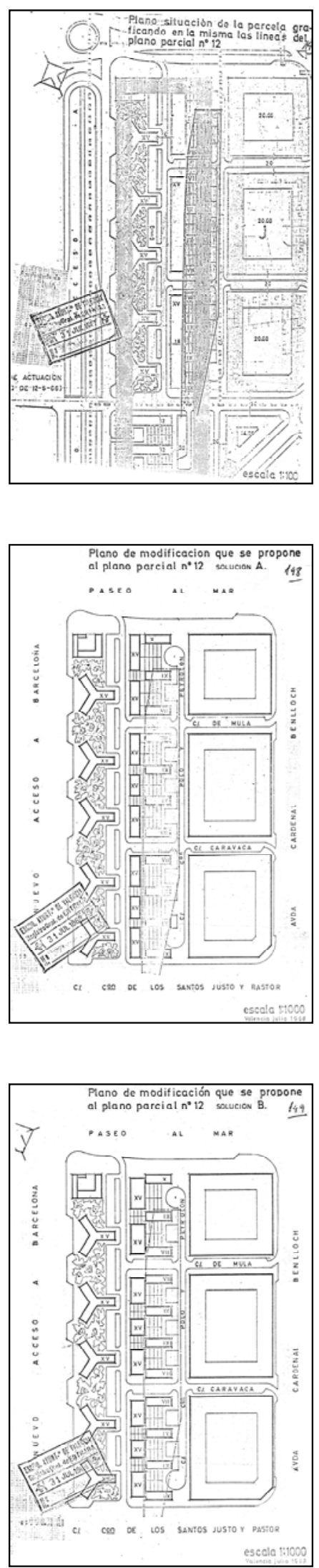

Reclamación de D. Manuel Chabrera cuela de Maestría Industrial. Estimo que es atendible.

Las de DON ANTONIO BLASCO (hoja no 117) de D. JOSÉ BATALLER CARRERES (hoja no 119), la de don RAMÓN BALLESTER NAVARRO, la de don JOAQUIN GINER, la de don RICARDO FONT y la de don VICENTE BELENGUER, solicitan la reparcelación equiparando el polígono $\mathrm{D}$. A los restantes.

La reparcelación puede hacerse ahora con validez a la aprobación del plano, pero estimamos preferible hacerlo cuando al plano esté aprobado, así como también lo que proceda entre la reparcelación dentro del polígono o la extensión de éste a la totalidad del plano.

La reclamación de D. MANUEL CHABRERA BELTRAN, es por la forma de la edificación en las manzanas al Oeste de calle de Polo y Peyrolon y Norte de calle de Santos Justo y Pastor.

Presenta esquemas que perfeccionan el plano, puesto que independiza la edificación en las distintas parcelas. Estimo que puede aceptarse una de las soluciones.

La reclamación de D. JOSE ALBALAT GARCIA, es por poca edificabilidad. Presenta esquema que estimo que podría adoptarse como solución.

V.E. resolverá.

Valencia 19 de Agosto de 1968 EL ARQUITECTO

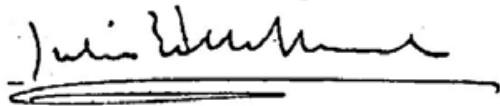


Redactor: Comisión de Urbanismo. Ayuntamiento de Valencia.

Fecha: 26-08-1968

Asunto: Resolución sobre alegaciones y propuesta de aprobación provisional del PP12.

Fuente: Ayuntamiento de Valencia. Sección de Urbanismo. Negociado de Suelo y Ordenación urbana. Expte. 330/67. Reg. General 60.885 (Archivo de Planeamiento No 96).

\section{M.I. AYUNTAMIENTO DE VALENCIA}

COMISION DE URBANISMO

\section{SESIÓN EXTRAORDINARIA DEL 26 DE AGOSTO DE 1968}

Dada cuenta del expediente relativo al Plan Parcial no 12, la Comisión acordó proponer al Excmo. Ayuntamiento Pleno, se apruebe provisionalmente, con las siguientes particularidades:

PRIMERO.- Que se desestimen las siguientes reclamaciones por no ser atendibles desde el punto de vista urbanístico:

No 29935 de D. Vicente Barraquer Pérez.

No 29936 de D. Vicente Barraquer Pérez.

No 30820 de Da. Juana Roig Arnal

No 34624 de D. José Sala Marco.

No 30821 de D. Blas Giner Quiles.

No 36566 de Da María Luisa Garrigues Villacampa.

No 37012 de Da Trinidad Morete Aparisi.

No 37015 de D. Francisco Mandingorra Rodriguez.

No 37020 de D. Pedro y Edmundo Peyrat Colín.

No 37021 de D. Antonio Girona Busutil.

No 37427 de D. Rafael Cardona Pérez.

No 59825 de D. Manuel Chabrera Beltrán.

SEGUNDO.- Que se desestimen asimismo por no ser momento procesal adecuado, las reclamaciones:

No 37013 de D. Antonio Martí Blasco.

No 37014 de D. José Bataller Carreras.

No 37727 de D. Joaquín Giner Planes.

No 37728 de D. Ricardo Font Belenguer.

No 37729 de Da Luisa León Valencia.

No 37730 de D. José Font Belenguer.

No 37732 de D. Vicente Font Belenguer.

No 37733 de Da Amparo Font Belenguer.

No 37734 de D. Vicente Belenguer Belenguer.

TERCERO.- Que se desestime, por no ser atendible urbanísticamente, la petición no 31334 de D. José castro Llibrer; si bien deberá corregirse el bloque recayente a la calle de Campoamor alargándolo hasta el camino con el fin de que el plano se atenga a la realidad.

CUARTO.- Que se acepten de acuerdo con las soluciones dadas por el Arquitecto municipal, las siguientes reclamaciones:

No 34623 de D. Francisco Darder Salcedo.

No 35312 de D. Juan Llopis Mezquita.

No 36039 de D. Luís Martí Alegre.

No 63800 de D. José Albalat García.

QUINTO.- Propone se modifique en el sector $X$ los bloques recayentes a la prolongación de la calle Industria unificándolos y manteniendo la profundidad edificable, así como disponiendo chaflán en la conjunción de la prolongación de la calle de la Industria y la calle de Ramiro de Maeztu.

Asimismo propone que en el sector $\mathrm{V}$ se remodele la prolongación del bloque procedente del sector $X$ sustituyéndola por un bloque similar a los cuatro situados al Norte. 
SEXTO.- Propone que las líneas de viario marcadas en lo que son terrenos del Jardín de Ayora tienen carácter indicativo y en el estudio de pavimentación se señalará el viario conveniente para respetar el mencionado jardín de alto valor.

V.E., no obstante, resolverá.

Plano inicial

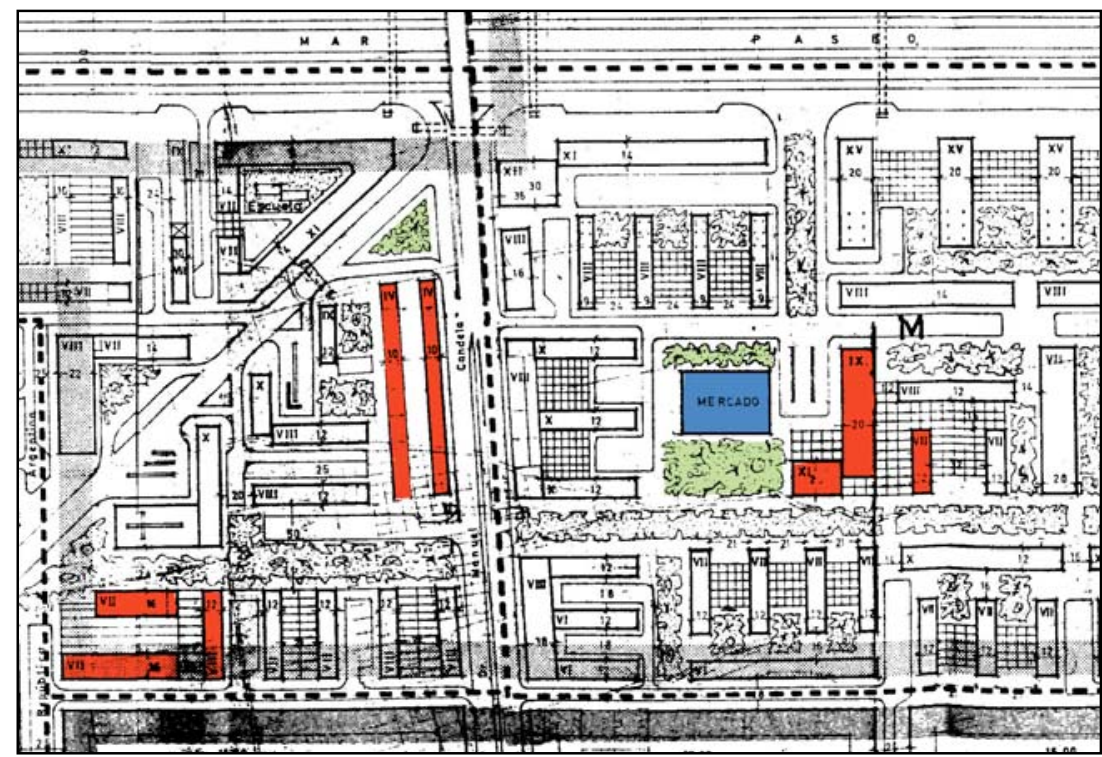

Plano modificado

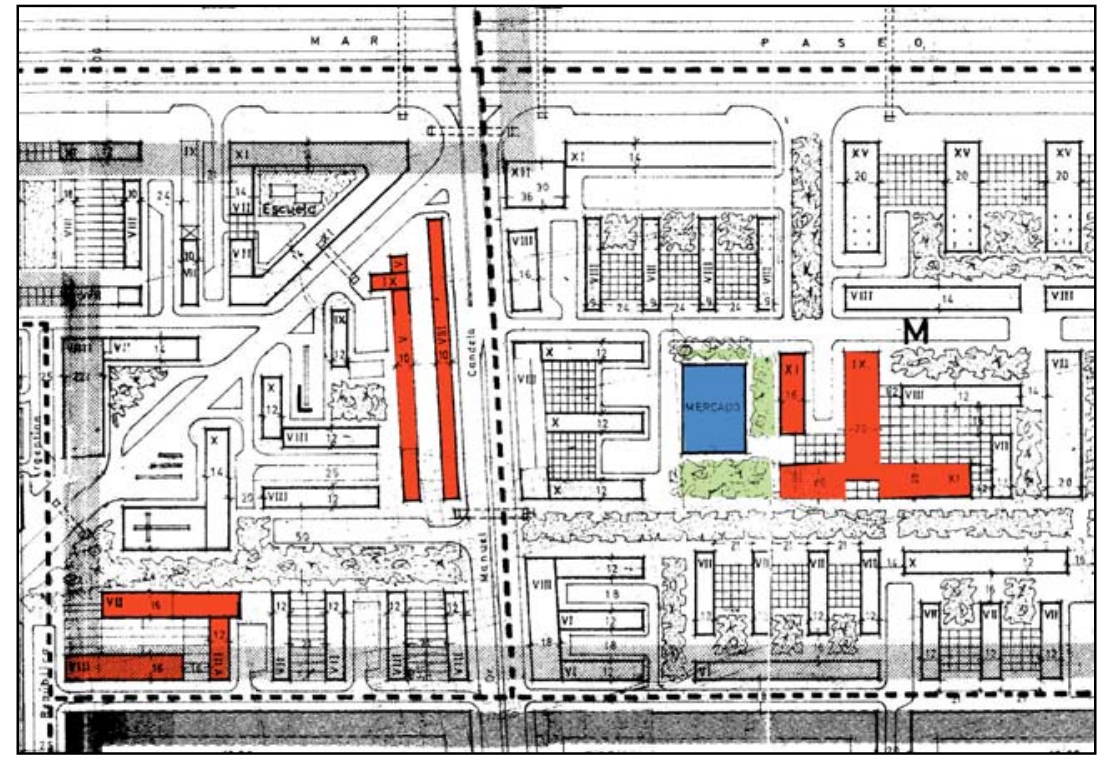

Modificaciones derivadas de reclamaciones en la zona de Paseo al Mar. 
Redactor: Dirección General de Urbanismo del Ministerio de la Vivienda / Ministerio de la Vivienda.

Fecha: 24- 10-1969.

Asunto: Resolución de aprobación del Plan Parcial 12.

Fuente: Archivo de Planeamiento. Ayuntamiento de Valencia.

Documento No 96 (Expte. 330/67. Reg. General 60.885)

MINISTERIO DE LA VIVIENDA

Dirección General de Urbanismo.

Ilmo Sr.:

El Excmo. Sr. Subsecretario del Ministerio de la Vivienda, actuando por delegación del Excmo. Sr. Ministro, con fecha 22 de los ctes., me dice lo siguiente:

"VISTO el Plan Parcial de Ordenación Urbana no 12, de Valencia, adaptado al vigente Plan General de Ordenación Urbana de Valencia y su Comarca, presentado por el Ayuntamiento de dicha ciudad por conducto de la Corporación Administrativa Gran Valencia, y VISTO el informe emitido por los servicios competentes de la Dirección General de Urbanismo, Este Ministerio, teniendo en cuenta lo dispuesto en la vigente Ley sobre Régimen del Suelo y Ordenación Urbana de 12 de Mayo de 1956 y en el Decreto 63/1968 de 18 de Enero, acuerda aprobar dicho Plan Parcial y que esta resolución sea notificada a la referida Corporación Local, y a la Corporación Administrativa Gran Valencia."

Lo que comunico a V. I. para su conocimiento y efectos.

Dios guarde a V.I. muchos años.

Madrid, 24 de Octubre de 1.969.

EL DIRECTOR GENERAL.

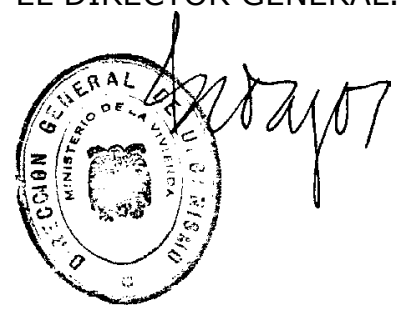

Ilmo. Sr. Alcalde Presidente del Ayuntamiento de VALENCIA. 



\section{PP13}

Redactores: Excmo. Ayuntamiento de Valencia. Oficina Técnica Municipal de Urbanismo. Arquitectos: Julio Bellot Senent, Antonio García Heredia.

Fecha redacción: Octubre 1968.

Fecha aprobación: Aprobación inicial municipal: 2-10-1968. Propuesta de aprobación provisional: 1-12-1969.

\section{Contenido:}
I. MEMORIA
II. ORDENANZAS.

III. PLANOS:

1. ESTADO ACTUAL Y FOTO AÉREA

2. RELACIÓN CON EL PLAN GENERAL

3. ZONIFICACIÓN

$1: 2000$

4. RED VIARIA

$1: 2000$

5. ESTRUCTURA URBANÍSTICA

$1: 2000$

6. ALINEACIONES

$1: 2000$

7. ESQUEMA AGUA POTABLE

$1: 2000$

9. ESQUEMA ALCANTARILLADO

$1: 2000$

10. ESQUEMA ALUMBRADO

$1: 2000$

Fuente: Ayuntamiento de Valencia. Sección de Urbanismo. Negociado de Suelo y Ordenación urbana. Expte. 364/67. (Archivo de Planeamiento, sección de expedientes antiguos, No E2/12).

\section{Notas:}




\author{
EXCMO. AYUNTAMIENTO DE VALENCIA \\ OFICINA TÉCNICA DE URBANISMO \\ PLAN PARCIAL NO 13 (ADAPTADO A LA SOLUCIÓN SUR)
}

\title{
1. MEMORIA
}

1.1. La redacción del presente Plan Parcial tiene su origen en la Adaptación del Plan General de Ordenación Urbana de Valencia y su Comarca a la Solución Sur.

Los límites del Plan Parcial $n^{\circ} 13$ son los definidos por la calle de Dr. J.J. Domine, La Avd. del Doncel Luis Felipe García Sanchiz, la calle de la Serrería,el F.F.C.C. de Valencia a Tarragona, la acequia de Vera (límite del término municipal de Valencia) el mar Mediterráneo y las instalaciones portuarias de la dársena interior del Puerto de Valencia.

1.2. El Plan General determina las siguientes zonas:

1.2.1. Zona de Extensión Exterior a Tránsitos.

Queda definida esta zona en cuatro sectores cuyos límites son los siguientes: del primero, Autopista del Mediterráneo, zona portuaria y calle del Dr. Lluch; del segundo, la calle de J.J. Domine, Avd. del Doncel L.F. García Sanchiz, calle de Serrano, calle de Francisco Cubells, F.F.C.C. Valencia a Tarragona, calle de Marti Grajales, calle de las columbretes y calle del Doctor Lluch; el tercero por la calle de Carlos Ros, el F.F.C.C. de Valencia a Tarragona, la Ronda Exterior y calle del Dr. Lluch; y el cuarto por la Ronda Exterior, el F.F.C.C. de Valencia a Tarragona, la Acequia de Vera y la Autopista del Mediterráneo.

1.2.2. Zona de tolerancia industrial.

Queda definida esta zona por los límites siguientes: Avenida del Doncel L. F. García Sanchiz, calle de la Serrería, calle de Francisco Cubells y calle de Serrano.

1.2.3. Zona industrial.

Dentro de los límites definidos para la zona de tolerancia industrial marcado en el Plan General se ha adoptado esta zonificación de industrial para las dos manzanas de limitadas por las calles de Marino Cuber, Arquitecto Alfaro, Plaza del Mercado Nuevo, calle de Martí Grajales y vía férrea de Valencia a Tarragona. El uso exclusivo de industria en estas dos manzanas y la gran importancia económica y social de las mismas aconseja claramente adoptar esta zonificacion.

1.2.4. Zona comercial intensiva.

Está constituida esta zona por dos sectores paralelos al Paseo de Valencia al Mar y con una profundidad comprendida entre los 16 y los 24 metros desde la fachada del mismo hacia el interior del barrio del Cabañal en cada uno de los dos paramentos del Paseo.

1.2.5. Zona turística.

Se destina esta zona al uso exclusivo de playa con insta laciones de baños y restaurantes. Queda definida por la Autopista del Mediterráneo en su parte occidental y por el mar Mediterráneo por la oriental ocupando todo el sector que entre estas dos líneas abarca el Plan Parcial número 13.

1.2.6. Ciudad jardín.

Dado el interés privado manifestado en las sugerencias motivadas por la exposición al público de que la línea de chalets comprendida entre las calles de Isabel de Villena y de Cavite siga 
siendo tratada en su zonificación como de ciudad jardín, se recoge esta sugerencia en el Plan redactado y adoptando el acuerdo de la Comisión en este sentido se le determina un coeficiente de edificabilidad de $3 \mathrm{~m} 3 / \mathrm{m} 2$.

1.2.7. Unidad vecinal autónoma para profesionales del mar.

Dada la importancia que este grupo profesional tiene dentro del marco del barrio del Cabañal se ha previsto una unidad vecinal para ubicar sus viviendas y edificaciones anejas propias de su profesión. Queda definida esta unidad por los límites siguientes: Paseo de Valencia al Mar, calle del Doctor Lluch, prolongación de la calle Gobernador Moreno y calle de Eugenia Viñes.

Se pretende con ello, además conseguir un ambiente cívico mas digno sustituyendo la edificación actual en esta zona, cuyo estado podemos definir como de semichabolismo, por una edificación moderna y en perfectas condiciones de habitabilidad.

1.2.8. Zona deportivo-cultural.

Delimitada por las calles de Dr. Lluch, Ronda Exterior de la Red Arterial y Paseo de Valencia ai Mar se define una zona para uso deportivo-cultural con arreglo a las determinaciones que para esta zonificación determina el Plan General. Se incluye en ella, además, los siguientes edificios públicos: Centro Parroquial de la Buena Guía, Grupo Escolar, Casa Cuartel de Carabineros e Instituto de Enseñanza Media. Los tres primeros existen en la actualidad y quedando afectados en mayor o menor grado por el trazado de la Ronda Exterior prevista en la Red Arterial se define para ellos un nuevo emplazamiento; el último es de nueva previsión y se pretende con ello dotar mejor a este barrio en el sector de la enseñanza.

1.2.9. Zonas verdes.

Define el Plan General las siguientes zonas verdes: Paseo de Valencia al Mar, zona comprendida entre la calle del Doctor Lluch y la Autopista del Mediterráneo que en la actualidad está ocupada por las instalaciones ferroviarias llamadas a desaparecer y espacios libres que complementan las instalaciones de la zona turística.

Se incluye además en este Plan el trazado previsto para la plaza de la Armada Española que según expediente independiente del Excmo. Ayuntamiento ha sido aprobado ya por el Pleno.

1.3. Red Arterial.

La Red Arterial afecta al Plan Parcial no 13 en los siguientes extremos:

1.3.1. Autopista del Mediterráneo.

Cruza el trazado de esta Autopista todo el área del Plan Parcial no 13 de Norte a Sur y manteniéndose sensiblemente paralela al mar delimita perfectamente a uno y otro lado zonas de uso muy distinto y a las cuales nos hemos referido en el apartado 1.2. Sus características, como tal Autopista ayudan perfectamente a esta delimitación ya que la prohibición de cruces a nivel y la de accesos directos es absoluta.

1.3.2. La Ronda Exterior.

Este anillo de circunvalación, que se proyecta con la intención de delimitar todo el perímetro urbano de Valencia, en el Plan Parcial $n^{\circ} 13$ se ha visto forzado su trazado de forma que excluye de este perímetro una zona edificable. Se aprovecha para su ubicación el hueco que el tendido del ferrocarril marca y se establece la conexión con la Autopista del Mediterráneo de forma que sea éste el único punto en el que se puede acceder o abandonar ésta. Será también esta Ronda el perímetro del Plan 
Parcial $n^{\circ} 13$ en su conexión con las instalaciones portuarias definiendo los distintos usos a cada uno de sus lados.

1.4. Viario interno.

1.4.1. Red azul. (Vías de relación entre barrios).

Se compone ésta de las siguientes vías: Paseo de Valencia al Mar en su ultimo tramo con acceso directo al mar sin interferencias con la Autopista ni con la Ronda Exterior. Se proyecta esta vía con un ancho de 100 metros libres de edificación y tiene enlaces con el viario de los barrios en el cruce con la Avenida en proyecto sobre la línea del P.F.C.C. de Valencia a Tarragona, en el cruce con las calles de Doctor Lluch y de Almirante Mercer y en el punto de su terminación con un paseo marítimo que se proyecta para servicio exclusivo de la zona turística.

Avenida en proyecto sobre el tendido del ferrocarril de Valencia a Tarragona que sirviendo de límite entre dos parciales tiene continuidad a través de los que limitan los anteriores en sus extremos.

Sobre esta Avenida se traza un paso superior para enlazar a distinto nivel las calles de Francisco Cubells y Ramiro de Maeztu, situada esta ultima en el área del Plan Parcial n 12.

1.4.2. Red verde o de colectores de barrio.

Se han definido de esta categoría aquellas que con un ancho superior a 14 metros para una sola dirección y 16 metros para dos direcciones, establecen conexiones con las vías más importantes y penetran hasta el interior de todos los barrios. Componen estas vías un tejido conexo y completo para una efectiva fluidez del tráfico.

1.4.3. Red amarilla.

Esta destinada a permitir el acceso a la propiedad en todos los puntos de las zonas edificables y dotar al Plan Parcial de los necesarios aparcamientos. Se conecta con la red verde y la constituyen todas las calles que no se han definido en los apartados anteriores.

1.4.4. Secciones transversales.

Se han estudiado con todo detalle las secciones transversales para permitir el máximo aprovechamiento de las calzadas tanto para el tráfico rodado como para las superficies destinadas a aparcamiento.

1.5. Alineaciones.

En su mayoría todas las alineaciones grafiadas en el Plan Parcial no 13 anteriormente redactado se han respetado y las modificaciones que se han marcado obedecen a los criterios siguientes:

1.5.1. Supresión de las manzanas delimitadas por las calles de Francisco Cubells, del Arquitecto Alfaro, del Marino Cuber y ferrocarril de Valencia a Tarragona para poder ubicar el paso superior mencionado en el apartado 1.4.1.

1.5.2. Definir profundidades de edificación en las manzanas que en el parcial anterior quedaban incompletas sin marcar los patios de manzana necesarios.

1.5.3. Tender a una edificación semiabierta haciendo penetraciones en las manzanas que dignificando las fachadas recayentes al patio interior de manzana permiten un acceso claro al mismo para su utilización cono espacio ajardinado y aparcamiento.

1.5.4. Retirar la fachada en aquellos paramentos que lo permitan por no haber ninguna edificación reciente consiguiendo una sección más amplia de la calzada con vistas a una superficie necesaria de aparcamiento y permitiendo a la edificación con 
seguir una altura mayor para que no se vea perjudicada la iniciativa privada.

1.5.5. Para conseguir una zona deportivo-cultural y edificios públicos aceptable para todo el Plan Parcial se ha prescindido de toda la edificación privada que en la zona marítimo-terrestre está ubicada entre la playa de vías del ferrocarril de Obras del Puerto y la Autopista del Mediterráneo.

1.6. Servicios Generales.

1.6.1. Centros comerciales.

Se ha dotado al Plan Parcial no 13 con un centro comercial de segundo orden situado en la primera alineación de edificios a lo largo del Paseo de Valencia al Mar y a ambos lados de este. Sus características quedan definidas por la especificación que para las zonas comercial intensivas establece la Norma 35 del Plan General.

Asimismo se prevén dos centros comerciales de barrio localizados en el núcleo central del barrio del Cabañal actualmente existente y en la zona de ampliación del barrio de la Malvarrosa.

1.6.2. Centros parroquiales.

Se conservan todos los existentes en la actualidad. Uno de ellos al quedar afectado por la Ronda Exterior se traslada de emplazamiento y se sitúa éste en el parque previsto entre la Autopista y la calle del Doctor Lluch.

Se propone la creación de otro nuevo en el sector del barrio de la Malvarrosa recayente a la vía del F.F.C.C. de Valencia a Tarragona y que siendo hoy en su mayor parte zona de huerta se prevé para el futuro un crecimiento considerable de la edificación.

1.6.3. Centros escolares.

Se prevé la creación de dos nuevos centros escolares en el sector del barrio de la Malvarrosa antes aludido. Todos los demás centros existentes en la actualidad se mantienen para el futuro.

1.7. Zonas peatonales.

Se ha estudiado en el proyecto de Plan Parcial no 13 la creación de sectores con uso exclusivo para los peatones. Estos sectores obedecen a los criterios siguientes:

1.7.1. Accesos a la playa y zona turística.

Se da la máxima facilidad para que tanto el barrio del Cabañal como el de la Malvarrosa tengan un acceso peatonal directo a toda la playa, cuidando especialmente que ni la Autopista del Mediterráneo ni la Ronda Exterior que son límites de áreas de uso del suelo distinto representen el menor obstáculo. Se prevé para ello cuatro pasos a distinto nivel desde el barrio de la Malvarrosa como prolongación de las calles perpendiculares al mar de mayor densidad de población y que lógicamente recogerán la afluencia máxima de sus habitantes hacia el mar.

También desde el barrio del Cabañal el acceso a la playa será fluido y sin obstáculo ya que a la altura de este barrio tanto la Autopista. del Mediterráneo como la Ronda Exterior al pasar en elevado permiten la multiplicidad de pasos directos. El Paseo de Valencia al Mar que cruza estas vías también a distinto nivel será el acceso más importante de todos los habitantes del barrio a la playa, tanto en vehículo como a pie.

1.7.2. Calles de peatones.

Dado el tipo de edificación que cubre el área del barrio del Cabañal se ha considerado muy interesante el crear un determi 
nado número de calles cuyo uso sea exclusivo para peatones. Son éstas las que teniendo un trazado perpendicular a la playa no dan servicio directo a la propiedad y sí beneficio por otra parte a la fluidez del tráfico el no permitir por ellas el paso de vehículos.

1.8. Polígonos de actuación.

Para la mayor facilidad de ejecución del Plan Parcial número 13 se han considerado 10 sectores independientes y cuyas características son muy diferentes.

Los sectores son los siguientes:

Polígono $1^{\circ}$. Paseo de Valencia al Mar.- Recoge éste el proyecto redactado para el tramo final del Paseo de Valen, cia al Mar incluyendo algunas ligeras modificaciones que para su actualización son necesarias.

Polígono 20. Barrio de Regiones Devastadas.- Está compuesto por los edificios de esta denominación existentes completado por una ampliación del barrio sobre terrenos ocupados por las vías del ferrocarril de la Junta de Obras del Puerto y por un gran centro comercial adyacente al Paseo de Valencia ai Mar y situado sobre un grupo de edificación de la más ínfima categoría.

Polígono 30. Zona deportivo-cultural.- Se sitúa éste sobre la playa de vías del ferrocarril de la Junta de Obras del Puerto y afecta además a una línea de edificaciones cuyo terreno es zona marítimo-terrestre. Se prevé en este parque la edificación de servicios comunitarios exclusiva mente.

Polígono $4^{\circ}$. Zona turística.- Recoge este polígono la zona designada con este nombre en la zonificación determinada por el Plan General.

Polígono $5^{\circ}$. Zona de tolerancia industrial.- Queda definido este polígono por los mismos límites que definen la zona de tolerancia industrial determinada por el Plan General.

Polígono 60. Sector sur del barrio del Cabañal.

Polígono 70. Sector norte del barrio del Cabañal.

Polígono $8^{\circ}$. Barrio de la Malvarrosa de edificación actual.

Polígono 90. Extensión del barrio de la Malvarrosa de edificación futura.

Polígono $10^{\circ}$. Edificación abierta entre el barrio de la Malvarrosa y la Autopista del Mediterráneo.

El plan de etapas queda regulado por esta división en polígonos correspondiendo a la iniciativa pública los designados con los números $1,2,3$ y 4 y la iniciativa privada los designados con los números 5, 6, 7, 8, 9 y 10 .

1.9. Medios económico-financieros.

Constituyen estos medios el Presupuesto Ordinario de urba nismo del Excmo. Ayuntamiento más los presupuesto extraordinarios que sean establecidos para promover el desarrollo de los polígonos de actuación pública y el de los barrios en los polígonos de iniciativa privada a través de realizaciones comunitarias tal como centros asistenciales, escuelas, etc.

Con todo lo descrito creemos haber expresado suficientemente el alcance de este estudio que proponemos al Excmo. Ayuntamiento para que tramitado logre su aprobación.

Valencia, 7 de Noviembre de 1.968 LOS ARQUITECTOS,

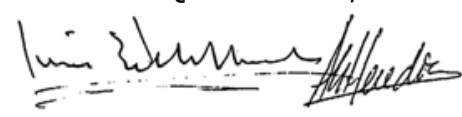


EXCMO. AYUNTAMIENTO

DE

VALENCIA

PLANO PARCIAL No 13

PROYECTO DE ALINEACIONES Y ZONIFICACIÓN DEL SECTOR LIMITADO POR EL PERÍMETRO DE LAS CALLES SIGUIENTES:

NORTE: Acequia de Vera.

SUR: Av. Doncel y Puerto.

ESTE: Mar Mediterráneo.

OESTE: C/ de la Serrería, actual FF.CC. a Tarragona.

\section{ORDENANZAS}

Hasta que no se aprueben las Ordenanzas adaptadas a la Solución Sur en estudio, se aplicarán las vigentes aprobadas por la Comisión Central de Sanidad en 23 de octubre de 1.956 y 26 de enero de 1.955, en los casos no previstos en las normas urbanísticas del Plan de Ordenación de Valencia y su Comarca adaptado a la Solución Sur, por la que tendrá que regirse actualmente este Ayuntamiento.

A este Plano Parcial le corresponde la zonificación de Extensión Exterior a Tránsitos, Tolerancia Industrial y reserva Zona Turística.

Valencia, octubre de 1.968

LOS ARQUITECTOS MPLES. DE URBANISMO,

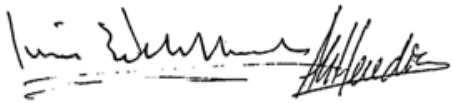


1.FOTOPLANOS
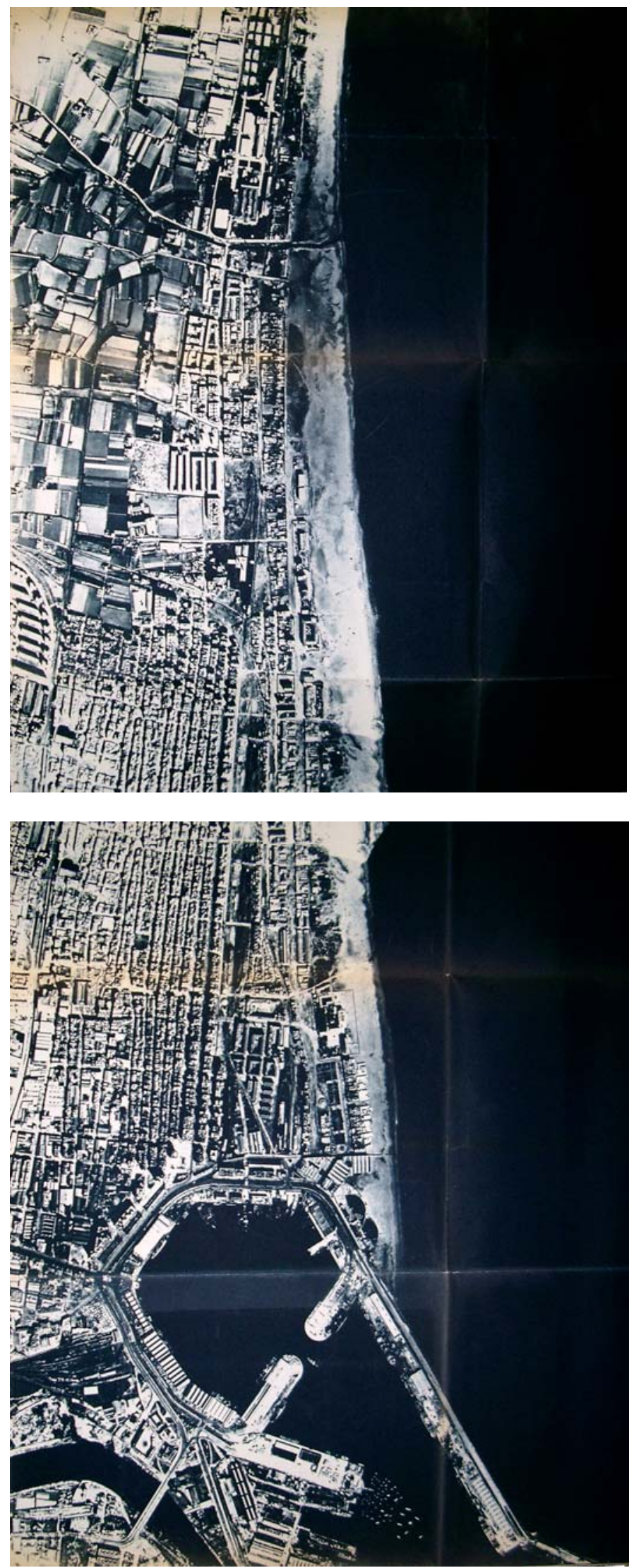


\section{ZONIFICACIÓN}

Escala original: 1:2000

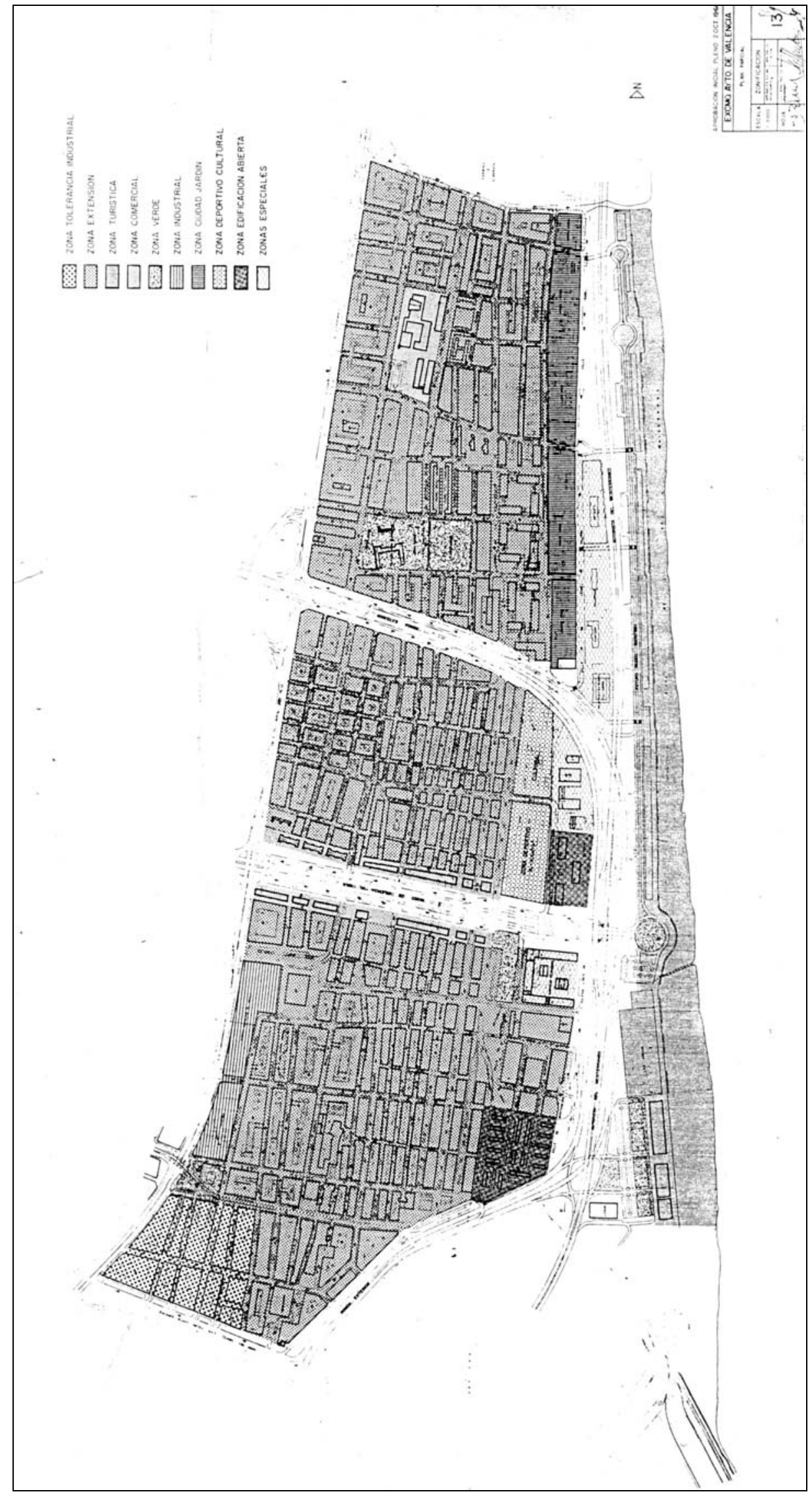


6. ALINEACIONES.

Escala original 1:2000

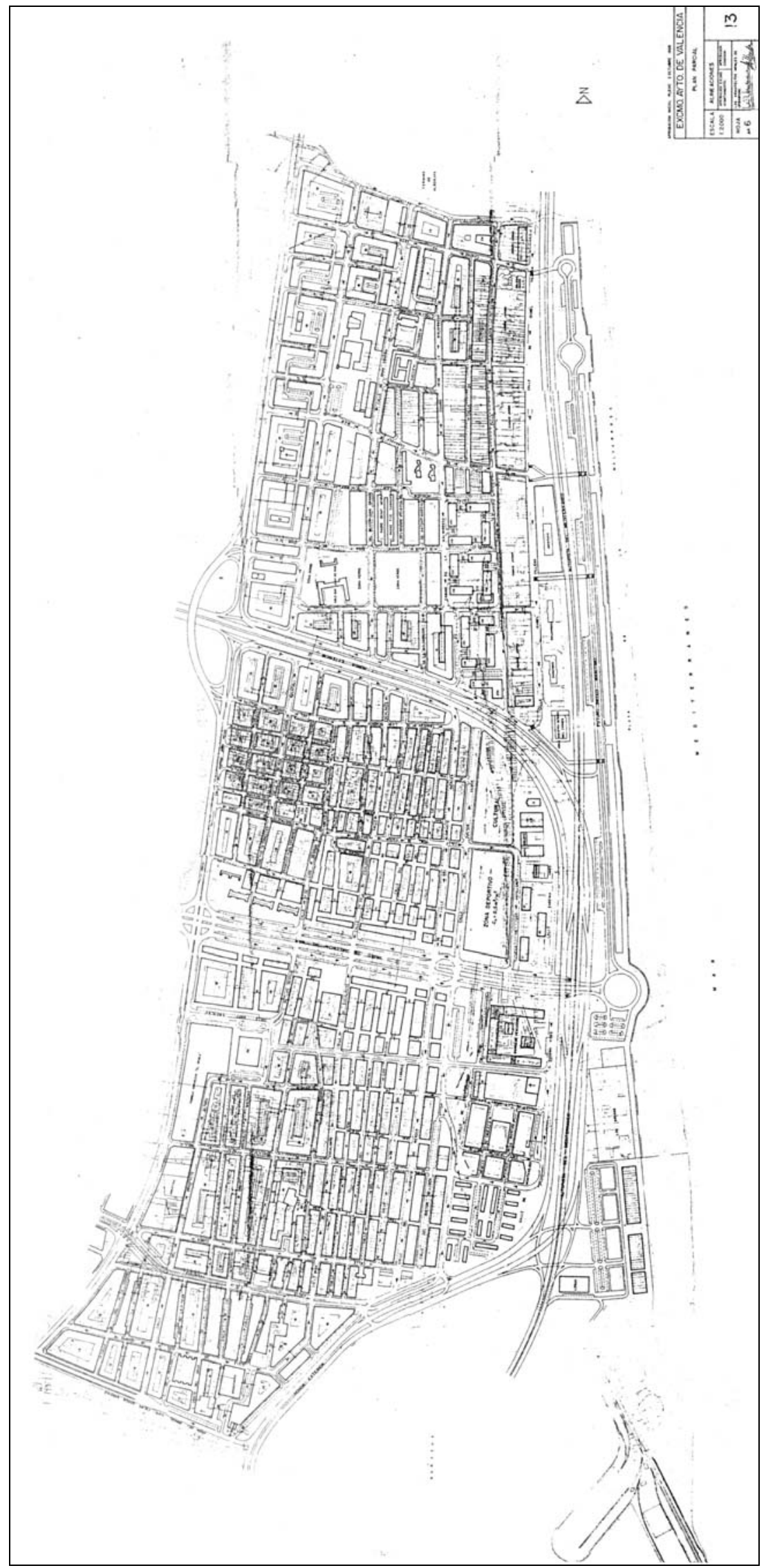




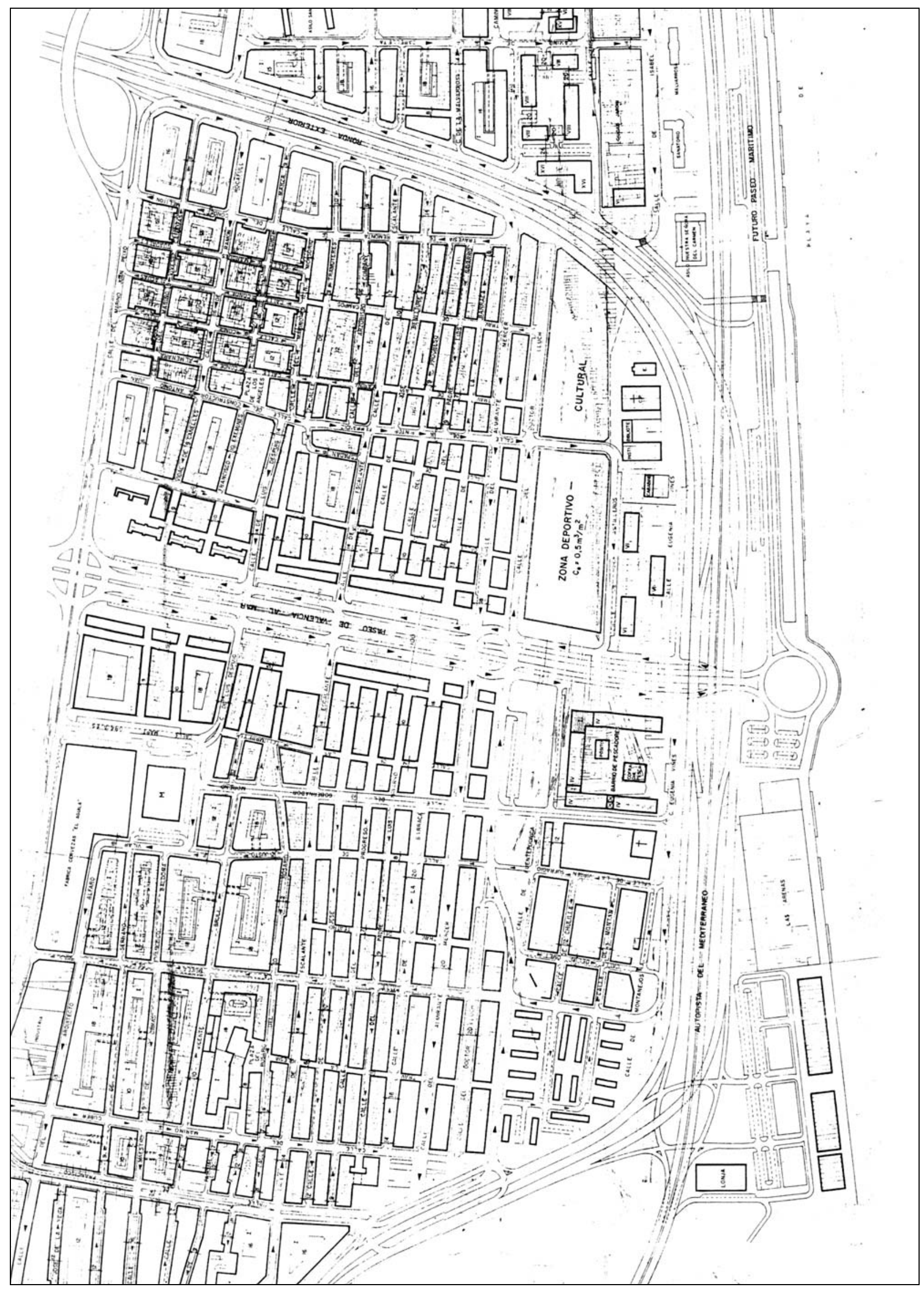

Detalle del >plano de alineaciones. Zona del Cabanyal. 


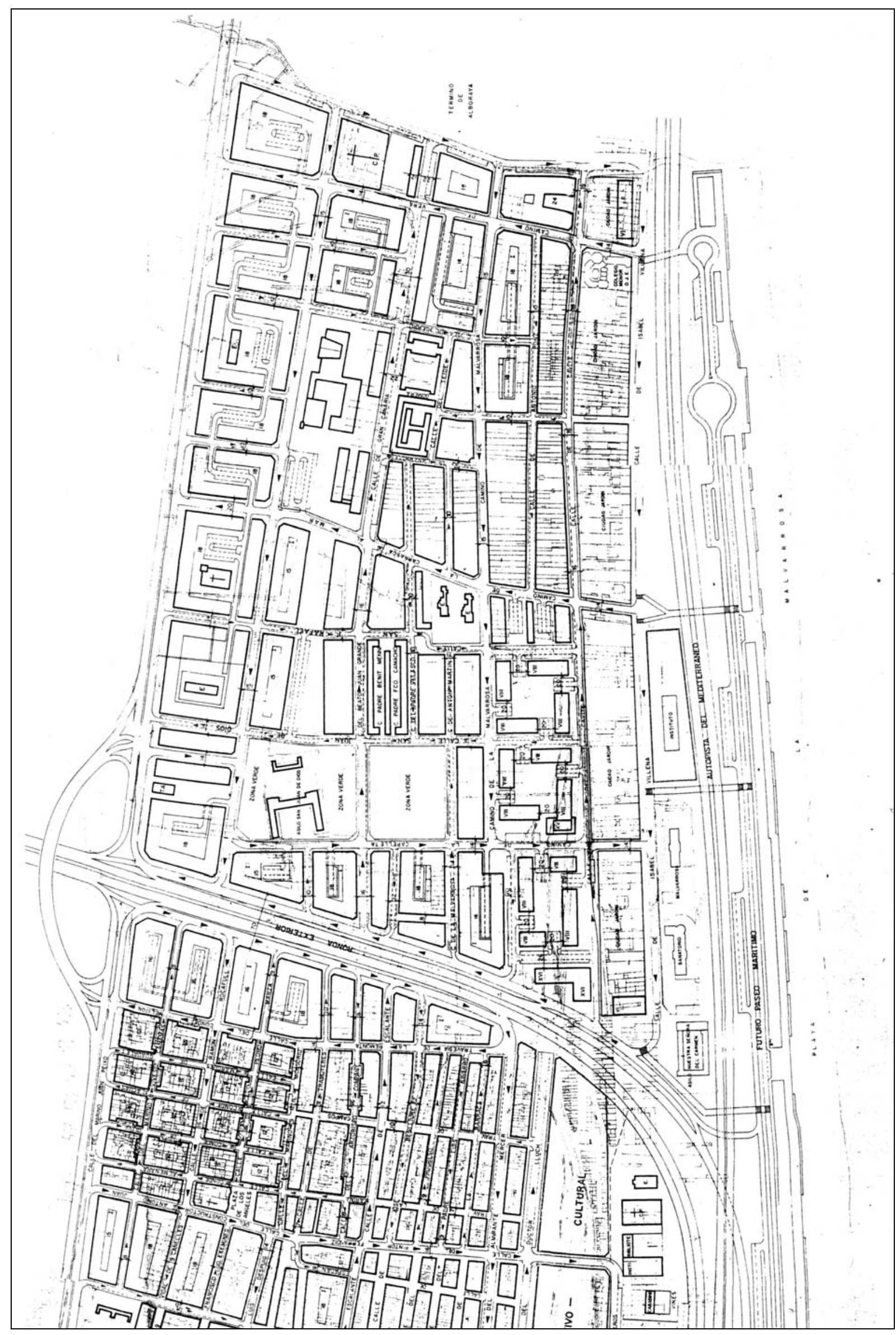

Detalle del Plano de Alineaciones. Zona de la Malvarrosa 


\section{PP13}

Redactores: EXCMO. AYUNTAMIENTO DE VALENCIA. OFICINA TÉCNICA DE URBANISMO.

Fecha redacción: Abril 1974.

Fecha aprobación: O.M. 15-09-1975 (B.O.E. 7-11-75). Anulado por sentencia T.S. 27-01-82.*

\section{Contenido:}

I. MEMORIA

II. ORDENANZAS.

III. PLANOS:

1. PLANO DE SITUACIÓN DENTRO DE LA CIUDAD. $\quad 1: 10.000$

2. SITUACIÓN EN EL PLAN GENERAL $1: 22.500$

3. INFORMACIÓN Y FOTO AÉREA $1: 2000$

4. ZONIFICACIÓN $1: 2000$

5. ESTRUCTURA URBANÍSTICA $1: 2000$

6. ALINEACIONES $\quad 1: 2000$

7. RED VIARIA $1: 2000$

8. ALUMBRADO $1: 2000$

9. AGUAS POTABLES $\quad 1: 2000$

10.ALCANTARILLADO $1: 2000$

Fuente: Ayuntamiento de Valencia. Sección de Urbanismo. Negociado de Suelo y Ordenación urbana. Expte. 2.465/74. Reg. General 80.600 (Archivo de Planeamiento No 107).

\section{Notas:}

* Aprobación provisional: 6-12-74. 


\section{PLAN PARCIAL NO. 13 \\ MEMORIA Y ORDENANZAS DEL PLANEAMIENTO}

El presente Plan. Parcial tiene por objeto el desarrollo del Plan General de Ordenación Urbana de Valencia y su Comarca adaptado a. la Solución Sur, en la zona con los siguientes límites:

Norte: Acequia. de Vera (linde término municipal de Alboraya)

Sur: Puerto y Avda del Doncel Luis Felipe García Sanchiz.

Este: Mar Mediterráneo

Oeste: Calle de la Serrería, actual trazado del ferrocarril a Barcelona.

La zona así limitada comprende los barrios llamados del Grao, Malvarrosa y Cabañal (en lenguaje Oficial Distrito Marítimo).

Su superficie es de 2.307.500 M2.

Actualmente la edificación está más concentrada cuanto más próxima está al Puerto, es decir, al Sur.

Dividiendo el Plan en tres zonas por medio del Paseo al Mar y la Ronda Exterior, la comprendida entre el Puerto y el Paseo al Mar tiene actualmente un $80 \%$ de ocupación del suelo edificable, la comprendida entre el Paseo al Mar y Ronda Exterior un $75 \%$ y la que hay entre la Ronda Exterior y la Acequia de Vera, un $50 \%$.

Como vemos, las dos primeras zonas tienen un alto grado de edificacion, lo que nos lleva, dado el planteamiento del Plan de respetar la trama existente al máximo, a que las modificaciones que se proyectan sean escasas.

Es un barrio con una vida propia muy intensa, que depende relativamente poco del centro urbano, con una. trama y tipologías de edificación propias. El Plan se limita, por un lado a reflejar la red de comunicaciones que el Plan General proyecta en este sector, que realmente lo destroza, y por otro a dotar de los equipamientos mínimos que establece la legislación vigente.

Los datos de población de este Plan Parcial se han calculado en base a las siguientes hipótesis:

A) El promedio de edificabilidad de los terrenos susceptibles de edificación privada es de Planta baja (con supuesto destino comercial y cuatro plantas altas, para vivienda.

Con esta suposición creemos aproximarnos suficientemente a la realidad y siempre con exceso, puesto que, en primer lugar, no se construyen viviendas en las plantas bajas en dicha zona, al monos en los últimos años; en segundo lugar la consideración de planta baja y cuatro altas, supone anchos de calle de 9 a 12 metros, cuando, excepto las vías perimetrales, son de anchuras de 8 a 10 $\mathrm{m}$.

B).Las viviendas son de un promedio de $150 \mathrm{~m} 2$. 
En esta superficie consideramos incluidos además de los elementos comunes de comunicación vertical y horizontal de cada edificio, los patios interiores, que dado que existen planeados pocos patios de manzana, será necesaria la provisión de patios interiores a cada edificio en una proporción mayor de lo usual.

La aplicación de estas dos hipótesis de trabajo a la superficie edificable privadamente, da una cifra de 17.375 viviendas.

C) Un promedio de cuatro habitantes por vivienda.

Esto nos da 71.500 habitantes.

Conviene indicar que siendo la superficie total del Plan de 230,75 Ha, la densidad es de 310 habitantes/Hectárea, lo que, teniendo en cuenta que no es un polígono que se proyecta como nuevo, sino que se trata del desarrollo del Plan General en una zona ya muy ocupada, creemos es aceptable.

D) La población escolarizable es de un $17 \%$.

Son pues 12.155 niños, que necesitando $10 \mathrm{~m} 2$ de escuela cada uno, nos da la cifra de $121.550 \mathrm{~m} 2$ de escuelas.

En este Plan tenemos $87.830 \mathrm{~m} 2$, contados todos ellos en las diez zonas escolares, de las cuales, solamente la E2 y la E9 están actualmente en funcionamiento; la primera es un colegio privado y la segunda un centro del Plan de Urgencia, recientemente terminada.

La E7 existe pero con una superficie inferior a la mitad de la proyectada.

El problema de las escuelas es que solamente hemos contabilizado las que tienen una superficie mayor de $5.000 \mathrm{~m} 2$, siendo así que actualmente funcionan otras varias, que con superficies inferiores, tienen a la población escolarizada. En el plano de información se han procurado indicar todas las que nos constan en funcionamiento.

La mayor parte del terreno del Plan es zona de Extensión Exterior a Tránsitos, que se mantiene, y un pequeño sector de Tolerancia Industrial.

La autopista de penetración al Puerto, deja, en el Plan General una franja de reserva turística entre ella y el Mar.

En este Plan Parcial, debido a que la superficie entre autopista y la playa es casi nula, sólo existe en lo que ahora es zona de baños, restaurantes, etc., unas zonas turísticas.

El resumen de superficies del Plan es el siguiente:

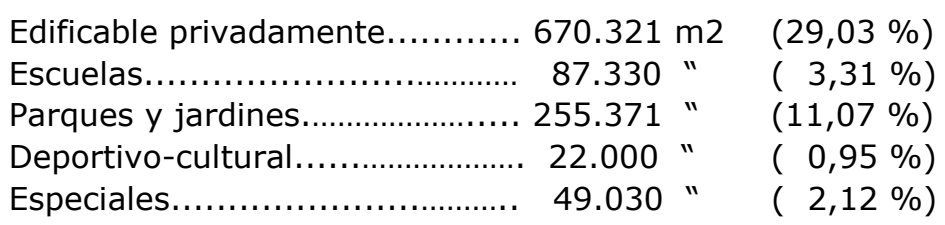




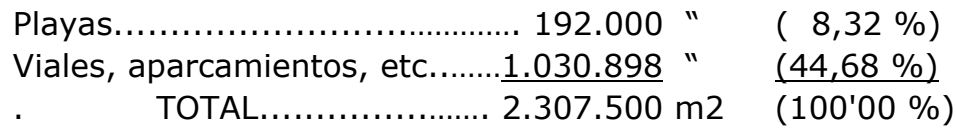

\section{1.- EXTENSIÓN EXTERIOR A TRANSITOS}

Las Ordenanzas vigentes serán las de 1950-55, en lo que no contradigan a las normas del Plan General, que son prioritarias.

La única excepción será en las manzanas en que por restos del anterior Planeamiento se han efectuado y grafiado con retranqueo las calles, el criterio fundamental de cambio de altura se efectuará coincidiendo exactamente con el retranqueo a $20 \mathrm{~m}$. de la esquina precisamente.

\section{2.- TOLERANCIA INDÜSTRIAL.-}

La misma disposición exactamente que la anterior

\section{3.- MANZANAS DE ORDENACION ESPECIAL 1,2,3.4 y 5}

Zonificación: Extensión Exterior a Tránsitos.

Uso: Residencial

Alineaciones: $\quad 4$ metros de separación a fachadas

$$
3 \text { metros a lindes }
$$

Altura máxima: 12,50 m.

Número de plantas: Máxino de cuatro.

Tratamiento de fachadas en todo el edificio, incluso en lindes.

Volumen:

$\begin{array}{ll}\text { Manzana 1: } & 47.000 \mathrm{m3} . \\ \text { Manzana 2: } & 57.000 " \\ \text { Manzana 3: } & 46.000 " \\ \text { Manzana 4: } & 44,000 " \\ \text { Manzana 5: } & 14.000 "\end{array}$

\section{4.- ZONA TURISTICA 1 y 2}

En el Plan figuran dos alineaciones a fachada, la primera es un porche que podrá elevarse hasta el piso de la planta baja, pero no cerrarse ni lateramente ni a fachada. La otra línea es la del edificio propiamente dicho. No se permitirán vuelos sobre el plano de fachada.

Los solares, para ser edificables, deberán tener fachadas a las calles opuestas.

Altura máxma: 14,00 metros, en cuatro plantas.

Uso: Turístico (Hostelería, restaurante, balnearios, etc)

\section{5.- ZONA TURÍSTICA 3}

Uso: Instalaciones turísticas y deportivas.

Edificabilidad de la parcela: $50 \%$

Volumen total máximo: $70.000 \mathrm{m3}$.

Altura máxima: 12'50 m.

\section{6.- ZONA SANITARIA: Á}

Uso: Asistencial, sanitario y subsidiarios

Altura máxima: 14'00 m. en cuatro plantas. 
Ocupación de la parcela: $75 \%$ máximo.

Volumen máximo de la manzana: $180.000 \mathrm{~m} 3$.

\section{7.- ZONA SANITARIA 2}

Uso: Asistencial, sanitario y subsidiario

Alturas y vuelos: Los correspondientes a Extensión Exterior a Tránsitos como máximo.

La manzana está libre en cuanto que las alineaciones sólo son obligatorias en planta baja, pudiendo retranquearse en las demás plantas libremente.

\section{8.- CENTRO COMERCIAL}

Uso: Comercial en más del 30\% del volumen de cada manzana

Volumen: $5 \mathrm{~m} 3 / \mathrm{m} 2$ en cada manzana.

\section{9.- FACHADAS AVENIDA J.J. DOMINE}

En la Avenida J.J. Dómine y según indica el Plano correspondiente, existe un proyecto promovido y aprobado por el Ayuntamiento para la Ordenación de las fachadas recayentes al puerto.

Debido a que esta ya casi todo construido con este criterio, nos limitamos a incorporarlo al Plan.

Pórticos en Planta baja y entresuelo.

Altura máxima: VII plantas y ático.

Modulación de fachada en ambas dimensiones y textura y materiales los aprobados en su día por el Ayuntamiento.

En las manzanas indicadas en el plano con las siguientes características: Manzanas do Ordenación Especial 1,2,3, 4 y 5 Zona Turística 3, Zona Sanitaria 1 y Centro Comercial, el Ayuntamiento, para poder conceder licencia, deberá antes recabar de los propietarios o desarrollarlo de oficio, un proyecto que comprenda toda la manzana y en el que se desarrollen las anteriores ordenanzas.

Lo expondrán al público durante un mes, y luego de atender las reclamaciones que estime justas y hechas las oportunas modificaciones, lo aprobará definitivamente para proceder a la concesión de licencia. Dicho proyecto de manzana, constará de todos y cada uno de los documentos que exige la vigente Ley del Suelo para un Plan Parcial de Ordenación Urbana.

Valencia, 2 de Abril de 1.974

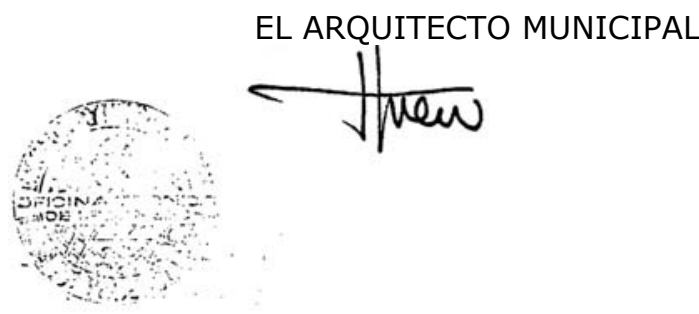




\section{PLAN DE ETAPAS Y MEDIOS ECONOMICOS}

Las etapas en que están previstas las realizaciones de las diversas obras de infraestructura son las que el Plan de Inversión Municipal determina, teniendo en cuenta que actualmente está pavimentándose casi totalmente el sector limitado por la calle Serrería, Avda. Doncel L.F.G.S., Avda. J.J. Dómine, calle Doctos Lluch y futura Ronda Exterior.

Las obras da autopista y Ronda Exterior corresponde a la iniciativa del Ministerio de Obras Públicas y Junta de Obras del Puerto, la supresión del Ferrocarril a la RENFE, la creación del Paseo Maritimo a la Jefatura de Costas y las Escuelas al Ministerio de Educación y Ciencia.

Dado que es un Plan Parcial cuyos terrenos están ya muy ocupados por edificaciones, el sistema de actuación previsto para la realización de las obras de Urbanización es el de cesión de viales, regulado por los artículos 129 y 130, de la vigente Ley de Régimen del Suelo y Ordenación Urbana.

La primera fase prevista, es la urbanización (excepto vías perimetrales) del sector limitado por C/ Serrería (F.F.C.C. a Barcelona), acequia de Vera, Playa da la Malvarrosa y Futura Ronda Exterior.

Las grandes vías arteriales previstas en el Plan General y mencionadas anteriormente: Autopista de penetración al Puerto, Ronda Exterior, Paseo al Mar, Paseo Marítimo, Supresión del Ferrocarril, se formará una Comisión Mixta del Ayuntamiento con los Organismos implicados, a fin de realizarlas en breve plazo.

Los medios económicos que se proveen son los que el Ayuntamiento disponga en cada presupuesto ordinario y los extraordinarios que en su caso dispusiera, de acuerdo con el Plan de Inversiones Municipal.

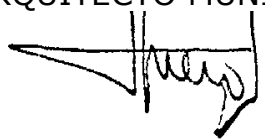


6. ALINEACIONES.

Escala original 1:2000

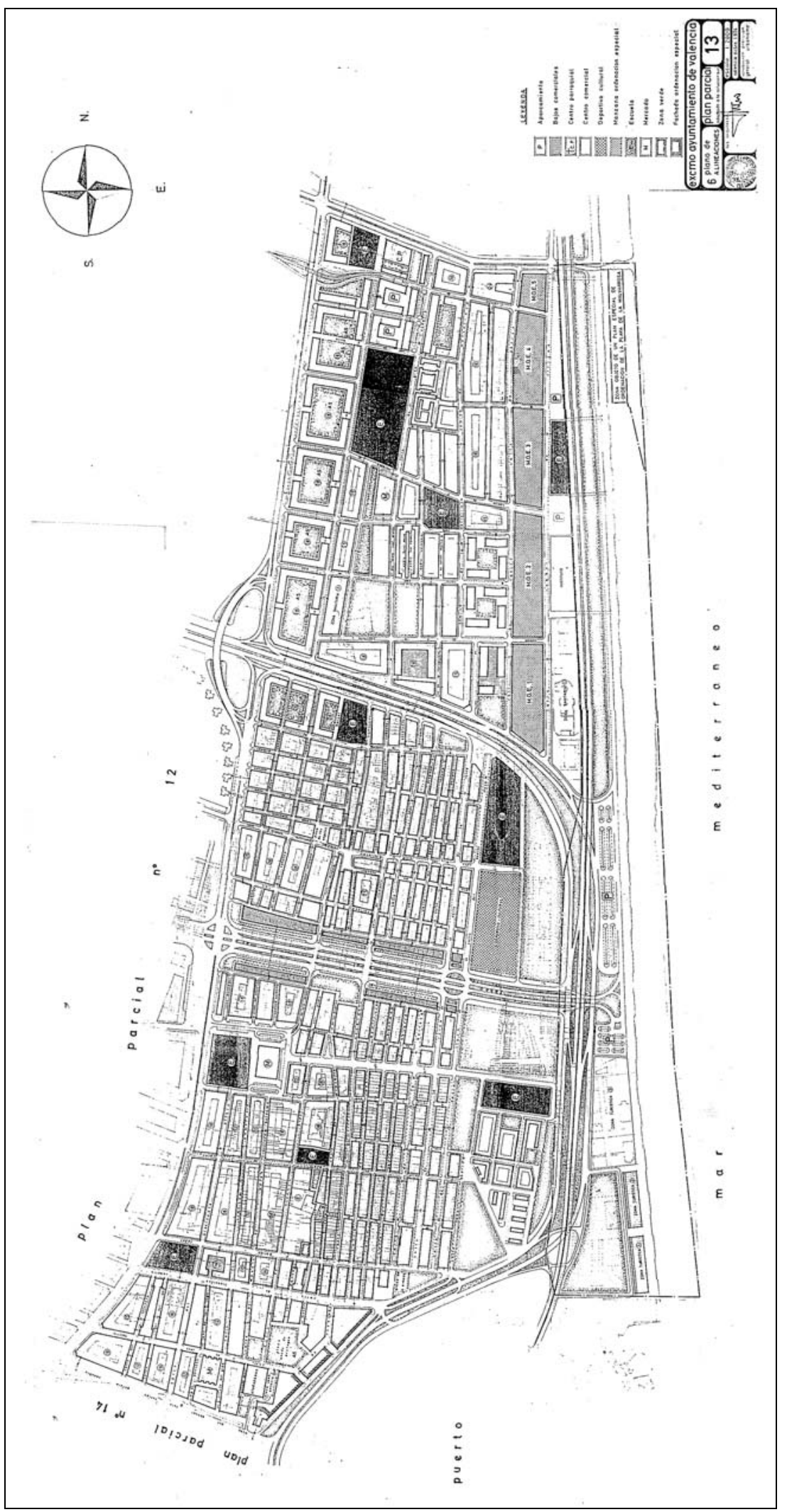


7. RED VIARIA

Escala original: 1:2000

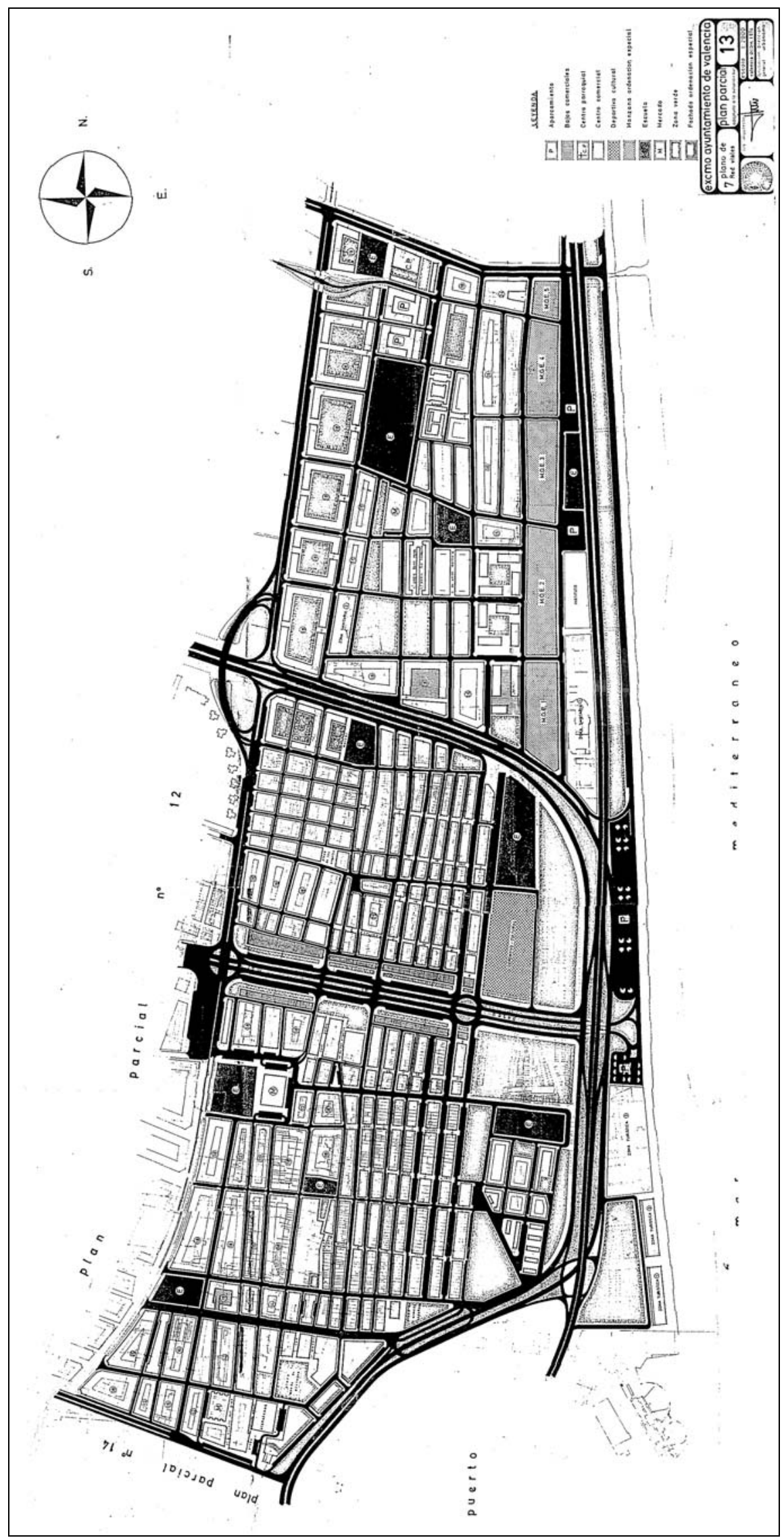


Redactor: Oficina Técnica. Corporación Administrativa Gran Valencia.

Fecha: 24-02-1974.

Asunto: Informe sobre el Plan Parcial No 13.

Fuente: Ayuntamiento de Valencia. Sección de Urbanismo. Negociado de Suelo y Ordenación urbana. Expte. 2.465/74. Reg. General 80.600 (Archivo de Planeamiento No 107).

\section{CORPORACION ADMINISTRATIVA GRAN VALENCIA}

\section{PLAN PARCIAL NO 13}

INFORME DE LA OFICINA TÉCNICA DE LA C.A. GRAN VALENCIA

Visto el Plan Parcial no 13 de Desarrollo del Plan General Adaptado a la Solución Sur, el Arquitecto que suscribe tiene el honor de informar:

Está limitado el Norte por el termino municipal de Alboraya,(Acequia de Vera), al Sur por la Avda. del Doncel Luis Felipe García Sanchiz y Puerto, al Este por el Mar Mediterráneo y por el Oeste por el Ferrocarril a Barcelona que discurre actualmente por la calle de la Serrería.

Corresponde al distrito marítimo y más concretamente a los antiguos poblados de Malvarrosa, Cabañal y parte de Villanueva del Mar (Grao).

Se amolda al Plan General en cuanto a zonificación y viario fundamental.

La mayor parte está edificada, con excepción de la parte que linda con el Ferrocarril de Tarragona en la zona situada el Norte de la Ronda.

El tipo de edificación es modesto sobre todo la situada mas al Norte, cuyo uso actual es Residencia, para familias de obreros.

Hemos comprobado las cifras que se aportan en la Mlemoria y consideramos que no se llegará nunca a 70.000 habitantes, dadas las características tradicionales de la construcción en este barrio que no destinan las plantas bajas en los nuevos edificios a viviendas.

El equipamiento urbanístico es correcto.

Las zonas verdes previstas sobrepasan el $11 \%$.

En la zona objeto de Plan Especial grafiado en los planos, se deberá tenar en cuenta el Acceso Norte al Puerto y su enlace con la Ronda.

Asimismo en la Zona Turística 3, donde hoy en dia se orienta la Playa de las Arenas con sus Balnearios, no consideramos que se deba aumentar la edificabilidad actual, y los $3 \mathrm{~m} 3 / \mathrm{m} 2$ los consideramos excesivos con mucho. Como quiera que esta zona será objeto de Plan Especial lo indicamos solo a titulo de recomendación.

Las futuras manzanas, en donde hoy están ubicadas los edificios e instalaciones del Asilo de San Juan de Dios, convendría que se segregaren para que fuesen objeto de estudio de Plan Es-pecial, dado, el interés social y sanitario que presta el Asilo.

Es cuanto tiene que informar el Arquitecto que suscribe.

Valencia 24 de Febrero de 1.975

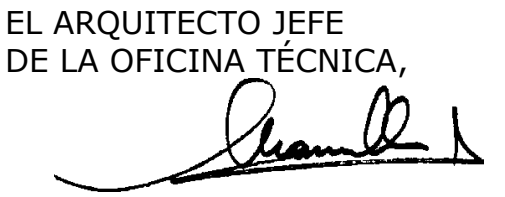


Redactor: Ministerio de la Vivienda.

Fecha: 15- 09-1975.

Asunto: Resolución de aprobación del Plan Parcial 13 con rectificaciones.

Fuente: Ayuntamiento de Valencia. Sección de Urbanismo. Negociado de Suelo y Ordenación urbana. Expte. 2.465/74. Reg. General 80.600 (Archivo de Planeamiento No 107).

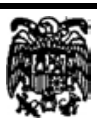

\section{MINISTERIO DE LA VIVIENDA}

IImo Sr.:

VISTO el Plan Parcial de Ordenación Urbana no 13 do Valencia, presentado por el Ayuntamiento de dicha capital y elevado a este Departamento, por la Corporación Administrativa Gran Valencia, con su aprobación.

VISTOS las Leyes de 18 de diciembre de 1946 sobre Ordenación Urbana de Valencia y su Comarca, la de 12 de mayo de 1956 sobre Régimen del Suelo y Ordenación Urbana y la de 2 de mayo de 1975 sobre reforma de la anterior, los Decretos de 14 de octubre de 1949, de 18 de enero de 1963 y de 13 de julio de 1972, y el informe emitido por los Servicios competentes de la Dirección General de Urbanismo.

Este Ministerio Acuerda:

10.- Aprobar, excepto en las zonas a que se refiere los apartados $2^{\circ}$ y $3^{\circ}$ de la presente resolución, el Plan Parcial precitado, con las rectificaciones siguientes:

a) La. altura del edificio situado en la esquina de la Avda. del Doncel Luis Felipe García Sanchíz y la calle de J. J. Domine, no podrá sobrepasar de siete plantas y ático, que es la que le corresponde como máximo, según las Ordenanzas de ensanche exterior a tránsitos, comportando la altura propuesta una reserva de dispensación injustificada.

b) Las determinaciones sobre aparcamientos que figuran en el informe emitido el 23 de noviembre de 1974 por el autor del Plan se incorporarán a las Ordenanzas, a fin de dotarlas de fuerza de obligar.

c) El sistema elegido de cesión de viales se sustituirá por el de cooperación. que es el que guarda más analogía con él, ya que según la Disposición Transitoria Segunda de ia Ley de 2 de mayo de 1975 los Planes Parciales que se aprueben definitivamente con posterioridad a su entrada en vigor, se ejecutaran con arreglo a sus preceptos, que han supuesto entre otros efectos, la supresión del referido sistema de cesión de viales.

20.- A tenor de lo acordado en la aprobación provisional del Plan, se confirma, la exclusión de la Zona constituida por la franja litoral y comprendida entre la Autopista y el mar y desde la acequia de Vera hasta la zona portuaria, que deberá ser objeto de una nueva Ordenación, previa o simultáneamente la correspondiente modificación del Plan Comarcal, conducente a 
organizar la zona del modo expresado en el aludido informe de 23 de noviembre de 1974, y en la que además se reservarán terrenos para dotaciones escolares que vengan atender las necesidades de la población del Polígono.

30.- También se excluye de la presente aprobación la Ordenación de la zona delimitada por las calles San Juan de Dios Prolongación de la de Antón Martín, de Capelleta y primera transversal a la izquierda de la Ronda exterior, que deberá ser objeto de nuevo estudio de planeamiento en el que se conserve el actual Asilo de San Juan de Dios, habida cuenta del fin social y asistencial que desarrolla.

Las precitadas rectificaciones y exclusiones, se reflejarán en la correspondiente documentación del Pian, que debidamente rectificada, se remitirá, por triplicado ejemplar, a este Departamento en el plazo de tres meses, a efectos de su debida constancia.

Esta resolución se notificará al Ayuntamiento y a laCorporación Administrativa Gran Valencia, y se publicará en el Boletín Oficial del Estado.

Lo que comunico a V. I. para su conocimiento y efectos oportunos.

Dios guarde a V. I.

Madrid, 15 de septiembre de 1975

P.D.

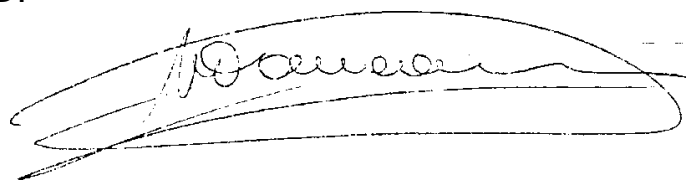


Redactor: Ministerio de la Vivienda. Servicio Central de Recursos.

Fecha: 24- 03-1976.

Asunto: Resolución referente al recurso de reposición presentado por el Ayuntamiento de valencia en relación con el Plan Parcial 13.

Fuente: Ayuntamiento de Valencia. Sección de Urbanismo. Negociado de Suelo y Ordenación urbana. Expte. 2.465/74. Reg. General 80.600 (Archivo de Planeamiento No 107).

MINISTERIO DE LA VIVIENDA
SUBSECRETARIA
SERVICIOCENTRAL DE RECURSOS

Con esta fecha, el Ilmo. Sr. Subsecretario, por delegación del Excmo. Sr. Ministro, ha resuelto lo siguiente:

"Visto el recurso de reposición formulado por el Ayuntamiento de valencia contra la Orden Ministerial de 15 de septiembre de 1975 , en su apartado 10 , rectificación a) de dicha resolución y que se refiere al emplazamiento de un edificio de 18 plantas en el chaflán de la Avenida del Puerto (Doncel García Sanchiz) y calle de J.J. Dómine, y

RESULTANDO: Que el recurrente solicita, en base a las alegaciones contenidas en el escrito de recurso, se revoque la Orden Ministerial impugnada y se apruebe definitivamente al Plan parcial respecto al edificio singular de referencia.

RESULTANDO: Que los Servicios Técnicos de la Dirección General de Urbanismo, la Dirección General de Urbanismo y la Asesoría Jurídica del Departamento han evacuado sus respectivos informes oportunamente solicitados.

CONSIDERANDO: Que el escrito de recurso reúne los requisitos adjetivos de su admisibilidad exigidos por el Ordenamiento Jurídico, al haber sido interpuesto en tiempo y forma hábiles.

CONSIDERANDO: Que el problema debatido es de carácter eminentemente técnico y conforme a lo expuesto en el informe emitido por el Arquitecto-Jefe de la Sección de Asistencia Técnica a la Gestión en 19 de diciembre de 1975, que textualmente dice "No se justifica la situación del edificio de 18 plantas propuesto en el Plan Parcial no 13 de Valencia en las esquinas de Doncel García Sanchiz y J.J. Dómine, por el mero hecho de estar el solar en la confluencia de dos calles, y frente al puerto, habida cuenta de que los espacios contiguos libres aledaños a la edificación son extremadamente exiguos, lo que produciría una indudable congestión de tráfico en su entorno, urbanísticamente no recomendable. Si se ha tenido buen cuidado de proteger mediante oportunas disposiciones toda la composición de fachadas que dan a la dársena resulta incompatible con este criterio la ubicación de un edificio torre, con 13 plantas más que su contiguo", las razones alegadas por la Corporación recurrente para justificar la proyección de un edificio singular en el Plan parcial del polígono no 13 de esa Ciudad son inaceptables toda vez que el ser principio y fin de una perspectiva no obvia el hecho de que los espacios aledaños libres son exiguos lo que supondría una indudable congestión de tráfico en su entorno urbanísticamente no apropiada y estaría además, en contradicción con la protección que el Plan da a la composición de fachadas que dan a la dársena la implantación de una torre con 13 plantas más que su 
contiguo, que se pretende hacer al amparo de la calificación de edificio singular dado al mismo.

En su virtud,

Este Ministerio, de conformidad con el Servicio central de recursos y con el informe de la Asesoría Jurídica del departamento, desestima el recurso de reposición interpuesto por el Ayuntamiento de Valencia contra la orden Ministerial de 15 de septiembre de 1975, que se confirma en todos sus términos".

Lo que con devolución del expediente y de orden del Ilmo. Sr. Subsecretario comunico a V.I. para su conocimiento y notificación en forma legal a los interesados.

Dios guarde a V.I.

Madrid, 24 de Marzo de 1976.

EL JEFE DEL SERVICIO CENTRAL DE RECURSOS,<smiles>CCCCCCC#CCCCCCCCCC</smiles>

Ilmo, Sr. Director General de Urbanismo. 



\section{PP14}

Redactores: EXCMO. AYUNTAMIENTO DE VALENCIA. OFICINA TÉCNICA DE URBANISMO.

Fecha redacción: Febrero 1977.

Fecha aprobación: O.M. 28-1-1977.

Contenido:

I. MEMORIA (*)

II. ORDENANZAS

III. PLAN DE ETAPAS

PLANOS:

1. PLANO DE SITUACIÓN DENTRO DE LA CIUDAD 1:50.000

2. SITUACIÓN EN EL PLAN GENERAL

$1: 22.500$

3. INFORMACIÓN

$\begin{array}{ll}\text { 3.1. INFORMACIÓN } & 1: 2000 \\ \text { 3.2. ALINEACIONES } & 1: 2000 \\ \text { 3.3. FOTO AÉREA } & 1: 2000 \\ \text { CACAÓN } & 1: 2000 \\ \text { CTURA URBANÍSTICA } & 1: 2000 \\ \text { ACIONES } & 1: 2000 \\ \text { IARIA YCIRCULACIÓN } & 1: 2000 \\ \text { RADO } & 1: 2000 \\ \text { ATAUA } & 1: 2000 \\ & 1: 2000\end{array}$

Fuente: Ayuntamiento de Valencia. Sección de Urbanismo. Negociado de Suelo y Ordenación urbana. Exp. 2422/74 (Archivo de Planeamiento, No 115)

\section{Notas:}

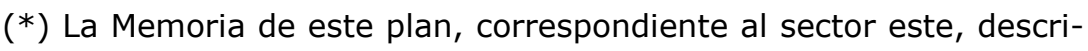
be la totalidad del área ordenada en el Plan Parcial 14.

(**) En el expediente del plan figuran también los planos correspondientes a una versión anterior del mismo, que coincide sensiblemente con la que figura en el Informe PREVASA. 


\title{
EXCMO. AYUNTAMIENTO DE VALENCIA
}

\author{
PROYECTO DE PLAN PARCIAL DE ORDENACIÓN URBANA No 14 \\ TERCER SECTOR (ESTE)
}

\section{MEMORIA.-}

1.- El Plan Parcial da Ordenación Urbana no 14 se redacta para el desarrollo del Plan General de Ordenación de Valencia y su Comarca, aprobado por decreto del 30 de junio de 1966, adaptado a la Solución Sur. Con anterioridad a la vigencia del Plan General actual, el sector estaba desarrollado en el Plan Hoja no 14, aprobado por la Comision Central de Sanidad Local con fecha del 10 de mayo de 1954.

2.- AMBITO DEL PLAN.- El perímetro que delimita el Sector que se ordena con el Plan Parcial no 14, es el formado por los ejes de la proyectada calle prolongación del Paseo de la Alameda, entre el Puente de Aragón y el Puente del Angel Custodio, situado al Oeste; el eje dela proyectada Avenida de Francia, de tráfico rápido, para el principal acceso de Valencia al centro del Puerto, situada al sur; el eje de la proyectada Ronda Exterior prevista en la Red Arterial de Valencia, situada al Este; y el eje de la Avenida del Puerto, denominada del Doncel Luís Felipe García Sanchiz, existente, situada al Norte.

3.- DELIMITACIÓN DE LAS ZONAS EN QUE SE DIVIDE EL TERRITORIO URBANO.- EI Plan General establece las siguientes zonas en el ámbito del Plan Parcial no 14:

A) ZONA ESPECIAL - CENTRO COMERCIAL.

B) ZONA DE EDIFICACIÓN INTENSIVA - TOLERANCIA INDUSTRIAL EN EXTENSION EXTERIOR A TRANSITOS.

C) ZONA DE EDIFICACIÓN INTENSIVA -EXTENSIÓN EXTERIOR A TRÁNSITOS

La primera zona está situada en el extremo oeste del Plan Parcial, comprendida entre la prolongación del Paseo de la Alameda, la Avenida de Eduardo Boscá (antiguo Camino de Tránsitos); y la Avenida del Puerto. La zona de Tolerancia Industrial está situada en el centro del Plan, abarcando la mayor parte de su superficie, comprendida entre la Avenida de Eduardo Boscá, la Avenida de Francia, la calle de Bello, y la Avenida del Puerto. La tercera zona es la de Extensión Exterior a Tránsitos, situada al este del Plan, comprendida entre la calle de Bello, la Avenida de Francia, la Ronda Exterior en su tramo junto a las instalaciones del Puerto de Valencia, y la Avenida del Puerto.

Es importante hacer notar que el Plan General -Solución Sur, no dispone la ubicación de ninguna superficie para espacios libres en el ámbito del Plan Parcial $n^{\circ} 14$.

3.1.- DELIMITACION DE LOS SECTORES EN QUE SE DIVIDE EL TERRITORIO DEL PLAN.- El ámbito del Plan Parcial no 14 se divide, a los efectos de una posterior determinación en cada uno de ellos de la división del territorio en polígonos para la actuación urbana, conforme a lo previsto en el artículo 104 y siguientes de la Sección segunda del Capítulo primero del Título tercero de la Ley sobre Régimen del Suelo y Ordenación Urbana de 12 de Mayo de 
1956, la cual división no se considera preciso contenerla en este Proyecto de Plan Parcial, en tres sectores, a saber:

PRIMER SECTOR (situado al Oeste del Plan) delimitado por los propios límites del Plan, que se señalan en el Punto 2 de esta Memoria, y la calle Padre Tomás de Montañana, que está prevista cono integrante de la Red Viaria en el Plan General, y por lo tanto forma parte de la Red Roja, como se indica en el punto 5 de la presente Memoria.

SEGUNDO SECTOR (situado en el centro del Plan), está delimitado por la calle Padre Tomás de Mlontañana y la calle Ibiza, la cual también forma parte de la Red Roja por estar prevista cono integrante de la Red Viaria del Plan General. Los otros límites son los del Plan Parcial al Norte y al Sur.

TERCER SECTOR (situado al Este del Plan), que está comprendido entre la calle Ibiza y los límites del Plan en los puntos cardinales de orientación que definen su situación,

4.- ESTADO ACTUAL.- Como se indica en el punto 1. de la presente Memoria, el territorio objeto del presente Plan Parcial estaba ya ordenado anteriormente por un Plan, el cual desarrollaba el Plan de Ordenación de Valencia y su Cintura, aprobado por Ley del 18 de diciembre de 1946 . El antiguo Plan partía ya de la existencia de algunos conjuntos de edificios, inconexos entre sí, sin formar barrios coherentes como eran los desarrollados, al Norte, entre la Avenida del Puerto y el Camino Viejo del Grao; el grupo de viviendas recayentes a las calles de Peñarrocha y de Carles, al Oeste; los almacenes e instalaciones industriales sitas junto al Camino de Peñarrocha, al Sur, próximas al antiguo tendido de las vías del ferrocarril a Barcelona, y junto al Camino Hondo del Grao en la zona central del sector; las instalaciones de la Compañía Española de Electricidad y Gas Lebón, S.A., que ocupaban una gran extensión en superficie; un conjunto de edificios recayentes a las calles de Verdún, Juan Bautista Marco y Trafalgar, situados junto a los antiguos almacenes de la Compañía de Tranvías y Ferrocarriles de Valencia y al antiguo campo de fútbol del Levante U.D.; y por ultimo, el conjunto, siendo éste el que más coherencia presentaba, que, situado al Este, se desarrollaba entre el ferrocarril de Barcelona, la Avenida del Puerto, las instalaciones del Puerto y la Estación del ferrocarril del Grao. Entre los edificios de este barrio fueron, precisamente los más próximos al Puerto los que sufrieron los efectos de los bombardeos de la Guerra Civil; la zona, todavía no se ha urbanizado.

Como consecuencia de que el territorio está emplazado entre la Ciudad y el Mar; de su proximidad al Puerto y de los fáciles accesos, que lo eran en la época, puesto que existían la Avenida del Puerto, el Camino Viejo del Grao, el Camino Hondo del Grao y los ferrocarriles; al amparo conjunto de una falta de análisis de las circunstancias a tomar en cuenta para el planeamiento urbanístico y como consecuencia de la escasez de suelo industrial en la ciudad en lugar más apropiado, se fueron implantando progresivamente una. serie de almacenes e instalaciones industriales, muchos de ellos permitidos sin una aplicación rigurosa de los Reglamentos vigentes, que albergaban actividades nocivas para la salud de los habitantes, problema éste que se fue multiplicando cono consecuencia de la acelerada construcción de viviendas, autorizadas por cuanto que la Bonificación de Tolerancia Industrial permitía y de hecho permite hoy en día la convivencia de "de terminadas industrias" con los núcleos residenciales. Esta serie de circunstancias anómalas desde el punto de vista urbanístico, ha traído como consecuencia el que el 
Sector sea actualmente uno de los más afectados de la Ciudad al sufrir permanentemente un nivel de contaminación ambiental notable, muchas semanas intensa, según, datos facilitados por el Instituto de Física Corpuscular que posee en el Sector dos estaciones de medida diaria de anhídrido sulfuroso y humos negros.

Como el Plan anterior no las preveía, no existe ninguna zona verde por pequeña que fuera, que pudiera ahora conservarse. La dotación escolar era tan mínima que las instalaciones existentes ni siquiera se han ubicado con sujeción al Plan sino adaptándose en lugares sin condiciones; se parte pues, también, de cero en este aspecto. Tampoco el anterior Plan preveia la necesidad de una Mercado Municipal; vista la necesidad social de los mercados, debe tenerse en cuenta su no existencia actual.

Se propone con el presente Plan, dado que la zonificación de Tolerancia Industrial, que le asigna para la mayoría de su superficie el Plan General, lo permite, y el resto del ámbito posee zonificación idónea, la transformación del territorio en una zona esencialmente residencial, con la consiguiente propuesta de calificar como fuera de ordenación a los edificios e instalaciones erigidos con anterioridad a la aprobación del Plan que resultaren disconformes con el mismo.

La actual Estación de ferrocarriles denominada del Grao, que se utiliza para el servicio de mercancías del Puerto, está afectada en una pequeña porción de su emplazamiento por el trazado de la proyectada Avenida de Tráfico Rápido, futura Avenida de Francia, tanto en el Plan General cono en el Plan de la Red Arterial de Obras Públi cas, aprobada en el mes de octubre de 1966. En este ultimo se propone una nueva ubicación en terrenos pertenecientes al colindante Plan Parcial de Ordenación 14 Bis, en trámite de aprobación.

Tampoco en el Plan Parcial vigente anteriormente se preveía una Red viaria que solucionara los múltiples problemas de conexión del Sector con el resto de la Ciudad, la Comarca y el Puerto. Ahora se propone la solución que se ha considerado más idónea de acuerdo con los Proyectos de rango superior ya citados, según se indica en el punto 5 de esta Memoria.

5.- RED VIARIA.- En la presente redacción del Plan Parcial No 14 se ha estudiado detenidamente el viario de todo su ámbito y su conexión con los sectores urbanos colindantes que son objeto de ordenación en los Planes Parciales números 12 y 13 al Norte; y el número 14 Bis al Sur. El Plan Parcial No 14 se apoya por su lado Sur en la denominada Avenida de Francia, perteneciente a la Red Arterial y que es el acceso desde el centro de la Ciudad y Ronda de Tránsitos al Puerto.

El límite Este lo forma el Secundo Cinturón de Ronda de la Red Arterial.

El límite Norte corresponde a la Avenida del Doncel Luis Felipe García Sanchiz, calle de Rango Azul, y finalmente, el límite Oeste lo forma la prolongación del Paseo de la Alameda.

La Red Viaria del Plan está clasificada en cuatro tipos de calles, denominadas:

- Red Roja

- Red Azul

- Red Verde

- Red Amarilla

La Red Roja es la Red Arterial de la ciudad. La Red Azul la forman las calles que sirven de interconexión entre barrios y, como tales, son vías fundamentales para el tránsito de la ciudad. La Red Verde la forman las calles colectoras del barrio y sirven como reco 
gedores del tráfico de una parte del mismo, para llevarlo hasta la red Azul. La Red Amarilla son aquellas calles cuyo uso es el acceso y servicio a la propiedad.

La Red Roja del Plan está formada por la Avenida de Eduardo Boscá, la Avenida de Francia, la prolongación del Paseo de la Alameda, y el secundo Cinturón de la Ronda (Ronda Exterior). Los encuentros de estas vías están resueltos con enlaces a desnivel.

La Red Azul la forman como ejes Este-Oeste la avenida del Doncel Luis Felipe García Sanchiz y la avenida de Baleares, cada una en su sentido; que serán la comunicación de los barrios adyacentes con el Puerto. En sentido Norte-Sur, se dispone la calle En Proyecto que enlazará, como prolongación de la calle Antonio Suárez, la Avenida del Puerto, a través del Centro Comercial, con el puente En Proyecto que se utilizará como desdoblamiento del actual puente del Angel Custodio y será la prolongación de la calle Mestre Racional; la calle Padre Tomás de Montañana, que forma parte del semi-cinturón de Ronda, y la calle Ibiza, como prolongación de la calle Serrería, que alcanzará toda su utilización una vez desaparezca el actual tendido de las vías del ferrocarril. El cruce de la prolongación de la calle Serrería (calle Ibiza) con la Avenida de Francia se efectúa mediante un paso a desnivel, así también su cruce con la Avenida del Puerto.

La avenida de Baleares, provisionalmente y hasta tanto desaparezca la Estación del Ferrocarril y se abra la Avenida de Francia, llegará hasta el Segundo Cinturón de Ronda, para servir de vía complementaria a la Avenida del Doncel Luis Felipe García Sanchiz, -que actualmente tiene carácter de Red Roja al no existir otra conexión con el Puerto. Una vez abierta al tráfico la Avenida de Francia, la de Baleares terminará en el parque sito junto al Puerto, enlazando a través de la avenida del Doncel Luis Felipe García Sanchiz.

La Red Verde está formada por la calle Islas Canarias como retorno de la Avenida del Doncel Luis Felipe García Sanchiz y las de Méndez Núñez, Rodrigo Pertegás y Asturias como retorno de la Avenida de Baleares. En sentido Norte-Sur, tenemos las calles Rodrigo de Osuna y José Faus, cada una en un sentido de circulación, que sirven a la Zona Oeste. Las calles de Río Escalona, Gas Lebón, Pintor Maella, Samuel Ros, Dama de Elche y Noguera, en la zona Centro, y la calle Menorca, Padre Porta y Bello en la Zona Este.

El resto de las calles pertenece a la Red Amarilla.

6.- CALIFICACIÓN DEL SUELO.- Las facultades del derecho de propiedad se ejercerán dentro de los límites y con el cumplimiento de los deberes establecidos en la Ley del Suelo o, en virtud. de la misma, por el Plan General y por el presente Plan Parcial de Ordenación, con arreglo a la calificación urbanística de los predios.

El suelo urbano se clasifica, según su destino en la ordenación, en las siguientes modalidades:

a) Viales, dedicados a calles y plazas;

b) Parques y jardines;

c) De edificación pública, y

e) De edificación privada.

7.- SEÑALAMIENTO DE ALINEACIONES.- Con ellas se determina el uso de los terrenos susceptibles de edificación privada o pública, y se indican las características de las vías y plazas que se deben conservar, modificar o crear. Las alineaciones son obligatorias, tanto para la propiedad como para la Administración*

Según los casos, las manzanas se resuelven cono la edifica 
ción intensiva propone; es decir, con o sin patio central. O bien se disponen como la solución más evolucionada de manzanas abiertas; es decir, con el patio central en conexión con los viales perimetrales. En aquellas manzanas en que se prevé patio central, se indica en los planos la cota que en metros equivale a la profundidad edificable en varias plantas; el perímetro así determinado, que es homólogo al exterior de la manzana, define el entorno del aptio, del cual se excluye la posibilidad de destinar las construcciones a viviendas, debiendo respetar la altura especificada en las Ordenanzas.

En otros casos se proponen manzanas Objeto de Uso Especial, para las cuales las alineaciones señalan el plano vertical que la construcción no debe rebasar, pudiendo sin embargo disponerse retranqueada hacia dentro si así se estimara. Se caracterizan dichas manzanas por el uso al que deben destinarse las construcciones, así como por el volumen máximo que puede realizarse y que no debe rebasarse.

Otro caso similar al anterior es el de las manzanas reservadas para la dotación de escuelas. Las alineaciones en ellas delimitan exclusivamente la parcela al servicio de los centros escolares. Los planos se grafían a escala 1:2000.

8.-SUPERFICIES PARA ESPACIOS LIBRES.- Para su previsión se ha adoptado el criterio de considerar como necesidad el que su ubicación abarcara proporcionalmente a todos los sectores del Flan Parcial con proximidad a los barrios. Dada la estructura alargada del Plan, los espacios libres debían poseer una forma similar con el fin de que alcanzara su utilidad proporcionalmente a la mayor superficie residencial.

8.1.- En el Primer Sector, el situado al Oeste del ámbito del Plan, se ha previsto el aprovechamiento de varias parcelas para jardines públicos, zonas de recreo y expansión en proporción adecuada a las necesidades colectivas.

Así, aprovechando el trazado de las vías de tránsito que son prolongación del actual Paseo de la Alameda, se dispone la denominada parcela I, la. cual posee una superficie de 25.837 metros cuadrados, de los cuales están incluidos en el Plan 11.977 metros cuadrados.

Se han dispuesto otros jardines al servicio de los barrios ubicándolos en puntos concretos con el criterio de conseguir unas plazas ajardinadas, rodeadas de edificios, para que sirvieran de expansión de las viviendas u oficinas limítrofes. Poseen en conjunto, 19.618 metros cuadrados. Son las parcelas designadas con las signaturas II, III, IV y $V$.

La parcela señalada con la letra A, posee unas especiales características que se detallan en el punto 9. apartado e) de esta Memoria. Posee una superficie de 10.511 metros cuadrados.

En conjunto, y dadas las dimensiones del Primero Sector, el porcentaje reservado para espacios libres es del orden de un 13,06 $\%$.(El total de la superficie de espacios libres es $42.106 \mathrm{~m} 2$, y la superficie del Sector es $322.290 \mathrm{~m} 2$.)

8.2.- En el Segundo Sector, cuya ubicación está en el centro del Plan, se ha planteado cono criterio básico el aprovechar el trazado de la futura avenida de Francia, sita al Sur del ámbito del Plan, para apoyándose en ella, disponer un conjunto de parques de regalar superficie con el fin de que su situación permitiera su fácil acceso desde todos los barrios del Sector. Las parcelas se designan como las VII, VIII, IX y X, con un total de 53.534 metros cuadra 
dos. Su ubicación está en función de la poca edificación existente allí.

Además se han previsto otras dos parcelas que cumplen la función de jardín de barrio, son designadas con las signaturas VI y XI entre ambas se dispone de 8.204 metros cuadrados.

En conjunto y en función de las disensiones del Segundo Sector, los espacios libres representan un porcentaje de un 10,64 $\%$ (La superficie total de zonas verdes es de $61.733 \mathrm{~m} 2$.y la superficie del Sector es de $579.867 \mathrm{m3}$.).

8.3. En el Tercer Sector, el situado más próximo al Puerto, se ha previsto un importante espacio, el designado con. el número XVI; por cuanto con él se contribuye a dar una solución urbanística al barrio en que se ubica, dado el estado actual, descampado y desolado, resultado del derribo de las edificaciones ruinosas desde la época de la Guerra Civil, circunstancia ya mencionada en el punto 4 de la Memoria. Además, se contribuye a realizar una aspiración popular entre la población del Distrito Marítimo y se propone una alternativa a la cuestión estética de los paramentos enfrentados al Puerto, que en el Plan Parcial no 13, colindante, se resuelve con una Ordenación de fachadas impuestas a los edificios. Dicho parte poseerá una superficie de 12.884 metros cuadrados. En una primera fase, de carácter provisional, de la urbanización, se dispondrá a través del mismo la prolongación de la avenida de Jacinto Verdaguer hasta la actual Avenida Ingeniero Manuel Soto -futura Ronda Exterior- y ello en tanto se proceda a la apertura de la Avenida de Francia, en cuyo momento los terrenos ocupados se destinarán a espacio libre según es su calificación en el Plan.

Además, se cuenta con las parcelas designadas como XII, XIII, XIV, XV y XVI, que en total representan la cifra .de 11.922 metros cuadrados.

El porcentaje en este Sector es de un $11,11 \%$.

9. EMPLAZAMIENTOS RESERVADOS EN CADA ZONA A EDIFICIOS Y SERVICIOS PÚBLICOS.- La programación del equipo urbano en este Plan Parcial $n^{\circ} 14$ se ha realizado tomando como dato de partida la no existencia de ninguna previsión previa al respecto y tampoco una realidad. física adaptable. Se propone en consecuencia, la colaboración privada en el desarrollo de las necesidades colectivas. Se ha previsto atender las actividades formativas y culturales; las asistenciales y servicios públicos; las actividades liberales múltiples; y las actividades del tiempo libre.

a) Actividades formativas.- En el presente Plan se han previsto diversas parcelas para instalaciones escolares, lindantes a las zonas verdes y agrupadas en los tres sectores en que se divide el Plan. Cada Sector escolar intenta resolver independientemente el problema de dotación escolar en los distintos niveles educativos de Enseñanza Pre-escolar, Enseñanza General Básica (EGB) y BachiIlerato Unificado Polivante (BUP), con el fin de evitar largos desplazamientos a los alumnos y permitiendo al mismo tiempo a los distintos componentes de una. familia el recibir la enseñanza en el mismo sector en que habitan.

A continuación se expone un estudio teórico de las unidades de enseñanza previstas en cada parcela, que se han numerado correlativamente, habiéndose realizado para ello una agrupación de los Centros según las parcelas y éstas a su vez englobadas en cada uno de los tres Sectores del Plan. 
PRIMER SECTOR (Oeste).- La reserva de terrenos se ha dispuesto en tres parcelas. La superficie total destinada a fines escolares es de $28.158 \mathrm{~m} 2$.

\begin{tabular}{|c|c|c|c|c|c|}
\hline \multirow{3}{*}{$\begin{array}{l}\text { Parcela } \mathrm{n}^{0} 1 \\
\text { superficie: } \\
11.656 \mathrm{~m} 2\end{array}$} & \multirow[t]{2}{*}{ Centro } & \multirow[t]{2}{*}{ Unidades } & \multirow[t]{2}{*}{ Alumnos } & \multicolumn{2}{|c|}{ Superficie en m2 } \\
\hline & & & & Mínima & Máxima \\
\hline & 1 Preescolar & 8 & 320 & 3.000 & 4.000 \\
\hline & 1 E.G.B. & 8 & 320 & 4.000 & 5.000 \\
\hline & 1 B.U.P. & 6 & 240 & 3.000 & 4.000 \\
\hline Parcela no 2 & 1 Preescolar & 8 & 320 & 3.000 & 4.000 \\
\hline superficie: & 1 E.G.B. & 8 & 320 & 4.000 & 5.000 \\
\hline $10.920 \mathrm{~m} 2$ & 1 B.U.P. & 6 & 240 & 3.000 & 4.000 \\
\hline Parcela no 3 & & & & & \\
\hline $\begin{array}{l}\text { superficie: } \\
5.582 \mathrm{~m} 2\end{array}$ & 1 E.G.B. & 8 & 320 & 4.000 & 5.000 \\
\hline
\end{tabular}

El número total de alumnos según las etapas de la educación, en este Primer Sector (Oeste), es el siguiente:

$\begin{array}{cc}\text { Preescolar ...................... } & 640 \text { alumnos } \\ \text { Enseñanza General Básica.... } & 960 " \\ \text { Bachiller Unificado Polivalente } & 480 " \\ \text { Total .......... } & 2.080 \text { alumnos }\end{array}$

SEGUNDO SECTOR (Centro).- La reserva de terrenos se ha dispuesto en dos parcelas. La superficie total es de 40.208 m2.

\begin{tabular}{l|lccrr|}
\cline { 2 - 6 } Parcela 4 & Lentro & Unidades & Alumnos & \multicolumn{2}{c|}{ Superficie en m2 } \\
Superficie: & & & & Mínima & Máxima \\
\cline { 2 - 6 } $20.672 \mathrm{~m} 2$ & 2 Preescolar & 12 & 480 & 5.000 & 6.000 \\
& 1 E.G.B. & 24 & 960 & 13.000 & 14.000 \\
\cline { 2 - 6 } & & & & & \\
Parcela 5 & 2 Preescolar & 12 & 480 & 5.000 & 6.000 \\
superficie: & 1 B.U.P. & 24 & 960 & 12.000 & 13.000 \\
19.536 m2 & & & & & \\
\cline { 2 - 6 } & & &
\end{tabular}

El número total de alumnos según las etapas de la educación, en este segundo Sector (Centro), es el siguiente:

$\begin{array}{cc}\text { Preescolar ...................... } & 960 \text { alumnos } \\ \text { Enseñanza General Básica.... } & 960 " \\ \text { Bachiller Unificado Polivalente } & 960 \text { " } \\ \text { Total .......... } & 2.880 \text { alumnos }\end{array}$

TERCER SECTOR (Este): La reserva de terrenos se dispone en una parcela de superficie total de $15.030 \mathrm{~m} 2$.

\begin{tabular}{l|lllll|}
\cline { 2 - 6 } Parcela 6 & Superficie: & Centro & Unidades & Alumnos & \multicolumn{2}{c|}{$\begin{array}{l}\text { Superficie en m2 } \\
9.750 \mathrm{~m} 2\end{array}$} & & & & Mínima & Máxima \\
\cline { 2 - 6 } & 1 Preescolar & 8 & 320 & 3.000 & 4.000 \\
& 1 E.G.B. & 8 & 320 & 4.000 & 5.000 \\
& 1 B.U.P. & 6 & 240 & 3.000 & 4.000 \\
\hline
\end{tabular}




\begin{tabular}{l}
$\begin{array}{l}\text { Parcela 7 } \\
\text { superficie: } \\
5.280 \mathrm{~m} 2\end{array}$ \\
\cline { 2 - 3 }
\end{tabular}

El número total de alumnos según las etapas de la educación, en este Tercer Sector (ESTE), del Plan, es:

$\begin{array}{cc}\text { Preescolar ...................... } & 320 \text { alumnos } \\ \text { Enseñanza General Básica.... } & 640 " \\ \text { Bachiller Unificado Polivalente } & 240 " \\ \text { Total .......... } & 1.200 \text { alumnos }\end{array}$

Dado que el numero de habitantes previstos como moradores en todo el ámbito del Plan Parcial es de 47.872 y el número de plazas escolares es de 6.160, el porcentaje de población que puede acudir a recibir enseñanza en el propio barrio es de un $12.86 \%$, equivalente, si bien por defecto, al número de habitantes en edad escolar. En el Resumen de los Datos estadísticos del Plan, que se aporta como punto 11.9 de esta Memoria, se indica la superficie de los terrenos dedicados para centros docentes por cada una de las viviendas que se prevé exista en el ámbito de esta Ordenación.

b) Actividades culturales.- Se programa, en una de las manzanas objeto de uso especial, la designada, con la sigla $\mathrm{M}-4$, un uso específico de las construcciones optativo entre el destinarlas a biblioteca y centro de lectura, museo, salas de exposiciones, cine club, o bien centro de cultura y centro de relación social en general. Se detallan sus características en el punto 10.1 de esta Memoria. Se ubica en el Sector Centro del Plan.

c) Actividades asistenciales.- Existe un centro sanitario ya construido por el Ministerio de Trabajo, Instituto Nacional de Previsión, que es el Ambulatorio de la Seguridad Social "ENRIQUE OJEA GONZÁLEZ". En este Plan se ha considerado oportuno considerarlo así, por lo que se ha determinado como manzana de uso especial; es la designada con la sigla U-8. Se ubica en el Tercer Sector (Este) del Plan.

Los servicios religiosos están atendidos con. la previsión de un Centro parroquial, el cual se dispone también en una manzana objeto de uso especial; se trata de la designada con la sigla M-5. Se ubica en el Segundo Sector (Centro) del Plan.

d) Actividades liberales múltiples.- Son las que se desenvuelven para el intercambio de servicios o productos. En los bajos de los edificios destinados a viviendas se autoriza instalar servicios artesanos, también almacenes y aquellas industrias en la Zona de Tolerancia que, según el Reglamento de Actividades molestas, insalubres, nocivas y peligrosas, no produzcan incomodidades ni alteren las condiciones normales de salubridad e higiene del medio ambiente, ni ocasiones daños a la riqueza pública o privada, ni impliquen riesgos graves para las personas o los bienes.

La venta de alimentos y artículos de primera necesidad, se centraliza con la disposición de un edificio para Mercado Municipal. Se ubica en el Segundo Sector (Centro) del Plan.

Existe además previsto en el Plan General un Centro Comercial, el cual es objeto en el presente Plan Parcial del estudio detaIlado que se exige en las Normas urbanísticas para estos Centros; y ello se detalla en el punto 10.2 de esta Memoria. Pertenece al Primer Sector (Oeste) del Plan. 
En cuanto a hostelería, se ha previsto la ubicación de una manzana objeto de uso especial, la que posee la sigla $M-2$, destinada a usos turísticos. Dado. que sirve a un barrio céntrico, se dispone la localización de un Hotel de viajeros, de cuatro estrellas, así cono los servicios complementarios como son agencias de viajes, bares, cafeterías, restaurantes, salas de fiestas, gimnasios, que forman parte del equipo hotelero. Se planea en el Primer Sector (Oeste) del Plan.

e) Actividades de tiempo libre.- Se dispone la previsión de un centro deportivo para la instalación de pistas polideportivas descubiertas y cubiertas, en cuyo caso la densidad de edificación no deberá sobrepasar de $1 \mathrm{~m} 3 / \mathrm{m} 2$. del total de la manzana, construidas conforme a las especificaciones de la Delegación Nacional de Educación Física y Deportes. Se emplaza en el Segundo Sector (Centro) del Plan.

En el Centro Comercial se propone una manzana en la que debe ubicarse una zona de juego de niños y ágora pública, es la denominada $A$, en la que cabe la posible instalación de algún auditorium de música o cualquier otro elemento que sirva para la convivencia y el esparcimiento publico; las construcciones no deben exceder del porcentaje de $1 \mathrm{~m} 3 / \mathrm{m} 2$. de la manzana; todo este conjunto deberá ser objeto de un Plan detallado, a autorizar por el Ayuntamiento, previamente a la fase de urbanización del sector; esta zona está emplazada sobre una propuesta construcción, bajo rasante, de sótanos destinados a aparcamiento de vehículos. Pertenece al Primer Sector (Oeste) del Plan.

En la Mianzana objeto de uso especial, sigla M-4, ya mencionada al detallar las actividades culturales, se podrá construir una sala de espectáculos, una discoteca o un club de juventud.Esta pertenece al Segundo Sector (Centro) del Plan.

10.- REGLAMENTACION DE LOS TERRENOS EN CUANTO A VOLUMEN, DESTINO Y CONDICIONES SANITARIAS Y ESTÉTICAS DE LAS CONSTRUCCIONES EN CADA ZONA.- El ámbito que comprende este Plan, conforme a las zonas previstas en el Plan General, puede considerarse dividido en dos sectores diferenciados: el Centro Comercial y la zona de Edificación Intensiva., tanto la que posee Tolerancia Industrial cono la que no la tiene. En el primer sector, las construcciones deben destinarse esencialmente a permitir los usos comerciales de todo orden, a albergar salas de espectáculos, hoteles, oficinas y apartamentos; siendo las viviendas autorizadas, pero nunca como elemento fundamental en el cómputo de las superficies construidas. En el otro sector, es pretensión de este Plan el transformarlo paulatinamente en una zona eminentemente residencial, para lo cual debe considerarse que las actividades no compatibles con las viviendas deberán erradicarse conforme en el plan de actuación se señale por el Ayuntamiento.

A los efectos del cómputo de los volúmenes edificables se consideran como factores que lo proporcionan: la altura de los edificios, los patios de ventilación tanto interiores coso exteriores y los voladizos sobre viales de uso público o privado. En la zona de Edificación Intensiva, en la que se incluye la de Tolerancia Industrial, se establecen las limitaciones, según las regulaciones del Cuadro que forma parte de las Normas del Plan General, en función de los anchos de las calles.

10.1.- Como salvedad en lo dicho en el párrafo precedente, 
se dispone para algunas manzanas lo que el Plan califica como Objeto de Uso Especial, Se caracterizan dichas manzanas por poseer sus edificaciones un uso específico y tener asignado un volumen máximo, el cuan bajo ningún concepto cabe sobrepasar. En los planos se señalan con una sigla especial cada una de ellas y su relación es la siguiente:

MANZANA, M-1:

Uso exclusivamente comercial.

Superficie $3.500 \mathrm{~m} 2$.(5 plantas ).Volumen, $59.500 \mathrm{~m} 3$.

MANZANA M-2:

Uso turístico residencial.

Superficie $2.330 \mathrm{~m} 2$.(16 plantas en el $20 \%$ del solar y 8 plantas en el resto). Volumen $73.143 \mathrm{~m} 3$.

MANZANA M-3:

Uso exclusivamente aparcamiento.

Superficie $14.245 \mathrm{~m} 2$.(8 plantas).Volumen $313.390 \mathrm{m3}$.

MANZANA M-4:

Uso cultural y recreativo,

Superficie $8.509 \mathrm{~m} 2$.(2 plantas en el $80 \%$ del solar y el resto libre). Volumen, $43.544 \mathrm{m3}$.

MANZANA M-5:

Uso exclusivamente religioso.

Superficie $2.160 \mathrm{~m} 2$.(2 plantas en el $80 \%$ del solar y el resto libre). Volumen, $10.800 \mathrm{~m} 3$.

MANZANA M-6:

Uso exclusivamente deportivo.

Superficie $40.960 \mathrm{~m} 2$. Volumen, $40.960 \mathrm{~m} 3$.

MANZANA M-7:

Uso exclusivamente para aparcamiento Superficie 17.136

m2.(8 plantas). Volumen $376.992 \mathrm{~m} 3$.

MANZANA M-8:

Uso exclusivamente sanitario.

Superficie $2.145 \mathrm{~m} 2$.(4 plantas). Volumen $12.812 \mathrm{m3}$.

Para el cómputo del volumen en la fase de construcción se seguirá el criterio fijado por el Plan General al disponer los factores que lo proporcionan, Norma $1^{\mathrm{a}}$, bien entendido que el volumen a construir es el producto de la altura media de cada edificio, medida desde el nivel del suelo a la superficie exterior de la cubierta, por la superficie media a construir, .definida como la suma de la de cada una de las plantas del edificio o edificios medida dentro de los límites definidos por las líneas perimetrales de las fachadas, tanto exteriores cono interiores, y los ejes de las medianerías, en su caso; los cuerpos volados sobre viales públicos o privados, balcones o terrazas que estén cubiertos por otros elementos análogos o por tejadillos o cobertizos, tomarán parte de la superficie total construida cuando se hallen limitados lateralmente por paredes; en caso contrario se computará únicamente el 50 por cien de su superficie, medida en la misma forma.

La realización de cada una de estas manzanas deberá ajustarse a la redacción previa de un proyecto conjunto que desarrolle todo el volumen edificable asignado. En dicho proyecto deberá tenerse en cuenta que en las alineaciones perimetrales que definen la manzana no podrán superponerse más alturas que las señaladas para cada una de ellas. Cualquier modificación de las formas volumétricas planeadas deberá serlo permitiendo la liberación de espacios libres junto a las calles, es decir, retirando las alineaciones de 
las fachadas hacia dentro de las manzanas. Se adoptará como techo la altura de cornisa que se deduzca de la zonificación del Sector en que se ubiquen según los anchos de calle obtenidos. La parcela mínima, que expresa la superficie susceptible de aprovechamiento independiente de los solares, para estas manzanas objeto de uso especial, será aquella que en las Ordenanzas de este Plan Parcial se determina para cada una de ellas el artículo 3.1.

10.2.- CENTRO COMERCIAL.- El Plan General de Ordenación Urbana de Valencia y su Comarca, adaptado a la Solución Sur, clasifica a un amplio polígono perteneciente al ámbito del presente Plan Parcial como Centro Comercial, y por ese mismo hecho debe considerársele de $1^{\text {a }}$ Categoría; es la Zona A. del Plan y se emplaza toda ella en el Primer Sector (Oeste) del Plan. Está concebido para constituir una unidad al servicio del concepto de Distrito, es decir, para una población de cien mil habitantes. Ahora bien, el Centro de que se trata está previsto en el Plan Comarcal con unas dimensiones en cuanto a su superficie que rebasan los límites del presente Plan Parcial, toda vez que se extiende además por los planes colindantes, concretamente los designados con los números 11 y 12 , ambos definitivamente aprobados.

En la porción correspondiente al presente Plan se propone el estudio con todo detalle exigido por la Norma Urbanística No 35 del Plan General para estos Centros Comerciales. El volumen que se le impone para un aprovechamiento edificable, deberá ser de cinco metros cúbicos por metro cuadrado del polígono.

10.2.1.- USOS.- La porción de territorio que es objeto de ordenación en este Plan Parcial $n^{\circ} 14$, perteneciente al Centro Comercial, se halla en gran parte edificada, habiéndose destinado gran porcentaje de la superficie ya construida a viviendas. No estando las viviendas excluidas de los programas previstos para estos Centros, se ha considerado la conveniencia de legalizar su existencia. Se ha procedido por tanto, a respetar la forma de las manzanas abiertas señalando la profundidad edificable de los bloques en varias plantas e indicando los terrenos edificables en I planta, junto a los mismos, con el fin de que aquellas parcelas que no estén edificadas lo sean de una manera uniforme con las colindantes que sí lo estén. En todas estos casos será condición indispensable que cuanto menos el treinta por ciento de la superficie que se construya lo sea para un exclusivo uso comercial.

10.2.2.- VIARIO.- Se ha considerado conveniente, como consecuencia del estudio de circulaciones, el disponer de una calle de 20 metros con un trazado en lo posible paralelo a la Avenida de Eduardo Boscá, que enlazará con el proyectado puente, sobre el actual cauce del río Turia, prolongación de la calle Mestre Racional. Esta vía servirá además de penetración en el Centro Comercial, y lo enlaza con el resto del casco de la Ciudad así como con el sector del Centro Comercial situado al Norte en el Plan Parcial No 12. Se han estudiado además las vías de tráfico rodado dentro del ámbito del Centro Comercial y las zonas peatonales.

10.2.3.- EDIFICIO COMERCIAL.- Se ha previsto la instalación de una manzana Objeto de uso Especial, la designada con la nomenclatura $M-1$, exclusivamente destinada para comerciales, entendiendo por usos comerciales la venta al por menor de mercancías comprendidas en las siguientes agrupaciones relacionadas de 
acuerdo con la Clasificación Nacional de Actividades Económicas:

- Alimentación

- Vestido, calzado y tocado

- Mobiliario, artículos viaje y guarnicionería

- Droguería, perfumería, limpieza, productos químicos y farmacéuticos,

- Maquinaria, productos metálicos y material saneamiento.

- Juguetería

- Papel, Artes Gráficas, Material oficinas y Loterías.

- Aparatos e instrumentos sanitarios,

- y Varios (de Regalo, efectos navales, pesca. etc).

Se excluirán de los usos citados anteriormente todos aquellos que se puedan considerar peligrosos, nocivos y molestos.

Se permitirán también usos para oficinas y despachos comerciales en esta manzana.

10.2.4.- ESPACIOS LIBRES Y APARCAMIENTOS.- Se ha dispuesto una. extensa superficie designada con la signatura $A$, que poseerá una doble utilización: sobre rasante puede servir como lugar descubierto para el esparcimiento de los habitantes del sector, y en el subsuelo se deberán construir sótanos para el aparcamiento de vehículos con un mínimo de cuatro plantas. La capacidad del mismo se indica en el punto 10.2.1. de esta Memoria, y en el punto 11.11, que en esta Memoria trata sobre la reserva de aparcamientos. La realización de este complejo deberá solicitarse, previo proyecto a autorizar por el Ayuntamiento, conjuntamente como una unidad arquitectónica. Las plazas de aparcamiento no deberán ser privadas sino públicas mediante la tasa que sea legal por arbitrio de estacionamiento.

Las parcelas de espacios libres para jardines y zonas de recreo y expansión adscritas a este Centro Comercial son las designadas por las signaturas I, $\mathrm{U}$ y $\mathrm{A}$.

10.2.4.- DATOS ESTADÍSTICOS SOBRE ESTE CENTRO COMERCIAL.

a) La superficie total del ámbito de este Centro Comercial que se incluye como plan especial dentro del Plan Parcial No 14, Primer Sector, nos da una cifra de 86.994.- $\mathrm{m} 2$.

b) La superficie total de espacios libres es de..26.787.- $\mathrm{m} 2$

b1) La superficie de espacio libre del área descubierta edificable privadamente en cuyo subsuelo se proveerán plazas para aparcamiento, es de $10.511,-\mathrm{m} 2$.

b2) La superficie de los terrenos que se destina a jardines públicos es de $16.276 \mathrm{~m} 2$.

c) La superficie edificable privadamente, medida en planta, es de............................................... 21.780.-m2.

d) La superficie destinada a viales, tanto calzadas de Tráfico rodado cono aceras peatonales, es de 38.427.- $\mathrm{m} 2$.

e) La capacidad de plazas de aparcamiento previstas en el área señalada a tal fin y que se dispondrán en cuatro plantas de sótano, es de :..... 1.892 plazas.

f) El volumen total edificable privadamente, es de 400.760.- m3.

(Esta cantidad proporciona una densidad de $4,60 \mathrm{m3} / \mathrm{n} 2<5$ $\mathrm{m} 3 / \mathrm{m} 2)$.

f1) El volumen total edificable destinado a comercios es de $133.900,-\mathrm{m} 3$. (Ello representa un 33,41\% del total, superior al $30 \%$ exigido). 
s) EL volumen edificable en la parcela $A$, que debe destinarse a aparcamiento público, es de .................... 10.511.- m3 (Lo que equivale a una densidad de $1 \mathrm{~m} 3 / \mathrm{m} 2$ de la manzana)

10.3. - CONDICIONES SANITARIAS Y ESTETICAS.- En cuanto a las condiciones sanitarias y estéticas de en este Plan Parcial, deben tenerse en cuenta las correspondientes del Plan General de 30 de junio de 1966, así como las de las vigentes Ordenanzas de la Edificación de Valencia, con el fin de que se adecúen al carácter de los diferentes barrios.

11.- DATOS ESTADÍSTICOS RESULTANTES DE ESTE ESTUDIO.- Se reseñan a continuación, en apartados sucesivos, los datos de cada uno de los Tres Sectores en que se divide el Plan.

11.1.- Superficie total del ámbito del Plan;

SUPERFICIE TOTAL DEL PLAN .............. 1.125.237,- m2.

11.1.1.- Superficie total del Primer Sector (Oeste):

SUPERFICIE TOTAL PRIMER SECTOR ...... 322.290,- $\mathrm{m} 2$.

11.1.2.- Superficie total del Segundo Sector (Centro):

SUPERFICIE TOTAL SEGUNDO SECTOR ..... 579.867,- m2.

11.1.3.- Superficie total del Tercer Sector:

SUPERFICIE TOTAL TERCER SECTOR ....... 223.080,- m2.

11.2. - Superficie total edificable privadamente, medida en planta, en todo el ámbito del Plan.

SUPERFICIE TOTAL EDIFICABLE PRIVADAMENTE. 427.066,- m2.

11.2.1.- Superficie total edificable Primer Sector (Oeste):

SUPERFICIE; TOTAL EDIFICABLE PRIVADAMENTE EN EL PRIMER SECTOR......................... 119.665.- m2

11.2.2.- Superficie total edificable privadamente en el Segundo Sector (Centro):

SUPERFICIE TOTAL EDIFICABLE PRIVADAMENTE EN EL SEGUNDO SECTOR ........................ 220.556,- m2.

11.2.3.- Superficie total edificable privadamente en el Tercer Sector (Este):

SUPERFICIE TOTAL EDIFICABLE PRIVADAMENTE EN EL TERCER SECTOR .......................... $86.845,-\mathrm{m} 2$.

11.3.- Superficie total espacios libres y deportivos en todo el ámbito del Plan.

SUPERFICIE TOTAL ESPACIOS LIBRES......... 169.610,- m2.

11.3.1.- Superficie total espacios libres en el Primer Sector (Oeste);

SUPERFICIE TOTAL ESPACIOS LIBRES EN EL PRIMER

SECTOR ................................... 42.106,- m2.

11.3.2. - Superficie total espacios libres y deportivos del Segundo Sector (Centro):

SUPERFICIE TOTAL ESPACIOS LIBRES EN EL SEGUNDO SECTOR .................................. 102.698,- m2.

11.3.3.- Superficie total espacios libres en el Tercer Sector (Este):

SUPERFICIE TOTAL ESPACIOS LIBRES EN EL TERCER

SECTOR ................................ 24.806.- $\mathrm{m} 2$

11.4. Superficie total edificable para Escuelas en todo el Plan. SUPERFICIE TOTAL ESCUELAS 83.396. - $\mathrm{m} 2$. 11.4.1»- Superficie total edificable para escuelas en el Primer 
Sector (Oeste):

SUPERFICIE TOTAL TERRENOS PARA ESCUELAS EN EL PRIMER SECTOR …......................... 28.158,- m2.

11.4.2,- Superficie total edificable para escuelas en el Segundo Sector (Centro):

SUPERFICIE TOTAL TERRENOS PARA ESCUELAS EN EL SEGUNDO SECTOR ............................ 40,208,- $\mathrm{m} 2$.

11.4.3.- Superficie total edificable para escuelas en el Tercer Sector (Este):

SUPERFICIE TOTAL TERRENOS PARA ESCUELAS EN EL TERCER SECTOR ............................. 15.030,- m2.

11.5.- Superficie total edificable usos públicos, religiosos y sanitarios.

SUPERFICIE TOTAL EDIFICABLE USOS

PÚBLICOS ................................... 7.905,- m2.

11.5.1.- Superficie total edificable usos públicos Segundo Sector.

SUPERFICIE TOTAL EDIFICABLE PARA MERCADO

PUBLICO ........................................ 3.600.- m2

11.5.2.- Superficie total edificable usos religiosos, en el segundo Sector.

SUPERFICIE TOTAL EDIFICABLE PARA IGLESIA.. $2.160,-\mathrm{m} 2$.

11.5.3.- Superficie total edificable usos sanitarios en el Tercer Sector.

SUPERFICIE TOTAL EDIFICABLE PARA

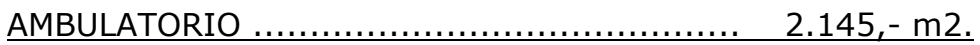

11.6.- Superficie total viales en todo el ámbito del Plan:

SUPERFICIE TOTAL VIALES DEL PLAN ........ 437.260,- $\mathrm{m} 2$.

11.6.1.- Superficie total viales Primer Sector (Oeste)i

SUPERFICIE TOTAL VIALES EN EL PRIMER

SECTOR .................................... 132.361,- m2.

11.6.2.- Superficie total viales Segundo Sector (Centro):

SUPERFICIE TOTAL VIALES EN EL SEGUNDO

SECTOR ....................................... 210.645,- m2.

11.6.3.- Superficie total viales Tercer Sector (Este):

SUPERFICIE TOTAL VIALES EN EL TERCER

SECTOR .................................. 94.254,- m2.

11.7.- Superficie edificable para viviendas en todo el Plan:

SUPERFICIE TOTAL EDIFICABLE PARA VIVVIENDAS EN EL PLAN...............................................1.801.429.-m2

11.7.1.- Superficie edificable viviendas 1er Sector(Oeste)!

SUPERFICIE TOTAL EDIFICABLE VIVIENDAS

EN EL PRIMER SECTOR ...................... 539.554,- m2.

11.7.2.- Superficie edificable para viviendas en el Segundo Sector (Centro):

SUPERFICIE TOTAL EDIFICABLE VIVIENDAS EN EL SEGUNDO SECTOR ....................................... $868.592-\mathrm{m} 2$

11.7.3.- Superficie edificable para viviendas en el Tercer Sector (Este):

SUPERFICIE TOTAL EDIFICABLE VIVIENDAS EN EL TERCER

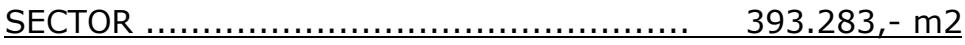

11.8.- Volumen total edificable privadamente en el Plan, VOLUMEN EDIFICABLE EN EL PLAN ......... 7.570.459,- m3.

11.8.1.- Volumen total edificable privadamente en el Primer 
Sector (Oeste):

VOLUMEN TOTAL PRIMER SECTOR ............ 2.129.782,- m3.

11.8.2.- Volumen total edificable privadamente en el Segundo Sector (Centro):

VOLUMEN TOTAL SEGUNDO SECTOR ........ 3.978.827,- m3.

11.8.3.- Volumen edificable privadamente en el Tercer Sector (Este):

VOLUMEN TOTAL TERCER SECTOR …....... $1.461 .850,-\mathrm{m} 3$.

11.9.- Resumen de los datos estadísticos;

11.9.1.- EL número total de viviendas previsto en el Plan supuesta una superficie total construida por vivienda, de $150 \mathrm{~m} 2$., es

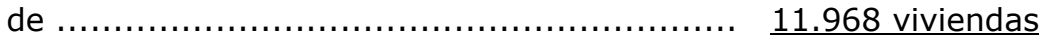

11.9.1.1.- En el Primer Sector, el número de viviendas es de............................................. 3.597 viviendas

11.9.1.2.- En el Segundo Sector, el número de viviendas es de ................................................ 5.790 viviendas

11.9.1.3.- En el Tercer Sector, el número de viviendas es de 2.581 viviendas

1I.9-2.- El número de habitantes que se prevé en todo el Plan, supuesto que la célula familiar la componen cuatro personas, es de ............................................ 47.872 habitantes

11.9.2.1.- La cantidad total de población en el Primer Sector,

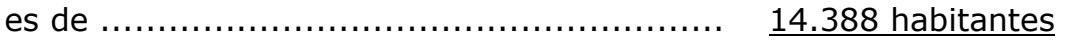

11.9.2.2.- La cantidad total de población en el Segundo Sector, es de ........................................ 23.160 habitantes

11.9.2.3.- La cantidad total de población en el Tercer Sector, es de ............................................ 10.324 habitantes

11.9.3.- La reserva de terrenos para parques y jardines públicos, zonas deportivas y de recreo y expansión, en el total del Plan representa por cada vivienda,

una superficie de ..............................

(constituye el 15,07 \% de la superficie total ordenada).

11.9.3.1.- En el Primer Sector, por cada vivienda

hay ............................................ $11,70 \mathrm{~m} 2$.

(constituye el 13,06 \% de la superficie de este Sector Oeste).

11.9.3.2,- En el Segundo Sector, por cada vivienda

hay .........................................

(constituye el $17,71 \%$ de la superficie de este Sector Centro).

11.9.3.3.- En el Tercer Sector, por cada vivienda

hay ........................................... $9.61 \mathrm{m2}$.

(constituye el $11,11 \%$ de la superficie de este Sector Este).

11.9.4»- La reserva de terrenos para centros culturales y docentes, públicos y privados, representa

por cada vivienda

$\underline{6,96 \mathrm{~m} 2}$.

11.9.1. En el Primer Sector,

por cada vivienda hay

$\underline{7,82 \mathrm{~m} 2 .}$

11.9.4.2.- En el Segundo Sector

por cada vivienda hay

$\underline{6,94 \mathrm{~m} 2 .}$

11.9.4.3.- En el Tercer Sector,

por cada vivienda, hay

$5,82 \mathrm{~m} 2$.

11.9.5.- La densidad de edificación privada en el ámbito del

Plan, es de

$6,72 \mathrm{~m} 3 / \mathrm{m} 2$.

11.9.5.1.- La densidad en el Primer Sector

es de

11.9.5.2.- La densidad en el Segundo Sector,

es de

$\underline{6,60 \mathrm{~m} 3 / \mathrm{m} 2}$.

$6.86 \mathrm{~m} 3 / \mathrm{m} 2$. 
11.9.5.3.- La densidad en el Tercer Sector,

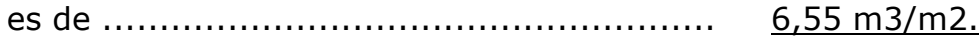

11.10,- El número de habitantes referidos a la unidad de superficie, una hectárea, del territorio objeto de esta ordenación es de:

DENSIDAD DE POBLACIÓN ........... 427 habitantes/hectárea

12.- ESTUDIO PARA LA DETERMINACION SOBRE APARCAMIENTO DE VEHICULOS.- Para este estudio se adopta como criterio base para la determinación del programa de necesidades, una proporción mínima de una plaza de $20 \mathrm{~m} 2$. cada una por cada $100 \mathrm{~m} 2$. construibles. Como se ha utilizado para la expresión de los datos estadísticos, se desglosa a los efectos de este estudio el ámbito del Plan Parcial en los tres Sectores en que se ha dividido el mismo. La ubicación de locales a propósito se organiza en edificios o construcciones de uso exclusivo, en los edificios de viviendas y comerciales y en los espacios expresamente determinados en el Plan.

12.2.- Se ordena este apartado con la expresión previa de los datos mínimos a tener en cuenta para el cálculo de las plazas que se precisan y, posteriormente se indican las previsiones adoptadas.

12.2.1.- PRIMER SECTOR (Oeste),- Se calcula en función del criterio base adoptado teniendo en cuenta la superficie edificable.

\section{DATOS:}

1) Plazas por vivienda;

Polígono Centro Comercial

970 plazas

Polígono Tolerancia Industria

$4.425 \quad "$

Total.....

5.395 plazas

2) Plazas por locales comerciales:

Polígono Centro Comercial

182 plazas

Id. Manzana M-1

175 "

Polígono Tolerancia Industrial

Total.

1.313 plazas

CALCULO:

Por consiguiente se precisa disponer de 6.708 plazas. Veamos el lugar y el número de plazas que se preven.

- A reservar en cada edificio que se construya, supuesta una unidad de superficie de $150 \mathrm{~m} 2$. por cada vivienda:

Plazas por vivienda;

Polígono Centro Comercial

647 plazas

Polígono Tolerancia Industrial

$$
\begin{aligned}
& 2.950 \text { " } \\
& \text { Total ............. } \quad 3.597 \text { plazas }
\end{aligned}
$$

-A reservar en cada edificio según el uso de comerciales que se construya, atribuyendo un porcentaje del $15 \%$ de la superficie con dicho uso;

Plazas por comerciales:

Polígono Centro Comercial

137 plazas

Polígono Manzana M-2

472

Polígono Tolerancia Industrial

$\underline{717 \quad 17}$

Total

1.326 plazas

-A disponer en los sótanos previstos en la Parcela A, con uso exclusivamente de aparcamiento.

Plazas de explotación privada. 1.892 plazas 
Por lo tanto, el número de plazas que se prevé en el Primer Sector es de 6.815. superior a las necesidades.

- Además, en la Manzana M-2, se deberá disponer, en función de sus usos hoteleros, una plaza por cada 4 habitaciones o según la normativa al respecto del Ministerio de Información y Turismo.

\subsubsection{SEGUNDO SECTOR (Centro)}

DATOS.

1) Plazas por viviendas

8,696 plazas

2) Plazas por comerciales

El total de plazas aparcamiento a reservar es 10.502 plazas

CALCULO.

- A reservar en cada edificio por viviendas:

Plazas por viviendas

5.797 plazas

- A reservar en cada edificio por comerciales:

Plazas por comerciales 1.355 plazas

- A reservar en. edificios exclusivamente destinados a aparcamiento, las manzanas $\mathrm{M}-3$ y $\mathrm{M}-7$,

Plazas en Manzana M-3

6,410 plazas

Plazas en Mlanzana $M-4$ $7.711 "$

El total de las previsiones en el

Segundo sector es.

$\underline{21.274 \text { plazas }}$ muy superior a los mínimos

\subsection{3.- TERCER SECTOR (Este)}

DATOS.
1) Plazas por viviendas
3.932 plazas
2) Plazas por comerciales 868
El mínimo a reservar, es de
4.800 plazas

\section{CALCULO.}

- A reservar en cada edificio por viviendas;

Plazas por viviendas.

\subsection{1 plazas}

- A reservar en cada edificio por comerciales;

Plazas por comerciales

652 plazas

El total de plazas que se dispone es de 3.233. El déficit de este Tercer Sector, estimo está compensado ampliamente con la realidad de la ubicación de la manzana objeto de uso exclusivo para aparcamientos $M-7$, que es colindante con el perímetro de este Sector.

Valencia, Abril de 1970

EL ARQUITECTO,
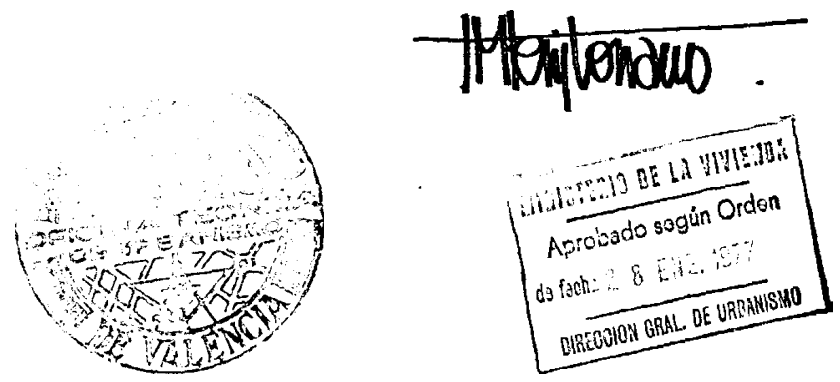
1. ALINEACIONES

Escala original: 1:2.000
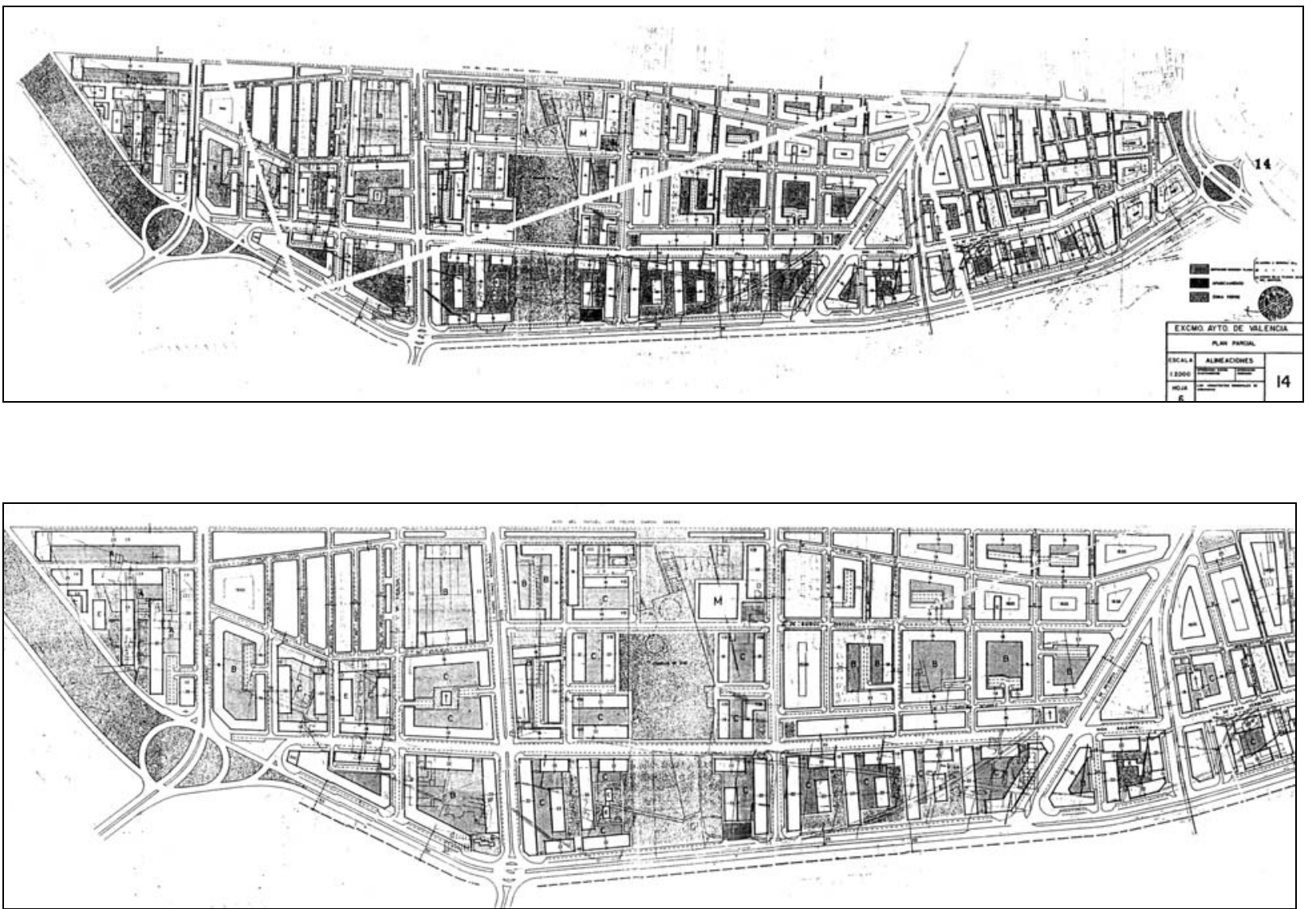

Detalle de la zona de edificación abierta 
1. SITUACIÓN DENTRO DE LA CIUDAD

Escala original: 1:50.000

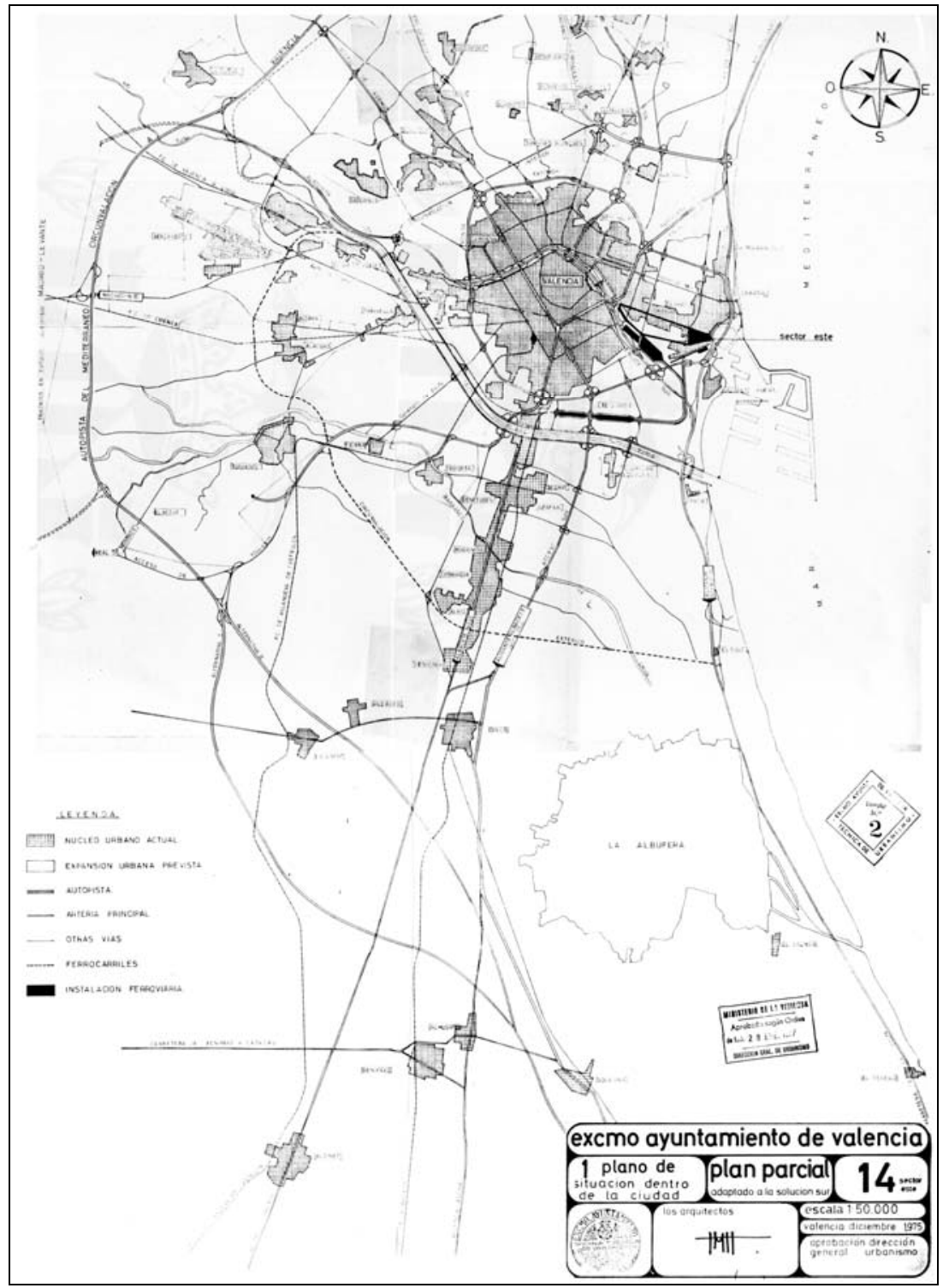

\section{FOTOPLANO}

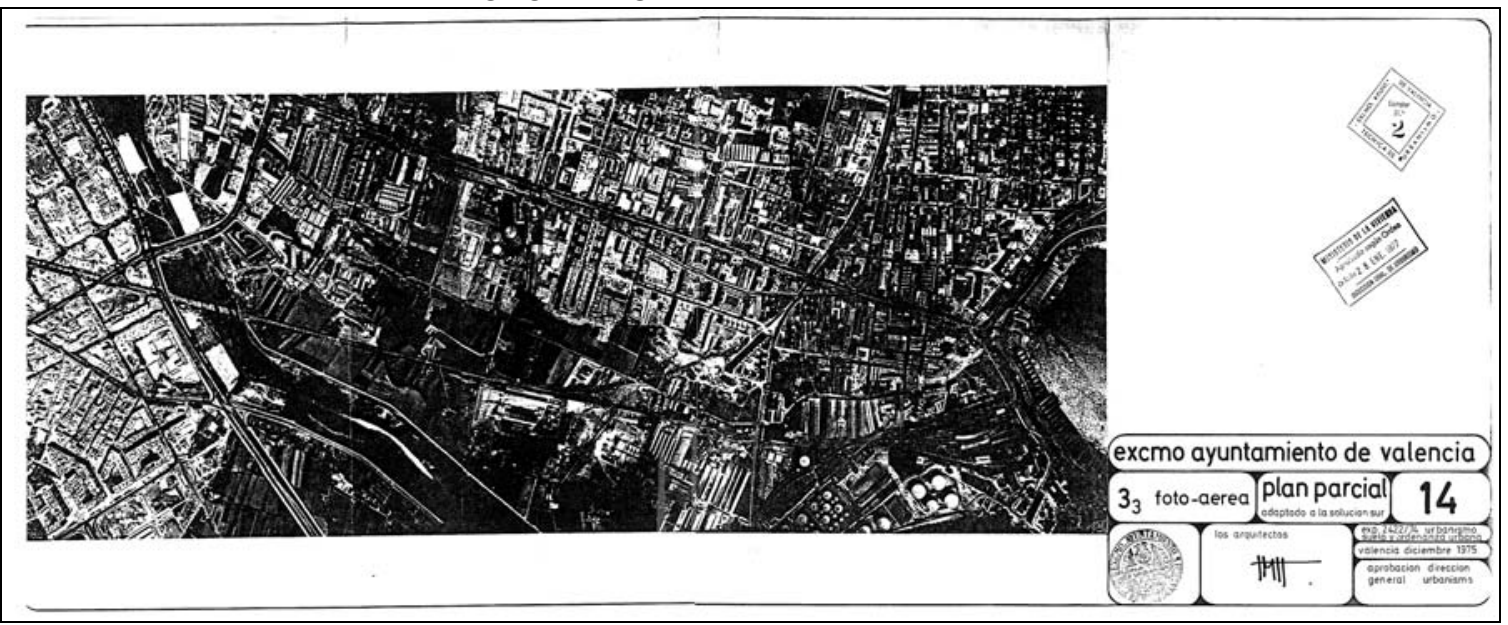




\section{ESTADO ACTUAL}

Escala original: $1: 2.000$

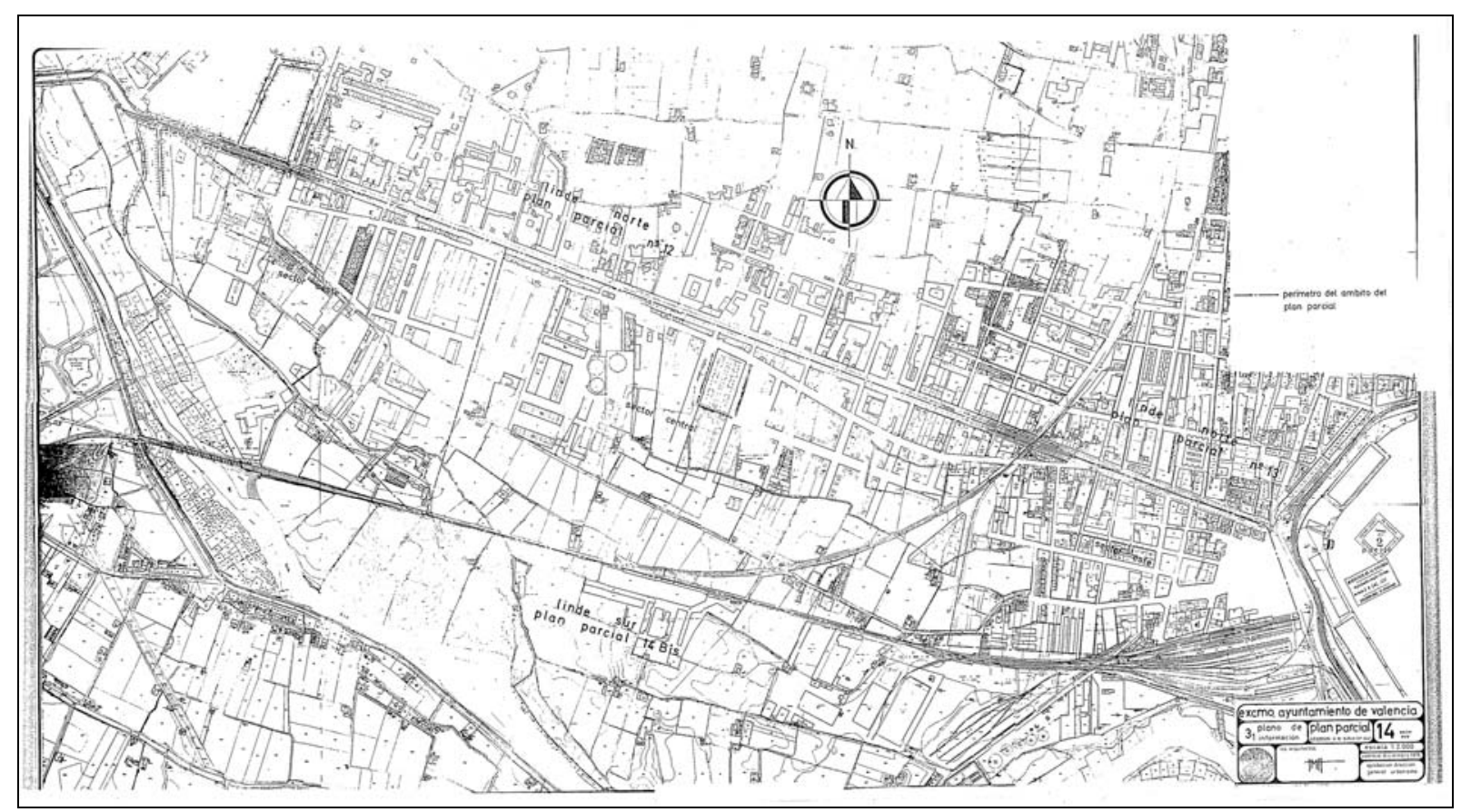

\section{ALINEACIONES}

Escala original: 1:2.000

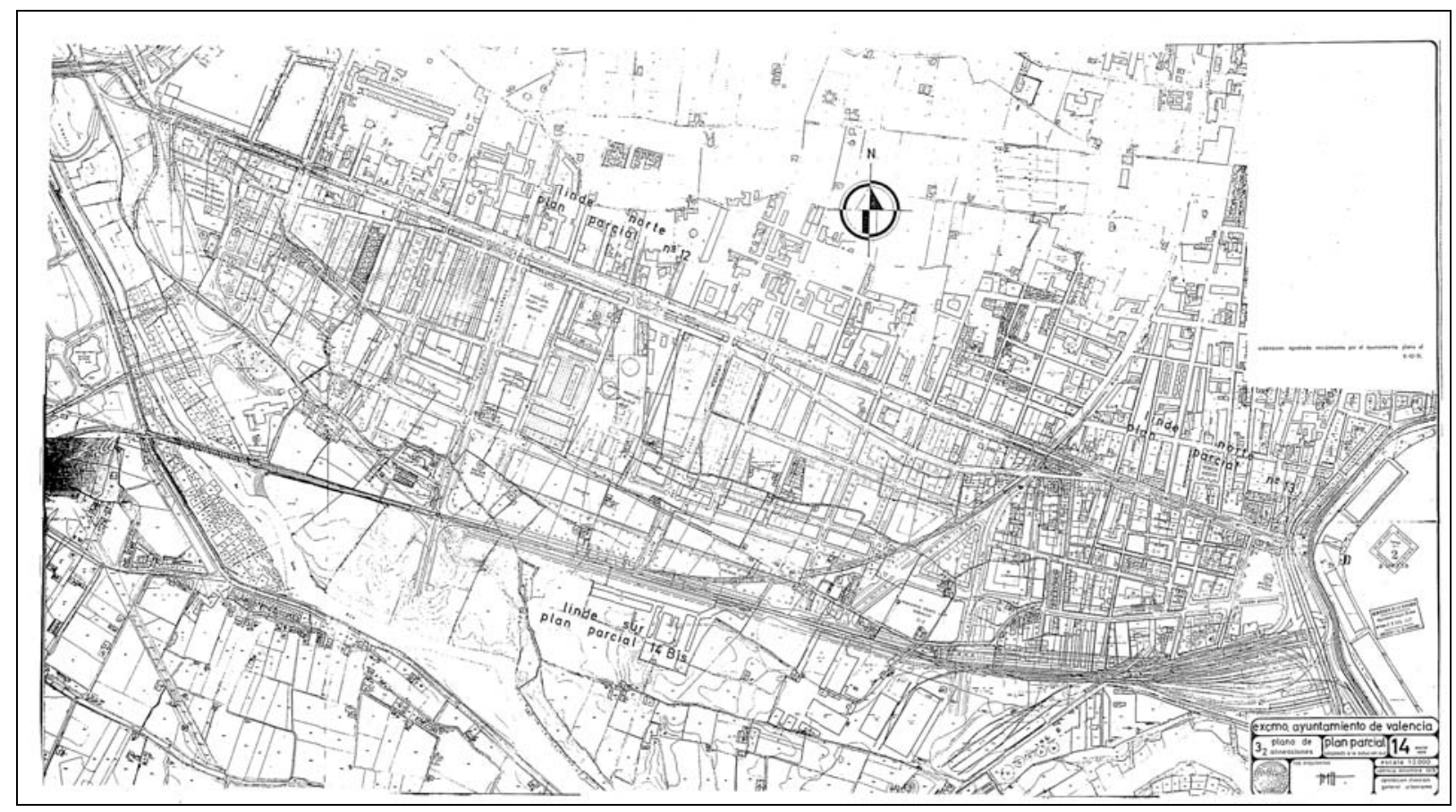


Redactor: Ministerio de la Vivienda.

Fecha: 28- 01-1977.

Asunto: Resolución de aprobación del Plan Parcial 14 Sector Este. Fuente: Ayuntamiento de Valencia. Sección de Urbanismo. Negociado de Suelo y Ordenación urbana. Exp. 2422/74 (Archivo de Planeamiento, $\mathrm{N}^{\circ} 115$ ).

\section{MINISTERIO DE LA VIVIENDA}

DIRECCIÓN GENERAL DE URBANISMO

Excmo. Sr.:

VISTO el Plan Parcial de Ordenación urbana no 14, Sector Este, de Valencia, presentado por el Ayuntamiento de la citada Capital.

VISTO el informe técnico evacuado al efecto y la Ley sobre Régimen del Suelo y Ordenación urbana, Texto Refundido de 9 de Abril de 1976.

Esta Dirección General, teniendo en cuenta que el Plan presentado, se ajusta a las determinaciones del vigente Plan General de Ordenación Urbana de Valencia y su Comarca, adaptado a la Solución Sur, tiene el honor de proponer a V.E. que le otorgue la aprobación definitiva, con la indicación expresa de que en el planeamiento del Sector Centro limítrofe se deberán establecer dotaciones en cuantía suficiente para ampliar las del Plan que ahora de aprueba.

La resolución se notificará al Ayuntamiento de Valencia y se publicará en el Boletín Oficial del Estado.

No obstante, V.E. resolverá.

Dios guarde a V.E.

Madrid, 28 de Enero de 1977.

EL DIRECTOR GENERAL

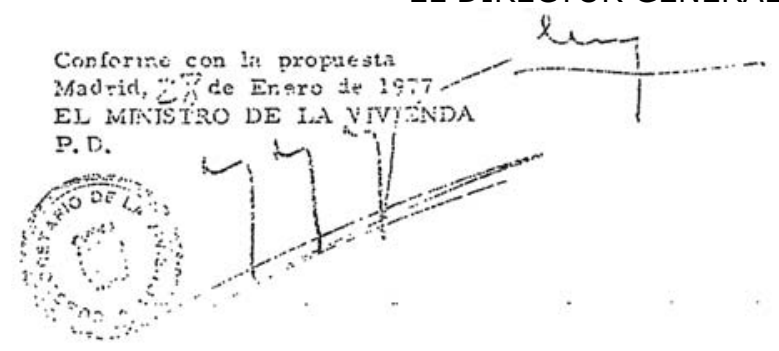


Redactor: Ayuntamiento de Valencia.

Fecha: 16- 02-1977.

Asunto: Informe del Arquitecto Mayor sobre la resolución ministerial de aprobación del Plan Parcial 14, Sector Este.

Fuente: Ayuntamiento de Valencia. Sección de Urbanismo. Negociado de Suelo y Ordenación urbana. Exp. 2422/74 (Archivo de Planeamiento, No 115).

Expte. 2422/74 S. y O. Urbana

El Arquitecto Mayor que suscribe, en cumplimiento del decreto de la Secretaría General que antecede y visto el texto de la Resolución Ministerial adoptada en relación con el Plan Parcial de Ordenación Urbana signatura 14.-SECTOR ESTE, de Valencia, de fecha 28 enero 1977, tiene que informar:

Que, según se deduce de la parte expositiva de la citada Resolución, concretamente en la que se señala haberse tenido en cuenta la Ley sobre Régimen del Suelo y Ordenación Urbana, Texto refundido de 9 de abril de 1976, cabe interpretar, el párrafo en que se dice "con indicación expresa de que en el planeamiento del Sector Centro limítrofe se deberán establecer dotaciones en cuantía suficiente para ampliar las del Plan que ahora se aprueba", en el sentido de que se está solicitando que se cumpla lo indicado en el artículo 13 del citado Cuerpo legal. Podría también interpretarse como que simplemente se pretende que se amplíen las dotaciones previstas en la cuantía que se estime oportuna para las necesidades del Plan, dado que no se precisa el tipo de dotación que se considera deficitaria.

En el primer supuesto comportaría el señalamiento de terrenos para establecer las reservas para parques y jardines públicos, para zonas deportivas publicas y de recreo y expansión, en la cuantía suficiente para que su determinación se obtenga de prever una superficie de $18 \mathrm{~m} 2$. por cada vivienda programada en cuanto a parques y jardines, superficie que no deberá ser inferior al $10 \%$ de la total superficie del sector que se ordena; y asimismo en la proporción de $10 \mathrm{~m} 2$. por vivienda en cuanto a centros culturales y docentes, públicos y privados, superficies que estarán agrupadas según los módulos necesarios para formar unidades escolares completas; además, deberán fijarse los emplazamientos para templos, los centros asistenciales y sanitarios y los demás servicios de interés público y social. Tanto en el Sector ESTE, ahora aprobado, como en el Sector CENTRO, aprobado inicialmente por el Ayuntamiento pleno en 6 de diciembre de 1974, no se cumplen estas proporciones pues se redactaron conforme a las condiciones señaladas por la Ley del Suelo de 12 de mayo de 1956. Esto significa un aumento en la reserva de terrenos para las dotaciones $y$, en definitiva, supone que estas previsiones deben hacerse a costa de una nueva calificación de parte de los terrenos antes señalados como susceptibles de ser edificados privadamente en el Sector CENTRO, para que en el nuevo estudio no comporte detrimento de las dotaciones ya previstas.

Se ha procedido a hacer un análisis de las repercusiones que esta interpretación da la Resolución Ministerial comporta sobre la Ordenación del Plan Parcial 14- SECTOR CENTRO, aprobado inicialmente, dado que la reducción de la superficie destinada a edifica 
ción privada supone a su vez una disminución en el número de viviendas programadas; el análisis se ha acomodado a estas circunstancias. Por ello se ha tenido en cuenta para determinar las reservas a disponer, y ello ha llevado a la necesidad, de reservar terrenos para parques y jardines y para escuelas pues se ha eliminado la hipótesis de suponerse preciso incrementar las reservas de templos, centros asistenciales y demás servicios, por considerarse que están suficientemente previstos para atender las necesidades del conjunto de los tres sectores en que se dividió el ámbito del Plan Parcial 14.

Se adjunta un plano de información en el que se señalan las reservas necesarias, grafiándose con contorno de color verde los terrenos destinados a jardines, y con color amarillo los terrenos reservados para escuelas, precisando que se han ubicado en aquellos terrenos que actualmente no están edificados o cuanto menos, no lo están conforme a la Ordenación.

La superficie para JARDINES posibles de crear, da un total de ............................ $7.336 \mathrm{~m} 2$.

La superficie destinada a ESCUELAS posible de reservar es

de $15.364,-\mathrm{m} 2$.

El número de viviendas elimiinadas es de ............................. 825 unidades

Con arreglo a los porcentajes de la Ley, no es posible absorber su totalidad,

- faltan $988 \mathrm{~m} 2$. de parques y jardines, y

- $\quad 4.858 \mathrm{~m} 2$. de escuelas.

En conclusión, en el SECTOR CENTRO, los terrenos no edificados actualmente deberán destinarse prácticamente a dotaciones públicas, salvo algunas manzanas en las que, para respetar las edificaciones ya existentes, procede se realice la completa construcción de las mismas $y$, sin embargo, como queda expuesto, no se agota el porcentaje legal.

Con independencia de lo antedicho, estimo que debería solicitarse informe del Servicio de Asesoría Jurídica sobre la aplicación, para este Plan Parcial 14- SECTOR ESTE, del Texto refundido de la Ley del Suelo de 9 de abril de 1976.

Valencia, 16 de febrero de 1977 EL ARQUITECTO MAYOR,

\section{Mbingondow}




\section{PP 22}

PLANO PARCIAL No 22 (ADAPTADO A LA SOLUCIÓN SUR)

1974

Redactores: EXCMO. AYUNTAMIENTO DE VALENCIA. OFICINA TÉCNICA DE URBANISMO.

Fecha redacción: Diciembre 1972- mayo 1974.

Fecha aprobación: O.M. 23-12-1974 (B.O.E. 06-02-75).

Contenido:

I. MEMORIA. Diciembre 1972. MEMORIA. DOCUMENTO ANEJO. Abril 1975.

II. ORDENANZAS. Diciembre 1972. ORDENANZAS. DOCUMENTO ANEJO. Abril 1975.

III. PLAN DE ETAPAS. Diciembre 1973.

PLANOS: $(*)$

1. PLANO DE SITUACIÓN DENTRO DE LA CIUDAD. $1: 10.000$

2. SITUACIÓN EN EL PLAN GENERAL

$1: 22.500$

3. INFORMACIÓN Y FOTO AÉREA

$1: 2000$

4. ZONIFICACIÓN

$1: 2000$

ZONIFICACIÓN RECTIFICADO

5. ESTRUCTURA URBANÍSTICA

$1: 2000$

6. ALINEACIONES

$1: 2000$

7. RED VIARIA

$1: 2000$

RED VIARIA RECTIFICADA

$1: 2000$

8. REDES FUNDAMENTALES DE SERVICIO.
RED DE ALCANTARILLADO
$1: 2000$
ESQUEMA DE RED DE AGUAS POTABLES
$1: 2000$
ESQUEMA DE ALUMBRADO.
$1: 2000$

\section{Fuente:}

Ayuntamiento de Valencia. Sección de Urbanismo. Negociado de Suelo y Ordenación Urbana. Expte. 295/73. (Archivo de Planeamiento. No 136).

\section{Notas:}

* Fecha planos: mayo 1974; planos rectificados: abril 1975. 
EXCMO. AYUNTAMIENTO DE VALENCIA.

\section{PROYECTO DE PLAN PARCIAL NO 22 - BENIMACLET}

\section{I.- MEMORIA.}

1.1.- Este proyecto parcial comprende el ámbito de la antigua población de Benimaclet y sus alrededores.

\subsection{2.- Los límites del plan son:}

El Plan Parcial No 22 está ubicado entre los accesos Norte a la autopista del Mediterráneo al Este, ronda exterior y calle en proyecto Polígono Industrial al Norte, al Oeste con el Ferrocarril eléctrico de Valencia a Rafelbuñol (futuro acceso Norte), hasta encontrar la ronda exterior, cerrando el mismo por el Sur la Avenida de Primado Reig.

\section{2.- ESTADO ACTUAL.}

Las zonas edificadas en el momento actual sobre la superficie de este proyecto de plan parcial son las del viejo poblado de Benimaclet, limitado por la Avda. de Emilio Baró al Oeste, calle de Francisco Martínez al Norte, calle Mistral al Este y por ella hasta encontrar el Ferrocarril del Grao.

Las construcciones de los inmuebles en el mismo son bajas, a excepción de las ubicadas a lo largo de la Avenida de Emilio Baró y pequeños sectores, entre ellos los situados en el ferrocarril del Grao y Avenida del Primado Reig, zona. que fue en su día aprobada por la Dirección General de Urbanismo en 27 de julio de 1961, en la que no se tuvo en cuenta los espacios libres exigidos en la redacción del mismo.

El acoplamiento de las zonificaciones correspondientes a la edificación existente, se ha tratado con las nuevas normas, adaptando la estructura urbanística por zonas, respetando el coeficiente de edificabilidad de las mismas.

\section{3.- ZONIFICACIÓN.}

Según el Plan General, la Zonificación que corresponde al Plan Parcial No 22, es de:

- EXTENSIÓN EXTERIOR A TRÁNSITOS.

- EDIFICACIÓN ABIERTA.

- INDUSTRIA ESPECIAL Y

- ORDENACIÓN ESPECIAL.

La situación de las mismas es la siguiente:

\subsection{1.- EXTENSIÓN EXTERIOR A TRÁNSITOS.}

Grafiada en el plano de zonificación con trama cuadriculada. Es la que, partiendo de la Avda. del Primado Reig sigue en perpendicular por la calle en Proyecto formando una pequeña inflexión hasta encontrar el ferrocarril del Grao, y por el mismo hacia el Sureste siguiendo hasta encontrar la calle del Arquitecto Arnau, Padre Alegre hasta la Escuela No 7, sigue por calle al Norte en Proyecto, la. primera al Oeste y luego la primera al Norte hasta la calle de las Fuentes, y vuelve a la calle Arquitecto Arnau, que, siguiendo la misma directriz atraviesa el parque $\mathrm{n}^{\mathrm{O}} 4$ y entre las manzanas semiabiertas al Oeste y los bloques lineales de edificación abierta al Este, por la Ronda Exterior hasta encontrar la Avenida de Emilio Baró, y por la misma a la Avenida del Primado Reig.

\subsection{2.- EDIFICACION ABIERTA.}

Se halla separada en dos sectores: "A" y "B", uno el situado al Este por el límite indicado calle del Arquitecto Arnau hasta la 
Ronda exterior, y otra al Oeste limitada por la Avenida de Emilio Baró, Primado Reig y ferrocarril de Rafelbuñol. Ambas con un coeficiente de edificabilidad de $5 \mathrm{~m} 3 / \mathrm{m} 2$. según norma del Plan General.

Las manzanas comprendidas entre las calles de Emilio Baró, Casas del Ingeniero, Dolores Marqués, continuación oblicua de calle Torreta Miramar, calle Poeta Altet, calle Albocácer, Camino Viejo de Alboraya y Avenida del Primado Reig, forman parte del Sector "B" de edificación abierta, ya construidos anteriormente al Plan General, aprobado en BOE. de 27 de julio de 1966, como manzanas cerradas y zonificación de ensanches. En el presente Plan Parcial se respeta la forma, ya que los edificios se encuentran en buen estado y es aconsejable, desde un punto de vista estético, a fin de no dejar a la vista patios interiores de manzana. No obstante, cualquier modificación de lo construido se hará basándose en el coeficiente de $5 \mathrm{~m} 3 / \mathrm{m} 2$. que le corresponde como edificabilidad a cada parcela según el Plan General vigente, citado con anterioridad.

\subsection{3.- INDUSTRIA ESPECIAL.}

Los límites son: Acceso norte a la autopista del Mediterráneo al Este, calle en Proyecto al Norte hasta encontrar la vía del ferrocarril de Aragón; hacia el Sur y por ella, hasta unirse al nudo del paso elevado del Acceso norte a la autopista del Mediterráneo.

La edificabilidad en la Zona Industrial tendrá un coeficiente de $6 \mathrm{~m} 3 / \mathrm{m} 2$. sobre superficie de parcela y el aprovechamiento máximo en planta será del $70 \%$ sobre la misma superficie. Todas las fachadas deberán ostentar aspecto decoroso y los cerramientos serán calados en todos los patios.

La Zona Industrial queda separada por el parque no 5 y la Ronda Exterior, formando un gran pulmón de separación con la Edificación Abierta.

\subsection{4.- ORDENACIÓN ESPECIAL.}

El Plan General prevé una superficie situada en la confluencia de la Avenida del Primado Reig y Acceso norte a la autopista del Mediterráneo al sureste del Plan Parcial No 22 que nos ocupa, con la calificación de Ordenación Especial. Sobre la superficie en cuestión se podrán realizar edificaciones con un coeficiente de 5 $\mathrm{m} 3 / \mathrm{m} 2$. y el uso, el previsto en el Plan General.

\subsection{5. - CENTROS COMERCIALES.}

Estarán constituidos por planta baja y entresuelo comerciales, formando una plataforma de $8 \mathrm{mts}$. de altura a cumbrera, sobre la que puede edificarse en altura con destino a viviendas dentro del coeficiente establecido para la zona, de $5 \mathrm{~m} 3 / \mathrm{m} 2$. (en este coeficiente está incluido el volumen destinado tanto a comerciales como a viviendas). Y del volumen total resultante se destinará el $30 \%$ a usos comerciales.

\subsection{6.- ZONAS VERDES.}

Ha tenido importancia al iniciar la redacción del presente Plan Parcial, la realidad actual de la zona. El criterio adoptado ha sido el repartir de una manera proporcionada para toda el área del plan de ubicación, con ello se compaginan las superficies pequeñas y más fáciles de una pronta realidad, con el más equitativo beneficio de todos los fabricantes del Polígono.

Los dos módulos de zonas verdes adoptados varían desde la pequeña plaza aislada por vías de tránsito o edificaciones, formando unidades intercaladas en el reticulado de calles, hasta las fajas verdes que enlazan los barrios a lo largo de los paseos. Una disposición singular es la prevista para algunas manzanas abiertas y consiste en que, a nivel del suelo, se proyecta un parque de vegetación baja y en cuyo subsuelo se dispone la ubicación de superficies de aparcamiento de vehículos. 
Quedan establecidas y enumeradas como parques, siendo el número total de ocho, con una superficie de $123.440 \mathrm{~m} 2$. distribuidos por zonas para expansión de la población y que, unidos a los $80.106 \mathrm{~m} 2$. creados entre bloques, suman $203.546 \mathrm{~m} 2$., superficie que excede del $10 \%$ exigido.

\subsection{7.- ZONA ESCOLAR.}

Es la formada por ocho grupos distribuidos en el Plan Parcial de forma que la distancia a recorrer por la población escolar sea la menor posible, aunque en el sector central del Plan Parcial será mayor, debido a no poder situar grupo alguno por la cantidad de expropiaciones que sería preciso realizar por lo compacta que se halla la edificación actual.

La superficie de esta zona es de $80.000 \mathrm{~m} 2$.

\section{4.- RED VIARIA.}

La red viaria de Valencia y su Comarca afecta al presente proyecto en los siguientes extremos:

\subsection{1.- RONDA EXTERIOR.}

Es uno de los límites del Plan, como se ha indicado; sobre él deberá mantenerse un riguroso control de accesos regulado por los servicios de la Dirección General de Carreteras. Para uso de la zona lindante se establecen las oportunas vías de servicio, paralelas al acceso principal, y guarnecidas de aparcamientos en toda su longitud.

\subsection{2.- VIARIO INTERNO.}

El esquema de viario interno ha sido concebido para la totalidad de este Plan y de su futura expansión, con objeto de asegurar la continuidad lógica de sus vías principales. Con este criterio han sido establecidas las redes azul y verde.

1.4.2.1.- Red -Amarilla.- De carácter eminentemente local y circunscrita a unidades residenciales reducidas; no tiene ni debe tener repercusión al exterior, limitándose a su función inmediata.

1.4.2,2.- Red Azul.- La componen las vías de relación entre barrios. Son ellas: la. Avenida del Poeta Emilio Baró, que es el límite separador entre el ámbito de edificación abierta y el núcleo antiguo de Benimaclet, y la Avenida del Doctor Zaragoza, que no separa zonas de características diferentes.

1.4.2.3.- Red Verde.- La componen los colectores de barrio; ordena el tráfico fundamental dentro de los propios barrios y guarnece las arterias principales de uso restringido con aquellos.

\section{5.- ALINEACIONES.}

Fijan los terrenos que serán edificables y según los casos, se resuelve en manzana cerrada o en manzana abierta. En el primer caso se fija la profundidad máxima, siendo ésta obligatoria para todo solar en el segundo caso. En la edificación abierta, las alineaciones grafiadas son también obligatorias. Los planos se grafían a escala 1.2000.

1.5.1.- Entre las alineaciones de calles y del patio de manzana, podrá edificarse el máximo de alturas permitidas por el Cuadro Anexo a las Normas Urbanísticas del Plan General, según el ancho de las calles en la zona de extensión. En la zona de Edificación abierta, las alturas están acotadas con números romanos.

1.5.2.- Las zonas edificables en patio de manzana tendrán una planta y sus usos, que excluyen el destino a viviendas, deben ser 
compatibles con la zona, la cual es eminentemente residencial. Cuando el patio de manzana se destina a otros usos, se grafía convenientemente: son ellos, el aparcamiento, el jardín y la unión de ambos resuelta con la propuesta de jardín a nivel de suelo y aparcamiento en el subsuelo. En todas las manzanas en cuyo patio se prevé un jardín, se procura abrir uno o dos de sus lados para facilitar el soleamiento, la aireación, el ambiente, dejando como último condicionante la estética -muchas manzanas están fuertemente edificadas y sus fachadas al patio no son de ninguna belleza-, pero ello no se estima motivo suficiente para desechar la solución propuesta.

\section{6.- RESUMEN DE SUPERFICIES.}

La superficie total del Polígono entre ejes es de $1.328 .420 \mathrm{~m} 2$.en zona residencial y de $294.400 \mathrm{~m} 2$. en zona industrial, sumando ambas $1.622 .820 \mathrm{~m} 2$. distribuidos en la forma siguiente:

Edificación abierta "A" y "B" $146.896 \mathrm{~m} 2$.

Edificación actual $233.270 \mathrm{~m} 2$.

Viales. $894.402 \mathrm{~m} 2$.

Zonas Verdes $203.546 \mathrm{~m} 2$.

Escuelas $80.000 \mathrm{~m} 2$.

Centros Comerciales

$16.760 \mathrm{~m} 2$.

Aparcamiento Red Viaria

$47.946 \mathrm{~m} 2$.

Valencia, Diciembre de 1.972.

EL ARQUITECTO,

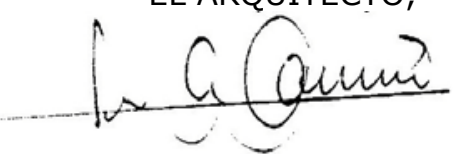




\section{EXCMO. AYUNTAMIENTO DE VALENCIA}

\section{PROYECTO DE PLAN PARCIAL NO 22}

\section{I.- MEMORIA. DOCUMENTO ANEJO.}

En virtud. de la Resolución ministerial del día 23 de diciembre de 1974, referente al Plan Parcial de Ordenación Urbana no 22, publicada, en el B.0. del Estado de fecha 6 febrero 1975, por la cual se aprobaba el mismo, se imponen determinadas rectificaciones que expresamente se citan en el texto de la misma; en consecuencia, se ha procedido a complementar y adaptar loe párrafos de la Memoria del citado Plan para su acomodación a ella.

a) Párrafos que se modifican.

1.3.1.- EXTENSION EXTERIOR A TRÁNSITOS.- EL perímetro del sector así calificado está grafiado en el plano de zonificación rectificado, con trama cuadriculada. Está comprendido por la Av. Primado Reig; calle En Proyecto que se prolonga en la de Hermanos Villalonga hacia el Norte; calle Mallorca; calle Arquitecto Arnau; calle Padre Alegre; calle En Proyecto, que es la única travesía perpendicular a la anterior hacia el Norte; calle En Proyecto, que es la primera travesía de la anterior hacia el Oeste; calle de Las Fuentes; calle Arquitecto Arnau; calle En Proyecto, que es travesía de la anterior hacia el Oeste y que a su vez limita por el linde Sur la manzana en la que se dispone un Mercado público; calle En Proyecto, que es prolongación hacia el Norte, de la calle Buenaventura Pascual; Ronda Exterior, en proyecto; nudo de enlace de esta última con el futuro Acceso Norte de la carretera a Barcelona N-340; avenida Poeta Emilio Baró; calle casas del Ingeniero; calle Dolores Marques; calle En Proyecto, que es prolongación de la de Torreta de Miramar hacia el Oeste; calle Poeta Altet; calle Albocácer; camino viejo de Alboraya hasta la avenida de Primado Reig.

1.3.2.,- EDIFICACIÓN ABIERTA.- Comprende dos sectores independientes, en su localización en el Plan, entre sí, que se designan con las letras "A" y "B". El primero de ellos está emplazado en el Oeste del Plan y linda con el futuro Acceso Norte en medio, con el Plan Parcial n 23; el segundo se emplaza en el Este del Plan y linda con la Ronda Exterior. Ambas zonas a su vez lindan con el sector antes definido de Extensión Exterior a Tránsitos, cuya situación es intermedio de ambas.

En ambos sectores el coeficiente de edificabilidad máximo es de $5 \mathrm{~m} 3 / \mathrm{m} 2$, según directrices del Plan General de Valencia y su Comarca adaptado a la Solución Sur.

Los perímetros de ambos sectores están grafiados en el plano de zonificación, rectificado, con trama rayada.

1.3.4.- ESPECIAL. - El Plan General citado, y para cuyo desarrollo se proyecta el presente Plan Parcial no 22, dispone como Zona Especial el sector comprendido entre la avenida Primado Reig; autopista. de enlace Norte, existente, con la carretera por la Costa; nudo de enlace de la anterior con la Ronda Exterior; calle de MaIlorca; y calle En Proyecto, primera travesía hacia el Sur de la anterior hasta la avenida Primado Reig.

Conforme a las previsiones del Plan General, en dicho sector deberán reunirse condiciones especiales en cuanto a su edificación, en uso y volumen y que deben ser reguladas previo Proyecto de Ordenación, el cual se someterá en cuanto a procedimiento, conforme se especifica en el articulo 32 de la Ley del Suelo de 
12 de mayo de 1956, como si de un Plan Parcial se tratara.

En cuanto al volumen de edificación, y sólo en el supuesto de que el uso previsto lo requiera, se alcanzará como máximo el coeficiente de edificabilidad de $5 \mathrm{~m} 3 / \mathrm{m} 2$.

Deberán preverse los correspondientes espacios libres que marca la Ley del Suelo, dentro de este Sector especial.

El sector deberá ser autosuficiente en la previsión de las plazas de aparcamiento que el uso demande, conforme a los criterios del Plan General. Para ello se fijará la superficie mínima para aparcamientos grafiando su respectiva situación y capacidad mínima de estacionamiento.

\section{b) Párrafos que se añaden.}

1.4.2.4.- PASOS PEATONALES.- Se incorpora un estudio de pasos peatonales a distinto nivel sobre la Ronda Exterior, a fin de facilitar la utilización de la zona verde, signatura 5, por la población colindante a dicha Ronda.

1.7.- ESTUDIO SOBRE PREVISION DE APARCAMIENTOS.A los efectos de dicha previsión se fija la superficie mínima para aparcamientos, grafiando su respectiva situación y determinando la capacidad mínima de estacionamiento. Siendo el número de plazas no inferior a una por vivienda, el criterio básico adoptado para el estudio.

Con dicho criterio de base se mejoran con exceso las obligaciones que sobre el tema se disponían en la Norma Urbanística ${ }^{\circ}$ 33 del Plan General vigente, el cual para las barriadas de "mayor categoría" considera necesario el prever un vehículo por cada tres familias y en las barriadas "modestas" un vehículo por cada cinco familias.

Dado que el número de viviendas previsto en el Plan será de 20.384 y supuesto un espacio de $20 \mathrm{~m} 2$. para cada plaza de aparcamiento, la superficie a reservar será de 407.680 m2.

En los viales está prevista una superficie para aparcamientos de $47.948 \mathrm{~m} 2 \ll$, lo que proporciona 4.794 plazas. que pueden descontarse del total previsto. La superficie a reservar se reducirá a $311.800 \mathrm{~m} 2$.

Según las Normas Urbanísticas del Plan General, cada edificio destinado a viviendas deberá reservar el $5 \%$ de la superficie construida para aparcamientos. Según ello, dado que la superficie construible en el Plan para viviendas es de 3.057.574 m2., se deduce una superficie de $152.878 \mathrm{~m} 2$, que proporcionan $\underline{7.643 \text { plazas }}$ que, a su vez, podrían descontarse del total. Con lo que, la superficie a reservar se reduciría a $158.940 \mathrm{~m} 2$.

Bajo el subsuelo de las zonas verdes de uso público, números $1,3,4$ y 5 , se dispone la previsión de unos sótanos para aparcamiento público que, a razón de dos plantas como mínimo, nos proporcionan un total de $173.664 \mathrm{~m} 2$. útiles para aparcamiento, con lo que se dispondrá de 8.683 plazas. El aprovechamiento de estos subsuelos por particulares deberá ser en régimen de concesión del Municipio conforme el articulo 160 de la Ley de Régimen Local de 24 junio 1955 y los artículos 114 y siguientes del Reglamento de Servicios.

El total de plazas es, pues, de 21.120 , con lo que se excede del número necesario.

Valencia, abril de 1975

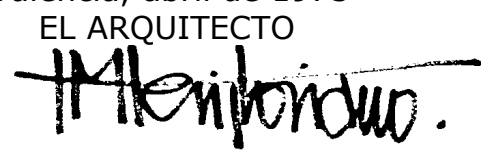




\section{EXCMO. AYUNTAMIENTO DE VALENCIA}

\section{PROYECTO DE PLAN PARCIAL NO 22 - BENIMACLET.}

\section{II.- ORDENANZAS.}

El presente Plan Parcial No 22, comprende, dentro de su ámbito, las zonificaciones siguientes de acuerdo con el Plan General de Adaptación de la Ordenación Urbana de Valencia y su Comarca a la Solución Sur:

a) Zona de Edificación Intensiva:

EXTENSIÓN EXTERIOR A TRÁNSITOS.

b) Zona de Edificación Abierta Alta.

(Coeficiente de edificabilidad $5 \mathrm{~m} 3 / \mathrm{m} 2$.)

c) Zona Industrial

(Coeficiente $6 \mathrm{m3} / \mathrm{m} 2$. edificabilidad $70 \%$ de la parcela)

\section{d) Zona Verde.}

Hasta que no se aprueben las Ordenanzas de la edificación de la ciudad de Valencia, adaptadas a las Normas Urbanísticas del Plan General -Solución Sur-, actualmente están en trámite de redacción, en este Plan Parcial serán preceptivas las antedichas Normas urbanísticas (B.O.E. de 27 de julio de 1966), y según la disposición final de las mismas, aquellos casos que no se hallen previstos se regirán por las Ordenanzas de la Edificación vigentes, que poseen aprobación por la Comisión Central de Sanidad Local en las fechas 23 de octubre de 1950, y de 26 de enero de 1955. Se acompañan dos fotocopias.

\section{APÉNDICE.}

Como complemento de lo antedicho se entenderá como ordenanzas vigentes en la zona de Extensión Exterior a Tránsitos, los artículos:

- 129 PARCELACIÓN de solares en manzanas; incluso los casos especiales de solares recayentes a chaflanes.

- 159 Calificación de manzanas según su estructura urbanística; a) cerradas; b) abiertas; c) semiabiertas.

- 161 ORNATO de las edificaciones en manzanas abiertas y semiabiertas: Ios solares deben poseer fachada a calle y a patio de manzana, no pudiendo quedar retrasada la edificación respecto a la línea de profundidad edificable.

Valencia, diciembre de 1.973
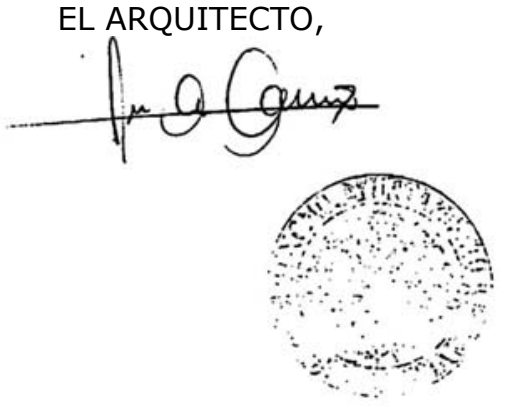


\section{EXCMO. AYUNTAMIENTO DE VALENCIA}

\section{PROYECTO DE PLAN PARCIAL NO 22}

\section{II.- ORDENANZAS. DOCUMENTO ANEJO.}

En virtud de la Resolución ministerial del día 23 de diciembre de 1974. referente al Plan Parcial de Ordenación Urbana n²2, por la que, aprobado definitivamente, se imponen determinadas rectificaciones que expresamente se citan en el texto de la misma, y como consecuencia de ello se ha procedido a complementar los párrafos de las Ordenanzas para su acomodación a ellas.

Párrafo que se añade:

ZONA. ESPECIAL.- En el sector calificado con dicha zonificación, señalado gráficamente en los documentos gráficos del Plan, y determinados sus límites en el párrafo 1.3.4 de la Memoria, previamente a cualquier solicitud de edificación que se pretenda realizar en el mismo deberá haberse aprobado definitivamente el Plan de Ordenación -cuya tramitación deberá seguir el procedimiento señalado en el artículo 32 de la Ley del Suelo, de 12 de mayo de 1956.

En dicho Plan deberán señalarse específicamente los usos del suelo, que necesariamente deberán estar suficientemente justificados, y que no deberán incluir otros aprovechamientos que no sean culturales, sanitarios, deportivos y turísticos. Si el uso previsto lo requiriera, el volumen edificable podría alcanzar el coeficiente de 5 $\mathrm{m} 3 / \mathrm{m} 2$ del polígono.

Toda la superficie del sector se considera unitaria a los efectos de edificación, por lo que procede se tramite el proyecto de parcelación y reparcelación de las fincas afectadas, conjuntamente con el Plan de Ordenación.

Deberá determinarse en el citado Plan el sistema de ejecución conforme a lo especificado en los artículos 113 y siguientes del capítulo segundo del Título Tercero de la citada Ley del Suelo»

Deberá reservarse un porcentaje equivalente cuanto menos al $10 \%$ de la superficie del polígono para espacios libres.

Deberá preverse las plazas de aparcamiento que el uso del suelo demande según el Plan de Ordenación, conforme a los criterios del Plan General, y en el Plan se fijará gráficamente su situación, asi como se indicará la capacidad de estacionamiento.

Valencia, abril de 1975

EL ARQUITECTO,

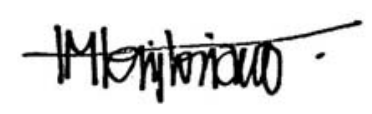




\section{EXCMO. AYUNTAMIENTO DE VALENCIA}

\section{PROYECTO DE PLAN PARCIAL n०22 - BENIMACLET-}

\section{III.- PLAN DE ETAPAS.}

El Plan Parcial No 22, Benimaclet, bastante construido en la actualidad, por particulares, deberá seguir el mismo ritmo, por lo cual no se puede marcar plan de etapas de realización pues dependerá de la actividad constructiva.

El Excmo. Ayuntamiento, además de construir los elementos urbanísticos generales, se mantendrá siempre en la urbanización adelantado sobre la iniciativa particular, urbanizando zonas en que se prevea la edificación inmediata.

\section{MEDIOS ECONÓMICO - FINANCIEROS.}

Son los del Presupuesto ordinario de Urbanismo del Excmo. Ayuntamiento de Valencia y los extraordinarios que se establezcan a medida que se cuMpla lo dicho en el párrafo anterior y se disponga de proyectos detallados de urbanización.

Con lo dicho creemos suficientemente expuesto el alcance del estudio realizado para que, si el Excmo. Ayuntamiento lo estima conveniente, lo eleve a la aprobación por la Superioridad.

Valencia, diciembre de 1.973

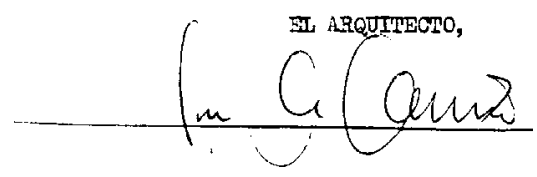


1. PLANO DE SITUACIÓN EN LA CIUDAD

Escala original: $1: 10.000$

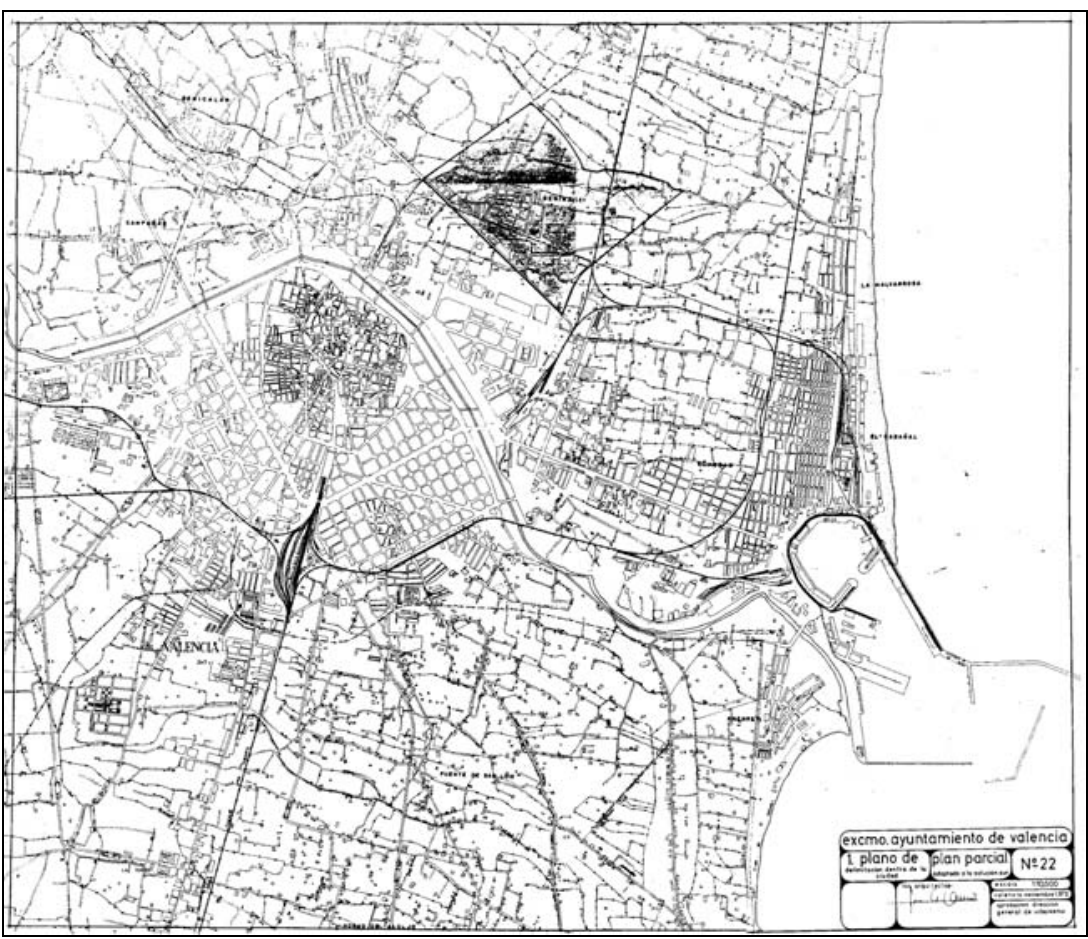

2. PLANO DE SITUACIÓN EN EL PLAN GENERAL (Fragmento) Escala original: $1: 22.500$

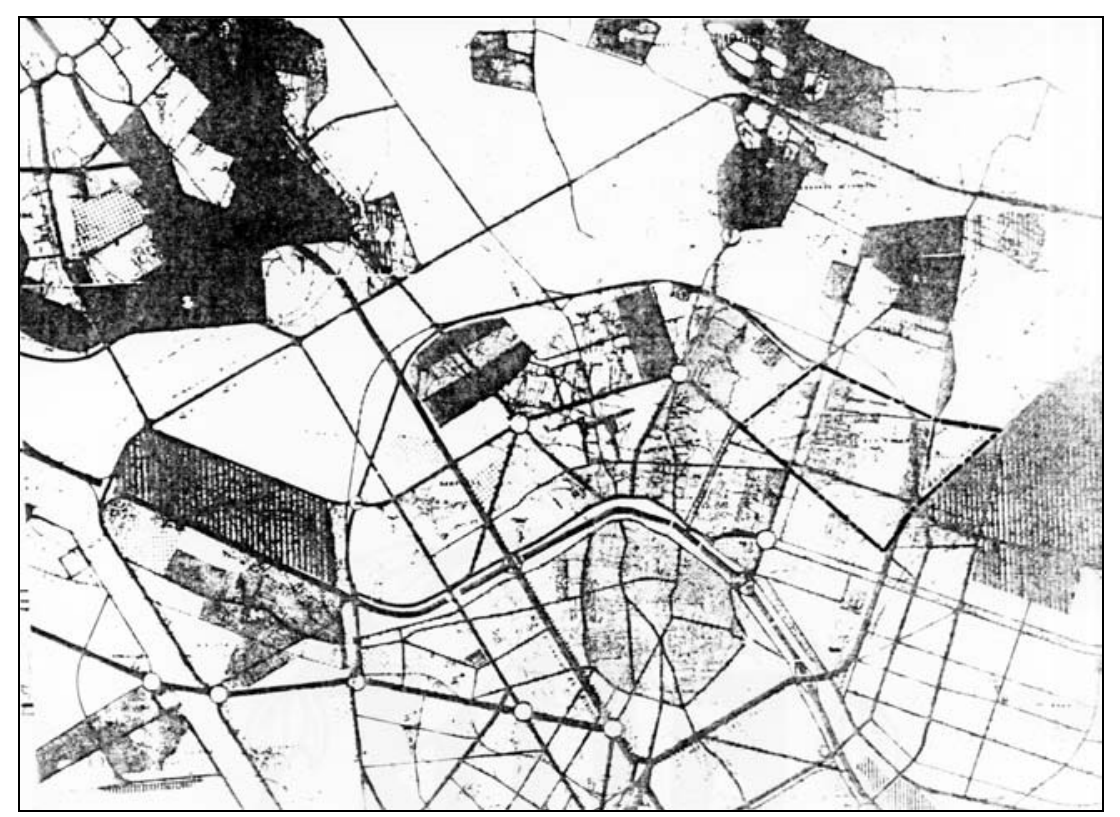


3. PLANO DE INFORMACIÓN.

Escala original 1:2000

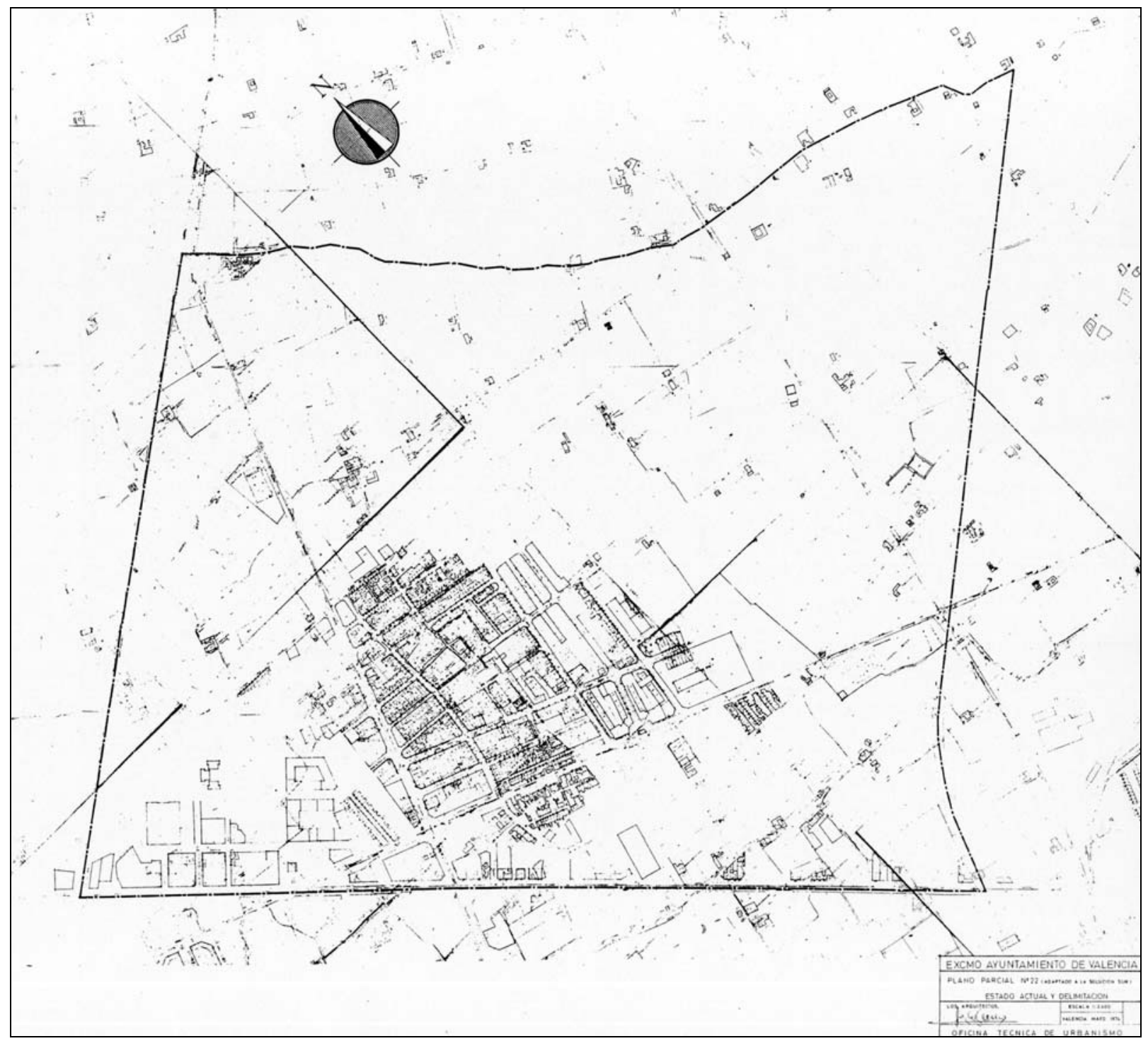


6. ALINEACIONES.

Escala original 1:2000

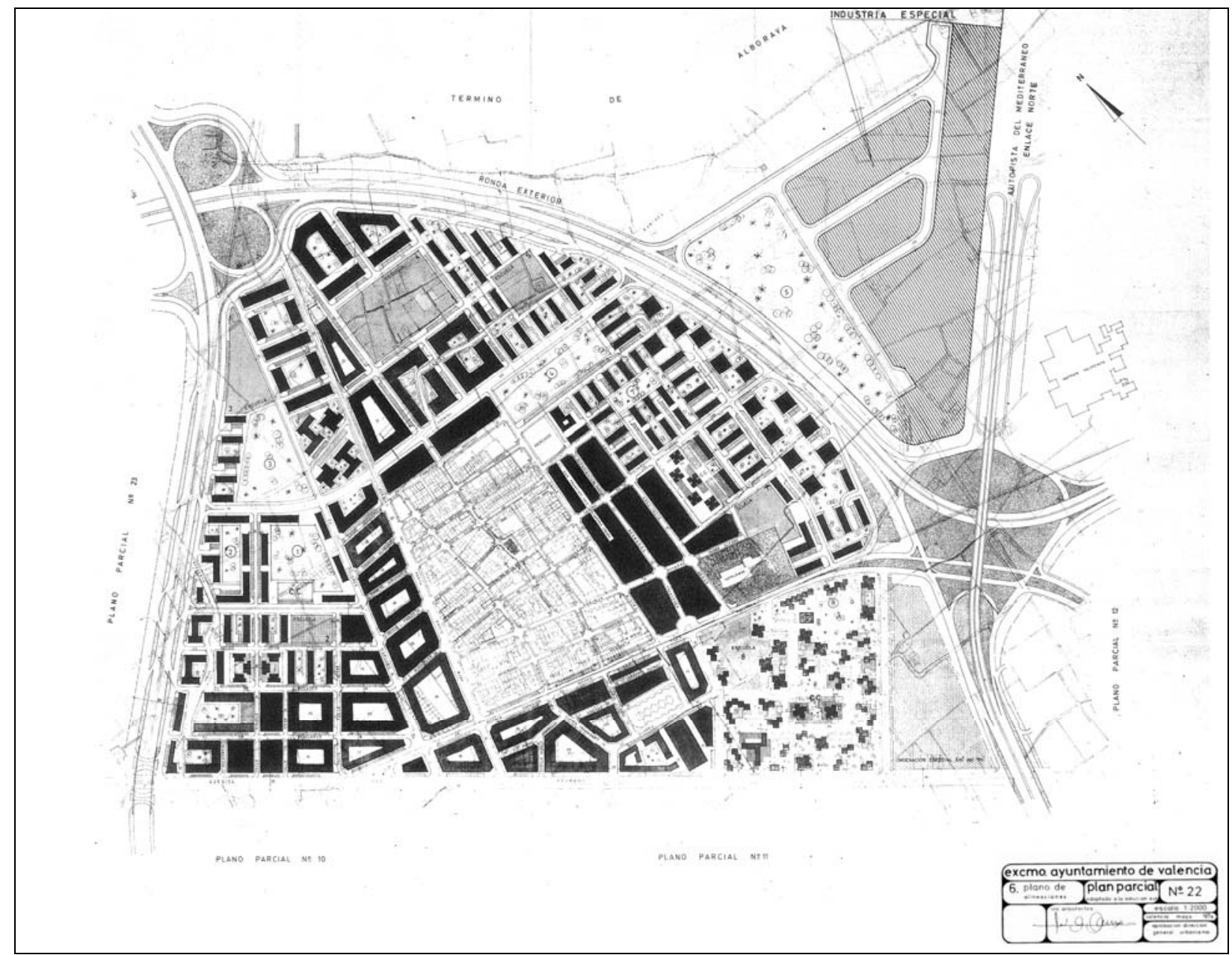




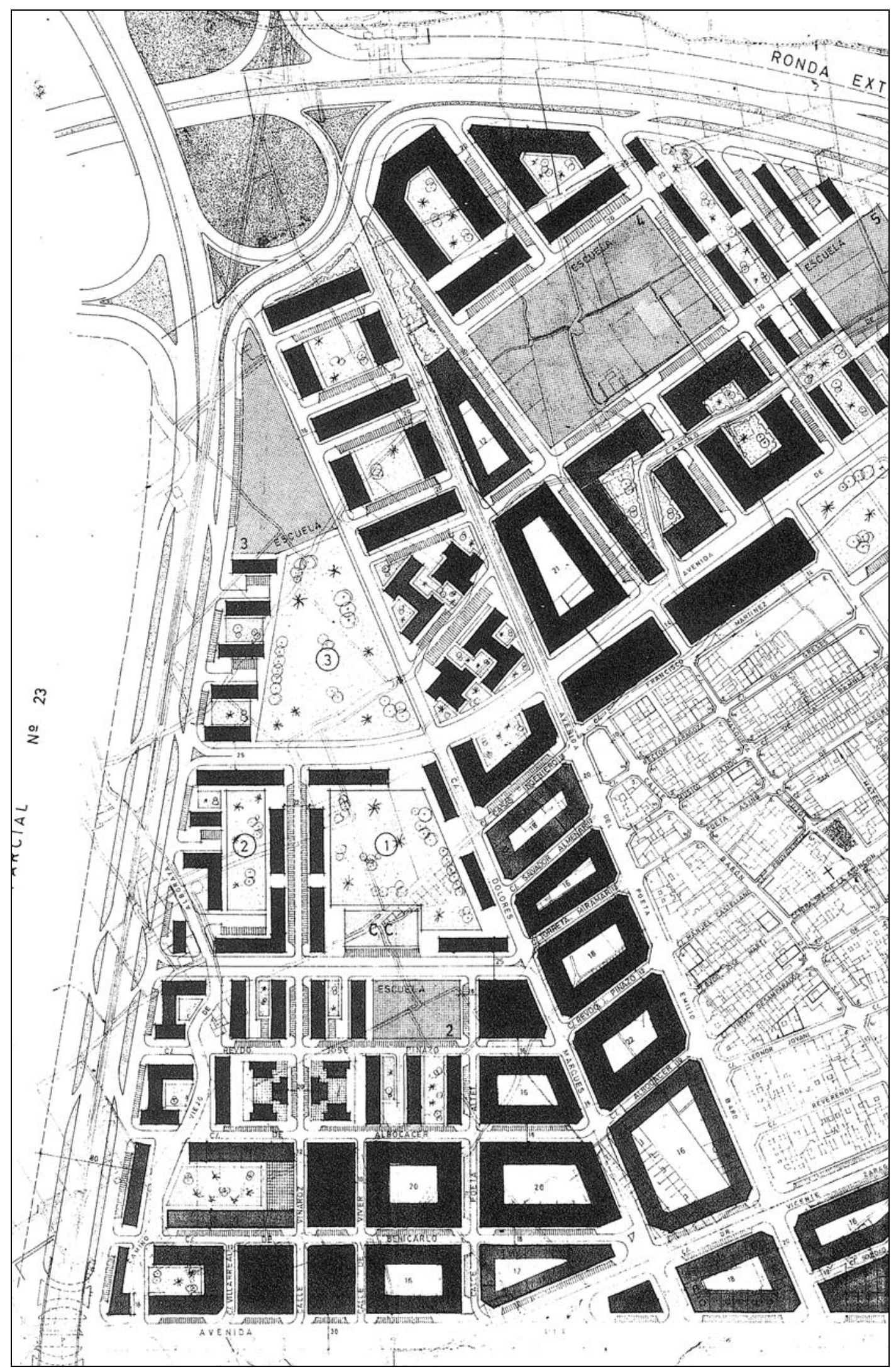

Detalle del plano de alineaciones. Zona de edificación abierta al oeste de Benimaclet. 


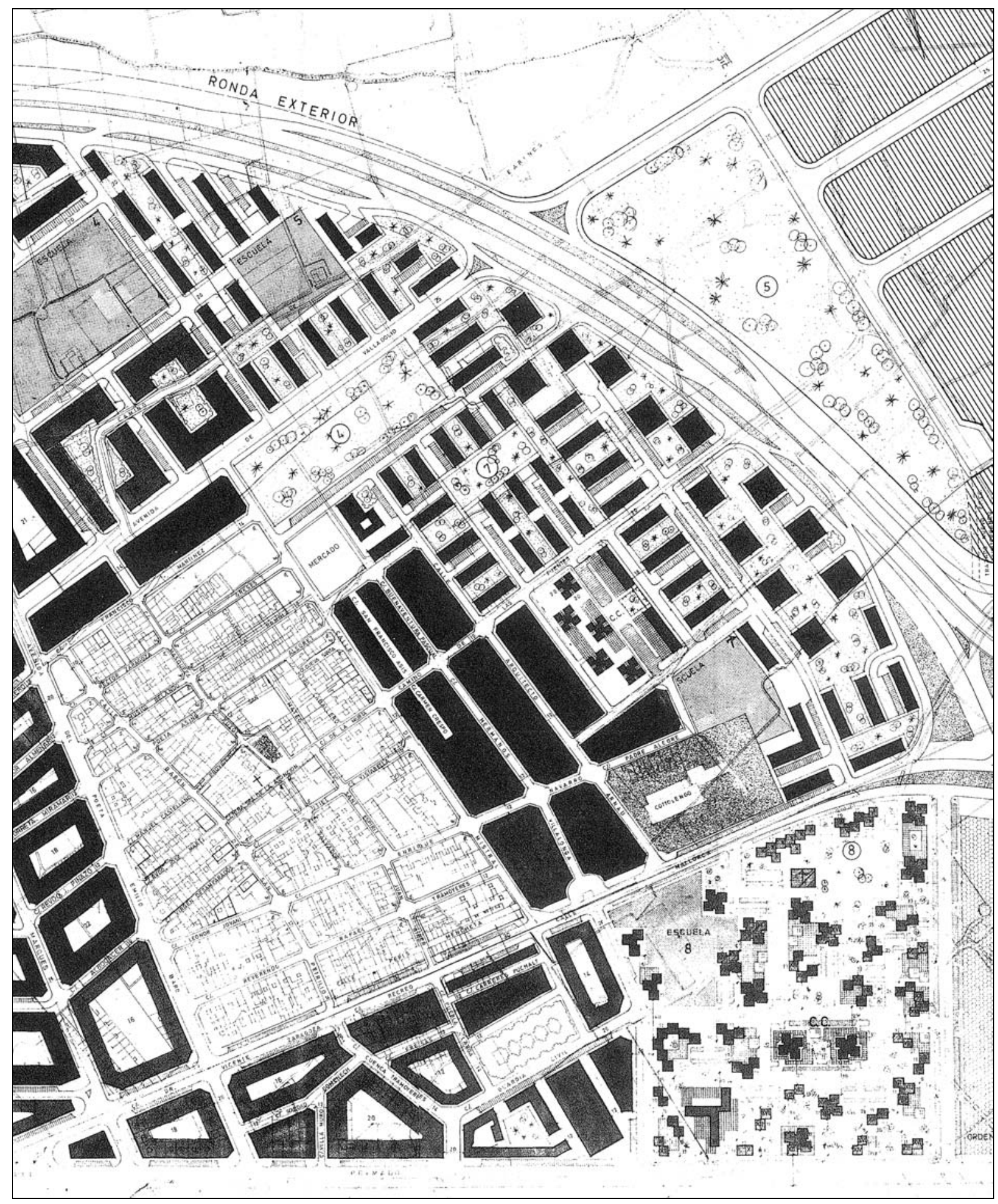

Detalle del plano de alineaciones. Zona de edificación abierta al este de Benimaclet. 
7. RED VIARIA RECTIFICADA

Escala original: 1:2000

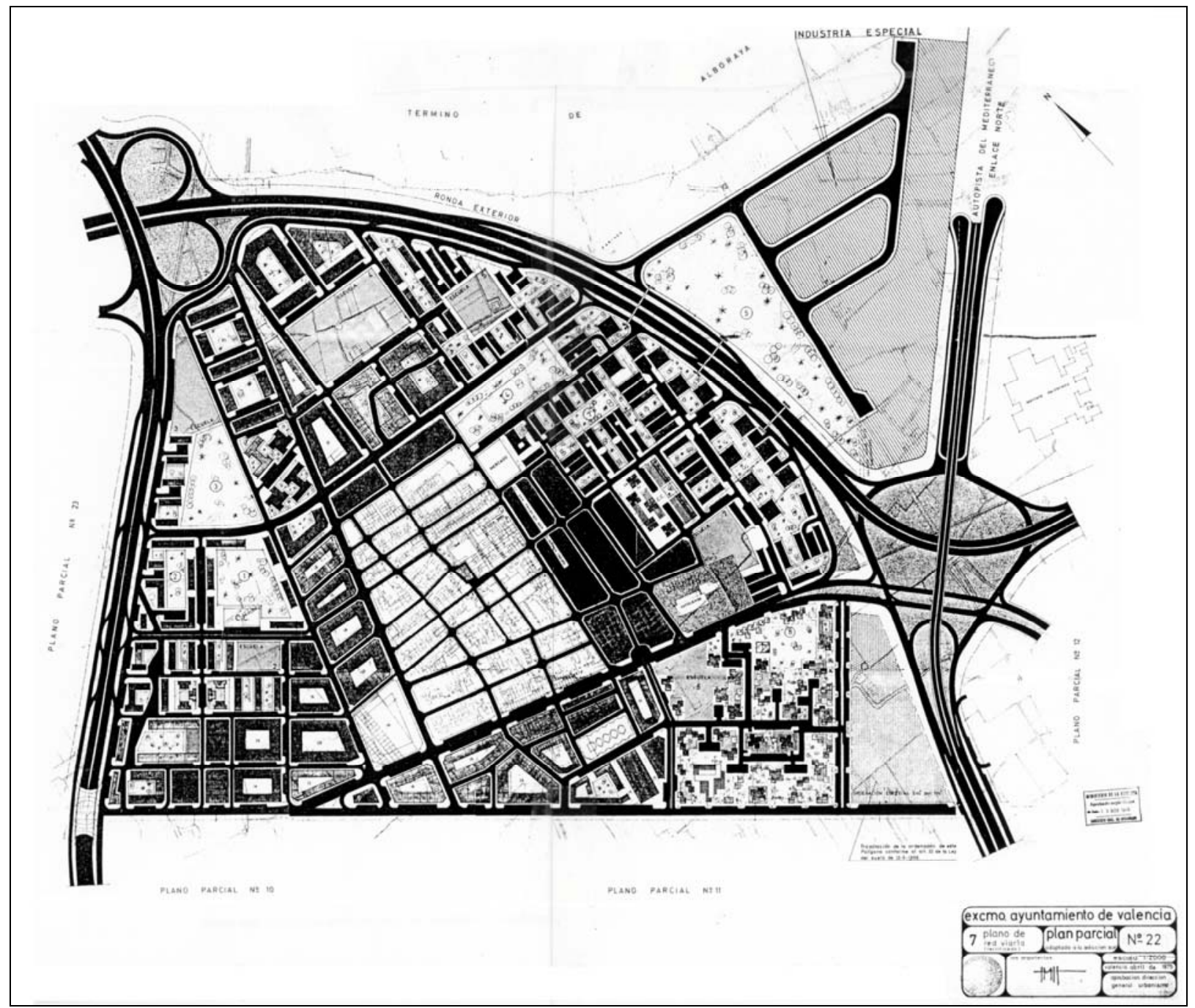


Redactor: El Arquitecto Municipal de Urbanismo. Ayuntamiento de Valencia.

Fecha: 18-02-1974

Asunto: Informe sobre la primera ronda de alegaciones presentadas a la versión inicial del Plano Parcial No 22.

Fuente: Ayuntamiento de Valencia. Sección de Urbanismo. Negociado de Suelo y Ordenación Urbana. Expte. 295/73. (Archivo de Planeamiento. No 136).

Expte. 295/73. S.y O.U.

El Arquitecto Municipal que suscribe, encargado del nuevo estudio del Plan Parcial No 22 en su adaptación a la Solución Sur, y tras el estudio de las reclamaciones formuladas al mencionado estudio tiene a bien informar lo siguiente:

No 4797.- Reclamación formulada por D.MANUEL BENITO GOMEZ, en representación de VALINPROSA.- Propone una nueva ordenación que respeta las alineaciones y mantiene el volumen asignado en el Plan. Considera por tanto el que suscribe, que debe accederse a lo que se solicita ya que se respeta, como se ha dicho, el volumen y las alineaciones fijados.

No 4846.- Formulada por D. MANUEL RUBIO GINER.- Solicitan mayor aprovechamiento de su parcela. Respecto a lo que proponen, el Técnico que suscribe considera que es abusivo ya que sobre la parcela en cuestión se le ha asignado un volumen aproximado de $8 \mathrm{~m} 3 / \mathrm{n} 2$. Por lo tanto, estimo que no se puede aceptar esta reclamación.

No 4900 .- ARTURO MIGUEL MONFORT.- Respecto a esta reclamación considero que debe desestimarse porque la zonificación es de Edificación Abierta según el Plan General, con un coeficiente de $5 \mathrm{~m} 3 / \mathrm{ci} 2$. En su día, podrán remodelar sobre esta base. EL resto de la manzana tiene esa forma para que permita construcciones suficientes como para cubrir las fachadas posteriores existentes. Debe pues, desestimarse esta reclamación.

No 5043.- EMILIO BELENGUER GIMENO.- Solicita reparcelación. Respecto a lo que solicita, considera el Técnico que suscribe que en su día podrá accederse cuando el Plan Parcial esté aprobado, entre tanto no puede accederse a ello. Además, no aporta plano de emplazamiento, por lo que ha sido imposible apreciar la situación de la parcela.

No 5082.- RAFAEL MAZARREDO IRIARTE.- Este. señor anuncia reparcelación en su día y reclama la mala situación de las escuelas. Visto que esta reclamación no afecta para nada al planeamiento previsto en el Plan Parcial, estimo que no es aceptable.

No 5083.- JOAQUIN PETIT ILLUECA.- Alega no estar ordenados los terrenos y expone la nulidad del acuerdo municipal que aprobó inicialmente el Plan. Considero que este extremo debería ser informado por la Asesoría Jurídica Municipal. $Y$, en cuanto al primer punto del escrito de reclamación, hemos de exponer que esta zona no está ordenada por estar situada en Zona Especial en el Plan General. Según la Norma 26, párrafo $2^{a}$, todas estas zonas serán objeto

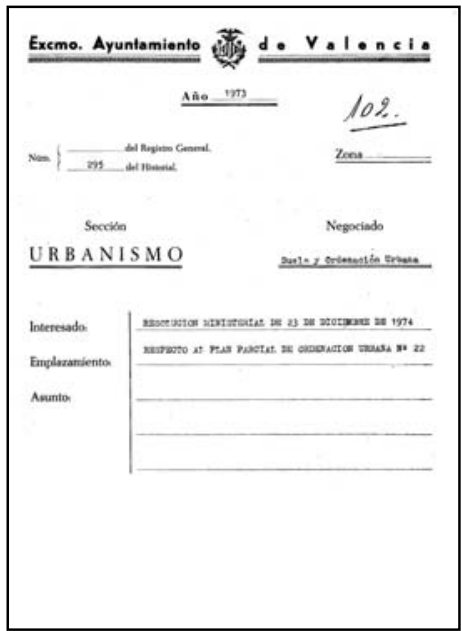




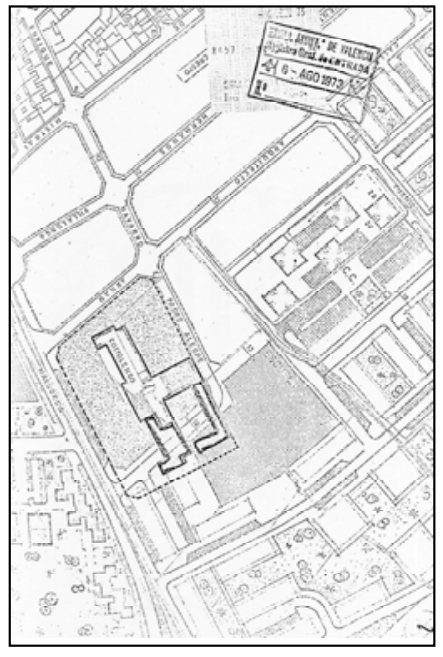

Alegación no 5013
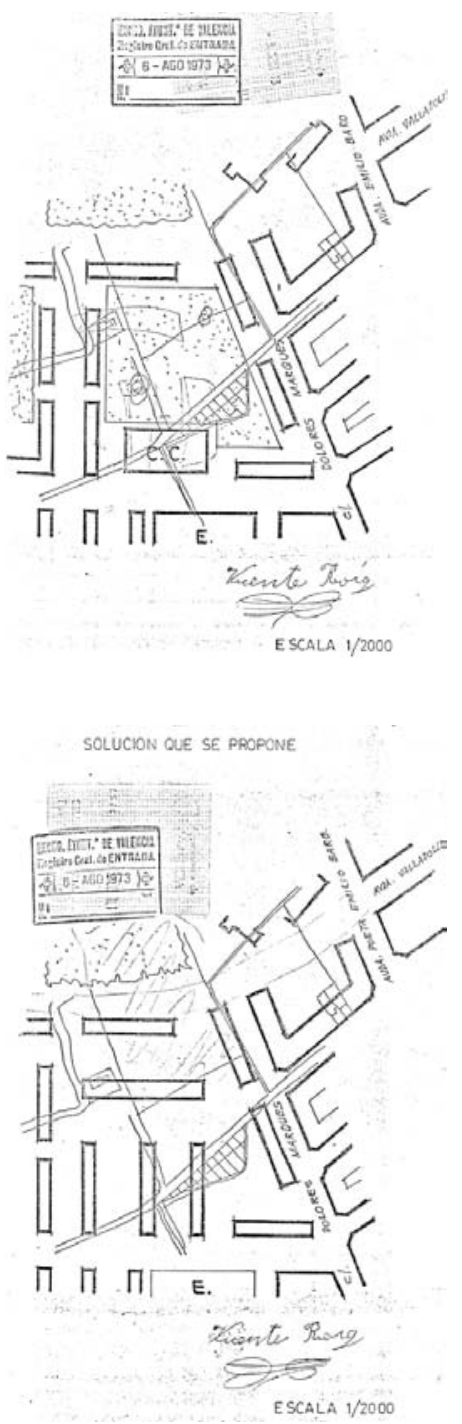

Alegación No 5117 de planes especiales, y por esta razón no ha sido, como queda dicho, ordenada la parcela del interesado.

No 5084.- VICENTE SOTO SOLER.- No aporta plano de emplazamiento ni dice nada referente a donde están situados sus terrenos. No obstante, esta alegación considero que debe ser informada por Asesoría Jurídica ya que los argumentos expuestos son jurídicos y no urbanísticos.

No 5013.- ISABEL GARCÍA MARTIN (Cotolengo del P. Alegre). Propone la reclamante nueva solución. Estima el Técnico que suscribe que debe aceptarse la solución que propone la interesa en su escrito, ya que estimo que no perjudica a terceros y se trata además, de una Institución Benéfica.

No 5115.- JOSÉ ALBERT GINER y otros.- Propone ordenación de la Zona Especial. Creo que en su día, podría accederse a lo que solicita, una vez haya sido aprobado el Plan Parcial y respetando los usos previstos en el Plan General.

No 5117.- VICENTE ROIG GINER.- Respecto a esta reclamación, no puede accederse a la solución que propone el interesado, de suprimir el centro comercial previsto en el Plan.

No 5118.- JOSE MARTI PEREZ. Manifiesta el interesado que se conSidera perjudicado por tener aprobadas dos grupos de viviendas subvencionadas. Entiende el Técnico que suscribe que debe denegarse esta reclamación ya que podrá construir uno de los dos grupos que tiene aprobados, por ser la otra parte de un terreno asignado a escuelas.

No 5119.- ELISA OLCINA DOMENECH - Solicita sea modificado un vial por zona industrial. No debe accederse a lo que propone por quedar las parcelas de un tamaño excesivamente irregular y afectar su solución a otros propietarios.

No 5134.- ENCARNACION BELLOCH FERRIOLS.- Solicita una modificación de forma del edificio para Colegio Mayor, manteniendo el volumen previsto en el Plan, de $5 \mathrm{~m} 3 / \mathrm{m} 2$. Puede accederse, a juicio del Arquitecto que suscribe, a la reclamación formulada ya que no afecta ni a viales ni hay incremento de volumen del previsto en el Plan Parcial.

No 5174.- MARÍA LUISA FERRER PASCUAL.- Expone que los daños son superiores a $1 / 6$ en el caso concreto de su propiedad. El Arquitecto autor del estudio de este Plan Parcial estima que a la parcela en cuestión y al bloque de la misma se le ha fijado un volumen de $5 \mathrm{~m} 3 / \mathrm{m} 2$, por lo que no hay perjuicio alguno. Estimo por tanto, que se debe desestimar esta reclamación.

No 5542.- JOSE BERMUDEZ DE CASTRO (RENFE).- No aporta plano de emplazamiento, no habiéndose podido apreciar el grado de afección de la parcela, pero dice estar gravada con una zona verde. Respecto a ésto, considero que no es aceptable la reclamación porque la zona verde a que alude no puede ser otra que la prevista en el Plan General, estando por consiguiente, fuera de tiempo esta reclamación.

No 5613.- RAMÓN ZARZO SANCHIS. Pretende en su reclamación, cambios que afectan al Plan General, por lo que ha de ser desestimada la misma.

No 5081.- OMAR FERRERES CARCELLER. - No aporta plano de empla zamiento, motivo por el cual fué citado para que informara sobre la ubicación de su parcela.

Estudiada la reclamación que formula el interesado, el 
Arquitecto que suscribe ha de proponer a V.E. sea desestimada la misma ya que se fundamenta en la gran afección a la parcela por una vía de tráfico rápido que separa este Plan Parcial del correspondiente a la signatura 23, y no en el planeamiento previsto al correspondiente a su reclamación.

Con cuanto queda expuesto, el Arquitecto Municipal que suscribe considera que han sido estudiadas las reclamaciones formuladas al Plan Parcial No 22, pudiendo por tanto éste continuar su trámite hasta su ulterior aprobación si procede.

V.E. no obstante, acordará como mejor proceda.

Valencia, 18 de febrero de 1.974

EL ARQUITECTO MUNICIPAL,

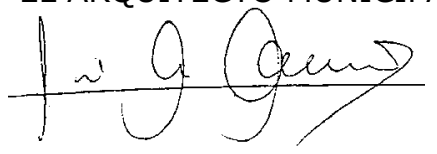

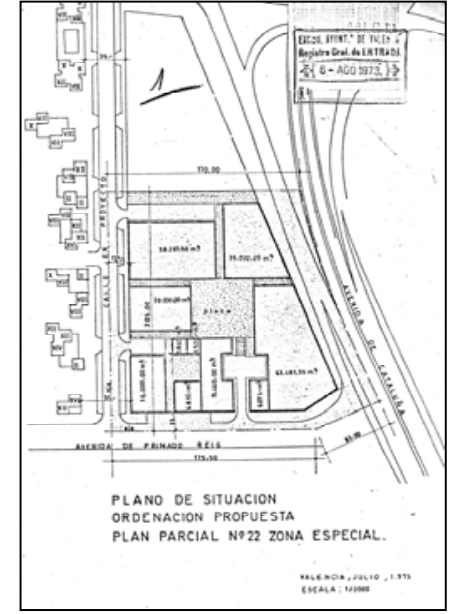

Alegación no 5115
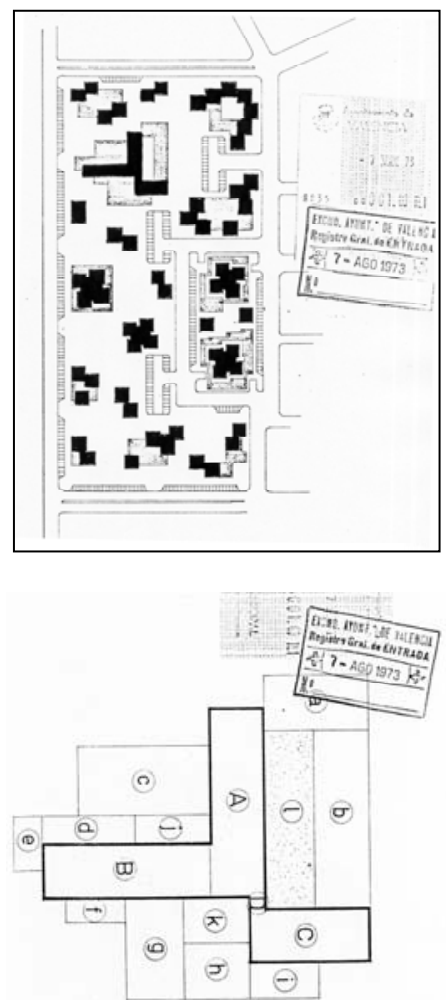

Alegación No 5134 
Redactor: Corporación Administrativa Gran Valencia.

Fecha: 3- 07-1974.

Asunto: Informe sobre el Plan Parcial No 22.

Fuente: Ayuntamiento de Valencia. Sección de Urbanismo. Negociado de Suelo y Ordenación Urbana. Expte. 295/73. Pag. 201 (Archivo de Planeamiento. No 136).

\section{INFORME DE LA OFICINA TÉCNICA GRAN VALENCIA}

Este Plan Parcial, limita por el Norte con la Ronda Exterior, por el Sur con la Avda. del primado Reig (Camino de Tránsitos), por el Este con el nuevo Acceso de Barcelona y por el oeste con el plan parcial no 23.

Estructura Viaria.- En el Plan general se preveía una vía fundamental Norte-Sur, que partiendo de la iniciación del paseo de la Alameda y lindando con el parque de los Viveros, se prolongaba en línea recta hasta Alboraya. A partir de la C/ de Vicente Zaragozá, las construcciones últimamente ejecutadas, en esta prolongación (actualmente $\mathrm{C} /$ de Dolores Marqués) hacen prácticamente imposible la ejecución de dicha vía Norte Sur. Entonces se ha sustituido, de acuerdo con la Red Arterial de Obras Públicas, por la que se sitúa en el límite entre el Plan 23 y el que nos ocupa. No hay inconveniente en aceptar esta modificación, ya que viene forzada por un hecho real, e indudablemente resuelve la comunicación con Alboraya y con la circunvalación Interior.

Zonificación.- En cuanto a zonificación, observamos que el triángulo limitado por Primado Reig, Calle Vicente Zaragozá, Avda. del Poeta Emilio Baró y límite con el Plan parcial no 23, en el Plan general está zonificado como "Edificación Abierta" La realidad es que las franjas de dicho triángulo, junto a Primado reig y la limitada entre Poeta Emilio Baró, Poeta Altet y Dolores Marqués, están en su mayor parte construidas, con manzanas cerradas con patio interior de manzana lo que desvirtúa el concepto fundamental de Edificación Abierta. Consideramos que es imposible y engañoso llamar a estas manzanas "Edificación Abierta". Lo mismo que se ha hecho con las manzanas situadas entre las calles Buenaventura pascual, Hermanos Villalonga, Arquitecto Arnau y Padre Alegre, que ante la realidad existente, de manzanas cerradas, se cambia la zonificación de "Abierta" a "Extensión Exterior a Tránsitos" debería hacerse con la zona a que anteriormente nos hemos referido. Esto, caso de considerar imposible la demolición de lo construido, para transformarse en una auténtica Edificación Abierta.

Zonas verdes de uso público y equipamiento.- Al situar la ronda exterior, tal como está replanteada en el terreno por Obras Públicas, la zona verde grafiada con el no 5 , ha quedado en su totalidad al Este de la mencionada Ronda. Lo cual no es ningún inconveniente, ya que de esta forma, queda totalmente aislada la Zona Industrial de la residencial. El total de Zonas Verdes previstas asciende a $203.550 \mathrm{~m} 2$. Lo que representa el $15,4 \%$ de la superficie total del Polígono que ocupa el Plan 22.

El equipamiento es correcto.

Valencia, 3 de Julio de 1.974.

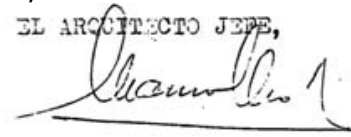


Redactor: Ministerio de la Vivienda.

Fecha: 23- 12-1974.

Asunto: Resolución de aprobación del PP 22 con rectificaciones.

Fuente: Ayuntamiento de Valencia. Sección de Urbanismo. Negociado de Suelo y Ordenación Urbana. Expte. 295/73. Pag. 193 (Archivo de Planeamiento. No 136).

MINISTERIO DE LA VIVIENDA

Ilmo Sr.:

VISTOS la Ley sobre Régimen del Suelo y Ordenación Urbana de 12 de mayo de 1.956, los Decretos 63/1968 de 18 de enero y 1994/72 de 13 de julio, y el informe emitido por los Servicios competentes de la Dirección General de Urbanismo.

Este Ministerio Acuerda aprobar el Plan Parcial precitado, en los mismos términos que lo fue por la Corporación Administrativa Gran Valencia, en la sesión celebrada por su Consejo General el 1 de agosto de 1.974, con las rectificaciones siguientes:

$1^{\circ}$.- Se amplía la calificación urbanística de Extensión Exterior a Tránsitos a las dos manzanas limitadas por la Avenida de Emilio Baró y calles Primado Roig y Vicente Zaragozá, que según el plano de estado actual, están casi en la totalidad construidas en manzana cerrada.

$2^{\circ}$.- para el polígono situado al sur del Plan Parcial delimitado por el Acceso Norte a. la autopista del Mediterráneo, Avda. de Primado Reig, calle Mallorca y calle en proyecto, que en la Memoria se somete a ordenación especial, se hace la observación de que dicha Ordenación deberá tramitarse con sujeción a lo establecido en el Art. 32 de la Ley del Suelo y que el volumen de edificación alcanzará $5 \mathrm{~m} 3 / \mathrm{m} 2$, solo en el supuesto de que el uso previsto lo requiera.

$3^{\circ}$.- Se fijará la superficie mínima para aparcamiento grafiando su respectiva situación y capacidad mínima de estacionamiento, siendo el número de ellas no inferior a una plaza por cada vivienda en todos los terrenos afectados por el Plan, con excepción de la zona limitada por la calle de Francisco Martínez Mistral, Vicente Zaragoza y Recreo y Avda. del Poeta Emilio Baró, y

$4^{\circ}$.- Se incorporará un estudio de pasos peatonales a distinto nivel sobre la Ronda Exterior, a fin de facilitar la utilización de la zona colindante a dicha Ronda.

Las determinaciones a que se refieren los apartados precedentes, así como las rectificaciones impuestas por la Corporación Administrativa Gran valencia, se incorporarán a la documentación correspondiente del Plan parcial que, por triplicado ejemplar, se elevará a este Departamento, en el plazo de tres meses para su constancia y estudio y resolución definitiva en lo que afecta a estacionamientos y pasos peatonales mencionados.

Esta resolución se notificará al Ayuntamiento de Valencia y se publicará en el Boletín Oficial del Estado.

Lo que comunico a V.I. para su conocimiento y efectos.

Dios guarde a V.I.

Madrid, 23 de Diciembre de 1.974

P.D.

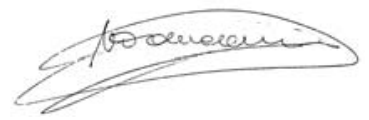

Ilmo. Sr. Director General de Urbanismo.- 
Redactor: Ministerio de la Vivienda.

Fecha: 19- 11-1975.

Asunto: Resolución de aprobación de las modificaciones introducidas en el Plan Parcial 22.

Fuente: Ayuntamiento de Valencia. Sección de Urbanismo. Negociado de Suelo y Ordenación Urbana. Expte. 295/73. Pag. 208 (Archivo de Planeamiento. No 136).

\section{MINISTERIO DE LA VIVIENDA}

Ilmo. Sr.:

VISTA la documentación del Plan parcial de Ordenación Urbana no 22 de Valencia, presentada por el Ayuntamiento de dicha capital, a tenor de la Orden Ministerial de 23 de diciembre de 1974 que al conocer el Plan, lo aprobó con modificación en la calificación urbanística de dos manzanas y con determinada observación en cuanto a tramitación y volumen asignable a la Ordenación especial que se prevé, y dispuso, al propio tiempo, que se realizase un estudio de pasos peatonales y aparcamientos, que debían ser sometidos a la aprobación de esta Departamento.

VISTOS las Leyes de 12 de mayo de 1.956 sobre Régimen del Suelo y Ordenación Urbana y de 2 de mayo de 1975 sobre reforma de la anterior, los Decretos 63/1968 de 18 de enero y 1994/72 de 13 de julio, y el informe emitido por los Servicios competentes de la Dirección General de Urbanismo.

Este Ministerio, considerando correctas las determinaciones contenidas en la documentación presentada, Acuerda declarar cumplida la obligación impuesta en su anterior resolución de 23 de diciembre de 1974 en lo referente a sus apartados $1^{\circ}$ y $2^{\circ}$, y aprobar, como parte integrante del referido Plan parcial, la solución de pasos peatonales y aparcamientos que ahora se presenta.

Esta resolución se notificará al Ayuntamiento de Valencia y se publicará en el Boletín Oficial del Estado.

Lo que comunico a V.I. para su conocimiento y efectos.

Dios guarde a V.I.

Madrid, 19 de Noviembre de 1.975 .

P.D.

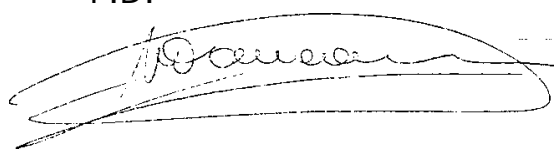

IImo. Sr. Director General de Urbanismo.- 


\section{PP 23}

PLANO PARCIAL No 23 (ADAPTADO A LA SOLUCIÓN SUR). 1967

Redactores: EXCMO. AYUNTAMIENTO DE VALENCIA. OFICINA TÉCNICA DE URBANISMO. ARQUITECTOS: Julio Bellot, Román Giménez, Cándido Orts. $(*)$

Fecha redacción: Enero 1967.

Fecha aprobación: O.M. 27-11-1968 (B.O.E. 9-01-69).(**)

Contenido: (Fecha documentos Enero 1967)

I. MEMORIA

II. ORDENANZAS $(* * *)$

III. PLANOS

1. PLANO DE SITUACIÓN DENTRO DE LA CIUDAD. $1: 10.000$

2. SITUACIÓN EN EL PLAN GENERAL $1: 22.500$

3. FOTOPLANOS

4. ESTADO ACTUAL Y DELIMITACIÓN $1: 2000$

5. ESTRUCTURA URBANÍSTICA $1: 2000$

6. ZONIFICACIÓN $1: 2000$

7. RED VIARIA FUNDAMENTAL (****)

8. ALINEACIONES (****)

9. REDES FUNDAMENTALES DE SERVICIO.
RED DE ALCANTARILLADO ESQUEMA DE RED DE AGUAS POTABLES. $\quad 1: 2000$ ESQUEMA DE ALUMBRADO. $1: 2000$

10. PLANO DE ETAPAS (****)

\section{Fuente:}

Ayuntamiento de Valencia. Sección de Urbanismo. Negociado de Suelo y Ordenación urbana. Expte. 339/1967. Reg. General 3.866 (Archivo de Planeamiento No OM-258).

\section{Notas:}

* Los nombres de estos arquitectos no figuran en los planos, sino únicamente en la portada del expediente del PP 8-B.

** Fechas del listado del Archivo de Planeamiento. Esta versión del PP 23 es la redactada una vez introducidas en la versión inicial las modificaciones derivadas de las alegaciones.

*** Las ordenanzas son las mismas que las incluidas en el PP 12.

**** Planos que no se aportaron al Plan enviado para su aprobación al Ministerio de la Vivienda: la subcarpeta que supuestamente los contenía estaba vacía, como indica la anotación ministerial.

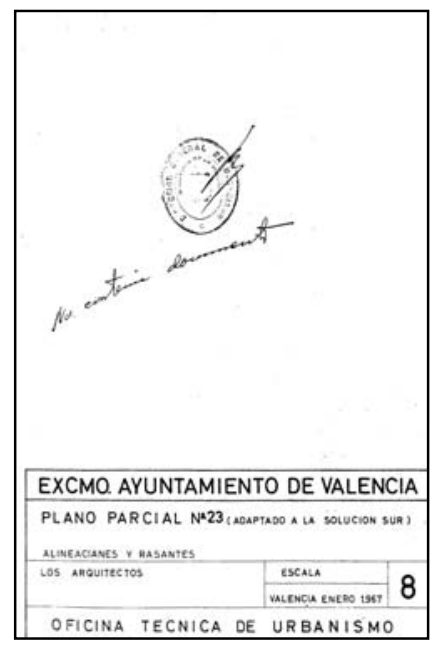




\section{EXCMO. AYUNTAMIENTO DE VALENCIA}

DESARROLLO DEL PLAN GENERAL DE ORDENACIÓN DE VALENCIA Y SU COMARCA, ADAPTADO A LA SOLUCIÓN SUR

PLANO PARCIAL NO. 8-B

\section{ME MOR I A}

\section{OBJETO DE ESTE ESTUDIO}

La redacción y aprobación en 30 de Junio de 1.966 del Plan General de Ordenación de Valencia y su Comarca, adaptado a la Solución Sur, ha traído consigo, además del cambio del Río y de algunos elementos, la sujeción a las nuevas exigencias del momento urbanístico, principalmente el que se refiere a tráfico de vehículos y aparcamiento de los mismos. Como consecuencia, la Jefatura de Obras Públicas en su Oficina Regional de Proyectos de Carreteras, redactó un estudio de todos los accesos a la Ciudad por carretera y las carreteras de tránsito y circunvalación, con gran anchura (80 metros en la mayor parte) y uniones a niveles distintos, con gran superficie, amen de la autopista por el cauce actual del Río.

Naturalmente, casi todos los planos parciales han resultado afectados con mayor o menor intensidad, no habiendo sido una excepción el que nos ocupa, por lo que el objeto de este estudio es la adaptación a las modificaciones precitadas, el establecimiento de los aparcamientos posibles, sin producir exceso de trastornos a la propiedad particular y pequeñas modificaciones parciales del esquema urbanístico para mejorar aspectos estrictamente necesarios

\section{JUSTIFICACIÓN DE LA ORDENACION}

Lo dicho anteriormente justifica ya por sí solo la ordenación propuesta, pero es que además el Plan General, aunque pretendiendo seguir en todo las zonificaciones establecidas en los planos parciales que el Ayuntamiento tenía redactados y en redacción, ha modificado pequeñas zonas, ha establecido zonas comerciales y ha añadido alguna zona periférica.

Todo ello se ha plasmado en la redacción del Plan Parcial presente y aunque parece que haya modificación sobre el Plan general, no es así ya que, en los polígonos que se forman en el Plan General, éste tiende a generalizar zonificaciones sin las particularidades que existían y deben continuar.

Los que hemos seguido atentamente la redacción del Plan General, sabemos que éste se ha trazado respetando al máximo lo establecido en los planos parciales anteriormente, o pendientes de aprobación.

Por todo ello la justificación de la ordenación es la de desarrollar el Plan General y adaptarse a él.

La única diferencia es que hemos establecido al N.E. un nuevo centro comercial, por creer que el establecido en el Plan General de frustrará por no tener posibilidad de zonas de aparcamiento y tener ya algunos edificios construidos. Por ello creemos que el futuro de este centro comercial será su construcción con edificios de viviendas y bajos comerciales. 
Por otra parte, situado en zona de manzanas cerradas, no es muy necesario, pues en estas manzanas todos los bajos se destinan a comercio por la iniciativa particular.

En el plano de este Plan Parcial se distinguen perfectamente las vías de gran tráfico de las de tráfico mediano y las de distribución.

En el mismo se diferencian claramente dos zonas de distinto carácter: Las actuales zonas construidas, compuestas de manzana cerrada que ocupa la mayor parte del centro del conjunto, y que se ha ordenado en lo posible, rectificando las alineaciones y el ancho de las calles principales, y la que por no haber construcciones de gran importancia se ha procurado ordenarla en un plan más orgánico colocándole los servicios y edificios públicos, espacios libres, aparcamientos, etc.

Dentro del presente proyecto en el aspecto de zonificación hay que distinguir tres clasificaciones: una de tolerancia industrial en la parte Oeste, prolongada con una zona industrial, otra, la central con zonificación de extensión exterior a Tránsitos y en los espacios libres que quedan en grandes edificaciones se han colocado Mercado, Centro Comercial, Edificios Religiosos y Escuelas, completándola con pequeñas zonas de edificación abierta. La tercera y última zona es la situada al Este, destinada la mayor parte de ella a edificación abierta y que, como hemos dicho anteriormente, se ha podido seguir un criterio urbanístico mas actual. Dentro de esta zona se sitúan espacios libres deportivos, grandes aparcamientos, edificios públicos, etc. En esta última zona se ha dispuesto grandes manzanas disponiendo calles en fondo de saco o quebradas, para distribuir el interior de las mismas y poder llegar a los edificios.

Se han proyectado centros comerciales, pudiendo construirse en ellos mas de dos metros cuadrados por habitante.

Se ha reservado terreno para Escuelas.

Se ha reservado terreno para aparcamientos.

Se ha reservado terreno para jardines.

Se ha reservado terreno para centros religiosos.

En todo ello se ha procurado que domine la prudencia, si bien es cierto que no señalar el futuro emplazamiento de algún edificio público, compromete su futura situación, también es cierto que señalar mas elementos que los que se prevé que el Municipio construya, o por lo menos adquiera los terrenos, tiene él inconveniente de se cumpla lo establecido en el arto 56 de la Ley del Suelo sobre recobro del libre ejercicio de las facultades dominicales.

La superficie que abarca el Plan, desde el eje de las calles que lo limitan, es de 192,10 $\mathrm{Ha}$.

La superficie de edificación destinada a viviendas es de 2.722.938 metros cuadrados, lo que destinando a cada vivienda $100 \mathrm{~m} 2$, incluidos patios y escaleras, da un total de 27.229 viviendas.

El número de habitantes, calculando un promedio de cuatro habitantes por viviendas, es de 108.916 habitantes.

La densidad del polígono será de 565 habitantes por $\mathrm{Ha}$. Aproximadamente.

La superficie de aparcamientos, considerando que el barrio es de condición modesta, es de 20 metros cuadrados por cada cinco viviendas, lo que daría una superficie de 108.916 metros cuadrados. La superficie destinada especialmente para aparcamientos en elPlan, es de 94.461 metros cuadrados, sin contar los aparcamientos que se sitúan en las vías importantes que, de incluirlos, rebasarían con mucho la cifra necesaria. 
La superficie de espacios libres es de 167.033 metros cuadrados. En esta cifra se refleja en hecho que en el casco actual no existe espacio libre alguno.

La superficie destinada a edificación abierta, es de 428.205 metros cuadrados: $Y$ el volumen de edificación es de 2.021.542 metros cúbicos, lo que supone 4,75 metros cúbicos por metro cuadrado, inferior a los cinco metros cúbicos por metro cuadrado necesarios.

La superficie de terrenos destinada a zona de "Extensión Exterior a Tránsitos" es de 347.929 metros cuadrados.

La superficie destinada a Tolerancia Industrial, es de 113.684 metros cuadrados.

La superficie destinada a Zona Industrial, es de 117.293 metros cuadrados.

La población escolar, incluido maternales, es del $15 \%$ de la población, o sea, 16.337 escolares, lo que a razón de $6 \mathrm{~m} 2$ por alumno, se necesitarían 98.024 metros cuadrados. En el presente plan se ha alcanzado la cifra de 18.703 metros cuadrados, notoriamente inferior a la necesaria, a pesar de haber dotado todas las agrupaciones nuevas con sus correspondientes escuelas. Ello es debido en gran parte porque el núcleo actual de población tiene resuelto en parte esta necesidad por medio de escuelas en edificios no especiales y de colegios oficiales situados en las manzanas construidas, particulares y religiosos.

En documentos aparte se desarrollan las Ordenanzas de uso de los terrenos y edificación, planos topográficos, de ubicación, de alineaciones y ordenación, así como los esquemas de servicios de agua, alcantarillado y alumbrado.

\section{ETAPAS}

Siendo este plan parcial destinado, por el momento, a la edificación por particulares, no pueden marcarse etapas de realización que dependerán de la actividad constructiva de los mismos. Sin embargo, el Excmo. Ayuntamiento, además de construir los elementos urbanísticos generales en una primera etapa, se mantendrá siempre en la urbanización adelantando sobre la iniciativa particular, urbanizando zonas que se prevea edificación inmediata.

\section{MEDIOS ECONÓMICOS FINANCIEROS}

Son los del presupuesto ordinario de Urbanismo del Excmo. Ayuntamiento de Valencia y los extraordinarios que se establezcan a medida que se cumpla lo dicho en el párrafo anterior y se disponga de proyectos detallados de urbanización.

Con lo dicho creemos suficientemente expuesto el alcance del estudio realizado para que, si el Excmo. Ayuntamiento lo estima conveniente, lo eleve a la aprobación por la superioridad.

Valencia,

EL ARQUITECTO MUNICIPAL,

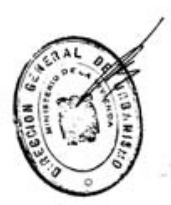


1. PLANO DE SITUACIÓN EN LA CIUDAD

Escala original: $1: 10.000$

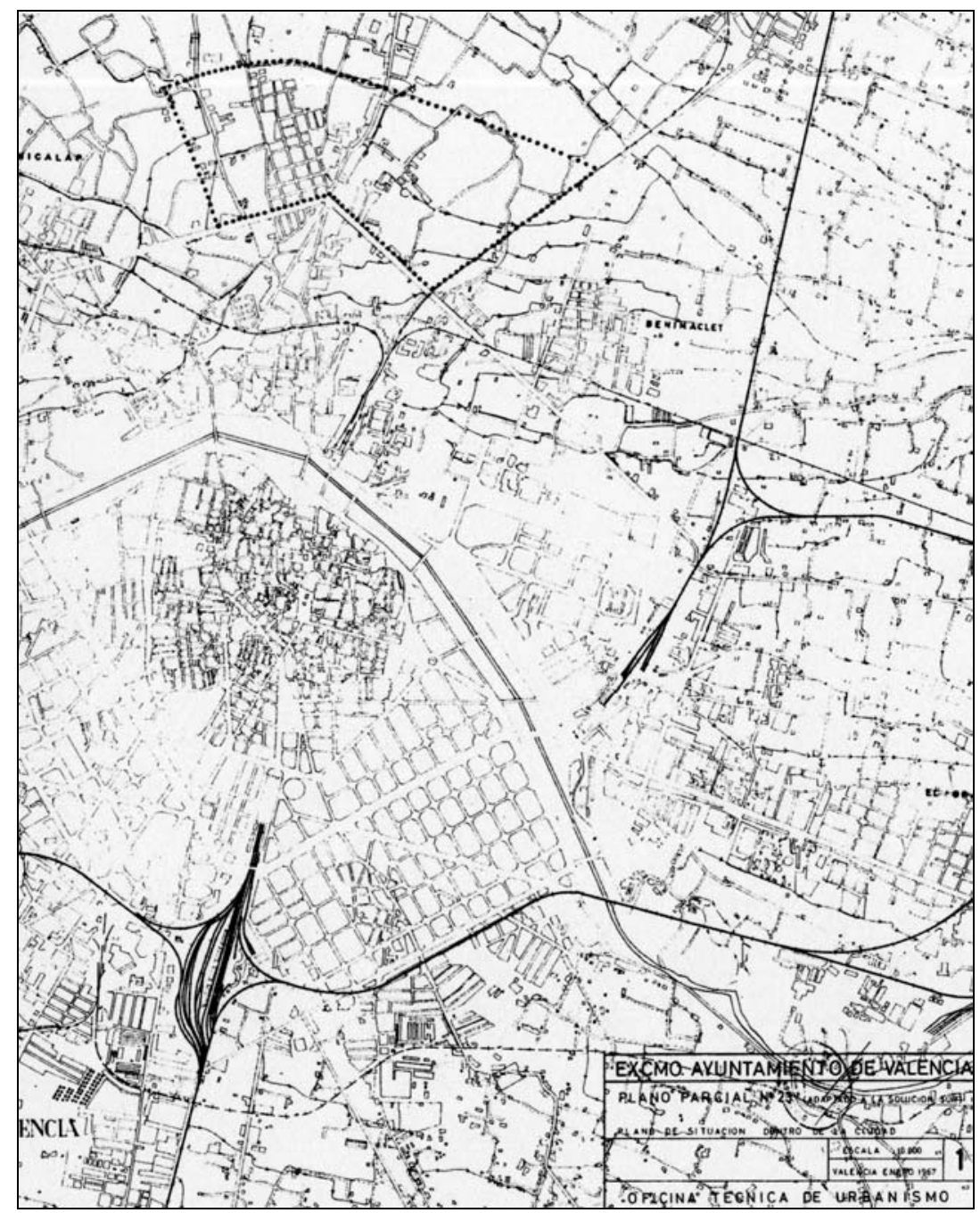

2. PLANO DE SITUACIÓN EN EL PLAN GENERAL (Fragmento) Escala original: 1:22.500

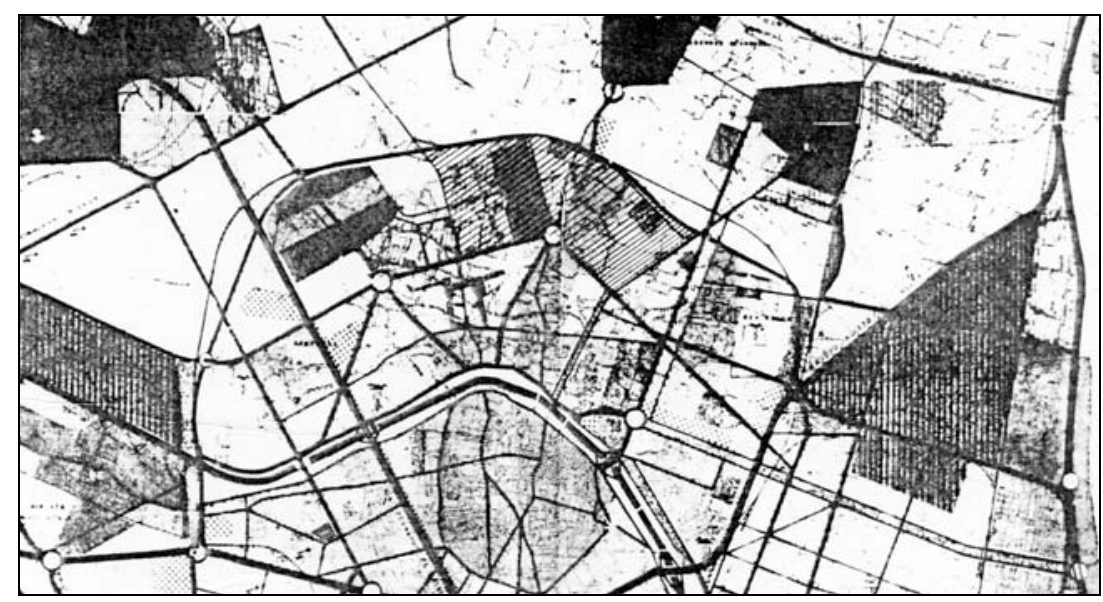


3. FOTOPLANOS
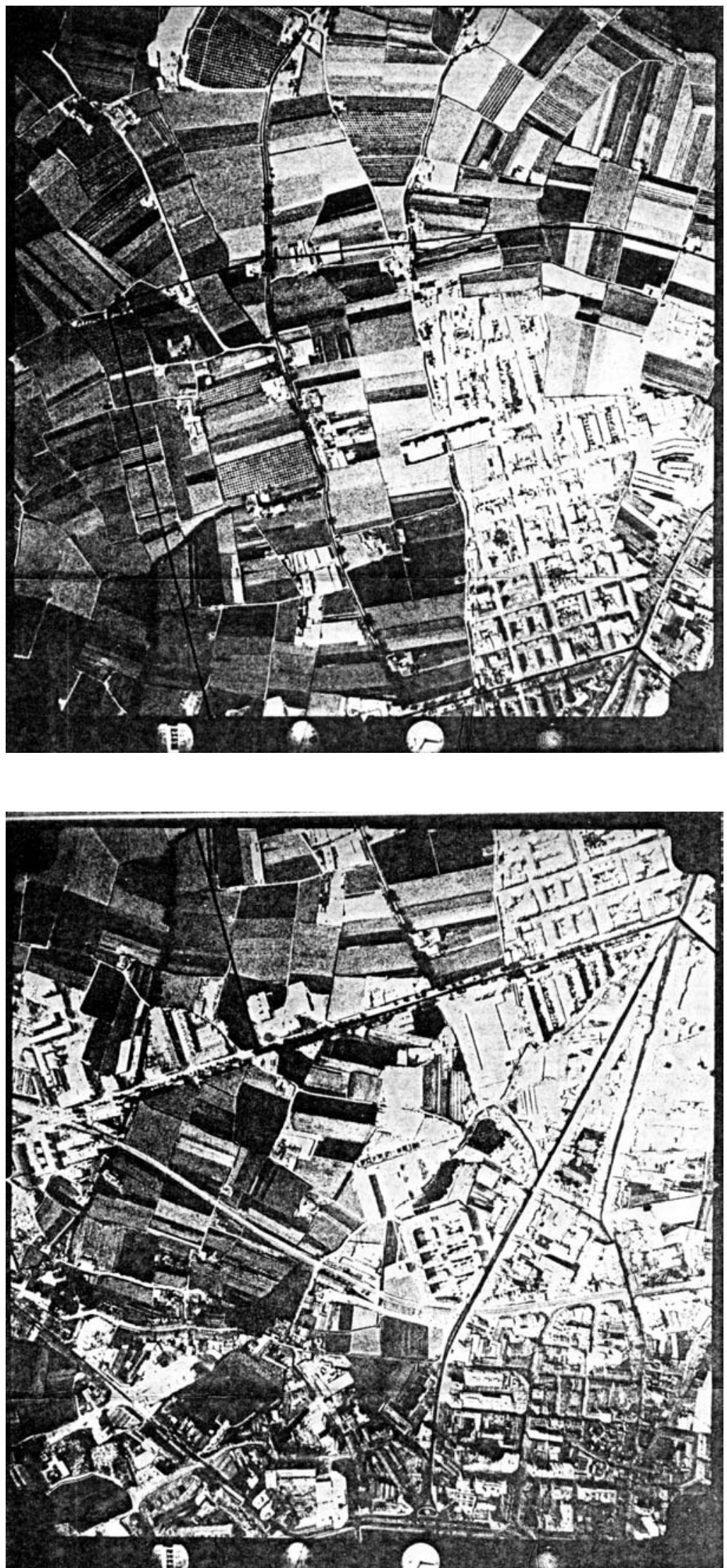

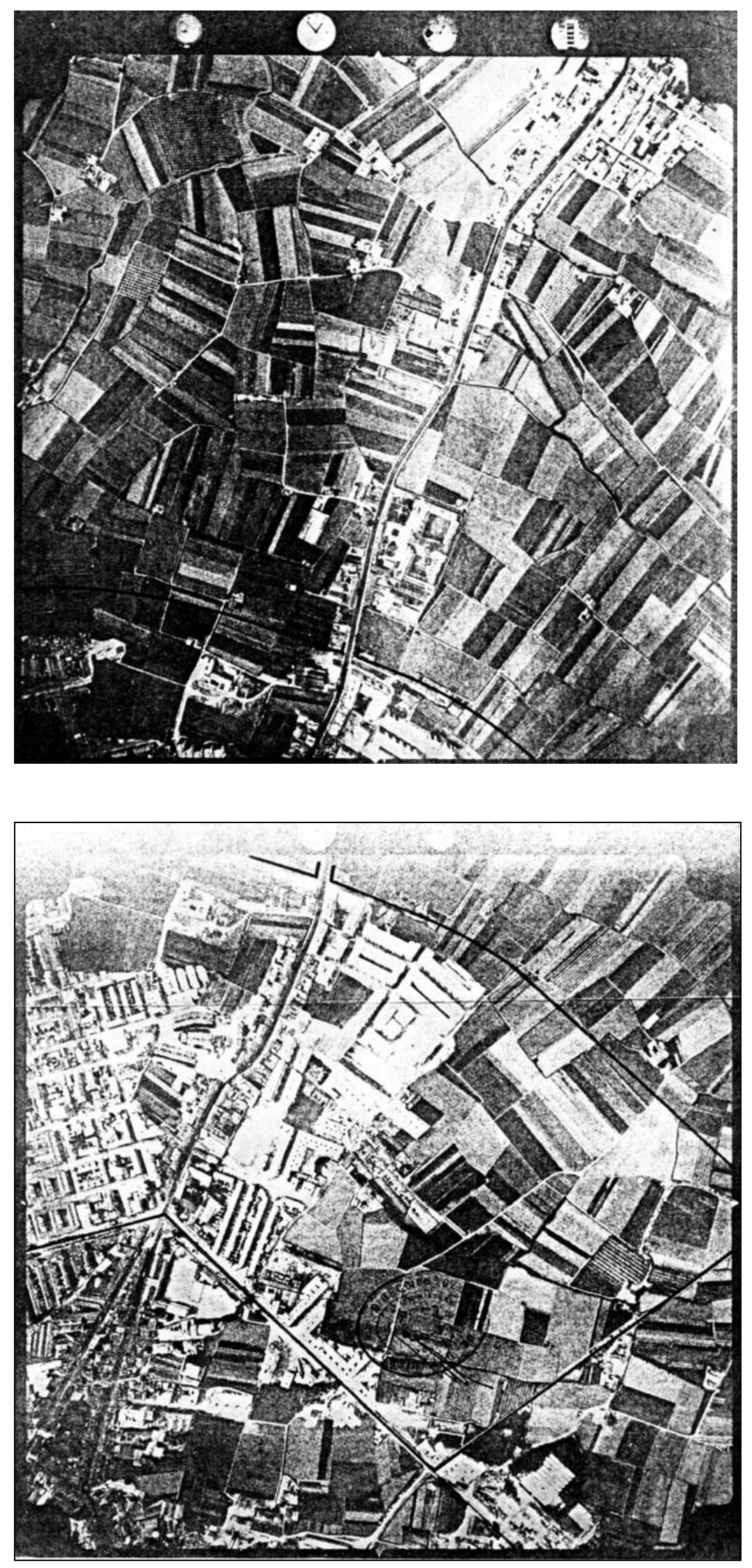
4. ESTADO ACTUAL Y DELIMITACIÓN

Escala original: 1:2000

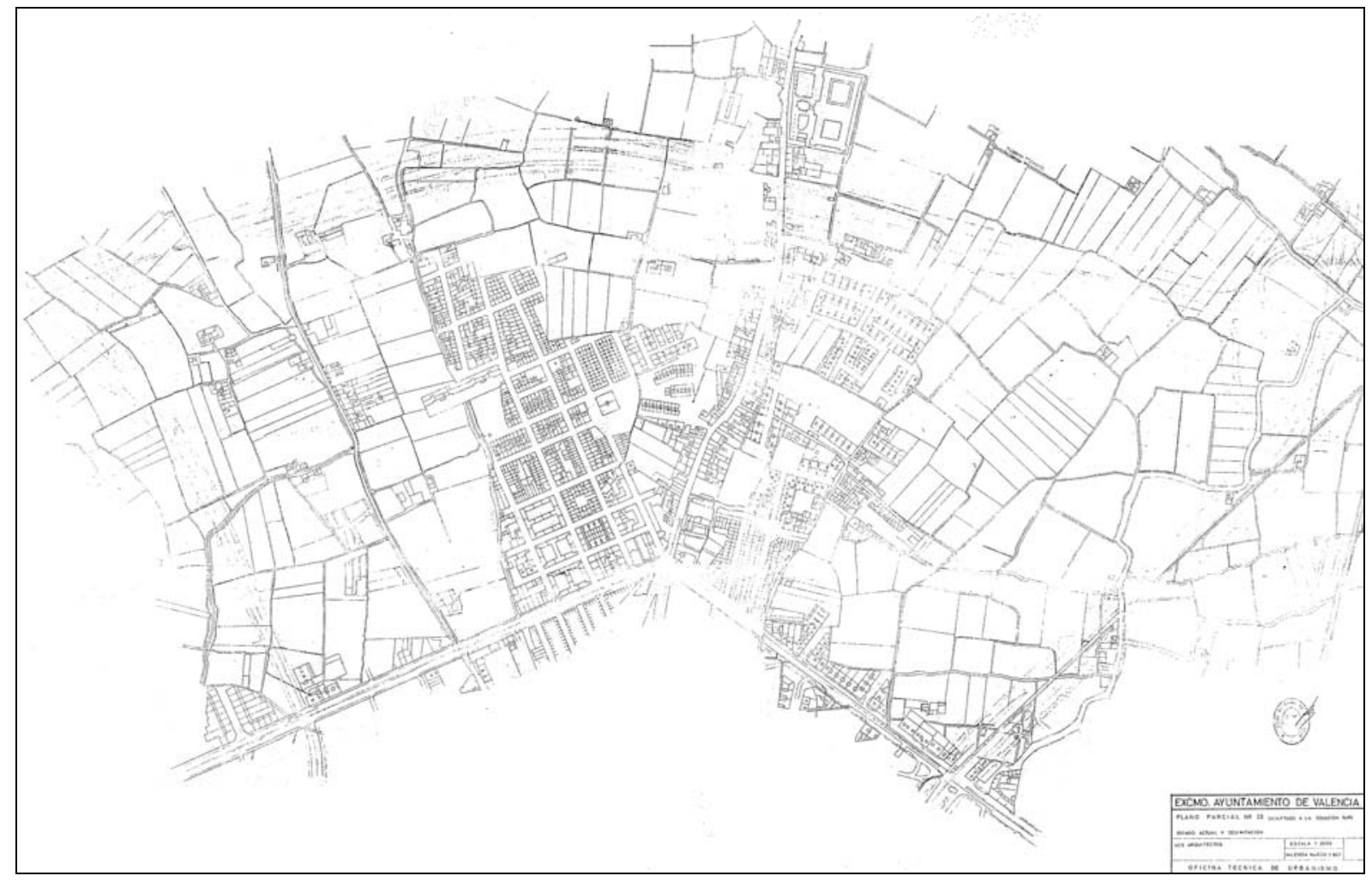

\section{ZONIFICACIÓN}

Escala original: 1:2000

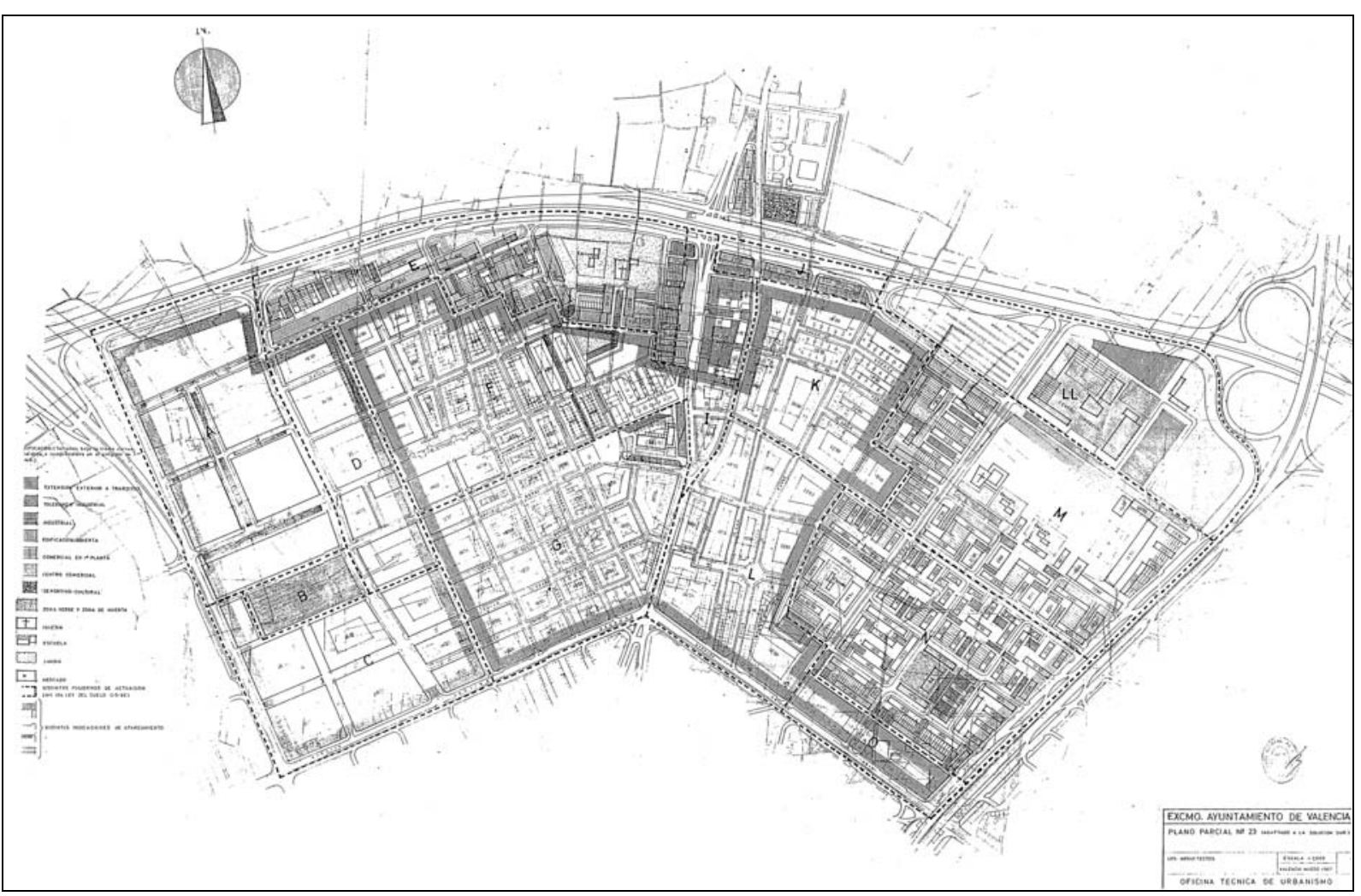




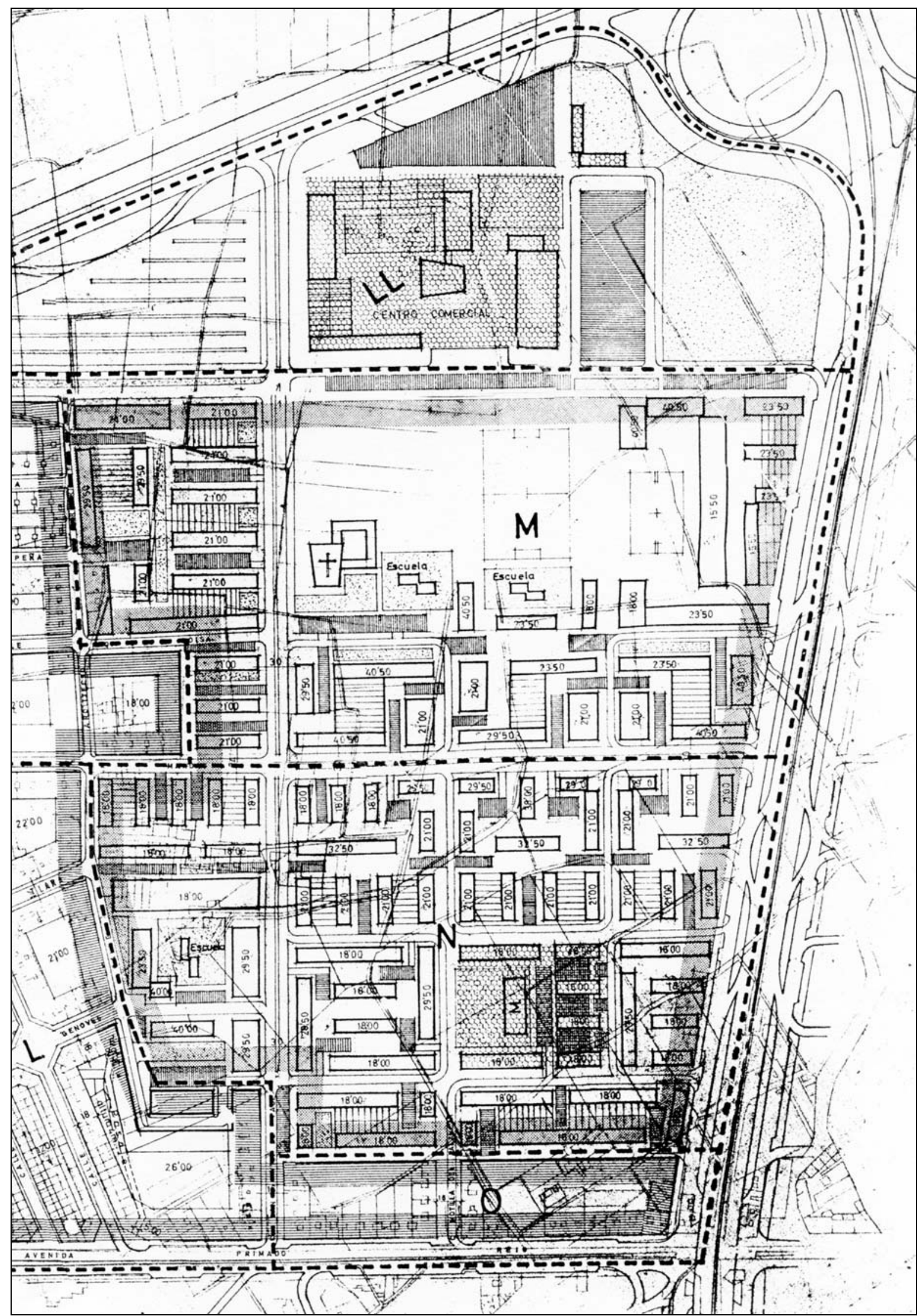

Detalle del Plano de zonificación. Zona este. 


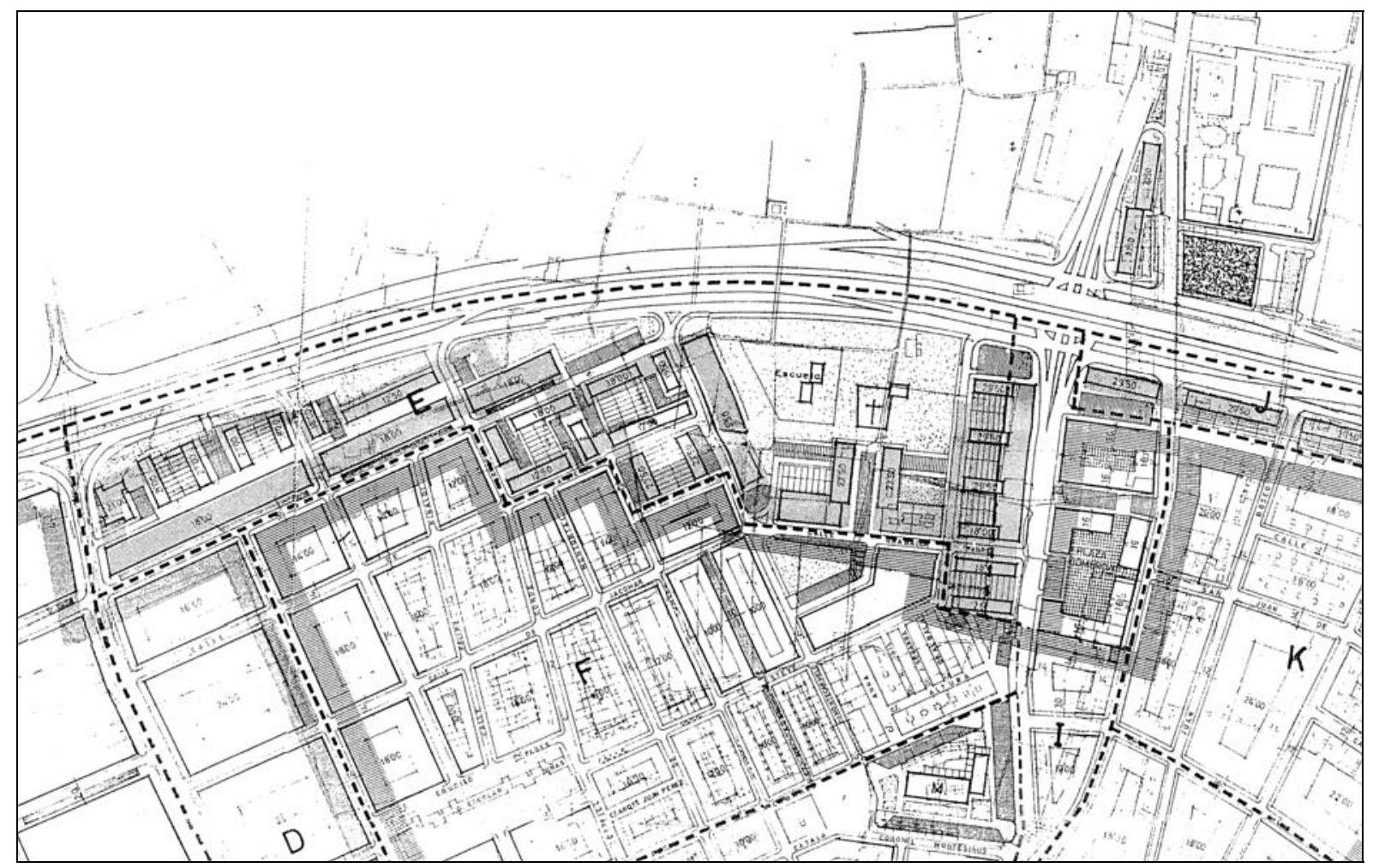

Detalle del Plano de zonificación. Zona noroeste. 
Redactor: El Arquitecto Mayor. Ayuntamiento de Valencia.

Fecha: 23-11-1967.

Asunto: Informe sobre reclamaciones presentadas al PP23.

Fuente: Sección de Urbanismo. Negociado de Suelo y Ordenación Urbana. Expte. 339/1967. Reg. General 3.866 (Archivo de Planeamiento No OM-258).

El Arquitecto que suscribe, a la vista de las reclamaciones presentadas al proyecto de Plan Parcial no 23, tiene el honor de informar:

Reclamación de Hijas de Maria Auxiliadora:

Estimo que puede aceptarse, pero mejor todavía que en la forma que se indica en la reclamación sería suprimiendo salida de vehículos al camino de Barcelona y dejando en lugar de calle un paraje de 6,00 metros de anchura, ensanchando el actual de 2,00 metros por ambas partes. Se une croquis de solución.

\section{Reclamación de don Joaquín Vila-Belda Estellés}

Es porque queda poco espacio edificable en sus terrenos y mucha vía pública. Es cierto. Por ser zona límite de plano después de los 80,00 metros de la carretera se establece una amplia acera ajardinada, de tal manera que entre carretera y acera ocupan casi toda la parcela. Sin embargo, el reclamante, con gran espíritu de comprensión, solo reclama la supresión de un retranqueo en la esquina que estimo puede atenderse. Se une croquis de la solución.

\section{Reclamación de don Narciso Rodrigo Molins}

Pide mayor edificabilidad para no salir tan perjudicado. Visto resulta que tiene edificabilidad parecida a otras parcelas y la edificabilidad complementaria que solicita está sobre aparcamiento, por lo que debe denegarse. Veo sin embargo que podría favorecerle, sin gran perjuicio, como se indica en el croquis adjunto.

\section{Reclamación de don Salvador Martí Garcés}

Se refiere a la Avenida de Ramiro Ledesma, a partir de la Ronda Exterior hasta San Miguel de los Reyes.

Es cierto que el Plan General tiene zonificación, pero en el Plan General Reformado esta zonificación es zona Deportivo Cultural y no huerta como erróneamente se ha marcado en el Plan Parcial. Al otro lado de la Avenida, es edificable también con zonificación de Edificación Abierta. Se unen dos croquis de solución del Plan Parcial.

\section{Reclamación de don Jaime Bofill Campmajó}

Tiene dos partes: una relativa a calles y manzana recayentes a calle de San Vicente de Paúl. Son pequeñas rectificaciones de alineación que se plasman en croquis adjunto; la otra parte de la reclamación es sobre ancho de calle de Alfahuir, que ha pasado de 30 a 80 metros. No puede atenderse desde el Ayuntamiento, porque forma parte de la Red de Carreteras y accesos de Obras Públicas, debiendo, en todo caso, consultarse a la Oficina de Proyectos de Carreteras del Ministerio de Obras Públicas en Valencia.
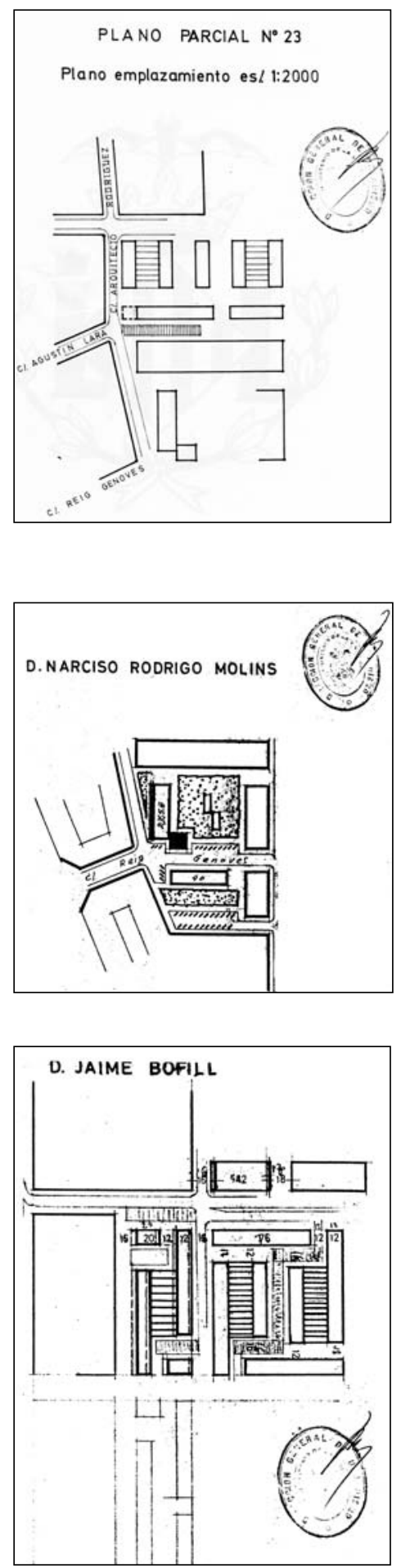

Reclamación de don Antonio Bauset Monreal 
D. VICENTE ANTONIO BAUSET (1)
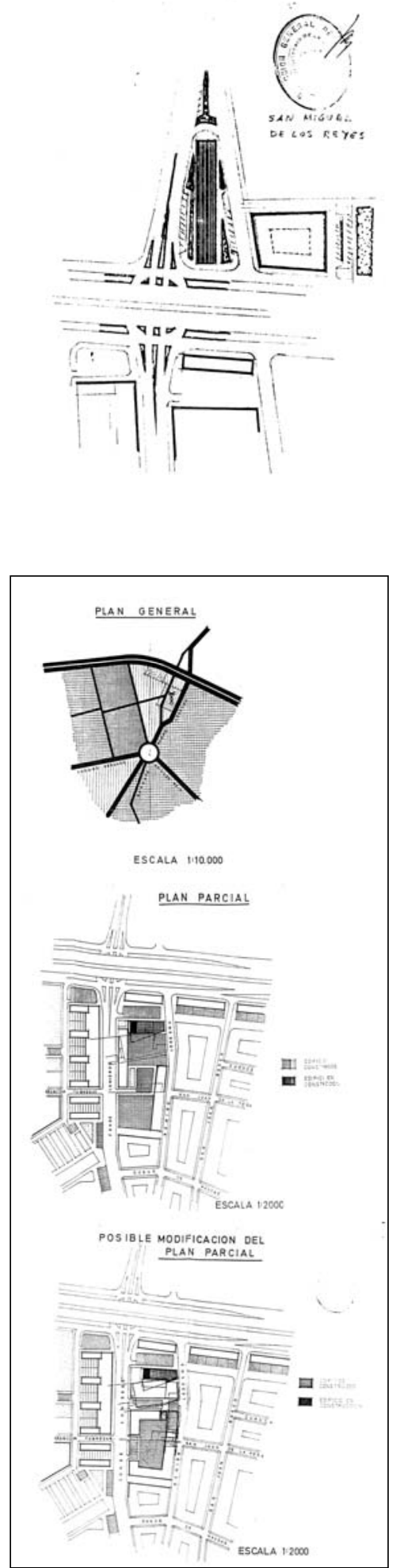

Se refiere también al trazado de la carretera circunvalación, que daría lugar a la expropiación de Estación de Servicio concedida, que forma parte de la Red de Carreteras y accesos proyectados por la Oficina de Proyectos del Ministerio de Obras Públicas en Valencia.

No puede pues aceptarse desde el Ayuntamiento $y$, en todo caso, debería consultarse a la precitada Oficina de Proyectos de Carreteras.

Reclamación de doña Carmen Giner Miralles

Asegura que es principio fundamental de Urbanismo que las calles que embocan a otra enfrenten. Con ello tendría que ser desplazada la calle de Agustín Lara o Coronel Montesinos. Esta última tiene su dirección marcada ya por edificaciones. La calle de Agustín Lara, al desplazarse liberaría de la expropiación algunas casas, pero caería sobre obras. No conocemos tal principio, sino al contrario: Conviene que las calles secundarias no se enfrenten al embocar con otra principal, si ésta es de gran tráfico.

Por todo ello estimo que no puede atenderse la reclamación.

\section{Reclamación de don José Real Sales}

Es por quedar en Centro Comercial un edificio de viviendas subvencionadas ya ocupado. Al desarrollar el proyecto de Centro comercial, no cabe duda que tendrá que tenerse en cuenta esa realidad existente, tanto mas cuanto que las viviendas no son incompatibles con el Centro Comercial. Además este Centro Comercial habrá de ser modificado según acuerdo de 30 de octubre de la Comisión Permanente.

Por todo ello estimo deberá tenerse en cuenta cuando se haga el estudio de Centro Comercial y no ahora.

\section{Reclamación de don Ángel Marzal Carsí.}

Sugiere otras formas para la manzana recayente a Primado Reig, entre calles del Padre Viñas y San Vicente de Paúl. Su aceptación no desvirtuaría el plano, urbanísticamente son formas equivalentes la proyectada y la sugerida.

Valencia 23 de noviembre de 1967.

El Arquitecto Mayor,

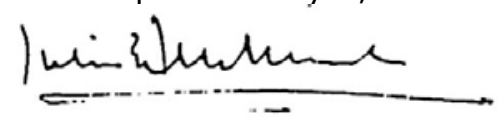


Redactor: Dirección General de Urbanismo del Ministerio de la Vivienda / Ministerio de la Vivienda.

Fecha: 30- 10-1968.

Asunto: Resolución de aprobación del Plan Parcial 23 con modificaciones.

Plano adjunto: Zonas excluidas de aprobación.

Fuente: Sección de Urbanismo. Negociado de Suelo y Ordenación Urbana. Expte. 339/1967. Reg. General 3.866 (Archivo de Planeamiento No OM-258).

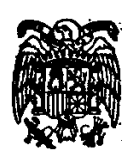

MINISTERIO DE LA VIVIENDA

Dirección General de Urbanismo.

Ilmo Sr.:

El Excmo. Sr. Subsecretario del Ministerio de la Vivienda, actuando por delegación del Excmo. Sr. Ministro, con fecha 27 de los ctes., me dice lo siguiente:

"VISTO el Plan Parcial de Ordenación Urbana no 23, de Valencia, adaptado al vigente Plan General revisado de dicha localidad, presentado por el Ayuntamiento de Valencia, y VISTO el informe emitido por los servicios competentes de la Dirección General de Urbanismo, Este Ministerio, teniendo en cuenta lo dispuesto en la vigente Ley sobre Régimen del Suelo y Ordenación Urbana de 12 de Mayo de 1.956, en el Decreto 63/1.968, de 18 de enero, en el Plan general de Ordenación Urbana de Valencia y su Comarca aprobado por Decreto de 30 de junio de 1.966, y que el Plan Parcial presentado se ajusta a las determinaciones del Plan General excepto en las zonas destinadas a aparcamientos, centro comercial y uso escolar, que modifican una zona verde, Acuerda aprobar el referido Plan Parcial, excluyendo de esta aprobación las indicadas zonas que habrán de ser objeto de nuevo estudio y cuya ordenación deberá ser resuelta de modo que se respete la zona verde antes mencionada. La nueva solución de las citadas zonas deberá someterse a la tramitación establecida en el artículo 32 de la Ley del Suelo. Esta resolución deberá ser notificada al Ayuntamiento de Valencia."

Contra esta resolución cabe la interposición, en el plazo de un mes a contar desde la fecha de notificación de la presente, del recurso de reposición; y en su día, el contencioso-administrativo que habrá de interponerse ante el Tribunal Supremo, en el plazo de dos meses contados desde el día siguiente a la notificación del acuerdo resolutorio del recurso de reposición, si es expreso, ó, si no lo fuere, en el plazo de un año a contar de la fecha de interposición del recurso de reposición.

Lo que comunico a V. I. para su conocimiento y efectos.

Dios guarde a V.I. muchos años. 
Madrid, 30 de Noviembre de 1.968.

EL DIRECTOR GENERAL.

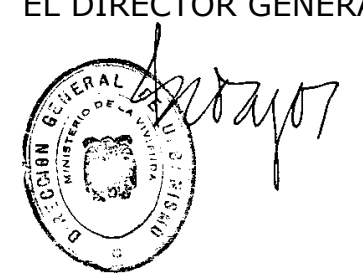

Ilmo. Sr. Alcalde Presidente del Ayuntamiento de VALENCIA.

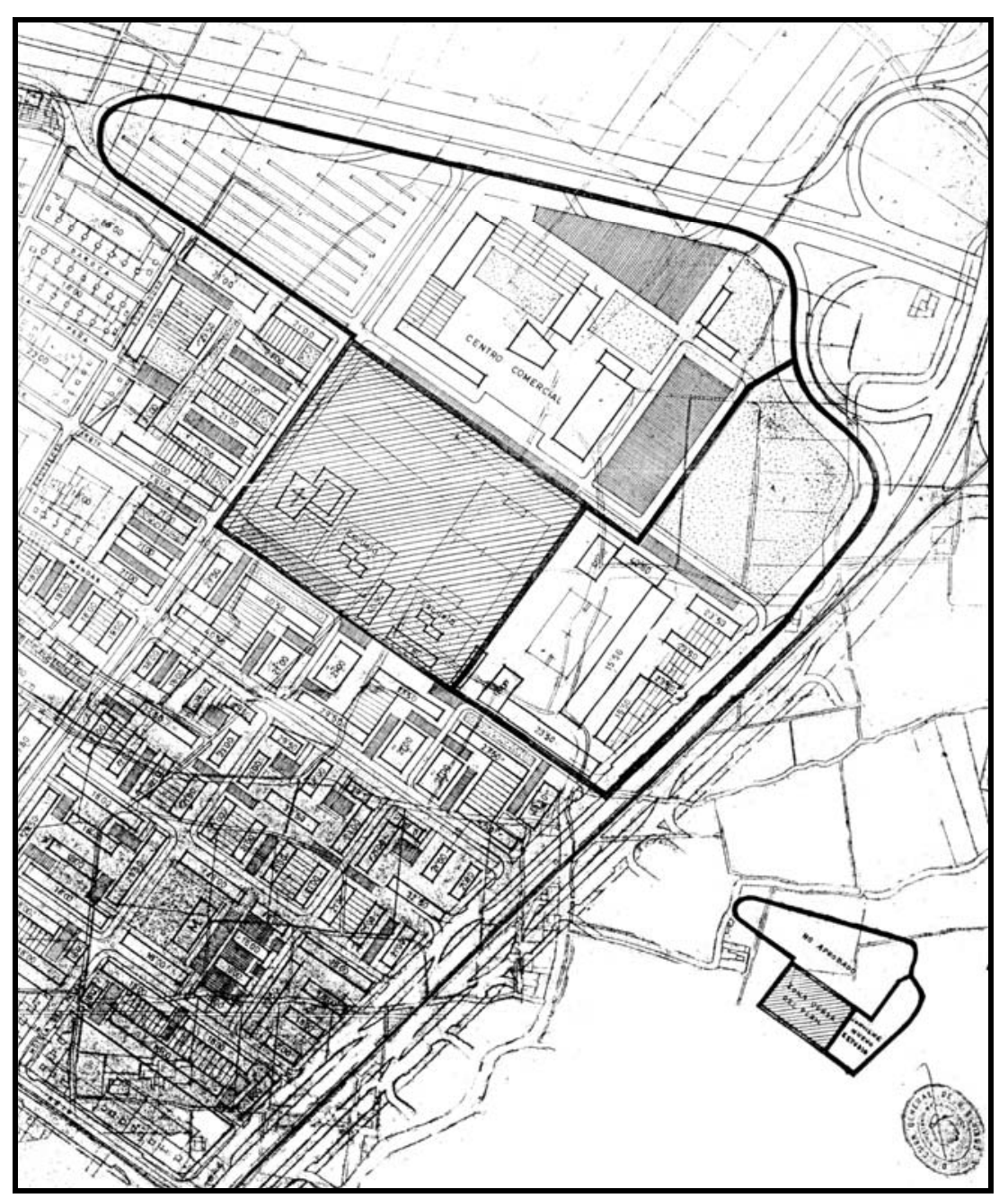


Redactor: AYUNTAMIENTO DE VALENCIA. Oficina Técnica de Urbanismo.

Fecha: Febrero 1969.

Asunto: Modificación del PP23.

Plano Adjunto: Modificación zona norte del PP23.

Fuente: Sección de Urbanismo. Negociado de Suelo y Ordenación Urbana. Expte. 339/1967. Reg. General 3.866 (Archivo de Planeamiento No OM-258).

\section{MODIFICACION DEL PLAN PARCIAL NO 23 (BARRIO TORREFIEL)}

\section{MEMORIA}

En la aprobación del Plan Parcial no 23 por el Ministerio de la Vivienda, se dejó, por el mismo, fuera de la aprobación, "la zona destinada a aparcamiento, centro comercial y uso escolar que modificaba una zona verde", esta zona que ahora se ordena siguiendo las indicaciones del Ministerio.

En el nuevo esquema se deja completamente libre la zona verde que se manifiesta en el Plan General de Ordenación de Valencia y su Comarca, adaptado a la Solución Sur, quitando de él las escuelas y el Centro Religioso.

Se completa esta zona verde con otra al Norte de carácter privado destinada a Escuelas, que toman muy poca superficie comparativamente, y un enorme campo de deportes escolares para uso de los escolares valencianos.

Se ubica en la zona en estudio el nuevo campo del Levante U.D., ya que la redacción y gestión del Plan Parcial no 23 fue simultánea a la gestación de la idea y compra de terrenos para ubicar el campo de fútbol indicado, hecho ignorado por el autor del plano que suscribe, que ahora rectifica con la introducción de tan deseable elemento deportivo.

Por último, a instancia de la Jefatura de Industrias de Valencia, se ubica instalación para reconocimiento de Camiones.

La zona comercial, como aneja a este Plan Parcial, no es realmente necesaria, porque, siendo edificación, en general, cerra$\mathrm{da}$, todos los bajos, tradicionalmente son comercios o pequeñas industrias. No podemos decir lo mismo de zona comercial que sirva a toda la ciudad, una o varias, de llegada en vehículos automóviles. Estas zonas comerciales que se van imponiendo podrán establecerse, en cualquier momento en cualquier terreno despejado junto a una gran circunvalación. Por el momento creemos preferible prescindir de la misma.

Se presenta plano de proyecto de la modificación.

Todos los demás documentos del apartado 2) del arto.- 10 de la Ley del Suelo, relativos a: Medios económico-financieros; etapas; planos de información; esquemas de servicios y Ordenanzas reguladoras, no se redactan porque sirven los mismos del Plan Parcial, que no resultan variados sustancialmente por este proyecto de modificación.

Con lo dicho creemos suficientemente expuesto el alcance del estudio realizado para que, si el Excmo. Ayuntamiento lo estima 
conveniente lo eleve a la aprobación por la superioridad.

Valencia, febrero de 1.969

EL ARQUITECTO MAYOR,

Inindun
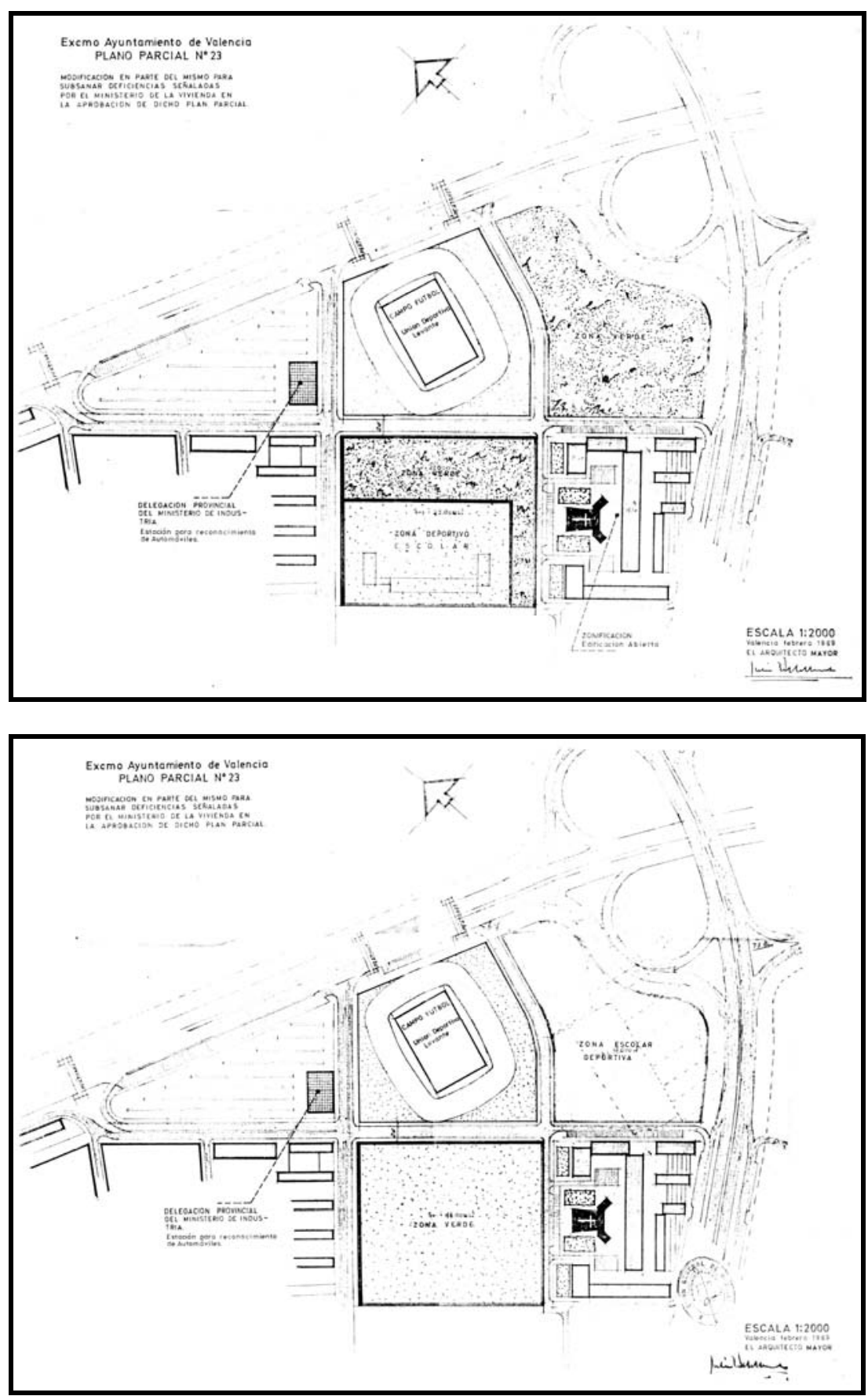


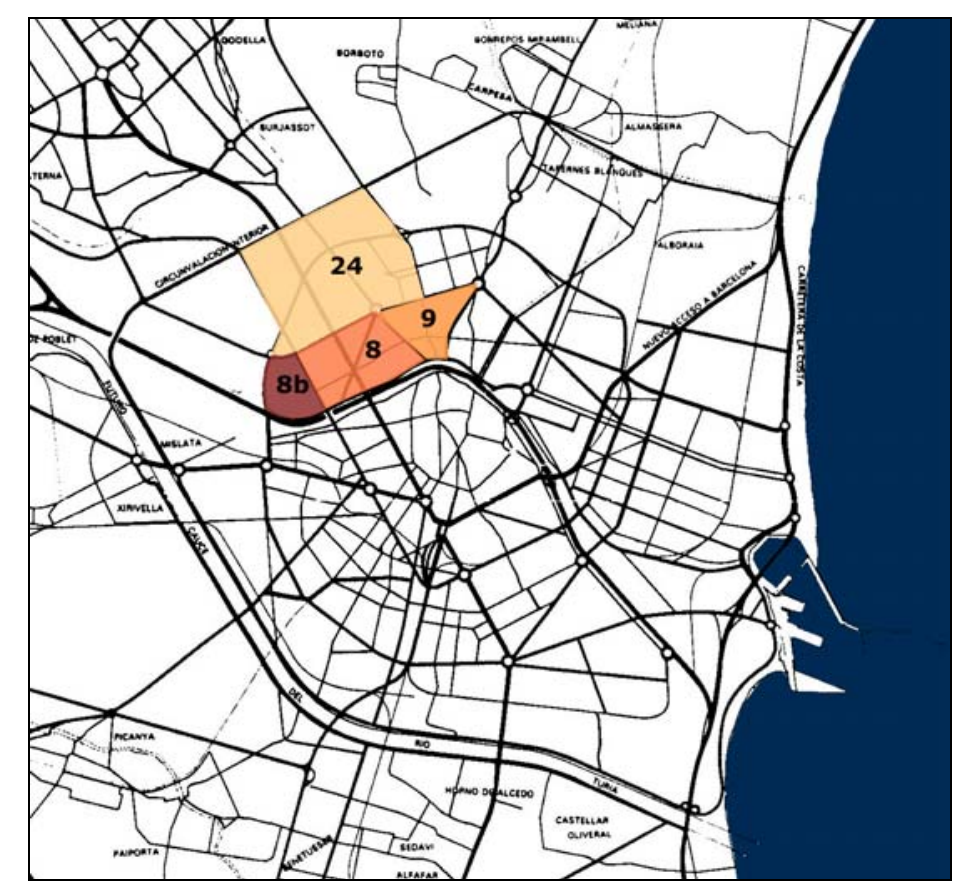

\subsection{ZONA NOROESTE}

PLAN PARCIAL NO 8-B (CAMPANAR OESTE), 1967. PLAN PARCIAL NO 8 (CAMPANAR-TENDETES), 1967/1972. PLAN PARCIAL No 9 (MARXALENES), 1967/1973. PLAN PARCIAL NO 24 (BENICALAP-ACCESO ADEMUZ), 1970/1974. 



\section{PP 8-B}

PLANO PARCIAL No 8-B (ADAPTADO A LA SOLUCIÓN SUR).

1967

Redactores: EXCMO. AYUNTAMIENTO DE VALENCIA. OFICINA TÉCNICA DE URBANISMO. Arquitectos: Julio Bellot, Román Giménez, Cándido Orts $(*)$.

Fecha redacción: Agosto 1967.

Fecha aprobación: O.M. 21-12-1968 (B.O.E. 31-01-69) (**).

Contenido:

I. MEMORIA

II. ORDENANZAS $(* * *)$

III. PLANOS:

1. PLANO DE SITUACIÓN DENTRO DE LA CIUDAD. $1: 10.000$

2. SITUACIÓN EN EL PLAN GENERAL $1: 22.500$

3. FOTOPLANO

4. ESTADO ACTUAL Y DELIMITACIÓN $1: 2000$

5. ESTRUCTURA URBANÍSTICA $1: 2000$

6. ZONIFICACIÓN $1: 2000$

7. RED VIARIA FUNDAMENTAL $1: 2000$

8. ALINEACIONES Y RASANTES $1: 2000$

9. REDES FUNDAMENTALES DE SERVICIO.
RED DE ALCANTARILLADO ESQUEMA DE RED DE AGUAS POTABLES. $\quad 1: 2000$ ESQUEMA DE ALUMBRADO. $1: 2000$

10. PLANO DE ETAPAS $\quad 1: 2000$

Fuente: Ayuntamiento de Valencia. Sección de Urbanismo. Negociado de Suelo y Ordenación urbana. Expte. 366/1967 (Archivo de Planeamiento No 74).

\section{Notas:}

* Los nombres de estos arquitectos no figuran en los planos, sino únicamente en la portada del expediente del PP 8-B.

** Esta versión del PP 8-B es la redactada una vez introducidas en la versión inicial las modificaciones derivadas de las dos rondas de alegaciones, antes y después de la aprobación inicial, que es de fecha 7-02-1968. No se adjunta documentación relativa a dichas alegaciones, ni el informe relativo a las mismas de Arquitecto Municipal, por ser las modificaciones de muy poca importancia.

*** Las ordenanzas son las mismas que las utilizadas en el PP 12. 


\author{
EXCMO. AYUNTAMIENTO DE VALENCIA \\ DESARROLLO DEL PLAN GENERAL DE ORDENACIÓN DE VALENCIA Y \\ SU COMARCA, ADAPTADO A LA SOLUCIÓN SUR
}

PLANO PARCIAL NO. 8-B

\author{
ME MOR I A
}

\title{
OBJETO DE ESTE ESTUDIO
}

La redacción y aprobación en 30 de Junio de 1.966 del Plan General de Ordenación de Valencia y su Comarca, adaptado a la Solución Sur, ha traído consigo, además del cambio del Río y de algunos elementos, la sujeción a las nuevas exigencias del momento urbanístico, principalmente el que se refiere a tráfico de vehículos y aparcamiento de los mismos.

Como consecuencia, la Jefatura de Obras Públicas en su Oficina Regional de Proyectos de Carreteras, redactó un estudio de todos los accesos a la Ciudad por carretera y las carreteras de tránsito y circunvalación, con gran anchura (80 metros en la mayor parte) y uniones a niveles distintos, con gran superficie, amen de la autopista por el cauce actual del Río.

Naturalmente, casi todos los planos parciales han resultado afectados con mayor o menor intensidad, no habiendo sido una excepción el que nos ocupa, por lo que el objeto de este estudio es la adaptación a las modificaciones precitadas, el establecimiento de los aparcamientos posibles, sin producir exceso de trastornos a la propiedad particular y pequeñas modificaciones parciales del esquema urbanístico para mejorar aspectos estrictamente necesarios

\section{JUSTIFICACIÓN DE LA ORDENACIÓN}

Lo dicho anteriormente justifica ya por sí solo la ordenación propuesta, pero es que además el Plan General, aunque pretendiendo seguir en todo las zonificaciones establecidas en los planos parciales que el Ayuntamiento tenía redactados y en redacción, ha modificado pequeñas zonas, ha establecido zonas comerciales y ha añadido alguna zona periférica. Todo ello se ha plasmado en la redacción del Plan Parcial presente.

Por todo ello la justificación de la ordenación es la de desarrollar el Plan General y adaptarse a él.

En el plano de este Plan Parcial se distinguen perfectamente las vías de gran tráfico de las de tráfico mediano y las de distribución.

En el mismo se diferencian claramente dos zonas de distinto carácter. Una situada al Oeste del conjunto de carácter industrial apoyada en las vías de gran tráfico y separada de las zonas de huerta por la misma. Y la otra, la situada al Este, de carácter residencial, separada por la prolongación de la Avenida de Pérez Galdós del Plano Parcial no 8.

Dentro de la zona residencial, por ser sobre zona poco edificada, se ha adoptado el esquema de supermanzana, ya sea compuesta de bloques abiertos o de manzanas semiabiertas, procurando para formarla imposibilitar el tráfico veloz de vehículos por su interior, disponiendo fondos de saco o bien calles quebradas, 
para distribuir en el interior de la manzana o bien llegar a los aparcamientos.

La zona residencial se ha proyectado orgánicamente estableciéndose el centro comercial en el emplazamiento que marca el Plan General, pudiendo construirse en el más de 2,00 metros cuadrados por habitante, por lo que resultará holgados.

Se ha reservado terreno para escuelas.

Se ha reservado terreno para aparcamientos.

Se ha reservado terreno para jardines.

Y se ha ubicado espacio para centros religiosos.

En todo ello, dada la pequeñez del conjunto y su relación con el proyecto parcial contiguo, o sea el número 8 , se ha procurado que domine la prudencia, si bien es cierto que no señalar el futuro emplazamiento de algún edificio público, compromete su futura situación, también es cierto que señalar mas elementos que los que se prevé que el Municipio construya, o por lo menos adquiera los terrenos, tiene él inconveniente de se cumpla lo establecido en el artículo 56 de la Ley del Suelo sobre recobro del libre ejercicio de las facultades dominicales.

La superficie que abarca el Plan, desde el eje de las calles que lo limitan, es de 61,97 $\mathrm{Ha}$.

La superficie de edificación destinada a viviendas es de 536.643 metros cuadrados, lo que destinando a cada vivienda 100 $\mathrm{m} 2$, incluidos patios y escaleras, da un total de 5.366 viviendas.

El número de habitantes, calculando un promedio de cuatro habitantes por viviendas, es de 21.464 habitantes.

La densidad del polígono es de 340 habitantes por hanegada aproximadamente, densidad algo baja, pero hay que tener en cuenta la parte importante del mismo que se destina a zona industrial.

La superficie de aparcamientos, considerando que el barrio es de condición modesta, es de 20 metros cuadrados por cada cinco viviendas, lo que daría una superficie de 21.474 metros cuadrados, sobrepasándose esta cantidad y alcanzando la superficie de 38.061 metros cuadrados, que consideramos lógica dado que las zonas industriales también tienen que tener su aparcamiento; ello se ha conseguido ampliamente entre los establecidos a lo largo de las vías públicas y los especiales.

La superficie de espacios libres es de 63.670 metros cuadrados, sin tener en cuenta el espacio libre que existe tras edificaciones abiertas y rebasando ampliamente el $10 \%$ de la superficie del plano.

La superficie destinada a edificación abierta, en metros cuadrados edificables, es de 276.592 metros cuadrados, y el volumen de la misma es de 1.235.324 metros cúbicos, lo que da un coeficiente de edificabilidad de 4,65 m3 por m2, inferior a los cinco metros cúbicos por metro cuadrado permitidos.

En las manzanas recayentes a la prolongación de la Avenida de Pérez Galdós, con zonificación de "Extensión exterior a Tránsitos", se destina una superficie edificable de 36.393 metros cuadrados.

La superficie de terreno edificable destinado a "Zona Industrial" es de 109.266 metros cuadrados.

La población escolar, incluido maternales, es del $15 \%$ de la población, o sea, 3.219 alumnos, lo que a razón de $6 \mathrm{~m} 2$ por alumno necesitarían una superficie de 19.317 metros cuadrados. La superficie destinada en el presente proyecto es de 8.600 metros cuadrados, cifra al parecer insuficiente a pesar de haber ubicado los 
centros de enseñanza que creemos necesarios en la parte Norte y Sur del polígono. Pero dada la circunstancia de no existir en el mismo ningún centro de enseñanza media, y sí en los próximos relacionados, con el objeto de este proyecto creemos que es suficiente. Ya que si fuera preciso en el futuro podría aprovecharse el excedente de espacios libres para construir algún grupo escolar más.

En documentos aparte se desarrollan las Ordenanzas de uso de los terrenos y edificación, planos topográficos, de ubicación, de alineaciones y ordenación, así como los esquemas de servicios de agua, alcantarillado y alumbrado.

\section{ETAPAS}

Siendo este plan parcial destinado, por el momento, a la edificación por particulares, no pueden marcarse etapas de realización que dependerán de la actividad constructiva de los mismos. Sin embargo, el Excmo. Ayuntamiento, además de construir los elementos urbanísticos generales en una primera etapa, se mantendrá siempre en la urbanización adelantando sobre la iniciativa particular, urbanizando zonas que se prevea edificación inmediata.

\section{MEDIOS ECONÓMICOS FINANCIEROS}

Son los del presupuesto ordinario de Urbanismo del Excmo. Ayuntamiento de Valencia y los extraordinarios que se establezcan a medida que se cumpla lo dicho en el párrafo anterior y se disponga de proyectos detallados de urbanización.

Con lo dicho creemos suficientemente expuesto el alcance del estudio realizado para que, si el Excmo. Ayuntamiento lo estima conveniente, lo eleve a la aprobación por la superioridad.

Valencia, agosto de 1967.

EL ARQUITECTO MUNICIPAL,
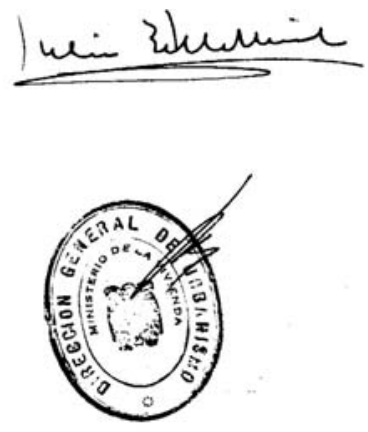
1. PLANO DE SITUACIÓN EN LA CIUDAD

Escala original: $1: 10.000$

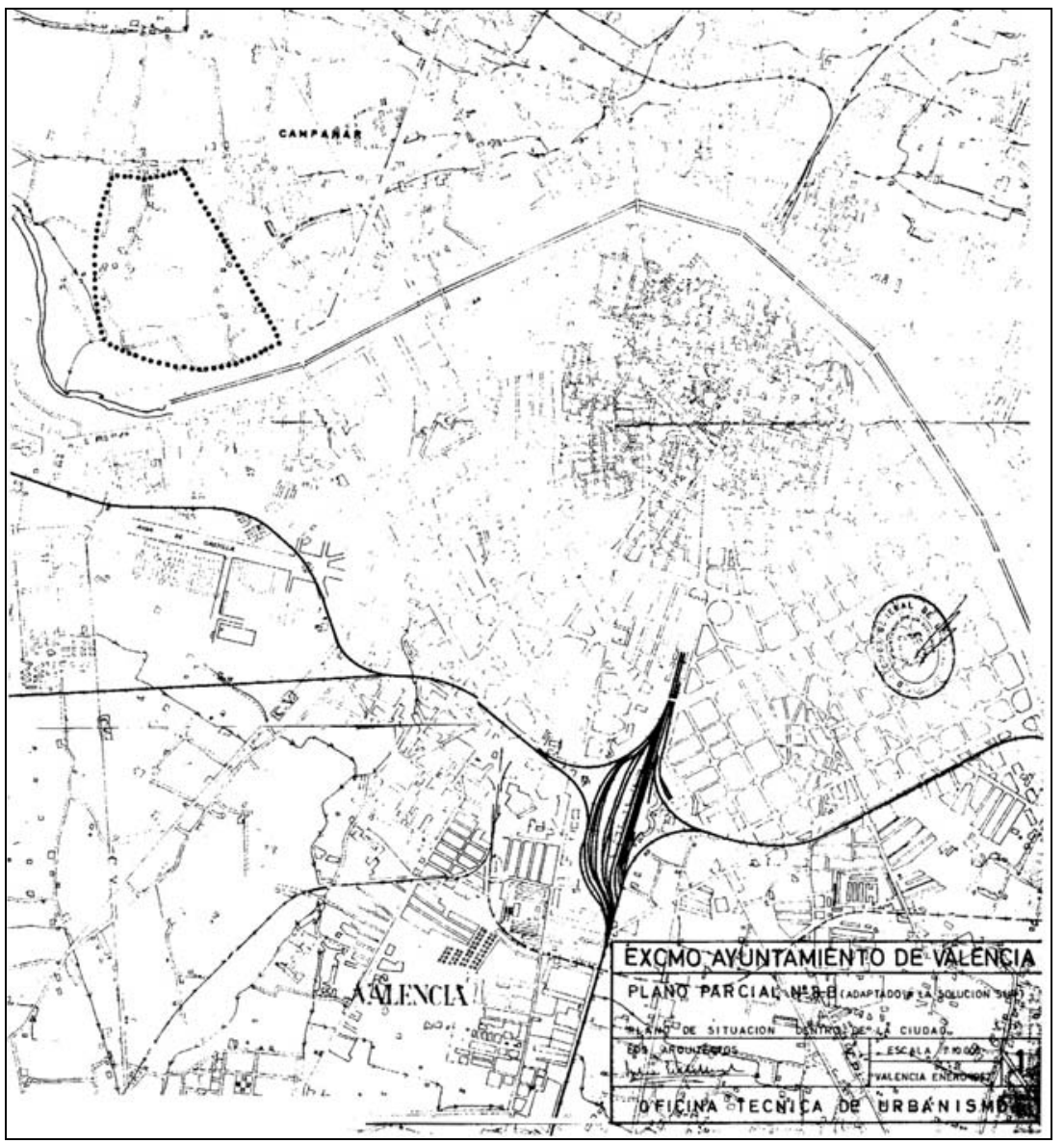

2. PLANO DE SITUACIÓN EN EL PLAN GENERAL (Fragmento) Escala original: $1: 22.500$

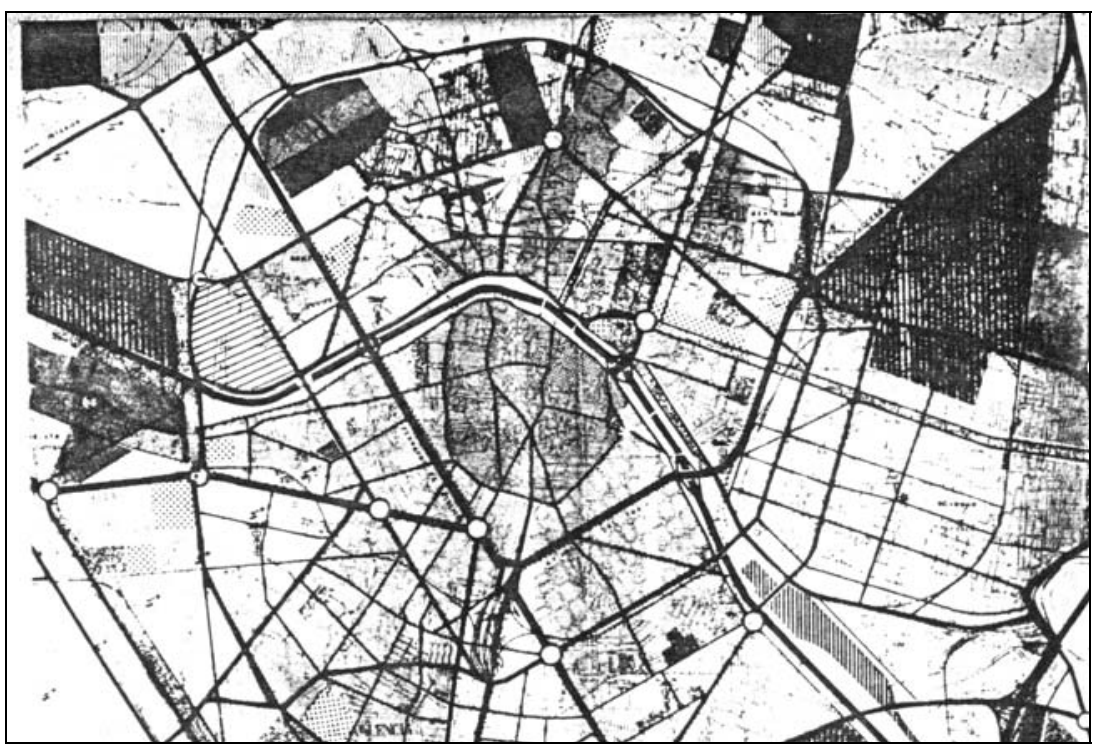




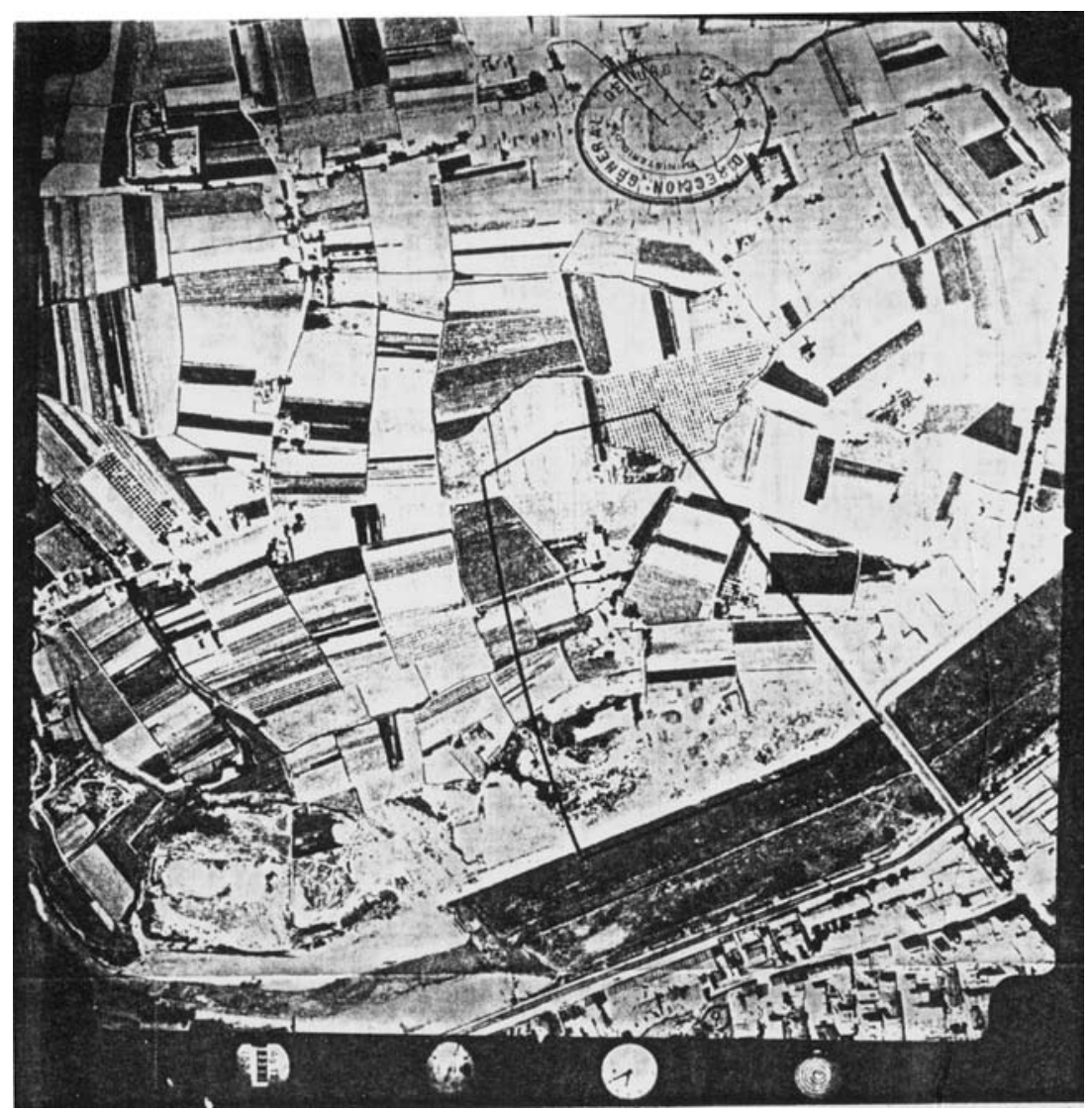

4. ESTADO ACTUAL Y DELIMITACIÓN

Escala original: 1:2000

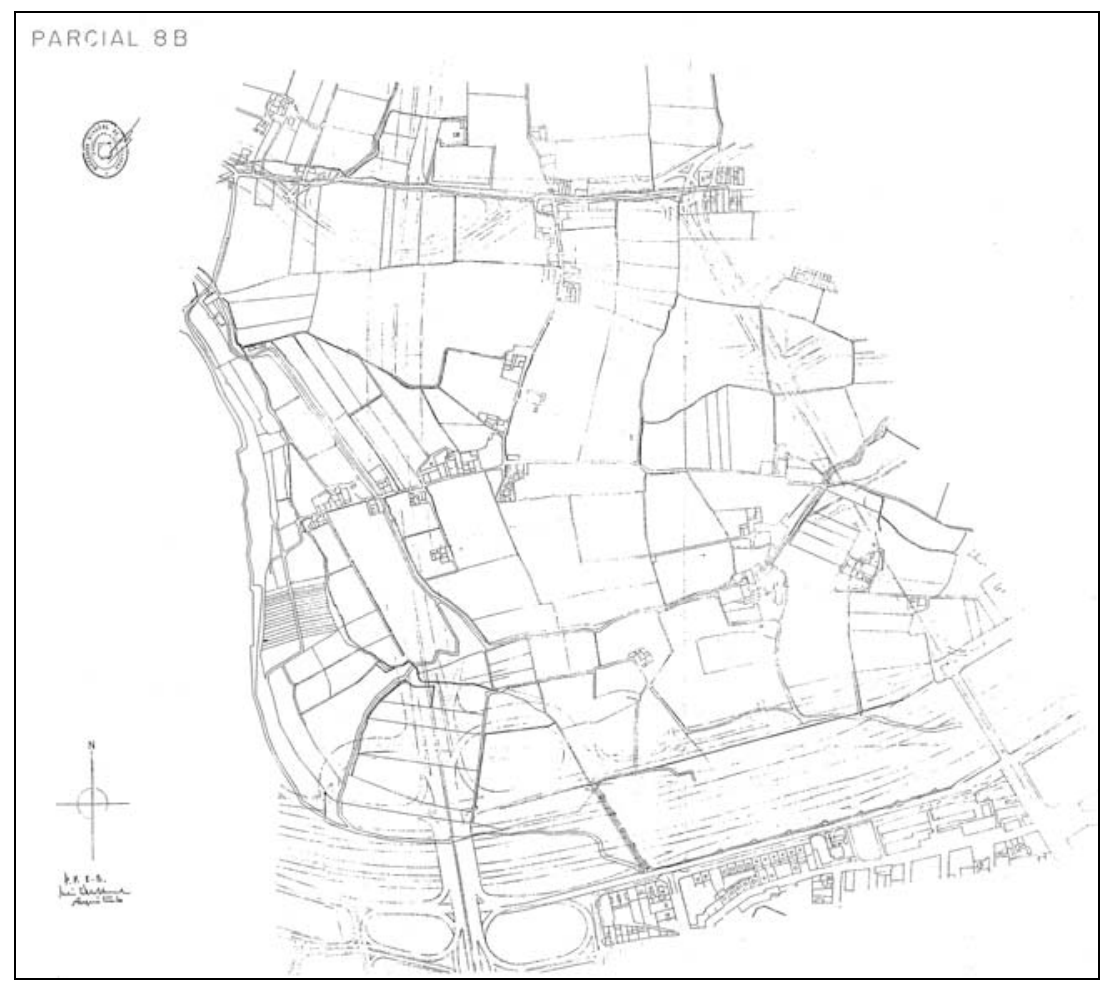


6. ZONIFICACIÓN.

Escala original: 1:2000

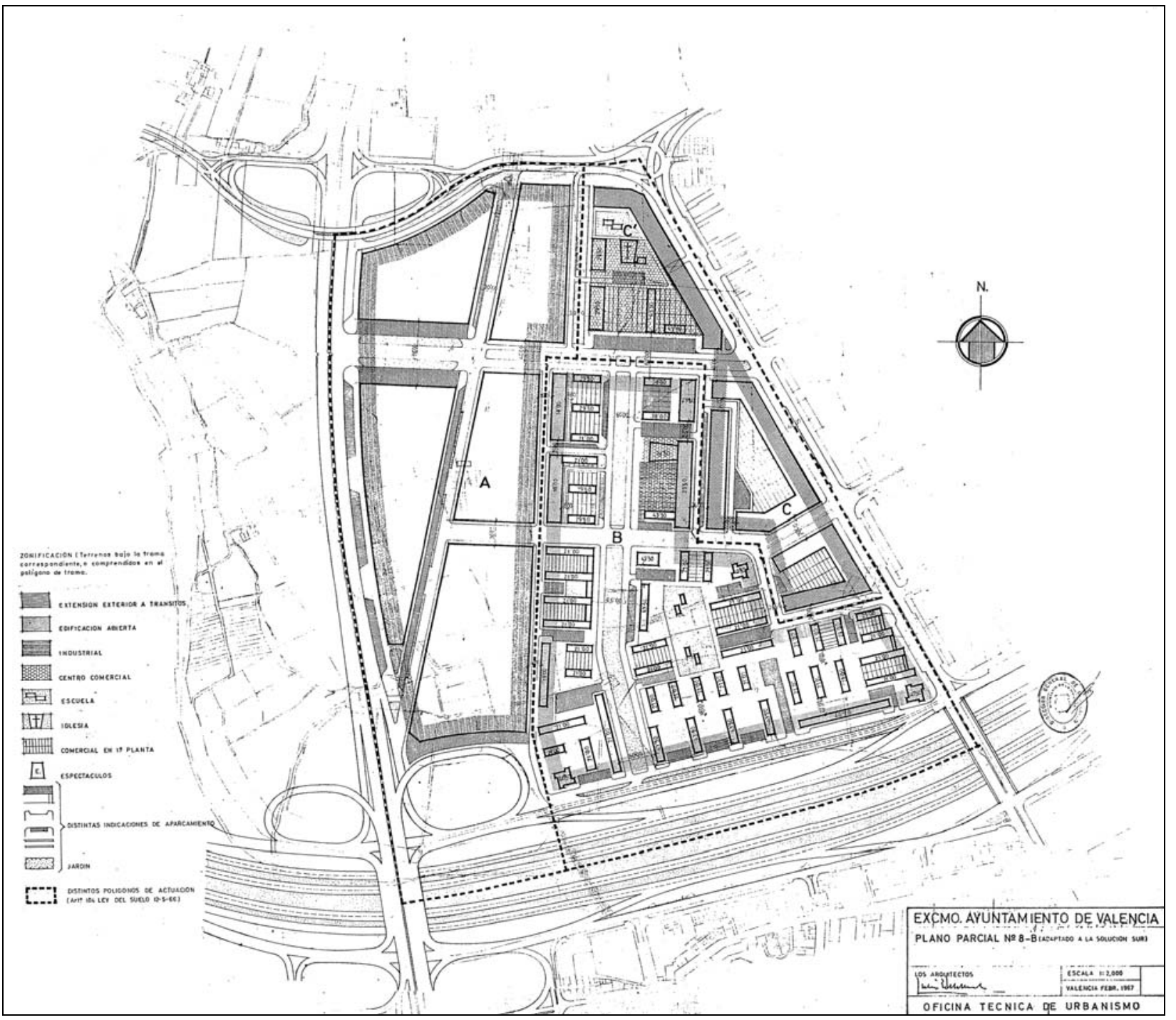

ZONIFICACION (Terrenos bajo la trama correspondiente, o comprendidos en el polígono de trama.

सागएणा

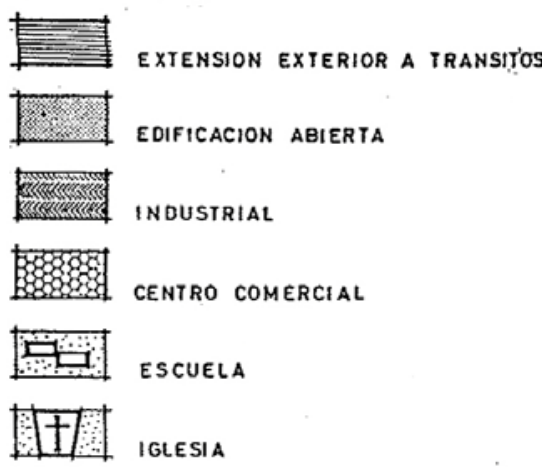

DISTINTOS POLIGONOS DE ACTUACION

(Art? 104 LEY DEL SUELO 12-5-66) 
7. RED VIARIA FUNDAMENTAL

Escala original: 1:2000

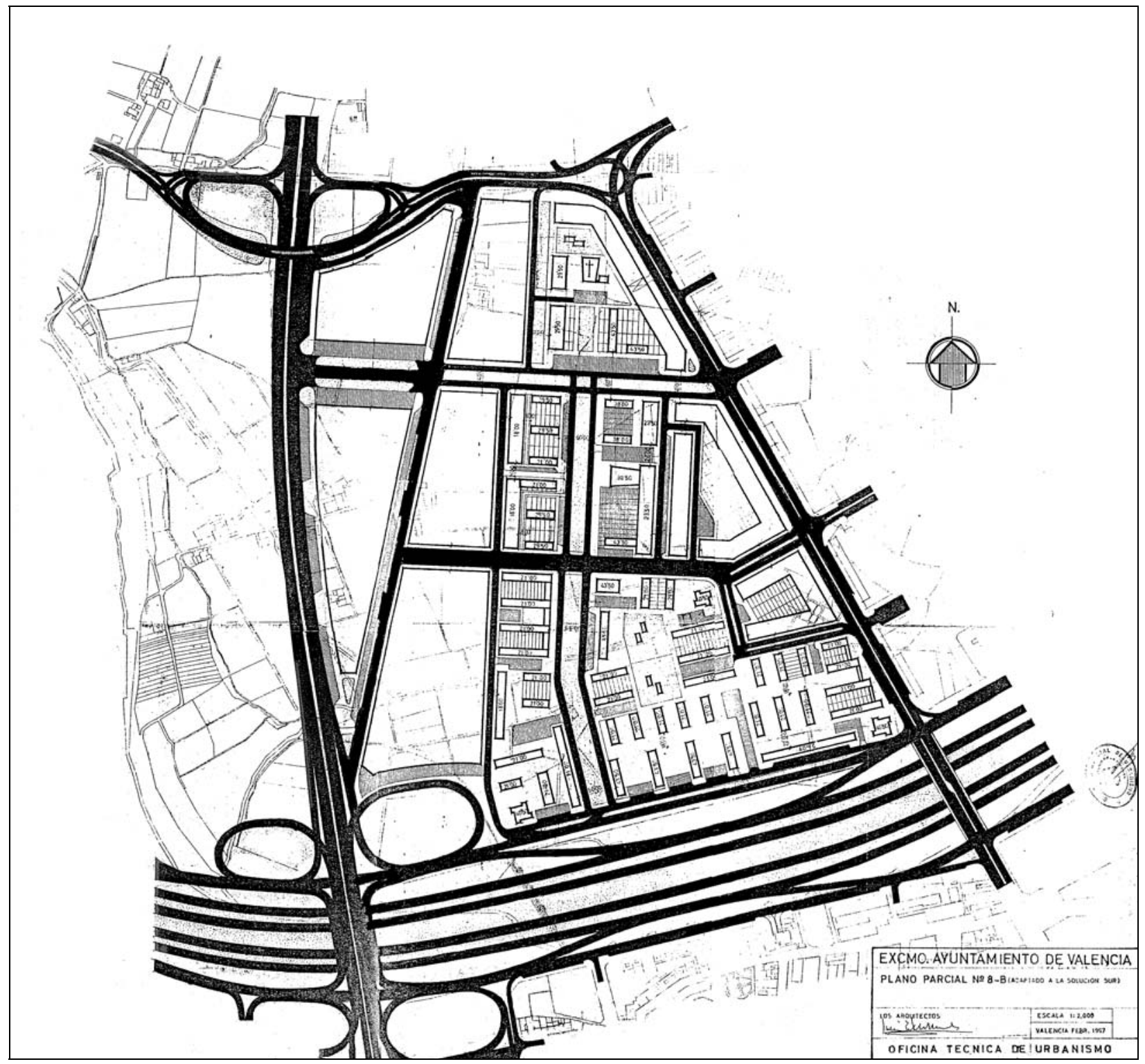


8. ALINEACIONES Y RASANTES.

Escala original 1:2000

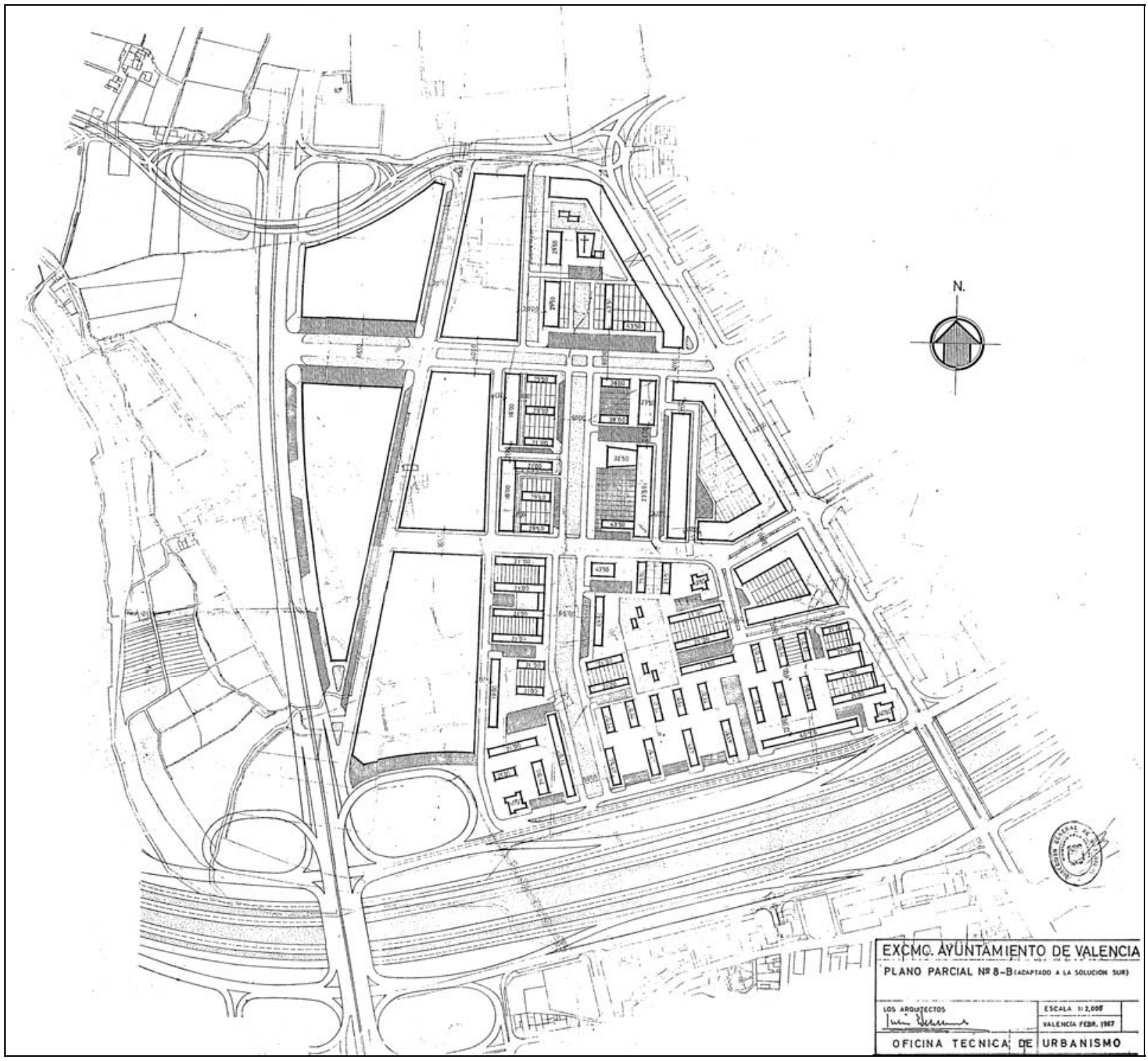




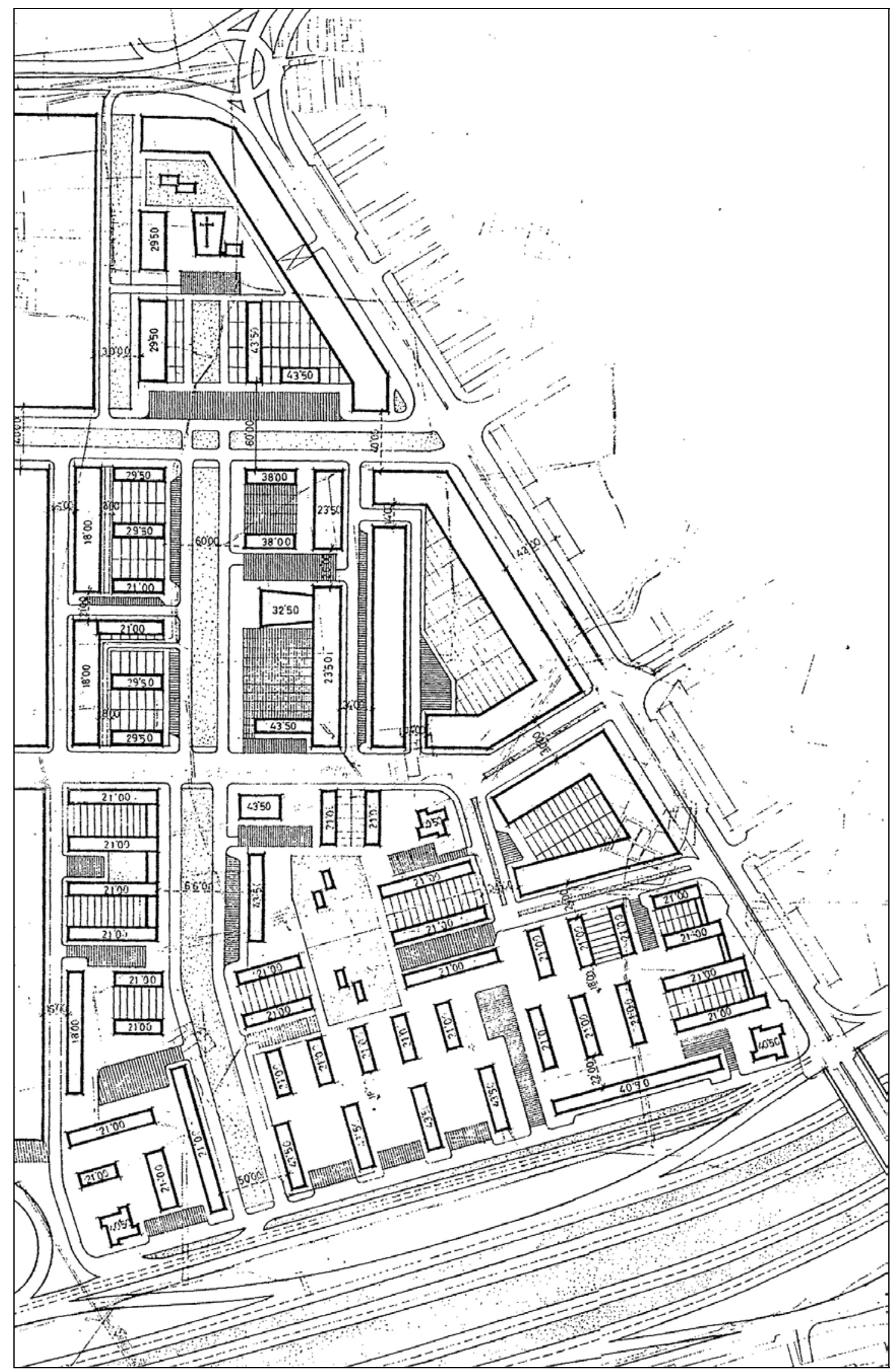

Detalle del Plano de alineaciones. 
Redactor: Dirección General de Urbanismo del Ministerio de la Vivienda / Ministerio de la Vivienda.

Fecha: 11- 01-1969.

Asunto: Resolución de aprobación del Plan Parcial 8-B.

Fuente: Ayuntamiento de Valencia. Sección de Urbanismo. Negociado de Suelo y Ordenación urbana. Expte. 366/1967 (Archivo de Planeamiento No 74).

MINISTERIO DE LA VIVIENDA

Dirección General de Urbanismo.

SECCIÓN: Planeamiento

Ilmo Sr.:

El Excmo. Sr. Subsecretario del Ministerio de la Vivienda, actuando por delegación del Excmo. Sr. Ministro, con fecha 21 de diciembre de 1968, me dice lo siguiente:

"VISTO el Plan Parcial de Ordenación Urbana no 8-B adaptado al vigente Plan General de Valencia y su Comarca, presentado por el Ayuntamiento de dicha localidad y remitido por la Corporación Administrativa "Gran Valencia", y VISTO el informe emitido por los servicios competentes de la Dirección General de Urbanismo, Este Ministerio, teniendo en cuenta lo dispuesto en la vigente Ley sobre Régimen del Suelo y Ordenación Urbana de 12 de Mayo de 1956 y en el Decreto 63/1968 de 18 de Enero, Acuerda aprobar dicho Plan Parcial y que esta resolución sea notificada al Ayuntamiento de Valencia y a la Corporación Administrativa Gran Valencia."

Lo que comunico a V. I. para su conocimiento y efectos.

Dios guarde a V.I. muchos años.

Madrid, 11 de Enero de 1.969.

EL DIRECTOR GENERAL.

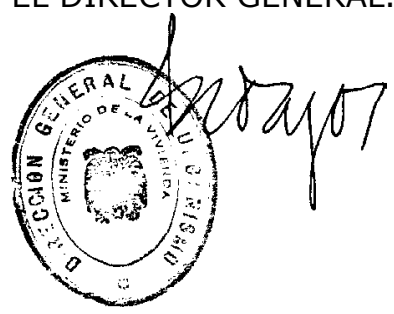

Ilmo. Sr. Alcalde Presidente del Ayuntamiento de Valencia. 



\section{PP 8}

Redactores: Excmo. Ayuntamiento de Valencia. Oficina Técnica de Urbanismo.

Fecha redacción: 1967.

Fecha aprobación: Aprobación inicial Ayuntamiento: 7-02-1968. Aprobación provisional Ayuntamiento: 6-11-1968. Denegada aprobación por Ministerio de la Vivienda el 30-11-1969.

\section{Contenido:}

I. MEMORIA

II. ORDENANZAS

III. PLANOS:

1. PLANO DE SITUACIÓN DENTRO DE LA CIUDAD. $1: 10.000$

2. SITUACIÓN EN EL PLAN GENERAL $1: 22.500$

3. FOTOPLANO

4. ESTADO ACTUAL Y DELIMITACIÓN $1: 2000$

5. ESTRUCTURA URBANÍSTICA $1: 2000$

6. ZONIFICACIÓN $1: 2000$

7. RED VIARIA FUNDAMENTAL $1: 2000$

8. ALINEACIONES Y RASANTES $1: 2000$

9. REDES FUNDAMENTALES DE SERVICIO.
RED DE ALCANTARILLADO ESQUEMA DE RED DE AGUAS POTABLES. $\quad 1: 2000$ ESQUEMA DE ALUMBRADO. $1: 2000$

10. PLANO DE ETAPAS $1: 2000$

Fuente: Ayuntamiento de Valencia. Sección de Urbanismo. Negociado de Suelo y Ordenación urbana. Expte. 366/1967.(Archivo de Planeamiento, sección de expedientes antiguos) 
EXCMO. AYUNTAMIENTO DE VALENCIA

DESARROLLO DEL PLAN GENERAL DE ORDENACIÓN DE VALENCIA Y SU COMARCA, ADAPTADO A LA SOLUCIÓN SUR

PLANO PARCIAL NO. 8

\section{MEMOR I A}

\section{OBJETO DE ESTE ESTUDIO}

La redacción y aprobación en 30 de Junio de 1.966 del Plan General de Ordenación de Valencia y su Comarca, adaptado a la Solución Sur, ha traído consigo, además del cambio del Río y de algunos elementos, la sujeción a las nuevas exigencias del momento urbanístico, principalmente el que se refiere a tráfico de vehículos y aparcamiento de los mismos. Como consecuencia, por la Jefatura de Obras Públicas en su Oficina Regional de Proyectos de Carreteras, se redactó un estudio de todos los accesos a la Ciudad por carretera y las carreteras de tránsito y circunvalación, con gran anchura (80 metros en la mayor parte) y uniones a niveles distintos con gran superficie, amen de la autopista por el cauce actual del Río.

Naturalmente, casi todos los planos parciales han resultado afectados con mayor o menor intensidad, no habiendo sido una excepción el que nos ocupa, por lo que el objeto de este estudio es la adaptación a las modificaciones precitadas, el establecimiento de los aparcamientos posibles, sin producir exceso de trastornos a la propiedad particular y pequeñas modificaciones parciales del esquema urbanístico para mejorar aspectos estrictamente necesarios

\section{JUSTIFICACIÓN DE LA ORDENACIÓN}

Lo dicho anteriormente justifica ya por sí solo la ordenación propuesta, pero es que además el Plan General, aunque pretendiendo seguir en todo las zonificaciones establecidas en los planos parciales que el Ayuntamiento tenía redactados y en redacción, ha modificado pequeñas zonas, ha establecido zonas comerciales y ha añadido alguna zona periférica.

Todo ello se ha plasmado en la redacción del Plan Parcial presente.

Por todo ello la justificación de la ordenación es la de desarrollar el Plan General y adaptarse a él.

Se excluye de este Plan Parcial el polígono de expropiación, que ha sido delimitado y redactado en su esquema urbanístico por la Gerencia de Urbanismo, aunque figuran sus alineaciones junto con las privativas del Plan Parcial, para que se vea su conexión con las mismas y porque ambas zonas forman un conjunto bien definido.

En el plano de este Plan Parcial, se distinguen perfectamente las vías de gran tráfico de las de tráfico mediano y las de distribución.

Se ve perfectamente que se ha procurado, allá donde ha sido posible, por ser sobre zona poco edificada, adoptar el esquema de supermanzana, ya sea compuesta de bloques abiertos o de manzanas semiabiertas, procurando para formarla imposibilitar el 
tráfico veloz de vehículos por su interior, disponiendo fondos de saco o bien calles quebradas, para distribuir en el interior de la manzana o bien llegar a los aparcamientos.

Se ha establecido los centros comerciales en los emplazamientos que marca el Plan General, pudiendo construirse en ellos más de dos metros cuadrados por habitante, por lo que resultará holgados.

Se ha reservado terreno para escuelas.

Se ha reservado terreno para aparcamientos.

Se ha reservado terreno para jardines.

Se han ubicado los centros religiosos.

Se ha reservado terreno para una estación de autobuses, un centro sanitario y un instituto de segunda enseñanza.

En todo ello se ha procurado que domine la prudencia, si bien es cierto que no señalar el futuro emplazamiento de algún edificio público, compromete su futura situación, también es cierto que señalar mas elementos que los que se prevé que el Municipio construya, o por lo menos adquiera los terrenos, tiene él inconveniente de se cumpla lo establecido en el artículo 56 de la Ley del Suelo sobre recobro del libre ejercicio de las facultades dominicales.

La superficie que abarca el Plan, desde el eje de las calles que lo limitan, es de 133,38 $\mathrm{Ha}$.

La superficie de edificación destinada a viviendas es de 1.634.048 metros cuadrados, lo que destinando a cada vivienda $100 \mathrm{~m} 2$, incluidos patios y escaleras, da un total de 16.340 viviendas:

El número de habitantes, calculando un promedio de cuatro habitantes por viviendas, es de 65.361 habitantes.

La densidad del polígono será de 495 habitantes por hanegada.

La superficie de aparcamientos, considerando que el barrio es de condición modesta, es de 20 metros cuadrados por cada cinco viviendas, lo que daría una superficie de 65.361 metros cuadrados. La superficie proyectada para estos fines rebasa la necesaria alcanzando los 85.457 metros cuadrados.

Como espacios libres se proyectan un centro deportivo con una superficie de 16.900 metros cuadrados Como cerca de la mitad de la superficie total del plano se destina a edificación abierta en la que los espacios libres de la misma, descontando los viales, sobrepasa el $30 \%$ de la superficie de las manzanas, la cifra total de espacios libres dentro del plan es muy superior al $10 \%$ del mismo necesarios.

La superficie destinada a edificación abierta es de 680.418 metros cuadrados, y el volumen de la misma es de 2.721 .681 metros cúbicos. La edificabilidad máxima en las supermanzanas creadas es de 4,25 metros cúbicos por metro cuadrado.

Existen dentro del plan una zonas: la situada a lo largo de la Avenida de Burjasot; al Este del mismo; la situada al final de la Avenida de Campanar y la situada en la vía Norte que por estar, la mayor parte de ellas, edificadas, se ha tenido que conservar el carácter de manzana cerrada, con zonificación de Extensión Exterior a Tránsitos. Hay otra zona situada al Noroeste que es el núcleo del poblado de Campanar, que no ha habido más remedio que conservarlo y limitar su extensión.

La población escolar, incluido maternales, es del $15 \%$ de la población, o sea, 9.804 alumnos, lo que a razón de seis metros cuadrados cada uno, se necesitaría una superficie de 58.824 metros cuadrados. En el presente plano la superficie destinada a escuelas 
es de 60.480 metros cuadrados. Sin contar un centro Cultural que se emplaza en el centro comercial más importante.

En documentos aparte se desarrollan las Ordenanzas de uso de los terrenos y edificación, planos topográficos, de ubicación, de alineaciones y ordenación, así como los esquemas de servicios de agua, alcantarillado y alumbrado.

\section{ETAPAS}

Siendo este plan parcial destinado, por el momento, a la edificación por particulares, no pueden marcarse etapas de realización que dependerán de la actividad constructiva de los mismos. Sin embargo, el Excmo. Ayuntamiento, además de construir los elementos urbanísticos generales en una primera etapa, se mantendrá siempre en la urbanización adelantando sobre la iniciativa particular, urbanizando zonas que se prevea edificación inmediata.

\section{MEDIOS ECONÓMICOS FINANCIEROS}

Son los del presupuesto ordinario de Urbanismo del Excmo. Ayuntamiento de Valencia y los extraordinarios que se establezcan a medida que se cumpla lo dicho en el párrafo anterior y se disponga de proyectos detallados de urbanización.

Con lo dicho creemos suficientemente expuesto el alcance del estudio realizado para que, si el Excmo. Ayuntamiento lo estima conveniente, lo eleve a la aprobación por la superioridad.

Valencia,

[ Documento sin fecha ni firma ] 


\section{FOTOPLANOS}
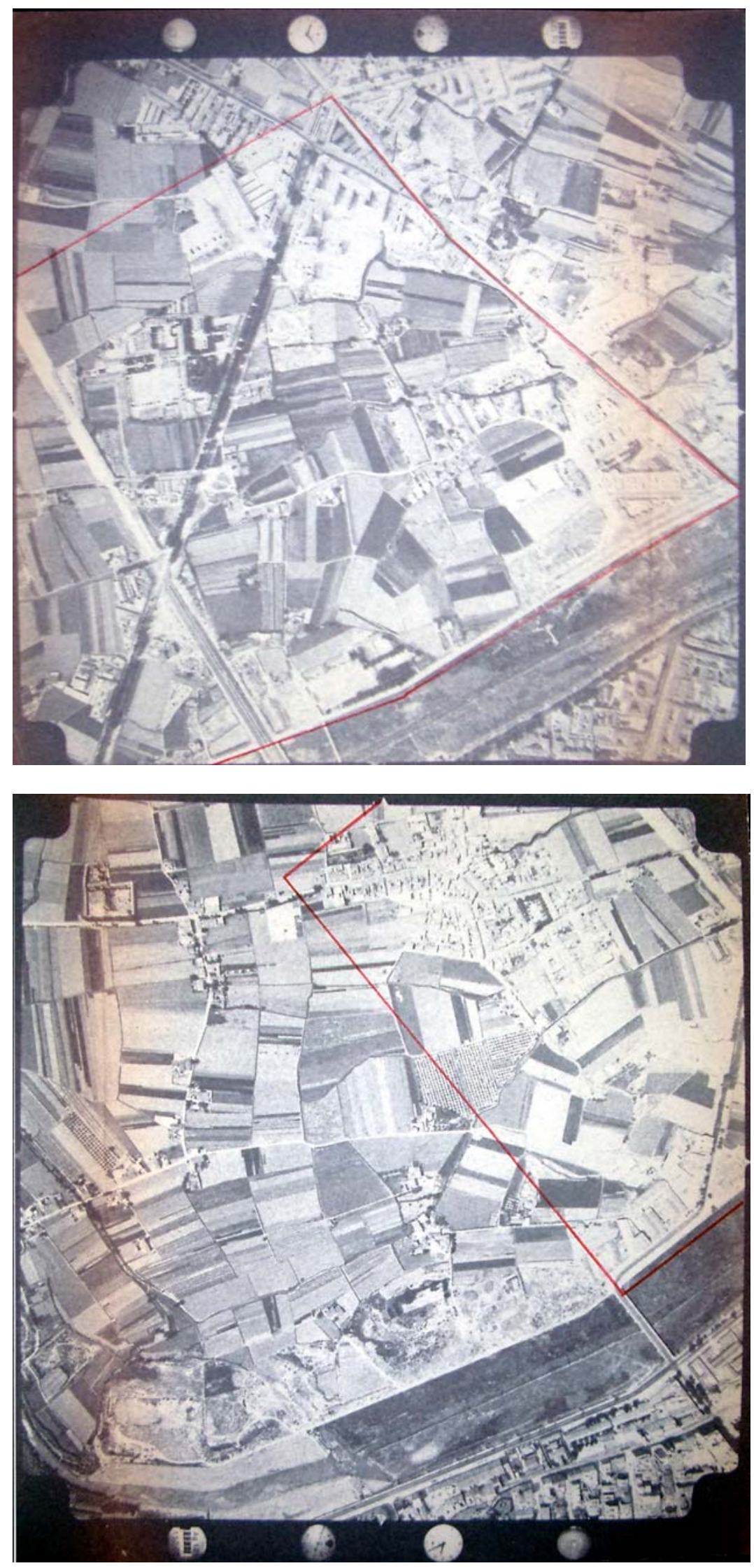
VIARIO (Enero 1967).

Escala original 1:2000.

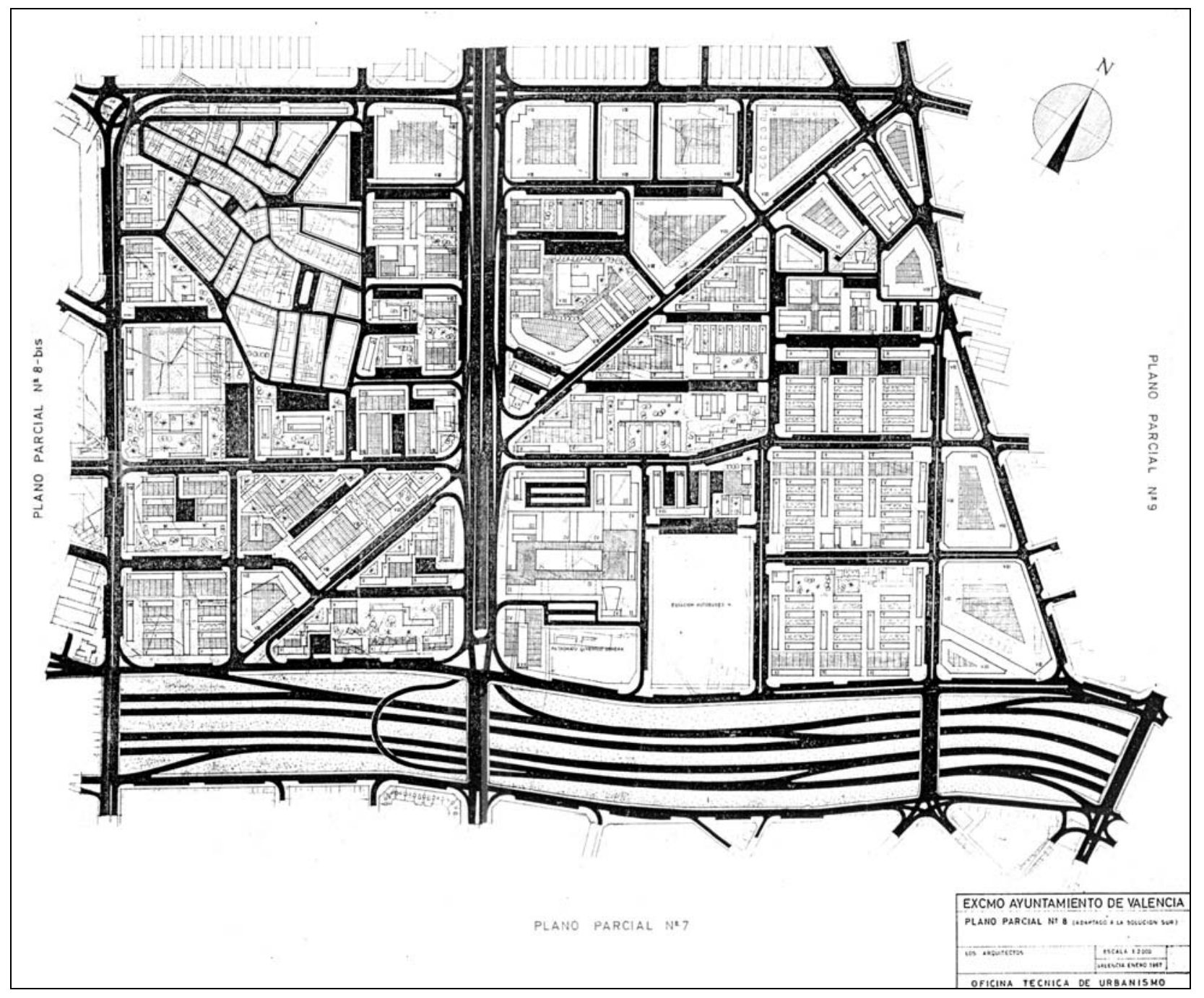


ZONIFICACIÓN. (Junio 1968)

Escala original 1:2000

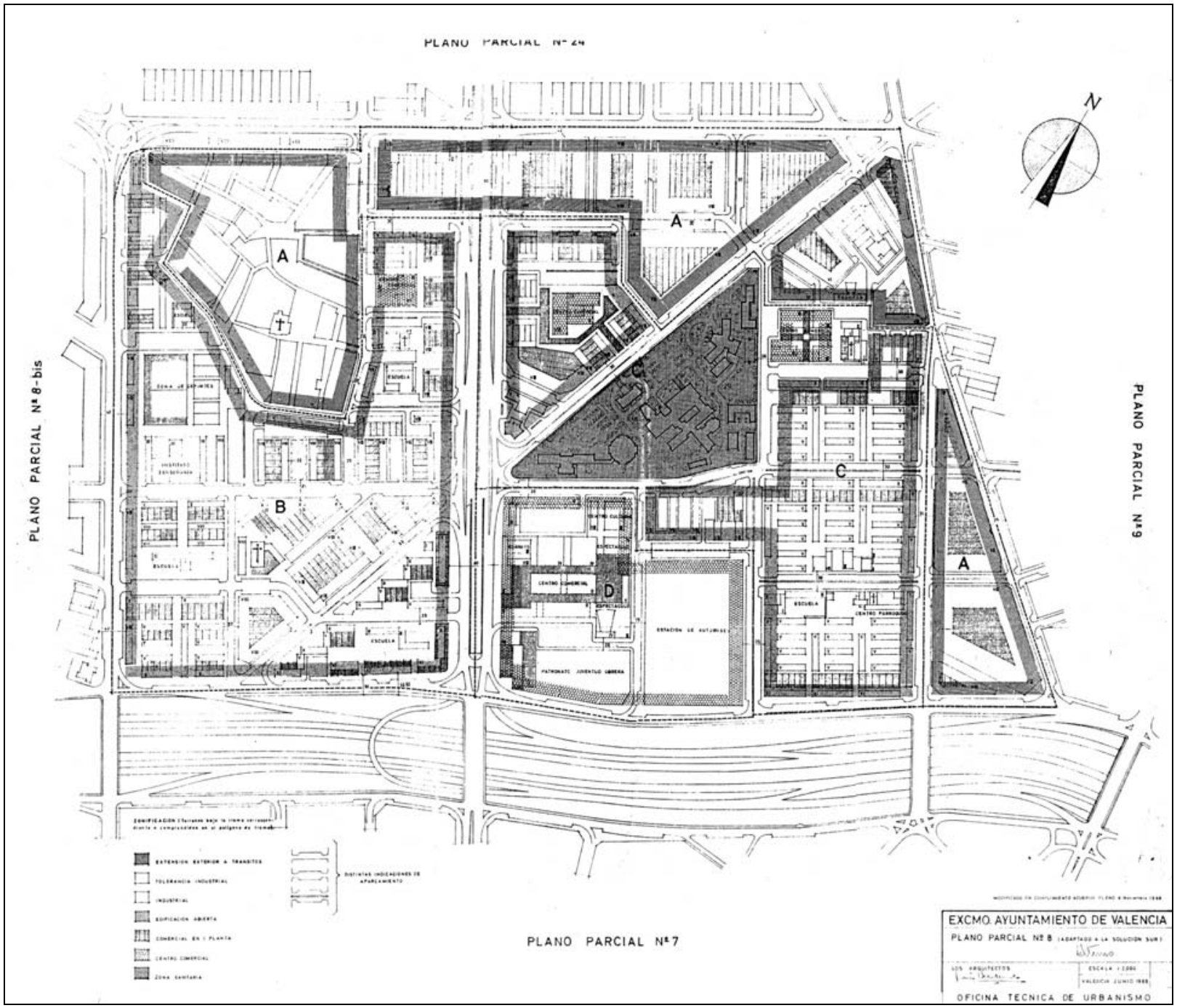





\section{PP 8}

PLANO PARCIAL No 8 (ADAPTADO A LA SOLUCIÓN SUR). 1972

Redactores: Excmo. Ayuntamiento de Valencia. Oficina Técnica Municipal de Urbanismo.

Fecha redacción: Agosto 1972.(*)

Fecha aprobación: O.M. 16-07-1974 (B.O.E. 29-08-74).

Contenido:

I. MEMORIA

II. ORDENANZAS

III. PLANOS:

1. PLANO DE SITUACIÓN DENTRO DE LA CIUDAD. $1: 10.000$

2. SITUACIÓN EN EL PLAN GENERAL $1: 22.500$

3. INFORMACIÓN Y FOTO AÉREA $1: 2000$

4. ZONIFICACIÓN $1: 2000$

5. ESTRUCTURA URBANÍSTICA $1: 2000$

6. ALINEACIONES $1: 2000$

7. RED VIARIA FUNDAMENTAL $1: 2000$

8. REDES FUNDAMENTALES DE SERVICIO.

$\begin{array}{ll}\text { RED DE ALCANTARILLADO } & 1: 2000 \\ \text { ESQUEMA DE RED DE AGUAS POTABLES. } & 1: 2000 \\ \text { ESQUEMA DE ALUMBRADO. } & 1: 2000\end{array}$

Fuente: Ayuntamiento de Valencia. Sección de Urbanismo. Negociado de Suelo y Ordenación urbana. Expte. 365/1967. Reg. General 67.718 (Archivo de Planeamiento, No 67).

\section{Notas:}

(*) El avance del plan está fechado en 1971. 


\section{MEMOR I A}

El Plan Parcial No 8 comprende los terrenos limitados al Sur por el actual Cauce del Río Turia, al oeste por la calle Prolongación del Puente de Campanar, al Norte por Avenida del General Avilés y al Este por la Avenida de Burjasot.

Su superficie total, de $1.176 .990 \mathrm{~m} 2$, queda desglosada de esta forma:

- Plan Parcial del Polígono de Campanar

(de la Gerencia de urbanización).............. $\quad 509.000$ m2

- Preventorio de S. Francisco Javier

(objeto de Proyecto especial).

$80.000 \mathrm{~m} 2$

- Plan parcial No 8 (Campanar)

$587.990 \mathrm{~m} 2$

a) El Plan parcial de la Gerencia de urbanización (comprensivo de la Ciudad Sanitaria de la Seguridad Social, Estación Norte de Autobuses, etc.), fue aprobado con las últimas remodelaciones el 24 de abril de 1971 por la Dirección General de urbanismo.

b) El Preventorio de S. Francisco Javier, son todos sus terrenos propiedad del Estado, y zona especial según el Plan general de Valencia y su Comarca adaptado a la Solución Sur.

Por ello, nos limitaremos en el presente Plan Parcial a reflejar en el Polígono de la Gerencia lo que ya fue en su día aprobado; en el Preventorio de Campanar, a asignarle la calificación de zona especial, como en el Plan General.

El resto del Plan, el que estrictamente nos interesa, comprende:

1.- La Zona Noroeste de Extensión Exterior a Tránsitos, formada por el poblado de Campanar, que se ha respetado, y zonas limítrofes.

En este sector, la manzana definida por Avda. de Pío XII, Avda. General Avilés, c/ Aparicio Albiñana y c/ Monestir de Poblet, con el mismo volumen que le corresponde según Ordenanzas, se ha distribuido de diferente forma, por lo que se le asigna la calificación de singular.

Al Norte y Este del actual poblado se han colocado unos edificios-pantalla, que ya existían en anteriores planeamientos.

Esta zona, dado el estado poco avanzado de las construcciones, se ha diseñado con un tratamiento más higiénico y menos denso que la típica construcción de Ensanche.

A pesar de ello, no se vulnera el Plan General, puesto que la unidad formada por un bloque o por dos bloques unidos por plantas bajas comerciales, son manzanas elementales de ensanche.

En algunas de ellas, y en evitación de que la aplicación de Ordenanzas obligase a distintas alturas, se ha dispuesto una altura a cornisa uniforme, por lo que podrían calificarse como edificios singulares aunque en el sentido más restrictivo de tal calificación, ya que no produce aumento de volumen ni superación del techo de la zona, sino sólo una positiva disposición de bloques.

2.- La zona Sur-Oeste, de Edificación Abierta, separada de la anterior por la calle de la Ballestera, en la cual por encontrarse en estos momentos ya construida, se producen aumentos de volumen 
en el sector limitado por c/ Tirso de Molina, Avda. Pío XII, Avda. Alférez Provisional, y en el cual se ha establecido espacios libres adicionales para compensar el exceso de volumen.

Asimismo, las dos manzanas semiabiertas que lindan con la antes aludida por la Avda. Alférez Provisional, en las cuales se ha previsto unos cortes en la edificación perimetral y más baja altura de aquella con la que se han iniciado las construcciones.

3.- El triangulo de Edificación Abierta, limitado por la Avda. Alférez Provisional, Avda. Pío XII y c/ En proyecto, en el que se han situado en primer plano un edificio singular de XV plantas y otro entre éste y el Preventorio, de IX plantas.

4.- La zona de edificación abierta limitada por la Avda. Pío XII, Avda. General Avilés, carretera de Paterna, Avda. Alférez Provisional y c/ Monestir de Poblet, la cual consta de cuatro manzanas, una de ellas completamente construida y las otras parcialmene, construcciones que se han iniciado con la aplicación de la calificación de Extensión Exterior a Tránsitos y en las que, dado el aumento de volumen, se ha dispuesto dos espacios libres para compensar aquél, de un total de $4.520 \mathrm{~m} 2$.

En cuanto a reserva de escuelas, se han previsto tres solares: uno de $10.550 \mathrm{~m} 2$ y otros de 5.008 y $5.040 \mathrm{~m} 2$, con capacidad total para 32 aulas y 1.280 alumnos.

A la superficie de zonas verdes, mayor del $10 \%$, hay que sumar las que se sitúan en puntos en que hay exceso de volumen $y$, en todo caso, habría que considerar lo siguiente:

El actual cauce del Río Turia, destinado según el Plan General a viales (enlace de la autopista del mediterráneo con la de Madrid), está en trámite de desafectación como cauce de río.

Del estudio de viales, se ha deducido la no necesidad de esta autopista con el cauce, bastando con dos calzadas laterales de tráfico rápido, con lo cual quedaría el $80 \%$ del cauce como espacio libre, de los cuales al menos el 505 sería zona verde $(70.080 \mathrm{~m} 2$ corresponden a este Plan), siendo el resto deportivo-cultural, lo que supone, no sólo para toda la ciudad sino especialmente para las zonas limítrofes con el cauce, una beneficiosa descongestión que habría que considerar como muy beneficiosa, y compensatoria de los posibles aumentos de volumen.

La superficie total del Polígono se distribuye de esta forma:

\begin{tabular}{lr} 
Viales.................. & $254.296 \mathrm{~m} 2$ \\
Zonas verdes....... & $59.296 \mathrm{~m} 2$ \\
Escuelas............... & $20.598 \mathrm{~m} 2$ \\
Edificación............ & $253.800 \mathrm{~m} 2$ \\
TOTAL................. & $587.990 \mathrm{~m} 2$ \\
\hline
\end{tabular}

Volumen promedio: $6 \mathrm{~m} 3 / \mathrm{m} 2$

M2 edificados.

1.522.800.-

$25 \%$ plantas bajas............... 380.700.- m3

$75 \%$ destino viviendas........ 1.142.100.- $\mathrm{m} 3$

Tomando como base un promedio de $300 \mathrm{~m} 3$ por vivienda, nos da ---------------------------3.807 viviendas.

A razón de 4,5 personas por vivienda, 17.131 habitantes.

La densidad total (sobre superficie total del Plan) de:

17.131/58.799 $\mathrm{Ha}=291$ habitante/Ha. 
En documento aparte se desarrollan las Ordenanzas de uso de los terrenos y edificación, planos topográficos, de ubicación, de alineaciones y de ordenación, así como los esquemas de servicios de agua, alcantarillado y alumbrado.

\section{ETAPAS}

Siendo este Plan Parcial destinado, por el momento, a la edificación por particulares, no pueden marcarse etapas de realización que dependerán de la actividad constructiva de los mismos. Sin embargo, el Excmo. Ayuntamiento, además de construir los elementos urbanísticos generales, en una primera etapa, se mantendrá siempre, en la urbanización, adelantando sobre la iniciativa particular, urbanizando zonas en que se prevea la edificación inmediata.

\section{MEDIOS ECONÓMICOS FINANCIEROS}

Son los del presupuesto ordinario de Urbanismo del Excmo. Ayuntamiento de Valencia y los extraordinarios que se establezcan a medida que se cumpla lo dicho en el párrafo anterior y se disponga de proyectos detallados de urbanización.

Con lo dicho creemos suficientemente expuesto el alcance del estudio realizado para que, si el Excmo. Ayuntamiento lo estima conveniente, lo eleve a la aprobación por la Superioridad.

Valencia,

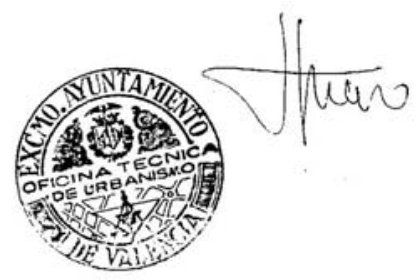

\section{ORDENANZAS}

En tanto no se aprueben las Ordenanzas Generales para la edificación en el territorio de este Municipio, y dado que el estudio de ellas solamente para este Plan parcial no es conveniente, regirán las Ordenanzas Municipales de 1.950-55, en todo lo que no contradigan a las normas urbanísticas del Plan general.

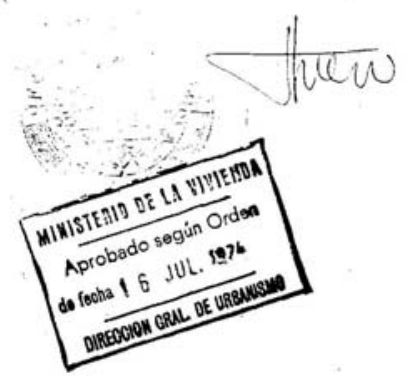


1. PLANO DE ALINEACIONES.

Escala original 1:2000

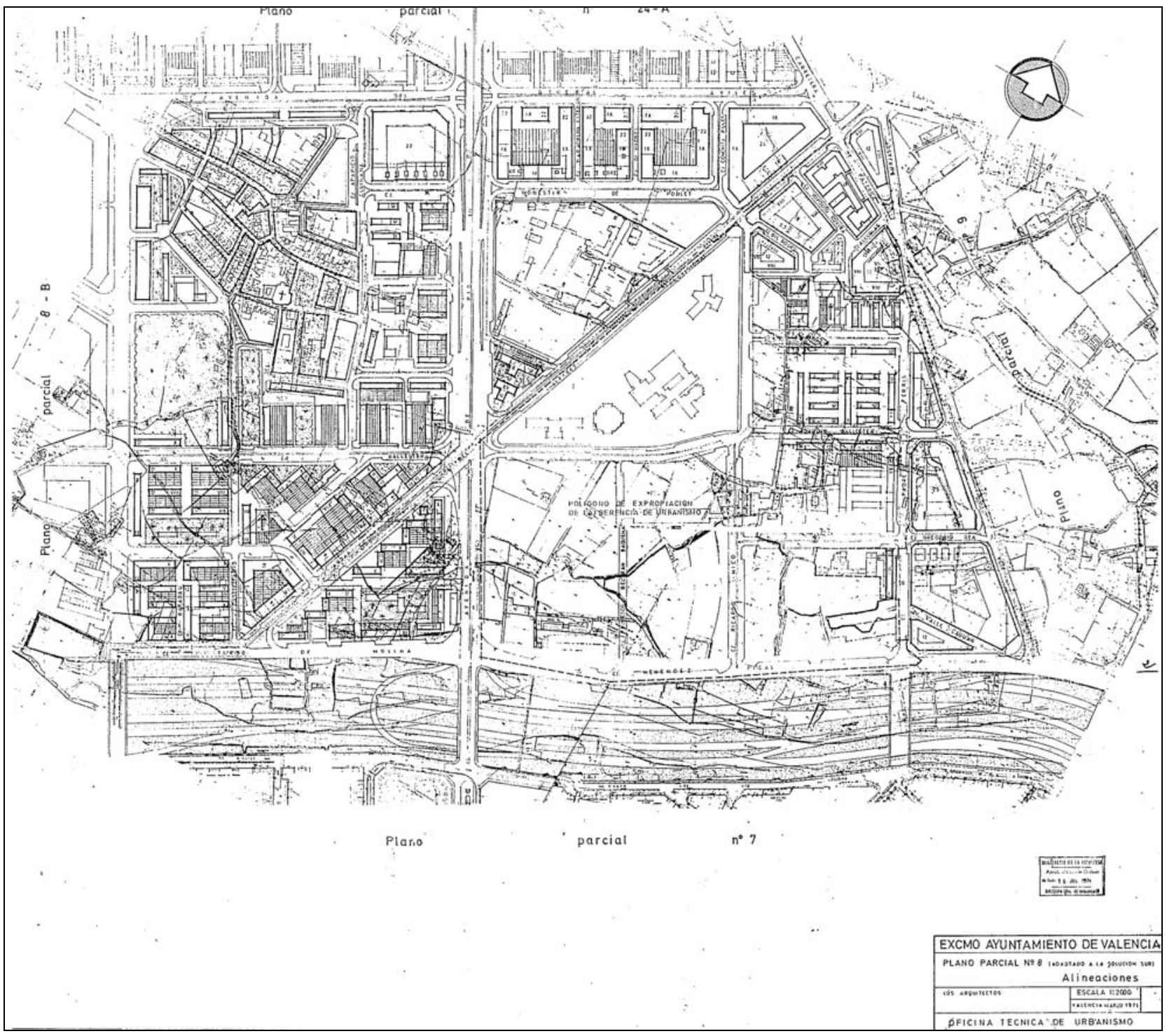


1. PLANO DE SITUACIÓN EN LA CIUDAD

Escala original: 1:10.000

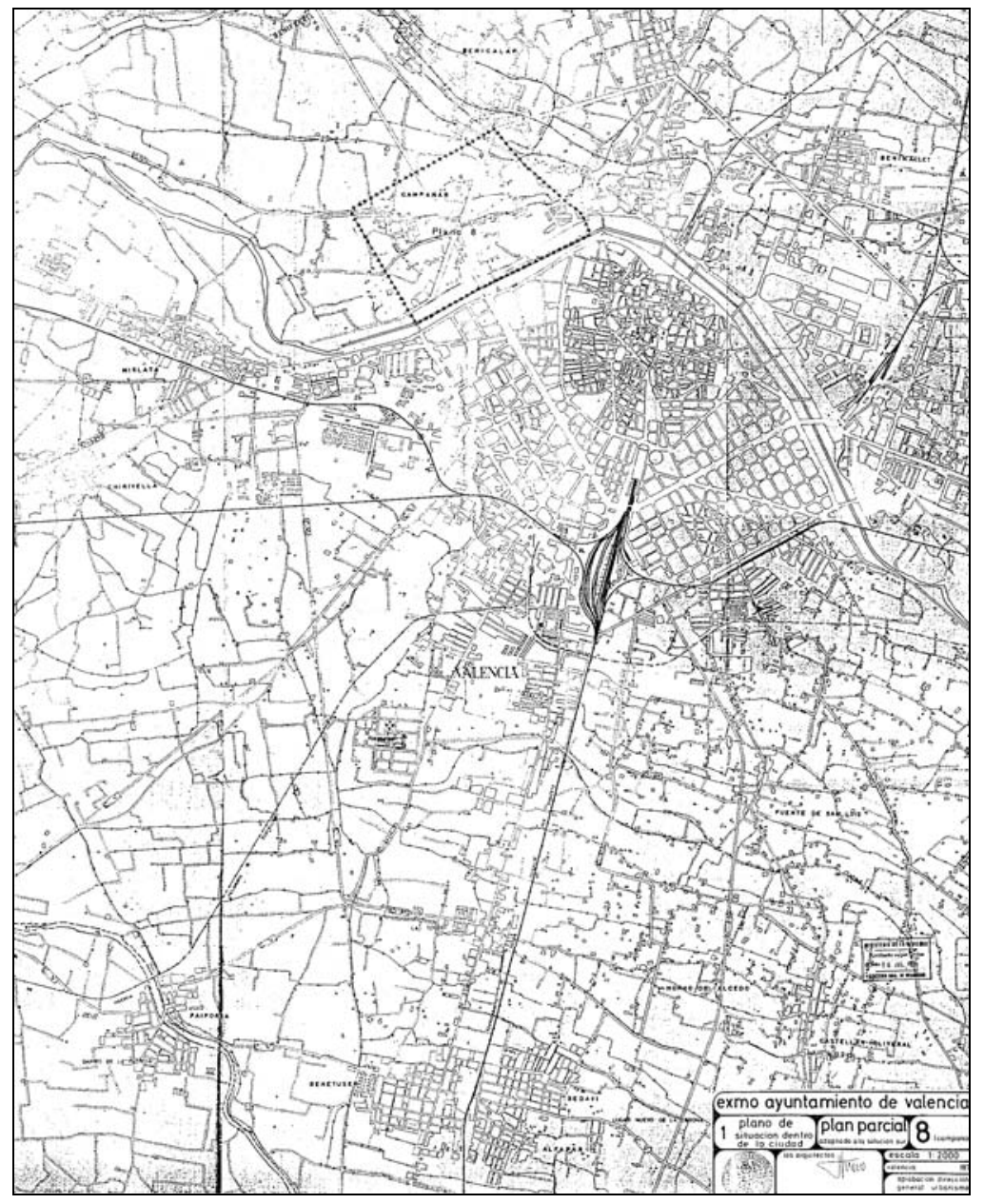

2. PLANO DE SITUACIÓN EN EL PLAN GENERAL (Fragmento) Escala original: 1:22.500

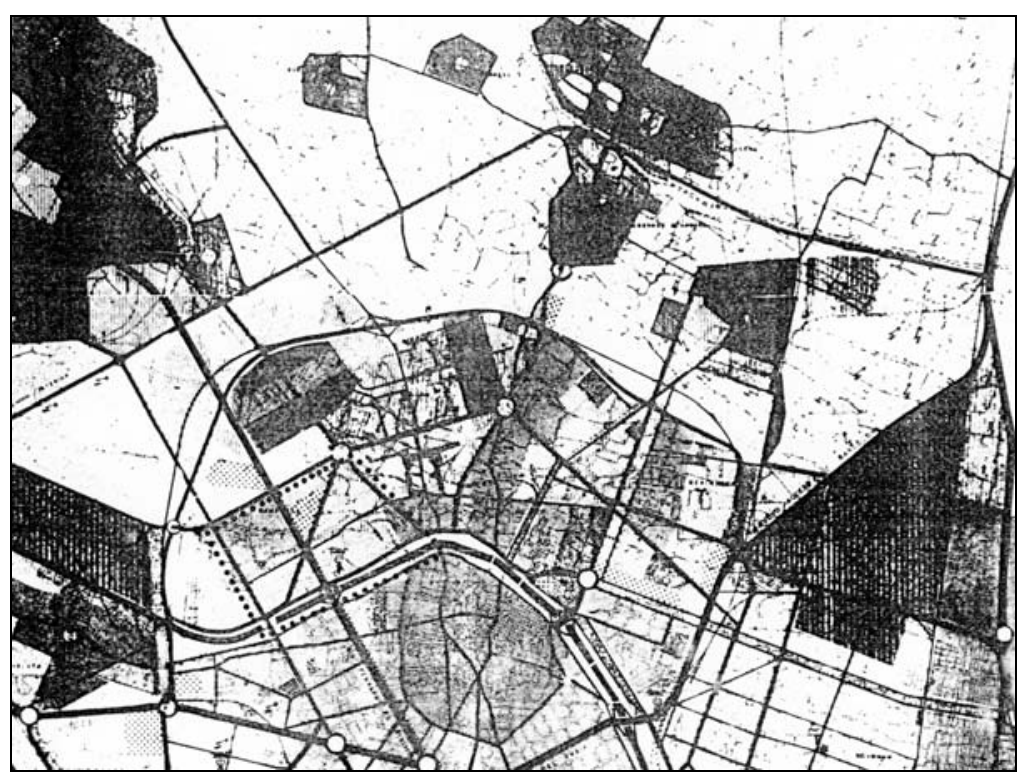


3. PLANO DE INFORMACIÓN.

Escala original: 1:2000

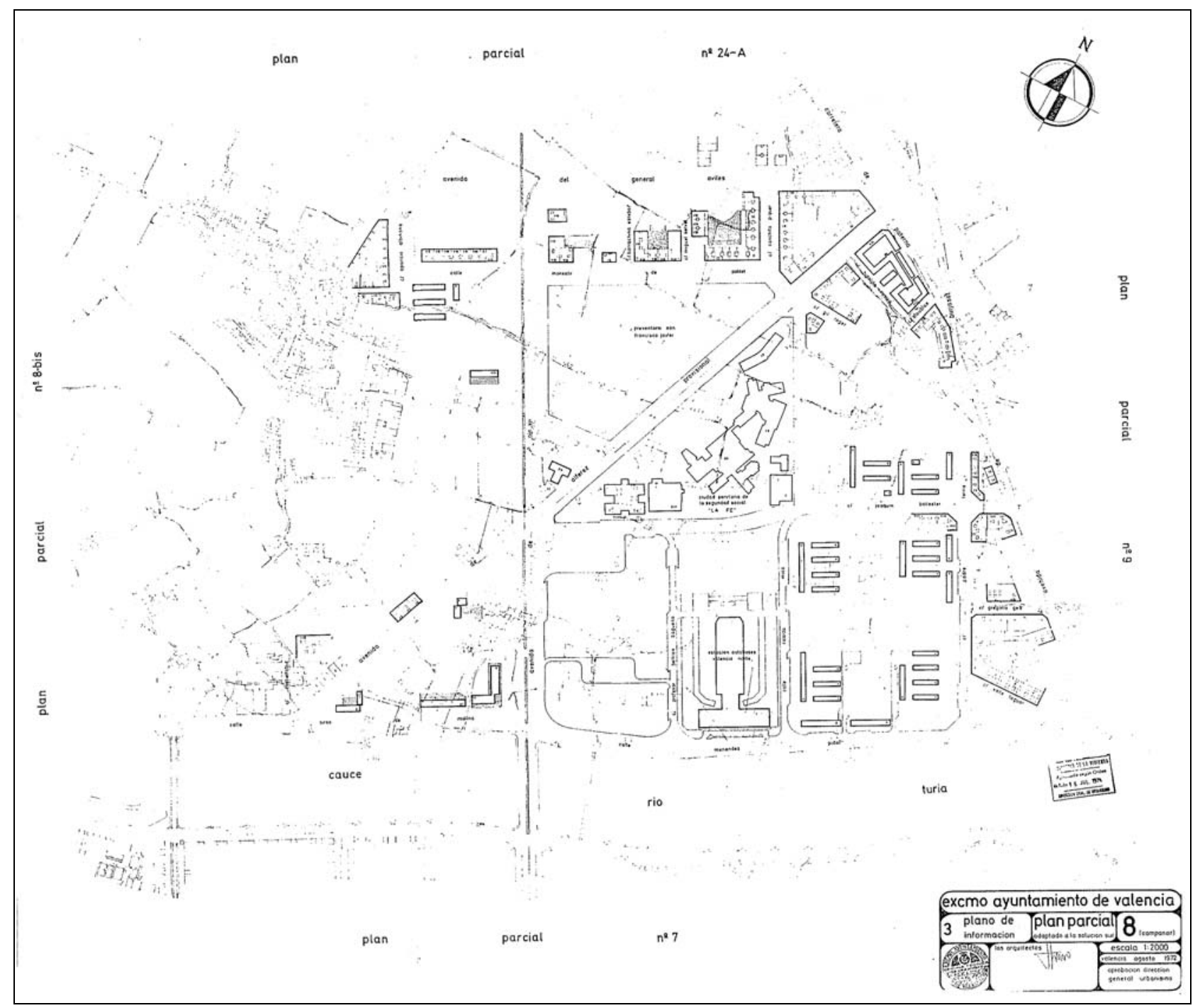


4. ZONIFICACIÓN.

Escala original: 1:2000

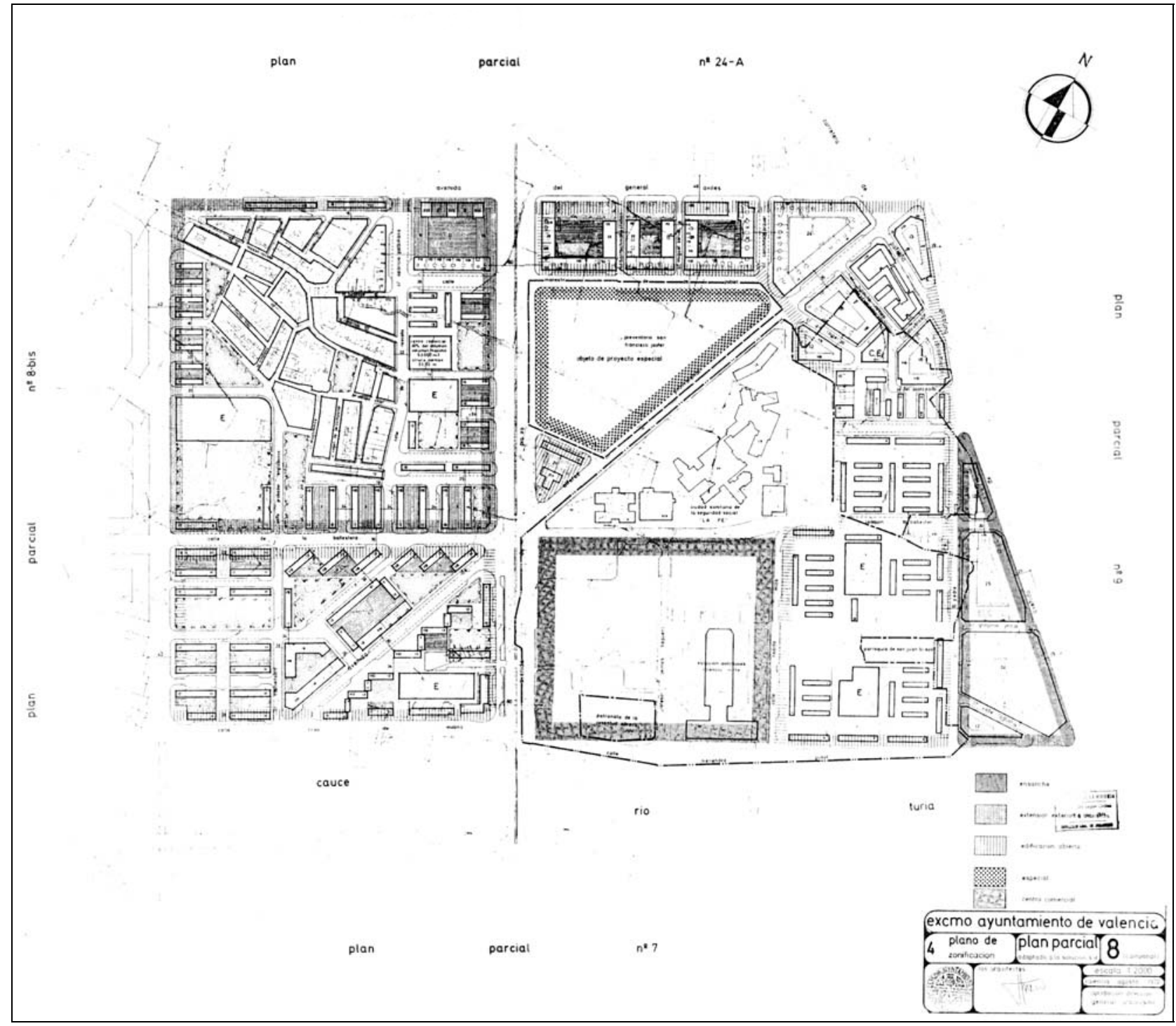




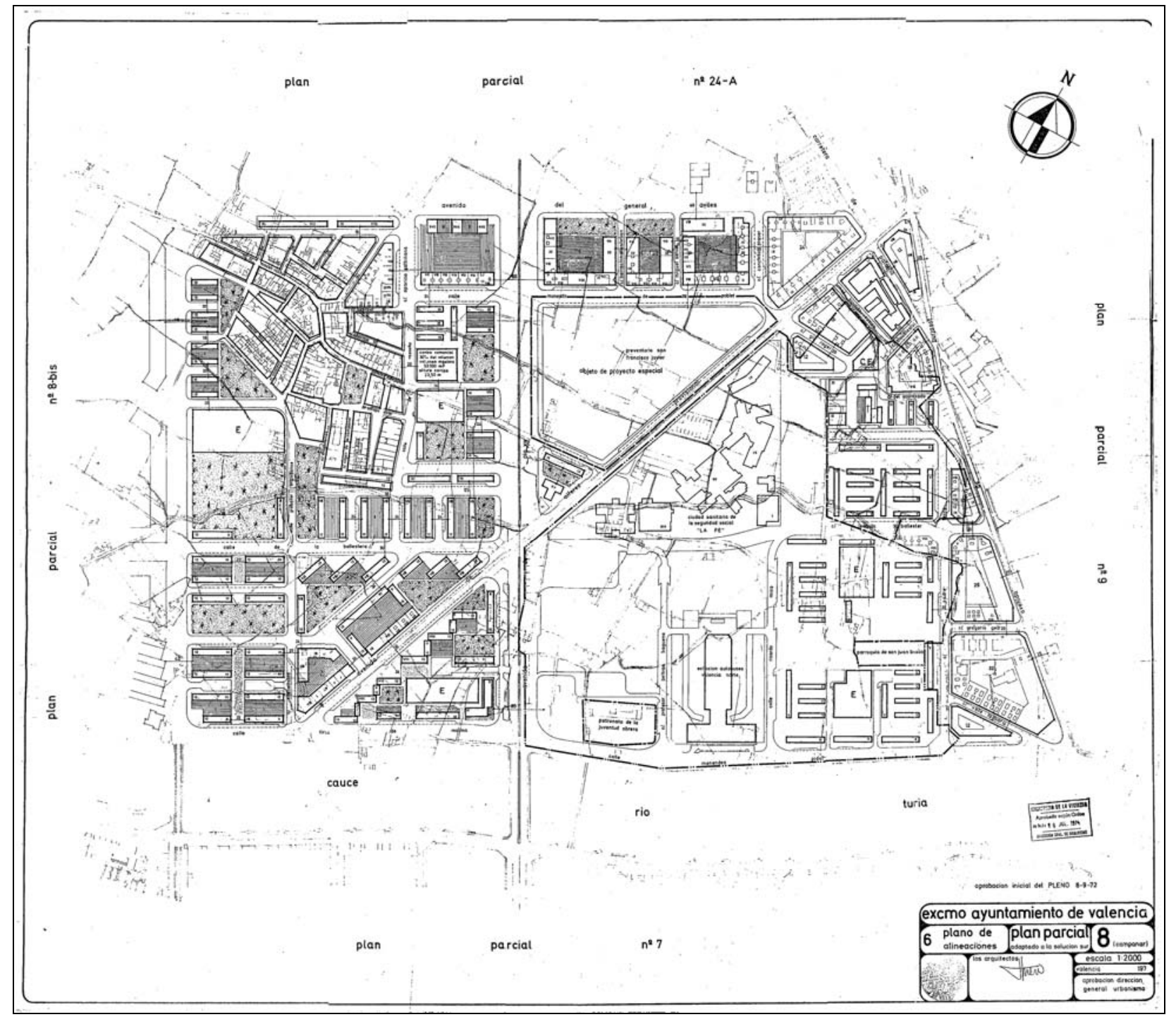




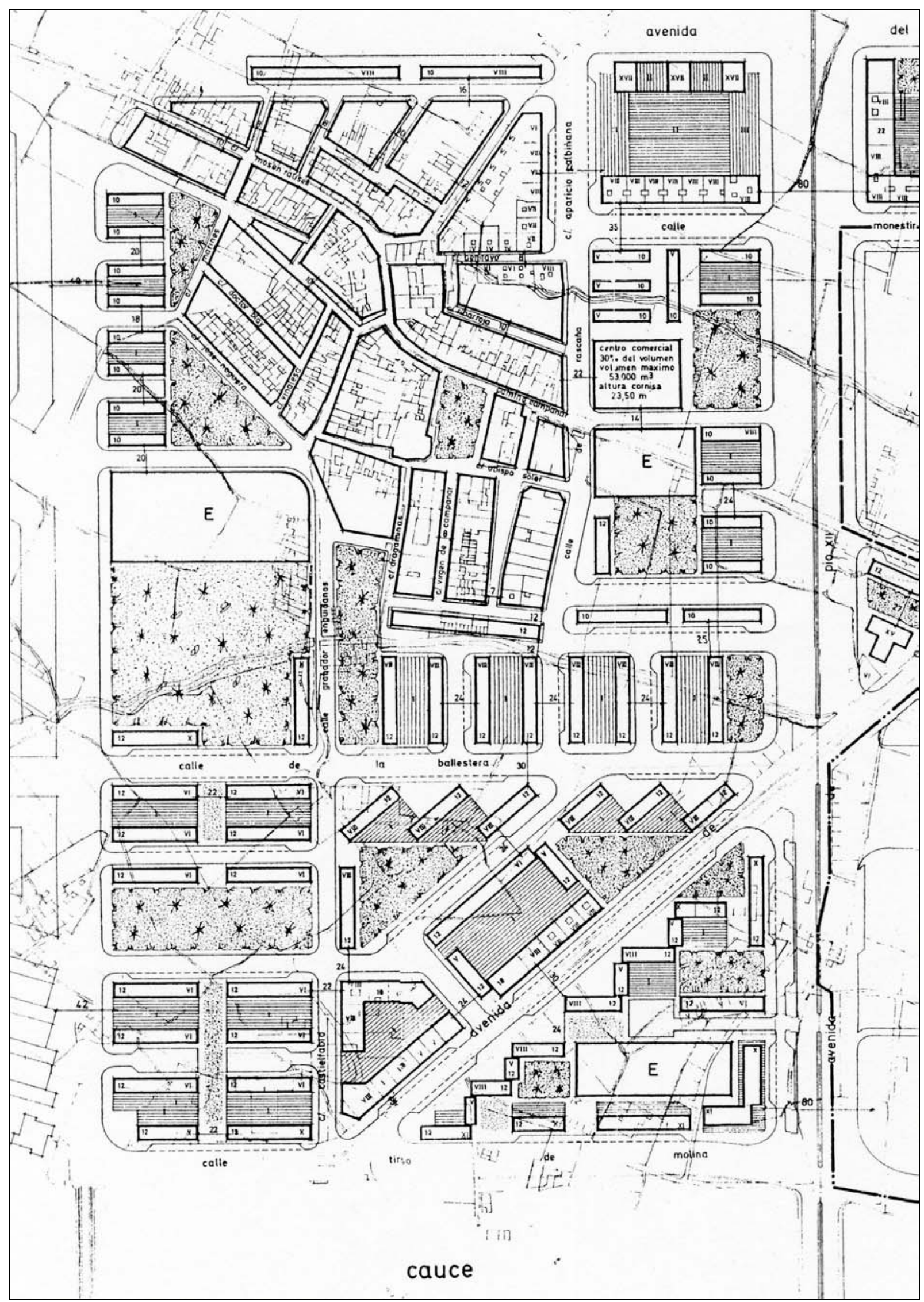

Detalle del Plano de alineaciones.Zona en torno a Campanar. 


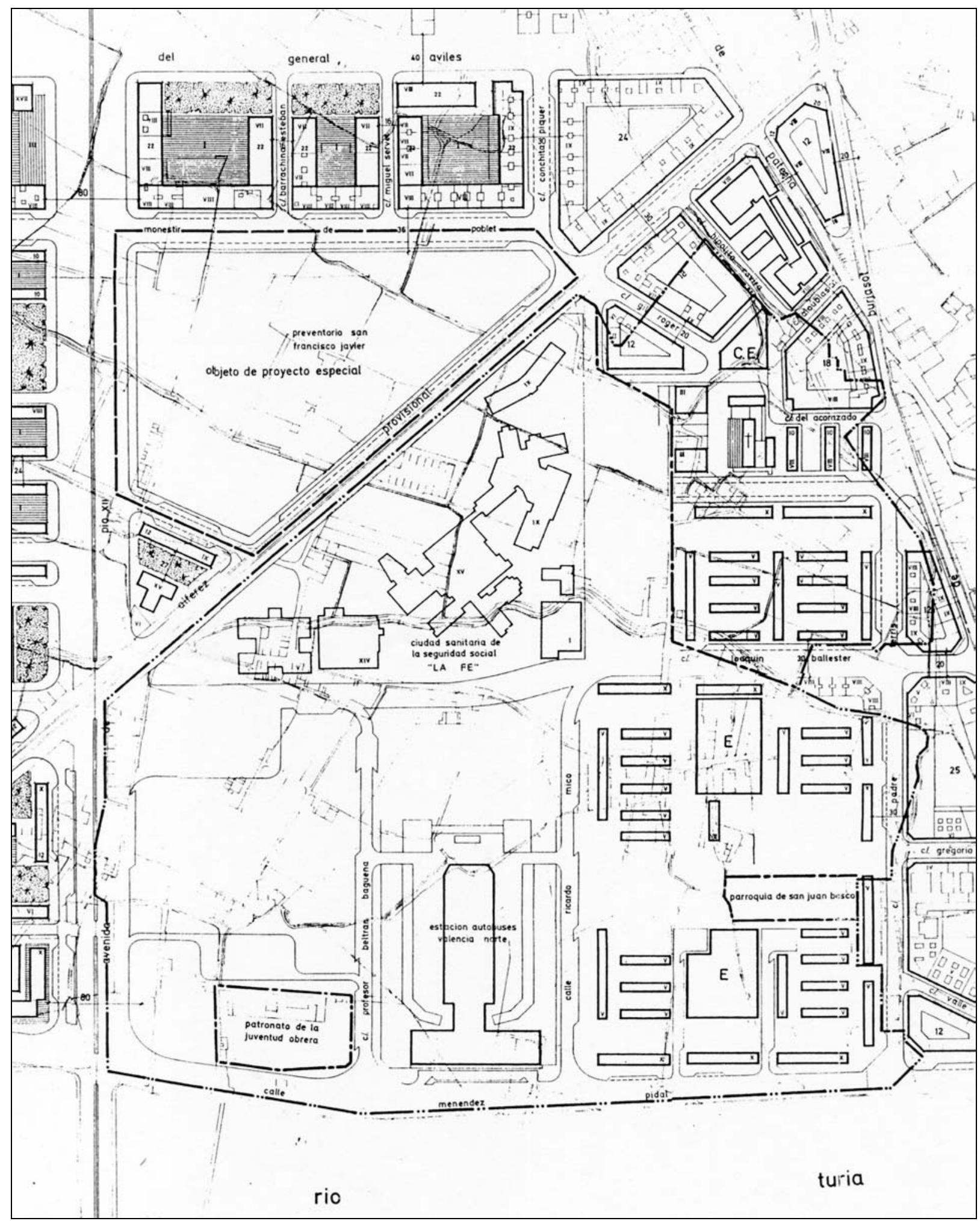

Detalle del Plano de alineaciones. Zona de Tendetes. 
7. RED VIARIA FUNDAMENTAL

Escala original: 1:2000

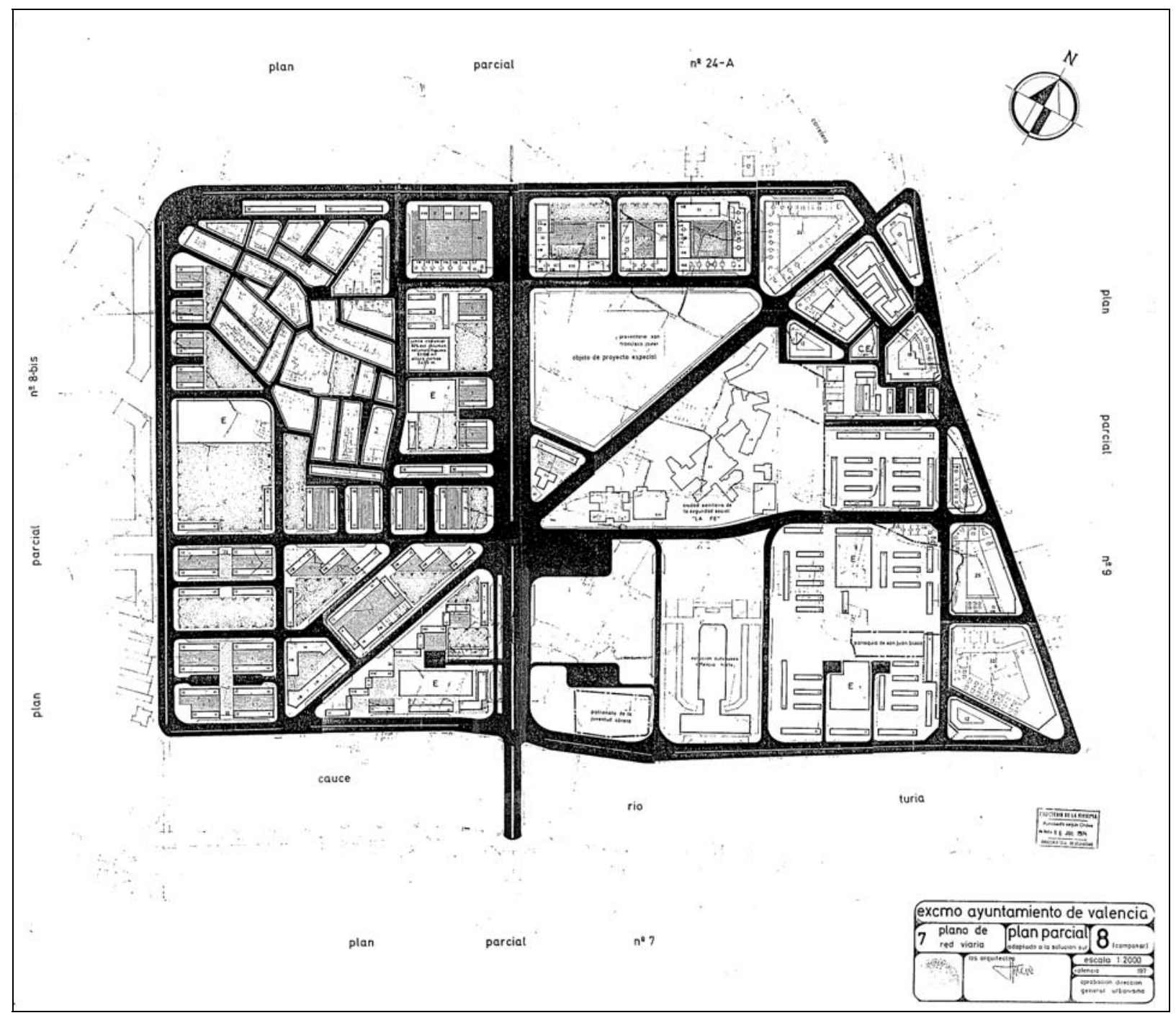


Redactor: El Arquitecto Municipal de Urbanismo. Ayuntamiento de Valencia.

Fecha: 13-01-1973

Asunto: Informe sobre alegaciones presentadas a la versión inicial del PP 8.

Fuente: Ayuntamiento de Valencia. Sección de Urbanismo. Negociado de Suelo y Ordenación urbana. Expte. 365/1967. Reg. General 67.718 (Archivo de Planeamiento, No 67).

El Arquitecto Municipal que suscribe, encargado del nuevo estudio del Plan Parcial No 8, tras el oportuno estudio de las reclamaciones presentadas al mismo, ha de informar lo siguiente:

10.- Reclamación del Párroco de la Parroquia de la Resurrección del Señor. No 74.905. Solicita se sustituya la leyenda C.E. (Centro Escolar) por la de "Centro Parroquial".

Los terrenos están incluidos en el Polígono de Campanar, aprobado definitivamente por la Superioridad, por tanto, no es momento para la reclamación.

20.- Reclamación de D. Joaquín Vicente Giménez, Presidente de la Cooperativa OMEGA. No 76.601. Solicita se acote la altura del bloque que pretende construir, con VIII plantas en todo el bloque.

Con esta cota no tendría que hacerse un retranqueo de 3,50 metros en la última planta, que en un bloque de 10,00 metros de profundidad es realmente una mala solución constructiva.

En otros bloques similares, con la misma edificación, se ha acotado la altura por el mismo motivo. Estimo se puede atender dicha reclamación.

30.- Reclamación de D. Rafael Viguer Salvador. No 78.373. Solicita se cambie el destino de una parcela de su propiedad, que es zona verde.

Estimo que no se puede acceder a ello por ser necesaria la reserva de zonas verdes.

De no accederse, solicita la reparcelación de unidad superior, que se efectuará al aprobarse el Plan.

40.- Reclamación de D. Manuel Falcó Cabrelles. No 78.734 y No 84.975. Solicita el cambio de destino de dos parcelas de su propiedad, situando bloques de edificación.

Pero, es el caso que una de ellas es zona verde y zona escolar, fundamentales para cumplir los requisitos legales, y que además, basan sus "razonamientos" en hipótesis temerarias e indamisibles: por ejemplo, "que un cálculo elemental del censo de población... no dará de sí para cubrir las plazas escolares..."

En la otra zona, en la cual tienen parte de viales, parte de zonas verdes y parte edificable, basándose en argumentos similares y claramente contradictorios con la decisión del Ministerio sobre zonas verdes: por ejemplo, "...unos espacios verdes entre edificaciones cumplen el mismo fin..." que las zonas verdes.

Considero no aceptable la solución de aumentar la edificabilidad a costa de las zonas verdes y escolares.

50.- Reclamación de Da Antonia Valleres Alfonso. No 78.375. Solicita se reduzca la distancia entre dos bloques de 10 y 11 plantas de edificación abierta, de 24 metros que figuran, a 10 metros. 


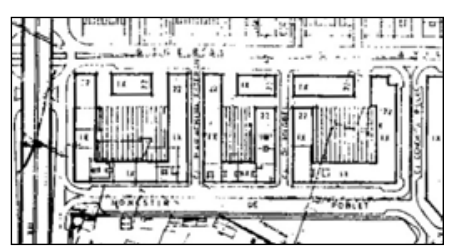

Versión inicial

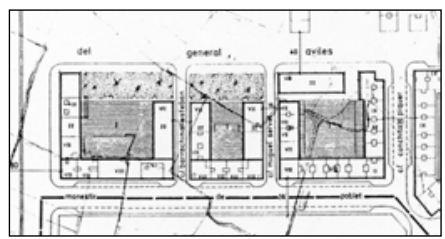

Versión final
Estimo que las distancias son lo suficientemente exiguas como para no reducirlas más.

60.- Reclamación de D. Melchor y D. Juan Hoyos Pérez. No 78.925. Solicita que en el terreno de uso comercial se diga "Centro Comercial" y no se limite la altura a cornisa.

Centro Comercial es una denominación del Plan General que exige unas superficies mínimas de 2 y 6 Has. Según categoría.

Dado que lo que interesa a los reclamantes es la posibilidad de dedicar parte del volumen a viviendas, se puede tomar de "Centro Comercial" el mínimo del $30 \%$ del volumen de uso comercial.

Respecto a la limitación de altura, que en el plano expuesto figura de 18,00 metros (VI plantas), considero que debe existir una limitación de altura, y dado que la zona es Extensión Exterior a Tránsitos y el techo de 23,50 m. y VIII plantas, propongo que se coloque la siguiente leyenda:

$$
\begin{array}{ll}
\text { Uso comercial } & 30 \% \text { del volumen } . \\
\text { Volumen máximo }= & 53.000 .-\mathrm{m} 3 \\
\text { Altura máxima }= & 23,50 \mathrm{~m} .
\end{array}
$$

70.- Reclamación de D. Fernando Musoles Barber. No 79.190 y No 86.358. Hace petición en el sentido de que se ejecute reparcelación.

Tal reparcelación sería firme sólo cuando esté el Plan Parcial aprobado. Pero, resulta que sus terrenos están situados dentro del Plan Parcial del Polígono de Campanar del Ministerio de la Vivienda, aunque fuera de los límites de expropiación.

Por tanto, no es momento para dicha reclamación puesto que el Plan parcial que ordena sus terrenos está aprobado definitivamente, y en el Plan Parcial No 8 solamente se refleja el Polígono de Campanar porque está dentro de los terrenos asignados al Plan Parcial No 8, pero no se hace ninguna propuesta de Ordenación.

$8^{\circ}$.- Reclamación de D. Vicente Santonja Mercader y otros. Número 79.509. Solicitan aumento de edificabilidad en sus terrenos.

Estas manzanas fueron objeto de la denegación de este Plan Parcial por el Ministerio de la Vivienda, por exceso de volumen.

Con la nueva ordenación se ha paliado en parte el exceso de volumen, precisamente eliminándolo de esta zona y colocando zonas verdes, que lo compensan.

Estimo no puede accederse a lo solicitado, por estar el volumen por encima ya del máximo.

90.- Reclamación de D. Antonio Salóm Comos. No 79.510. Solicita se ubique sobre un edificio de su propiedad, un bloque de $X$ alturas en vez de la zona verde.

Dicho bloque ya figuraba en el Plan parcial No 8 anterior y aprobado provisionalmente por la Corporación en fecha 4 de noviembre de 1.968 .

Estimo que no es procedente volver a la situación anterior, por exceder del volumen previsto en el Plan general para Edificación Abierta.

No obstante, adjunto croquis con una solución intermedia situando un bloque de seis plantas.

100.- Reclamación de D. Alfredo y D. Enrique Ciurana Real. No 79.511. Manifiestan que se convierten en vía pública unos edificios recientemente construidos por ellos.

Comprobada la veracidad de las afirmaciones, se procede a restituir la zona, con las alineaciones anteriores. 
Se adjunta croquis.

110.- reclamación de D. Francisco Mir Andrés y D. José Ruiz Farinós. Número 79.871. Solicitan se mantenga la altura de 10 plantas en bloque de su propiedad, y se suprima planta baja de unión.

La altura está calculada en función del volumen y estimo no sería procedente volver al antiguo volumen, superior al actualmente propuesto.

120.- Reclamación de D. Miguel Blasco Armela. No 79.872. Solicita se acote C/ Juan Aguilar con su ancho real de 8 metros, respetando las actuales alineaciones.

Comprobada la veracidad de las afirmaciones, se procede a la rectificación según croquis adjunto.

130.- Reclamación de D. Vicente Santonja Mercader. No 79.873. Solicita aumento de la edificabilidad de sus terrenos por medio de dos soluciones.

El mismo reconoce que la calificación de Edificación Abierta es la aplicable a la zona, aunque luego se pierda en consideraciones sobre la calidad visual de las viviendas subvencionadas, lo descongestivo volumétricamente del Preventorio de San Francisco Javier, haciendo comparaciones con la manzana lindante al otro lado de Pio XII, manzana singular en que no se ha superado el volumen total que le corresponde, mientras que en la manzana de la reclamación se ha superado, siendo objeto de la denegación por el Ministerio de la Vivienda.

La única solución para aumentar algo la edificabilidad es suprimir el entrante existente en Pío XII / General Avilés, convirtiéndolo en esquina, solución que propongo puesto que no existe simetría en el caso de hacerse entrantes a ambos lados de Pío XII, al ser uno de ellos el encuentro de un bloque de tres alturas con otro de diecisiete y el que nos ocupa su corte en un bloque de ocho.

Se adjunta croquis.

140.- Reclamación de Da María Milagro Giner Giner. No 79.874. Propone a su solar dos "soluciones" para paliar el exceso de volumen en la zona; ambas se parecen en que su solar se califica de singular y se diferencian en que una es más singular todavía que la otra.

Ambas son en sí inaceptables, por estar en zona de edificación abierta con limitación de volumen a $5 \mathrm{~m} 3 / \mathrm{m} 2$.

La única solución para aumentar algo la edificabilidad sin alteración de zonas verdes ni altura, es eliminar el entrante en cruce Pío XII / General Avilés (ver reclamación No 79.873).

Se adjunta croquis.

150.- Reclamación de D. José Alfonso Badía. No 80.107. Solicita se mantenga las alineaciones y alturas del anterior planeamiento.

Pero, se ha variado para mantenerse dentro de los límites del volumen marcado por el Plan General para Edificación abierta y precisamente en la zona en que se reclama hay una congestión local superior a la del resto del polígono.

160.- Reclamación de D. Francisco López Juncos. No 80.108. Solicita se aumente la edificabilidad, en el sentido de mantener el anterior planeamiento.

Pero, se ha variado la planificación, entre otras cosas para adaptarse al volumen marcado en el Plan general para edificación abierta, por tanto no estimo aceptable la reclamación.

170.- reclamación de D. Vicente Longo Vila y otros. Número 80.776. Solicitan la vuelta al planeamiento anterior, en el cual figuraba un bloque de 12 metros de profundidad en sus terrenos.

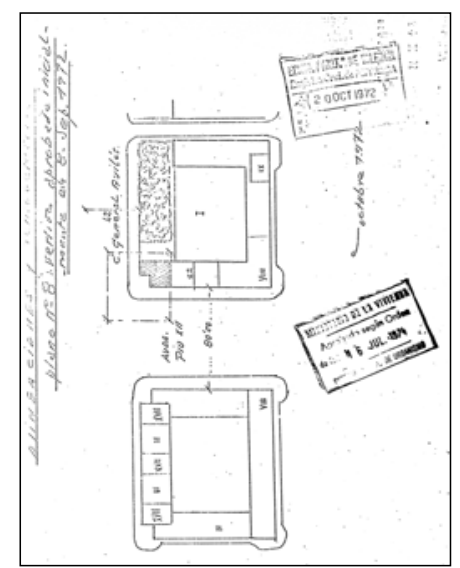

Reclamación No 79.873

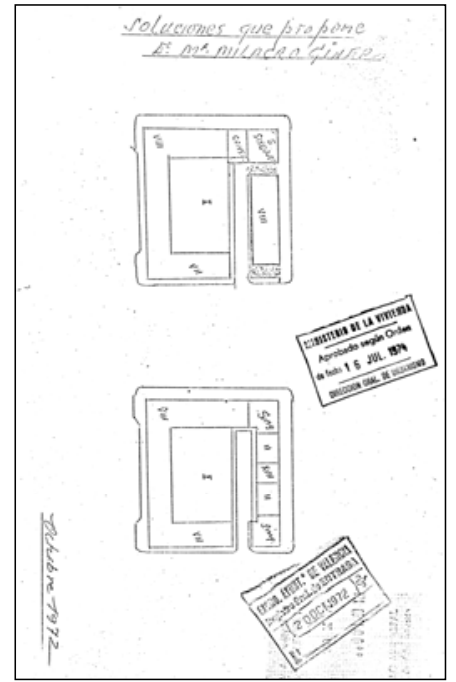

Reclamación No 79.874 
Comprobada la suficiente dotación de zona verde, se adjunta croquis de la propuesta de modificación.

18ㅇ.- Reclamación de D. Francisco Vila Casani. No 80.777. Solicita por medio de una extensa alegación, se mantenga el anterior planeamiento o bien que se efectúe la reparcelación.

La necesidad de la reserva legal para zonas verdes ha hecho que se elimine el terreno dedicado a nave comercial para calificarlo como zona verde.

En cuanto al volumen, respetando sus opiniones al respecto, se ha tenido que reducir alturas para no exceder del marcado por el Plan general para Edificación Abierta.

Se adjunta croquis grafiando modificación en que se acepta en parte la reclamación.

El bajo comercial se sitúa como antes y la altura queda de VIII plantas (antes $\mathrm{X}$ ).

Con la solución indicada, el volumen total de la manzana es inferior al anterior planeamiento y por otro lado, no se perjudica a dichos propietarios.

Es cuanto tiene el honor de informar a V.E. a los oportunos efectos.

V.E. o obstante con su superior criterio resolverá.

Valencia, 13 de Enero de 1973.

EL ARQUITECTO MUNICIPAL,
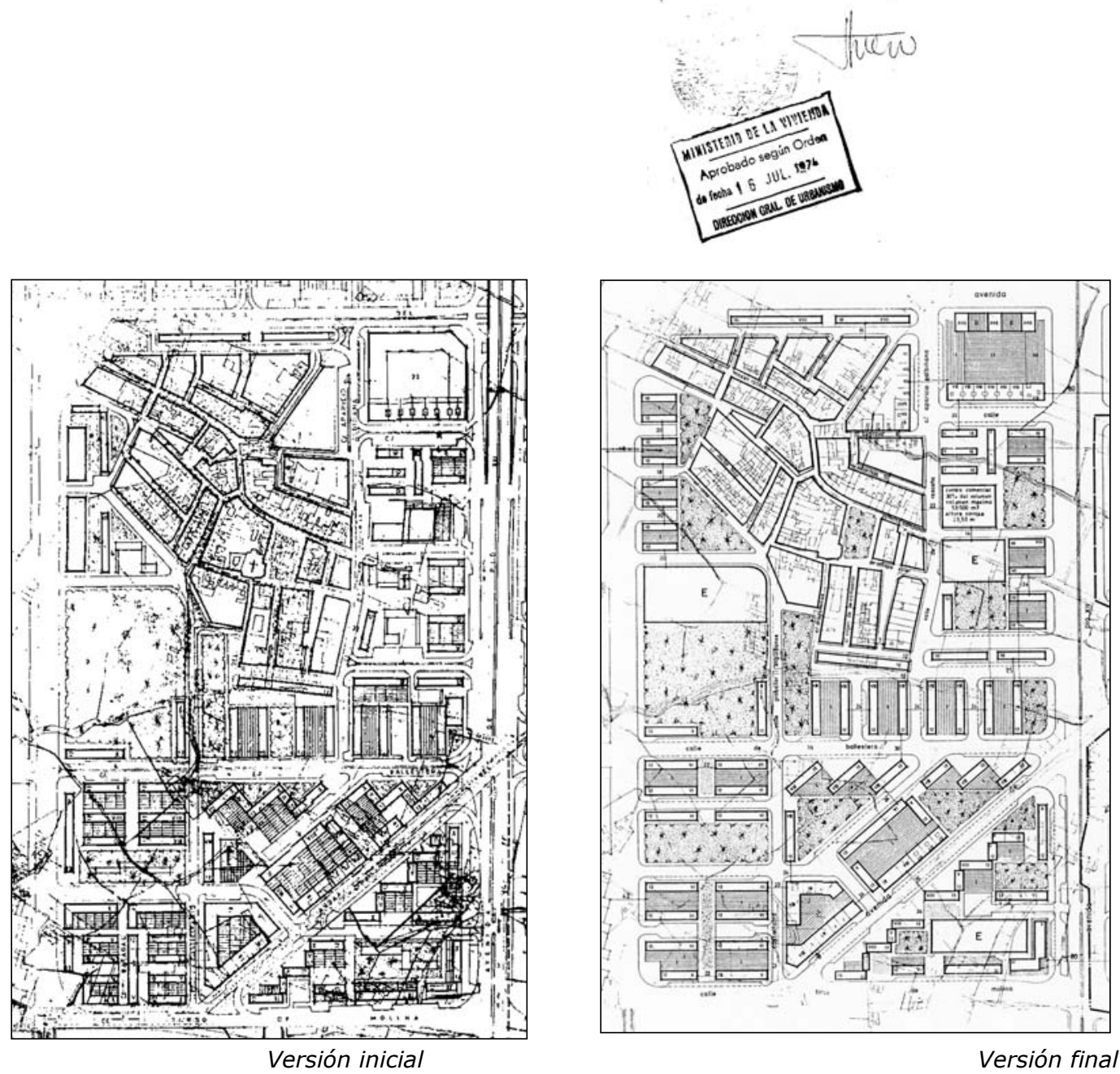
Redactor: Dirección General de Urbanismo del Ministerio de la Vivienda / Ministerio de la Vivienda.

Fecha: 16- 07-1974.

Asunto: Resolución de aprobación del Plan Parcial 8 con rectificaciones.

Fuente: Ayuntamiento de Valencia. Sección de Urbanismo. Negociado de Suelo y Ordenación urbana. Expte. 365/1967. Reg. General 67.718 (Archivo de Planeamiento No 67).

\section{MINISTERIO DE LA VIVIENDA}

\section{Ilmo Sr.:}

VISTO el Plan Parcial de Ordenación Urbana no 8, Campanar, , de Valencia, presentado por el Ayuntamiento de dicha Capital.

VISTOS la Ley sobre Régimen del Suelo y Ordenación Urbana, de 12 de mayo de 1956, los Decretos 63/1968, de 18 de enero y $1994 / 72$, de 13 de julio, y el informe emitido por los Servicios competentes de la Dirección General de Urbanismo.

Este Ministerio Acuerda: guientes:

10.- Aprobar el referido Plan Parcial, con las rectificaciones si-

a) Para la manzana delimitada por la Avenida del general Avilés, calles Aparicio Albiñana, Monasterio de Poblet y Avenida de Pío XII, se reducen las alturas de edificación a las que determina el Plan General para las zonas de extensión exterior a tránsitos, por no resultar justificada la reserva de dispensación en alturas de edificación pretendida, que sólo puede concederse para edificios monumentales o singulares, y conforme al procedimiento señalado en el apartado $3^{\circ}$ del artículo 46 de la Ley del Suelo.

b) A efectos de previsión de aparcamientos, se fijará como mínimo una plaza por vivienda, y

$2^{\circ}$.- Declarar que la zona calificada como especial en el Plan General, y cuya ordenación se difiere a un Proyecto Especial, deberá destinarse a edificios y servicio de interés público, con exclusión de usos residenciales.

La determinación a que se refiere el apartado b) $1^{\circ}$ de esta resolución se establecerá en el presente Plan Parcial de la forma que estime más oportuna el Ayuntamiento; la documentación correspondiente que la recoja, en unión de la debidamente rectificada, incorporando la modificación a) 1 y observación contenida en el pronunciamiento $2^{\circ}$ de esta resolución, se elevarán a este Departamento, por triplicado ejemplar, en el plazo de tres meses para su debida constancia.

Esta resolución se notificará al Ayuntamiento de Valencia y se publicará en el Boletín Oficial del Estado.

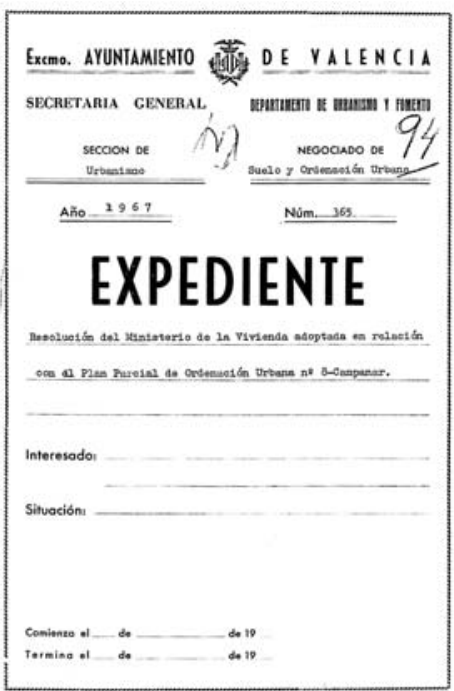


Lo que comunico a V. I. para su conocimiento y efectos.

Dios guarde a V.I.

Madrid, 16 de Julio de 1974

P.D.

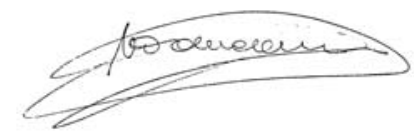

Ilmo. Sr. Alcalde Presidente del Ayuntamiento de Valencia. 
Redactor: El Arquitecto Municipal. Ayuntamiento de Valencia.

Fecha: 16- 07-1974.

Asunto: Informe sobre rectificaciones realizadas en el PP8.

Fuente: Ayuntamiento de Valencia. Sección de Urbanismo. Negociado de Suelo y Ordenación urbana. Expte. 365/1967. Reg. General 67.718 (Archivo de Planeamiento No 67).

A la vista del escrito del Ministerio de la Vivienda debo manifestar, que se adjunta por triplicado, para su remisión al citado Ministerio, la documentación del Plan Parcial no 8 modificada en los siguientes extremos:

10.- La manzana limitada por la Avda. General Avilés, calles Aparicio Albiñana, monasterio de Poblet y Avda Pio XII, se reducen las alturas de edificación, de acuerdo con la solicitud de la propiedad, que limita el numero de plantas en la calle General Avilés a zonas de 2, 3 y 7 plantas, por debajo siempre de las 8 que determina el plan general. Con esta nueva propuesta de volúmenes se termina la modificación de dicha manzana, de una forma que puede considerarse positiva en el sentido de la reducción del volumen total permitido en principio por el plan general y por el hecho de construirse un número bastante elevado de plazas de aparcamiento en el edificio de 7 plantas recayente a Avda. General Avilés.

20.- A efectos de la previsión de aparcamientos, y con los datos obtenidos de la memoria, para las 3.807 viviendas que se proyectan, serán necesarias 3.807 plazas.

Una parte de esas plazas se cubrirán con la reserva de aparcamiento obligatoria que establece la norma 33 del plan General y que ofrece las siguientes cifras:

En locales comerciales, los $380.700 \mathrm{~m} 3$ significan, tomando una altura promedio de 4'00 m, $95.175 \mathrm{~m} 2$, de los cuales un 15\% será destinado a aparcamiento, es decir $14.276 \mathrm{~m} 2$

En viviendas, los $1.142 .100 \mathrm{~m} 3$, con un promedio de 3'00 m de altura, nos arrojan una cifra de $380.700 \mathrm{~m} 2$, lo cual obligará a una reserva como mínimo del 5\%, es decir, a 19.035 m2 de aparcamiento.

En total se destinarán $33.311 \mathrm{~m} 2$. Si consideramos un mínimo de $20 \mathrm{~m} 2$ por plaza, en este plan parcial son necesarios para las 3.807 plazas, $76.140 \mathrm{~m} 2$.

Es decir que tendremos que afrontar ta construcción, en áreas dedicadas a aparcamiento, de un mínimo de $42 \gg 829 \mathrm{~m} 2$.

No consideraremos a estos efectos, la superficie que en los viales está dedicada a estacionamiento de vehículos, sino que vamos a concentrar en varios edificios subterráneos repartidos por toda la zona, las plazas que quedan por cubrir.

La única posibilidad de que disponemos para no modificar toda la trama del plan parcial, es usar las zonas verdes como aparcamiento subterráneo y para evitar afectar a una gran superficie de aquellas y por motivos de mayor rentabilidad, supondremos dos plantas de aparcamiento.

El objetivo pretendido al dispersar en 6 zonas, en vez de una concentración (posible) es múltiple.

Por un lado evitar que la mayor zona verde, la 7, con cerca 
de $20.000 \mathrm{~m} 2$, pierda posibilidades de arbolado, puesto que al ser pequeño el espesor de la tierra, estas zonas verdes quedan limitadas en cuanto su vegetación a césped y arbustos.

Por otro lado, evitar los problemas de tráfico de una gran concentración de vehículos, con sus salidas y entradas, cambios de dirección etc.

También logramos una mayor efectividad, en el sentido de que cada supermanzana, aproximadamente, tiene su zona de aparcamiento.

Asimismo creemos que puede potenciarse la vida de barrio, si se realizan estas zonas públicas-jardines-aparcamiento- con una cierta calidad técnica y ambiental.

Por último, pero no menos importante, la posibilidad de hacer escalonadamente la inversión necesaria y resolver el problema del aparcamiento a la vez que se produce, por partes, puesto que no todo el plan parcial se va a construir de una sola vez.

La forma de construcción, adjudicación y explotación de estos aparcamientos, se dejan a criterio del ayuntamiento, puesto que el tema no está estudiado suficientemente.

La relación de superficies es la siguiente, contando con dos plantas en cada zona verde:

\begin{tabular}{|c|c|c|}
\hline $\begin{array}{l}\text { Z Verde } \\
\text { " }\end{array}$ & $n^{\circ} 2$ & $\begin{array}{l}4.048 \mathrm{~m} 2 \\
4.048 "\end{array}$ \\
\hline$"$ & no 4 & 3.978 " \\
\hline$"$ & & 3.978 \\
\hline$"$ & no 5 & $3.720 "$ \\
\hline$"$ & & $3.720 "$ \\
\hline$"$ & no 8 & 4.800 \\
\hline$"$ & & 4.800 \\
\hline$"$ & no 9 & 3.588 \\
\hline$"$ & & 3.588 \\
\hline " & no 10 & $2.756 "$ \\
\hline " & & $2.756 "$ \\
\hline $\begin{array}{l}\text { TOTAL } \\
====\end{array}$ & $===$ & $\begin{array}{l}45.780 \mathrm{~m} 2 \\
======\end{array}$ \\
\hline
\end{tabular}

El total de superficie destinada a aparcamiento es pues, do $79.091 \mathrm{~m} 2$, lo que nos permite la reserva de 3.954 plazas.

30.- La zona calificada como especial en el plan general, delimitada por las calles Monasterio de Poblet, Avda Pio XII, Avda Alférez Provisional y calles en proyecto, se especifica en todos los planos de plan parcial que su uso será el de edificios públicos con exclusión del uso residencial.

Con todo ello estimo el Plan Parcial no 8 puede ser remitido al ministerio a los efectos de su aprobación definitiva.

Valencia 5 de Noviembre de 1.974

El Arquitecto:

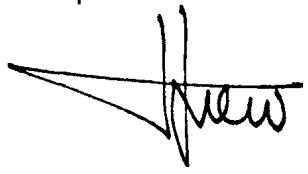


Redactor: Dirección General de Urbanismo del Ministerio de la Vivienda / Ministerio de la Vivienda.

Fecha: 7- 06-1975.

Asunto: Nueva resolución de aprobación del Plan Parcial 8.

Fuente: Ayuntamiento de Valencia. Sección de Urbanismo. Negociado de Suelo y Ordenación urbana. Expte. 365/1967. Reg. General 67.718 (Archivo de Planeamiento No 67).

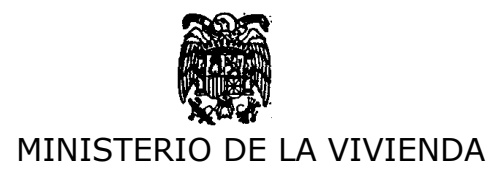

Ilmo Sr.:

VISTA la documentación rectificada del Plan Parcial de Ordenación Urbana $\mathrm{n}^{\circ}$. 8, Campanar, de Valencia, presentada por el Ayuntamiento correspondiente, según lo prevenido en la Orden Ministerial de 16 de Julio de 1.974, que al aprobar el precitado Plan con las rectificaciones de reducir alturas en determinada manzana, mantener para la zona especial su destino para edificios de interés público y fijar la proporción de aparcamientos, dispuso que estas rectificaciones debían ser incorporadas al Plan.

VISTOS las Leyes de 12 de Mayo de 1.956 sobre Régimen del Suelo y Ordenación Urbana y de su reforma de 2 de mayo de 1.975, Ios Decretos 63/1.968 de 18 de Enero y 1994/72 de 13 de Julio y el informe emitido por los servicios competentes de la Dirección General de Urbanismo.

Este Ministerio considerando que con la documentación aportada se han introducido convenientemente en el Plan las modificaciones impuestas en la precitada resolución de 16 de Julio de 1.974, Acuerda declararla debidamente cumplimentada.

Esta resolución se notificará al Ayuntamiento de Valencia, y a la Corporación Administrativa Gran Valencia y se publicará en el Boletín Oficial del Estado.

Lo que comunico a V.I. para su conocimiento y efectos.

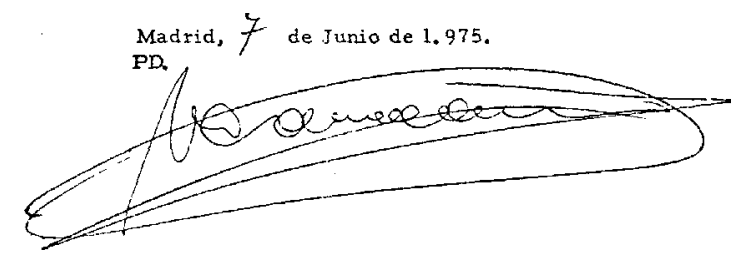

IImo. Sr. Director General de Urbanismo. 



\section{PP 9}

PLANO PARCIAL No 9 (ADAPTADO A LA SOLUCIÓN SUR). 1973.

Redactores: EXCMO. AYUNTAMIENTO DE VALENCIA. OFICINA TÉCNICA DE URBANISMO.

Fecha redacción: Febrero 1973.(*)

Fecha aprobación: O.M. 11-07-1974 (B.O.E. 06-09-74) (**).

Contenido: (Fecha documentos Febrero 1973; Addenda: Enero 1975)

I. MEMORIA

II. ORDENANZAS.

PLANOS:

1. PLANO DE SITUACIÓN DENTRO DE LA CIUDAD. $1: 10.000$

2. SITUACIÓN EN EL PLAN GENERAL $1: 22.500$

3. INFORMACIÓN Y FOTO AÉREA $\quad 1: 2000$

4. ZONIFICACIÓN $1: 2000$

5. ESTRUCTURA URBANÍSTICA $1: 2000$

6. ALINEACIONES $1: 2000$

7. RED VIARIA FUNDAMENTAL $1: 2000$

8. REDES FUNDAMENTALES DE SERVICIOS.
RED DE ALCANTARILLADO

ESQUEMA DE RED DE AGUAS POTABLES $\quad 1: 2000$

ESQUEMA DE ALUMBRADO. $1: 2000$

III. ADDENDA: PREVISIÓN DE APARCAMIENTOS. (***)

Fuente: Ayuntamiento de Valencia. Sección de Urbanismo. Negociado de Suelo y Ordenación urbana. Expte. 781/1973 (Archivo de Planeamiento No 79).

\section{Notas:}

* Existe una versión previa del Plan Parcial 9 redactada en 1967, firmada por los arquitectos Julio Bellot y Joaquín Arnau, con No de Expediente 187/1967, que fue aprobada inicialmente con fecha 5.03-1968 y provisionalmente con fecha 6-05-1970, y cuyo expediente fue finalmente anulado en 1970. Adjuntamos plano de alineaciones de la misma.

** El PP 9 no sufrió ninguna modificación significativa durante el periodo de alegaciones, ya que estas fuerosn desestimadas en su práctica totalidad (ver Documento 9A.1). La aprobación del Ministerio de la Vivienda de fecha 11-07-1974 es con exclusiones (ver Documento 9.1). La aprobación completa es de 11-07-1975, con condiciones (Ver Documento 9.2).

*** De fecha Enero de 1975. Sustituye al Plano no 5. 


\section{EXCMO. AYUNTAMIENTO DE VALENCIA}

\section{PROYECTO PLAN PARCIAL NO 9}

\section{MEMORIA}

\section{1.- ZONIFICACIÓN Y LIMITES DEL PLAN}

La adaptación del Plan General de Ordenación Urbana de Valencia y su Comarca a la Solución Sur dispone para el ámbito de este Proyecto Parcial, dos zonas claramente diferenciadas, sectores separados por la calle Reus. Las zonificaciones que establece, son:

Sector norte - ZONA DE EDIFICACIÓN ABIERTA ALTA (densidad $5 \mathrm{~m} 3 / \mathrm{m} 2$ )

Sector sur - ZONA INTENSIVA Sector ENSANCHE HASTA TRÁNSITOS

El Plan general considera un enclave de zona verde que es reflejo de la existente en el antiguo Plano Parcial No 9 (POLÍGONO V), vigente hasta la aprobación del mismo y cuyos presupuestos, ya establecidos, en parte ejecutados e inexcusables, son la base para el presente estudio de adaptación.

La zona de edificación abierta comprende lo que hemos denominado sector norte del proyecto parcial, lindante con el Camino de Tránsitos, hoy Avenida de Onésimo Redondo (Ronda Interior), Camino de Burjasot, hoy Avenida del mismo nombre, viejo acceso de Barcelona, hoy Avenida de Ramiro Ledesma, y la mencionada calle de Reus. Es necesario observar que, dentro de esta zona existen una serie de manzanas cerradas recayentes a las citadas avenidas, que el Plan General no contempló en su zonificación, manzanas que están en su mayor parte terminadas siguiendo la ordenación del antiguo Polígono V.

La Zona Intensiva, sector Ensanche hasta Tránsitos, situada debajo de la anterior, linda con la calle Reus, avenida de Burjasot, avenida de Ramiro Ledesma y por el sur con el río Turia (Ilano de la Zaidía).

Así pues, los lindes de este Plan parcial son:

norte - Avenida de Onésimo Redondo (limite del Plan Parcial signatura $24-\mathrm{B}$ y el 23 )

sur - río Turia

este - Avenida de Ramiro ledesma (límite del Plan Parcial signatura 10)

oeste - Avenida de Burjasot (límite del Plan parcial signatura 8)

\section{2.- ESTADO ACTUAL}

El proyecto que se redacta está adaptado a las directrices del Plan General, y se realiza sobre la estructura urbanística existente del antiguo Plan Parcial signatura 9, Polígono $\mathrm{V}$, el cual poseía aprobación de la Dirección general de Urbanismo, de fecha 4 de noviembre de 1961. Según disposición del Consejo general de la Corporación Administrativa "Gran valencia", este Plan parcial debe ser sometido a la reglamentaria tramitación al estar afectado en parte por el Plan General.

Las zonas edificadas en el momento actual sobre la superfi 
cie de este Proyecto Parcial son las siguientes:

1.2.1.- Poblado de Marchalenes. Este caserío, de ordenación lineal, se inserta en torno al Viejo Camino del mismo nombre, que atraviesa el área del Plano parcial desde su ángulo sur-este hasta el punto del Camino actual de Burjasot, distante del Camino Tránsitos, aproximadamente, un tercio de la longitud total del tramo que nos afecta. Este caserío no fue tenido en cuenta en la redacción del Proyecto parcial vigente hasta la aprobación del Plan General, por lo que en parte ha desaparecido en virtud de las alineaciones del Polígono $V$, y siendo criterio de este estudio el máximo respeto a las alineaciones en él proyectadas, impuesto por el gran número de edificios ejecutados, hemos mantenido esta omisión.

1.2.2.- Edificación antigua a lo largo de las vías más importantes. Esta edificación viene a flanquear en forma prácticamente continua los viejos accesos de Burjasot y Barcelona y la margen del cauce del río, formando aglomeraciones más o menos libres sin otro criterio ordenador que el del Camino que las ha hecho surgir. Incluyen naves artesanales de la misma antigüedad y dispuestas con anarquía. Este edificación, respondiendo a redes viarias que, con mayor o menos rango, se mantienen, fue incorporada al antiguo Proyecto Parcial.

1.2.3.- Edificación reciente. Ésta ha aparecido con carácter intensivo en ambas zonificaciones. En la de edificación abierta, cubre los extremos oeste y este del Plano parcial, enlazados a lo largo del Camino de Tránsitos, al norte del Plano. En la Intensiva, se encuentra distribuida por toda la zona, abarcando las dos terceras partes aproximadamente de la edificación prevista.

Todas estas construcciones, habiendo emergido posteriormente a la redacción y aprobación del antiguo Proyecto parcial, se atienen, al menos en cuanto a alineaciones, a dicho Polígono $V$, quedando sin embargo sus alturas en plantas grafiadas en los planos de Estado Actual en números romanos.

\subsection{RED VIARIA.}

Las redes viarias afectas a este proyecto parcial se clasifican, según su uso y carácter, en los rangos siguientes:

Red roja.- Se entiende como tal el conjunto de vías establecidas por la Dirección General de Carreteras del Ministerio de Obras Públicas en su Estudio Previo de la Red Arterial, que entran total o parcialmente en el campo de acción del referido organismo. Los viales de esta red son: al norte el Camino de Tránsitos, y al sur el Llano de la Zaidía, en sentido este-oeste del Plano Parcial. Y en sentido norte-sur, el Nuevo Acceso a Bétera (calle Dr. Olóriz), que impone una serie de modificaciones en las alineaciones próximas a su embocadura norte.

Red azul.- Se entiende como tal el conjunto de vías urbanas cuya función es el enlace de barrios contiguos. En estas vías predomina la capacidad de circulación. Los viales de este red son, la calle Reus, bidireccional este-oeste, prevista ya en el antiguo proyecto, que separa las dos zonas de este Plan parcial y establece la conexión de toda una cadena de barrios comprendidos entre el ca 
mino de Tránsitos y el cauce del Río Turia. También corresponde a este grupo la Avenida de Ramiro Ledesma, sentido norte-sur, que se complementa con el vecino Proyecto Parcial signatura 10. Ambas vías con manifiesta continuidad fuera del ámbito de este Plan parcial No 9.

Redes Verde y Amarilla.- Son el conjunto de vías urbanas cuya función básica es el enlace y distribución dentro del Plan parcial y barrios, de sus diversos sectores o núcleos residenciales. La red amarilla enlaza de forma inmediata la propiedad y unidades de aparcamiento. Los anchos totales de todas estas redes han sido acotados en el Plano de Alineaciones.

Secciones Transversales.- Se obtienen directamente partiendo del rango asignado a cada una de estas vías, el cual prevé de antemano los sentidos de circulación, la fluidez que debe exigirse a ésta, el control de accesos, posibilidad de giros a la izquierda y la conveniencia de aparcamientos. Estas secciones tipo admiten cierta oscilación en el grado de servicio a prestar, entendiéndose que la sección escogida está comprendida entre una sección tipo ideal o deseable y una sección tipo mínima o exigible. En estas márgenes se incluye la apreciación de anchos de aceras. El criterio pues aplicado ha sido la comparación ponderada de posibilidades y exigencias. Según él, se ha impuesto la sección tipo óptima cuando no era obstáculo para ella ninguna edificación reciente o de especial valor y las licencias municipales ya concedidas, y se ha limitado la sección de carácter mínimo en el resto de los casos.

Aparcamientos.- Por ser de absoluta necesidad y estimarse necesaria la previsión de aparcamientos concentrados en los sectores edificados en manzana cerrada, se ha estudiado, la previsión de ubicación en los mismos de aparcamientos de vehículos. Se toma idéntica medida en la zona de Edificación Abierta. Esta previsión queda reflejada en las Ordenanzas anejas.

\section{4.- ALINEACIONES.}

El estudio de adaptación que nos ocupa ha sido restringido a la modificación de aquellas alineaciones que incumplen las normas urbanísticas del Plan General, que entorpecen el desarrollo de un viario coherente y lógico, o bien han sido estimadas inadmisibles para unos criterios actuales.

El Plan Parcial (Polígono V) vigente hasta la aprobación del Plan general, resolvía la edificación antigua, existente en las zonas perimetrales del proyecto, englobándolas en diversas manzanas cerradas con patio interior. Estando estas manzanas iniciadas y prácticamente terminadas en su mayor parte, siguiendo dicho Plano y el posterior Plan parcial aprobado provisionalmente por el Excmo. Ayuntamiento, se mantiene la profundidad edificable y alineaciones exteriores de las mismas.

En la Zona Intensiva, sector Ensanche hasta Tránsitos, sólo dos manzanas recayentes a Ramiro Ledesma, Llano de Zaidía, calle Reus y Avenida Doctor Olóriz, no construidas totalmente en la actualidad, han sido modificadas agrupándolas en una sola, abierta, para ubicar en parte de ella una zona escolar que recoge y amplía las escuelas existentes del Dr. Olóriz, satisfaciendo las necesidades que el Plan de Urgencia Escolar precisa en dicha zona.

En la Zona de Edificación Abierta, las modificaciones propuestas 
son como sigue: rectificación de alineaciones promovidas por la embocadura norte del nuevo Acceso de Bétera (cruce con el Camino de Tránsitos), que se desplaza al este sensiblemente por exigencias de su continuidad.

Desplazamiento de bloques en el sector noroeste, con el fin de rectificar el colector paralelo al Camino de Tránsitos de la Red Verde, cuya embocadura, recayente al camino de Burjasot, viene fijada por manzanas con patio interior de edificación reciente. Los bloques desplazados hacia el norte conservan dimensiones en plantas sensiblemente coincidentes con las del antiguo Polígono V. Dos de dichos bloques se suprimen por exigencias de continuidad de la zona verde grafiada en el Plan General.

Los bloques de manzana abierta al sur de los antedichos se reducen en altura con el fin de que cumplan con la separación por aplicación de la correspondiente norma. Esta pauta de reducir alturas ha sido general durante la nueva redacción de este Proyecto. Junto al Centro Comercial existe una zona verde en el Plan general; la ubicación de la misma obliga a la supresión de los bloques previstos en el anterior estudio, ubicando sólo tres en sentido norte-sur y reduciendo cinco plantas, quedando con siete. En el sector noreste, la manzana cerrada recayente a Ramiro Ledesma y al Norte, a la calle Economista Gay, ha pasado a ser bloque abierto siguiendo el Plan General, pues no está iniciada. Se mantiene la alineación de la citada Avenida.

Quedan no obstante, en esta zonificación de Edificación Abierta, las siguientes manzanas tratadas como cerradas con la ordenación equivalente a Ensanche hasta Tránsitos, pues están todas ellas iniciadas y en su mayor parte totalmente terminadas: Las tres situadas al oeste de la zona, recayentes a la Avenida de Burjasot. Una, al este, recayente a la Avenida Ramiro Ledesma, al sur de la Avenida de Portugal. Las situadas al noreste de la zona, en la confluencia del camino de Tránsitos con la Avenida de Ramiro Ledesma. Manzanas que han recibido el tratamiento de cerradas ordenado por el Polígono $\mathrm{V}$ y que esta revisión no puede ignorar, por estar edificadas. No obstante, en el cómputo del volumen total del polígono se ha tenido en cuenta el de las mismas.

Las restantes modificaciones han venido impuestas por la necesidad de ubicación de zonas verdes, la ampliación y nueva implantación de espacios escolares con el fin de cumplir con las últimas disposiciones y el ceñirse al volumen total en esta zona de Edificación Abierta, que ya queda sujeto a la Norma del Plan General.

\section{5.- ESTRUCTURA URBANÍSTICA.}

Queda señalada en el plano correspondiente, que refleja el equipamiento urbano del Polígono.

\subsection{SERVICIOS GENERALES.}

Ha sido estudiado un nuevo centro comercial de la zona, manteniendo la ubicación proyectada anteriormente, que estará provisto de los correspondientes aparcamientos, tanto de suministro de mercancías como de clientes, dispondrá de plazas y zonas peatonales accesibles por zonas porticadas y masas vegetales de aislamiento. El volumen previsto para el mismo es de $6 \mathrm{~m} 3 / \mathrm{m} 2$. En el uso de este volumen está excluido el de función residencial. Será objeto de proyecto especial, cuya aprobación estará únicamente condicionada a la del Excmo. Ayuntamiento, que podrá reservar en él la superficie 
necesaria para ubicar servicios asistenciales, administrativos, culturales, etc. Dicho anteproyecto, una vez aprobado, será norma de obligado cumplimiento.

Las escuelas previstas en el Polígono $\mathrm{V}$ y posterior estudio, son insuficientes al contemplar lo dispuesto por las nuevas normas. Las escuelas del Doctor Olóriz, como se ha dicho, se amplían para ubicar en ellas un grupo Escolar de 32 unidades. Las restantes zonas escolares del estudio anterior quedaban en zona verde, por lo que, al respetar ésta, se han ubicado tres zonas escolares de $10.000 \mathrm{~m} 2$ precisas para atender la población en edad escolar del Polígono, cubriendo sus necesidades.

\section{7.- ZONA VERDE.}

Se ha respetado la zona verde incorporada al Plan general que ha sido prácticamente reproducida. Se ubica en terrenos no edificables en su mayor parte, debiendo señalar que se ha ampliado la del Polígono V, aprobado definitivamente en el año 1.961, superando ligeramente las previsiones a este respecto del Plan general, con lo que se mejora sensiblemente el planeamiento. Estas zonas estarán en lo posible conectadas mediante pasos peatonales, a nivel inferior, en los que se prevé la posible ubicación de servicios higiénicos. Son zonas anchas, parques de dimensiones regulares acordes con las necesidades del polígono. En una manzana recayente al noreste del Plano parcial, en una zona sin espacios verdes, se ha remodelado la misma, liberando terreno para este fin y ubicando aparcamientos debajo de esta zona verde, sin que esta pierda su carácter de espacio público.

En la Edificación Abierta se dispondrán zonas, entre los bloques, para jardines y pasos peatonales que poseerán el carácter de espacios públicos.

Valencia, Diciembre de 1.973 LOS ARQUITECTOS,

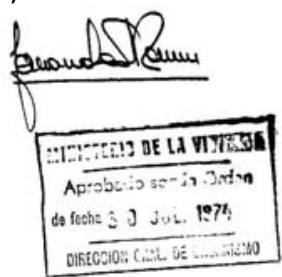




\section{I.1.- DATOS ESTADÍSTICOS}

1.1. Superficie total del Polígono que abarca este Plan parcial

SUPERFICIE TOTAL $664.970 \mathrm{~m} 2$.

1.2. Superficie destinada a zonas

Verdes, parques y jardines. SUPERFICIE ZONAS VERDES $\quad 68.436 \mathrm{~m} 2$
1.2.1. Porcentaje zonas verdes $10,61 \%$

1.3. Superficie destinada a viales,

plazas, aparcamientos, etc.:
SUPERFICIE VIALES $324.997 \mathrm{~m} 2$

1.4. Superficie destinada a centros escolares:

SUPERFICIE ESCUELAS $45.000 \mathrm{~m} 2$

1.5. Superficie edificable para servicios públicos, mercado, centro comercial, etc.
SUPERFICIE SERVICIOS $14.120 \mathrm{~m} 2$

1.6. Superficie total de la zona de Edificación Abierta:

SUPERFICIE ZONA EDIF. ABIERTA $\quad 517.412 \mathrm{~m} 2$

1.7. Superficie de suelo edificable en Zona de Edificación Abierta, en varias plantas: SUPERFICIE VIVIENDAS $112.092 \mathrm{~m} 2$

1.7.1. Idem. En bajos comerciales:

SUPERFICIE EDIFICABLE COMERCIAL $28.791 \mathrm{m2}$

1.8 Superficie de suelo edificable en Zona Intensiva. Sector Ensanche hasta

Tránsitos, en viviendas:

SUPERFICIE EDIF. VIVIENDAS $\quad 37.014 \mathrm{m2}$

1.8.1. Idem. En bajos comerciales: SUPERFICIE EDIF. COMERCIAL $\quad 14.520 \mathrm{~m} 2$

1.9. Volumen edificable para viviendas En Zona de edificación Abierta: VOLUMEN EDIFICABLE VIVIENDAS $\quad 2.438 .043 \mathrm{m3}$

1.9.1. Idem en bajos comerciales: VOLUMEN EDIFICABLE BAJOS $\quad 129.560 \mathrm{m3}$

1.9.2. Coeficiente de edificabilidad en la Zona de edificación Abierta COEFICIENTE DE EDIFICABILIDAD $\quad 4,96 \mathrm{~m} 3 / \mathrm{m} 2$ 
1.10. Estudio para Centros de Enseñanza:

Superficie destinada a viviendas...... $832.512 \mathrm{~m} 2$.

Número de viviendas: $832.512 / 175=4.757$ viviendas.

4.757 viv. $\times 4$ hab/viv. $=19.028$ habitantes

Población escolar:

19.028 hab. $\times 0,17=3.234$ plazas.

3.234 plazas $\times 15 \mathrm{~m} 2 /$ plaza.

$\underline{48.521 \mathrm{~m} 2}$

Superficie ligeramente superior a la prevista, de $45.000 \mathrm{~m} 2$. No obstante, totalmente justificada si se tiene en cuenta las plazas que serán absorbidas por los centros escolares privados ubicados en este Polígono.

Valencia, Diciembre de 1.973.

LOS ARQUITECTOS,

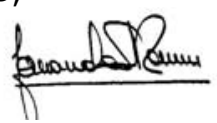




\section{EXCMO. AYUNTAMIENTO DE VALENCIA}

\section{PROYECTO PLAN PARCIAL NO 9}

\section{II.- ORDENANZAS.}

El Plan Parcial No 9 dispone, dentro de su ámbito, dos zonificaciones, de acuerdo con el Plan General adaptado a la Solución Sur:

a) Zona de EDIFICACIÓN INTENSIVA: Sector Ensanche hasta Tránsitos.

b) Zona de EDIFICACIÓN ABIERTA ALTA ( $5 \mathrm{~m} 3 / \mathrm{m} 2$ ).

Hasta la aprobación de las Ordenanzas de la Edificación de la Ciudad de valencia, en trámite de redacción, en este Plan parcial serán de aplicación las disposiciones de las Normas Urbanísticas del Plan General (B.O. del estado 27 junio 1966) y de su cuadro anexo. $Y$, en virtud de la Disposición final de las citadas Normas, aquellos casos no previstos en ellas se regirán por los artículos de las ordenanzas de la Edificación vigentes, que son los aprobados por la Comisión Central de Sanidad Local en fechas 23 de octubre de 1950 y 26 de enero de 1955.

Como complemento de lo antedicho, serán de aplicación los artículos siguientes:

$\left.1^{\circ}\right)$ Edificación en patio de manzana: [...]

20) Centro comercial.

En las manzanas expresamente señaladas en el Plan, su ordenación tendrá que ser objeto de Plan especial de acuerdo con lo dicho en la Norma 26 del Plan General.

Dichos Planes Especiales, que podrán ser promovidos por la iniciativa privada, deberán ser estudiados con todo detalle, estableciendo los volúmenes, su composición y los usos a que se destinan, con sujeción a lo expresamente grafiado en el Plan y a lo que al respecto dice la Norma 35 del Plan General.

Previamente a su construcción deberán ser sometidos a la aprobación municipal.

Una vez aprobado, el Plan podrá ser ejecutado, bien en su totalidad o por fases, pero, en cualquier caso, las construcciones deberán someterse a lo allí establecido.

Valencia, diciembre de 1.973.

LOS ARQUITECTOS,

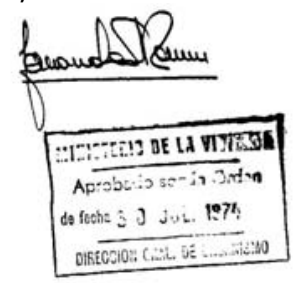




\section{PROYECTO PLAN PARCIAL NO 9}

\section{III.- PLAN DE ETAPAS.}

El Plan parcial No 9, bastante construido en la actualidad por la iniciativa privada, deberá seguir el mismo ritmo, por lo que el plan de etapas dependerá de la actividad constructiva.

El Excmo. Ayuntamiento, además de construir los elementos urbanísticos generales, se mantendrá siempre en la urbanización adelantado sobre la iniciativa particular, urbanizando zonas en que se prevea la edificación inmediata.

\section{MEDIOS ECONÓMICOS FINANCIEROS}

Son los del presupuesto ordinario de Urbanismo del Excmo. Ayuntamiento de Valencia y los extraordinarios que se establezcan a medida que se cumpla lo dicho en el párrafo anterior y se disponga de proyectos detallados de urbanización.

Con lo dicho creemos suficientemente expuesto el alcance del estudio realizado para que, si el Excmo. Ayuntamiento lo estima conveniente, lo eleve a la aprobación por la Superioridad.

Valencia, Diciembre de 1.973 LOS ARQUITECTOS,

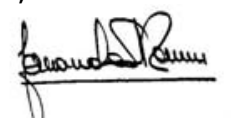




\section{EXCMO. AYUNTAMIENTO DE VALENCIA}

\section{PLAN PARCIAL DE ORDENACION URBANA No 9}

\section{III.- DETERMINACION SOBRE PREVISION DE APARCAMIENTOS}

Por acuerdo del Ministerio de la Vivienda, a afectos de previsión de aparcamientos, se fija como mínimo una plaza por vivienda, estimando dimensiones en superficie, de $20 \mathrm{~m} 2$ por plaza.

Quedan por tanto mejoradas las obligaciones que sobre el tema se disponían en la Norma Urbanística 33 del Plan General de Ordenación de Valencia y su Comarca adaptado a la Solución Sur, por cuanto de su texto se deduce que en las barriadas de "mayor categoría", se consideraba la necesidad de preveer un vehículo por cada tres familias y en las barriadas modestas un vehículo cada cinco familias.

1.- JUSTIFICACIÓN DE LA RESERVA DE APARCAMIENTOS.Teniendo en cuenta que las citadas Normas Urbanísticas, en su Cuadro anexo, indican también que se deberá reservar el $15 \%$ de la superficie construida en edificios destinados a usos comerciales y el $5 \%$ de la superficie de los edificios destinados a viviendas para aparcamientos, y estando dicha normativa vigente desde la aprobación del Plan General, tales porcentajes se consideran reales en cuanto reservas en el Plan.

Asimismo se dispone en las Ordenanzas que en los patios interiores de manzana existe la posibilidad de un mayor aprovechamiento por superficies de entreplanta, no sujetas a la restricción de una sola naya y ocupación del $25 \%$ de la planta, pudiendo construirse las que resulten hasta la cota de $8,00 \mathrm{mts}$. con una luz libre de 2,10 mts. siempre que se destinen a garages o aparcamientos. $Y$ estimando un mínimo de un $20 \%$ de la superficie de estos patios interiores de manzanas y tres el número de plantas al efecto (aunque normalmente serán cuatro sin más que efectuar un rebaje de 1 mts. de la cota del solar y sin considerar las superficies que en plantas de sótanos se destinen), resultan $11.755,00 \mathrm{~m} 2$. para aparcamientos.

Igualmente en tres manzanas de edificación abierta, se prevé en el Plan la necesidad de disponer en el subsuelo de las mismas un mínimo de dos plantas en sótano para aparcamientos públicos; los accesos a los mismos y su conexión a la red viaria, deberán ser objeto de un proyecto especial en el momento de realizarse la urbanización. En la ejecución de dichos aparcamientos en sótano, se deberá tener en cuenta toda la Normativa sobre garages y aparcamientos públicos existe legislada.

No se toman en cuenta las superficies que para aparcamiento de vehículos se destinan normalmente junto a los bordillos de las aceras de las calles que lo permiten tanto en cordón como en batería. Y si se toman en consideración los aparcamientos previstos en el Plan a nivel de calles, conectadas con la red viaria, su superficie total es de 9.115,00 m2. en la zona de Ensanche y 33.509,00 m2. en zona de Edificación Abierta.

2.- DATOS ESTADISTICOS.- El número de viviendas previstas en el Plan es de 4.757. La superficie para aparcamientos, supuesto que cada plaza ocupa $20 \mathrm{~m} 2$., es de $95.140 \mathrm{~m} 2$.

La reserva de aparcamientos en las plantas 
bajas o sótanos, de los edificios de varios pisos y bajos comerciales, según las Normas Urbanísticas será:

En zona de Edificación Abierta:

$5 \%$ de viviendas $\mathrm{s} / 112.092 \mathrm{~m} 2 \quad 5.604,60 \mathrm{~m} 2$

$15 \%$ de los comerc. s/ $28.895 \mathrm{~m} 24.334,25 \mathrm{~m} 2$

En la zona de Ensanche:

$5 \%$ de viviendas $\mathrm{s} / 37.014 \mathrm{~m} 2 \quad 1.850,70 \mathrm{~m} 2$

$15 \%$ de los comerc. s/ $14.520 \mathrm{~m} 22.178,00 \mathrm{~m} 2$

TOTAL......... 13.967,55 m2

La reserva de aparcamientos mínima previsible, en los interiores de patios de manzanas cerradas será:

$20 \% \mathrm{~s} / 26.124 \mathrm{~m} 2 \times 3$ plantas

$15.674,40 \mathrm{~m} 2$

La reserva de aparcamientos previstos en sótanos, en las tres manzanas así ordenadas, suponiendo la existencia mínima de dos plantas, sobre la superficie de las mismas es de:

$18.403 \mathrm{~m} 2 \times 2$ plantas.

La reserva de aparcamientos previstos en el Planeamiento a nivel de la red es de:

Total de la superficie prevista para aparcamientos.

Como se puede deducir del estudio que antecede, ni siquiera se ha tenido en cuenta para el mismo el cómputo de las superficies que junto a los bordillos de aceras antes se mencionaba en la parte justificativa del estudio.

Valencia, Enero de 1975.

EL ARQUITECTO MUNICIPAL,
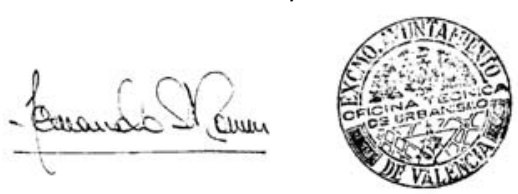
1. PLANO DE ALINEACIONES

Escala original: 1:2.000
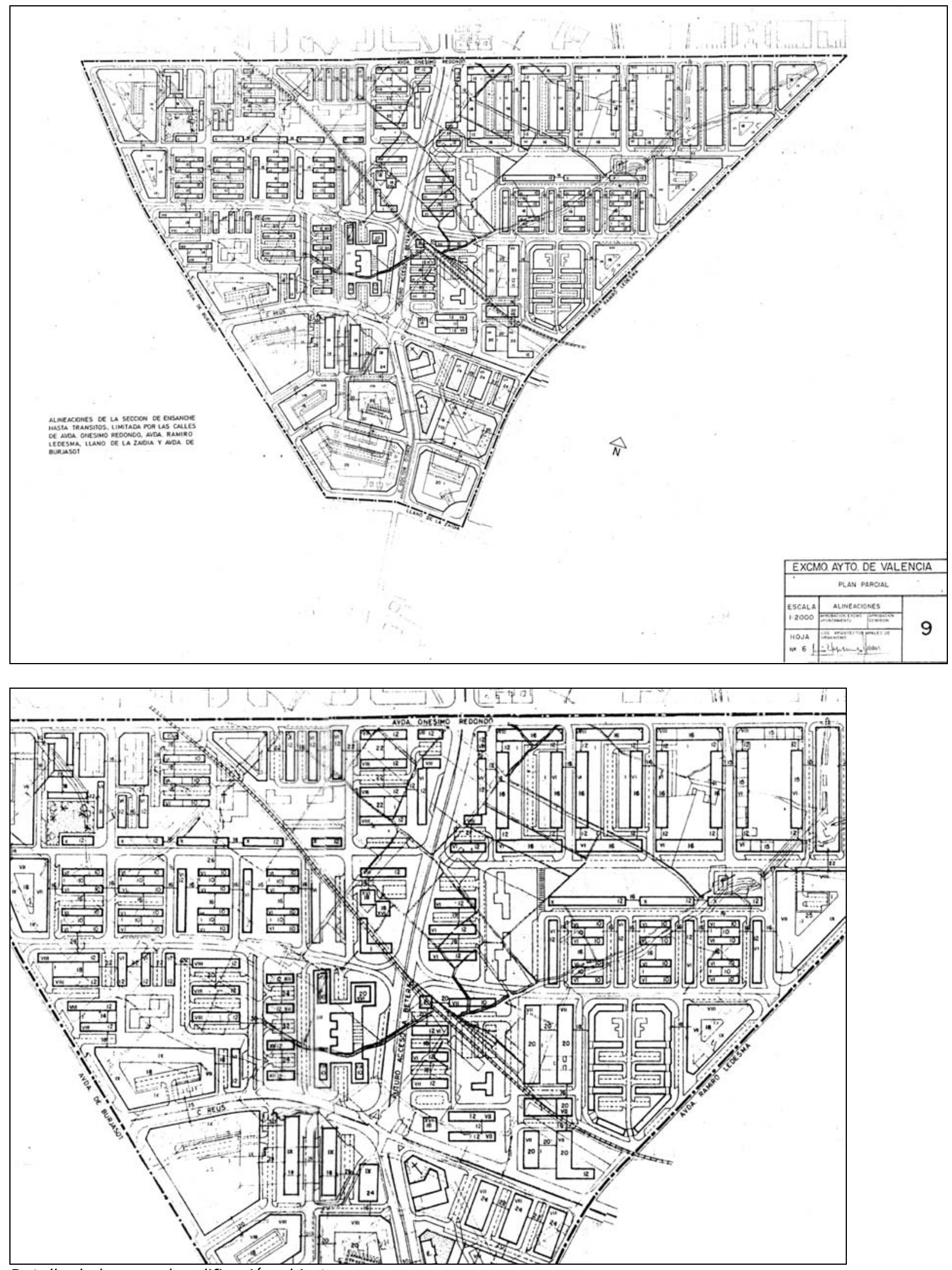

Detalle de la zona de edificación abierta 
1. PLANO DE SITUACIÓN EN LA CIUDAD

Escala original: $1: 10.000$

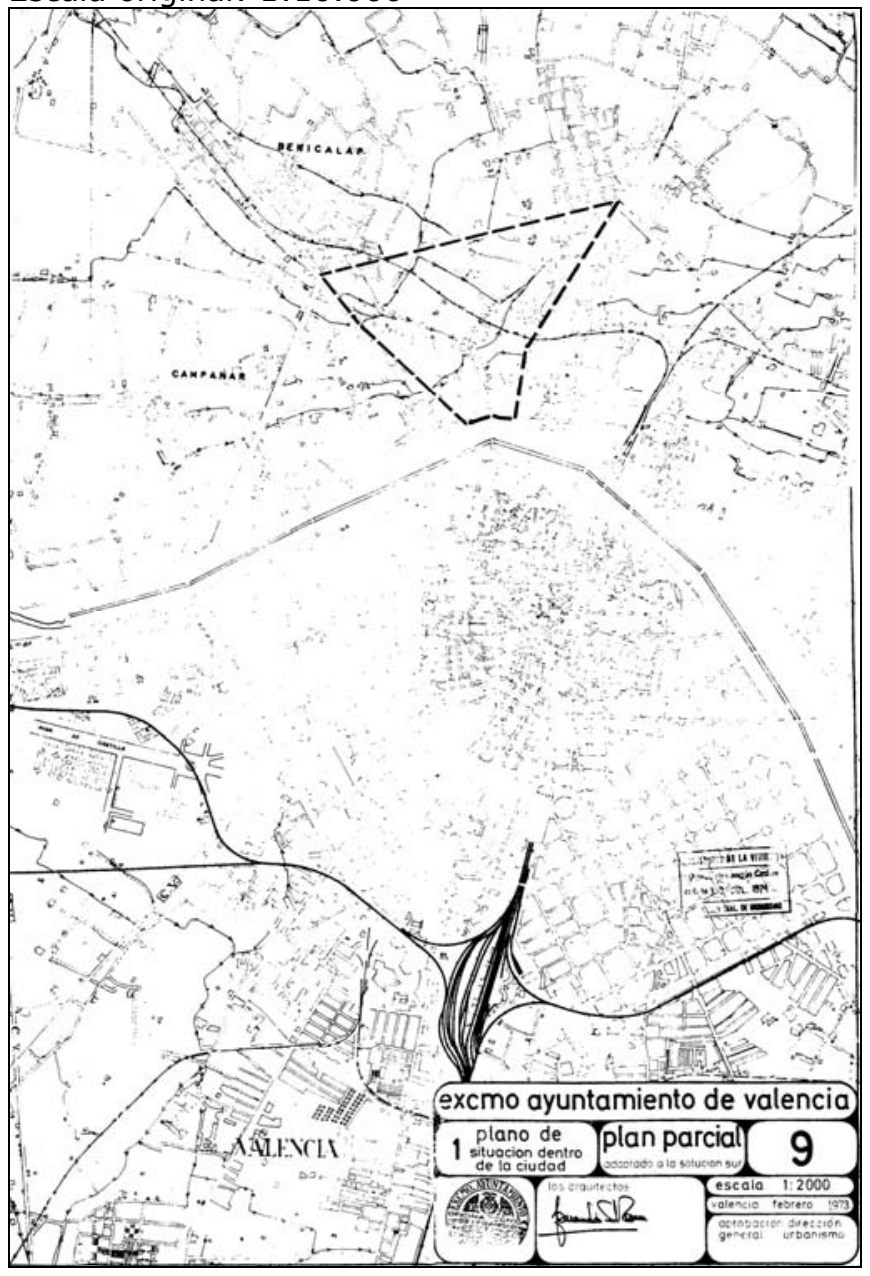

2. PLANO DE SITUACIÓN EN EL PLAN GENERAL (Fragmento) Escala original: $1: 22.500$

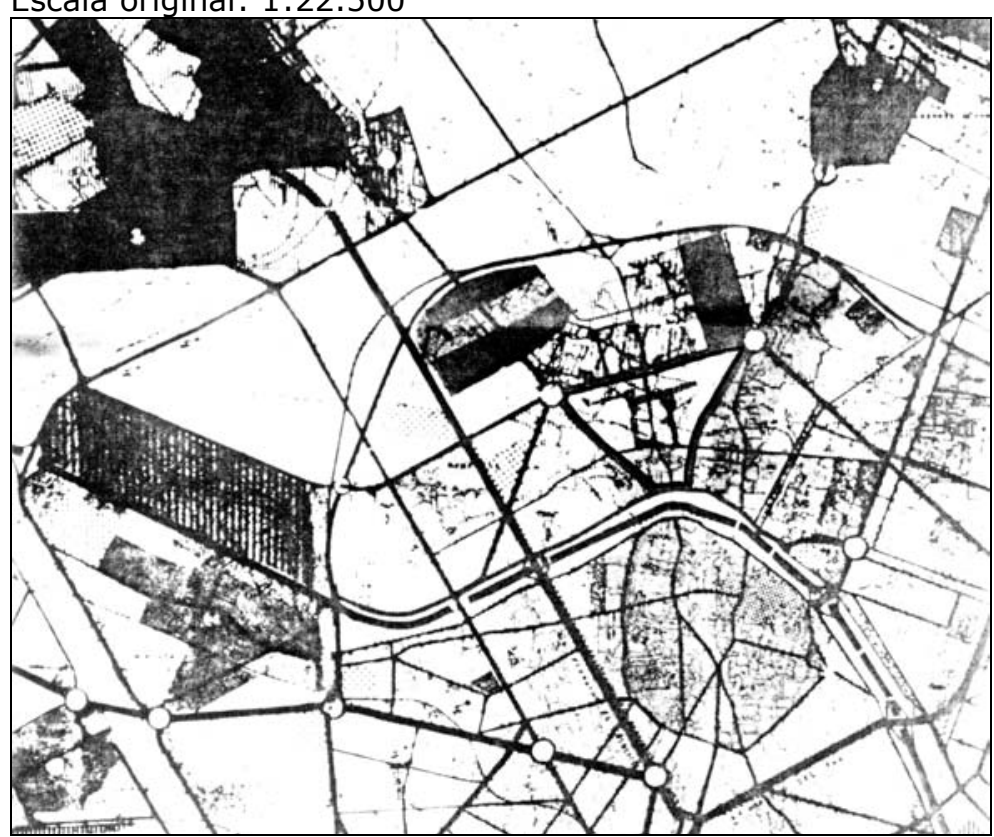



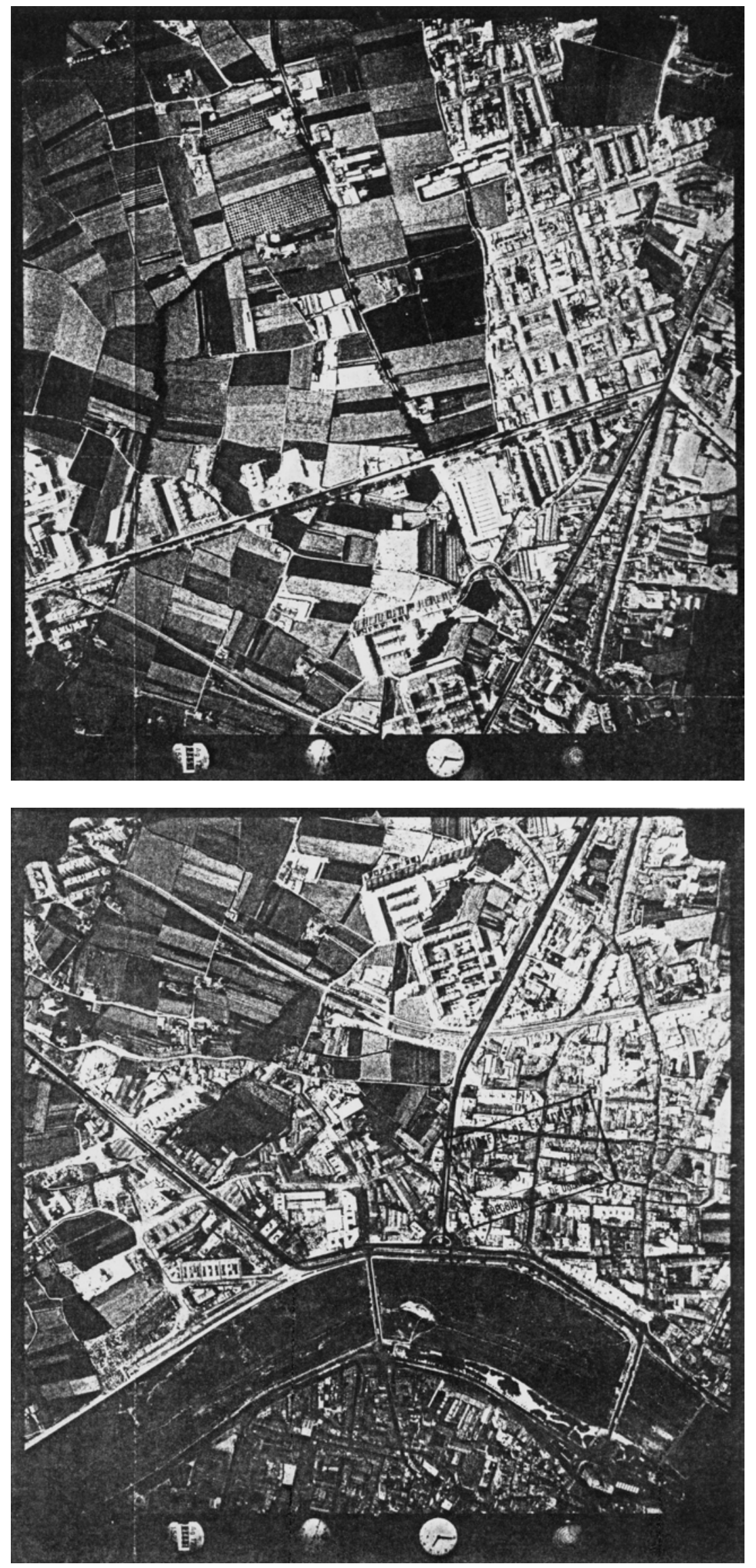


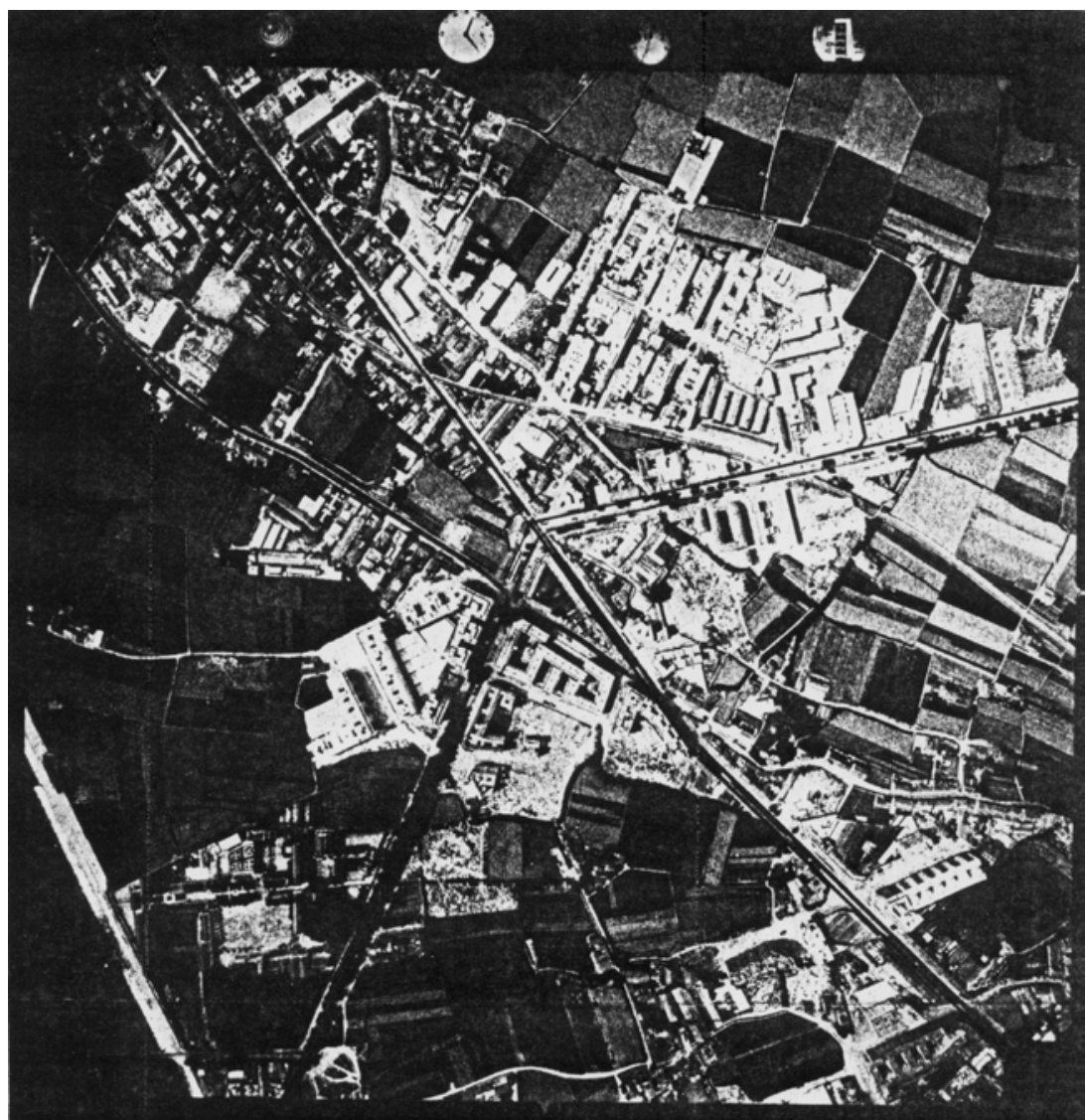

x. PLANO DE INFORMACION

Escala original: 1:2000

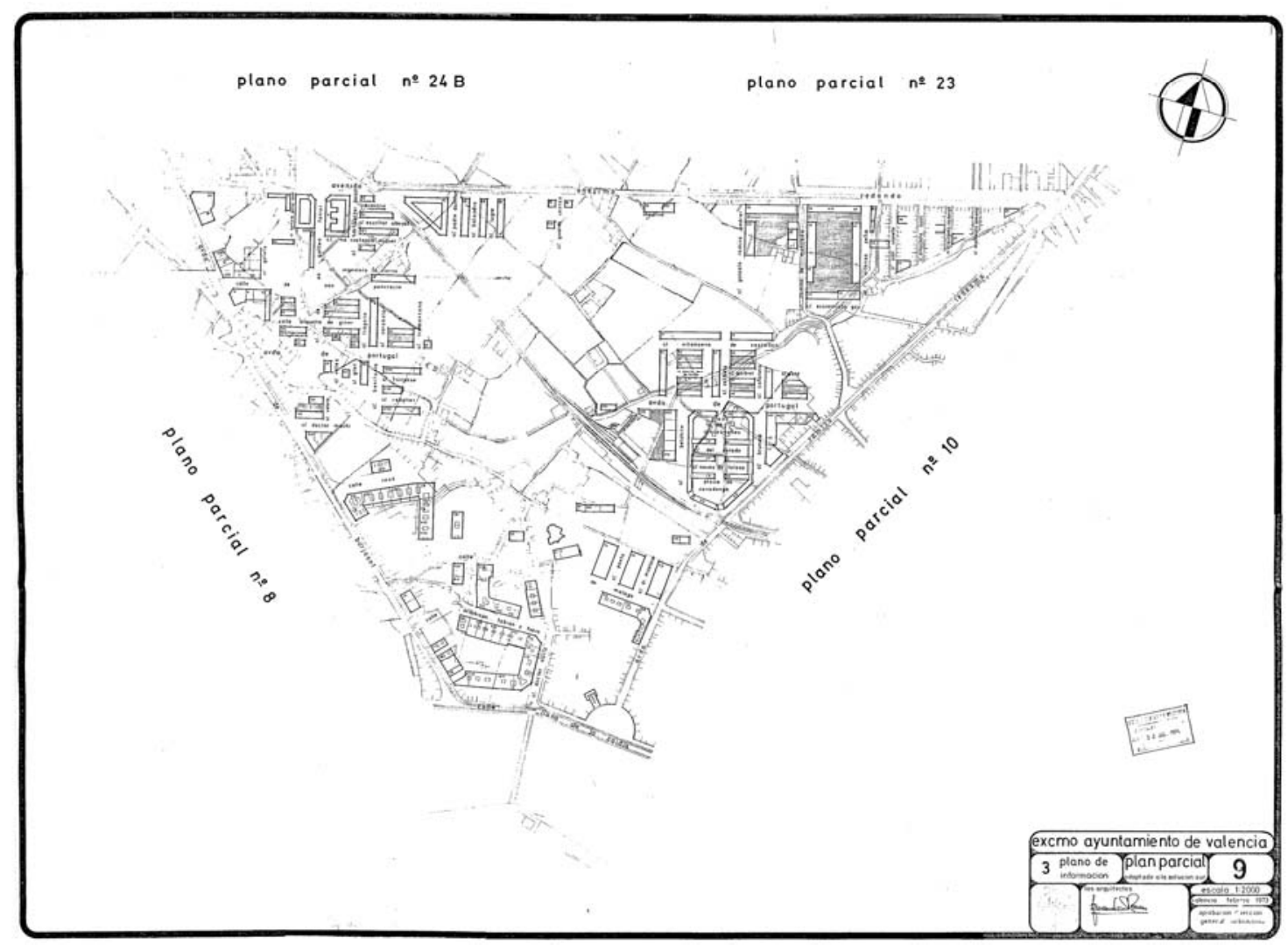


7. RED VIARIA FUNDAMENTAL

Escala original: 1:2000

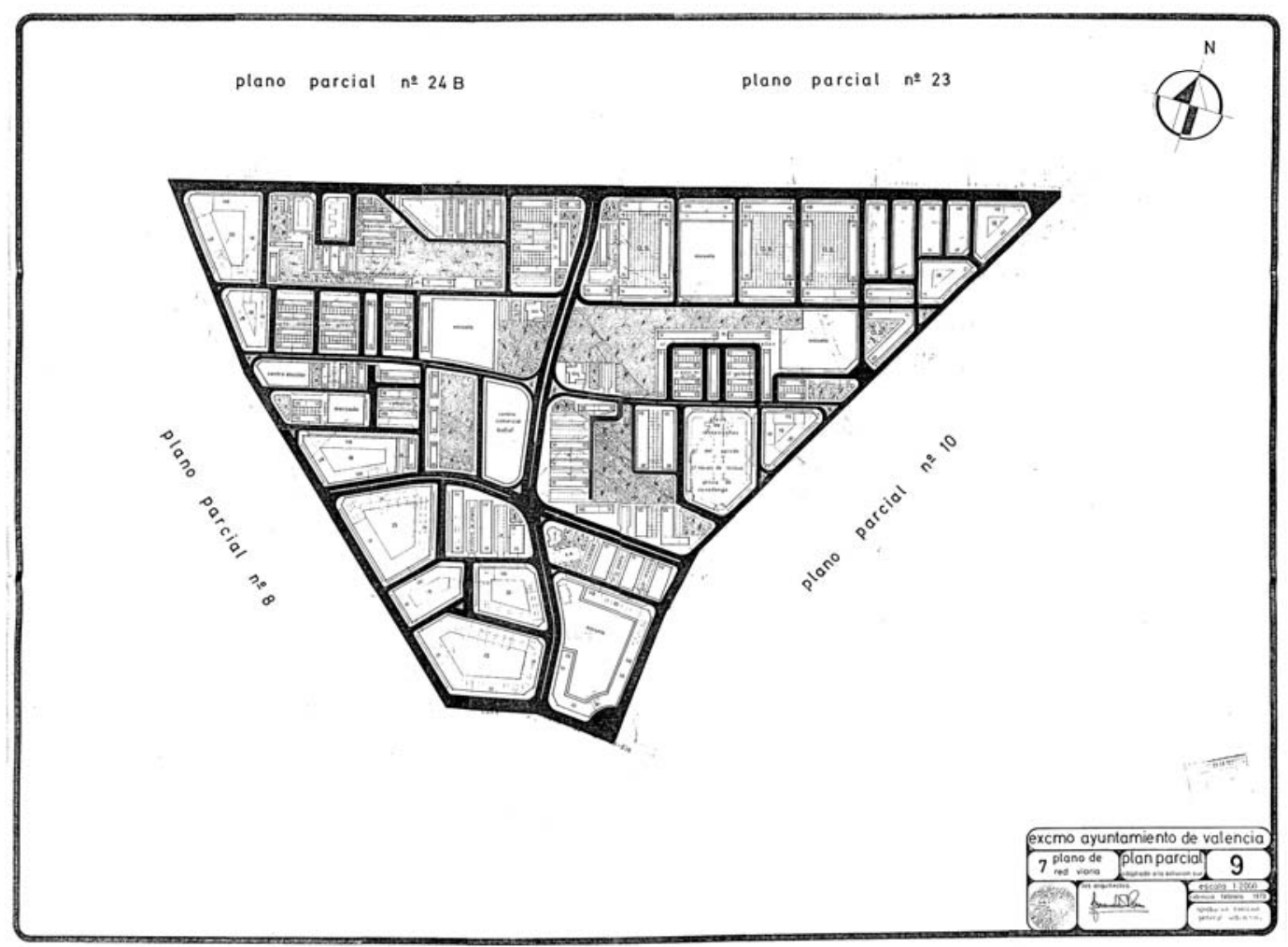

7. ESTRUCTURA URBANÍSTICA (Enero 1975)

Escala original: 1:2000

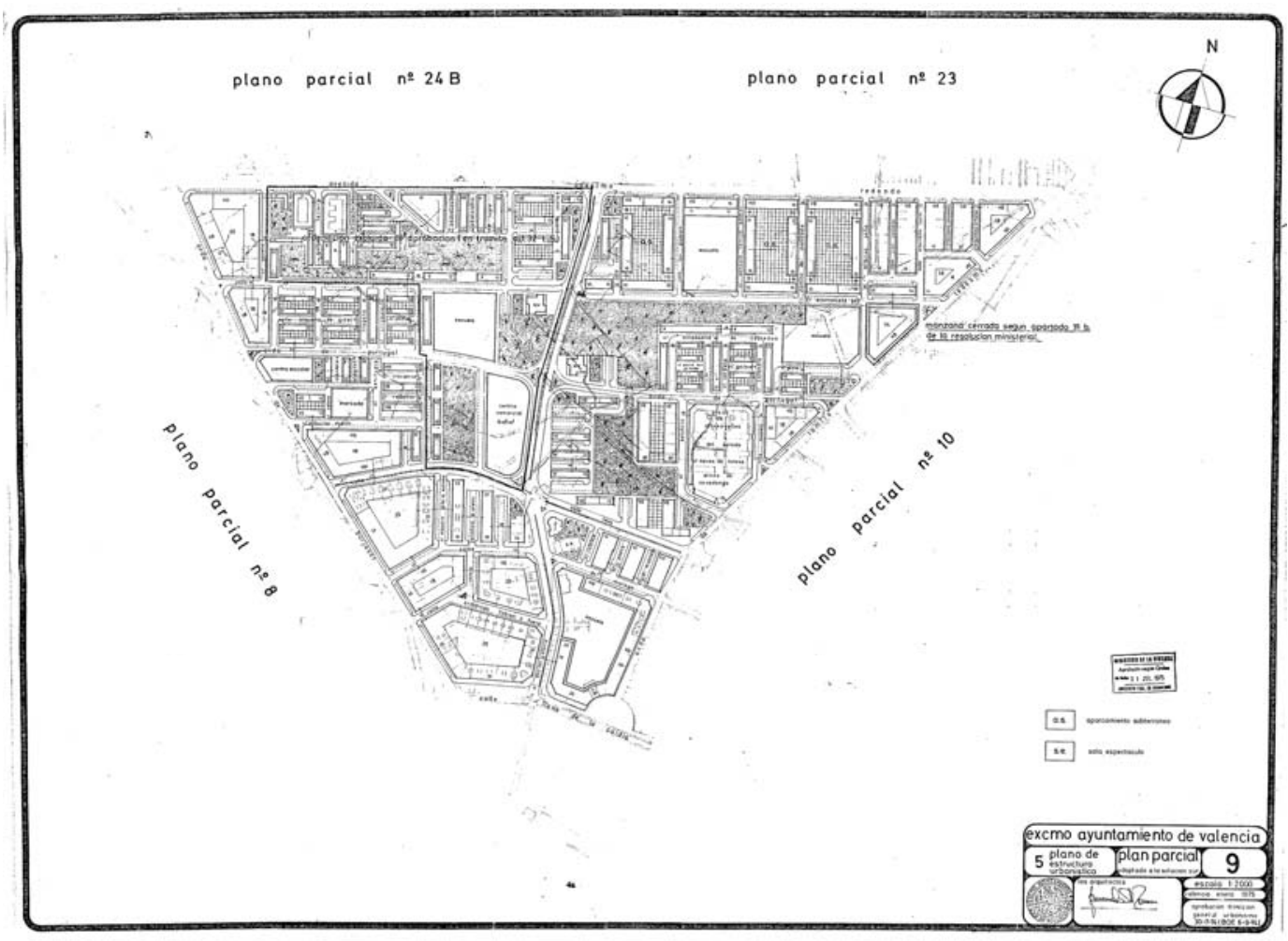


8. ALINEACIONES Y RASANTES.

Escala original 1:2000
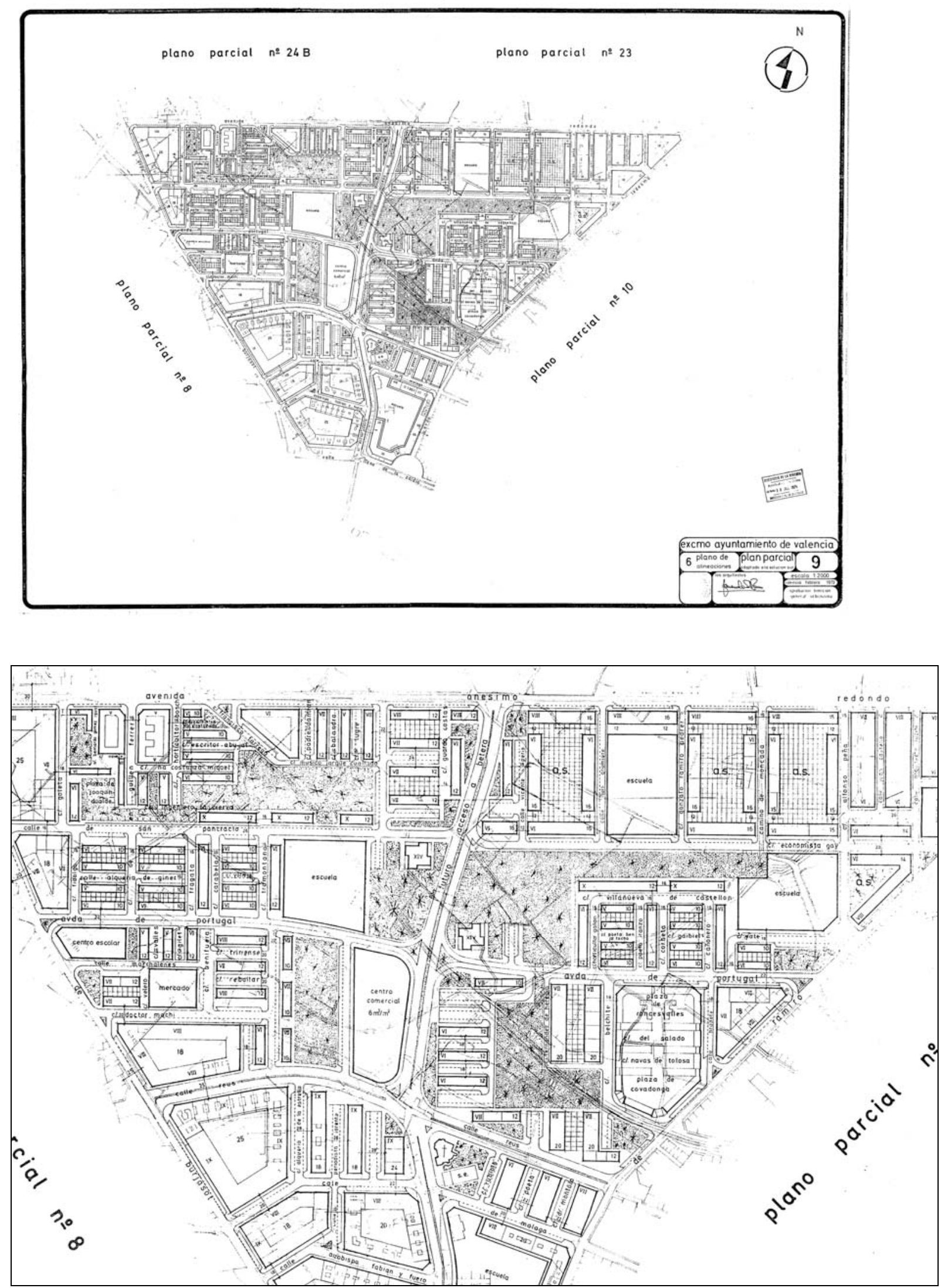

Detalle del Plano de alineaciones. 
Redactor: El Arquitecto Municipal. Ayuntamiento de Valencia.

Fecha: 15-10-1973.

Asunto: Informe sobre alegaciones al Plan Parcial 9.

Fuente: Ayuntamiento de Valencia. Sección de Urbanismo. Negociado de Suelo y Ordenación urbana. Expte. 781/1973 (Archivo de Planeamiento No 79).

El Arquitecto Municipal que suscribe a la vista de las reclamaciones presentadas al Plan Parcial de Ordenación urbana no 9, durante el periodo de exposición al público. Tras detenido estudio de las mismas, tiene el honor de informar:

\section{RECLAMACIÓN}

No. 36.697 - Se solicita en esta reclamación un aumento de volumen, pasar de las VI plantas previstas a VIII o $X$, en dos bloques recayentes a C/ Economista Gay y Camino de Moncada, por cambio del uso de una pequeña parcela de su propiedad, destinada a zona verde, que en el anterior estudio formaba parte de un centro parroquial.

Estimo no es atendible la reclamación, pues la zona verde responde a criterios del Plan General, por lo que debe conservarse estrictamente cono ha sido grafiada en el estudio del Plan Parcial. Por lo demás el aumento de volumen es totalmente inviable.

No 36.699 - La reclamación viene a expresar el perjuicio que se ocasiona a la interesada por el supuesto escaso volumen que le corresponde.

Estimo no es atendible la reclamación, pues el Plan Parcial responde a criterios del Plan General, que ordena la ubicación de zona verde en gran parte de las parcelas de los peticionarios. La elevación en alturas no es viable.

Asimismo por aumentar el volumen, obligaría a supresión de la zona verde, pues el cumplimiento de la norma $17^{a}$ del Plan General relaciona las alturas de bloques con la separación entre ellos.

No 36.700 - Vista la reclamación, y tras detenido estudio considero que no hay inconveniente en estimarla por estar justificada. A tal efecto he procedido al nuevo estudio de la zona ubicando el mercado y centro escolar, queda reflejada la solución en el plano adjunto.

No 38.034 - Solicita en esta reclamación la ubicación de un bloque de VI plantas perpendicular a calle Reus, solución no estimable, puesto que la ubicación del bloque en cuestión alteraría las condiciones urbanísticas del entorno y densificaría fuera de las previsiones del Plan General, la Zona de Edificación Abierta.

No 38.940 - Solicita en su reclamación la ubicación de un bloque paralelo al existente, con un aumento de 27.400 m3. de edificación.

Debe desestimarse la reclamación, puesto que el Plan Parcial tiene previsto en dichos terrenos un Cen
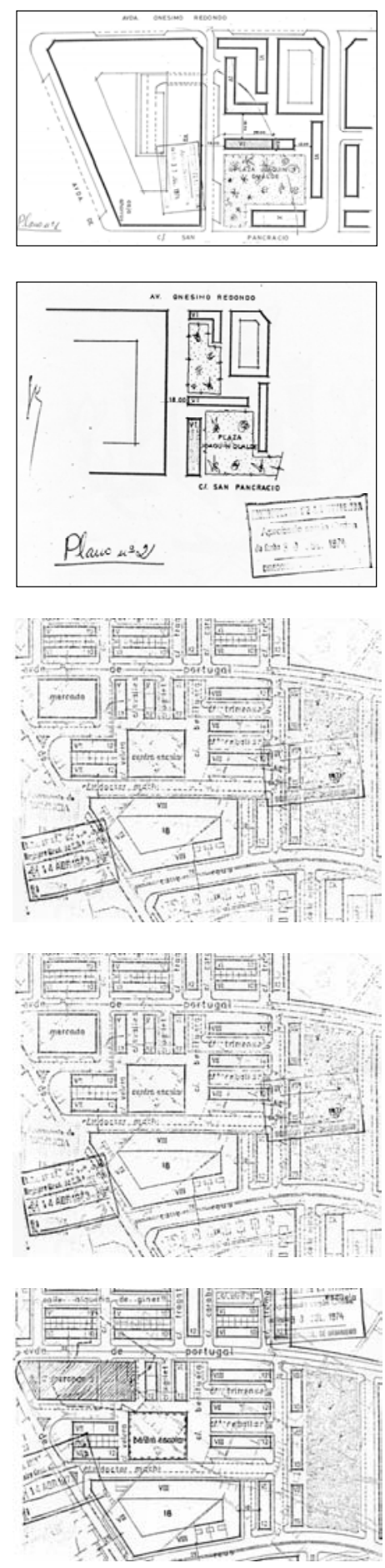

Alegación No 36.700 

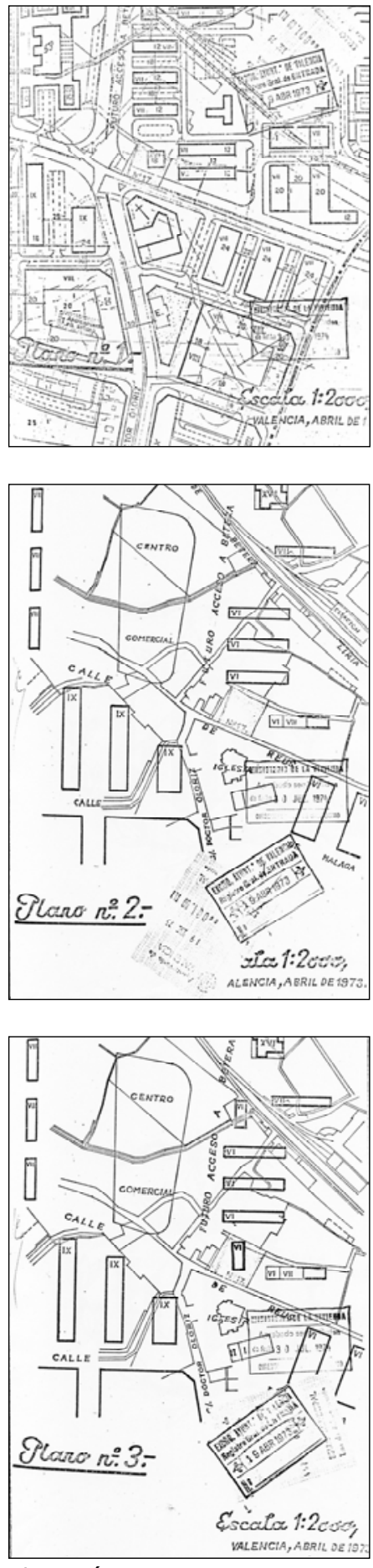

Alegación No 38.034 tro Escolar por necesidades de planeamiento, a tenor de lo dispuesto en la norma -32 del Plan General y conforme a las directrices establecidas por el Ministerio de Educación y Ciencia; se han ubicado los centros escolares en aquellos lugares urbanísticamente más idóneos, respetando la superficie de parques y zonas verdes que prevé la Ley del Suelo. La solución que propone el reclamante anularía la zona verde prevista.

En todo caso se deben tomar en consideración los posibles perjuicios ocasionados por el planeamiento, a tenor de lo dispuesto en la Ley del Suelo y a la hora de la ejecución Plan.

No. 38.939 - La reclamación viene motivada por la supresión de un bloque de $\mathrm{X}$ plantas en $\mathrm{C} /$ San Pancracio, previsto en el anterior estudio.

No es estimable, puesto que la supresión ha venido motivada por la necesidad de continuidad de la zona verde señalada por el Plan General, ajustándose el volumen del polígono al previsto en dicho Plan General. La reclamación propone una reestructuración de la zona verde del Plan General, introduciendo en ella zona de edificación abierta con aprovechamiento intensivo, lo que supone una modificación substantiva del mismo.

No 39.353 - La reclamación viene motivada por "la extraordinaria extensión de las zonas no edificables privadamente incluidas en mi finca y la superficie de la misma".

Se refiere a la existencia de zonas verdes. En el estudio se han grafiado en líneas generales, las Zonas Verdes impuestas por el Plan General, condicionadas a la edificación construida siguiendo lo aprobado por el anterior estudio,

La proporción de afección de las propiedades del reclamante puede ser objeto de una reparcelación, si procede, en la fase de ejecución del Plan.

No 39.354 - Esta reclamación la provocan los comerciantes e industriales del entorno donde se ha ubicado una zona escolar de $10.000 \mathrm{~m} 2$. Modificando la previsión anterior, manzana de edificación abierta, lo que según los exponentes perjudica sus intereses.

Estimo no es atendible la reclamación, pues el numero de zonas escolares que los reclamantes consideran excesivas, vienen impuestas por necesidades de planeamiento siguiendo las directrices del Ministerio de Educación y Ciencia, que son de obligado cumplimiento.

No 39.617 - Esta reclamación viene motivada por la ubicación de una zona escolar, en la manzana definida por las caIles Doctor Oloriz, Malaga y Av. de Ramiro de Ledesma, con supresión de la prolongación de la calle Arzobispo Fabian y Fuero, entre Doctor Oloriz y la Avenida citada.

Considero no estimable la reclamación, la disposición de una zona escolar viene motivada por necesidades de planeamiento, colocándolas en los puntos más idóneos y alejados del trafico rodado y cubriendo las necesidades de la zona intensiva de edificación. 
La reparcelación pedida se debe tomar en consideración a tenor de lo dispuesto en la Ley del Suelo y a la hora de la ejecución del Plan.

No 39.618 - La reclamación viene motivada por la ubicación de zonas verdes y escolares en terrenos de su propiedad. Esta reclamación como la anterior considero no es estimable, pues es competencia del planeamiento la ubicación de las zonas escolares. En todo caso los perjuicios derivados deben de tomarse en consideración en la fase de ejecución del Plan.

No 39.619. $1^{\text {a }}$ Parte.

En zona de Edificación Abierta, solicita en su reclamación la ubicación de una torre de XIV plantas en terrenos de su propiedad con supresión del bloque de VI plantas previsto en parte sobre terrenos de su propiedad. Aumento a $8 \mathrm{~m} 3 / \mathrm{m} 2$ del coeficiente de edificabilidad del Centro Comercial, que en parte está sobre terrenos de su propiedad.

No contiene ningún razonamiento que mejore el planeamiento urbanístico, por el contrario, pretende un beneficio sin tener en cuenta a los colindantes. No procede, por otra parte, el aumento de volumen edificado para el Centro Comercial, por tenerlo establecido en la norma 35 del Plan General.

Esta primera parte de la reclamación considero debe desestimarse.

2a. Parte.

En Zona de Edificación Abierta, sobre una extensión de terrenos de su propiedad, solicita la inclusión de cuatro torres de XIV plantas y bajos comerciales de I planta, con la consiguiente disminución de la zona Escolar. Se solicita aumento del volumen previsto en los bloques colindantes.

No procede admitir la reclamación, es competencia del planeamiento el disponer las zonas para atender las necesidades de servicios sociales, como son escuelas que puedan acoger el futuro numero de alumnos cuando se cumplan las previsiones del Plan Parcial, es decir, cuando se encuentre totalmente edificado. Según dispone la Ley de Régimen del Suelo y norma 32 del Plan General.

La reparcelación es uno de los métodos a tener en cuenta en la ejecución del Plan.

No 39.620 - Esta reclamación expresa el perjuicio ocasionado al interesado, por estimar que le corresponde más volumen que el previsto en el Plan Parcial. Y por ello solicita la inclusión de: una torre de XIV plantas (en terrenos destinados a parques), aumento de una planta en el primer bloque de la C/ Economista Gay, prolongación, en toda su altura, de los dos bloques paralelos a la Av. del futuro acceso a Betera (con aumento de volumen y mayor ocupación de solar), disposición de una planta baja comercial (sobre el aparcamiento previsto), y la ubicación de un bloque de VII plantas (en terrenos destinados a parques).

Por los criterios apuntados en la Memoria del Plan Parcial, cono consecuencia del escrito de devolución del anterior estudio por la Corporación Administrativa Gran Valencia, no debe estimarse la reclamación pre
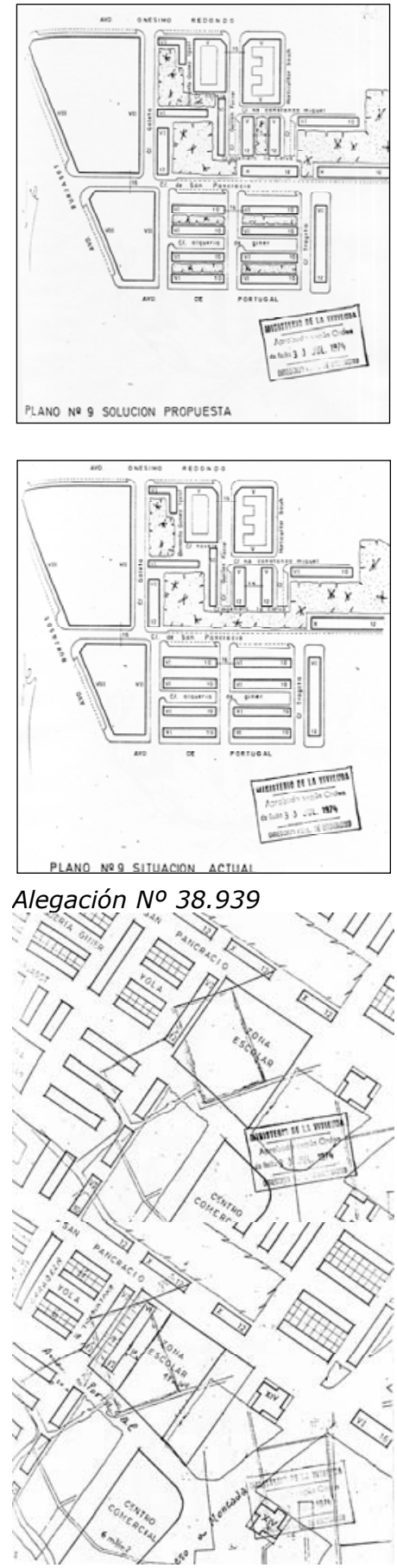

Alegación No 39.534 

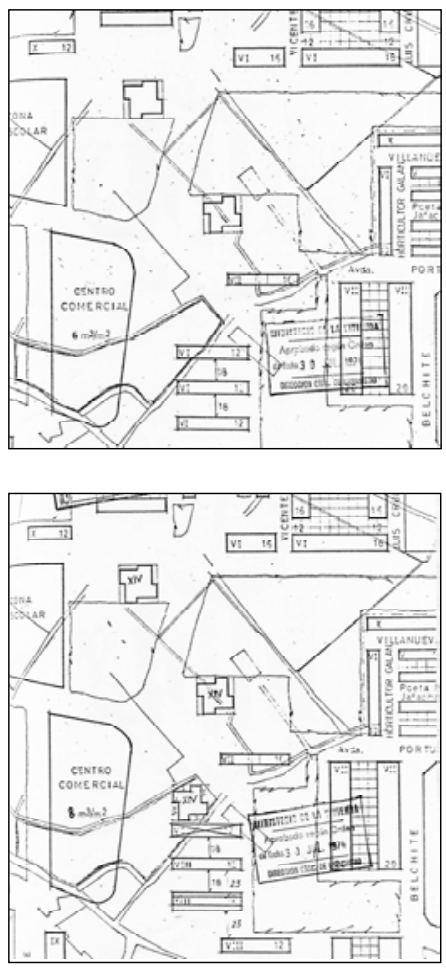

Alegación No 39.619

(1a Parte)
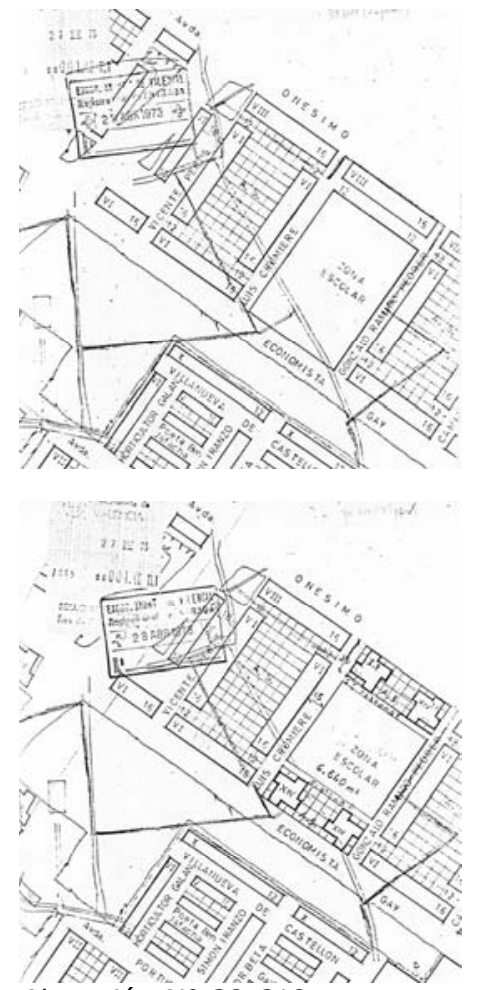

Alegación No 39.619

(2a Parte) sentada por el interesado, siendo totalmente inviables las soluciones aportadas.

La reparcelación solicitada, es uno de los métodos a tener en cuanta en la fase de ejecución del Plan»

No 67.778 - Esta reclamación esta presentada fuera de plazo. No obstante se ha procedido a su estudio.

Alega en la reclamación que en la zona de Edificación Abierta del Plan Parcial y en su propiedad se han transformado arbitrariamente los terrenos en jardines, viales y escuelas, con lo que según el artículo 81 de la Ley del Suelo procede la reparcelación, caso de la aprobación del Plan, por ser la lesión superior al sexto.

Estimo no es atendible la reclamación, pues es competencia del planeamiento la ubicación de las zonas de servicios.

No obstante, la reparcelación solicitada, es uno de los métodos a tener en cuenta en la fase de ejecución del Plan.

Se adjunta plano con el estudio de las reclamaciones.

Valencia 15 de Octubre

EL ARQUITECTO MUNICIPAL,
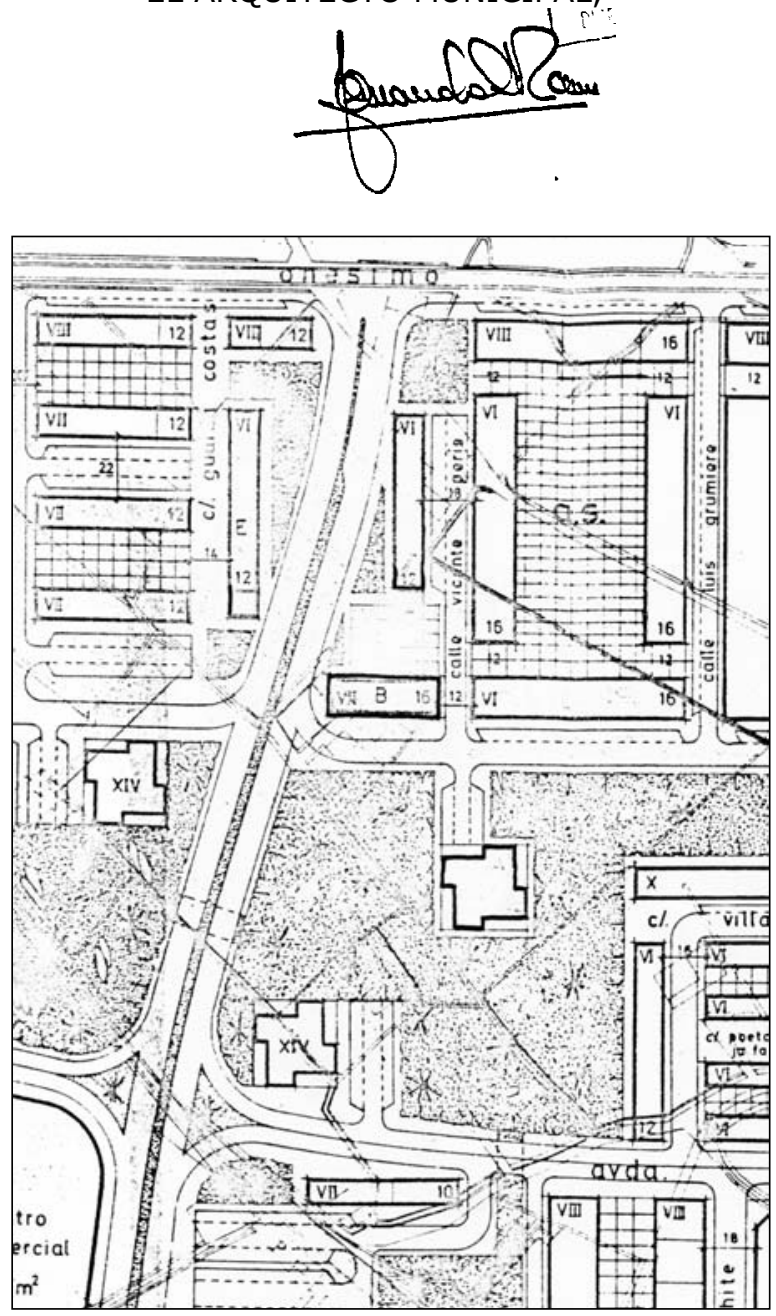

Alegación No 39.620 
Redactor: Dirección General de Urbanismo / Ministerio de la Vivienda.

Fecha: 30- 07-1974.

Asunto: Resolución de aprobación del Plan Parcial 9 con rectificaciones.

Fuente: Ayuntamiento de Valencia. Sección de Urbanismo. Negociado de Suelo y Ordenación urbana. Expte. 781/1973 (Archivo de Planeamiento No 79).

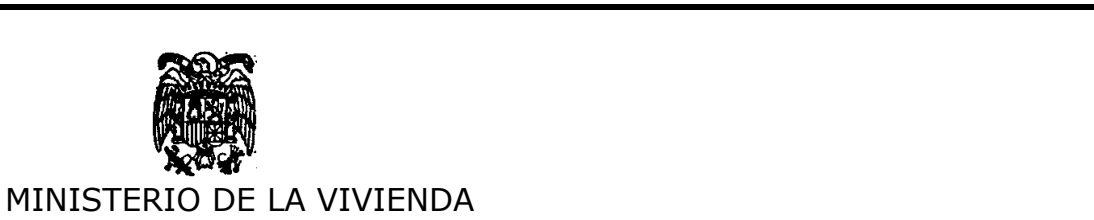

Ilmo Sr.:

VISTO el Plan Parcial de Ordenación Urbana no 9, de Valencia, presentado por el Ayuntamiento de dicha Capital.

VISTOS la Ley sobre Régimen del Suelo y Ordenación Urbana, de 12 de mayo de 1956, los Decretos 63/1968, de 18 de enero y $1994 / 72$, de 13 de julio, y el informe emitido por los servicios competentes de la Dirección General de Urbanismo.

Este Ministerio Acuerda:

10) Aprobar, excepto en la parte a que se refiere el apartado $2^{\circ}$ de esta resolución, el Plan Parcial precitado, con las rectificaciones siguientes:

a) A efectos de previsión de aparcamientos, se fijará como mínimo una plaza por vivienda y

b) La manzana delimitada por la Avenida de Ramiro Ledesma y Calles Economista Gay y Alfonso Peña, se cerrará con una profundidad edificable de 14 metros, por considerar conveniente mantener lo previsto en el anterior Plan Parcial, aprobado por Orden Ministerial de 4 de noviembre de 1.961 , y

$2^{\circ}$. Excluir la Ordenación referida a los terrenos situados entre la Avenida de Onésimo Redondo, Avenida de doble dirección que une esta vía con la de Reus (Prolongación de la del Doctor Olóriz), calle Reus, la vía transversal entre la de Reus y Portugal en la que en su lado este se proyectan tres bloques de siete plantas, calles Tramontana y La Goleta hasta su encuentro con la citada Avenida de Onésimo redondo, cuya aprobación se suspende a fin de que sea objeto de un nuevo estudio de ordenación, en la que se respete la Zona Verde de uso público prevista en el Plan General, que resulta invadida por una parte del Centro Comercial, por la Escuela y por un bloque de catorce plantas, otro de diez y parte de otros de cinco y seis plantas.

La determinación sobre aparcamientos a que se refiere el apartado a) $1^{\circ}$ de esta resolución, se establecerá en el Plan Parcial 
de la forma que estime más oportuna el Ayuntamiento y la documentación correspondiente que la recoja, en unión de la debidamente rectificada, conteniendo la modificación b) $1^{0}$ de la presente, se remitirá a este departamento, por triplicado ejemplar, en el plazo de seis meses para su debida constancia.

La nueva Ordenación que se requiere en el apartado $2^{\circ}$ de esta resolución se tramitara con sujeción a lo dispuesto en el artículo 32 de la Ley del Suelo, y se elevara, dentro del aludido plazo de seis meses y por triplicado ejemplar, a este Ministerio para su estudio y resolución definitiva.

Esta resolución se notificará al Ayuntamiento de Valencia y se publicará en el Boletín Oficial del Estado.

Lo que comunico a V. I. para su conocimiento y efectos.

Dios guarde a V.I.

Madrid, 30 de Julio de 1974

P.D.

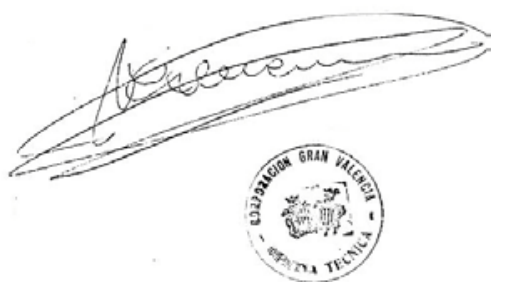

Ilmo. Sr. Director General de urbanismo. 
Redactor: Dirección General de Urbanismo del Ministerio de la Vivienda / Ministerio de la Vivienda.

Fecha: 11- 07-1975.

Asunto: Nueva resolución de aprobación parcial del Plan Parcial 9. Fuente: Ayuntamiento de Valencia. Sección de Urbanismo. Negociado de Suelo y Ordenación urbana. Expte. 781/1973 (Archivo de Planeamiento No 79).

\section{MINISTERIO DE LA VIVIENDA}

Ilmo. Sr. :

VISTA la documentación complementaria del Plan Parcial de Ordenación Urbana $n^{\circ} 9$ de Valencia, presentada por el Ayuntamiento de dicha capital, en cumplimiento de lo dispuesto en la Orden Ministerial de 30 de julio de 1974.

RESULTANDO que por la referida Orden de 30 de julio de 1974, se aprobó el Plan Parcial citado, con rectificaciones en cuanto a previsión de aparcamientos y a fondos edificables de determinada manzana, y se excluyó de la aprobación la Ordenación que contenía para los terrenos que expresamente se delimitaron en dicha resolución, que debía ser objeto de otro planeamiento, en el que se respetase la zona verde prevista en el Plan comarcal, y tramitado de nuevo.

RESULTANDO que en cumplimiento de lo dispuesto en la citada resolución, en lo referente al tema de aparcamientos y fondos edificables, el Ayuntamiento eleva la presente documentación, y manifiesta que se encuentra en tramitación la Ordenación de los terrenos que comprenden la zona verde del Plan Comarcal; dicha documentación ha sido informada por los Servicios competentes de la Dirección General de Urbanismo.

CONSIDERANDO que las rectificaciones sobre aparcamientos y fondos edificables de la manzana delimitada por la Avda. de Ramiro Ledesma y calles Economista Gay y Alfonso Peña, han sido convenientemente cumplimentadas, si bien se ha reflejado parcialmente lo que respecta al fondo edificable de 1a citada manzana, ya que solo consta en el plano de estructura urbanística, cuando a efectos de la debida coherencia de la documentación del Plan, también debería haberse incorporado al plano de alineaciones y red viaria.

VISTOS la Ley sobre Régimen del Suelo y Ordenación Urbana de

12 de mayo de 1956 y la de su reforma de 2 de mayo de 1975, y los Decretos 63/1968 de 18 de enero y 1994/72 de 13 de julio.

$1^{\circ}$. Declarar cumplida la obligación impuesta en el apartado $1^{\circ}$ a) de su anterior resolución de 30 de julio de 1974 .

$2^{\circ}$. Conceder un nuevo plazo de seis meses para que el Ayuntamiento lleve a efecto lo dispuesto en los apartados $2^{\circ}$ y último de dicha resolución de 30 de julio de 1974, y también deberá elevar dentro del aludido plazo los planos 6 y 7 (alineaciones y red viaria), corregidos en concordancia con lo que ahora se refleja en el plano $\mathrm{n}^{\circ} 5$ (estructura urbanística), ambos por triplicado ejemplar, 
Esta resolución se notificará al Ayuntamiento de Valencia.

Lo que comunico a V.I. para su conocimiento y efectos Dios guarde a V.I.

Madrid, 11 de julio de 1.975

P.D.

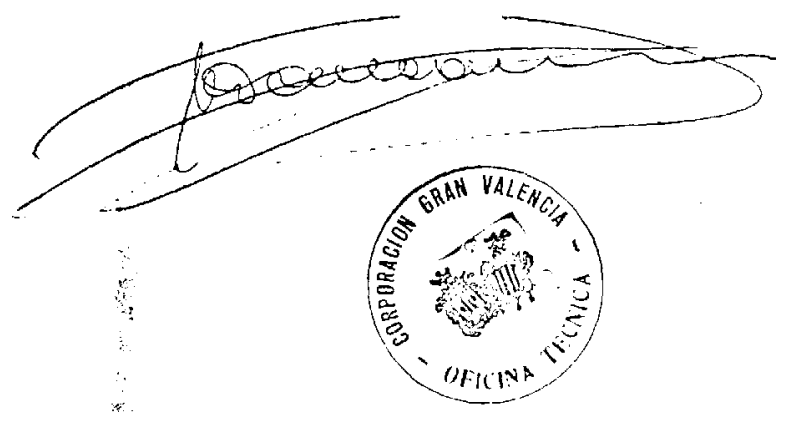


Redactor: El Arquitecto Municipal. Ayuntamiento de Valencia.

Fecha: 9- 06-1976.

Asunto: Informe sobre el nuevo estudio del PP9.

Fuente: Ayuntamiento de Valencia. Sección de Urbanismo. Nego-

ciado de Suelo y Ordenación urbana. Expte. 781/1973 (Archivo de

Planeamiento No 79).

Expte. 2549/76. S. Y Ord. Urbana.

El Arquitecto Municipal que suscribe, en cumplimento del decreto que antecede y de conformidad con el dictamen de la Comisión de Urbanismo de 22 de octubre pasado, tiene a bien informar que por esta Oficina Técnica se ha procedido al estudio del sector del Plan Parcial n० 9, excluido de aprobación ministerial y comprendido entre la Avenida de Onésimo Redondo, la calle Goleta, calle San Pancracio, Tramontana, Reus y futuro Acceso a Bétera (prolongación calle Dr.Olóriz), respetando totalmente la zona verde prevista en el Plan General y exactamente la grafiada por el Ministerio de la Vivienda en copia del Plan Parcial obrante al folio 8 del presente expediente.

En consecuencia de ese estudio, se ha procedido a reajustar y adaptar determinados elementos de la Sed Viaria, ubicación definitiva de la Escuela y del Centro Comercial allí previstos, así como resolver la situación de ciertos bloques de edificación abierta, dejando fuera de ordenación parte de los mismos que invadían la citada zona verde. Igualmente, se ha introducido un bloque con destino a edificio publico, en previsión de posibles necesidades futuras de esta índole. Extremos todos ellos que se recogen en el plano $\mathrm{n}^{\circ} 2$ (propuesta de Ordenación) en comparación con el plano $n^{\circ} 1$ (Ordenación excluida).

Ahora bien, no obstante lo dicho, el que suscribe considera su deber poner en conocimiento de la Corporación que la propuesta de Ordenación trae como consecuencia, la ruptura de la estructura viaria del Plan Parcial no 9, perjudicando el normal desarrollo del tráfico rodado en el sector. En efecto, la acomodación exacta a la zona verde trae cono consecuencia la desaparición de dos elementos de la Red Viaria, como son: el tramo de la calle de San Pancracio, comprendido entre la de Tramontana y el futuro Acceso a Bétera, y el tramo de la Avenida de Portugal comprendido igualmente entre dichas calles, pertenecientes respectivamente a la Red Secundaria, y a la principal del barrio.

En el primer caso, el hecho en realidad no reviste gran importancia por cuanto que dicha calle es un elemento de la Red Secundaria del barrio que no tiene continuidad en el sector situado al otro lado del Acceso a Bétera, e incluso el trazado de este Acceso en subterráneo le impediría la posible continuidad.(Nótese que en la confluencia se produce el cambio de pendiente del citado Acceso), pero, en el segundo caso se trata de un elemento principal del Barrio, vía transversal que forma parte, junto con la avenida de Onésimo Redondo, de la calle de Reus y del Llano de la Zaidía, la avenida de Burjasot y Ramiro de Ledesma, de los tres anillos de tráfico rápido colectores de la circulación de todo el ámbito del Plan Parcial no 9. La supresión por tanto, de este tramo de calle, traería como resultado la congestión de las vías de servicio al Acceso de Bétera, situadas en superficie, dificultando las entradas y salidas a la vía rápida; 
igualmente, la del nudo de enlace de éstas con la calle de Reus; la propia calle de Reus y la calle de Tramontana, quedaría convertida en colectora de todas las calles transversales a ella, con el inconveniente de que, al llegar a la calle Reus, al existir un seto separador de conformidad con las especificaciones del Plan, solo podría girarse a la derecha, con lo cual el tráfico iría a desembocar a la avenida de Burjasot (aún en el supuesto de que se autorizara el cruce o el giro a la izquierda eliminando el seto central, el problema de la congestión de trafico quedaría agravado en dicho tramo y repercutiría igualmente en el nudo de enlace antes citado). Por otra parte, los accesos al centro escolar y al centro comercial, enclavados en el sector, quedarían igualmente dificultados.

Es por ello que el que suscribe propone que se mantenga la continuidad de la Avenida le Portugal, aún cuando ello suponga, el no respetar íntegramente la zona verde señalada y en este sentido se adjunta en el plano no 3 solución propuesta.

No obstante lo dicho, sugiero que tal vez podría recabarse informe de la Oficina Municipal de Tráfico sobre la conveniencia o no de la supresión de esta calle o por si se encuentra alguna solución al problema en forma de paso aéreo o subterráneo, que permita salvar la porción de zona verde afectada; todo ello, sin olvidar que, de acuerdo con el Plan General y el Parcial, la vía del ferrocarril de F.E.V.E. que discurre por terrenos destinados a zona verde, está previsto que desaparezca o, en todo caso, que vaya subterráneo,,

Valencia, 9 de junio de 1.976

EL ARQUITECTO MUNICIPAL,
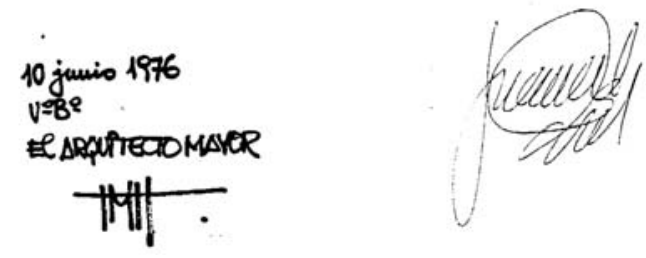
Documento 9.4. Plano adjunto no 1 (Fragmento)

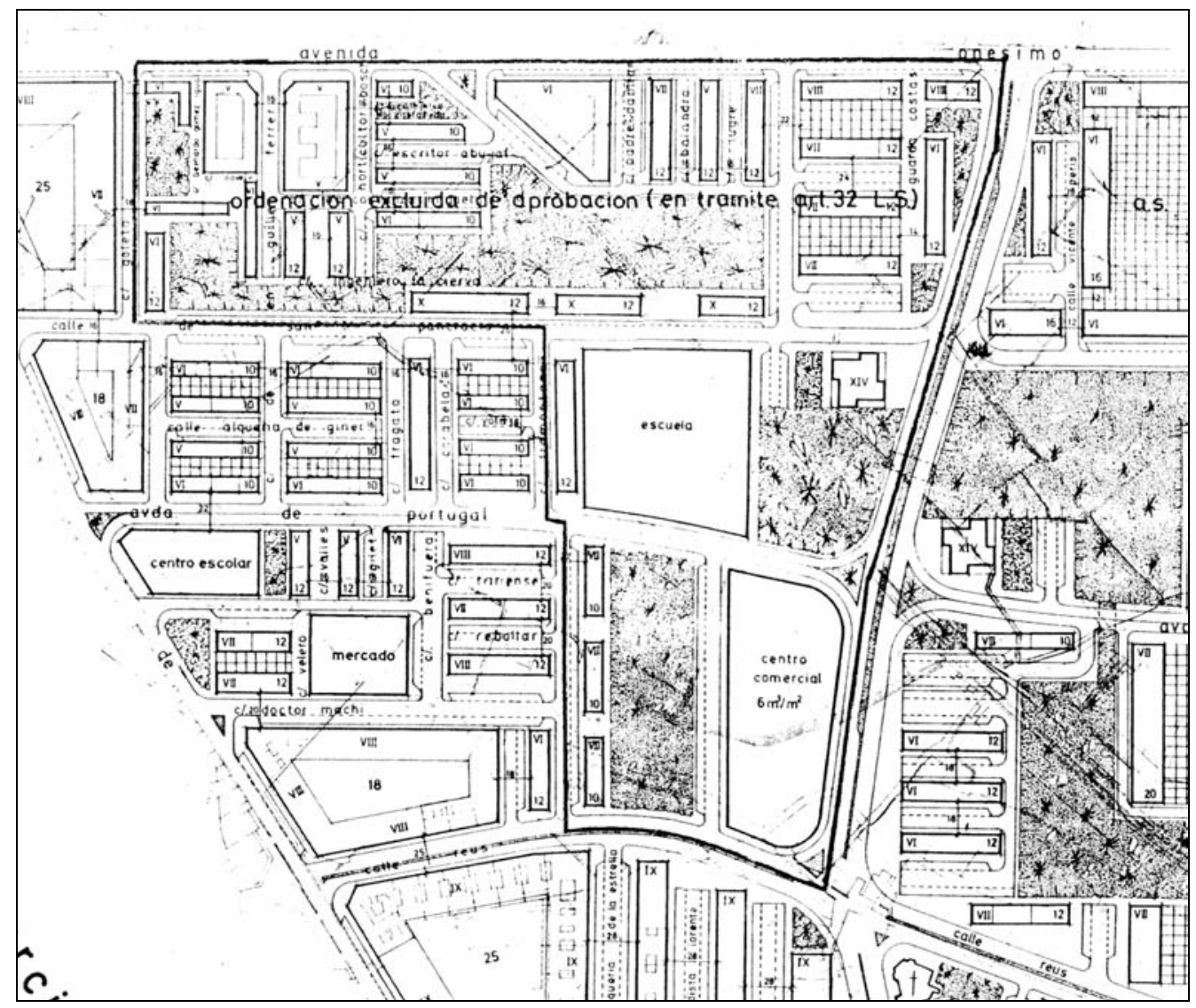

Documento 9.4. Plano adjunto no 2 (Fragmento)

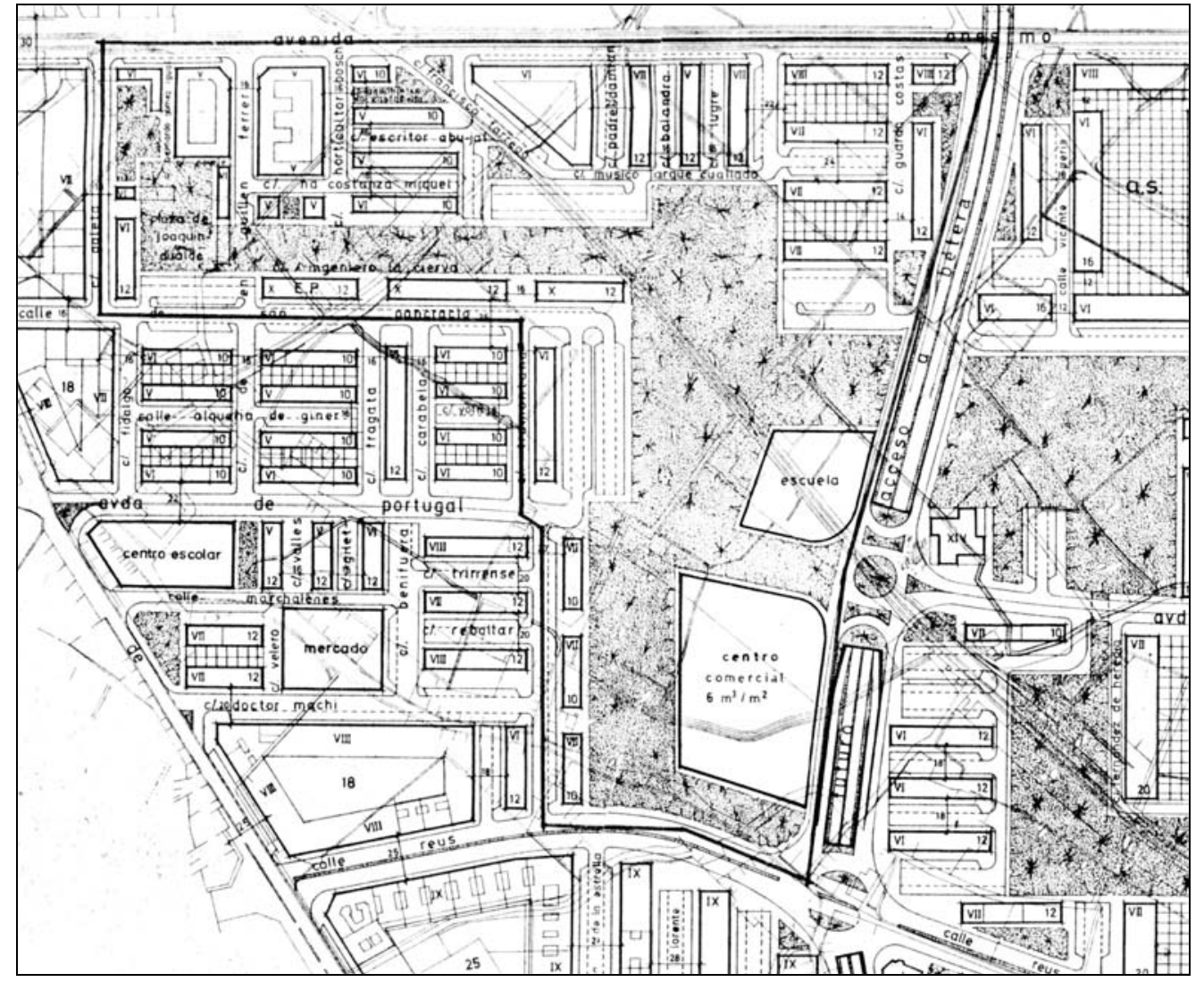


Documento 9.4. Plano adjunto no 3 (Fragmento)

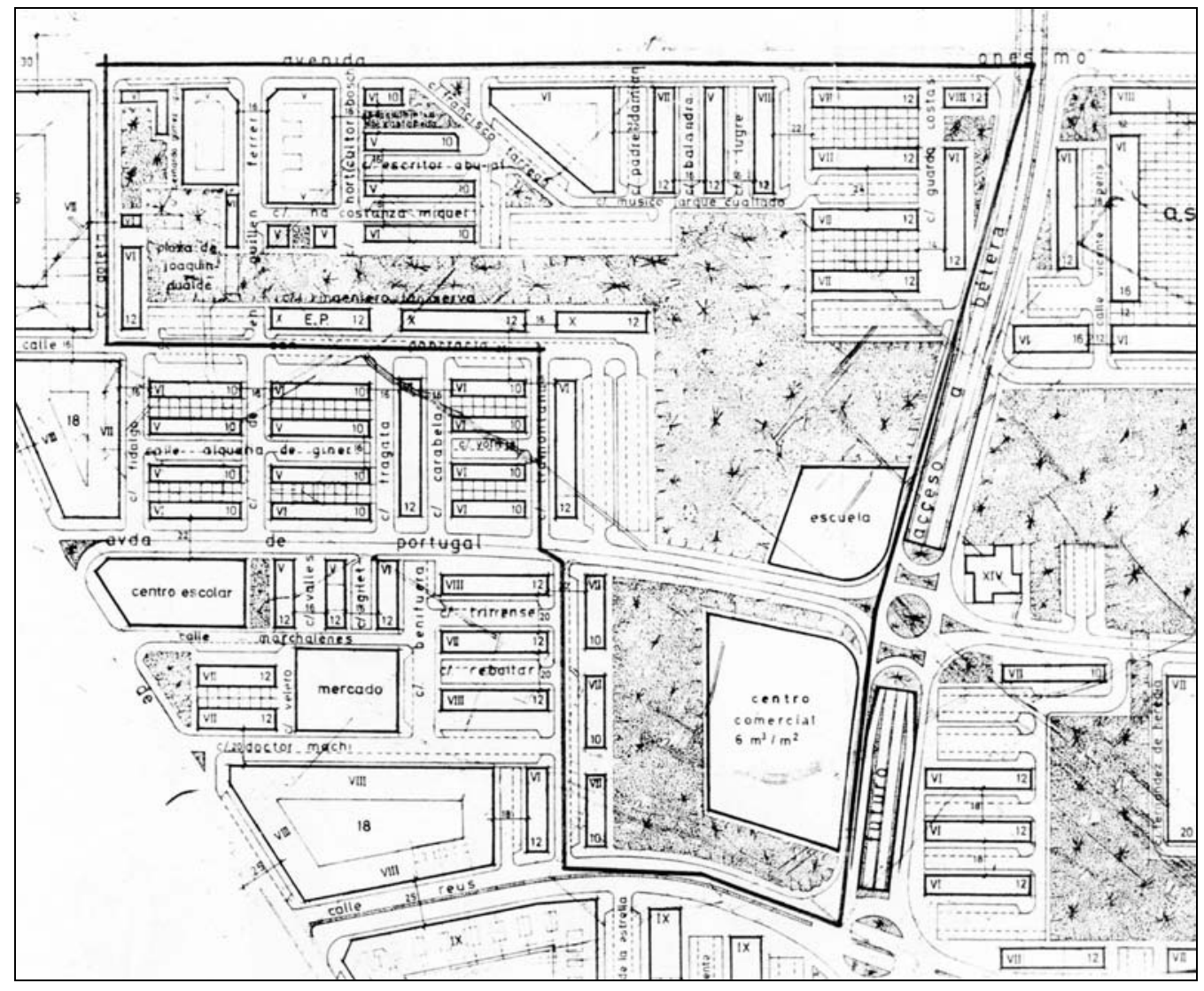




\section{PP 24}

Redactores: Excmo. Ayuntamiento de Valencia. Oficina Técnica de Urbanismo. Arquitecto: Julio Bellot Senent.

Fecha redacción: Marzo 1970.

Fecha aprobación: -

Contenido:

I. MEMORIA

II. ORDENANZAS.

\section{PLANOS:}

1. INFORMACIÓN.SITUACIÓN EN EL PLAN GENERAL $1: 22.500$

2. INFORMACIÓN. ESTADO ACTUAL. ZONAS 24A/24B $1: 2000$

3. ORDENACIÓN. ZONIFICACIÓN. ZONAS 24A/24B $1: 2000$

4. ORDENACIÓN. ALINEACIONES. ZONAS 24A/24B 1:2000

5. ORDENACIÓN. ESCUELAS, ZONAS VERDES Y EDIFICIOS PÚBLICOS. ZONAS 24A/24B $1: 2000$

6. ORDENACIÓN. RED VIARIA. ZONAS 24A/24B $1: 2000$

7. ORDENACIÓN. ALCANTARILLADO $1: 2000$

7. ORDENACIÓN. AGUA POTABLE $1: 2000$

7. ORDENACIÓN. ALUMBRADO. $1: 2000$

\section{Fuente:}

Ayuntamiento de Valencia. Sección de Urbanismo. Negociado de Suelo y Ordenación urbana. (Archivo de Planeamiento. Sección de expedientes antiguos) 


\title{
EXCMO. AYUNTAMIENTO DE VALENCIA
}

\author{
DESARROLLO DEL PLAN PARCIAL DE ORDENACION \\ PROYECTO DE PLAN PARCIAL NO 24 - BENICALAP
}

\section{MEMORIA}

El Plan Parcial $n^{\circ} 24$, fue redactado como desarrollo del Plan General de 1.946, siendo empleado para fijar líneas desde aquel momento. Poco antes del Plan General Adaptado a la Solución Sur, se hizo la última redacción, de las muchas que ha tenido, que fue aprobada por el Excmo. Ayuntamiento, llegando a serlo por la Corporación Administrativa Gran Valencia y volviendo al Ayuntamiento para grafiar en el plano los acuerdos tomados.

Simultáneamente se había estado redactando el Plan General adaptado a la Solución Sur y este Plan General, en cuanto a los detalles particulares del Plan Parcial, procuró adaptarse a los mismos pero se cometieron como en casi todos los planes, una serie de errores o diferencias que hoy obligan a redactar el Plan Parcial de nuevo, para adaptarse al nuevo Plan General, como es preceptivo y a las nuevas exigencias del momento actual urbanístico.

Como quiera que, como se ha dicho, durante largos años se ha ido concediendo licencias con sujeción a los Planes Parciales redactados, el nuevo trazado tiene que sujetarse a tantos puntos fijos, que en parte es simple legalización de la zona ya urbanizada y construida.

El presente Plan Parcial está destinado, en cuanto a su realización, a encauzar la iniciativa particular. Es pues, en principio un plano de alineaciones, sin perjuicio de que, en el futuro, pueda ser tomado por el Ayuntamiento, en todo o en parte, como objeto de realizaciones urbanísticas directas.

\section{JUSTIFICACION DE LA ORDENACION}

La ordenación sigue exactamente el Plan General adaptado a la Solución Sur, con todo detalle que le ha dado Obras Públicas al viario, especialmente a las dos carreteras que atraviesan el ámbito del Plan Parcial: nuevo acceso de Ademúz, de Norte a Sur y Ronda Interior, de Este a Oeste, amén de las carreteras que circundan el ámbito que son: Continuación de Tránsitos por el Sur; Continuación de Tránsitos por el Oeste; Plan Parcial no 23, nuevo acceso de Moncada por medio, por Levante y nueva circunvalación de poblados por el Norte.

Resuelta esta relación con la Ciudad, en cuanto a tráfico de vehículos, ya que el de peatones se realizará comunicándose por el final de los ejes con los de las otras zonas, por pasos superiores o inferiores, que atraviesan las vías límite, se ha resuelto la habitabilidad de la zona en la forma siguiente:

El tráfico entre las distintas agrupaciones del Plan, se realiza por calle eje de barrio muy arboladas, cuando es posible, que atraviesan las grandes circulaciones con pasos superiores o inferiores, tanto para rodado como para peatones. Hay algunos tramos sin tránsito rodado.

Estas uniones, entre barrios, dan unidad al Plan y claridad a la relación de unos barrios con otros. Como se dice la unión es por los centros, no por las calles límite.

Toda la parte del Plan, a los lados y entre los actuales ejes 
que son las Avenidas de Burjasot y la de la vía de Ferrocarriles Económicos, así como el antiguo poblado de Benicalap, están constituidas por manzanas cerradas y calles sin intento de ordenación especial.

Por el contrario, todas las partes del plano restantes de nuevo esquema, se caracterizan por el intento de formar agrupaciones definidas con elemento ajardinado central, formando lo que se ha dado en llamar supermanzanas, dentro de las cuales el tráfico rodado es tranquilo, ya que las calzadas para el mismo no atraviesan las supermanzanas, sino que entran y salen por la misma calle para distribuir y llegar a los aparcamientos. Al no haber beneficio de acortar camino, por no atravesar, el tráfico es solamente el propio de la supermanzana y por lo tanto lento.

En cada una de estas agrupaciones hay un elemento central de jardín o público, que es el centro de la agrupación y también en el centro se ubica la Escuela Maternal o el Grupo Escolar, para que los niños no tengan que desplazarse ni atravesar calles de tránsito intenso.

Así pues, las agrupaciones humanas viven, dentro de lo posible, alrededor de un jardín central y una Escuela, lo que nos parece ha de ser muy interesante para la convivencia de estas agrupaciones.

Este Plan, como se ha dicho, estaba redactado antes de la aprobación definitiva del Plan General y aunque, en la redacción de este último, se procuró mantener las zonificaciones, no se hizo así completamente. Así pues, se ha zonificado, en el Plan General, como Núcleos Periféricos o Actuales, zonas que estaban redactadas como abiertas, en el anterior Plan Parcial.

Por lo anterior y con el fin de no volver a cambios radicales de los esquemas, hemos mantenido las formas de edificación abierta, en cuanto a vivienda, zonificando como Núcleos Actuales o Periféricos.

Algo parecido ocurre con las zonas de Tolerancia Industrial, al Suroeste del plano.

El Plan general, al señalar las zonas de Tolerancia, lo hace con la trama de industrial colocando una $T$ sobre esta trama. Pero esto último no lo hace en cada uno de los cuadros contiguos separados por vías de tráfico, sino en una sola de ellas. Esto de presta a interpretación, pero nosotros no hemos dudado porque, en toda la zona de Tolerancia Industrial, hay muchas viviendas edificadas y casi ninguna industria de suelo a cubierta. Casi todo industrias en plantas bajas con viviendas en altos. Es decir, lo característico en la Tolerancia Industrial. Por todo ello interpretar Zona Industrial sería una solemne equivocación.

En el Plan anterior existía una Zona Comercial que mantenemos como Zona especial, por creerla más apropiada, a los nuevos esquemas urbanísticos que los antiguos.

Un pequeño poblado, el de Beniferri, lo hemos desarrollado también como una supermanzana de manzanas cerradas y semiabiertas entre las cuales hay pequeños jardines, de tal manera, que se divisa el siguiente antes de haber dejado el presente.

El Plan contiene na superficie de 32,07 hectáreas y tiene dedicado a parques o jardines de uso público 5,13 hectáreas, lo que representa una superficie de $16 \%$ mayor del $10 \%$ que exige la Ley del Suelo. Se ha confeccionado un plano único, sin copias, de espacios verdes, que debe obrar en el expediente, para la medición y comprobación.

La edificabilidad de las zonas abiertas es inferior a la máxima 
marcada por las Normas. No sobrepasa la de $4,76 \mathrm{~m} 3 / \mathrm{m} 2$ en su conjunto, ni la de $5 \mathrm{~m} 3 / \mathrm{m} 2$ en ningún punto.

En las zonas de manzana cerrada la edificabilidad es la que resulta de la aplicación de las Normas. De todas formas, no es excesiva.

Supuesta la densidad de 400 habitantes por hectárea, tanto para la zona abierta, como para la manzana cerrada, dentro del ámbito de este Plan Parcial podrá albergarse 12.832 personas.

La población escolar, incluyendo maternales, es de $1.925 \mathrm{ni}-$ ños. El cálculo de superficies reservadas para escuelas es intermedio entre los 6,00 m2 necesarios por alumno y los 13,33 m2, para grupos escolares subvencionados con viviendas para maestros y comedores. En los casos en que el Excmo. Ayuntamiento pretenda lo último, ya se procuraría la superficie necesaria por expropiación o compra.

Se han destinado los necesarios terrenos para Centros Parroquiales e Iglesias.

Se han destinado los necesarios terrenos para aparcamientos públicos. Como éstos son arbolados, representan un aumento de parque público.

\section{ETAPAS}

El presente Plan es más un plan de alineaciones, que encauce la iniciativa particular, que un plan de realizaciones urbanísticas. Por ello, no puede establecerse etapas ya que el procedimiento de realización por cesión de viales, será que el Excmo. Ayuntamiento irá realizando urbanizaciones donde la iniciativa particular demande, procurando adelantarse a ella. Naturalmente, una primera etapa, ya en ejecución, es la construcción de colectores de alcantarillado, ya iniciada por el camino de Paterna, así como vías principales, de las cuales está ya en funcionamiento el eje principal Norte Sur de acceso a Ademúz.

\section{MEDIOS ECONOMICOS FINANCIEROS}

Serán los del presupuesto ordinario del Ayuntamiento de Valencia y los de los extraordinarios que se establezcan, para realizaciones parciales, a medida que se redacten los correspondientes proyectos.

Con lo dicho creemos suficientemente expuesto el alcance del estudio realizado para que, si el Excmo. Ayuntamiento lo estima conveniente, lo eleve a la aprobación por la Superioridad.

Se ha de tener presente que el presente Plan no 24, porque tal vez sea conveniente para la tramitación, así como para cumplir lo ordenado por el Excmo. Ayuntamiento, se ha dividido en dos: Plan No 24-A y 24-B, pero se ha estudiado y calculado como único que es.

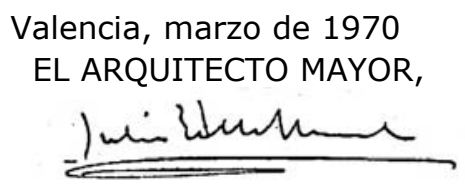


ALINEACIONES. SECTOR 24-A

Escala original 1:2000

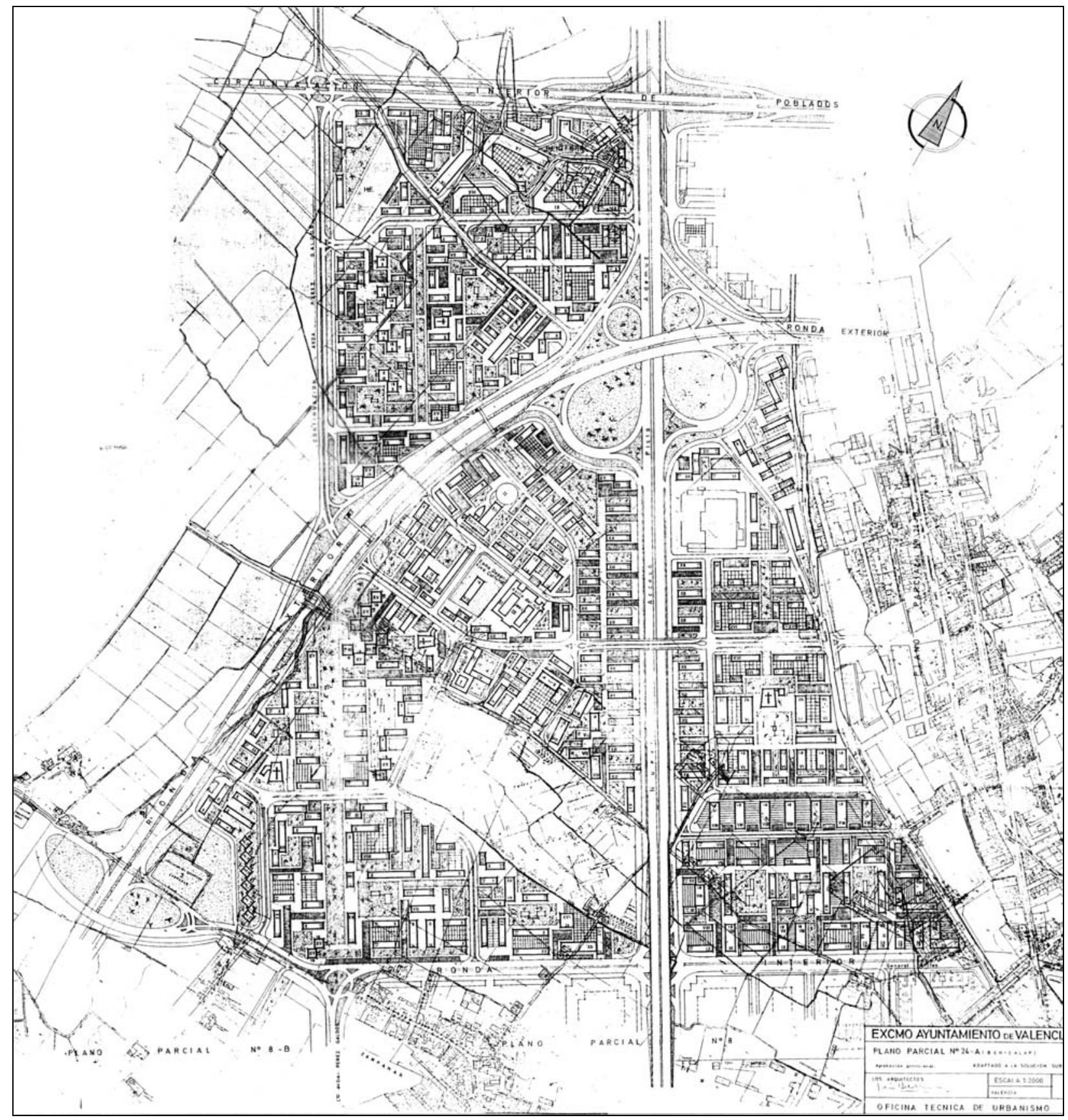




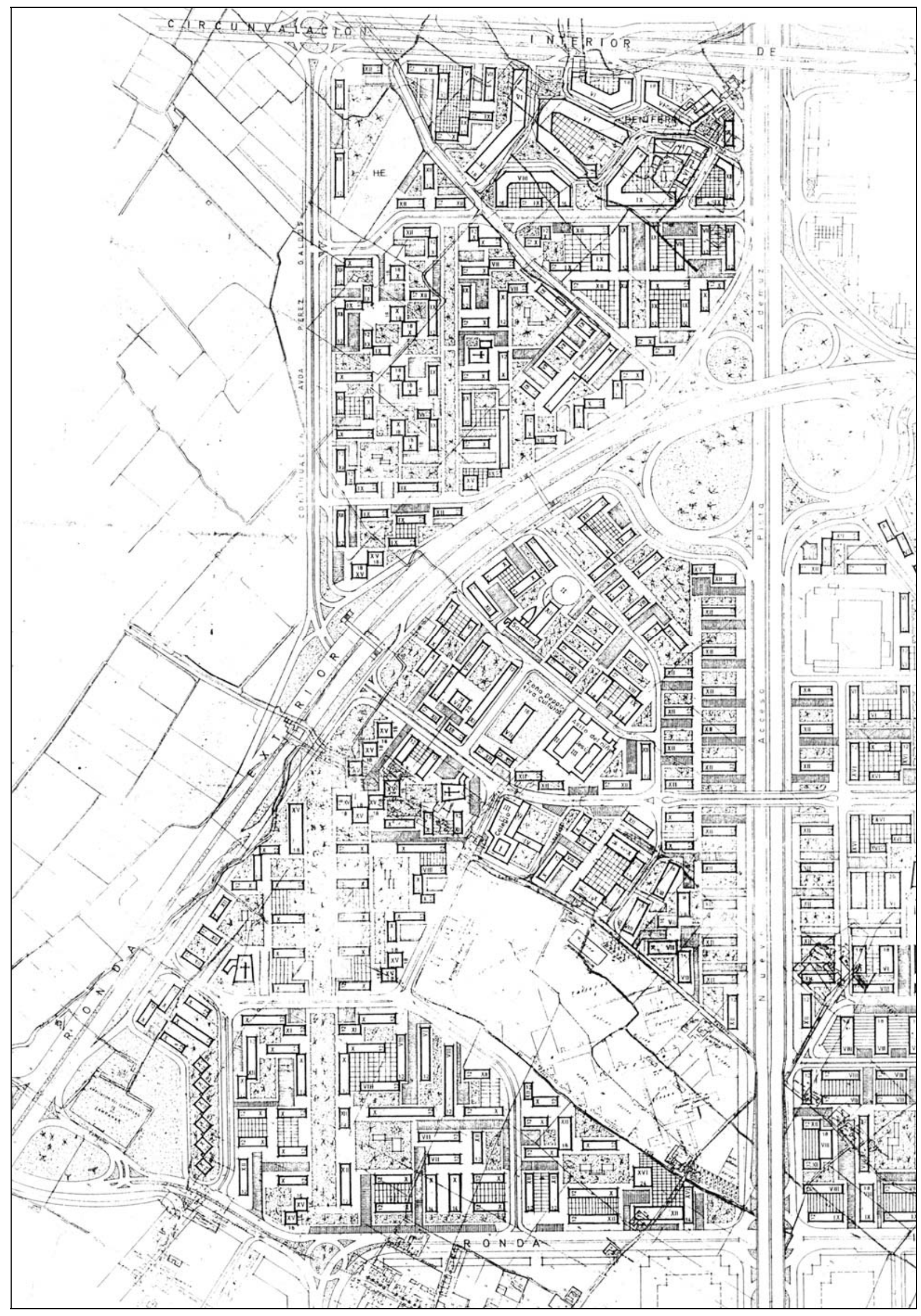

Sector 24-A. Detalle de la zona oeste. 


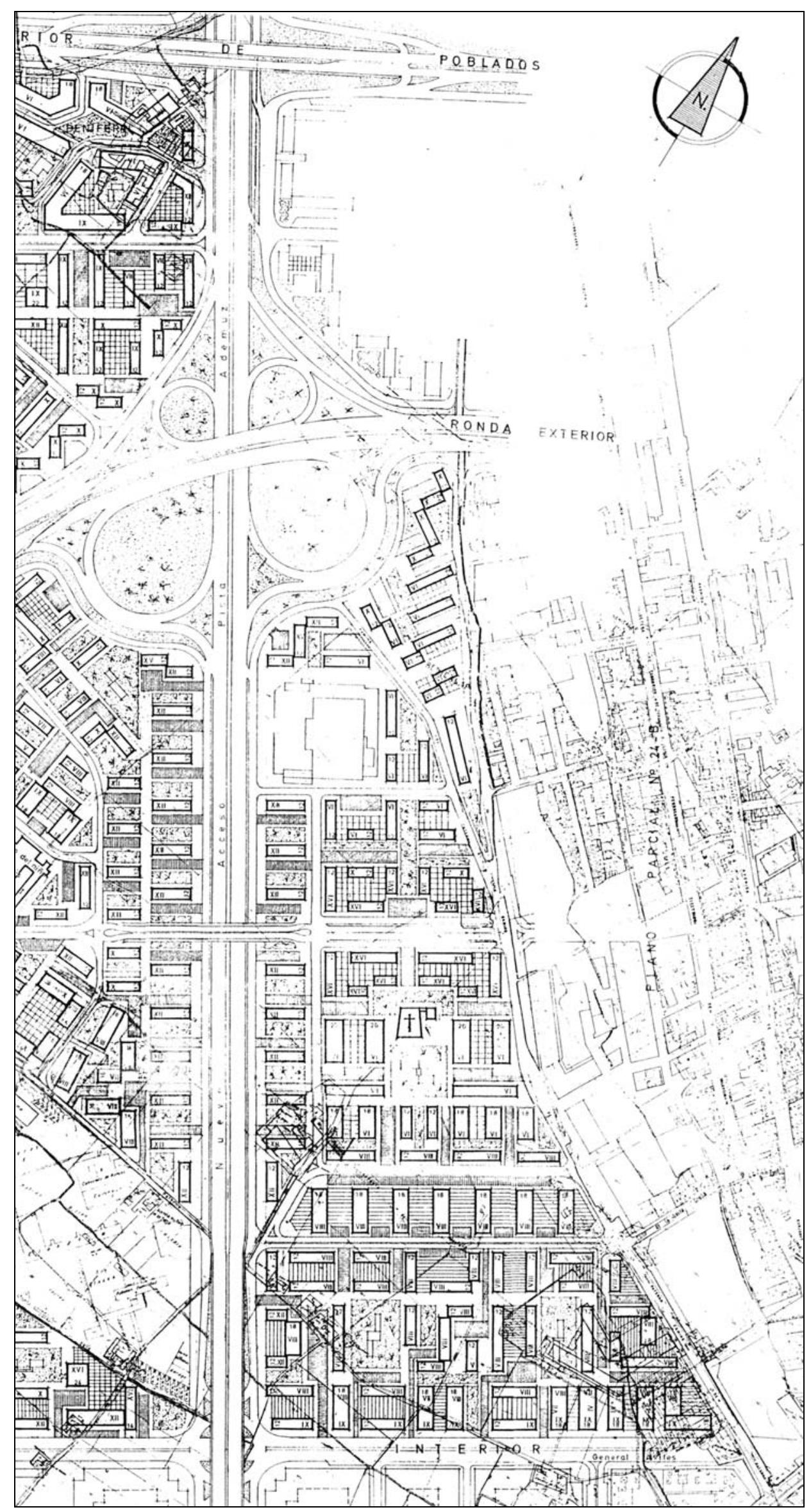

Sector 24-A. Detalle de la zona este. 


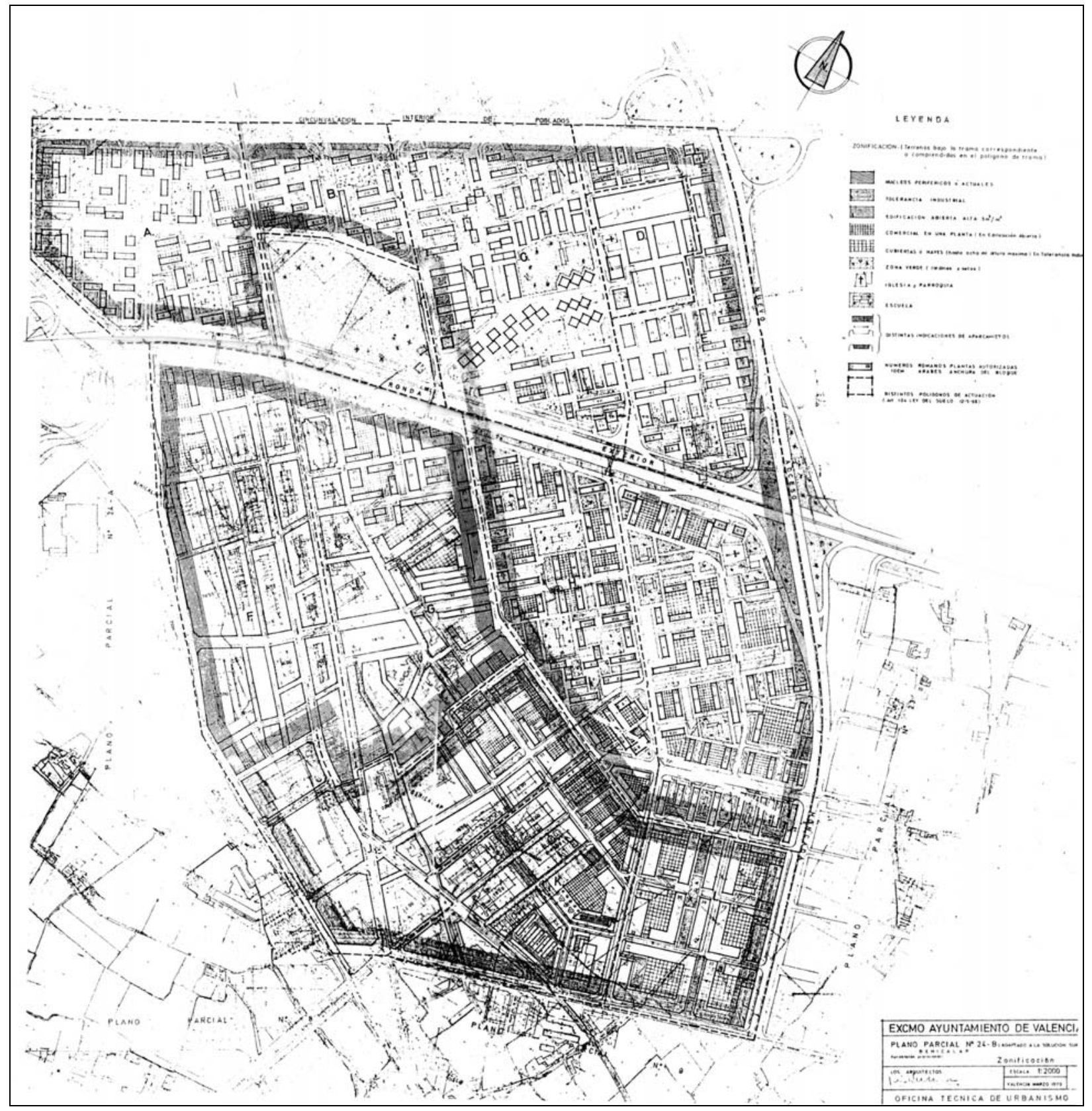




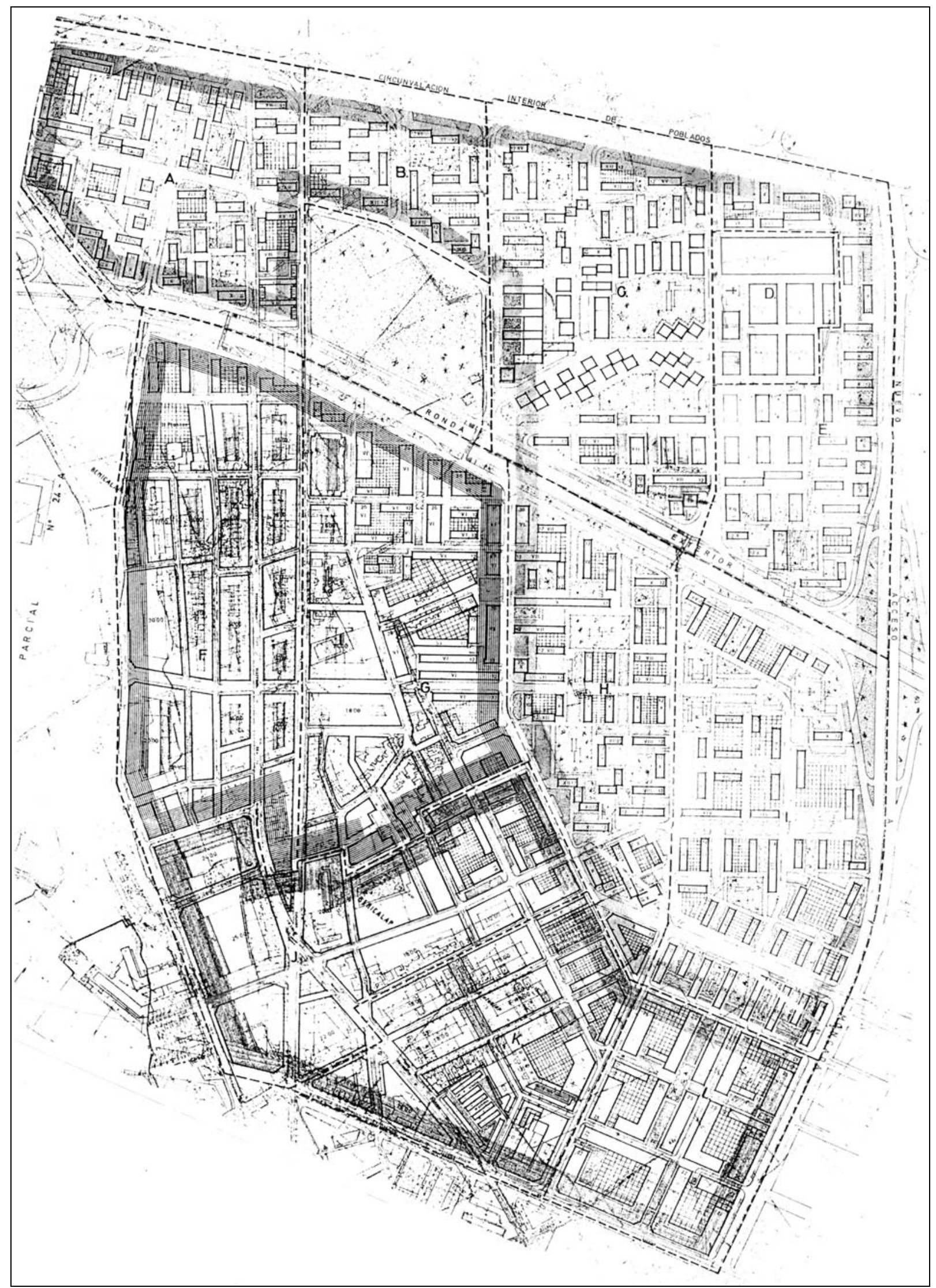

Sector 24-B. Detalle de la zona de edificación abierta. 



\section{PP 24}

PLANO PARCIAL No 24 (ADAPTADO A LA SOlUCIÓN SUR). $1975 / 77$

Redactores: EXCMO. AYUNTAMIENTO DE VALENCIA. OFICINA TÉCNICA DE URBANISMO.

Fecha redacción: Enero 1975.

Fecha aprobación: O.M. 28-02-1976 (B.O.E. 06-04-76)

Contenido: (Fecha documentos Enero 1975; Documentos rectificados, Noviembre 1977 y Octubre 1978)
A) PLAN PARCIAL:
I. MEMORIA
II. ORDENANZAS.

\section{PLANOS:}

1. INFORMACIÓN.SITUACIÓN EN EL PLAN GENERAL $1: 22.500$

2. INFORMACIÓN. ESTADO ACTUAL. ZONAS 24A/24B $1: 2000$

3. ORDENACIÓN. ZONIFICACIÓN. ZONAS 24A/24B $1: 2000$

4. ORDENACIÓN. ALINEACIONES. ZONAS 24A/24B 1:2000

5. ORDENACIÓN. ESCUELAS, ZONAS VERDES Y EDIFICIOS PÚBLICOS. ZONAS 24A/24B $1: 2000$

6. ORDENACIÓN. RED VIARIA. ZONAS 24A/24B $1: 2000$

7. ORDENACIÓN. ALCANTARILLADO $1: 2000$

7. ORDENACIÓN. AGUA POTABLE $1: 2000$

7. ORDENACIÓN. ALUMBRADO. $1: 2000$

B) DETERMINACIÓN DEL SISTEMA DE ACTUACIÓN:

I. MEMORIA

PLANOS:

1. UNIDADES DE ACTUACIÓN.

\section{Fuente:}

Ayuntamiento de Valencia. Sección de Urbanismo. Negociado de Suelo y Ordenación urbana. Reg. General 1.830 (Archivo de Planeamiento No 149). 


\title{
EXCMO. AYUNTAMIENTO DE VALENCIA
}

\author{
PLAN PARCIAL 24
}

RECTIFICADO CON ARREGLO R.M. 21-6-78 EN CUMPLIMIENTO EXTREMOS O.M. 28-2-76

\section{MEMOR I A}

PLANO PARCIAL DE ALINEACIONES Y ZONIFICACIÓN NO 24 (BENICALAP) VALENCIA

\section{ME MOR I A}

\section{OBJETO DE ESTE ESTUDIO.-}

Los fundamentos del presente estudio se hallan en el Plan Parcial de Ordenación de Valencia y su Comarca, adaptado a la Solución Sur y con los condicionamientos que impone la red arterial de Valencia, realizada por la Oficina regional de proyectos del Ministerio de Obras Públicas. En consecuencia el presente estudio queda totalmente adaptado a las obligadas premisas que significarán los conceptos invocados.

Este ha sido el criterio del presente trabajo ejecutado por los técnicos municipales que suscriben.

Por consideraciones de formato y en orden a su fácil consulta se ha resuelto según se observa en los planos que se acompañan, el total del presente Plano Parcial de Alineaciones y Zonificación no 24, el trazado de las alineaciones y zonificación que le constituyen en dos amplios sectores que con el nombre de " $A$ " y " $B$ " cubren la totalidad de este Plano Parcial.

Se significa este fraccionamiento como únicamente motivado por consideraciones de formato, habiéndose estudiado como conjunto y cuidado en consecuencia el correcto encaje de alineaciones y zonificaciones entrambos planos de forma que no ofrezca ambigüedad ni duda.

\section{JUSTIFICACIÓN DE LA ORDENACIÓN.-}

Los criterios adoptados para la redacción de este Plan Parcial son los que ofrecen, con la normativa del Plan general las normas urbanísticas que a criterio de quien suscribe aconseja la correcta solución de los problemas de salubridad, vialidad, etc, y cuantos criterios han sido coordinados hasta llegar a la definición de este conjunto habitable; que es en definitiva el objeto del presente Plan Parcial.

\section{VIALIDAD.-}

El esquema vial se apoya en las arterias principales previstas en la red Arterial de Valencia, y que en el ámbito del presente Plan Parcial son:

- Circunvalación interior de poblados.

- Ronda Interior (actual camino de Tránsitos).

- Futuro acceso de Moncada.

- Actual acceso de Ademuz.

- Actual acceso de Paterna-Benimamet.

Estas son las arterias que atraviesan este Polígono aparte una 
Ronda Exterior con rango de autovía.

Las cuatro vías: Ronda Exterior, Circunvalación Interior, Nuevo Acceso de Moncada y Acceso de Ademuz, por su importancia han de servir para la continuidad de comunicación entre distintos polígonos y poblados, ya que por su condición de vías rápidas, actúan urbanísticamente como elementos separadores, siendo sus vías auxiliares o de servicios las que han de atender las necesidades de los barrios o sectores de este polígono.

La Ronda Interior (actual camino de Tránsitos) como también el actual Camino de Burjasot, son arterias netamente urbanas al servicio del tráfico interior de este polígono.

A la red principal apuntada hay que añadir una red complementaria de carácter estrictamente urbano, que adaptándose a las arterias anteriores ya definidas, ha de canalizar el tráfico por este Polígono, ofreciendo con ello tres tipos de calle, de acuerdo con su categoría de tráfico.

a) Calles de ronda son vías envolventes de unidades residenciales previstas preferentemente como unidireccionales, al concreto fin de lograr relativa fluidez en el tránsito.

b) Calles de unión dispuestas para la comunicación de diversas unidades vecinales igualmente unidirecionales y flanquedas de aparcamientos, previéndose tales vías para el tráfico lento.

c) Calles de acceso exclusivo a aparcamientos o bloques de viviendas en la zona residencial, que carentes de continuidad para el servicio, sirven únicamente a los inmuebles que las bordean; estas vías flanqueadas de aparcamientos, quedan previstas para el tráfico local.

\section{APARCAMIENTOS.-}

Aparte los aparcamientos laterales previstos en algunos viales, se definen en el Plan Parcial solares determinados, reservados en su edificabilidad para este concreto fin.

También en las ordenanzas de edificación redactadas para este Plan Parcial, se incluye la obligación de reserva a este respecto de cada edificio.

La previsión que significan la reserva de solares y de edificios según la Ordenanza, vienen a significar el 13,7\% de la superficie total construida como reservada para aparcamiento de vehículos.

\section{DELIMITACIÓN DE BARRIOS.-}

Estos, quedan definidos según el plano que se acompaña, por las arterias de tráfico importante siguiendo un paralelismo con la zonificación que en este Plano Parcial se desarrolla de acuerdo con el Plan General.

\section{EDIFICACIONES.-}

Siguiendo la normativa dictada por el Plan General, se han definido las siguientes zonificaciones:

- Edificación abierta.

- Núcleos periféricos.

- Tolerancia Industrial.

- Ordenanza especial (cultura y deportes).

- Ordenación especial.

Respecto de esta ordenación especial, cabe comentar que según el plano hoja no 1 (copia del Plan General), existe en la actualidad un paramento del nuevo acceso de Ademuz previsto en el Plan 
General como Edificación Abierta, en tanto que el paramento opuesto al dicho acceso, quedaba previsto como núcleos periféricos de lograr una unidad en ambos paramentos, según Norma Plan General no 15.

A ello se atiende con la "Ordenación Especial" que considera "Edificación Abierta" el total de la primera línea de edificios a la Avenida que inicialmente estaba regida por la Ordenanza de Núcleos Periféricos:

Las edificaciones previstas para la zona de Edificación Abierta se han proyectado en la planificación con criterio de máxima sencillez en orden a mayor libertad en la iniciativa particular, en cualquier caso, las distancias máximas establecidas en las Normas Generales prescribiendo la "Separación" se han respetado mejorándolas en lo posible a base de moderar las alturas en orden a la uniformidad en todo el polígono.

También es criterio proyectivo la orientación Norte-Sur o Levante-Poniente con pequeñas variaciones angulares en orden a la identidad y personalidad de los barrios, logrando de este modo que cada uno de ellos se ordene en comunión visible a un eje de orientación único. El soleamiento eficaz de los paramentos externos de los bloques, se ha previsto siempre en el caso de los orientados como queda dicho en forma tal que admita la posibilidad de doble alineación de viviendas al concreto fin de estimular la posibilidad del proyectista en orden a su personal criterio.

Generalmente han sido modulados los bloques a una anchura de 12 mts. Que con los voladizos previstos en la Ordenanza ofrecen la posibilidad de realizar viviendas a doble orientación, o en el caso de que al proyectista le interese gran superficie de fachada. En lo que atañe a la longitud de los bloques, se ha procurado en lo posible dado el minifundio de los terrenos en esta ciudad y zona, el que pueda llegarse en orden a posible a un máximo de dos proyectistas distintos, si bien lo interesante sería que cada bloque poseyera unidad arquitectónica como mejor solución estética.

También podrá observarse que en el Plano Parcial se preveen manzanas sin definir edificación alguna, ofreciéndolas como simple unidad de terreno con un volumen de edificación asignado, para que la agrupación de propietarios pueda resolver según criterio del proyectista los bloques a su conveniencia, siempre acordes con los límites definidos en la Ordenanza correspondiente, previa aprobación Municipal.

Los edificios en manzana cerrada se acepta en todos los casos donde ya existen edificios rigiéndose según emplazamiento por la Zonificación de Núcleos Periféricos o Tolerancia Industrial.

Se han previsto en ella, patios interiores de manzana y también bajos entre bloques destinados en principio a la industria de la artesanía de tipo familiar muy frecuente en ellos esta riqueza artesanal en que Valencia es tan pródiga.

Se define como se observa en los planos las alturas en los bloques de la zonificación "Edificación Abierta", no así en las zonificaciones de Núcleos Periféricos y Tolerancia Industrial ya que sus alturas vienen definidas de acuerdo con el ancho de calles y con la ordenanza correspondiente basada a las que en su día ofrecieran las normas del Plan General.

\section{AREAS PEATONALES.-}

Estas áreas han sido acotadas y definidas para conseguir zonas tranquilas, en las que los peatones puedan circular libremente sin los inconvenientes que el tráfico rodado les obliga. 


\section{ESCUELAS.-}

De acuerdo con las normas dictadas en las que establece 15 m2 de solar por plaza escolar $17 \%$ de habitantes como población escolar, la unidad vivienda de $120 \mathrm{~m} 2$ y partiendo del total de la superficie construida en viviendas nos ofrece según se observa en el estudio estadístico que se acompaña, una superficie necesaria escolar de $248.190 \mathrm{~m} 2$, habiendo previsto en el Plan Parcial una superficie escolar de $249.081 \mathrm{~m} 2$, lo cual cubre las necesidades previstas para este menester.

\section{DENSIDAD.-}

La densidad prevista en este polígono como se observa en el estudio estadístico que se acompaña queda definido según sigue:

Densidad media de todo el polígono $=313 \mathrm{hab} / \mathrm{hec}$.

Zonificación Núcleos Periféricos:

$$
24 \mathrm{~A}) 148 \mathrm{hab} / \mathrm{hec} \text {. }
$$

24 B) 485 " "

Zonificación Tolerancia Industrial:

$24 \mathrm{~A}) 217 \mathrm{hab} / \mathrm{hec}$.

24 B) 531 " "

Volumen de edificación en edificación abierta:

24 A) $4,51 \mathrm{~m} 3 / \mathrm{m} 2$.

24 B) 4,08 " "

Como se observa pues, las densidades previstas están muy por debajo de las que usualmente vienen aplicándose.

\section{EDIFICABILIDAD.-}

Como se observa en el estudio estadístico presentado y dada la idiosincrasia de esta Ciudad, puesto que generalmente se resuelven las plantas bajas para usos comerciales o de servicios, no se suele proyectar en muchos edificios que se construyan en las plantas bajas viviendas y ello nos ha llevado a definir que los centros comerciales han de estar agrupados alrededor de los mercados previstos, y resolviendo las plantas bajas para también estos menesteres.

\section{ZONAS VERDES.-}

La disposición de zonas verdes con espacios de tamaño medio se ven esparcidos en todo el Plan Parcial ya que entendemos que estas zonas verdes de uso inmediato por los vecinos, ofrecen un mejor esparcimiento y un mayor soleamiento a la vez que unas cualidades higiénicas y de salubridad ventajosas que pueden llegar a eliminar la polución hoy tan al día en las teorías urbanísticas, estos espacios verdes entendidos en su más amplio concepto de espacio libre y abierto para uso de todos los ciudadanos que a ellos acudan. Se ha previsto también un gran espacio verde que junto con los espacios verdes de tamaño medio completan las necesidades que urbanísticamente requiere este polígono.

Superficie total del Polígono: 2.978 .000

Superficie total de zonas verdes: $301.000 \mathrm{~m} 2$

Como se observa, los espacios definidos para zonas verdes, suponen un $10,13 \%$ de la superficie total del Polígono.

\section{ESQUEMA DE SERVICIOS.-}

Se acompañan planos con los esquemas de aplicación, habiendo aplicado en su estudio las ordenanzas que rigen en el actual Ayuntamiento de los años 1950 las normas dadas en el Plan Gene 
ral y las normas dictadas por el Ministerio de la Vivienda en su orden de 4 de mayo de 1970 ordenanzas de aplicación oficial con estos tres antecedentes se ha procurado ofrecer las ordenanzas.

ETAPAS.-

De acuerdo con el desarrollo que ofrezca la iniciativa privada adelantándose a ella el Ayuntamiento en la construcción de la infraestructura necesaria, financiando estas por sus canales normales (presupuestos extraordinarios), con la aplicación de las contribuciones especiales que la legislación ofrezca para este tipo de obras.

Está prevista la pronta iniciativa del Colector Norte, a lo largo de la Avda. Onésimo Redondo, también por Obras Públicas se han proyectado con vistas a su próxima ejecución la Ronda Exterior.

Realizadas ambas, podrán resolverse la total urbanización del polígono.

\section{ESTUDIO ESTADÍSTICO.-}

Superficie de los terrenos comprendidos en los Polígonos A y B.

Zonas verdes:

$\begin{array}{ccc}\text { Sup. Pol. A } & \text { Sup. Pol. B } & \text { Total } \\ 1.347 .500 \mathrm{~m} 2 & 1.630 .500 \mathrm{~m} 2 & 2.978 .000 \mathrm{~m} 2\end{array}$

Zonas escolares:

$$
125.160 \mathrm{~m} 2 \quad 175.840 \mathrm{~m} 2 \quad 301.000 \mathrm{~m} 2
$$

$170.905 \mathrm{~m} 2 \quad 78.176 \mathrm{~m} 2 \quad 249.081 \mathrm{~m} 2$

Zonas públicas (Mercados, Bomberos y P. Deportes):

Rondas y nudos:

$$
15.296 \mathrm{~m} 2 \quad 13.880 \mathrm{~m} 2 \quad 29.176 \mathrm{~m} 2
$$

$$
308.000 \mathrm{~m} 2 \quad 303.000 \mathrm{~m} 2 \quad 611.000 \mathrm{~m} 2
$$

\section{SUPERFICIE EDIFICACIÓN EN PLANTA PISOS (VIVIENDAS)}

$$
\text { Sup. Pol. A Sup. Pol. B Total }
$$

Superficie en edif. abierta:

$$
\begin{array}{lll}
797.570 & 701.000 & 1.498 .570
\end{array}
$$

Superficie en Ordenanza Especial:

$$
89.750 \quad--\quad 89.750
$$

Superficie en tolerancia industrial:

$$
\begin{array}{lll}
127.420 & 7525.400
\end{array}
$$

Superficie en Núcleos Periféricos:

$90.000 \quad 438.860$

TOTAL SUPERFICIE EDIFICABLE.............. 2.920 .000

\section{ESTUDIO SUPERFICIE ZONA ESCOLAR.-}

Superficie const. en viv...

Viv. tomada como tipo $120 \mathrm{~m} 2$

$$
\frac{2.920 .000 \mathrm{~m} 2}{120,00 \mathrm{~m} 2}=24.333 \mathrm{~m} 2 \text {. Viv }
$$

Hab. por viv. (familia tipo) $=4$ pers.

Num. Habitantes:

$$
24.333 \text { viv } \times 4 \text { hab/viv. }=97.332 \mathrm{n} \% / \text { hab. }
$$

CALCULO DE AREA DE ESCUELAS.-

Módulo de aplicación. $15 \mathrm{~m} 2 /$ escolar.

Area de escuelas: $15 \mathrm{~m} 2 \times 16.546$ escuelas $=248.190 \mathrm{~m} 2$. Sup. Escuelas.

ESTUDIO DENSIDAD DE POBLACION.-

Habitantes Hectárea: $\underline{97.332 \mathrm{hab}}=325 \mathrm{hab} / \mathrm{hec}$. 


\section{SUPERFICIE EN BAJOS.-}

Superficie de las pl. bajas bajo bloque

\begin{tabular}{lccr} 
& Pol. A & Pol. B & \multicolumn{1}{c}{ Total } \\
Edif. Abierta: & $123.000 \mathrm{~m} 2$ & $152.400 \mathrm{~m} 2$ & $275.400 \mathrm{~m} 2$ \\
Nucleos perif: & $29.500 \mathrm{~m} 2$ & $157.000 \mathrm{~m} 2$ & $186.500 \mathrm{~m} 2$ \\
Tol. Industrial & $28.200 \mathrm{~m} 2$ & $159.700 \mathrm{~m} 2$ & $187.900 \mathrm{~m} 2$ \\
Ord. Especial & $7.000 \mathrm{~m} 2$ & -- & $7.000 \mathrm{~m} 2$ \\
\cline { 2 - 3 } & TOTAL SUPERFICIE ..................... & $656.800 \mathrm{M2}$
\end{tabular}

Superficie en patio de manzana o entre bloques

\begin{tabular}{lccr} 
& Pol. A & Pol. B & \multicolumn{1}{c}{ Total } \\
Edif. Abierta: & $54.860 \mathrm{~m} 2$ & $39.600 \mathrm{~m} 2$ & $94.460 \mathrm{~m} 2$ \\
Nucleos perif: & $19.460 \mathrm{~m} 2$ & $50.000 \mathrm{~m} 2$ & $69.460 \mathrm{~m} 2$ \\
Tol. Industrial & $15.700 \mathrm{~m} 2$ & $60.350 \mathrm{~m} 2$ & $76.050 \mathrm{~m} 2$ \\
Ord. Especial & $6.800 \mathrm{~m} 2$ & -- & $6.800 \mathrm{~m} 2$ \\
& TOTAL SUPERFICIE & $-\ldots \ldots \ldots \ldots \ldots \ldots \ldots \ldots \ldots \ldots \ldots \ldots$ & $246.770 \mathrm{M} 2$ \\
\hline
\end{tabular}

SUPERFICIE TOTAL DE TERRENOS. $2.978 .000 \mathrm{~m} 2$

SUPERFICIE SOLARES EDIFICABLES: $656.800+246.770=903.570 \mathrm{~m} 2$.

SUPERICIE ZONAS VERDES.... $301.000 \mathrm{~m} 2$.

SUPERFICIE ESCOLARES......... $249.081 \mathrm{~m} 2$.

SUPERFICIE ZONAS PÚBLICAS (Mercados, P. Bomberos, M. Fallero, P. Deportes). $29.176 \mathrm{~m} 2$.

RONDAS Y NUDOS.................. $611.080 \mathrm{m2}$.

SUPERFICIE DE VIALES........... $884.173 \mathrm{~m} 2$.

SUPERFICIE TOTAL DE TERRENOS COMPRENDIDOS EN EL PLAN PARCIAL "A" $Y$ "B"................. 2.978.000 m2.

PORCENTAJE DE SOLARES EDIFICABLES...30,34 \% de 2.978.000

$(903.570 \mathrm{~m} 2)$

PORCENTAJE DE ZONAS VERDES. $10,13 \%$ de 2.978 .000 $(301.000 \mathrm{~m} 2)$

PORCENTAJE DE ZONAS ESCOLARES. $8,36 \%$ de 2.978 .000 (249.081 m2)

PORCENTAJE DE ZONAS PÚBLICAS:

(Patios Bomberos, Mercados, Pabellón Deportes, etc.)

$0,93 \%$ de 2.978 .000 $(29.176 \mathrm{~m} 2)$

PORCENTAJE DE RONDAS Y NUDOS. $26,51 \%$ de 2.978 .000 (611.000)

PORCENTAJE DE VIALES $29,63 \%$ de 2.978 .000

(884.173)

SUPERFICIE TOTAL CONSTRUIDA DEL PLAN PARCIAL 24

En planta pisos................................. $4.920 .000 \mathrm{~m} 2$.

En pl. baja: $656.800+246.770 \mathrm{~m} 2 \quad 903.570 \mathrm{m2}$. TOTAL.......... $3.823 .570 \mathrm{~m} 2$.

EDIFICIOS PÚBLICOS........................ $29.176 \mathrm{m2}$

ZONAS VERDES................................ $301.000 \mathrm{m2}$.

ZONAS ESCOLARES............................ $249.081 \mathrm{~m} 2$. $579.257 \mathrm{~m} 2$.

$$
\frac{579.257 \mathrm{~m} 2}{3.823 .570 \mathrm{~m} 2}=0,151
$$

Por cada m2. de construcción le corresponde 0,151 de zonas de interés social (Verdes mas Escuelas). 


\begin{tabular}{lcc} 
& Pol. A & Pol. B \\
Tolerancia Indust. & 122.600 & $343 . x x x$ \\
Núcleos periféricos & 176.400 & 298.400 \\
Edif. Abierta (incl. & & \\
Ordenanza esp. & 740.500 & 685.300 \\
Núcleos Rondas & 308.000 & 303.000 \\
\cline { 2 - 3 } & $1.347 .500 \mathrm{~m} 2$ & 1.530 .500
\end{tabular}

\section{ESTUDIO DE DENSIDADES}

Habitantes Hectárea en Núcleos Periféricos

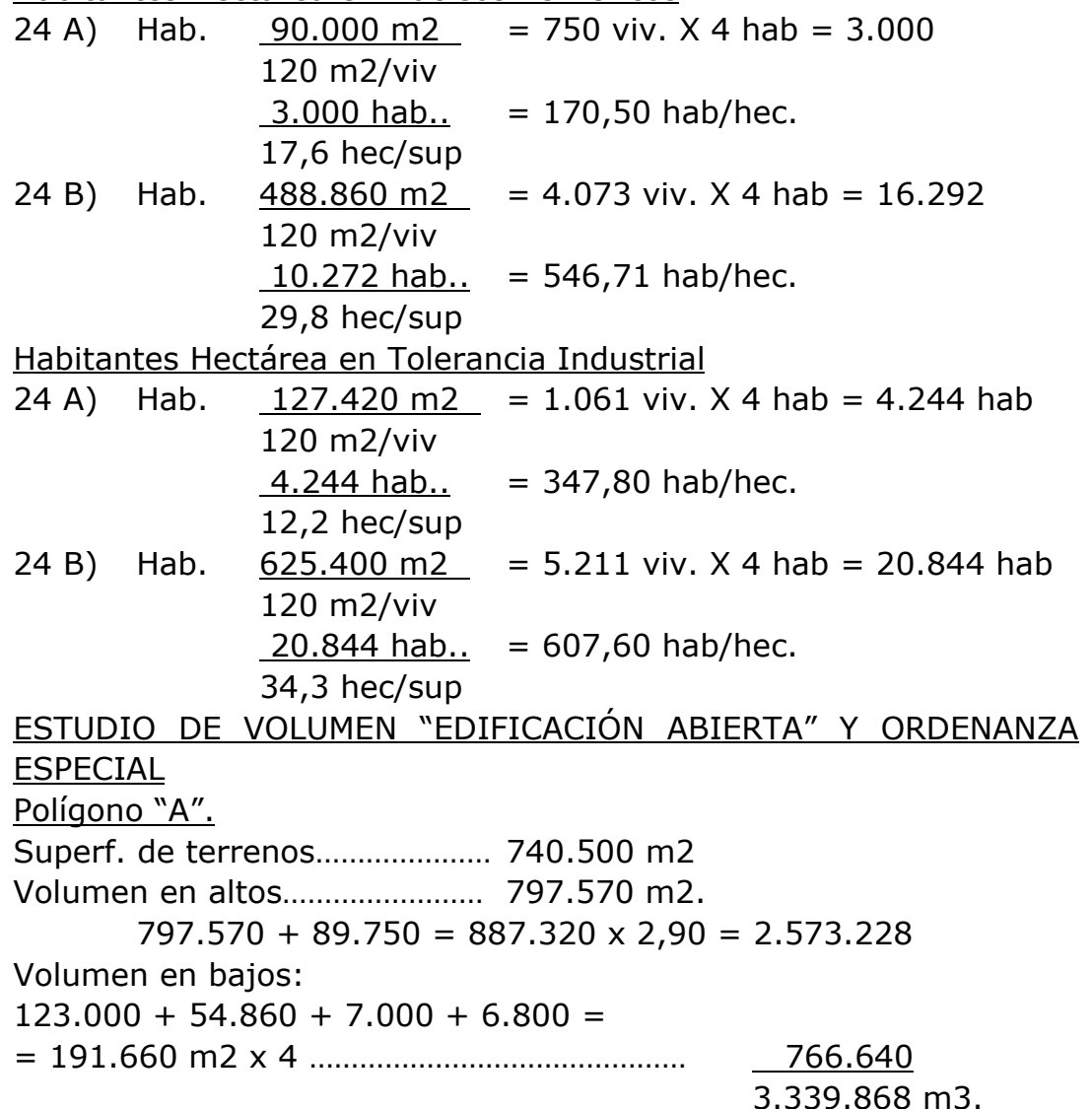

Volumen: $\underline{3.428 .600 \mathrm{~m} 3}=4,51 \mathrm{~m} 3 / \mathrm{m} 2$.

$$
740.500 \mathrm{~m} 2
$$

Polígono "B".

Superf. de terrenos $685.300 \mathrm{~m} 2$

Volumen en altos. $701.000 \mathrm{~m} 2$

$701.000 \mathrm{~m} 2 \times 2,90=$

Volumen en bajos:

$152.400+39.600=192.000 \mathrm{~m} 2 \times 4=$

\section{$2.032 .900 \mathrm{~m} 3$}

Volumen: $\frac{2.871 .000 \mathrm{~m} 3}{685.300 \mathrm{~m} 2}=4,08 \mathrm{m3} / \mathrm{m} 2$.

\section{ESTUDIO PARA APARCAMIENTOS DE VEHICULOS}

Superf. En vía pública prevista para aparcamiento de vehículos.-

Pol A......... $49.386 \mathrm{~m} 2$

Pol.B. $30.670 \mathrm{~m} 2$

TOTAL $80.056 \mathrm{~m} 2$

En vía pública se puede admitir m2. Por plaza de vehículos: $2,5 \times 5=12,5 \mathrm{~m} 2$. 
Número de vehículos previstos:

$$
\underline{80.056 \mathrm{~m} 2}=\underline{6.404 \text { vehículos }}
$$

$12,50 \mathrm{~m} 2$

Superficie de solares previstos para construcción de parking.

Pol A

$18.057 \mathrm{~m} 2$.

Pol B.......... $13.730 \mathrm{~m} 2$.

TOTAL $32.387 \mathrm{~m} 2 \times 5$ plantas $=161.935 \mathrm{~m} 2$.

Previsión $\mathrm{m} 2$ de plaza de aparcamiento: $20 \mathrm{~m} 2$.

$$
\frac{161.935 \mathrm{~m} 2}{20 \mathrm{~m} 2}=8.096 \text { vehículos. }
$$

Aparcamientos previstos s/ Ordenanzas.-

Superficie construida en viv 2.920 .000

$5 \%$ de previsión s/ Ordenanzas

Sup. Constr. en loc. comer... 903.535

$15 \%$ previsión s/ Ordenanzas

135.535

TOTAL...................... 281.535

$$
\underline{281.535 \mathrm{~m} 2}=14.076 \text { vehículos. }
$$

$$
20 \mathrm{~m} 2
$$

\section{TOTAL PREVISIÓN DE APARCAMIENTOS}

$6.404+8.096+14.076=28.576$ vehículos.

Dado que se prevee en el Plan Parcial 24.333 viviendas; las 28.576 plazas de aparcamientos, supondrían la prevención de una plaza de aparcamiento por vivienda.

\section{SISTEMA DE ACTUACION}

El presente Plan Parcial será ejecutado en su día y según los sectores que se vayan determinando según la prioridad de necesidades, como ya se ha indicado en el capítulo de "Etapas", por el sistema "Cesión de terrenos viales" y regula los art. 129 y 130 de la vigente Ley del Suelo.

Valencia, Noviembre de 1977

EL ARQUITECTO MUNICIPAL,
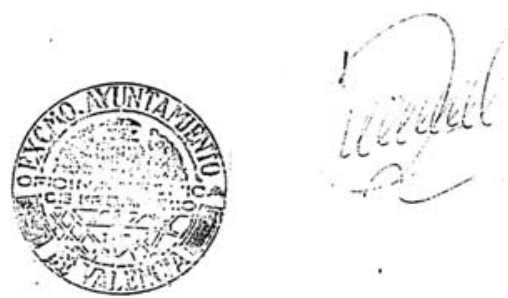


\title{
EXCMO. AYUNTAMIENTO DE VALENCIA
}

\author{
PLAN PARCIAL 24
}

RECTIFICADO CON ARREGLO R.M. 21-6-78 EN CUMPLIMIENTO EXTREMOS O.M. 28-2-76

\section{ORDENANZAS}

\author{
ORDENANZAS REGULADORES DE LA EDIFICACIÓN \\ PARA EL PLANO PARCIAL DE ALINEACIONES $Y$ \\ ZONIFICACIÓN NO 24 (BENICALAP) VALENCIA
}

\section{USO Y APROVECHAMIENTO DEL SUELO}

Art.1. Al concreto fin del uso y aprovechamiento del suelo, y en el ámbito del Plano Parcial de Alineaciones y Zonificación no 24, se define gráficamente sobre el, la concreta zonificación que corresponde a sus diversos sectores.

Art. 2. El carácter eminentemente residencial del dicho Plano Parcial, obliga a considerar las siguientes zonificaciones, de acuerdo con el Plan General.

- Nucleos Periféricos.

- Tolerancia Industrial (Extensión Exterior a Tránsitos).

- Edificación Abierta.

- Ordenanza especial (Cultura y Deportes).

- Ordenación especial.

La propiedad, a efectos de construcción, quedará obligada a los usos específicos de esta zonificación, según prescribe la vigente Ley del Suelo.

$[\ldots]$

Art. 43.- Edificación abierta.

Quedan definidas las alturas en el plano correspondiente (con números romanos).

Se define como altura de cornisa el número de plantas multiplicadas por tres.

Los voladizos serán de dimensión hasta 1,50 cuando la separación entre bloques sea mayor o igual a $16 \mathrm{mts}$. Cuando sea mayor o igual a $10 \mathrm{mts}$. Se realizarán voladizos de $1 \mathrm{~m}$., cuando sea mayor o igual de $7 \mathrm{~m}$. se autorizarán voladizos de 0,70, inferior a $7 \mathrm{~m}$. no se autorizarán voladizos.

Se autorizarán voladizos en todas las longitudes de fachada y de acuerdo con la norma anterior.

Se consideran a efectos de volúmenes los voladizos tratados con miradores, no los que se definen como solanas.

Cuando se proyecta una planta baja con una altura inferior o igual a 2,50 mts. Para usos comunes del inmueble o zonas ajardinadas, reflejadas en el acta notarial como un bien en copropiedad del inmueble, no se contará esta planta a efectos de altura no volumen, siempre que esta planta esté considerada en un bloque completo. Los usos comunes a los que se alude serán aquellas instalaciones propias del edificio que constituyan elemento común del inmueble, tales como zaguanes, escalera, ascensor, cuartos de contadores, cuartos de basura, aseos de servicio, cuartos de limpieza, cuarto de almacenaje, etc.

En aquellas zonas en las que no se determina la ubicación de 
los bloques, sino que simplemente se señala el volumen de aplicación, deberá agruparse la propiedad para definir los bloques a construir en la manzana completa, debiendo guardar estos bloques las normas siguientes:

a) Separación entre bloques, según lado mayor o paralelo igual a la altura del edificio; cuando la distancia sea desde el testero de un bloque perpendicular a otro en un eje longitudinal, la separación será igual a la mitad de la altura del mayor, con una dimensión mínima, cualquiera que sea la altura, de $10 \mathrm{mts}$.

b) Cuando los bloques no sean paralelos, la distancia entre ellos mínima será igual a la semisuma de las alturas de ambos, medida en el punto medio de la fachada.

[...]

Art. 46.- ORDENANZA ESPECIAL (Cultura y Deportes)

Se ajustará a lo establecido en el Plan General, a efectos de volúmenes.

Será además de obligada observancia el total de la reglamentación vigente que les corresponde por razón de uso, sin cuyas pruebas documental no se concederá licencia de obras.

Art. 47.- ORDENACION ESPECIAL

Comprende la primera línea de edificios sobre el nuevo Acceso de Ademuz, que inicialmente estaban regulados por la Ordenanza de Núcleos Periféricos y que dan frente a una zona de edificación abierta.

Esta Ordenanza prescribe: que en consideración a la uniformidad de Ordenación de dicho acceso, será obligada la aplicación de la Ordenanza de Edificación Abierta, en concreta zona.

Esta zonificación se realiza de acuerdo con las Normas Generales del Plan General (Norma $5^{a}$ ). "En las calles que son límite de zona deben tener las mismas alturas ambos paramentos, aunque correspondan a distintas zonas, aplicándose la que determine mayores alturas".

Valencia, Noviembre de 1978.

EL ARQUITECTO MUNICIPAL,
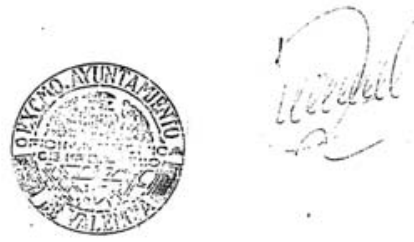
EXCMO. AYUNTAMIENTO DE VALENCIA

PLAN PARCIAL 24

DETERMINACIÓN DEL SISTEMA DE ACTUACIÓN EN EL AMBITO DEL PLAN PARCIAL NO 24 (SECTORES A $Y$ B) APROBADO DEFINITIVAMENTE EN 28 DE FEBRERO DE 1.976 (B.O.E. 6-4-76)

\section{MEMORIA}

1. OBJETO.

Es objeto del presente proyecto la determinación del sistema de actuación del Plan Parcial no 24 (Sectores A y B), aprobado definitivamente en 28 de febrero de 1976 (B.O.E. 6-4-76) de conformidad con lo indicado en la resolución ministerial de 6 de mayo de 1977 y en cumplimiento del decreto de la Alcaldía de 26 de mayo de 1977. Todo ello al amparo del art. 114 uno "La ejecución de los planes de ordenación corresponde al Estado, a las Entidades locales y a ....." y 119 dos y tres "La Administración actuante elegirá el sistema de actuación aplicable según necesidades, medio económico financiero con que cuente, colaboración iniciativa particular y demás circunstancias que concurran....."; cuando el plan de ordenación o programa de actuación urbanística no precisaren el sistema, su determinación se llevará a cabo con la delimitación del polígono o unidad de actuación....", del texto refundido de 9 de abril de 1976 de la Ley sobre régimen del Suelo y Ordenación Urbana.

\section{2.- JUSTIFICACIÓN}

La justificación de la determinación que se propone por el presente proyecto, está contenida obviamente en lo dicho en el punto anterior y más concretamente en los artículos del texto legal indicado.

En efecto, en la resolución ministerial anteriormente citada de fecha 6 de mayo de 1977, queda patente la competencia municipal en la materia y por tanto puede, siguiendo los criterios establecidos en el art. 119 dos, anteriormente indicado, elegir el sistema de actuación aplicable, es decir, determinar en función de las circunstancias que concurren (entre ellas las necesidades y medios económico-financieros con que se cuentan) el sistema de actuación aplicable al caso, dando preferencia al de compensación y cooperación, sin descartar el de expropiación cuando razones de necesidad o urgencia lo exijan.

Son pues las circunstancias que concurren las que en definitiva justificarán la elección del o los sistemas de actuación y por tanto, desde el punto de vista de la ejecución del planeamiento, pueden tomarse como factores determinantes. Estas circunstancias son las que a continuación se analizan:

$1^{a}$.- El plan parcial aprobado en 28 de febrero de 1976, fue redactado en 1974 , es decir, con anterioridad a la vigencia de la Reforma de la Ley sobre Régimen del Suelo y Ordenación Urbana, y por lo tanto la planificación obedeció a los criterior de la Ley de 12 de mayo de 1956, prueba de ello es que se adoptó el sistema de cesión de viales previsto por ella y ahora suprimido. 
2a.- Dicho documento legal por otra parte, no puede considerarse como un hecho aislado o una planificación "ex novo" ya que con anterioridad a su redacción, e incluso antes de la aprobación del Plan general de Valencia y su Comarca (O.M: de 30 de junio de 1966) ya se redactó un plan parcial que llegó a aprobarse provisionalmente por la Corporación Municipal en 4 de diciembre de 1964 y lo fue en desarrollo del Plan general en aquel entonces vigente (aprobado por Decreto de 27-7-1946 y que calificaba como urbanos gran parte de los terrenos incluidos dentro del ámbito del plan parcial no 24) teniendo en cuenta la existencia de un núcleo de población habitado cual era el pueblo de Benicalap, que evidentemente constituía un núcleo urbano consolidado. El propio Plan general, al calificar estos terrenos como núcleos periféricos, en definitiva no deja de reconocer la naturaleza urbana de los mismos, ya que acudiendo a la definición que en las normas urbanísticas se da: "Son estos los grafiados en los planos de esta adaptación a la solución sur y que corresponden en su mayoría a los actuales Poblados de la Comarca", queda patentizado el hecho.

3a.- Abundando en la idea anterior y tomando como base el Plan general de valencia y su Comarca, en definitiva una adaptación del anterior de 1946, el sector al que nos estamos refiriendo, podría considerarse como urbano no solo en cuanto al núcleo del poblado, sino también la totalidad del ámbito, ya que en definitiva, acudiendo a la definición que la Ley de 12 de mayo de 1956 daba para el suelo urbano, los terrenos en cuestión estaban comprendidos dentro del perímetro que definía el casco de la población. En efecto, en la memoria del Plan General y en el apartado Limitación de la Ciudad se dice: "El casco se limita al $\mathrm{N}$ y por el NO por la circunvalación interior, por el S. y por el SO. Por el futuro cauce y por el N. Por la Carretera de la Casta", y precisamente el plan parcial no 24 tiene como límite Norte el trazado de la circunvalación Interior, lo que supone que están dentro del casco de la población.

4a.- El plan en algunas zonas ya está ejecutado o en curso de ejecución e incluso edificado con anterioridad al momento que nos ocupa, fruto de diversas actuaciones urbanísticas, tanto públicas como privadas. Así, por ejemplo, además del núcleo urbano de Benicalap con sus aledaños más actuales, prácticamente urbanizado y consolidado por la edificación, existe también el núcleo de la Ciudad fallera prácticamente en las mismas circunstancias, incluso con equipamiento escolar en funcionamiento; un pequeño sector apoyado en la Carretera de Burjasot prolongación del núcleo de Benicalap, (todas ellas en el sector B). En el sector A, existe también un pequeño núcleo construido apoyado en la Av. De Gral. Avilés y urbanizado prácticamente en su totalidad, así como equipamientos de carácter general no asimilables al concepto barrio, como son las Escuelas Profesionales de San José, consideradas como una unidad independiente por sí sola, dada su calificación de zona Especial del Plan General, el asilo de NIÑO JESUS, el Colegio "Sagrada Familia" y el Sanatorio "18 de julio", todos ellos construidos. En definitiva, circunstancia esta que nos lleva a establecer una primera diferenciación del plan, y esta en base al diferente grado de urbanización y consolidación de unas zonas comparadas con otras prácticamente vírgenes.

5a.- Por otra parte y tomando como base la propia estructura viaria del plan, reflejo de la prevista en el Plan General, el territorio ámbito del mismo en ningún modo puede conceptuarse como un ente unitario, sino más bien como un conjunto de unidades vecinales o barrios totalmente independientes, ya que las grandes vías 
que lo atraviesan, trocean y separan, al ser de rango fundamental (autopistas o autovías), constituyen auténticas barreras que imposibilitan la relación de unos sectores con otros. Es decir, el tratamiento en ningún caso podrá ser unitario, debiendo obedecer la adopción de criterios, más a la estructura urbana y las determinaciones que el plan prevee en cada sector A y B, y dentro de ellas a los diferentes subsectores o barrios, que a la concepción global del planeamiento como unidad a nivel de plan parcial.

6a.- Los medios económico-financieros de los que se dispone en este momento en la Corporación Municipal, aconsejan la determinación de sistemas que supongan la menor carga posible (o que en todo caso supongan el mínimo de carga). Es decir, que la ejecución por parte del Ayuntamiento de los diferentes elementos del equipamiento urbano, se resuelva sólo en aquellos casos donde sea imprescindible e inevitable, dada la situación existente, para completar, terminar o rematar sectores ejecutados o en curso de ejecución, o en su caso, para facilitar la ejecución de los nuevos.

7a.- La iniciativa particular en repetidas ocasiones ha manifestado y así lo demuestran diversos escritos dirigidos a la Corporación, la necesidad de agilizar la resolución del problema en aras a la obtención de suelo edificable que permita continuar el ritmo de la construcción y evitación de otros males que de una paralización de obras en sectores tan amplios o de gran expectativa, pudieran derivarse, aportando fórmulas más o menos viables para solucionar el problema. En definitiva, solicitando la total colaboración.

\section{3.- CRITERIOS BASICOS.}

En base a las circunstancias que en el presente caso concurren, analizados en el punto anterior y que a título resumido ahora se enumeran:

10.- La planificación se realizó teniendo en cuenta la Ley del Suelo de 12 de Mayo de 1956, puesto que la fecha de su redacción fue en 1974.

20.- La planificación no fue un hecho "ex novo" puesto que gran parte de los terrenos estaban consolidados de hecho -el poblado de Benicalap- y de derecho -la especificación del Plan general de Valencia y su comarca de 1.946. y el reconocimiento como Núcleos Periféricos (urbanos) del actualmente vigente.

30.- La totalidad del ámbito del plan puede considerarse como suelo urbano, puesto que el plan general vigente los incluyó en el casco de la población.

40.- Ciertas zonas, por estar consolidadas por la edificación y urbanizadas total o parcialmente, merecen la calificación de suelo urbano con arreglo a los criterios de la ley del Suelo vigente, texto refundido de 9 de abril de 1976.

50. - Tratamiento sectorial en base a la propia estructuración urbana prevista, como consecuencia del desarrollo de las especificaciones fundamentales del Plan General.

60.- la carencia de medios económico-financieros de la Corporación para acometer por sí sola la ejecución material de los diferentes elementos, y

70. - La manifestación de una eficaz colaboración por parte de la iniciativa particular en la resolución del problema.

Se ha adoptado los criterios básicos en orden a la determinación del sistema de actuación que se propone y ello de conformidad con lo prevenido en el título III "Ejecución de los planes de Ordenación" del texto refundido de 9 de abril de 1976 de la ley sobre Régimen del Suelo y Ordenación Urbana, y dentro de dicho título y 
concretamente los arts. 117 uno, tres y cuatro, 119 dos y 134 dos. Estos sistemas básicos son:

a) Excluir del tratamiento conjunto del plan los sistemas generales del mismo, bien por venir su determinación del Plan General o por constituir elementos de carácter general supravecinales que está previsto ejecutarlo directamente en coordinación con otros organismos de la Administración.

b) Dado el carácter de suelo urbano y como quiera que no es posible determinar los polígonos con arreglo a los requisitos establecidos por la Ley, las operaciones urbanísticas se llevarán a cabo mediante la delimitación de unidades de actuación que permitan al menos, la distribución justa entre los propietarios de los beneficios y cargas derivadas del planeamiento definitivamente aprobado.

c) En aquellos sectores consolidados y urbanizados, que reúnan los mínimos exigidos para ser calificados de forma efectiva como suelo urbano, las operaciones urbanísticas se ejecutarán mediante actuaciones aisladas y por tanto quedarán excluidos del tratamiento unitario del tema.

d) A la vista de las circunstancias que concurren en el presente caso, se estima como más adecuado para la ejecución de las unidades de actuación, el sistema de compensación.

e) Los sistemas generales de la ordenación urbanística del territorio a la que se ha hecho referencia en el punto a), así como las actuaciones aisladas que sea necesario determinar como consecuencia de e) se ejecutarán por expropiación.

\section{4.- DESCRIPCION DE LA SOLUCION ADOPTADA.}

En base a los criterios anteriormente expuestos, la solución adoptada ha consistido en desglosar el ámbito del Plan parcial en tantos sectores como las circunstancias de su propia diferenciación lo aconsejen. Así de una parte, el plan se subdivide en los dos sectores ya clásicos A y B que ya figuraban en la documentación del plan que fue aprobado; y estos a su vez en subsectores, atendiendo principalmente a la propia delimitación que establecen las vías principales de la red Arterial de Tráfico, tanto los que constituyen sistemas generales del plan, como aquellos otros que por su anchura o rango, separan igualmente. En segundo lugar, esta segunda subdivisión obedece al criterio expuesto en cuanto a aquellos terrenos que se califican como suelo urbano. Posteriormente evaluados tanto el aprovechamiento de cada uno de ellos, es decir, el volumen edificable que permite el planeamiento; como las cargas que derivan del mismo, es decir, de una parte la cesión de terrenos con destino a usos públicos y de otra, el costo de las obras de urbanización correspondientes, se obtiene el coeficiente denominado de servicios en cada uno de ellos, pasándose entonces la determinación concreta de las unidades de actuación correspondientes. Estas unidades se an determinado buscando que su coeficiente particular se aproximara cuanto más al coeficiente del sector donde se enclava, buscándose así un equilibrio entre las diferentes unidades dentro de cada sector. El coeficiente en cada caso se obtiene como suma del que resulta del coeficiente superficial de terrenos de cesión por volumen edificable $(\mathrm{m} 2 / \mathrm{m} 3)$ y del que resulta del cociente de gastos de urbanización por volumen edificable (pts./m3). Traducido el primero a pts/m3, (otorgando al $\mathrm{m} 2$ de terreno de cesión un valor en función en cada caso del aprovechamiento del sector) y sumados ambos, se deduce el coeficiente definitivo que permite llegar a la delimitación gráfica. 
De esta forma, se considera que existen una distribución equitativa, o al menos lo más justa posible, entre los beneficios y cargas derivados del planeamiento, conforme dispone el art. 117 tres, toda vez que el beneficio del plan es el volumen edificable y la carga es en definitiva el montante económico, suma del valor de los terrenos mas el coste de las obras de urbanización correspondientes.

Como nota aclaratoria, conviene indicar que las cantidades evaluadas en cada caso, lo han sido como resultado de las mediciones hechas sobre planos; que los costes de urbanización se han tomado en virtud del tipo medio empleado por los servicios municipales correspondientes y que por tanto, las cifras no pueden darse como exactas, siendo su carácter aproximado. Como quiera que se producen de partida estas circunstancias y teniendo en cuenta que pueden existir errores de medición, errores derivados de efectuarlas sobre plano y no sobre la realidad, errores de cálculo e incluso de apreciación en cuanto al tipo medio de obras a realizar, se adopta como válido un margen de entre un 10 y $12 \%$ de diferencia en los coeficientes correspondientes a cada unidad, al compararlas con su coeficiente sectorial, y más aún teniendo en cuenta que las líneas de delimitación se ha procurado que fuesen por los ejes viarios, con el fin de no partir bloques edificables o terrenos de servicios públicos que requieran posteriormente de una edificación. Asimismo dentro del concepto costos de urbanización, solo se han tenido en cuenta los viales (calles o plazas), las infraestructuras tipo de suministro de aguas, alcantarillado y alumbrado público y las zonas verdes cuya extensión superficial total está dentro de la propia unidad, y ello en base a que se estima que las zonas verdes compartidas por varias unidades de gran extensión superficial debe, al calificarse como parques, obedecer en su tratamiento a criterios unitarios en cuanto a concepto y características ambientales; lo que se estima es procedente resolver por la Corporación Municipal. Igualmente en la ejecución de la infraestructura, se excluyen aquellos elementos viarios o de conducciones que por su envergadura o por pertenecer a la red principal, no deben suponer carga para los propietarios de cada unidad.

5.- DETERMINACION DE LAS UNIDADES DE ACTUACION CON INDICACION DEL SISTEMA DE EJECUCION CORRESPONDIENTE:

En base a los criterios expuestos y con arreglo ala sistemática descrita en los puntos anteriores, los sectores y las unidades de actuación en los que se divide el plan parcial no 24, para su ejecución, así como el señalamiento del sistema adecuado en cada caso es el siguiente:

\section{PLAN PARCIAL 24 A}

SECTOR $a$, incluye las unidades de actuación no 1 y no 2 y cuyas características principales son:

U.A. no 1

Delimitada por la Av. del General Avilés, c/Nicasio Benlloch, c/ en Proyecto, primera de circulación rodada paralela a Gral Avilés y Avda. de Pio XII (Nuevo Acceso de Ademuz).

- Superficie total.. $94525 \mathrm{~m} 2$

- Superficie pública

ZONAS VERDES $10456 \mathrm{~m} 2$

VIALES $43465 \mathrm{~m} 2$ 
- Observaciones:

No se incluyen en obras de urbanización las correspondientes a la Av. de Pio XII, a la Av. de General Avilés y a la c/Nicasio Benlloch.

- Sistema de actuación: COMPENSACIÓN.

U.A. no 2

Delimitada por calle en Proyecto primera de circulación rodada paralela a Gral Avilés, c/Nicasio Benlloch, calle en Proyecto segunda de circulación rodada paralela a Gral Avilés y Av. Pio XII (Acceso Ademuz).

- Superficie total

$104686 \mathrm{~m} 2$

- Superficie pública

ZONAS VERDES............ $5520 \mathrm{~m} 2$
VIALES ........................... $50186 \mathrm{~m} 2$
ESCUELAS..................... $10000 \mathrm{~m} 2$

- Volumen edificable.

528840

- Observaciones:

No se incluyen las obras de urbanización de la c/Nicasio Benlloch, Av. Pio XII y calzada central de la c/ en proyecto que une las anteriores, que da lugar al paso elevado sobre la segunda y dicho paso elevado.

- Sistema de actuación: COMPENSACIÓN.

$\underline{\text { SECTOR } b}$, se corresponde con la unidad de actuación no 3 .

U.A. no 3

- Delimitada por la calle en proyecto segun de circulación rodada paralela a General Avilés, c/Nicasio Benlloch, Ronda Exterior y Av. Pio XII.

- Superficie total. $97130 \mathrm{~m} 2$

- Superficie pública $\begin{array}{ll}\text { ZONAS VERDES } \ldots \ldots \ldots \ldots . . . & 19476 \mathrm{~m} 2 \\ \text { VIALES } . . \ldots \ldots \ldots \ldots \ldots \ldots \ldots \ldots \ldots . . . \ldots \ldots \ldots \ldots & 44346 \mathrm{~m} 2\end{array}$

- Volumen edificable

- Observaciones: $465300 \mathrm{~m} 2$

No se incluyen en obras de urbanización la correspondientes a la c/Nicasio Benlloch, a la Av. De Pio XII, a la calle coincidente con el actual Camino de Paterna y la calzada central de la c/ en Proyecto que une la Av. De Pio XII con la c/Nicasio Benlloch, que da lugar al paso elevado sobre la primera y dicho paso elevado.

- Sistema de actuación: COMPENSACIÓN.

SECTOR c, incluye las unidades de actuación números 4, 5 y 6, cuyas características son:

U.A. n० 4

- Delimitada por ACCESO DE ADEMUZ, RONDA DE CIRCUNVALACION INTERIOR, VIA ROTULADA EN EL PLANO COMO CONTINUACION DE PEREZ GALDOS, CAMINO DE PATERNA Y RONDA EXTERIOR.

- Superficie total..

$160.398 \mathrm{~m} 2$

- Superficie pública

ZONAS VERDES

VIALES 
- Volumen edificable.

- Observaciones:

No se incluyen en obras de urbanización las correspondientes a la calle coincidente con el Camino de Paterna y la ejecución de la zona verde (parque) situada al Oeste de la unidad.

- Sistema de actuación: COMPENSACIÓN.

\section{U.A. no 5}

- Delimitada por RONDA EXTERIOR, CAMINO DE PATERNA, zona verde U.A. no 4 y c/ en proyecto primera paralela a la rotulada en el plano como continuación de Pérez Galdós.

- Superficie total...... $75040 \mathrm{~m} 2$

- Superficie pública

\begin{tabular}{|c|c|}
\hline ZONAS VERDES............... & $19880 \mathrm{~m} 2$ \\
\hline 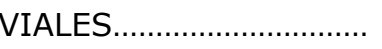 & $11920 \mathrm{~m} 2$ \\
\hline ESCUELAS & $10062 \mathrm{~m} 2$ \\
\hline
\end{tabular}

- Volumen edificable... $233.733 \mathrm{~m} 3$

- Observaciones:

No se incluye en obras de urbanización las correspondientes a la calle coincidente que coincide con el Camino de Paterna y la ejecución de la zona verde (Parque) situada al noroeste de la unidad.

- Sistema de actuación: COMPENSACIÓN.

U.A. $n^{\circ} 6$

- Delimitada por RONDA EXTERIOR, calle en proyecto primera paralela a la rotulada en el plano continuación Av. Pérez Galdós, zona verde U.A. no 5 y 4, Av. Rotulada como prolongación de la de Pérez Galdós.

- Superficie total..

$72859 \mathrm{~m} 2$

- Superficie pública

$\begin{array}{lr}\text { ZONAS VERDES } \ldots \ldots \ldots \ldots . . . & 20411 \mathrm{~m} 2 \\ \text { VIALES ........................... } & 12344 \mathrm{~m} 2 \\ \text { MERCADO ................... } & 2816 \mathrm{~m} 2 \\ \text { PALACIO DEP ................ } & 3500 \mathrm{~m} 2\end{array}$

- Volumen edificable. $218768 \mathrm{~m} 3$

- Observaciones:

No se incluye en obras de urbanización las correspondientes Al aparcamiento frente al Palacio de deportes y la ejecución de la zona verde situada al norte de la unidad.

- Sistema de actuación: COMPENSACIÓN.

SECTOR d, incluye las unidades de actuación no 7 y 8, así como dos elementos consolidados cuales son la Residencia sanitaria "18 de Julio" y el Asilo del Niño Jesús.

\section{U.A. n०7}

- Delimitada por la Ronda Exterior, la Residencia Sanitaria 18 de Julio, el sector correspondiente al Asilo del Niño Jesús Asilo del Niño Jesús, calle en proyecto segunda que enlaza con la rotulada en el plano como prolongación de Pérez Galdós.

- Superficie total.. $39680 \mathrm{~m} 2$

- Superficie pública

ZONAS VERDES

VIALES

MERCADO
$5196 \mathrm{~m} 2$

$23684 \mathrm{~m} 2$

$2400 \mathrm{~m} 2$ 
- Volumen edificable.

- Observaciones:

No se incluye en obras de urbanización las correspondientes a la calzada central de la vía que enlaza con la denominada prolongación de Pérez Galdós, donde prevé un paso subterráneo, y a la Av. de Pío XII.

- Sistema de actuación: COMPENSACIÓN.

U.A. $n^{\circ} 8$

- Delimitada por la Av. de Pío XII (Acceso Ademúz), Ronda Exterior, Residencia Sanitaria 18 de julio, Asilo del Niño Jesús Asilo del Niño Jesús y c/ en proyecto segunda de tráfico rodado paralela a General Avilés que enlaza con la denominada prolongación de Pérez Galdós.

- Superficie total.

$67892 \mathrm{~m} 2$

- Superficie pública

ZONAS VERDES............. $9012 \mathrm{~m} 2$

VIALES......................... $35966 \mathrm{~m} 2$

ESCUELAS....................... $5646 \mathrm{~m} 2$

- Volumen edificable....................................... 344200 m3

- Observaciones:

No se incluye en obras de urbanización las correspondientes a la calzada central de la vía que enlaza con la denominada prolongación de Pérez Galdós, coincidente con paso elevado sobre la Av. de Pío XII y dicho paso elevado.

- Sistema de actuación: COMPENSACIÓN.

SECTOR e, se corresponde con la unidad de actuación no 9.

U.A. n० 9

- Delimitada por la Av. Pío XII (Acceso Ademuz), vía que enlaza esta con la denominada prolongación de Pérez Galdós, Colegio Sagrada Familia y calle junto a las Escuelas Profesionales de San José.

- Superficie total.

$57068 \mathrm{~m} 2$

- Superficie pública

$\begin{array}{ll}\text { ZONAS VERDES............ } & 12508 \mathrm{~m} 2 \\ \text { VIALES ............................ } & 32284 \mathrm{~m} 2\end{array}$

- Volumen edificable. $270726 \mathrm{~m} 3$

- Observaciones:

No se incluyen las obras de urbanización correspondientes a la calzada central de la vía que enlaza con la denominada prolongación de Pérez Galdós, el paso elevado sobre la Av. de Pío XII, a la Av. de Pío XII.

- Sistema de actuación: COMPENSACIÓN.

SECTOR f, incluye las unidades de actuación nº 10 y 11.

U.A. n० 10

- Delimitada por vía que enlaza con la denominada prolongación de Pérez Galdós, Ronda Exterior, zona verde de la unidad de actuación no 11, c/ en Proyecto que enlaza la ronda Exterior con la Av. General Avilés, Escuelas Profesionales de San José y Colegio de la Sagrada Familia.

- Superficie total. $131763 \mathrm{~m} 2$

- Superficie pública ZONAS VERDES $28286 \mathrm{~m} 2$ 
VIALES ........................... $47938 \mathrm{~m} 2$

ESCUELAS........................ $10097 \mathrm{~m} 2$

- Volumen edificable

$402887 \mathrm{~m} 3$

- Observaciones:

No se incluyen en obras de urbanización las correspondientes a la calzada central de la vía que enlaza con la denominada prolongación de Pérez Galdós, el paso subterráneo de dicha vía y la ejecución de la zona verde (Parque) situada al sur de la unidad.

- Sistema de actuación: COMPENSACIÓN.

U.A. no 11

- Delimitada por Av. General Avilés, calle en proyecto perpendicular a la anterior, calle Puerto de Santa María, calle en proyecto que une a esta con la Ronda Exterior, zona verde U.A. no 10, Ronda Exterior y enlace de la anterior con Gral. Avilés.

- Superficie total................................. 118173 m2

- Superficie pública

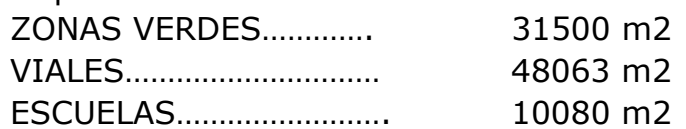

- Volumen edificable...

$418438 \mathrm{~m} 3$

- Observaciones:

No se incluyen en obras de urbanización las correspondientes a la Av. General Avilés, al enlace de esta con la Ronda Exterior y la ejecución de la zona verde situada al oeste de la unidad.

- Sistema de actuación: COMPENSACIÓN.

SECTOR g, incluye la unidad de actuación no 12 y dos elementos consolidados, cuales son las Escuelas Profesionales San José y el Colegio Sagrada Familia.

\section{U.A. no 12}

- Delimitada por la Av. General Avilés, Av. Pío XII, Escuelas Profesionales San José, calle Puerto de Santa María y en proyecto hasta su enlace con G. Avilés.

- Superficie total $43060 \mathrm{~m} 2$

- Superficie pública $\begin{array}{lr}\text { ZONAS VERDES .............. } & 3791 \mathrm{~m} 2 \\ \text { VIALES ........................... } & 20167 \mathrm{~m} 2\end{array}$

- Volumen edificable. $242153 \mathrm{~m} 3$

- Observaciones:

Se califica como suelo urbano al amparo de lo ordenado en la Ley sobre Régimen del Suelo y Ordenación Urbana.

- Sistema de actuación: Actuaciones aisladas de la forma en que de hecho se venían desarrollando.

\section{PLAN PARCIAL 24 B}

SECTOR a, se corresponde con la unidad de actuación no 1 (Benicalap).

U.A. $n^{\circ} 1$

Delimitada por la Av. Juan XXIII, calle Castellonet, Av. del Ecuador, Ronda Exterior, calle Nicasio benlloch y Av. Onésimo redondo. 
- Superficie total

$617020 \mathrm{~m} 2$

- Superficie pública

$\begin{array}{lr}\text { ZONAS VERDES .............. } & 13858 \mathrm{~m} 2 \\ \text { VIALES ......................... } & 217220 \mathrm{~m} 2 \\ \text { ESCUELAS .................... } & 13858 \mathrm{~m} 2 \\ \text { MERCADO ......................... } & 2800 \mathrm{~m} 2\end{array}$

- Volumen edificable.

$6.118 .338 \mathrm{~m} 3$

- Observaciones:

Se considera calificado como suelo urbano al amparo de lo ordenado en la Ley sobre Régimen del Suelo y Ordenación Urbana.

- Sistema de actuación: Actuaciones aisladas de la forma en que de hecho se venían desarrollando o por expropiación.

SECTOR $b$, incluye las unidades de actuación no 2-3-4-5-6-7, cuyas características son:

U.A. n० 2

- Delimitada por Av. Juan XXIII, Av. del Ecuador, calle General Llorens y calle Castellonet.

- Superficie total...

- Superficie pública

$\begin{array}{lr}\text { ZONAS VERDES.............. } & 4320 \mathrm{~m} 2 \\ \text { VIALES........................... } & 13860 \mathrm{~m} 2\end{array}$

$\begin{array}{lr}\text { ZONAS VERDES.............. } & 4320 \mathrm{~m} 2 \\ \text { VIALES............................ } & 13860 \mathrm{~m} 2\end{array}$

$23220 \mathrm{~m} 2$

- Volumen edificable

$118.440 \mathrm{~m} 3$

- Observaciones:

No se incluye en obras de urbanización la calzada central de la Av. del Ecuador y paso elevado sobre Av. Juan XXIII.

- Sistema de actuación: COMPENSACIÓN.

U.A. n० 3

- Delimitada por Av. Juan XXIII (Nuevo Acceso Moncada), calle en proyecto peatonal, calle en proyecto y Av. del Ecuador.

- Superficie total.

$34416 \mathrm{~m} 2$

- Superficie pública

ZONAS VERDES

$8424 \mathrm{~m} 2$

VIALES.

$6492 \mathrm{~m} 2$

- Volumen edificable...

$97.500 \mathrm{~m} 3$

- Observaciones:

No se incluye en obras de urbanización la calzada central de la Av. del Ecuador y paso elevado sobre Nuevo Acceso de Moncada y Nuevo Acceso a Moncada.

- Sistema de actuación: COMPENSACIÓN.

\section{U.A. no 4}

- Delimitada por Av. del Ecuador, calle en proyecto en medio, calle peatonal en proyecto y calle prolongación de General Llorens.

- Superficie total. $38724 \mathrm{~m} 2$

- Superficie pública

$\begin{array}{ll}\text { VIALES.......................... } & 14976 \mathrm{~m} 2 \\ \text { ESCUELAS.................... } & 10080 \mathrm{~m} 2\end{array}$

- Volumen edificable. $194.354 \mathrm{~m} 3$

- Observaciones:

No se incluye en obras de urbanización la calzada central de la Av. del Ecuador y paso elevado sobre el Nuevo Acceso a Moncada. 
- Sistema de actuación: COMPENSACIÓN.

U.A. no 5

- Delimitada por Av. del Ecuador, calle en proyecto prolongación de General Llorens y calle en proyecto.

- Superficie total

$49098 \mathrm{~m} 2$

- Superficie pública

ZONAS VERDES............. $12417 \mathrm{~m} 2$

- Volumen edificable.

$217.938 \mathrm{~m} 3$

- Observaciones:--

- Sistema de actuación: COMPENSACIÓN.

U.A. n० 6

- Delimitada por Nuevo Acceso a Moncada, Ronda Exterior, calle en proyecto prolongación de General Llorens y calle peatonal.

- Superficie total

$58496 \mathrm{~m} 2$

- Superficie pública

\begin{tabular}{|c|c|}
\hline 5 VERDES................ & $7966 \mathrm{~m} 2$ \\
\hline VIALES........... & $30714 \mathrm{~m} 2$ \\
\hline 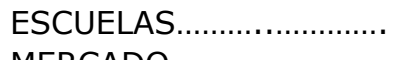 & $5600 \mathrm{~m}$ \\
\hline
\end{tabular}

- Volumen edificable.

$156.234 \mathrm{~m} 3$

- Observaciones:

No se incluyen en obras de urbanización las correspondientes al nudo de enlace de Ronda Exterior con Nuevo Acceso a Moncada.

- Sistema de actuación: COMPENSACIÓN.

U.A. n० 7

- Delimitada por calle en proyecto, calle en proyecto prolongación de General Llorens, Ronda Exterior y Av. del Ecuador.

- Superficie total

$71248 \mathrm{~m} 2$

- Superficie pública

$\begin{array}{lr}\text { ZONAS VERDES............. } & 3316 \mathrm{~m} 2 \\ \text { VIALES ............................ } & 34896 \mathrm{~m} 2 \\ \text { ESCUELAS .................... } & 10296 \mathrm{~m} 2\end{array}$

- Volumen edificable.....

$413.322 \mathrm{~m} 3$

- Observaciones:

No se incluyen en obras de urbanización las correspondientes a la calzada central de la Av. del Ecuador y paso subterráneo bajo Ronda Exterior.

- Sistema de actuación: COMPENSACIÓN.

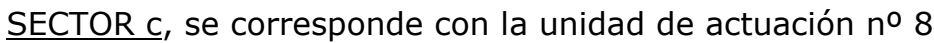

U.A. $n^{\circ} 8$

- Delimitada por Ronda Exterior, Nuevo Acceso a Moncada y calle Salvador Cervero.

- Superficie total.

$69390 \mathrm{~m} 2$

- Superficie pública

$\begin{array}{lr}\text { ZONAS VERDES .............. } & 9260 \mathrm{~m} 2 \\ \text { VIALES......................... } & 36980 \mathrm{~m} 2 \\ \text { MERCADO .................. } & 2160 \mathrm{~m} 2 \\ \text { PARQUE BOMBEROS...... } & 3080 \mathrm{~m} 2\end{array}$

- Volumen edificable $357.304 \mathrm{~m} 3$ 
- Observaciones:

No se incluyen en obras de urbanización el paso subterráneo de la calle Salvador Cervero bajo Ronda Exterior.

- Sistema de actuación: COMPENSACIÓN.

SECTOR d, se corresponde con la unidad de actuación no 9

U.A. no 9

- Delimitada por calle Salvador Cervero, Nuevo Acceso de Moncada, calle Amadeo Desfilis y calle Francisco Morote Greus.

- Superficie total. $148502 \mathrm{~m} 2$

- Superficie pública

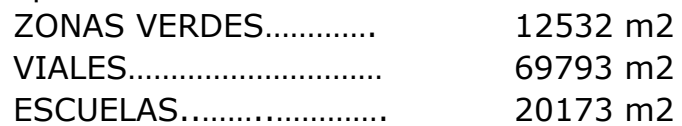

- Volumen edificable... $645.036 \mathrm{~m} 3$

- Observaciones:

Se considera calificado como suelo urbano al amparo de lo ordenado en la Ley del Suelo.

- Sistema de actuación: Actuaciones aisladas de la forma en que venían de hecho desarrollando o por expropiación.

SECTOR e, incluye las unidades de actuación no 10,11 y 12 cuyas características son:

U.A. $n^{\circ} 10$

- Delimitada por calle Amadeo Desfilis, enlace Circunvalación Interior y calle Sánchez Arjona.

- Superficie total............................... 12804 m2

- Superficie pública

$\begin{array}{ll}\text { ZONAS VERDES............. } & 1760 \mathrm{~m} 2 \\ \text { VIALES } & 6820 \mathrm{~m} 2\end{array}$

- Volumen edificable.

$66432 \mathrm{~m} 3$

- Observaciones:

No se incluye en obras de urbanización las correspondientes al enlace de Circunvalación Interior con Nuevo Acceso a Moncada.

- Sistema de actuación: COMPENSACION.

\section{U.A. no 11}

- Delimitada por calle Amadeo Desfilis, calle Sánchez Arjona, Circunvalación Interior y calle que une la calzada junto a la vía de servicio de la anterior con Amadeo Desfilis.

- Superficie total. $23430 \mathrm{~m} 2$

- Superficie pública

$\begin{array}{lc}\text { ZONAS VERDES................ } & 1928 \mathrm{~m} 2 \\ \text { VIALES.......................... } & 12584 \mathrm{~m} 2\end{array}$

- Volumen edificable. $128.443 \mathrm{~m} 3$

- Observaciones:

No se incluye en obras de urbanización las correspondientes a la vía de servicio de la Circunvalación Interior.

- Sistema de actuación: COMPENSACION.

U.A. n० 12

- Delimitada por Circunvalación Interior, calle Francisco Morote Greus, calle Amadeo Desfilis y calle en proyecto que une la anterior con la calzada junto a la vía de servicio de la 
rrespondientes al paso subterráneo bajo la Ronda Exterior y las de la calle Florista por subsistir de momento el ferrocarril.

- Sistema de actuación: COMPENSACION.

\section{6.- CONSIDERACIONES FINALES.}

La ejecución de las diferentes unidades de actuación delimitadas, se hará de acuerdo con el sistema determinado para cada una de ellas, con lo previsto en el capítulo tercero y quinto, respectivamente para el de compensación y expropiación, del título III del texto refundido de la ley sobre Régimen del Suelo y Ordenación Urbana.

Con independencia de la ejecución de los sistemas generales de la Red Arterial que afecta al plan, correrán de cuenta de la Corporación Municipal o de las Sociedades correspondientes, la ejecución de las redes principales de las infraestructuras de servicio, especialmente en lo que se refiere a los colectores generales de evacuación de aguas, tubería principal de abastecimiento de aguas y red general de suministro de energía eléctrica, no pudiéndose autorizar la ejecución de una unidad sin que se haya aprobado el correspondiente proyecto de las redes que la sirvan. La Corporación Municipal, a través de los representantes municipales en las respectivas y diferentes juntas de compensación, establecerá la coordinación adecuada para llevar a la práctica dichas obras de carácter general, pudiendo en todo caso establecer, si ello fuera necesario, el adecuado orden de prioridad; que podría ser alterado en el supuesto de que por parte de la iniciativa privada, a través de la junta correspondiente, asumiera a su cargo la ejecución de las obras de carácter general, que además de las incluidas en la propia unidad, posibiliten la conexión con los sistemas generales del plan o sus adyacentes.

Igualmente, a través de dichos representantes, la Corporación indicará los tipos, secciones, características y demás circunstancias de cualquiera de los elementos que constituyan las obras de urbanización interior de cada unidad, en especial las que hacen referencia a las infraestructuras de servicio, pavimentado de calles, encintado y formación de aceras, alumbrado público, tratamiento de las zonasajardinadas, ..., al objeto de colaborar con las diferentes juntas de compensación y unificar criterios. Todo ello por supuesto, previamente a la aprobación de los proyectos de urbanización correspondientes.

Valencia, noviembre de 1977

EL ARQUITECTO MUNICIPAL,

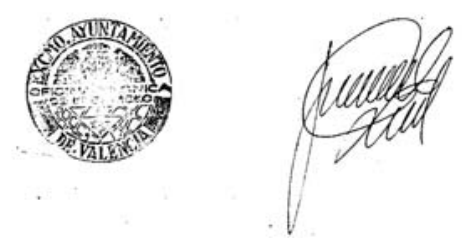


2. PLANO DE SITUACIÓN EN EL PLAN GENERAL (Fragmento) Escala original: $1: 22.500$

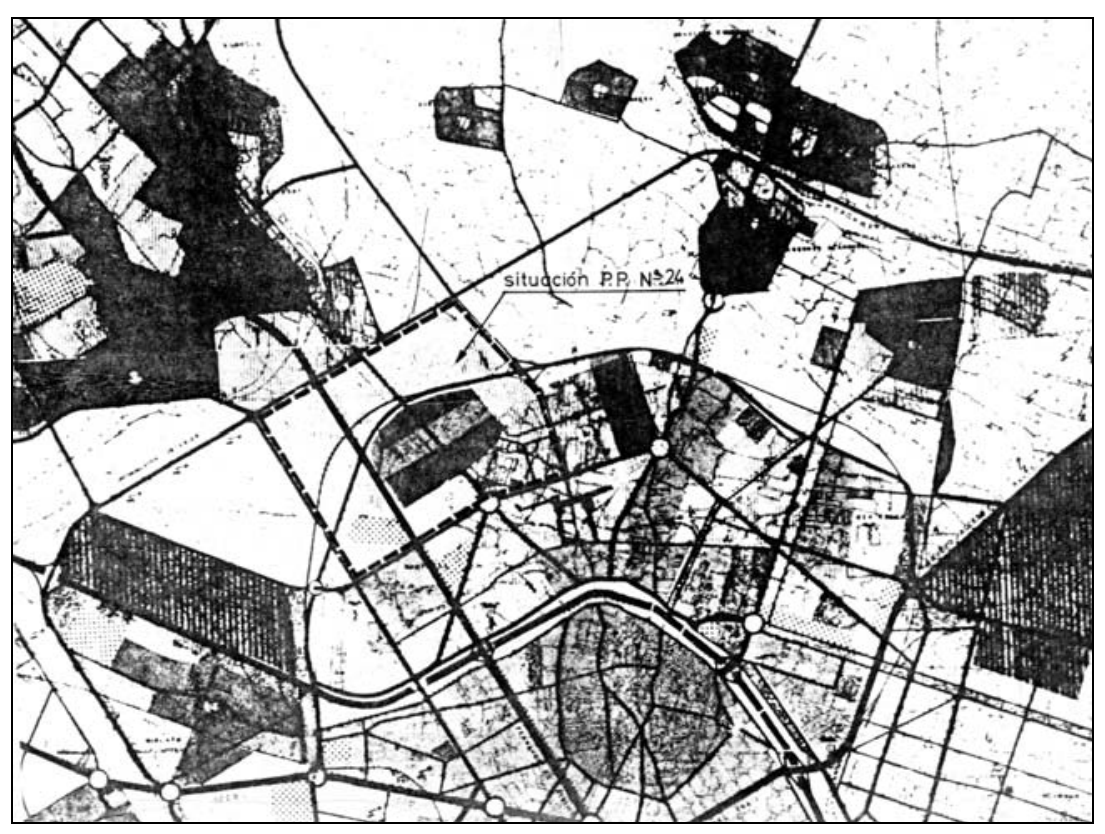


3. PLANOS DE INFORMACIÓN.

Escala original: 1:2000

\section{ZONA 24-A}

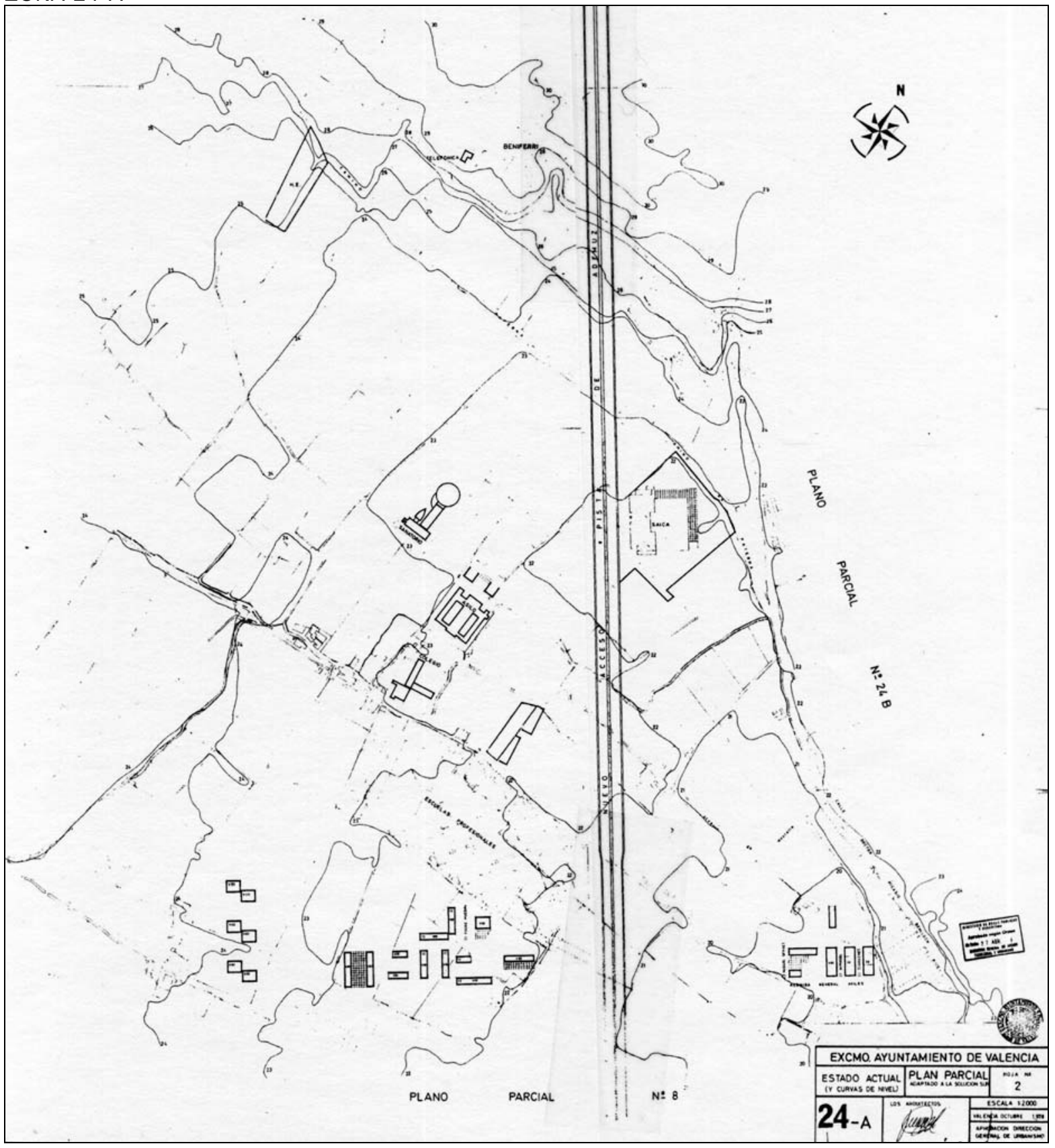




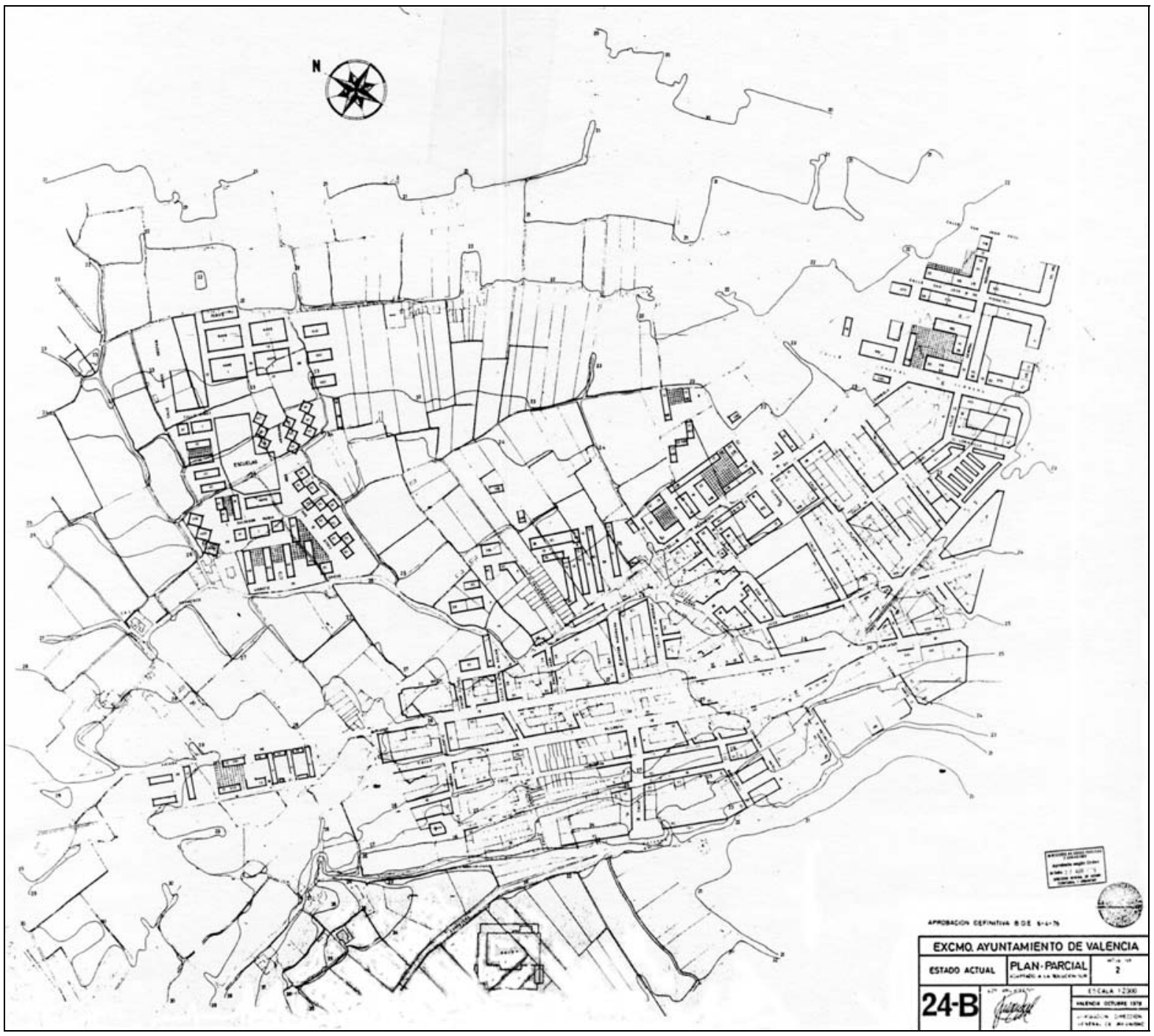


4. ZONIFICACIÓN.

Escala original: 1:2000

ZONA 24-A

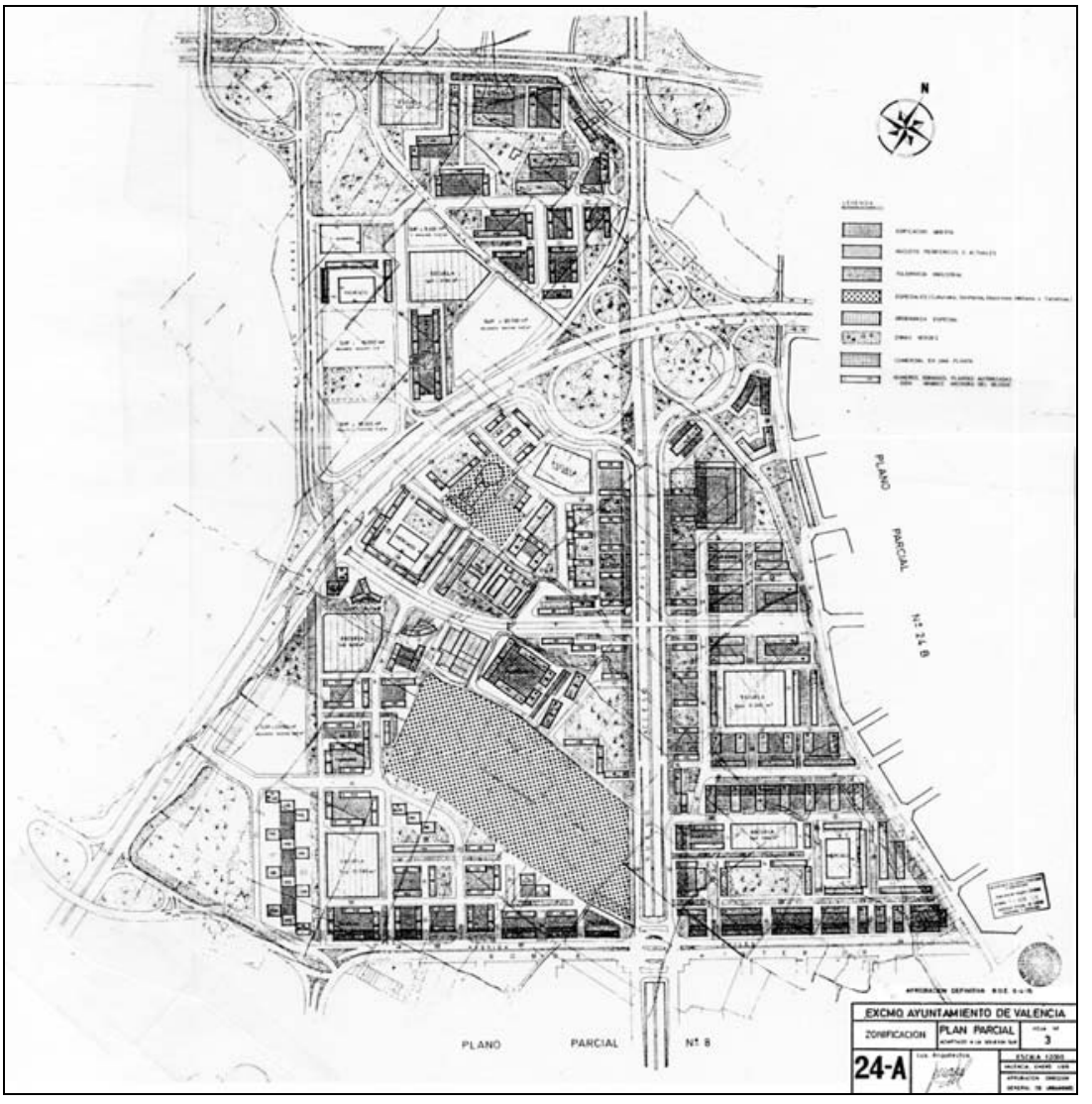

ZONA 24-B

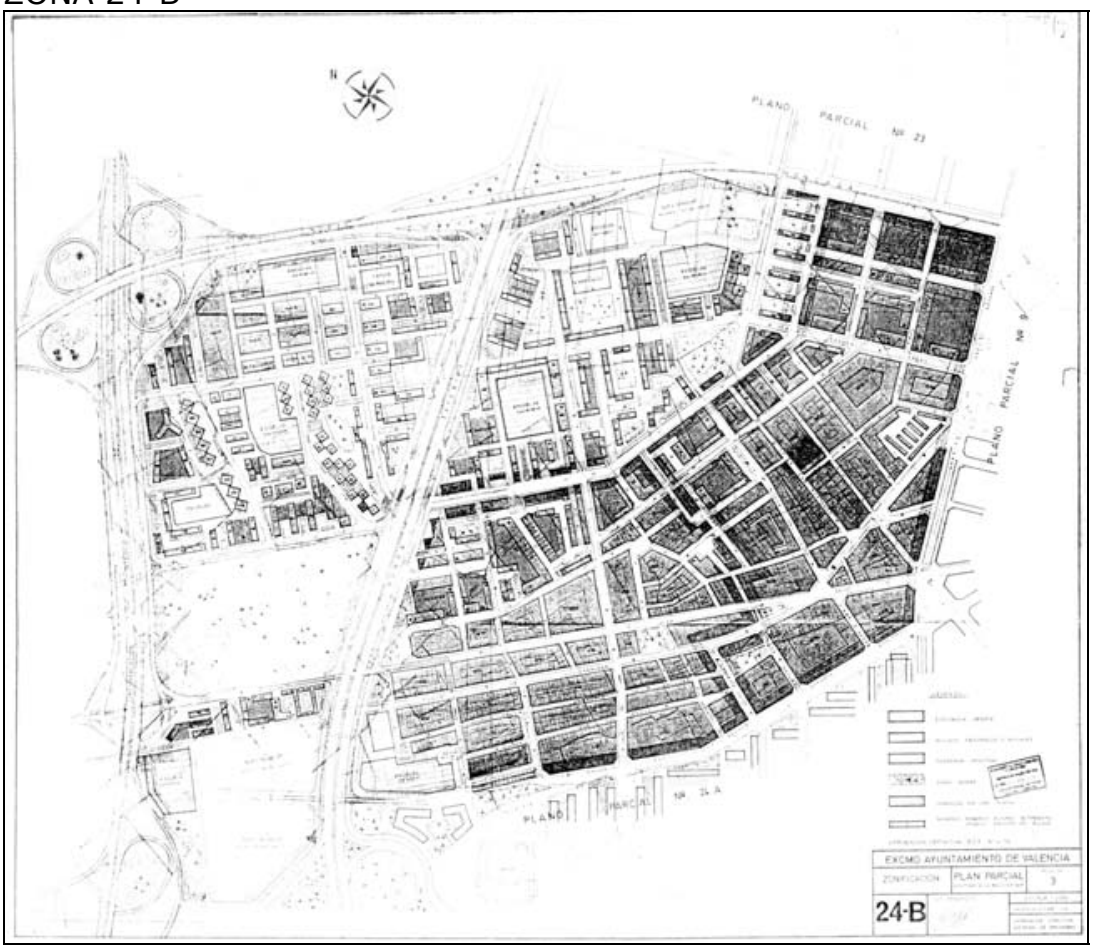


6. ALINEACIONES. ZONA 24-A

Escala original 1:2000

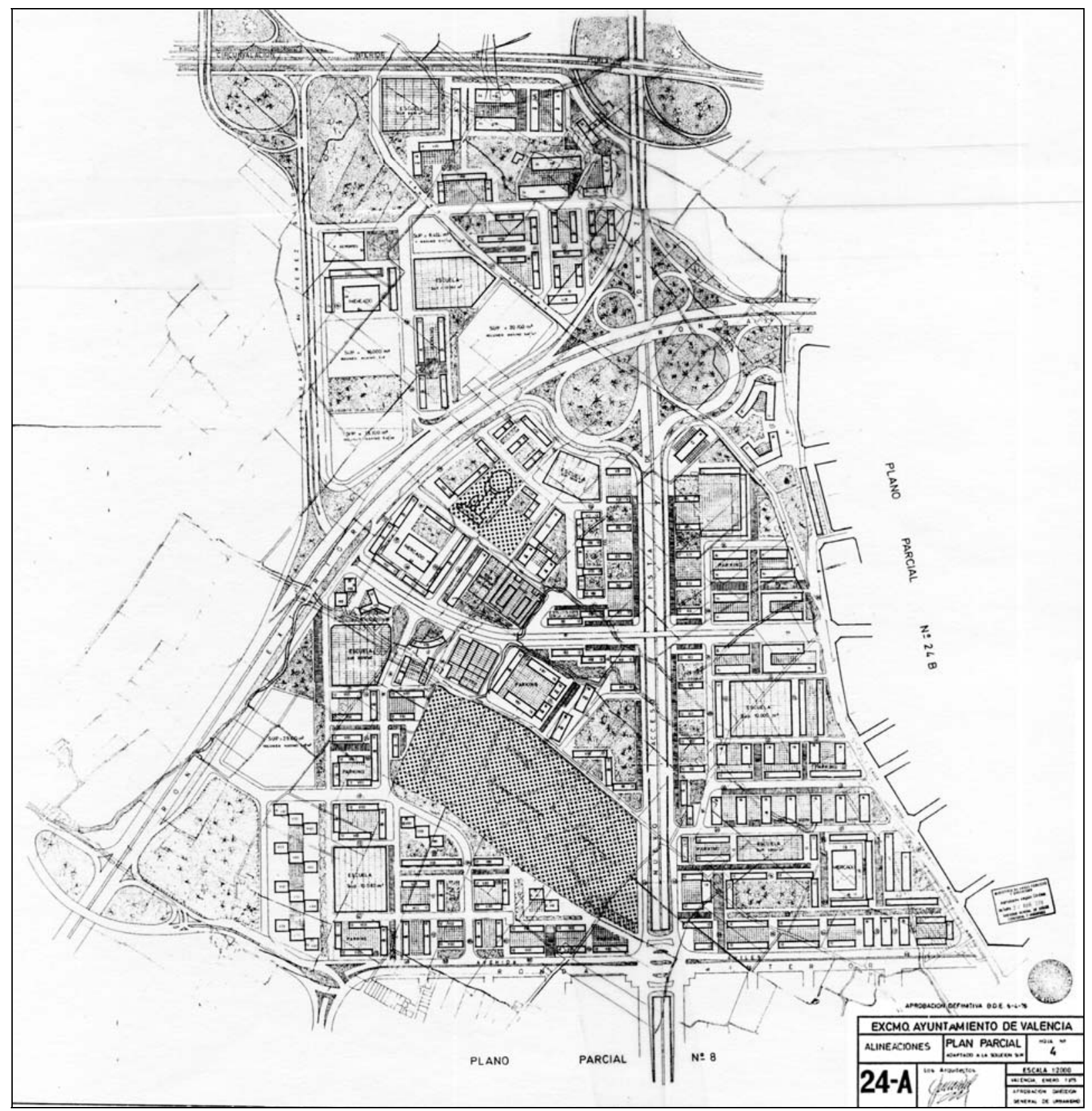




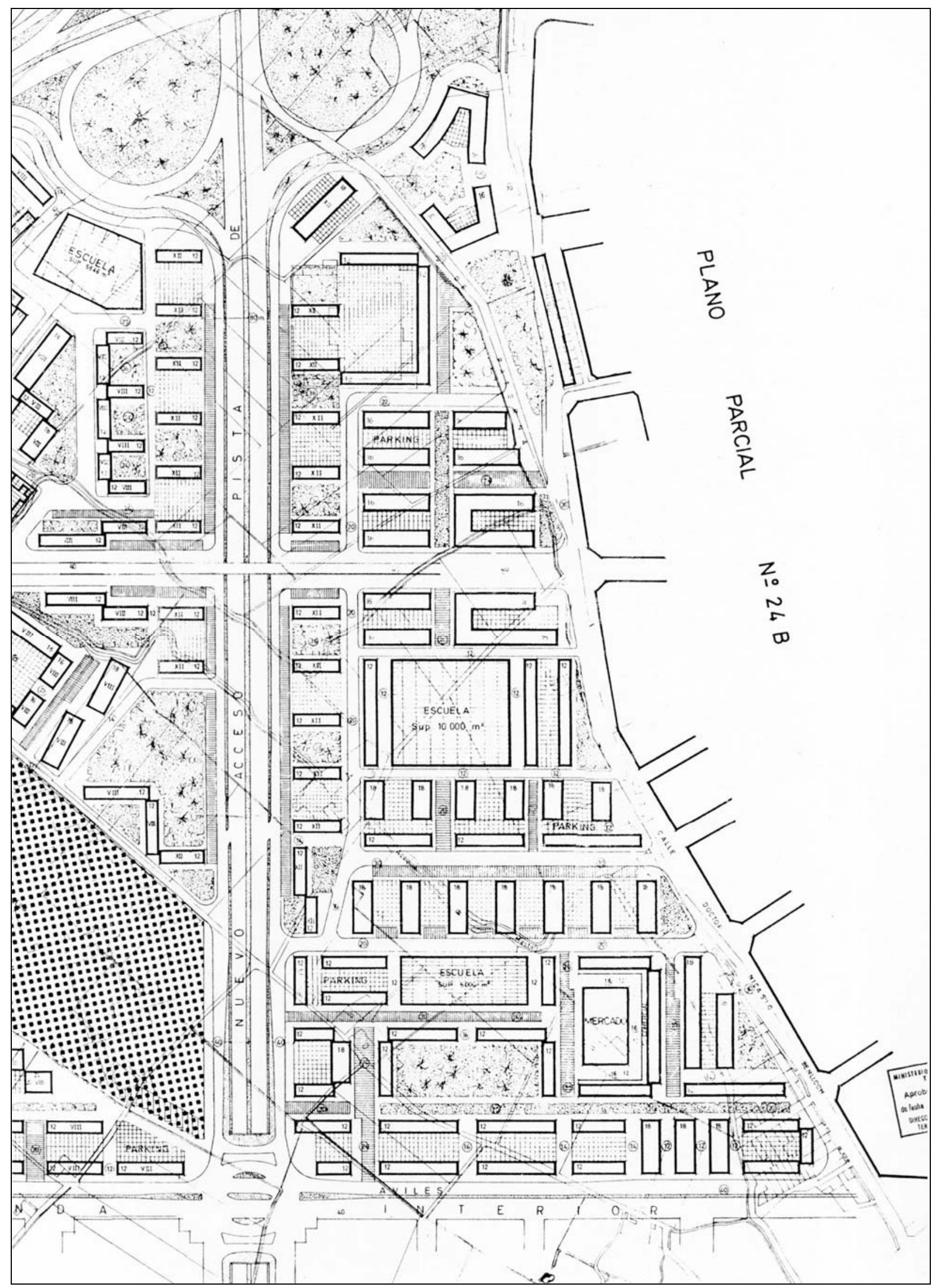

Zona 24-A. Detalle del Plano de alineaciones.Zona 1 


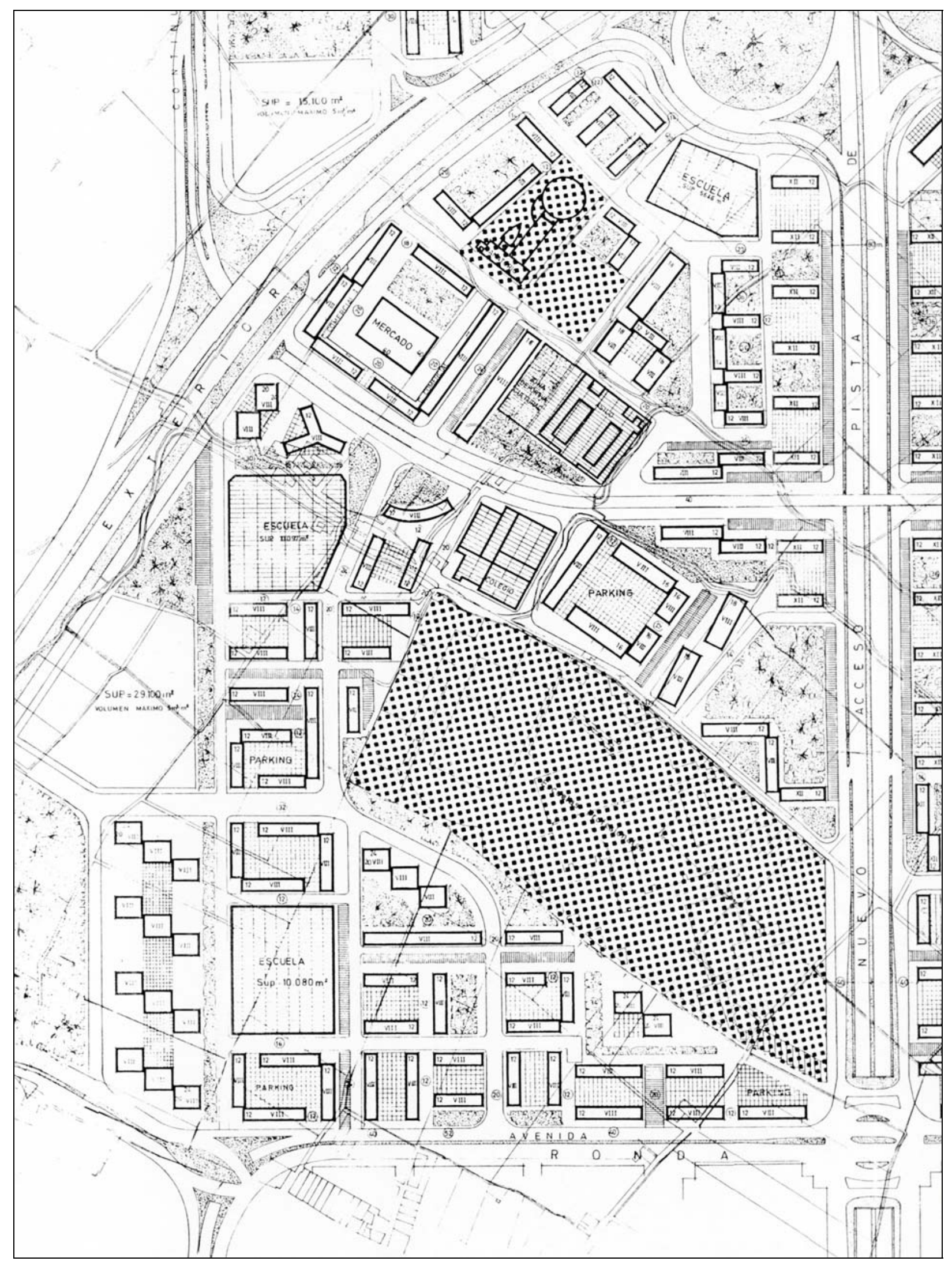

Zona 24-A Detalle del Plano de alineaciones. Zona 2. 


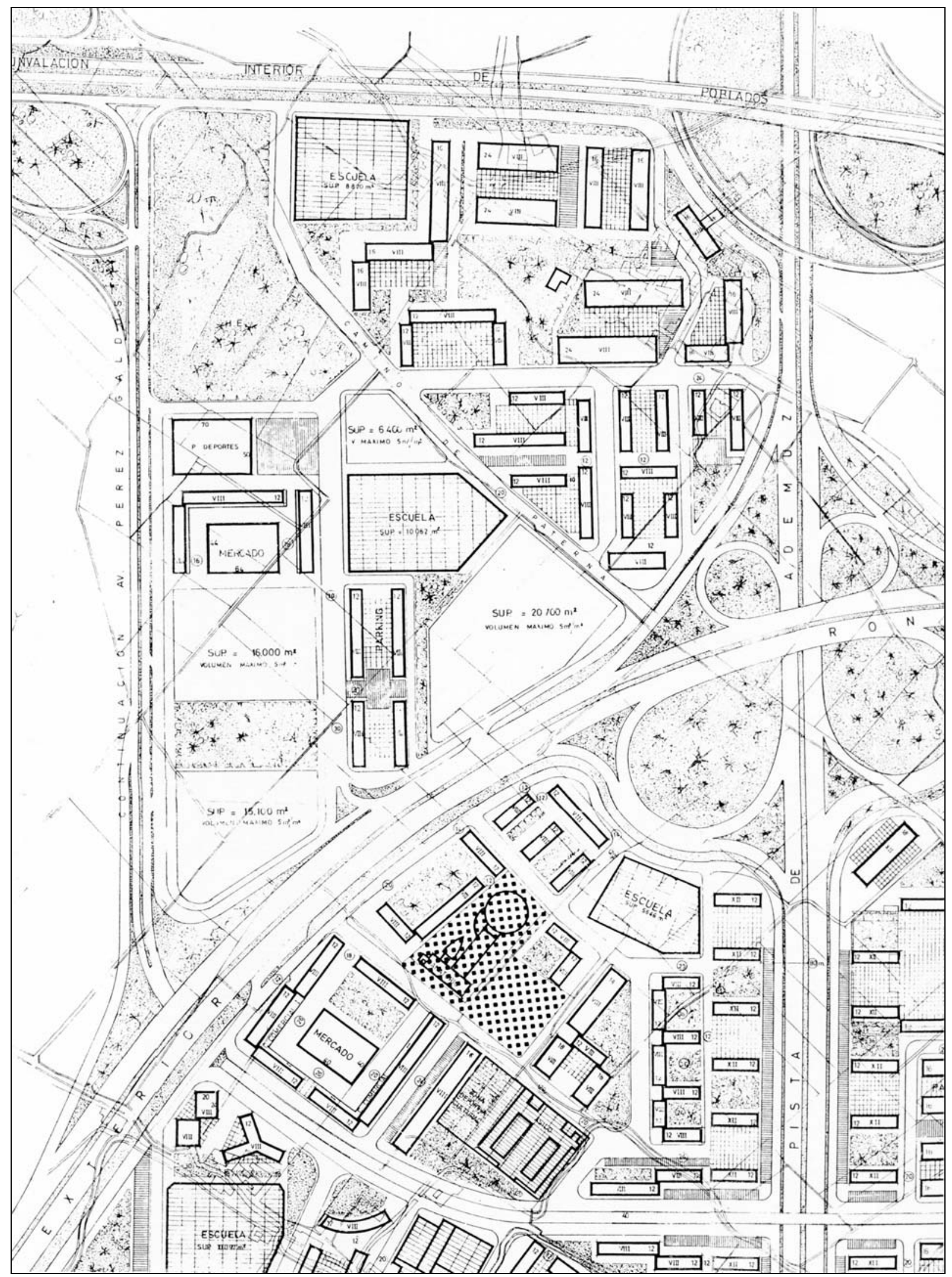

Zona 24-A Detalle del Plano de alineaciones. Zona 3. 
6. ALINEACIONES. ZONA 24-B

Escala original 1:2000

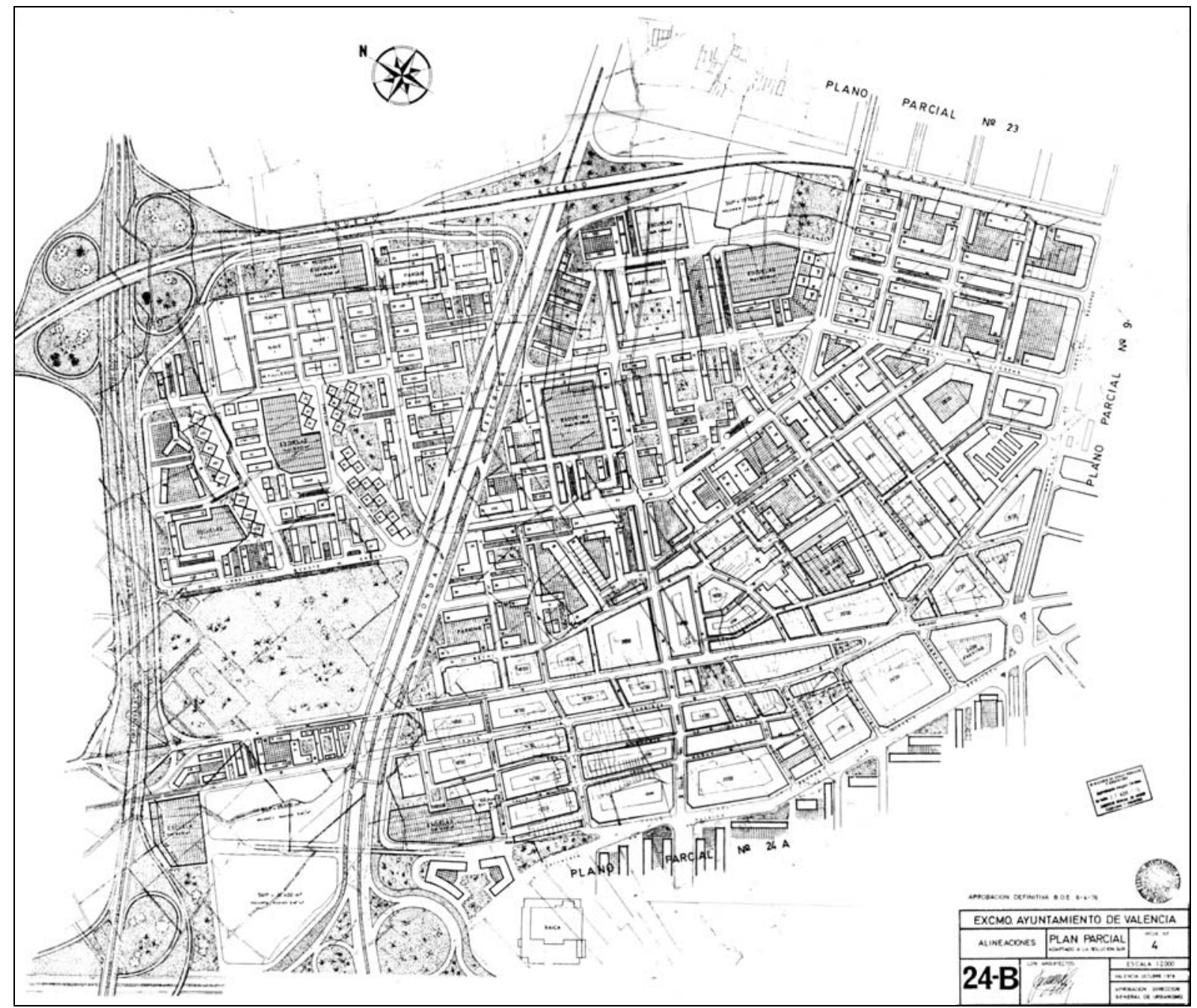




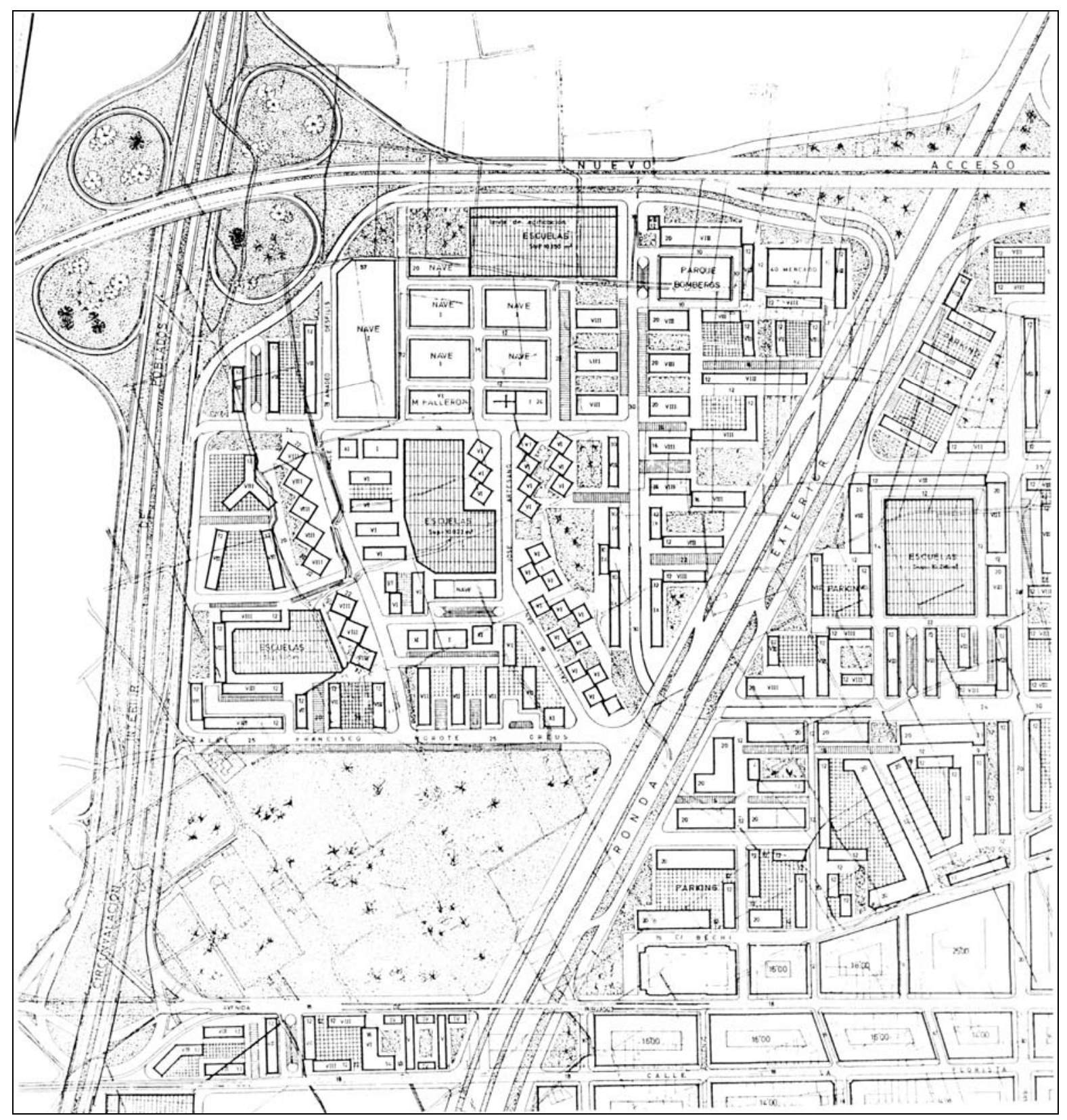

Zona 24-B. Detalle del Plano de alineaciones. 


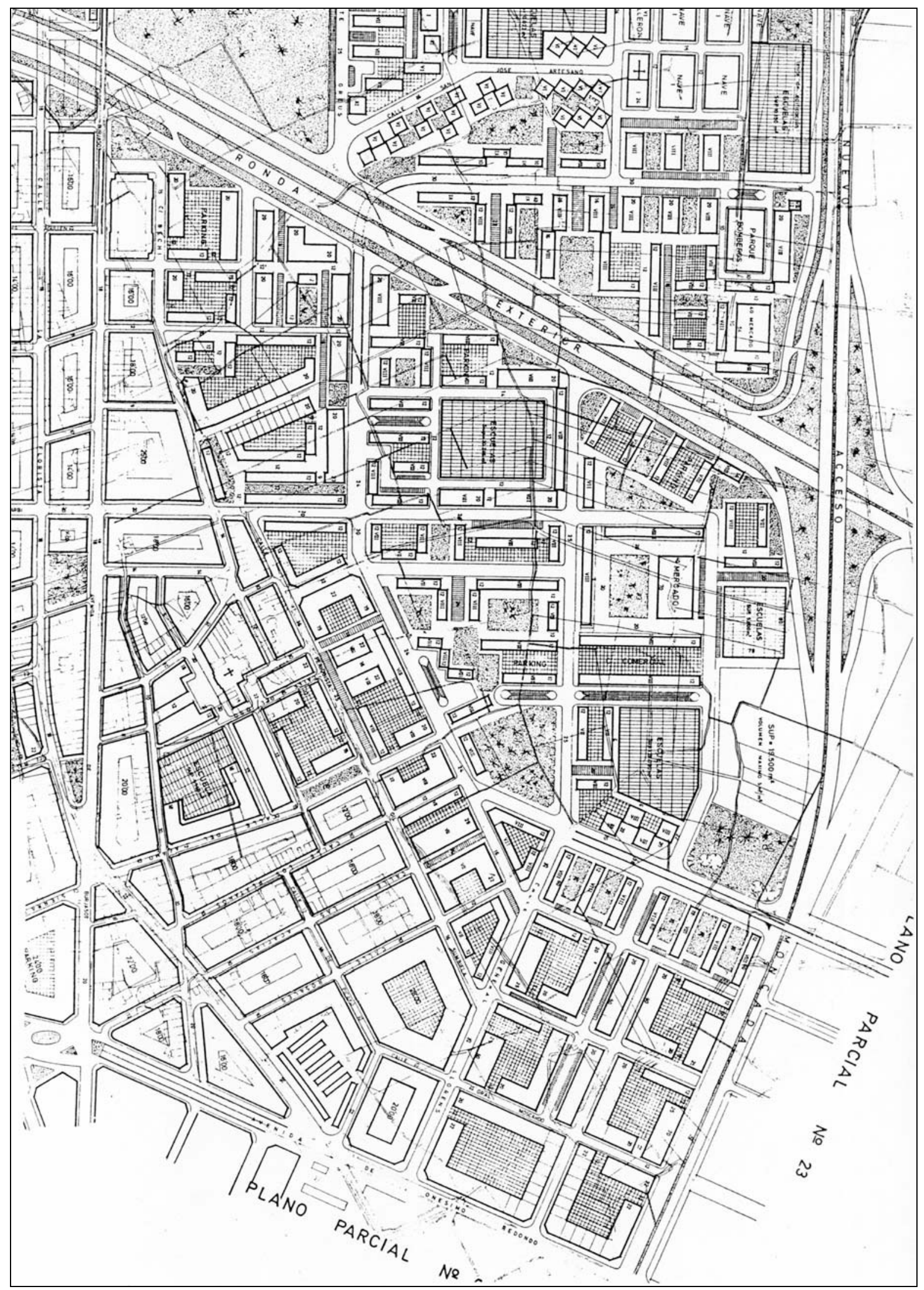

Zona 24-B. Detalle del Plano de alineaciones. 
PP 24.

1. UNIDADES DE ACTUACIÓN. ZONA 24-A

Escala original: 1:2.000

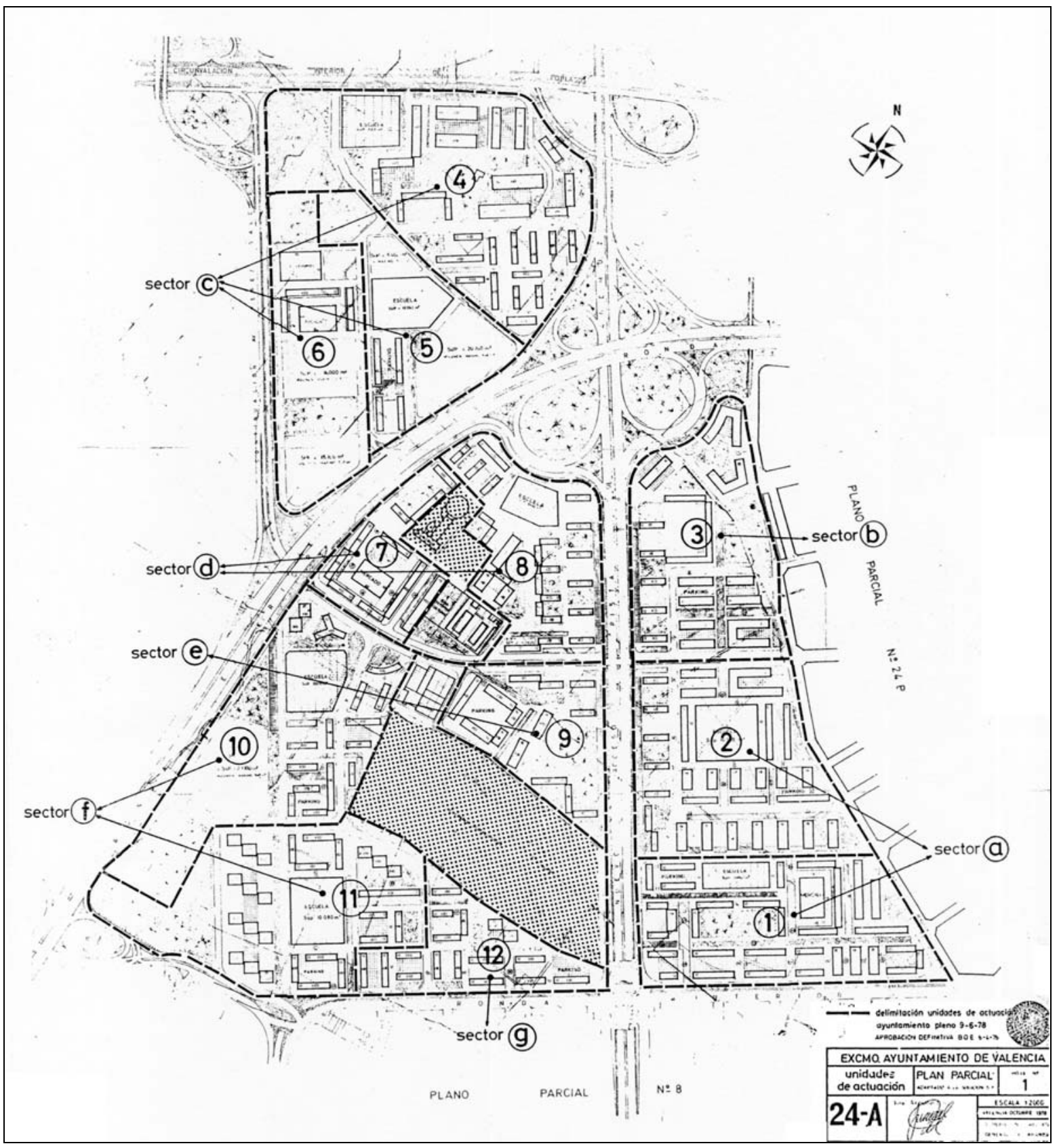


1. UNIDADES DE ACTUACIÓN. ZONA 24-A

Escala original: $1: 2.000$

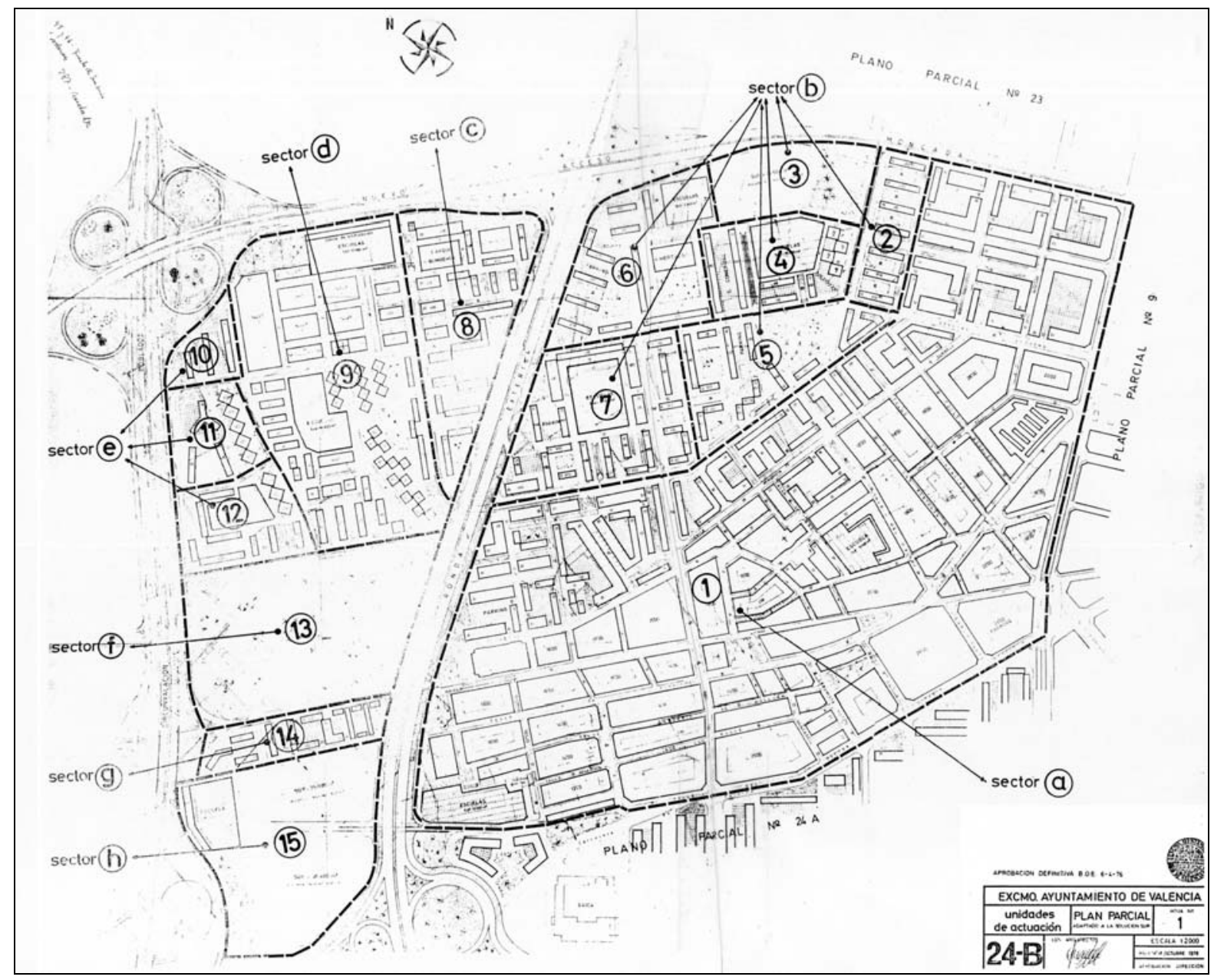


Redactor: Corporación Administrativa Gran Valencia.

Fecha: 9- 03-1975.

Asunto: Notificación al Ayuntamiento de Valencia acerca del Plan Parcial 24.

Fuente: Ayuntamiento de Valencia. Sección de Urbanismo. Negociado de Suelo y Ordenación urbana. Reg. General 1.830 (Archivo de Planeamiento No 149).

\section{CORPORACION ADMINISTRAIIYA GRAN VALENCIA}

Excmo. Sr.

En escrito de fecha 1. de Agosto de 1.975 se remitió al Ilmo. Sr. Director General de Urbanismo el Plan Parcial no 24, presentado por ese Excmo. Ayuntamiento y sobre el cual el Consejo General de esta Corporación, en sesión celebrada el 31 de Julio de 1.975, adoptó el siguiente acuerdo:

"10.- Aprobar el Plan Parcial no 24 de Valencia con las siguientes observaciones: a) Deberán introducirse las rectificaciones de alineaciones exigidas por la Red Arterial de Valencia señaladas por la Jefatura Provincial de Carreteras; en las zonas escolares afectadas será suficiente la indicación de que la parte señalada no será edificada, destinándose a patios o similares. b) Deberá sustituirse el sistema señalado de ejecución por cesión de viales por algunos de los previstos en la Ley de 2 de Mayo de 1.975. $2^{\circ}$.- Elevarlo al Ministerio de la Vivienda para su resolución definitiva". miento.

Lo que tengo el Honor de comunicar a V,E. para su conoci-

Dios guarde a V.E. muchos años.

Valencia 9 de Marzo de 1.975.

EL PRESIDENTE DE LA

COMISIÓN EJECUTIVA.

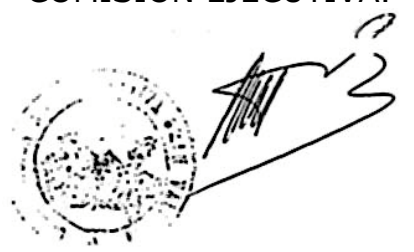

REGÍSTRESE A URBANISMO

El Secretario

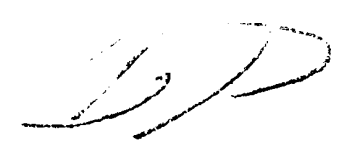

Ilmo. Sr. Alcalde Presidente del Excmo. Ayuntamiento de Valencia. 
Redactor: Dirección General de Urbanismo del Ministerio de la Vivienda / Ministerio de la Vivienda.

Fecha: 28- 02-1976.

Asunto: Resolución de aprobación del Plan Parcial 24 con reparos.

Fuente: Ayuntamiento de Valencia. Sección de Urbanismo. Negociado de Suelo y Ordenación urbana. Reg. General 1.830 (Archivo de Planeamiento No 149).

MINISTERIO DE LA VIVIENDA

DIRECCIÓN GENERAL DE URBANISMO.

Excmo. Sr.:

VISTO el Plan Parcial de Ordenación Urbana numero 24, de Valencia, presentado por el Ayuntamiento de dicha Capital y remitido a este Departamento por la Corporación Administrativa Gran Valencia, mediante acuerdo de 31 de julio de 1975 otorgándole la aprobación, con determinadas rectificaciones.

VISTO el informe emitido por los servicios competentes de este Centro Directivo.

Esta Dirección General, teniendo en cuenta lo dispuesto en las Leyes de 12 de mayo de 1956 sobre Régimen del Suelo y Ordenación Urbana y de 2 de mayo de 1975 sobre Reforma de la anterior, y en los Decretos 63/1968, de 18 de enero y 1194/72, de ]3 de julio, tiene el honor de proponer a V. E. lo siguiente:

I. Que se apruebe el Plan Parcial precitado, con las siguientes rectificaciones:

$1^{\circ}$. Se incorporara la modificación a que se contrae el apartado a) del referido acuerdo de la Corporación Administrativa Gran Valencia, de fecha 31 de julio de 1975.

$2^{\circ}$. Los artículos 4,15 y 45 , deberán rectificarse en el sentido de que las condiciones para la edificación de viviendas calificada de tolerancia industrial, serán las correspondientes a "núcleos periféricos", en base a lo prevenido en la Norma 25 del Plan Comarcal, ya que la zona en cuestión esta enclavada en el poblado de Benicalap que viene calificado como núcleo periférico y no como zona de extensión, encontrándose la mas cercana en el polígono 8, situado al Sur del 24 y separado del mismo por la Avenida del General Avilés y el nuevo acceso a Ademuz, por lo que no procede aplicar en este caso, las condiciones de edificabilidad de la zona de extensión.

$3^{\circ}$. El artículo 43 -edificación abierta, deberá ser rectificado como a continuación se indica:

a) Se concretarán los usos permitidos en planta baja a que se alude, que deberán corresponder, en todo caso, a instalaciones, que constituyan elementos comunes del inmueble.

b) La separación entre bloques de ejes loncitudinales perpendiculares será como mínimo la mitad de la altura del mayor, además de conservar la separación mínima de 10 metros.

c) La separación de bloques no paralelos sera igual a la semisuma de las alturas de ambos, medida en el punto medio de la fachada.

40. En el artículo 44 se suprimirá toda referencia a la posible propiedad privada de las zonas verdes dispuestas entre bloques, ya que todas las zonas que en el Plan vienen calificadas como zonas 
verdes han de ser de dominio y uso público.

$5^{\circ}$. Se suprimirá la posibilidad, prevista en la Memoria del Plan, de realizar aparcamientos subterráneos en las zonas verdes, ya que, por una parte, pueden desvirtuar su carácter de parque o jardín de uso publico, y por otra, con los previstos en los viales y en los edificios con este destino, y con los que hay que reservar en cada inmueble, resultan suficientes para el servicio del sector.

$6^{\circ}$. El sistema de cesión de viales que se establece para ejecutar el Plan, deberá ser sustituido por el de cooperación, que es el que guarda mas analogía con él, dentro de los previstos en la Ley de Reforma de 2 de mayo de 1975, ya que de conformidad con lo que establece su Disposición transitoria segunda, los Planes parciales que se aprueben definitivamente después de su entrada en vigor deberán ejecutarse con arreglo a sus preceptos, que han supuesto, entre otros extremos, la supresión del referido sistema de cesión de viales.

II. Recordar al Ayuntamiento, que en el tema de concesión de licencias, deberá tener en cuenta previamente, lo prevenido en los artículos 117, 118 y 119 de la precitada Ley de Reforma de 2 de mayo de 1975.

Las rectificaciones a que se refiere el apartado I de esta propuesta, se incorporarán a la documentación correspondiente del Plan, que por triplicado ejemplar, se remitirá a este Departamento, en el plazo de tres meses, para su debida constancia.

La resolución se notificará al Ayuntamiento de Valencia y se publicará en el Boletín Oficial del Estado.

No obstante, V.E. resolverá

Dios guarde a V.E.

Madrid, 28 de Febrero de 1976

EL DIRECTOR GENERAL

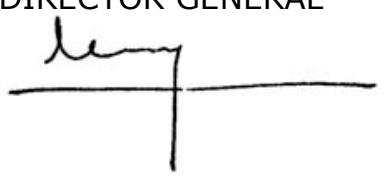

Conforme con la propuesta

Madrid, 28 de Febrero de 1976

EL MINISTRO DE LA VIVIENDA

P.D.

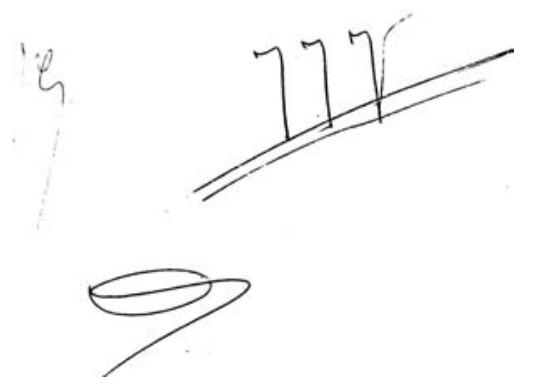

Excmo. Sr. Ministro de la Vivienda. 
Redactor: El Arquitecto Mayor.

Fecha: 25- 03-1976.

Asunto: Informe sobre el Plan Parcial 24.

Fuente: Ayuntamiento de Valencia. Sección de Urbanismo. Negociado de Suelo y Ordenación urbana. Reg. General 1.830 (Archivo de Planeamiento No 149).

Expte. 1830/74. S.y 0.Urbana

El Arquitecto Mayor, que suscribe, tiene que informar sobre la Resolución Ministerial, referida al Plan Parcial de Ordenación Urbana signatura 24, Polígonos A y B, de fecha 28 febrero 1976, a los efectos de un posible recurso de reposición.

Ante todo debe hacerse notar que la Resolución es eminentemente positiva: el Plan Parcial precitado se aprueba.

$\left.1^{\circ}\right)$ Sobre la incorporación a las previsiones del Plan, de unas rectificaciones de alineaciones exigidas por la Red Arterial de Valencia, señaladas por la Jefatura Provincial de Carreteras dependiente del Ministerio de Obras Publicas; sobre que las zonas escolares afectadas será suficiente la indicación de que la parte afectada no sea edificable, estimo que no cabe sino aceptarlas.

$\left.2^{\circ}\right)$ Sobre la rectificación de los artículos 4, 15 y 45 de las Ordenanzas específicas del Plan Parcial en el sentido señalado por la Resolución Ministerial de que no procede aplicar en este caso las condiciones de edificabilidad de la zona de Extensión en la de Tolerancia Industrial, estimo existen razones que pueden dar lugar al recurso de reposición. Y son ellas:

a) El sector de Tolerancia Industrial posee como límite sur el antiguo Camino de Tránsitos, actualmente denominado avenida de Onésimo Redondo. Con independencia de la zonificación que el otro margen del Camino posee (concretamente Edificación Abierta), un análisis de la zonificación del Plan Comarcal nos permite indicar que desde la $1^{\text {a }}$ Ronda hasta la $2^{a}$ Ronda de Circunvalación (caminos de Tránsitos) se califica como ensanche hasta Tránsitos y entre la $2^{a}$ Ronda y la $3^{a}$ Ronda (Exterior, según el Plan Comarcal) está calificada genéricamente cono extensión Exterior a Tránsitos. Y ello, insisto, es independiente de que por circunstanciar específicas como son el respetar en el Plan Comarcal las características de los Planes precedentes a su vigencia, se zonificaran determinados polígonos de ambos anillos como Edificación Abierta, como Tolerancia Industrial e incluso como Núcleos Periféricos. Por lo que toda la zona de Tolerancia Industrial que comprende el presente Plan se ubica en el espacio al que puede denominarse como Extensión Exterior a Tránsitos.

b) No existe con esta interpretación ninguna vulneración de lo indicado por la Norma $25^{a}$ del Plan General. Pero es que además, con ella se está de acuerdo con las condiciones que para la edificación de viviendas se imponen en el Cuadro Anexo, documento al que la Norma $1^{\text {a }}$ se remite a los efectos de las limitaciones de uso y aprovechamiento del suelo, y que exige para la zonificación de Tolerancia Industrial una altura de edificios en función de los anchos de las calles idéntica a la de Extensión. De aplicar las condiciones de Núcleos Periféricos existiría una discrepancia con las Normas Urbanísticas del Plan Comarcal,

En conclusión, se propone que se suprima la imposición de que las condiciones para la edificación de viviendas sean las de Núcleos Periféricos y se apliquen las de la zona de Tolerancia Industrial.

Para ello, el artículo 4 quedará redactado en los siguientes términos: "En la zona de Tolerancia Industrial se permitirá la in 
dustria en las plantas bajas; pudiendo edificarse viviendas en los pisos del edificio a fachada. La parte de edificación para viviendas se hará con las condiciones prescritas por el Cuadro Anexo de las Normas Urbanísticas para la zona de Tolerancia Industrial."

El artículo 15 se rectificará suprimiendo de su redacción el paréntesis complementario de la referencia a la zona de Tolerancia Industrial a los efectos de que no se mencione la zona de Extensión Exterior a Tránsitos.

El artículo 45 quedará redactado así:

\begin{tabular}{ccc} 
Ancho de calle en metros & Altura en metros & Número de plantas \\
\hline 9 & 15,50 & V \\
12 & 18,00 & VI \\
16 & 21,00 & VII \\
20 & 23,50 & VIII
\end{tabular}

El resto del artículo, idéntico.

30) Sobré las rectificaciones que deberá introducirse al artículo 43 de las Ordenanzas específicas del Plan, estimo no existe motivos para su recurso, no cabe sino aceptarlas, si bien es estimación que se adelanta por quien suscribe, que en la solicitud de concreción de usos permitidos de plantas bajas a que se alude y que se refieren a elementos comunes del inmueble, en la rectificación que como documentación complementaria se incorporará en su día deberá eliminarse de dicho artículo 43, el párrafo a que se refiere la observación ministerial, por entender difícil la concreción de los usos comunitarios de un inmueble y por considerar que dicha Ordenanza discrepa sensiblemente de las Ordenanzas idénticas que para otros Planes Parciales se han redactado en el Término Municipal de Valencia.

$4^{\circ}$ ) Con relación a lo indicado, en el artículo 44, visto que las zonas previstas en este Plan están todas ellas computadas a los fines de la dotación mínima exigida por la Ley, considero muy oportuna la observación ministerial referente a la supresión de toda referencia a la posible propiedad privada de las zonas verdes dispuestas entre bloques.

50) Estimo no existe materia recurrible en la rectificación exigida para que se suprima la posibilidad prevista en la Memoria del Plan, de realizar aparcamientos subterráneos en las zonas verdes pues considero que, tal como dicha resolución hace ver, ello contribuye a desvirtuar el carácter de parque o jardín de uso publico.

60) El acuerdo de Gran Valencia referente a dicho Plan ya hacía observar la necesidad de sustitución del sistema señalado de ejecución por cesión de viales, por alguno de los previstos en la Ley de 2 de mayo de 1975. La resolución ministerial lo que hace es completar dicho dictamen ajustado a Ley, con la sugerencia, por estimarla como la que guarda más analogía con la antes señalada, de que se aplique el sistema de cooperación. Procederá, por tanto, que por el Ayuntamiento se redacte la división de polígonos de la que pueda deducirse que algunos sectores con dotación de servicios de urbanización y prácticamente construidos, no sea necesario ejecutarlos por el sistema de cooperación, pero no es materia recurrible el que la ejecución de todo el Plan, en general, se realice por el sistema de cooperación.

II.- Referente al recordatorio que se hace al Ayuntamiento en materia del tema de concesión de licencias, estimo que no es cuestión de la competencia del facultativo que suscribe.

Valencia, 25 de marzo de 1.976

EL ARQUITECTO MAYOR,

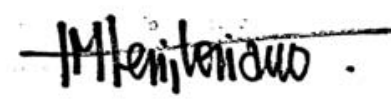


Redactor: Servicio Central de recursos. Ministerio de la Vivienda.

Fecha: 6- 05-1977.

Asunto: Respuesta al recurso presentado por el Ayuntamiento de Valencia y por algunos particulares contra la O.M. de 28-02-1976.

Fuente: Ayuntamiento de Valencia. Sección de Urbanismo. Negociado de Suelo y Ordenación urbana. Reg. General 1.830 (Archivo de Planeamiento No 149).

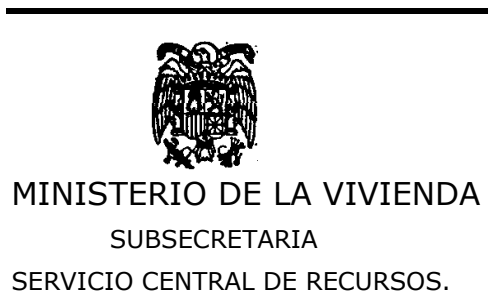

Con esta fecha el Ilmo. Sr. Subsecretario, por delegación del $\mathrm{ExCm}^{\circ}$. Sr. Ministro ha resuelto lo siguiente:

"Vistos los recursos de reposición interpuestos por el Ayuntamiento de Valencia y por D. José Luis Miguel Camps y D. José Martínez Pascual en nombre y representación de la entidad "Promotora Astur-Valencia, S.A." contra la Orden Ministerial de 28 de febrero de 1.976 por la que se aprobó con rectificaciones el Plan Parcial de ordenación Urbana número 24 de Valencia, y

RESULTANDO: Que los interesados, en sus escritos de recurso, solicitan se deje sin efecto la rectificación introducida en la Orden Ministerial impugnada en el apartado I, $2^{\circ}$; proponiendo la entidad Astur-Valencia, S.A. que permanezcan los artículos 4, 15 y 45 de las Ordenanzas del Plan Parcial tal y como se propusieron por el Ayuntamiento al presentar el mismo para aprobación, es decir que las condiciones do edificabilidad de las viviendas sean las correspondientes a las zonas de Extensión Exterior a Tránsitos, mientras que el Ayuntamiento solicita se redacten los citados artículos de la forma propuesta en el escrito de recurso.

RESULTANDO: Que con posterioridad al escrito de interposición del recurso el Ayuntamiento solicita se modifique la resolución impugnada en el punto $I, 6^{\circ}$, en el sentido de suprimir la exigencia del sistema de cooperación para la ejecución del mismo, puesto que dado que el Planeamiento fue redactado previendo otro sistema, no resulta posible obtener polígonos equilibrados y que cumplan todos los requisitos legales, solicitando se permita al Ayuntamiento adoptar las decisiones más ajustadas en cada caso, definiendo polígonos o unidades de actuación y estableciendo el sistema más conveniente para la ejecución de cada uno de ellos, además de la posibilidad de realizar actuaciones aisladas en aquella parte del territorio que por disponer de una urbanización y edificación muy consolidadas, debe ser calificado como suelo urbano.

RESULTANDO: Que la Dirección General de Urbanismo y la Asesoría Jurídica del Departamento han evacuado sus respectivos informes oportunamente solicitados.

CONSIDERANDO: Que dada la íntima conexión existente entre los escritos de recurso, procede acumularlos en virtud de lo dispuesto en el articulo 73 de la Ley de Procedimiento Administrativo.

CONSIDERANDO: Que los escritos de recurso reúnen todas las condiciones adjetivas para su admisibilidad al ser los recursos procedentes, a la vista del articulo 52 de la Ley sobre la Jurisdicción 
Contencioso-Administrativa y dentro del plazo legal de un mes por personas legitimadas para ello, procede entrar a conocer sobre las cuestiones de fondo planteadas en el mismo.

CONSIDERANDO: Que la Norma 25 del Plan Comarcal de Valencia dice textualmente! "La parte de edificación para viviendas se hará con las condiciones previstas para la zona de extensión o periférica según esté enclavado en un conjunto y otro", y teniendo en cuenta que el terreno objeto de ordenación está situado entre la segunda y tercera ronda pudiera ser calificado, según las calificaciones del Plan Comarcal, de "Extensión exterior a tránsitos", pero al mismo tiempo es ampliación del núcleo de Benicalap clasificado por el mismo Plan Comarcal como "Núcleo Periférico". Por lo que tiene por tanto las dos calificaciones definidas en la Norma 25 anteriormente citada. Interpretando la citada Norma, se estima que en cada caso la ordenación propuesta tome las características del sector al que amplía. En este caso, el sector ampliado es Benicalap, con calificación de "Núcleo Periférico", por lo que las condiciones para la edificación de viviendas calificadas de tolerancia industrial serán las correspondientes a "Núcleos Periféricos", ya que la zona de extensión más próxima está en el polígono 8 , situado al Sur del 24 y separado por la Avda. del General Avilés y el nuevo acceso a Ademuz. Por todo ello se entiende que procede, en este punto, mantener la Orden Ministerial impugnada.

CONSIDERANDO: Que el Texto refundido de la Ley del Suelo de 9 de abril de 1.975, en su artículo 119-2, establece que la Administración actuante, elegirá el sistema de actuación aplicable para la ejecución de los Planes de Ordenación y el citado artículo prevé la posibilidad de que esta elección no venga determinada por el propio Plan y por tanto pueda efectuarse con posterioridad, y en base a este precepto legal, puede estimarse la pretensión del Ayuntamiento deducida en su escrito de 16 de diciembre de 1.976, como ampliación del escrito de recurso presentado por la Corporación municipal por el que se solicitaba se suprimiera la exigencia establecida por la Orden Ministerial, de 28 de febrero de 1.976, en su apartado I, 60, de ejecutar el Plan Parcial con carácter general bajo el sistema de cooperación, puesto que como expone el Ayuntamiento, el Plan fué redactado previendo otro sistema, el de cesión de viales, que fué suprimido por la Ley de Reforma de 2 de mayo de 1.975. Por todo ello, se entiende que el Ayuntamiento es competente como órgano actuante, para elegir el sistema de actuación aplicable, siguiendo los criterios establecidos en el artículo 119-2 de la Ley de Reforma. Debiendo tener en cuenta el Ayuntamiento las normas de la citada Ley, para la delimitación de polígonos, unidades de actuación o realización de actuaciones aisladas.

En su virtud,

Este Ministerio, de conformidad con el Servicio Central de Recursos y con el informe de la Asesoría Jurídica del Departamento acuerda lo siguiente: $1^{\circ}$.- Desestimar el recurso interpuesto por $\mathrm{D}$. José Luis Miguel Camps y D. José Martínez Pascual en representación de la entidad "Promotora Astur-Valencia, S.A" contra la Orden Ministerial de 28 de febrero de 1.976 , por la que se aprobó con rectificaciones el Plan Parcial de Ordenación Urbana número 24 de Valencia. $2^{\circ}$.- Estimar en parte el recurso interpuesto por el Ayuntamiento de Valencia, en el sentido de suprimir la exigencia establecida en la citada Orden Ministerial en su apartado I, $6^{\circ}$ y en virtud de ello se faculta al Ayuntamiento, de conformidad con las disposiciones de la Ley del Suelo, para elegir el sistema de actuación aplicable para la ejecución del Plan Parcial n²4." 
Lo que con devolución del expediente y de orden del Ilmo. Sr. Subsecretario comunico a V.I. para su conocimiento y notificación en forma legal a los interesados.

Dios guarde a V.I.

Madrid, a. 6 de mayo de 1.977

EL JEFE DEL SERVICIO CENTRAL DE RECURSOS,

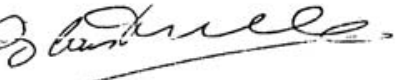

Ilmo. Sr. Director General de Urbanismo.- 
Redactor: El Arquitecto Municipal de Planeamiento urbano.

Fecha: 18-11-1977.

Asunto: Informe sobre el Plan Parcial 24, como consecuencia de la resolución ministerial de 6-05-1977.

Fuente: Ayuntamiento de Valencia. Sección de Urbanismo. Negociado de Suelo y Ordenación urbana. Reg. General 1.830 (Archivo de Planeamiento No 149).

Expte. $7455 / 76$

El Arquitecto Municipal de Planeamiento urbano que suscribe, en relación con las actuaciones practicadas tanto en el presente expediente como las existentes en el expediente 1830/74 de Urbanismo, Suelo y Ordenación urbana, antecedente directo de este, informa lo siguiente:

10.- Que a la vista de la resolución ministerial de 6 de mayo de 1977 en contestación al recurso interpuesto por la Corporación Municipal en base al acuerdo plenario de 9 de abril de 1976, la situación urbanística del plan parcial 24 (sectores A y B) queda pendiente de dar solución a los puntos principales que de ella, así como de la anterior resolución de 28 de febrero de 1976, se deduce.

a) La rectificación de ciertos extremos de la ordenanza, concretamente de los arts. 4,15 y 45 relativos a la edificación de viviendas en tolerancia industrial, así como la del 43, relativo a edificación abierta; y la del 44 relativa a la propiedad de zonas verdes.

b) La rectificación de ciertos extremos de la Memoria relativos a la posibilidad de efectuar aparcamientos subterráneos bajo zonas verdes.

c) La incorporación a que se hace referencia en base a acuerdo de la Corporación Administrativa Gran Valencia de gfecha 31 de julio de 1975.

d) La determinación del sistema de actuación de conformidad con las disposiciones de la Ley del Suelo, una vez aceptado por dicha resolución el recurso municipal referido a la supresión de la exigencia de aplicar el sistema de cooperación a la totalidad del mismo.

$2^{\circ}$.- Con respecto a los puntos a), b) y c), por esta oficina técnica se ha procedido a introducir las oportunas rectificaciones en los documentos correspondientes, copia de los cuales se adjunta por triplicado ejemplar, a los efectos de que sustituyendo a la inicialmente remitida, surtan los efectos oportunos.

30.- Respecto a la determinación del sistema de actuación, el que suscribe estima que debe poner de manifiesto y previamente ciertas consideraciones, cuales son:

- El plan parcial 24, con independencia de la fecha de su aprobación, fue redactado con bastante anterioridad a la entrada en vigor, concretamente un año antes, y a tenor de los dispuesto en la Ley del Suelo vigente en aquel momento -la de 12 de mayo de 1956- y en desarrollo del Plan General de Valencia, aprobado en 30 de junio de 1966, y por tanto su planificación obedeció a los criterios imperantes en aquel momento. En lo que se refiere al sistema de actuación, siguiendo la costumbre y modo usual de las ejecuciones urbanísticas, se adoptó el de cesión de viales como más ade 
cuado para instrumentar el desarrollo urbano. Quiere esto decir, que una planificación pensada para ejecutarse con un sistema concreto, difícilmente, por no decir imposible, puede adaptarse una vez aprobado, a un sistema totalmente distinto y sobre todo con los requisitos que impone una nueva Ley que parte de unas nuevas inquietudes socio-urbanísticas.

En este sentido se motivó la moción interpuesta por el teniente de Alcalde, Presidente de la Comisión de Urbanismo, que dio origen al acuerdo plenario de 3 de diciembre de 1976 y posteriormente a la resolución ministerial de 6 de mayo de 1977.

- Que en dicha resolución ministerial se reconoce tácitamente y por los motivos aludidos "puesto que dado que el planeamiento fue redactado previendo otro sistema" la imposibilidad por parte del Ayuntamiento de obtener polígonos equilibrados y que cumplan todos los requisitos legales, facultando al mismo tiempo, para elegir al sistema de actuación aplicable para la ejecución del plan parcial, "adoptando las decisiones más ajustadas en cada caso, definiendo polígonos o unidades de actuación..., además de la posibilidad de realizar actuaciones aisladas en aquella parte del territorio que por disponer de una urbanización y edificación muy consolidada, debe ser calificado como suelo urbano".

- Por último, dentro del ámbito del plan parcial, existen efectivamente sectores "muy consolidados" por disponer de una urbanización y estar edificados, como puede apreciarse en la documentación adjunta y que obviamente "deben ser calificados como suelo urbano" y por otra parte, fruto de su adaptación al plan general, la planificación dispone de una serie de elementos que forman parte de la estructura general y orgánica del territorio. Son pues elementos determinantes del desarrollo urbano incluibles por su propia definición o por sus características supravecinales, dentro de la denominación sistemas generales a la que alude la vigente Ley del Suelo.

Hechas estas consideraciones, se plantean dos posibles opciones: Encuadrar el problema dentro del marco legal en vigor, reconociendo el desfase entre la planificación y los criterios de ejecución y en consecuencia proceder, dejando sin efecto el plan aprobado, a una revisión del mismo, adaptándolo a la nueva situación, o dar por bueno el planeamiento aprobado, reconociendo la falta de operatividad de los criterios nuevos ante la realidad palpable de una ciudad en curso de ejecución, procediendo dentro de una interpretación razonablemente lógica del texto legal, a la determinación de unos polígonos o unidades de actuación, para el caso da lo mismo, que hagan posible la ejecución adecuada del plan.

Ante esta situación, el que suscribe, que duda cabe que, desde una posición estricta, se inclina por la primera de las opciones y en este sentido se ha expresado en diferentes ocasiones en que se le ha consultado su opinión. No obstante ello, conocedor de la problemática que ello conllevaría -tal vez fuera imprescindible y previamente, proceder a la adaptación del plan general a lo dispuesto en la nueva Ley del Suelo, en virtud de la disposición transitoria primera - visto el espíritu que animan los antecedentes obrantes en el presente expediente, y consciente de la enorme trascendencia que supone la resolución del problema, sugeriría el desarrollar la segunda opción y para el caso de que así se estimara, se ha elaborado una propuesta concreta.

40.- Esta propuesta parte fundamentalmente de considerar dos factores concretos: el primero de ellos, la diferenciación de la zona en diversos sectores, toda vez que, tanto las características 
urbanísticas como el grado de urbanización, no son los mismos en la totalidad del ámbito; y el segundo, la existencia dentro del plan, de ciertos elementos que por pertenecer a los sistemas generales, deben excluirse del tratamiento conjunto del tema.

Una vez delimitado el campo de acción, la determinación de los polígonos o unidades de actuación se ha resuelto dentro de una razonable interpretación de la Ley, tomando como criterio básico, el concepto Beneficio-Carga de la urbanización, entendiendo por el primero, el aprovechamiento del suelo, o sea, el volumen edificable, y por el segundo, el conjunto de elementos que conforman el equipamiento urbano, tal como terrenos para viales, escuelas, zonas verdes y los costos de las obras de urbanización, que traducidos en cifras y efectuando la operación cociente carga-beneficio, nos da como resultado un coeficiente. Obtenidos los distintos coeficientes generales según los distintos sectores del plan (atendiendo tanto a la situación como a las características urbanísticas propias derivadas de su zonificación y estructura), la delimitación concreta de cada polígono o unidad de actuación se ha reflejado buscando un cierto equilibrio de unos con otros, es decir, buscando que los coeficientes parciales de cada uno de ellos fueran similares en relación con su sectorial respectivo, pero procurando que las líneas perimetrales coincidieran siempre con ejes viales, y ello con el fin de obtener siempre unidades susceptibles de una ejecución completa, tanto en lo que se refiere $[\ldots]$

50.- Conclusión. Como conclusión a todo lo anteriormente expuest, el que suscribe estima lo siguiente:

1/. Que se proceda a la reforma del plan parcial número 24, con el fin de acomodar la estructura urbana a las exigencias del texto refundido en la Ley del Suelo de 9 de abril de 1976 y en especial a los criterios que sobre sistemas de actuación y delimitación de polígonos se contienen en el art. 117 punto dos.

2/.- Que alternativamente, dando por válido el planeamiento, se admita la propuesta presente para su consideración y efectos oportunos, si ello se estima adecuado de conformidad con la situación, y previos los informes jurídico-administrativos que procedan en todo caso. Propuesta que bajo el título de "Determinación Sistema de Actuación" igualmente se adjunta.

Valencia, 18 de noviembre de 1.977

EL ARQUITECTO MUNICIPAL,

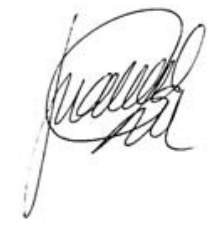


Redactor: El Arquitecto Municipal de Planeamiento urbano.

Fecha: 24- 04-1978.

Asunto: Informe sobre alegaciones presentadas al Proyecto de Determinación del Sistema de Actuación del Plan Parcial 24.

Fuente: Ayuntamiento de Valencia. Sección de Urbanismo. Negociado de Suelo y Ordenación urbana Reg. General 1.830 (Archivo de Planeamiento No 149).

\section{Expte. 7455/76}

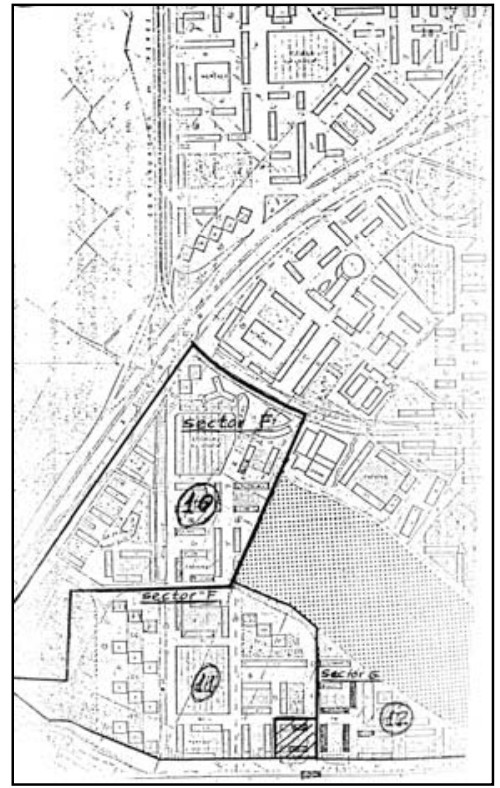

El Arquitecto Municipal de Planeamiento Urbano que suscribe, vistas las alegaciones formuladas al proyecto de Determinación del Sistema de Actuación del Plan Parcial no 24, durante el periodo de información publica, informa lo siguiente:

Alegación no 6025 y 6026, D, José Ignacio Criado García, en nombre de Entidades Mercantiles Triangulo I, S.A. y Entidad Mercantil PROLEVAN, S.A. respectivamente, el cual solicita que parte de los terrenos incluidos en la unidad no 11 , pasen a la unidad no 12 (ambas en el Plan 24-A) dado que estando edificadas y urbanizadas, reúnen los requisitos para ser considerado suelo urbano, en la misma manera que por esta razón están incluidas en la unidad n० 12.

Analizadas las circunstancias y hechas las oportunas comprobaciones, se estima que no hay inconveniente en acceder a lo solicitado y en este caso, variar loa límites de ambas unidades colindantes.

Alegación no 6028 Da Dolores Navarro Albert y Da Matilde Gañón Jara, las cuales solicitan se reforme el Plan Parcial no 24-B, por entender que la calificación de zona verde en la totalidad de los terrenos de su propiedad les perjudica.

Se estima que el contenido de esta alegación no afecta al tramite concreto del expediente, toda vez que el documento expuesto se refiere a la Determinación del Sistema de Actuación y no al proyecto del Plan Parcial que ya esta aprobado definitivamente por 0.M. de 28 de febrero de 1976 (B.O.E. 6-4-76), por lo que no se toma en consideración.

Alegación no 6548 D. José Luís Alfonso Llorens y otros, el cual solicita se retrotraigan las actuaciones y se proceda a un nuevo estudio y planeamiento que comporte una real, equitativa, y justa distribución de las cargas y beneficios, fijando para todos los sectores y unidades de actuación un mismo sistema de ejecución.

La presente alegación plantea de entrada el que la diferenciación de sectores y delimitación de unidades efectuada, es contraria a derecho, e infringe loa preceptos del texto refundido de la Ley del Suelo. El que suscribe, estima que esta cuestión excede de su competencia puramente técnica y por tanto somete el análisis de la alegación a la consideración de los servicios jurídicos de la Corporación.

Ahora bien, para un mejor conocimiento de la situación se hace notar que la delimitación efectuada se ha hecho sobre base de un planeamiento aprobado definitivamente, redactado pensando en ejecutarse por un sistema que el nuevo Texto do la Ley del Suelo ha suprimido, y me refiero al de cesión de viales, por lo que sí puede admitirse que desde el punto de la distribución de volúmenes, es decir, del análisis de los coeficientes de edificabilidad (m3 edificable 
sobre $\mathrm{m} 2$ de terreno) de las diferentes unidades, se deduce desigualdad, esta no es imputable a la delimitacion, sino al planeamiento en todo caso y sus propias condicionantes básicas. (A este respecto se hace notar que el que suscribe ya analizó las posibles incidencias do la situación en su informe de previo de 18 de noviembre del pasado año, obrante en el expediente). El pretender equilibrar, con arreglo al coeficiente de edificabilidad unas unidades con otras, nos hubiera llevado a la delimitación de macrounidades y con toda probabilidad a considerar la totalidad del ámbito del Plan como un solo polígono, lo cual, técnica y jurídicamente podría ser valido, pero desde el punto de vista operativo hubiera sido dificultosísimo y costoso en el tiempo de llevar a la practica, y este espíritu, es decir, la operatividad de la ejecución del plan, es el que ha animado el proyecto sometido a información publica, buscando en lo posible, el encuadramiento dentro del marco legal como se desprende de la documentación obrante en el expediente y sus motivaciones iniciales. Todo ello sin olvidar que la Ley del Suelo carece del adecuado reglamento para su aplicación y parece que si se me permite la crítica, estar pensada para barrios o unidades totalmente de nueva creación, con olvido de que tanto unos como otras existían mucho antes de su aparición.

Respecto a la división en sectores, se hace notar que ello ha sido inevitable, dado las circunstancias derivadas del planeamiento, por cuanto que aunque a nivel de Plan Parcial lleve todo ello la misma signatura, el ámbito está troceado por elementos del sistema general de la red viaria del Plan General, y ello unido al que existen sectores consolidados por la edificación, urbanizados totalmente o en curso de ejecución con anterioridad a la aparición de la nueva Ley, suponía de entrada una división sectorial previa a la delimitación de unidades (extremos estos que se ponen de manifiesto en la memoria del proyecto). No admitir esta división sectorial previa, nos hubiera llevado igualmente a considerar todo el plan como un solo polígono, es decir, a la cuestión inicial del tema. El hecho que se adopten sistemas de actuación distintos, según los casos, viene motivado en la clara diferenciación de los terrenos en cuanto a su consolidación y grado de urbanización, y evidentemente, en estos casos, al estimar la inoperancia del sistema de compensación, se ha optado por que su ejecución en aquellos elementos todavía no ejecutados, se continuara haciendo por el mismo sistema que se venia desarrollando, es decir, la cesión de viales o la expropiación, según conviniera, apoyándose para ello en la posible aplicación de la disposición transitoria tercera de la nueva Ley. A este respecto se hace notar como antecedente, el acuerdo de la Comisión Provincial de Urbanismo de 1 de febrero de 1978, relativa al sistema de actuación del Plan Parcial no 13, recientemente publicada en el boletín.

Respecto a las omisiones relativas a documento económico que justifique numéricamente el porque de la delimitación, se estima que si ello es necesario, puede subsanarse tal deficiencia, y en lo que se refiere a que existen edificaciones en la unidad $n^{0} 7$, ello es cierto, pero en ningún caso el número de fincas, el volumen que representan y el grado de urbanización de lea terrenos adyacentes, son suficientes para justificar el que esos terrenos se incluyan en la unidad de actuación no 1 , modificando la línea divisoria entre esta unidad y aquella, trasladándola a la vía paralela situada al norte, como se desprende de los planos de información del proyecto.

Alegación no 7063, Da María Asunción Alfonso Llorens, la cual solicita se deje sin efecto la división prepuesta y se realice un 


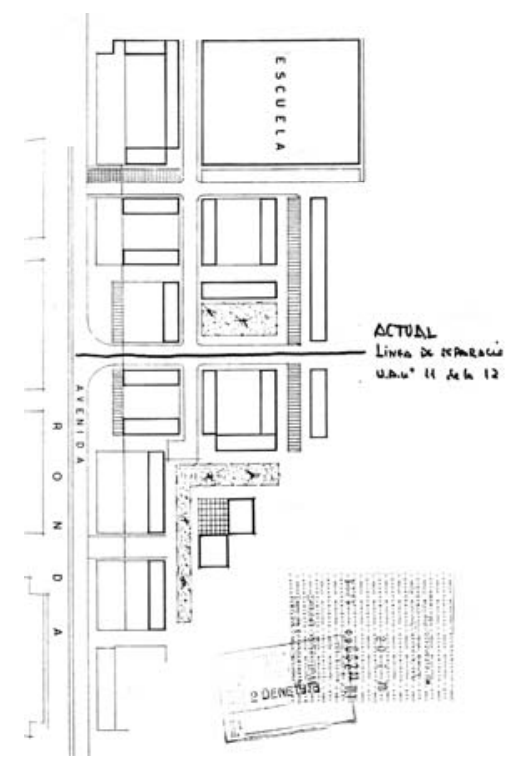

nuevo estudio per estimar no se ha procedido a la distribución justa de beneficios y cargas entre los propietarios afectados.

En síntesis la presente reclamación viene a plantear cuestiones y argumentos similares a loa que se contienen en la anterior alegación no 6648 , por lo que en principio vale lo dicho para aqueIla.

En cuanto a algunos aspectos concretos del tema, se hace notar que de conformidad con el planeamiento vigente, no existen edificaciones, y la referencia a la que alude el interesado, no puede tomarse en consideración por constituir edificios en general fuera de ordenación. Desde el punto de vista de urbanización, la unidad no 8 carece prácticamente de les mínimos exigidos por la Ley. Referente al estudio económico, se estima que no es necesario, por no ser éste un documente exigido por la normativa de aplicación.

Alegación 7060 D. José Rico Seguí, en representación de D. Francis-

co Pascual Caballer y D. José Cuñat Roig, el cual solicita que ciertos terrenos incluidos en la unidad $n^{0} 11$, pasen a la unidad $n^{\circ} 12$, colindantes ambas en el sector A del Plan Parcial, per estar construidas y urbanizadas y entender que ello es posible por las mismas razones que han justificado los criterios que configuran dicha unidad $n^{\circ} 12$.

El contenido de la presente alegación es básicamente el mismo que las alegaciones no 6025 y 6026, y se refiere a las mismos terrenos, por lo que se estima que no hay inconveniente alguno en acceder a lo solicitado.

Alegación no 7061 D. José Ignacio Velas Erre y otros, los cuales solicitan se revise el Plan Parcial no 24 (A y B) ajustándose a las determinaciones de la vigente Ley del Suelo, con anterioridad o simultáneamente a la determinación del sistema, por las consideraciones contenidas en el escrito.

Se estima que el contenido de la presente alegación va mas allá del trámite que nos ocupa, ya que lo que solicita, en base a los argumentos expuestos, supone no solo la revisión del Plan Parcial aprobado definitivamente (B.O.E. 6-4-70), sino igualmente la del Plan General de Valencia y su Comarca, por ser aquel desarrollo de este, y contener este último las determinaciones básicas que las alegaciones denuncian cono perjudiciales para los vecinos de Benicalap. En este sentido, se hace notar que la alternativa que proponen los interesados, ya fue puesta de manifiesto por el que suscribe en su informe previo de 18 de noviembre del pasado año, como un reconocimiento tácito al desfase existente entre la planificación aprobada y los criterios de ejecución y en consecuencia se decía proceder dejando sin afecto el plan aprobado, a una revisión del mismo, adaptándolo a la nueva situación, incluso señalando que "tal ves fuera imprescindible y previamente proceder s la adaptación del Plan General a lo dispuesto en la nueva Ley del Suelo".

Como quiera que el Pleno posteriormente acordó llevar a efecto la otra alternativa, que es la que ahora se ha sometido a información pública, el que suscribe no tiene mas que añadir a lo ya expuesto en su día, sometiendo el argumento a la consideración de la Comisión correspondiente.

Alegación no 7062 D. Juan de Otegui y Tellería, el cual solicita que en base a las consideraciones expuestas, se suprima la exigencia de cesión obligatoria a los terrenos destinados a Parque de Bomberos y Mercado, incluidos en la unidad de actuación no 8, sector $C$ del Plan 24-B.

A este respecto, el que suscribe hace notar que en efecto en la propia Memoria del proyecto se hace referencia a la condición de 
suele urbano relativa a les terrenos ámbito del Plan Parcial, pero existe una cierta matización entre le dicho en el punto $3^{\circ}$ de los Criterios Básicos "la totalidad del ámbito del plan puede considerarse como suele urbano" y lo dicho en el punto 40 "ciertas zonas por estas consolidados por la edificación y urbanizadas total o parcialmente, merece la calificación de suelo urbano". El sector c) concretamente, correspondiente con la unidad de actuación no 8 , no puede acogerse al segundo de los criterios citados, por cuanto que aunque esté junto a la Ciudad Fallera y limitado por esta y la Rambla Exterior, no alcanza por contra de lo dicho por el interesado, los dos tercios exigibles, máxime teniendo en cuenta que si adoptamos el concepto "área", como así se indica, no podemos limitarnos a computar aisladamente el sector c) junto con el d) (Ciudad Fallera), sino que habría que tomar en consideración les sectores e) y f), que igualmente están Junto a la Ciudad Fallera, e incluso, por que no, la g) y h). Por otra parte, no hay que olvidar que el proyecto pretende abarcar la ejecución del planeamiento dentro de los criterios de la nueva Ley, como consecuencia de la resolución ministerial; dando por buena una planificación aprobada y al objeto de una distribución adecuada entre los propietarios afectados de cualquier zona ámbito del plan, esta unidad, caso de que no cedieran esos terrenos destinados a parque de bomberos y mercado, resultaría favorecida en gran medida respecto de otras.

No obstante lo dicho, se somete el asunto a la consideración de los servicios jurídicos correspondientes.

Alegación no 7844, D. Antonio Almenar Andrés, el cual solicita que se supriman las subdivisiones efectuadas en el sector e) del plan 24-B, al ob590jeto de que resulte mas justa la distribución de cargas entre todos los propietarios afectos al sector de referencia.

Se estima que aun cuando la delimitación efectuada supone una adecuada distribución de cargas, que duda cabe que si todo constituyera una misma unidad, esa distribución tendría una mayor coherencia, pero también es cierto que, dado el sistema de actuación a aplicar, las dificultados para su puesta en marcha, serían mayores, al ser más los propietarios implicados. El que suscribe, por tanto y dado el punto estrictamente técnico, no tiene en principio nada que objetar por cuanto que, en base al resultado final, lo que importa es la ejecución del plan y ésta, lo mismo da que se resuelva en tres unidades o en una sola suma de las otras. Ahora bien, desde un punto de vista operativo, y esto ha sido una de los factores que ha pesado a la hora de efectuar las subdivisiones, el propugnar unidades lo mas pequeñas posible, se entiende es favorecedor para el administrado, ya que al ser menor el numero de propietarios afectados, la constitución de la junta correspondiente es mas viable, por no decir más rápida. No obstante ello, como quiera que el reclamante considera mas beneficioso lo contrario, tal vez podría admitirse como solución técnica eI proceder a la agrupación en una.sola unidad, las unidades no 10, 11 y 12, aunque como ya se ha dicho anteriormente, en opinión del que suscribe, considera más operativo mantener la situación con arreglo al proyecto.

Valencia, 24 de abril de 1978

EL ARQUITECTO MUNICIPAL.

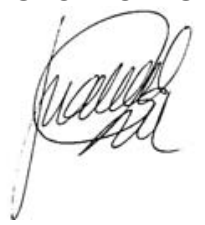

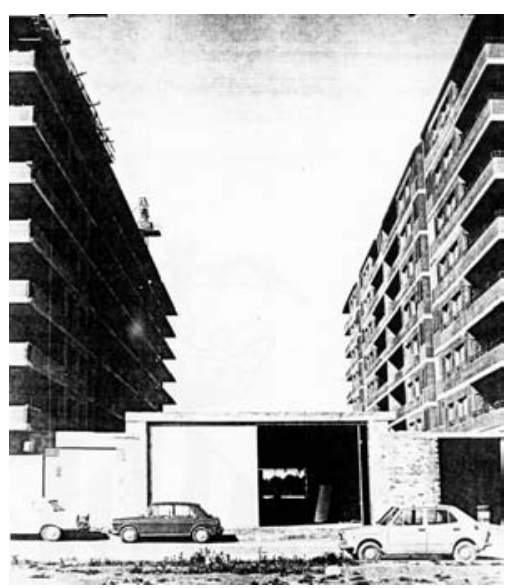





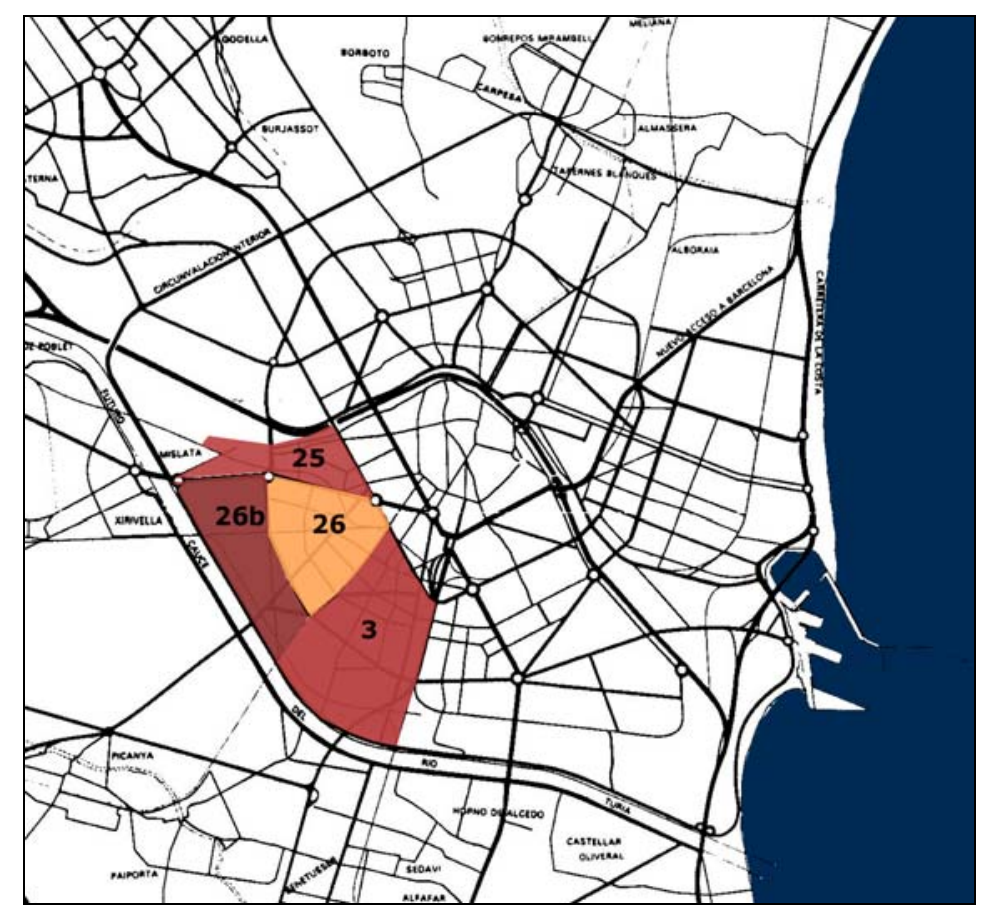

\subsection{ZONA SUROESTE}

PLAN PARCIAL NO 25 (NOU MOLES-SOTERNES), 1969. PLAN PARCIAL NO 26 (PATRAIX), 1967/1973.

PLAN PARCIAL NO 26-B (LA LUZ-FUENSANTA-SAN ISIDRO), 1967. PLAN PARCIAL NO 3 (PATRAIX-CAMI REIAL), 1967. 



\section{PP 25}

PROYECTO PARCIAL No 25 (ADAPTADO A LA SOLUCIÓN SUR)

1967

Redactores: EXCMO. AYUNTAMIENTO DE VALENCIA. OFICINA

TÉCNICA DE URBANISMO.

Fecha redacción: Abril 1967.

Fecha aprobación: B.O.E. 3-12-69.

Contenido:

1. PLANO DE RELACIÓN CON LA COMARCA

$1: 25.000$

2. SITUACIÓN EN EL PLAN GENERAL

$1: 10.000$

3. DELIMITACIÓN Y ESTADO ACTUAL

$1: 2000$

4. ESTRUCTURA URBANÍSTICA

$1: 2000$

5. ZONIFICACIÓN

$1: 2000$

6. RED VIARIA

$1: 2000$

7. REDES FUNDAMENTALES DE SERVICIO.

7.A. ESQUEMA DE ALCANTARILLADO

$1: 2000$

7.B. ESQUEMA DE ALUMBRADO

$1: 2000$

7.C. ESQUEMA DE RED DE AGUAS POTABLES. $1: 2000$

8. MEMORIA

9. ORDENANZAS

10. ESTUDIO ECONÓMICO-FINANCIERO Y PLAN DE ETAPAS

Fuente: Ayuntamiento de Valencia. Sección de Urbanismo. Negociado de Suelo y Ordenación urbana (Archivo de Planeamiento No 281-283). 

VALENCIA Y SU COMARCA A LA SOLUCION SUR

PROYECTO PARCIAL No 25 (Antiguo II romano, parte del I romano y el I-C).

En la adaptación y desarrollo de los Proyectos Parciales, el Plan General de Ordenación Urbana de Valencia y su Comarca a la Solución Sur, se ha tenido que hacer previamente una reconsideración de los espacios que los Planes Parciales aprobados comprendían y así el Proyecto Parcial que nos ocupa comprende el antiguo II romano, parte del I romano y el I-C.

Este proyecto queda relativamente poco afectado, excepto una vía de tráfico importante que afecta principalmente a la actual Cárcel Modelo, aprovechando esta circunstancia para emplazar en estos terrenos un centro comercial de importancia.

En lo que respecta al antiguo Proyecto Parcial I-C incluido en el presente proyecto, se ha respetado las alturas de edificios que figuraba en él, por dos razones fundamentales, $1^{a}$, porque en su inmensa mayoría, pues solo falta por construir tres edificios, están terminados o en avanzado estado de construcción, al parecer con licencia Municipal y, $2^{\circ}$ que si está justificado en algún sitio la ubicación de edificios en altura, es en este polígono, con fachada a la Av. De Castilla, de gran anchura y con calles particulares que no interfieren el tráfico de dicha vía.

Hemos tratado de ser realistas y conservadores en las zonas en donde la promoción de construcciones estaba iniciada, tratando en lo posible, de incluir las normas del Plan General de Adaptación en cuanto a aparcamientos, zonas de uso público y emplazamiento de edificios escolares.

Es fundamental en este Plan Parcial el viario obligado por el Plan General, en cuanto a su trazado se ha mantenido una coordinación con la Oficina Regional de Carreteras para la situación exacta de los accesos.

En la estructura mantenemos, en todo lo posible, lo existente en el Plan Antiguo con un criterio realista, conveniente para no dañar las parcelaciones que se pudieran haber ejecutado basadas en aquel. Las manzanas previstas antiguamente, se mantienen idénticas en las zonas en que se ha iniciado la construcción. En las aún libres de construcciones pero rodeadas de zonas ya construidas se han tratado de mejorar.

Los aparcamientos se han estudiado, siguiendo el criterio de un vehículo por cada seis familias. Esto se ha podido conseguir con cierta holgura en las zonas remodeladas y con mayor dificultad en las ya construidas.

La superficie total que abarca este Plan parcial es de un total de $915.350 \mathrm{~m} 2$.

A continuación se expresa un resumen de superficies:

Superficie edificable con promedio de cinco alturas........ 303.725 m2

Superficie edificable con promedio de siete alturas......... 14.850 "

Superficie construida para una altura............................... 106.997 "

Aparcamiento....................................................................... 48.829 "

Zona verde de uso público.................................................. 19.402 "

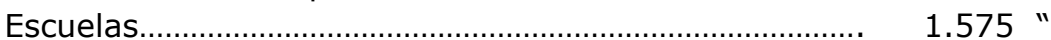

Zona verde en escuelas...................................................... 6.475 "

Zona verde en viales....................................................... 8.035 " 
Edificación en centro Parroquial.

Parcela propiedad de la Sociedad Española de

Automóviles de Turismo S.A. (S.E.A.T.).

Parcela propiedad del Colegio Pureza de María.

Superficie en viales...... $361.732 "$

Total.

Creemos conveniente señalar que lindando este polígono, en una parte importante en longitud, con al actual cauce del río que según la Solución Sur desaparece como tal cauce, gran parte de los terrenos ocupados por él podrán ser destinados a zonas verdes o de aparcamientos si ello fuera necesario y las necesidades futuras lo hicieran aconsejable. ción:

Los planos que se adjuntan son los relacionados a continua-

Plano no 1.- Plano de relación con la comarca

" no 2.- Situación en el Plan General

" no 3.- Delimitación y Estado Actual

" no 4.- Estructura Urbanística

" no 5.- Zonificación

" no 6.- Red viaria

" no 7.- Esquema red de alcantarillado (a)

" no 7.- Esquema red de agua potable (b)

" no 7.- Esquema de red de energía eléctrica (c)

El sistema de ejecución, mientras el Exm. Ayuntamiento no decida otro más adecuado, será el tradicional de servidumbre de alineaciones con cesión de viales.

Será posible también el de reparcelación.

Valencia, Abril de 1967

El Arquitecto,

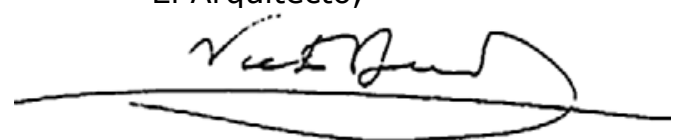


1. PLANO DE RELACIÓN CON LA COMARCA Escala original: $1: 25.000$

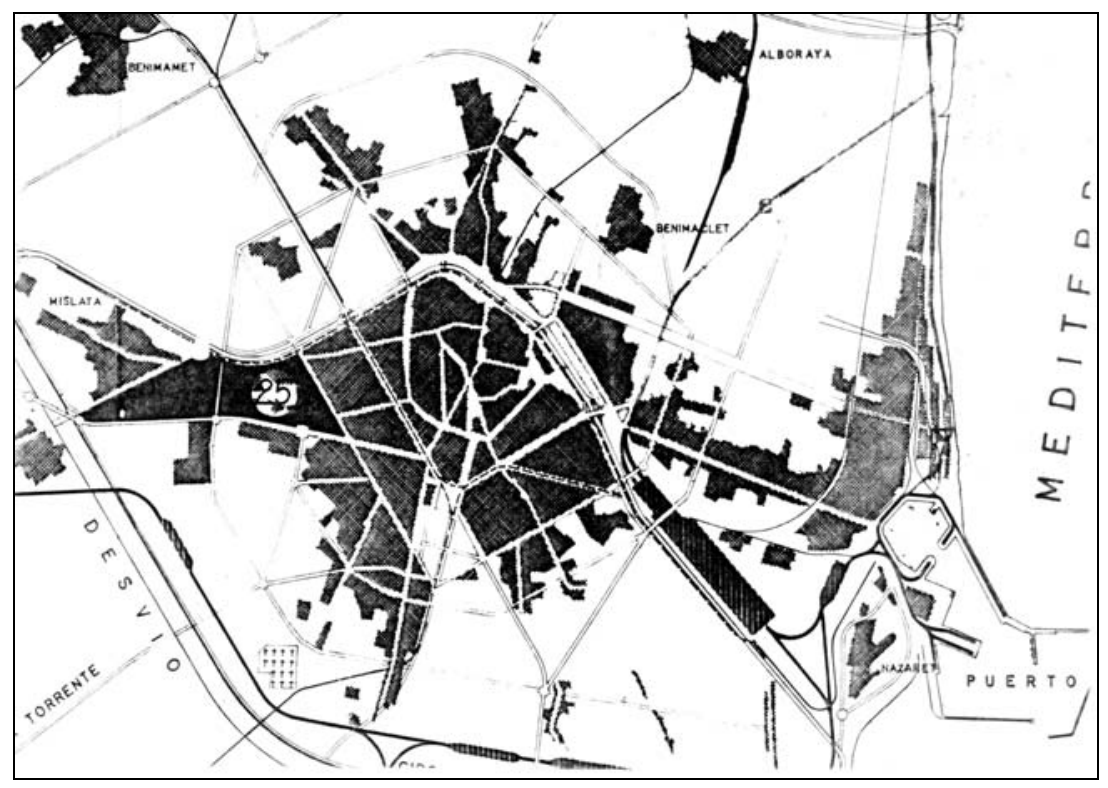

2. PLANO DE SITUACIÓN EN EL PLAN GENERAL (Fragmento) Escala original: $1: 10.000$

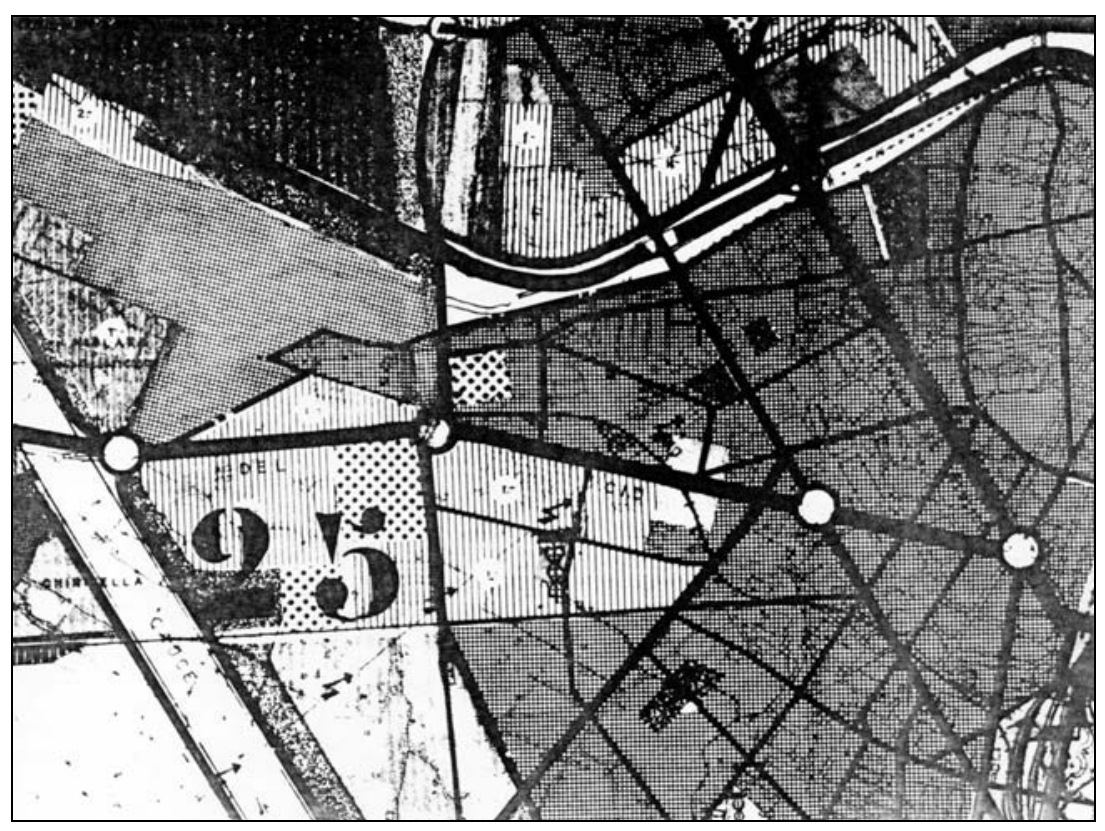


4. ESTRUCTURA URBANÍSTICA (Fragmento)

Escala original: 1:2000

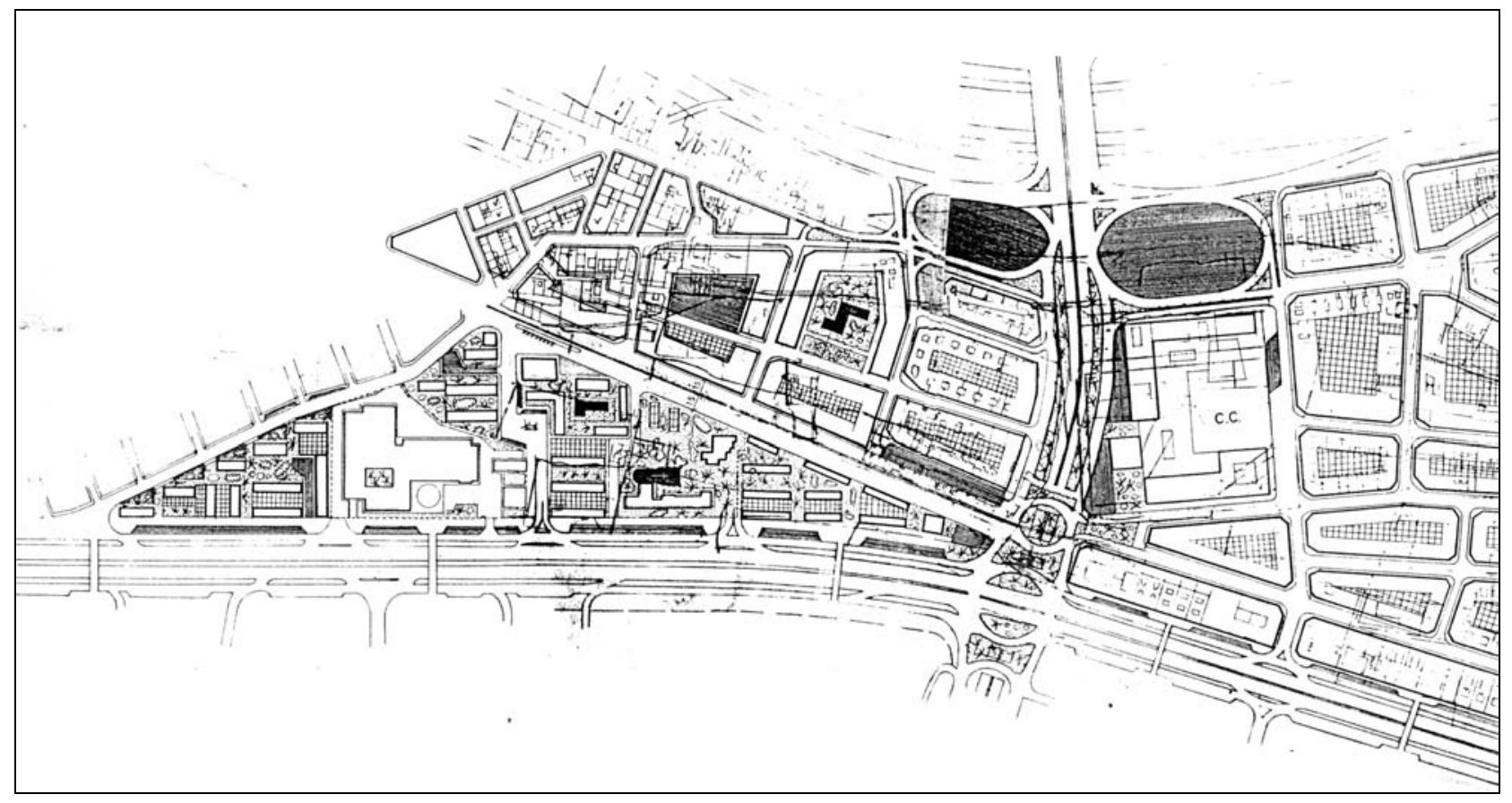

5. ZONIFICACIÓN.

Escala original: 1:2000

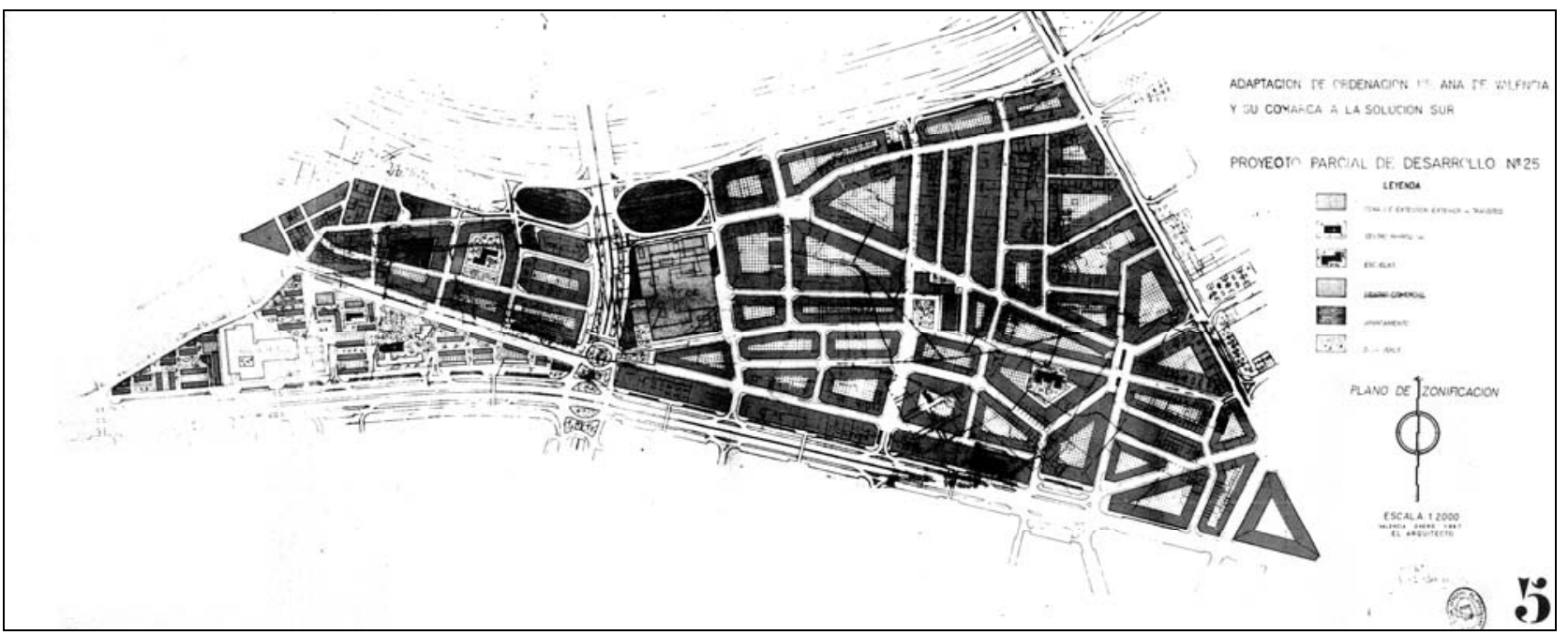


6. RED VIARIA (Fragmento).

Escala original: 1:2000

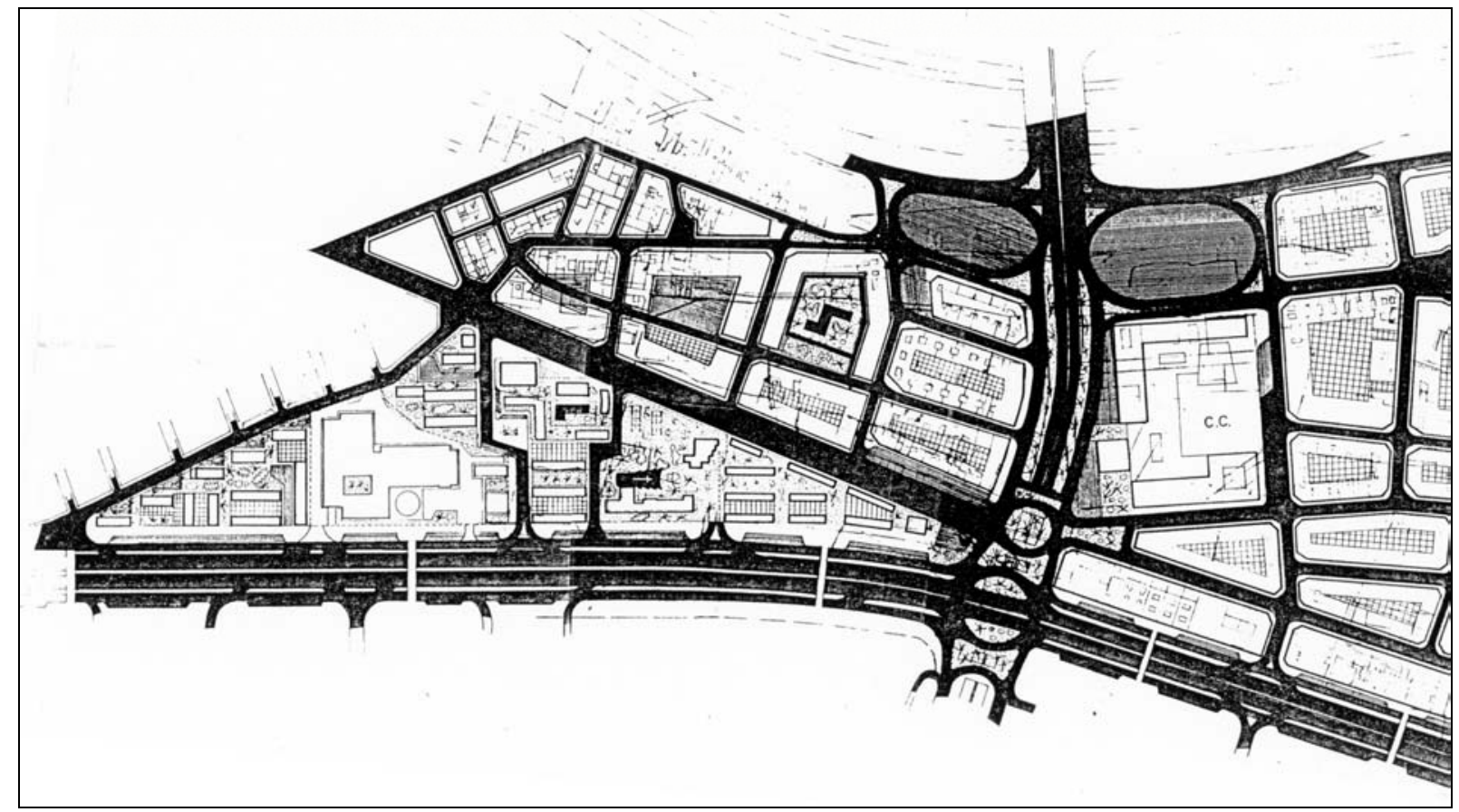




\section{PP 26}

Redactores: Excmo. Ayuntamiento de Valencia. Oficina Técnica Municipal de Urbanismo.

Fecha redacción: Febrero 1967.

Fecha aprobación 5-02-1970 (Aprobación inicial Ayuntamiento). Contenido:

1. PLANO DE RELACIÓN CON LA COMARCA $1: 25.000$

2. SITUACIÓN EN EL PLAN GENERAL

3. ESTADO ACTUAL Y DELIMITACIÓN

4. ESTRUCTURA URBANÍSTICA

$1: 2000$

5. ZONIFICACIÓN

$1: 2000$

6. RED VIARIA

$1: 2000$

7. REDES FUNDAMENTALES DE SERVICIO. 7.A. ESQUEMA DE ALCANTARILLADO

7.B. ESQUEMA DE ALUMBRADO

7.C. ESQUEMA DE RED DE AGUAS POTABLES. $1: 2000$

8. MEMORIA

9. ORDENANZAS

10. ESTUDIO ECONÓMICO-FINANCIERO Y PLAN DE ETAPAS

Fuente: Ayuntamiento de Valencia. Sección de Urbanismo. Negociado de Suelo y Ordenación urbana (Archivo de Planeamiento. Sección de expedientes antiguos). 


\section{ADAPTACION DE ORDENACION URBANA DE VALENCIA Y SU COMARCA A LA SOLUCION SUR}

\section{PROYECTO PARCIAL DE DESARROLLO NO 26}

\section{Memoria descriptiva}

Debido a la adaptación del Plan General de Ordenación Urbana de Valencia y su Comarca a la Solución Sur, que introdujo o solo el cambio del curso del río sino nuevos trazados de carreteras, accesos, enlaces, nuevas zonificaciones, etc., se ha considerado necesaria la revisión de los planos aprobados formando tres grupos 10 Plano no afectado por esta Solución Sur, $2^{\circ}$ poco afectados y $3^{\circ}$ muy afectados.

El plano no 26 objeto de este Proyecto, proviene del antiguo no I pero con objeto de tener los límites más claros la parte situada al Norte de la Avenida del Cid pasa a constituir otro plano junto al antiguo II. Por tanto el no 26 que se considera como muy afectado debido a que cambia dos grandes zonas que pasa de industrial y zona Jardín a extensión exterior a tránsitos, quedará limitado por: Avenida del Cid, Perez Galdós, Prolongación calle de Cuenca y la Ronda Exterior.

Dentro de este plano no 26 queda englobado el polígono de la Avenida de Castilla que lleva la Gerencia de Urbanismo y los terrenos de Aviación.

Vías principales.- Tangenciales: Avenida del Cid, Ronda Exterior y Avda. de Pérez Galdós.

Queda atravesado por la vía formada por parte de la calle Tres Forques, y Continuación de Archiduque Carlos (Camino Nuevo de Picaña). Con menor importancia la calle Archiduque Carlos. Todas estas vías van de este a oeste. De Norte a Sur aproximadamente calles Salavert-Venerable Agnesio-Enguera, Calles n० 2-n०8, y calles no $1-n^{0} 6-n^{0} 7$.

Plan Parcial.- El Plan Parcial se ha desarrollado respetando totalmente las directrices del Plan General, tanto en zonificación como en el trazado de vías importantes.

Se ha respetado al máximo la zona construida así como el Polígono de la Gerencia de Urbanismo y los terrenos de Aviación.

Existe un sector casi totalmente construido comprendido entre la Avda. del Cid, Perez Galdós, Prolongación Cuenca, Salavert, Venerable Agnesio y Enguera, por lo que se ha respetado al como está siendo muy difícil sin causar graves perjuicios, el establecer edificios públicos, escuelas, centros comerciales, grandes aparcamientos, etc. No obstante se ha procedido a un ensanchamiento de la Plaza de Patraix para resolver las comunicaciones.

Así se ha procedido a una remodelación de las zonas en que por cambiarse la zonificación, se han transformado totalmente estableciéndose los correspondientes aparcamientos, grupos escolares, zonas comerciales, Iglesias y zonas deportivas, tal como se aprecia en los planos que se acompañan.

Se han proyectado los esquemas de los servicios de agua potable, alcantarillado y alumbrado público.

Se acompañan los siguientes documentos que determina la Ley del Suelo:

10.- Plano de Situación general en la Comarca.

20.- Plano de situación en el Plan Geneal. 
30.- Plano de estado actual y delimitación.

40.- Plano de estructura urbanística.

50.- Plano de zonificación.

60.- Plano de red viaria

70.- Plano de redes fundamentales de Servicio.

80.- Memoria

90.- Ordenanzas Municipales y

$10^{\circ}$.- Plan de etapas.

Valencia, Febrero de 1.967

EL ARQUITECTO;

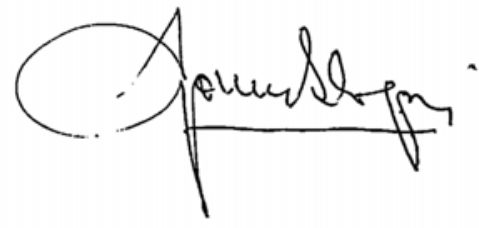


5. ZONIFICACIÓN.

Escala original: 1:2000

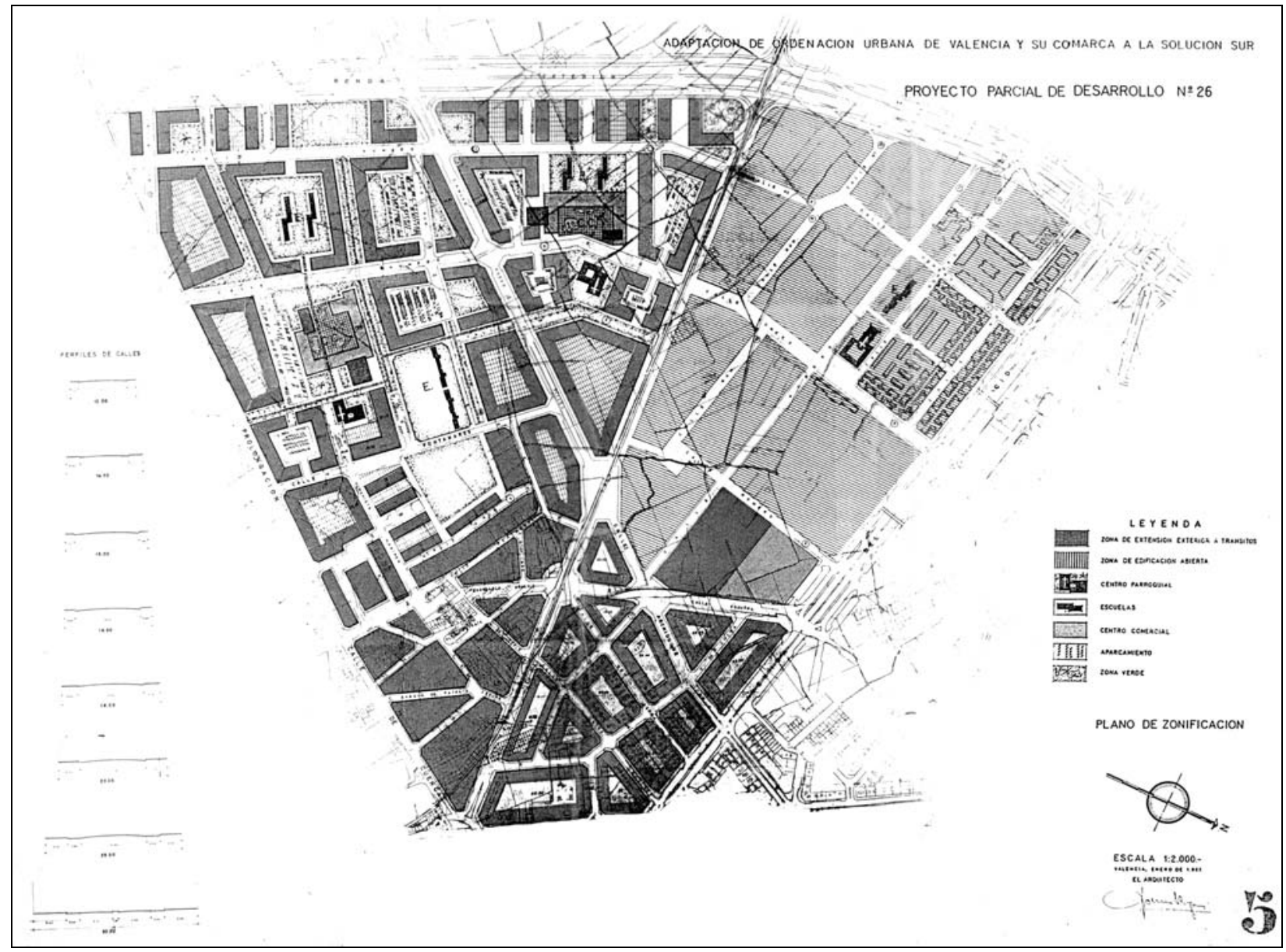

LE YEN DA

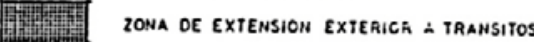

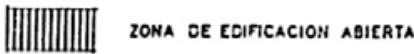

保然武 CENTRO PARRCQUIAL

Escuetas

CENTRO comereial

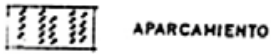

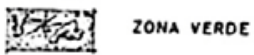

PLANO DE ZONIFICACION 


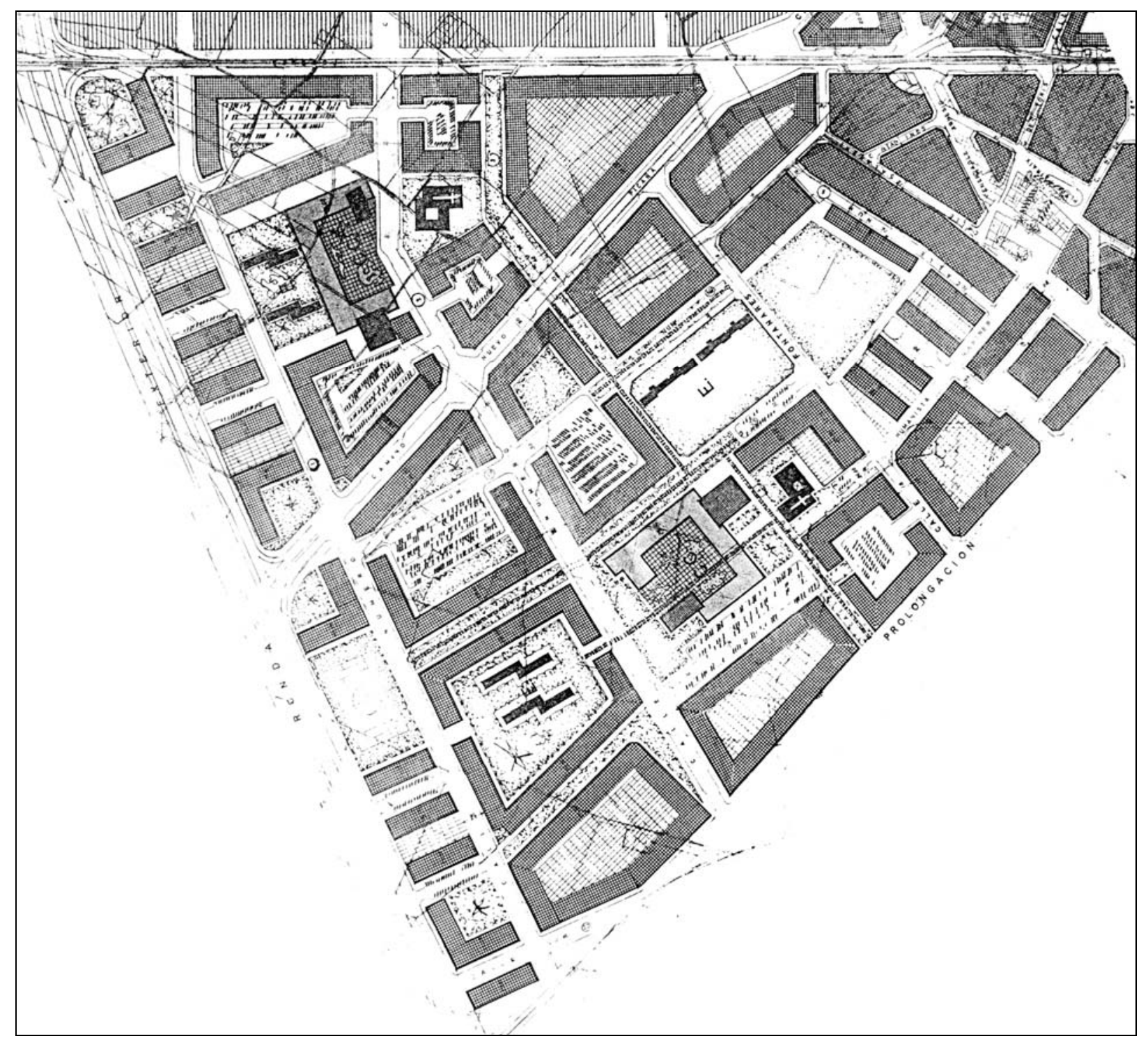

Detalle del plano de zonificación. 



\section{PP 26}

PLANO PARCIAL No 26 (ADAPTADO A LA SOlUCIÓN SUR).

1973.

Redactores: EXCMO. AYUNTAMIENTO DE VALENCIA. OFICINA TÉCNICA DE URBANISMO.

Fecha redacción: Febrero 1973.

Fecha aprobación: O.M. 23-09-1974 (B.O.E. 25-10-74) (*).

\section{Contenido:}

I. MEMORIA

II. ORDENANZAS.

III. PLAN DE ETAPAS

\section{PLANOS:}

1. PLANO DE SITUACIÓN DENTRO DE LA CIUDAD. $1: 10.000$

2. SITUACIÓN EN EL PLAN GENERAL $1: 22.500$

3. INFORMACIÓN Y FOTO AÉREA $1: 2000$

4. ZONIFICACIÓN $1: 2000$

5. ESTRUCTURA URBANÍSTICA $1: 2000$

6. ALINEACIONES $1: 2000$

7. RED VIARIA FUNDAMENTAL $1: 2000$

8. REDES FUNDAMENTALES DE SERVICIOS.
RED DE ALCANTARILLADO
7:2000

ESQUEMA DE RED DE AGUAS POTABLES $\quad 1: 2000$

ESQUEMA DE ALUMBRADO. $1: 2000$

\section{Fuente:}

Ayuntamiento de Valencia. Sección de Urbanismo. Negociado de Suelo y Ordenación urbana. Expte. 285/1973 (Archivo de Planeamiento No 154).

\section{Notas:}

* El PP 26 no sufrió ninguna modificación relevante en las dos rondas de alegaciones, antes y después de la aprobación inicial. 
EXCMO. AYUNTAMIENTO DE VALENCIA

OFICINA TÉCNICA DE URBANISMO

PLAN PARCIAL No 26

(adaptado a la Solución Sur)

\section{MEMORIA}

1.1.- El Plan Parcial no 26 objeto de este Proyecto, proviene del antiguo Plan Parcial No I, aprobado por la Comisión Central de Sanidad en 15 de marzo de 1950, al adaptar el Plan General de Valencia y su Comarca a la Solución Sur.

Está limitado por: Avenida del Cid, Avenida Pérez Galdós, Prolongación calle de Cuenca y la Ronda Exterior.

Dentro de este Plan Parcial No 26 se halla enclavado el Polígono de la Avenida de Castilla que lleva la Gerencia de Urbanismo.

\section{2.- ZONIFICACIONES}

La Solución Sur ha afectado notablemente al Plan Parcial No 26 en lo que se refiere a zonificación con respecto al Plan General anterior. Desaparecen la Zona Industrial y la de Ciudad Jardín.

Zonificaciones:

El nuevo Plan General determina las siguientes

\subsubsection{ZONA DE EXTENSIÓN EXTERIOR A TRÁNSITOS.}

Está limitada por la Avenida del Cid, Avenida de Pérez Galdós, calle de Cuenca y su Continuación (Pio XII y Campos Crespo), Ronda Exterior, calle límite con el Polígono de la Avenida de Castilla, calle Archiduque Carlos y calle de Enguera.

\subsubsection{ZONA DE EDIFICACIÓN ABIERTA.} Comercial.

Comprende el resto del Plan, a excepción del Centro

En esta zona se halla el Polígono de Castilla anteriormente citado. El resto de edificación abierta, con el fin de solucionar el problema que tenía la ciudad, consecuencia de la riada en 1.957, se edificó con anterioridad a la aprobación del Plan General adaptado a la Solución Sur.

Enclavado en esta zona y junto a la futura Ronda Exterior, hay una edificación tratada como manzana cerrada casi totalmente construida.

PLAN PARCIAL.- El Plan Parcial se ha desarrollado respetando totalmente las directrices del Plan general, tanto en zonificación como en el trazado de vías importantes.

Se ha respetado al máximo la zona construida en Patraix, así como el Polígono de la Gerencia de Urbanismo y los terrenos de Aviación.

Existe un sector casi totalmente construido, comprendido entre la Avenida del Cid, Pérez Galdós, Prolongación Cuenca, Salavert, Venerable Agnesio y Enguera, por lo que se ha respetado tal como está, siendo muy difícil, sin causar graves perjuicios, el establecer edificios públicos, escuelas, centros comerciales, grandes aparcamientos, etc., que junto con lo exigido por las ordenanzas 
municipales en cada uno de los edificios, resolverán el problema de estacionamiento de vehículos. No obstante, se ha procedido a un ensanchamiento de la Plaza de Patraix para resolver las comunicaciones.

Asimismo se han remodelado las zonas que por cambiarse la zonificación anterior, se han transformado totalmente estableciéndose los correspondientes aparcamientos, grupos escolares, zonas comerciales y zonas deportivas, tal como se aprecia en los planos que se acompañan.

Las superficies son:

- Superficie Plan Parcial.

- Superficie de zonas verdes

- En cuanto a la reserva de Escuelas, Han sido previstos:

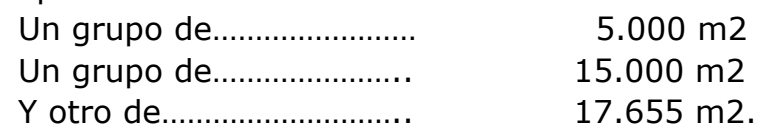

Se han proyectado los esquemas de los servicios de agua potable, alcantarillado y alumbrado público.

Se acompañan los siguientes documentos, que determina la vigente Ley del Suelo.

10) Plano de Situación general en la Comarca.

$2^{\circ}$ ). " " en el Plan General.

$3^{\circ}$ ). " " de estado actual y limitación.

$4^{\circ}$ ). " " de estructura urbanística.

$\left.5^{\circ}\right)$. “ de Zonificación.

$\left.6^{\circ}\right)$. “ de Red viaria.

$7^{\circ}$ ). “ de redes fundamentales de servicios.

$\left.8^{\circ}\right)$ Memoria.

$\left.9^{\circ}\right)$ Ordenanzas Municipales, y

10) Plan de Etapas.

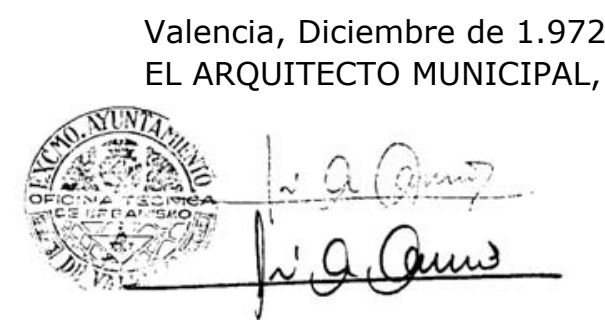




\section{ORDENANZAS.}

En tanto no se aprueben las Ordenanzas Generales para la edificación en el territorio de este Municipio, y dado que el estudio de ellas solamente para este Plan parcial no es conveniente, regirán las Ordenanzas Municipales de $1.950-55$ en todo lo que no contradigan a las normas urbanísticas del Plan general.

Valencia, Diciembre de 1.972

EL ARQUITECTO MUNICIPAL,

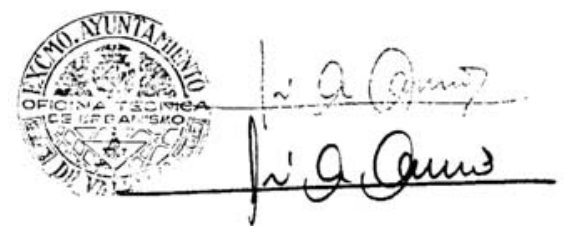


PROYECTO PLAN PARCIAL NO 26

\section{III.- PLAN DE ETAPAS.}

El Plan parcial No 26, bastante construido en la actualidad por particulares, deberá seguir el mismo ritmo por lo cual no se puede marcar plan de etapas de realización, pues dependerá de la actividad constructiva.

El Excmo. Ayuntamiento, además de construir los elementos urbanísticos generales, se mantendrá siempre en la urbanización adelantado sobre la iniciativa.

\section{MEDIOS ECONÓMICOS FINANCIEROS}

Son los del presupuesto ordinario de Urbanismo del Excmo. Ayuntamiento de Valencia y los extraordinarios que se establezcan a medida que se cumpla lo dicho en el párrafo anterior y se disponga de proyectos detallados de urbanización.

Con lo dicho creemos suficientemente expuesto el alcance del estudio realizado para que, si el Excmo. Ayuntamiento lo estima conveniente, lo eleve a la aprobación por la Superioridad.

Valencia, Diciembre de 1.972

LOS ARQUITECTOS,

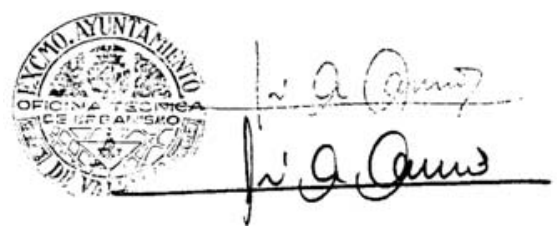


1. PLANO DE SITUACIÓN EN LA CIUDAD Escala original: $1: 10.000$

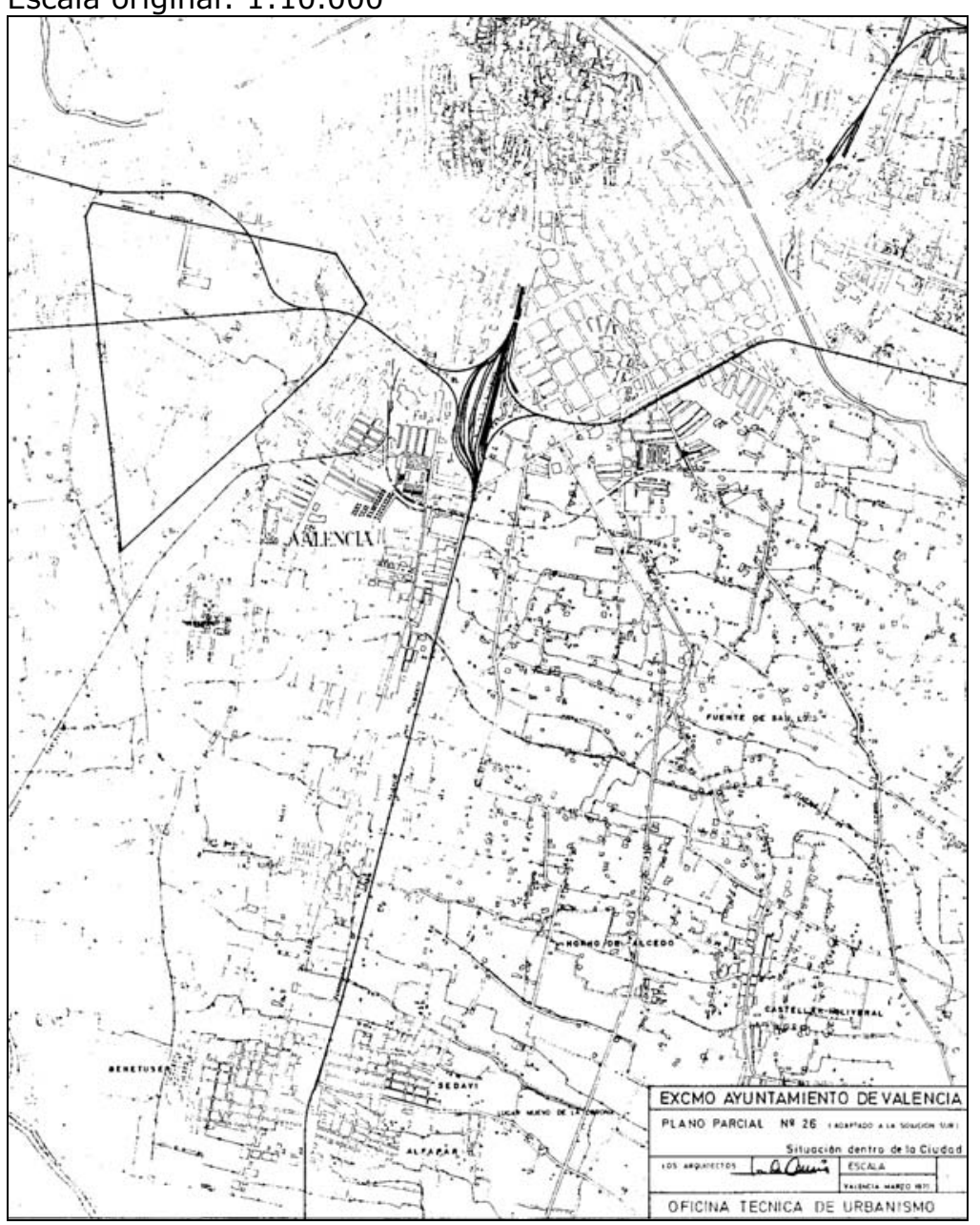

2. PLANO DE SITUACIÓN EN EL PLAN GENERAL (Fragmento) Escala original: $1: 22.500$

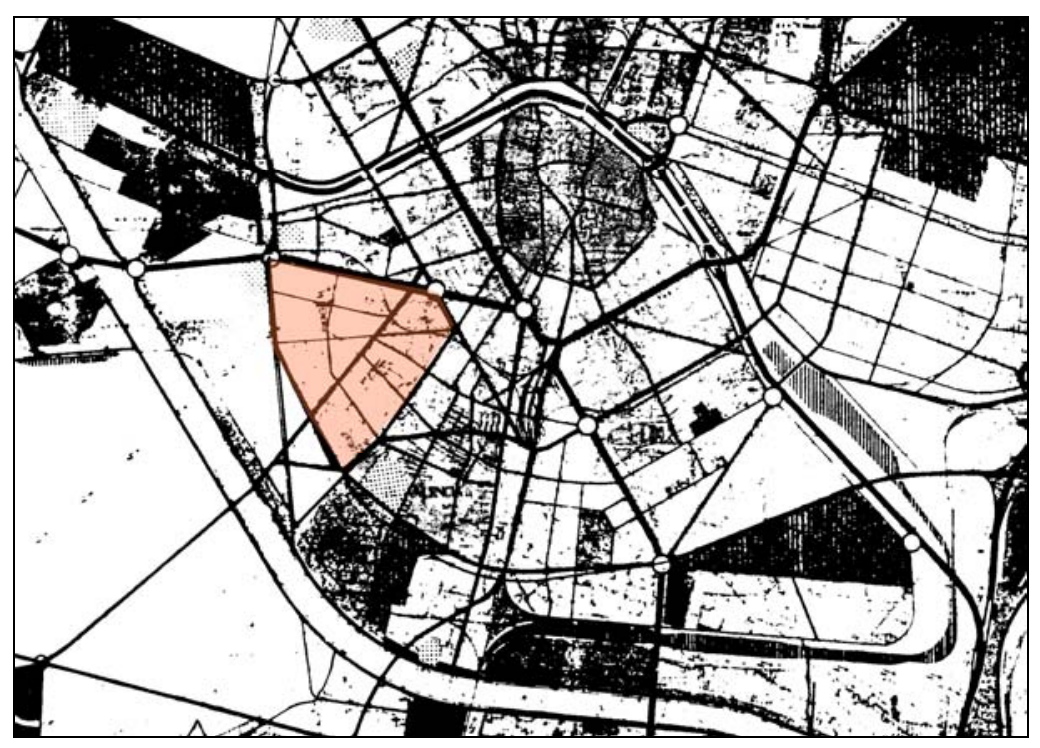


4. ESTADO ACTUAL Y DELIMITACIÓN

Escala original: 1:2000

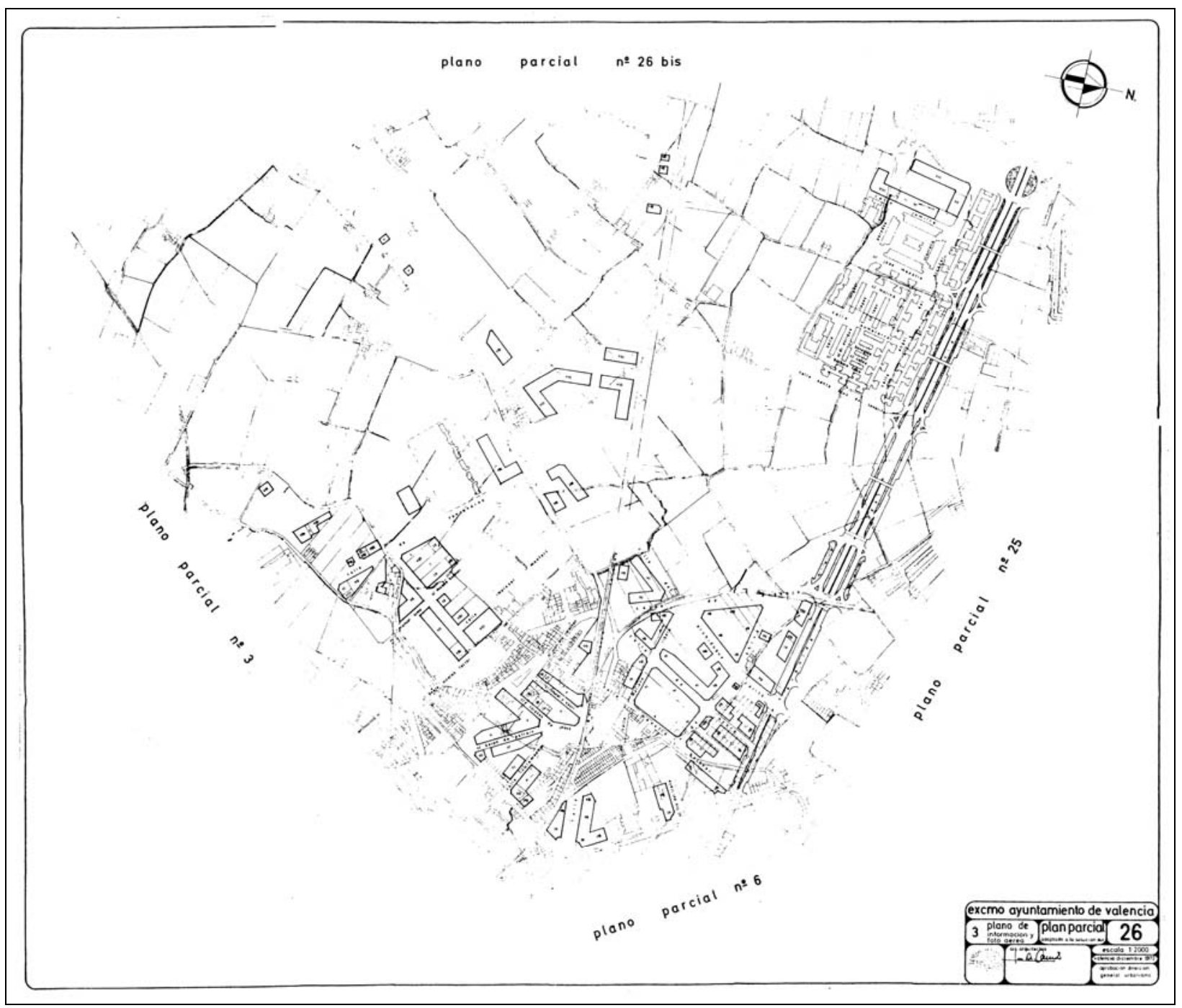


7. RED VIARIA FUNDAMENTAL

Escala original: 1:2000

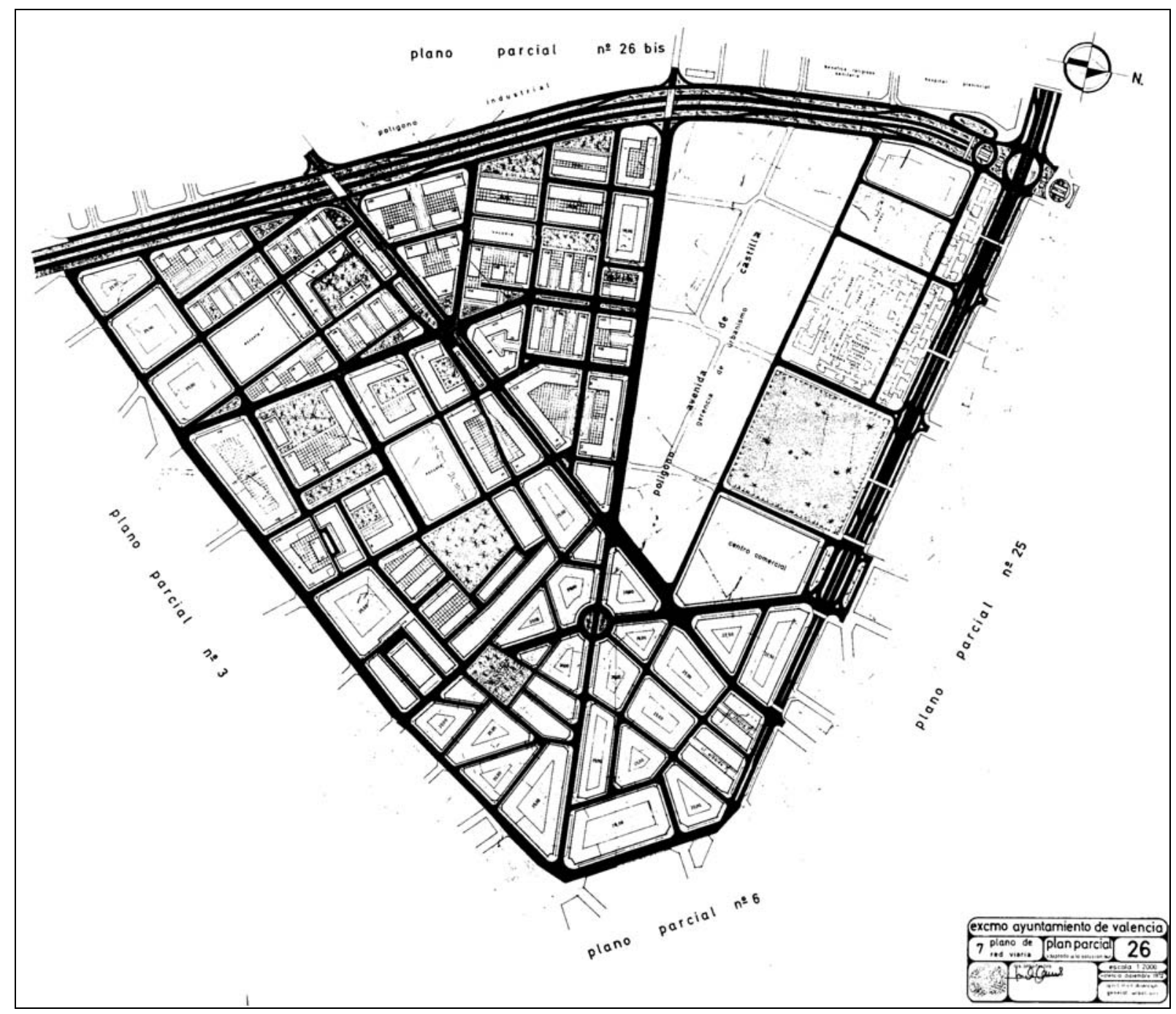


8. ALINEACIONES Y RASANTES.

Escala original 1:2000

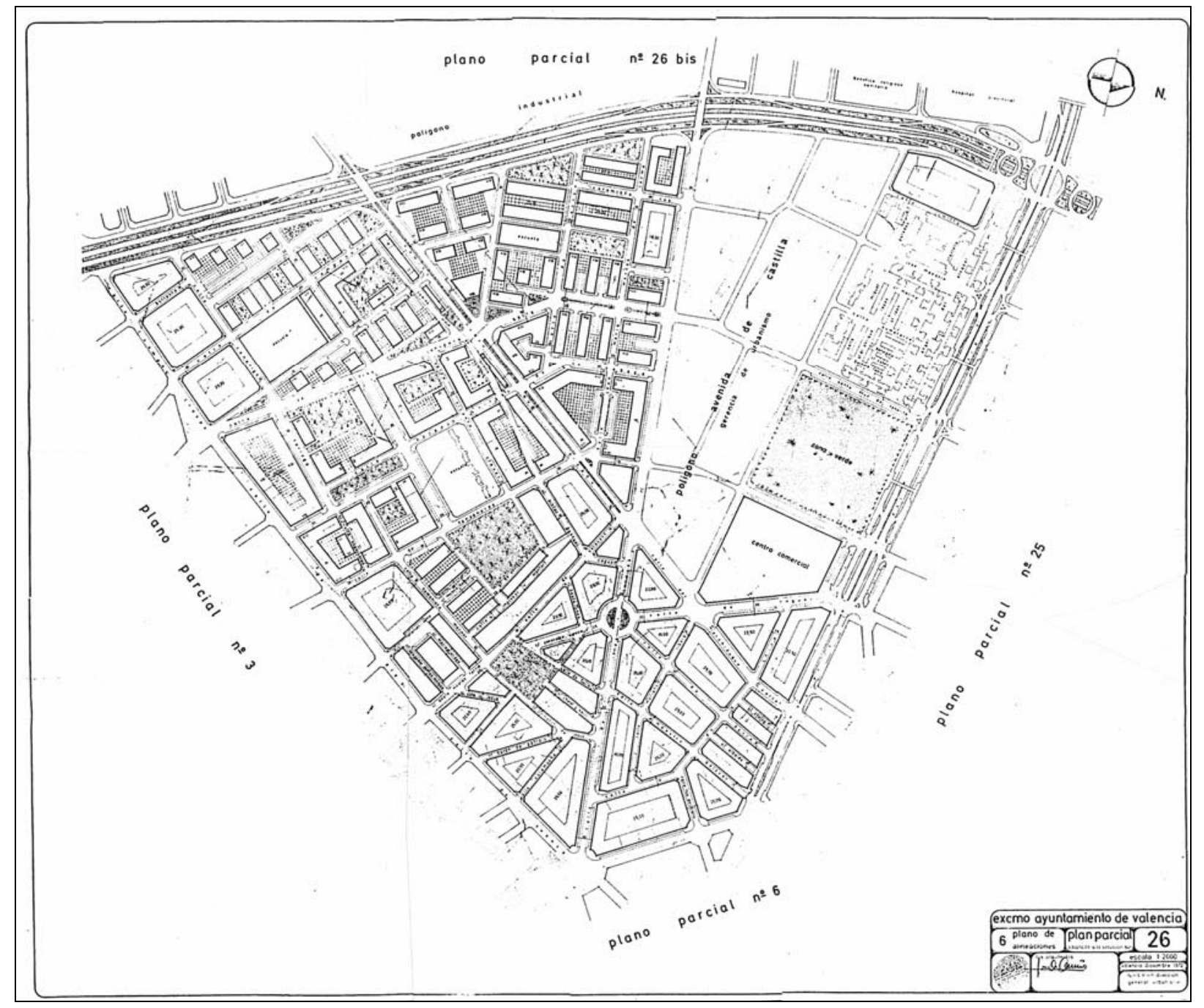




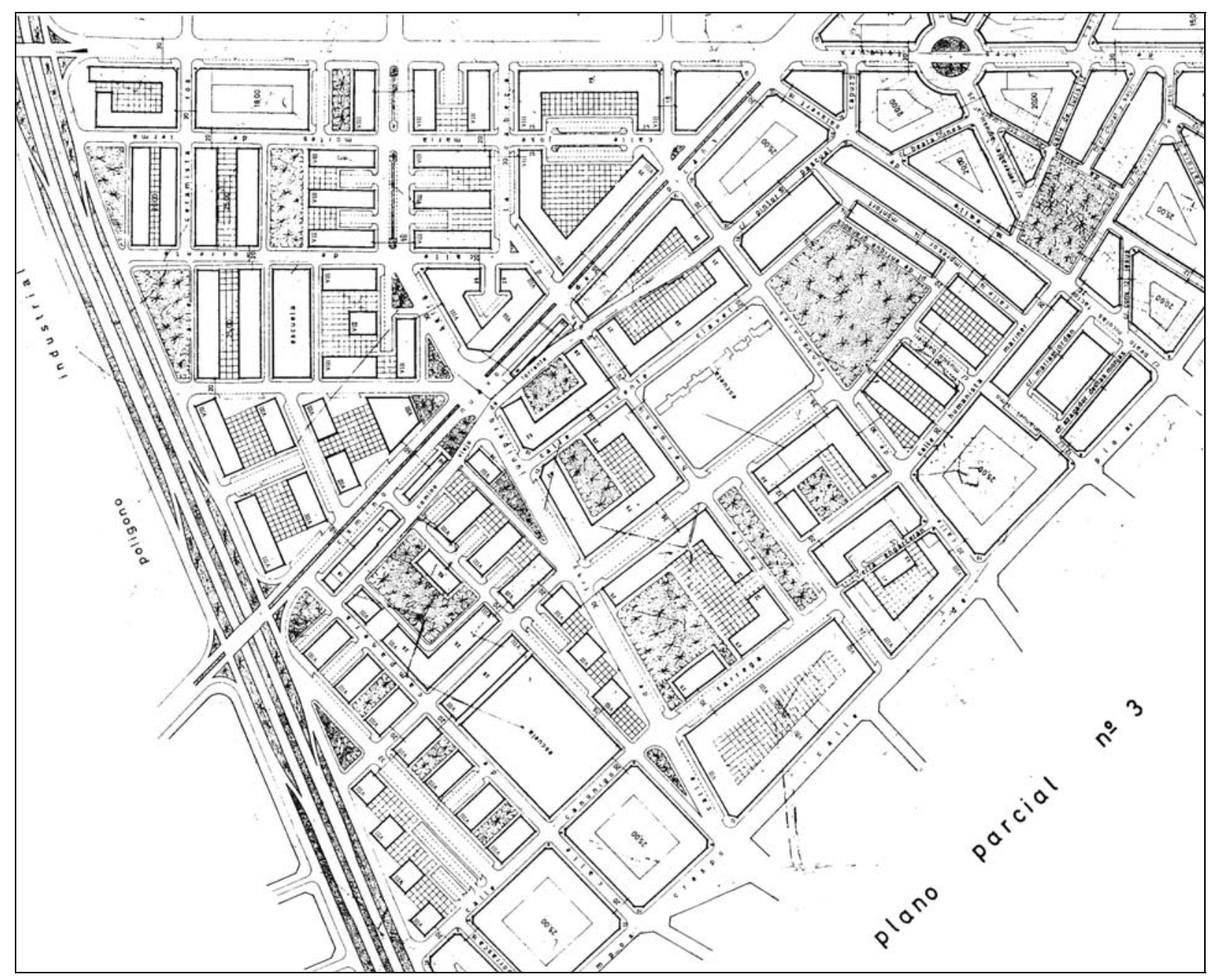

Detalle del Plano de alineaciones. 
Redactor: Dirección General de Urbanismo del Ministerio de la Vivienda / Ministerio de la Vivienda.

Fecha: 23- 09-1974.

Asunto: Resolución de aprobación del Plan Parcial 26 con modificaciones y exclusiones.

Fuente: Ayuntamiento de Valencia. Sección de Urbanismo. Negociado de Suelo y Ordenación urbana. Expte. 285/1973 (Archivo de Planeamiento No 154).

\section{MINISTERIO DE LA VIVIENDA}

Iltmo Sr.:

VISTO el Plan Parcial de Ordenación Urbana del Polígono núm. 26 de Valencia, presentado por el Ayuntamiento de dicha Capital.

VISTOS la Ley sobre Régimen del Suelo y Ordenación Urbana, de 12 de mayo de 1956, los Decretos 63/1968, de 18 de enero y $1994 / 72$, de 13 de julio y el informe emitido por los servicios competentes de la Dirección General de Urbanismo.

Este Ministerio Acuerda:

10) Aprobar, excepto en los extremos a que se refieren los apartados siguientes, $2^{\circ}$ y $3^{\circ}$ de esta resolución, el Plan Parcial precitado, con las rectificaciones siguientes:

a) Mantener la calificación de zona verde de uso público atribuida por el Plan Comarcal ala manzana limitada por las calles Fontanares, Vicente Clavel, Héroes de Virgen de la Cabeza, y vía de 36 metros que une las calles de Fray Junípero Serra y Fontanares, y que en la ordenación presentada aparece destinada a escuela, y

b) A efectos de previsión de aparcamientos, se fijará como mínimo una plaza por vivienda, y

$2^{\circ}$.-Se excluyen las ordenaciones propuestas para las manzanas limitadas por las calles Canónigo Tárrega, Fray Junípero Serra, campos Crespo y Ronda Exterior, y para las comprendidas entre la Av. Del Cid, Archiduque Carlos, Prolongación de la de Mariano Ribera, y límite Este de la zona verde, cuya aprobación se suspende a fin de que los terrenos que las constituyen sean objeto de unas nuevas ordenaciones en las que, respectivamente, la calle Campos Crespo tenga una anchura no inferior a 25 metros, que permita resolver el enlace de dicha calle con su prolongación, de manera que no interfiera el tránsito de la Ronda Exterior y se mantenga la situación y extensión prevista en el citado Plan Comarcal para el Centro Comercial, y se reserven terrenos para dotaciones escolares en proporción adecuada a la población prevista.

Las ordenaciones que se requieren en el apartado $2^{\circ}$ de esta resolución, se tramitarán con sujeción a lo dispuesto en el Arto. 32 de la Ley del Suelo, y se elevaran, por triplicado, a este Departamento en el plazo de seis meses, para su estudio y resolución definitiva.

La determinación sobre aparcamientos a que se refiere el apartado b) $1^{\circ}$ de esta resolución, se establecerá en el Plan Parcial de la forma que estime más oportuna el Ayuntamiento y la documentación correspondiente que la recoja, en unión de la que con 
tenga la modificación impuesta en el apartado a) $1^{\circ}$ de la presente, se remitirá también, por triplicado ejemplar, y en el aludido plazo de seis meses, para su debida constancia en este Departamento.

Esta resolución se notificará al Ayuntamiento de Valencia y se publicará en el Boletín Oficial del Estado.

Lo que comunico a V. I. para su conocimiento y efectos. Dios guarde a V.I.

Madrid, 23 de septiembre de 1.974

P.D.

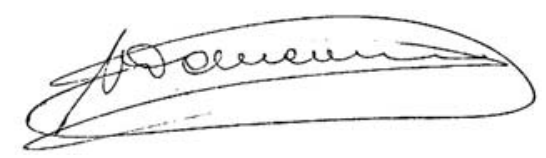

Ilmo. Sr. Director General de Urbanismo. 
Redactor: El Arquitecto Municipal. Ayuntamiento de Valencia.

Fecha: 23- 10-1974.

Asunto: Informe en respuesta a la resolución del Ministerio de la Vivienda sobre el PP26.

Fuente: Ayuntamiento de Valencia. Sección de Urbanismo. Negociado de Suelo y Ordenación urbana. Expte. 285/1973 (Archivo de Planeamiento No 154).

Sección TECNICA URBANISMO

Negociado PLANEAMIENTO URBANO

Excmo. Señor:

Leída la notificación del Ministerio de la Vivienda fechada en Madrid el 23 de septiembre de 1974, referente al Plan Parcial de Ordenación Urbana del Polígono No 26 de Valencia, tengo a bien informar, cono autor del estudio de dicho Plan Parcial, respecto a los Puntos siguientes:

10. a).- El Plan General califica como Zona Verde al espacio delimitado por las calles de Fontanares, Vicente Clavel, HéroesVirgen de la Cabeza y vía de 36 metros que une las calles de Fray Junípero Serra y Fontanares.

Este espacio es una escuela, existente hace bastante tiempo. Por lo tanto, considero inadecuado y costoso el suprimir la escuela para ser trasladada a otro lugar, ya que si el problema es de respetar el $10 \%$ de zonas verdes, este Plan Parcial mantiene dicho porcentaje.

10. b).- La previsión de aparcamientos se realiza en el propio edificio de viviendas. Por lo tanto, considero que ésto no es un reparo al Plan Parcial sino una medida preventiva que ya tenía en consideración el Ayuntamiento en sus Ordenanzas, ya que exije en el propio edificio una reserva de plazas de aparcamiento.

20. - Referente a mantener la calle de Carlos Crespo con una anchura no inferior a $25 \mathrm{mts}$., es un problema de ordenación de tráfico que no creo sea básico representarlo en el Plan Parcial ya que por dicha calle circula un ff.cc.de vía estrecha.

Respecto a las manzanas comprendidas entre la Avda. del Cid y Archiduque Carlos, prolongación de Mariano Ribera, considero que la forma del Centro Comercial existente en el Plan Comarcal no debe llevarse hasta el extremo de considerarlo como diseño de un centro comercial, ya que la manzana comprendida entre las calles citadas está en gran parte edificada y el espacio ocupado por ella es mínimo en comparación con el centro comercial que ya se reserva en el Plan Parcial. Por otra parte, las calles que la circundan están completamente urbanizadas y pavimentadas. Estimo, por tanto, que debe respetarse la forma que tiene en el Plan Parcial,

Dios guarde a V.E. muchos años.

Valencia, 23 de octubre de 1974

EL ARQUITECTO MUNICIPAL,

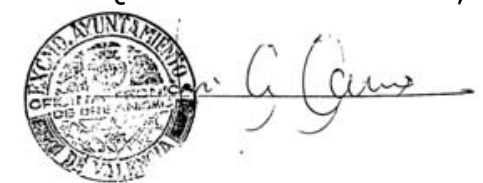

Excmo. Sr. Alcalde Presidente del Excmo. Ayuntamiento de Valencia. 
Redactor: Ayuntamiento de Valencia.

Fecha: 26- 10-1974.

Asunto: Recurso de reposición interpuesto al Ministerio de la Vivienda contra la resolución de 23-10-74 relativa al PP26.

Fuente: Ayuntamiento de Valencia. Sección de Urbanismo. Negociado de Suelo y Ordenación urbana. Expte. 285/1973 (Archivo de Planeamiento No 154).

\section{AL EXCMO. SR. MINISTRO DE LA VIVIENDA}

El Alcalde-Presidente del Excmo. Ayuntamiento de Valencia, actuando en representación del mismo, interpone en su nombre recurso de reposición contra la resolución de V.E. de 23 de octubre de 1974 por la que deniega la aprobación, respecto a varios sectores del Plan Parcial de Ordenación Urbana no 26 de Valencia, y a sus efectos somete a la consideración de V.E. las siguientes

\section{A LE G A C I O N E S}

Primera.- Se hace observar que según el propio Plan General de Ordenación Urbana de Valencia y su Comarca es posible cohonestar la calificación de zona verde de uso público con el destino a Escuela proyectado en el Plan Parcial.

Dejemos a un lado el hecho de que tal destino es anterior al Plan General y que el Plan Parcial ya cubre -sin ese sector- el $10 \%$ mínimo exigido por la legislación vigente como zona verde.

Además de ello significamos que la Norma 31, es decir, el propio Plan General (ya que las Normas Urbanísticas son uno de sus elementos componentes según art. 9-d) de la Ley del Suelo) permite construcciones en las zonas verdes de carácter público, siempre que su volumen no exceda de un $\mathrm{m} 3$ por cada $5 \mathrm{~m} 2$. En consecuencia es posible según el Plan General la construcción de referencia siempre que respete el volumen autorizado.

Segunda.- En cuanto se refiere al ancho de la calle Campos Crespo sugerimos que el Plan Parcial debe considerar las situaciones de hecho ya existentes para conseguir la máxima viabilidad de la nueva ordenación urbanística y, en este caso, como indica el Arquitecto municipal se trata de "un problema de ordenación de tráfico que no cree sea básico representarlo en el Plan Parcial ya que por dicha calle circula un ff.cc. de vía estrecha."

Tercera.- La misma alegación fáctica puede repetirse en el problema del Centro Comercial pues, según el Arquitecto municipal, las calles que lo circundan -nos referimos a la pequeña parte no incluida en dicho Centro- constituyen una manzana en gran parte edificada, resaltando que dichas calles están completamente urbanizadas y pavimentadas.

Significamos que las previsiones urbanísticas del Plan General son meramente indicativas y han de ser desarrolladas por los Planes Parciales que marcan para cada zona su alineación, altura, volumen y destino o uso. Invocamos el art. 10 de la Ley del Suelo que en su epígrafe 1. e), previene que los Planes Parciales contendrán, entre otros extremos, la "reglamentación del uso de los terrenos".

Luego la regulación específica de cada sector, la atribuye el legislador a los Planes Parciales. En efecto, el Tribunal Supremo, en sentencia de 27 de junio de 1964 ha sentado doctrina, según la cual 
el Plan General es la base de la orientación del suelo, y solamente puede trazar los principios fundamentales, correspondiendo al Plan Parcial la concreción del volumen y aprovechamiento del suelo para cada zona del Plan General.

Debe considerarse que el Plan General señala directrices indicativas para cada zona y es propio del Plan Parcial distribuir los volúmenes señalando zonas verdes, escuelas, mercados, iglesias, campos deportivos, viviendas, aparcamientos, etca, etc, es decir, que la norma indicativa permitida se distribuye entre las edificaciones señaladas por el Plan Parcial.

Es pues, evidente, que el Plan Parcial distribuye el volumen autorizado para la zona, señalando espacios libres y características y ubicación de edificaciones públicas y privadas que, necesariamente, por su finalidad, han de tener volumetría diferente.

Conviene consignar también que es propósito del legislador no considerar que existe modificación del Plan General cuando al ser desarrollado en Planes Parciales se interpreten sus determinaciones mediante reajuste del trazado de vías de comunicación PARA ADAPTARLAS AL TERRENO y, en su caso, de alineaciones y rasantes, precisión de límites de las diversas zonas, cambio de tipo de ordenanzas de edificación que no altere esencialmente el uso previsto ni suponga variación superior al $5 \%$ en el aprovechamiento del suelo (art. 27, párrafo 2, del Decreto de 28 septiembre 1964), considerando sin duda que resulta prácticamente imposible al replantear sobre el terreno conseguir una exacta coincidencia con las líneas proyectadas en un Plan General que además de ser solamente indicativo se redacta a escala $1: 10.000$.

A mayor abundamiento el Tribunal Supremo ha sentado doctrina según la cual es admisible incluso la modificación del Plan Comarcal al desarrollarse en Planes Parciales (sentencias 8 febrero 1969, 17 mayo, 22 noviembre 1963, 14 mayo 1964, etca, etc.).

En su virtud,

SUPLICO A V.E. acuerde estimar este recurso revocar la parte de la resolución impugnada y aprobar definitivamente todo el Plan Parcial de Ordenación Urbana no 26 de Valencia propuesto por el Ayuntamiento de esta ciudad.

Valencia, 26 de Octubre de 1974.

EL ALCALDE, 
Redactor: Subsecretaría. Servicio Central de Recursos. Ministerio de Obras Públicas y Urbanismo.

Fecha: 22- 09-1977.

Asunto: Resolución sobre el Recurso presentado por el Ayuntamiento de Valencia relativo al PP 26.

Fuente: Ayuntamiento de Valencia. Sección de Urbanismo. Negociado de Suelo y Ordenación urbana. Expte. 285/1973 (Archivo de Planeamiento No 154).

MINISTERIO DE OBRAS PUBLICAS Y URBANISMO
SUBSECRETARÍA
SERVICIO CENTRAL DE RECURSOS
FS/alb
439/77

Estudiado el presente recurso, este Servicio Central tiene el honor de someter a V.E. la siguiente propuesta de resolución:

"Visto el recurso de reposición interpuesto por el AlcaldePresidente del Excmo. Ayuntamiento de Valencia, contra la Orden Ministerial de 23 de septiembre de 1.974, que aprobó con rectificaciones el Plan Parcial de Ordenación Urbana del Polígono $n^{\circ} 26$ de Valencia, y

RESULTANDO: Que el interesado, en su escrito de recurso, solicita se revoque en parte la resolución impugnada y se apruebe definitivamente el Plan Parcial propuesto por el Ayuntamiento, formulando cuantas alegaciones estima oportunas en defensa de su pretensión.

RESULTANDO: Que la Dirección General de Urbanismo y la Asesoría Jurídica del Departamento han emitido sus respectivos informes oportunamente solicitados.

CONSIDERANDO: Que el escrito de recurso reúne todas las condiciones adjetivas para su admisibilidad, al ser el recurso procedente a la vista del artículo 52 de la Ley sobre la Jurisdicción Contencioso-Administrativa e interpuesto dentro del plazo legal de un mes, por persona legitimada para ello, procede entrar a conocer sobre las cuestiones de fondo planteadas en el mismo.

CONSIDERANDO: Que el Ayuntamiento impugna el apartado $1^{\circ}$ a) de la resolución de 23 de septiembre de 1.974 , alegando la posibilidad de hacer compatible la calificación de zona verde de uso público con el destino a Escuela proyectada en el Plan Parcial, en la manzana a la que se refiere la resolución, en virtud de la Norma 31 del Plan General de Valencia, que permite construcciones en las zonas verdes de carácter público, siempre que su volumen no exceda de $1 \mathrm{~m} 3$ por cada $5 \mathrm{~m} 2$; consultado el Plan General se observa, que la citada Horma, no permite construcciones para uso escolar, ya que las construcciones a las que se refiere, lo son con destino a restaurantes, bares y teatros al aire libre, zonas-deportivas y en general construcciones de tipo recreativo, especificando además que estas construcciones se podrán interpolar cuando sena compatibles con el destino de uso público del Parque, y el destinar la parcela de referencia a escuela supondría desvirtuar el uso atribuido por el Plan General y desde la normativa aplicable al Plan Parcial objeto de re 
curso, que es la Ley del Suelo de 12 de mayo de 1956, los espacios libres para parques y jardines públicos han de establecerse, según el artículo $3^{\circ}$, en proporción adecuada a las necesidades colectivas, y los Planes Generales, como instrumentos de ordenación integral de los términos municipales, deben establecer un sistema de espacios libres equilibrado en función de los núcleos de edificación y suficientes para la normal expansión de la vida humana, por lo que cualquier supresión de una zona verde, de un Plan de Ordenación, debe venir compensado por otro espacio destinado al mismo uso, a fin de no romper el equilibrio del sistema de espacios libres, que toda planificación urbana debe comportar y por otra parte suponer una mejora urbanística para la ciudad, requisito y característica que no concurren en el expediente.

CONSIDERANDO: Que por lo que se refiere al apestado $2^{\circ}$ de la Orden Ministerial impugnada, en lo que respecta al ancho de la calle Campos Crespo, el Ayuntamiento alega que el Plan Parcial debe considerar las situaciones de hecho ya existentes y que en este caso se trata de un problema de ordenación de tráfico, que no cree sea básico representarlo en el Plan Parcial, ya que por dicha calle circula un f.f. c.c. de vía estrecha; analizada esta alegación se observa que no existen razones de mejora urbanística, para disminuir el ancho de la citada calle, por lo que debe mantenerse en este aspecto la resolución impugnada.

CONSIDERANDO: Que la Orden Ministerial impugnada, determina que se mantenga la situación y extensión prevista en el Plan Comarcal para el Centro Comercial y el Ayuntamiento alega que las calles que lo circundan constituyen una manzana en gran parte edificada y que las calles están completamente urbanizadas y pavimentadas; el informe técnico evacuado por los servicios competentes de la Dirección General de Urbanismo estima que puede aceptarse la solución propuesta por el Plan Parcial, al coincidir prácticamente su situación con la del Plan General y dado que la superficie planificada para este uso es superior a la del Plan General y habida cuenta de la existencia y urbanización de las calles adyacentes. Por lo que en este punto puede estimarse la pretensión del Ayuntamiento.

CONSIDERANDO: Que la Orden Ministerial impugnada establecía también la necesidad de previsión de aparcamientos, como mínimo una plaza por vivienda y la reserva de terrenos para dotacioncs escolares, en proporción a la población prevista y estos puntos no han sido cuestionados en el escrito de recurso, por lo que se mantiene en todos sus extremos, en este aspecto, la resolución impugnada.

En su virtud,

Este Ministerio, de conformidad con el servicio Central de Recursos y con el informe de la Asesoría Jurídica del Departamento acuerda estimar en parte el recurso de reposición interpuesto por el Alcalde-Presidente del Excmo. Ayuntamiento de Valencia, en el sentido de revocar en parte la Orden Ministerial de 23 de septiembre de 1.974, relativa al Plan Parcial de Ordenación Urbana del Polígono 26 de Valencia, en su apartado $2^{\circ}$ y en lo que respecta al Centro Comercial, y en consecuencia aprobar la ordenación prevista para el mismo por el Plan Parcial presentado por el Ayuntamiento, y confirmar en los restantes extremos la resolución recurrida." 
No obstante V.E. resolverá.

Dios guarde a V.E.

Madrid, a 22 de septiembre 1977

EL JEFE DEL SERVICIO

CENTRAL DE RECURSOS,

C O F O R M E:

Madrid, a 30 de septbre de 1.977

P.D.

EL SUBSECRETARIO,

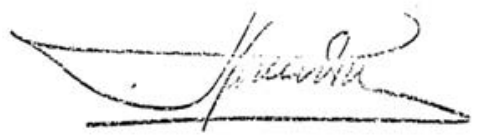

Excmo. Sr. Ministro del Departamento 
Redactor: El Arquitecto Municipal. Ayuntamiento de Valencia.

Fecha: 10- 11-1977.

Asunto: Informe sobre el PP26.

Fuente: Ayuntamiento de Valencia. Sección de Urbanismo. Negociado de Suelo y Ordenación urbana. Expte. 285/1973. (Archivo de Planeamiento No 154).

El Arquitecto Municipal de Planeamiento Urbano que suscribe, a la vista de la resolución ministerial en relación al Plan Parcial no 26, informa de lo siguiente:

10.- En relación con el considerando primero relativo a la compatibilidad del uso escolar con el de zona verde limitada por las calles Héroes Virgen de la Cabeza, Vicente Clavel, Fontanares y Vall de Uxó, la resolución se reafirma en la primitiva de 23 de septiembre de 1974, y por tanto, dicho sector permanece excluido de aprobación.

Ante esta situación y vistas las consideraciones expuestas por el Ministerio, caben tres alternativas. O mantener la zona verde como tal en su integridad, conforme a la previsión del plan general, dejando la escuela fuera de ordenación hasta tanto y cuanto pueda trasladarse a otro emplazamiento idóneo con el destino; o proceder a la modificación del plan general, transformando el uso de la zona verde por el de escolar, pero sobre la base de preveer en otro sector del plan próximo a éste, un espacio al menos de igual superficie con destino a zona verde "a fin de no romper el equilibrio del sistema de espacios libres", como indica la propia resolución; ó realizar una reforma del plan en el sentido de que manteniendo la zona verde del plan general, reservar en otro lugar terrenos para trasladar la escuela existente.

De las tres alternativas, la segunda y la tercera suponen evidentemente un nuevo estudio del plan, con la incuestionable suspensión de licencias por este motivo, al objeto de efectuar un análisis preciso de la situación que permita adecuar cada una de las soluciones: Localizar terrenos para zona verde o para el grupo escolar respectivamente, con detrimento en ambos casos del destino o calificación que el plan aprobado haya [...].

La primera y la tercera implican en definitiva un traslado del grupo escolar con todos los inconvenientes que ello conlleva, con el agravante para la primera de que no podrán realizarse obras de reforma o ampliación por considerarse edificio fuera de ordenación, y además al trasladarla a otro terreno mermaría obviamente la dotación escolar prevista.

20.- En relación con el considerando segundo, solo procede efectuar una modificación del sector en el sentido de grafiar la calle campos Crespo a 25 mts., mínimo exigido por la resolución, ya que se ratifica en la anterior.

30. - En relación con el considerando tercero, como quiera que se acepta el recurso, procede simplemente darse por enterados de que la estructura urbanística del centro comercial y sus adyacentes, prevista en la documentación del plan parcial, es válida y por tanto dicho sector queda aprobado definitivamente con fecha 30 de septiembre de 1977.

40. - En relación con el considerando cuarto, la resolución viene a recordar un extremo relativo a aparcamiento y a su previsión, 
que al parecer no fue objeto de recurso por la Corporación y que por tanto ha quedado sin justificar. Estimo procedente efectuar las justificaciones necesarias a tal fin y remitir la documentación complementaria.

Valencia, 10 de noviembre de 1.977 EL ARQUITECTO MUNICIPAL,

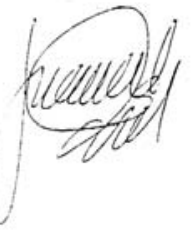


Redactor: El Arquitecto Municipal. Ayuntamiento de Valencia.

Fecha: 24- 05-1978.

Asunto: Informe sobre el PP26.

Fuente: Ayuntamiento de Valencia. Sección de Urbanismo. Negociado de Suelo y Ordenación urbana. Expte. 285/1973 (Archivo de Planeamiento No 154).

Expte. 285/73 S.y O.U.

El Arquitecto Municipal que suscribe, informa lo siguiente:

10.-Que por estos servicios técnicos, se ha procedido, de conformidad con el acuerdo plenario de 9 de diciembre del pasado año, a reflejar en el ámbito del Plan Parcial no 26, las previsiones adoptadas por la Orden Ministerial de 30 de septiembre de 1977, en lo que se refiere al ancho de la calle Campos Crespo, no menor de 25 mts., a mantener la zona verde del Plan General y prestar su conformidad a los límites propuestos del centro comercial.

$2^{\circ}$. Con independencia de los extremos reflejados y teniendo cono base la resolución ministerial primera, de fecha, 23 de septiembre de 1974, se hace notar que el plan no queda todavía definitivamente aprobado, ya que de la interpretación de ambas resoluciones ministeriales, se deduce que el sector colindante a la calle Campos Crespo, queda excluido de aprobación, con el fin de que se reserven terrenos para dotaciones escolares y falta establecer, a nivel de todo el plan, la previsión en materia de aparcamientos de la forma que estime más oportuna el Ayuntamiento.

(Circunstancias ambas que se reflejan en la copia adjunta).

30. Que efectuado un análisis de la situación y en lo que se refiera a materia de previsión de aparcamiento, resulta que por aplicación de las normas urbanísticas relativas a la reserva del 5\% de la superficie construida en viviendas mas el $15 \%$ de la construida en locales comerciales y añadiendo las áreas grafiadas como complemento de la red viaria, el número de plazas obtenidas es de 16.300, que comparadas con el número de viviendas, que se han calculado en 20.000 aproximadamente, arroja un déficit de 3700 plazas, necesaria para obtener la proporción de 1 plaza por vivienda, conforme a la citada Resolución Ministerial. Ello obligaría a incrementar la proporción que como mínimo se exige en las normas, en el sentido de elevar, si ello es posible, el porcentaje sobre la superficie construida en viviendas a cuando menos el $10 \%$ que nos daría un aumento de 1500 plazas mas, y establecer simultáneamente una obligación mayor en el centro comercial, con una exigencia concreta en esta materia, para paliar las 1200 plazas que seguirían faltando.

40. En cuanto al tema de la reserva escolar, la única posibilidad sería establecer tal dotación en una o en dos de las tres manzanas que comprende el sector excluído, ya que en una de ellas sería imposible por existir edificaciones situadas a línea que ocupan gran parte de la superficie.

Ahora bien, si esa reserva la establecemos en base proporcional a la población prevista, resultaría lo siguiente :

No Viviendas ....... 20.000

Población prevista tomando una media familiar de

3-4 individuos/vivienda. 68.000

Población escolar $16 \%$ 10.000 niños 
Reserva mínima por niño.

$12 \mathrm{~m} 2$.

Reserva necesaria $120.000 \mathrm{~m} 2$.

Prevista en el Plan 20.000

Como quiera que la posibilidad máxima de actuación se limita a esas dos manzanas, que suponen $25.000 \mathrm{~m} 2$ aproximadamente, y ello suprimiendo la calle intermedia, se obtendría que todavía faltaban $75.000 \mathrm{~m} 2$. , lo cual nos llevaría a revisar totalmente el plan, en el sentido de dotación de reservas escalares, reduciendo manzanas edificables y destinándolas a escuelas, siempre en base a los criterios y estándares expuestos, anteriores a la Ley de 1975, ya que en el supuesto de su aplicación, el tema se agravaría, circunstancias todas ellas que se ponen de manifiesto como ampliación de mi anterior informe del 10de noviembre del pasado año, para conocimiento y efectos oportunos que procedan.

Valencia, 24 de mayo de 1.978

EL ARQUITECTO MUNICIPAL,

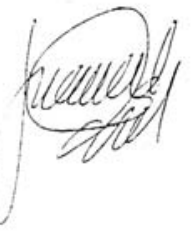




\section{PP 26 Bis}

PLANO PARCIAL No 26 Bis (ADAPTADO A LA SOLUCIÓN SUR)

1967

Redactores: EXCMO. AYUNTAMIENTO DE VALENCIA. OFICINA TÉCNICA DE URBANISMO. Arquitectos: Julio Bellot, Cándido Orts, Joaquín Roselló (*).

Fecha redacción: Junio 1967.

Fecha aprobación: O.M. 11-01-1969 (B.O.E. 31-01-69) (**).

Contenido:

I. MEMORIA

II. ORDENANZAS $(* * *)$

III. PLANOS:

1. PLANO DE SITUACIÓN DENTRO DE LA CIUDAD. $1: 10.000$

2. SITUACIÓN EN EL PLAN GENERAL $1: 22.500$

3. FOTOPLANOS

4. ESTADO ACTUAL Y DELIMITACIÓN $1: 2000$

5. ESTRUCTURA URBANÍSTICA $1: 2000$

6. ZONIFICACIÓN $1: 2000$

7. RED VIARIA FUNDAMENTAL $1: 2000$

8. ALINEACIONES Y RASANTES $1: 2000$

9. REDES FUNDAMENTALES DE SERVICIO.
RED DE ALCANTARILLADO

ESQUEMA DE RED DE AGUAS POTABLES. $\quad 1: 2000$

ESQUEMA DE ALUMBRADO. $1: 2000$

\section{Fuente:}

Ayuntamiento de Valencia. Sección de Urbanismo. Negociado de Suelo y Ordenación urbana. Expte. 289/1967. Reg. General 3.074 (Archivo de Planeamiento, No 156)

\section{Notas:}

* Los nombres de estos arquitectos no figuran en los planos, sino únicamente en la portada del expediente del PP 26-B.

** Esta versión del PP 26-B es la redactada una vez introducidas en la versión inicial las modificaciones derivadas de las alegaciones.

*** Las ordenanzas son las mismas que las utilizadas en el PP 12. 
EXCMO. AYUNTAMIENTO DE VALENCIA.- OFICINA TÉCNICA DE URBANISMO.

PLAN PARCIAL No. 26 BIS (ADAPTADO A LA SOLUCIÓN SUR)

\section{MEMOR I A}

La redacción del presente Plan Parcial tiene su origen en la adaptación del Plan General de Ordenación Urbana de Valencia y su Comarca a la Solución Sur.

Los límites del Plano Parcial no 26 bis son los definidos por la Avenida del Cid al Norte, la vía de ferrocarriles de Villanueva de Castellón al Sur, la Ronda exterior al Este y el nuevo cauce del río al Oeste.

El Plan General provee dos zonas distintas en este Plano Parcial:

Edificación abierta en baja con coeficiente de edificabilidad $3,5 \mathrm{~m} 3 / \mathrm{m} 2$.

Zona de tolerancia industrial.

Entre estas dos zonificaciones existe el Polígono Industrial vara de Quart, aprobado por la Gerencia de Urbanismo.

Zonificación edificación abierta en bajos:

Esta zona ya existía planeamiento anterior, respetando al máximo las alineaciones, haciendo las modificaciones necesarias para cumplir con el Plan General en cuanto al coeficiente de edificabilidad y Ordenanzas.

En el Planeamiento anterior existían tres zonas para escuelas, actualmente se han dejado dos, pero con mayor superficie por considerar suficientemente resuelto el problema escolar. En cuanto a Centros Parroquiales se ha mantenido uno y se ha suprimido otro, por estar en construcción en el término de Chirivella un Centro parroquial muy cerca del ubicado en el anterior Planeamiento.

Se han mantenido los centros comerciales y mercado, ampliando las zonas para aparcamiento.

Polígono parcial de Edificación abierta:

\begin{tabular}{|c|c|c|c|}
\hline \multicolumn{2}{|c|}{ Superficie en } & 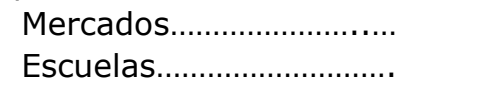 & $\begin{array}{l}1.344 \mathrm{~m} 2 \\
6.478 "\end{array}$ \\
\hline \multicolumn{3}{|c|}{ Zona verde........... } & $122.976 "$ \\
\hline & \multicolumn{2}{|c|}{ Hospital Provincial.......................... } & $72.032 "$ \\
\hline & \multicolumn{2}{|c|}{ Edificios benéfico religiosos sanitarios } & $18.150 "$ \\
\hline & \multicolumn{2}{|c|}{ Casa de la Misericordia................. } & $34.890 "$ \\
\hline " & \multicolumn{2}{|c|}{ Edificios viviendas y comerciales } & $50.908 "$ \\
\hline " & \multicolumn{2}{|c|}{ Vías públicas.................................... } & $65.590 "$ \\
\hline \multicolumn{3}{|c|}{ 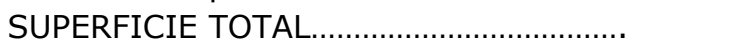 } & $392.368 \mathrm{~m} 2$ \\
\hline \multicolumn{3}{|c|}{ Superficie barrios construidos................. } & \\
\hline \multicolumn{3}{|c|}{ SUPERFICIE TOTAL POLIGONO............... } & \\
\hline \multicolumn{3}{|c|}{ Volumen edificios viviendas y comerciales } & \\
\hline
\end{tabular}

\section{Polígono industrial vara de Quart:}

Está enclavado entre la Edificación abierta en baja y la zona de tolerancia Industrial.

Este polígono está aprobado por la Gerencia de Urbanismo.

\section{Tolerancia Industrial.}

El Plano General señala a esta parte del Plano Parcial 26 bis como de tolerancia industrial.

Las Ordenanzas que rigen para esta zona son las de zona 
extensión exterior a tránsitos.

La profundidad edificable está acotada en el plano de alineaciones.

Se permitirá en esta Zona, además de viviendas, el establecimiento de industrias, talleres, almacenes, garajes etc. No pudiendo instalarse los que sean peligrosos o insalubres.

En cuanto a incómodos, se asegurará siempre el aislamiento de toda clase de ruidos, trepidaciones y olores. Al efecto de cortar trepidaciones, en ningún caso los motores y piezas móviles se sujetarán a elementos de estructura de edificios de viviendas.

Aparte lo anterior, se seguirán los Reglamentos y normas industriales vigentes, tanto generales como municipales.

\section{Servicios comunitarios:}

Se ha ubicado para esta zona un Centro Parroquial, y Grupo Escolar y un Mercado con lo que se considera suficiente para su desarrollo.

Polígono parcial de Tolerancia Industrial:

Superficie Mercado

$$
4.000 \mathrm{~m} 2
$$

" Aparcamiento Mercado

1,600 "

Escuelas y Centro Parroquial

$7.968 "$

en edificación cerrada

$151.800 "$

Zona verde

$83.938 "$

Vías Públicas

$137.581 "$

Total Superficie Polígono

$\underline{386.887 \mathrm{~m} 2}$

\section{ETAPAS}

Siendo este plan parcial destinado, por el momento, a la edificación por particulares, no pueden marcarse etapas de realización que dependerán de la actividad constructiva de los mismos. Sin embargo, el Excmo. Ayuntamiento, además de construir los elementos urbanísticos generales en una primera etapa, se mantendrá siempre en la urbanización adelantando sobre la iniciativa particular, urbanizando zonas que se prevea edificación inmediata.

\section{MEDIOS ECONÓMICOS FINANCIEROS}

Son los del presupuesto ordinario de Urbanismo del Excmo. Ayuntamiento de Valencia y los extraordinarios que se establezcan a medida que se cumpla lo dicho en el párrafo anterior y se disponga de proyectos detallados de urbanización.

Con lo dicho creemos suficientemente expuesto el alcance del estudio realizado para que, si el Excmo. Ayuntamiento lo estima conveniente, lo eleve a la aprobación por la superioridad.

Valencia, junio de 1967.

LOS ARQUITECTOS MUNICIPALES,

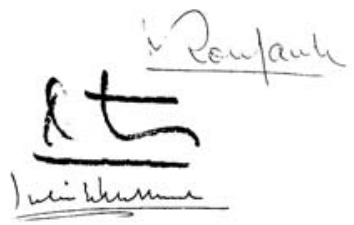




\section{DISPOSICIÓN TRANSITORIA UNICA}

Serán normas subsidiarias

10.- Las normas urbanísticas del Plan General.

$2^{\circ}$.- Las Ordenanzas generales para la edificación vigentes en el Municipio de Valencia.

Valencia, Julio de 1968. LOS ARQUITECTOS MUNICIPALES, $\because$ Sentauh $(4$

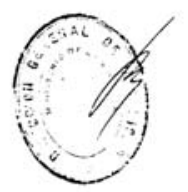


1. PLANO DE SITUACIÓN EN LA CIUDAD

Escala original: $1: 10.000$

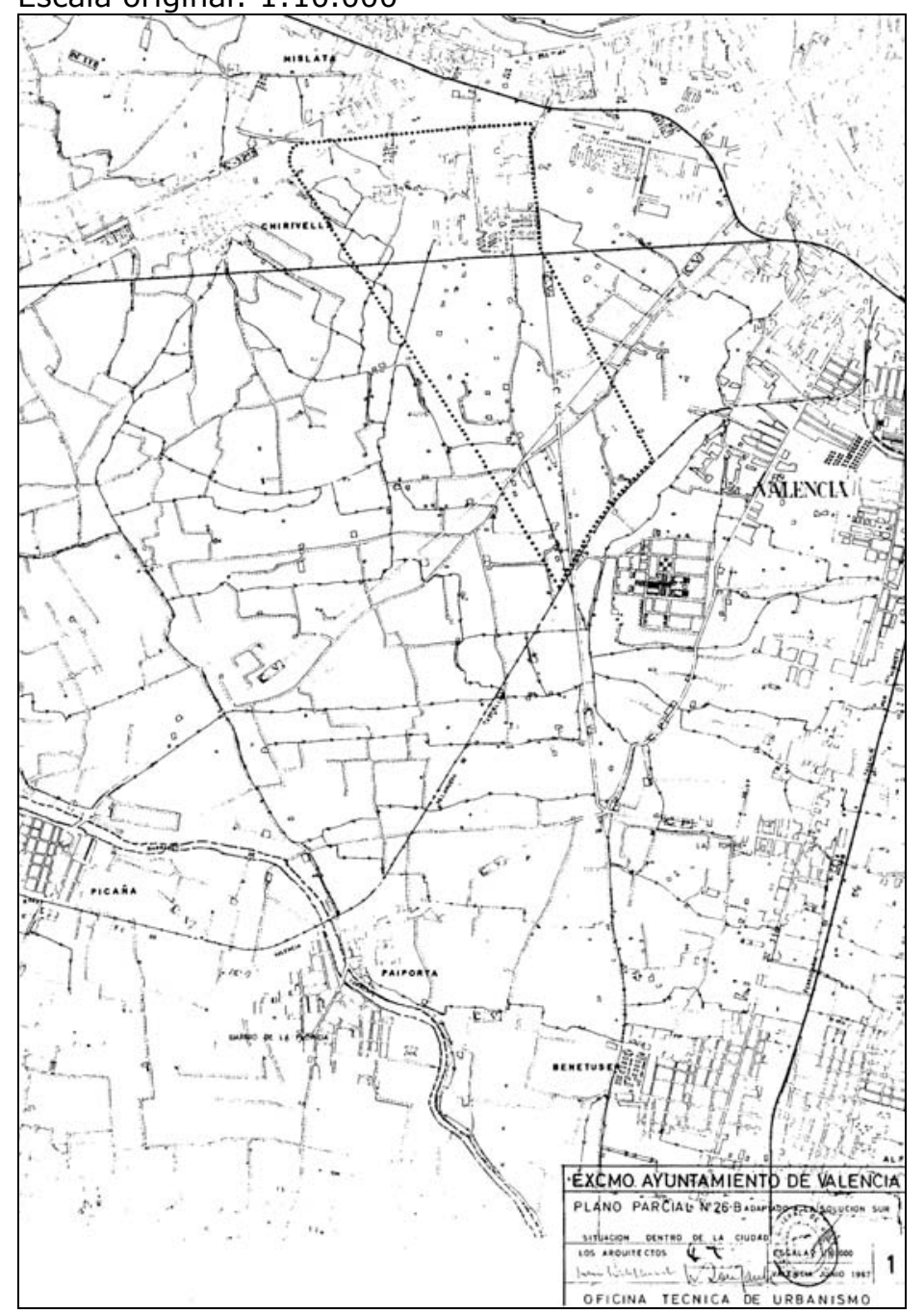

2. PLANO DE SITUACIÓN EN EL PLAN GENERAL (Fragmento) Escala original: 1:22.500

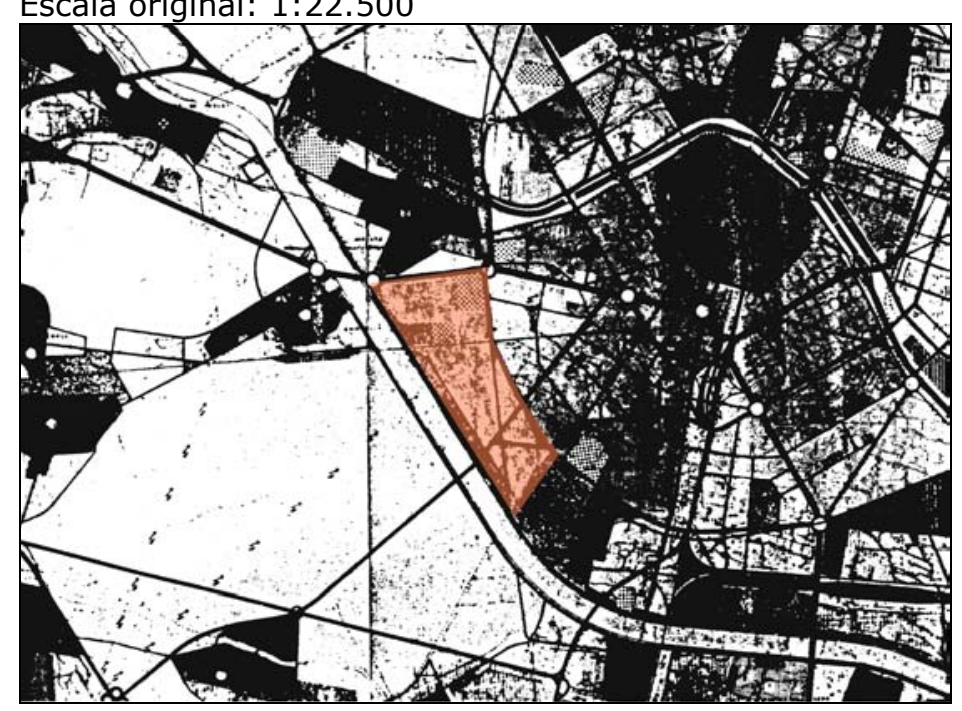


3. FOTOPLANOS.
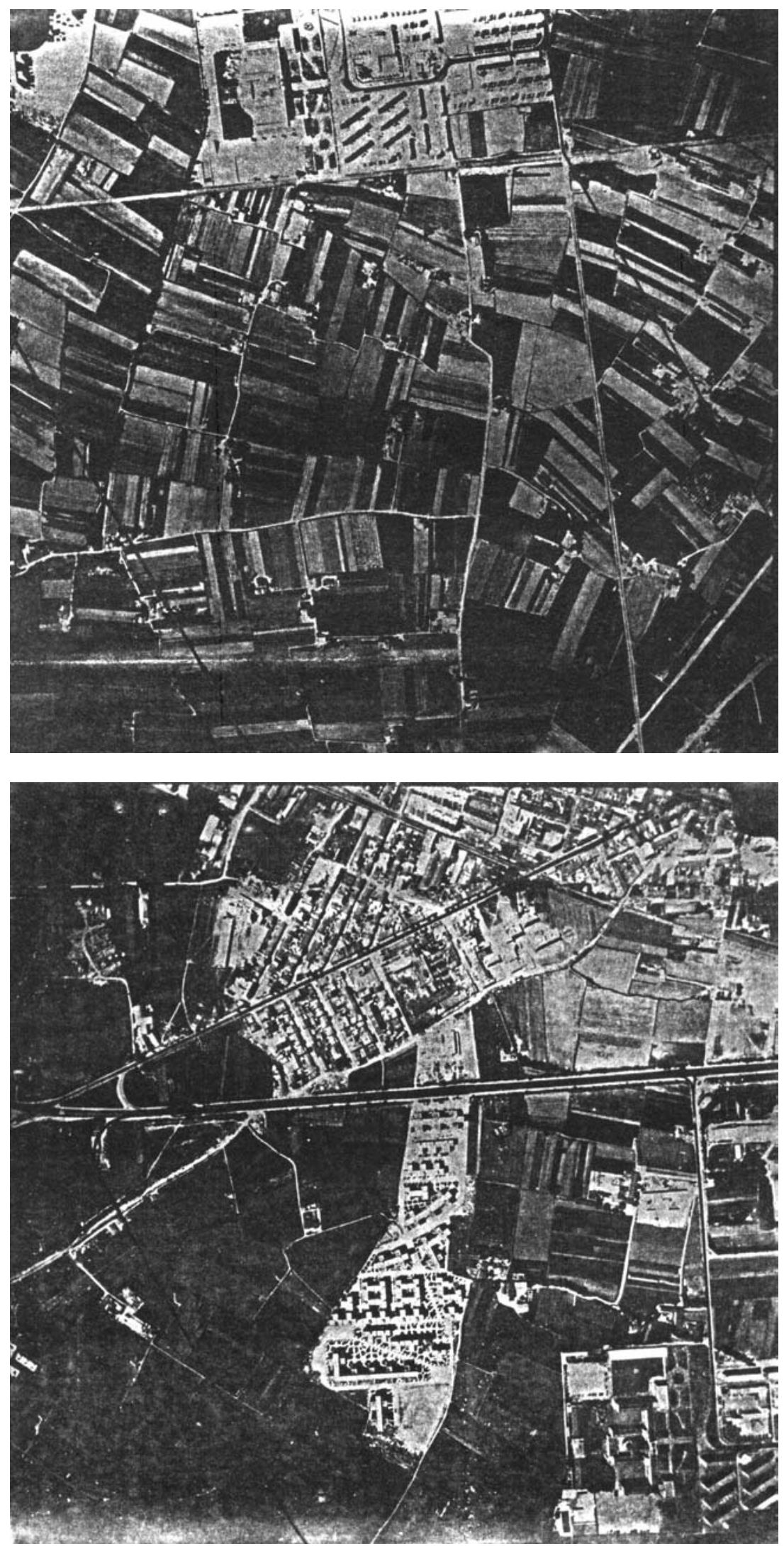
4. ESTADO ACTUAL Y DELIMITACIÓN

Escala original: 1:2000

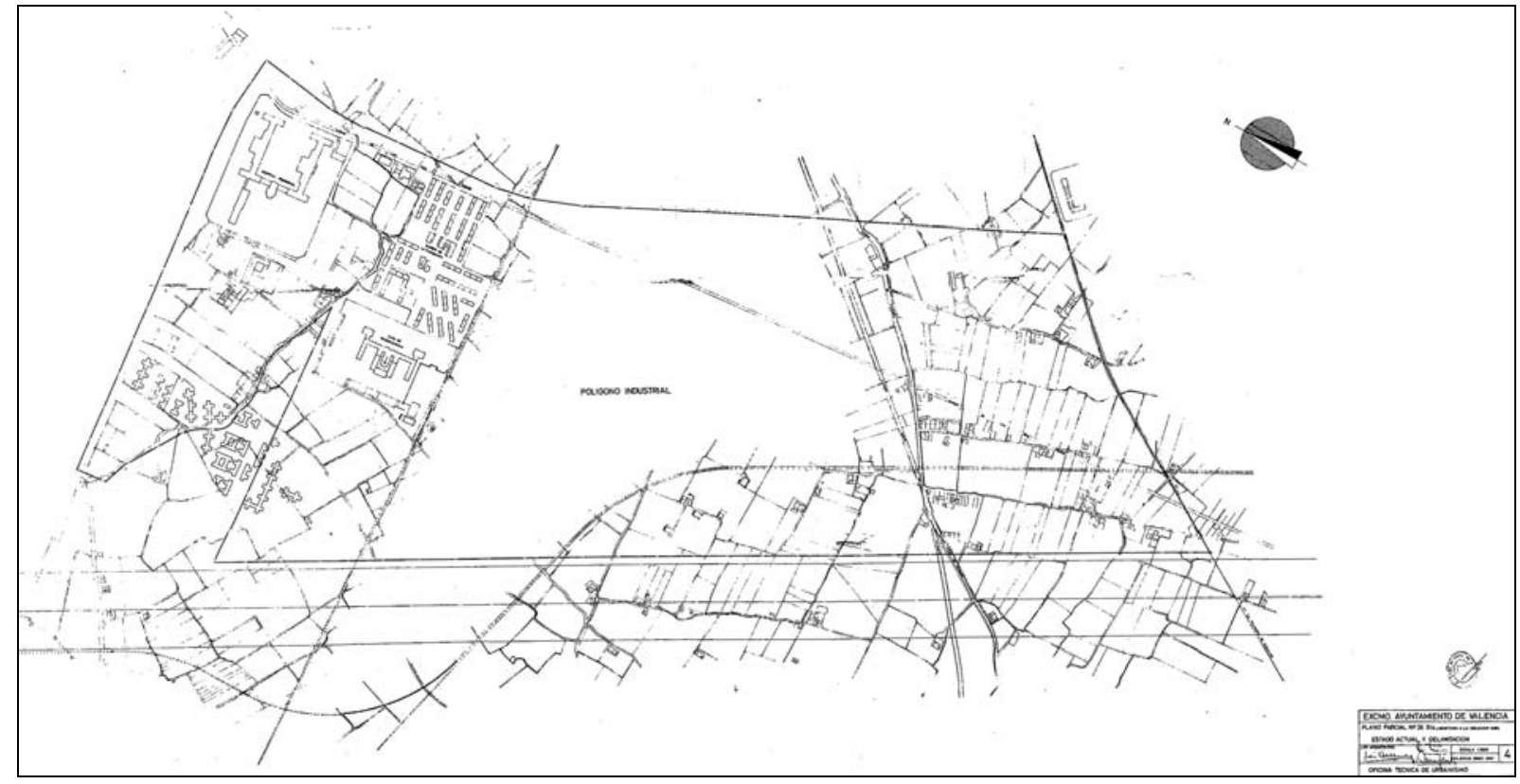

7. RED VIARIA FUNDAMENTAL (Fragmento)

Escala original: 1:2000

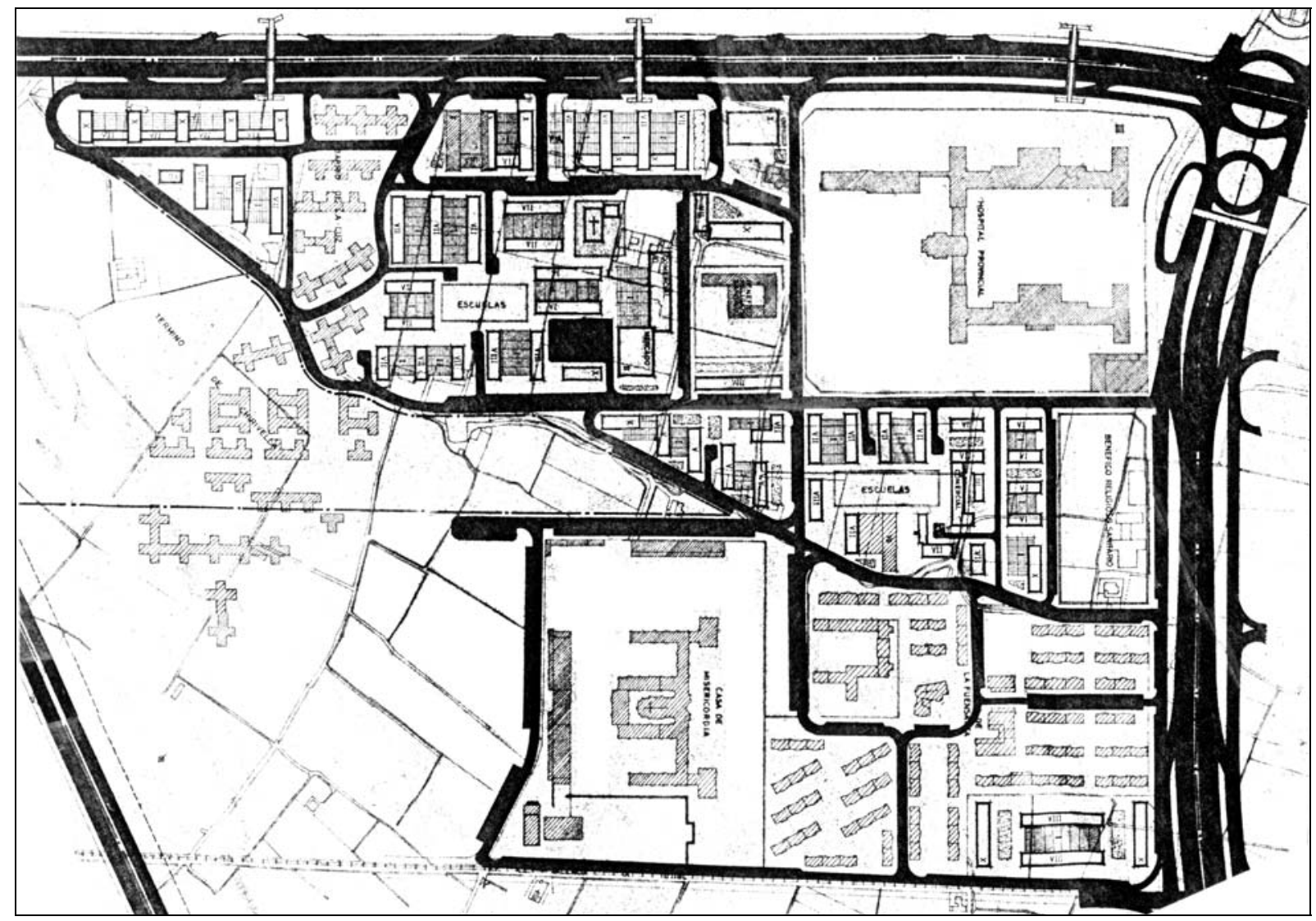


8. ALINEACIONES Y RASANTES.

Escala original 1:2000
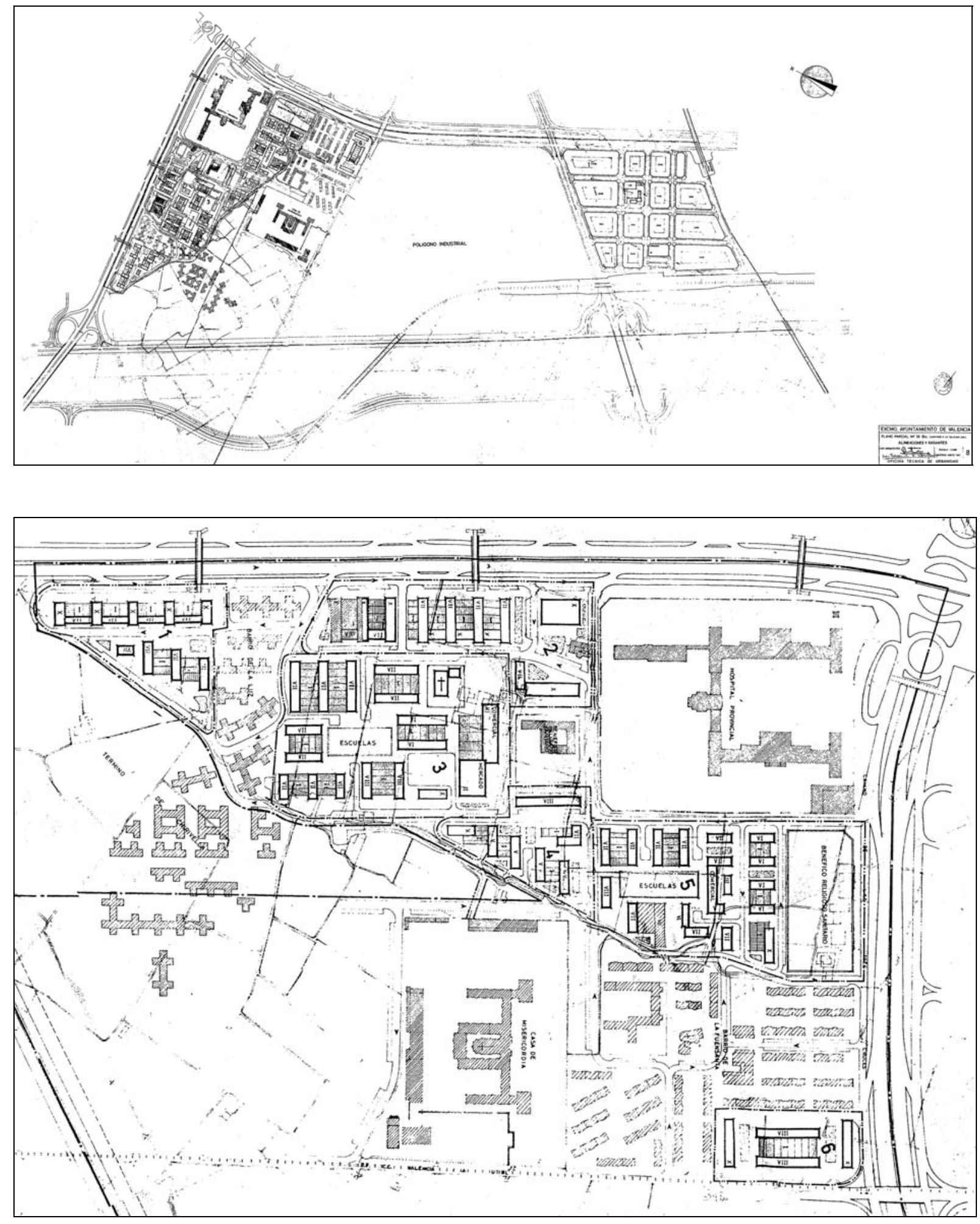

Detalle del Plano de alineaciones. 
Redactor: Dirección General de Urbanismo del Ministerio de la Vivienda / Ministerio de la Vivienda.

Fecha: 11- 01-1969.

Asunto: Resolución de aprobación del Plan Parcial 26-B.

Fuente Ayuntamiento de Valencia. Sección de Urbanismo.

Negociado de Suelo y Ordenación urbana. Expte. 289/1967. Reg.

General 3.074 (Archivo de Planeamiento, N 156 )

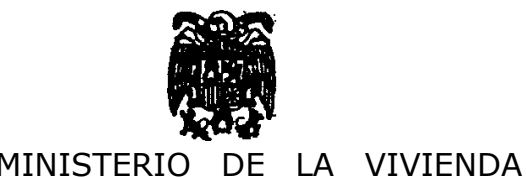

Dirección General de Urbanismo.

SECCIÓN: Planeamiento

\section{Ilmo Sr.:}

El Excmo. Sr. Subsecretario del Ministerio de la Vivienda, actuando por delegación del Excmo. Sr. Ministro, con fecha 21 de diciembre de 1968, me dice lo siguiente:

"VISTO el Plan Parcial de Ordenación Urbana $n^{\circ} 26$ bis adaptado al vigente Plan General de Valencia y su Comarca, presentado por el Ayuntamiento de dicha localidad y remitido por la Corporación Administrativa "Gran Valencia", y VISTO el informe emitido por los servicios competentes de la Dirección General de Urbanismo, Este Ministerio, teniendo en cuenta lo dispuesto en la vigente Ley sobre Régimen del Suelo y Ordenación Urbana de 12 de Mayo de 1956 y en el Decreto 63/1968 de 18 de Enero, Acuerda aprobar dicho Plan Parcial y que esta resolución sea notificada al Ayuntamiento de Valencia y a la Corporación Administrativa Gran Valencia."

Lo que comunico a V. I. para su conocimiento y efectos.

Dios guarde a V.I. muchos años.

Madrid, 11 de Enero de 1.969. EL

DIRECTOR GENERAL.

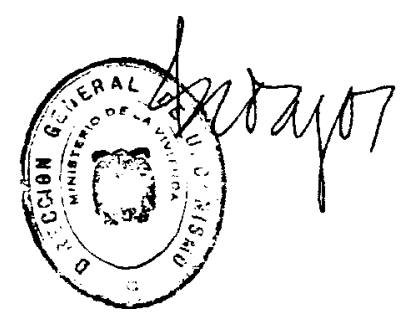

limo. Sr. Alcalde Presidente del Ayuntamiento de Valencia. 



\section{PP 3}

PLANO PARCIAL No 3 (ADAPTADO A LA SOLUCIÓN SUR).

1968

Redactores: Ayuntamiento de Valencia. Oficina Técnica Municipal de Urbanismo. Arquitectos: J. Bellot, Mauro Lleó (*).

Fecha redacción: Abril 1968

Fecha aprobación: O.M. 22-10-69 (B.O.E. 15-11-69) (**).

\section{Contenido:}

I. MEMORIA

II. ORDENANZAS.

III. PLANOS $(* *)$

1. PLANO DE RELACIÓN CON LA COMARCA $1: 25.000$

2. SITUACIÓN EN EL PLAN GENERAL $1: 10.000$

3. DELIMITACIÓN Y ESTADO ACTUAL. $1: 2000$

4. ESTRUCTURA URBANISTICA $1: 2000$

5. ZONIFICACIÓN $1: 2000$

6. RED VIARIA FUNDAMENTAL $1: 2000$

7. REDES FUNDAMENTALES DE SERVICIO.

RED DE ALCANTARILLADO. $1: 2000$

ESQUEMA DE RED DE AGUAS POTABLES. $1: 2000$

ESQUEMA DE ALUMBRADO. $1: 2000$

Fuente: Ayuntamiento de Valencia. Sección de Urbanismo. Negociado de Suelo y Ordenación urbana. Expte. 183/1967. Reg. General 1.883 (Archivo de Planeamiento, No A-2/3)

\section{Notas:}

* Los nombres de estos arquitectos no figuran en los planos, sino únicamente en la carpeta del PP 3.

** Esta versión del PP 3 es la redactada una vez introducidas en la versión inicial las modificaciones derivadas de las dos rondas de alegaciones, antes y después de la aprobación inicial, de fecha 2904-1968. 


\section{PLAN PARCIAL No 3 (ANTIGUO III)}

\section{$\underline{\text { MEMOR I A }}$}

En el desarrollo del Plan Parcial de Ordenación Urbana de Va lencia y su Comarca adaptado a la Solución Sur, observamos que existen planes Parciales, que prácticamente se mantienen igual en cuanto a zonificación y alineaciones, por no ser afectados por el plan de Adaptación, en cambio otros son seriamente afectados y tienen que ser objeto de un estudio detenido de adaptación y remodelacion; este es el caso concreto del Plan Parcial no 3, (antiguo III).

Este Plan queda afectado por el nuevo cauce del río, por el nuevo trazado del ferrocarril, por el nuevo trazado de la Ronda y por el desdoblamiento del acceso Sur.

Hemos tratado de ser realistas y conservadores en las zonas en donde la promoción de construcciones estaba iniciada, tratando en lo posible, de incluir las normas del Plan General de Adaptación en cuanto a aparcamientos, zonas de uso publico y emplazamiento de edificios escolares.

Es fundamental en este Plan Parcial el viario obligado por el Plan General, en cuanto a su trazado se ha mantenido una coordinación con la Oficina Regional de Carreteras para la situación exacta de los accesos.

En la estructura mantenemos, en todo lo posible, la existente en el plan antiguo con un criterio realista, conveniente para no dañar las parcelaciones que se pudieran haber ejecutado basadas en aquel.

Las manzanas previstas antiguamente, se mantienen idénticas en las zonas en que se ha iniciado la construcción. En las más libres de construcciones pero rodeadas de zonas ya construidas se han tratado de mejorar, abriendo en parte las manzanas, de tal forma que se consigue mayor aireación e insolación y posibilidad de viviendas recayentes a estos patios abiertos.

La profundidad de $22 \mathrm{mts}$. en los bloques permite un sistema muy útil de 4 viviendas por escalera y con muy buenas condiciones de insolación y ventilación.

En las grandes zonas, hoy dedicadas a huerta o en manos de una sola propiedad se proponen supermanzanas con aparcamientos, servicios y pocas vías pavimentadas.

Los aparcamientos se han estudiado siguiendo el criterio de un vehículo por cada 5 familias. Esto se ha podido conseguir con cierta holgura en las zonas remodeladas y con mayor dificultad en las ya construidas.

La superficie total que abarca este Plan Parcial es de 3.218.843 m2. Ahora bien en el mismo esta ubicado el Cementerio General de Valencia que abarca 181.596.- $\mathrm{m} 2$ y una zona verde que lo circunda de 498.039.- m2, que a efectos de las superficies de zonas de uso publico deben descontarse en su mayor parte, por estar al servicio de toda la Ciudad.

A continuación se expresa un resumen de superficies: 
Superficie edificable con promedio de 5 alturas...

" " " " " 9 "

" " en edificación abierta................

"

" para 1 altura en Zona Industrial.

Aparcamiento

Iglesias

Zonas escolares

Suma y sigue.

Zona cultural deportiva

Superficie edificable en "Ciudad del Aprendiz" ... " libre

"

"

Centros Comerciales (edificable)

Superficie edificable en Residencia Sanitaria...

" libre ajardinada en idem.

Zona verde en viales de uso público.

$$
\text { " " de uso público }
$$

Parque alrededor Cementerio

Superficie Cementerio General.

Superficie en viales

Total

776.619.- m2.

15.264.- ".

9.794.- "..

158.434.- "..

80.926.- "..

101.100.- "..

5.732.- "..

56.036.- "..

1.204.705.- m2.

192.220.- m2

10.260.- ".

26.620.- ".

11.702.- ".

11.794.- "

71.618.- ".

130.134.- ".

181.367.- ".

498.039.- ".

181.596.- ".

698.788.- ".

$3.218 .843 \mathrm{~m} 2$.

Una vez descontado de la superficie total las de Cementerio e influencia nos resta una superficie para el polígono de 2.539.208.$\mathrm{m} 2$. El $10 \%$ de zonas verdes queda sobradamente rebasado entre las propiamente de uso público y las verdes en viales sin tener en cuenta, las que quedarán en la Cultural deportiva. El parque alrededor del Cementerio, podría contarse que una cuarta parte será de uso para la zona que abarca este Plan.

El Centro Comercial que figura en el Plan General en el vértice de unión de la diagonal E-O, sobre el actual ferrocarril de Villanueva de Castellón y la calle prolongación de Cuenca, figura en el Plan Parcial no 26 (antiguo I), y en las proximidades del Plan que nos ocupa, por ello solo figuran en este dos centros comerciales de verdadera importancia.

A la zona que atraviesa la Ronda, se trata de darle cierta categoría, $y$ al tener una anchura superior a los cien mts. es el único emplazamiento lógico para edificios singulares de altura.

Los planos que se adjuntan son los relacionados a continuación:

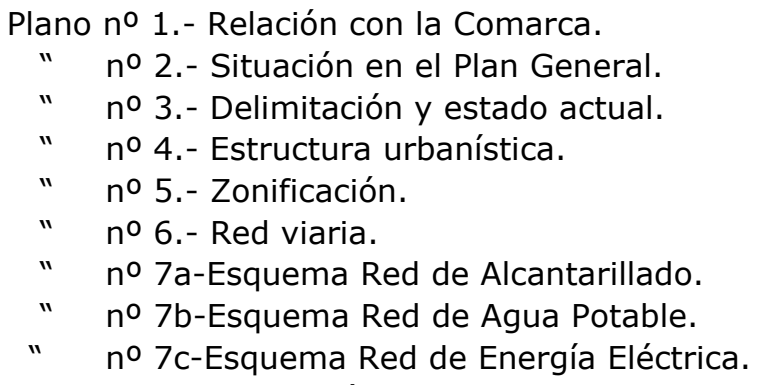

El sistema de ejecución, mientras el Excmo. Ayuntamiento no decida otro mas adecuado, será el tradicional de servidumbre de alineaciones con cesión de viales. 
Será posible y se propugna como más justo y regularmente más eficaz el de reparcelacion.

Valencia, Febrero de 1.967

BL ARCOIRECTO JEFE DE IAA OFI-

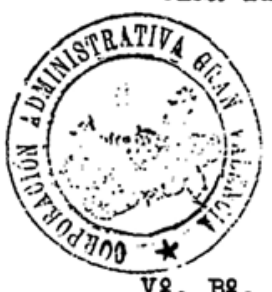

VQ. $\mathrm{B}^{2}$.

El Arquitecto Nayor,

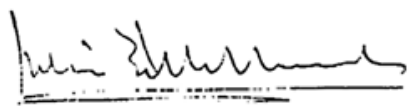

690 
EXCMO. AYUNTAMIENTO

$D E$

VALENCIA

\section{PLANO PARCIAL NO 3}

Proyecto de Alineaciones y Zonificación del Sector limitado por el Perímetro de las calles siguientes:

NORTE.- Avda. César Giorgeta y Pérez Galdós.

SUR.- Lado izquierdo del nuevo cauce del Rio Turia.

ESTE.- Ferrocarril de Madrid.

OESTE.- Prolongación calle Cuenca-Ferrocarril de Utiel.

\section{ORDENANZAS}

Hasta que no se aprueben las ordenanzas adaptadas a la Solución Sur en estudio, se aplicarán las vigentes aprobadas por la Comisión Central de Sanidad en 23 de octubre de 1.950 y 26 de enero de 1.955, en los casos no previstos en las normas Urbanísticas del Plan de Ordenación de Valencia y su Comarca, adaptada a la "Solución Sur" por la que tendrá que regirse actualmente este Ayuntamiento.

A este Plano Parcial le corresponde la Zonificación de Extensión Exterior a Tránsitos, Tolerancia Industrial - En esta zona la edificación de viviendas se regirá por la zona Extensión exterior a Tránsitos.-

Valencia, abril de 1968.

LOS ARQUITECTOS MPLES. DE URBANISMO,

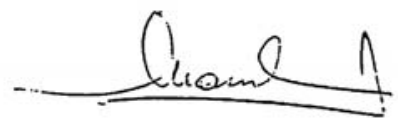

Vo. Bo.

El Arquitecto mayor,

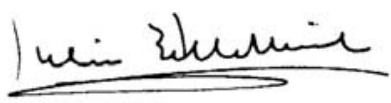




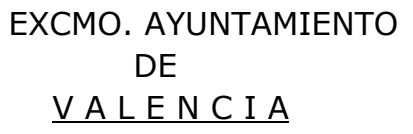

$\underline{V A L E N C I A}$

PLANO PARCIAL NO 3

\section{MEDIOS ECONÓMICO-FINANCIEROS}

Son los ordinarios del Presupuesto de Urbanismo del Excmo. Ayuntamiento de Valencia y los extraordinarios que con tal fin se establezcan.

\section{PLAN DE ETAPAS}

No puede establecerse en un Plan parcial que no trata más que de encauzar la iniciativa particular. El futuro puede hacer interesante establecerlas para ultimar lo que se haya ido realizando.

El Excmo. Ayuntamiento atenderá la urbanización en los puntos en que vaya siendo necesaria.

Valencia, abril de 1968.

LOS ARQUITECTOS MPLES. DE URBANISMO,

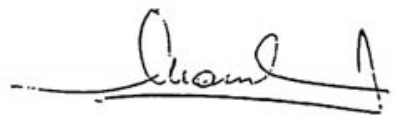

Vo. Bo.

El Arquitecto mayor,

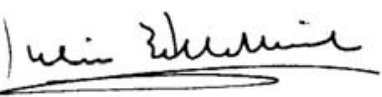


1. PLANO DE SITUACIÓN EN LA COMARCA (Fragmento)

Escala original: 1:25.000

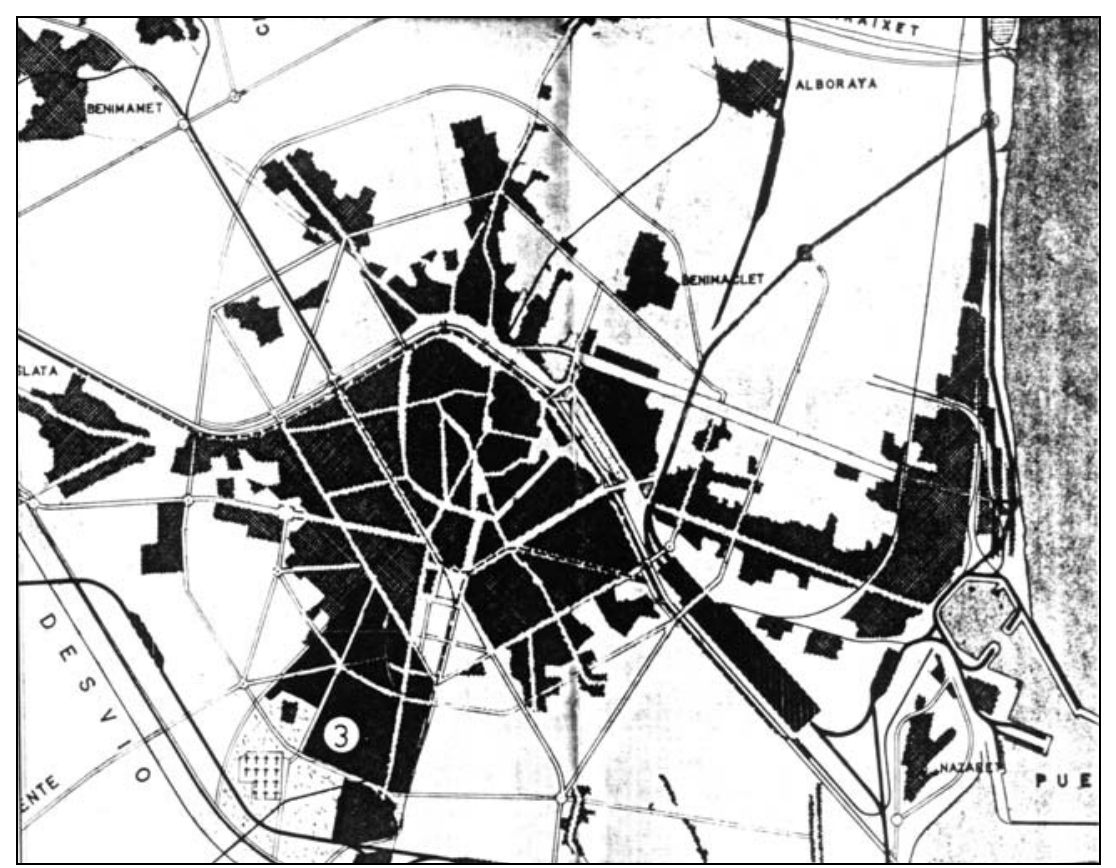

2. PLANO DE SITUACIÓN EN EL PLAN GENERAL (Fragmento) Escala original: $1: 10.500$

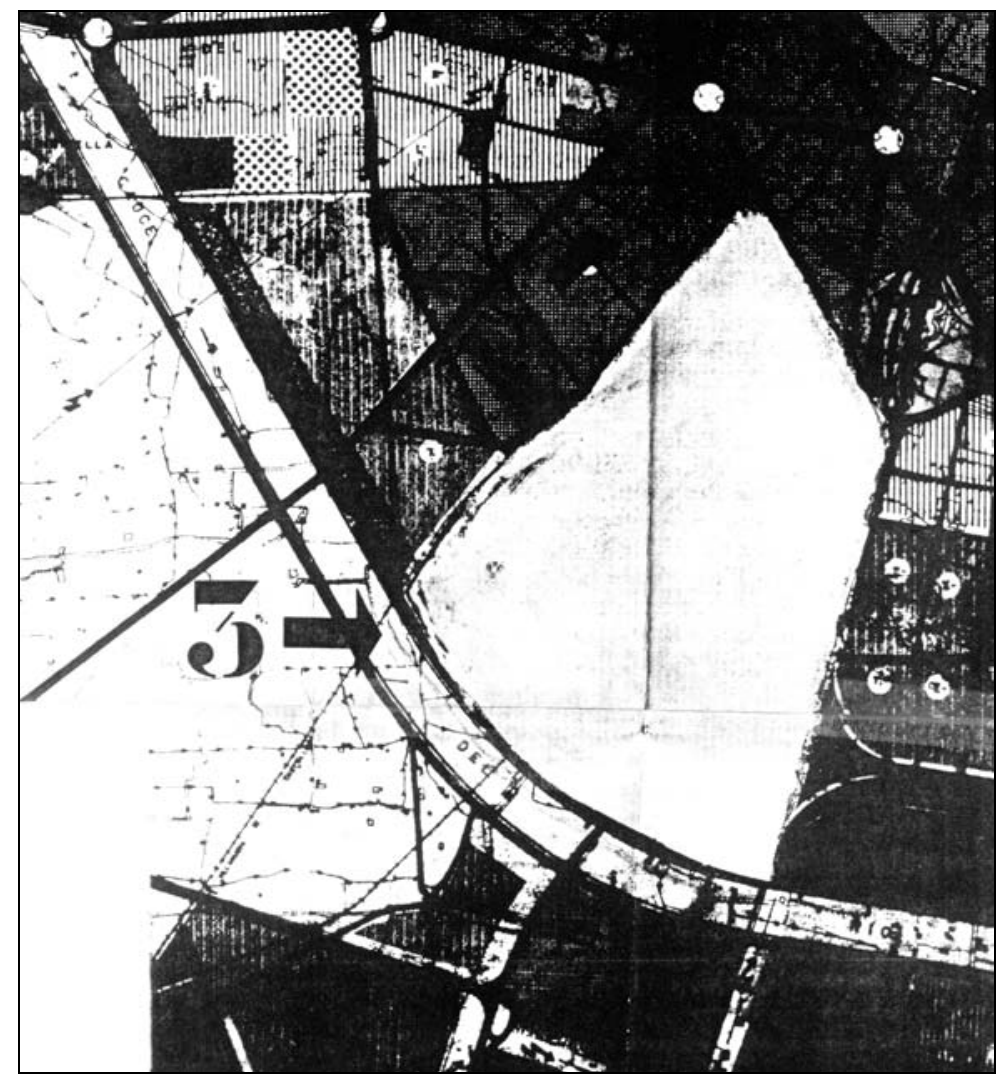


3. DELIMITACIÓN Y ESTADO ACTUAL

Escala original: 1:2000

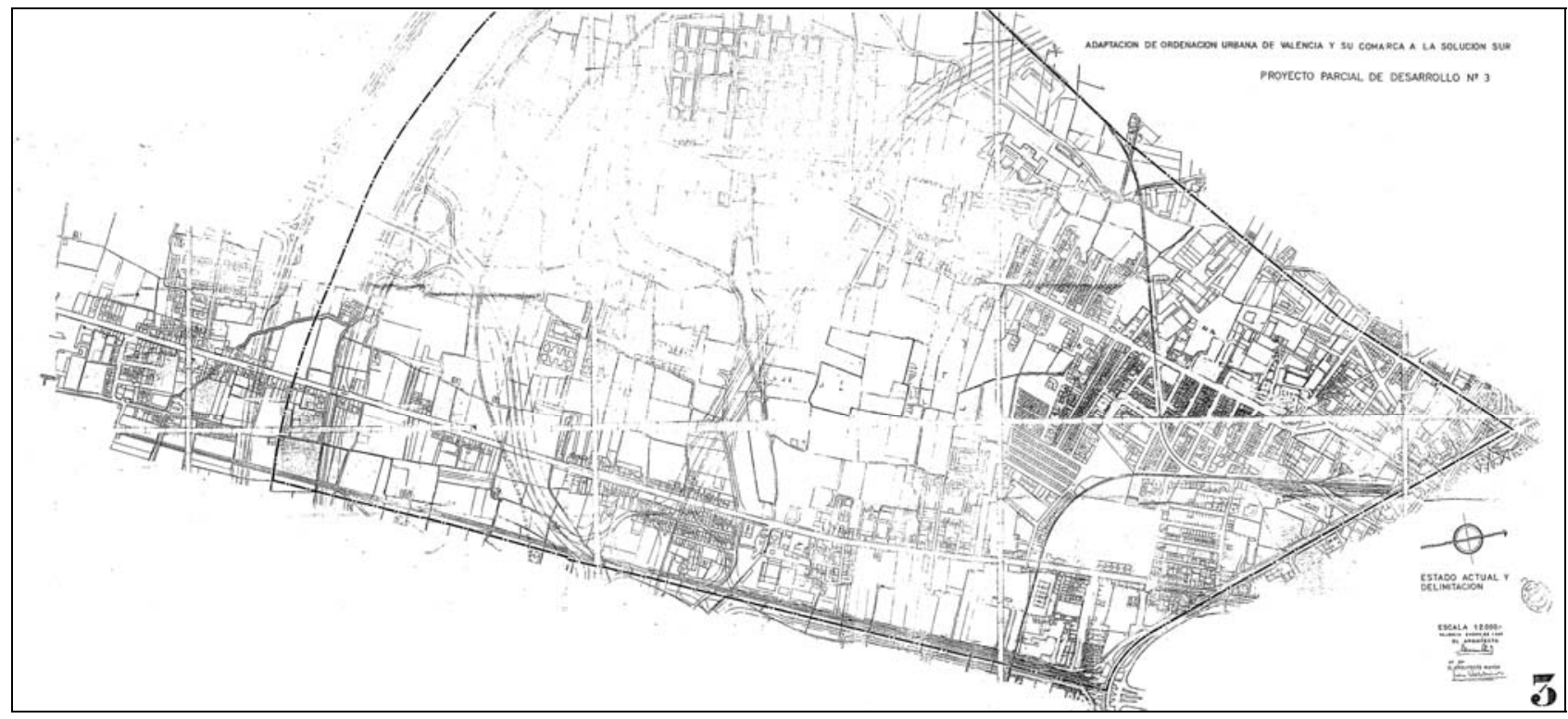

5. ZONIFICACIÓN.

Escala original: 1:2000

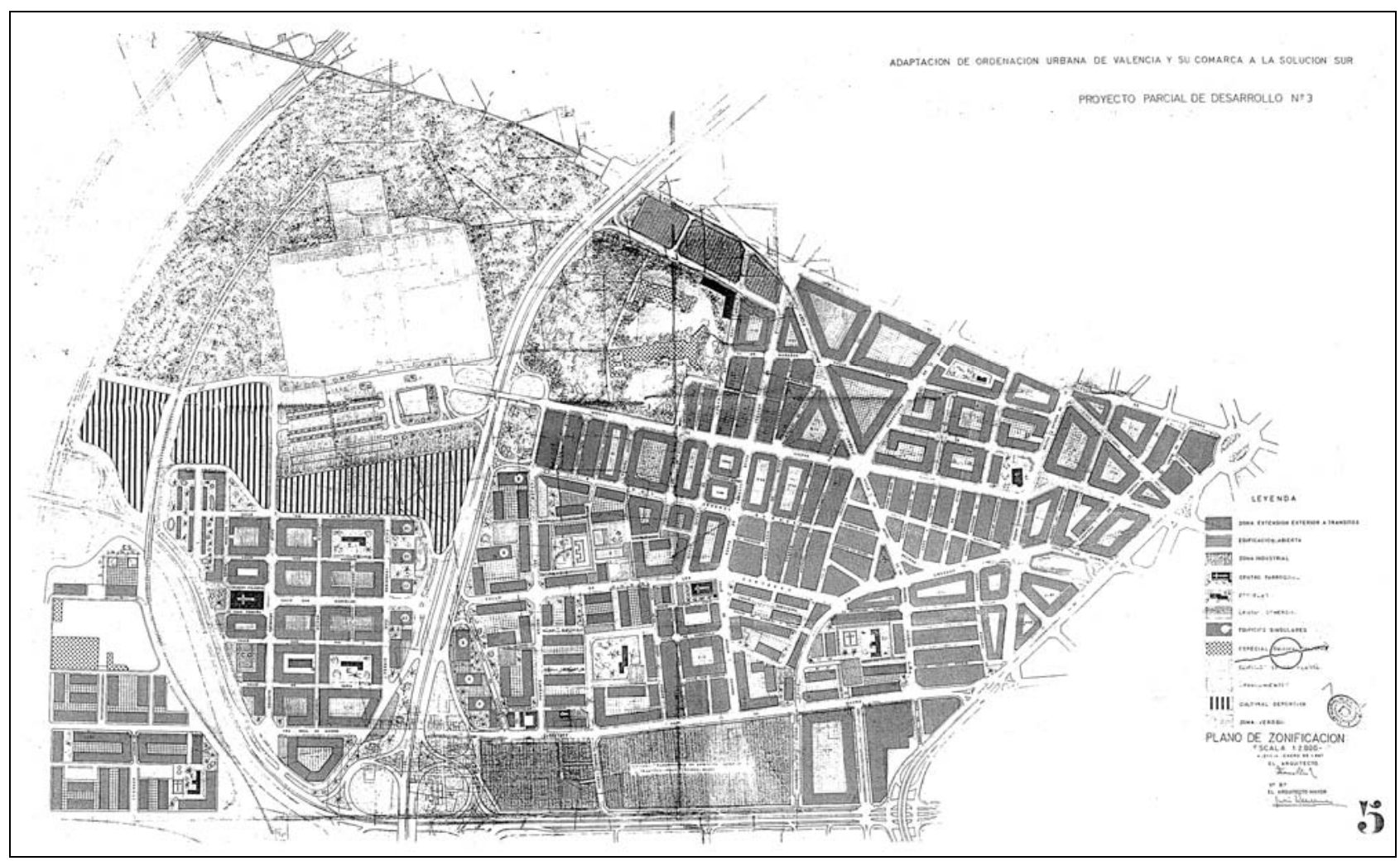




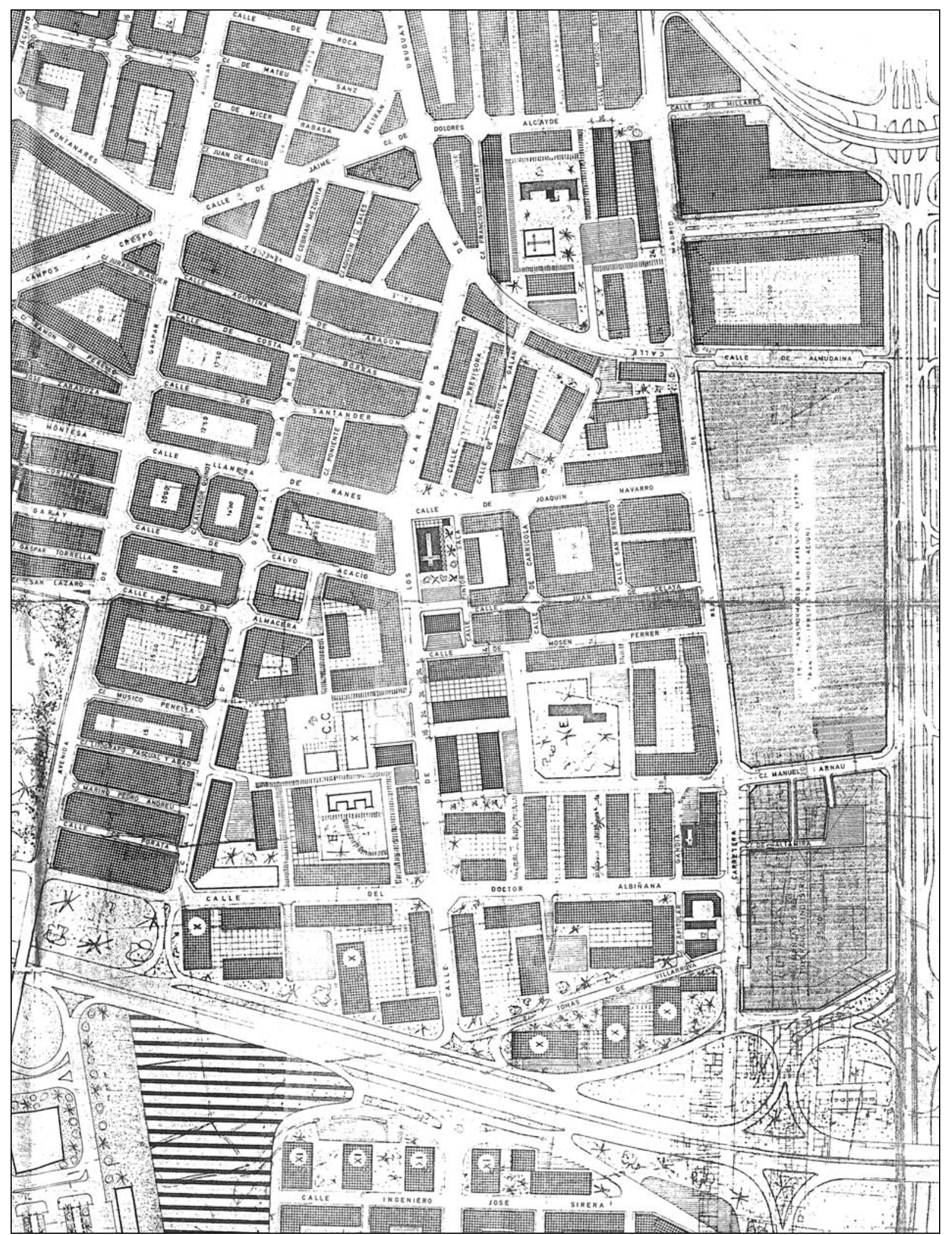

Detalle del plano de zonificación. 


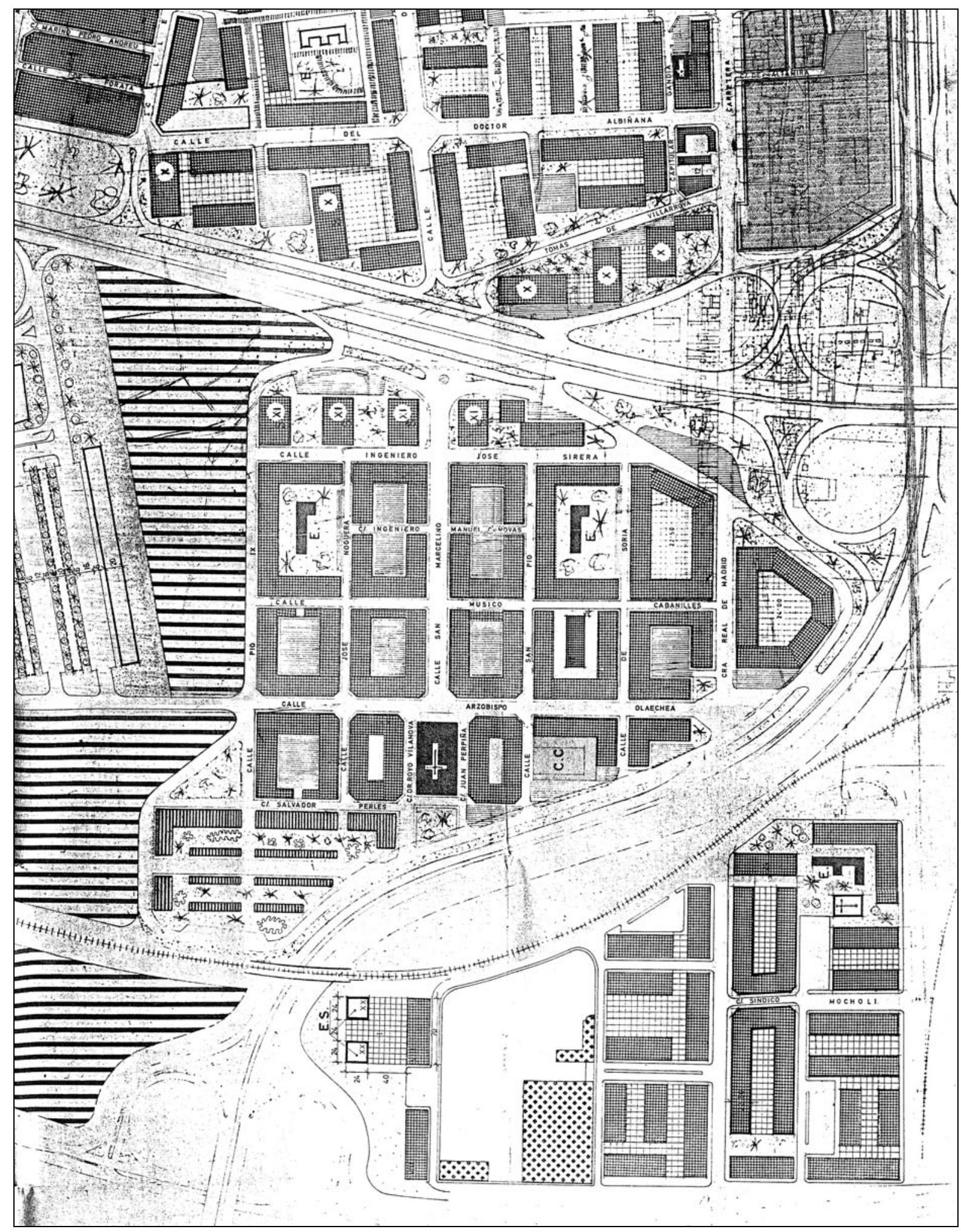

Detalle del plano de zonificación. 
6. RED VIARIA FUNDAMENTAL

Escala original: 1:2000

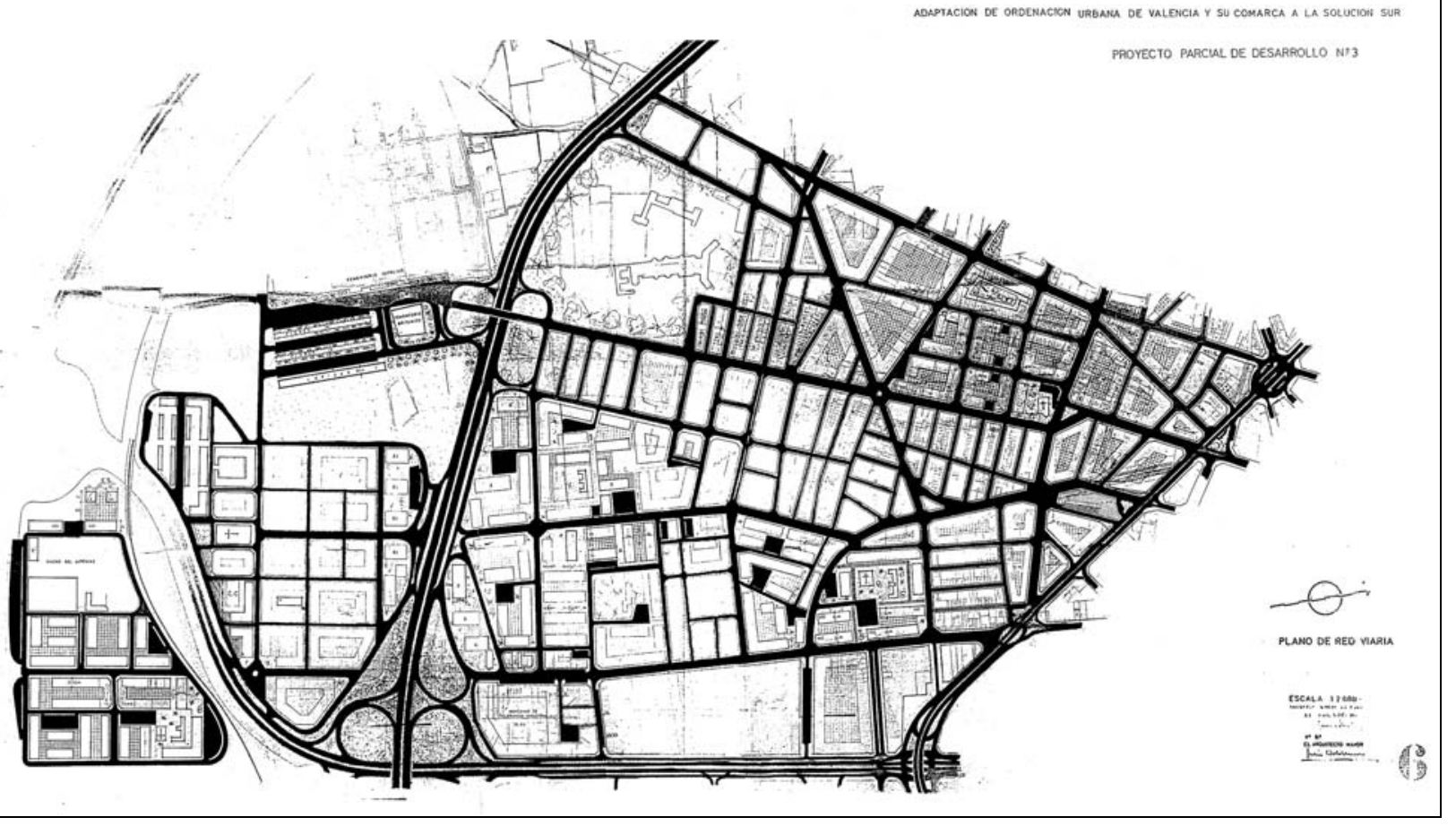




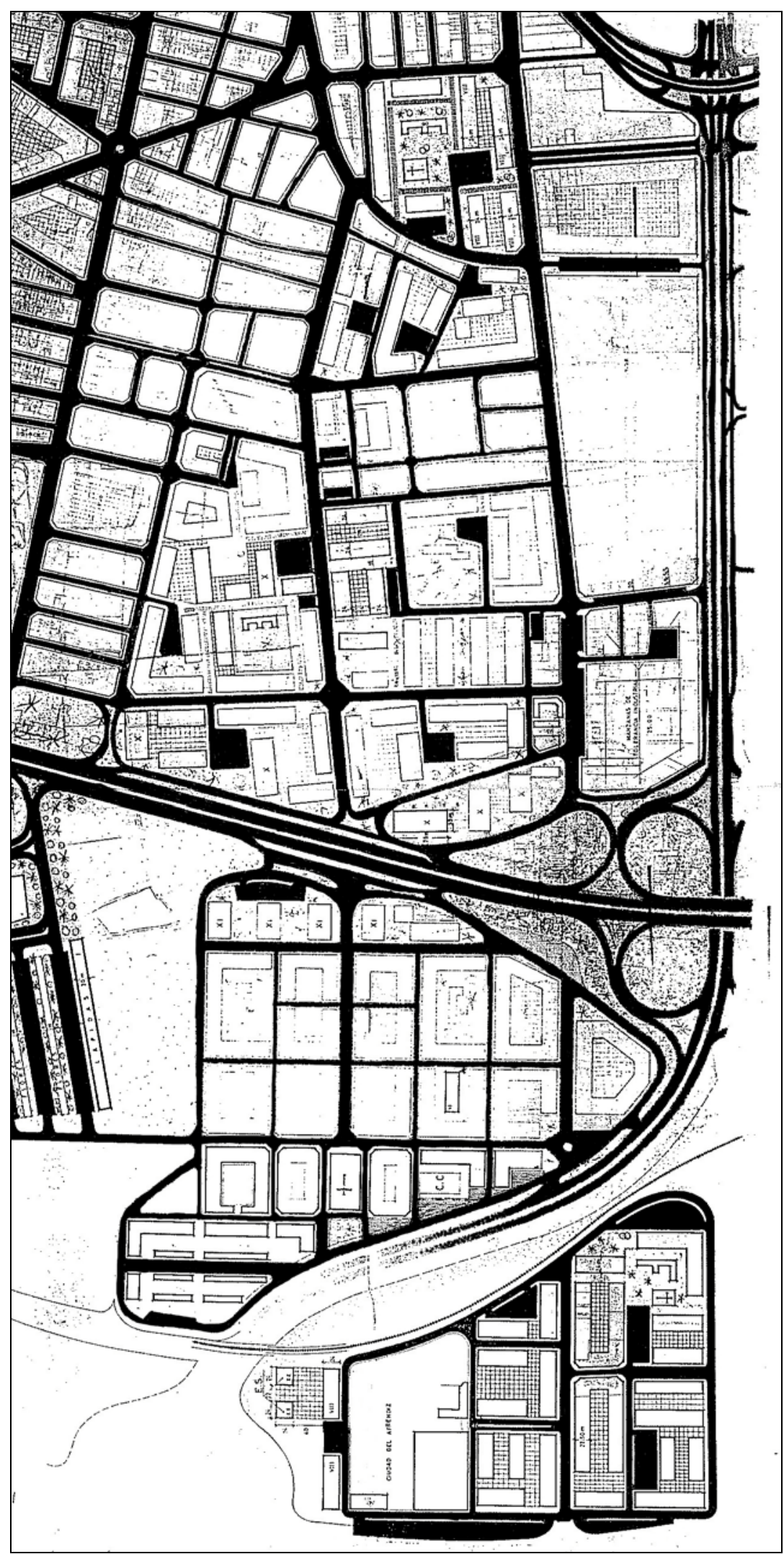

Detalle del plano de red Viaria Fundamental. 
Redactor: Dirección General de Urbanismo del Ministerio de la Vivienda / Ministerio de la Vivienda.

Fecha: 24- 10-1969.

Asunto: Resolución de aprobación del Plan Parcial 3.

Fuente: Ayuntamiento de Valencia. Sección de Urbanismo. Negociado de Suelo y Ordenación urbana. Expte. 183/1967. Reg. General 1.883 (Archivo de Planeamiento, No A-2/3)

MINISTERIO DE LA VIVIENDA

Dirección General de Urbanismo.

Ilmo Sr.:

El Excmo. Sr. Subsecretario del Ministerio de la Vivienda, actuando por delegación del Excmo. Sr. Ministro, con fecha 22 de los ctes., me dice lo siguiente:

"VISTO el Plan Parcial de Ordenación Urbana no 3, adaptado al vigente Plan General de Ordenación Urbana de Valencia y su Comarca, presentado por el Ayuntamiento de dicha ciudad por conducto de la Corporación Administrativa Gran Valencia, y VISTO el informe emitido por los servicios competentes de la Dirección General de Urbanismo, Este Ministerio, teniendo en cuenta lo dispuesto en la vigente Ley sobre Régimen del Suelo y Ordenación Urbana de 12 de Mayo de 1956 y en el Decreto 63/1968 de 18 de Enero, acuerda aprobar dicho Plan Parcial y que esta resolución sea notificada a la referida Corporación Local y a la Corporación Administrativa Gran Valencia."

Lo que comunico a V. I. para su conocimiento y efectos.

Dios guarde a V.I. muchos años.

Madrid, 24 de Octubre de 1.969.

EL DIRECTOR GENERAL.

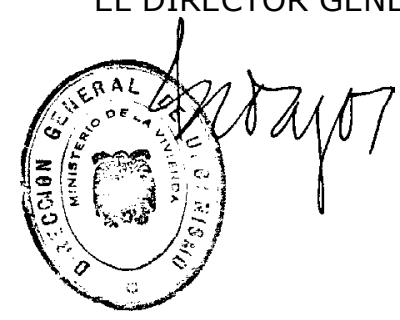

Ilmo. Sr. Alcalde Presidente del Ayuntamiento de VALENCIA. 



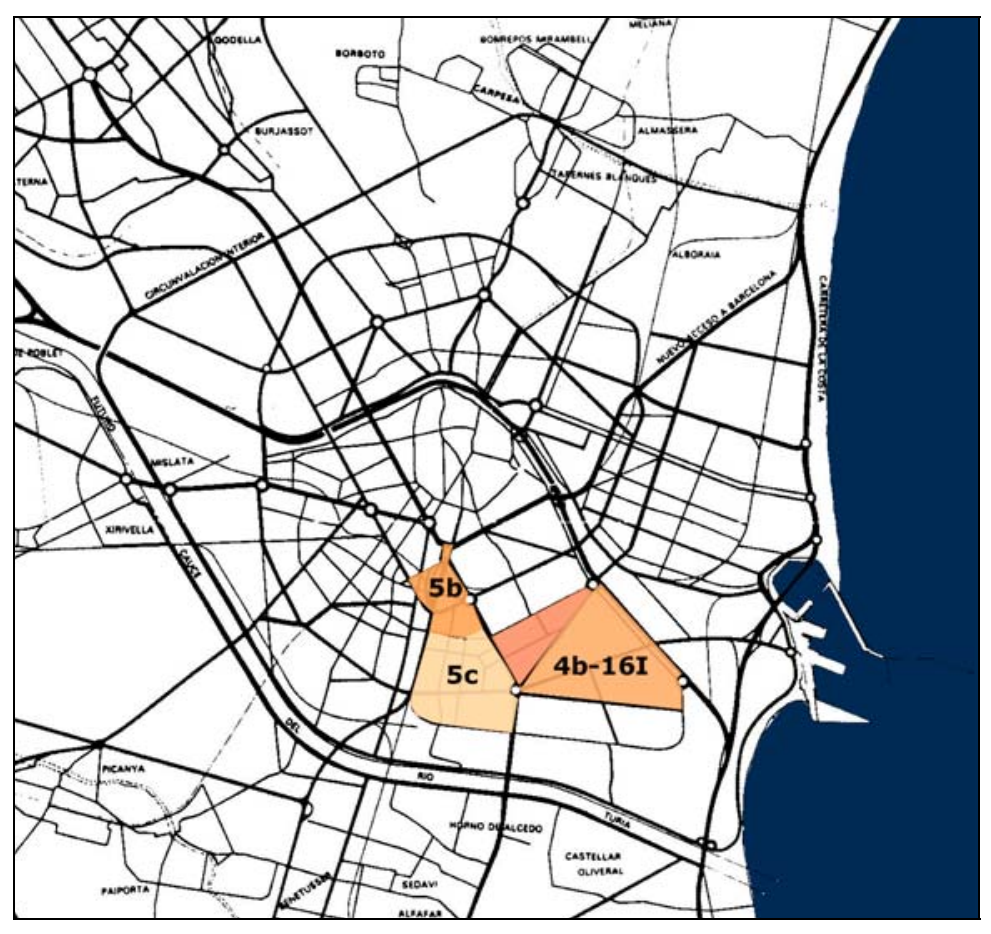

7.4. ZONA SURESTE

PLAN PARCIAL No 5-B (ESTACION CENTRAL), 1969. PLAN PARCIAL NO 5-C (MALILLA), 1968/1975. PLAN PARCIAL NO 4B-16I (FUENTE SAN LUIS), 1973. 



\section{PP 5-B}

PLANO PARCIAL No 5-B (ADAPTADO A LA SOLUCIÓN SUR).

1968

Redactores:

EXCMO. AYUNTAMIENTO DE VALENCIA. OFICINA TÉCNICA DE URBANISMO.

Fecha redacción: Marzo 1968

Fecha aprobación: O.M. 10-10-69 (B.O.E. 30-10-69) (*).

Contenido:

I. MEMORIA

II. ORDENANZAS.

III. PLANOS $(* *)$

1. PLANO DE SITUACIÓN DENTRO DE LA CIUDAD. $1: 10.000$

2. SITUACIÓN EN EL PLAN GENERAL $1: 22.500$

3. FOTOPLANO. S/E

4. ESTADO ACTUAL Y DELIMITACIÓN. $1: 2000$

5. ESTRUCTURA URBANISTICA $1: 2000$

6. ZONIFICACIÓN $1: 4000$

7. RED VIARIA FUNDAMENTAL $1: 2000$

8. ALINEACIONES Y RASANTES. $\quad 1: 2000$

9. REDES FUNDAMENTALES DE SERVICIO.

RED DE ALCANTARILLADO. $1: 2000$

ESQUEMA DE RED DE AGUAS POTABLES. $\quad 1: 2000$

ESQUEMA DE ALUMBRADO. $1: 2000$

10. PLAN DE ETAPAS.

Fuente: Ayuntamiento de Valencia. Sección de Urbanismo. Negociado de Suelo y Ordenación urbana. Expte. 348/1967. Reg. General 4.056 (Archivo de Planeamiento, No 46/47)

\section{Notas:}

*Esta versión del PP 5B es la redactada una vez introducidas en la versión inicial las modificaciones derivadas de las alegaciones.

** Los planos de proyecto ( $n^{\circ} 5$ a 8 ) son todos el mismo en cuanto a dibujo; tan sólo varía el cajetín. 
EXCMO. AYUNTAMIENTO

DE

VALENCIA

\section{PLANO PARCIAL NO 5-B}

Este plano fue aprobado por el Ayuntamiento Pleno de 3 de junio de 1964, y el que ahora nos ocupa es el adaptado a la Solución Sur del Plan de Ordenación de Valencia y su Comarca de fecha 30 de junio de 1966 B.0. del E. no 178 así como las Normas para su desarrollo.

Sus lindes son:

Norte: Galle Gil y Morte y Gran Vía Gemianías.

Sur: Antiguo ferrocarril de Nazaret

Este: Avda.de Ausias March -Nuevo Acceso de Alicante.

Oeste: Camino Real de Madrid.

Corresponde este plano parte de los terrenos de la actual estación principal de la Renfe en Valencia.

Que con terrenos colindantes constituye una zona señalada en el Plan General o sea como Centro Comercial cuyos límites son:

Calle Játiva, Alicante, Trafalgar, Ausias March, Peris y Valero, Cesar Giorgeta, Camino Real de Madrid, fachadas posteriores a la manzana recayentes a la cílle Gil y Morte y calle Bailén.

Por la importancia que en un futuro tiene para Valencia este Centro Comercial se reserva para un futuro y más detenido estudio.

Por ello se redacta este plano con la aspiración de servir de guía para la futura urbanización de terrenos de la estación del Norte y ordenar la construcción en los terrenos colindantes.

La zona resulta un importante nudo de comunicaciones, por lo que, tanto en la zona desde la Gran Vía de Germanías hasta el antiguo Ferrocarril de Nazaret como en el resto del plano se establecían gran cantidad de espacios libres que servirán de aparcamiento entre arboledas»

Se le da un carácter de edificación abierta en las zonas sin ninguna edificación y manzana cerrada en las ya iniciadas.

Las ordenanzas a aplicar son las que se aprobaron por el Ayuntamiento, del desarrollo del Plan General de Ordenación adaptado a la Solución Sur.

Las Zonificaciones que corresponde este plano son, Ensanche hasta Tránsitos, Edificación abierta, y zona Exterior a Tránsitos.

Con lo dicho creemos suficientemente expuesto al alcance del estudio realizado para que si el Excmo Ayuntamiento lo estima conveniente lo eleve a la aprobación por la superioridad.

Valencia, marzo de 1968.

LOS ARQUITECTOS MUNICIPALES,

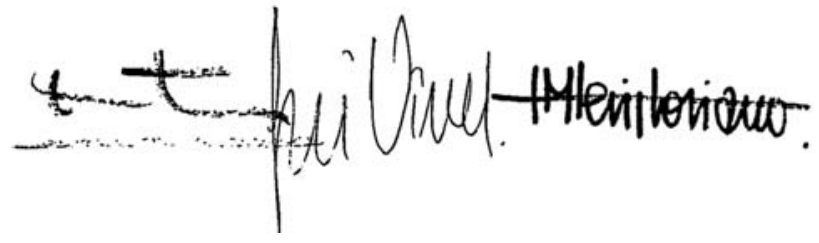


EXCMO. AYUNTAMIENTO

DE

VALENCIA

\section{PLANO PARCIAL NO 5-B}

Proyecto de Alineaciones y Zonificación del Sector limitado por el pavimento de las calles siguientes:

NORTE: Calle de Gil y Morte y Gran Vía Germanías.

SUR: Antiguo ferrocarril de Nazaret.

ESTE: Av. De Ausias March-Nuevo Acceso Alicante.

OESTE: Camino Real de Madrid

\section{ORDENANZAS}

Hasta que no se aprueben las ordenanzas adaptadas a la Solución Sur en estudio, se aplicarán las vigentes aprobadas por la Comisión Central de Sanidad en 23 de octubre de 1.950 y 26 de enero de 1.955, en los casos no previstos en las normas urbanísticas del Plan de Ordenación de Valencia y su Comarca, adaptada a la "Solución Sur" por la que tendrá que regirse actualmente este Ayuntamiento.

A este Plano Parcial le corresponde la Zonificación de Ensanche hasta Tránsitos, Centro Comercial, Edificación Abierta con Bajos Comerciales, Extensión Exterior a Tránsitos, y Escuelas y edificios Públicos.

Valencia, marzo de 1968.

LOS ARQUITECTOS MUNICIPALES,

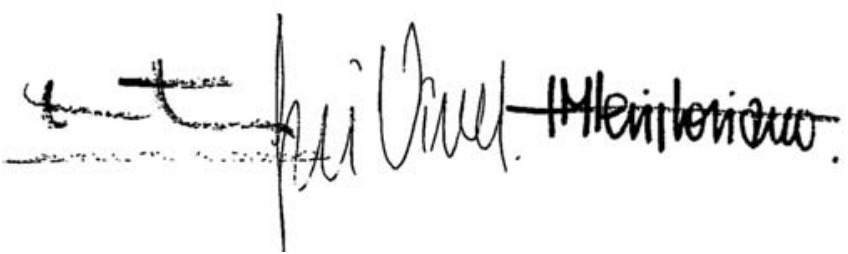


EXCMO. AYUNTAMIENTO

DE

VALENCIA

PLANO PARCIAL NO 5-B

\section{PLAN DE ETAPAS}

No puede establecerse en un Plan parcial que no trata más que de encauzar la iniciativa particular. El futuro puede hacer interesante establecerlas para ultimar lo que se haya ido realizando.

El Excmo. Ayuntamiento atenderá la urbanización en los puntos en que vaya siendo necesaria.

Valencia, marzo de 1968.

LOS ARQUITECTOS MPLEZ. DE URBANISMO,

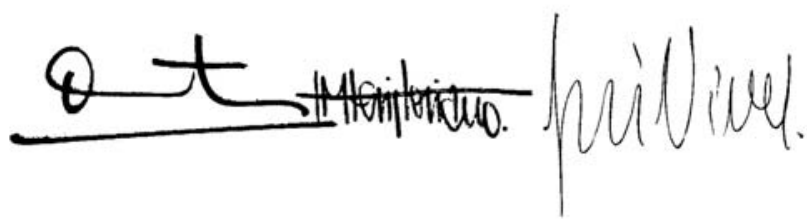

PP 5-B

EXCMO. AYUNTAMIENTO

DE

VALENCIA

PLANO PARCIAL NO 5-B

MEDIOS ECONÓMICO-FINANCIEROS

Son los ordinarios del Presupuesto de Urbanismo del Excmo. Ayuntamiento de Valencia y los extraordinarios que con tal fin se establezcan.

LOS ARQUITECTOS MPLES = DE URBANISMO,

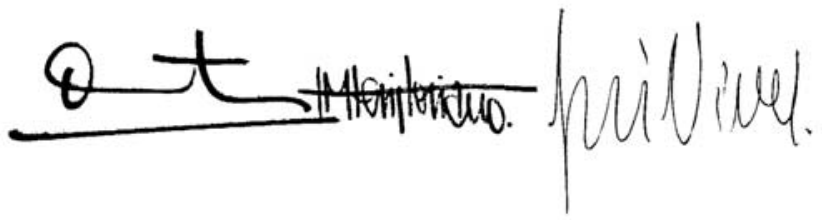


1. PLANO DE SITUACIÓN EN LA CIUDAD

Escala original: $1: 10.000$

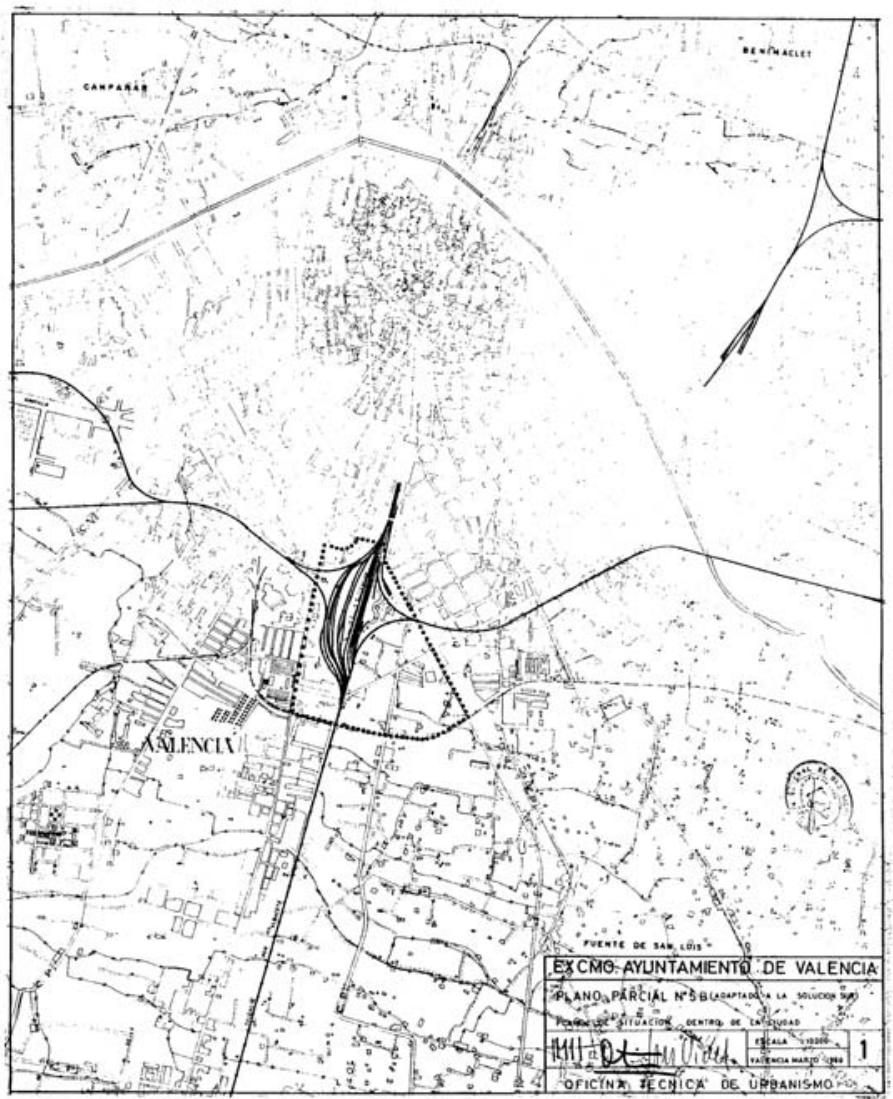

2. PLANO DE SITUACIÓN EN EL PLAN GENERAL (Fragmento)

Escala original: $1: 22.500$

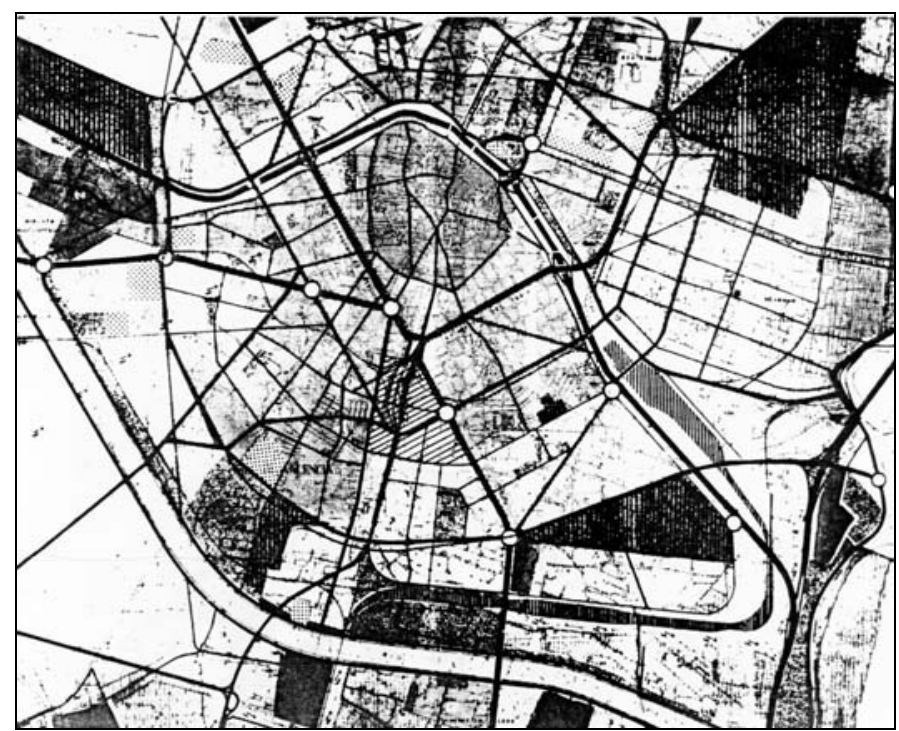


3. INFORMACIÓN Y FOTO AÉREA

Escala original: 1:2000
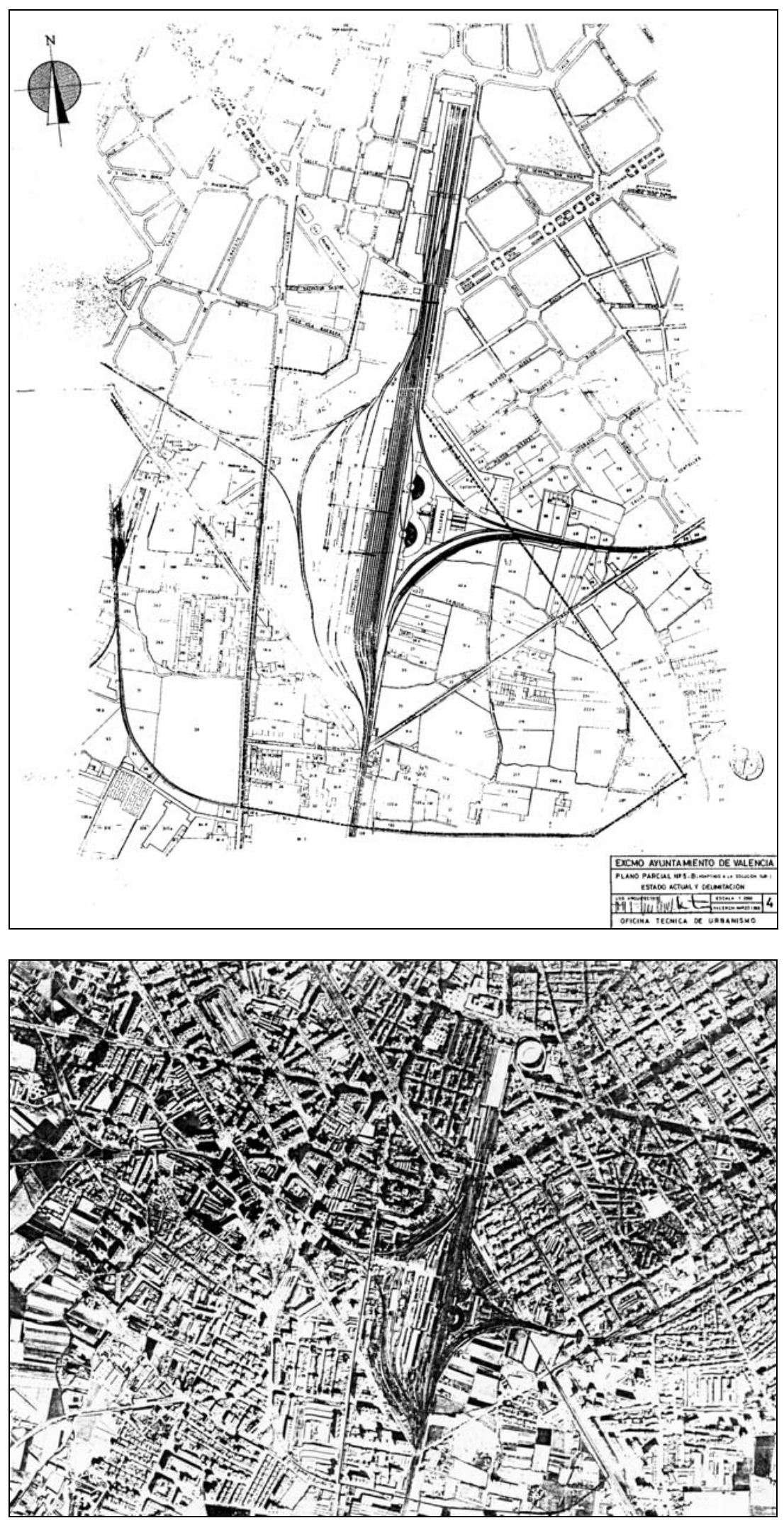
8. ALINEACIONES

Escala original: 1:2000

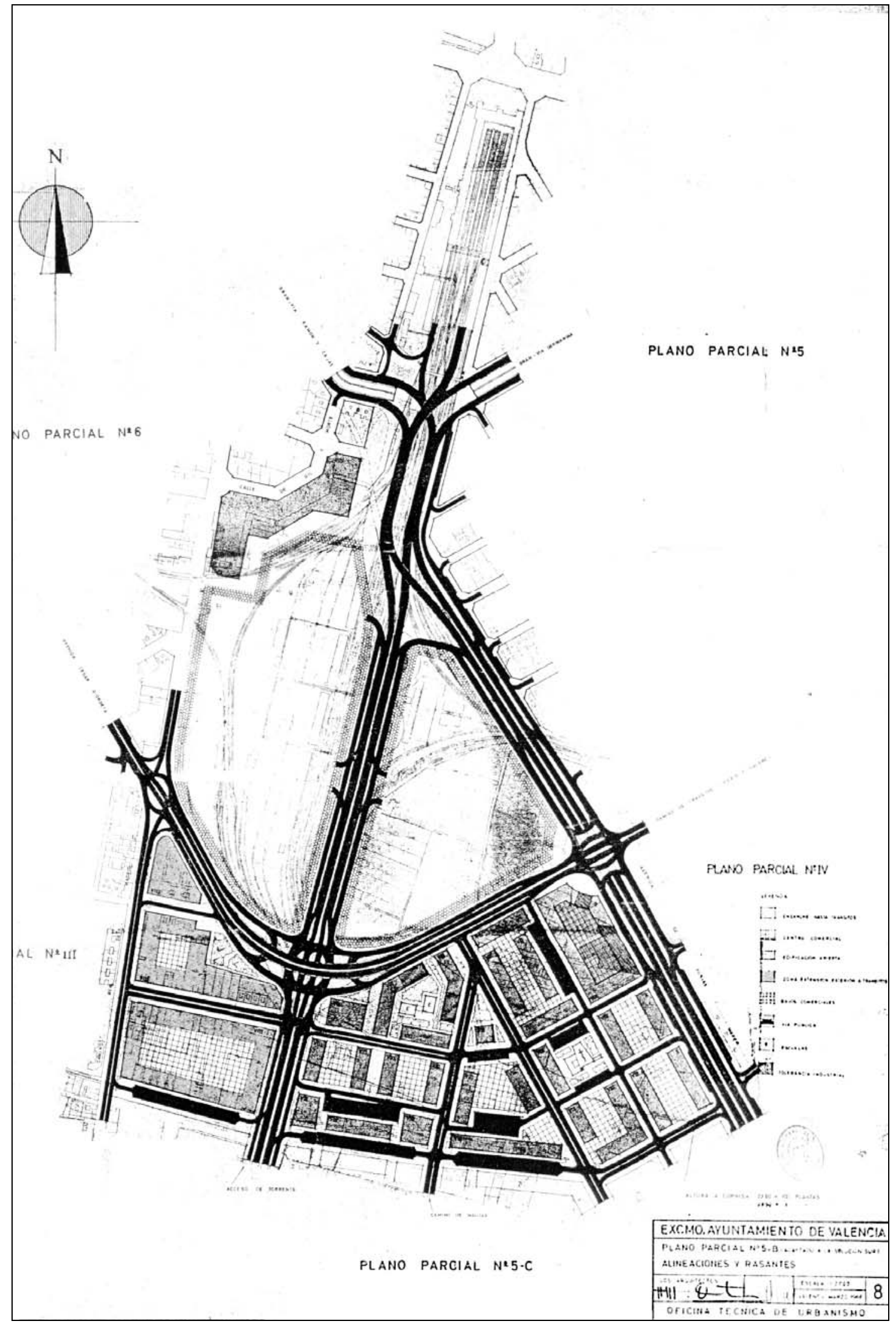




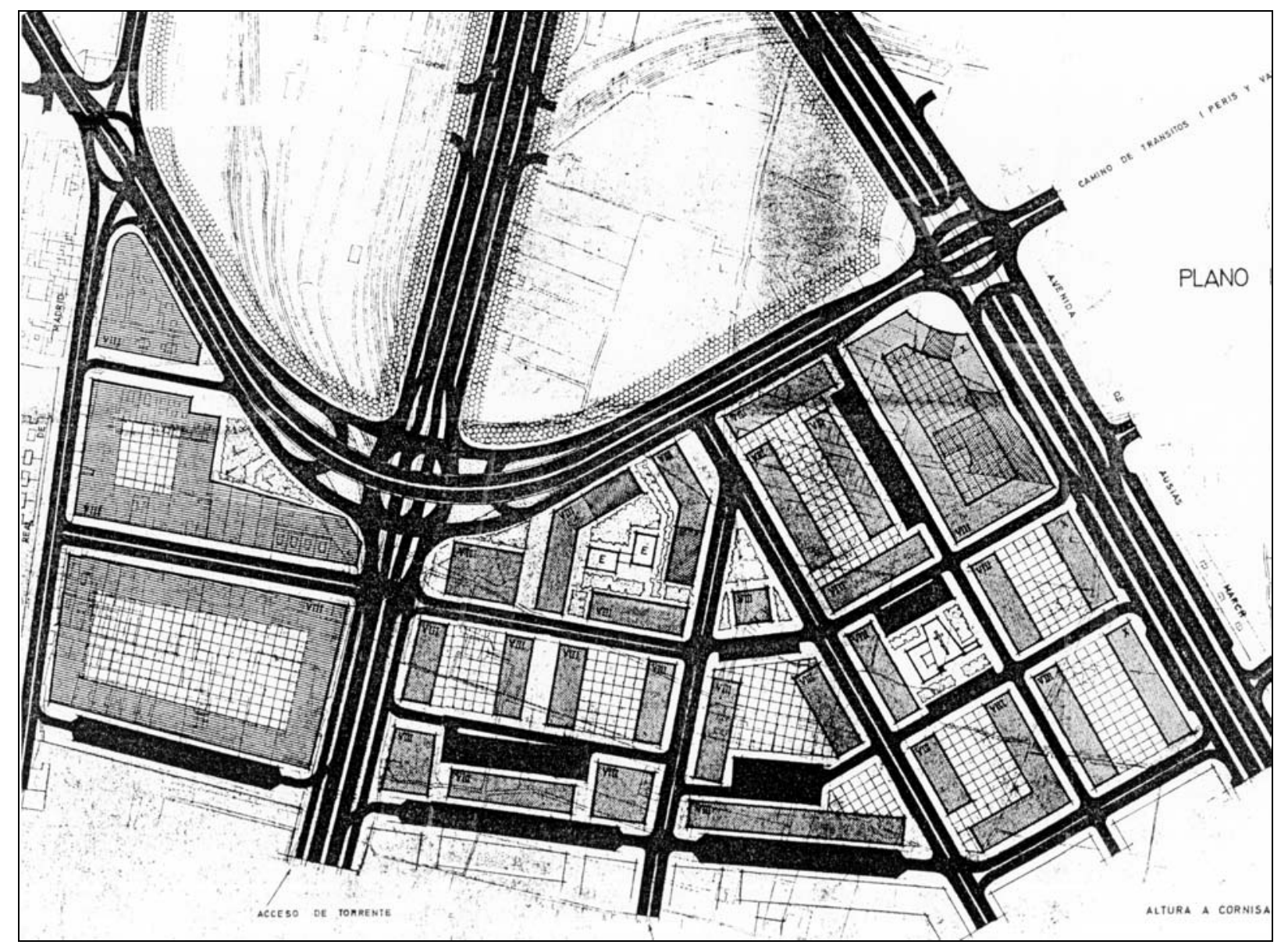

Detalle del Plano de Alineaciones. 
Redactor: Dirección General de Urbanismo del Ministerio de la Vivienda / Ministerio de la Vivienda.

Fecha: 14- 10-1969.

Asunto: Resolución de aprobación del Plan Parcial 5-B.

Fuente: Ayuntamiento de Valencia. Sección de Urbanismo. Negociado de Suelo y Ordenación urbana. Expte. 348/1967. Reg. General 4.056 (Archivo de Planeamiento, No 46/47)

MINISTERIO DE LA VIVIENDA

Dirección General de Urbanismo.

Ilmo Sr.:

El Excmo. Sr. Subsecretario del Ministerio de la Vivienda, actuando por delegación del Excmo. Sr. Ministro, con fecha 10 de los ctes., me dice lo siguiente:

"VISTO el Plan Parcial de Ordenación Urbana no 5-B, de Valencia, adaptado al vigente Plan General de Ordenación Urbana de Valencia y su Comarca, presentado por el Ayuntamiento de dicha ciudad por conducto de la Corporación Administrativa Gran Valencia, y VISTO el informe emitido por los servicios competentes de la Dirección General de Urbanismo, Este Ministerio, teniendo en cuenta lo dispuesto en la vigente Ley sobre Régimen del Suelo y Ordenación Urbana de 12 de Mayo de 1956 y en el Decreto 63/1968 de 18 de Enero, acuerda aprobar dicho Plan Parcial y que esta resolución sea notificada a la referida Corporación Local, y a la Corporación Administrativa Gran Valencia."

Lo que comunico a V. I. para su conocimiento y efectos.

Dios guarde a V.I. muchos años.

Madrid, 14 de Octubre de 1.969.

EL DIRECTOR GENERAL.

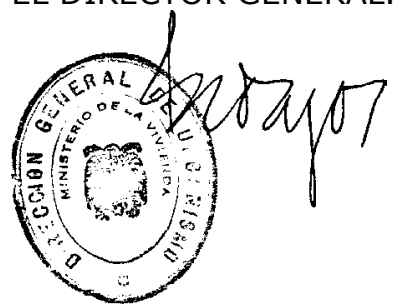

Ilmo. Sr. Alcalde Presidente del Ayuntamiento de VALENCIA. 



\section{PP 5-C}

PLANO PARCIAL No 5-C (ADAPTADO A LA SOLUCIÓN SUR).

1973

\section{Redactores:}

EXCMO. AYUNTAMIENTO DE VALENCIA. OFICINA TÉCNICA DE URBANISMO. Arquitectos: José Ma Peris, Cándido Orts, José Vives. Fecha redacción: Enero 1973, Julio 1975.

Fecha aprobación: Plan 1973: O.M. 23-09-74 (B.O.E. 25-10-74). Plan 1975, Sector edificación Abierta: O.M. 30-04-76 (B.O.E. 25-0676) $(* *)$.

\section{Contenido:}

I. MEMORIA

II. ORDENANZAS.

III. PLANOS

1. PLANO DE SITUACIÓN DENTRO DE LA CIUDAD. 1:10.000

2. SITUACIÓN EN EL PLAN GENERAL $1: 22.500$

3. INFORMACIÓN Y FOTO AÉREA $1: 2000$

4. ZONIFICACIÓN $1: 4000$

5. ESTRUCTURA URBANISTICA $1: 2000$

6. ALINEACIONES Y RASANTES. $1: 2000$

7. RED VIARIA FUNDAMENTAL $1: 2000$

8. REDES FUNDAMENTALES DE SERVICIO.

$\begin{array}{ll}\text { RED DE ALCANTARILLADO. } & 1: 2000 \\ \text { ESQUEMA DE RED DE AGUAS POTABLES. } & 1: 2000 \\ \text { ESQUEMA DE ALUMBRADO. } & 1: 2000\end{array}$

Fuente: Ayuntamiento de Valencia. Sección de Urbanismo. Negociado de Suelo y Ordenación urbana. Expte. 349/1967, 82/1973 (Archivo de Planeamiento, No 51/52, 53/54).

\section{Notas:}

* Los nombres de estos arquitectos no figuran en los planos, sino únicamente en la carpeta del PP 5-C.

** El PP 5-C, una vez aprobado provisionalmente por el Ayuntamiento con fecha 3-08-1973, fue remitido al Ministerio de la Vivienda, y posteriormente al trámite de exposición pública. La versión definitiva de 1975 recoge tanto las modificaciones exigidas por el Ministerio (ver Documento 5C.1) como las resultantes de alegaciones de particulares. 


\section{PLAN PARCIAL NO $5-C$}

\section{$\underline{\text { MEMOR I A }}$}

La presente Memoria es complemento de la Memoria General del Plan Parcial $n^{\circ} 5-C$, redactada en Enero de 1973, y hace referencia a la zona calificada como de EDIFICACION ABIERTA, que por Resolución Ministerial de 29 de Septiembre de 1974 (B.0.E. 25Octubre-1974) fue excluida de la aprobación del Plan, con el fin de que, y se cita textualmente: "Se redacte una nueva ordenación de la misma ajustándola al volumen de edificación marcado por el Plan comarcal, $5 \mathrm{~m} 3 / \mathrm{m} 2$. y que en la presente alcanza 5'40 m3/m2".

De conformidad, por tanto, con la citada resolución se ha procedido a un nuevo estudio de la zona de Edificacion Abierta en el sentido expresado; estudio que afecta fundamentalmente a las alineaciones de los bloques de edificios anteriormente proyectados y al uso de los terrenos, buscando respetar lo más posible el estado actual y los criterios establecidos, toda vez que el sector aparece construido en un $80 \%$ de su edificabilidad y prácticamente en su totalidad con edificios acogidos a la protección oficial.

Es por ello que al proceder dentro del nuevo estudio a plantear las posibles modificaciones, éstas han quedado limitadas en grado máximo por la circunstancia antedicha y por tanto solo en aquellas manzanas donde aparecían libres de edificación o en bloques parcialmente construidos se ha podido buscar la reducción de volumen requerido.

Por otra parte al establecer una cierta división en polígonos dentro de la zona, al objeto de proceder a un ponderado estudio de volúmenes, éste dio como resultado que el exceso de volumen aparecía claramente en el polígono limitado por la Av. de Ausias March (Acceso a Alicante) y las calles Olta, Ingeniero Joaquín Benlloch y Prolongación de Isla Cabrera, al otro lado de la zona del Plan Comarcal, y por consiguiente el criterio de reducción de volumen establecido en el párrafo anterior se ha centrado en este sector.

Por último, la previsión de plazas de aparcamiento en proporción de una por vivienda, determinada en la misma Resolución ministerial ha obligado a que en la modificación de la zona de Edificación Abierta, se haya tenido igualmente en cuenta, toda vez que es aquí donde el numero de viviendas es mayor y al mismo tiempo más necesitada de áreas de aparcamiento.

Consecuencia de todo lo expresado, la modificación del Plan Parcial $\mathrm{n}^{\circ} 5-\mathrm{C}$ y en la zona de Edificación Abierta se concreta en los puntos siguientes:

10.- Reducción de la longitud de los bloques situados entre la Av. de Ausias March y las calles Olta, Juan Ramón Jimenez y Bernat Descolls; y los situados entre la Av. de Ausias March, Na Robella, Juan Ramón Jiménez y prolongación Isla Cabrera.

20.- Supresión de los bloques situados entre las calles Bernat Descolls, Ingeniero Joaquín Benlloch, Juan Ramón Jiménez y En Proyecto, transformando el conjunto en una manzana especial para la construcción de un edificio singular con destino a aparcamiento público, a la que se le asigna un volumen máximo edificable.

$3^{\circ}$.- Supresión de una zona comercial entre los bloques ya 
construidos y situados entre la Av. de Ausias March y la calle Juan Ramón Jiménez, en la manzana inmediata a la calle Na Robella y al norte de la misma, destinando el terreno a aparcamiento público.

Posteriormente, transcurrido el periodo de exposición publica, y como consecuencia de la aceptación de, en parte o en su totalidad, ciertas reclamaciones habidas, se introducen nuevas variaciones en el plan, siendo las más importantes a destacar, la inclusión de un Mercado Municipal, la reserva de una zona para templo y la delimitación exacta, como tal, de una estación de servicio, en la actualidad en funcionamiento, junto a la Av. de Ausias March.

Motivo de la introducción de estos elementos ha sido el reajuste en los diferentes bloques de edificación circundante; reajuste que en cualquier caso se mantiene en lo que al volumen se refiere por bajo del Índice del Plan General.

Circunstancias todas ellas que quedan reflejadas en los planos y documentación adjunta, y cuyo resumen es el siguiente:

\section{A.- ZONA DE EDIFICACION ABIERTA.-}

Superficie total del sector

$254.400 \mathrm{~m} 2$.

Superficie edificable total en planta .......

En bloques de vivienda y comerciales:

En servicios:

$74.639 \mathrm{~m} 2$.

Volumen total

$48.959 \mathrm{~m} 2$.

$25.680 \mathrm{~m} 2$.

Coeficiente de edificabilidad

$1.270 .843 \mathrm{~m} 3$ $4,99 \mathrm{~m} 3 / \mathrm{m} 2$

Zonas Verdes $(12,62 \%)$ 


\section{PLAN PARCIAL No 5-C}

\section{ORDENANZAS}

Serán de aplicación los artículos correspondientes a la zona de edificación abierta de las Ordenanzas redactadas en Enero de 1973, que forman parte de la documentación general del Plan Parcial no 5-C, toda vez que el nuevo estudio de remodelación del sector de edificación abierta, no ha afectado para nada a los criterios de Ordenanza contenidos en la documentación primitiva.

Valencia, Julio de 1975.

EL ARQUITECTO MUNICIPAL,

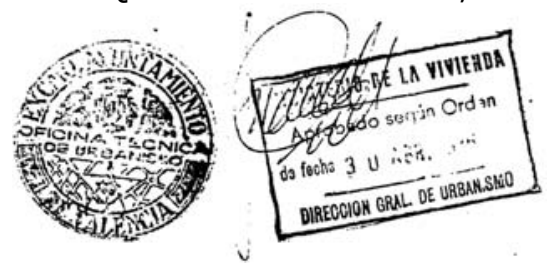


1. PLANO DE SITUACIÓN EN LA CIUDAD

Escala original: $1: 10.000$

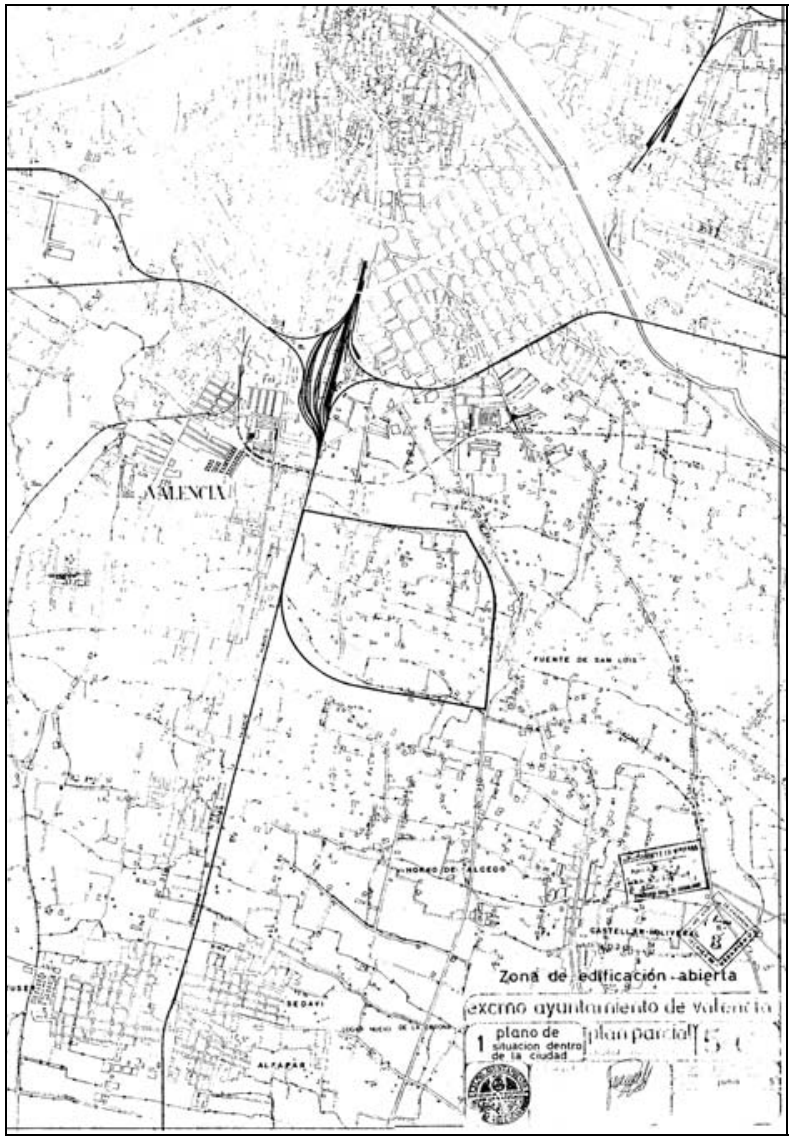

2. PLANO DE SITUACIÓN EN EL PLAN GENERAL (Fragmento)

Escala original: $1: 22.500$

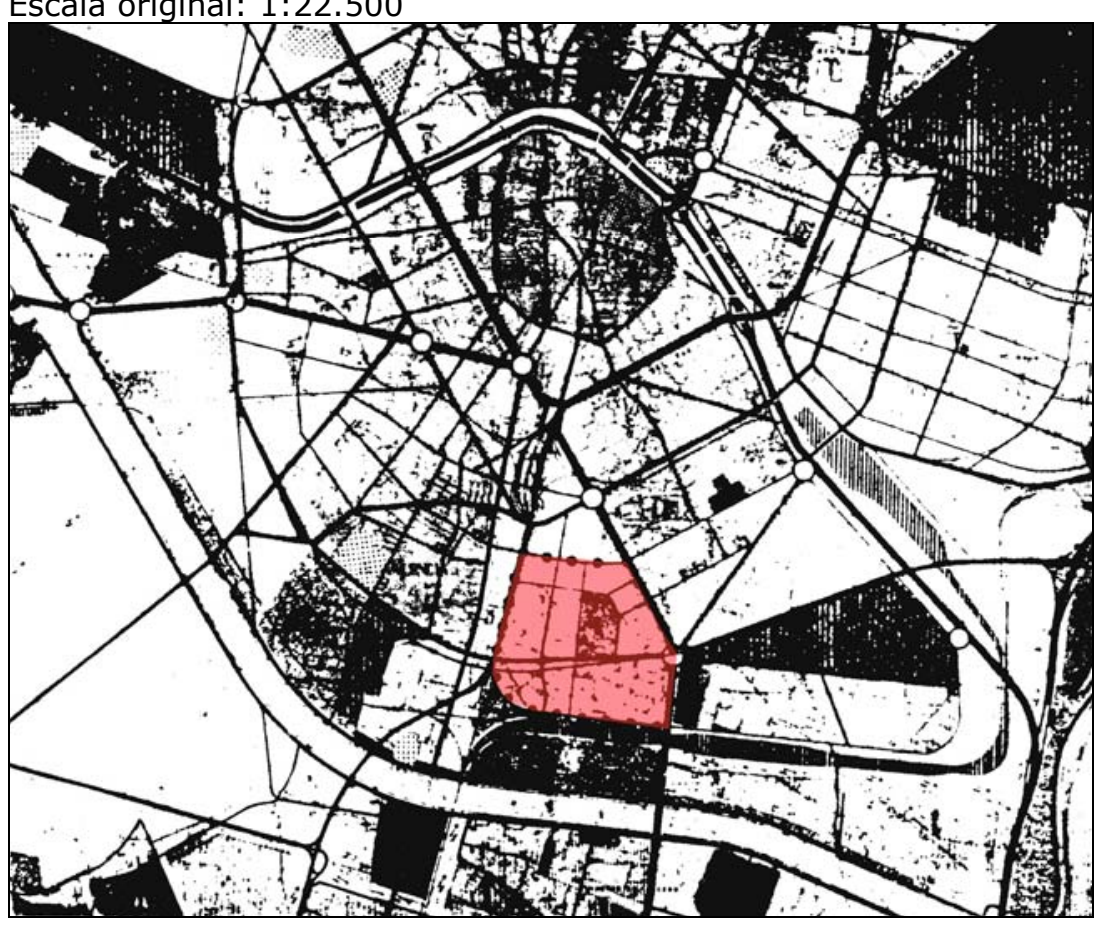




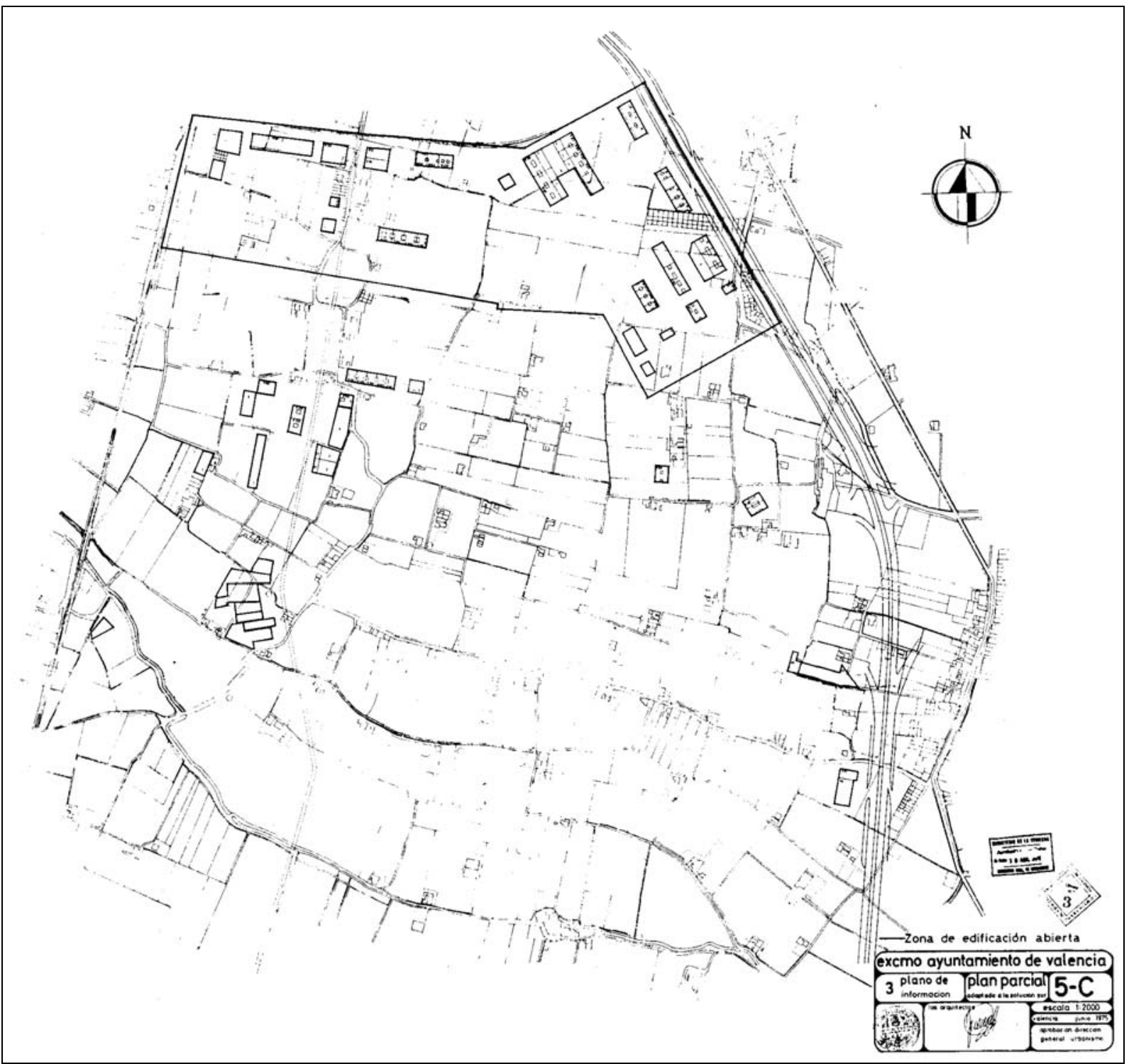


6. ALINEACIONES Y RASANTES.

Escala original 1:2000

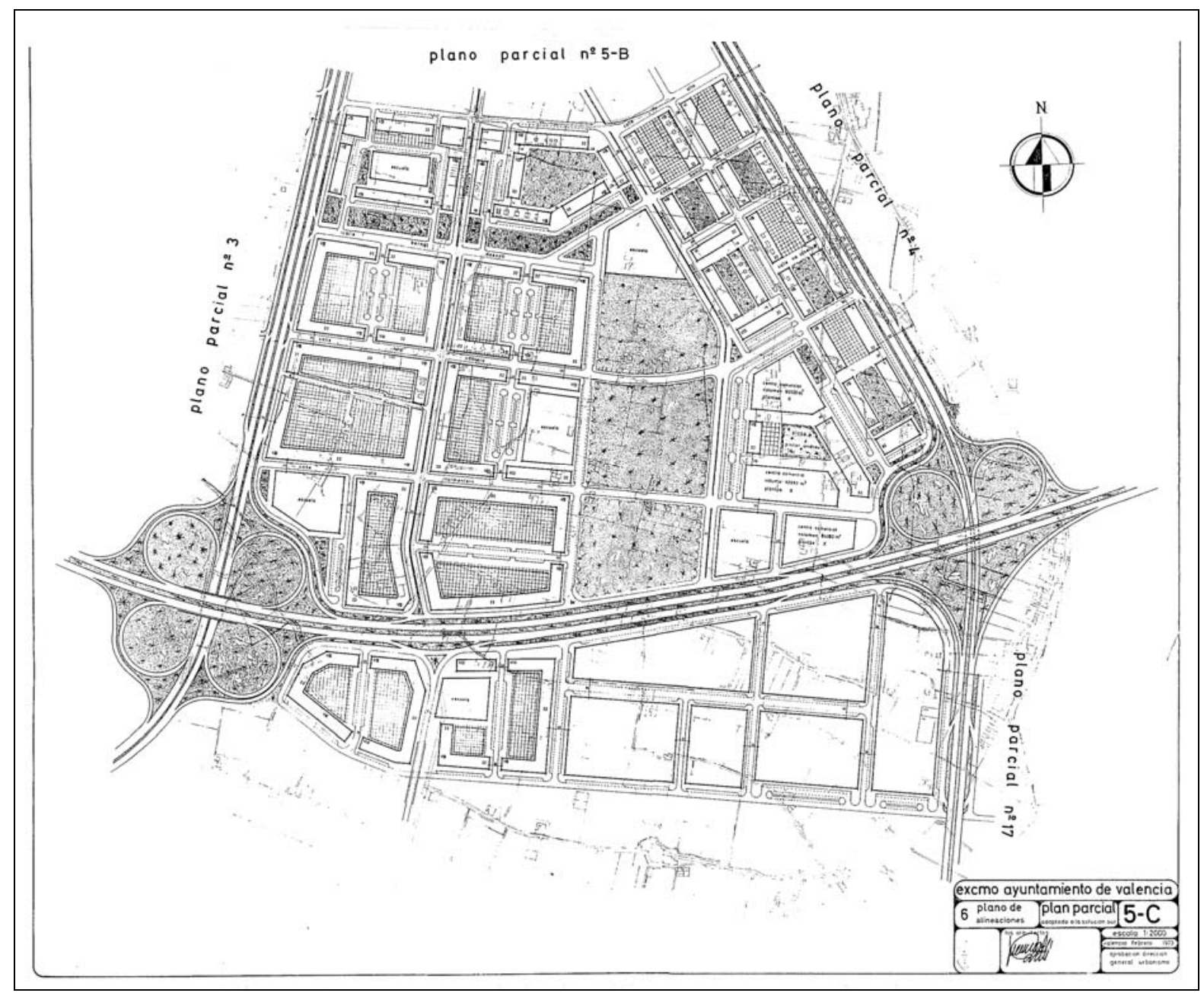




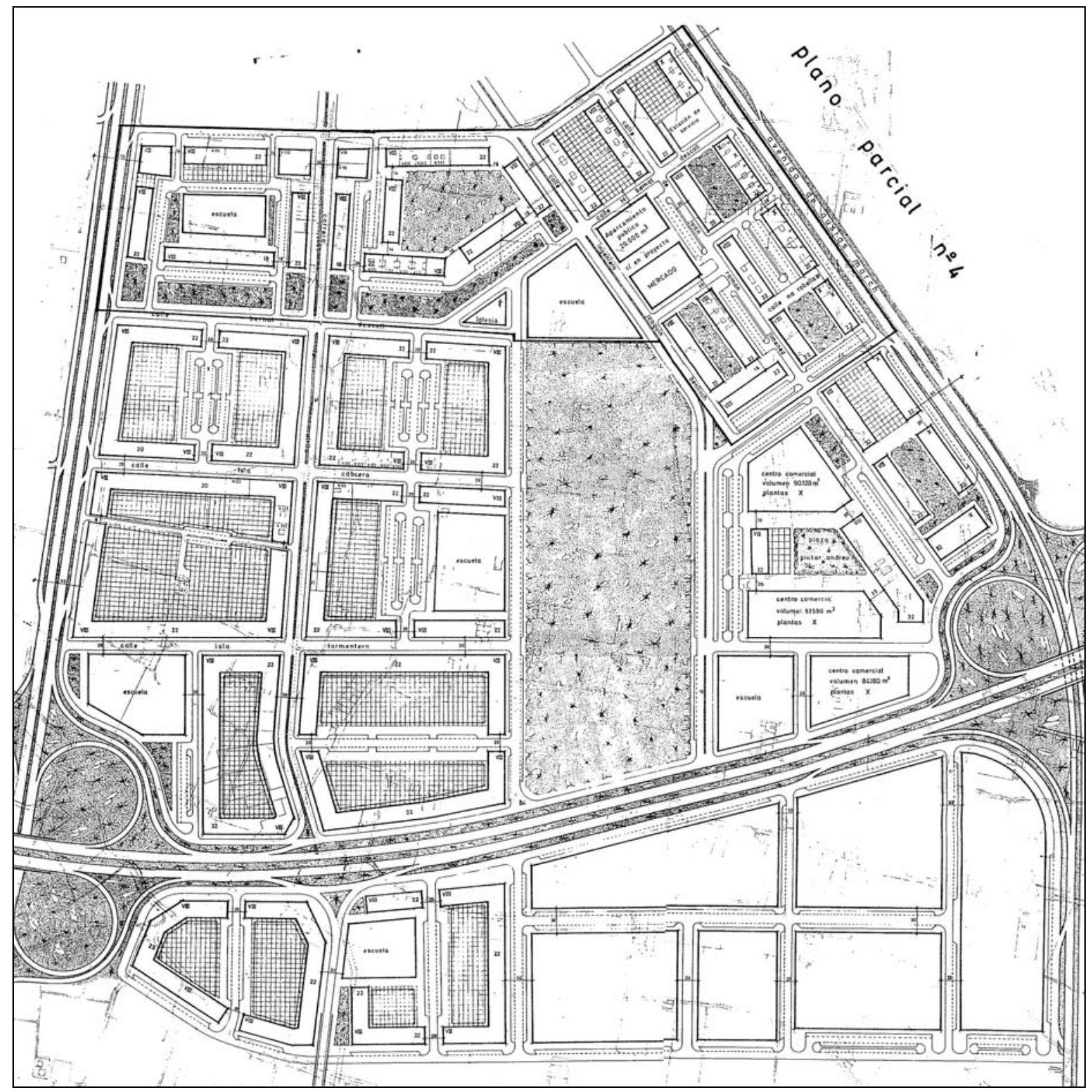

Detalle del Plano de alineaciones 
7. RED VIARIA

Escala original: 1:2000

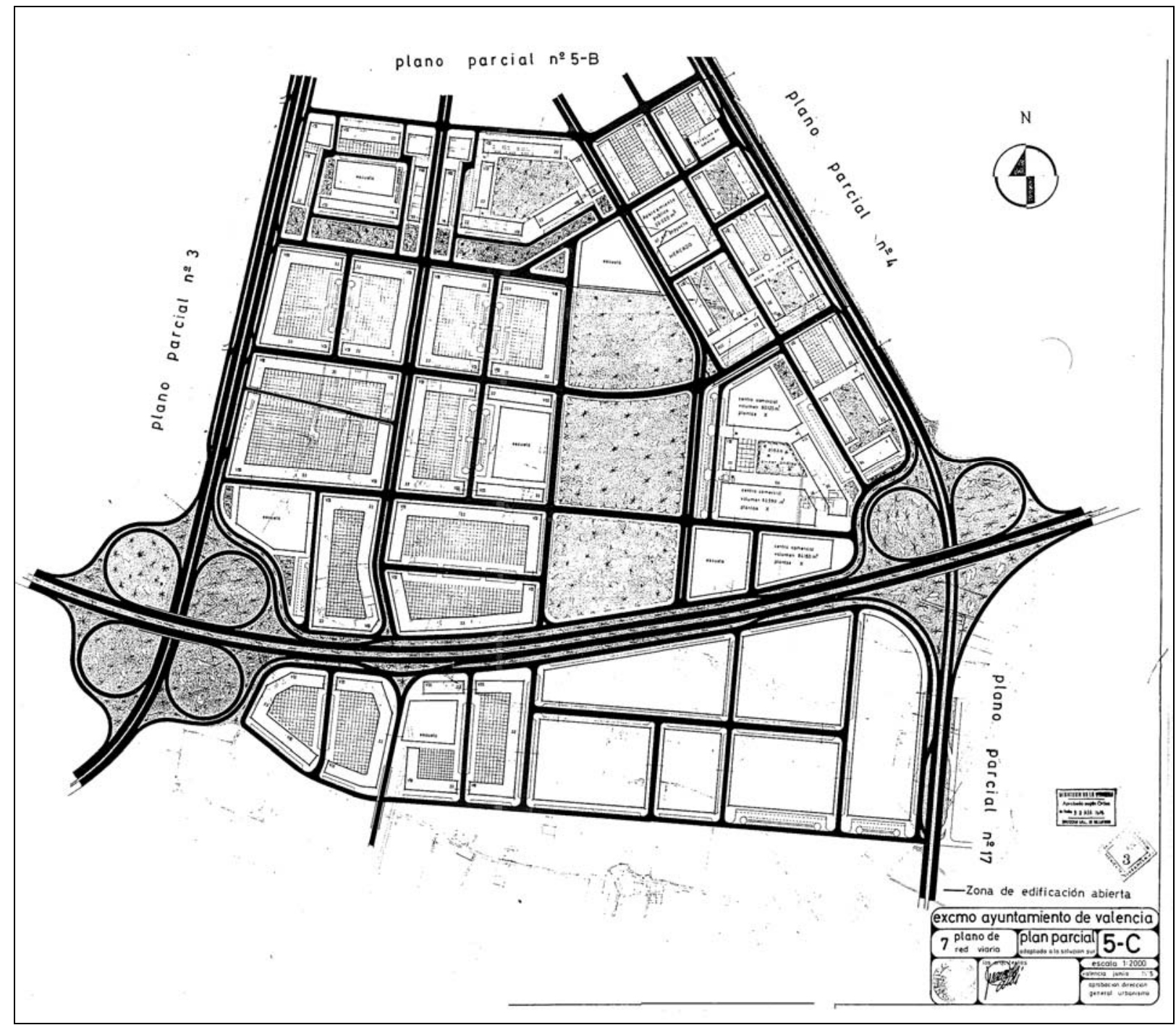


Redactor: Dirección General de Urbanismo / Ministerio de la Vivienda.

Fecha: 29- 09-1974.

Asunto: Resolución de aprobación del Plan Parcial 5C con rectificaciones.

Fuente: Ayuntamiento de Valencia. Sección de Urbanismo. Negociado de Suelo y Ordenación urbana. Expte. 82/1973 (Archivo de Planeamiento No 51/52).

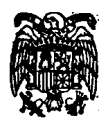

MINISTERIO DE LA VIVIENDA

Ilmo Sr.:

VISTO el Plan Parcial de Ordenación Urbana no 5-C, de Valencia, presentado por el Ayuntamiento de dicha Capital.

VISTOS la Ley sobre Régimen del Suelo y Ordenación Urbana, de 12 de mayo de 1956, los Decretos 63/1968, de 18 de enero y $1994 / 72$, de 13 de julio, y el informe emitido por los servicios competentes de la Dirección General de Urbanismo.

Este Ministerio Acuerda:

10) Aprobar, excepto en la parte a que se refiere el apartado $2^{\circ}$ de esta resolución, el Plan Parcial precitado, con las rectificaciones siguientes:

a) Se suprimen los tramos de las calles isla Cabrera e Isla Formentera, que atraviesan la zona verde del Plan General, a efectos de conservar la necesaria unidad de esta, y

b) A efectos de previsión de aparcamientos, se fijará como mínimo una plaza por vivienda y

$2^{\circ}$. Se excluye la ordenación de la zona destinada a edificación abierta, cuya aprobación se suspende a fin de que se redacte una nueva ordenación de la misma ajustándola al volúmen de edificación marcado por el Plan General, $5 \mathrm{~m} 3 / \mathrm{m} 2$, y que en la presente alcanza 5,40 m3/m2.

La requerida ordenación se tramitara con sujeción a lo dispuesto en el Art. 32 de la Ley del Suelo y se elevara, por triplicado ejemplar, a este Departamento, en el plazo de seis meses, para su estudio y resolución definitiva.

La determinación sobre aparcamientos a que se refiere el apartado b) $1^{\circ}$ de esta resolución, se establecerá en el Plan Parcial de la forma que estime más conveniente el Ayuntamiento, y la documentación correspondiente que la recoja, en unión de la que incorpore la rectificación a)10 de la presente, se remitirá también por triplicado ejemplar y en el aludido plazo de seis meses para, su debida constancia en este Departamento.

Esta resolución se notificará al Ayuntamiento de Valencia y se publicará en el Boletín Oficial del Estado.

Lo que comunico a V. I. para su conocimiento y efectos.

Dios guarde a V.I.

Madrid, 29 de septiembre de 1974

P.D.

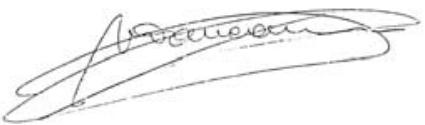

Ilmo. Sr. Director General de Urbanismo. 
Redactor: El Arquitecto Municipal. Ayuntamiento de Valencia.

Fecha: 22- 10-1974.

Asunto: Informe en relación con la resolución del Ministerio de la Vivienda de 29-09-74.

Fuente: Ayuntamiento de Valencia. Sección de Urbanismo. Negociado de Suelo y Ordenación urbana. Expte. 82/1973 (Archivo de Planeamiento No 51/52).

\section{PLAN PARCIAL 5-C}

Informe en relación con la notificación del ministerio de la Vivienda de 29 de Septiembre de 1974.

El Plan Parcial no 5-C, excepto en la zona de Edificación Abierta se aprueba con las rectificaciones señaladas en el punto $1^{\circ}$ en los apartados a) y b). Estas rectificaciones se han analizado y estudiado llagando a la conclusión siguiente:

Respecto a la señalada en el apartado a), considero que no hay inconveniente alguno, si bien es materia discrecional la eliminación de dos tramos de calle, que quizás pudieran dar una mayor fluidez al tráfico dentro de la zona.

Respecto al apartado b) en relación con la previsión de aparcamientos en proporción de una plaza por vivienda, considero que, salvo disposición posterior que desconoce el que suscribe, vulnera el Plan General, toda vez que en la Norma 33 del mismo se establece que la obligación de aparcamientos sará de una cada tres viviendas, que en las barriadas modestas será cada cinco, si bien hay que decir que en la misma Norma parece establecerse como mínimo. No obstante, desde el punto de vista urbanístico, la proporción 1-1 supone una mejora del planeamiento.

Ahora bien, teniendo en cuenta que las mismas Normas establecen que la reserva de aparcamientos para viviendas será en una superficie equivalente a un $5 \%$ de la superficie destinada a vivienda, más un $15 \%$ de la superficie destinada a locales comerciales, sobre la base de una plaza cada $20 \mathrm{~m} 2$.,(obligación que tiene el interesado de cumplir en las edificaciones cuya licencia se solicita,) efectuadas las mediciones correspondientes y añadiendo los aparcamientos grafiados como complemento de las vías de tráfico, el Plan Parcial no 5 -C cumple la Norma del Plan General con creces y la proporción 1-1 sin dificultad.

Respecto a la parte que se excluye de la Ordenación (zona de edificación abierta) el que suscribe considera que no tiene nada que oponer, por cuanto es cierto que excede del volumen autorizado por el Plan General; estudiándose en este momento la modificación del Plan en dicha zona, buscando el ajuste de volumen necesario, si bien dado de que prácticamente está construido el $80 \%$ de la zona con anterioridad a esta resolución, la modificación afectará en gran medida el diseño urbano, pudiendo quedar edificios fuera de ordenación.

Valencia, 22 de Octubre de 1974.-

El Arquitecto municipal,

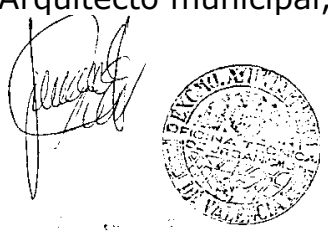





\section{PP 4-bis}

PLAN PARCIAL No 4-bis (ADAPTADO A LA SOLUCIÓN SUR).

1968

Redactores: Excmo. Ayuntamiento de Valencia. Oficina Técnica Municipal de Urbanismo. Arquitectos: Antonio García Heredia, Julio Bellot Senent.

Fecha redacción: Noviembre 1968.

Fecha aprobación: -

Contenido:

I. MEMORIA

II. ORDENANZAS

III. PLANOS: $(*)$

1. PLANO DE SITUACIÓN DENTRO DE LA CIUDAD. $1: 10.000$

2. SITUACIÓN EN EL PLAN GENERAL $1: 22.500$

3. FOTOPLANO

4. ESTADO ACTUAL Y DELIMITACIÓN $1: 2000$

5. ESTRUCTURA URBANÍSTICA $1: 2000$

6. ZONIFICACIÓN $1: 2000$

7. RED VIARIA FUNDAMENTAL $1: 2000$

8. ALINEACIONES Y RASANTES $1: 2000$

9. REDES FUNDAMENTALES DE SERVICIO.
RED DE ALCANTARILLADO ESQUEMA DE RED DE AGUAS POTABLES. $\quad 1: 2000$ ESQUEMA DE ALUMBRADO. $1: 2000$

10. PLANO DE ETAPAS $1: 2000$

Fuente: Ayuntamiento de Valencia. Sección de Urbanismo. Negociado de Suelo y Ordenación urbana (Archivo de Planeamiento. Sección de expedientes antiguos).

\section{Notas:}

(*) Se adjunta además plano de planta general del Plan Parcial 16I, que se refundirá posteriormente con el 4-b. 


\section{EXCMO. AYUNTAMIENTO DE VALENCIA}

OFICINA TECNICA DE URBANISMO

\section{PLAN PARCIAL No 4-bis (ADAPTADO A LA SOLUCION SUR)}

\section{MEMORIA}

1.1. La redacción del presente Plan Parcial tiene su origen en la adaptación del Plan General de Ordenación Urbana de Valencia y su Comarca a la Solución Sur.

Los límites del Plan Parcial no 4-bis son los definidos por el tramo Sur de la Autopista de enlace de la de Madrid-Levante con la del Mediterráneo, la Ronda Exterior proyectada en el estudio de la Red Arterial y la Avenida en Proyecto que limita al SE. el Polígono de "la Fuente de S.Luís" promovido por la Gerencia de Urbanización.

1.2. El Plan General determina las siguientes zonificaciones:

1.2.1. Zona de edificación abierta.

Todo el Plan Parcial no 4-bis queda zonificado en el Plan General como de edificación abierta con un coeficiente de $5 \mathrm{m3} / \mathrm{m} 2$.

\subsection{Red Arterial.}

La Red Arterial de Valencia afecta al Plan Parcial número 4-bis en los siguientes trazados:

1.3.1. Autopista de Enlace de la de Madrid-Levante con la del Mediterráneo.

Constituye este trazado el límite NE del Plan Parcial y las necesidades de sus calzadas laterales, así como las de las calzadas de servicio a la propiedad establecen para las alineaciones de la edificación en esta zona una distancia de $106 \mathrm{~m}$. desde el eje de la Autopista.

1.3.2. Ronda Exterior.

Su trazado es el SE del Plan Parcial. El ancho establecido para esta vía y sus zonas de influencia es de $80 \mathrm{~m}$. Sobre esta Ronda se establecen varios pasos superiores de peatones para acceso a la zona deportivo-cultural definida en el Plan Parcial no $16-$ I.

1.4. Viario interno.

De acuerdo con las necesidades viarias del Plan y su correcta conexión con los adyacentes se han estudiado y proyectado una red de calles de 3 categorías distintas:

1.4.1. Red azul.

Está constituida esta red por aquellas calles que establecen continuidad entre varios parciales colindantes, es decir, son vías de relación entre barrios.

1.4.2. Red verde.

La componen las calles más importantes desde el punto de vista de fluidez del tráfico dentro de cada sector del Plan Parcial; pueden denominarse pues colectores de barrio.

Se proyecta esta red en anillos cerrados unidireccionales.

1.4.3. Red amarilla.

Está destinada a permitir el acceso a la propiedad en todos los puntos de las zonas edificables y dotar al Plan Parcial de los necesarios aparcamientos. Su fluidez de tráfico está mediatiza 
da por aquellas necesidades.

1.4. Secciones transversales.

Se han estudiado con todo detalle las secciones transversales para permitir el máximo aprovechamiento de las calzadas tanto para el tráfico como las superficies destinadas a aparcamiento.

\subsection{Alineaciones.}

Se han proyectado las alineaciones de este Plan Parcial definiendo por un lado bloques en altura para uso de viviendas y por otro edificaciones en una planta para uso de comerciales, de talleres de artesanía, garajes y aparcamientos cubiertos y locales de espectáculos exclusivamente.

En la disposición de los bloques y edificaciones además de las orientaciones, alturas, óptimas distribuciones posibles de viviendas, etc., se ha pretendido crear ambientes públicos de alto grado compositivo dentro de cada supermanzana, definiendo al mismo tiempo los espacios verdes, viarios de peatones, superficies de aparcamiento público, plazas para juegos infantiles y plazas de convivencia ciudadana.

No obstante lo proyectado en cada supermanzana, se aceptarán las propuestas de los propietarios interesados de acuerdo con lo que define el artículo 0.13 de las Ordenanzas Reguladoras de la Edificación, ateniéndose a él punto por punto en todos sus extremos. La delimitación de supermanzanas a estos efectos coincide con la de Polígonos de actuación y como tal quedan definidos en el Plano de Alineaciones.

\subsection{Servicios Urbanos.}

Para las previsiones de estos servicios se ha partido de las determinaciones que especifica el Plan Nacional de la Vivienda para cada uno de ellos.

1.6.1. Centros parroquiales.

Se ubican 4 centros parroquiales en todo el Plan Parcial. Uno de ellos con una superficie total en planta de $3.500 \mathrm{~m} 2$ para atender a las necesidades de todo el barrio y los otros 3 de unos $1.000 \mathrm{~m} 2$ cada uno para las necesidades de las distintas unidades vecinales.

1.6.2. Grupos escolares.

Se ha establecido la creación de 5 grupos escolares- cuatro de ellos con superficies comprendidas entre los 4.000 y los 5.000 $\mathrm{m} 2$ y el quinto ubicado en la zona más central del Plan Parcial con una superficie de $14.000 \mathrm{~m} 2$.

1.6.3. Centros comerciales.

Sólo se establece en los planos la ubicación de un centro comercial de barrio en el que se ha previsto que tengan cabida una Tenencia de Alcaldía, una central telefónica y una Administración de Correos. Los comercios de uso diario y para servicio de las unidades vecinales se podrán ubicar libremente en las plantas bajas previstas en cada una de ellas, alternando con los otros 3 usos permitidos en ellas, es decir, talleres de artesanía, garajes y aparcamientos cubiertos y locales de espectáculos.

\subsection{Zonas de peatones.}

Se ha tenido especial intención de enlazar todas las unidades vecinales entre sí mediante viarios exclusivos de peatones y de crear espacios abiertos dentro de cada supermanzana, alejados de la circulación rodada, para uso de estancia y convivencia ur 
bana. Todo ello queda reflejado en el plano "Viario de peatones" que acompaña a la documentación del Plan Parcial.

1.8. Polígonos y sistema de actuación.

Para mayor facilidad en la ejecución del Plan Parcial no 4-bis se han considerado trece polígonos de actuación independientes, cuyos límites se definen en el Plano de Alineaciones.

Se establece como fase previa a la urbanización de cada polígono y a la concesión de licencias de edificación la resolución de un expediente de reparcelación que podrá ser promovido por los particulares o por la Administración indistintamente y ajustándose en todo caso al Reglamento de Reparcelaciones establecido por la Superioridad.

1.9. Medios Económico-Financieros.

Constituyen estos medios el presupuesto ordinario de urbanismo del Excmo. Ayuntamiento más los presupuestos extraordinarios que sean establecidos para promover y fomentar el desarrollo de la zona.

Con todo lo descrito creemos haber expresado suficientemente el alcance de este estudio que proponemos al Excmo. Ayuntamiento para que logre su aprobación.

Valencia, Noviembre de 1.968

EL ARQUITECTO,

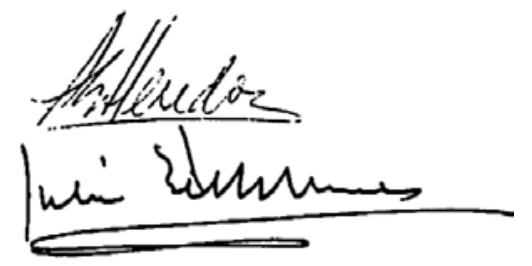


ALINEACIONES.

Escala original 1:2000

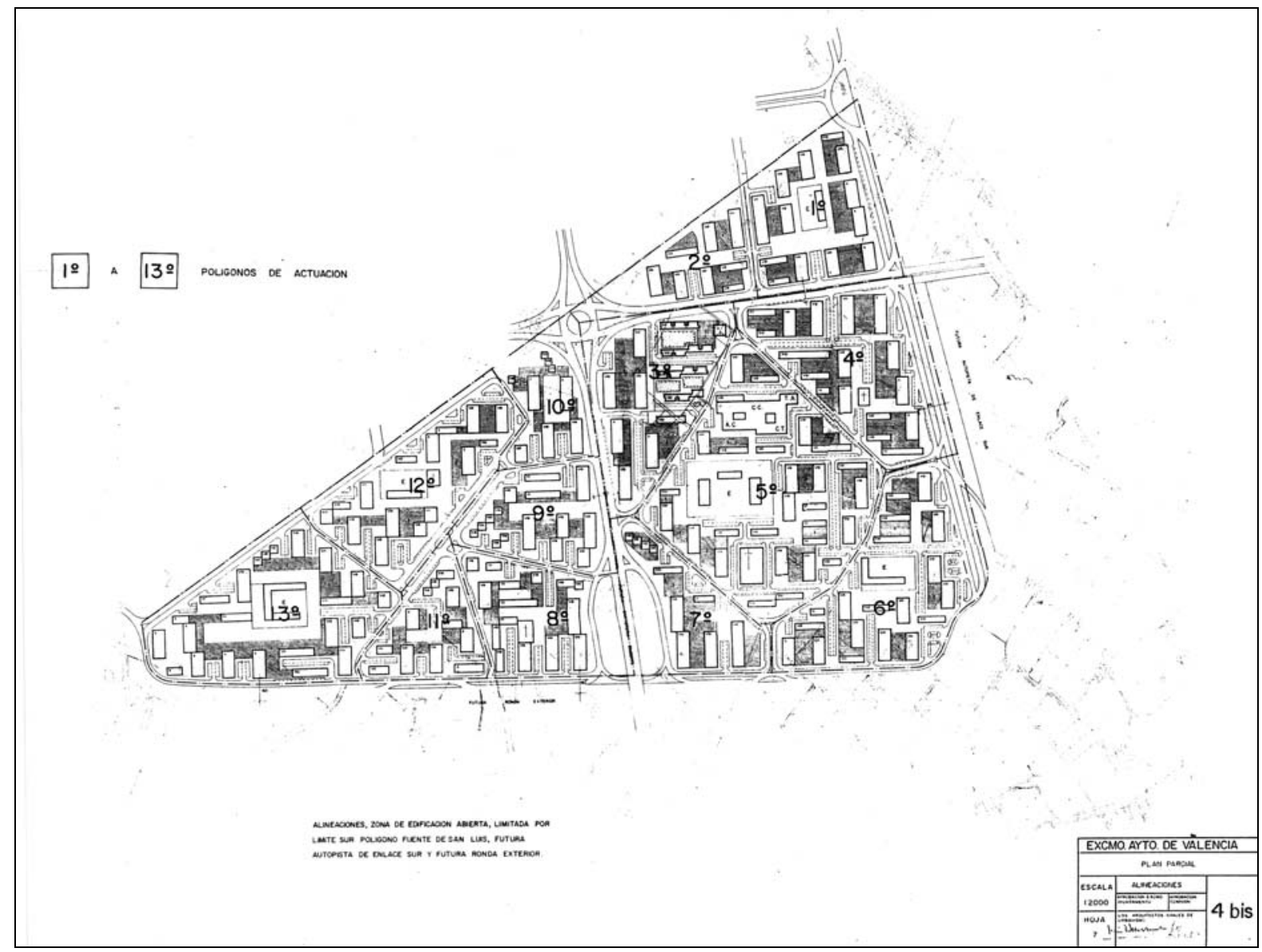




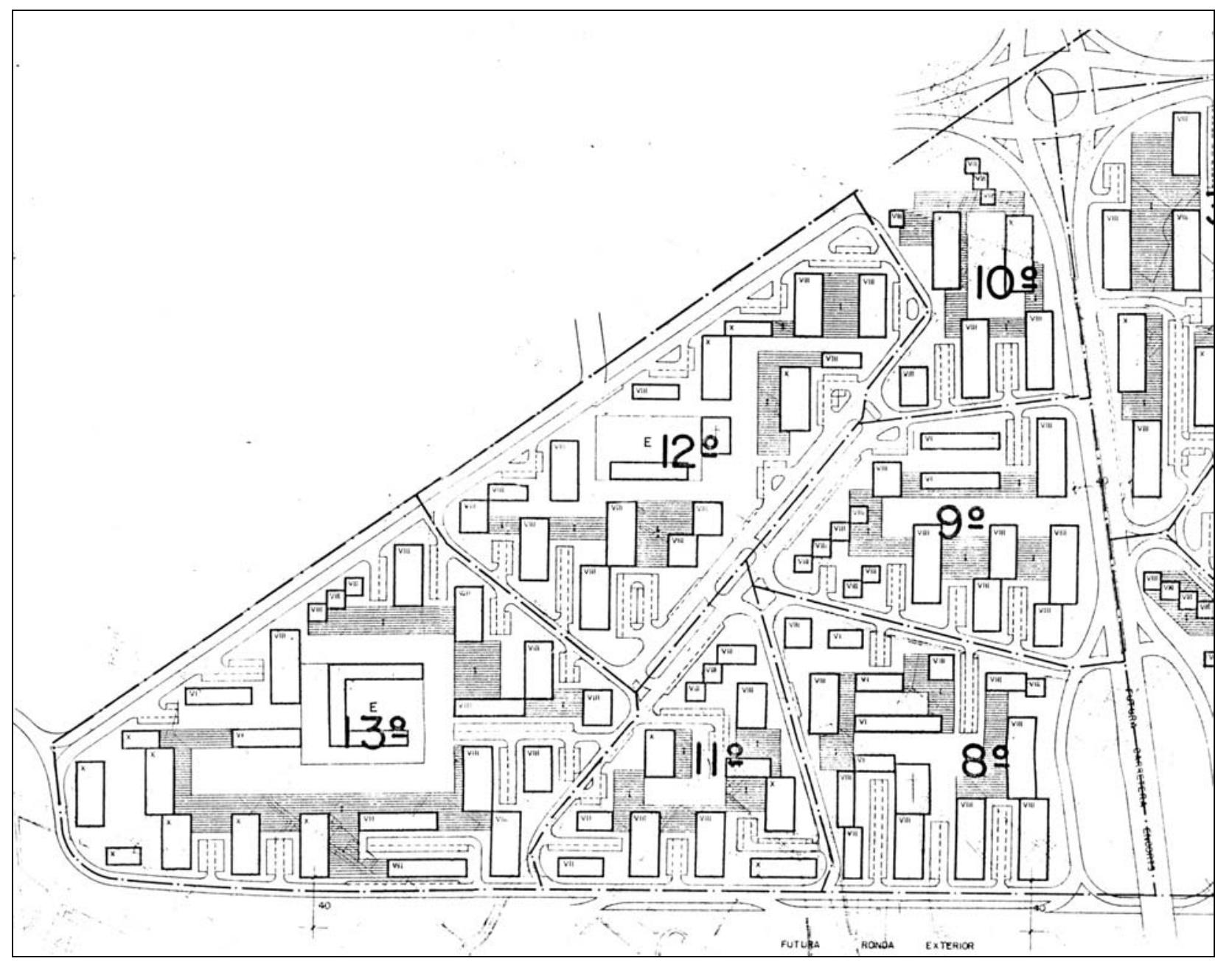

Detalle de la zona oeste 


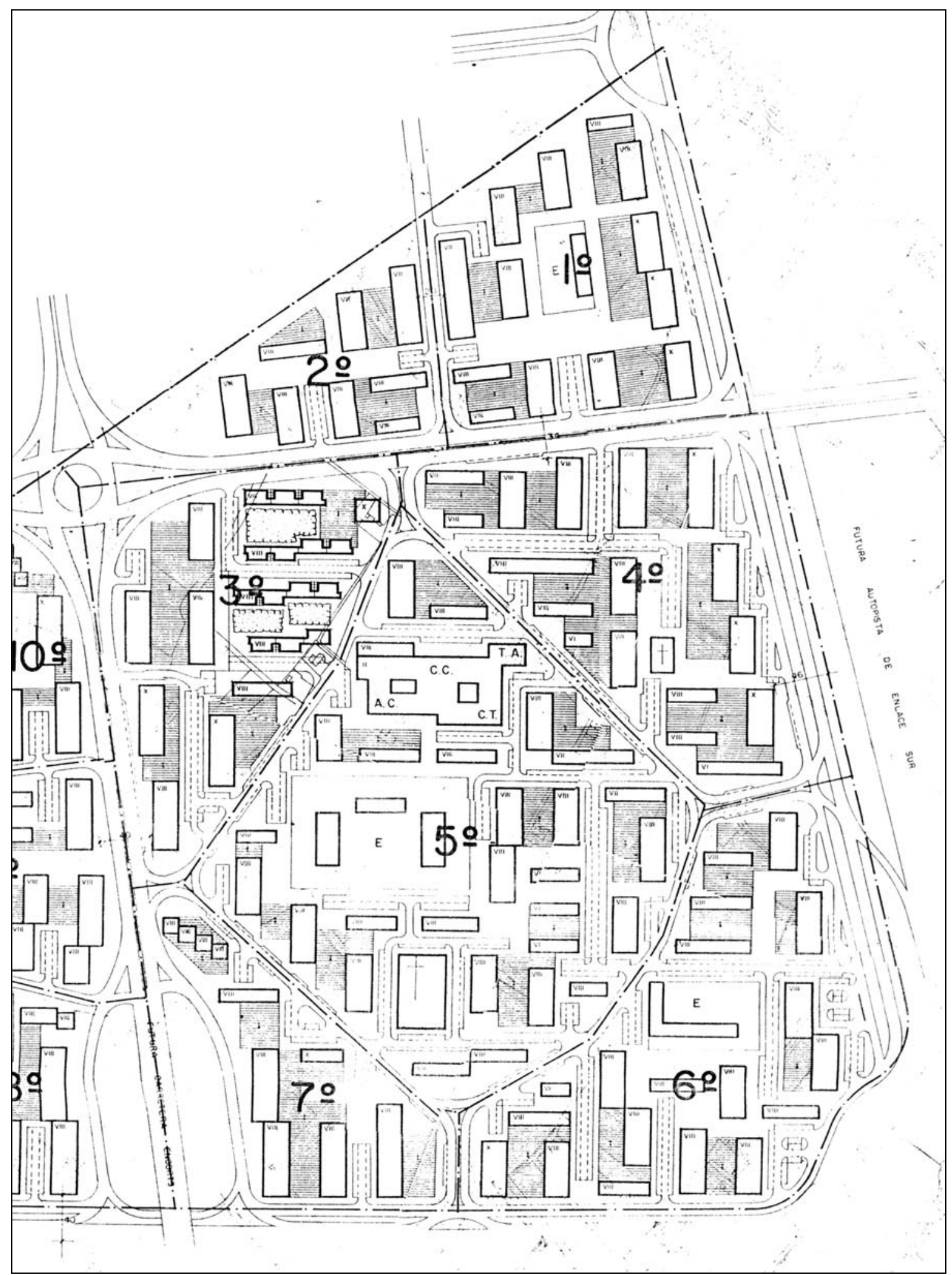

Detalle de la zona este 
1. PLANTA GENERAL.

Escala original 1:2000

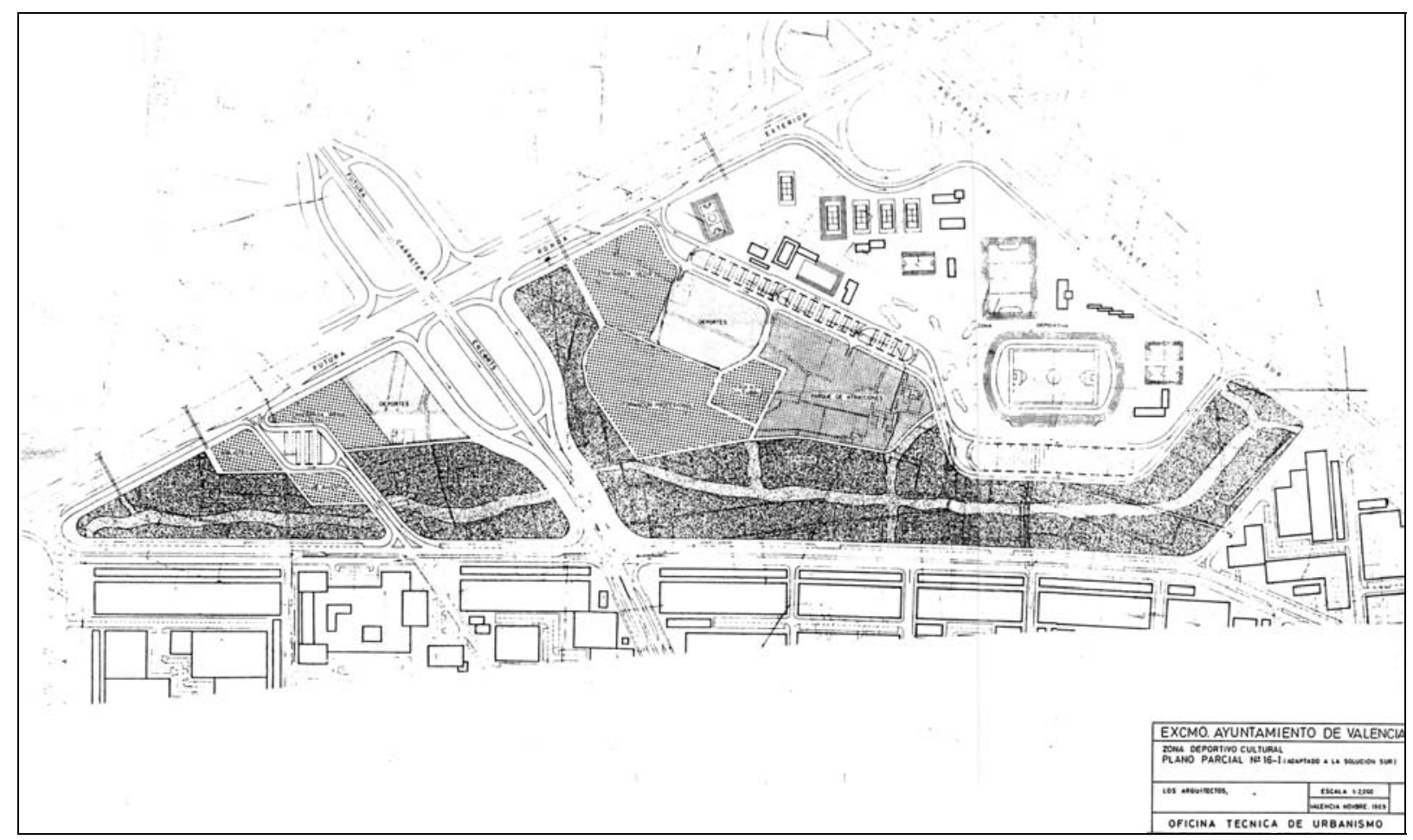




\section{PP 4bis-16I}

\section{PLAN PARCIAL No 4bis-16I(ADAPTADO A LA SOLUCIÓN SUR)}

1973

Redactores: Excmo. Ayuntamiento de valencia. Oficina Técnica de Urbanismo.

Fecha redacción: Agosto 1973

Fecha aprobación: O.M. 24-09-75 (B.O.E. 01-11-75) (*).

Contenido:

I. MEMORIA

II. ORDENANZAS.

III. PLANOS

1. PLANO DE SITUACIÓN DENTRO DE LA CIUDAD. $1: 10.000$

2. SITUACIÓN EN EL PLAN GENERAL $1: 22.500$

3. INFORMACIÓN Y FOTO AÉREA $1: 2000$

4. ZONIFICACIÓN $1: 4000$

5. ESTRUCTURA URBANISTICA $1: 2000$

6. ALINEACIONES $1: 2000$

7. RED VIARIA $1: 2000$

8. RED DE ALUMBRADO 1:2000

9. RED DE AGUA POTABLE. $1: 2000$

10. RED DE ALCANTARILLADO. $1: 2000$

Fuente: Ayuntamiento de Valencia. Sección de Urbanismo. Negociado de Suelo y Ordenación urbana. Expte. 3.897/1974 (Archivo de Planeamiento, No 31)

\section{Notas:}

*La aprobación inicial es de fecha 19-06-1974. Todas las alegaciones presentadas al Plan durante la exposición al público fueron desestimadas, de conformidad con el informe del Arquitecto Municipal de 23-09-1974. La propuesta de aprobación provisional es de fecha 27-09-1974. 


\author{
EXCMO. AYUNTAMIENTO \\ DE \\ VALENCIA \\ OFICINA TÉCNICA DE URBANISMO \\ PLAN PARCIAL No 4-bis-16-I -ADAPTADO A LA SOLUCIÓN SUR
}

\title{
MEMOR I A
}

1.1 La redacción del presente Plan Parcial -fusión del 4-bis y de la zona deportivo-cultural del 16-1- tiene su origen en la adaptación del Plan General de Ordenación Urbana de Valencia y su Comarca a la Solución Sur.

A la zona deportivo-cultural del Plan Parcial 16-I le falta la aprobación por la Superioridad, por lo que dada su colindancia con el 4-bis y sus implicaciones urbanísticas, se ha desarrollado conjuntamente con él, con la designación de Plan Parcial 4-bis-16-I, teniendo en cuenta que las dotaciones de zonas verdes de este Plan, se contabilizan también para el resto del Plan 16-I aprobado, y que tiene en su totalidad la calificación de zona industrial.

Los límites del Plan Parcial 4-bis-16-I son los definidos por un tramo de la Autopista de enlace Sur por el NE., Planes Parciales 16-I y 17 por el S., y el Polígono de la Fuente de S. Luis del Plan Parcial 4 por el NO.

\subsection{ZONIFICACION.}

El Plan General determina las siguientes zonificaciones:

Edificación Abierta Alta.

Deportivo-Cultural.

\subsubsection{Edificación Abierta Alta.}

Esta zonificación viene delimitada por el Plan Parcial 4, la futura Autopista de enlace, y la futura Ronda Exterior proyectada en el estudio de la Red Arterial.

El volumen para esta zona según el Plan General es de 5 $\mathrm{m} 3 . / \mathrm{m} 2$. Según el Plan Parcial se ha ocupado una superficie de_ $739.187 \mathrm{~m} 2$., con un volumen total de 3.494.706 m3. lo que nos da el siguiente coeficiente de edificabilidad:

coeficiente de edificabilidad $=\underline{3.494 .706 \mathrm{~m} 3}=4,727 \mathrm{m3} . / \mathrm{m} 2$.

$$
739.187 \mathrm{~m} 2
$$

\subsubsection{Deportivo-cultural.}

Esta delimitada por la futura Ronda Exterior, los Planes 16-I y 17, y la futura Autopista de enlace. Tiene una superficie de 576.518 $\mathrm{m} 2$. El volumen según el Plan General es de 0,5 m3./m2.

En el Plan Parcial se han distinguido tres zonas:

Una verde de protección de la zona industrial del Plan 16-I con una superficie de $139.770 \mathrm{~m} 2$; otra compuesta por dos parcelas con destino a escuelas de $31.800 \mathrm{~m} 2$. de superficie total, con un coeficiente de edificabilidad de $1,7 \mathrm{~m} 3 . / \mathrm{m} 2$. y una altura máxima de $15,50 \mathrm{~m}$.; y una deportivo-cultural de $293.342 \mathrm{~m} 2$. con un coeficiente de edificabilidad de $0,8 \mathrm{~m} 3 . / \mathrm{m} 2$. y una altura máxima de 23,50 m., donde podrán establecerse todo tipo de construcciones con fines culturales o de enseñanza, instalaciones deportivas, parques públicos y zonas verdes, previos proyectos singulares a tenor 
de lo dispuesto en las Normas Urbanísticas del Plan General.

El resto de superficie hasta los $578.518 \mathrm{~m} 2$. esta ocupada por viales y zonas de influencia.

El coeficiente de edificabilidad de esta zona según el Plan Parcial es el siguiente:

escuelas. $\quad=\quad 31.800 \mathrm{~m} 2 . \times 1,7 \mathrm{m3} . / \mathrm{m2} .=54.060 \mathrm{~m} 3$.

deportivo-cultural $=293.342 \mathrm{~m} 2 . \times 0,8 \mathrm{m3} . / \mathrm{m} 2 .=234.673 \mathrm{m3}$.

Total $288.733 \mathrm{~m} 3$.

coeficiente de edificabilidad $=\underline{288.733 \mathrm{~m} 3}=0,499 \mathrm{~m} 3 . / \mathrm{m} 2$.

1.3. RED VIARIA.

$578.518 \mathrm{~m} 2$

La Red Arterial de Valencia afecta a este Plan Parcial en los siguientes trazados:

a) Autopista de enlace Sur, constituye el límite HE.

b) Ronda Exterior, su trazado separa la edificación abierta de la zona deportivo-cultural.

También, de acuerdo con las necesidades viarias del Plan y su correcta conexión con los adyacentes, se han estudiado y proyectado una red de vías, compuesta por la Carrera de Encorts en su nuevo trazado con paso superior sobre la Ronda Exterior, y unas calles colectoras que conectan aquella con la futura Autopista de en lace y con el Polígono de "la Fuente de S. Luis" del Plan Parcial 4.

\subsection{DENSIDAD DE POBLACIÓN}

Se ha realizado este estudio con arreglo a los siguientes datos:

Superficie ocupada por la edificación abierta......... 73,91 Ha.

Volumen ocupado por la edificación abierta........... 3.494 .706 m3.

Porcentaje ocupado por las viviendas $(70 \%)$......... 2.446.294 m3.

Porcentaje ocupado por otros usos $(30 \%) \ldots \ldots \ldots \ldots . . .1 .048 .412 \mathrm{m3}$.

Volumen medio por vivienda $(120 \mathrm{~m} 2 . \times 3 \mathrm{~m}$.).... $\quad 360 \mathrm{~m} 2$.

Número de viviendas $=2.446 .706: 360=\ldots \ldots \ldots . .6 .795$

Numero medio de personas por vivienda............. 4

Numero total de habitantes $=6.795 \times 4=\ldots \ldots \ldots . . \quad 27.180$

La densidad referida a la zona ocupada por la edificación abierta es:

Densidad $=\underline{27.180 \mathrm{hab}} .=367 \mathrm{hab} . / \mathrm{Ha}$.

$73,91 \mathrm{Ha}$

\subsection{SERVICIOS URBANOS.}

\subsubsection{Zonas verdes.}

La superficie de zonas verdes en el área de la edificación abierta es de $140.206 \mathrm{~m} 2$., que con los $139.770 \mathrm{~m} 2$. de la zona deportivo-cultural suma $279.976 \mathrm{~m} 2$.

La superficie del Plan Parcial 16-I aprobado es $1.319 .135 \mathrm{~m} 2$. y la del 4-bis-16-I 1.317.705. El total será $2.636 .840 \mathrm{~m} 2$.

El porcentaje de zonas verdes es:

Zonas verdes $=\underline{279.976 \mathrm{~m} 2 . \times 100}=10,617 \%$

$$
2.636 .840
$$

\subsubsection{Centros parroquiales.}

No se ha señalado ninguno en el Plan, dada la tendencia a ubicarse estos centros en las plantas bajas, de las cuales existen proyectadas de amplias dimensiones.

1.5.3. Grupos escolares. 
Se ubican cinco centros, cuatro de $10.000 \mathrm{~m} 2$. y uno de $21.800 \mathrm{~m} 2$.

\subsubsection{Centros comerciales.}

Solo se establece la existencia de un centro comercial con un volumen de $50.880 \mathrm{m3}$ y una altura máxima de VIII plantas.

Los comercios de uso diario y para servicio de las unidades vecinales se podrán ubicar libremente en las plantas bajas previstas en ellas.

\subsubsection{Aparcamientos.}

Las superficies exigidas para aparcamientos en el interior de los edificios según las Normas del Plan General son:

$5 \%$ de superficie destinada a vivienda:

$(0,05 \times 2.446 .294 \mathrm{~m} 3 / 3 \mathrm{~m})=0,05 \times 815.431=40.771 \mathrm{~m} 2$.

$15 \%$ de superficie destinada a otros usos:

$(0,15 \times 1.048 .412 \mathrm{~m} 3 . / 3 \mathrm{~m})=0,15 \times 349.470=\underline{52.420 \mathrm{~m} 2}$.

$$
\text { Total } \quad 93.191 \mathrm{~m} 2 \text {. }
$$

que a una media de $20 \mathrm{~m} 2$. por plaza de aparcamiento, representan 4.660 plazas.

Los aparcamientos que existen proyectados en superficie en el Plan dan cabida a 4.125 plazas, que junto con las anteriores ascienden a 8.784.

Se prevee además, que en las zonas grafiadas en los planos como aparcamientos en superficie o zonas verdes puedan construirse aparcamientos subterráneos.

\subsection{MEDIOS ECONOMICO-FINANCIEROS.}

Constituyen estos medios el presupuesto ordinario de urbanismo del Excmo. Ayuntamiento, más los presupuestos extraordinarios que sean establecidos para promover y fomentar el desarrollo de la zona.

Con todo lo descrito creemos haber expresado suficientemente el alcance de este estudio que proponemos al Excmo. Ayuntamiento para que si lo estima conveniente, lo eleve a la aprobación por la Superioridad.

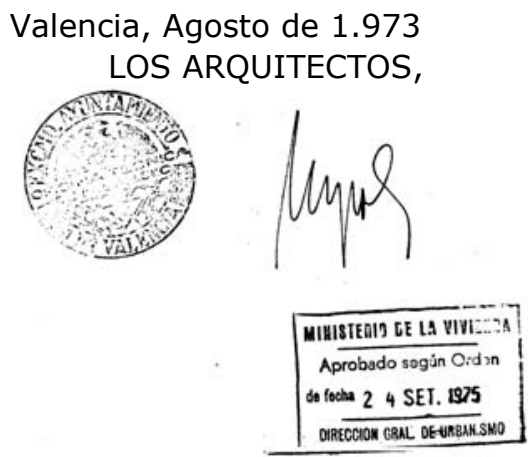


EXCMO. AYUNTAMIENTO

DE

VALENCIA

OFICINA TÉCNICA DE URBANISMO

PLAN PARCIAL No 4-bis-16-i ADAPTADO A LA SOLUCIÓN SUR

\section{ORDENANZAS}

Hasta que no se aprueben las Ordenanzas adaptadas a la Solución Sur, en estudio, se aplicarán las vigentes, aprobadas por la Comisión Central de Sanidad, en 23 de octubre de 1.950 y 26 de enero de 1.955, en los casos no previstos en las Normas Urbanísticas del Plan de Ordenación de Valencia y su Comarca, adaptadas a la "Solución Sur" por la que tendrá que regirse actualmente este Ayuntamiento.

A este Plan Parcial le corresponden las zonificaciones Edificación Abierta Alta y Deportivo-Cultural.

Valencia, Agosto de 1973

LOS ARQUITECTOS

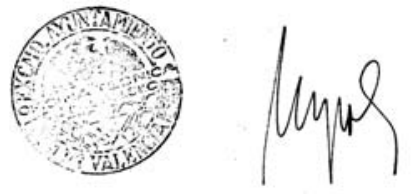

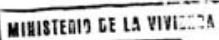

Aprobado sogún O:d $x$

do focha 24 SEI. 2375

DRRECCION GSRL DEURBAKSWO 
1. PLANO DE SITUACIÓN EN LA CIUDAD

Escala original: 1:10.000

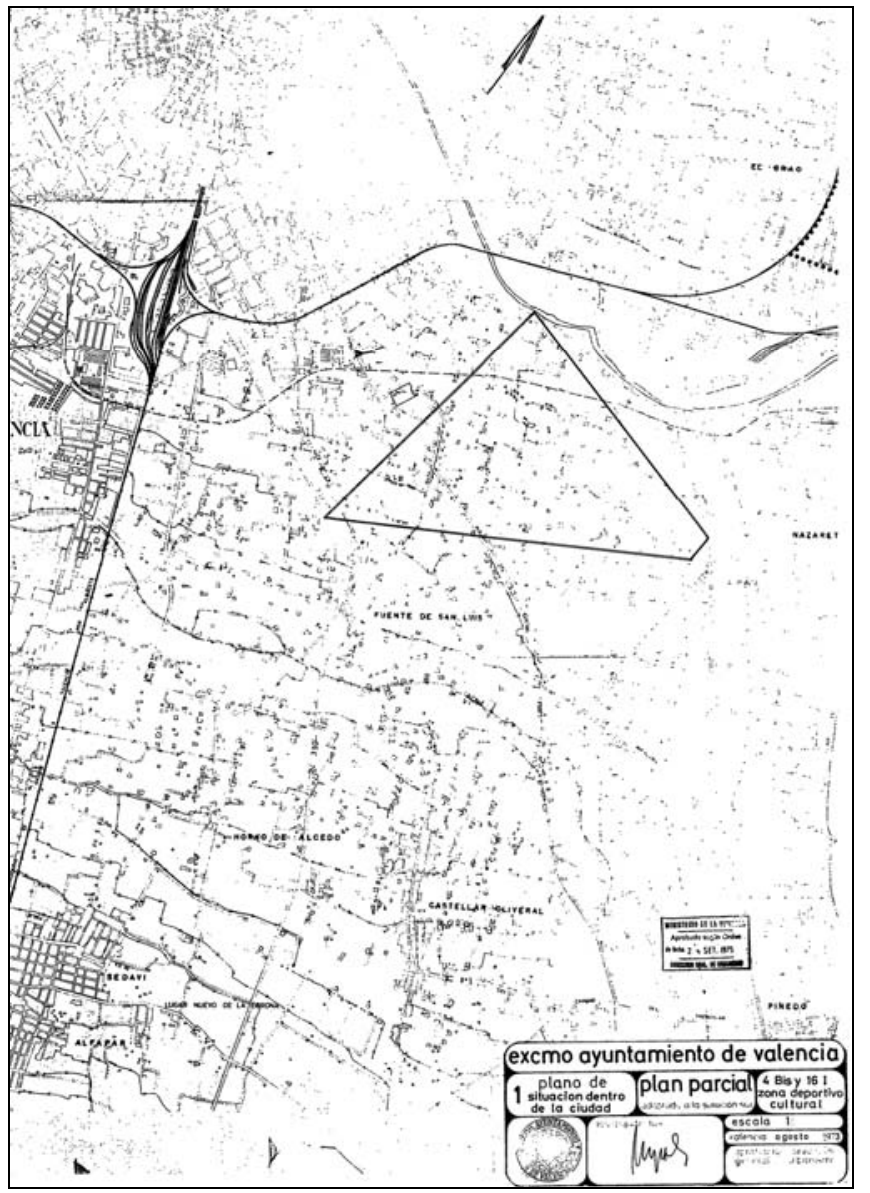

2. PLANO DE SITUACIÓN EN EL PLAN GENERAL (Fragmento) Escala original: 1:22.500

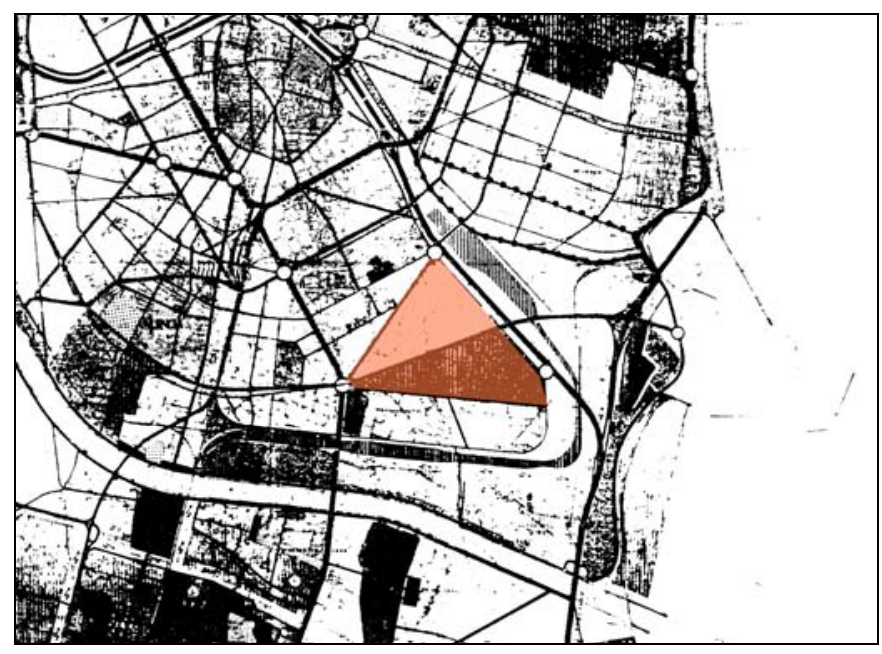


3. INFORMACIÓN Y FOTO AÉREA

Escala original: 1:2000

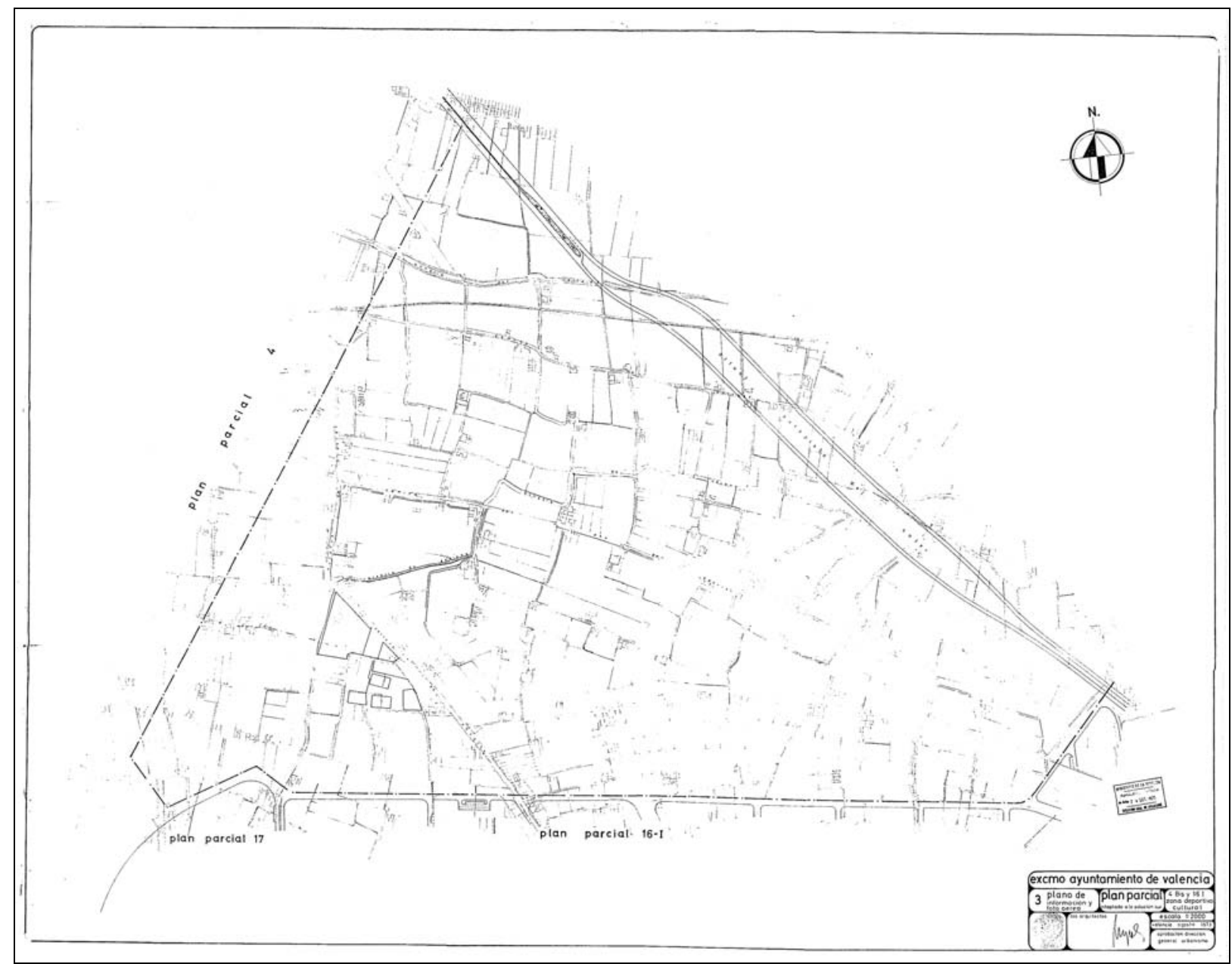

Escala original: 1:2000 
6. ALINEACIONES Y RASANTES.

Escala original 1:2000
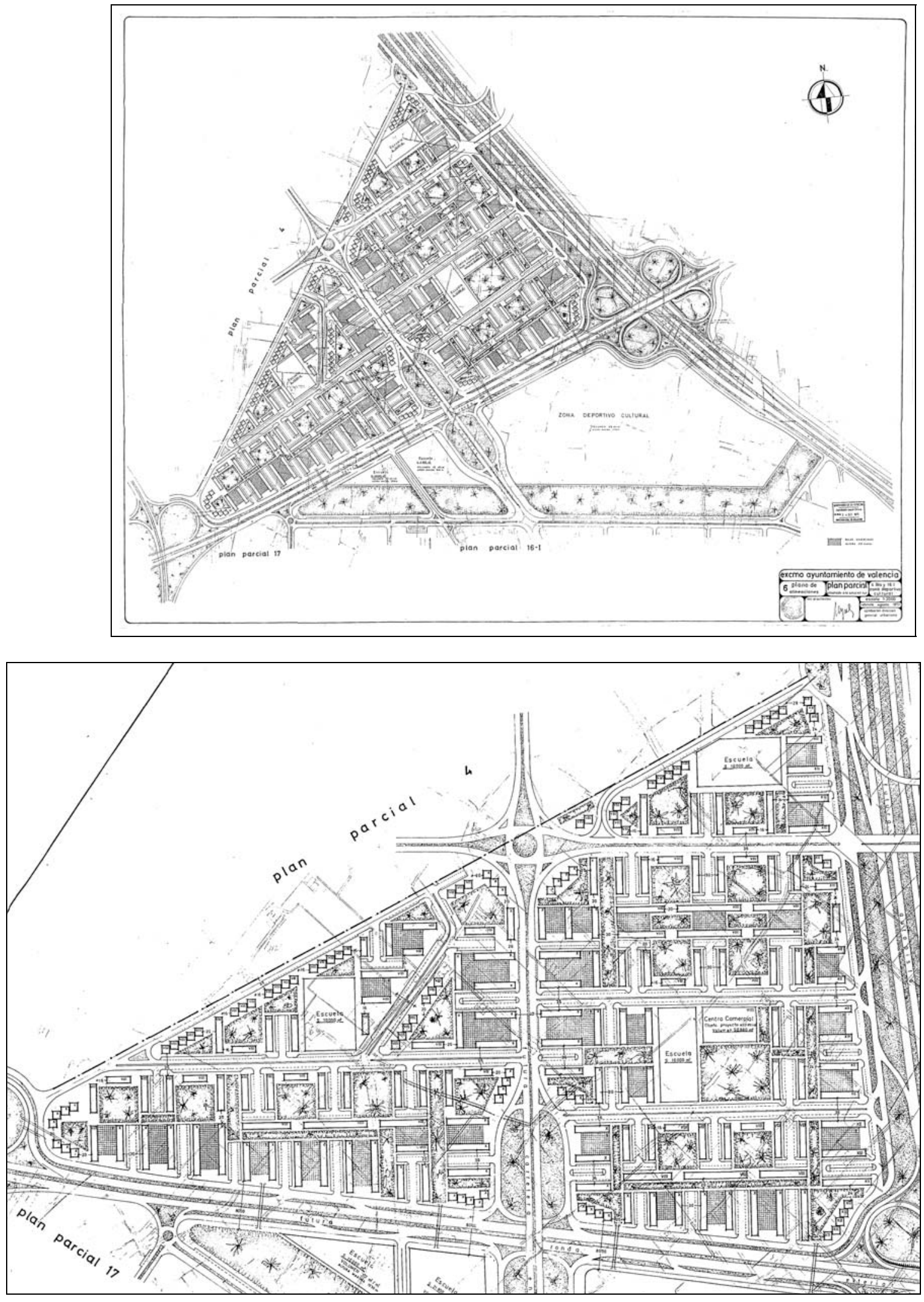

Detalle del Plano de alineaciones 
7. RED VIARIA

Escala original: 1:2000
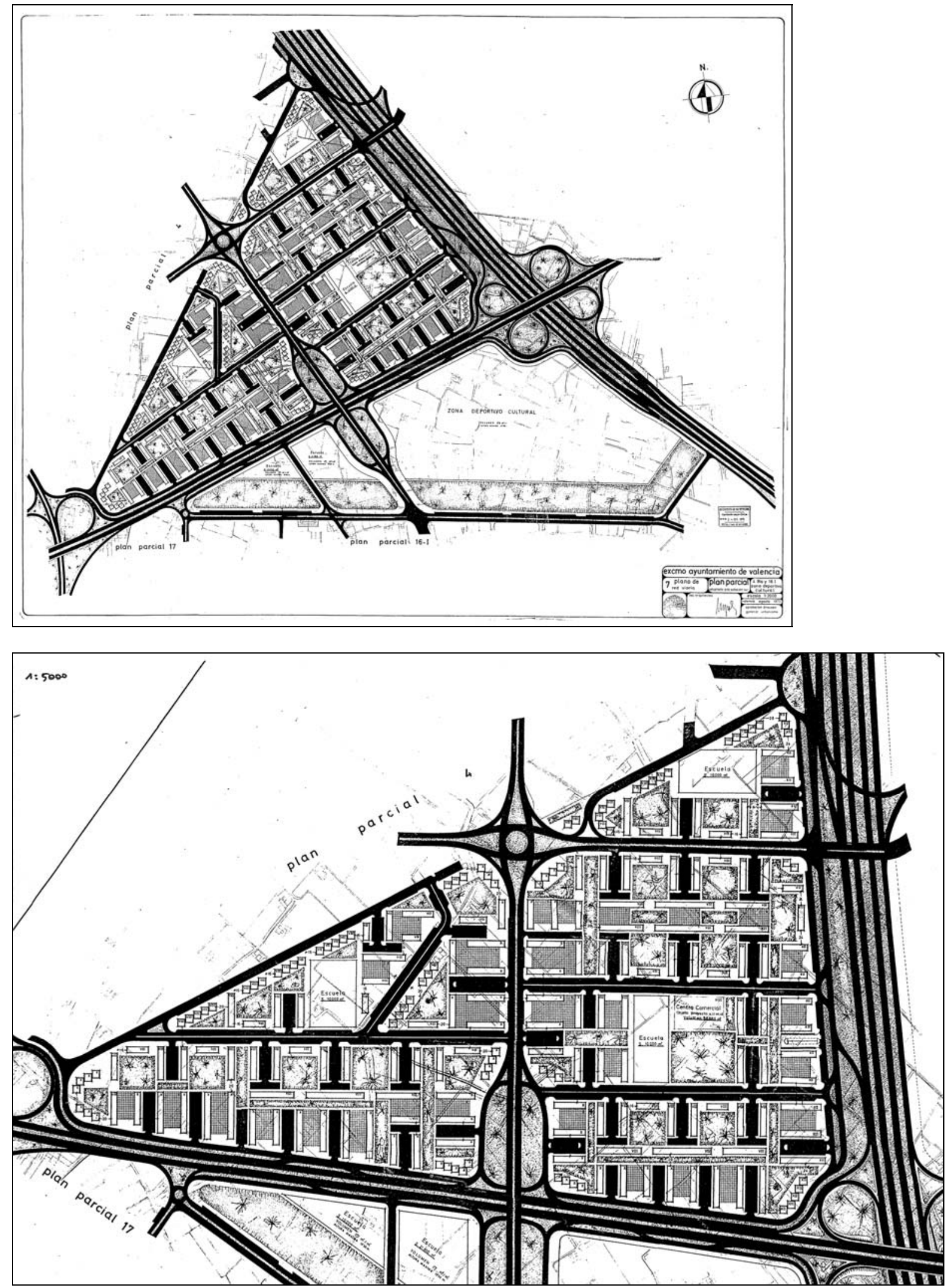

Detalle del plano de red viaria. 
Redactor: Oficina Técnica de la Corporación Administrativa Gran Valencia.

Fecha: 24- 01-1975.

Asunto: Informe sobre el Plan Parcial 4bis-16I.

Fuente: Ayuntamiento de Valencia. Sección de Urbanismo. Negociado de Suelo y Ordenación urbana. Expte. 3.897/1974 (Archivo de Planeamiento, No 31)

\section{PLAN PARCIAL NO 4-BIS Y 16-I \\ INFORME DE LA OFICINA TECNICA DE LA C.A. GRAN VALENCIA}

El Proyecto Parcial 4-Bis y 16-I zona deportivo cultural,

Limita al Norte con el Plan Parcial 4 al Sur con el 16-I al Este, con la Autopista da enlace $y$ al Oeste igualmente con el Plan Parcial 4 polígono de ejecución fuente de San Luis.

Un Plan Parcial de redacción anterior al que nos ocupa y que se refería a la misma zona fue presentado a esta Corporación por el Ayuntamiento de Valencia en Julio del año 1.971 y por la Comisión de fecha 13 de Enero de 1.972 se devolvió al Ayuntamiento para nuevo estudio, ya que faltaban zonas verdes y en al plano topográfico del estado actual, no figuraban edificios de reciente construcción, así como no se incluían en el estudio datos sobre densidad de población, volúmenes de edificabilidad, etc. Estos extremos han sido subsanados en al Plan que ahora se remite.

La redacción es correcta; la zonificación de edificación abierta alta $(5 \mathrm{~m} 3 / \mathrm{m} 2)$ y Deportivo Cultural en al triángulo al sur de la futura Ronda exterior se amolda al Plan General.

La densidad de población de 367 habitantes/ha la consideramos optima.

La dotación de Zonas verdes 10,617\%. Aun teniendo en cuenta la superficie del 16-I cumple el mínimo exigido.

En cambio no consideramos como solución conveniente, el no marcar la dotación y situación de Centros parroquiales, pues opinamos deben ubicarse funcionalmente, con dignidad, y aprovechables como elementos urbanos singulares, de ambientación.

La dotación escolar cumple las Normas actuales de Educación General Básica.

Las dotaciones de Centro Comerciales y aparcamientos son suficientes.

Consideramos, que el grafiado de bloques de edificación, debiera ser orientativa; no pudiéndose dar una licencia de construcción en ninguna supermanzana, mientras no se presentara por loa propietarios la propuesta definitiva, con su reparcelación o sistema de Junta de Compensación, pues de otra forma y dadas la parcelación agrícola actual es sumamente difícil proceder a la edificación con una base de justicia.

Valencia 24 de Enero de 1.975

EL ARQUITECTO JEFE,

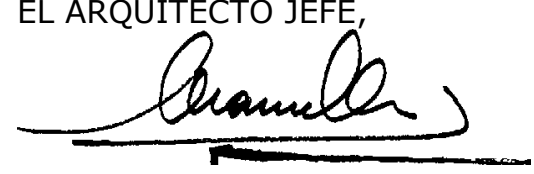


Redactor: Dirección General de Urbanismo del Ministerio de la Vivienda / Ministerio de la Vivienda.

Fecha: 24- 09-1975.

Asunto: Resolución de aprobación del Plan Parcial 4bis-16I.

Fuente: Ayuntamiento de Valencia. Sección de Urbanismo.

Negociado de Suelo y Ordenación urbana. Expte. 3.897/1974

(Archivo de Planeamiento, No 31)

\section{MINISTERIO DE LA VIVIENDA}

IImo Sr.:

VISTO el Plan Parcial de Ordenación Urbana no 4-Bis 16-I, zona deportivo cultural, de Valencia, tramitado por el Ayuntamiento de dicha capital y elevado a este Departamento por la Corporación Administrativa Gran Valencia, con su aprobación.

VISTOS las Leyes de 18 de diciembre de 1.946 de Ordenación Urbana de Valencia y su comarca, de 12 de mayo de 1956 sobre Régimen del Suelo y Ordenación Urbana y de 2 de mayo de 1975 sobre reforma de la anterior, los Decretos de 14 de octubre de 1949, de 18 de enero de 1968 y 13 de julio de 1972, y el informe emitido por los Servicios competentes de la Dirección General de Urbanismo.

Este Ministerio, a la vista de que el referido Plan se ajusta a las determinaciones del Plan de Ordenación Urbana de Valencia y su comarca y de que ha sido tramitado conforme a lo dispuesto en el Arto 32 de la Ley del Suelo, Acuerda aprobarlo definitivamente.

Esta resolución se notificará al Ayuntamiento y a la Corporación Administrativa Gran Valencia, y se publicará en el Boletín Oficial del Estado.

Lo que comunico a V. I. para su conocimiento y efectos.

Dios guarde a V.I.

Madrid, 24 de Septiembre de 1.975

P.D.

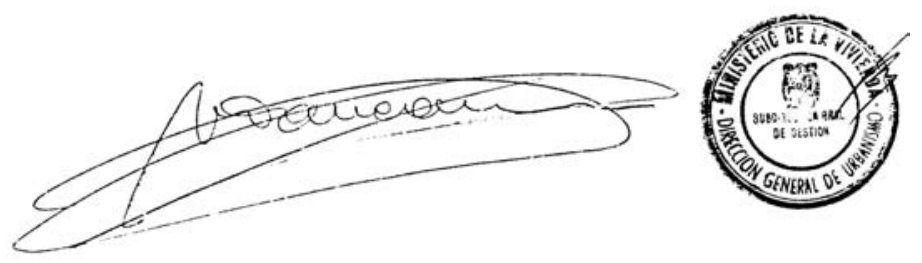

Ilmo. Sr. Director General de urbanismo. 

8. POLÍGONOS, 1968-1971 



\section{Polígono Avenida de Castilla}

Redactores: INSTITUTO NACIONAL DE URBANIZACIÓN (I.N.U.R.). MINISTERIO DE LA VIVIENDA.

Fecha redacción: Septiembre 1968.

Fecha aprobación: O.M. 19-12-1974

Contenido:

I. MEMORIA Y VALORACIÓN.

II. CUADRO DE CARACTERÍSTICAS

III.PLANOS:

1. RELACIÓN CON LA CIUDAD $1: 10.000$

2. ORDENACIÓN GENERAL $1: 1000$

4. PARCELACIÓN $1: 1000$

5. RED DE ABASTECIMIENTO DE AGUA $1: 1000$

6. ALUMBRADO PÚBLICO Y RED DE ALTA $1: 1000$

7. RED DE ALCANTARILLADO $1: 1000$

Fuente:

Ayuntamiento de Valencia. Archivo de Planeamiento, No OM-289 


\title{
INSTITUTO NACIONAL DE URBANIZACION.
}

\author{
PROYECTO DE MODIFICACIÓN POR OBRAS SUPLEMENTARIAS \\ DE LA DELIMITACIÓN Y PLAN PARCIAL DEL POLÍGONO \\ AVENIDA DE CASTILLA -SITO EN VALENCIA.-
}

\section{I.1. Memoria}

\section{Necesidad y objeto del presente trabajo}

El Plan Parcial de Ordenación del polígono Avenida de Castilla fue redactado en el año 1.962. Aprobado el mismo fueron redactados los correspondientes Proyectos de Urbanización, a fin de materializar sobre los terrenos, mediante la realización de las obras, la estructura urbanística que el Plan Parcial determinada.

Durante el tiempo transcurrido desde la redacción y aprobación del proyecto de Plan Parcial se ha venido produciendo en el país una notable alza en el nivel económico que ha tenido como consecuencia inmediata una gran demanda de bienes de consumo y servicios.

Manifestación patente de ello es el gran aumento que experimenta el parque automovilístico de nuestras ciudades, y que en Valencia ha rebasado ampliamente las previsiones de hace unos pocos años.

Otra manifestación del aumento experimentado en el nivel económico de la población es la posibilidad de acceso de los jóvenes matrimonios a un hogar independiente del paterno matrimonios que suelen instalarse preponderantemente en los nuevos núcleos residenciales, con lo que la estructura demográfica de estos nuevos núcleos residenciales habrán de presentar durante el primer periodo de su vida, un desequilibrio en la pirámide de distribución por edades de su población, con una base de gran desarrollo correspondiente a la población comprendida en las edades escolares para la que el planeamiento urbanístico debe preverse a toda costa, las necesarias áreas con destino a establecimientos de enseñanza primaria y de grado medio, así como a guarderías infantiles.

Por todo ello se hace necesario proceder en el polígono "Avenida de Castilla" con anterioridad la futura fase de enajenación de parcelas y construcción de las mismas, a un estudio de remodelación en cada uno de los siguientes aspectos:

- De red viaria en cuanto a una completa revisión de superficies de aparcamientos.

- De reserva de los necesarios espacios para la instalación de dotaciones complementarias, con superficies que garanticen un óptimo servicio de la población que habrá de asentarse en el polígono.

- De reducción del índice viv/Ha como consecuencia de las mayores superficies destinadas a dotaciones complementarias y aparcamientos.

\section{Descripción de las modificaciones introducidas en el Plan Parcial}

- Red viaria.

Con relación al Plan Parcial aprobado se ha tenido en cuenta la red de viales proyectada. Solo se propone la ejecución de nuevos aparcamientos en superficie que el día que las necesidades lo re 
quieran podrá ser transformados en aparcamientos en varias plantas.

- Redes de servicios.

Las superficies reservadas para futuros aparcamientos deberán el día que se acometa su ejecución, ser dotadas de las necesarias instalaciones de saneamiento agua y alumbrado. Su realización no altera las redes proyectadas en los correspondientes proyectos de urbanización, consistiendo únicamente en la adición a las mismas de pequeños ramales para servicios de las nuevas superficies a pavimentar.

El Proyecto de tales redes complementarias no ha sido reflejado en los esquemas de redes de servicios que acompañan a este trabajo dado su carácter marginal a las redes fundamentales definidas en los proyectos de urbanización.

\section{- Dotaciones complementarias y viviendas}

Han sido tenidas en cuenta las parcelas ya adjudicadas de acuerdo con la relación suministrada a los autores del presente trabajo.

Han sido revisadas cada una de las superficies con destino a dotaciones de uso complementario y previsto nuevas reservas con destino a usos no tenidos en cuenta en el Plan Parcial aprobado.

El numero inicial de viviendas del Plan Parcial aprobado era de 3.908 con una densidad de $136 \mathrm{viv} / \mathrm{Ha}$. equivalente a 542 hab/Ha.

El numero definitivo de viviendas en el Plan Parcial reformado queda en 2.050 con una densidad de $71 \mathrm{viv} / \mathrm{Ha}$, equjvalente a 285 $\mathrm{Hab} / \mathrm{Ha}$.

Los datos numéricos relativos a las modificaciones introducidas con respecto al Plan Parcial aprobado se expresan en el cuadro que sigue:

\section{Dotación \\ Enseñanza Media \\ Guarderías \\ No de Viv. \\ $\mathrm{Hab} / \mathrm{Ha}$ \\ Viv/Ha \\ Plazas de} aparcamientos

\begin{tabular}{cr} 
P.P. aprobado & P.P. reformado \\
\hline- & 16.655 \\
- & 3.294 \\
3.908 & 2.050 \\
542 & 285 \\
136 & 71 \\
251 & 480
\end{tabular}

Madrid, de Noviembre de 1.968

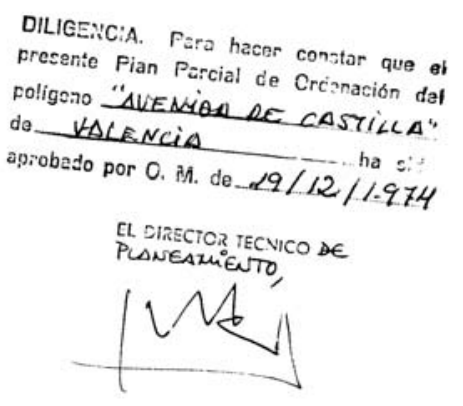




\subsection{VALORACIÓN}

En la imposibilidad de establecer una exacta valoración de las obras suplementarias a efectuar en el polígono, que se estima, sólo puede deducirse por medio de los estudios en detalle que proporcionan los correspondientes proyectos de urbanización, se presente un avance de costos, que obtenido a partir de una estimación aproximada de las obras a realizar, puede permitir determinar, con unos márgenes razonables de variación, la importancia económica de las modificaciones que se proponen.

- Red viaria

El presupuesto de las obras de explanación y pavimentación según el correspondiente proyecto de urbanización el correspondiente proyecto de urbanización redactado sobre el Plan Parcial aprobado, asciende a 21.395.607 Ptas. Se han calculado con toda la aproximación que el grado de Plan Parcial permite, las superficies a nueva pavimentación, ya sea en calzadas o nuevos aparcamientos, que asciende a $8.000 \mathrm{~m} 2$.

Se emplea un precio unitario de $140 \mathrm{Ptas} / \mathrm{m} 2$. que engloba las obras adicionales a efectuar, tales como desmontes, rellenos, compactaciones, colocación de bordillos nuevas aceras etc.

$8.000 \mathrm{~m} 2$. a $140 \mathrm{Ptas} / \mathrm{m} 2$. 1.120 .000 .-

El importe calculado por obras suplementarias relativos a la red viaria representa un 5,23\% del presupuesto calculado según el proyecto de explanación y pavimentación del Plan Parcial redactado.

- Redes de servicios.

Los presupuestos de las obras de urbanización correspondiente a alcantarillado, agua y alumbrado publico según los proyectos de urbanización redactados son los siguientes:

Alcantarillado y Agua .......... 5.918.303.-

Alumbrado Público............. 2..417.850.-

Total.... 8.336.153

Los costos por obras suplementarias relativos a los servicios de alcantarillado, agua y alumbrado publico, se puede estimar que representan un porcentaje similar al correspendiente por obras suplementarias en explanación y pavimentación.

Costos por obras suplementarias en redes de agua,

alcantarillado y alumbrado público:

$5,23 \%$ s/8.336.153........ 435.980,80

COSTO TOTAL EN OBRAS

SUPLEMENTARIAS.

Siendo la superficie del polígono $287.950 \mathrm{~m} 2$ de repercusión del costo total por obras suplementarias, calculado, repercute por metro cuadrado de terreno del polígono en 5,40 Ptas.

Al ser la superficie edificable en viviendas de 192.872 metros cuadrados, la repercusión de tales obras por metro cuadrado de viviendas es de Ptas 8.06

Madrid, Noviembre de 1968.

LOS ARQUITECTOS 


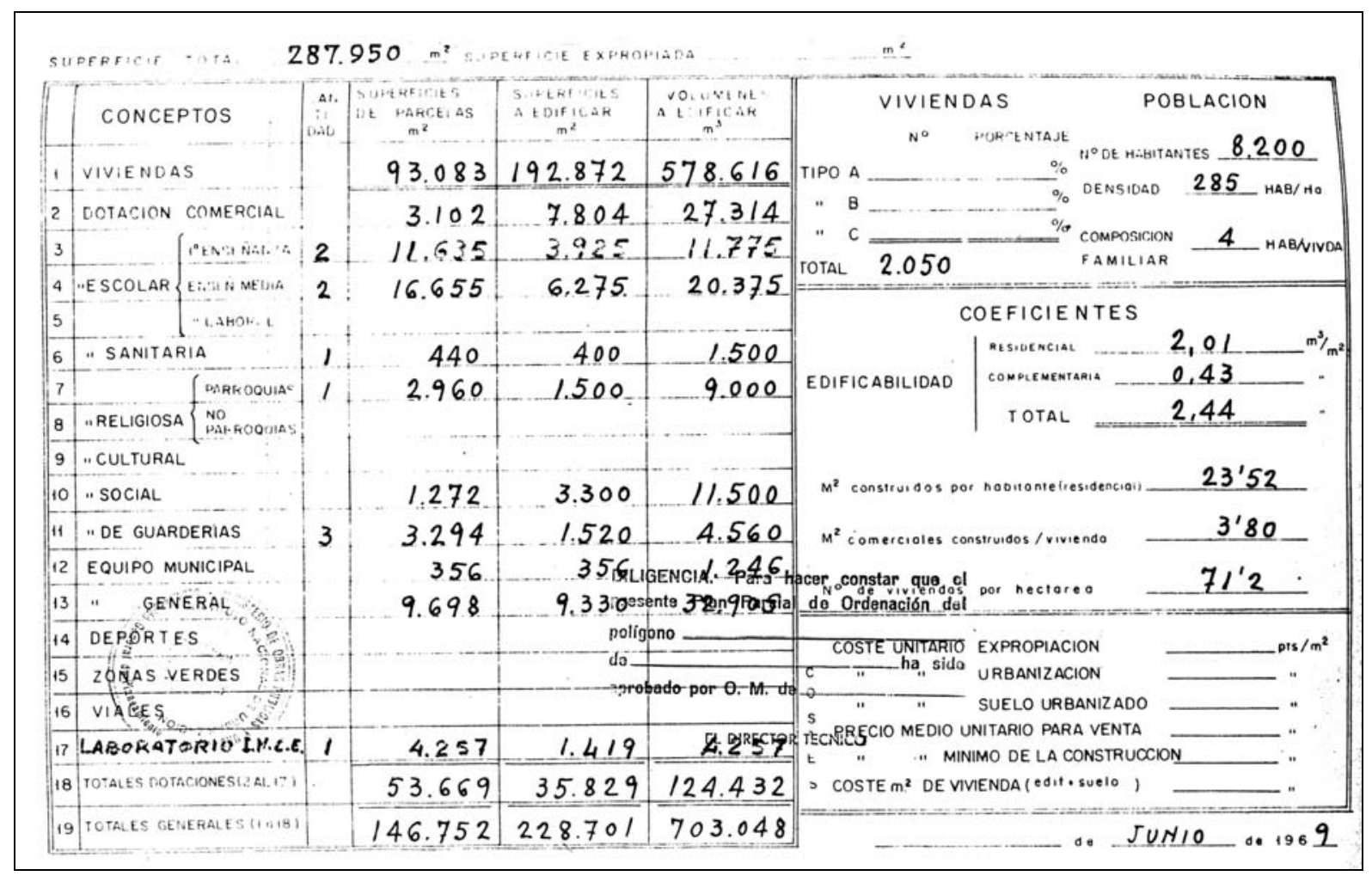

Cuadro de características adjunto a la Memoria. 
2. ORDENACIÓN GENERAL

Escala original: 1:1000

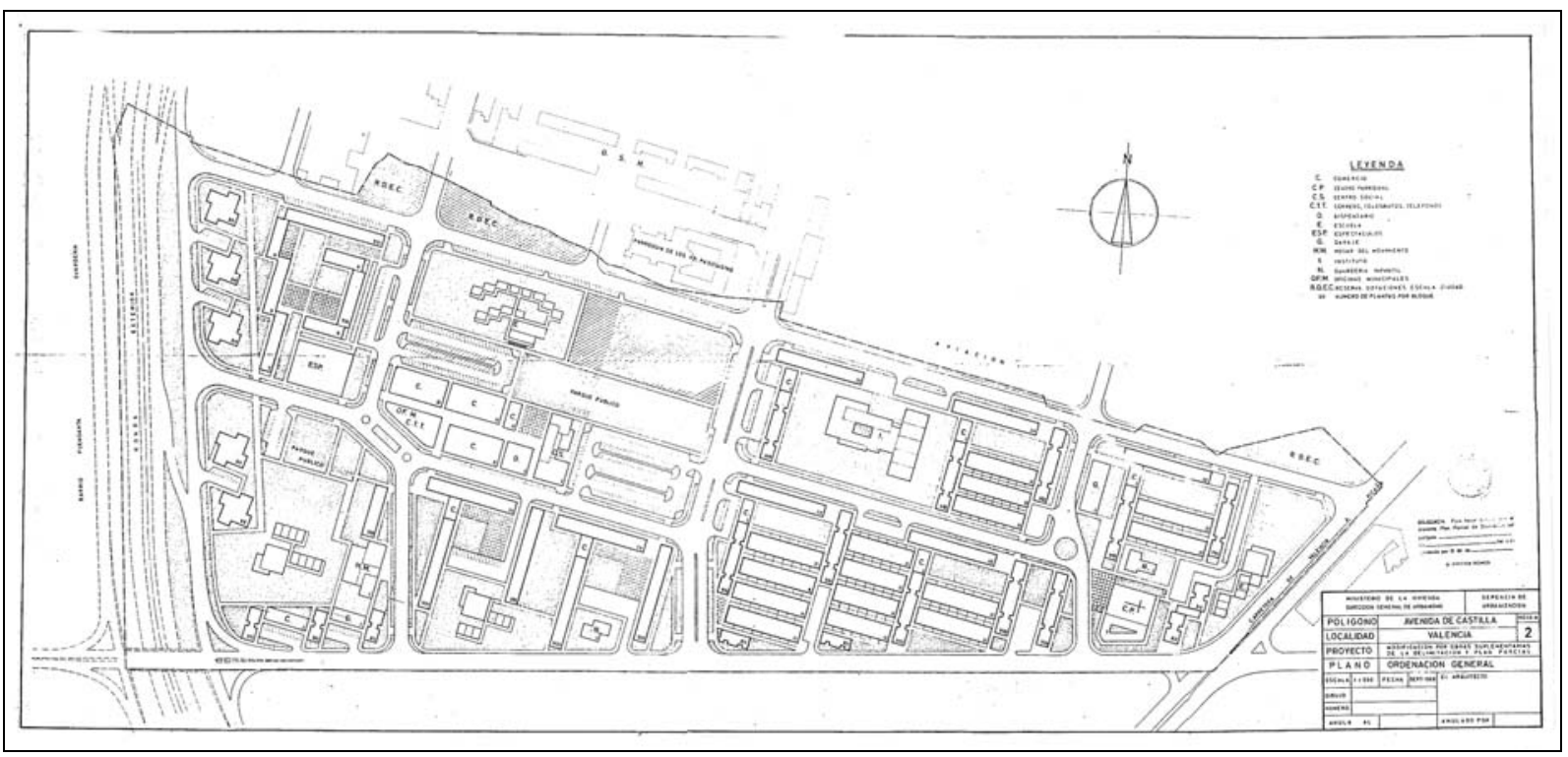

3. PARCELACIÓN

Escala original: 1:1000

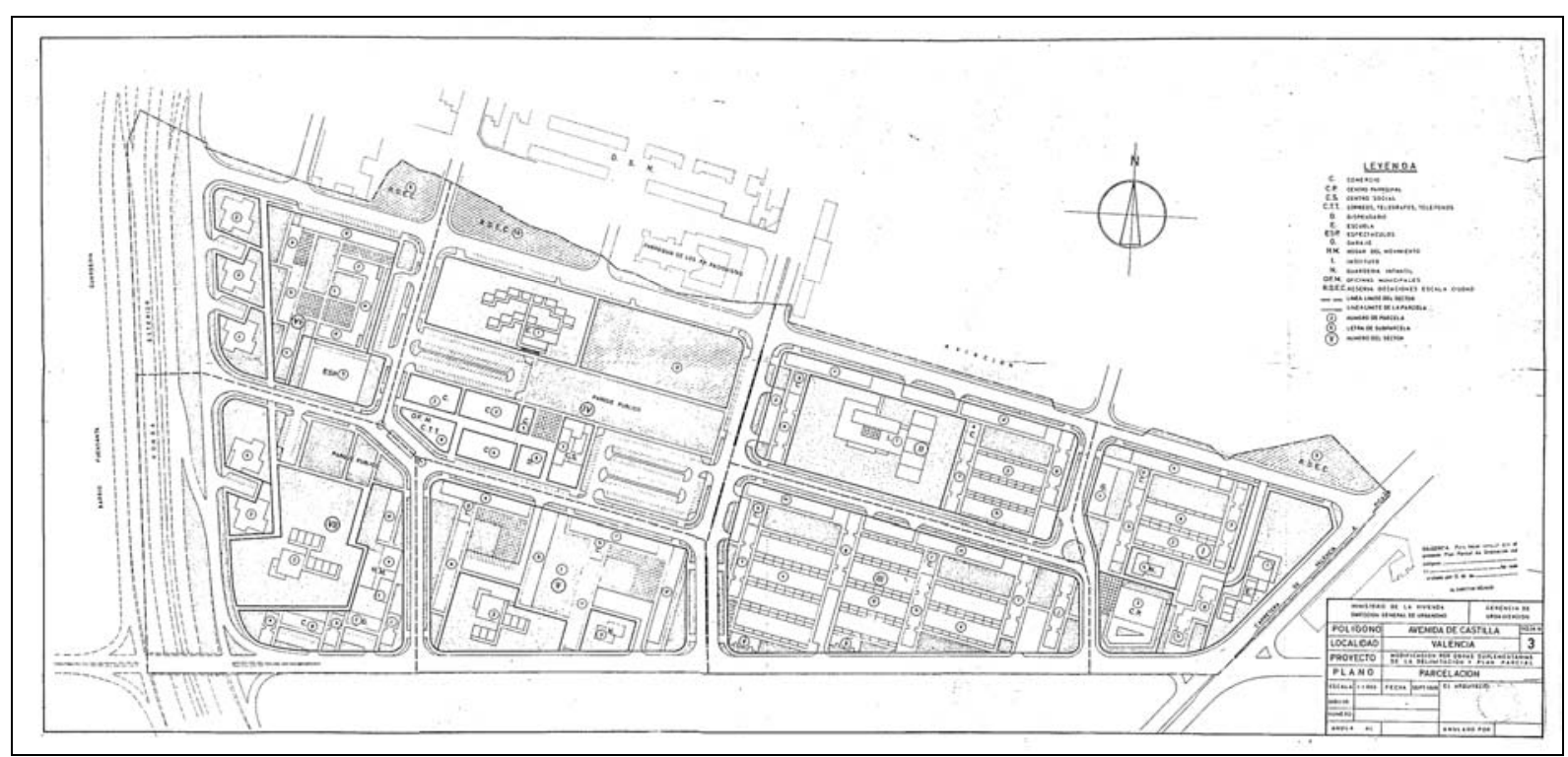




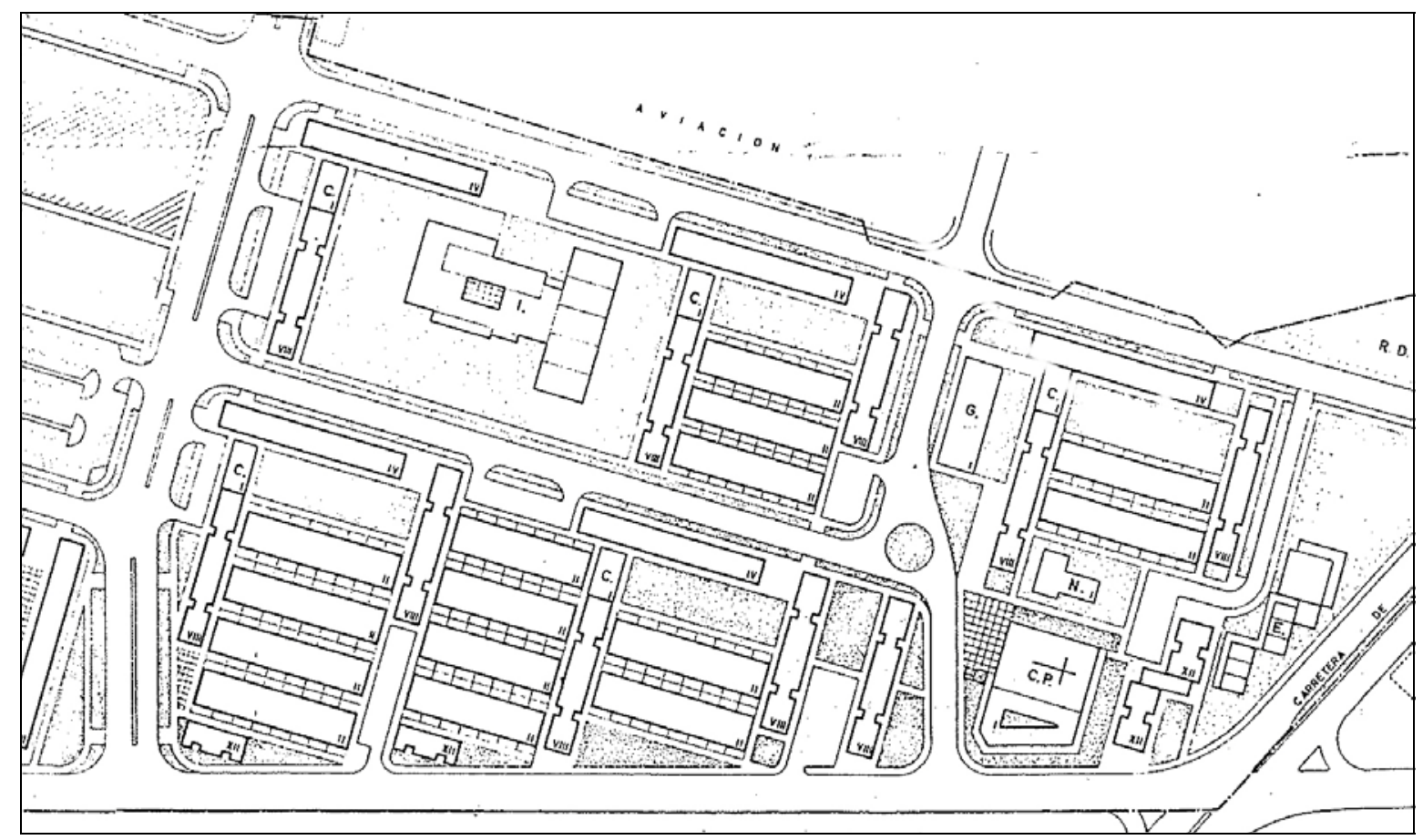

Ordenación general. Detalle del sector este (Grupo Antonio Rueda).

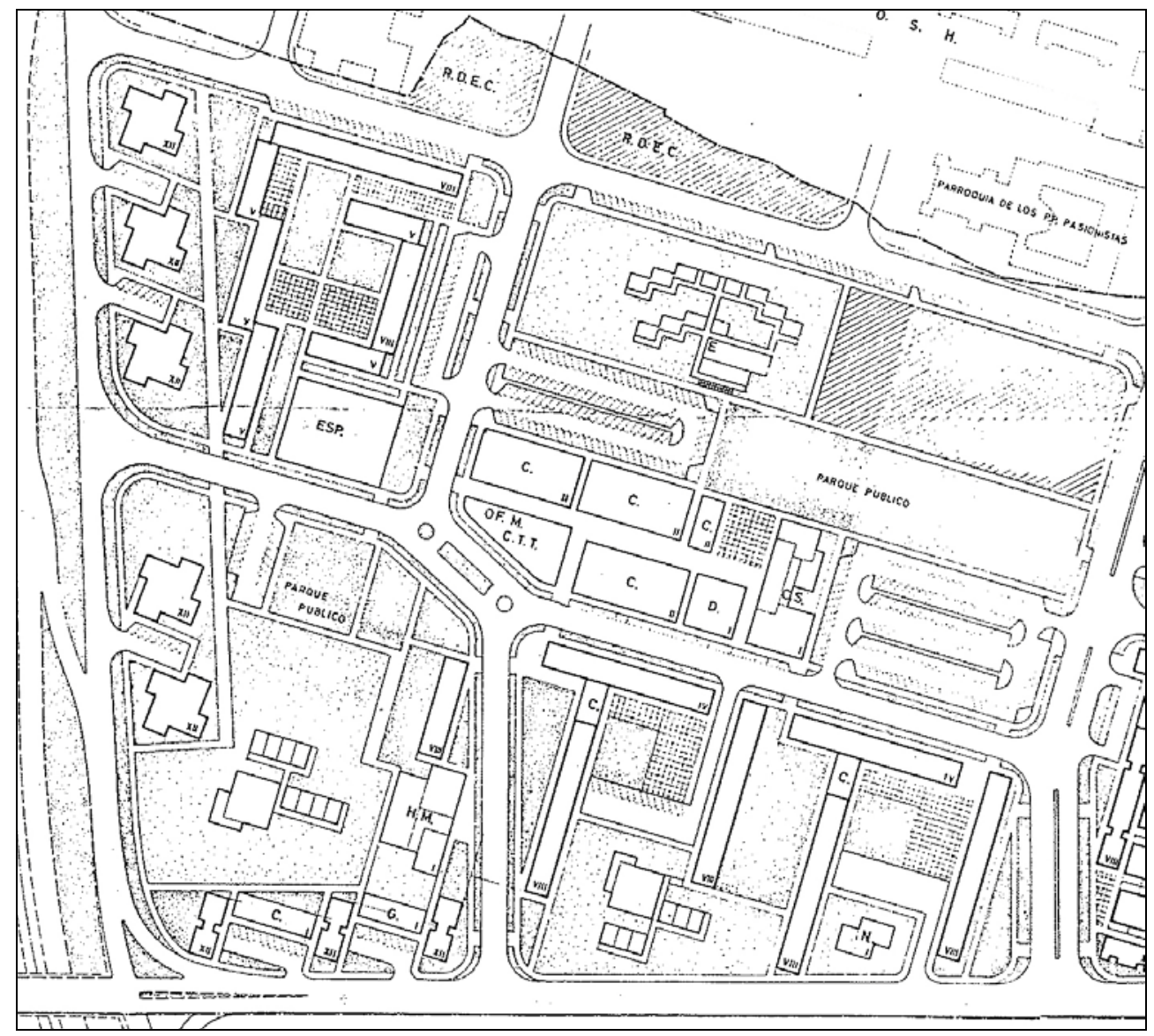

Ordenación general. Detalle del sector oeste. 



\section{Polígono de Campanar}

Redactores: GERENCIA DE URBANIZACIÓN. MINISTERIO DE LA VIVIENDA.

Fecha redacción: 1970 .

Fecha aprobación: O.M. 10-05-1971

Contenido:

I. MEMORIA, ESTUDIO ECONÓMICO Y ORDENANZAS.

II.PLANOS:

1. SITUACIÓN

$1: 10.000$

2. ESTADO ACTUAL

$1: 1000$

3. ORDENACIÓN GENERAL

$1: 1000$

4. PARCELARIO

$1: 1000$

5. RED DE ALCANTARILLADO

$1: 1000$

6. ABASTECIMIENTO DE AGUA

$1: 1000$

7. RED DE ALUMBRADO PÚBLICO

$1: 1000$

III. CUADRO DE CARACTERÍSTICAS

Fuente:

Ayuntamiento de Valencia. Archivo de Planeamiento, No 66 
PLAN PARCIAL DE ORDENACIÓN (REFORMADO) DEL POLÍGONO "CAMPANAR" SITO EN VALENCIA.

MEMORIA, ESTUDIO ECONÓMICO Y ORDENANZAS.

PROYECTO DE PARCELACIÓN DEL PLAN PARCIAL DEL POLÍGONO

"CAMPANAR", SITO EN VALENCIA.

\section{MEMOR I A}

I.- Consideraciones generales

A) Antecedentes

El Excmo. Ayuntamiento de Valencia convocó a últimos del año 1959 un concurso Nacional que motivó el encargo a una serie de equipos de los proyectos de planeamiento en varios polígonos enclavados en distintas zonas de expansión de la ciudad.

Posteriormente la Gerencia de Urbanización del Ministerio de la Vivienda, acordó proceder a la expropiación de varias zonas de terrenos enclavados en los antedichos polígonos. Una de dichas zonas, correspondía a parte del polígono denominado "Campanar", cuya expropiación dividió en varias fases; la $1^{a}$ cuyo proyecto de expropiación y urbanización ha sido ya realizado, y las dos siguientes previstas como zonas de actuación posterior, cuyos proyectos de expropiación no han sido llevados a la práctica.

B)- Objeto del presente proyecto

La Gerencia de Urbanización encarga a los arquitectos que suscriben, la redacción de un proyecto de parcelación, correspondiente a la primera fase cuyos terrenos han sido expropiados, urbanizados y adjudicados ya en gran parte.

C) Límites

Los límites de la zona objeto del presente proyecto de parcelación quedaron ya definidos en su día por la Gerencia de Urbanización en la $1^{\text {a }}$ fase de expropiación.

D) Casos singulares

Antes de estudiar el proyecto de parcelación, conviene considerar los antecedentes relativos a la existencia de algunos casos singulares»

10) Parcelas de uso especial

Existen tres parcelas de uso especial y que son:

a) Gran Centro Comercial de Valencia Norte

b) Estación Central de Autobuses de Valencia Norte

c) Residencia Sanitaria del Seguro de Enfermedad.

El Centro Comercial de Valencia-Norte está situado al Oeste del polígono y lindante con el nuevo acceso de Valencia-Ademuz.

La Estación Central de Autobuses de Valencia-Norte se emplazó a la derecha del Centro Comercial de Valencia Norte por acuerdo del Excmo. Ayuntamiento de Valencia y se encuentra en la actualidad totalmente construida. 
La Residencia Sanitaria se situó al Oeste del polígono, al Norte del Centro Comercial de Valencia-Norte con fachada a la Avenida de Campanar y se encuentra en avanzado estado de construcción.

$2^{\circ}$ ) Parcelas excluidas del proyecto de expropiación

Una vez redactado el proyecto de expropiación de la $1^{a}$ fase $y$ en virtud de las reclamaciones presentadas se procedió a la exclusión de la expropiación de las siguientes parcelas:

a) Parcela correspondiente al patronato de la Juventud Obrera.

La encomiable labor cultural y social de dicho Patronato, aconsejó la exclusión parcial de los terrenos por ella ocupados. Los terrenos de dicha parcela necesarios para la construcción de la Estación de Autobuses y vía Publica fueron expropiados. La parcela triangular situada entre dicho Patronato y el Gran Centro Comercial, por el contrario, puede ser anexionada a dicha Institución.

b) Terrenos correspondientes a la Parroquia de San Juan Bosco ya construida y casas existentes con fachadas a la calle del Padre Ferris, que no obstante quedan sujetas a ordenación.

c) Terrenos ocupados por la fábrica de Tableros de Benlloch y Castellano S.A. Su exclusión de expropiación obedecía a motivos económicos, pero dada la incompatibilidad existente entre el complejo industrial citado y uso residencial del polígono se ha llegado con la propiedad de dicha fábrica a un acuerdo por el que la ocupación de los terrenos podrá efectuarse en breve.

E) Parcelas adjudicadas

Durante el tiempo transcurrido en la ejecución de las obras de urbanización de la $1^{a}$ fase del polígono, han sido llevados a cabo por el Instituto Nacional de la Vivienda las siguientes adjudicaciones de terrenos:

a) Parcelas $n^{\circ} \mathrm{s}, 2,3,4,5,6$ y 7 del sector $C$. y $n^{\circ} 3,4,5$ y 7 del sector D a la Cooperativa Santa Isabel para la construcción de 260 viviendas.

b) Parcelas $n^{\circ} 6$ y 12 del Sector $D$ a la Cooperativa San Francisco de Sales para la construcción de 120 viviendas.

c) Parcelas $n^{\circ} 14,15,16,17.19$ y 20 del Sector $D$ y $n^{\circ} 14,15,16$, 17, 18 y 19 del Sector C. adjudicadas a la Cooperativa "Cid Campeador", para la construcción de 325 viviendas.

d) Parcela no 2 del Sector $\mathrm{H}$ adjudicada para la construcción de un Centro de lucha contra el Cáncer.

e) Parcela $\mathrm{n}^{\circ} 3$ del Sector $\mathrm{H}$ adjudicada a Don Anadeo Ferrer salvo para la construcción de una estación de Servicio.

f) Parcela no 4 del Sector $\mathrm{H}$ adjudicada al Patronato de la Juventud Obrera.

g) Sector G. adjudicado para la construcción de la Estación de Autobuses de Valencia Norte.

h) Parcela no 1 del Sector E adjudicada al Instituto Nacional de Previsión para la construcción de la "Ciudad Sanitaria La Fé".

i) Parcela $n^{\circ} 2$ del Sector E adjudicada al Instituto nacional de Previsión para ampliación de la "Ciudad Sanitaria La Fe".

j) Parcela no 1 del Sector $D$ con destino, a la construcción de viviendas experimentales del Ministerio de la Vivienda.

F) Parcelas libres existentes. 
Con relación a las parcelas no adjudicadas del polígono, y por tanto disponibles, se ha procedido a un estudio de remodelación, con el fin de dotar al núcleo de viviendas existentes en los sectores $\mathrm{G}$ y $\mathrm{D}$ y en gran parte ya adjudicadas a Cooperativas de construcción, de los servicios y edificios complementarios necesarios para el buen funcionamiento del mismo.

Así pues teniendo en cuenta el $n^{\circ}$ de viviendas previsto en dichos sectores $C$ y $D$ se han reservado espacios para escuelas primarias y guarderías de la siguiente forma:

-En el sector $C$, se agrega parte de la parcela no 8 que unida a las correspondientes a los no 9, 10,11 y 12 se destinarán a Escuela Primaria.

-También el Sector $C$ se segrega parte del terreno de la parcela $n^{\circ} 1$ con destino a una guardería infantil.

-En el Sector $D$, se prevé una Escuela primaria por agrupación de las parcelas $8,9,10,11,13$.

-En el Sector F, se destina en su totalidad el uso de parque público, dado su excelente situación para tal fin y la falta de parque público en el planeamiento primitivo.

-En el Sector H destinado a Centro Comercial de ValenciaNorte se mantiene con este uso especial. Dentro de este sector $\mathrm{H}$, el I.N.V, ha adjudicado ya una parcela de terreno para la creación de un centro de lucha contra el Cáncer.

Por tratarse de un sector completo y afectarle una ordenanza especial, ya que los servicios públicos que habrá de incluir estarán a escala de la ciudad de Valencia, cuyo centro urbano se pretende descongestionar, sería posible considerar en su día una remodelación del sector, salvando las vías ya urbanizadas, siempre que se respetase la edificabilidad prevista o se autorizasen los volúmenes necesarios en la forma que regula ordenanza 29 del Plan Parcial.

\section{G) Características generales}

\section{Superficies}

La superficie del Polígono Campanar $1^{\text {a }}$ Fase es de 322.400 m2. La distribución de los sectores que la componen por usos es la siguiente:

$\begin{array}{ccll} & & \text { Superficie } & \\ \text { Sector C } & 49.400 \mathrm{~m} 2 & \text { Uso } \\ \text { " } & \text { D } & 52.000 " & \text { Residencial } \\ \text { " } & \text { E } & 87.000 " & \text { " } \\ \text { " } & \text { F } & 20.000 " & \text { Cdad. Sanitaria } \\ \text { " } & \text { G } & 43.000 " & \text { Est. De Autobuses } \\ \text { " } & \text { H } & 71.000 " & \text { Gran Centro Comercial }\end{array}$

Volumen, índice de edificabilidad, densidad

Volumen edificable según cuadro de Características

$1.042 .916 \mathrm{m3}$.

Indice de edificabilidad $\underline{1.042 .916} \mathrm{m3}=3,23 \mathrm{M} 3 / \mathrm{M} 2$

$$
322.400 \mathrm{~m} 2
$$

Número de viviendas en Sector C $\underline{865}$ Viviendas.

$$
\text { " } \quad \text { TOTAL } 1.173 \text { Viviendas. }
$$


Número de habitantes $=1.173$ Viviendasx4 Hab/Viv=4.692 Habt. Densidad de población referida a los sectores $C$ y $D=455 \mathrm{Hab} / \mathrm{Ha}$ Densidad de población referida a la totalidad de la $1^{\text {a }}$ fase $=145$ $\mathrm{Hab} / \mathrm{Ha}$.

Previsión de dotaciones de la unidad residencial formada por los sectores $C$ y $D$.

Centros Escolares.- Teniendo en cuenta la Orden de 24 de Mayo de 1962 que regula la reserva de espacios escolares en función del no de viviendas, se prevén dos centros escolares al Servicio del Barrio Residencial integrado por los Sectores C y D, con una superficie total de $10.170 \mathrm{~m} 2$.

Centros Parroquiales. -Las necesidades relativas a la dotación religiosa de la $1^{\text {a }}$ fase del polígono Campanar está perfectamente cubierta con la existencia de la parroquia de San Juan Bosco enclavada en el Sector D.

Centros asistenciales.- Se prevén dos guarderías infantiles de unos $800 \mathrm{~m} 2$. Para atender a cada uno de los dos sectores residenciales.

Centros cívicos.- Se mantiene el Centro cívico-comercial ya previsto en el primitivo planeamiento, en el sector C, con $4.340 \mathrm{~m} 2$. Comerciales, sala de espectáculos y edificios de oficinas que cubren ampliamente las necesidades del núcleo residencial.

Madrid, Diciembre de 1.970.

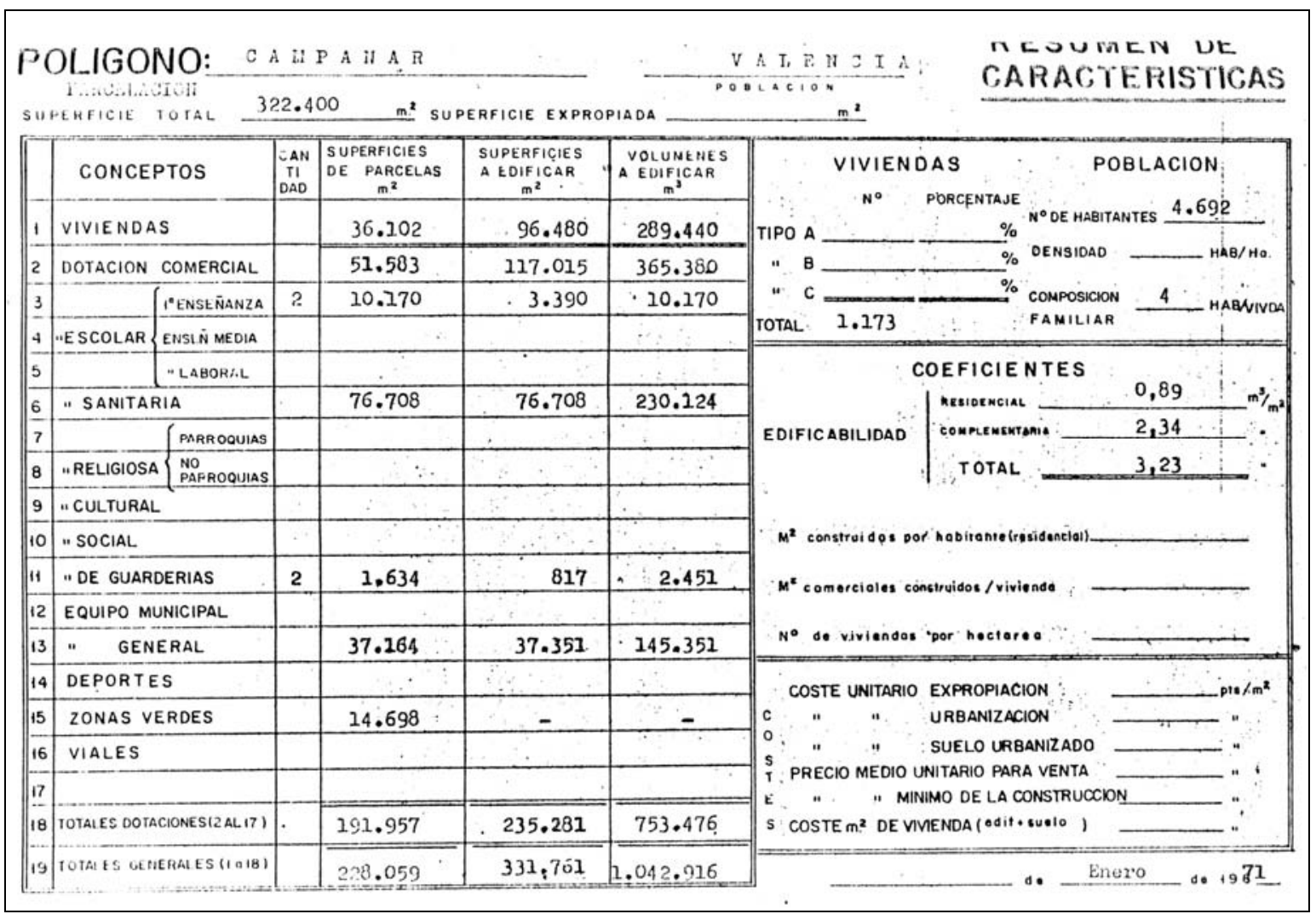

Cuadro de características 
PROYECTO DE PARCELACIÓN DEL PLAN PARCIAL DEL POLÍGONO "CAMPANAR", SITO EN VALENCIA.

\section{INDICE}

\section{ORDENANZAS}

Título I.- Definiciones.

II.- Edificación en manzana cerrada.

III.- Edificación abierta a) viviendas.

IV.- Centro comercial Valencia Norte.

b) edificios públicos

V.- Estación de Autobuses Valencia-Norte.

VI.- Residencia Sanitaria del Seguro de Enfermedad.

ORDENANZAS REGULADORAS DEL USO, VOLUMEN Y EDIFICACIÓN DEL POLÍGONO "CAMPANAR" SITO EN VALENCIA

\section{TITULO III.- EDIFICACIÓN ABIERTA}

Arto 170 .- Límites.- Prácticamente el polígono objeto del presente trabajo, es de edificación abierta, con excepción de las pequeñas zonas, descritas en el título anterior, de transición entre las edificaciones actuales en manzanas cerrada al resto del polígono en edificación abierta.

Arto $18^{\circ}$.- Usos, - En la edificación abierta, los usos no se superponen. Se separan las funciones y en consecuencia, los edificios que tienen la misión de cumplirlos. Las distintas funciones tienen un orden jerárquico de subordinación para la mayor eficacia del conjunto.

Así partiendo de la vivienda en bloque, conjunto de bloques y unidad vecinal, se establecen para su servicio las funciones: garajes, talleres, comercial, negocios, cultural y social, educativa, religiosa.., en edificios propios, conectados con la unidad pero con absoluta independencia de los edificios de vivienda.

El uso, por consiguiente, queda perfectamente definido y delimitado por la separación de la función familiar (viviendas) de las de relación (edificios públicos o de uso publico y de las de trabajo (oficinas, talleres, etc.).

Arto 190.- Volúmenes.- EI volumen de edificaciones previstas, tanto las destinadas a vivienda, como a edificios públicos o de uso publico queda definido en los planos de la siguiente manera:

1) Viviendas

a) por el tamaño en planta de las edificaciones.

b) Por el $n^{\circ}$ de plantas que figura en números romanos supuesto en $3 \mathrm{~m}$. la altura de cada planta, incluyendo el espesor del forjado, no admitiéndose sobre las mismas mayor volumen que el que pueda suponer los servicios de: escalera, ascensores, depósitos, chimeneas, pero nada que suponga pie 
zas habitables como estudios, porterías... etc.

2) Edificios públicos

a) Centros cívicos de barrio, en los que se especifican el $n^{\circ}$ de plantas para los distintos usos: A) Comercios de una o dos plantas, según los casos; B) Cines o salas de espectáculos de dos plantas a excepción de la sala que se le supone una altura media de $9 \mathrm{~m}$. ; C) Edificio de negocios y oficinas en el que se señala el $n^{\circ}$ de plantas a razón de $3 \mathrm{~m}$. por planta.

b) Centros escolares que se suponen de 2 plantas, incluido el salón de actos.

c) Centro a sanitarios de urgencia, también de 2 plantas

d) Centros Parroquiales. La nave principal de cultos se supone de $9 \mathrm{~m}$. de altura y las dependencias parroquiales, oficinas, abadías... de 2 plantas.

e) Garages, talleres, almacenes, de una sola planta de altura de 4 ni máximo.

Todos estos volúmenes, tanto los de edificaciones con destino a viviendas, cono' los de edificaciones públicas o de uso publico, quedan especificados y desglosados, en cada parcela resultante, en el cuadro da características de parcelas que se adjunta al presente trabajo.

Arto 20.- Cambios de volumen y ordenación

1) Viviendas.- No se podrá, variar el volumen previsto en los edificios destinados a vivienda, ni en cada bloque ni en su conjunto. Unicamente y cuando se plantee un gran conjunto de edificación que comprende una unidad vecinal, con la agrupación de varias parcelas resultantes, podrá reconsiderarse la forma de agrupación de bloques y variar por lo tanto, sus volúmenes relativos y su ordenación, pero sin aumentar el coeficiente de edificabilidad, es decir que el volumen total (suma de los volúmenes de cada parcela) será el mismo que se especifica en cuadro de características de las parcelas.

2) Edificios públicos.- La situación de las parcelas en que se hallan ubicados estos edificios serán inamovibles, por lo que cada una de estas parcelas deberá ser utilizada exclusivamente para la construcción del edificio publico o conjunto de edificaciones de uso publico, según los casos que en los planos se especifican.

El volumen de estos edificios esta previsto de acuerdo con las necesidades del conjunto, por lo que en general, no debe ser modificado; no obstante, si se solicitase un aumento sobre el previsto tendrá que ser debidamente justificado y aprobado por la Superioridad.

Este aumento de volumen, cuando se conceda no tendrá repercusión económica, en los edificios públicos siguientes:

a) Centros escolares

b) Centros Parroquiales

c) Centros sanitarios y asistenciales

así como en todas las edificaciones de carácter público, no lucrativo tales como:

a) Centros cívicos (oficinas, para negocios, comercios, ci 
nes o salas de espectáculos, grandes almacenes, etc.

b) Talleres, garajes

c) Escuelas de tipo particular no gratuito

El aumento de volumen, si procede repercutirá económicamente, sobre su propietario o usuario, proporcionalmente a dicho aumento, mediante el pago de un mayor canon de urbanización.

Arto $21^{\circ}$.- Voladizos.- En las parcelas con destino a viviendas, no se autorizarán cuerpos volados de ninguna clase, permitiéndose únicamente los voladizos en forma de terraza, con un vuelo máximo de $5 \%$ de la distancia entre bloques. Estos voladizos pueden autorizarse en todas las plantas altas sin más limitación que un mínimo de $3 \mathrm{~m}$. de altura desde la rasante de la calle al techo de la primera repisa.

Arto 220.- Patios.- En edificación abierta no cabe el utilizar patios interiores de ventilación, por lo que caso de que la ordenación del polígono fuese variada en alguna de sus parcelas, no se autorizaran.

$\mathrm{Si}$, en cambio, se permiten las chimeneas de ventilación para aseos y baños, debiendo ser registrables y con tiro forzado por su parte inferior, por medio de conducto comunicado al exterior.

Arto $23^{\circ}$.- Composición.-

a) La composición de los bloques para viviendas, será única para cada uno de ellos y ligada al contiguo, caso de que no estuviesen aislados.

Será de líneas sencillas y claras, con expresión actual de la arquitectura, y con correcto y buen acabado en todas sus fachadas.

Se cuidará el componer los elementos que forzosamente han de salir de la altura utilitaria de los bloques, debiendo tener, estos elementos, análogos tratamiento exterior que las fachadas.

b) La forma y composición, de las edificaciones de uso público:

centros cívicos (oficinas, comercios, espectáculos..)

" escolares

" parroquiales

" sanitarios y asistenciales

dependerá exclusivamente del proyectista, si bien teniendo en cuenta su integración con los espacios envolventes.

c) Los talleres, garajes, y almacenes por ser edificaciones de una sola planta, tendrán que guardar armonía tanto en lo que afecta a sus fachadas como a su forma de cubrición con la edificación circundante, con formas sencillas y soluciones claras.

En los 3 casos, será preceptivo el informe favorable del control de edificaciones que establezca la Gerencia de Urbanización.

Arto 24.- Sistema de actuación. El sistema de actuación propia de este polígono y específicamente de estas zonas de edificación abierta, se fijará en su día, por el organismo a que corresponda. 
3. ORDENACIÓN GENERAL.

Escala original: 1:1000

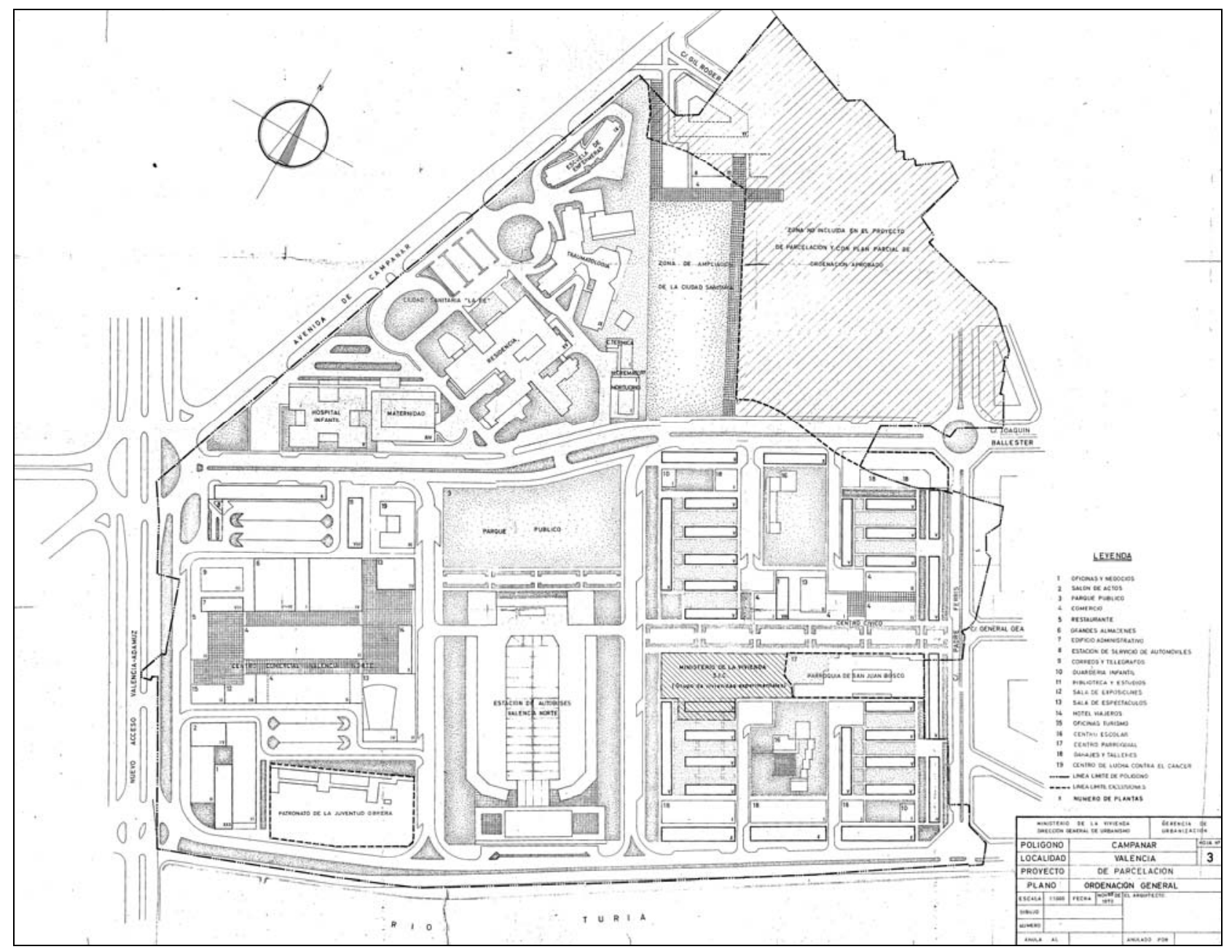




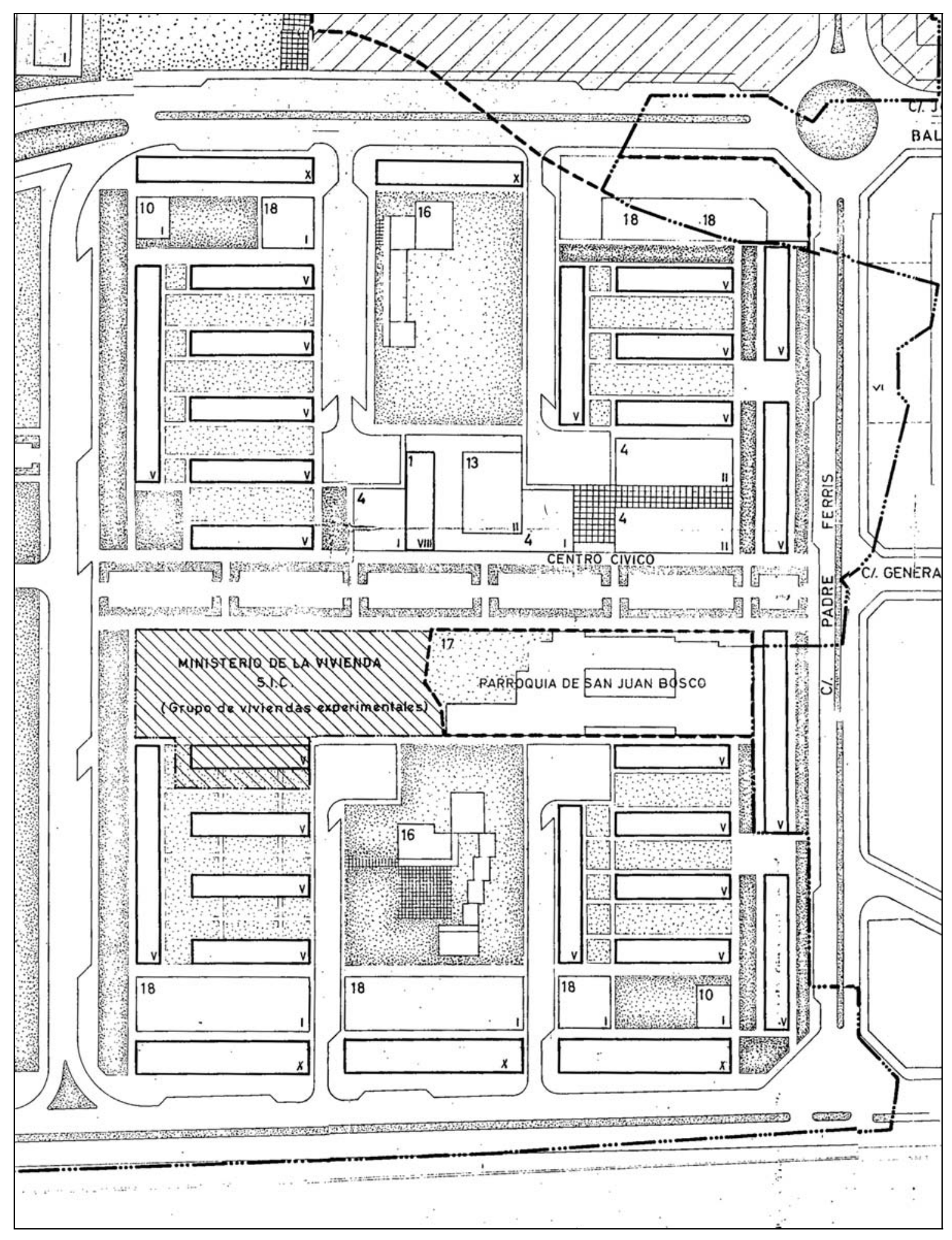

Detalle del Plano de Ordenación General. Zona de Tendetes. 
4. PLANO DE PARCELACIÓN.

Escala original: 1:1000

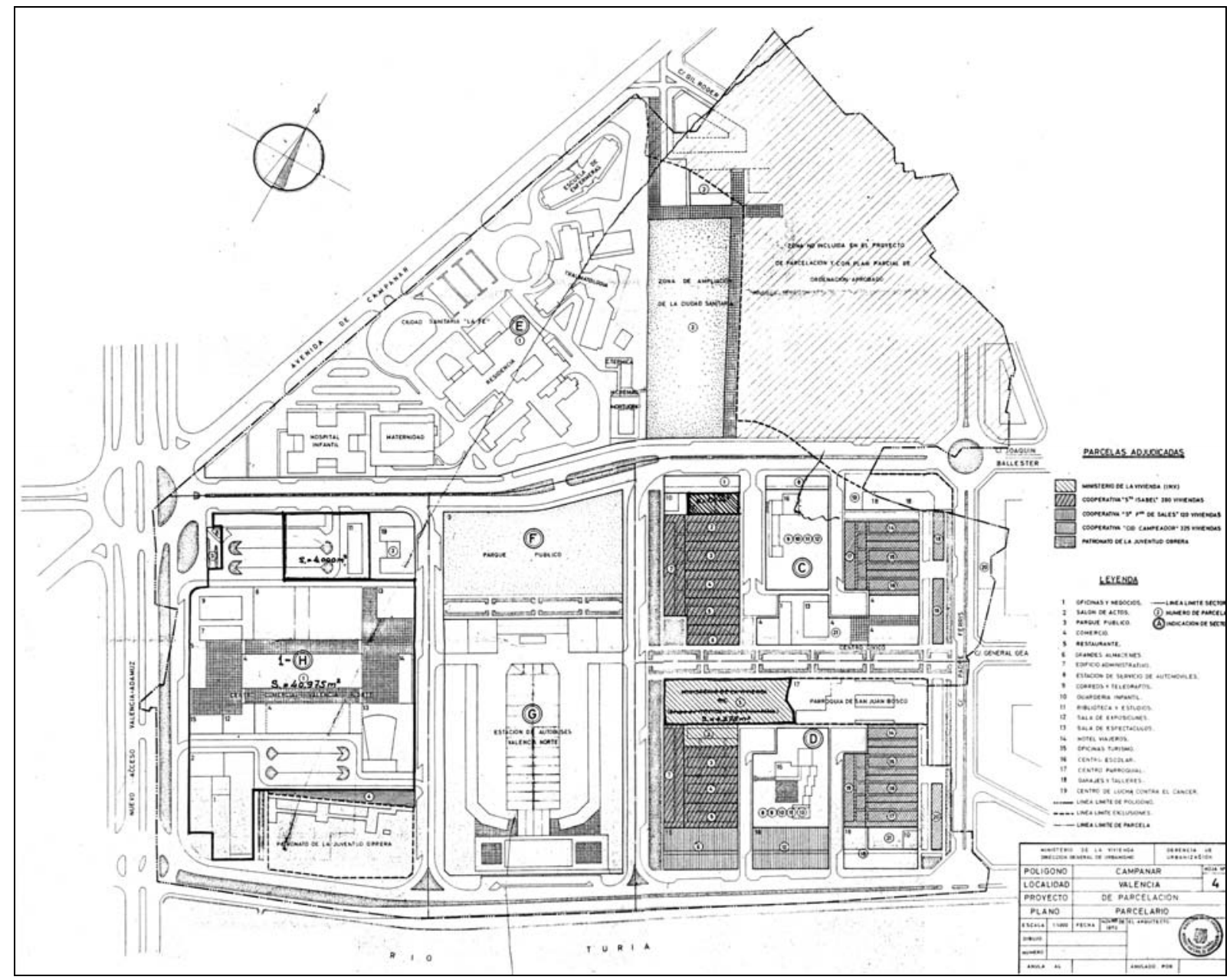





\section{Polígono Fuente de S. Luís}

Redactores: GERENCIA DE URBANIZACIÓN. MINISTERIO DE LA VIVIENDA.

Fecha redacción: Octubre 1969.

Fecha aprobación: O.M. 18-03-1971.

Contenido:

I. MEMORIA Y CUADRO DE CARACTERÍSTICAS.

II. ORDENANZAS.

III. ESTUDIO ECONÓMICO.

IV.PLANOS: (Fecha)
1. SITUACIÓN
$1: 3000$
2. ESTADO ACTUAL
3. RED VIARIA
$1: 2000$
4. ORDENACIÓN GENERAL
$1: 1000$
5. ESTRUCTURA URBANISTICA
$1: 1000$
6. PARCELARIO
$1: 1000$
7. ABASTECIMIENTO DE AGUA
$1: 1000$
8. ESQUEMA DE SANEAMIENTO
$1: 1000$
9. ELECTRICIDAD Y ALUMBRADO
$1: 1000$

Fuente:

Ayuntamiento de Valencia. Archivo de Planeamiento, No 41c. 


\author{
PLAN PARCIAL REFORMADO DEL POLÍGONO \\ "FUENTE DE SAN LUIS". DE VALENCIA.
}

\title{
MEMOR I A
}

La necesidad de someter el planeamiento del polígono "Fuente de San Luis" al Nuevo Plan General de Ordenación Urbana de Valencia, adaptado a la Solución Sur de desvío del Río Turia, aprobado en Consejo de Ministros al 27-7-66, ha obligado a revisar el Plan Parcial del polígono y a reformarlo de forma sustancial, ajustándolo, al mismo tiempo, a unas más adecuadas condiciones de uso y edificabilidad de los terrenos delimitados. Esta es la justificación del presente estudio, que viene a rectificar el planeamiento aprobado anteriormente sobre el polígono.

\section{Emplazamiento}

El polígono está situado en el Sureste de la Ciudad; tiene la forma de un triángulo rectángulo, limitado al noroeste por la Avenida de la Plata, (cateto mayor) al Suroeste por el Acceso Sur de la Red Arterial (cateto menor), y al Sureste por una línea quo constituye el trazado de una antigua vía del Plan General anterior, ya suprimida, que unía el nudo de enlace del Acceso Sur y Ronda Exterior con la Autopista de Enlace Sur (hipotenusa).

En el ángulo occidental de este triángulo, que corresponde a los lados formados por la Avda. de la Plata y el Acceso Sur, existe una zona de terreno que urbanísticamente forma parte del polígono por estar dentro de sus límites naturales, pero que no está afectada de expropiación. La ordenación de esa zona queda sometida al Plan Parcial y regulada por sus ordenanzas, por la necesidad de desarrollar la unidad urbanística completa y no solo el polígono expropiado.

\section{Características}

La superficie total del polígono objeto del estudio es de $572.912,00 \mathrm{~m} 2$. y el área de la zona delimitada de $488.607 \mathrm{~m} 2$.

El terreno es prácticamente horizontal con ligeros desniveles que principalmente corresponden a los límites de las parcelas cultivadas. En general se presenta un ligero declive hacia el Este que no llega a rebasar los tres metros en las cotas extremas. Esta circunstancia unida a que la contextura del terreno es aceptable en cuanto a su calidad y resistencia (tierras arcillosas compactas) permitirán que los gastos de urbanización resulten muy pequeños.

Por lo que respecta al clima puede hacerse extensivo cuanto se tiene estudiado para la Capital, dada su proximidad al casco urbano. Conviene apuntar únicamente que, por su posición al Este de la ciudad, recibe de un modo más directo el influjo de las brisas marinas que, aunque no pueden calificarse de vientos dominantes, contribuyen a condicionar el clima. de la zona y precisa tener en cuenta a efectos de la disposición y orientación de los bloques residenciales.

La distancia al casco urbano de la Capital, entendiendo cono tal la zona, totalmente urbanizada, es aproximadamente de unos cuatrocientos metros. 
En contacto con el polígono, solamente existen algunos núcleos de edificación dispersa, mas bien inconexa, urbanísticamente hablando, que no pueden servir de pauta para una ordenación.

\section{Justificación de la ordenación}

Conviene destacar, antes de iniciar el estudio del planeamiento proyectado, las características fundamentales que reúne el polígono como base de una urbanización. Entre los factores más destacados que abonan la elección del emplazamiento y condicionan las soluciones adoptadas, destacan:

a) Proximidad de los terrenos al nuevo eje de Valencia que habrá de discurrir en forma de gran avenida, por el antiguo cauce del río (solución Sur), aprobado en Consejo de Ministros.

b) Contigüidad a la estación central de los ferrocarriles, proyectada como terminal de todas las líneas importantes.

c) Facilidad de salida de sus habitantes hacia los centros fabriles, rurales e instalaciones portuarias.

d) Descongestión de los sectores que, por diversas causas, resultaban más atractivos urbanísticamente en la zona Oeste de la ciudad.

e) Rotura del cinturón suburbial que, en forma de edificaciones anárquicas y mal ordenadas, amenazaba el vértice Sureste de la capital.

\section{Estructura}

La urbanización del polígono se plantea, de acuerdo con sus condiciones naturales y los factores determinantes citados, como una unidad residencial autónoma en la que, teniendo en cuenta el aprovechamiento volumétrico, se podrá llegar a una población total de 15.000 personas.

Cuatro vías fundamentales constituyen la red de penetración en el polígono. Tres de ellas nacen en la Avda. de la Plata, y son paralelas al acceso Sur. La cuarta, perpendicular al Acceso Sur, divide el polígono longitudinalmente en dos partes. En el lado Norte de esta vía se proyecta un parque o paseo central, de unos 50 metros de anchura, paralelo a ella.

De las tres vías perpendiculares a la Avda. de la Plata, la primera, al Oeste, coincide sensiblemente con la carrera de San Luis. La segunda, en el centro del polígono, termina en una gran plaza de aparcamiento, contigua a la zona deportiva, a la parroquia y a uno de los institutos de Enseñanza Media; pero al oeste de la parcela de la Parroquia se ha reservado terreno, con el fin de hacer posible un enlace futuro con los terrenos existentes al Sur del Polígono.

La tercera vía, más al Este, con $40 \mathrm{~m}$. de distancia entre fachadas, es prolongación de la Avda. del General Urrutia, quedando enlazada al eje longitudinal paralelo al parque.

Se han previsto además, otros accesos al polígono que terminan en fondos de saco y amplias zonas de aparcamiento.

La red de peatones también es importante, constituída por vías de $9 \mathrm{~m}$. de anchura, y en contacto con la red de circulación rodada sólo en los puntos indispensables.

Para describir someramente la estructura del polígono se considera convencionalmente dividido en dos partes, separadas por la vía longitudinal y el parque público:

La parte Sur, de forma triangular, concentra, en su mitad occidental, el $42 \%$ de la población total del polígono, en torres de 15 
y 12 plantas y bloques de 4 y 6 . Hay dos parcelas para escuelas de enseñanza primaria, dos para guarderías, una para Instituto de Enseñanza Media, la zonas deportiva y la Parroquia.

El emplazamiento del Centro parroquial se ha elegido teniendo en cuenta una equidistancia entre parroquias próximas al polífono, un acercamiento a la zona de mayor densidad y un aislamiento de la edificación de altura.

En el interior de las manzanas se han reservado terrenos para parques infantiles.

La zona norte del polígono, apoyada en la Avda. de la Plata, tiene, en su centro de gravedad, el centro cívico del polígono, constituido por edificios para Oficinas municipales, comunicaciones, mercado, centros cultural y social, oficinas particulares, sala de espectáculos, hotel y grandes almacenes. Grandes zonas de aparcamiento de vehículos sirven esta unidad, que, a su derecha e izquierda, con fachadas a la Avda. de la Plata, se completa con edificios a escala ciudad, que tienen reservadas sus parcelas correspondientes.

La dotación de terrenos para edificios a escala ciudad puede considerarse complementada por las instalaciones docentes del Colegio Salesiano, que actualmente sirven a la Ciudad de Valencia y que se integran en la unidad urbanística del polígono.

En esta zona norte se ubicaran dos escuelas, dos guarderías, más otra ya existente, enclavada en el ángulo Este del polígono; un Instituto de Enseñanza Media, un centro sanitario y algunos parques infantiles.

\section{Aparcamientos}

Ya se ha aludido a la dotación de aparcamientos, que se considera suficiente para atender las necesidades de la población. Si en el futuro fuere preciso un incremento del número de plazas para vehículos, la solución prevista es edificar en dos, tres plantas las actuales playas de estacionamiento.

A continuación se describen, sucintamente, las características más destacadas de las redes de distribución de agua, saneamiento y energía eléctrica.

\section{Redes de servicios}

A) Red de abastecimiento de agua.

En la Avda. de Peris y Valero, vía sensiblemente paralela a la Avda. de la Plata y situada a unos 500 metros al norte de ella, existe la más próxima red que puede ser utilizada para el abastecimiento del polígono.

La conexión será doble, para asegurar el suministro por dos puntos, y se hará uniendo los extremos de la Avda. de la Plata con la arteria de la Avda. de Peris y Valero.

La disposición de la red se prevé, en lo posible, en anillos cerrados, para disminuir las pérdidas de carga y evitar, en caso de averías, faltas de suministro.

El circuíto principal, formado por conductos de diámetro mínimo de 200 mm., discurre por las calles Avda. de la Plata, prolongación de Avda. del General Urrutia, "Acceso Sur", y vía. Iongitudinal paralela al parque.

Los circuitos interiores se apoyan en el principal, $y$ completan la red. Aparte de estos circuitos, hay terminales ramificadas, a las 
que conectarán los circuitos interiores de parcelas para dar suministro a la edificación.

La dotación de agua prevista es de 250 l/hab./ día.

B) Red de Alcantarillado

Todos los ramales afluirán a un colector principal, que se desarrolla en las calles Avda. de la Plata, Avda. General Urrutia, calle longitudinal paralela al parque $y$ calle perpendicular a ésta última, que atraviesa de Sureste a Noroeste el lado Suroeste del polígono.

Las alcantarillas y ramales siguen, en general, el trazado de la urbanización proyectada y la pendiente natural del terreno, aunque ésta es tan poco pronunciada que permite invertir el sentido de la circulación cuando así lo aconseje el mejor acoplamiento de la red.

El colector principal vierte en un emisario de 70 metros de longitud, que provisionalmente desemboca en la Acequia Fabiana. Para una solución definitiva, será necesario construir un colector de unos 1.100 metros de longitud, a lo largo del lado izquierdo del Acceso Sur.

C) Red de electricidad y alumbrado público

Se ha previsto una red subterránea de alta tensión, estableciendo once transformadores., Las líneas de alimentación a los bloques de mayor altura y volumen serán también subterráneas. Para las demás edificaciones, se utilizarán cables aéreos.

El alumbrado público se resolverá con báculos en los espacios amplios y con brazos murales en calles más reducidas.

Madrid, Octubre 1969. 


\begin{tabular}{|c|c|c|c|c|c|c|c|c|}
\hline \multicolumn{6}{|c|}{$\begin{array}{l}\text { HULIGUNU: + UENTE DE SAT LUIS } \\
\text { SUPERFICIE TOTAL } 573.912 \mathrm{~m}^{2} \text { SUPERFICIE EXPROP }\end{array}$} & \multicolumn{2}{|c|}{$\frac{\text { VALENCIA }}{\text { PIADA } 488.607^{\mathrm{m}^{2}}}$} & CARACTERÍSTICAS \\
\hline & \multicolumn{2}{|c|}{ CONCEPTOS } & \begin{tabular}{|c|c|} 
& $A R$ \\
AI \\
OAD
\end{tabular} & $\begin{array}{l}\text { SUPERFICIES } \\
\text { DE PARCELAS } \\
m^{2}\end{array}$ & $\begin{array}{l}\text { SUPERFICIES } \\
\text { A EDIFICAR } \\
\mathrm{m}^{2}\end{array}$ & $\begin{array}{c}\text { VOLUMENES } \\
\text { AEUIFICAR } \\
m^{3}\end{array}$ & \multirow{5}{*}{\multicolumn{2}{|c|}{ 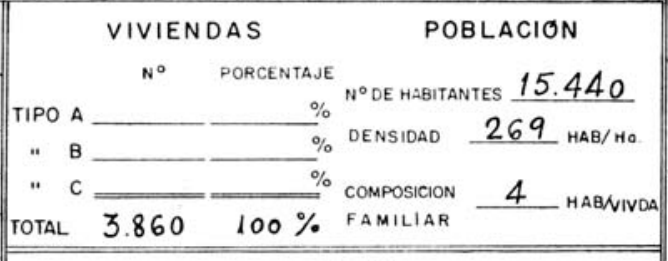 }} \\
\hline 1 & \multicolumn{2}{|c|}{ VIVIENDAS } & & 112.387 & 356.584 & 1.069 .752 & & \\
\hline 2 & \multicolumn{2}{|c|}{ DOTACION COMERCIAL } & & 3.375 & 29.138 & 90.436 & & \\
\hline \multirow{2}{*}{\begin{tabular}{|l|}
3 \\
4
\end{tabular}} & \multirow{2}{*}{ ES SCOLAR } & aEsSENAt:2A & 4 & 30.085 & 10.070 & 30.210 & & \\
\hline & & E1.3LA.MEDIA & 2 & 20.250 & 9.700 & 29.100 & & \\
\hline 5 & & $1^{*}, 2^{*}$ ENSEN. & 1 & 31.795 & 28.616 & 95.385 & \multirow{5}{*}{ EDIFICABILIDAD } & OEFICIENTES \\
\hline 6 & \multicolumn{2}{|c|}{ "SANITARIA } & 1 & 2.520 & 2.100 & 6.300 & & RESIOENCIAL \\
\hline 7 & & SMRROQUIAS & 1 & 4.096 & 2.050 & 10.150 & & COMPLEMENTARIA \\
\hline 8 & - RELIGIOSA & $\left\{\begin{array}{l}\text { No } \\
\text { PAFROOUIAS }\end{array}\right.$ & & & & & & TOTAL \\
\hline 9 & \multicolumn{2}{|l|}{. CULTURAL } & 1 & 1.470 & 5.112 & 15.336 & \multirow{2}{*}{\multicolumn{2}{|c|}{$M^{2}$ construidos por habirante (residenciai) $23^{\prime} 09$}} \\
\hline 10 & \multicolumn{2}{|l|}{. SOCIAL } & 1 & 1.470 & 5.112 & 15.336 & & \\
\hline 11 & "DE GUARD & DERIAS & 5 & 10.219 & 4.335 & 13.005 & \multirow{3}{*}{\multicolumn{2}{|c|}{ 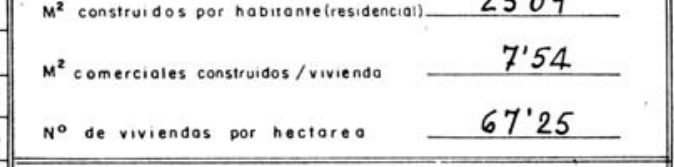 }} \\
\hline 12 & \multicolumn{2}{|c|}{ EQUIPO MUNICIPAL } & 2 & 3.709 & 14.416 & 48.372 & & \\
\hline 13 & \multicolumn{2}{|c|}{$"$ GENERAL } & 3 & 5.035 & 14.864 & 50.872 & & \\
\hline 14 & \multicolumn{2}{|c|}{ DEPORTES } & & 23.760 & - & - & \multirow{5}{*}{\multicolumn{2}{|c|}{ 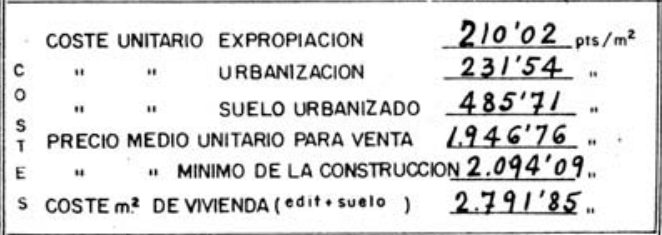 }} \\
\hline 15 & \multicolumn{2}{|c|}{ ZONAS VERDES } & & & & & & \\
\hline 16 & \multicolumn{2}{|c|}{ VIALES } & & & & & & \\
\hline 17 & \multicolumn{2}{|c|}{ ESCALA CIUDAD } & & 18.823 & & & & \\
\hline 18 & \multicolumn{2}{|c|}{ TOTALES DotaCioneS(2AL I7) } & & 156.607 & 125.513 & 404.502 & & \\
\hline 19 & \multicolumn{2}{|c|}{ TOTALES GENERALES $(10,8)$} & & 268.994 & 482.097 & 1.474 .254 & \multicolumn{2}{|c|}{ MADRID OO OCTUBRE de 1969.} \\
\hline
\end{tabular}


PLAN PARCIAL DE ORDENACION DEL POLIGONO "FUENTE

DE SAN LUIS" (REFORMADO).

\section{e-1 ORDENANZAS REGULADORES GENERALES}

(Artículo $10^{\circ}$ de la Ley sobre Régimen del Suelo y Ordenación Urbana)

\section{$\underline{\text { I N D I C E }}$}

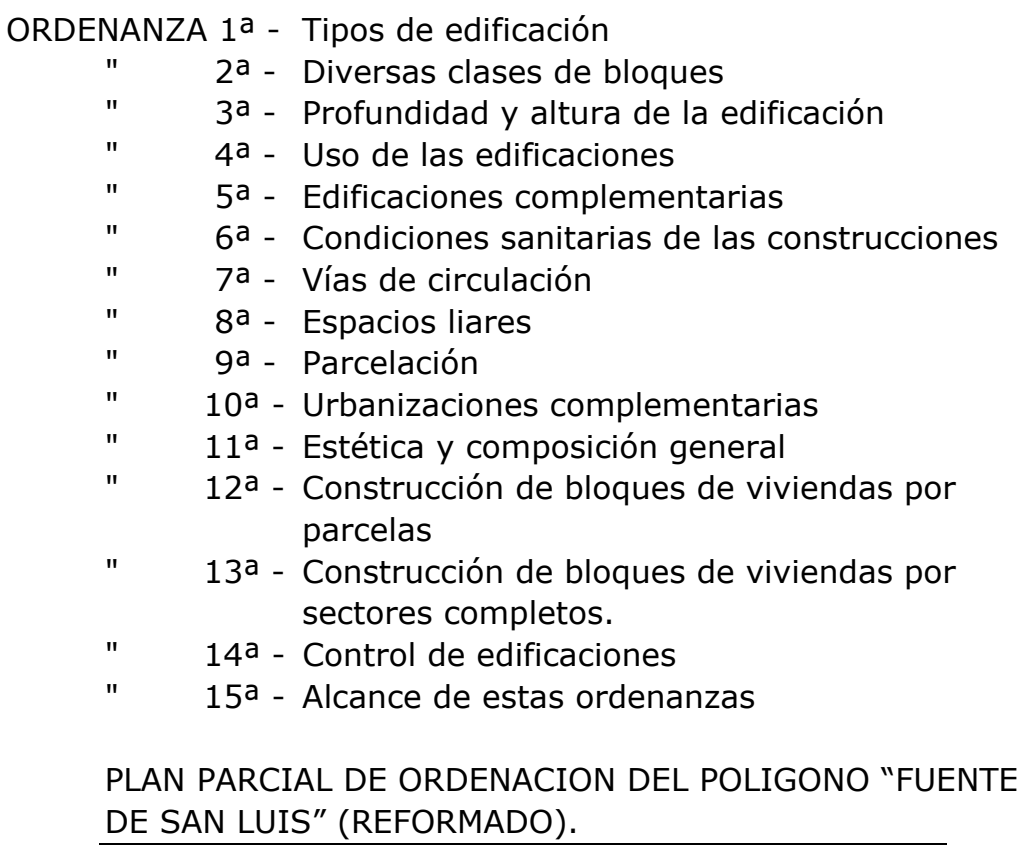

ORDENANZAS REGULADORES GENERALES

(Artículo $10^{\circ}$ de la Ley sobre Régimen del Suelo y Ordenación Urbana)

Para que el conjunto de las edificaciones y urbanizaciones complementarias que efectúen los promotores de viviendas, esté coordinado de manera que resulte un todo armónico, de acuerdo con los criterios de la Ordenación General prevista para este polígono, se establecen las siguientes Ordenanzas Reguladoras. Ellas permitirán a los promotores efectuar las distintas obras dentro de las normas .generales, que proporcionan la elasticidad necesaria para satisfacer los deseos particulares, sin que por ello se pierda la unidad de criterio en la ordenación ni se malogre la organización urbanística general dentro de las directrices estéticas que se han previsto en el planeamiento.

\section{ORDENANZA $1^{a}$ - TIPOS DE EDIFICACION}

Artículo $1^{\circ}$.- Los diferentes tipos de edificación que se realizarán SITUACIONES en este polígono corresponderán a una de las tres situaciones siguientes:

Situación a) Construcción en bloque

Situación b) Cuerpos bajos y construcciones entre bloques

Situación c) Edificaciones complementarias 
ORDENANZA $2^{\mathrm{a}}$ - DIVERSAS CLASES DE BLOQUES

$\begin{array}{ll}\text { Artículo } 2^{\circ} \cdot- & \left.1^{\circ}\right) \text { Bloque de doble crujía } \\ \text { TIPOS DE } & \left.2^{\circ}\right) \text { Bloques con patios interiores } \\ \text { BLOQUES } & 3^{\circ} \text { ) Torres }\end{array}$

Todos los tipos de bloques corresponderán a una de las formas siguientes:

Bloques de doble crujía: De 4 plantas, con fondo de 10,9 y 8 metros.

- De 7, 8 y 15 plantas, con fondo de 9 metros.

Bloques con patios interiores:

- De 4 y 6 plantas, con 20 metros de fondo.

- De 4 y 5 plantas, con más de 20 metros de fondo.

Torres;

De 12 y 15 plantas, de $20 \times 20 \mathrm{~m}$.

Artículo $4^{\circ}$.- $\quad$ Las alineaciones exteriores de cada uno de los blo-

ALINEACIONES ques que componen la ordenación de este polígono quedan especificadas en el plano de ordenación, quedando prohibida toda construcción o elemento constructivo fuera de estas alineaciones, a excepción de lo especificado en el artículo $5^{\circ}$.

Artículo $5^{\circ}$.- Se permitirán fuera de las alineaciones anteriorCONSTRUCCIO mente especificadas los motivos decorativos y reNES FUERA DE saltes de portadas comerciales y portales de los ediALINEACION

ficios, así como jambas, escaparates, etc. Etc., que no sobresalgan más de $20 \mathrm{~cm}$. Sobre la alineación de la línea de fachada en que estén superpuestas. Igualmente se permitirán marquesinas y voladizos, siempre y cuando no sobresalgan al paso de peatones o aceras con las que linde la fachada del edificio correspondiente.

ORDENANZA 3a.- ALTURA Y PROFUNDIDAD DE LAS EDIFICACIONES

$[\cdots]$

ORDENANZA 4a.- USO DE LAS EDIFICACIONES

Artículo 14 a.- Los usos a que se refieren la edificaciones del políCLASIFICACION DE LOS USOS gono, son los definidos en el plano de Estructura Urbanística, clasificándose de la siguiente forma:

Uso de vivienda

Uso comercial

Uso público

Edificación escala ciudad

Artículo 150.- El uso de vivienda colectiva se ajustará a las condiUSO DE VIVIENDA ciones sanitarias que se prevén en estas Ordenanzas y solamente podrá establecerse el uso de viviendas en las parcelas que indiquen este uso, reflejadas en el plano de estructura urbanística y en el cuadro de características.

El uso de vivienda unifamiliar queda totalmente prohibido, a excepción de las viviendas dependientes de los edificios públicos o edificaciones complementarias. 
Artículo 160.- El uso comercial se clasifica a su vez en

USO COMERCIAL Uso comercial de abastecimiento diario

Uso comercial: Talleres artesanos

[...]

Garajes

Artículo 170.- Se dividirá en:

USO PÚBLICO Uso escolar

Uso recreativo y deportivo

Uso oficial administrativo

Uso religioso

$[\cdots]$

Uso sanitario

\section{ORDENANZA 7a - VIAS DE CIRCULACION}

Artículo 330.- Las vías de circulación se clasificarán en:

CLASIFICACIÓN Circulación rodada perimetral

DE LAS VÍAS Circulación rodada interior

Penetraciones y fondos de saco

$[\cdots]$

ORDENANZA 8a - ESPACIOS LIBRES

Artículo 350.- Los espacios libres que comprende el polígono CLASIFICACION 'Fuente de San Luís" (Reformado) se clasificarán en espacios libres de carácter público y en espacios libres privados.

Artículo $36^{\circ}$.- Los espacios libres de carácter público comprendeESPACIOS LIBRES PÚBLICOS rán, además de los viales, los espacios no comprendidos en ninguna de las parcelas que se determinan en la ordenación del presente polígono. Estos espacios carecerán totalmente de cerramientos y podrán tener pavimento en algunos puntos, según se indica en los planos, formar zonas ajardinadas o bien constituir un pavimento con arena lavada de río. Los pasos de peatones y los pavimentos se realizarán como en el resto de la urbanización.

Artículo 370.- Los espacios libres privados son los que, estando ESPACIOS LIBRES incluidos dentro de una parcela privada, están fuera PRIVADOS de las alineaciones determinadas para la edificación.

Artículo 380.- Estos espacios privados, siempre y cuando no están CERRAMIENTOS afectados por una servidumbre de paso, podrán tener un cerramiento formado por seto vivo, con menor altura de 1,40 m., sin que sea permitida ninguna obra de fábrica en ellos. Estos espacios libres no podrán ser utilizados para otros servicios distintos que el de jardín o espacio arbolado, prohibiéndose totalmente el uso de cualquier elemento auxiliar como gallineros, tendederos de ropa, lavaderos, ni podrán ser utilizados como almacenamiento de cualquier material.

$[\cdots]$ 
Artículo $41^{\circ}$.- $^{-}$Las parcelaciones a que ha quedado sujeto el políPARCELAS gono "Fuente de San Luís" vienen determinadas exactamente en el plano de parcelación y en el cuadro de parcelas que contiene este trabajo. En ellos vienen definidas, exactamente, tanto su localización como límites, así como la utilización volumétrica en

$[\cdots]$ ellas permitida.

\section{ORDENANZA $11^{\mathrm{a}}$ - CONDICIONES ESTETICAS Y COMPOSICION GENERAL}

Artículo 430.- El tipo de composición arquitectónica de todos los CRITERIOS edificios incluidos en el polígono se ajustará a los GENERALES criterios actuales, quedando prohibida cualquier imitación de estilos tradicionales.

Artículo $44^{\circ}$.- El tipo de composición arquitectónica de los diferentes edificios del polígono es totalmente libre, sin otra limitación que la de seguir el criterio general estipulado en el artículo precedente, y el de procurar armonizar con las edificaciones próximas que hayan sido edificadas o estén planeadas en el momento de redactar el proyecto correspondiente.

Artículo $45^{\circ}$.- Los materiales empleados en las fachadas de los MATERIALES edificios del polígono, serán de elección de los arquitectos que redacten los distintos proyectos, siempre que reúnan las suficientes garantías para asegurar el buen aspecto durante su periodo de vida. Quedará totalmente prohibida la aplicación sobre fachada de cornisas, molduras o cualquier ornamento de escayola u otro material de características análogas.

$[\cdots]$

\section{ORDENANZA 15a- ALCANCE DE LAS PRESENTES ORDENANZAS}

Artículo $49^{\circ}$.- Los preceptos de las presentes ordenanzas habrán OBLIGATORIE de aplicarse obligatoriamente a todas las construcDAD DE LAS ciones de edificios que se lleven a cabo en el polígoORDENANZAS no. 
2. ESTADO ACTUAL

Escala original: $1: 1000$

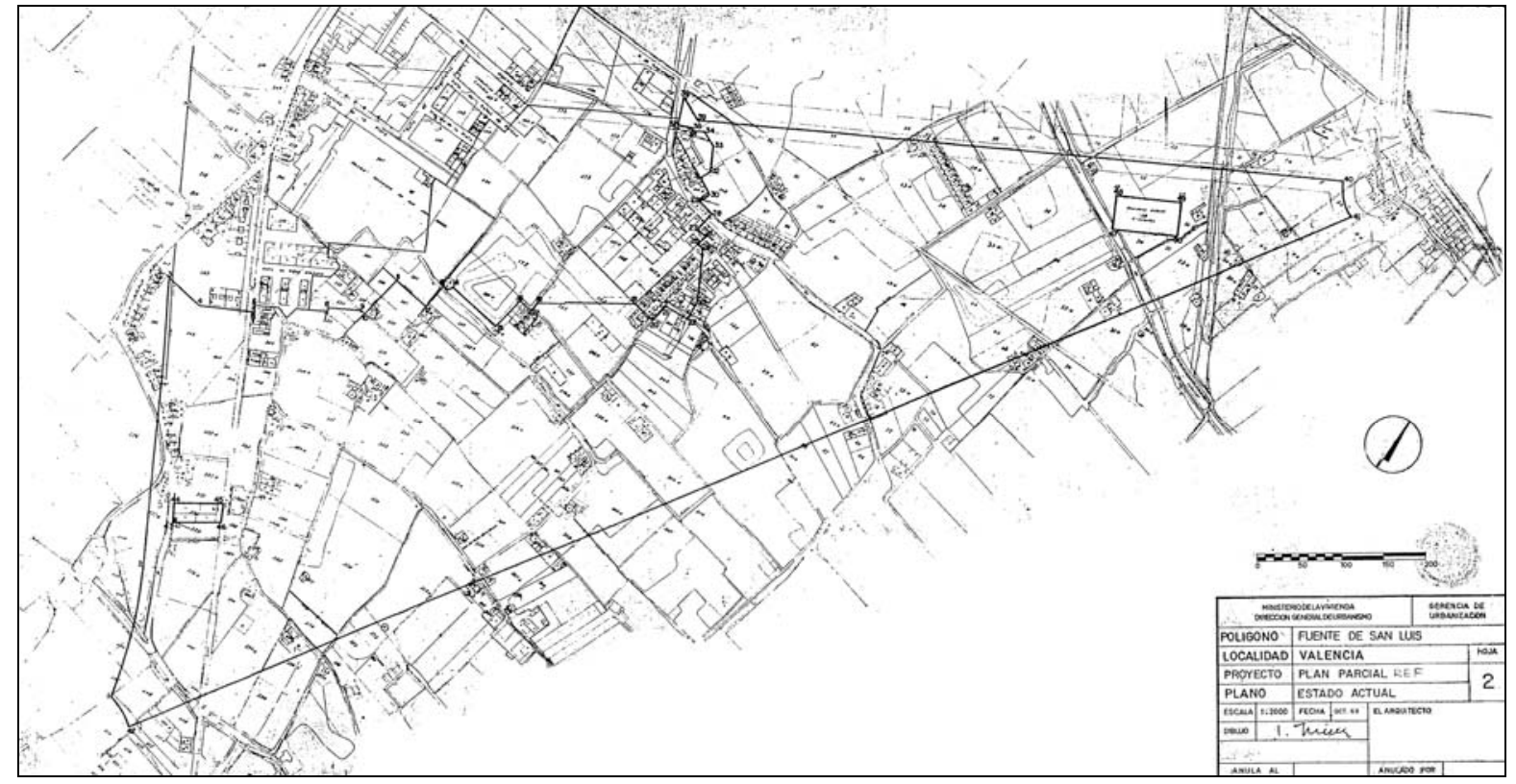

3. RED VIARIA

Escala original: $1: 1000$

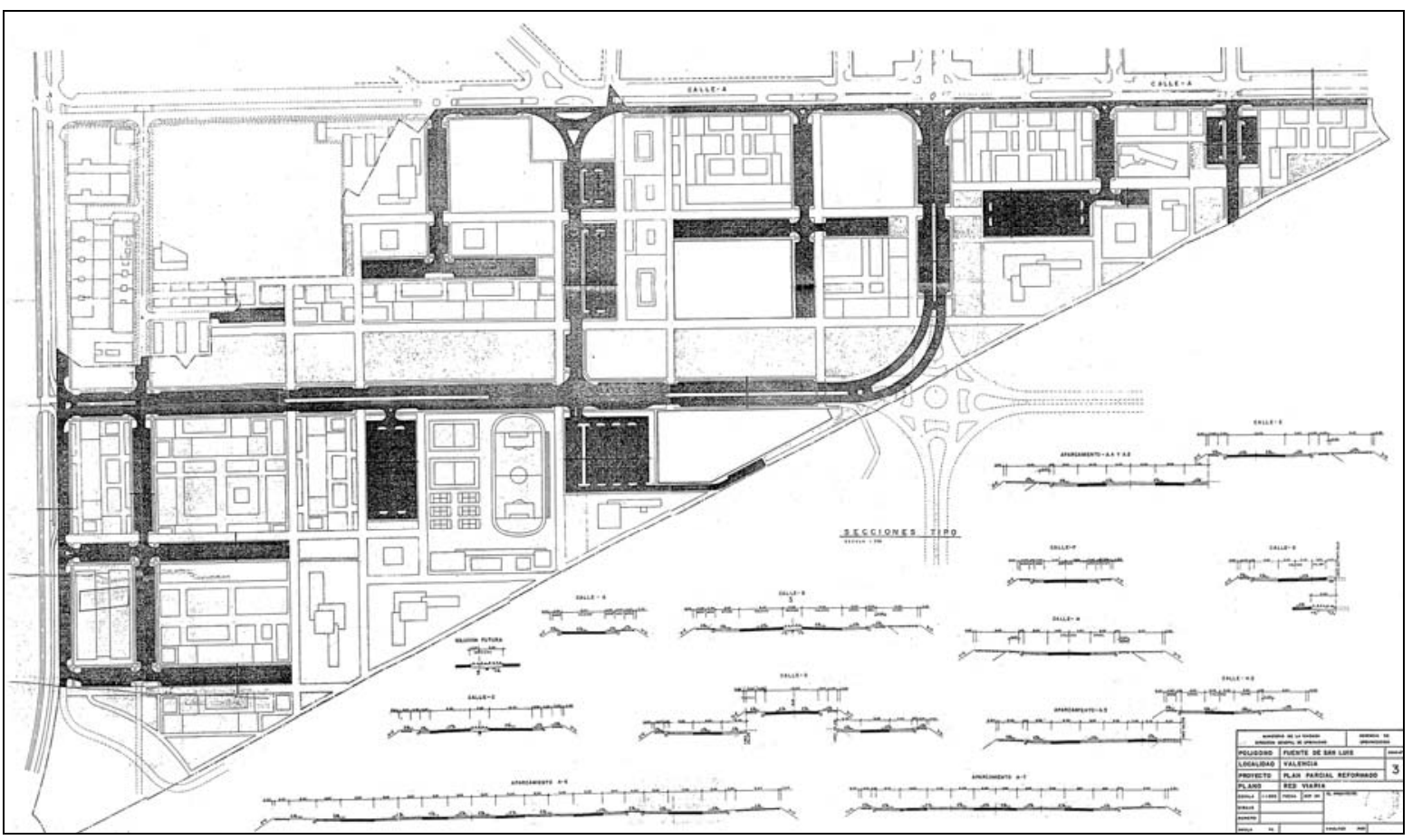


4. ORDENACIÓN GENERAL

Escala original: 1:1000
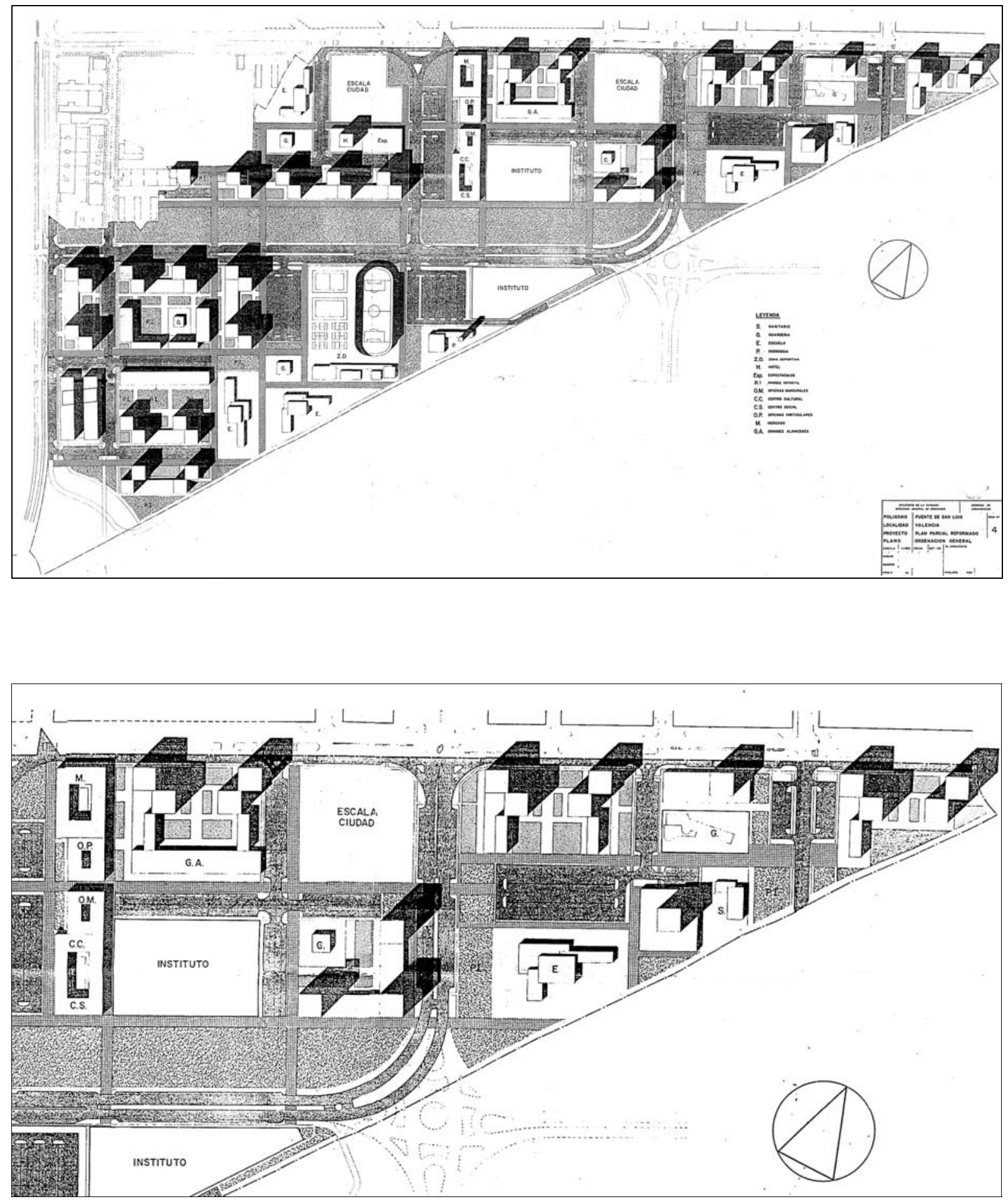

Detalle de la zona este. 


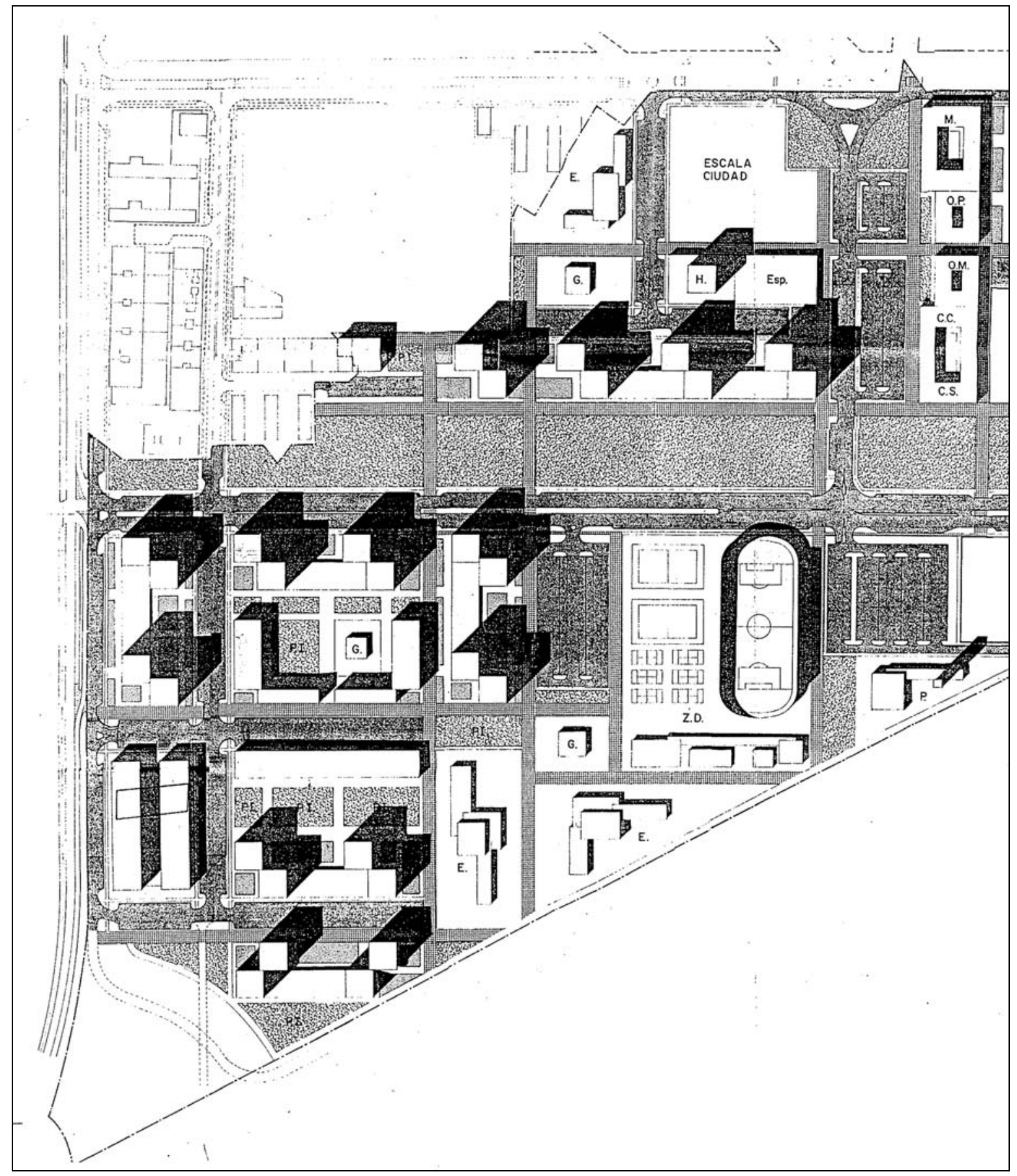

Detalle de la zona oeste 

9. PLANES ESPECIALES DE REFORMA INTERIOR 



\section{PERI SECTOR 4. PP 22}

PLAN ESPECIAL DE REFORMA INTERIOR. SECTOR 4.

PLANO PARCIAL NO 22.

Promotor: Valencia Urbana S.A.

Redactor: Joaquín Hernández M., Arquitecto.

Fecha redacción: Febrero 1984.

Fecha aprobación: Ayuntamiento de Valencia: Aprobación inicial, 23-02-1984; aprobación provisional, 26-04-1984; aprobación definitiva: 17-05-1984 (B.O.P. 30-05-1984). Anulado por el Tribunal Supremo, 31-12-1988.

\section{Contenido:}

1. MEMORIA INFORMATIVA.

1.1. OBJETO

1.2. ANTECEDENTES Y PLANEAMIENTO VIGENTE.

1.3. ESTADO ACTUAL

1.4. DEMOGRAFÍA

1.5. DOTACIONES Y EQUIPAMIENTOS

2. MEMORIA JUSTIFICATIVA.

2.1. ANTECEDENTES Y PUNTO DE PARTIDA.

2.2. OBJETIVOS.

2.3. ORDENACIÓN PROPUESTA

2.4. ORDENANZAS

2.5. CRITERIOS PARA LA GESIÓN Y PLAN DE ETAPAS.

3. ESTUDIO ECONÓMICO-FINANCIERO.

PLANOS:

- PLANOS DE INFORMACIÓN:

1. RELACIÓN CON LA CIUDAD.

$1: 20.000$

2. ZONIFICACIÓN PLAN GENERAL

$1: 20.000$

3. PLANEAMIENTO VIGENTE

$1: 2000$

4. ESTADO ACTUAL

$1: 2000$

5. ESTADO INFRAESTRUCTURA.

5.1. RED ALCANTARILLADO.

$1: 2000$

5.2. RED ALUMBRADO

$1: 2000$

5.3. RED VIARIA

$1: 2000$

- PLANOS DE ORDENACIÓN:

1. GESTIÓN

2. RÉGIMEN URBANÍSTICO

3. USO DEL SUELO. SUPERFICIES. $1: 1000$

4. INFRAESTRUCTURA.

4.1. FUTURA RED ALCANTARILLADO $1: 1000$

4.2. FUTURA RED ALUMBRADO $1: 1000$

4.3. FUTURA RED VIARIA $1: 1000$

\section{Fuente:}

Ayuntamiento de Valencia. Sección de Urbanismo. Negociado de Suelo y Ordenación Urbana. Expte. 295/73. (Archivo de Planeamiento. No 980). 


\section{PLAN ESPECIAL DE REFORMA INTERIOR. SECTOR 4. PLAN PARCIAL} NO 22

\section{MEMORIA INFORMATIVA}

\subsection{OBJETO.}

El presente documento tiene por objeto la redacción de un Pian Especial de Reforma Interior en Suelo Urbano, en el Sector 4 del Plan Parcial no 22, delimitado por la Avda. Primado Reig, c/ Ramón Asensio, c/ Doctor Vicente Zaragoza y c/ En Proyecto, de Valencia.

Para la delimitación del área de reforma descrita se han tenido en cuenta los siguientes criterios:

- El ámbito del planeamiento vigente.

- El trazado de las infraestructuras viarias que se deducen del Plan General vigente.

- La zonificación prevista en el mismo planeamiento.

- El límite del suelo que merece la clasificación de urbano.

- Seguimiento de lo dispuesto en el artículo 17 de la Ley del Suelo y los artículos 76.2.C. y 83 y s.s. del Reglamento de Planeamiento

\section{2.- ANTECEDENTES Y PLANEAMIENTO VIGENTE.}

En primer lugar aparece el Plan General de Valencia, y su Comarca, adaptado a la solución Sur, aprobado el 30 de Junio de 1.966 y que en estos momentos constituye el marco de planeamiento dentro del cual han de quedar inscritas las nuevas actuaciones.

El Pian Parcial $n^{\circ} 22$ fue aprobado definitivamente el 6 de Febrero de 1.975 .

El Pleno del Excmo. Ayuntamiento de Valencia, en sesión de 20 de Abril de 1.983, aprobó definitivamente el Proyecto de delimitación de suelo urbano en el cual quedaba incluido el Sector 4 , objeto del presente P.E.R.I.

El Planeamiento vigente recoge a dicho Sector cono zonificación abierta alta con una volumetría de $5 \mathrm{~m} 3 . / \mathrm{m} 2$.

El diseño urbano no cumple las normativas del Reglamento de Planeamiento quedando las zonas verdes muy diseminadas y estando incompleto en dotaciones, y la tipología de edificios no se adecúa a diseños actuales, especialmente en Viviendas de Protección Oficial.

Existen unos edificios junto a la avda. de Primado Reig, grafiados en el plano del estado actual que se consideran consolidados.

El planeamiento no tiene para su desarrollo ningún sistema de Actuación Urbanística.

\section{3.- ANÁLISIS DEL ESTADO ACTUAL.}

Este sector limita al Norte con un nuevo apeadero del tren eléctrico que va al Grao, lindante con esta vía están situadas las casas de Santa Ana, actualmente en gran parte desocupadas. 
En la zona comprendida entre la avda. Primado Reig, y parte de la c/ Ramón Asensio, existen unos edificios consolidados según el Planeamiento anterior.

El resto del terreno está atravesado por el camino de Vera y la senda de la Carrasca, y dividido en parcelas, como consecuencia de la estructura rústica anterior. En el ángulo NW., existe una industria, cuyos terrenos se destinarán a Usos Públicos.

En el lado Este, una amplia avenida en Proyecto de $30 \mathrm{mts}$. de ancho, separa el P.E.R.I. de un Plan Especial.

Este sector no tiene usos industriales, y las edificaciones existentes en la zona consolidada son recientes de nueva planta y de una tipología moderna.

\section{4.- DEMOGRAFÍA.}

Una aproximación al estudio de la población asentada en el área del Planeamiento consolidado, entre las edificaciones formadas por las Comunidades, Aitana, Siete Torres y Seguros, suponen una población actual de 362 habitantes con un total aproximado de 150 viviendas.

Encontrándose además un Colegio Mayor Universitario Privado.

El planeamiento anterior se encuentra en su mayor parte sin realizar por ello el presente P.E.R.I., debería intentar alcanzar los standares que el Reglamento de Planeamiento atribuye al suelo clasificado como urbanizable programado.

\section{5.- DOTACIONES Y EQUIPAMIENTOS.}

Este punto se desarrolla sobre la base del Planeamiento anterior y que servirán como datos comparativos con el P.E.R.I. que se realizará en dicho sector.

\section{PLAN PARCIAL ANTERIOR SIN REALIZAR}

Superficie en Has

9,2435

Uso comercial (m2.)

20.060.-

Uso residencial (m2.)

133.191.-

Total Edificable (m2.)

155.251.-

$\mathrm{N}^{\circ}$ de viviendas/ 120

1.109.-

Densidad viviendas / has

120.-

Población / 3,75

4.158.-

Aprovechamiento $\mathrm{m} 2 . / \mathrm{m} 2$.

1,66

Aprovechamiento $\mathrm{m} 3 . / \mathrm{m} 2$.

5. -

JARDINES (m2.)

11.452.-

AREAS DE JUEGO (m2.)

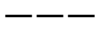

PARQUE DEPORTIVO $(\mathrm{m} 2$.

9.000.-

ESCUELA E.G.B. (m2.)

PREESCOLAR, GUARDERÍA (m2.) .....

EQUIPAMIENTO SOCIAL (S.P.) (m2)..

APARCAMIENTOS

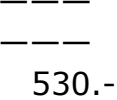

El hasta ahora vigente sector 4 del Plan Parcial 22 preveia un cierto equipamiento. EI P.E.R.I. lo respetará y naturalmente los incrementa como se desprenderá de la nueva oferta de Planeamiento. 
Una importante conclusión es la importancia de preveer mecanismos de gestión que garanticen la realidad del Plan, otro objetivo a contemplar en este P.E.R.I.

Valencia, Febrero de 1.984
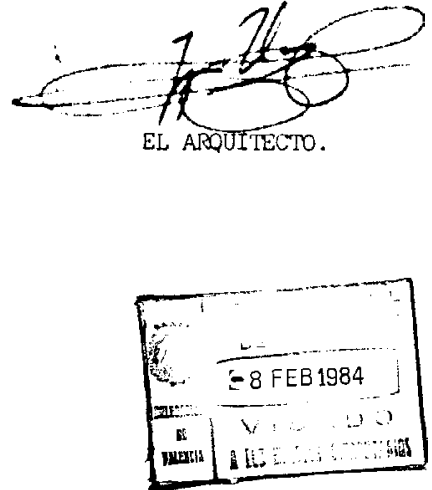


\section{MEMORIA JUSTIFICATIVA}

\section{1.- ANTECEDENTES Y PUNTO DE PARTIDA.}

El presente Plan Especial de Reforma Interior se sitúa en el ámbito del Plan Parcial 22 y afecta exclusivamente al suelo que merece la clasificación de urbano a tenor de las determinaciones que marca el Decreto.

Se ha pretendido tener en cuenta y cumplir, las determinaciones de la Legislación del Suelo y Ordenación Urbana, fundamentalmente la Reforma de la Ley del Suelo del 2 de Mayo de 1.975 y del Reglamento de Planeamiento, en Plan General de Valencia y su Comarca, adaptado a la Solución Sur y el Programa de Actuación Municipal.

La propuesta del Planeamiento, en su punto de partida se estructura en base a los siguientes puntos que se consideran motivadores de la redacción del Plan Especial:

- La necesidad de desarrollar las determinaciones del Plan

General.

- Los déficits dotacionales del área en el Plan Parcial anterior.

- La determinación y regulación de usos.

\section{2.- OBJETIVOS.}

La definición de los objetivos de actuación en el planeamiento a nivel metodológico supone la justificación de las acciones concretas que se plasman en los documentos.

- Descongestión del Suelo urbano.

- Alcanzar niveles de equipamientos comunitarios, en relación con la población prevista. existente.

- Saneamiento del área constituida por una industria

- Aplicar sistemas de gestión que permitan la obtención gratuita de equipos comunitarios.

- Garantizar la urbanización de su conjunto, mediante un sistema de actuación.

- Disminución del volumen edificable y densidad de poolación, mejorando el diseño urbano, con destino principal a viviendas de Protección Oficial, con una mayor racionalidad en la volumetria y en los espacios abiertos.

\section{3.- ORDENACIÓN PROPUESTA}

La Ordenación que se propone sigue las directrices establecidas en el Programa de Actuación Municipal por el Ayuntamiento; ajustándose a las determinaciones del Plan General, y trata de concretar los objetivos definidos en el apartado anterior.

1.- Zona consolidada, formada por varios edificios, reflejados en el plano 4 de información, según el Planeamiento anterior.

2.- Ordenación de suelo libre existente, con un total de 92.435.-m2., dividido en cinco unidades de actuación.

La delimitación de unidades de actuación equilibrarán las cargas y beneficios que se deducen del Plan.

La tipología de la edificación en consecuencia de las determinaciones que impone la zonificación del Plan General y el planeamiento más adecuado para este tipo de viviendas. 
La actuación propuesta es un intento de diferenciación de usos. Separando la que es peatonal de la circulación y aparcamientos.

Se crea un paseo ajardínado-peatonal, a través del cual se penetra en los espacios abiertos y zonas verdes de las edificaciones. El diseño del mismo se realizará en el Proyecto de Urbanización.

El parque deportivo y Centro docente, se sitúan fundamentalmente en el Norte, paralelo a la c/ Dr. Vicente Zaragoza y por donde pasa el tren eléctrico.

En dicha ordenación se ha cumplimentado en lo posible la Normativa exigida para una unidad integrada por el Reglamento de Planeamiento en Suelo Urbanizable Programado. La división en 5 unidades de actuación corresponden a la eficacia y viabilidad de ejecución del P.E.R.I.

La fijación de un aprovechamiento medio inferior al anterior planeamiento, deriva en una disminución del volumen edificable, lo que se ha postulado como un objetivo fundamental de la reforma.

Valencia, Febrero de 1.984

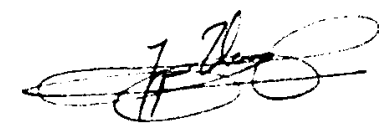




\section{ORDENANZAS}

\section{4.- ORDENANZAS}

A.- Se regirán por las Ordenanzas vigentes tanto en el Plan General como en el Plan Parcial 22.

B.- El P.E.R.I. tendrá las Ordenanzas Especiales según el siguiente articulado.

1.- Las alturas reguladoras serán:

I planta........... 4,50 mts.

II plantas ........ 8,00 mts.

III plantas ....... 10,00 mts.

VIII plañías ...... 24,00 mts.

IX plantas ........ 27,00 mts.

$X$ plantas ......... 29,50 mts.

XI plantas ........ 32,50 mts.

XII plantas ....... $35.00 \mathrm{mts}$.

2.-Los pórticos vienen reflejados en los planos, siendo su estructura libro y con la misma altura de las edificaciones en planta baja. Se ha computado su volumetría al $50 \%$, por ello se podrán ubicar servicios e instalaciones, escaleras de acceso a aparcamiento y conserjerías.

Se cerrarán en su fachada mediante una verja.

3.- El cómputo del $50 \%$ de miradores se realizará en el conjunto de una unidad de edificación.

4.- Las marquesinas serán de un vuelo igual ó inferior a 2 mts. y en las zonas interiores de jardín privado, se podrá realizar un vuelo de 1,50 en las plantas bajas para cubrir aguas.

5.- Los tratamientos de materiales y tipología de edificios, tomarán como referencias los correspondientes al carácter propio de la arquitectura existente en la zona.

6.- Todo elemento que sobresalga de los planos de cubierta será construido y tratado con la misma calidad que la fachada del edificio a que pertenece.

7.- Se admitirán, sobresaliendo del plano de cubierta solamente cajas de escalera, cuartos de máquinas, ascensores y cuartos de instalaciones.

8.- Se protege un Edificio grafiado en los planos, destinado a Servicios Públicos.

9.- Los voladizos serán de 1,50 mts., pudiendo situar los pilares dentro del vuelo de edificación, siempre que se ubiquen en la zona de uso privado en planta baja.

Valencia, Febrero de 1.984.

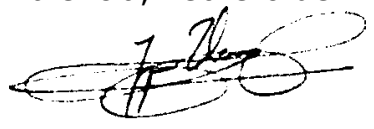

EL ARQUITECTO 


\section{5.- CRITERIOS PARA LA GESTIÓN DEL PLAN}

El texto refundido de la Ley del Suelo en su art. 117, señala que la ejecución de los planes, en suelo urbano, se realizará a través de actuaciones aisladas ó delimitando unidades de actuación que permitan, la distribución justa entre los propietarios, de los beneficios y cargas derivadas del Planeamiento

Es evidente que se conjugan estos mecanismos con el objetivo señalado en el programa de Actuación Municipal, de aplicar, en la medida de lo posible, sistemas de gestión, que permitan la obtención gratuita de equipamientos comunitarios, se define como conclusión la necesidad de utilizar el Sistema de Compensación.

Así pues, siguiendo estas directrices se ha procedido a delimitar unidades de actuación teniendo en cuenta como criterios prioritarios los siguientes:

- Que las cargas derivadas del Planeamiento reguladas en el artículo 83 de la Ley del Suelo estén incluidas dentro de unidades, en la medida que lo permitan los beneficios de las mismas.

- Que no existan dentro de la unidad edificaciones consolidadas de acuerdo con el Plan, ya que ello dificultaría la gestión.

Al mismo tiempo se han tenido en cuenta los requisitos señalados en el articulo 117 del texto refundido y son:

a.- Que por las dimensiones y características de la Ordenación son susceptibles de asumir las cesiones de suelo derivadas de la ejecución del Plan.

b.- Que hagan posible la distribución equitativa de los beneficios y cargas de la urbanización.

c.- Que tengan entidad suficiente para justificar técnica y económicamente la autonomía de la actuación.

La metodología utilizada se ha apoyado fundamentalmente en el cálculo del aprovechamiento que se deduce de la ordenación propuesta que es de $1,40 \mathrm{~m} 2 . / \mathrm{m} 2$. para pasar a continuación a delimitar las unidades, de las cuales se adjunta la hoja de características.

Desde nuestro punto de vista, entendemos que el hecho de asignar un aprovechamiento igual en cada una de ellas, supone una garantía de la equidad en la distribución de las cargas y de los beneficios.

En consecuencia el Plan preveé la cesión de todos Los equipamientos públicos incluidos en las uds. Eliminando la expropiación de dichas dotaciones.

Los límites de las 5 Unidades de Actuación, viene grafiado en los Planos y el desglose de superficies, aprovechamientos, equipamientos y cesiones queda reflejado en los cuadros correspondientes al Anexo Estadístico.

La Unidad de Actuación $n^{0} 1$ tiene una superficie de 76.824.$\mathrm{m} 2$. siendo la propiedad de todos los terrenos de un solo propietario, Valencia Urbana, S.A., a excepción del ocupado por el Camino de Vera, y con el fin de agilizar el tramite de gestión, la edificabiiidad del citado Camino de Vera en lo que se encuentra afectado en su trazado es de $1.300 \mathrm{~m} 2$. de suelo, que se concretará en un solar de $1.820 \mathrm{~m} 2$. de superficie total edificable ó su equivalente en locales comerciales ó importe económico.

La Unidad de Actuación no 2, pertenece a un propietario y su superficie total es de 1.275 .- $\mathrm{m} 2$.

La Unidad de Actuación $n^{\circ} 3$, pertenece a varios propietarios y tiene una superficie de 7.924.- $\mathrm{m} 2$.

La Unidad de Actuación $n^{\circ} 4$, pertenece a varios propietarios, con una superficie de 2.262.- $\mathrm{m} 2$. 
La Unidad de Actuación $n^{\circ} 5$, pertenece al conjunto de propietarios de las casas de Santa Ana y tiene una superficie de actuación de 4.150.- m2.

Las cinco Unidades tiene una superficie de Actuación de 92.435.- $\mathrm{m} 2$.

\section{PLAN DE ETAPAS.-}

La Unidad de Actuación $\mathrm{n}^{\circ} 1$, comenzará su realización dentro del $1^{\circ}$ año. La Unidad de Actuación $n^{\circ} 2$, comenzará su realización dentro del $1^{\circ}$ año, especialmente por las dificultades que ofrece una casa existente en dicha unidad y situada en la vía pública c/ Ramón Asensio.

El resto de las Unidades comenzarán su realización dentro del primer cuatrienio

Valencia, Febrero de 1.984.

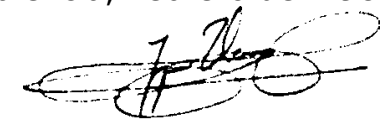


1.- SUPERFICIE

2.- CESIONES;

76.824.- $\mathrm{m} 2$

2.1.- Zonas verdes

2.2.- Parque deportivo

2.3.- Areas de juego

2.4.- Servicios públicos (en III plantas)

2.5.- Centro docente

14.200.- m2.

5.800.- m2.

1.400.- m2.

1.600.- m2.

9.500.- m2.

2.6.- Preescolar

1.525.- m2.

2.7.- Viario y aparcamiento

2.8.- TOTAL

8.631.- m2.

3.- USOS RESIDENCIALES Y COMERCIALES.

3.1.-Comercial

52.656.- m2.

3.2.- Residencial. $76.824 \times 1,40=107.553-15.660$.

3.3.- TOTAL

15.660.- m2.

91.893.- m2.

107.533. $-\mathrm{m} 2$

4.- OCUPACIÓN EN PLANTA:

4.1 - Suelo uso privado

24.168. $-\mathrm{m} 2$

5.- ÍNDICES:

5.1.- No de viviendas 3.2/120

766.-

5.2.- Densidad vivi. /ha. 5.1/1

100.-

5.3.- Aprovechamiento 3.3/1.

1,40

0,49

5.4.- Cesiones / techo 2.8/3.3.

69,92

6. SISTEMA ACTUACION:

6.1.- Compensación.

Unidad 2.

1.- SUPERFICIE

2.- CESIONES;

2.1.- Zonas verdes

2.2.- Parque deportivo

2.3. - Areas de juego

2.4.- Servicios públicos

2.5.- Centro docente

2.6. - Preescolar

2.7.- Viario y aparcamiento

2.8.- TOTAL

5. $-m 2$

3.- USOS RESIDENCIALES Y COMERCIALES.

3.1.-Comercial

3.2.- Residencial. $1.275 \times 1,40-1.785-380$.

3.3.- TOTAL

4.- OCUPACIÓN EN PLANTA:

4.1 - Suelo uso privado

1.275.- $\mathrm{m} 2$

5.- ÍNDICES:

5.1.- No de viviendas 3.2/120

100.

5.2.- Densidad vivi. /ha. $5.1 / 1$

1,40

5.3.- Aprovechamiento 3.3/1.

0,50

5.4.- Cesiones / techo 2.8/3.3.

74,58

6. SISTEMA ACTUACION:

6.1.- Compensación. 
Unidad 3.

1.- SUPERFICIE

7.924.- m2

2.- CESIONES;

2.1.- Zonas verdes

2.2.- Parque deportivo

2.3.- Areas de juego .....

2.4.- Servicios públicos

2.5. - Centro docente

2.6. - Preescolar

2.7.- Viario y aparcamiento

2.8.- TOTAL

\begin{tabular}{l}
$\cdots \overline{2.950 .-} \mathrm{m} 2$. \\
$\cdots \overline{-}$ \\
$\cdots \overline{\text { 2.910.- } \mathrm{m} 2 .}$ \\
\hline
\end{tabular}

5.860.- $\mathrm{m} 2$.

3.- USOS RESIDENCIALES Y COMERCIALES.

3.1.-Comercial

3.2.- Residencial. $7.924 \times 1,40=11.093-1.824$..

3.3.- TOTAL

1.824.- $\mathrm{m} 2$.

9.269. - m2.

11.093.-m2

4.- OCUPACIÓN EN PLANTA:

4.1 - Suelo uso privado

2.064.-m2

5.- ÍNDICES:

5.1.- No de viviendas 3.2/120

77.-

97.-

1,40

0,53

76,10

6. SISTEMA ACTUACION:

6.1.- Compensación.

Unidad 4.

1.- SUPERFICIE

2.262.- $\mathrm{m} 2$

2.- CESIONES;

2.1.- Zonas verdes

2.2.- Parque deportivo

2.3.- Areas de juego

2.4.- Servicios públicos

2.5. - Centro docente

2.6.- Preescolar

2.7. - Viario y aparcamiento

2.8.- TOTAL

3.- USOS RESIDENCIALES Y COMERCIALES.

3.1.-Comercial

3.2.- Residencial. $2.262 \times 1,40=3.167-264 \ldots \ldots$

3.3.- TOTAL

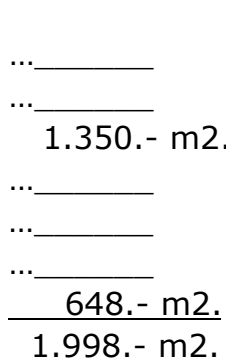

1.998.- m2.

264.- $\mathrm{m} 2$.

2.903.- m2.

3.167.- m2

4.- OCUPACIÓN EN PLANTA:

4.1 - Suelo uso privado

264. $-m 2$

5.- ÍNDICES:

5.1.- No de viviendas $3.2 / 120$

24.-

107.-

1,40

0,63

83,50

6. SISTEMA ACTUACION:

6.1.- Compensación. 
2.- CESIONES;

2.1.- Zonas verdes

2.2.- Parque deportivo

2.3.- Areas de juego

2.4.- Servicios públicos

2.5. - Centro docente

2.6.- Preescolar

2.7.- Viario y aparcamiento

2.8.- TOTAL

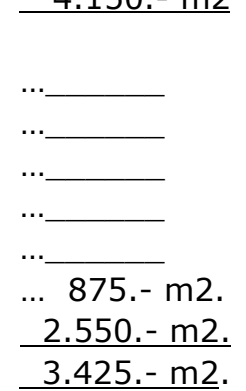

3.- USOS RESIDENCIALES Y COMERCIALES.

3.1.-Comercial

3.2.- Residencial. $4.150 \times 1,40=5.180-725 \ldots \ldots$.

3.3.- TOTAL

725.- $\mathrm{m} 2$

5.085.- $\mathrm{m} 2$.

5.810.- m2

4.- OCUPACIÓN EN PLANTA:

725.- $\mathrm{m} 2$

5.- ÍNDICES:

5.1.- No de viviendas $3.2 / 120$

42.-

5.2.- Densidad viv. /ha. $5.1 / 1$

102.-

5.3.- Aprovechamiento 3.3/1.

1,40

5.4.- Cesiones / techo 2.8/3.3.

0,58

5.5.- Cesiones / Vivienda 2.8 / 5.1.

81,55

6. SISTEMA ACTUACION:

6.1.- Compensación.

SINTESIS ESTADÍSTICA

\begin{tabular}{|c|c|c|c|}
\hline & $\begin{array}{c}\text { PLAN } \\
\text { PARCIAL }\end{array}$ & $\begin{array}{c}\text { PROPUESTA } \\
\text { P.E.R.I. }\end{array}$ & $\begin{array}{c}\% \\
\text { VARIACION }\end{array}$ \\
\hline Superficie en Has. & 9,24 & 9,24 & ----- \\
\hline Uso comercial.- & 20.060.- & 18.848.- & $-6,05$ \\
\hline Uso residencial.- & 133.383.- & 110.561.- & $-17,42$ \\
\hline Total edificable.- & 153.443.- & 129.409.- & $-15,67$ \\
\hline Número de viviendas. & 1.109.- & 922.- & $-16,87$ \\
\hline Densidad viviendas/has.- & 120.- & 100.- & $-16,67$ \\
\hline Población.- & 4.158.- & 3.457.- & $-16,86$ \\
\hline Aprovechamiento $\mathrm{m} 2 / \mathrm{m} 2$ & 1,66 & 1,40 & $-15,67$ \\
\hline $\mathrm{m} 3 / \mathrm{m} 2$ & 5.- & 4,20 & $-16,00$ \\
\hline
\end{tabular}

EQUIPAMIENTOS M2

\begin{tabular}{lccc}
\hline & P.E.R.I. & $\begin{array}{c}\text { PLAN } \\
\text { PARCIAL } \\
\text { ANTERIOR }\end{array}$ & $\begin{array}{c}\text { REGLAMENTO } \\
\text { DE } \\
\text { PLANEAMIENTO }\end{array}$ \\
\hline ZONAS VERDES & $14.200 .-$ & $11.452 .-$ & $13.830 .-$ \\
PARQUE DEPORTIVO & $5.800 .-$ & ---- & $5.532 .-$ \\
$\quad---$ & $5.700 .-$ & ---- & $5.532 .-$ \\
SERVICIOS PUBLICOS 1.600X & & & $3.688 .-$ \\
III plantas & $4.800 .-$ & ---- & $9.220 .-$ \\
EQUIPAMIENTO DOCENTE & $9.500 .-$ & $9.000 .-$ & $1.844 .-$ \\
PREESCOLAR & $2.400 .-$ & ---- & 922 \\
APARCAMIENTOS & 922 & $530 .-$ & \\
\hline
\end{tabular}



NO 22

\section{ESTUDIO ECONÓMICO-FINANCIERO.}

\section{CRITERIOS GENERALES}

El estudio económico-financiero tiene por objeto la evaluación de los costes que originará la ejecución del Plan, así como la determinación de recursos, que deberán movilizarse para su financiación.

Dado el nivel de agregación con que se trabaja, los resultados constituyen siempre una estimación global de los costes y de la participación de los diferentes agentes que intervienen en la ejecución. No obstante, ello permite el establecimiento de los criterios de financiación, programación y gestión de las actuaciones, .al mismo tiempo que, por su carácter legal, se comprometen y se completan las obligaciones económicas que se derivan de la aprobación del Plan, con la clara intención de asegurar su viabilidad y eficacia.

De acuerdo con lo anterior, el estudio económico-financiero se lleva a cabo mediante el procedimiento que a continuación se enuncia.

Primero.- Evaluación de los costes de ejecución del P.E.R.I., en aplicación de las determinaciones contenidas en él. Al respecto, se consideran generadores de coste y objeto, por tanto, de valoración las obras necesarias para la creación ó consolidación de los equipamientos y servicios públicos de interés general. El suelo será cedido por las distintas unidades de actuación así como la pavimentación, saneamiento, alumbrado, etc.

Segundo.- Determinación del sujeto financiero que deberá asumir las diferentes cargas que representan los costes así evaluados. El criterio general consiste en distinguir entre aquella inversión que correrá a cargo del Sector Público y la que deberá soportar el conjunto de los particulares que ostentan la propiedad del suelo. Así mismo, se descompone la inversión pública, señalando aquella que deberá sufragar la Corporación Municipal, y separándola de la que se efectuará con cargo a los presupuestos de otros Organismos ó Entidades de la Administración de Estado.

El criterio que orienta la imputación de los costos del planeamiento a los diferentes agentes sobre los que recaen aquellos, viene indicado de forma más ó menos directa y taxativa en la vigente legislación del Suelo y especialmente en los Reglamentos de Planeamiento y Gestión Urbanística respectivamente. Con carácter general, la normativa vigente tiende a hacer recaer las cargas de planeamiento sobre aquellos particulares que directamente beneficiados de la ejecución de aquél.

Dado que el Plan Especial que nos ocupa considera 5 unidades de actuación y una zona consolidada se aprovecha al máximo la posibilidad de utilizarla como sistema de gestión, la compensación, dejando excluido el sistema de expropiaciones por estar incluido todo el terreno en las Unidades de Actuación. 


\section{2.- METODOLOGIA DE LA VALORACION.}

La valoración se ha realizado diferenciando aquellos elementos que integran los costes de ejecución y requieren las valoraciones mediante procedimientos no homogéneos. En todo caso hay que advertir que el resultado será una estimación global que los posteriores proyectos de urbanización precisaran con mayor exactitud.

\section{1.- Valoración del suelo.-}

Al no ser preciso usar el sistema de expropiación no es necesario valorar el terreno como seria en otros casos, pero no está de más puntualizar que esta valoración se obtendría tomando como precio inicial el valor medio de la repercusión por $\mathrm{m} 2$. edificable del valor del suelo en la zona y modificándolo en función del aprovechamiento urbanístico que el plan permite, corrigiendo este ultimo precio con unos coeficientes que recogen el estado de la infraestructura, nivel de accesibilidad, grado de urbanización, etc.

\section{2.- Valoración de edificios.-}

En el ámbito de aplicación del presente P.E.R.I., existe una casa ocupando la via pública en la Unidad de Actuación $n^{\circ} 2$; la citada casa obstaculiza La circulación a la calle Ramón Asensio.

No procede la valoración de la casa para su expropiación, ya que queda fijado en el P.E.R.I. el plazo de un año para comenzar la realización de dicha Unidad y su CESION.

2.3.-Estimación del coste de ejecución de infraestructuras y de creación de equipamientos.

La valoración de los elementos que comprende este epígrafe se ha estimado mediante la aplicación de módulos de costes de edificación y urbanización constituidos por promedios obtenidos de las recientes actuaciones llevadas a cabo por la Corporación. Lógicamente como ya se ha indicado en otra ocasión, los proyectos individuales de urbanización precisan con mayor exactitud el importe de dichas actuaciones.

Los módulos utilizados proceden de los siguientes:

- Un modulo de 1.000.- pts./m2. de ejecución de las zonas verdes, que incluyen elementos de jardinería y todos aquellos propios de la urbanización, tales como alumbrado, pavimentación de acceso, etc. $<$

- Un módulo de 22.000.- pts./m2., construido para el cálculo de los casos de edificación de guarderías, centro de salud, de E.G.B. y otros inmuebles dedicados a servicios públicos.

- Respecto a los costes de urbanización, se han tomado como base de estimación, los módulos de precios aprobados por la Corporación recientemente, con la finalidad do calcular el depósito previo a la concesión de Licencias en los casos en que son de aplicación los art. 39 y 40 del Reglamento de Gestión Urbanística, como medio de garantizar la obra urbanizadora. Estos precios se expresan en ptas./m. lineal de vial y es variable atendiendo al ancho de la calle.

De forma resumida se expresan en la siguiente tabla: 


\begin{tabular}{|c|c|c|c|c|}
\hline Ancho del vial & $\begin{array}{l}\text { Pavimento } \\
\text { (aceras) } \\
\text { pts./ml. }\end{array}$ & $\begin{array}{l}\text { Alcantarillado } \\
\text { Ptas./ml. }\end{array}$ & $\begin{array}{l}\text { Alumbrado } \\
\text { Ptas./ml. }\end{array}$ & $\begin{array}{l}\text { Total } \\
\text { Pts. }\end{array}$ \\
\hline Hasta 6 m. & 13.008.- & 10.569.- & 2.810.- & 26.287.- \\
\hline De 6 a $10 \mathrm{~m}$ & 21.680.- & 11.735.- & 5.858.- & 38.943.- \\
\hline De 10 a $16 \mathrm{~m}$ & 34.688.- & 17.074.- & 6.016.- & 57.448.- \\
\hline $\begin{array}{l}\text { De } 16 \text { a } 20 \text { m. y } \\
\text { más }\end{array}$ & 43.360.- & 20.100.- & 6.162.- & 69.282.- \\
\hline
\end{tabular}

\section{DOTACION DE EQUIPAMIENTOS EN UNIDADES DE ACTUACION}

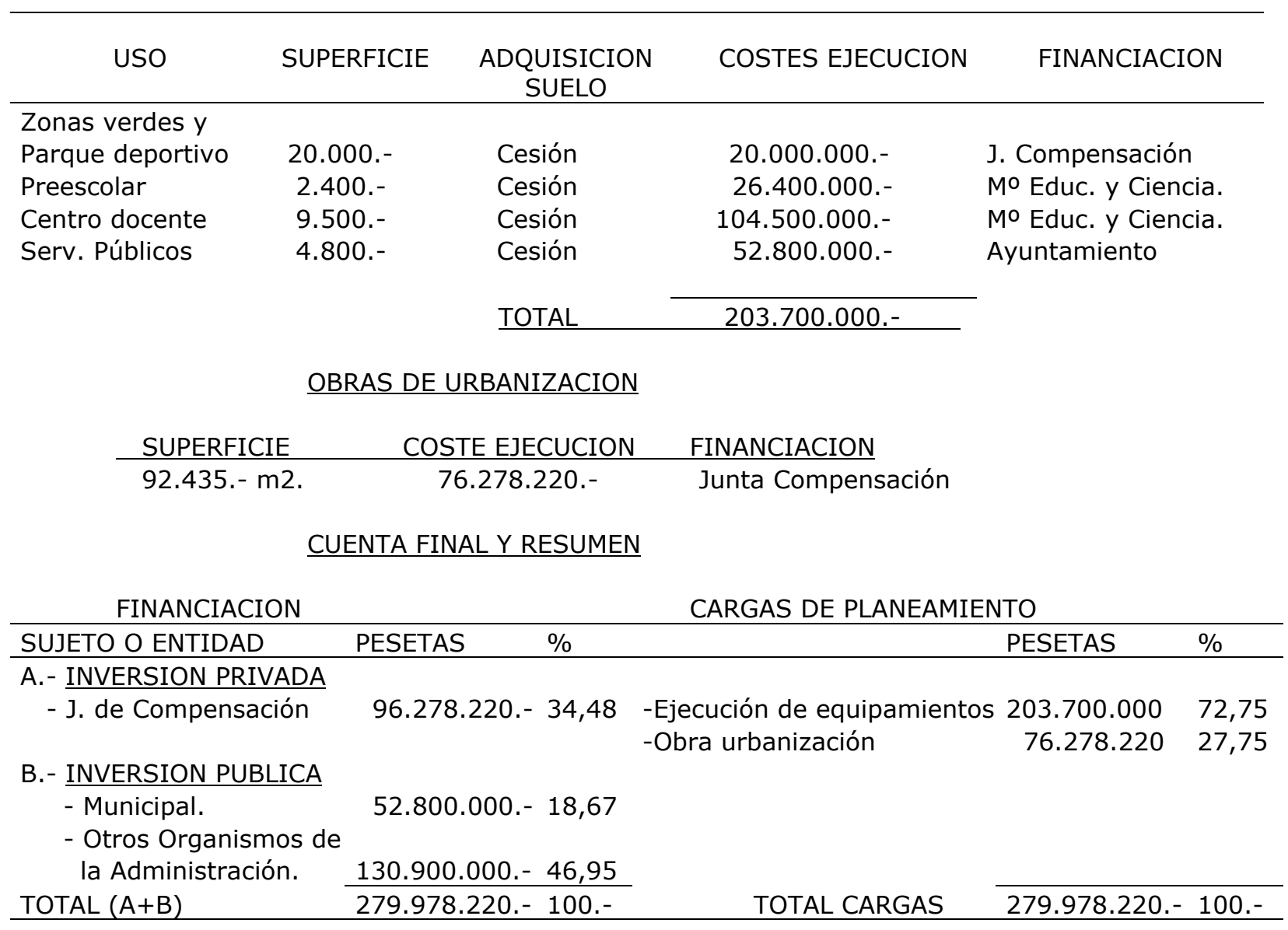

\section{3.- RESULTADOS DE LA VALORACIÓN Y FINANCIACIÓN.--}

Los cuadros expuestos a continuación recogen las valoraciones de las diferentes partidas que integran Los costos de ejecución del plan. Al mismo tiempo se indica, en cada caso, el sujeto financiero que deberá asumirlos y a cuyo cargo corre inicialmente la ejecución, lo que conduce a la cuenta final ó resumen que indica cual será la participación económica de la administración y de los particulares en la ejecución.

La práctica totalidad de la urbanización y de la obtención de suelo para equipamiento se gestionará por el sistema de compensación.

Con todo la participación Municipal en la inversión pública a efectuar en la ejecución del plan alcanza una cifra del orden de 53 millones de pesetas y representa el 18,67 de la inversión total pre 
vista. Esta cantidad como todas las demás viene expresada en pesetas corrientes del presente año, razón por la que la elaboración del plan de etapas deberá incluir las correcciones que recojan la previsible depreciación del dinero por la tasa de inflacción esperada.

El resto de la inversión pública (casi 131 millones de pesetas) se ha asignado de acuerdo con participaciones habituales de otros Organismos de la Administración del Estado, en nuestro caso dicha inversión está destinada a la creación de equipamientos escolares y se inscribe dentro de las competencias que tiene atribuidas el Ministerio de Educación y Ciencia, por lo que se preveé la realización con cargo a sus presupuestos.

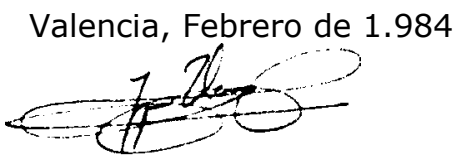

EL ARQUITECTO. 
I. INFORMACIÓN. 4. ESTADO ACTUAL

Escala original: $1: 1.000$
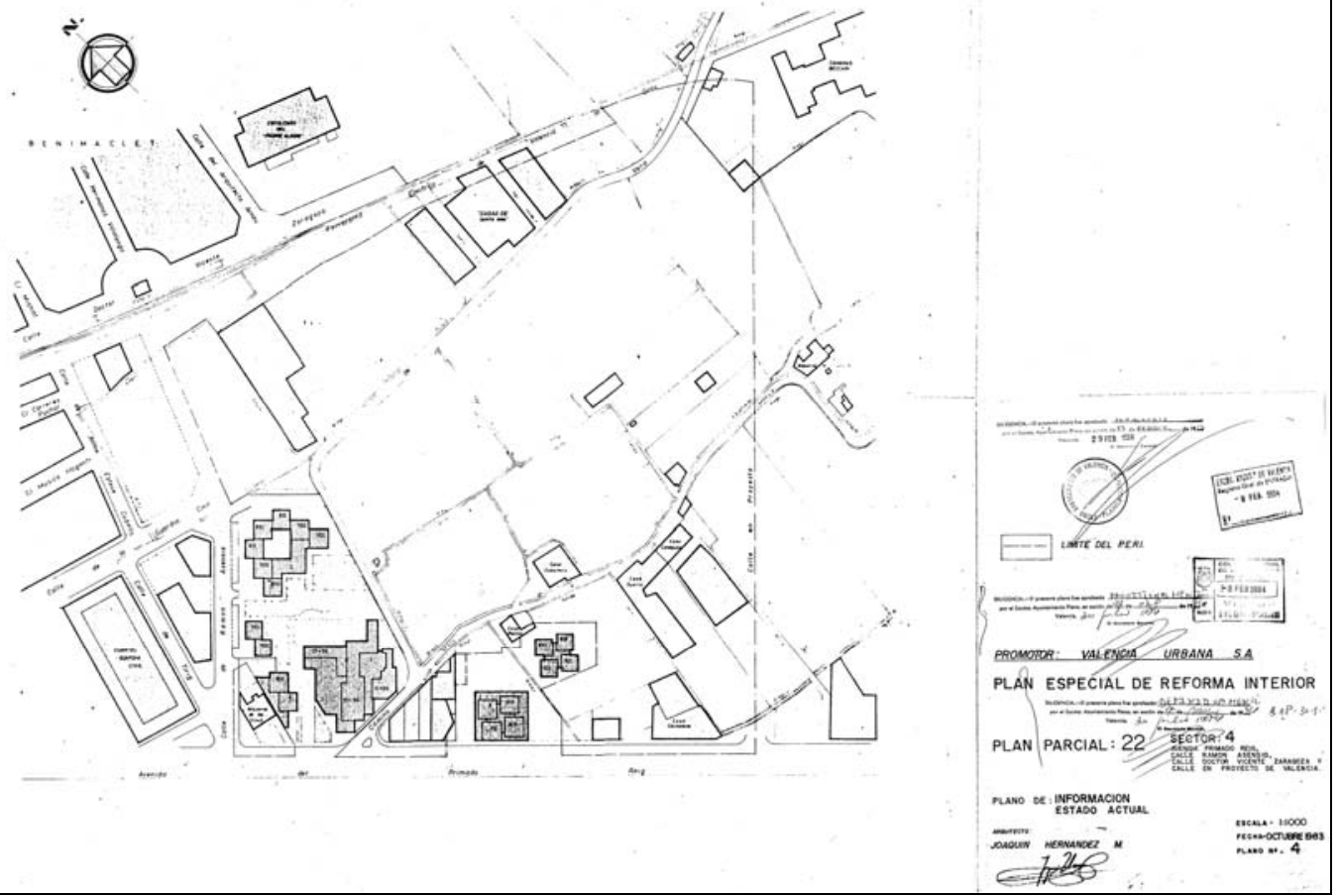

II. ORDENACIÓN. 3. USO DEL SUELO. SUPERFICIES

Escala original: $1: 1.000$
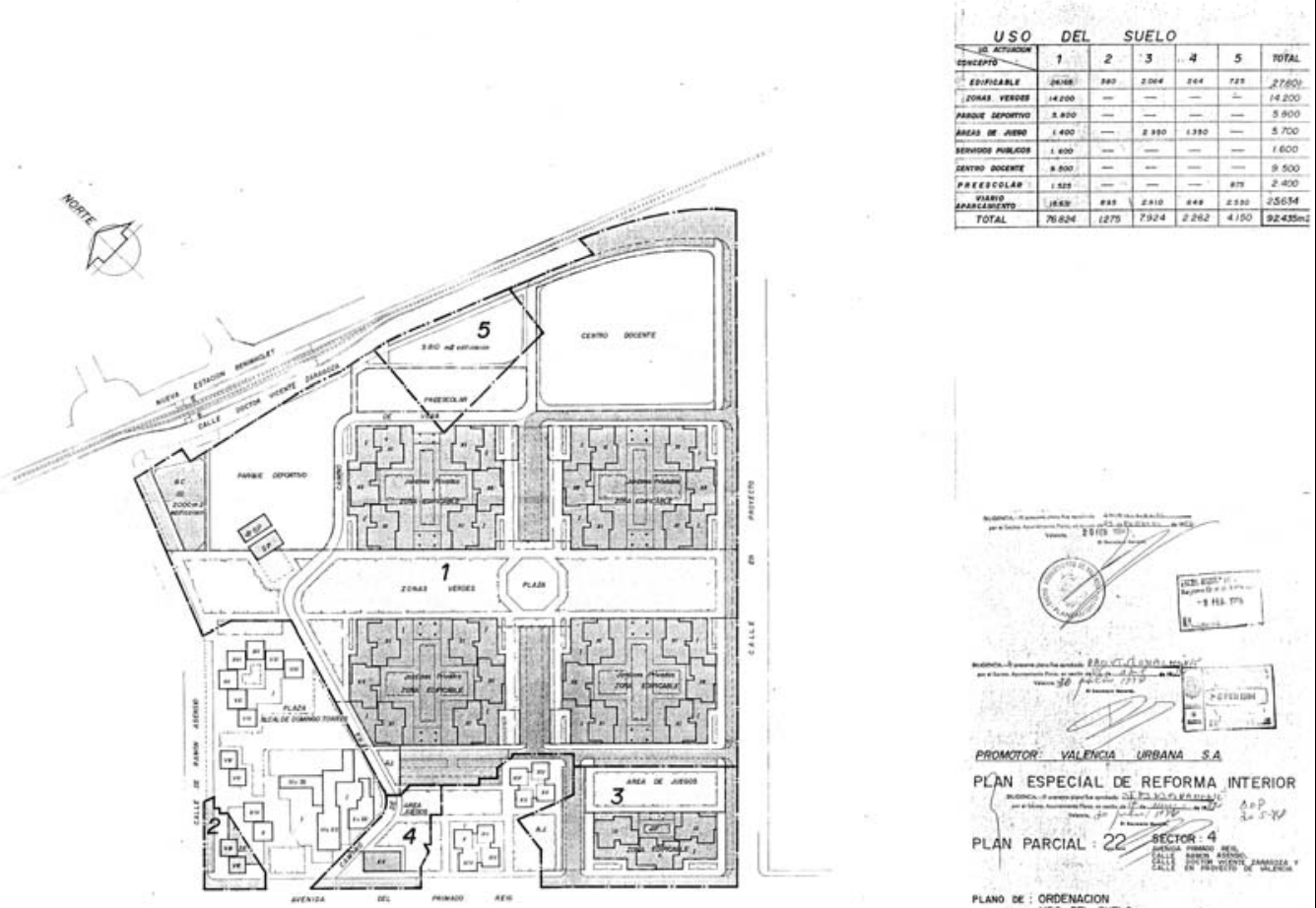

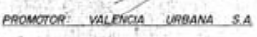

PLAN ESPECIAL DE REFORMA INTERIOR

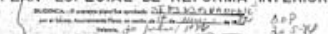

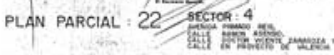

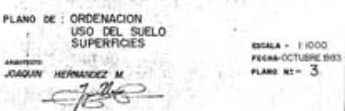


II. ORDENACIÓN. 1. GESTIÓN.

Escala original: 1:1.000

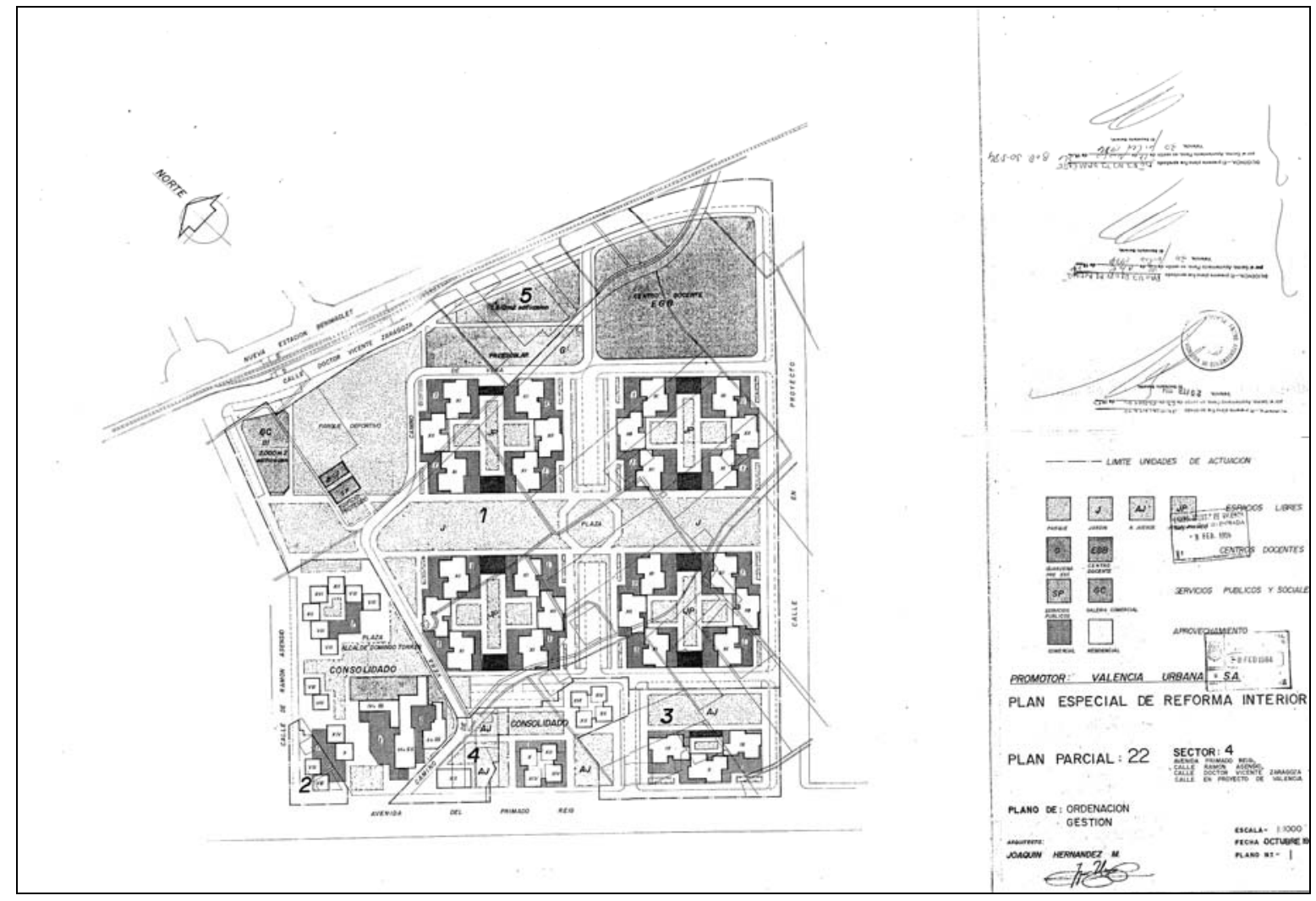




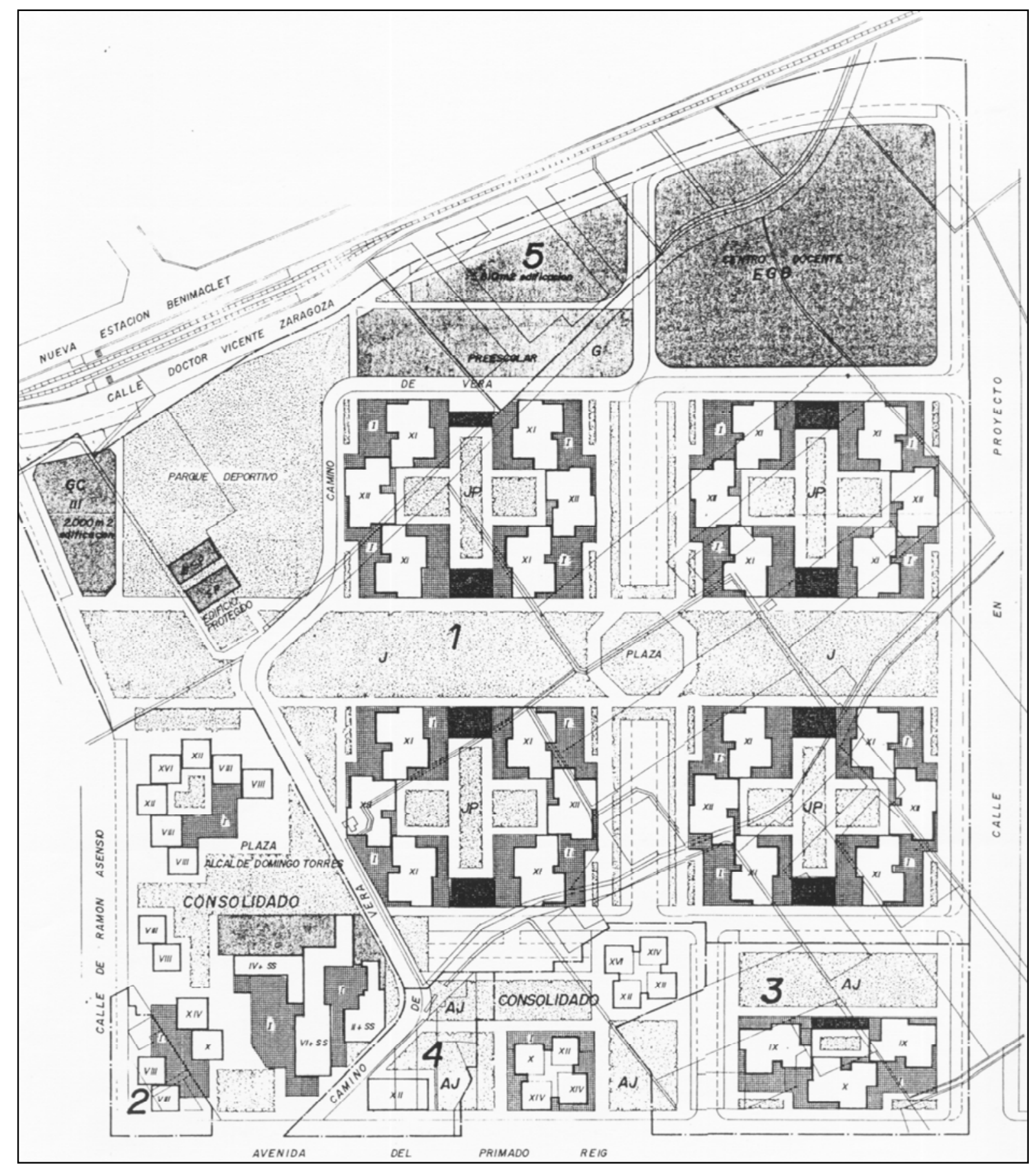

Detalle del Plano de Ordenación. Gestión.

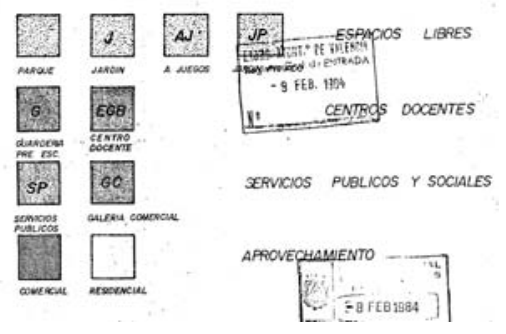

